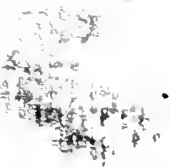

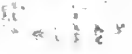

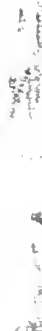

绦

k.

i

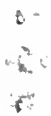

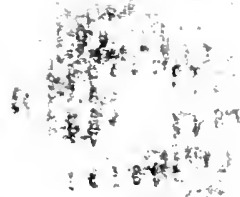
Stotist

-70 30 .

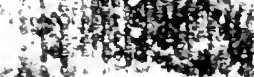

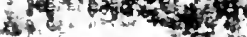

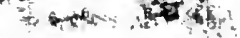





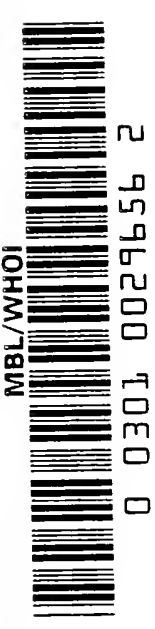





\title{
VORLESUNGEN ÜBER \\ VERGLEICHENDE ANATOMIE
}

VON

\section{OTTO B ̈̈́TSCHLI}

PROFESSOR DER ZOOLOGIE IN HEIDELBERC:

\author{
ERSTER BAND \\ EINLEITUNG; VERGLEICHENDE ANATOMIE DER PROTOZOEN \\ INTEGUMENT UND SKELET' DER METAZOEN; ALLGEMLINE \\ KÖRPER- UND BEWEGUYGSIIUSKULATUR; ELEKTRISCHE \\ ORGANE; NERVENSTSTEI, SINNESORGANE \\ UXI) LELCHTORGANE \\ MIT DEN TEXTFIGUREN 1-722
}

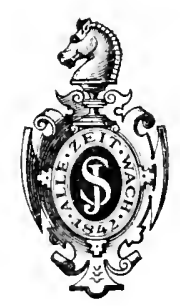

BERLIN

VERLAG VON JULIUS SPRINGER 
Alle Rechte, insbesondere das der Übersetzung in fremde Sprachen, vorbehalten. Copyright 1921 by Julius Springer in Berlin. 


\section{Inlaltsverzeichnis.}

1. Abschnitt: Einleitung. . . . . . . . . . . . . . 1

A. Aufgabe der vergleichenden Anatomie . . . . . . . . . . 1

Phylogenie . . . . . . . . . . . . . . . 1

Homologie und Anslogie . . . . . . . . . . . . . . . .

Funktionswechsel, Difterenzierung . . . . . . . . . . . . . 3

Bedeutung der Ontogenie nnd Paliontologie . . . . . . . . . 4

Organe und Organellen . . . . . . . . . . . . . . 5

B. Allgemeiner Aufbau des tierischen Organismus und seine allmähliche Komplizierung in den Hauptgruppen . . . . . 6

Ableitung der Netazoen von Kolonien Einzelliger. . . . . . . . . . . 6

Spongien . . . . . . . . . . . . . . . . . . . 7

Eumetazoa (Gastraea) . . . . . . . . . . . . . . 8

Coelenterata (Radiïre Symmetrie) . . . . . . . . . . . 10

Homonomie . . . . . . . . . . . . . 11

Bilateralia. . . . . . . . . . . . . 12

Afterbildung . . . . . . . . . . . . . . . . 14

Nemathelminthen und Verwandte, primäre Leibeshöhle. . . . . . . 15

Metamerie nnd sekundiire Leibeshöhle . . . . . . . . . . . . 16

Blutgefißsystem . . . . . . . . . . . . . . 20

Weniggliedrige . . . . . . . . . . . . . 22

Echinodermata . . . . . . . . . . . . 24

Einfluß der Metanerie auf Körpergestalt. Regionenbildung . . . . . 25

Bewegungsorgane . . . . . . . . . . . . . . . . 26

Riickbildungserseheinungen (Neotenie) . . . . . . . . . . . 28

2. Abschnitt: Übersicht des Systems der Tiere mit Charakteristik der größeren Gruppen. . . . . . . . . . . . . . . . . . 29

3. Abschnitt: Vergleichende Anatomie der Protozoen . . . . . . . 66

Einleitung . . . . . . . . . . . . . . . . . 66

A. Euplasmatische Organellen . . . . . . . . . . . . . . . . 67

1. Bewegungsorganellen. . . . . . . . . . . . . . . 67

Pseudopodien . . . . . . . . . . . . . . . 67

Undulipodien . . . . . . . . . . . . . . . . . . . . . . 69

Flagellen der Mastigophoren . . . . . . . . . . . 70

Cilien . . . . . . . . . . . . . 72

2. Eeto- nnd Entoplasma, Pellicula, Myoneme . . . . . . . . 70

3. Einrichtungen zur Nahrungsaufnahme . . . . . . . . . . 76 
4. Einrichtungen zur Ausstoßung unverdauter Nahrungsreste . . 78

5. Stoffwechselorganellen (Nahrungsvacuolen, contractile Vacuolen) 78

6. Stigmata oder Angenflecke . . . . . . . . . . . . 80

B. Alloplasmatische Organellen . . . . . . . . . . . . . . . 80

1. Trichiten, Trichocysten, echte Nematocysten. . . . . . . . 80

2. Schutzhüllen, Gehïuse und Schalengebilde . . . . . . . . 81

3. Skeletgebilde. . . . . . . . . . . . . . . . 85

C. Autonome Organellen . . . . . . . . . . . . . . . . 88

1. Chromatophoren (Chromoplasten, Leucoplasten). . . . . . 88

2. Nuclei, Centrosom, Chromidien (Chromidialnetze) . . . . . . 89

Zahlenverhältnisse der Nuclei . . . . . . . . . . . . . . 90

Differeuzierung der Kerne mehrkerniger Protozoen, Centrosom. 90

Gestaltsverhältnisse der Protozoen-Zellkerne . . . . . . . . . 93

4. Abschnitt: Vergleichende Anatomie der Metazoen . . . . . . . . . 94

1. Kapitel: Integument . . . . . . . . . . . . . . . . . 94

A. Epidermis . . . . . . . . . . . . . . . . . . . . . . . . . . . 94

1. Einschichtige Epidermis der Wirbellosen und dievon

ihr a usgehenden Schutzeinrichtungen. . . . . . . . 94

Einrichtungen zur Bewegung mittels der Epidermis. . . . . 95

Besondere Schutzeinrichtungen der einschichtigen Epidermis der

Wirbellosen (Cuticula) . . . . . . . . . . . . . . . . . . . 97

Schalen und Gehäusebildungen der Netazoen . . . : . . . . 99

Coelenterata und Vermes . . . . . . . . . . . . . 99

Brachiopoda . . . . . . . . . . . . . . . . . 100

Mollusca . . . . . . . . . . . . . . . . . . . 101

Epidermis der Tunicaten . . . . . . . . . . . . . 110

2. Geschichtete Epidermis derVertebrata und ihreSchutz-

einrichtungen . . . . . . . . . . . . . . . . . . 110

Allgemeines, Verhornnng, Häutung. . . . . . . . . . . 110

Hornschuppen und -Platten . . . . . . . . . . . . 112

Haare . . . . . . . . . . . . . . . . . . . . . 114

Federn. . . . . . . . . . . . . 116

Wechsel und Genese von Feder und Haar . . . . . . . . . 118

Lokale stïrkere Verhornungen zu besonderen Leistungen . . . 120

3. Die secretorischen Leistungen der Epidermis. . . . . 122

Allgemeines . . . . . . . . . . . . . . . . . 122

Einzellige Driisen mit ungeformtem Secret. . . . . . . . 123

Bei Wirbellosen . . . . . . . . . . . . . . . . . 123

Bei Virbeltieren . . . . . . . . . . . . 126

Einzellige Drüsen mit bestimmt geformtem Secret (Morphite), speziell sogenannte Nesselkapseln (Nematocysten) und verwandte Gebilde 128

Mehrzellige Driisen . . . . . . . . . . . . . . 133

Allgemcines . . . . . . . . . . . . . . . . . . 133

Bei Wirbellosen ... . . . . . . . . . . . . 135

Annelides. . . . . . . . . . . . . . . . 130

Mollnsea . . . . . . . . . . . . . . 135

Arthropoda. . . . . . . . . . . . . . . 137

Bei Vertebrata . . . . . . . . . . . . . 141

Amphibia. . . . . . . . . . . . . . . 141

Sauropsida . . . . . . . . . . . . . . . 142

Nammalia. . . . . . . . . . . . 145 
Komplexe Hantdrisen . . . . . . . . . . . . . . . 146

Mammardriisen

B. Mesodermaler Teil des Integuments, Corium (Cutis. Lederhant).

1. Das bindegewebige Corium . . . . . . . . . . . . 151

Bei Wirbellosen. . . . . . . . . . . . . . . . 151

Bei Vertebraten. . . . . . . . . . . . . . . 151

Coriumpapillen . . . . . . . . . . . . . . 152

Fetteinlagernng . . . . . . . . . . . . 153

Pigmentzellen (Chromatophoren . . . . . . . . . . . . . . 153

Bei Wirbellosen................... . . 153

Bei Wirbeltieren .. . . . . . . . . . . . . . 154

2. Schutz- nnd Skeletgebilde des bindegewebigen Integuments, sowie mesodermale Skeletgebilde bei Wirbellosen iiberhaupt. . . . . 156

Skeletbildungen der Wirbellosen . . . . . . . . . . . 156

Skelete aus kohlensaurem Kalk, Kieselsiure und organischen

Secreten . . . . . . . . . . 156

Knorpelskelete der Wirbellosen ............ 163

C. Skelet der Wirbeltiere . . . . . . . . . . . . . . . 165

1. Hautskelet der Wirbeltiere . . . . . . . . . . 166

Fische . . . . . . . . . . . . . . . 166

Amphibien . . . . . . . . . . . . . . . . . . 171

Reptilien . . . . . . . . . . . . . . . . . 172

Mammalia. . . . . . . . . . . . . . . . 173

2. Inneres Skelet der Vertebrata und Chordata überhaupt . . . . 173

A. Achsenskelet.

Chorda dorsalis . . . . . . . . . . . . . . . . 173

Tunicata, Enteropneusta . . . . . . . . . . . 173

Pterobranchia ................ . . . 175

Acrania . . . . . . . . . . . . . 176

Wirbelsïule der Cyclostomen und Fische. . . . . . . . . 178

Cyclostomen . . . . . . . . . . . . . . 178

Chondrostei . . . . . . . . . . . . . . . 181

Dipnoi und Holocephala. . . . . . . . . . . . . . . 183

Vollstïndige Wirbelkörper der Fische . . . . . . . . . . . 184

Chondropterygii . . . . . . . . . . . . . . 184

Holostei . . . . . . . . . . . . . . . 186

Teleostei . . . . . . . . . . . . . . . 188

Wirbelsäule der tetrapoden Vertebrata . . . . . . . . . . 191

Wirbel der Amphibien. . . . . . . . . . . . . . . . 191

Wirbel der Amnioten . . . . . . . . . . . . . . . . . 194

Querfortsätze und Rippen . . . . . . . . . . . . . . . 198

Fische . . . . . . . . . . . . . . . . 198

Tetrapode Vertebrata . . . . . . . . . . . . . $20 \%$

Amphibia . . . . . . . . . . . . . 208

Amniota . . . . . . . . . . . . . . 205

Das Brustbein oder Sternum . . . . . . . . . . . . . 207

Regionenbildung der Wirbelsäule. . . . . . . . . . . . . . . . 209

Gelenknng der Wirbelsäule mit dem Schïdel und die besondere Ausbildung der beiden vordersten Halswirbel . . . . . . . . 216

Hautskeletteile der Amnioten, die in nähere Beziehung zum Achsenskelet treten 
B. Schidelskelet der Wirbeltiere.

Allgemeines, Cranium und Visceralskelet. . . . . . . . . 223

Schädelskelet der Cyclostomen und Fische . . . . . . . . . . 226

Craninm der Cyclostomen . . . . . . . . . . . 226

Cranium der Chondropterygier. . . . . . . . . . . 228

Cranium der iibrigen Fische . . . . . . . . . . . . . 231

Visceralskelet der Cyclostomen und Fische. . . . . . . . 242

Cyclostomen ................. . 243

Chondropterygier . . . . . . . . . . . . 244

Chondrostei. . . . . . . . . . . . . . . . 249

Holostei und Teleostei. . . . . . . . . . . . 251

Beziehungen des Fischschädels zu den vordersten Wirbeln. . ¿อ́s

Cranium der tetrapoden Vertebratil. . . . . . . . . . 258

Allgemeines. . . . . . . . . . . . . . . . 258

Schäidel der Amphibien . . . . . . . . . . . . . . . . 259

Ilyobranchialskelet der Amphibien . . . . . . . . . . 268

Schiidel der Amnioten. . . . . . . . . . . . . . . . 271

Schiidel der Sauropsida . . . . . . . . . . . . . . 271

Schïdel der Manmalia. . . . . . . . . . . . . . . . . . 291

Visceralskelet (Zungenbeinapparat) der Amniota. . . . . . . 307

Sanropsida . . . . . . . . . . . . . 307

Nammalia. . . . . . . . . . . . . . . . . 309

C. Skelet der unparen Flossensäume und der paarigen

Extremititen der Vertebrata. . . . . . . . . 310

Unpare Flossen. . . . . . . . . . . . . . . . . 310

Allgemeines. . . . . . . . . . . . . . 310

Skelet . . . . . . . . . . . 313

Yaarige Extremititen der Vertebrata . . . . . . . . . 318

Allgemeines und parige Flossen der Fische . . . . . . . . 318

Skelet der parigen Flossen . . . . . . . . . . . . 320

Allgemeines. . . . . . . . . . . . . . . 320

Flossenskelet der Chondropterygier. . . . . . . . 320

Gïrtel S. 320, skelet der freien Flosse S. 322.

Extremititengiirtel der iibrigen Fische . . . . . . . . . 327

Schultergiirtel . . : . . . . . . . . . . . . . . . 327

Beckengiirtel . . . . . . . . . . . . . . . . 332

Skelet der freien Flosse. . . . . . . . . . . . . . 333

Extremitaitenskelet der tetrapoden Vertebrata. . . . . 336

Schultergiirtel . . . . . . . . . . . . . 336

Amplibien S. 337, Reptilien S. 340, Vügel S. 346,

Nammalia S. 349.

Beckengiirtel . . . . . . . . . . . . . . . . 3503

Amphibien S. 353, Reptilien S. 355, Vügel S. 361,

Mammalia S. 363.

Skelet der freien Extremitit der Tetrapoden . . . . . . 368

Allgemeines. . . . . . . . . . . . . . 368

Vorderextremitat . . . . . . . . . . 373

Amphibien S. 373, Reptilien S. 375. Vögel S. 379 ,

Nammalia S. 380.

Hinterextremitiit .

Amphibien S. 389, Reptilien S. 391, Vögel S. 394,

Mammalia S. 396. 
2. Kapitel: Allgemeine Kïpper- nnd Bewrgungsmuskulatur. . . . 401

A. Wirbellose . . . . . . . . . . . . . . . 401

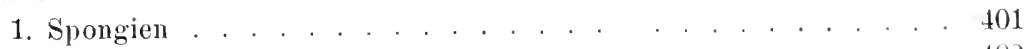

2. Cölenteraten. . . . . . . . . . . . . . 402

3. Wirbellose Bilaterien . . . . . . . . . . . . . 406

Vermes . . . . . . . . . . . . . 406

Arthropoden ...................... 411

Hollusken . . . . . . . . . . . . . $\$ 10$

Echinodermata . . . . . . . . . . . 419

Tunicata . . . . . . . . . . . 422

B. Wirbeltiere . . . . . . . . . 423

1. Einleitung. Muskulatur der Acranier und Ontogenie der Stammmuskulatm . . . . . . . . . . . 423

2. Rumpf- und Kopfmuskulatur her Cyclostomen und Fische. . . 428

Stammuskulatur . . . . . . . . . 428

Viseerale Muskulatur der Kopt- und Kiemenregion der Cyclo-

stomen und Fische . . . . . . . . . . . . . . 434

3. Rumpf- und Kopfmuskulatur ler tetrapoden Wirbeltiere. . . . 439

Stammuskulatır . . . . . . . . . . . . . . 439

Die hypobranchiale Stammuskulatur der Tetrapoda. . . . . 447

Visceralmuskulatur der Tetrapoda . . . . . . . . . . . 448

4. Muskulatur der parigen Extremitäten der Wirbeltiere ... . . 452

5. Hautmuskulatur der Wirbeltiere . . . . . . . . . . 455

3. Kapitel: Die Elektrischen Organe der Fische . . . . . 4506

4. Kapitel: Ilas Nervensystem. . . . . . . . . . . . . 464

Einleitung. . . . . . . . . . . . . . 464

A. Coelenterata . . . . . . . . . . . . . . . . 460

B. Bilateria . . . . . . . . . . . . . . . . . 471

1. Vermes . . . . . . . . . . . . . 471

Plathelminthes . . . . . . . . . . . . . 471

Turbellaria . . . . . . . . . . . . . 472

Trematorles. . . . . . . . . . . . 474

Cestodes . . . . . . . . . . . . 476

Nemertina . . . . . . . . . . . . . 478

Nemathelminthes . . . . . . . . . . . 481

Nematodes . . . . . . . . . . 481

Rotatoria, Nematorlyyneha . . . . . . . . . 484

Aeanthocephaliı.... . . . . . . . . . . 480̃

Annelida . . . . . . . . . . . . . . 486

Oligowera . . . . . . . . . . . . . . . . 493

2. Artliropoda . . . . . . . . . . . . . . . 497

Allgemeines und Cerebralganglieı . . . . . . . . . . . 497

Bauchmark . . . . . . . . . . . . 500

Besondere Verhältnisse des IJirns . . . . . . . . . . . . 509

Schlund- oder Eingeweidenervensystem. . . . . . . . . . 511

3. Mollusca . . . . . . . . . . . . . . . 514

Amphineura. . . . . . . . . . . . . . 514

Gastropoda . . . . . . . . . . . . . 517

Lamellibranchiata. . . . . . . . . . . . . 520 
Scaphopoda

Cephalopoda . . . . . . . . . . . . . . . . . . . . . . . 528

Sclilurd- und Buccalnervensystem der Mollusken . . . . . . . 531

4. Echinodermata . . . . . . . . . . . . . . . 533

Ectoneurales oder ectodermales System. . . . . . . . . . 534

Hyponeurales System . . . . . . . . . . . . . . . . . . 539

Apicales System . . . . . . . . . . . . . 541

5. Chordata . . . . . . . . . . . . . . 542

Einleitung . . . . . . . . . . . . . . . 542

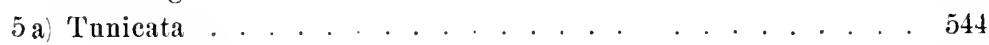

Copelatae. . . . . . . . . . . . . . . . 545

Ascidiae . . . . . . . . . . . . . . . 546

Thaliaceae . . . . . . . . . . . . . . . . 548

5b) Vertebrata . . . . . . . . . . . . . . . . . 549

Acrania. . . . . . . . . . . . . . . . . 549

Craniota . . . . . . . . . . . . . . 551

Riickenmark . . . . . . . . . . . . 551

Gehirn . . . . . . . . . . . 556

Einleitung . . . . . . . . . . . . . 556

Schilderung d. Hirnbildung in den einzelnen Gruppen 564

Cyclostomita . . . . . . . . . . . 564

Pisces . . . . . . . . . . . . . . 567

Amphibia . . . . . . . . . . . . . . 578

Sauropsida . . . . . . . . . . . . . 582

Mammalia . . . . . . . . . . . . . . 587

Periphere Nerven der Wirbeltiere . . . . . . . . 606

Acrania . . . . . . . . . . . . . 606

Riickenmarksnerven (Spinalnerven) der Craniota 609

Sympathisches (viscerales) oder Eingeweidenervensystem . . . . . . . . . . . 616

Hirnnerven der Craniota. . . . . . . . . 622

Hirn- und Riickenmarkshïute. . . . . . . . . . . . 641

5. Kapitel: Simesorgane . . . . . . . . . . . . . 644

Einleitung. . . . . . . . . . . . . . . . . . . . . . 644

A. Hautsinnesorgane einschließlich Geschmacksorgane mit Ausnahme derer der Arthropoda)

1. Coelenterata . . . . . . . . . . . . . . 648

2. Vermes . . . . . . . . . . . . . . . . . . . 649

3. Nollusea .. . . . . . . . . . . . . . . . . . 655

4. Echinodermata. . . . . . . . . . . . . . . 657

5. Chordata . . . . . . . . . . . . . . . 659

a) 'lunicata . . . . . . . . . . . . . . 659

b) Vertebrata. . . . . . . . . . . . . . . . 660

Acrania . . . . . . . . . . . . . 660

Craniota . . . . . . . . . . . . . 661

Sensillenartige Sinnesorgane der iußeren Hant. . . . . 661

Seitenorgane. . . . . . . . . . . . . 662

Cyclostomata. . . . . . . . . . . . . 662

Pisces. . . . . . . . . . . . . . 664

Amphibia . . . . . . . . . . . . . 671 
Becherförmige Organe und Geschmacksorgane der Wirbeltiere.

Cyclostomata . . . . . . . . . . . . . 674

Pisces . . . . . . . . . . . . . . . 674

Amphibia . . . . . . . . . . . . . . . . 675

Reptilia . . . . . . . . . . . . . . 675

Vögel . . . . . . . . . . . . . . . . 676

Mammalia . . . . . . . . . . . . . 677

Freie Nervenendigungen und aus ihnen hervorgehende

Hautsinnesorgaue der Wirbeltiere . . . . . . . . . 679

B. Geruchsorgane (einschließtich der Geschmacksorgane der Arthropoda) . . 688

Einleitung. . . . . . . . . . . . . . . . . . . . . . . . . 688

1. Coelenterata . . . . . . . . . . . . . . . 690

2. Vermes . . . . . . . . . . . . . . . . 690

3. Mollusca. . . . . . . . . . . . . . . 695

4. Chordata . . . . . . . . . . . . . . . . 701

a Tunicata . . . . . . . . . . . . . . . 701

b) Vertebrata ................ . . . 704

Acrania . . . . . . . . . . . . . 704

Craniota . . . . . . . . . . . . . . 704

Cyclostomata. . . . . . . . . . . 704

Gnathostomata . . . . . . . . . 707

Pisces............... . . . 708

Amphibia . . . . . . . . . . . . . . . 712

Reptilia . . . . . . . . . . . 717

Vögel . . . . . . . . . . . . . . . . . . 721

Mammalia . . . . . . . . . . . . . . . . . . . . . 723

Inscheln . . . . . . . . . . . . . . . . 724

Nebenhöhlen. . . . . . . . . . . . . 729

Jacobsonsches Organ . . . . . . . . . . . . 730

Änßere Nase, Riechepithel . . . . . . . . . 732

๊. Geruchs- und Geschmacksorgane der Arthropoda . . . . . . . . 733

C. Statische Organe (Gleichgewichtssinnesorgane) und Hörorgane . . . . . . . 739

Einleitung . . . . . . . . . . . . . . . . . . . 739

1. Coelenterata . . . . . . . . . . . . . . . . . 741

2. Vermes . . . . . . . . . . . . . . . 746

3. Mollusca. . . . . . . . . . . . . . . . . 748

4. Echinodermata. . . . . . . . . . . . . . 754

5. Chordata . . . . . . . . . . . . 754

a) Tunicata . . . . . . . . . . . . . . 754

b) Statisch-akustische Organe der Vertebrata. . . . . . . 75う

Einleitung . . . . . . . . . . . . $75 \tilde{5}$

Cyclostomatil . . . . . . . . . . . 757

Gnathostomata.............. . . 759

Hïutiges Labyrinth. . . . . . . . . . . . . . . 759

Cochlea . . . . . . . . . . . . 767

Ductus endolymphaticus . . . . . . . . . . . 768

Cristae 'und Naculae . . . . . . . . . . . . . . . . 769

Cortisches Organ. . . . . . . . . . . . . 770

Perilymphatische Rïume . . . . . . . . . . . 773 
Accessorische schalleitende 'Teile des Hörorgans

Gehörskelet . . . . . . . . . . 778

ÄuBeres Ohr Ohrmnschel. . . . . . . . . . 786

6. Statische und Hörorgane der Arthropoda . . . . . . . . . . . 788

Statische Trgane der Crustaceal . . . . . . . . . . . . . . 788

Statische und Hörorgane der Arachnoidea, Myriopoda u. a. . . . 792

Chordotonale und tympanale Organe der Insecta. . . . . . . . 793

Chordotonaloreane . . . . . . . . . . . . . 793

Tympanalorgane . . . . . . . . . . . . . . . . 796

Papillen- und kuppelförmige Organe . . . . . . . . . . . 803

D. Sehorgane.

Einleitung und allgemeine Horphologie der Augen . . . 805

¿

gruppen . . . . . . . . . . . . . . . 813

1. Coelenterata . . . . . . . . . . . . . . . 813

๖. Echinodermata. . . . . . . . . . . 815

3. Vermes . . . . . . . . . . . . . . . 817

a) Converse Angen . . . . . . . . . . . 817

b) Inverse Angen. . . . . . . . . . . . . . . 821

4. Mollusca . . . . . . . . . . . . . . 826

a Converse Angen. . . . . . . . . . . . . 826

b. Inverse Altgen. . . . . . . . . . . . . . 835

๖. Chordata . . . . . . . . . . . . 838

a) Tunicata . . . . . . . . . . . . . . 838

b Craniota Lateralangen) ............ 841

Einleitung und Ontogenese . . . . . . . . . . . 841

Allomeines iiber den Bulbus. . . . . . . . . . . . 844

Cornea . . . . . . . . . . . . 846

Linse . . . . . . . . . . . 847

Glaskürper. . . . . . . . . . . . 850

Retina. . . . . . . . . . 850

Chorioidea Ciliarkörper, lris, Tapetum . . . . . . 854

Processus falciformis (Zapfen. Pecten) . . . . . . . 856

Sclera (Scleroticalring) . . . . . . . . . 858

Accomodationsmuskel ........... . 859

BlutgefiiBe des Auges . . . . . . . . . . . 860

Augenlider (Nickhant). . . . . . . . . . . . 861

Bulbusmuskeln . . . . . . . . . . . . 863

Angendriisen . . . . . . . . . . . . . . . . . 867

c. Unpaare Augen der Craniota. . . . . . . . . . . . 868

ti. Arthropodit .. . . . . . . . . . . . . . 872

a) Blasenanyen der Protracheatal . . . . . . . . . 872

b) Unpaares Medianange . . . . . . . . . . . . 872

c) Ocellen . . . . . . . . . . . . . 875

Allgemeines 875. Entstehung von Linse nud Glaskörper

876. Ban der Retina 879. Invertierte Ocellen der Arachnoideen 882. Lateralocellen (Xiphosuren, Strepsipteren) 884

Lateralocellen (Insektenlarven und Scutigera) 885.

a Complexangen Facettenaugen) 
Allgemeines 886. Kristallkegel 888. Retinula 892. VerSeite schiedene Umgestaltungen der Complexangen 893. Optische Verhïltnisse der Arthropodenaugen 895.

7. Allgemeiner Bau der Sehzellen . . . . . . . . . . . . . . 896

6. Kapitel: Lenchtorgane. . . . . . . . . . . . . . . 900

Einleitung. . . . . . . . . . . . . . . . . . 9900

1. Coelenterata . . . . . . . . . . . . . . . . . . . 902

2. Vermes . . . . . . . . . . . . . . . . . . . 904

3. Arthropoda. . . . . . . . . . . . . . . . . . . . . . . . . . . . . 907

Crustacea 907. Insecta Allgemeines 910. Coleoptera 911.

4. Mollusea . . . . . . . . ... . . . . . . . . . . . . . 916

Gastropoda 916. Lamellibranchiata 916. Cephalopoda 918.

5. Echinodermati . . . . . . . . . . . . . . . . . . 921

6. Chordata . . . . . . . . . . . . . . . . . . . . . 922

a) Tunicatil . . . . . . . . . . . . . . . . 922

b) Vertebrata . . . . . . . . . . . . . . . 924 


\section{Berichtigungen:}

Seite VII Zeile 9, 10 v. o. lies ,2. Kapitel, Skeletbildungen

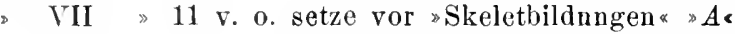

VII » 15 v. o. setze vor "Skelet der Wirbeltiere $\diamond B$.

35 Zeile 12 v. o. lies »2. Ordnung \& statt s3. Ordnung«.

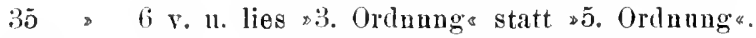

36 " 9 v. o. lies "Klasse statt »3. Klasse".

38 \$ 12 v. o. lies »Keine Cloake statt »Cloake nicht

40 " 7 u. 8. v. o. lies s Thalassemar statt "Thalassonema".

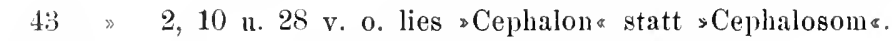

44 \$ 2 v. o. lies s Cephalon « statt >Cephalosom.

- 44 D20 v. u. lies sTergite statt "Tergita".

- 45 " $5,10,14,21$ u. 22 v. u. lies sCephalons statt "Cephalosom*.

-46 " 2 v. o. lies „Cephalon" statt "Cephalosom".

" 47 " 14 v. o. lies »Aselluse statt "Assellus*.

49 , 25 v. o. lies s Tethyss statt "Thetys\&.

50 \& 12 v. u. lies 5 . Phylum * statt $\gg 6$. Phylum .

- 52 ๖ 6 v. u. lies $* 6$. Phylum s statt 7 . Phylum.

52 > 3 v. u. lies »Riickensaite" statt »Riickenseites.

- 54 » 19 v. u. lies sverkïmmert statt s verkiimmer

- 55 , 23 v. o. lies »Brustflossens statt *Bauchflossen«.

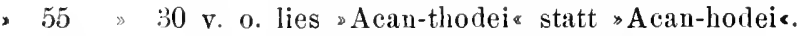

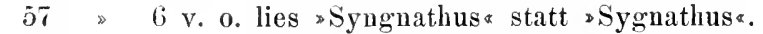

59 * 9 v. o. lies "Mosasaurus s statt \$Mesosaurus".

60,8 v. u. ist vor $\nsim 5$. Klassec einzufügen 2 . Kreis ‘.

65 " 5 v. o. lies $» 1$. Unterordnung statt $\$ 1$. Ordnung «.

, 65 > 9 v. o. lies $\$ 2$. Unterordnung statt $>2$. Ordnung $\propto$.

- 71 Fig. 8 setze hinter sBlochmanu" - saus Bronu Cl. n. Ord.

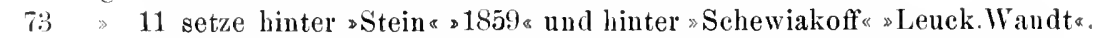

75 क 13 lies s Original v. O. Schr. $₫$ statt s nach O. Schr. 1906«.

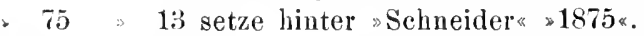

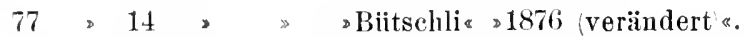

85 in Fig. 18 lies ,Pompholyxophrys statt sompholyxophris

118 Zeile 13 v, o. fiige linter $\gg$ Federfluren ,Raine getrennt sind *.

- 118 \$ 15 v. o. lies seine Hanpt- mit einer bis mehreren Fadenfedern.

- $118>17$ v. o. lies streten glatte Hautmuskelnc.

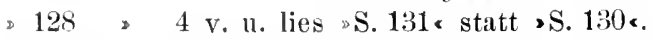

, 134 Fig. 49 lies »v. Bn.\& statt 0 . B.\&

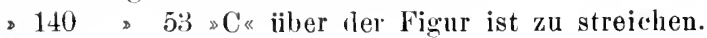


Seite 148 Zeile 3 v. o. lies svascularisierten "statt smuskularisierten".

$» 156$ \ 3,4 v. o. setze $\gg 2$. Kapitel, Skeletbildungen«.

156 " 12 setze $* A$ * vor $^{*}$ Skeletbildungens.

- 161 " 19 v. o. lies "Tunieaten statt s'Tunciaten .

- 162 lig. 68 lies "Pannychia" statt »Pananychias.

* 165 Zeile 19 v. o. »Lepidotenthis" statt $\gg$ Lepidothentis\&.

$165 » 22$ v. 0 . lies $\gg B \ll$ statt $\gg C_{*}$.

166 Fig. 71 hinter sErsatzschiippchen ist einzusehieben s(e)

169 Zeile 2 v. 11 . lies (Fig. 74/s statt "(Fig. 74a)».

170 Fig. 74 streiche sa\& iiber der Fig. und in der Legende.

- 175 , 79 setze hinter s Sehepotieff $* 1906$ i

177 ٪ 81 » „Laukester* "1889\%.

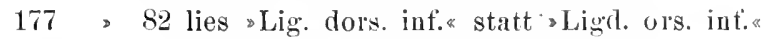

177 Zeile 12 v. II. ist „Myocommata zn streichen.

$183 \gg 11$ v. o. lies $>$ S. $2: 34$ statt $\gg$ S. 2:32\%.

- 184 Fig. 89,2 lies „Interealare« statt » Neuralbogen«.

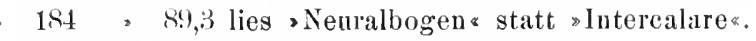

189, 98 lies \& Lig. longit. dors. sup. *

201 Zeile 19 v. o. lies »Dipnoern, den Knorpel- und Knoehenganoidens.

203 » 10 v. u. lies »Fig. $99 \mathrm{D}$.

$203 \gg 1$ v. u. lies $\gg$ Fig. $99 \mathrm{D}$ statt $\nsim$ Fig. $99 d *$.

204 » 8 v. u. lies »der dorsale Gabelast statt »das proximale Gabelende.

$227 \gg 5$ v. u. lies »unparen $\approx$ statt »paarigen

$2: 36,16 \mathrm{v}$. o. lies $» s 0 \%$. Musenlus temporalis.

241 "3 v. o. lies (Fig. 136, W) \& statt " Fig. 136) *

$241 \mathrm{Fig} .138$ fiige in der legende (7. 2) hinter Dorsalseite ein: •Die punktierten Linien geben den Verlauf der Schleimkanïle in den Schidelknochen an.

244 Zeile 18 v. u. lies »Chondropterygier

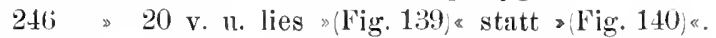

253 > 7 v. o. lies s nach innen vom Zwischenkiefer s statt sunter dem Zw.

255 . 19 v. u. lies »Iypobranehiale statt $\gg$ Hyobranchilia

$25 \mathrm{~s}, 1$ v. o. lies, 1 . bis 4 . Kiemenbogen dreigliedrig *.

260) Fig. 146 fitige zur Legende als Zeichner \&E. W.

264 * 149 lies "Iehthyophis statt sehthryophis.s

267 Zeile 7 r. o. lies sebensos statt salso".

$269 » 17$ v. o. setze hinter » Figur $-» 147$ C, S. $261 \ll$.

294 "13 v. 1. lies $\gg($ Fig. 173) « statt $\gg($ Fig. 174)

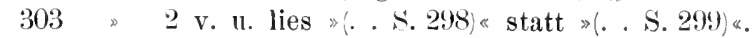

316 " 6 v. o. lies *(. . Fig. 187 B) s statt "(. . Fig. 188B)".

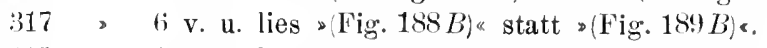

$318 \gg 1$ v. o. lies $\gg($ Fig. $188 B / \propto$ statt $\gg(\mathbf{F i g} .189 B)$.

321 »1:3 v. o. lies * Fig. 189 \& statt s/Fig. 190) «.

332 " 4 v. o. lies "Supraclaviculares statt supraseapulare.

333 » 1 v. o. lies $\gg($ Fig. 2034) statt $\gg($ Fig. 2044)\&.

334 » 2 v. o. lies »(Fig. 2042)《 statt > Fig. 2044)《.

339 > 13 v. u. lies w Fig. 207 s statt s Hig. 208*.

341 " 2 v. o. lies $\gg$ Fig. $208 C$ statt $*$ Fig. $209 C$.

361 » 2 . o. lies $\gg$ die Verkümmerung des Distalteils des eigentlichen Pubisastes".

, 363 » 3 v. u. lies "proximal statt sanfïinglich». 
Seite 365 Zeile 21 v. o. lies *Fig. 231 a und $232 b$ " statt 2333 b*.

- 376 Fig. 2391 u. 2 lies sMetac.e statt "Metat.*

379 "244 lies Metae. statt setat.

383 „247 fïge zur Legende als Zeichner „C. H.»

393 Zeile 7 v. o. lies Metatarsus $V *$ statt "Metacarpus $V$ *.

" 393 > 18 v. u. lies "Die 5. Zehe statt »Der 5. Finger

393 » 5 v. u. lies sfibularen statt »ulnareu $\%$.

397 „ 4 v. o. lies „Epicondylus fibularis statt »Condylus fib.

399 , 19 v. o. lies »Calcaneus statt »Talus*.

399 „ 13 v. n. lies Didelphyiden" statt »Didelphiden *

$400^{\circ}, 2$ v. n. lies sacroscelididen statt $\$$ Macrosceliden.

450 » 4 v. u. lies »Hypobranchialmuskulatur statt $\gg$ Hyobranchialmuskulatur $\%$.

$452>11$ v. 11. lies > Fig. 294, S. 431 \& statt Fig. 234, S. 431 .

" 457 \$ 6 . o. lies sTorpedinidae statt "Torpedinida .

» 513 Zeile 21 v. u. lies »Fig. 366« statt >Fig. 361.

^530 Fig. 381 vor »C. H.« fïge ein »präip. u. gez.«

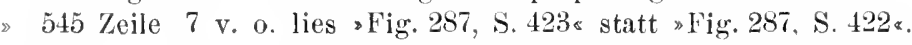

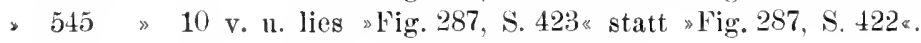

, $547 \gg 12$ v. 11. lies »S. 422 «tatt »S. $421 \ll$.

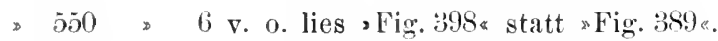

> $\check{50}$ » 1 v. u. lies Fig. 399* statt sFig. 398*.

*571 \& 11 v. u. lies sie eigentlichen *

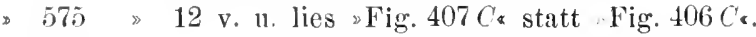

» 576 » 3 v. u. lies »Rautenohr" statt »Rautenrohr*.

" 581 Fig. 415 lies stets "Ram. statt "Rad.»

- 587 " 15 v. o. lies »Rautenohr s statt »Rauteurohr».

597 » 1 v. u. lies $\gg$ Fig. 428 u. $430 \ll$ statt $\gg$ Fig. 427-429.

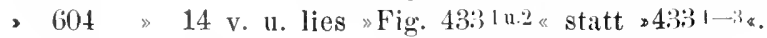

\$ 615 \% $18 / 17$ v. u. lies $>N$. obturatorius s statt $* N$. opturatorius

$\gg 621 \gg 5$ v. o. lies $\gg$ Fig. 447, S. 629 statt $\gg$ Fig. 446, S. 628 .

" 635 , 16 v. o. lies "superficialis statt "superfacialis

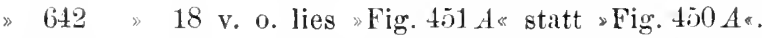

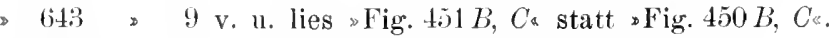

$\gg 644 \gg 12$ v. 0. lies $\gg$ Fig. $451 C$ statt $»$ Fig. $450 C$.

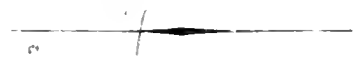




\section{VORLESUNGEN ÜBER \\ VERGLEICHENDE ANATOMIE}

VON

\section{OTTO BÜTSCHLI}

PROFESSOR DER ZOOLOGIE IN HEIDELBERG

1. LIEFERUNG:

EINLEITUNG; VERGLEICHENDE ANATOMIE LER PROTOZOEN; INTEGUMENT UND SKELET DER METAZOEN

MIT TEXTFIGUR 1-264

MANULDRUCK 1921

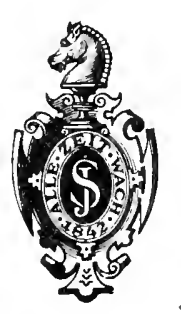

BERLIN

VERLAG VUN JULIUS SPRINGER 
Alle Rechte, insbesondere das der Übersetzung in fremde Sprachen, vorbehalten. 


\section{Vorwort.}

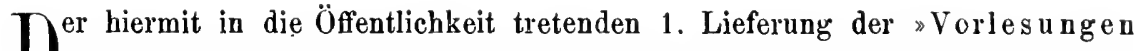
iiber vergleichende Ánatomie* sende ich einige einleitende Worte voraus. Die Anregung zur Ausarbeitung der Vorlesungen entsprang dem öfter wiederholten Wunsche einiger meiner Schüler, welche die Vorträge über Vergl. Anatomie, die ich nun seit fast 30 Jahren im Sommersemester gehalten habe, gerne veröffentlicht sehen wollten. Die großen Schwierigkeiten einer solchen Aufgabe ließen mich lange zaudern, diesem Gedanken näher zu treten. Wenn ich mich endlich doch dazu entschloß, so war ich mir voll bewußt, daß dieser Versuch, wenn seine Ausfïlhung auch einem einzelnen gelingen sollte, weit hinter dem gesteckten Ziele zurïckbleiben miisse, und daß er der Kritik jedes genaueren Kenners eines Spezialgebiets Angriffspunkte genug darbieten werde. Wie es bei ähnlichen Unternehmen meist der Fall, konnte nur eine gewisse Nichtachtung der im Laufe der Arbeit sich häufenden Schwierigkeiten den Entschỉuß zeitigen, der nie ins Leben getreten wäre, wenn dem Verfasser die Hindernisse und $Z$ weifel sofort gegenwärtic gewesen wären, die ihm im Laufe der Arbeit begegneten.

Die Vorlesungen schließen sich im allgemeinen den Vortrïgen über vergl. Anatomie an, die ich seit 1884 hielt. In diesem Jahre überließ mir der nnvergeßliche Meister der vergleichenden Anatomie, C. Gegenbaur, die seither von ihm in Heidelberg gehaltenen Vorlesungen iiber dieses Cebiet, die ihm bei vorrïickendem Alter beschwerlich wurden. Ich bin meinen hochverehrten ehemaligen Kollegen, und, wie ich sagen darf, auch Lehrer - obgleich ich nur aus seinen Schriften lernte -- für das ehrende Vertrauen, das er mir s. Z. hierdurch erwies, und für das schöne Arbeitsgebiet, welches er mir damit eröffnete, stets zu aufrichtigstem Danke verpflichtet geblieben.

Natürlich mußten die zu veröffentlichenden Vorlesungen etwas mehr bieten, als sich in einer fünfstündigen Vorlesung darlegen läßt. Eine vollständig neue Durcharbeitung war daher notwendig. - An der Verfolgung der einzelnen Organsysteme durch die gesamte Reihe der Metazoen, wie es Gegenbamr in seinen Vorlesungen und auch ich in den meinigen durchführte, glanbte ich festhalten zu sollen, obgleich ich nicht verkenne, daß damit auch gewisse Unzuträglichkeiten verknüpft sind; so namentlich ein nicht unerhebliches Zurücktreten der Wirbellosen gegenüber den Wirbeltieren. Doch hat dies anch seine 
Berechtignug, einmal wegen der Wichtigkeit der letzteren und ihrer großen Komplikation, weiter aber auch wegen ihrer weitgehenden vergleichend-anatomischen Durchforschung, indem sich ja die vergl. Anatomie aus dem Studium der Vertebraten allmählich entwickelt hat.

Das Zicl, welches ich erstrebte, war eine kurze Darlegung der wichtigsten Errungenschaften der vergleichenden Anatomie in möglichst klarer und objektiver Form, was bei dem großen Widerstreit der subjektiven Meinungen auf fast sämtlichen Einzelgebieten nicht obne erhebliche Schwierigkeiten sein konnte. Immerhin ist die Darstellung etwas breiter ausgefallen, als anfänglich beabsichtigt war, trotz der Bemiihung so knapp zu sein, wie es die Verständlichkeit erlaubte. - Nenes zu bieten, konnte nicht in meinem Plan liegen, und ist auch nicht die Aufgabe eines derartigen Werkes. Nur in einzelnen Fällen habe ich eigene, etwas abweichende Ansichten vorgetragen, wo mir dies begrïndet erschien; ob mit liecht, steht dahin.

Ich bin mir wohl bewußt, $d a ß$ ich mein Ziel nur sehr unvollkommen erreicht habe. 'Sollte sich das Vorliegende, trotz seiner Mängel, als eine Einleitung in das Studium der vergl. Anatomie nützlich erweisen, so wäre sein Zweck mehr wie erfüllt.

Auf Autoren- und Literaturhinweise im Text mußte verzichtet werden; dagegen soll am Schlusse des Ganzen eine Übersicht der wichtigsten Literatur gegeben werden.

Die beigefügten Abbilduugen sind fast durchweg neu hergestellt, und zahlreiche nach eigenen Präparaten angefertigt worden. Nicht wenige habe ich selbst gezeichnet; andre wurden in freundlichster Weise von einer Anzahl ehemaliger Schïler ausgeführt. Bei den einzelnen Figuren ist dies angegeben; so bedeutet O. B. den Verfasser, v. Bu. Dr. W. v. Buddenbrock, C. H. Frl. Dr. Clara Hamburger, P. He. Dr. P. Heyder, Schr. Dr. O. Schröder, E.W. Dr. E, Widmann. Ich danke meinen verehrten Mitarbeitern auch an dieser Stelle herzlichst; im besondern aber Frl. Dr. Hamburger, deren freundliche, vielfache Unterstützung meine Arbeit in hohem Maße förderte. Mein verehrter Freund, Herr Prof. Blochmann hatte die große Güte, die Korrekturbogen dieser Lieferung durchzusehen nnd mir auf Grund seiner reichen Erfahrungen vielfache Verbesserungen vorzuschlagen, sowie Mängel im Text und den Figuren zu berichtigen. Ich bin ihm für die recht erhebliche Mühe, die er auf die Durchsicht verwendete, zu ganz besonderem Danke verpflichtet. Auch den verehrten Herren Kollegen Prof. Fiurbringer und Prof. Salomon bin ich für gütige Unterstützung mit Literatur und Präparaten aufrichtig dankbar. -Möge es mir vergönnt sein, die folgenden Lieferungen möglichst bald zu vollenden, was jedoch wegen der umfangreichen Berufstätigkeit, die mir nur verhältnismäßig wenig Zeit ibrig läßt, recht schwicrig sein wird.

Heidelberg, Oktober 1910.

0. Bütschli. 


\section{Abschnitt.}

\section{Einleitung.}

\section{A. Anfgabe der vergl. Anatomie. Phylogenie. Homologie und Analogie. Funktionswechsel. Differenzierung. Bedentang der Ontogenie and Paläontologie.}

Die vergleichende Anatomie ist ein Teil der Morphologie, der Lehre vom Bau der tierischen Organismen, und zwar ein sehr wesentlicher und wichtiger Teil. Lehren uns die systematische Beschreibung ond die Zootomie den äußeren und inneren Aufbau des Körpers der unzähligen Tierformen kennen, seine Zusammensetzung aus dem Ganzen untergeordneten Bestandteilen oder Organen, so fällt der vergleichenden Anatomie die bedeutsame Aufgabe zu, jene, bei den verschiedenen Tierformen gefundenen Organe zu vergleichen hinsichtlich ihrer Ähnlichkeit oder Verschiedenheit; die übereinstimmenden zusammenzufassen, die verschiedenen voneinander zu sondern. Auf diesem Wege muß die vergleichende Anatomie schließlich auch dazu gelangen, ein Urteil zu fälleu über die morphologische Übereinstimmung oder Verschiedenheit der einzelnen Tierformen, d. h. über ihre nähere oder entferntere Verwandtschaft.

Nun erhebt sich jedoch sofort die Frage: welche Berechtigung haben wir denn, die bei den verschiedenen Tieren gefundenen Organe, auch wenn sie sich sehr gleichen, für etwas wirklich Übereinstimmendes zu erklären, d. h. für etwas, dem Gemeinsames zugrunde liegt. A priori ist dies doch keineswegs zulässig und selbstverständlich. Wir gründen aber diese Berechtigung heutzutage auf unsere Überzeugung von der überaus großen Wahrscheinlichkeit der allmählichen Entwicklung der zahlreichen tierischen Formen aus einfacheren, ihnen vorausgegangenen, auf die Überzeugung von der Gültigkeit der Descendenz- oder Abștammungslehre. Die gefundene morphologische Übereinstimmung der Organe bei verschiedenen Tieren, sowohl nach Bau als Entwicklung, findet nach dieser Ansicht ihre materielle Ursache darin, daß sie sich aus dem Organ einer früheren gemeinschaftlichen Ausgangsform heraus entwickelten, daß ihnen also bei den verschiedenen Tieren, soweit die Hypothese zutrifit, wirklich etwas Gemeinsames zugrunde liegt. — Nun hat jedoch die vergleichende Anatomie schon lange bestanden, bevor die eben erörterte Ansicht über die Descendenz der Tierwelt, über ihre allmähliche phylogenetische Entwicklung im Lanfe langer Zeitrüume, sich Geltung erwarb. Dies rührt aber daher, daß man bei der Betrachtung der Tierwelt sofort eine verhältnismäßig nahe 
Übereinstimmung im Bau zahlreicher Formen wahrnimmt, welche daher leicht, als zu zusammengehörigen Gruppen vereinbar, erkannt werden. Die innigere Übereinstimmung der Organisation innerhalb dieser einzelnen Gruppen mußte aber notwendig den Gedanken anfdrängen, daß diese Ähnlichkeit auch die Folge eines gemeinsamen Grundes sein müsse. Auch nach dieser Auffassung war also die Ähnlichkeit der Organe, welche die vergleichende Anatomie feststellte, die Folge von etwas ihnen Gerneinschaftlichem, d. b. eben die Folge dieses hypothetischen gemeinsamen Grundes, welcher das Hervorgehen entsprechender Organe bedingte. Jetzt erblicken wir diesen gemeinsamen Grund, wie vorhin hervorgehoben wurde, in einer ehemaligen gemeinsamen Ursache, nämlich dem oder den identischen Vorfahren. Früher galt als ein solcher Grund ein gemeinsamer Organisationsplan oder eine Gesetzlichkeit, welche der letzten Ursache (dem Urheber) der Tierwelt oder ihrer einzelnen Gruppen eigen gewesen sei, bzw. von ihr jedem Individuum in irgend einer Weise eingeprägt werde.

Wie aus dem Bemerkten hervorgeht, hat es die vergleichende Anatomie zunächst ausschließlich mit der Vergleichnng des morphologischen Banes und der Entwicklung der Organe zu tan; sie abstrahiert von deren Funktion oder physiologischen Tätigkeit. Ihre spezielle Anfgabe ist es eben, die morphologischen Ủbereinstimmungen oder die sog. Homologien festzustellen und sie. von den nur physiologischen Übereinstimmungen oder den Analogien scharf zu scheiden. Da sich hierin die Haupttätigkeit der vergleichenden Anatomie konzentriert, so haben für sie diese Begriffe der Homologie und Analogie eine besonders wichtige Becientung. Ein etwas eindringenderes Studium der Organe verschiedener Tiergruppen mußte nämlich bald ergeben, daß bei verschiedenen Gruppen die Organe von gleicher physiologiseher Tätigkeit durchaus nicht immer anch morphologiseh und genetisch übereinstimmen; und đaß nmgekehrt morphologisch gleichwertige Organe häufig physiologisch recùt verschiedenes leisten. Hieranf basierî eben die Unterscheidung anaioger und homoioger Organe.

Verfolgen wir beispielsweise das wichtige bauchständige Kriechorgan der Schnocken (Gastropoden), den sog. FuB, bei den Mollusken, 3o findeil wir, dab er in der Gruppe der Cephalopoden durch ein ganz anders funktionierendes, zwar ebenfalls zur Bewegnng dienendes Organ, den sog. Trichter, wahrscheinlicb aber auch gleichzeitíg durch die auf den Kopf gerückten, eigenartig susgebildeten Kopfarme repräsentiert wird. - Bei niederen Wirbeltieren (gewissen Fischen) fiaden wir in der Haut knöcherue Schutzgebilde, sog. Schuppen, welche einen über die Hautoberfläche vorspringenden Zahnfortsatz tragen. Diese Placoidschuppengehilde breiten sich auch anf die Mundhöhle aus, wo ihre Zahnfortsätze sish zu den eigentlichen Zähnen entwickeln, die bei den höheren Wirbeltieren als alleiniger Rest jenes ursprïnglick iber die gesamte Oberfläche verbreiteten Schuppenkleides übrig bleiben. - Beiniederen Wirbeltieren (Fischen) findet sich ferner ein ansehnliches gaserfilltes Organ über dem Darm, die sog. Schwimmblase, deren Funktion im allyemeinen eine hydrostatische ist, $d$. h. mit der Veränderung des specifischen Gewichts des Fisches una dem Schwimmen in Beziehung steht. Bei den höneren Wirbel- 
tieren begegnen wir etwa an gleicher Stelle ebenfalls einem lufterfüllten Orgai, der Lunge, welche jedoch der Atmung dient. Es läßt sich nun recht wahrscheinlich machen, daß die Schwimmblase nnd die Lunge morphologisch identische, homologe Organe sind. Die mitgeteilten Beispiele lebren also, daß homologe Organe hänfig physiologisch sehr ungleichwertig geworden sind.

Andrerseits finden wir oft genng Organe gleicher Fnnktion, die morphogenetisch ohne jede Vergleichbarkeit erscheinen. Um dies zu belegen genügt es, anf die Flügel der Insekten und der Vögel hinzuweisen, oder auf die Kiefer der Arthropoden und jene der Wirbeltiere.

Dic verschiedene Funktion homologer Organe bei velschiedenen Gruppen erweist, daß in der phylogenetischen Geschichte dieser Organe eine Veränderung der Funktion, ein Funktionswechsel eingetreten sein muß. Gerade diese Funktionsänderung aber muß auch für die morphologische Abänderung jener Organe von größter Bedentung erscheinen, obwohl natürlich die Änderung in beiden Richtungen gleichzeitig und parallel laufend eingetreten sein muß. Hieraus folgt, daß die physiologische Tätigkeit der Organe für die vergleichende Anatomie dennoch von größter Wichtigkeit sein muß, um die Abändernng homologer Organe dureh ihre Funktionsänderung zu verstehen und zu erklären. Man darf daher wohl sagen, daß wir die Morphologie der homologen Organe erst dann wirklich verstehen, wenn wir sie in jedem Einzelfall mit ihrer besonderen Funktion in Einklang zu bringen vermögen.

Es ist verständlich, daß der Grad der Übereinstimmung sich entsprechender, homologer Organe ein recht verschiedener sein muß; so wird er naturgemäß bei Tierformen, die sich verwandtschaftlich sehr nahe stehen, $d \cdot h$. die sich von einer Ausgangsform relativ wenig entfernt haben, viel inniger sein, als bei solchen, die sich nach verschiedenen Richtungen in verschiedenen Entwicklungsbahnen von einem gemeinsamen Vorfahren weit entfernten. Man hat für diese verschiedenen Grade der Homologie zuweilen besondere begriffliche Kategorien aufzustellen versucht, so von kompletter und inkompletter, von defektiver und augmentativer Homologie gesprochen, Begriffe, die sich z. T. schon aus den Bezeichnungen verstehen lassen und denen wir keine sebr erhebliche Bedeutung zuzuschreiben vermögen, da sie doch nur gewisse Grenzpunkte herrorbeben, welche nicht durch scharfe Unterschiede gesondert, sondern durch sehr allmähliche Übergänge rẹknüpft sind.

Ebenso häufig finden wir jedoch, daß ein Organ bei fortschreitender Kompliziernng des Tierkörpers seine Funktion nicht eigentlich ändert, sondern dieselbe in verschiedenen seiner Teile gewissermaßen spezialisiert, d. h. daß seinen einzelnen Teilen spezielle Leistungen übertragen werden, welche in ihrem Zusammenwirken die Gesamtfunktion des früher einheitlichen Organs repräsentieren. Ein solcher Vorgang läßt sich beispielsweise am Ernährungsapparał gat verfolgen, der von sehr einfachen Zuständen aus zu einem aus zablreichen Abschnitten zusammengesetzten und mit vielen Anhangsorganen (Drüsen) versehenen Apparat werden kann. Wir finden bier also eine verschiedenartige funktionelle und morphologische Ansgestaltung eines Organs in seinen perschiedenen Abschnitten, ein different werden einzelner Abschnitte, eine sog. Differenzierung. Eine solche Differenzierung, d. h. das Hervorgehen verschioden gestalteter Unterteile aus einem nroprünglich 
einheitlich gebauten Organ oder Organismus, spielt in der anfsteigenden Komplizierung des tierischen Körpers eine sehr wichtige Rolle und muß daher von der vergleichenden Anatomie eingehendst beriicksichtigt werden.

Der vergleichenden Anatomie bietet sich zur Lösung ihrer Anfgabe, d. h. der Feststellnng der wahrscheinlichen Homolugien der Organe, sowohl durch die zahlreichen Tiergruppen lindurch als innerhalb derselben, zunächst die sorgfältige Vergleichung der Gesamtbauverbältnisse wie der der Einzelorgane bei den verschiedenen Gruppen. Je größer der Grad der Übereinstimmung der verglichenen Organe im gröberen wie feineren Bau ist, um so größer ist auch die Wahrscheinlichkeit ihrer genetischen Identität. Wenn aher diese Identität der Organe auf gleicher Abstammang beruhen soll, so erfordert dies auch ihre iibereinstimmende ontogenetische Entwicklung, oder falls diese durch die Untersuchung nicht bestätigt werden sollte, eine plausible Erklärung für die Abweichungen. Ergibt daher die Ontogenie eine übereinstimmende Entwicklung der nach ihrem fertigen Bau als homolog angesprochenen Organe, so wird dadurch diese Anffassung sehr wesentlich verstärkt. Andrerseits kann jedoch auch der Bau der fertigen Organe dürch den erlittenen Funktionswechsel so verschiedenartig gew orden sein, daß die anatomische Vergleichung kaum sichere Anhaltspunkte für ihre Homologie zu bieten vermag. Erweist nun aber die Ontogenie einen übereinstimmendeu Entwicklungsgang der Organe, der erst in seinen späteren Stadien verschiedene Bahnen einschlägt und so zu stark differierenden Endergebnissen führt, so wird die Ontogenie zu dem ausschlaggebenden Beweis der Homologie.

Der Fall kann jedoch anch so liegen, daß die ansgebildete Tierforn ein gewisses Organ, wie es den Verwandten zukommt, iiberhaupt nicht mehr besitzt, die Ontogenie jedoch lehrt, daß bei der betreffenden Form das fragliche Organ auf einem gewissen Stadium der Ontogenese auftritt, um sich später völlig zuriickzubilden. In diesem Fall lehrt uns demnach die Ontogenie, daß der Verwandtschaftsgrad jener Tierformen ein innigerer ist, als vor dieser Kenntnis zu vermuten war. Andrerseits läßt sich aber aus dieser Erfahrung auch der sehr wahrscheinliche Schluß ziehen, daß die Form, welcher das betreffende Organ jetzt fehlt, ans Vorfahren hervorgegangen ist, denen es zukam; denu ohne daß wir hier tiefer in die mögliche Begriindung des sog. biogenetischen Grundgesetves und seiner Tragweite eingehen, d. h. der Regel: daß in der Ontogenese einer Tierform ihre phylogenetischen Entwicklungsstadien durchlaufen werden, ist der obige Schluß schon deshalb sehr einlenchtend, weil sich schwer angeben läßt, auf welch anderem Wege das später sich riickbildende Organ in die Ontogenese dieser 'Tierform gelangen konnte. Aus diesen Erwägungen folgt schon die hohe Bedeutung, welche die Ontogenie für die Aufklärung der vergleichend-anatomischen Probleme besitzt.

Das tiefere Studium der Ontogenie und die Vergleichung ilırer Ergebnisse mit dẹnen der anatomischen Vergleichung hat jedoch gelehrt, daß die Entwicklung zweifellos homologer Organe in nahe verwandten Gruppen nicht stets ganz übereinstimmend verlänft. Eine eingehendere Erwägung läßt erkennen, daß auch der ontogenetische Eutwicklungsgang Abänderungen seines ursprünglichen Verlaufs 
erfahren kann. In solchen Fällen treten demnach die Schlüsse der anatomischen Vergleichung und die Folgerungen der Ontogenie in Widerspruch, und es muß entschieden werden, auf welcher Seite das Übergewicht der Gründe liegt; was natürlich nicht selten bedeutende Schwierigkeiten bietet.

Erheblichen Gewinn und Förderung wird die vergleichende Anatomie weiterhin aus den Ergebnissen der paläontologischen Forschung, der Morphologie der Reste ausgestorbener Tierformen ziehen. Die paläontologischen Funde bieten uns ja das einzig Tatsächliche, was wir über die Vorläufer der heutigen Tierwelt erfahren können. Das, was sie uns über das phylogenetische Auftreten, über die Umbildung, event. auch das Schwinden von Organen lehren, muß daher für die vergleichende Anatomie von größtem Wert sein.

So wichtig die paläontologischen Erfahrungen nun auch sind, so wenig Aufschluß können sie bäufig doch geben, schon aus dem Umstand, daß so zahlreiche und wichtige Tiergruppen überhaupt keinerlei fossile Reste zu hinteriassen imstande waren. Von anderen, bei denen dies der Fall ist, sind es vielfach nur Reste, welche wenig über die eigentliche Organisation besagen, äußere Schalen oder innere Hartteile, die sich mit recht verschiedenartiger Organisation vertragen; selten so bedeutsame Skeletteile wie die der Wirbeltiere. Im ganzen, abgesehen von gewissen sehr belehrenden und aufklärenden Fallen, darf man daher wohl sagen, daß die vergleichende Anatomie mehr zum Verständnis dieser fossilen Reste beigetragen hat, als nmgekehrt letztere zur Aufklärung der vergleichend-anatomischen Probleme. Dazu gesellt sich, daß bis jetzt noch ein überaus großer Teil der außereuropäischen Erdschichten unvollkommen oder nicht durchforscht ist; sowie daß es zweifellos erscheint, daß die verschiedenen Tierstämme sich schon in einer sehr früben Zeit gesondert haben, in welcher erhaltbare Teile noch nicht existierten oder aus der Reste nicht erhalten sind. Im allgemeinen bestätigt jedoch das zeitliche paläontologische Auftreten der verschiedenen tierischen Gruppen, besonders in gewissen Phylen, die ausgiebigere Reste hinterlassen konnten; die Schlüsse der vergleichenden Anatomie über die wahrscheinliche phylogenetische Anfeinanderfolge dieser Gruppen.

Obgleich den Ausgangspunkt beider organischen Reiche Organismen von so einfachem Bau bilden, daß ihr Körper eine Zusammensetzung aus untergeordneten Bestandteilen oder Organen kaum verrät, so gilt dies doch bei den ubrigen Formen durchans. Im allgemeinen bezeichnet man jeden untergeordncten Bestandteil, insofern er einen gewissen Grad von Abgrenzung, d. b. morphologischer Selbständigkeit und namentlich auch eine besondere physiologische Leistung, also eine gewisse physiologische Selbständigkeit besitzt, als ein Organ. Bei einer solchen Definition des Begriffs können und müssen die Einzelorgane natürlich von sehr verschiedener morphologischer Komplikation und Wertigkeit sein. Während wir einerseits den Bestandteil einer einfachen Zelle, insofern er der aufgestellten Forderung entspricht, als ein Organ bezeichnen, nennen wir beispielsweise die Extremität eines Wirbeltieres ebenso, obwohl sie aus zahllosen Zellen besteht, die selbst wieder zu untergeordneten Organen oder Suborganen zusammentreten. Die im obigen Sinne 
definierten Organe sind also von morphologisch sehr verschiedener Dignität. Dennoch dürfte es sich kaum empfehlen, die Organe nach dem Grad ihrer morphologischen Komplikation in verschiedene Kategorien zu sondern, da dies bei der sehr allmählichen Steigerung ihrer Komplikation notwendig zu morphologischen Spitzfindigkeiten, ohne scharfe Grenzbestimmungen und ohne erheblichen praktischen Wert, führen muB. Nur eine solche Kategorie hat sich allgemeinerer Anerkennung erfreut, nämlich diejenige, welche die Organe der Einzelligen, also die untergeordneten Bestandteile einer einfachen Zelle umgreift. Diese Organe werden daher häufig als Organula oder Organellen von den zelligen Organen der Metazoa unterschieden.

\section{B. Allgemeiner Aufbau des tierischen Organismus und seine allmälliche Komplizierung in den Hanptgruppen.}

Nach dem einzelligen oder mehrzelligen Aufbau scheidet sich die Tierwelt in die beiden Unterreiche der Protozoa und Meiazoa. Soeben wurde auf die fundamentale Verschiedenheit der Organe in diesen beiden Unterreichen hingewiesen. Hieraus folgt, daß, auch ihro vergleichende Anatomie selbständig behandelt werden muß; denn die Organellen der Protozoen können, als Bestandteile einer einzigen Zelle, mit den Organen der Metazoen morphologisch nicht verglichen werden, wohl aber physiologisch.

Die morphologische Ausgestaltung des einzelligen Protozoenkörpers, so mannigfaltig sie anch ist, interessiert uns hier nicht näher und wird, soweit nötig, im Kapitel uber die vergleichende Anatomie der Protozoen geschildert werden. Was uns dagegen hier besonders angeht, ist dio mögliche Entstehung der Metazoen aus einzelligen, protozoenartigen Urformen. Natürlich kann alles, was sich hierüber sagen läßt, nicht mehr als eine mehr oder weniger wahrscheinliche Hypotbese sein, wie demn überhaupt die Schlüsse der vergleichenden Auatomie diesen hypothetischen Charakter sämtlich besitzen, wenn auch in sehr verschiedenem Grade der Wahrscheinlichkeit.

Nicht wenige Protozoen aus verschiedenen Abteilingen, besonders zahlreiche Formen des umfangreichen Stammes der Mastigophora insbesondere der Flagellaten), haben eine Weiterbildung über die uisprüngliche Einzelligkeit insofern erfahren, als sie aus successiver Teilung hervorgehende Zellgruppen, sog. Stöcke oder Kolonien, bilden, deren Einzelzellen oder -Individuen sogar bäufig plasmatische Verbindungen untereinander aufweisen. Die Einzelzellen sind fast stets alle gleich und auch fähig isoliert weiterzuleben, was die Zugehörigkeit solcher Kolonien zu den nicht koloniebildenden Formen bedingt, abgesehen von dem sonstigen nahen verwandtschaftlichen Bau der Individuen. $x$ ie Möglichkeit des Hervorgehens der Metazoen aus Protozoenvorfahren wird daher naturgemä $\beta$ an solche koloniebildende Protozoenformen, insbesondere flagellateuartige, anzuknïpfen sein. Der Bau solcher Flagellatenkolonien (s. Fig. 1) ist selbst wieder recht verschiedenartig, indem sie teils auf Stielen festsitzende, teils freischwimmende und dann gewöhnlich kugelig geformte Zellgruppen sind. Sie besteben entweder aus kugeligen Gruppen von 
Zellen, die sämtlich bis zum Centrum reichen (A), oder aus Zellen, welche der Oberflächenregion einer kngeligen Gallertmasse eingelagert sind $(B)$. Nicht unwichtig erscheint aber, daß sich anch tafelförmige Kolonien finden, deren Zellen eine einschichtige, frei umherschwimmende Platte bilden (s. Fig. 1, C).

Hinsichtlich ihrer Ernährung sind die heute lebenden Flagellatenkolonien von der geschilderten Baureise fast ausnahmslos pflanzlicher Natur, d. h. sie ernähren sich wie die grünen Pflanzen. Da jedoch der Ernälırungs- und Stoffwechselcharakter gerade bei den Flagellaten ungemein rechselnd ist, so steht der Annahme nichts im Wege, daß zn gewissen Zeiten anch ähnliche flagellatenartige Kolonien existierten, die sich tierisch ernährten, d. h. deren Einzelzellen sämtlich befähigt waren, feste Nahrungskörper anfzunehmen.

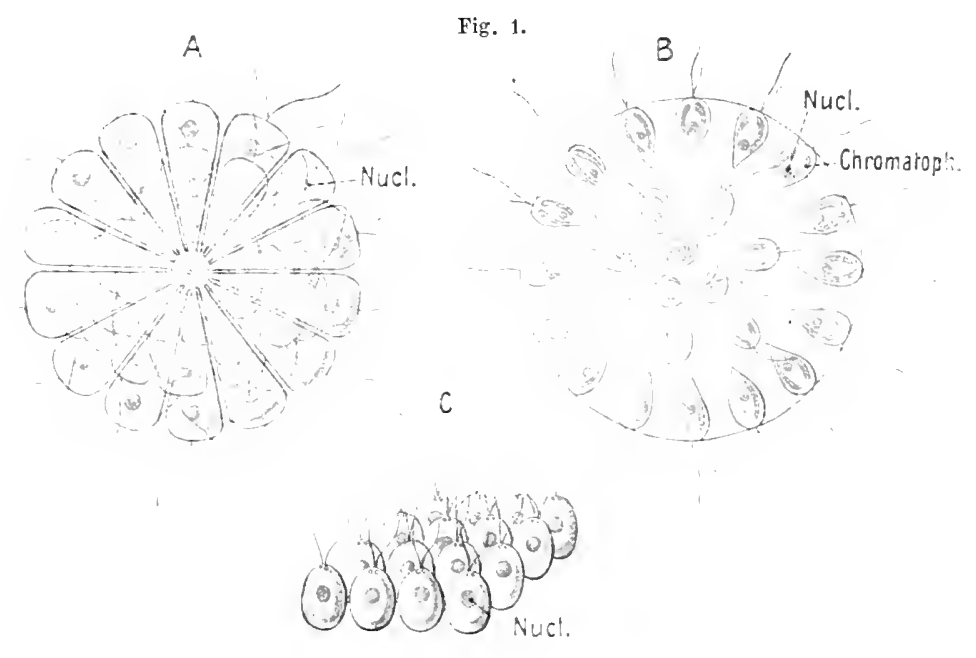

Schematische Darstellung dreier Flagellatenkolonien. A Synura mit in Centruro vereinigten Zellen; sowohl Oberfächenansicht als optischer Āquatorialschnitt eingezeichnet. $B$ Uroglena, Oberłächenbild. $c^{+}$t on inm, schiefseitliche Ansicht der viereckigen Platte.

c. $\mathrm{H}$.

Die mögliche Ableitnng der Metazoen von soleh flageilatenartigen Kolonien mit tierischer Ernährung weist nun auf zwei verschiedene Ansgangspunkte mit verschiedener Fntwieklungsrichtung hin. Eine Gruppe der niedersten Metrzoen nämlich, die sog. Spongien (tierische Schwämme), verraten sowohl in ihrem Bau als in ihrer Ontogenie viel Besonderes, und dabei gleichzeitig nahe Beziehungen zu einer besonderen Gruppe der Mastigophoren, den sog. Choanoflagellaten, weshalb es recht wahrscheinlich ist, daß sie gesondert von den übrigen Metazoen aus choanoflagellatenartigen Kolonien hervorgingen. Diese Ansicht basiert vornehmlich darauf, daß die nahrungsautnehmenden Zellen der Spongien (sog. Kragenzellen) ganz den typischen Bau der Choanoflagellatenzelle besitzen, speziell den charakteristischen, die Geißel umscheidenden Kragen (vgl. später Fig. 9 A), wie er sich bei Zellen der übrigen Metazoen nie findet. Es wiirde hier zn weit führen, die mögliche Ableitnng der Spongien von choanoflagellatenartigen Kolonien spezieller zu erörtern. Es sei 
nur bemerkt, daß sie jedenfalls aus freischwimmenden Kolonien entstanden sind, die sich festhefteten und früher oder später eine Differenzierung ihrer ursprünglich gleichartigen Zellen erfuhren, wobei sich die äußeren zu einem stützenden und skeletbildenden Gewebe entwickelten, die inneren dagegen, unter Bewahrung ihres ursprünglichen Baus, eine Höhle auskleideten, die mit der Außenwelt durch eine größere und zahlreiche feine Öffnungen in Verbindung trat. Mancherlei in der Ontogenie der Spongien deutet vielleicht darauf hin, daß eine solch einfachste Schwammform in nicht unähnlicher Weise entstand wie die einfachste Form der übrigen Metazoen.

Letztere traten ursprünglich jedenfalls in einer sehr einfachen Form auf, wie sowohl die primitivsten Zustände der niedersten Gruppe, der Cölenteraten, erweiseu, als anch die Übereinstimmung der Anfangsstadien in der Ontogenese der verschiedensten Metazoengruppen es ergibt. Man hat diese wahrscheinliche Urform der eigentlichen Metazoen (Eumetazoa), wie sie unter den Cölenteraten noch am wenigsten verändert erhalten blieb, als Gastraea bezeichnet und das ihr entsprechende Stadium in der Ontogenese als Gastrula. Der Bau einer solch einfachen Gastraea ist folgender (s. Fig. 2, C): der etwa kugelige bis ellipsoidische Körper enthält einen weiten Hohlraum, die verdauende oder Gastralhöhle, welche an dem einen Pol durch eine Öffnung, die Urmundöffinung (Prostoma, Blastoporus) nach außen mündet. Die Körperwand setzt sich aus zwei Zelllagen zusammen, einer äußeren, dem sog. Ectoderm, und einer inneren, dem Entoderm. Letzteres ist die nahrungsaufnehmende Zellschicht, die daher auch samt der von ihr umschlossenen Gastralhöhle als Urdarm bezeichnet wird. Das Ectoderm dagegen dient einerseits zum Schutz des Innern, andrerseits kann es sich jedoch an der Bewegung, Atmung und sonstigen Stoffwechselvorgängen beteiligen, namentlich aber auch die Beziehungen zur Außenwelt vermitteln.

Das Problem der möglichen Ableitung solch einer hypothetischen Urform der Metazoen von flagellatenartigen Protozoenkolonien wurde nun in verschiedener Weise zu lösen gesucht. - Die verbreitetste Ansicht sucht die Gastraea aus einer hohlkugeligen Flagellatenkolonie mit einschichtiger Zellwand abzuleiten, mittels der Annahme, daßzunächst eine Differenzierung der Zellen der entgegengesetzten Kugelhemisphären eintrat, indem die der einen Hemisphäre ausschließlich nahrungsaufnehmend wurden, die der anderen dagegen diese Betätigung verloren und vornehmlich als Bewegungszellen funktionierten (Fig. 2, $b^{1}$ ). Allmählich trat dann eine Einsenkung oder Einstïlpung der nahrungsaufnehmenden Hemisphäre in die andere auf $\left(b^{2}\right)$, so daß letztere zum Ectoderm, erstere zum Entoderm wurde. Unter Verengerung der Einstülpungsöffinung zur Urmundöffinung bildetesich die typische Gastraeaform hervor. Dieser Ableitungsmodus stützt sich hauptsächlich darauf, daß die Gastrulaform in der Ontogenese häufig auf solche Weise entsteht. Er begegnet jedoch einer gewissen Schwierigkeit, da, die Differenzierung der beiden Hemisphären der kugeligen Ausgangsform vorausgesetzt, nicht recht einzusehen ist, welcher Vorteil einem solchen Organismus durch die allmähliche Einstülpung der von den Ernährungszellen gebildeten Hemisphäre erwachsen sein sollte; ein solcher Vorteil konnte 
doch wohl erst hervortreten, wenn dic Einsenkung schon zu einer wirklichen Höhle geworden war, in welche Nahrungskörper eingeführt und darin festgehalten werden konnten.

Eine zweite Ansicht sucht diese Schwierigkeit zu überwinden, indem sie nicht von einer kugeligen, sondern einer tafelförmigen einschichtigen Kolonie ausgeht, wie sie bei Flagellaten gelegentlich vorkommt. Diese Hypothese nimmt an, daß eine solche Urform zunächst durch Querteilung ihrer Zellen zweischichtig wurde und daß die eine der so gebildeten Zelllagen sich zur ernährenden, die andere

Fig. 2.
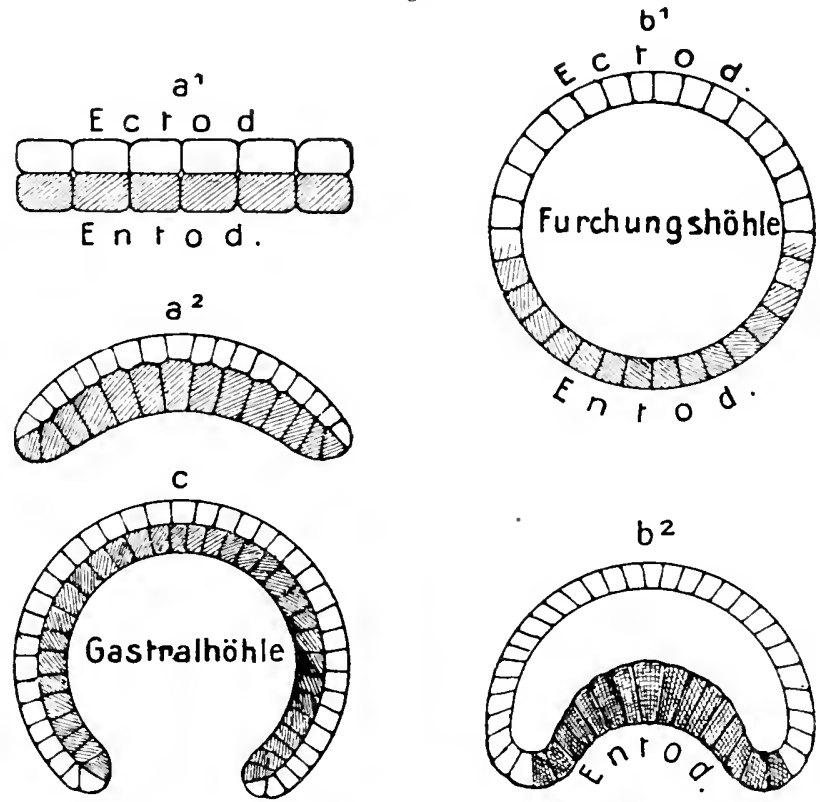

\section{Urmund}

Schematische Darstellung der Entstehung einer gastraeaartigen Urform ans einer Protozoenkolonie. $a^{1}, a^{2}-c$ durch Einkrămmang einer zweischichtigen plattenfōrmigen Kolonie; $b^{1}, b^{2}-c$ durch Einstûlpung einer kugelfôrmigen. Vie ernährenden Zellen (spāteres Entoderm) schraffiert.

o. B.

zur schützenden und bewegenden differenzierte (s. Fig.2, $a^{1}$ ). Ein ähnliches plattenartiges Stadium kann vorübergehend in der Ontogenese einzelner Metazoengruppen auftreten. Wenn nun eine derart gebaute zweischichtige, plattenartige Form sich so bewegte, daß die ernährende Zelllage gegen den Boden gerichtet war und hier ihre Nahrung suchte, so mußte es von Vorteil sein, wenn der Organismus sich allmählich zu einer uhrglasartigen Form mit nach unten gerichteter Konkavität einkrümmte (Fig. $2 a^{2}$ ). Jetzt vermochte er sich über auf dem Boden liegende Nahrangskörper herabzusenken, sie cinznfangen und in seiner Höhle festzuhalten. Eine stärkere Einkrümmung konnte dann zur typischen Gastraeaform $(c)$ führen, in deren Gastralhöhle die Nahrungskörper durch den Urmund eingeführt und worin sie weiter verarbeitet wurden. 
Eine dritte Meinang ging, wie die erste, ron einer einschichtigen kugeligen Urform aus, ließ aber die spätere Entodermschicht nicht durch Einstülpung, sondern durch Einwanderung ron Zellen der einschichtigen Wand ins Innere entstehen; worauf der Ümund sich erst nachträglich als Durchbruch nach außen bildete. Gegen liese Meinung spricht aber sehr bestimmt, daß die einwandernden Entodermzellen sich durch die Einwanderung ihrer späteren Bestimmung eigentlich entzögen, was es unbegreiflich macht, daß gerade sie im weiteren Verlauf $z u$ den ernährenden Zellen werden sollen. Auch für den Durchbruch des Urmunds läßt sich auf diesem Wege Keine vorteilhafte Bedingung erkennen.

Möge nun aber die phylogenetische Entstehung der Gastraeaform so oder so verlaufen sein, so scheint doch sicher, daß eine ihrem Ban entsprechende Urform den Ausgangspunkt der typischen Metazoen (mit Ausschluß der Spongien) bildete.

Gewisse einfach gebaute, isoliert stehende Metazoengrupyen, wie der sog. Trichoplax, die Dicyemiden, Orthonectiden und einige andere, wurden manchmal als Übergangsformen zur Gastraea aufgefaßt, und daher gelegentlich auch als Mesozoa bezeichnet. Die beiden letzterwähnten Gruppen sind parasitische und daher wohl eher als durch Parasitismus vereinfachte, einst höher organisierte anzusehen. Der sog. Trichoplax ist recht unsicher geworden und neverdings sogar als Umbiłdungszustand einer Hydromedusenlarve gedeutet worden. Jedenfalls aber lehrten uns diese Formen, selbst wenn man ihnen eine Stellung zwischen Protozoenkolonien und den Cölenteraten zuerkennen möchte, níchts Positives über die mögliche Entstehnng der gastraeaartigen Urformen.

Es wurde schon oben hervorgehoben, daß das große Phylum der Cölenteraten in seiner einfachsten Ausbildung den gastraeaartigen Ban noch recht wohlerhalten darbietet. Immerhin machte jedoch die Organisation innerhalb dieses Phylums bedeutende Fortschritte, welche im wesentlichen mit der Hervorbildung eines mehr oder weniger ausgesprochenen strahligen oder radiärsymmetrischen Baus zusammenhängen. Die vorausgesetzte Gastraea-Ausgangsform zeigt hiervon nichts; ihr Bau ist, wie man sagt, monaxon, d. h. er läßt eine Hauptachse erkennen, welche den Urmund mit dem entgegenstehenden Pol verbindet, und um welche alles gleich ist, so daß beliebige, durch die Hauptachse gelegte Längsschnitte völlig gleich sind.

Das Entstehen der strahligen Symmetrie aus einer freischwimmenden monaxonen Gastraeaform wird am begreiflichsten, wenn wir annehmen, daB es dnrch den Übergang zur festsitzenden Lebensweise bedingt wurde, und daß daher die Ausgangsformen aller Cölenteraten, auch der jetzt freischwimmenden, festsitzende gastraeaartige Organismen waren, wie sie sich heute noch in den Hydroid- und Korallenpolypen erhalten haben. Die Festheftung geschah mit dem dem Urmund entgegenstehenden Pol, und die Körperform wurde schlauch-bis becherförmig oder cylindrisch. Für einen festsitzenden Organismus dieser Art mußte es von großem Vorteil werden, wenn er um den Urmund Greif- nnd Fangorgane, Tentakel, hervorbildete, welche ihm bei der mangelnden Beweglichkeit den Nahrungserwerb ermöglichten. Ebenso ist aber auch einzusehen, đaß eine gleichmäßige Verteilung dieser Tentakel nach allen Richtungen im Umkreis des Urmund̉s von Vorteil war, indem sie sich dann nach allen Seiten gleichmäßig betätigen konnten. Hiermit war die Grundlage des radiärsymmetrischen Baues gegeben. - Wegen der in regelmäßigen Abständen um den Urmund stehenden Tentakel sind nun nicht mehr alle Längsschnitte durch die Hauptachse untereinander gleich, sondern nach 
der Zahl der Tentakel läßt sich der Körper durch einige solche Längsschnitte in eine Anzahl unter sich kongruenter sog. Strahlstticke (Antimeren) zerlegen (s. S.17, Fig. 4a). Der auf solche Weise in erster Anlage gegebene strahlige Bau, dem bei den Cölenteraten gewöhnlich die Vier- oder Sechszahl, bzw. ein Vielfaches dieser Zahlen, zngrunde liegt, kann nun durch weitere, in entsprechender Weise sich wiederholende und strablig gruppierende Organbildungen noch verstärkt werden.

Die Erscheinnng, daß gleichartige Organe sich in größerer Zahl an dem Körper wiederholen, finden wir auch bei anders gebauten Metazoen recht häufig, ja wenn man auch die einfachen und einfachsten Organe berücksichtigt, ist dies eine allgemein verbreitete Erscheinung. Diese an einem Individuum sich wiederholenden homologen Organe hat man auch als homonome bezeichnet.

Wir rerwenden diesen Ausdruck hier für jegliche sich an einem Tierkörper mehrfach wiederholenden Organe derselben Art, also für alle homologen Organe eines Individuums, wie man auch sagen könnte, ohne Rücksicht auf ihre besondere Anordnung an dem betreffenden Tierkörper. Im Hinblick auf die letztere Beziehung hat man versucht, verschiedene Kategorien solcher Organe zu unterscheiden. So hat man die sich strahlig, oder bei den bilateralen Metazoen rechts- und linkseitig gegeniberstehenden als homotype bezeichnet, die bei den metameren Bilateralia sich bintereinander wiederholenden als homodyname, und endich die gewissermaßen als Unterteile eines Organs auftretenden gleichwertigen Abschnitte, so 2. B. Finger und Zehen der Wirbeltiere, speziell als homonome. Auch diesen morphologischen Subtilitäten dürte für das tiefere Yerständnis kein großer Wert zukommen, so daß wir uns hier in obigem Sinne auf den gemeinsabten Begrifi der Homonomie beschränken.

Wenn wir uns Rechenschaft darüber zu geben versuchten, was wohl der Grund der C̈bereinstimmung solch homonomer Organe des Individuums sein könnte, so werden wir auf Aie schwer zu umgehende Annahme geführt, daf dieser Grund, ebenso wie ler der homologen Organe rerschiedener Individuen, ihr Herrorgehen aus einer gemeinsamen oder übereinstimmenden Uranlage sein muß. Obgleich sich dies ontogenetisch bis jetzt noch wenig sicher nachweisen ließ, wüssen wir es doch gewissermaßen als notwendig voraussetzen, daß die komonomen Organe eines Individuums sich aus übereinstimmender materieller Anlage herleiten und eben diesem Umstand ihre Übereinstimmnng verdanken; sei es daß diese übereinstimmenden Grundlagen schon in der Eizelle selbst gegeben waren, sei es, daB sie durch (1. Zerlegung einer späteren gemeinsamen Anlage in die Einzelanlagen der homonomen Organe whrend der Ontogenese entstanden.

Die radiärsymmetrische Bildung dehnte sich bei den Cölenteraten namentlich auch anf die Gastralhöhle aus, wie es bei den polypenfürmigen Korallentieren (Anthozoa) in steigeader Komplikation hervortritt. Dies geschieht so, daß die Gastralhöhle radiär gestellte taschenförmige Aussackungen (Gastraltaschen oder -Kammern) bildet, welche durch radiäre Scheidewände (Gastralsepten) gesnndert werden is. Fig. 4, a). Die physiologische Bedeutung dieser Einrichtung ist in cr'ster Linie wchl eine Vergrößerung der ernährenden Fläche der Gastralhöhle.

Au festsitzenden polypenartigen Organismen sind aber sicher die freischwimmenden medusenartigen Cölenteraten hervorgegangen, was bei der Gruppe der Hydrornedusa durch das gemeinsame Auftreten beider liormen im Lebenscyclus einer Species 'Generationswechsel) besonders klar hervortritt. Als Beweis dieser Ableitung darf auch der stets ausgesprochene Strahlenbar. der Medusenformen 
angesehen werden, welcher nach dem oben dargelegten auf festsitzende Ausgangsformen bestimmt hinweist. Daß die radiäre Symmetrie durch den Übergang der Medusen znm freischwimmenden Leben nicht beeinträchtigt wurde, bängt mit der Art ihrer Bewegung zusammen, die stets in der Richtung der Hauptachse erfolgt. Der Radiärban der Medusenformen ist namentlich dadurch so scharf ausgepräigt, daß ihre Gastralhöhle stets solch taschenartige Ausbuchtungen bildet, die sehr häufig durch Verengerang kanalartig werden (Gastrovascularsystem).

Eine eigenartige Ausbildung erlangto der im Prinzip vierstrahlige cölenteratenartige Bau in der Klasse der freischwimmenden, sich jedoch durch besondere Wimperapparate bewegenden Ctenophoren (Kammquallen): Obgleich diese Gruppe die abweichendste der Cölenteraten ist und daher jetzt häufig abgesondert wird, dürfte ihr Zusammenhang mit ihnen doch zweifellos sein. Ebenso scheint es mir, trotz mancher Einwendungen, wohl möglich, $\mathrm{da} ß$ sie aus sehr ursprünglichen vierstrahligen hydromedusenartigen Formen hervorgingen, ihr Strahlenbau daher wie der der übrigen Cölenteraten von der ursprünglich festsitzenden Lebensweise herrührt. Eine besondere Bedeutung besitzen gerade die Ctenophoren für die Ableitung der bilateralen Eumetazoen, weil sich mancherlei dafür anführen läßt, daß es event. ctenophorenartige Formen gewesen sein könnten, welche sich zu den ursprünglichsten Bilaterien entwickelten.

Der Körper der einfachsten Cölenteraten besteht, wie bemerkt, nur aus den beiden Zelllagen der Gastraea, dem Ecto- und Entoderm. Die geringe Verschiedenheit dieser beiden Zellblätter spricht sich noch darin aus, daß beide, abgesehen von ihren specifischen Leistungen, imstande sind, Muskelzellen- und Nervenelemente hervorzubringen. Bei den primitivsten Cölenteraten (Hydroidea) findet sich zwischen dem Ecto- und Entoderm nur ein dünnes nichtzelliges Häntchen, ein Produkt des einen oder der beiden Blätter, welches als Stützgebilde fungiert, die sog. Stïtzlamelle. Bei den komplizierteren Cölenteraten wird durch Abscheidung der Blätter eine gallertige bis feste Stätzsubstanz zwischen sie abgelagert, in welche bei vielen (Acalepha, Anthozoa, Ctenophora) auch Zellen des Ectoderms (zum Teil wohl auch des Entoderms) einwandern und sie in ein wirkliches stützendes Zwischengewebe oder Mesenchym überführen. Wie wir später sehen werden, kann die stützende Funktion dieses Zwischengewebes durch die Bildung fester, ihm eingelagerter Fasern und Skeletgehilde noch gesteigert werden.

Sahen wir im vorhergehenden den monaxonen Bau der gastraeaartigen Urform durch Festheftung sich radiär symmetrisch ausgestalten, so mußte andrerseits eine bewegliche, mit der Mundōffnung auf dem Boden kriechende Lebensweise zu. einer wesentlich verschiedenen Weiterbildung führen ${ }^{1}$ ). Ein solehes Verhalten mußte zunächst zu einer Abplattung der gegen den Boden schanenden, den Urmund tragenden Region, zu einer ventralen Kriechfläche oder Bauchseite führen, welche sich von der mehr gewölbten Rückenfläche unterschied. Für einen solchen Organismus, der

1) Indem wir bei unseren Betrachtungen über die Entstehung. der bilateralen Metazoen von der Gastraea ausgehen, wollen wir damit nicht behaupten, daß die Bilaterien direlit ans einer ursprünglichen Gastraea hervorgingen. Vielmehr sollen hier nur die wesentlichen Bedingungen für die Ausbildung des Bilateralbaues eröstert werden. Im weiteren Verlauf unserer Besprechung wird sich ergeben, daß wir' es für wahrscheinlicher erachten, daß die existierenden einfachsten Bilaterien an wenigstrahlige, cölenteratenartige Formen ankuüpfen. 
sich in einer zur ursprünglichen Gastraeahauptachse senkrechten Richtnng durch das Wasser bewegte, mußte es ferner vorteilhaft werden, wenn er sich in einer zu dieser Achse senkrechten Richtung verlängerte, also eine längliche, mehr wormförmige Gestalt erlangte, indem er dann das umgebende Wasser mit geringerem Widerstand dorchschnitt (siehe Fig. $3 a-b$ ). Fernerhin erkennen wir unschwer, $\mathrm{da} ß$ es einer so gestalteten und sich bewegenden Tierform erheblichen Vorteil bieten mußte, wenn der Urmund, der anfänglich die Mitte der Bauchfläche einnahm, an eins der beiden Enden verlagert wurde. Da ja die Enden bei der Bewegung zunächst auf eine Bente stoßen, so war es sicher vortẹilhaft, wenn der Mund, der diese Beute festzuhalten und in die Gastralhöhle zu führen hatte, sich an einem Ende fand, bzw. sich auch eventuell schlitzartig bis zu den Enden ausdehnte. Nehmen wir nun an, daß eine solch vorteilhafte Verlagerung des Urmundes an eines der Enden eingetreten war, so war damit eine Körperform erreicht, wie sie für sämtliche über den Cölenteraten stehende Metazoen gilt, die

Fig. 3.

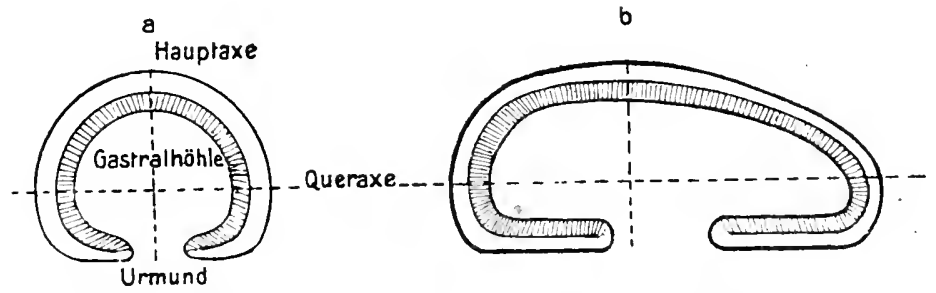

Schenata znm Hervorgehen der Bilateralităt aus der monaxonen Gastraea $(a) ; \quad b$ Auswachsen in einer

sog. bilaterale Bauweise, die auch dem menschlichen Körper zukommt. Wie bei jeder bilateralen Form kőnnen wir jetzt eine Bauch- und Rückenfïiche, ein vorderes und hinteres Korperende und damit auch eine rechte und linke Seite unterscheiden. Der Körper ist durch eine Mittelebene (Sagittalebene), welche durch die Vornhintenachse (die senkrecht zur ursprünglichen Gastralachse steht) geht, in eine rechte und linke Hälfte zerlegbar, welche nicht kongruent, sondern symmetrisch gleich sind; $d$. h. jede IIälfte erscheint wie das Spiegelbild der andern. - War einmal eine Verlagerung des Urmunds an ein Körperende gegehen, so mußte es anch von großem Vorteil werden, daß dies Ende bei der Bewegung in der Regel vorausging, da ja dann der Mund stets für die Beuteaufnahme bereit war. Andrerseits aber mußte es für einen so beschaffenen Organismus von großem Gewinn werden, wenn Sinnesorgane, die eine Witterung naher Beute ermöglichten, sich an dem Vorderende entwickelten oder konzentrierten, während sie bei den radiulsymmetrischen Cölenteraten sich vorteilhafterweise gleichmäßig im Umkreis der Hauptachse verteilten. Die besondere Ausbildung von Sinnesorganen an Vorderende hatte aber zur Folge, daß auch das Nervensystem, welehes wir uns ursprünglich wohl ziemlich gleichmäßig und in sehr primitiver Ausbildung über die gesamte Körperfläche verbreitet denken müssen, sich im Zusammenhang nit jenen 
Sinnesorganen stärker entwickelte, und daher im Vorderende ein Centralteil des Nervensystems hervorgebildet wurde, in welchem die verschiedenen Reflexbahnen zusammenliefen, ein primitives Gehirn- oder Cerebralgauglienpaar.

Hiermit wäre eine Stufe der Ausbildung erreicht, wie sie etwa bei den primitivsten Bilaterien, den Plathelminthen, noch jetzt besteht; ahgesehen von den besonderen Einrichtungen des Mesenchymgewebes, auf das wir später zurückkommen. Auffallend erscheint, daß bei vielen der primitivsten Plathelminthen (Turbellaria) der Urmund noch in der Mitte der Bauchseite, ja hinter ihr liegt. Da damit jedoch stets ein vorderständiges Cerebralganglienpaar vereint ist, so könnte diese Mundlage möglicherweise auch das Ergebnis einer aus gewissen Gründen später wieder eingetretenen Rückwärtsverlagerung sein.

Ein weiterer Fortschritt, der schon bei den nächsten Verwandten der Plattwürmer erzielt wurde, war die Ausbildung eines Afters, d. h. einer besonderen Öffnung, welche (neben der Einfuhröffnung oder dem Mund) zur Ausstoßung der unverdauten Nahrungsreste aus der Gastralhöhle dient. Sowohl bei den Cölenteraten als den meisten Plathelminthen verrichtet der Urmund diese beiden Tätigkeiien, wenn auch bei gewissen Cölenteraten zuweilen außerdem noch feinere porenartige Öfinungen der Gastralböhle existieren, welche jedoch nicht als Afteröffnung dienen. Die gewöhnliche Vorsteliung ist nun, daß eine solche Afteröflinung, wie sie schon bei den, an die typischen Plathelminthen sich nabe anschließenden Nemertinen besteht und allen übrigen Bilateralia zukommt (wenn auch zuweilen rückgebildet), durch einen Durchbruch der Gastralhöhle nach außen entstand. Doch halte ich die Möglichkeit nicht für ausgeschlossen, daß die Afteröffnung anderer Entstehung ist, d. h. daß sie wie die Mundöffnung aus dem ursprünglichen Urmund hervorging. Hierfür sprechen einzelne Ergebnisse der Ontogenie, welche einen solchen Vorgang in der Tat zeigen (Protracheata), ferner auch das häufige Hervorgehen des Afters aus dem Blastoporus der ursprüngiichen Gastrula, andrerseits aber auch die besondere Gestaltung des schlitzförmigen Urmunds gewisser Korallenpolypen (Anthozoa), der schon eine Art Differenzierung in einen einführenden und ausführenden Abschnitt zeigt. Man kann sich vorstellen, daß der Urmund der primitivsten Bilaterien sich lang spaltförmig über die Bauchseite erstreckte und sich vorn zu einer Einfuhr- hinten zu einer Ausfuhröffnung etwas erweiterte. Eine mittlere Verwachsung dieses schlitzförmigen Urmunds führte dann direkt zu seiner Sonderung in Mund and After. Diese Möglichkeit, obwohl bis jetzt noch wenig sicher, böte dem Verständnis den erheblichen Gewinn, daß die Afterötfnung nicht als völlige und schwerverständliche Nenbildung, sondern als die Umformung eines friiher bestandenen Organs erschiene.

Neuerdings will man dem verschiedenen Verhalten des Urmunds (Blastoporus) in der Ontogenie der Bilaterien eine tiefgehende Bedeutung für die Unterscheidung zweier, ron ihrer Wurzel an in divergierender Richtung fortgeschrittener Stämme der Bilaterien zuschreiben. Während bei dem einen Stamm, den sog. Protostomia (Würmer, Arthropoden, Mollusken, Brachiopoda, Bryozoa mit Ausnahme der Entoprocta) der Urmund zum Mund geworden sei, habe er sich bei dem zweiten Stamm, den Denterostomia (Enteropneusta, Ecbinoderma, Chaetognatha, Chordata) znm After entwickelt. Im ersteren Falle sei also der 
After, im zweiten der Mund eine sekundäre Bildung. Nun läßt sich zwar nicht leugnen, daß die sog. Deuterostomia sehr wahrscheinlich eine gewisse nähere Verwandtschaft untereinander besitzen und daher eine solche Zusammenfassung vielleicht verdienen. Was aber den Unterschied der Protostomia und der Deuterostomia hinsichtlich des Urmundschicksals angeht, so halte ich dieses Merkmal für verfehlt, da unter den Protostomia sich Formen finden, deren Blastoporus zum After wird (z. B. die Schnecke Paludina und vielleicht auch andere Mollusken), ferner solche, wo sich Mund und After auf den Blastoporus zurückführen lassen (Protracheata, wahrscheinlich auch Insekten) und weil das Schicksal des Blastoporus überbaupt in vielen Fällen noch recht zweifelhaft ist. Die von mir schon 1876 geäußerte Ansicht, daß Mund oder After der Metazoen wahrscheinlich aus einem ursprünglich lang schlitzförmigen Urmund hervorgingen, scheint mir auch jetzt noch die tatsächlichen Verbältnisse am ehesten zu erklären. Dazu kommt, daß sich die sehundäre Bildung eines Afters zwar einigermaßen begreifen läßt, dagegen die einer Mundöffnung, des für den tierischen Organismus wichtigsten Organs, schwerlich. Die Gruppe der Deuterostomia (zu der jedoch die Brachiopoden und Bryozoen ebenfalls nahe Beziebungen haben) für einen vou den Protostomia von Anfang am gesonderten Stamm der sog. Coelomatạ oder Bilateria zu halten, scheint mir also nuwahrscheinlich. Ich kann in ihnen nur einen Stamm erblicken, der sich von einfachen wurmartigen Vorfahren, also Protostomia, abzweigte und dessen ursprünglichere Formen recht wohl noch zu den Würmern gerechnet werden könnell.

Auf der jetzt erreichten Ausbildungsstufe der bilateralen Tierformen verharren im allgemeinen die sog. Nemathelminthen, insbesondere die Rotatorien und Nematoden. Bei jhnen begegnet uns jedoch noch eine Einrichtung, welche den Plathelminthen im allgemeinen fehlt, nämlich das Vorhandensein einer sog. Leibeshöhle, eines mit Flüssigkeit erfüllten Raumes zwischen der Körperwand. und dem die Darmwand bildenden Entoderm. Diese Leibeshöhle der Nemathelminthen wird in der Regel als eine sog. primäre oder nrsprïngliche aufgefaßt. Man versteht darunter einen Hohlraum, welcher zwischen dem Ecto- und Entoderm der ursprïnglichen Gastraea durch Auseinanderweichen ihrer beiden Zelliagen entstanden sei, ein Hohlraum, welcher in der ontogenetischen Entwicklung in der Tat weit verbreitet ist und als Furchungshöhle bezeichnet wird. Daß eine solche primäre Leibeshöhle wirkiich bei den Larven-vieler Bilaterien auftritt, unterliegt keinem Zweifel. Vom Eutoderm ans, vielleicht auch zum Teil vom Eetoderm, wandern dann fribzeitig Zellen iu diese Höhle hinein, welche sich teils an das Ectoderm, teils an das Entoderm anlegen, sich jedoch auch durch die Hŏhle ausspannend, muskulöse oder stïtzende Bedeutung erlangen nnd ein Mesenchym darstellen. So sicher demnach auch das Anftreten einer primären Leibeshöhle in der Ontogenese and deshalb wobl auch bei den Vorfahren der Bilaterien erscheint, so ist es doch $z$ weifellaft, ob in der Tat die definitive Leibeshöhle der Nemathelminthen eine solch primäre ist. - Bei den Plathelminthen existiert im ausgebildeten Zustande gewöhnlich keine solche Höhle, vielmehr findet sich eine ansehnliche Gewebsmasse, aus Muskel- und Bindegewebszellen bestehend (sog. Parenchym), zwischen Ectound Entoderm. Das Entstehen dieser Gewebsmasse bei den Turbellarien aber dentet auf Beziehungen zu den bei den höheren gegliederten Bilaterien zwischen Ectoderm and Entoderm sich entwickelnden Gewebsmassen hin, welche sich in innigem $\mathrm{Zu}$ sammenhaug mit der sog̣. sekundären Leibeshöhle bilden. Hieraus wäre event. zu schließen, daß die Vorläufer der Plathelminthen schon vor dibergehend eine sekundäre 
Leibeshöhle besaßen, wạs denn auch die Leibeshöhle der Nemathelminthen eher auf eine sekundäre zurückführbar erscheinen ließe, um so mehr, als die Ontogenese der Leibeshöhle der ibnen verwandten Acanthocephalen an die der sekundären lebhaft erinnert. Wir werden später nochmals auf dies Problem zurückkommen müssen.

Die Bildung einer solchen sekundären Leibeshöhle tritt am ausgeprägtesten bei denjenigen Bilaterien hervor, welche durch die sog. Gliederung oder Segmentation ihres Körpers eine bedentend höhere Ausbildungsstufe erreichen als die seither besprochenen. Es dürfte daher angezeigt erscheinen, zunächst diese Komplizierung des Körperbaues etwas näher zu betrachten. - Im allgemeinen spricht sich die Gliederung oder Metamerie in einer paarweisen Wiederholung homonomer (homodynamer) Organe oder Organteile hintereinander in der Längsrichtung des Körpers aus. Ursprünglich kann dieser Eau allein durch eine solche Wiederholung einzelner Organe angedeutet sein, ohne sich auch in der Bildung entsprechender Körperabschnitte auszusprechen. Schon bei gewissen Turbellarien, namentlich aber den verwandten Nemertinen, tritt dergleichen hervor.

Bei höherer Entwicklung der Metamerie wiederholen sich gleichzeitig ein großer Teil der Organe oder Organabschnitte; sowohl äußerc Anhänge (Bewegungsorgane, Atemorgane), als innere Teile (Abschnitte und Anhänge des Darmes, Excretionsorgane, Geschlecitsorgane, Abschnitte des Nervensystems, Sinnesorgane, Abschnitte der Muskulatur und so fort) treten in Mehrzahl auf, so daß die Gesamtorganisation aufs dentlichste der Metamerie unterliegt. Auch der Gesamtkörper wird dann, wie es besonders deutlich bei den Anneliden, Arthropoden und Wirbeltieren sich zeigt, aus mehr oder weniger zahlreichen, hintereinander gereihten Abschnitten (Metameren) aufgebaut, deren Organisation in gewissem Grade an die der nicht segmentierten verwandten Bilaterien erinnert. Dies hat früher die Ansicht hervorgerufen, daß die typische Metamerie durch einen ungeschlechtlichen Vermehrungsvorgang, eine Art Kolonic- oder Stockbildung ursprünglich unsegmentierter Vorfahren entstanden sei, eine Ansicht, welche durch die sehr allmählichen Übergänge zu Formen, bei welchen die Wiederholung nur auf wenige Organe beschränkt ist, widerlegt erscheint.

Durch jede Wiederholung eines Organs, welches bei der Ursprungsform nur in der Einzahl vorkommt, ist eigentlich schon eine Hinneigung zur Verdoppelung des Individuums gegeben. Je nach der Wichtigkeit und Bedeutung, die wir diesem Organ für das Individuum zuschreiben, prägt sich diese Hinneigung zur Verdoppelung schärfer oder schwächer aus. Verdoppelung eines wenig bedentsamen Tentakels oder Sinnesorgans wird das Bild der Einheitlichkeit des Indiriduums wenig stören, wogegen wir bei Verdoppelung des Darmapparats uns schwer der Vorstellung zweier, teilweis zur Einheit verbundener Individuen erwehren künnen. Ein Wirbeltier mit zwei Köpfen wird uns in große Verlegenheit setzen, speziell wenn wir uns den Menschen in dieser Verfassung vorstellen, dessen morphologische Individualität wir besonders geneigt sind, mit seiner psychischen $z u$ indentifizieren. Hieraus geht aber herror, daß keine scharfe Grenze zwischen einfacher Vermehrung von Organen und Individualitätsvermehrung zu ziehen ist. Was die Metamerie, angeht, so spricht für die oben vorgetragene Auffassung hauptsächlich der Umstand, daß sich nichts dafür anführen läßt, daß die Metamerie etwa durch Merabsinken von dem früheren Zustand èiner Kolonie, mit 
vollständiger àusgebildeten, durch ungeschlechtliche Fortpflanzung hervorgegangenen Individuen, auf den eines einheitlich gewordenen Individuums mit unvollständigeren Metameren entstanden sei. Im Gegenteil spricht alles dafür, daß die metameren Bilaterien durcb successive gesteigerte Wiederholung eines größeren Komplexes von Organen allmählich erst die an Individualität erinnernde Ausbildung ibrer Metameren erlangten. Bei der Cestodenkette, die häufig mit den metameren Bilaterien verglichen wird, liegt übrigens die Proglottidenentstehung wohl ebenso wie die Metamerenbildung bei den letzteren. Auch hier ist der Ausgangszustand, aller Wahrscheinlichkeit nach, nicht ein ungeschlechtlicher Vermehrungsakt, sondern die Wiederholung eines Organs, nänlich des komplizierten Geschlechtsapparates, ohne gleichzeitige äußere Sonderung einzelner Körperabschnitte. Erst später trat dazu die Befähignng der reifen Glieder des Hinterendes, sich abzulösen; womit die Möglichkeit gegeben war, viel größere Mengen solcher Gescblecbtsapparate und Glieder zu bilden. Die Berechtigung, diese durch Ablösung selbständig werdenden Giieder mit einem einfachen Bandwurmindividunm von unvollständiger Ausbildung, d. h. mit mangelndem Vorderende (Scolex) zu vergleichen, ist nun nicbt zu bestreiten, wohl aber ihre Auffassung als eine besondere, vom Scolex hervorgebrachte Geschlechtsgeneration; es sind vielmebr Teile, welche einem einfachen Bandwurm, d. h. einem mit einfachen Geschlechtsapparat ansgerüsteten Scolex entsprechen.

Die Wiederholung der Organe, welche zur Metamerie führt, darf mit Recht jener verglichen werden welche bei den Cölenteraten den radiären Bau bedingt.

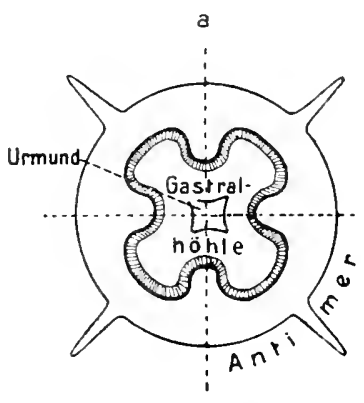

Fig. 4.

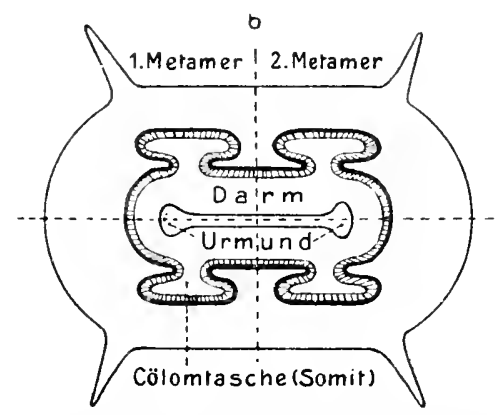

a Schema einer vierstrahligen einfachen Cölenteratenform, Ansicht anf den Urmund. $b$ Enteprechende Form in einer Querachse ausgewachsen, zur Erläuterung der Beziehung zwischen Radiärban und Metamerie. 0 . B.

Wenn wir uns erinnern, daß die Hauptachse der Bilaterien senkrecht zu der der Cölenteraten sich entfaltete, so bedingt dies, daß Organwiederholungen, welche bei den Cölenteraten radiär, in Umkreis der Hauptachse auftreten, bei den Bilaterien zu beiden Seiten der neuen Hauptachse in regelmäßiger Folge hintereinander geordnet sein müssen (s. Fig. 4). Jedes sog. Metamer .der gegliederten Bilaterien entspricht also einem Paar Antimeren der Cölenteraten.

Wenn die Metamerie die gesamte Organisation ergreift; so gilt dies namentlich auch für einen Teil des Körpers, den wir hier eingehender betrachten müssen, nämlich die schon erwähnte sekundäre Leibcshöhle oder das sog. Cölom. Das Cŏlom zeigt bei den typischen metameren Bilaterien selbst eine Gliederung, indem es durch Querscheidewände (Dissepimente), die sich zwischen dem Darm nnd der Körperwand ausspannen, in einzelne, den Metameren entsprechende Kammern 
gesondert ist. Ontogenetisch entsteht das Cölom innerbalb einer embryonalen Gewebsmasse, die hauptsächlich vom ursprünglichen Entoderm ausgeht und sich zwischen Ecto- und Entoderm einlagert, weshalb sie als Mesoderm bezeichnet wird. Am häufigsten erfolgt die Cölombildung derart, daß dies embryonale Mesoderm, von vorn beginnend, sich in pare Anteile (sog. Somiten) für die späteren Segmente sondert, in welchen dann durch Auseinanderweichen der Zellen die Cölomhöhlen der Einzelsegmente angelegt werden. Viele Morphologen sind der Meinung, daß dieser oder ein ähnlicher Entwicklungsgang der Cölomhöhle der primitive sei. Trotz seiner ontogenetischen Häufigkeit, erachten wir ihn jedoch nicht für den ursprünglichen. Bei gewissen Bilaterien entwickeln sich nämlich die Somitenpaare in anderer Weise, d. h. durch Bildnng einer rechts- und linkseitigen taschenförmigen Ansstülpung des Urdarms in jedem Segmente (s. Fig. 4b). Diese paarigen Ausstülpnngen oder Cölomtaschen schnüren sich schließlich vom Urdarm völlig ab und stellen die Somiten dar, welche also in diesem Fall von Anfang an eine Höhle enthalten, einen Teil der Gastralhöhle des Urdarms. In ihrer weiteren Entwicklung verhalten sich die, auf die eine oder andere Weise entstandenen Somiten gleich, d. h. sie liegen anfänglich mehr ventral oder seitlich, umwachsen hierauf dorsal und ventral den Darm, bis ihre Wände zur Bildung des späteren dorsalen und ventralen Mesenteriums, die sich zwischen Darm und Körperwand ausspannen, zusammenstoßen. Die äußere Wand jedes Somites legt sich dem Ectoderm innen an, die innere dem Entoderm des Darmes anßen. So verdrängt die sich entwickelnde Cölomhöhle die frühere Furchungshöhle oder primäre Leibeshöhle und setzt sich gewissermaßen an ihre Stelle.

Wie gesagt, erachten wir die Entstehnng der Somiten durch Ausstülpung des Urdarmes und damit die des sog. Mesoderms, welches in ihrer Gesamtheit besteht, fiir die primäre. Hierzu veranlaBt uns, trotz des selteneren Anftretens dieses Modus, der Umstand, daß die Cölomhöhle bei dieser Entstehung nicht als eine Nenbildung, sondern als ein Abkömmling der ursprünglichen Gastralhöhle erscheint, was den Vorgang begreiflicher macht; und daß ferner, wenn dies der ursprüngliche Bildungsvorgang ist, die als taschenförmige Ausstülpungen des Urdarms auftretenden Somiten von den Einrichtungeu der Cölenteraten abgeleitet werden können. Sie erscheinen dann etwa als Homologa der Taschen der Gastralhöhle bei den Anthozoen die bei den Bilaterien entsprechend bilateral angeordnet sind, wie wir für die bei den Cölenteraten radiären Organe überhaupt fanden. Ist diese Ansicht begründet, so folgt aus ibr natürlich, daß das sog. Mesoderm der cölomaten „Bilaterien, wenigstens ursprünglich, von rein entodermaler Entstehnng gewesen sein muß. Der Umstand, daß die Anlage der Somiten jeder Seite hänfig eine gemeinschaftliche ist und die Abschnürung in Einzelsomiten erst später erfolgt, kann dann nur als eine Modifikation angesehen werden, sei es von nrsprünglicherer oder sekundärer Natur.

Wie wir später sehen werden, sind die Geschlechtsorgane der Cölenteraten gewöhnlich Wucherungen an den Wänden der Gastraltaschen oder -kalläle. Wenn dies bei den Urformen jener cölomaten Bilaterien ebenso war, so läßt sich viel- 
leicht auch ein Grund angeben für die Abtrennung der Cölomtaschen vom Urdarm als Somiten. Bei den Cölenteraten entleeren die Geschlechtsorgane ihre Produkte in der Regel in die Gastraltaschen, sie gelangen daher durch die Gastralhöhle und den Urmund nach außen. Ein solcher Zustand kann gewiß nicht als sehr vorteilhaft angesehen werden, wenigstens dann nicht, wenn die Gastralböhle sich zu einer wirklich verdanenden, mit Secretion verdauender Säfte, entwickelte. In diesem Fall mußte eine Abtrennung der Taschen, welche die Geschlechtsprodukte aufnahmen, vom Centralteil der Gastralhöhle, der als Darm verblieb, vorteilhaft werden,weshalb hierin vielleicht das bedingende Moment für die Abtrennung gesncht werden darf. - Schon öfter wurde versucht, die erste Entstehung der Somiten ron den Geschlechtsorganen (Gonaden) herzuleiten (Gonocöltheorie); der eben geschilderte Weg scheint uns dagegen der wahrscheinlichere.

Bei den gegliederten Würmern und Arthropoden liegt das vorderste Somitenpaar dicht hinter dem Mnd. In dem davor befindlichen zapfenartigen vordersten Körperende tritt kein Somitenpaar auf. Erst später wachsen Zellen des ersten Somitenpaars in dies sog. Prostomium (Kopfzapfen, Acron) hinein und bilden Muskulatur und Bindegewebe. Die Frage, ob das Prostominm stets ohne besondere Mesodermanlage (Somitenpaar) war, ist schwer zu beantworten; um so mehr, als bei den Hirudineen eine besondere paarige Mesodermanlage für diesen Kopiteil vorkommt und bei Bryozoen, Brachiopoden, Chätognathen, Echinodermen, Pterobranchiern, Enteropneusten und Acraniern ein vorderstes Somitenpaar in einen wohl entsprechenden Kopfteil eingeht. Auffallend ist ferner, daß in der Entwicklung der Nemertinen und Turbellarien das Mesoderm in zwei Par gesonderten Anlagen auftritt, von welchen bei den Nemertinen das vorderste Paar für den vor dem Mand gelegenen Kopfteil, das hintere für den gesamten übrigen Körper (Rnmpf) bestimmt ist. Diese Verhältnisse machen es doch erwägenswert, ob nicht das Prostomium der Anneliden nnd Arthropoden ursprünglich ein besonderes Mesodermtaschenpaar besessen hat und daher anfänglich dem Rumpfteil gleichwertig war, dessen ursprüngliches Taschenpaar sich späterhin zu den Rumpfsomiten vermehrte. Bei der Reduktion des Taschenpaares des Prostomiums wäre dessen sekundäre Leibeshöhle wohl mit der primären zusammengeflossen. Die Möglichkeit einer solchen Anschanung vorausgesetzt, würden uns die ursprünglichen Bilaterien als zweigliedrige Tiere mit zwei Cölomtaschenpaaren (Somiten) erscheinen, von welchen das erste, wie der gesamte Kopfabschnitt, bald rudimentär wnrde, während das hintere mit dem Rumpfabschnitt stark auswuchs. Die Anknüpfung solcher Formen an cölenteratenartige Vorfahren hätte keine große Schwierigkeit. Bei der Beobachtnng der einzelnen Organsysteme soll später erwogen werden, ob auch der fertige Bau der ursprünglichen Bilaterien etwaige Anzeichen erkennen läßt, welche für eine solche Auffassung sprechen.

Jene Gonocöltheorie, welche die sekundäre Leibeshöhle von dem inneren Hohlraum säckchenartiger Geschlechtsorgane abzuleiten sucht, steht eigentlich der oben vorgetragenen Ansicht prinzipiell nicht gegenüber. Denn auch die letztere bringt ja die Abtrennung der zur sekundären Leibeshöhle werdenden Gastraltaschen in innige Beziehung mit 
"ihrer Funktion als Räume, in welche die Geschlechtsprodukte entleert werden. Gleichzeitig berücksichtigt sie aber die für eine Reihe von Bilaterien sichere Tatsache, daß die Anlagen des Cöloms, der Somiten des sog. Mesoderms, als Ausstülpungen der Urdarmwand auftreten. Abgesehen davon, daß letztere Bildungsweise des Mesoderms eine Anknüpfung an den Cölenteratenbar gestattet und daber ein gewisses Recht hat, als die primitive angesehen zu werden, läßt sich letzteres auch deshalb annehmen, weil sowohl die solide Anlage des Mesoderms, als auch sein Hervorgehen aus einer oder wenigen Zellen, die sich aus dem Verband des Entoderms, bzw. auf der Grenze ron Ento- und Ectoderm, ablösen, sich wohl ron seiner Entstehung durch Ausstülpungen des Urdarmes durch Vereinfachung des Vorganges und frühzeitigere Absondernng ableiten lassen, umgekehrt dagegen die Ableitung der Ausstülpungen ans einer ursprünglich soliden Zellenanlage, einer Ansammlung von Propagationszellen etwa zwischen Ectom und Entoderm, kaum möglich erscheint. Dazu gesellt sich die gewiß recht schwierige Vorstellung, daß ein ursprünglich nur als Geschlechtsapparat funktionierendes Organ, indem es sich zur sekundären Leibeshöhle eines Segments erweiterte, in seiner grüßten Ausdehnung ganz andere Funktionen erlangte, sich an der Excretion ond vor allem an der Muskelbildung innigst beteiligte, indem es zum mindesten einen ansehnlichen Teil der Körper- und Darmmuskulatur lieferte. Besonders der letztere Umstand dürfte für eine ursprünglich nur als Geschlechtsorgan funktionierende Anlage der Somiten wenig wahrscheiulich sein. Dazu gesellt sich, daB von den Somiten der gegliederten Tiere doch stets nur ein relativ kleiner Teil zum Aufbau der Geschlechtsorgane verwendet wird (wenn die Gonaden nicht überhaupt schon vor den Somiten angelegt werden), der größere Teil anderweitig rerwertet wird; und daß vielfach nur wenige Somiten Geschlechtsprodukte bilden, bzw. die Geschlechtsorgane auch ohne jede Beziehung zur Segmentation sind(Arthropoda, Vertrebrata mit Ausnahme der Acrania). Auch hieraus dürfte eher zu folgern sein, daß schon rom Anfang an nur ein kleinerer Anteil der Sumiten zur Produktion ron Geschlechtszellen in Beziehung stand, der größere dagegen eine andere Funktion besaß, die späterhin weiter ausgebildet wurde. Schon bei den Cölenteraten finden wir, daß das Entoderm der Gastralböhle und ihrer Taschen starke Muskulatur hervorzubringen vermag (z. B. an den Septen der Anthozoa und weiterhin), so daB wir bei eventueller Ablösung solcher Taschen als Anlagen der sekundären Leibeshöhle uns von vornherein ibre wesentliche Beteiligung an der Bewegung, als Muskelfasern hervorbringende Teile, wohl vorstellen können. Ich erachte daber die oben vorgetragene Ableitung der Somiten für die wahrscheinlichere und bin geneigter, die Verhältnisse der Geschlechtsorgane bei den Plathelminthen und speziell den Nemertinen nicht den ersten Anlagen einer sekundären Leibeshöhle entsprechend zu betrachten, sondern eher umgekehrt als durch Rückbildung einer. solchen entstanden.

Oben wurde hervorgehoben, daß die änßere Wand der hohlen Somiten (sog. Somatopleura) sich an das Ectoderm anlegt, die innere (sog. Splanchnopleura) an das Entoderm des Darms. Hier bilden sie ein das Cölom auskleidendes Epithel (Peritonealepithel, Cölothel), ferner jedoch Bindegewebe nebst Muskulatur und tragen zum Aufbau noch vieler besonderer Organe bei. Indem durch die Ausbreitung der Cölomanlagen die primäre Leibeshöhle verdrängt wird, können deren Mesenchymzellen, die ja häufig vom Eictoderm herkommen, sich dem sog. Mesoderm zugesellen; vielleicht mag hierin ein Grund dafür liegen, daß in der Ontogenie dem Mesoderm zum Teil auch ectodermale Zellen zugeführt werden.

Die Verdrängung der primären Leibeshöhle durch das Cölom gibt uns jedoch noch Aufschluß über die wahrscheinliche Entstehung eines Organsystems, welches nur bei einem Teil der Würmer vorkommt, aber den meisten cölomaten Bilaterien eigen ist, des Blutgefäßsystems nämlich. Bei der Verdrängung der pri- 
mären Leibeshöhle durch das Cölom konnten sich Reste der ersteren erhalten, als ein von Anfang an zusammenhängendes Gefäßwerk, eiu Blutgefäßsystem einfachster Art. Da die ontogenetische Entstehnng der Bluträume dieser Voraussetzung vielfach völlig entspricht, so halte ich sic für recht wahrscheinlich. Vom Mesodermgewebe aus wurden die ursprünglich nur als Lücken sich darstellenden Gefüßräume mit Wandungen bindegewebiger bis muskulöser Natur versehen. - Für diese Ableitung des Blutgefaßsystems spricht vor allem, daß es so von Anfang an als ein in sich geschlossenes, zusammenhängendes Liicken-oder Kanalsystem auftritt und von einem präexistierenden Hohlraum seinen Ursprung nimmt; die verbreitete Ansicht, daß das Blutgefäßsystem aus Lückell oder Aushöhlnngen, die im bindegewebigen Mesoderm zerstrent auftraten, hervorgegangen sei, ist unwahrscheinlicher, da es sich dabei einmal um wirkliche Neubildungen handeln wïrde und weiterhin um ein Organsystem, welches erst in dem Maße allmählich funktionsfähig wurde, als sich die ursprünglich fehlenden Zusammenhänge der Bluträume herstellten. Für die ersterwähnte Ableitung spricht ferner die Erfahrung, daß sich auch aus der sekundären Leibeshöhle unter Umständen ein sekundäres Blutgefäßsystem neben dem eigentlichen hervorbilden kanu (Hirudineen). Immerhin erscheint die Entstehung eines Blutgefäßsystems aus der primären Leibeshöhle nicht unbedingt an die Ausbildung einer sekundären gebunden. Es könnte sich auch bei Bilaterien hervorgebildet haben, die keine solche besaßen, durch starke Entwicklung eines Mesenchyms, welches die primäre Leibeshöhle zu einem Kanalsystem einengte, ähnlich wie dies mit der Cölomhöhle der Hirudineen geschah. Es fragt sich nur, ob solche Formen existieren?

Dies führt uns wieder zu dem Problem der Leibeshöhle bei den sog. ungegliederten Wurmern zurüick.

Im Gegensatz zu der eben erörterten Ansicht über die wahrscheinliche Herleitung des BlutgefäBsystems, die auch als Blastocöltheorie bezeichnet wurde, steht eine zweite, welche sich zwar in dem eigentlichen Kardinalpunkt von der ersten kaum prinzipiell unterscheidet, jedoch von anderen Anschauungen über den wahrscheinlichen Bau der Vorfahren der olutgefäßfübrenden Netazoen ausgeht, und deshalb auch das BlutgefäBsystem etwas anders entstehen läßt. Es ist dies die sog. Hämocöltheorie. Nach ihr sind die segmentierten Metazoen aus plattnarmăhnlichen Vorfahren entsprungen, die gar keine primäre Leibeshöhle besaßen, sondern ein Mesenchym, welches den ganzen Raum zwischen Ecto- und Entoderm erfüllte, insbesondere wurden dabei nemertinenartige Formen als Vorläufer der Anneliden ins Auge gefaßt. Die Blutgefäße aber seien derart entstanden, daß durch Zurückziehung der Urdarmwand Lückenräume zwischen Mesenchym und Entoderm aufgetreten seien, die sich mit ernährender Blutflüssigeit füllten.

Man erkennt, daß diese Lehre prinzipiell eigentlich mit der ersteren übereinstimmt, da sie die Blutgefăße gleichfalls als Räume auffaßt, die der Furchungshöhle (primären Leibeshöhle) entsprechen. Sie unterscheidet sich jedoch insofern, als sie die Existenz einer primären Leibeshöhle bei den Vorfahren der segmentierten Metazoen leugnet, nnd daber auch das Blutgefäßsystem nicht von ihr abzuleiten rermag. Die zweifellos primäre Leibeshöhle vieler Larven (insbesondere der Anneliden) gilt der IIämocöltheorie nicht als Beweis einer ehemaligen Existenz einer solchen bei den Ahnen der Bilaterien; im Gegenteil faßt sie alle diese Larven als später erworbene auf, welche also kein phylogenetisches Vorfahrenstadium darstellen. Ebenso gelten ihr auch jene Rnndwärmer (speziell die Rotatorien, aber wohl auch die 
Nematoden), welche anscheinend und nach der gewöhnlichen Ansicht eine primäre Leibes- höhle besitzen, für geschlechtsreif gewordene Larvenformen, also für Formen, welche den abweichenden Larrenbau im fertigen, geschlechtsreifen Zustand bewahrten, und die daher ebenfalls keine phylogenetische Bedeutung besäßen. Immerhin müßte die Hämocöltheorie doch wohl die sog. primäre Leibeshöhle der erwähnten Larven und der ungegliederten Rondwürmer als den Bluträumen der gegliederten Metazoen entsprechend auffassen; was wieder die prinzipielle Übereinstimmung der beiden Lehren erwiese.

$\mathrm{Ob}$ die gegliederten Metazoen aus leibeshöhlenlosen Vorfahren hervorgingen, wie sie die Plattwürmer darstellen, ist ein Problem, das, wie schon erwähnt, äußerst schwierig mit unseren heutigen Kenntnissen zu lösen ist. Jedenfalls läßt sich demgegenüber die Möglichkeit, daß sie aus Formen mit primärer Leibeshöhle entstanden, d. h. mit einem zwischen Ecto- und Entoderm gelegenen Hoblraum, der nur von einer mäßigen Menge von Mesenchymzellen durchsetzt war; mit ebenso großem Recht vertreten. Wenn wir eine so beschaffene primäre Leibeshöhle bei vielen Larven der verschiedensten Stămme (gewisse Plathelminthen, Anneliden, Mollusken, Echinodermen usw.) auftreten sehen, so spricht dies schon für die Wahrscheinlichkeit, daß diese Einrichtung nicht ein besonderer, erst von den Larven erworbener Charakter 1st, sondern ein phylogenetisch begründeter, d. b. einer, der bei den Vorfahren bestanden hat. Selbst wenn wir zugeben, daß jene Larvenformen erst nachträglich entstanden seien, daß ihle Vorfahren sich direkt entwickelten, so spricht doch die Wahrscheinlichkeit dafür, daß ihr gemeinsamer Grundcharakter ein solcher ist, der sich bei ihrem frühzeitigeren Austritt aus dem Ei erhielt, weil er eben schon in der phylogenetisch-ontogenetischen Entwicklung bestand; nicht aber ein solcher, den diese Larven erst in Anpassung an die schwimmende Lebensweise erwarben. Dazu kommt, daB die Auffassung der Nemathelminthen, als auf der Larrenstufe stehen gebliebener Formen, doch sehr wenig begründet erscheint, wie weiter unten noch dargelegt werden soll.

Auf Grund dieser Erwägungen halten wir vorerst die Meinung, daß den Vorfahren der blutgefäßführenden, höher organisierten Metazoen eine primäre Leibeshöhle zukam, für wahrscheinlicher, ja sind eher geneigt, die Leibeshöhlenlosigkeit der Plathelminthen, ähnlich wie die der Hirudineen, auf eine nachträgliche Ausfüllung der Höhle zurückzuführen; wir balten es sogar nicht für unmöglich, daB den Vorfahren dieser niederen Würmer einmal ein Cölom zukam. Die bedenklichste Schwäche dieser, mit der sog. Gonocöltheorie eng verkuüpften Hămocöltheorie liegt jedoch darin, daß sie über das Blutgefäßsystem der Nemertinen keinen genügenden $A u f s c h l u ß$ zu geben weiß, gerade jener Formen, auf die sie sich für die Ableitung der Verhältnisse der gegliederten Würmer hauptsächlich stützt und die daher der Lehre nach eigentlịch kein Blutgefäßsystem besitzen dürften. Wir sind überzeugt, daß das Blutgefäßsystem der Nemertinen ebenso ein Leibeshöhlenrest ist wie das der übrigen Würmer, und wenn nicht der Rest einer ehemaligen primären Leibeshöhle, dann der einer früher bestandenen sekundären, dann also vergleỉchbar dem sekundären Blutgefäßsystem der Hirudineen, was um so weniger ausgeschlossen erscheint, als in der Ontogenie dieser Abteilung Anzeichen der früheren Existenz einer seknndären Leibeshöhle aufzutreten scheinen.

Zunächst wollen wir einen Blick auf gewisse cëlomate Bilaterien werfen, die eine Art Metamerie, jedoch eine solche von sehr geringer Ausbildung, zeigen.

Eine Anzahl äußerlich recht verschiedener Bilateriengrnppen nämlich: die Brachiopoden, die ihnen wohl nahe verwandten Bryozoen, die äußerlich ganz different erscheinenden Chätognathen, die Enteropneusten, sowie die ihnen verwandten, nur in wenigen Formen vertretenen Pterobranchier nnd schließlich die in ihrer Jugend rein bilateralen, später jedoch sich radiär umgestaltenden Echinodermen besitzen ein Cölom, welches durch quere Scheidewände in drei (vielleicht znm Teil auch nur zwei) Räume zerlegt erscheint, was also einer sehr geringen 
Segmentzahl entsprechen wtirde. Wahrscheinlich dürfte diese Eigentümlichkeit der genannten Formen auf eine alte Vorfahrengruppe hinweisen, welche nur wenige Segmente besaß, aber möglicherweise durch Reduktion schon vereinfacht worden war. Nun tritt in der Ontogenie der ungegliederten Würmer (Plat- wie Nemathelminthen), andrerseits aber auch der ebenfalls ungegliederten Mollusken, eine embryonale parige Mesodermanlage auf, welche mit der der segmentierten Cölomaten die größte Ähnlichkeit besitzt, ja bei den Turbellarien sogar eine Sonderung in zwei Paar hintereinander gelegene, somitenartige Partien erfährt. Diese Eigentümlichkeit läßt erwägen, ob die letzterwähnten Gruppen nicht ursprünglich auch ein cölomatisches Mesoderm besaßen, wic es für die Mollusken auch aus vergleichend-anatomischen Grïnden fast zweifellos erscheint, und ob daher die anscheinend primäre Leibeshöhle der ungegliederten Würmer nicht doch anf ein ursprïngliches Cölom hinweist. Da auch bei cölomatischen segmentierten Bilaterien (speziell Arthropoden) ein Wiederzusammenfluß der beiden ursprünglich gesonderten Leibeshöhlen vorzukommen scheint, so ließe sich erwägen, ob nicht etwas dieser Art auch bei jenen nngegliederten Würmern eingetreten sei. Ferner drängt sich die Erwägung auf, ob nicht jene jetzt, scheinbar ungegliederten Würmer und Mollusken vielleicht ihren Ausgangspunkt von ähnlichen·weniggegliederten Urformen genommen haben, wie sie als Vorfahren der oben aufgezählten Gruppen anzunehmen sind. Einzelnes in der Organisation jener Würmer und der Mollusken ließe sich wohl in dieser Richtung aufführen und soll später hervorgehoben werden. Hier möge es genügen, auf die Schwierigkeiten und Unsicherheiten hinzuweisen, welche in dieser Hinsicht und insbesondere bei der Beurteilung der Leibeshöhle der ungegliederten Rundwürmer noch bestehen.

Die ron uns im Gegensatz zu den Radiaten (Cölenteraten) als Bilaterien bezeichneten Metazoen wurden in neuerer Zeit auch häufig als Coelomata zusammengefaßt. Der maßgebende Gesichtspunkt ist dabei, daß ihnen sämtlich ein Cölom, eine seknndäre Leibeshöhle, wenigstens ursprünglich eigen gewesen sei: In den Fällen, wo eine solche Höhle nicht vorzukommen scheint und auch zugegeben wird, $\mathrm{daß}$ die bestehende Leibeshöhle eine primäre ist (Nemathelminthen), oder wo eine Leibeshöhle überhaupt fehlt (Plathelminthen), sucht man dann den Rest des angenommenen Cöloms in den IIöhlen der Gonaden, die jedoch zuweilen überhaupt nicht existieren, oder deren Herleitung von einer ursprünglichen Cölomhöhle doch sehr unsicher ist. Wie aus unseren Darlegungen hervorgeht, halten auch wir es für wahrscheinlich, daß das Mesoderm sämtlicher Bilaterien aus ursprünglichen Cölomtaschen hervorging, daß sie daher sämtlich ursprünglich cölomatisch waren. Dagegen erachten wir es für recht unsicher, daß die Gonadenböhle aller Bilaterien stets einem ursprünglichen Cölomhöhlenteil entspricht, da die Aushöhlung einer ursprünglich soliden Gonade auch leicht selbständig auftreten kounte. Hieraus folgt, daß die Erhaltung von Cölomräumen bei den Plathelminthen doch recht nnsicher erscheint. Aus diesem Grund und auch deshalb, weil unter Coelomata früher gerade die Würmer mit typischer sekundärer Leibeshöhle rerstanden wurden, scheint uns die Bezeichnung Bilateria sachgemäßer, wenn auch nicht ganz typisch, da ja Andeutungen ron Bilateralität schon bei den Cölenteraten auftretèn und die Echinodermen eine so tiefgehende Umformung ihrer ursprünglichen Bilateralität erîuhren.

Die besondere und recht verschiedenartige Ausgestaltung in den verschiedenen aufgezählten Gruppen der weniggliedrigen Formen sowie der Mollusken, welche 
Abteilungen fast alle etwa auf dem in unserer Schilderung zuletzt erwähnten Stadium verbleiben, kann hier nicht näher erörtert werden. Nur die ganz eigenartige Richtung, welche die Körperentwicklung im Stamm der Echinodermen einschlug, maß in Kürze besprochen werden. Wie schon hervorgehoben, sind die Jugendformen oder Larven aller Echinodermen streng bilateral gebaut, mit drei Paar Somiten vergleichbaren Cölomsäcken, von welchen der mittlere der linken Seite eine ganz eigenartige Weiterentwicklung einschlägt, indem er zu einem besonderen Gefäßapparat, dem sog. Ambulacralgefäßsystem wird, das mit eigentümlichen Bewegungsorganen in Beziehnng tritt. Späterhin bildet sich dieser typisch bilaterale und segmentierte Bau der Jugendformen in besonderer Weise zu einem radiärsymmetrischen um, welchem die Fünfzahl zugrunde liegt, im Gegensatz zu dem der Cölenteraten. Dieses schwer verständliche und bis jetzt auch noch nngenügend erforschte Hervorgehen eines radiärsymmetrischen Baus aus dem bilateralen dürfte jedoch wahrscheinlich, wie schon für die Radiärsymmetrie der Cölenteraten dargelègt wurde, in ursächlichem Zusammenhang mit einer festsitzenden Lebensweise gestanden haben, zu welcher die bilateralen Vorfahren der Echinodermen übergingen. Diese Annahme ist um so möglicher, als die älteste Echinodermenklasse (die Pelmatozoa) fast ausschließlich noch diese Lebensweise zeigt. Wir dürfen es deshalb als wahrscheinlich erachten, daß die übrigen freilebenden Echinodermenklassen den Strahlenbau jenen ursprünglich festgehefteten Vorfahren verdanken. Daß sie ibn nicht wieder verloren haben, hängt einerseits damit zusammen, daß er den Gesamtbau schon zu intensiv beherrschte, um völlig rückgängig gemacht zu werden, andrerseits jedoch auch mit der relativ geringen Beweglichkeit dieser Tiere. Dennoch wurde er bei den freibeweglichen Echinodermen zum Teil wieder sekundär bilateral modifiziert, wie die irregulären Seeigel and zahlreiche Holothurien zeigen.

Bevor wir auf die typische Metamerie der höheren Bilaterien etwas genauer eingehen, wäre zanächst das Problem kurz zu erörtern, welche Vorteile wohl die Veranlassung zu der allmählich inmer reicher sich ausbildenden Metamerie gegeben haben dürften. Vielleicht liegen ihre ersten Anfänge so weit zurück, wie die Entstehnng der radiären Symmetrie der Cölenteraten, denn auch bei diesen kann in der Ontogenie schon eine vorübergehende bilaterale Anordnung der Antimeren auftreten, ja es kann sich auch im ausgebildeten Zustand durch besondere Anordnung gewisser Organe eine bilaterale Bildung mit der radiärsymmetrischen kombinieren (Octocorallia).- Immerhin maßjedoch die scharfe Ausprägung der Metamerie in den Gruppen der Anneliden, Arthropoden nnd Wirbeltiere besonderen, damit verknüpften Vorteilen ihre höhere und reichere Entfaltung verdanken. Eine genügende Beantwortung hat dies Problem noch nicht gefunden. Man hat darauf hingewiesen, daß der metamere Ban, der eine reiche Wiederholung vieler und wichtiger Organe im Körper bedingt, einen Vorteil bei Verlusten von Körperpartien biete, indem ja hierbei stets ein Teil jener metameren Organe erhalten bliebe. Obgleich dies gewiß nicht außer acht zu lassen ist, so scheint doch, daß die typische Metamerie der cölomatischen Bilaterien hauptsächlich mit vorteilhafteren 
Bewegungsverbältnissen, welche mit dem metameren Bau sich ausbilden konnten, näher zusammenhängt. Besonders die Wirbeltiere, deren Metamerie sich ursprünglich vorwiegend in der Muskulatur ausprägte, scheinen für diese Auffassung zu sprechen.

Die Entwicklung der reichen Metamerie bei Anneliden, Arthropoden und Vertebraten blieb nicht ohne Einfluß auf die gesamte Körpergestalt. Bei Anneliden und Arthropoden sind die Metameren meist auch äußerlich durch ringförmige Körpereinschnürungen deutlich kenntlich, was die Gesamtgestalt wesentlich bestimmt. Bei den Vertebraten fehlt dagegen jede äußere derartige Anszeichnung der Segmente; die Metamerie spricht sich nur im inneren Bau, vor allem in der Musknlatur, dem von dieser bedingten Skelet, dem Nervensystem und sonstigen Organen aus.

Bei den Anneliden sind die Segmente meist alle nahezu gleich gebaut, es herrscht eine homonome Gliederung. Dennoch finden sich auch Formen, bei welchen sie in verschiedenen Körperregionen erheblich differieren, so daß eine heteronome Gliederung des Gesamtkörpers in zwei oder mehr Regionen hervortritt. Diese bei den Gliederwürmern wenig verbreitete Heteronomie und die damit zusammenhängende Regionenbildung des Gesamtkörpers beherrscht dagegen die Organisation der Arthropoden fast stets in hohem Maße. Die Segmente werden nicht nur in den einzelnen Regionen verschieden, sondern sie vereinigen sich auch innerhalb dieser inniger, so daß letztere sich schärfer von einander absetzen. Die Bildung solcher Körperregionen wird von besouderen physiologischen Leistungen bedingt, welche sich auf sie lokalisieren: - Die vorderste oder Kopfregion trägt den Mund und daher auch die zur Nahrungsaufnahme dienenden Mundwerkzeuge oder Kiefergebilde; andrerseits ist sie aber auch der Sitz der hauptsächlichsten Sinnesorgane, der Fühler und Augen, sowie des Cerebralganglienpaares. - Die mittlere, oder Brustregion, fungiert als Sitz der Hauptbewegungswerkzeuge. Die hintere Region, der Hinterleib oder das Abdomen, wirkt teils bei der Bewegung mit, teils ist sie der Sitz der wichtigsten Eingeweide; sie verhält sich also etwas verschieden, wie denn überhaupt die Regionenbildung bei den Arthropoden vielen Modifikationen unterliegt.

Unter ähnlichen Bedingungen hat sich eine analoge Regionenbildung der Vertebraten allmählich und selbständig herausgebildet. Auch hier führte die Lokalisierung des Mundes und der Hauptsinnesorgane am Vorderende zur Differenzierung einer Kopfregion, welche sich durch die stetige ansehnliche Vergrößerung des in ihr liogenden Hirnteils des Centralnervensystems, andrerseits aber auch durch die Lokalisation der Kiemenatmungsorgane der ursprünglichen Wirbeltiere auf die hintere Kopfregion noch schärfer abgrenzte. Bei den neogenen Vertebraten wird diese Abgrenzung durch die Sonderung einer Halsregion noch schärfer. Die mittlere und ansehnlichste Region, der Rumpf, ist auch bei den Vertebraten der Sitz der Bewegungsorgane, umschließt aber, im Gegensatz zu vielen Arthropoden, auch stets die Ernährungs- und Fortpflanzungsorgane. Die hinterste oder Schwanzregion dagegen, welche anf den After folgt, funktioniert bei den urspring- 
lichen wasserlebenden Wirbeltieren als das Hanptbewegangsorgan und erhält sich in dieser Bedeutung anch bei den höheren, wenn auch nur als Hilfsorgan bei der Bewegung, nicht mehr als eigentlich bewegender Apparat.

Bei der eben kurz erwähnten Regionenbildung der höheren Bilaterien wurde schon mehrfach auf die Bewegungsorgane als bedingende Momente hingewiesen. Die Bildung besonderer Bewegungsorgane hat natürlich überhaupt großen Einfluß anf die äußere Körperform und soll deshalb, aber auch ihrer selbständigen Bedeutung wegen, kurz betrachtet werden. Den ursprünglichsten Metazoen, Cölenteraten und Plathelminthen, fehlen besondere Bewegungsorgane völlig, der Körper bewegt sich als Ganzes, böchstens $d a B$ sich in die Bewegung eingreifende Haftorgane, Sangnäpfe und dergleichen (Plathelminthen) vorfinden, oder daß die abgeplảttete Ventralfläche als Kriechfläche (Turbellaria zum Teil) eine gewisse Rolle bei der Bewegung spielt.

Ganz eigenartige Bewegungseinrichtungen herrschen in dem großen Phylum der Mollusken. Obgleich hier bei den einfachsten und ursprünglichsten Formen, ähnlich wie bei manchen Plattwürmern, anscheinend die ganze Ventralfläche zu einer vom übrigen Körper etwas abgesetzten muskulösen Kriechfläche, dem sog. $\mathrm{Fn}$, entwickelt ist, scheint doch die ontogenetische Bildung dieses Fußes, namentlich bei den Gastropoden, darauf hinzuweisen, daß er seinen Ursprung nicht der ganzen Banchfläche verdankt, sondern anfänglich als ein besonderes, aus einem mittleren Teil der Ventralfäche hervorwachsendes Organ entsteht, das sich erst später häufig so ausdehnen kann, daß es fast über die ganze Bauchseite ausgebreitet ist. Bei den, im übrigen recht umgebildeten Muscheln (Lamellibranchiata, ebenso den Scaphopoden s. Fig. 35, 36, 50) erhält sich der Fuß häufig in dieser ursprünglicheren Form, als ein zum Kriechen dienendes muskulöses Anhangsorgan der mittleren Bauchregion. Bei den Schnecken (Gastropoden s. Fig. 29) wird er dagegen viel ansehnlicher, dehnt sich über den größten Teil der Bauchfläche aus nnd erhält eine umfangreiche abgeplattete Kriechfläche, auch nicht selten seitliche lappenartige Anhänge (Epipodien und Parapodien), kann sich jedoch bei Formen, die zum Schwimmen übergegangen sind (Heteropoda), eigentümlich umgestalten, indem sich sein vorderer Teil za einer vertikalen Schwimmflosse entwickelt. - Bei den gleichfalls schwimmenden Pteropoden wurde der FuB in anderer Weise zu einem Schwimmorgan umgebildet. Während sich der eigentlichę Fuß stark rückbildete, wuchsen die oben erwähnten Parapodiallappen zu zwei flügeiartigen Flossengebilden aus, welche durch ihr Schlagen das Schwimmen ermöglichen.

Noch eigentümlicher endlich verhalten sich die Cephalopoden, deren Ontogenie jedoch nur für die Dibranchiaten bekannt ist. Die sich flügelartig entwickelnden Epipodiallappen bilden durch Zusammenkrümmen nach der Ventralseite ein vorn und hinten offenes, trichterartiges Gebilde, den sog. Trichter, der bei Nautilus (Tetrabranchiata) noch ohne Verwachsung der beiden Lappen, geschlitzt offen ist (s. Fig. 31), bei den Dibranchiaten dagegen dnrch Verwachsung der beiden Lappen ein trichterfŏrmiges Rohr wurde (Fig. 32). Dieses Organ dient den Ccphalopoden anch zum Schwimmen, indem das Wasser der Mantelhőhle durch den Trichter mit 
Gewalt ausgespritzt wird, wobei sich der Tierkörper durch den Rïckstoß fortbewegt. Der eigentliche $F u ß$ der Cephalopoden dagegen wird in den um den Mund entspringenden 8 oder 10 großen, bei Nantilus dagegen viel zahlreicheren, jedoch kleineren Tentakeln (s. Fig. 31 und 34) gesucht, hauptsächlich wegen ihrer Innerviernng durch dieselben Centralteile des Nervensystems, welche sonst den Faß versorgen. Es müßte demnach hier eine eigentümliche Verschiebnng des Fußes an den Kopf, bzw. auch des Mundes nach hinten auf die Fußfäche, eingetreten sein.

Unter den Nemathelminthen treten bei vereinzelten Rotatorien zum erstenmal extremitätenartige seitliche Körperanhänge als bewegliche Ausstülpungen der Körperwand in verschiedener Form auf (s. Fig. 23). Dazu gesellt sich aber fast regelmäßig anch ein unpaarer ventraler Anhang, der in mancher Hinsicht an die einfachste Fußbildung der Mollusken erinnert.

$\mathrm{Da} ß$ die Extremitäten, welche bei den marinen Anneliden (Polychäten) in so großer Zahl auftreten, möglicherweise an die eben erwähnten einfacheren Bildungen rotatorienartiger Vorfahren anknüpfen, ist wohl möglich. Von diesen Fußstammeln oder Parapodien der Polychäten trägt jedes Segment ein Paar. Es sind seitliche, kürzere oder mäßig lange, gelappte, borstentragende Gebilde, die, von Muskeln bewegt, bei den schwimmenden Formen als Ruderorgane dienen und verschiedene woitere Anhänge (Cirren, Kiemen) tragen können. Ihre zuweilen verschiedenartige Ausbildung an den verschiedenen Segmenten bewirkt hanptsächlich die Differenzierung der bei gewissen Polychäten unterscheidbaren Körperregionen.

Viel höhere Ausbildung erlangen dagegen die im allgemeinen ähnlichen Gliedmaßenbildangen der Arthropoden. Obgleich sie bei einzelnen Formen noch kurz und stummelartig sind, werden sie bei der Mehrzahl recht lang, wobei ihre Beweglichkeit durch ihre Gliederung in zahlreiche gegeneinander bewegliche Abschnitte viel größer und mannigfaltiger wird. Wie die Parapodien der Anneliden können sie sich an sämtlichen Segmenten hervorbilden, wenn sie auch hänfig gewissen Segmenten oder selbst ganzen Regionen fehlen. Viel mehr als bei den Anneliden differenzieren sie sich an den verschiedenen Körperregionen zu besonderen physiologischen Leistungen. Das vorderste oder die beiden vordersten Extremitätenpare werden häufig, unter Anfgabe ihrer Bewegungsfunktion, zu Trägern besonderer Sinnesorgane (Fühler, Antennen). Die hierauf folgenden, den Mund umstehenden Gliedmaßen der Kopfregion werden, unter Verkürzung und eigentümlicher morphologischer Umbildung, zu Kiefergebilden (Gnathiten), während sich am hinteren Kopfabschnitt oder dem Thorax die Bewegungsextremitäten als lange Anhänge finden. Die Segmente des Abdomens tragen ebenfalls häufig, wenn auch kleinere Bewegungsextremitäten, die jedoch zuweilen teilweise oder sämtlich weitere Funktionen erlangen können.

Im größten Gegensatz zu den Arthropoden stehen die Gliedmaßen der Wirbeltiere. Sie zeigen nie Beziehnng zur Segmentation, sondern treten unabhängig von ihr in zwei Paaren auf, von welchen das vordere die vorderste, das hintere die hinterste Rumpfregion einnimmt. Daß diese Extremitäten sich erst in der Reihe der Wirbeltiere entwickelten, scheint sicher. Wie wir schon oben sahen, bildet ja 
der Schwanz das eigentliche Vorwärtsbewegungsorgan der ursprünglichen schwimmenden Formen. Die mögliche erste Entstehungsweise der Vertrebratenextremitäten soll später bei ihrer Skeletbildung erwogen werden; hier sei nur bemerkt, đaß die Gliedmaßen ursprünglich als einheitliche ruderartige Gebilde, zum Schwimmen eingerichtete sog. Flossen, auftreten. Der Übergang zum Landleben und zur Bewegung auf festem Untergrund bedingte eine ansehnliche Verlängerung der Extremitäten und ihre Gliederung in hebelartig gegeneinander bewegliche Abschnitte, wie es in analoger Weise anch bei den Arthropoden eintrat. Beide Extremitätenpaare differenzierten sich so in übereinstimmender Weise in Oberarm (Oberschenkel), Unterarm (Unterschenkel) und Hand (Fuß). Daß sich bei verschiedenen Vertebratengruppen die Extremitäten wieder teilweis bis völlig rückbilden, ist hinreichend bekannt.

Wenn wir in der Tierreihe im allgemeinen eine sich fortgesetzt steigernde Entfaltung vom Einfacheren zum Komplizierteren finden, so darf doch nicht übersehen werden, daß in zahlreichen Gruppen auch ein rückläufiger Bildungsgang einsetzen konnte, eine Rïckkehr zn einfacherer Organisation. Es ist keineswegs immer ganz leicht, derartig vereinfachte Formen als solche zu erkennen, weshalb sie auch hänfig, manche vielleicht noch heute, irrtïmlich als primitivere Ausgangsformen in das System eingeordnet wurden. Die Bedingungen für das Eintreten einer solchen Vereinfachung sind vor allem zweierlei. Einmal der Parasitismus, dessen Einfluß auf die Rückbildung der Elnähı'ungsorgane, des Sinnes-, Bewegungs-und Muskelapparats sich häufig in ganz erstaunlicher Weise äußert. Die Beieinflussung durch Parasitismus ist jedoch meist leicht festzustellen und daher in ihren Wirkungen unschwer zu erkennen. Andrerseits hat jedoch anch die Größe der Tiere einen erheblichen EinfluB. Eine beträchtliche Größe kann ohne relativ hohe Organisation nicht bestehen, was aus den allgemeinen Größenverhältnissen, die iu den verschiedenen Gruppen erreicht werden, hervorgeht. Dagegen kann die Größenabnahme innerhalb einer gewissen Gruppe von einer Vereinfachung der Organisation begleitet sein, indem die Stoffwechselprozesse bei verringertem Körpervolum anch durch die vereinfachte Organisation ausreichend vollzogen werden können. Beispiele einer solchen Vereinfachung finden sich in verschiedenen Tiergruppen, so z. B. bei den Arthropoden, wo sowohl bei Krebsen als Tracheaten Atmungs- und Blutgefäßsystem mit der Reduktion der Körpergröße gauz schwinden können. Auch weitere, zum Teil wenig ermittelte Bedingungen müssen Reduktionen einzelner Organe oder Organteile hier und dort hervorrufen, so z. B. des Afters in manchen Gruppen oder bei einzelnen Formen, ferner namentlich auffallende Rückbildung der früher bestandenen Segmentation in geringerem oder höherem Grad, der Bewegnngswerkzeuge nnd noch vieler anderer Organe. Ja es dürfte kaum eine Gruppe geben, wo nicht einzelne solche Rückbildungen die typische Charakteristik der Gruppe erschweren. Ferner kommt anch die Beschränkung der Rückbildung auf das eine Geschlecht vor bei Kurzlebigkeit desselben (Männchen der Rotatorien) oder bei der Entwicklung der Weibchen zu Hermaphroditen (Nematoden, Cirripedien). Jedenfalls ist die Möglichkeit von Rückbildung und Vereinfachung stets im Auge zu behalten, da sie nicht 
selten auftritt und auch zuweilen wobl da, wo die Ontogenie tiber die stattgefundene Reduktion nichts Sicheres mehr aussagt.

In neuerer Zeit hat man auch auf eine weitere Quelle nachträglicher Vereinfachung des tierischen Organismus hingewiesen und ihr zum Teil eine besondere Bedeutung für die Entstehung ganzer Gruppen einfacher Tiere erteilt. Gestützt auf gewissc Erfahrungen über gelegentliche Reife der Geschlechtsorgane vor endgültiger Entwicklung der übrigen Organe bei einzelnen Tierformen, hat man die Hypothese aufgestellt, daß in gewissen Fällen Larvenformen schon auf frühzeitiger Stufe ihrer Ausbildung geschlechtsreif werden konnten, und daß sie damit die, bei ihren Vorfahren folgenden späteren Stadien höherer morphologischer Ausbildung wieder allmählich oder event. auch plötzlich verloren hätten. Dieser, Neotenie benannte Vorgang führte also zu der Hypothese, daß gewisse Tiergruppen, die früber stets als ursprüngliche, vorfahrenähnliche anderer betrachtet wurden, so die Rotatorien unter den Würmern, die Copelaten unter den Tunicaten, geschlechtsreif gewordene Larvenformen wären, die phylogenetisch aus den höher organisierten Gruppen durch Vereinfacbung hervorgegangen seien; die Rotatorien aus Annelidenlarren, die Copelaten aus Ascidienlarren. Diese etwas paradox erscheinende Lehre, die ja in einzelnen Fällen zutrifft, wie bei der gelegentlich geschlechtsreif werdenden Tritonlarve, die sich vom erwachsenen Tier durch sehr geringfügige Larvencharaktere unterscheidet, bedürfte doch für ihre Ausdehnung auf ganze Gruppen noch eigentlicher Beweise. Wenn sich etwa zeigen ließe, daß bei den, als neotenisch rereinfacht angesprochenen Formen gelegentlich ein Rückschlag auf die höher entwickelten Stammformen vorkommt, dann könnte dies als ein solcher Beweis gelten. Ebenso erforderte diese Lehre zunächst eine Erklärung des Larvenbaues, wobei zu berücksichtigen sein wird, daß die Larven, wenn sie auch zum Teil besondere Anpassungscharaktere ausbilden, die erst durch ihre eigentümlichen Lebensverhältnisse entstanden, doch im Grundbau ihres Körpers auf einem gewissen ontogenetischen Stadium stehen geblieben sind, und daß diesem Stadium und daher auch dem Bau der Larven stets eine gewisse phylogenetische Bedeutung zukommt.

\section{Abschnitt.}

\section{Übersicht des Systems der Tiere mit Charakteristik der größeren Gruppen.}

Im Interesse des leichteren Gebrauchs dieses Buches und wegen der immerhin noch recht erheblichen Verschiedenheiten in der Abgrenzung der systematischen Gruppen ist es angezeigt, an dieser Stelle eine Übersicht der systematischen Einteilung einzuschalten, welche wir in den folgenden Kapiteln zugrunde legen. Hierdurch werden Mißverständnisse verhütet und die Orientierung erleichtert. Wie leicht begreiflich, können in einer linearen Aneinanderreihung der Gruppen ihre verwandtschaftlichen Beziehungen nicht zu korrektem Ausdruck gebracht werden; dies ist nur möglich in der Form eines sich verzweigenden Stammbaums. Ebenso muß es stets in gewissem Grade dem Belieben, bzw. dem Takt des einzelnen anheimgegeben bleiben, wo er die Grenzlinien höherer Abteilungen zieben, und auch welchen systematischen Rang er einzelnen Seitenzweigen des Stammbaumes beilegen will. Z. B. wăre es jedenfalls phylogenetisch durchaus korrekt, sämtliche rierfißßigen Wirbeltiere zu einer großen Abteilung der Tetrapoda zu vereinigen, da sie zweifellos gemeinsamen Ürsprungs sind. Ebensi korrekt erscheint es aber auch, die Anarnia (Pisces und Amphibia) zn einer Gruppe zu vereinigen, im Gegensatz zu den Amniota; es hăngt eben hier von dem Belieben ab, ob man die Grenzlinien tiefer oder höher zieht. Auch für die zweite Eventualität lassen sich viele Beispiele aufführen. So kann man die Gruppe der Pteropoden unter den Mollusken 
den Opisthobranchiaten, aus denen sie hervorgingen, unterordnen, oder kann sie auch nnter höherer Bewertung ihrè besonderen Charaktere als eine neben den Opisthobranchiata stehende Gruppe anspreçhen. Das gleiche gilt für das Verhältnis der Heteropoda zu den Prosobranchiata. - Eine befriedigente Übersicht des natürlichen Systems wird noch dadurcb sehr erschwert, daß namentlich in neuerer Zeit die Tendenz besteht, selbst in Lehrbüchern, welche doch vor allem den derzeitigen festen Bestand der Wissenschaft darlegen sollen, durch Reformen, unter Aufstellung vieler neuer ungebräuchlicher Namen, Neues zu bieten. Ebenso wird in den Spezialarbeiten durch beständige Aufstellung neuer Namen eine große Erscbwerung herbeigeführt. Auch für die größeren systematischen Gruppen sollte man das für die Species adoptierte System konservativer Bewahrung der älteren Bezeichnungen mehr festhalten, da sonst eine verwirrende Zersplitterung unausbleiblich ist.

\section{Unterreich (Subregnum): Protozoa.}

Einzellige, sich tierisch (ausnabmsweise auch zugleich pflanzlich, bis ganz pflanzlich) ernährende Formen; seltener zu Kolonien gleichartiger Individuen vereinigt.

\section{Phylum: Sarcodina.}

Bewegung und Nabrungsaufnahme durch Pseudopodien. Geißeln nur vorübergehend bei Fortpflanzungszuständen auftretend.

1. Klasse: Rhiz o poda. Wurzelfüßer. Fig. 6, $7,16$.

Teils nackt, teils beschalt. Schale von monaxonem Typus, einfach bis sehr kompliziert; teils häutig, meist kalkig, selten kieselig oder aus verkitteten Fremdkörpern bestehend. Pseudopodien lobos bis reticulos. Amoeba, Areella, Difflugia, Miliola, Pencroplis, Orbitolites, Lagena, Nodosaria, Rotalia, Opcrculina, Nummulitcs usw. Süßwasser und Meer. Seit Cambrium.

2. Klasse: Heliozoa. Sonnentierchen. Fig. 18.

Meist kugelig. Pseudopodien fädig, unverzweigt, häufig mit Achsenfaden. Keine Centralkapsel. Skelet fehlend, oder lose Kieselgebilde, selten Gitterkugel. Actinophrys, Actinosphaerium, Acanthocystis, Clathrulina usw. Meist Süßwasser.

3. Klasse: Radiolaria, Strahlfüßer. Fig. 19, 20 .

Urform kngelig, jedoch häufig abweichend. Hauptcharakter: Centralkapsel, welche den Hauptteil des Körpers mit den Kernen umschließt. Pseudopodien feinfädig bis schwach reticulos. Gallerthülle. Skelet meist vorhanden und sehr mannigfaltig. Lose Kieselgebilde, kieselige Gitterkugeln oder Gitterschalen bis poröse Schalen usw. Bei einer Gruppe aus radiären Stacheln von Strontiumsulfat bestehend (Acantharia). Sehr umfangreiche marine Gruppe. Seit Silur.

2. Phylum: Mastigophora (Flagellata). Geißelinfusorien.

Bewegung und Aufnahme fester Nahrung mit Hilfe von Geißeln. Fast stets einkernig. Vermehrung in der Regel durch Längsteilung.

1. Klasse: Flagellata (Euflagellata). Eigentliche Flagellaten. Fig. 8.

Ohne Kragen oder Bandgeißel. Zahl der Geißeln sehr verschieden. Körper teils nackt, teils mit häutiger, schaliger oder gehäuseartiger Umhüllung aus Cellulose oder Albuminoid, selten kieselig oder kalkig. Holozoisch bis holophytisch. Monas, Trichomonas, Trypanosoma, Petalomonas, Euglena, Chilomonas. Chlamydomonas, Volvox usw. Süßwasser, Meer nnd parasitisch.

2. Klasse: Choan of lagellata (Craspedomonadina). Fig. $9 \mathrm{~A}$.

Mit sog. Kragen um die Geißelbasis. Nackt oder mit gehănseartiger hăutiger Umhüllung. Holozoiscb. Codonosiga, Salpingoeca usw. Süßwasser und Meer.

3. Klasse: Dinoflagell at a (Peridinea), Bandgeißler. Fig. $9 B$.

Mit einer nach binten gerichteten Schleppgeißel und einer in Ringfurche den Körper umziehenden Bandgeißel. Nackt oder mit komplizierter Cellulosebülle. Meist holopbytisch. Peridinium, Ceratium usw. Meist Meer. 
4. Klasse: Cyst oflagè ll at a, BlasengeiBler.

GroB. Blasig-kugelig bis scheibenartig Ansehnliches Cytostom. Mit tentakelartiger Bandgeißel und kleiner gewöhnlicher Geißel. Keine Hülle. Holozoisch. Besonders Noctiluca. Meer.

\section{Phylum: Sporozoa.}

Geißeln nur bei Fortpflanzangsstadien. Meist keine Pseudopodien Weder Cytostom noch feste Nahrungsaufnahme. Bildung sporenartiger Fortpflanzungskörper. Parasitisch.

1. Klasse: Gregarinaria. (Telosporidia.) (Gregarinida, Coccidida und IIaemosporidia.) Fig. $13 e$.

Klein bis ansehnlich. Kugelig bis langgestreckt schlauchförmig. Fast stets einkernig. Keine Pseudopodien oder Geißeln. Intracelluläre oder extracelluläre Schmarotzer. Bei geschlechtlicher Fortpflanzung treten zum Teil geißeltragende spermoide Individuen auf. Coecidum, Plasmodium, Gregarina usw.

\section{Klasse: Sarcosporaria.}

(Diese und die zwei folgenden Klassen auch als Neosporidia zusammengefaßt.)

Ansehnliche schlauchförmige bis unregelmäßige Formen. Zahlreiche Kerne; mit fortdauernder Bildung einkerniger, nicht umhüllter kleiner Sprößlinge (Sporozoiten). Sareocystis.

3. Klasse: Myxosporaria und 4. Klasse: Microsporaria.

Unregelmäßige nicht umbüllte Protoplasmakörper mit zahlreichen Kernen. Zum Teil Pseudopodienbildung. Bildung zahlreicher endogener Sporen mit Nesselkapseln (Polkapseln). Sehr fraglieh, ob mit den typischen Gregarinaria näher verwandt und ob daher bierhergehörig. Myxobolus, Myxidium, Nosema usw.

4. Phylum: Infusoria. Infusorien.

Bewegung und Nahrungsaufnahme gewöhnlich mit Hilte von Cilien, oder doch während der Fortpflanzung Cilien vorübergehend auftretend. Meist zweierlei verschiedene Kerne (Macro- und Micronucleus). Fortpflanzung durch Querteilung oder Knospung.

1. Klasse: Ciliata. Wimperinfusorien. Fig. 11.

Im freien, wicht encystierten Zustand Bewegung und Nahrungsaufnahme stets mit Hilfe von Cilien. Cytostom selten rückgebildet. Bewimperung teils total, teils sehr verschiedenartig differenziert und reduziert. Macronucleus meist ansehnlich und recht verschiedenartig ausgebildet, selten mebrfach bis sehr fein zerteilt. Micronuclei ein- bis mehrfach. Selten nur eine Art von Kernen. Fortpflanzung fast stets $\mathrm{Zweiteilung,} \mathrm{selten} \mathrm{Knospung.} \mathrm{Pro-}$ rodon, Amphileptus, Chilodon, Paramaecium, Opalina, Stentor, Stylonychia, Oxytricha, Vorticella usw.

2. Klasse: Suctoria. Sauginfusorien (Acineten). Fig. 14.

Festsitzend. Bewimperung rückgebildet, nur während der Fortpflanzung auftretend. Ernährung durch ein bis zahlreiche hoble Saugtentakel. Fortpflanzung durch einfache Querteilnng oder äußere bis innere Ein- bis Mebrknospung. Podophrya, Acineta, Dendrocometes, Ophryodendron usw.

\section{Unterreich (Subregnum): Metazoa.}

Vielzellige Tiere mit differenten Geweben und Bildung. von sich ablösenden Propagations-(Geschlechts-) zellen für die geschlechtliche Fortpflanzung.

1. Kreis: Spongiae. Tierische Schwämme.

Fast stets aufgewachsen. Einfachster Bau etwa becher-bis schlauchförmig; mit zwei Gewebslagen. Innere Lage, welche die Centralhöhle auskleidet, einfache Kragenzellenschicht. ÄuBere Lage (Epiblast) mesenchym-bindegewebsartig; fast stets mit Skeletelementen. Centralhöhle mündet am Apicalpol durch sog. Osculum aus (zuweilen rückgebildet). Körperwand mit zahlreichen Einlaßporen für das Wasser und die Nahrung. Bei entwickelteren Spongien die Centralhöhle sehr kompliziert umgebildet; die Kragenzellen dann nur in zahlreichen Auswüchsen derselben, Syconröhren oder Geißelkämmerchen, die durch ein kompliziertes, mit den 
Poren und dem Rest der Centralhöhle zusammenhängendes Kanalsystem in Verbindung stehen. Keine eigentlichen Gonaden; Propagationszellen einzeln im Epiblast zerstreut. Getrenntgeschlechtlich oder hermaphroditisch. Entwicklung stets mit frei beweglichen Larren.

1. Klasse: Calcaria. Kalkschwämme.

Hierher einfachste bis komplizierter gebaute Schwämme. Skelet aus einfachen bis 3und 4-strahligen Kalknadeln (Spicula) bestehend. Meer. Seit Deron.

2. Klasse: Silicosa. Kieselschwämme.

Einfacher bis sehr kompliziert gebaute Schwämme mit aus sechs- bis einstrahligen Kieselnadeln bestehendem Skelet (selten Nadeln rückgebiidet). Spicula entweder lose oder durch Kieselsäure oder Spongin zu zusammenhängendem Skeletwerk rereinigt. Euplectella, Hyalonema, Geodia, Spongilla usw. Meist Meer. Seit Cambrium.

3. Klasse: Ceratosa. Hornschwämme.

Ohne Kieselnadeln. Nit Sponginfaserskelet. Euspongia (Badeschwamm) usw. Meer. 2. Kreis: Eumetazoa.

Metazoen, die sich von typisch gastraeaartigen Urformen herleiten.

1. Unterkreis: Radiata.

1. Phylum: Coelenterata.

Primitive Eumetazoenformen, welche den typischen Gasträabau bewahren. Kein After, nur Urmund. Fast durchaus regulär radiärsymmetrisch. Olnne primäre oder sekundäre Leibeshöhle. Mesenchym sehr verschiedengradig entwickelt. Einfache Gonaden, in Ecto- oder Entoderm entstehend und in der Regel sich in die Gastralhöble entleerend. Fast nur marin.

1. Subphylum: Cnidaria. Nesseltiere.

Mit Nesselkapseln im Ectoderm (zum Teil auch im Entoderm).

1. Klasse: Hydrozoa.

Individuen entweder polypenartig und festsitzend bis ïestgewachsen, oder medusenartig und freischwimmend. Gastralhöhle der Hydropolypen einheitlich, obne regelmäßige Septenbildung. Um den Mund fast stets zahlreiche, meist solide radiär geordnete Tentakel. Medusen glocken- bis schirmförmig mit musknlösem IIautsaum am Schirmrand (Velum) und nach der 4 bis $6-Z a h l$ geördneten taschenförmigen oder kanalartigen peripheren Ausläufern des centralen Gastralraums (Magen), ohne Gastralfilamente. Urmund der Meduse auf sog. Manubrium = Rüssel des Polypen. Mesenchym bei den Hydropolypen einfache Stützlamelle, bei den Hydromedusen Gallerte ohne Zellen. Gonaden, soweit bekannt, aus Ectodermzelleu hervorgehend.

\section{Unterklasse: Hydroidea.}

Sämtliche Individuen der Art entweder Hydropolypen oder Hydromedusen (kein Generationswechsel). Oder die ungeschlechtlich durch Knospung sich fortpflanzenden und in der Regel stockbildenden Individuen Hydropolypen, die geschlechtlich sich vermehrenden Individuen entweder freie Hydromedusen, oder an den sie bervorbringenden Polypen dauernd festsitzende Gonophoren (Geschlechtsgemmen).

1. Ordnung: Hydraridae.

Sämtliche Individuen Polypen, ohne Periderm- und ohne Stockbildung. Keine Gonophoren; Polypen hermaphroditisch.

Hyılra, Süßwassernolyp.

2. Ordnung: Tubularidae (Anthomedusae).

Polypen mit cuticularem Stielperiderm, obne cuticulares Gehäuse (Hydrotheca) des Polypenkörpers. Meist stockbildend. Mit Gonophoren oder freien Ilydromedusen (sog. Ocellątae oder Anthomedusae, meist mit Ocellen des Randes und mit Gonaden am Manubrium). Generationswechsel. Syncoryne, Eudendrium, Tubularia usw.

3. Ordnung: Campanularidae (Leptomedusae). Fig. 27.

Hydropolypen mit sog. IIydrotheca um den Körper. Stockbildend. Gonophoren teils festsitzend, teils sich ablösend, gewöhnlich an besonderen reduzierten Polypen (Blastostylen) 
entstehend. Hydromedusen (sog. Vesiculatae oder Leptomedusae) obne Ocellen, mit Statocysten; Gonaden an Radiärkanälen. Campanularia, Sertularia, Plumularia usw.

4. Ordnung: Hydrocorall in a (Milleporen).

Hydroidpolypenstöcke mit Ausscheidung ansehnlicher, zusammenhängender, feinnetziger Kalkskeletmasse zwischen den Zweigen der Kolonie. Polypen ohne Hydrotheca, teils mit Mund (Gastrozoid), teils ohne solchen (Dactylozoid). Medusoide Gonophoren; zum Teil auch sich ablösende Medusen. Millepora usw. Seit Tertiär (wenn die Stromatoporiden hierher gehören seit Silur).

\section{Ordnung: Trachymedusae ( + Narcomedusae).}

Sämtliche Individuen medusenartig (kein Generationswechsel). Mit aus Tentakeln hervorgegangenen Statocysten des Randes. Gonaden an Radiärkanälen oder -taschen.

2. Unterklasse: Siph on ophora. Röhrenpolypen.

Freischwimmende, von hydromedusenartigen Vorfahren sich ableitende, meist mehr oder weniger ausgesprochen koloniebildende Formen. Stets medusoide, zuweilen sich ablösende Gonophoren hervorbringend. Marin.

1. Ordnung: Disconanthae.

Mit kreisrunder, bis vierseitiger medusenschirmartiger Scheibe, die im Centrum der Unterseite ein ansehnliches Mannbrium trägt (Sipho). Um dieses einige toundlose Siphonen (Taster, Palponen), oder außerdem noch weitere kleinere Sipbonen. Rand der Scheibe mit Fangfäden, Im Dorsalteil der Scheibe ein ansehnlicher sog. Luftsack (Pneumatophore), der meist aus zahlreichen konzentrischen Ringkammern besteht, die durch Poren auf der Oberseite ausmünden. Gonophoren an Palponen entstehend, sich ablösend. Porpita, Velella usw.

2. Ordnung: Siphon anthae.

Kein schirmförmiger Stammteil mehr, sondern dieser nur durch blasen- bis flaschenartige Pneumatophore mit einfacher Öffnung (selten reduziert) gebildet. Der zuerst entstehende Sipho an seiner Basis stark auswachsend zn kürzerem oder längerem Stamm, an dem successiv weitere Siphonen, Palponen, Gonophoren und auch zum Teil medusenartige Anhănge gebildet werden. Siphonen an ihrer Basis gewöhnlich mit Tentakel; Palponen mit sog. Palpakel (ohne Seitenzwcige). Diese verschiedenartigen Anhänge häufg in regelmäßigen Gruppen angeordnet (Cormidien).

\section{Unterordnung: Cyst onectae.}

Die Anhănge bestehen nur aus Siphonen, Palponen sowie Gonophorentrauben. Pneumatophore sehr groß bis klein; im ersteren Fall (Physalia) bilateral symmetrisch mit seitlich verschobener Öffnung. Stamm teils sehr knrz (Physalia), teils sebr lang (Rhirophysa). Gonophoren sich selten ablösend (Q Physalia).

2. Unterordnung: A uronectae.

Pneumatophore sehr groß blasenartig, mit seitlichem eigentümlichem Anhang (Aurophore), der die Öffnung trägt. Stamm sehr kurz, mit einem Kranz sog. Schwimmglocken (Nectones), d. b. rudimentärer Medusen ohne Manubrium und Mund.

3. Unterordnung: Physonectae.

Mäßig große Pneumatophore mit apicaler Öffnung. Apicales Stammende (Nectosom) mit mebrreihiger Säule von Schwimmglocken (Nectones); seltener statt ihrer sog. Deckstücke (Bracteen, sehr rückgebildete Medusen ohne Glockenhöhle). Übriger Stamm kurz bis sehr lang. Hăufig Deckstücke zum Schutz der Gruppen von Anhängen. Physophora, Apolemia usw.

\section{Unterordnung: Calyconectae.}

Pneumatophcre rückgebildet. Apicales Stammende mit zahlreichen, zwei oder nur einem Necton. Palponen fehlen. Hippopodius, Diphyes, Monophyes. usw

\section{Klasse: S c y p ozoa.}

Individuen entweder polypenartig (sog. Scyphopolypen) oder medusenartig. Scyphopolypen mit vier bis mehr Gastralsepten. Medusen ohne eigentliches Velum, dagegen meist mit Randlappen, zum Teil mit Velarium. Gonaden aus Entodermzellen hervorgehend. 
1. Unterklasse: Acal e phae (Acraspedae). Scheibenquallen.

Erwachsene Formen von Medusenbau, jedoch zuweilen in festsitzenden Zustand übergegangen. Gestalt glocken-, becher- bis schirmförmig. Mesenchymgallerte in der Regel mit Fibrillen und Zellen. Ursprünglich vier Hauptsepten der Gastralhöhle und vier Gastraltaschen. All diesen Septen (interradial) Gastralfilamente. Gonaden 4 (selten 8) in den Interradien; meist mit sog. Trichter- oder Subgenitalhöhlen unter den Gonaden. Marin. Seit Cambrium.

1. Ordnung: Tesseroniae.

Größe mäßig. Kegel-, glocken-bis becherförmig; zum Teil mit stielförmig ausgewachsenem Apicalpol festgeheftet (speziell. Lacernaridae). Manubrium schwach, ohne Mundarme. Gastralhöhle mit vier Gastraltaschen, die meist nur durch kleine Verwachsungsstelle getrennt șind, seltener durch langes Septum (jedoch stets Ringkanal). Rand mit vier bis zahlreichen Tentakeln; teils ohne, teils mit zahlreichen Lappen. Zuweilen velnmartiger Randsaum (Cubomedusae). Randkörper teils fehlend (Stauromedusae), teils vier. Hufeisenförmige Gonaden interradial, zum Teil (Peromedusae, Lucernaridae und Cubomedusae) zu acht geteilt. Trichterhöhlen schwach bis ansehnlich entwickelt. Entwicklung wohl meist ohne Strobilation. Tessera, Lucernaria, Peromedusae, Charybdaea nsw.

2. Ordnung: Ephyroniae (Discomedusae). Scheibenquallen im engeren Sinne.

Mäßig bis sehr groß. Flach schirmförmig. Die vier ursprünglichen Septen der vier Gastraltaschen völlig rückgebildet, die peripherische Gastralhöhle in der Schirmregion in acht bis zablreiche, nach der Vierzahl angeordnete radiäre Taschen oder Kanäle zerlegt. Peripherer Ringkanal häuflg. Manubrium einfach (Cannostomeae) oder in 4-8 ansehnliche Mundarme ausgewachsen. Mund offen (Cannostomeae und Semaeostomeae) oder verwachsen und dafür zahlreiche seknndäre Saugöffnungen an den Armen (Rhizostomeae). Randlappen und Tentakel ursprünglich acht, häufig viel zahlreicher (die Tentakel zuweilen rückgebildet). Gonaden 4-8. Subgenitalhöhlen meist ansehnlich. Entwicklung gewöhnlich durch Scyphopolyp und Strobilation; selten direkt. Nausithö̈, Medusa, Rhizostoma nsw.

2. Unterklasse Anthozoa. Korallenpolypen.

Sämtliche Individuen stets scyphopolypenartig, von etwa cylindrischer Gestalt. Mit breiter Fußfäche festsitzend oder aufgewachsen. Mund schlitzartig; führt in Schlundrohr, das eine Einstülpung der Mundfläche, und sich in Gastralhöhle öffnet. Letztere mit nach der Vier- oder Sechszahl angeordneten, meist starken Septen, deren freier Rand sich zu sog. Mesenterialfilamenten verdickt. Um den Mund acht bis zahlreiche hohle Tentakel. An diesen und der Körperwand zuweilen feine Poren, die in Gastralhöhle führen. Skelet häufig. Ungeschlechtliche Fortpflanzung fast stets; sebr bäufig Koloniebildung. Gonaden an den Septen. Kein Generationswechsel. Marin.

1. Ordnung: Octocorallia. Achtstrahlige Korallen.

Acht Septen und acht gefiederte Tentakel. Mit innerer Bilateralität, da sämtliche Längsmuskeln (Muskelfahnen) der Septen in jeder Körperhälfte nach derselben Seite gerichtet sind. Ein Richtungsseptenpaar und eine Schlundrinne (Siphonoglyphe). Im Mesenchym fast stets freie Kalkskeletgebilde (Sclerodermiten).

1. Unterordnung: Alcyonaria ( + Pseudaxonia v. Koch).

Selten einzellebend. Kolonien teils aufgewachsen, teils frei. Kein horniges Achsenskelet (z. T. ein kalkiges bei Pseudaxonia, Corallium). Alcyonium, Corallium usw.

2. Unterordnung: Gorgonaria (Axifera v. Koch). Hornkorallen. Fig. 66.

Meist verzweigte, aufgewachsene Kolonien mit hornigem, oder hornig-kalkigem Achsenskelet, welches die ganze Kolonie durchzieht. Gorgonia usw.

3. Unterordnung: Pennatularia. Seefedern.

Kolonien meist nicht aufgewachsen. Stamm der Kolonie von anșehnlichem erstem Polyp gebildet, von dem die späteren seitlich hervorsprossen. Stamm häufig mit zwei Reihen seitlicher Zweige, an denen die Individuen sitzen. Meist horniges bis verkalktes Achsenskelet. Individuen zum 'I eil tentakellos. Pennatula usw. 
4. Unterordnung: Tubiporaria (Stolonifera). Orgelkorallen und Verw.

Kein massiges Cönenchym der Kolonie, sondern die Einzelpolypen durch Stoloneu iler durch plattenartige Ausbreitungen verbunden. Einzelpolypen zum Teil mit röhrenförmigem Kalkskelet in der Körperwand. Cornularia, Clavularia, Tubipora. Zahlr. fossile Genera.

5. Unterordnung: H elioporaria (Coenothecalia).

Massige Kolonien mit reichem Cönenchym, das von fein tubulärem Kalkskelet röhrig durchzogen ist. Die weiteren Röhren, welche den Einzelpolypen entsprechen, mit septenartigen radiären Vorsprüngen. Keine Sclerodermiten. Heliopora und zahlr. fossile Genera.

6. Unterordnnng: Tabulata.

Nur fossil, von Paläozoicum bis Mesozoicum. Teils mehr den Tubiporiden, teils den Helioporiden ähnlich.

3. Ordnung: Hexacorallia (Zoantharia). Sechsstrahlige Korallen.

Mit zwei Systemen ineinander geschachtelter Gastralsepten, deren Muskelfahnen nach entgegengesetzten Richtungen schauen. Die Septen in der Regel ein Vielfaches von sechs (häufig jedoch auch Abweichungen von dieser Regel). Die Septen der beiden Systeme meist paarweise zusammengeordnet, so daß die Muskelfahnen jedes Paares einander zugewendet sind; ansgenommen die beiden in die Mittelebene fallenden Paare, sog. Richtungsseptenpaare, deren Fahnen voneinander abgewendet sind. Sechs bis zahlreiche nicht gefiederte Tentakel. Ein oder zwei sog. Siphonoglyphen. Znm Teil mit Skelet; keine Sclerodermiten. Einzellebend oder koloniebildend.

1. Unterordnung; Antipatharia.

Individnen klein und jedenfalls mehr oder weniger rückgebildet. Stockbildend, gorgonienartig, mit Hornachse ähnlich Gorgonaria. Sechs Tentakel, zwei Siphonoglyphen, sechs stärkere Septen, von denen nur zwei mit Gonaden; dazu noch 4-6 schwăchere und kürzere Septen. Obne Muskelfahnen, Antipathes usw.

2. Unterordnung: Cerianth aria.

Einzellebend, actinienartig, skeletlos. Eine Siphonoglyphe. Zahlreiche völlig bilateral geordnete Septen ohne Muskelfahnen. Von dem achten Paar an entstehen die neuen Septenpaare successive in dem an der Siphonoglyphe gelegenen Binnenfach. Cerianthus usw.

3. Unterordnung: $\mathrm{Z}_{0}$ an $\mathrm{th}$ aria.

Meist stockbildend. Skeletlos. Eine Siphonoglyphe. Septenpaare bilateral angeordnet, da die seknndären Paare successive nur in den neben dem einen Richtungsseptenpaar gelegenen. beiden Binnenfächern auftreten. Zoanthus nsw.

4. Unterordnung: Hexactinari a (Cryptoparamera).

Typisch mit sechs ursprünglichen Septenpaaren, in deren Zwischenfächern successive neue Paare 2., 3. und weiterer Ordnung auftreten. Daher im allgemeinen sekundär zweistrahlig. Abweichungen treten auf durch noch nicht völlige Ausbildung der ursprünglichen sechs Paare, oder dadurch, daß gewisse Paare der zweiten und folgenden Ordnungen sich stärker elıtwickeln.

1. Actinaria (einschließlich Edwardsida und Goniactida).

Mit Fußscheibe festgeheftet, nicht aufgewachsen. Ohne Skelet und Koloniebildung. Actinia usw.

2. Madreporaria. Steinkorallen, Fig. 67.

Mit zusammenhängendem kristallinischem Kalkskelet, das sich im Bau dem Einzelpolyp anschlieBt. Einzellebend, meist stockbildend. Madrepora, Fungia, Astraea, Maeandrina, Oculina, Caryophyllia usw. Seit Paläozoicum.

5. Ordnung: Tetracorallia (Rugosa).

Nur fossil (Silur bis Perm). Meist aufgewachsen. Skelette sehr ähnlich denen der Madreporaria, meist stockbildend, ohne Cönenchym. Skeletsepten der Einzelkelche mehr oder weniger dentlich in vier Grnppen geordnet, welche von einem Haupt-, einem Gegenseptum und zwei Seitensepten geschieden werden. In den durch diese vier Septen gebildeten Räumen treten die sekundären Septen successive in bilateraler Folge auf. Zahlreiche Gattungen. 
Der bilaterale Bau wird häufig undeutlich und in einen strahligen umgewandelt. (Die Selbständigkeit dieser Gruppe wird heute vielfach angezweifelt und vermutet, daß sie richtiger den Madreporaria unterzuordnen sei, sich aus solchen durch Modifikation der Septenanordnung herleitete. Für die typischen Tetrakorallen scheint mir dies wonig wahrscheinlich, doch wäre ihr Bau auch bei dieser Auffassung so eigentümlich, um eine besondere Ordnung za rechtfertigen.)

\section{Subphylum : Aenidaria.}

Nesselkapseln sehr selten.

3. Klasse: C ten ophora: Rippenquallen. Fig. 22.

Freischwimmend, mäßig bis recht groß. Vierstrahliger Bau, der jedoch durch Auftreten paariger Organe sekundär zweistrahlig. Wahrscheinlich v on primitiven hydromedusenartigen Formen ablejtbar. Schirmhöhle der Meduse stark verengert zu sog. Schlundrohr, das in den Centralteil des Gastralapparates (sog. Trichter) führt. Von diesem gehen vier Radialgefäße aus, die sich gabeln und unter der Körperoberfläche in acht meridjonale Rippengefäße übergehen. Über diesen auf der Körperoberfläche acht Reihen von Ruderplättchen. Vom Trichter steigen zum Apicalpol zwei Gefäße auf, die hier ausmünden. Meist jederseits vom Mund ein Tentakel. Auf dem Apicalpol eigentümliche Statocyste. Körpergestalt kugelig (Cydippe, Eucharis), bis fingerbutförmig (Berö̈). Zuweilen in der Mittelebene etwas abgeplattet bis lang bandförmig ansgewachsen (Cestus). Hermaphroditisch. Entwicklung direkt. Marin.

\section{Anhang zu Coelenterata.}

Planuloidea (Mesozoa, Moruloidea).

Kleine bis sehr kleine, wahrscheinlich durch Parasitismus stark rückgebildete Metazoen, obne Gastralhöhle und Urmund. Mit solider innerer Zellmasse, die nur der Fortpflanzong dient (sog. Entoderm) und äußerer, gewöhnlich bewimperter einfacher Zelllage (sog. Ectoderm) ohne Nesselkapseln. Fortpflanzung sowohl durch befruchtete Eier als durch unbefruchtete Propagationszellen. Generationswechsel. Meist getrenntgeschlechtlich.

Die systematische Stellung dieser Formen ist sehr unsicher, da sie ebensowohl aus einfachen cölenteratenartigen Formen als aus plathelminthenartigen hervorgegangen sein könnten. Zuweilen werden sie auch als besondere Mittelstufe zwischen Protozoen und Metazoen (sog. Mesozoa) aufgefaßt.

\section{Klasse: Orthonectida.}

Körper der geschlechtlichen Generation wurmähnlich bis etwas abgeplattet. Äußere einschichtige, größtenteils hewimperte Zellschicht, deren Zellen in Gürteln angeordnet sind. Das Innere von einer Masse kleiner Zellen erfüllt, welche als Geschlechtszellen funktionieren. Unter der äußeren Zellschicht zum Teil (besonders bei ô) zarte längsmuskelfasern oder -fibrillen. Geschlechter getrennt oder zwitterig. Die ungeschlechtliche, durch Teilung sich vermehrende Generation tritt in Form sog. Plasmodien auf: unregelmäßi žal Protoplasmamassen mit Zellkernen. Die Geschlechtsgeneration bildet sicb aus endogen in diesen Plasmodien auftretenden Propagationszellen. Parasitisch in Ophiuren (Bursae), Turbellarien und Nemertinen (in Gonaden und an anderen Orten), sowie Polychäten (Cölom und an a. O.) Rhopalura usw.

2. Klasse: Rhombozoa (Dicyemida).

Gestalt der sich ungeschlechtlich (parthenogenetisch?) fortpflanzenden Generation (sog. Agamozoen) wurmastig. ÄuBere Zellschicht mit Gilien, die bei den Erwachsenen zuweilen rückgebildet. Vorderende gewöhnlich besonders differenziert (sog. Kopfkappe). Das Innere von einer einzigen großen einkernigen Axialzelle gebildet, in welcher die Propagationszellen (Agameten) endogen entstehen. Männchen klein kugelförmig, nur hinterer Teil bewimpert. Tnnerlich mehrere Zellen, ron denen sich vier zu Spermatozoen weiter vermehren. Die Weibchen bleiben auf früher Entwicklungsstufe stehen und verweilen in der Axialzelle des Muttertieres, indem ihre Zellen sich sämtlich zu Eizellen ausbilden. Die ơ werden dagegen frei. Generationswechsel. In den sog. Venenanhängen verschiedener dibranchiater Cephalopoden. Dicyema usw. 
Gewisse, ebenfalls parasitische Formen, wie Amoebophrya, Lohmanella usw., die man zuweilen dieser Gruppe anschließt, sind zu unsicher, um ihre Beziehungen genügend zu beurteilen.

\section{Unterkreis: Bilateria.}

Bilateraler Grundbau.

1. Phylum: Vermes. Würmer.

Typische, meist langgestreckte (swurmförmi $i_{\mathcal{C}}$ ) Bilaterien. Mit Protonephridien oder Nephridien, Cerebralganglien und Bauchnervensträngen.

Die hier aufgestellten Subphylen. ja einzelne Klassen, sind zuweilen auch als selbständige Phylen bezeichnet worden. Es ist dies, wie schon oben betont, mehr eine Nomenklaturfrage, da ja kaum Zweifel darüber bestehen, daß die hier unter dem alten Namen Vermes belassenen Gruppen gemeinsamer Herkunft sind.

\section{Subphylum: Amera.}

Unsegmentiert. Mit Protonephridien.

1. Klasse: Plathelminthes. Plattwürmer.

Meist dorsoventral stark abgeplattet. Unsegmentiert, doch zum Teil mit Wiederholung innerer Organe. Leibeshöhle fehlt (wohl rückgebildet). Dorsoventralmuskeln gut entwickelt. Keine Bauchganglienkette. Protonephridien.

\section{A. Aprocta.}

Obne After und Blutgefäße. Fast stets hermaphroditisch.

1. Unterklasse: Turbeliaria. Strudelwürmer.

Meist stark abgeplattet, oval bis langgestreckt. Oberfläche total bewimpert. Mund auf Ventralseite etwa in Mitte, oder weiter hinten, bei einem Teil auch weit nach vorn gerückt; fast stets mit vorstülpbarem Rüssel. Saugnäpfe selten. Geschlechtsorgane meist sehr kompliziert, zum Teil mit Dotterstöcken. Freilebend. Süßwasser und Meer, selten Erde.

1. Ordnung: Rhabdocoela. Fig. 48.

Meist klein. Darm sackartig, ohne Verzweigungen, höchstens gelappt (Alloiocoela). Zum Teil ohne Darmböhle, nur mit entodermaler Zellenmasse (Acoela). Meist Dotterstöcke. Geschlechtsöffnung einfach. Convoluta, Microstomum, Mesostomum usw.

\section{Ordnung: Dendrocoela.}

Meist größer. Darm mit zahlreichen seitlichen Zweigen.

1. Uritrordnung: Triclades.

Der vordere und die beiden hinteren Darmäste gleich gut entwickelt. Datterstöcke. Geschlechtsöffnung einfacis. Planaria, Geodesmus, Gundo usw.

2. Unterorinung: Polyclades.

Die beiden hinteren Darmäste kurz und schwach, 우 und of öf isg meist etrennt. Dotterstöcke fehlen. Thysamozoon, Eurylepta, Leptoplana nsw.

2. Unterklasse: Trematodes. Saugwürmer.

Mäßig bis mittelgroß. Meist stark abgeplattet, oval bis länger gestreckt. Mund am Vorderende, zum Teil im Grund von Mundsaugnapf, zum Teil Saugnäpfe neben ihm. Weiterhin ein bis mehrere Saugnäpfe auf der Bauchseite bis Hinterende. Vorderer Darmast fehIt; Darm meist zweigabelig, Äste einfach bis verzweigt. Dotteistücke stets. Geschlechtsöffnung einfach bis gesondert. Parasitisch.

1. Unterordnung: Polystomea (Monogenea).

Ventralfläche des Hinterendes meist mit mehreren zu Haftsoheibe vereinigten Saugnäpfen, häufig auch cuticulare Haken. Vorderende meist mit zwei kleinen Saugnäpfen neben dem Mund. Meist ectoparasitisch. Ohne Heterogonie. Polystomum, Tristomum, Diplozoon usw.

2. Unterordnung: Distomeae (Digenea).

Vorderende mit Mundsaugnapf. Ventralfäche meist noch mit einem Bauchsaugnapf. Entoparasitisch. Entwicklung mit Heterogonie und Wirtswechsel. Monostomum, Distomum usw. 


\section{Unterklasse: Cestodes. Bandwürmer.}

Mund und Darm völlig rückgebildet. Einfachste Formen trematodenähnlich, mit e in e m Geschlechtsapparat. Vorderende fast stets mit Saugnäpfen und zum Teil auch Hafthaken. Bei den späteren Formen Vermehrung der Geschlechtsapparate und starkes Auswachsen in die Länge; endlich Sonderung der Körperstrecken mit den einzelnen Geschlechtsapparaten als sog. Proglottiden. Entwicklung fast stets mit Wirtswechsel und eigentïmlicher Metamorphose; auch Vermehrung im Larvenzustand. Arehigetes, Caryophyllaeus, Ligula, Bothriocephalus, Taenia usw.

\section{Mit After und Blutgefäßen.}

\section{B. Proctucha.}

4. Unterklasse: Nemertina. Schnurwürmer.

Mäßig bis sehr groß. Langgestreckt, meist abgeplattet, selten rund. Oberfläche total bewimpert. Mund ventral, dicht hinter Kopfende; feine Afteröffnung hinten, endständig bis etwas dorsal. Über Darm ein langer ausstülpbarer Rüsselschlauch, der nahe an Kopfspitze ausmündet, oder mit dem Mund zusammen. Darm einfach, mit regelmäßig sich wiederlıolenden seitlichen Ausbuchtungen. Ansehnliche Cerebralganglien und darunter gelegene Ventralganglien, von denen zwei starke Bauchnerven nach hinten abgehen. Zwei seitliche Bauchcefäße und meist auch ein Dorsalgefäß. Zwei Protonephridien, meist auf Vorderregion beschränkt, mit ein bis mehreren öffnungspaaren. Getrenntes Geschlecht. Einfache Gonadenpaare, die sich mehrfach wiederholen. Hierin und in anderem eine Hinneigung zu metamerer Ausbildung. Carinella, Cerebratulus, Nemertes, Malacobdella usw. Meist Meer, doch auch Süßwasser und Land.

2. Klasse: Nemathelminthes. Rundwürmer.

Querschnitt meist rundlich bis völlig kreisrund. Unsegmentiert. After selten rückgebildet. Meist ein Paar Protonephridien. Leibeshöhle fast stets vorhanden, selten nachtrăglich ausgefüllt. Dorsoventralmuskeln fehlend bis wenig entwickelt. Ohne Blutgefäße. Getrenntgeschlechtlich.

1. Unterklasse: Rotatoria. Rädertierchen. Fig. 23.

Klein bis sehr klein. Querschnitt meist rundlich, seltener abgeplattet. Zweireihiger Wimperkranz (Räderorgan) in der Mundgegend. Mund selten in der Mitte der Bauchseite, sonst stets mit dem Räderorgan an das Vorderende gerückt. In der Regel fußartiger Anhang an der hinteren Bauchfläche, daher der After (der selten rückgebildet) dorsal gerückt. Die Protonephridien sowie die unpaare oder paarige Gonade münden fast stets in Enddarm (Cloake). Getrenutgeschlechtlich. ô fast stets sehr klein und stark verkümmert. Trochosphaera, Brachionus, Lacinularia, Asplanchna, Hexarthra, Rotifer, Floscularia usw.

2. Unterklasse: Nematorbyncha.

Sehr klein. Langgestreckt. Bauchfläche mehr oder weniger abgeplattet. Mund terminal, mit vorstülpbarem Borstenkranz in der Mundhöhle. After nahezu terminal zwischen zwei Furcalfortsätzen oder -borsten des Hinterendes, die selten rückgebildet. Wimperkranz feblt. Cloake nicht. Ein Paar Gonaden, die am Hinterende münden.

1. Ordnung: Gastrotricba.

Abgeplattete Ventralfläche von zwei Längscilienstreifen durchzogen; am Kopfende stärkere Cilien. Körpercuticula nicht geringelt, sondern fast stets zu Schuppen mit Stachelfortsatz entwickelt. After etwas dorsal gerückt. Furcalfortsätze selten rückgebildet. Ein Paar Protonephridien mit schwacher innerer Bewimperung. Chaetonotus, Ichthydium. Süßwasser.

2. Ordnung: Echinoderida.

Körperquerschnitt nahezu rund, Bauchfläche etwas abgeplattet. Cuticula dick und in eine Anzahl Ringe gegliedert; borstig. Vorderende mit Kränzen von Cuticularstacheln, kopfartig abgesetzt und rüsselartig aus- und einstülpbar. After terminal. Protonephridien münden hinten im vorletzten Körperring, die Geschlechtsöffnnngen im letzten Körperring. Echinoderes. Marin. 
3. Unterklasse: Nematodes. Fadenwürmer.

Klein bis ziemlich groß. Körper fast stets sehr langgestreckt, drehrund. After ventral, fast stets ziemlich weit vor Hinterende, selten terminal; daher mehr oder weniger langer Schwanz, der gewöhnlich einfach zugespitzt. Cuticula dick. Äußere und innere Wimperung fehlt völlig. After und Darm selten rückgebildet. Nur einfache Längsmuskellage. Protonephridien mehr oder weniger, zum Teil röllig rückgebildet; ihre Öffnung einfach, auf vorderer Bauchfläche. Gonaden einfach bis parig; bei $q$ fast stets durch einfache öffnung auf Bauchseite mündend, bei of siets durch Enddarm. Selten hermaphroditisch ron $\&$ Charakter.

1. Ordnung: Eunematodes.

Leibeshöhle nicht durch Zellgewebe ausgefüllt. Die ㅇ Gonaden mit besonderer bauchständiger Iündung. đ Gonaden in Enddarm mündend. Freilebend oder parasitisch. Dcsmoscolex, Tylenchus, Rhabditis, Sclerostomum, Ascaris, Oxyuris, Trichocephalus, Trichina, Filaria, Mermis usw.

2. Ordnung: Gordiida. (Nematomorpha,)

Darm stark rückgebildet. Leibeshöble alurch Zellgewebe ausgefüllt. Gonaden beider Geschlechter in Enddarm führend. Geschlechtsreif freilebend, frühere Entwicklung parasitisch. Gorlius usw. Süßwasser.

\section{Unterklasse: Acanthocephala. Kratzer.}

Ziemlich groß; langgestreckt, drehrund. Darm völlig rückgebildet. Vordere Körperregion zn einstúlpbarem, mit Kränzen von cuticularhaken bewaffnetem Rüssel rerschmälert. Ring- und Längsmuskulatur. Ligentünliches Gefäßsystem der Haut und der in die Leibesböhle hängenden sog. Lemnisken. Leibesnöhle weit. Protonephridien meist rückgebildet. Gonaden ursprünglich parig; mit paarigen Leitern, die am Hinterende durch einfache Öffnung münden. Bei $\subseteq$ hängen die Cronaden mit den Leitern nicht direkt zusammen. Echinorhynchus. Parasitisch.

2. Subphylum: Annelida (Annulata, Polymera). Gliederwürmer.

Typisch segmentiert, jedoch die Metamerie zum Teil wieder stark rückgebildet. Cölom, das jedoch ebenfalls zum Teil wieder sehr rückgebildet. Blutgefäßsystem (selten reduziert).

After stets. Nephridien. Geschlechtsverhältnisse verschieden.

1. Klasse: Chaet o poda. Borstenwürmer.

Klein bis sehr groß. Meist drehrund, äußere Gliederung deutlich. Borstentaschen mit Cuticularborsten an den Segmenten (sclten rückgebildet). Cölom nicht reduziert; Dorsoventralmuskeln wenig. Blutgefäße meist reich entwickelt, selten reduziert. Entleerung der Geschlechtsprodukte meist durch Nephridien.

1. Ordnung: Oligochaeta.

Ohne Parapodien der Segmente und ohne besondere Auszeichnungen des Kopfendes. Hermaphreditisch. Nais, Chaetogaster, Tuhifex, Criodrilus, Lumbricus usw. Süßwasser und Land.

\section{Ordnung: Polychaeta.}

Mit Parapodien (selten rückgebildet). Kopf bildung häufig kompliziert. Kiemen häuftg. Meist getrenntes Geschlecht. Sehr große Ordnung. Nereis, Alciope, Aphrodite, Arenicola, Terebella, Scrpula usw. Fast nur marin.

2. Klasse: Hirudinea. Blutegel.

Äußere Metamerie stark rückgebildet. Bauchseite abgeplattet. Ohne Parapodien, Borsten meist völlig reduziert. Mundsaugnapf und hinterer Saugnapf. Cölom zu sekundärem Blutgefäßsystem reduziert. Dorsoventralmuskeln reich entwickelt. Hermaphroditisch, Geschlechísprodukte durch eigenartige Leiter entleert. Piscicola, Clepsine, Nephelis, Haemopis (Aulastomum), Hirudo usw. Süßwasser und Meer.

3. Klasse: Ge phyrea. Sternwürmer.

Äußere Metamerie stark rückgebildet. Cölom gut entwickelt, jedoch Dissepimente völlig reduziert. Blutgefäße mäßig ansgebildet; rielleicht bis völlig reduziert. Borsten nahezu 
bis völlig geschwunden. Nervöser Bauchstrang ungegliedert. Nephridien auf wenige, bis ein Paar reduziert. Getrenntgeschlechtlich. Ausleitung der Geschlechtsprodukte durch Nephridien. Marin.

1. Unterklasse: Cha etiferi.

Kopfzapfen (Rüssel) meist sehr ansehnlich (selten rückgebildet). Einige Borsten gewöhnlich erhalten. After terminal. Echte Blutgefäße. 1-2 Paar vordere Nephridien (selten unpaar); eigentümliches hinteres Nephridienpaar in Verbindung mit Enddarm. Echiurus Thalassonema, Bonellia usw.

2. Unterklasse: A chaeta (Inermes).

Kopfzapfen ganz rückgebildet, Mund daher terminal, auf ein- und ausstülpbarem vorderem Körperabschnitt (Riissel). Borsten fehlen. Echte Blutgefäße wohl fehlend. After terminal oder auf Rücken weit nach vorn gerückt. Höchstens ein Nephridienpaar.

1. Ordnung: Sipunculida.

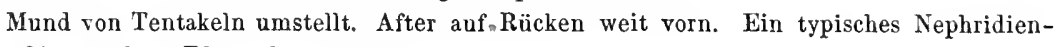
paar. Sipunculus, Phascolosoma usw.

\section{Ordnung: Priapulida.}

Ohne Tentakel. After terminal, etwas rückständig. Keine typischen Nephridien, dagegen ein hinteres Paar meist mit Gonaden in inniger Verbindung; Öffnung neben After. Halicryptus, Priapulus.

\section{Subphylum: 0ligomera.}

Zwei bis drei wenig deutliche Segmente.

1. Klasse: Tentaculata (Oligomera, Prosopygia).

Bilateral, mit zum Teil stielförmig ausgewachsener hinterer Bauchfläche festgeheftet. Wenig deutlich segmentiert (wahrscheinlich mehr oder weniger reduziert); 2-3 Segmente, ăußerlich nicht kenntlich. Mund im 2. Segment ventral, bis terminal verschoben, von wimpernden Tentakelcirren umstellt. After auf Dorsalseite oder seitlich nach vorn verschoben. Blutgefäße bei einem Teil. Cerebralganglien und Schlundring. 1-2 Paar Gonaden an Cölomwand, durch Nephridien entleert.

\section{Ordnung: Phoronidi.}

Mäßig groß. Körper langgestreckt wurmförmig, in aufgewachsener cuticularer Röhre. 1. Segment zu sog. Epistom verkümmert, 2. sehr kurz, hinteres sehr lang. Mund etwas ventral; Tentakelcirren jederseits rom Mund in spiral eingerollter Doppelreihe (auf nur schwach erhobenen zwei Lophophorarmen), wovon die äußeren ventral vom Mund ineínander übergehen. After dorsal, dicht hinter Lophophor. Cölom weit; ein Dissepiment hinter dem Mund; Lăngsmesenterium im Rumpfsegment (3.) erhalten. Ein Paar Nephridien. Hermaphroditisch. Ungeschl. Fortpflanzung fehlt. Marin.

\section{Ordnung: Bryozoa. Moostierchen.}

Élein, festsitzend bis aufgewachsen; meist mit starker, häufig verkalkter Cuticula (sog. Ectocyste). Um den Mund eir Kranz von Tentakelcirren. Erstes Segment zu Epistom oder ganz rückgebildet. After dorsal, weit vorn. Ein Dissepiment wie Phoronida; Längsmesenterium rückgebildet. Ein Paar Nephridien bei Teil erhalten. Meist hermaphroditisch. Ungeschlechtliche Fortpflanzung durch Knospung, daher fast stets reiche Koloniebildung. Seit Silur.

1. Unterordnung: Ectoprocta.

After außerhalb des Tentakelcirrenkranzes. Cölomhöhle erhalten. Vorderende mit Tentakelcirren einstülpbar. Stets Kolonien.

\section{Lophopoda.}

Tentakelcirrenkranz zu hufeisenförmigem Lophophor nach der Dorsalseite ausgewachsen. Epistom. Plumatella, Cristatella usw. Süßwasser. 


\section{Stelmatopoda.}

Kein Lophophor, Tentakelcirren im Kreis um den Mund. Epistom fehlt. Zahlreiche Gattungeu. Fast nur marin.

\section{Unterordnung: Entoprocta.}

Tentakelcirren im Kreis um den Mund. Epistom fehlt. After ins Innere des Cirrenkranzes gerückt. Vorderende nicht einstülpbar. Cölom von Zellgewebe erfüllt. Zum Teil Kolonien. Marin. Pedicellina usw.

2. Klasse: Brachiopoda. Armfüßer. Fig. 28.

Mäßig große Tiere, ınit stielförmig, ausgewachsener, hinterer ventraler Körperfläche sich festheftend (Stiel selten rudimentär). Körper breit; dorsorentral, mehr oder weniger abgeplattet. Wahrscheinlich drei Segmente und zwei Dissepimente. Von der Vorderregion des 2. Segments erhebt sich ventral und dorsal je ein ansebnlicher Hautlappen (Mantel). Beide Mantellappen, samt der hinteren Körperfläche, scheiden je eine verkalkte Schalenklappe ab. Mund ventral schanend; jederseits von ihm ein meist langer, spiral aufgerollter Mundarm, der zwei (selten nur eine) Reihen von Tentakelcirren trägt. Selten statt frei sich erhebender Arme nur Tentakelcirrenkranz. Das zu einer sog. Mundfalte ausgewachsene Epistom setzt sich ais Armfalte auf die Arme fort. Mantelränder mit cuticularen, chätopodenartigen Borsten besetzt. Paarige Leberdrïse stets. After meist rückgebildet (Testicardines); wenn vorhanden auf rechter Seite, oder bei fehlendem Stiel am Hinterende. Blutgefäßsystem nit dorsalem Herz. Cerebral- und Ventralganglien. 1 bis 2 Paar Nephridien und Gonaden. Erstere funktionieren als Geschlechtsleiter. Getrenntgeschlechtlich. Obne ungeschlechtliche Fortpfanzung. Lingula, Crania, Terebratula, Rhynchonella usw. Marin. Seit Cambrium.

3. Klasse: Chaetognatha. Pfeilwürmer.

Typisch bilateral. Langgestreckt; Querschnitt rund. Drei Segmente; mäßiges Kopf-, langes Rumpf- und mäßiges Schwanzsegment. Mund ventral auf Kopf oder nahezu terminal; jederseits mit Gruppen kieferartiger Haken (event. aus Tentakelcirren hervorgegangen). Mantelartige, nach vorn gerichtete Hautduplicatur am Kopf. After ventral, auf Grenze von Rumpfund Schwanzsegment. Nur Längsmuskellage. Cerebral- und ansehnliches Ventralganglion im Rumpf. Cölom mit zwei Dissepimenten; Längsmesenterien in Rumpf. Blutgefäße fehlen. Nephridien fehlen oder eventuell zu Geschlechtsleitern geworden. Ein Paar Ovarien in Rumpf, ein Paar Hoden in Schwanz. Marin. Sagitta usw.

\section{Klasse: Brauchiotremata (Willey).}

Bilateral. Drei Segmente. Vorderdarm mit einem Paar Kiemenrinnen oder ein bis zahlreichen Kiemenspalten. Vorderes Ende des Mitteldarms mit nach vorn gerichtetem solidem Divertikel (Chorda?). Marin.

1. Unterklasse: Pterolranchia (Diplochorda, Discocephala). Fig. 79.

Sehr klein, festsitzend oder festgewachsen. Mit lophophorartigen, zwei Reihen bewimperte Tentakelcirren tragenden Mundarmen, die vom 2. Segment entspringen. Drei Segmente, Kopfschild, Kragen (Hals) und Rumpf. Hintere Bauchfläche des Rumpfes zu contractilem Stiel ausgewachsen. Ein Paar Kiemenrinnen oder Kiemenspalten führen in vorderen Darmabschnitt. Kopfschild- und Kragencölom je mit einem Paar Poren (Nephridien?). Vorderende des Mitteldarms mit nach vorn gerichtetem solidem Divertikel (Chorda?). After weit vorn, dorsal. Blutgefäßsystem rudimentär. Eine paarige oder unpaare Gonade im Rumpf, in Aftergegend ausmündend. Getrenntgeschlechtlich. Ungeschlechtliche Fortpflanzung durch Knospung.

\section{Ordnung: Rhabdopleurida.}

Zwei lophophorartige, Tentakelcirren tragende Arme. Zwei in den Mund fübrende F iemenrinnen; keine Kiemenspalten. Koloniebildend. Starke cuticulare Röhren der Einzeltiere, die durch einen eigentümlichen sog. Stolo, der in die Wand der Gehäuseröhren aufgenommen ist, sämtlich zusammenbängen. 
2. Ordnung: Cephalodiscida.

Mit zwei Tentakelcirren tragenden Armen. Ein Paar Kiemenspalten. Koloniebildend, doch die Einzeltiere nicht durch Stolo verbunden, in unregelmäßig rerzweigten, zusammenbängenden Röhren.

\section{Unterklasse: Graptolithida. Graptolithen.}

Eigentümliche, nur auf die Silurformation beschränkte Gruppe, die gewöhnlich zu Hydroida gestellt wird, jedoch sehr wahrscheinlich mit den Rhabdopleurida nahe verwandt war. Nur die cuticularen Gebäuse der kleinen, meist festgewachsenen Kolonien bekannt. Von recht mannigfaltigem Ban. Die wichtigste Übereinstimmung mit den Rhabdopleurida ist das Vorhandensein einer, dem Stolo der letzteren vergleichbaren Achse (Virgula) in der gemeinsamen. Gehäusewand.

3. Unterklasse: Enteropneusta (Hemichorda). Fig. 78.

Khlein bis groß. Freilebend. Kopfsegment zu ansehnlicher sog. Eichel entwickelt, ohne Arme und Tentakelcirren. Hierauf folgt kurzes Kragensegment; dann langes, wurmartiges Rumpfsegment, das mehrere Abschnitte unterscheiden läßt. Mund rentral, auf Grenze ron Kopf- und Kragensegment. After terminal. Mundhöhle mit Divertikel (Chorda`), das in Eichel hineinragt. Vorderdarm mit zahlreichen parigen Kiemenspalten, die auf Dorsalseite des Rumpfsegments sich öffnen. Eichelsegment mit 1 bis 2 Poren, Kragensegment mit 2 Poren. Blutgefäßsystem vorhanden. Gonaden in vielen Paaren im Rumpf. Getrenntes Geschlecht. Entwicklung mit sog. Tomaialarve oder direkter. Balanoglossus usw.

3. Phylum: Arthropoda. Gliederfüßler.

Stets typisch bilateral. Segmentiert, mit fast immer scharfer Ausprägung der äußeren Segmentation (selten stark rïickgebildet). Cuticula chitinös, meist dick. Segmente mit je einem Paar meist ansehnlicher und dann gegliederter Extremitäten. Heteronomie der Extremitäten und damit Regionenbildung des Körpers gewöhnlich sehr ausgeprägt. Blutgefäßsystem typisch; zuweilen jedoch reduziert und dann mit Cölom zusammengeflossen, oder dies eventuell auch stark reduziert. Nephridien gewöhnlich nur in wenigen Segmentẹn oder ganz fehlend. Cilienbildnng fehlt stets. Fast nie geschlossener Hautmuskelschlauch. Muskelzellen fast stets sämtlich quergestreift. Getrenntgeschlechtlich (ausnahmsweise sekundär hermaphroditisch). Gonaden nicht segmentiert, stets mit besonderen Leitern. Entsprangen wahrscheinlich nicht von typischen Anneliden, sondern von rundwurmartigen Ausgangsformen derselben.

1. Subphylum: Tardigrada. Bärtierchen.

Sehr kleine, jedenfalls etwas verkümmerte Formen, mit nur vier Segmenten; ohne Regionenbildung, Gnathiten, Nephridien, Atemorganen und Blutgefäßen. Gonaden münden in Enddarm (Cloake). Land und Wasser (auch Meer).

2. Subphylum: Tracheata. Tracheenatmer.

Gnathiten (Kiefer) und Körperregionen stets entwickelt. Keine Cloake. Atmung durch Luftröhren (Tracheen), wenn nicht rückgebildet. Malpighische Gefäße i.d. R. - Blutgefäße selten ganz rückgebildet. Keine Statocysten.

1. Klasse: Protracheata (Onychophora).

Nur̉ Kopf und wielgliedriger langer Rumpf. Gliedernng äußerlich undeutlich. Cuticula dünn. Kopf mit ein Par Fühlern und zwei Paar reduzierten Gnathiten, sowie ein Paar eigentümlicher Augen. Extremitäten kurz stummelförmig, mit Coxaldrüsen. Geschlossener Hautmuskelschlauch aus glatten Muskelfasern. Nephridien in fast allen Segmenten. Zahlreiche feine Tracheenöffnungen auf jedem Rumpfsegment. Malpighische Gefäße fehlen. Bauchnervenstränge nicht zu Bauchmark vereinigt. Einfache Geschlechtsöffnung dicht vor After. Peripatus usw. Land.

\section{Gruppe: Eutracheata.}

An den Rumpfsegmenten nicht mehr wie je ein Paar Tracheenöffnungen (Stigmen). Kein gesehlossener Hautmuskelschlauch, Muskeln quergestreift. Nephridien in geringer Zahl, stark reduziert bis fehlend. Meist Malpighische Gefäße (Excretionsorgane). 
2. Klasse: Arachnoidea (Chelicerata). Spinnenartige.

Körper in Kopf (Cephalosom, früher sog. Cephalothorax) und Rumpf (früber Abdomen), oder in Rumpf und Abdomen (früher Postabdomen) differenziert. Kopf ohne dorsalständige Antennen, gewöhnlich mit sechs Extremitätenparen (jedoch wahrscheinlich überall ursprünglich 7 Segmenten). 1. und 2. Extremitätenpaar gnathitenartig, 3. bis 6. lange Bewegungsbeine. Rumpf (sog. Abdomen) bei Teil mit wenigen rudimentären Extremitätenpaaren. Ein bis mehrere Paare Ocellen, keine Komplexaugen. Darm meist mit seitlichen Drüsenanhängen (zum Teil leberartig). Malpigh. Gefäße meist, Coxaldrüsen (Nephridien) zuweilen.

\section{Tribus: Euarachnoidea.}

Nur sechs Extremitätenpaare am Cephalosom. Geschlechtsöffnung unpaar, an Ventralflăche der Vorderregion des Rumpfes, bis weiter vorgerückt.

1. Unterklasse: Arthrogastres.

Mit äußerlich deutlich segmentiertem Rumpf.

1. Ordnung: Scorpionida. Skorpione.

Groß. Rumpf in vorderen Abschnitt (sog. Präabdomen) und hinteren (sog. Postabdomen) differenziert. Endsegment des letzteren mit Giftstachel. 1. Gnathiten klein scherenförmig, 2. Gnathiten sehr lang, mit Schere. Vier Paar Stigmen mit Tracheenlungen an 3 . bis 6. Rnmpfsegment. Land. Scorpio usw. Seit Silur.

2. Ordnung: Pseudoscorpionida. Bücherskorpione.

Klein; ähnlich Scorpionida, jedoch ohne Differenzierung des Rumpfs in zwei Abschnitte und ohne Giftstachel. Zwei Par Stigmen (2. und 3. Rumpfsegment), Tracheen. Chelifer usw. Land.

3. Ordnung: Pedipalpi. Geißelskorpione.

Groß. 1. Gnathiten klanenförmig, 2. klauen- bis scherenförmig, mittellang. 1. Beinpaar lang geißelartig. Rumpf einfach bis Hinterregion etwas differenziert. Zwei Paar Tracheenlungen am 2. bis 3. Rumpfsegment. Telyphonus, Phrymus usw. Land. Seit Karbon.

4. Ordnung: Solifugae (Solpugida). Wüstenspinnen.

Groß. Die drei hinteren Segmente rom Cephalosom abgegliedert. 1. Gnathiten scherenförmig; 2. Gnathiten lang beinartig. Rumpf einheitlich. Tracheen mit vier Paar Stigmen. Galeodes, Solpuga usw. Land.

5. Ordnung: Opilionida (Phalangida). Weberknechte.

Mäßig groß. Rumpf einheitlich, klein. 1. Gnathiten scherenförmig; 2. klein palpen„ürmig. Beine bei Teil sehr lang. Tracheen. Ein Paar Stigmen. Phalangium, Trogulus "Isw. Land.

\section{Unterklasse: Hologastres.}

Rumpf einheitlich, äußerlich nicht segmentiert.

\section{Ordnung: Araneida. Webespinnen.}

1. Gnathiten klauenförmig mit Giftdrüse, 2. Gnathiten kurz palpenförmig. Zwei Stigmenpaare am Rumpf, beide mit Lungen oder das hintere, häufig in unpaare Spalte zusammengerückte, mit Tracheen. Spinnwarzen mit Spinndrüsen am ventralen Rumpfende. Epeira, Avicula usw. Land und Süßwasser. Seit Karbon.

2. Ordnung: A carina. Milben.

Klein; häufig parasitisch. Rumpf mit Cephalosom verschmolzen. Gnathiten häuflg zu Stechrüssel umgebildet. Ein Paar Stigmen mit Tracheen (bei Teil ebenso wie Blutgefäße verkümisert). Ixodes (Zecke), Gamasus (Küfermilbe), Hydrueluna (Wassermilbe), Sarcoptes (Krätzmilbe) usw.

\section{Tribus: Linguatulida. Zungenwürmer.}

Endoparasitisch und daher stark rückgebildet und umgestaltet. Äußere Segmentation geschwunden; Körper langgestreckt, abgeplattet bis rund. Extremitäten rückgebildet bis auf zwei Klammerhaken in der Mundgegend. Blutgefäße und Respirationsorgane fehlend. Einfache Geschlechtsöffnuug bei $Q$ am Hinterende, bei $\delta$ in Mundgegend. Pentastomum usw. 


\section{Tribus: Pantopoda. Asselspinnen.}

Spinnenartige, marine, mäßig große Tiere. Cephalosom mit 2 bis 3 Paar gnathitenartigen Extremitäten, die jedoch bei Teil rudimentär werden bis auf das eiertragende 3 . Paar der $\widehat{ }$. 1. Gnathiten scherenförmig, 2. bis 3. tasterförmig, 4. bis 7. Extremitäten beinförmig. Coeca des Darmes sehr lang, die Beine durchziehend. Atmungsorgane fehlen. Herz vorhanden. Paarige Geschlechtsöffnungen an einem bis sämtlichen Beinpaaren. Meer.

3. Klasse: Myriopoda. Tausendfüßer.

Klein bis groß. Nar Kopf und Rumpf; Kopf ursprünglich wohl mit sechs Segmenten. Rumpf meist sehr segmentreich. und fast sämtliche Segmente mit mäßig langen, gutgegliederten Extremitảten. Kopf mit einem dorsalen Antennenpaar. Cuticula stark, zum Teil verkalkt. Ocellen zahlreich, selten komplexaugenartig zusammengedrängt. Leberdrüsen fehlen. Land. Seit Devon.

1. Ordnung: Diplopoda (einschließlich Scolopendrella und Pauropus).

Kopf fast stets mit nur zwei Paar Gnatbiten. Querschnitt meist rund. Cuticulare Rücken-

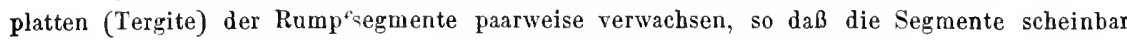
zwei Paar Extremitäten tragen. Paarige Geschlechtsöffnungen weit vorn.

Iulus, Polydesmus, Glomeris usw.

\section{Ordnung: Chilopoda.}

Querschnitt abgeplattet. Kopf mit drei Paar Gnathiten; die 3. zu einer Unterlippe verwachsen. 1. Rumpfextremitäten zu sog. Raubfüßen mit GifŁdrüse entwickelt. Keine Verwachsungen der Tergita. Einfache Geschlechtsöffnung hinten, dicht vor After. Scolopendra, Lithobius, Geophilus, Seutigera usw.

4. Klasse: Insecta (Hexapoda). Insekten, Kerle:

Kopf (fünf Segmente); Thorax (drei Segmente) und Abdomen (wohl ursprünglich zwölf Segmente). Kopf mit Antennen und drei Paar Gnathiten; die 3. zu Unterlippe verwachsen. Thorax mit drei Paar ansebnlichen Bewegungsextremitäten und häufig am 2. und 3. Segment zwei dorsalen Flügelpaaren. Abdomen zum Teil mit einigen rudimentären Extremitäten. Meist ein Paar sehr ansehnliche Komplexaugen; dazu häufig Scheitelocellen. Einfache Geschlechtsöffnung dicht vor After. Land, Wasser und parasitisch. Seit Karbon.

1. Unterklasse: A p teryg ota.

Klein. Stets flügellos. Ametabol. Campodea, Podura (Springschwänze), Lepisma (Zuckergast) usw.

\section{Unterklasse: Pterygota.}

Geflügelt, jedoch Flügel zuweilen teilweise bis völlig rückgebildet.

1. Ordnung. Orthoptera. Geradflügler.

Beißende Mundwerkzeuge. Zwei gleiche bis wenig ungleiche Flügelpaare, die entweder nicht oder fächerartig einfaltbar sind (zuweilen rückgebildet). Ametabol bis hemimetabol. Die frühere Ordnung wird jetzt häufig in zablreiche zerlegt; so: eigentl. Orthoptera (Schaben, Heuschrecken, Grillen); Dermaptera (Ohrwürmer); Thysanoptera (Blasenfüßer); Corrodentia (Bücherzäuse, Termiten, Pelzfresser); Embidaria; Plecoptera (Afterfrühlingsfliegen); Ephemeroidea (Eintagsfliegen); Odonata (Libellen).

\section{Ordnung: Nenroptera. Netzflügler .}

Beißende Mundwerkzeuge. Zwei gleiche feinnetzig geäderte, nicht einfalthare Flügelpaare. Holometabol. Auch diese frühere Ordnung wird jetzt häufig in mebrere zerlegt, so: die Neureptera im engeren Sinne (Ameisenlöwen und Verw.); Panorpatae (Skorpionsfliegen); Trichoptera (Kö̀cherfliegen).

\section{Ordunng: Strepsiptera. Fächerfiügler.}

Kleine Gruppe, deren 우 Endoparasiten sind und daher auf Larvenstadium verweilen. Bei $₫$ die Vorderflügel rudimentär, die Hinterflügel groß, fäeherartig faltbar wie die der Orthoptera. Metabol.

4. Ordnung: Coleoptera. häfer.

Beißende Mundwerkzenge. Dás vordere Flügelpaar zu Flügeldecken (Elytren) verdickt; das hintere auch von hinten nach vorn einfaltbar. Metabol. Ungemein große Gruppe. 
5. Ordnung: Hymenoptera. Hautflügler.

Mundwerkzeuge beißend bis leckend, durch Umgestaltung und Verlängerung der Unterlippe zu Leckapparat. Die beiden Flügelpaare gleich, spärlich geädert. Metabol. Blattwespen, Holzwespen, Gallwespen, Schlupfwespen, Ameisen, Grabwespen, Bienen, Hummeln.

6. Ordnung: Rhynchota. Schnabelkerfe.

Mundwerkzeuge saugend und stechend; Unterlippe zu gegliederter Rïsselröhre ausgewachsen. Mandibeln und 1. Maxille Stechborsten. Flügel gleich bis ungleich, spärlich geädert (zuweilen verkümmert). Netamorphose der Geflügelten unvollkommen. Cicaden, Blattläuse, Schildläuse, Landwanzen, Wasserwanzen, Läuse.

7. Ordnung: Diptera. Zweiflügler.

Mlundwerkzeuge saugend bis stechend; Unterlippe zu fleischiger ungegliederter Rüsselröhre ausgewachsen. Mandibeln und 1. Mlaxillen zu Stechborsten oder rndimentär. Hinteres Flügelpaar zu sog. Schwingkölbchen (Halteren) rückgebildet (selten beide Paare). Metabol. Sehr große Gruppe: Stechmücken, Gallmücken, Bremsen, Scbwebfliegen, Fliegen, Dasselfliegen, Lausfliegen.

8. Ordnung: A p baniptera (Siphonaptera). Flöhe.

Flügellos, parasitierend. Schließen sich den Diptera am nächsten an; wie diese metabol. Pulex (Floh), Sarcopsylla (Sandfloh).

9. Ordnung: Lepidoptera. Schmetterlinge.

Mundwerkzeuge saugend. 2, Gnathitenpaar (1. Maxille) zu zweihälftigem spiralem Saugrohr (Rüssel) ausgewachsen. 1. nnd 3. Gnathiten stark reduziert. Die beiden gleichen Flügelpaare groß und mit Schuppen bedeckt. Netabol. Sehr große Gruppe.

3. Subphylum: Branchiata. Kiemenatmer.

Atmungsorgane Kiemen, welche Anhänge der Beine sind. Leberdrüsen des Darmes häufig. Malpighische Gefäße fehlen; dagegen wenige Nephridienpaare in der Kopfregion gewöhnlich vorhanden.

\section{Klasse: Pal a eostraca.}

Kopf (Cephalosom) und Rumpf in arachnoideenartiger Weise ausgebildet. Cuticula stark. Das große Cephalosom aus 6 bis 7 Segmenten bestehend. Keine dorsalen Antennen. 5 bis 6 Paar Kopfextremitäten; das 1. Paar fühlerartig vor dem Mund, die übrigen Bewegungsextremitäten, die jedoch sämtlich mit ihrem Basalglied als Gnathiten fungieren. Rumpf mit zahlreichen gespaltenen Extremitäten, die zur Atmung oder auch gleichzeitig zur Bewegung dienen. Ein Paar mittlerer Ocellen und ein Paar Komplexangen gewöhnlich. Geschlechtsöffnungen paarig, am ventralen Vorderende des Rumpfes. Marin.

1. Ordnung: Merostomea (Gigantostraca).

Nur fossil (Paläozoicum). Cephalosom mäßig groß mit sechs Extremitätenpaaren. Rumpf langgestreckt (12 gliederig), Endsegment häufig lang stachelförmig. Rumpfgliedmaßen wahrscheinlich ähnlich denen der Poecilopoda.

2. Ordnung: Poecilopoda (Xiphosura). Pfeilschwänze, Molukkenkrebse.

Kleine Gruppe (einzige lebende Gatt. Limulus). Cephalosom groß, mit sechs Extremitätenpaaren. Rumpf verkürzt, ohne deutlic ${ }^{\top}$ äußere Gliederung, mit langem Schwanzstachel und sechs Paar blattförmigen gespaltenen Extrenitäten, von denen 2. bis 5. dichte Büschel von Kiemenhlättern tragen. Ansehnliches Leberdrüsenpaar. Coxaldrüsen vorhanden. Seit Trias.

3. Ordnung: Trilobita.

Nur fossil (Paläozoicum). Cephalosom mäßig groß mit fünf Paar Extremitäten. Komplexaugen meist ansehulich. Rumpf groß und meist sehr segmentreich; in größeren Vorderteil (Thorax) und kleineren Hinterteil (Pygidium, Abdomen) gesondert. Kein Schwanzstachel. Beide Regionen des Rumpfs mit zahlreichen gespaltenen, nicht blattförmigen Extremitäten, die wahrscheinlich je einen Kiemenauhang trugen. 


\section{Klasse: Crustacea. Krebstiere.}

Körper in Kopf (Cepbalosom), Thorax und Abdomen gesondert. Zu Kopfabschnitt werden gewöhnlich die fünf vordersten Segmente gerechnet; häufig sind damit jedoch mehr oder weniger zahlreiche bis sämtliche Segmente des Thorax vereinigt. Die beiden vordersten Extremitäten als Antennen vor dem Mund und mehr oder weniger dorsal gerückt. Extremitäten meist gespalten. Abdomen mit oder ohne Extremitäten. Kiemen (wenn nicht rückgebildet) an der Basis der Rumpfextremitäten, oder Abdominalbeine zu Kiemeı umgebildet. Meist ein bis mehrere Paare Leberdrüsen bei Teil wohl rückgebildet). Kopfständige nephridienartige Excretionsorgane (Antennen- oder Maxillendrüse) gewöhnlich vorhanden. Paarige Geschlechtsöffnungen am Thorax bis Vorderende des Abdomens.

1. Unterklasse: Entomostraca.

Größe gering, häufig stark rückgebildet. Abdomen ohne Extremitäten. Komplexaugen mäßig groß oder fehlend. Einfache Augen gewöhnlich vorhanden. Häufig Naupliuslarven, wenn nicht direkte Entwicklung.

1. Ordnung: Phyllopoda. Blattfüßer.

Klein bis mäßig groß. Langgestreckt und sehr segmentreich oder kürzer. Hänfig mit von der Dorsalseite der hinteren Kopfregion ausgehender, den Körper mehr oder weniger einschließender Schalenduplicatur. 1. Gnathite (Mandibel) ohne Taster. Innenast der Thoraxbeine mit blattförmigen Lappen. Gewöhnlich blatt- bis sackförmige Kieme an der Basis der Beine. Komplexaugen vorbanden. Entwicklung direkt oder dnrch Nauplius. Branchipus, Apus, Limnadia, Daphnia usw. Süßwasser und Meer. Seit Devon.

2. Ordnung: Ostracoda. Muschelkrebse.

Klein. Stets mit ansehnlicher, den Körper völlig umschließender, meist verkalkter Schalenduplicatur. Körper stark verkürzt und segmentarm. Regionen wenig deutlich; nur sieben Paar Extremitäten überhaupt. Mandibel mit ansehnlichem beinförmigem Taster. Keine eigentlichen Kiemen. Komplexaugen zum Teil vorhandell. Entwicklung mit oder ohne Naupliuslarve. Cypris usw. Süßwasser und Meer. Seit Cambrium.

\section{Ordnung: Copepoda.}

Klein bis mäßig groß. Freilebende (Natantia) oder ectoparasitische Formen (Suctoria). Jedenfalls stark rückgebildet. Stets ohne Schalenduplicatur. Körper ziemlich langgestreckt. Vier Paar Gnathiten (sog. Mandibel, Maxille und zwei Paar Maxillarfüße. Brustfüße gespalten, ohne Kiemenanhänge (nicht mehr wie fünf Paar). Komplexangen fast stets fehlend. Parasitische Formen, zum Teil stark um- und rückgebildet. Entwicklung gewöhnlich mit Naupliuslarve. Cyclops,. Ergasilus, Chondracanthus, Caligus, Lernaea, Achtheres, Argulus usw. SüBwôsser und Meer.

4. Ordnung: Cirripedia Rankenfüßer.

Marin. Klein bis ziemlich groß. Von ostracoden- bis copepodenartigen Formen ableitbar, die zu festsitzender bis parasitischer Lebensweise übergingen. Befestigung mit der Dorsalseite des Kopfes (mit vorderen Antennen). Ansehnliche, häufig durch Kalkplatten verstärkte Schalen- (Mantel-) Duplicaturen, die den gesamten Körper einschließen. Bei den ursprünglichsten, den sog. Thoracica, sechs Paar lange, tief gespaltene sog. Ranken-oder Strudelfüße; bei den übrigen zum Teil sehr stark rückgebildeten parasitierenden Abteilungen die Beine mehr oder weniger bis völlig (auch zum Teil die Kopfanhänge) verkümmert. Bei Rhixocephala Darm völlig rückgebildet. Zum Teil mit zwittrigen Weibchen und die Männchen rudimentär. Lepas, Balanus, Alcippe, Peltogaster usw. Marin. Seit Silur.

2. Unterklasse: Malacostraca.

Kopf (5), Thorax (8), Abdomen fast stets 7 Segmente (ausgen. Leptostraca). Hänfig mehrere vordere bis sämtliche T'boracalsegmente mit dem Kopf vereinigt (Cephalothorax). Abdomen in der Regel mit gespaltenen Extremitäten. Komplexaugen ansehnlich. Ocellen fehlen. Weibliche Geschlechtsöffnungen am drittletzten, männliche am letzten Thoracal- oder 1. Abdominalsegment. Entwicklung in der Regel ohne Naupliuslarve. 


\section{Ordnung: Leptostraca.}

Mit phyllopodenähnlicher zweiklappiger Schalenduplicatur, die bis über Anfang des Abdomens reicht. Brustfüße etwas phyllopodenähnlich, mit Kiemenanhăngen. Abdomen mit acht Segmenten. Entwicklnng direkt. Marin. Nebalia. usw.

2. Ordnning. Arthrostraca. Ringelkrebse.

Kopf nur mit 1 bis 2 vorderen Thoracalsegmenten vereinigt, daher der Thorax gegliedert. Schalenduplicatur, nur bei Ahisopoda schwach entwickelt. Abdomen länger (Amphipoda) oder kürzer (Isopoden). Brustfüße ungespalten; bei Amphipoda mit basaler blattförmiger Kieme; bei Isopoda die Abdominalfüße zu Kiemen ausgebildet. Komplexaugen nicht gestielt. Entwioklung direkt. Seit Karbon.

1. Unterordnung: Amphipoda. Flohkrebse.

Gammarus usw. Süßwasser nnd Meer.

2. Unterordnung. Isopoda. Asseln.

Assellus (Süßwasserasseln) und zahlreiche marine. Oniscus usw. (Landasseln) Tanais Bopyrus usw. (parasitische marine Asseln).

3. Ordnung: Thoracostraca (Podophthalmata).

Schalenduplicatur von hinterer Kopfregion nach hinten über den Thorax wachsend, so daß eine verschiedene $Z$ ahl von Thoraxsegmenten (drei bis alle) mit Kopf zu Cephalothorax vereinigt sind. $1-5$ vordere Thoraxbeinpare zu Kieferfüßen umgestaltet. Das sechste Abdominalfußpaar bildet mit dem 7. Segment meist eine Schwanzflosse. Kiemen gewöhnlich an der Basis der Brustfüße. Komplexaugen meist gestielt. Meist Statocysten. Entwicklnng direkt oder mit Metamorphose.

1. Unterordnang: Schizopoda Spaltfüßer.

Klein, langgestreckt. Kopfschild über den ganzen Thorax nach hinten ansgedehnt. Brustfüße gespalten, Anßenast kurz. 1 bis 2 Paar Kieferfüße. Kiemenanhänge zuweilen an Brustfüßen. Komplexangen gestielt. Bei Teil Statocysten in letzten Abdominalfüßen. Entwicklung direkt oder mit Nauplius. Euphausia, Mysis usw. Marin und Süßwasser.

2. Unterordnung: Cumacea.

Klein. Fünf freie Thoracalsegmente. Zwei Kieferfußpare. Brustfüße zum Teil gespalten, ohne Kiemen. Keine Schwanzflosse. Komplexaugen nicht gestielt. Statocysten fehlen. Entwicklung direkt. Diastylis (Cuma) usw. Marin.

3. Unterordnnng: St omatopoda. Heuschreckenkrebse.

Ansehnlich; langgestreckt. Drei Toraxsegmente frei. Fünf Par ansehnliche ungespaltene Kieferfüße, die sich jedoch anch an der Bewegung beteiligen. Abdomen groß, mit blattförmigen Spaltfüßen, welche die Kiemenbüschel tragen. Schwanzflosse. Fodophthalm. Metamorphose mit eigentümlichen Larven. Squilla usw. Marin.

4. Unterordnung: Decapoda. Zehnfüßige Krebse.

Fast stets einheitlicher Cephalothorax. Drei Paar Kieferfüße, fünf Paar Gehfüße der Brust, die zum Teil mit Scheren endigen. Kiemen an Thoraxbeinen jederseits unter Cephalothoraxschild in Atemhöhle. Abdomen lang bis stark verkürzt. Komplexaugen meist gestielt. Statocyste in 1. Antennen. Metamorphose gewöhnlich, häufig mit Zoëalarve. Crangon, Palaemon, Palinurus (Languste), Homarus (Hummer), Astacus (Flußkrebs), Pagurus, Maja, Cancer, Carcinus usw. Süßwasser, Land und Meer. Seit Perm.

\section{Phylum Mollusca. Weichtiere.}

Bilateral, zum Teil mit ausgesprochener Asymmetrie. Körperhaut ohne stärkere Cuticula, dagegen sehr häufig mit Schalenbildung. Segmentation wenn je vorhanden gewesen, undeutlich. Muskulöses Fußorgan von Bauchseite entspringend und sich in verschiedener Weise ausgestaltend. Verkalkte Schale auf Dorsalseite abgesondert, ursprünglich meist einheitlich; ihr Rand wird von einer die Rückenfläche umziehenden Hautfalte unterlagert (Mantelfalte). Unter dieser die Mantelrinne bis -höhle. Ursprünglich jederseits in dieser eine Kieme neben After. Mundhöhle wohl ursprünglich stets mit cnticularer sog. Zunge (Radula). Schale, Mantelfalte und Kiemen 
in verschiedenen Gruppen mehr oder weniger rudimentär bis völlig rückgebildet. Mitteldarm fast stets mit paariger ansehnlicher Leberdrüse. Cölom, sowie ein Nephridienpaar vorhanden. Ersteres jedoch meist stark rückgebildet und zu Pericardialsinus und Gonadenhöhle geworden. Blutgefäßsystem stets, jedoch häufig iast völlig lacunär; mit dorsal auf hinterem Darm gelegenem Herz und ein Parr seitlicher Vorböfe. Gonaden ursprünglich wohl parig; Gesehlechtsleiter von Nephiidien sich herleitend. Häufig Zwitter. Entwicklung bäufig mit Trochophoralarve. - Die Mollusken weisen auf rotatorien- bis plathelminthenartige Vorfahren hin, die frübzeitig eine besondere Entwicklungsrichtung einschlugen.

\section{Subphylurn: Amphineara.}

Langgestreckt und völlig symmetrisch. Gleichmäßige, den ganzen Rücken umziehende Mantelfalte, wenn nicht rückgebildet; unter der Mantelfalte die Kiemen, wenn vorhanden. Kriechfuß über ganze Bauchfläche ausgedehnt, oder reduziert. Kopf nicht deutlich. Manteloberfläche mit verkalkten Stacheln. Keine einheitliche Schale. Nervensystem primitiv: Cerebralganglien nebst Pedal- und Palliovisceralsträngen. Statocysten fehlen.

1. Klasse: Pla cophora (Polyplacophora). Käferschnecken.

Ansehnlicher „Kriechłuß (selten stark verschmälert.) Schale aus acht queren Rückenplatten bestehend. Geflederte Kiemen in Mantelrinne, stark vermehrt zu einer Reihe zahlreicher jederseits (4-80). Radula kräftig. Leber ansehnlich. Getrenntes Geschlecht. Gonade einfach (selten parig) mit 2 Ausführgängen in die Mantelrinne. Chiton, Chitonellıts usw. Marin.

2. Klasse: Solen ogastres (Aplacophora).

In mancher Hinsicht ursprünglicher als die Placophora, jedoch auch sicher stark rückgebildet. Fuß sebr verkümmert, zu schmaler Längsfalte auf Bauchfläche oder ganz reduziert; ebenso auch die Mantelfalte. Bei Teil noch ein Paar Kiemen am After. Keine Schale, sondern nur Kalkstacheln auf der Rückseite. Radula rudimentăr. Leber fehlt meist. 1 bis 2 Gonaden, die in Pericard münden; die beiden Nephridien dienen als Ausführgänge und münden hinten neben After. Zum Teil Zwitter. Neomenia, Chaetoderma nsw. Marin.

2. Subphylum: Ganglionenra (Conchifera).

Nicht selten Störung der ursprünglichen bilateralen Symmetrie. Einheitliche, zuweilen jedoch verkümmerte Schale. Nervensystem mit Cerebral-Pedal- und Visceralganglien; letztere in einer den Darm ventral umgreifenden Schlinge der ursprünglichen Palliovisceralstrănge gelagert, die im übrigen zu Pallialnerren reduziert. Statocysten. Leher siets.

1. Klasse: Gastropoda. Schnecken. Fig. 29.

Asymmetrisch mit nach vorn und in der Regel rechts verlagertem After, dem die beiderseits vor $\mathrm{hmm}$ stehenden Kiemen, das Herz, sowie die Mündungen der Nephridien und der Gonade gefolgt sind. Bei gewissen Formen jedoch wieder starke Rückbildung der Asymmetrie. Kopfbildung meist gut, mit 1 bis 2 Paar Fühlern. Einheitliche Schale (zum Teil jecioch rückgebildet) bedeckt den Rücken, der häufig zu ansehnlichem Eingeweidesack auswächst und dann samt der Schale sich schraubig aufrollt. Kriechfuß mit ansehnlicher Kriechsohle. Radula meist stark ausgebildet (selten verkümmert). Gonade nnpaar. Seit Cambrium.

1. Ordnung: Prosobranchiata (Streptoneura). Vorderkiemer.

Asymmetrie stets stark ausgeprägt. Schale und Eingeweidesack meist ansehnlich, erstere gewöhnlich mit Deckel. Fuß gut entwickelt. Mantelrinne zu kopfwärts gewendeter Kiemenhöhle vertieft; darin liegen die Kiemen, der After, die Öffnungen der Nephridien und der Gonade. Vorhöfe vor der Herzkammer und hinter den Kiemen. Visceralcommissur lang, asymmetrisch achterförmig. Geschlecht fast stets getrennt. Seit Cambrium.

1. Unterordnung: Aspidobranchiata (Diotocardia).

Ursprünglichere Formen. Entweder beide oder nur die linke vordere gefiederte Kieme vorhanden (selten beide reduziert). Meist zwei Vorhöfe und die beiden Nephridien erbalten. Gewöhnlich kein besonderer Ausführgang der Gonade, sondern Entleerung durcb die rechte Niere. Marin (selten Süßwasser). Fissurella, Haliotis, Pleurotomaria, Trochus, Neritina, Patella usw. 
2. Unterordnung: Ctenobranchia (Monotocardia, Pectinibranchia). Kammkiemer.

Kriechfuß. Nur die linke (rordere) Kieme ernalten und nicht fiederartig, sondern fast stets aus einer Reihe Kammblättchen bestehend. Nar ein Vorhof. liechte Niere rückgebildet. Gonade mit besonderem Ausführgang. Sehr große Gruppe. Süßwasser und Meer.

3. Unterordnung: Heter o poda. Kielfüßer.

Jedenfalls durch Anpassung ctenobranchiatenartiger Vorfahren an die pelagische Lebensweise hervorgegangen. Vorderer Fußteil in sagittale Flosse umgebildet, meist mit Saugnapf. Schalc und Mantelfalte zum Teil ganz reduziert. Marin. Atlanta, Carinaria, Pterotrachea usw.

2. Ordnung: Opisthobranchiata. Hinterkiemer.

Asymmetrie meist mehr oder weniger stark rückgebildet. After und Kieme (wenn nicht rückgebildet) daher meist rechtseitig; doch stets nur die linke (vordere) gefiederte Kieme nebst Vorhof und Nephridium erhalten. Kriechfuß, dessen Basalrand häufig in zwei starke Lappen (Parapodien) ausgewachsen. Visceralcommissur meist stark verkürzt und danu wieder symmetrisch. Der Vorhof fast stets hinter der Herzkammer und dahinter die Kieme. llermaphroditisch. Marin.

1. Unterordnung: Tectibranchiata.

Die ursprüngliche gefiederte Kieme vorhanden, in rechtsəitiger, selten vorderständiger schwacher Kiemenhöhle. Schale und Eingeweidesack gewöhnlich stark rückgebildet, jedoch meist noch vorhanden. Actaeon, Aplysia usw.

2. Unterordnung: Nudibranchiata.

Ursprüngliche Kieme, Kiemenhöble, Mantelfalte und Schale reduziert; Fußfläche nicht abgesetzt, so daß eigentlicher Fuß nicht unterscheidbar. Asymmetrie noch weiter rückgebildet, so daB After wieder nahezu oder ganz symmetrisch anf hinterer Dorsalflärhe. Mleist sekundäre Kiemenbildungen in verschiedener Gestalt und Anordnung auf der Dorsalseite. Radula häufig mehr oder weniger rudimentär. Thetys, Phyllirhoe, Doris, Aeolis usw.

3. Unterordnung: P te r op oda. Flossenfüßer.

Eigentlicher Fuß stark reduziert, dagegen die beiden Parapodiallappen zu großen tlügelartigen Schwimmflossen entwickelt. Kiemen meist ganz rückgebildet. Schale und Eingeweidesack selten schraubentörmig, meist gerade entwickelt. Zuweilen Schale und Mantelfalte völlig rückgebildet. Hermaphroditisch. Sind jedenfalls durch Anpassung an die rein pelagische Lebensweise aus tectibranchiatenähnlichen Vorfahren entstanden. Marin. Limacina, Cymbulia, Clio, Pneumodermon usw. Sicher seit Kreide (? ob paläozoisch).

3. Ordnung: Pulmonata. Lungenschnecken.

Beschalt bis unbeschalt, mit teilweis starker Rückbildung der ursprünglichen Asymmetrie. Kieme fehlt (selten accessorische Kiemengebilde in der Mantelrinne oder sogar der Lungenböhle entwickelt); dagegen besondere Lungenhöhle, die in der Nähe des Afters aus der Mantelrinne ins Körperinnere hereingewachsen ist. Vorhof und Niere asymmetrisch einfach, Lage des Vorhofes zur Herzkammer meist prosobranchiat. Visceralcommissur fast stets symmetrisch rückgeformt. Hermaphroditisch. Süßwasser und Land. Seit Carbon.

1. Unterordnung: Basommatophora.

Ein Paar nicht retractiler Fühler ähnlich Prosobranchiata. Schale stets; meist ohne Deckel. Limnaea, Planorbis, Physa usw. Süßwasser.

2. Unterordnung: Stylommat o phora.

Meist zwei (selten ein) Paar retractiler Fühler. Schale und Asymmetrie zum Teil rückgebildet. Land, selten Meer. Helix, Arion, Vaginula, Oncidium usw.

2. Klasse: Cephalopoda. Kopffüßer.

Symmetrisch, nur Ausführgänge der Gonade häufig asymmetrisch. Kopf und Augen sehr ansehnlich. Kopf mit zahlreichen, häufig sehr kräftigen Tentakeln (Armen), die vom kand des kopfwärts rerschobenen Fußes abgeleitet werden. Epipodiallappen des Fußes zu Trichter zusammengekrümmt oder verwachsen, durch den das Wasser der Mantelhöhle ausgestoßen wird. Schale vorhanden bis fehlend. Eingeweidesack fast stets hoch ausgewachsen und Mantelrinne 
an seiner Hinterseite zu tiefer Kiemenhöhle eingesenkt. Darin symmetrisch der After, zu dessen Seiten die Kiemen, die Nieren- und die Geschlechtsöffnungen. Kiefer und Radula kräftig (letztere selten rüickgebildet). Torhöfe symmetrisch. Gonade einfach; besondere Ausleiter teils parig, teils unpaar. Getrenntes Geschlecht. Marin. Seit Cambrium.

1. Ordnung: Tetrabranchiata. Vierkiemer. Fig. 31.

Zwei Paar Kiemen, Vorhöfe und Nephridien. Zahlreiche retractile Tentakel ohne Sauguäpfe. Trichterfalten nicht verwachsen. Äußere gekammerte, gerade bis spiral anfgerollte Schale. Nautilus, Orthoceras, Ammoniten usw. Seit Cambrium.

2. Ordnung: Dibranchi ata. Zweikiemer.

8 oder 10 Tentakel mit kräftigen Saugnäpfen oder Haken. Ein Par Kiemen, Vorhöfe und Nieren. Nur die zwei Fangtentakel der Decapoda retractil. Trichter geschlossen. Äußere Schale selten und dann klein; häufig innere. Tintensack gewöhnlich. Seit Trias.

1. Unterordnung: Decapoda. Tintenfische. Fig. 32, 34.

Acht nicht retractile Tentakel und zwei retractile Fangtentakel. Schale fast stets zu immerem Schulp geworden. Belemnites (fossil), Spirula, Loligo, Sepia (Tintenfisch) usw.

2. Unterordnung: Octopoda. Kraken.

Acht Tentakel, ohne Fangtentakel. Innere Schale fast bis völlig rudimentär; selten Weibchen (Argonanta) mit äußerer, nicht gekammerter Schale. Octopus, Argomauta usw,

3. Klasse: Sol enoconcha (Scaphopoda).

Symmetrisch. Mantelfalte jederseits gegen die Ventralseite herabgewachsen und wit der der anderen Seite zu rïhrenförmigem Jantel verwachsen, der den ganzen Körper umgibt und voln, wie linten geïfnet ist. Die einheitliche Schale dementsprechend ebenso gestaltet. Fuß ein Ianger cylindrischer Anhang mit meist etwa kleeblattförmigem Ende. Kienen rückgebiluet. Cirrenartige Ankïnge an zwej Vorsprüngen ïber dem Munde. Radula sorhanden. Blutgefäßsystem fast ganz lacunär. After auf Ventralseite nach vorn geschoben. Nephridien parig. Getrenntes Geschlecht. Gonade unpaar durch das rechte Nephridium mündend. Den. talizm usw. Marin. Seit Silur.

4. Klasse: Lamellibranchiata. (Pelecypoda, Arephala). Muscheln. Fig. 35, 36, 50.

Stark einseitig umgebildet. Mejst ganz symmetrisch. Mantelfalte jederseits zu Mantellappen herabgewachsen, die den Körper ganz umschließen und auch bäuig mehr oder weniger verwachsen. Die urpprïnglich einheitliche Schale entsprechend zweiklappig ausgewachsen. Kopf und liadula rückgebillet. Jederseits vom Mund ein Paar Mundlappen. Die heiden ursprüıglichen, gefiederten Kiemen zu einer Doppelreihe von Kienenfäden jederseits zwischen Mantel und Körper ausgewachsen, die sich meist zu zwei Paar zusammenhängender Kiemenbiätter weiterentwickeln. Fuß ein keilförmiger bis eylindrischer Anhang olıne eigentliche Kriechlläche (bei Teil rückgebildet). Nephridien und Gonaden paarig. Getrenntgeschlechtlich orler hermaphroditish. Seit Cambrium. Marin um Süßwasser. Nucula, Mytilus (Miesmuschel), Pecten (Kammmuschel), Ostrea (Anster), Anodonta, Unio (Flußmuscheln), Cardium (Herzmuschel), Pholas (Bohrmuschel), Teredo (Bohrwurm) usw.

\section{Phylum: Eehinodermata. Stachelhäuter.}

Vou vilateralen, wahrscheinlich dreisegmentierten Formen ableitbar, dic durch Festheftung zum radiären Bau ïbergingen (meist fünfstrahlig). Die Cölomhohle des 2. Segments, unter Verkümmerung der rechten Hälfte, zu einem eigentïmlichen Gefảßapparat(sog. Ambulacralgefäßsystem) entwiskelt, das durch Vermittelung der vorderen rechten Cölomhöhle, zum 'Teil auch der Cölomhöhlen des 3. Segments, die zu der eigentlichen Leibeshöhle werden, nach außen mïnlet. Das Ambulacralgefäßsysten dient zur Anschwellung von füßchen- oder tentakelartigen Ilautfortsätzen, die zur Ernährung oder auch zur Bewegung und Atmung dienen künnen. Blutgefäße stets vorhanden. Stets reiches Kalkskelet im Bindegewebe, namentlich der llaut. Geschlechter meist getrennt. Gonaden, dem strahligen Ban entsprèthend, mehrfach geworden. Entwicklung durch bilaterale freischwimmende bewimperte Larven. Seit Silur. (Die typischen Charaktere werden in einzelrien Gruppen durch Reduktionen etwas verändert.) 


\section{Subphylum: Semiambulacrata.}

Das ambulacrale Gefäßsystem breitet sich nur über die orale oder ambulacrale (ventrale) Fläche aus, der eine meist ebenso große oder sogar größere antiambulacrale Fläche entgegensteht. IRadien bei Teil in freivorspringende Arme ansgewachsen.

Gruppe der l'elmatozoa (umfaßt die drei folgenden Klassen):

Körper kugel- bis kelchartig; fast stets mit dern Antiambulacralpol aufgewachsen, der bänflg in Stiel verlängert ist. Körperwand mit dicht zusammenschließenden Skeletplatten. Ambulacralfüßchen, wenn vorhanden, nicht locomotorise Mund im Centrum der Ambulacralfläche; After dem Mund stets genähert, nicht apical.

1. Klasse: Cystoidea. Blasenstrahler (einschließlich Edrioasteridae).

Schon im Silur höchstentwickelte und in der Kohlenformation erlöschende paläozoische Gruppe der zweifellos ursprünglichsten Echinodermen.

Mit Antioralpol festgeheftet, selten frei; häufig kurzer bis mäßiger Stiel. Körper unregelmäßig sackartig bis kugelig oder kelchảrtig. Bei ursprünglicheren Fornıen mit ganz unregelmäßig álgeordneten zahlreichen Skeletplatten, die bei späteren in geringerer Zahl und mehr oder weniger regelmäßig radiär, ăhnlich Crinoideen. Skeletplatten meist mit eigentiimlichen Strukturen (Poren, Doppelporen oder Porenrauten), die jedoch keine wirklichen Durchbrechungen der Plate $n$ sind. Entweder ganz ohne Ambulacralrinnen um Mund, oder mit 1 bis 5, die sich nach kurzen oder längerem Verlauf in kurze freie Arme fortsetzen. Die Ambulacralrinnen seltạ mit arnıs'igen sog. Pinnulae gesänmt. Die Rinnen sowie der Mund bäufig von Skels: "z̈ttchen ijberdeckt. Eigentliche Ambulacralporen und Füßchen scheinen slch jedocb nur ei Edrioasterida gefunden zu haben. After mit Skeletplättchen versehen, seitlich oder dem Mund mehr genähert; zwischen After und Mund teils zwei Öffnungen, dle dann als Öffnung hes Embulacralsystems und der Geschlechtsorgane angesehen, oder nur eine, die dann als geneinsame beider Organsysteme gedeutet wird.

\section{Klasse: Blastoidea. Knospenstrahler.}

Von Stlur bis Kohlenformation. Meist mit kurzem Stiel festgeheftet. Körper etwa kelch- błs eiförmig. Skeletplatten des Körpers unregelmäßiger, bis sehr regelmäßig 5 strahlig angeordnet, ähnlich Orinoideen. Stets fünf sog. A unbulacralfelder mit Rinnen (Psendambulacralfelder), dle, vom centralen Mund ausgehend, einen kleineren oder größeren Teil der Oberfläche überziehen, und jederseits von einer Reihe ansehnlicher Pinnulae (Brachiolae) gesäunt werden. After interradial, nabe bei Mund. Mund, After und Ambulacralrinnen meist von Skeletplättchen äberdecḱt. Längs jeder Seite der Ainbulacturimen meist win System innerer Längsialten der Skeletwand, die in die Kelehhöhle hineinragen (Hydrwspien) und entweder frei auf Oberfläche münden oder dur n Poren längs der Anbulatralrinnen, oder ilurch je zwei größere Öffnungen $\left(S_{1}\right.$ iren) in jedem Interradins, dicht bei Mund. I vie liydrospiren haben Äbnlichkeit rait den Bursae der Ophinroiden.

\section{Klasse: Crinoided. Haarsterne.}

Körper kelchartig, meist mit langem Stiel aufgewachsen, selten vich von liesetn später ablösend. After anf Ambulacralfläche interradial. Ambulacral- und Anizimbulacralfläche scharf geschieden; die letztere mit strahlig angeordneten Kelchskeletplatten, die auf der Grenze beider Flächen in die fünf (selten weniger) Arme auswachsen. Arme meist mehr oder weniger reich verzweigt; gewöhnlich mit Pinnulae. Mit Ambulacralrinnen, die vom Mund ausgehen und sich über alle Verzweigungen der Arme fortsetzen. Diese Pinnen sowie die Arabulacralfläche nackt oder mit Skeletplättchen ỉberdacht, die dann auch den Nund überdecken. Ambulacralsystem durch Vermittlung des Cöloms ausmündend. Gonaden erstrecken sich bis in die Pinnulae, wo sie allein reifen. Seit Silur. Pentacrinus, Antedon usw.

\section{Klasse: Asteroidea (Stelleroidea). Seesternartige.}

Freilebend; meist mit fünf, selten bis zahlreichen Radien und Armen. Körper scheibenartig abgeflacht. After, wenn nicht rückgebildet, dicht bei Antiambulacralpol. Ambulacralsystem durch Steinkanal direkt ausmündent. 


\section{Unterklasse: Asteriae. Seesterne.}

Arme stets unverzweigt, meist groß and von Scheibe nicht scharf abgesetzt; mit zwei Reihen sog. Skeletwirbel und weiter Leibeshöhle. Ambulacralrinnen offen und ansehnlich. Füßchen groß, locomotorisch, mit Ampullen. Steinkanal mündet interradial auf Apicalfläche. Fast stets ansehnliche radiale Leberdrüsen. Meist feiner After. Pedicellarien meist. Gonaden münden auf Apicalfläche. Astcrias, Solaster, Astropecten usw. Seit Silur.

2. Unterklasse: Ophiuroidea. Schlangensterne.

Arme ansehnlich, selten verzweigt(Euryaleae), von der mäßig großen Scheibe scharf abgesetzt; mit einer Reihe von Skeletwirbeln und sehr reduzierter Leibeshöhle. Ambulacralrinnen geschlossen. Füßchen klein, nicht oder wenig locomotorisch, ohne Ampullen. Steinkanal mündet auf Ambulacralfläche. Pedicellarien fehlen. Gonaden münden durch die sog. Bursae auf Ambulacralfläche. Leberdrüsen und After fehlen. Ophioglypha, Gorgonocephahus (Euryale) us:. Seit Silur.

\section{Subphylum: Totiambulacrata.}

Antiambulacralflüche sehr reduziert, bildet nur ein kleines Feld am Apicalpol. Radien nicht in Arme verlängert. Ambulacralrinnen geschlossen. Stets 5 strahlig.

1. Klasse: Echinoidea. Seeigel.

Körper kugelig bis stark abgeplattet; zum Teil (Irregularia) mit sekundärer bilateraler Umbildung. Körperøberlläche stets reich bestachelt. Pedicellarien vorhanden. Mäßig weiter bis feiner After im Apicalfeld, oder (Irregularia) in den hinteren Interradius gerückt. Steinkanal mündet im Apicalfeld. Füßchen meist ansehnlich, sämtlich oder zum Teil locomotorisch. Starkes, aus (bei den Recenten) stets 20 Plattenreihen bestehendes Hautskelet. Gonaden fünf bis weniger im Apicalfeld ausmündend.

1. Unterklasse: Regularia. Regelmäßige.

After im Apicalfeld. Körper meist annähernd kugelig. Stacheln häufig groß. Füßchen meist sämtlich locomotorisch. Ohne petaloide Ambulacren. Mit Kanapparat. Cidaris (Turbanigel), Echinus usw. Seit Silur.

2. Unterklasse: Irregularia. Unregelmäßige.

Bilateral umgebildet. Stacheln meist klcin. After in hinteren Interradius verschoben. Füßchen im Apicalfeld häuflg zu Kiemen entwickelt; häufig petaloide Ambulacren.

1. Ordnung: Clypeastroidea (Gnathostomata). Schildigel.

Meist stark abgeplattet. Mund central, mit Kauapparat. Die Ambulacralfüßchen der Oralseite auf die Interambulacren ausgebreitet. Clypeaster usw. Seit Mesozoicum.

2. Ordnung: Spatangoidea (Atelostomata). Herzigel.

Mund meist gegen vorderen Radius verschoben. Vorderes Ambulacrum meist vertieft und dann Umriß herzförmig. Wenig abgeplattet. Kauapparat feblt. Gonadenzahl häufig verringert. Spatangus usw. Seit Mesozoicum.

2. Klasse: Hol othurioidea. Seewalzen.

Körper in der Hauptachse verlängert, daher walzenförmig oder seitlich abgeplattet und dann häuflg stark bilateral modifiziert. Mund von fünf bis mehr ansehnlichen, zu Tentakeln entwickelten Ambulacralfüßchen umstellt. After groß, apical. Übrige Füßchen sämtlich oder nur zum Teil locomotorisch; zuweilen (Apodes) völlig rückgebildet. Meist kein Hautplattenskelet, sondern eine Lage kleiner Kalkkörperchen in der lederartigen Haut (zuweilen ganz reduziert). Steinkanal selten direkt ausmündend, meist mit Cölom in Verbindung. Zum Teil mit sog. Wasserlungen, die vom Enddarm entspringen. Nur eine Gonade, die bei Teil hermaphroditisch, und dicht hinter Mund ausmündet. Seit Carbon.

\section{Phylum: Chordata. Chordatiere.}

Bilateralia, welche sich durch Besitz paariger Kiemenspalten des entodermalen Vorderdarms an die Branchiotremata anschließen. Danernd oder vorübergehend mit einer, aus der dorsalen Urdarmwand hervorgehenden, zelligen stabartigen Skeletachse (Rückenseite; Chọrda). Dorsal von dieser das durch Einstülpung des Ectoderms entstehende, ursprünglich stets hohle, lange Centralnervensystem. Blutgefäßsystem stets mit ventral vom Darm gelegenem Herz. 
1. Subphylum: Tunicata (Urochorda). Manteltiore.

Chorda nur selten danernd erhalien, meist eingehend. Stets mit respiratorischem Vorderdarm und Kiemenspalten. Keine deutliche Segmentation. Nervenrohr mit vorderer Gehirnanschwellung; meist stark reduziert. Blutgefäßsystern zum Teil stark reduziert und dann größtenteils lacunär; Herz stets. Körperoberfläche meist mit starker, eigentümolicher, zellulosehaltiger, sog. Mantelschicht. Hermaphroditisch, meist mit je einer männlichen und weiblichen Gonade. Nephridien fehlen. Hăufig ungeschlechtliche Fortpflanzung. Marin.

1. Klasse: Copelatae. Appendicularien. Fig. 77.

Klein und in manchen Teilen wohl ziemlich rückgebildet. Vorderdarm mit einem Paar nach außeu geöffneter Kiemenspalten (Spiracula). After auf der Ventralseite. Dahinter entspringt ein ansehnlicher, nach vorn gerichteter platter Ruderschwanz, den die Chorda durchzieht. Centralnervensystem in ganzer Ausdehnung erhalten. Zellulosemantel fehlt. Appendicularia usw.

\section{Klasse: Thaliaceae. Salpen.}

Mäßig groß. Schwanz und Chorda rückgebildet. Die beiden Spiracula (Kiemenspalten) sind an das hintere Körperende gerückt und samt dem After und den Mündungen der Gonadenleiter in den Grund einer hinteren Einstülpung (Cloake) verlagert. Die beiden Spiracula so stark erweitert, daß zwischen ihnen und dem respiratorischen Vorderdarm nur ein blutgefäßreicher, schief herabsteigender Kiemenbalken bleibt, oder auch zwei vertikale Reihen sekundärer Kiemenspalten (Doliolum). Nutritorischer Darm schwach. Generationswechsel sehr ausgeprägt. Salpa, Doliolum usw.

3. Klasse: Ascidiae. Seescheiden.

Gewöhnlich aufgewachsen und mit dickem Zellulosemantel. Schwanz und Chorda reduziert. Die Cloacalhöhle, deren Eingang fast stets mehr oder weniger dorsal nach vorn verschoben ist, nmwächst den ganzen respiratorischen Vorderdarm als Peribranchialböhle. Zu den zwei ursprünglichen Spiracula, die in die Peribranchialhöhle führen, treten zahlreiche sekundäre hinzu, so daß die respiratorische Darmwand gitterförmig durchbrochen erscheint. Die Gonaden münden dicht neben After in die Cloacalhöhle. Ungeschlechtliche Fortpflanzurı häutig.

1. Ordnung: Monascidiae.

Ziemlich groß; aufgewachsen. Ohne ungeschlechtliche Fortpflanzung; keine Stockbildung. Ascidia, Cynthia usw.

\section{Ordnung: Aggregatae.}

Individuen mäßig groß. Aufgewachsen. Mit ungeschlechtlicher Fortpfianzung; Stöcke ohne gemeinsame Mantelmasse; die Individuen sind durch Ausläufer verbunden. Clavellina usw.

3. Ordnnng: Synascidiae.

Individuen klein. Aufgewachsen. Mit ungeschlechtlicher Fortpflanzung. Stöcke mit gemeinsamer Mantelmasse nnd die Individuen häufig in Gruppen mit gemeinsamer Cloacalhöhle vereinigt. Botryllus usw.

4. Ordnung: Salpae formes (Luciae).

Freischwimmende, etwa tingerhutförmige, synascidienartige Stöcke. Sämtliche Individuen mit zu gemeinsamem weiten Cloacalraum zusammengeflossenen Cloacalhöhlen. Pyrosoma (Feuerwalze).

2. Subphylum: Vertebrata. Wirbeltiere.

Freibewegliche Chordata mit langgestrecktem, stets bilateralem, reich segmentiertem Körper. Respiratorischer Vorderdarm mit ursprünglich sehr zahlreichen, segmental angeordneten, nach außen geöffneten Kiemenspalten. Mund ventral, dicht hinter Kopfende; führt stets in ectodermale Mundhöhle. After ventral, typisch auf Grenze von Schwanz und Rumpf. Die Chorda erstreckt sich fast durch den gesamten Körper. Segmentierte Längsmuskulatur ursprünglich längs der ganzen Chorda. Centralnervensystem stets hohles Rohr, das sich durch den 
ganzen Rücken hinzieht (Rückenmark); vorderster Abschnitt zu Gehirn differenziert. Ausgebildetes Cölom stets ohne Dissepimente. Nephrjienartige Excretionsorgane zahlreich, ursprünglich segmental. Blutgefäßsystem stets; ventrales Herz, ursprünglich weit vorn (selten reduziert). Stets (mit seltenen Ausnahmen) getrenntgeschlechtlich. Ungeschlechtliche Fortpflanzung fehlt.

1. Tribus: Acrania (Leptocardii). Lanzettfischchen. Fig. 80.

Chorda ansehnlich und bleibend, ohne accessorisches Achsenskelet. Eigentliche Extremitäten fehlen, aber wohl durch zwei ventrale längsgerichtete Hautsäume (Seitenfalten) repräsentiert. Unpaare Flosse über die ganze Dorsalseite und die Ventralseite bis zum Porus nach vorn ziehend. Respiratorischer Vorderdarm sehr lang, mit zahlreichen, auch sekundär vermehrten Kiemenspalten. Dieselben führen nicht direkt nach außen, sondern in Peribranchialraum; der durch Einsenkung zweier ventraler seitlicher Längseinstülpungen der Körperoberfläche entstand und etwas vor dem After durch einen Porus branchialis nach außen mündet. Zahlreiche nephridienartige, segmentale Excretionsorgane, die einzeln in Peribranchialraum münden. Herz reduziert. Centralnervensystem, speziell Gebirn und Sinnesorgane, jedenfalls stark reduziert. Gonaden zablreich, sich segmental praarig längs des respiratorischen Darms wiederholend; in den Peribranchialraum sich öffnend. Branchiostoma (Amphioxus) und wenige weitere Genera. Marin.

2. Tribus: Craniota.

Meist zwei Paar Extremitäten. Stets accessorisches Achsenskelet, das die Chorda i. d. R. stark bis völlig verdrängt, und sich in Kopf zu Schädelkapsel (Craniun) entwickelt; unter und hinter diesem Skeletbogen (Visceralbogen), die den respiratorischen Darm umgreifen. Die Kiemenspalten münden (wenn varhanden) direkt nach außen. Gehim stets gut entwickelt. Sinnesorgane und dawit Kopfabschnitt gut entwickelt. Herz stəts. Die zahlreichen nephridienartigen Excretionsorgane miïnden jederseits in einen besonderen Längskaulal (Vornierengang) (vielleicht ein Rest der l'eribranchialhöhle der Acrania), der hinten in Enddarm (Cloake) fülurt und aus dem gewöhnlich auch die Ausleiter der beiden Gonadeu hervorgehen.

1. Subtribus: Cyclostomata. Rundzäuler.

lilasse: Marsipobranchii.

Wohl mehr oder weniger reduziert. Langgestreckt, drehrund. Unpaare Flosse stark entwickelt. Extremitäten fehlen (vielleicht rïckgebildet). Starke Chorda bleibend erhalten, mit geringer Ausbildung von knorpeligem Achsenskelet und knorpeliger Schädelkapsel. 1. Visceralbogen (lïeferbogen) verkümmert. Großer runder Saugmund am vorderen Körpercude. lieine echten Zähne. Kiemensjalten zahlreich (sechs bis mehr). Cloake verkümmer Riechorgan unpaar, dorsal. Labyrinth mit 1-2 Bogengängen. Gonaden ohne besondere Leiter. Sonstige Organisation fischähnlich. Süßwasser und Heer.

1. Ordnung: Petromyzontida. Neunaugen. Fig. 186.

Geruchsorgan auf Scheitel, ohne Verbindung mit Mundhühle. Unpaare Flosse in RückenSchwanz- und Analflosse differenziert. Keine Barteln an Mund. Sieben Kiementaschen, die innerlich von eimem besonderen Kiemengang entspringen. Petromỹon. Süßwasser und Meer.

2. Ordnung: Myxinoidea.

Geruchsorgan vorn, mit Mundhöhle in Verbindung. Unpaare Flosse einheitlich. Kiementaschen $(6-14)$ direkt von Darm entspringend. Barteln vorhanden. Myxine, Bdellostoma usw. Marin.

2. Subtribus: Gnathostomata. Kiefermäuler.

Kieferbogen stets gut entwickelt, den Mund, der ventral etwas hinter Kopfspitze liegt, umgreifend. Extremitäten selten rückgebildet. Echte Zähne (wenn nicht rückgebildet). Kiemenspalten höchstens sieben Paar. Geruchøorgane stets paarig. Labyrinth stets mit drei Bogengăngen.

1. Gruppe: Anamia.

Ammion und Allantois in der Ontogenie fehtend. Excretionsorgane die sog. Unnieren. Herzkammer einfach. Begattungsorgane selten und dann von anderem Typus als bei Amniota 
1. Klasse: Pisces. Fische.

Unpare Flosse stets, und Caudalflosse meist ansehnlich. Paarige Extremitäten ruderartige, einheitliche Flossen (zuweilen reduziert). Hant in der Regel mit knöchernen Schuppengebilden. Chorda meist stark reduziert, doch stets ansehnliche Reste erhalten. Achsenskelet gut entwickelt, meist mit geschlossenen Wirbelkörpern, die fast ausnahmslos amphicöl. Kiemenspalten stets vorhanden (selten mehr wie 5, höchstens 7). Geruchsorgane paarige Gruben, iast stets ohne Verbindung wit Mundhöhle. llerzvorhof fast stets einfach. Vena cava inferior fehlt oder nur angedentet.

1. Unterklasse: Choudropterygii. Kinorpeltische.

Bauchflossen stets auf Grenze von Rumpf und Schwanz. Candalthosse heterocerk. Flossen mit Hornfäden. Haut mit Placoidschuppen oder nackt. Skelet knorpelig. Erste Visceralspalte (Spritzloch) häufig erhalten. Fünf (selten 6-7) Kiemenspalten; ueist frei, ohne wirklichen Kiemendeckel. Spiralklappe des Darms und Conus arteriosus des Herzens stets. Cloake. Schwimmblase fehlt. Geschlechtsprodukte wie bei löheren Vertebłaten durch Müllerschen Gang (q) und Urnierengang ( $\vec{J})$ in Cloake geleitet. Marin.

1. Ordnung: Plagiost 0 mi (Selachii).

Palatoquadrat nicht mit Schädel vereinigt. Wirbelkörper fast stets gut ausgebildet. Ohne Andeutung von Kiemendeckel. Zahlreiche Zähne. Seit ob. Silur.

1. Unterordnung: Squalidae. Haie. lig. 186?.

Körper nicht dorsoventral abgeplattet. Kiemenspalten seitlich. Brustllossen nicht besonders vergrößert. Hexanchus, Cestracion, Scyllium, Acanthias usw.

2. Unterordiung: Rajidae. Rochen.

Körper dorsoventral meist stark abgeplattet. Kiemenspalten rentral. Bauchflossen vergrößert bis sehr groß. Raja, Torpedo usw. Seit Carbon.

2. Ordnung: II olocephala. Chimïren (Seekatzen).

Palatoquadrat mit Schädel verwachsen. Keine geschlossenen Wirbelkörjer. Kiemenspalten zusammengedrängt, mit Andeutung eines liemendeckels. Wenige grnße Zahnplatten. Cloake rückgebildet. Chimaera usw. Seit Jnsaformation (" ob Deven).

Ausgestorbene ordnungen: Pleuracanthodei. Devon bis Perm. (Pleuracanthns, Xenacanthus, Cladodus.) - Cladoselachii. Devon bis Carbon. (Cladoselache.) - A canhodei. Devon bis Perm. (Acantlodes, Diplacanthus.)

2. Unterlilasse: Operculata (Osteichthyes).

Fünt Kiemenspalten (hier und da lie hinteren etwas rükkgebildet), stark zusannengedrängt in Kiemenhöhle, die rom liemendeckel überlagert wirl. Skelet teilweise oder ganz knöehern. Knöcherne Flossenstrablen mit Ausnahme iler Dipnoi. Schwimmblase stets (wenn nicht rückgebildet).

\section{A. Arehiopereulata.}

Bauchflossen in ursprünglicher Stellung. Mit Spiralklappe im Darn, Conus arteriosus und Nüllerschem Gang.

1. Orduung: Ganoidei. Ganoiden (Schmelzschupper).

Ganoidschuppen oder Knochenplatten in der IIaut, wenn nicht nackt. Skelet in verschiedenem Grad verknöchert. Schwanzflosse heterocerk, selten diphycerk. Spritzlörher zum Teil. Schwimmblase stets. Cloake rückgebildet. Seit oberem Silur.

1. Unterordnung: Chondrostei. Kuorpelganoiden.

Chorda voll erhalten; keine geschlossenen Wirbelkörper. Skelet wenig verknöchert. Ifaut mit Knochenplatten oder nackt. Acipenser (Störe); Polyodon (Löffelstör) usw. Süßwasser und Meer.

2. Unterordnung: IIolostei. Knochenganoidell.

Ganoidschuppen. Skelet stark verknöchert. Die recenten Formen mit geschlossenen, meist amphicölen Wirbelkörpern. Polypterus (Flösselhecht), Lepidosteus (Knochenlielit), Amia (Kahlhecht) usw. Süßwasser. - 
In neuerer Zeit wurde vorgeschlagen, die Gruppe der Ganoiden völlig aufzulösen; namentlich die Gattung Polypterus, samt den sich ihr nähernden fossilen Formen von den übrigen sog. Ganoiden als eine besondere Gruppe abzusondern, neben welche noch die fossilen Gruppen der Osteolepidoti und Coclacanthini gestellt werden. Die Chondrostei (einschlieBlich der fossilen Palaeoniscidei und Platysomidae) sowie die übrigen Holostei dagegen werden mit den Teleostei zu einer umfangreichen Gruppe der Actinopterygii vereinigt. -

Gewöhnlich werden zu den Ganoiden auch jene höchst merkwürdigen ältesten fischartigen Vertebraten gestellt, die in der Silur- und Devonzeit lobten, und sich durch einen knöchernen Panzer des Kopfes und Vorderkörpers auszeichneten, dagegen kaum Spuren eines inneren erbaltungsfähigen Skelets besaßen, die Ostracodermi (Pteraspis, Cephalaspis, Pterichthys usw.), denen gewöhnlich auch die Coccosteidae angeschlossen werden, die dorsale und ventrale knorpelige Wirbelbogen besaßen. Andere wollen letztere den Dipnoi zurechnen. Die allgemeinen Gestaltsverhältnisse, sowie die Schuppenbildung machen die Zngehörigkeit dieser uralten Wirbeltierformen zn den Fischen sehr wahrscheinlich; doch lassen die sehr wenig bekannten Kiemenverhältnisse und anderes ihre wahre Stellung etwas zweifelhaft. Auch die gelegentlich geäußerte Vermntung, daß sie nähere Beziehungen zu den Cyclostomen besäßen (CoPE), ist nicht unmöglich, um so mehr, da letztere, heutzutage sehr spärliche und jedenfalls verkümmerte Abteilung einmal eine reichere und wahrscheinlich fischähnlichere Entfaltung besessen haben muß.

2. Ordnong: Dipnoi (Dipneusta). Doppelatmer, Lurchfische.

Charaktere der Recenten: Schwanzflosse diphycerk (bei fossilen zum Teil heterocerk). Paarige Flossen lang, eigentümlich beschuppt. Flossen mit hornfädenartigen Strahlen (bei fossilen zum Teil knöchern). Große Cycloidschuppen ohne Ganoinschicht. Chorda völlig erhalten, keine geschlossenen Wirbelkörper. Palatoquadrat mit Schädel vereinigt. Spritzlöcher fehlen; zum Teil änßere Hautkiemen. Wenige große Zahnplatten. Cloake. Schwimmblase ansehnlich, zu Lunge entwickelt. Nasengruben münden in Mundhöhle. Vorhof mit Anfang von Längsteilung. Süßwasser. Seit Devon.

1. Unterordnung: Monopneumona.

Lunge einfach. Parige Flossen ansehnlich, keine äußeren Hautkiemen. Ceratodus.

2. Unterordnung: Dipnenmona.

Lunge paarig. Paarige Flossen sehr schmal, fadenartig. Zum Teil (Protopterns) äußere Hautkiemen. Lepidosiren, Protopterus.

B. Teleostei. Knochenfische.

Skelet stark verknöchert; stets geschlossene amphicöle Wirbelkörper. Schuppen ohne Ganoin; cycloid oder ctenoid (doch auch zuweilen rückgebildet, bis eigentümlich modifiziert). Spritzlöcher, Cloake, Spiralklappe und Conus arteriosus rückgebildet. Schwanzflosse hoinocerk. Schwimmblase einfach bis kompliziert (wenn nicht reduziert). Gonaden mit besonderen eigentümlichen Ausführgängen, die hinter dem After münden (die $ᄋ$ jedoch selten obne Leiter). Seit Trias. Süßwasser und Meer. - Die Teleostei werden neuerdings in eine größcre Zahl von Untergruppen zerlegt. Wir ziehen es hier vor, die ältere Gruppierung beizubehalten, auch wenn sie nicht völlig natürlich sein dürfte.

\section{Ordnung: Physostomi.}

Paarige Flossen in ursprünglicher Stellung. Schwimmblase (wenn nicht rückgebildet) mit Ductus pneumaticus. Flossenstrablen sämtlich (mit Ausnahme des vordersten) gegliedert (weich). Anguilla (Aale), Clupea (Heringe), Esox (Hecht), Salmo (Lachs, Forellen), Carpio (Karpien, Weißfische), Silurus (Welse) usw.

2. Ordnung: Physoclysti.

Schwimmblase ohne Ductus. Bauchflossen fast stets nach vorn verschoben.

1. Unterordnung: Anacanthini. Weichflosser.

Mit weichen Flossenstrahlen. Bauchflossen stark nach vorn gerückt, in der Regel kehlständig. Gadus (Dorsch, Kabeljau, Schellfisch), Pleuroncetes usw. (Flunder, Scholle, Sole) usw. 
2. Unterordnung: Acanthopterygii. Stachelfiosser. Fig. 186 $3-1$.

Vordere Flossenstrahlen der Dorsalfiossen hart, ungegliedert. Pcrca (Barsch), Gasterosteus (Stichling) und ungemein zahlreiche ${ }^{*}$ Vertreter. Marin und Süßwasser.

3. Unterordnung: Lophobranchii. Büschelkiemer.

Kiemenblättchen kolbig verdickt. Haut mit Reihen von Knochenplatten. Schnauze stark röhrig verlängert. Zahnlos. Brustflossen klein, Bauchflossen rückgebildet. Sygnathus, Hippocampus usw. Marin.

\section{Unterordnung: Plectognathi. Haftkiefer.}

Prämaxille und Maxille jederseits verwachsen. Gestalt zum Teil sehr abweichend. Beschuppung und Bezahnung häufig eigentümlich modifiziert. Marin. Balistes, Ostracion (Kofferfisch), Orthagoriscus (Mondfisch), Diodon (Igelfisch) usw.

Die beiden letzten Unterordnungen werden neuerdings. häufig unter gewisse Gruppen der übrigen Knochenfische eingeschaltet; ihre systematische Wertung in obigem Sinne also herabgesetzt.

Die folgenden vier Vertebratenklassen könnten mit Recht als eine phylogenetisch aus gegemeinsamer Wurzel entsprungene Gruppe der Tetrapoda zusammengefaßt werden mit folgenden Charakteren :

Paarige, zur Bewegung auf dem Land eingerichtete gegliederte Extremitäten (zuweilen reduziert). Palatequadrat mit Schädel vereinigt. Lungenatmung. Cloake selten rückgebildet. Untere Hohlvene stets. Geruchsorgane in Mundhöhle mündend. Fenestra ovalis und mindestens ein Gehörknöchelchen stets vorhanden. Zwei Vorhöfe des Herzens. Ausleiter der Gonaden wie bei Chondropterygii und Archioperculata.

Da die gleichfalls natürliche Gruppe der Anamnia bei dieser Einteilung zerrissen würde, so weisen wir nur auf diese ebenso berechtigte Groppierung hin.

2. Klasse: Amphibia. Lurche.

Beinartige Extremitäten wie bei den Höheren (wenn nicht rückgebildet). Haut sehr drüsenreich, bei Recenten fast stets obne Verknöcherungen. Kiemenspalten und äußere Kiemen zum Teil bleibend érhalten (im Larvenzustand stets). Bei den Recenten stets geschlossene Wirbelkörper. Chorda bei Teil ansehnlich erhalten. Ein Kreuzbeinwirbel. Rippen schwach, ohne Verbindung mit Sternum. Doppelter Occipitalcondylús. Einfache Lungen (selten rückgebildet). Herzkammer einfach. Cloake stets; mit Harnblase. Urniere bleibend. Ausleiteapparat der Gonaden wie bei Chondropterygii.

1. Ordnung: Stegocephala.

Fossil, von Kohlenformation bis Trias. Gestalt urodelenartig mit langem Schwanz; zuweilen (Aistopoda) langgestreckt und Extremitäten rückgebildet. Wirbelkörper teils ungeschlossen, teils geschlossen und amphicöl; Chorda jedenfalls meist stark erhalten. Rippen stets. Zusammenhängende knöcherne Schädeldecke, ähnlich paläogenen Dipnoi und Ganoidei, mit zwei Hautknochen in der Occipitalgegend (sog. Supraoccipitalia). Parietalloch stets. Scleroticalring häufig. Reiche Bezahnung. Zähne kegelförmig, hăufig mit tiefgefaltetem Dentin (labyrinthodont). Haut mit mehr oder weniger reichen schuppenartigen Verknöcherungen von verschiedener Form. In der Brustgegend der Bauchseite drei Hautknochenplatten, die dem Schultergürtel angeschlossen sind. Branchiosaurus, Archegosaurus, Mastodonsaurus usw.

2. Ordnung: Urodela. Schwanzlurche.

Ansehnlicher Schwanz. Ohne Hautverknöcherungen. Mit freien kippen. Paukenhöhle und Paukenfell fehlen.

1. Unterordnung: Ichthyoidea. Fischlurche.

Mit 1 bis 4 Kiemenspalten (selten ganz rückgebildet) und bei Teil mit äußeren Hautkiemenpaaren (Perennibranchiata). Extremitäten zuweilen ziemlich verkümmert. Wirbel meist amphicöl. Proteus (Olm), Siren, Necturus (Menobranchus), Amphiuma, Megalobatrachus (Cryptobranchus). Süßwasser. 
2. Unterordnung: S a la mall drina. Salamander. Fig. 110.

Kiemen und Kiemenspalten nur im Larvenzustand. Zähne an oberer und unterer Kinnlade. Extremitäten gut ausgebildet. Wirbel opisthocöl. Salamandra (Salamander), Triton (Molge, Molche) und viele andere. Süßwasser und Land. Seit Beginn der Kreideformatlon.

3. Ordnung: Anura. Froschartige.

Kiemen und Kiemenspalten nur im Larvenzustand. Sch̀wanz verkümmert. Extremitäten stärker entwickelt, hintere häufig mit Schwimmhäuten. Wirbel im allgemeinen procöl. Freie Rippen f'ehlen. Paukenhöhle und Paukenfell meist (zuweilen rückgebildet). Zähne häufig stark bis ganz rückgebildet, am Unterkiefer stets fehlend. Pipa, Rana (Frösche), Bombinator (Unken), Bufo (Kröten), Hyla (Laubfrosch) usw. Süßwasser und Land. Seit Eocän.

4. Ordnung: Gymnophiona (Coeciliae, Apoda). Blindwiihler.

Langgestreckt, schlangenförmig. Extremitäten und Schwanz ganz rückgebildet. Körper regenwurmartig geringelt. Kiemenspalten und Kiemen nur im Larvenzustand. In der Haut zum Teil knöcherne Schüppchen. Paukenhöhle und Paukenfell fehlen. Bezahnung vollständig. Coecilia und andere. Land.

2. Gruppe der Gnathostomata: Ammiota. Amnioten.

In der Ontogenie treten Amnion und Allantois auf. Unniere (Mesonephros) durch bleibende Niere (Metanephros) ersetzt. Kiemenspalten und Kiemen völlig rückgehrildet, nur die ersteren treten ontogenetisch noch auf. Schneckenorgan des Labyrinths besser entwickelt und stets eine Fenestra rotunda neben der F. ovalis. Herzkammer stets teilweise bis völlig geteilt. Begattungsorgane (zuweilen rückgebildet). Rippen mit Sternum verbunden (wo letzteres nicht rückgebildet). Kreuzbein mindestens aus zwei Wịbeln bestehend.

\section{1. líreis: Sauropsida. Sauropsiden.}

Hant sehr drüsenarm (keine Mammardrüsen), mit stark verhornten Integumentalanhängen. Einfacher Occipitalcondylus. Quadrat ansehnlich, den Unterkiefer tragend. Gehörknöchelchen (Columella) meist einfach. Cloake stets.

3. Kilasse: Reptilia. Reptilien.

Integument mit Hornschuppen oder Hornplatten. Bezahnung meist reich und gewöhn lich annähernd homodont. Stets mindestens ein Paar Aortenwurzeln.

Über die systematische Gruppierung der ausgestorbenen Reptilien bestehen noch viele Meinungsverschiedenheiten. Sogar eine Auflösung der Klasse wird zum Teil rorgeschlagen,

1. Unterklasse: Rhynchocephala.

Gestalt eidechsenartig. Beschuppt. Extremitäten gut entwickelt, zuweilen zum Schwimmen umgebildet. Quadrat und Kiefer-Gaumenapparat fest mit Schädel verbunden. Bezabnung reich. Zähne acrodont; auch an Gaumen. Wirbel amphicöl. Bauchrippen. Cloakenöffnung ein Querspalt. Ohne Begattungsorgane. Jedenfalls sehr alte Gruppe (seit Dyas). Sphenodon (recent). Land.

2. Unterklasse: Squamata (Lepidosauria, Streptostylica Stann.).

Beschuppt. (uadrat stets beweglich am Schädel und bei Teil der ganze Kiefer-Gaumenapparat; letzterer meist mit Columella cranii. Zähne bei Teil auch an Gaumen. Wirbel fast stets procöl (Ausn. Ascalabotae, amphicöl). Cloakenöffnung ein Querspalt. Begattungsorgane zwei ausstülpbare Schläuche der hinteren Cloakenwand. Bezahnung meist reich, Zähne nicht iı Alveolen.

1. Ordnung: Sauria (Lacertilia). Eidechsen.

Extremitäten meist gut, zuweilen jedoch ganz rückgebildet; Reste von Brustgürtel jedoch stets. Schwanz gewöhnlich ansehnlich. Nur Quadrat beweglich am Schädel. Parietalloch meist. Unterkieferhälften fest verbunden. Paukenhöhle selten rückgebildet. Harnblase fast immer. Ascalabotae, Varanus, Laeerta (einheim. Eidechsen), Anguis (Blindschleiche), Iguana, Amphisbaena, Chamaeleo usw. Land und Süßwasser. Seit oberem Jura. 
2. Ordnung: Oplidia. Schlangen.

Extremitäten bis auf seltene Reste der hinteren rückgebildet. Brustgürtel und Sternnm stets ganz rückgebildet. Kiefer-Gaumenapparat meist sehr beweglich am Schädel. Unterkieferäste nicht fest rerbunden. Parietalloch fehlt. Paukenhühle und llarnblase stets fehlend. Giftdrüse in Verbindung mit Oberkieferzähnen (Giftzähnen) läufig. Boa, Puthon (Riesenschlangen); Tropidonotus (Ringelnatter), Naja (Brillenschlange), Crotalus (Klapperschlangen). Pelias (Kreuzotter) usw. Land, Süßwasser und Meer. Seit Kreide.

3. Orduung: Pytholl o morpha.

Fossil (ob. Kreide). Große Meeresbewohner. Extremitâten zu Flossen verkürzt. Schädel eidechsenartig. Unterkieferäste nicht erweiterbar. Bezahnung reich. Parietalloch vorhanden. Brustund Beckengürtel, jedoch letzterer meist ohne Verbindung mit einem Sacrum. Mesosaurus usw.

3. Unterklasse: Placoidea (Momimostylica Stann.).

Mit Hornplatten und Hautverknöcherungen darunter. Quadrat fest mit Schädel ver bunden und Gaumendach mehr oder weniger geschlossen. Parietalloch fehlt. Schädel ohne Columella cranii. Cloakenöffnung ein Längsspalt. Paukenböhle und Pauk̉enfell stets. Einheitliches Begattungsorgan an vorderer Cloakenwand.

\section{Ordnung: Crocodilia. Krokodile.}

Langgestreckt, eidechsenförmig. Schnauze lang bis sehr lang. Hautverknöcherungen ohne Verbindung mit Achsenskelet. Wirbel der Recenten procöl, der Älteren amphicöl. Bauchrippen vorhanden. Gaumendach mehr oder weniger geschlossen. Clavicula rückgebildet. Zähne nur in Zwischen-, Ober- und Unterkiefer, in Alveolen; bei Recenten etwas hetero dont. Sekundärer Nasen-Rachengang wenig bis sehr ausgebildet. IIerzkammer völlig geteilt. Harnblase fehlt. Alligator, Crocodilus, Gavialis usw. Süßwasser. Seit Trias.

2. Ordnung: Cheloniae (Testudinata). Schildkröten.

Rumpf verbreitert, mit meist starkem dorsalen und ventralen Hautknochenpanzer; der erstere fast stets mit Achsenskelet vereinigt. Extremitäten bei Teil flossenartig. Schnauze kurz. Sekundärer Nasen-Rachengang wenig entwickelt. Zähne fehlen; dagegen häutig Hornschnabel. Uarnblase stets. Sphargis, Chelone, Trionyx, Chelydra, Ernys, Testudo usw Süßwasser, Meer und Land. Seit oberer Trias.

4. Unterklasse: I chthy opterygia.

An das Meerleben angepaßte Formen von fischartiger Gestalt, mit Candal- und Rücken flosse, zwei Paar flossenartigen Extremitäten, ohne Schuppen oder Hautverknöcherungen. Schnauze lang ausgezogen. Schädel squamatenähnlich; Quadrat fest. Parietalloch. Zähne (homodont) nur in Kieferknochen, in einer Rinne eingepflanzt. Hals kurz. Wirbel amphicöi. Sacrum nicht ausgebildet. Bauchrippen. Iehthyosaurus usw. Trias bis Kreide.

5. Unterklasse: Sauropterygia.

An das Meerleben angepaßte Formen. Mit meist flossenartigen Extremitäten. IIals meist sehr verlängert. Schnauze mäßig. Schädel etwas schildkrötenartig, ein Jochbogen. Parietalloch. Quadrat fest. Sacrum ausgebildet. Zähne ziemlich Lomodont, nur an Kieferknochen, in Alveolen. Wirbel amphicöl bis platycöl. Bauchrippen. Nothosaurus, Plesiosaurus usw. Dyas bis Kreide. 6. Unterklasse: Theromorpha.

Fossil, von Dyas bis Trias. Große Landtiere, mit starken, zum Gehen eingerichteten Extremităten. Wirbel amphicöl, Sacralwirbel häufig vermehrt, bis auf sechs. Quadrat fest; Gaumen geschlossen. Schnauze mäßig bis kurz. Zähne in Alveolen, homodont bis säugetierähnlich heterodont, zuweilen sehr stark reduziert bis ganz fehlend; meist nur in Kieferknochen (selten am Gaumen, Placodus). Becken amphibien- bis säugetierähnlich; Pubis und Ischium nach hinten gerichtet, wenig gesondert. For. obturatum klein bis fehlend. Parietalloch zum Teil vorhanden. Pareıosaurus, Dicynodon, Placodus, Clepsydrops, Galesaurus usw.

7. Unterklasse: Dinosauria (Ornithoscelidae).

Fossil, von Trias bis Kreide. Meist große bis sehr große Landtiere mit kräftigen Extremităten, von denen die hinteren etwas bis viel länger als die vorderen. Im ersteren Falle 
Gestalt eidechsenartig, im letzteren känguruhartig, anf den Hinterbeinen aufgerichtet. Schwanz lang. Haut ohne oder mit Verknöcherungen. Wirbel amphicöl, bis opistho- und platycöl. Sacralwirbel häufig vermebrt bis auf sechs und mehr. Bauchrippen bei Teil. Schnauze mäßig bis etwas verlängert. Quadrat unbeweglich. Bezahnung reich, homodont, nur an den Kieferknochen; in Alveolen. Becken krokodil- bis vogelartig; Ileum stets lang bis sehr lang. Brontosaurus, Morosaurus, Diplodocus, Megalosaurus, Scelidosaurus, Triceratops, Iguanodon usw.

8. Unterklasse: Pteros auria.

Fossil; von oberer Trias bis Kreide. Bis mäßig groß. Ohne Hautverknöcherungen. Vordere Extremität zu Flugorgan entwickelt durch Flughaut, die sich zwischen Körper und dem stark verlängerten fünften Finger ausspannt. Schwanz kurz bis lang. Bauchrippen. Wirbel amphi- bis procöl. Sacralwirbel drei bis fünf. Schnauze stark verlängert. Quadrat unbeweglich. Schädel mehr squamatenartig. Ganmen meist geschlossen. Parietalloch nicht. Alveolarzăhne in Kieferknochen, homodont; auch zahnlos (Pteranodon). Pterodactylus, Rhamphorhynchus, Pteranodon.

4. Klasse: Ares. Vögel.

Integument mit besonderen verhornten Anhängen, Federn. Vorderextremität in besonderer Weise zu Flügel umgebildet, dessen Fläche wesentlich von den langen Schwungfedern gebildet wird. Hand stark verkümmert, jedoch zuweilen lang. Hinterextremität meist sehr kräftig entwickelt; fünfte Zehe stets verkümmert. Quadrat sehr beweglich und Kiefer-Gaumenapparat etwas. Kreuzbein sebr wirbelreich. Beckensymphyse fast stets rückgebildet. Zähne bei recenten völlig reduziert; dagegen Hornschnabel. Herzkammern völlig geteilt. Nur eine rechte Aortenwurzel. Harnblase fehlt. Begattangsorgan ähnlich dem der placoiden Reptilien bei Teil vorhanden; meist jedoch rückgebildet. Rechtes Ovarium und Eileiter rückgebildet. Seit Juraformation bekannt.

1. Unterklasse: Sa arurae. Urvögel.

Fossil (Oberer Jura). Mit'langem, zweireihig befiedertem Schwanz. Zähnchen in Zwischen-, Ober- und Unterkiefer. Drei freie Finger der Hand mit Krallen. Metacarpalia nicht verwachsen. Wirbel amphicöl. Bauchrippen. Archaeopteryx.

\section{Unterklasse: Ornithurae.}

Schwanz äußerlich verkümmert. Nur gewisse fossile Formen noch mit Zähnen. Hals- und Rumpfwirbel mit Sattelgelenken. Metacarpalia verwachsen und die Finger (bis drei) sehr verkümmert. Höchstens der erste, seltener noch der zweite mit Kralle.

1. Ordnung: Ratitae. Straußartige Vögel.

Sternum ohne Carina; mit verkümmerten Flügeln. Federn ohne feste geschlossene Fahne. Begattungsorgan stets vorhanden. Apteryx, Rhea, Dromaeus, Casuarius, Struthio. Bei den zuweilen bierhergezogenen fossilen (Kreide) Odontolcae (Odonthornithes) noch Zähne.

2. Ordnung: Carinatae.

Mit Carina des Sternums. Flügel nur ausnahnsweise verkümmert. Kontarfedern mit gescblossener Fahne. Begattungsorgan meist verkümmert. Sehr große Abteilung. Bei fossilen Odontornae Zähne.

Wir gehen hier auf die schwierige Systematik dieser Ordnung nicht ein, die jetzt gewöhnlich in eine große Anzahl kleiner Gruppen zersplittert wird, ein Zeichen, daß die richtige Erkenntnis der Zusammenbänge noch fehlt.

5. Klasse: Mammalia. Sängetiere.

Integument sehr drüsenreich (wo nicht Rückbildung), und bei den Weibchen auf der Banchseite stets Mammardrüsen zur Ernährung der Jungen. Integumentale verhornte Anhänge in Form von Haaren (selten verkümmert). Wirbel meist ohne Gelenke, mit Zwischenwirbelscheiben. Doppelter Occipitalcondylns. Quadrat beweglich, zu einem Gehörknöchelchen reduziert, dazu noch die Columella, sowie ein drittes. Der Unterkiefer gelenkt daher am Squamosum. Schnecke des Gehörorgans ansehnlich entwickelt. Äußeres Ohr meist ansehnlich. Alveolarzăhne (wo nicht rückgebildet) nur in Zwischen-, Ober- und Unterkiefer; Heterodontie 
(zuwcilen rückgebildet). Einmaliger Zahnwechsel (wenn nicht rückgebildet). Cloake meist rückgebildet; dann die Urogenitalöffnung vor After. Aorta mit einfacher linker Wurzel. Harnblase und Urogenitalsinus stets. Begattnngsorgan nach Typus der placoiden Reptilien stets; bei Rückbildung der Cloake änßerlich.

1. Unterklasse: Aplacentalia.

Entwicklung ohne Placenta, oder diese doch nur bei einzelnen Marsupialia schwach angedeutet. Beutelknochen rorhanden. Vaginae nicht verwachsen, oder doch nur teilweise.

1. Ordnung: Monotremata. Cloakentiere.

Cloake rorhanden, das Begattungsorgan einschließend. Schultergürtel mit Coracoid, das das Sternum erreicht, and ansehnlichem Episternum. Zähne bei recenten Formen rückgebildet. Zwei obere Hohlvenen. Ein Paar Milchdrüsen ohne Zitzen. Beutel bei $\&$ zuweilen temporär gebildet. MưlLERsche Gänge ganz getrennt. Vaginen nicht deutlich. Scrotum fehlt. Eierlegend. Ornithorhynchus (Schnabeltier), Echidna (Ameisenigel).

2. Ordnung: Marsupialia (Didelphia). Beuteltiere.

Cloake rückgebildet, böchsteus ganz schwach angedentet. Zahnbildung gut und mit sehr verscbiedenen Anpassnngen, ähnlich wie bel den Ordnungen der Placentalia. Zabnwechsel fast oder völlig rückgebildet. Coracoid rückgebildet. Beutelknochen stets. Beutel bei $Q$ fast stets, darin ein bis zahlreiche Mammardrüsenpare mit Zitzen. Fast immer zwei obere Hohlvenen. Vaginen gut entwickelt; ganz getrennt oder nur ihre proximalen Enden verwachsen. Uteri ganz gesondert. Scrotum ror Peniswurzel. Peniseichel häufig gabelig. Junge frühzeitig geboren. Phascolomys (Wombat), Macropus (Kängurub), Phalangista, Perameles (Beuteldachse), Dasyurus (Beutelmarder), Thylacinus (Beutelwolf), Didelphys (Beutelratten) usw.

Die ältesten Säuger treten (soweit bekannt) in der oberen Trias anf. Leider geben jedoch die mesozoischen Săugerreste nur wenig Aufschluß, da sie sich fast ausschließlich auf Zähne und Unterkiefer beschränken; ja sogar binsichtlich ihrer Säugernatur z. T. noch zweifelhaft sind. Bei einem Teil der ältesten (sog. Microtuberculata oder Mllotheria), von denen sich noch Ausläufer bis ins Tertiär erhielten, waren die zwei- bis dreiwurzeligen Backzähne mit meist zahlreichen Höckern ihrer Krone versehen, die in zwei bis drei Längsreihen angeordnet waren. Das übrige Gebiß war ziemlich spezialisiert. Mancherlei spricht dafür, daß diese Formen mit den heutigen Monotremen näher verwandt waren.

Bei einer zweiten Reihe alter Säuger, die ebenfalls schon in der oberen Trias begann, und deren rordere GebiBregion weniger spezialisiert war, waren die Kronen der häufig sehr zahlreichen Backzähne mit drei Zacken verseben, die entweder in einer längsreihe standen (triconodont), oder in einem Dreieck angeordnet waren (trigonodont). Ursprünglicb einwurzelig, wurden die Backzähne der späteren zwei- bis dreiwurzelig und ibre Krone komplizierter. Man erachtet die Formen der zweiten Reihe teils für Vorlüufer der heutigen Marsupialia, teils für solche der Insectivora.

\section{Unterklasse: Placentalia (Nonodelphia).}

Mit Placenta, die recht verschieden gebaut. Bentel und Bentelkuochen fehlen. Coracoid reduziert. Die beiden Vaginen stets ganz rerwachsen. Lteri nicht, teilweise (U. bicornis) bis ganz rerwachsen (U. simplex). Scrọtum, wenn ausgebildet, hinter Peniswurzel: Glans penis nicht gegabelţ.

\section{Ordnnng: Ungulata. Huftiere.}

Mäßig bis sehr groß. Extremitäten lang und stark, nur zum Gehen eingerichtet. Unguligrad (auf den Endphalangen gebend); selten digitigrad. Endphalangen zu Hufen verbreitert, die ron dem Hornnagel schuhartig umgeben. Die Zehenzahl meist stark reduziert. Clavicula reduzie t. Gebiß vollständig bis unrollständig. Backzähne mit breiter, höckeriger bis faltiger Krone, zum Zermalmen eingerichtet. Zahnwechsel stets gut. Darm meist sehr lang; Blinddarm ebenso, selten kurz oder fehlend. Gewöhnlich nor rechte obere Hohlrene. Zitzen meist inguinal. Uterus zweihürnig. Placenta adecidnat. Scrotum meist. 
Die Groppe der Ungulata wird häufig viel weiter gefaßt, als eine Überordnung, die unsere drei ersten Ordnungen umgreift. Wir führen letztere gesondert auf, da der Beweis, daß sie einem gemeinsamen Stamm entsprangen, doch wohl noch nicht scharf genug geführt ist.

1. Unterordung: Perissodactylia. Unpaarzehige Huftiere.

Dritte Zehe stark entwickelt, als Mittelstamm der Füße. Die äußeren Zehen mehr oder weniger bis völlig verkümmert. Hintere Prämolaren von den Molaren wenig scharf unterschieden. Thoracolumbarwirbel 22 und mehr. Keine Geweihe oder Hörner auf Stirnbein. Magen stets einfach. Zwei Zitzen. Scrotum nur bei Equus. Placenta diffus. Tapirus (Tapire), Rhinoceros (Nashörner), Equıs (Pferde). Fossile Vorläufer seit Eocän.

\section{Unterordnung: Artiodactylia. Paarzehige Huftiere.}

Dritte und vierte Zehe symmetrisch gleich entwickelt; die Mittelebene des Fußes fällt zwischen síe. Äußere Zehen mehr oder weniger, bis völlig verkümmert. Hintere Prämolaren von den Molaren schärfer unterschieden. Eckzähne und obere Schneidezähne bäufig reduziert. Thoracolumbalwirbel 19. Placenta diffus bis cotyledonär. Magen einfach bis zusammengesetzt. Geweihe oder Hörner häufig. Zitzen ein bis zahIreiche Paare; inguinal bis abdominal. Fossil seit Eocän.

1. Nonruminantia, Schweineartige. Hippopotamus (Nilpferd), Sus (Schweine) usw.

2. Ruminantia (Wiederkäuer). Tragulus (Zwerghirsch), Moschus (Moschustier), Cervus (Hirsohe), Camelopardalis (Giraffe), Ovis (Schafe), Capra (Ziegen), Antilope usw. (Antilopen), Bos (Rinder), Camelus (Kamele), Auchenia (Lama) usw.

Eine große Anzabl fossiler, hier nicht näher zu charakterisierender Ordnungen schließen sich an die typischen Ungulata an, so die Condylarthra, Ancylopoda, Lipopterna, Amblypoda und Toxodontia.

2. Ordnung: Нугасоidea. Klippschliefer.

Klein. Mäßig hohe Extremitäten. Zehen 4/3. Plantigrad. Krallen nagelartig. Gebiß erwachsen $\frac{1043}{204}$. Vordere Prämolaren allmählich ansfallend. Oberer Schneidezahn wurzellos, nagezahnähnlich. Backzähne ungulatenähnlich. Thoracolumbarwirbel 28-29. Mageı einfach. Scrotum fehIt. Penis bängend. Uterus bicornis. Zitzen ein bis mehrere Paare. Placenta deciduat, gürtelförmig. Hyrax usw.

3. Ordnung: Proboscidea. Elefanten.

Bis sehr groß. Körper plump. Schädel sehr aufgetrieben. Nase zu langem Greifrüssel verlängert. Extremitäten sehr plump, mit fünf fest verwachsenen Zehen, typisch unguligrad mit starkem Fußballen. Krallen mehr nagel- als hufartig. Schneidezähne bei Recenten auf einen Stoßzahn im Zwischenkiefer reduziert, bei fossilen zum Teil noch ein unterer Stoßzahn. Eckzähne fehlen. Backzähne sehr groß, bei den Recenten reich querfaltig, successive hintereinander hervortretend, daher nicht eigentlich gewechselt. Magen einfach; Blinddarm sehr lang. Zwei obere Hohlvenen. Ein Paar brustständige Zitzen. Uterus zweihörnig. Scrotum fehlt. Placenta deciduat gürtelförmig. Elephas. Fossil: Mastodon, Dinotherium usw. Seit Mitteleocän.

4. Ordnung: Sirenia. Seekühe.

Groß. An das Meeresleben völlig angepaßte, von elefantenartigen Vorfahren herleitbare Săuger. Hintere Extremitäten bei Recenten völlig reduziert; vordere flossenartig, ohne freie Finger. Schwanz zu dorsoventral abgeplatteter Schwanzflosse verbreitert. Haare fast völlig, äußeres Ohr ganz reduziert. Schneidezähne und Eckzähne fast völlig rückgebildet (Ausnahme Halicore ơ, ein großer oberer Schneidezahn). Backzähne zahlreich, buftierartig. Clavicula fehIt. Magen etwas kompliziert, Coecum kurz. Zwei obere Hohlvenen. Uterus zweihörnig; ein Paar brustständige Zitzen. Placenta adeciduat, gürtelförmig. Scrotum fehlt. Manatus. Halicore usw. Seit Mitteleocän. 
5. Ordnung: Rodentia, Nagetiere.

Klein bis mäßig groß. Extremitäten mäßig. Zehen meist $5 / 5$ (nicht unter $3 / 3$ ); plantigrad bis semiplantigrad; mit stumpfen bis hufartigen Krallen. Schneidezähne oben und unten auf ein Paar sebr langer wurzelloser Nagezähne reduziert (selten hinter dem oberen ein kleines zweites Par). Eckzähne fehlen. Backzähne mit flacher ansehnlicher lirone, meist reich querfaltig; ihr Wechsel zum Teil unvollständig. Magen meist einfach, selten etaws zweiteilig. Coecum fast stets sehr lang (selten zwei oder fehlend). Meist zwei obere Hohlvenen. Zitzen meist zahlreich (ein bis neun Pare) über die ganze Bauchseite. Uterus doppelt bis zweihörnig. Placenta deciduat, discoidal. Scrotum schwach bis fehlend. Penisknochen bäufig. Herbi-bis omnivor. Seit Eocän.

Lepus (Mase), Cavia (Meerschwein), Hystrix (Stachelschwein), Dipus (Springhase), Castor (Biber), Mus (Mäuse), Arvicola (Wühlmäuse), Myoxus (Siebenschläfer), Sciurus (Eichhorn), Arciomys (Murmeltier) usw.

6. Ordnung: Insectivora. Insektenfresser.

Klein bis mäßig groß. In mancher Hinsicht Parallelgruppe zu Rodentia. Extremitäten mäßig; meist plantigrad. Zehen gewöhnlich fünf (nicht unter vier), mit Krallen. Schneidezähne oben stets mehr wie ein Paar, nicht nagezahnartig. Kleine Eckzähne stets, jedoch wenig herrortretend. Backzähne spitzhöckerig. Claricula fast stets. Magen einfach; Coecum selten vorhanden. Zum Teil zwei obere Hohlvenen. Zitzen ähnlich Nagetiere (ein bis zehn Pare). Uterus zweihörnig. Scrotum meist fehlend. Peniskrorpel selten. Placenta deciduat und discoidal. Erinaceus (Ige]), Sorex (Spitzmaus), Talpa (Maulwurf). Galeopithecus (Fliegender Maki), auch als besondere Ordnung der Galeopithecidae aufgestellt, usw. Seit Eocän.

7. Ordnung: Chiroptera. Fledermäuse.

Vorderextremitäten zu großen Flügẻln entwickelt, durch Flughaut, die sich zwischen den stark verlängerten Fingern 2 bis 5 , den liörperseiten und den hinteren Extremitäten ausspannt und z. T. auch den Schwanz einschließt. Clavicula stets. Schneidezähne klein (im Maximum $\frac{2}{3}$, bäufig Reduktion); Erkzähne ansehnlich, raubtierartig; Backzähne spitzhöckerig. Magen einfach bis mit Anhang. Kleiner Blinddarm selten. Lin Paar brustständige Zitzen. Uterus doppelt bis einfach. Placenta deciduat, scheibenförmig. Penis hängend; Scrotum feblt. Rhinolophus (IIufeisennase), Plecotus. Vesperugo, Vespertilio, Ptcropus (Fliegender Hund) usw. Seit Eocän.

8. Ordnung: Edentata (Bruta). Zahnarme.

Klein bis mäßig groß (fossile zum Teil sehr groß). Extremitäten mäßig bis ansehnlich, plantigrad. Zehen wenig reduziert (meist fünf, selten unter vier). Endphalangen ansehnlich, mit starken bis sehr starken, zum Graben oder Klettern dienenden gekrïnmten Krallen. Gebiß stets stark vereinfacht. Schneidezähne und Eckzähne meist ganz reduziert; Backzähne fast immer völlig homodont, schmelzlos und meist wurzellos, einfach cylindrisch mit flacher Krone. Zahnwechsel mehr oder weniger rudimentär. Scrotum fehlt. Placenta verschieden.

1. Unterordnung: Tubulidentata (Orycteropodidae).

Schnauze verlängert. Extremitäten mäßig lang. Zehen 4/5, zum Graben eingerichtet, mit langen Krallen. Schwanz lang. Behaarung spärlich. Erwachsenes Gebiß ziemlich homodont, mit vier bis fünf Backzähnen, die statt einfacher Pulpa von zahlreichen aufsteigenden seknndären Pulpen durchsetzt werden (tubulidentat). Insektenfressend, Zunge lang. ThoracoIumbarwirbel ohne accessorische Gelenkfortsätze. Clavicula vorhanden. Magen einfach. Cöcum lang. Uterus doppelt. Ein Paar abdominale und ein Par inguinale Zitzen. Placenta adeciduat (?) gürtelförmig. Orycteropus (Erdschwein).

2. Unterordnung: Pholidota (Squamata, Manidae). Schuppentiere.

Körpergestalt, Extremitäten und Lebensweise ähnlich Tubulidentata. Zehen $5 / 5$ mit starken Grabkrallen. Rücken mit großen Hornschuppen und spärlicher Behaarung. Wirbel wie bei der 1. Unterordnung. Clavicula reduziert. Zunge lang. Magen einfach. Ein Paar achselständige Zitzen. Uterus zweihörnig. Placenta adeciduat, diffus. Manis. 


\section{Unterordnung: Xenarthra.}

Schnauze mäßig verlängert (Gürteltiere und Ameisenfresser) bis kurz (Faultiere). Entweder dichtes Haarkleid (Ameisenfresser und Faultiere) oder Behaarung sehr spärlich und der Rücken ruit Hornplatten, unter denen Hautverknöcherungen liegen (Gürteltiere). Extremitäten mäßig lang, mit Grabkrallen und meist fünf Zehen, oder sehr lang bei Faultieren, deren Zehen bis auf zwei und drei reduziert und mit langen Kletterkrallen versehen sind. Schwanz lang bis mäßig oder ganz reduziert (Faultiere). Zähne teils ganz rückgebildet (Ameisenfresser), teils auf wurzellose homodonte Backzähne $\left(\right.$ bis $\left.\frac{9}{9}\right)$ beschränkt, selten der erste obere Zahn im Zwischenkiefer. Bei Faultieren zum Teil die vordersten Zähne abweichend eckzahnartig. Clavicula vorhanden. Magen einfach bis kompliziert (Faultiere). Uterus einfach, jedoch nicht scharf von Vaginalabschnitt geschieden. Myrmecophaga (Ameisenfresser); Dasypus (Gürteltiere); Bradypus(Faultiere) usw. Zahlreiche und zum Teil recht große fossile Formen seit älterem Tertiär.

\section{Ordnung: Carnivora. Raubtiere.}

Mäßig bis groß. Extremitäten verschieden; bei Fissipedia ansehnlich mit mindestens vier Zehen, die meist mit stark gekrümmten, großen und spitzigen, häufig retractilen Krallen versehen sind. Plantigrad bis digitigrad. Bei Pinnipedia stark verkürzt flossenartig, mit Schwimmhäuten. Schneidezähne klein (meist $\frac{3}{3}$ jederseits). Eckzähne groß, spitz und gekrümmt. Backzähne mit Ausnahme der hintersten stark komprimiert, mit schneidender mehrspitziger Krone, seltener plumper. Clavicula rudimentär bis fehlend. Magen stets einfach. Blinddarm meist, aber klein. Nur rechte obere Hohlvene. Zitzen in der Regel zahlreich (ein bis sieben Paar), abdominal. Uterus zweihörnig. Scrotum meist. Penisknochen häufig. Placenta deciduat, gürtelförmig.

\section{Unterordnung: Fissipedia.}

Klein bis groß. Extremitäten ansehnlich, zum Gehen eingerichtet. Nur selten schwache Schwimmhäute. Schwanz lang bis kurz. Backzähne nicht gleichmäßig, sondern stark differenziert; meist ruit stark hervortretenden sog. Reißzähnen. Äußeres Ohr gut. Scrotum. Viverra (Zibetlkatze), Hyacna (Hyänen), Felis (Katzen), Canis (Hunde), Mustela (Marder), Procyon (Waschbär), Ursus (Bären) usw. Seit Oligocän.

2. Unterordnung: Pinnipedia. Robben.

Mittel bis sehr groß. Extremitäten flossenartig verkürzt, mit Schwimmbäuten, bintere nach hinten gerückt und gerichtet. Nägel mehr oder weniger rudimentär. Schwanz stark verkümmert. Haarkleid kurz. Äußeres Ohr meist ganz verkümmert. Eckzähne meist wenig hervortretend. Backzähne gleichartig. Ein bis zwei Paar abdominale Zitzen. Scrotum fehlt. Marin. Phoca (Seehund), Otaria (Ohrrobben), Trichechus (Walroß) usw. Seit Miocän.

\section{Unterordnung: Creodonta.}

Eocăn bis Miocän. Die ältesten carnivorenartigen Säuger werden häufig unter dem obigen Namen zusammengefaßt. Es waren plantigrade Formen mit mäßig langen Extremitäten und einem

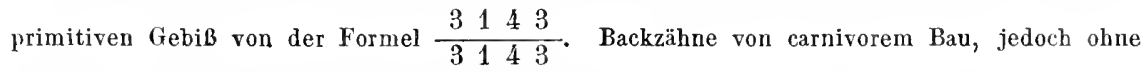
Reißzähne und ohne Verkümmerung hinterer Molaren. Sie standen in Beziehung zu den ältesten Huftierèn und den carnivoren Marsupialia.

10. Ordnung: Cetacea. Waltiere.

Groß bis sehr groß. An das Meerleben völlig angepaßte, wohl aus raubtierartigen Vorfahren hervorgegangene Säugetiere. Hintere Extremitäten rückgebildet. Vordere völlig flossenartig, ohne freie Finger und Nägel, sowie ohne jegliche Beweglichkeit der Abschnitte gegeneinander. IIorizontale Schwanzflosse und meist unpaare Rückenflosse entwickelt. Kopf groß; mit stark verlängerter Schnauze. Haarkleid und Hautdrüsen ganz rückgebildet. Nasenöffnungen stark nach hinten, gegen den Scheitel emporgerückt. Äußeres Ohr fehlt stets 
völlig. Glavicula fehlt. Zähne sämtlich wieder gleichmäßig kegelförmig (homodont), oder ganz verkümmert. Magen sompliziert zusammengesetzt. Cöcum bei Teil, kurz. Nur rechte obere Hohlvene. Uterus zweihörnig. Ein Paar inguinale Zitzen. Scrotum fehlt. Placenta adeciduat und diffus. Seit Mitteleocän.

1. Ordnung: Denticeti (Odontoceti). Zahnwale.

Kopf mäßig bis sehr groß. Sehr zahlreich€ bis wenige Zähne vorhanden. Sog. Barten fehlen. Nasenöffnungen zu einer zusammengeflossen (Spritzloch). Zeuglodon usw. (fossil), Physeter (Pottwal), Delphinus, Phocaena (Delphine, Meerschweine), Monodon (Narwal) usw.

2. Ordnung: Mysticeti (Mystacoceti). Bartenwale.

Zahnlos. Kopf sehr groß. Nasenlöcher gesondert. Barten jederseits längs des harten Gaumens. Balaena, Balaenoptera usw.

\section{Überordnung: Primates. Primaten.}

Extremitäten ansebnlich, zum Gehen, Klettern und Greifen eingerichtet; plạtigrad; Zehen $5 / 5$, die größtenteils (mit vereinzelten Ausnabmen) oder sämtlich, mit PIattnägeln rerseben sind. Daumen meist, häufig auch große Zehe opponierbar. Gebiß vollständig. Zahnwechsel vollkommen. Schneidezähne nicht mehr wie $\frac{2}{2}$ jederseits; Eckzähne meist ansehnlich. Backzähne mebrhöckerig mit flachen Kronen. Augenhöhlen mehr oder weniger stark nach vorn gerichtet. Clavicula stets. Magen einfach. Coecum stets. Nur rechte obere Hohlvene. Penis hängend Scrotum meist.

\section{Ordnung: Prosimiae. Halbaffen.}

Habitus teils mehr raubtierartig, teils mehr affenartig. Gebiß gewöhnlich $\frac{2133}{2133}$; Schneidezähne bei manchen mehr oder weniger rudimentär; Eckzähne ansehnlich (selten rudimentär). Extremitäten lang (Klettertiere); die hinteren meist etwas länger als die vorderen. Daumen und große Zebe meist opponierbar (Chiromys nur große Zehe). Plattnägel, mit Ausnahme der zweiten Zehe, die bekrallt (Ausnahme Chiromys, wo nur erste Zehe mit Plattnagel). Schwanz sehr rerschieden. Angenhöhlen gegen die Schläfengrubell nicht knöchern ā̄geschlossen. Unterkieferhälften meist nicht verwachsen. Uterus zweihörnig. Zitzen ein bis drei Paare, inguinal bis pectoral. Scrotum mäßig; Penisknochen meist. Clitoris durchbohrt. Placenta meist diffus und adeciduat bis discoidal (Tarsius). Vorläufer seit Eocän. Tarsizıs (Gespenstmaki), Lemur (Lemuren), Nycticebus, Chiromys (Fingertier) usw. Seit Eocän.

\section{Ordnung: Simiae. Affen.}

Augenhöhlen gegen die Schläfengruben knöchern abgeschlossen. Gebiß $\frac{212(3) 3(2)}{212(3) 3(2)}$. Schneidezähne in geschlossener Reihe. Eckzähne fast stets stark herrorragend。Vordere Extremitäten in der Kegel lïnger als hintere. Schwanz sebr verschieden. Daumen und große Zehe opponierbar. Unterkieferäste verwachsen. Uterus einfach. Ein Paar brustständige Zitzen. Scrotum stets. Penis hängend, mit Knochen. Placenta decidrat, discoidal.

1. Unterordnung: Arctopitheci. Krallenaffen.

Sämtliche Finger und Zehen mit Krallen, außer der großen Zehe, die mit Plattnagel.

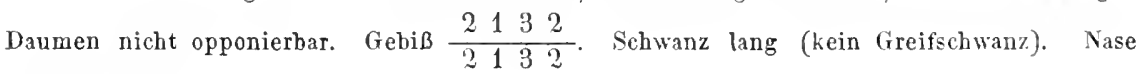
wie bei Platyrrhira. Hapale.

2. Unterordnung: Platyrihina. Affen der neuen Welt.

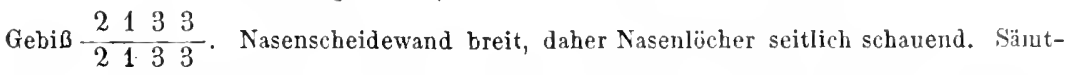
liche Zehen mit Plattnägeln. Daumen mäßig opponierbar. Schwanz lang, häufig zum Greifen eingerichtet. Weder Backentaschen noch Gesäßschwielen. Keine seitlichen Kehlвäcke; zum Teil unparer. Cebus (Kapuzineraffe), Mycetes (Brüllaffe) usw. Seit Oligocän. 
3. Unterordnung: Catarrhina. Affen der alten Welt.

Gebil $\frac{2}{2} \frac{2}{2} 1 \frac{2}{2}$. Nasenscheidewand schmal, Nasenlöcher nach rorn schauend. Backentaschen und Gesäßschwielen häufig. Daumen stets opponierbar (selten rudimentär). Schwanz sehr verschieden, nie Greif́schwanz. Seitliche Kichlsäcke bei Teil.

1. Cynomorpha. Paviane.

Vordere Extremitäten nicht, oder wenig länger ais die hinteren. Mit der ganzen Handund Fußfläehe auftretend; sich nicht aufrichtend. Gesäßschwielen stets, Backentaschen meist. Schnauze meist stark rorspringend. Inpaarer. Kehlsack. Cynocepluahes (Paviane), Macacus Cercopithecus usw. Seit Miocän.

2. Anihropomorpha. Menschen̈̈hnliche Affen.

Vorderextremitäten sehr stark verlängert. Mit dem Außenrand des Fußes auftretend (Ausnahme Irylobates). Sich häufig aufrichtend. Schwanz verkünmert. Ohne Backentaschen. Kleine Gesäßschwielen nur bei Hylobates. Meist seitliche Kehlsäcke. Coecum mit Processus vermieularis. Hylnbates (Siamang), Simia (Orang), Anthropopithecus (Troglodytes, Schimpanse), Gorille (Gorilla). Vorläufer seit Miocän.

\section{Bimana. Menschen.}

Die Unterschicle ron den Anthropomorpha sind ausschließlich quantitative. Gebiß3 wic Catarrhina. Eckzähne nicht oder wenig vorspringend. Schwanzlos. Vorderextremität nicht verlïngert. Bewegung nur auf Hinterextremität. Auftreten mit der ganzen Fußsohle; große Zche nicht oder sehr wenig opponierbar. Körperbehaarung stark reduziert. Nammardrüsen zu Brüsten entwickelt. Homo.

\section{Abschnitt.}

\section{Vergleichende Anatomie der Protozoa.}

\section{Einleitnng.}

Dic Grïnde, welche eine gesonderte Behandlung der vergleichenden Anatomie der Protozoen erfordern, wurden schon in der Einleitung lurz erörtert. Die untergeordneten Teile oder Organe, aus welchen sich der Protozoenkörper anfbaut, sind Teile einer einfarhen Zelle und daher morphologiseh unvergleichbar mit den Organen des Metazoenkörpers, dio znm mindosten selbst eine einfache Zelle sind, in der Regal aber Komplexe zahlreicher, ja nngehener vieler Einzelzellen. So viel berechtigte Vergleichspmnkte die Organe der Protozoen und Netazoen daher auch in physiologiseher IIinsicht darbieten, so sehart miissen sie morphologisch auseinander gehalten werden. Man hat deshalb anch häufig vorgoschlagen, die Protozoenorgano durch eine besondere Bezeichnung, als Organula, Organoide ofler Organellen, von den Metazoenorganen zu nnterscheiden.

Fine Übersicht dex Protoznenorgane läßt leicht erkennen, daß sie morphologisch nielt gleichwertig sind; uach ihrer Entstehung können sie vielmehr in zwei Kategorien gesondert werden. Eine Reihe der Organellen erweist sich nämlich bei genanerer Untersuchung als Erzeugnisse des Protoplasmas; sei es, daß sie direkt durch Umbildung gowisser Anteile des Zellplasmas entstehen, sei es, daß sie mehr als Produkte des Protoplismas aufgefaßt werden miisseu. Diese Organellen können daher anch eventucll nach ihrem Verlust oder ihrer liiickbildung, ebenso auch bei der Vermolirung vom l'rotoplasma neu hervorgebracht werden. Wir können sie 
daher als die plasmatischen bezeiehnen. Die plasmatischen Organellen selbst lassen sich jedoeh wieder unterseheiden, insofern sie nïmlich nach ihrer Besehaffenheit als relativ wenig verändertes, in besonderer Weise modifiziertes Plasma anzusehen, und daher auch wie das übrige Plasma als eigentlieh lebendig, d. h. an der Hervorbringung der Lebenserscheinungen direkt beteiligt, zu beurteilen sind. Solehe plasmatische Organellen kömmen wir daher als lebendige oder cuplasmatisehp von denen der zweiten Gruppe unterseheiden. Letztere sind, obgleieh für die Erhaltung des Lebens der Zellen hïufig sehr wertvoll, denmoelı nicht eigentlich lebendig, d. h. sie nehmen keinen direkten Anteil an deien eigentlichen Lebensprozessen. Wir können sie daher als michtlchendige, oder besser als alloplasmatische von den explasmatischen tremen. Es liegt iibrigens anf der Hand, daß diese Unterschểdung in einzelnen häufig bedentende Schwierigkeiten bietet, da die Lebensvorg:inge sehr verwickelt ineinander greifen und das Leben des Zellindividuums sich nicht wohl in einzelne Anteile zerlegen läßt. Auch ist die Herkunft und Entstehung vieler Organellen noch wenig sieher. Andrerseits wird sich jedoch ergeben, daß die Unterscheidung der beiderlei plasmatischen Organe von Wert ist.

Den plasmatischon Organcllen steht eine zweite Gruppe gegeniiber, die wir als autonome bezeichnen wollen, insofern sie hinsichtlich ihrer Entstehung auf sich selbst angewiesen sind, d. h. nur auf die Weise nengebildet werỏer können, daß die schon vorhandenen sieh vermehren. Wie wir finden werden, sind eshauptsächlich die Kcrne (Nuclei), welche diesen autonemen Charakter besitzen; ebenso oder doch prinzipiell ähnlich verhält sich das sog. Centrosom, wo es sieh findet; endlich gehören zn dieser Kategorie aueh die sog. Chromoplastcn Farbstufikörper, Chlorophyllkörper), die jedoch bei tierischen Einzelligen selten vorkommen. Obgleich die Organellen der letzterwälnnten A rt antonom sind, weil sie, soweit bekinnt, nie von dem Plasma hervorgebracht werden, sondern nu' durch Selbstvermehrung nen entstehen, so sind sie doch hinsiehtlieh ihrer Ein̈̈hrung anf das Plasma angewiesen.

Der folgenden Übersicht der Organellen legen wir eine physiologische Einteilung zngrunde, wie dies ja in der vergl. Anatomie, trotz der Betonung ihres rein morphologisehen Standpunktes, noch gewöhnlich geschieht. Eine rein morphologisch-genetische Gruppierung wäre bei lem heutigen Stand unserer Kenntnisse schwerlich durchführbar.

\section{A. Euplasmatische Organellen.}

\section{Bewegungsorganellen.}

Pscudopodien. Die Angehörigen der umfangreiehen Abteilung der Sarcodinen bewegen sich ohne bleibende, dauernde Organe. Ja es gibt darunter sogar einfache Formen (gewisse Amöben), welche dabei nicht einmal voribergehend organartige Bildungen hervorbringen. Die charakteristische Bewegnugsart der Sarcodinen ist die sog. Plasmabewegung oder amöboide Bewegung, die sich in Strömungsvorgängen des Plasmas äußert, deren Ursachen hier nicht näher erörtert werden können. Im einfaehsten Fall strömt das Plasma in der Achse des einzelligen Wesens vor, um, 
wenn es dic Oberfläche erreicht hat, nach allen Seiten riickwärts umzubiegen (s. Fig. 5); da diese Rückströmung des peripherischen Plasmas fast immer sehr bald stockt, so führt der Axialstrom fortgesetzt einen Überschuß von Plasma nach vorn. Infolgedessen wächst das Vorderende andauernd vor, während das Hinterende gewisserinaßen einschrumpft. Es ist ersichtlich, daß die ganze Zelle sich so

Fig. 5.

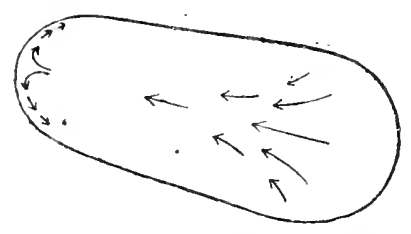

Schema der Protoplasmaströmung einer ein. fachen Amóbe. Die Pfoile geben die Richtung des Stromes an. allmählich vorwärts bewcgt, ohne ihre Gestalt wesentlich zu verändern. Da jedoch der ursprüngliche Plasmastrom erlöschen und dafür ein anders gerichteter auftreten kann, so ist mit dieser einfachsten Art der plasmatischen Ortsbewegung dennoch ein zeitweiliger Gestaltswechsel verbunden.

Tritt ein solcher Vorstrom des Plasmas mehr lokal am Zellkörper auf, so ruft er an dem Punkt der Oberfäche, gegen welchen er gerichtet ist, das Hervorwachsen eines lappen- bis fingerartigen Plasmafortsatzes hervor, eines sog. Scheinfüßchens oder Pseudopodiums. Treten gleichzeitig mehrere solche Ströme gegen die Oberfläche, so bilden sich mehrere Pseudopodien (s. Fig. 6).

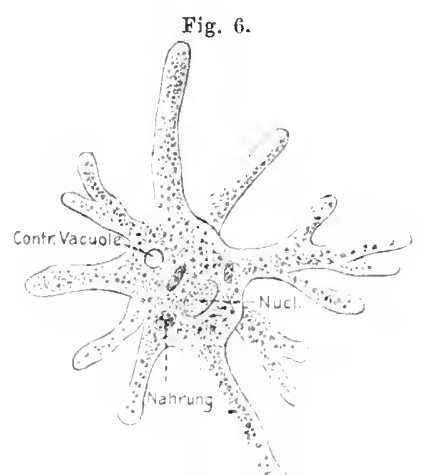

A moeba proteus. Nach Leidy (1879). Da sich der Strom innerhalb eines solchen Pseudopodiums selbst wieder verteilen und gegen verschiedene Punkte seiner Oberfläche richten kann, so vermögen sich auf diese Weise auch mehr oder weniger verzweigte fingerartige Pseudopodien (Lobopodien) zu bilden. Erlischt die Zuströmung des Plasmas, so hört natïrlich das Wachsen des Psecidopodiums auf; treten dann an anderen Stellen des Körpers stärkere Strömungen auf, so wird das Plasma des Pseudopodiums wieder in das allgemeine KKörperplasma rückströmen. Natürlich ist mit diesem wechselnden Vor- und Rückströmen von C. H. Pseudopodien ein mehr oder weniger energischer amöboider Gestaltwechsel der Zelle verbunden. -

Da die Pseudopodien aus dem vorströmenden Körperplasma hervorgehen, so wird der Körper, wenn die Pseudopodien vorwiegend nach einer gewissen Richtung auswachsen, bzw. hervorströmen, in dieser Richtung fortschreiten.

Aus dem Bemerkten folgt, daß die Pseudopodien keine bleibenden Organellen sind, sondern vorubergehende organartige Bildungen, die, wie wir finden werden, such noch zu anderen Lebensverrichtungen dienen können.

Viele Sarcodinen entwickeln in ïnnlicher Weise feinere, mehr fadenförmige, gegen ihr Ende zugespitzte Pseudopodien (Filipodien), die auch häufig mannigfaltig verzweigt sind (s. Fig. 7 und die Fig. 18 u. 19 anf S. 85, 87). Es finden sich alle Abstufungen zwischen den lappig-fingerartigen und den fädigen Pseudopodien. Die Mehrzahl der Sarcodinen, insbesondere die marinen, bilden meist große Mengen 
äußerst. feiner fadenförmiger Pseudopodien, die sich reich verzweigen und untereinander netzartig verbinden, indem sie sich auf eine weite Strecke im Umkreis der Zelle ausbreiten. Die Ortsbewegung beruht anch hier auf dem lebhaften Strömen solcher Pseudopodiennetze wach einer gewissen Richtung. - Während die fädigen Pseudopodien der Rhizopoden sich meist auf einer Unterlage ausbreiten, strahlen dagegen die ähnlichen der schwimmenden Radiolarien allseitig von der Oberfläche des Körpers in das nmgebende Wasser aus (s. Fig. 19 S. 87). Auch sie zeigen häufig Netzbildung, wenn auch weniger entwickelt als die der Rhizopoden.

Etwas anders geartet sind die Psoudopodien der gleichfalls meist schwimmenden Sonnentierchen oder Heliozoen des süßen Wassers, welche unverzweigte, feinstrahlige Scheinfüßchen allseitig sounenartig aussenden. Diese Pseudopodien verdanken ihre relative Starrheit, wenigstens bei den größereu Formen, welche eindringendere Untersuchnng gestatten, der Anwesenheit eines besonderenPlasmafadens, der ihre Achse durchzieht (Achsenfaden) und sich mehr oder weniger tief in den Zellkörper hinein erstreckt. Bei vielen Heliozoen können die Achsenfäden bis zu einem im Centrum des Körpers gelegeneu Köruchen(Achsenkorn,Centrosom) verfolgt werden (s. Fig. 18, S. 85). Da jedoch die Pseudopodien der Heliozoen rückgebildet werden

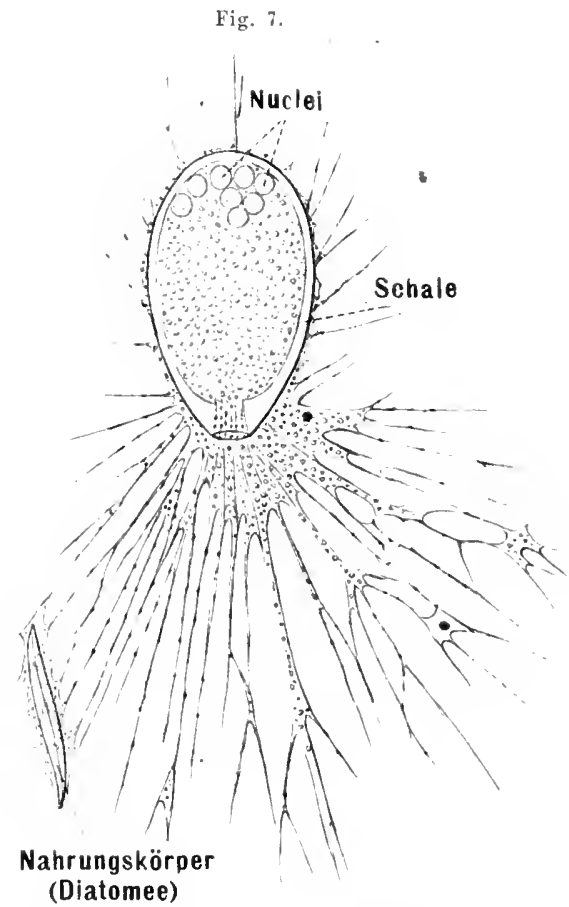
können, wenngleich sie dauerhafter Gromia oviformis (Rhizopoda). (Nach M. Schultze 1854). sind als die rasch wechseluden der Rhizopoden, so wird bei der Einziehung auch der Achsenfaden rïckgebildet, d. h. verschwindet, anscheinend durch Auflösung im Plasma. Bei der Entwicklung nener Pseudopodien differenziert er sich, soviel man weiß, von neuem. Ähnliche Achsenfäden wurden auch bei deu fadenförmigen Pseudopodien gewisser Radiolarien beobachtet und selbst für die der Rhizopoden als wahrscheinlich vermutet.

Undulipodien. Die Beweguugsorganellen, welche wir unter diesem Namen zusammenfassen, verdienen die Bezeichnung echter Organtllen in dem Sinne, als sie im allgemeinen dauerhaftere Bildungen sind; hieraus folgt jedoch kein durchgreifender Unterschied gegen die Pseudopodien, weil sich einmal auch die Undulipodien zuweilen rïckbilden und neu hervorwachsen können, und weil andrerseits manche Pseudopodien etwas dauerhaftere Gebilde sind. Wichtiger schcint daher 
der Unterschied, welcher sich in der Bewegungsweise dieser Organellen ansspricht. Es sind im allgemeinen feinfadenförmige Plasmagebilde, die sich teils hin- und herschwingend, teils eigentiumlich schraubenförmig bewegen und dadurch den Zellkörper in Bewegnug setzen können. Anch dieser Charakter begründet keine völlige Yerschiedenheit ron den Psendopodien, da man an den Pseadopodien gewisser lihizopoden zuweilen auch schwache schwingende oder pendelnde Bewegungen beobachtet hat. Hicraus wäre wohl zu schließen, daß beiderlei Organe sich aus gleicher Grundlage entwickelten, so verschieden sie auch in ihrer typischen Ansgestaltung erscheinen.

Als bleibende Beregungsorganellen finden wir die Lndulipodien in der Klasse der Nrestigophora und der Unterklasse der Citiata (der Infusoria). Die Undulipodien der Mastigophoren treten in der Regel in beschränkter Zahl, jedoch in relativ ansehnlicher Länge auf und werden daher seit alter Zeit als Geißeln oder Flagellen. bezeichnet. Im Gegensatz dazu besitzen die Ciliaten stets sehr zahlreiche, aber kïrzere Undulipodien, die man deshalb Wimperhaare oder Cilicn nennt.

Den Sareodinen und Sporowoen fehlen jedoch solche Organellen nicht völlig. Abgesehen von einzelnen sarcodinenartigen Formen, welche ein Flagellum danernd neben Psendopodienentwicklung besitzen, treten Flagellen bei gewissen Vermehrnngsvorgängen der Sarcodinen und Sporozoen als voribergehende Bewegungsorganellen auf. Dies dürfte beweisen, daß die Ausgangsformen aller dieser Gruppen die Befühigung zur Pseudopodien- und Undulipodienbildung besaßen.

Analog verhalten sich unter den Infusorien die Suctorien (s. Fig. 14 S. 77) zu den Ciliaten. Die festsitzenden Suctorien haben ihre Cilien verloren und bilden sie nur wïhrend der Vermehrung auf kurze Zeit voriibergehend wieder aus.

Die Flugellen der Mustigophoren sind feine bis sehr feine, nahezu gleichdicke Färchen, die fast stets vou dem bei der Bewegung vorangehenden Körperende entspringen (s. Fig. 8). Hure /ahl ist meist geriug (1, 2, 3, 4 u. melur); ihre Länge, in bezug anf die der Zelle, dagegen häufig recht ansehnlich. Der Qnerschnitt der Flagellen ersche'nt iu der hegel kreisrund bis oval : loch finden sich auch bandförmige Geißeln in der Abteilung der Dinoflaypllatr. Bei Anwesenheit mehrerer Geißeln begegnen wir interessinterweise zuweilen einer morphologischen Differenzierung derselben, womit wohl stets anch ein verschiedenartiges Funktionieren verbunden ist. So kann sich nehen einer langen Hantgeißel eine kleine Nebengeißel finden (Fig. 82). Die eine Geißel gewisser zweigeißeliger Formen (Fig. 83) kann als eigentliche Bewegungsgeißel nach vori gerichtet sein, während die zweite ansehnlichere sog. Schleppgeißel nach hinten dïuft und zur $\ddot{A}$ derung der Bewegungsrichtung, aber anch zu gelegentlichem $\Lambda$ nheften dienen kann. Eigentumlich ist die Differenzierung zweier Geißeln bei den Dinothagellaten Fig. 9 B,S.72), von welchen die eine bandformig ist und, in eine äquatoriale Furche der Körperoberfläche eingelagert, den Körper ringförmig umzieht; die kleinere Geißel, von gewöhnlichem Ban, ist dagegen wie eine Schleppgeißel nach hinten gerichtet. - Ein eigentümliches Organ steht mit der Geißel der sog. Choanoflagellaten in Beziehung. Hier (Fig. 9 A) erhebt sich nämlich eine äußerst zarte plasmatische Membran um die Geißelbasis und bildet eine Art Kelch oder 
Kragen. Dieses Organell dient zum Einfaneren kleinster Nahrungskörperchen, die an seiner Außenseite festkleben und an ihr zum Körper herabgleiten.

Wie erwihnt, ist das Flagellum ein fast in seiner ganzen Ausdehnung gleich dieker, feiner Faden; nur das äußerste Endstück erscheint bei größeren Geißeln

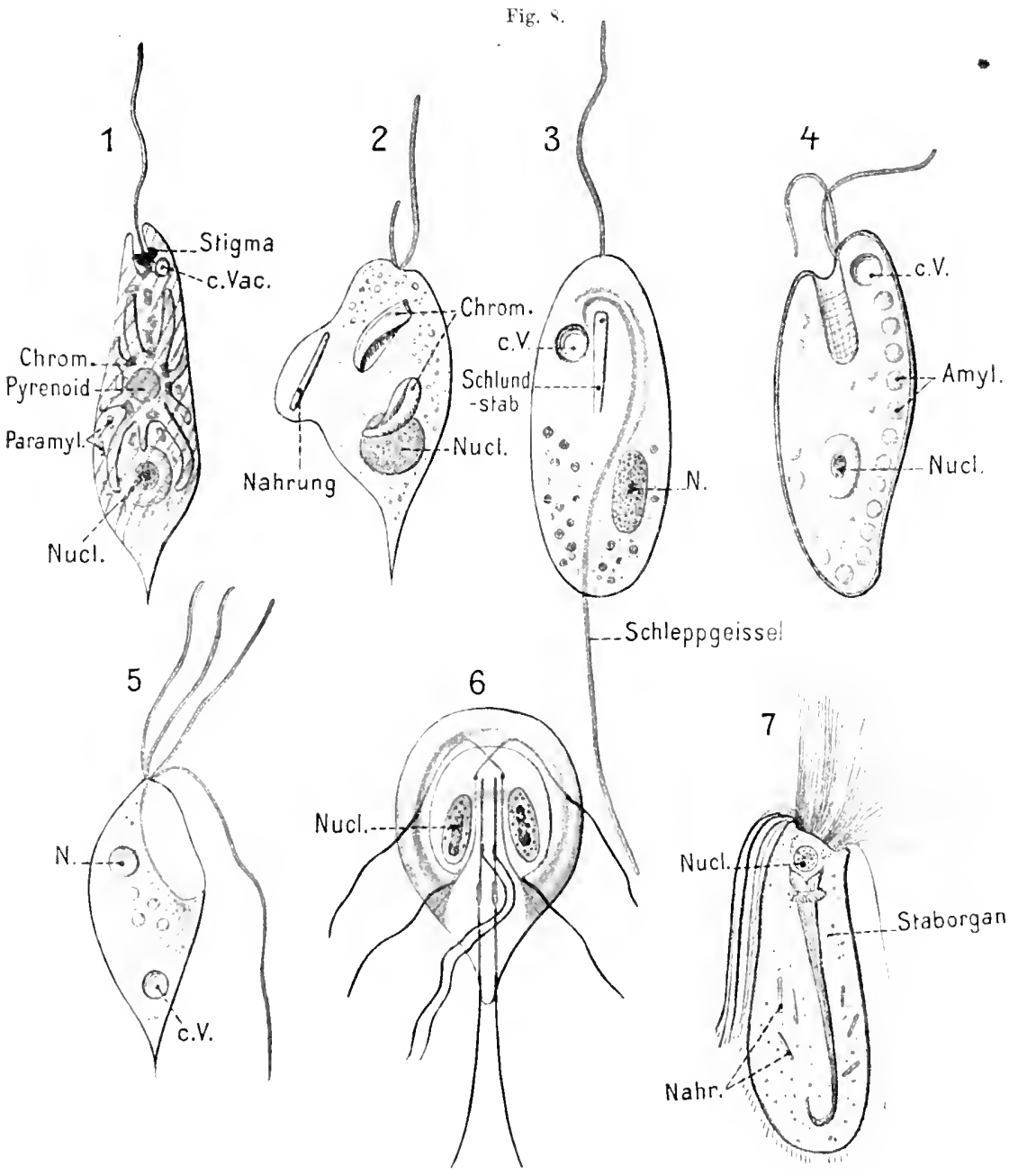

Verschiedene Flagellaten. 7. Euglena viridis. 2, 0chromonas mutabilis (nach SEN 1900). 3. An is onema acinus (n. Bürschli) v. Rückseite. 7. Chilomonas paramaecium. 5. Jetramitus descissus (n. KLeBs 1592). G. Lamblia intestinalis (n. WeNron). 7. Joenia andectens (n. Bütschl. and Bugchuavil.

etwas dünner. Die dauernde Erhaltung eines soleh feinen Geißelfadens ist nur denkbar, wenn er fest ist, oder doeh einen festen Faden einschließt. Die neveren Beobachtungen machen es denn auch sehr wahrscheinlich, daß das oben erwähnte Endstiick das freie Ende eines solchen Achsenfadens ist, der die Geißel durchzieht, 
umhülltt von wenig eigentlichem Plasma (s. Fig. 10b). - An der Geißelbasis läßt sich in der Regel ein kleines dichteres und stärker färbbares Körperchen nachweisen,

Fig. 9.

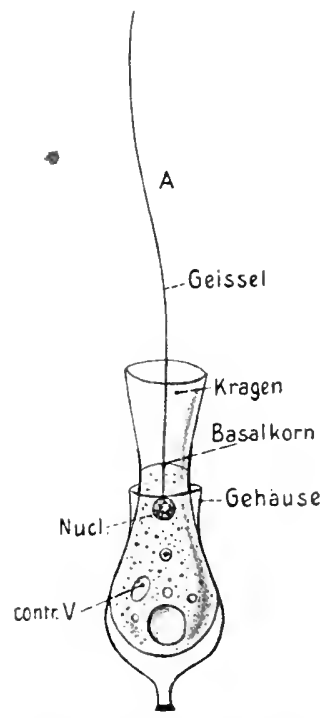
dassog. Basalkörperchen(Basalkorn, Blepharoplast), welches wohl dem Achsenfaden angehört und oberfiächlich oder tiefer im Zellkörper liegt. Von ihm ist zuweilen noch ein feiner $F$ aden ins Plasma der Zelle zu verfolgen, manchmal bis zur Kernoberfläche, ja bis in den Kern hinein. Auch diese mor"phologischen Ergebnisse verstäken die Beziehungen zwischen Flagellen und Pseudopodien, besonders denjenigen mit Achsenfaden. Die möglichen Beziehungen, welche die neuere Forschung zwischen dem Achsenfaden der Flagellen und dem Nucleus oder gewissen Bestandteilen desselben (Centrosom) wahrscheinlich gemacht Salpingoeca amphoridinm (Choanoflagellate) n. Bणrck 1909 - Glenodinium pulviscalus (Dinoflagellate, nach STEIN). C. H.

haben, sind bis jetzt noch zu unaufgeklärt, um hier genauer erörtert zu werden. Cilien. Die kürzeren Wimpern der Ciliaten zeigen bei genauer Untersuchung Fig. 10.

a

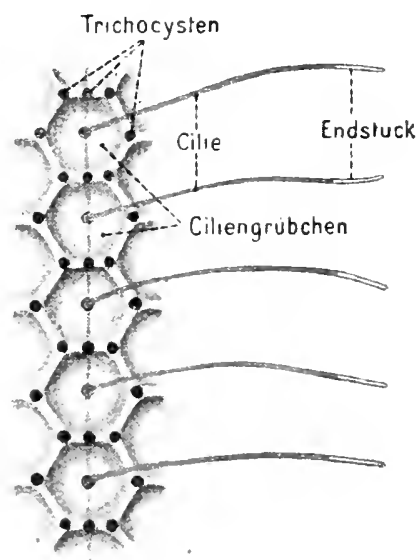

Paramaecium b

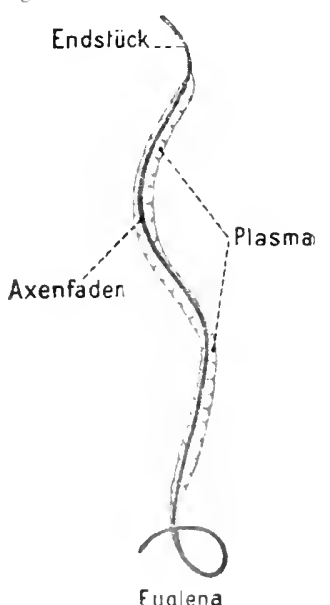

Euglena

a Kleiner Teil der Oberfleche von Paramaecinm aurelia mit einer Reihe von Cilien, die in Grübchen entspringen. In den Ecken der Grūbchen und in der Mitte der Kanten, die in die Cilienręihe fallen, je eine Trichocyste. Nach Scuuberg (1905) und nach Hasssir verändert. $b$ Englena: Isolierte Geißel mit Achsenfaden und Plasma, welches ersteren schraubig umbüllt. Original von 1895. Trockenpräparat, Löfflerfārbung. E. W. 
ganz dieselben feineren Bauverhältnisse wie die Geißeln, so daß die morphologische Identität beider Organellen sicher erscheint (s. Fig. 10a). Nur selten hat man jedoch bis jetzt an den Cilien fadenförmige Verlängerungen des Achsenfadens in das Zellplasma beobachtet, obgleich Basalkörperchen gewöhnlich vorhanden sind. Dagegen ließen sich an den, genetisch wohl Cilienreihen entsprechenden, sog. Membranellen,

Fig. 11 .

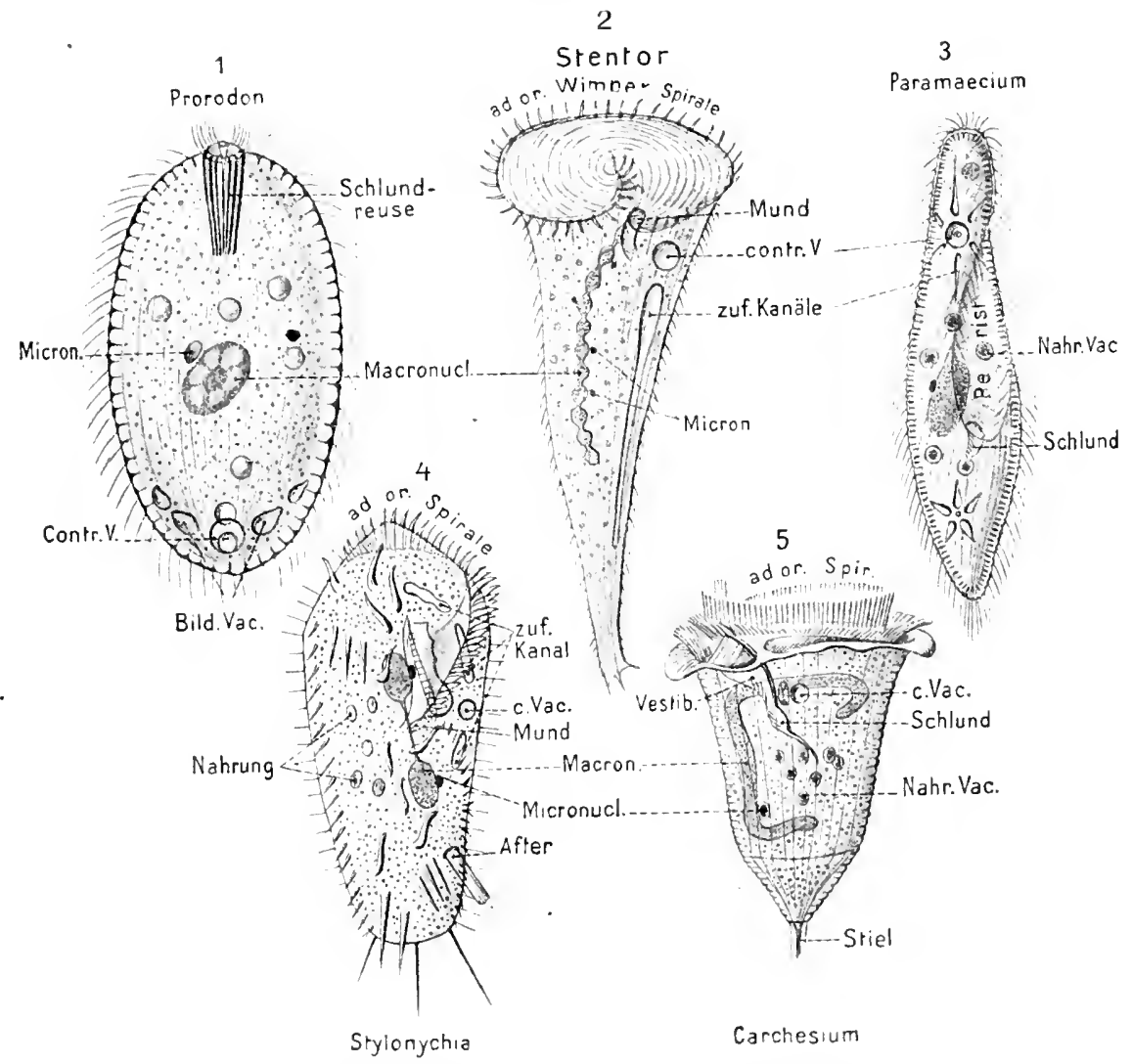

Verschiedene Formen ron Ciliata. 1. Prorodon teres (n. Schewiarorf 1889). 2. Stentor polymorphus (Heterotricha) von der Ventralseite. 3. Paramaecium aurelia (Holotricha). 4. 8tylonyehia mytilas (Hypotricha, n. Stein). 5. Carchesiam polypinum (Peritricha, nach Bütscel n. Schewiakofr). C. H.

von welchen weiter unten die Rede sein wird, blättchenartige Verlängerungen in das Plasma dentlich wahrnehmen, die sogar sämtlich durch einen Faden oder ein Band verbunden sind (s. Fig. 12). Vermutlich handelt es sich funktionell um eine Stützeinrichtung für diese Organellen.

Die äußerst reichhaltige morphologische Verteilung und Anordnung der Cilien der Ciliaten kann hier nur in den Grundzügen kurz berührt werden. Der ursprünglichste Zustand ist wohl sicher der einer gleichmäßigen Bedeckung der Körperoberfläche mit Wimperhaaren (Holotricha, Fig. 11 ${ }^{1,3}$ ); dabei stehen jedoch die Cilien 
in der Regel deutlich in Längsreihen, die in Meridianen oder häufig auch etwas schraubig vom vorderen zum hinteren Körperpol ziehen. Aus solchen Zustïnden können sich jedoch durch teilweise Riickbildung der Wimperhaare anf gewissen Körperstrecken reeht mannigfaltige Bewimperungsverhältnisse ableiten.

Bei den hypotrichen Ciliaten (s. Fig. 114) beschränkt sich die Bewimperung anf die Bauchseite, indem sich gleichzeitig die Wimpergehilde häufig zu dickeren, griffel- bis borstenartigen Organellen entwicheln. Eime solche Differenziernng der Ciliengebilie kann sich bei gewissen Ciliaten auch im Vorkommen einzelner geißelartig.r, lïngerer Cilien neben gewölnlichen anssprechen; ebenso im Auftreten

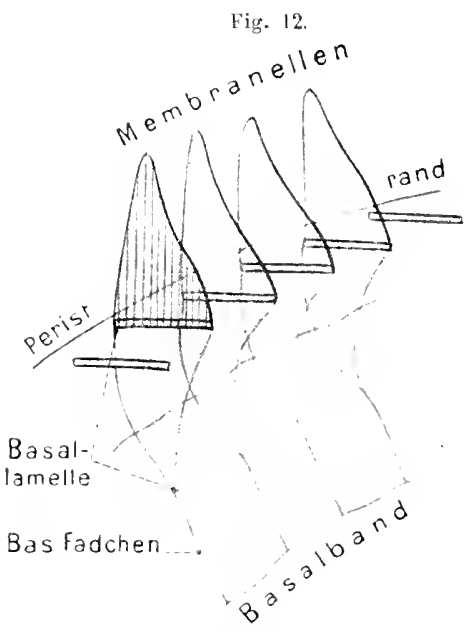

Kloiner Teil der adoralen Spirale von Stentor. Die Merobranellen setzen sich mit ihren sog. Basal. lawellen ins Innere fort und rerschmälem sich zn den sog. Basaltädehen, die sieh, sowie die inneren l'artien der Lamellen, an das sog. Basalband heften. Schewatisch. Nach Scrröner 1906). Sehr. steifer unbeweglicher Härchen zwischen den beweglichen, oder anf der sonst cilienlosen Dorsalseite der Hypotrichen.

Die wichtigste und interessanteste Differenzierung von Ciliengebilden findet sich jedoch bei der Mehrzahl der Ciliaten (Spirotricha) in Verbindmug mit der Mundöfnumg und Nihrungsaufnahme. Eine bandformige, meist etwas spiral verlaufende Zone eigentïmlicher Ciliengebilde umzieht hier einen Teil des Vorderendes und führt direkt in den Mund und Schlund. Diese adorale Wimperzone (oder Spirale) wird von einer Reihe dreibis viereckiger schwingender, plasmatischer Blättchen, sog. Membrancllen, gebildet (Figur 112,4,5). Wahrscheinlich dürfen wir diese Membranellen (s. Fig. 12) als ans einer oder zwei Reihen Cilien entstanden auffassen, deren Plasma verschmolzeu oder doch nicht gesondert ist, während sich ihre Achsenfäden erhalten haben und die feine Längsstreifung der Membranellen bilden. Auch die dicken Cilienborsten der Hypotrichen können vielleicht als Bündel vereinigter Cilien aufgefaßt werden, da sie sich sehr leicht zerfasern.

Daß sich die adorale Zone an der Körperbewegung beteiligt, ist selbstverständlich, und deshalb auch begreiflich, daß sich bei gewissen Ciliaten die gesamte Bewimperung fast oder ganz auf diese Zone reduziert (Fig. 115). Hänfiger ist diese Reduktion jedoch mit dauernder Festheftung verbunden (bei den meisten Peritrichen).

Eine an die Membranellen anschließende besondere Art beweglicher Organellen sind endlich die sog. undulierenden Membranen, welche bei gewissen Ciliaten in Verbindung mit der Mundöffnung vorkommen, jedoch auch schon bei einigen Flagellaten neben Geißeln enwickelt sind. 


\section{Ecto- und Entoplasma, Pellicula, Myonemo.}

Der gestaltsverå̉nderliche, Psendopodien anssendende Zellkörper der Sarcodinen besitzt in der Regel kein festeres, plasmatisches Hïutehen der Körperoberfläche, obgleich anzunehmen ist, daß die äußerste Grenzschicht des Plasmas zühflüssiger ist als das Innere. Diejenigen Protozoen aber, die eine von der Kugelgestalt abweichende dauerhafte Form haben, besitzen ein, wenn auch häufig sehr zartes solches Häutchen, eine sog. Pellicula (Cuticula), deren Entstehung durch Erhärtung und Veränderung der ärßeren Grenze sicher erscheint. Dennoch tritt auch bei den Sarcodinen zuweilen eine Differenzierung der oberflächlicken Plasmaregion auf. Manche Rhizopoden besitzen eine äußerste Plasmazone von hyaliner

Fig. 13.

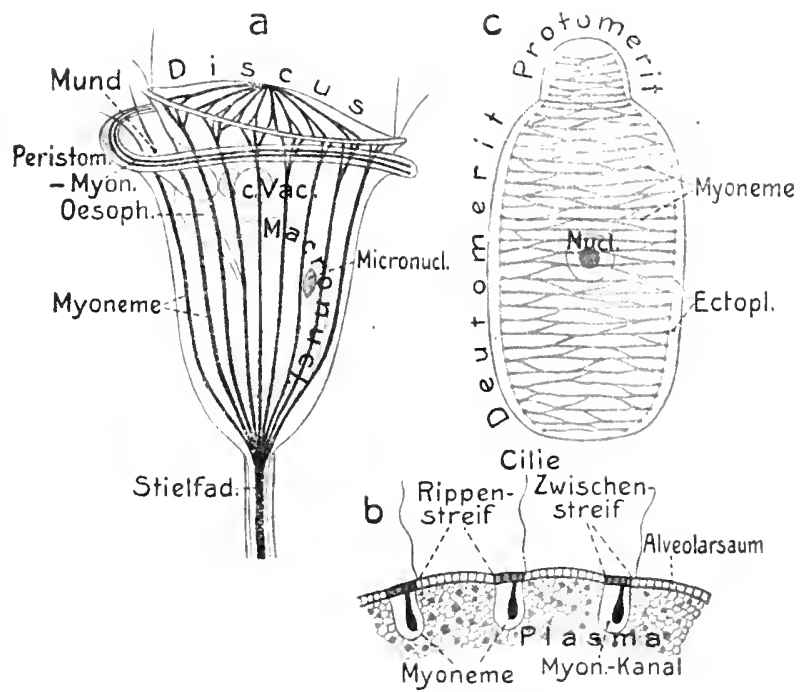

II yoneme von Protozoen. Schematisch. a Verticella (nach 0. Scrronder 1906). U Stentor, Querschnitt durch Körperoberıảche. Myoneme, im Querscbnitt in besonderen Kanälen. $c$ Ulopsidrina in unieri (Gregarine) nach Armé Schnetuer. Schr.

Beschaffenheit, ein sog. Ectoplasma, das sich danernd oder anch nur voribergehend von dem körnigen und wahrscheinlich anch flüssigeren Entoplasma sondert. Sehr charakteristisch tritt eine solche Differenziernug zweier Plasmazonen meist bei den Heliozoen hervor (s. Fig. 18, S. 85). Bei gestaltsbeständigen Mastigophoren, Sporozoen und Infusorien finden wir ïberall die vorhin erwähnte Pellicula von bald äußerst feiner, bald etwas dickerer und resistenterer Beschaffenheit. Bei größeren Formen (speziell Gregarinen, Ciliaten) erlangt auch das die Pellicula unterlagernde äußerste Plasma eine besondere, von dem Entoplasma abweichende und starrere Beschaffenheit, und wird dann als Ectoplasma oder Corticalplasma unterschieden. Bei gewissen Ciliaten kann man sogar verschiedene Schichten dieses Ectoplasmas erkennen.

Das Ectoplasma vermag außer den schon besprochenen Undulipodien besondere Bewegungsorganellen hervorzubringen, welche befähigt sind, sich wie dic contrac- 
tilen Elemente der Muskelzellen zu verkürzen (kontrahieren) und so Gestaltsveränderungen der Zelle za bewirken. Bei den Ciliaten, welche solche Myoneme besitzen, verlaufen sie in der Regel als zarte Fädchen dicht unter den längsgerichteten Cilienreihen in dem äußersten Ectoplasma (s. Fig. 13), und bewirken daher bei ihrer Kontraktion eine Zusammenziehung des Körpers in der Längsrichtung. Bei den Peritrichen (Glockentierchen) finden sich außer solch längsgerichteten Myonemen noch verschiedene anders verlaufende im Bereich der adoralen Zone und deren Umgebung (s. Fig. 13a). Ferner ist bei gewissen festsitzenden Formen dieser Gruppe das hintere Körperende za einem fadenförmigen contractilen Fortsatz ausgewachsen, der in steilen Schraubenwindungen einen hohlen cuticularen Stiel durchzieht, auf dem die Zelle sitzt (s. Fig. 13a). Die Kontraktionen dieses sog. Stielmuskels bringen den Stiel zum Zurückschnellen; die Elastizität seiner cuticularen Wand streckt ihn wieder aus.

Unter der Pellicula größerer Gregarinen findet sich im Ectoplasma gleichfalls ein System feiner Myoneme (s. Fig. 13c), die jedoch den Zellkörper quer umgürten und daher bei der Kontraktion ringförmige Einschnürungen erzeugen. Diese Myoneme sind netzartig verbunden, eine Erscheinung, die anch bei den Peritrichen vorkommt.

Die genaue Untersuchung dickerer Myonemfäden ließ Andentungen von Querstreifung an ibnen wahrnehmen.

\section{Einrichtungen zur Nahrungsaufnahme.}

Parasitische Protozoen (z. B. Sporozoen, Opaliniden) nehmen häufig keinerlei feste Nahrung auf und besitzen daher auch keine Einrichtungen zur Nahrungsaufnahme, oder haben die ehemals vorhandenen rïckgebildet. Den pseudopodienbildenden Sarcodinen dienen die Scheinfüßchen auch zur Nahrungsaufnahme. Nahrungskörper können hier im allgemeinen an jeder beliebigen Stelle der Körperoberfläche eingeftihrt werden. Gröbere, lappige Pseudopodien umfießen den Nahrungskörper und verschmelzen endlich um ihn, wodurch er in das Plasma gelangt. - Feine reticuläre Pseudopodien heften sich in größerer Zahl an einen Nahrungskörper (s. Fig. 7, S. 69), fließen um ihn zu einer Plasmapartie zusammen, oder führen ihn auch in den Zellkörper selbst, indem sie eingezogen werden.

Bei den von einer festen Pellicula umschlossenen Einzelligen lokalisiert sich die Nahrungsaufnahme notwendigerweise anf eine bestimmte Stelle der Körperoberfläche (Cytostom), die dazu besonders eingerichtet ist, indem hier die Pellicula fehlt, also die Einführung von Nahrung in das zähflüssige innere Plasma möglich ist. Bei kleineren Mastigophoren kann sich ein solches Cytostom als eine nicht weiter ausgezeichnete Stelle an der Geißelbasis finden. Zuweilen besteht auch die Einrichtung, daß sich an dieser Stelle zeitweise eine kleine Vacuole, ein Flüssigkeitstropfen, im Plasma bildet, in den kleinste Nahrnngskörperchen durch die Geißel geschlendert werden können. Wie schon oben erwähnt, dient bei den Choanoflagellaten der zarte plasmatische Kragen um die Geißelbasis zum Fang kleinster Nahrungskörper, welche dann an der Kragf "rbasis in das Körperplasma eindringen. - Selten kann sich an der Mundstelle gewisser Flagellaten auch eine 
röhrenförmige Einstiilpung der Pellicala in das Zellinnere bilden, eine Art Zellschlund zur Einfuhr der Nahrung. Zuweilen steht mit der Mundstelle ein eigentiimliches Stiutz- oder Staborgan in Verbinduug (Fig. $8^{3}, \mathrm{~S} .71$ ).

Viel komplizierter entwickelt sich das Cytostom der Ciliaten (s. Fig. 11, S. 73). Bei den ursprünglichsten Formen lag es wohl am vorderen Körperpol; sehr häufig wird es jedoch mehr oder weniger auf der Bauchseite nach hinten verlagert. Im einfachsten Fall ist es eine rundliche bis schlitzförmige Unterbrechung der Pellicula und des Ectoplasmas, so daß an dieser Stelle Nahrungskörper in das freiliegende Entoplasma eingeführt werden können. Bei höherer Entwicklung bildet sich eine besondere, mehr oder weniger lange, röhrenförmige Plasmamasse, welche sich schlundartig dem Cytostom anschließt und auch wio ein Schlund funktioniert. Wabrscheinlich ist sie ectoplasmatischer Herkunft. Häufig findet sich um diesen Schlund eine Art Schlundreuse (Fig. 11), die ans längsgerichteten Stäbchen besteht, die den später zu erwähnenden Trichiten wohl verwandt sind. Im untätigen Zustand ist die Mundstelle solcher Ciliaten meist nahezu geschlossen und öfnet sich erst bei der Nahrungsaufuahme. Die Schlundrense dürfte vorwiegend als Stiitzapparat dienen.

Bei den meisten Ciliaten ist der an das Cytostom anschließende Schlund nach einem andern Plan gebaut. Indem sich nämlich das Ectoplasma, samt der Pellicula, von der Mund- Tokophrya quadripartita (Suctoria) stelle aus röhrenförmig ins Zellinnere einsenkt,

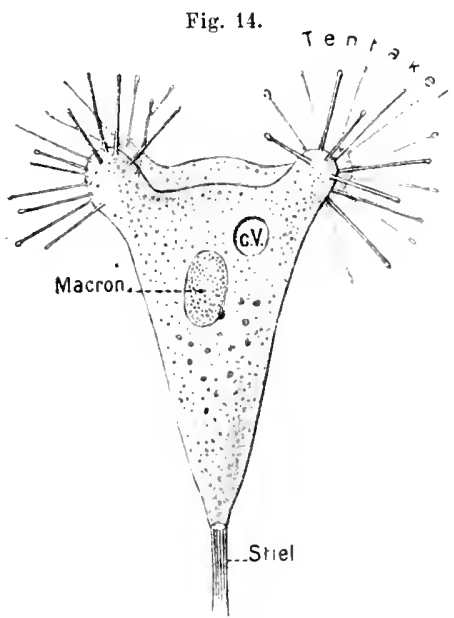
bildet sich ein kürzerer bis längerer Schlund (Fig. 112-5). Seiner Entstehung entsprechend ist er stets mit einer inneren Bewimperung ausgerïstet, der Fortsetzung der Körperbewimperung, die zar Einstrudelung der Nahrung in den stets offen stehenden Mund dient, oder zu ihrer Weiterbewegung in der Schlundröbre. Bei den Spirotrichen ist es die oben erwähnte adorale Zone, welche sich in den Schlund fortsetzt. Doch können auch noch mancherlei besondere Wimpergebilde als Hilfsorgane zur Nahrungsaufnabme in der Mundgegend entwickelt sein. Ansebniich lange Schlundbildungen können sich sogar in verschiedene Abschnitte differenzieren (Peritricha, Fig. 115).

Ganz isoliert stehen die nahrungsaufnehmenden Organellen der Suctorien. Es sind lange fadenförmige Fortsätze des Vorderendes (Saugtentakel) oder auch der gesamten Körperoberfläche (Fig. 14). Jeder Tentakel ist ein feines bohles Röhrchen, dessen Achsenkanal sich zuweilen noch selbständig in das innere Körperplasma fortsetzt. Das distale Tentakelende erscheint häufig knopfartig verdickt. Im einfachsten Fall findet sich nur ein einziger Sangtentakel; gewöhnlich sind jedocb zahlreiche vorbanden, die dann bäufig auf lappenförmigen Vorsprüngen zu 
Gruppen vereinigt stehen. Sie funktionieren in der Tat als Organellen, welche das Plasma kleiner Ciliaten anssaugen. Morphologisch könnte man daran denken, den einfachen Saugtentakel aus der besonderen Umbildung eines ursprünglichen Cytostoms herzuleiten, und cine successive Vermehrung solcher Cytostombildungen annehmen. Die geuetische Ableitung der Suctoriententakel von Pseudopodien, die hänfig versucht wurdt, erscheint dagegen aus verschiedenen Gründen wenig wahrscheinlich.

\section{Einrichtungen zur Ausstoßung unverdauter Nabrungsreste.}

Während die Nahrungsreste bei den Sarcodinen im allgemeinen an beliebigen Stellen der Körperoberfläche austreten können, dient hierzu bei den mit Pellicula versehenen Mastigophoren und Infusorien in der Regel eine besonders vorgebildete Stelle der Oberfläche, ein Zellenafter oder Cytoproct. Bei den Mastigophoren ist Näheres hieriiber wenig bekannt; das Cytoproct der Ciliaten dagegen wurde vielfach beobachtet. Da man es gewöhnlich nur im Noment der Ausstoßung der Nahrungsreste bemerkt, so kam es sich nur nm eine minutiöse Unterbrechung der Pellicula und des Ectoplasmas handeln. Das Cytoproct kanu an sehr verschiedenen Stellen vorkommen (Fig. 114, S. 73), ja selbst (Peritricha) in den Eingang des Schlundes (Vestibulum) rïcken.

\section{Stoffwechselorgane.}

Das Auftreten und Verschwinden von wässerigen Fliissigkeitstropfen (Vacnolen) im Entoplasma der Protozoen ist eine sehr gewöhnliche Erscheinung. Da es sich dabei meist um voriibergehende Abscheidung wässeriger Fliissigkeit handelt, so können solche Vacnolen, ähnlich den Pseudopodien, nicht als wirkliche Organellen angesprochen werden, sondern uur als temporäre Abscheidungen des Plasmas. Manchmal kann die Vacnolisation so reichlich werden, daß das gesamte Plasma, oder anch nur gewisse Regionen desselben, grohblasig oder alveolär erschcinen. Auf dieselben Vorg:inge ist anch das netzig-vacnoläre Entoplasma mancher Ciliaten und der Noctiluca zuriekzufïhren.

Ein sehr verbreitetes Vorkommen ist der FinschluB der anfogenommenen Nahrungskörper in einen Tropfen wässeriger Flüssigkeit, eine sogenannte Nahmengsvacuole (s. Fig. 113.5). Häufig geschieht dies so, daß zugleich wit dem Nahrungskörper etwas Wasser anfgenommen wird. Doch können sich Nahrungsvacnolen auch sekundïr, durch Abscheidung von Flüssigkeit um den Nahrungskörper bilden. So wichtig die Nalırungsvacuolen physiologisch als verdaluende Höhleu sind, so wenig morphologische Beständigkeit haben sie dagegen in Simne bleibender Organellen. Sie führen direkt über zn den un Verlauf des Plasma-Stoffwechsels gebildeten mannigfaltigen l'rodukten organischer und anorganischer Natur: Fetttropfen, Pigmentkörnchen, Stïrkekörnern, Kristallen, Excretkörneru, Concretionen u. dgl., die hier keine Besprechung verdienen.

Contractile oder pulsierende Vacuolen. Unter den vacuolären Bildongen dos Plasmas begegnen wir jedoch einer besonderen Art, welche größere 
Ansprüthe besitzt, als wirkliche Organellen bezeichnet zu werden. Dies sind die contractilen oder pulsierenden Vacuolen; im allgemeinen Tropfen wässeriger Flüssigkeit, die sich durch Abscheidung des Plasmas bilden, um an der Körperoberflächo entleert zu worden, nachdem sie eine gewisse Größe erreicht haben. So verbreitet solche Bildungen bei den Protozoen anch sind, so fehlen sie doch den marinen Sarcodinen, den Sporozoen und einzelnen Infusorien. - Die physiologische Funktion der contractilen Vacuolen ist jedenfalls eine sehr wichtige, indem sie nicht nur dem Wasserwechsel des Plasmas dienen, sondern zweifellos àuch Stoffwechselprodukte in gelöstem Znstand entfernen.

Die contractilen Vacnolen der einfacheren Sarcodinen (z. B. Fig. 6, S. 68) zeigen ein primitives Verhalten, iudem sie bei lebhaft strömendem Plasma in demselben umhergefuhrt werden können und erst bei der Entleerung an die Oberfitiche treten, wo sie platzen. In anderen Fällen bilden sie sich schon direkt unter der Körperoberfläche ind springen sogar im Zustand stiarkster Anschwellnng (Diastole) tiber sie vor (Fig. 18, S. 85). Bei den Mastigophoren (Fig. 8, S. 71) und Ciliaten (Fig. 11, S. 73 ) sind die Vacuolen im Zusammenhang mit der bestimmteren und bleibenden Diferenzierung der Körperregionen auch örtlich fest lokalisiert. Ihrer Funktion gemäß bilden sie sich stets nahe nnter der Körperoberfäche, etwa im Grenzhereich von Ecto- und Entoplasma. Sowohl ihre Zahl als Lage bietet jedoch die größten Verschiedenheiten. Von der Einzahl bis zur Vielzahl finden wir die mannigfaltigsten Übergänge; ebenso ist ibre Lage bald vorn, bald hinten, bald seitlich eine äußerst verschiedene. Die größeren Infusorien lassen bestimmt erkennen, daß die Pellicula ïber der contractilen Vacuole stets eine oder melırere feinste Öffnungen besitzt, darch welche die Entleerung der Vacuolenflüssigkeit geschieht. Bei einzelnen Formen kann diese Öfrinung sogar zu einem feinen Kanälchen auswachsen, welches zu der tiefer im Kïrper liegenden Tacuele führt.

Obgleich die contractilen Vacuolen in hohem Maße den Eindruck wirklicher danernder Organellen hervorrufen, so gilt dies doch nur in beschrïnktem Grad, wonn man ihr Entstehen genauer verfolgt. Gewöhnlich treten schon vor der Entleerung (Systole) in ihrer nächsten Umgebnng einige kleine Vacuolen anf, die allmählich heranwachsen und während der Systole der contractilen Vacuole an deren Stelle riicken Fig. 11 1, S. 73). Während nnd nach der Systole fließen diese Bildungsvacuolen zu einer neuen Vacuole zusammen. Hierans folgt, daß es sich nicht etwa um die Wiederfüllnng eines bleibenden Organells handelt, sondern daß die nene Vacnole ein ganz newer Fliissigkeitstropfen ist. Jedenfalls ist jedoch die Stelle des Körperplasmas, wo die contractile Vacuole entsteht, in hesonderer Weise differenziert, was ihr eben die Fühigkeit zu fortlanernder Vaculenbildung verleiht, wenn sich diese Differenzierung auch nicht sichtbar ausspricht. In diesem Simne also können wir wenigstens die bestimmt lokalisierten conlractilen Vacuolen als bleibende Organellen ansprechen.

Der Vorgang der Vacuolenbildung kann bei gewissen Ciliaten in oigentümlicher Veise modifiziert sein, indem statt Bildungsvaenolen flïssigkeitserfüllte Kanälchen in versehiedener, aber konstanter Zahl und Lage um die alte Vacuole auftreten, 
welche nach deren Systole zur neuen Vacuole zusammenfließen (Fig. 11 2-4, S. 73). Es wïrde zu weit fiihren, diese interessanten Komplikationen näher zu erörtern.

\section{Stigmata oder Augenflecke.}

Bei den Mastigophoren, insbesondere den mit Chromatophoren versehenen Flagellaten, seltener bei farblosen, findet man häufig ein intensiv rot gefärbtes Körperchen an der Körperoberfläche, dicht nnter der Pellicula (Fig. 81, S. 73). In der Regel enthält jede Zelle nur ein solches Stigma (frïher Augenfleck), selten mehrere. Meist liegt das Stigma dem Vorderende näher, nicht weit von der Geißelbasis. Es besteht aus einer plasmatischen Grundsubstanz, der zahlreiche rote Farbstoffkiigelchen (Hämatochrom) dicht eingelagert sind. Die stark lichtbrechenden Körperchen, die gewissen Stigmata auf- oder eingelagert sein sollen (Amylum oder Paramylum) bediirfen genanerer Untersuchung. - Die in älterer Zeit verbreitete Ansicht, daß die Stigmata lichtpercipierende Organellen (Augenflecke) seien, wurde in neuerer Zeit wieder aufgenommen, ohne jedoch experimentell gesichert za werden. Daß Beziehungen zwischen der Lichtreizung und den Stigmata bestehen, ist nicht unwahrscheinlich, vermutlich aber nicht in dem Sinne einer direkten Reizbarkeit dieser Organellen. Da eine gewisse Abhängigkeit der Stigmata von den Chromatophoren zu bestehen scheint, die sicher zu den autonomen Organellen gehören, so ließe sich eventuell ähnliches auch für crstere vermuten, doch hat die Verfolgung ihrer Vermehrungserscheinungen bis jetzt eher das Gegenteil wahrscheinlich gemacht.

\section{Alloplasmatische Organellen.}

\section{Trichiten, Trichocysten, echte Nematocysten.}

Im Plasma einzelner Ciliaten können sich zarte stäbchenartige Gebilde entwickeln, denen vermutlich meist eine Art Stiitzfunktion zukommt. Selten tritt ein stäbchenartiges, offenbar stuitzendes, achsenartiges Gebilde auch im Zellkörper gewisser Flagellaten auf (Fig. 87, S. 71). Die sogenannten Trichiten der Ciliaten haben eine gewisse Ähnlichkeit mit den oben erwähnten Stäbchen der Schlnndreuse. Sie können bei einzelnen auch beim Fang der Beute aus dem Mund bervorgeschleudert werden und diese lähmen.

Ähnliche stäbchenartige Gebilde finden sich jedoch bäufiger an verschiedenen Stellen der Körperoberfläche der Ciliaten (besonders der Holotricha), vorzugsweise in der vorderen Region, jedoch auch an anderen Stellen; zuweilen auch über die gesamte Oberfläche gleichmäßig verteilt (s. Fig. $11^{3}$ u. 10a) Sie liegen dann natürlich im Corticalplasma. Diese Gebilde (Fig. 15, 1a) besitzen die Fähigkeit, bei Drnck und anderweitigen Einwirkungen plötzlich zu einem vielfach längeren Faden gewissermaßen auszuschnellen (Fig. 15, 1b), wobei sie gleichzeitig meist aus der Oberfliche der Zelle herausgeschleudert werden. Die Explosion dieser sogenannten Trichocysten findet wahrscheinlich anch spontan zur Abwehr von Angriffen, eventnell auch zur Bewältigung von Beute statt. In anderen Fällen, wo ein Ausschnellen der Trichocysten nicht nachzuweisen ist, wurde dagegen ihr Hervor- 
schnellen beim Fang der Bente vielfach angegeben. - Von einer feineren Struktur, welche die Explosion der ansschnellbaren Trichocysten verständlich machen könnte, istnichts sicheres bekannt. Es ist wahrscheinlich, daß zwischen den Trichiten und den explosibeln Trichocysten Übergänge existieren.

Bei einer peritrichen Ciliate (Umbellaria) finden sich unter der Pellicula zuweilen kleine hohle bläschenartige Körperchen paarweise vereint, die einen feinen, schraubenförmig aufgerollten Faden einschließen (Fig. 15, 2). Durch gewisse Manipulationen gelingt es, diesen langen Faden zum Ausschnellen aus dem Bläschen zu bringen. Letztere Gebilde sind demnach ebenso gebaut wie die in den Zellen gewisser Metazoen auftretenden Nesselkapseln oder Nematocysten. Ob sie bei Umbellaria als Schutzgebilde funktionieren, ist unbekannt. Interessant ist das vereinzelte Vorkommen ähnlicher Nesselkapseln bei Protozoen anderer Abteilungen, so bei der Gattung Polycricos nnter den Dinoflagellaten and regelmäßig in den Sporen der Myxo-

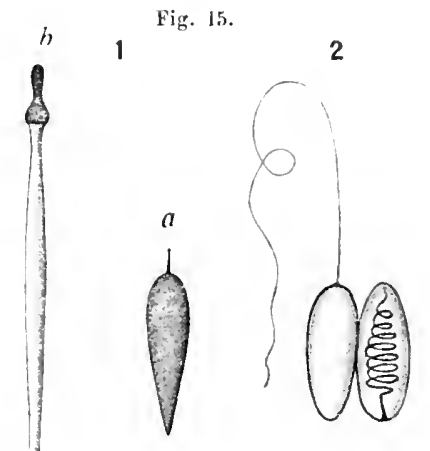
und Microsporidien. In letzterem Falle dürften die ausschnellbaren Fäden als Haftorgane dienen.

\section{Schutzhüllen, Gehäuse- und Schalengebilde.}

Es gibt zahlreiche Protozoen der verschiedensten Abteilungen, welche außer der Pellicula keinerlci Zellhüllen bilden. Andrerseits finden wir in allen Gruppen, mit Ausnahme der parasitierenden Sporozoa, vereinzelter oder regelmäßiger, die Entwicklung schiitzender Hüllen. Während die Pellicula sich durch ihren innigen Zusammenhang mit dem Plasma, sowie ihre sonstigen Eigenschaften als ein direktes Differcnzicrungsprodukt des Ectoplasmas erweist, sind die Hüllgebilde morphologisch und chemisch vom Plasma schärfer geschieden. Erstens dadurch, daß sie häutig nicht mehr direkt mit dem Plasmakörper zusammenhängen, letzterer vielmehr von der Hïlle zurïckgezogen ist; zweitens dadurch, daß die Hïllen aus einer vom Plasma wesentlich verschiedenen chemischen Substanz bestehen, die an den Stoffwechsclvorgängen der Zelle keinen Anteil mehr nimmt, und daher anch nicht mehr als eigentlich lebendig gelten kann. - Trotz mancherlei Schwierigkeiten, welche der sicheren Beurteilıng der Bildung solcher Hüllen aus dem Plasma entgegenstehen, dürfte ihre Auffassung als Abscheidungen der Plasmaoberfläche die gerechtfertigteste sein, wenngleich ja Abscheidung und Umbildung nicht ganz scharf unterscheidbar sind. Solche IÏ̈llen zeigen daher auch den allgemeinen Charakter der Zellmembranen, wie sie insbesondere den Pflanzenzellen zukommen.

Die einfachste Hüllbildung ist wohl eine wasserreiche Gallertmasse organischer Būtschli, Vergl. Anatomie. 
Natur, die den ganzen Zellkörper umgibt. Dergleichen findet sich regelmäßig bei den marinen Radiolarien (Fig. 19c, S. 87), jedoch auch bei gewissen Heliozoen und vereinzelten Rhizopoden. Zu einer solchen Gallerthülle können sich außerdem noch weitere Hïllen oder Schalen gesellen. - Bei sehr vielen Formen wird die Hülle membranös und fest, ja ist sogar häufig mit anorganischer Substanz reieh impräguiert. Dann verdient sie die Bezeichnung eines Gehäuses oder einer Schale. Als unterscheidendes Mırkmal von den später zu erörternden Skeletgebilden.wäre hervolzuheben, daß Gehäuse oder Sehalen von Anfang an als zusammenhängende membranöse Bildungen auftreten und so verbleiben.

Die Substanz der gallertigen Hüllen, sowie die vieler Sehalen ist eine stickstoffhaltige organische, wohl meist von albuminoidähnlichem Charakter. Beiden holophytisch sich ernährenden Flagellaten dagegen und Dinoflagellaten ist die Schalensubstanz meist Cellulose und verrät dadurch auch chemiseh ihre Identität mit den Zellmembranen der Protophyten und höheren Pfianzen. In der Abteilung der Sareodinen jedoch, deren Mehrzahl Sehalen bilden, tritt meist anorganisches Material an Stelle des organischen, das dann nor noch in geringer Menge beigemischt ist. Die anorganische Sehalensubstanz der Rhizopoden ist fast aussehließlich Calciumearbonat, seiten amorphe Kieselsäure (Fig. 16, S. 83, Euglypha). Bei nicht wenig Rhizopoden kann aber die Festigkeit der Schale auch dadurch erzielt werden, daß Fromdkörperchen, Sandkörnchen, Schalengebilde anderer Einzelliger u. dgl. durch eine organisehe oder anorganische Kittmasse zu einer Schale verbacken (agglutinierte Schalen, Fig. 16, Diffugia).

Eine erstaunliche Reichhaltigkeit und eine überraschende Höhe der Komplikation erreichen dio Schalen der Rhizopoden. Vereinzelter and einfacher finden sie sich bei den Mastigophoren (Fig. 9 A, S. 72) und Infusorien. Der morphologische Grundbau aller solcher Schalen ist jedoch ziemlich übereinstimmend ein monaxoner, etwa becher-bis beutelförmiger, indem der eine Schalenpol eine weitere bis engere Mündung besitzt, dureh welche die Zelle mit der Umgebung in Beziehung tritt, während der Gegenpol geschlossen ist (Fig. 7, 9 u. 16). Beiderseits geöffnete Schalen sind sehr selten.

Während die Schalen oder Gehäuse der Süßwasserrbizopoden, der Magistophoren und der Infusorien sich nicht wesentlich über diesen Grundbau erheben, entfalten dagégen die Kalksehalen der marinen Rhizopoden (sog. Foraminiferen) eine Mannigfaltigkeit der Ausgestaltung und Komplikation, welche die analogen Bildungen der Metazoen weit übertriût. Ein genaueres Eingehen auf die Einzelhciten würde die hier gestellte Aufgabe weit übersehreiten; es kann sich allein darum handeln, einige Grundzüge des Baues darzulegen.

Die Komplizierung der Rhizopodenschalen (s Fig. 16) spricht sich zunäehst in einer verschiedenen Besehaffenheit der verkalkten Schalınwand aus. Diese ist entweder solid, oder von gröberen bis äußerst feinen, dicht gesäten Poren durchsetzt (Imperforata und Perforata). In letzterem Fall kann das Protoplasma auch durch die poröse Wand auf die Schalenoberfläche treten und allseitig Pseudopodien entwickeln. Ein zweiter Charakter, welcher zur Komplikation der Schalengebilde 
fuihrt, hängt mit dom meist fortdauernden Wachstım der Zelle und Schale zusammen. Die seither besprochenen einfachen Schalen (Fig. 7, 16, Diffugia, Euglypha, Lagena) können sich in der Regel durch weiteres Wachsen nicht vergrößern; nur selten findet dies bei vereinzelten statt, deren Sebalenmündung etwas seitlieh verschoben ist, und führt dann zu einer spiralen Autrollung der au der Mündung fortwachsenden Schale (Fig. 16, Cornnspira). Der innere Hohlrarm aller seither besprochenen Schalen ist demnach einheitlich, eine einfache Kamuer (monothalame

\section{Difflugia} (agglutinierte Schale)

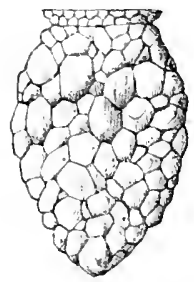

\section{Lagena Nodosaria} (Medianschnitte)

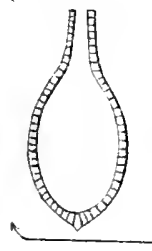

Fig. 16.

\section{Euglypha (Kieselplättchen)}
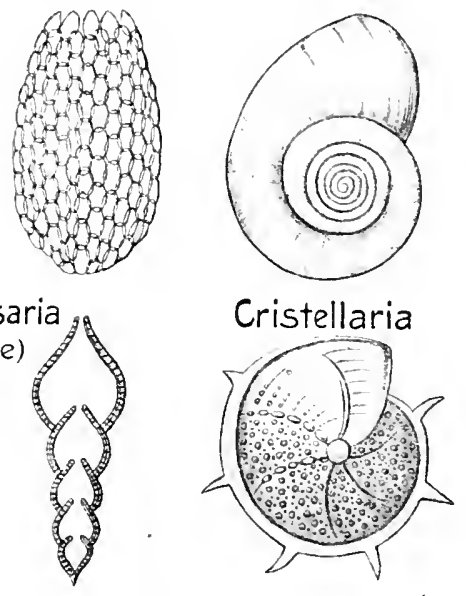

Spiroloculina

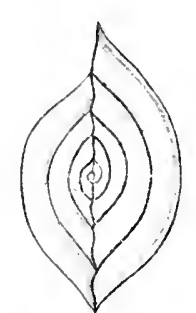

Peneruplis

(Medianschnitt)

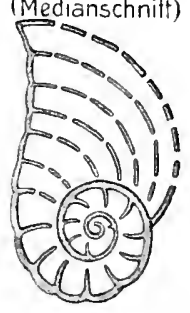

\section{Orbitolites}

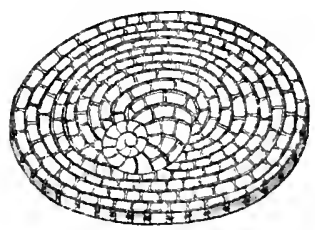

\section{Perforata}

Schemata von Schalen verschiedener Rhizopoden.

C. H.

Sehalen). Bei andauernd fortwachsenden Schalen, deren Vergrößerung natürlich auch die Folge einer fortdauernden Volumzunahme des Plasmakörjers ist, geschieht das Waehstum in der Regel nicht stetig, sondern periodisch und mehr oder weniger plötzlieh. Das Ergebnis hiervon ist, daß sieh in den Waehstumscpochen um das ans der Mündung hervorgequollene Plasma rasch ein neuer Schalenabschuitt bildet. Der neue Abschnitt wiederholt etwa die Form der urspriinglichen (ersten) Schale, iubertrifft sie jedoch etwas an Größe und ist der Mündurg der ersten Schale (Embryonalkammer) als eine zweite Kammer aufgesetzt (Fig. 16, Nodosaria). Das weitere Wachstum führt in entsprechender Weise zur Entstehnng zahlieicher folgender Kammern, die successive an Größe zunehmen, und deren Hohlräume sämtlich untereinander kommunizieren. Auf dicsem Wege bilden sich die polythalamen Schalen, die sowohl bei den imperforaten wie perforaten kalkschaligen Rhizopoden die Mehrzahl bilden. Die Reichhaltigkeit der Gestaltung und dẹ Art der Zusammenfügung der Eammern bei solch polythalamen Schalen ist so groß, daß von einer Einzelbeschreibung hier nicht die Rede sein kann. Die Waclistumstypen, 
welche sich dabei ergeben, sind etwa folgende: Aneinanderreihung der successive sich bildenden Kammern in gerader Linie (Nodosaria, Fig. 16). Weiterhin Krümmung dieser Wachstumslinie in verschiedenem Grade bis zu völlig spiraler Aufrollung der Kammern (Spiroloculina, Peneroplis, Cristellaria, Fig. 16). Dabei können die Kammern sich nur wenig umfassen, so daß sie äußerlich alle sichtbar sind, oder sich teilweise bis völlig umschließen, so daß äußerlich nur eine, oder nur die Kammern des letzten Umgangs der spiraligen Schale zn sehen sind. Häufig werden die spiral aufgerollten Schalen ach asymmetrisch schraubenförmig nach Analogie der Schneckenschalen. - Endlich entwickeln sich auch Schalen, deren Kammern sich so ansdehnen, daß sie zu ringförmig in sich geschlossenen Röhren wer Ten, die sich, in einer Ebene angeordnet, successive nmfassen (cyclisches Wachstuu. Orbi-

Fig. 17.

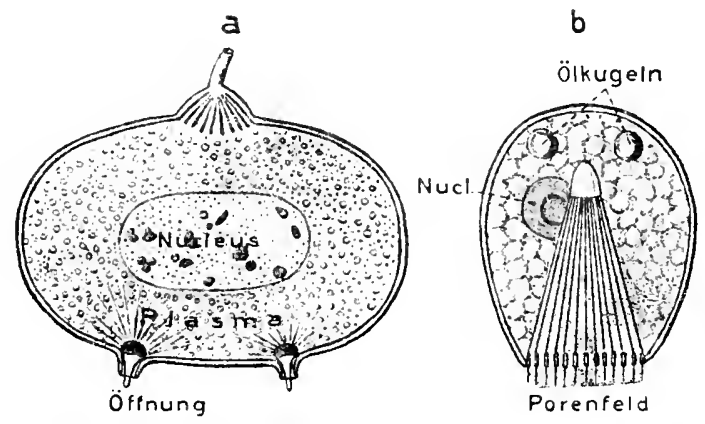

Centralkapseln von Radiolarien. $a$ einer Phaeodarie (Tripylea). $b$ einer Monopylarie. (Nach R. Hertwig 1879). C. H. tolites, Fig. 16). Hiermit ist ferner eine sekundäre Teilung der ringförmigen Kammern durch radiäre Scheidewände in kleine Kämmerchen verbunden. Auch sehr unregelmäßige Zusammenhäufung der Kämmerchen polythalamer Schalen kommt vor. Unsere Schildernng kounte, wie gesagt, nur einige Grundzüge der Vielgestaltigkeit der marinen Rhizopodenschalen andeutend hervorheben. - Die Schalenoberfläche bietet ebenfalls mancherlei Jomplikationen dar; so ist sie teils glatt, warzig, gerieft oder bestachelt.

Ihrem Wesen nach mit den Schalenbildungen identisch sind auch die sog. Stielbildungen mancher festgehefteter Heliozoen, Mastigophoren und Infusorien (speziell Peritricha und Suctoria, Fig. $11^{5}$ und 14). Ein Stiel entsteht durch fortdauernde Ausscheidung organischen Schalenmaterials an dem festsitzenden Zellpol. Er kann solid oder hohl sein und erlangt bei einem Teil der peritrichen Ciliaten eine löhere Eutwicklung durch den schon oben (S. 76) erwähnten Stielmuskel, welcher ibn zu einem contractilen Organell macht. Bei gleichzeitiger Entwicklung einer Schale sitzt letztere dem apicalen Stielende anf, bildet gewissermaßen dessen Krönung.

Bei der großen Abteilung der Radiolarien findet sich anscheinend nichts von einer Schale, wie sie den Rhizopoden eigentümilch ist. Dennoch läßt sich die sog. Centralkapsel der Radiolarien mit einer gewissen Berechtigung als morphologisch entsprechende Bildung betrachten; wenn es auch wahrscheinlich ist, daß sie selbständig entstand, nicht aus einer RLizopodenschale hervorging. Der wesentliche Charakter dieser Kapsel ist, daß sie nur einen centralen, aber den ansehnlichsten Teil des Plasmakörpers einschließt und ihn von dem peripheren oder extrakapsulären Plasma scheidet (Fig. 19, $a, c, d$, S. $\$ 7$ ). Die Nuclei liegen stets im intra- 
kapsulären Plasma. Bei den ursprtinglichsten Radiolarien war diese äußerst dinnwandige, aus organischer Substanz bestehende Kapsel wohl regulär kugelig und wie die Schalenwand zahlreicher perforater Rhizopoden, von schr feinen Poren allseitig dicht durchsetzt (Peripylaria). Durch die Poren stehen intra- und extrakapsuläres Plasma im Zusammenhang, ja das extrakapsuläre kann nach Herausschälen der Kapsel von dem intrakapsulären völlig restituiert werden. - Bei einer anderen großen Abteilung der Radiolarien wurde die Kapsel monaxon, was sich in der Regel schon in ihrer äußeren Form ausspricht, vor allem aber darin, daß die feinen Poren auf ein sog. Porenfeld an einem Kapselpol beschränkt sind (Monopylaria, Fig. $17 b$ u. 19d). Die Abteilung der Phaeodaria schlicßlich (Fig. $17 a$ ) zeigt überhaupt keine feinen Poren ihrer doppelwandigen Kapsel, sondern uur 1-2, meist jedoch drei, seltener auch zahlreichere größere Öfinungen.

\section{Skeletgebilde.}

Im Gegensatz 7.u den besprochenen zusammenhängenden Schalen- oder Gebäusebildungen bringen gewisse Sarcodinen große Mengen nicht zusammenhängender

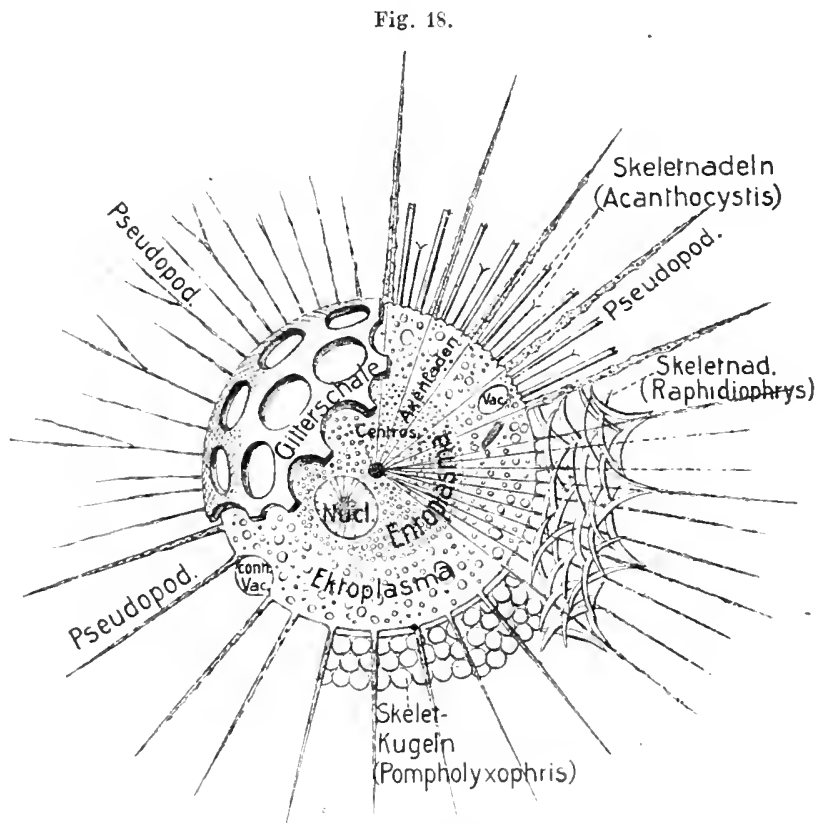

Schema von Heliozoe mit Andeutung der verschiedenartigen Skeletgebilde und Psendopodien. C. H.

Hartgebilde hervor, welche, in sine Gallertmasse eingebettet, den Plasmakörper umlagern, und sowohl als Schutz-, wie als Stütz- und Festigungsgebilde dienen. Derartige Skeletgebilde sind in den Gruppen der Heliowoen und Radiolarion sehr verbreitet und bestehen fast immer aus amorpher Kieselsäure nebst sehr wenig 
organischer Substanz. Eine eigentümliche Abweichung bietet allein die Radiolarien-Gruppe der Acantharia, da ihre Skeletnadeln aus Strontiumsnlfat bestehen.

Da es jedoch sowohl nackte, skeletlose Heliozoen als auch ebensolche Formen ir deu ver'schiedenen Hauptgruppen der Radiolarien gibt, so dürfte dies anzeigen, daß sich die Skelete dieser verschiedenen Gruppen selbständig entwickelt haben. Dafür spricht auch ihr morphologischer Aufban in den einzelnen Gruppen.

Die Skeletgebilde der Heliozoen und gewisser peripylarer Radiolarien sind isolierte, in keinem Zusammenhang untereinander stehende Kieselnädelchen (Spicula) von einfacher bis verzweigter Bildung, die sich regelmäßiger oder unregelmäßiger um die Zelle herumlagern, von der Gallerte zusammengehalten (s. Fig. 18, Acanthocystis, - Raphidiophrys). Bei gewissen Heliozoen können auch kleing Kieselkügelchen statt der Spicula entwickelt sein (Fig. 18, Pompholyxophrys). Nur in einem Fall begegnen wir bei den Heliozoen statt der losen Nadelhülle einer gitterförmig gebanten kugeligen Kieschülle (Clathrulina, Fig. 18). - Bei den peripylaren Radiolarien sind solche Gitterkngeın dagegen häufiger als lose Kieselgebilde. Der gittrige, weitlöcherige Charakter solcher Skelete macht es wahrscheinlich, daß sie ursprünglich aus der Vereinigung loser Gebilde hervorgingen, d. h., daß ihre Gitterstäbe den lusen Spicula gleichwertig sind.

Die überaus große Mannigfaltigkeit und Kompliziertheit, welche die Skeletgebilde der Peripylaria, von solch einfachen Gitterkugeln ausgebend, erreichen, verbietet das nähere Eingehen, weshalb wir uns hier darauf beschränken, einige Grundziige der weiteren Ausgestaltung hervorznheben. - Zunïchst tritt häufig eine mit dem Wachstum der Zelle fortschreitende successive Nenbildung solcher Gitterkugeln auf, so daß der ansgebildete Organismus zwei bis vicle ineinander geschachtelte besitzt, welche durch radiäre Kieselstäbe untereinander verbundeu sind (Fig. 19a). Bemerkenswert ist, daß in solchen Fällen die centralen Gitterkngeln durch eigentümliche Wachstumsprozesse ins Innere des Zellkörpers selbst, die innerste sogar in den Zellkern aufgenommen werden. Eine linsenförmige Abplattung der äußeren Gitterkugeln führt zu mehr scheibenartigen Skeleten; ja, indem die zahlreichen äußeren Kugelı unvollständig werden, sich nur noch als Ringe nmeinander legen, zu scheibenförmigen Skeleten von sehr eigentümlichem Ban (Fig. 19b). Eiue besondere Weiterbildung können derartige Skelete dadurch erfahren, daß sie von einem gewissen Stadium ab keine Gitterkngeln mehr bilden, sondern ein änßeres schwammiges Kieselwerk, das die inneren Skeletteile völlig oder teilweise umhüllt.

Ein ganz anderer Skelettypus entwickelte sick in der großen Abteilung der Monopylaria, iiber den hier ebenfalls einige Andeutungen folgen mögen. Wahrscheinlich ausgehend von Formen, bei welchen die Centralkapsel durch drei central verwachsene Kieselstacheln getragen wird, trat bei der Weiterentwicklnng, von dem Centrum der Stacheln emporwachsend, zunächst ein Kieselring auf, der in der Ebene des einen Stachels liegt (Fig. $20 J 3, a$, S. 88). Zu diesem Ring gesellt sich ein zweiter $(b)$ in der auf dem ersten senkrechten Ebene hinzu. Durch Fortsatzbildung beider Ringe entstand um den erstgebildeten eine gitterförmige, köpfchenartige 
monaxone Schale, in deren Wand der zweice Ring einging (s. Fig. 20 B, links). Bei den komplizierteren Formen fügen sich an die Basis dieses Köpfchens successive ringfërmige.Schalenglieder in verschiedener Zahl an, so daß sich mehrgliederige monaxone Skelete entwickelten von helm- bis vogelkäfigartiger, häufig sehr zierlicher Form (Fig. 19d). - Wohl die größte Reichhaltigkeit erlangte die Skeletbildung in

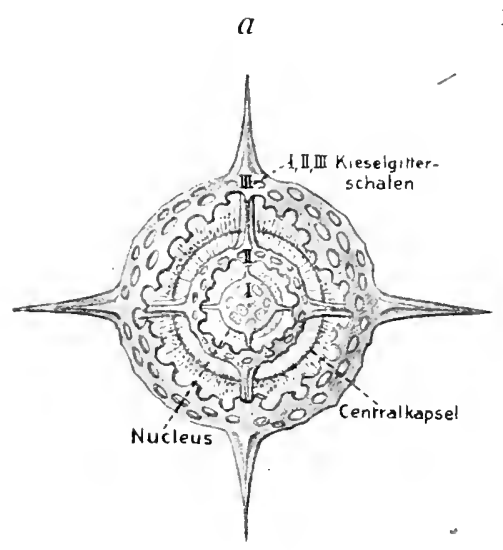

Fig. 19.
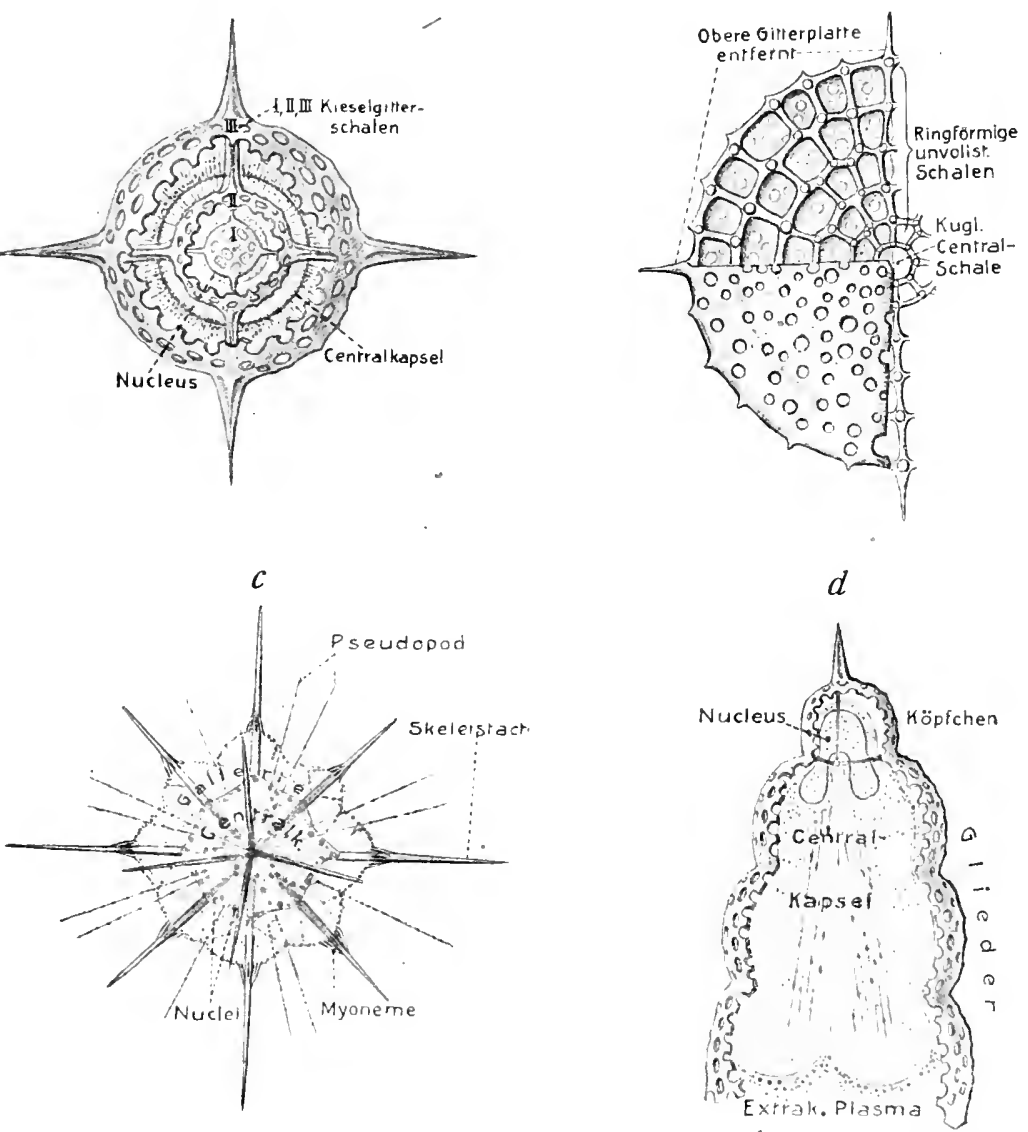

Verschiedene Radiolarien. a-f. Puripylarien: a Actinomma astracanthion; die beiden āußeren Gitterskeletschalen aufgebrocben. b Stylodyctia quadrispira. (Nach Harckec.) Hëlfte des Kieselskelets. c Acanthometra elastica (Acantharia). dEncyrtidium galea. (Monopylaria), das Skelet aufgebrochen, um die Centralkapsel zu zeigen. Fig. $a, c, d$ nach Heatwig 1879.

der großen Abteilung der Phaeodaria. Dieser Formenreichtum zwingt uns zur Beschränkung anf wenige Bemerkungen. In dieser Abteilung begegnen wir neben Formen mit losen nadelartigen, zum Teil hohlen Skeletgebilden, solchen mit ein bis $z$ wei Gitterkugeln, deren Stäbe zuweilen ebenfalls hohl sind; ferner Formen mit monaxoner, an die monothalamen perforierten Rhizopodengehäuse erinnernden Skeletschalen (Fig. $20 \mathrm{~A}$ ); schließlich Skeleten, die aus zwei muschelartig 
zusammengelagerten Gitterklappen bestehen, von denen zuweilen sehr lange nnd reichverzweigte Stacheln ausgehen.

In mancher Hinsicht eigentümlich sind die Skelete der zu den Peripylaria gehörigen Acantharien, welche ja auch durch ihre besondere chemische Natur auffallen. Der von den seither erwähnten Skeletbildungen völlig abweichende Grundcharakter besteht darin, daß sich das Skelet ans radiär angeordneten Stacheln

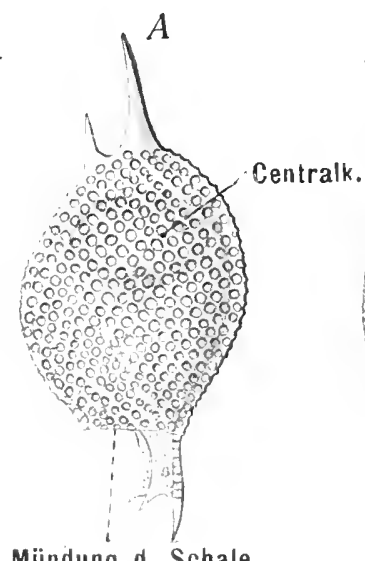

Mündung d. Schale

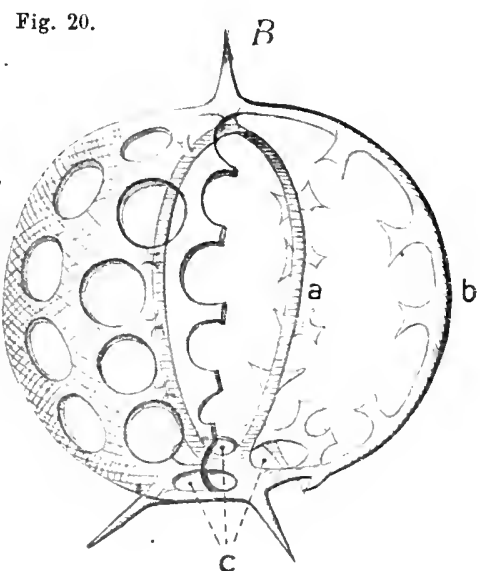

c

A Protocystis (Phaeodarie). $B$ Schema znr Erlänternng des Skelets der Monopylarien. $a$ der primäre Skeletring am die Centralkapsel. b der hierauf senkrechte sekundäre Ring. In der rechten Hälfte das Skelet so gezeichnet, wie es sich bei den primitiveren Formen erhält, wo es nur ans diesen heiden Ringen hesteht. Aus der Bestachelung der Ringe geht hei den komplizierteren Formen die Gitterwand des Kópfchens hervor, wie auf der linken Hälfte gezeichnet. $c$ die charakteristischen drei Basallöcher, ans denen bei den mehrgliedrigen Formen die Centralkapsel hervorwachsen kann. An die Basis des Kôpfchens setzen sich dann die Glieder an (s. Fig. 1yd). C. H.

aufbant, die bis zum Centrum der Centralkapsel reichen nnd hier entweder nur fest zusammengestemmt oder verwachsen sind (Fig. 19c). Durch verschiedene Zahlen-, Gestalts- und Größenverhältnisse dieser Stacheln sowohl, als auch durch Fortsatzbildungen, die von ihnen ansgehen, entwickelt sich auch bei den Acantharien ein sehr großer Formenreichtum.

\section{B. Autonome Organellen.}

1. Chromatophoren (Chromoplasten, Leucoplasten).

Organellen dieser Art kommen unter den Protozoen fast ansschließlich nur den Mastigophoren zu (Flagellaten und Dinoflagellaten; ganz vereinzelt bei Rhizopoden). Auch unter diesen finden sie sich nur bei den Formen, welche sich pflanzlich * (holophytisch) ernähren. Die Chromatophoren sind grün bis braun oder gelb gefärbte Körper, welche dem Plasma eingelagert sind. Sie bestehen selbst aus einor plasmatischen Substanz, welche entweder einen rein grünen Farbstoff (Chlorophyll) oder daneben noch einen gelben bis braunen enthält. Ihre Form sowohl als ihre Zablenverhältnisse sind sehr mannigfaltig. Es gibt Flagellaten mit einem einzigen, 
relativ sehr ansehnlichen Chromatophor (z. B. Fig. ${ }^{1}$, S. 71, Euglena), solche mit zwei und mehr (Fig. 82, Ochromonas), endlich solche mit sehr vielen, verhältnismäßig kleinen. In letzterem Fall liegen sie gewöhnlich oberflächlich unter der Pellicula. Auf die Mannigfaltigkeit ihrer Form, die von scheibenförmiger bis bandförmiger, auch zersehlitzter bis verzweigter Gestalt variiert, sei hier kurz hingewiesen. Häufig finden sich in der Substanz des Chromatophors 1-2, eventuell auch mehr kleine, kugelige ungefärbte, jedoch intensiv tingierbare Einlagerungen, die sog. Pyrenoide (Fig. 81), um welche sich meist feine Stärkekörnchen oder eine zarte zusammenhängende Hülle von Amylum (oder Paramylum bei Euglenoidinen) finden. - Die physiologische Bedeutung der Chromatophoren ist dieselbe wie die der Chlorophyllkörner der echten Pflanzen. Daß sich auch farblose ähnliche Körper (Leucoplasten) bei gewissen farklosen stärkebildenden Flagellaten finden, ist möglich.

Neue Chromatophoren entstehen stets durch Teilung der schon vorhandenen. Hierin äußert sich ihr autonomer Charakter. Diese Erseheinung, in Verbindung mit den Bauverhältnissen, speziell dem Pyrenoid, das eine gewisse Ähnlichkeit mit dem kernartigen Centralkörper der Cyanophyceen besitzt, ließ die Möglichkeit erwägen, daß die Chromatophoren ursprünglich von selbständig lebenden Organismen abstammen, welche zu einer engen Symbiose (Ineinanderleben) mit ursprünglich farblosen Protozoen übergegangen sind.

Nicht zu verwechseln mit den Chromatophoren sind die grünen oder gelben kleinen Zellen (Zoochlorellen und Zooxanthellen), die im Plasma zahlreicher Protozoen (Rhizopoden, Radiolarien, Ciliaten) recht häufg, vielfach sogar regelmäßig vorkommen. Sie wurden deshalb früher für Organellen des Protozoenkörpers gehalten, bis ihr Fortleben und Vermehren nach der Isolierung ihre selbständige Natur als einzellige, wahrscheinlich flagellatenartige Organismen erwies, die in den Protozoenzellen, aber auch manchen Metazoenzellen symbiotisch leben.

\section{Nuclei und Centrosom, Chromidien (Chromidialnetze).}

$\mathrm{Da} B$ diejenigen eiuzelligen Organismen, welche im Unterreich der Protozoa zusammengefaßt werden, stets Zellkerne (Nuclei) in ihrem Plasma enthalten, dürfte heutzutage kaum mehr ernstlich angezweifelt werden. Unsicher dagegen liegt dies Problem noch für die sog. Schizophyceen (Cyanophyceen und Bacteriaceen!, welche zweifellos phylogenetisch tiefer stehen als die eigentlichen Protozoen und Protophyten. Div neuere Forschung ist jedoch darin ziemlich einig, daß auch den Zellen dieser Protisten kernartige Bestandteile zukommen, wenngleích die Ansichten noch sehr auseinander gehen über die Form, in welcher diese Bestandteile auftreten, sowie über den Umfang des Körperanteils der Schizophyceenzelle, der als kernartig aufzufassen ist. Eine genanere Erörterung dieser Frage uberschreitet den Rahmen dieses Buches.

Ebenso müssen wir darauf verzichten, die feineren Bau- und Strukturverhältnisse der Nuclei der Protozoenzellen in ihrer Mannigfaltigkeit zu erörtern; bier interessieren uns nur die vergleichend anatomischen Verhältnisse näher, welche sich in der Zahl, der Gestalt und den eventuellen Differenzierungserscheinungen der Kerne aussprechen. Ebensowenig kann auch, abgesehen von kurzen 
Hinweisen, die fundamentale physiologische Bedeutung der Kerngebilde für das Gesamtleben der Zelle berilcksichtigt werden.

Zahlenverhältnisse der Nuclei. Bei gewissen Abteilungen (Mastigophoren, den typischen Sporozoen) findet sich, abgesehen von gewissen Fortpflanzungszuständen, ein einziger Zellkern so regelmäßig, daß wohl die Frage aufgeworfen werd̄en darf, ob ein solcher Zustand nicht der phylogenetische Ausgangspunkt für die Protozoen überhaupt ist. Die eventuelle Bejahung dieser Frage würde auch darin eine wesentliche Stütze finden, daß der einkerrige Zustand des: Zelle in der hŏheren Organismenwelt der weit vorherrschende ist.

In anderen Protozoenabteilungen ist dies wesentlich verschieden. So finden wir zwar in allen Abteilungen der Sarcodinen einkernige Formen; sehr gewöhnlich jedoch auch mehrkernige bis solche, welche eine sehr große Zahl von Kernen enthalten. Da jedoch auch diese Protczoen, wenigstens bei gewissen Vermehrangsvorgängen, stets einkernige Ausgangsformen bilden, so da:f man im allgemeinen wohl behaupten, $d a ß$ die Vielkernigkeit erst allmählich mit dem Wachstum der Zelle eingetreten ist. Damit stimmt überein, $\mathrm{da} B$ sich sehr zahlreiche Kerne gewöhnlich nur bei großem Plasmakörper finden. Im einzelnen bestehen jedoch in dieser Hinsicht viele Verschiedenheiten, insofern die Kernvermehrung bei gewissen Formen sehy frühzeitig im vegetativen Leben eintritt, bei anderen erst kurz vor oder während der Reproduktion; ja es kŏnnen in dieser Beziehung sogar bei verschiedenen Generationen einer und derselben Art Verschiedenheiten bestehen.

Mehrkernigkeit darf auch als der charakteristische Zustand der Infusorien (vor allem der besser bekannten Ciliaten) bezeichnet werden. Die Verhältnisse liegen hier nur insofern komplizierter, als mit dieser Mehrkernigkeit auch eine Differenzierung der Kerne in zwei verschiedene Arten (Macro- und Micronucleus) verbunden ist, wovon sogleich genauer die Rede sein soll. Der einfachste Zustand ist demnach bei den Ciliaten der zweikernige, mit je einem Keru jeder Sorte. Hieraus entwickelten sich andere Formen, wo bald nur die eine Kernsorte (Micronucleus) in Mehrzahl anftritt, bald jedoch auch die andere (Macronucleus). Es finden sich schließlich anch hier Formen mit sehr zahlreichen Kernen, wenn auch selten. Wichtig und bezeichnend für die Ciliaten ist jedoch ebenfalls, daß auf einem gewissen Stadinm ihres Lebenscyclus einkernigeZustände gebildet werden, ans welchen die mehrkernigen erst durch Kernteilung hervorgehen.

Differenzierung der Kerne mehrkerniger Protozoen. Wie soeben angedeutet wurde, begegnen wir einem solchen Differenzierungsproze $B$ am ansgeprägtesten und besten erkannt bei den ciliaten Infusorien. Aus den Teilprodukten eines ursprünglichen Kerns bilden sich hier im einfachsten Fall ein größerer Kern (Macronucleus) und ein viel kleinerer (Micronucleus), die beide auch in ihrem feineren Bau recht verschieden sind. Ebenso grundverschieden sind sie auch physiologisch, indem der Macronucleus wesentlich vegetative Bedeutung für die Stoffwechselvorgänge hat und bei der Conjugation zugrunde geht; wogegen der Micronuclens bei der Conjugation die beiden Kernsorten aus sich neu hervorbringt und daher reproduktiv oder generativ wirksam ist. Wis schon angedeutet, begegnen 
wir bei den Ciliaten den verschiedensten Zahlenverhältnissen für die beiderlei Nuclei. Neben einem einzigen Macronucleus kőnnen sich ein (Fig. 11, S. 73, Prorodon, Paramäcium, Carchesinm) bis zahlreiche Micronucle: finden (Stentor). Selten sind auch die Macronuclei vermehrt, und in vereinzelten Fällen läßt sich dann kein Unterschied zwischen beiden Kernsorten erkennen.

Eine solche Differenzierung der Zellkerne, wie sie die Infusorien zeigen, findet sich in anderen Protozoenabteilungen in entsprechender Weise kaum wieder. Immerhin konnte die neuere Forschung auch hier zum Teil Verhältnisse aufdecken, welche gewisse Analogien erkennen lassen. Da jedoch die Untersuchnrgen noch keine befriedigende Übereinstimmung erlangten, so können hier nur einige Andeutungen über die Verhältnisse gegeben werden. Ein zweiter Kern von abweichendem Bau und besonderer physiologischer Bedeutung findet sich bei gewissen Flagellaten (Trypanosoma nnd Herpetomonas); ein kernartiges Gebilde neben dem eigentlichen Kern bei einem amöbenartigen Organismus (Paramoeba). In beiden Fällen ist jedoch die physiologische Bedeutung dieses Kleinkerns nicht diejenige des Micronucleus der Infusorien, vielmehr tritt bei der Copulation der ersterwähnten Flagellaten eine Wiedervereinigung der beiden Kerne auf, indèm der Kleinkern (auch Blepharoplast genannt) ins Centrum des Großkerns aufgenommen wird. Aus solch einkernigen Zuständen entstehen die beiden Kerne wie bei den Infusorien wieder durch Teilung.

Chromidien. Bei andderen Protozoen (insbesondere Sarcodinen) tritt früher oder später im Leben eine Differenzierung der Kerne in verschiedener Weise hervor. Einmal in der Art, daß bei melr- bis vielkernigen Formen während der Vorbereitung zur Copulation ein Teil der Kerne zugrunde geht, die übrigen sich dagegen erhalten. Obgleich also hier keine äußeren Verschiedenheiten der beiderlei Kerne erkennbar sind, so müssen sie doch in gewissem Grade innerlich vorhanden sein und das verschiedene Verhalten der Kerne bedingen. Die Vermehrung des Kerns und seine Differenzierung in sich erhaltende generative und zugrunde gehende Kerne kann anch erst mit dem Eintritt in die Copulation oder geschlechtliche Fortpflanzungsperiode auftreten, oder sich sogar darauf beschränken, daß ein großer Anteil des Kerns zugrunde geht (Sporozoa). - Bei manchen Sarcodinen (besonders Rhizopoden) tritt früher oder später im Leben eine Ablösung oder Ausstoßung gewisser Kernsubstanzen (Chromatin) aus dem Kern anf. Die ins Plasma übergetretene Kernsubstanz ist darin bald mehr als körnige (Chromidien) oder bald mehr als netzig znsammenhängende Einlagerung (Chromidialnetz) verteilt, ohne jedoch vom Plasma scharf abgegrenzte, kernartig umhüllte Gebilde zu formieren. Aus diesen Chromidien aber, die sich auch zuweilen erst beim Eintritt in die Epoche der geschlechtlichen Fortpflanzang bilden, können sich wieder typische generative Kerne entwickeln, während die früheren Kerne zugrunde gehen. Die Chromidiensubstanz spielt daher hier im allgemeinen die Rolle der Micronuclei der Infusorien, während die zugrunde gehenden ursprünglichen Kerne die Natur der Macronuclei angenommen haben. Es sind jedoch auch Fälle bekannt geworden, in welchen.die von den Kernen abgesonderte Chromidialsubstanz allmählich zugrunde zu gehen scheint, wogegen die restierenden Kerne nach 
dieser Absonderung den Charakter generativer erlangen. Ebenso soll Chromidienbildung auch pathologisch auftreten.

Aus alledem scheint hervorzugehen, $\mathrm{daB}$ in den gewöhnlichen Zellkernen zwei Substanzen nebeneinander vorkommen, die physiologisch verschieden wirksam sein müssen, und die sich früher oder später im Lebenscyclus der Protozoen auch räumlich voneinander sondern können, in Form wirklicher Kerne oder in Form der Chromidien. Die eine dieser Substanzen, welche sich in dem generativen Kern (Micronucleus oder generativen Chromidien, Sporetien) findet, besitzt jedoch die Fähigkeit, die andere wieder hervorzubringen; worans folgen dürfte, daß letztere Substanz nur ein Derivat oder Umbildungsprodukt der ersteren sein muß.

Centrosom. Wenn damit die Kernverhältnisse der Protozoen bedeutend komplizierter erscheinen, als dies früher vermutet wurde, so wird die Verwicklung noch größer durch ein weiteres kernartiges Gebilde, das sich bei einigen Protozoen und sonstigen Einzelligen (Diatomeen) neben dem Kern findet. Es ist dies ein sehr kleines Körperchen, welches sich, ähnlich gewissen Kernbestandteilen, stark färben läßt. Dies sog. Centrosom wurde zuerst bei Metazoenzellen gefunden und spielt bei der karyokinetischen Kernteilung eine wichtige Rolle. Fin dem Centrosom der Metazoenzelle sicher vergleichbares Organell wurde aber bis jetzt nur bei zahlreichen Heliozoen beobachtet und bildet hier in der Regel das Centrum des Plasmakörpers, an das die früher beschriebenen Achsenfüden der Pseudopodien herantreten (s. Fig. 18, S. 85). Bei der gewöhnlichen Teilung des Kerns spielt es dieselbe Rolle wie das Centrosom der Metazoenzelle. Daß das Centrosom der Heliozoen jedoch ein aus dem Kern herstammendes Organell ist, scheint sicher erwiesen, da es bei der Fortpflanzung durch Knospung aus dem Kern neu gebildet wird. - Dies läßt es verständlich erscheinen, daß bei gewissen anderen Protozoen ein centrosomähnliches Gebilde erst während der Kernteilung auftreten kann (Actinosphaerium, Noctiluca, Sporozoen) und später wieder verschwindet. - Nun finden sich jedoch auch Fälle, wo der Kern ein kleines Körperchen enthält (frühher Nucleolus, jetzt Nucleolocentrosom, anch Caryosom, Centralkorn usw. genannt), das bei der Kernteilung eine Rolle spielt, welche an ein echtes, außerhalb des Kerns befindliches Centrosom orinnert. Aus diesem Grunde hat man es einem dauernd im Kern befindlichen Centrosom mit einer gewissen Berechtigung verglichen. Während nun eine Ansicht dahin geht, in dem eigentlichen freien Centrosom einen dem Kern entstammenden, von ihm gewissermaßen emanzipierten, nrsprünglichen Kernbestandteil zu erblicken, sucht eine andere Meinung das Verhältnis gerade nmzukehren und das Centrosom als einen zweiten, besonders differenzierten und speziell bei den Teilungsvorgängen funktionierenden Kern zu deuten, der bei gewissen Protozoen in den anderen Kern eingedrungen sei und hier das sog. Nucleolocentrosom bilde. Es wäre jedoch meiner Ausicht nach auch eine dritte Möglichkeit zu erwägen, die nämlich, daß das Centrosom ursprünglich gar nichts mit einem eigentlichen Kern zu tun gehabt hätte, sondern ein plasmatisches Gebilde sei, welches aber bei der Bildung membranumbüllter Kerne, wie sie den ursprünglichsten Einzelligen noch nicht zukamen, in den umbüllten Kern aufgenommen wurde, ähnlich wie es die zweite Ansicht 
annimmt. Die eigentümlichen bis jetzt noch nicht genügend aufgeklärten Beziehungen zwischen Centrosom und Achsenfäden der Geißeln und Cilien lassen eine solche Möglichkeit erwägenswert erscheinen.

Die Gestaltsverhältnisse der Protozoen-Zellkerne verdienen noch einige vergleichende Bemerkungen. Bei der Mehrzahl der Protozoen sind die Kerne in der Regel kugelige bis ellipsoidische Gebilde (s. Fig. 6-9). Viel mannigfaltiger ist der Macronucleus der Infusorien gestaltet, während die Micronuclei sehr kleine kugelige bis spindelförmige Gebilde sind. Bei den kleineren Infusorien bewahrt der Macronucleus in der Regel eine ursprünglichere Form. Bei den größeren dagegen wird er häufig mehr oder weniger lang wurst- bis bandförmig (Fig. 115), ja zuweilen (Suctoria) auch verschiedenartig verzweigt. Der bandförmige Macronucleus ist nicht selten durch eine bis zahlreiche Einschnürungen in zwei bis viele rundliche oder ellipsoidische Glieder geteilt, die nur durch einen feinen Verbindungsfaden zusammenhängen (Fig. $11^{2}$ u. 4 ); solche Macronuclei gleichen dann einem Rosenkranz oder eịer Perlenschnur. In gewissen Fällen schreitet die Zergliederung des Macronucleus noch weiter, so daß er in sehr zahlreiche kleine Fragmente zerlegt erscheint, deren Zusammen'uang neuerdings bestimmt geleugnet wird. - Alle diese besonderen Ausgestaltungen der Macronuclei finden ihre Bedeutung wohl in einer relativen Vergrößerung der Grenzfläche zwischen Keru und Plasma und damit einer Erleichterung und Steigerung des Stoffwechselaustauschs beider.

Organellen, welche analog den Geschlechtsorganen der Metazoen die Funktion haben, neue Individuen hervorzubringen, gibt es bei Protozoen nicht. Da ihre Vermehrung durch einfache Zwei- oder simultane Mehrteilung (bzw. Knospung) geschieht, so kann ja von solchen Organellen nicht die Rede sein. Wenn sich etwas im Lebenslauf der Protozoen mit den in den Geschlechtsorganen der Metazoen gebildeten sog. Geschlechts- oder Propagationszellen vergleichen läßt, so können dies eben nur besondere Generationen der einzelligen Protozoen selbst sein.

So ist es denn auch in der Tat, wie wir später bei den Generationsorganen der Metazoen noch klarer sehen werden. Bei Protozoen aller Abteilungen wurde nachgewiesen, daß in gewissen Epochen des Lebenscyclus Individuen auftreten, die ebenso wie die weibliche Eizelle und die männliche Samenzelle der Metazoen sich durch einen sog. Copulationsakt zu einer einzigen Zelle vereinigen. Diese Individuen nennt man daher auch Gamonten (Gameten). Sie können völlig gleich sein, und dies ist wohl sicher der ursprüngliche Zustand, oder können in Größe und sonstigem Bau mehr oder weniger differieren, ähnlich wie die Ei- und Samenzelle der Metazoen. In letzterem Fall lassen sie sich auch als Oonten (entsprechend der Eizelle) und als Spermonten (entsprechend der Samenzelle) unterscheiden. - Die Differenzierung zweier Kernsorten bei den Infusorien Iäßt sich im allgemeinen mit der Diferenzierung des Körpers der Metqzoen in Körperzellen (Somazellen) und Propaçations- (Generations-)Zellen vergleichen, nur daß sich diese Differenzierung hier auf die Kerne beschränkt. Der Macronucleus entspricht den Kernen der Somazellen der Ketazoen, der Micronucleus denen der Propagationszellen. 


\section{Abschnitt. \\ Vergleichende Anatomie der Metazoen.}

\section{Kapitel: Integument.}

Als Integument bezeichnet man die äußere Lage oder Bedeckung des Körpers, die mehr oder weniger scharf von dem Innern abgegrenzt und in verschiedenem Grad ablösbar sein kann. Als einfachste oder Urform eines solchen Integuments lernten wir in der Einleitung das Ectoderm, die änßere Zelllage der zweischichtigen Gasträaform, kennen. Dies primitive Integument oder Ectoderm mußte oder konnte eine ganze Anzahl physiologischer Leistnngen erfüllen: 1. Schutz des inneren Kürpers (des Entoderms), 2. Bildung besonderer Einrichtungen zur Körperbewegung, 3. Beteiligung am Stoffwechsel, durch Lieferung von Secreten sowie durch den Wasser- und Gaswechsel an der Körperoberfläche (Respiration), 4. die Reize, welche von außen auf den Organismus trefien, aufzunehmen und weiterzugẻen, also im allgemeinen die Beziehungen zur Außenwelt zu vermitteln. Von diesen verschiedenen Leistungen verbleibt die des Schutzes dauernd dem Integument und entfaltet sich allmählich zu seiner Hanptfunktion; die ibrigen Leistungen können dem Integument noch in verschiedenem Grad verbleißen, werden jedoch bei den böheren Metazoen meist besonderen Organsystemen übertragen, welche aber, wenigstens zum Teil, ans dem Eetoderm hervorgehen.

Bei größeren und komplizierteren Metazoen mit erhöhtem Schutzbedürfnis kann sich das Integument verstärken, indem zu dem äußeren Epithel (Epidermis), das vom ursprünglichen Ectoderm abstammt, eine tiefere mesodermale Gewebslage (Bindegewebe) hinzutritt (Lederhaut, Cutis oder Corium).

\section{A. Epidermis.}

Wir müssen hier zunächst den ectodermalen Teil des Integuments, die sog. Epidermis, besprechen, die man, wenn sie noch von einer äußeren, nichtzelligen Lage iiberkleidet wird, zuweilen auch Hypodermis nennt. Die Epidermis ist also stets eine epitheliale Zelllage, welche direkt aus dem embryonalen Ectoderm hervorgeht, also gewissermaßen dessen Rest vorstellt, nach Absonderung sonstiger Organe, die etwa noch aus ihm entstanden. Sie ist bei den Wirbellosen fast stets ein einschichtiges Fpithel und erhält sich auch bei den primitivsten Wirbeltieren (Acrania) noch in dieser Form. Bei deu übrigen Vertebraten wird sie dagegen durch Zellvermehrung melrsehichtig, was mit erhöbter Schutzleistung zusammenhängt.

\section{Einschichtige Epidermis der Wirbellosen und die von ihr aus- gehenden Schutzeinrichtungen.}

In ihrer besonderen Ausbildung bei den vielen Gruppen der Wirbellosen zeigt die einschichtige Epidermis große Mannigfaltigkeit, was hier nur durch Hinweis anf einige hervorstechende Typen gekennzeichnet werden kann. (Fig. 21). Die Epithelzeilen können äußerst niedrig, flach sein (Plattenepithel, Spongien, manche 
Coelenterata usw.); sie können von mittlerer Höhe sein (Cylinderepithel, ein sehr häufiger Fall); sie werden sehr langgestreckt, fadenfürmig bis faserig (Actinien, manche Würmer usw.). Je nach seinen besonderen Leistnngen zeigt jedoeh auch das Epithel einงr und derselben Tierform an verschiedenen Körperstellen häufig große Versehiedenheiten.

Bei Wirbellosen scheint es ziemlich oft rorzukommen, dáB die Epidermiszellen sich nur äußerlich ganz dicht berühren, während sio in ihrem tieferen Verlauf etwas voneinander abstehen, ja durch dazwischen gedrungenes Bindegewebe mehr oder weniger getrennt werden. Auf diesem Wege kïnnen auch Pigmentzellen, Nervenfasern, Blutgefäße und Muskelzellen tief zwischen die Epidermiszellen eindringen (gewisse Hirudineen, Chätopoden, Gastropoden).

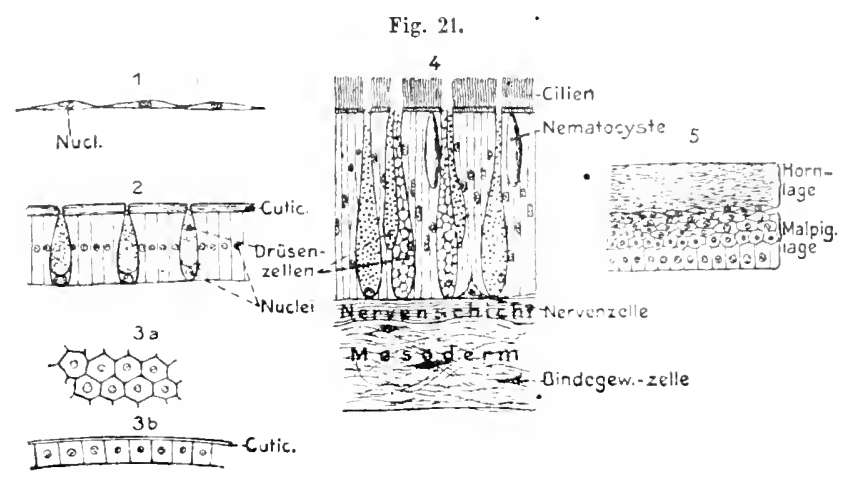

Schemata verschiedenen Epidermieepithels. 1 Ganz niederes Plattenepithel. 2 Cylinderepithel mit eingestrenten Drüsenzellen und Caticula im Durchschnitt (etwa Lumbricus). 3 Pflasterepithel mit Cuticula. ( $a$ Flächenbild; b Durchschnitt.) 4 Sehr hohes wimperndes Fadenepithel mit Drüsen- nnd Nesselzellen. Dnrehschnitt (Actinie). Nach 0. und R. HenTwig (1878\%. 5 Geschichtetes Epithel eines Sácgetiers. Dnrchschnit.

Auch die eigentümlichen Epidermisverhältnisse der parasitischen Plathelminthen (Trematoden und Cestoden) erklären sich wohl zum Teil anf diese Weise, indem die spindelförmigen Epithelzellen durch zwischengerücktes Bindegewebe und Muskulatur ganz auseinander geschoben wurden; wobei sie sich noch dadurch eigentïmlieh gestalteten, daß sie sich meist nach außen zu in mehr oder weniger feine Ausläufer verzweigen. Da jedoch in der sog. Cuticula, welche die Epidermiszellen amßen bedeckt, zuweilen Zellkerne vorkommen sollen, so wäre es möglich, daß die beschriebene Epidermisschicht jener Plattwürmer nicht die gesamte ursprüngliche Epidermis repräsentiert.

Eine besondere Modifikation erfährt die Epidermis zaweilen dadurch, daß ihre Zellen unter Verschwinden der ursprünglichen Grenzen zu einem sog. Syncytium zusammenfließen (Nematoden, Acanthocephalen).

Einrichtungen zur Bewegung mittels der Epidermis. Bei einfachen, kleinen Metazoen kann das Schwimmen dadurch geschehen, daß die Epidermiszellen Cilien tragen, deren Schlagen den Gesamtkörper fortbewegt (kleinere Turbellaria). Obgleich diese gleichmäßige Bewimperung der Epidermis auch den 
größeren Turbellarien und den Nemertinen allgemein zukommt, so dient sie ihnen doch nicht mehr zur Ortsbewegung; hier blieb sie wohl aus anderen physiologischen Gränden erhalten. - Daß die totale Bewimperung der Epidermis eine phylogenetisch alte und weitverbreitete Einrichtung war, sprieht sich darin aus, daß sie bei den Larven der Cölenteraten sehr allgemein vorkommt, ähnlich aneh vereinzelt bei den Larven von Würmern und Bryozoen; selbst unter den Wirbel-

Fig. 22.

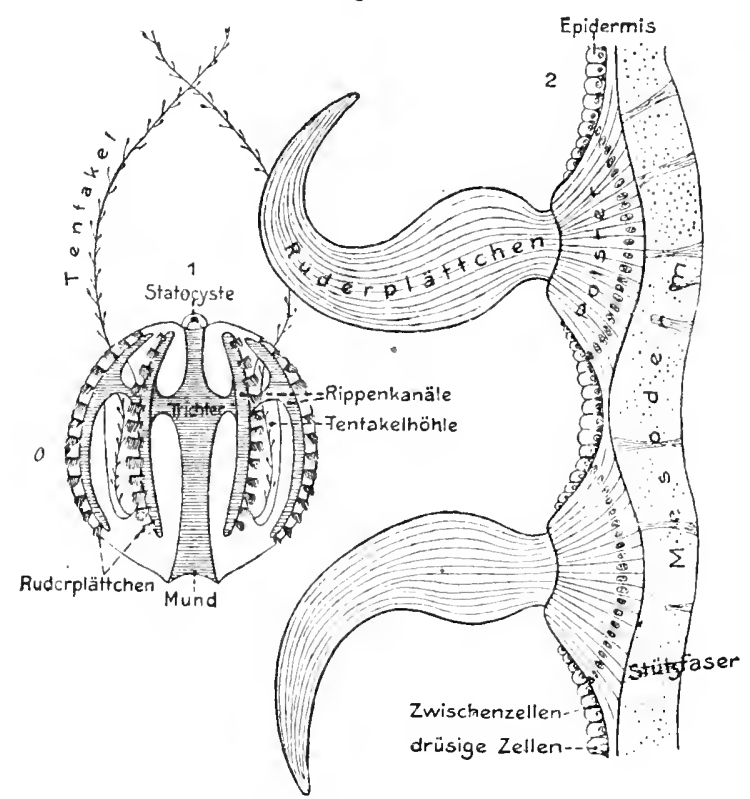

Ctenophere (Plenrobrachia). 1 Schematische Totalansicht in der Sagittal ebene. 2 Zwei Ruderplättchen von Callianira und die darunter liegende Epidermis im Längsschnitt. Das obere Plättchen in aufwäts gekrümmter Stellung, das untere herabgeschlagen. Mit Benutzung von Figuren Samassias (1892). tieren besitzt die Amphioxuslarve noch cin totales Wimperkleid, und die Körperoberflüche ganz junger Knochenfisehe und Anurenlarveu(Kaulquappen) ist ebenfalls noeh reichlich bewimpert.

Die Cilienbekleidung der Epidermis kann sieh im Dienste der Ortsbewegung inversehiedenster Weise spezialisieren und lokalisieren, indem sieh gleichzeitig meist stärkere Ciliengebildeoderansehnlichere Wimperzellen hervorbilden. Ein interessantes derartiges Beispiel bieten die sog. Kammquallen (Ctenophora). Über den Kï̈rper dieser meist annïhernd kugelig gestalteten Tiere

ziehen acht längere oder kürzere meridionale Reihen eigentümlicher sog. Ruderplättchen (s. Fig. 22). Dies sind die Bewegungsorgane, welche durch ihr Seblagen gegen das Wasser den Organismus sehwimmend erhalten. Jedes Ruderplättehen entspringt von einew Polster höherer Epidermiszellen und erweist sich als ein Verwachsungsprodukt zahlreicher Cilien dieser 'Zellen.

Unter den Würmern sind es die Rüdertierchen (Rotatorien), welche ein meist ansehnliches sog. Wimperorgan (Räderorgan) am Kopfe besitzen. Ursprünglieh ging es aus einem doppelten Wimperkranz hervor, der den etwa kugeligen Körper in der Gegend der Mundöffinung äquatorial umgürtete (Trochosphaera). Bei den übrigen Formen (Fig. 23) wurde es dureh stärkeres Hervorwachsen der hinteren Körperhälfte kopfständig. Der hintere der beiden Wimperkränze dient auch zur Nahrungszufuhr in den Mund. - Die Larven vieler mariner Chätopoden, Gephyreen, Bryozoen und Mollusken wiederholen dureh die vorübergehende Entwick- 
lung zweier entsprechender Wimperkränze (Trochophoralarven, Fig. 24) die bei den Rotatorien vorgezeichnete Bildurg. - Auch die Larven der Echinodermen bewegen sich mittels eines solchen Wimperkranzes (Wimperschnur), der jedoch dem der Trochophoralarve nicht direkt homolog ist Diese Wimperschntur erlangt bei dell verschiedenen Echinodermenklassen eine recht mannigfaltige Ausgestaltung und Differenzierung, im Zusammenhang mit den besonderen Gestaltsverhältnissen der Larven.

Wie wir fanden, erbält sich die Cilienbekleidung anch in vielen Fällen, wo sie zur Ortsbewegung nicht mehr beiträgt. Sie kann dann andere Leistnngen übernehmen. So dient sie an den Mundtentakeln der Bryozoen und den Cirren der Brachiopodenarme der Nahrungszufuhr zum Munde. - Häufig erhält sich auch die Cilienbekleidung der Epidermis auf den Kiemen, den Geruchsorganen und an andern Körperstellen, indem sie sich besonderen Leistungen anpaßt.

Fig. 23.

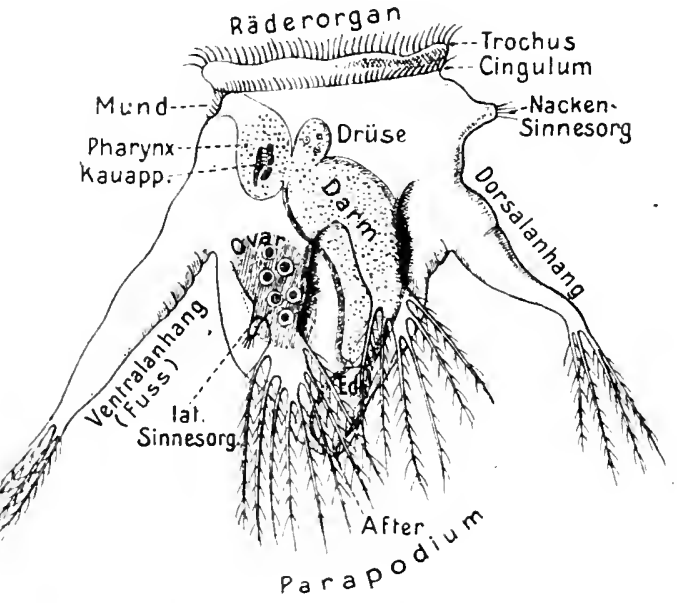

Fig. 24 .

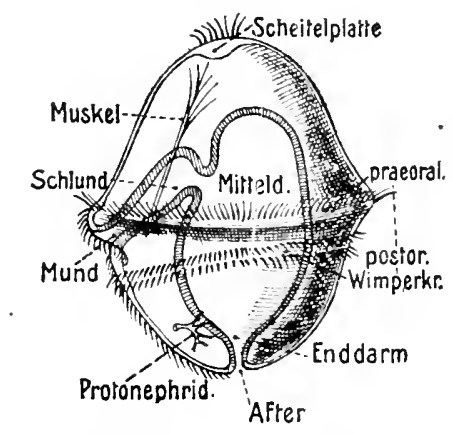

Trochophoralarve v. Echiurus von linis. (Etwas schematisiert nach HATS'HEK 15s0.) 0. B.

Pedalion (Hexarthra) fennicum. Larve von links. Etwas schema-

tisiert. (Nach LevaNdels 1594.)

Besondere Schutzeinrichtungen der einschichtigen Epidermis der Wirbellosen (Cuticula). - Ein stärkerer Schutz, als ihn die einfache Epidermis zu gewähren vermag, wird bei Wirbellosen dadurch erreicht, daß die Epidermiszellen eine nichtzellige änßere Lage hervorbringen, eine Cuticula, welche durch ihre Widerstandsfähigkeit schïtzend wirkt (s. Fig. 212, 25). Eine stärkere Entwicklung dieser Cuticula ist natiurlich nur bei nichtbewimperter Epidermis möglich; an bewimperten Stellen fehlt sie daher ganz oder bleibt sehr zart. Das Hervorgehen der Cuticula aus den Epiderniszellen, ob durch Secretion oder durch Umbildung des äußersten Plasmas der Epidermiszellen, ist ebenso schwer sicher zu entscheiden, wie die Entotehung der Zellhïllen der Protozoen. Chemisch sind die Cuticulae recht verschieden, indem sie sich teils wie Albuminoide verhalten, teils aus Chitin bestehen (speziell Artbropoden). Bei den Wirbellosen sind solche Cuticulae 
nngemein verbreitet, mit Ausnahme der Mollnsken, wo nur bei Placophoren und sonst zuweilen lokale Cuticularbildungen vorkommen (Saugnäpfe und Haken bei Cephalopoden). Ihre Dicke ist im allgemeinen mäßig, wird jedoch in gewissen Gruppen ansehnlicher bis sehr bedenteud. Unter den Würmern besitzen namentlich die Nematoden, zum Teil auch die Rotatorien, recht dicke Cuticulae; vor allem erreicht aber dic Chitincuticula der Arthropollen meist eine bedentende Stärke, weshalb sie mit Recht als ein Panzer bezeichnet warde. Die Widerstandsfähigkeit dieses Cuticularpanzers wird bei vielen Krebsen und gewissen Myriopoden (Diplopoda) durch Einlageruig von kohlensaurem und phosphorsaurem Kalk bedeutend verstärkt.

In gewissem Znsammenhang mit dieser Dicks der Cuticula steht jedenfalls die bei den Arthropoden und Nematoden allgemein verbreitete Erscheinung, daß

Fig. 25.

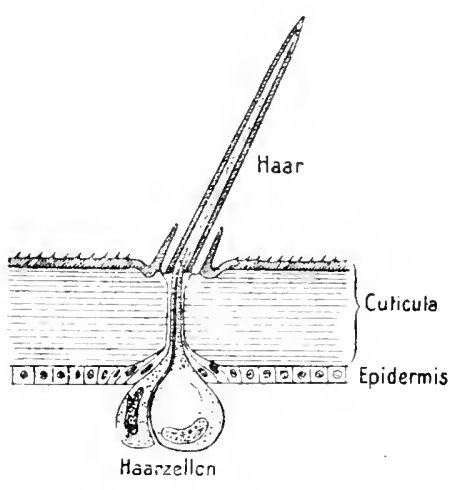

Schematischer Längsschnitt durch Epidermis, Caticula und Haar einer Raupe. O. B. die Cuticula zu gewissen Zeiten durch Flüssigkeitsabscheidung zwischen ihr und der Epidermis (Hypodermis) abgehoben und schließlich abgeworfen wird, nachdem sich unter ihr eine neue angelegt hat (Häutung). In gewissem Grad steht diese Erscheinung mit dem Wachstum in Beziehung, dem die dicke Cnticula nicht zu folgen vermag. Aber auch sehr dünne Cuticulae können periodisch gehäutet werden (Hirudineen).

Bei dicker und fester Cuticularbildung und mannigfaltigeren Körperbewegnngen sind besondere Einrichtnngen erforderlich, um die Bewegungen zu ermöglichen. Schon bei gewissen Rotatorien und an die Nematoden sich anschließenden kleinen Rundwürmern (Echinoderen), viel besser jedoch bei den Arthropoden, werten die Körperbewegungen dadurch ermöglicht, daß festere und dickere ringförmige Abschnitte der Cuticnla, welche bei den Arthropoden den Segmenten entsprechen, durch dïnnere biegsamere und eingefaltete Zwischenringe (Gelenkhäute) verbunden sind. Dieselbe Einrichtung besteht auch an den gegliederten Extremitäten der Arthropoden nnd bedingt deren ausgiebige Beweglichkeit.

Dickere Cuticulae sind stets mehr oder weniger deutlich geschichtet nnd lassen gewöhnlich auch verschieden strukturierte Lagen nnterscheiden, deren feinerer Bau sehr verwickelt sein kaun (Fig. 25).

Weitere Komplizierungen können besonders bei den Arthropoden in mannigfaltigster Weise durch Fortsatz- und Anhangsbildnngen entsteben, die sich auf der Oberfäche der Cuticula erheben. Dornen, Borsten, Haare und Schuppen (Fig. 25 u. 26) sind die Haupttypen solcher Erzeugnisse, deren gemeinsames Bildungsprinzip darin besteht, daß sich eine Epidermiszelle oder eine Groppe solcher, iiber die Oberfäche auswachsend, verlängert und durch ihre eigene Abscheidungstätigkeit einen 
cuticularen Überzug erhält. So ihnlich daher das Haarkleid vieler Arachnoideen und Insekten (Bienen, Fliegen) außerlich mit dem der Säugetiere, auch in seiner Bedeutung als Schutz gegen Nässe erscheint, so fundamental verschieden sind beiderlei Bildungen morphologisch und genetisch. Gleichzeitig kann jedoch die äußerste Lage der Cuticula häufig ein dichtes feines Börstchen- oder Haarkleid bilden, das, ohne Beziehung zu den Epidermiszellen, rein cuticular erscheint.

Schalen und Gehänsebildıngen der Metazoen. - - Wenn sich eine Cuticularabscheidung von der Epidermis abhebt und isoliert, jedoch den Tierkörper als schützende IIülle danernd umgiht, so nenuen wir sie eine Schale oder ein Gehäuse. Schalen oder Gehäuse traten bei den verschiedensten Abteilungen selhständig auf; ihre Homologie reicht daher nicht über die größeren Gruppen hinaus. Chemisch bestehen sie zum Teil wie die Cuticulae nur aus organischer Substanz. Bei stärkerer Entwicklung werden sie dagegen meist aus wenig oder sehr wenig organischer Substanz und großen Mengen von Calciumkarbonat (Brachiopoden, Mollusken) gebildet, seltener mit erheblicher Beimischung von Calciumphosphat (gewisse Brachiopoden).

Schon unter den Cölenteraten begegnen wir bei einem Teil der Hydroidpolypen (Campanulariden) Gehänsebildungen, die ihre nabe Beziehung zur Cuticula, welche bei den iibrigen Hydroiden die Stiele der Einzeltiere nnd der Kolonie als sog. Periderm uberzieht, deutlich zeigen.

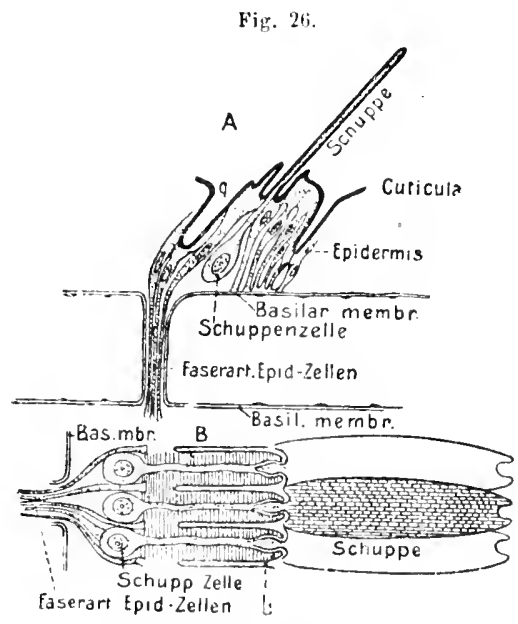

Schuppen vom Schmetterlingstïgel nach A. G. Marer (1896). I Kleiner Teil eines Langsschnitts durch FJügel der Puppe (7 Tage vor A usschlūpfen). Die Qnerfalten $q$ der beiden Flügelfiachen verstreichen nach Ausschlúpfen. Nur die Epidermis der oberen Flügelflache dargestellt. Die verläugerten Lpidermiszellen treten durch den Blutraum des Flugels bis zur Unterflächehindurch. $B$ Schiefer Querschnitt in d. Schuppenebene fi Tage vor Ausschlüpfen). "3 Schuppen mit ihren Zellen sowie die faserartigen Epidermiszellen dargestellt. Die Längsfalten $b$ der Flügelfäche verstreichen mach dem Ausschlüpfen. $O$. B.

Bei den Campanulariden hebt sich dies

Periderm als becherförmiges Gehäuse (Hydrotheca) von Körper des Einzelpolypen ab (Fig. 27). - In die Kategorie der Gehäusebildungen haben wir anch die von der Oberfläche der koloniebildendenden Hydrocorallinen unter den Hydroiden abgeschieden€ Kalkmasse zn rechnen, welche eine gemeinsame Stockmasse bildet, in der die Einzeltiere eingeschlossen sind.

Gehäusebildungen sind bei marinen Polychäten (besonders Sedentaria) ziemlich verbreitet. Die Abscheidung solcher Wurmröhren, deren Form die der 'Tiere mehr oder weniger nachahmt, hängt zusammen mit der reichlichen Schleimabsonderung, welche lem Integument vieler Gliederwürmer zukommt. Solche Wurmröhren können aus abgeschiedener organischer Substanz, aus Calcinmkarbonat, aber auch aus verkitteten Fremdkörpern (z. B. Sandkörnern) bestehen.

Die reichste Verbreitung, Mannigfaltigkeit und Komplikation erlangen die 
Schalengebilde aber bei den Brachiopoden und dem großen Stamm der Mollusken. Die auffallende Übereinstimmung der Schalen in beiden Abteilungen wurde früher als ein Zeichen näherer Verwandtschaft gcdeutet; denuoch handelt es sich nur um analoge Bildungen. In beiden Gruppen fiudet sich eine eigentümliche Beziehung der Schale zum Körper; dieselbe wird nämlich nur von einem beschränkten Teil der eigentlichen Körperoberfläche hervorgebracht. Um jedoch den Körper dennoch allseitig zu umhüllen, oder um seine Zurïckziehung in die Schale zu ermöglichen, wächst das Integument der schalenbildenden Körperregion zu einer

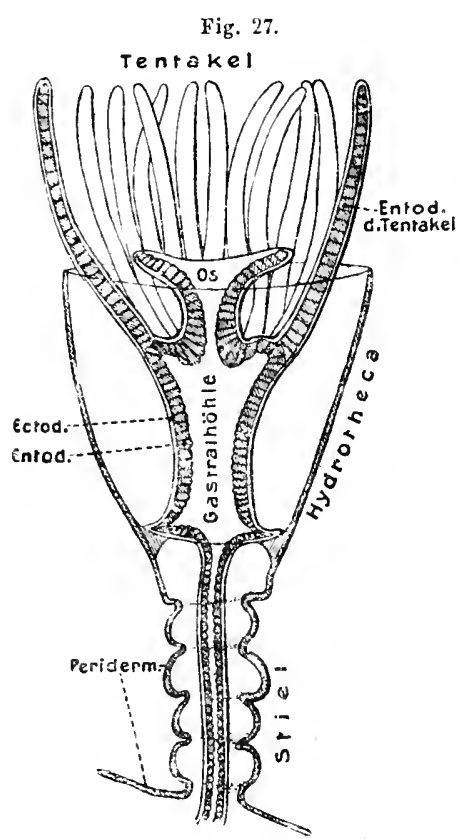

Obelia flabellata. Ein Polyp mit Hydrotheca; die Tentakel der dom Beschauer zngewendeten Seite nicht gezeichnet. Entoderm dunkel. Etwas schematisch.
Hantfalte aus, welche als sog. Mantel den Körper nmgibt. Indem sich die Schalenbildung bis zum Rande dieses Mantels fortsetzt, umhïllt sie also gleichfalls den Körper in größerer Ausdehnung. Dabei bewahrt der Hauptteil des Tierkörpers innerhalb des die Schale tragenden Mantels eine gewisse Beweglichkeit, kann sich mehr oder weniger aus der Schale hervorstrecken und wieder zurïckziehen.

Bei den Brachiopoden (Fig. 28) wachsen die Dorsal- und Ventralfäche des etwa eiförmigen Körpers nach vorn zu je einem ansehnlich langen Mantellappen aus, wäbrend das hintere Körperende stielförmig verlängert ist und zur Befestigung dient. Jeder Mantellappen scheidet auf seiner ganzen Oberfläche eine ihm genau entsprechende Schalenklappe ans, die sich auch über die beiden Körperflächen bis zum Stielursprung fortsetzt. Der Stiel tritt daher ursprünglich zwischen den Hinterrändern der beiden Schalenklappen (Schloßregion) heraus. Bei den

Tcsticardincn verlängert sich das Hinterende der größeren Ventralklappe rinnenförmig zur A ufnahme des Stiels in einen sog. Schnabel. - Die beiden Schalenklappen der Brachiopoden sind also völlig getrennte Bildungen und in sich symmetriseh gebildet, wie es ihrer Lage auf der Ventral- und Dorsalseitc entspricht. Dies sei betont im Gegensatz zu den Schalenklappen der Muscheln, welche als seitlich liegende Gebilde in der Regel in sich asymmetrisch sind. - Bei den Testicardinen gelenken die Schalen mit ihren Hinterrändern (Schloßränder) am Ursprung des Stiels aufeinander, indem diese Ränder mit ineinander greifenden Zähnchen verseben sein können. Vom Schloßrand der dorsalen Klappe entspringen bei einem Teil der Testicardinen zwei bandartige, in die Körperwand eingelagerte Fortsätze, die gewöhnlich schleifenartig miteinander verbunden sind und ins Körperinnere hineinragen, die sog. Armstiitzen. Bei manchen Formen können diese Armstützen sehr groß and 
kempliziert werden. - Den feineren Bau der Brachiopodenschale werden wir gemeinsam mit dem der Nollusken besprechen.

Mollusken. Die ursprünglichsten Schalen finden wir bei den einfachsten Kiemenschnecken (Prosobranchiata); doch ist es nicht unmöglich, daß sie sich durch Rückbildung vereinfacht haben. Jedenfalls darf aber als sicher erachtet werden, laß lie ältcsten Gastropoden eine ähnliche Schale besaßen. Der äußerlich bilaterale Körper einer primitiven Gastropodenform (wie der Urmollusken überhaupt) besitzt, etwas über dem zur Bewegung dienenden ventraleu FuB, eine, die ganze Riickenfläche umziehende ringförmige Hautfalte, die sog. Mantelfalte (Fig. $29^{2}$ ). Die Rïtkenfläche, welche von dieser Falte umgrenzt wird, steigt mehr oder weniger kegelfölmig auf' und bildet den sog. Fingeveidesack (häufig auch samt der Mantelfalte Mantel genannt, obgleich es angemessener scheint, nur die vorspringende Mautfalte so zu bezeichnen). Der von der Mantelfalte überdachte Raum wird Mantelrinne oder -höhle genannt. - Die ursprünglichste Gastropodenschale ist nun eine kegel- bis mützenförmige Bedeckung des Eingeweidesacks, die bis zum äußersten Rand der Mantelfalte reicht; ihre Form entspricht daher anch ganz der des Eingeweidesacks (s. Fig. 292,3); letzterer erscheint also wie ein Änguß der Schalenhöhle. Die Vergrößerung der Schale geschieht zunächst am Mantelrand; in dem Maße als dieser auswächst, wächst auch die Schale.

Eigenartig vollzieht sich die erste embryonale Anlage der Schale, welche bei allen Mollusken im wesentlichen dieselbe zu sein scheint. Die erste Anlage wird nämlich auf dem Rïcken des Embryo gebildet, da wo später der ailteste 'Teil der Schale, ihre Spitze (Apex) liegt. Die Anlage tritt jedoch nicht frei auf dem Ectoderm des Rückens

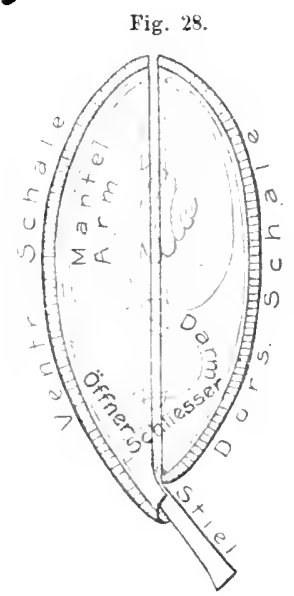

Schewat. Figur eiser testicardinen Brachiopoden. An. sicht ron links. C. H. auf; vielmehr stülpt sich dieses an der angegebenen Stelle zunächst zu einem drïsenartig gestalteten Säckchen ein, der sog. Schalendrüse (s. Fig. 291). Auf dem lioden dieser Schalendrüse tritt die erste Schalenanlage als ein unverkalktes Conchiolinblittchen, also gewissermaßen als eine innere Bildung auf. Beim weiteren Wachstum des Rückens und der Schale weitet sich die Öffuung der Schalendrüse ans, wodurch die Schale frei auf dem Rücken hervortritt. Ihr äußerster Rand aber bleibt stets von dem Einstiilpungsrand der ehemaligen Schalendrüse umfaßt, der sich am Mautelrand erhält (Schalenfalz). In dieser Hauteinsenkung erfolgt das Weiterwachstum des primären äußeren Schalenhäutchens, wie dies bei Gastropoden und Lamellibranchiaten (Fig. 35, S. 108) iberall deutlich nachweisbar ist. Die Verdickung der Schale durch die Abscheidung von Kalkschichten geschieht dann durch die Oberfläche ies Mantels und des Eingeweideßacks.

Aus diesem Entwieklungsprozeß scheint zu folgen, daß eine solche, ins Integument großenteils eingesenkte Schale bei den Urmollusken die Regtl war. Auch der Umstand, daß die zalılıeichen Schalenplatten der Placophoren (Käferscinnecken) 
an ihren Seitenrändern noch tief im Integument stccken, scheint für die Richtigkeit dieser Vermutung zu sprecken.

Über die S'hale der I'lacophoren, deren Ableitn's vou der der iibrigen Mollusken bis jetzt noch maufgeklärt ist, sei hier nur weniges be lerkt. Wie Schale besteht aus arht queren Platten, welche den Rücken (Eingeweirlesack) dicht bintereinander liegend bederken, uud in der oben angegebenen Weise seitlich in das Interument eingesenkt sind. Jede Platte überdeckt den vorderen Rand der darauffolgenden etwa. Bei gewissen Formen sind die Schalenplatteı sebr verkümmert (Chitonellus), ja sogr vollständig vom Integument überwachsen (Cryptocbiton), nach Analugie mit inneren Schal, ngebilden anderer Molluskenklassen.

Fig. 2!?.
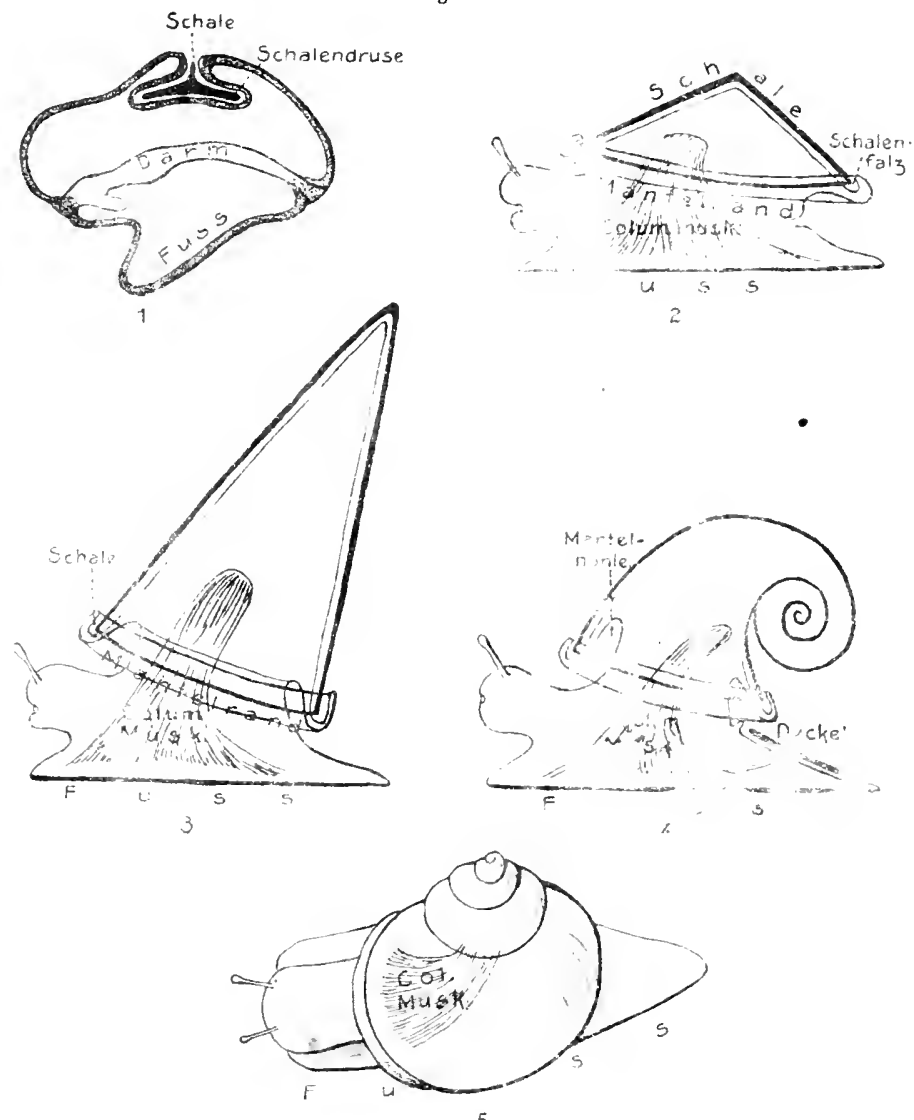

5

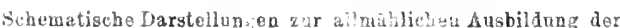

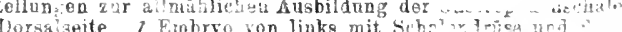

iva links, 5 \&n ther

Die priphere, von den Schalenplatten freie Ritu?

bettet, zallireiche kilkgebilde in Furm von Stache?

liegenden Epitbeleinsenkung abgerchieden werden.

Gastropoden. Wie bemerkt, wird die Forr Ter Gastroporenschal ron des Eingeweidesacks bedingt. Bei den meisten $P_{i}$ sobranchiater und Pulmorater 
wächst derselbe nun sebr stark dorsal und etwas uach hinten geneigt empor (Fig. $29^{3}$ ), so daß er, wenn er gerade ausgestreckt bliebe, einen hohen, schief aufsteigenden Kegel bilden wurde. Eine solche Form des Eingeweidesacks und der Schale wäre fuir kriechende Tiere, wie es die allermeisten Gastropoden sind, eine sehr unzweckmäßige. Nur bei schwimmenden Formen könnte ein solcher Eingeweidesack ohne Beeinträchtignng der Locomotion bestehen. In der Tat finden wir denn auch, daß bei schwimmenden Pteropoden nnd ansgestorbenen alten Cephalopoden (Orthoceratiden) ein soleh langer gerader Eingeweidesack tatsiichlich vorkommt. Für kriechende Gastropoden wäre er dagegen, wie gesagt, direkt schädlich; einmal wegen der starken Ritckwärtsverlegung des Schwerpunkts, was die Stabilität beeinträchtigte, und dann auch deshalb, weil der hohe Turm des Eingeweidesacks durch Anstoßen und leichte Beschädigung ein Hindernis bildete. Wir begreifen daher, daß eine Einrollung des langen Sacks und seine Konzentrierung zo einer kompakteren Form erhaltungsgemäß sein mußte. Diese Einrollung geschah durch besondere Wachstumsverhältnisse. Indem die vordere Region der Mantelfalte und des Eingeweidesacks stärker wuchs als die hintere, wurde letzterer in der Mittelebene des Tiers nach hinten zu spiral eingerollt, womit die Schale natülich dieselbe Ausgestaltung erfuhr (Fig. 294). Solche annähernd oder fast vollkommen spiralig eingerollte Schalen finden sich denn auch bei einigen Gastropoden. - Dennoch konnten derart eingerollte Schalen nicht sehr stabil sein, Ca sie auf dem Rücken des Tieres gewissermaßen balanciert werden mußten. Wir begreifen daher wieder in gewissem Grad, daß durch gleichzeitiges, etwas stärkeres Wachstum der linken Mantelregion der Eingeweidesack und die Schale zu einer schraubigen Spirale (Kegelschraube) wurden, die dann mit ihrer ganzen Basis dem Rücken des Tiers auflag und so viel stabiler war (Fig. 295). Die schraubige Gastropodenschale wurde so zu einer sog. likotropen (rechtsgewundenen der Conchiologen); doch gibt es anch einzelue Formen und Abnormitäten mit dexiotroper Schale.

Auf die große Mannigfaltigkeit in der Gestaltung der Gastropodenschalen kann hier nicht näher eingegangen werden. Sie beruht teils auf dem verschiedenen Grad der Steilheit der Schraube, dem langsameren oder rascheren Anwachsen des Umfangs der Windungen und den Besonderheiten der Schalenöffnung oder'-mündung; abgesehen von änßeren Verzierungeu und Färbungen der Schaleuoberfläche. - Eine Besonderheit der meisten Kiemenschnecken ist die Bildung eines Deckels zum Verschluß der Schaienmündung beim Zurïckziehen des Tiers. Dieser Deckel entsteht ganz unabhängig von der Schale auf der Dorsalseite des hinteren Fußabschnitts (s. Fig. 294). In seiner Entwicklung und Beschaffenbeit erinnert er fast etwas an eine zweite rudimentäre Schale.

Bei gewissen Prosobranchiaten (Heteropoden), Opisthobranchiaten, Pteropoden und Pulmonaten wird die Schale nicht selten stark oder ganz rïckgebildet. Auch bei den beschalten Opisthobranchiaten (Tectibranchiata) ist sic meist schon recht rudimentär; bei den schalenlosen Opisthobranchiaten (speziell Nudibranchiata) wird sie frühzeitig ganz abgew orfen und die Mantelfalte rückgebildet. Die schalenlosen Heteropoden und Pulmonaten zeigen dagegen die Mantelfalte gewöhulich 
erhalten, wenn auch samt dem Eingeweidesack sehr verkleinert. Ein Teil der änßerlich schalenlosen Pulmonaten besitzt jedoch ein Rudiment der Schale, indem sich die Schalendrüse durch Verwachsung ihrer Öffnung vom äußeren Epithel ganz abschließt. Die rudimentäre Schale wurde so zu einer inneren, unter der Rückenhant liegenden.

Cephalopoden. Eigenartige interessante Bildungswege schlug die Schale in der Klasse der Cephalopoden ein. Es unterliegt keinem Zweifel, daß sie von einer Urform ansging, wie wir sie bei den Gastropoden besprachen. Bei den äItesten Formen der Tetrabranchiaten (von welchen jetzt nur noch die Gattung Nautitus erhalten ist) wuchs die Schale samt dem Eingeweidesack zu einer schiefkegelförmig aufsteigenden aus, wie wir es bei den Gastropoden schilderten und wie sie bei schwimmenden Pteropoden hente noch vorkommt. Ohne Zweifel waren diese alten Tetrabranchiaten

Fig. 30 .

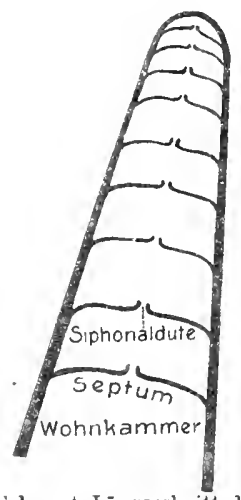

Schemat. Lāngsschnitt d. Schale oines Orthoceras. C. H. gleichfalls schwimmende Tiere, welche jedoch zur Verstärkung des Schwimmvermögens ihre Schale in sehr eigentümlicher Weise weiterbildeten (Fig. 30). Indem nämlich der apicale Teil des Eingeweidesacks zu einem strangförmigen Gebilde (Sipho) verkümmerte, wurde der Gipfel der Schale leer, d. h. durch Abscheidung des Eingeweidesacks mit Gas erfïllt. Die gegen diesen Gasraum schauende Fläche des Eingeweidesacks schied nun Schalensubstanz aus, welche als eine quere Scheidewand (Septum) den apicalen Gasraum von der übrigen Schalenhöhle abschloß. Durch dies Septum trat der zum Sipho verkümmerte apicale Teil des Eingeweidesacks. Beim Weiterwachsen des Tiers und der'Schale wiederholt sich der gleiche Vorgang successive in gewissen Perioden, so daß zahlreiche Septen und durch sie geschiedene Gaskammern gebildet werden, wïhrend der Sipho immer länger wird und vou dem Eingeweidesack des Tiers, das nur die letzte ansehulichste Kammer (Wohnkammer) erfïllt, bis zur ersten Anfangskammer alle Gaskammern durehzieht. Die Erfïllung der Kammern mit Gas machte aus đem größten Teil der Schale einen wirksamen, ijber dem Rücken des Tiers liegenden Schwimmapparat.

- Schon sehr fruihzeitig traten neben solch uralten Tetrabranchiaten mit gerader gekammerter Schale (Orthoceratiden) auch solche auf, deren gekammerte Sehalen mehr oder weniger gebogen bis symmetrisch spiral aufgerollt waren, wie die gekammerte Schale des lebenden Nantilus es noch zeigt (s. Fig. 31). Letztere Form läßt ferner feststellen, daß die spiralige Aufrollung dieser gekammerten Schalen genan umgekchrt erfolgt wie bei den Gastropoden, nämlich durch stärkeres Wachstum der hinteren Mantelregion, so daß der $\Lambda$ pex der Schale kopfwärts eingerollt wird. Daß dies für eine Schale, welche als Schwimmsack dient, leistnngsgemäß ist, ist leicht begreiflich, indem der Schwimmsack so über den Rücken des Tiers zusammengedringt wird.

Die Mannigfaltigkeit der geraden und der spiral aufgerollten, gekammerten 
'T'etrabranchiatenschalen ist eine ungeheure, so daß ein näheres Eingehen hierauf unmöglich ist. Betont werde nur, daß, abgesehen von äußeren Verzierungen, die Mannigfaltigkeit besonders anch auf der Lage des Siphos und der Siphonalöffinungen in den Septen beruht, indem der Sipho die Septen bald central, bald exzentriseh, d.h. mehr kopf-oder analständig durchzieht. Fernerbieten auch die Scheidewände selbst große Mannigfaltigkeit; indem sie sich ursprünglich in geschwungener Linie an die äußere Schalenwand ansetzen, bei den phylogenetisch jüngeren Formen dagegen in ibrer Ansatzregion mehr oder weniger gezackt verlaufen und ihre Ansatzlinien sich daher sehr somplizieren.

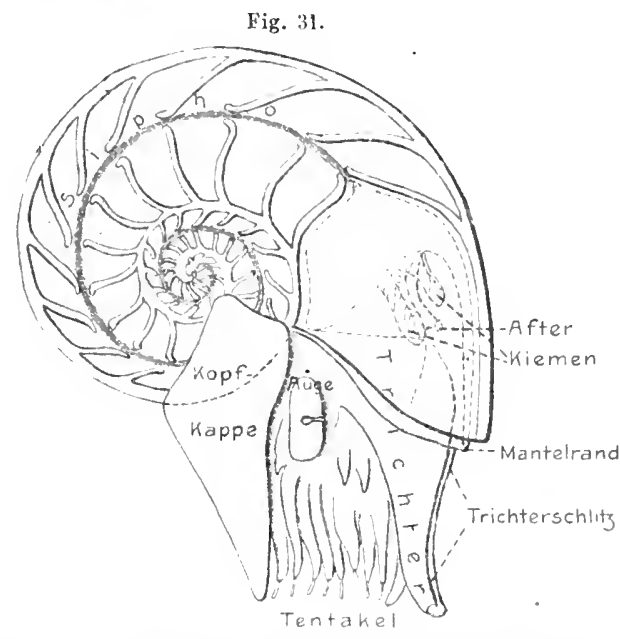

Nautilus. Schematische Ansicht von der linken Seite. Die Schale ist im Medianschnitt dargestellt. Die Mantelböhle etwas dunkler gebalten. C. H.

Die Schalen der erst viel später aufgetretenen dibranchiaten Cephalopoden gingen jedenfalls von Formen aus, die wie die Tetrabranehiaten eine gekammerte Sehale besaßen. Den Beweis hierfür liefert die Fig. 32. noch lebende Spirula aus der Gruppe der Decapoden. Sie ist gleichzeitig diejenige Dibranchiatenform, deren Sehale der der Tetrabranchiaten am nïehsten steht. Es ist eine (Fig. 32) an Größe sehr zurüekgetretene, spiral anfgerollte gekammerte Schale mit Sipho, welehe sich aber dadurch $\nabla \circ$ der Nautilnsschale wesentlich unterseheidet, daß sie naeh hinten zu aufgerollt ist wie die Gastropodenschale. Sie ist ferner so klein, daß nur die äußerste Spitze des Eingeweidesacks in der Wohnkammer Raum findet. Ferner wird sie von zwei seitliehen Integumentlappen fast vollständig umwachsen, so daß sie nur auf der Vorder- nnd Hinter'seite ein wenig unbedeekt frei liegt. Ob diese beiden Integumentlappen etwa auf Auswiichse des urspringlichen Schalendrüsensaums zurïckzufïuren, oder ob sie besondere integumentale Fortsätze der freien Oberfläche des Eingeweidesackes sind, ist unsicher. Da die stark reduzierte Spirula-

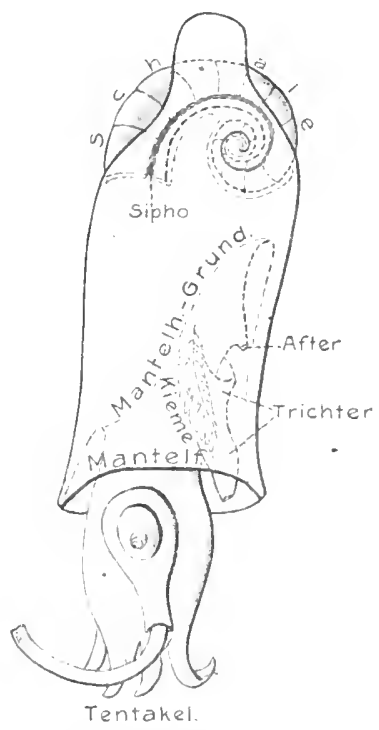

Spirula. Sehematische Darstellung von der linken Seite. C. H. schale jedenfalls keine besondere Bedeutung als. Sehwimmsack mehr besitzt, so erklärt dies wohl zum 'Teil ihre Aufrollung nach hinten. 
Die ausgestorbene mesozoische Abteilung der Bclemnitiden unter den Decapoden besaß ebenfalls noch eine kleine gekammerte Schale wie Spirnla und von ähnlichem Verhältnis zum Tierkörper (s. Fig. 33). Diese Schale (Phragmoconns) war jedoch gerade kegelförmig wie die der Orthoceratiden nnd durch einen eigentïmlichen aecessorischen 'Teil verstäkt. Dies sog. Rostrum war ein aus radiärfaseriger Kalkmasse bestehender, dorsal zugespitzter Stab, von gewöhnlich viel größerer Länge als der Phragmoconus; es gab jedoeh auch Formen, wo es sehr

Fig. 33 .

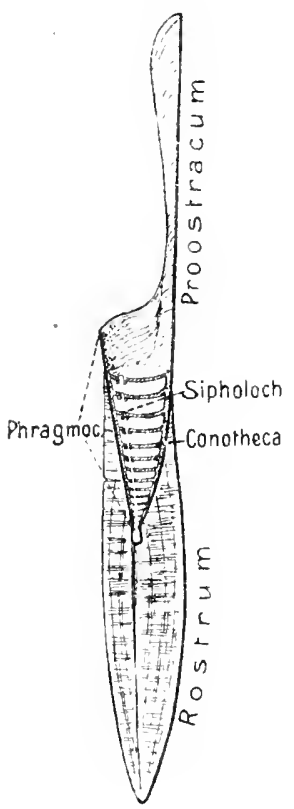

Bebemnites. Schema der inno ren Sohale, die in der Medianebene längs durchschnitten, so daf duf die Schnittiazche der rechten Hälftegesehen wird. (Nach ZitTkiLB Handbuch konstrulert.l O. B wenig entwickelt war. In der unteren Aushöhlung des Rostrums stak der Phragmoconus. Diese beiden Gebilde waren wie die Spirulasehale von Integumentallappen des Eingeweidesackes wahrscheinlich völlig umwachsen und so zu einer ganz inneren Schale, einer Art innerem Skelet geworden. Der vordere, nach dem Kopf des Tiers gerichtete Rand des kegelförmigen Phragmoconus war in ein dïnnes Kalkblatt ausgewachsen (Proostracum), das sich nnter dem Integument der vorderen Rtickenseite des Tiers bis gegen den Kopf ausbreitete. - Die jetzt lebenden Decapoden leiten sich wohl von belemnitenähnlichen Formen mit sehr schwach entwickeltem Rostrum ab. Ihre innere blattförmige Schale, der sog. Schulp der Sepien (s. Fig. 34), entwickelte sich hauptsächlich aus dem sehr groß werdenden Proostracum des Phragmoconus, während das Rostrum (Fig. 34b) dem Apicalende dieses Proostracum nur noch als ein kleines Spitzchen angewachsen ist. Die zahlreichen, successive abgelagerten Kalklamellen auf der Hinterseite (Innenseite) des llattförmigen Proostracum (s. den Längsschnitt des Sebulps b) werden nenerdings gewöhnlieh als die rudimentären Septen, und die $z$ wisehen ihnen liegenden, von Kalkpfeilerchen durchzogenen Schichten als den Kammerränmen des Phragmoconus entsprechende unvollständige Kammern gedentet. Meiner Meinnng nach ist dies insofern unrichtig, als diese Lamellen wahrscheinlich nur diejenigen Teile der Septen der gekammerten Schalen repräsentieren, welehe sich als sog. Siphonalscheiden oder -tïten um den Sipho fortsetzen, und : uch diese nur zu einem Teil. - Bei gewissen Decapoden bleibt der Schulp ganz unverkalkt und entbehrt anch der lamellösen Auflagerung des Sepiasehnlpes; er entspricht hier wohl ausschließlich dem ursprünglichen Proostracum, vielleicht noch mit einem Riudiment des Plragmoconus an der Spitze.

Die Octopolden besitzen nur noeh in einigen Fälen geringe Rudimente der imeren Schale, welche erweisen, daß anch die Ausgangsformen dieser Abteilung beschalt waren. - Als eine Bildung ganz ah)weiehender Art, die mit den Schalen der iibrigen Cephalopoden genetisch nicht zusammenhängt, ist die der Weibchen 
der Octopode Argonanta zu erachten. Sie ist ungekammert, nach vorn spiral aufgerollt, wie jene von Nautilus, und steht also völlig isoliert unter den iabrigen Cephalopoden.

Lamellibranchiaten. Eine sehr eigenatige Bntwicklung schlugen Mantel und Schale bei den Lamellibranchiata (Muscheln) ein. Dis ursprünglich ringförmige Mantelfalte wuchs an jede! Seite ventralwärts in einen Lappen ans, so daß der Körper zwischen den beilen, sjch ventral berührenden Mantellappen, die auch hänfig streckenweise verwahsen, eingeschlossen wird (Fig. 35). Dieser Mantelbildung entsjrechext, wirdauch dieurspringe is einheitic! Shale zweiklapps, : lem sie, von den b l w w allappen ausges. I: ' ' Ir, deren Form gensu wiederholt. DieursprünglicheEinheitlichkeit der Schale zeigt sich jedoch noch darin, daß beide Schalenklappen an einer mittleren Partio ihrer Rückenkante durch einen weniger verkalkten Schalenteil zusammenhängen, d. h. hier direkt ineinander übergehen. Dies ist das sog. Schalenbandoderligament /s. die Fig.), welches durch seine Elastizität die Srhale öffnet, weun die thließmuskeln erchlaffen. Da

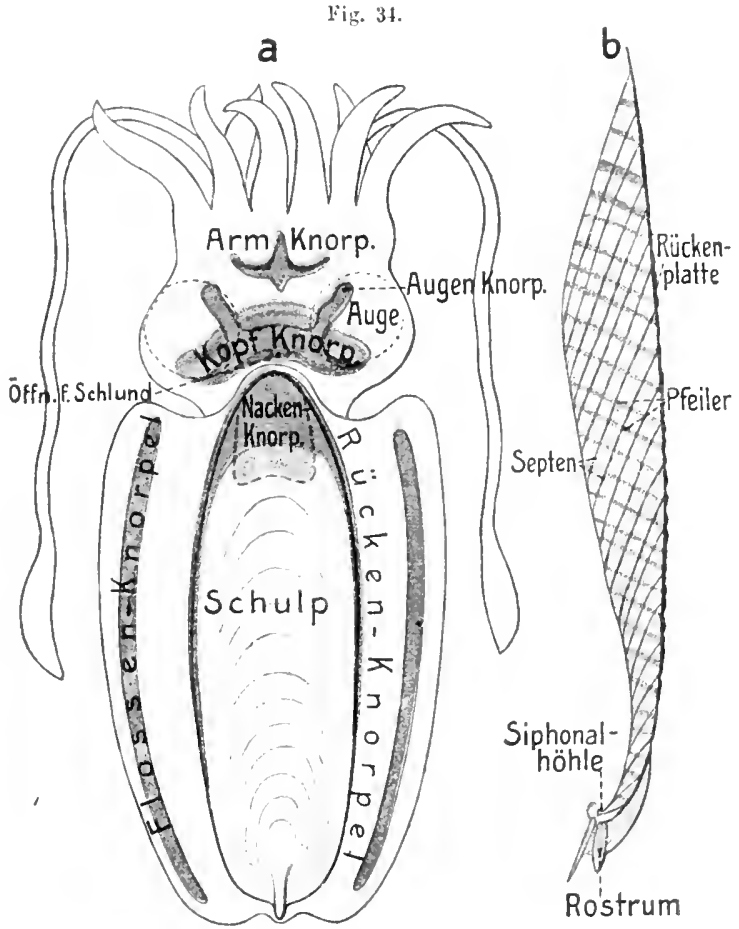

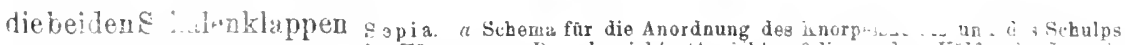
den bilater.:? Mu Mupl-

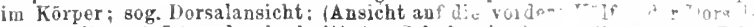
soite). b Lägsdurchschnitt tes Schn!

körper stitli"h bedacker,

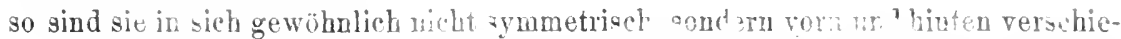

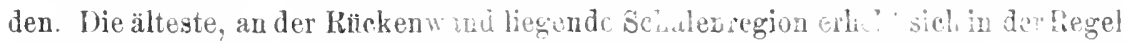
mehr oder weniger und bildet Hen sog. Nabel juler Klappe (Fig. 36). - Auf die

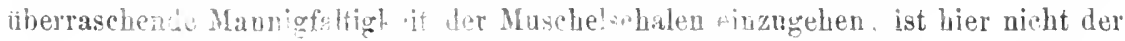

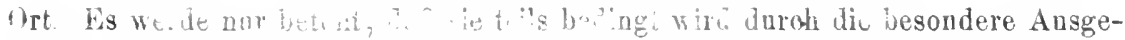

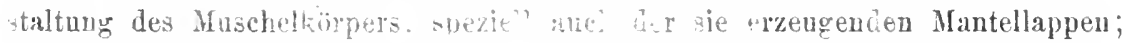

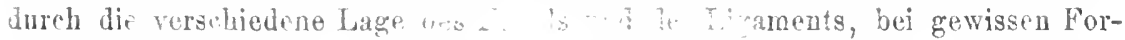

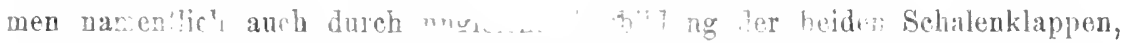

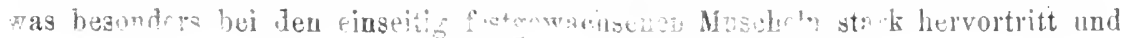


bei gewissen fossilen (Rudisten) dazn führte, daß die eine Klappe wie ein Deckel der hoch ausgewachsenen anderen auflag.-- Auch die innere Fläche beider Schalen kann durch das Anwachsen des Mantelrandes, der Schließ- und Fußmuskeln in

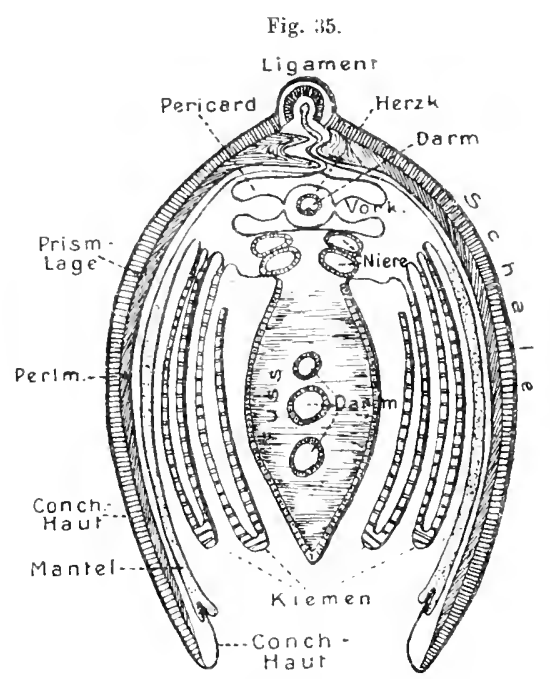

Schematischer Quersehnitt einer Flußmuschel (Unio) in der Herzgegend. verschiedener Weise mit Eindrücken versehen sein, deren genaue Schilderung zu weit führęn würde (s. Fig. 36).

Mit den Mantel- und Schalenverhältnissen der Musebeln zeigen die der kleinen Klasse der Scaphopoden mancherlei Übereinstimmung. Ihr Mantel ist wie bei den Muscheln beiderseits ventral herabgewachsen und bildet, indem beide Lappen ventral vollständig verwachsen, eine vorn nnd hinten geöffinete Röhre. Dementsprechend besitzt auch die Schale die Form einer vorn nnd hinten offenen Röhre, die langkegelförmig oder stoßzahnartig (Dentalium) erscheint, vorn etwas weiter als binten.

Feinerer Schalenbau bei Brachiopoden und Mollusken. Die kurze Übersicht der Schalenmorphologie beider Abteilungen müssen wir noch durch einige Bemerkungen ïber den feineren Bau der Schalen ergänzen. Bei beiden Gruppen

Fig. 36 .

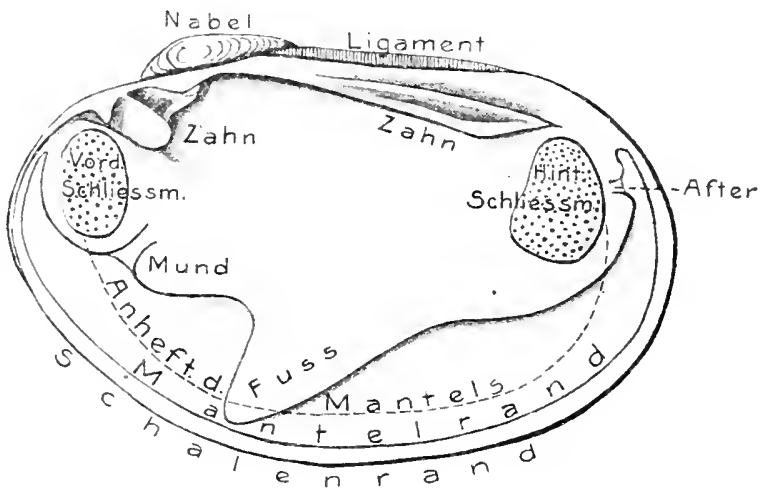

Flußmuschel (Unio liganentosa, N. Amerika) naeh Entfernung der linken Schale, des Mantels, der Kiemen und Nundsegel. Ansicht von links.

wird die äußere Schalenfläche đurch ein unverkalktes Häutchen (Periostracum) gebildet, das namentlich bei den Molluskenschalen manchmal recht stark ist. Dies Periostracum ist der erstgebildete Schalenteil, was sich bei den Mollusken auch 
am erwachsenen Tier ch deutlieh erkennen läßt, da der fortwachsende äußerste Schalenrand nur aus ihm besteht und in dem Schalenfalz des Manteliandes abgesondert wird (s. Fig. 35). Unter dem Periostraeum scheidet hierauf die Cberfläche des Mantel-, bzw. des Eingeweidesacks, die Kalklagen aus, die entweder Aragonit oder: Kalkspat sind, ja anch zum Teil beides in einer Sclale. Dickere Molluskenschalen bestehen wohl immer ans mehreren successiven Lagen von Kalkmasse, die häufig recht verschieden gebaut sein können. Dies tritt besonders bei vielen Muscheln hervor, bei welchen unter dem l'eriostracum eine änßere Schalenlage folgt, die aus senkrecht oder etwas schief zur Schalenoberfläche stehenden Prismen aufgebaut ist (Prismenlage, Fig. 35). Darunter folgt eine Lage, die äußerst fein parallel der Oberfäche geserichtet ist, das sog. Perlmutter. Die Prismenlage wird von der peripheren Mantelregion algesondert, die Perlmutterlage von der übrigen Oberflüche des Mantel Migertheb sind dalıer die beiden Lagen nicht etwa nacheinander gebildet, sondern gleichzeitig. Mas Dickenverhältnis beider Lagen ist sehr verschieden, bald kan die Prismen-, bald die Perlmutterlage sehr zurïektreten; ja es giht auch Sehalen, die fast nur aus Perlmutter oder aus Prismenlage bestehen. Gewisse Musehelschalen besitzen anch mehr den feinerer Bau der Fastropodcaschalcn. - Letztere zeigen im allgemeinen selten eiae innere Perlmutterlage. Ihro Schalenwand ist in der Regel ans drei Kalklagen zusammengesetzt, die aus dünnen, zur Schalenoberfläche senkreebten Lamellen bestehen. Diese Lamellen verlanfen in den abwechselıden Lagen versehieden, sich senkrecht kreuzend. Jede Lamelle zeigt einen feinfaserigen Buu, wobei diẹ Faserung in den alternierenden Lamellen einer Lage etwa rechtwinkelig zueinander verläuft und schiof gegen die Sehalenoberfïiche. - Die Schale von Nantilus (und der Tetrabranchiatan iiberhaupt) wird von einer äußeren weißen Porzellanlage und einer inneren dickeren Perlmutterlage anfgebaut; letztere bildet anch die Septen. Die Spirulasehale besteht aus Perlmutter.

Die Brachiopodenschalen gleiehen den Muschelsehalen gewöhnlich darin, daß die auf das Periostracum folgende Kalksubstanz ans Prismen zusammengesetzt ist, die jedoch häufig, recht schief zur Schalenoberfläche verlaufen. Eine Perlmutterlage fehlt stets. Die meisten Brachiopodenschalen sind von feinen oder etwas gröberen Poren durchsetzt, welche bis zur Oberflïche reichen und sich unter dieser auch manehmal verzweigen. Diese Porenkanäle sind von einem Bitndel faseriger Epithelzellen der Manteloberfläche erfïllt. Die physiologische Bedentung der Einrichtung ist wenig bekannt. - - Bei den Lamollibranchiaten kommen ähnliche Bildungen nur vereinzeit vor (Cycladidae; Larvenschale von Flußmuscheln), indem eine lang ausgewachsene Epithelzelle die Kanälchen bis zum Periostracum durehzieht. - Analoge Bildungen finden wir auch in den Schalenplatten der Placophoren in großer Menge. Die Platten werden von vielen senkreeht aufsteigenden Kanälen durchsetzt, welche bis zum Periostracum reichen und unter der Oberflïche zahl- reiche sekundäre feinere Kanälchen abgeben. In die größeren Kanälchen (Megalästhetes) dringt auch hier ein Bündel von Epitlielzellen ein; in die von ihnen entspringenden kleineren dagegen je nur eine Zelle (Micrästbetes). Die größeren 
Kanälchen entbalten anch Sinneszellen und sind daher jedenfalls Sinnesorgane, dercn Enden sich bei gewissen Formen sogar zu einfachen Augen entwickeln könuen; die sog. Micrïstheten dagegen sind wahrsclieinlieh nur Schutzorgane.

Epidermis der. Tunicaten. Die Tunicata zeigen recht eigentiimliche Verhältnisse ihres Integuments, welche an dieser Stelle kurz erwähnt werden mögen. Bei den primitivsten Formen (Copelatae) erscheint es noch als eine einschichtige Epidermis, welche ein gallertiges, bïufig erneutes Gehïuse anszuscheiden vermag. Bei den Ascidien und Salpen (Thaliadae) scheidet das einschichtige Epithel eine cellulosehaltige äußere Schutzlage aus, in welche aus der tieferen Körperschicht frïhzeitig Mesodermzellen (Blutzellen) ein wandern, indem sie durch die Epidermis treten. Auf solche Weise bildet sich der sog. »Mantcl dieser Formen als eine äuBere Schutzlage des Integnments und erlangt namentlich bei den Ascidien häufig eine recht bedeutende Dieke und Festigkeit. Die in die eellulosehaltige Grundsubstanz des Mautels eingelagerten Zellen betrachtet man jetzt gewöhnlieh sämtlich als eingewanderte Mesodermzellen, nur die basale einsehichtige Zelllage als die eigentliche Epidermis. Die Mantelzellen differenzieren sich allmählich in reich verästelte, netzartig zusammenhängende, in blasige unverzweigte und häufig auch Pigmentzellen. Sie beteiligen sich wohl auch an del Abseheidung der Grundsubstanz. Der histologische Charakter dieses Mantelgewebes ist der eines Bindegewebes mit eellulosehaltiger, häufig auch mehr oder weniger fibrillär differenzierter Grundsubstanz, abgesehen vou der basalen Hachen einschichtigen Epidermis. Daß letztere gar keine Zcllen liefere, die in das Mantelgewebe einwandern, seheint mir noeh nicht völlig erwiesen. - - Diese merkwiirdige Bildung einer bindegewebsartigen Hiille außerhalb der Epidermis seheint etwas weniger anffallend, wenn wir beriieksichtigen, daß anch in die Epidermis und die Sehleimhautepithelien der Vertebraten häufig mesodermale Zellen (Lymph- und Pigmentzellen) einwandern, ja sie auch durchwandern und anf ihrer Oberfläehe frei heraustreten. - Der Ascidienmantel wird schließlich häufig noch dadurch kompliziert, đaß ans dem unterliegenden Körper Blntgefäße in ihn hineinwachsen und ihn reichlich durchziehen.

\section{Geschichtete Epidermis der Vertebrata und ihre Schutgeinrichtungen.}

Wie wir schon sahen, ist die Epidermis der Acrunier noch ein einschichtiges Cylinderepithel. Bei sämtlichen übrigen Wirbeltieren entwickelt sich dagegen die einsehichtig angelegte Epidermis durch Teilung ihrer Zellen zu einer mehr- bis vielschichtigen. Die Zahl der Sehichten kann sehr verschieden sein, von relativ wenigen bei diinner Epidermis (Amphibien zum 'Teil nur 5 bis 10 schichten) bis zu sehr vielen. Im allgemeinen wird schon durch diese Dickenzunahme der Epidermis ihre Schutzleistung ansehnlich gesteigert. Bei einem und demselben 'Tier variiert jedoeh die Epidermisdicke an verschiedenen Körperstellen erheblich; ebenso kann auch durch besondere Verlältuisse (Häntung) eine Dickenschwanknng zu versehiedenen Zeiten lervortreten. Die basale Zellschicht, in welcher sich gewissermaßen die embryonale Ansgangsschicht erhïlt, besitzt zeitlebens die Fähigkeit, durch Teilung nene \%ellschichten zu bilden. Dies steht im Zusammenhang mit der weit 
verbreiteten Erscheinung, daß die oberflächlichen Zellen der mehrsehichtigen Epidermis fortdauernd zugrunde gehen und abgestoßen oder abgerieben werden, was einen stetigen Ersatz hedingt.

Die basale oder Keimsehieht der Epidermis bewahrt iiberall danernd den ursprüngliehen Bau eines Cylinderepithels (s. Fig. 215 , S. 95); die Zellen der aus ihr hervorgegangenen distalen Schichten dagegen nehmen gegen die Oberfläche zu eine mebr rundliche bis polygonale Form an; die der äußersten Sehicht platten sieh häufig anch etwas mehr ab. Eine solehe Bildung zeigt im allgemeinen die Epidermis der Cyclostomen und maneher Fisehe (Fig. 45, 46), wogegen bei den meisten Fischen und den Amphibien die Abplattnng in der äußersten oder cinigen änßersten Sehichten zu tlachen bis sehüppehenartigen Zellen sehon sehärfer ansgeprägt ist. Bei den wasserlebenden Cyclostomen (Fig. 45, S. 126) und Fischen (Fig. 46, S. 127) bewahren sämtliche Zellen der mehrschichtigen Epidermis in der Regel den ursprünglichen plasmatischen Charakter, wenn sie sich nicht zum Teil zu besonderen Drïsenzellen umbilden, wovon später die Rede sein wird. Die Zellen der äußersten Sehichten bilden bei den myxinoiden Cyelostomen sogar sämtlieh oder großenteils in ihrem Innern Sehleim, werden daher blasig drïsig. Die äußerste Zellsehicht der beiden Gruppen entwiekelt auf ihrer Außentläehe einen dünnen Salum, der gewöhnlich als Cutienlarsaum bezeichnet und anch wohl riehtig mit der Cutienla der Wirbellosen verglichen wird. Ien Amphibien kommt ein solcher Cuticularsaum nur noch im Larvenzustand zn; den übrigen Wirbeltieren fehlt er überhaupt.

Von den Amphibien an erfahren die äußerste oder einige der änßersten Epidermissehichten, deren Zellen stark abgeplattet sind, eine chemisehe Veränderung ihres Plasmas, das sich in sog. IIornsubstanz (Keratin) umwandelt, wobei die Zellen absterben. So entsteht eine äußere, aus verhornten Zellen bestehende Epidermislage, welehe als Stratum. corneum oder Hornlage von der tiefen Epidermislage, deren Zellen lebendig sind, der Schleimlage oder dem Stratum malpighii)(Str. germinativum) unterschieden wird (Fig. 215). Die Ausbildung einer widerstandsfähigeren Hornlage, wie sie den höheren Wirbeltieren zukommt, erhöht nattirlich sehr erheblich den Sehutz, welchen die Epidermis zu bieten vermag, und zwar nicht nur gegen mechanische Verletzungen, sondern namentlieh atuch gegen die Austroeknung bei des luftlebenden Formen. Wenn daher auch die stärkere Entwieklnng der Hornlage der höheren Wirbeltiere (Amnioten) sicher von ihrem Luftleben bedingt ist, so wurde das erste Auftreten von Verhornungen doch nicht durch das Luftleben verursacht. Dies beweisen die Cyeiostomen und Fische, bei denen schon lokal oder sogar in etwas weiterer Ausdehnung iiber den Körper Verhornung der änßeren Epidermissehichten eintreten kann (Cyelostomen: Flossen, Hornzähne der Mundhöhle; l'erlanssehlag der Männehen von Cyprinoiden). Es scheint daher auch nicht nötig, ans der Hornlage der wasserlebenden Amphibien auf ihr ursprüngliches Luftleben zn schließen.

Bei den Amphibien bleibt das Stratum corneum gewöhnlieh noch recht dünn, beschränkt sieh zuweilen sogar nur auf die äußerste Zellschicht, kinn jedoch auch bis 8 und 10 \%ellsebichtendicke erreichen (besonders bei Perennibranchiateu). Wie 
luftlebenden Ammioten dagegen bilden eine viel dickere Hornlage mit viel mehr \%ellschiclitcn. Die verhornten Zellen selbst werden zu ganz flachen Schüppchen, deren Kern meist nicht mehr deutlich ist; iuch die Zellen selbst sind wenigstens in den :̈ußereu Schichten nur mit besonderen Hilfsmitteln zu unterscheiden. Natürlich variiert die Stärke der Iiornlage auch bei diesen Formen lokal sehr, wie wir gleich genaner erfahren werden.

Eine gauz allgemeine Erscheinung ist, daß die verhornte Epidermis eine fortdanernde Ernenerung erfährt, was durch die Kellneuhildung der malpighischen. Lage bewirkt wirl. Dabei wird die alte Hornlage entweder langsam durch Abschilferung kḷciner Anteile der Oberfläche entfernt, wie es bei Säugern und Vögeln, auch den placoiden Reptilien, soweit hier Abstoßung stattfindet, geschieht; oder der Frneuerungsprozeß verlänft periodisch als sog. Häitung. Schon die Hornziihne der Cyclostomen werden anf solche Weise periodisch ernenert. Bei den Amphibien löst sich die IIornsehicht zeitweise in Fetzen oder gelegentlich auch

Fig. 37.

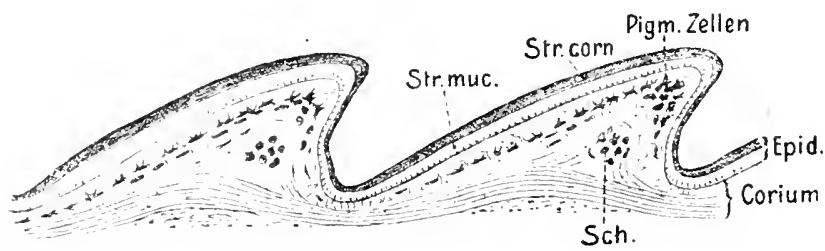

Lacerta agilis. Medianer Längsschnitt lurch zwei Sehuppen. Sch. wird als Rudinent einer Knocher. schuppo gedeutet. (Nach Maurer 15!9j.)

0 . $B$.

zusammenlängend ab. Bei den lreschuppten Reptilien findet sich letzteres regelmäßig und ist namentlich bei Schlangen schön zn verfolgen. Hier löst sich die Iornlage an den Kieferrändern ab, worauf die Schlange ans dem alten Hornschlanche hervorkriecht, indem sie ihn gleichzeitig hervorzieht nnd umstiilpt, so daß seine lnnenseite zur äußeren wird. -- Die Häutung wird durch die Bildnng einer neuen Hornlige aus der Schleimlage eingeleitet (manchmal sind auch schon melırere solcher Anlagen untereinander vorhanden); hierauf erfolgt durch Verschleimung gewisser Zellschichten zwischen der alten und nenen Lage eine Abhebung des alten Stratum corneum und schließlich seine Abstreifung.

In der Verhornung der Epidermis hat sich eine Kinrichtung entwickelt, welche durch Forddauer des Prozesses, d. h. Bildung neuer Zellschiciten und ihre Verhornung, eine weitgehende Verstärkung erfahren kann, wodurch der Organismus sich erhöhtem allgemeinem oder lokalem Schutzbedürfnis anzupassen vermag.

Hornschuppen und-I'latten. Schon die Amphibien (z. B. Kröten) zeigen zıweilen lokale stärkere Verhornung auf Warzen der Hautoberfläche. Bei den Reptilien, deren Hornlage ïberhaupt sehr dick wird, erlangen solch lokale stärkere Verhorunngen auf dem gesamten Integument eine besondere Bedeutung. Die Haut der Sqquamata (Eidechsen und Schlangen) ist in der Regel dicht mit Längsreiben alternierender, sich dachziegelartig nach hinten deckender Schnppen 
bekleidet. .Jede Schuppe ist ein nach hinten gerichteter abgeplatteter Answuchs des gesamten Integuments, in den also auch das Corium einen Fortsatz sendet (Papille). Die Hornlage der Epidermis wird auf der Oberseite der Schuppen besonders dick, auf ihrer Unterseite und zwischen den Schuppen bleibt sie dünner (Fig. 37). Auf Grundlage dieses allgemeinen Bauprinzips können sich die Hornschuppen in der mannigfaltigsten Weise weiter ausgestalten, indem sie zu dornbis stachelartigen Gebilden, oder auch zu warzen- bis körnerartigen werden, die sich nicht mehr ïberdecken. Andrerseits können sich jedoch die Schuppen anch stark in der Fläche vergrößern, wobei sie gleichzeitig wenig oder nicht mehr iihereinander greifen, also zu schilder- bis plattenartigen Gebilden werden, wie es häufig am Kopf und Bauch der Squamaten vorkommt. - Dieser plattenartige Charakter der epidermoidalen Horngebilde herrseht bei den placoiden Reptilien. Die einzelnen Platten sind durch schmale, schwächer verhornte $Z$ wischensäıme voneinander gesondert. Thre Form ist bald regelmäßiger, bald unregelmäßiger. Besonders regelmäßig und groß werden die Hornplatten gewöhnlich auf dem Rumpf der Schildkröten (Schildpatt); doch gibt es anch Chelonier mit sehr verkümmerten Hornplatten. Daß die Platten leicht wieder in schuppenartige Gebilde auswachsen, ist bei gewissen Cheloniern (Karettschildkröte) zu beobachten.

Die nahen Beziehungen der Vögel zu den Reptilien treten noch deutlich hervor, indem die unbefiederten Partien ihrer Beine (insbesondere Zehen und Lauf) gewöhnlich von körner- bis plattenartigen Horngebilden beleckt sind, welche denen der Reptilien sehr gleichen. Im einzelnen unterliegt diese Hornbekleidung der Vogelfüße großen Variationen.

Bei nicht wenigen Süugern finden sich neben der Beharung auch Gebilde, welche den Hornschuppen oder -platten der Reptilien recht ähnlich sind. Es wurde jedoch noch keine Übereinstimmung darüber erzielt, ob sich diese Schnppengebilde genetisch von denen der Sauropsiden ableiten lassen. Mir ist es wahrscheinlicher, daß es sich nur um analoge Bildungen handelt. Nur bei gewissen Edentaten treten derartige integumentale Hornbildungen über den ganzen Rücken hin auf. Bei Manis (Schuppentier) sind es sehr große längsgestreifte wirkliche Schuppen, die sich dachziegelartig nach hinten iiberdecken. Die Gürteltiere (Loricata, Dasypodidae) besitzen dagegen plattenartige Horngebilde, analog denen der Placoidea, welche den Rücken bekleiden. Sie ordnen sich mehr oder weniger deutlich in quere Gürtel an und treten auf Kopf, Schulterregion, Rumpf, Beckenregion und Schwanz zu besonderen Panzerabschnitten in engere Verbindung. Jede Platte läßt sich bei näherer Untersuchung als eine Verwachsung ursprïnglich kleinerer erkennen: Zwischen diesen Horngebilden von Manis und den Dasypodiden sind jedoch auch Haare spärlich zerstreut. - Kleinere Horngebilde von schuppenartigem Charakter finden sich häufig am wenig behaarten Schwanz zahlreicher Nager (Biber, Ratten, Mäuse), Insektenfresser und Beuteltiere (Beutelratten). Anch die unbehaarten Stellen der Füße sind zuweilen mehr oder weniger beschuppt.

Federn und Haare. Das Integument der Vögel und Säuger hat auf seinor ganzen Oberfläche verhornte Integumentalanhänge entwickelt, die Federn der Vögel 
and die Haare der Sängetiere. Diese Gebilde haben morphologisch und physiologisch mancherlei Gemeinsames, obgleich es zweifelhaft, ja unwahrscheinlich ist, daß sie genetisch denselben Ursprang besitzen. Beide sind verhornte Epidermoidalanhänge, die, lang fadenförmig auswachsend, sich hoch über die Haut erheben und sie meist als dichter Überzug bedecken. Es scheint daher begreiflich, daß so lange Anhangsgebilde eine festere Einpflanzung im Integument erlangten, als sie der Reptilienschuppe zukommt. Diese Einpflanzung entstand bei beiderlei Gebilden anf die Weise, daß die Epidermis im nächsten Umkreis des anfänglich kurzen Anhangs schlauchförmig in das unterliegende Corium als sog. Feder- oder Haarbalg (Follikel) hineinwuchs. So wurde die Basis der Feder oder des Haares in den Grund dieses, häufig tief in die Lederhaut hinabreichenden Balges verlegt, womit eine feste Einpflanznng im Integument erzielt war. In die Basis beider Anhänge ragt wie bei der Schuppe eine Cutispapille hinein, deren Größe jener der Anhangsgebilde selbst koordiniert ist.

Die physiologische Bedeutung und damit auch der Grund der phylogenetischen Entfaltung des Feder- und Haarkleides ist vor allem in der konstanten und meist die der Umgebung übertreffenden Temperatur der Vögel und Sängetiere zu suchen, also im Schutz gegen Wärmeverlust; weiterhin kommt hauptsächlich noch der Schutz gegen Nässe in Betracht.

Haare. Wenn wir zunächst von der phylogenetischen Herleitang absehen, so repräsentiert sich das Haar als das einfacher gebaute Organ, weshalb wir es zuerst betrachten wollen (s. Fig. 38). Es ist ein aus verhornten Epidermzellen bestehender, meist cylindrischer, selten abgeplatteter, bis im Querschnitt ovaler, solider Faden, dessen freies Ende zngespitzt ausläuft. Der Faden entspringt vom Grande des Follikels, wo das die Follikelwand (äußere Haarwurzelscheide) bildende Epiderm in eine Anschwellung von Zellen übergeht (Bulbus), durch deren fortgesetzte Vermehrung die allmählich verhornenden Bildungszellen des Haares entstehen. In diese Anschwellung agt die Coriumpapille hinein, die gewöhnlich klein bleibt. Bei der Verhornung der Bildungszellen entsteht um das eigentliche Haar noch eine röhrenförmige Lage verhornter Zellen, die distal im Follikel aufsteigt bis etwa zur Einmündung der Talgdruisen (sog. innere Haarwurzelscheide). Die Haarfollikel, und damit auch die Haare selbst, sind meist ziemlich schief zur Hautoberfäche eingepflanzt, wobei sich die Haare in der Regel caudalwärts richten ; doch variiert ihre Richtung an verschiedenen Körperregionen sehr. - Die Hornzellen des Haares sind nicht alle von gleicher Beschaffenheit; vielmehr lassen sich gewöhnlich unterscheiden: 1. ein einschichtiges sog. Oberhäutchen (Cuticula) aus ganz flachen Zellen; 2. eine Rindensubstanz aus längsfaserigen Zellen, und 3. die Marksubstanz, aus mehr rundlichen bis polygonalen, häufig gashaltigen Zellen bestehend.

Die Ausgestaltung der Haare bei den verschiedenen Säugern sowobl, als auch lokal bei einer und derselben Form ist so mannigfaltig, daß hierüber nur Andeutungen gegeben werden können. Vor allem variieren Länge und Dicke außerordentlich und, wie allbekannt, auch an verschiedenen Stellen des Körpers. Mäh- 
nen, Schweife, Bärte und dergleichen sind Beispiele lokaler Ë̈twiè:lnng sehr verlängerter Haare. -- Die Stachelbedeckung des Rückens mancher Säugetiere (Igel, Stachelsçhwein, Echidna u. a.) ergibt sich leicht als eine exzessive Entwicklung besonders dicker und häufig auch langer Haare, die sich zum Teil nur durch stärkere und etwas kompliziertere Bildung der Coriumpapille auszeichnen. Diese in den verschiedenen Gruppen der Säuger selbständig entwickelten Stacheln sind

Fig. 38 .

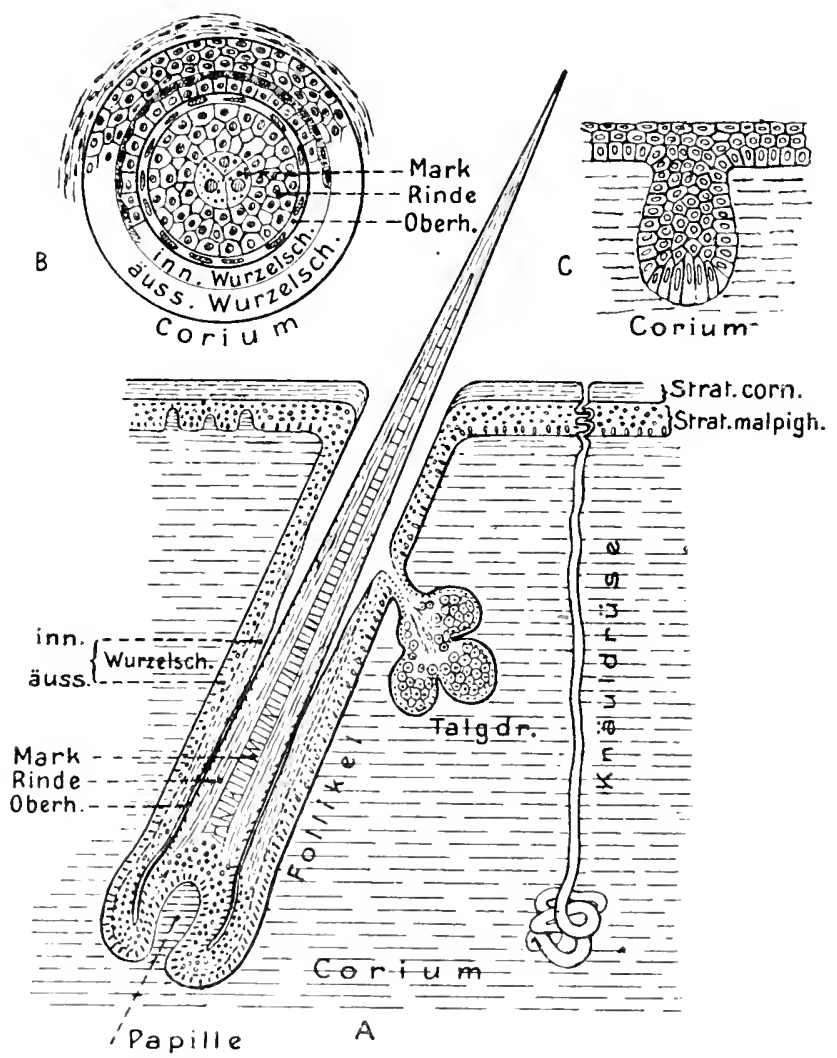

Schemata zum Baudes Haares, seines Follikels und seiner Entwicklumg. A Längsdurchsehnitt eines Haares in seinem Follikel $b$ Qnerschnitt durch Haar und Follikel (etwa in der Mitte des Follikels). C' Frühzeitige Anlage eines liarfollikels mit knuspenfermiger Gruppierung der tiefsten Epidermiszellen. (Mit Benutzung Y. MaUlex J495 konstruiert.)

durch alle Größenüh)ergänge mit den gewöhulichen Haaren verbunden, welche sich. neben ihnen finden. - Die sog. Tast- oder Sinushaare der Schnauzengegend sollen bei den Sinnesorganen besprochen werden.

Weiter zeigen auch die Haare in der feineren Zusammensetzung große Mannigfaltigkeit, besonders im Dickenverhältnis von Mark und Rintle. Ersteres kanı sich zuweilen so rerstärken, daß die linde fast schwindet; andrerseits kann es jedoch auch gauz fehlen, was sogar der ursprünglichste Zustand zu sein scheint. Bei starker Behaarung sind die Haare häutig in größere Stichel- oder Konturbaare und feinere Wollhare differenziert; die crsteren bewirken dann allein das äußere Aussehen des Haarkleids. 
Von besonderem Interesse ist die eigentümliche Anordnung der Haare in kleine Gruppen, wie sie die genauere Untersuchung bei vielen Säugern zeigt. Dabei ergab sich, daß eine Gruppe von drei quergestellten Haaren einen ursprünglichen Zustand zu repräsentieren scheint. Bei gleichzeitiger Gegenwart von Schuppen steht hinter jeder Schuppe gewöhnlich eine solche Gruppe. Diese Dreiergruppen komplizieren sich zim Teil durch Vermehrung der Haare, häufiger jedoch durch Zutritt kleinerer Haare um und zwischen den drei ursprünglichen. Eine weitere Komplikation kann dadurch eintreten, daß alle oder nur die seitlichen Haare der Dreiergruppe zu Haarbündeln werden, die aus einem gemeinsamen Follikel entspringen. Ein solch komplexer Follikel kann entweder durch gemeinsame Einsenkung dicht benachbarter Follikel zu einem entstehen; gewöhnlich jedoch so, daß der ursprüngliche Follikel zahlreiche neue hervorsprossen läßt. $\mathrm{Zu}$ den drei Haupthaarbündeln können sich auch noch sekundäre gesellen. Übrigens kann die Gruppenbildung der Haare auch ganz verwischt werden.

Eine nahezu vollständige Rückbildung der Haare ist bei den Waltieren eingetreten, wo sie jedoch noch embryonal anzutreffen sind und sich bei Erwachsenen

Fig. 39 .

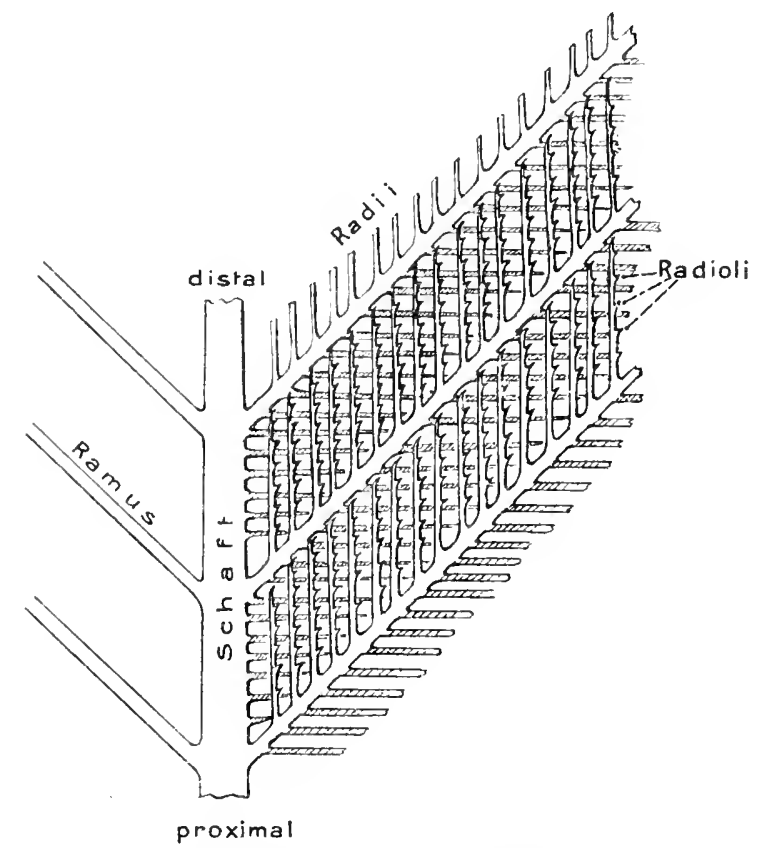

an der Sehnanze rudimentär erhalten. Weitgehende Rüickbildung findet sich auch bei Formen mit sehr dickem Integument (Sirenia, Nilpferd, Nashorn, Elefant).

Die Federn. Ihre Analogie mit den Haaren geht rechtweit. Der charakteristische Unterschied besteht darin, daß sich die Feder distal in mehr oder weniger zahlreiche Strahlen verzweigt, was bei den Haaren nie der Fall ist, oder doch nurgelegentlich durch unregelmäßige Zersplitterung der Enden im Alter auftritt. Jedenfalls war der Ban der ursprïngKleiner Teil einer Federfahne von der Außenflăche (schematisch). Anord- lichen Fedel verhältnisnung der Rami, Radii und Radioli.

O. B.

mäßig einfach. Dies folgt

daraus, daß die beim Embryo der hentigen Vögel zaerst entstehenden Federn (Erstlingsdunen) diesen einfachen Bau bewahrten, und daß sich ferner zwischen den größeren und komplizierteren Federn (Konturfedern) des erwachsenen Vogels in der Regel noch solch einfachere dauernd erhalten. Eine solche Erstlingsdnne, aber auch viele Dunen der erwachsenen Vögel (Fig. 40 3 ) bestehen aus einem kurzen basalen Stamm, dessen Distalende sich in eine Anzahl Strahlen spaltet, die gewöhnlich selbst wieder beiderseits mit einer Reihe feinerer Nebenstrahlen besetzt 
sind. In den basalen Teil des Stammes ragt die Coriumpapille (Puipa) hinein, die sich jedoch bei der Entwicklung stark verkiurzt, so daß der Stanm hohl wird (Spule, Calamus).

Aus solchen Primitivfedern haben sich die großen komplizicrten Konturfedern dadurch entwickelt, daß der Stamm oder Kiel (Scapus) sehr ansehnlich lang und entsprechend dick auswuchs, womit sich die Strahlen (Rami) an dem hervorwachsenden Schaft (Rhachis) seitlich in je eine dichte Reihe geordinet haben (Fig. 404). Diese Rami tragen selbst wieder zwei Reihen von Nebenstrablen

Fig. 40.

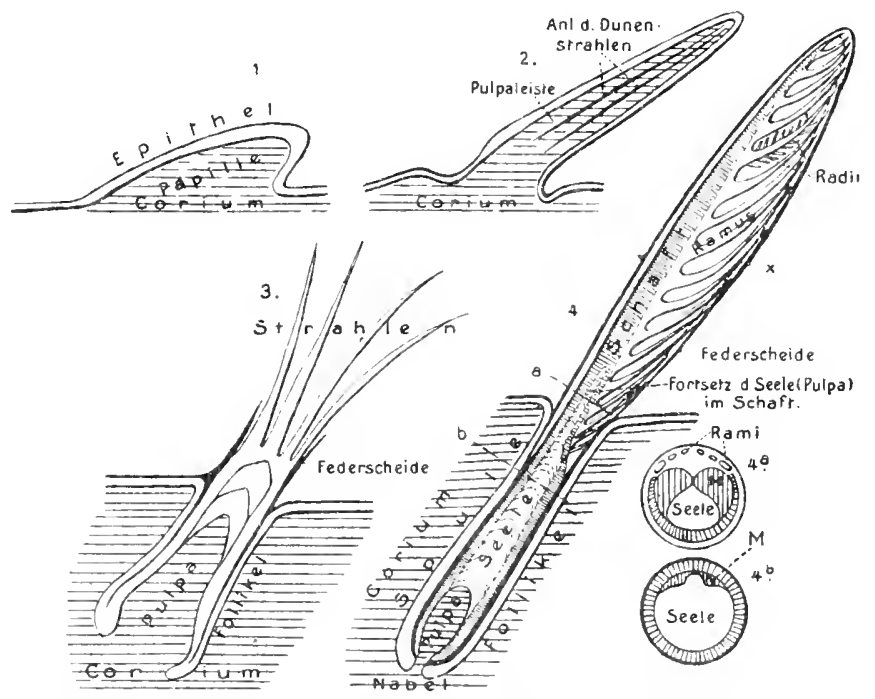

Schemata zur Entwicklung der Feder (nach Davies isfi konstruiert). 1 Erste Aulage. 2 Beginnende Einsenkang des Follikels und des Hervorwachsens der längs gerichteten Pulpaleisten. $\ddot{Z}$ Erstlingsaune in ihrem Follikel. 4 Konturfeder in ihrem Follikel, noch von der Federscheide pmschlossen gedacht. Die ursprūngliche Ausdehnung der Pulpa bis ans Ende des Schafts ist durch eine Strichlinie angerlentet. $4 a$ u, $4 b$ zwei Querschnitte eines solchen Stadinms in der Höhe von $a$ und $b$ Fig. $\%$. If Verhornang zum Abschluß der Seele, bzw. der Calamushôhle.

(Radii), von welchen die distale Reihe jedes Strahls die proximale des distal folgenden mehr oder weniger überdeckt. Bei den Konturfedern mit fest geschlossener Fahne greifen diese überdeckenden Radien mit kleinen häkchenartigen Fortsätzen (Radioli) in einen Falz des oberen Rands der überdeckten Radien hinein (s. Fig. 39). So entsteht ein fester Zusammenhalt der Gesamtheit der Rami und Radii, eine feste Fahne, wie sie besonders an den Schwung- und Steuerfedern gut entwickelt ist und deren Wirksamkeit beim Schlagen gegen die Luft bedingt. Der basale Teil des Federkiels, der keine Strahlen trägt, ist hohl (Spule, Calamus) und sein Basalende offen, da hier die Federpapille eindringt. In die erwachsene Feder reicht die Papille (Pulpa) nur ganz wenig himein (Fig. 404); in dem darauffolgenden Hohlraum der Spule findet sich eine lockere Hornmasse (Federseele), die bei der Reduktion der die Spule ursprünglich ganz erfüllenden Papille gebildet wurde. -Eine besondere Eigentïmlichkeit zahlreicher Konturfedern und Dumen ist die 
Entwicklung eines zweiten sog. Afterschafts (Hyporhachis), der von der Übergangsstelle der Spule in den Schaft entspringt und eine ähnliche Fahne bildet wie der Hauptschaft. Dieser Afterschaft liegt an der dem Vogelkörper zugewendeten Innenfläche des Hauptschafts und ist von sehr verschiedener Länge; meist sehr klein, wird er bei gewissen Ratitac (Strauße) so lang wie der Hauptschaft. Mannigfaltige Übergänge verbinden die Konturfedern mit geschlossener Fahne mit den Dunen; so die Ratitenfedern mit lockerer, nicht geschlossener Fahne. Reichlich zwischen den Konturfedern finden sich gewöhnlich auch sehr vereinfachte Federn mit dünnem Schaft, welcher nur am Ende ein Fabnenrudiment trägt, oder ohne Fahne ist (Filoplumae).

Die ansehnlichen Konturfedern sind es, welche die äußere Gefiederfläche bilden. Dennoch sind sie meist nicht gleichmäßig über den Vogelkörper verteilt, sondern stehen nur in gewissen Zonen oder Regionen (sog. Pterylae, Federfluren). Bemerkenswert erscheint, daß bei einzelnen Vögeln an gewissen Körperstellen auch Gruppenbildungen von Federn (eine Haupt- mit mehreren Nebenfedern) beobachtet wurden.

$\mathrm{Zu}$ den Bälgen der stärkeren Haare und Federn treten Hautmuskeln (Arrectores), welche sie bewegen können.

Wechsel. Haare wie Federn werden im Leben vielfach gewechselt, d. h. die alten fallen aus, während neue an ihre Stelle treten. Für beiderlei Anhänge scheint es sicher, daß sich die nenen in den alten Follikeln entwickeln, wobei sie die alten, welche ihr Wachstum abgeschlossen haben, aus diesen verdrängen und zum Ansfallen bringen. Bei Säugern wie Vögeln werden so die embryonal entwickelten Haare (Lauugo) oder Federn (Erstlingsdunen) sehr frühzeitig, schon während oder kurz nach Abschluß des Embryonallebens, abgestoßen und durch neue ersetzt. Der Haarwechsel erfolgt im weiteren Leben teils mehr periodisch (Frühjahrs- und Herbstwechsel), teils unregelmäßig andauernd. Der Federwechsel (Mauserung) vollzieht sich bei unseren Vögeln teils im Herbst, teils zweimal, im Herbst und Frühjahr, teils auch kontinuierlich.

Genese von Feder und Haar. Obgleich beiderlei Organe in ihrem Bau viele Übereinstimmungen bieten, zeigen sie in ihrer Ontogenie erhebliche Verschiedenheiten, welche dazu fiihrten, sie als primär verschiedene Organe zu deuten.

Die Entwicklung der einfachen Erstlingsfedern läßt in den Anfangsstadien wahe Beziehungen zu Schuppengebilden erkennen. Die erste Anlage ist ein caudalwärts gerichtetes, frei sich erhebendes schuppenartiges Gebilde, dessen Hervorwachsen auf der Wuchernng der Corimmpapille beruht (Fig. 40 ). Die weitere, recht komplizierte und schwierig zu schildernde Entwicklung kann hier nur in ihrem Ergebnis angedeutet werden. Die schuppenartige Anlage senkt sich allmählich an ihrer Basis zur Bildnng eines Follikels in das Corium ein (Fig. 402). Gleichzeitig ${ }^{*}$ wachsen von der Oberfläche der Papille (Pulpa) schmale Längsleisten in die Epidermis hinein (Fig. 402), welche diese in eine Anzahl Längsbezirke zerlegen, wïhrend die änßersten Epidermisschichten zu einer Federscheide verhornen, die später von der hervortretenden Dune durchbrochen wird und abfällt (Fig. 403). 
Die erwähnten Längsbezirke der Epidermis bilden durch Verhornung die Strahlen der Dune, während in der basalen Federregion, wo sie nicht zur Sonderung gelangen, die Hornwand der Spule entsteht. Die ursprïnglich lange Coriumpapille beginnt an ihrer Spitze zu atrophieren, zieht sich daher allmïhlich zwischen den Strahlen zurück und bleibt schließlich nur noch als ein seln verkürzter Rest in der Spule der Dune erhalten. Da sie von der innersten Epidermisschicht stets überkleidet bleibt, so bildet sie bei ihrem Riickzug sucessive kegelförmige Hornlamellen, die sich in der hohlen Spule als sog. "Seele" erhalten, sonst aber verloren geheu.

Die Entwicklung der komplizierteren späteren Feder geschicht prinzipiell auf gleiche Weise wie die der Dune und geht von derselben Papille und demselben epidermalen Federkeim im Grunde des Erstlingsdnnenfollikels ans. Da sogar die Pulpaleisten der Erstlingsdune in die der späteren Feder geradezu übergehen, so ist letztere gewissermaßen eine Fortsetzung der Dune. Dies zeigt sich auch bei manchen Vögeln darin, daß die Erstlingsdune der Spitze der späteren Feder als ein Anhang direkt aufsitzt und die Dunenstrahleu unter Spaltung der Dunenspule in die der Feder gewissermaßen iibergehen. Aus der schematischen Figur $40^{4}$ ist der Entwicklungsgang der bleibenden Feder zu erschließen. Auf der Fignr ist eine zusammenhängende Federscheide gezeichnet, wie sie sich bei der bleibenden Feder in dieser Weise gewöhnlich nicht erhält, sondern schon beim Hervorwachsen der Feder durchbrochen wird und verloren geht.

Die Ontogenie der Feder läßt vermuten, daß sie ursprünglich aus reptilienschuppenähnlichen Gebilden hervorging, welche stark auswuchsen und durch Rückzug, bzw. partielle Resorption der Papille hohl wurden. Dieser hohl gewordene distale Teil zersihlitzte dann in einzelne Strahlen, was wohl ron Anfang an durch Papillenleisten, velche uur yon dünuer Hornschicht überzogen waren, begünstigt wurde. - Eine gewisse Schwierigkeit erwächst dieser Auffassung jedoch daraus, daß die Schuppen des Vogellaufs zuweilen je éne Feder tragen oder ihnen je eine Federgruppe zugesellt ist.

Im Gegensatz zur Feder springt das sich entwickeinde Haar niemals als sehuppenartiges Gebilde über die Epidermistläche vor; nur. di. Anlage grnßer stachelartiger Haare zeigt zn weilen eine gauz flache Erhebung. Di A lage des Harfollikels wächst vielmehr von der tiefen Epidermisschicht aus in tas Corinm ninab, indem sich zunächst eine Gruppe von Zellen dieser Schicht knospenartig umgestaltet (Fig. 38c). Erst wenn der Follikel eine gewisse Länge erreicht hat, wächst in seinen Grund eine Coriumpapille hinein. Dann erfolgt durch Differenzierung der Follikelepidermiszellen die Bildung der Wurzelscheiden und die erste kurzkonische Anlage des Haars samt seinem basalen Epidermiskeim (Matrix). Indem das Haar basal weiter wächst, tritt es später mit seiner Spitze aus dem Follikel hervor.

Es ist nicht zu leugnen, daß die Entwicklung des $U^{-11}$ res zu bewejsen scheint, daß es selbständiger Herkunft ist und in keiner Weise phylogenetisch mit der Feder verknüpft; wofür ja auch spricht, daß Vögel und Säuger phylogenetisch in keinem näheren Zusammenhang stehen körnen. Man hat nun die Vermutung erwogen und verteidigt, daß die Haare phylogenetisch aus Hautsinnesorganen hervorgegangen seien, wie sie sich in der Epidermis der geschwänzten Amphibien und der Larven der ungeschwänzten finden. Wir werden später bei der Schilderung dieser Sinnesorgane hierauf zurückkommen und bemerken hier nur, daß 
diese Hypothese sehr beachtenswert ist, aher doch noch weiterer Sicherung hedarf. - Sogar von den Placoidschuppen der Knorpelfische und anderem hat man die Haare herzuleiten versucht. Viele Anhänger besitzt immer noch ihre direkte Ableitung von reptilienartigen Schuppen oder Teilen derselben und daher auch ihre allgemeine Homologisierung mit den Federn.

Lokale stärkere Verhornungen $z u$ besonderen Leistungen. Da die gesamte Epidermis befähigt ist, dickere Hornmasse hervorzubringen, so finden wir Betätigungen dieser Fähigkeit bei den verschiedenen Wirbeltierklassen zu recht verschiedenen Leistungen. - Hierher gehört die starke Hornbekleidung der Kieferränder, welche sich in analoger Weise, unter Rückbildung der Bezahnung, schon bei Siren unter den Amphibien, bei vielen Schildkröten, den Vögeln und den Monotremen (besonders dem Schnabeltier, Ornithorhynchus) als ein Hornschnabel ausgebildet hat.

Als Waffe entwickelten sich Horngebilde auf der Nase der Nashörner (Rhinozeros) in Ein- oder Zweizahl und als die starke Hornscheide der Hörner auf ủem Stimbein der Cavicornia, welche einen stützenden Knochenzapfen umkleidet. Es kann hier nicht unsere Aufgabe sein, alle solche lokalen Hornbildungen, die namentlich auch bei ausgestorbenen Reptilien und Sängern eine Rolle spielten, zu besprechen.

Krallen. Eine besondere Bedeutung und allgemeine Verbreitung erlangen bei den Amnioten jedoch lokale Verhornungen an den Enden der Finger und Zehen zu deren Schutz bei der Bewegung; sekundär häufig auch als Waffen. Es siud dies die Krallenbildngen. Im allgemeinen bilden sich die Krallen durch Verhornung der gesamten Epidermis, welche das distale knöcherne Zehenglied (Endphalange) überzieht. Die Form der Kralle wird daher auch durch die des letzten Phalangengliedes bestimmt; die Kralle sitzt diesem Glied wie eine Kappe auf. - Schon bei den geschwänzten Amphibien zeigt sich gewöhnlich eine stärkere Verhornung um die Endphalangen, und bei einzelnen Formen (Siren, besonders Onychodactylus) wird dieser Hornüberzug dicker, die Endphalange spitzer, so daß hier eine wirkliche zugespitzte Kralle vorliegt. Nur ganz vereinzelt findet sich dagegen eine Krallenbildung an gewissen Zehen der Anuren (Dactylethra) und beweist die Möglichkeit selbständiger Hervorbildung solcher Organe an den Zehenenden.

Ganz regelmäßig ist die Krallenbildung bei den Sauropsiden. Thre Krallen sind kegelförmige bis mehr oder weniger gekrïmmte, distal abgerundete bis scharf zugespitzte Gebilde (Fig. $41^{1}$ ). An ihrem proximalen Rande werden sie von einer Falte des Integuments etwas uberwallt (Krallenwall). Auf diese Weise entsteht eine Einfalzung des proximalen Krallenrands in das Integument, und in diesem sog. Krallenfalz eine Bildungsstätte für das Längenwachstum, besonders der dorsalen Krallenfläche, zum Ersatz der endständigen Abnutzung. Das Horngewebe der dorsalen Krallenwand ist fester und stärker als das der Ventralwand, und beide setzen sich mehr oder weniger scharf voneinander ab, was auch schon au den Amphibienkrallen angedeutet ist. Man bezeichnet daher die festere dorsale Hornwand als die Krallenplatte, die weichere ventrale als die Krallensohle. Diese Differenzierung hängt jedenfalls mit der Funktion zusammen, indem es die Ventral- 
seite ist, welche bei der Bewegnng auf den Boden aufgesetzt wird, während die Krallenplatte mehr bei der Betätigung der Kralle als Greif- oder Scharrvorrichtung und als Waffe wirksam ist. Die Hornsubstanz der Samropsidenkralle ist gewöhnlich deutlich geschichtet, als Ausdruck der von der gesamten unterlagernden Schleimschicht successive gebildeten Hornlagen.

Bei den Säugern erlangt die Krallenbildung die größte Mannigfaltigkeit im Zusammenhang mit der sehr mannigfaltigen Bewegung dieser Tiere. Aus der mehr indifferenten stumpfen Klaue, welche der Krallenbildung der Reptilien am ähnlichsten ist, entwickelt sich die lange, gekrümmte und spitzige Kralle der Carnivoren (Fig. $41^{2}$ ) oder die lange starke Kralle grabender, scharrender oder auch kletternder Formen. - Bei den Huftieren, welche auf den Endphalangen ihrer Zehen gehen, bildete sich die Kralle dagegen samt dieser Phalange zu einem plumpen, schuhartigen Huf um (Fig. 415). Eine besondere Form erlangt sie schließlich bei den Halbaffen, Affen und dem Menschen als der sogenannte Plattnagel (Fig. $41^{3-4}$ ). - Bei allen diesen, durch die besonderen Funtionsverhältnisse bedingten Ausgestaltungen kebrt die schon erwähnte Differenzierung in die Krallenplatte und Krallensoble wieder. Erstere greift in der Regel noch etwas um den Rand der Endphalange auf die Ventralscite herum. Die Krallensohle variiert in ihrem Umfang mit der Gesamtgestalt der Kralle, erstreckt sich jedoch nicht so weit proximal als die Krallenplatte, so daß dieser Teil der

Fig. 41.

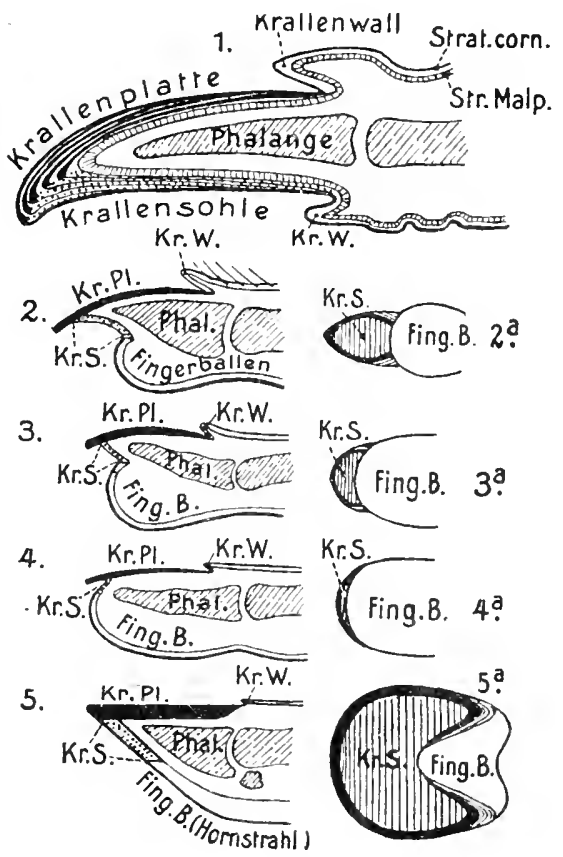

Schemata zur Bildung der Krallen bei Wirbeltieren. 1. Medianschnitt durch das Zehenende eines Reptils (Grundlage Krokodil nach GöPPERT 1S98). 2-5 Schematisuhe Medianschnitte dureh Zehenenden von Mammalia (BoAs). 2a-5a die betreffenden Zehenenden in der Ansicht von der Unterseite (Volarseite). - 2. bekrallte Zehe (etwa Carnivor). 3. Plattnagel (Affe). 4. Plattnagel (Mensch). 5. Huf (Pferd).

Ventralseite der Endphalange von weicherem Integument, dem sog. Sohlenballen (Fingerballen), gebildet wird. - Die Krallensohle wird natürlich bei den breiten, auf der Ventralseite abgeflachten Hufen meist sehr groß, bleibt dagegen schmal und lang bei den typischen Krallen, und verkürzt sich zum Teil auch, unter Vergrößerung des Sohlenballens, nach dem Zehenende zu. Eine solche Reduktion der Krallensohle führt endlich zur Bildung des Plattnagels der Primaten. Die Krallenplatte wird hier sehr flach, wenig gekrümmt, die Sohle dagegen so stark rückgebildet, daß nur ihr distalster Endteil noch erhalten bleibt und beim Menschen kanm noch zu erkennen ist. Die Krallenplatte wächst bei den Plattnägeln distal ïber die 
Krallensohle selbständig vor und bildet allein das freie Ende des vorwachsenden Nagels. Die Entwicklung zeigt aber auch beim Menschen als früheste Nagelanlage noch ein kappenförmiges Gebilde am Zehenende und bestätigt daher das vergleichend anatomische Ergebnis.

Während bei den Amphibien und Sauropsiden meist die gesamte Schleimschicht unter den Krallen durch Produktion neuer Hornschichten deren Dickenwachstum fördert, soll dies bei den Säugern anders sein, indem sich die Schleinschicht unter der mittleren Region der Krallenplatte nicht mehr an der Hornbildung beteiligt, so daß eine proximale bis in den Krallenfalz reichende und eine distale (terminale) Matrix oder Bildungsstätte des Horns existierte; ähnliches findet sich unter den Sauropsiden nur bei den Sauriern.

Besondere Verhältnisse können auch die Krallenbildung mehr oder weniger zum Schwinden bringen, so die Umbildung der Extremität zu einer Flosse (Sirenia, Waltiere) oder zu einem Flïgel (Vögel, Fledermäuse). In beiden Fällen finden sich nur Rudimente von Krallen an einzelnen Zehen oder gar keine mehr.

\section{Die secretorischen Leistungen der Epidermis.}

Allgemeines. In der Hervorbringung cuticularer Schutzdecken liegt schon eine ahscheidende 'Tätigkeit der gesamten oder größerer Strecken der Epidermis vor. Die in diesem Kapitel zu behandelnden Drüseubildungen dagegen entstehen durch Entwicklung und Differenziernng gewisser Epidermiszellen zu besonderen secretorischen Leistungen. Im einfachsten Fall sind es einzelne Epidermiszellen, welche sich zu Drüsenzellen umgeformt haben und zwischen den indifferenten gewöhnlichen Epidermiszellen vereinzelt bis sehr reichlich eingelagert sind. Bei höherer Ausbildung sind es Zellgruppen, d. h. mehrzellige bis hoch komplizierte Hautdrüsen. Meist ist das Hautsecret schleimig bis flüssig; doch kann es auch in Form eigentümlich gestalteter Gebilde abgeschieden werden, die wir von den ungeformten Secreten jedoch kaum ganz scharf trennen können.

Die physiologische Bedeutung der Hautsecrete ist in den einfacheren und ursprünglicheren Fällen vorwiegend eine schüitzende. Indem die Körperoberfläche von einem Schleimüberzug bedeckt wird, kann dieser als Schutzmittel gegen Angrifie, bei Luftleben eventuell auch als Schutz gegen Verdunstung dienen. Schleimiges Secret vermag ferner die gleitenden Bewegungen zu erleichtern, wie umgekehrt das Anhaften zu anterstützen. Solche Hautsecrete gewähren, je nach ihrer Beschaffenheit, auch gegen Nässe und sonstige Einflüsse Schutz und vermögen durch Giftwirkung Feinde abzuwehren. Unter Umständen fördern sie jedoch die Verdunstung und können sich daher an der Abscheidung schädlicher Stoffwechselprodukte beteiligen. Verschiedenartige Wirkungen vermögen sich hier mannigfaltig zu kombinieren. Zuweilen nützen die Hautsecrete auch durch ihren Geruch; häßlicher Geruch kann zur Abwehr, anziehender umgekehrt zur Anlockung, besonders im Geschlechtsleben, dienen. Erhärtende Secrete treten als Haft- oder Spinndrüsen vielfach auf. - Endlich kann das Secret bei der Fortpflanzung in verschiedener Weise nützlich sein, sei es als erste Nahrung der Jungen (Mammalia) 
oder auch auderweitig. - Unsrer Aufgabe gemäß betrachten wir die Hautdrüsen hier speziell vom morphologischen Gesichtspunkte und beriihren daher das Physiologische nur nebenbei. Wir unterscheiden die Drüsen iu ein-und mehrzellige, ohne damit ausdrücken zu wollen, daß diese Trennung ganz scharf durchzuführen sei, was ja in der Natur der Dinge liegt.

Einzellige Epidermisdriisen mit ungeformtem Secret:

Bei Wirbellosen. - Einzellige Drüsen sind bei den Wirbellosen so verbreitet, daß wohl kaum eine Gruppe zn finden ist, der sie völlig fehlen. Auch bei den niederen Wirbeltieren treten sie noch auf. Bei reichlich Schleim absondernden Formen, wie zahlreichenHexacorallen, Ctenophoren, Würmern besonders Oligachäten und Hirudineen, doch auch Turbellarien, Nemertinen, Polychäten) undMollusken sind sie über den ganzen Körper oder doch große Strecken desselben zwischen die gewöhnlichen Epidermiszellen eingelagert, und von ihnen meist durch mehr bauchige bis schlauchartige Form und Füllung mit Secret unterschieden. Entweder liegen sie noch völlig in der Epidermis selbst (Fig. 21 2,4, S. 95) oder sind über deren innere Grenze in das unterliegende Gewebe Fig. 42.

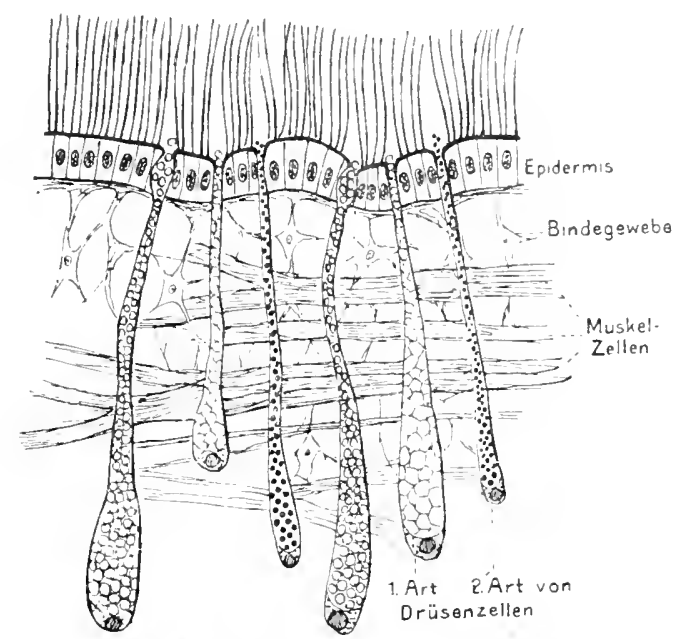

Pectunculus (Muschel). Bewimpertes Epithel von der lnnenseite des Mantelrands; mit zweierlei Drüsenzellen. hineingewachsen als beutelbis schlauchförmige Zellen(Fig. 42). Solch lange einzellige Drïsenschläuche sind sehx verbreitet bei den Hirudineeu und Mollusken; ja sie erreichen namentlich bei den ersteren zuweilen eine erstaunliche Länge. - Lokale stärker'e Entwicklung solcher Driisen kommt häufig vor, so z. B. im sog. Clitellum (Sattel) der Oligochäten und Hirudineen, dessen Secret die Hülle der Eikokons bildet. Auch der Mantelrand der Mollusken ist in der Regel durch besonders reichliche Entwicklung solcher Drüsen ausgezeichnet. - Bei Gegenwart einer Cuticula zeigt diese über jeder Drüse gewöhnlich einen deutlichen Ausfïhrporus; zuweilen kann sich sogar von ihm aus ein cuticulares Ausfuihrröhrchen in das Plasma der Drüsenzelle hineinsenken (Fig. 44a-b). An größeren einzelligen Drüsen bildet sich in seltenen Fällen sogar ein kleiner Ausführgang durch röhrenförmige Einsenkung der umgebenden Epidermis (Fig. 43); zuweilen tritt selbst ein feiner Muskelbelag auf der Oberfläche der Drïsenzelle auf, zur Austreibung des Secrets (Fig. 43). Herrorzuheben ist, a a B nicht selten verschiedene Arten einzelliger Drïsen vermischt nebeneinander vorkommen. 
Lokalisierung und Spezialisierung solcher Driisen findet sich bei den verschiedenen Abteilungen in mannigfachster Ausbildung, was hier nur durch wenige Beispiele erläutert werden kann. - Als spezifische Haftdrüsen, welche ein erhärtendes

Fig. 43.

Ausführg.

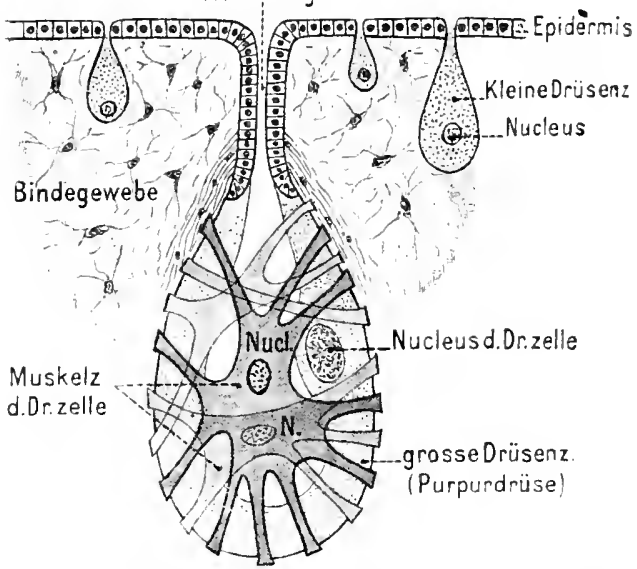

A p lysia (Opisthobranch. Schnecke). Durchschnitt dureh den Mantelrand mit großen und kleinen Drüsenzellen. Die großen mit zelligem Ausführgang und besonderer Muskulatur. (Nach Blocumass 18.3.)
Secret abscheiden, finden wir einige ansehnliche Drüsenzellen am Fußende der Rädertierchen und am Schwanzende der freilebenden Nematoden.

Ferner mögen als eine sehr eigentümliche Form von Haftdrüsenzellen noch die sog. Greifoder Klebzellen der Ctenophoren erwähnt werden, welche deren Tentakelepithel dicht durchsetzen. Das körnige Secret an threr Außenfläche bewirkt ihre. Klebrigkeit, welche zum Fang der Beute dient. Vom inneren Ende des sehr niedrigenZellkörpers entspringen zwei feine Fädchen, ein gerade einwärts ziehender Centralfaden, sowie ein diesen umwindender contractiler Spiralfaden. Ob diese Fäden Erzeugnisse der Zellen selbst sind

oder von einer besonderen Zelle gebildet werden, ist unsicher. - Klebzellen sind auch bei Turbellarien nicht selten und können auf besonderen Haftpapilien oder in saugnapfartigen Gruben reichlicher angehäuft sein. Ebenso finden sie sich auch zum Teil an den Ambulacralfüßchen der Echinodermen.

Bei den Arthropoden ist die allgemeine Verbreitung einzelliger Drüsen über

Fig. 44.

b

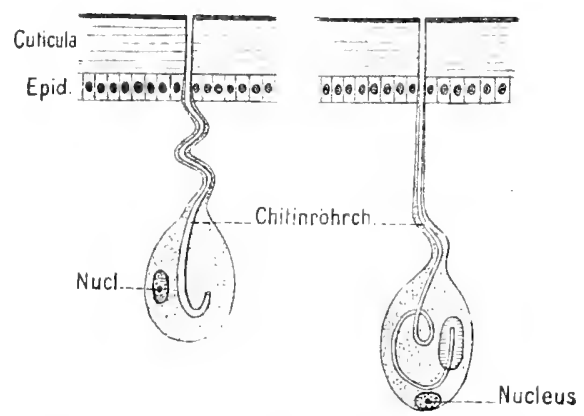

Einzellige Drüsen eines Käfers (Dytiseus) (nach Leydc. 1859). a von der Haut. $b$ von der Vagina. E. W. die Epidermis seltener. Dennoch findet sich dergleichen bei zahlreichen Käfern, so auf den Elytren, auch an den Tarsen, wie auch bei anderen Insektenordnungen; auch sind einzellige Drüsen häufig in den Gelenken der Extremitäten bei Insekten ausgebildet, wo ihr Secret wohl als Schmiermittel dient. Im iibrigen weiß man wenig von ibrer Furktion. Anbäufungen solcher Drüsenzellen kommen nichtselten bei Insekten(besonders Käfern) an der Ausmündung der weiblichen Geschlechtsorgane und des Afters als sog. Scheiden- und Cloacaldrüsen vor. Durch innigere Vereinigung bilden sie zuweilen auch Übergangszustände zu mehrzelligen Drïsen. Ihr feinerer Bau zeigt meist die erwïhnte Eigentümlich- 
keit, $\mathrm{da} B$ von der Ausführöffnung in der Cuticula ein feines cuticulares Röhrchen bis tief in das Zellplasma sich hinabsenkt, das zuweilen stark gewunden und an seinem inneren Ende sogar eigentümlich kompliziert ist (Fig. 44).

Zum Schutz gegen Nässe entwickeln sich bei den Schnabelkerfen (Aphiden, Schildläusen, gewissen Cicaden) wachsabscheidende einzellige Drüsen, die uber den ganzen Körper verbreitet oder auch mehr in Gruppen lokalisiert sein können. Ihr Secret bildet weiße Fäden, welche den Körper umhüllen. - Eine ganz andere Bedeutung hat die Wachsabscheidung der Bienen, da das Secret hier zum Bau der Waben dient. Es sind in letzterem Falle nicht einzelne Zellen, welche das Wachs liefern, sondern ganze Strecken der Hypodermis, welche hier etwas höher und eigenartig ausgebildet ist. Bei der Honigbiene liegen diese wachsabsondernden Epidermispartien an den Ventralringen des Abdomens; bei anderen Bienen dagegen dorsal oder noch anders.

Geruchsstoffe ansscheidende einzellige Drusen können in Verbindung mit Haaren und Schuppen (Dufthaare, Duftschuppen) bei männlichen Schmetterlingen auftreten.

Diese von den gewöhnlichen Schuppen rerschiedenen, recht mannigfaltig gestalteten Duftschuppen (Männchenschuppen) sind häuffg in Gruppen vereinigt (Duftflecke), die zoweilen auch etwas grnbenartig in die Flügelfläche eingesenkt sind. Ähnliches gilt auch für die Dufthaare, die sich namentlich an den Beinen finden und zu Duftpinseln zusammengehăuft sein können, die gleichfalls nicht selten in besonderen, sogar verschließbaren Groben eingelagert sind.

Giftige Wirkung sollen dagegen zum Teil Drüsenzellen oder Gruppen solcher haben, welche bei gewissen Raupen (Bären-, Prozessionsraupen) mit den hohlen Haaren in Verbindnng stehen; ihr Secret kommt wohl meist erst zur Wirkung, wenn das Haar abgebrochen wird.

Überhaupt scheinen die Raupenhaare (Fig. 25, S. 98) in der Regel mit mindestens zwei Zellen in Verbindung zu stehen, von welchen die eine (trichogene) das Haar erzeugt, während die andere drüsig ist. Die gegenseitigen Beziehungen beider Zellen sind zuweilen recht kompliziert.

Auch die zahlreichen Spinndrüsen, welche bei den Embiiden an Tarsenhaaren der Vorderbeine ausmünden, scheinen einzellige, wenngleich mehrkernige Drüsen zu sein. - Einzellige Drüsen sollen auch bei der Häutung vieler Insektenlarven (speziell Lepidoptera nnd Coleoptera) eine Rolle spielen, indem sie Flüssigkeit abscheiden, welche das Abheben der alten Cuticula fördert (Exuvialdrüsen).

Bei den Crustaceen scheinen einzellige Drüsen im allgemeinen nicht allzu häufig zu sein, weın sie auch bei gewissen Formen weiter über den Körper an den Segmenten und Beinen verbreitet sind (z. B. Branchipus, manche Arthrostraca usw.). Bei gewissen Isopoden kann ihr Secret unter Mitwirknng von Fremdkörpern zum Anfbau einer Wohnröhre dienen. - Ein drüsiges Haftorgan wird bei Phyllopoden (besonders Cladoceren und gewissen Branchiopoden in der hinteren dorsalen Kopfregion durch die drüsige Entwicklung der Epidermiszellen eines umschriebenen Feldes gebildet (sog. Nackendrüse). Interessanterweise ist es embryonal im allgemeinen besser ausgebildet; auch deutet manches darauf hin, $\mathrm{da} ß$ es ursprünglich bei den Crustaceen weiter verbreitet war. 
Einzellige Driisen, welche auch den Copepoden nicht fehlen, erlangen hier zuweilen eine besondere Funktion, indem sie bei gewissen marinen Formen ein leuchtendes Secret liefern, also als Leuchtorgane funktionieren (ob es rein einzellige Drïsen sind, ist jedoch nicht ganz sicher). Einzellige bis mehrzellige Leuchtdrüsen sind jedoch noch in weiteren Abteilungen verbreitet; ihre Besprechung geschieht später bei den Leuchtorganen.

Bei Wirbeltieren. Wie bemerkt, kommen auch bei den niederen Wirbeltieren (Cyclostomen und Fischen) einzellige Driisen reichlich vor. Sie liefern vor allem den Schleim, welcher die Oberfläche dieser Tiere gewöhnlich bedeckt.

Schon in der tiefsten Schicht der geschichteten Epidermis dieser Vertebraten differenzieren sich einzelne Zellen zu solchen Drüsenzellen. Sie wachsen mit der

Fig. 45.

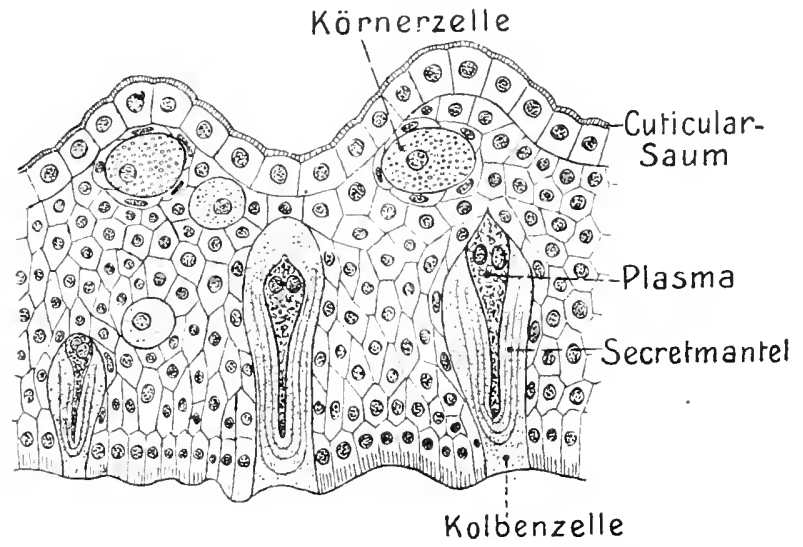

Durcbschnitt durch die Räckenepidermis von Petromyzon fluviatilis. (Nach Maurer 1895.) E. W.

Abscheidung des Secrets in ihrem Innern ziemlich stark heran, so daß sie größer werden als die indifferenten Epithelzellen. Aus ihrer nrsprïnglichen basalen Lage steigen sie dann in der Epidermis allmählich bis zur Oberfläche empor und treten endlich mit ihrem distalen Teil zwischen den äußersten Epidermiszellen frei hervor. Da sie in dieser Lage gewöhnlich becherförmig erscheinen, werden sie häufig als Becherzellen bezeichnet. Jetzt stoßen sie ihr Secret aus, wobei jedoch die gesamte Zelle selbst in der Regel ausgeworfen wird. Es muß demnach ein ständiger, aus der Tiefe kommender Ersatz dieser Driisenzellen stattfinden (Fig. 46). Für die Cyclostomen und Fische ist charakteristiseh, daß die Drüsenzellen wohl fast immer zweierlei Art sind, die sich sowohl durch verschiedene Form als durch verschiedenes Secret unterseheiden. Es dürfte daher auch sicher sein, daß die beiderlei Zellen etwas verschiedene Funktion haben. Bei gewissen Cyclostomen (Myxinoiden) unterscheidet man Schleim- und Körnerzellen; die ersteren mit homogenem schleimigem, die zweiten mit körnigem Secret. Bei den Neunaugen (Petromyzon) finden sich statt der Schleimzellen sog. Kolbenxellen (Fig. 45), so genannt, weil sie als lange, kolbenförmige Gebilde emporwachsen, die mit ihrem Stiel noch zwischen den Cylinderzellen der tiefsten Epidermisschicht wurzeln. Sie sind ferner durch Zweikernigkeit 
nnd ein eigentümliches Secret charakterisiert, das die Peripherie des Kolbens mantelartig bildet. Schließlich sollen jedoch die Kolbenzellen ebenso ausgeworfen werden wie die Körnerzellen.

Bei den Fischen, besonders den Teleostei, findet sich ähnliches (Fig. 46). Die Drüsenzellen sind hier sog. Schleim- und Kolbenzellen, jedoch lassen sich bei gewissen auch noch mehr Sorten nnterscheiden. Die Schleimzellen kommen auf der ubberdeckten Oberfläche der Schuppen besonders reichlich vor, die Kolbcnzellen dagegien auf der freien (besonders bei den Physostomen). Die Schleimzellen entsprächen daher wohl den Körnerzellen der Cyclostomen.

Bei den Larven von Petromyzon (Ammocoetes) zeigen die Kolbenzellen das Eigentümliche, daß ihr Secretmantel als ein schraubig um die Achse der Zelle gewundener Faden ausgebildet ist. Im erwachsenen Zustand verliert sich diese Bildung wieder; das Secret wird gleichförmig. Die Myxinoiden dagegen besitzen in den ventralenSeitenlinien des Körpers sackartige, segmental angeordnete Organe, welche durch Einsenkung der Epidermis gebildet werden und oberflächlich mit einer Öffinung münden. Die Epidermis dieser sog. Schleimsäcke hat sich völlig zn großen Schleim- und Fadenzellen nmgebildet, welche wenigstens bei den erwachsenen Formen dasInnere derSäcke Fig. 46.

a

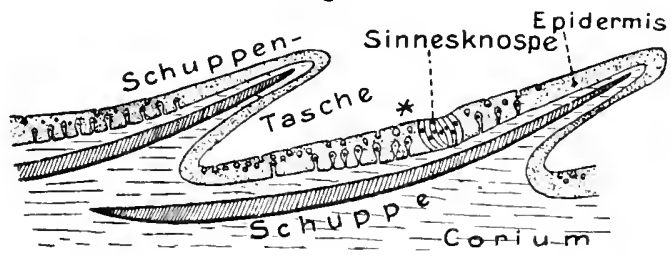

b

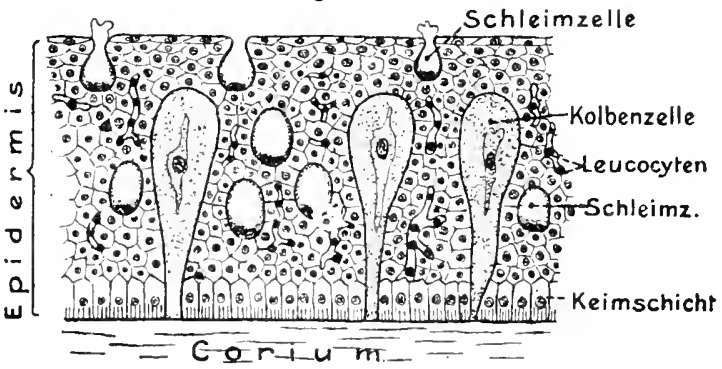

Barbns fluviatilis. Haut. a Längsschnitt durch die Haut mit zwei Schuppen. $b$ die Stelle * der Epidermis in Fig. $a$ stark tergrößert, mit Schleim- und Kolbenzellen. (Nach Madreir 1895 sehematisiert.) E. W. ganz erfïllen. Der Körper der Fadenzellen besteht zum größten Teil aus dem dicht aufgeknäuelten feinen Faden. - In dem Faden solcher Zellen begegnen wir zum erstenmal einem charakteristisch geformten und jedenfalls auch mit besonderen Leistungen begabten Secret; es wird daher an späterer Stelle hierauf nochmals zurückzukommen sein.

Die Schleimsäche der Myxinoiden treten eigentlich aus dem Bereich der streng einzelligen Drüsen heraus, wurden jedoch wegen ilser nahen Beziehungen zu ihnen gleich hier erwähnt. - Dasselbe gilt von gewissen drïsigen Organen der Fische; welrhe sich aus einzelligen Drüsen entwickelten und zu Giftorganen wurlen, indem ihr Secret giftige Eigensibaften erlangte. Sie dienen besonders als Verteidigungswaffen. Es spricht dies auch dafür, daß, wie erwähnt, die verschiedenen einzelligen Drüsen verschiedene Funktion besitzen. Bei gewissen Rochen (Stech- oder Stachelruchen) hat der Stich der in Ein- bis Mehrzahl auf dem Schwanz stebenden ansehnlichen Stacheln giftige Wirkung, was von dem Schleim herrüht, der von 
sehr zahlreichen einzelligen Drüsen der Stachelepidermis abgeschieden wird. Eine ăhnliche Giftwirkung besitzen fèmer die Stacheln der Rückenflosse, zuweilen aber auch die des Kiemendeckels gewisser Knochenfische (besonders zahlreicher Scorpäniden, doch auch von Trachinus und gewissen Batrachiden). Das Ende der Rückenstacheln besitzt hier gewöhnlich seitlich je eine Rinne, die mit sehr drüsenreicher Epidermis ausgekleidet sind oder auch an ihren Basalenden zu einer Hautanschwellung führen. Letztere wird dadurch gebildet, daß eine große Menge dicht gestellter einzelliger Drüsen in das Corinm hineingewachsen sind und so eine Art kompakter mehrzelliger Drüse darstellen. Ein eigentlicher Ausführgang existiert jedoch nicht, sondern entsteht erst durch den Zerfall der Drïsenzellen bei der Secretbildung. Selten sollen sich auch hohle Stacheln mit Secretkanal und sackförmiger Drüse fiuden (Thalassophryne).

Nur dic Amphibien verraten in ihrer Epidermis noch Anklänge an die einzelligen Drüsen, welche bei den besprochenen Gruppen eine so wichtige Rolle spielen. Einzellige Drüsen treten als Schleim- oder sog. Leydigsche Zellen bei den Larven der Caudaten und Gymnophionen noch reichlich auf, fehlen dagegen denen der Anuren, sowie den erwachsenen Amphibien überhaupt. Sie rücken jedoch bei den Caudaten nicht mehr bis zur Oberfläche der Epidermis empor, öffnen sich also auch nicht, während dies bei den Gymnophionenlarven noch vorkommt. Alles dies weist auf hochgradige Rückbildnng dieser Einrichtung bei den Amphibien hin, was sich aus der reichen Ausbildung, welche die mehrzelligen Drüsen erlangten, erklärt. Bei den Amnioten findet sich selbst vorübergehend nichts mehr von einzelligen Drüsengebilden.

Einzellige Driisen mit bestimmt geformtem Secret (Morphite), speziell sog. Nesselkapseln (Nematocysten) und verwandte Gebilde.

Obgleich die hier zu besprechenden Zellprodukte in ihren hoch ausgebildeten Zuständen nicht die leiseste Beziehung zu den umgeformten Secreten zu besitzen scheinen, so finden sich doch eine große Reihe von Übergangsformen, welcho es unmöglich machen, sie scharf von letzteren zu scheiden.

Schon bei vereinzelten Protozoen beobachteten wir, daß das Zellplasma eigentïmliche kleine Gebilde, sog. Nesselkapseln und die wahrscheinlich verwandten Trichocysten, hervorbringen konnte. Derselben Erscheinung, jedoch in viel größerer Verbreitung und Bedeutung, begegnen wir in den Epidermiszellen vieler Metazoen, vor allem jedoch im ursprünglichsten Phylum, dem der Coelenterata. Bei sämtlichen Klassen derselben, mit Ansnahme der Ctenophoren (die man jedoch auch häufig von ihnen absondern will), enthält die Epidermis stets zahlreiche dieser eigentiimlichen mikroskopischen Waffen. Die Nesselkapseln oder Nematocysten (Cnidocysten) erweisen sich überall als Gebilde, die nnabhängig vom Nucleus, obgleich häufig in seiner Nähe, im Plasma der Epidermiszellen entstehen. Charakteristisch für die Cölenteraten ist, daß stets nur eine einzige Kapsel in der Bildungszelle (Cuidoblast) entsteht. Die ausgebildete Kapsel wird häufig so groß, daß das Zellplasma um sie nur noch einen sehr dünnen Mantel bildet, in dem der Zellkern gewöhnlich gut erhalten ist (Fig. $47^{4-5}$, S. 130). Charakteristisch ist ferner, daß die Bildungszellen ursprünglich zwischen den Basen der gewöhnlichen Epidermiszellen liegen und daher gewissermaßen eine tiefere Lage der Epidermis bilden (sog. interstitielle Zellen). Streng genommen ist dies jedoch insofern nicht richtig, als, wie 
gesagt, die gewöhnlichen Epidermiszellen zwischen die Bildungszellen hinabreichen; es wäre daher korrekter, zu sagen, daß diese Bildungs- oder interstitiellenZellen nicht bis zur Oberfläche der Epidermis reichen. Letzteres tritt jedoch gewöhnlich ein, wemn ihre Nesselkapseln die volle Ausbildung erlangt haben und zum Funktionieren bereit sind. Dann schieben sich die Bildungszellen mit der Kapsel bis zur Epidermisoberfläche hindurch; häufig sogar derart, daß sie die flachen gewöhnlichen Epidermiszellen durchbohren. Wenn die Nesselzellen die Oberfläche erreicht haben, bilden sie einen haar- bis dornartigen, über die Körperfläche aufsteigenden Fortsatz, das sog. Cridocil (Fig. 475), neben dem seIten noch einige kleinere Börstchen sich erheben sollen, und das gelegentlich als ein modifiziertes Wimperhaar betrachtet wird. Das Cnidocil hat jedenfalls die Bedeutung eines Reize aufnehmenden Organells und ist daher vergleichbar den später zu betrachtenden Sinneshaaren eigentlicher cpidermaler Sinneszellen.

Die typischen Nesselkapseln selbst sind kugelige bis ellipsoidische, häufig auch länger gestreckte schlauchartige Gebilde, die im Maximam etwa $1 \mathrm{~mm}$ erreichen können, gewöhnlich jedoch viel kleiner bleiben. Es sind hohle Kapseln mit flüssigem bis gallertigem Inhalt, deren mäßig dicke, jedoch recht widerstandsfähige Wand aus zwei Lagen bestehen soll, die aber häufig wenig deutlich sind. Am äußeren Pol der Kapsel stülpt sich die Wand (nach der gewöhnlichen Angabe ihre innere Lage) schlauchförmig ins Kapselinnere hinein und zieht zuerst eine Strecke weit gerade durch die Achse, worauf sich die dünnere Fortsetzung des sehr langen Schlauchs oder hohlen Fadens, in vielen Schraubenwindungen aufknäuelt, das Kapselinnere mehr oder weniger erfüllend (Fig. $47^{3 a}$ ). Die feinere Beschaffenheit des Einstülpungspols der Kapsel ist noch etwas zweifelhaft; bei gewissen Kapseln (Hydromedusae) soll diesen Pol eine Art Deckelchen verschließen (Fig. 474), bei anderen dagegen (Anthozoa) soll das modifizierte Plasma des Distalendes der Nesselzelle einen Verschluß bilden.

Die charakteristische Eigenschaft der Nesselkapseln ist nun, daß sie bei mechanischem Druck, bei Einwirkung verschiedener Reagenzien, im Leben jedoch durch Reizung der Zellen, ihren Faden, rasch herauszuschleudern vermögen, wobei er itber die Oberfläche der Epidermis hervortritt, sich an die Beute oder den Angreifer heftet, ja in ibn einbohren kann, wobei auch die Kapsel häufig aus der Epidermis herausgerissen wird. Damit sind meist noch besondere Wirkungen verknüpft, von welchen gleich die Rede sein wird. Bei dem Herausschleudern stülpt sich der hohle Faden vollständig um (Fig. $47^{3 b}$ ), so daß seine ehemalige Innenseite zur Außenseite wird. Der ausgetretene Faden zeigt gewöhnlich noch feinere Bauverhältnisse. Sein Basalteil ist meist dicker und häufig mit mehr oder weniger zahlreichen, rückwärts gerichteten Härchen oder Börstchen besetzt, die in drei steilen Schraubenlinien verlaufen. Die drei hintersten Börstchen können zuweilen zu stachel- oder stilettartigen Gebilden (Widerhaken) entwickelt sein (Fig. 474). An dem unausgestïlpten Faden bildet der dickere Basalteil den Achsenteil, in welchem die drei Stacheln stilettartig hervorragen; sie wirken wohl auch bei der Kapselexplosion stilettartig. 
Aus dem Geschilderten folgt, daß die Nesselkapseln sowohl als Schutz-wie als Angriffsorgane funktionieren, teils durch bloßes Anhaften und gewissermaßen Verstricken der Beute oder des Feindes, teils aber auch durch eine weitere Wirkung, welche von dem übrigen Kapselinhalt ausgehen muß. Viele Nesselkapseln (speziell der Hydromedusen und Acalephen) rufen bei ihrer Entladung einen brennenden Schmerz und eine Rötung auf der menschlichen Haut hervor. Dies ist jedenfalls eine Giftwirkung des Kapselinhalts, über deren Art jedoch kaum etwas Bestimmtes bekannt ist. Der Faden solcher Kapseln soll am Ende geöffuet sein.

Eigentümlich erscheint, daß bei vielen Cölenteraten gleichzeitig eine ganze Anzahl verschiedener Nesselkapseln (bis 4 und 5 Sorten) vorkommt, die sowohl in Größe und Form, als im feineren Ban differieren. Daß hieraus auch anf ein etwas verschiedenes Funktionieren zn schließen ist, dürfte wohl sicher sein.

Bei den Anthozoen findet sich neben den gewöhnlichen Nematocysten noch eine besondere Form mit relativ dünner Kapselwand und einfachem, schraubig aufgerolltem Faden, der nach frïheren Angaben bei der Explosion nicht umgestülpt, sondern einfach aus der Kapsel herausgeschleudert werden sollte (sog. Spirocysten, s. Fig. $\left.47^{1-2}\right)$. Neuere Untersuchungen ergaben jedoch, daß der Faden bei der Kapselexplosion ebenfalls umgestülpt wird wie bei den gewöhnlichen Nematocysten, und $\mathrm{da} B$ er zum 'Teil einen Klebstoff enthält, der bei der' Explosion stark aufquillt nnd sein Anhaften bewirkt (sog. Klebkapseln).

Über den Mechanismus der Kapselexplosion ist wenig Sicheres bekannt; dieser Vorgang liegt uns hier auch ferner. Erwähnt werde nur, daß die Meinung, es werde die Kapsel durch die Kontraktion muskulöser Differenzierungen im Plasma der Nesselzelle zur Explosion gebracht, vielfach bezweifelt, jedoch durch neuere Erfahrungen wieder bestätigt wurde. Fig. $47^{5}$ zeigt die Anordnung solcher myonemartiger Fibrillen im Plasma der Zelle. In dem häufig stielartig ausgezogenen Basalende der Zelle (Cnidoblast) wurden ebenfalls myonemähnliche Fibrillen gelegentlich beobachtet, zuweilen jedoch auch eine Art elastischer (eventuell auch contractiler) Achsenfaden, dessen Redeutung wohl darin besteht, die explodierte Zelle und Cuidocyste in der Epidermis festzuhalteu. Wahrscheinlich duirften jedoch auch die Elastizität der Kapselwand, sowie osmotische Vorgänge bei der Explosion im Spiele sein, wolche in der Kapsel einen hohen Turgor hervorbringen.

Die Nematocyste entsteht im Plasma als kleines, einer Vacuole ähnliches Bläschen, das sich allmählich vergrößert, eine Wand erhält und dann an einem Pol einen Faden bildet, der seltsamerweise, wenigstens zuerst, auf eine größere Strecke als eine äußere Verlängerung des Kapselpols ins umgebende Plasma hervorwächst. Erst später zieht er sich in die Kapsel vollständig zurück.

In nevester Zeit wurde jedoch nachzuweisen gesucht, daß dies nicht der eigentliche Faden sei, sondern nur eine Secretmasse. aus der erst im Innern der Kapsel der Faden entstehe.

Die Funktion der Nematocysten macht es begreiflich, daß sie vor allem an den Tentakeln der Cölenteraten massenhaft auftreten. Nicht seltcn hänfen sie sich hier an bestimmten Stellen in großer Menge zusammen, unter Bildung von Epidermisanschwellungen, als Nesselwülste, Nesselknöpfe, Nesselbatterien und dgl., 
was namentlich an den Tentakeln der Hydromedusen in großer Mannigfaltigkeit hervortritt.

Die weite Verbreitung ähnlich geformter Secrete in den Epidermiszellen der Plathelminthen, ja auch der Chaetopoden, spricht für die verwandtschaftlichen Beziehnngen der Würmer zu cðlenteratenartigen Vorfahren. Die Turbellarien besitzen fast stets solche Morphite; auch die Nemertinen sind mit ihnen versehen, nur beschränken sie sich hier in der Regel anf das Epithel des Rüssels. Meist bleiben die Morphite der Plattwürmer viel unentwickelter als die Nematocysten der Cölenteraten, indem sie gewöhnlich sehr kleine (bis etwa 0,06 mm lange) stäbchen- bis spindelartige solide Körperchen sind, sog. Rhabditen (Fig.48). Größe und Form variieren jedoch sehr. AuBer diesen eigentlichen Stäbchen findet man zuweilen anch sog.

Pseudorhabditen. die unregelmäßiger, körnig und auch weniger widerstandsfähig sind. Letztere Gebilde lassen sich von unFig. 47.

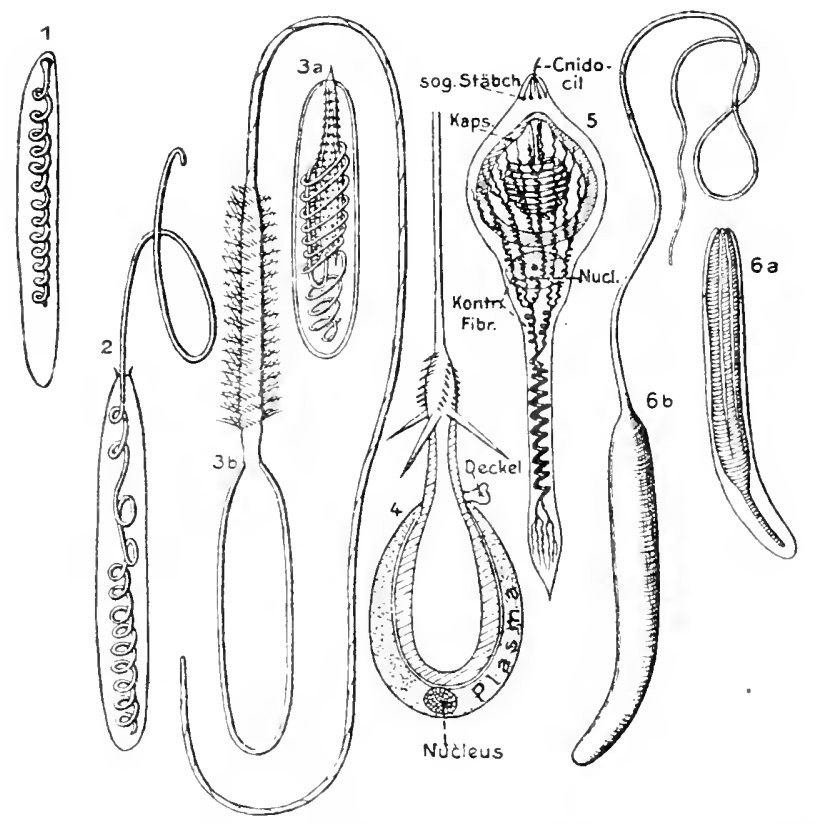

1 - 5 rerschiedene Nesselkapseln (Nematocysten) von Cólenteraten; $f$ eine solche einer Nemertine. 1 sog. Spirocyste (Cerianthus) mit angeblich einfach auswerfbarem Faden. 2 Ebensolche von Anemone mit $\mathrm{z}$. T. ausgeworfenem Faden. - Nematocysten $\mathbf{n} n$ Caryophyllia: a nichtexplodierte, $b$ solche mit vollig aus. gestūlptem Faden. \& Nematoc. von Pennaria in dem Nematoblast; der ansgest. Faden nur z. T. dargestellt 5 Kleiner Nematoblast ron Physalia mit Kapsel and contractilen Fibrillen. b Nematocysten ron Micrura. a nichtexplodiert, $b$ explodiert. ( $1-4$ nach IWaxzofF $15 ! 6,5$ nach WiLL 1909, 6 nach Bügre 1S95.)

geformten Drüsensecreten häufig kaum scharf unterscheiden. Eine seltenerẹ Form sind die sog. Sagittocysten (gewisser Acölen, Dendrocölen und Nemertinen, Fig. 48 ${ }^{3}$ ), hohle, schlauchformige Kapseln, die eine freie, vorschnellbare Nadel enthalten. Daß alle diese Morphite in der Tat prinzipiell mit den Nematocysten der Cðlenteraten zusammengehören, folgt wohl sicher daraus, $\mathrm{da} B$ zuweilen bei Turbellarien wie Nemertinen auch echte Nesselkapseln neben, oder an Stelle solcher Rhabditen vorkommen und sogar durch Übergangsbildungen mit ihnen zusammenhängen (Fig. 48 $147^{6}$ ). Wie bei den Cŏlenteraten finden sich nämlich auch hier häufig verschiedene Morphite bei einem und demselben Tier. - Sie werden bei den marinen Dendrocölen und den Nemertinen in den eigentlichen Epidermiszellen gebildet, bei den Süßwasser- 
turbellarien dagegen fast stets in tieferen, im Bindegewebe des Körpers liegenden Zellen. Doch ist wohl kaum zweifelhaft, daß diese Zellen aus der Epidermis in die Tiefe gerückt sind; sie erinnern daher etwas an die interstitiellen Zellen der Coxlenteraten. Aus solch tiefliegenden Bildungszellen gelangen die Rhabditen in die Epidermis; wie es scheint, stets auf die Weise, daß die Zellen mit Fortsätzen zwischen die Epidermiszellen hineinwachsen, also die Form tiefer liegender Drüsenzellen annehmen. In den Fortsätzen schieben sich die Morphite dann gegen die Epidermisoberfläche. Die Morphite entwickeln sich in ihren Zellen jedenfalls prinzipiell ähnlich wie bei den Cölenteraten, woriiher jedoch wenig

Fig. 49.
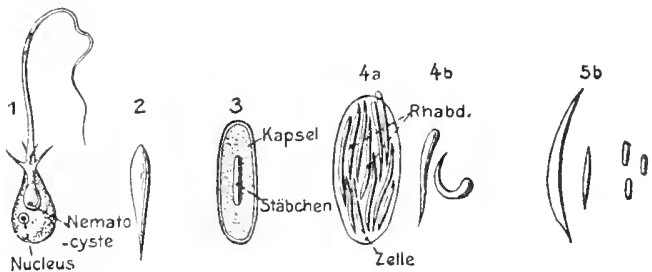

5 a

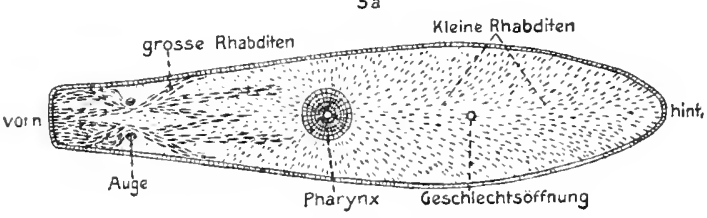

Horphite von Turbellarien (n. v. GRAFF). 1 Nematoblast mit explodierter Nematocyste von Microstom am lineare. 2 Rbsbdit von Steno. stoma sieboldij 3 Sagittocystevon Mesostomum banaticam. $4 a-b$ Convoluta paradoxa. "Zelle mit zahlroichen Rhabditen; $b$ isolierte Rhabditen. $5 a-b$ Proxenetes gracilis. a Individuum von der Bauchseite; in der Vorderregion mit größeren, in Straßen angeordnoten Rhabditen, wäbrend kleine über die ganze Oberflache zerstreut sind. bekannt ist. Im Gegensatz zu den Cölenteraten werden aber meist mehrere, häufig sogar große Mengen von Rhabditen in einerZelle gebildet (Fig. $48^{\text {ta }}$ ). - Die Verteilung der Rhabditen, bzw. ihrer Bildungszellen, über den Körper ist teils mehr gleichmäßig, teils ungleichmäBig. Namentlich bei den Turbellarien sind sie zuweilen in eigentümlichen straßenartigen Zügen über den Körper verbreitet (s. Fig. $48^{5 a}$ ).

Die physiologische Bedeatung der Morphite der Plattwürmer, insbesondere ihrer verbreitetsten Form,

ist immer noch nicht ganz aufgeklärt. Die eigentlichen Nematocysten werden ja wohl ähnlich funktionieren wie die der Cölenteraten. Die Rhabditen dagegen sind in sehr verschiedener Weise beurteilt worden. Da es sicher scheint, daß sie ausgestoßen werden können, so dürfte wohl die Ansicht die richtigste sein, welche ihnen eine Wirkung beim Einfangen der Beute, vielleicht auch bei der Abwehr zuschreibt, was ja auch mit ihren Beziehungen zu den Morphiten der Cölenteraten im Einklang stäude.

Einzellige Drüsen mit Rhabditenbildung sind auch bei marinen Polychäten recht verbreitet, ja in der Epidermis gewisser Abteilungen der Sedentaria in sehr großer Menge vorhanden. Meist scheinen diese Rhabditenzellen zwischen die Epidermiszellen selbst eingelagert zu sein; jedoch ist es wohl sicher, daß sie sich auch schlanchartig tiefer in den Körper einsenken können; gelegentlich findet sich auch grappenartige Vereinigung solcher Zellen. Eine scharfe Grenze zwischen ihnen und den sonstigen Drüsenzellen mit homogenew oder körnigem Secret besteht wohl kaum. 
Die Rhabditen sind meist denen der Plathelminthen sehr ähnlich, werden jedoch auch länger fadenartig. $\mathrm{Ob}$ aber die feinen Fäden, welche bei manchen Formen von der Epidermis abgeschieden werden, als solche schon in den Driisenzellen vorhanden sind, dürfte nicht immer ganz sicher sein. Daß die Rhabditen mit dem Schleim nach außen entleert werden, wurde beobachtet; auch besitzen die betreffenden Zellen einen deutlichen Ausführporns in der Cuticula. - Die physiologische Bedeutung ihres Secrets ist ebensowenig ganz klar wie bei den Plathelminthen und dïrfte jedenfalls eine verschiedenartige sein; zuweilen scheint es als Haftmittel zu dienen und die Drïsenzellen sich daher Haft- oder Spindrïsen zn nähern.

Bis in die jüngste Zeit galt es für sicher, $₫ a ß$ echte Nesselkapseln auch bei gewissen Mollusken gebildet werden; bei den schaleulosen marinen Äolidiern (Opisthobranchiata) schien ihr Vorkommen in den eigentïmlichen, bäuftg sehr zahlreichen Rückenanhängen $z$ weifellos. Dieser Befund war um so auffallender, als die Nematocysten nicht in der Epidermis der Räckenanhänge, sondern in den Zellen ron Leberfortsätzen, die in die Anhänge hineinragen, also in Entodermzellen entstehen sollten. Der distale Endteil dieser Leberfortsätze ist durch eine Einschnürung rom proximalen Hauptteil abgesetzt und öffnet sich gleichzeitig auf der Spitze des Rückenanhangs durch eine feine Mlündung. In gewissen Zellen dieses Endsäckchens (Cytophor) finden sich Nesselkapseln, welche auch sicher gegen Feinde der Schnecke durch die öffnung ausgestoßen werden können. Trotz dieser Verhältnisse, welche bestimmt für die Bildung der Nematocysten in der Schnecke zu sprechen schienen, ergaben die genaueren Untersuchungen, daß es sich nur um Kapselı handelt, welche die Äolidier, die sich häufig von Ilydroidpolypen oder Actinien erıähren, mit der Nahrung anfnebmen. Immerhin ist dieser Fall sehr lehrreich. Die nicht explodierten Nematorysten dringen bis in dłe erwähnten Nesselsäckchen der Leberfortsätze vor, werden hier von gewissen Wandzellen aufgenommen und, wie gesagt, nutzbringend verwertet. - Ebeuso hat sich eine frühere sngabe über Nematocysten an den Tentakeln gewisser Cephalopoden als irrtïmlich ergeben. Auch das Vorkommen kleiner Nematocysten in den meisten Epidermiszellen der Oberfläche einer Copelate (Fritillaria urticans) bedarf noch weiterer Sicherung.

Schon früher (S. 127) wurden die eigentümlichen Drüsenzeilen der Cyclostomen mit fadenartigem Secret (Faden- und Kolbenzellen) kurz erwähnt; hier sei nur darauf bingewiesen, daß sie in mancher Ilinsicht an die Zellen der Wirbellosen mit Fadensecret erinnern.

\section{Mehrzellige Drïsen.}

Allgemeines. Wenn es für den Organismus nützlich erscheint, an einem Punkt der Kðrperoberfläche eine größere Secretmenge abzuscheiden, so kann dies dadurch erreicht werden, daß sich eine Gruppe von Dritsenzellen der Epidermis an diesem Punkt vereinigt und ihr Secret, bei Gegenwart einer Cuticula, durch einen gemeinsamen Porus entleert, oder selbst einen röhrenförmigen Ausführgang, der durch Einsenkung der Epidermis entstand. Solche liomplexe einzellige Drïsen, wie diese Bildungen genannt werden könnten, sind ebenfalls weit verbreitet; sie finden sich namentlich bei Nemertinen (s. Fig. 49), Gephyreen, auch Polychäten und Arthropoden (s. Fig. 53, S. 140), wie wir zum Teil schon hervorhoben. Auch gewisse Drusen der Mollusken reihen sich hier am besten an.

Bei zablreichen Nemertinen ist der Kopfregion eine häufg recht ansehnliche Drüse dieser Art eingelagert (Kopfdrüse). Sie wird meist van sehr zahlreichen langen >Drüsenzell- 
schläuchen gebildet, die aus mehreren Zellen bestehen sollen. Ihre einfache bis mehrfache Mündung liegt an der Kopfspitze über der Rüsselöffnung; zuweilen mündet sie in das als Sinnesorgan gedeutete grubenförmige Frontalorgan. Auch bei gewissen primitiven Cestoden (Amphiline, Archigetes, Rhynchobothrien) finden sich äbnlich gelagerte Drüsen im Scolex, dauerna oder nur in der Jugend.

Handelt es sich jedoch um eine ausgiebigere Secretbildung an einer gegebenen Stelle, so wird die eben besprochene Einrichtung nicht geniigen. Leistungsfähigere Drüsen bilden sich dann in der Weise, daß die Epidermis an der betreffenden Stelle

Fig. 49.

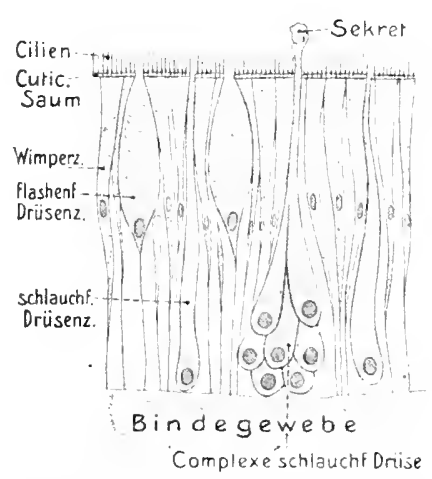

Durchschnitt durch wimpernde Epidermis einer Nemertine (Carinella) mit dreierlei ein. zelligen Hantdrüsen. (Nach Büraer 1צ95.) O. B. als ein Drüsenschlauch oder -säekchen in das Körperinnere hineinwächst. Die Zellen, welche diesen Schlauch bilden, werden zu abscheidenden, abgesehen von denen des distaren Teils, der sich in der Regel zu einem Ausfuhrgang entwickelt. Das Secret, welches sich in das Schlauchinnere ergießt, tritt durch den Gang nach außen, so daß also eine erhebliche Menge an diesem Punkt entleert werden kann. Es ist leicht verständlich, wie von einer solch einfachsten Form aus die mehrzellige Drüse sich unter morphologischer Komplizierang zu immer höherer Leistung zu entwickeln vermag. Dazu ist nur nötig, daß der Drłusenschlauch sehr lang auswächst, oder durch weitgehendeVerz weigung eine immer größere abscheidende Fläche erlangt. Daß sich derartig reicher entwickelte. Drüsen tief in das Körperinnere oder die Leibeshöhle einsenken kơnnen und müssen, ist begreiflich. Ebenso, daß sich bei weiterer Komplikation an ihrem Aufbau auch Bindegewebe als Stütze, Blutgefüße zur Ernährung, ebenso Muskeln und Nerven beteiligen werden. Eine weitere Komplikation kann zuweilen noch dadurch erreicht werden, $\mathrm{da} ß$ sich eine ganze Gruppe einfacherer solcher. Drüsen in eine dnrch Einsenkung des Integuments gebildete Tasche ergießt. - Die physiologischen Leistungen der mehrzelligen Hautdrttsen sind ebenso mannigfaltig wie die der einzelligen.

Bei dieser Gelegenheit werde betont, $\mathrm{da} B$ auch andere Epithelien, vor allem die des Entoderms, auf prinzipiell gleiche Weise ihre Drüsen bilden; das über die Hautdrusen Bemerkte gilt daher ebenso fïr jene entodermalen Drüsengebilde.

In der folgenden Übersicht berücksichtigen wir nur solche Hautdrusen, welche nicht in innigerer Verbindung mit anderen Organsystemen, wie z. B. den Verdaunngsorganen oder dem Fortpflanzungsapparat, getreten sind, also nur die selbständigen Drüsenanhänge des Integuments. 


\section{Wirbellose.}

Sie treten schon bei relativ einfachen Metazoen auf und dienen dann bäufig der Schleimabsonderung, oder bilden auch ein erstarrendes Secret, das in verschiodener Weise Verwendung findet. So kommen bei gewissen I'olychäten in den Parapodien schlauchförmige Hautdriisen vor, die sieb segmental wiederbolen und ein feinfädiges erbärtendes Secret zum Aufbau einer Wohnröhre liefern (Polyodontus), oder auch einen Haarfilz, der den Rücken tiberkleidet (Aphrodite). Man hat diese Drüsen daher zuweilen auch als Spinndrüsen bezeichnet.

Mollusken. Mehrzellige Drusen von recht primitivem Bau, d. ł. zur Kategorie komplexer einzelliger Drüsen gehörig, finden sich bei den Mollusken an verschiedenen Körperstellen und sondern wohl hauptsächlich Schleim ab. Die kiemenatmenden Gastropoden besitzen in der Regel eine solche Drüse (Sehleim- oder Hypobranchialdrüse) an der Decke der Kiemen- oder Mantelhǒhle, zwischen der Kieme und dem Enddarm; bei den Pulmonaten fehlt sie fast stets. Die Drüse ist teils ein einfaches Feld von Drüsenzellen, teils etwas komplizierter, indem das Drüsenfeld sich in viele quere oder netzige Falten erhebt. Sie scheidet massenhaft Schleim ab. - Bei den sog. Purpurschnecken (Purpura, Murex) bildet sie, oder ein von ihr abgesonderter Teil, das eigentiimliche Purpursecret, das urspriunglich farblos ist, aber unter dem Einfluß des Lichts den charakteristischen Purpurfarbstoff entwickelt.

Besondere Drüsen haben sich gewöhnlich auch am Fuß der Gastropoden gebildet, und zwar von zweierlei Art. Die eine geht aus dem Vorderende des Fußes hervor und mündet daber auch an der vorderen Fußspitze oder zwischen dieser und dem Mund aus (sog. vordere oder obere Fußdrüse; auch Lippendriise). Sie. zieht bei Prosobranchiaten und den stylommatophoren.Pulmonaten als langer horizontaler Drüsenschlauch parallel der Fußsohle oft weit nach hinten. - Eine $z$ weite Fußdrüse findet sich bäufig bei den Prosobranchiaten und wurde frïher für die Einfuhrstelle ron Wasser in das Blut angeseben. Ihre Muindung liegt in der Mittellinie der Fußsohle, mehr oder weniger weit hinter dem Vorderende. Diese untere Fnßdrüse ist eine sackförmige Höhle, deren Epithelwand faltig in das Lumen vorspringt. Bei den primitiveren Formen ist sie weniger tief eingesenkt. Ihr Secret soll manchmal fädig erhärten und sogar so feste Fäden bilden können, daß gewisse Schnecken sich damit aufhängen oder herablassen können; die obere FnBdrüse dagegen ist eine Schleimdrüse. In beiden Fällen sind es eigentlich einzellige Drüsen, die das Secret liefern, indem sie in dichter Menge den Ausführgang oder dic Höhle umlagern und zwischen den Epithelzellen, welche diese auskleiden, münden. Ner Charakter dieser Drüsen ist daher sehr ausgesprochen der komplexer einzelliger Drüsen.

Auch bei den Lamellibranchiaten scheinen die beiderlei geschilderten FuBdrüsen entwickelt zu sein. Die sug. obere oder vordere ist jedoch keine eingesenkte Drüse, sondern nur ein Feld einzelliger Schleimdrïsen an der Kopfseite des Fußes oder an der Fußspitze. Dagegen ist die hintere oder untere Fußdriise bei vielen Muscheln sehr stark entwickelt und bildet eine charakteristische Haftdríse, 
die sog. Byssusdrüse. Im voll ausgebildeten Zustand (Fig. 50) besteht sie aus einer Rinne, welche an der Fußspitze beginnt und von hier an der Analseite des FuBes nach hinten zieht. Das hintere Ende dieser Byssusrinne seukt sich als ein aufstei-

Fig. 50

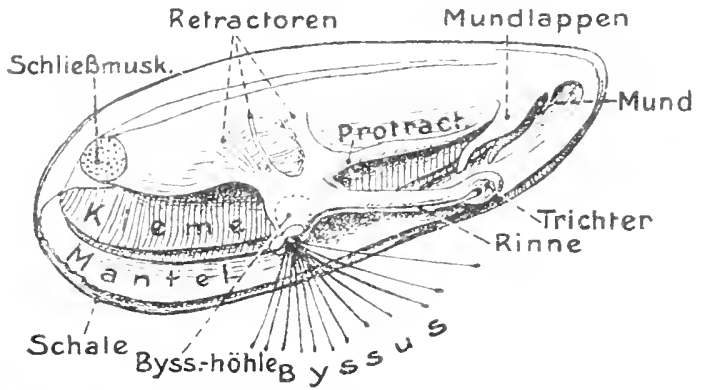

Mytilus edulis (Miesmuschel). Eine Mnschel nach Entfernung der rechten Schale, Mantellappen ond Kiemen, ron rechts. FuB mit sog. Spinnfinger, Rinne und Offinung der Byssushöhle, aus der die Byssusfăden hervortreten, zu sthen; Byssushōhle punktiert angedeutet. 0 . B. gender Kanal in das $\mathrm{FuB}$ innere ein, der sich schließlich zu einer Höhle erweitert. Die Wand der Höhle springt in zahlreichen senkrechten Längsfalten vor (Fig. 51), so daß das Lumen der Höhle sich dorsalwärts in viele schuale sekundäre Spalträume zerteilt. Zuweilen entwickelt sich auch eine mittlere Falte stärker, so daß die Höhle parrig er-

scheint. Die eigentlichen secerniereuden Zellen umlagern die Höhle als eine dichte Masse einzelliger Drüsen von zweierlei Art, die sich in die Spalten der Höhle, die

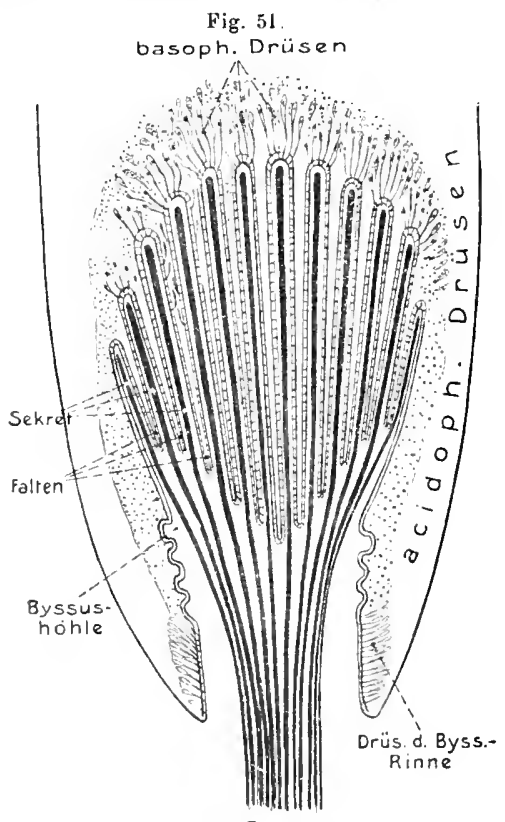

Byssus

Mytilug odnlis. Sehema iseber Querschnitt der Byssushôhle and ihrer offnung. Die Zahl der Falten in der Hōhle sebr vermindert und die Einzel. falten vergröhert. (Nach SErDEL 1903.) O. B. von gewöhnlichem Wimperepithel ausgekleidet sind, öffnen. Sowohl der Kanal wie die Rinne sind meist ebenfalls reich mit einzelligen Drüsen besonderer Art versehen. - Das Secret der Byssushöhle wird bei den Muscheln, welche eiuen fadenförmigen Byssus bilden, in der Rinne zu einem erhärtenden Fadeu geformt, und mit diesen Byssusfäden heften sich solche Muscheln an fremde Gegenstände fest, wobei ein vorderer fingerartiger Fortsatz des Fußes (sog. Spinnfinger), auf dem die Rinno hinzieht, verwendet wird (Fig. 50). Auf der Spitze dieses Fortsatzes, vor dem Ende der Rinne, findet sich häufig noch eine drüsige Vertiefung (Trichter). In anderen Fällen kann das Byssussecret auch als ein zusammenhängendes plattenartiges Gebilde erstarren. - Bei zahlreichen Lamellibranchiern ist die Drüse mehr oder weniger rudimentär und scheidet keinen Byssus mehr ab, oder fehlt auch völlig. Die ontogenetischen Befunde sprechen dafür, daß die Byssusdrüse früher allgemeiner verbreitet war, ihr Mangel daher häufig auf totaler Ruckbildung heruhen dürfte. - Erwähnuvg verdienen auch die sog. Bohrdrüsen gewisser boh- 
render Muscheln (Lithodomus, Lithophagus, Petricola), komplexe einzellige Driisengruppen an verschiedenen Stellen der Dorsalregion und des Mantels. Ihre Wirksamkeit soll auf saurem Secret beruhen.

Arthropoden. Bei den wasserlebenden Crustaceen sind mehrzellige Hautdrüsen wenig ausgebĩdet, doch ist bei den festsitzenden Cirripedien eine anf der Dorsalseite des Kopfes mündende Haftdrïse (Zementdrüse) stalk entwickelt und steht vielleicht in genetischer Beziehung zn der früher erwähnten Nackendrïse der Phyllopoden. Bei den luftlebenden Tracheaten erreichen sie eine physiologisch wie morphologisch reiche Entfaltung, was wobl mit dem Luftleben direkt zusammenhängt. Die vergleichend anatomischen Beziehungen dieser Drüsen untereiuander sind bis jetzt noch wenig aufgeklärt; dennoch läßt sich eine Gruppe durch die Klassen einigermaßen verfolgen. Dies sind die sog. Cruraldrïsen, so hezeichnet, weil sie in der Regel am Basalteil der Extremitäten (Hüfte oder Schenkelabschnitt) ausmünden.

Scbon bei dén zweifellos uralten Protracheaten (l'eripatus) finden sie sich als einfache kurze Drüsensehläuche an vielen Beinpaaren, oder auch in geringerer Zahl, meist in beiden Geschlechtern oder auf die Männehen beschränkt; doch kann ihre Zahl bei derselben Speeies variieren, selbst an den einzelnen Beinen, die ein bis drei solcher Drüsen enthalten können. Die Cruraldrüsen gewisser Segmente vermögen sich ansehnlicher zu entwickeln. So gilt dies für das vorderste Paar in beiden Geschlechtern, welches in der Kopfregion, auf den sog. Oralpapillen (den zweiten Gnathiten) ausmündet. Die Drüsen dieses Segments werden zu langen Drüsensehläuchen, die beiderseits des Darmes weit nach hinten reichen und sich in ihrem hinteren Abschnitt sekundär verzweigen. Das Secret dieser sog. Schleimdrüsen ist zähe fadenbildend und dient daher wohl beim Fang der Beute. Auch das hinterste Paar der Cruraldrüsen wächst bei den Männchen gewisser Arten zu langen Sehläuchen aus.

Homologe Drüsen wiederholen sich, wenn auch seltener, bei den Myriopoden (speziell gewissen Chilopoden), welche an den Hüftgliedern der vier bis sechs hinteren Beinpaare Drüsen besitzen (sog. Coxal- oder Pleuraldrüsen), die Spinnfäden zu bilden scheinen. Bei den diplopoden Myriopoden finden sich zuweilen ähnliche Bildungen an mehr oder weniger Beinparen und sind bei gewissen Formen dadurch eigentümlich, daß die sehr klein gewordenen Drüsensäckchen ausgestülpt werden können und daun als Wärzchen hervorragen. - Anch die meisten Beinpare der sog. Symphila, die meist zu den Myriopoden gestellt werden, jedoch auch nahe Beziehungen zu den primitivsten Insekten (Apterygota) besitzen, Iragen solch ausstülpbare drüsige Säekchen an ihrem Hüftglied. Doch findet sich hier auch noch eine ausgebildete Spinndrüse im hintersten, zu den sog. Spinngriffeln umgebildeten Beinpaar. Auch für einzelne Arachnoideen (gewisse Pedipalpen) wurden sog. Coxalsäckclrell am Abdomen beschrieben. - Dieselben Organe kehren bei den Thysanura unter den apterygoten Insekten wieder, bei denen eine verschiedene Zahl von Abdominalsegmenteı ein Paar solcher ausstülpbarer Säckchen besitzen kann (zum Teil jedoch auch zwei Paar) ind dicht daneben znweilen auch noch griffelförmige Rudimente von Abdominalbeiner..-- Diese Vorkommnisse sind um so interessanter, als die Embryonen vieler pterygoter Insekten an der Ventualseite des ersten Abdominalsegments ein Paar kleiner Anhänge (sog. Pleuropoden) zeigen, deren Ectoderm drüsig umgebildet ist. Da diese Pleuropoden zuweilen auch etwas eingesenkt, oder gar nur Komplexe drüsiger Eetodermzellen sind, so erinnerı sie leblaft an die ausstïlpbaren Cruraldrüsen der Thysanuren und Myriopoden und gehören daher wahrscheinlich anch zur Kategorie dieser Organe. $O b$ der als Haftorgan dienende sog. Ventraltubus der collenbolen Apterygota ebenfalls hierher gehört, scheint fraglich.

Den typischen Cruraldrüsen homolog sind wohl die Spinndrüsen der Inselten, 
welche jedoch nur als Larvenorgane auftreten ond den ausgebildeten Formen fehlen. Wie die Schleimdrüsen des Peripatus beschränken sie sich auf ein Segment, das hinterste des Kopfes, und münden stets durch eine unpaare Öffnung auf der Unterlippe (2. Maxille), dem hintersten Gnathitenpaar aus. Es sind zwei lange Drüsenschläuche, die seitlich vom Darm häufig die ganze Leibeshöhle durchziehen, indem sie sich vorn zu einem kurzen unparen Ausfïhrgang vereinigen. Sie sind

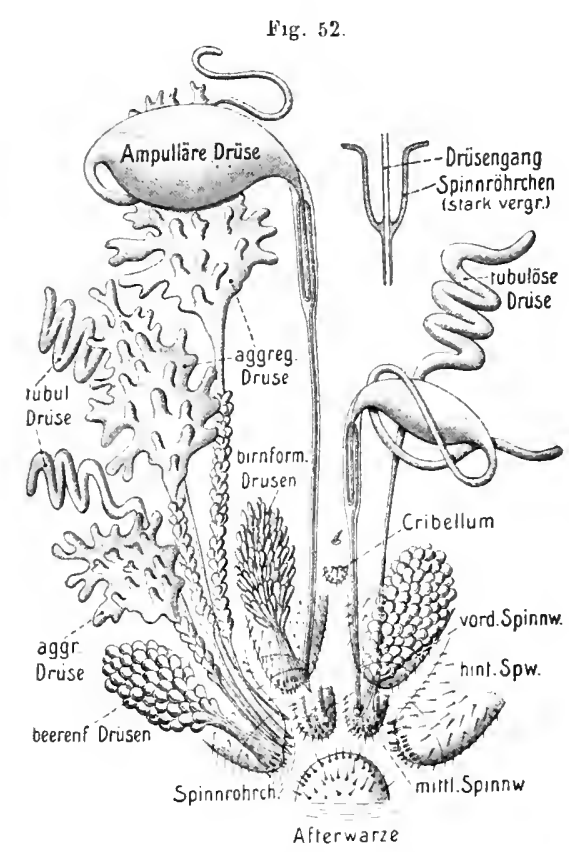

Epeira diad $\theta$ ma (lireuzspinne). Schematische Darstellung der Spinnwarzen und Spinndrüsen. Die zu jeder Warze gehör:gen Drüsen sind nur jeweils an einer der Warzen dargestellt. Oben rechto atāker vergrößertes Spinnrobrchen einer größeren Drüse. (Nach APstary 1859.) E. W.

bei den Insektenlarven sehr weit verbreitet (Lepidoptera, Coleoptera, Hymenoptera, auch Neuroptera z. T.). Ihr Secret, die Seide (Fibroin), gehört zu dèn Albuminoiden und dient vor allem bei der Anfertigung des Puppenkokons.

Obgleich nun die Spinndrüsen der Webespinnen (Araneinen) gleichfalls an rudimentären Extremitäten, jedoch hinterständigen des sog. Abdomens, ausmtinden, so scheint ihre eventuelle Ableitung von Cruraldrüsen doch wenig sicher, wenn auch nicht unmöglich. Die meist sehr zahlreichen Spinndrüsen münden durch viele feine Röhrchen auf den sog. Spinnwarzen an der hinteren Ventralseite des A bdomens aus. Solcher Warzen finden sich teils zwei, meist jedoch drei Pare (Fig 52). Wenigstens die beiden ersterwähnton sind rudimentäre Gliedmaßen des 4. und 5. Abdominalsegments. Was dic Beziehung der Spinndrüsen zu Cruraldrüsen unsicher macht, ist ihre meist ungemein große Zahl, die sich schon in der zum Teil ganz außerordentlichen Menge ihrer Öfinungen dokumentiert (bis einige hundert). Letztere finden sich am Ende der Warzen auf je einem feinen haarartigen sog. Spinnröhrchen. Jedom Röhrchen entspricht daher eine Drase, deren Gesamtheit einen ansehnlichen Teil des Abdomens erfüllt. Die Driusen selbst sind recht verschieden gebaut, selbst bei einer und derselben Spinne; teils klein, kugelig bis birnfürmig, teils lang schlauchförmig, teils verästelt und auch blasig angeschwollen. Im ganzen wurden so sechs verschiedene, zu den Spinnwarzen gehörige Drüsenformen unterschieden, von denen jedoch nicht mehr wie fünf bei einer Species gleichzeitig vorkommen. Häufig ist anch nur eine geringere Zahl von Irỉsenarten vorhanden, ja bei gewissen (z. B. Vogelspinne) nur eine einzige. Am zahlreichsten sind die kleinen kugeligen oder birnförmigen Drüs_ chen, während die größeren schlauch-oder ampullenförmigen und die aggregierten 
sich nur in geringerer Zahl und auf gewissen Warzen finden. DaB auch die Funktion der verschiedenen Drüsen etwas verschieden sein muß, ist sicher und zum Teil erwiesen; dies folgt auch daraus, daß die Spinnfäden je nach ihrer Verwendung verschieden beschaffen sind und von verschiedenen Drüsen gebildet werden. - Ein unpaares Drüsenfeld (sog. Cribellım), das ebenfalls Spinndrüsen besitzt, findet sich zuweilen noch vor den eigentlichen Warzen. Das Spinnsecret ist dem der Insektenlarven ähnlich.

Drüsen, welche bei den sog. Pseudoskorpionen an dem Ende der Cheliceren (Kieferfïhler), also an den vordersten Extremitäteu ausmünden, werden gleichfalls meist als Spinndrüsen angesehen, obgleich sie ihrer Lage nach den Giftdrüsen der Araneinen entsprechen dürften. Auch die 2. Gnathiten der Spinnentiere enthalten zuweilen Drüsen, uber deren Funktion wenig Sicheres bekannt, die jedoch ebenfalls zu den Crural- oder Beindrüisen gerechnet werden könnten.

Berücksichtigt man die Möglichkeit, daß die Epidermis zweifellos befähigt ist, an verschiedenen Stellen selbständig Drthsengebilde hervorzubringen, so erscheinen die im vorstehenden zum Teil versuchten Homologisierungen der recht verschiedenartigen Hautdrïsen der Tracheaten immerhin noch sehr unsicher. Dies folgt z. B. auch daraus, $d a B$ sich funktionell entsprechende Driisen entwickeln konnten, die mit den aufgezählten jedenfalls nichts zu tun haben. So wurde der gegen den Mitteldarm abgeschlossene und erweiterte Enddarm der Larven des Ameisenlöwen (Myrmeleo) und der verwandten Hemerobiiden zu einem Spinnorgan, dessen Secret jedoch von den in ihn mündenden ectodermalen Malpighischen Gefäßen erzeugt wird. - Da sich die Crurald riisen der Protracheata schon zu verschiedenen Leistungen differenzieren, so erscheint es nicht unmöglich, daß auch die beiden schlauchförmigen Giftdruisen, welche bei den chilopoden Myriopoden an den Endspitzen der ersten Rumpfbeine, den sog. Raubfïßen, ausmünden, in die Reihe der Cruraldrüsen gehören. Ihre Ausmündung am Endglied widerspricht dem jedoch etwas. - Das gleiche gilt von der schlauch- bis beutelförmigen Giftdriise der Araneinen, die am Ende der ersten Extremitäten, den sog. Cheliceren, milndet und sich häufig ziemlich weit nach hinten erstreckt. Ob gar die beiden Giftdrtisen, welche sich bei den Skorpionen an der Spitze des Giftstachels offnen, zu welchem das hinterste Abdominalsegement (Telson) umgebildet ist, hierherzurechnen sein dürften, ist eher unwahrscheinlich.

Die Giftsecrete der Myriopoden und Arachnoideen sind flüssig und bäufig außerordentlich wirksam. Ihre Entleerung beim Biß oder Stich wird durch einen Muskelubberzug der Drtise begünstigt. - Es wäre auch mŏglich, daß diese Giftdrtisen nähere Beziehungen zu den Geruchsstoffe absondernden Hautdrüsen hätten, die schon bei den diplopoden Myriopoden recht entwickelt und jedenfalls von den eigentlichen Cruraldrüsen verschieden sind. Sie wiederholen sich meist zahlreich in den Doppelsegmenten als je ein Paar Drüsensäckchen, die an den Seiten des Rückens durch die sog. Foramina repugnatoria münden. Ihr Secret ist eine scharf riechende Flüssigkeit, welche in einem Fall (Fontaria) sogar freie Blausäure enthalt. Sie sind zweifellos Wehrdrüsen. Vielleicht gilt dies auch von den beiden Drïsensäckchen der 
Phalangiden (Weberknechte), welche an den vorderen Seitenwinden des Cephalothorax ausmünden. - Ihrer Lage nach ähnliche Stinkdrüsensäckchen, die jedoch etwas einfacher gebant sind, kommen bei den Larven vieler Landwanzen (Hemiptera) auf dem Abdomen in drei Paaren vor. Sie verschwinden bei der letzten Häutung, indem sich die für die entwickelten Landwanzen charakteristische Stinkdruse auf der Ventralseite des Thorax hervorbildet. Letztere mündet am Metathorax durch eine oder zwei Öffnungen aus. Ihr meist stinkendes, öliges Secret dient wohl in der Regel zur Abwehr. - An die erwähnten Larvendrüsen der Wanzen und die Foramina repıonatoria erinnern etwa die paarigen Seitenđ̄rüsen gewisser Käferlarven (Chrysomela), die sich an.Thorax und Abdomen segmental vielfach wiederholen

Fig. 5.3.

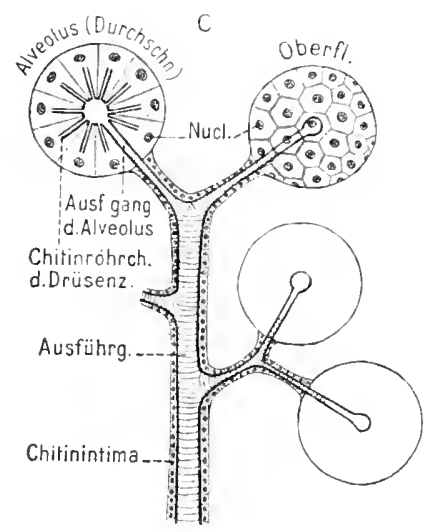

Carabus. Klein. Teil einer alveolaren Anal. dräse. Der linke obere Alvenlus im Durchschnitt, der rechte in Oberflächenansicht. In die Einzelzellen des Alveolus drinzen Chitinröhrehen vom Ausführgang des Alveulus oin. (Nach Lerdig issy.) E. W. und etwas ausstiilpbar sind. Noch mehr gilt dies für die häufig ausstülpbaren Drüsen, welche zu ein bis mehreren Paaren auf dem Rucken nicht weniger Schmetterlingslarven auftreten (z. B. Orgyia, Leucoma, Papilio). Auch sie gehören in die Kategorie der Wehrdrüsen. Dies gilt auch von der $z$ wischen Kopf und Prothorax ventral mündenden sog. Bauchdrüse mancher Ranpen (z. B. Harpyia, Vanessa usw.), die jedoch morphologisch eher an die Cruraldrüsen erinnert. Das vereinzelte Vorkommen ähnlicher Drïsen bei anderen Insektengruppen kann hier nicht näher geschildert werden. - Zahlreiche Käfer, jedoch anch einige andere Insekten (so namentlich viele Ameisenweibchen und -Arbeiter), besitzen ähnlich wirkende Wehrdrüsen am Hinterende des Abdomens, zu den Seiten oder oberhalb des Afters, die jedoch zuweilen in das Darmende selbst münden (Fig. 53). Diese einfach bis etwas kompliziert gebauten Drüsen sind meist paarig bis vielfach, seltener unpaar. Ihr bei den Käfern meist übelriechendes, manchmal auch ätzendes Secret kann bei gewissen Formen mit Gewalt hervorgespritzt werden und ist manchmal recht flủchtig (Bombardier-Käfer, Ameisen).

Die mehrzelligen Hautdrüsen der Tracheaten besitzen häufig eine das Drüsenlumen auskleidende Chitinhaut, welche von feinen Poren durchbohrt ist, zum Durchtritt des Secrets der einzelnen Zellen; von den Poren können feine Ausführröbrchen in die Drüsenzellen führen, wie dies schon obeu für die einzelligen Druisen beschrieben wurde (Fig. 53). Der Charakter dieser Driisen erinnert daher vielfach noch an die mehrzelligen Drüsen der ersten Kategorie (komplexe einzellige Drüsen). - Daß die beschriebenen Drüsen hänfig auch mit Muskeln ausgeruistet sind, so besonders die aus- und einstülpbaren mit Retractoren, sei hier nur kurz erwähnt. - Die Flẗssigkeitstrŏpfchen, welche bei gewissen Insekten (z. B. Meloë und andere Käfer) an den Gelenken der Beine und ander- 
weitig hervortreten können, und die fruher für Secrete besonderer Hautdrüsen gehalten wurden, ergaben sich bei genauerer Untersuchung als Blut.

Die Haut der Echinodermen ist im allgemeinen wenig reich an einzelligen wie mehrzelligen Drüsen. Erwähnt möge hier nur werden, daß bei gewissen Asterien säckchenförmige mehrzellige Schleimdrüsen (wohl Wehrdrüsen) über Scheibe und Arme verbreitet sind. Bei manchen Echinoiden sind die eigentïmlichen Pedicellarien mit ansehulichen melirzelligen Giftdrüsen ausgestattet. Auf die einzelligen bis mehrzelligen Leuchtdrüsen gewisser Ophiuren werden wir später eingehen.

\section{Vertebrata.}

Amphibien. Während den Fischen mehrzellige Hautdrüsen völlig fehlen (abgesehen von den später zu betrachtenden Leuchtdriảsen gewisser Formen), ist

Fig. 5t.

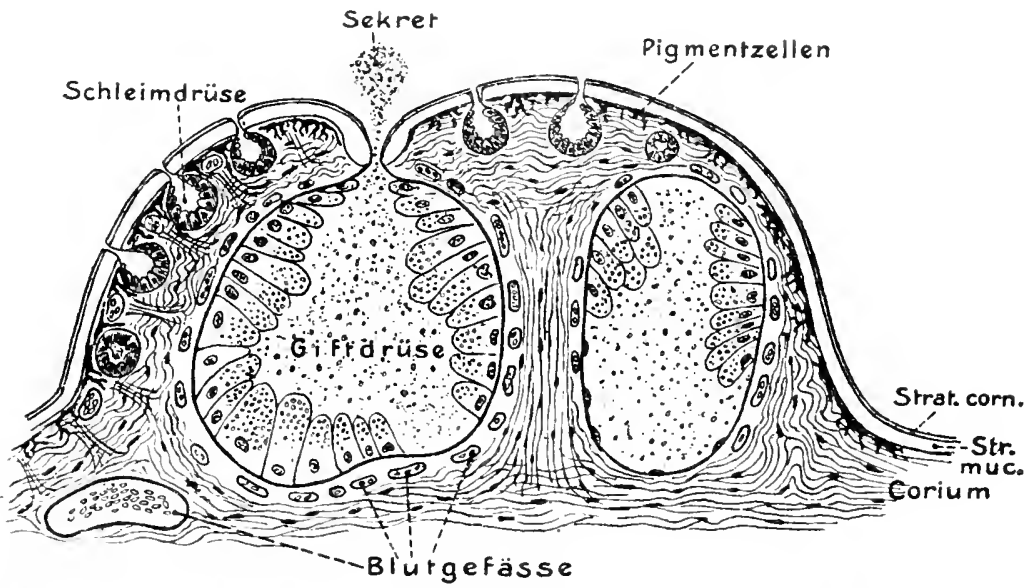

Salamandra maculoss. Querschnitt der Haut in der Gegend der soge. Parotis, wo die Giftdrūsen sehr groß sind. Die Giftdrūser sind von dem durch Zerfall der Zellen entetandenen Secret erfállt und von Blut. gefäßen reich umsponnen, die sich auch dicht unter der Epidermis ausbreiten. Etwas schematisiert. 0. B.

die Amphibienhaut damit ungemein reich ausgerüstet. Sie finden sich in so großer Menge und so dicht (selbst am Trommelfell und der Nickhaut), daß kaum ganz drusenlose Stellen rorkommen. Die Drüen sind meist klein, kugelig und aus relativ wenig Zellen zusammengesetzt, ohne oder mit einem sehr kurzen Ausführgang, abgesehen von dem engen Ausfuhrröhrchen, welches die geschichtete Epidermis durchsetzt und mit einem feinən Porus auf deren Oberfläche mündet (s. Fig. 54). Zwei Drïsenarten lassen sich mehr oder weniger scharf unterscheiden: 1. die meist kleineren Schleimdrtsen, die im funktionierenden Zustand ein deutliches Lumen besitzen und homogenes bis feinkörniges, schleimhaltiges bis klebriges Secret abscheiden; 2. die meist größeren Gift- oder Körnerdrüsen, deren Zellen bei der Funktion so anschwellen, daß sie das Lumen ganz verdrängen. Ihr Secret ist meist milchig, trib, körnig, z. T. riechend, auch ätzend und bei vielen Formen (Salamandra, Krŏten) recht giftig. Beiderlei Drüsen besitzen oine zarte Hülle glatter Muskelfasern, zuweilen auch eine Art Sphincter am Ausführgang. - Regeneration 
der Giftdrüsen wurde durch Hervorwachsen neuer am Mündungspol der alten beobachtet. - Die beiderlei Drïsen sind teils unregelmäßig, teils in bestimmterer Ordnung über den Körper verbreitet. So stehen bei den Gymnophionen (Fig. 55) die großen sog. Riesendrtisen, welche jedenfalls den Giftdrusen entsprechen, am vorderen Rand jedes Körperringels als ein den Körper umziehender Ring; dahinter finden sich die kleineren Schleimdrüsen, auch Spritzdrüsen genannt. - Sowohl bei Salamandrinen als Anuren (speziell Kröten) bäufen sich besonders große Giftdrüsen jederseits in der hinteren seitlichen Kopfregion so sebr zusammen, daß sie zwei wulstige Vorsprünge, die sog. Parotiden, bilden. Ähnliche Anhäufungen von Giftdrïsen treten anch bei gewissen Anuren an den Extremitäten auf (Oberarm von

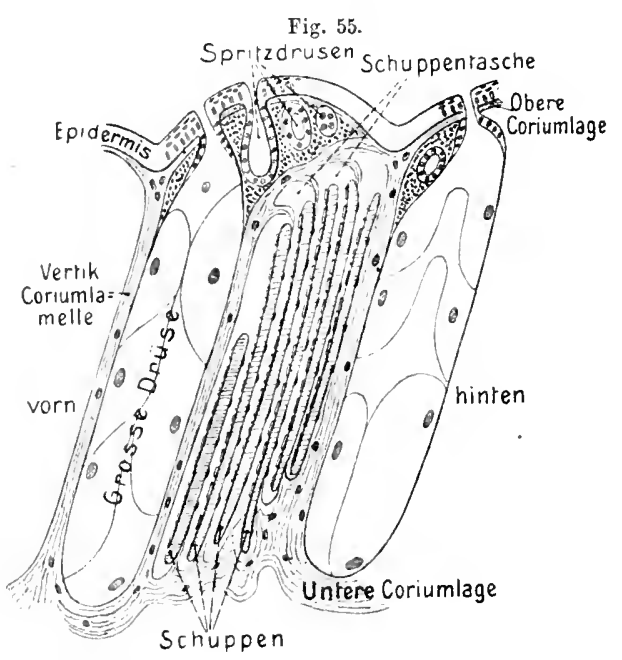

lehthyophis glatinosus (Gymnophione). Längschnitt durch die Hant dreier Körperringel mit den beiden Drūsenarten nnd einer Schuppentasche. (Nach SARAsIs 1sb7.) O. B. Pelobates z. B.). - An gewissen Körperstellen können die Drüsen (wohlhauptsächlichSchleimdrüsen) zu Schläuchen auswachsen, die sich zuweilen sogar verästeln. Derartiges findet sich besonders an der Unterseite der Zehen bei Salamandrinen und Anuren. Das Secret dient hier wohl hauptsächlich als Haftmittel. Sehr anschnliche Schlauchdrüsen dieser Art bilden die sog. Daumendrüsen der Männchen vieler Frösche.

Die Salamandrinen-Männchen besitzen eine recht ansehnliche Hautdrüse, deren Einzelschläuche auf fädigen Hautpapillen imCandalteil des Cloakenspaltes münden. Außer dieser sog. *Bauchdriise * ist die Cloake noch mit weiteren Drüsen ausgestattet, die jedoch entodermaler Herkunft zu sein scheinen und deshalb erst später zu besprechen sind.

Sauropsiden. Im Zusammenhang mit der starken Verhornung sind die Hantdrüsen bei dieser Gruppe fast verschwunde, $;$ nur lokal haben sie sich an verschiedenen Körperstellen erhalten, wie es scheint meist im Dienste der Geschlechts funktion. So findet sich bei den Krokodilen etwa in der Mitte der Außenfläche jeđes Unterkieferastes ein ziemlich großer, sekundär gelappter Drüsensack, der aussttilpbar ist. Das Secret soll aus dem Zerfall der Drüsenzellen hervorgehen (jedoch auch Verhornung der Zellen vorkommen); es riecht stark moschusartig und hat daher wohl Beziehungen zum Geschlechtsakt. - Auch für gewisse Schildkröten wird eine unpaare Riechdrüse ähulicher Art angegeben, die in der ventralen Mittellinie des Unterkiefers ausmündet. - Bei den Crocodilinen findet sich längs des Rückens jederseits eine Reihe kleiner säckchenartiger Drüsen, deren Ausführöffinnng gewöhnlich geschlossen erscheint. Ihre Funktion ist vorerst noch unsicher. 
Eine äbnliche Bedentung haben wohl zum Teil diø zu ein oder zwei Paaren (einem vorderen und einem hinteren) seitlich am Rumpfe zahlreicher Schildkröten durch rundliche oder spaltartige Öffnungen mündenden Drüsen. Die Öffnungen liegen in der Randlinie des Rumpfes, da wo Banch- und Rückenpanzer sich berühren oder ineinander übergehen. Die Drüsen selbst sind sack- bis schlauchförmig, mit weitem inneren Lumen oder schwammig-netzigem inneren Faltenwerk. Bei wenigen Schildkröten (gewissen Trionychidae) mündet ein weiteres Paar ähnlicher Drüsen am Vorderrand des Bauchpanzers.

Fig. 56.

A
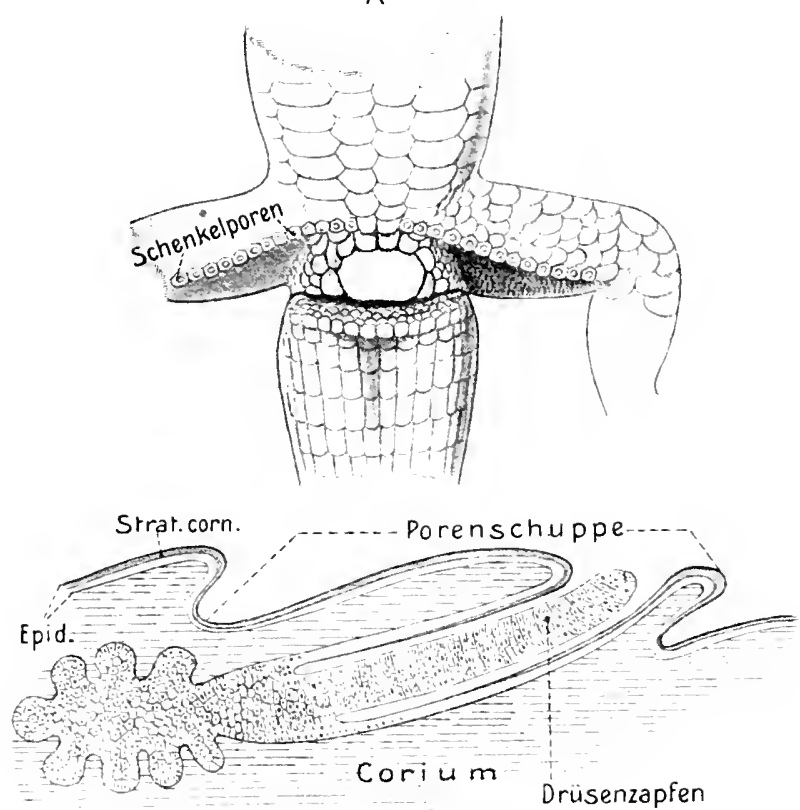

$B$

Lacerta agilis. Schenkeldrūsen. A Analgegend des Mānnchens von der Banchseite mit den Schenkelporen $B$ Eine Schenkeldrüse mit der Schuppe and dem Porns im Längsechnitt. (Schematisch nach Madrer ]n:15, nnd SCHĀFrE 1902.) o. B.

Vorwiegend in die Kategorie der riechenden Drüsen gehören auch jene, welche sich sowohl bei squamaten als placoiden Reptilien (speziell Krokodilen) am Hinterende des Cloakenspaltes paarig oder zuweilen auch unpaar finden. Bei den Männchen der Squamaten stehen sie meist mit der änßeren öffnung der Copulationsschläuche in Verbindung.

Bildungen ganz besonderer Art sind die sog. Schenkeldrüsen oder -Poren der Saurier (Femoralorgane), die mit wenigen Ausnahmen bei den Mänrchen vorkommen, den Weibchen dagegen vielfach fehlen. Schon diese Verbreitung läßt vermulen, $\mathrm{d} \mathbf{a} ß$ sie mit den Geschlechtsvorgängen in Beziehung stehen, obgleich Näheres hiertiber bis jetzt unbekannt blieb. Diese Schenkeldrüsen (s. Fig. 56 A) stehen meist ịn einer Längsreibe auf der Innenfläche der Oberschenkel, dehnen 
sich jedoch zuweilen noch als eine Querreihe vor der Cloakenöffinung aus, wo sie sich beim Mangel hinterer Extremitäten (aber auch sonst zuweilen) allein finden. Jede Drüse besteht im allgemeinen aus einer ziemlich weiten schlauchförmigen Epidermiseinsenkung, deren proximales Ende sich häufig in eine Anzahl kurzer Divertikel verzweigt. - Die Drüsenmündung liegt auf einer Schuppe der Haut. Das Secret erhebt sich als ein Zapfen vom Grunde des Drtisenschlauchs (s. Fig. 56 B) und besteht aus ziemlich wohl erhaltenen Epidermiszellen. Der Zapfen hat daher eine gewisse Ähnlichkeit mit einem verhornten Epidermoidalgebilde, znmal bei gewissen Sauriern die äußeren oder die Mehrzahl der Zellen des Secretzapfens auch wirklich verhornen können. Da aber bei anderen Formen die Zellen zerfallen, und

Fig. 57.

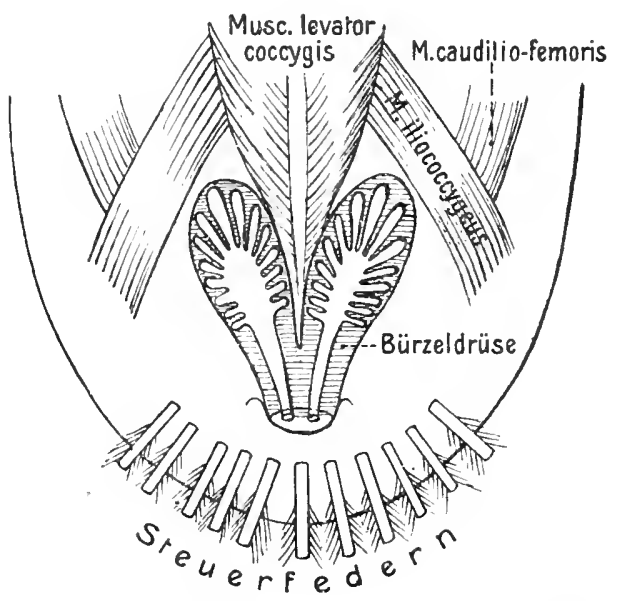

Schema der Būrzeldrūse eines Vogels. Ansicht von der Dorsalseite. Die benachbarten Muskeln sind angegeben. Nach KossMANN 1871 und GaDow in Bronn.) O. B. auch bei denen mit starker Verbornnng während der Fortpflanzungszeit unverhornt sind, so scheint es, daß die eigentliche Bedeutung des Secretzapfens doch eine besondere ist, und er vielleicht mehr als ein Haftmittel bei der Begattung dient.

Bei den Vögeln haben die auf eine einzige Stelle dær Körperoberfläche beschränkten Hautdriisen eine andere physiologische Funktion erlangt; sie sondern ein fettreiches öliges Secret ab, das zur Einfettung des Gefieder's als Schutz gegen die Nässe dient. Dièse sog. Bürveldrüse (Gl. uropygii) kommt der großen Mehrzahl der Vögel zu (ausgenommen namentlich Strauße, gewisse Papageien und Tauben). Sie mündet stets anf der Dorsalseite des rudimentären Schwanzes ans, häufig auf einem etwas verlängerten zitzenartigen Fortsatz, der nicht selten von einem Kranz von Federchen umsäumt wird (Fig. 57). Daß ibr Entwicklungsgrad in gewissem Zusammenhang mit dem Einfettungsbedürfnis des Gefieders steht, daß sie also bei Wasservögeln besonders stark entwickelt ist, ist begreiflich. Die Bürzeldrüse erstreckt sich von ihrer Mündungsstelle nach vorn. Sie ist schon äußerlich meist deutlich paarig gebildet, was sich auch darin ausspricht, daß.gewöhnlich für jede Hälfte eine äußere Mündung besteht (selten nur eine gemeinsame unpaare); doch können sich die Öffnungen jeder der beiden Drüsen bis auf sechs vermehren. Jede Drüsenmündung führt in einen innern Hohlraum des Drtisensackes, von dem radiär zahlreiche feine, zuweilen selbst wieder verzweigte Drüsenschlänche ausstrahlen, die das eigentlich secernierende mehrschichtige Epithel tragen. Sind die Öffnungen der jederseitigen Drüse zahlreicher, so führtjede in ein besonderes Lumen, das sich noch weiter verzweigen kann und schließlich mit Drüsenschläuchen besetzt 
ist. Das Secret der letzteren entsteht durch Zerfall der Zellen (holocrin) und ist, wie gesagt, stark fetthaltig, zuweilen jedoch auch iibelriechend. - Die Bürzeldriisen besitzen eine gut entwickelte Mnskelhaut. Auf die sog. Ohrenschmalzdrüsen (Talgdrüsen) im äußeren Gehörgang (z. B. beim Auerhahn) weisen wir nur hin.

Mammalia. Der große Drüsenreichtum der Hant hat sich jedenfalls von amphibienähnlichen Vorfahren auf die Säugetiere vererbt; ja in dem Vorkommen zweier verschiedener Drüsenarten tritt eine gewisse Anknüpfung an die Verhältnisse der Amphibien hervor, obwohl dies kaum auf direkter Vererbung beruhen dürfte. Lie beiden Driisenformen, welche sich bei vielen Säugern iiber das gesamte Integument in dichter Nenge ausbreiten, sind: 1. die tuhulösen oder Schweißdrësen, und 2. die acinösen (alveolären) oder Talgdriisen. Die tubulösen Drünen (s. Fig. 38 A, S. 115) sind, wie ihre Bezeichnung andentet, stets mebr oder weniger röhrẻnförmig; bald kurz schlauchartig, gewöhnlich jedoch länger anggewachsen, so $\mathrm{da} B$ sie tief in das Corinm, ja sogar das Unterhautbindegewebe hinabreichen, wobei ihr blindes Ende sich häufig mehr oder weniger anfknäuelt. Nur selten verzweigen sie sich (Bär, Nilpferd nsw.). Das Epithel des Drüsenschlauchs ist einschichtig. Ein meist feinerer mehrschichtiger Ausführgang ist stets wohl entwickelt und durchsetzt die Epidermis gerade oder gewunden. Das ölige bis wässerige und riechende Secret bildet sich ohne Zerfall der Zellen (merocrin). Eine zarte Fülle glatter Muskelfasern ist vorhanden. - Die geschilderte Beschaffenheit nähert demnach die tubulösen Drüsen den sog. Schleimdrüsen der Amphibien. Sehr häufig mïnden sie nicht direkt auf der Oberfläche der Haut aus, sondern in Ein-, selten in Melızahl, in den distalen Teil der Haarbälge. Dies Verhalten wird nach den verschiedenen Ansichten über die Phylogenie der Haare verschieden beurteilt; teils als ursprünglich, teils dagegen als sekundär entstanden. Mir scheint vieles für die erstere Ansicht zu sprechen.

Die zweite Drïsenart, die acinöscn oder Talgdrüsen (s. Fig. 38 A), ist dagegen fast stets an die Haarfollikel gebunden, aus deren Wand sie etwa in der mittleren Region hervorwachsen, als ursprünglich bentelförmige, bei reicherer Entwicklung traubenartig sich verzweigende Anhänge. Ihre Zahl ist an einem Haarbalg recht verschieden, von einer einzigen bis ziemlich vielen, die dann ringförmig den Follikel umgeben. Die Talgdriisen sind muskellos. Ihr Secret entstebt durch Zerfall der fettig degenerierenden Epithelzellen, welche die Drüsenacini völlig erfüllen. Die Art der Secretion erinnert daher an die der Körner- oder Giftdrüsen der Amphibien, doch besitzen letztere Muskeln. Das Secret (Hanttalg) ist fettreich, doch auch riechend und dient zum Einfetten der Haare sowie der Haut. Bei zärteren und kleineren Haaren (Wollhaaren) kann sich das Verhältnis zwischen Haarfollikel und Talgdrïsen gewissermaßen umkehren, so daß ersterer als ein Anhang der relativ großen Drüse erscheint. - Auch an haarlosen Stellen können sich Talgdrüsen finden (Lippen, Augenlidrand, After, Eichel des Penis); doch scheint es sicher, daß diese Drüsen erst durch Reduktion der Haarfollikel selbständig wurden.

So weit verbreitet auch die beiderlei Drüsen sind, so kommen doch auch starke Reduktionen vor. So beschränken sich die tubulösen Drüsen gewöhnlicher Art bei Bütsehli, Vergl. Anatomie. 
vielen Rodentien und Insectivoren anf die Fußsohlen; ja sie fehlen sogar bei gewissen Säugern völlig (Edentata und Insectivora z. T., Sirenia und Cetacea). Doch ist hier vieles noch wenig sicher. - Eigentāmlich erscheint das Fehlen der Talgdrïsen bei gewissen Faultieren (Choloepus) und Insectivoren (Chrysochloris) trotz starker Behaarung. Daß bei den haarlosen Cetaceen und Sirenen auch die Talgdrüsen und damit die Hantdrüsen äberhaupt fehlen, ist natürlich und hängt zum Teil mit dem Wasserleben zusammen.

Die Größenentwicklung, sowie die Verteilung der beiderlei Drüsen über die Kärperoberfläche ist keine gleichmäßige, sondern den besonderen lokalen Bedingungen angepaßt. Ans diesem Gesichtspunkt wird anch begreiflich, daß es bei

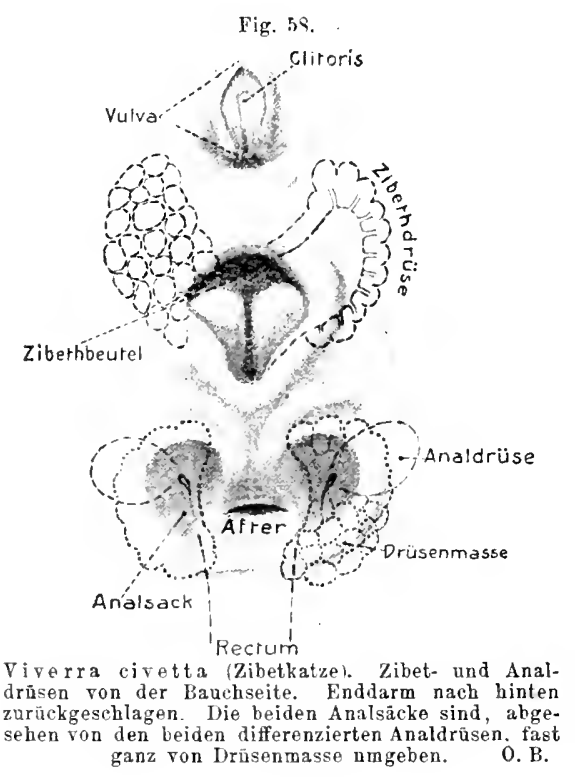
vielen Säugern an gewissen Körperstellen zu reichlicherer und stärkerer Entwicklung von Hautdrüsen komimt. So vermögen sich größere Drüsenkomplexe zu bilden, welche jedoch ihre zusammengesetzte Natur meist dentlich verraten, da sie in der Regel aus einer taschenartigen Einsenkung der änßeren Haut bestehen, in welche große Mengen von Einzeldrüsen münden, die meist auch stärker sind als die gewöhnlichen. Häufig sind es beiderlei Drüsen, welche solch eine komplexe Hantdrüse aufbauen, zuweilen jedoch auch nur eine Art. Interessant erscheint, daß diese Drüsensäcke gelegentlich vorstuilpbar sein können, was an analoge Verhältnisse bei deu Arthropoden erinnert. - Man kann sagen, daß sich derartige Driisensäcke an allen Stellen der Hautoberfläche bilden können, wenn auch gewisse Orte bevorzugt sind. Ihre Mannigfaltigkeit, sowohl in bezug auf ortliche als morphologische und physiologische Eutfaltung, ist so reich, daß hier nur kurze Hinweise gegeben werden können. Das Secret, welches sich in der Drüsentasche anhäuft, ist zum Teil ein spezifischer Riechstoff, der zur Abwehr, zur Erkennung, oder zur Geschlechtsreizung dienen kann, und sich im letzteren Fall häufig auf die Männchen beschränkt. In anderen Fällen ist das Secret schmierig-fettig (zuweilen auch pigmenthaltig) und dient dann zur Minderung der Reibung an Gelenken oder sonstigen Orten. In nicht wenigen Fällen ist seine B:dentung noch unklar. - Einige Beispiele dienen zur Erliuterung.

Die riechenden Komplexdrüsen finden sich meist in der Gegend des Afters und der äußeren Geschlechtsorgane; einerseits als Drüsenanhäufungen um den After selbst, andrerseits als Komplexdrüsen (Analsäcke), die sich in verschiedener Zahl, ein bis mehrere Paare, doch anch in ungerader Zahl, in den After öffnen (viele 
Carnivora, s. Fig. 58, doch auch andere Ordnungen). Außer diєsen Analsäcken finden sich bei Carnivoren häufig noch ein Paar Drüsensäcke zwischen After und Geschlechtsöffnung (Viverridae, Zibetdrüsen bei beiden Geschlechtern, Fig. 58). - Auf der Bauchhaut, vor dem Penis, liegt bei den Moschustiermännchen der Moschusbeutel, während sich bei vielen Männchen der Rodentia in die Präputialtasche ein Paar ansehnliche Drüsensäcke öfrnen (Bibergeil des Bibers); beim Weibchen entsprechende in die Clitoristasche. - Drüsengebilde ähnlicher Art können an der Schwanzwurzel, den Rumpfseiten, an Brust und Rticken, sowie im Gesicht auftreten. Unter denen des letzteren Orts verdiezen die sog. Tränengruben zahlreicher Wiederkäuer besonderer Erwähnung; ihr Secret ist schmierig, zuweilen auch stark riechend. - Die analogen Drüsengebilde der Extremitäten dienen gewöhnlich zur Einfettung und Verminderung der Reibung und finden sich ziemlich zahlreich und verschiedenartig bei den Ungulaten. Am bekanntesten sind die sog. Klauendrüsen vieler Wiederkäuer, welche zwischen den beiden Hufen liegen und deren Reibung vermindern. - Eigentiimlich ist die sog. Cruraldrüse der männlichen Monotremen, welche auf einem verhorntem Sporn an der Innenseite der Fußwurzel mündet. Die Drïse selhst liegt teils in der Beckenregion (Ornithorhynchus), teils in der Kniegegend (Echidna); wahrscheinlich steht sie mit dem Geschlechtsakt im Zusammenhang.

Mammardrïsen. Die weiblichen Säugetiere besitzen zur ersten Ernährung der Jungen allgemein komplexe Hautdrüsen, welche jenen, die wir soeben besprachen, prinzipiell gleich stehen. Es sind dies die sog. Mammar- oder Milchdrüsen. Den Männchen kommen sie in rudimentärem Zustand ebenfalls zu, gelangen jedoch utur in abnormen Fällen einmal zur Secretion. Vermutlich dürfte es auch nie männliche Säuger gegeben haben, deren Drüsen funktionierten; es handelt sich vielmehr wahrscheinlich $1 \mathrm{~m}$ eine Übertragung ursprïnglich rein eingeschlechtlicher Organe auf das andere Geschlecht, wofür auch in anderen Organsystemen Beispiele auffindbar sind. Um die wahrscheinliche phylogenetische Entwicklung der Mammardrüsen zu verstehen, mïssen wir auf die Fortpflanzungsverhältnisse der primitivsten Säuger etwas näher eingehen. Wie die Monotremen verraten, hat sich die rein vivipare Entwicklung erst innerhalb des Säugerstamms entwickelt, da diese Formen ihre mit lederartiger Schale versehenen, relativ großen Eicr auf einer frühzeitigen Entwicklungsstufe nach außen ablegen und sie entweder in einem Nest bebrïten (Ornithorhynchus), oder (Echidna) das einzige Ei in einem auf der hinteren Bauchhälfte, von einer schwach vorspringenden bogigen Hautfalte gebildeten Beutel (s. Fig. 59 A) herumtragen, was auch mit dem Jungen noch eine gewisse Zeit geschieht. Dieser Beutel der weiblichen Echidna tritt jedoch nur temporär während der Fortpflanzungszeit auf, um später wieder zu verstreichen. Wenn wir annehmen, daß die Entwickinng eines solchen Bentels den Weibchen der Ursäuger allgenein zukam, wofür ja seine weite Verbreitung bei den Marsupialiern spricht, so können wir es als eine sehr erhaltungsgemäße Fortbildung bezeichnen, wenn die Hautdrïsen in diesem Beutel durch reichere Entwicklung in Zahl und Stärke eine erheblichere Secretmenge lieferten, welche von den Bentel- 
jungen als Nahrung verzehrt wurde. Ob die reichere Entfaltung soleher Drüsen eventuell auch durch die Ausbildung eines besonderen, weniger behaarten und reich muskularisierten Brutfelds an äer Bauchwand des Bentels begünstigt war, analog dem Brutfleck vieler Vögel, ist möglich, wenn auch nicht gerade sehr wahrscheinlich, da Vögel und Säuger nicht in direktem phylogenetischen Zusammenhang stehen. Jedenfalls repräsentieren die Einrichtungen der Monotremen, insbesondere die von Echidna, einen Zustand, wie wir ihn eben angenommen haben. An der Bauchwand des Beutels, oder bei dem Schnabeltier trei auf der Bauchfläche, findet

Fig. 59 .

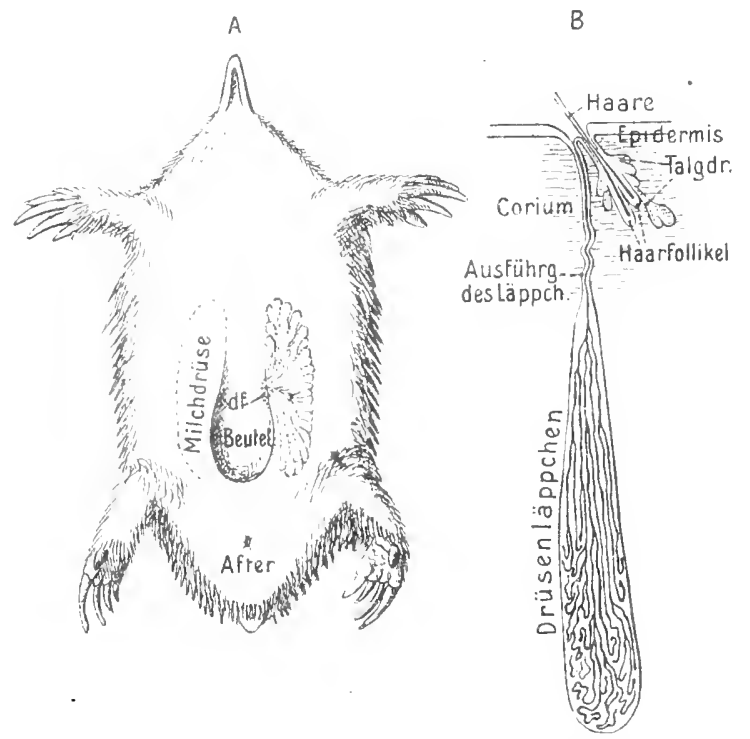

Echidna hystrix. A Ventralansicht des Weibchens in der Fortpflanzungszeit mit Bentel und Milchdrūsen, im Umriß angedentet inach HAaсke $1 \$ \$ 9$, die Drủse nach eigenem Prāparat). df Drūsenfeld. $B$ ein Orüsenläppchan schemat. nach GeGenBACK 1886. Der Ansfūhrgang des Lăppchens mündet in das Endstūck eines zusammengesetzten Haarfollikels, aus dem $\mathrm{z}$ wei Haare hervorragen.

sich jederseits ein schwächer behaartes Hautfeld (Drüsenfeld $d f$ ), auf welchem sich die tubuḷöseu, verzweigten Drüsen stark entwickeln und ein ansehnliches, etwa ovales, plattes Drüsenpaket bilden (s. Fig. $59 A$ u. $B$ ). Doch fehlen im Bereich des Drüsenfelds auch Talgđdrïsen an den Haarbälgen nicht, ja sind hier sogar ansehnlicher ausgebildet. Das Secret dieser Mammardrüsen wird nun bei Echidna von dem Jungen aufgezehrt.

Die Milchdrüsen der übrigen Säuger besitzen insofern einen ganz entsprecheuden Ban, als sie fast stets Komplexdruisen sind, die aus einer größeren Zahl Einzeldrüsen bestehen, welche sich im allgemeinen sehr reich verzweigen und in acinöse Läppchen endigen.

Die Zahl der Einzeldrüsen ist, soweit sich dies nach der der Ausführgänge in der Zitze benrteilen läßt, sehr verschieden, zuweilen auch recht nieder.

Es gibt sogar eine ganze Anzahl kleinerer Säugetiere (speziell Rodentia), welche nur einen einzigen Drüsenausführgang in der Zitze haben. Auch die Drüsen der Wiederkäuer gehören hierher, wenn, wie dies wahrscheinlich, der sog̣. Strichkanal der Zitze ein Drüsenausführgang ist. $O b$ jedoch in diesen Fällen tatsäehlich nur eine einzige sehr reich entfaltete Drüse die gesamte Milchdrüse bildet, oder ob es zu einer eigentümlichen Vereinigung mehrerer ursprünglich getrennter Drüsen gekommen ist, scheint fraglich.

Auf den acinösen Bau gründet sich die herrschende Ansicht, daß die Milchdrüsen der ditremen Säuger aus stärker entwickelten Talgdrüsen hervorge- 
gangen seien. Da jedoch auch in den Mammardrïsen die Secretion im wesentlichen ohne Zugrnodegehen der Zellen erfolgt, und außerdem eine ziemliche Variation der tubulösen Drüsen, sowohl in der Form als im Secret, bei den Sängern vorkommt, so scheint es nicht unmöglich, $₫ a ß$ die phylogenetische Beziehung zwischen den Driisen der Monotremen und denen der übrigen Mammalier vielleicht doch eine engere ist; auch ist beachtenswert, daß, wie bemerkt, den Drisenfeld der Monotremen auch Talgdrüsen nicht fehlen. Das Drisenepithel ist in der Regel zweischichtig; die äußere Schicht scheint aus glatten Muskelfasern zu bestehen (Monotremata und Marsupialia) oder doch kontraktionsfühig zu sein.

Eine erhebliche Weiterbildung zeigen die Mammardrüsen der Ztremen Säuger dariu, daß sie sehr gewöhnlich in vermehrter Zahl auftreten (bis im Maximum elf Paare, Centetes unter den Insectivoren), was im allgemeinen parallel geht mit der Zahl der Jungen eines Wurfs. Bei dieser Vermehrung, die fast stets in Paareu geschieht (nur die Marsupialia können auch unpaarige Drïsen besitzen), erstrecken sich die Milchdrïsen entweder über einen größeren 'Teil der Bauchseite, ja über die ganze, ođer beschränken sich auch auf deren hinteren Teil (Inguinalgegend, viele Ungulata). Bei auftretender Reduktion kann sich ein Paar Brustdriisen erhalten (Simiae, gewisse Prosimia, Elephas, Chiroptera, Sirenia, gewisse Edentata) oder auch zwei inguinale (Cetacea usw.).

Wie eben bemerkt, erhält sich bei den weiblichen Marsupialiern der Beutel fast allgemein auf der hinteren Bauchseite und entsteht ursprïnglich aus zwei längsgerichteten Hantfalten, die später entweder vorn oder hinten verwachsen, so daß der Bentel teils hinten, teils vorn, teils mitten geöffnet sein kann. Die Milchdrüsen beschränken sich fast stets auf die Bauchwand des Beutels und sind mehr oder weniger kreisförmig angeordnet.

Reste des Beutels hat man bei den Placentaliern vielfach naclizuweisen gesuclit, teils als Reste der Beutelfalten, die namentlich in den sog. Milchleisten rermutet wurden, Epithelrerdickungen an jeder Bauchhälfte, welche auf einem gewissen Enıbryonalstadinm die Anlagen der jederseitigen Mammarituisen als ein zusammenhängender schmaler Streif verbinden; tails in be-onderer Beharung des die zitzen tragenden Feldes, teils in einer Wiederkehr des Muskelpares (Sphincter marsupii), das bei Echidna una den Marsupialia den Beutel jederseito umgrenzt. - Die embryologischen Erfahrungen an Beuteltielen lassen es sogar nicht ganz sicher ersheinen ob deren Beutel völlig dem der Echidna entspricht. Es wird nämlich bei den Marupialiern vorüberthehend, eine ringförnige Einsenkung der Epidermis, d. h. eine ursprünglirlıe Hautfalte um jedes Drüsenfeld (Anlage jeder Mammardrüse), gebildet. Die beiden urspritnglichen längsgerichteten Bentelfalten gehen hierauf aus diesen Ringfalten um die einzelnen Drüsenfelder auf die Weise hervor, daß die seitlichen Partien der aufeinander folgenden Ringfalten jeder Bauchseite sich zu einer Längsfalte vereinigen, während die übrigen Reste der Ringfalten (der sog. Marsupialtaschen) verschwinden. Wollte man liesen Bildung:vorgang des Marsupialier-Beutels mit dem der Echidna vereinigen, so müßte man wohl annehmen, daß auch letzterer ursprünglich parig gewesen sei, woron jedoch die Ontogenie nichts Sicheres zeigt. Dennoch scheint mir vorerst keine Nötigung vorzuliegen, die Homologie des Beutels bei beiden Gruppen zu bezweifeln, um so mehr als die Verhälnisse der Monotremen wohl andeuten, daß der Beutel in dieser Abteilung nie besonders entwickelt war, oder wieder rudimentär gewurden ist.

Bei den Marsupialiern erfaluen die Drïsenfelder eine bedeutsame Weiter- 
entwicklnng, indem sie sich zu schlanchartigen Vertiefungen einsenken, in derem Grunde die Milchdrusen auf einem sich erhebenden Fortsatz münden (Fig. 60 $a{ }^{1}$ ). Solche Bildungen fehlen den Monotremen; oder das, was dariiber berichtet wurde, ist doch ganz unsicher. Diese Zitxentaschen (frther gewöhnlich Mammartaschen) der Marsupialier entsprechen wohl den Drüsentaschen, wie sie den Komplexdrüsen der Säuger so häufig zukommen. Erst bei der Milchabsonderung der Drüsen, zur Fortpflanzungszeit, sttilpen sich die Zitzentaschen der Beuteltiere teilweis oder voll-

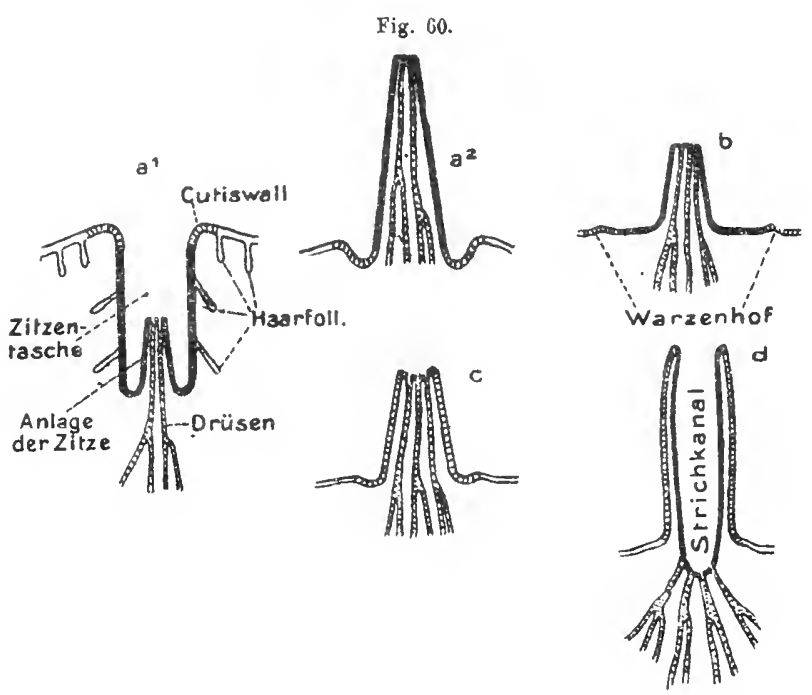

Schemata der Zitzenbildung einiger ditremer Sîuger, nach der Auffassung von GECENBAIR und KLAATSCH, al Zitzentasche mit Anlage der Zitze eines Marsupialiers vor der Lactation. $a^{2}$ die Zitze und Zitzentakche ansgestalpt bei Eintritt der Laktation. Auf den ubrigen Schemata ist der von der Epidermis der Zitzentasche abgeleitete Teil der Zitzenepidermis schwarz, der von dem sog. Cutiswall abgeleitete, gestrichelt dargestellt. Die Milchdrüsen punktiert. $b$ Schema der Zitze von Primaten (spez. Mensch). $c$ ron Carnivor. $d$ von Wiederkäuer. ständig als frei hervorragende Zitzen nach außen um (Figur $\left.60 a^{2}\right)$ - eine Erscheinung, die sich ja auch bei anderen Komplexdrüsen der Säuger zuweilen findet. Die umgestülpten Zitzen ermöglichen denJungen das Saugen. -- Bei den Placentaliern ist die Bildung einer Zitze für jede Mammardrüse allgemein verbreitet. Trotz vielfacher Untersuchungen bestehen jedoch noch erhebliche Zweifel über die Beziehung ihrer Zitzen

zil denen der Marsupialier. Sicher scheint, daß bei der Entwicklung aller dieser Zitzen eine Zitzentasche angelegt wird. Sicher scheint weiterhin, daß bei den Primaten und dem Menschen die definitive Zitze mit den Drüsenmü̈ndungen vom Boden der sich allmählich abflachenden und ausbreitenden Zitzentasche emporwächst, so daß der ausgebreitete Teil der urspriinglichen Tasche zu dem späteren sog. Warzenhof (Areola) wird und die Driisenmindungen auf dem Ende der Zitze stehen (Fig. b). Diese Zitzenbildung ließe sich daher auf eine Art Hervorstiilpung der Zitzentasche zurïckfiihren, wie wir ihr bei den Beuteltieren begegneten.

Bei der Mehrzahl der übrigen Piacentalier hingegen scheint die Zitzenbildung im allgemeinen durch ein Hervorwachsen des die Zitzentasehen tragenden Hantfelds zu geschehen (Fig. e). Die Tasche wird so an die Spitze der sich bildenden Zitze emporgehoben und verkümmert mehr oder weniger, bis völlig. Eine eigentliche Areola bildet sich bei diesem Vorgang natiirlich nicht. - Die Zitze der Ungulaten, welche häufig sehr groß wird, ist von einem weiten Gang (Strichkanal der 
Wiederkïuer, Fig. $d$ ), oder auch von zwei bis drei derartigen Gängen durchsetzt (Pferd, Esel). Wenn, wie wahrscheinlich, die letzterwahnte Bildungsgeschichte anch für diese Zitzen zutrifft, so sind diese Gänge als erweiterte Ausführgănge der eigentlichen Milchdriise aufzufassen, nicht aber als die stark entwickelten Zitzentaschen, wie eine andere Auffassung sie deutet (Gegenbaur, KraAtsch; der Fig. $d$ ist die letzterwähnte Ansicht zugrunde gelegt). Sicher scheint jedoch za scin, daß die Pferd- und Eselzitze zwei ursprünglich getrennten, miteinander vereinigten Zitzen und Drilsen entspricht.

Bei manchen Nagern erhebt sich die Zitze vor der Laktation vom Boden einer Tasche, aus der sie bei der Funktion herausgezogen wird. Die Verhälnisse erinnern daher auffallend an die der Marsupialier. Die Ontogenie scheint dagegen mehr daftr zu sprechen, daß die Tasche kein Homologon der Zitzentasche der Beuteltiere, sondern eine eigenartige Bildung ist.

\section{B. Mesodermaler Teil des Integuments, Corium (Cutis, Lederhaut).}

\section{Das bindegewebige Corium.}

Wo eine kräftigere Schutzleistung des Integuments nutzlich erscheint und nicht von einer besonders starken Cuticula bewirkt wird, vereinigt sich eine mehr oder weniger ansehnliche Lage des mesodermalen Bindegewebes inniger mit der Epidermis zu einem gemeinsamen Integument, dessen innere oder tiefe Zone, das sog. Corium (Cutis) oder die Lederhaut bildend. Naturlich findet sich ein solches Corium besonders bei größeren nnd komplizierter gebauten Metazoen, allgemein daher bei den Wirbeltieren; doch kommt es in analoger Weise auch zahlreichen Wirbellosen zu. Schon bei Nemertinen und gegliederten Würmern, besonders solchen, die ein Cölom besitzen, låßt sich hăufig ein bindegewebiger Teil des Integuments unterscheiden; noch mehr gilt dies fur die Mollusken. - Gut ausgebildet ist das Hautbindegewebe bei den Echinodermen, wo es die Bildungsstätte des Hautskeletes ist; ihr Corium wird sogar zuweilen recht dick (Holothurieu). - Stark entwickelt ist es, wie gesagt, bei allen typischen Wirbeltieren; nur bei den Acraniern bleibt es noch sehr gering. Gebildet wird das Corium der Vertebraten aus einer verschieden dicken Lage fibrillären Bindegewebes, dem häufig auch elastische Fasern und glatte Muskelfasern beigemengt sind, was natürlich nach den Besonderheiten der einzelnen Körperstellen variiert. Wie schon bei Wirbellosen, treten Blutgefäße und Nerven in das Corium ein, in dem ferner besondere accessorische Bildungen, von welchen später die Rede sein wird, entstehen können. - Gegen die es unterlagernde Gewebsmasse ist das Corium der Wirbeltiere geworhnlich mehr oder weniger abgesetzt, was meist dadurch hervorgerufen wird, daß eine lockere Bindegewebslage, die sog. Subcutanea, es mit den tieferen Geweben und Organen verbindet. Daher rührt es, daß das Corium, deutlicher wie bei den Wirbellosen, als ein mit der Epidermis innig zusammenhängender Teil des Integuments erscheint, und daß das Gesamtintegument sowohl etwas verschiebbar, als mehr oder weniger leicht abziehbar ist. 
Die Gesamtstärke des Vertebraten-Coriums wechselt natürlich beträchtlich; doch ist es schon bei gewissen Fisehen recht dick; bei großen Säugern (Rhinozeros, Elephas, Cetaceen) wird es sehr stark. Bei Amphibien, squamaten Reptilien und Vögeln bleibt es relativ mäßig. - Im allgemeinen ist die Lederhant ein Flechtwerk von Bindegewebsbündeln, die sich bei den Anamnia meist ziemlich regelmäßig in mehr oder weniger zahlreichen horizontalen Schichteu iibereinander ordnen (s. Fig. 54, 62, 72), wobei die Bündel der alternierenden Schichten sich rechtwinkelig kreuzen. Außer?ern treten jedoch noch senkrecht aufsteigende Bündel hinza, welche, ans einer cer Schichten aufbiegend, in eine höhere eintreten. Das Corium der Reptilien ist ähnlich; bei Vögeln und Säugern dagege` wird die Verflechtung der Bindegewebshündel inniger, weshalb der geschichte،. Bau zuriicktritt. Die oberste Lage der Lederhaut besteht hänfig aus einem lockereren Bindegewebe.

Corizmpapillen. Ein innigerer Zusammenhang von Epidermis und Corium wird bei vielen Vertebraten, wenigstens an gewissen Körperstellen, dadurch bewirkt, daß das Corium in Form papillöser oder leistenartiger Fortsätze in die Epidermis anfsteigt (Fig. 38, C). Solche Coriumpapillen sahen wir schon früher an der Bildung der verhornten Integumentalanhänge der Saưropsiden und Mammalier innigen Anteil nehmen. Die hier zu erwähnenden Papillenbildungen dagegen sind im allgemeinen solche, welche nicht zn Hautauswiichsen Veranlassung geben. Sie bestehen häufig aus etwas lockererem Bindegewebe und sind vielfach Träger von Blntgefäßen, welche so in innige Beziehung znr Ernährung der Epidermis treten, oder sich in gewissen Fällen sogar an der allgemeinen Respiration beteiligen können; andrerseits liegen in solchen Papillen häufig auch nervöse Endorgane der Hant. - Schon bei Cyclostomen, verbreiteter dagegen bei den Fischen, treten solch papillöse Bildungen auf. Bei gewissen Amphibien sind leisten- bis papillenartige Coriumfortsätze über die gesamte Haut verbreitet (einzelne Perennibranchiaten) und werden hier wesentlich durch in die Epidermis vorspringende Blutcapillaren mit wenig Bindegewebe gebildet; sie stehen jedenfalle mit der respiratorischen Hauttätigkeit im Zusammenhang. Die Anuren zeigen leistenartige und papillöse Bildungen vorwiegend an den Hand- und F'ußflächen, namentlich ist auch die sog. Daumenschwiele der Männchen mit Papillen versehen.

Wenn wir von den papillösen Bildungen absehen, die mit den Hautverhornungen der Sauropsiden zusammenhängen, so finden sich bei ihnen freie Papillen des Joriums selten. Bti Vögeln kennt man sie in der Schnabelregion, der Augengegend, sowie an der Fußsohle. - Eine besonders reiche Entwicklnng erlangen dagegen die Papillen bei den Süugern, jedoch nur an unbehaarten Körperstellen, besonders den Hand- und Fußfächen, sowie der Schnauze. In dem Maße, als die Behaarung bei gewissen Säugern zurücktritt (gewisse Ungulata, Elephas, Sirenia, Cetacea), breiten sich die freien Papillen uiber das ganze Integument ans und werden gleichzeitig sehr lang, da die Epidermis dieser Formen besonders dick ist. Sehr lang und kompliziert können sie jedoch auch an Hautstellen werden, wo eine starke Hornbildung stattfindet, so an den Hufen der Ungulaten, dem Horn 
Vertebrata. (Allgemeines. Papillen. Fett). Chromatophoreu (Cephalop.) 153

des Rhinozeros, den Barten der Wale. Auch sonst finden sich gelegentlich zusammengesetzte Papillen; ferner an den Hand-und Fußtächen Coriumleistchen in dichter und zum Teil verwickelter Anordnung, die ihrerseits Papillen tragen. Ob die Papillen der Sänger in nähere Beziehung zu denen gebracht werden können, welche bei den Sauropsiden den Horngebilden angehören, scheint eher zweifelhaft.

Fetteinlagerung im Corium kommt bei deu Säugern zuweilen vor. In der Regel ist jedoch das sog. Unterbauthindegewebe der Ort, wo sich bei guter Frnährung Fettzelleu reichlich anhäufen (Speck). Bei den Cetaceen erlangt diese Fettentwicklung (Trari) eine besondere Mächtigkeit (Wärmeschutz) und greift anch auf das eigentliche Corium über, so daß es von Fettzellen ganz erfüllt wird. - Lokale Fettanhäufungen in der Subcutanea können bei gewissen Säugern Hauterhebungen hervorrufen (Höcker der Kamele, Fettsteiß gewisser Schafe, Rückenflosse der Cetaceen usw.).

Pigmentiellon (Chromatophoren) finden sich sehon im Corium mancher Wirbellosen in schöner Entwicklung. Das bekannteste und beststudierte Beispiel bieten die Cephalopoden, obgleich Pigmentzellen auch bei andern Mollusken vielfach vorkommen. Anch bei Abteilungen, welche uur wenig ron einem eigentlichen Corium zeigen, so gewissen Krebsen, finden sich zuweilen sehr große, reich verästelte Chromatophoren dicht unter der Epidermis.

Die Pigmentzellen oder Chromatophoren der dibranchiaten Cephalopoden (Nautilus fehlen sie) werden meist so groß (bis etwa $1 \mathrm{~mm}$ ), daß sie mit bloßem Ange sichthar sind. Sie liegen in einer oberflächlichen Lage des dicken Coriums und enthalten meist körniges Pigment; häufig finden sich auch verschiedenfarbige Zellen. Bei mauchen Formen (Sepia, Octopus) wird die Chromatophorenlage von einer Schicht eigentümlich differenzierter, irisierender Zellen (Iridocyten) unterlagert, welche durch ihre Reflexions- und Interferenzwirkung wesentlich zu dem eigentümlichen Farbenspiel beitragen (Fig. 61). - Die Chromatophoren gehen aus Bindegewebszellen hervor, nicht aus Epidermiszellen, wie auch vermutet wurde. Im Ruhezustand sind sie etwa linsenförmige Gebilde, von deren äquatorialem Rand eine Anzahl contractiler kernhaltiger Fasern in das umgebende Bindegewebe ausstrahlen. Die Kontraktion dieser Fasern bewirkt eine starke sternartige Ausbreitung und Vergrößerung der Chromatophore unter gleichzeitiger Abplattung und Verdünnung. Da die contractilen Fasern mit dem feinen Hantnervennetz zusammenhängen, so steht das Farbenspiel unter dem Einfluß des Nervensystems, wie auch der physiologische Versuch zeigt. 'Die periphere Region der Chromatophore selbst soll zuweilen auch contractile Substanz enthalten, so daß ihre Zusammenziehnng nicht immer aur eine elastische Wirkung der Umgebung, sondern zum Teil eine aktive der Chromatophore selbst wäre. Die neneren Beobachtungen machen es wahrscheinlich, daß die radiären Faserzellen Erzeugnisse der ursprünglichen Chromatophorenzellen selbst sind, ans ihr durch Teilung hervorgehen. Die Gestaltsverändernngen der Chromatophoren mit ihrem verschiedenfarbigen Pigment und die irisierende Schicht rufen den lebhaften schønen Farbenwechsel 
der Cephalopoden hervor. Reizung scheint im allgemeinen eine Verdunkelung zu bewirken.

Chromatophoren sind auch im Corium der niederen Wirbeltiere sehr verbreitet und bestimmen wesentlich deren Hautfärbung. Viele führen dunkles,

Fig. 61.

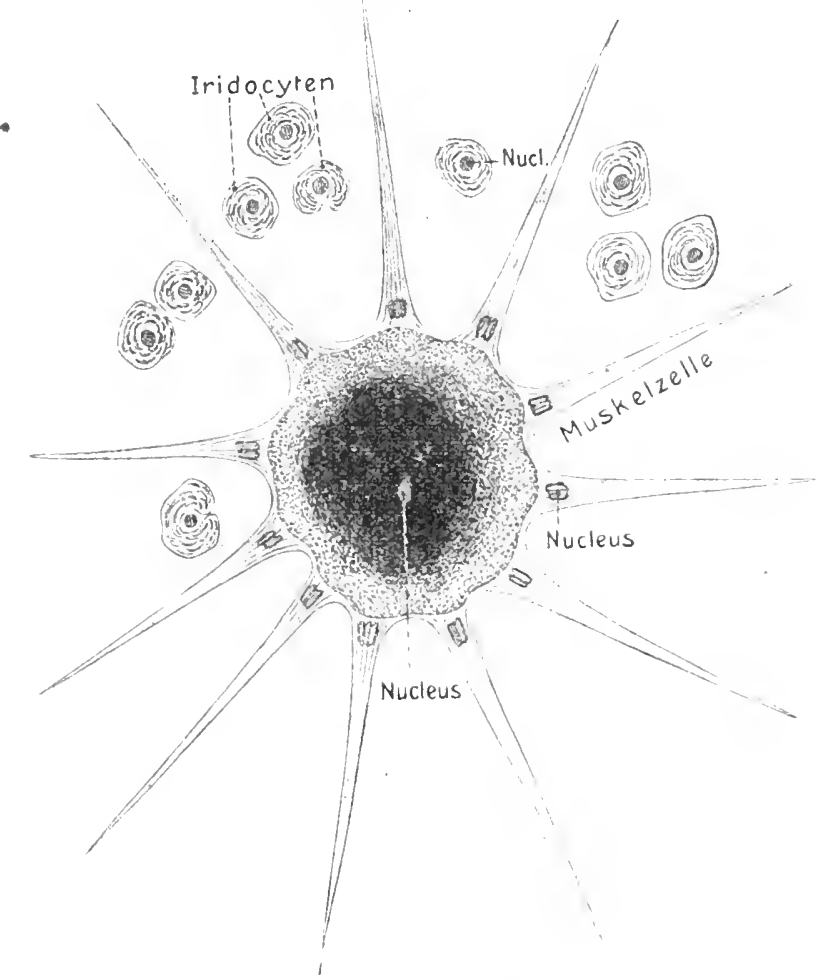

Sepiola. Chromatophore mit des hier stark verkürzt wiedergegebenen con. tractilen Radiărfasern. Die Kerne der Radiārfasern durch die contractilen Fibrillen eingeschnürt. Um die Chromatophore eine Anzahl irisierender Zeilen (Iridocyten) mit ihren eigentümlichen Einschlüssen. 0 . B. braunes bis schwärzliches Pigment und sind gewöhnlich sehr reich verästelt, so daß die einzeluen Zellen sich über einen weiten Bezirk erstrecken. Ans dem Corium wandern sie recht häufig auch in die Epidermis hinein, indem sie sich in den Intercellularräumen derselben ausbreiten. Diese Erfahrung hat die Vermutung hervorgerufen, daß auch das Pigment, welches die Zellen der tieferen Epidermislage bei vielen Wirbeltieren (speziell Mammalia) enthalten, von den Chromatophoren herstamme und von ihnen anfdieEpidermiszellen übertragen werde. Obgleich dies in vielen Fällen zutreffen mag, scheint doch nicht ausgeschlossen, daß die Epidermiszellen auch selbständig Pigment erzengen, wie es für Haare und Federn wohl sicher erscheint.

Selır große reichverästelte Chromatophoren finden sich bei vielen Knochenfischen und bewirke n bei gewissen auch einen Farbenwechsel, wie er namentlich den Pleuronectiden eigen ist. Der Farbenwechsel bernht auf der Verlagerung des Pigments im Plasma der reichverästelten Chromatophoren. Verteilt sich das Pigment durch die ganze Zelle, so breitet sie sich wie ein dunkler Schleier iiber die von ihr bedeckte Region aus; konzentriert es sich dagegen im Centrum der Zelle, so fällt diese Wirkung weg. Auf solche Weise können die erwähnten Fische ihre Färbung der des umgebenden Bodens mehr oder weniger anpassen, woraus schon hervorgeht, daß das Spiel ihrer Cbromatophoren unter dem Einfluß des Nerven- 
systems steht (vermittelt durch Augenreize), was durch den Nachweis der Verbindung der Pigmentzellen mit Nervenfäserchen bestätigt wird.

Sehr reich entwickelte Chromatophoren besitzen im allgemeinen anch die Amphibien (s. Fig. 54, S. 141) und Reptilien; auch verkntipft sich damit nicht selten in verschiedenem Grade ein Farbeuwechsel. Diese Erscheinung findet sich in mäßigerer Ausbildung bei vielen Anuren (Frösche, Laubfrosch, Kröten); unter den Reptilien vor allem bei den Chamäleonten. Doch zeigen auch gewisse Schlangen (besonders Baumschlangen) einen Farbenwechsel, der wohl in schwächerem Grad weitverbreitet ist. - Im allgemeinell scheint der Farbenwechsel bei beiden Klassen auf ähnlichen Einrichtungen $\mathrm{zu}$ beruhen, so $\mathrm{da}$ es genügen diurfte, diesehierimPrinzip zu erörtern. Die histologische Grundlage bildet das Vorkommen zweier Lagen verschieden gefärbter Chro-

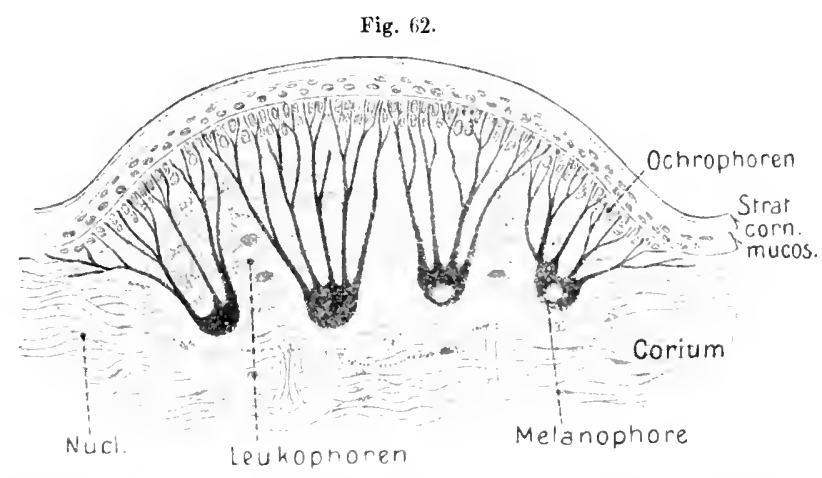

Chama eleo. Wuerschnitt durch eine Hautpapille (Kôrnerschnppe). In der tieferen Corinmregion Melanophorenzellen; darūber Leucophoren mit Guaninkalkeinschlössen und oberflächlich Ochrophoren, deren Zellnatur noch etwas unsicher. Daneben auch noch gelbe sog. Xanthophoren, die nicht dargestellt. (Nach KeLLER matophoren im Corium; einer oberflächlichen, deren Zellen weißes bis gelbes Pigment (auch Fett), doch auch zum Teil kristallinisch-körnige nnd Interferenz hervorrufende Einschlïsse enthalten, und einer tieferen Lage schwarzer Chromatophoren (s. Fig. 62). Die oberflächlichen Zellen, welche selbst wieder nach der Art ihres Pigments verschiedene Sorten unterscheiden lassen können (Chamaeleo), sind rundlich bis netzig und weniger veränderlich. Die schwarzen Chromatophoren (Melanophoren) dagegen sind reich verästelt, senden zahlreiche feine Ausläufer gegen die Epidermis hinauf, die zwischen den hellen Chromatophoren durchtreten und sie mehr oder weniger umspinnen. Ihr Pigment kann verlagert werden, sich entweder auf die Centren der Zellen in der Tiefe konzentrieren, oder in die Ausläufer emporsteigen nnd die helle Chromatophorenschicht überdecken. Im ersteren Fall wird die Hautfarbe hell, bzw. weißlich oder gelblich; im zweiten Fall wird sie in verschiedenem Grade dunkel.

Die blauen und grünen Farbentöne (speziell der Frösche) sollen in diesen Fällen, wie es jedoch auch sonst häufig scheint, keine Pigment-, sondern Interferenzfarben sein, welche von dem an der hellen Chromatophorenschicht reflektierten Licht erzengt werden; wogegen bei Chamaeleo lufthaltige Interferenzzellen in der Tiefe der Epidermis vorkommen. Das Grin ist zum Teil eine Mischfarbe des Gelb der oberen Chromatophorenschicht und der blanen Interferenzfarbe. Temperatur, Licht, nervöse Affekte verändern die Farbe, die auch hier un ${ }^{+}$er dem 
Einfluß des Nervensystems steht. Bei Chamaeleo bewirkt starke Reizung helle Färbung.

2. Schutz- und Skeletgebilde des bindegewebigen Integuments, sowie mesodermale Skeletgebilde der Wirbellosen überhaupt.

Wie die Epidermis kann anch das Corium bei Wirbellosen und Wirbeltieren Schutz- und Skeletgebilde hervorbringen. Zuweilen schließen sich dieselben den Schutzorganen der Epidermis näher an. Da das Corium derselben Gewebsforn angehört, aus welcher auch die inneren Skeletgebilde der Metazoen hervorgehen, so ist verständlich, daß seine Skeletgebilde mit denen des inneren Skelets nahe übereinstimmen, ja beiderlei Gebilde sich morphologisch schwer auseinander halten lassen, um so mehr, als sie sich zuweilen innig niteinander verbinden.

\section{Skeletbildungender Wirbellosen.}

Unter Skeletgebilden im engeren Sinn versteht man feste, im Innern des Körpers, d. h. in der Regel zum mindesten unter der Epidermis, gelegene Teile (oder Organe), welche den Körper oder seine Organe stützen, und häufig anch der Muskulatur Ansatz gewähren. Sie sind đaher auch für die Bewegungen von großer Wichtigkeit.

In der Einleitung fanden wir, daß das Zwischengewebe (Mesenchym), welches schon bei den Cölenteraten zwischen Ecto- und Entoderm spärlich oder reichlicher auftritt, in der Hauptsache eine Stützfunktion hat und daher in seiner Gesamtheit als eine Art Skeletgewebe wirkt. Auch die äußere Gewebslage der Spongien, der sog. Epiblast oder Skeletoblast, funktioniert in seiner Hauptmasse als Stütggewebe. Bei den höheren Metazoen tritt das Mesoderm an die Stelle des Nesenchyms; demgemäß geht hier das Skeletgewebe und das Skelet aus dem ursprünglichen Mesoderm hervor.

Die Stützleistung des bindegewebigen Mesenchyms der Cölenteraten und des ähnlich gebauten Epiblastgewebes der Spongien wird recht häufig dadurch erhöht, da $\beta$ sich feste Einlagerungen in ihnen bilden, sie mehr oder weniger reichlich durchsetzen und ihre Festigkeit erhöhen. Durch Verwachsung solcher Gebilde nntereinander, jedoch auch noch in anderer Weise, können sich zusammenhängende Skelete bilden, welche das Innere des ganzen Organisuis durchziehen. Bei den Spongien finden sich Skeletgebilde fast stets; bei den Cölenteraten sind sie auf die Klasse der Korallentiere (Anthozoa) beschränht. Im einzelnen besteht eine ziemlich weitgehende Analogie der Skeletgebilde beider Abteilungen.

Dies zeigt sich einmal darin, daß die Skeletsubstanz in beiden Groppen: teils eine rein organische, stickstoffhaltige sein kann (ein Albuminoid), teils dagegen kohlensaurer Kalk (Calcispongia, Anthozoa), wogegen nur bei der großen Gruppe der Silicispongia (Kieselschwämme) amorphe Kieselsäure das Skeletmaterial bildet.

Bei Kalk- und Kieselschwämmen, ähnlich aber auch bei den Octocorallen, 
bilden sich im Skeletgewebe eine Menge kleinerer bis ansehnlicherer Skeletgebilde, die bei den Spongien wegen ihrer Form als Spicula bczeichnet werden; bei den Octocorallen nennt nan sie Sklerodermite. Ihre erste Anlage entsteht bei beiden Abteilungen ursprünglich im Innern einer Zelle des Skeletgewebes, seltener (z. B. die Sechsstrabler der Hexactinelliden) in einer syncytial vereinigten Zellgruppe. Bei ihrem Heranwachsen liegt ihnen der Rest der Bildungszelle oder -zellen äußerlich an (Fig. $63^{6}$ ), oder es köunen sich anch weitere Zellen an ihrem Auswachsen beteiligen (Fig. $63^{1,3}$ ). Bei den Kalkschwämmen sind die aus Calcit bestèhenden Spicula einfach nadelförmig, oder drei- und vierstrahlig. Die mehrstrahligen

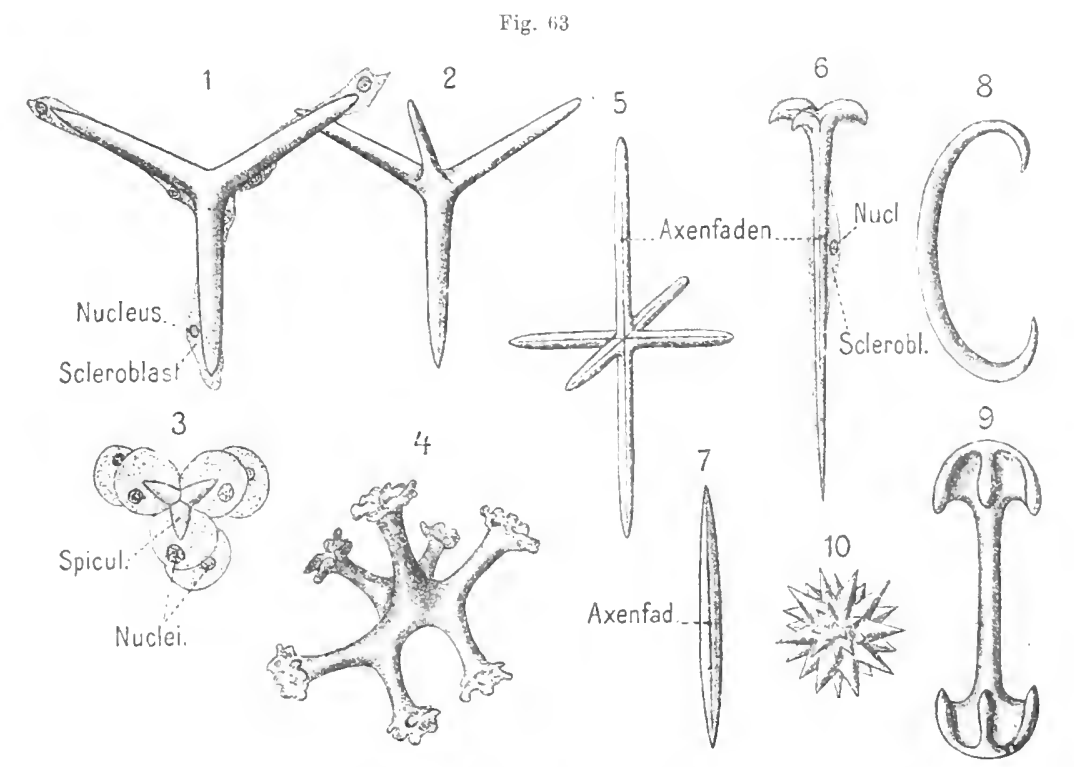

Spicula verschiedener Spongien. 1-3 Kalkspicula von Calcispongien. 1 Droistrabler mit Resten der Bildungszellen. 2 Vierstrahler. 3 Gruppe der 6 Bildungszellen, die einen Dreistrahler abscheiden. $4-10$ Silicispongien. 4 Vierstrahler eines Lithistiden (Jerea). 5 Sechsstrahler eines Hexactinelliden. 6 Vierstrahler (sog. Ankernadel) von Steletta mit Rest der Bildungszelle. 7 Einfache Stabnadel (Rhabdus). 8 spangenartige Nadel. 9 grabscheitartige Nadel (Chela). 10 Kieselstern (Oxyaster) von Tethya (Tetractinellide). E. W.

\&cheinen aus einfachen Anlagen durch Verwachsung hervorzugehen (Fig. $63^{3}$ ). Untereinander sind die Kalkspicula fast nie verbunden, sondern liegen lose im Skeletgewebe (Ausnahme bei Lithoninae), jedoch meist in gewissen regelmäßigen Anordnungsverhältnissen. - Von den Spicula der Kieselschwämme unterscheiden sie sich wesentlich durch das Fehlen oder die schwache Entwicklung eines Achsenfadens im Spiculum.

Die Nadeln der Kieselschwämme enthalten stets einen solchen, aus organischer Substain bestehenden Achsenfaden (Fig. $63^{5-7}$ ). Ihre Formen sind ungemeir mannig ialtig; doch lassen sie sich im großen nnd ganzen auf die Typen der Sechs-

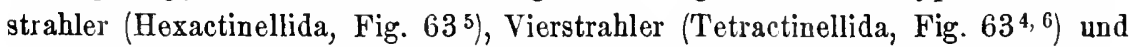
Einstrahler (Monactinellida, Fig. $63^{7-9}$ ) zurückführen. Wie bemerkt, ist die 
Ausgestaltung im einzelnen so reich, daß hier kein Raum für eine genauere Schilderung bleibt. Bemerkt sei jedoch, daß bei den Hexactinelliden und Tetractinelliden neben den typischen Mehrstrahlern anch weniger- bis einstrahlige Nadeln vorkommen, was die Mannigfaltigkeit noch vermehrt. - Während bei gewissen Hex- und den Tetractinelliden die Spicula völlig unverbunden sind, tritt bei anderen Hexactinelliden eine Vereinigung der ansebnlichen Sechsstrahler durch Kieselsäure zu zusammenhängenden und häufig ebenso regelmäßig als zierlich gebauten Skeleten auf. Auch die Spicula der Monactinelliden sind häufig größtenteils zu fädig - netzig zusammenhängenden Skeletgerïsten vereinigt; hier ist es aber eine organische Substanz (Spongin), welche die Vereinigung bewirkt.

Fig. 64.

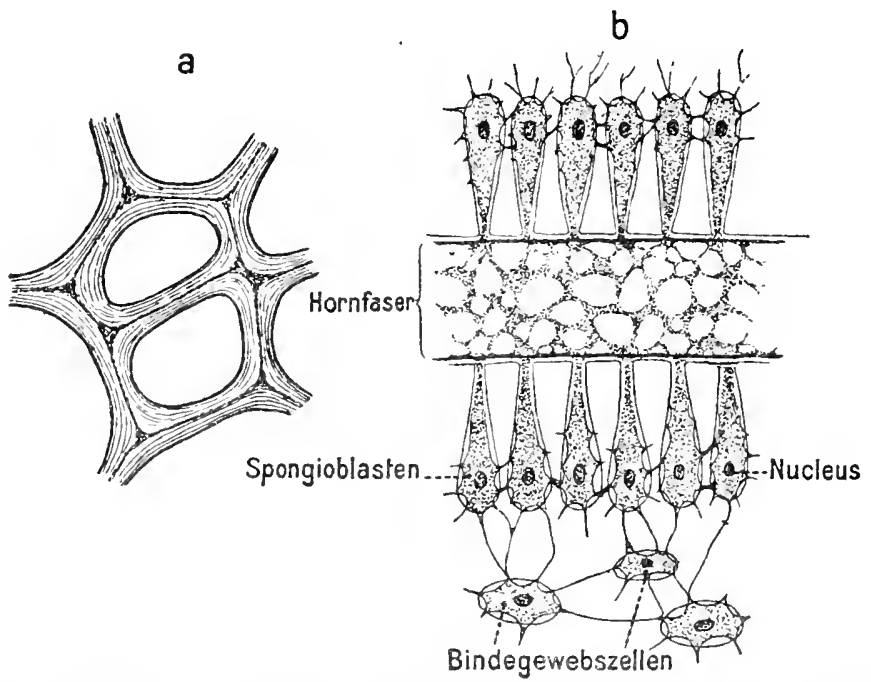

Skelet eines Hornschwamms (Ceraospongie), a kleines Sttuck eines Hornfaserskelets. $b$ kleine Partie eines Hornschwamms (Euspongia) mit 2 Reihen der sie umgebenden Bildungszellen (Spongioblasten), deren Plasma auf der Oberfache der Faser ein Netzwerk bildet. (Nach Bukck 1909.)

Es scheint sicher, daß durch Verkümmerung der Kieselspicula und stärkere Entwicklung der'Sponginabscheidung ursprünglicher Kieselschwämme die rein organischen, netzförmigen Faserskelete der Hornschwämme (Ceraospongia) hervorgingen (Fig. $64 \mathrm{a}$ ). Interessanterweise nehmen jedoch zablreiche Hornschwäinme, wahrscheinlich vermittels amöboider Zellen ihrer Oberfläche, wieder fremde feste Partikel in ihre Fasern auf und ersetzen so gewissermaßen die Spicula, welche sie nicht mehr hervorzubringen vermögen. Nur vereinzelt können auch spiculaartige Gebilde aus Spongin auftreten. Die Hornfasern werden durch besondere Zellen des Skeletgewebes (Skeletoblasten) abgeschieden, wie Fig. $64 b$ zeigt.

Die Sclerodermiten (Calcit), welche bei allen Octocorallia verbreitet sind (Fig. 65), ähneln den Spicula der Kalkschwämme in vieler Hinsicht, sind jedoch fast stets durch mehr oder weniger reiche Fortsatzbildungen ihrer Oberfläche nnregelmäßiger. Sie sind teils einfach gerade oder gebogen, teils jedoch auch durch 
Verwachsung mehrstrahlig. Während die Spongiennadeln stets farblos sind, erscheinen die Sklerodermiten nicht selten lebhaft gefärbt und tragen zur Färbung der'Tiere bei. Fast stets liegen sie lose im ganzen Mesenchymgewebe des Einzeltiers sowohl, als in gemeinsimen der Kolonien Cönosarki. - - . Bei gewissen Getocorallen scheint es jedoch zul einer Verwachsung zahlieicher Kalkgehilde in der Kolonieachse zu kommen, worans eine feste, die Gesamtkolonie Aurchziekende Kalkachse resultiert (Edelkoralle, Coral-

Fig. 65

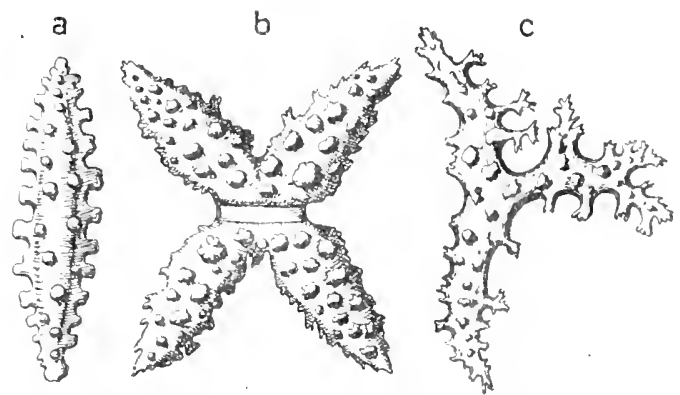

Sclerodermiten von Octerorallen a ron Gorgonia bon $P \perp e x a n$

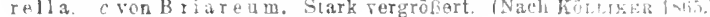
lium). Bei den Tubiporaria (Orgelkorallen) dagegen bildet sich auf diese Weise eine feste Skeletröhre in der Wand der Einzeltiere.

Eine in ihrer allgemeinen Erscheiunng und Funktion ganz ihnliche Skeletachse entwickelt sich unter den Octocorallen in der Grnppe der Goryonaric Hornkorallen), währeud bei den verwandten Pennatularia (Seefedern) eine unverzweigte ähnliche Achse den Stamm der federförmigen Kolonie durchzieht. I)iese Achsen bestehen gewöhulich nur aus organischer Substanz Colnein), oder bei gewissen Gorgonarien ans alternierenden Gliedern von organischer Snbstanz und Calcit. Aueh eine Gruppe der Hexacorallia, dio eigentiimlichen Antipatharia, besitzen eine Hornachse, ähnlich der der Gorgonaria. Dats Eigentümliche dieser Skeletachsen ist num, daß wie urspriinglich nicht im Mesenchym der jungen Kolonie entstehen, sondern ihre erste Anlage an der Basalflache der Kolonie von dem Fig. 66.

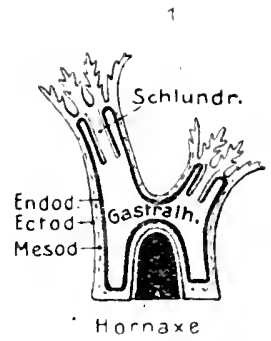

2

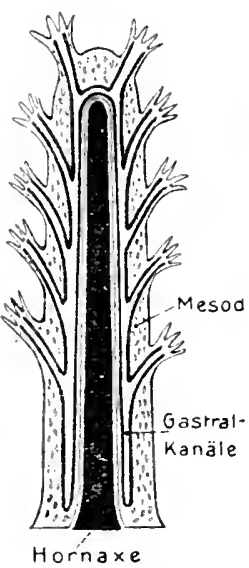

Schemata zar Bildnng der Hornachse bei den Hornkorallen Gorgonarial. I junge holonie aus zwei Individuen mit erster Ankage der llornachso. "Weiterentwiekelte Kolonie. O. B.

Eetoderm abgeschieden wird, als ein dic Basis bildendes Zäpfchen, das also mspringlich außerhalb der Kolonie liegt und in diese nur wenig emporragt (siehe Fig. $66^{\text {}}$ ). In dem Maße als die Kolonie durch Vermehrung ihrer Individnen emporwächst, wächst anch die Hornachse in ihr anfwärts $\left(66^{2}\right)$. Sie bleibt dabei stets 
von einer Fortsetzung des basalen Ectoderms amhülli, welches ihre Abscheidung bewirkt. Obgleich nun diese Hornachsen ursprünglich nicht im Skeletgewebe entstehen, glauben wir sie doch an dieser Stelle anfführen zu dürfen; um so mehr, als auch die skelethildenden Zellen des Nesenchyms aus eingewanderten Ectodermzellen hervorgehen solleı, und die fertige Achse tjef im Körper liegt, allseitig von Skeletgewebe umschlossen.

Interessanterweise entstehen auch dio starken, anscheinend rein inneren Kalkskelete đer Hexacorallen (sog. Madreporaria ode? Steinkorallen) in ähnlicher

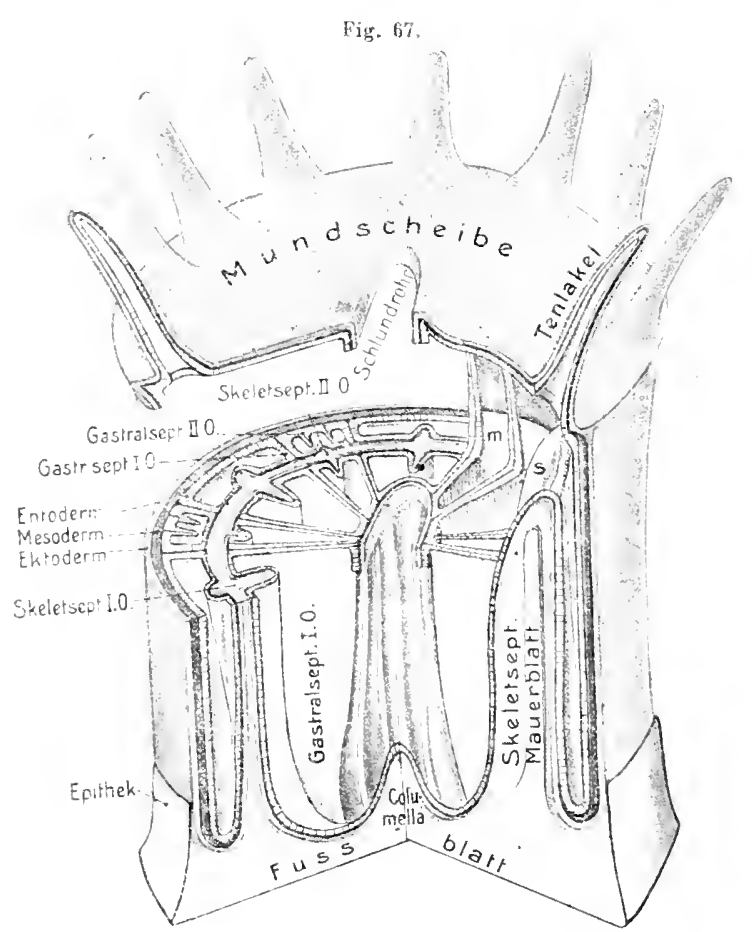

Schematisch I tarstellung des Skelets einer Steinkoralle (Madreporarie) nach v. Koch mit Benutznng einer Figur von Bovrne (1900) kopetruiert. Dorch zwei Querschnitte, yon denen einer dicht unter der Mundscheibe, der andere etwa in der Mitte der Hōho geführt ist, wurde ein ansehnlicher Teil des Körpers heransgeschnitter, ebenso etwa $1 / 4$ ảes Körpers durch zwei bis zur Längsachse gehende Radiarschnitte. Aut diese Weise ist links ein Qnerschnilt Jureh die Korperwand, das Manerblatt die Septen and das Schlnndrohr bloßselegt. Rechts sieht man ein Stūck des Manerblatts $(m)$ von innen. indem die Gastralsepteu $z$. T. weggesehnitten sind; ferner ein Kalkseptum $(s)$ in ganzer Höhe, ein anderes mit dem Ansatz des Mauerblatts steht dapor. Ectoderm blau, Entoderm gestrichelt. Meso. derm schwart. Kalkskelet weiß.
Weise.Lose Skeletgebilde finden sich hier gewöhnlich nicht; das Skelet ist vielmehr eine zusammenhängende Masse, welche die Form und den Ban des Einzeltiers nachahmt. Fs besteht ans einer feinfaserigen Kalkmasse (Aragonit), der bei den Spongien bis jetzt nicht sicher erwiesen wurde. Die erste Anlage eines solchen Einzelskelets entsteht ebenfalls als eine äußere Kalkabscheidung des Ectoderms nnter der Fußscheibe des festsitzenden Tiers (s. Fig. 67). Auf diese Weisebildet sich das sog. Fußblatt des Skelets. Entsprechend dem radiären Bau der Gastralböhle des Korallentiers wachsen dann von der Fußscheibe aus in die Gastraltaschen, dievon den Gastralseptenpaaren gebildet werden, radiäre Erhebungen hinein, in welchen sich auch ein Teil des basalen Ectoderms erhebt un Kalkmasse abscheidet, die dann von dem FuBblatt als ein kalkiges Radiärseptum in die Gastraltasche emporsteigt. Die äußeren Räuder dieser Kalksepten können hierauf mit ihren sie úberziehenden Weichteilen verwachsen, wodurch eine Verwachsung der äußeren Ränder der Kalksepten zu einem kalkigen Mauerblatt hervorgerufen wird, das der Cylinderwand 
des Tiers parallel zieht. Die Zahl der Kalksepten erhöht sich, wie die der Gastralsepten, mit dem Alter und der Größe der 'Tiere. Weitere Komplikationen können sich noch hinzugesellen, namentlich auch eine Kalkabscheidung auf dem äußeren Epithel des Tiers (Epithek), welche besonders bei der Koloniebildung zur Vereinigung der Einzelskelete eine Rolle zu spielen vermag. Hier kann es sich jedoch uur um das Prinzip der Bildung handeln.

Lose Kalkkörperchen, ähnlich den Sclerodermiten der Octocorallia, treten auch im Hautbindegewebe anderer Abteilungen auf. Sehr reichlich finden sie sich bei den Brachiopoden (Mantel, Körperwand und Arme). Es sind meist reich rerzweigte (iebilde. - Spiculartige, auch mehrstrahlige Kalkgebilde, die denen der Kalkschwänme zum Teil recht ähnlich sind, finden sich in der Hant mudibranchiater Mollusken (Opisthobranchiata). Auch in der Haut der Prosobranchiaten und Pulmonaten können zuweilen Kalkeinlagerungen stellenweise oder verbreiteter auftreten.

Wie gleich erwähnt werden mag, wird auch der Mantel gewisser Ascidien durch Kalkgebilde gefestigt, namentlich bei koloniebildenden Synascidien ist dies bäufig. Außer körnigen feineren Einlagerungen findet man auch sternartige, vielstrahlige lialkkörperchen bis sphärolithartige Bildungen; zuweilen auch sebr seltsam gestaltete. $O b$ es sich überall um Calciumkarbonat handelt, ist jedoch nicht genügend festgestellt. - Auch bei den Salpen unter den Tunciaten kommen zuweilen feste Einlagerungen im Mantel vor, sogar in Form reich verästelter, feinkörniger, büschelartiger Gebilde; sie sollen aus Kieselsäure bestehen, die sonst unter den Skeletgebilden der typischen Metazoen völlig fehlt.

Eine besonders mächtige und charakteristische Entfaltung erreichen die Kalkskelete der Echinodermen. Die Abscheidung des Kalks beschränkt sich nicht nur auf das die Haut bildende Skeletgewebe, sondern erstreckt sich meist tiefer ins Körperinnere hinein. Ihrer ganzen Natur nach schließen sich die Kalkskelete der Echinodermen recht innig an die der Cölenteraten und Spongien an; die Skeletsubstanz besteht wie die jener Abteilungen fast nur aus Calciumcarbonat (Calcit) mit sehr wenig organischer Substanz. Auch morphologisch gleichen sie den Skeletgebilden jener zuweilen noch sehr, indem das Skelet der Holothurien (Seewalzen) in der Hauptsache aus losen kleinen Kalkkörperchen besteht, die eine äußere Lage des dicken Coriums dicht erfüllen. Obgleich die Holothurien sicher nicht zu den ältesten Echinodermen gehören, so zeigen sie doch in der Bildung ihres Skelets eine gewisse Ursprünglichkeit. Ihre Kalkkörperchen (s. Fig. 68) sind von recht verschiedener Gestalt, jedoch in der Regel scheibchenförmig abgeplattet uud gitterartig gebildet, mit runden oder sechsseitigen Maschen $(a-b, d)$, doch finden sich anch viele kompliziertere $(e, e)$. Die erste Anlage ist ein kleines, bald dreistrahlig werdendes Kalkgebilde, das im Innern einer Zelle oder einer syncytialen Zellgruppe des Bindegewebes entstehen soll, und lebhaft an die dreistrahligen Spicula der Kalkschwämmo erinnert. Es wächst dann weiter durch fortgesetzte Verzweigung der Strahlen, oder auch durch Zutritt aufsteigender vierter und sich an den Knotenpunkten weiter verzweigender Strahlen, so daß körperlich entwickelte Kalkgebilde entstehen $(68 c)$. Die so gebildeten Maschen dieser Kalkgebilde werden ïberall von dem Bindegewebe ausgefüllt, so daß sich dieses und das Skelet auf das innigste durchdringen. Die Formmannigfaltigkeit der auf solche Weise bei den Seewalzen gebildeten Kalkkörperchen ist erstaunlich groß, wovon Fig. 68 
einiges zeigt. Bei manchen entstehen durch Auswachsen solcher Kalkkörper größere schuppenartige Platten in der Haut, und bei allen Holothurien bilden sich um den Schlund eine Anzahl größerer Skeletstücke, welche zusammen den sog. Kalkring formieren, der der Mundhöhle zur Stütze dient und den Längsmuskeln Ansatz bietet.

Bei den übrigen Echinodermenklassen kommt es stets zur Eutwicklung größerer Kalkskeletstücke, welche, meist in der Haut liegend, ein geschlossenes Hautskelet

Fig. 69.

a
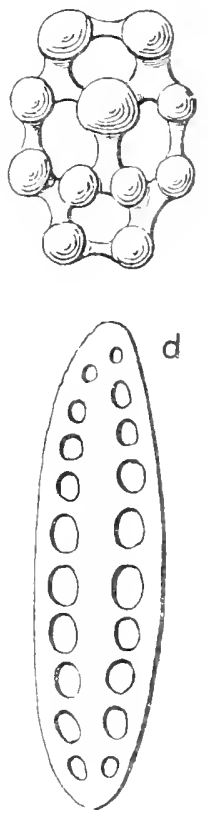

b

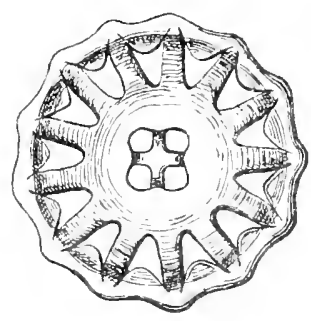

e

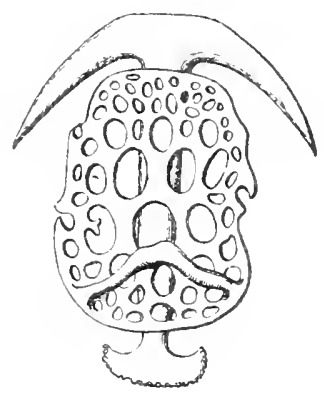

C
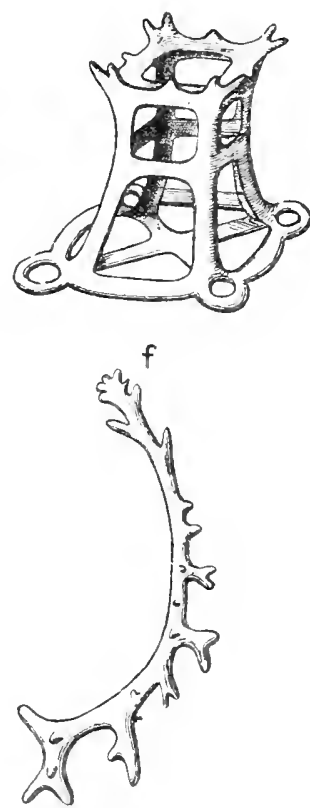

Kalkkörper yon Holothurien. a Cucumaria. b großes Kalkrädchen von Pananjehia moseleyi. $c$ sog. Stühlchen $v o n$ Stichopus regalis in perspektivischer Ansicht konstruiert. $d$ Leist $\theta$ ans Ambnlacralfüßchen von Stichopns. e Anker mit Platte ron Synapta besselii. $f$ Stäbchen ans dorsalen Ambulacralankângen ron Pannychis. ( $a$ und $e$ Original. die übrigen Figuren von verschiedenen Antoren ans Lunwig, Brove.) E. W.

bilden, die jedoch anch tiefer im Körperinnern auftreten können. Daneben erhalten sich aber an weicheren Hautstellen und im Bindegewebe des mneren Körpers kleinere Kalkkörperchen, welche an die der Holothurien erinnern.

Bei den Seeigeln (Echinoiden) entwickelt sich so ein typisches Hautskelet, das fast stets aus zwanzig meridionalen Plattenreihen besteht. Bei den Pelmatozoen (Crinoidea) und den Asteroiden kommen ähnlicheVerhältnisse an dem eigentlichen Centralkörper vor, während die freien Arme von tiefer ins Innere gerückten, in einer oder zwei Reihen sie durchziehenden Skeletstïcke gestützt werden (Armglieder, Wirbel), zu denen sich jedoch noch Hautskeletstücke in Platten- oder Schuppenform gesellen. - Fïr Seeigel nnd Seesterne ist die Stachelbekleidung der ganzeu oder eines Teils der Körperoberfläche charakteristısch. Auch diese Stacheln enthalten je 
einen starken Skeletstab, der ihre Hauptmasse bildet; wie die übrigen Skeletgebilde ist er jedoch ein innerer, im Bindegewebe eines Körperanswnchses gebildeter Teil, der also von einer, wenn auch zarten Hautlage ïberzogen wird. Dies macht es verständlich, daß sich Muskeln an die Basis der Stacheln, die den Skeletplatten lose oder gelenkig aufsitzt, begeben und sie bewegen.

Der feinere Bau aller dieser Skeletteile derEchinodermen ist der schon oben geschilderte feinmaschige, wobei alle Maschenliucken von Bindegewebe ansgefüllit werden (s. Fig. 69). Die ersten Anlagen sind auch hier in Abscheidungen innerhalb der Scleroblasten beobachtet worden. - Die größeren Skeletstücke können entweder unbeweglich miteinander verbunden sein, wie dies für das Hautskelet der meisten rezenten Seeigel und die Skeletstücke des Kelchs

Fig. 69.

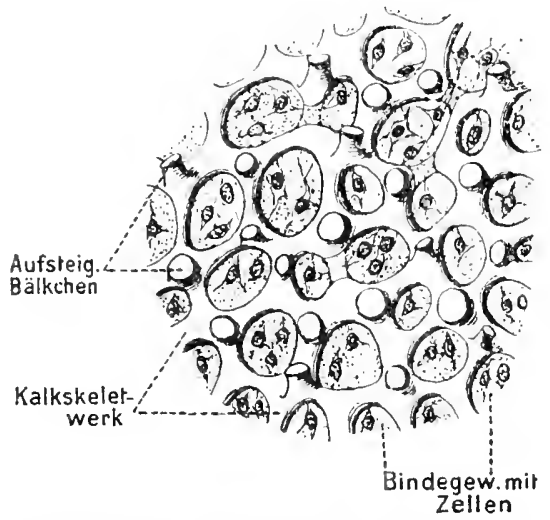

Schematischer Durchschnitt durch Skeletgewebe einer Ophiure samt dem die Haschen erfállenden Binde gewebe. E. W.

der Pelmatozoa häufig gilt, oder ähnlich wie die inneren Skeletteile der Wirbeltiere durch Muskeln beweglich miteinander verknüpft sein, wie es vor allem in den Armen der Asteroiden und Crinoiden der Fall ist.

\section{Knorpelskeleteder Wirbellosen.}

Während die seither besprochenen Skeletgebilde feste, durch Abscheidung erzengte Einlagerungen im Bindegewebe darstellen, entstehen die in diesem Kapitel zu betrachtenden durch besondere Entwicklung und Differenzierung der Bindesubstanz selbst, welche sich zu Knorpel umbildet, einer Moditikation der Bindesubstanz, die durch besondere Festigkeit der Grundsubstanz ansgezeichnet ist, und daher selbst als Skelet zu funktionieren vermag. Schon bei manchen Wirbellosen tritt in gewissen Körperteilen knorpelartiges Mesodermgewebe auf. So wird der Zellgewebsstrang, der die Kiemenfäden mancher Kopfkiemer unter den Polychäten durchzieht, meist als Knorpelgewebe gedeutet, obgleich seine Intercellularsubstanz nur wenig entwickelt ist; selbst das entodermale Stïtzgewebe der Cölenteratententakel ist schon ähnlich aufgefaßt worden. - Typischem Knorpel begegnen wir bei den gastropoden und vor allem den cephalopoden Mollusken. Bei den ersteren beschränkt er sich auf eine einzige Kọ̈perstelle, nämlich die sog. Mundmasse (Anfangsteil des Vorderdarmes), in deren Ventralwand knorpelartiges Gewebe eine polsterartige Stïtze für die dicht anfgelagerte Radula (Reibplatte, Zunge) bildet, die von dem Knorpe'. sowohl getragen als auch durch seine Vermittlung bewegt wird. Bei den Prosobanchiaten besteht dieser Zungenknorpel gewöhnlich aus zwei längsgerichteten, nebeneinander licgenden Stäckeu, die jedoch auch verwachsen können. Bei gewissen Formen exscheint 
jedes Stück in mehrere (bis vicr jederseits, Patella) gesondert. Bei den Pulmonaten ist der Knorpel einfach; den Cephalopoden fehlt er. Die Muskeln der Mundmasse befestigen sich zum Teil an dem Krorpel. -- Obgleich die Intercellularsubstanz auch im Zungenknorpel der Gastropoden nur wenig entwickelt ist (speziell dem der Pulmonaten), nähert er sich dem typischen Knorpel doch sehr.

Letzterer ist un bei den Cephalopoden viel reicher vertreten und zeigt alle charakteristischen Merkmale des Knorpelgewebes, wenn auch nicht ohne Be-

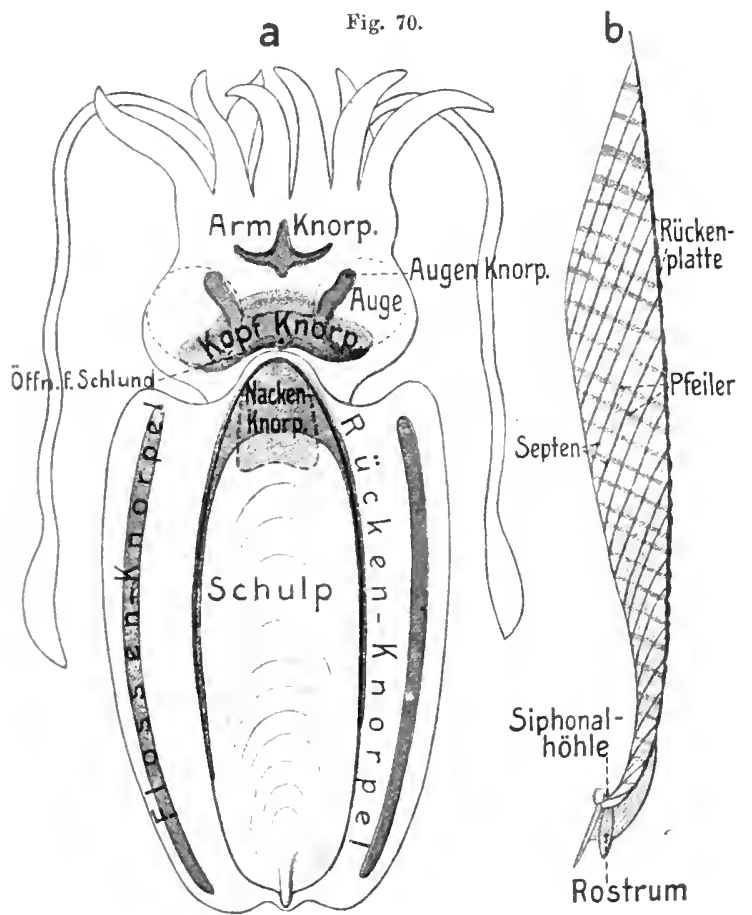

Sepia. a Schema für die Anordunng des Knorpelskelets und des Schulps im Körper; sog. Dorsalansicht (Ansicht auf die vordere Hälfte der Dorsal. seite). b Langsdurchscbnitt des Schulps in der Medianebene. Sch. sonderheiten. Man kann wohl sagen, daß sich üherall im Cephalopodenkörper Knorpel bilden kann, wo dies vorteilhaft ist. Alle besitzen in ihrem Kopf einen ansehnlichen Knorpel (Kopfknorpel), der bei Nautilus und den Octopoden das Knorpelskelet allein vertritt. Bei Nautilus ist er noch einfacher gebildet, da er in Form eines ansehnlichen, etwa X-förmigen Körpers ventral unter dem Beginn des Darms und dem Centralnervensystem liegt. Seine beiden ansehulichen vorderen Schenkei ziehen zom Trichter und stiutzen ihn, indem sie zugleich seiner Muskulatur Ansatz bieten.-DerKopfknorpel der Dibranchiaten (siehe Fig. 70 ist insofern weitergebildet, als sein centraler ${ }^{\top}$ Teil den Schlund dorsal nmwachsen hat, so daß dieser ihn durchsetzt. Im allgemeinen hat der Knorpel etwa eine schüsselförmige Gestalt, mit gegen den Mond gerichteter Konkavität und einem centralen Loch zum Durehtritt des Schlunds. In der centralen Region der Schiissel, un den Schlund, liegt geschuitzt das Centralnervensystem. Die beiden seitlichen Regionen des Kuorpels umgreifen die hintere Wand der Augäpfel mehr oder weniger und bieten ihnen Halt, während von dem dorsalen Rand des Kopfknorpels bei einigen Decapoden (auch Sepia) jederseits ein etwa lanzettförmiger, schmaler Knorpelfortsatz (sog. Augendeckknorpel) über die vordere Region der Augäpfel zieht. Nur gewisse Decapodeu besitzen an der Tentakelbasis, etwas vor dem 
Kopf knorpel, einen sog. Arminorpel, welcher die Armbasen zum Teil stiitzt. Bei den Sepien liegt nach Innen vom Kopfende des Schulps, der in die vordere Region der Mantelfalte hineinragt, ein flaches Knorpelblatt (sog. Rückenknorpel), dessen Seitenränder sich als schmale Knorpelleisten längs der Seitenränder des Schulps, die sie umfassen, mehr oder weniger weit, ja bis zum Schulpende, erstrecken können. Unter der Haut der Nackenregion, welche von der eben erwähnten vorderen Partie der Mantelfalte überdeckt wird, findet sich dann eine ähnliche Knorpelplatte (Nackenknorpel), welche einen dichten Anschluß der Rückenknorpelplatte (oder auch des vorderen Teils des Schulps) gestattet, was zum dichten Abschluß der Mantelhöhle dient. Denjenigen Dibranchiaten, bei welchen diese vordere Region der Mantelfalte rückgebildet ist, fehlt die beschriebene Einrichtung. Zum besseren Abschluß der Mantelhöhle dienen bei den Decapoden ferner zwei napfförmige Knorpelbildungen am aboralen Trichterrand, in deren Ausłöhlungen zwer Vorsprünge der inneren Mantelfäche eingreifen. Zur Stütze der bei vielen Decapoden ansehnlichen Seitenflossen sind längs deren Basis ebenfalls Knorpelstreifen entstanden (Flossenknorpel, Fig. 70), deren Bildung sich innig an die der Flossen anschließt. - Wie schon bemerkt, dient das Knorpelskelet der Cephalopodeu anch ausgiebig zum Ansatz der Muskulatur.

Eine bis jetzt ungenügend bekannte Decapodengattung (Lepidotheutis) besitzt ein fischähnliches Schuppenkleid der Körperoberfläche. Die rhombischen, dicht gestellten Schuppen liegen im Corium und sollen knorpelig sein. Doch ist die rorliegende Beschreibung unklar.

\section{Skelet der Wirbeltiere.}

Mit Ausnahme der Acranier sind bei den Vertebraten Skeletgebilde aus Knorpel oder Knochen allgemein verbreitet. Die primitivsten Skelete bestehen entweder nur aus Knorpel, oder dieser überwiegt doch anfänglich sehr. In der Ontogenie der höheren Wirbeltiere tritt das gleiche an vielen Skeletgebilden hervor, indem sie knorpelig angelegt und später in Knochen übergeführt werden. Wenn nun auch bei den erwachsenen höheren Vertebraten der Knochen sehr vorherrscht, so bleibt doch an gewissen Stellen stets noch Knorpel erbalten, wenn auch zuweilen nur spärlich.

Nahezu gleichzeitig entstanden bei den Wirbeltieren tiefer gelegene, als Stützund Bewegungsorgane funktionierende Skeletgebilde und oberflächliche, im Corium liegende, die als Schutzgebilde funktionieren. Diese Hautskeletgebilde unterscheiden sich von den ersteren darin, daß sie fast nie knorpelig sind, sondern sofort knöchern aus dem Bindegewebe hervorgehen. Die beiderlei Skeletsysteme treten jedoch allmählich in nahe Beziehungen zueinander, so daß sogar für manche Skeletteile unsicher bleibt, ob sie von dem einen oder dem andern herzuleiten sind. - Endlich begegnen wir aber bei den Vertebraten noch einem sehr eigentiimlichen Skeletorgan, welches weder aus Knorpel, noch Knochen besteht, sondern eine diesen Geweben phylogenetisch vorangehende Bildung ist, ein selbständiges, uraltes Skeletorgan (Chorda), das auch schon den Tunicaten, sowie wahrscheinlich stark rück- 
gebildet den sog. Branchiotremata zukam. Bei den Vertebraten, die ein inneres Knorpel- oder Knochenskelet entwickeln, bildet diese Chorda dorsalis gewissermaßen die Grundlage oder Achse, um welche sich der Centralteil des Innenskelets, die eigentliche Wirbelsänle, hervorbildet.

\section{Hautskelet der Wirbeltiere.}

Indem wir die Betrachtung der Chorda und des Innenskelets auf später verschieben, wenden wir uns zunächst dem Hautskelet zu, von welchem wir jedoch diejenigen Teile, die sich dem innern Skelet eng anschließen, erst bei letzterem behandeln werden.

Das Hautskelet, welches, wie bemerkt, fast stets rein knöchern auftritt, spielt gerade bei den niederen Wirbeltieren, den Fischen, eine hervorragende Rolle, indem es deren Schuppen, typische Schutzorgane der Haut, darstellt.

Fische. Bei der primitivsten Gruppe der

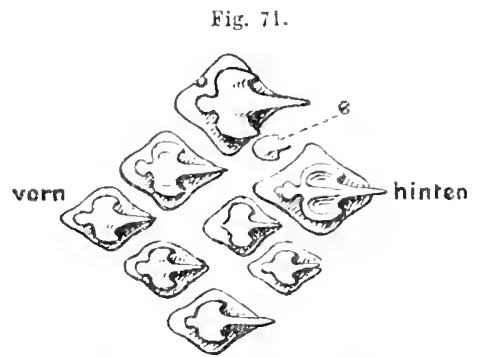

Scylliam. Die Placoidschüppchen oines kleinen Stücks der Haut. $Z$ wischen den größeren ein kleines Ersatzschūppchen in Entwicklung. (Nach KLAATSCH $15 ! 90$.$) O. B.$ heutigen Fische, den Chondropterygii (Knorpelfische), sind die Hautskeletgebilde (Placoidschuppen) sogar die einzigen Verknöcherungen, welche überhaupt vorkommen. Diese zweifellos ursprïnglichsten Schuppengebilde sind aber keineswegs sehr einfacher Natur, sondern relativ kompliziert. Bei den Haifischen bleiben die Placoidschüppchen ziemlich kleine rhombische Plättchen(Fig. 71), die in quincunxialer Stellung dem Corium dicht eingebettet sind, ohne sich jedoch zu iiberlagern. Jedes Schiippchen trägt außen einen nach dem Schwanzende gekrümmten, spitz endenden Stachel oder Zahn, der die Epidermis durchbricht und sich etwas über sie frei erhebt. Gewöhnlich ist dieser Zahn einfach, selten verzweigt er sich in einige Endspitzen. Er besitzt eine innere Höhle, welche sich auf der Unterseite der Schuppenplatte öffnet (Fig. 72 B), wo das Corium nebst Gefäßen usw. in die Höhle eindringt und sie erfïllt (Pulpa). Die Oberfläche des Zahns wird von einem dünnen, harten, homogenen Überzug bedeckt, dem sog. Schmelz (Vitrodentin), der wenig organische Substanz enthält, also fast nur aus Kalksalzen besteht, und dessen Identität mit dem echten Schmelz der Mundhöhlenzähne nicht ganz sicher ist. Die Hauptmasse des Zahns dagegen besteht aus einer besonderen Art von Knochensubstanz (Zahnbein, Dentin), olne eingeschlossene Knochenzellen (Knochenkörperchen), jedoch durchsetzt von feinen, meist distal reich verïstelten Röhrchen, die Ausläufer der Pulpazellen enthalten. Doch kann anch das Pulpagewebe selbst zuweilen stärkerere Fortsätze in das Dentin senden, von denen dann erst die Dentinröbrchen entspringen. Die Schuppenplatte (Basalplatte) selbst enthält keine Knochenkörperchen und scheint aus einer oberflächlichen Lage, einer Ausbreitung des Dentins, und einer tiefen dickeren Lage zu bestehen, welche durch Verknöcherung des fibrillären Bindegewebes des Coriums 
entsteht. Aus dieser Schilderung folgt, daß die Placoidschuppen große Ähnlichkeit mit den Zahngebilden in der Mundhöhle der Wirbeltiere haben; es ist denn anch sicher, daß beiderlei Gebilde desselben Ursprungs, also homolog sind.

Den Rochen fehlt gewöhnlich das gleichmaßige Schuppenkleid der Haifische, dagegen entwickeln sich stellenweise viel ansehnlichere Placoidschuppen, deren starke Zăhne die Bestachelung gewisser Formen bilden; doch kann auch vollständige Reduktion des Schuppenkleids vorkommen (Torpedo oder Zitterrochen, auch Chimaera annähernd). Besonders ansehnlich ausgewachsene Placoidschuppen sind die Zähne der săge der Sägefische (Pristis u. Pristiophorus). - Die Entwicklung der Placoidschuppen

Fig. 72.

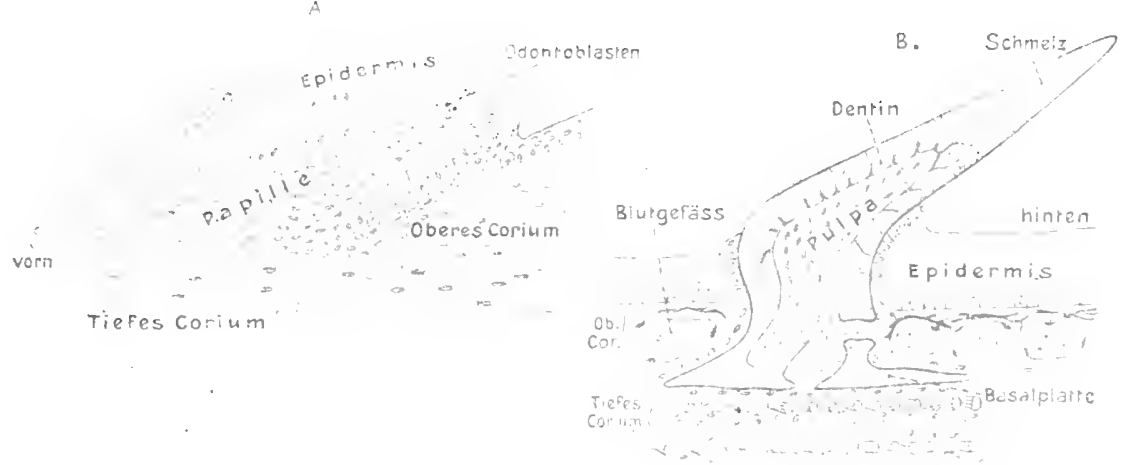

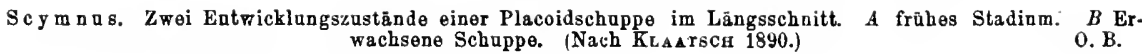

beginnt mit der Bildung einer Cutispapille, die sich in die schwach verdickte Epidermis erhebt (Fig. 72 A). Auf diesei Papille erhöht sich die tiefste Schicht der Epidermiszellen zu einem Cylinderepithel und scheidet als erste Schuppenanlage den Schmelz nach innen zn aus; letzterer ist also ein Epidermisprodukt. Unter der Schmelzschicht erfolgt dann die Dentinbildung durch die äußere Lage der. Zellen der Coriumpapille (Odontoblasten). Darch weitere Verdickung und Verlängerung des Dentins nach innen wird endlich die Spitze des Zahns durch die Epidermis herausgeschoben und frei, während sich an seiner Basis die Basalplatte hervorbildet. Das in den Zahn aufgenommene Corium bildet die Pulpa. - Nicht nur bei heranwachsenden, sondern auch bei erwachsenen Knorpelfischen findet Neubildung von Placoidschuppen statt; in letzterem Fall zum Ersatz verloren gehender (Fig. $71 \mathrm{e}$ ).

Die Schuppen der ïbrigen Fische werden gewöhnlich direkt von den Placoidschuppen abgeleitet durch Reduktion der Zähne und stärkere Entwicklung der Basalplatte zur Schnppe. Daß in der Tat eine nahe Beziehung der Placoidschuppen zn denen der übrigen Fische besteht, geht vor allem daraus hervor, daß bei Ganoiden und gewissen Teleosteern (Panzerwelsen) noch Gebilde auftreten, welche den Schuppenzähnen der Knorpelfische zweifellos entsprechen. Sicher ist auch, 
daß die Ganoiden die Vermittlung zu den Knochenfischen bilden. Bei den Knochenganoiden, die wir zuerst betrachten, da das. Hautskelet der in vieler Hinsicht primitiveren Knorpelganoiden starke Umbildungen erfahren hat, ist die Haut dicht von ziemlich großen, rhombischen, seltener mehr abgerundeten Schuppen erfüllt (Fig. 73 A). Dieselben stehen in schiefen Reihen zur Längsrichtung. Mit ihren Hinterrändern schieben sich dic jeder vorhergehenden Reihe etwas über die folgende, ohne daß jedoch die Hinterränder der Schuppen die Haut wesentlich erheben; auch sind die benachbarten Schuppen zuweilen durch Gelenkfortsäłze verbunden. Die Schuppeuoberfäche wird von einer glänzeuden schmelzartigen Lage gebildet (Ganoin; Fig. 73 B), die recht verschieden dick sein, zuweilen anch ganz fehlen kann (Amia usw.). Die tiefere Hauptmasse dagegen (Isopedin) ist echtes

Fig. 73.

A

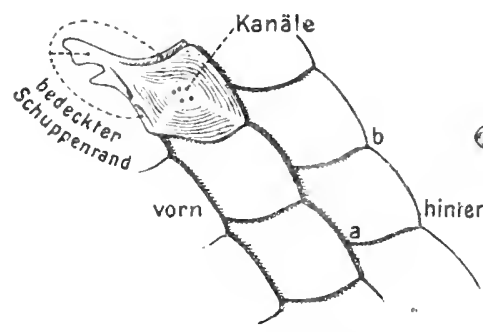

B

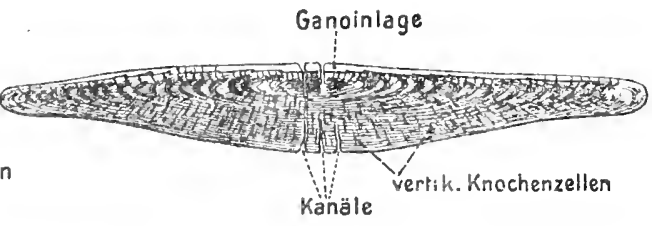

Lepidostens essens. A einige Schuppen in natürlicher Lage von anßen. Die Schuppe in der linken oheren Ecke zeigt den von den Nachbarschuppen bedeckten Teil, die durchsetzenden Kanāle, sowie die feinere Zeich. nung der Obertäche. B Querschnitt einer Schappe (Richtung $a-b$ Fig. $A$ ). In der Mitte sind die die Schnppe durchsetzenden Kanāle zu sehen, ferner Ganoin und Knochensubstanz; die Knochenkörperchen nur als Punkte angedentet, besenders hervortretend die aufsteigenden Knochenzellen.

O. B.

Knochengewebe mit vielen Knochenkörperchen, die in der Regel auch senkrecht aufsteigende Röhrchen bilden, so daß gewisse Anklänge an Dentin bestehen. Die Übereinstimmung mit echtem Knochengewebe wird noch größer, da das umgebende Bindegewebe samt Blutgefäßen in vereinzelte, oder reichlicher entwickelte Kanăle des Schuppengewebes eindringt, ja dieses sogar völlig durchbohrt. - Zahnartige Gebilde finden sich auf den erwachsenen Schuppen gewöhnlich nicht mehr vor, abgesehen von vereinzelten Körperstellen. Dagegen treten Zähnchen bei der Entwicklung der Schuppen des Lepidosteus (Knochenhecht) reichlich auf, gehen jedoch später wieder bis auf geringe Reste ein; ebenso finden sie sich auf den Polypterusschuppen.

Jede größere junge Lepidosteusschuppe kann so eine beträchtliche Zahl frei hervorragender Zähnchen tragen. Die Entwicklung der Schuppen zeigt jedoch das Eigentümliche, daß 1. die eigentliche Schuppenplatte völlig innerbalb des Coriums, gesondert von der Epidermis, entsteht, und 2. die erst nach der Anlage der Platte auftretenden Zahngebilde, welche sich wesentlich wie die Placoidzähne entwickeln und wie diese epidermoidalen Schmelz besitzen, anfänglich ohne Zusammenhang mit der Platte sind, erst später mit ihr verwachsen. Aus der ersten Tatsache ergibt sich, daß das sog. Ganoin der fertigen Schuppe nicht von der Epidermis gebildet wird und daher trotz mancherlei Ähnlichkeiten nichts mịit wahrem Schmelz zu tun hat; das zweite Moment läßt berechtigte Zweifel entstehen, ob die Schuppenplatte 
der sog. Basalplatte der Placoidschuppen wirklich homolog ist. Vielmehr wäre zu erwägen, ob nicht die Schuppenplatten der Ganoiden selbständige Verknöcherungen des Coriums sind, mit denen sich sekundär die in Reduktion geratenen Reste der Placoidschuppen vereinigen. Die bestehenden Zweifel über die Auffassung der rielzähnigen jungen Lepidosteusschuppe, entweder als einer Placoidschuppe entsprechend (KLAATsCH), oder als ein Verschmelzungsprodukt ebenso vieler, wie Zähnchen vorhanden sind (O. HERTwiG), würden sich hiermit aufheben.

Eine solche Auffassung wird auch durch den Bau der häufig recht komplizierten Schuppen vieler fossiler Ganoiden, sowie der uralten sog. Ostracodermi unterstützt. Die wohl ursprünglichsten Formen der letzteren besaßen kleine zähnchenartige Schuppen ohne Basalplatte, ähulich den echten Placoidschuppen. Durch Verwachsung dieser Schüppchen mit unter ihnen auftretenden plattenartigen Verknöcherungen (ohne oder mit Knochenzellen) scheinen die größeren Panzerplatten der liopf- und Rumpfregion entstanden zu sein; wobei die Zähnchen meist eigentümlich modifiziert und zu einer äußeren Lage der Platten wurden. In ähnlicher Weise könnten anch die Schuppen der ursprünglicheren Ganoiden entstanden sein, die zuweilen auch zahnartige Fortsätze der Oberfläche zeigen. Diese Schuppen besitzen gewöhnlich keine dickere Ganoinschicht, dagegen eine äuBere Lage (sog. Cosmin), welche etwa wie eine große Zahl dicht nebeneinander gestellter Pulpahöhlen von Placoidschuppen erscheint, ron denen Dentinröhrchen gegen die Oberfläche ausstrahlen. Diese sog. CosminJage wird denn auch häufig auf verwachsene ursprüngliche Placoidzähnchen zurückgeführt. Die erwähnten Pulpakanälchen entspringen aus einem reichen Netzwerk anastomosierender Kanäle, das sich wnterhalb der Cosninlage ausbreitet (Gefäßlage), und das sowohl durch absteigende Kanäle, welche die dicke, geschichtete, tiefe Knochenschicht (Isopedin) durchsetzen, auf der Unterfläche der Schuppe ausmündet, als auch durch aufsteigende Kanälchen auf deren Oberfläche. Von rezenten Ganoiden besitzt nur noch Polypterus eine schwache Cosminlage. Die dicke Ganoinschicht der neogenen Ganoidschuppen scheint damit zusammenzuhängen, daß die Schuppen auch auf ihrer Oberfläche durch Auflagerung neuer Schichten wachsen, was namentlich dadurch kenntlich wird, daß die Schichten der Isopedinlage um den Schuppenrand umbiegen und sich in die Ganoinschichten fortsetzen (Fig. 73 B).

Bei den Knorpelganoiden, speziell Acipenser (Störe), ist die Beschuppung auf größeren Strecken der Haut stark rückgebildet (bei Polyodon sogar auf der ganzen Oberfläche), während sich in mehreren Längsreihen über den Körper größere rhombische schmelzfreie Knochenplatten hervorgebildet haben. Wahrscheinlich sind dies stark ausgewachsene ursprüngliche Schuppengebilde. Sie tragen vielfach schmelzlose zahnartige Erhebungen in größerer Zahl. In der zwischenliegenden Haut finden sich häufig kleinere Knachenplättchen mit nur einem oder wenigen solcher zahnartigen Fortsïtze. Das Verhältnis dieser Zahngebilde zu den Knochenplatten ist entwicklungsgeschichtlich noch nicht aufgeklärt.

Die Schuppen der rezenten Dipnoer und der Teleosteer stimmen im wesentlichen überein und unterscheiden sich von denen der Ganoiden hauptsächlich dadurch, daß sie meist viel dünner bleiben und keine Ganoinlage besitzen, die ja schon manchen Ganoiden fehlt, so besonders Amia (Kahlhecht), dereu Schuppen sich denen der Teleosteer sehr nähern. Die wohl entwickelten Schuppen der beiden genannten Ordnungen überdecken sich von vorn nach hinten dachziegelartig stärker als die der Ganoiden, so daß der hintere Schuppenteil, in eine dünne Ausstïlpung des Integuments eingeschlossen (sog. Schuppentasche), ïber die Hantfläche vorspringt (Fig. $74 a$ ), was natïrlich in sehr verschiedenem Grad geschieht und bei verkümmerten Schuppen ganz zurïcktritt. An der Schnppe läßt sich eine dünnere 
strukturlose Außenlage, die zuweilen Knochenkörperchen enthält, und eine tiefe dickere Lage nnterscheiden. Letztere besteht ans zarten, übereinander liegenden Lamellen, die feine fibrilläre Bündel enthalten, wobei die Bündel der alternierenden Lamellen sich kreuzen, ähnlich wie die des Coriuns. Dies stets zcllenlose Ge-

Fig. 74.

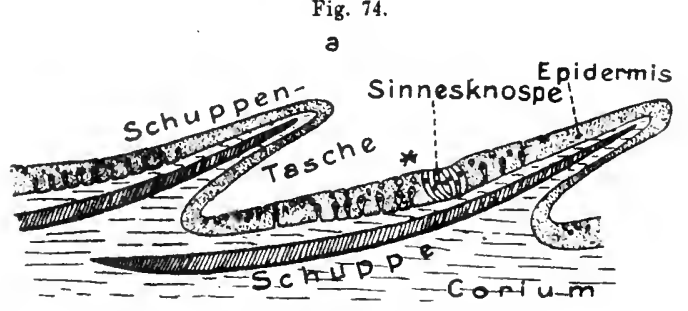

Barbua fluriatilie (nach Madrer 189j). a Schematischer Lāngeechnitt durch die Hant mit zwei Schuppen. webe wird daher als verkalktes zellenfreies Bindegewebe betrachtet. Auch Kalkeoncretionen (Calcosphäriten) treten, abweichend von sonstigen Knochenbildungen, in dieser Lage zuweilen auf. Beide Lagen zeigen jedoch keine scharfe Grenze gegeneinander. Hieraus, wie aus dem Gesamtverhalten dürfte hervorgehen, daß die fraglichen Schuppen den ganoinlosen gewisser Ganoiden entsprechen. - Die Oberflăche der erwähnten Außenlage erhebt sich in der Regel zu zahlreichen konzentrisch verlaufenden Leistchen, welche um ein, etwas gegen den Hinterrand der

Fig. 75 .

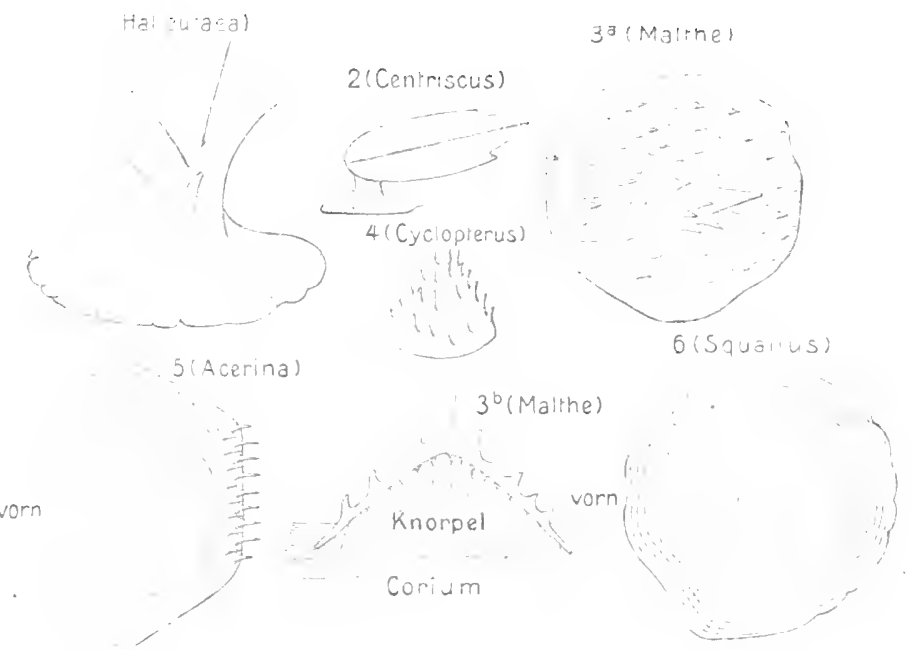

Schuppen verschiedener Teleosteer. 1-4 ahweichende Schuppenformen (nach 0 . Hentu IG 1852). 1, 2 und $t$ Seitenansicht; $3 a$ Flăchenansicht von außen. $3 b$ Längsschnitt. 5 Ctenoidschnppe. 6 Cycloidschuppe. 0. B.

Schuppe verschobenes Centram angeordnet sind und mit dem Wachstum an Zahl zunehmen (Fig. 75 5 ); letzteres repräsentiert die früheste Schuppenanlage. Außerdem strahlen von diesem Centrum meist noch radiäre Linien gegen den Hinterand Vorderrand aus, welche durch Unterbrechungen (Liicken) in der AuBenlage, oder auch gleichzeitig durch mangelnde Yerkalkung in der Hauptlage gebildet werden. 
Die bis jetzt gegebene Schilderung entspricht etwa der Beschaffenheit der sog. Cycloidschuppen, welche die Abteilnng der Physostomen nnd Anacanthinen (zum Teil) charakterisieren. Der Hinterrand der Acanthopterygier-Schuppen dagegen ist anßen mit stacheligen Fortsätzen in verschiedenem Grade besetzt (Ctenoidschoppen, 755). Dies sind Bildungen von der Beschaffenheit der Außenlage, die weder nach ibrer Entstehung, noch nach ihrem Anftreten bei phylogenetisch jüngeren Formen etwas mit Placoidzähnchen zu tun haben können. Dasselbe gilt von den zähnchenartigen Fortsätzen auf der Gesamtaußenfläche der Dipnoer-Schuppen. - Dagegen treten bei einer Abteilung der Physostomen, den sog. Panzerwelsen, Zähnchengebilde anf, welche sowohl nach ihrer Ontogenie, als ibrer fertigen Bildung den Placoidzähnchen gleichstehen. Die Panzerwelse besitzen in ihrer Haut, äbnlich den Stören, statt kleinerer Schuppengebilde Reihen größerer Knochenplatten. Diesen Knochenplatten sitzen Zähnehen anf, welche von je einem niederen Sockel beweglich getragen werden, und ther die Haut hervorragen. Wio bemerkt, gleichen sie nach Bar und Entstehung ganz den Placoidzähnen. Der Fall scheint also hier ähnlich zu liegen wie bei Lepidosteus; d. h. etwas reduzierte Placoidschüppchen sind mit unter ihnen entstanđenen Hantverknöcherungen in Verbindung getreten, ohne jedoch damit za verwachsen. Recht eigentumlich bleibt aber immerhin dies Wiederanftreten von Placoidzähnchen bei einer von den Knorpelfischen weit entfernten Groppe.

Bei den aberranten Gruppen der Knochenfsche (besonders Plectognathi, jedoch auch gewissen Acanthopterygii) kann es zu recht eigentümlichen Schuppenmodifikationen kommen (Fig. $75^{1-4}$ ). Die Mannigfaltigkeit dieser Bildungen verbietet năheres Eingehen. Bemerkt sei daher nur, daß sie zum Teil so entstehen, daß das Centrum der Schuppe zu einem hohen, teils einfachen, teils verzweigten, oder auch an seinem Ende blattartig verbreiterten Stachel auswächst, der solid oder hohl sein kann. Die Höhle ist dann von einem pulpaartigen Fortsatz des Coriums erfüllt, zuweilen jedoch sogar von Knorpel, der hier zweifellos selbständig im Corium entstand (Pediculati, $75^{36}$ ). Bei den Plectognathen finden sich ähnliche, zum Teil aber auch sehr reichbestachelte Schuppen ror (Sclerodermi), während bei den Gymnodontes ein ansehnlicher, weit über die Haut aufsteigender solider Stachel entwichelt ist, dagegen die eigentliche Schuppenplatte sich auf einige, von dessen Basis ausstrahlende FuBleisten reduziert hat. - Ihrer äußeren Ähnlichkeit wegen hat man diese abweichenden Schuppengebilde mit Placoidschuppen direkt vergleichen wollen. Ihr Auftreten bei mehr oder weniger aberranten Gruppen der Knochenfische sowohl, als ihre Ableitbarkeit von den gewöhnlichen Teleosteerschuppen, erweist jedoch, daß es sich um sekundäre Modifikationen solcher handelt, die teils durch Umformung der ganzen Schuppe, teils durch ansehnlichere Entwicklung des Stachelbesatzes der Ctenoidschuppe entstanden sind. - Ansehnlichere Knochenplatten in der Haut, eine Art.Panzerung, finden sich, außer den schon erwähnten Fällen, bei gewissen Acanthopterygiern, bei den Lophobranchiern und den sog. Kofferfischen (Ostracion der Plectognathen). Die Ableitung dieser Bildungen aus der gewöbnlichen Beschuppung ist noch wenig aufgeklärt; im besonderen, ob es sich um Verwachsung kleinerer Schuppen, oder um das Auswachsen einzelner zu größeren Knochengebilden handelt.

Amphibien. Hautskeletbildnngen, welche lebhaft an die der Fische erinnern, besitzen unter den Lebenden nur die Gymnophionen (Cöcilien); doch nicht allgemein. Viel reicher waren sie bei der ausgestorbenen Amphibiengruppe der Stegocephalen entwickelt. - Die quergeringelte dicke Hant der Cöcilien enthält in der 
hinteren Hälfte der Ringel sehr zahlreiche, etwa ovale Schüppchen, die in einer ringförmig den Ringel durchziebenden Tasche in größerer Anzahl hintereinander liegen (Fig. 55, S. 142).

Die gemeinsame Tasche für die Schüppchen eines Ringels, sowie die mehrfachen Lagen ron Schuppen hintereinander, ist eine Besonderheit, die bei den Fischen nicht vorkommt. Der Bau der Schüppchen erinnert wohl am meisten an die der Dipnoer. Sie bestehen aus den für die Knochenfischschuppen erwähnten beiden Lagen, von denen die obere wie bei den Dipnoi durch netzige Unterbrechungen in viele kleine Felder zerlegt ist. Die tiefe bindegewebige Lage hängt am Grunde der Schuppentasche direkt mit dem Corium zusammen. Die Verkalkung der Schüppchen, speziell ihrer tiefen Lage, scheint nur gering zu sein. - Daß diese Schuppengebilde der Cöcilien direkt von deren fischartigen Vurfahren abstammen, ist wahrscheinlich.

Das aus echter Knochensubstanz bestehende Schuppenskelet der fossilen Stegocephalen (Fig. 76) war vorzugsweise auf der Ventralseite entwickelt, teils nur am Rumpf, teils auch an den

Fig. 70.

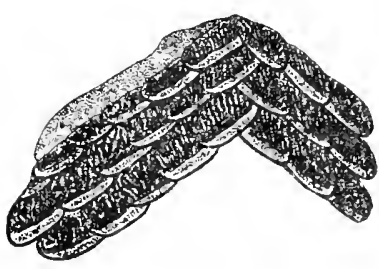

Bauchscluppen von Limnerpeton obtusatum. (Nach A. Fritsch aus Gegexbaur 1898.) Extremitäten. Auf der Kückenseite trat es seltener und dann schwächer auf. Es hat zuweilen recht erhebliche Ähnlichkeit mit dem der Fische, weun es aus mäßig großen, rundlichen bis querovalen Schuppen besteht, die sich dachziegelartig etwas decken. Sie bilden dabei nach vorn, gegen die Bauchmittellinie konrergierende Reihen; an der Brustregion zum Teil auch nach binten konvergierende. Bei anderen Formen wurden die Schüppchen schmäler bis stäbchenartig, so daß sich ibre schiefen Reihen nicht mehr berührten. - Auf die wahrscheinlichen Beziehungen dieses Hautskelets zu den sog. Bauchrippen der Reptilien werden wir später eingehen.

Ganz isoliert stehende Bildungen sind plattenartige Hautverknöcherungen gewisser Anuren (Ceratophrys dorsata und Brachycephalus), die in mehrfacher Zahl und verschiedener Anordnung über der Vorderregion der Wirbelsäule in der Haut liegen, oder sogar (Brachycephalus) mit den Dornfortsätzen einiger vorderer Wirbel verwachsen.

Reptilia. Unter den Squamaten besitzen nur gewisse Saurier (besonders die Scincoiden, z. B. die Blindschleiche, jedoch auch einzelne Ascalaboten) knöcherne Schüppchen, welche in der oberen Coriumschicht der Hornschuppen liegen. Für ihre etwaige phylogenetische Beziehnng zu denen der Fische und Amphibien mangeln die Beweise. - Sehr kräftig ist dagegen das Hautskelet der Placoiden. Bei den rezenten Krokodilen sind die Hautverknöcherungen meist auf die Dorsalseite beschränkt, die einzelnen Hornschilder unterlagernd; bauchseitig finden sie sich selten (Jacare, Caiman). Die Knochenschilder stehen wie die Hornschilder in Längs- und Querreihen und sind durch Naht miteinander verbunden, so daß ein relativ fester Rücken- oder auch Bauchpanzer gebildet wird. An den Seiten sind die beiden Panzer unverbunden. - Bei den fossilen Crocodiliden war der Panzer zuweilen noch vicl kräftiger entwickelt, auch schobèn sich die Schilder nach hinten zuwcilen etwas schuppenartig übereinander.

Auch gewisse Dinosaurier besaßen ein mehr oder weniger reiches Hautskelet, das bei Stegosaurus einen mächtigen Rückenkamm stützte.

Die reichste Entfaltung erlangt das Hautskelet der Chelonier und tritt hier mit dêm Innenskelet in so innige Beziehung und zum Teil Vereinigung, daß es geeigneter erscheint, seine nähere Besprechung erst bei diesem vorzunehmen. 
Mammalia. Während Hautverknöchernngen den Vögeln vüllig fehlen, treten sie bei den Säugern in der Ordnung der Edentaten (speziell bei den Gürteltieren) hoch entwickelt anf, unter innigem Anschluß an die früher (S. 113) besprochenen Hornschilder. So finden sich hier den placoiden Reptilien analoge Verhältnisse, die jedoch wohl sicher selbständig entstanden. Der Hautknochenpanzer der Gürtcltiere besteht aus zahlreichen vier- bis vielcckigen Platten, die sich übcr die ganze Rückenseite, vom Kopf bis Schwanzende, und auch auf die Extremitäten ausdehnen. Die Knochenplättchen entsprechen nur teilweise den iiber ihnen liegenden Hornschildern. Auf dem Kopf, der Schulter- und Beckengegend stoßen die Platten dichter und fester zusammen zur Bildang des Kopf-, Schulter- und Beckenschilds. Am Rnmpf dagegen, zwischen Schulter- und Beckenschild, finden sich je nach den Arten 3-13 Gürtel beweglicherer Platten.

Bei dem fossilen Glyptodon waren sämtliche Rumpfplatten zu einem dem Rückenpanzer der Schildkröten ähnlichen Schild fest vereinigt. Der eigentümliche Chlamydophorus enthält in seinem an beiden Körperseiten herabhängenden Hautmantel ebenfalls zarte Hautverknöcherungen.

Einen aus Hautknochenplatten bestehender Panzer besaßen auch die ausgestorbenen Vorfahren heutiger Cetaceen, die Zeuglodonten. Als Reste eines solchen Hautskelets betrachtet man zum Teil tuberkelartige Hauterbebnngen auf dem Rücken und der Rïckenflosse gewisser lebender Zahnwale, in denen jedoch sichere Verknöcherungen nicht nachgewiesen sind.

$Z_{\imath l}$ den Hautverknöcherungen werden zuweilen auch die Knochenzapfen gerechnet, welche die Hörner der Cavicornier (Wiederkäuer) stützen, und ferner die ihnen entsprechenden, jedoch meist viel ansehnlicher entwickelten knöchernen Geweihe der birschartigen Wiederkäuer. Die Entstehung dieser Verknöcherungen unter dem Periost (Knocbenhaut) der Stirnbeine lehrt aber, daB sie nicht als Neubildungen in dem eigentlichen Corium entstehen, sondern den Stimbeinen nälıer zugehörige Teile sind. Da sich jedoch die Frontalia, wie wir später sehen werden, als ursprüngliche Hautskeletknochen erweisen, so sind die Beziehungen der Geweibe und Knochenzapfen zu der Haut doch sehr innig, und ihre Zurechnung zum Hautskelet scheint nicht ohne Berechtigung. Wir werden im AnschluB an die Stirnbeine der Säuger später auf sie zurückkommen. - Auch gewisse Dinosaurier (Ceratopsia) besaßen 1 Paar ansehnlicher Stirnbeinhörner.

\section{Inneres Skelet der Vertebrata und der Chordata überhaupt.}

A. Achsenskelet (Chorda und Wirbelsäule).

Chorda dorsalis. Als charakteristische, dem Knorpel- und Knochenskelet der Wirbeltiere vorausgehende Bildung lernten wir schon die Chorda dorsalis kenuen. Es ergab sich jedoch, daß dies Organ nicht allein den Wirbeltieren zukcmmt, sondern anch den Tunicaten; ja daß bei einigen weiteren Gruppen der Wirbellosen, den Enteropneusten und Pterobranchiern, ein Gebilde anftritt, welches nicht ohne eine gewisse Berechtigung der Chorda verglichen wird; um so mehr als diese Metazoen, ebenso wie die Tunicaten, noch weitere Übereinstimmungen mit den Vertebraten darbieten. - Der Mehrzahl der erwachsenen Tunicaten fehlt jedoch die Chorda völlig; nur die Copelaten (Appendicularien), die auch in sonstiger Hinsicht primitivste Gruppe, besitzen sie als bleibendes Organ, das bei den ausgebildeten Formen als ein stabförmiges Gebilde (Fig. 77) die Achse des ansebnlicheu 
Schwanzes durchzieht, und ihm sowohl zar Stütze, als zum Ansatz seiner Maskulatur dient. $\mathrm{Da} \beta$ jedoch die Chorda den Urformen der Tunicaten wohl allgemein

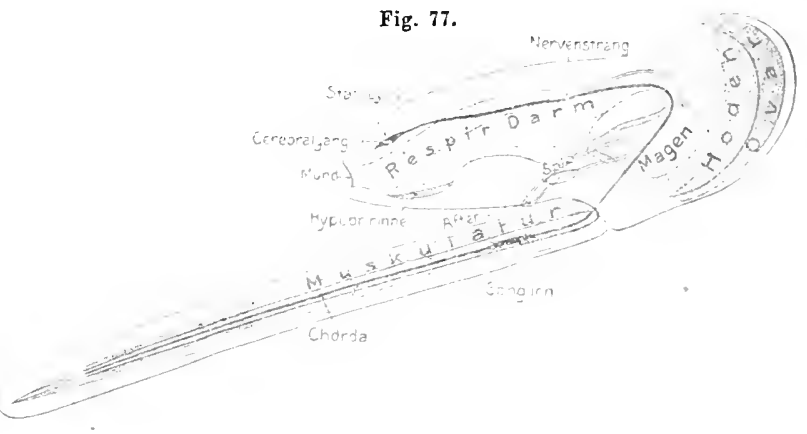

Oicoplenra cophocerca. Schematische Ansicht von der linken Seite. (Nach FOL 1872.)

P. He.

zukam, folgt daraus, daßs sie sowohl im Schwanz der Ascidien- als der Doliolumlarven vorkommt, aber mit dessenRückbildang eingeht. Diese Tunicatenchorda gehr aus einem Streifen von Entodermzellen hervor, welche die Mittellinie der dorsalen Urdarmwand des Embryo einnehmen, direkt unter der ectodermalen Anlage des Centralnervensystems.

Fig. 78 .

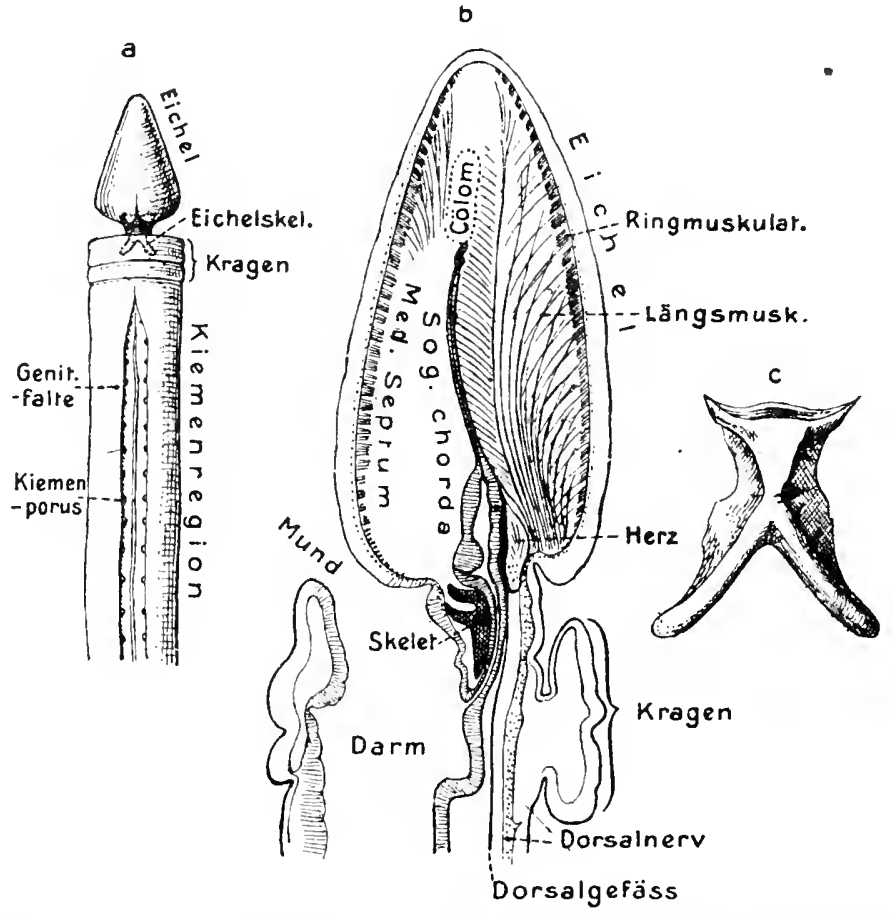

Schizocardium brasiliense Sp. (Enteropneuste). a Vorderes Körperdrittel in Dorsalansicht. Die Lage des Eichelskelets ist punktiert eingezeichnet. $b$ Medianschnitt durch Eichel und Kragen. $c$ Isoliertes Eichelokelet in Dorsalansicht; das letzteres umgebende , chondroide. Gewebe nicht dargestelit. (Nach SPENGEL 1843. Etwas schematisiert.) 
Dieser Zellenstreifen stülpt sich allmählich dorsalwärts ctwas rinnenförmig empor nnd löst sich schließlich vom Urdarm ab. So entsteht ein mehrreihiger Zellstrang, der jedoch bald einreihig wird, indem die Zellen sich zwischeneinander schieben. - Die Chorda des Ascidienembryo reicht vorn etwa bis an dic Gehirnanschwellung des Centralnervensystems (Gehirnblase), hinten bis zur Schwanzspitze. Indem zwischen den aufeinander folgenden Chordazellen eine gallertige Substanz abgeschieden wird, dic sich weiter vermehrt, vereinigen sich diese Gallertmassen schließlich zu einem zusammenhängenden Strang, wobei die Reste der ursprünglichen Bildungszellen als dünner Belag an die Oberfiäche des Strangs gedrängt werden. Nach gewissen Angaben soll auf der Chordaoberfläche eine feine cuticulare Hülle ausgeschieden werden. In der fertigen Chorda ist es aber jedenfalls die Gallertmasse, die ihr Festigkeit und Elastizität verleiht.

Bei den primitirsten Wirbeltieres, den Acraniern, bildet sich die Chordaanlage in fast identischer Art aus dem Entoderm hervor, wenngleich ihr fertiger Bau nicht unwesentliche Unterschiede zeigt. Auch bei den höheren Wirbeltieren läßt sich der gleiche entodermale Ursprung der Chorda an dem angegebenen Ort z. T. klar nachweisen, sowie erklären, wie es kommt, daß bei den Amnioten ein scheinbares Hervorgehen der Chorda aus dem Mesoderm oder Ectoderm von dem ursprünglich entodermalen Ursprung abzuleiten ist.

Was man bei den wurmartigen Enteropneusten and den festsitzenden, in ihrer Erscheinung an Bryozoen erinnernden Pterobranchiern als chordaartiges Organ(Notochord) bezeichnet, ist eine kurze röhrenartige mediane Ausstülpung des Vorderendes des entodermalen Mitteldarmes, die sich gegen das vorderste Segment des Körpers (sog. Eichel oder Rüssel der Enteropneusten, Kopfschild der Pterobranchier) erstreckt (s. Fig. 78 $a, b$ und 79), ohne jedoch in dessen Cölomhöhle einzudringen. Im ausgebildeten Zustand ist

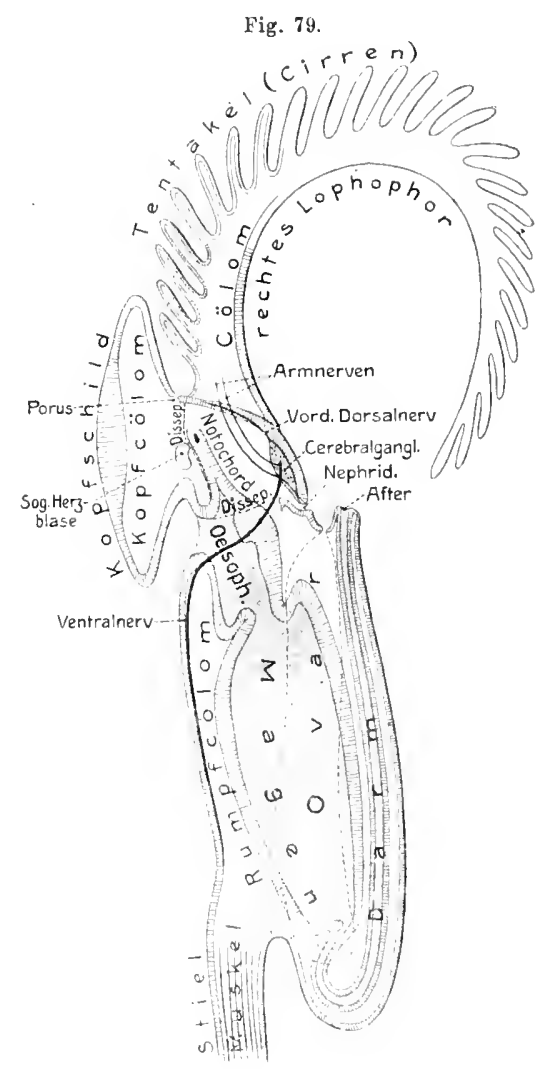

Rhabdoplenra. Schema eines Einzelindividuns einer Kolonie von der linken Seite. (Nach SchkpoTJEFF konstruiert.) O. B. u. P. He. das feine Lumen der Röhre stets sehr verengt, streckenweise auch ganz obliteriert. Die Zellen, welche in mäBiger, bei den Enteropneusten auch reicherer Zahl das Organ aufbauen, werden z. T. stark vacuolär, was das Gewebe dem der Wirbeltierchorda ähnlich machen kann. Bei den Pterobranchiern finden sich im Lumen des Organs cin bis mehrere nichtzellige Körper, dic vielleicht zu seiner Festigkeit beitragen. - Der Ursprungsteil der Enteropneustenchorda wird von einem plattenartig geschichteten Skeletgebilde unterlagert (Fig. 78c), das nach hinten in zwei Fortsätze ausläuft, die in den sog. Kragen hineinragen. In die hyaline Substanz dieses Skelets werden selten Zellen aufgenommen, wodurch es etwas knorpelartig wird. Noch mehr zeigt diesen Charakter das sog. schondroide Gewebec, welches sich in der Umgebung und im AnschluB an das orwähnte Skeletgebilde in der Wand der sog. Eichel (Rüssel) entwickelt. 
Jedenfalls kann die sog. Chorda der beiden letzterwähnten Abteilung enals Skeletgebilde nur von geringer Bedeutung sein, wie denn das Organ überhaupt den Eindruck eines rudimentären macht. $\mathrm{Daß}$ es wirklich ein Homologon der typischen Chorda ist, läßt sich mit voller Sicherheit vorerst wohl nicht behaupten, ist jedoch wahrscheinlich. Wenn daraus geschlossen werden müßte, daß die ursprüngliche Chorda nur in der vorderen Körperregion, unter dem Hirnteíl des Centralnervensystems entwichelt war, so lieBe sich damit in Zusammenhang bringen, daß auch bei den Chordaten die Entwicklung der Chorda von vorn nach hinten fortschreitet.

Acranier. Die Chorda, deren entodermalen Ursprung wir schon oben betonten, bildet das eigentliche dauernde Achsenskelet, da neben ihr weder knorpelige noch knöcherne Skelctteile vorkommen. Sie erlangt gieichzeitig die ansehnlichste Längenausdehnung unter allen Chordaten, indem sie von der vordersten Körperspitze, der sog. Kopfflosse, durch den ganzen Körper bis zur hintersten Schwanzspitze (Schwanzflosse) zieht (Fig. 80). Ihr Vorderende reicht daher weit iiber das

Fig. 80 .

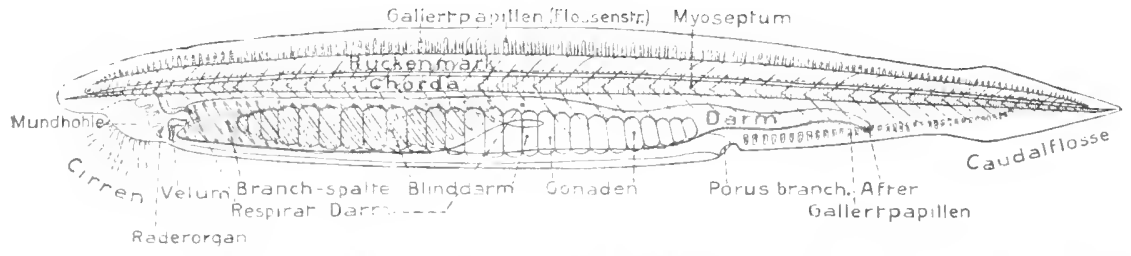

Branchiostoma (Amphioxus) 1anceolatam. Schematische Ansicht von links. Darm rot. (Nach R. LANKESTER 1889 modifiziert.)

o. B. u. He.

Centralnervensystem nach vorn; doch tritt dieser vorderste Teil erst relativ spät anf und wächst dann mit dem vorderen Körperende noch weiter aus. Der ansehnlich dicke, cylindrische Chordastrang liegt direkt über der dorsalen Mittellinie des Darms nnd ventral unter dem Centralnervenstrang (Rückenmark).

Anfänglich besteht die Chordaanlage aus einem mehrreihigen, auf dem Querschnitt ovalen Zellenstrang. Bald schieben sich jedoch die mittleren Zellen des Stranges so zwischeneinander, daß sie einreihig hintereinander folgen. Indem in den Zellen, welche in der Querebene stark abgeplattet sind, große Vacuolen anftreten, werden die aneinander stoßenden Zellpartien stark verdünnt, so daß sie die Chorda wie eine dichte Reihe quergestellter dünner Platten durchziehen, getrennt von je einer der erwähnten Vacuolen. In diesem Bau ist schon der der ausgebildeten Chorda angedeutet (Fig.81 u. 82). - Diese besteht aus einer ziemlich dicken äußeren Hülle (Chordascheide), deren innerste Partie von einer zarten Haut gebildet wird (sog. Elastica). Die von der Scheide umhüllte Chordamasse selbst erscheint von einer Unmasse dünuer Querplatten gebildet, welche den ganzen Innenraum durchziehen, und fein querfaserig strukturiert sind. In den Zwischenräumen der aufeinauder folgenden Platten finden sich spärlich verästelte Zellen, während in der Dorsal- und Ventrallinie der Chorda, wo die Platten nicht ganz bis zur Scheide reichen, faserartige bis verästelte Zellen reichlicher angehänft sind und sich von hier auch oberflächlich noch etwas gegen die Mittelregion der Chorda erstrecken (Fig. 82). 
Wie bemerkt, ist dieser Bau schon beim Embryo angedeutet, obgleich noch nicht hinreichend aufgeklärt erscheint, wie die Querplatten der fertigen Chorda aus jenen Zellpartien hervorgehen, welche die Vacuolen der embryonalen Zellen trennen; weshalb auch die richtige Deutung der Chordaplatten bis jetzt mangelt. Die Chordascheide wird, außer von der oben erwähnten innersten sog. Elastica, von einem bedeutend dickeren, fein ringfaserigen, zellfreien Gewebe gebildet, das gegen das umbüllende Bindegewebe nicht sehr scharf abgegrenzt ist. Die Herkunft der Chordascheide ist noch nicht völlig klar; nur die sog. Elastica wird allgemein.als ein Abscheidungsprodukt der Chordazellen betrachtet; die dickere faserige Scheidenlage dagegen teils in gleichem Sinn, teils dagegen als eine besonders differenzierte Partie des umhüllenden perichordalen Bindegewebes gedeutet, wofür auch vieles spricht.

Das perichordale feinfaserige Bindegewebe umhüllt in relativ dünner Lage die gesamte Chorda (Fig. 81), erhebt sich ferner jederseits an ihrer Dorsalseite zu zwei Lamellen, welche dasRückenmark

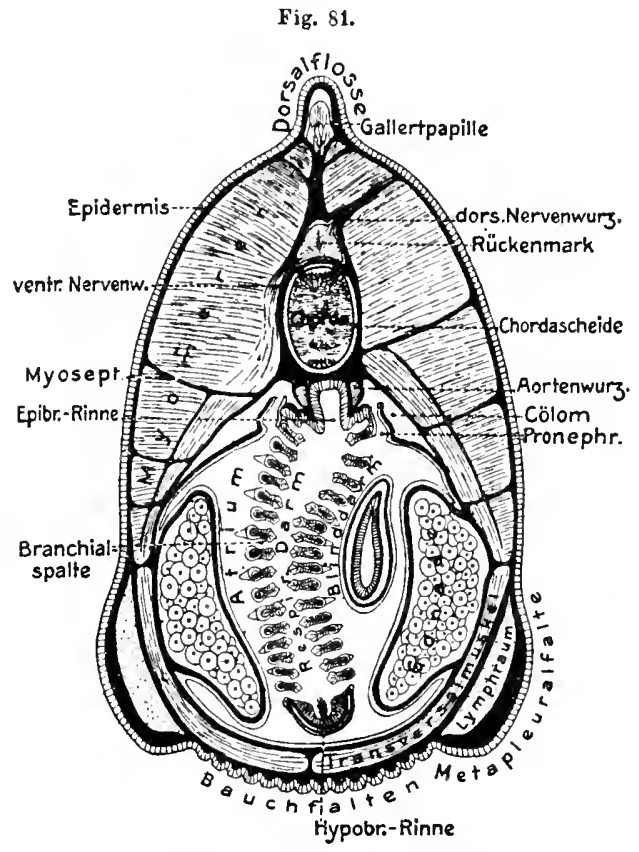

Branchiostoma lanceolatnm. Querschnit dorch die respiratorische Darmregion. Bindegewebe schwarz. (Nach R. LANkegter modifiziert.) O. B. u. P. He. (Medulla) nmgreifen und sich uber ihm vereinigen, so daß letzteres von ihm umhüllt wird. Ventral setzt sich das perichordale Gowebe in ähnlicher Weise in das die Leibeshöhlc umkleidende fort, im Schwanz in die mediane Bindegewebsscheidewand zwischen den beiden Seitenmuskeln (Fig. 183). Seitlich geht es ferner überall in die Bindegewebsscheidewände (sog. Myosepten, Myocommata) zwischen den Längsmuskelsegmenten(Myomeren) iiber. Durch diese Myosepten, welche schief von innen und vorm mach außen und hinten ziehen, wird der Zug der sich kontrahierenden Myomeren auf die Chorda übertragen.

Der ziemlich feste und elastische Chordastrang des Branchiostoma funktioniert daher einmal als eine innere Stiitze, andererseits wird er jedoch bei den Bewegungen von Bedeutung sein,

Fig. 82.

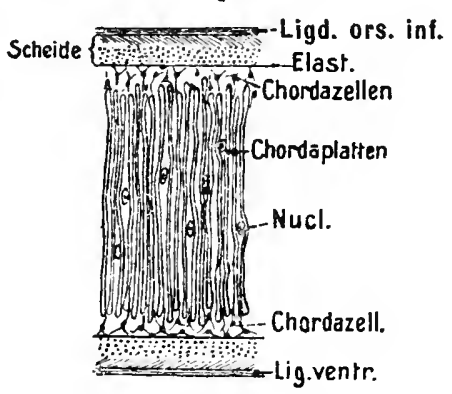

Branchiostoma lanceolatum. Klei. nes Stūck eines medianen Längsschnitts durch die Chorda. (Nach JosepH 1895. (Etwas schematisiert.) O. B. welche in abwechselnden Biegungen des Körpers nach den beiden Seiten bestehen. 
Man hat die Bedeutung der Chorda für die Bewegungen namentlich darin gesucht, da $B$ sie als ein elastischer Stab die Rückkehr in den gestreckten Zustand ohne Hilfe der Muskulatur bewirke. Hierin dürfte jedoch kein eigentlicher Vorteil zu finden sein, da die Chorda zwar sicher in dieser Weise tätig ist, ibre Biegung durch die Muskeln jedoch deren Arbeitsleistung auch um ebenso viel erhöht, dls hierauf durch die Elastizität wieder gewonnen wird. Der eigentliche Vorteil der Chorda dürfte daher darin zu suchen sein, daß durch die Einschiebung einer solch' elastischen Skeletachse der Zug, welchen die einzelnen Myosepten ausüben, zu einer Biegung des Chordastabs in seiner Gesamtheit, und so zu Biegungen des Gesamtkörpers führt, während beim Mangel einer solchen Achse die Kontraktion einzelner Myomeren nicht so ausgiebig und sicher in dieser Weise zu wirken vermöchte."

\section{Wirbelsäule der Cyclostomen und Fische.}

Bei den Cyclostomen, sowie einer Anzahl primitiver Fische, bleibt die Chorda als dauerndes Organ ähnlich den Acraniern erhalten (bei Holocephalen und ge-

Fig. \$3.

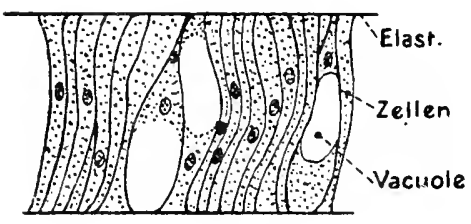

Medianer Lăngssebnitt durch die Chorda einer eehr jungen Larve von Petromyzon planeri (Ammocoetes). (Nach A. Albrecht aus SchaurssLAND 1906, etwas schematisch.) O. B. gewissen Haien unter den Knorpelfischen, denKnorpelganoiden, speziell Stör, und vielen fossilen Ganoiden, den Dipnoi, auch noch bei vielen Stegocephalen unter den Amphibien). Sie wird in diesen Fällen recht ansehnlich und von komplizierterem Bau, was sich besonders in der Fortbildung ihrer Scheide ausspricht. Aber auch das zellige Chordagewebe selbst entwickelt sich viel mächtiger und in besonderer Weise. - Auf einem frühen Entwicklungsstadium scheinen sich jedoch die jugendlichen Chordazellen stets als sehr stark abgeplattete Gebilde in einfacher oder nahezu einfacher Reihe geldrollenartig hintereinander zu schieben (Fig. 83), ein Zustand von prinzipieller Ähnlichkeit mit dem, welcher bei den Acraniern die Plattenbildung einleitete. In den Chordazellen treten nun ansehnliche Vacuolen reichlich auf, so daß ibr Protoplasma samt den Kernen vorwiegend an die Chordaoberfläche gedrängt wird. Gleichzeitig werden die Grenzen der Zellen nndeutlich, das Chordagewebe erscheint als ein vacuolig-blasiges Netzwerk, dem hier und da Zellkerne eingelagert sind, während sich an del Oberfläche, die frühzeitig eine dünne cuticulare Membran ausscheidet (sog. Elastica externa), eine zusammenhängende Plasmalage mit vielen Zellkernen findet (Fig. 84). Jedenfalls scheint es hiernach unrichtig, jede der mit Flüssigkeit oder Gallerte gefüllten Blasen oder Vacuolen als eine Zelle anzusehen. Dies blasige Chordagewebe wächst bei der mächtigen Ausbildung der Chorda stark heran, wobei in der oberflächlichen Lage später oft wieder Zellgrenzen hervortreten, die ihr einen epithelartigen Charakter verleihen (Chordaepithel). In der Chordaachse strecken sich die Vacuolen häufig in die Länge, während sie sonst mehr oder weniger radiär gegen die Chordaoberfläche verlaufen; so entsteht ein axialer sog. Chordastrang. Hervorgehoben werde gleich, daß auch die embryonale Chorda der höheren Vertebraten dieselben Bauverhältnisse zeigt. 
Die Entwicklung der Chordascheide beginnt überall mit der Abscheidung einer recht dünnen cuticularen Hülle, der Elastica externa. Unter dieser bildet sich aber bald eine viel dickere, häufig sogar sehr mächtige Lage, welche ebenfalls von dem Chordaepithel, ausgeschieden wird, die sog. Faserscheide (Fig. 84). Diese Lage fehlt daher den Acraniern wahrscheinlich noch völlig.

Bei den Cyclostomen, Ganoiden und Teleosteern bleibt die Faserscheide stets zellenfrei; bei den Chondropterygiern und Dipnoern dagegen wandern auf einem gewissen Entwicklungsstadium Zellen aus dem perichordalen Bindegewebe durch die Elastica externa in die Faserscheide hinein, wodurch ihr Gewebe dem Faserknorpel ähnlich wird (s. Fig. 85). Diese Einwanderung geschieht dorsal und ventral an der Chordaoberfläche jederseits da, wo sich, wie beim Amphioxus, das perichordale Bindegewebe zur Umhüllung des Rückenmarks, bzw. der ventral von der Chorda liegenden Aorta, erhebt, und zwar nur an den Stellen, wo sich später

Fig. 84 .

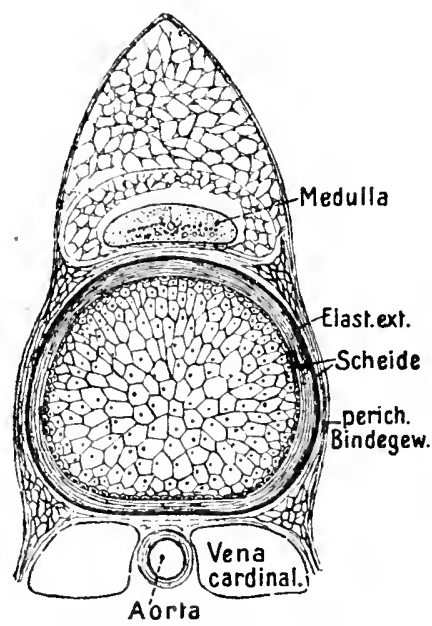

Larre ron Petromyzon planeri (Ammocoetes). Quersehnitt dnreb die Rumpfregion knorpelige Skeletteile, die sog. Wirbelbogen, entwickeln werden.

Bei den Cyclostomen läßt die dicke Faserscheide drei Lagen unterscheiden, deren Faserzüge sich alternierend kreuzen. Ähnlich verbält sich auch die zellenlose Scheide der Knorpélganoiden (Störe). Die Fibrillen der Faserscheide scheinen denen des gewöbnlicben Bindegewebes völlig $z u$ entsprechen, auch leimgebend zu sein.

Obgleich die Einwanderung von Zellen in die Faserscheide bei den Knorpelfischen und Dipnoern an den Stellen geschieht, wo die Basen der sich entwickelnden Knorpelbögen der Chorda anliegen, also auf dem Querschnitt an zwei dorsalen und zwei ventralen Stellen jedes Segments, so verbreiten sich die eingewanderten Zellen allmählich doch durch die ganze Faserscheide. Nur ihre innerste Lage bleibt häuflg zellenfrei und wird dann zuweilen als Elastica interna unterschieden. Die faserknorpelig gewordene Scheide, welche außen von der Elastica externa abgeschlossen wird, läßt zuweilen auch mehrere etwas verschiedene Lagen nnterscheiden. In einer mittleren Lage treten bei den Holocephalen (besonders Chimaera, Fig. 88, S. 184) ringförmige Verkalkungen auf, wobei sich mehrere in einem Körpersegment bilden.

Hypochorda. Bei den Embryonen der Fische und Amphibien entsteht nach Ablösung der Chorda ron der dorsalen Medianlinie des Urdarms in ähnlicher Weise unter ihr ein $z$ weiter, schmächtigerer Zellenstrang, die sog.

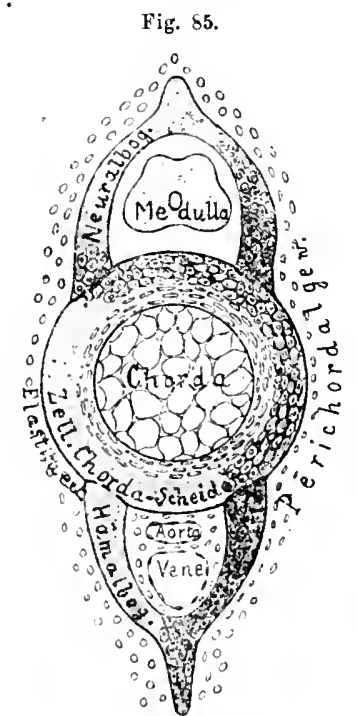

Schematischer Querschnitt zur Entwicklung der Wirbelkôrper eines $\mathrm{Hai}$ fisches. (Mit Benutzung v. SchaurssLASD 1906.)
$12 *$ 
Hypochorda, in der zuweilen auch ein Lumen auftritt. Sie geht schließlich wieder zugrande. Die gelegentlich versuchte Rückführung der Hypochorda auf die bei den primitiven Chordaten, an der dorsalen Mittellinie des respiratorischen Darms, sich findende sog. Epibranchialrinne ist nicht unmöglich und wird später bei diesem Organ nochmals zu erwähnen sein.

Aus der gegebenen Schilderung folgt, $\mathrm{da} B$ die dauernd persistierende Chorda der obenerwähnten Vertebraten völlig einheitlich und ungegliedert ist, daß also ihre mechanische Wirkung ähnlich sein muß wie bei den Acraniern. Die Gliederung des höher entwickelten Achsenskelets beginnt erst mit dem Auftreten knorpeliger, segmental angeordneter Skeletelemente im AnschluB an die Chorda, welche sie bei stärkerer Entwicklung in die segmentale Gliederung hereinziehen. Diese der

Fig. 86.

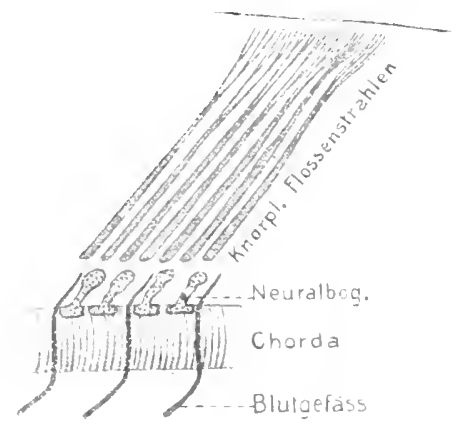

Petromyzon marinas. Ein Stáck der Chorda mit den knorpeligen Neuralbogen und Flossenstrablen von links. Die in den Myosepten verlanfenden Blatgefāße geben die Grenze der Muskelsegmente an. P. He. Chorda sich beigesellenden Knorpelteile treten dorsal, in den das Rückenmark, und ventral, in den die Aorta und die Cölomwand umgreifenden Fortsetzungen des perichordalen Bindegewebes auf; sie funktionieren einerseits als schützende Skeletteile für diese Organe, andrerseits dienen sie anch zur besseren Befestigung der Myosepten und zur Übertragung von deren Zugwirkung auf die Chorda. Letzteres dürfte wohl ursprünglich ihre Hauptbedeutung und die wesentliche Bedingung ihres Entstebens geweseu sein. Die hauptsächlichsten knorpeligen Bogengebilde entstehen daher auch an den Übergangsstellen der Myosepten in die Bindegewebsumhüllung des Rückenmarks und der Aorta. Daraus folgt, wie dies auch die mechanischen Einrichtungen erfordern, daß diese Skeletgebilde, und damit anch die ersten Anlagen der späteren Wirbelkörper, intersegmental, d. h. auf den Grenzen der Körper- oder Muskelșegmente liegen.

$\mathrm{Zu}_{1}$ Beurteilnng der Lagebeziehungen dieser Skeletgebilde zu den Segmenten dienen daher hauptsächlich die Myosepten, sowie die in ihuen laufenden Blutgefäße, welche regelmäßig auf den Segmentgrenzen von der Aorta abzweigen, bzw. als Venen gegen die Chorda heraufsteigen.(sog. Intercostalgefäße). Andrerseits geben jedoch auch die Wurzeln der Spinalnerven Anhaltspunkte, welche jederseits ${ }^{\circ}$ in doppelter Zahl (dorsale und ventrale) in jedem Segment aus dem Rückenmark hervortreten.

Die knorpeligen Bogenbildungen der Cyclostomen sind nur schwach und etwas unregelnäßig entwickelt; den Myxinoiden fehlen sie sogar ganz. Bei Petromyzon (Neunauge, Fig. 86) finden wir an den beiden. Seiten des Rückenmarks, in der sie umschlieBenden Bindegewebslamelle, Knorpelbogen, und zwar in jedem Segment zwei, je einen Bogen zwischen einer ventralen und einer dorsalen Nervenwurzel des Segments. Die zusammengehörigen rechten und linken Bogen schließen dorsal über dem Rückenmark nicht zusammen.

In der vorderen Körperregion weichen sogar ihre Dorsalenden etwas nach außen vom Rückenmark ab. Die Bogen sind in der mittleren Körperregion schwächer und unregelmäßiger, 
z. T. in mehrere Stückchen aufgelöst; in manchen Segmenten fehlen sie sogar. Diese Unregelnäßigkeit scheint darauf hinzudeuten, $\mathrm{da} B$ das knorpelige Achsenskelet bei den Cyclostomen etwas rudimentär geworden ist. Am Schwanzende verscbmelzen die Bogen zu einer unpaaren zusammenhängenden Knorpelleiste, von der Knorpelfortsätze in den dorsalen Schwanzlossensaum aufsteigen (sog. Dornfortsätze oder Flossenstrahlen). Da in den weiter vorn gelegenen Regionen solch unpaare KnorpeIstäbchen (vier pro Segment) frei über dem Rä̈ckenmark vorkommen (s. Fig. 86), so ist anzunehmen, daß sie in der hinteren Schwanzregion mit den Bogen verwuchsen. An der Ventralseite der Chorda finden sich nur in der hinteren Körperregion Kinorpelbildungen, welche in der hinteren Schwanzregion zn einer der dorsalen ăhnlichen Kuorpelleiste mit sog. Dornfortsätzen verwachsen, die an der Schwanzspitze mit der dorsalen verschmilzt. Diese beiden caudalen Knorpelleisten nit Dornfortsätzen finden sich auch bei den Myxinoiden.

Fig. 87.

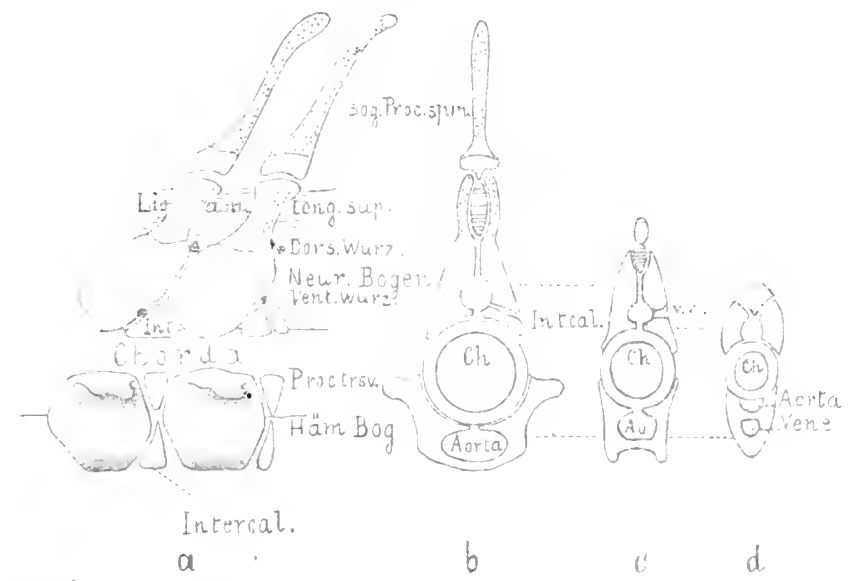

Acipenser sturio. Scbemata zum Bau des Achsenskelets. a bleines Stâck der Chorda aus der Rumpfregion mit $\mathrm{zwei}$ Neuralbogen, von links. $b$ Querschnitt durch die Chorda nebstr Kuorpelbogen aus dieser Region. $c$ Querschnitt durch Chorda und Bogen aus vorderer Schwanzregion; $d$ aus hinterer Schwanzregion. Knochen punktiert.

0. B.

Bei den Knorpelganoiden (besonders Acipenser), deren Chorda sich als mächtiges Organ dauernd erhält, sind dorsale wie ventrale knorpelige Bogenpaare viel kräftiger entwickelt. Sie bilden sich in den dorsalen und ventralen Leisten des perichordalen Bindegewebes, besonders dessen innerer Region, welche deshalb (wie bei den höheren Wirbeltieren gewöhnlich) als skeletogenes oder skeletoblastisches Gewebe bezeichnet wird. In jedem Segment treten anch hier zwei hintereinander folgende dorsate und ventrale Bogenpare auf, von welchen jedoch die vorderen. Paare klein bleiben und sich daher nur wenig über die Chorda, der sie aufsitzen, erheben; wogegen die hinteren sehr hoch werden. Man bezeichnet daher gewöhnlich diese hinteren Bogenpaare allein als Skeletbogen (dorsale oder Neuralbogen und ventrale oder Hämalbogen), die vorderen kleinen Knorpelpaare dagegen als Intercalarstücke (Fig. 87 a). An die großen Bogen heften sich die Myosepten, sie liegen daher etwa auf den Segmentgrenzen.

Betrachten wir zunächst die vordere Schwanzregion, wo die dorsalen nnd ventralen Einrichtungen sehr ähnlich geblieben sind, so finden sich also auf der 
Chorda in jedem Segment ein Paar ansehnlicher dorsaler, schief nach hinten aufsteigender Neuralbogen (Fig. 87 c), deren Basen, ebenso wie die Intercalarstücke, unter dem Rïckenmark nahe zusamınentretend, den Boden des Spinalkanals bilden. Diese Neuralbogen umschließen das Riickenmark und stoßen dorsal itber ihm zusammen, setzen sich jedoch noch eine ansehnliche Strecke dorsal fort, indem sie über dem Rückenmark eiuen Raum umschließen, der von ainem elastischen Längsband (Lig. longitudinale dorsale superius) erfült wird, das sämtliche Bogen verbindet. Auch bei den Acraniern und den Cyclostomen ist dieser Raum schon angedeutet, jedoch nur von dem perichordalen Gewebe häutig umgrenzt und von besonderem Gewebe erfitilt.

Das Ligam. longit. dorsale superius kehrt ebenda auch bei den Fischen und den iöheren Vertebraten wieder. Ventral an der Chorda findet sich bei den Acraniern auch ein ähnliches Ligam. rentrale, das an diesem Ort, die Wirbelkörper verbindend, auch bei den Anamnia rorkommt. Ihm gegenüber findet sich auf der Dorsalseite der Chorda bei den Acraniern ein Lig. dorsale, long. inferius (s. Fig. 82, S. 177).

Die ähnlich den Neuralbogen gebildeten Ventralbogen des Schwanzes umschließen die dicht nnter der Chorda liegende Aorta und die direkt unter dieser befindlicha Candalvene (Fig. $87 d$ ), weshalb sie auch hämale genannt werden. Indem sich die Verknorpelıng von der Innenseite der Hämalbogen auch zwischen die beiden Gefäße fortsetzt, bildet sich bei älteren Tieren eine knorpelige Scheidewand zwischen ihnen. - Als dorsaler Abschlu $B$ der Neuralbogen treten unparre stabförmige Knorpelstücke auf, sog. Dornfortsätze (auch als Flossenträger aufgefaßt), die sich zum Teil in Zweizahl über einem Bogen finden können. Die Enden der Neuralund Hämalbogen sind in der hinteren Schwanzregion knorpelig verschmolzen, die Bogen also geschlossen und die ventralen mit Dornfortsätzen versehen (Fig. 187).

In der Rumpfregion $(87 a, b)$ behalten die Neuralbogen die geschilderte Beschaffenheil im allgemeinen bei; die Hämalbogen dagegen verändern sich mit dem Auftreten der Leibeshöhle sehr. Ihre beiden Bogenlälften trennen sich in der Ventrallinie voneinander und liegen dann divergierend dicht unter dem Peritonenm des Cöloms, da, wo die Myosepten an dieses herantreten. Dagegen erhält sich de dio Aorta umgreifende knorpelige Scheidewand an allen Hämalbogen des liumpres, mit Ausnahme der vordersten (Fig. 87 b). Das distal von dieser Scheidewand gelegrene Stück jeder Bogenbälfte gliedert sich embryonal frühzeitig von dem basalen Teil durch bindegewebige Einschaltung ab und stellt nun eine Rippe dar, während die basalen, an der Chorda anliegenden Teile jedes Bogenpaares (Basalstümpfe) ebenfalls miteinander unter der Chorda zusammenstoßen und an seitlichen Vorsprïingen (Processus transversi, Parapophysen, Fig. 87a,b) die Rippen tragen. In der Rumpfregion entsprechen demnach die der Chorda anliegenden unteren Bogengebilde nicht mehr den völligen Bogen der Schwanzregion, sondern nur deren Basalteilen; man könnte daher diese Teile der Bogen, nach Abgliederung der Rippen, auch als ventralc Wirbelkörperteile bezeichnen, da sie sich bei den höheren am Aufbau der Wirbelkörper beteiligen, wie wir später sehen werden. Zwischen die Basen der Bogen der Dorsal- und Ventralseite sind überall die er- 
wähnten Intercalarstücke eingeschaltet; doch unterliegen diese mancher Unregelmäßigkeit, da sich bảufig an der Stelle eines mehrere finden.

$\mathrm{Daß}$ an dem geschilderten Achsenskelet der Knorpelganoiden schon stellenweise Verknöcherung anftritt, indem sich an den dorsalen nnd ventralen Dornfortsätzen, den distalen Teilen der Dorsalbogen sowie an den Rippen eine dünne Knochemrinde bildet (Stör), ist morphologisch von geringer Bedeutung. Wichtiger dagegen, daß die Neural- nnd Hämalbogen kopfwärts immer mehr seitlich um die Chorda herumgreifen, so daß letztere in der vorderen Rumpfregion völlig umschlossen wird. Beim Stör verwachsen schließlich in der auf den Schädel folgenden Region die Neural- nnd Hämalbogen mehrerer Segmente zu einem geschlossenen Rohr um die Chorda (Fig. 131 u. 132, S. 232), das mit dem Hinterende des Schädels verschmilzt. Die von den Hämalbogen abgegliederten Rippen erhalteis sich jedoch auch in dieser Region gesondert.

Bei den Dipnoern und den Holocephalen, deren Chorda dauernd persistiert, finden sich recht ähnliche Einrichtungen der Skeletbogen. Die Dipnoi zeigen insofern eine Vereinfachnng, als Intercalaria nur in der Schwanzregion zwischen den Neuralbogen vorkommen (Ceratodus). Bei Protopterus sind sie noch rudimentärer. Die weite Verbreitung der Intercalaria bei den niederen Fischen sowie ihre später roch genauer zu betonende Bedeutung dürfte es 'wahrscheinlich machen, daß sie bei den Dipnoi mit den Bogen verwachsen sind. Dornfortsätze finden sich an den Dorsalbogen stets und sind kontinuierlich mit ibnen verbunden; auch den Hämalbogen der Schwanzregion kommen sie zu. Sie sind äußerlich verknöchert wie bei den Stören.

Eigentümlich verhält sich die hinterste Schwanzregion bei Ceratodus, indem die hier vorhandenen Intercalaria nach binten größer werden als die Bogen und schließlich mit deren Resten, so wie die beiderseitigen Intercalaria untereinander zu verschmelzen schemen. Auf diese Art läuft das Ende des Achsenskelets in eine Reihe wirbelartig hintereinander gefügter Knorpelstïcke aus, von welchen die dorsalen und rentralen rerknöcherten Dornfortsätze entspringen. Die vorderen dieser Knorpelstücke umschließen noch Reste der Chorda, die hinteren nicht mehr; die Chorda ist hier vom Knorpel völlig verdrängt worden. Die beschriebene Erscheinung erinnert daher an die Bildung diskreter Wirbelkörper, wie wir sie gleich ïăher betrachten werden.

Die Holocephalen zeigen, wie die Chondropterygii überhanpt, noch keinerlei Spur von Verknöcherung. Ihr Achsenskelet stimmt mit dem der Knorpelganoiden näher überein, da zwischen die Basen der Neuralbogen regelmäßig Intercalaria eingeschaltet sind (s. Fig. 88). Auch zwischen den Hämalbogen treten embryonal Intercalaria auf, verschmelzen jedoch später in ziemlich unregelmäßiger Weise mit dem Bogen desselben Segments oder dem benachbarter. Der dorsale Abschln $\beta$ des Rückgratskanals wird durch die Einschaltung rhombischer Knorpelstückchen zwischen die Dorsalenden der Bogen hergestellt, die vielleicht Dornfortsätzen verglichen werden dürfen. Auch im Schwanz, wo die ventralen Bogen die Candalgefäße umschließen, kommen ähnliche Schlußstückchen vor. - Der direkt an den Schädel stoßende Teil des Achsenskelets zeigt Verschmelznngserscheinungen der Knorpelbogen einer giößeren Anzahl von Segmenten unter völliger 
Umwachsung der Chorda, ähnlich wie es oben für die Knorpelganoiden geschildert wurde. - Die Besprechung der Rippenbildungen, welche den Dipnoern, ähnlich

Fig. 88.

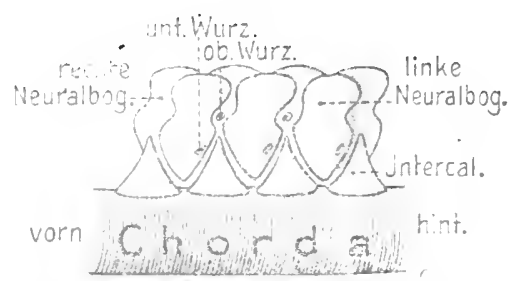

Chimaera monstrosa. Stūck der Chorda mit Neuralbogen nnd Intercalatia von links. Leider sind in der Figar die Hāmalbogen nicht eingezeichnet. P. He. den Stören zukommen, verschieben wir auf später, da diese Abkömmlinge der Hämalbogen in einem besonderen Kapitel gemeinsam behandelt werden sollen.

Unter den Plagiostomen erhält sich die Chorda bei den Notidaniden ohne geschlossene Wirbelkörper sehr ansehnlich; jedoch auch bei Laemargus und Echinorhinus. Die übrigen Haie und Rochen bilden diskrete Wirbelkörper, die sich aus den bisher betrachteten Zuständen des

Achsenskelets folgendermaßen ableiten. In der zelligfaserigen Chordascheide (s. S. 179) treten etwa auf den Segmentgrenzen, d. h. auch etwa entsprechend

Fig. 89.

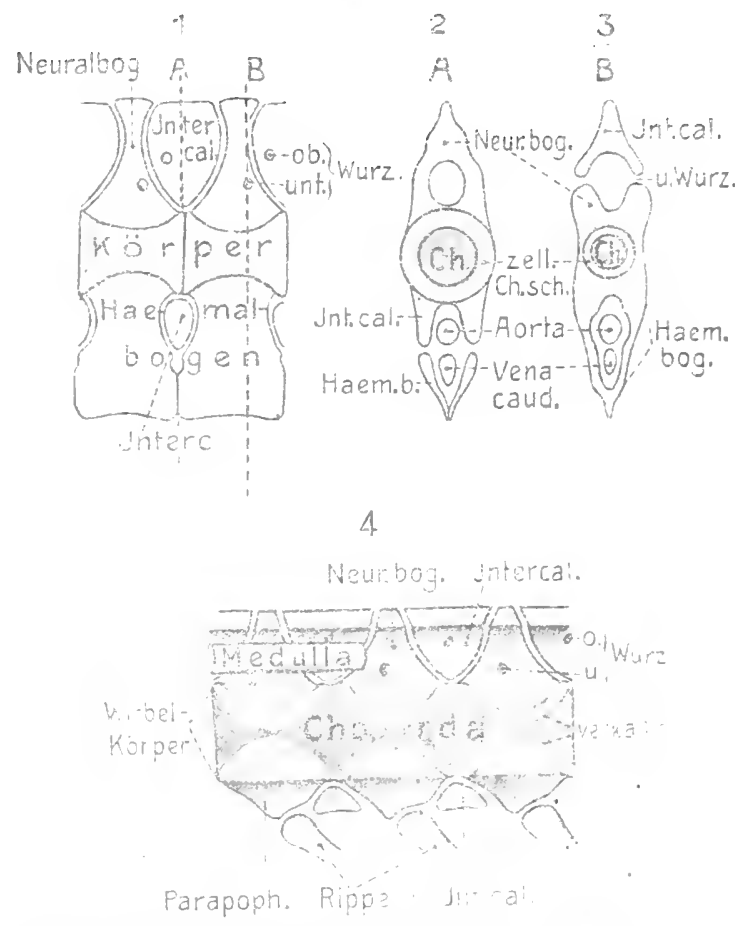

Acanthias valgaris, 1 Zwei Wirbelkörper der Schwanzregion von links. 2-3 Querschnitte durch Schwanzwirbel; $2 A$ in der Richtung der panktierten Linie $A$ Fig. $1 ; 3 B$ der Linie $B$ Fig. 1.4 Medianschnitt dnrch die Wirbelsáule der Rnmpfregion. den Wirbelbogenanlagen, ringförmige Verknorpelungen auf, während die dazwischen liegendeu $\mathrm{Ab}$ schnitte der'Scheide bindegewebig bleiben (vgl. Figur85). Jeder ringförmige Knorpel ist die Anlage eines Wirbelkörpers. Der Knorpelring verdickt sich gegen die Achse der Chorda zu und schnürt sie schließlich allseitig ein. Gleichzeitig bewirkt er, daß beim Weiterwachsen des Achsenskelets die Chorda nur intervertebral wachsen kann, dagegen in der Mitte jedes späteren Wirbels nicht. Der aus der Chordascheide entstehende Teil der Wirbelkörper erhält daher eine etwa sanduhrförmige, amphicöle Gestalt, mit hinterer und vorderer Aushöhlung, sowie einer axialen Längsdurchbohrung (Fig. $89^{4}$ ). Durch diesen Kanal zieht der eingeschnürte Teil der Chorda und erweitert sich intervertebral, den 
Raum erfüllend, welchen die aufeinander stoßenden Aushöhlungen der Wirbel bilden. Aus den intervertebralen Partien der Chordascheide entsteht endlich eine ligamentöse Bindegewebsverbindung der Ränder der aufeinander folgenden amphicölen (bikonkaven) Wirbel, in der zuweilen auch Verknorpelung auftreten kann.

In der Regel beteiligen sich jedoch auch die frühzeitig angelegten knorpeligen Wirbelbogen an der Vervollstindigung der Wirbelkörper. Übereinstimmend mit

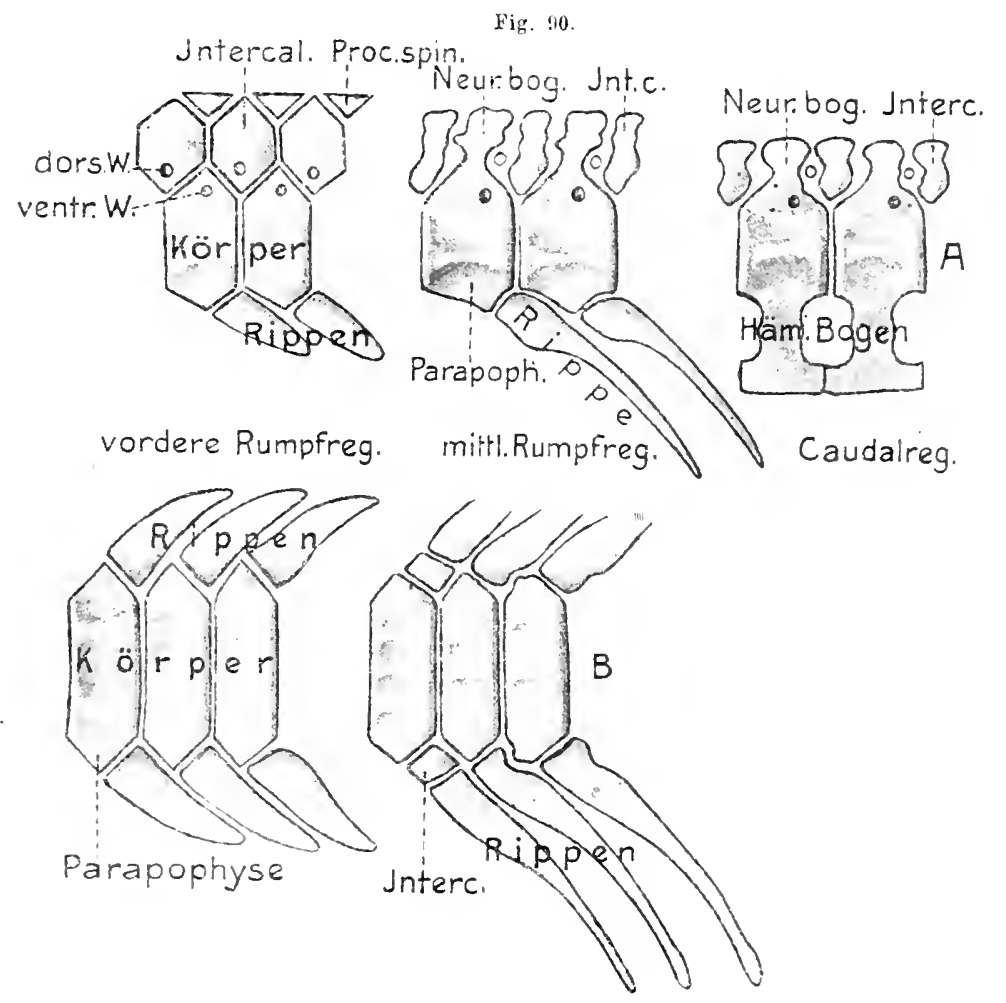

Squatina angelns. Wirbelsäule. $A$ ron der linken Seite, aus vorderer und mittlerer Rumpf-, sowie Caudalregion. $B$ ron der Ventralseite, aus vorderer und mittlerer Rumpfrogion.

den seither betrachteten Formen bilden sich auch bei den Plagiostomen in jedem Segment zwei Paar dorsale und zuweilcn auch, besonders in der Schwanzregion, zwei Paar ventrale Bogenanlagen (sonst hier nur ein Paar). Von diesen entwickeln sich die hinteren zu den Neural- und Hämalbogen, die vordes enzu sog. Intercalarien. Indem nun die Neural- und Hämalbogen ųm die Außenfläche der aus der faserigen Chordascheide entstandenen, sog. primären knorpeligen Wirbelkörper hinab und hinauf wachsen und schließlich, seitlich verschmelzend, sie ganz umhïllen, bildet sich eine äußere Zone des Wirbelkörpers, die von den Bogen gebildet wurde; doch erhalten sich noch ziemlich lang Reste der Scheide zwischen den beiden Wirbelteilen. - Zwischen die Neuralbogen schỉeben sich die erwähnten Intercalarien 
regelmäBig ein, die zuweilen stärker werden als die Bogen und dann den Dorsal-" abschluß des Spinalkanals bilden (Fig. 90, vordere Rumpfregion), was bei ansehnlicherer Höhe der Neuralbogen gemeinsam von ihnen und den Intercalarien geschieht (Fig. $89^{14.4}$ ). - Zuweilen treten jedoch noch unpaare dorsale Schlußstücke (ev. Processus spinosi) hinzu, zur Vervollständigung des Kanaldachs (Fig. 90, vordere Rumpfregion). Die Hämalbogen sind in der Schwanzregion geschlossen (Fig. 89 1-3) und nicht selten durch Intercalarien getrennt, welche sich gelegentlich in die Rumpfregion fortsetzen. In letzterer sind meist Rippen von den Hämalbogen abgegliedert, so daß hier nur der Körperteil der Bogen als sog. Parapophyse am Wirbelkörper vorspringt (Fig. $89^{4}$ u. 90). Ein Fortsatz zur UmschlieBung der Aorta (wie wir ihn bei den Knorpelganoiden sahen) ist nur zuweilen angedeutet, bildet aber nie einen geschlossenen Kanal um die Aorta.

In der Mittelzone der primären Wirbelkörper tritt fast stets Verkalkung des Knorpels auf, welche einen verkalkten Doppelkegel im knorpeligen Körper bildet (Fig. 894), von dem häufig verkalkte Lamellen gegen die Oberfläche ausstrahlen, oder um den sich weitere cylindrische Kalkschichten bilden können. Gewöhnlich verkalken jedoch auch der oberflächliche, von den Bogenanlagen gebildete Knorpel des Körpers, sowie die Bogen selbst teilweise.

Der Bildung eines besonders festen vorderen Abschnitts der Wirbelsäule durch Verschmelzung vorderer Wirbel begegnen wir auch in dieser Gruppe, was bei den Rochen am stärksten ausgeprägt ist.

Interessante Unregelmäßigkeiten treten häufig in der Schwanzregion auf, indem auf den Raum zwischen zwei Spinalnerven zwei bis mehr Wirbelkörper kommen können (Diplo- und Polyspondyli). Die wahrscheinlichste Erklärung bierfür dürfte die Annahme sein, daß einzelne Muskelsegmente verschmolzen (bzw. auch rudimentär geworden sind), während sich ihre Wirbel erbielten, was auch durch das Vorkommen rudimentärer Nerven begründet erscheint. Bei gewissen Haien beobachtet man in der hinteren Rumpfregion Besonderheiten, welche die eben erwähnten fortsetzen, d. b. abnorm lange Wirbel, die 2-4 Bogenpaare tragen können. Man muß also annebmen, daß es hier zur Verschmelzung ron Wirbelkörpern der vereinigten Muskelsegmente kam, während sich die Bögen erhielten.

Gesonderte Wirbelkörper mit weitgehender Verknöcherung. charakterisieren die Knochenganoiden im Gegensatz zu den Knorpelganoiden. Die Ontogenese (speziell Amia) erweist áuer, daß diese Körper aus Zuständen hervorgingen, welche denen der Störe ähnlich waren. Zwischen den Anlagen der knorpeligen Neuralbogen traten auch hier Intercalarien auf, die zwischen den Hämalbogen in der Regel nur noch im Schwanz gebildet werden, im Rumpf dagegen wohl mit den Wirbelkörperteilen der Ventralbogen vereinigt șind. Frühzeitig tritt an den Bogenbasen und Intercalarien oberflächliche Verknöcherung auf, die allmählich auch auf das die Chorda umgebende Bindegewebe übergreift, und so einerseits eine Verbindung der beiderseitig zusammen gehörenden Bogenhälften herbeiführt, andrerseits aber von der Basis der Hämalbogen gegen die Dorsalseite herauf steigt, wie denn diose Bogen in der vorderen Rumpfregion stark dorsalwärts emporwachsen, was schon den seither beschriebenen Formen eigen war. Auf solche Weise wird schlieBlich ein Knochenring gebildet, wẹlcher ventral die Hämalbogen trägt, wäh- 
rend ihm dorsal die Neuralbogen aufsitzen. - Gleichzeitig geht von den dorsalen Intercalarien, welche auch hier die vordere Segmenthälfte einnehmen, die Bildung eines ähnlichen Knochenrings aus, der von der Dorsalseite aus die Chorda allmählich umwächst. Durch diesen Vorgang, welcher in der Schwanzwirbelsäule von Amia deutlich zn verfolgen ist, werden also in jedem Segment zwei Wirbelringe, ein vorderer und ein hinterer gebildet. Solche Doppelwirbel erhalten sich in der Schwanzregion von Amia vereinzelt bis ins Alter (Fig. 91), während sie in den übrigen Schwanzsegmenten zu einheitlichen Wirbelkörpern verwachsen; doch können auch noch ausgedehntere Verwachsungen auftreten, so daß z. B. drei der aufeinander folgenden Halbwirbelringe zu einem Körper znsammentreten. - Im Rnmpf tritt dagegen die erstgeschilderte Verschmelzung zweier Halbwirbel regelmäßig auf, wobei sich gleichzeitig die Neuralbogen nach vorn auf die Intercalarien hinaufschieben.

Die so gebildeten knöchernen Wirbelkörper sind amphicöl, mit schwacher vorderer und hinterer Aushöhlung, was auf der vertebralen Verknöcherung beruht, welche nur ein intervertebrales Weiterwachsen der Chorda erlaubt. -

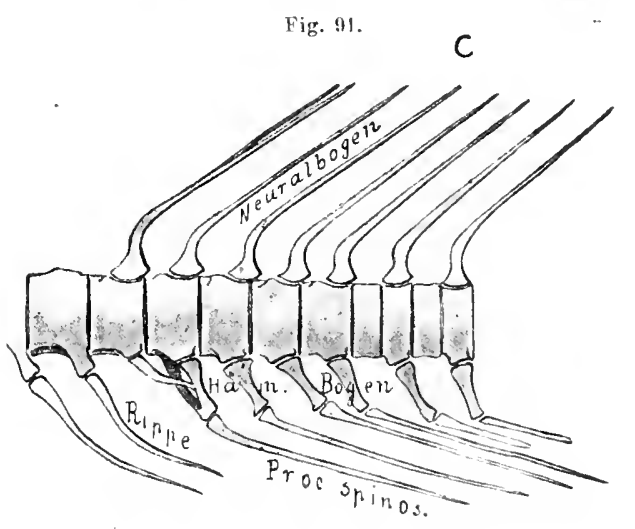

A mia calva. Teil der Wirbelsāule aus Grenze von Rumpf und Schwanz; ron links. O. B. Ähnliche Wirbelkörper besitzt auch Polypterus. Bei Lepidosteus dagegen, in dessen Entwisklung Intercalarien nicht beobachtet wurden, treten die Basen der knorpeligen Bogenanlagen bei ihrer Weiterentwicklung intervertebral in knorpelige Verbindung um die Chorda; die so gebildete Knorpelhülle verdickt sich hieranf auf der Grenze der späteren Wirbelkörper, wodurch sie die Chorda hier stark einschnürt. Indem schließlich in diesen Intervertebralknorpeln eine quere Sonderung auftritt, bildet sich ein Gelenk der zusammenstoßenden Wirbelkörper aus, indem eine vordere konvexe Gelenkfläche und eine hintere konkave jedes Körpers entsteht. Die fertigen Wirbelkörper des Lepidosteus sind daher nicht amphi-, sondern opisthocöl.

Die Wirbelkörper der Amia ergaben sich als das Verwachsungsprodukt der beiden Skeletbogenpaare, welche bei den ursprünglichsten Formen jedem Körpersegment zukommen. Die Richtigkeit dieser interessanten Tatsache wird durch die Bauverhältnisse des Achsenskelets der fossilen Vorläufer der Knochenganoiden bestätigt, bei denen die Chorda hïufig noch danernd und vollständig bestand, ähnlich den Knorpelganoiden. Da sich jedoch nur die verknöcherten Teile des Achsenskelets erhalten konnten, nicht die knorpeligen, welche zweifellos gleichfalls vorhanden waren, so erfordert die Beurteilung dieser Verhältnisse immerhin einige Vorsicht. Besonders fossile Amiadei zeigen Bauverhältnisse, welche sich den Entwicklungsstadien der rezenten A mia nahe anschließen. Das Achsenskelet 
bestand nämlich aus Neuralbogen, die der Chorda aufsaßen, und zwischen deren Basen sich halbringförmige Knochenstïcke einschalten, welche der Chorda dorsal auflagen (Fig. 92). Letztere, gewöhnlich Pleurocentra genannt, entsprechen daher wohl sicher den verwachsenen beiderseitigen Intercalarien. Die Hämalbogen (bzw. ihre Körperteile) umgreifen gleichfalls die Ventralseite der Chorda halbringförmig (sog. Hypocentra). Indem sich die dorsalen Intercalarien tiefer ventral hinab, die Körperteile der Hämalbogen hingegen dorsal hinauf ausdehnen, wird schließlich die Chorda allseitig von diesen knöchernen Skelethalbringen umfaßt. Von hier ist dann nur noch ein Schritt bis zur Vervollständigung der beiden Halbringe jedes Segments zu Vollringen und daher zwei Doppelwirbelringen pro Segment; wie es

Fig. 92.

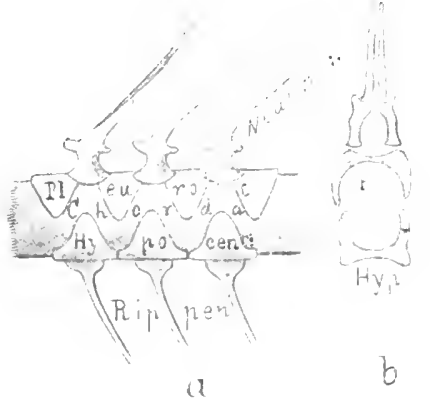

Wirbelsāule fossiler Ganoiden. "C C a turus furcatus. Teil der Wírbelsăule aus Rumpfregion rou links. b Callopterusagassizii. Wirbelkörper von vorn. (Nawh ZrTTELS Handbuch.) in der Schwanzregion gewisser Formen auftritt, die im Rumpf noch die zuerst erwähnte Bildung zeigen. Endlich führt die Verwachsung der beiden Doppel wirbelringe zur Entstehung von Vollwirbeln, was sich an der Wirbelsäule einer und derselben Form zuweilen noch direkt nachweisen läßt, ähnlich wie bei Amia.

Teleostei, Die Enitwicklung der Wirbelkörper der Knochenfische um die mit zellenloser Faserscheide versehene Chorda verläuft ähnlich wie bei den Knochenganoiden, daher genügen einige Bemerkungen. Die Bildung des fast stets ansgeprägt amphicölen Körpers geschieht auch hier ohne Beteiligung der Chordascheide ans dem perichordalen Bindegewebe, und beginnt mit der Anlage knorpeliger Neural- nnd Hümalbogen, welche jedoch nicht die Größe erreichen wie bei den seither besprochenen Formen. Zwischen den knorpeligen Bogenanlagen wurden in einigen Fällen noch kleinere Knorpelgebilde aufgefunden, meist dorsal, seltener auch ventral im Schwanz, die eventuell Intercalarien homolog sein könnten; jedoch liegen sie hier neben den Distalenden der Neuralbogen. Eine knorpelige Unwachsung der Chorda durch die Bogenbasen findet nur in der vorderen Rumpfregion zum Teil noch statt, wo die Körperteile der Hämalbogen wieder stark dorsal emporsteigen. - Die Verknöcherung der Bogen beginnt frühzeitig und greift bald auf das perichordale Bindegewebe über, so daß ein knöcherner Ring in der Mitte des späteren Körpers entsteht, welcher nur ein intervertebrales Weiterwacbsen der Chorda gestattet und den amphicölen Wirbelbau bedingt. So wird ein ansehnlicher Teil des Wirbelkörpers nicht knorpelig vorgebildet, sondern sofort knöchern angelegt; dies gilt anch für die distalen Partien der Neuralbogen und weiteres: Teile des Wirbelkörpers, die bei den primitiveren Formen knorpelig vorgebildet werden. Die oben erwähnten intercalarartigen Knorpel werden bei der Verknöcherung in die Neuralbogen einbezogen. Auch bei den Knochenganoiden finden siç ähnliche Gebilde. Den eigentlichen Intercalarien können sie nicht wohl entsprechen, da diese ja bẹi Amia sehr gut und an anderer Stelle ent- 
wickelt sind. - Der ursprünglich dünne knöcherne Wirbel verdickt sich unter gleichzeitigem Längenwachstum durch Auflagerung von Knochensubstanz, sowie durch den Übergang der knorpeligen Bogenanlagen in Knochen. Letzteres geschieht jedoch in verschiedenem Grad; zum Teil vollständig, so daß die knöchernen Bogén kontinuierlich mit dem Wirbelkörper znsammenhängen, was das gewöhnliche ist. Oder die Basen der Bogen bleiben knorpelig und setzen sich dann entweder knorpelig in die Knochenmasse des Körpers fort (z. B. bei dem Hecht), oder es erhäit sich seltener eine dünne Knorpellamelle, welche den Bogen vom Körper sondert.

Die Chorda bleibt ebenso erhalten wie bei den Plagiostomen und füllt die intervertebralen Räume aus. Das Chordagewebe erleidet bei den Teleosteern eigentümliche Umbildungen, indem in der Regel weite, mit Flüssigkeit erîullte Räume in ihm entstehen in verschiedener, jedoch in jedem Wirbelabschnitt sich regelmäßig wiederholender Anordnung; was zur Folge hat, daß das Gewebe in gewissen Abständen quere Scheidewände in der Chorda bildet.

Die voll entwickelten Wirbelkörper der Teleosteer (Fig.93-94) sind also gewöhnlich tief amphicöl, selten vorn weniger oder nicht ausgehöhlt. Die Neuralbogen entspringen meist von der vorderen Hälfte des Körpers, rücken jedoch gegen die Schwanzregion immer mehr auf die hin-

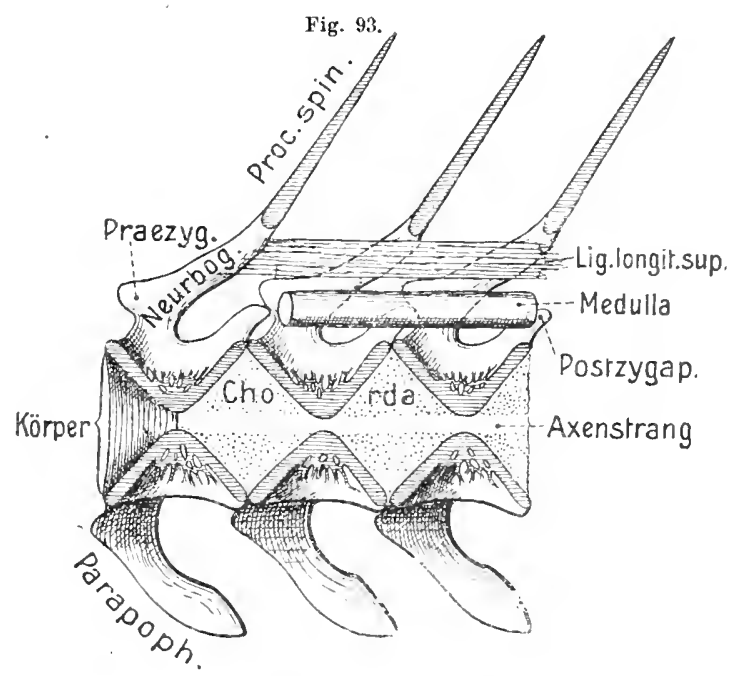

Gadus morrhua. Drei Wirbelkörper der Rumpfregion median durehschnitten. Medulla and Ligamentum longitudin. sup. eingezeichnet. Schnittfächen der Wirbelkörper sehraffiert. tere. Sie umschließen das Rückenmark seitlich und dorsal; doch vereinigen sie sich gewöhnlich nicht über dem Rückenmark, sondern laufen schief caudalwärts aufsteigend in ansehnliche Fortsätze aus, welche zunächst über dem Rückenmark den Kanal umschließen, in dem das dorsale Wirbelligament verläuft (93). Ihre dïnn auslaufenden dorsalen Enden können völlig getrennt bleiben und dicht nebeneinander hinziehen; gewơhnlicher verwachsen sie aber miteinander zu einem einheitlichen Dornfortsatz, dessen ursprüngliche Paarigkeit häufig durch eine vordere und hintere Furche angedeutet bleibt. Andeutungen einer anfänglichen Zusammensetzung jeder Bogenhälfte aus zwei Teilen sind bei manchen Fischen erkennbar, was wahrscheinlich anf die beiden oben erwähnten knorpeligen Anlagen rückführbar sein dürfte.

In der Schwanzregion finden sich stets untere Bogen, die in der Regel geschlossen und in Dornfortsätze verlängert sind (Fig. 94, 96). In zahlreichen Fällen scheint es sicher, daß diese ventralen Bogen denen der seither besprochenen Fische homolog, 
d. h. vollständige Hämalbogen sind; doch kann diese Frage erst im Kapitel über die Rippen genauer behaudelt werden. In anderen Fällen dagegen scheint ebenso klar, daß die ventralen Bogen der Schwanzregion nicht vollständigen Hämalbogen

Fig. 94.

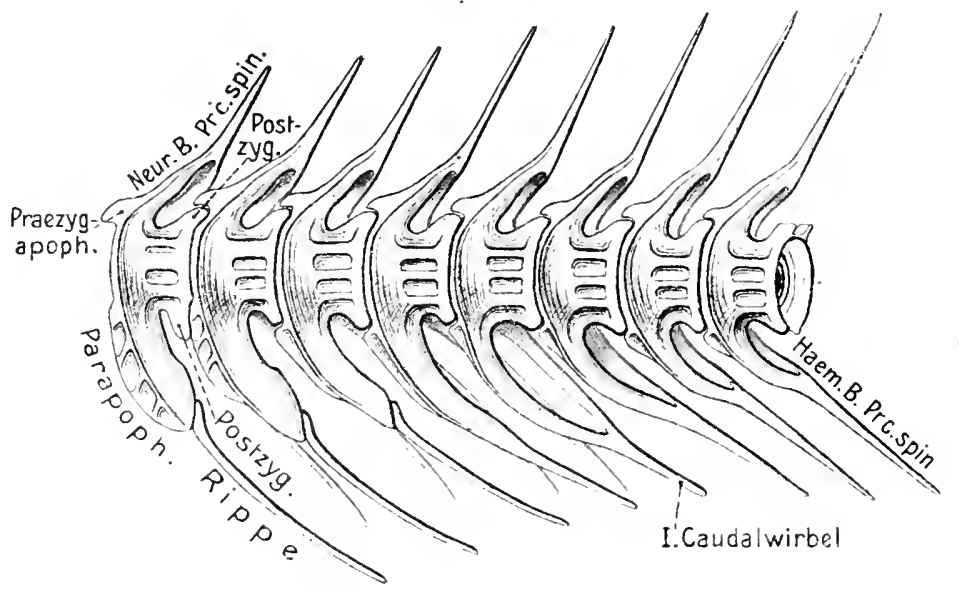

Gadus morrhua. Stūck der Wirbelsänle ans Grenze von Rumpf und Schwanz; von links. v. Bu.

gleichzusetzen sind, sondern nur deren Körperteil, welcher sich, unter Verlust des im Rumpfe als Rippe abgegliederten Teils der ursprünglichen Hämalbogen, um die Caudalgefäße geschlossen hat, ähnlich wie es beim Stör um die Aorta geschieht.

Fig. 96.

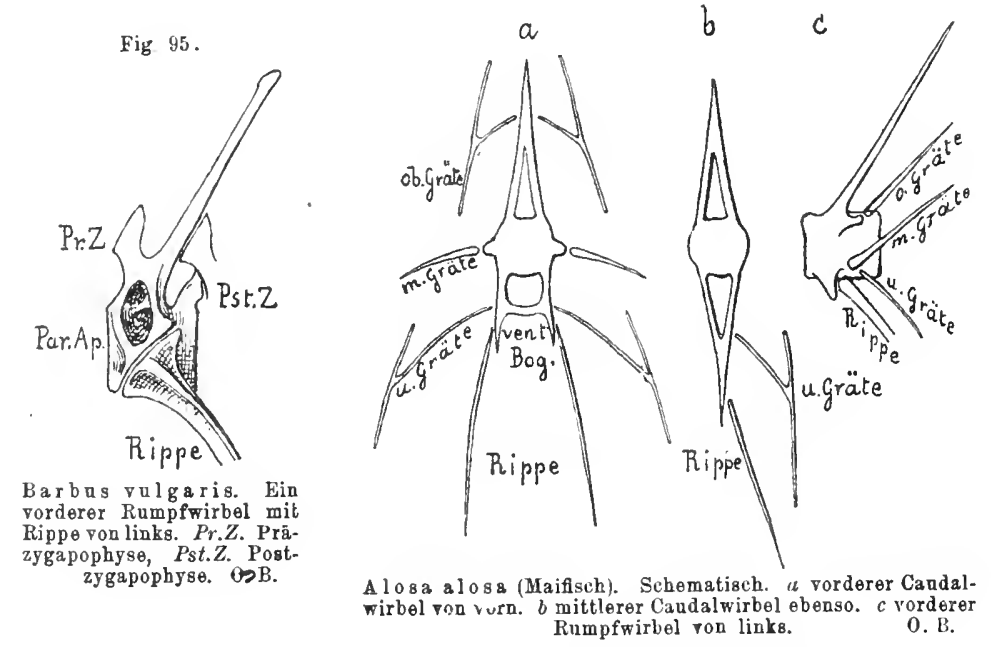

Die Parapophyse (Querfortsatz) zur Befestigung der Rippen entspringt in der hinteren Rumpfgegend tief am seitlichen Ventralrand der Wirbel (94), nach vorn steigt sie jedoch meist höher, ja gelangt bisweilen bis an die Basen der Neural- 
bogen (Fig. 95); gleichzeitig nehmen die Parapophysen an Länge ab. Schon in der hinteren Rumpfregion bilden sie häufig unter die Aorta hinabgreifende Fortsätze, die sich schließlich vereinigen nnd in die unteren Schwanzbogen der zweiten Art übergehen (Fig. $96 a, b)$. Ja es können sich selbst durch die ganze Rumpfregion untere Bogenbildungen fortsetzen, die denen der Schwanzregion völlig entsprechen (gewisse Pleuronectiden). - Neben den eigentlichen Parapophysen treten zum Teil in der mittleren Seitenregion der Wirbelkörper entspringende Fortsätze auf $(96 a)$, die, wie wir später sehen werden, ebenfalls eigenartige Anhänge tragen können.

Von der Basis der Neural- nnd Hämalbogen erheben sich nach vorn senkrecht oder etwas schief auf-, bzw. absteigende Fortsätze, sog. Gelenkfortsätze (Präzygapophysen), die sich ähnlichen Fortsaitzen, welche vom Hinterende des vorhergehenden Wirbels entspringen (Postzygapophysen), anlegen oder sie anch umgreifen (Fig. 93 bis 95). Die dorsalen Gelenkfortsätze tragen hänfig wesentlich zur Vervollständigung des Spinalkanals bei.

Die Ontogenie scheint darauf hinzuweisen, $\mathrm{la}_{\mathrm{B}}$ auch die Teleosteerwirbel ursprünglich wie die der Knochenganoiden, aus zwei Halbwirbelringen, bzw. vier Paar Bogenanlagen, hervorgingen. Im Gegensatz zu den bei Amia bestehenden Verhältnissen wird jedoch rermutet, daß bei den Knochenfischen gewöhnlich ein dorsaler und ventraler Bogeu mit den Intercalarien des nachfolgenden Segments zu einem Wirbelkörper zusammengetreten seien, d. h., daß der Wirbelkörper aus dem hinteren Paar Bogenanlagen (eigentlichen Bogen) und dem vorderen Paar des folgenden Segments (Intercalaria) entstanden sei, wofür sich auch bei Amia Beispiele an einzelnen Wirbeln finden. Der Wirbelkörper wäre so, wie natürlich, auf der Grenze zweier Muskelsegmente entstanden. Ob jedoch, bei Anerkennung dieser Annahme, die Deutung der Postzygapophysen als Vertreter der Interealaria gerechtfertigt erscheint, dürfte weder durch die Ontogenie noch die vergl. Anatomie erweisbar sein, um so weniger, als ja die ganz ähnlichen Präzygapophysen besondere Bildungen sind, die sich erst von den Bogen aus entwickelten.

\section{Wirbelsiule der tetrapoden Vertebrata.}

Obgleich die Chorda aller höheren Vertebraten ontogenetisch in ähnlicher Weise auftritt wie bei den seither besprochenen, so bleibt sie doch immer schwächer. Namentlich gilt dies für ihre Scheide. Wenn auch die Amphibien beide Scheiden, die :iußere Elastica und die Faserscheide, noch besitzen, so bleiben sie doch stets relativ dünn gegenüber der Dicke, die sie bei gewissen Fischen erlangten. - Der Chorda der Amnioten fehlt die Faserscheide dagegen fast stets vốllig, ebenso auch der sog. axiale Chordastrang.

Amphibien. Das Achsenskelet der Amphibien begann mit Zuständen, welche sich von denen primitiver Fische kaum entfernten, sich sogar in Einzelheiten den Einrichtnngen der ursprünglicheren Knochenganoiden anschlossen. Wir begimnen unsere Besprechung daher mit jenen fossilen Amphibien (Stegocephalen). Die Chorda der ursprünglicheren Formen war ein bleibender mächtiger Bestandteil des Achsenskelets und trug, ähnlich gewissen fossilen Knochenganoiden und den Knorpelganoiden, verknöcherte Neural- und Hämalbogen (Fig. 971-2). Den mit einem Dornfortsatz, sowie meist mit vorderen und hinteren Zygapophysen versehenen Neuralbogen lagen im Rumpf, an der Ventralseite der Chorda, etwa halbringförmige Knochenstïcke gegeniiber (sog. Hypocentra, auch Intercentra genannt), 
in welchen leicht die Körperteile der Hämalbogen zu erkennen sind; um so mehr, als sie in der Schwanzregion in nntere Bogen mit Dornfortsätzen auslaufen (Fig. 972), ja im äußersten Schwanzende paarig werden können. Zwischen je zwei aufeinander folgenden Neuralbogen war jederseits noch ein kleineres Knochenstück (sog. Pleurocentrum) eingeschaltet, zu denen sich in der hinteren Schwanzregion ventrale paarige oder unpaare Stiicke gesellen können (Hypocentra pleuralia), die jedoch bei gewissen Formen auch noch weiter über die Wirbelsänle verbreitet sind. Daß die Pleurocentra den Interealarien gleichznsetzen sind, dürfte wohl sicher sein. Derartig gebante rliachitome Wirbel gleichen also auffallend den früher geschilderten gewisser

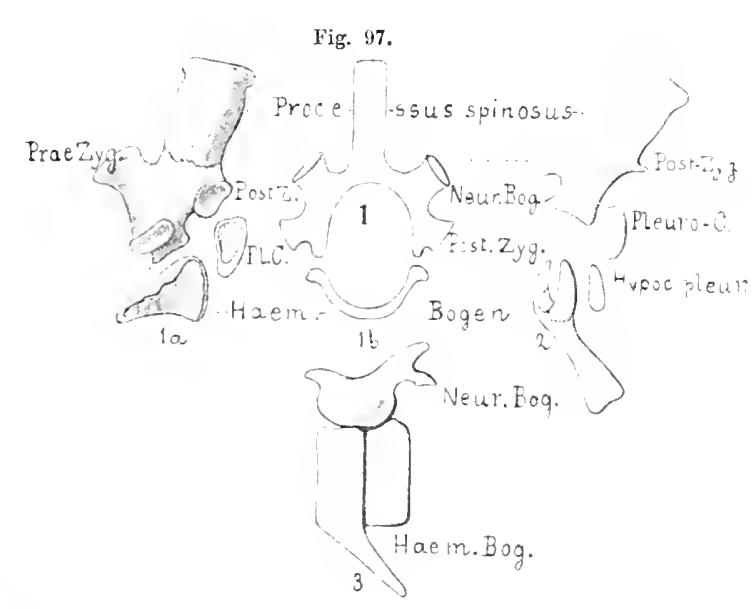

Wirbelvon Stegocephalon. 1 Euchis a rus rochai (nach GAoder). $1 a$ Rumpfwirbel von links. $1 b$ von vorn. PLC Pleurocentrum. 2 A rehe tosaurus decheni Schwanzwirbel von links. 3 Cricotus erasi discus. Schwanzwirbel von links. (Nach ZIT'TeLs Handbuch). O. B. fossiler Knochenganoiden, mit dem Hauptunterschied, daß die beiderseitigen dorsalen Intercalarien (Pleurocentra) der Stegocephalen nichtpaarweise verwachsen sind.

Die Übereinstimmung wird noch größer, indem sich in der Scliwanzregion verwandter Stegocephalen Wirbel finden, die aus zwei Halbwirbeln und zugehörigem Neuralbogen, sowie Hämalbogen bestehen (Fig. 973). Es ist kJar, daß diese sog. embolomeren Wirbel durch

Auswachsen der Hypocentra und Pleurocentra zu Halbwirbelkörpern entstanden. Es läßt sich auch leicht erkennen, daß die Neuralbogen den ans den Hämalbogen entstandenen Halbwirbeln aufsitzen, und daß die amphicölen Vollwirbel der sich anschließenden Formen aus der Vereinigung je eines hämalen Halbwirbels mit dem darauf folgenden intercalaren hervorgingen, also in derselben Weise, die für die Knochenfische angenommen wird. Daß die amphicölen Vollwirbel gewisser Stegocephalen sich in der Tat so hervorbildeten, wird dadurch bestätigt, daß man vereinzelt rhachitome Jugendstadien derselben beobachtet bat (Mastodonsaurus). Andrerseits wird jedoch anch wahrscheinlich gemacht, da $B$ die geschlossenen Vollwirbel höherer Stegocephalen unter Verkümmerung der Plenrocentra nur aus dem Hypocentrum entstanden. - Dennoch scheint sich unter den Stegocephalen ein zweiter Bildungsmodus amphicöler Wirbelkörper zu finden, der mit dem Auftreten einer einheitlichen diinnen Knochenhülse um die ursprïnglich stark erhaltene Chorda begann, und durch deren Verstärkung schließlich zn fischähnlichen amphicölen Wirbeln führt. Letzterer Entwicklungsgang scheiut sich dem der hentigen Caudatenwrrbel näher anzuschließen. 
Knorpelige Neuralbogen werden bei den rezenten Amphibien in der ganzen Ausdehnung des Achsenskelets angelegt, verschmelzen jedoch bei den Anuren friihzeitig jederseits zu einem zusammenhängenden Knorpelstreif. Nur bei Caudaten treten zuweilen zwischen den Bogenanlagen eingeschaltete Knorpelstücke auf, welche Intercalarien (Pleurocentren der Stegocephalen) entsprechen könnten. Hämalbogen entwickeln sich in der Schwanzregion der Candaten noch gut; in der Rumpfregion hingegen nur selr geringfügig, als parig gesonderte Gebilde, welche den Körperteilen der Hämalbogen entsprechen. Wie bei den Rippenbildangen genauer erörtert werden soll, wächst jedoch von dieser jederseitigen Anlage ein Fortsatz gegen die Basis des Neuralbogens empor und verbindet sich schließlich mit ihr. Aus dieser Stelle entwickelt sich später der sog. obere Querfortsatz oder die Diapophyse, an der die Rippe hauptsächlich befestigtist. - Ähnlich den Teleosteern verknöchert bei den Caudaten das Perichordalgewebe frühzeitig zu einem dünnen, etwas amphicölen Wirbelkörper (Fig. 98), indem gleichzeitig auch die Bogen zu verknöchern beginnen. Auf den späteren Wirbelgrenzen bildet das perichordale Gewebe, ähnlich wie bei Lepidosteus,

Fig. 95.

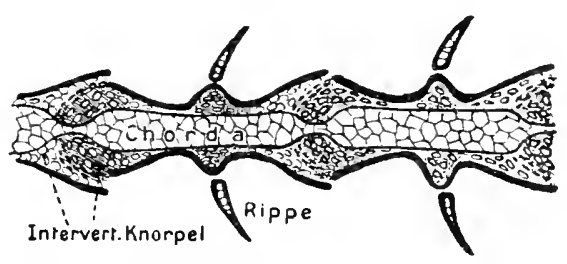

Triton jung. Schematischer Horizontalschnitt durch zwei Rumpfwirbel. Knochen schwarz. (Nach SchaurnsLAND 19U6.) O. B. einen ringförmigen Intervertebralknorpel aus, der gegen die Chordaachse wuchert und sie intervertebral einschnürt. Dieser Knorpel wächst jedoch auch in dünner Schicht zwischen die Çorda und denknöchernen Wirbelkörper hinein. Am geringsten entwickelt er sich bei den Perennibranchiaten, wo sich auch kein Gelenk in ihm sondert. Dieselbe Beschafienheit bewahren ferner die Wirbel der Gymnophionen dauernd, verharren daher anf einer recht primitiven Stufe.

Der Intervertebralknorpel der Salamandrinen wird viel stärker und sondert sich, wie bei Lepidostens, auf der Grenze der Wirbelkörper in zwei Teile, von welchen sich der vordere als die hintere konkave Gelenkfläche dem cranialen Wirbel anschließt, der hintere als vorderer konvexer Gelenkkopf dem caudalen (98). Die Wirbel der Salamandrinen sind daher im entwickelten Zustand opisthocöl, von einer Art amphicöler Anlage ausgehend, wie sie sich bei den Pereunibranchiaten und Gymnophionen noch ziemlich ursprünglich erhält. Im Innern der Wirbelkörper verbleibt daher bei den Caudaten nnd Gymnophionen immer ein ansehnlicher Chordarest, welcher in der Mitte sogar knorpelartig werden kann (sog. Chordaknorpel). - Auch bei den Anuren bildet sich der Intervertebralknorpel ansehnlich aus und verdrängt die Chorda intervertebral ganz. Wie bei den Caudaten bildet er das Wirbelgelenk, das jedoch hier in der Regel vorn konkav, hinten konvex ist. So entsteht die procòle Forin der Wirbel, von der jedoch zuweilen vereinzelte abweichen (bei gewissen Gattungen, Pipa, Bombinator u. a., sind die Wirbel opisthocöl). - Ein Chordarest findet sich daher nur noch intravertebral, geht aber im Alter bei manchen Anuren ganz ein. 
Nicht wenige Anuren (ron einheimischen Pclobates, Bombinater, Alytes) entwickeln jedoch das Achsenskelet sehr abweichend, indem es sich, abgesehen von dem Schwanzteil (sog. Urostyl, Os coccygis), iiber der Chorda hervorbildet, die also gar nicht in die Wirbelkörper eingeht. Daß hier eine sekundäre, sehr eigentümliche Modiflkation des ursprünglichen Entwicklungsgangs vorliegen $m u ß$, scheint sicher. Die Wirbel gehen in diesem Fall allein aus den knorpeligen Anlagen der oberen Bogen hervor, welche das Rückenmark umwachsen. Da wir schon sahen, daß bei den Amphibien, wie bei den höheren Wirbeltieren überhaupt, Teile der Ventralbogen, welche bei den niederen Vertebraten den letzteren zugehören, mit den Basen der Neuralbogen vereinigt zu werden scheinen, so läßt sich vermuten, daß dies bei der epi-

Fig. 99.

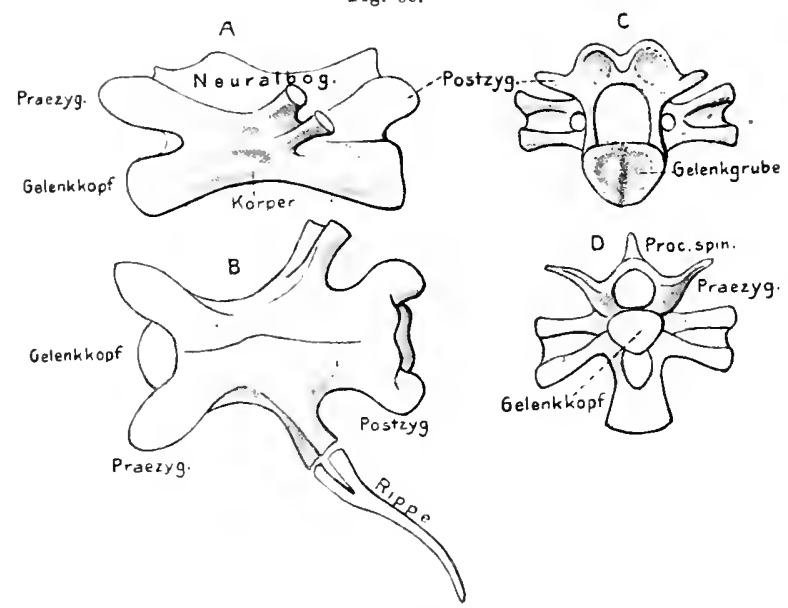

Salamandra maculosa. A Rompfwirbel von links. $B$ Rompfwirbel vor der Dorsalseite. $C$ Rumpfwirbel von hinten. $D$ Schwanzwirbel von vorn. $0 . B$.
chordalenEntwicklung der Wirbel gewisser Anuren in noch stärkerem laße eingetreten ist, so daß schließlich die Wirbelbildung ganz über die Churda verlegt wurde.

Die allgemeine Form der ausgebildeten Amphibienwirbel, amphicöl, opisthocöl und procöl, wurde schon oben erwäbnt. Bei den geschwänzten Amphibien (Fig. 99) sowie den Gymncphionen sind die Wirbel meist ziemlichlang, bei den Anuren (Fig. 100)

dagegen kurz. Die allen Wirbeln zukommenden Neuralbogen erheben sich im ganzen mäßig, jedoch fast in der ganzen Länge der Körper, und sind kontinuierlich knöchern mit dem Körper vereinigt. Von ihrer dorsalen Vereinigungsstelle entspringt ein mäßiger Dornfortsatz, der bei den Caudaten nur am Schwanz stärker hervortritt, bei den Gymnophionen fast fehlt. Vordere und hintere Gelenkfortsätze (Zygapophysen) entspringen von den Seiten des Neuralbogens. Zwischen ihnen erhebt sich der meist ansehnliche, bei den Anurcn oft sehr lange Querfortsatz (Diapophyse) vom oberen Bogen. Bei den Caudaten tritt zu ihm zuweilen noch eine tiefere, von dem eigentlichen Wirbelkörper entspringende Wurzel (Fig. 99), die sich mit ihm vereinigt. Auf die Bedeutung dieser Erscheinung kann erst bei der Besprechung der Rippen näher eingegangen werden.

Ventrale Bogen finden sich nur in der Schwanzregion der Caudaten (Fig. 99 D) und entspringen vorn von der hinteren Region des Körpers, weiter hinten von seiner Mitte. Sie laufen in einen Dornfortsatz aus. Im Rumpf gehen die Ventralbogen der Caudaten in die erwähnten tiefen Wurzeln der Querfortsätze über. Wie bemerkt, sollen diese Verhältnisse später noch genauer erläutert werden.

Amniota. Daß die Wirbel dieser umfangreichen Gruppe aus Zuständen her- 
vorgingen, wie sie bei den niederen Vertebraten dauernd bestehen, folgt daraus, $\mathrm{da} B$ sich ber zahlreichen fossilen Abteilungen der Reptilien so den Ichthyosauria, Plesiosauria, einem Teil der Dinosauria, Theromorpha und gewissen fossilen Krokodilen), jedoch auch den ältesten Vögeln, amphicöle Wirbelkörper erhielten. Unter den jetzigen Reptilien finden wir diese Wirbelform nur noch bei den Ascalaboten unter den Sauriern und den Rhynchocephalen (Sphenodon), deren, an die perennibranchiaten Amphibien erinnernde Wirbel im erwachsenen Zustand auch noch eine starke Erhaltung der Chorda zeigen. In der Entwicklung der Amniotenwirbel spricht sich zuweilen vorübergehend eine amphicöle Bildung noch ziemlich dentlich aus.

Im allgemeinen dürfte sich aus diesen Gestaltungsverhältnissen der Wirbelkörper schließen lassen, daß ihre Urform überall amphicöl war. Die Sonderung der verschiedenen Wirbeltierklassen trat wahrscheinlich so frühzeitig ein; daß die Urformen aller den ampbicülen Wirbelbau überkamen, oder sogar noch frühzeitiger (Stegocephalen), so daß sie nur die Anlage hierzo ererbten. Hieraus folgte denn, daß die procöle und opisthocöle, bzw. auch acöle Ausgestaltung in den einzelnen Klassen selbständig entstanden sein muß.

Abgesehen von der bindegewebigen, um die Chorda anftretenden Anlage der Wirbelkörper
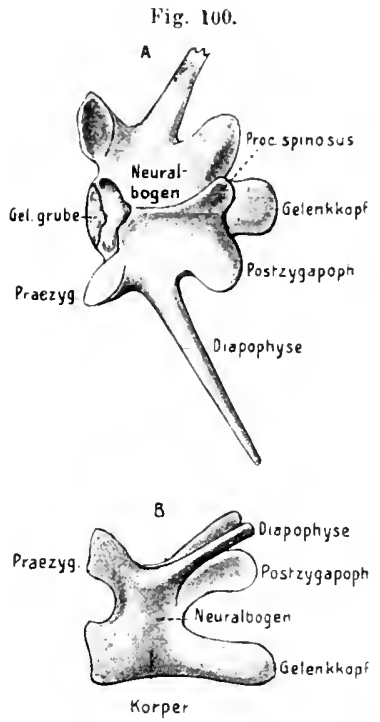

Rana mugiens. A Rumpfwirbel von der Dorsalseite. $B$ von links. $0 . B$. bilden sich auch bei den Amnioten zunächst knorpelige Neuralbogen, zwischen welchen in der Schwanzregion gewisser Eidechsen und Sphenodon selten noch intercalare Zwischenstücke gefunden wurden, die sich jedoch bald mit den davor liegenden Haupthogen vercinigen, was auf eine ursprüngliche Doppęlbildung der Wirbel hinweist. Ventrale Bogenanlagen in ursprünglicherer Bildung sind nur der Schwanzregion eigentiimlich, wo sie sich auch im erwachsenen Zustand häufig finden. Im Rumpf treten sie bei den Reptilien und Vögeln als sog. hypochordale knorpelige Spangen noch auf, verbleiben jedoch bei letzteren nur kurze Zeit selbständig. Bei den Mammalia werden sie wenigstens im Rumpf nur bindegewebig angelegt. - Die knorpeligen Neuralbogenanlagen ireten früh in Zusammenhang mit einer knorpeligen Anlage des eigentlichen Wirbelkörpers, die bei den Sauropsiden durch nicht verknorpelndes Intervertebralgewebe von den benachbarten Wirbelanlagen gesondert bleibt, während sich die knorpeligen Körperanlagen der Mammalia vorübergehend zu einem zusammenhängenden Rohr um die Chorda vereinigen, das sich später in die Intervertebralknorpelscheiben und die eigentlichen Wirbelkörper sondert. - Bei den Sanropsiden wird die Chorda durch das intervertebrale Gewebe eingeengt und schließlich durchgeschnürt (abgesehen von den schon o hen erwähnten Ausnahmen mit amphicölen Wirbeln), weshalb die Chordareste, wie bei den höheren Amphibien, intravertebral in den Wirbelkörpern verbleiben, 
jedoch in der Regel frühzeitig schwinden. - Die Chorda der Säugetiere hingegen wird vertebral am stärksten verdrängt, weshalb sich ein Chordarest intervertebral, in den späteren $Z$ wischen wirbelscheiben erhält, ja hier sogar wuchert. Dieser Rest verbleibt als sog. Nucleus pulposus bis in den erwachsenen Zustand. - Aus dem Intervertebralgewebe der Sauropsiden bilden sich, ähnlich wie bei den Amphibien,

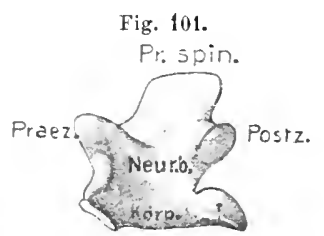

Gel Kopf

Varanus.
linbs.
P. He. die Gelenke hervor, doci ist über das Nähere wenig bekannt. Bei den placoiden Reptilien erhält sich zwischen den Gelenken eine knorpelige, scheibenartige Bildung (Meniscus), und auch bei den Vögeln findet sich ähnliches; Verbältnisse also, die etwas an die Säugetiere erinnern.

Die Verknöcherung der Wirbel geht in verschiedener Weise vor sich, doch meist so, daß in den Neuralbogen selbständige Verknöcherungsherde auftreten, woher es kommt, daß sie zuweilen auch im Alter von den Körpern gesondert bleiben können. Bei den Säugèrn kann die Wirbelverknöcherung recht kompliziert verlaufen, mit vielen accessorischen Centren, ja sogar Epiphysenbildung der Körperenden (Fig. 118).

Die entwickelten Körper der rezenten Reptilien haben meist procölen Bau, wit gut entwickelten Gelenken (s. Fig. 101-2); bei gewissen fossilen Dinosauriern

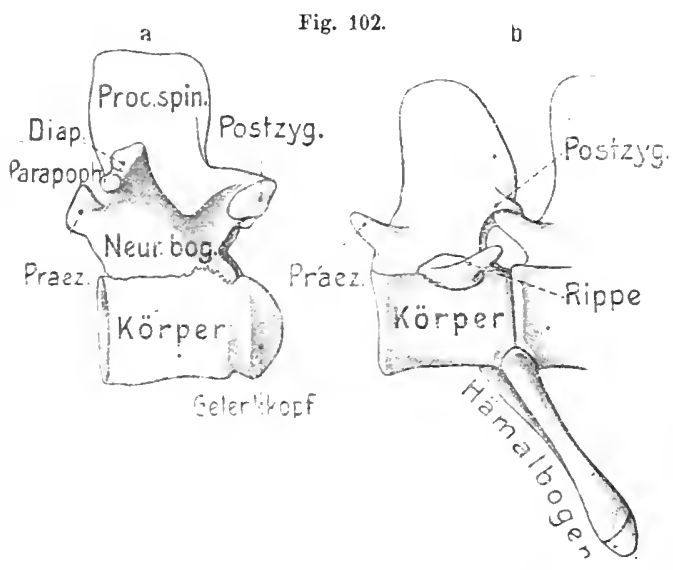

Alisgator. a Rumpfwirbel von links. $b$ Schwanzwirbel von links. waren sie auch opisthecorl. Modifikationen erfährt dieser Bau durch besondere mechanische Verhältnisse; so sind die Rumpfwirbel der Schildkröten ohne Gelenke, durchZwischenknorpel fest verbunden. Auch die Brustwirbel der Vögel sind meist sehr fest vereinigt, ja zum Teil sogar verwachsen.

Besondere Verhältnisse können in solchen Regionen der Wirbelsäule auftreten, die besonder's beweglich sind, so in der Halsregion der Schildkröten und Vögel. In der Halswirbelsäule der ersteren wechselu verschiedenartig gebaute Wirbel miteiuander ab; es finden sich sowobl procöle als opisthocöle, was dadurch ermöglicht wird, $d a ß$ zwischen sie bikonvexe und sogar amphicöle eingeschaltet sind. - Bei den Vögeln dagegen wird die Beweglichkeit der Halswirbelsäule dadurch erhöht, daß die Gelenkflächen der Körper doppelt gekrümmt, also sattelartig sind (Sattelgelenke). Die craniale Gelenkfläche ist von rechts nach links konkav, dorsoventral dagegen konvex gekrümmt; die caudale dementsprechend in umgekehrter Weise. Die Wirbel erscheinen also im Vertikal- 
schnitt opisthocöl, im Horizontalschnitt procöl. Auch die Brustwirbel. der Vögel zeigen gewöhnlich noch denselben Bau.

Die Süugerwirbel besitzen in der Regel keine eigentlichen Gelenkflächen, sondern sind vorn und hinten eben bis schwach ausgehöhlt. Die Beweglichkeit der Wirbelsäule wird durch die Einschaltung der faserknorpeligen Zwischenwirbelscheiben (Ligamenta intervertebralia) bedingt (Fig. 103). In der sehr beweglichen Halswirbelsäule der Huftiere tritt jedoch zum Teil opisthocöle Wirbelform anf und kann sich bis in die Rumpfregion fortsetzen.

Über die Neuralbogen ist wenig zu bemerken, sie erinnern an die der Amphibien, indem sie ebenfalls in ganzer Länge vom Körper entspringen, mit dem sie meist frühzeitig knöchern verwachsen; nur bei den Krokodilen und Cheloniern bleiben die Bogen gewöhnlich bis ins Alter durch Naht oder Knorpel von den Körpern getrennt (Figar 102). - Die Ausbildung der Dornfortsätze variiert sowohl bei den verschiedenen

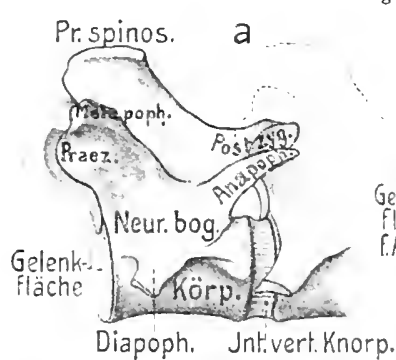

Fig. 103 .

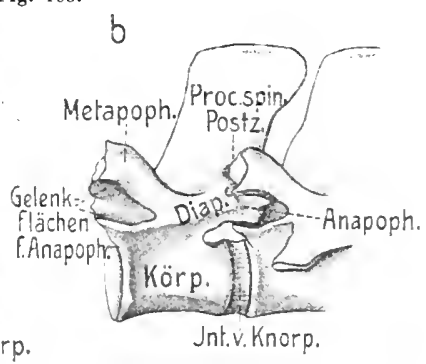

Rumpfwirbel von Mammalia von links. $\alpha$ ein hinterer Brustwirbel von Felis onca. $b$ letzter Brust- und erster Lendenwirbel von Myrmecophaga jubata.

Formen, als in den

verschiedenen Regionen derselben Form sehr, doch bleiben sie im ganzen mäßig. Die der Reptilien sind meist ziemlich gleichmäßig über die Wirbelsäule hin entwickelt, im Schwanz zuweilen höher. Bei den Vögeln werden sie am Hals häufig höher, sind sonst aber niedrig, dagegen sehr lang, so daß sie sich berïhren, ja sogar in gewissen Regionen verwachsen können. Die Dornfortsätze der Säuger treten dagegen gerade am Hals vielfach stark zurück, ja fehlen hier zuweilen ganz. In der Rumpfregion werden sie meist hoch, besonders manchmal in der vorderen (Widerrist). Etwa in der vorderen Hälfte der Wirbelsäule steigen sie gewöhnlich schief nach hinten empor, in der hinteren dagegen nach vorn, was in der Mitte durch allmähliche Richtungsänderung vermittelt wird (s. Fig. 112, \$. 211). An den Kreuzbein wirbeln bleiben die Processus spinosi meist kurz, fehlen jedoch nur selten ganz; am Schwanz treten sie in der Regel sehr zurück.

Über die Gelenkfortsätze, die, wie schon bei den niederen Formen, fast iiberall vorn und hinten von den Neuralbogen entspringen, ist wenig zu sagen; sie sind fast immer kräftig ausgebildet. Bei den Schlangen (selten anch gewissen Sauriern) wird die Gelenkung der Wirbel gewöhnlich noch dadurch vervollständigt, daß zwischen den Präzygapophysen, vor dem Dornfortsatz ein mittlerer Fortsatz (Zygapophysen) entspringt, der zwei seitliche Gelenkflächen besitzt, die in zwei Aushöhlungen (Zygantrum) an der Hinterseite des Bogens des vorausgehenden Wirbelkörpers eingreifen (s. Fig. $107^{6}$, S. 204). - Bei zahlreichen Säugern (besonders gewissen 
Edentata) wird die Gelenkung dadurch kompliziert, daß sich an den Zygapophysen neben der gewöhnlichen Gelenkfläche noch weitere bilden, die auch von besonderen Vorsprüngen (Metapophyse, Anapophyse) getragen werden (Fig. 103).

Querfortsätze (sog. Diapophysen), die auf der Grenze von Bogen und Körper oder am Bogen entspringen, fehlen nie und setzen sich auf die Schwanzregion fort. Da jedoch auf diese Anbänge im Kapitel über die Rippen näher eingegangen wird, beschräuken wir uns hier auf diese kurze Bemerkung.

Ventralbogen treten als spangenartig geschlossene Gebilde nur in der Schwanzregion auf und finden sich hier, wie bei den Amphibien, gleichzeitig mit Diapophysen vor (Fig. 102b). Sie haben daher morphologisch dieselbe Bedeutnng wie die der Amphibien und gehen ontogenetisch aus den oben erwähnten hypochordalen Spangen hervor. Charakteristisch ist, daß sie gewöhnlich nicht mit dem Körper verwachsen sind und sich diesem ganz hinten anfügen, so da $B$ ihre Basis zwischen die aufeinander folgenden Körper gerät; doch war dies an den vorderen Schwanzwirbeln der Urodelen schon angedeutet. Ontogenetisch soll sich jedoch ergeben, daß ein solcher Bogen eigentlich dem daranf folgenden Wirbel angehört. Bei guter Entwicklung lanfen sie in einen Dornfortsatz ans. Die Vögel zeigen sie nur schwach entwickelt und nach vorn geneigt. Auch bei den Mammaliern kommen sie, bei starker Schwanzentwicklung, meist noch an einer größeren Zahl vorderer Schwanzwirbel vor und werden namentlich bei den Cetaceen, mit der erhöhten Bedeutung des Schwanzes als Ruderorgan, wieder zahlreicher und ansehnlicher.

Bei Sphenodon und gewissen Sauriern (Ascalaboten usw.) finden sich nach vorn von der Stelle ab, wo die Hämalbogen in der vorderen Caudalregion aufhören, homologe, zwischen die Wirbelkörper eingeschaltete Knochenstückchen, sog. Intercentra, die bei nicht wenigen der übrigen Reptilien nur in der Halsregion als selbständig gebliebene Gebilde vorkommen. Unter den Säugern treten sie bei manchen Insectivoren in der Lendenregion anf.

In der Schwanzregion der Schlangen finden sich an Stelle der unteren Bogen schwache, ungeschlossene absteigende Fortsätze der Wirbelkörper, welche die Caudalgefäße umgreifen. $\mathrm{DaB}$ diese Bildungen den geschlossenen Ventralbogen der übrigen Amnioten entsprechen, ist insofern wahrscheinlich, als letztere sich zuweilen an jedenfalls entsprechende schwache Fortsätze der Wirbelkörper anfügen, diese gleichsam fortsetzen. In der Rumpfregion der Schlangen gehen diese paarigen Fortsätze in unpaare domartige über, die von der ventralen Mittellinie der Wirbel entspringen und nach vorn zu länger werden, oder sich auch nur in der vorderen Region der Wirbelsäule finden. Diese sog. Processus spinosi inferiores (Hypapophysen) sind demnach wohl sicher auf Teile ursprünglicher Hämalbogen zurückzuführen, wenn sich dies im einzelnen auch bis jetzt nicht näher aufklären läßt.

Bei den übrigen Sauropsiden (Sauria, Crocodilia und Ares), jedoch auch nicht wenigen Mammaliern können dieselben Fortsätze besonders am Hals und den vorderen Rumpfwirbeln auftreten, bei den Säugern zuweilen auch noch an Lenden- und Schwanzwirbeln.

\section{Querfortsätze und Rippen.}

Fische. Für die Kuorpelganoiden und Knorpelfische wurde früher hervorgehoben, daß die ventral geschlossenen Hämalbogen der hinteren Schwanzregion, welche die Caudalgefäße umfassen, schon in der vorderen Schwanzregion ibren ventralen Zusammenschluß aufgeben, seitlich etwas weiter auseinander rücken und 
schließlich sogar divergieren. Mit dem Auftreten der Leiheshöhle im Rumpf treten nun, in Anschluß an die paarigen Vorsprünge, welche die Hälften der Hämalbogen darstellen, besondere knorpelige, stab- bis bogenartige Skeletgebilde anf, die diesen Vorsprüngen angefügt sind, die Rippen (Costae). - Diese Rippengebilde, welche bei den Knorpelfischen relativ zart und kurz sind, liegen in den sog. Myosepten oder Ligamenta intermuscularia der Seitenrumpfmnsknlatur, also auf den Grenzen der Muskelsegmente, und tragen sowohl zu deren Festigung, als zur Übcrleitung des Mnskelzuges auf die Wirbelsäule bei. Bei den Plagiostomen (Fig. 104 ${ }^{1}$ ) liegen die Rippen in diesen

Septen ungefähr da, wo jene von dem horizontalen Septum, welches die Seitenrumpfmuskulatur in eine dorsale und ventrale Partie scheidet, geschnitteu werden. Die Rippen verlaufen daher hier etwa borizontal. - Bei den übrigenFischen (Fig. 104 2,3) biegen

Fig. 104.

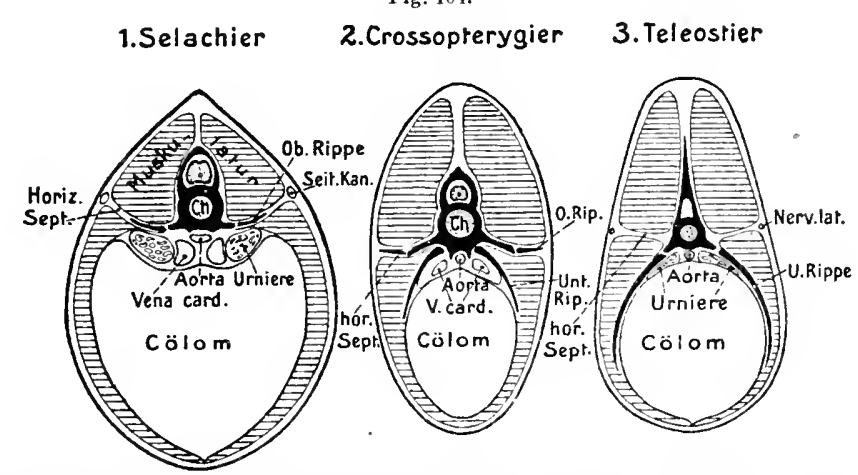

Schematische Querschnitte zur Lage der beiderlei Rippen bei den Fischen; die Krümmng der Myosepten ist nicht berücksichtigt, da sonst die Rippen nicht in ihrer ganzen Ausdehnung za sehen sind. (Nach GöpPEat 1s95 konstruiert.) $0 . \mathrm{B}$.

sie dagegen sofort gegen die Ventralseite hinab und liegen in den Myosepten da, wo diese sich mit der Haut, welche die Leibeshöhle auskleidet (Peritonenm), verbinden. Die Rippen finden sich daher hier ganz dicht unter dem Peritoneum und stehen in viel direkterer Beziehung zur Leibeshöhle, wëlche sie umfassen und auch schützen.

Die morphologische Bedeutung der Rippen wird verschieden beurteilt. Sowohl aus der vergleichenden anatomischen Betrachtung der erwachsenen Formen, als der Ontogenie schließen viele Forscher, daß die Rippen durch Abgliederung aus den divergierend geöffneten und verlängerten Hälften der Hämalbogen der Rumpfregion durch Abgliederung hervorgehen, während die basalen Bogenteile als deren Körperteile an der Chorda verblieben, bzw. in die Bildung der Wirbelkörper eingingen. Ein Basalvorsprung dieses Körperteils des Bogens, an dem sich die Rippe befestigt, bildete den sog. Querfortsatz (Parapophyse) des Wirbelkörpers. Als ursächliches Moment für die Abgliederung der distalen Bogenteile als Rippen werden die schwankenden Volumverhältnisse der Leibeshöble angesehen, was die bewegliche Ablösung der sie schützenden Bogenhälften vorteilhaft machte.

Eine zweite Ansicht dagegen bält die Rippen für in den Myosepten selbständig entstandene Skeletgebilde, die erst sekundär mit den ans den Hämalbogen der Schwanzregion abzuleitenden Parapophysen in Verbindung traten. 
Für letztere Meinung läßt sich anführen, daß gewisse ontogemetische Erscheinungen der Rippenbildung in diesem Sinne zu sprechen scheinen; daß fermer in den Myosepten der Knochenfische selbständige Skeletgebilde reichlich auftreten, die sog. Fleischgräten, welche sich häufig dèr Wirbelsäule angliedern, ähnlich wie Rippen. Ein Unterschied besteht jedoch insofern, als diese rippenartigen Gräten, soweit bekannt, stets sofort knöchern entstehen, während die eigentlichen Rippen, mit seltenen Ausnabmen, knorpelig vorgebildet werden. Schließlich Iieße sich auch anführen, daß sowohl bei Knorpelganoiden als Plagiostomen die hinteren Rippen des Rumpfs meist allmählich rudimentär werden, worauf eine Region folgt, die rippenlose Parapophysen zeigt, aus deren ventralem Zusammenschluß schließlich die geschlossenen Hämalbogen hervorgehen, welche also hier ausschließlich oder doch vorwiegend auf die Vereinigung der Querfortsätze zurückzuführen sein dürften. Das Problem wird schließlich noch verwickelter durch die Kompliziertheit des Achsenskelets der Plagiostomen, die Einschaltung von Intercalarien zwischen die Hämalbogen, wobei erstere zuweilen eine rippenartige Form annehmen, bzw. auch mit einer Rippe verwachsen können (s. Fig. 90 B, S. 185).

Die morphologische Herleitung der Rippen dürfte daher vorerst noch nicht genügend aufgeklärt erscheinen, wozu noch die weitere Frage tritt, welcher Zustand des Achsenskelets, der der Schwanz- oder der der Rumpfregion, eigentlich als der ursprünglichere anzusehen ist.

$\mathrm{Zu}$ dem eben erwähnten Problem gesellt sich noch ein zweites. Oben warde schon geschildert, daß die Lage der Plagiostomenrippen in den Myosepten von der bei den übrigen Fischen verschieden ist. Bei der Auffassung der Rippen als selbständige Skelє ‘́gebilde hat diese Differenz nur geringe Bedeutnng; für diejenige Ansicht dagegen, welche sie als abgegliederte Teile der Hämalbogen deutet, ist sie von prinzipieller Wichtigkeit. Dazu gesellt sich endlich die Tatsache, daß bei den sog. Crossopterygiern (Knochenganoiden) neben den der Leibeshöhlenwand anliegenden Rippen noch eine zweite Reihe knorpelig vorgebildeter Rippengebilde vorkommt, welche sich in bezug auf das Horizontalseptum etwa ebenso verhalten, wie die der Plagiostomen (Fig. 1042). Man unterscheidet deshalb hier die ersteren als untere Rippen (oder Pleuralbogen), die zweiten als obere. Diese oberen Rippen der Crossopterygier cntspringen von sehr langen querfortsatzartigen Ausläufern der Wirbelkörper, welche an ihrer Basis und medial noch je einen kleineren Vorsprung tragen (untere Querfortsätze). Die unteren Rippen heften sich in der vorderen Körperregion an die mittlere Gegend der oberen Querfortsätze, weiter hinten, wo sie stärker werden, dagegen an die erwähnten unteren Querfortsätze; im Schwanz schließen sie sich samt letzteren Querfortsätzen zu den Ventralbogen zusammen, von denen außen noch die ansehnlichen oberen Querfortsätze entspringen. Demnach scheint hier in der Tat eine den beiderlei Rippen entsprechende Gabelung des sonst einfachen Querfortsatzes zu zweien stattgefunden zu haben, von dewen man den unteren, wegen seiner Beziehung zu den unteren Rippen, auch hier als Parupophyse, den mit der oberen Rippe neu hinzugetretenen dagegen als Diapophyse bezeichnen kann. Die gewöhnliche Ansicht ist nun, daß die Plagiostomenrippen, welche ebenso wie die oberen der Crossupterygier liegen, anch letzteren entsprechen, im Gegensatz zu den Rippen der übrigen Fische, welche den unteren der Crossopterygier (Pleuralbogen) homolog wären. Für diese Ansicht dürfte auch die Erfahrung sprechen, daß in der Schwanzregion gewisser Haie an der Außeuseite 
der nahezu oder ganz geschlossenen Hämalbogen noch Rippenrudimente auftreten können. Hieraus muß gefolgert werden, daß die Plagiostomenrippen ähnlich wie die oberen der Crossopterygier aus einer dorsaler gelegenen Region des ursprïnglichen Hämalbogens hervorgogangen sein müssen, wenn die Abgliederungslehre recht hat.

Die unteren Rippen oder Pleuralbogen der Ganoiden, Dipnoer und Knochenfische werden in der Regel viel kräftiger und verknöchern frïhzeitig, was schon bei den Knorpelganoiden eintritt. Daß bei gewissen Knochenfischen (z. B. Lophobranchii, Plectognathi), wie unter den Chondropterygiern bei den Holocephalen, völlige Verkümmerung der Rippen vorkommen kann, wird durch besondere Körperverhältnisse begreiflich. Die unteren Rippen der genannten Abteilungen reichen bei guter Entwicklung bis nahe an die Bauchlinie herab, ohne sich hier mit irgendwelchen anderen Skeletteilen zu verbinden. Die vordersten sind gewöhnlich am längsten; nach hinten werden sio successive kürzer. Das Umgekehrte gilt dagegen in der Regel von den die Rippen tragenden Querfortsätzen (Parapophysen), die vorn am kürzesten sind, um nach hinten allmäblich länger zu werden.

Von besonderer Wichtigkeit erscheinen natilrlich die Beziehungen der unteren Rippen und Parapophysen zu den Ventralbogen der Schwanzregion. Bei den Dipnoern und Knochenganoiden (abgesehen von den schon erwähnten Crossopterygiern) gehen die Ventralbogen des Schwanzes sicher durch Zusammenschluß der Parapophysen samt den Pippen hervor; wobei noch von Interesse ist, daß die Rippen hier zu Ventralbogen zusammenschließen, welche sich von den den Parapophysen entsprechenden Basalteilen abgegliedert erhalten (s. Fig. 91, S. 187). Bei den Knochenfischen finden wir dagegen recht verschiedene Verhältnisse. Einerseits solche, welche den eben erwähnten völlig entsprechen, d. h. die klein gewordene Rippe verwächst allmählich mit der Parapophyse, und die so entstandenen beiderseitigen Spangen schließen sich hierauf in der ventralen Mittellinie zu einem Ventralbogen (Gadidae, Fig. 94, S. 190). Hieran reihen sich Fälle, wo sich die Parapophysen ventral schließen und die Rippen unter Zusammenschluß in die Dornfortsätze dieser Ventralbogen ubberzugehen scheinen. - Ein dritter, nicht seltener Fall ist endlich der, wo die Parapophysen kurz vor Beginn des Schwanzes auf ihrer Innenseite schief gegen die Ventrallinie gerichtete Fortsätze (sog. Hämalfortsätze) entsenden, die sich schließlich vereinigen und den Ventralbogen bilden (siehe Fig. $106 a, b)$. Diese Fortsätze entsprechen etwa denen, welche beim Stör den Aortakanal bilden.

Bei gewissen Knochenfischen (einzelne Pleuronectiden) kaun der merkwürdige Fall auftreten, $d a B$ sich auch an der Ventralseite der Rumpfiwirbel untere Bogen finden. Da in diesem Fall Rippen fehlen, so scheinen diese ventralen Rumpfbogen in der Tat Fortsetzungen der echten Hämalbogen des Schwanzes zu sein.

Die Parapophysen entspringen in der hinteren Rumpfregion vom ventralen Seitenrand der Wirbelkörper. Dies kann sich durch die ganze Wirbelsäule erhalten, oder die Fortsätze nach vorn nur wenig dorsalwärts rücken. Bei anderen Formen, schon bei den Rochen nnd Knorpelganoiden, steigen die Fortsätze nach 
vorn recht hoch.an den Körpern hinauf, so daß die vordersten sogar an die Basis der Neuralbogen gelangen können. Jedenfalls berubt dies daranf, daß die Körperteile der Hämalbogen, von welchen ja die Parapophysen herstammen, in dieser Region immer höher emporwuchsen, ein Verhalten, das wir schon beim Stör usw. antrafen. Gleichzeitig können sich die proximalen Rippenenden, welche den Parapophysen angehängt oder angelenkt sind, nach vorn immer stärker verbreitern, wobei anch die Parapophysen entsprechend höher werden. In extremen Fälen (z. B. Cyprinoiden, Fig. 106) steigen letztere so vom ventralen Seitenrand der Wirbel schief bis zur Basis der Nenralbogen empor ${ }^{1}$ ).

Fleischgräten. Wie erwähnt, treten außer den eigentlichen oder unteren Rippen in den Myosepten der Knochenfische meist noch weitere rippenartige Ge-

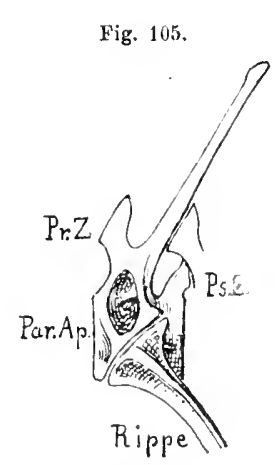

Barbus vulgaris. Ein vorderer Rumpfwirbel mit Rippe von linke. I'r.Z. Prāzygapopbyse, I'st.Z. Postzygapophyse. 0. B.
Fig. 106.

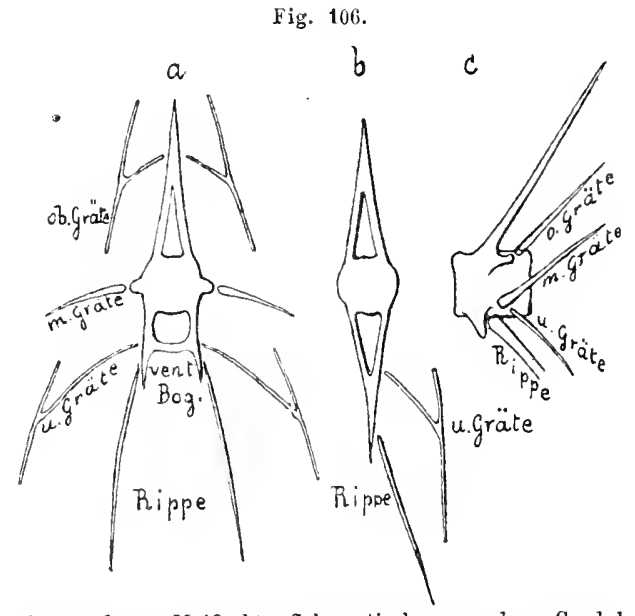

Alosa alosa (Maifisch). Schematisch. $a$ vorderer Caudal wirbel von vorn. $b$ mittlerer Caudalwirbel ebenso. $c$ vorderer Rumpfwirbel ron links.

bilde anf, die sog. Fleischgrütcn. Bei reicher Entwicklung dieser Skeletgebilde finden sich jederseits gewöhnlich drei übereinander liegende Reihen solcher Gräten (s. Fig. 106). Eine dorsale,-welche sich den Neuralbogen anschließt, eine mittlere, längs der Wirbelkörper, und eine ventrale, die den Hämalbogen und Rippen entlang zieht. Diese Gräten sind entweder einfache zarte Knochenfäden, oder gehen an ihrem distalen Ende in einen parallel der Körperoberfäche ziehenden, etwas schief zum inneren Arm gerichteten Ast ans. Der innere Arm heftet sich, wie gesagt, dem Achsenskelet an, wozu auch an den betreflenden Stellen Vorsprünge, ähnlich Querfortsätzen, vorhanden sein können. Bei manchen Kuochenfischen tritt ein solcher Vorsprung an der Seite jedes Wirbelkörpers für die Seitengräte stärker bervor, ähnlich einem oberen Querfortsatz (Diapophyse). Diese Seitengräten verdienen anch besondere Beachtung. Während die Fleischgräten, so-

1) Eine Eigentümlichkeit ist in diesem Fall ferner zu beachten, daß nämlich diese vorderen Parapophysen rom Körper abgegliedert sind (ebenso bei Gymnarchus). 
weit bekannt, stets durch direkte Verknöcherung entstehen, treten die Seitengräten gewisser Teleosteer (Clupeiden) peripher mit Knorpel in Verbindung, während sich bei Salmoniden vorübergebend knorpelige, den oberen Rippen der Crossopterygier ähnliche Bildungen finden. Diese Knorpelbildungen dïrften daher wohl sicher als Homologa der sog. oberen Rippen der Crossopterygier angesehen werden.

Dies macht es in gewissem Grade wahrscheinlich, daß die Seitengräten überhaupt als eine Art Ersatz ursprünglich vorhandener echter oberer Rippen auftraten und daher auch in diesem Sinne ihnen gleichwertig erachtet werden dürften. In der Rumptregion steigen die Seitengräten zuweilen auf die Rippen herab und befestigen sich an ihnen; ja es scheint sogar in der vordersten Rumpfregion manchmal zu einer Verwachşung des proximalen Endes je einer unteren Rippe und einer Seitengräte zu kommen. Ob etwa gar die stark verbreiterteu Rippen, wie sie z. B. die Cyprinoiden besitzen, aus der Verwachsung zweier solcher Gebilde hervorgingen und ihre ansehnlichen Querfortsätze daher gleichfalls aus einem Paar unterer und oberer Querfortsätze hervorgegangen sind, bedürfte näherer Untersuchung.

Tetrapode Wirbcltiere. Die Rippen der Tetrapoden werden wegen ibrer ursprïnglichen Lage in dem Horizontalseptum der Muskulatur meist als den oberen der Fische gleichwertig erachtet; doch soll anf dies Problem gleich noch näher eingegangen werden.

Unter den erwachsenen Amphibien finden sich diskrete Rippen nur bei den Urodelen, Gymnophionen und den ausgestorbenen Stegocephalen. Doch bleiben sie stets relativ kurz und sehwach, so daß sie nie die Bauchlinie erreichen und stets ohne Verbindung mit anderen Skeletteilen frei endigen. Da die Rippen der Stegocephalen häufig länger waren, so ist es wahrscheinlich, daß bei den rezenten Ampbibien erhebliche Verkïmmerung der Rippen vorliegt, welehe bei den Amuren sogar zu ilırem völligen Schwinden, d. h. zur Verwachsung ihrer Reste mit den Querfortsätzen gefïhrt hat. Was letztere angeht, so läßt die Ontogenie der Crodelen erkennen, daß der Körperteil der paarigen Hälften der Hämalbogen in der Rumpfregion ursprünglich einen. Querfortsatz am unteren Seitenrand der Wirbelkörper bildet, eine echte Parapophyse, von der die Rippe sich abgliedern soll. Hierauf wäcbst aber der Körperteil an der Außenseite der Chorda und des Neuralbogens stark dorsal empor und entwickelt etwas iiber der Yarapoplyyse einen zweiten ähnlichen Querfortsatz, die Diapophyse (Fig. 1072). Letztere nimmt daher ihren Ursprung scheinbar am Neuralbogen, obgleich sie ihrer Entwicklung nach zum Hämalbogen gehört. Die Diapophyse entspringt etwa auf der Grenze von Neuralbogen und Wirbelkörper, ja im Schwanz auch ganz von letzterem (s. Fig.99, S. 194). Beide Querfortsätze stehen dicht übereinander, etwas divergierend, und nehmen die an der Wirbelsäule jederseits herabziehende Arteria vertebralis zwischen sich. Nach außen von ihr verwachsen sie gewöhnlich mehr oder weniger innig, bleiben aber meist deutlich kenntlich und bilden distal je eine Gelenkfläche futr das gegabelte proximale Rippenende (s. Fig. $99 B$ ). - In der vorderen Schwanzregion erhalten sie sich meist ganz in derselben Weise; doch treten zwischen den Basen der Parapophysen anf der Ventralseite des Wirbels zwei Fortsätze auf, welche weiter hinten am Schwanz in die sich schließenden Ventralbogen answachsen (Fig. $99 d$ u. Fig. $107^{2} a$ ). Hieraus folgt, daß diese caudalen Ventralbogen, wie bei 
den höheren Vertebraten überhaupt, nicht den gesamten ursprünglichen Hämalbogen entsprechen, welche wesentlich durch die Parapophysen (und ev. Rippen) repräsentiert werden, sondern daß sie wie die gewisser Knochenfische von den sog. Hämalfortsätzen der Hämalbogen gebildet werden.

Entsprechend den beiden Querfortsätzen (Para- und Diapophysen) ist das proximale Rippenende bei den Urodelen in der Regel mehr oder weniger tief gegabelt (Fig. 99b, 1072); auch das distale gabelt sich häufig in einen dorsal und

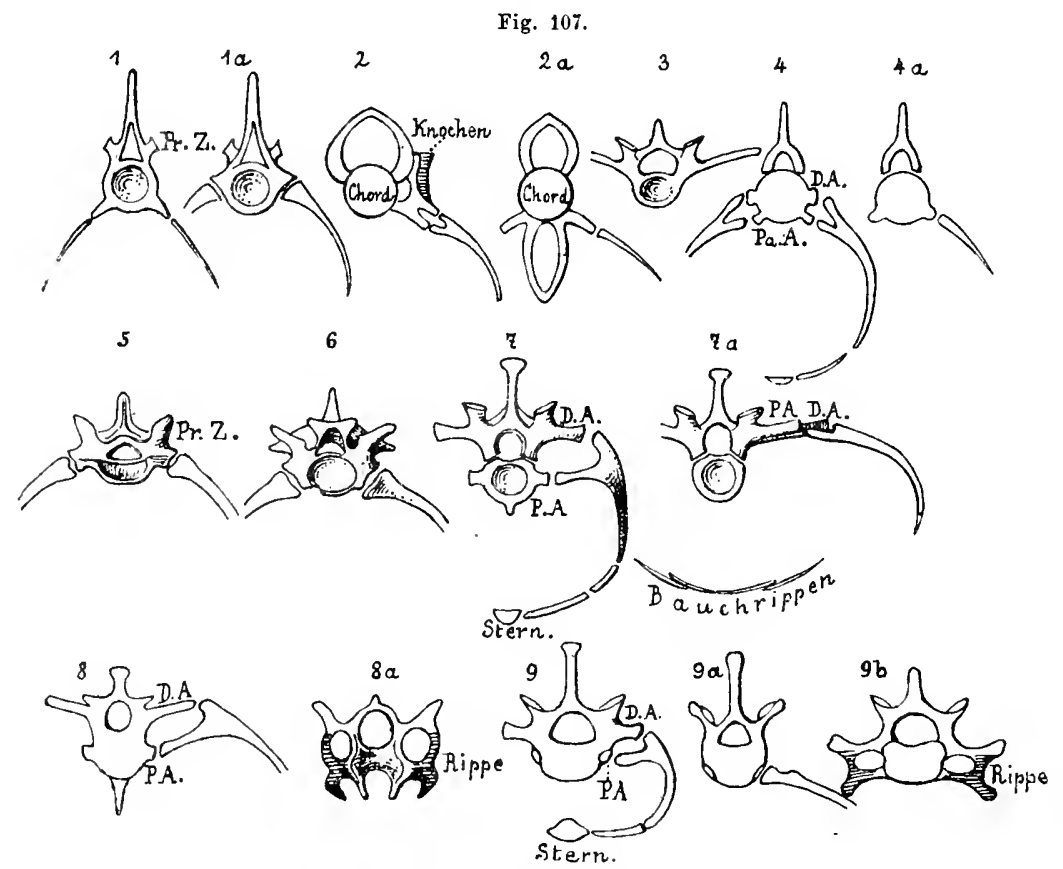

Schemata zur Illustration der Querfortsätze nuj der Befestigung der Rippen an den Wirbeln. D.A. Diapophyse. P.A. Parapophyse. Pr.Z. Präzygapophyse. 1-1a Teleosteor (Barbus), 1 hintere Rumpfregion, 1a vordere Rumpfregion. 2-2a Menobranchus (Urodele), 2 Sacralregion, 2 a vordere Schwanzregion. 3 Rana, Rumpfregion 4-4e Tchthyosanrns, 4 Rumpfregion, $4 a$ Schwanzregion, 5 Saurier (Varanus) Rnmpf. 6 Ophidier (Python) Rumpf. 7-7a Alligator, 7 vordere Brustregion, $7 b$ hintere Brustregion. $8-8 a$ Vogel, 8 Brust-, $8 a$ Halsregion. $9-9 b$ Sanger (Felis), 9 vordere Brust-, $9 a$ hintere Brustregion, $9 b$ Halsregion. 0 . B.

einen ventral gerichteten Fortsatz; was auch gewissen Stegocephalen eigentümlich war, wogegen das proximale Rippenende zum Teil zwei Gelenkköpfe besaß oder einfach war.

Dieser Gabelung wird meist wenig Bedeutung beigelegt, und das proximale Gabelende nur als ein sekundärer Fortsatz zur Gelenkung an der Diapophyse beurteilt. Mir scheint dagegen die andere Ansicht nicht ausgeschlossen, welche in der Gabelung eine ursprüngliche Doppelrippe erblickt, die durch mittlere Verwachsung teilweise einheitlich wurde. Ist dies richtig, so wäre auch wohl nicht $\mathrm{zu}$ bezweifeln, daß die gegabelte Urodelenrippe und ebenso wohl auch die Rippen der höheren Vertebraten auf eine Verwachsung der unteren und oberen der Crossopterygier zurückzuführen sind, was um so möglicher ist, als sich schon bei den Knochenfischen ähnliche, wenn auch wohl nur analoge Verwachsungsprozesse finden. 
Die Rippen der Gymnophionen sind proximal gleichfalls gegabelt und zeigen das Eigentümliche, daß der dorsale Cabelast an der vorderen Zygapophyse des Wirbelkörpers articuliert, der ventrale dagegen an der Parapophyse, welche auf der Grenze zwischen Neuralbogen und Körper entspringt und eigentümlicherweise nach vorn gerichtet ist.

Die ansebnlichen Querfortsätze der Anuren (s. Fig. 100, S. 195 u. 1073) entspringen vom Neuralbogen, scheinen aber dennoch wesentlich Parapophyseu zu repräsentieren, wie daráus geschlossen wird, daß die Arteria vertebralis dorsal thber sie hinzieht.

Die Rippen der Amnioten sind im allgemeinen viel kräftiger und länger als die der Amphibien, so daß sie in der Brustregion bis zur Bauchlinie hinabreichen und hier einem besonderen Skeletteil, dem Brustbein oder Sternum, den Ursprung geben. Dieses wird später besonders besprochen werden. Die Gelenkung der Rippen an den Wirbeln geschieht in der Regel wie bei den urodelen Amphibien schon angedeutet, d. h. mit einem proximalen gegabelten Ende (s. Fig. 107 ${ }^{-9}$ ). Der dorsale Rippenast (sog. Tubercularfortsatz, Tuberculum) heftet sich an die meist viel ansehnlichere Diapophyse, während der ventrale, bald stärkere, bald schwächere Ast (Capitularfortsatz, Capitulum) sich an eine nur schwach entwickelte Parapophyse des Wirbelkörpers ansetzt. - Sehr ursprïingliche Verhältnisse zejgen jedenfalls noch gewisse fossile Reptilien, die Ichthyosauria (Fig. 1074). Bei ihnen entspringen in der Rumpfregion kurze Di- und Parapophysen seitlich am Wirbelkörper zur Befestigung der gegabelten Rippen; weiter hinten nähern sich die beiden Querfortsätze mehr und mehr und verschmelzen endlich in der Schwanzregion, wo denn anch die vertebralen Rippenenden ungegabelt sind. Dies Beispiel beweist ebenso, wie die schon bei den Amphibien dargelegten Verhältnisse, daß die beiderlei Querfortsätze Produkte des urspriinglich einheitlichen Querfortsatzes des Hämalbogens sind.

Die Verhältnisse der beschuppten Reptilien (Fig. 107 ${ }^{5, \text { ij }}$ ) erinnern etwa an die, welche eben von der Schwanzregion der Ichthyosaurier geschildert wurden. Die recht kurzen Qnerfortsätze entspringen auf der Grenze von Körper und Neuralbogeu, unterhalb der vorderen Zygapophyse. Sie siud einfach oder zeigen doch nur eine Andentung von Gabelung. Ebenso verhalten sich die proximalen Rippenenden. In der Sacral- und Schwanzregion werden die Querfortsätze dagegen recht ansehnlich, was wahrscheinlich anf Verwachsung mit rudimentären Rippen beruht.

Aus dem Mitgeteilten geht hervor, daß wir die.Vereinfachung der Gelenkungsverhältnisse der Rippen bei den Squamaten auf eine Reduktion oder nachträgliche Vereinigung der früher gesonderten beiden Querfortsätze, unter Rückbildung der Gabelung des Rippenendes, zurückführen möchten; wofür auch schor gewisse Urodelen Beispiele bieten.

Bei den Krokodilen (Fig. 107\%), ähnlich auch den meisten fossilen Reptiliengruppen, den Vögeln (Fig. $107^{8}$ ) und Säugern (Fig. $107^{9}$ ) ist die Gabelung der proximalen Rippenenden an Hals und Brust stark ausogeprägt, so daß durch ihre Anfügung an die Di- und Parapophysen ein Kanal gebildet wird, in dem auch hier die Arteria vertebralis verläuft. In der Halsregion sind die beiden Querfortsätze, sowie die Gabelenden der Rippen ziemlich gleich stark entwickelt. Bei den Vögeln 
(Fig. $107^{\mathrm{s}^{a}}$ ) und Sängern (Fig. $107^{9^{b}}$ ) verwachsen jedoch die rudimentären Halsrippen in der Regel fruibzeitig mit den Wirbeln, so daß sie als Fortsätze derselben erscheinen. - In der Rumpfregion liegen die Verhältnisse etwas verschieden. Bei den Vögeln (Fig. 1078) erhält sich die Gelenkung ähnlich wie am Hals. Bei den Krokodilen dagegen rückt die schwache Parapophyse an der Brust rasch am Wirbel in die Höhe nnd vereinigt sich schließlich mit der langen Diapophyse (Fig. $107^{7}$ n. Fig. $102 a$ ), wobei anch der Capitularfortsatz der Rippez rasch verkümmert, so daß die vern so ausgesprochene Gabelung an den hinteren Rippen nur noch schwach angedeutet isı. - Hiermit übereinstimmende Verhältnisse zeigen unter den Säugern die Cetaceen. Bei den meisten Sängetieren aber geht an den hinteren Brustrippen der Tubercularfortsatz ein, so daß sich allein die Befestigung der Rippe am Wirbelkörper, bzw. auch zwişhen je zweien, erhält (Fig. $\left.107^{9 a}\right)$, was bei den Monotremen für alle Rippen der Fall sein kann. Dieselbe Veränderung in der Gelenkung der hinteren Brustrippen fand sich bei gewissen fossilen Dinosauriern; die hier besser ausgeprägten Parapophysen entsprangen teils vom Körper (hinten), teils stiegen sie bis zum Neuralbogen empor.

Auch bei den Schildkröten hat sich die Gelenkung der Brustrippen in ähnlicher Weise vereinfacht und geschieht durch Anlagernng des proximalen Endes auf der Grenze zwischen je zwei Wirbelkörpern, jedoch höher, etwa da, wo die Bogen sich an die Körper anfïgen.

Während die Rippen der Anamnier stets einfache Gebilde sind, werden die ansebnlichen Brustrippen der Amnioten komplizierter. Dies hängt wohl zum Teil mit der Befestigung der ventralen Rippenenden am Brustbein zusammen, feblt daher auch bei den Amnioten, deren Sternum rïckgebildet ist (Schlangen, Amphisbänen, Schildkröten), oder tritt doch an deren Rippen stark zurïck; ebenso jedoch auch an den hinteren Rippen der übrigen, welche das Brustbcin nicht erreichen. Die Brustrippen der ersterwähnten Amnioten gliedern sich nämlich in zwei Stücke, ein vertebrales (Vertebralstück) und ein sternales (Sternalstück), die beide schief nach hinten gerichtet sind, so daß sie unter einem kopfwärts offencn Winkel zusammenstoßen (Fig. 112, 115, S. 211-13). Jedenfalls hängt diese Gliederuug der Rippen auch mit der Tätigkeit des Brustkorbes bei der Inspiration zusammen, welche sich mnter den Amnioten immer besser hervorbildet. Die Vertebralstücke sind stets verknöchert, die sternalen hingegen meist knorpelig oder kalkig-knorpelig; bei den Vögeln und einigen Säugern verknöchern jedoch auch sie. Die Rippengliederung kompliziert sich bei den Krokodilen noch mehr, indem die Brustrippen meist ans drei Stïcken bestehen (Fig. 1077, 209), da der ventrale Teil des vertebralen Stiicks knorpelig-kalkig bleibt. - Das Vertebralstiick der Brustrippen (seltener auch hinterer Halsrippen, Sphenodon) trägt bei den Krokodilen, bei Sphenodon, namentlich aber den Vögeln, einen wach hinten schief aufsteigenden Fortsatz (Processus uncinatus), der sich bei stärkerer Ausbildung (besonders Vögel) der nüchstfolgenden Rippe anflegt; eine Einrichtung, welche jedenfalls darauf hinzielt, den Zusammenhalt des ganzen Brustkorbs zu verstärken und seine Bewegnngen zu vereinheitlichen (s. Fig. 115, S. 213, Fig. 209). 
Die Rückführung dieses Processus uncinatus auf den dorsalen distalen Gabelast der Urodelenrippen scheint nicht unmöglich, bedürfte aber nocb genaucren Nachyeises, zumal schon bei gewissen stegocephalen Amphibien ein ähnlicher Fortsatz neben einem distal gegabelten Rippenende vorkommt. Der Processus uncinatus scheint sich stets selbständig knornelig anzulegen und bleibt auch bei den Reptilien so, während er bei den Vägeln rerknöchert und meist frühzeitig mit der lippe rerwächst.

\section{Das Brustbein oder Sternum.}

Wie schon bemerkt, reichen die Rippen der Fische nicht bis zur Bauchlinie herab. Bei den Amphibien bleiben sie noch kürzer und endigen daher weit von der Ventralseite. Es wird dieser Klasse deshalb auch von manchen Morphologen das Brustbein völlig abgesprochen. Dennoch findet sich bei sämtlichen Amphibien, mit Ansnahme der Gymnophionen, ein Skeletgebilde, das, nach seiner Lage und seiner innigen Beziehung zum Schultergürtel, große Ähnlichkeit mit dem Sternum der Reptilien besitzt, weshalb es meist âls ein solches aufgefaßt wird. Es wird sich jedoch empfehlen, vor der Betrachtung dieses Amphibiensternums das der Amnioten zu besprechen, um bei der Beurteilung der Amphibienverhältnisse hieran anknüpfen zu könuen.

Die Ontogenie erweist recht bestimmt, daß sich die ventralen Enden der vorderen Brustrippenanlagen im vorknorpeligen Stadium zunächst jederseits zu einer Längsleiste vereinigen. Indem die beiden Leisten in der Ventrallinie zu einem einbeitlichen Skeletgebilde verwachsen, verknorpelnd, bzw. später verknöchernd, entsteht das Sternum. Daß dies neu erworbene Skeletgebilde hauptsächlich unter dem Einfluß der besonderen Entfaltung, welche die vordere Extremität bei den Tetrapoden erlangte, entstand, was ibre Befestigung an Teilen des Achsenskelets erforderte, folgt einmal daraus, đaß die Rückbildung der Vorderextremität der Amnioten stets von einer Reduktion, oder sogar dem völligen Ausfall des Brustbeins begleitet wird. Weiterhin jedoch auch daraus, daß die ventralen Teile des Schultergürtels gewöhnlich in Verbindung mit dem Sternum treten. Diese Verbindung gestaltet sich so innig, daß vom Schultergürtel aus entstehende"Teile (Episternum). so eng mit dem Brustbein zusammentreten, daß sie, abgesehen von ihrer Herkunft, als Teile desselben angesprochen werden können.

Unter den Sauriern ist das Sternum nur bei den fußlosen Eidechsen stark verkümmert (Fig. 208 A) und bei gewissen ganz eingegangen. An sein Rudiment treten gewöhnlich keine Rippen mehr heran. Daß es auch den Schildkröten fehlt, hängt mit deren knöchernem Bauchpanzer ursächlich zusammen. Die meist kleine bis mäßig große Brustbeinplatte der Saurier (s. Fig. 108, S. 208, Fig. 208) ist gewöhnlich annähernd rbombisch und verlängert sich bäufig nach hinten in einen mittleren unpaaren Fortsatz, oder zwei paarige längere, in welchen sich die unvereinigt bleibenden Abschnitte der hinteren Sternalanlagen wiederfinden (Xiphisternum, Metasternum). Die eigentliche Platte verbindet sich nur mit zwei bis vier vorderen Brustrippen; der hintere oder die beiden hinteren Fortsätze gleichfalls mit einigen Rippen, während die darauf folgenden gewöhnlich frei endigen (sog. falsche Brustrippen). Es ist jedoch recht interessant nnd wirft Licht auf die Entstehung des 
Brustbeins, $\mathrm{da} B$ diese hinteren Rippen sich zuweilen parweise in der Ventrallinie vereinigen können (Chamaeleo und andere, Fig. 108); ja es können sogar zwischen ihre Ventralenden unpaare Knorpelstiicke eingeschaltet sein, welche also gewissermaßen wie isolierte vielfache Sternalgebilde erscheinen.

Das Brustbein der Krokodile ist mäßig entwickelt und setzt sich in einen langen Xiphisternalfortsatz fort, der sich hinten gabelt (Fig. 209).

Im allgemeinen erhält sich das Brustbein der Reptilien knorpelig-kalkig. Dies gilt anch für die meisten ausgestorbenen Gruppen; doch wurden unpaare oder

Fig. 108.

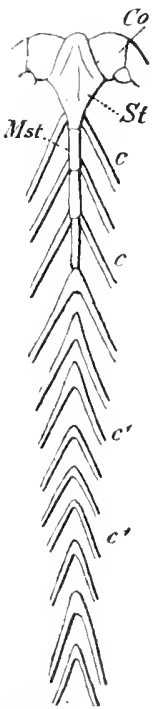

Chamaeleo. Verhalten der Rippen an ihrem ventralenEnde; der proximale Verlauf der Rippen ist nicht dargestellt. St Sternum. Mst Metasternum. Co Coracoid. $c, c^{1}$ Rippen. (Aus Gegenbaur 1598.) paarige Sternalverknöcherungen bei Pythonomorpha, Dinosauria (selten), Pterosauria und Theromorpha gefunden.

Bei den geschwänzten und ungeschwänzten Amphibien (Fig. 205, 206) ist dem hinteren Rand der sog. Coracoidea des Schultergürtels, die in der ventralen Mittellinie der Brust zusammentreten, ein teils rein knorpeliges, bei den Anuren auch teilweise verknöchertes, plattenförmiges Skeletstück angefügt, das caudalwärts in zwei Fortsätze auslaufen kann. Es entsteht aus einem oder mehreren Paren knorpeliger Anlagen, die in einigen Ligamenta intermuscularia (Myosepten) auftreten. Seiner Lage nach entspricht es völlig dem Sternum der Reptilien.

Es darf diesem und so mehr gleichgesetzt werden, als sowohl bei geschwänzten Amphibien als Eidechsen gelegentlich rudimentäre Rippen vorkommen, die mit der Wirbelsäule nicht mehr direkt zusammenhängen, oder auch ventrale Rippenstücke in der Bauchlinie, die mit den zugehörigen dorsalen außer Zusammenhang sind. Da es nun sehr wahrscheinlich ist, da $\beta$ die Rippen der Uramplibien stärker entwickelt waren und ein Sternum gebildet hatten, so dürfen wir das Brustbein der rezenten Amphibien als den Rest einer Sternalbildung auffassen, der selbst in der Ontogenie den Zusammenhang mit den dorsalen Rippenresten verlor.

Mit der mächtigen Entwicklung, welche die Brustmuskulatur der Vögel zur Bewegung der Flügel erlangte, wurde auch das Sternum zu einer großen, etwa rechteckigen Platte, - die völlig verknőchert ist und sich mit einer größeren Zahl Brustrippen verbindet als bei den Reptilien (s. Fig. 214). Zur Vergrößerung

der Ansatzfläche der starken Brastmuskeln, den Herabziehern des Flügels, hat sich in der ventralen Mittellinie der Sternalplatte ein mehr oder weniger hoher Längskamm (Carina) entwickelt, der nur den straußartigen Vögeln (Ratiten) ganz fehlt. - Als analoge Bildung fand sich eine solche Crista auch bei manchen Pterosauriern. - Wie eine Art Ersparnis der Knochensubstanz der großen Brustbeinplatte erscheint es, daß sie bei manchen Vögeln von großen, nur häutig geschlossenen Löchern durchbrochen ist, oder, indem diese Löcher am Hinterrand des Brustbeins sich öffnen, dieser Rand in einige hintere Fortsätze ausläuft. Ähnliche Durchbrechungen der Sternalplatte înden sich gelegentlich auch schon bei Sauriern.

Im Gegensatz zu dem breiten und langen Brustbein der Vögel ist das der Säuger meist recht schmal und lang, da sich gewöhnlich ziemlich viele echte 
Brustrippen mit ihm verbinden. Es besitzt ferner die Eigentümlichkeit, daß es sowohl in seiner knorpeligen Anlage, als besonders nach der ersten Verknöcherung aus hintereinander gereiliten (selten paarigen) Gliedstiucken besteht, welche sich zwischen je zwei aufeinander folgende Rippenpaare einschalten (Fig. 215). Das vorderste Gliedstiick ist in der Regel verbreitert (Manubrium) und dient auch zur Befestigung der Schlüsselbeine des Schultergürtels, wo diese nicht rückgebildet sind. Im Alter tritt häufig Verwachsung der ursprünglichen Brustbeinglieder zu einer einheitlichen knöchernen Sternalplatte ein. Das hinterste Sternalglied ist meist in einen knorpeligen, oder verknöchernden sog. Schwertfortsatz verlängert (Xiphisternum).

Bei gewissen Schuppentieren (Manis) kann das Xiphisternum, indem es sich paarig spaltet, abnorm lang werden, so da $\beta$ es bis in die Beckengegend nach hinten reicht, ja nach vorn umbiegend bis in die Nierengegend wieder aufsteigt. Diese Modifikation hängt mit der besonderen Ausbildung der langen Zunge zusammen, wie bei dieser später zu erörtern sein wird.

In das Manubrium, welches zuweilen vor die erste Brustrippe fortsatzartig vorspringt, sind wahrscheinlich sternale Reste der hintersten (7.) Halsrippen eingegangen, ebenso häufig gewisse Teile des Schultergürtels, was erst bei letzterem erörtert werden kaun.

Die starke Reduktion, welche das Sternum bei den Cetaceen erlitt, erklärt sich aus der fischartigen Umbildung der vorderen Extremität und des Gesamtkörpers, was wieder ähnliche mechanische Bedingungen wie bei den Fischen hervorrief. - Schwache Entwicklung einer Carina (Fledermäuse und einige grabende Sängetiere) wird wie bei den Vögeln durch die besonders starke Entfaltung der Brustmuskeln bedingt.

\section{Regionenbildung der Wirbelsäule.}

Die Zahl der Wirbel, welche die Säule bilden, unterliegt den größten Schwankungen, je uach der Länge der betreffenden Formen. Bei sehr langgestreckten Vertebraten, wie Schlangen und schlangenartigen Sauriern, wächst die Wirbelzahl erstaunlich (bis auf 400-500), wogegeu sie bei den anuren Amphibien auf 10 (einschließlich des weiter unten zu besprechenden sog. Urostyls) herabsinkt (Aglossa nur 9). Ganz allgemein verschmächtigt sich die Wirbelsäule am Schwanzende immer mehr, indem die Wirbel successive kleiner werden und ihre Fortsätze mehr und mehr verkümmern, so daß das hinterste Ende hänfig von einer Anzahl stark reduzierter Wirbel gebildet wird.

In der Wirbelsäule der Fische (Fig. 109) lassen sich nur zwei Regionen unterscheiden, eine Rumpfregion, die in der Regel freie Rippen trägt, und eine Schwanzregion mit geschlossenen Ventralbogen.

Wie wir schon früher bei der. Wirbelsäule der primitiveren Fische hervorhoben, so bildet sich auch bei Knochenganoiden und. Teleosteern bäufig ein besonder's fester vorderster Abschnitt der Wirbelsäule aus, indem einige der vordersten Wirbel miteinander verwachsen, ja sogar mit dem Hinterende des Schädels sich vereinigen können. Diese Einrichtung bewirkt, daß der das Wasser durchschneidende Kopf eine feste Stütze an der Wirbelsäule findet. Analoge Verhältnisse können daher auch bei höheren Wirbeltieren unter ähnlichen Bedingungen wieder auftreten, so bei den Cetaceen, deren Halswirbelsäule sich ungemein 
verkürzt und ihre Gelenkigkeit einbüßt, was ebenfalls eine möglichst feste Verbindung des mächtigen Schädels mit der Wirbelsänle hervorruft.

Die kräftigere Entwicklung der hinteren Extremitïten bei den Tetrapoden, als Yorwärtsschieber des Körpers, bedingt ihre Befestigung an der Wirbelsäule, auf welche sie bei der Vorwärtsbewegung wirken. Dies geschieht, indem sich das

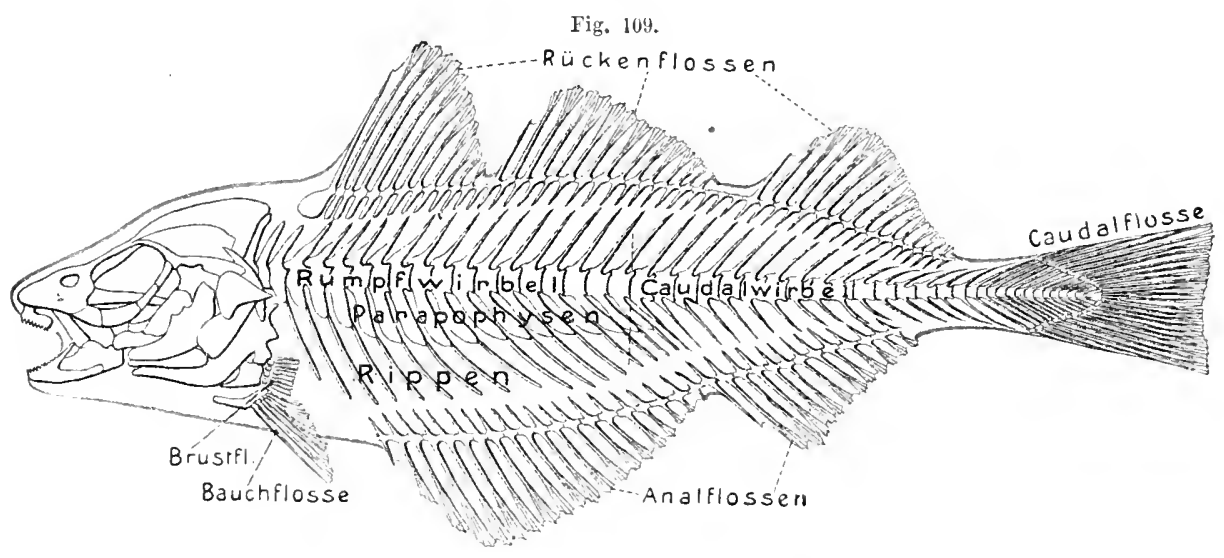

Gadus a eglefinus (Schellfisch). Skelet ron links zur Domonstration der Regionen. v. Bu.

dorsale Ende des sog. Beckengürtels, der das Skelet der freien hinteren Extremität trägt, an den verkürzten Rippen eines oder mehrerer der hintersten Rumpfwirbel (Sacralwirbel) befestigt. - Anf diese Weise bildet sich eine sog. Sreral- oder hreuibeinregion aus, die zwischen Schwanz- und Rumpfregion eingeschaltet ist.

Fig. 110 ,

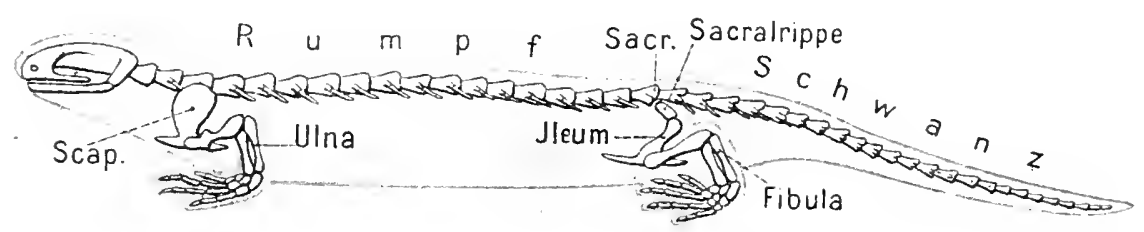

Salamandra maculosa. Schema des Skelets von links. (Aus Versehen sind 17 statt is Prāsacralwirbel gezeichnet.) v. Bu.

Bei den Amphibien (s. Fig. 110) besteht sie nnl aus einem einzigen Sacralwirbel, welcher bei den Urodelen vermittels einer Sacralrippe das Darmbein (Ileum) des Beckengiïtels trägt. - Die Darmbeine der Anuren befestigen sich direkt an den ansehnlichen Querfortsätzen des Sacralwirbels, indem die Sacralrippe in den Querfortsatz eingegangen ist (Fig. 111). - Die anschnliche Schwanzregion der Urodelen verkümmert bei den Anuren zu einem dem Sacralwirbel hinten angefïgten langen schmalen Knochen, dem sog. Urostyl oder Os coccygis, das als Versclımelzungsprodukt einer Anzahl vorderer urspriinglicher Caudalwirbel aufzufassen ist, obgleich solche in der Ontogenie nicht mehr diskret angelegt werden. 
Das Urostyl kann zuweilen mit dem Sacralwirbel verwachsen. - Die Schwanzwirbelsäule der Gymnophionen ist fast ganz verkümmert.

In der Rumpfwirbelsäule der Amphibien läßt sich wegen der geringen Ausbildung oder der Verkümmerung der Rippen keine weitere Sonderung durchfuihren. Die Rippen der Urodelen (Fig. 110) und Grmnoplinnen erstrecken sich gleichmäßig iiber diese Region und noch auf die vordersten Schwanzwirbel.

Bei sämtlichen Amnioten mit unverkiimmerten vorderen Extremitäten ist wegen der Verbindung der vorderen Brustrippen mit dem Sternum die Unterscheidung einer Hals- und Brustregion gegeben (Fig. 112, 115). Indem man die Brustregion von jenem Wirbel an rechnet, dessen Rippe sich zuerst an dem Sternum befestigt, faßt man die davor liegenden Wirbel als Halsregion zusammen. Wie schon bemerkt, erreichen die hinteren Rippen der Brustregion das Brustbein. nicht mehr und werden daher als falsche Brustrippen bezeichnet. - Wenn einige der hinteren Rumpfwirbel rippenlos bleiben, so werden sie Lenden-(Lumbar-) wirbel genannt. Bei den Sauriern sind solche nicht, oder nur in sehr geringer Zahl entwickelt; etwas zahlreicher werden sie bei den Krokodilen, mehr noch bei den Säugern (Fig. 112). Die Lendenwirbel der Vögel vereinigen sich, wie gleich zu schildern sein wird, mit dem Sacrum.

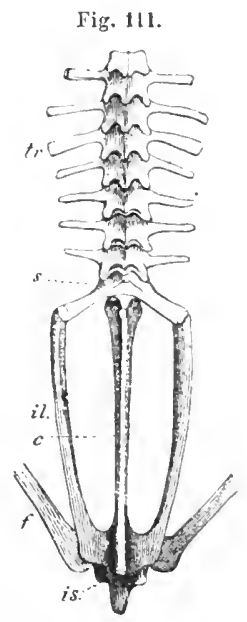

Wirbelsãule und Becken von Rana esculenta. tr Diapophyse. s Sacrum. c Urostyl.il Ilenm. is Ischi. um. $f$ Femar.

(Ans Gegenbace is95.)

Die interessantesten Verhältnisse zeigt die Kreunbeinregion, welche, mit Ausnahme der extremitätenlosen Formen, stets gut entwickelt ist. Auch bei denjenigen Säugern, deren hintere Extremitäten verkümmerten (Sirenen und

Fig. 112.

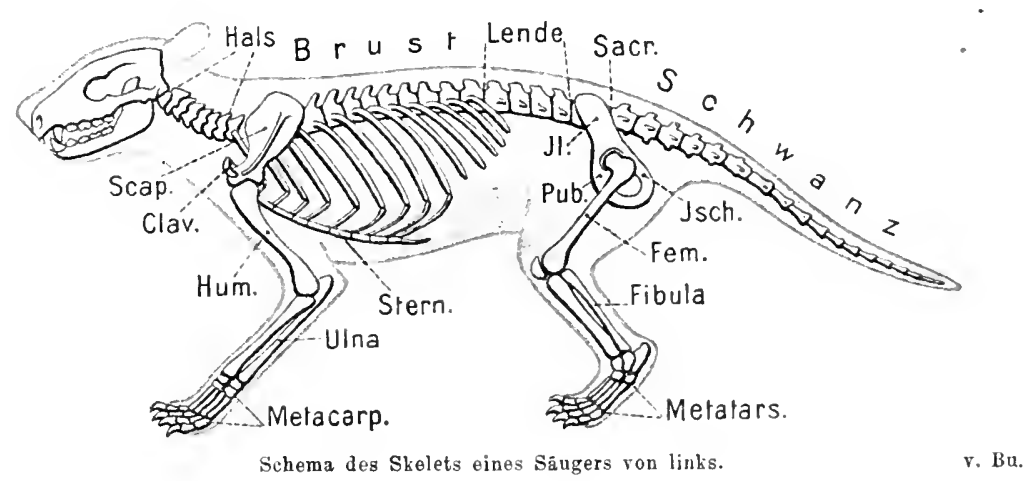

Waltiere), analog auch bei den fossilen Ichthyosauriern, ist das Sacrum geschwunden, obgleich letztere noch hintere Extremitäten besaßen, deren Becken jedoch die Wirbelsäule nicht erreichte. - Die einfachste Sacralregion der Amnioten kuïpft an 
die Einrichtungen der Amphibien an, indem bei manchen Sauriern, jedoch auch nicht wenigen Säugern (Fig. 118), der ansehnliche Qnerfortsatz eines einzigen Sacralwirbels das Darmbein trägt. In beiden Fällen gesellt sich jedoch der darauf folgende erste Caudalwirbel diesem ursprünglichen Sacralwirbel inniger zu, indem sein Querfortsatz kräftiger entwickelt ist und sich dem des ersten nahe anschließt. Diese beiden Sacral wirbel verwachsen bei den Säugern häufig frühzeitig miteinander. Bei den meisten lebenden und fossilen Reptilien (Fig. 114, 223, 225) geht die Anheftung der Darmbeine auf beide Wirbel über, die sich dann in der Regel gleichmäßig hieran beteiligen; dasselbe gilt für die meisten Säuger.

Die kräftige Entwicklung der hinteren Extremitäten vieler Sänger bedingt jedoch eine weitere Verstärkung der Sacralregion durch Zutritt einiger folgender

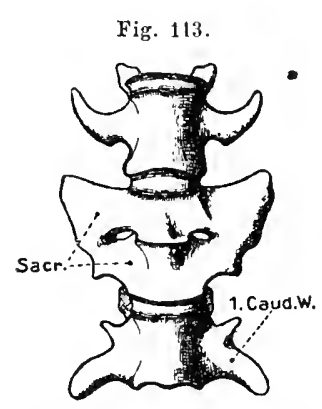

Halmaturus ruficollis. Sacrum von der Ventralseite.
P. He.
Fig. 114.

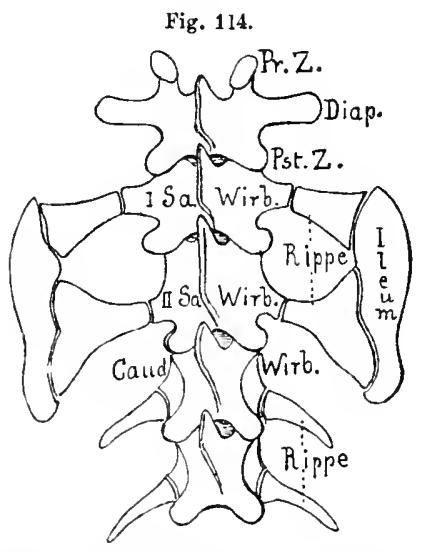

Junger Alligator mississipiensis. Sacrum mit Sacralrippen nnd Ileum ron der Dorsalseite. 0 . B.

Schwanzwirbel und ihre Verwachsung mit den beiden ursprünglichen, so daß die Sacralwirbelzahl auf drei, ja bis auf fünf und sechs steigen kann (Fig. 229-231). Auch kann sich gelegentlich der hinterste Lendenwirbel diesem Komplex zugesellen. - In vereinzelten Fäilen erfährt die Sacral wirbelzahl eine abnormeSteigerung auf sieben bis neun (Phascolomys, Faultiere Fig. 231b, Gürteltiere), indem sich die Sitzbeine des Beckens mit weiter hinten gelegenen Schwanzwirbeln verbinden und letztere dann ebenfalls mit dem Sacrum verwachsen. - Alle diese Verhältnisse hängen zweifellos mit besonders kräftiger Funktion der hinteren Extremitäten zusammen. Das zeigt sich ebenso in der Sacralbildung, wie sie sich schon bei gewissen fossilen Reptilien anbahnte, und bei den Vögeln ibre höchste Entfaltung fand. Diese Entwicklung war jedenfalls hauptsächlich bedingt durch die Aufrichtung anf den hinteren Extremitaten und deren vorzugsweise Verwendung zur Bewegung auf dem Boden.

So stieg die Zahl der Sacralwirbel bei den fossilen Flugsauriern (Pterosauria) auf 3, 4 und 5, mit Verschmelzung der drei vorderen, da sich diese Reptilien auf dem Land wohl nur mit den hinteren Extremitäten bewegten wie die Vögel. Am interessantesten entwickelte sich das Sacrum in der großen Reihe der Dinosauria. Viele derselben besaßen nur drei rerwachsene Sacralwirbel, von denen der hinterste zuweilen noch frei blieb. Bei zahlreichęn Formen erhöhte sich die Kreuzbeinwirbelzahl bis auf fünf, ja bis zehn, unter Verwachsung der Wirbel; es waren dies Dinosaurier, welche sich wohl rorzugsweise auf den hinteren Extremitäten bewegten. - Auf anderen Bedingungen beruht es dagegen, da $B$ auch bei gewissen Schild- 
kröten, dauernd oder nur vorïbergehend in der Entwicklung, zu den beiden ursprünglichen Sacralwirbeln einige davor liegende, ja sogar auch Schwanzwirbel zugezogen werden, indem ihre Rippen sich ebenfalls am Tragen des Darmbeins beteiligen. - Das gleiche gilt auch für die fossilen Theromorpha, deren Kreuzbein $2-6 \mathrm{~W}$ irbel in sich vereinigt.

In derselben Richtung, wahrscheinlich sogar in plylogenetischem Zusammenhang mit den Dinosauriern, entfaltete sich die Sacralregion der Vögel. Sowohl die Ontogenie, als die Betrachtung des ausgebildeten Sacrums und die Berücksichtigung derNerven ursprünglicherer Vögel, läßt noch zwei mittlere Wirbel erkenuen, welche den beiden ursprünglichen Sacral wirbeln derReptilien entsprechen (Fig. $116 s^{1} s^{2}$, w. Fig. 227). Ihre Querfortsätze stehen mit der mittleren Region der sehr lang ausgewachsenen Darmbeine in Verbindung. $\mathrm{Zn}$ diesen beiden ursprünglichen Wirheln gesellen sich aber nicht nur eine beträchtliche Zahl vorderer Candalwirbel, sondern auch eine große Anzahl hinterer Rumpfwirbel, d. h. sämtliche rippenlose Lendenwirbel und meist noch einige hin-

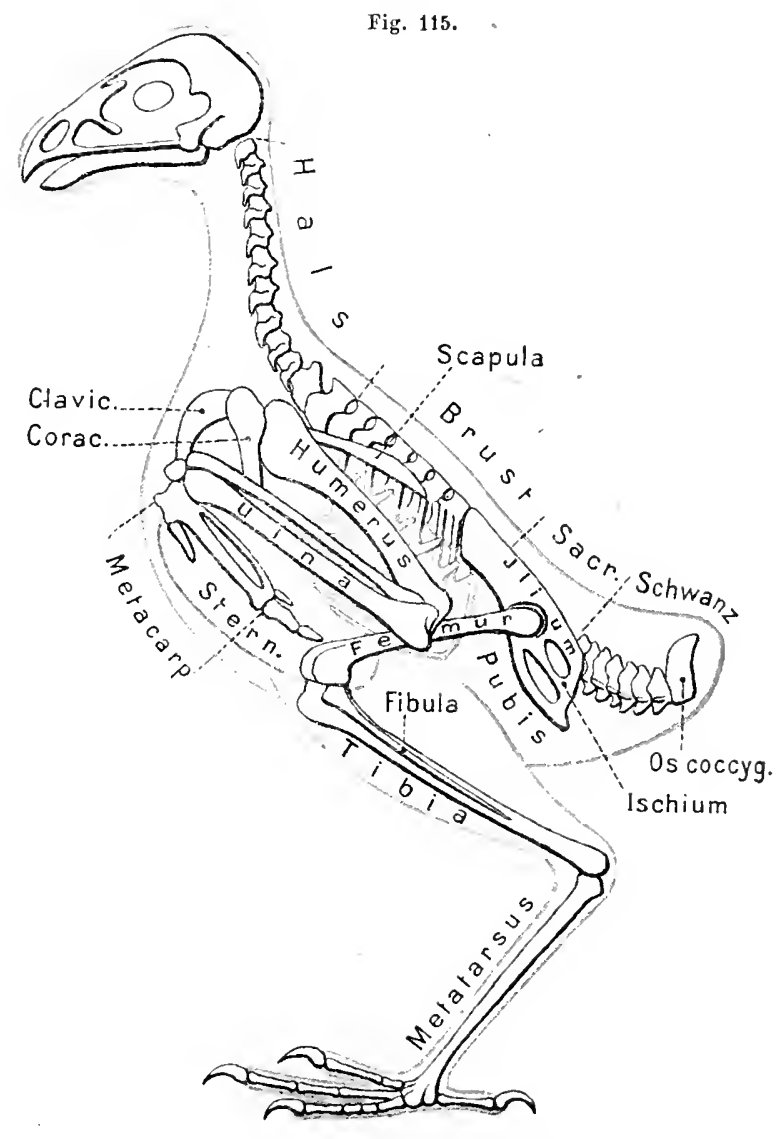

Schematisches Skelet eines Vogels von links. v. Bu.

tere Brustwirbel. Alle diese Wirbel sind gewöhnlich (mit gelegentlicher Ausnahme der vordersten und hintersten) fest verwachsen, was nnr bei gewissen Ratiten unterbleibt. Die Wirbelzahl des ausgebildeten Sacrums beträgt 9-20 (Casuar).

Obgleich das Darmbein der Amnioten an den Querfortsätzen der Sacralwirbel direkt befestigt scheint, so läßt sich doch nachweisen, daß auch ihnen ursprünglich kırze Sacralrippen zukamen, welche jedoch frühzeitig mit den Diapophys der Sacralwirbel verschmolzen. Auch für dic Lumbarwirbel einzelner Säuger ist die Anfuahme eines Rippenrudiments in die Querfortsätze ontogenetisch erwiesen. 
Bei jungen Krokodileñ (s. Fig. 114 S. 212, 117) bemerkt man, daß der größte Teil des Querfortsatzes aus einer selbständigen Sacralrippe hervorgeht und daß auch die Diapophysen der anschließenden Caudalwirbel in ähnlicher Weise mit rudimentären Rippen verbunden sind. Bei den Schildkriten, sowie vielen fossilen Reptilien, erhalten sich die Sacralrippen meist dau-

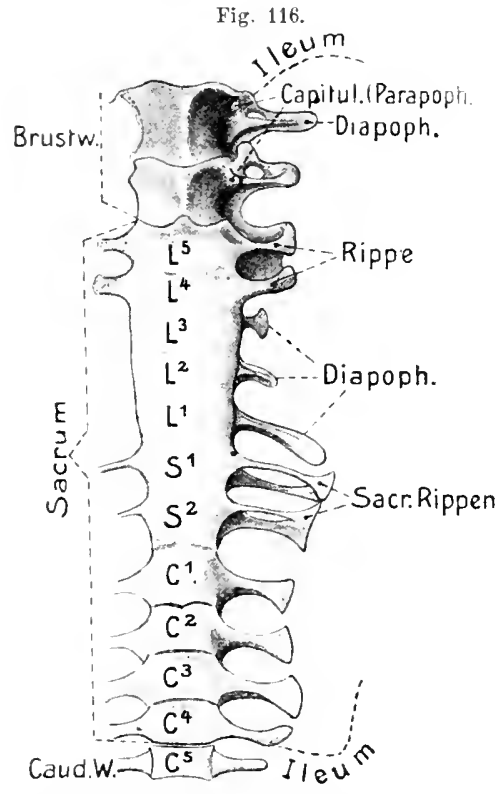

Columba domestica kurz nach Ausschlüpen. Sacrum nebst den beiden hintersten Brustwirbeln und dem ersten laudalwirhel von der Ventralseite. $S^{1} 1$ a. $S^{2}$ die beiden primāen Sacralwirhel. $L^{3}-L^{5}$ Lendenwirbel; $C^{1}-C^{4}$ die rorderen Cauduwirbel, welche noch mit dem Sacrum verwachsen werden.

o. B. ernd gesondert, ebenso die Rippen (sog. Querfortsätze) der vorderen Caudalwirbel. Ähnliclıes zeigen auch junge Säuger (s. Fig. 118). — Bei Vögeln (s. Fig. 116, läßt sich gleichfalls nachweisen, daß von den beiden urspünglichen Sacralwirbeln, unter der mehr dorsal stehenden Diapophyse, noch das Capitularende einer rudimentären Rippe entspringt, das ebenso an den darauf folgenden caudalen Sacralwirbeln erkennbar ist; wahrend die lumbalen Sacralwirbel gewöhnlich nur eine Diapophyse besitzen.

Die Längenentwicklung der übrigen Regionen der Amnioten - Wirbelsäule schwankt sehr, vor allem die der Hals- und Schwanzregion. Bei den rezenten Reptilien bleibt die Halsregion zwar gewöhnlich mäßig, wurde jedoch beigewissen fossilen, so den Sauropterygia (besonders Plesiosaurus), sehr lang (bis 70 Wirbel). Die Krokodile besitzen gewöhnlich nur neun Halswirhel, die typischen Saurier acht. Lang und wirbelreich wird die Halsregion vieler Tögel, die sich von etwa 11 auf 23 bis 25 Wirbel erheben kann (Schwäne). Charakteristisch erscheint dagegen die groBe Konstanz der Halswirbelzah! der

Sänger, die, ohne Riäcksicht auf die Halslänge, fast stets sieben beträgt, und sich nur in vereinzelten Fälleu auf sechs vermindert (Manatus, Choloepus hoffimanni),

Fig. 117.

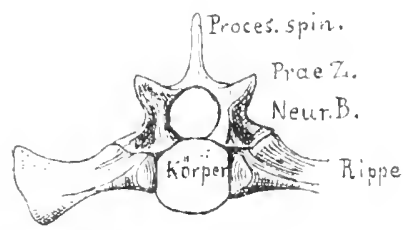

Alligator jung (s. Fig. 114). Yorderer sacritwirbel von vorn mit nuch freier Sacribripe. $\quad 0 . \mathrm{B}$. oder auf acht bis neun erhöht (Bradıpus).

Brnst- und Lendenregion unterliegen natiirlich bei den Säugern erheblichen Schwankungen; doch zeigt sich häufig eine gewisse Konstanz in der Gesamtzahl ihrer Wirbel; diese schwankt nicht allzu sehr, von 16--17 bei den anthropoiden Affen bis 29 bei Hyrax. - Bei den Sauropsiden sind die Extreme in der Gesamtwirbelzahl der Thoraculumbalregion viel größer.

Die anfiallendsten Unterschiede bietet begreiflicherweise die Schwanzregion, die sowohl bei Feptilien als Säugern von einer sehr groBen Wirbelzabl bis auf wenige herabsinkt. Bei letzteren finden wir im Maximum 49 (Manis macrura); im Minimum drei bis fünf Wirbel bei den anthropoiden Affien. 
Sehr verkümmert ist stets die Candalregion der rezenten Vögel (Fig. 115), was sich jedoch erst in dieser Klasse allmählich entwickelte. Die ältesten bekannten Vögel des oberen Jura (Archaeopteryx) besaßen noch einen langen, wirbelreichen freien Schwanz, der jederseits eine Reihe ansehnlieher Steuerfedern trug. Der Sehwanz der heutigen Vögel springt nicht mehr vor, und die Stenerfedern sind auf seiner Dorsalseite in eine bogige Querreihe zusammengezogen (Fig. 57, S. 144). Die hintersten Wirbel der stark reduzierten und aufwärts gekriimmten Caudalregion verwachsen bei Carinaten und Struthio zu einem vertikalen plattenförmigen Kuöchelehen $\left(\mathrm{Os}_{\mathrm{s}}\right.$ coccygis, Uro- oder Pygostyl), welches die Steuerfederu stützt. Davor finden sich noch vier bis neun freie Caudalwirbel.

Die so variablen Zahleuverhältnisse der Wirbel bei den verschiedenen Wirbeltieren, namentlich aber die großeu Schwankungen der Wirbelzahl, welehe sich innerhalb der einzelnen Regionen zeigen, bedürfen noch einer Erläuterung.

Man könnte deuken, daß die Znoder Abnahme der Wirbel in der Säule durch Neuauftreten oder Schwinden von Wirbeln zwischen den vorbandenen geschehe, oder auch durch Vermehrung, hrzw. Schwinden, einzelner Segmente zwisehen den iibrigen. Fiu solcher Vermehrungsvorgang der Segmente, sei es durch Einschaltung neuer, oder durch Teilung einzelner, wurde jedoch nie sicher beobachtet.

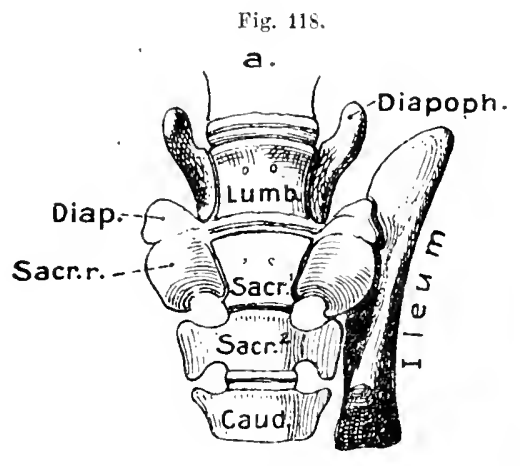

b.

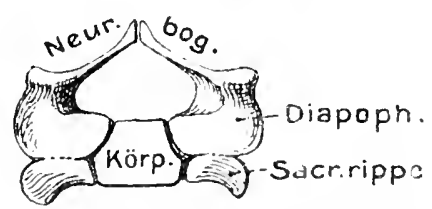

Felis concolor (Puma) jung. "Sacrum ren dur Tintralseite mit Sacralrippen und linken lleum. $b$ vorderer Sacralwirbel von vorn mit noch freier Sacralripe. $\quad$ o. 1.

Neubildung von Segmenten finlet uur am Hintereude des Körpers statt. Hieraus müssen wir auth schließen, daß bei Zunahme der Gesamtwirbelzallal der Siule der Zutritt nener Wirbelkörper nur am Hinterende geschieht. Die Erfahrungen stimmen hiermit gut iiberein. Ehenso fiuden wir anch, daß die Verkürzung der Wirbelsuule sich in der Regel durch Verkïnmerung am Schwanzende vollzieht. Immerhin war jedoch auch an der vordersten, auf den Schädel folgenden Region zuweilen Verkïmmerung zu beobachten, ja die gesante Halsregion in gewissen Fällen stark rtickgebildet. Ia bei der Besprechung des Schädels sich die Höglichkeit weitgehender Verkiimmerung von Segmenten auf der Grenze von Kopf nud Rumpf ergeben wird, so erseheint also der Ausfall einzelner Wirbel inuerlalb der Sänle möglieh.

Wie dargelegt wurde, beruht die Unterscheidung der Regionen der Saule anf recht geringfügigen Merkmalen, im besouderen auf dem Verhalten der lippen, ob dieselben frei (Hals), ob mit dem Sternum verbunden (Brust), ob Mangel derselben (Lende), ob ventrale Bogen (Schwanz). Hieraus geht hervor, daß durch geringe 
Verschiedenheiten im Verhalten der Rippen die Grenzen zwischen Hals-, Brust- und Lendenregion verschoben und damit die Zahlenverhältnisse dieser Regionen verändert werden köunen. Dies spricht sich auch bei den verschiedenen Abteilungen der Amnioten häufig darin aus, daß die Gesamtzahl der Hals-, Brust- und Lendenwirbel relativ konstant, die Wirbelzahl innerhalb der einzelnen Regionen dagegeu wechselnder ist, was sich ans obigem leicht erklärt. - Etwas anders verhält es sich dagegen mit der Sacralregion. Da den Sacralwirbeln in der Gesamtreihe der Wirbel bei den verschiedenen Tetrapoden recht verschiedene Numerierung zukommt, jedoch kein Grund für die Annahme vorliegt, daß dies anf Ausfall oder Einschaltung von Wirbeln in dem vor dem Sacrum gelegenen Teil der Säule beruht, so bleibt nur die Möglichkeit, daß das Darmbein samt den ïbrigen Beckenteilen sich verschieben konnte, daß seine Befestigung, je nach Vorteil, auf weiter vorn oder hinten gelegene Wirbelkörper veriegt wurde. Daß sich ein solcher Vorgang etwa durch ganz minimale, allmählich successive Wanderung der Darmbeine vollzogen haben könnte, dafür sprechen keine sicheren Erfahrungen; eher möchte es daher scheinen, daß plötzliche, sprungweise Abänderungen bei der Verlagernng der Sacralregion im Spiel waren.

Gelenkung der Wirbelsänle mit dem Schädel und die besondere A usbildung der beiden vordersten Halswirbel.

Schon früher wurde erwähnt, daß bei den Fischen meist das Gegenteil einer gelenkigen Verbindung zwischen Sänle und Schädel besteht, nämlick eine möglichst feste Vereinigung beider. Nur bei den Rochen nnd Holocephalen, sowie vereinzelten Teleosteern, ist eine Gelenkung mit der Säule ausgebildet. Für die Tetrapoden gilt dies allgemein, wobei die beiden vordersten Halswirbel Veründerungen erfahren können.

Der rippenlose vorderste Halswirbel (sog. Atlas) der Urodelen zeigt an der Vorderfläche seines Kürpers einen meist schwachen unpaaren Fortsatz, der zwischen die beiden Hinterhauptshöcker des Schädels eingreift. Manche wollen in diesem sog. Zahnfortsatz das Rudiment eines besonderen vordersten Halswirbels (Proatlas) erkennen; doch ist dies nicht wahrscheinlich. Bei den Anuren ist der Fortsatz wenig angedeutet oder fehlt ganz, wie auch den Gymnophionen.

Die Schädelgelenkung der Amnioten ist überall in gleicher Weise gebildet, indem stets die beiden vordersten Halswirbel an ihr teilnehmen. Die Ontogenie, wie die genanere Verfolgung der vom Gehirn und Rückenmark entspringenden Spinalnerven machen es jedoch wobl sicher, daß bei sämtlichen Amnioten einige der vordersten Halswirbel in die Hinterregion des Schädels einbezogen worden sind, woraus folgt, daß jene beiden vordersten Wirbel der Amnioten richt denca der Amphibien entsprechen, sondern etwas weiter hinten gelegenen.

Der erste Amniotenwirbel (Atlas) ist dadurch merkwürdig, daß sein Neuralbogen vom Körper gesondert bleibt, was sowohl durch die Ontogenie, als die Vergleichung der erwachsenen Formen bewiesen wird. Die Neuralbogenhälften wachsen seitlich um den schmächtig bleibenden Körper ventralwärts hinab uná 
treten ventral in Verbindung mit einer sog. hypochordalen Spange (Iutercentrum), dem Rest eines Hämalbogens des ersten Wirbels. - Der Körper dagegen schließt sich, wie wir sehen werden, dem zweiten Wirbel an.

Bei den Reptilien verknöchern die beiden Bogenhälften und die hypochordale Spange gesondert, so daß der ausgebildete Atlasring aus zwei dorsal meist verwachsenen Bogenhälften und einem unpaaren, ventralen Schlußstück (Mittelstück) besteht (Fig. 119, 120). Alle drei Stücke beteiligen sich an ihrer Vorderseite an der Bildung von Gelenkflächen für den einfachen Schädelcondylus.

Der Atlas der Vögel (Fig. 121) ist ein völlig geschlossener Knochenring geworden, indem die Bogenhälften dorsal verwuchsen, rentral mit dem unpaaren Stück zusammenschmolzen.

Fig. 119.

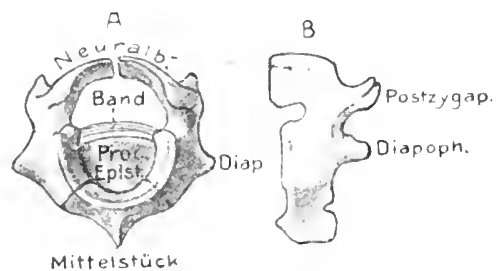

Varanus. $A$ Atlas von vorn mit Proc. odontoidens (dens) des Epistrophens. $B$ Derselbe von links.

Bei den Säugern verschmelzen die Dorsalenden der Bogen ebenfalls gewöhnlich miteinander. Ventral bleibt bei manchen primitiveren (gewissen Beuteltieren) die hypochordale Spange als ein Ligament zwischen den Ventralenden der Atlasbogen erhalten; bei anderen tritt in diesem Band, wie bei den Reptilien, eine unpaare, dauernd selbständig bleibendeVerknöcherung auf (Fig. 122A, B). Bei den meisten Formen aber verwächst dieses Schlußstiick fruhzeitig mit den Bogenhälften zu einemgeschlossenen Atlasring. Er trägt an den Seiten seiner Vorderfläche je eine ansehnliche Gelenkfläche für die beiden Hinterhauptscondyli.

Der gesondert bleibende Atlaskörper schließt sich frühzeitig der Vorderfläche Fig. 120.

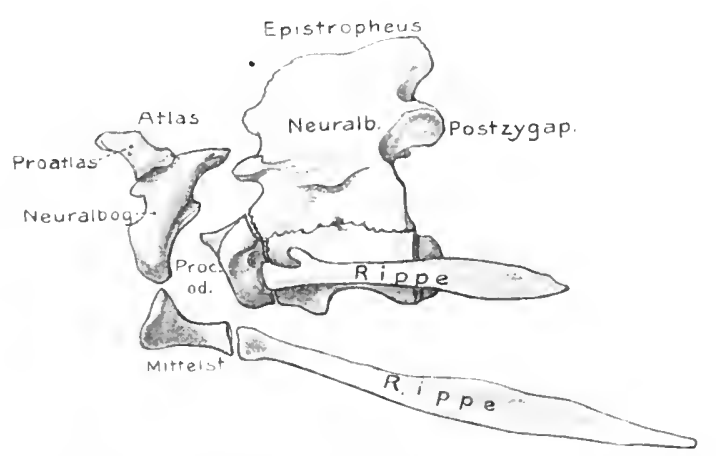

Alligator raississipiensis. Atlas und Epistropheus etwas auseinander gerûckt, ron links.

o. B. des zweiten Wirbelkörpers (Epistropheus) nnbeweglich an als dessen sog. Zahnfortsatz (Dens, Processus odontoideus) (Fig. 120). Bei den meisten Reptilien und niederen Säugern (Beuteltieren) erhält er sich jedoch als gesondertes Knochenstuck, das bei letzterer Klasse nicht nur den Zahnfortsatz, sondern die ganze vordere Region des Epistropheuskörpers bildet, an deren Aufban bei den Sauropsiden auch die hypochordale Spange des Epistropbeus teilnimmt. Bei den Vögeln (Fig. 121) und den übrigen Säugern dagegen verwächst er frühzeitig knöchern mit dem Epistropheus.

Gewöhnlich sind die zum Atlas gehörigen Rippen fast oder völlig verkümmert; 
die des Epistrophens sehr rückgebildet bis fehlend, und bei Vögeln und Säugern mit dem Körper verwachsen. Bei den Krokodilen dagegen trägt das hypochordalo SchluBstiick des Atlas zwei ansehnliche freie Rippen (Fig. 120), und auch die Rippen des Epistropheus sind stark entwickelt, jedoch etwas nach vorn auf den Zahnfortsatz geschoben. - Der Sängetieratlas zeichnet sich gewöhnlich durch sehr

Fig. 121.

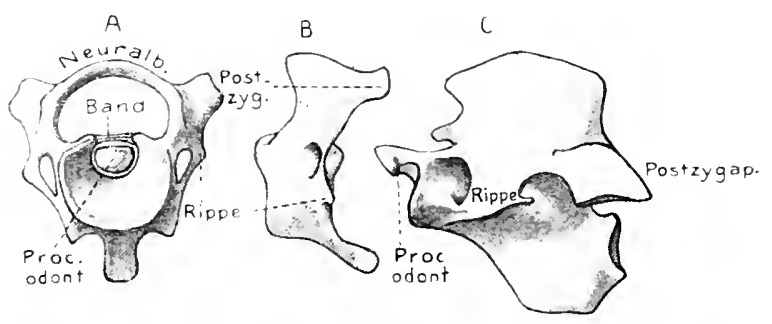

Struthio camelus. A Atlas nnd Zahn des Epistropheus von rorn. $B$ Atlas vor links. $C$ Epistrophens von links. o. B. starke Entwicklung der Querfortsätze (Diapophysen)ans, in die jedoch möglicherweise auch ein Rippenrudiment einbezogen sein könnte.

Der Processus odontoideus schiebt sich zwischen die Basalregion der Atlasbogen hinein und wird an diesem Ort

durch ein queres Band-(Lig. transversum) festgehalten, das sich zwischen den Atlasbogen über ihn hinzieht (s. dic Fignren). Dies Band geht aus dem Zwischengewebe zwischen Atlas nnd Epistropheus bervor. Bei den Vögeln verknöchert es gewöhnlich.

Während sich bei den Sauropsiden die Schädelbewegung vorwiegend in dem Hinterhaupts-Atlasgelenk vollzieht, ist dies bei den Saugern komplizierter. Die

Fig. 122.
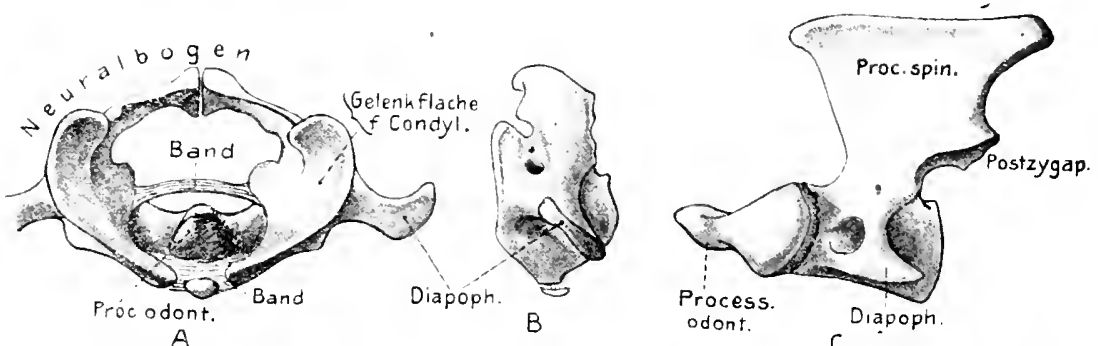

C.

Thylacinus eynocephalus. A Atlas von vorn mit Processns odont. deg Epistrophens. B Atlas von links. $C$ Epistrophens mit noch nicht verwachsenem Atlaskörper.

beiden Hinterhauptscondyli bedingen hier, daß in dem genannten Gelenk nur die Beuge- and Streckbewegungen des Schädels stattfinden können, wogegen bei den Drehbewegungen der Atlas mitsamt dem Schädel um den Zabnfortsatz rotiert; ein Verbalten, welches auch die starken Querfortsätze des Atlas bedingt, die zur Anbeftung der Drehmuskeln dienen. In geringerem Maße muß diese Drehbewegung jedoch auch schon bei den Sauropsiden entwickelt sein, da sonst die ganze Umbildung der beiden vorderen Halswirbel nicht recht begreiflich wäre.

Vor der dorsalen Schlußstelle des Atlasbogens findet sicb bei den Krokodilen (s. Fig. 120) ein dachörmig über dem Rückenmark gelagerter Knochen, der ursprünglich aus zwei bogenartigen Hälften hervorgeht. Sphenodon besitzt zwei ähnlich gelagerte kleine Knöchelchen, 
ebenso auch gewisse Dinosauria. Ein Knöchelchen, das beim Igel (Erinaceus) an ähnlichem Ort vorkommt, wird gleichfalls hierhergestellt. Da auch die Ontogenie dafür spricht, daß vor dem Atlas ein rudimentärer Wirbel (sog. Proatlas) bestanden hat, so erscheint die Deutung der erwähnten Skeletgebilde als Reste ron dessen Neuralbogen wohl möglirb.

\section{Hautskeletteile der Amioten, die in nähere Beziehung zum A chsenskelet treten.}

Bei den meisten ansgestorbenen Reptiliengruppen (mit Ausnahme der Theromorpha nnd der meisten Dinosauria), sowie bei den rezenten Krokodilen und Rhynchocephalen(Sphenodon) findet sich ain System rippenartiger Knochen, welche in der Banchwand, im Anschlnß an die hintersten Brustrippen, bis zum Becken hiuzieken, ohne Verbindung mit der* Wirbelsărle (s. Fig. 123). Diese sog. Bauchmppen (Parasternum) erhielten sich noch bei den ältesten Vŏgeln (Archaeopteryx), fehlen dagegen den tibrigen, sowio den Säugern, stets. Sie lagern sich dem geraden Bauchmuskel (Rectus), dem oberflächlichsten der Bauchmuskeln, ein. Sowohl die direkt knöcherno Entstehnng der Bauchrippen in dem tiefen Bindegewebe des Integaments, als auch die Vergleichung mit dem Hautskelet der Stegocephalen, machen es sicher, daß es sich nm urspriingliche Hautskeletbildungen handelt, die etwas in die Ticfe gerückt nnd zur Muskulatur in Beziehung getreten sind. Es scheint nämlich zweifellos, daß die Bauchrippen auf jene, häufig stäbchenförmigen Hautverknöcherungen zurückzuführen sind, die im Banchiniegument der Stegocepbalen vorkommen (s. S. 172). Wie diese konvergieren sie kopfwarts, was auch mit dem Verlanf der Muskelligamente (Nyosepten) zusammenhängt, die sich im geraden Bauchwuskel erhaiten. Für die erwähnte Ableitung spricht ferner, daß die Bauchrippen der Reptilien nie einheitliche Knochenstäbe sind, sondern sich jederseits aus zwei bis drei, bei fossilen auch mehr Stiicken zusammensetzen.

Bei den Krokodilen (Fig. 1077 a) besteht jede Bauchrippe aus zwei, teilweise aneinander liegenden Stïcken; die in der Bauchlinie zusammentrefrenden medianen sä̈cke sind nicht miteinander verwachsen. - Bei den Rhynchocephalen (Fig. 123) und den meisten ausgestorbenen Reptilienordnungen sind dagegen die beiden medianen Stücke zu einem unparen verwachsen, dessen seitlichen Enden sich die lateralen anschließen. - Nur die Ichthyosauria besaßen zum Teil zhei laterale Stücke jederseits. Archae-

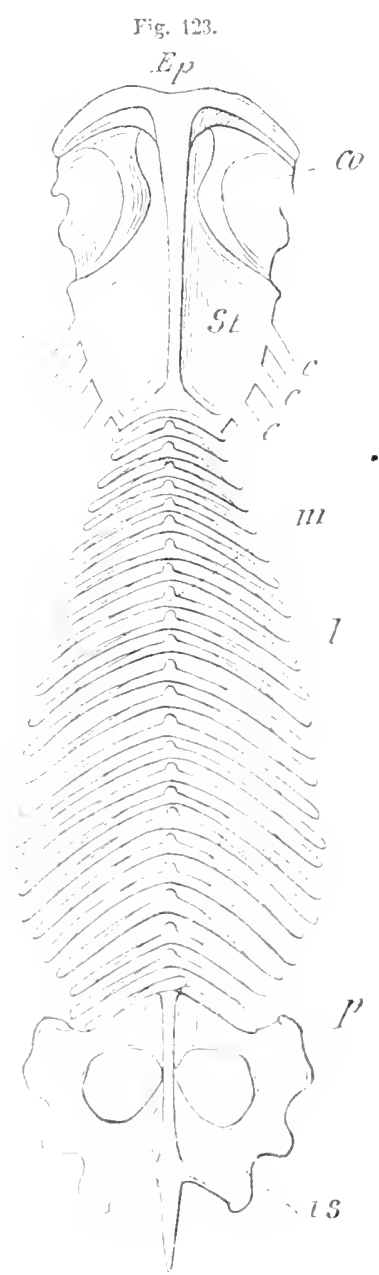

Parasternum mit Schnltergürtel una Becken ron sphenodon punctatu ro, yon Ventralseite. St Sternum. c Rippen. Ep Episternam. co Coracoid. $m$ mediane, $l$ latersle Stũcke des Parasternums. $p$ Pabis. is schium. (Aas 
Vertebrata. Achsenskelet.

opteryx fehlte ein unpaares Mittelstück, es fand sich jederseits nur eine seitliche Reihe. Die Zahl der Bauchrippen schwankt im Zusammenhang mit der Rumpflänge und kann recht hoch werden. Bei den Krokodilen, Ichthyopterygiern und Pterosaurierr kommt auf jedes der betreffenden Körpersegmente ein Bauchrippenparr, bei den Rhynchocephalen zwei, bei gewissen älteren fossilen Reptilien sogar bis sechs, was wohl einem urspruinglichen Zustand entsprechen lürfte.

Besondere plattenförmige Hautverknöcherungen treten, wie erwähnt, schon bei den Ganoiden und den Knochenfischen in innige Beziehung zu dem, die vordere Extremität tragenden Brust- oder Schultergürtel. Dies wiederholte sich bei den fossilen Stegocephalen, woraus sich gewisse Bestandteile des Schultergürtels der höheren Wirbeltiere ableiten. Da diese Hautknochenbildungen jedoch so innigen Anteil am Anfbau des Schultergürtels nehmen, werden sio besser erst bei diesem besprochen.

Hautverknöcherungen, die keine Verbindung mit dem Achsenskelet eingehen, fanden wir sowohl bei den squamaten (Sauria) als placoiden Reptilien (Crocodilia) als Schutzgebilde in Verbindung mit den epidermoidalen Hornschuppen oder -Platten über große Hautstrecken verbreitet. Eine ganz besondere Entwicklung erlangen sie abel bei den Sehildkröten, wo sie sich z. T. mit dem Achsenskelet zar Bildung eines mächtigen, den Rumpf umkleidenden Knochenpanzers verbinden.

Die große Mehrzabl der Schildkröten zeigt folgende Verhältnisse (Fig. 124 ${ }^{1}$ ). Ein knöchernes Schild (Carapax), das dicht unter dem Hornschild liegt, bedeckt die dorsale Rumpffäche. Lie Bauchseite wird gleichfalls von einem solchen Knochenschild geschützt (Plastron), das seitlich mit dem Carapax knöchern verbunden sein kann, ursprünglich jedoch nur durch Bandmasse mit ihm zusammenhing. Der Carapax wird gebildet von einer medianen Plattenreihe (bis 15), von welchen die vorderste (Nuchalplatte) iiber dem hintersten Halswirbel liegt, mit ihm jedoch nicht vereinigt ist, sondern sich nur durch einen Vorsprung an seinem Dornfortsatz anlegt. Darauf folgen acht Platten (Neuralplatten, selten mehr), welche mit den Dornfortsätzen des zweiten bis neunten Rumpfwirbels ein Continuum bilden, bzw. wie deren plattenartige Ausbreitungen erscheinen.

Die mediane Reihe wird hinten fortgesetzt durch einige freie Platten (alle oder die hinterste meist Pygalplatten genannt), die bis ans hintere Ende des Carapax reichen, und ohne Verbindung mit den unterliegenden drei hintersten Rumpfwirbeln und den Schwanzwirbeln sind. Jederseits an die zweite bis neunte Neuralplatte schließen sich acht ansehnliche Costalplatten an, welche in der größten Länge ihres Verlaufs wie plattenartige Vcrbreiterungen der zweiten bis neunten Rippe erscheinen. Medial gehen die Costalplatten in der Gegend der Wirbelsäule in einen tiefer gelegenen Fortsatz aus, der sich als freier Teil der Rippe an die Wirbelsäule befestigt. Die eigentliche Costalplatte dagegen setzt sich dachartig über diesen Rippenfortsatz fort und verbindet sich mit dem Seitenrand der zugehörigen Neuralplatte (Fig. 1243). Der Rand des Carapax, von der Nuchal- bis zur hintersten Pygalplatte, wird endlich von meist elf Marginalplatten gebildet, mit denen sich die distalen rippenartigen Fortsätze der Costalplatten verbinden. 
Das Plastron (Fig. 1242) besteht gewöhnlich ans vier paarigen, jederseits in der seitlichen Bauchregion hintereinander folgenden Stïcken und einem unpaaren (Entoplastron), das sich der medianen Verbindung der vordcrsten paarigen Stücke hinten anlegt. Den Dermochelydae und Cinosternidae fehlt dies unpare Stück. Ein außen zwischen die beiden mittleren paarigen Plastromplatten und die Marginalplatten des Carapax eingeschaltetes pariges Stïck kann bei manchen Flußschildkröten noch aútreten.

Der Ausbildungsgrad dieses Knochenpanzers wechselt sehr. Bei den Dermochelydae(Dermochelys, Lederschildkröte) finden sich vom Carapax nur die Nuchalplatte und die Costalplatten; letztere sind jedoch so wenig verbreitert, daß sie untereinander nicht zusammenstoßen. Die vier paarigen Hautknochen des Plastrons sind vorhanden, jeduch so schmal, daß sie zusammen am Bauchrand nur eine Art Knochenring bilden. Dagegen ist in der Haut ein Mosaik polygonaler, schuppenartiger Knochenplättchen entwickelt, welche, dicht zusammenstoßend, einen förmlichen Rückenpanzer bilden, der aus vielen Längsreihen besteht, unter denen auf dem Rücken sieben, aus etwas größeren, gekielten Plättchen bestehende, stärker hervortreten (die beiden äußersten am Rande desRückens). Auf der Baụchseite finden sich

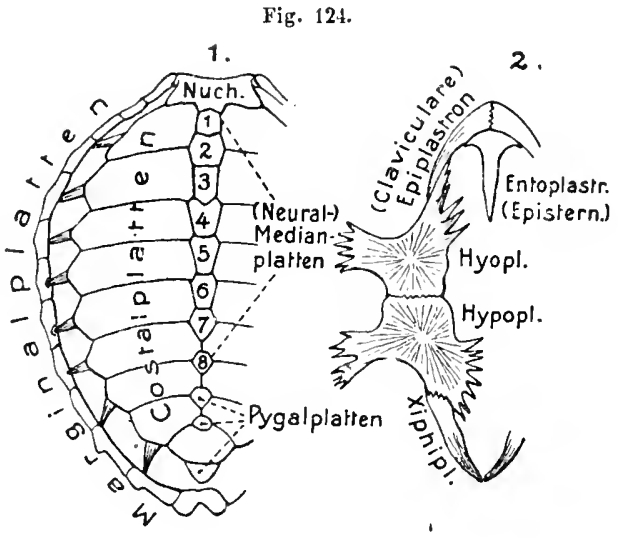

3.

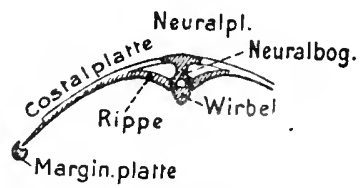

Thalassochelys caretta L. (corticata). 1 Carapax von der Dorsalseite. 2 Plastron von der Ventralseite. 3 Querschnitt durch Carapax und die Rumpfwirbelsāule (n. HuxLer). entsprechende Bauchplättchen in den seitlichen Regionen. Der integumentale Hautknochenpanzer der Dermochelyden liegt also nach anßen von der Nuchalplatte und den Plastronplatten. - Bei den übrigen Schildkröten findet sich von diesem Hautknochenpanzer der Lederschildkröten nichts, wenn man nicht etwa die Neural- und Marginalplatten auf ihn zurückführen will, wovon unten weiteres.

Die Costalplatten sind sonst stets so verbreitert, daß sie untereinander and mit den Neuralplatten zusammenstoßen; distal bleiben sie jedoch bei den Seeschildkröten nnd den Trionychidae schmal, so daß sich hier zwischen ihnen und den Marginalplatten Lücken finden. Letztere Platten können jedoch bei den Trionychidae auch ganz fehlen. In den beiden letzterwähnten Gruppen bleibt auch das Plastron unvollständig (Fig. $124^{2}$ ), indem seine Platten in der mittleren Bauchregion nicht zusammenschließen, auch nicht bis zum Rumpfrand reichen. Die 
Verbindung zwischen Plastron und Carapax ist daher nur lose und wird dureh seitliche Fortsätze der beiden mittleren paarigen Plastronplatten hergestellt. Eigentümlich ist die teilweise, ja völlige Rückbildung der Neuralplatten bei gewissen Flußschildkröten, so daß die Costalplatten median zusammenstoßen.

Bei zahlreichen Fluß- und den Landschildkrơten dagegen kommt es zu völligem SchluB des Carapax und Plastions, sowie zu inniger Nahtverbindung oder Verwachsung zwischen beiden. Bei Landschildkröten, deren Panzer ungemein stark wird, kann im erwachseoen Zustand eine völlige Verschmelzung aller Panzerknochen zu einer einheitlichen, dicken und festen Kapsel eintreten, di nur Öffnungen für den Hals, die vorderen Extremitäten, den Schwanz und dis hinteren Extremitäten besitzt. Gewisse Flußschildkröten zeigen Teile des Pls $t$ ng beweglich an die übrigeu angefïgt.

Der Zusammenhang von Panzer und Skelet kann noch dadurch verstärkt werden, daß sich be einigen Flußschildkröten (Pleurodira, im Gegensatz zu den Cryptodira) sowohl die Darmbeine mit dem Carapax, als Scham- und Sitzbeine mit dem Plastron knöchern verbinden.

Über die rmorphologische Auffassung des Schildkrötenpanzers wurde bis jetzt keine Einigung erzielt. Daß zwar die Knochen des Plastrons, sowie die Marginal-, die Nuchal- und die Pygalplatten des Carapax Hautverknöcherungen sind, die sich in der tiefen Bindegewebsschicht der Cutis bilden, wird allgemein zugegeben. - Die wahrscheinliche Homologie des unpaaren Entoplastrons und der beiden anstoßenden Epiplastronplatten mit dem sog. sekundären Schultergürtel (Episternum und Claviculae) wird später noch erörtert werden. Die weiteren Plastronplatten werden häufig dem Parasternum der übrigen Reptilien homologisiert. - Für die Costalplatten und die 2. bis 9. Neuralplatte, welche mit Achsenskeletteilen zusammenhängen, wird die Hautknochennatur z. T. geleugnet auf Grund der Ontogenese, welche ihre Bildung durch das Periost (Knochenhaut) der Rippen, bzw. der Dornfortsătze, wahrscheinlich macht. Sie werden dann als Teile des Achsenskelets, verbreiterte Dornfortsätze und Rippen angesehen. - Trotz der ontogenetischen Befunde dürfte diese Deutung unwahrscheinlich sein, wegen der großen Äbnlichkeit, die die Neuralplatten mit der Nuchal- und den Pygalplatten besitzen. Das gleiche gilt auch für die Costalplatten, die bei gewissen Formen den Plastronplatten sehr gleichen. Daß zwar die Costalplatten, wahrscheinlich auch die Neuraiplatten, nicht von dem äußeren Hautskelet der Dermochelyden abstammen, dürfte zweifellos sein; liegt doch die Nuchalplatte bei Dermochelys, ebenso wie die sicher auch schon vorhandenen Costal- und Plastronplatten unter diesem Hautskelet. Hieraus scheint hervorzugehen, daß bei den Schildkröten zwei übereinander gelagerte Hautskelete vorkommen können, von denen es zweifelhaft ist, ob das äuBere der Dermochelyden ein primäres oder ein sekundäres ist. Auf Grund dieser Erwägungen halte ich es zunächst für das wahrscheinlichste, daß sowohl die Neural- als die Costalplatten in der Hauptsache auf tiefe Hautverknöcherungen zurückzuführen sind.

Die echte Rippe des ersten Brustwirbels ist ein sehr kurzes Skeletstück, das sich der ersten Costalplatte anlegt, ohne mit ihr zu verwachsen. Auch die darauf folgenden Rippen lassen zuweilen an ihren Verbindungsstellen mit den Costalplatten noch mehr oder weniger deutliche Anzeigen von Grenzen erkennen. Hiernach scheint es möglich, daß die scheinbaren Fortsetzungen der Rippen auf der Unterseite der Costalplatten, sowie ihre freien distalen Verlängerungen über diese hinaus, Bildungen der Costalplatten selbst sind, nicht jedoch Verlängerungen der sehr kurz bleibenden Ripf: 2 ; daß also die Costalplatten Hautverknöcherungen sind, die nur proximal mit den kurzen Rippen in Verbindung treten; im übrigen aber nicht aus der Verwachsung mit Rippen oder aus Rippen 3ervorgingen. 


\section{B. Schädelskelet der Wirbeltiere.}

Da sich bei den Acraniern weder etwas ron einer Wirhelsänle noch von einem, den vordersten Teil des Centralnervensystems einschlieBenden Schädelskelet findet, so folgt, daB auch dieses in der Wirbeltierreihe erst allmählich entstand.

Zwar finden sich im Bereich des Munds und des Kiemenlarms der Acranier gewisse Skeletelemente, so die Stäbchen, welche die Mundeiren durchzichen und sich proximal zu einem zarten gegliederten Skeletring im Mundsaum verbinden, iann die sog. Kiemenstäbchen in -der Wand des Kicmendarms; doch haben diese Skcletgebilde wit solchen des Schädels der Craniota keine direkte Beziebung. Mundring und Cirrenstäbchen bestehen aus einem dem Chordainhalt sebr ähnlichen Gewebe, das eine liülle von Ǩnorpelgrundsabstanz besitzen soll; die Kiemenstäbchen dagegen scheinen besonders differenziertes, elastisches Bindegewebe zu sein.

Das Kopfskelet der Cranioten wird von zwei Bestandteilen gebildet; einmal einer Skeletkapsel, welche den vorderen Teil des Centralnervensystems, der sich znm Gehirn entwickelt hat, umschließt und schützt, dem eigentlichen Schädel (Hirnschädel), nnd zweitens einem diesem ventral angehängten Teil, der aus zahlreichen, etwa balbkreisförmigen Bogen besteht, die den vordersten, respiratorischen Darmabschnitt umschließen und stützen, dem sog. Visceralskelet. Letzteres erstreckt sich bei den kiemenatmenden Formen so weit nach hinten wie die Kiemenspalten des respiratorischen Darms, indem zwischen je zwei dieser Spalten, die Mundspalte als vorderste mitgezähit, je ein Visceralbogen liegt. Der hinterste Bogen folgt auf die letzte Spalte. Bei den lungenatmenden Formen orfährt das Visceralskelet weitgehende Umbildungen und Reduktionen. - Bei den Acraniern ist die Zahl der Spalten sehr groß, und der Kiemendarm erstreckt sich etwa dureh die ganze vordere Körperhälfte. Die Cranioten besitzen viel weniger Kiemenspalten ( seltenen Ausnahmen abgesehen, höchstens bis acht, meist jedoch nur sechs oder fünf). Es ist daher sehr wahrscheinlich eine von hinten nach voln fortschreitende Reduktion der Spalten eingetreten, was auch bei Fischen nd Amphibien noch weitergehend zu verfolgen ist. Wenn man nun die Ausdehnung der Kopfregion nach hinten durch die des Kiemenapparats bestimmen wollte, so müBte man die ganze vordere Hälftc des Amphioxuskörpers, sow eit sich der Kiemendarm erstreckt, als Kopf ansprechen. - Nun ist aber als sicher zu betrachten, daß das Kopfskelet der Höheren nur einer vorderen Partie der vielen Segmente entspricht, welche bei den Acraniern die Kiemendarmregion bilden. Der Kopf der Cranioten dürfte daher auch nur einer Auzahl der vorderen Segmente der Acranier entsprechen, die darauf folgenden dagegen zu gewöhnlichen Rumpfsegmenten geworden sein.

Ein noch nicht hinreichend gelöstes Prablem ist ferner, ob die Visceralbogen, die, mit Ausnahme der beiden vordersten, bei den niedersten Cranioten hinter, ja weit hinter dem eigentlichen Schädel liegen, sämtlich zu den Segmenten gehören, in welchen sich die Schädelkapsel (das Cranium) bildete, oder z. T. zu Segmenten, welche auf die eigentlichen Schädelsegmente folgten. Gewöhnlich wird angenommen, daß in diesen Fällen die rückwärtige Lage der meisten Visceralbogen ron einer sekundăren Verschiebung nach hinten herrühre, wofür auch die Ontogenese bei den Cyclostomen spricht. Das Problem wird noch dadurch kompliziert, daß nach dem Ausweis der Ontogenie niederer Fische (speziell Rochen) in der Region des Vorderendes der Chorda, in welcher sich später die Schädelkapsel bildet, eine erhebliche Anzahl vorderer Muskelsegmentanlagen zugrunde gehen, und $\mathrm{da} B$ das Gewebe, aus welchem sich die Visceral- 
bogen entwickeln, in seiner von vorn nach hinten fortschreitenden Entstehung eine gewisse Unabhängigkeit von den ursprünglichen Muskelsegmenten der Kopfregion zeigt. Immerhin spricht alles dafür, daß die Segmente, zu welchen die Visceralbogen der Cranioten gehörten, zu jenen rückgebildeten der hinteren Kopfregion zu reclmen sind; und in diesem Sinne anch sämtliche Visceralbogen der ursprünglichen Kopfregion zugeteilt werden dürfen.

Die Hervorbildung eines besonderen Skelets der Kopfregion, im Anschluß an die Wirbelsäule, wurde durch verschiedene Faktoren bedingt. In erster Linie waren es jedenfalls die am vorderen Körperende sich entwickelnden ansehnlichen Sinnezorgane, Nasengruben, Angen und Hörorgane, welche direkt oder mittelbar in dieser Richtung wirkten, indem sie zunächst die voluminösere Entfaltung des Kopfteils des Centralnervensystems zum Gehirn bedingten. In zweiter Linie waren es die Mundhöhle und der Kiemendarm, deren besondere Funktion geeignete skeltbildungen erforderte, welche das Entstehen des Visceralskelets hervorriefen. Daß ferner für das vordere Körperende, welches beim Schwimmen das Wasser zu durchschneiden hat, die Festigung durch ein starkes Skelet vorteilhaft sein mußte, ist verständlich.

Es liegt nahe, zu vermuten, daß das eigentliche Schädelskelet wenigstens teilweis aus der Umbildung des vordersten Abschnittes des Wirbelskelets, wie es die Rumpfregion dauernd zeigt, hervorgegangen sei. Jedenfalls kann dies aber nur für den Teil des Schädelskelets gelten, welcher ähnliche Beziehungen zu dem vorderen Ende der Chorda besitzt, wie das übrige Achsenskelet zu deren Fortsetzung. Das vordere Chordaende erstreckt sich nun bei den Cranioten bis etwa in die Mitte des Bodens der Schädelkapsel; hier endigt es dicht hiuter dem sog. unteren Hirnanhang (Hypophysis), während es bei den Acraniern bis zur vordersten Körperspitze reicht. Hieraus wird es schon wahrscheinlich, daß nur diese hintere, chordale Schädelhälfte als Fortsetzung des Achsenskelets betrachtet werden kann; die vordere, prächordale dagegen in besonderer Weise entstand und sich der ersteren zugesellte. Auch die Ontogenie spricht einigermaßen hierfür.

Die Anlage der Schädelkapsel tritt gleichfalls znerst rein knorpelig anf und erhält sich bei den Cyclostomen und Chondropterygiern danernd so, wogegen sie bei den übrigen Cranioten durch Knochenbildungen ergänzt, oder teilweise bis völlig ersetzt wird. Doch beginnt bei letzteren die Schädelbildung stets mit der knorpeligen Anlage, sog. Primordialcranium, das in recht verschiedener Ausdehnung und Vollständigkeit auftritt. Bei den Anamnia bleibt es im erwachsenen Zustand in verschiedenem Grad erhalten; bei den erwachsenen Amnioten tritt es dagegen stark zurück.

Die erste Anlage der knorpeligen Schädelkapsel entsteht allgemein in Form zweier, an derSeite des vorderen Chordaendes liegender Knorpelstreifen, welche vorn bis zur Chordaspitze reichen (Fig. 125). Vor diesen sog. Parachordalia treten, gewissermaßen in ihrer Verlängerung, zwei ähnlich€ Streifen auf, welche nach vorn bis in die Schnauzengegend ziehen, die sog. Trabeculae. Früher oder später verschmelzen diese beiderseitigen Knorpelstreifen, wobei jedoch znnächst eine Litcke für den Durchtritt des unteren Hirnanhangs zwischen ibnen bleibt. Bei manchen Wirbeltieren werden sogar die Parachordalia und Trabeculae jeder Seite von.vornherein zasammenhängend angelegt. 
Schon früher fanden wir, daß bei zahlreichen Fischen in der vordersten Rumpfregion keine gesonderten Wirbelelemente mehr auftreten, oder eine frühzeitige Verwachsung einer Anzahl Wirbel stattfindet. Man darf rermuten, daß diese Tendenz zur Vereinigung der Wirbel in der hinteren Schädelregion zu der einheitlichen knorpeligen Anlage der Parachordalia führte, die einer Anzahl verschmolzener Wirbelkörper entsprechen. Zuweilen läßt sich an den Parachordalia auch eine gewisse Gliederung durch successive Erhebungen zwischen den hinteren Hirnnerven erkennen. Jedenfalls entsprechen jedoch die ursprünglichen Parachordalia nicht Neuralbogen, sondern eher Anteilen de: Hämalbogen.

Jederseits der Parachordalia liegt das Gehörbläschen, das zukünftige Hororgan, das frühzeitig von einer Knorpelkapsel umhüllt wird. Seitlich von den Trabeculae finden sich die Augenanlagen; etwas vor den Trabeculae die beiden $\mathrm{Na}$ sengruben, die gleichfalls eine umhällende Knorpelkapsel bilden. Indem die Parachordalia die Chorda umwachsen, verschmelzen sie zu einer sog. Basalplatte, welche die Basis der späteren Schädelkapsel bildet. Die knorpeligen Ohrkapseln verwachsen frühzeitig mit den seitlichen RändernderParachordalia, wodurch das Hörorgan in

Fig. 125

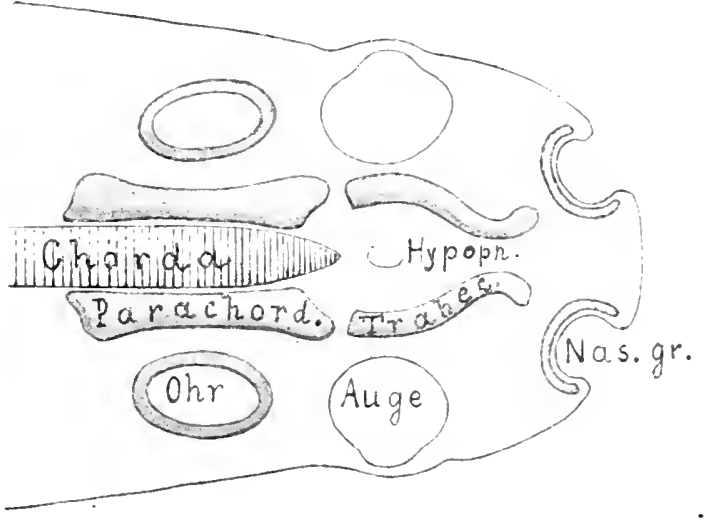

Schema zur Entwicklung des Primordialeraniums. Dorsalansicht. $0 . \mathrm{B}$. die Wand des Primordialcraniums aufgenommen wird. Indem die so angelegten Seitenwände der Schädelkapsel sich durch weitere Verknorpelung dorsal crheben und schließlich bei den knorpeligen Schädeln der Fische dorsal zur Verwachsung gelangen, entsteht die eigentliche Hirnschädelkapsel. - Die Trabeculae bilden, wie erwähnt, nach ihrer Vereinigung mit den Parachordalia deren vordere Verlängerungen. Wegen der bedeutenden Größe der Augen werden sie meist gegen die Mittelebene zusammengedrängt, während ihre Vorderenden, die sich an die Nasengruben anschließen, divergieren. Sowohl durch die mehr oder weniger weitgehende Vereinigung der beiderseitigen Trabeculae in der Mittellinie und ihr dorsales Auswachsen, als auch durch selbständige Verknorpelungen in dieser Region, bildet sich die Fortsetzung der knorpeligen Hirnkapsel zwischen den Augen bis zur Nasalregion, wo sich die 'Trabeculae mit den Knorpelhüllen der Nasengruben vereinigen, insofern letztere überhaupt selbständig angelegt werden, d. $h$. nicht aus den Trabecnlae hervorgehen. Der zwischen den Aagenhöhlen sich bildende scheidewandartige Teil kann entweder eine Fortsetzung der Gehirnkapselhø̆hle enthalten, in welcher die Lobi olfactorii verlaufen, oder wird, bei stärkerer Zusammenpressung durch die Angen, eine solide Scheidewand zwischen den Orbiten. 
Anf diesem Stadium des knorpeligen Primordialcraniuns bleibt das Schädelskelet der Cyclostomen und der Knorpelfische dauernd steheu una soll daher als einfachste Bildung zunächst erörtert werden.

\section{Das Schïdelskelet der Cyclostomen und Fische.}

\section{Das Cranium.}

Das Schädelskelet der Cyclostomen beharrt auf einer relativ niederen Stufe, erlangt jeach durch eine Reihe von Zutaten, die bei den Guathostomen nicht, oder

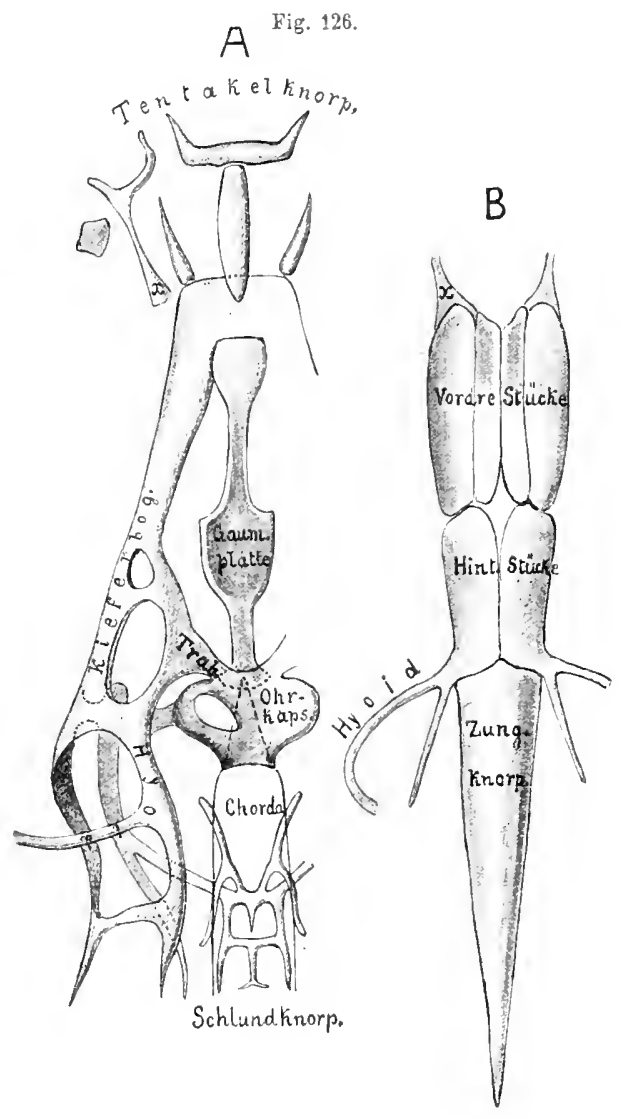

Bdellostoma (Myxinoide). A Knorpelcranium von der Ventralseite. $B$ der Zungenknorpel von der Ventralseite auf die Seite gerfickt, in seiner Lage zn Hyoid und Tentakel. knorpeln (x) (nach JoH. Múller 1836). O. B. nicht mehr vertreten sind, einen in vieler Hiusicht recht eigenartigen Bau, der mit dem der Gnathostomen mancherlei Unvereinbares bietet. Dio eigentliche Hirnschädelkapsel bleibt sebr klein und ist nur unvollständig verknorpeit. Sie reicht weniger weit nach hinten als bei den Höheren, da der Nervus vagus erst hinter ihr entspringt. Bei den Myxinoiden (Fig. 126) beschränkt sich der Knorpel nur auf den hinteren Abschnitt des Kapselbodens. Mit diesem Teil, in welchem das vordere Chordaende sich dauernd erhält, sind seitlich die beiden $\mathrm{Obr}-$ kapseln vereinigt; er entspricht daher den verwachsenen Parachordalia. Vorn setzt sich die Basalplatte in zwei divergierende Äste fort, welche wohl die Trabeculae sind, die also hier ganz unvereinigt bleiben. Die seitliche und die Dorsalregion der Gehirnkapsel bleiben häutig bis schwach knorpelig. Bei den Petromyzonten (Fig. 127) hat sich dagegen die knorpelige Schädelkapsel seitlich und dorsal sehr vervollständigt, so daß nur an ihrer Decke(Fig. 127 A) eine häutige Stelle bleibt. Die Trabeculae bilden die vordere Region der Kapsel und sind vorn vereinigt, so daß ein Loch zum Durchtritt der Hypophyse bleibt (Fig. 127 B). Auf der Dorsalseite ist die unpaare knorpelige Nasenkapsel mit den Trabeculae vereinigt. In der Gegend der Ohrkapseln entspringen von dem hinteren Teil der Schädelkapsei jederseits zwei Fortsätze, die man mit guten Gründen als die dorsaIen Teile der 
beiden ersten Visceralbogen, des Kiefer- und Zungenbeinbogens, deutet. - Die dem dorsalen Teil des Kieferbogens, oder dem sog. Palatoquadrat, entsprechende Spange vereinigt sich vorn mit den Vorderenden der Trabeculae. Wir werden bei dem Visceralskelet auf diese Teile nochmals eingehen müssen.

Endlich schlieBt sich bei Petromyzon vorn an die Trabecularregion, mit ihr direkt knorplig zusammenhüngend, eine ansehnliche Knorpelplatte an, die in der Decke der Mundböhle liegt (hintere Deckplatte, hintere Gaumenplatte, Ethmoid). Die Platte entspricht wohl der schmäleren, welche sich boi den Myxinoiden an dieBasalplatte vorn anreiht (s. Fig. $126 A$ ).

Außer diesem eigentlichen Schädelskelet treten bei Petromyzon noch eine große Zahl isolierter Knorpelstücke auf, die sämtlich mit dem sehr großen Saugmund in Beziehnng stehen, und für welche bei den Gnathostomen nur schwiorig Beziehungen zu finden sind. Die wichtigsten sind (s.

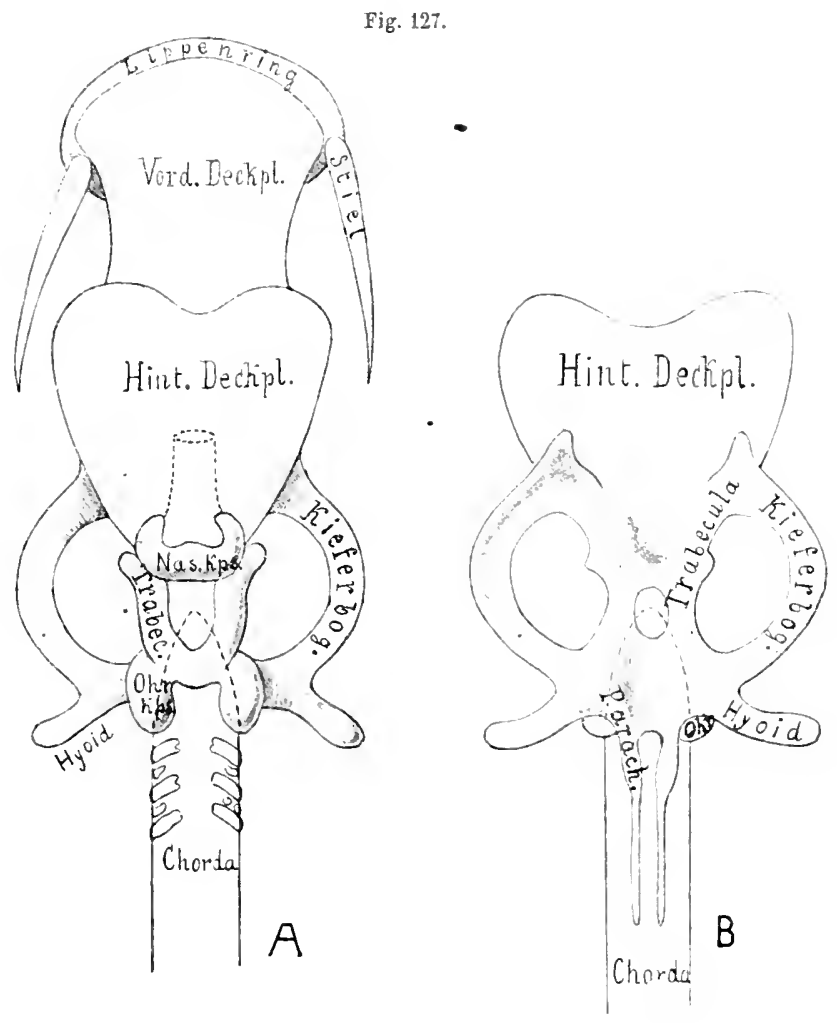

Petromyzon marinus. Knorpelcranium und Vorderende der Chorda. $\rightarrow A$ von der Dorsalseite. $-B$ von der Ventralseite, ohne die vorderen Teile. (Nach JoB. Fig. 127, 128): eine IIULLER 1836.) 0.8 .

unpaare vordere Gaumen- oder Deckplatte (Cartilago semianuularis) und, im Anschluß an sie, in der seitl:chen Mundhöhlenwand je zwei parrige Stucke (Fig. 128, hintere und vordere Seitenleiste); ferner der knorpelige Lippenring mit dem jederseitigen Lippenknorpel (Stiel, Cart. spinosus) und einem dahinter liegenden stabforrmigen paarigen Knorpel ( $Z$. $b$, Copula); schließlich der mächtige Zungenknorpel.

B $\rightarrow$ i den Myxinoiden (Fig. 126) ist das Mundskelet gleichfalls recht kompliziert, $\mathrm{j}$ ×doch anders gebaut. Wir können hier wohl noch die beiden Fortsätze des Kiefer-uבd Zangenbeinbogens (Hyoid) erkennen, von welchen der erstere eineähnliche Spange bildet wie bei Petromyzon, sich jedoch noch weit in die Schnanzenregion 
fortsetzt, bis zur Vereinigung mit den der anderen Seite. Ein Apparat kleiner isolierter Knorpelchen schließt sich vorn an, zar Stïtze der Mundtentakel. Die beiden nach hinten ziehenden, frei endigenden Fortsätze, die vom Palatoquadratknorpel ausgehen, sind wohl auf Reste des Visceralskelets zurückznführen, das im übrigen bei den Myxinoiden verkümmert ist. Auch der ziemlich korplizierte Apparat knorpeliger Spangen, die der oberen Schlundwand eingelagert sind, und vorn ebenfalls von der Palatoquadratspange entspringen, leitet sich mŏglicherweise auch vom Visceralskelet ab. - Sehr măchtig ist der Zangenknorpelapparat entwickelt, der aus einer ganzen Anzahl Stücke besteht, wie Fig. $126 \mathrm{~B}$ erkennen läßt.

Fig. 128.

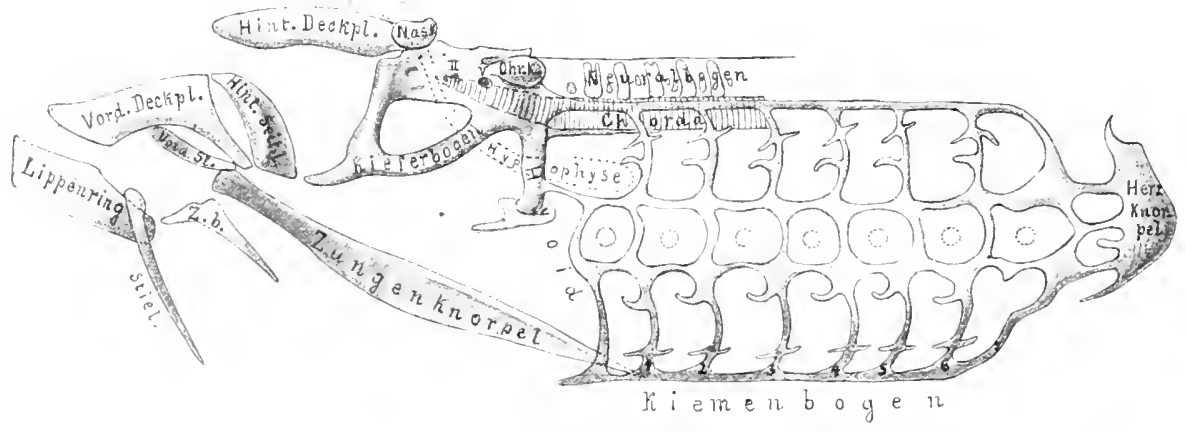

Petromyzon marinns. Knorpelcraninm nnd Visceralskelet von links. (Mit Benntznng von JoH. Mürler.) Die kleinen punktierten Kreise im Kiemenbogenskelot geben die Lage der Kiemenöffnungen an. Z, b. sog. Zungenbein oder Copula.

o. B.

Chondropterygii. Der Schädel der Knorpelfische ist nicht nur viel größer und voluminöser als der der Cyclostomen, sondern auch viel vollkommener und übereinstimmender mit dem der höheren Vertebraten. Die bedeutendere Größe hängt mit der ansehnlicheren Entwicklung des Gehırns und der höheren Sinnesorgane zusammen. Die vollkommenere Entwicklung dokumentiert sich haup tsächlich auch darin, daß sich die knorpelige Schädelkapsel weiter nach hinten erstreckt als bei den Cyclostomen, indem der Ursprung des Nervus vagus stets in sie aufgenommen wurde, dieser Nerv daher durch eine seitliohe Öffnung in der hinteren Schädelwand anstritt (Fig. $129 B, C, x$ ). Bei den Haien finden sich hinter der Vagusöffnung noch einige (1-5) feinere Nervenöffnungen (für die sog. Spinooccipitalnerven), welche beweisen, $\mathrm{da} B$ hier noch einige weitere Segmente in den hinteren Schädelabschnitt eingegangen sind. Im Gegensatz zu den Cyclostomen hat sich so, übereinstimmend mit den höheren Wirbeltieren, ein hinterster Occipitalabschnitt des Schădels entwickelt, dessen Umfang jedoch recht gering ist, und der bei den Rochen entweder fehlt, oder mit der besonderen Ausbildung der Gelenkungsverhältnisse ihres Schädels wieder verkümmerte.

Der Schädel der Chondropterygier bleibt dauernd knorpelig und völlig einheitlich; or ist also ein reines Primordialcranium. Wie überall sind im ausge- 
bildeten Primordialcranium keine besonderen getrennten Knorpelstücke zu nnterscheiden. Die Entwicklung vollzieht sich im allgemeinen nach dem früher geschilderten Schema durch Bildung von Parachordalia und Trabeculae. Die ersteren stehen jedoch von Anfang an in kontinuierlichem Zusammenhang mit den knorpeligen Anlagen der vorderen Wirbel der Säule, von denen sich die Schädelkapsel erst später absondert, oder mit denen sie anch (wie bei den Notidaniden) in dauerndem Zusammenhang bleibt.

Die starke Herabkrümmung des vorderen Hirnteils, sowie die Rückwärtsverlagerung des Mundes bewirken, wie bei den Gnathostomen meist, daß die Trabeculae nicht in der horizontalen Verlängerung der Parachordalia, sundern senkrecht absteigend zu ihnen liegen, so daß ursprünglich eine starke Herabknickung des prächordaleu Teils der späteren Schädelbasis besteht. - Die Ohrkapseln treten in direktem Zusammenhang mit den Parachordalia aufund werden ihnen (bzw. der aus ibnen hervorgehenden seitlichen Schädelwand) so innig einverleibt, $\mathrm{da}$ sie äußerlich nicht mehr vorspringen. Durch Vereinigung der Parachordalia und Trabeculae, sowie einer, etwa im Grunde der späteren Augenhöhle, jederseits selbständig entstehenden Knorpelplatte,
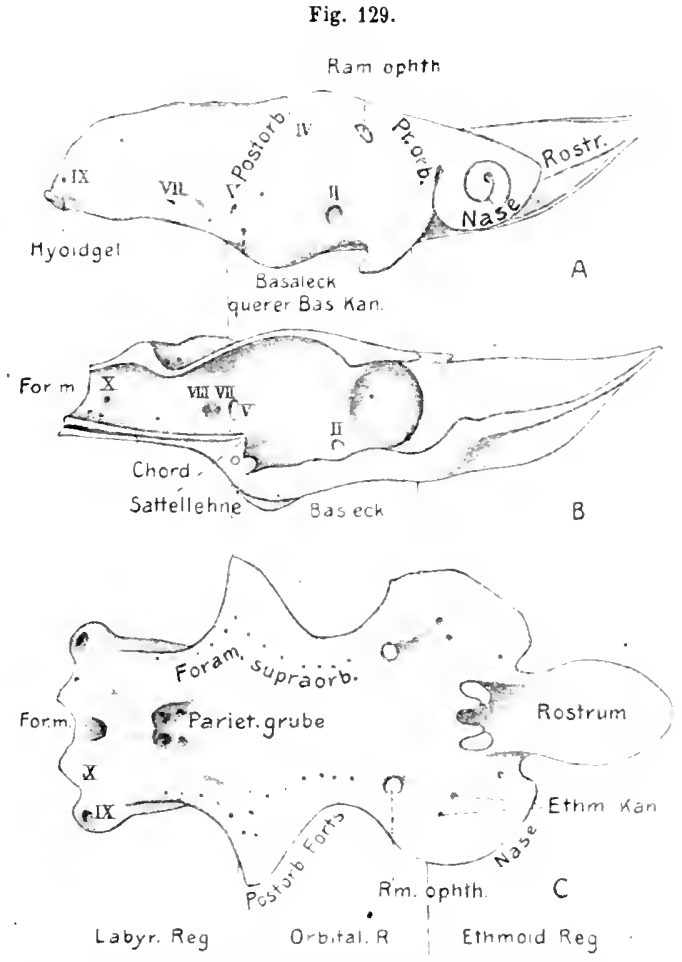

Acanthias, Knorpelschädel. (Nach Gegenbaur 1972) A von rechts. $B$ in Medianebene halbiert. $C$ von Dorsalseite. Die römischen Zahlen bezeichnen die Austrittsstellen der betreff. Hirnnerven. F'or. m. Hinterhsuptsloch (Foramen magnum); Pr. orb. Práorbitalfortsatz.

sowie durch die weitere Entfaltung dieser Anlagen entsteht schließlich der fertige Knorpelschädel, dessen Ontogenese hier nicht genauer verfolgt werden kann.

Die oben erwähnte Herabknickung des prächordalen Schädelbodens wird durch seine Aufwärtskrümmung später wieder ziemlich ausgeglichen, erbält sich jedoch bei den Haien mehr oder weniger dentlich in einer inneren sattelartigen Erhebung des Bodens anf der Grenze der beiden Regionen (sog. Sattellehne, Fig. 129 B) und außerlich in einem vorspringenden Eck an der Ventralseite der Kapsel (sog. Basalẹck, Fig. 129 A). - Bei den Rochen geht die Ausgleichung viel weiter, so daß die Schädelbasis ganz horizontal wird und weder Sattellehne noch Basaleck hervor- 
treten. - Bis zur Sattellehne reichte ursprünglich die Chorda. Sie kann sich als verkümmerter fadenartiger Rest bei gewissen Haien erhalten (Fig. 129 B), verschwindet jedoch meist ganz.

Äußerlich läßt der Knorpelschädel von hinten nach vorn folgende Regionen unterscheiden (Fig. 129). Die eigentliche Hirnschäde'kapsel, hauptsächlich gebildet durch die sog. Labyrinth- oder Ohrregion, deren seitliche Wände die Hörorgane einschließen. Von ihr grenzt sich die wenig entwickelte Occipitalregion, welche von dem ansehnlichen Foramen magnum (For. m.) zum Durchtritt des Rückenmarks durchbrochen ist, nur' wenig ab. - An den Seiten des Hinterbauptslochs springt bei den Rochen und Holocephalen (Fig. 130) je ein Gelenkhöcker für die Articulation

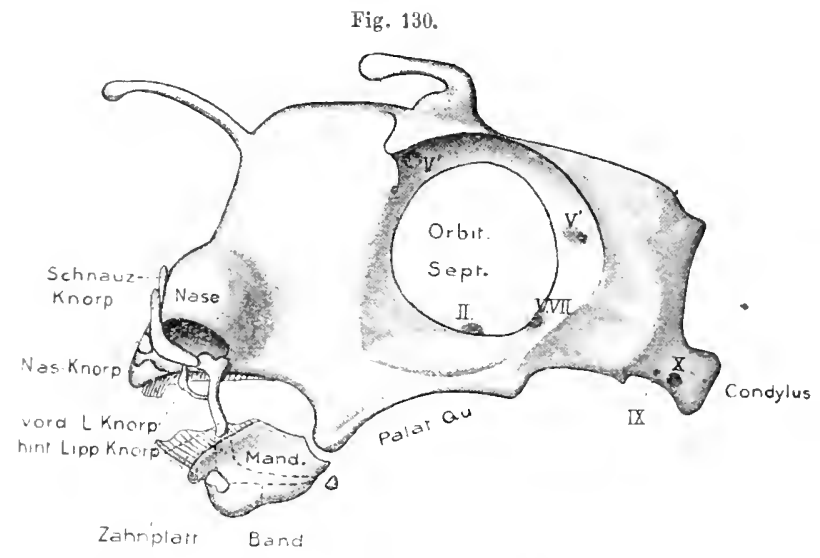

Chima era monstrosa $\vec{\delta}$. Sehäel yon links. (Mit Benutzung v. Hurrecht $1876 / 77$ and Originalpräparat.) $V^{\prime}$ Aus- ua Durebtrittsstelle des 1. Trigeminus astes. mit der Wirbelsäule vor. - An die Labyrinthregion schließt sich vorn die Orbital- oder Orbitotemporalregion an, welche durch die Einlagerung der ansehnlichen A ugen jederseits grubenartig vertieft bis eingeschnürt ist. Die so gebildeten Augenhöhlen (Orbitae) können durch dorsale, vorn und hinten an ihnen vorspringende Fortsätze (Prä- und Postorbitalfortsatz), zuweilen auch durch einen ventralen plattenartigen Fortsatz noch schärfer amgrenzt werden.

Den vorderen Schädelabschnitt bildet die Ethmoidal- oder Nasalregion, welche durch den Anschluß der knorpeligen Nasenkapseln an die Vorderenden derTrabeculae entstand. Diese Region ist bald kürzer, bald lünger, und vorn durch die, als seitliche Anschwellungen mehr oder weniger hervortretenden Nasenkapseln gewöhnlich stark verbreitert. Zwischen diesen Kapseln verlängert sie sich meist in einen unparen Fortsatz, das sog. Rostrum, das in sehr verschiedenem Grad entwickelt ist; bald sehr klein, ja fehlend, bald ungemein grob, was mit der Gestaltung der Schnanze zusammenhängt. $\mathrm{Ob}$ das Rostrum nicht gewisse Beziehungen zu der hinteren Deckplatte oder dem Rostrum der Cyclostomen besitzt, bedürfte genauerer Untersuchnng. - Charakteristisch für den Schädel der Knorpelf́sche ist die Erstreckung der Schädelhöhle von der eigentlichen weiten Gehirnhöhle in der Labyrinthregion dnrch die Orbital- bis in die Ethmoidalregion (Fig. 129B), wo sie tiber dem Rostrum nur häutig geschlossen ist, so daß der Knorpelschädel hier eine weitê Öffnung zeigt (Fig. 129 C). 
Abweichend verhält sich der Schädel der Holocephalen (Fig. 130), da die tiefen Augenböhlen die Orbitalregion so zusammenpressen, daß die Fortsetzung der Gehirnhöhle auf deren Basalregion beschränkt wird, während sich zwischen den Augenhöhlen nur ein häutiges Septum ausspannt, das auch die stellenweise nicht knorpelige Schädelwand abschließt. Die oben erwähnte vordere Öffnung in der Ethmoidalregion fehlt dem Holoceplaalenschälel.

Der Schnauzenteil des Selachierschädels gestaltet sich ganz besonders mannigfaltig, was mit der sehr wechselnden länge des Rostrums und dessen z. T. sehr eigenartiger Bildung zusammenhăngt. Wie bemerkt, erlangt es bei gewissen Rochen eine ganz exzessive Entwicklung; so durchzieht es z. B. bei den Sägefischen (Pristis) einen ansehnlichen Teil der Säge. Bei anderen (Torpedo) wird es sogar paarig. Bei zahlreichen Haitischen besteht es aus einem mittleren Stab, an dessen Ende sich zwei seitliche ansetzen, die von den Nasenkapseln entspringen, so daß das gesamte Rostrum wie eine Art Pyramide erscheint. Dieser Zustand soll durch Auftreten zweier fontanellenartiger Durchbrechungen aus dem einbeitlichen Rostrum entstanden sein. - Ganz besondere Verhältnisse haben sich in der Rostralregion der Rochen ausgebildet, indem sich bei gewissen Formen die Brustflossen nach vorn bis zum Rostrum ausdehnen und ihr Skelet sich an die Präorbitalfortsätze des Schädels anschließt. Dem Präorbitalfortsatz reiht sich infolge dieser besonderen Funktion bei gewissen Rochen ein sehr mächtiges Knorpelstück (Schädelflossenknorpel) an, das mit einem der Basalknorpel der Flosse (Propterygium) durch ein Band zusammenhängt. Auf diese, sowie andere eigenartige Bau- und Anpassungsverhältnisse der Schnauzenregion kann hier nur andeutungsweise eingegangen werden.

Ganoidei, Dipnoi und Teleostei. Wie bemerkt, wiederholt sich das Primordialcranium der Knorpelfische in der Schädelanlage der übrigen, ja es erhält sich sogar in ähnlicher. Vollständigkeit zeitlebens bei denjenigen (Knorpelganoiden, Dipnoi), welche in dieser, wie in anderer Hinsicht den Knorpelfischen näher stehen. Stets gesellen sich jedoch dem Primordialcranium Verknöcherungen za, welche es verstärken. Die Knorpelganoiden (besonders Störe, Acipenser) besitzen eine aus vielen Knochenplatten bestehende Decke, welche dem Knorpelschädel dorsal dicht aufliegt (s. Fig. 131); auch auf seiner Ventralseite findet sich ein langer Knochen (Parasphenoid, s. Fig. 132), der die Schädelbasis fast in ihrer ganzen Ausdehnung stützt. - Die genauere Untersuchung ergibt, daB alle Schädelknochen der Chondrostei aus der Haut hervorgchen, die den Knorpelschädel dorsal nnd ventral iiberzieht. Dies folgt nicht nur aus ihrer völligen Ưbereinstimmung mit den Hautknochenplatten, welche wir am Rumpf der Störe schon früher fanden (s. auch Fig. 198) und deren eventuelle Beziehungen zu den Placoidschuppen der Chondropterygier dort erörtert wurden (s. S. 169), sondern auch daraus, daß die Deckknochen der Dorsalseite noch durch eine Bindegewebsschicht vom Krnorpelschädel gesondert bleiben, daher auch leicht abiöshar sind. Das Gleiche ergibt auch die Ontogenie. Hieraus folgt, daß die ersten Knochenbildungen, welche sich dem Primordialcranium zugesellten, im Integument auftraten und sich erst sekundär mit ihm verbanden. Aus diesem Grund hat man derartige Schädelknochen als Deck- odcr Hautknochen bezeichnet. Der Name » secundäre Knochen *, den man ihnen znweilen auch gab, ist nicht zutreffend, da sie ja phylogenetisch die primären waren.

Bei den ẗbrigen Fischen wiederholen sich solche Deckknochen in der Bil_ dung des knöchernen Schädels, sowohl auf der Dorsal- als Ventralseite. Sie treten jedoch meist sofort in tieferer Lage, also in nächster Nähe des Perichondriums 
des Knorpelschädels auf, und können, den unterliegenden Knorpel allmählich verdrängend, an seine Stelle treten, indem von ihrer Anlage aus die Verknöcherung sowohl nach außen als in die Tiefe fortschreitet.

Beim weiteren Fortgang dieses Prozesses scheint auch nicht ansgeschlossen, daß die erste Verknöcherangsanlage bis in das Perichondrium selbst in die Tiefe rückte. Hiermit wäre aber ein Zustand eingetreten, welcher einen so entstehenden Knochen schwer von einer zweiten Art unterscheiden läßt, die bei der fortschreitenden Weiterbildung des Schädels auftrat. Auf letztere Weise entstehen nämlich auch die sog. Ersatz- oder Knorpelknochen, die zuweilen, aber unrichtig, als Primärknochen bezeichnet wurden, denn sie traten phylogenetisch später auf als die Deckknochen. Die Bildung solcher Ersatzknochen geht (wie wir dies auch bei der Verknöcherung der knorpeligen Wirbelanlagen fanden) vom Perichondrium des Primordialcraniums aus und dringt von hier in die Tiefe vor, kann sich jedoch auch centrifugal nach außen fortsetzen. Manchmal treten auch gleich auf der Innen- und Anßenseite des Knorpels zwei perichondrale Knochenlamellen anf, welche sich erst später vereinigen. Das Ergebnis ist ein Knochen, welcher den Knorpel direkt ersetzt. Än typischen Ersatzknochen ist dies häufig sehr charakteristisch zu sehen, indem sie direkt als Ersatz in die Wand des knorpeligen Primordialeraniums eingeschaltet sind (s. Fig. 134, S. 236) und sich anch im Aussehen von Deckknochen auffallend unterscheiden. Es dürfte daher, trotz mancher Anzweiflungen, sicher sein, daß wir diese beiden Knochenarten auseinan der halten müssen, so schwer es zuweilen auch sein mag, die Natur eines gewissen Knochens festzustellen.

Wenn die erste Anlage eines Deckknochens sehr tief, bis zum Perichondrium verlegt wurde, so wird ja seine Unterscheidung. von einem Ersatzknochen auf ortogenetischem Wege recbt unsicher; hier tritt die vergleichende Betrachtung in den Vordergrund, d. h. die Rückführung des betreffenden Knochens durch Vergleichung auf einen solchen, der sicher ursprünglich ein Deckknochen war. Die Sachlage wird noch dadurch komplizierter, daß sich gewisse Knochen ontogenetisch als von gemischter Natur ergaben, d. h. als Verwachsung eines ursprünglichen äußeren Deckknochens mit einem darunter entstandenen Ersatzknochen. Einzelne Knochen des Teleosteerschädels lassen sogar diese beiden Elemente zuweilen noch getrennt nebeneinander erkennen. Auch macht es die Vergleichung der Schädelknochen der primitiveren und höheren Fische recht wahrscheinlich, daß unter ursprünglich allein vorhanden gewesenen Deckknochen später Ersatzknochen auftraten und sich beide Elemente schließlich zu Mischknochen vereinigten. Doch ist auch wohl die umgekehrte Folge vertreten. Es hat dies zu gewissen Verwirrungen in der Bezeichnung geführt, indem man ảie zusammengehörigen Deck- und Ersatzknochen verschieden benannte. So entspricht wohl das Postfrontale als Deckknochen dem Sphenoticum als Ersatzknochen, das Squamosum dem Pteroticum, das Dermsupraoccipitale dem eigentlichen Supraoccipitale. - Wenn nun in der Tat solche Mischknochen auftreten, so läßt sich auch verstehen, daß unter gewissen Verbältnissen geradezu die Substitution eines ursprünglichen Deckknochens durch einen Ersatzknochen eingetreten sein kann; denn wir brauchen uns nur vorzustellen, daß ein ursprünglicher Deckknochen im Laufe seiner weiteren Entwicklung zu einem gemischten wurde, und $\mathrm{da} ß$ schließlich der ursprüngliche Deckknochenanteil völlig degenerierte. Auf diese Weise wäre dann ein ontogenetisch reiner Ersatzknochen entstanden, welchen wir dennoch in gewissem Sinne als homolog mit dem ursprünglichen Deckknochen zu betrachten hätten. - Die zuweilen ausgesprochene Ansicht, daß sămtliche Schädelknochen sich ursprünglich von Deckknochen abgeleitet hätten, erscheint vorerst, angesichts der vielfach frappanten Verschiedenheit zwischen typischen Deck- und Ersatzknochen, nicht haltbar. 
Eine weitere Erschwerung des Problems kann auch daraus hervorgehen, daß sich, wie es sicher scheint, zuweilen zu einem Deckknochen sekundär Knorpel gesellen kann.

Die knöchernen Skeletelemente, seien es sog. Ersatz- oder Ilautknochen, treten ontogenetisch in der knorpeligen oder bindegewebigen Anlage zuerst als hleine lokale Verknöcherungspunkte auf, die allmählich heranwachsen. In beiden Fällen kann der eigentlichen Verknöcherung eine Verkalkung des Knorpels oder des Bindegewebes vorangehen. - Sehr häufig erfolgt jedoch die Verknöcherung ansehnlicherer Skeletelemente nicht nur von einem einzigen sog. Knochenkern aus, sondern zu dem erstentstandenen, der sicb auch bei der weiteren Verbnöcherung gewöhnlich als ansehnlicherer Hauptkern erhält, treten noch weitere sekundäre hinzu. Erst später, jâ für gewisse Knochen nicht selten lang nach der embryonalen Zeit, verwachsen die sekundären Kerne mit dem Ilauptkern zu einem einbeitlichen Knochen. Dic Zahl der Knochenkerne, die so ein später einbeitliches Skeletelement erzeugen, kann zuweilen recht erheblich sein und ist auch nicht selten etwas variabel.

Von besonderem Interesse erscheint diese Bildung sekundärer Knochenkerne bei langgestreckten Knochen, welche erhebliche Zeit in die Länge. wachsen; was besonders für die Extremitätenknochen tetrapoder Wirbeltiere (besonders Mammalia) gilt. Bei diesen rerknöchert zuerst der mittlere Teil der langen knorpeligen Anlage zu einem mittleren Stück, der sog. Diaphyse, während sich die beiden Enden der Anlage (seltener nur das eine) knorpelig erhalten. Später verknöchern diese knorpeligen Enden (Epiphysen) selbständig und erhalten sich auch als selbständige knöcherne Epiphysen, bis der betreffende Knochen seine definitice Länge erreicht hat; erst dann verwachsen sie mit der Diaphyse. Nicht nur die Extremitätenknochen zeigen solche Epiphysenbildung, auch die Knochen der Extremitätengürtel, die Wirbel und andere Skeletelemente verhalten sich vielfach äbnlich. Auch besondere Fortsätze und Aus wüchse an Knochelı können häufig durch selbständige Verknöcherung entstehen.

Diese kurz erläuterten Verhältnisse erschweren nicht selten die rergleichend anatomische Beurteilung der Skeletelemente. Da nämlicb sekundäre Verwachsung ursprünglich selbständiger, benachbarter knöcherner Skeletelemente häufig vorkommt, so kanu das Hervorgehen eines Knochens aus mehreren selbständigen Verknöcherungspunkten leicht zor Vermutung führen. daß er auch phylogenetisch aus mehreren, ursprünglich gesonderten knöchernen Elementen entstanden sei. Daß eine solche Auffassung für Diaphysen und Epiphysen der Extremitätenknochen ganz unmöglich ist, liegt auf der Hand. In anderen Fällen dagegen ist die Entscheidung weniger leicht, und damit erscheint eine Quelle verschiedenartiger Deutungen gegeben, worüber später, bei der Schilderung der einzelnen Skeletabschnitte, mehrfach die Rede sein wird.

Benachbarte Knochen können sich in verschiedener Weise miteinander zu einem gemeinsameu skeletteil verbinden, wie es in der Wirbelsäule, dem Schädel und den Extremitäten berrortritt. Entsprechend der Beschaffenheit der ursprünglichen Anlage, in welcher die Verknöcherungen auftreten, können die fertigen Knochen durch Bindegewebe, das häufig sehnig und bandartig geworden ist (Syndesmose), oder durch Knorpel (Synchondrose) mehr oder weniger innig vereinigt seiu. Wird dieses $Z$ wischengewebe sebr gering, so daß die benachbarten Knochen, häufig mit zackig vorspringeuden Räudern, dicht zusammenstoßen, so spricht man von Nahtrerbindung (Verbindung durch Sutur). Durch fortschreitende Verknöcherung des Zwischengewebes kommt es jedoch, wie erwähnt, vielfach auch zur knöchernen Verwachsung ursprünglich getrennter Knochen (Synostose), was im Skelet zahlreicher Wirbeltiere in verschiedenem Grade auftritt. - Bei Verbindung der Knochen durch Bindegewebe oder Knorpel können die rereinigten Skeletelemente in gewissem Grade bewerlich gegeneinander bleiben. Ausgiebigere Beweglichkeit benachbarter Elemente gegeneinander, wie sie namentlich in der Wirbelsäule und dem Extremitätenskelet notwendig wird, erfordert dagegen meist die Ausbildung wirklicher Gelenke (Diaithrose). Diese kommen im allgemeinen so zustande, daß in dem Zwischengewebe zwischen den benachbarten Knorpeln oder Knochen eine mit Flüssigkeit erfüllte löhle (Gelenkhöhle) auftritt. An den Gelenkenden der Knochen entwickeln sich ineinander passende Flächen, die mit Knorpel überzogen bleiben. Das Zwischengewebe im 
Umkreis der Gelenkhöhle und der Gelenkenden beider Knochen entwickelt sich sebnig zu einer sog. Gelenkkapsel, welche die beiden Knochenenden miteinander verbindet. Zuweilen köınen auch Partien des $Z$ wischengewebes zwischen den Gelenkenden der Knochen verknorpeln zu sog. Zwischenknorpeln oder Menisci.

Das vollständig erhaltene Primordialcranium der Knorpelganoiden gleicht in seiner Konfiguration sebr dem der Haie (s. Fig. 131-132). Seine Hinterhaupts-

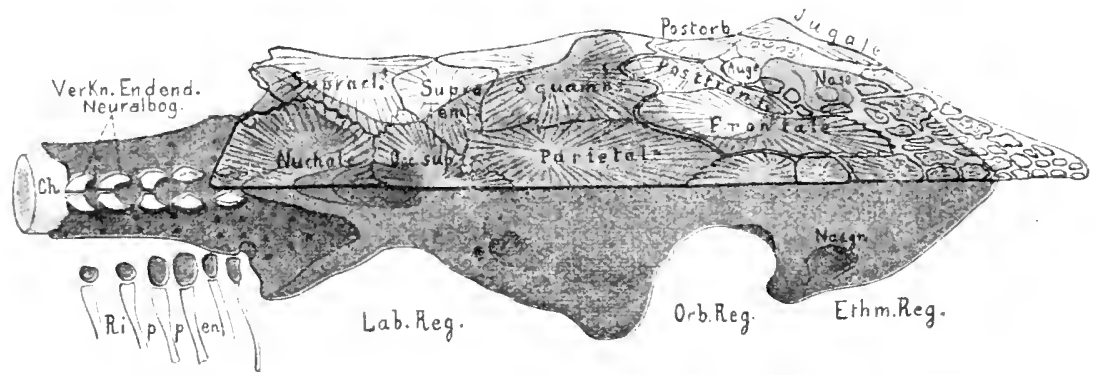

Acipenser sturio. Sehādel und Anfang der Wirbelsāule von der Dorsalseite. In der rechten Hālfte die Deckknochen entfernt. Knorpelcranium blau. Vgl. auch Fig. 198. Die knorpeligen Basalteile der Rippen sind von dem Parasphenoid, dem sie anfsitzen, abgetrennt gezeichnet; die Dornforteătze der Neuralbogen weggelassen. Ch. Chorda.

O. B.

region geht direkt in den Anfang der Wirbelsänle über, deren Bogenelemente um die erhaltene Chorda eine Strecke weit kontinuierlich zu einem Knorpelrohr verschmolzen sind. Dorsal wird das Cranium, wie bemerkt, von einer großen Zahl Deckknochenplatten überkleidet, welche einen zusammenhängenden Panzer bilden, und von denen einige randliche der Labyrinthregion anch absteigende Fortsätze

Fig. 132.

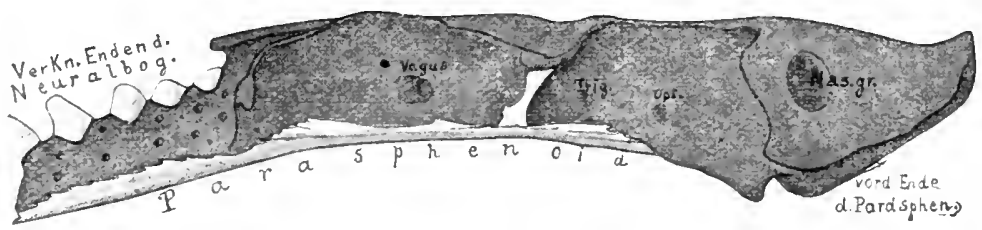

Acipenser sturio. Knorpelcranium und Anfang der Wirbelsāule von rechts.

O. B.

an der Seitenwand des Schädels bilden. Eine orhebliche Anzahl dieser Platten lassen sich sicher mit gewissen Deckknochen der Knochenganoiden und Knochenfische identifizieren, so die Scheitelbeine (Parietalia), Stirnbeine (Frontalia), Sphenotica (Postfrontalia), Pterotica (Squamosa), Postorbitalia nnd eventuell noch weitere (s. Fig. 131). - Bei dem Lơffelstör (Polyodon) sind die dorsalen Deckknochèn weniger zablreich und denen der Knochenganoiden ähnlicher. - Die gesamte Schädelbasis stützt ein sehr langer stabförmiger Deckknochen (Parasphenoid). der von der Ethmoidalregion längs der ganzen Schädelbasis hinzieht, ja sich uber diese hinaus bis ans Hinterende des verschmolzenen vorderen Wirbelsäulenabschnittes 
erstreckt. Dies Parasphenoid entsendet enter dem Postorbitalfortsatz jederseits einen aufsteigenden Stützast. - Eigentümlicherweise wird das Vorderende des Parasphenoids (Stŏr) rom Knorpel des Craniums überwachsen, tritt jedoch zuweilen in der Schnanzenregion wieder etwas hervor; auch sein hinterer Abschnitt wird von den knorpeligen Basalteilen der vordersten Rippen iberlagert.

Ein bis mehrere schmale Hautknochen an der Ventralseite der Schnauzenregion des Knorpelcraniums werden gewöhnlich dem Vomer der Teleostei verglichen.

So bleibt der Schädel der Chondrostei in der Regel ganz ohne Ersatzknochen. DaB diese aber doch zuweilen schon angedeutet sein können, zeigen sehr alte Störe, bei denen in der Orbitalregion einige etwas unregelmäßige Ersatzknochenbildungen beobachtet wurden, welche sich mit den als Pleuroethmoid, Orbito- und Alisphenoid, sowie Prooticum bei den Holostei und Teleostei bekannten vergleichen ließen. - Es wird jedoch auch die Ansicht vertreten, daß die heutigen Chondrostei stark rückgebildete Formen seien, also der primitive Bau ihres Schädels auf teilweiser Reduktion beruhe. Mir scheinen die primitiven Charaktere doch zu überwiegen.

Fig. 133.

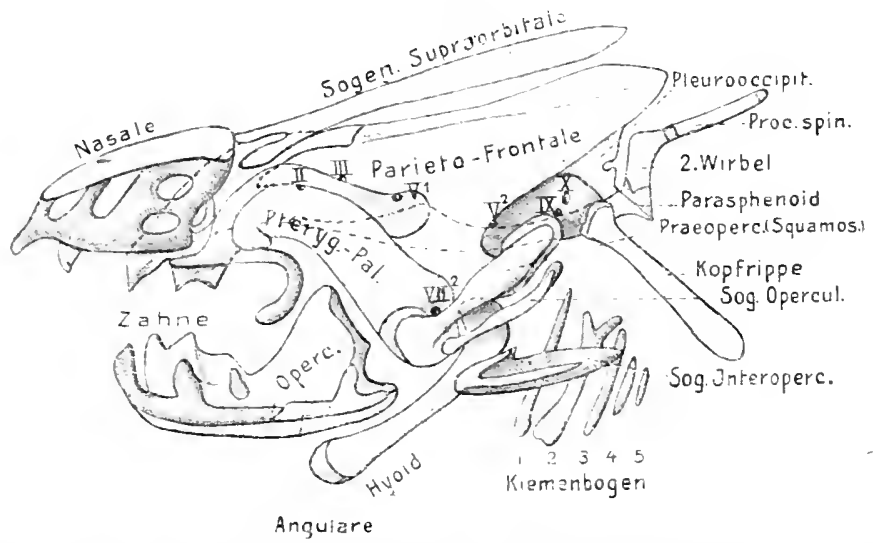

Lepidosiren paradoxa. Schādel von links. Knorpel dunkel, Knochen hell. Die punktierten Linien, die von dem ganz hinten sichtbaren Parasphencid ausgehen, geben dessen Ausdehnung naeh vorn an der Unterseite des Schädels an. Ebenso die beiden, vom vorderen siehtbaron Ende des Pterygopal. (Palatopterygoid) ausgehenden, dessen weitere Ansdehnung nach vorn und oben. (Nach BRideE 159s.) E. W.

Kaum stärker verknöchert erweist sich das Primordialcranium der Dipnoi, das sich namentlich boi Ceratodus in großer Ausdehnung erhält. Wie bei den Chondrostei bleibt die Chorda im Schädelboden dauernd bestehen; auch verschmelzen einige Wirbelelemente mit dem Hinterhaupt. Das Primordialeranium ist wie bei den Cyclostomen und Holocephalen dadurch modifiziert, daß das dorsale Stück des Kieferbogens (sog. Palatoquadrat mit der hinteren Seitenwand des Schädels verschmolzen ist. Es treten daher einige Verknöcherungen, welche sich an diesem Teil bilden, in Verbindung mit dem eigentlichen Schädel (sog. Präoperculum oder Squamosum und Palatopterygoid); sie sollen deshalb erst beim Visceralskelet besprochen werden. - Die Weiterbildung des Dipnoerschädels besteht darin (Fig. 133), $\mathrm{da} B$ in seiner Occipitalregion, jederseits vom For. magnum, ein Ersatzknochen auftritt, die seitlichen Hinterhauptsbeine (Pleurooccipitalia oder Exoccipitalia, Occipitalia lateralia); sonst finden sich nur Deckknochen. - Ein langes Parasphenoid 
erstreckt sich wie bei den Knorpelganoiden nach hinten bis auf den Anfang der Wirbelsäule (auf der Fig. punktiert angedeutet). In der Schnanzenregion liegt vor ihm eine Zahnplatte mit zwei Zähnen; sie wird zuweilen als Vomer gedeutet. Dorsal wird das Primordialcranium von Lepidosiren und Protopterus voil einem langen und breiten plattenförmigen Deckknochen ergänzt, welcher wegen seiner Ausdehnung gewöhnlich als Parietofrontale bezeichnet wird, d. b. die Scheitel- und Stirnbeine der Knochenfische umgreifend. - Die dorsale Ethmoidregion ist von einem sog. Nasale (auch Dermethmoid genannt) überdacht. - Eine Absonderlichkeit

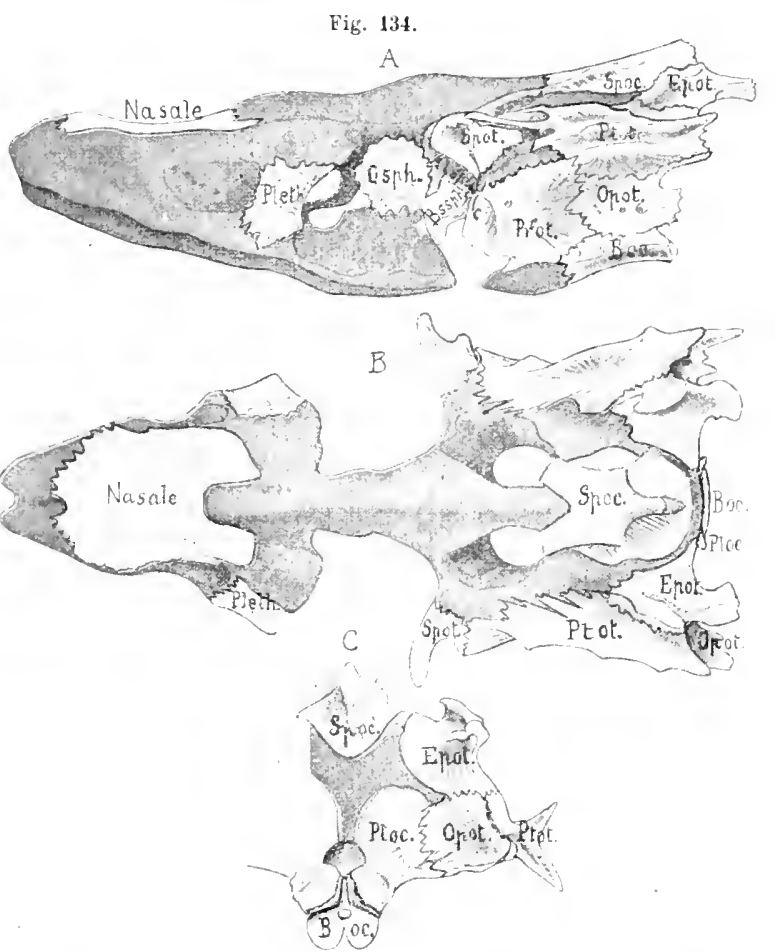

Salmo salar. Schādel nach Entfernung der Deckknowhen (mit Ausnabme des Nasale). Knorpel blau. A von links. $B$ von der Dorsalseite, $C$ Occipitairegion von binten. Alisph. Alisphenoid, Boc.Basioccipitale, Bssph. Basisphenoid, Epot. Epioticum, Optst. Opisthoticum, Osph. Orbitosphenoid, Ploc. Pleurooccipitale. Ileth. Plearoethmoid, Ftot. Pteroticum (Squamosum). Spoc. Supraoccipitale, Spot. Sphenoticum (Postfrontale). gegenüber allen Fischen bilden (Lepidosiren, Protopt.) zwei ansehnliche Hautknochen, die sich vomHinterrand des Nasale, den Musculus temporalis überdeckend, frei iiber dem Schädel bis in die Occipitalgegend "erstrecken (teils Supruorbitalia, teils dermales Ectethmoid genannt). Bei Ceratodus sind sie durch eine zwischengelagerte dünne Knochenplatte vereinigt, die auch zuweilen als Parietofrontale betrachtet wird, ihrer Lage nach aber kaum diesem entsprechen kann (sog. Scleroparietale).

Ebenso finden sich bei letztererGattung noch einige Hautknöchelchen unter und hinter dem Auge. Dies weist darauf hin, daß bei den rezenten Dipnoern Reduktion in der Hautknochendecke des Primordialcraniums vorliegt, was denu auch die ausgestorbenen Dipnoer der palăozoischen Zeit bestătigen. Wie Fig. 1382, S. 241 zeigt, war bei diesen die ganze Dorsalseite des Craniums von llautknochen koutinuierlich bedeckt, ähnlich wie bei den Chondrostei und Holostei. Aus ihrer Bezeichnung ergibt sich auch ihre Vergleichbarheit mit denen die beiden letzteren Abteilungen.

Holostei und Teleostei. Bei diesen Gruppen vermehrt sich die Zahl der Verknöcherungen sebr; der Teleosteerschädel gehört zu den knochenreichsten 
der Wirbeltiere. Das knorpelige Primordialcranium ist im erwachsenen Schădel meist stark riickgebildet, wenn auch bei primitiveren Formen (Holostei, doch anch Teleosteern: Salmo, Esox) noch recht ausgedehnt erhalten (s. Fig. 134). Meist wird es jedoch weniger vollständig angelegt als bei den primitiveren Fischen; die Decke, häufig auch die Orbitalregion, bleiben in größercm Umfang häutig.

Die meist ansehnliche Größe der Augen bedingt bei den Knochenfischen eine sehr tiefe und geräumige Entwicklung der Orbiten. Wie bei den Holocephalen bewirkt dies eine starke Einschniirung des Schädels in der Orbitalgegend, die so weit geht, daß die Schädelhöhle in diescr Region fast stets vollständig rückgebildet wurde und die beiden Orbiten nur durch ein knorpeliges bis knöchernes, oder häıtiges Septum geschieden werden (s. Fig. 135). - Bei den Holostei und Dipnoi dagegen erhält sich die ursprünglichere Schädelbildung der Knorpelfische und Knorpelganoiden, indem die Schädelhöhle zwischen den Orbiten hindurch bis in die Ethmoidalregion reicht; nnter den Teleostei findet sich ähnliches nur bei gewissen Physostomen (Cyprinoidei).

Wir beginnen mit der Schilderung der in den Schädel eingehenden Ersatzknochen, wobei jedoch zu betonen ist, daß die Natur einzelner Knochen noci unsicher erscheint, indem die ontogenetische Untersuchung sich bis jetzt nur auf wenige Formen erstreckte.

Die Occipitalregion (s. Fig. 134 a. 135) wird von den sehon den Dipnoi zukommenden beiden seitlichen Hinterhauptsbeinen (Pleurooccipitalia) gebildet, aber vervollständigt durch den steten Zutritt eines nnpaaren, die ventrale Umgrenzung des Hinterhauptslochs bildenden Basioccipitale, zu dem sich bei sämtlichen Knochenfischen noch ein gegenüberstehendes dorsales Hinterhauptsbein gesellt (Supraoceipitale), das den Holostei noch fehlt (s. Fig. 136 u. 137, S. 239) 1). Das Supraoccipitale nimmt fast nie an der Umschließung des Hinterhauptslochs Anteil, da die Pleurooccipitalia über letzterem zusammenschließev $(134 C)$; auch das Basioccipitale kann gelegentlich von der Umrandung ausgeschlossen sein. - Diese Bildnng der Hinterhanptsregion aus vicr Ersatzknochen erbält sich bei voller Verknöcherıng in der ganzen Reihe der amnioten Wirbeltiere typisch. - Indem sich an die Hinterhauptsbeine Muskeln ansetzen, kann es zur Ausdehnung der Verknöcherung au deren Ansatzstellen kommen und so zu Fortsatzbildungen. Namentlich erbebt sich das Supraoccipitale zuweilen in einem starken mittleren Kamm (Crista, Fig. 135).

Die Pleurooccipitalia der karpfenartigen Fische (Cyprinoidei) sind fast stets durch eine besondere Eigentümlichkeit ausgezeichnet. Jedes besitzt neben dem Foramen magnum ein meist sehr großes, in die Schädelhöhle führendes Loch, das, wie wir später sehen werden. in Beziehung zu dem Apparat von Knöchelchen steht, die die Schwimmblası mit dem Gehörorgan in Verbindung setzen. Von der Ventralfläche des Basioccipitale dieser Fische entspringen zwei Fortsătze, welche die Aorta umgreifen und sich unter ihr zu einem meist

1) Dagegen finden sich bei diesen auf dem Primordialcranium an Stelle des Supraoccipitale zwei bis mehr Deckknochen, ähnîich dem sog. Occip. superius des Störs, die auch noch bei den stegocephalen Amphibien wiederkehren. Sie werden wohl am geeignetsten als Dermoccipitalia bezeichnet. 
ansehnlichen Fortsatz vereinigen. Dieser meist nach hinten ziehende sog. Pharyngealfortsatz dient den sog. unteren Schlundzähnen des 5 . Kiemenbogens bei ihren Bewegungen als Widerlager und ferner als Ursprungsort für ein Muskelpaar, das sich zu dem 5 . Kiemenbogen begibt.

Die an die Pleurooccipitalia nach vorn anschließende Labyrinthregion, d. h. die Seitenwand der eigentlichen Hirnscliädelkapsel, ist bei den Knochenfischen besonders reich au Ersatzverknöcherungen (Otica). Bei voller Ausbildung schließt sich jederseits vorn an das Pleuro- und Basioccipitale zunächst ein mehr oder weniger ansehnlicher Knochen an (Opisthoticum oder Intercalare), welcher das

ig. 135 .
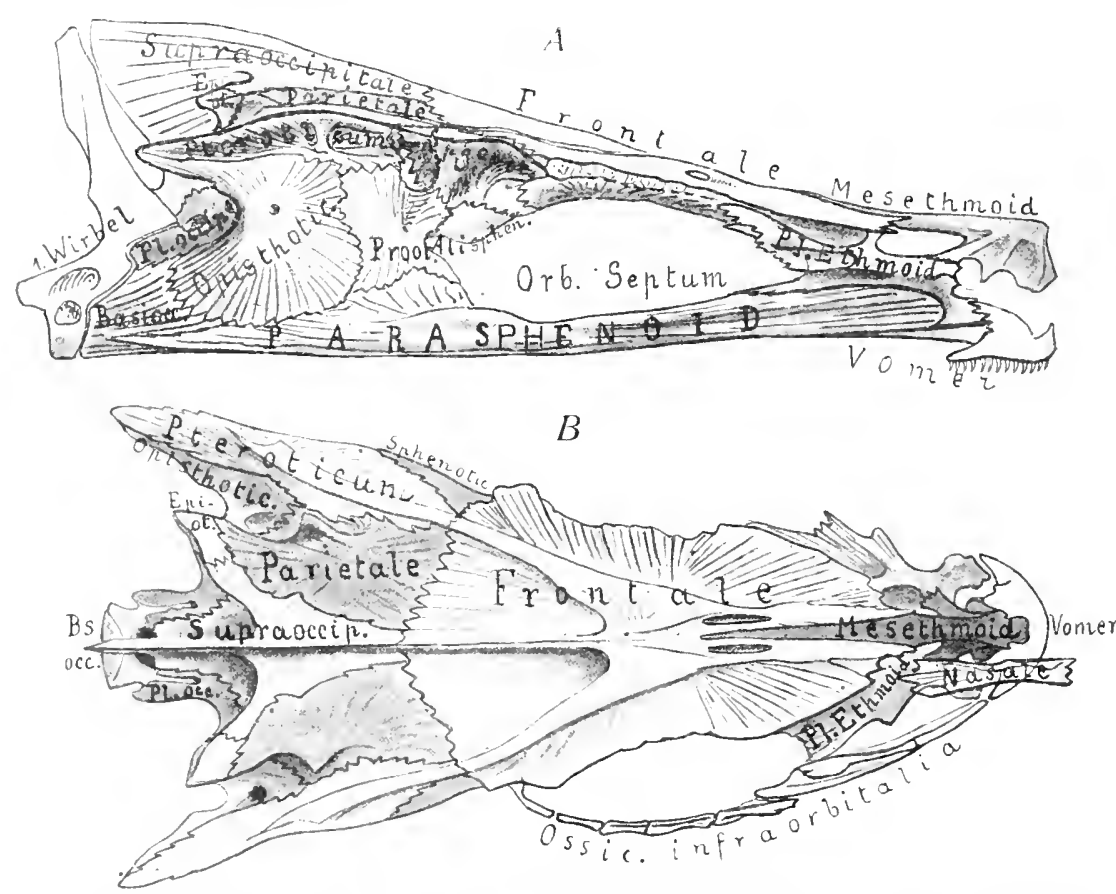

Gadus morrhua (Kabeljau). Schädel. A von rechts. $B$ von der Dorsalseite. In der Seitenansicht sind die Infraorbitalia weggelassen.

0. B

Labyrinth hinten umfaßt, aber auch als Deckknochen gedentet wird. Die Fortsetzung nach vorn, bis in die seitliche Orbitalregion, bildet das Prooticum (Petrosum) in der Ursprungsgegend des Nervus trigeminus, dessen Äste, ebenso wie der Nervus facialis z. T., durch diesen Knochen treten, oder doch von seinem Vorderrand umfaßt werden. Dor'sal über diesen beiden Knochen liegen von vorn nach hinten das sog. Sphenoticum (Postfrontale) und das Pteroticum (Squamosum); das erstcre entsteht im Postorbitalfortsatz des Primordialcraniums. Das Pteroticum ist interessant, weil es wenigstens bei Salmo als ein Mischknochen erkannt wurde. - Zwischen Pteroticum, Supra- und Pleurooccipitale schiebt sich ein meist ziemlich kleiner Ersatzknochen (Epioticum, Paroccipitale) ein, welcher ähnlich wie das Pteroticum und Opisthoticum ein hinteres oberes Schädeleck bildet, das sich am 
Tragen des Schultergürtels beteiligt. Selten (z. B. gewisse Plectognathi) können die Epiotica so groß werden, daß sie sich zwischen Supra- und Pleurooccipitale einschieben und zusammenstoßen. Von den besprochenen Otica ist das Opisthoticum sehr variabel, da es recht klein werden, ja sogar ganz fehlen kann.

Die in der Verlängerung des Basioccipitale nach vorn ziehende Schädelbasis wird wie bei den Knorpelganoiden hauptsächlich durch den langen Hautknochen, das Parasphenoid, gestützt (Fig. 135), weshalb in ihr Ersatzknochen wenig ausgebildet sind. Dennoch findet sich namentlich bei paläogenen ${ }^{1}$ Formen in dem Schädelboden, zwischen den beiden Prootica, eine kleine parige oder unpaare Verknöcherung, welche auf der Grenze gegen die Orbiten liegt, das sog. Basisphenoid (Keilbein). Diesem können sich in der vorderen Wand der ejgentlichen Gehirnkapsel, die häufig größtenteils häutig-knorpelig bleibt,.paarige kleine Alisphenoide (s. Fig. 134, 135, 137) anschließen, anf welche dann in dem interorbitalen Septum primitiver Formen noch sog. Orbitosphenoide folgen können, als ursprünglich paarige, meist jedoch nupaar verwachsende kleine Verknöcherungen (Figur 134, 136, 137).

Fig. 136 .

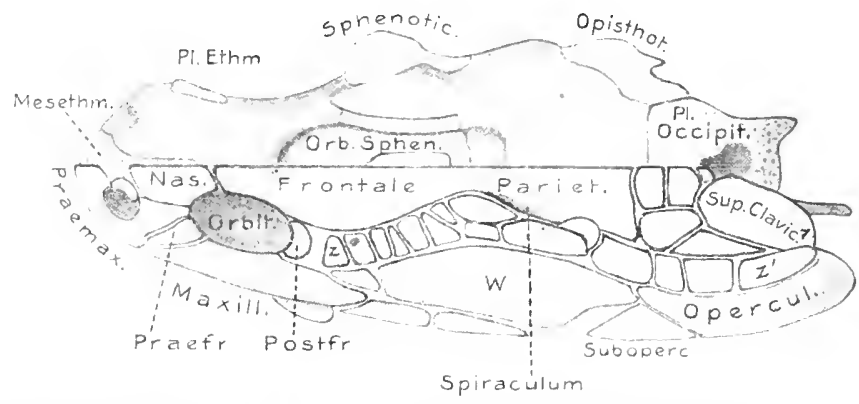

Poly pterns bi chir. Schādel von der Dorsalseite, In der rechten Hälfte die Deckknochen entfernt. Knorpel dunkel, Ersatzknochen pnnktiert. Deckknochen hell. (Mit Benntznng von Traquale 1871 u. Originalprāparat.) $\varepsilon-\varepsilon^{\prime}$ Reihe sog. Temporalia. $W$ geworhnlich als Präoperculnm gedentet, ist jedoch wohl erst aus Verwachsung von Pr. op. mit Postorbitalia hervorgegangen.

Das Interorbitalseptum bleibt so bei vielen Knochenfischen auf weite Strecken rein häutig; ventral von dem Parasphenoid, dorsal von den dorsalen Deckknochen gestützt.

In der Ethmoidalregion orhalten sich meist bedeutende Reste des Knorpelschädels (Fig. 134, 136). Als Ersatzknochen tritt in den Präorbitalfortsätzen jederseits ein Pleuroethmoid (sog. Ethmoidalia lateralia, Präfrontalia) auf; zwischen ihnen gewöhnlich ein unpaarer Knochen (Mesethmoid, Fig. 135), der wohl sicher in gewissen Fällen ein Ersatzknochen ist, sich aber von einem ähnlichen unpaaren Deckknochen dieser Region (Nasale) nicht stets scharf unterscheiden läßt, vielleicht auch zuweilen mit ihm vereinigt ist.

Hiermit wären die Ersatzknochen erledigt. Die Deckknochen, welche großen Anteil am Schädelaufbau nehmen, wiederholen znm Teil die schon bei den Knorpelganoiden angetrotfenen Verbältnisse. Auf der Ventralseite bildet das lange, zuweilen bezahnte Parasphenoid die Stütze des Schädels, vom Basioccipitale bis zur Ethmoidalregion. In letzterer schließt sich ihm vorn ein bei den Holostei paariger, bei den Teleostei stets unpaarer Vomer (Pflugscharbein, Fig. 135) an, der gewöhnlich Zähne trägt.

1) Wir gebrauchen die Bezeichnungen paläogen und sneogen für phylogenetisch ältere und jüngere Formen. 
Eine besondere Eigentümlichkeit vieler.Knochenfische (zahlreiche Physostomi und Acanthopterygii) ist die Bildung eines sog. Augenhöhlenkanals (Myodom), welcher von den Orbiten aus zwischen dem Parasphenoid und dem Basisphenoid (bzw. der knorpeligen Basis der Schädelkapsel) nach hinten zieht; er dient zur Aufnahme einiger stark verlängerter Augenmuskeln.

Die dorsale Schädeldecke wird hinten durch parige Parietalia (Scheitelbeine) and weiter vorn durch Frontalia (Stirnbeine) gebildet, von welchen die letzteren meist länger sind und durch Verwachsung unpaar werden können; auch eine Vereinigung beider zu einem Parietofrontale kann vorkommen (Fig. 136). Bei den Knochenfischen werden die beiden Parietalia hänfig durch die Frontalia und das Supraoccipitale getrennt (s. Fig. $135 B$ ). - In der Ethmoidalregion finden sich paarige Nasalia (Nasenbeine) oder ein unpares, deren Beziehung zum sog. Mesethmoid oben betont wurde.

Die Deckknochenbildung ist damit nicht erschöpft. Der ausgedehnte Knochempanzer der Schädeloberfläche, welcher den Knorpelganoiden und den paläo-

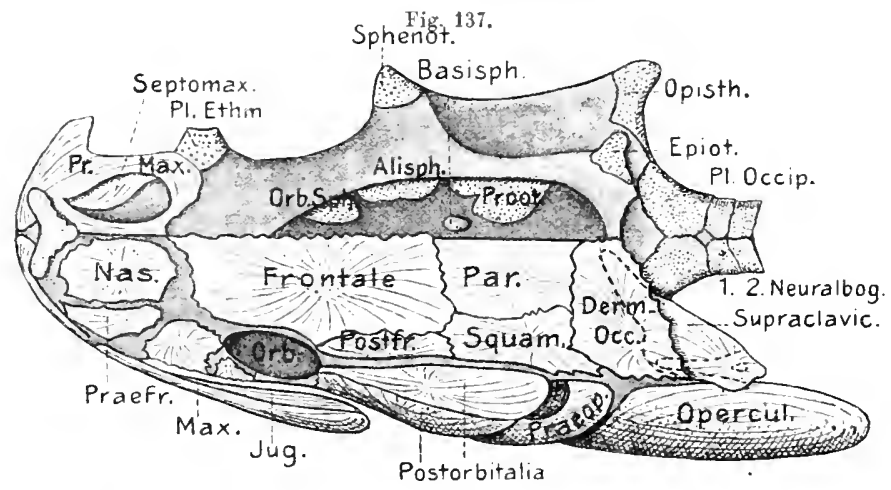

A m is calva. Schädel von der Dorsalseite. In der rechten Hälfte die Deckknochen entfernt mit Ausnahme der Prämaxille. Knorpel dunkel; Ersatzknochen punktiert. Deckknochen hell. (Nach Bridge 1877 konstruiert.)

O. B.

genen Dipnoi zukommt, fand sich in ahnlicher Ausdehnung und Bildung auch bei den Vorläufern der Knochenganoiden und daher jedenfalls auch der Knochenfische: Urspriunglich dürften wohl eine große Zahl kleiner Knochenplättchen die orbitale und Labyrinthregion des Schädels bedeckt haben. Bei vielen fossilen Ganoiden finden sie sich hier noch in großer Zahl (s. Fig. 1383), mdem sie sich entweder mehr in Längsreihen ïber, unter und hinter der Orbita anordnen, oder sich mehr in einigen konzentrischen Kreisen um die Orbita lagern. Es lassen sich so Supra-, Infra- (Sub-) und Postorbitalia unterscheiden, nach ibrer Lage zur Orbita.

In die Reihe der Supraorbitalia kann man auch die schon erwähnten sog. Präfrontalia (Pleuroethmoid) und Postfrontalia (Sphenotica) sowie das sog. Squamosum (Pteroticum) ziehen. Bei Polypterus hat sich die Supraorbitalreibe noch als ein Zug zahlreicher kleiner Knochenplättchen erhalten (Fig. 136z-z1), auch Lepidosteus ist noch ähnlich. Bei Amia ist sie auf Prä-, Postfrontale und Squamosum reduziert. Die hinter der Orbita, in der Labyrinthregion liegenden Knochenplatten, 
die man im allgemeinen als Postorbitalia bezeichnen kann, sind teils sehr zahlreich (Lepidosteus), teils wohl durch Verschmelzung verringert. So besitzt Amia noch zwei große Postorbitalplatten (Fig. 137); Polypterus (Fig. 136) eine ansehnliche, die gewöhnlich als Präoperculum gedeutet wird, meiner Meinung nach aber wahrscheinlich aus der Verwachsung einer oder. mehrerer Postorbitalplatten mit dem Präoperculum hervorging. - Eine Qnerreihe von Platten legt sich gewöhnlich der Occipitalregion des Schädels auf und verbindet die beideu Supraorbitalreiben (s. Fig. 138 ${ }^{3}$ ). Diese Platten werden gewöhnlich Supratemporalia genannt und ihre beiden mittleren auch Occipitalia. Vielleicht wären sie am besten sämtlich Dermoccipitalia zu nennen. Bei Polypterus sind sie noch dorch mehrere kleine, bei Amia

Fig. 138.

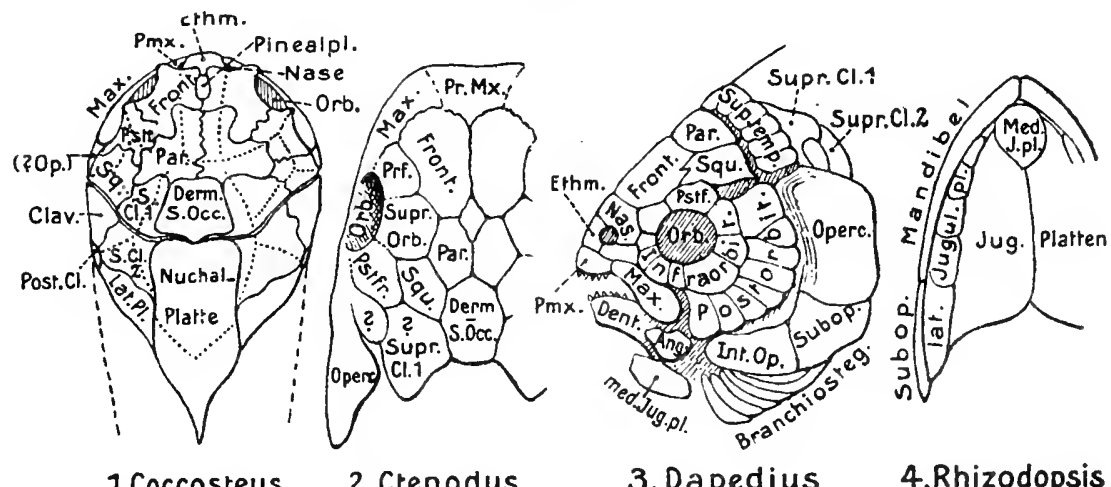

Schădel fossiler Ganoiden nnd Dipnoi. 1. Coccosteus (Devon; jetzt gewöhnlich den Dipnoern angeschlossen). Schädel and Knochenpanzer des rorderen Rnmpfabschnitts ron der Dorsalseite. 2. Ctenodus (Dipnoer, Carbon). Schadel ron Dorsalseite. 3. Dapedius (Amiadei, Lias). Sehädel von links. 4. Rhizodopsis (Carbon, Crossopterygii). Unterkinnlade von der Ventralseite. (Nach verschiedenen Autoren teils ans Goovescu 1909, teils aus ZITTELS Handbuch.) 0 . B.

jederseits nur durch eine einzige Platte repräsentiert. - Bei vielen Teleostei erhält sich zwischen Epioticum und Pteroticum ein meist kleines Knöchelchen, das wohl ein Rest dieser Supratemporalia ist (Supratemporale, Extrascapulare).

Auf ihm teilt sich in der Regel der sog. Seitenkanal in drei auf dem Kopf sich verbreitende Äste. Bei gewissen Physostomen kann es so groß werden, daß es das Parietale überdeckt und mit dem der Gegenseite zusammenstößt; ja es kann zuweilen sogar noch von einer Querreihe von Knochenplättchen repräsentiert werden, also ganiz ähnlich wie bei Holostei.

Die Reihe der Infraorbitalia erhält sich bei den Teleostei gewöhnlich (Fig. $135 \mathrm{~B})$ als ein Zug von Knöchelchen, der die Orbita ventral umrandet. Bei gewissen Formen kőnnen sie sich zum Teil ansehnlich vergrößern und verstärken, was eine Panzerung der Wangen- oder Temporalregion des Kopfs hervorruft (z. B. Cataphracti). Zu den Infraorbitalia im weiteren Sinne kann man auch die dem Oberkiefer sich näher anschließenden Hautknochen stellen, die wir später als Admaxillaria oder Jugalia betrachten werden.

Auch die paläozoischen Ostracodermi und Coccosteidae besaßen eine starke Knochenpanzernng des Kopfs und vorderen Rumpfabschnitts. Wenn dieser Kopf- 
panzer aus zahlreichen Stücken besteht, tritt sogar eine gewisse Übereinstimmung mit dem der älteren Ganoiden hervor. Wir beschränken uns darauf, eine Abbildung (Fig. $138^{1}$ ) einer dieser Formen zu geben, mit der möglichen Deutang der Elemente.

Visceralskelet der Cylostomen und Fische.

Im einleitenden Abschnitt über das Kopfskelet lernt’n wir das sog. Visceralskelet als eine Reihe segmental aufeinander folgender, etwa halbkreisförmiger Skeletbogen kennen, welche, hinter der Mundöffnung beginnend, die Mnndhöhle and den respiratorischen Abschnitt des Vorderdarms ventral umfassen. Sie dienen diesem Darmabschnitt als Stütze und Schutz. Die Möglichkeit, daß anch vor dem Mund Reste ehemaliger Visceralbogen vorkommen, wird später erörtert werden. - Jeder Visceralbogen scheint nrsprünglich aus zwei Hälften bestanden zn haben, die in der Ventrallinie zusammenstießen, gewöhnlich unter Vermittlung eines unpaaren kleinen Zwischenstücks, einer sog. Copula. Im allgemeinen schreitet ihre ontogenetische Entwicklung von vorn nach hinten fort.

Bei den Gnathostomen entstehen die Visceralbogen, speziell die hinteren oder sog. Kiemenbogen, verhältnismäBig tief im Mesoderm, nahe dem Darmepithel; bei den Cyclostomen dagegen relativ oberfächlich. Ans diesem Grunde warde vielfach bezweifelt, daß die Bogen der Cyclostomen denen der höheren Vertebraten gleichwertig seien. In nenerer Zeit hält man dies, trotz ihrer auch bei den Erwachsenen verschiedenen Lage, für sehr wahrscheinlich.

Die boiden vordersten Visceralbogen, welche auf den Mund folgen, treten stets in den Dienst der Nahrungsaufnahme und daher in nahe Beziehung zur Mundhöhle. Dies gilt vor allem für den ersten oder den Kieferbogen (Mandibularbogen), welcher den Rand der Mundöffnung stützt. Aach für den zweiten Bogen trifft dies in gewissem Grad za, wegen der nahen Verbindung, die er gewöhnlich mit dem ersten eingeht, sowie wegen seiner Beziehungen zn der auf dem Mandhöhlenboden sich entwickelnden Zunge. Aas diesem Grunde wird er als Zungenbeinbogen (Hyoidoder Hyalbogen) bezeichnet.

Auf die beiden ersten Bogen folgen in der Regel noch fünf weitere, die sich nach hinten fast stets etwas verkleinern. Da sie die Kiementaschen oder -spalten stiutzen, werden sie als Kiemenbogen (Branchialbogen) bezeichnet. Je ein Bogen liegt zwischen zwei aufeinander folgenden Kiemenspalten; der hinterste folgt auf die letzte Spalte. Auch zwischen Kiefer- and Zungenbeinbogen findet sich ursprünglich eiue Kiemenspalte. - Da bei den Cyclostomen und gewissen primitiveren Selachiern (Notidaniden) die Zahl der Kiemenbogen sechs bis sioben beträgt, so ist nicht unwahrscheinlich, daß ursprünglich überhaupt eine größere Zahl bestand, und allmählich eine von hinten nach vorn fortschreitende Reduktion eintrat, die, wie wir finden werden, bei den höheren Vertebraten noch weiter geht.

Schon früher wurde betont, daß sich die Visceralbogen der Cyclostomen und Chondropterygiel nach hinten beträchtlich uber den eigentlichen Schädel hinaus erstrecken können. Nur die beiden vordersten Bogen liegen auch bei ihnen stets in dessen Bereich. 
Es wurde schon hervorgehoben, daB die rerbreitetste Ansicht in dieser liemenbogenlage eine nachträgliche Rückwärtsverschiebung erkennen will. $\mathrm{Da}$, wie wir später genauer erfahren werden, die Kiemenbogen, vom 2. ab, sämtlich vom zehnten Hirnnerv, dem Vagus, innerviert werden, der mit Ausnahme der Cyclostomen, innerhalb der Schädelkapsel entspringt, so dürfte auch nicht zweifelhaft sein, daß sämtliche Visceralbogen der Kopfregion im weiteren Sinne angehören. Hiermit aber kann nicht als ausgemacht gelten, daß sie ursprünglich sämtlich der Region der primitiven Schädelkapsel zugehörten. Bei den Cyclostomen. wo der Vagus hinter dieser entspringt, gilt dies ja überhaupt nicht. Auch bei den Guathostomen ist dies wohl nöglich, da die Nerven, die zu den hinteren Kiemenbogen gehen, dem ursprünglichen Vagusstamm auch erst sekundär angeschlossen sein könnten, wie wir später sehen werden.

Cyclostomen. Die Beurteilung des Visceralskelets dieser Gruppe, welche sehr primitive Charaktere mit einer gewissen Rückbildung kombiniert, nnterliegt noch mancher Schwierigkeit. Vor allem gilt dies für den Mandibular- nnd den Hyoidbogen; doch bieten auch die Kiemenbogen, besonders in ihrer oberflächlichen Lage, gewisse Abweichungen. Das Visceralskelet ist allein bei den Petromyzonten vollständig ansgebildet, da nur sie Kiemenbogen in der Zahl von sieben Paaren besitzen. Den Myxinoiden febleil die Kiemenbogen fast vollständig, was in Berücksichtigung der Gesamtverhältnisse wohl nur als Reduktion anfgefaßt werden kann.

Die beiden vorderen Bogen zeigen gegenüber denen der Fische bedentende Rïck- nnd Umbildungserscheinnngen, ja weisen sogar auf nähere Beziehungen zu den Verhältnissen der Amphibien hin, was die sehr ursprüugliche Stellung der Cyclostomen, sowie ihre teilweise Rückbildung bestätigen dürfte. Ein Hauptcharakter dieser beiden Bogen oder Bogenreste ist, daß ihre dorsalen Enden in Kontinnität mit der knorpeligen Schädelkapsel getreten sind, als deren direkte Fortsetzungen sie erscheinen; sie mußten daher anch schon bei der Besprechung der Schädelkapsel berïcksichtigt werden. Als Kieferbogen dentet man bei Petromyzon (s. Fig. 127, 128, S. 227, 228) einen spangenartigen Knorpelfortsatz, der von der Chrregion der Schädelkapsel entspringt und sich vorn mit den Euden der Trabeculae vereinigt. Ontogenetisch wäehst er ein wenig vor der Ohrkapsel, etwa auf der Grenze der Trabeculae und Parachordalia, allmählich nach vorn hervor. Daß er dem dorsalen Teil des Mandibularbogens (Palatoquadrat) entspricht, ist wohl sicher. Oh aher vom ventralen Teil des Kieferbogens in den zahlreichen accessorischen Skeletknorpeln des Petromyzon etwas erhalten blieb, scheint zweifelhaft. - Bei den Myxinoiden (s. Fig. 126, S. 226) entspringt diese Knorpelspange in ähnlicher Weise von der Schädelkapsel, wächst jedoch noch weit ïber die Vereinigungsstelle mit den Trabeculae nach vorn in die Schnauzenregion vor, wo sie mit der der anderen Seite verschmilzt.

Der Hyoidbogen der Petromyzonten (Fig. 127, 128) entspringt als Fortsatz der Schädelkapsel direkt hinter dem Mandibularbogen und wendet sich nach außen nnd ventral. Ontogenetisch hat er jedoch dentlich einen gemeinsamen Ursprung mit dem ersten Bogen. Seine, den Kiemenbogen sehr ähnliche ventrale Fortsetzung ist bedeutend schmäler und daher scharf von dem dorsalen Stiick abgesetzt. - Bei den Myxinoiden (Fig. 126, S. 226) erhält sich der gemeinsame Ursprung des Hyoidbogens mit dem mandibularen deutlich, von dem er dann nach hinten abbiegt, 
um sich hierauf verschmälert gegen die Ventralseite zu wenden und onter der Mondhöhle in Teile des Zangenskelets direkt überzugehen (s. Fig. $126 \mathrm{~B}$ ). - In dieser Beziehung zeigt also der Hyoidbogen der Myxinoideu wohl primitivere Verhältnisse als der der Petromyzonten, bei welchen der große Zungenknorpel (siehe Fig. 128), sowie der vorn an ihn angeschlossene sog. Zungenbeinknorpel (Z.b) mit dem Hyoid nicht zusammenhängen. Der Knorpelapparat der Myxinoidenzunge ist recht kompliziert, wie Fig. $126 B$ lehrt. Sowohl der Kieferbogen als der Dorsalteil des Hyoidbogens der Myxinoiden verlängern sich nach hinten, spitz auslaufend. Eine quere Verbindung dieser beiden Auslänfer könnte eventuell als Rest eines ersten Kiemenbogens gedentet werden.

Auf den Hyoidbogen der Neunangen folgen sieben Kiemenhogen, welche ursprtinglich isoliert zwischen den sieben Kiementaschen nnd hinter der letzten angelegt werden; später aber durch Fortsätze in Verbindung treten, so daß sie im erwachsenen Zustand einen zusammenhängenden Kiemenkorb bilden. Dorsal und ventral von den sieben Kiemenöffnungen verbinden sich die Bogen untereinander und mit dem Hyoidbogen durch längsverlaufende Fortsätze. In ähnlicher Weise treten auch die Dorsalenden der Bogen, die sich der Chorda anlegen, nnd die ventralen Enden zu einer Längsleiste jederseits zusammen. Die beiden Ventralleisten berïhren sich in der Mittellinie, oder verwachsen auch zum Teil. - Außer diesen Fortsätzen entwickeln die Dorsal- and Ventralbälften jedes Bogens noch weitere freiendigende, wie Fig. 128 zeigt. - In der Herzbeutelwand, hinter der siebenten Kiementasche, bildet sich ein becherförmiger Knorpel (Pericardialknorpel), der mit dem siebenten Kiemenbogen durch seitliche Spangen zusammenhängt. $\mathrm{Ob}$ dieser Knorpel eventuell noch Reste eines achten Visceralbogens einschließt, wäre zu ermitteln.

Chondropteryyier. Das knorpeligeVisceralskelet dieser Ordnung bietet in vieler Hinsicht $z$ weifellos Ursprünglicheres als das der Cyclostomen, läßt jedoch andrerseits auch schon die Anlagen für die besondere Entwicklung des Visceralskelets, der übrigen Fische erkennen. Charakteristisch für die Knorpelfische und die Gnathostomen überhanpt ist die tiefere Lage der Kiemenbogen, und für die Fische im besonderen, daß die Dorsalenden der beiden ersten Bogen mit dem Scbädel nicht verwachsen. Nur vereinzelt (Holocephalen, Dipnoer) tritt dies für den Mandibularbogen ein und ist von großer Bedeutung, wegen der gleichen Erscheinung bei den Cyclostomen wie den tetrapoden Vertebraten.

Die Kiemenbogen erreichen bei den Notidaniden (unter den Haien) noch die Sieben- oder Sechszabl, wogegen sie bei den übrigen Knorpelfischen nud sämtlichen sonstigen Fischen auf fünf herabsinken.

Gegenüber den Cyclostomen fällt vor allem die mächtige Entwicklung des Mandibularbogens auf, was damit zusammenhängt, $\mathrm{daB}$ er die Mundränder stützt und bei den carnivoren Knorpelfischen als Kiefer funktioniert, die reich bezahnt sind. Da der Mund der Knorpelfische fast stets anf der Ventralseite nach hinten verschoben ist, so tritt die jederseitige Anlage des Kieferbogens als ein ventralwärts konkaver Knorpelbogen auf, dessen vorderer, richtiger dorsaler Teil dem 
vorderen Rand der Mundöffunng, dessen hinterer oder ventraler dem hinteren sich anschließt. Der dorsale und ventrale Abschnitt jeder Bogenhälfte sondern sich später voneinander, indem sich zwischen beiden, in der Gegend des Mundwinkels, ein Gelenk bildet; gleichzeitig wachsen sie nach vorn aus. Doch wird für gewisse

Fig. 139.
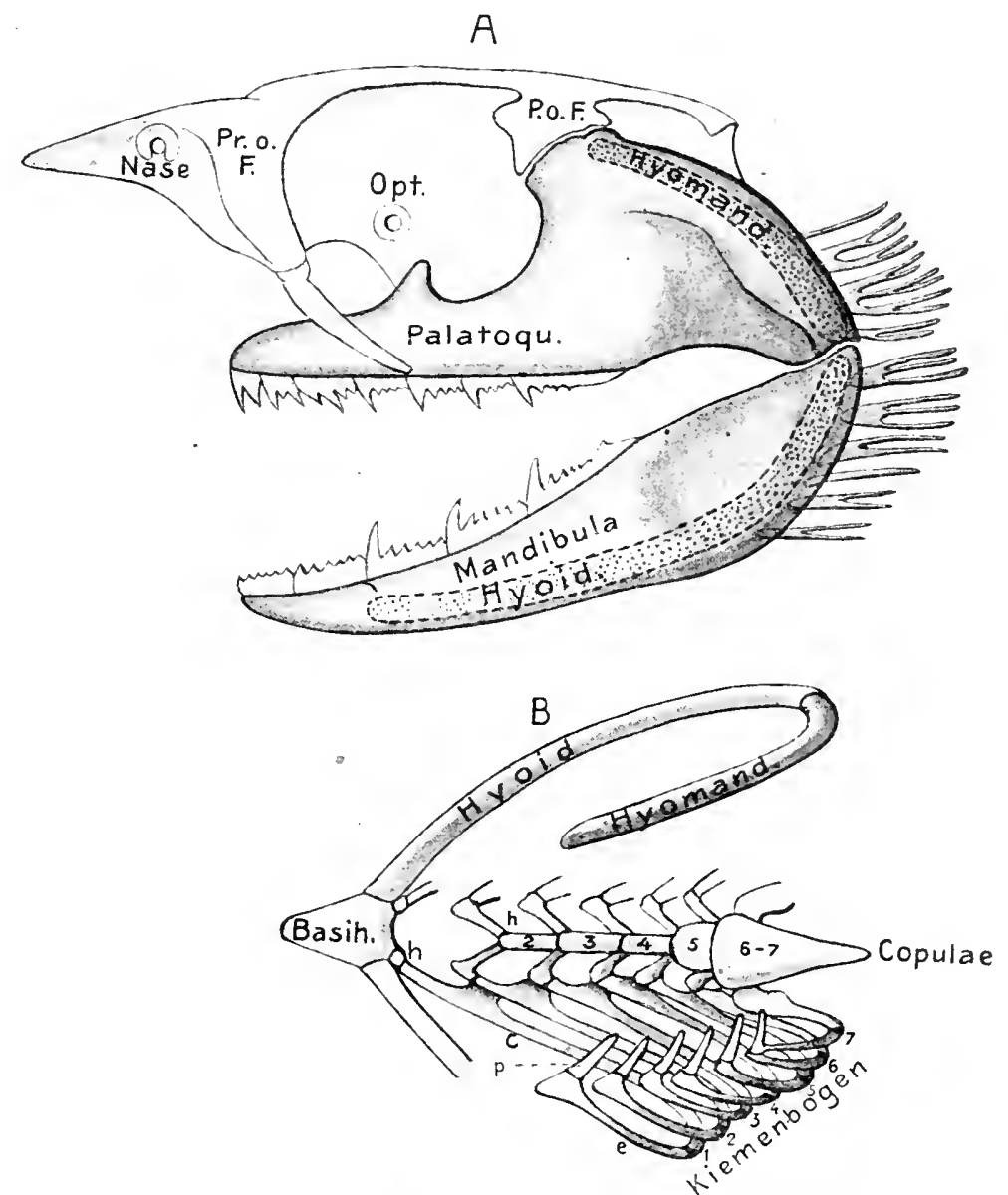

Heptanchus. A Schādel mit den beiden ersten Visceralbogen von links. Hyoidbogen, der dicht unter dem Kieferbogen liegt, pnaktiert. Pr. o. F. und $P, O . F=$. Prā- und Postorbitalfortsatz. $B$ Hyoid- u. Kiemenbogen von der Dorsalseite in seiner richtigen Stellung zum obenstehenden Schādel. $h=$ Hypobranchiale, $c=$ Cerato-, $e=$ Epi-, $p=$ Pharyngobranchiale. (Nach Gegkasaur 1872.)

Formen auch eine gesonderte Anlage beider Abschnitte beschrieben. Die beiden dorsalen Bogenabschnitte gelangen so nnter der Ethmoidalregion des Schẩels zum ZusammenschluB, ohne jedoch zu verwachsen; ebenso schließen sich die ventralen Abschnitte zur Bildung des Unterkiefers (Mandibula) in der Ventrallinie zusammen. 
Das dorsale Stïck der so gegliederten beiden Hälften des Mandibularbogens bezeichnet man aus Gründen, die später hervortreten werden, als Palatoquadrat; das ventrale als Unterkiefer (Mandibula, s. Fig. 139, 140). Bei gewissen Haien kann zwischen beide Hälften des Unterkiefers ein kleines unpaares Knorpelstückehen (wohl Copula) eingeschoben sein. Palatoquadrat wie Unterkiefer sind gewöhnlich reich bezahnt. - Der dorsale Rand des Palatoquadrats befestigt sich bei den Haien durch Bänder, seltener durch Gelenk am Schädel. Am Palatoquadrat der Notidaniden (besonders Heptanchus, Fig. 139) steigt etwa von der Mitte des Dorsalrands ein starker Fortsatz auf, der sich am Hinterrand des postorbitalen Schädelfortsatzes befestigt oder gelenkt. Ferner besteht hier noch eine zweite Befestigung, etwa in der mittleren Orbitalregion, an der sog. Basalecke der Schädelbasis, vermittels eines schwächeren Palatoquadratfortsatzes (Palatobasilarfortsatz). Diese Art der Befestignng des Palatoquadrats darf wohl als primitiv angesehen werden. - Bei den übrigen Haien (Fig. 140) geschieht die Befestigung allein durch letzteren Fortsatz, der erstere fehlt oder ist nur angedeutet; doch kann auch die Anheftung durch den Palatohasilarfortsatz stark zurückgehen, indem das Dorsalstück des Hyoidbogens die Befestigung des Palatoquadrats übernimmt. - Den Rochen fehlt überhaupt jede Befestigung des cinfach bogenförmigen Palatoquadrats am Schädel.

Jede Hyoidbogenhälfte ist bei den Haien ebenfalls in ein Dorsal- und ein Ventralstück gesondert. Das dorsale Stück oder Hyomandibulare befestigt sich durch Band bis Gelenkung an der mittleren bis hinteren ventralen Seite der Labyrinthregion des Schädels. -- Die beiden Ventralstücke (Hyalia, Hyoidea) verbinden sich in der Bauchlinie nicht direkt, sondern vermittels eines unparen Zwischenstücks, einer sog. Copula (Basityale, Fig. 139, 140 B). - Während sich bei den Notidaniden (Fig 140) dio beiden schmalen Hälften des Hyoidbogens dicht hinten und innen den Kieferbogenhälften anschließen, sind Hyomandibulare und Hyale bei den tibrigen Chondropterygiern vom Kieferbogen nach hinten verschoben und differenter geworden. Das Hyomandibulare wird kürzer und breiter, rückt mit seinem Schädelcnde gewöhnlich weiter nach hinten vom Kieferbogen ab, während sein Ventralende mit dem Hinterende des Palatoquadrats in Bandverbindung bleibt und an dieser Stelle meist auch einen gegen das Palatoqnadrat gerichteten Fortsatz bildet (Fig. 140). Das Hyalstiick erscheint nun schärfer vom Hyomandibulare abgesetzt.

Bei gewissen kochen tritt dies durch Verschmälerung des Hyalstücks (Torpedo) noch stärker bervor; auch ist deren Hyale in zwei Stücke gegliedert. Bei den lajae (nnter den Rochen) lüst sich das Hyale vom Hyomandibulare ab, verlängert sich dorsalwärts hinter diesem und giledert sich in rier Stïcke, von welchen das dorsale direkt hinter dem Hyomandibulare am Schädel befestigt ist. So erhält hier das sog. Hyalstück eine große Ähnlichkeit mit den daranffolgender Kiemenbogen; weshalb auch die Ansicht vertreten wird, daß das IIyale der Rochen einem selbstäıdigen Visceralbogen (Hyobranchiale) entspreche, der bei den Haien rïrkgebildet (v. WTJHE), oder in seinem dorsalen Teil mit dem Hyomandibnlare verschmolzen sei (Dourn). Nach der ersten Ansicht gehörte das Hyalstück der Haie als Ventralglied zum Hyomandibular (Hyoid)-bogen, wogegen den Rochen ein entsprechendes Hyalstück fehlte; nach der zweiten Ansicht bilde das Ifyalstück der Haie den Ventralteil des Hyobranchialbogens, dessen Dorsalteil mit dem Hyomandibulare vereinigt sei. 
Die folgenden fünf bis sieben Branchialbogen der Chondropterygier liegen hinter dem Schädel, mit dem sie keine direkte Verbindung mehr besitzen. Bei den Rochen können sie sich jedoch am Anfang der Wirbelsäule befestigen.

Jede Bogenhälfte besteht in der Regel aus vier Stücken (Fig. 139, 140), von welchen das dorsale (Pharyngobranchiale) und das ventrale (Hypobranchiale oder Copulare) meist klein bleiben, die mittleren (Epi- und Ceratobranchiale) die ansehnlicheren sind. Nach hinten werden die Bogen kleiner; der hinterste kann auch mehr oder weniger rudimentär sein. Indem sich letzterer Bogen durch Band mit dem Schultergürtel verbindet, lieferter diesem einen Stützpunkt, was erklärlich macht, daßsich bei den Rochen wegen der GröBe der Brustflossen der fünfte Kiemenbogen sehr erheblich verstärkt und verlängert,indem diese Nebenfunktion hier überwiegt.

In der Ventrallinie schieben sich zwischen die Hypobranchialia der

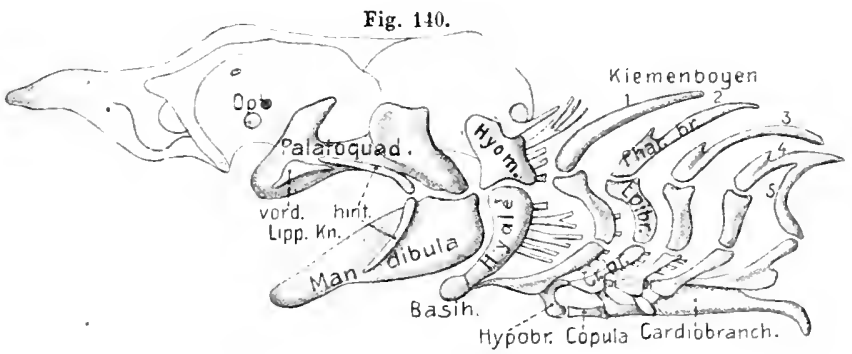
Kjemenbogen un-

Acanthias. A Schādel mit Visceralskelet von links $B$ Visceralskelet von der Dorsalseite. Die dorsalen Teile der Bogen nicht gezeichnet. (Mit Benutzung von
Gegenbacr 1y72)

paare Stücke eil, die sog. Copulae odcr Basibranchialia, ähnlich wie das Basihyale zwischen die Hyalstïcke des Zungenbeiuhogens. Das Basihyale ist bei den Haien meist recht groß und entsendet häufig nach vorn einen kräftigen Znngenfortsatz, wegegen es bei den Rochen zu einer schmalew, jedoch sehr breiten fortsatzlosen Querspange wird. - Die Copulae đer Kiemenbogen bleiben hingegen mit Ausnahme der hintersten recht klein und sind nie in voller Zabl der Bogen vorhanden. Bei größerer Zahl, wie z. B. Heptanchus (s. Fig. 139 B) tritt deutlich hervor, daß sie sich zwischen die Ventraleuden je zweier aufeinander folgender Paare der Hypobranchalia einschalten. - Die hinterste Copula ist stets recht groß and nach hinten fortsatzartig verlängert. Sie dient zur Befestigung des unter ihr liegenden Herzbentels, weshalb sie auch als Cardiobranchiale bezeichnet wird. Bei den meisten Haien sind jedoch die vorderen Copulae stark reduziert, während sich die hinterste stets ausehnlich erhält, ja grőßer wird oder schließlich allein übrig bleiben kann, was auch bei den Rochen die Regel ist. Die vorderen Kiemenbogen heften sich dann dem Vorderrand des Cardiobranchiale an. 
Ob die Copulae von varnherein selbstăndig entstanden sind, wie es ontogenetisch jetzt scheint, oder ob sie aus den Ventralenden der Visceralbogen hervorgingen und daher ursprünglich parig waren, was durch Befunde an gewissen rezenten und fossilen Haien unterstützt wird, ist unentschieden. Wie schon hervorgehoben wurde, sprechen gewisse Beobachtungen bei Haien auch für die früher verbreitetere Existenz einer Copula des Kieferbogens. Auch wäre es nicht unmöglich, $d a ß$ in den Zungenfortsatz des Basihyale ein Teil einer ursprünglichen Kieferbogen-Copula eingegangen sei. Ebenso verdient erwähnt zu werden, daß zwischen Mandibula und Hyale noch kleinere, schwer deutbare Knorpelpaare auftreten können.

Eine Besonderheit der meisten Visceralbogen bilden die ihnen außen angefügten knorpeligen Fortsätze oder Kiemenstrahlen, welche an den beiden mittleren Stücken der Branchialbogen (mit Ausnahme des hintersten) stets vorkommen und die Scheidewände zwischen den Kiementaschen stützen (Fig. 140). Sie finden sich an jedem Bogen in recht verschiedener Zahl; bei den Rochen im allgemeinen zahlreicher. Durch besonderebogenförmige Verlängerung des dorsalsten und ventralsten Kiemenstrahls ventral- und dorsalwärts, parallel dem Kiemenbogen, kann bei gewissen Haien eine Art äußerer Kiemenbogen (Extrabranchialia) gebildet werden, die eine oberflächliche Stütze der Kiementaschenwände bilden (z. B. Cestracion u. a.).

Anch den beiden Stücken des Zungenbeinbogens heften sich solche Strahlen mehr oder weniger reichlich an (Fig. 139, 140) und treten hier z. T. eigentümlich verästelt, jedoch auch in verschiedenartiger Verwachsung auf, was an die Bildung des Opercularapparats der höheren Fische erinnert.

Dem hinteren Palatoquadratteil der Haie schließen sich meist ein bis drei, zuweilen strahlige kleine Knorpelstückchen an, die sog. Spritzlochknorpel, welche die Spritzlochkieme stützen. Bei gewissen Rochen finden sich ähnliche Knorpelstückchen, welche iedoch die Beziehung zum Palatoquadrat aufgegeben und sich dem Hyomandibulare angeschlossen haben. Es ist wahrscheinlich, daß diese Spritzlochknorpel Kiemenstrahlenreste des Kieferbogens darstellen.

Sog. Lippenknorpel (Labialknorpel) sind bei den Chondropterygiern recht allgemein verbreitet, wenn sie auch bei den Rochen zurücktreten und gewissen Haien fehlen. Bei den Haien und Holocephalen liegen sie dem Kieferbogen änßerlich an, gewissermaßen als ihm parallele Bildungen (Fig. 140, 130, S. 230). - Bei voller Entwicklung finden sich zwei hintere stabförmige Knorpel jederseits, die sich ähnlich wie Palatoquadrat und Mandibula im Mundwinkel aneinander schließen. Vor dem dorsalen liegt, außen am Palatoquadrat, noch ein oberer vorderer sog. Prämaxillarknorpel. Den vorderen Mundrand erreichen diese Knorpel nie. - Die Lage, sowie die Parallelität der Labialknorpel mit dem Kieferbogen legt den Gedanken nahe, daß sie zwei, noch vor letzterem befindliche Visceralbogen repräsentieren; wenngleich diese morphologisch wichtige Frage sich vorerst nicht sicher entscheiden läßt. Ontogenetisch treten sie selbständig, jedooh später als die eigentlichen Visceralbogen anf.

Eigenartige Verhältnisse zeigt der Kieferbogen der Holocephalen, da hier ein gesondertes Palatoquadrat fehlt und die Mandibel mit einem weit vor der Augenhöhle gelegenen Vorsprung des seitlichen unteren Schädelrands gelenkt (s. Fig. 130, S. 230). Dies erklärt sich zweifellos durch die Verschmelzung des Palatoquadrats mit diesem Scitenrand des Schädels, so daß der erwähnte Vorsprnng vom Ventral- 
ende des nrsprünglichen Palatoquadrats gebildet wird. Ontogenetisch lie $B$ sich aber bis jetzt eine selbständige Anlage des Palatoquadrats nicht nachweisen. - Unter diesen Verhältnissen entsteht jedoch die Frage nach dem Verbleib des Hyomandibulare, welches ja schon bei den meisten Plagiostomen zum Befestigungsapparat des Palatoquadrats am Schädel wurde. Die verbreitetste Ansicht ist, daß das Hyomandibulare als relativ kleincs Stïck den oberen Teil des Hyoidbogens bilde, also nicht gleichfalls mit dem Scbädel verschmolzen sei. Eine andere Meinung dagegen läBt auch das Hyomandibulare mit dem hinteren Teil des Schädelseitenrands vereinigt sein und erklärt so z. T. die starke Vorwärtsverlagerung des Untcrkiefergelenks.

Letzterer Auffassung scheint jedoch die vollständige Entwicklung des Hyoidbogens aus vieı Stücken, wie die Kiemenbogen, zu widersprechen; da jedoch auch die sog. ventrale Hälfte des Hyoidbogens der Rochen ebenso vollständig wie der der Holocephalen ist, so besagt dies nicht allzu viel. Mir scheint die gleichzeitige Aufnahme des Hyomandibulare in den Schädel der Holocephalen wahrscheinlicher.

Wie schon früher bemerkt, treten die Holocephalen durch die geschilderte sog. Autostylie in Beziehung zu den Dipnoern und den tetrapoden Wirbeltieren; eventuell könnten dariu je? och auch Anknüpfungspunkte an die Einrichtungen der Cyclostomen gefunden werden.

Die Visceralbogen der tibrigen Fische schließen sich denen der Chondropterygier an, speziell denjenigen, bei welchen das Hyomandibulare zum Träger der beiden vorderen Bogen wurde. Die Dipnoi wiederholen, wie bemerkt, die Autostylie der Holocephalen; bei allen Ganoiden und Teleostei erhält sich dagegen das ersterwähnte Verbalten. Kompliziert wird der Visceralapparat durch reichliche Verknöcherung bei den Knochenganoiden und Knochenfisehen, während die Knorpelganoiden nur Anfärige davon zeigen.

Chondrostri. Wir legen der folgenden Beschreibung den Visceralapparat des Störs zugrunde (Fig. 141). Ier Mandibnlarbogen ist sehr schwach ausgebildet, was mit der Rückbildung der Zähne zusammenhängt. Das Palatoquadrat besitzt keine besondere Gelenkung mit der Schädelbasis, wird also nur vom Hyomandibulare getragen. Eine gewisse Ursprünglicbkeit verrät es dadurch, daß es mit dem der Gegenseite in langer Au dehnung zusammenstößt, ja z. T. verwächst. - Der Hyomandibularteil des Zungenbeimbogens ist lang und sein ventraler Abschnitt als besonderes Stïck, sog. Symplecticum, abgegliedert. Man bezeichnet dann das dorsale größere Stück als Hyomandibulare im engeren Sinne. Das proximale Ende des letzteren befestigt sich durch Band an der Hinterseite des Postorbitalfortsatzes, während der Hyalteil des Zungenbeinbogens dem Symplecticum hinten angehänct ist.

Am Palatoquadrat treten jederseits vier Verknöcherungen auf, welche wohl teils Ersatz-, teils Deckknochen sind; zwei kleinere vordere, die als Palatinum (Grumenbein) und Mesopterygoid bezeichnet wurden, und eine viel ansehnlichere hintere, ein sog. Pterygoid, welche alle drei Ersatzknochen zu sein scheinen. In der hinteren Zusammenstoßnngszone der Palatoquadrate haben sich einige besondere Fnorpel differecziert. Die Gelenkregion des Palatoquadrats wird außen von einem 
Deckknochen belegt, welcher gewöhnlich dem sog Präoperculare der Teleostei verglichen wird, der jedoch trotz seiner Hautknochennatur auch an ein Quadrat erinnert. - Ein ansehnlicher Hautknachen, der vom Gelenkfortsatz des Palatoquadrats bis zum vorderen Mundrand zieht und hier mit dem der Gegenseite zusammenstößt, wird als Oberkiefer (Maxilla) bezeichnet. Die Verhältnisse bei Polyodon machen es sehr wahrscheinlich, daß er als Deckknochen auf einem besonderen Knorpel entsteht, der dem hinteren oberen Labialknorpel der Haie ent-

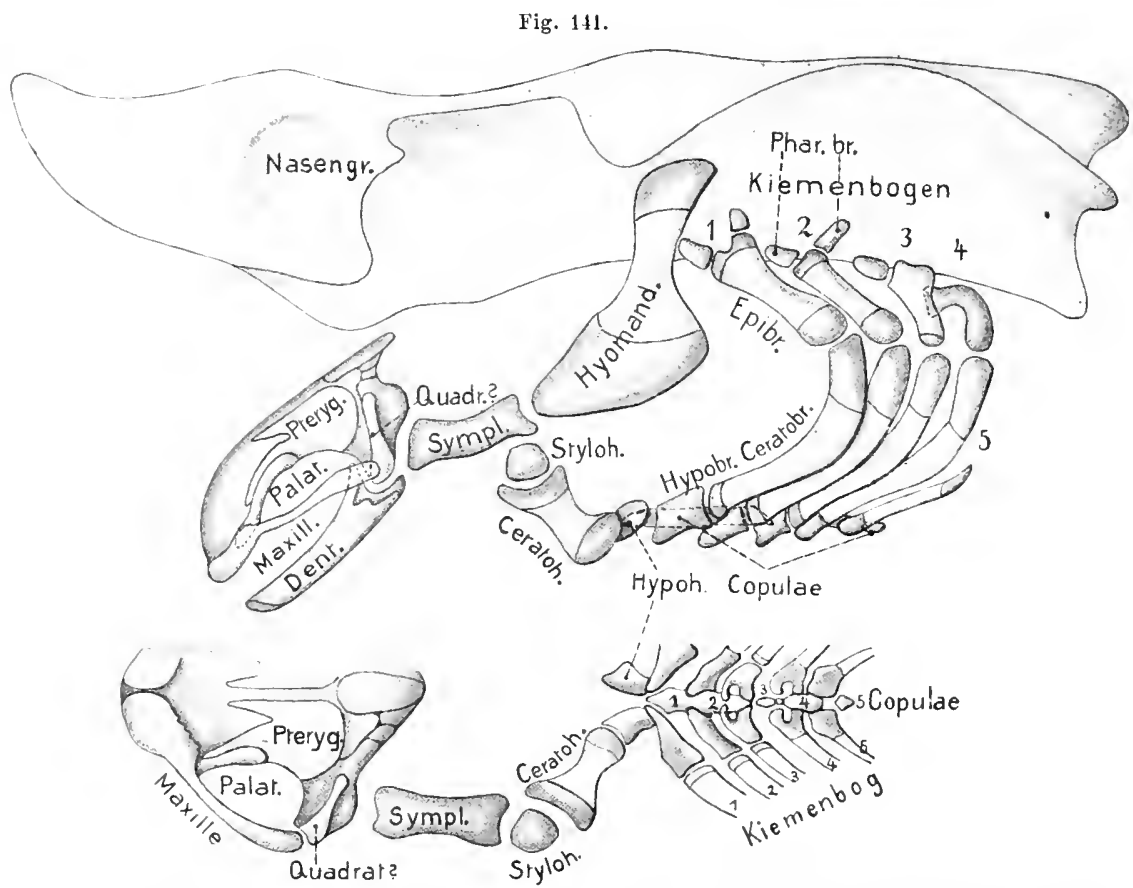

Acipenser sturio. A Schädel mit Visceralskelet von links. Im Visceralskelet Knorpel dunkel, Knochen hell. $B$ Visceralskelet von der Dorsalseite. Die Kiemenbogen nur teilweiso ausgezeichnet. E. W.

spricht, so daß diese Beziehung für den Oberkiefer überhaupt gelten dürfte. - Der Mandibularknorpel wird von einem Hautknochen, dem Dentale, zum größeren Teil umscheidet.

Auf seiner Innenseite tritt an dem sog. Coronoidfortsatz noch eine kleine Hautverknöcherung (Coronale) anf. An der Symphyse kann der Knorpel einen kleinen Ersatzknochen (Mentomandibulare) bilden (Polyodon).

Am Hyomandibularknorpel erhält nur der mittlere Teil eine periostale Knochenrinde, seltener auch das Symplecticum. Der ventrale Abschnitt des Hyoidbogens (Hyale) hat sich in drei Stücke gegliedert, von welchen das mittlere (Ceratohyale) das größte ist. Die Kiemenbogen dagegen bestehen aus je vier Stücken, einem dorsalsten, das an dem ersten und zweiten Bugen von Aripenser aus zwei übereinander liegenden Knorpeln besteht (Pharyngobranchialia), welche die Befestigung 
am Schädel bewerkstelligen. Die beiden mittleren Stücke (Epi- nnd Ceratobranchiale) sind die größten und in der Mitte mit einer Knochenrinde versehen. Das Ventralstück (Hypobranchiale) ist klein. Der Copularapparat (Fig. $141 B$ ) besteht ans einem vorderen langen Knorpelstäck, das das Basihyale nebst erstem und zweitem Basibranehiale umgreift; daranf folgen drei kleine knorpelige Copulae. Kiemenstrahlen fehlen den Chondrostei völlig, wenn nicht etwa die die Kiemenblättchen stätzenden Knorpelftden auf sie bezogen wcrden dürfen.

Fig. 142 .

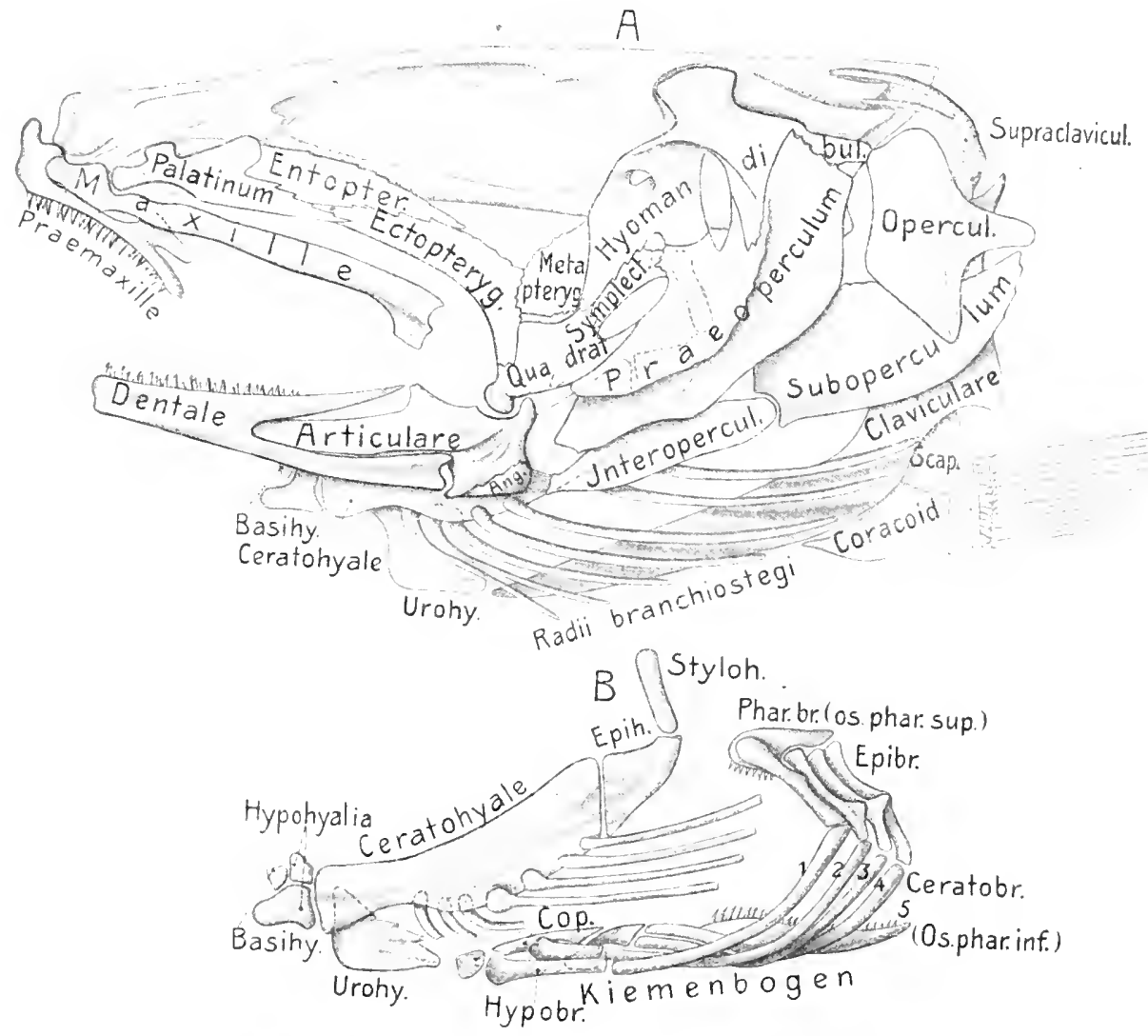

Gadus morrhua (Kabeljau). A Schädel mit Visceralskelet und Schultergürtel von links. $B$ Visceral. skelet in derselben Stellung und Lage von links.

E. W.

Die Knochenganoiden und Knochenfische stimmen so wesentlich überein, daß sie gemeinsam betraehtet werden können. Gegenüber den Knorpelfischen und -ganoiden werden sie durch die Nichtvereinigung der Gaumenfortsätze der beiden Palatoquadrata charakterisiert. Letztere erstrecken sich nach vorn bis in die Ethmoidalregion und gelenken meist mit dem Pleuroethmoid, so daß eine bessere Befestigung am Schädel besteht. Der Hyomandibularteil des Zungenbeinbogens oder der sog. Kieferstiel (Suspensorium) ist stets recht kräftig. Ein knorpelig differen- 
ziertes Symplecticum, wie es den Chondrostei zukam, tritt zwar ontogenetisch auf, verschmilzt jedoch bald wieder mit dem Hyomandibulare; erst bei der Verknöcherung sondern sich beide Teile von neuem. Die Gelenkung des Hyomandibulare am Schädel liegt an derselben Stelle wie bei den Chondrostei und geschieht gewöhnlich am äußeren Rand des Sphen- und Pteroticums, erstreckt sich jedoch zuweilen auch abwärts auf das Prooticum. - Ein Hauptcharakter besteht ferner darin, daß mit der reichlicheren Verknöcherung des Palatoquadrats der hinterste seiner Knochen, das Quadrat, welches den Gelenkkopf für den Unterkiefer bildet, sich mit dem Kieferstiel fest verbindet, so daß letzterer nun ans drei Knochen, dem Hyomandibulare, Symplecticum und Quadrat besteht (Fig. 142 A): Von diesen ist das Hyomandibulare (Ersatzknochen) der ansehnlichste; oben mit langer Gelenkfläche und hinten meist mit einem Fortsatz zur Anheftung des Operculnms des Kiemendeckels versehen (s. auch Fig. 143). Es wird in der Rcgel von einer manchmal ziemlich weiten Öffnung für den Facialisnerv durchbohrt. - Dem Hyomandibulare fügt sich distal das meist kleine Symplecticum (Ersatzknochen) fest an; weiter vorn und distal das fast stets ansehnlichere Quadrat (E. Kn.). Zuweilen fellt das Symplecticum (Polypterus, gewisse Physostomen).

Der verknöcherte Gaumenteil des Palatoquadrats schließt sich dem distalen Vorderrand des Kieferstiels fest an, und baut sich von hinten nach vorn in der Regel aus vier Verknöcherungen auf, zwischen denen sich jedoch zuweilen noch reichlich Knorpel erhält (Fig. 143). An das Hyomandibulare und Quadrat stoßen zunächst das Meta- und Eetopterygoid, von denen das erstere ein Ersatz-, das letztere ein Deckknochen ist. Als ein zweiter Deckknochen reiht sich weiter vorn und innen das Entopterygoid an; den vorderen Abschluß bildet das Palatinum (Gaumenbein), das meist am Pleuroethmoid gelenkt, sich jedoch auch noch weiter vorwärts erstrecken kann. Das Palatinum crgitt sich als ein sog. Mischknochen, d. h. aus einem Ersatz- und einem Deckknochen hervorgehend. - Der geschilderte komplizierte Apparat kann sich jedoch auch vereinfachen, indem einzelne Pterygoidea ausfallen, so daß schließlich nur das Mezapterygoid und Palatinum verbleiben (z. B. Silmrus).

Der eigentliche obere Mnndrand wird jederseits von zwei länglichen Deckknochen gebildet, vorn dem Zwischenkiefer (Prämaxillare), der mit dem der Gegenseite in einer Symphyse vereinigt ist, und dem sich nach hinten der Obcrkiefer (Maxillare) anschließt. Letzterem begegneten wir schon bei den Chondrostei. Diese beiden Knochenpaare (wesentlich Deckknochen) finden sich von hier an als typische Elemente bei sämtlichen Wirbeltieren. Wie wir das Maxillare schon anf den oberen hinteren Lippenknorpel der Chondropterygier zurückzuführen suchten (s. S. 250), so steht wahrscheinlich auch der Zwischenkiefer in ähnlicher Beziehung zum vorderen oberen Lippenknorpel.

Diese Deutungen werden noch dadurch unterstïtzt, daß auf der Innenseite der Prämaxillaria und Maxillaria Knorpelbildung vorkommen kann. - Dem hinteren Teil des Maxillare schließen sich zuweilen ein (auch zwei) Deckknochen innig an, welcher als Admaxillaria (auch Supramaxillaria oder Jugalia) bezeichnet werden und wohl in die Reihe der unter der Augenböhle meist reichlicher vertretenen Hautknochen gehören. 
Daß das Maxillare bei Lepidosteus aus zahlreichen (bis 15) hintereinander gereihten Knochenstückchen zusammengesetat ist, hängt wohl mit der starken Verlängerung der Schnauze zusammen.

Die Längenentwicklung der beiden Kieferknochen geht in allgemeinen parallel mit der der Schnauze. Der Oberkiefer ist gewöhnlich länger als der Zwischenkiefer, doch kann er auch bedeutend hinter ihm zurückbleiben, ja fast verkümmern. Nicht selten rückt sein vorderer Teil auch unter den Zwischenkiefer und nimmt dann an der Bildung des Mundrands nicht mehr teil. Beide Knochen sind gewöhnlich mehr oder weniger beweglich und zahntragend, doch beschränkt sich die

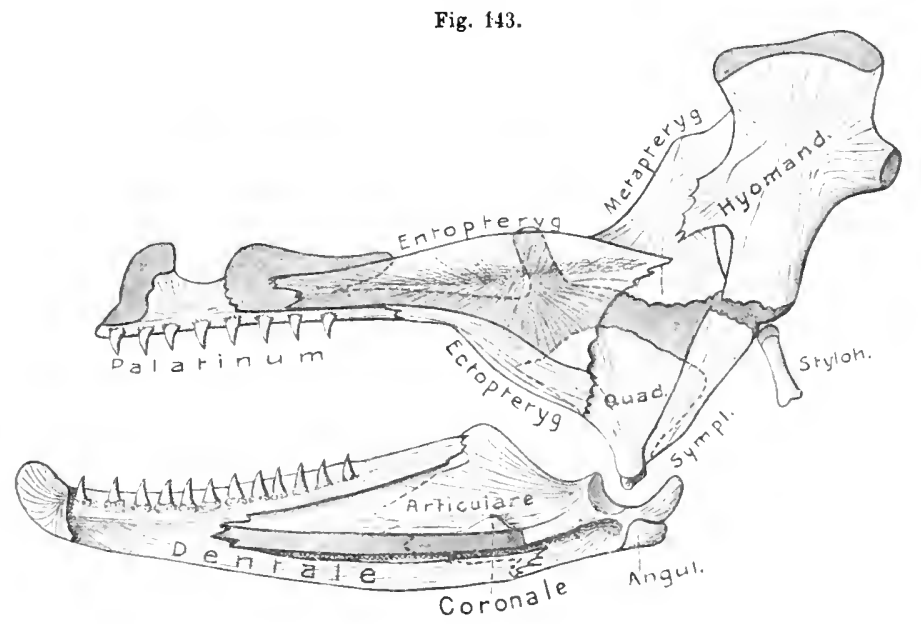

Salmo balar. Rechter Kieferbogen und HJomandibulare von Medialseite. Kinorpel dunkel, Knochen hell

Bezahnung nicht seiten anf die Prämaxillen. Bei den Plectognathen verwachsen Zwischen- und Oberkiefer miteinander.

Der Mandibularknorpel des Kieferbogens verknöchert gieichfalls teilweis und bildet den Unterkiefer, welcher am Quadrat gelenkt. Stets bleibt aber ein bedeutender Rest des knorpeligen Unterkicfers erhalten und wird als Meckelscher Knorpel bezeichnet (Fig. 143). Die geringfügige Ersatzknochenbildung, die schon bei den Chondrostei im Symphysenteil des Kieferhogens vorkommt, erhält sich such bei gewissen Knochenganoiden noch selbständig (Mentomandibulare); bei den Knochenfischen scheint sie stets in das gleich zu erwähnende Dentale eingegangen zu sein.

Án der Gelenkstelle des Unterkiefers tritt uberall ein Ersatzknochen auf, mit dem sich jedoch, wie es scheint, noch eine IJantverknöcherung vereinigen kann, die sich bei gewissen Physostomen sogar im Alter gesondert erhält. Der so entstehende Knochen ist das Articulare (Fig. 142, 143). Im ventralen hinteren Winkel des Unterkiefers entsteht als Ersatzknochen das sog. Angulare, das sich verschieden weit nach vorn erstreckt; anch zuweilen am Gelenk teilnimmt. Der ansehnlichste Unterkieferknochen ist das schon den Knorpelganoiden zukommende Dentale. Es umscheidet die vordere Region des knorpeligen Unterkieferbogens völlig und 
erstreckt sich nach hinten bis zum Angulare und Articulare. Vorn scheint es sieh, wie erwähnt, mit einer Ersatzknochenbildung zu vereinigen. Auf der Innenseite bleibt das Dentale häufig unvollständiger und wird hier nicht selten durch einen Deckknochen, das Operculare (Spleniale) ergänzt. - An der hinteren Hälfte des Dorsalrands des knorpeligen Unterkiefers springt ein sog. Kron- oder Coronoidfortsatz mehr oder weniger empor, an welchen sich der Anziehmuskel des Unterkiefers heftet. An diesem Fortsatz tritt zuweilen ebenfálls eine Verknöcherung gemischter Natur auf, das Coronalc (oder Supraangulare), was schon bei Knorpelganoiden angedeutet war. Bezahnt ist gewöhnlich nur das Dentale, selten das Operculare(A mia, wo es auch aus mehreren Stiicken besteht).

Der Hyalteil des Zungenbeinbogens (s. Fig. 142B) besteht in der Regel aus zwei mittleren ansehnlichen Stiicken (Epi- und Ceratohyale); dem ersteren fïgt sich dorsal ein kleines stielartiges oberstes Stück an (Stylohyale), welches die Befestigung an der Innenfläche des Kieferstiels, zwischen Hyomandibulare und Symplecticum, bewerkstelligt (vgl. Fig. $142 \mathrm{~A}$ ). Das ventrale Hypohyale ist klein und besteht bei den Teleostei in der Regel ans zwei iibereinander liegenden Knöchelchen, die sich dem Basihyale anfügen.

Im Gegensatz zu den Knorpelganoiden ist ein System von Kiemenhantstrallen, analog den Kiemenstrahlen der Knorpelfische, am Zungenbeinbogen sehr entfaltet. Vom hinteren Rand des Hyale nnd des Kieferstiels entspringt eine deckelartige Hautfalte, die sich n̈ber die Kiemenspalten hiniberlegt und den sog. Kiemendeckel, sowie seine ventrale dïnuhäutige Fortsetzung, die sog. Kiemenhaut bildet. Letzterei sind zur: Stütze eine Anzahl verkuöeherter Kiemenhautstrahlen (Radii branchiostegi, Branchiostegalia) eingelagert (Deckknochen), die vom Ilinterrand des Epi- und Ceratohyale entspringen (Fig. $142 \mathrm{~B}$ ). Schon bei den Holostei finden sie sich z. T. (Lepidosteus und Amia) und dehnten sich bei den ausgestorbenen Vorläufern bäufig am Innenrand der Unterkiefer bis zur Symphyse, als sog. laterale Jugularplatten, in großer Zahl aus (Fig. 138*, S. 241). Arch die sog. Jugularplatten, die sich bei vielen Holostei paarig bis unpar (Amia) zwischen die Unterkiefer einschieben (Fig. 138 ${ }^{4}$ ) und vorn zuweilen noeh durch ein bis zwei kleinere ergänzt werden, gehören wohl in die Reihe der Branchiostegalia. Bei den Knochenfischen treten die Kiemenhautstrahlen regelmäßig, jedoch in sehr verschiedener Zahl auf, als bald mehr plattenförmige, bald mehr stabförmige Knochen.

Der über der Kiemenhaut liegende Kiemendeckel wird vou plattenförmigen Hantknochen gestützt, die vom Hinterrand des Kieferstiełs entspringen. Schon die Knorpelganoiden besitzen einen ansehnlichen solchen Deckknochen, das Operculure (Fig. 198, S. 327), das bei sämtlichen ïbrigen Ganoiden und Teleosteern wiederkehrt. Es ist stets der dorsalste der Opercularknochen und sehließt sieh dem hinteren Fortsatz des Hyomandibulare der Holostei (Fig. 136, 137, S. 239, 240) und Teleostei (Fig. 142) gelenkig an. Bei den letztereu Gruppen tritt iberall noch ein ansehnlicher Hautknochen, das Praeoperculare, hinzu, weleher sich als bogenförmiges Gebilde dem Ilinterrand des Kieferstiels in ganzer Länge anfụgt und so gewissermaßen zu einem Tragapparat für die sieh ihm hinten anschließenden übrigen Opercularknochen 
wird. Ventral an das Operculare, es auch z. T. unterlagernd, reiht sich gewöhnlich ein Suboperculare, und diesem sich ähnlich anfitgend ein Interoperculare, das daher den Ventralrand des Kiemendeckels bildet. (Andentungen dieser beiden Knochen können auch schon bei den Chondrostei vorkommen.) Das Interoperculare besitzt $z$ weilen große Ähnlichkeit mit den obersten Kiemenhautstrahlen und dïrfte daher auch als ein emporgerïckter derartiger Strahl gedentet werden: wie denn die gesamten Opercularknochen (mit Ausnahme des Prïoperculare) und die Kiemenhautstrahlen ursprïnglich eine zusammenhängende Reihe von Hautknochen bildeten (s. Fig. $138^{3}$, S. 241). - Bei gewissen Knochenfischen wird aber das Kiemendeckelskelet mehr oder weniger rïckgebildet, namentlich fehlt das Interoperculare zuweilen ganz (z. B. Welse u. a).

Die fün Kiemenbogen (Fig. 142 B, 144) sind ziemlich eitförmig gebaut und denen der Knorpelganoiden ähnlich. Sie liegen dicht znsammengedrängt unter der hinteren Schädelregion, da die Kiemenspalten sebr schmal geworden und dicht zusammengerïckt sind. Znweilen (Apodes) rïcken sie caudalwärts iuber den Schädelteil hinans. Nach hinten verkleinern sie sich, und der fünfte Bogen ist stets stark rïckgebildet, so daß er jederseits nur aus einem einzigen Stiick besteht, das nicht mehr bis zur Dorsalseite reicht. Da diese Stiicke gewöhnlich Zähne tragen, welche sich in der Ventrawand des Schinndanfangs entwickeln, so werden sie meist als untere Schlnndknochen (Ossa pharyngea inferiora) bezeichnet. Gelegentlich (Pluaryngognathen) verwachsen sie miteinander. Reste der Dorsalsiuke des fünften Bogens scheinen sich jedoch gelegentlich zu crhalten.

Die Kiemenbogen, welche eimheitlich knorpelig angelegt werden, sondern sich bei der Verknöcherung in mehrere Stücke. Die drei ersten erhalten so, wie die Selachierbogen, gewölnnlich vier Stïcke. Sie werden anch hier von der Dorsal-zur Ventralseite als Pharyugo-, Epi-, Cerato- mu Hypobranchialia bezeichnet. Dem

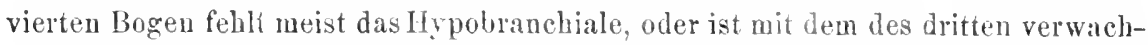
sen. Am mannigfaltigsten gestalten sich die Dorsalstiicke Pharyngobranchialia, auch obere Schlundkuochen genanzt, die fast stets in der Längsrichtung sehr dicht zusammengedrängt und häufig zahutragend sind. Auch diebeiderseitigen Pharyngobranchialia treten unter dem Schädel nalue zusammen. - Zuwcilen sind alle vier noch völlig gesondert, oder nur das dritte und vierte verschmolzen. Hänfig verwachsen sie jedoch jederseits bis zu einem einzigen Knnchen Os pharyngenm superius). Die Bezahnug kann sich auch ant die Epibranchialia mo noch weiter ausdehnen.

Bei den Kuochenfischen trägt die Haut anf ler Vorder- und Hinterkante der nach der Mundhöhle schauenden Kiemenbogentläche fast stets eine lieihe warzen- bis kegelförniger oder sogar langstachelartiger Fortsätze ( $50 g$. Siebfortsütze). Dieselben ragen in den Eingang der Kiemenspalten hinein und geben ihnen eise mehr oder weniger siebfümige Beschaffenheit. Die Fortsätze enthalten eine sie stützende Bindegewebsverknöcherung, die jedoch mit den knöchernen Kiemenbogen nicht in Verbindung oder Verwachsung tritt. Sehr gewöhnlich trägt diese Verkiöcherung Zähnchen, welche ïber die Schleimhaut der Kiemenbogen etwas, zuweilen sogar langborstenartig vorspringen.

Die Reihe der Copulae (Fig. 142 B, 144) wird einheitlich angelegt und sondert sich erst später in eiue Anzahl Knorpelstiucke. Das vorderste (Basihyale) verbindet 
die beiden Hypohyalia des Zungenbeinbogens; eine Ersatzverknöcherung tritt in ihm häufig auf. Nicht selten ist das Basihyale stark rückgebildet; bei vielen Knoch." ischen und Lepidostens aber auch zu einem weit uber den Zungenbeinbogen nach vorn vorspringenden Fortsatz entwickelt, der Zähne tragen kann und den Zungenwulst stutzt (Fig. 144). Dies sog. Glossohyale (Os entoglossum) wird zuweilen als Repräsentant einer Kieferbogencopula angesehen, die mit dem eigentlichen Basibyale verwachsen sei.

An dem folgenden knorpeligen Copulastück bilden sich in der Regel einige knöcherne Copulae aus (zwei bis drei), die sich zwischen die Hypobranchialia der drei ersten Kiemenbogen einschieben. Der darauf folgende Teil der Copulaanlage bleibt gewöhnlich knorpelig. - Bei gewissen Teleosteern verkümmert der Copularapparat so stark, daß die meisten Kiemenbogen ventral frei endigen (z. B. Lophius).

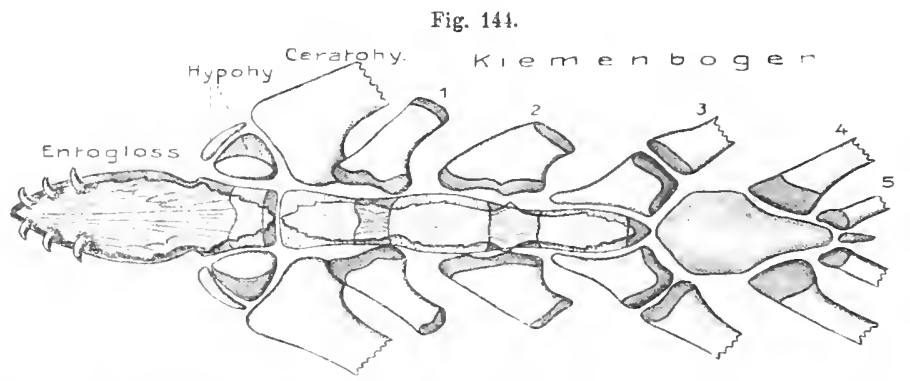

Sal mo salar. Copularapparat des Visceralskelete mit dem Ansatz der Visceralbogen, von der Dorsalseite. Knorpel dunkel, Ersatzknochen der Copulae punktiert, Deckknochen hell. E. W.

Die Verkıöcherungen des Branchialapparats sind Ersatzknochen. Wenn sich jedoch Zähne mit thnel verbinden, so gesellen sich dem ursprünglichen Frsatzknochen meist noch Hautknochen hinzu, welche jene tragen. Es läßt sich sogar nicht selten die doppelte Herkunft der beiderlei Knochen noch deutlich erkennen, da sie nur oberflächlich oder nicht rerwachsen sind (Fig. 144).

Dem Basihyale, bzw. den Hypohyalia, schließt sich bei den Krochenfischen ventral ein eigentümlich vertikalplattenförmiger bis mehr horizontal abgeplatteter Knochen an (sog. Znugenbeinstiel, Carina, Urohyaie), der den von hinten zam Hyalbogen ziehenden Maskeln (Coracohyoidei) Ansatz bietet und daher wohl eine Sehnenverknöcherung darstellt (Fig. 142).

Bei Polypterus finden sich an seiner Stelle zwei Knöchelchen, woraus auf eine ursprünglich parige Anlage des Urohyale geschlossen wird.

Visceralapparat der Dipnoer. Wie schon erwähnt, gelenk乞 der Unterkiefer der Dipnoer (Fig. 145) weit vorn direkt am Schädel. Diese Autostylie beruht auf der Verwachsung des knorpeligen Palatoquadrats mit dem Primordialcranium. Eine beträchtliche Vorwärtsverlagerung des Unterkiefergelenks ist auch bei gowissen Holostei (Lepidosteus) eingetreten und rief hier eine starke Verlängerung des Kieferstiels (besonders des Symplecticums) hervor. Die Frage, ob nur das Palatoquadrat oder auch der Hyomandibularabschnitt des zweiten Bogens mit dem Primordialcranium vereinigt ist, scheint auch für die Dipnoi unentschieden, denn 
die als Reste eines Ilyomandibulare gedeuteten Skeletteile sind recht unsicher, wie denn überhaupt in der vergl. anatomischen Deutung der Verknöcherungen des Dipnoerschädels noch erhebliche Widersprüche bestehen. Gesichert erscheint, daß der, jederseits an der Ventralseite des Knorpelschädels, von der Gelenkstelle des Unterkiefers bis zur Nasenregion ziehende Knochen einem Palatopterygoid entspricht, d. h. den bei den Holostei durch das Palatinum und die Pterygoide repräsentierten Verkaöcherungen. Beide Palatopterygoide stoßen in der Nasenregion zusammen und tragen dort große Zahnplatten. In der Schädelregion, welche etwa dem Kieferstiel und Quadrat entspricht, tritt eine Verknöcherung auf, die bald als Quadrat, bald als Squamosnm oder als Operculum (s. Fig. 145) gedeutet wird. Ihr Distalende

Fig. 145.

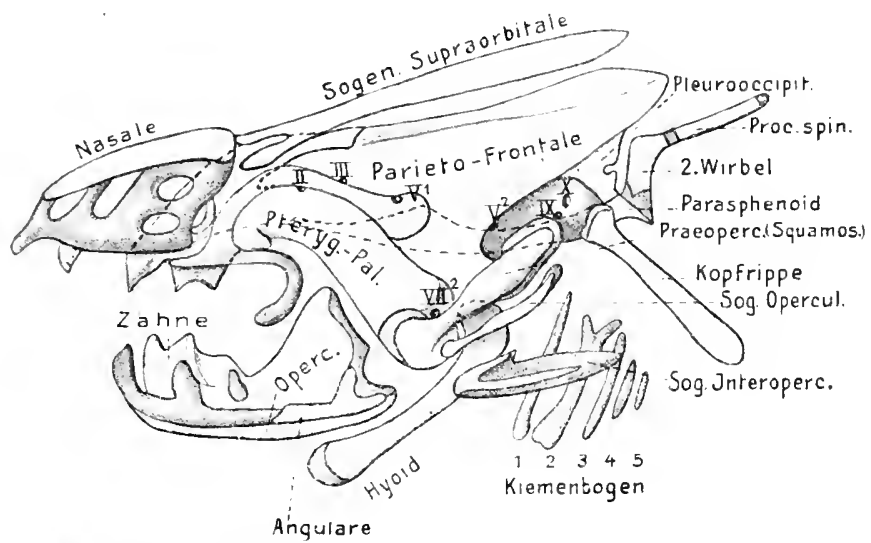

Lepidosiron parsdoxa. Schädel von links. Knorpel donkel, Knochen hell. Die punktierten Linien, die von dem ganz hinten sichtbaren Parasphenoid ausgeben, geben dessen Ausdehnung nach vorn an der Unterseite des Schảdele an. Ebenso die beiden, vom vorderen eichtbaren Ende des Pterygopal. (Palalopterygoid) arsgehenden, dessan weitere Ausdehnnng nach vorn und oben. (Nach BaIpGe 1998.) E. W.

bildet den Gelenkhöcker fur den Unterkiefer. Da es sich aber um einen Deckknochen zu handeln scheint, so ware er anch eventuell dem Präoperculum der Fische, oder dem sog. Paraquadrat (Squamosum) der Amphibien zu parallelisieren; die Vergleichung mit dem Schädel der Holostei scheint namentlich hierfür zn sprechea. Die Mandibol wird hauptsächlich von einem als Operculare gedeuteter, die Zâhne tragenden Hautknochen und einem Angulare gebildet; cin Articulare scheint ganz zu fehlen.

Der übrige Visceralapparat ist relativ stark rückgebildet. DerHyalbogen $\mathbf{z}$ war ist ziemlich kräftig und teilweise verknöchert, besteht jedoch nur bei Coratodus noch aus einigen Stücken; sonst ist er eisfach. Dorgal befestigt er sich durch Band am Parasphenoid. An seinem oberen Hinterrand trägt er einen teilweise von Knochen überzogenen Knorpelstrahl (sog.Interoperculum); ein ähnlicher(Operculum) entspringt etwas darubber vom Hinterrand des sog. Qnadrats. Die Deutung dieser Teile als Interoperculam und Operculum scheint nicht völlig sicher, ist aber doch wohl möglich wegen der reicheren Knochenentwicklung der paläogenen Formen. Die fünf eigentlichen Kiemenbogen, sowie der Copnlarapparat sind jedenfalls stark vereinfacht. 
Bei Ceratodus sind der erste bis vierte dreigliederig; bei den Dipneumona dagegen alle eingliederig und immer knorpelig. Copulae fehlen den Dipneumona völlig; bei Ceratodus finden sich ein Basihyale und Reste von Basibranchialia. Sowohl bei Ceratodus als Protopterus wurden Rudimente eines sechsten Kiemenbogens beschrieben, doch ist ibr Nacbweis bis jetzt nicht gesichert, eher sogar unwahrscheinlieh.

Beziehungen des Fischschädelszu den vordersten Wirbeln der Wirbelsäule. Schon früher wurle betont, daß bei den Fischen ein fester Anscbluß des Schädels an die vordere Wirbelsäule nützlicb erscheint. Es kann bei vielen sogar zur Vereinigung einiger vorderster Wirbel mit des Occipitalteil des Schădels kommen. Unter den Haien findet sicb bei Mustelus die Vereinicing des vordersten Wirbels mit dem Hinterhauptsabschnitt, bei Carcharias eine Überwachsung der vordersten Wirbel durch die caudalwärts verlängerte Occipitallegion. - Charakteristisch für die Chondrostei (speziell Acipenser) ist die völlige V'erschmelzung der krorpeligen Occipitalregion mit den sechs vorderen Wirbelelementen, die einen hinteren einheitlichen Anhang der Schädelbasis bilden und von einem Caudalfortsatz des Parasphenoids unterlagert werden (s. Fig. 131, 132). - Die Holostei zeigen ähnliches, jedoch in geringerem Maße. So besitzt Amia (Fig. 137) zwei vorderste rudimentäre Neuralbogen de: Wirbelsäule, welche dem stark caudalwărts verlängerten Basioccrpitale aufsitzen, und der Rand des Foran. magnum läßt erkennen; daß noch ein vorderster dritter Bogen mit den Pleurooccipitalia vereinigt ist. Bei Lepidosteus und Polypterus läBt sich nur ein solch rudimentärer Bogen zwiscben Pleurooccipitale und erstem vollständigen Wirbel erkennen. Bei Lepidosteus wnrde jedoch ontogenetisch erwiesen, daß die drei ersten Wirbel, Körper samt Bogen, in die Occipitalia eingehen.

Die Dipnoi zeigen ähnliche Verhältnisse durch Angliederung von ein bis zwei rudimentären Neuralbogen an die hinterste Occipitalregion des Knorpelschädels (s. Fig. 145), so $\mathrm{da}$, wie es auch die Ontogenese ergibt, etwa dasselbe Verhalten wie bei Amia vorliegt. Im Zusammenbang damit stebt das Auftreten eines rippenartigen Anhangs (Kopfrippe) jederseits an der basalen Hinterhauptsregion dieser Fische, welcher zur Befestigung des Schultergürtels dient. Daß es sich wirklich um eine Rippe handelt, ist sebr wahrscbeinlich; doch entspringt sie bei den Dipneumona weiter vorn, in der Region der Pleurooccipitalia, die den Neuralbogen entsprechend, als einem vordersten Wirbel angehörig aufgefaßt werden, wegegen die Kopfrippe ron Ceratodus zom zweiten der zugetretenen Wirbel gebört.

Feste Vereinigung eines bis mehrerer vorderster Wirbel mit der Hinterbauptsregion kommt auch bei Knochenfischen nicht selteu vor, so bei Gadidae (s. Fig. 135) u. a. Äbnlich wie bei Knochenganoiden schiebt sich ein rudimentärer erster Neuralbogen bei manchen Physostomen (Esox, Salmo) auf das Basioccipitale, ja Pleurooccipitale vor.

Wie S. 237 geschildert, wird bei den Cyprinoiden das Foram. magnum von einem Bogen umschlossen, neben dem sich rechts und links noch eine ansehnliche Öffnurig im Pleurooccipitale findet; anch dieser Bogen ist wabrscheinlich ein mit dem Occipitale verwachsenes vorderstes Neuralbogenrudiment.

\section{Schädel dertetrapoden Vertebrata.}

Der Schädel der Tetrapoden zeigt eine Anzahl gemeinsamer Eigentümlichkeiten. Die wichtigste ist die schon bei den Cyolostomen und gewissen Fischen bestehende Autostylie, die Verwachsung des Palatoquadrats mit der Labyrinthregion des Schädels. Da sich die Dipnoi auch in ibrer sonstigen Organisation den luftatmenden Tetrapoden nähern, so scheint die Annahme berechtigt, daB die Antostylie der letzteren von dipnoerähnlichen Vorfahren ererbt wurde. - Eine weitere Eigentïmlichkeit ist die stete Bildung von Gelenkköpfen am Hinterhanpt, was wir seither fast nur bei gewissen Chondropterygiern fanden. Im Gegensatz zu den 
Fischen mit l'eich verknöchertem Schädel gilt ferner für alle Tetrapoden die einfachere Verknöcherung des Pterygopalatinfortsatzes des Palatoquadrats, der fast stets von nicht mehr als zwei Knochen ersetzt wird, einem hinteren Pterygoid und einem vorderen Palatinam; anch dies verrät Beziehungen zu den Dipnoern und den Ganoiden. Da die an der Stelle des Palatoquadrats anftretenden Knochen, sowie die Kieferknochen, sich dem eigentlichen Schädel viel inniger anschließen als bei den Fischen, so werden wir sie künftig gemeinsaim nit der Schädelkapsel besprechen; sie bilden, samt dem sich ihnen anschließenden Vomer, den sog. Fiefergaumenapparat, der das Mundhöhlendach formiert.

Die Frage nach dem Verbleib des Hyomandibularteils (Kieferstiels) der Fische bei der Autostylie der Tetrapoden wird gewöhnlich dahin beantwortet, da $\dot{B}$ nur das Palatoquadrat mit dem Primordialcranium rereinigt sei, das Hyomandibulare dagegen unter starker Reduktion zu dem Gehörskeletgebiłde, der sog. Columella, wurde. - Wie schon früher für die betreffenden Fische dargelegt wurde, halte ich die gegenteilige Meinung für wahrscheinlicher, nach der auch das Hyomandibulare mit dem Schädel sich rereinigte und den sog. Suspensorialteil des Palatoquadrathnorpels bildete.

\section{Amphibien.}

Der Schädel schließt sich durch eine Reihe primitiver Merkmale dem der ursprünglicheren Fische am meisten an. Zunächst ist die in der Regel sehr ausgiebige Erhaltung des knorpeligen Primordialeraniums im erwachsenen Zustand hervorzuheben. Bei Urodelen, Anuren und den fossilen Stegocephalen ist dies sehr ausgeprägt; bei den fußlosen Gymnophionen tritt dagegen der Knorpel am stärksten zurück. - Ein phylogenetisch alter Charakter liegt feruer darin, daß in den Hinterhauptsabschnitt keine auf den N. vagus folgenden spinooccipitalen Spinalnerven einbezogen sind, $\mathrm{da} B$ daher, soweit sich erkennen läßt, nichts für den Anschluß von hintel dem Vagus folgenden Wirbeln an die ursprüngliche Hinterhauptsregion spricht; der hiermit gegebene Zustand des Schädels erscheint also ursprünglicher als der der meisten Chondropterygier und übrigen Fische. — Die Schädelhöhle erstreckt sich nach vorn bis in die Ethmoidalregion, so daß ein Orbitalseptum fehlt; ein gleichfalls primitiver Charakter, der an die Urfische anknüpft.

Die relative Armut des Amphibienschädels an Ersatzknochen erinnert an die Dipnoer und Ganoiden. Die Deckknochen nehmen daher durch ihre Entfaltung großen Anteil am Aufban des knöchernen Schädels der recenten Amphibien. Bei der ausgestorbenen ältesten Gruppe, den Stegocephalen, waren sie aber auf der Schädeloberfläche als eine kontinuierliche Decke in so großer Zahl entwickelt, daß dies lebhaft an die Verhältnisse der Knorpel- und Knochenganoiden erinnert. Aus allem dürfte hervorgehen, daß der Ursprung des Amphibienschädels auf recht alte Vorfahren hiuweist, aus welchen auch die Ganoiden und Dipnoer hervorgingen, ja die sogar vielleicht Beziehungen zu den Cyclostomen besaßen.

Ans der Entwicklung des Primordialcraniums sei nur erwähnt, daß die Chordaspitze, welche in der knorpeligen Schädelbasis zwischen die, mit den Parachordalia verschmolzenen anzehnlichen Ohrkapseln hineinragt, allmählich ganz rïckgebildet wird, zuweilen unter Verknorpelung. Zwischen den beiden nach vorn 
ziehenden Trabekeln bleibt bei Urodelen und Gymnophionen ein weites Fenster offen, das bis in die Nasenregion reicht (Fig. $147 A, B$ ); bei den Anuren wird es später durch Knorpel basal abgeschlossen. Im Anschlnß an die Vorderenden der Trabekel, die sog. Trabekelhörner, bildet sich das knorpelige Skelet der Nasenkapseln, welches sehr kompliziert wird. - Der Palatoquadratknorpel legt sich in der Ohrregion selbständig an und, im Anschluß an ihn, auch die knorpelige Mandibel (Meckelscher Knorpel). - Das proximale Ende des Palatoquadrats, in welchem wir den Kieferstiel der Fische erblicken, tritt hierauf durch mehrere Fortsätze mit der hinteren Trabecularregion (aufsteigender Fortsatz) und der Ohrregion (Ohr- und Basalfortsatz) in Kontinuität. - Den Gymnophionen fehlt eine solche Verbindung des knorpeligen Palatoquadrats mit dem Schädel, und bei gewissen Urodelen kann nachträglich wieder eine gelenkige Abgliedernng eintreten.

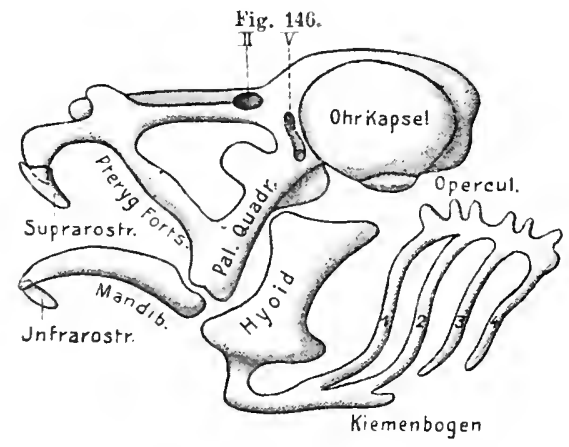

Rana fusca. Knorpelsebädel und Visceralbogen ler Larve; von der linken Seite. (Nach PARker 1572.)

Fast stets wächst aus dem mittleren Vorderrand des Palatoquadratknorpels ein gegen die Nasalregion gerichteter Fortsatz hervor, der dem Palatopterygoidfortsatz der Fische entspricht (s. Fig. 146, 147). Er reicht gewöhnlich bis in die Ethmoidalregion, obne sich jedoch mit dem der anderen Seite za verbinden, verbält sioh also wie der der Knochenganoiden und Knochenfische. - Bei den Anaren verwächst sein Vorderende mit der seitlichen Ethmoidalregion(Fig.146). Der Palatopterygoidfortsatz der Urodelen hingegen verrät deutlich einen Verkümmerungszustand, da seine Verbindung mit der Ethmoidalregion nur ausnahmsweise (Ranodon) noch erhaiten ist, obgleich sie den alten Stegocephalen jedenfalls in anurenartiger Ausbildung zukam. Der Fortsatz endigt daher bei den Uroảelen vorn frei. Zuweilen hat sich sogar sein Zusammenhang mit dem vom Schädel absteigenden Teil des Paiatoquadrats (Suspensorinm) gelöst (Fig. 147 A, B), und endlich (Perennibranchiata) verkümmert er sogar völlig.

Besondere Verhältnisse zeigt das Palatoquadrat samt Suspensoriun bei den Anurenlarveu, Verhältnisse, welche größtenteils auf einer besonderen Anpassung des Larrenmunds mit seiner Hornbekleidung beruben dürten, die aber vielleicht doch auf sehr alte Beziehungen der Amphibienvorfahren zu den Cyclostomen linweisen könnten. Der ansehniche Palatoquadratknorpel der Anuren steht ursprünglich in einer ähnlichen binteren Verbinđung mit der Ohr- und Trabekelregion, wie sie vorhin beschrieben wurde und die sich bei den Urodelen in allgemeinen dauernd erhält. Sehr frühzeitig vereinigt sich jedoch sein Vorderende mit der vorderen Trabekelregion, so daß das Primordialcranium in diesen Zustand dem der Cyclostomer ähnlich wird (Fig. 146). Hierauf gliedert sich vom Palatoquadrat ein kleines Stück $a b$, welches sich mit dem der anderen Seite ventral von der Nasenregion rerbindet, indem sich ron ihm gleichzeitig jederseits noch ein distalstes Stück abtrennt (Infrarostralia). Die er:terwähnten Stücke sind die kleinen Mandibulae (Meckelscher Knorpel), welche durch die beiden Infrarostralia in der Symphyse vereinigt werden. Im Anschluß an die Ethmoidal- 
Fig. 147.
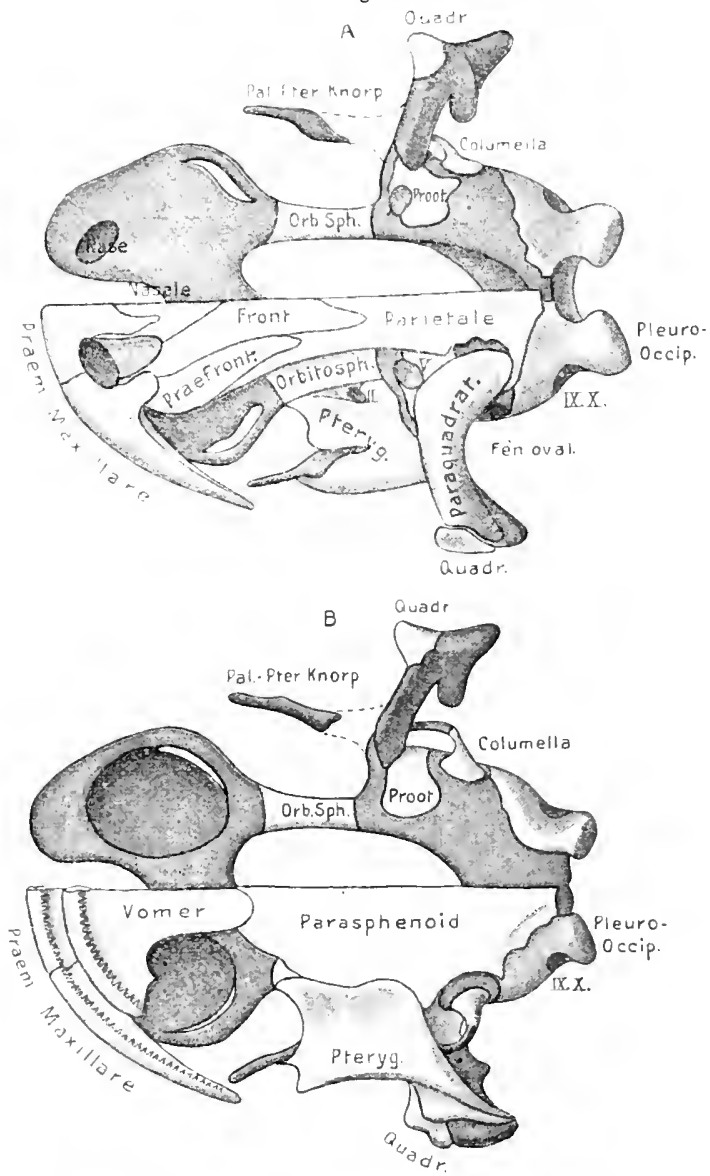

Nas Frorir. C I Faraquadr. Columell

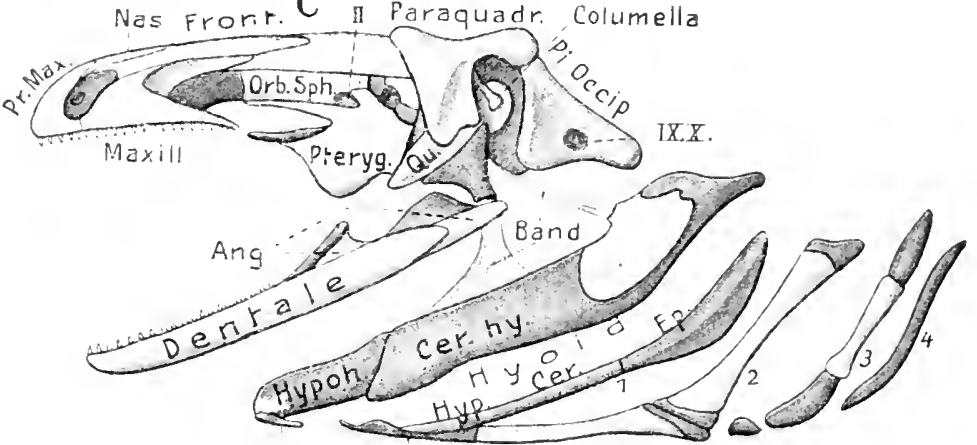

Basih. region haben sicb schon früher selbständig zwei über den Infrarostralia gelegene Suprarostralia gebildet, gewissermaßen dieknor peligen Oberkiefer des Larvenmunds. Diese Infra- und Suprarostralia lassen sich vielleicht von den hinteren Lippenknorpeln der Haiflsche ableiten. Auf die geschilderte Weise ist bei den Anurenlarven die Gelenkstelle des Palatoquadrats für die Mandibel bis in die Ethmoidalregion vorgeschoben, stärker als dies bei Fischen irgend der Fall war; am äbnlichsten noch mit den Einrichtungen der Holocephalen. Es dürfte daher auch der ansehnlichste Teil dieses Palatoquadrats dem Hyomandibulare (Kieferstiel, Suspensorium) der Fische entsprechen.

Erst bei der Metamorphose wächst aus dem Vorderrand der vorderen Verbindung des Palatoquadrats mit der Ethmoidalregion der eigentliche bleibende Palatopterygoidfortsatz allmählich hervor, wobei sich die frühere vordere Verbindung mit dem Schädel löst und der ganze dahinter gelegene Abschnitt des

\section{Básibr. I}

Mi enopoma alleghaniense. Knorpel blau. A Schädel von der Dorsalseite; von der rechten Hălfte sind die Deckknochrn eutfernt. b' Schädel von der Ventralseite, anf det liaken Hälfte dif Deckknochen. entfernt. Der ursprāngliche Zusaramenbang des Palatopterygoidlinorpels mit dem Quadratknorpel punktiert angedeatet $C$ schüdel mit Visceralskelet von links. (Nach WIErksheiN In77.) 
Palatoquadrats durch das starke Auswachsen des Unterkiefers immer mehr nach hinten zusammengedrängt und reduziert wird, sowie gleichzeitig seinen Zusammenhang mit der Obrregion wesentlich verändert. So bildet sich schließlich die Konfiguration des bleibenden Primordialcraniums der Anuren aus (s. Fig. 148), wo der Suspensoriaiteil etwas schief nach hinten gerichtet won der seitlichen Ohrregion entspringt und der ansehnlich ausgewachsene Palatopterygoilfortsatz sich vorn in der hinteren Nasenregion mit dem Schädel verbindet.

Bei der Mehrahl der Urodelen und den Gymnophionen zieht das Suspensorium dagegen von seinem Ursprung in der Ohrregion mehr oder weniger schief rach vorn, so daß die Gelenkstelle für hen Kiefer bis in die Mitte des Schädels vorgerückt sein kann (besonders Perenmibranchiaten) und die Mandibel kurz bleibt. Bei Derotremen und Salamandrinen ist dies weniger ansgesprochen die Richtung des Suspensoriums zum Teil schon ähnlich wie bei Aen Anuren. - Obgleir mn auch das Suspensorium der Stegocepbalen sich anurenartig erhält, so dïrfte doch die Vurwärtsrichtung das Ursprünglichere sein, wofür ja auch die Ontogenie der Ariuren spricht.

Ersatiknorken treten, wie erwähnt, in geringer Zahl auf, ähnlich den Dipnoern. Wie bei diesen finden wir im Hinterhaupt nor die beiden Pleuroocipitalia, von welchen jedes einen Gelenkhöcker (Condylus) bildet. Im erwachsenen Schädel sind sie meist so ansehnlich, daß sie ventral und dorsal nur von wenig Knorpel getrennt werden. - In der lateraleu vorderen Ohregion findet sich ein Prooticu., (auch Petrosum genannt), das seitlich eine ziemlich große Öffnung, die sog. Fenestra ovalis, besitat, die jedoch bei geringer Entwicklung des Prooticum im Knorpel zwischen diesem und dem Pleurooccipitale liegt. Bei den ichthyoden Urodelen, einigen Salamandrinen, sowie den Anuren bleibt das Prooticum gewŏhnlich gesondert vom Pleurooeeipitale seiner Seite; bei den meisten Salamandrinen verwächst es dagegen frühzeitig damit. Bei den Gymnophionen endlich verwachsen die so vereinigten ()tooccipitalia in der ventralen Mittellinio zu einem einheitlichen Basalknochen Fig. 149/, mit dem sich auch das vorn, auf der Ventralseite entstehende große Parasphenoid vereinigt. So wird hier eir beträchtlicher Teil der Schädelhöhle von dem ansehnlichen Basalknochen umschlossen.

In der vorderen Schïdelbältte (Angenregion) verknöchern die unvereinigten beiden Trabekel der Urodelen jederseits bis zum Beginn der Nasenregion (Fig. 147). Diese beiden Knochen werden gewöhnlich Orbitosphenoide genant und mit den ähnlich gelagerten gleichnamigen der. Fische verglichen. Im allgemeinen dürfe dies anch zutreften. - Die Anuren (Fig. 148) bilden in dieser Gegend zaerst gleichfalls eine parrige Verknöcherung, welche jedoch, basalwärts uud in die Nasenregion weitergreitend, durch Verwachsung unpaar wird (sog. Gürtelbein).

Das Ihntin gelagerte mpare sog. Ethmoid der Gymmophionen ist wohl sicher homolog dem nuparen Urbitosphenoid der Anuren, jedoch komplizierter gebaut. Ob sich erentuell anch das l'lenrethmoid der Fische an der Bildung der sog. Orbitosphenoide der Amphibien beteiligt, ist fraglinh.

the Tptiknothen sind bei der spärliehen Entwicklung der Frsatzknochen sohr ansehnlich, jedoch bei den rezenten Amphibien stark reduziert, wio die Vergleichng mit den vorausgegangenen Stegoeephalen ergibt. - Vie Schädeldecke der Urodelen und Anuren wird von großen Parietalia und Frontalia gebildet Fig. $1474,148.1)$, von welchen die letzteren bis in die Nasenregion reichen. 
Hier schließen sichibnen zwei Nasalia an, die nur selten fehlen. Die Reihe wird endlich vorn durch die beiden Prämaxillen abgeschlossen, welche ähnlich denen mancher Fische aufsteigende Fortsätze gegen die $\mathrm{Na}$ salia entsenden, Sekundärer Natur ist die Verwachsung der beiderseitigen Parietalia und Frontalia der Anuren zu sog. Parietofrontalia (Fig. 148).

In der vorderen $\mathrm{Or}-$ bitalregion des Urodelenschädels tritt neben dem Frontale meist ein Deckknochen auf, welcher den Vorderrand der Orbita umzieht, das sog. Präfrontale(Fig. 147 1); er findet sein Homologon wohl in dem ähnlich bezeichneten Knochen vielerGanoiden(s.Fig.136, 137). Auch den Gymnophionen (Fig. $149 \mathrm{~A}, \mathrm{C}$ ) kommt er zu; fehlt dagegen den Anuren.

Etwas vor dem Präfrontale, zwischen ihm und den Oberkiefer, schiebt sich bei gewissen Salamandrinen noch ein kleines Deck-

Rana fusca. Schädel. Knorpel blau. A Schádel von der Dorsal seite. Die Deckknochen der rechten Hālfte entfernt. $B$ Schădel inVentralansicht, ron der linken Hâlfte sind die Deckknochen mit Ausnahme des Parasphenoids entfernt. Sehs̄del von links. Dí Aasdehnung der Schādelhōhle ist durch eine punktierte Linie angedentet. E. W.
Fig. 148.
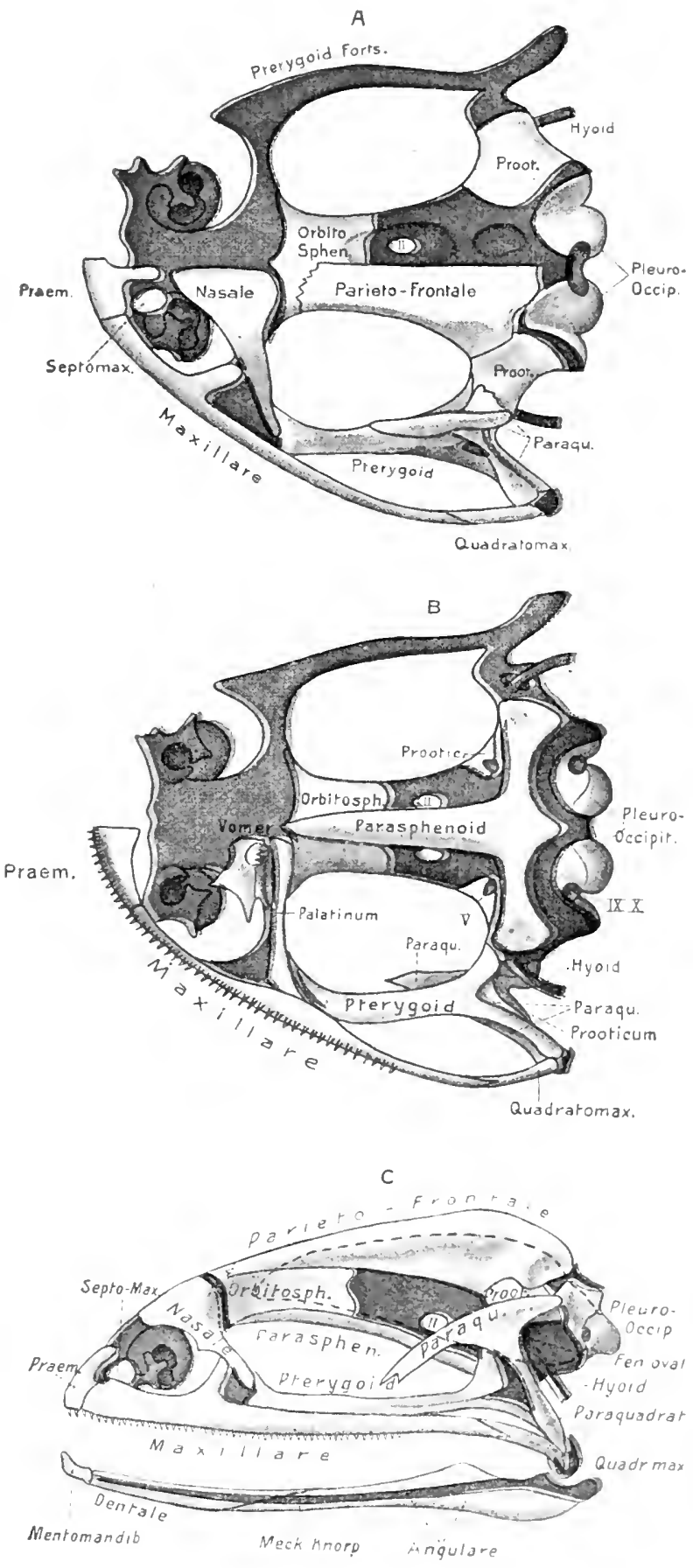
knöchelchen (selten zwei) ähnlicher Herkunft ein, das als vorderes Präfrontale oder Lacrimale bezeichnet wird, da es Beziehungen zum Tränennasengang besitzt.

Ein kleiner Deckknochen, der bei dell Anuren in der Nasenhöhle und der Umgebung des Tränennasengangs, zwischen dem oberen und mittleren Nasenblindsack, auftritt, wird gewöhnlich als Septomaxillare bezeichnet. Auch bei einigen Salamandrinen soll sich ein entsprechendes, oberflächlicheres Knöchelchen finden, und ebenso wird ihm ein ähnlich gelagerter

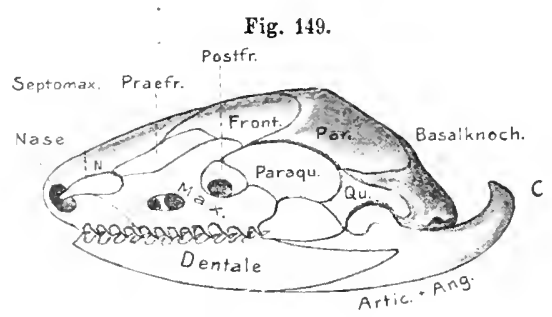
Knochen der Gymnophionen (s. Fig. $149 A, C$ ) verglichen. Bei letzteren kann er zuweilen mit Nasale und Präfrontale verschmelzen.

Die Orbita der Gymnophionen wird ferner von einem über ihr liegenden kleinen Deckknochen umfaßt. Ob er richtig als ein Postfrontale, wie wir es bei den Stegocephalen antreffen, gedeutet wird, steht d hin.

Die ventrale Schädelfläche der Urodelen ist von einem meist recht mächtigen Parasphenoid unterlagert (Fi-

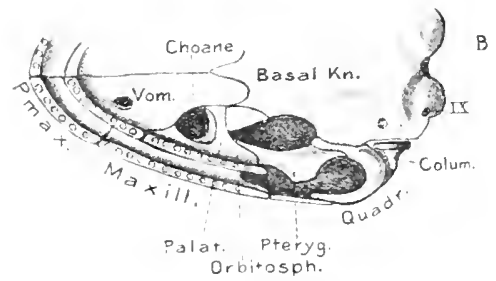
gur $147 B$ ), das als breite Platte von der Hinterhaupts-bis in die Nasenregion reicht. Bei den sog. lechriodonten Salamandrinen trägt es zwei Zahnreihen, welche dic beiden Reihen der Vomerzähne nach hinten fortsetzen. - Das ansehnliche Parasphenoid der Gymno-

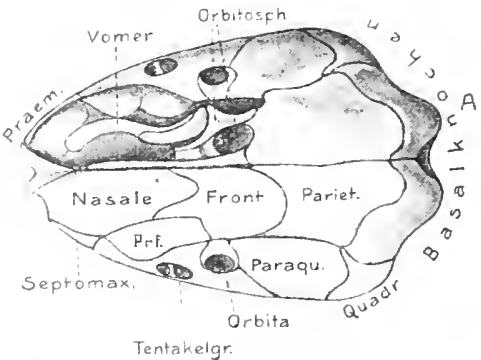

I c h thryophis glatinosus. Seltadel. Nach SARAis Is90.) A Schädel von der Torsalseite. In der rechten Hälfte Nasale, Präfrontale ind Frontale ent fernt. $B$ Schädel in Ventralansicht. "Sihädel von links. phionen ist, wie erwähnt, in den sog. Basalknochen aufgenommen worden. Das der Anuren (Fig. 148B) bleibt schmäler und entsendet hinten seitliche Fortsätze gegen die Ohrregion und den Ursprung des Suspensoriums, in welchen wir die schon bei den Knorpelganoiden auftretenden Seitenfortsätze des Parasphenoids wiederfinden. Diese Fortsätze können denn auch in ZnsammenschluB mit den Verknöcherungen des Suspensoriums treten.

Vorn schließen sich dem Parasphenoid die parigen, fast stets zahntragenden Vomer an, welche bei den Urodelen und Gymnophionen groß, bei den Anuren weniger ansehulich sind. - Über die gelegentliche Verbindung des Vomer mit dem Palatinum wird gleich berichtet werden.

Fieforgaumenapparat. Als solchen bezeichnen wir die Verknöcherungen, welche im Bereich des Suspensorinms und des Palatopterygoidfortsatzes anftreten, samt den Zwischen- und Oberkiefern.

Als einziger Ersatzknochen entsteht im Suspensorium an der Gelenkstelle für den Unterkiefer ein Qnadrat, das bei den Urodelen (Fig. 147) fast stets ver- 
knöchert ist, aber klein bleibt, so daß es nur das Gelenkende des Suspensoriums bildet. Bei den Gymnophionen (Fig. 149) wird es ansehnlicher und schließt sich dem Basalknochen jederseits an. Eigentümlich verhalten sich die Annren, bei welchen zuerst in einem Band das rom Ende des Suspensoriums zum Oberkiefer zieht, eine Bindegewebsverknöchernng auftritt, die sich später bis anf den Knorpel des Suspensoriums ausdehnt und diesen ergreift. Der so entstehende Knochen, das sog. Quadratomaxillare (oder Quadratojugale, Fig. 148) amfaßt daher in seinem hinteren Teil sicher das Quadrat der Urodelen. Ob sein vorderer, nicht knorpelig vorgebildeter 'Teil als ein ehemals selbständiger Deckknochen anfgefaßt werden darf, der sich mit dem eigentlichen Quadrat verband, scheint zweifelhaft, obgleich bei den Stegocephalen unter dem zweifellosen Quadratomaxillare ein selbständiges Quadrat vorkommt. Vorn tritt das Quadratomaxillare der Anuren mit dem langen Oberkiefer in direkte Nahtverbindung.

Anf der Außenfläche des Suspensoriums entsteht immer ein sehr ansehnlicher Deckknochen, der bei den Urodelen meist vom Parietale bis zum Quadrat hinabreicht. Bei den Autren wird er durch die Einschiebung des Prooticums vom Parietale seitlich abgedrängt. Das distale Endo dieses Knochens beteiligt sich ebenfalls an der Bildung des Unterkiefergelenks, ja kanu sogar mit dem Quadrat verwachsen. Es scheint unzweifelhaft, daß diescr Deckknochen dem bei den Dipnoern in entsprechender Lage am Suspensorium befindlichen, entspricht, ja man könnte sogar die ähnlich gelagerte Verknöcherung am Gelenk des Palatoquadratknorpels der Knorpelganoiden (Fig. 141) vielleicht hierher ziehen. Der fragliche Enochen wird daher bei den Amphibien, wie jener der Dipnoer, gewöhnlich Squamosum genannt, in neverer Zeit anch häufig Paraquadrat. Wie für die Dipnoi hervorgehoben, deute ich ihn als Homologon des Prïoperculums der Knochenganoiden und Teleosteer, welches sich in ähnlicher Entwicklung längs des ganzen Hinterrands des Suspensoriums (Kieferstiel) hinzieht und mit dem Quadrat in sehr innige Beziehung treten kann, da es z. B. bei Lepidostens mit ihm verwächst. Wir werden den Knochen auch weiterhin als Paraquadrat bezeichuen. Sein Dorsalende länft bei den Anuren ( $F i g .148 C$ ) in einen vorderen und hinteren Fortsatz aus. Ler hintere wird durch Knoppel zu eivem weiten Ring ergänzt, an dem, nad dem Hinterrund des Paraquadrats, sich das Pankenfell befestigt, weshalb das Paraqnaủrat frỉher häufig Tympanicum genannt wurde.

Der voriere absteigende Fortatz kann zuweilen (z. B. Pelobates) mit der Maxille zusammenstoßen. wodurch eine Art unterer Schläfengrube abgegrenzt wird; zuweilen vermag das Paraquadrat sogar das Parietale zu erreichen. Jies sind Anklänge an die Stegocephalen. Ein Yergieich mit diesen könnte wohl vermuten lassen, daß das sog. Paraquadrat der Anuren aus der Vereinigung nehrerer ihrer Deckknochen hervorging; d. b. erwa aus den als Parajuadrat, Postorbitale, Squamosum uud Jugale bezeichneten.

Auf der Veutralseite des Palatopterygoidfortsatzes bildet aich bei den Ichthyoden, entsprechend den Dipnoern, nu! ein ansehulicher Deckknochen, ein Palatopterygoid (Pterygoid). Nur bei gewissen Salamandrinen (Siredon) sondert sich von ihm voru danernd ein relativ kleiner Knochen als Palatinum ab. Bei den tibrigen kommt es zwar in ähnlicher Weise zur Ablösung des Palatiunms, das sich aber bald 
mit dem jederseitigen Vomer zu einem zahntragenden Vomeropalatinum vereinigt. Bei den Gymnopbionen hingegeu verwächst das Palatinum mit dem Maxillare. Die Anuren und Stegocephalen dagegen besitzen stets ein bleibendes Palatinum als quer gelagerten, außen an das Vorderende des Pterygoids, innen an den Vomer und das Orbitosphenoid ansebließenden Knochen (Fig. 148B), der selten riickgebildet wird. - Das Pterygoid (bzw. Palatopterygoid der Ichthyoden) der Urodelen ist meist ziemlich breit plattenförmig. Gewissen Salamandrinen (lechriodonte mit Parasphenoidzähnen) und Siren fehlt es jedoch ganz.

Fig. 150 .

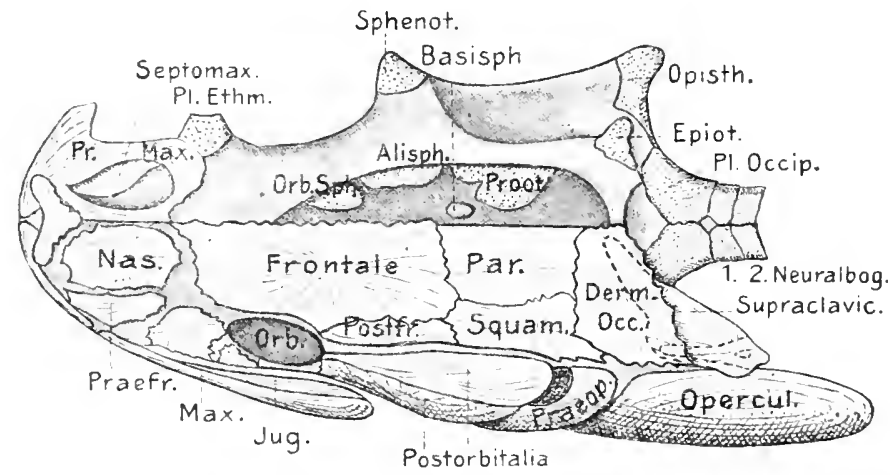

Amia calva. Schädel von der Dorsalseite. In der rechten Hālfte die Deckknochen entfernt mit Ausuahme der Prämaxille. Knorpel dunhel; Ersatzknochen panktiert. Deckknochen hell. (Nach Brroge 1877 konstruiert.)

o. B.

Das Pterygoid der Anuren wird schmäler, reicht jedoch weiter nach vorn, indem es sich der Maxille und dem Palatinum anlegt. Nach hinten entsendet es zwei mehr oder weniger entwickelte Fortsätze, einen inneren, der sich an die seitlichen Fortsätze des Parasphenoids anschließt, wie auch schon bei Knochenganoiden (Lepidosteus) eine ähnliehe Verbindung $z$ wischen Metapterygoid nnd den Parasphenoidfortsätzen besteht. Der zweite Fortsatz erstreckt sich nach hinten auf das Suspensorium unter das Paraquadrat.

Den oberen Kieferrand bilden vorn die kleinen Prämaxillen, denen sich die meist längeren Naxillen anschließen. Letztere bleiben bei den Urodelen kleiner und enden histen frei, ja sind bei den Perennibrancbiaten ganz verkümmert. Die Maxillen der Anuren hiugegen erstreckèn sieh weit nach hinten, so daß sie, mit den Quadratomaxillaria zusammenstoßend, einen geseblossenen Kieferrand bilden.

Wie schon bemerkt, besitzt der Stegocephalenschädel in seiner Gesamtkonfiguration Ähnlichkeit mit dem der Anurell, was sich namentlich im Bau des Gaumendachs ausspricht; das recht anurenartig erscheint. Von besonderer Bedeutung ist aber, daß bei gewissen Gattungen zwischen dem Pterygoid und dem Maxillare jederseits ein kleiner Knochen eingeschaltet sein soll, der bei den Reptilien, als sog. Transversum, sehr verbreitet vorkommt.

Un so auffallender ist die von allen rezenten Amphibien abweichende Schädeloberseite wegen ihres Reichtums an Deckknochen, die einen geschlossenen Panzer bilden (stegocrotaph). 
Sie verrät dadurch einerseits Beziebungen zu den Ganoiden, andrerseits jedoch auch zu den Reptilien. Nach beifolgender Figur 151 läßt sich die Schädeldecke der Stegocephalen, auch ohne eingehende Beschreibung, leicht beurteilen, sowie ihre Beziehungen zu dem danebengestellten Amiaschädel (Fig. 150) erkennen. Von besonderem Interesse ist die stets in der Nabt der Parietalia befindliche Öffnung, das sog. Scheitelloch, das auch vielen Reptilien zukommt.

$\mathrm{Zu}$ bemerken wäre ferner, $\mathrm{da} B$ das meist Supratemporalia genannte Knochenpaar wohl zweifellos dem Paraquadrat entspricht, wogegen das sog. Squamosum dem häufig also be-

Fig. 151.

A

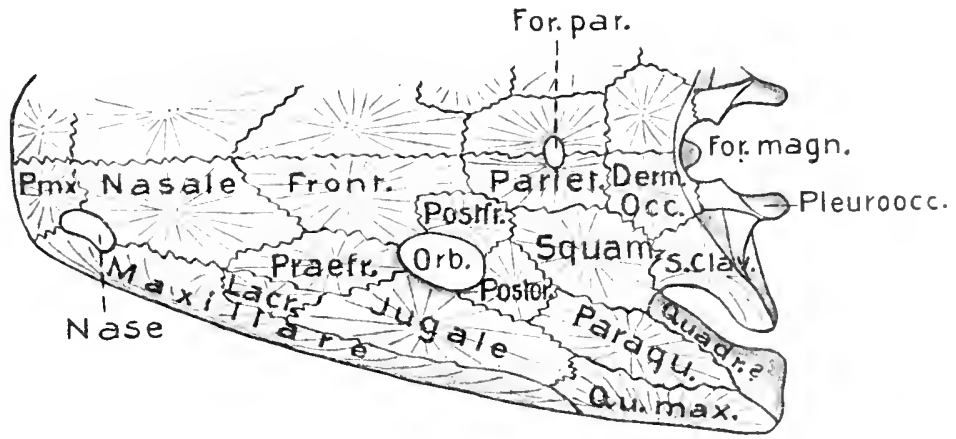

B

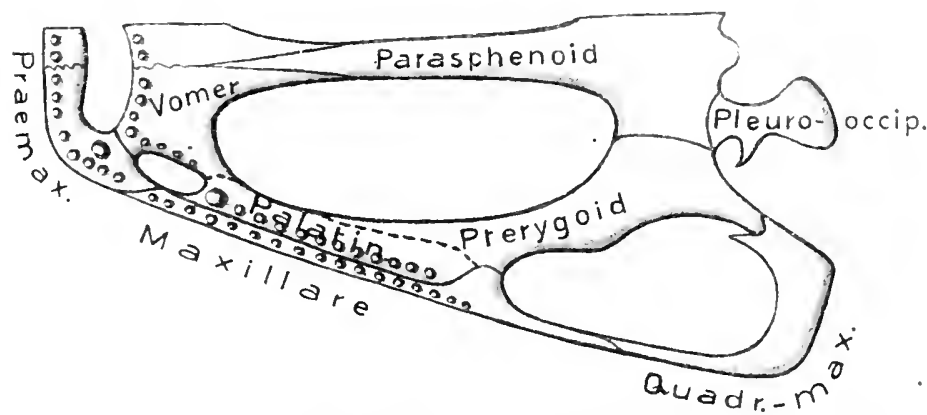

Capitosaurns nasutus. Schädel scheratisch, $A$ von der Dorsalseite. $B$ von der Ventralseite. (Nach H. v. Merer und Zittels Handbuch.)

zeichneten Knochen der Fische (Pteroticum) gleichzusetzen sein dürfte, obgleich es bei Amia und den Stegocephalen jedenfalls ein reiner Deckknochen ist.

Die beiden hier Dermoccipitalia genannten Knocben werden bei den Stegocephalen gewöhnlich als Supraoccipitalia bezeichnet, entsprechen aber zweifellos den sog. Dermoccipitalia (auch Supratemporalia genannt) der Ganoiden. Der von uns als Supraclaviculare bezeichnete Knochen (bei Holostei auch Postternporale genannt) ist bei letzteren sicher das mit dem Schädel fest verbundene Supraclaviculare des Schultergürtels der Ganoidfische. Bei den Stegocephalen wurde diesr Knochen seither gewöhnlich als Epioticum gedeutet; da er jedoch sicher ein Deckknochen ist, so scheint die Bezlehung auf das Supraclaviculare der Fiscbe recht sicher. Präfrontale, Postorbitale und Jugale sind Deckknochen, die im Fischschädel in den Infraorbitalia und dem sog. Admaxillare ihre Vorzeichnung finden. Ersatzknochen waren im Schädel der 
Stegocephalen jedenfalls nur sehr spärlich vorhanden; Pleurooccipitalia nur bei einem Teil; auch überall wohl ein vom Quadratomaxillare gesondertes kleines Quadrat. - Die Hinteransicht der Occipitalregion des Schädels (s. Fig. 152) ergibt, daß die Deckknochen der Schläfenregion die eigentliche Schädelkapsel seitlich dachartig überlagern. Doch fehlt ein hinteres Temporalloch, wie es bei den primitiveren Reptilien charakteristisch hervortritt.

Der Bau des Stegocephalenschädels und andere Skeletverhältnisse lassen es wohl zweifellos erscheinen, daß die rezenten Urodelen und Anuren wenigstens in ihrem Skelet stark rückgebildete Formeri sind, was für den Schädel der Urodelen noch mehr gilt als für den der Anuren.

Der Unterkiefer der rezcnten Amphibien ist gewöhnlich schlank und hänfig recht schmächtig. In seinem Aufbau wiederholen sich die knöchernen Bestandteile der Fische.

Von Ersatzknochen tritt im Unterkiefergelenk der Stegocephaten und vieler Urodelen ein knöchernes Articulare auf, während diese Region bei den Anuren knorpelig bleibt. Das Arti-

Fig. 152.

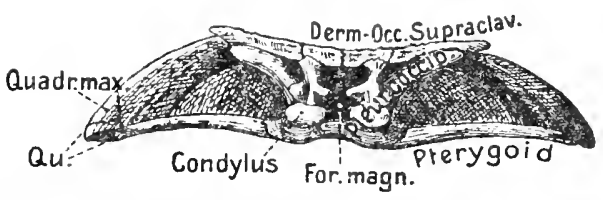

Mastodónsaus gigantens. Schādel von der Hinterseite. (Nach E. Fraas 1899/90.)

0 . B. culare der Gymnophionen rerwächst mit dem Angulare. Der bei den Auurenlarren als sog. Infrarostrale abgegliederte vorderste Teil des Meckelschen Knorpels verknöchert zu einem sog. Mentomandibulare (Fig. $148 C$ ), das später mit dem Vorderende des Dentale rerwächst. Auch bei einzelnen Urodelen soll es vorkommen. - Von den Deckknochen sind die Dentalia ansehnlich und, mit Ausnahme der Anuren, gewöhnlich bezahnt. Die auf der Innenseite des Knorpels bei den Urodelen und Stegocephalen gewöhnlich vorhandenen Opercularia tragen bei ersteren eine innere zweite Zahnreihe, ähnlich wie sie auch bei Fischen vorkommt. -- Die Gymnophionen besitzen diese innere Zahnreihe gleichfalls; ihre Opercularia sind aber mit den Dentalia vereinigt. Den Anuren feblen die Opercularia ganz. - Das stets vorhandene Angulare ist gewöhnlich ansehnlich lang und greift zum Teil auch auf die Innenseite über; von ihm oder dem Articulare (Stegocephalen) wird der schwache Kronfortsatz gebildet. Bei Gymnophionen rerwächst es, wie bemerkt, mit dem Articulare und bildet einen sehr weit nach hinten rorspringenden Fortsatz des hinteren Unterkieferwinkels (Fig. 149 C).

Hyobranchialskelet. Dieser Teil des Visceralskelets bietet besonderes Interesse, weil die bei einem Teil der Amphibien noch bleibende, bei den übrigen im Larvenzustand bestehende Kiemenatmung die allmähliche Umformung des Apparats aus dem fischartigen Zustand in den der luftatmenden Wirbeltiore vorzitglich erläutert. Außer dem Hyoidbogen treten auch bei den Larven nur die vier ersten Kiemenbogen kenntlich anf; obgleich es wahrscheinlich ist, daß ein Rest des fünften, welcher ja auch bei den Fischen schon stark vertummert war, durch einen Funktionswechsel als Stïtzapparat mit dem Eingang der Luftröhre in Verbindung trat. Hierüber wird später genaueres mitzuteilen sein.

Die Bildung dieser funf Bogen bei den erwacisenen Ichthyoden, welche natürlich die primitivsten Zustände bewahren, sowie ihr Ban bei đen Larven der ubrigen Amphibien ist wesentlich der gleiche. Der Zungeubeinbogen (Fig. 147 C, S. 261) ist stets der ansehnlichste; die folgenden vie: Kiemenbogen werden nach hinten rasch kleiner und rudimentärer. Dies spricht sich namentlich darin aus, daß nur 
der Zungenbein- nnd der erste Kiemenbogen (seltener auch der zweite) sich an den, anf die vordere Region beschränkten Copularapparat anschließen; die folgenden Kiemenbogen sich hingegen mit ihren Ventralenden aneinander fugen. Bei gewissen Ichtbyoden findet sich schon ein Ausfall des vierten, ja anch des dritten Kiemenbogens. Die Reduktion äußert sich ferner darin, da $B$ nur der Zungenbein- and der erste Kiemenbogen gewöhnlici ans zwei Stücken (Нypound Ceratohyale, bzw. -branchiale) bestehen, die darauffolgenden dagegen ungegliedert bleiben.

Der Copularapparat der Ichtbyoden besteht in der Regel nur aus zwei schmalen stabförmigen Stücken, dem Basibyale (meist Basibranchiale I genannt) und einem anschließenden sog. zweiten Basibranchiale, dessen Hinterende sich zuweilen gabelt. Über die Verknőcherungen im Visceralskelet, welche natürlich etwas variieren, gibt die Figur Aufschluß. Am Ceratohyale von Amphiuma wird ein Deckknochen (Parahyale) beschrieben.

Das äbnliche Visceralskelet der Salaman-

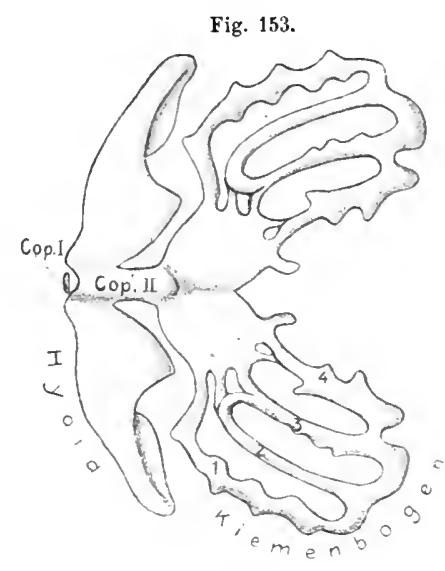

Rana fusca, Larve $\left(L_{0}=29 \mathrm{~mm}\right)$. Visceralskelet Yon der Ventralseite. (Nach drinen- und Anurenlarven erfährt bei der Metamorphose mehr oder weniger starke Umbildungen. Für die larvalen Kiemenbogen erscheint charakteristisch, daß ibre Dorsalenden verschmolzen sind (Fig. 153), was ja auch schon bei Fischen gelegentlich auftrat. Bei älteren Salamandrinenlarven sondern sie sich aber. - Bei den erwachsenen Salamandrinen bleibé die Reduktion relativ gering, da nur der dritte und vierte Kiemenbogen eingehen, wihrend die beiden vorderen sich erhalten.

Eigentümliche Einrichtungen treten all den Ventralenden des in der Regel viergliederigen IIyoidbogens der Salamandrinen auf, da diese sich zu langen, bis an den Kieferwinkel vor- und dann wieder zurückgebogenen Schleifen entwickeln können. Ferner tritt zwischen den Ventralenden der Hyoidbogenhälften häufig ein queres besonderes Knorpelstück (sog. Bügelknorpel) auf. - Der erste Kiemenbogen ist einfach und häufig ungegliedert, der zweite meist stärker verknöchert und zweigliederig. Jie Copulae werden gewöhnlich nur noch durch ein einziges Stück Fig. 154 .

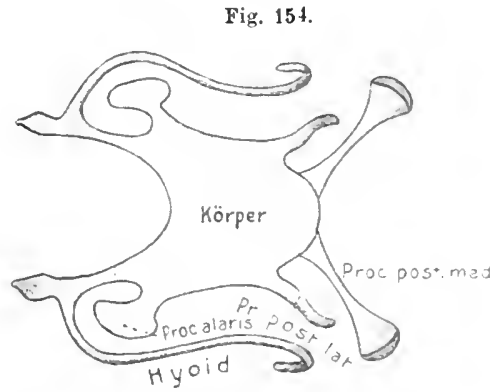

Ra в fusca. Erwachsen. Zungenbein von der Ventralseite. (Nach PARKkR 1872 and GAUPP 1906.) E. W. repräsentiert (Basihyale), dessen hinterer Fortsatz gegabelt sein kann. Dieser meist frühzeitig verknöchernde Gabelfortsatz (auch als Basibranchiale aufgefaßt) löst sich häufig ab und tritt als sog. Os thyreoideum an die Schlundwand in der Nähe des Pericards. Die Verknöcherungen sind auch im Visceralapparat der Salamandrinen recht verschieden.

Die stärkste Umbildung erfährt der Apparat der Anuren. Fig. 153 zeigt ihn im Zustand der erwachsenen Froschlarve, vollkommen knorpelig nnd nngegliedert. 
Bci der Metamorphose verschmelzen die ventralen gemeinsamen Teile der vier Kiemenbogen zu einer ansehnlich auswachsenden Knorpelplatte, dem eigentlichen Zungenbeinkörper' (Fig. 154). Die Zungenbeinbogen wachsen zu langen schmalen Hörnern aus, deren Verbindung mit dem Vorderrand des Körpers sich auch wesentlich ändert. Die beiden hinteren Paare hornartiger Fortsätze der Zungenbeinplatte sind wenigstens bei Rana keine Reste der Kiemenbogen; doch wird dies für das vordere Paar anderer Formen angegeben. Nur das hinterste Fortsatzpaar verknöchert gewöhnlich, sonst bleibt alles knorpelig.

Relativ ursprünglich erhält sich der Visceralapparat der Gymnophionen (Fig. 155) und bleibt auch im erwachsenen Zustand knorpelig. Besonders bemerkenswert ist die Abtrennung

Fig. 155.

A

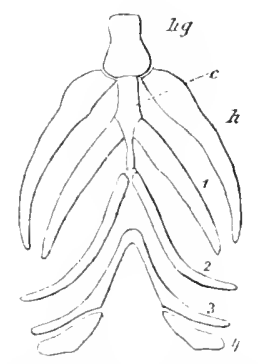

Visceralskelet ron $1 \mathrm{chthy} v \mathrm{ph}$ is glutinosus. A das der Larve. $B$ im ausgebildeten Zustande. $h$ Hyoid. $h g, c$ Copulae. (Nach Salisin aus Gegenbaur 1898.) der hinteren Kiemenbogen im erwachsenen Zustand und die starke Entwicklung der vorderen Copula der Larve (Entoglossum, was auch bei Anurenlarven schwach angedeutet sein kann); später geht diese vordere Copula ganz ein.

Die Dorsalenden des Hyoids der Urodelen sind durch Bänder an dem hinteren Rand des Snspensoriums befestigt (Fig. $147 C$, S. 261); bei gewissen Formen bildet das Snspensorium sogar einen nach hinten gerichteten stielförmigen Fortsatz, an welchen sich das Band ansetzt: Diese Befestigung desHyoidbogens erinnert durchaus an die Einrichtungen der Fische und spricht dafür, daß der Kieferstiel der Fische in das Suspensorium einbezogen wurde; der stielförmige Fortsatz ähnelt sogar dem Stylohyale der Fische. -- Die Anuren zeigen ursprünglich denselben Zusammenhang von Zungenbeiubogen nd Suspensorium. Bei der Metamorphose riackt jedoch das Proximalende des Hyoids an die Ohrkapsel empor, mit aer es in kontinuierliche und bleibende Knorpelverbindung tritt (Fig. 148, S. 263).

Wie schon angegeben, wird das Suspensorium des Amphibiensehädels meist allein auf' das Palatoquadrat zurückgefïhrt. Der Hyomandibularteil des Zungenbeinbogens dagegen soll unter starker Reduktion in den Skeletapparat des Obres (Columella auris, s. Fig. 147, S. 261), übergegangen sein, welcher sich der Fenestra ovalis der Ohrkapsel auflegt. Dieser Auffassung widerspricht ror allem die Tatsache, laß die Ontogenie der Amphibien von einer Beziehung des Hyoidhogens zu dem Gehörknöchelchen nichts erkenmen läßt. Vielmehr entsteht dessen Anlage sulbstindig als eine deckelartige Verknorpelung (Operculum) in der häutigen Schlußmembran der Fenestra ovalis, eventuell als Auswuchs von deren knorpeliger Umrandung. J)urch ein Band und knorpelige stilartige Verlängerung des Operculums tritt sie dann in Verbindung mit dem IJinterrand des Suspensoriums, ja dieses kann einen Fortsatz bilden (gewisse Urodelen), mit welthem die Columella in Zusaumenhang tritt. Obgleich die Hörskeletbildungen erst bei dem Iförorgan genauer betrachtet werden, sei doch hier schon bemerkt, daß sich das Homologon dieser Columella vielleicht in dem dem Suspensorium der Dipnoi linten argefügten sog. Operulum suchen läßt. 
Schädel der Amnioten.

Dẹr Amniotenschädel zeigt eine Reihe übereinstimmender Züge, welche auf gemeinsamen Ursprung hinweisen. Die größere Knochenzahl dentet gegenüber den rezenten Amphibien auf Beziehungen zu den Stegocephalen und Fischen hin, welche anch in dem doppelten Occipitalcondylus der Säuger sich erhalten haben dürften. Im Gegensatz zu den Anamnia tritt das bei letzteren stets ansehnliche Parasphenoid sehr zurück, indem sich seine Reste mit dem Basisphenoid (Ersatzknochen) zu einem Mischknochen vereinigten. - Den Ausgangsformen der Amnioten scheint ferner ein dem Suspensorialteil des Schädels beweglich angefügtes Quadrat eigentïmlich gewesen zu sein, welches sich erst bei der Weiterentwicklung in der Reptilienreihe $z$ wischen die benachbarten Schädelknochen fest einfügte. - Sämtlichen Amnioten gemeinsam ist weiter, daß sich die Reste dreier vorderster verkümmerter Wirbel der occipitalen Schädelregion angeschlossen haben müssen. Dies ist aus den Resten der Spinalnerven jener Wirbel (Spinooceipitalnerven, Hypoglossiswurzeln) za erschließen, deren Urspringe in die Occipitalregion des Schädels aufgenommen wurden. Andeutungen dieser Wirbelkörper selbst finden sich jedoch am Hinterhaupt nicht mehr vor. - Jedenfalls folgt aus den erwähnten Schädelmerkmalen, daß sich die Amnioten recht frïhzeitig von der Wurzel des Amphibienstamms abgegliedert haben mïssen.

Sauropsida. Die gemeinsamen Charaktere des Sauropsidenschädels sind hauptsächlich folgende:

1. der einfache Hinterhauptscondylus, welcher meist derart aus dem doppelten der Amphibien hervorging, daß das Basioceipitale zwischen die beiden Condyli der Pleurooccipitalia einen Fortsatz entwickelte, welcher sich mit letzteren zu dem einfachen Condylus vereinigte (s. Fig. 161 E, S. 281). Daß den Sauropsiden ursprünglich ein doppelter Condylus zukam, scheinen die schwachen Condyli der Pleurooccipitalregion am Primordialcranium zu erweisen.

2. Bei fast allen Sauropsiden (Ausnahme Schlangen und in geringerem Grad Chelonier) besteht in der Orbitalregion ein meist langes, häutig-knorpeliges, seltener knöchernes Interorbitalseptam, ähnlich dem der Knochenfische, welches vou der Vorderwand der Schädelkapsel bis zur Ethmoidalregion zieht, wo es in die Scheidewand der beideu Nasenhöhlen übergeht.

3. Charakteristisch ist ferner das stets ansehnliche Quadrat, an welchem der Unterkiefel gelenkt; ebenso die kräftige Entwicklung der Pterygoide.

4. Die reichere Zahl der Deckknochen in der Augen- nnd Schläfenregion, in Erinnerung an die Verhältnisse der Stegocephalen und Fische.

Die rezenten Sauropsiden lassen in ibrer Schädelbildung zwei Reihen erkennen, welche jedenfalls schon recht frühzeitig divergierten. Die woh! ursprünglichere wird von den Sauriern, Ophidiern und Vögeln gebildet, bei welchen sich die Beweglichkeit des Quadrats am Schädel erhielt (Streptostylie), zum Teil sogar eine Steigerıng erfuhr; die Beweglichkeit kann sich schließlich auf den gesamten Kiefergaumenapparat ausdehnen. Gleichzeitig erhält sich dieser Apparat ursprünglicher, amphibienähnlicher, indem die Flügel- nnd Gaumenbeine in der Mittellini 
gewöhnlich nicht zasammenstoßen, also kein gesehlossenes Gaumendach bilden. Die zweite Reihe, die der Rhynehocephalen, Schildkröten, Krokodile hingegen, und ebenso die meisten ausgestorbenen Reptiliengruppen (ausgenommen die an die Squamaten sich anschließenden Pythonomorpha) besitzen ein mit dem Sehädel fest verbundenes Quadrat (Monimostylie). Ferner ist bei ihnen (mit Ansnahme der Ichthyosauria und Pterosauria) ein gesehlossenes Gaumendach mebr oder weniger entwickelt.

Auf das Primordialcranium können wir nicht genauer eingehen. Scine dorsale Schädelkapseldeeke ist, wie schon bei den Amphibien, stets ganz unverknorpelt und wird erst darch die Deekknoehen abgeschlossen. Das Palatoquadrat tritt selbstindig anf, auch da, wo das Quadrat später dem Schädel fest eingefügt ist. Sein Palatopterygoidfortsatz bleibt im allgemeinen schwaeh und entsteht zum Teil selbstïndig, ohne Zusammenhang mit dem Quadratteil (Sauria). Im erwaehsenen Zustand erhält sieh der Knorpel des Primordialcraniums am reichsten in der Ethmoidalregion.

Vor der genaueren Scbilderung des Sauropsidenschädels sei noch bemerkt, daß im höheren Alter zum Teil eine Verwachsung der anfänglich gesonderten Knochen eintreten kann. Besonders bei den Vögeln verwachsen zahlreiche Schädelknochen in der Regel so frühzeitig und völlig, daß nur Embryonen und junge Tiere den Sehädelanfbau erkenneu lassen. Bei den straußartigen Vögeln bleiben die Knoehen relativ länger gesondert.

Wir beginnen mit der Betraehtung der Hinterhauptsregion, welche wie bei den Knochenfischen aus einem Basioccipitale, zwei seitlichen Pleurooccipitalia und einem Supraoceipitale besteht. Oben wurde schon bemerkt, daß der einfache, nierenförmige bis kugelige Hinterhauptseondylus in der Regel von den Pleurooceipitalia und dem Basioecipitale gebildet wird, seltener, unter Rüucktritt der ersteren, fast nur vom Basioecipitale (meiste Krokodile, Ichthyosauria, viele Tögel).

Manchmal kann jedoch auch die Teinnahme des Basioccipitale am Condylus stark zurücktreten, ja selbst aufhören (gewisse Chelonier und Anomodontia), oder der kugelförmige Condylus sich drei- bis zweilappig entwickeln (einzelne Saurier, Chelonier und Anomodontia).

An der Umgrenzung des Illinterhauptslochs nehmen meist sämtliche vier Occipitalia teil. Dorh kann (hrokodile und Schlangen) das Supraoccipitale ausgeschlossen werden; bei letzteren und gewissen Cheloniern zuweilen anch das Basioccipitale, so daß nur die Pleuronecipitalia die Umrahmung bilden. Das Foramen magnum der Reptilien schaut stets nach hinten. Bei den Tögoln (s. Fig. 159 B, S. 278) dagegen wendet es sich, im Zusammenhang mit de1 nach hinten aufgetriebenen Schädelkapsel, schief nach hinten und unten; wobei auch der Condylus eine entsprechende Richtungsänderung erfährt.

Das Supranccipitale gewisser Saurier und Schildkröten kann einen ansehnlichen Kamm entwickelu.

Im Ansehln $B$ an das Basioceipitale wird der Schädelkapselboden stets von einem sog. Basisphenoid gebildet, das zuweilen ziemlich ansehnlich wird. Es geht aus einem Ersatzknoehen, dem eigentlichen Basisphenoid, dem der Fische annähernd vergleiehbar, und einer Hautverknöcherung hervor, welche dem Parasphenoid der Anamnia entspricht. Das Parasphenoid der Vögel tritt anfänglich in drei Anlagen 
auf, einer vorderen (späteres Rostrum) und zwei hinteren paarigen (Basitemporalia, s. Fig. 159). Para- und Basisphenoid verwachsen später miteinander. - In der Squamatenreihe, ferner bei Rhynchocephalen, Ichthyosauriern, auch Dinosauriern, entsteht aus dem Parasphenoidanteil ein mehr oder weniger ansehnlicher, schmaler vorderer Fortsatz (Rostrum) des Basisphenoids, welcher die stritzende Basis des Orbitalseptums bildet und zuweilen (gewisse Vögel, Schlangen) bis iu die Nasenregion

Fig. 15ti.
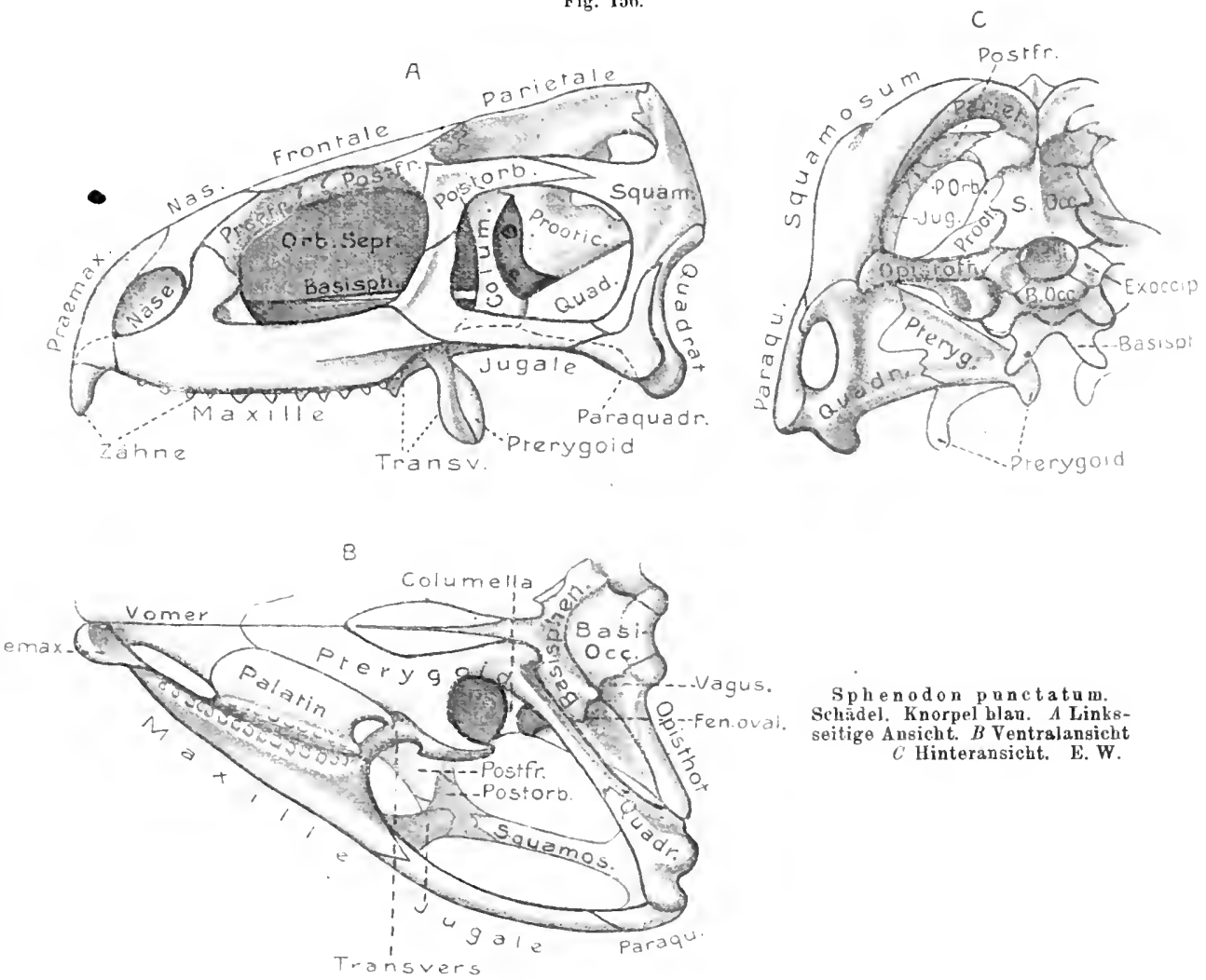

Sphenodon panctatum. Sehadel. Knorpel blan. $A$ Link8seitige Ansicht. $B$ Ventrslansicht C Hinteransicht. E. W.

reichen kann (Fig. $156 B, 157 A, 159 B, 169^{2}$, S. 290). In der Placoidreihe (Fig. $161 C, 162$ A) bleibt dieser Fortsatz klein. - Seitlich und etwas nach vorn entsendet das Basisphenoid in der Squamatenreihe ansehnliche Pterygoidfortsätze, an welche sich die Flügelbeine anlegen. Das Basisphenoid dieser Formen erinnert daher in seiner Gesamtgestalt noch ziemlich an das Parasphenoid der Anuren und Stegoce. phalen, was wohl dafür spricht, daß seine Grundlage hauptsächlich aus diesem hervorging. - Auf der Schädelnnterseite tritt das Basisphenoid der Squamatenreihe vőllig sichtbar hervor, bei den Schildkröten hingegen nur teilweise, bei den Krokodilen sogar nur sehr wenig. 
Die seitliche Wand der eigentlichen Schädelkapsel wird, im Anschluß an die Pleurooccipitalia, in der hinteren Labyrinthregion der Chelonier, der ältesten Krokodile, Ichthyosaurier, Sauropterygier, Pythonomorpha, wahrscheinlich auch einem Teil der Theromorpha, von einem Knochen gebildet, der wohl sicher dem Opisthoticum der Knochenganoiden und Knochenfische entspricht (Fig. 161 B-E, S. 281). Auch in der Ontogenie der übrigen Sauropsiden tritt er neben den Pleurooccipitalia auf, verwächst aber bald mit letzteren, was bei deu Rhynchocephalen (Sphenodon, Fig. $156 C$, S. 273) erst nachembryonal geschieht. - Vorn stößt an das Opisthoticum das iiberall vorhandene Prooticum (Petrosum), welches schon in die Vorderwand der eigentlichen Schädelkapsel übergr'eift, und allein, oder gemeinsam mit dem Opistboticum das Labyrinth umschließt.
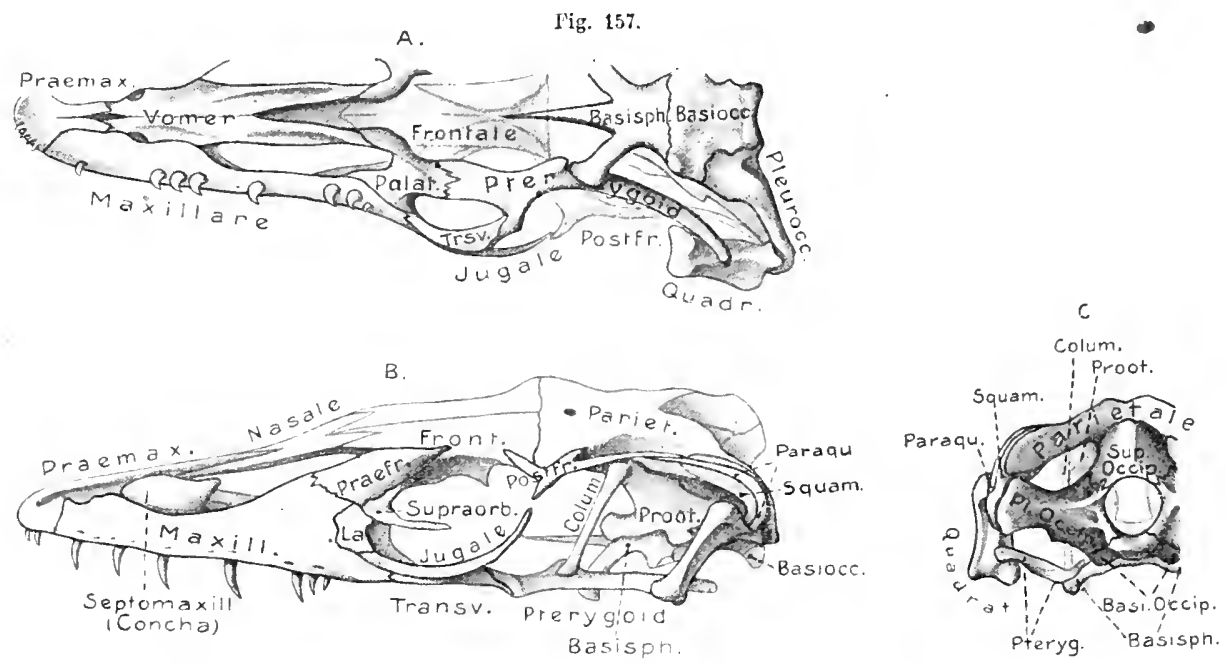

Varanas salvator. Schädel. A Ventralansicht. $B$ Linkseitig und etwas dorsal. $C$ Hinteransicht. P. He.

Ein in der Ontogenie mancher Reptilien und Vögel in der dorsalen hinteren Ohrregion auftretendes kleines sog. Epioticum vereinigt sich bald mit dem Supra- oder zugleich auch dem Pleurooccipitale, ist jedoch in seiner Deutung weniger sicher; dasselbe gilt wohl von dem als Epioticum bei einzelnen fossilen Reptilien beschriebenen Knochen (s. Fig. 167, $168 E$, S. 288). Jedenfalls deutet aber die kompliziertere Bildung der Labyrinthregion der Sauropsiden auf sehr weit zurïckreichende Beziehungell zu den Ausgangsformen der Knochenganoider. Dipnoer und Teleosteer hin.

Die seitliche Vorderregion der Schädelkapsel wird im Auschluß an das Basisphenoid und das Prooticum bei den Krokodilen (Fig. $162 A, B$, S. 283) und Vögeln (Fig. 159 A, S. 278), sowie gewissen fossilen Reptiliengrappen, durch zuweilen recht ansehnliche seitliche Flügelbeine (Alisphenoide) ergänzt, welche bis zu den Frontalia emporsteigen and auch an der hinteren Begrenzung der Augenhöhle teilnehmen. Die Vögel zeigen vor ihnen im hinteren Teil des Orbitalseptums noch ein Paar kleine Verknöcherungen, welche den Orbitosphenoiden der Fische homologisiert werden; sie verwachsen jedoch hald mit den benachbarten Knochen. 
Bei Sauriern und Rhynchocephalen bleibt die an die Orbiten grenzende Vorderwand der"Schädelkapscl größtenteils häutig-knorpelig, doch treten kleine Orbitosphenoide zuweilen auf. - Obgieich nun auch den Cheloniern und Schlangez Alisphenoide fehlen, wird bei ihnen doch ein vorderer Aischluß der Schädelkapse? dureb die Scheitel- und Stirnbeine in nachher zu beschreiberider Weise hergestellt.

Die Deckknochen der Schädelkapseloberfäche sind dic uns von frïher bekannten Scheitel- und Stimbeine, von welchen die letzteren meist ansehnlicher sind und bis in die Ethmoidalregion nach vore reichen, wo sie an die Nasalia stoßen. Unpaare Yerwacbsung der Scheitelbeine (Squanata, Fig. $157 \mathrm{~B}$, Orocodilia), auch der Stirnbeine (Crocodilia, Fig. 162 C) kommt vor.

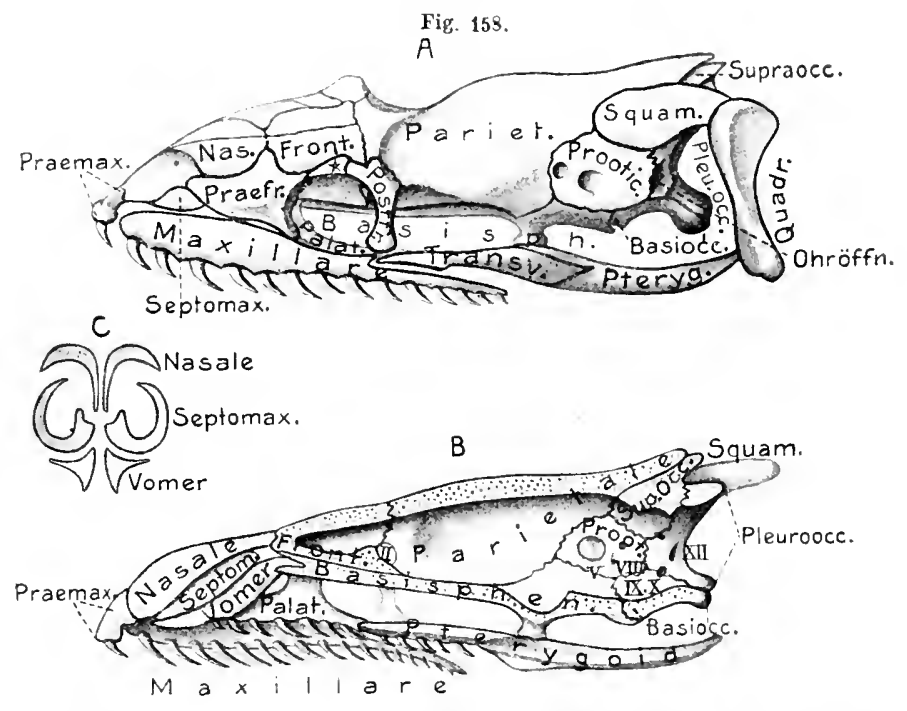

Python. Schādel. A linkseitig und etwas dorsal. * Supraorbitale. $D$ In der Nedianebeve dorchschnitten rechte Hālfte. Schnittstellen der Knochen punktieri. $C$ schematischer Querschaitt dareh die Naseagegend zar Demoastration der Anordang von Nasale, Septomaxillare und Vomer. W.

Die großen Parietalia der Schildkröten senảen starke platte Fortsätze senkrecht abwärts bis auf die Fluggelbeine, welche za dem erwähnten vorderen Abschlu $B$ der Schädelkapsel beitragen (Fig. $161 \mathrm{D}$ ). Im Schlangenschädel (Wig. 158 B) wird ein vollständiger knöcherner Abschluß der Kapsel dadurch erreicht, daß die Seitenränder der Parietalia sich bis zum Basisphenoid herabkrummen und auch die Frontalia ähnliche Fortsätze abwärts schicken, welche die vordere Region der Scbädelkapsel völlig unschlieisen und ventral etwas über dem Rostrum des Basisphenoids miteinander zusammenstoßen. Hiermit hängt zusammen, daß sich die Schädelhöhle der Schlangen nach vorn zwischen die Orbiten erstreckt und ein Orbitalseptum fast oder völlig fehlt; ein Yerhalten, dem sich auch die Schildkröten etwas nähern.

In der Naht beider Parietalia der meisten fossilen Reptilicngruppen (nicht bei Dinosauria and Pterosauria), unter den rezenten nur bei den Sauriern und 
Rhynchocephalen findet sich das schon den Stegocephalen eigentümliche Parietalloch, dessen Beziehung zu dem sog. Scheitelauge oder Parietalorgan später darzulegen sein wird. Dies Parietalloch kann jedoch zuwoilen weiter nach vorn, anf die Grenze zwischen Parietalia und Frontalia, ja zwischen letztere rucken.

Bei gewissen fossilen Theromorpha (so Dicynodon, Fig. 168, S. 289) wurde zwischen den Parietalia und dem Supraoccipitale ein sog. Interparietale beschrieben, wie es den Mammalia eigen ist. $\mathrm{Da}$ gerade diese erloschenen Reptilien verwandtschaftliche Beziehungen zu den Säugern besitzen, ist dies von erheblichem Interesse.

Die Nasenregion wird durch paarige oder nnpaar verwachsene (gewisse Sauria) Nasalia ergänzt, deren Längenentwicklung natürlich von der der Schnauze bedingt wird; sie sind daher bei den Krokodilen, Ichthyosauriern u. a. sehr Iang. Nur den Schildkröten fehlen sie meist, indem die Praefrontalia an ihre Stelle treten (Ausnahme Chelydae), - Der den Boden der Nasenregion bildende Vomer soll beim Kiefergaumezapparat l erücksichtigt werden.

Die Rhynchocephalen und Squamaten besitzen im Bodẹn der Nasenhöhle, zwischen dieser nnd dem sog. Jacobsonschen Organ, jederseits eine platte Verknöcherung (Fig. 157.B, 158), das sog. Septomaxillare (frtiher als Concha bezeichnet), das wir scbon bei Anuren antrafen.

Erst neueritings wurde es auch bel gewissen fossilen alten Krokodilen (Phytosaurus) sowie einzelnen Therororpha aufgefunden. Auch das bei letzteren zum Teil erwähnte sor. Infranasale (s. Fig. 16? JN, S. 288) dürfte vielleicht hierher gebören.

Allein bei den Vögeln fuden wir in der Grenzregion zwischen dem Orbitalund Nasalseptum eine Ersatzverknöcherung, welche sich von hier auf das Orbitalseptum nach hinten und das Nasalseptum nach vorn ausdehnt. Sie wird berechtigterweise als Mesethmoid bezeichnet und vereinigt sich frïhzeitig mit anstoßenden Knochenbildungen. Ihr Wachstum nach hinten, sowie sonstige im Orbitalseptum anftretende Knochencentren bewirken die bei den meisten Vögeln völlige Verknöcherung des Orbitalseptums.

Das System der die Orbiten umrandenden Hautknochen, das schon bei den Fischen so reichlich vertreten war, erhält sich anch bei den Sauropsiden noch. So finden sich am hintercn und vorderen Augenhöhlenrand der Reptilien allgemein die uns von den Stegocephalen bekannten Post- und Pracfrontalia; den Vögeln fehlt jedoch das Postfrontale allgemein. Unter dem Postfrontale besitzen die meisten fossilen Reptiliengruppen noch ein sog. Postorbitale, welches sich unter den lebenden nur bei den Rhynchocephalen (Fig. $156 \mathrm{~A}$, S. 273) und vielen Eidechsen erhalten hat; doch dürfte das allein vorkommende Postfrontale wohl häufig aus der Verwachsung mit dem Poștorbitale entstanden sein. - Das Präfrontale findet sich allgemein, fehlt auch denVögeln nicht; unter ihm nimmt ein Lacrimale bei vielen Reptilien (zahlreiche Sauria, Rhynchocephala, Crocodilia, viele fossile Grnppen) an der Begrenzung des Vorderrands der Orbita teil.

Es wurde jedoch neuerdings mit guten Gründen nachzuweisen gesucht, daß das Prăfrontale der Sauropsiden dem Lacrimale der Säuger homolog sei; das viel veniger häufige sog. Lacrimale, das nur bei den Krokodilen von dem Tränennasenkanal durchbohrt wird, dagegen etwas Besonderes sei, das besser als Adlacrimale bezeichnet werde. Bei Gegenwart beider 
Verlnöcherungen tritt der Linul meist zwischen ihnen durch. Wemn diese Auffassung zutrifft, so muß ratürlich auch die der ähn:

Boi gewissen Squamaten (Lscertilia und Verwandten, Python), den Krokodilen und einigun Dinosauriern können ncch weitere Hautknochen am dorsalen Orbitalrand anftreten, so ein bis mehrere Suprav - titalia; doch auch bei Eidechsen weitere am Hinter- und Unterrand, die als Verknöcharungen unter den Hornplatten des Kopfs entstehı.

Als Suspen sorialteil des Schädels bezeichnen wro die Einrichtungen an der Schädelkapsel zw: Gelenkung oder Befestigung des Quad:its. Dieser Teil wird, ahnlich wie bei des Amphibien, von einem ansehnlichen Futsaiz gebildet, der von der hinteren latı! alen Schädelkapsel seitlich und nach hintes absteigt, und mit dem sich das Quaa it gelenkig oder fest verbindet.

Bei den Reptilien is. dieser Fortsatz in der Regel sehr kräftig entwickeit. An seinem Aufbau beteiligt si'h vor allem ein Deckknochen, welcher nnter den Amphibien nur den Stegocephalın zukam und sich wohl schon bei den Fischen als ein Bestandteil des Pteroticum ro fand, das sog. Squamosum (Schuppenbein). - Es liegt bei den Reptilien der eigntlichen Schädelkapsel in der Ursprungsgegend des Suspensorialfortsatzes stets ä.Berlich an, nimmt also keinen Anteil am Aufhan der Kapselwand selbst, und is deshalb auch auf der Innenseite der Kapsel nie zu sehen. Das Squamosum schlit $3 t$ sich proximal an den hinteren Seitenrand des Parietale an, erlangt jedoch, wie wir gleich seben werden, noch anderweitige Verbindungen. Zur Stätze·dieses, vom Sq:amosum zum Teil gebildeten seitlichen hinteren Schädelfortsatzes besteht bei den Revtilien jedoch noch ein meist ansehulicher lateraler Fortsatz der Occipitalregion (Paroccipitalfortsatz), der von dem Plenrooccipito-Opisthoticum gebildet wird, an sem sich jedoch auch ein hinterer Fortsatz des Prooticum beteiligen kann (Fig. $161 \mathrm{E}, 156 \mathrm{C}$ ). Der Squamosumfortsat $z$ vertingt sich distal mit diesem mehr ventralen Paroccipitalfortsatz zur Bildung der Anheftungsstelle für das Quadrat. - Die Entstehnng, bzw. Sonderung dieser beiden Fortsätze, welche den Amphibien fehlt, hängt wohl mit der Ausbildung und der mehr oder weniger ansehnlichen Erhebung des Supraoccipitale zusammen, das den Amphibien abgeht.

Bei den Sauriem und Rhynchocephalen tritt dieser Bau, welcher wohl sicher der ursprüngliche ist, sehr deutlich hervor. - Die beiden erwähnten Fortsätze entsprechen zusammen wohl dem Suspensorialteil der Amphibien, obgleich sie, wie gesagt, nur distal verbunden, sonst bei den genannten Reptilien durch ein weites Loch an der Hinterseite des Schädels getrennt sind (hinteres Temporalloch). Zur Verstärkung des Squarosumfortsatzes entsendet das Parietale der Rhynchocephalen, namentlich aber das der Saurier (Fig. $157 C$, S. 274) einen starken Fortsatz, der gemeinsam mit dem Squamosum verläuft. Ähnliches findet sich auch bei fossilen Reptiliengruppen. - Bei den Krokodilen haben sich der Squamosum- und Paroccipitalfortsatz, die weniger stark entwickelt sind, miteinander vereinigt, so daß das erwähnte Temporalloch $z$ wischen ihnen fast völlig geschwunden ist. - Die Schildkröten dagegen leiten sich umgekehrt von Formen ab, bei welchen dies 
Loch ungemein erweitert wurde (Fig. $161 E$, S. 281), so daß die Verbindung zwischen Parietale und Squamosum schließlich völlig aufgehoben werden kaun, was in der Reihe der Chelonia noch zu verfolgen ist.

Die Einrichtungen der Schlangen sind im Zusammenhang mit der weiten Aufreißbarkeit des Mauls sehr eigentïmlich umgestaltet (Fig. 158 A). Ihr Squamosum legt sich der hinteren Region des Parietale als ein platten- bis stabförmiger, mittels Band befestigter Knochen auf. Indem sich gleichzeitig der bei den Sauriern

Fig. 159 .
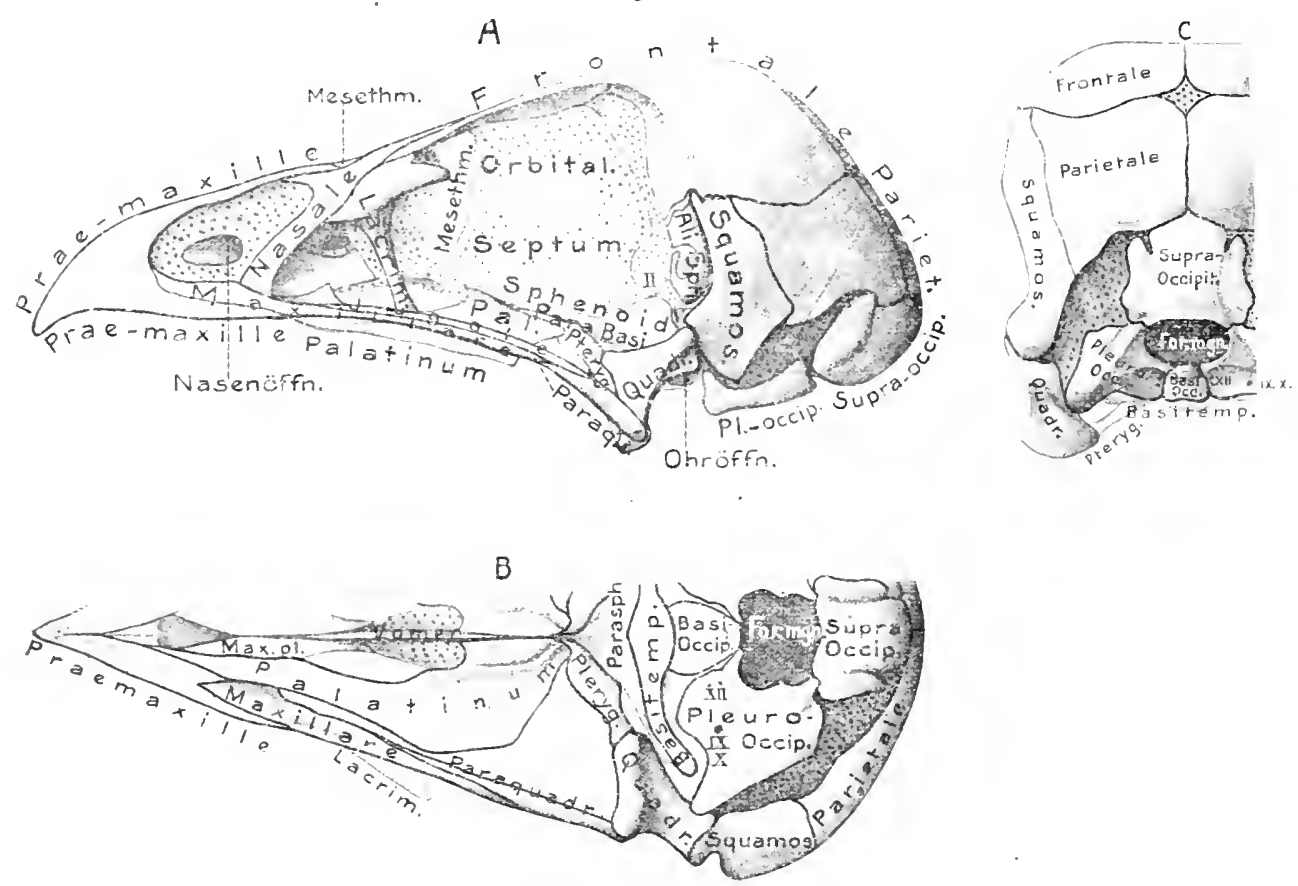

Buteo vulpinus Menzb. Schādel von jungem Nestrogel. Knorpel dunkel, punktiert. A linkseitig Max. pl. plattenfōrmige Ausbreitung des Maxillare gegen die Medianlinie. $B$ Ventralseite. $C$ Hinterseite. - Die als Basitemporale bezeichnete Verknöcherung ist der hintere Teil des Parasphenoids, der sich spāter mit dem vorderen vereinigt.

P. He.

so stark ausgebildete absteigende Fortsatz des Parietale riickgebildet hat, springt der hintere Teil des frei gewordenen Squamosum über den Hinterrand des Parietale caudalwärts fast immer weit vor und trägt an seinem Ende allein das Quadrat. Auch der Paroccipitalfortsatz ist fast völlig riickgebildet, so daß das Squamosum ganz frei vorspringt (einzelnen Typhlopiden soll es fehlen).

In anderer. Richtung haben sich die Verhältnisse der Vögel modifiziert, im Zusammenhang mit der starken Vergrößerung des Gehirns, die eine bedeutende Erweiterung der Schädeldecke bedingte. Das zwischen Parietale, Pleurooccipitale und Prooticum eingeschobene Squamosum (Fig. $159 \mathrm{~A}$ ) wurde bei der Erweiterung der Schädelkapsel in deren Wand einbezogen und tritt daher auch auf ihrer InnenAäche hervor; es ist also zu einem wirklichen Wandknochen der Schädelkapsel ge- 
worden. Der suspensoriale Fortsatz des Squamosum, an dem und den anstoßenden Knochen das Quadrat gelenkt, ist noch angedeutet, ebenso der Paroccipitalfortsatz (Fig. 159 C), welcher mit dem Squamosum in Berührung tritt, ja noch an der Bildung der Gelenkstelle für das Quadrat teilnehmen kann.

Der obere Suspensorialfortsatz der Reptilien wird durch einen weiteren Deckknochen verstärkt, der in der Regel als Quadratojugale bezeichnet wird, neuerdings jedoch häufig als Paraquadrat (GAUPP), womit denn auch ausgesprochen ist, daß er dem ron uns ebenso bezeichneten Deckknochen der Amphibien verglichen wird. Auf unseren Figuren der Reptilieuschädel ist die Bezeichnung als Paraquadrat ebenfalls acceptiert worden. - Der Knochen schließt sich im allgemeinen dem Distal- oder Seitenrand des Squamosum an und lagert sich dem Quadrat äußerlich mehr oder weniger auf. Bei den stegocephalen Amphibien (Fig. 151 A, S. 267), welche den Urreptilien jedenfalls am nächsten standen, sich sogar teilweise schwer von ihnen nnterscheiden lassen, fanden wir in der Gegend dieses Knochens zwei, den als Paraquadrat bezeichneten (meist Supratemporale oder auch Prosquamosum genannt) und das distale sog. Quadratomaxillare. Nun gibt es in der Tat gewisse alte Reptilien (Pareiosauros, Ichthyosauria, Fig. 168, S. 289 u. Fig. 169 1, S. 290), die gleichfalls noch zwei Knochen in dieser Gegend zeigen, von welchen der proximale gewöhnlich Supratemporale, der distale Quadratojugale genannt wird. Der erstere entspricht daher nnserem Paraquadrat bei den Stegocephalen (das ja meist auch Supratemporale genannt wird), der zweite unserem Quadratom-illare (oder Quadratojugale) der Stegocephalen. Es fragt sich nun, wie sich dazu der einfache Knochen der übrigen Reptilien (sog. Paraquadrat oder Quadratojugale) verhält. Schon seine gewöhnliche Bezeichnung als Quadratojugale ergibt, daß er meist dem sog.Qnadratomaxillare der Stegocephalen und der sich ähnlich verhaltenden Reptilien homologisiert wird, wogegen das sog. Supratemporale (d.h. unser Paraquadrat) der Stegocephalen und der erwähnten primitiven Reptilien als reduziert oder mit dem Squamosum vereinigt gedentet wird. Es wäre jedoch wohl ebenso möglich, daß sich das sog. Supratemporale (Paraquadrat) von Ichthyosaurus und Pareiosaurus bei den übrigen Reptilien mit dem Quadratomaxillare zn einem Knochen vereinigt hätte, eben dem sog. Paraquadrat oder Quadratojugale. Aus dieser Darlegung folgt, daß gerade die Dentung dieses.sog. Paraquadrats oder Quadratojugale der Reptilien noch recht unsicher erscheint und unsere Bezeichnung daher nur eine provisorische sein kann.

Die Rhynchocephalen zeigen das Paraquadrat (hier meist Quadratojugale genannt) wohl mit am ursprünglichsten (Fig. 156, S. 273). Es erstreckt sich als ein schmaler Knochen auf der Anßenseite des fest eingefügten Quadrats, längs des Hinterrands des absteigenden Squamosumfortsatzes. Dabei bleibt zwischen Paraquadrat nod Quadrat ein Loch (s. Fig. 156 C), das auch bei den Ichthyosauriern sehr deutlich hervortritt (Fig. 1693). - Das Distalende des Paraquadrats entsendet einen vorderen Fortsatz, der sich mit dem später zn erwähnenden Jugale zu einem sog. unteren Jochbogen vereinigt, während ein oberer vom Squamosum und Postorbitale gebildet wird. 
Von diesen Verhältnissen leiten sich die der Eidechsen (Fig. 157, S. 274) wohl derart $a b, d a ß$ mit der Beweglichkeit des Quadrats das Paraquadrat weiter hinauf rückte und sioh als schmaler gebogener Knochen an die Außenseite des hinteren Teils des stark verkümmerten Squamosums legte. Das Paraquadrat sendet einen nach vorn gerichteten Fortsatz gegen das Postfrontale oder Postorbitale zur Bildung eines oberen Jochbogens. Zuweilen ist jedoch das Paraquadrat auch stark bis ganz rückgebildet und damit auch dieser Jochbogen (s. Fig. 1602). Letzteres ist auch bei allen Ophidiern eingetreten.

Bei gewissen Sauriern (s. Fig. 1601) nimmt auch das später zu besprechende Jugale an der Bildung des Jochbogens teil, indem sein oberes Ende bis zum Paraquadrat aufsteigt.

Fig. 160.

1.

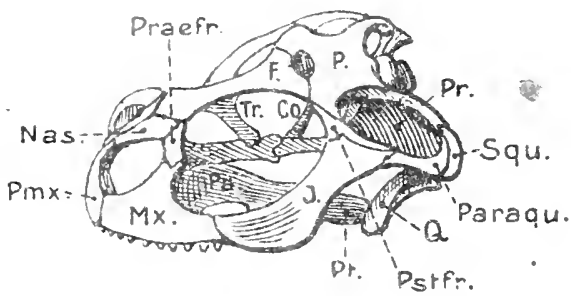

2.

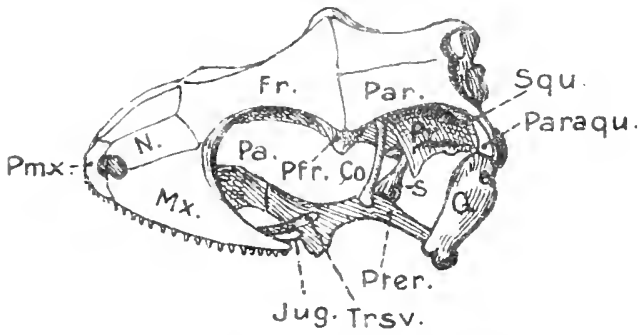

Schādel von Sa uriern. Iinkseitig nnd etwas dorsal. 1. Stel iio. 2. Gecko (Ascalabote). (Nach Currer 14:33.) F. oder Fr. Frontale, Co Columella, J. Jugale. N. oder Nas. Nasale, $\boldsymbol{M} \boldsymbol{x}$. Maxillare, P.oder P'ar. Parietale, PA. Palatinum, Pfr. oder Pstfr. Postfrontale, $P$. Prootienm, Pt. od. Pler. Pterygoid, Qu. Quadrat, S. Pterygoidfortsatz des Basisphenoid, Squ. Squamosnm, Tr. oder f'rst. Transversum.
Wenn man, wie dies nicht unwahrscheinlich, die Einrichtung der Saurier von Rhynchocephalen ähnlichen Vorfahren ableiten darf, so scheint es wohl möglich, daß mit dem Freiwerden des Quadrats der Saurier der sog. untere Jochbogen (Jugale und Paraquadrat) der Rhynchocephalen emporrückte und sich schließlich mit dern oberen vereinigte. Indem das Squamosum sich stark rückbildete, trat das Paraquadrat in der Bildung des oberen Jochbogens an seine Stelle.

Es ist schon herrorgehoben worden, daß das von uns als Paraquadrat bezeichnete Element der Saurier zuweilen auch als alleiniger Repräsentant des sog. Supratemporale (unser Paraquadrat) der Stegocephalen gedeutet und benamnt wird und daun als nicht homolog dem sog. Quadratojugale der übrigen Reptiiien, welches bei den Sauriern reduziert sei.

Die Bildung des Paraquadrats (Quadratojngale) bei den Reptilien mit feststehendem Quadrat läßt sich nicht ohne

Berücksichtigung des letzteren besprechen, weshalb dies zuerst betrachtet werden soll. - Bei Rhynchocephalen und Sauriern (Fig. 156, S. 273, 157, S. 274) steigt das etwa stabförmige Quadrat von der Vereinigungsstelle der beiden Suspensorialfortsätze schief nach vorn und unten herab. Diese jedenfalls ursprüngliche Richtung des Quadrats, welche sich auch bei vielen Urodelen fand, war auch gewissen fossilen Reptiliengruppen eigen. - Das Quadrat der Squamaten ist leicht beweglich aufgehängt. Bei den Eidechsen begreezt es die Paukenhöhle von vorn und ist daher hinten mehr oder weniger tief ausgehöhlt (Fig. $157 \mathrm{~B}, \mathrm{C})$. - Die Bewegliehkeit des Quadrats erhielt sich bei den Vögeln ausgiebig (Fig. 159, S. 278). Es gleicht im allgemeinen dem der Saurier, begrenzt auch wie dort die Paukenhöhle 


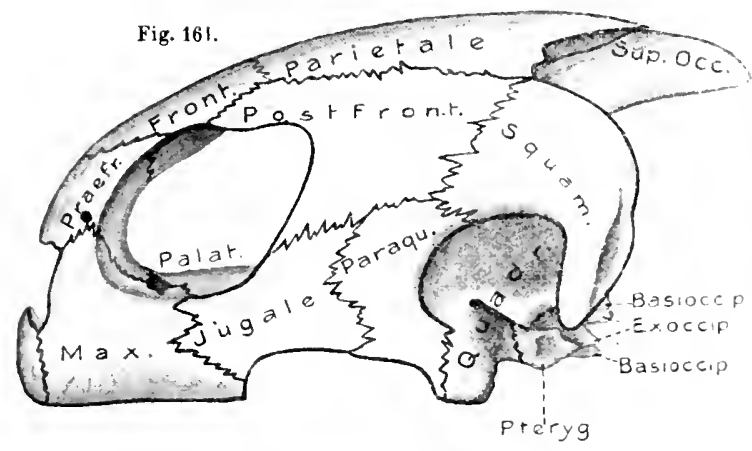

B

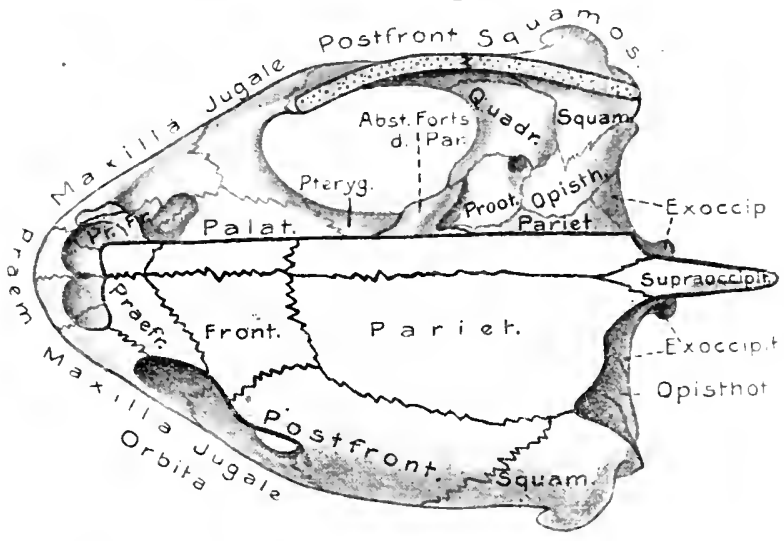

Choane

c
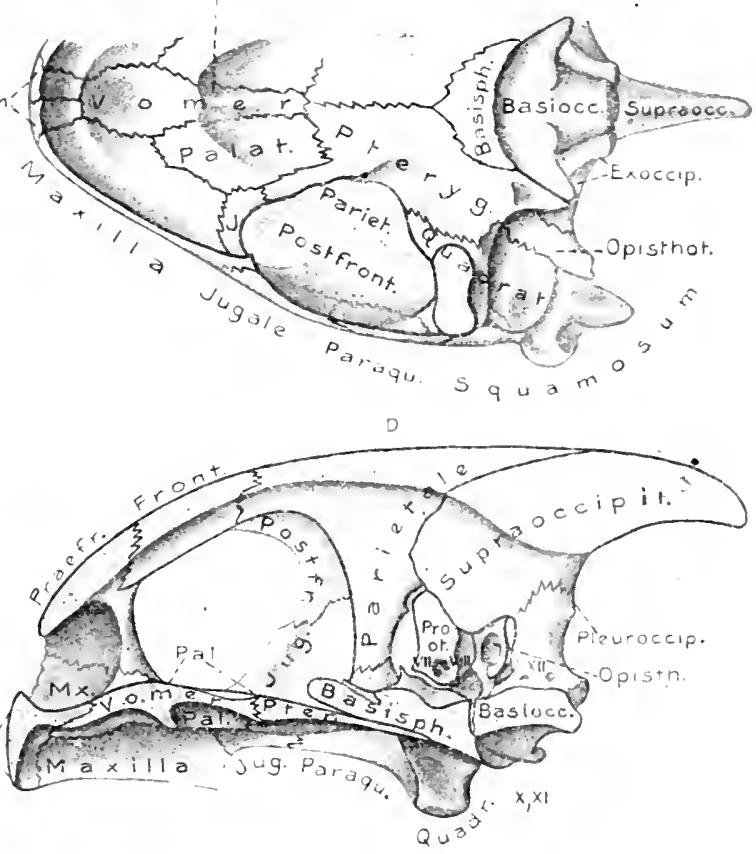

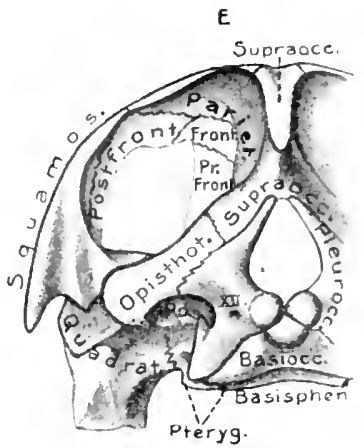

Chelone viridis. Schädel. $A$ Linkseitig. $B$ Dorsalansicht. In der rechten Halfte die die Schläfengrube überdachendeDecke teilweis weggesãgt, so daß die eigentliche Schãdelkapsel wand sichtbar iet. Schnittiâche des Postfront. u. Squamos. punktiert. C' Ventralansicht. in ln der Mediauebene durchgesehnittener Schảdel. Rechte Hălfte. Die innere Fláche der Schādelhöhle ist auch im erwachsenen Zustand von einer Knorpelschicht überzogen, die hier entfernt ist, so daB die Knochen sichtbar sind. $E$ Hinteransicht. E. W.

vorn; dagegen bildet es an seinem unteren Ende einen kräftigen, zum Pterygoid ziehenden, schief nach innen und vorn gerichteten Fortsatz, der auch bei den Rhynchocephalen schon gut ausgeprägt ist (Fig. $156 \mathrm{~B}$, S. 273).

Die Verhältnisse der Chelonier und Krokodile lassen sich von denen der Rhynchocephalen herleiten. Daskräftige Quadrat der Schildkröten hat sich, wie das der Rhynchocephalen, ziemlich senkrecht gestellt und ist proximal mit lem Opisthoticum, Prooticum und Squamosum verbunden (Fig. 161 A-C); einkräf- 
tiger innerer Fortsatz vereinigt $\lrcorner s$ auch mit den Flügelbeinen; binten zeigt es eine tiefe Einsenkung für die Paukenhöble, ja bei gewissen Formen umwächst es die Paukenhöhle in großer Ausdehnung und wird daher zu einem blasenartig aufgetriebenen Knoehen (s. Fig. 166, S. 288).

Sehr umgestaltet haben sich diese Verbältnisse bei den Krokodilen (Fig. 162). Der vom Suspensorialteil der Sehädelkapsel herabsteigende Teil des Quadrats ziebt sehief naeh hinten und außen und hat sieh erheblich verkürzt, weshalb die Gelenkstelle für den Unterkiefer viel höher gerüekt ist. - Das Paraquadrat (Quadratojugale) zieht als relativ schmaler Knoehen längs des Vorderrands des Quadrats hin. Die übrigen Verbindungen des ansebnlichen Quadrats sind ähnlieh wie bei den Schildkröten. Seine Streckung naeh hinten bewirkt, daß die Paukenhöhle iiber ihm liegt.

Ein wesentliehar Charakter des Reptiliensehädels besteht in der Bildung eines sog. oberen Jochbogens, der nur bei Schlangen und Vögeln rüekgebildet ist. Der Bogen entsteht, wie schon erwähnt, bei den Rhynehocephalen (Fig. 156, S. 273) dadurch, daß das Postorbitale einen freien Fortsatz nach hinten sendet, weleher mit dem vorderen des Squamosums zusammentrift. Bei den Sauriern (Fig. 157, S. 274) wird er vom Postorbitale (bzw. Postfrontale) und dem Paraquadrat gebildet; mit der Reduktion des letzteren (z. B. Ascalabotae Fig. 1602, Amphisbaenoida) fällt der Bogen daher aueh aus. - Zwischen dem oberen Joehbogen und der vom Parietale gebildeten Schädeldecke bleibt eine mehr oder weniger weite Lücke, das obere Scbläfenloch (Grube, Fossa supratemporalis). Mit der Verlagerung des Squamosum nach hinten bei den Sehlangen fallen die genannten Fortsätze des Postfrontale und Squamosums, sowie das Paraquadrat, fort und damit auch der obere Jochbogen. - Das gleiche trat mit der Rüekbildung des Postfrontale und der Veränderung des Squamosums bei den Vögeln ein; doeh entsendet das Squamosum gewisser Vögel (besonders Hühner) oberhalh des Quadrats einen vorderen Fortaatz, der als Rest des oberen Joshbogens gedentet wird, und in den sogar ein Rudiment des Postorbitale eingehen soll.

Bei den Cheloniern (Fig. 161 u. $166^{2}$, S. 288), welehen ein Postorbitale fehlt, wird der obere Jochbogen von einem hinteren Fortsatz des Postfrontale gebildet, der' sich mit dem vorderen oberen Fortsatz des Paraquadrats verbindet, an das sieh weiter hinten das Squamosum ansehließt. - Doch beteiligt sich aneh das emporsteigende Jugale, ähnlieh wie bei Rhynchocephalen und gowissen Sauriern, an der Bogenbildung, wie später noeh genaner geschildert wird. - Am oberen Jochbogen der" Krokodile (Fig. $162 B, C)$ endlieh nimmt das Paraquadrat nieht mehr teil, so daß der kleine hoeh hinauf gerïckte Bogen nur aus Postfrontale und Squamosum besteht. Indem sich bei den See- und einigen Flnßschildkröten (Fig. $161 A, B$ ) die mittleren Ränder der Parietalia zu ansehnlichen, seitlieh herabsteigenden Flügeln entwicke!n, denen aufsteigende der Postfrontalia und Squamosa entgegenkommen, wird das obere Schläfenloch völlig geschlossen. Es ist dies eine Einriehtung, die wohl ans dem oberen Suspensorialfortsatz der ursprïnglichen Reptilien hervorging und zur Vergrößernng der Ansatzfläehe der vom Riicken zum Schädel tretenden Muskulatur beiträgt. 
Die Schilderung des Kiefergaumenapparats, zu der wir uns nun wenden, wird die des oberen Jochbogens vervollständigen. - Die allgemeine Bildung des Apparats wiederholt die schon bei den Amphibien, besonders den Stegocephalen und

Fig. 162.
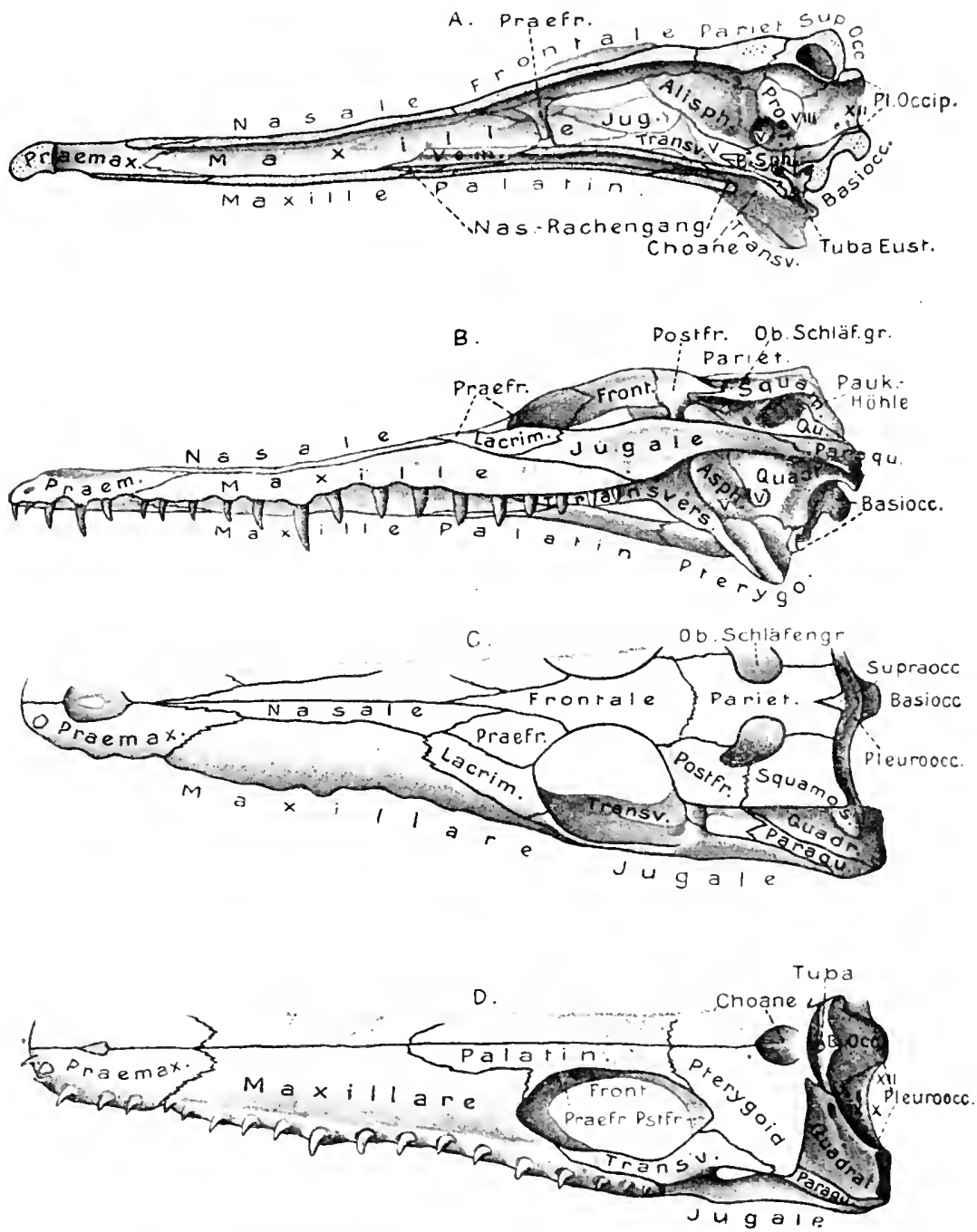

Crocodilus acutus. Schadel. A In der Medianebene halbierter Schädel; rechte llalfte. B linkseitige Ansicht. (') Horsalansicht. I) Ventralansicht.

Anuren, angetroffenen Verhältnisse. Aus dem beifolgenden Schema (Fig. 163) elgibt sich der allgemeine Aufhali aus einer inneren Pterygopalatinreihe und einer äußeren Mixillarreihe jederseits, die sich beide hinten dem (quarlat anfügen können, nnd die ferner hinten am Basisphenoid, vorn am Vomer Stiitzpunkte finden. - 
Die änßere Reihe vervollständigt sich bei den meisten Sauropsiden durch die Einschaltung eines Jochbeins (Jugale) zwischen Paraquadrat (Quadratojugale) und Maxillare. Ferner tritt bei den meisten Reptilien eine innigere Verbindung der beiden Reihen durch einen etwas schief vom Pterygoid zur Maxille ziehenden Hantknochen anf, das Transversum, dessen Vergleichung mit dem Ectopterygoid der Fische wohl nicht ganz ungerechtfertigt ist. Das Transversum, das schon gewissen Stegocephalen zukommen soll, fehlt unter den rezenten Reptilien nur den Schildkröten, von fossilen Gruppen den Sauropterygia, Theromorpha und Pterosauria; ebenso den Vögeln.

Schließlich tritt bei den meisten Sauriern (ausgenommen Amphisbaenoiden und Chamäleonten), sowie den Rhynchocephalen, ein Paar eigentümlicher stabförmiger

Fig. 163.

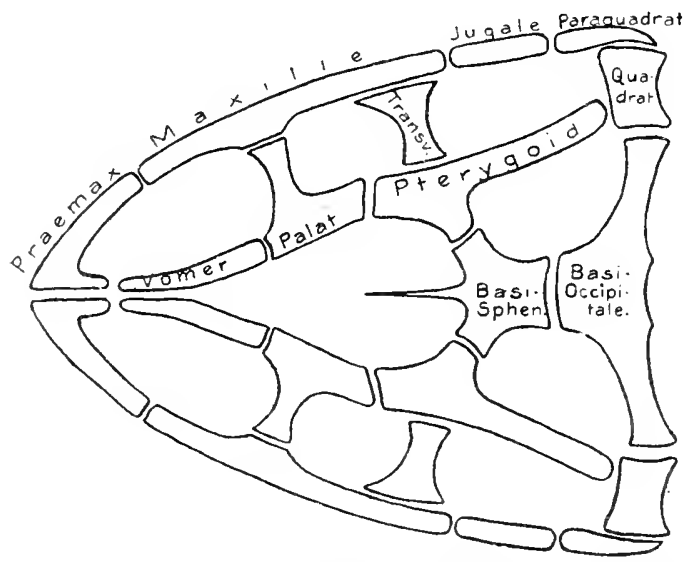

Schema des Kiefergaumenapparats der Sauropsida. Ventralansicht.

Ersatzknochen (Columella cranii, Epipterygoid) auf, welche etwa von der Mitte der Pterygoide aufsteigen und die Scheitelbeine stützen, sowie die seitlichen vorderen Schädelkapselwände vervollständigen. - Da diese Columella auch vielen ausgestorbenen Reptiliengruppen zukommt (alte Krokodile [Parasuchia], Anomodontia, Ichthyosauria, Dinosauria, siehe Fig. 168, 169, S. 289, 290), so ist sie jedenfalls eine recht ursprüngliche Einrichtung. Sie gehtals Ersatzverknöche-

rung ans dem aufsteigenden Fortsatz des knorpeligen Palatopterygoids hervor. Möglicherweise ließe sie sich mit einem der drei Pterygoidknochen der Fische in Beziehung setzen.

$\mathrm{Ob}$ die oben erwähnten absteigenden Scheitelbeinfortsätze der Chelonia nicht Beziehungen zu diesen Columellae haben, scheint mir noch fraglich.

Die ursprünglichste Beschaffenheit bewahrt der Kiefergaumenapparat bei den Squamaten, wo die beiden Palatopterygoidreihen schmal bleiben und in der Mittellinie des Gaumendachs nicht zusammenstoßen, sondern durch einen weiteren bis schmäleren Zwischenraum getrennt sind (Fig. 157 A, S. 274). Bei den Rhynchocephalen (Fig. 156 B, S. 273) stoßen die Pterygoide porn zusammen. Bei den Vögeln bleibt die Lücke im allgemeinen schmäler, die Gaumenbeine berühren sich häufig in der Mittellinie (Fig. 159 B, S. 278). - Die Pterygoide erreichen hinten die Quadrate, oder stützen sich auf sie, und gelenken in ihrem Verlauf nach vorn an den Pterygoidfortsätzen des Basisphenoids. Vorn verbinden sie sich mit den Palatina, welche ihrerseits an die paarigen (Squamata) oder 
den unpaaren Vomer (Aves) anschließen und sich auch seitlich an die Maxillen anlehnen.

Die äußere Reihe des Kiefergaumenapparats der Squamaten besteht vorn ans den meist mäßig großen Prämaxillen, die teils gesondert bleiben, häufiger jedoch verwachsen, was bei Schlangen und Vögeln stets der Fall ist. Die Prämaxillen der ersteren sind sehr reduziert und nur selten (Riesenschlangen) noch zahntragend (Fig. 158, S. 275). - Der Zwischenkiefer der Vögel hat sich bei der Schnabelbildnng stark verlängert, bleibt jedoch im allgemeinen schmal. - An die meist ansehnliche Maxille, die nur bei den Giftschlangen sehr klein wird (Fig. 164), schließt sich hinten das Jugale, welches in der ganzen Squamatenreihe ein schmächtiger länglicher Knochen bleibt. Den Schlangen fehlt es: Das Jugale der Rhynchocephalen (Fig. $156 \mathrm{~A}, \mathrm{~B}$, S. 273) reicht von der Maxille bis zum Quadrat und Paraquadrat, so da $B$ die Maxillarreihe durch einen sog. Unteren Jochbogen vervollständigt erscheint. Gleichzeitig sendet es einen Fortsatz aufwärts zum Postorbitale, welcher den hinteren $\mathrm{Au}$ genhřhlenrand ergänzt. Zwischen dem oberen und

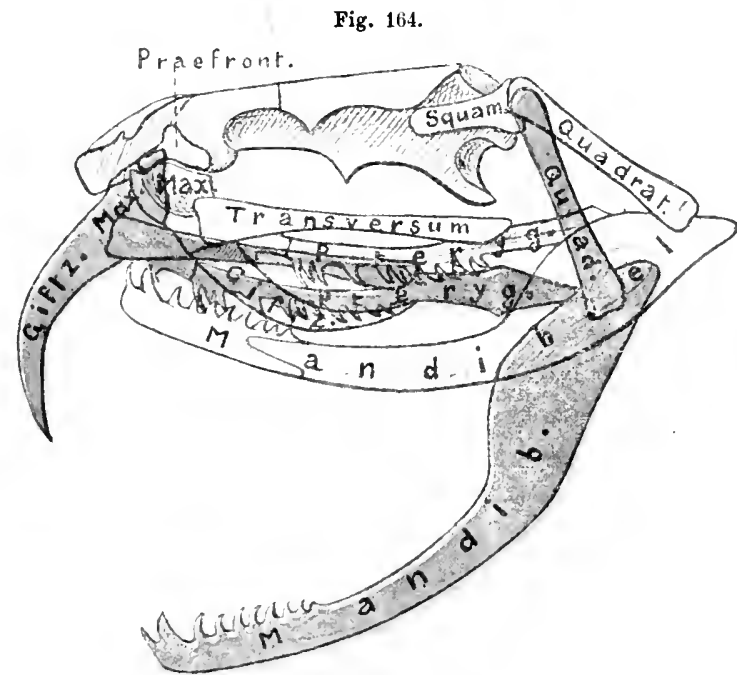

Schematische Darstellung des Schádele einer Giftechlange (Solenoglypha) Der Kiefergatumenapparat bei aufgesperrtem Manl braun eingezeichnet, bei geschlossenem hell.

unteren Jochbogen besteht also hier eive Öffnung, die untere Schläfengrube (Fossa infratemporalis).

Die vollständige Ausbildung der Maxillarreihe hat sich bei den Vögeln (Fig. 159, S. 278) erhalten und damit der untere Jochbogen, während der obere, wie erwähnt, fehlt. Das schmale Jugale der Vogel verbindet sich mit dem Quadrat durch eineu stabförmigen Knochen, der wohl richtig als das stark verkleinerte Paraquadrat (Quadratojugale) gedeutet wird.

Den Sauriern (Fig. 157) fehlt das Jugale nur selten (Ạphisbaenoida), hat jedoch die Verbindung mit dem Paraquadrat oder Quadrat aufgegeben, so daß ein unterer Jochbogen fehlt. Dagegen blieb der Orbitalfortsatz des Jugale stets erhalten und begrenzt die Orbita hinten, indem er gewöhnlich mit dem Postorbitale oder Postfrontale zusammenstößt; zuweilen (Fig. 1602) ist er jedoch auch sehr verkïmmert. - Mit dem Ansfall des Jugale haben die Schlangen (Fig. 158, S. 275) natürlich den nnteren Jochbogen ebenso verloren wie den oberen. 
Die Beweglichkeit des Quadrats in der Squamatenreihe greift zum Teil auch auf die übrigen Knochen des Kiefergaumenapparats über. Die Eidechsen zeigen dies nur venig, die Schlangen dagegen in hoher Ausbildnng, besonders die eigentlichen Giftschlangen (Fig. 164).

Die Beweglichkeit des Kiefergaumenapparats an der Unterseite des Schädels (mit einziger Ausnahme der Prämaxille, wo diese nicht verkümmert) hat die Bedeutung, den bei den Riesenschlangen reich bezahnten Kieferapparat beim öffnen des Mauls etwas vorzuschieben; bei den Giftschlangen aber, den kleinen Oberkiefer mit dem sehr langen Giftzahn, der bei geschIossenem Maul nach hinten umgelegt ist, aufznrichten. Dies geschiebt so, daß beim Herabziehen des Unterkiefers das untere Ende des Quadrats etwas nach vorn geschoben wird. Hierdurch werden auch die mit dem Quadrat verbundenen Flügelbeine vorgeschoben and drehen, vermittels der sehr langen Transversa, den Oberkiefer um seinen oberen Drehpunkt am Präfrontale vorwärts, wobei sich der Giftzahn aufrichtet (Fig. 164).

Der Kiefergaumenapparat der Vögel ist gleichfalls in seiner Gesamtheit mehr oder weniger beweglich. Hierauf beruht es, daß beim Herabziehen des Unterkiefers, wobei sich das Unterende des Quadrats ebenfalls vorwärts bewegt, der Oberschnabel mehr oder minder stark aufwärts bewegt wird. Dies wird dadurch ermöglicht (vgl. Fig. 159, S. 278), daß zwischen dem Mesethmoid, den Frontalia und Praefrontalia hinten, und den sich daran vorn anschließenden Nasalia eine bäutigknorpelige Lücke bleibt, weshalb der Oberschnabel hier beweglich ist. Bei den Papageien, wo die Beweglichkeit besonders groß ist, besteht an dieser Stelle eine wirkliche Gelenkung.

Der Kiefergaumenapparat der Placoiden und sämtlicher ausgestorbener Reptilienordnungen (vgl. Fig. 168, 169, S. 289, 290) ist dadurch charakterisiert, daß die Quadrate wie bei den Rhynchocephalen fest zwischen die benachbarten Knochen eingefügt sind. Ferner stoßen die Knochen der inneren Reihe in der Gaumenmittellinie bei Placoiden, Sauropterygia (Fig. 1698), Theromorpha (Fig. 168²) und Dinosauria (Fig. 169 ${ }^{7}$ za einem geschlossenen Gaumendach zusammen.

Indem die Flügelbeine der Chelonier (Fig. 161C, S. 281) in dieser Weise zusammentreton und sich gleichzeitig in bedeutender Ausdehnnng dem Basisphenoid jederseits direkt anlegen, meist an Fortsätze desselben, wird das Basisphenoid von ihnen stark tiberdeckt, so daß nur sein hinterer Teil (vgl. Fig. 161 D) an der unteren Schädelfläche sichtbar bleibt. Seitlich stehen die Flügelbeine in breiterVerbindung mit dem Quadrat. Die Palatina haben sich ebenfalls staris verbreitert und stoßen vorn an die stark entwickelten einspringenden Ganmenlamellen der Maxillen und den hier unpaaren Vomer, so daß die bei den Sauriern in dieser Region vorhandenen weiten Löcher, in welchen die inneren Nasenöffnungen (Choanen) liegen, bei den meisten Schildk:öten stark verengt sind, und nur ein relativ kleiner Teil des Vomer auf der Gaumenfläche hervortritt. Die in der Mittellinie stark geuäherten Choanen werden innen vom Vomer begrenzt (s. Fig. 165 1), seitlich von den Maxillen und Palatina, hinten von den Palatina. Indem sich nun die Gaumenbeine mit ihren seitlichen Teilen ventral herabkrümmen, und diese absteigenden Fortsätze schließlich in gegen die Mittellinie gerichtete horizontale Lamellen auswachsen, die die ursprüngliche Choanenöffnung etwas nach hinten verlängern, bilden sie die erste 
Anlage eines sekundären Nasenrachengangs, wie er bei den Seeschildkröten in der Anlage schon deutlich hervortritt (vgl. das Schema Fig. 165).

Dieser bèi den Schildkröten im Entstehen begriffene Gang nnd die damit verbundene Ruckwärtsverlagerung der Choanen ist bei der rezenten Krokodilen aßBerordentlich entwickelt, hat sich jedoch erst in der Krokodilreihe hervorgebildet, wic die fossilen Formen erweisen. Die plattenförmigen Gaumenlamellen der Prämaxı'len und der hier sehr langen Maxillen (Fig. 162 A, D, S. 283) sind in der Mittellinis zu einem Iangen geschlossene? vorderen Gaumendach zusamm ngetreten. Die Abwärtskrümmıng der äußeren Ränder der Palatina und die Bildung ihrerhorizon alenGaumenlamellen hat sich uber ihre ganze Länge ausgedehnt. Diese ventralen Gaumenlamellen stoßen in der Mittellinie zusan men und bilden so den ventralen Abschlnß eines Nasenrachengangs, der weiter vorn von den Kieftrgaumenlamellen fortgesetzt wird. Mit dieser Umformung der Palatina ist ihr primitiver Teil, Jer dorsal iber dem Nasenrachengang lag, schwächer geworden als die ventralen Lamellen. - Die Bildung horizontaler Gaumenlamellen dehnt sich jedoch bei den neogenen Krokodilen noch weiter nach hinten auf die vordere Region der Pterygoide aus, so daß der Nasenrachengang erst Fig. 165 .

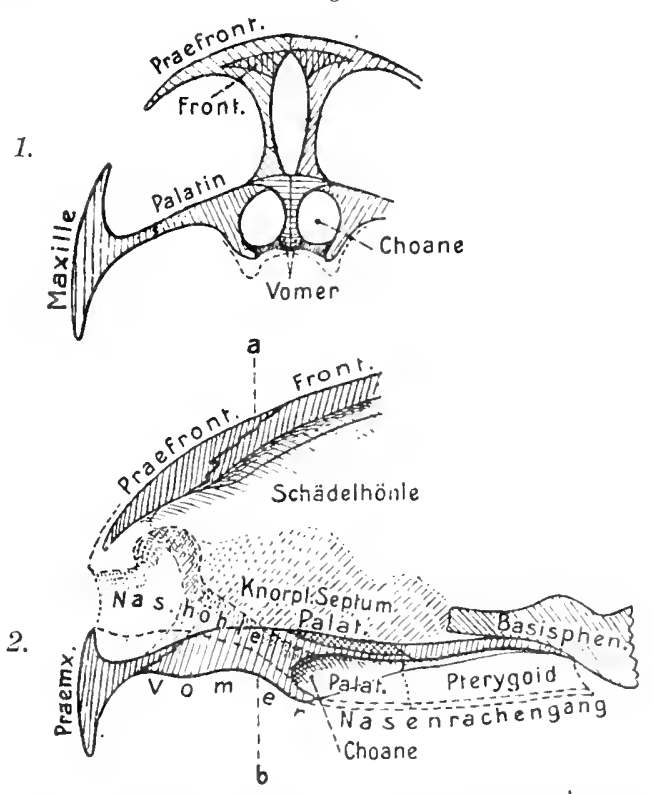

Schematische Erläuterung zur Bildung des Nasenrachengange bei den Krokodilen. 1. Querschnitt durch die Nasenregion einer Schildkrote; er zeigt die Bildיng absteigender Lamellen der Palatina zur Umfassung der Choanen. 2. Medianer Lāngsschnitt durch den vorderen Teil dosselben Schädels mit Um. riß der rechten Nasenhöhle. Die weitere Entwicklung der absteigenden Lamellen der Palatina nnd Pterygoidea zur lildnng eines weit nach hinten reichenden Nasenrachengangs ist dnrch punktierte Linien angedeutet. Linie $a b$ bezeichnet ongefähr die Durchschnittsebene von Figur $1 . \quad 0$. B.

etwa in der Mitte der Flügelbeine, ganz am Hinterende des Schädels, und nahezu unter dem Hinterhauptloch durch dio sekundäre Choane ausmündet. Die Entstehungsweise eines solchen Nasenrachengangs ist im Schema Fig. $165^{2}$ angedeutet.

Dio bei den paläogenen Krokodilen, ähnlich wie bei Cheloniern, noch am Gaumendach hervortretenden parigen Vomer werden bei den neogenen von den Maxillen und Palatina aus der Gaumenfläche ganz verdrängt und sind als zwei lange dünne Knochenlamellen der Nasenhŏhlenwand eingelagert (s. Fig. 152 A). Wie schon früher angedeutet, kommt den Krokodilen allgemein ein kräftiges Transversum za, das den Schildkröten fehlt.

Die äußere Reiho der Kiefergaumenknochen ist bei den Krokodilen vollständig, ein unterer Jochbogen daber vorhanden (Fig. 162 B, C). Er wird von einem kräftigen 
Jugale gebildet, das einen Orbitalfortsatz zum Postfrontale emporschickt und sich hinten dem Paraquadrat anschließt.

Fig. 166 .

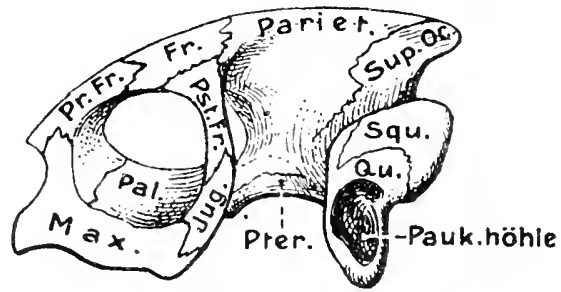

1. Cistudo

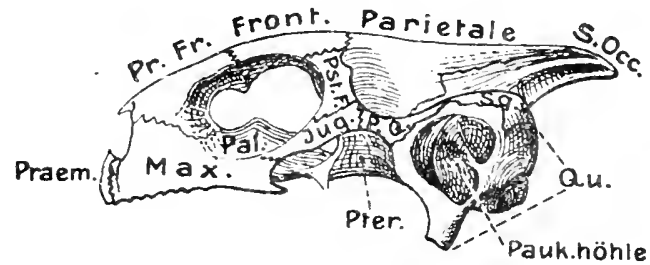

2.Testudo

Schildkrötenschādel. Linkseitige Ansicht. 1. Cistudo (nach RABL 1903). 2. 'T'estndo. o. B.
Die Schildkröten zeigen, wie schon obẹn (S. 282) erwähnt, z. T. einen Jochbogen, welcher dem oberen der Saurier und Rhynchocephalen sehr gleicht (Fig. 1662). Er wird vom Orbitalfortsatz des Jngale, dem Postfrontale und den vordereu Fortsätzen des Squamosum und Paraquadrats (Quadratojugale) gebildet (Testudo). Ein unterer Jochbogen fehlt. - Bei manchen Flußscbildkröten wächst aber der untere Rand dieses Jochbogens durch plattenförmige Ausdehnung des Paraquadrats und des Jugale herab, so daß sein unterer Rand nahezu an dio Stelle eines unteren Jochbogens rüekt. - Bei den Seeschildkröten (Fig. $161 \mathrm{~A}, \mathrm{~S}$. 281) ist dies am stärksten ansgebildet; doch findet sich auch bei ihnen noch ein schwacher Ansschnitt zwischen

Fig. 167.
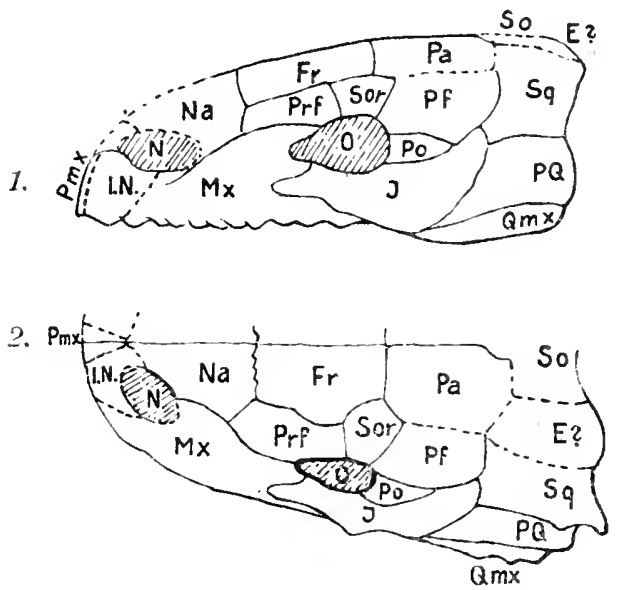

Pareiosaurus (theromorphes Reptil) schematisch. (Nach SEELEY 1858.) Zweifelhafte Grenzen puntiert. 1. Linksseitig. 2. Dorsalseite, $E ?=$ ? Epioticum. I.N. Internasale (ob Septomaxillare?), $N$ Nasenōffunng, Orbita, Po Postorbitale, Sor Supraorbitale. 0. B.
Maxille und Paraquadrat, was darauf hinweist, daß die Sachlage in der angegebenen Weise entstand. $\mathrm{Da}$, wie früher bemerkt, die obere Schläfengrube der Seeschildkröten von den Parietalia nnd Squamosa ganz überdacht ist, und sich die Verbreiterung des oberen Jochbogens hieran direkt anschließt, so findet sich hinter der Orbita eine zusammenhängende äußere Überdachung der seitlichen Schädelwand (Fig. $161 B, E$ ). - Andrerseits kann jedoch bei gewissen Flußschildkröten, unter Rückbildung des Paraquadrats, der Jochbogen ganz eingehen (s. Fig. $166^{1}$, Cistudo), so daß die obere Schläfengrube nur von einem hinteren Fortsatz des Parietale, der zum Squamosnm zieht, iiberdacht wird, oder auch völlig offen liegt. 
Dies geschlossene Schläfendach der Seeschildkröten besitzt eine gewisse Übereinstimmung mit dem ursprünglichsten Schädelbau der Sauropsiden, wie er sowoll durch paläontologische Funde (gewisse Theromorpha, s. Fig. 167), als durch die notwendige Ableitung der Sauropsiden von stegocephalenartigen Vorfahren sehr wahrscheinlirh wirl.

Neuere Funde haben permische Formen mit röllig geschlossenem stegocephalenartigen Schädeldach zutage gebracht, welche durch ein sehr reduziertes Parasphenoid, sowie einen einfachen Occipitalcondylus nächste Beziehungen zu den Reptilien rerraten. Daneben stehen selır alte reptilienartige Formen, wie z. B. der auf Fig. 167 abgebildete Pareiosaurus (Theromorpha) mit völlig gescblossenem Schläfendach von stegocephalenartigem Habitus. - Wenı es daher auch wohl sicher erscheint, daß ein solcher Zustand den Ausgangspunkt des Sauropsidenschädels bildete, so scheint es dagegen mehr wie fraglich, ob in dem geschlossenen Schläfendach der Sceschildkröten eine solch primitive Fildung erhalten blieb. Im Gegen-

Fig. 168.
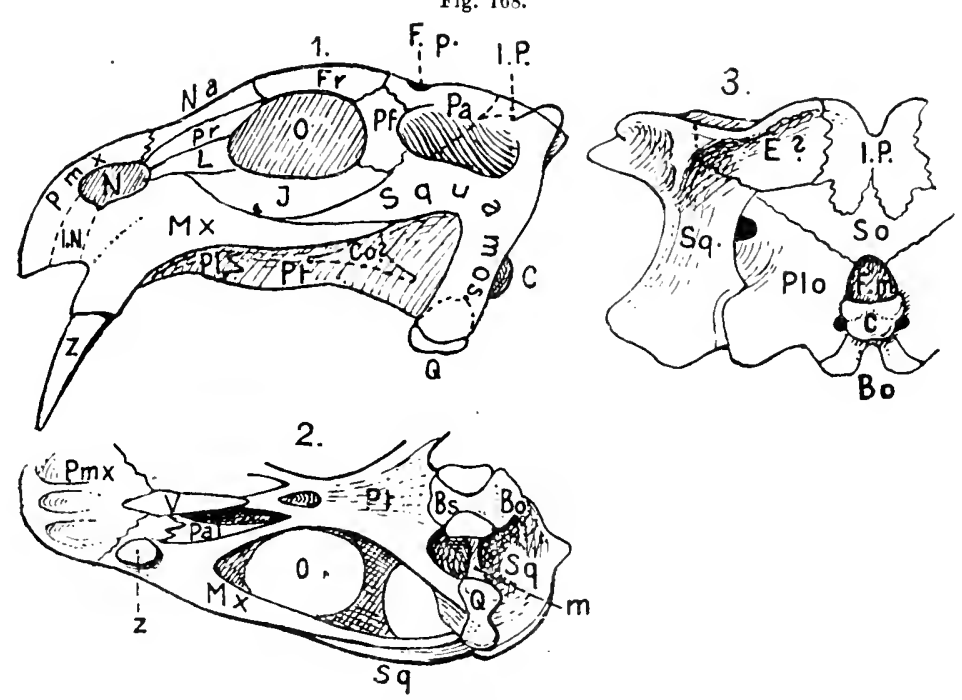

Dic ynodon (theromorphes Reptil). Schädel echematisch. (Nach SEeLEr 1889.) 1. linkseitig. 2. Ventralseite.

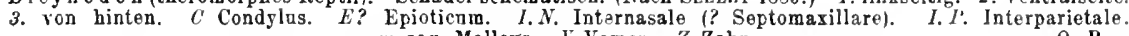
$m$ sog. Malleus. $Y$ Vomer. $Z$ Zahn.

teil weisen sowobl die paläontologiscben Befunde, als die jedenfalls sekundäre Anpassung der Seeschildkröten an das Meerleben, darauf hin, daß sie phylogenetisch jüngere Formen sind und ihr geschlossenes Schläfendach daher aus einer Suhädelform mit oberer Schläfengrube hervorging. Dies wird auch durch die Beziehungen des Chelonierschädels zu den zahlreichen Theromorphen mit oberer Schläfengrube (Fig. 168) bekräftigt. Die erste Entstehung einer oberen Schläfengrube, und damit eines oberen Jochbogens, muß wohl durch einen Durchbruch zwischen Parietale, Supraoceipitale, Postfrontale und Squanosum erfolgt sein; denn daß sich diese obere Schläfengrube etwa auf den Abschluß les binteren Einschnitts, den der Stegocephalenschädel zeigt, und der sich sogar zuweilen schließen kann (Cyclotosaurus), zurückführen ließe, ist wenig wahrscheinlich. Allen Sauropsiden kam daher dieser obere Durchbruch (Schläfengrube) wohl ursprünglich zu und ist bei den Seeschildkröten höchstwahrscheinlich şekundär wieder geschlossen worden. - Bei einer Reihe ron Reptilien (Theromorpha [Fig. 168], Sauropterygia, Ichthyopterygia [Fig. 1691], Clılonia und älteste Crocodilia [Fig. 1694]) findet sich nun allein diese obere, engere bis weitere Schläfengrube und ein einziger. breiterer bis schmälerer Jochbogen, der im allgemeinen aus Postfrontale, Syuamosum, Jugale und Paraquadrat (Quadratojugale) besteht (sog. Synapsidia). Bei rielen dieser Furmen bildet 
sich jedoch eine mehr oder weniger tiefe Einsenkung oder ein Ausschnitt des unteren Kieferrandes dieses Jochboge..3 aus, wodurch er verschmälert und scheinbar als ein oberer in die Höhe gehoben wurde, der eine unabgeschlossene untere Schläfengrube teilweise umrandet, wie dies bei den Sauropterygia, Chelonia, auch einem Teil der Theromorpha (Fig. 1681) deutlich hervortritt.

Bei den Rhynchocephalen, Krokodiliern und Dinosauriern (Fig. 1695) flndet sich nun ein ähnlicher oberer Jochbogen, gebildet vom Postorbitale (bzw. Postfrontale) und dem Squamosum;

Fig. 169.

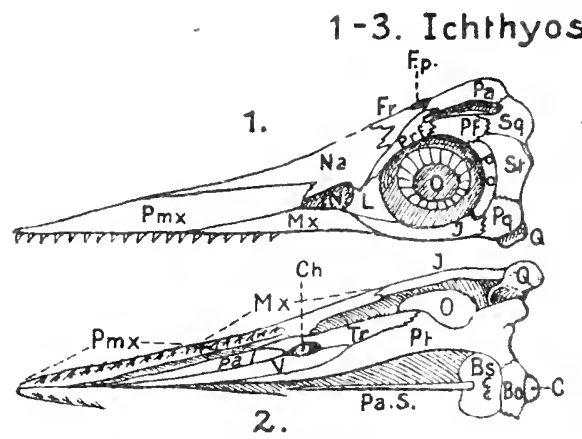

5-6. Ceratosaurus
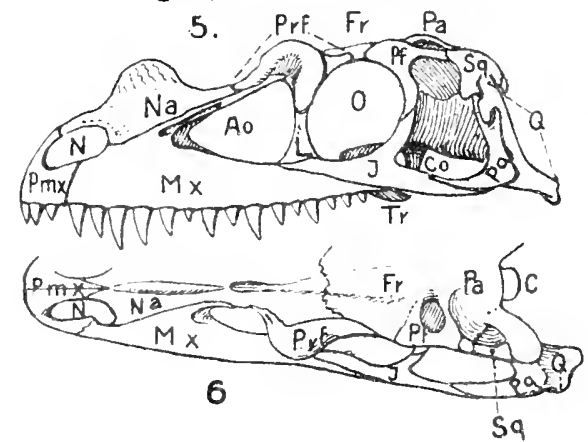

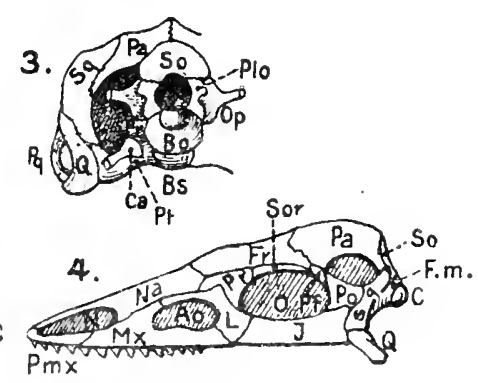

4. Aerosaurus 7. Diplodocus
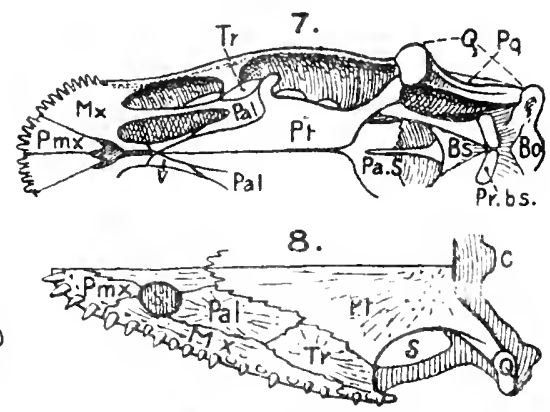

8. Simosaurus

Sehematische Darstellung ron Schadeln einiger fossiler Reptilien. 1-3. Ichthyosadras; 1. linkseitig. 2. von der Ventralseite. 3. von hinten. (Naé E. FraAs 1s9l.) \&. A etosauras (Crocodilia) linkseitig. (Nach 0. FraAs ans Ziter.) $5-6$. Ceratosanrus (Dinosaria). 5 . linkseitig. (5. Dorsalseite. (Nach Marse 1896.) 7. Diplodocus (Dincsarria) Ventralseite. (Nach March 1896.) 8. Simosantas (Sauroptergiii) Ventralseito. (Nach JaEkEL 1910.) Ao Antorbitalloch. Bo Basioccip. Bs Basisphenoid. C Condylus occipit. Ca Columella anris. Ch Choane. Co Colunella. F. m. For. magn. F. p. For. parietale. Fr Frontale. $I$ Jugale. $L$ Lacrimale. $M_{x}$ Maxiilare. $N$ Nasenöffnung. Na Nasale. Op Opisthotic. Pa Pariet. Da. $S$ Parasphenoid. I'al Palatinum. Pf Postfrontale. Plo Pleurooccip. Pmx Praemax. Proder Prf Praefront. Pr Prooticum. Prbs Fortsãtze des Basisphen. Pi Pteryg. $Q$ Quadrat. $S$ obere Sthläfengrube. So Supraoccip. Sor Supraorbit. Sq Squamos. St sog. Supratempor. I vomer.

0.3

daneben jedoch noch ein unterer, als hintere Fortsetzung des Maxillarrandes, der vom Jugale und Paraquadrat formiert wird. Er bewirkt den Abschluß einer unteren Schläfengrube (sog. Diapsidia). Daß dieser untere Jochbogen eine spätere Bildung ist als der Bogen der sog. synapsiden Reptilien, kann kaum fraglich sein. Dagegen ist wohl noch etwas zweifelhaft, wie er entstand. Einerseits kann er sich durch einen zweiten Durchbruch in dem einfachen Bogen der synapsiden Ansgangsformen gebildet haben; andrerseits ließe sich jedoch erwägen, ob er nicbt durch einen sekundären AbschluB der offenen unteren Schläfengrube der Synapsiden herrorgegangen sei. Das erstere dürfte das Wabrscheinlichere sein. Daß der ursprünglich 
vorhandene untere Jochbogen bei den Squamaten reduziert wurde, bei den Schlangen auch der obere, ist wohl sicher. Bei den Vögeln dagegen erhielt sich der untere, während der obere einging.

Unterkiefer. Der Aufbau jeder Unterkieferhälfte der Sauropsiden ist noch komplizierter als bei den Fischen (s. Fig. 170). Der Meckelsche Knorpel erhält sich häufig bis in höheres Alter als Fortsetzung des Articulare. Gewöhnlich sind die beiden Dentalia in der Symphyse durch Knorpel oder Naht vereinigt. Die Schlangen besitzen dagegen in der Regel eine Bandverbindnng, welche erlaubt, daß die Unterkieferäste weit voneinander gespreizt werden können, zur Erweiterung des Mauls. Bei den meisten Schildkröten, vielen Anomodontien und allen Vögeln verwachsen die Dentalia in der Symphyse einheitlich; wie denn bei den Vögeln und den fossilenPterosauria sämtliche Unterkieferknochen gewöhnlich frühzeitig verschmelzen. Hinsichtlich der komplizierten Zusammensetzung derUnterkieferhälften sei auf die beifolgende Figur 170 verwiesen, welche die rechte Unterkieferhälfte der HauptChelone Fig. 170

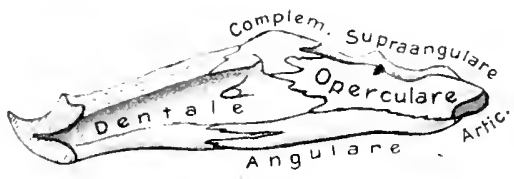

Alligator

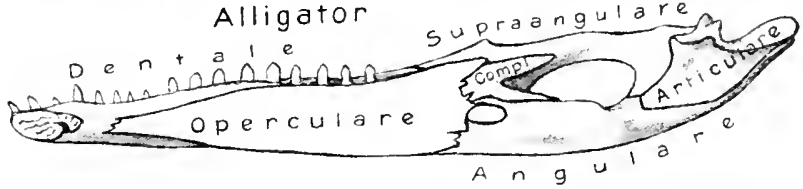

Varanus

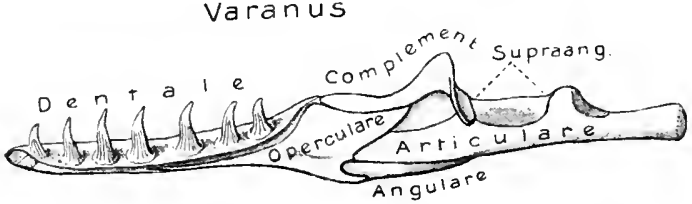

Struthio

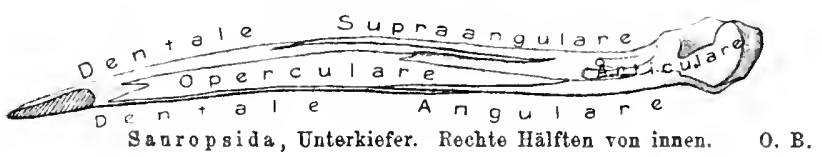

grappen von der Innenseite zeigt. - Bei gewissen Sauriern und Cheloniern tritt in der Ontogenese auf der hinteren Medialfläche ein sog. Postoperculare oder Dermarticulare auf, das jedoch meist bald mit dem Articulare verwächst. Im einzelnen gibt es natürlich mancherlei Abweichungen und Besonderheiten in der $\mathrm{Zn}$ sammensetzung des Unterkiefers, teils durch Verwachsung gewisser Knochen (so Angulare $\dot{r}$ Artic., auch + Supraangulare), teils durch gelegentliches Fehlen (Operculare, Complementare) oder durch Zutritt weiterer Elemente, worauf hier nicht näher eingegangen werden kann.

Mfammalia. Der Säugerschädel bietet eine eigentümliehe Mischung älterer, auf die Amphibien hinweisender Charaktere und jüngerer, welche Beziehungen zu den ursprünglichen Sauropsiden verraten. Dies stimmt im allgemeinen auch 
mit dem ibberein, was aus den sonstigen Organisationsverhïltnissen über die phylogenetische Abstammung der Säuger za erschließen ist; da sie ja einerseits gemeinsamen Ursprungs mit den ubrigen Amnioten sein müssen, sich jedoch von dieseu schon sehr frïhzeitig, vor Ansbildung der typischen Sanropsidencharaktere, abgezweigt haben. Es scheint daher, trotz einzelner reptilienartiger Züge im Schädel, nicht möglich, die Mammalia von einer der bekaunten Reptiliengrappen her'ujeiten.

Leider haben die zahlreichen fossilen Sängetierreste bis jetzt über die phylogenetische Entwicklung, speziell die des Schädels, fast nichts ergeben, da von àen ältesten Formen Schädelteile kaum bekanit sind. Auch die primitivsien lebenden Sänger, die Monotremen, bieten in dieser Hinsicht Schwierigkeiten, da ihre Schädelknochen, ähnlich wie die der Vögel, sehr frühzeitig verwachsen, und die erhaltenen wenigen Formen jedenfalls äußerst spezialisierte sind, was sclion der völlige Mangel der Zälne ergibt, ihr Schädel sich daher von dem Urtypus wohl weit entfernt hat.

Einen Charakter, der besonders ursprünglich erscheint, bilden vor allem die vorwiegend von den Pleurooccipitalia gebildeten beiden Condyli, welche auf dio Amphibien hindeuten.

Der Versuch, die doppelten Condyli von dem unpaaren der fossilen Reptilien, speziell der Anomodontia, der zweilappig sein kann, durch Reduktion des Anteils des Basioccipitale herzuleiten, ist vorerst noch nicht geglückt. Wahrscheinlicher ist die Ableitung von dem quer nierenförmig gestalteten Condylus mancher Saurier und Rhynchocephalen, indem auch die Condyli mancher Mammalia sich noch auf das Basioccipitale ausdehnen können, ja bei Echidna gewöhnlich noch durch einen Knorpelstreif vereinigt sind. Wichtig erscheint für dies Problem ferner, daß bei Echidna danernd, bei anderen Mammalia embryonal, eine einheitliche sauropsidenartige Gelenkspalte zwischen den beiden Condyli und dew Atlas besteht, während die höberen Säuger gesonderte Spalten für jeden Condylus besitzen. Erschwert wird das Problem ferner dadurch, daß nach der gewöhnlichen Ansicht die drei vorderen Wirbel der Amphibien in den Schädel der Amnioten eingingen.

Auch in seinen Beziehungen zu den Reptilien verrät der Schぬdel eine eigentümliche Mischung von Charakteren. Das für alle Sänger bezeichnende Ansscheiden des Quadrats aus seiner ursprünglichen Funktion als Träger des Unterkiefers, indem es sich, unter starker Verkleinerung, als ein Gehörknöchelchen der Columella auris del Sauropsiden beigesellt, konnte nur aus einer Urform mit beweglichem Quadrat hervorgehen. Dies wiese daher anf Beziebungen zu der Squamatenreihe der Sauropsiden hin; doch wird auch die Meinnng vertreten, daß die Beweglichkeit des Quadrats im Säugerstamm erst sakundär, sus ursprünglich fester Verbindnng hervorgegangen sei. -- Dagegen schließt sich der übrige Kiefergaumenapparat der Säuger ofienbar näher an den der Placoidreihe der Reptilien an, doch fehlt ihn stets das Transversum, sowie die Columella eranii, was ebenfalls auf frubere $\mathrm{Ab}-$ stammung hinweist. Also verrät sich auch in diesen Punkten ein tiefer Uraprung der Säuger, der vor die Trennung der Sauropsiden in jene beiden Reihen fällt. — Mit der Umbildung des Quadraìs mußte cine Verlagernng der Gelenkstelle für den Unterkiefer korrespondieren; dieselbe wurde hoher hinanf an das Squanosum verlegt, was sich bei den Ursäugern wohl sicher mit der Erhebung des Gelenkteils des Unterkiefers zu einem aufsteigenden Gelenkast verband. - Weiterhin zeigt sich die 
Eigenart des Schädels im Mangel gewisser, bei den Reptilien sehr verbreiteter Knochen. Zwar fur das mit dem Quadrat der Amphibien und Reptilien innig verbnndene Paraquadrat (Quadratojugale) gilt dies wohl nur scheinbar, denn es ist wahrscheinlich, daß dieser Knochen bei dem Funktionswechrsel des Quadrats zu dem sog. Tympanicum der Säuger wurde.

Diese gewöhnliche Deutung des Tympanicum wirl jedoch auth bezweifelt, indem es entweder als Repräsentant des Quadrats, oder als ein ehemaliger Deckknochen des Unterkiefers, a!s ein bei gewissen Anomodonten vorhandener besonderer Knochen (sog. Malleus, s. Fig. 1682 $m$, S. 289), sogar als Gelenkteil des Squamosum, oder noch anderes angesehen wurde.

Dagegen fehlt das Postfrontale völlig und, wie seither gewöhnlich angenommen wurde, auch das Prififrontale. Für das erstere wird zwar bei den Mollotremen eine Art Vertreter angegeben, der jedoeb als ein Ersatzknoehen etwas unsicher ist. Die gewöluuliche Beteilignng der Frontalia an der hinteren Umgrenzung der Orbiten, wobei sie die Stelle einnehmen, welche bei den alten Amphibien und den Reptilien vou den Postfrontalia und Postorbitalia okkupiert wurde, läßt aber vermuten, daß deren Bezirk bei den Säugern in die Frontalia einging. - Am Vorderrand der Orbita findet sich fist regelmäßig ein Lacrimale, das, wie schon S. 276 hervorgehoben wurde, wahrseheinlich dem sog. Präfrontale der Sauropsiden entspricht, wonach also bei den Sïugern nieht das Präfrontale, sonderu das sog. Lacrimale der Sauropsiden (Adacrimale) fehlte.

Ein weiterer wichtiger Charakter des Säugerschädels ist die viel ausgiebigere Verknöcherung der Sphenoidalregion des vorderen Sehädelkapselbodens, was sich in ansehnlicherer Entfaltung des Basisphenoids und der beiden Alisphenoide, besonders aber in einem stets vorhandenen ansehnlichen Präsphenoid und paarigen Orbitosphenoiden anssprieht. Kin Parasphenoidteil des Basisphenoids ist jedenfalls noch weniger erhalten als bei den placoiden Reptilien, denen sich die Sphenoidalbildung der Säuger wohl näher anschließt als der der Squamatenreihe. Neuerdings wnrde auch bei Echidnaembryonen (GAUP) ein pariger, bei Marsupialierembryonen (Fuchs) ein mit dem Basisphenoid verschmelzender Rest des Parasphenoids nachgewiesen.

Die erwähute stärkere und kompliziertere Entfaltung der Sphenoidregion hängt wohl zusammen mit der für die Säuger charakteristischen Erweiterung der Schädelkapsel nach vorn bis in die Ethmoidalregion, was den steten Mangel des bei den Sauropsiden in der Regel ansehnlichen Orbitalseptums bedingt, das jedoeh ontogenetisch in Resten noch anzutreffen sein soll. Diese Ausdehnung der vorderen Sehädelkapsel zwischen die Orbiten bis in die Ethmoidalregion bewirkt, daß die in letzterer auftretende Ersatzverknöcherung, das Ethmoid, in den vorderen $\mathrm{Ab}$ schluß der eigentlichen Schädelkapsel eintritt, also zu einem eigentliehen Schädelwandknochen wird, während diese Region bei den Sauropsiden weit vor der eigøntlichen Schädelkapsel verbleibt. Letztere Besonderheit des Säugersehädels, zu deren Entstehen anch die starke Ausdehnung der Nasenhöhlen naeh hinten beitrug, knüpft daher wohl nicht an die Reptilien an, sondern weist wiederum auf eine tiefere Stnfe zariick; in welcher Beziehung wichtig ist, daß den Amphibien 
ein Orbitalseptum fehlt, ihre Schädelböhle sieh bis in die Ethmoidalregion ausdehnt. Die ansehnliche Ersatzverknöeherung, welche hier bei den Anuren die Schädelkapsel vorn abschließt (Orbitosphenoid), könnte eben doch, wie dies seit alter Zeit vermutet ${ }^{\circ}$ wurde, Beziehungen zu dem Ethmoid der Säuger haben. Jedenfalls ist es weit wahrscheinlicher, daß die Einbeziehung des Ethmoids in die Schädelkapsel der Säuger direkt aus amphibienartigen Zuständen hervorging.

Wie schon bemerkt, wurde dieser Charakter des Schädels dureh die ansehnliche Ausweitung und Ausdehnung der Sehädelkapsel nach vorn bedingt, was von dem, bei den Säugern immer mehr wachsenden Hirnvolum, speziell des Großhirns, herrïhrt. Diese Volumzunahme des Gehirns führt ferner in der Säugerreihe zu einem immer mächtigeren Ansehwellen der Sehädelkapsel nach oben und gleich-

Fig. 171.

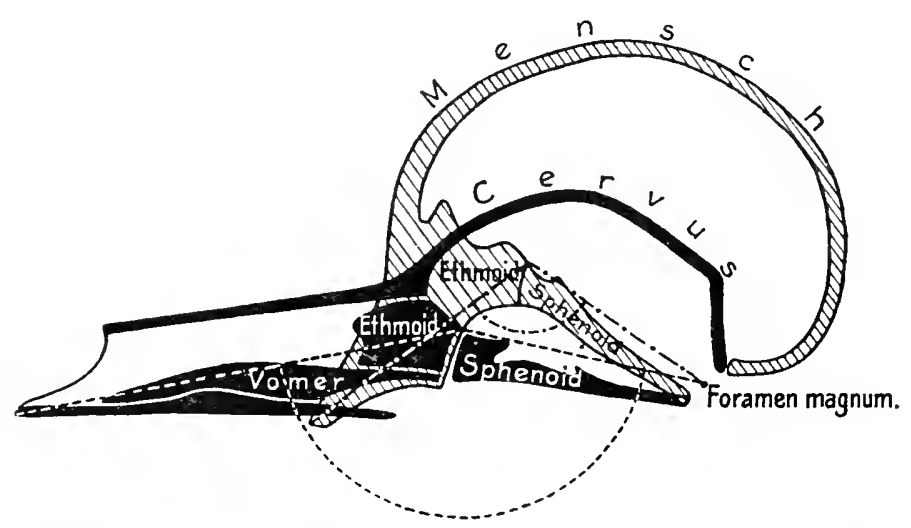

Schematische Medianschnitte des Schädels von Cervos und Homo übereinandergezeichnet, um das Answachsen der Schädelkapsel und die Umlagerung der Gesichtsknochen zu verdeutlichen; die gestrichelte Kreislinie gibt den Huxleyschen Gesichtswinkel für Cervus, die.- - Linie den für Homo an. O. B. u. E. W.

zeitig nach hinten über das Hinterhauptsloeh hinaus. Bei den Monotremen steht das Foramen magıum noch völlig hinten, eaudalwärts schanend wie bei ursprünglichen Sauropsiden und Amphibien (Fig. 174, S. 296). Auch bei deu höheren Sïugern erhält sieh dies im allgemeinen häufig noch so. In dem Maße aber, als die dorsale Occipitalregion durch die stärkere Entfaltung des hinteren Großhirns nach hinten ausgew ̈̈lbt wird, richtet sich das Foramen schief nach hinten und abwärts und gelangt schließlich bei den Primaten, durch immer stärkere hintere Auswölbung der Oecipitalregion, auf die Unterseite der Schädelkapsel, indem hier gewissermaßen die basale Hinterhauptsregion eine Fortsetzung des Schädelkapselbodens hinter das Foramen bildet (Fig. 171). Gleichzeitig damit crfolgt jedoch anch eine Lageveränderung des Sehïdelkapselbodens vor dem Foramen, der bei den ursprünglicheren Säugern, wie bei den Sauropsiden, nahezu in einer Flucht mit den sieh vorn ansehlieBenden vorderen Kiefergaumenknoehen liegt, oder doch nur wenig sehief aufsteigt. Der Sehïdelkapselboden riehtet sich immer steiler empor, was seine höchste Entwicklung beim Menschen erreicht. Dies Emporsteigen wird von einer 
Verkürzung der Kiefer begleitet, so daß gewissermaßen ein dachartiges Zusammenschieben des Schädelbodens und der sog. Gesichtsknochen stattfindet, welches sich bei den Primaten und dem Menschen am höchsten stejgert. - Den präzisesten Ausdruck findet dieses Zusammenschieben des Schädelbodens und der Schnauzenknochen wohl in dem sog. Huxleyschen Gesichtswinkel, wclcher den Winkel dej Schädelbodenachse und der ungefähren Mittelachse der Schnauzenknochen angibt (s. Schema Fig. 171).

Auf dem Medianschnitt des Schädels wird dieser Winkel angegeben durch zwei Linien, von welchen die eine rom Mittelpunkt des Foramen magnum nach dem Berührungspunkt zwischen Präsphenoid und Ethmoid auf dem Schädelboden zieht, die zweite von letzterem Punkt nach dem unteren Zusammenstoßungspunkt der Prämaxillen in ihrer Symphyse. Der ventral schauende Winkel dieser beiden Linien ist jener Gesichtswinkel, der bei niederen Mammaliern (Monotremen) nahezu $180^{\circ}$ beträgt, bei dem Menschen sich dagegen von $120^{\circ}$ bis unter $90^{\circ}$ verkleinert.

Die etwas genanere Besprechung des Schädelbans wird noch weitere Vergleichs- und Differenzpunkte mit den seither besprochenen Abteilungen ergeben.

Die vier stets gut entwickelten Knochen der Occipitalregion (Fig. 172) umschließen das ansehnliche For. magnum und verwachsen meist recht frühzeitig miteinander. Die sehr großen,

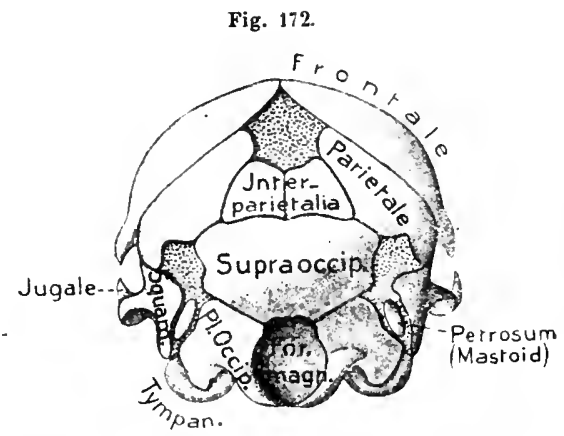

Bos tanrus (neugeboren, Kalb). "Schädel ron hinten. Knorpel dunkel punktiert. P. He. etwas schief nach oben divergierenden Condyli werden, wie bemerkt, ansschließlich oder doch ganz überwieg'nd von den Pleurooccipitaiia gebildet; zuweilen greifen sie jedoch ventral etwas auf das Basioccipitale über. Das Supraoccipitale (sog. Hinterhauptsschuppe) ist sehr ansehnlich und steigt bei den Niederen schwach nach vorn anf; bei den Höheren (Fig. 174, S. 298, Fig. 176, S. 303) erhebt es sich gauz senkrecht, mit zuweilen geringem oberen horizontalen Teil; bei den Primaten schließlich hat es sich sogar schief nach hinten gerichtet. Eine ähnliche Lageveränderung zeigen auch die seitlichen Hinterhanptsbeine. - Der Ausschluß des Supraoccipitale (viele Ruminantia), oder auch des Basioccipitale (einige Cetacea) von dem Foramen ist im ganzen selten. Seitlich bilden die Pleurooccipitalia in der Regel einen ausehnlichen, flügelartig frei absteigenden Fortsatz (Proc. paramastoideus) (Fig. 174A,C), auf den wir später noch zurückkommen. Zuweilen, so namentlich auch bei den Primaten, sind diese Fortsätze stark verkümmert oder fehlen.

An das Basioccipitale schließt sich vorn die Keilbeinregion, welche stets aus dem ansehnlichen Basisphenoid und dem davor liegenden schwächeren Präsphenoid besteht (Fig. 174 B, C). Jedem dieser unpaaren Sphenoide legt sich ein Paar seitlicher ansehnlicher Flügel an, dem Basisphenoid die Alisphenoide (Alae magnae), dem Präsphenoid die Orbitosphenoidc (Alae parvae). Die in Klammer angegebene 
Bezeichnung dieser Teile beim Mensehen trifft nur für wenige Säuger zu, da das Größenverhältnis meist umgekehrt ist. Diese seitlichen Sphenoide verwachsen jedoch in der Regel frühzeitig mit den zugehörigen unparren. Ebenso tritt bei manchen Säugern, wie beim Menschen, bald eine Vereinigung der beiden unpaaren Keilbeinknochen ein, so daß ein einheitliches Keilbein entsteht mit seinen beiden Flügelpaaren. Zuweilen verwächst anch das hintere Keilbein frilhzeitig mit dem Basioccipirale, während sich die Trennngy vom Präsphenoid erbält, das jedoch auch mit dem Ethmoid verwachsen kann. - Die obere Fläche des Basisphenoids zeigt stets cine melur oder weniger tiefe Grube, die sog. Sella tureica, zur Aufnahme

Fig. 173.
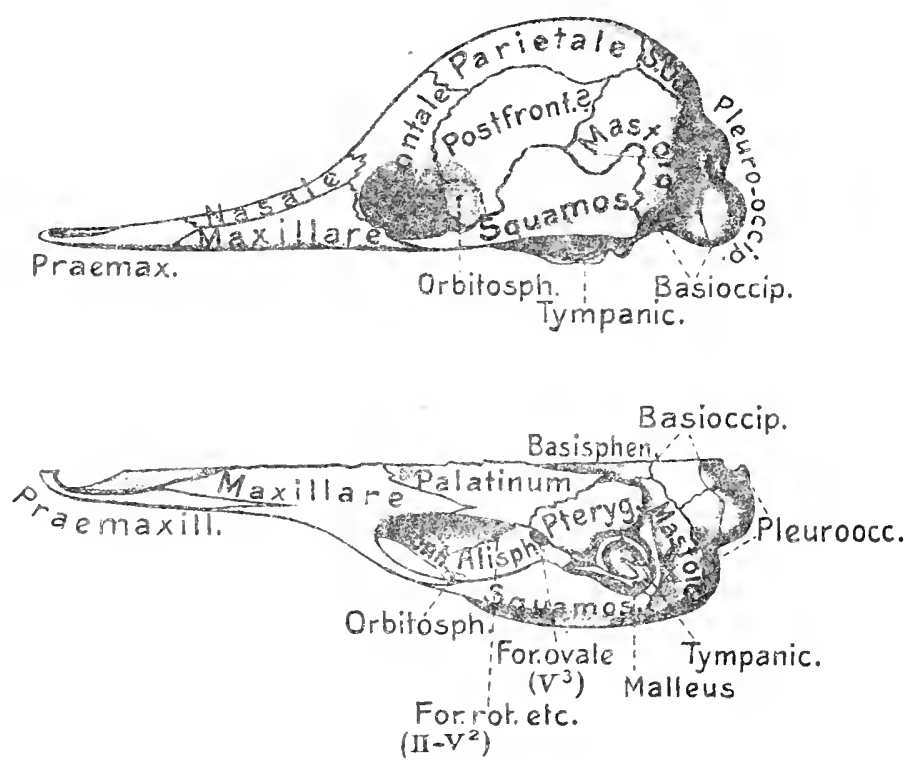

Schádel von Echidna. Oben ron links; nnten Veitralseite. (Mit Benutzung von van Bemmelen 1901.) E. W.

der Hypophysis; das Präsphenoid dagegen eine Vertiefung zur Einlagerung des Chiasmas der Sehnerven. Hintere wie vordere Keilbeinflugel nehmen teil am Aufban des vorderen seitliehen Sebädelbodens, wobei jedoch zuweilen die Basen der Orbitosphenoide, über dem Präsphenoid verwachsend, letzteres vom Schädelboden ansschließen können. Das Orbitosphenoid bildet einen mehr oder minder ansehnliehen Teil des tieferen Augenhöhlengrunds, und der Sebnerv durchsetzt es gewöhnlich.

Die Schädelkapseldecke wird von den stets sehr ansehnlichen Parietalia und Frontalia gebildet, die sich natürlich mit der allmähధ̌ichen Aufwölbung des Schädeldachs bei den Höheren stark vergrößern. Verwachsnng der beiden Parietalia untereinander tritt nicht selten bald ein. Wichtig erscheint die znweilen beobachtete Erhaltung eines kleinen Foramen parietale bei Ornithorhynehus, was auf die alten Ansgangsformen binweist. 
Eigentümlich moditiziert sind die Parietalia der Waltiere (Fig. 1763, S. 303). Durch die mächtige Entfaltung des Supraoccipitale, welches einen großen Teil des oberen Schädeldachs bildet, werden nämlich die beiden Parietalia ganz auseinander gedrängt, so daß sie an ảie tiefere Partie der seitlichen Schädelkapselwand rücken und nur schmale Ausläufer dorsalwärts senden. Die Frontalia reichen daher bei den Cetr aen bis zum Supraoccipitale nach hinten, bzw. bis zu dem gleich zu besprechenden Interparietale.

Das Interparietale ist ein bei den Mammalia sehr verbreiteter Hautknochen, der sich auf dem Scheitel zwischen die Parictalia und das Supraoccipitale einschiebt (Fig. 172, 176 ${ }^{1,3}$ ).

Die früher besprochenen Wirbeltiere zeigen kaum Vergleichbares (s. bei Sauropsida, S.276). Bei gewissen Säugen tritt das Interparietale von Anfang an unpaar, bei anderen embryonal parig auf. Es kann sich bis ins hohe Alter als gesonderter Knochen (zuweilen paarig) erhalten; häufiger verwächst es dagegen frühzeitig mit dem Supraoccipitale, bei anderen mit dem Scheitelbein. Die Yerwachsung kann abnormerweise unterbleiben, so gelegentlich beim Menschen, wo der liest des mit dem Supraoccipitale mcht verwachsenen Anteils des Interparietale daun das sog. Os incae darstellt. - Das Interparietale ist ein so regelmäßiger Bestandteil des Säugerschädels, daß es nicht zu den in den Schädelknochennähten hăufig und unregelmäßig auftreteaden kleinen Schaltknöchelchen gerechnet werden kann.

Die Frontalia, welche ebenfalls zuweilen frrühzeitig verwachsen, senden in ihrer vorderen Region seitlich stets eine mehr oder weniger ansehnliche Lamelle abwärts zur Bildung dез Angenhöblenbodens; sie kann hier mit dem Lacrimale, Orbitosphenoid, der Maxille und auch dem Palatinum zusammenstoßen. Zur hinteren Umgrenzung des oberen Orbitalrandes entwickeln die Stirnbeine häufig einen Postorbitalfortsatz, auf welchen bei dern Jochbogen zurüekzukommen isí. Im allgemeinen nimmt dieser Fortsatz die Stelle ein, welche bei den Sauropsiden von dem Postfrontale (bzw. anch dem Postorbitale) besetzt ist. Nur bei den Monotremen wurde jedoch eine selbstandige Ersatzverknöcherung in dieser Gegend an jugendliehen Schädeln beobachtet, welche aber später in das Orbitosphenoid aufgeht. - Bei den gehörnten Wiederkäuerı erheben sich die Frontalia zu zwei Knochenzapfen, die bei den Cavicornia die Stütze der hohlen Hornscheiden bilden, bei den birschartigen dagegen, als sog. Rosenstöeke, die jährlich erneuten Knochengeweihe tragen, anf die schon früher (S. 173) bei deu Hautverknöcherungen hingewiesen warde.

Die Ohrregion der seitlichen Schädelkapselwand (s. bes. Fig.173, 174), zu deren Betrachtung wir uns jetzt wenđén, wird zunächst gebildzt von dem sog. Felsenbein (Os petrosum) oder Perioticum, einem Ersatzknochen, der im allgemeinen dem Prooticum der Reptilien entspricht, wahrscheinlich jedoeh noch mehr von den sog. Otica der ursprünglichen Anamnia enthält. Dazu gesellt sich das sog. Paukenbein (Tympanicum), welches wir schon oben vom Paraquadrat (Quadratojngale) ableiteten, und schließlich das Śquamosum, über dessen Homologie mit dem der Sauropsiden kein ' $Z$ weifel zu bestehen scheint. Das Perioticum, nimmt die innerste Region dieser Knochengruppe ein und betgiligt sich daher stets an der Bildung der eigentlichen seitlichen Sehädelkapselwand zwischen Basi- und Pleurooccipitalo hinten, Alisphenoid vorn und Pilrietale oben. Wenn das Squamosum am Aufbau der Sebädelkapselwand größeren Auteil hat, so schỉeßt es sich vorn gleichfalls an 
Fig. 174.
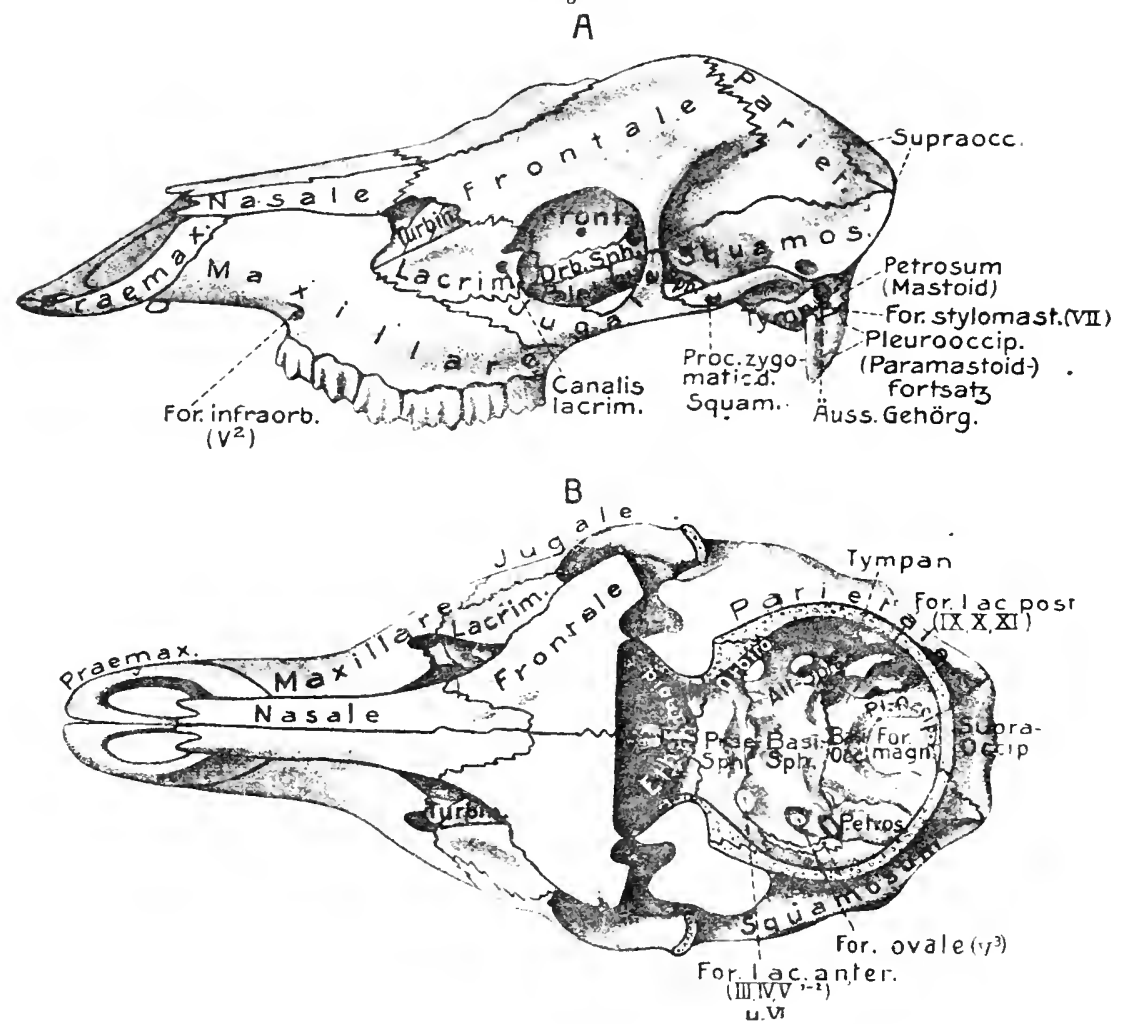

C
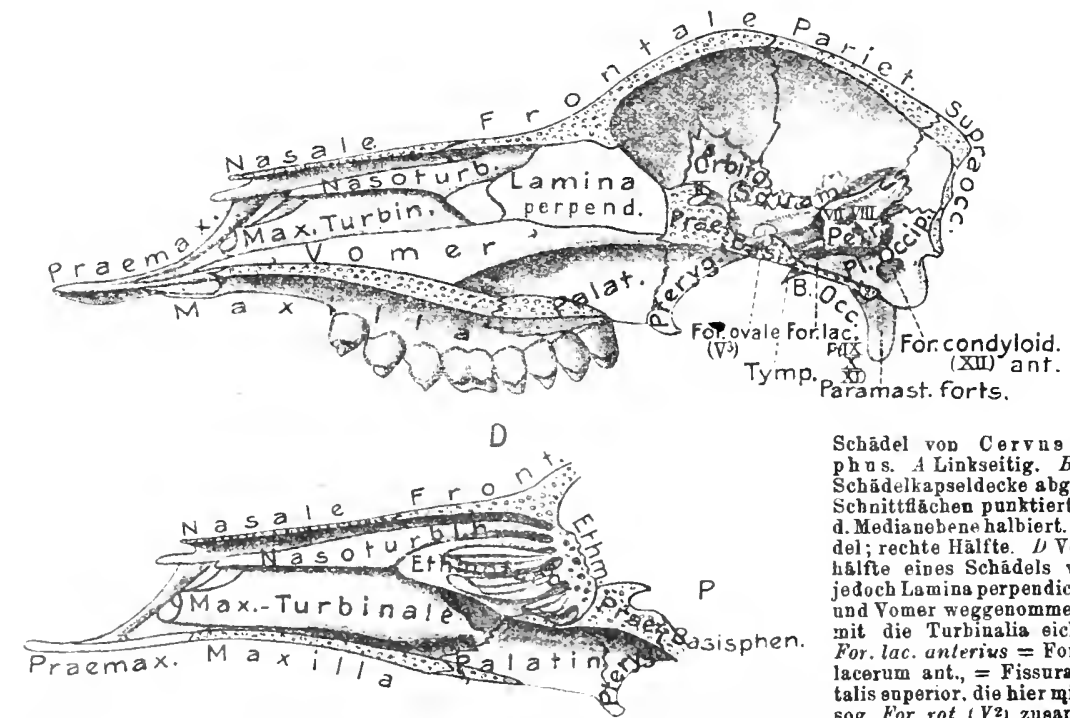

Schädel vop Cervng ela phus. A Linkseitig. B Dors. Schădelkapseldecke abgesāgt, Schnitteachen puntiert. CIn d. Medianebene halbiert. Schādel; rechte Hālfte. $L$ Vorderhalfte eines Schädels wie $t^{\prime}$ jedoch Lamina perpendicularis und Vomer weggenommen, da. mit die Turbinalia eichtbar. For. lac. anterius = Foramen lacerum ant., = Fissura orbitalis on perior, die hier mit den sog. For. rot. $\left(V^{2}\right)$ zueammengeflossen. For. lac. p. = Forsmen lacerum posterus. Die römischen Zsblen geben die Nummern der Hirnnerven an, welche durch die betreffenden öftinngen sustreten. E. W. 
das Perioticum an. Im allgemeinen ist daher das Perioticum der Säuger viel mehr gegen die Schädelbasis gedrängt als das Prooticum der niederen Wirbeltiere, was mit der ansehnlichen Hirnentwicklung zusammenbängt. Dieser sehr feste und dichte Knochen umschließt das Labyrinth völlig und hat daher innen eine Öffinung für den Eintritt des IIörnervs und des Facialis. Die Verknöcherung des Perioticums beginnt stets an mehreren Centren (bis sechs und mehr), was dazu geführt hat, die sämtlichen Otica der Fische in ihm vercinigt zu denken, ohne daß sich jedoch eine solche Dentung bis jetzt sicher durchführen ließe. Immerhiu erhält sich seine hintere Partie, welche auf der äußeren Scbädeltläche hinten und seitlich vor dem äußeren Rand des Plenrooccipitale hervortritt, etwas länger gesondert und wird daher häufig als Mastoid bezeichnet. Bei stärkerer Ausbildung des Paramastoidfortsatzes nimmt sie an der Bildung seiner Basis teil. Nach der Verwachsung dieses Mastoids mit den übrigen Verknöcherungen des Perioticums bildet es dessen Pars mastoidea, in welche das häutige Labyrinth nicht eintritt.

Am wenigsten ausgebildet ist letztere bei Monotremen und Cetaceen. Ihrer Lage nach und wegen ihrer Teilnahme an der Bildung der seitlichen hinteren Schädelvorsprïnge, die sich in die Paramastoidfortsätze verlängern und wohl den Paroccipitalfortsätzen der Sauropsiden vergleichbar sind, wäre es wohl möglich, daß die Pars mastoidea dem Opisthoticum der Reptilien entspräclıe.

Im Umkreis des Paukenfells lagert sich dem vorderen Teil des Perioticums äußerlich das sog. Tympanicum an, dessen allmählich aufsteigende Entfaltung in der Säugerreihe klar hervortritt. Ursprünglich, bei Monotremen (Fig. $173 \mathrm{~B}$ ), manchen Benteltieren (Fig. 175), Edentaten, Sirenia, ja Halbaffen ist es nur ein zarter Ring, der hinten und oben ungeschlossen und mit dem Perioticum nicht verwachsen ist. Er dient als Stiitze des sich an ihm befestigenden Paukenfells. In dieser Form tritt das Tympanicum auch bei den übrigen Säugern embryonal stets auf, bildet sich jedoch allmählich weiter fort, indem es sich zunächst zu einem vollständigen Ring schließt, von welchem ans die Verknöcherung nach innen auf die Wand der Paukenhöhle mehr und mehr fortschreitet, andrerseits auch nach außen auf den äußeren Gehörgang. So wird das Paukenbein zu einem ansebnlichen Knochen (Fig. 174, 176 y, dessen innere Partie einen kleineren bis sehr ansehnlichen Teil der Paukenhöhle umschließt, an deren Umgrenzung jedoch stets noch das Perioticum und, bei geringerer Entfalturig des Tympanicums, auch das Squamosum, ja das Basisphenoid (Myrmecophaga) und das Alisphenoid teilnehmen können. Wenn die Paukenhöhle groß wird, so bläht sich der sie umschließende innere Teil des Tympanicums zu einer meist dönnwandigen Blase, der sog. Bulla ossea, auf, welche auf der Schädelunterseite, jederseits neben dem Basioccipitale stark vorspringt.

Am Aufbau dieser Bulla beteiligt sich bei manchen Säugern noch ein selbständiger medialer, aus Knorpel hervorgehender Knochen (sog. Ento- oder Metatympanicum), der sich vereinzelt auch gesondert erhält. - Die Bulla wird besonders groß bei Nagern und Raubtieren; bei den Ungulaten und Primaten bleibt sie dagegen klein, oder tritt gar nicht mehr hervor. Die Marsupialia, deren Tympanicum klein bleibt, besitzen zum Teil doch eine starke Bulla (s. Fig. 175), die jedoeh vom Alisphenoid gebildet wird. - Der knöcherne ̈̈ußere Gehörgang ist sehr verschiedengradig entwickelt; lang wird er namentlich bei den catarrhinen Affen und den Ungulaten. 
Das Tympanicum, welches dem Perioticum außen und vorn dicht angefügt ist, bleibt nur bei verhältnismäßig wenig Säugern völlig von diesem gesondert (Marsupialia und Monotremen, sonst vereinzelt). In der Regel verwachsen beide frihzeitig, so daß das Tympanicum als eine nach vorn, außen und unten gewendete Partie des Perioticums erscheint. Die Einfügung dieses Tympano-Perioticums zwischen die benachbarten Knochen ist meist eine feste; bei den Cetaceen jedoch nur so lose durch Ligamentgewebe hergestellt, đaß sich dieser sog. »Hörknochen « leicht herauslöst.

Der dritte Bestandteil der Ohrregion, das Squamosum, entfaltet sich bei den Säugern sehr ausehnlich, was zum Teil sehon dadurch bedingt wird, daß es hauptsächlich die Gelenkstelle für den Unterkiefer bildet. Bei den Monotremen (Fig. 173, S. 296) bleibt es noch ziemlich klein und nimmt etwa auf der Zusammenstoßungsstelle von

Fig. 175.

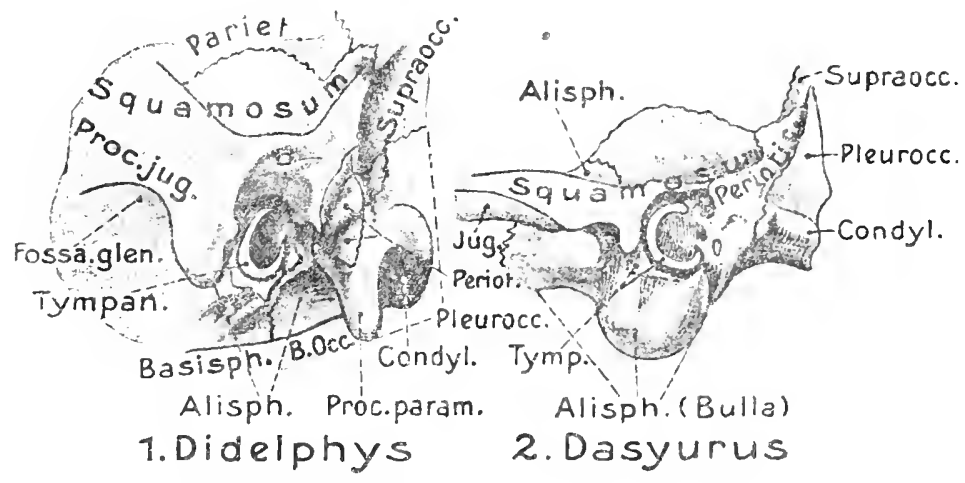

Linke Ohrregion des Schädels ron Di delphys(virginiana) u. Das y urus (viverrinus) von außen gesehen. 0. B.

Parietale oben, Basi- und Pleurooccipitale hinten, Alisphenoid und Perjoticum vorn, nur sehr geringen Anteil am Aufbau der Schädelkapselwand, was sich anch bei höheren Sängerv zum Teil erhält oder wiederfindet (Wiederkïuer und andere Ungulata Fig. $174 \mathrm{~B}, \mathrm{C}$, Cetacea). Die primitivste Bildung bewahrt das Squamosum der Monotremen, wo es sich mit einem schuppenartig verbreiterten Teil (sog. Squama), der jedoch bei Ornithorhynchus nur klein ist, dern zur Ohrregion herabsteigenden Teil des Parietale anßen auflegt. Der untere Rand dieses Schuppenteils springt schief nach außen von der Schädelwand frei vor. Dieser Vorsprung entsendet dann einen schief nach abwärts und einwärts zum Mastoidteil des Perioticums gehenden breiten Fortsatz, der auf seiner Unterseite die ansehnliche Gelenkfläche für den Unterkiefer bildet. Wo die beiden erwähnten Fortsätze außen ineinander übergehen, entspringt nach vorn ein langer, zum unteren Augenhöhlenrand ziehender Jochfortsatz (Proc. zygomaticus). Durch die Vereinigung der beiden ersterwähnten Fortsätze wird ein Kanal umschlossen, der von der Hinterseite des Schädels in die sog. Schläfengrube führt; dieser, bei Echidna schon sehr verengte Temporalkanal darf sehr wahrseheinlich als das Homologon des so ansehnlichen hinteren 'Temporallochs der Saurier betrachtet werden (vgl. Fig. 157 C, S. 274); der 
obere Fortsatz des Squamosums entspricht dem zum Parietale aufstèigenden Teil bei den Sauriern, der untere dagegen der Verbindung des Squamosums mit dem Paroccipitalfortsatz. Letztere Verbindung luat sich bei den Sängern sehr ansehnlich verbreitert, da sie zur Gelenkstelle des Unterkiefers wurde. - Ier schon bei den Monotremen im Verschwinden begriffene Temporalkanal fehlt den übrigeu Säugern, da bei ihnen die beiden genannten Fortsätze zusammengeschmolzen sind.

Der erwähnte Schuppenteil des Squanosums nimmt in dem Maße, als sich die Schädelhöhle erweitert, an Größe zu, indem 'r sich, mit Áusuahme der schon genannten Formen, an der Bildung der Fapselwand betciligt, ähnlich wie bei den Vögeln. Das Squamosum schiebt sich dabei zwischen Parietale, Perioticnm nud Alisphenoid ein und schickt häufig einen ahsteigenden Ast nach dem Paramastoidfortsatz, der sich, vor der Pars mastoidea des Perioticums, an der Bildung des Paramastoidfortsatzes beteiligt. Auf deu Jochfortsatz des Squamosums und das Unterkiefergelenk wird beim Kiefergaumenapparat einzugehen sein. - Nur bei wenigen Sängern verwachsed Squamosum und Tympano-Perioticum zu einem sog. Schläfenbein (Os temporale) wie beim Mensehen (Fig. 176\%).

Den Abschluß der Hirnhöhle gegen die Nasenhöhlen bildet vorn, zwischen Präsphenoid und Orbitosphenoid unten und den Frontalia seitlich nnd obev, das Ethmoid (Siebbein), dessen knorpelige Grundlage sich vorn in die knorpclige Nasenscheidewand fortsetzt. Im allgemeinen beginnt seine Verkuöcherung einerseits im linteren 'Teil des knorpeligen Nasenseptums, so daß hier eine sagittale, vertikal anfsteigende Knochenplatte entsteht, die sog. Lamina perpendicularis (Mesetlımoid, Fig. $174 \mathrm{C}$ ), nnd andrerseits in den seitlichen Partien des Ilintergrunds der beiden knorpeligen Nasenkapseh. So bildet sich als $A$ bschluß des Hintergrunds der Nasenhöhlen gegen die Hirnhöhle jederseits eine schief aufsteigende Platte, welche in der Regel von vielen kleinen Löchern, zum Austritt der Fäden des Riechnervs, durehbohrt ist, die sog. Siebplatten (Lamiza cribrosae, seitlicbe Ethmoide, Fig. 174B). Nur bei den Primaten, wo das seitliche Ethmoid zwischen Lacrimale und Orbitosphenoid, in die Begrenzung der Augenhöhle eintritt, entsteht als seitliche und hintere Fortsetzung des Seitenrands der Lamina cribrosa eine dünne Knochenlamelle, die sog. Lamina papyracea.

Von der Seitenwand des hiuteren T'eils Ier knorpeligen Nasenkapseln entwickeln sich wehr oder weniger zahlreiche, nach innen gegen das mediane Nasenseptum vorspringende Schleimhautfalten (Riechmuscheln), in welchen knorpelige Lamellen auftreten. Diese zerteilen sich an ihrem freien Rand vielfach und rollen sich auf. Sie sind ron sehr verschiedener Größe (Fig. 174D). Später verknöchern die Muscheln and reichen nach hinten bis zu! Lamina cribrosa, mit der sie sich als sog. Ethmoturbinalia knöchern vereinigen. Die vielen Löchelchen der Lamina cribrosa führen in die engen Hohlräumchen zwischen den Ethmoturbinalia, welche anch durch Verwachsungen der letzteren noch komplizierter werden können. Die Gesamtheit der Muschelu und Hohlrïumchen bildet das sog. Siebbeinlabyrinth.

Rclativ spät verwächst die Lamina perpendicularis mit den beiden Seitenteilen zu einem gemeinsamen Knochen, dem sog. Siebbein (Ethmoid). 
Die Beziehung des Ethmoids der Säuger zu den Ethmoidalbildungen niederer Vertebraten ist schwierig zu beurteilen. Wie schon hervorgehoben, wäre wohl ein Anschluß an die Verhältnisse der Amphibien am ehesten möglich. Das sog. Orbitosphenoid der Anuren erinnert in mancher Ilinsicht an die Einrichtung der Sänger. - Die Laminae cribrosae steigen in der Regel schief von hinten unten nach oben und vorn empor, können sich jedoch auch nahezu senkrecht aufrichten. In dem Maße, als sich die Gesichtsknochen bei den Primaten verkürzen und die hintere Partie der Nasenhöhlen unter die Schädelbasis schiebt, wird die Stellung.der Laminae immer horizontaler, so daß sie die Nasenhöhlen von oben decken. Die reiche Durchbohrnng der Siebplatten, welche ontogenetisch aus einem einfachen Foramen olfactorium hervorgeht, hat sich wohl erst in der Säugerreihe entwickelt; denn Ornithorhynchus besitzt noch das einfache Olfactoriusloch, welches auch bei einigen altweltlichen Affen wiederkehrt. - Bei den Cetaceen schwand mit der Rückbildung der Riechorgane und Riechnerven die Durchbohrung der Laminae, wie auch das ganze Siebbeinlabyrinth, fast oder völlig.

Paarige Nasalia, die jedoch in einigen Fällen frühzeitig verwachsen, bedecken die Nasenregion oben nnd richten sich daher in ihrer Länge im allgemeinen nach der Schnauzenentwicklung Abnorm verkümmert sind sie bei den Waltieren (s. Fig. $176^{3}$ ), im Zusammenhang mit der bedeutenden Rückwärtsverlagerung der äußeren Nasenöffnungen und der starken, fast senkrechten Aufrichtung der Nasenhöhlen, die sie daher auch nicht mehr bedecken. Ähnliches zeigen auch die Sirenia und Proboscidea. - Die Innenfläche der Nasalia trägt zum Teil die vordere Fortsetzung des obersten Ethmoturbinale, das sog. Nasoturbinale (Fig. 174 D, S. 299).

Auf der Grenze zwischen den äußeren Rändern der Frontalia und Nasalia, im vorderen inneren Winkel der Orbita, schiebt sich das Tränenbein (Lacrimale) ein, das als ein kleiner, fast stets vom Tränengang durchbohrter Knochen (Ausnahme Cetacea, Sirenia, Elephas, annähernd Mensch) am Aufbau der Orbitalwand teilnimmt, sich aber auch bei vielen Säugern mehr oder weniger weit vor der Orbita auf der Schnanzenfläche ausbreitet. Das Tränenbein fehlt selten als selbständiger Knochen (so bei Monotremen, Zahnwalen, Robben, Manis).

Ein sehr eigentümlicher, ursprünglich paarig angelegter kleiner Hantknochen tritt bei Ornithorhynclius vor den Nasenbeinen im Boden der Nasenhöhlen ans und bildet eine Stütze für die Jacobsonschen Organe (Os paradoxum, Prävomer). Vieles dürfte dafür sprechen, diesen Knochen als ein Homologon der Septomaxillaria (sog. Concha) der Sanria anzusprechen. Bei Echidna treten ontogenetisch paarige Septomaxillaria auf, die später mit den Prämaxillen verwachsen und deren Processus extranasalis bilden.

Stärkere Entwicklung les Knorpels der vordersten Nasenregion führte bei gewissen, mit eiuem Rüssel versehenen Säugern zur Bildung eines sog. Rüsselknorpels (Sehweine), und Verknö herung a» diesem Ort zur Bildung eines sog. Os pracnasale (zum T'eil auch paarig), wie es gewissen Edentaten und Insectivoren (Talpa) zukommt.

Kiefergumenapparat. Wie schon bemerkt, verrät dieser Apparat nälıere Beziehungen zu dem der plaeoiden als dem der squamaten Sauropsiden. Wir ziehen es vor, bei der Beschreibung von vorn nach hiuten zu gehen. Die stets vorhandenen Prümaxillen (s. Fig. 173, 174) sind meist ansehnlich, können jedoeh in besonderen Fíllen auch rudimentär werden (Fledermäuse, gewisse Edentaten), was mit der Verkïmmernug der Schneidezïhne zusammenliängt; obgleich dies in anderen Fällen die Prämaxillen nur wenig beeintnßt (z. B. Wiederkïuer, Bartenwale). Sie um- 
grenzen die Nasenöffuungen vorn und durch äußere, aufsteigende Fortsätze seitlich. Dagegen fehlen hier gewöhnlich die bai den Sauropsiden zwischen die Nasenöffnungen sich einschiebenden medianen Fortsätze. Bei Echidna umschließen die Prämaxillen die Nasenöffnung völlig; bei Ornithorhynchus dagegen wurden sie mit der Schnabelbildung eigentiimlich umgestaltet, indem sie vorn, ohne Symphysenbildung, weit divergieren. - Bei den Cetaceen haben sich mit dem Empor-

Fig. 176.

\section{Castor}
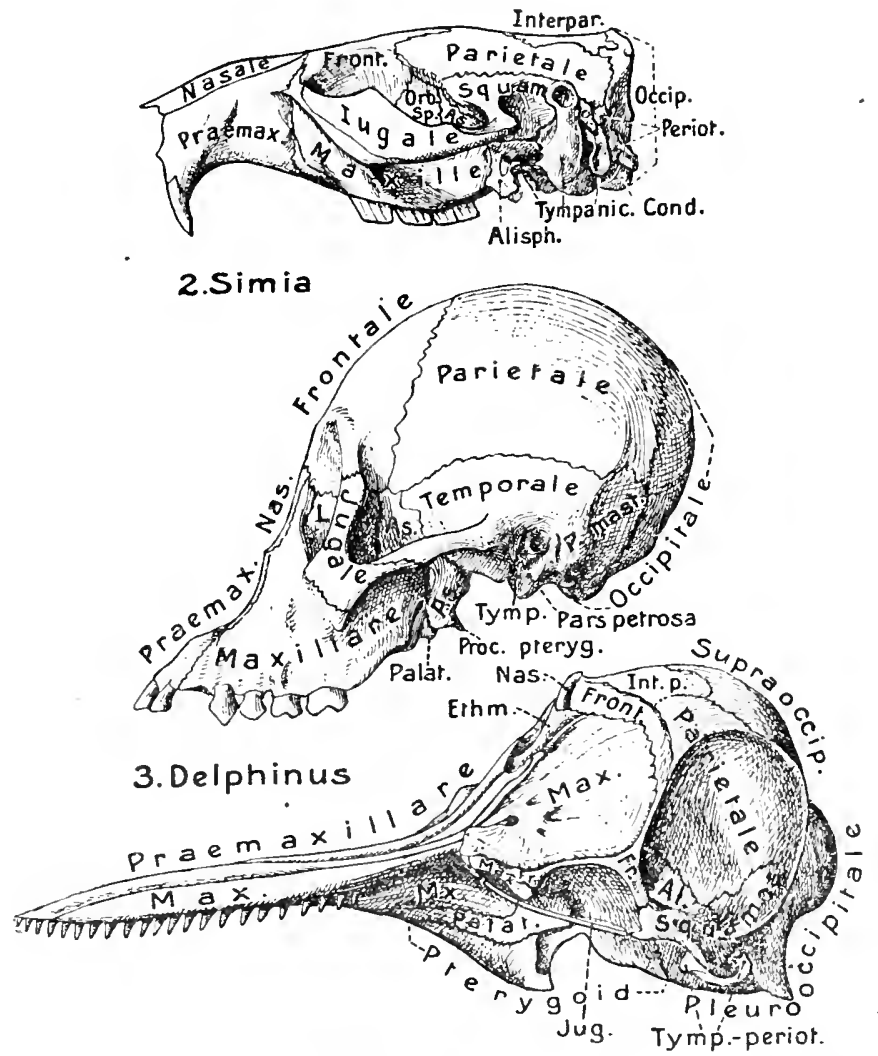

Schādel von 1. Castor (fiber). 2. Simia (satyrus, Orang) und 3. Delphinus (tursio) von links. As. oder

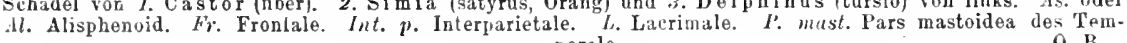
porale.

riicken der Nasenöffinungen auf deu Seheitel, oder in dessen Nühe, die Zwischenkiefer ungemein verlängert (Fig. $176^{3}$ ). Durch horizontale Gaumenfortsätze bilden sie bei allen Säugern den vordersten Teil des knöchernen Gaumendachs.

Die Maxillen sind meist reeht kräftig; ihre horizontalen Gaumenlamellen verlängern den knöchernen Gaumen nach hinten und bilden in der Regel dessen ansehulichsten Teil (Fig. 174C, S. 299). Die hintere Region der Maxille entwickelt häufig einen verschieden stark anfsteigenden Hortsatz zum Jugale und beteiligt sich 
auch an der Bildung des Orbitalgrunds. Die Lünge der Oberkiefer hängt natürlick. von der der Schnauze direkt ab. Ganz abnorm lang werden die der Cetaceen (Fig. $176^{3}$, S. 303); bei den Zahnwalen verbreitert sich ihr hinterer Teil ungemein und überlagert fast die gesamten Frontalia, während er sich bei den Bartenwalen unter letztere schiebt. Die hintere Partie der Maxille erscheint häufig stark anfgebläht durch die von der Nasenhöhle eindringende Kieferhöhle, wclche bei den Geruchsorganen genauer zu bespreehen sein wird. - Auf der Imenfläche jedes Oberkiefers, welche gegen die Nasenhöhle schant, entspringt die in die Nasenhöhle meist mächtig vorragende Kiefermuschel (Maxilloturbinale, Fig. 174 D). Sie entsteht als selbständige Ersatzverknöcherung der, an der Seitenwand der knorpeligen Nasenhöhle entspringenden, knorpeligen Kiefermaschel und verwächst erst nach Schwund der knorpeligen Nasenhöhlenwand mit dem Oberkiefer.

Die Fortsetzung des geschlossenen knöchernen Gaumens uach hinten bildeu die Palatina (Fig. 173, 174C,D), welche denen der Krokodile ähnlich sind, indem sie als etwa senkrecht gestelltø Platten die Seitenwände der Nasenhöhlen nach hinten verlängern, und mit ihrem oberen, sich ansbreitenden Teil gewöhnlich auch an der Bildung des Orbitalgrunds teilnehmen. Der Ventralrand ihrer senkrechten Lamellen biegt in horizontale Gaumenlamellen um, welche sich denen der Maxillen anschließen. So verlïngern die Palatina den bei allen Sängern ausgebildeten sekundären Nasenrachengang (Ductus nasopbaryngens) nach hinten. Durch die Bildung des Nasenrachengangs wird der anpaare Vomer (s. Fig. $174 C, D$ ), der sich vor dem Präsphenoid zwischen die aufsteigenden Lamellen der Palatina einschiebt, mehr oder weniger verdeckt; sein Hinterende ist jedoch gewöhnlich in der knöchernen Choane noch sichtbar. Bei abnormer Verlängerung des sekundären Nasenrachengangs nach hinten wird der Vomer jedoch ganz verdeckt wie bei den Krokodilen. Die meist dïnne schmale Vomerplatte sendet in ibrer Mittellinie eine senkrecht absteigende Knochenlamelle in die Nasenscheidewand hinab, welche bis anf das knöcherne Ganmendach reicht. Je nach der Schnáuzenlänge variiert die Vomerlänge sehr.

Die Homologie des Vomers der Mammalier mit dem der Sauropsiden wurde mehrfach bezweifelt, doch können die Versuche, ihn auf das Parasphenoid zurückzuführen (Sctros, Broom), nicht als gelungen bezeichnet werden.

Die Pterygoidca sind meist sehr reduziert, indem sie sich als kleine und dinne senkreclite Knochenlamellen den senkrechten Lamellen der Palatina linten und iunen anlagern (Fig. 174C,D). Nach hinten reichen sie bis zu den sog. Pterygoidfortsätzen der Alisphenoide, denen sie sich innen anlegen. Bei den Primaten wird das Pterygoid sehr klein und verwächst beim Menschen frühzeitig mit dem Pterygoidfortsatz des Alisphenoids, dessen Lamina interna bildend.

Im Gegensatz hierzı vergrößert sich das Pterygoid gewisser niederer Gruppen mehr und entwickelt an seinem Ventralrand, :ilnnlich den Krokodilen, eine horizontale Ganmenlamelle, welche sich der des Palatinums hinten anschlieft und den sekundären Nasemrachengang verlängert. Die Monotremen (Fig. $173 \mathrm{~B}$ ) zeigen dies im ganzen wenig, und die Gaumenlamellen ihrer Pterygoide bleiben durch. 
die hintere Verlängerung der Palatina voneinander getrennt. - Auch die Cetaceen besitzen ziemlicb stark entwickelte Gaumenlamellen, die jedoch in der Mittellinie nicht dicht zusammenstoßen, wenn sie sich auch zuweilen fast berühren. - Bei Myrmecophaga (Ameisenfresser) unter den Edentaten sind dagegen die Gaumenlamellen so stark entwickelt, daß sie in ihrer ganzen Länge zusammentreten und das knöcherne Gaumeudach bis nahe ans Hinterhauptsloch verlängern, ähnlich wie bei den Krokodilen.

Ein unter allen Vertebraten isoliert stehendes Verhalten zeigen die Palatina und Pterygoidea der Monotremen, indem ein Teil von ihnen in die Bildung des seitlichen Schädelkapselbodens eingeht; was sonst bekanntlich nie der Fall ist. - Die Ansicht (Gaupr), daB nur die Pterygoide der Monotremen denen der Sauropsiden entsprechen, die der iibrigen Säuger dagegen den hinteren seitlichen Teilen des Parasphenoids, ist wenig wahrscheinlich.

Typisch für die Sänger ist die Bildung eines Jochbogens durch Einschiebung eines Jugale $\mathrm{z}$ wischen den Oberkiefer und den Jochfortsatz des Squamosum. Dieser Jochbogen (s. Fig. 174 A, 176) begrenzt die Orbita von unten und hinten und entspricht jedenfalls im allgemeinen dem oberen der Sauropsida, was ja schon wegen der Reduktion des Quadrats wahrscheinlich ist. Vermutlich leitet er sich jedoch von dem einfachen Bogen der sog. synapsiden Reptilien her. An der Ventralseite seines hinteren Ursprungs, der rom Jochfortsatz des Squamosums gebildet wird, liegt die Gelenkstelle für den Unterkiefer, an deren Bildung sich selten auch das Jugale und sogar das Alisphenoid beteiligen. Das Squamosum sendet hinter der Gelenkfläche gewöhnlich einen Processus postglenoidalis abwärts, welcher zur Sicherung der Gelenkung beiträgt. Vom Tympanicum kann zuweilen ein präglenoidaler Fortsatz ausgehen. - Bei starker Eritwicklung bildet der Jochbogen meist durch einen aufsteigenden Fortsatz des hinteren Teils des Jugale, der sich mit einem absteigenden des Frontale verbindet, eine hintere Begrenzung der Orbita nnd damit eine äußerliche Scheidung zwischen Augenhöhle und der dahinter liegenden Schläfengrube. Die Beziehungen zu den Sauropsiden machen es eher wahrscheinlich, daß diese Abgrenzung der Orbita das Ursprunglichere sein dürfte und ihre Unvollständigkeit, oder ihr Mangel bei zahlreichen Säugern eine Rückbildung, welche mit der gewaltigen Entwicklung der Kaumuskulatur zusammenhängt. Bei den meisten Säugern bleibt diese Scheidung von Orbita und Schläfengrube eine äußerliche, indem beide innerhalb des Jochbogens in weitem Zusammenhang stehen. Erst bei den Halbaffen bahnt sich eine vollständigere Trennung an, die jedoch nur bei den Primaten und Menschen bis anf eine geringe Spalte komplett wird, indem die Knochenteile, welche die Orbitalwand bilden, untereinander zusammenschließen. - Die Stärke des Jugale und die des Jochbogens überhaupt, namentlich auch seine bedeutende Ausbuchtung nach außen, bängt mit der Stärke der Kaumuskulatur des Unterkiefers zusammen. Wo dieser unter besonderen Ernährungsbedingungen sich verschmächtigt, wird der Jochbogen rudimentär, indem das Jugale sehr verkümmert oder schwindet.

Das Jugale der Cetaceen wird so zu einem zarten Knochenstäbchen (Fig. 1763). Dagegen bildet sich hier ein ansehnlicher Supraorbitalfortsatz des Frontale, der den Jochfortsatz des 
Squamosums erreichen kann. - Bei gewissen Edentaten (Manis, Myrmecophaga, Faultiere) erhält sich nur noch der vordere Teil des Jugale und ist bei Myrmecophaga sehr klein, bei Manis wohl mit dem Frontale verwachsen. Dagegen bleibt das Jochbein der Faultiere sehr stark und sendet einen gegen den Unterkiefer absteigenden Fortsatz aus, der namentlich bei den fossilen Verwandten recht groß wurde. Die Unvollständigkeit des Jochbogens hat daher hier andere Grü̈nde. - Vielen Insectivoren fehlt das Jugale ganz, oder ist sehr rudimentär und der Jochbogen daher unvollständig bis fehlend, ohne daß die Kaumuskulatur defekt wăre. - Andrerseits kann jedoch auch (Monotremen, Fig. 173) das Jugale als selbständiger Knochen mangeln, bei vollständig ausgebildetem, wenn auch nicht sehr kräftigem Jochbogen.

Fig. 177.
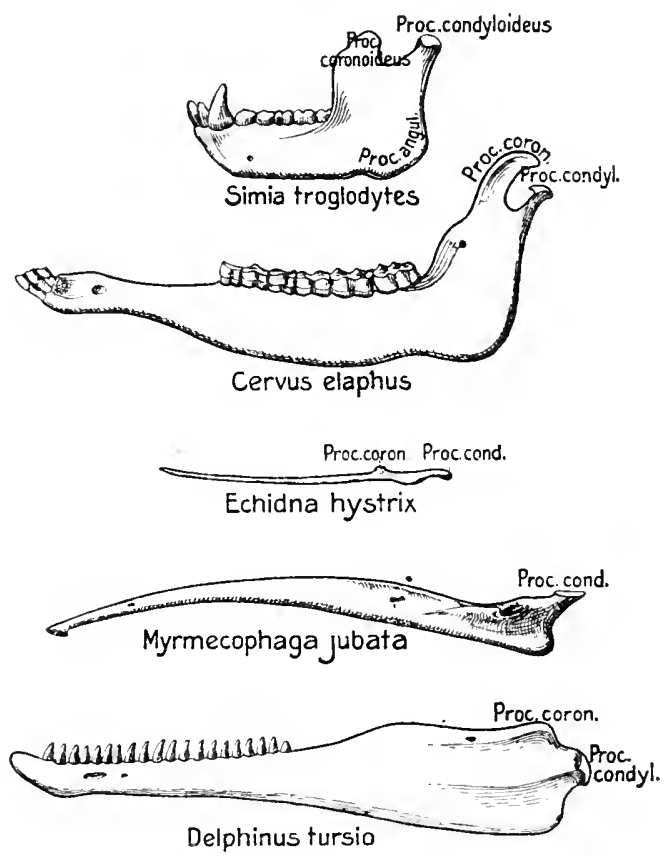

Unterkiefer von Mammalia. Linke Hälfte von außen. E. W.

Der Unterkiefer (Fig. 177) ist in der Regel kräftig und gegeniiber dem der früheren Abteilungen dadurch ausgezeichnet, daß jede Hälfte nur aus einer einzigen Verknöcherung hervorgeht, welchein der Hauptsache dem Dentale entspricht.

Diese Vereinfachung des Unterkiefers wird meist darauf zurückzuführen gesucht, daß das dem Articulare der Niederen entsprechende Gelenkstïck, samt dem Angulare, sich von ihm abgetrennt hätten und zu einem der Gehörknöchelchen (Hammer) geworden seien. Hieraus müßte notwendig folgen, daß der Gelenkteil des Säugerunterkiefërs nicht dem der Niederen entspreche, sondern neuer Entstehung sei. Wir werden später bei den Hörknöchelchen auf diese Frage eingehen. Wenn man diese Ansicht annimmt, so ließe sich der Unterkiefer der Mammalia jedenfalls eher von amphibien- als sauropsidenartigen Zuständen ableiten. Übrigens divergieren die Meinungen über den Säugerunterkiefer noch sehr.

Die höhere Gelenkung des Unterkiefers am Ursprung des Jochfortsatzes des Squamosum bedingt die Entwicklung eines hinteren, mehr oder weniger anfsteigenden Gelenkfortsatzes (Proc. condyloideus), dessen oberes Ende den meist stark in die Quere gezogenen Condylus bildet. Vor dem Gelenkfortsatz erhebt sich der Oberrand der Mandibel meist zu einem Kronfortsatz (Proc. coronoideus) zum Ansatz des Mnsculus temporalis. Der Grad seiner Entwicklnng wird daher durch den der Kaumuskulatur bedingt; er ist deshalb z. B. besonders kräftig bei den Raubtieren. - Der hintere Winkel des Unterkiefers setzt sich zum Teil (Marsnpialia, Rodentia, Insectivora) in einen postarticulären Fortsatz fort. - Die beiden Unterkieferhälften vieler Säıger bleiben dauernd in Nahtverbindung; bei anderen 
(z. B. Perissodactylia, Elephas, Chiroptera, gewissen Cetacea und Affen) verwachsen sie wie beim Menschen frühzeitig in der Symphyse. - Die Reduktion der Kaumuskulatur läßt den Unterkiefer schmächtiger und einfacher werden. Dies tritt bei den Monotremen (besonders Echidna), Myrmecophaga, Manis und den Cetaceen sebr auffallend hervor (s. Fig. 177); unter Rïckbildung des Kronfortsatzes nnd Erniedrigang des Gelenkfortsatzes wird jede Unterkieferhälfte ein schlanker Knochenstab, welcher an jene der Vögel erinnert.

\section{Visceralskelet der Amnioten (Zungenbeinapparat).}

Aus den Resten des Hyoid- und der Branchialbogen der Amnioten geht ein Zungenbeinapparat hervor, ïhnlich wie es unter den Amphibien bei đen Anuren stattfindet. Auf die eventuelle Beteiligung hinterer Branchialbogen an der Bildung des Skelets der Luftröhre und des Kehlkopfs soll erst später bei diesen Organen eingegangen werden, ebenso auch auf das Problem der Entstehung von Gehörknöchelchen aus dem cranialen Ende des Hyoidbogens. - An dem entwickelten Zungenbeinapparat der Amnioten nehmen im Höchstfalle noch drei vordere Visceralbogen, nämlich der Hyal- und die beiden ersten Branchialbogen teil, welche ventral durch ein oder mehrere unpaare Stücke, den sog. Zungenbeinkörper, verbunden werden, der von den Resten der Copulae, zum Teil aber auch von Basalteilen der

Fig. 178.

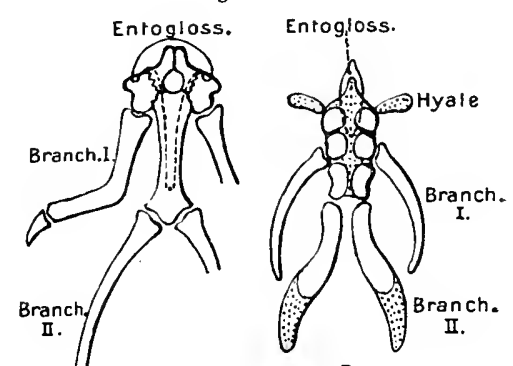

A.

B. Bogen gebildet wird. Der Zungenbeinkörper unterlagert den Kehlkopf und den Anfang der Luftröhre ventralwärts und dient häufig auch zur Stütze der Zunge.

Wie zu erwarten, zeigen die Reptilien zum Teil noch die ursprünglichsten Verhältnisse, was sich bei Cheloniern und Sauriern in der häufigen Erhaltung von drei Bogen oder sog. Zungenbeinhörnern ausspricht. Die Schildkröten zeigen vielleicht die primitivsten Einrichtungen, insofern die drei Hörner (Hyal-, erster und zweiter Branchialbogen) als selbständige, teilweise verknöcherte Skeletgebilde dem einheitlichen länglichen Körper angefïgt sind (Fig. 178). Der erste Bogen (Hyale) ist stark verkümmert und knorpelig, manchmal sogar als selbständiges Gebilde geschwunden. Der zweite Bogen erscheint teils einheitlich, teils zweigliederig, der dritte einheitlich. Der Körper bleibt hänfig knorpelig, oder ist größtenteils einheitlich verknöchert; gelegentliches Auftreten dreier paariger Verknöcherungen in ihm (Trionyx, s. Fig. $178 B$ ) weist vielleicht auf das Eingehen basaler Bogenteile in den Körper hin; ebenso spricht dafür wohl die vordere paarige Verknöcherung und die Durchbrechung im Körper von Chelys $(A)$. Ein knorpeliger vorderer Fortsatz des Körpers zur Stütze der Zunge (Processus entoglossus) ist stets nur wenig 
entwickelt. - Dagegen wird der vordere Abschnitt des Körpers von einem besonderen, meist rein knorpeligen Skeletstick unterlagert dem sog. Entoglossum, das den ijbrigen Amnioten fehlt, wenn es nicht is das Vorderende des Körpers anfgegangen ist. Die morphologisebe Bedeutung dieses Gebildes, insbesondere seine eventuelle Beziehung zu einem sog. Glossohyale, einer zwisehen Kiefer- und Hyoidbogen mögliehen Copula, ist unsicher.

Der Zungenbeinkörper đer Saurier (Fig. 179) bleibt in der Regel klein, meist etwas quer spangeaartig, setzt sich aber vorn in einen häufig sehr langen knorpeligen Processus entoglossus (lingualis) fort. Der Hinterrand des Körpers entsendet gewöhnlich zwei kürzere oder längere hornartige Fortsätze, die nicht von ihm abgegliedert sind; sie entsprechen wobl sieher dem zweiten Branchialbogen. Bei gewissen Eidechsen legen sich diese, zuweilen recht langen Hörner dicht

Fig. 179.

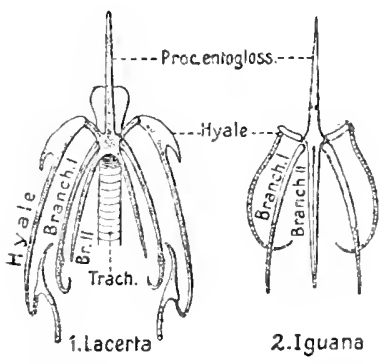

Zungenbein ron Sa uriern. Dorsal. ansicht. Knorpel punztiert. 1.L a certa (viridis). Völlig knerpelig, z. T. verkalkt, was durch dichtere Punktierung angedeatet. Das dem Ende des Hyale angefügte Stūck heftet sich der Ventralseite des Schādels in der Ghrregion an und wird zuweilen als dem Branchiale $I I$ an. gehōrig gedeutet. 2. Iguana (nach Cuvizr, Oss. fossiles). O. B. zusammen (Fig. 1792), oder divergieren erst an ihren Enden. Charakteristisch für die Saurier ist die ausehnliche Länge der beiden.vorderen Hörnerpaare (Hyale und erster Branchialbogen). - Die Hyalhörner sind in der Regel zweigliederig, wobei die Glieder winkelig ansammenstoßen. Das Basalglied ist seiten verknöchert, dagegen der Basalteil des ersten Eranchialhorns meist.

Während die Zungenbeinhörner der Schildkröten mit dem Schädel gar nicht verbunden sinả, erhält sich bei den Rhynchoeephalen, wie später noch genauer zu besprecher sein wird, eine solche mit der Columella des Ohr. Bei manchen Sauriern (Lacerta usw.) steht das Hyalhorn durch ein Band, dem ein Knorpelstab eingelagert sein kann (siehe Fig. $179^{1}$ ), mit dem Paroccipitalfortsatz des Schädels in Verbindung. Die Bedeutung dieses Knorpels, ozw. seine Zugehürigkeit zum Hyoidbogen ist noeh unsieber. - Der Zungenbeinapparat der Schlangen ist auf einen meist zarten Knorpelbogen reduziert.

Der der Vögel (Fig. 180) dagegen zeigt ziemlich nahe Beziehungen zu dem der seither besprochenen Reptilien, besonders der Schildkröten. Der lange und sehmale Körper besteht aus zwei knorpelig angelegten und auch im erwachsenen Zustand häufig noch gesonderten Copulae 1 und II (Basihyale und Basibranchiale $I=$ sog. Urohyale), beide meist mehr oder weniger verknöehernd. - Dem Vorderende der Copula I schließt sich ein paariges oder unpares verknöehertes Stück an (Os entoglossum), das sich vorn meist in einen paurigen oder unpaaren Koorpel fortsetzt, der als Processus entoglossus in die Zunge tritt. Häufig bleibt zwischen beiden Stiicken eine Lüicke oder ein Loch, wie es anch den Schildkröten zum Teil zukommt. Die hinteren seitlichen Ecken beider Stüeke verlängern sich in kurze hornartige Fortsätze. Daß die sog. Ossa entoglossa den Basalstücken (Hypohyale) des Hyoidbogens entsprechen, darf wohl als sicher betrachtet werden; es ist sogar unwahr- 
scheinlich, daß irgend ein Copularteil in sie eingeht. Die Verhältnisse erinnern daher an die gewisser Chelonier. - Der erste Branchialbogen bildet die langen, meist zwei-, selten dreigliederigen Hörner, die sich bei Spechten (Fig. 180D) und Kolibris so verlängern, daß sie hinten um den ganzen Schädel herumziehen und sich mit ihren proximalen Enden in der Gegend der dorsalen Schnabelwurzel befestigen. Daß in die zweite Copula (II) Reste eines Branchialbogens eingehen, ist nicht nachweisbar.

Der Zungenbeinkörper der Krokodile weicht von dem der übrigen Sauropsiden sehr ab, indem er eine ansehuliche, nahezu quadratische Knorpelschale darstellt, in deren dorsaler Konkavität der Kehlkopf ruht (Fig. 181). Jederseits entspringt nur ein größtenteils verknöchertes Horn, das wahrscheinlich dem ersten Branchialbogen entspricht.

Der Zungenbeinapparat der Süuger zeigt im allgemeinen ähnlich primitive Einrichtungen wie der der urspriinglichen Reptilien und schließt sich wegen der bedeutenden Lünge der

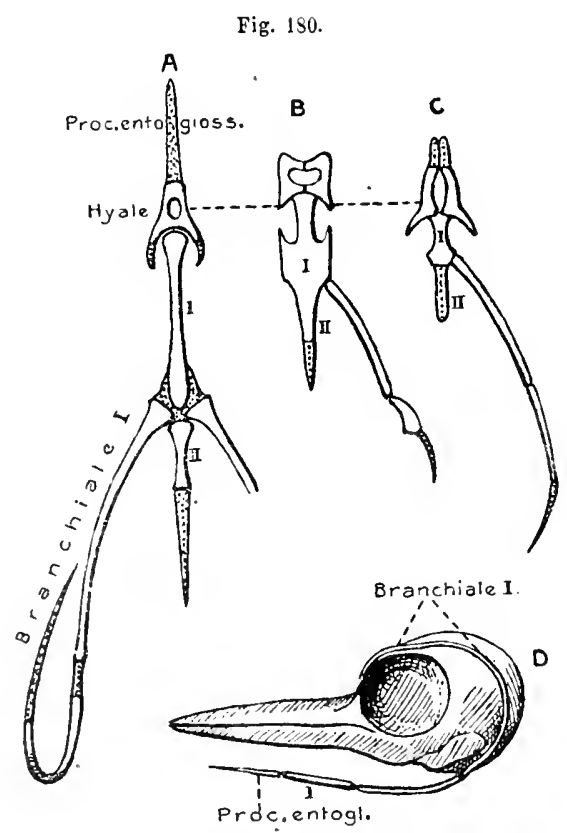

Zun cenbeine von Vögeln. Dorsalansicht. A Tetrao alogallus. $B$ Psittacus. $C$ Garrolus glandarius $(B-C$ nach Giebel 1858$)$. I Schädel ron Dendrocopus major (Buntspecht) mit Zungenbein von links. Hyalhörner, sowie ihrer Aufhängung an der Ohrregion des Schädels den Amphibien und Sauriern am ehesten an. Wie wir später finden werden, beteiligen sich an der Bildnng des sog. Schildknorpels des Säugerkehlkopfs der zweite und dritte Kiemenbogen, was bei den erwachsenen Monotremen noch zu erkennen ist. Da nun das dorsale Ende des ersten Branchialbogens mit dem des zweiten knorpelig verbunden ist, so erhält sich bei den Säugern stets eine Verbindung zwischen dem hinteren Zungenbeinhorn, das aus dem ersten Branchialbogen hervorgeht, und dem sog. vorderen Horn des Thyreoidknorpels, sei es durch knorpeligen Zusammenhang (gewisse Carnivoren), sei es durch ein Band (siehe Fig. 182). Der Zungenbeinkörper, der wohl nur einer Copula (doch fraglich, ob Basihyale) entspricht, bleibt meist klein, gewöhnlich einer Querspange ähnlich. Zuweilen wird Fig. 181. er durch Ausdehnung nach binten mehr plattenastig; besonders ansehnlich manchmal bei solchen Affen, die einen unpaaren Kehlkopfsack zwischen Schild- und Epiglottisknorpel entwickeln, der sieh gegen den Zungenbeinkörper richtet und 
ihn bei den Brüllaffen (Mycetes) zu einer großen hohlen Trommel aufbläht (ähnlich Fig. 182 4).

Das Hyalhorn ist bei den meisten Säugetieren (Fig. $182 B, C$ ) viel länger als das hintere und dann gewöhnlich aus drei knöohernen Gliedern zusammengesetzt, die vom Körper an gewöhnlich als Cerato-, Epi- und Stylohyale bezeichnet werden, obgleich es mehr wie fraglich ist, ob sie mit den ähnlich benannten der Fische und Amphibien verglichen werden dürfen. Nicht selten bleibt jedoch das vordere Horn in seinem eranialen Teil ligamentös, so daß weniger Glieder, ja nur ein ventrales Ceratohyale sich finden (s. Fig. 182 A), ja schließlich (Mycetes) das ganze Horn dureh Ligament vertreten sein kann. - Das craniale Ende des Vorder-

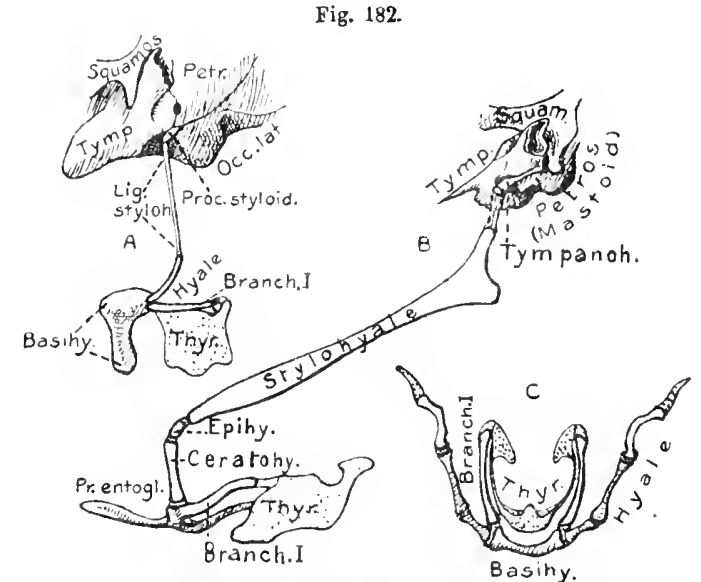

Zungenbeine von Mammalia. 1 Macacus cynomolgus, linke Ohrregion des Schädels ron außen mit anhängendem Zungenbein. Knorpel punktiert. $B$ von Equs, ebenso wie Fig. $A$. C Ca n is von vorn. Thyr. Thyreoidknorpel des Kehlkopfs. 0 B. horns ist stets durch ein Band an der Ohrregion des Schädels, etwa auf der Grenze zwischen Tympanicum und Petrosum, aufgehängt (Figur $182 A, B)$. An dieser Stelle geht ein oberster Teil der Hyalbogenanlage in die knorpelige Ohrkapsel ein. Bei manchen Sängern eroält sich dieser Teil als ein knöcherner Fortsatz des Petrosum (sog. Tympanohyale Fig. 182 , Processus styloinleus der Affen und des Menschen), an dem sich das craniale Ende des Horns durch ein kurzes, oder bei geringer Verknöcherung des Horns langes Ligament (L. stylohyoideun) befestigt (Fig. $A$ u. $B$ ).

Das hintere oder Branchialhorn (auch Thyreohyale), das selten fehlt, entspringt stets dicht hinter dem vorderen, ist nur eingliederig und verwächst bänfig knöcher'n mit dem Körper. Seine Befestigung am Thyreoidknorpel wurde schon oben hervorgehoben.

\section{Skelet der unparen Flossensäume und der paarigen Extremitäten der Vertebrata.}

Unpaare Flossen.

Bevor wir die parrigen Extremitäten und ihr Skelet besprechen, ist es nötig, die sog. unpaaren Flossensäume der primitiven Wirbeltiere zu schildern, da sie sowohl in ihrer physiologischen Bedeutung, als Hilfsorgane bei der Bewegung, wie auch in ihrem morphologischen Aufbau vielerlei Übereinstimmung mit den ursprünglichen paarigen Flossen zeigen. Es ist dies um so nötiger, als eine der Hypothesen, welche über die Herkunft der paarigen Extremitäten anfgestellt wurden, sie geradezu vòn, dem unpaaren Flossensaum ähnlichen, paarigen Säumen abznleiten sucht. 
Bei allen primitiven schwimmenden Wirbeltieren, Acranieru bis Fischen, ist. solch ein unparer, sich in der Mittelebene des Körpers erhebender Flossensaum längs des Rückens in größerer oder geringerer Ausdehnung entwickelt; hinten umgreift er das Schwanzende und kann sich auch ventral bis zum After, ja noch dariiber hinaus, fortsetzen. Sein Caudalteil ist in der Regel stärker ausgebildet und scheint anch zuerst aufgetreten zu sein, worauf dio Ontogenie von Branchiostoma und der Cyclostomen hinweist. Dies hängt jedenfalls damit zusammen, daß der Candalteil der unpaaren Flosse bei den primitiven Wirbeltieren das eigentliche Organ der Vorwärtsbewegung ist, die durch abwechselndes Schlagen des Schwanzes nach beiden Seiten zustande kommt. Die übrigen Teile der unparen Flosse haben dagegen hauptsächlich die Bedentung, die senkrechte Stellung der mittleren Köıperebene zu sichern, ähnlich dem Kiel der Schiffe. - Der Flossensarm ist eine Emporfaltung der Haut; er wird daher äußerlich ra der Epidermis, innerlich von Bindegewebe zabildet, in welchem in der Regel stïtzende Skeletgebilde anftreten.

Der unpaare Flos nsaum der Acranier (Fig. 80, 81, S.176, Fig.183) erlangt die ansehnlichste Ausdehnung, indem er als mäßig hohe Falte von der vorderen Körperspitze über den gesamten Rïcken zieht, den Schwanz umgreifend, sich ventral nach voln fortsetzt, indem er neben dem etwas linkseitig verschobenen After vorbeizieht, and erst am Porus branchialis endigt. - Die Ontogenie der Ganoiden, Dipnoer und Teleosteer scheint zu erweisen, daß die unpaare Flosse der Fische von einem acranier-ähnlichen Zustand ausging, der bei Dipnoi nnd Teleostei sogar den präanalen ventralen Teil.noch erkennen läßt. Bei den Cyclostomen und den meisten Chondropterygiern dagegen reicht der dorsale Saum

Fig. 183.

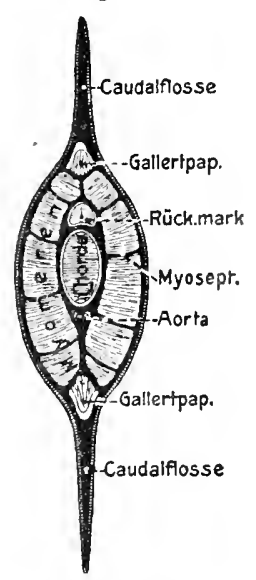

Branchiostoma (Amphi. oxus). Schematischer Quersehnitt durch den Schwanz. Bindegewebeschwarz. P.He. nicht über die Körpermitte nach vorn und der präanale fehlt (vgl. Fig. 184). Fast stets entwickelt sich jedoch der Caudalteil stärker zu einer Schwanzflosse, die jedoch, wie die von Branchiostoma, bei den Cyclostomen und Dipnoi mit dem Rüicken- und Analteil noch kontinuierlich zusammenhängt, was auch bei gewissen Knochenfischen (z. B. Aalen und manchen anderen, s. Centronotus, Fig. 184⿻) sich erhält, wo der primitive kontinuierliche Saum danernd verbleibt. - Auch dies erweist, daß die Abtrennung einer besonderen Caudalflosse bei den meisten Fischen, sowie die Auflösung des übrigen Saums in eine bis mehrere Rücken- nnd ventrale Analflossen durch Differenzierung des primitiven einheitlichen Saums entstand. Schon die Cyclostomen (speziell Petromyzon, Fig. 184'1) zeigen zwei schwach erhobene, doch noch nahezu zusammenhängende Rückenflossen. Bei Chondropterygiern (Fig. $184^{2}$ ), Ganoiden und den meisten Knochenfischen (Fig.184 ${ }^{3}$ ) sind aus dem Dorsalteil eine bis einige gesonderte Rïckenflossen entstanden, indem der übrige Teil des embryonalen Saums verkümmerte. Die Mannigfaltigkeit im einzelnen ist sehr groß; doch gibt es, wie bemerkt, auch nicht wenige Knochenfische, deren 
einheitliche Rücken- und Analflosse sich fiast in embryonaler Ausdehnnng erhält (Fig. 1844).

Eine bemerkenswerte Weiterbildung erfährt die für die Bewegung so wichtige Caudalflosse. Bei den Acraniern, Cyclostomen und Dipnoern ist sie nur mäßig entwickelt und dorsoventral ganz ṡymmetrisch ausgebildet; wie man sagt: dipleycerk. Bei den Chondropterygiern (Fig. $184^{2}$ u. Fig. 187) und Ganoiden entwickelt sich ihr ventraler Saum stärker als der dorsale, indem sich gleichzeitig die Mittellinie des Schwanzendes emporkrümmt; heterocerke Candalflosse. Bei vielen Haien tritt dies dadurch besonders hervor, dal' das Vorderende des Ventralsaums in einen besonderen

Fig. 181 .

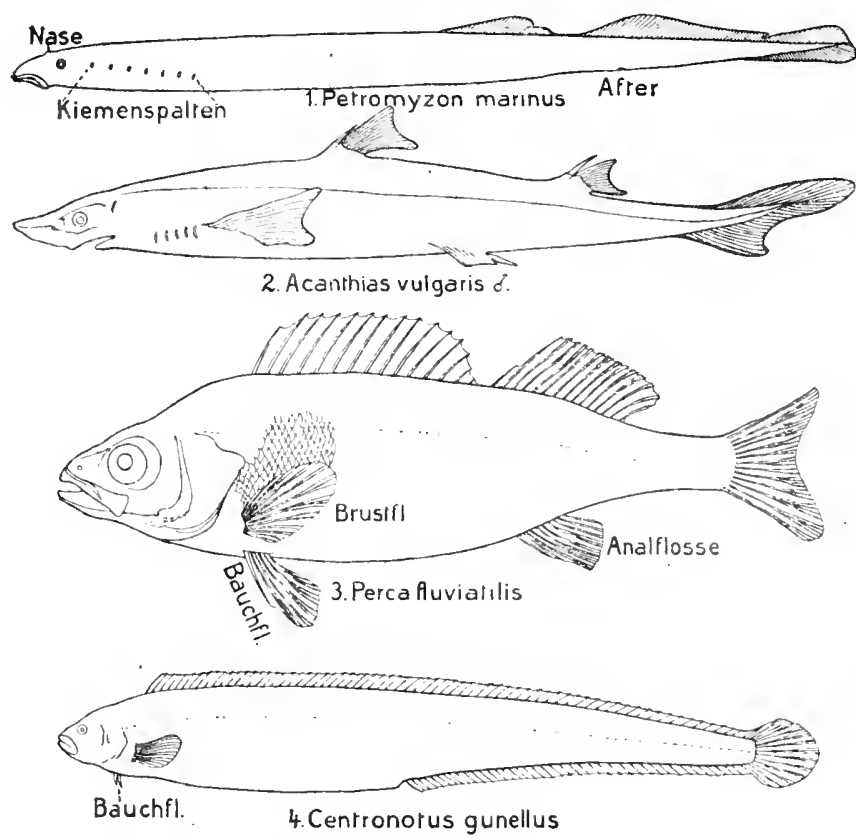

Znr Demonstration der unpaaren und paren Flossen bei Cyclostomen und Fischen.
Lappen auswächst, der an eine Analflosse etwals erinnert (Fig. 187, S. 316). Auch die Ganoiden zeigen diesen Lappen erwachsen (Acipenser) oder embryonal recht dentlich. Die diphy cerke Bil- . dung der Candalflosse bei Polypterus unter den Ganoiden ist wahrscheinlich nicht mehr die ursprïngliche, sondern aus der heterocerken wieder hervorgegangen.

Die Caudalflosse der Knochen-

fische geht ontogenetisch ans dem anfänglich diphycerken Zustand in den heterocerken ïber, um schließlich durch Reduktion des anfsteigenden Endteils des Schwanzes und starke Entwicklung des erwähnten Ventrallappens der heterocerken Flosse änßerlich wieder völlig symmetrisch zli werden (homocerk, Fig. 184 ${ }^{3}$ ). Ihre gewöhulich tief gabelig eingeschnittene Schwanzflosse scheint so entstanden zu sein, daß der erwähnte Ventrallappen der heterocerken Flosse dem Ventralsaum des anfwärts gekriimmten Endlappens ganz gleich wurde. In anderen Fällen, wo die Caudalflosse nicht gabelig ist (Fig. 1844), scheint sie dagegen völlig ans dem Ventrallappen hervorgegangen zu sein. Die ganz symmetrische Bildung des Caudalteils des kontinuierlichen Flossensaums der Aale dürfte wohl als eine Rückkehr zu den primitiven ähnlichen Verhältnissen zu deuten sein. 
Bei einem Teil der geschwänzten Amphibien blieb der unpaare Flossensaum des Rückens und Schwanzes erhalten und kommt ebenso dem Schwanz der Anurenlarven noch zu. - Ob dagegen der Rückenkamm, der sich bei gewissen Sauriern und Krokodilen findet, noch als eine Wiederholung des primitiven Flossensaums der Fische betrachtet werden darf, ist unsicher. Eher könnte dies noch für die dorsale und die Schwanzflosse der Ichthyosaurier vermutet werden. Die letztere war in weiterem Sinne gleichfalls heterocerk, jedoch insofern von umgekehrter Bildung wie die der Fische, als das hinterste Schwanzende abwärts gekrümmt und die Flosse daher hauptsächlich vom dorsalen Flossensaum gebildet war. Da sich jedoch bei den Sirenen und Cetaceen, in Zusammenhang mit der schwimmenden Lebensweise, eine Schwanzflosse entwickelte, welche sich schon durch ihre horizontale Ausbreitung als etwas Besonderes erweist, und sich bei den Cetaceen hierzu auch eine Rückenflosse gesellt, deren selbständiges Entstehen nicht zu bezweifeln ist, so wäre auch für die Ichthyosaurier eine unabhängige Hervorbildung der Flossen wohl möglich.

\section{Skelet der unpaaren Flossen.}

Die in den unpaaren Flossensaum der Acranier eingelagerten sog. Flossenkästchen (Cölomräume) mit ihren Gallertpapillen (Flossenstrahlen, s. Fig. 80, S. 176) durften kaum in genetischer Beziehung zum Flossenskelet der Cranioten stehen. Anf jedes Segment finden sich etwa drei bis fünf solcher Kästchen.

Im unparen. Flossensaum der Cyclostomen treten schon knorpelige, fadenartige, jedoch ziemlich unregelmäßige Stützgebilde auf (Flossenträger, bzw. Dornfortsätze, s. vorn Fig. 86, S. 180). Jedem Segment (Petromyzon) kommen meist vier zu, deren Distalenden sich wiederholt dichotomisch zerspalten. Sie ragen weit, bis gegen den freien Rand in den Flossensaum hinein, mit ibren proximalen Enden dagegen zwischen die dorsalen Partien der Seitenrumpfmuskeln. Währeud sie (Dorsalflosse) vorn ohne Verbindung mit den knorpeligen Neuralbogen sind, hängen sie hinten (Schwanzflosse) mit der dorsalen und ventralen Knorpelleiste, zı welcher die Bogen vereinigt sind, direkt zusammen.

Knorpelige Strahlen ähulicher Art kommen den Fischen allgemein zu, gehen jedoch häufig in Ersatzknochen über und reichen meist nicht weit in den Basalteil der Flossen hinein, indem deren peripherer größerer Teil von besonderen accessorischen Stützgebilden dnrchzogen wird. Aus diesen Gründen werden diese knorpeligen oder knorpelig angelegten Strahlen gewöhnlich als Flossentrüger bezeichnet.

Bei deu Knorpelfischen (speziell Haien), deren Flossenträger knorpelig bleiben, dringen sie zuweilen noch ziemlich tief in die Flossen hinein und sind in der Regel gegliedert (meist dreigliederig, Fig. 185). Dieser Skeletapparat liegt entweder frei zwischen der Muskulatur, oder lehnt sich mit den proximalen Gliedern an die Dorsalbogen der Wirbel. Die freie Flosse wird von einer Menge feiner, selten verzweigter, sog. Horntäden (Ceratotrichia) gestützt, die mesodermalen Ursprungs sind und sich wahrscheinlich elastischen Fasern nähern.

Die ursprünglichste Bildung dieses Skeletapparats zeigen wohl jene Haie, wo er aus zahlreichen gleichmäßigen, gegliederten Strahlen besteht (s. Fig. 185 A), die zu mehreren in jedem Segment auftreten, häufig, wie es scheint, in der Zweizahl, im AnschluB an die Bogen und Intercalaria. Sehr gewöbnlich tritt jedoch Verwachsung der proximalen unl auch mehr 
distalen Glieder der aufeinander folgenden Strahlęn auf, so daß sich einige, ja schließlich ein einziges großes Basalstück bilden kann, dem die unverwachsenen, odor weniger verwachsenen peripheren Strahlen aufgesetzt sind (s. Fig. $185 \mathrm{~B}$ ).

Die proximalen Glieder scheinen den morphologischen Wert von Dornfortsätzen zu haben, was namentlich aus dem Bau der Caudalflossen hervorgeht, sowie aus ihrem Verbalten zur Wiıbelsäule; sie finden sich nicht selten auch an Stellen, wo keir Flossensaum mehr besteht (Fig. 185 B). Dies Verhalten spricht für die mögliche Ableitung der Flossenträger von den Bogen

Fig. 185.
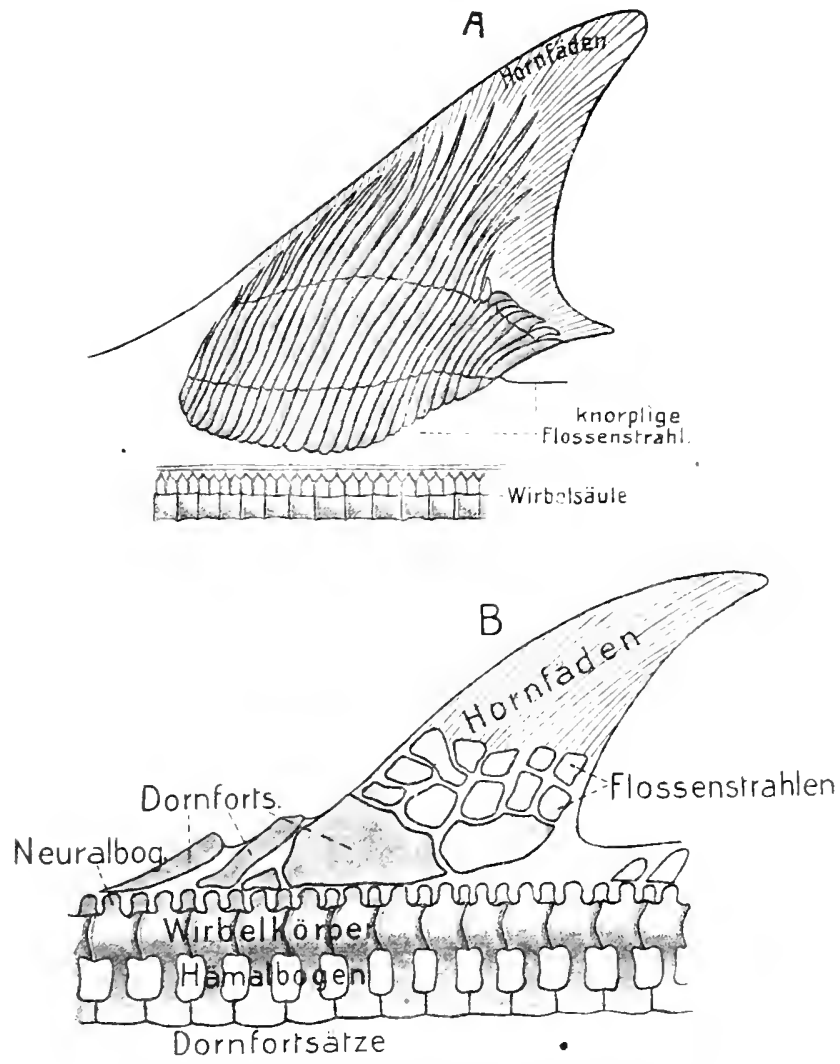
und Intercalarien der Wirbelsäule durch Abgliederung, gegenüber der Meinung, welche sie als selbständig entstandene Skeletgebilde betrachtet, die erst nachträglich AnschluB an die Wirbelsäule erlangten. - Als accessorisches Gebilde gesellt sich bei gewissen Haien (Spinaciden, Cestraciontiden, ähnlich Holocephalen) dem Vorderrand der Rükkenflossen ein ansebnlicher Knochenstachel (ein modifizierter Hautzahn) zu, der von einer größeren Knorpelplatte verwachsener Flossenträger gestützt wird. Solche Stacheln sind auf Placoidschuppenbildungen rückführbar und können bei den Rochen, deren unpaare Flossen stark reduziert sind, am Schwanz anch isoliert Rūckenfiosse von Knorpelfischen. Linkseitige Ansicht. A Zygaena malleus. auftreten (Stachel1. Ruckenflosse. (Nach ÄIvali 1879.) $B$ Squatinalaevis. P. He. rochen).

Von den übrigen Fischen schließen sich die Dipnoer den Chondropterygiern insofern zunächst an, als ihr freier Flossensaum noch durch hornfädenartige, jedoch zellenhaltige Gebilde gestitzt wird (sog. Camptotrichia). Diese werden ihrerseits wieder von zweigliederigen, äußerlich verknöcherten Flossenträgern getragen, deren distale Gilieder bis in die Flossenbasis eindringen. Das proximale Glied jedes Trägers schließt sich dem Distalende je eines der langen Dornfortsätze der Neural-oder Hämalbogen an, so daß also auf jedes Segment nur ein Flossenträger kommt und die eventuelle Abgliederung der Trïiger von den Dornfortsắtzen hier recht plansibel erseheint. 
Dieselben Verhältnisse kehren bei den Ganoiden und Knoehenfischen wieder, indem siclı im Bereich der Flossensäume an jeden Dornfortsatz ein verknöcherter Träger anschließt. Doch treten bei Knochenfischen (ebenso Acipenser) nicht selten streekenweise auch zwei, sogar drei Träger zwischen je zwei Dornfortsätzen auf, und die Träger breiten sich häufig auch über flossenfreie Partien der Rïcken- und Bauchkante aus. - Jeder Träger besteht in der Regel aus zwei Gliedern, von denen das proximale stets lang ist und sich bei den Teleosteern zwisehen die aufeinander folgenden Dorufortsätze hineinschiebt (Fig. 186 B). Das distale Glied bleibt dagegen sehr kurz und ragt wenig in die Flossenbasis hinein.

Während diese kleinen distalen Glieder der Flossenträger bei den Ganoiden noch gesondert bleiben (Fig. $186 A$ ), verwachsen sie bei den Knoehenfischen in der Regel mit den Endeu der großen proximalen Glieder in winkeliger Stellung (s. Fig. $186 \mathrm{~B}$ ). Zwischen je zwei soleher Endglieder gelenkt die za einer Art Gelenkkopf verbreiterte Basis eines Flossenstrabls.

Embryonal wird auch die Flosse der Teleosteer von Hornfäden (Actinotrichia) gestützt, die sich in gewissen Flossen (Fettflosse der Salmoniden), sowie am fortwachsenden Flossenrand dauernd erhalten können. Sonst werden sie später durch die Bildung hautknöcherner Flossenstrahlen (Lepidotrichia)

Fig. 186.

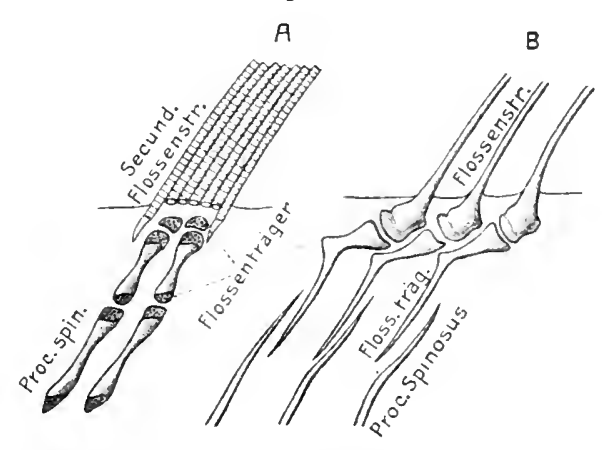

Flossenträger und knōcherne Flossenstrahlen der Rủckenflosse. Linkseitige Ansicht. A ron Acipenser sturio. $B$ ron $\mathrm{G}$ adus morrhna. verdrängt. Diese knöchernen, wohl von Knochenschuppen ableitbaren Flossenstrahlen durchziehen also hier die freien Flossen und reihen sich als Verlängerung je an das Distalende eines Flossenträgers an. Da der Flossensaum durch Emporfaltung der Haut entsteht, so erscheint es verständlich, daß jeder knöeherne Flossenstrahl doppelt angelegt wird, nämlich von der rechten und linken Hautlamelle der Flosse. An den ursprïnglicheren, gegliederten, oder sog. weichen Flossenstrahlen (Fig. $186 \mathrm{~A}$, Fig. $187 \mathrm{~B}$ ), wie sie die Ganoiden besitzen, die Knochenfische stets in der hinteren Region der unparen Flossen, erhält sich die Zusammensetzung aus zwei Hälften dauernd (s. Fig.187 C). Diese weichen Flossenstrahlen zersehlitzen sich distal in mehr oder weniger sekundärt Strahlen und sind ferner, Basalstrahl wie sekundäre, aus zahlreichen einzelnen Knochenstïckchen gliederig aufgebant.

Bei den Teleosteern werden der erste, oder eine verschieden große Zahl (Acanthopterygii) der ersten Rücken- und der Analflossenstrablen zu ungegliederten, einheitlichen und nicht zerschlitzten, sog. harten Strahlen (Fig. 184 ${ }^{3}$, S. 312), die auch gelegentlich isoliert vor den Flossen auftreten können (z. B. Stichling). 
Caudalflosse. Das Skelet der Schwanzflosse zeichnet sich im allgemeinen dadurch aus, daß in seinem Bereich keine eigentlichen Flossenträger vorkommen, sondern nur dorsale und ventrale Bogen mit zugehörigen Dornfortsätzen, weshalb sich die Hornfäden oder. die knöchernen Flossenstrahlen direkt an die Dornfortsätze anschließen. Nur in der Vorderregion des ventralen Schwanzflossenlappens lassen sich zuweilen (z. B. Acipenser, Fig. $188 B$ ) Reste knorpeliger Flossenträger unterscheiden.

A Fig. $187 .^{\text {Fin }}$
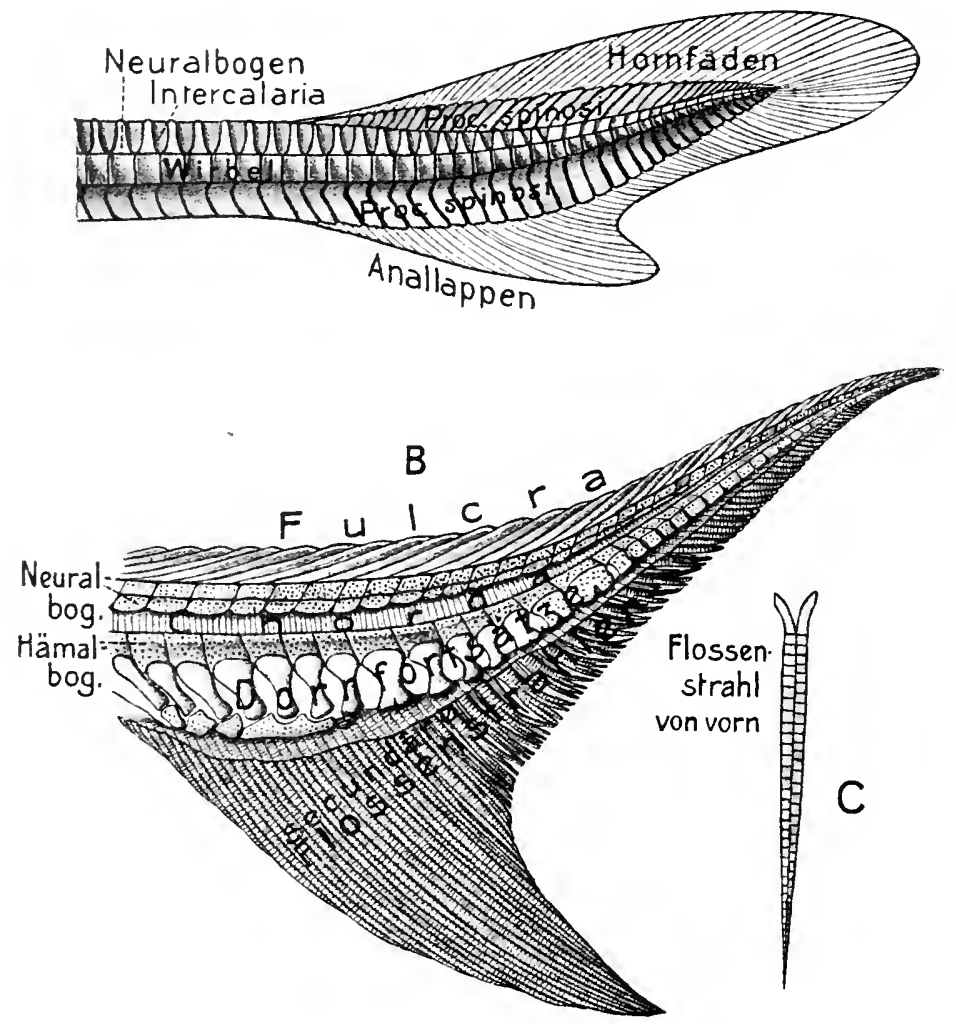

Candalfosse. Linkseitige Ansicht. $A$ von Acanthias volgaris. $B$ von Acipenser sturio. Enorpel punktiert nnd dnnkel. Die Basen der Strableu sind linkseitig abgeschnitten, um die Hămalbogen zu zeigen. $C$ ein kuöcherner Flossenstrahl des Acipenser von vorn.

In der diphycerken Schwanzflossenregion der Dipnoi verhält sich das Skelet 'dorsal und ventral völlig symmetrisch.

In der heterocerken Caudalflosse der Chondropterygier und Ganoiden entwickeln sich dagegen die Dornfortsätze der Hämalbogen viel ansehnlicher als die der Neuralbogen, was mit der starken Entfaltung des ventralen Flossensaums zusammenhängt (Fig. 187). Die Aufwärtshiegung des hinteren Endes der Wirbelsäule, die in den Dorsallappen der heterocerken Flosse reicht, wird bei den 
Ganoiden (abgeseben von Polypterus) im allgemeinen viel stärker als bei den Haien. In der homocerken Schwanzflosse der Knochenfische erlangt sie schließlich ihr Extrem, indem gleichzeitig das stark anfwärts gekrümmte Ende der Wirbelsäule sehr verkümmert (Fig. 188). Übergangszustände zu den Ganoiden zeigen zum Teil noch die Physostomen, da ibre hintersten Wirbel noch aufwärts gekrümmt sind (Fig. 188A). An den letzten Wirbel schließt sich ein schief aufsteigender Knorpelfaden an, der das hinterste Chordaende nmhüllt. Diesem verkümmerten Wirbelsäulenende setzen sich ventral einige Dornfortsätze an, die zn den reduzierten Wirbeln gehören, und die Dorsalhälfte der Schwanzflosse stutzen, während deren ventrale Halfte von den besser entwickelten Dornfortsätzen (samt den damit verwachsenen Resten der Hämalbogen) der hintersten Schwanzwirbel gebildet wird. Einige parige Knochenstückchen, welche die hintersten Wirbel und den Knorpelfaden dorsal bedecken $(x, y, z)$, dürfen wohl als Reste hinterster Neuralbogen betrachtet
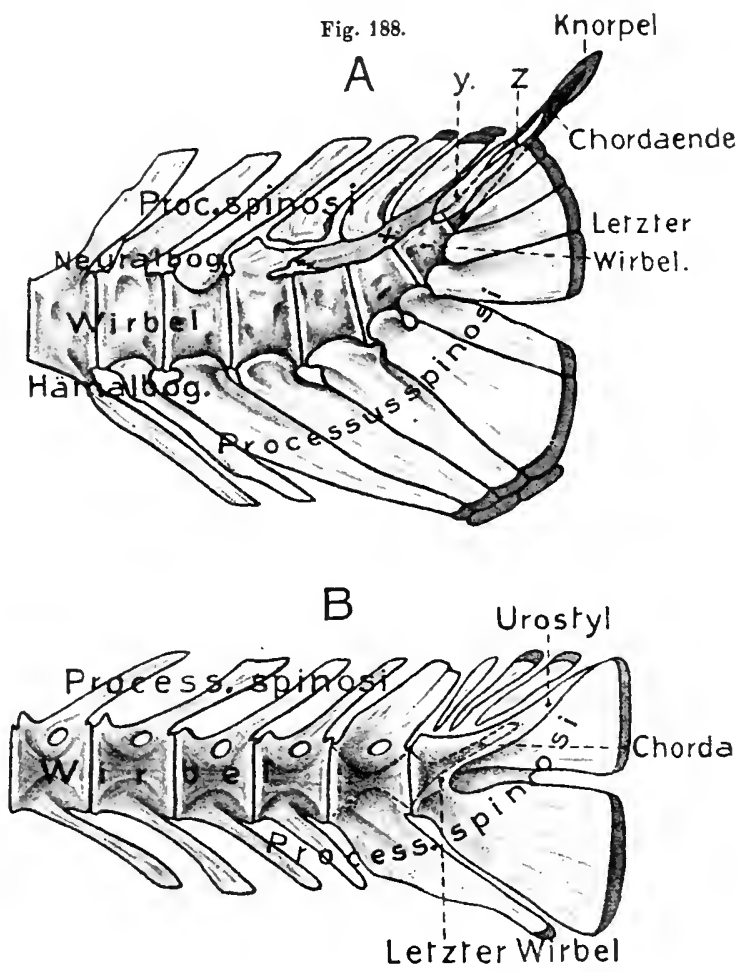

Skelet der Candalflosse von Teloosteern. Linkseitige Ansicht. Knorpel dunkel. A Thymallus thymallus, $x, y, z$ Neuralhegen ver. kúmmerter hinterer Wirbel. $x$ ans Verwachsung solcher Bogen hervorgegangen. Chordaende schraffiert, von Knorpel umgeben, seine Fortsetzung bis zum letzten Wirbel puntiert angegeben. $B$ Cottus gobio. Chordaende im sog. Urostyl and dem hintersteu Wirbel in punktiertem UmriB $\begin{array}{ll}\text { angegehen. (Nach Lijt 1564.) } & \text { P. He. }\end{array}$ werden, deren Dornfortsätze abgelöst sind (s. Fig. 188 A).

Bei anderen Physostomen, sowie den Physoclysten, verwachsen diese Reste der hintersten dorsalen Bogen mit dem letzten Wirbel zu einem schief aufsteigenden knöchernen Fortsatz desselben (sog. Urostyl, Fig. $189 \mathrm{~B}$ ), in welchem das Chordaende eingeschlossen ist. - Während ursprünglich eine ansehnliche Zahl ventraler Dornfortsätze und eine geringe dorsaler an dem Aufhau der Caudalflosse teilnehmen, reduziert sich bei vielen Knochenfischen die Zahl der ventralen, heterocerk emporgerichteten Dornfortsätze sehr, indem sie zu größeren Platten verschmelzen, so daß sich häufig je eine einzige solche Platte für den dorsalen und 
ventralen Lappen findet (Fig. 189 B). Auch diese beiden können schließlich zu einer einzigen verwachsen. Indem diese Platte klein wird und sich gleichzeitig der sog. Urostyl reduziert, oder mit der Platte verwächst, während der dorsale und ventrale Schwanzflossensaum sich stärker nach vorn ausdchnen, kann bei manchen Knochenfischen sekundär ein Schwanzflossenskelet, sowie ein Hinterende der Wirbelsäule ausgebildet werden, das wieder ganz symmetrisch erscheint $(z . B$. bei Aalen usw.), welches jedoch sicher durch Umbildung aus dem homocerk asymmetrischen Zustand der ursprünglichen Teleosteer hervorgegangen ist.

\section{Paarige Extremitäten der Vertebrata.}

Die paarigen Extremitäten haben sich zweifellos erst im Phylum der Vertebrata selbst hervorgebildet und stehen in keiner phylogenetischen Beziehung zu den Extremitätenbildungen der Gliederwürmer und Arthropoden. Dies folgt schon daraus, daß die Acranier sicherlich nie Extremitäten im Sinne der höheren Wirbeltiere besaßen; weiterhin jedoch auch aus dem Umstand, daß die Wirbeltierextremităten, im Gegensatz zu denen der Gliederwürmer und Gliederfüßer, ganz unabhängig von der Segmentation sind, d. h. regelmäßig nur in zwei Paaren auftreten; keinerlei Anzeigen sprechen dafür, daß je mehr vorhandeu waren, oder daß eine Beziehnng zur Segmentation bestand. Der Extremitätenmangel der Cyclostomen dagegen dürfte wahrscheinlicher auf Rückbildung beruhen, wie sie bei höheren Vertebraten recht häufig eintrat; etwaige Beweise aus der Ontogenie fehlen jedoch.

Die ursprünglichsten paarigen Extremitäten, wie sie den Fischen zukommen, sind einheitliche, ruderartige Flossenbildungen (Pterygien), welche in ihrem allgemeinen Bau, namentlich auch ihrem Skelet, große Ähnlichkeit mit den unparen Flossensäumen besitzen. Dicht hinter den Kiemen, anf der Grenze von Kopf und Rumpf, entspringen die vorderen Extremitäten oder Brustflossen, die stets größer werden als die hinteren, die Bauchflossen, welche bei allen ursprünglichen Fischen (Chondropterygier bis Physostomen) am Hinterende des Rumpfes, dicht vor dem After stehen. Sekundäre Rüickbildung der Banchflossen, ja der beiden Extremitätenpaare, trat zuweilen bei Knochenfischen (z. B. Aalen) ein.

Die Ontogenie ergab einige interessante Aufschliisse, welche auf die mögliche phylogenetische Herleitung der Extremitäten Licht werfen. Die Anlagen der paarigen Flossen treten nämlich als paarige Längsleisten der seitlichen Rumpfregion anf, deren Erhebung ursprïnglich vom Mesoderm ausgeht, die jedoch später auch durch eine Epidermiswucherung auf ihrcm freien Rand (Epithelfaite) verbreitert werden. Diese Längsleisten springen anfänglich ganz horizontal am Rumpf vor. - Von besonderer Bedeutung ist, daß sie sich über eine größere Zahl von Körpersegmenten erstrecken, ja, wenn die fertigen Flossen sehr groß werden (z. B. Brustflossen der Rochen), über eine sehr große. Da nun auch die Muskeln nnd Nerven der paarigen Flossen von einer größeren Anzahl Segmente geliefert werden, so beweist dies die schon erwähnte Unabhängigkeit der Extremitäten von der Segmentation, bzw. ihr Hervorgehen aus einer über mehrere Segmente sich erstreckende Region. 
Die frühere Vermutung, daß die Leisten der vorderen und hinteren Extremitäten jeder Seite kontinuierlich zusammenhingen, lat sich nicht bestätigt; nur Torpedo zeigt einen solchen Zusammenhang, welcher durch die zwischen den Extremitätenanlagen sich fortsetzende Epithelfalte bergestellt wird. Immerhin erstrecken sich jedoch die Leisten längs des Rumpfs meist über eine viel längere Strecke als die fertigen Flossen, so daß die Flossenanlagen sich viel näher treten als die ausgebildeten Extremitäten. Wenn es daher auch nicht sicher erweisbar scheint, daß die parigen Flossen jeder Seite das Differenzierungsprodukt eines ursprünglich einheitlichen Flossensaums sind, analog etwa, wie die unpaaren Einzelflossen aus dem kontinuierlichen medianen Saum hervorgingen, so ist doch wohl möglich, wenn nicht wahrscheinlich, $\mathrm{da} B$ sie phylogenetisch auf diese Weise entstanden. In dieser Hinsicht ist besonders interessant, $\mathrm{d} a \mathrm{~B}$ schon bei den Acraniern jederseits an den seitlichen ventralen Rumpfkanten eine vorspringende Längsfalte von der Mundregion bis zum Porus branchialis zieht, die sog. Metapleuralfalten (Fig. 81, S. 177). Es erscheint nicht unmöglich, daß diese Falten der Acranier ein Homologon des Faltenpaars darstellen, aus welchem die paarigen Flossen hervorgingen.

Durch Auswachsen der leistenförmigen Anlage entwickelt sich allmählich die Form der fertigen Flosse, wobei an Brust- wie Bauchflossen der kopfwärts gerichtete Rand der Leiste fast stets stärker wächst als der hintere oder caudalwärts schauende, woraus die in der Regel etwas trapezförmige bis dreieckige Gestalt der fertigen Flossen resultiert (Fig. 184, S. 312). Die besondere Form der Dipnoerflossen wird später besprochen werden.

Die ursprünglich ganz horizontal verlanfende Ursprungslinie der Flossen am Rumpf erhält sich bei manchen Chondropterygiern fast unverändert, was namentlich für die ungemein großen und langen, zu flügelartigen Körperverbreiterungen auswachsenden Brustflossen der Rochen gilt. Schou bei den Haifischen, deutlicher bei Ganoiden und Teleosteern, tritt eine Verschiebung der horizontalen Ursprungslinie hervor, besonders an den Brustllossen. Die Ansatzlinie richtet sich schief anf, so daß sie von unten und hinten schief nach vorn und oben zieht, sogar nahezu vertikal werden kann (vgl. Fig. 184). Gleichzeitig verändert sich anch die ur'sprünglich horizontale Stellung der Flossenplatte selbst, indem sie sich in ihrer Rubelage aufrichtet, d. b. ibre ursprüngliche Dorsalfäche der Körperseite mehr oder weniger anlegt. - Die Bauchflosse zeigt gewőhnlich eine geringere Lageveränderung ihrer Ansatzlinie, die annähernd horizontal verläuft, oder schwach geneigt im Sinne der Brustflosse. Die Haltnng der Bauchflosse im Ruhezustand ist der der Brustflosse entgegengesetzt, sie ist uicht aufgerichtet, sondern abwärts gesenkt (Fig. 184).

Diese Verschiedenheit in der Stellung und Haltung der beiden parigen Extremitäten bängt jedenfalls enge mit ibrer Funktion zusammen. Die eigentliche Vorwärtsbewegung der Fische geschieht mit der Schwanzflosse, wie schon früher hervorgeboben wurde. Die paarigen Flossen werden gewöhnlich als Organe zur Erhaltung des Gleichgewichts betrachtet; doch geht ihre Funktion jedenfalls noch weiter. Die ansehnlicheren Brustflossen müssen bei ihrem schief von oben nach abwärts und etwas nach vorn gerichteten Schlag die Vorwärtsbewegung hemmen können, aber auch Rückwärtsbewegungen hervorrufen; andrerseits werden sie auch den Vorderteil des Fisches heben und so das Aufwärtsschwimmen begünstigen. Die Bauchflosseu dagegen scheinen in mancher Hinsicht wie Antagonisten der 
Brustflossen zu wirken, namentlich fuir schiefes Abwärtsschwimmen, können aber durch geeignete Bewegungen wohl auch die Brustflossen unterstützen.

Wir fanden, daß die Bauchflossen der ursprünglichen Fische weit hinten, dicht vor dem After stehen (Fig. 1842). Auch die Ontogenie erweist daß dies ihre ursprtingliche Stellung ist. Bei der großen Abteilnngder Physoclysti unter den Knochenfischen ist jedoch, mit wenigen Ausnahmen, eine weite Vorwärtsverlagerung der Bauchflossen eingetreten, bis nahe an, oder zwischen die Brustflossen (brustständig, s. Fig. $184^{3}$ ), ja zuweilen sogar noch vor die Brustflossen (kehlständig, Fig. 1844). Ermŏglicht wird diese, von besonderen Wachstumsprozessen hervorgerufene Wanderung anch dadurch, $\mathrm{da} ß$ die Ansatzlinien der Bauchflossen stets dicht neben der ventralen Mittellinie des Körpers stehen, während die der Brustflossen den Seitenlinien des Körpers genähert sind. - Auf die zahlreichen eigentümlichen Formmodifikationen der Flossen (z. B. bei fliegenden Fischen, Umbildung der Bauchflossen zu Haftorganen usw.) kann nicht näher eingegangen werden.

\section{Skelet der parigen Flossen.}

Entsprechend den unpaaren Flossen zeigen auch die paarigen ein Skelet doppelter Art. Einmal knorpelige (auch verknöchernde) Skeletgebilde, die jedoch nur den Basalteil der Flosse stützen, und fernerStützgebilde des peripheren Flossensaums, welche wie die der unpaaren Flossen bei den Chondropterygiern und Dipnoern von Hornfäden, bei den Ganoiden und Teleostei von hautknöchernen Flossenstrahlen gebildet werden. Letztere sind in der Regel weiehe, gegliederte Strahlen; nur der vordere längere Flossenrand wird häufig von einem harten Strahl gestützt.

Das knorpelig angelegte Flossenskelet läßt selbst wieder zwei Abschnitte unterscheiden. Erstens einen peripheren, ursprünglich stets dem Basalteil der eigentlichen Flosse eingelagerten und mit ihr beweglichen Abschnitt und zweitens einen im Körper eingelagerten, in dessen Muskulatur mehr oder weniger eingebetteten, welcher dem ersteren zur Stütze und Anheftung dient. Letzterer Skeletabschnitt wird als Gürtel (Zonoskelet) bezeichnet und an der vorderen Extremität Brust- oder Schulter-, an der hinteren Beckengürtel genannt.

Flossenskelet der Chondropterygier. Bevor wir die Ansichten iber die mögliche phylogenetische Entstehnng des paarigen Flossenskelets betrachten, wird es angezeigt sein, als Beispiel seiner einfachen Gestaltung das der Chondropterygier etwas näher zu betrachten, wobei wir mit den Gürteln beginnen. Entsprechend der bedeutenderen Größe der Brustflossen ist auch der Schultergürtel viel ansehnlicher als der Beckengürtel. Er besteht bei Sclaehiern nnd Holocephalen ursprünglich aus zwei Bogenhälften, die dicht hinter dem bintersten Kiemenbogen, ziemlich oberflächlich liegen und in der ventralen Mittellinie zusammenstoßen, selten hier noch gesondert, meist miteinander verwachsen (Fig. 189 Mustelus, Squatina). Das Dorsalende jeder Bogenhälfte läuft verschmälert aus und steht nicht in Verbindung mit der Wirbelsäule oder dem Schädel. Etwa in der Mitte ihrer Höhe gelenkt an jeder Bogenhälfte das freie Flossens'selet an einer nach hinten und außen schauenden Leiste, die auch einige 
vorspringende Gelenkhöcker bildet. Diese Gelenkstelle läßt einen dorsal von ihr gelcgenen, scapularen Teil jedes Schultergiurtelbogens von einem ventralen, coracoidalen Teil unterscheiden. Etwa auf der Iöhe des Gelenks findet sich anf der Medianseite ein kleines Loch $(e)$, in welches ein Nerv eintritt, der sich beim Verlauf im Gürtel in zwoi Äste teilt, von denen der obere, der für die Dor'salfläche der Flosse bestimmt ist, auf der Außenseite etwas über der Gelenkstelle austritt $(o)$, der untere, zur ventralen Flossenfläche gehende, etwas unter derselben $(u)$ auf derAußen-oder Hinterseite des Guirtels.

Der Schultergürtel der Rochen (Hig. 190, Raja vou außen) ist niederer geworden und steht mit seinem scapnlaren Teil zuweilcn durch Band oder Gelenk mit der Wirbelsäule in Verbindung. Durch die Erweiterung der bei den Haien erwähnteu Nervenkanäle $(e, o, u)$, welche durch Einlagerung von MuskeIn hervorgerufen wird, bzw, auch durch dercn Zusammenfluß und den Zutritt weiterer Durchbrechungen, wird die Form des Roehenschultergürtels zuweilen recht eigentümlich.

Fig. 189.
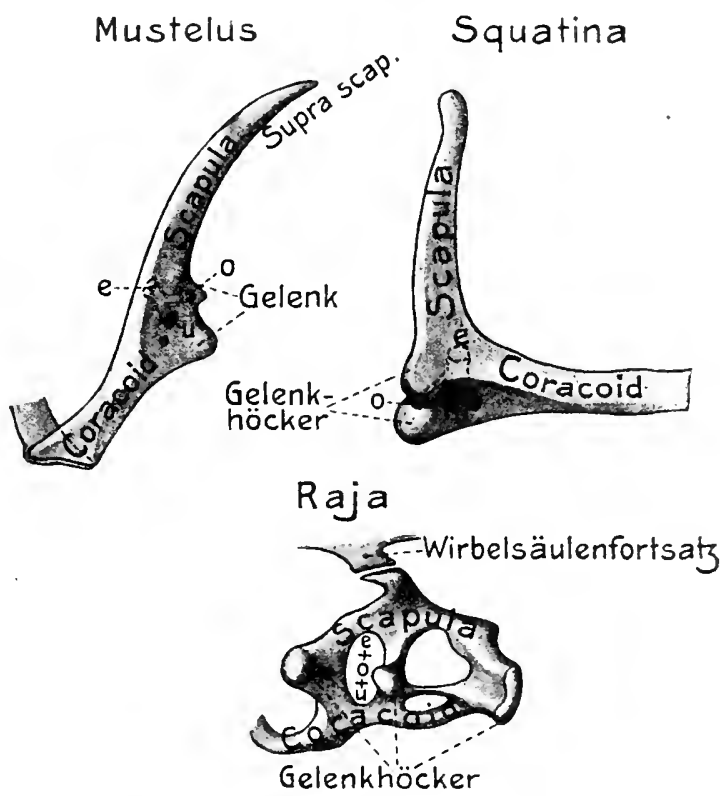

Schultergürtel von Chondropterygi. Mastel as, linke Schultergürtelhälfte von anßen. Squatina, linke Schultergürtelhälfte von hinten. Raja, linke Schultergürtelhälfte von außen. $e$ Eintrittsloch des Flossennervs, $a$ and $u$ oberes nnd unteres Anstrittsloch desselben. Kanalverbindung dieser Lōcher punktiert angedentet. Hei Raja sind die erweiterten Löcher zusammengeflossen. E. W.

Wie erwähnt, bleibt der Beckengürtel fast stets viel schmächtiger (Fig. 191). Eine Ausnahme bildet der eigentümliche, sehr primitive IIai Chlamydoselache mit langem und breitem, plattenförmigem Gürtel (s. Fig. 190). Nur bei den Holoeephalen (Fig. 191) und Rochen (Fig. 191) besitzt er den dorsalen, über die Gelenkstelle aufsteigenden F'ortsatz (Ileum) '1), der dem Schultergürtel regelmäßig zukommt; bei den Squaliden ist dieser Fortsatz völlig oder fast völlig verkümmert (Fig. 191). Die Gelenkstelle für das freie Flossenskelet liegt daher im letzteren Fall am äußeren Ende jeder Beckenhälfte, die meist nur schwach aufwärts gekrümmt ist, und mit der der anderen Seite fast stets zu einer queren Knorpelspange verwächst. - Der ventral von der Gelenkstelle liegende Beckenabschuitt wird Ischiomubis gonannt, aus Gründen, die sich später ergeben werden. Nur bei den Holocephalen

1) Richtiger sllium ; da die Bezeichnung „lleum \& jedoch auf den Figuren verwendet war, so wurde sie auch im Text benutzt.

Bútschli, Vergl. Anatomie. 
und wenigen Haien hat sich die Sonderung beider Beckenhälften erhalten, ein primitiver Zustand, ebenso wie die Bildung eines dorsalen Beckenfortsatzes; denn

Fig. 190.

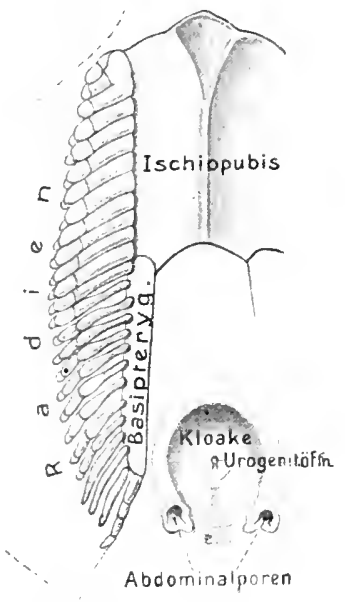

Chlamydoselache anguinens. Becken mit Skelet der rechten Bauchflosse ron der Ventralseite. Umriß der Bauchllosse gestrichelt. Gleichzeitig die Cloake mit ihren offnangen eingezeichnet. (Nach GARMAN 1855.) 0. B. die Ontogenie der Selachier erweist, daß. dieser Beckenteil erst während der Entwicklung allmäblich zurücktritt. - In der Gelenkgegend wird der Knorpel von ein bis mehreren Nervenkanälchen durchsetzt. Etwas unterbalb der Gelenkstelle entspringt häufig ein schwacher, nach answärts und abwärts gerichteter Fortsatz (sog. Präpubisfortsatz), der bei den Rochen zuweilen recht ansehnlich wird (Fig. 191 Raja).

Das freie Flossenskelet bat in der kleineren Bauchflosse ursprünglichere Verbältnisse bewahrt, wie diese ja überhaupt dem urspriinglichen Zustand ähnlicherbleibt. Wir beginnen deshalb mit der Betrachtung ibres Skelets (Fig. 192). Es wird gebildet von einem längs der basalen Ansatzlinie binziehenden Knorpel (Basalknorpel, Basipterygium), der vorn am Becken gelenkt, und an dessen Hinterrand sich als Verlängerung zuweilen noch einige kleinere Knorpelchen anschließen. Dem Außenrand dieses Basipteryginms sind zahlreiche, schief nach außen und hinten gerichtete Knorpel-

Fig. 191.

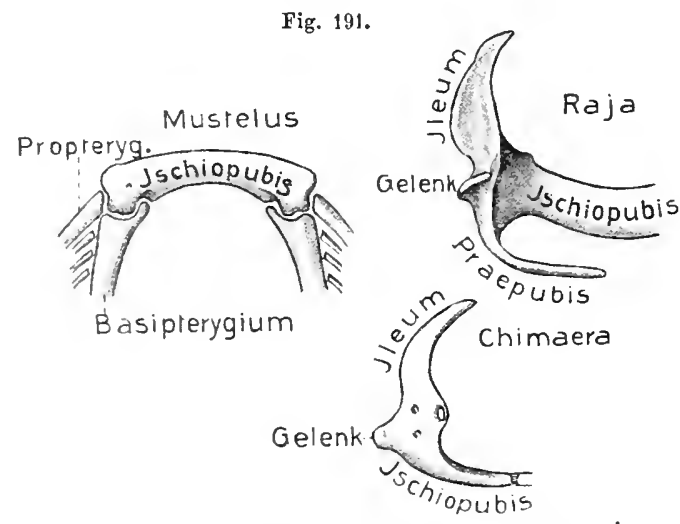

Becken von Chondropterygiern. Mnstelng von Dorsalseite. $\mathrm{Raj}$ a nd $\mathrm{Chima}$ ora rechte Halfte von rorn. $\mathrm{E}$. W. strahlen angefügt, die bei den Haien (Fig.: Scyllium, Mustelus) auf eine gewisse Strecke in den freien Flossensanm eintreten; bei den Rochen (Raja) durch den ganzen Sanm ziehen. Diese Flossenradien sind gegliedert; bei den Haien meist nur zwei- bis weniggliederig, bei den Rochen dagegen mebrbis vielgliederig und hier auch häufig mit dichotomisch verzweigten peripheren Enden. Der vorderste Randstrahl ist zuweilen stärker entwickelt; auch sind nicht seiten dis proximalen Glieder einiges der vordersten Radien zu einem größeren Knorpelstiick verschmolzen /sog. Propterygium, s. Scyllium, Mustelus, Chimaera); dieses kaun dann, wie der stärker entwickelte vordere Pandstrabl, direkt am Beckengürtel gelenken. 
Eine eigentümliche Bildung zeigt die Bauchflosse des in vieler Hinsicht sehr primitiven Haies Chlamydoselache (s. Fig. 190), da eine bedeutende Anzahl der zahlreichen Radien an der langen Beckenplatte inserieren. - Sowohl für die phylogenetische Ableitung der Extremitäten aus ursprünglichen Flossensäumen, als auch der Gürtel und Radien, dürfte dies Verhalten bedeutsam sein.

Fig. 192 .

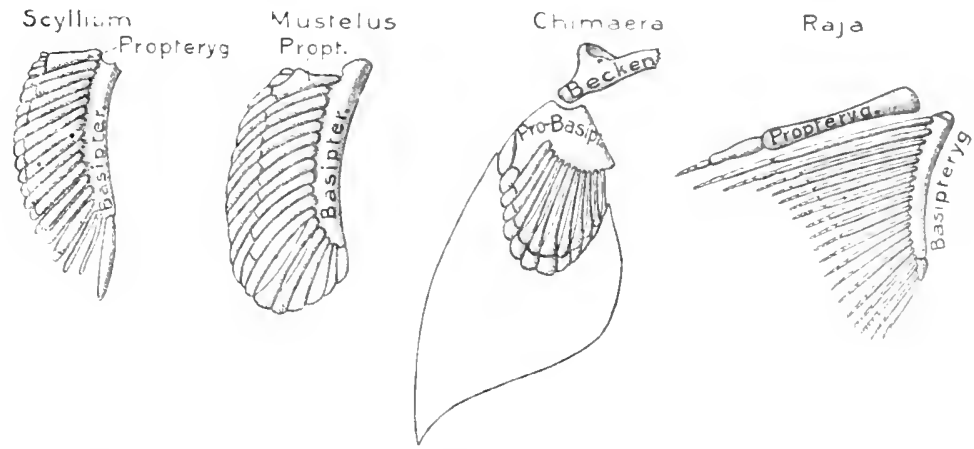

Skelet der rechten Ba chflosseron Chondropterygiern ron der Ventralseite. Bei Cbimara $O$ die Umrisse der Flosse und die Hornfäden eingezeichnet (z. T. nach GegenbaUr 187u). E. W.

Bei den Männchen der Chondropterygier wächst der Innenrand der Banchflosse zu einem als Begattungsglied dienenden Organ aus, in welchem sich ein aus Knorpelradien hervorgehendes eigentiimliches Skelet entwickelt. Hierauf soll erst bei den Geschlechtsorganen näher eingegangen werden.

Fig. 193.

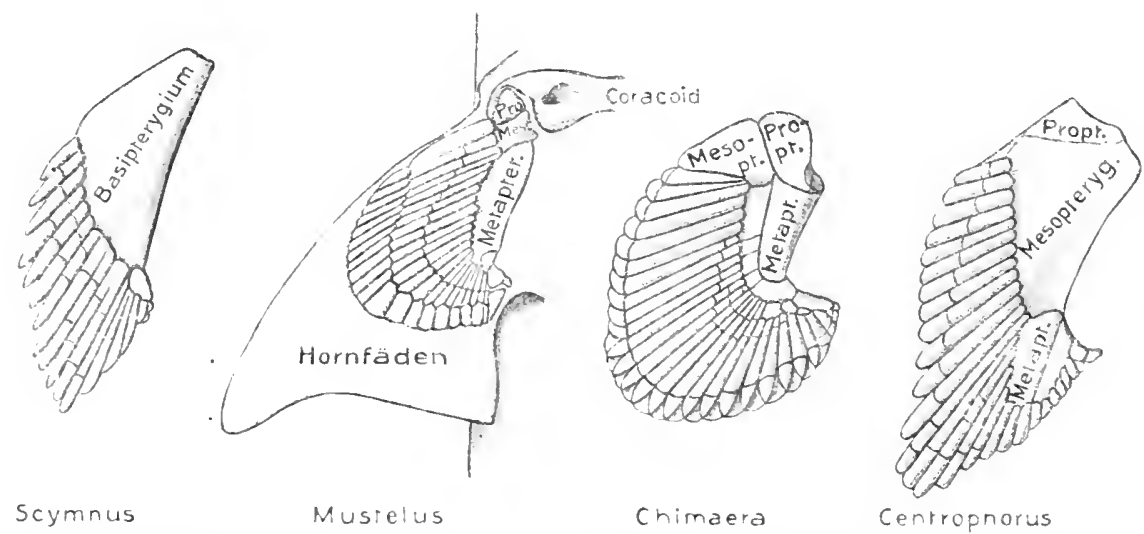

Skelet der rechten Brustflosse von Chondropterygiern von der Ventralseitc. Bei Instelus die Umrisse der Flosse nebst Hornfäden eingezeichnet (z. T. nach Gegenbaur 1565 and 1370). E. W.

Das Bildungsprinzip des Brustflossenskelets ist im allgemeinen das gleiche. Bei den Haien Fig. 193) findet sich längs der basalen Ansatzlinie der Flosse ebenfalls ein ansehnlicher Basalknorpel (Netapterygium), der am Schnltergürtel gelenkt. Bei gewissen Formen (Scymnus) können alle Knorpelradien der freien Flosse diesem einzigen Basalknorpel (Basipterygium) angefügt sein (doch könnte 
dies möglicherweise auch auf sekundärer Verschmelzung mehrerer ursprünglicher Basalknorpel beruhen). Nit der ansehnlicheren Entfaltung der Flosse, auch nach vorn, gelangen meist eine größere Zahl Knorpelradien zu direkter Anheftung am Gürtel. Der vorderste Radius, namentlich sein Basalglied, ist anch in der Brustllosse in der Regel stärker, und gelenkt dann als sog. Propterygium am Gürtel, ist jedoch wohl zu weilen aus einigen verwachsenen proximalen Radiengliedern hervorgegangen. Gewöhnlich verschmelzen ferner die Basalglieder einer Anzahl auf den ersten Radius folgender zu einem kleineren bis recht ansehnlichen dritten Basalknorpel, der sich als Mesopterygium zwischen Pro- und Metapterygium an den Schulter-

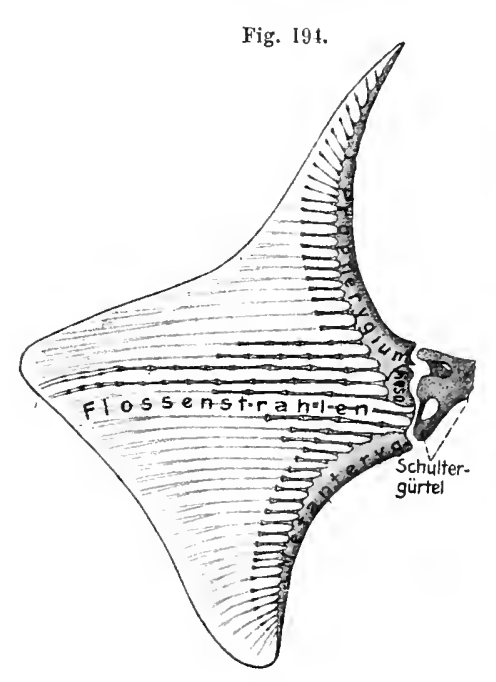

Kaj a (pagenstecheri). Skelet der linken Brustflosse von der Dorsalseite. Es setzen sich 4 Flossen. strahlen direkt an den Sehultergürtel, nieht nur zwei, wie hier gezeichnet. E. W. giirtel schiebt (s. Mustelus, Centrophorus). - Die Knorpelradien können wenig- bis mehrgliederig sein. Besonderes Interesse besitzt ihr Verbalten am hinteren freien Innenrand der Flosse. Wenn dieser, wie es bei Selachiern häufig ist, sich gegen die Medianlinie des Körpers verbreitert, so rücken die hinteren Knorpelradien mehr oder weniger um das Hinterende des Metapterygiums herum und auf dessen hinterer Medianseite sogar etwas nach vorn (Centrophorus). Der histerste- Teil des Flossenskelets erhält so, in bezug auf den Radienbesatz, einen sog. biserialen Charakter, in Gegensatz zu lem Hauptteil, in dem die Knorpelradien nur einreihig, außen an Basalknorpel stehen. An solchen, zur Biserialität neigenden Flossenskeleten erlangt zuweilen ein Radins, der in die

Verlängerung des Metapterygiums fällt, etwas größere Stärke und setzt letzteres gewissermaßen fort.

Mancherlei Concrescenzen von Gliedern benachbarter Radien treten nicht selten anf (vgl. Fig. 193 Chimaera); ebenso kann wohl gelegentlich dichotomische Teilung einzelner Radien eine Rolle spielen, was ja bei den Rochen peripher gewöhnlich vorkommt.

Die Brustflossen der Rochen (Fig. 194) sind fltigelartig so ansehnlich vergrößert, daß sie vorn bis in die vordere Kopfregion, hinten bis nahe an die Bauchflossen reichen. Schon bei einigen haiartigen Formen (Squatina z. B.) findet sich der Beginn einer solchen Vergrößerung. Damit hat sich auch das Flossenskelet stark verändert; die Zahl der Radien wurde nach hinten und vorn seh: vermehrt; sie sind ferner sehr lang, vielgliederig und, wie gesagt, peripher meist dichotomisch verzweigt. Das Metapterygium ist sehr verlängert, und hinten sind ihm mehr oder weniger ähnliche Basalknorpel als Verlängerung angefügt. Ein mäßig großes Mesopterygium ist vorhanden, aber an Stelle des Propterygiums findet sich ein, bis 
eine Reihe ansehnlicher Basalknorpel, welche dieselbe Rolle spielen wie die Metapterygialknorpel in der hinteren Flossenhälfte. Die vordersten Propterygialknorpel verbinden sich durch Band mit einem vom Präorbitalfortsatz des Kuorpelschädels abgegliederten sog. »Schädelflossenknorpel «, womit die große Flosse vorn am Schädel eine Stï̈ze findet (s. vorn S. 231).

Nachdem wir so die Grundzüge des Skeletaufbaus der parigen Chondropterygierflossen kennen lernten, können wir einige Worte über ihre mögliche phylogenetische Herleitung hinzufïgen, welche dann natürlich auch für die parigen Extremitäten der Wirbeltiere überhaupt gilt. - Die Ontogenie lehrt, daß nicht nur bei den Chondropterygiern, sondern den Fischen überhaupt, das gesamte Skelet (Gürtel- und Flossenskelet) im Vorknorpelstadium durch eine eirheitliche Gewebsanlage gebildet wird. Schon ror Eintritt der Verknorpelung sprossen die Anlagen einiger Flossenradien aus der in die Flossenleiste reichenden Gewebsmasse hervor, und zwar successive in cranio-caudaler Richtung. Später tritt eine sekundäre Vermehrung von Radien auch am Vorderrand der Flossenleiste auf, was namentlich bei den großen Rochen-

Fig. 195.
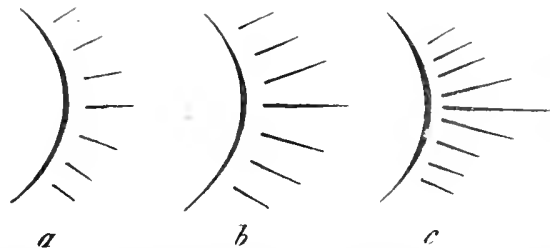

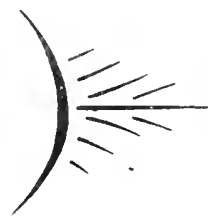

$d$

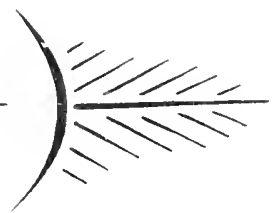

$\ell$

Schemata zur Erlāuterung des Ableitungstersucbs des Extremitātenskelets von einem Kiemenbogen. $a, b$, $c, d$ linke Kiemenbogenhălften von Selachiern mit allmăhlicher Annäherang der Kiemenstrablen an das Archipterygiumskelet. $e$ Schultergúrtel mit Archipterygium (aus GEgenBauk 18:s).

flossen sehr auffällt; es sind dies die späteren meso- und propterygialen Radien. Die Verknorpelung erfolgt für den Gürtel und den Basalknorpel gesondert, doch treten sie später bei der Gelenkkapselbildung in knorpelige Verbindung. Die Radien können successive gesondert verknorpeln, oder sich auch von der knorpeligen Anlage des Basalknorpels abgliedern; die drei Basalknorpel der Brustflossen treten in der gemeinsamen vorknorpeligen Anlage gesondert auf.

Über die phylogenetische Entstehung der Extremitäten wurden zwei Hypothesen ẹıtwickelt, von welchen die eine das Schwergewicht auf die Skeletgürtel und ihre Ähnlichkeit mit den Visceralbogen legt, die zweite dagegen auf das Skelet der freien Flosse und seine Ähnlichkeit mit dem der unparen Flossen. Nach der ersten Hypothese (Gegenbaur) sollen die Gürtel modifizierte Visceralbogen sein und die Knorpelradien der freien Flosse sich von knorpeligen Kiemenbogenstrablen ableiten, in einer Weise, wie sie sich aus der schematischen Figur 195 leicht ergibt. Die biseriale Ausbildung des Flossenskelets (sog. Archipterygium, $d-e$ ) wäre also nach dieser Hypothese das Ursprüngliche, die uniseriale das Sekundäre, wofür die Verbältnisse bei fossilen Haien (Xenacanthidae, s. Fig. 196) angeführt werden.

Die Schwierigkeiten; welche dieser Hypothese entgegenstehen, sind: 1. die Unwahrscheinlichkeit, daß der ursprünglich in der Aftergegend auftretende Beckengürtel mit einem Visceralbogen etwas zu tun habell sollte, sowie die schwache Begründung dieser Homologie überhaupt, welche nicht über eine allgemeine Formähnlichkeit linansgeht; 2. die horizontale Leistenform der ursprünglichen Flossen, während die Iypothese eine schref aufgerichtete Stellung als die ursprüngliche verlangte; 3. die Erstreckung der Flossenanlagen über eine größere Anzahl Segmente, was nicht nur für Muskulatur und Nerven gilt, sondern auch für das freie Flossenskelet, und mit der seine Ableitung von den Radien eines Visceralbogens schwer vereinbar erscheint; 4. die Annahme, daß das biseriale Skelet das ursprüngliche sei, 
während die vergleichende Anatomie, sowie die Ontogenie der Chondropterygier wohl sicher das Umgekehrte lehren, und die Dipnoer, bei welchen die biseriale Flosse allein typisch vorkommt, gewiß nicht für primitiver angesehen werden können als die Chondropterygier.

Die zweite Hypothese dürfte den vergleichend anatomischen Tatsachen besser entsprechen. Sie stützt sich, wie bemerkt, auf die weitgehende Übereinstimmung des Radíenskelets der paarigen Flossen mit dem der unpaaren, sowie auf die primitive Flossenform als horizontale Längsleisten. Sie erachtet daher lie uniserialen Knorpelradien für die zuerst anfgetretenen primitivsten Skeletteile der Flosse und leitet den sie tragenden Basalknorpel aus der Verwachsung von Basalgliedern der ursprünglich gesonderten Radien ab, eine Erscheinung, welche ja auch am Skelet der unparen Flossen häufig auftritt. Als letzte Konsequenz muß diese Hypothese

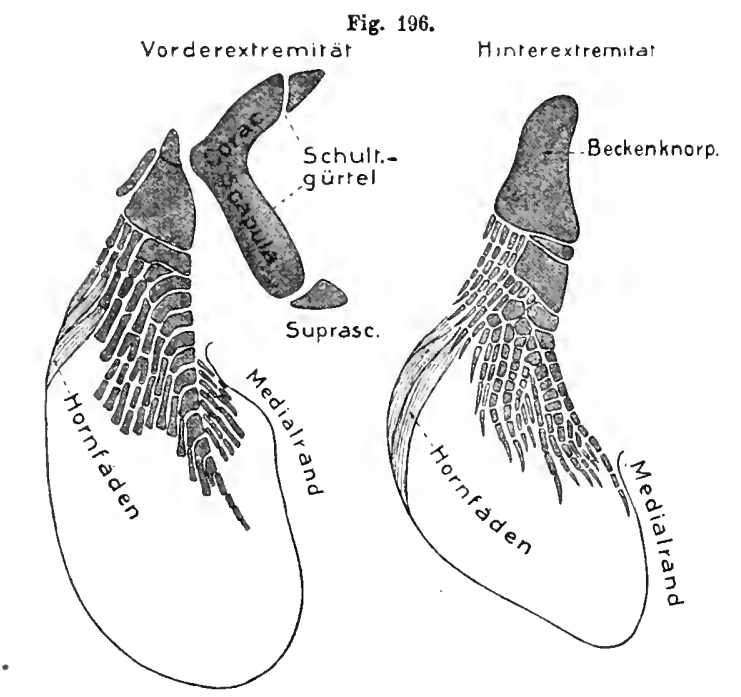

Xenacanthus decheni (Dyas). Skelet der linken Brust- u. Bauchflosse samt den Gürteln von der Dorsalseite. Umrisse der Flossen eingezeichnet. Hornfädon z. T. (Nach Fritsen 1590.) P. He. schließlich die Gürtel durch dorsales und rentrales Auswachsen des Vorderendes des ursprünglichen Basalknorpels entstanden denken. $\nu_{a}$ eine solche Einrichtung für die Festigung der Flossen im Körper bei stärkeren Bewegungen unerläßlich war, und da vor allem eine mediane Verbindung dieses inneren Tragapparats für abwärtsschlagende Flossen nötig war, so erscheint diese Ableitung der Gürtel ziemlich plausibel. - Mit dieser Entstehung des Basalknorpels stimmt wohl ïberein, daß sich bei den paläozoischen Xenacanthiden an Stelle eines einheitlichen Basalknorpels eine Reihe kleinerer solcher findet, von denen im allgemeinen jeder einen Radius trägt (Fig. 196). Wir dürfen daher diese metapterygiale

Knorpelreihe für die noch unverschmolzenen oder wenig verschmolzenen, etwas verstärkten Basalglieder der Radien halten. Charakteristisch und wichtig ist ferner, daß hier am Hinterende der Metapterygialreihe der Brustflosse die biseriale Ausbildung viel ausgeprägter auftritt, als bei lebenden Haien, während die Bauchflosse (s. die Figur) uniserial erscheint. - Das gleiche Verhalten des mehrteiligen Metapterygiums findet sich jedoch auch bei den Rochen, aber wohl als sekundäre Erscheinung, in Verbindung mit dem starken hinteren Auswachsen der Brustflosse. - Das Mesopterygium und Propterygium beurteilt auch die erste Hypothese als Concrescenzen von Radiengliedern, und das lange, häufig mehrgliederige sog. Propterygium der Rochen läßt sich nicht etwa als eine sekundäre Differenzierung und Gliederung des ursprünglichen Propterygiums deuten, sondern als eine mit der starken Vermehrung vorderer Radien fortschreitende Neubildung entsprechender Stücke durch Concrescenz. Die biseriale Bildung am Hinterende der Brustflosse erscheint im Sinne der zweiten Hypothese als etwas Sekundäres, das erst mit der Verbreiterung des hinteren Innenrandes der Flosse eingetreten ist. 
Die Extremitätengurtol der ubrigen Fische.

Schultergürtel. Bei den übrigen Fischen gesellen sich zu dem knorpeligen primären Schultergürtel Deck- und Ersatzknochen, wobęi erstere durch ihre allmählich überwiegende Entfaltung die mehr oder weniger weitgehende Reduktion des Knorpels bewirken.

Don nächsten Anschluß an die Knorpelfische bieten wohl die Nipnoer. Ihr knorpeliger Schultergürtel ähnelt in seiner Form ziemlich dem der Selachier, auch darin, daß seine Hälften median verwachsen sind. Durch eine Verknðcherung, welche etwa in der knorpelig bleibenden Gelenkgegend auftritt und sich von da

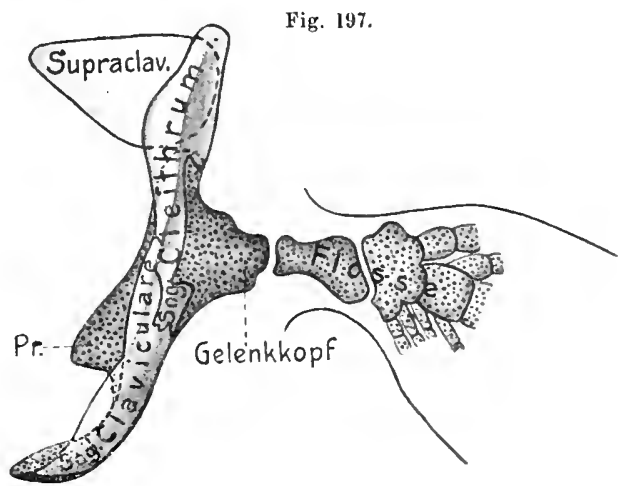

Ceratodus. Linke Hälfte des Schnltergürtels von anßen. Knorpel dunkel und panktiert. $\quad$ E. W. anf den scapularen und coracoidalen Teil ausdehnt, wird schließlich das mediane Verbindungsknorpelstück von dem thrigen Knorpel abgetrennt. Die bei Protopterus und Lepidosiren einheitliche Verknöcherung besteht bei Ceratodus (Fig. 197) ans einem scapularen (sog. Cleithrum) und einem coracoidalen (gew. Claviculare genannt). Das dorsale Gürtel-

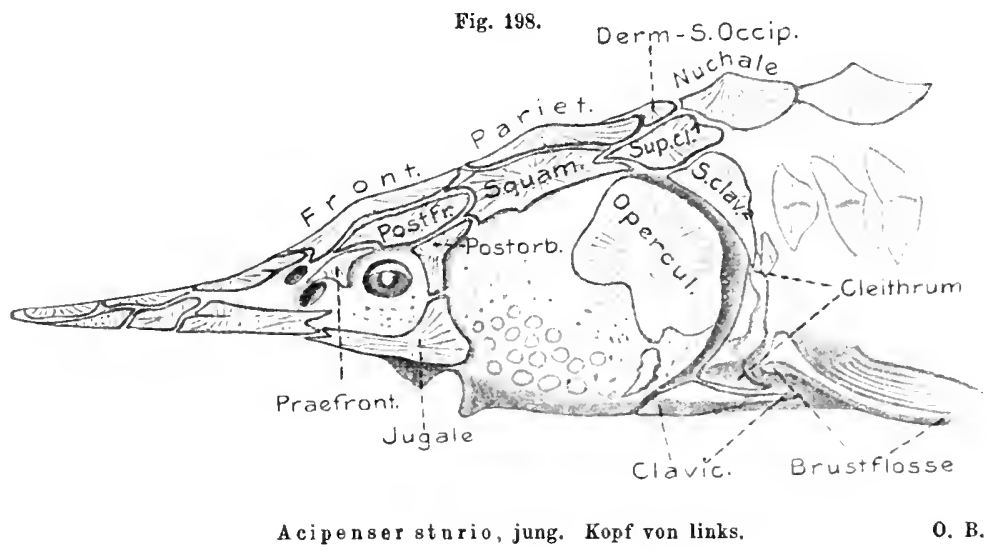

ende wird bei Ceratodus durch einen, bei Lepidosiren durch zwei blattförmige Knochen (Supraclavicularia), deren Hantknochennatur wohl sicher scheint, an der hinteren oberen Schädelkante aufgehängt; eine Befestigung des Gürtels, die allen noch zu besprechenden Fischen zukommt. - Da es zweifelhaft ist, ob die am Gürtel der Dipnoi auftretenden Verknöchernngen Ersatz- oder Deckknochen sind, so ist ihre Vergleichnng mit denen der Ganoid- und Knochenfische vorerst unsicher. 
Der primäre Schultergürtel der Knorpelganoiden (speziell Acipenser) erweist sich insofer'n primitiver als der der Dipnoer, als er in seiner Totalität knorpelig verbleibt und die ansehnlichen, sich mit ihm verbindenden Knochen wohl sicher Hantknochen sind. Bei der ä̉ßereu Betrachtung des Tieres treten sie denn auch als Hautgebildo ebenso deutlich hervor wie die übrigen Hautknochen (Fig. 198). Gegenüber den Dipnoern und Chondropterygiern zeigt sich jedoch insofern eine Rückbildung des primären Gürtels, als die mediane Verbindung seiner Hälften gelöst ist, oder nur durch ein Band geschieht; ein zweifellos sekundärer Zustand, welcher dadurch hervorgerufen wurde, daß ein Hautknochen die Verbindung übernahm.

Fig. 199 .

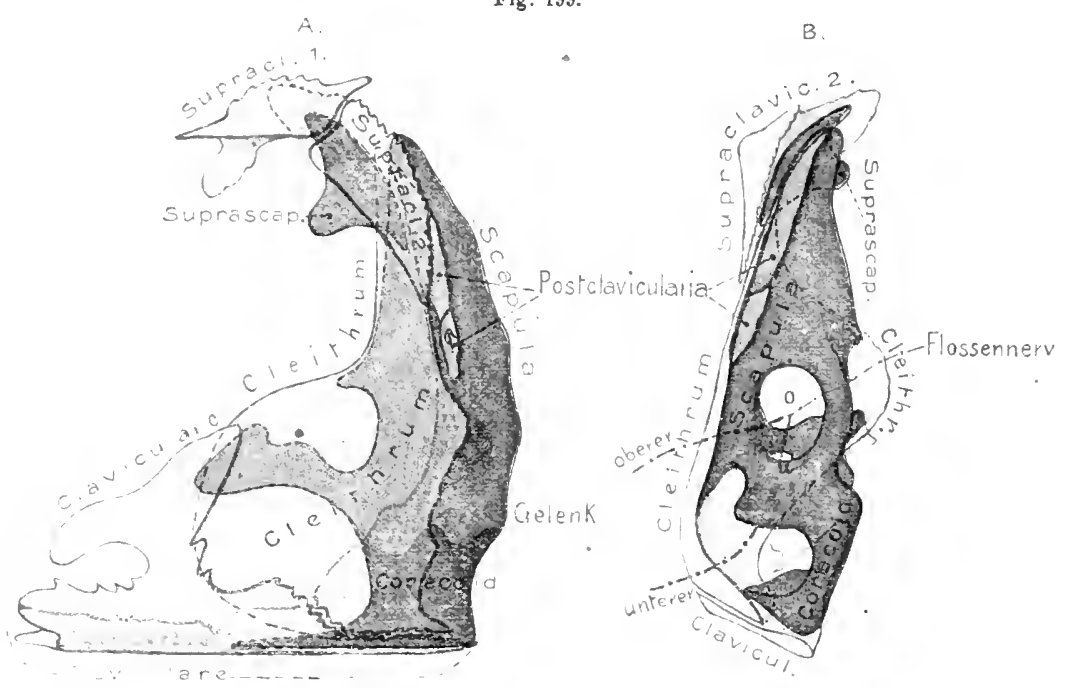

Acipenser sturio. Schultergürtel. Knorpeliger Gūrtel blau. Deckknochen hell. $A$ von außen. $B$ von hinten. $o$ und $u$ Löcher, die den ebeuso bezeichneten des Chondropterygiergürtels (Fig. 189) entsprechen. 0. B.

Die Gestaltung der knorpeligen massigen Schultergürtelhälfte der Störe erinnert etwas an die der Rochen, da die bei den Haien feinen Nervenkanäle sich auch hier durch Muskeleinlagerung sehr erweiterten und so einen etwas komplizierten Bau des Gürtels hervorriefen, der ans der Figur 199 erhellt. Vom Dorsalende des scapularen 'Teils hat sich ein Stïck abgelöst, wie es auch bei wenigen Haien und den alten Xenacanthiden (Fig. 196, S. 326) schon vorkommt (Suprascapularknorpel). Namentlich ist aber der coracoidale Teil des Gürtels von einem mächtigen, unter der etwa horizontalen Gelenkplatte von hinten nach vorn ziehenden Loch durchbrochen, dessen Außenwand jedoch nicht mehr vollständig ist, dies aber ursprünglich wohl war. Wie bei den übrigen Fischen erscheint hier dio Form des Gürtels im allgemeinen auch dadurch beeinflußt, daß er die hintere Wand der Kiemenhöhle bildet. Die Hautknochen, welcho sich diesem kıorpeligen Schultergürtel außen auflagern, sind: 1) ein nur dem vorderen Ventralteil der coracoidalen 
Region angehörender, der vorn mit dem der anderen Seite zusammenstößt und so die Gürtelhälften beim Stör fest vereinigt, das sog. Ciaviculare (früher Infraclaviculare); er ist von Knorpel unterlagert, der sich bis zu seinem Vorderende erstrecken kann. Bei anderen Arten gesellt sich an der Vereinigungsstelle der Clavicularia noch ein unpaares Interclaviculare zu. 2) ein sich dem Claviculare hinten anschließender Knochen, der bis auf die Außen- und Vorderseite des Scapularknorpels emporsteigt, das sog. Cleithrum (früher Claviculare); hinter seinem Dorsalende legen sich dom Scapularknorpel noch ein bis zwei kleinere längliche Knochen auf, die wohl sicher den sog. Postclavicularia der Holostei und Teleostei entsprechen. 3) ein der Außen- und Oberseite des Supraseapularknorpels aufgelagertes Supraclaviculare 2 (auch Supracleithrum genannt), dessen Vorderende sich einem mit den hinteren Schädeldeckknochen in inniger Verbindung stehenden Supraclaviculare ${ }^{1}$ anschließt und die Aufhängung des zweiten am Schädel bewerkstelligt. Auch das Supraclaviculare ${ }^{1}$ ist von Knorpel unterlagert. Die etwas komplizierten Formverhältnisse dieser Knochen gehen aus Fig. 199 einigermaßen hervor.

Bei den Knochenganoiden und Knochenfischen ist der primäre Schnltergürtel meist bedeutend verkleinert, indem sowohl sein coracoidaler, als auch sein scapularer Teil sich verkürzt. Dabei erhält sich bei den Knochenganoiden und den Physostomen (Fig. 201) das große scapulare Loch (o) der Störe meist gut, indem dio norizontale, nach außen ziehende Gelenkplatte,

Fig. 200.

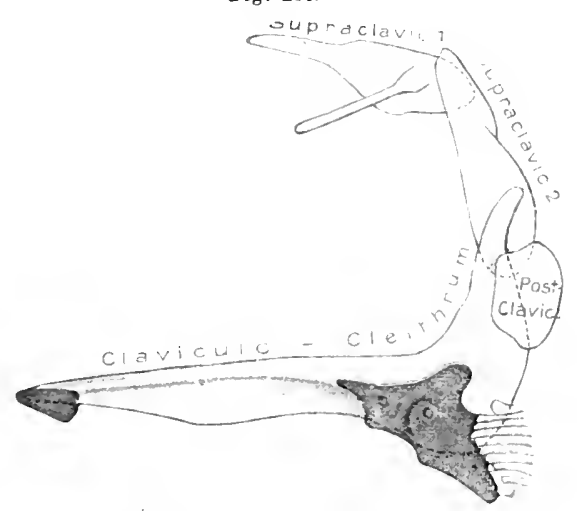

Amia calva. Rechte Sehultergurtelhälfte von innen. Knorpeliger Gürtel blau. Deckknochen hell. 0 . B. welche hinten die Gelenkleiste trägt, sowie die sie dorsal überragende scapulare Spange (Mesocoracoid) bestehen bleiben, während letztere bei den übrigen Knochenfischen schwindet. Mit Ansnahme vou Amia (Fig. 200) und Calamoichthys treten stets Ersatzknochen im primären Schnltergïrtel auf; bei Lepidostens ist er in geringem $\mathrm{MaBe}$ in der Gegend der Gelenkstelle verknöchert. Auf die Verhältnisse bei Polypterus werden wir später eingehen

Der Schultergürtel der physostomen Knochenfische (Fig. 201, Salmo und Barbus) zeigt im allgemeinen größere Übereinstimmung mit dem der Störe als der der Knochenganoiden, obgleich die Verknöcherung weiter geht. Die Form des - primären Gürtels ist im Prinzip ganz die der Knorpelganoiden, nur daß das scapnlare Loch $(o)$ noch weiter ist, und der coracoidale Ast (Coracoid) fast stets so weit nach vorn reicht, daß er mit dem der anderen Seite vorn zusammenstößt. Daß dies durch eine sekundäre Wiederverlängerung entstanden sei, ist wenig wahrscheinlich. Embryonal zeigt die Anlage des Coracoids häufig auch einen nach hinten gerichteten ansehnlichen Fortsatz, der jedoch bald verkümmert; er wurde anch als 
Homologon des Metapterygium des freien Flossenskelets der Chondropterygier gedentet. - Der scapulare Ast bleibt stets bedeutend kleiner als bei den Knorpelganoiden. - Bei der Verknöcherung geht der primäre Schultergürtel der Physostomen gewöhnlich in drei Knochen über; einmal verknöchert die horizontale Gelenkplatte zu einem von dem Loch $(u)$ durchsetzten Knochen (Scapulare), ferner

Fig. 201.

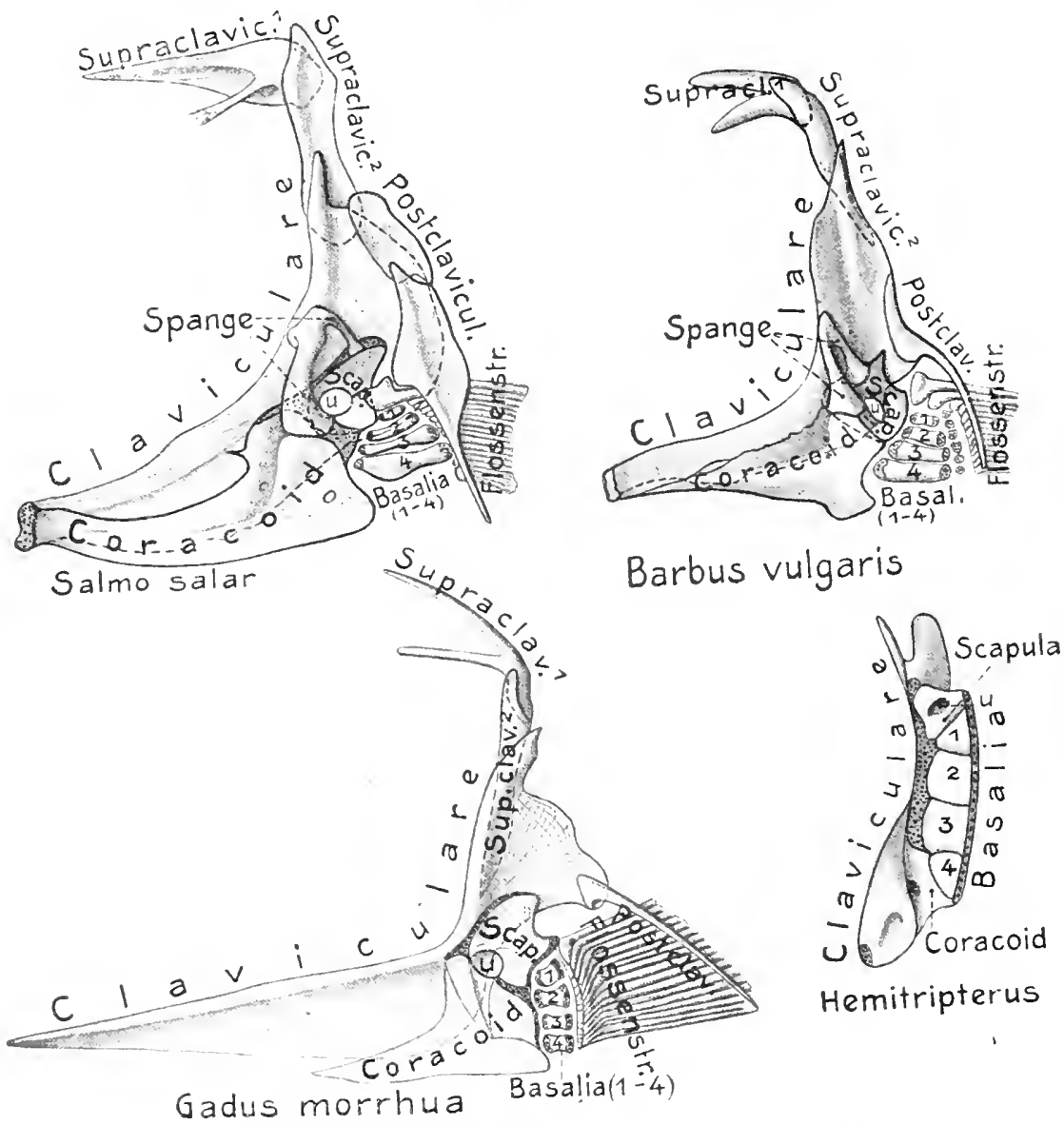

Schultergũtel von Teleosteern. Rechte Hellfte von innen. (Hemitripterus nach Gegenbadr 1865.)

E. W.

der scapulare Teil als eine bogige Knochenspange (auch Mesocoracoid genannt) • und 3. der coracoidale Ast als Coracoid. - An Stelle der beiden ansehnlichen Hautknochen der Störe, dem Claviculare und Cleithrum, findet sich bei den Teleostei, wie auch schon bei Amia (Fig. 200) nur ein einziger, der an Umfang jenen beiden entspricht und, meiner Meinung nach, auch wohl durch ihre Verwachsung entstanden ist. Er wird gewöbnlich als Claviculare, von Gegenbaur als Clei- 
thrum bezeichnet, da er nach ihm nur dem so bezeichneten Hautknochen der Störe entsprechen soll.

Diese Ansicht gründet sich auf die Verhältnisse bei Polypterus, Fig. 202 (ebenso auch Calamoichthys), bei welchem ein Claviculare, ähnlich wie bei Acipenser, sich flndet, sowie ein sog. Cleithrum, dessen vorderer und ventraler Teil sich nach innen vom Claviculare weit nach vorn erștreckt. Der primäre Schultergürtel zeigt eine scapulare und eine coracoidale Verknöcherung; die erstere entspricht in der Hauptsache der Gelenkplatte und verwächst mit dem sog. Cleithrum. Der vordere Fortsatz des letzteren, der innen von dem Claviculare verläuft, ist, wenn die Verhältnisse der Physostomen (z. B. Silurus) verglichen werden, wahrscheinlich kein Fortsatz des Cleithrums, sondern entspricht wohl einem vorderen Fortsatz des primären Schuitergïrtels. Ec 'äßt sich daher aus der Einrichtung bei Polypterus nicht wohl schließen, $\mathrm{da} B$ das sich verlăngernde Cleithrum an die Stelle des rückgebildeten Claviculare getreten sei. Man könnte zwar einwenden, daß bei manchen Knochenfischen (Panzerwelsen, Lophobranchii, Plectognathi) zwischen und an die Clavicularia sich noch Hantknochen sebieben, von denen zwei eventuell den sog. Clavicularia der Ganoiden verglichen werden könnten; doch bandelt es sich hier um spezialisierte Formen.

Bei deu ubrigen Knochenfischen (Fig. 201, Gadus) verkümmert der spangenartige scapulare Knochen der Physostomen völlig, es bleibt nur der aus der Gelenkplatte hervorgegangene, derjedoch höher am Claviculare emporsteigt und gewöhnlich Scapula genannt wird, sowie das sog. Coracoid. (Der Versuch, diesen Scapularknochen dem Metapterygium der Chondropterygii zu homologisieren ist wenig begründet.) Wie bei den Physostomen beteiligen sich beide Knochen

Fig. 202.

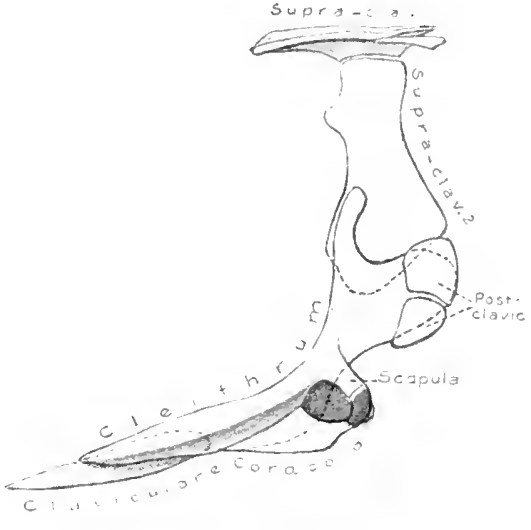

Polypteras biehir. Rechte Schultergūrtelhālfte von innen. Knorpel blav. 0.8 . dung, rücken jedoch zuweilen auch an der Gelenkstelle weit voneinander, nur durch Knorpel vereinigt, mit welchem sich die Basalknorpel der Flosse fest verbinden (s. Fig. 201, Hemitripterus). - Das Coracoid reicht zum Teil noch bis zur Symphyse der Clavicularia nach vorn, oder ist mehr oder weniger verkärzt. Häufig findet sich jedoch noch ein isolierter Knorpelrest an der Symphyse der Clavicularia. Der Anschlnß des Coracoids an das außen von ihm hinziehende Clavicnlare ist teils sehr innig, teils beschränkter.

Bei Knochenganoiden und Knochenfischen ist der Schultergürtel in der Regel durch zwei Supraclavicularia (selten nur eines) am Schädel aufgehängt, von welchen das obere (1, häufig Posttemporale genannt) gewöhnlich in zwei gegen den Schädel gerichtete Gabeläste ausläuft. Der obere dieser Äste befestigt sich bei den Knochenfischen in der Gegend des Epioticums, der untere am Opisthoticum oder dem Pleu:0occipitale (Fig. $142 A$, S. 251).

Bei vereinzelten Knochenflschen kann das obere Supraclaviculare anch noch an Querfortsätzen vorderer Wirbel befestigt, bei anderen fest zwischen die Schädelknochen eingekeilt 
sein. Bei gewissen Physostomen (z. B. Aalen) fehlt das Supraclaviculare 1, so daß die Aufhăngung des Gürtels durch ein Band geschieht, wăhrend bei gewissen Plectognathen das Supraclaviculare 2 direkt am Schädel articuliert. Manchen Formen kommt auch anscheinend nur das Suprascapnlare $1 \mathrm{zu}$ (speziell Silnriden), ist aber dann wohl mit 2 verschmolzen. Schließlich kann auch das Claviculare (unter Ausfall der Supraclavicularia) direkt am Schädel gelenken (namentlich gewisse Panzerwelse). Die Mannigfaltigkeit des Anfhängeapparats des Schultergürtels ist demnach sehr groß. - Etwa an der Verbindungsstelle des Claviculare und Supraclaviculare 2 schließen sich bei den Knochenganoiden und fast sämtlichen Knochenfischen der Innenfläche der erwähnten Gürtelknochen 1 bis 3 Hautknochen an (Fig. 202), sog Postclavicularia, die schief nach hinten und ventral in einer Reihe herabsteigen. Sie sind platten- bis stabförmig und reichen bei Knochenfschen zaweilen so tief hinab, daß sie den Basalknochen der bruststăndigen Bauchflosse erreichen.

Beckengürtel der Dipnoer, Ganoiden und Teleosteer. Bei den genannten Fischen tritt der Beckengürtel gegenüber dem der Knorpelfische mehr und mehr zurück, ja man kann eigentlich nur noch bei den Dipnoi von einem selbständigen Gürtel reden (Fig. $203^{3}$ ). Wie der der meisten Knorpelfische ist er ein einheitlicher Knorpel, der in der Breite stark verschmälert, dagegen nach vorn zu einem ansehnlichen sog. Epipubisfortsatz ausgewachsen ist, weniger zuweilen auch nach hinten. Die schon bei Knorpelfischen ausgebildeten Präpubisfortsätze sind kräftig entwickelt. - Bei den Ganoiden und Knochenfischen (Fig. 204 ${ }^{1,2,4}$ ) dagegen findet man an Stelle des Beckengürtels zwei stabförmige bis dreieckige Skeletstïcke, welche von der Basis der Bauchflosse ans schief nach vorn konvergieren und deren Enden sich vorn meist berühren. Diese, früher als Becken bezeichneten, jetzt Basalstücke (Basipterygium) der Flosse genannten Skeletgebilde sind entweder rein knorpelig (Chondrostei) oder großenteils verknöchert. Nur bei Polypterus (Fig. $203^{2}$ ) ist der vorderen Symphyse dieser Básalstücke ein paariger bis nnpaarer kleiner Knorpel eingelagert, der wohl dem Becken der Dipnoi entspricht. Auch bei den Stören ist das Vorderende des Basalknorpels zuweilen abgegliedert; das abgetrennte Stuck ließe sich dann dem eigentlichen Becken vergleichen. Daß das Basalstück aus der Verwachsung der Basalglieder einer Anzahl vorderer Flossenradien hervorging, lassen die Knorpelganoiden zweifellos erkennen (Fig. $203^{1}$ ). - Je nach der Ansicht über die Phylogenese der Flossen wird es verschieden beurteilt. Die Archipterygiumlehre erblickt in ihm ein Homologon des sog. Propterygiums der Haifischbauchflosse and erachtet den eigentlichen Beckengïrtel sowie das Basipterygium als völlig rückgebildet. Die andere Ansicht dagegen hält das Basalstück für ein dem Basipterygium entsprechendes, durch Radienverschmelzung entstandenes Gebilde und möchte den Zustand der Bauchflosse bei den Knorpelganoiden für ursprünglicher halten als den der Haifischflosse, d. b. als direkte Fortsetzung einas Urzustands, in welchem sich noch kein Beckenteil vom Basipterygialknorpel abgegliedert hatte. Letztere Meinung findet eine gewisse Stiitze in dem Bau der Bauchflossen der alten Xenacanthidae, die statt des Beckengïrtels der rezenten Haie zwei Basalstücke besitzen, ähnlich denen der Stŏre (s. Fig. 196, S. 326).

Bei den Knochenganoiden schieben sich die vorderen Enden der Basalstücke zuweilen übereinander (Lepidosteus, Amia). 
Die Basalstïcke der Teleosteer (Fig. 2044) sind meist lange und mebr oder' weniger dreieckige, durchaus verknöcherte Blätter, die häufig nur vorn durch Band oder Naht verbunden sind. Sehr gewöhnlich entwickelt sich an der Ursprungsstelle der freien Flosse noch ein median ziehender Fortsatz, der mit dem der Gegenseite zusammenstößt, so daß zwei Symphysen der Basalstiicke ansgebildet sind. Diese Symphysen, speziell die hintere, können sich so verlängern, daß schließlich beide Basalstücke in ihrer ganzen Ausuelnung median zusammenstoßen, ja sogar ver-

Fig. 203.

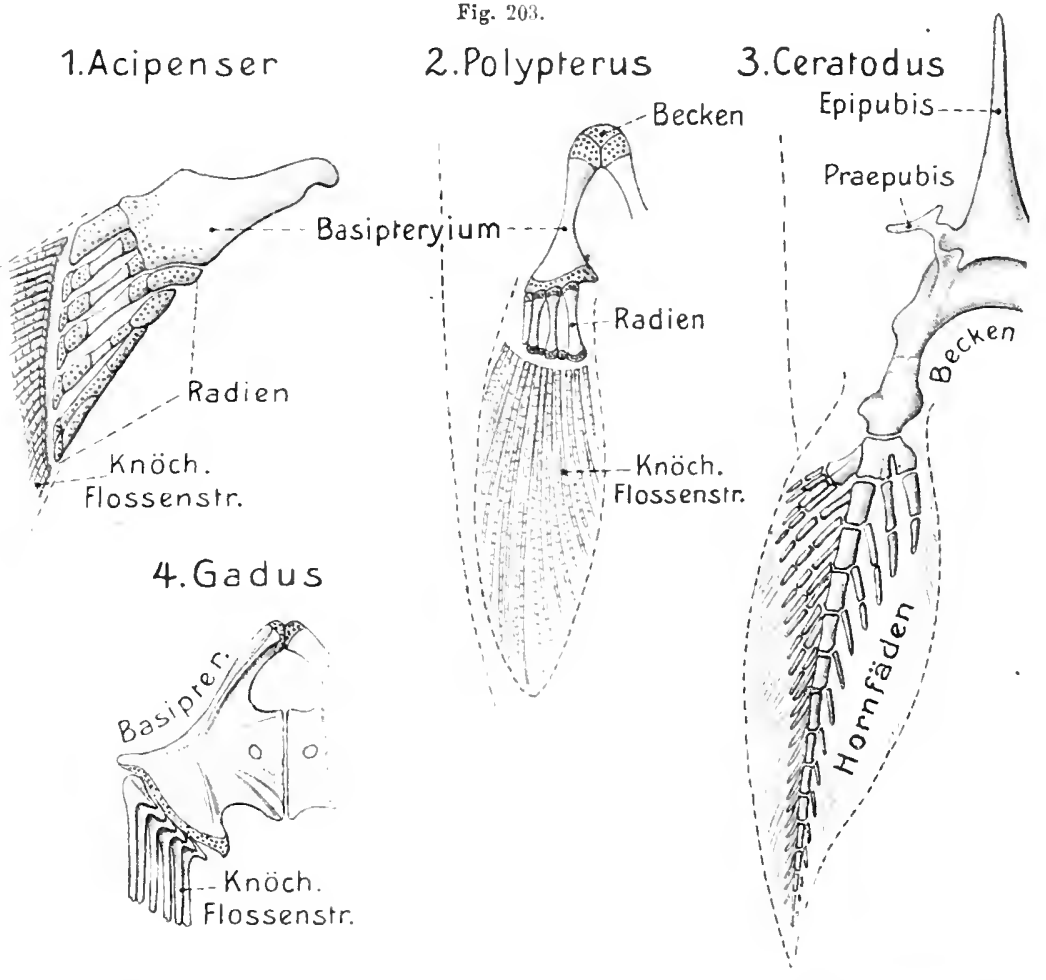

Beckengürtel und Skelet der rechten Bapchflossen. 1. A cipenser stario. 2. Polspterus (mit Benutzung von Davidoff 1880), "3 Ceratod us imit Benutzang von Davidoff 1844) von der Ventralseite. Bei Polypterus und Ceratodus der Umriß der Flosse und der rechte Körperrand gestrichelt angegeben. *. G ad us morrhua. - Knorpel dunkel punktiert (bei Ceratodus nicht).

o. B.

wachsen. Zuweilen kann anch die vordere Verbindung fehlen. Bei den Knochenfischen, deren Banchflossen in der Gegend der Brustflossen vorgeriickt sind, kann der Beckengürtel in Bandverbindung mit dem Schultergürtel treten, ja sich ihm fest anlegen (z. B. Uranoscopus).

Skelet der freien Flosse bei Ganoiden, Teleosteern nnd Dipnoern. Da bei Ganoid- und Knochenfischen der größere Teil der paarigen Flossen von hautknöchernen Flossenstrahlen gestützt wird, so treten dic primären, knorpelig angelegten Flossenradien sowohl an Zabl als Länge stark zurtick. - Die Brustflosse 
der Ganoiden besitzt z. 'T. noch eine ziemliche Zahl von Radien, besonders Polypterus (gegen 20), dessen Brustflosse jedoch recht eigentümlich ist (Fig. 2044); die ïbrigen nicht mehr als etwa 7-10. Am basalen Flossenrand wird, wie bei den Chondropterygiern, durch Verwachsung einer Anzahl proximaler Radienglieder ein Metapterygium gebildet; stets gelenken aber eine Anzahl der vorderen Radien direkt am Schultergürtel. Verknöcherung der proximalen Radienglieder hat sich in verschiedenem Grad entivickelt. - Wie bemerkt, ist das Brustflossenskelet von Polypterits eigentïmlich (Fig. $204^{2}$ ), was hauptsächlich daher rührt, daß die Flosse,

\section{i. Acipenser \\ Fig. 204.}

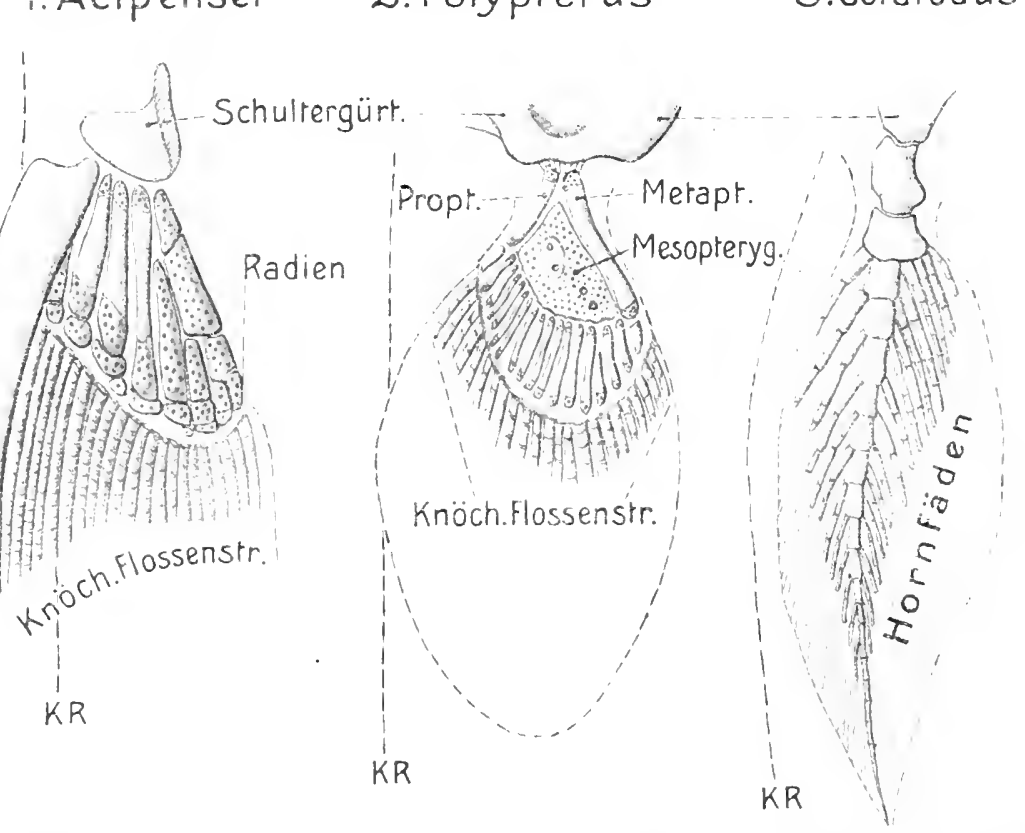

Rechte Brustflossen von der Ventralseite. 1. A c ip enser, 2. Pol g p terus (mit Benutzung von KaAatsch 1896 ) per Flosse gestrichelt angegeben. $K R$ rechter hōrperrand.

C. $\mathrm{H}$.

ähnlich wie die der Dipnoi, zu einem langen blattförmigen Ruder auswachs, deren Hauptfäche jedoch von den knöchernen Flossenstrahlen gestützt wird. Die Übereinstimmung mit den Knorpelfischen scheint noch größer als bei den übrigen Ganoiden, einmal durch die ansehnlichere Zahl der Radien und dann durch die umfangreiche Entwicklung eines wenig verknöcherten Mesopterygium, das mit der Verengerang der Flossenbasis vom Schultergürtel abgedrängt wurde. Die Fignr erläutert diese Verhältnisse und ihre wahrscheinliche Deutung, über die jedoch noch gewisse $Z$ weifel bestehen.

In der Brastflosse der Knochenfische (s. Fig. 201, S. 330) geht die Reduktion der Radien in Zahl und Länge noch weiter. Ein eigentlich knorpeliges Metapteryginm scheint kaum oder doch sehr wenig ausgebildet zu sein. Die Zahl der primären 
Radien beträgt selten mehr wie $4-5$, sinkt jedoch zuweilen anf 3 und 2 herab. Bei den ursprünglicheren Formen (Physostomen) bleiben sie meist noch länger, denen der Ganoiden ähulicher. Bei den Physoclisten werden sie kürzer, mehr plattenartig (s. Fig. 201, Hemitripterus) und schieben sich, wie schon beim Schultergürtel bemerkt wurde, bei gewissen Formen zwischen Scapula und Coracoid hinein, indem sie sich gleichzeitig mehr oder weniger fest mit dem Gürtel verbinden. Das Gelenk der Flosse wird so an den Distalrand dieser Basalradien veriegt. - Die Basalradien sind stets mebr oder weniger verknöchert. Distal können sich ihnen noch eine Reihe von Knorpelchen anschließen, deren Zahl häufig größer ist als die der Basalradien. Der vordere Flossenrand wird zuweilen von einem besonders starken Hautknochenstrahl gebildet, wie auch schon bei den Stören, in dessen Basis der äußere primäre Radius eingehen kann. - Auf die besonderen Bildungsverhältnisse der abnorm verlängerten Flosse, wie sie bei fliegenden Fischen, Lophius usw. vorkommt, einzugehen, fehlt der Ranm.

Das Skelet der freien Bauchflosse der Ganoiden und Telecsteer schließt sich dem der Brustflosse nahe an, so daß ein Hinweis auf die begleitenden Figuren (Fig. 203, S. 333), sowie das früher ubber die sog. Basalstücke der Bauchflossen Bemerkte genügen dürfte. Die sehr vereinfachten Verhältnisse sprechen sich namentlich in der einfacheren Beschaffenheit der Flosse bei Polypterus im Gegensatz zur Brustflosse aus. Die bei den Ganoiden, wenn auch in geringer Zahl, noch vorhandenen freien primären Radien sind bei den Teleosteern bis auf geringe Reste (bei gewissen Physostomen) eingegangen.

Das Flossenskelet der Dipnoer unterscheidet sich von den seither beschriebenen Bildungen sehr und ist von besonderem Interesse, da es nach der Archipterygiumlehre dem Urzustand an nächsten steht. Bei Ceratodus, dessen Flossen lange lanzettförmige, frei ausgewachsene Blätter darstellen (Fig. 203, 204), begegnen wir dem ursprünglicheren Zustand des Skelets, wogegen es in den, zu langen schmalen Fäden reduzierten Flossen von Protopterus und Lepidosiren sehr stark rückgebildet erscheint. Die Bauchflossen sind fast ebenso groß wie die Brustflossen und ihr Skelet daher auch mit dem der Brustflossen viel übereinstimınender als bei den seither besprochenen Fischen. - Das Skelet beider Flossen von Ceratodus besteht aus einem die Mittellinie (Achse) der Flosse durchziehenden gegliederten Knorpelstab, dessen Glieder distal immer kleiner werden. Das ansehnlichste basale Glied trägt keine weiteren Skeletstücke, während den übrigen bei Ceratodus im allgemeinen auf jeder Seite ein gegliederter Knorpelstrahl ansitzt, an deren Enden sich die Hornfäden der Flosse anschließen. Diese Flossenradien verhalten sich auf den beiden Seiten der Achse nicht ganz gleich, da sie auf der ursprünglichen Innen-oder Medianseito der Flosse etwas zahlreicher und feiner sind, indem sie an den proximalen Gliedern der Achse in mehrfacher Zahl sitzen. In der natürlichen Haltung der Flossen fällt es auf, daß die beiden verschiedemen Seiten des Flossenskelets an der Brust- und Bauchflosse entgegengesetzt gerichtet sind. Während an der Brustflosse die Seitc mit zahlreicheren Radien den ventralen Rand bildet, ist sie an den Bauchflossen dorsal gerichtet. Dieser Gegensatz ist 
jedoch nichts anderes als eine noch schärfere Ausprägung der verschiedenen Haltung der parigen Flossen, die schou oben (S. 319) firr die Fische im allgemeinen erörtert wurde; die Brustflosse ist nach der Dorsalseite emporgeklappt, so daß ihr in der ursprünglichen Horizontalstellung vorderer Rand nun der dorsale ist, und ihre Anßenfläche die tirsprünglich ventrale; die Bauchflosse dagegen ist nach der Ventralseite umgeklappt. - Bei Protopterus amphibius ist das Skelet schon recht stark reduziert. Der gegliederte Achsenstab trägt nur noch auf der nrsprïnglichen Innenseite, also an der Brustflosa ventral, an der Bauchflosse dorsal, kurze Radien. Den thrigen Dipnoern fehit der Radienbesatz völlig, es findet sich nur der gegliederte Achsenstab. Zweifellos liegt daher weitgehende Reduktion vor.

Wie hervorgehoben, erblickt die Archipterygiumtheorie in der Ceratodusflosse die primitirste Bildung, welche sie in der auf Fig. 195, S. 325 schematisch angegebenen Weise aus dem Urskelet des vorausgesetzten Visceralbogens herleitet. Die andere Flossentheorie dagegen mu $B$ die biseriale Ceratodusflosse für die ron der Urform des Flossenskelets am weitesten abweichende Modiflkation erklären, wofür ja schon die äußere Flossenform spricht, welche sich am meisten von der der embryonalen Flossenleiste entfernt. Die biseriale Radienstellung der Ceratodusflosse kann nach dieser Auffassung nicht das Ursprüngliche sein, wie die Archipterygiumtheorie meint, sondern $m u B$ erst allmählich in dem Maße entstanden sein, als sich mit dem freien Auswachsen der Flosse ein medianer Flossensaum entwickelte. Anfänge eines solchen Saums, medial rom Metapterygium, fanden sich.ja auch schon bei Haitischen, und in der Brustflosse der alten Xenacanthiden erreichte er schon eine Bildung, die sich der Ceratodusflosse stark näherte. Fraglich bleibt, ob wir die gegliederte Achse auf einen stark ausgewachsenen Radius beziehen dürfen, oder ob die einzelnen Gliedstücke des Aclisenstabs als Verschmelzungsprodukte der innersten Glieder der beiden Radienreihen aufgefaßt werden dürfen. Da die proximalen Glieder der Achse zuweilen eine Zusammensetzung aus zwei oder sogar mehr Längsstückchen zeigen, so wäre eine solche Entstehung nicht unmöglich. - Die einseitige Verkünmerung der Radien bei Protopterus amphibius läßt sich nicht wohl als eine Annäherung an die uniseriale Haitischftosse deuten, da sich gerade die Radien derjenigen Flossenseite erhalten, welche bei den Haifischen radienlos ist.

\section{Das Extremitätenskelet der tetrapoden Vertebrata.}

Der Schultergürtel.

Der Schultergürtel der 'Tetrapoden entsteht jederseits aus einer einheitlichen knorpeligen Anlage (primärer Gürtel), an welcher sich wie bei den Fischen, ein dorsaler oder scapularer und ein ventraler oder coracoidaler Abschnitt nnterscheiden läßt, die durch die Gelenkstelle der freien Extremität geschieden werden. Der scapulare Abschniťt befestigt sich fast nie an der Wirbelsäule oder am Schädel, sondern wird nur yon Muskeln getragen. Die beiden coracoidalen Hälften erstrecken sich bis zur ventralen Mittellinie der Brustregion und verbinden sich hier miteinander in ctwas versehiedener Weise häufig viel ansgiebiger, als dies bei Fìschen geschieht. Gleichzeitig stützen sie sich auch gewöhnlich auf den vorderen Rand des Steruums. Sie finden also an einem ventralen Teil des Rumpfskelets einen Stïtzpunkt, wie es die kräftigere Wirksamkeit der Vorderextremität erfordert. Zum primären Schultergiirtel, bzw. den ans ihm hervorgehenden Ersatzknochen, können sich, wie bei den Fischen, noch Hautknochen gesellen (sekuodärer Gürtel); 
doch ist das Problem der Unterscheidung beider Knochenarten noch ein viel umstrittenes und etwas unsicheres.

Amphibien. Der Scbultergürtel der Caudaten und besonders der der Ichthyoden erhält sich in ausgedehntem Maße knorpelig (Fig. 205). Der scapulare Knorpel bildet eine mehr oder weniger dreieckige Platte, die sich gegen die Gelenkgrube für den Oberarm etwas stielförmig verschmälert und ventral direki in die ansehnliche Coracoidplatte übergeht. Letztere erstreckt sich in der Regel bis ïber die Ventrallinie in die gegenliberliegende Körperseite, so daß beide Coracoide sich iibercinander schieben, das rechte dorsal über das linke. Der hintere Rand der Coracoide ist in den Vorderrand des rudimentären Sternums gewissermaßen eingefalzt.

Fig. 205 .

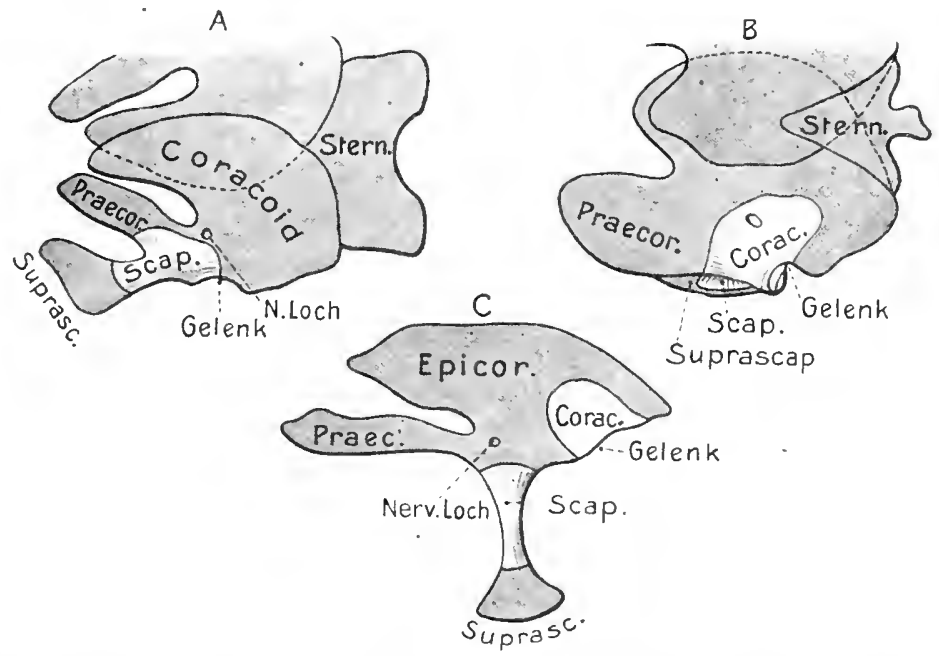

Schaltergürtel von urodelen Amphibien von der Fentralseite. A ron Menopoma. $B$ von Sala. mandra maculosa. $C$ von Siren ( $B$ nnd $C$ nach Pakker 1865). In $B$ die Scapula in naturlicher Lage, daber stark verdeckt; in $A$ und $C$ in die Ebene der Coracoide hernnter geklappt. P. He. Statt Pratcor. lies hier nud auf den folgenden Figuren l'rocontecoid.

Nahe der Gelenkregion wird die Coracoidplatte von einem Nervenloch durchsetzt. An der Übergangsstelle in die Scapula entspringt vom Vorderrand des Coracoids ein nach voru und etwas nach innen ziehender schmälerer Fortsatz, das sog. Procoracoid (auch Präcoracoid genannt), welches frei endigt, ohne Verbindung mit dem der Gegenseite. Die Einbuchtung zwischen Coracoid und Procoracoid, die zuweilen sehr schmal wird, ist von einer Membran durchzogen, die beide Knorpel vereinigt. Bei gewissen Ichthyoden (Menopoma, Siren) verbinden siel die freien Enden beider Knorpel im Alter sogar durch eine Knorpelspange (Epicoracoid). In der Gelenkgegend des Gürtels tritt stets eine Ersatzverknöcherung auf. Dieselbe dehnt sich zunächst hauptsäcblich dorsal auf den stielförmigen Teil des Scapularknorpels aus, kann sich jedoch auch tiefer in die Coracoidplatte hinein erstrecken. Man bezeichnet sie als Scapula und den sie dorsal fortsetzenden unverknöcherten Teil des Scapnlarknorpels als Suprascapula. Am hinteren Rand der Coracoidplatte 
findet sich bei einigen Ichthyoden (Siren Fig. $205 C$, Amphiuma) noch eine Verknöcherung, das knöcherne Coracoid. Eine entsprechende Verknöcherung ist bei anderen Formen wohl mit der knöchernen Scapula vereinigt (Fig. 205 B).

Der Gürtel der Amuren (Fig. 206) ist im allgemeinen kräftiger entwickelt. Die Einbuchtung zwischen der Coracoidplatte und dem Procoracoid ist weit, die Coracoidplatte daher schmäler, gewöhnlich mehr stielartig, und etwas schief nach hinten gerichtet; das Procoracoid zieht ziemlich quer gegen die Bauchlinie und etwas nach
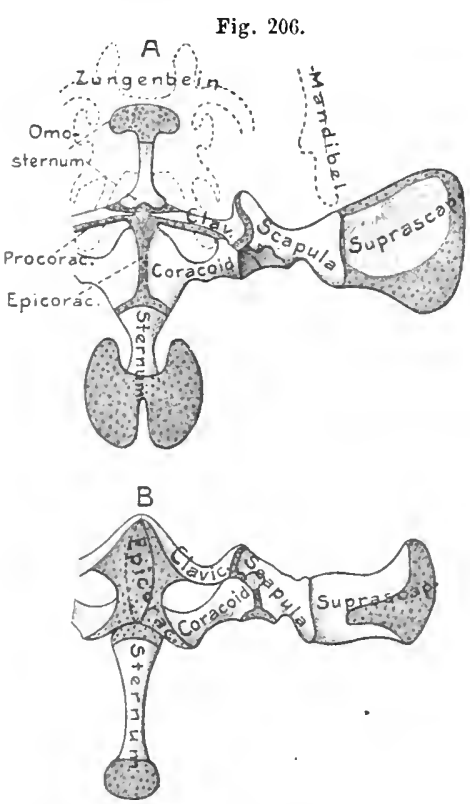

Schultergtirtel von anuren Amphibien. $A$ Ran a von der Ventralseite, $B P$ el o b a tes von der Dorsalseite (nach PARKER). In beiden Figuren die Scapula beruntergeklappt. In Fig. 4 Lage des Zungenbeins und der Mandibel punktiert eingezeichnet. vorn. Die Enden des knorpeligen Procoracoids und Coracoids jeder Seite sind stets zu einer längsgerichteten Knorpelspange vereinigt, sog. Epicoracoide, welche gewöhnlich in ihrer ganzen Länge zusammenstoßen; nur selten schieben sie sich etwas übereinander, ähnlich wie bei den Urodelen. Hinten fügt sich den Coracoiden das Sternum an. - Die Verknöcherung ist im allgemeinen stärker. Im Bereich der Gelenkgrube bildet sich in der Scapularplatte die knöcherne Scapula; der dorsale Rest erbält sich als knorpelige, oder knorpelig-kalkige Suprascapula, in der jedoch häufig eine Ersatzverknöcherung anftritt, so daß die Suprascapula sich gelenkig mit der Scapula verbindet (s. die Figur). — Die Coracoidplatte verknöchert vom Gelenkteil aus meist ansehnlich zn einem selbständigen Coracoid, wäbrend der Epicoracoidknorpel in der Regel unverknöchert bleibt, seltener dehnt sich die Verknöcherung weit auf ihn ans. Ebenso selten schwindet er, so daß die beider'seitigen Räume zwischen Procoracoid und Coracoid zusammenfließen (Dactylethra).

Der Procoracoidknorpel wird gleichfalls durch eine besondere Verknöcherung mehr oder weniger, bis völlig verdrängt. Dieselbe entsteht jedoch, im Gegensatz zur Scapula und dem Coracoid, welche typische Ersatzknochen sind, etwas abweichend. Sie tritt ähnlich einer Hautverknöcherung um die nach vorn schauende Fläche des Procoracoids auf und erhält sich auch so, als rinnenförmiger Knochenbelag des knorpeligen Procoracoids, bei den Formen, wo sie schwach bleibt. Bei stärkerer Entwicklung umwächst sie den Procoracoidknorpel völlig, der schließlich gleichfalls in Knochengewebe ïbergeht oder verschwindet. Der so entstandene Knochen, die sog. Clavicula (Schlüsselbein), reicht von der Scapula bis zur Berührung mit der der Gegenseite, nimmt jedoch keinen Teil am Aufban der Gelenkgrube für den Oberarm, die nur von der Scapula und dem Coracoid gebildet wird. 
Bei den meisten Anmren fügt sich vorn an die Symphyse der beiden Claviculae noch ein unpaares, in seinem Basalteil gewöhnlich verknöchertes Skeletgebilde an, das früher als Episternum, jetzt als Omo-oder Prosternum bezeichnet wird. Es scheint aus einer selbständigen paarigen Knorpelanlage vor dem Procoracoid hervorzugehen.

Mit der Rückbildung der Extremitäten bei den schlangenartigen Gymnophionen und den fossilen Aistopoda unter den Stegocephalen ist der Schultergürtel völlig geschwunden.

Leider ist der Schultergürtel der ältesten Amphibien, der Stegocephalen, bis jetzt noch etwas unsicher, weshalb er die Deutung der Einrichtungen bei den rezenten im ganzen wenig fördert. Wie bei den Urodelen war er jedenfalls in großem Umfang knorpelig. Charakteristisch für die Stegocephalen ist das stete Vorkommen dreier ansehnlicher Hautknochenplatten, die in der vorderen Brust- bis Kehlgegend liegen (Fig. 207), einer unpaaren, meist rhombischen Mittelplatte und zweier seitlich anschließenden. Letztere werden gewöhnlich und mit Recht als Homologa der Clavicularia (Infraclavicularia) der Chondrostei gedeutet und die unpaare Platte daher Episternum oder Interclaviculare genannt. $\mathrm{Zu}$ diesen drei Platten gesellen sich zwei weitere Verknöcherungen jederseits, eine etwa halbkreisförmige und eine gewöhnlich stabförmige. Erstere wird entweder als Scapula, oder wohl richtiger als Coracoid gedeutet, letztere als verknöchertes Procoracoid, oder als dem sog. Cleithrum der Chondrostei entsprechend. Entscheidende Gründe für diese Deutungen liegen jedoch kaum vor. Es wäre sogar

Fig. 207.

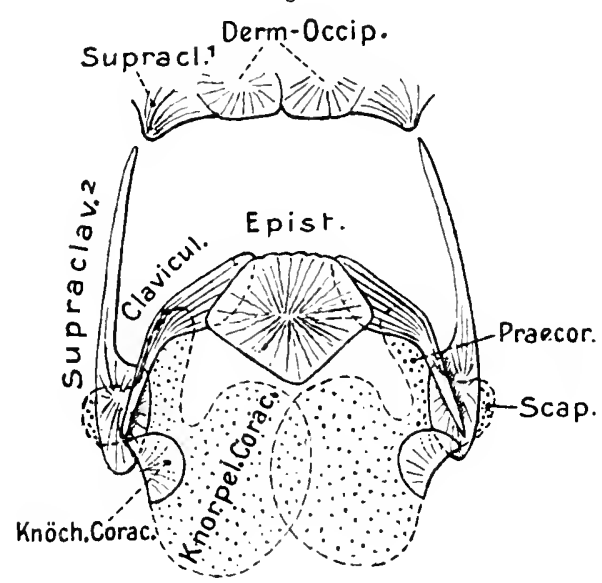

Schultergúrtel von Pelosauras laticeps (Stegocephale). Nach Credser (1885) konstruiert. Ventralansicht. Die sog. ClavicuJae Credners (Cleithra Gegexbaur Supraclavicula. ${ }^{2}$ der Fig.) sind so eingezeichnet, daß sie nach den Supraclavic. 1 (sog. Epiotica Autor) des hinteren Schadelrands ziehen, wo sie sich wahrscheinlich befestigten; der mōgliche knorpelige Schultergürtel ist punktiert angegehen. 0 . B.

die Möglichkeit nicht ausgeschlossen, daß die stabförmige Verknöcherung dem Supraclaviculare 2 . der Fische vergleichbar seí, da manches dafür spricht, daß der Schultergürtel der Stegocephalen noch am Schädel befestigt war, ähnlich dem der Ganoiden und Dipnoi. Diese Auffassung ist auf der Fig. 208 adoptiert und gleichzeitig die mögliche Beschaffenheit des knorpeligen Gürtels angedeutet.

Zutreflend ist wobl die Homologisierung der paarigen Hautknochenbrustplatten der Stegocephalen mit den Claviculae der Anuren, die ja in ihrer Entstehung auf Hautknochen hinweisen; diese ursprünglichen Ilautknochen bätten daher allmählich das knorpelige I'rocoracoid substituiert, bzw. sich auch, unter seiner Teilnahme an der Verknöcherung, zu einem Mischknochen, der Clavicula der Anuren, entwickelt. Hieraus ergäbe sicb danı für letztere eine substitutionelle Homologie mit dem Procoracoid der Urodelen, da es auch möglich ist, daß die Clavicularia der Stegocephalen von einem knorpeligen Procoracoid unterlagert waren. Die Clavicula der Anuren dürfte daher auch im allgemeinen dem Claviculare der Fische homolog betracbtet werden. Fraglich, jedoch nicht unmöglich erscheint es, daß auch das sog. Interclaviculare (Episternum) der Stegocephalen von Knorpel unterlagert war. Da eine mediane isolierte Knorpelmasse in der Symphysengegend der Iolostei und Teleostei zum Teil vorkommt, so wäre dies, wie gesagt, nicht unuöglich. Wäre letzteres aber der Fall, 
so könnte auch eine substitutionelle Homologie zwischen diesem Interclaviculare der Strgocephalen und dem sog. Omosternum oder Prosternm der Anuren wohl bestehen.

Das völlige Fehlen der Clavicnla, sowie des Omosternums (bzw. ihrer Repräsentanten bei den Stegocephalen) bei den Urodelen diirfte wohl auf eine gewisse Rückbildung des Schnltergürtels in dieser Gruppe hinweisen, da es wahrscheinlich ist, daß diese Bildungen den primitiven Amphibien allgemein zakamen. - Ob die Epicoracoidrerbindung zwischen den freien Enden der Coracoide und Procoracoide, wie sie den Anuren znkommt, das Ursprünglichere ist und bei den Urodelen mit der teilweisen Rüickbildung les Schultergürtels einging, ist fraglich. Die Ontogenie lehrt, daß die beiden Ventralknorpel des Amplibiengüitels ursprünglich frei endigen und ihre epicoracoidale Verbindnng erst später entsteht.

Ein schwieriges Problem bietet die Vergleichung des Amphibienschultergürtels mit dem der Fische. Wemn wir an diejenigen Fiscbe anknüpfen, welche die nächsten Beziehungen zu den Amphibieı baben dürften, also an die Ganoiden und Dipuoer, so finden wir nur bei letzteren eine ventrale Verbindung der primären Schultergürtelhälften, während sie bei den Ganoiden getrennt bleiben. Bei gewissen primitiveren Knochenfischen können sich aber die VentraIränder des sog. Coracoids gegen die Ventrallinie stïker ausbreiten, ohne sich jedoch zu erreichen. - $O b$ sich das Procoraccid auf den Knorpelfortsatz, der am Schultergürtel der Chonàrostei (Fig. 199 A, S. 328) ron der Gelenkplatte nach vorn zieht und.der auch am Gürtel von Ceratodus (Fig. 198 Pr) angedeutet scheint, zurückführen läßt, ist unsicher; ja meiner Meinung nacb wabrscheinlicher, đaß das sog. Coracoid der Teleosteer und Ganoiden dem Procoracoid der Amphibien entspricht; demnach der vorhin erwähnte Knorpelfortsatz der Chondrostei eher dem Coracoid der Amphibien zu vergleichen wäre. Möglich erscheint, daß der Gïrtel der Amphibien ron einer Urform des Gürtels ausging, dessen ventraler Teil durcb ein anselnnliches Loch in einen solchen äußeren, procoracoidalen und inneren coracoidalen Ast gesondert war.

Reptitien. Die Beurteilung des Schultergürtels dieser Klasse hängt wesentlich ab von der Deutung der Knochen der Ventralregion; hiernach wird auch die Ansicht äber diejenige Gruppe, in welcher sich der primitirste Zustand des Gintels erhielt, rocht verschieden ausfallen.

Da der Schultergürtel der. Saurier in seiner allgemeinen Bildung dem der anuren Amphibien noch ziemlich ähnlich erscheint, so wollen wir mit ihm be. gionen. Hie urspringlichsten Saurier besaßen, wie es Sphenodon (Fig. 208 B), sowie einige Eidechsen (so Heloderma und die Chamäleontiden) noch jetzt zeigen, wahrscheinlich eine einheitliche ansehnliche Coracoidplatte, deren vorderer Medianrand mit dem der Gegenseite, oder mit einer schmalen vorderen Verlängerung des Steruums zusammentrat, während der hintere Medianrand sich dem Vorderrand des Sternums anfügte, bzw. in ihn einfalzte. In der Gelenkgegend geht die Coracoidplatte in die Scapularplatte iiber, die jener der Anp̣ren im allgemeinen gleicht, und auch nur in ihrem Gelenkteil zu einer Scapula verknöchert, während sich der Dorsalteil als ansehnliches knorpeliges Snprascapulare erhält, in dem es nie zu einer besonderen Verknöcherung kommt. In jeder zusammenhängenden Schultergïrtelhälfte tritt im einfachsten Fall etwas vor der Gelenkgegend eine fensterartige Durchbrechung anf, wie sie sich wohl bei Splenodon nur als vorderer Einschnitt (Incisur) und bei schlangenartigen Sauriern (Anguis usw., Fig. 208 A) findet. In letzterem Fall handelt es sich jedoch wahrscheinlich um eine Ruickkehr zu primitivercr Bildung, die mit der Reduktion des Giirtels eintrat, und schlieBlich auch bei einigen diese Dnrehbrechung wieder ganz verschwinden ließ. - Bei den Eidechsen mit kräftiger entwickeltcm Gürtel gesellen sich zu dieser Durchbrechung in der Cora- 
coidplatte noch 1-2 weitere und ansehnlichere, und nicht selten anch eine in der Scapularplatte (Fig. 209 C). - - In der Gelenkregion der Coracoidplatte findet sich stets eine mehr oder weniger ansehnliche Verknöcherung, dasforacoid, das, weun größer, sich auch zwischen die Fenster ausdehnt. Es stößt mit der Scapuli in der Gelenkregion zusammen und verwächst gewöhnlich mit ihr. - Ist der Schulte:giirtel reduziert, so findet sich in der Gelenkregion häufig nur noch eine Verknöcherung, von weicher z. T. schwer zu sagen ist, ob sie mehr einer Scapula oder einem Coracoid entspricht.

Der knorvelig bleibende Medianrand der Coracoidplatte wird als Epicoracoud bezeichnet. Der vordere, die Fenster abschließende Rand der Coracoidplatte erhilt sich häunig knorpelig unt wird danu, naot Vergleich mit dem Giirtel der Anuren, Procoraroid genannt; bei manchen Samiern wird er jedoch auch nй durch cin Band reprisentiert. Charakteristisch fiur das Coracoid ist sein $\mathrm{F}_{1 ;-}$ ramen supracoracoideum, fuir den Durchtritt eines Nerven und von ! i :fäßen), das in der Nähe der Gelenkgrube das knö-

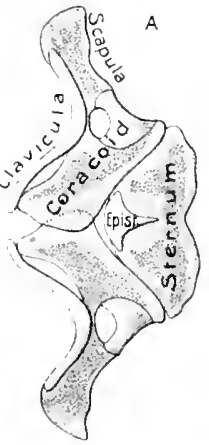
Fig. "2118.
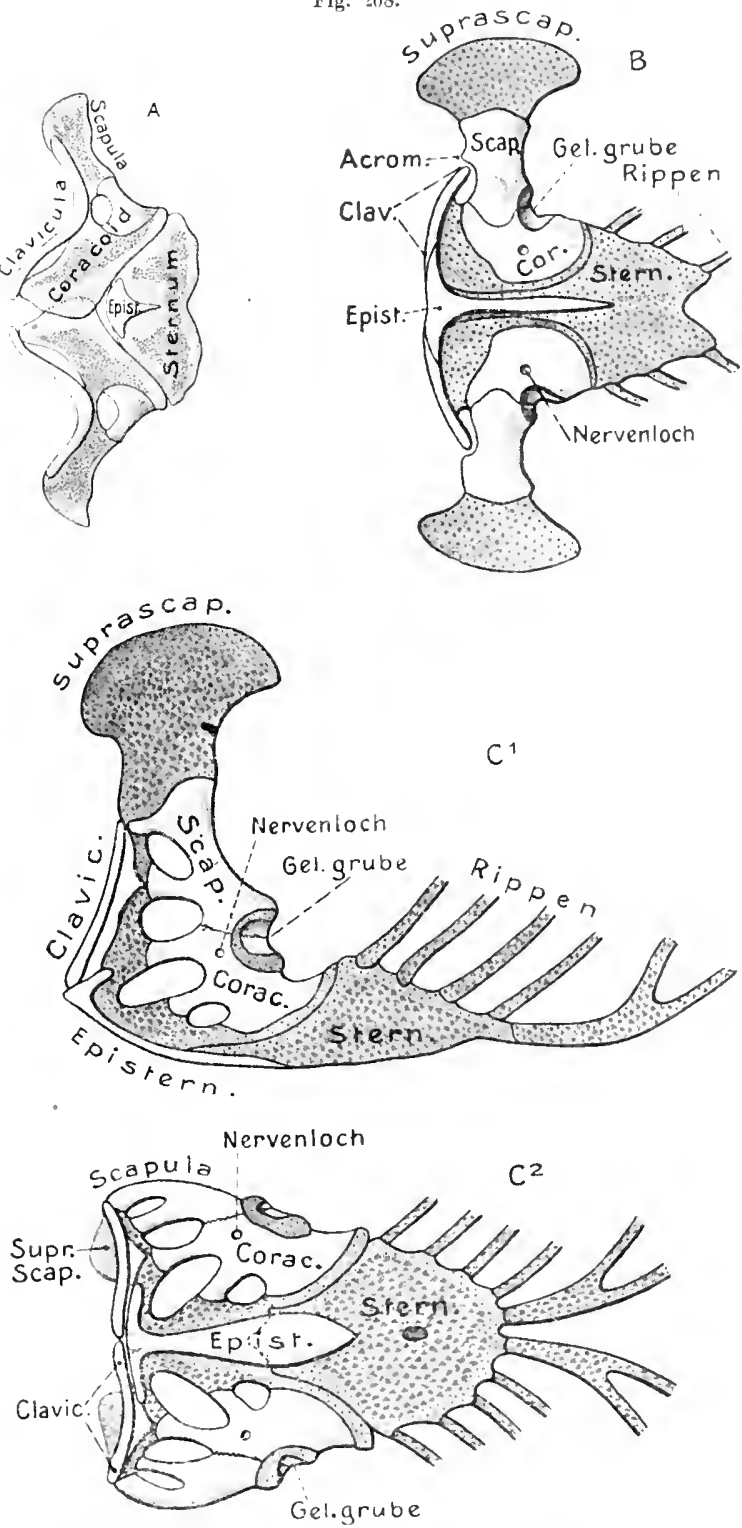

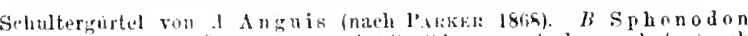

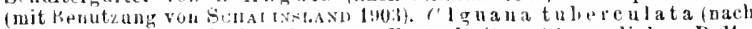
l'ARkili (4is). A, $b$ und $C^{\prime 2}$ ron Ventralseite. 'l von links. P. Jle. cherne Coracoid durchsetzt.

Dem vorderen Rand der Scapula und der Coracoidplatte legt sich ein etwas 
geschwungen verlaufender Knochen an, der gewöhnlich mit dem der Gegenseite in der Ventrallinie zusammentrifft; er wird als Clavicula bezeichnet. Die Scapula bildet an seiner Anlagerungsstelle meist einen schwachen, sog. Acromialfortsatz (Acromion). Die Medianenden der Claviculae sind nicht selten stark verbreitert, ja können sogar von einem Fenster durchsetzt sein; sie stützen sich auf das Vorderende eines unpaaren, schmalen uud langen Knochens, das sog. Episternum (Interclaviculare), der nach hinten die Symphyse der Coracoidea unterlagert und meist noch eine Strecke weit dem Sternum aufgewachsen ist. - Das Vorderende dieses Episternums entsendet fast stets zwei seitliche Fortsätze, an die sich die

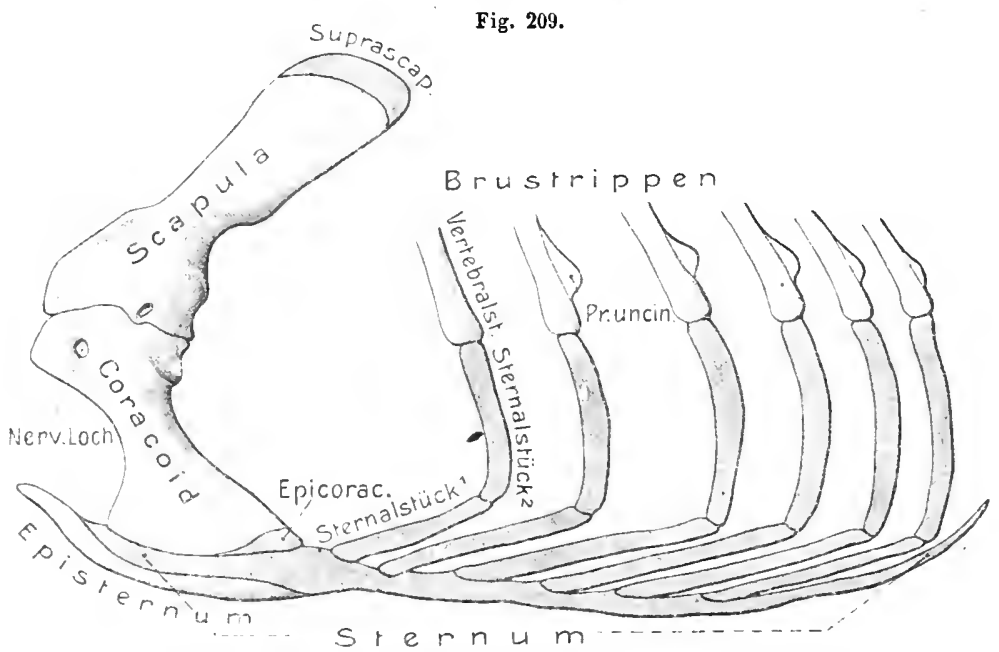

Alligator mississippiensis. Schultergŭrtel mit Sternmm and vorderen Brustrippen von links. Knorpel dunkel.

Ventralenden der Claviculae anschließen, weshalb das Episternum meist T-förmig erscheint. Indem sich sein Hauptstamm zuweilen über die Seitenfortsätze verlängert, kann es auch kreuzförmig werden, wobei sich die Claviculae mit dem Ende des vorderen Fortsatzes verbinden. Mit äer Ausbildung dieses vorderen Episternumfortsatzes entfernen sich die Claviculae häufig vom vorderen Rand der Coracoidplatte, so daß sie frei zwischen dem Schulterblatt und dem Episternum hinziehen (z. B. Lacerta!.

Bei den schlangenartigen Sauriern wird der Schultergürtel samt dem Sternum mehr oder weniger, bis stark oder völlig rudimentär, findet sich jedoch auch bei den Amphisbänen gewöhnlich noch in schwachen Resten, wogegen er bei den Schlangen stets völlig eingegangen ist. Episteruum und Claviculae schwinden zuerst; Reste der Scapula und des Coracoids erhalten sich am längsten.

Der Schultergürtel der Krokodile (Fig. 209) läßt sich von dem der Saurier leicht ableiten. Sein Hauptcharakter liegt in der völligen Verkümmerung der Claviculae, was unter den Sauriern nur bei den Chamäleonten eintrat, denen auch das Episternum fehlt. Die Krokodile dagegen besitzen das Episternum noch, 
das als stabförmiger Knochen dem Sternum aufgewachsen ist. Daß in der Tat eine Verkümmerung der Clavicula bei den Krokodilen vorliegt, erweisen ihre alten Vorfahren (Parasuchia), die sie noch besaßen. Die Scapularplatte ist in großer Ausdehnung verknöchert, so daß sich nnr ihr Dorsalrand als schmales knorpeliges Suprascapulare erhält. Das einheitliche Coracoid ist ohne Fenster, relativ schmal und mit dem bei den Sauriern gefuudenen Foramen supracoracoidenm versehen.

Die Claviculae dex Saurier entstehen als reine Bindegewebsknochen, und das Episternum dureh mediane Vereinigung und Abgliederung der ventralen Enden ibrer Anlagen, also ebenfalls als Hautknoehen. Die Homologie der Schlüsselbeine mit der hautknöchernen Anlage der Anurenclaviculae und denen der Stegocephalen sowobl, als den Clavicularia der Fische ist daher wohl nicht zu bezweifeln. Der Umstand, daß die dorsalen Enden der Saurierclaviculae sich hăufig sehr hoch am vorderen Rand der Scapulaplatte hinauf erstrecken, läßt sie in mancher Hinsiebt primitiver erscheinen als die der Anuren und erinnert zuweilen etwas an das Verbalten der Clavicularia bei Ganoid- und Knochenfischen. Daß die Form des Episternurn vielfach auffallend dem Interclaviculare oder Episternum der Stegocephalen gleicht, dürfte neben seiner Beziehung zu den Claviculae seine Homologie mit dem jener alten Amphibien wohl sicher hegründen. Da sich nun die Saurierclaviculae innig an den Vorderrand der knorpeligen Corcacoidplatte anschließen, so spricht dies auch dafür, daß dieser Vorderrand dem Procoracoidknorpel der Anuren gleichkommt, und daß in dem Fenster zwishen Coracoid und Procoracoid der Anuren eine der Fensterbildung des Sauriercoracoids im allgemeinen homologe Bildung vorliegt. Die Hauptdifferenz zwischen den Sauriern und Anuren wäre daher die, daß die Clavieulae der ersteren ihren ursprüngliclien Hautknochencharakter rein bewabrt haben, die der letzteren dagegen wenigstens zum Teil durch Einverleibung des verknöchernden Procoracoids zu Mischknochen geworden sind. - Zweifelhafter dagegen ist die eventuelle Beziehung des Saurierepisternums zu dem sog. Omosternum der Anuren. Ich möchte vermuten, daß zwischen beiden dennoch eine substitutionelle Homologie in dem Sinne existiert, $\mathrm{daB}$ sie aus einem ursprünglich knorpelig-hautknöchernen, also zusammengesetzten Skeletteil bervorgingen, von welchem sich bei den Reptilien allein der hautknöcherne, bei den Anuren der knorpelige erhielt. - Dieser Deutung des Saurierschultergürtels steht eine andere gegenüber, welche in der Clavicula der Saurier ein komplettes Homologon des Procoracoids samt der Clavieula der Anuren erblickt, also auch des knorpeligen Procoracoids der Urodelen, und welche daher auch die gesamte Coracoilplatte der Saurier nur dem krorpeligen Coracoid der Amphibien homolog setzen will.

Ganz besondere und eigentümliche Verhältnisse zeigen die Chelonier (Fig. 210), die wir daher, trotz ihres vielleicht in mancher Hinsicht ursprünglicheren Gürtelbaus, erst an letzter Stelle betrachten. - Zunächst ist ihr Schultergiirtel mit der Ausbildung des Rückenpanzers unter dessen vorderes Ende gerückt, und sein scapnlarer Teil hat sogar eine knorpelige oder ligamentöse Verbindung mit dem Neuralbogen des ersten Brustwirbels erlangt. - Die Scapula ist ein stielförmiger Knochen, der von jener Befestigungsstelle schief nach außen absteigt und nur dorsal anf eine geringt Ansdehnung knorpelig bleibt (Suprascapula). Dieser K uochen setzt sich auch noch jenseits der Gelenkstelle für den Oberarm ventral als ein stielförmiger, nach vorn und innen hinabziehender Fortsatz fort, dessen Ende sich knorpelig oder durch Band mit dem unpaaren Knochen des Bauchpanzers (Endoplastron) verbindet, oder sich anf ihn stützt (insofern letzterer nicht fehlt). - Von der Gelenkgrube entspringt ferner ein nach hinten und veutral ziehender Coracoidalast des Gürtels, der zu einem selbständigen Coracoid verknöchert, dessen Ventral- 
rand sich als Epicoracoid kuorpelig erhält (Fig. 210B). Die Ventralenden der Coracoide erreichen sich in der Regel nicht, sondern enden frei; bei Dermochelys schieben sie sich jedoch etwas übercinander. Die Enden der beschriebenen beiden ventralen Gürteläste sind jederseits durch ein Band, das zuweilen mehr oder weniger verknorpelt, verbunden.

Die Vergleichung und Deutung des Chelonierbrustgürtels hat zu verschiedenęn Ergebnissen gefïhrt. Die Verbindung des vorderen ventralen Astes mit der unparen Platte des

Fig. 210.

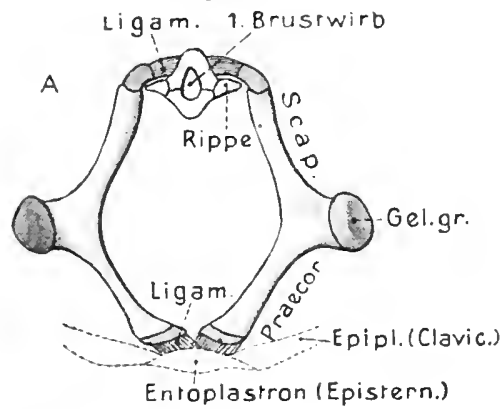

B

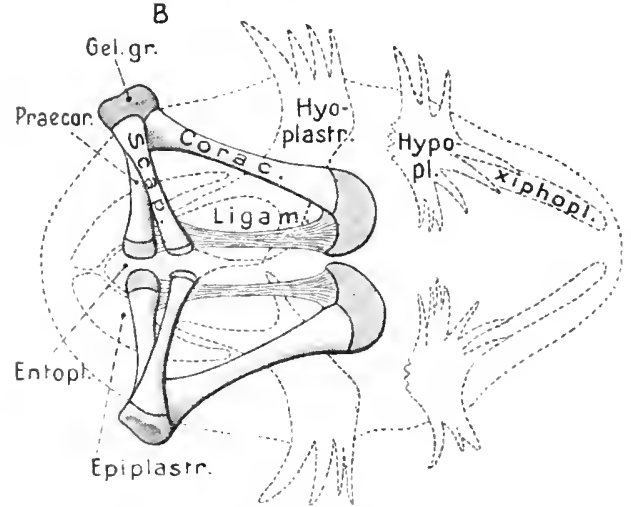

Cheloneviridis (mydas). Einige Tage alt. Schultergürtel. (Nach PARKeK 1860 , etwas verāndert.) A ron vorn (Kopfseitel; zeigt die Befestigung der Scapula am ersten Brustwirbel. $B$ von der Dorsalseite. Die Knochen des Plastrons punktiert eingezeichnet. Die pnnktierte Umrißlinie gibt den Rand des verknöcherten Carapax an. P. He.
Plastrons, sowie die meist T-förmige Gestalt dieses Panzerknochens begründeten den recht plausiblen SchluB, daB diese Platte dem sog. Interclaviculare oder Episternum der Stegocephalen und Squrier entsprechen müsse. Wenn dies richtig, so folgt hieraus als kaum abweisbare Konsequenz, daß auch die an jenes Episternum sich seitlich ansehlieBenden beiden vordersten paasigen Plastronplatten (Epiplastron) den Claviculae der Stegocephalen und Saurier homolog sind, worauf auch sowohl ihre Form als die Art ihrer Verbindung mit dem Episternum hinweist. Größere Schwierigkeiten bereitet dagegen die Deutung des vorderen Ventralastes des Gürters, der mit der Scapula einheiulich verknöchert. Er wird in der Regel dem rerknöcherten Procoracoidknorpel der Amphibien gleichgestellt, wofür seine Band- oder Knorpelverbindung mit dem Coracoidende spricht. In diesem Fall wären also Clavicula und Procoracoid, die sonst innig verbunden sind, weit soneinander getrenut, ein Zustand, der scliwerlich als ein sehr primitiver angesehen werden könnte. - Andrerseits lat jedoch auch die Meinung, welche in dem rorderen Ventralast einen sehr verlängerten Acromialfortsatz der Scapula erkenneu will, ihre erheblichen Schwierigkeiten. - Eine dritte Ansicht schließlich

verwirft die Deutung der vordersten paarigen Plastronplatten als Claviculae und hält den vorderen Ventralast trotz seiner Entstehung als reiner Ersatzknochen für ein völliges Homologon der Clavicula + dem Procoracoid der Amphibien, indem sie auch die phylogenetische Ableitung der Amphibienclavicula aus zwei differenten Bestandteilen ablehnt und die hierauf hinweisenden Besonderheiten im Verknöcherungsverlauf der Anurenclaicula nur für eine Modifikation des Verknöcherungsprozesses des Procoracoidknorpels hält. Nach letzterer Auffassung wären Procoracoid der Urodelen, Claricula + Procoracold der Anuren, Clavicula der Saurier und das sog. Procoracoid der Chelonier völlig honıloge Gebilde, die daher auch von dieser Lehre gleichmäßig als Clavicula bezeichset werden.

Die Mannigfaltigkeit der Differenzierung und spezialisierung, welche im Schultergürtel 
der zahlreicben ausgestorbenen Reptiliengruppen hervortritt, erfordert eine kurze Darlegung der wichtigsten Verhältnisse. Wie wir fanden, spricht rieles dafür, daß der Bau des Gürtels der Sauria und Rhynchocephala ein recht primitiver ist, was auch die fossilen rlynchocephalenartigen Formen erweisen. Daß die den Squamaten nahe verwandten marinen Pythonomorpha einen saurierartigen Gürtel besaßen (Coracoid mit einem Fenster und For. supracoracoideum), ist in Harmonie mit ihren sonstigen Bauverhältnissen; auffallend aber die starke oder völlige Rückbildung der Clavicula und des Episternums, was jedoch unter den Saurieru bei Reduktion der vordèren Extremität bäutig vorkommt. - Der ganz saurierartige Schultergürtel der Iehthyopterygia spricht ebenfalls für die primitive Natur des Squamatengürtels. - Die bei den Krokodilen angebahnte Reduktion des sog. sekundären Gürtels gilt ganz allgemein auch für die Dinosauria und Pterosauria, welche ja sowohl untereinander, als mit den Krokodilen verwandtschaftliche Beziehungen besitzen. Das Coracoid der Dinosaurier besitzt meist das Foram. supracoracoideum. Die Rückbildung des sekundären Gürtels in diesen Gruppen ist eigentümlich, wegen der genealogischen Beziehungender Dinosauria und der biologischen der Pterosauria zu den Vögeln. Interessant ist die bei gewissen Pterosauria Fig. 211.

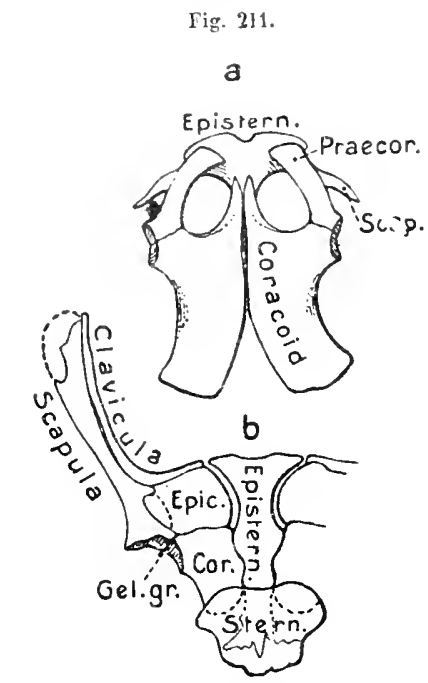

a Schultergirtel von Plesiosa u r a haw. kinsi (Sauropterygier), ventral. (Nach LYDEKKER aus FŨKBRINGER 1900.$)$ - $b$ ron $\mathrm{K}$ eirognathus (Theromorpha), dorsal inach SeElex aus Fülebrivger 1400). 0. B. eingetretene Befestigung der Scapula an einigen vorderen Brustwirbeln, ein bekanutlich sehr seltener Fall unter den Vertebraten. - Recht eigentümliche Umformungen erfuhr der Gürtel der marinen Sauropterygia, der andrerseits auch deshalb interessant erscheint, weil er unter allen Reptilien die nächsten Beziehungen zu dem der Chelonier besitzt. Im offenbaren Gegensatz zu letzteren war jedoch die Scapula der Sauropterygia in fortschreitender Reduktion begriffen, so daß sie bei den jüngeren (Plesiosaurus) fast auf ihren Gelenkteil reduziert ist. Dagegen entsendet sie, wie bei den Schildkröten, einen schief nach vorn absteigenden Ast, der mit einem ebenfalls etwas rudimentären parigen bis umpaaren sekundären Gürtel in Verbindung tritt (Fig. 211). Dieser Ast der Scapula unterliegt derselben verschiedenen Deutung wie bei den Schildkröten (s.oben). - Die rerknöcherten Coracoidea sind bei den jüngeren Sauropterygiern dadurch eigentümlich, daß sie mit einem nach binten gerichteten Medianfortsatz des sog. Procoracoidastes der Scapula zusammenstoßen, wodurch eine Konfiguration des Brustgürtels hergestellt wird, die an den Beckengürtel erinnert. - Eigentümliche und sehr interessante Verhältnisse bietet auch der Gürtel der sog. Theromorpha, zu welchen ja sehr alte Reptilien gehören. Der sekundäre Gürtel (Episternum und Claviculae) ist hier, so weit bekannt, sehr ansehulich und in primiticer

Fig. 212.

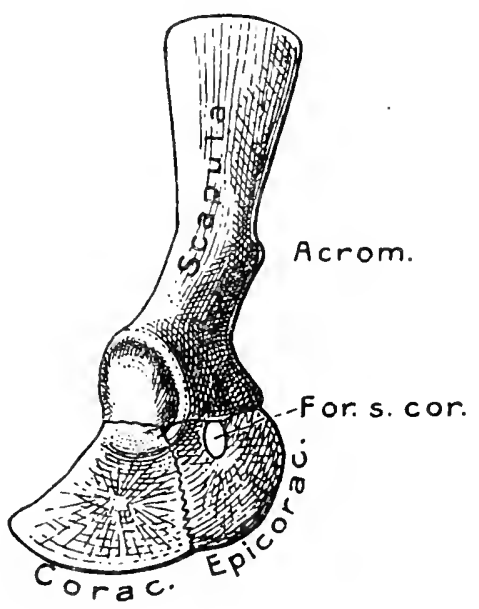

Schultergúrtel von Dic ynodon (Anomo dontia). Rechte Hälfte von außen. (Nach LY IEKKER 1893.) O. B.

Weise erhalten. Die Scapula ist zuweilen (Pareiosaurus) durch eine ibrem Vorderrond angelagerte Verknöcherung, die gelegentlich dem sog. Cleithrum der Stegocephalen homologisiert 
wird, ausgezeichnet. Das eigentümlichste ist jedoch die Zusammensetzung der ansehnlichen Coracoidplatte jederseits aus zwei Verknöcherungen, von welchen die rordere (Epicoracoid, Fig. $211 b$ u. 212) gewolnlich von dem Foramen supracoracoideum durchbohrt wird, die hintere (Coracoid) mit dem Vorderrand des Sternums sich verbindet. Beide, oder nur die hintere können an der Gelenkgrube teilnehmen. Gewöhnlich wird die vordere Verknöcherung als Procoracoid, die hintere als eigentliches Coracoid gedeutet. Da jedoch dies sog. Procoracoid gewöhnlich von dem For. supracoracoideum durchsetzt wird, das bei den Sauriern usw. dem eigentlichen Coracoid zukommt, so ist die Beziehung des vorderen Knochens zu dem sog. Procoracoid der Saurier etwas zweifelhaft. Es scheint eher, daß hier eine eigenartige Bildung vorliegt, welche durch besondere Verknöcherung des sog. Epicoracoidknorpels der Saurier entstand. Sehr bemerkenswert ist die Ähnlichkeit, welche das Coracoid gewisser Theromorpha durch diesen Bau mit dem der primitivsten Mammalia (Monotremen) erhâlt.

Vögel. Wie zu erwarten, schließt sich der Schultergürtel der Vögel ziemlich nahe an den der Reptilien, insbesondere den der Saurier an, hat jedoch durch die mechanischen Erfordernisse, welche die Umbildung der Vorderextremitäten zum Flugorgan hervorrief, zahlreiche Eigentümlichkeiten erlangt. - Der Gürtel setzt sich typisch aus den drei knöchernen Elementen, der Scapula, dem Coracoid und der Clavicula zusammen; dagegen findet sich im erwachsenen Zustand von einem Episternum nichts. Von seinem eventuellen Verbleib wird später die Rede sein.

Das Schulterblatt (Fig. 213) ist stets ein relativ langer und schmaler Knowhen geworden, der bei den Ratiten (s. Dromaeus) den Verlauf des Coracoids nahezu direkt fortsetzend, schief nach hinten gegen die Wirbelsäule anfsteigt; wogegen er bei den Carinaten (s. Pandion) mehr oder weniger parallel zar Wirbelsäule nach hinten zieht, also stark gegen das Coracoid geknickt ist; er kann sich manchmal bis in die Beckenregion erstrecken (s. auch Fig. 115, S. 213).

Das Coracoid, welches mit der Scapula zusammen das Schultergelenk bildet, zieht als mehr oder weniger abgeplatteter, mäBig breiter Knochen von der Gelenkgrube schief nach hinten, ventral und innen, um sich jederseits in den Vorderrand der breiten Sternalplatte gelenkig einzufalzen. Während bei den Carinaten Scapula und Coracoid in der Regel gesondert bleiben, verwachsen sie bei den Ratiten friihzeitig (s. Dromaeus).

Die Claviculae sind lange schmale, nach der Ventralseite und gewöhnlich auch etwas nach außen konvex gekrümmte Knochen, die, wenn voll ausgebildet, stets mit ihren Ventralenden frühzeitig zn einem einheitlichen, gabelförmigen Knochen verwachsen, der meist Gabelbein oder Furcula genannt wird (Fig. 213, 214). Eine kleine, zwischen ihren noch unvereinigten Ventralenden häufig auftretende Verknöcherung, die zum Teil knorpelig vorgebildet sein soll, wird zuweilen als Rest eines Episternums aufgefaßt. - In der Regel erieicht das Ventralende der Fnrcula das Sternum nicht; der ganze Knochen ist von den Coracoidea weit nach vorn abgerückt, was an die Verhältnisse jener Saurier erinnert, bei denen die Clavicnlae von den Coracoiden durch einen $Z$ wischenraum getrennt sind. Wie dori, so scheinen anch die Einrichtungen der Vögel dafür zu sprechen, daß in der vorderen Region der ursprünglichen Coracoide eine Reduktion eingetreten ist. Dies läßt sich auch in der Reihe der Vögel selbst noch verfolgen, da bei Struthio (Fig. 214) das Coracoid recht breit und von einem ansehnlichen Fenster durchbrochen ist, 
weshalb hier sein vorderer Ast gewöhnlich als Procoracoid vom hinteren als eigentliches Coracoid unterschieden wird. Schon bei den übrigen Ratiten (s. Apteryx, Fig. 214, und Dromaens, Fig. 213) ist jedoch dies Procuracoid so verkimmert, daß sich nur sein dorsaler Teil als ein sog. Processns coracoidens am Gelenkteil des Coracoids erhält. Dieser Processus findet sich anch bei den Carinaten noch allgemein; am besten entwickelt bei den Raubvögein (s. Buteo und Pandion, Fig. 213), wo er anch noch cine ventrale Verbindung mit dem Innenrand des Coracoids eingehen kann, so daß sich ein Rest des nrsprünglichen Fensters als Loch findet. Bei den Carinaten erhebt sich der die Gelenkgrube bildende Teil des Coracoids
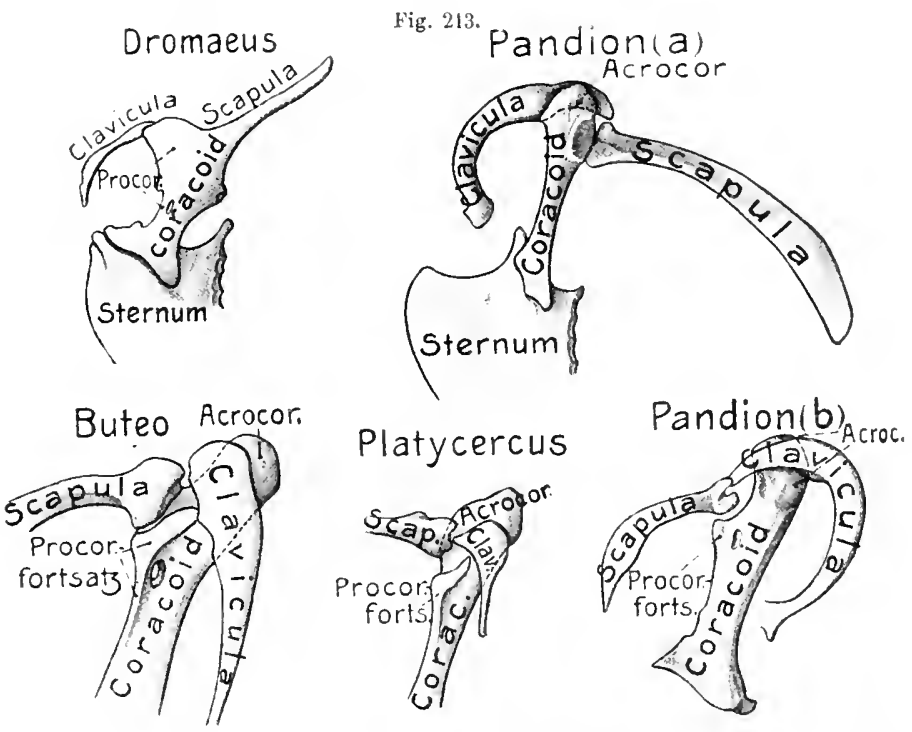

Sehultergürtel von Vögeln. Dromaens und Pandion $(a)$ linke Hālfte von auBen. Pandion (b) von innen. Buteo and Platycercus, linke Hälfte von innen.

P. He.

zu einem ansehnlichen Fortsatz, an welehen sich das verbreiterte Dorsalende der Clavicula anlegt. Er setzt sich als eine mehr oder weniger vorspringende Leiste (Spina) längs derVentralfläche des Coracoids fort. Dieser sog. Acrocoracoidfortsatz (s. Fig. 213) ist bei den Ratiten kaum entwickelt.

Die bei den Carinaten meist gut entwickelte Furcula, welche gewissermaßen eine elastische Feder zwischen den beiden Schultergelenken bildet, hängt mit dem Kamm des Sternums durch ein Band zusammen; indem dieses mehr oder weniger verknöchert, kann die Furcula zuweilen in Berührung mit dem Brustbeinkanm treten. Selten bildet das Ventralende der Furcula auch einen vorderen Fortsatz, was dann ene ziemliche Ähulichkeit mit einem Episternum bewirkt. - Wie bemerkt, stiitzt sich das verbreiterte Dorsalende der Clavicula bei den Carinaten an den Acrocoracoidfortsatz, setzt sich jedoch noch darüber hinaus fort bis zu dem ansehnlichen, am ventralen Inneurand der Scapula entspringenden Acromialfortsatz, an den sich das Ende anlegt (Fig. 213, Pandion b). Diese Verhindung der 
Clavicula mit dem Acromion ist die ursprüngliche, jene nit dem Acrocoracoidfortsatz des Coracoids eine sekundäre.

Auf diese Weise wird zwischen Acrocoracoid, Acromion und Clavicula ein Loch (For. triosseum) gebildet, durch welches die Sehne des Musculus supracoracoideus (pectoralis medius) zum Humerus zieht und das der sog. Incisur der Scapula bei den Sauriern entspricht. Durch hakenförmige Aufkrümmung des Processus procoracoideus des Coracoids kann dies Loch noch mehr umschlossen werden. Bei einem Teil der Carinaten wird es jedoch dadurch wieder geöffuet, daß das Dorsalende der Clavicula nicht mehr bis zum Acromion reicht, sich vielmehr nur mit dem Acrocoracoid verbindet.
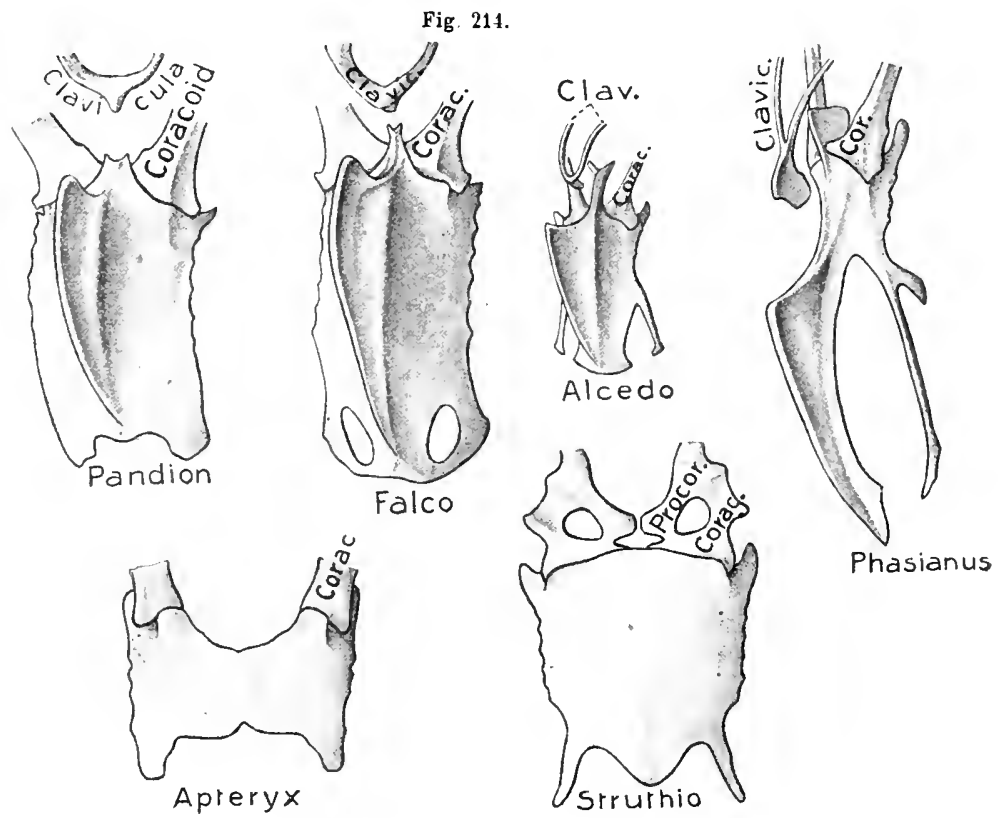

Brustbejne von Vögeln, die oberen etwas von links ventral, die unteren rein ventral gesehen. P. He.

Bei gewissen Carinaten und sämtlichen Ratiten verkümmert die Clavicula mehr oder weniger. Diese Verkümmerung beginnt stets am Ventralende und schreitet dorsalwärts fort. - Namentlich bei manchen Papageien ist, die Reduktion so weit gegangen, $d a B$ nur kurze Reste der Clavicala am Acrocoracoid haften (Fig. 213, Platycercus). Ein ähnlicher geringer Rest der Clavicula findet sich unter den Ratiten bei Dromaens (s. Fig. 213); den übrigen fehlt sie ganz, was auch für gewisse Papageien angegeben wird.

In dem die Kapsel des Schultergelenks bildenden Gewebe kann eine accessorische Verknöcherung auftreten (Os humero-scapnlare).

Die allgemeine Beurteilung des Schultergürtels der Vögel schließt sich eng der für die Reptilien dargelegten an. Nur hinsichtlich der Clavicula und des Episternums können Zweifel bestehen, da die rein hautknöcherne Entstehung der Vogelclaviculae nicht von allen Forschern anerkannt, von einigen vielmehr das Eingehen einer kuorpeligen Anlage, besonders in ihr Dorsalende, angegeben wird. Wenn dies richtig ist, so müßte diese Knorpelanlage, 
welche ursprünglich mit der Scapula zusammenhängt, wohl als dem eigentlichen Procoracoid der Saurier und Anuren entsprechenı aufgefaßt werden. - Ilinsichtlich des Episternums bestehen noch erhebliche Zweifel, da einige Beobachter geneigt sind, die Membranen, welche sich zwischen dem Brustbeinkamm, den Coracoidea und der Furcula, sowie zwischen den Furculaästen ausspannen, als Rudimente des Episternums zu deuten, was in dieser Ausdehnung sehr unwahrscheinlich ist. Andere vermnten, daß das Episternum in die Carina des Brustbeins eingegangen sei, was im Vergleich mit den Sauriern wohl plausibel erschiene, jedoch mit der knorpeligen Anlage des Kamms im Widerspruch steht. - Wie schon oben hervorgehoben, scheint auch der knorpelig vorgebillete kleine Knochen, der in das Ventralende der Furcula eingeht, als Episternum zweifelhaft, weshalb den Vögeln zuweilen auch jede eigentliche Episternalbildung abgesprochen wird.

Mammalia. Der Schultergürtel der Monotremen zeigt gegenüber dem der übrigen Sänger auffallend primitive, an die Saurier, besonders jedoch gewisse fossile Anomodontia erinnernde Charaktere. Es ist daher anch kanm zweifelhaft, daß cr sich von einem Urzustand herleitet, der dem der letzte-

ren noch nahe Ornithorhynchos paradoxas. Schnltergürtel, Sternum und Brastrippen ren noch nahe $a$ von links, b vonder Ventralseite. Frûhere Grenze der verwachsenen Scapnla und
stand inden er Coracoid punktiert angedeutet. Claviculae nnd Episternnm ebenfalls verwaclisen. stand, indenı er jederseits von einer

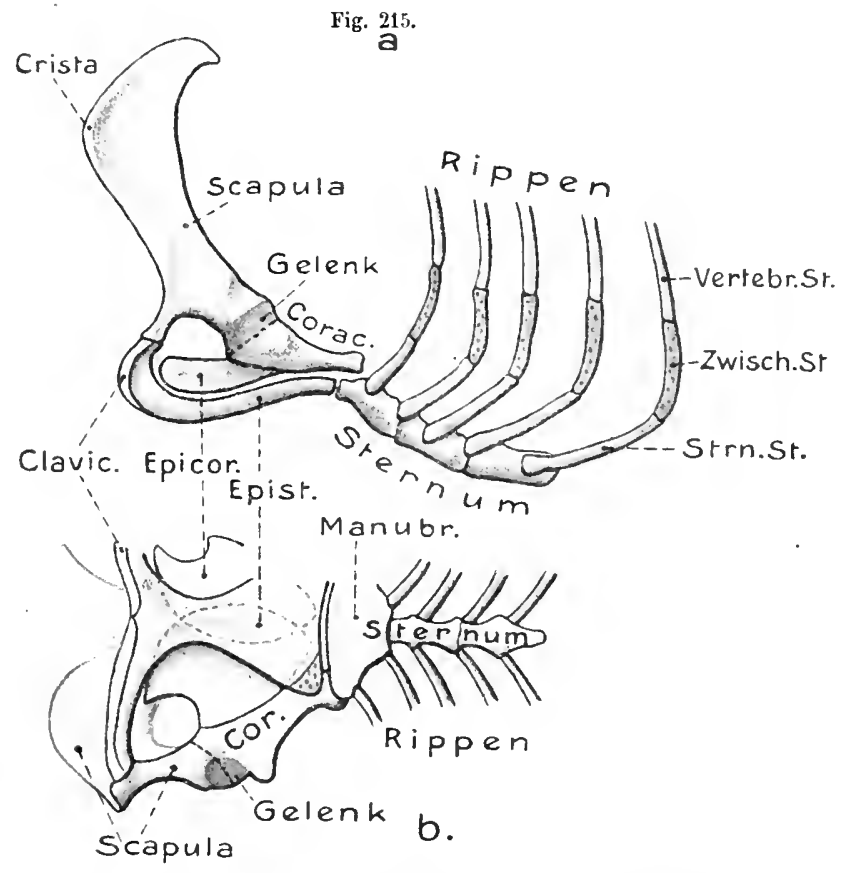
Knorpel dunkel, punktiert. P. $\mathrm{He}$.

Scapularplatte, sowie einer ansebnlichen knorpeligen Coracoidplatte gebildet wurde. Letztere schloß sich dem Vorderrand des Sternums an, das sich jedoch wie bei Sphenodon noch als sog. Prosternum zwischen die hintere Region der Coracoidplatten fortsetzte. An der Übergangsstelle von Scapular- und Coracoidplatte war eine tiefe, vorn offene Fensterbildung (Incisur), welche wohl dem primären Fenster der Saurier entsprach. Dazu gesellte sich ein ansehnliches T-förmiges Episternum, welches den vordersten Teil des Sternnms (Prosternum) unterlagerte, und mit dessen beiden Querästen die Claviculae sich verbanden, welche bis zum Acromialfortsatz des vorderen Scapularrandes zogen, die Incisur abschließend.

Durch die Verknöcherung wird jedoch an diesem Gürtel, wie ihn etwa die Monotremen (Fig. 215) noch darbieten, einiges Eigentiimliche hervorgerufen. 
Die Scapula verknöchert in ihrer größten Ausdehnung als eine Platte, die dorsal etwas nach hinten hakig "!mgebogen ist, so daß sich nur ein schwacher Suprascapularknorpel an ihrem Dorsalrand erhält, was für alle Mammalia gilt. Gegen die Gelenkgrube verschmälert sieh das Schulterblatt etwas halsartig, was gleichfalls allgemein vorkommt. - Der ansehnliche, vẹntralwärts gekrümmte Acromialfortsatz entspringt wie bei den Sauropsiden vom Vorderrand der Scapula, wenig oberhalb der Gelenkgrube. -- Eine ganz besondere Eigentümlichkeit bietet die Verknöcherung der Coracoidplatte, indem dabei ein hinterer schmälerer, etwa stielförmiger Knochen gebildet wird, der von der Gelenkgrube direkt zum verbreiterten vordersten Glied des Sternums zieht und sich darauf stützt, wogegen der Hanptteil des knorpeligen Coracoids zu einem platten Knochen wird, der sich demVorderrand des ersterwähnten anschließt, und sich median mit dem der Gegenseite etwas kreuzt. Bei jugendlichen Formen, deren Prosternum noch gut ausgebildet ist, tritt er an dieses heran. Der hintere Knochen wird als eigentliches Coracoid (auch Metacoracoid), der vordere gewöhnlich als Epicoracoid bezeichnet; seine Lageverhältnisse scheinen dies auch zu rechtfertigen, doch bewabrt er noch einen knorpeligen Medianrand. Nur das eigentliche Coracoid uimmt an der Bildung der Gelenkgrubs teil. - Einer ähnlichen Zusammensetzung der Coracoidplatte aus zwei Verknöcherungen begegneten wir nur bei den Anomodontia (s. S. 345), was deren eventuelle Beziehungen zu den Mammalia bekräftigt. Scapula und Coracoid verwachsen frühzeitig miteinander.

Das oben erwähnte Episternum der Monotremen ist ein ansehnlicher T-förmiger Knochen, dessen verbreiterter plattenförmiger Stamm sich hinten auf das Manubrium des Brustbeins stützt, während das Prosternum, das er unterlagert, sich bei den erwachsenen Monotremen stark reduziert, zum Teil jedoch auch wohl verknöchernd in das Episternum aufgenommen wird. Die beiden vorderen Queräste des Episternums sind so lang, daß sie das Acromion nahezu oder völlig erreichen. Die. schmalen Claviculae verwachsen im Alter mit den Querästen des Episteruums. - Obgleich die Ontogenie noch nicht hinreichend aufgeklärt ist, spricht doch vieles dafür, daß Episternum und Claviculae der Monotremen wie bei den. Sanropsiden Hantknochenbildungen sind.

Der Schultergürtel aller ïbrigen Säuger wird einmal gekennzeichnet durch die weitgehende Reduktion der Coracoidea, die das Sternum nie mehr erreichen, sondern nur Fortsatzbildungen der Seapula darstellen; ferner durch die starke oder völlige Rïckbildung des Episternums, hänfig jedoch anch der Claviculae.

Das Schulterblatt (Fig. 216) nimmt an Umfang zu und bildet in der Regel eine mehr oder weniger dreieckige Platte mit meist kleinerer, den Dorsalrand bildender Basis. Die Außenfläche erhebt sich etwa in der Mittellinie za einem mehr oder weniger aufsteigenden Kamm (Crista oder Spina), der als Vergrößerung der Muskelausatzfläche dient und nur selten stark rückgebildet ist (Cetacea, Fig. 216 ${ }^{3}$ ). Das Veutralende der Crista setzt sich in den frei vorspringenden Acromialfortsatz fort, der bei guter Ausbildung der Clavicula meist recht lang wird, so daß er über das Ventralende der Scapula herabreichen und wuweilen noch einen hinteren Zweig- 
ast entsenden kann. Die Verbreiterng des Schulterblatts d. böheren Süuger ribit von einem Answachsen des ursprünglichen Vorderrands nach vorn her, was daraus hervorgeht, daß bei den Monotremen der etwas cristaartig aufsteigende Vorderrand noch das Acromion entsendet, wie bei den Sauropsiden. Bci manchen Sängern entwickelt sich jedoch auch am Hinteriand der Scapula eine zweite Crista (z. B. manche Edentata Fig. 2164, Raubtiere, Insectivoren, Affen nsw.).

Wie bemerkt, sind die Coracoide stets sehr reduziert, doch erreichen sie im Embryonalzustand selten noch das Sternum (Beuteltiere). Bei den Erwachsenen bilden sie am vorderen Innenrand des Gelenkgrubenteils der Scapula einen schwachen bis ansehnlichen, und danu etwas gekrümmten Fortsatz, den Processus coracoideus (Figur 216). Er wird als selbständige Verknöcherung angelegt, welche später mit der Scapula verwächst. Bei einigen Säugern (gewissen Edentaten und Primaten) sendet er einen gegen den Vorderrand der Scapula aufsteigenden Ast aus, der mit der Scapula verwachsen kann, so daß diese an ihrem Vorderrand, über der Gelenkgrube, von einem Loch durchsetzt erscheint (Fig. 2164).

Gewöhnlich wird der Fig. 216.

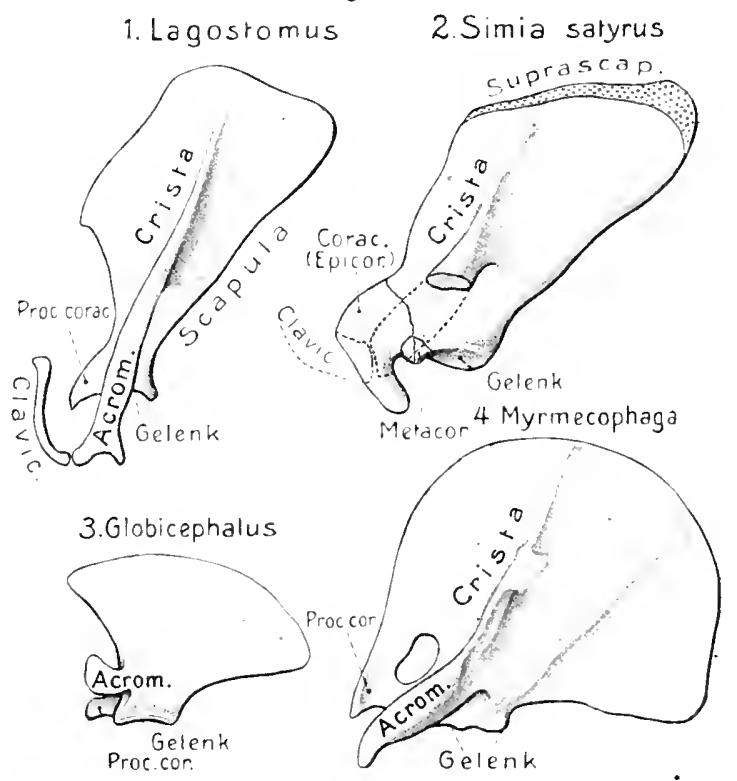

Linker Schultergürtel von Mammaliern von anßen. $i_{\text {. La }}$. gostomus (Nagetier). 2. Simia saty rus (Orang), jung; das Acromion abge schnitten, sein Umriß und der der Clavieula punktiert 3. Globicephalus (Waltier) (nach Giebel-Brons). 7 . My rmecophaga (Aneisen. fresser). P. He.

Processus coracoideus als dem eigentlichen Coracoid (Metacoracoid) der Monotremen entsprechend gedeutet.

Es läßt sich jedoch nicht leugnen, $\mathrm{daß}$ er eine gewisse Ähnlichkeit mit dem sug. Epicoracoid liat, insbesondere erinnert das letztbeschriebene Verhalten an das Epicoracoid von Ornithorhynchus. Da nun in neuerer Zeit bei der Entwicklung vieler Säuger hinter dem Hauptknochenkern des Processus coracoideus noch eine zweite kleinere Verknöcherung aufgefunden wurle, die später mit der Hauptserknöcherung oder mit der Scapula verwächst (s. Fig. 2162, 217), so hat man die vordere mit dem Epicoracoid, die hintere mit dem Coracoid (Metaroracoid) der Monotremen bomologisiert. Daß jedoch letztere Verknöcherung nicht nur eine Epiphyse der Scapula ist, scheint nicht sicher widerlegt, eher sogar wahrscheinlich. - Andrerseits wurde bei gewissen Säugern (speziell Insectivora, Rodentia und Chiroptera) jederseits dem Manubrium des Brustbeins anliegend, dicht ror der ersten Brustrippe, ein Knorpelehen oder Knöchelchen beobachtet, das zuweilen auch als ein Rest tes Coracoids (Grambaur) oder Epicoracoids (Parker) gedeutet wurde. 
Die Clavicula ist bei allen Säugern mit mannigfaltiger Beweglichkeit der Vorderextremität gut ausgebildet und erstreckt sich als schlanker Knochen vom Acromion bis zum Manubrium des Brustbeins (s. Fig. 252, S. 388). Bei denjenigen, welche nur einförmige, meist pendelnde Bewegungen der Vorderextremität ausführen (Ungulata, Probroscidea, Sirenia, Cetacea), wird sie ganz rudimentär; doch

Fig. 217.

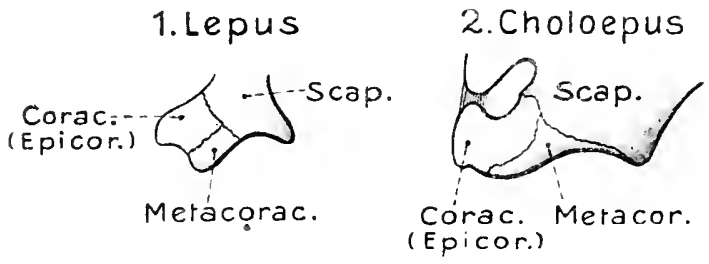

Gelenkteil der linken Scapnla mit Coracoid (Epicoracoid) nud sog. Metacoracoid von anßen. (Nach Howes 1593.) 1. Fon Lepus lein Honat alt). 2. Von Choloepus didactylus (halberwachseny. P. He. fehlt sie auch vielen Rodentien und Carnivoren, während sie andere Vertreter dieser Ordnungen in allen Graden der Verkümmerung aufweisen. Ihre Reduktion schreitet in der Regel von den beiden Enden gegen die Mitte fort.

Da sich an der Eutwick-

lung der Claviculae (besonders ihrer Sternalregion) höherer Säuger (spezieli Placentalia) eine Knorpelanlage beteiligt, so verrät sie doch eine gewisse Verschiedenheit gegenüber der der Sauropsiden. was möglicherweise auf.ältere Beziehungen hinweisen kann. Ob sich diese knor-

Fig. 215.

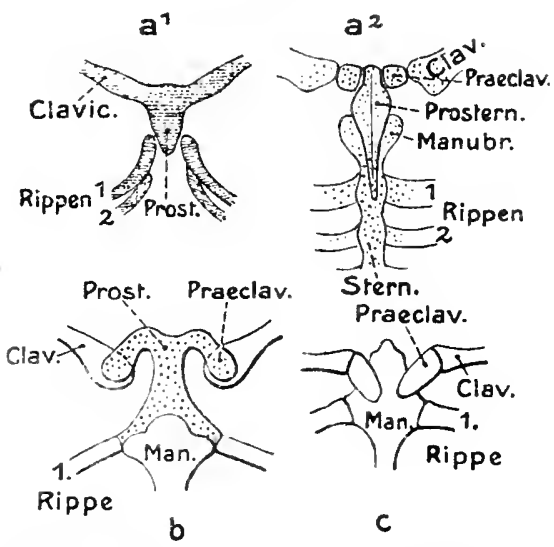

Sog. Episternalapparat verschiedener Mammalia (ron der Ventralseite). $\quad a^{1}-t^{2}$ von Tial patmbryonen (nach GóTte 1877) al vorknorpelige Anlage der Claviculae und der Ventralenden der beiden ersten Brusirippen. $a^{2}$ alterer Embryo; Differenzierang des nnyaren Prosternams und der beiden Präclabia aus dem Mittelstück der Clavicularanlage. Das knorpelige Sternnm gebildet. bunge Bentelratte. $c$ Cercolabes (Nage. tier). Vorderende des Sternnm mit den beiden Pră cla via ( $b$ und $c$ nach Gegenbaur 1865 und 1895). O. B. pelige Anlage auf den Procoracoidknorpel der Amphibien zurückführen läßt, bleibt zweifelhaft.

Die Frage nach dem Verbleib des Episternums bei den Beuteltieren und Placentalieru kann nicht als genügend aufgeklärt gelten. So viel ist sicher, $\mathrm{da} B$ bei ihnen ein hantknöchernes Episternum im Sinne der Sauropsiden, dem ja auch das der Monotremen wohl entspricht, nicht vorkommt. Dagegen finden sich bei vielen kleine, meist knorpelige, seltener verknöcherte parige Skeletgebilde, die sich zwischen das Vorderende des Sternums (sog. Manubrium) und die Sterualenden der Claviculae einschieben, und deren Lage sehr an ein Episternum erinnert (Fig. 218). - Soweit die Ontogenie aufgeklärt ist, sind es jedoch rein knorpelig angelegte Teile, die sich von den Sternalenden der knorpeligen Anlagen der Claviculae abgliedern (sog. Präclavia Gegenbaur, Omosterna Parker). Durch ihre Verbindung in der ventralen Mittellinie und weitere Abgliede-

rung tritt bäufig auch ein unpaares knorpeliges Mittelstück (auch Prosternum genannt) zwischen ihnen, und ventral bis vor dem Vorderende des Sternums auf (Fig. $218 a^{1}-a^{2}$ ), so da die Gesamtbildung dann sehr an den Mittelstamm und die beiden Queräste des T-förmigen Monotremen-Episternums erinnert, zumal das unpaare Stück und die paarigen auch zusammenhängend bleiben können (Fig. 218b). Doch soll sich das erstere auch paarig (entsprechend seiner ursprünglich paarigen Anlage aus den Claviculae) erhalten können; so besonders deutlich bei einer Art von Dasypus (Gürteltier). Auch die beim Menschen zuweilen vorkommenden 
sog. Ossa suprasternalia sollen hierher gehören. Häufig geht jedoch das Mittelstück im erwachsenen Zustand in das Manubrinm des Sternums auf, oder wird von ihm gewissermaßen substituiert (Fig. 218c).

Bei vielen erwachsenen Placentaliern ist ron diesen episternalen Skeletgebilden wenig oder nichts mehr vorhanden; ein letzter lest der sog. Präclavien bleibt zuweilen jederseits als ein reringfügiger Kuorpel (Cartilago interarticularis) zwischen Clavieula und Manubrium erhalten (Halbaffen, Primaten, Mensch).

\section{Der Beekengiirtel der tetrapoden Vertebrata.}

Der Beckengirtel der primitiveren Amphibien schließt sich noch recht nahe an den der Dipnoer an, besitzt jedoch schon den Charakter, welcher für alle 'Tetrapoden gilt, nämlich die Befestigung an der Wirbelsänle, samt der dadurch bedingten Entwicklung eines Sacrums. Diese, mit der Funktion der Hinterextremitäten als Vorschieber des Kärpers zusammenhängende Befestigung bedingte ihrerseits, da 3 die dursale oder iliacale Region des primären Gürtels, welche schon bei gèwissen Knorpelfischen relativ ansehnlich war, sich bei den Tetrapoden stärker dorsalwärts entfaltete und zunächst durch Vermittlung einer Rippe mit der Wirbelsäule in Verbiulung trat. Bei allen Tetrapoden (ausgenommen solche, deren Hinterextremität verkiummerte) ist also die dorsale Gürtelregion, das sog. Ileum (Darmbein) ${ }^{1}$ ), gut entwickelt und mit seinem Dorsalende an das Kreuzbein geheftet.

Amphibien. Der primitive Charakter des Amphibienbeekens spricht sich hauptsächlich darin ans, daß der ventrale Gürtelast ein einheitliches Skeletgebilde bleibt, das mit dem der Gegenseite frühzeitig in der Merlianlinie verwächst, wie bei den meisten Chondropterygiern mi Dipnoern. Doch tritt die Verwachsung bei den Salamandrinen häufig nur an der Ventralfläche der Beckenplatte ein, besehränkt sich selten sogar nur anf ilure vorderste Region (Amphiuma).

Bei den $T$ roflelon (s. Fig. $219 \mathrm{~A}, B$ ), welche natiurlich die primitiveren Verhältnisse darbieten, ist das relativ kurze Ileum ein etwa cylindrischer Knochen, der an der Sacralrippe durch Band (zum 'Teil noch recht lose) befestigt ist; ja das Ilem von Proteus bleibt so kurz, daß es die Sacralrippe nieht erreicht. Es verläuft nahezu senkrecht zur IVirbelsäule, oder wenig nach vorn herabsteigend (Fig. $219 J^{2}$ ). An seiner Übergangsstelle in die ventrale Beckenplatte findet sich die nach : 2 Ben und etwas nach hinten gerichtete Gelenkgrube(Ptanne, Acetabulum) für das Femur. Die ventrale Beckenplatte, das sog. Ischiopubis, ist eine großenteils oder gainzlich (Proteus) knorpelige, nahezu plane, bis mäßig nach der Dorsalseite konkave Platte. Bei Menobranchus (Fig. $219 A$ ) gleicht sie dureh ihre Kürze und ihren vorderen Fortsatz (Epipulis) sehr der der Dipnoi. Sonst wird sie gewöhnlich dnrch Auswachsen nach hinten länger. -- Der Epipubisfortsatz ist bald weniger, bald mehr entwichelt, zuweilen auch parig. Bei gewissen Ichthyoden und vielen Salamandrinen wird er (Cartilago ypsiloides) reeht lang und gabelt sich an seinem Ende, in Andentung der parrigen Anlage (Fig. $219 \mathrm{~B}$ ). In diesen Fällen gliedert

1) Obgleich, wie schon oben bemerht, die Bezeichnung Ilium (eigentlich Os ilium) statt Ileum gebränchlicher, auch wohl richtiger ist, wurde die letztere im Text beibehalten, weil sie auf den Figuren verwendet war.

Büts̈chli, Vergl. Anatomie. 
er sich von der Beckenplatte ab, mit der er durch Bindegewebe vereinigt bleibt (doch wird auch seine selbständige Entstehung angegeben). - Die vorderen seitlichen Ecken der Beckenplatte springen häufig als ziemlich ansehnliche Präpubisfortsätze vor, wie wir sie schon bei Chondropterygiern und Dipnoern trafen. Etwas vor der Gelenkgrube wird die Platte jederseits von einem Loch für den Nervus obturatorius durchbohrt. - Regelmäßig (mit Ausnahme von Proteus) bildet sich

Fig. 219.
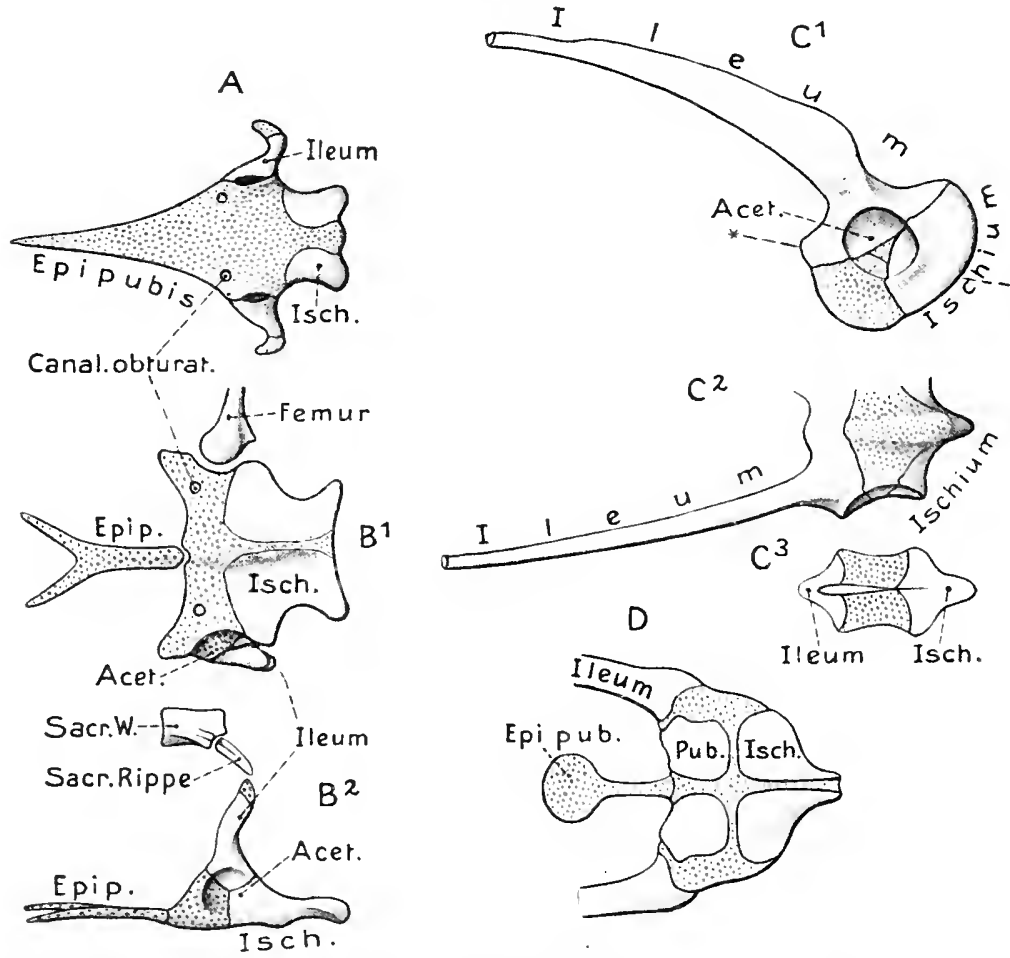

Becken von Amphibien. 1 Moubranchus von der Ventralseite (nach WiedersheIM 1892). $B$ Salamandra maculosa. $B^{1}$ von der Ventralseite. $B^{2}$ von links. $C$ Rana $\theta$ e 1 enta. $C^{\prime}$ von links. $C^{2}$ von der Ventralseite. $C^{3}$ Horizontalsehnitt in der Ebene* der Linie von $C$, $D$ Da etylethra von der Ventralseite

a (nach WIEDERSHEIM 1892). P. He.

in der postacetabularen Region jederseits eine mäßig große randliche Verknöcherung, das sog. Ischium oder Sitzbein, das sich znweilen bis in die Vorderregion ausdehnt. - Im Hinblick auf die Verhältnisse gewisser Amnioten ist es von Interesse, daß der Grund des Acetabulums maneher Ichthyoden von einem Loch durchbohrt ist.

Der Gürtel der Anuren (Fig. 219 C, D, Fig. 111, S. 211) hat mit der bedeutenden Großße, welche die Hinterextremität erlangt, besonders auch mit ihrer Fuuktion als Sprungorgane bei nicht wenigen, eine Umformung erfahren. Das Ileum ist zu einem sehr langen Knochen ausgewachsen, dessen Vorderende durch Knorpel und Band mit dem Ende des ansehnlichen Querfortsatzes des Sacralwirbels zusammen- 
hängt. Seine Stellnng zur Wirbelsäule hat sich gänzlich geändert, da es nahezu parallel mit dem Os coccygis nach hinten zieht und auch etwa so lang wie dieses ist. So wird das Acetabulum, und damit auch der Angriffspunkt der freien Extremität, ganz an das Hinterende des Körpers verlegt, was sowohl für die Sprungbewegungen, als für die starke Verlängerung der Hinterextremität vorteilhaft sein muß; andrerseits ist die Parallelität der Darmbeine mit der Wirbelsäule mechaniseh günstig für die direkte Übertragung des Stoßes der Hinterextremität auf die Sänle. - Auch die ventrale Beckenplatte erscheint wesentlich umgestaltet. Sie ist in der Querrichtung recht schmal geworden (s. Fig. $219 C^{2-3}$ ); dagegen wuchs die in ihrer ventralen Mittellivie schon bei den Urodelen zum Teil angedentete Leiste (Crista) sehr stark aus, so daß der ventrale Gürtelteil zu einer vertikalen, zwischen die beiden Gelenkgruben eingeschalteten Platte wurde, die sich dorsalwärts verdickt.Da die Ventralenden der beiden Darmbeine sich ebenfalls bis zur Beruhrung nähern, so bilden sie die dorsale Ergänzung dieser Beckenplatte. Sie verknöchern bis auf ihr dorsalstes Ende: ebenso verknöchert die hintere Hälfte der Beckenplatte zu einem Ischium, dem Verwachsungsprodukt der beiden Ossa ischii der Urodelen; wogegen die vordere Hälfte der knorpeligen Beckenplatte in der Regel verkalkt.

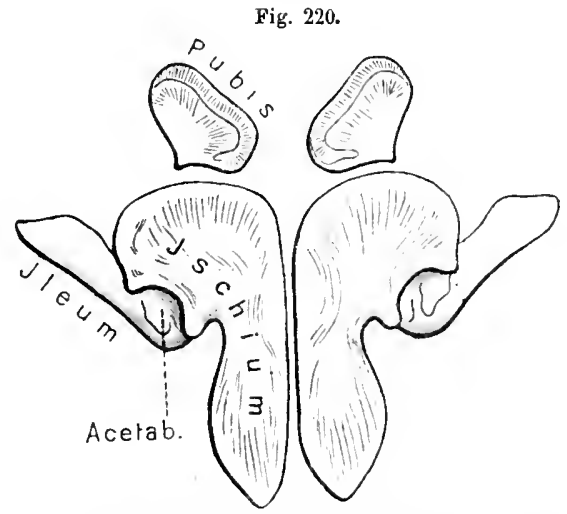

Mastodonsaurus giganteus. (Stegocephale!. Becken von derVentralseite. (Nach E. EraAs aus ZitTELs Handbuch.) P. He.

Bei Dactylethra (Fig. 219D), deren Beckenplatte weniger verschmälert ist, bleiben die beiden $O$. ischii gesondert wie bei den Urodelen, und zu ihnen gesellt sich in der Vorderhälfte der Beckenplatte noch ein Paar Verknöcherungen, die sog. Pubis (Schambeine), die bei Urodelen (z. B Salamandra) nur selten angedeutet sein konnen. Auch das den Anuren sonst fehlende Epipubis macht das Becken von Dactylethra urodelenähnlicher. - An der Bildung des Acetabulums der Anuren beteiligen sich die unteren Enden der Darm- und der Sitzbeine. Der Grund der Gelenkgrabe ist gewöhnlich nur häutig-knorpelig geschlossen, ein sog. Acetabularloch also auch hier angedeutet. Der Nervus obturatorius durchsetzt die Pubisregion nicht, sondern zieht vor der Beckenplatte hinab.

Das Becken der fossilen Stegocephalen (Fig. 220) war gewöhnlich recht urodelenähnlich, namentlich auch durch das kurze Ileum. Ventral entbielt es entweder nur ein Paar hinterer Verknöcherungen (1schium), oder ähnlich Dactylethra (z. B. Discosaurus, Mastodonsaurus) noch ein vorderes Pubispaar. Die Form dieser Knochen verrät, daß sie in einer knorpeligen Beckenplatte eingeschlossen waren.

Bei den extremitätenlosen Gymuophionen, sowie bei Siren, dem die Hinterextremitäten fehlen, ist das Becken völlig rückgebildet.

Reptilia. Das Becken gewisser fossiler Reptilien (so der Proterosauria, apeziell Palaeohatteria, ebenso das der Sauropterygia) glich ziemlich dem der 
Stegoeephalen mit zwei Paar Ventralknoehen. Andrerseits war das Beeken der fossilen Anomodontia recht ähnlich dem der Anuren, namentlich darin, daß die ventrale Beckenplatte sowohl in ihrer änßeren Form, als auch ihrer meist völligen Einheitlichkeit die Verhältnisse des Anurenbeckens wiederholt (s. Fig. 228, S. 363). Die iibrigen Reptilien dagegen zeigen diese Einheitliehkeit der ventralen Beekenplatte nicht, vielmehr in jeder ihrer Hälften stets eine nur hïutig geschlossene Durehbreehnng der Skeletsubstanz, eine Art Fenster (Foramen puboischiadieum oder Foramen ohturatum), ähnlich wie es im Brustgürtel Procoracoid und Coracoid

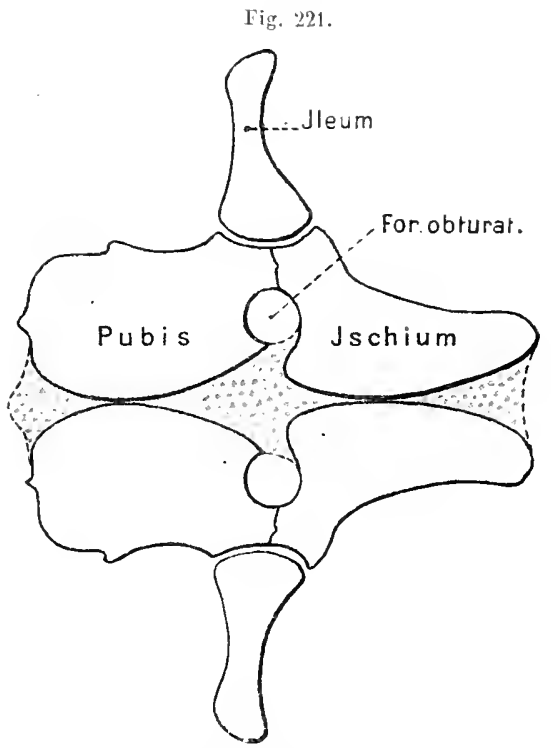

Plesiosaurus (Sauropterygier). Becken von d rVoutralseile (schematisch). Die wahrstheinliche Ausdehnung des Symphysenknorpels punktiert angederitet. (Nach Huxlex aus Zretels Handbach konstruiert.f P. He. trennte. Auch hier führt diese Fensterbildung zur Sondermug der beiden, allen Amnioten stets znkommenden zweiventriclen Knochenpare, der Pubis.und der Ossa ischii.

Ob dies Fenster, welches gewöhnlich als Foramen obturatum bezeichnet wird, eventuell aus einer Erweiterung des Canalis obturatorius des Urodelenbeckens hervorging: ist ein bis jetzt unentschiedenes Problem; wenn auch die Möglichkeit meist geleugnet wird.

Da sich sehwer entscheiden lißßt, ob die Ähnlichkeit des Beekens der Anomodontia mit dem der Anuren eine wirklich primitive, oder eine Kunvergenzerseheiuung ist, so beginnen wir unsere Betraehtung mit dem an die Stegocephalen erimernden Becken der Palaeohatteria und der Sauropterygier (Figur 221). Die ventrale, nahezu horizontale, wenig gekrummte Beckenplatte blieb hier jedenfalls stark knorpelig; die Pubis und Ossa ischii waren platte, bei den Samopterygiern nahezu gleieh große Knochen, und das jederseitige Fenster (Foramen obturatum) klein. Bei den Sauropterygiern erweist die Form der beiden Knochenpare wohl sicher die Existenz jenes Foramens; bei Palaeohatteria, wo der Knorpel wahrseheinlich reichlieher vorhanden war, seheint dies weniger sicher. Die Scham- und Sitzbeine der Sauropterygier erstreckten sich bis in die ventrale Medianlinie, in der sie in einer Symphyse zusammenstießen, oder doch un dureh wenig Enorpel verbunden waren. Am Aufhau des Acetabulums beteiligten sich alle drei Knochen.

Das Becken der Chelonier, Rhynchocephalen und Saurier (Fig. 222, 223) zeigt große Übereinstimmung, was auf eine gemeinsame Grundform hinweist. Die Darmbeine sind mäßig große, zemlich sehmale Knochen, welche von den beiden Sacralwirbeln, an deren Qnerfortsätzen sie sich befestigen, schief nach vorn herabsteigen. - - I Iie beiden Ventralknoehen haben sich unter starker Erweiterung 
der Foramina puboischiadica verschmälert. Zur Erweiterung dieser Foramina trug jedoch auch eine allmählich eingetretene Lageverschiebung beider Knochen bei, wie sie in der Ontogenie der Saurier dentlich hervortritt. Die Scham- nnd Sitzbeine gingen aus einer ursprïnglich annïhernd parallelen, etwa senkrecht zor Wirbelsänle gerichteten Stellung in eine abwïrts divergierende iber, die mehr oder weniger stark ausgeprägt erseheint. Am Auflan des undurchbohrten Aeetabulums beteiligen sich die drei Kinochen etwa zu gleichen'Teilen. - Der Nerrus obturatorius durchbohrt bei Sphenodon und den sauriern (Fig. 223) die Pubis nahe unter dem Acetabuinm, während er bei den theloniern (Fig. 222) durch das Foramen puboischiadicum tritt, wie es bei allen iibrigen Amnioten der Fall ist. Bei den meisten Cheloniern, sowie Sphenodon sind die Foramina tatsächlieh Fenster, da sie in der ventralen Mittellinie des Beckens durch Skeletmaterial geschieden sind (Fig. 222 b). Bei Sphenodon und zahlreichen Schildkröten gesehieht dies durch einen Knorpelstreif (Septum), welcher die knorpeligen Symphysen der Scham-und Sitzbeine verbindet. Daß dieser Zustand sich der Ausgangsform des Reptilienbeckens zunachst anreiht, ist recht wahrscheinlich. Die übrigen Sehildkröten dagegen zeigen zwei divergierende Entwicklungsreihen, indem das knorpelige Septum entweder mehr verkümmert und schließlieh (Trionyehidae) durch ein Ligament ersetzt wird, oder sich die knüchernen Pubis und $O$, ischii von ihrer urspüüuglichen Symplysengegend aus nach hinten und forn auf das knorpelige Septum ausdehnen und schließlich in der BeckenFig. 222.

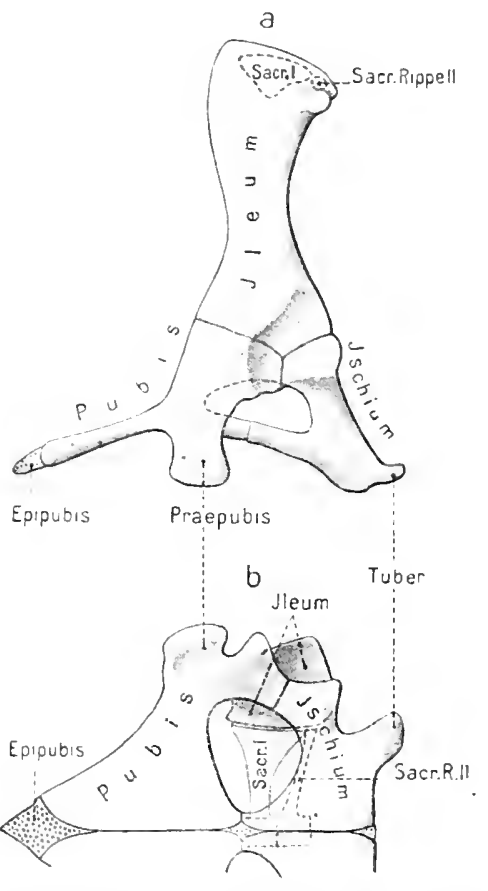

Clemmys deenssata (Schildkrōte). Becken. a linke Hālfte ron dufsen. Anheftung der beiden Sacralrippen an lleum punktiert angegeben. $b$ Ventralseite; Sacralwirhel und -rippen punktiert angegeben. mitte knorpelig oder durch Naht zusammenstoßen (besonders Emydae und Testudinidae). Auf diese Weise werden also die Foramina puboischiadiea völlig knöchern umrandet und median knöchern geschieden, wie es auch dem Sïngerbecken eigentiimlich ist. Gerade der letztere Umstand läßt daher vermuten, daß es sich hier nm eiuen sehr alten Zustand handelt.

Das Saurierbeeken dagegen zeigt stets die Verkümmerung des knorpeligen Septums und seinen Ersatz darch ein sebniges Ligament, das nur selteu mehr oder weniger verknöchern kann. Die Foramina puboischiadica werden daher nicht durch Skeletteile gesondert; die Symphysen der Scham- und Sitzbeine sind weit getrennt. 
Die Pubis der drei fraglichen Reptiliengruppen besitzen meist gut entwickelte Processus praepubici (Processus laterales), die bald schief nach außen, nach vorn, oder gar etwas nach innen gerichtet sind.

Als Epipubis wird bei gewissen Cheloniern (Fig. 222) ein meist knorpeliger Fortsatz betrachtet, der vom Knorpel der Schambeinsymphyse nach vorn entspringt und zuweilen recht ansehnlich werden kann. Selten erscheint dies Epipubis abgegliedert, oder in der Medianlinie parig gesondert; ebenso selten tritt Verknöcherung in ihm auf. Die Ontogenese weist auf seine paarige Entstehung aus den Pubis hin. - Eine ähnliche Epipubisbildung zeigen Spbenodon und nicht wenige Saurier (Fig. 223). Auch hier ist das sog. Epipubis teils unpaar, teils paarig; im Alter meist rerkalkt oder verknöchert und dann selbständig. - Bei Chamaeleo dagegen liegen der Pubissymphyse zwei kleine stäbchenförmige Knöchelchen an, deren Hervorgehen aus dem Epipubisknorpel nachgewiesen ist.

A Fig. 223.

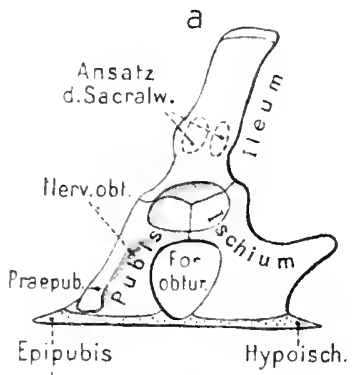

b

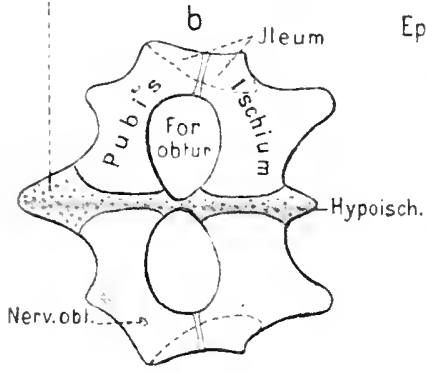

Sphenodon punctarum
$B$

a

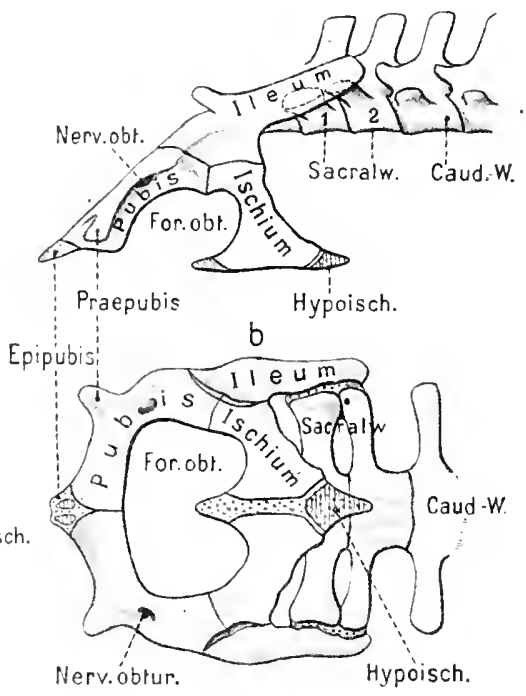

Varanus niloticus

A Becken ron $\mathrm{Sphenodon} \mathrm{punctatam.} \mathrm{a} \mathrm{Linkseitige} \mathrm{Ansicht.} b$ Ventralansicht. $B$ Becken von Varam mit Sacral- and vorderen Candsiwirbeln. a Linkseitige Ansicht. Ansatzstellen der Sacralwirbelfortsätze am lleum puntiert. $b$ Ventralansicht. Knorpel dunkel, punktiert. H. He.

Ähnlich wie das Epipubis zu den Schambeinen, verhält sich bei den Sauriern das sog. Hypoischium (Os cloacae) zu den Sitzbeinen (Fig. 223, Varanus). Es ist dies ein dreieckiges bis langgestrecktes Knöchelchen, das sich der Sitzbeinfuge hinten anschließt und bis zur vorderen Cloakenlippe nach binten reichen kann. Die Ontogenese erweist, daß es in ähnlicher Weise aus der knorpeligen Sitzbeinen hervorgeht, wie das Epipubis aus den Pubis. - In der Ontogenese der Schildkröten tritt dies Skeletgebilde ebenfalls auf, um sich später wieder rückzubilden. - Ob die als Epipubis und Hypoischium beschriebenen Verkalkungen oder Verknöcherungen in den Symphysenknorpeln wirklich den morphologischen Wert selbständiget Skeletbildungen besitzen, oder als zu den Scham- und Sitzbeinen gehörige Epiphysenverknöcherungen anzusehen sind, läßt sich nicht scharf entscheiden.

Bei den Sauriern mit verkümmerten oder fehlenden Hinterextremitäten ist das Becken stets stark rückgebildet, feblt jedoch nie völlig. Bei den ersteren (s. Fig. 224a) tinden sich 
gewöhnlich noch sämtliche drei Knochen, ron denen das lleum ill der Regel noch einem Sacralwirbel angeheftet ist. Bei völliger Verkümmerung der freien Extremität (z. B. Anguis, Fig. 224 (1) liegt jederseits ein Knöchelchen, das wohl ais Verwachsungsprodukt der drei Knochen aufgefaßt werden darf. Wine eigentliche Symphyse bilden diese Knöchelchen nicht mebr. Ähnlich verhält sich das Beckeı der Amphisbaenen. - Den Ophidiern fehlt das Becken meist völlig; doch finden sich Reste bei gewissen Angiostomata und Colubriformia, speziell den Riesenschlangen. Bei letzteren ist es, wie Fig. $224 c$

\section{Fig. 224.}
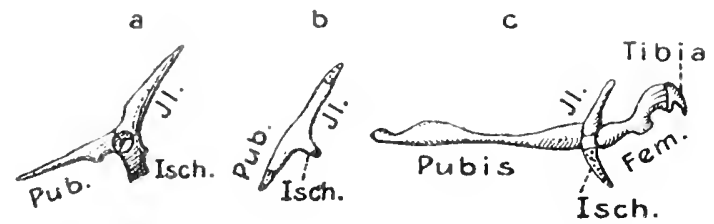

Beckengürtel von schlangenartigen $S$ aurjern und 0 phidiern, von links a Von Gonglus ocellatus (Suurier) bon Ang is fra gilis (Blindschleiche). $c$ Von B o a constrictor(liesenschlange) mit verkümmartem Extremitätenskelet. (Nach M. Fürbningkr 1870.) 0. b. zeigt, ziemlich wohl entwickelt, jedoch ohne Befestigung an der Wirbelsäule und ohne Symphyse. Bei den Angiostomata ist es meist auf ein Knöchelchen jederseits reduziert.

Ziemlich rudimentär war auch das Becken der fossilen Ichthyosaurier, seinem Typus nach jedoch etwa saurierähnlich. Das Ileum hatte seine Befestigung an der Wirbelsäule verloren.

Eigenartige Verhältnisse haben sich am Becken der Crocodilia (Figur 225) hervorgebildet. Das Sacralende des relativ kurzen Ileum hat sich stark nachvorn verbreitert, so daß die Gesamtform des Darmbeins etwa blattförmig wurde und seine Befestigung am Sacrum eine ausgedehntere. Das Ischium (Fig. 225 A) bleibt dem der seither betrachtetenReptilien im allgemeinen ähnlich, entwickelt jedoch an seinem Acetabularteil einen krăftigen, nach vorn gerichteten

Alligator mississippiensis, jung, Becken. A Von links, Ansatzstellen der Sacralrippen an lleum punkti»rt. $-B$ Von der Ventralseite mit hinterster Bauchrippe. Knorpel punktiert.
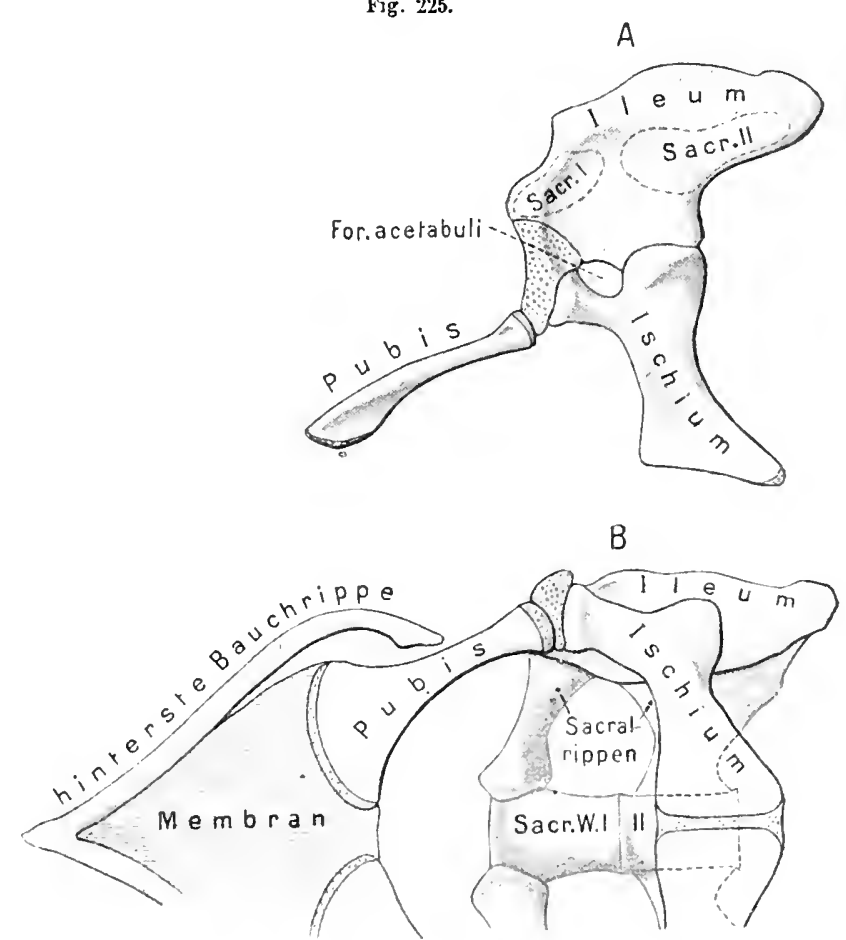

Fortsatz, welcher den ventralen Raud der Gelenkgrube bildet; da sein Vorderende durch Knorpel mit dem absteigenden Vorderteil des lleum zusanmenstößt, 
so wird das Pubis völlig von der Bildung der Gelenkgrube ausgeschlossen. Das Acetabulum selbst ist von einem ansehnlichen Loch durchsetzt. Dieser Ausschluß der Pubis vom Acetabulum scheint sich erst allmählich in der Krokodilreihe entwickelt za haben, da bei älteren fossilen Formen (Pseudosuchia) die Pubis noch Anteil an der Pfanne nehmen sollen. - Die Schambeine siud schmale, schief nach vorn absteigende, distal sich plattenförmig verbreiternde Knochen (Fig. 225 B), die keine eigentliche Symphyse bilden, sondern in eine häutig-knorpelige Platte übergehen, an die sich vorn die hinterste Bauchrippe anschließt. Die Foramina puboischiadica

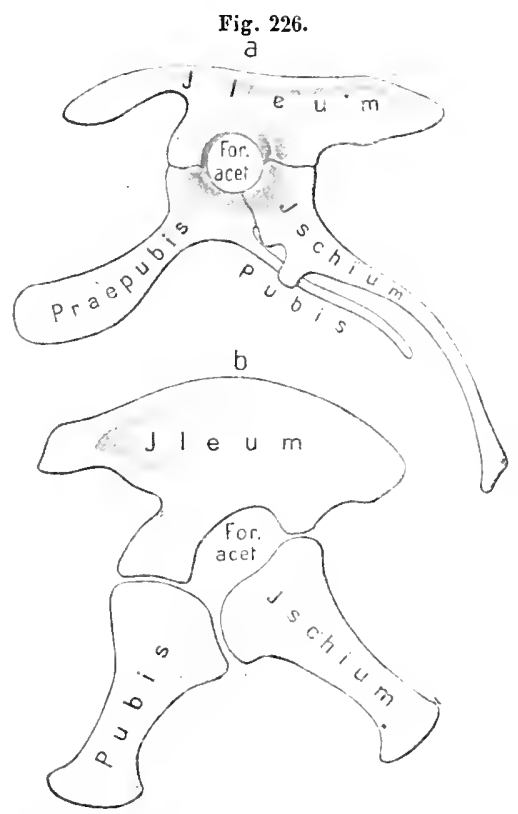

Dinosaurierbecken von links. $a$ I guanodon bernissartii (nach Dollo 1885). bBrontosanras excelsus (nacn Maksi; aus Zrtels Handbuch). sind demnach zu einer großen Öffnung zusammengeflossen. Irgendwelche besondere Fortsatzbildnngen zeigen dio Pabis nicht, ebensowenig findet sich ein Epipubis und ein Hypoischium.

Unter den ausgestorbenen Reptiliengruppen verraten gewisse Dinosauria (Sanropoda, Theropoda, Ceratopsia) nähere Beziehungen zu den Crocodilia. Alle Dinosauria aber stimmen im Besitz des Acetàbularloches mit den Krokodilen überein. Das Becken der ersteruähnten Dinosaurier (Fig. 226b) gleicht dem der Krokodile sebr, namentlich auch in der Beschaffenheit der Pubis, die jedoch, ähnlich wie bei den Sauriern, Anteil an der Gelenkgrube nehmen. Ihr Distalende ist mehr oder weniger verbreitert und tritt mit dem der Gegenseite zu einer Symphyse zusammen, welche jedoch nicht sehr innig zu sein scheint. Präpubisfortsätze finden sich nicht. Die Darmbeine aller Dinosaurier sind zwar im allgemeinen von krokodilartigem Typus, aber an ihrem Sacralrand mehr oder weniger stark nach rorn und hinten ausgewachsen, da sich die Zahl der Sacralwirbel sehr vermehrt hat (s. vorn S. 212), weshalb

die Darmbeine zum Teil ganz vogelartig wurden. - Bei den Stegosauria und Ornithopoda (Fig. 226a) trat diese vogelartige Verlängerung der Darmbeine besonders hervor, und die Bildung der Ventralknochen wurde ebenfalls der der Vögel ähnlich. Die Sitzbeine wurden wie bei den Vögeln länger und schlanker, und am Hinterrand des Acetabularteils des Pubis entwickelte sich ein langer schlanker Fortsatz (sog. Postpubis Marsh), der schief nach hinten, parallel dem Ischium herabstieg, ja sogar dem letzteren direkt anliegen konnte. Diese sog. Postpubis bilden eine Symphyse, die vorderen Schambeinäste (Präpubis) dagegen nicht. Der vogelartige Charakter dieser Beckenbildung ist so auffallend, daß trotz zahlreicher Einwendungen kaum bezweifelt werden kann, daß er einem wirklichen genetischen Zusammenhang entsprang. Wenn wir dies festhalten und beachtelı, daß das Pubis der Vögel aus einer embryonal saurierartigen Stellung allmählich die dem Ischium parallele, schief nach hinten gerichtete annimmt, so läßt sich kanm bezweifeln, $\mathrm{da} B$ auch das sog. Postpabis der Ornithopoda usw. dem eigentlichen Pubis der Vügel, der Saurier und Chelonier entspricht; daß hingegen der nach vorn gerichtete Ast, der ja auch keine Symphyse billet, den sog. Präpubisfortsatz der Saurier und Chelonier repräsentiert. Wenn dies für richtig erachtet wird, so müßte sich auch die Auffassung des Sauro- 
podenbeckens wohl wesentlich ändern, indem uns dies nun kaum mehr primitiver als das der Ornithopoda erscheint, soudern wahrscheinlich durch die Verkümmerung des eigentlichen Pubisastes und die starke Entfaltung des Präpubisfortsatzes aus dem ersteren hervorgegangen. Diese Konsequenz müßte jedoch weiterhin auch dazu führen, das eigentümliche Pubis der Krokodile in entsprechender Weise aufzufassen und es nur als den Präpubisast samt dem Basalteil des primitiven Reptilienpubis zu deuten.

Eine andere Meinung will jedoch umgekehrt in dem hinteren Pubisast der Ornithopoda den Präpubisfortsatz erkennen.

Aves. Eben wurde der Übereinstimmungen gedacht, welche die Beckenbildung zahlreicher Dinosaurier mit der der Vögel besitzt. Wie bemerkt, neigen wir, im Gegensatz zu vielen anderen, der Ausicht zu, daß diese Ähnlichkeit anf wirklicher Verwandtschaft beruht, wenn anch wohl Konvergenz einzelnes weiter annäherte. Bei den Vögeln, deren Bewegungen auf festem Grund noch muhr als bei vielen Dinosauriern auf die Hinterextremitäten beschränkt wurde, erfuhr das Becken, im Zusammenhang damit, tiefgehende Umformungen, welche, bei den Dinosauriern schon angebahnt, einerseits eine mächtige Entfaltung der Darmbeine und ihre ausgedehnte Befestigung an der Wirbelsäule bewirkten, andrerseits eine Verschmächtigung der ventralen Beckenknochen, sowie deren seitliches Auseinanderweichen und gewissermaßen ihre Anfügung an die postacetabulare Region der Darmbeine. Die Umbildung des Vogelbeckens scheint offenbar dahin gerichtet, es in eine mächtige einheitliche, der Wirbelsäule fest verbundene Platte umzuformen.

Schon bei der Schilderung des wirbelreichen Vogel-Sacrnms wurde auf die ansehnliche Ausdehnung der Darmbeine nach vorn bis in die hintere Brustregion, nach hinten bis über einen ansehnlichen Teil der vorderen Schwanzregion, hingewiesen. Die Darmbeine (Fig. 227) wurden so zu langen, etwas schief dachartig nach der Mittelebene aufsteigenden, dem langen Sacrum angelagerten Platten. Ihre vorderste Partie stößt sogar gewöhnlich über den vordersten Sacralwirbeln, in einer Firste verwachsend, zusammen, während die darauf folgende sich mit den Enden der Querfortsätze der Sacralwirbel verbindet, meist gleichfalls mit ihnen verwachsend. Anch wird der Zwischenraum zwischen den Dorsalrändern der Darmbeine hänfig durch sekundäre Verknöcherung ausgefüllt. Nahe der mittleren Region entsendet der seitliche untere Rand des lleums einen post- und einen präacetabulären Fortsatz zur Umrandung des gewöhulich sehr weiten Acetabularlochs (Fig. 227a). Mit dem kürzeren postacetabulären Fortsatz verbinden sich innen die beiden primitiven Sacralwirbelfortsätze (vgl. oben bei Sacrum), so daB in dieser Region anch der primitive Anteil der Darmbeine zu suchen ist.

Dem postacetabulären Fortsatz des Ileums schließt sich das Ischium, dem präacetabularen das Pubis an, von welchen das letztere nur geringen Anteil an der Bildung des Acetabnlums nimmt. - Ischium und Pubis sind zu langen schmalen, nach hinten ziehenden Knochenplatten geworden, von welchen sich das etwas breitere Sitzbein in der Regel, parallel dem postacetabularen Seitenrand des Ileums hinziehend, so weit wie dieses nach hinten erstreckt, während das schmälere Pubis, dicht neben dem Sitzbein nach hinten verlaufend, meist beträchtlich länger wird als das letztere und daher hinten frei vorspringt. Beide Ventralknochenpare 
steben daher geworhnlich in der Querrichtung weit voneinander ab, ohne Symphysenbildung ihrer Distalenden; der Ventralteil des Beckens ist aiso weit geöffnet. Die Verwachsung der dreiBeckenknochen in der Acetabularregion tritt meist sehr frih zeitig ein.

Während bei den Ratiten, deren Becken überhanpt mancherlei primitive Charaktere bewahrt, die Caudalenden der Sitzbeine gewöhnlich ticht mit dem hinteren Seitenrand des Ileums verwachsen (Ausnahmen Dromaeus und Rhea), tritt

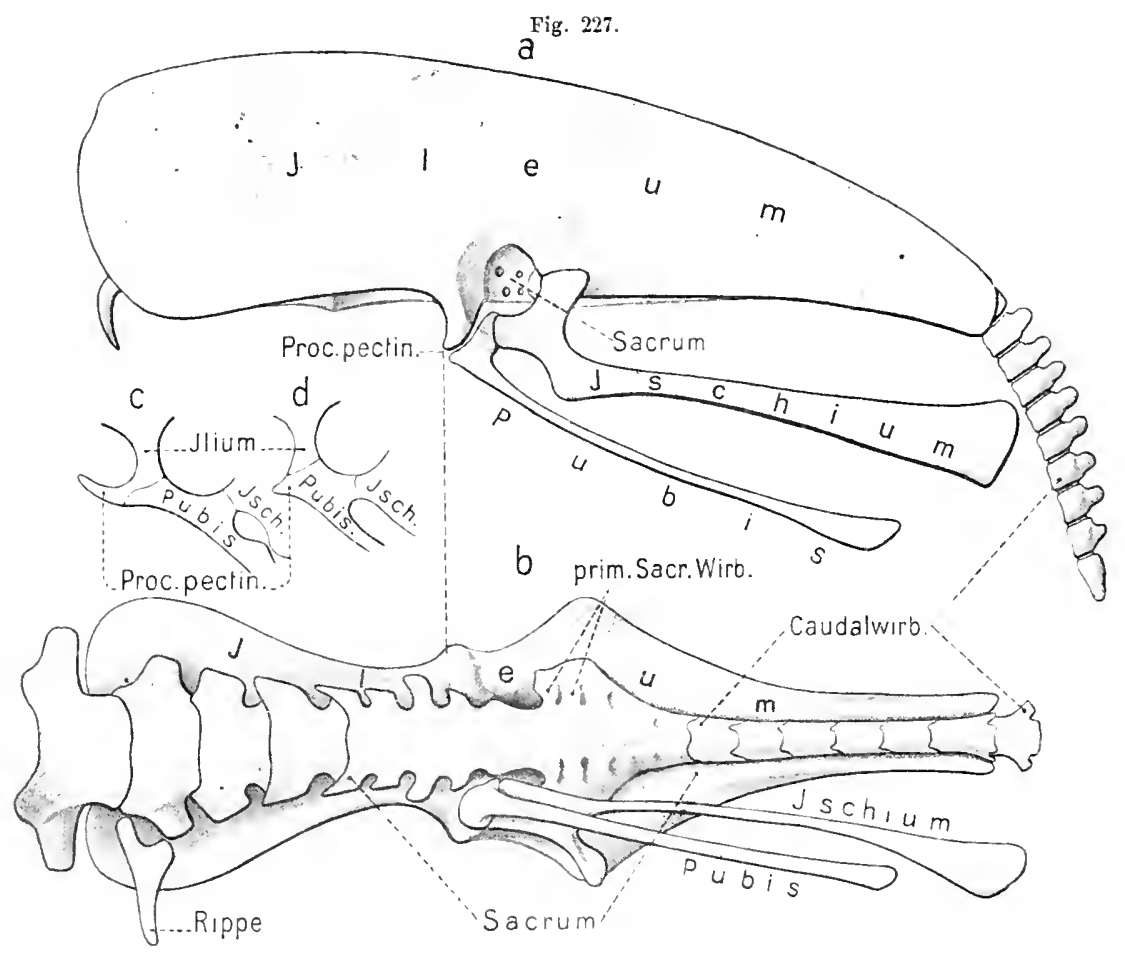

$a-b$ Becken von jüngerem Cas a a ri us mit Sacrum und Schwanzwirbelsāule. $a$ Von links. $b$ Von der Ventralseite. $c$ Processog pectinatus mit Znsammenstofungsstellen von Ileum, Pubis und lschium von Struthio. $d$ Ebenso ron Apteryx. P. He.

dies fast bei allen Carinaten mehr oder weniger ausgedehnt auf, mit Bildung eines Foramen ilio-isehiadicum. Das Ischium der Ratiten entsendet meist dicht hinter der Gelenkgrube einen absteigenden Fortsatz, der mit dem Pubis verwachsen kann; ein Verhalten, das schon bei gewissen Ornithopoden unter den Dinosauriern sich fand (s. Fig. 226, S. 360). Bei einzelnen Ratiten (Struthio, Dromaens) sehickt jedoch auch das Hinterende des Sitzbeins einen zum Pubis absteigenden Fortsatz herab, der mit letzterem verwachsen kann, eine Bildung, die sich bei zahlreichen Carinaten wiederholt und sogar zur Verkümmerung der Mitteiregion des hänfig sehr reduzierten Pubis führt (Raubvögel). Bei sehr siarker Verlängerung der Sehambeine (z. B. Raubvögel) können sich ihre Distalenden nahezu beriuhren, 
boi Struthio sogar eine Symphyse bilden, die aber wohl zweifellos sekundärer Entstehung ist. Rhea dagegen zeigt seltsamerweise eine Symphyse der mittleren Region der Sitzbeine unterhalb der Wirbelsäule.

In der Gegend, wo sich der prïacetabulare Fortsatz des lleum mit dem Pubis vereinigt, entspringt bei manchen Vögeln vom vorderen Beckenrand ein mäßiger, selten etwas ansehnlicherer Fortsatz nach vorn (Processus pectinatus, Spina iliaca), der, wie die Ontogenese lehrt, bei den Carinaten sicher vom präacetabulären Fortsatz des Ileums, an der Grenze mit dem Pubis ausgeht. Bei den Ratiten, wo dieser Processus häufig (Struthio, s. Fig. 227c) ziemlich ansehnlich ist, beteiligen sich Pubis und Ileum an seiner Bildung, bald vorwiegend das erstere (Apteryx, Fig. $d$ ), bald das letztere (Struthio). Die Ähnlichkeit dieses Fortsatzes mit dem rom Acetabularande des Pubis entspringenden Präpubisfortsatz der Dinosaurier fällt soFig. 225. fort auf.

Trotz der gewöhnlich geleugneten Homologie beider Bildungen halten wir ihre Übereinstimmung für sehr wahrscheinlich. Da das Präpubis der Dinosaurier direkt an der Grenze des Pubis und Ileum entspringt, so ist eine Beteiligung des letzteren an seiner Billung (Katitae) leicht begreiflich; ebenso aber auch sein endlich völliger Übergang auf das Ileum. Es würde sich hier also um eine Art substitutioneller Homologie (SchmкEwтscu) handeln. Wir deuten daher auch den Processus pectinatus als das IIomologon des Präpubis der Reptilien.

Mammalia. Die Beckenbildung der Säuger bestätigt von neuem den weit zurückreichenden Ursprung dieser Klasse aus zwischen den Uramphibien und den Urreptilien stehenden Formen. Einen Hauptcharakter des Säugerbeckens bildet die Stellung der Darmbeine (s. Fig. 229, 230), die von ihrer Anheftungsstelle am

a.
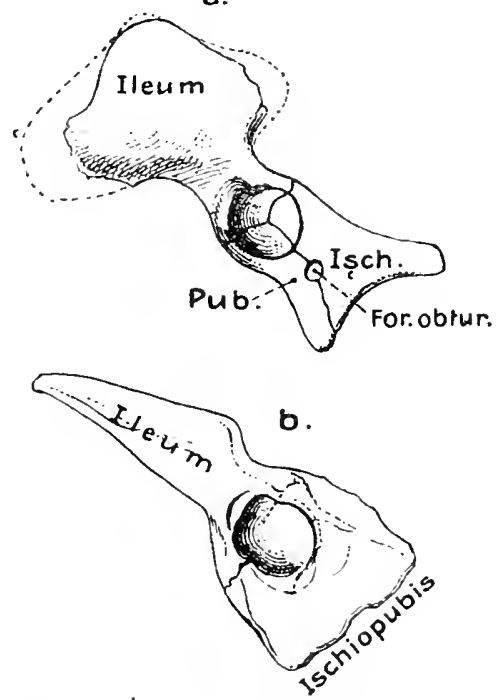

Becken yon theromorphen Reptilien von links. a Von Platypodosanrus robustus, b Vou Dicynodon tigriceps. (Nach SeELer 1889.) 0 . B.

Sacrum schief nach hinten und ventral ziehen (Descendenz), was wir schor bei den anuren Amphibien in hoher Ausprägung trafen. Andrerseits findet sich aber diese Richtung der Darmbeine auch bei den fossilen Anomodontin unter den Reptilien, deren Becken schon friiher als dem der Anuren ähnlich geschildert wurde, charakteristisch und sängerartig (Fig. 228). Dies scheint um so beachtenswerter, als diese Reptilien auch sonstige säugerähnliche Charaktere aufweisen. - Die beiden Ventralknochen des Säugerbeckens baben die durch das Ileum angedentete Lageveränderung ebenfalls erfahren, so daß das Ischium meist die Richtung des Darmbeins nach hinten direkt fortsetzt, während das Pubis anfänglich nahezu senkrecht absteigt, sich aber dann gleichfalls meist mehr oder weniger schief nach hinten richtet. Die Seitenansicht der ventralen Beckenhälfte der Säuger erinnert daher 
lebhaft an die der Anuren und Anomodontien, abgesehen von dem bei den Säugern stets gut entwickelten Foramen obturatnm (F. puboischiadicum), das nur bei einzelnen Anomodontien schwach vorhanden ist.

Aus diesen Verhältnissen folgt ferner, daß sich die Stellungsänderung des Säugerbeckens durch eine nach hinten gerichtete Drehung des Gesamtbeckens um seine Befestigungsstelle am Sacrum vollzogen haben muß, was sich auch leicht ergibt, wenn man z. B. ein Testudobecken in dieser Weise um etwa $90^{\circ}$ nach hinten dreht; es gleicht dann einem Säugerbecken sehr. Auch für die Beziehungen zum Vogelbecken, dessen Scham- und Sitzbeine ebenfalls schief nach hinten gerichtet sind, ist dies wichtig. Bei letzteren hat aber das primäre Ileum im allgemeinen seine reptilienartige Stellung bewahrt, und die Rückwärtsrichtung der Ventralknochen geschah selbständig, ohne Drehung der Darmbeine.

Fig. 229.

a

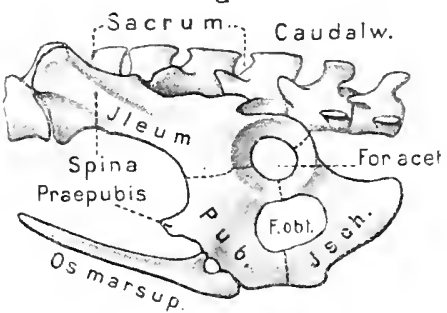

b

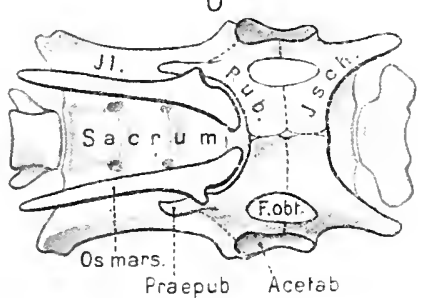

Echidna hystrix. Becken mit Sacrum und Vorderteil der Schwanzwirbelsäule. a Linkseitige Ansicht. $b$ Ventralansicht. Die nrsprunglichen Grenzen $z$ wischen den drei Beckenknochen punktiert.

Als weiterem Hauptcharakter des Säugerbeckens begegnen wir der steten Ausbildung zweier, von den Scham- und Sitzbeinen umrahmter For. obturatoria, welche durch die sich vereinigenden Symphysenäste dieser beiden Knochen voneinander geschieden werden. Den gleichen Charakter fanden wir unter den Reptilien nur bei einem Teil der Schildkröten; es sprach manches dafür, daß es sich anch bei letzteren um eine recht primitive Bildung handelt, die nicht ohne Beziehung zu den Urformen der Sänger war. - Sauropsidenartig erscheint ferner das bei Monotremen (Echidna, Fig. 229) noch auftretende Acetabularloch, das jedoch auch bei Amphibien vorkommt. - Die Verwachsung der drei Beckenknochen jeder Seite erfolgt meist frübzeitig (zum sog. Os innominatum, Oscoxae), während die beiden Beckenhälften gewöhnlich nnverwachsen bleiben.

Im besonderen bieten die Darmbeine eine ziemliche Mannigfaltigkeit ihrer Ansgestaltung. Ursprünglich sind sie ziemlich schmal und lang; auch erhalten sie sich bei den neogenen Säugern häufig noch so. Mit der Medianfläche seines Sacralendes heftet sich das Darmhein an die Qnerfortsätze der Sacralwirbel. Die Anheftungsfläche (Fossa od. Superficies auricularis) ist je nach Zahl unà Ausdehnnng der Sacralwirbel verschieden groß; doch springt das Sacralende des Darmbeins nicht selten nach vorn über die Anheftungsstelle frei vor (Fig. 230). Die Befestigung geschieht in der Regel etwas gelenkig durch Faserknorpel, seltener durch knöcherne Verwachsung (Ankylose). - Die Außenfläche des Ileums erhebt sich meist zu einer mehr oder weniger hohen Spina (Crista lateralis). Bei gewissen Säugern wächst diese Crista sehr stark ans, während sich gleichzeitig das Darmbein in der VornHintenrichtung (Dickenrichtung) sehr verschmälert(Fig. 231). Auf diese Weise wird 
es zu einer mehr oder weniger breiten Platte, die sich nahezu in der Horizontalebene des Sacrums nach außen erstreckt. Diese Umformung tritt in hohem Graüe namentlich bei Elephas, zahlreichen Edentaten, den neogenen A ffen und dem Menschen auf, im Znsammenhang mit den besonderen Musiolverhältnissen der Hinterextremität.

Das Acetabulum, an dessen Bildung sich bei den Mouotremen die drei Knochen ziemlich gleichmäßig beteiligen (Fig. 229), bẹsitzt bei sämtlichen ditremen Sängern àas Eigentümliche, daß sein Ventralrand durch einen Einschnitt (Incisura acetabuli, Fig. 230, 232) unterbrochen ist, eine Bildung, die wenigstens ursprünglich von einem starken Band (Ligam. teres) bedingt wird, das aus dem Grund des Acetabulums zur Nitte des Oberschenkelkopfes zieht.

Fig. 230.

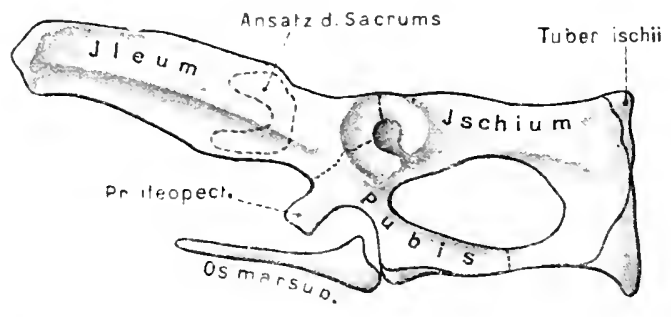

Halmaturus ruficollis. Becken ron links. Ansatzstelle der Sacralwirbel punktiert. Ursprüngliche Grenzen der Beckeakoochen an lleam panktiert. P. He.

Das Acetabulum ist in der Regel nach außen gerichtet, nur bei den Chiropteren stark dorsal. Es zeigt die Besonderheit, daß an seinem Aufbau meist ein besonderes viertes Skeletelement, das sog. Os acetabuli (Os condyloideum), teilnimmt (s. Fig. 2336). Dies tritt

Fig. 231.
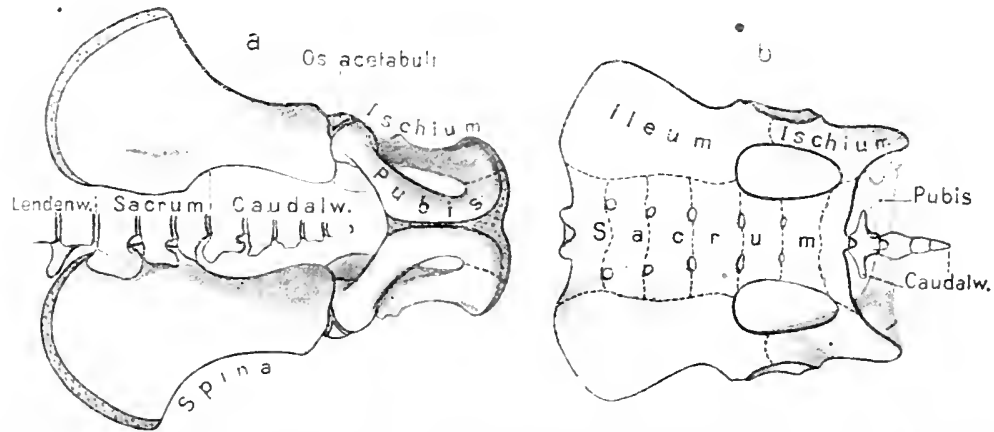

" Becken ron Simia satyrus (Orang, jung) mit Wirbelsănle, von der Fentralseite. Von der Wirbolsãule nur die rechte llälfte gezeichnet, um das linke lleum frei darzastellon. Knorpel donkel punktiert. $b$ Becken von Choloepus hof fmani, ron der Lorsalseite.

P. He.

relativ spät in-dem Pfannen'unorpel zwischen den drei Beckenknohen auf; meist zwischen dem vorderen Acetabularfortsatz des Ileum und dem Pubis, seltener in Pfannengrund. Es erstreckt sich bei starker Ausbildung bis zur Medianfläche des Acetabuluns. Es kann kalkigknorpelig oder knöchern sein. Früher oder später verschmilzt es mit einem der drej anstoßenden Beckenknochen, meist mit dem Ischium oder Heum. In beiden Fällen kann hicrdurch der Ausschlnß des Pubis rom Acetabulum herorgerufen verden, was bei nicht wenigen Säugern rorkommt (s. Fig. 232). Dab dus Os aretnbuli cin wirhlich selbständiges Element des Säugerbeckens und nicht nur eine. Epiphysenbilulung: oder eine Art Schaltknöchelchen darstellt, scheint vorerst wicht sicher eutscheidbar; noch weniger aber seine etwaige Homologisierung mit knorpeligen Teilen des Peckens paliogener Wirbeltiere. 
Bei paläogenen Säugern (Monotremata, Marsupialia, Ungulata, Carnivora meist, Insectivoren und Rodentia vereinzelt) dennt sich die Beckensymphyse auf Scham- und Sitzbeine gleichmäßig aus, ist daher ansehnlich lang. Bei den neo-

Fig. 232.
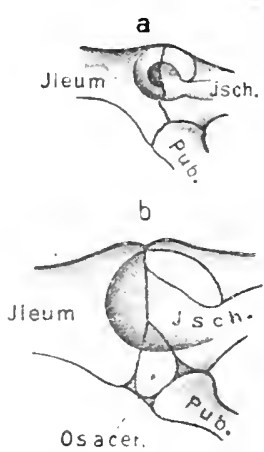

Acetabularregion der linken Beckenhālfte von außen (nach Leche 1884). a ron $L$ e $p$ us cuniculus. $b$ von Viverra ciretta. P. He. genen scheidet das Sitzbein allmählich aus der Symphyse aus (Fig. 231 $a$ ), und auch die der Pubis verkürzt sich von hinten fortschreitend immer mehr, womit im allgemeinen auch eine immer schiefere Richtung der Schambeine nach hinten verbunden ist. Die Mehrzahl der Insectivoren und Chiropteren geht hierin noch weiter (s. Fig. 233), indem die langen Schambeine fast parallel, oder sogar mehr oder weniger divergierend nach hinten ziehen, so daß ihre Distalenden voneinander abstehen und nur durch eine quere Knorpelspange (Epiphysenknorpel) verbunden sind. Bei manchen Insectivoren (z. B. Talpa) kann dieser Knolpel auch durch Ligament ersetzt sein, oder sogar jede Verbindıng der Schambeine aufhören, also eine Beckensymphyse völlig fehlen (Fig. 233b). Indem bei einzelnen Chiroptera und gewissen Edentata (auch Marsupialia zum Teil) in dem Symphysenknorpel des Pubis eine nnpaare, selter paare Verknöcherung oder Verkalkung (Os interpubicum) auftritt, bilden sich Zustände ähnlich dem sog. Epipubis der Saurier und Chelonier.

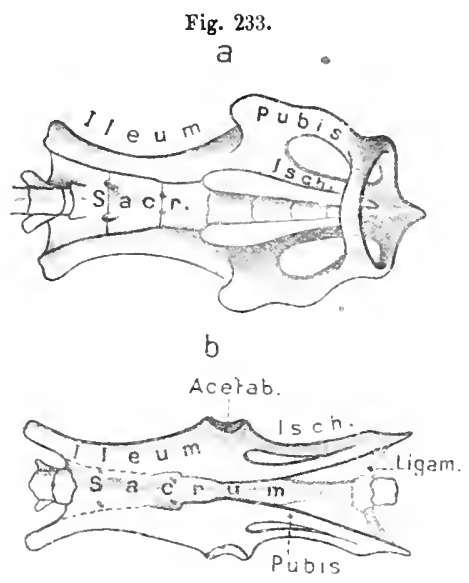

a Becken von Pteropus edulis mit Wirbelsănle. Ventralansicht. $b$ Von Talpa enropsea. Ventralansicht. (b nach LeCHE 1883.)

Von Interesse erscheinen wiederum Fortsatzbildungen (Processus oder Tuber) am vorderen Rand des Pubis, Bei den Monotremen (Fig. 229, S. 364) bildet es etwas ventral vom Acetabulum einen starken Fortsatz (Proc. iliopectineus), der wohl sicher dem Präpubis der Reptilien entspricht. Dieser Fortsatz kehrt auch bei den neogenen Säugern vielfach wieder und ist bei Marsupialiern (Fig. 230), Chiropteren (Fig. 233a) und gewissen Edentaten recht ansehnlich. Während er, wie gesagt, meist rom Pubis allein gebildet wird, nimmt bei den Edentaten auch das Darmbein an ihm teil, ja bildet ihn sogar meist allein. Es finden sich also ganz ähnliche Verhältnisse wie bei den Vögeln nnd bestätigen das dort über den homologen Processus Bemerkte. Ein sog. Processus pubicus ist an der Umbiegungsstelle des absteigenden Schambeinastes in den Symphỵsenast häufig mäßig entwickelt.

Das Ischium ist in der Regel etwas stärker als das Schambein. Vom Acetabulum aus zieht es zunächst schief absteigend bis parallel der Wirbelsäule nach hinten, nm dann scharf in den absteigenden Ast (Symphysenast) überzugehen, der bei den paläogenen Säugern mit seinem Partner in der Sitzbeinsymphyse zusammenstrßt. Hinten fügt sich letzterer zuweilen eine Epiphysenbildung an, die dem Hypoischium oder sog. Os cloacae der Saurier sehr gleicht (s. Fig. 230). Die 
Umbiegungsstelle ist stets durch einen schwachen bis recht starken Processus (oder Tuber) ischii (Sitzhöcker) ausgezeichnet, der schon bei manchen Reptilien entwickelt sein kann (s. Fig. 230). Bei mangelnder Sitzbeinsymphyse wird der absteigende Ast häufig verkürzt. - In gewissen Fällen trägt auch das Sitzhein zur ausgiebigeren Befestignng des Beckens an der Wirbelsäule hei. So verlängern sich bei den meisten Edentaten (Fig. 231b) die Querfortsätze einer Anzahl der hinteren sog. pseudosacralen Wirbel, welche sich mit den beiden primären Sacralwirbeln vereinigt haben, so stark, daß sie schließlich mit der hinteren Region des Acetabularasts des Ischiums verwachsen, woran sich jedoch auch die Verknöcherung des Ligaments beteiligt, welches das Sitzbein mit diesen Wirbeln verbindet. Anç bei Chiropteren tritt zuweilen eime äbnliche Befestignng der Sitzbeine an Schwanzwirbeln ein, oder auch das Eigentümliche, daß die Acetabularäste der Sitzbeine konvergieren und an ihrer Umbiegungsstelle in den Symphysenast eine sekundäre Verwachsung eingehen, die sich ihrerseits mit der Schwanzwirbelsäule verbinden kann (s. Fig. $233 a$ ).

Obgleich sich das Becken des Menseken dem der Anthropoiden (besonders Gorilla) direkt anschließt, erfuhr es doch durch den aufrechten Gang wesentliche Ungestaltungen, die sich z. T. noch in der ontogenetischen Entwicklung rerfolgen lassen. Es rerkürzte sich in der Vorn-hinten Richtung beträchtlich, so daß die größte Beckenbreite zwischen den Darmbeinen die Länge übertrifft; seine Stelìng zur Wirbelsäule wurde viel querer, wenn es auch noch etwas nach hinten (unten) und ventral geneigt ist. Dementsprechend wurde die Schambeinsymphyse relativ sehr kurz. Die Darmbeine sind sehr writ; beim Mann ventral ziemlich konkav, beim Weib dagegen sehr flach. Ülerhaupt sind die sexnellen Unterschiede im Becken des Menschen ansgeprägter als bei dẹn übrigen Säugern.

Beutelknoshen. Dem Vorderrand jedes Pubis der Aplacentalier fugt sich ein sog. Bentelknochen (Os marsupiale) an. Bei den Monotremen (Fig. 229) ist er etwa schief dreieckig gestaltet, mit seiner Basis vom Processus pubicus bis zur Symphyse reichend. Die Bentelknochen der Marsupialier (Fig. 230) werden meist schmäler, ja verkümmern sogar zuweilen mehr oder w̦eniger (bei Thylacinus bleiben sie knorpelig). Sie treten bei beiden Geschlechtern in glcicher Entfaltung auf, haben daher keine direkte Beziehung zum Marsupium der Weibchen. Da sie ontogenetisch ans der knorpeligen Pubisanlage, d. b. dem Symphysenknorpel, hervorgehen, so ist ihre Deutung als Sehnenverknöcherungen gewisser Bauchmuskeln wenig wahrscheinlich. Gewöhnlich werden sie daher jetzt mit dem sog. Epipubis der niederen Wirbeltiere, speziell der urodelen Amphibien, homologisiert. Zu beachten dürfte jedoch sein, daß das, was bei Reptilien (Chelonia, Sanria) als Epipubis gedeutet wird, viel mehr dem oben erwähnten Os interpubicum gleicht, welches bei Marsupialiern neben den Beutelknochen auftritt. Die Ossa marsupialia könnten daher wobl nur den Gabelästen des Epipubis der Urodelen entsprechen, eventuell anch den beiden Symphysenknochen der Chamäleonten.

Bei den Placentaliern wurden sichere Reste der Bentelknochen bis jetzt nicht nachgewiesen.

Mit der Rückbildung der hinteren Extremitäten bei den Sirenen und Cetaceen trat stets eine weitgehende Verkümmerung des Beckens ein, ähnlich wie bei den fußlosen Sauriem. 
Vollständiger Verlust findet sich jedoch nur sehr selten bei Cetaceen (Platanista). Bei beiden Ordnungen besteht das Beckenrudiment jeder Seite aus einem einzigen, der Muskulatur eingelagerten Knochen, der bei den Sirenell durch Ligament mit dem Querfortsatz eines Wirbels (Kreuzwirbel) verbunden ist. Da er bei der Sirene Halicore aus zwei ursprünglichen Verknöche-

Fig. 234.

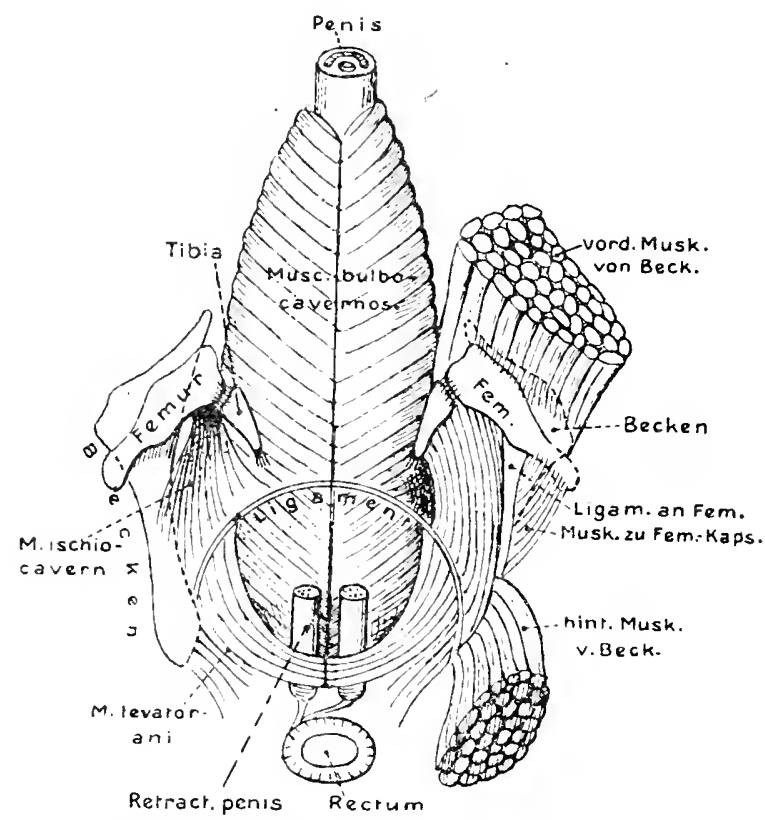

Balaena mysticetus $\overrightarrow{0}$. Ventralansicht der Rudimente des Skelets der Hinterextremitäten mit den IIuskeln. Die Skeletteile der rechten Extremităt bloßgelegt (links). (Nach Strutrkes 1850.) O. B. rungen hervorgeben soll, so ist wahrscheinlich, daß er zwei Beckenelemente (Ileum und Ischium) vereinigt. Auch die fussilen Sirenen bestätigen dies. Die älteste Form (Eotherium, unteres Mittelmiocän) besaß noch ein rollständiges Becken mit Pubis und For. obturatum. Bei den jüngeren wurden Pubis und Acetabulum rudimentär, bis ersteres bei den rezenten schließlich völlig schwand, letzteres höchstens in Spuren angedeutet ist. Bei Manatus ist jedoch auch das Ileum fast völlig eingegangen. Der Beckenknochen der Bartemale (Fig. 234) ist ein längsgerichteter, am Hinterende mit dem anderseitigen durch Ligament verbu dener Knochen, der zuweilen winkelig gebogen ist. Bci Erhaltung der Schenkelknochen kann er das Rudiment eines Acetabulums zeigen(Balaena).

Da sich sowohl die Penismuskeln als die Penisschwellkörper an die Knochen heften, was bei den übrigen Säugern an den Sitzbeinen geschieht, so entsprechen die Beckenrudimente der Cetaceen wohl hauptsächlich diesem Beckenteil. Mit dieser Bezielıung zu lem Begattungrsorgan hïngt denu auch wohl ihre Erhaltung, sowie die häufig stärkere Entwicklung bei den Männchen zusammen.

\section{Skelet der freien Extremitäten der Tetrapoden.}

Allgemeines.

Indem sich die Extremitäten der Tetrapoden zn Bewegungsorganen anf dem festen Boden entwickelten, die aber häıfig auch zum Schwimmen gebraucht werden, mußten sie einen eigenartigen Bau erlangen, welcher sich wohl sicher ans der Umbildung primitiver Flossenextremitäten fischartiger Vorfahren ableiten läßt. Dies bestätigt auch die Ontogenie, indem die tetrapoden Extremitäten zunächst als schwache, lappen- bis leistenartige einheitliche Auswüchse entstehen; ja bei den Amnioten hängen sogar beide Extremitätenanlagen jederseits urspriunglich noch durch eine sie verbindende Leiste zusammen. Ihrer nenen Aufgabe konnten die Extremititen nur dann genügen, wenn sie sich in einige, hebelartig gegenein- 
ander bewegliche Abschnitte gliederten, analog den Arthropodenextremitäten. Dies erfolgte bei beiden Gliedmaßen in ganz übereinstimmender (homonomer) Weise in drei sich entsprechende Abschnitte: Oberarm und Oberschenkel (Stylopodium), Unterarm und Unterschenkel (Zengopodium), Hand und Fuß (Autopodium), von welchen der letztere, oder distale Abschnitt selbst wieder eine untergeordnete sekundäre Gliederung erfuhr.

Diese Abschnitte sind in der Ruhestellung, also bei auf den Extremitäten ruhig stehenden Tieren, winkelig zueicander gestellt, und $\mathrm{zw}$ ar bei den paläogeuen

Fig. 235.

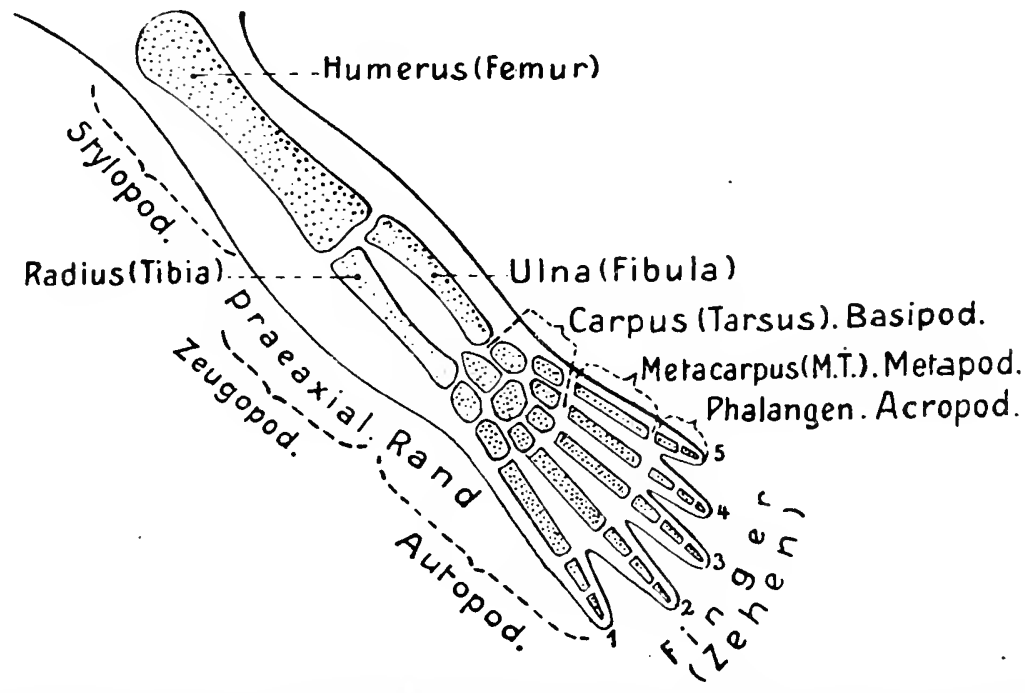

Schema des Skelets der linken Tetrapodenestremitāt von außen in der Lage nnd Haltung, welche etwa der der herabgeschlagenen Fischflosse entspricht. Die Bezeichnnngen der Skeletgebilde der Hinterextremität in Klammern.

Tetrapoden (Amphibien) im allgemeinen so, daß der proximale Abschnitt (Oberarm usw.) nahezu senkrecht zur Wirbelsäule horizontal nach außen gerichtet ist, der mittlere (Unterarm usw.) senkrecht abwärts, Hand und FuB schief nach auswärts und vorn. In jedem dieser Abschnitte wiederholen sich in beiden Extremitäten homonome typische Skeletgebilde, deren Anordnung und Bezeichnung aus der beifolgenden Figur 235 hervorgeht.

Dje Eigentümlichkeit, daß dem Zeugopodium zwei nebeneinander rerlaufende längsgerichtete Skeletstücke zukommen, hängt jedenfalls damit zusammen, daß dieser Abschnitt mannigfaltigere Bewegungen, namentlich auch in gewissem Maße Drehungen um die eigene Längsachse ausführen kann; ebenso wie der.Aufbau des Autopodiums aus sehr zablreichen Skeletstïcken durch die noch größere Mannigfaltigkeit seirler Bewegungen bedingt wird, was jedoch auch auf die parigen Elemente des Zeugopodiums nicht ohne Einfluß war.

Die Ontogenese scheint zu erweisen, daß die flossenartigen Anlagen der Extremitäten so gerichtet sind, wie etwas nach der Banchseite herabgeschlagene Fischflossen, an denen wir einen vorderen oder präaxialen und einen hinteren odex 
postaxialen Rand unterscheiden können (s. Fig. 235). Aus einer derartigen Flosse ließen sich die Extremitäten etwa so ableiten, daß sich in ihrer mittleren Region eine Einknickung bildete, zwischen dem zum Stylopodium werdenden proximalen Abschnitt und dem folgenden, dessen Endabschnitt sich als Autopodium nach außen und etwas nach vorn abknickte (Fig. 236b). Im Zusammenhang mit ihrer neuen Funktion mußte jedoch die Beweglichkeit der Extremität am Gürtel viel ansgiebiger: und mannigfaltiger werden, was sich im Gegensatz zu den Verhältnissen bei den Fischen darin ausspricht, daß diese Gelenkung überall zu einem Kugelgelenk mit einer Pfanne am Gürtel und einem Gelenkkopf am Humerus oder Femur wurde.

An der Vorderextremität erfolgte die Ellbogenknickung jedoch in etwas komplizierterer Weise, wie Fig. 236 a schematisch darzustellen sucht, indem der Ober-

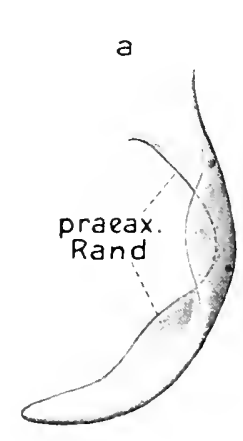

Fig. 236.

b

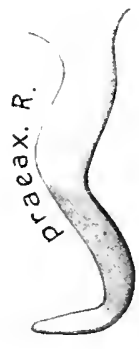

Schematische Darstellung der wahrseheinlichen Umformung der linken flossenartigen Extremitaten in die der Vorder(a) und Hinterextremitat $(b)$ der Tetrapoden. Ansicht links von außen. (Mit Benutzung von Braus 1906.) armabschnitt der flossenartigen Anlage in seinem Verlanf eine Torsion erfuhr, wodurch sein distaler postaxialer Rand nach außen, sein präaxialer nach innen geführt wurde. Diese Torsion prägt sich an dern Skeletstïck des Oberarms, dem Humerns, schon bei den Amphibien dentlich aus und bewirkt, daß sein distaler Gelenkteil sich in der Rnhestellung mit seiner Laingsausdehnung nahezu parallel der Wirbelsäule erstreckt. Der Unterarmabschnitt dagegen wurde nach vorn und abwärts eingebogen, ohne die Drehung des Oberarmteils mitzumachen; sein Präaxialrand mit dem zugehörigen Skeletelement (Radius) ist also nach vorn und etwas nach innen, der postaxiale (Ulna) nach hinten und etwas nach außen gerichtet. Die Handfiache setzt die Fläche des Unterarms fort. Die Bengebewegung zwischen Oberarm nnd Unterarm erfolgt in der Ruhestellung in einer zur Körpermittelebene nahezu senkrechten, etwas nach vorn gewendeten Ebene.

Die Hinterextremität hat jedenfalls schon frühzeitig bei den Vorfahreu der Tetrapoden eine Stellungsänderung erfahren, indem sie zum eigentlichen Vorschieber des Körpers wurde. Das Vorschieben des Körpers konnte nur so geschehen, daß die flossenartige Extremität eine schief-vorwärts gerichtete Stellung einnahm, und sich dabei mit dem Endabschnitt auf den Lntergrund stiitzte, worauf der proximale Teil der Extremität durch Muskel wirkung, bei auf der Unterlage festgestelltem Fuß, nach vorn geführt wurde. Diese Aktion der Hinterextremität bei der Vorwärtsbewegung mußte dazn führen, daß die Flosse allmählich auch in der Ruheiraltung dauernd in diese Stellung iiberging. Die Ausbildung eines Unterschenkelabschnitts erfolgte nun so (Fig. 236 b), daß sich die distale Hälfte einfach senkrecht abwärts nmbog und der Fußabschnitt als Fortsetzung des Unterschenkels nach außen und etwas nach vorn umknickte. Da der proximale Oberschenkelteil 
auch in der Ruhestellung schon etwas nach vorn gerichtet war, so erfolgt die Kniebeuge in einer nach innen und etwas nach hinten gerichteten Ebene. Eine Torsion des Oberschenkelteils bildete sich dabei nicht. - Es entwickelte sich also schon frühzeitig ein gewisser Antagonismus der Extremitäten, der sich hauptsächlich darin ausspricht, daß die Beugeebene (d. h. die Ebene, welche die Achse des Zeugopodiums bei der Beugung beschreibt) bei der nach vorn gestreckten Vorderextremität nach vorn und innen, bei der ebenso gerichteten Hinterextremität nach hinten und innen liegt, demnach anch der Ellbogenvorsprnng nach hinten, der Knievorsprung nach vorn schaut. - Die Hinterextremität wirkt als Vorwärtsbeweger des Körpers, indem sie aus der stark gebengten Stellung mit ziemlich weit hinten aufgesetztem Fuß in die Streckstellnng iibergeht, also durch ihre Streckmuskeln. Die Vorderextremität dagegen fördert die Vorwärtsbewegung, indem sie nach vorn gestreckt und die Hand weit vorn aufgesetzt wird, worauf der Oberarm durch Bengung, nach vorn geliihrt wird. Es ist ersichtlich, daß die Einrichtung der Hinterextremität für die Vorwärtsschiebung des Körpers viel ausgiebiger ist, als die der vorderen, welche den Körper vorwärts zieht, was bei einfachem Aufsetzen der Hand wenig wirksam sein kann. Der Antagonismus der beiden Extremitäten dürfte sich daher anch wohl von vornherein so entwickelt haben, daß der Hauptanteil der Vorwärtsbewegung der hinteren zukam, wahbrend die vordere in geringerem Maße dabei mitwirkte, vielmehr ihre besonderen Eigentiimlichkeiten gerade im Gegensatz zu der hinteren dadurch erlangte, daß sie gleichzeitig als ein Hemmapparat der Vorwärtsbewegung und auch als Organ für die Rückschiebung des Körpers eingerichtet wurde.

Bei den jüngeren Vertebraten, besonders den Säugern, steigerte sich die Stellungsdifferenz der beiden Extremuiden in der Ruhestellung noch mehr, indem Hand- und Fußabschnitt, und damit das Zengopodium, sich schärfer nach vorn richteten, sich also nach der Medianebene zu drehten. An der Hinterextremität geschah dies, indem gleichzeitig das Kniegelenk mehr nach vorn und gegen die Medianebene geführt wurde, so daß der Oberschenkel schief nach vorn absteigt und die Kniebeuge nach hinten schaut. An der Vorderextremität, deren Ellbogenbeuge von vornherein etwas nach vorn und innen schaute, wurde der Oberarm nach' hinten und gegen die Medianebene geführt, so da $B$ er nun schief nach hinten absteigt und die Ellbogenbenge ganz nach vorn schant (s. Fig. 245, S. 381). Die antagonistische Stellung der beiden Extremitäten kam so bei den Mammaliern zu schärfster Ausprägung.

Hand- und Fußabschnitt zeigen die gemeinsame Eigentïmlichkeit, daß sie in freie Finger oder Zehen (Acropodium) strahlig auslaufen, deren reihenförmig angeordnete Skeletelemente (Phalangen) an die knorpeligen, gegliederten Strahlen der primitiven Fischflosse erinnern. Die typische Zahl dieser Zehenbildungen ist fünf, wobei die am Präaxial- oder Radialrand stehende als die erste bezeichnet wird. Es hat sich wenigstens bis jetzt nie hinreichend sicher erweisen lassen, daß unzweifelhafte primäre Zehen über diese Zahl vorkommen, obgleich hăufig eine ursprüngliche Siebenstrahligkeit des Tetrapoden-Acropodiums angenommen wird, 
d. h. neben dem ersten und fünften typischen Strahl noch je einer am prä- und postaxialen Rande (sog. Präpollex oder Prähallux in Vorder- und Hinterextremität und Postminimus). Um so häufiger dagegen findet sich Zehenreduktion, so daß die fast allgemeine Meinung besteht, daß die Mindernng der Zehenzahl unter fünf stets

- durch Reduktion hervorgerufen sei.

Nnr bei den urodelen Amphibien, besonders den Ichthyoden, bestehen wesentliche $Z$ weifel, ob die geringere Zahl (zwei bis vier) der Finger und Zehen durch Reduktion entstanden ist, oder ob sich darin eine progressive Entwicklung der fünf Finger ausspricht. Die letztere Meinung stützt sich wesentlich auf die Erfabrung, daß die Finger und Zeben der Orodelen successive in der Reihenfolge $1-5$ hervorwachsen. Bei den Anuren ist es dagegen der dritte Finger, der zuerst deutlich wird, und die der Amnioten entstehen sämtlich ziemljch gleichzeitig. Das vorliegende Problem muß daher einstweilen unentschieden bleiben, wenn mir auch die Reduktionshypothese mehr im Einklang mit der wabrscheinlichen phylogenetischen Herleitung der Tetrapodenextremität zu stehen scheint.

Die typischen (kanonischen), in beiden Extremitäten wiederkehrenden Skeletelemente wurden oben schon anfgezählt. Von ihnen finden sich die der beiden proximalen Abschnitte ganz regelmäßig, wenn auch in verschiedener Ausgestaltung, and die des Zengopodiums auch durch gelegentliche Verwachsung und Reduktion verändert. Am mannigfaltigsten gestalten sich Hand- und Fußskelet (Antopodium), was ja schon durch die häufige Reduktion von Zehen bedingt wird. Der Proximalteil (Basipodium) des Autopodiumskelets (s. Fig. 235, S. 369), die sog. Handwurzel (Carpus) und Fußwurzel(Tarsus) zeigt bei primärer Zehenzahl dennoch eine typische Zusammensetzung aus primär 9-10 (eventuell auch mehr) Skeletelementen, von welchen die drei proximalen eine Querreihe bilden; vom Präxialrand beginnend: das Radiale (Tibiale), Intermedium und Ulnare (Fibulare). Da sich das Intermedium bei ichthyoden Amphibien und auch ontogenetisch bei höheren Formen zwischen die Distalenden des Zeugopodiums erstrecken kainu, so wird es hänfig als ursprünglich za diesem gehörig gedeutet. Die Distalreihe der Wurzel wird von fünf Elementen gebildet, die sich im allgemeinen den Zehenstrahlen durch die Mittelhand- und Fußknochen (Metapodium, Metacarpalia oder Metatarsalia) eng anschließen und daher als Carpalia $(1-5)$ oder Tarsalia $(1-5)$ bezeichnet werden. Zwischen die proximale und distale Querreike des Basipodiums schieben sich schließlich 1-2 (in gewissen Fällen auch mehr) sog. Centralia. - Das Skelet der Finger und Zehen (Acropodium) wird von einer Reihe von Elementen (Phalangen) gebildet, die je nach deren Länge in verschiedener Zahl auftreten.

Teils durch Reduktion, teils durch Verwachsung ihrer Skeletelemente bieten der Carpus und der Tarsus die größte Mannigfaltigkeit, was so weit gehen kann, daß diese Abschnitte fast oder ganz schwinden.

Die typischen Skeletelemente der Tetrapodenextremität werden sämtlich knorpelig angelegt und sind daher, wenn verknöchernd, Ersatzknochen. Außer ihnen treten jedoch häufig im Bereich des Autopodiums, seltener, jedoch zuweilen recht konstant, auch im Bereich der proximalen Abscbnitte, accessorisçe Knöchelchen in mehr oder weniger reicher Entwicklung auf. Viele derselben lassen sich als Verknöcherungen in Sehnen oder Bändern deuten (sog. Sesambeine), obgleich die meisten 
knorpeliz angelegt werden. Die Frage über die Natur gewisser accessorischer Skeletelemente: d. b. ob sie als Reste ursprünglich typischer Elemente, also etwa besonderer Strahlen des Acropodiums anzusehen sind, oder als neu hinzutretende Elemente von acropodialer Natur, d. h. neue Strahlen, oder endiich als atypische accessorische Elemente, ist für die meisten unentschieden und soll für einige der wichtigeren später noch besprochen werden.

Die Versuche, das Skelet der tetrapoden Extremität aus dem Flossenskelet der Chondropterygier, Crossopterygier oder Dipnoer abzuleiten, sind trotz vieler Bemühungen bis jetzt zu keinem überzeugenden Ergebnis gelangt, da noch zu wenig tatsächliche Anhaltspunkte für die Entscheidung $z$ wischen den einzelnen sich bietenden Möglichkeiten vorliegen. Die strahlige Anordnung der Phalangen der Finger und Zehen, die sich durch die Metapodialelemente auch auf die distale Reihe der Elemente des Carpus und Tarsus verfolgen läßt, bietet immerhin eine gewisse Annäherung an die knorpeligen Flossenstrahlen paläogener Fische; doch wird ein solcher Zusammenhang auch geleugnet und die Zehen dann als primäre Erzeugnisse der Tetraporlenextremität aufgefaßt. Jedenfalls müßte die Ableitung an Zustände anknüpfen, wie sie in der Ceratodusflosse noch am reinsten erhalten sind, bzw. wohl an eine Urform, welche zwischen der Flosse der Chondropterygier, Crossopterygier und Difnoer vermittelte.

\section{Vorderextremität.}

Den primitiven Verhältnissen der Vorderextremität, wie sie in Vorstehendem kurz geschildert wurden, begegnen wir bei den Urodelen. Ihre Extremitäten bleiben schwach und kurz, ja sind sogar mehrfach rückgebildet, so die hinteren bei Siren, dagegen beide bei der ausgestorbenen Stegocephalengruppe der Aistopoda, welche wohl za den extremitätenlosen rezenten Gymnophionen Beziehungen hatte. Unter diesen Umständen überwiegt die Wahrscheinlichkeit, daß die auffalleud schwache Entwicklung der Extremitäten bei den meisten ichthyoden Urodelen, welche mit Verminderung der Fingerzahl bis auf drei (Protens) verbunden ist, auf Rückbildung, nicht etwa anf fortschreitende Entwicklung der Extremität in der Gruppe zurïckzuführen ist (doch zeigen Finger- und Zehenzahl, sowie die Wurzelelemente zuweilen Variationen). - Die Fingerzahl der übrigen rezenten Amphibien beträgt vier, wozu sich jedoch bei gewissen Anuren am Radialrand des Carpus 1-2 kleine accessorische Skeletelemente gesellen, die hänfig als Rudimente des ersten Fingers betrachtet werden. Da die Hand einiger alter Stegocephalen fünf Finger besaß (die meisten zwar nur vier), so spricht anch dies für die Entstehung der Vierfingerigkeit durch Reduktion. Die Carpuselemente der Urodelen oleiben häufig knorpelig.

Urodelen. Der mäßig lange Urodelenhumerus (Fig. 237), welcher in der Rahestellung ziemlich senkrecht zur Wirbelsäule und nahezu horizontal nach außen gerichtet ist, zeigt die oben erwähnte Torsion recht ansgeprägt, in deren Folge seine distale, verbreiterte Gelenkfäche nahezu horizoutal von vorn nach hinten zieht. Dicht unter dem proxinalen Gelenkkopf besitzt der Humerus auf seiner cranialwärts schauenden Seite ein starkes Tuberculum radialis (majus) zur Anheftung von Muskeln, die den Arm nach vorn ziehen; auf der entgegengesetzten (hinteren) Seite findet sich cin ähnliches schwächeres Tuberc. ulnaris (minus) zur Anheftung von 
Rïckziehmuskeln. - Von den beiden ziemlich gleich starken Unterarmknochen liegt in der Ruhestellung der Radius etwas nach vorn und innen, die Ulna außen und

Fig. 237.

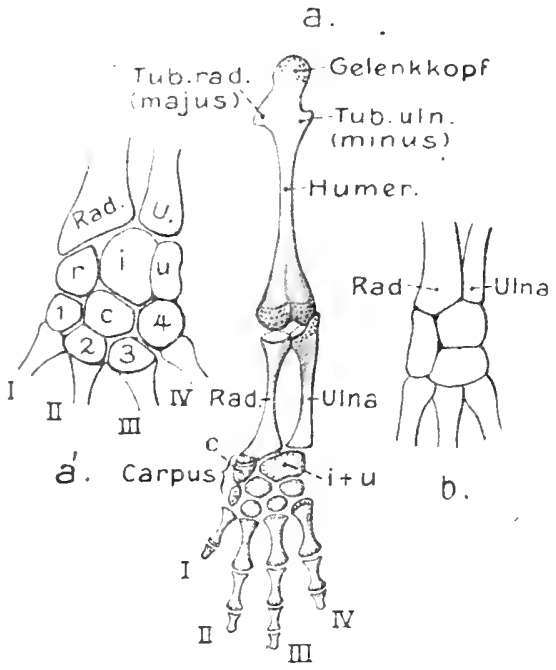

a Salamandra maculosa. a Linke Vorderextremität von außcn. $a^{\prime}$ Handwurzel jn gleicher Ansicht stärker vergrōßert. $b$ Halsdwurzel von Proteus in gleicher Ansicht (nach GEgesBaUr 1864). Hier und in den folgenden Figuren $R$ Radius, $U$ Ulna, $r$ Radiale, $i$ Intermedinm, $u$ Ulnare, $c$ Centrale. 1-5 Carpalia. $\begin{array}{ll}I-\gamma \text { Metacarpalia oder Finger. } & 0 . \mathrm{B} \text {. }\end{array}$ etwas nach hinten. Die Ebene, in der beide Knochen liegen, steht daher nahezu senkrecht zu dem distalen Humerusgelenk, das verbreitert und durch eine Einkerbung in zwei vorgewölbte Gelenkfacetten geteilt ist, von welchen die vordere dem Radius, die hintere der Ulna zur Gelenkung dient. Das proximale Ende der Ulna springt als sog. Olecranon über das Gelenk am Humerus empor, wodurch eine Hemmung bei der Streckung der Unterarmknochen gebildet wird.

Eine gewisse Beweglichkeit der Unterarmknochen gegeneinander und eine beschränkte Rotation des Vorderarms ist möglich.

Die Beurteilung des Carpus hängt in gewissem Grade von der der vier Finger ab. Die Frage, ob der erste oder fünfte Finger felılt, wird verschieden

beantwortet, doch scheint die größere Wahrscheinlichkeit für letzteres zu sprechen (ebenso anch bei den Anuren), und bei nur drei Fingern (Proteus, Amphiuma) fur

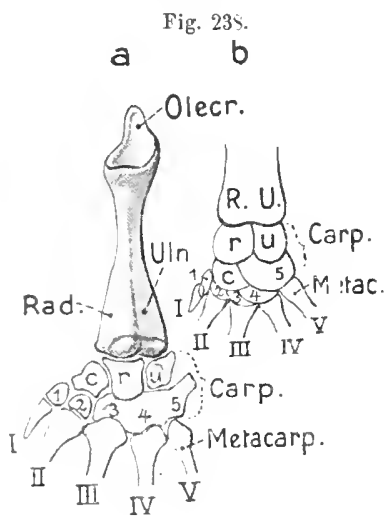

Carfus von Anura, a Rana esculenta. Unterarmknochen, Carpus und Metacarpus von auRen. $b$ Carpus ron Bom bin a tor in gleicher Ansicht nach Gegknbaur 1564). 0 . B. den Mangel von vier nnd fïnf. Der Carpus baut sich bei Gegenwart vou vier Fingern aus Radiale, Intermedium, Ulnare, einem Centrale, das jedoch auch durch zwei hintereinander gereihte Elemente vertreten sein kann (z. B. Cryptobranchus, Salamandrella), sowie den Carpalia 1-4 auf. Gewisse Stegocephalen (Eryops, Archegosaurus) besaßen drei Centralia, ein proximales und zwei distale. Verwachsung von U. und I. tritt häufig auf. - Im Carpus der dreifingerigen Extremität (Fig. 237b) finden sich meist nur drei Elemente (gelegentlich auch zwei), die sich eventuell als $R+C a^{I}, I+C$, und $C+C a^{I I}+C a^{I I}$ deuten ließen.

Anura. Die Vorderextremität der Anuren (Fig. 238) ist durch Verwachsung von Radius und Ulna gekennzeichnet. Ihr Carpus zeigt stark veränderte und bis jetzt schwer dentbare Verhältnisse, um so mehr als anch die Frage, ob die oben erwïhnten hänfigen accessorischen Radialelemente am Radial- 
rand als Finger I (wie es in der Figur geschehen) oder als accessorischer, überzähliger Finger (sog. Präpollex) aufgefaßt werden dürfen. - Fig. 238 zeigt den linken Carpus von Rana $(a)$ und Bombinator $(b)$ von vorn mit der Gegenbaurschen Deutung der Elemente. Die Verwachsung der Carpalia 3-5 (bzw. 2-4) findet sich sehr häufig.

Neuerdings wird nachzuweisen versucht, daß mit dem sog. Unnare ein Rest des Intermedium und das Pisiforme (Accessorinm) vereinigt sei; mit dem Radiale eines der drei wahrscheinlich ursprünglich vorhandenen Centralia, während ein zweites Centrale mit $\mathrm{Ca}_{4}$ verwachsen, das dritte dagegen, mit dem Element eines Präpollex und dem $\mathrm{Ca}$ v vereinigt, das sog. Centrale bilde (Scminumusen).

Die Phalangenzahl ist bei voller Ausbildung der vier Finger bei den Urodelen $2,2,3,2$; bei den Anuren gewöhnlich (1) 2, 2,3,2; bei Stegocephalen, soweit feststellbar, $2,2,3,3-4,2-3$.

Reptilia. Die Vorderextremität der Reptilien schließt sich in ihrer allgemeinen Konfiguration der der Urodelen nahe an. Wenn sie auch im ganzen etwas kräftiger entwickelt ist, so bleibt sie doch noch verbältnismäßig kurz. Die Stellung der Ober- und Unterarmknochen zueinander ist im wesentlichen die gleiche geblieben. Der stämmige, relativ kurze Humerus (s. Fig. 239) besitzt meist gut entwickelte Tubercula rad. und uln., zwischen welchen der gewöhnlich nicht kugelige, sondern mehr breite, rollenartige Gelenkkopf liegt, so da $B$ (namentlich bei den Cheloniern, Fig. 240) das ṕroximale Humerusende dreiteilig erscheint. - Besonderes Interesse bieten die Foramina, welche bei den lebenden Rhynchocephalen (Sphenodon), zahlreichen Sauriern und Cheloniern das Distalende des Humerus durchsetzen. Bei Sauriern, Cheloniern und Sphenodon findet sich am Vorderrand (Radialrand) des Humerns, etwas ïber dem Epicondylus radialis ein schief herabsteigendes sog. For. radiale oder ectepicondyloideum zum Durchtritt des Nervus radialis siehe Fig. 239 1, 240a, 242a). — Bei Sphenodon sowie fossilen Rynchocephalen tritt auch am Ulnarrand ein weiteres, ähuliches Loch auf (s. Fig. $242 a^{2}$ ), das For. ulnare oder entepiconlyloideum zum Durchtritt der Arteria brachialis und des Nervus medianus. Letzteres Foramen kam in sehr krïftiger Ausbildung auch den fossilen Theromorpha (Anomodontia und Theriodontia za, s. Fig. 242b). Da es sich auch bei den Säugern häufig findet, besitzt es besonderes pbylogenetisches Interesse. Auch bei den Nothosauridae, sowie gewissen Theromophoren sollen beide Kanäle gleichzeitig vorkommen. - Die Ulna ist stärker als der Radius und besitzt bei den Sauriern und Cheloniern in der Regel ein stark vorspringendes Olecranon. Bei den Krokodilen treten die Tubercula humeri und das Olecranon sehr zariick, wodurch die Unterarmknochen etwas beweglicher werden.

Der Carpus der Rhynchocephalen und Schildkröten (Fig. 240, 241) zeigt noch recht ursprüngliche Verbältnisşe durch die fast stete Erhaltung eines Centrale und Intermeट̉iums, sowie die gewöhnlich vorhandenen fünf Carpalia. Bei Sphenodon sowohl als einzelnen Schildkröten treten individucll und outogenetisch zwei Centralia auf; bei ersteren wurde embryonal sogar gelegentlich noch ein drittes beobachtet. Das radiale dieser beiden nebeneinander gelegenen Centralia verwiichst bei 
den Cheloniern wohl stets mit dem Radiale, mit dem sich auch noch ein radiales Accessorium (Radiale extern.) vereinigt, während bei Sphenodon die beiden ursprünglichen Centralia zu dem bleibenden zusammentreten. - Der Schildkrötencarpus kann sich jedoch vereinfachen durch nicht seltene Verwachsung von Radiale and Centrale (C. ulnare), sowie durch Verschmelzang von Carpalien (so $4+5$ oder $1+2)$.

Der Sauriercarpus (Fig. $239^{1}$ ) erscheint stets dadurch vereinfacht, daß das Intermedium, welches embryonal noch auftritt, den Erwachsenen meist fehlt, oder

Fig. 239.

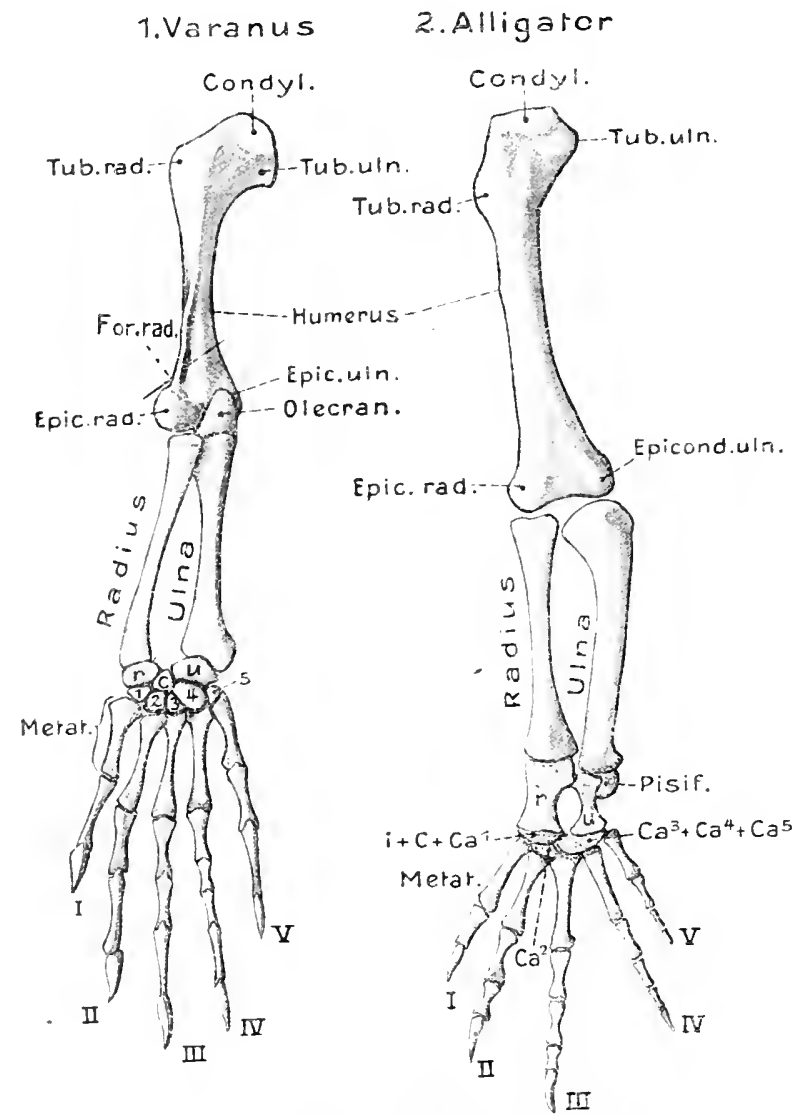

1. Varanus niloticus. Linke Vorderextremitāt von außen. von Alligatormississippiensis. doch nur rudimentär vorkommt. Das stets erhaltene Centrale schiebt sich dafür zwischen Radiale und Ulnare hinein. Spuren eines zweiten Centrale kommen selten vor. Bei Nichtverkïmmerung der Extremität sind die funf Carpalia vollständig erhalten, schließen sich jedoch zuweilen den Metacarpalia recht innig an. Die Krokodile (s. Fig. $239^{2}$ ) zeigen unter den rezenten Reptilien die stärkste Veränderung der Handwurzel, indem einmál in der proximalen Reihe nur zwei, jedoch sehr ansehnliche Knochen auftreten. Die Ontogenie scheint nachzuweisen, daß sie dem Ulnare und Radi-

2. Ebenso al (mit dem jedoch wohl das rudimentäre

Intermedium vereinigt ist) entsprechen. Von den beiden flachen Knochen der Distalreihe soll der ulnare aus den Carpalia 3-5 hervorgegangen sein, der radiale dagegen eine Verschmelzung dreier Elcmente darstellen, die als Intermedium (wallrscheinlicher Centrale ulnare), Centrale (radiale) und Carpale 1 gedeutet wurden; wogegen das Carpale 2 mit dem Metacarpus I verschmolzen sei. 
Sehr verbreitet tritt am ulnaren Rand des Reptiliencarpus ein Knöchelchen auf, das zu den früher erwähnten accessorischen Elementen gehört und bei den Mammalia als Pisiforme (Erbsenbein) bezeichnet wird. Es kann zuweilen (gewisse Chelonier, auch Krokodile, Fig. 239-241) recht ansehnlich werden und wird häufig als Element eines rudimentären postaxialen Fingers gedeutet.

Bei Nichtverkümmerung der Extremität beträgt die Phalangenzahl der Chelonia in der Regel 2, 3, 3(4),2(3); selten haben sämtliche Finger nur zwei Pha-

Fig. 241 .

Fig. 240.

a

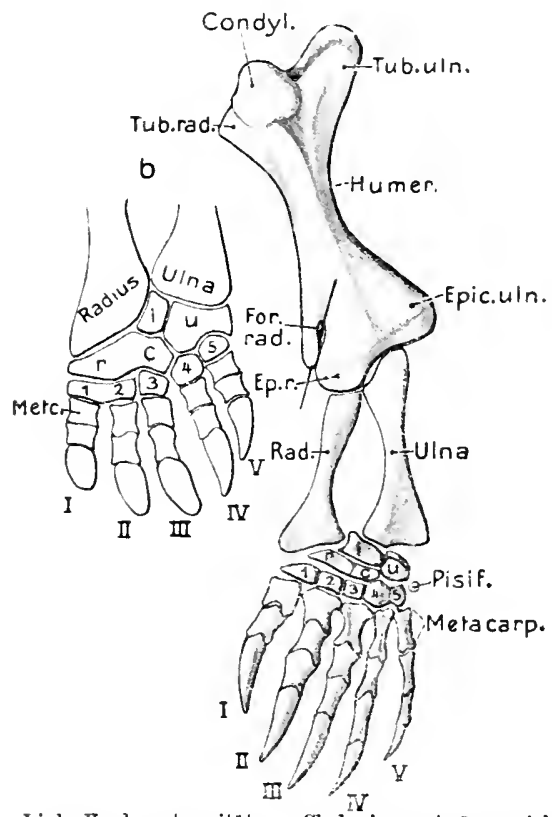

Linke Yorderestremität von Cheloniern. Anßenansicht. $a$ Von Chelydra serpentina. Darch das Foramen radiale (F. ectepicondyloidenm) eine Borste geführt. $b$ Hand ron Testado tabulata von anßen (wie vorn). c. H.

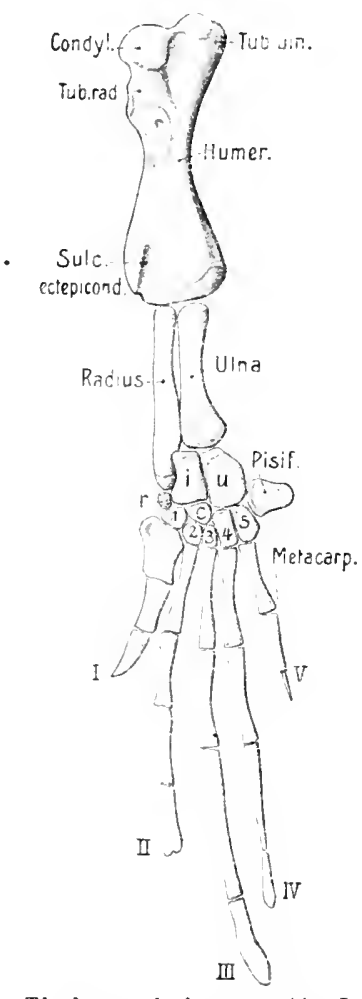

Thalassochelys caretta L. (corticata). Linke Vorderextremität ron anßen. C. H.

langen (Fig. 240b). Ähnlich verhalten sich im allgemeinen auch die Theromorpha. - Bei den Sauriern und Rynchocephalen steigt die Zaill auf 2, 3, 4, 5, 3; denen sich die Krokodile mit 2, 3, 4, 4, 3 anschließen, obgleich ihre IV. und V. Finger zuweilen ziemlich reduziert sind.

Besondere Umgestaltungen der Vorderextremitäten der Reptilien treten nach zwei Richtnngen auf. Bei den Seeschildkröten, ähnlich auch gewissen fossilen Meeressauriern (Mosasauridae) und -Krokodilen (Thalattosnchia), den Sauropterygiern und Ichthyosauriern bildete sich die Extremität wieder zu einer einfachen Rnderflosse zurück. Ausgehend von der Ruderhand, in welcher die Finger durch 
eine Schwimmhaut verbunden waren (Flußschildkröten), geschah dies so, daß die Reihen der Fingerphalangen wieder inniger nebeneinander iückten, ihre freie Be-

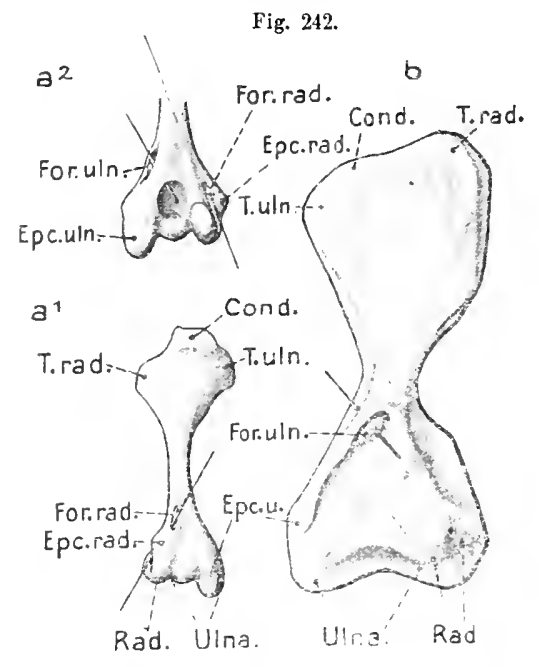

$a^{1}-a^{2}$ Linker Humerus von Sphanodon. $a^{1}$ von anßen, $a^{2}$ Distalende von innen (median). Dnreh die Foramina radiale und ulnare (entepicondyloideum) sind Borsten geführt. $b$ Humerus yon $\mathrm{Cy}$ odraco major (Theriodontia), von inren durch For. ulnare Borste gefuhrt (nach Owes 1876). P. He. n. C. H.

weglichkeit aufgaben und von der Haut gleichmäßig zu einem einheitlichen Ruder nmschlossen wurden. Oberarm und Unterarm verkiirzten sich dabei immer stärker und verloren endlich ihre Beweglicbkeit gegeneinander, so daß die Extremität wieder zu einer einfachen Ruderflosse wurde. Der von den Fingern gebildete Endabschnitt der Flosse verlängerte sich, was bei den Seeschildkröten (Fig. 241) durch starke Verlïngerung der Phalangen, bei den Sauropterygiern und namentlich den Ichthyosauriern durch. eine zum Teil ganz anffallende Vermehrung der Phalangenzabl der Finger hervorgerufen wird (bis iiber 20 , vgl. Figur 243). Dazu gesellte sich bei den zwei letzten Gruppen noch das Vorkommen einer Reihe accessorischer Knöchelchen am Ulnarrand des Carpus, oder neben

Fig. 243.

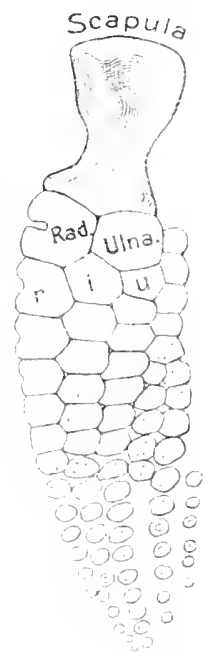

I chthyosaurus qadriscissug (comunis). Skelot der linken Vorderextremitāt von anßen. Der UmriB der Flosse nach E. FBaAs (1891) angegoben. $\mathrm{P}$. Ho. dem fünften Finger, Knöchelchen also, die in die Reibe des oben erwähnten Pisiforme fallen und daher häufig als ein accessorischer sechster Fingerstrahl gedeutet werden; dementsprechend auch das einfache Pisiforme häufig als Rest eines solchen sechsten Fingers. In der Flosse der Ichthyosaurier beobachtet man ferner zuweilen, wie sich ein bis mehrere Fingerstrahlen in ihrem Verlauf in zwei spalten, so daß gelegentlich bis zehn Endstrahlen beobachtet wurden. Diese Besonderheit ist jedenfalls eine Anomalie, nicht etwa eine Rückkehr zu primitiveren Verhältnissen.

Besonderes In eresse beansprucht die Umbildung der Vorderextremität zu einem Flugorgan bei den fossilen Pterosauriern. Der Arm war durch Auswachsen der beiden Unterarmknochen stark verlängert. Von den vier vorhandenen Fingern war der ulnare durch Auswachsen seiner vier Phalangen zu einem mächtigen Strahl verlängert, an dem sich die Flughant befestigte, die längs des Armes und der Körperseiten bis anf die Hinterextremitäten hinab- 
zog. Die drei übrigen Finger blicben kurz, frei und bekrallt. Der Carpus zeigte im Gegensatz zu dem der Vögel wenig Reduktion (sechs Elemente).

Aves. Der Vogelarm erfuhr bei seiner Entwicklung zum Fliigel tiefe Umgestaltungen, namentlich in der Hand, obgleich sich der reptilienartige Ban noch wohl erkennen läßt. Mit Ausnahme der Ratilen und gewisser Carinaten mit verkümmerten Flügeln, ist der Arm sebr verlängert, was sich anf seine drei Abschnitte erstrecken kann (Fig. 244). Meist sis Oberund Unterarm nahezu gleich lang; die Iland bleibt aber meist etwas kleiner als der Unterarm, oder wird ihm nahezu gleich; zuweilen crscheint sie aber auch excessiv verlängert. In der Ruhelage des Flügels (s. Fig. 115, S. 213) liegt der Humerus, schief nach hiuteu absteigend, dem Körper an, jedoch nicht so verdreht wie bei den Mammalia, daß seine Bengeseite nach vorn schaut, vielmehr ist dieselbe median gerichtet. Der Unterarm zieht längs des Oberarms wieder nach vorn, die Hand, in Abduktionsstellung \%, wieder längs letzterem nach hinten. Am ansgebreitcten Flügel ist der Oberarm naeh außen gerichtet, der Unterarm und die Hand sind ansgestreckt.

Das proximale Gelenkende des Humerus ist bei guter Entwicklung der Fliigel in der Regel stark verbreite' $t$, mit ansehnlichem radialen und nlnaren 'Tuberkel und starker Spina des ersteren, zuweilen auch des letzteren. Am Tuberculum ulnare findet sich auch das Loch für den Lufteintritt. - D Die Unterarmknochen sirud schlank; die Ulna meist bedeutend kräftiger als der Radius, unit wenig vorspringendem Olecranon. Sis zeigt auf ihrem Hinterrand häufig eine Reihe kuötchenartiger Erhebungen, hervorgerufen durch die Follikel der Armschwungfedern.

Wie bemerkt, wird die Hand meist lang bis sehr lang, ist jedoch stets vereinfacht, was sich vor allem in der Verminderung der Fingerzahl aussprieht, die schon bei dem illesten bekannten Vogel (Archaeo-

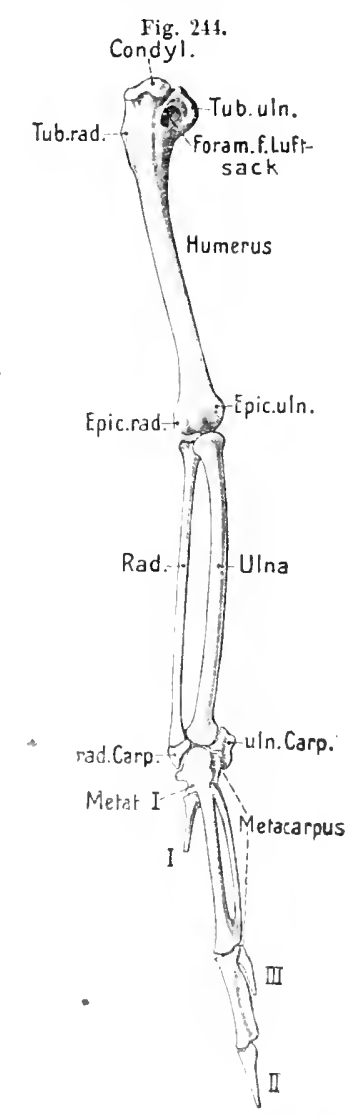

Anserdomesticus. Skelet der linken Vorderextremität ron außen. O. B. pteryx) anf drei herabgesunken war, ebenso wie bei den meisten rezenten Vögeln. Die Reduktion hat namentlich auch die Wurzel ergriffen, in der bei den lebenden und, soweit feststellbar, auch den fossilen Vögeln, nur zwei Knöchelchen auftreten. Jie Ontogenie erweist, daß sie der proximalen Reihe angehören, indem distal von

1) Unter Abduktion wird die bej den meisten Wirbeltieren sehr wenig entwickelte Bewegungsfähigkeit der Hand in der Handebene selbst gegen die Ulnarseite des Unterarms verstanden, wobei also der Finger $V$ gegen den äßBeren (bzw. hinteren) Ulnarrand bewegt wird. 
ihnen noch ein, oder $\mathrm{zwei}$ bis drei Skeletelemente angelegt werden, jedenfalls eine Anzahl Carpalia repräsentierend, die jedoch frühzeitig mit den Proximalenden der Metacarpalia verschmelzen. Die Deutung der beiden bleibenden Knochen der Proximalreihe ist wenig sicher; der radiale schiebt sich zwischen Radius und Metacarpus, berührt jedoch auch die Ulna nnd hat dadurch etwas Ähnlichkeit mit dem Radiale der Krokodile; der ulnare ist ganz an den Ulnarrand geschoben, so daß Ulna und Metacarpus sich direkt berühren (er fehlt bei Apteryx and Dromaens.) Die drei Finger werden in der Regel als I-III gedeutet und dementsprechend auch ihre Metacarpalia. Die knorpelige Anlage eines vierten nlnaren Metacarpale wurde bei gewissen Vögeln nachgewiesen, vereinigt sich jedoch frühzeitig mit dem dritten und verschwindet. Während die drei Metacarpalia bei Archaeopteryx noch völlig unvereinigt, und die drei Finger sämtlich gut bekrallt waren wenngleich der erste schon ziemlich verkleinert, sind bei den rezenten Vögeln die langen Metacarpalia II und III an ihren Enden verwachsen, und das sehr kurze Metacarpale I ist mit dem Proximalende des $z$ weiten verschmolzen; der Metacarpns ist also einheitlich geworden.

Der erste und dritte Finger sind fast stets sehr verkümmert und auf je eine Phalange reduziert, während der zweite recht lang ist und geworhnlich $z$ wei Phalangen besitzt (selten drei und der Daumen dann zwei); wogegan die drei Finger von Archaeopteryx noch zwei, drei und vier Phalangen aufwiesen, also reptilienartigere Verhältnisse bewahrten. - Bei Reduktion des Flügels, wie sie bei Pinguinen, wo er zu einer Art Flosse wird, und bei den Ratiten in verschiedenem Grad eintritt, wird auch die Hand vereinfacht. Den ersteren fehlt der Daumen, dagegen ist der dritte Finger abnorm lang; bei den Ratitae sind die Finger zum Teil auf zwei reduziert, seltener ist nur der zweite erhalten (Apteryx und Dromaeus).

Mammalia. Diø Vorderextremität der Säuger knüpft jedenfalls an recht niedere Zustände an, wie sie etwa von den Amphibien auf primitivere Reptilien (in dieser Hinsicht etwa chelonierähnlich) übertragen wurden. Diese verbältnismäßige Ursprünglichkeit der Säugerextremität spricht sich namentlich im Carpus ans, der bei den paläogenen Säugern noch die ursprünglichen neun Elemente aufweist, also ein Centrale enthält (embryonal zum Teil sogar zwei). - Schon oben (S. 371) wurde auf die Veränderung hingewiesen, welche die Vorderextremität in der Ruhestellung erfuhr. Bei dieser Stellungsänderung (s. Fig. 245) wurde der Humerus in seiner Pfanne so gedreht, daß er in der Ruhestellung schief ventralwärts und nach hinten herabsteigt, so daß der sog. Epicondylus uInaris (internus) seines Distalendes nun nach der Medianebene schaut. Durch diese Drehung hat der Humerus in der Ruhe dauernd eine Stellung angenommen, die er bei den Amphibien und Reptilien nur vorübergehend, im stark gebeugten Zustand der Extremität, in der Endstellung bei der Vorwärtsbewegung, einnahm. Die in der Ruhestellung der Amphibien dorsale Fläche des Humerus schaut nun nach hinten (caudalwärts), während das bei den ersteren längs gerichtete distale Gelenkende nun von innen nach außen zieht, also senkrecht zur Medianebene des Körpers. 
Dabei wurde die Hand noch mehr als bei den paliogenen Tetrapoden nach vorn gewendet, wobei der bei den ursprïnglicheren Formen vor der Ulua liegende Radius nummehr mit seinen Distalende anf dereu Inncnseite riicken mußte. Indem die Hand bei der geschilderten Stellungsveränderang des Humerus ihre nach vorn gerichtete Stellung auf dem Boden beibehielt, mußten auch die Distalenden von Radius und Ulna in ihrer oben erwähnten Stellung, das erstere innen, das letztere außen verharren, wogegen ihre Proximalenden durch die Drehung des distalen Humernsendes verschoben wurden, so daß das Proximalende des Ritius mit dem Epicondylus radialis humeri nach auBen, das der Ulna nach innen gefiihrt wurde (vgl, die Fig. 245). Die Folge hiervon ist, daß bei den meisten Sängern der Radius von seinem Distal-zum Proximalende schief nach außen anfsteigt und dabei das Proximalende der Ulna kreuzt. Bei den paläogenen Mammalia (z. B. Monotremen) ist diese Stellungsänderung des Humerns noch wenig entwickelt (abgesehen ron der Vorwärtsrichtung der Hand), die Kreuzung der Unterarmknochen daher auch nicht ausgesprochen; bei den jüngeren tritt sie immer schärfer hervor, vorausgesetzt, daß die Vorderextremität ihre vielseitige Beweglichkeit beibehält oder höher ausbildet, d. h. nicht einseitig zum ausschließlichen Bewegungsorgan umgebildet wird. Die Kreuzung entwickelt sich wohl sicher in der eben geschilderten Weise durch eine Drehung des gesamten Humerus in der

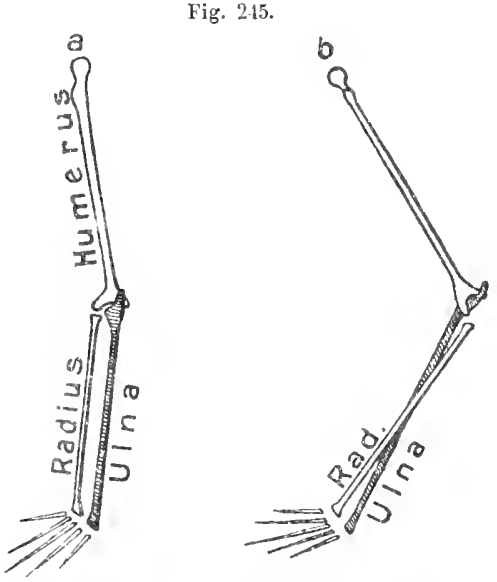

Schema für die Entstebung der líreuzung der Unterarmknochen der Mammalia. a Ursprüngliche stellung der Extremitat mit nach außen gerichtetem Ellbogengelenk. b Das Ellbogengelenk nach hinten und gegen di ${ }$ Medianebene verlagert und daher die Kreuzung von Radius und Uln: eingetreten. $\quad 0 . B$. Pfanne, nicht jedoch, wie dies häufig dargestellt wird, dureh eine Torsion der distalen Humerushälfte gegen die proximale.

Bei den Säugern, deren Vorderextremität maunigfaltigerer Bewegung und verschiedenartigen Gebrauches fähig bleibt, sich namentlich als Greif- und Kletterorgan entwickelt, werden die Unterarmknochen bewcglicher gegeneinander, indem das Distalende des Radius sich mehr oder weniger um das der Ulna herum zu bewegen vermag, wobei die Ventralfläche (Volarfiäche) der Hand nach innen gerichtet, oder sogar bis $180^{\circ}$ herumgedreht werden kann, so daß sie nun dorsalwärts schaut (Supinationsstellung im Gegensatz zu der ursprïnglichen Pronationsstellung). Je mehr diese Fähigkeit sich cntwickelt, desto größeren Anteil erlangt das Distalende des Radius an der Gelenkung mit dem Carpns, wälrend die Ulna allmählich mehr und mehr ausgeschaltet wird.

Wie schon hervorgehoben, erfährt die Vorderextremität der Säuger, von einfachen Bewegungsorgan ausgehend, eine sehr mannigfaltige Ausbildung, als Greif-, Kletter- und Graborgan, sogar als Flugapparat (Chiroptera), oder, wieder herab- 
sinkend, als Flosse (Sirenia, Cetacea); andrerseits jedoch auch als ausschließliches Bewegungsorgan sich spezialisierend (Ungulata). Auch in ihrer Wirksamkeit als Bewegungsorgan wird sie mannigfaltiger, insofern die Hand hierbei in sehr verschiedenem Grad den Boden berührt. Die paläogenen Tetrapoden setzen im allgemeinen die gesamte Ventralfläche der Haud, Finger und Metacarpalia bis zum Beginn des Carpus dem Boden auf; doch wurden bei gewissen fossilen Dinosauria die Metacarpalia nicht mehr anfgesetzt (digitigrad). Auch die paläogenen Sänger zeigen das ersterwähnte Verhalten, ihre Hand ist plantigraà, d. h. berührt

Fig. 246.

a. Condyl.

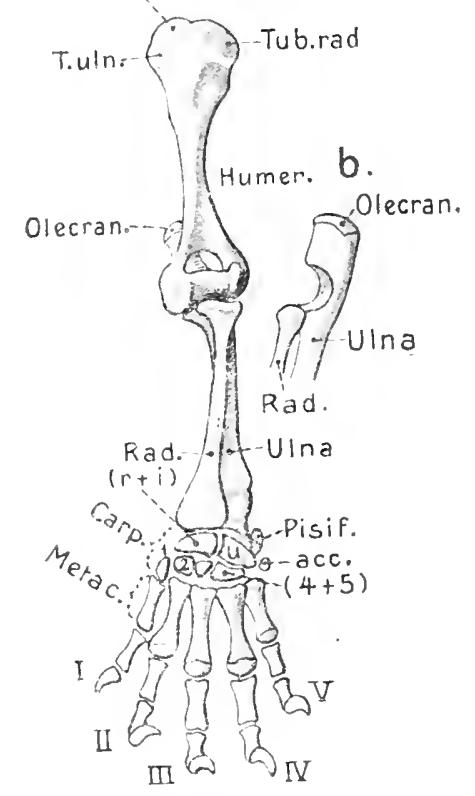

Erinacens ouropaeus (Igel). Skelet der linken Vorderextremităt von vorn. a Prorimalende der Untorarmknochen von der $\begin{array}{ll}\text { Aubenseite. } & 0 . \text { B. }\end{array}$ in ganzer Ausdehnung den Boden, wie es sich gewöhnlich bei Monotremen, Marsupialiern, Insectivoren, Edentateu, Carnivoren (zum Teil) und Primaten erhält. - Bei vielen, auch unter den obengenannten Ordnungen, erhob sich jedoch die Hand mehr vom Boden, die Metacarpalia richteten sich empor und nur die Finger legten sich dem Boden auf (digitigrad). Endlich konnten sich die Finger noch weiter aufrichten, so daß schließlich nur ihre Endphalangen den Boden berithren, wie os speziell fïr die Ungulaten gilt (unguligrad). Derartige Veränderungen haben sich in verschiedenen Gruppen selbständig hervorgebildet.

Die genauere Besprechuug beginnen wir mit der sich ursprünglicher erhaltenden, freierer Beweglichkeit fähigen Vorderextremität, welche kein3 Spezialisierung in einseitiger Richtung erfuhr.

Der Humerus besitzt gewöhnlich eine den Unterarmknochen nahezn gleiche Länge. An seinem Proximalende bewahrt der Gelenkkopf bei primitiverer Beschaffenheit die mehr rollenartige Bildung; je freier beweglich aber die Extremität wird, um so mehr nähert sich der Gelenkkopf der Kngelform. Die Tubercula radialis und ulnaris (majns und minus) sind in der Regel gat, zum Teil sogar sehr kräftig entwickelt und setzen sich häufig, namentlich an grahenden Extremităten, in kräftige Leisten (Spinae) znm Muskelansatz fort; in welchen Fall sich der Oberarm meist auch stark verkürzt. Sein Distalende besitzt gewöhnlich gut entwickelte Epicondylen; ansehließend an den Epic. radialis eine mehr oder weniger kugelig vorspringende Gelenkstelle (Capitulum) für den Radius und daneben eine meist ansehnlichere, mehr rollenartige, oder durch eine mittlere Rinne in zwei rollenartige geteilte für die Una (Trochlea). Letztere Bildung geht wohl darauf zuriiek, daß die Articulation der Uhna sich allmählich auf das Capitulum ausdehnte. Bei zahlreichen Säugern findet sich etwas über dem Epicondylus ulnaris ein Loch 
fur den Durchtritt des Nervus medianus und der Arteria brachialis (Foramen entepicondyloideum s. nlnare, Fig. 247), was̀ meben anderen Eigentümlichkeiten die verwandtschaftlichen Beziehungen der Süuger zu den ursprüinglicheren Reptilien bestätigt, walche, wie früher erwähnt (S. 375), dieselbe I) urchbrechung besitzen. Zuweilen sind die Fossae zwischen den beiderseitigen Epicondylen so vertieft, daß ein Durchbruch des Humerus an dieser Stelle eintrat (Fig. 246). - Die im allgemeinen stärker als der Radius ausgebildete, in der Regel mit einem kräftigen Olecranon versehene Ulna hat hei den palïogenen Säugern noch einen größeren Anteil an der Gelenkung mit dem Carpus, wogegen sich mit der allmählichen Steigerung der Supinationsbewegung des Unterarms die Gelenkung des Radius mit dem Carpus auf Kosten der Ulna vergrößert (Fig. 248).

Wie schon erwähnt, bewahrt der Carpus der paläogenen Säuger eine recht primitive Beschaffenheit, die sich bei den mit ursprtinglicherer Extremität versehenen Formen bis zu den jüngsten Gruppen erhielt; um so mehr, als eine etwaige Reduktion der Finger nie einen hohen Grad erreicht. - Die Anlage der primitiven Handwurzel enthält naben den drei Elementen der Proximal-und den fünf der Distalreihe noch ein bis zwei Centralia; doch bleibt im nachembryonalen Zustand höchstens ein Centrale erhalten (bei einzelnen Edentaten und Cetaceen, den Hyracoidea, vielen Rodentien, Insectivoren, Prosimiern und Simiern). Eine stete Eigentümlichkeit der Säuger bildet die Verschmelzung der Carpalia 4 und 5. Die Carpalknochen des Menschen haben

Fig. 247.

Condylus

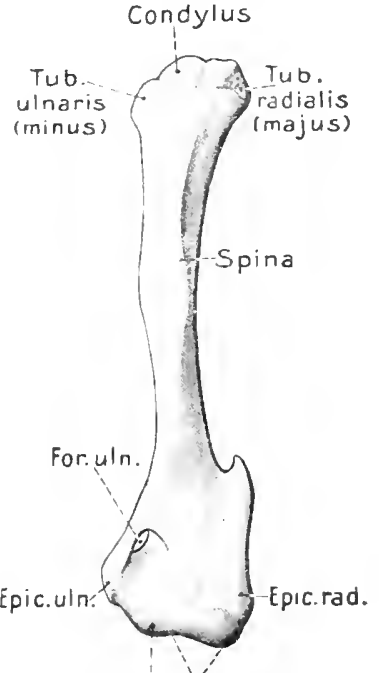

Gel.fl.f. Ulna u.'Radius

Phascolarctos cinereas (Bentelbăr). Humerus von vorn mit For. ulnare. besondere Namen erhalten, welche auch für die übrigen Sänger hänfig verwendet werden. Bẹifolgendes Schema läßt diese Benennungen erkennen:

Radiale

$\left(\begin{array}{c}\text { Nariculare oder } \\ \text { Scaphoid }\end{array}\right)$
Intermedium

$\left(\begin{array}{c}\text { Lunatum oder } \\ \text { Semilunare }\end{array}\right)$

Centrale

Ulnare

$\left(\begin{array}{c}\text { Triquetrum oder } \\ \text { Pyramidale }\end{array}\right)$

(Intermedium Cuviers)

Carpale 1 Carpale 2

Carpale 3

$\left(\begin{array}{c}\text { Trapezinm oder } \\ \text { Multangulum majus }\end{array}\right)$

$\left(\begin{array}{c}\text { Trapezoid oder } \\ \text { Mult. minus }\end{array}\right)$ $\left(\begin{array}{c}\text { Capitatum } \\ \text { od. Magnum }\end{array}\right)$

Wo das Centrale fehlt, ist es meist mit dem Naviculare vereinigt. Häufig tritt auch Verwachsung von Naviculare und Lunatum und eventuell damit auch des Centrale auf. Eine weitergehende Verwachsung der Carpalia ist sehr selten. Das Pisiforme am Ulnarrand des Carpus ist gewöhnlich vorhanden, zuweilen sogar 
zweigliederig und dann einem Fingerstrahl ähnlich. Ein rádialer sog. Präpollex kommt hänfig vor und kann zuweilen (so Maulwurf, Elefant) recht groß werden.

Die wohlentwickelten Finger besitzen fast ausnahmslos folgende Phalangenzahlen: I. zwei, II.--V. drei, was einerseits an die Verhältnisse der Chelonier, andrerseits an die der Anomodontia unter den theromorphen Reptilien erinnert.

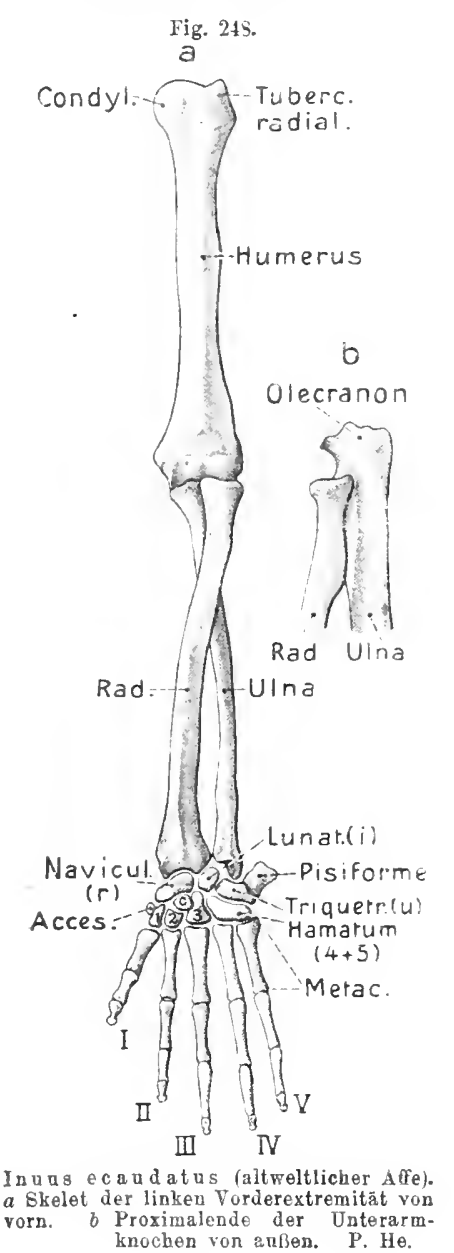

Auf der Ventralnärche der Hand (und ebenso des Fußes) finden sich an den Metacarpophalangeal- und den Phalangealgelenken häufig je ein Paar kleiner Knöchelchen (Sesambeine), die in den Gelenkkapseln liegen und den Verlauf der Sehnen der Fingerbeuger sichern. Seltener finden sich solche Knöchelchen auch an den Phalangealgelenken der Dorsalseite.

Die Fingerzahl der hier zunächst betrachteten Säuger kann auf vier bis drei reduziert werden, indem I und $V$ verkümmern. Auf den Carpus hat dies wenig Einfluß.

In der zum Greifell eingerichteteu Hand der Primaten (sowie einzelner Marsupialier und Rodentia) wird der Daumen (Pollex) freier beweglich, indem er von dem zweiten Finger stärker entfernt (abduziert) werden und sich ausgiebig

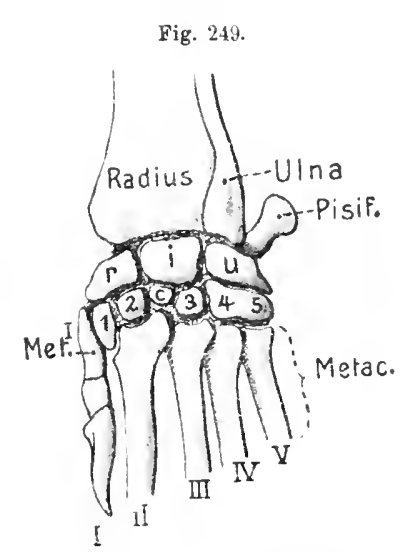

Lep us timidus. Linker Carpus ron
vorn (dorsal). gegen die Volarfläche beugen

(opponieren) kann. Dies berubt (abgesehen von der Anordnung der Muskulatur) anf besonderer Ausbildung der Gelenkflächen des Trapezinms (Carpale 1) und des Metacarpus I (Sattelgelenk).

Besondere Umgestaltungen der Vorderextremitä. Ungulata (Huftiere). Wie sich paläontologisch verfolgen läßt, entwickelten sich die Extremitäten in dieser großen Gruppe, von dor ursprünglichen Besehafienheit ausgehend, immer einseitiger zn Organen für ausschließlich pendelnde Bewegungen auf dem Boden. Diese Entwicklung ließ sie progressiv schlanker und länger werden, wobei vorzüglich die distalen Abschnitte, in der Vorderextremität also Unterarm und Hand, stark auswlichsen, während der Oberarm sich relativ verkleinerte und in den Rumpf aufgenommen wurde. Gleichzeitig wurde es für derartig funktionierende 
Extremitäten immer vorteilhafter, wenn sie den Boden nur mit einer wenig ausgedehnten und festen Fläche berührten. Dies wurde dadurch erzielt, daß die Hand sich mehr und mehr vom Boden erhob und schließlich, wie dies bei den rezenten Ungnlaten (mit Ausnahme der Tylopoden, Kamelartigen) durchaus ist, nur noch mit den Eudphalangen anftrat (unguligrad), die sich demgemäß mehr oder weniger hufartig verbleiterten.

Bei ciner so einseitigen Betätigung der Extremität fiel naturgemäß jeder Grund für die Erhaltung der freieren Beweglichkeit des Unterarms, und damit auch der Unterarmknochen gegeneinander, fort. Wie sich dieselben schon getegentlich in gewissen Gruppen der erstbetrachteten Säuger wenig oder nicht beweglich aneinander schließen (Monotremen, Edentaten, Insectivoren und Rodentien z. T.), bei den beiden letzterwähnten Ordnungen sogar zuweilen distal verwachsen, so trat dies anch hier ein. Sowohl bei den unparrzebigen als den paarzehigen Huftieren führt die fortschreitende Entwicklung der Extremität in der eingeschlagenen Richtung zll starker Verkümmerung der Ulna, unter gleichzeitiger Verstärkung des Radius. Die distale Hälfte der Pferde-Ulna (Fig. 2503) ist völlig reduziert, ein distalster Rest hat sich mit dem Carpalende des Radins vereinigt. Die Ulna der Wiederkäuer (Fig. 2512) ist zwar in ganzer Laange erbalten, ibr Mittelteil jedoch sehr schmächtig und samt dem Distalteil mehr oder weniger init dem Radius verwachsen; der, wie bei den Perissodactylia sehr ansehnliche Olecranonteil bleibt dagegen gewöhnlich frei, verwächst jedoch bei den Kamelartigen samt der übrigen Ulna vollstïndig mit dem Radius (Fig. 2513). Die Verstärkung des Radius ergreift. namentlich auch sein proximales Getenkende, das ursprünglich, wie bei den früher geschilderten Sängern, die Ulna kreazte und sich nur mit dem Capitulum des Humerus verband. Allmählich breitete sich dies Gelenkende des Radius inmer mehr vol die Ulua auf dio Trochlea aus, so daß es schließlich mit deren ganzer Breite gelenkt. Der Proximalteil der Ulna wurde so vollständig hinter den Radius verlagert, nicht eigentlich verschoben, sondern vom Radius bedeckt, und für die Gelenkung der Ulna blieb nur der hintere Teil der Trochlea übrig.

Der Bau der Hand (wie anch des Fußes) hat sich, von den Urungulaten ausgehend, in zwei divergenten Richtungen entwickelt. Die Erhebung von Hand und Fuß über den Boden, und der Vorteil einer möglichst festen und beschränkten Aufsatzfläche der Extremitätenenden fuhrte frtihzeitig zu einer Verkümmerung gewisser Finger und Zehen.

In der Reihe der sog. Perissodactylia (umpaarzehige Huftiere, Tapir, Rhinozeros, Pferd; Fig. 250) entwickelte sich der III. Finger am stärksten; der I. verkiimmerte friihzeitig; der V. blieb zum Teil noch gut erhalten (T'ipir), ebenso zunächst der II. und IV., die bei Tapir und Rhinozeros den Boden gerade noch erreichen. Der III. Finger wurde so zum Mittelstamm der Hand, um den sich die noch erhaltenen übrigen symmetrisch gruppieren. Die fortschreitende Entwicklung der Perissodactylia in dieser Richtung führte schließlich in der Equidenreihe, mit gleichzeitiger mächtiger Verlängerung des Metacarpus III, zu vollständiger Verkümmerung der freien Finger II und IV, unter immer kräftigerer Ausbildung des III. 
Vom II. und IV. Finger blieben bei den rezenten Pferden nur die Proximalenden der Metacarpalia erhalten, welche als sog. „Griffelbeine dem Metacarpale III (sog. Lauf) angefügt sind. Vom besonderen Interesse erscheint, daß gerade die phylogenetische Entwicklnngsreihe der Pferdeextremitäi aus der vierzebigen der ursprilnglichen Vorfahren durch paläontologische Funde fast lückenlos festgestellt wurde.

Fig. 250

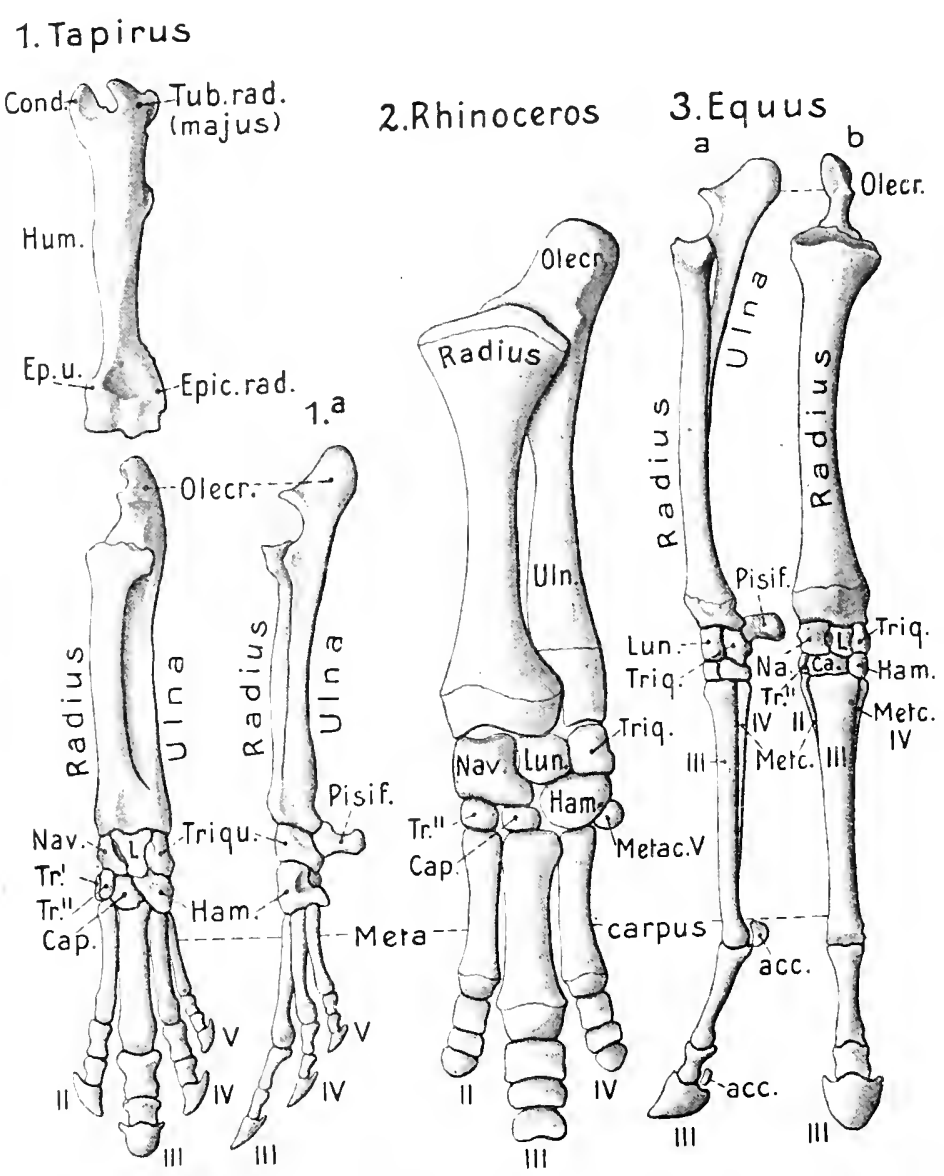

Perissodactyle Ungulata. Skelet der linken Vorderextremitát. 1. Tapiras von vorn. 1.a Unterarm und Hand von auben. 2. Rhinoceros (jung), Unterarm and Hand ron vorn. 3. Equa s. a Unterarm und Hand von außen. $l$ Von rorn. $q$ ' Trapez; T" Trapezoid.

Bei den parmeligen Hufticren (Artiodactylia, Fig. 251) entwickelten sich dagegen die Finger HI und IV gleichmäßig stark und bildeten den Mittelstamm der. Hand, wäbrend die Finger II und V, die bei den Nonruminantia /s. Phacochoerus) noch gut entwickelt sind, bei Hippopotamus sogar den Boden erreichen, sich symmetrisch zu III und IV gruppieren. Die Mittelebene der Hand fült also zwischen die Finger. III und IV. Der Finger I fehlt den Rezenten stets. - - Weiteres Fortschreiten in dieser Entwicklungsrichtung füht bei den Ruminantis (s. Oryx, 
Auchenia) zur Verlängerung der Metacarpalia III und IV, unter gleichzeitiger Verkïmmerung der Finger II und V, von denen sich jedoch meist noch Reste finden (Ausnalme besonders Kamelartige und Giraffe). Die sehr langen Metacarpalia III nud IV der Wiederkäner verwachsen fast stets zu dem sog. Laufknochen (Kanon; Ausnahme Hyaemoschus), mit dem sich Reste der Metacarpalia III und IV mehr oder weniger vereinigen.

Der Carpus des. T'ugulaten erlitt trotz dieser tiefen Umgestaltung der Hand relativ wenig Veräuderung; doch erfuhren bei sämtlichen Ungulaten die Carpalia eine gewisse Verschiebung gegen die Medianebene des Körpers, so daß sie mit den drei Elementen der Proximalreihe, sowie den Metacarpalia in gewissem Grade alternieren (Taxeopodie). Ein Centrale findet sich bei keinem der rezenten Ungulaten mehr; dagegen sind bei den Perissodactylia meist sämtliche ubrigen Elemente vorhanden;nurden PferFig. 251.

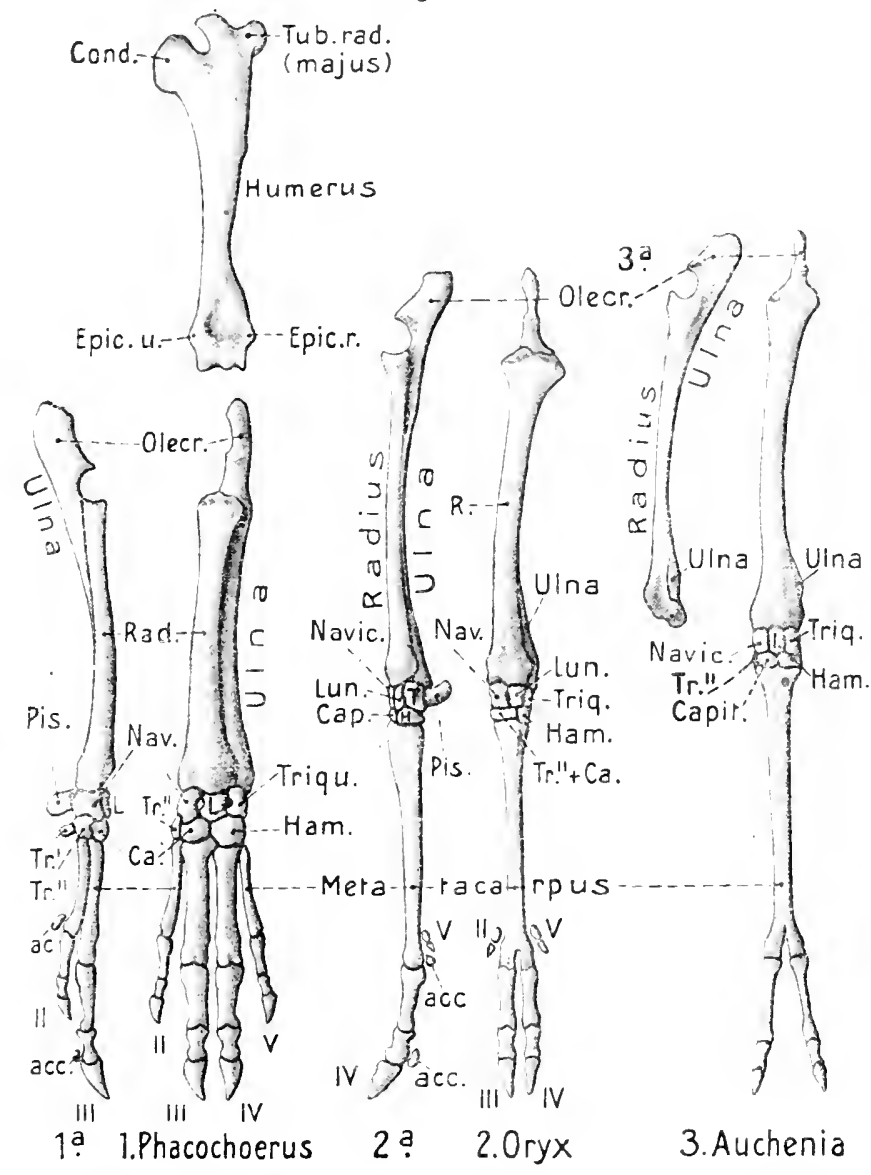

Artiodactyle Ungalata. Linke Vorderestremilat. 1. Phacochoeras (Warzenschwein). 1. Von vorn, 1 \& Unterarm und Hand von innen. 2. Oryy (Antilope) 2. Unterarm nod Hand von vorn. $2 \&$ Von außen. 3. A u ebenia (Lama). Unterarm den fehlt das Carpale I (Trapezium). Mit der Vergrößerung des Metacarpus IIX bei den Pferden wurde dessen Carpale (Capitatum) besonders ansehnlich. Der Carpus der Artiodactylia besitzt bei den Nonruminantia noch alle acht Elemente; den Ruminantia fehlt dagegen das Carpale I (Trapezium); die Carpalia II und III (Trapezoid + Capitatum) sind meist verwachsen (Ausnahme Kamelartige). 
Die Umbildung der Chiropterenhand (Fig. 252) zu einem Flugorgan erinnert an die Fliggelbildung der Pterosauria, erfolgte jedoch in besonderer Weise. Das Prinzip des Flïgelbaus bildet auch hier die mächtige Entwicklung einer Flughaut, die sich zwischen den ungemein verlängerten Fingern II-V, dem Arm und den Körperseiten ausspannt. Zur starken Verlängerung dieser Finger tragen sowohl die Metacarpalia als die Phalangen in verschiedenem Grade bei. Ober- und Unterarm sind sehr verlängert; letzterer jedoch in höherem Grad. - Ein accessorisches Knöchelcheu besitzen viele Chiropteren an der Ellbogenbenge (sog. Patella brachi-

Fig. 252.

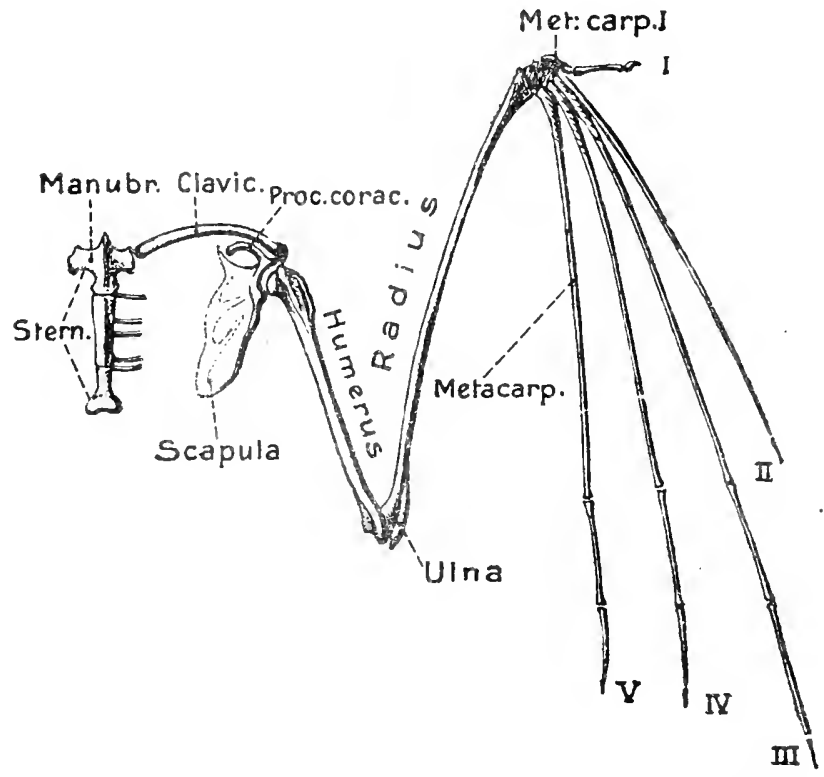

Vespertilio murinus (Eledermaus). Skelet der linken Vorderextremität von der Ventralseite des Tieres gesehen. Mit Schultergürtel and Sternum. 0, B. alis) in der Sehne des Streclmuskels des Unterarms, $M$. triceps), das also in der Tat Ähnlichkeit mit der Kniescheibe der Hinterextremität zeigt. Die Ulna rerkiummert sebr, ähnlich den Huftieren, indem sich nur ihr proximaler Teil schwach erhält, während ein Rest des Distalendes mit dem sehr verbreiterten Radiusende verwächst. Naviculare und Lunatum sind verschmolzen, zuweilen (Pteropus) ist mit ibnen auch das Triquetrum vereinigt. Die Carpalia zeigen mancherlei Eigentümliches.

Die Umbildung der Vorderextremität zu einer Flosse bei Sirenen und Cetaceen geschieht in ganz ähnlicher Weise wie bei den Reptilien, Der Arm der Sirenen bleibt viel ursprünglicher. W'enn auch Ober- und Unterarm beträchtlich verkürzt, sowie Radius und Ulna fest verbunden, an den Enden sogar gewöhnlich verwachsen sind, so erhält sich doch die Ellbogenbeuge gut. Die fünffingrige Hand besitzt nur mäßig lange Finger und geringe Veränderungen der Wurzel.

Die Cetaceenflosse erscheint stärker umgestaltet (Fig. 253). Die Armknochen sind sehr verkürzt, platt und untereinander, sowie mit der Wurzel und den Fingern nicht mehr gelenkig verbnnden; die Gesamtheit der Extremität kann also nur als einheitliche Flosse im Schultergelenk bewegt werden. Die Zahnwale besitzen gewöhnlich noch sämtliche fünf Finger, jedoch den ersten, zuweilen anch die ulnaren, 
stark verkürzt; die Bartenwale zum Teil nur vier Finger. In der Wurzel, die bei den letzteren meist weuig verknöchert, zeigen sich eigentümliche Verhältnisse. Ausnahmsweise finden sich noch füuf Carpalia; sonst sind sie meist anf zwei vermindert. Die Finger bleiben bald mäßig lang, bald werden die mittleren ungemein lang, wobei sich, ähnlich den Ichthyosauria, starke Vermehrung der Phalangen, bis anf 14, finden kann, was anch bei Sirenen schon in Andeutung vorkommt. Selten wurde bei Cetaceen auch Spaltung eines Fingerstrahls beobachtet. Alles dies sind konvergente Anpassungen, wie sie unter ähnlichen Bedingungen bei den Ichthyosamiern eintraten.

\section{Hinterextremität.}

Wie wir schon früher betonten, stchen Vorderund Hinterextremität funktionell in einem gewissen Gegensatz, der auch in ihrem Bau hervortritt, obgleich sich die Homonomie ihrer Skeletteile bis in Einzelheiten verfolgen läßt. Schon bei den Amphibien spricht sich dieser Gegensatz in der Ruhestellung des Femur ans, der von dem Gelenk am Becken etwas nach vorn und wenig abwärts gerichtet ist, so daß das Knie etwas nach vorn schaut; dieser Gegensatz verschärft sich bei den Vögeln und Säugern sehr, wie scbon früher dargelegt wurde.

Amphibien. Das mäßig lange Femur der Urodelen (Fig. 254) wiederholt mehr oder weniger deutlich die Bauverhältnisse des Humel'us. Fitwas distal vom Gelenkkopf und etwas medianwärts gerichtet findet sich an seiner Cranialseite ein zum Muskelansatz dienender Vorsprung, der sog. Trochanter tibialis (minor nach der Bezeichnung der menschlichen Anatomie), der also dem T'uberculum radialis (majus) des Humerus entspricht; ihm gegenüber, an der Caudalseite findet sich etwas mehr distal ein schwacher ähnlicher'Trochanter fibularis (major der menschlichen Anatomie), der dem Tuberculum ulnaris (minus) der Vorderextremität gleichkommt. Der Gelenkkopf ist daher gewissernaßen zwischen die beiden Trochanteren eingepflanzt. - Das Distalende des Femur zeigt nur sehr schwache

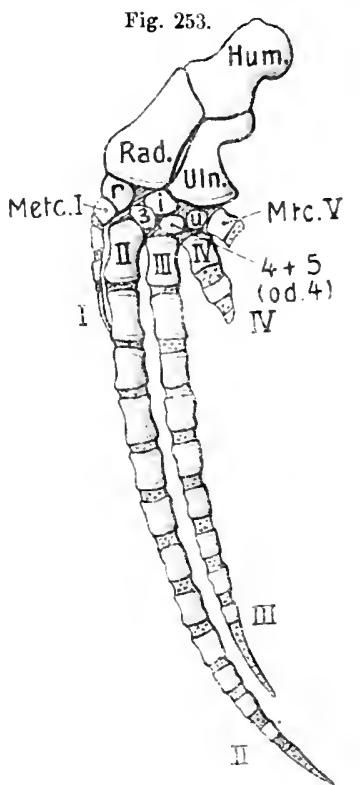

Gl obice phalns (Zahnwal). Skelet der linken Vorderextremität von außon. (Nach Flower tos8 nnd Originalpräparat.) P. He.

A. Fig. 251.

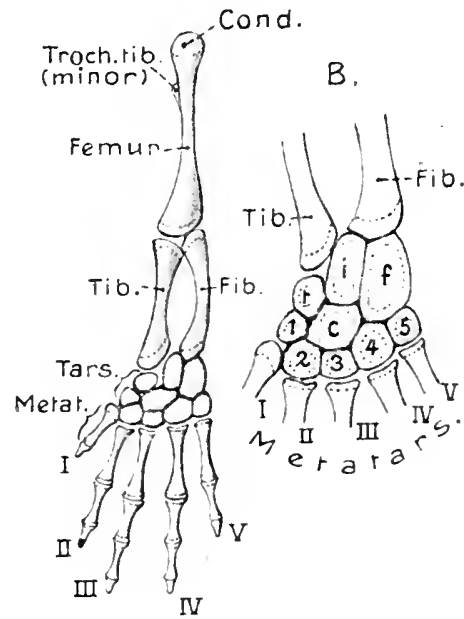

Salamandra maculosa. A Skelet der linken Hinterextremität von anßen. $B$ Tarsus in derselben Ansicht stārker vergrōßert. 0. B. 
Condylen firr die beiden Unterschenkelknochen. Die erwähnte Bildung des Femur läßt sich im allgemeinen durch die ganze Vertebratenreihe verfolgen. - Die beiden Unterschenkellinorhen sind ziemlich gleich stark, wenn auch die Tibia schon etwas itberwiegt.

Der Fu $\beta$ der Amphibien erscheint insofern primitiver wie die Hand, als er bei Salamandrinen, Anuren und einzelnen Ichthyoden (auch Stegocephalen) fünf Zeben besitzt; bei den ïbrigen Ichtlyyoden sinkt ihre Zahl bis auf zwei (Proteus!. Der

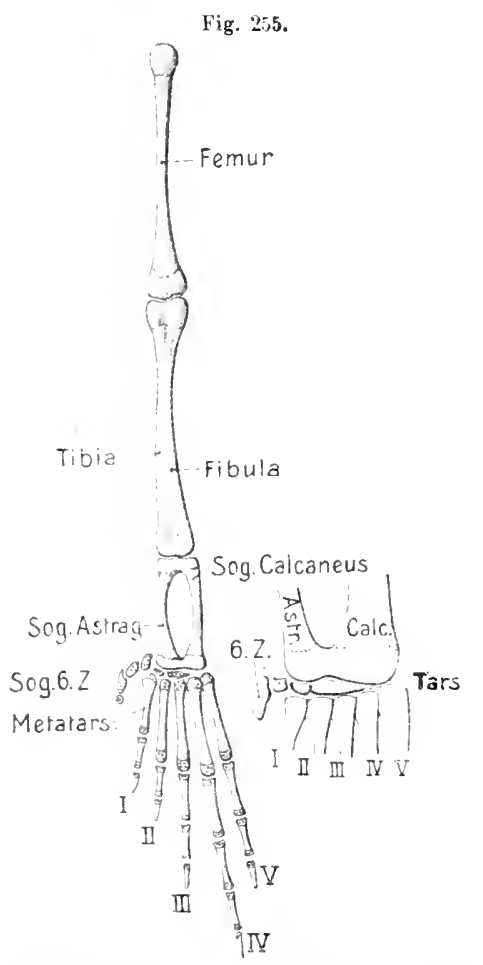

Rana escalenta, A Linke Hinterextremităt von außen. $b$ Tarsus atärker vergrößert. Die sogenannte (;. Zebe in verschiedenartiger Ausbildung.

Tarsus der Urodelen bewahrt ähnlich primitive Verbältnisse wic der Carpus, ja besitzt zuweilen noch eive höhere Zahl von Elementen, da sich nicht selten zwei Centralia, ja als individuelle Variation auch noch mehr finden. - In der Reihe der fünf Tarsalia können Verwachsungen auftreten (so $4+5$ oder $3+4)$. Bei Reduktion der Zehen vereinfacht sich auch der Tarsus, äbnlich wie es für den Carpus hervorgehoben wurde. - Die Phalangenzahl ist gewöhnlich $2,2,3,3$ (selten 4$), 2$; bei Stegocephalen 2, 2, 3 (4), 4 (5), $3(4)$.

Die Hinterextremitätder Anurẹn (Fig. 255) hat sich sehr verlängert und bei vielen zum Sprungorgan entwickelt. Die Verlängerung erstreckt sich gleichnäßig anf das Femur und die Unterschenkelknochen, die aber vollständig miteinander verwachsen. Die Trochanteren des Femur treten sebr zurück. - Auch der Tarsus beteiligt sich in eigentümlicher Weise an der Verlängernng der Extremität, indem die beiden Kuochen, welche die Proximalreıbe bilden, zu langen, stabförmigen Gebilden auswachsen, deren beide Enden gewöhnlich verschmelzen. Der tibiale der beiden

Knochen wird, nach Analogie mit den Säugern, meist Astragalus, der fibulare Calcaneus genannt. Die Riickfübrung dieser beiden Elemente auf die der primitiven Fußwurzel ist noch nicht genïgend aufgeklärt, doch entsprechen sie in ihrem Hanptteil sicher dem Tibiale und Fibulare. - Da Intermedium nnd Centralia fehlen, so könnten sie mit den beiden proximalen Knochen teilweise irgendwie vereinigt sein; $d a ß$ sie einfach ausfielen, ist weniger: wahrscheinlich. Die Tarsalia sind sehr stark riiekgebildet; es finden sich im Aøschluß an die Metatarsalia I- III noch ein bis drei Knorpelchen, welche den Tarsalia 1-3 eutsprechen diurften, wogegen die fibularen nur durch Bandmasse vertreten werden. Von Tarsale 4 wird auch angegeben, daß es mit dem sog. Calcaneus vereinigt sei. - Die fünf 
Zehen sind gut entwickelt und ihre Phalangenzahl in der Regel 2, 2, 3, 4, 3. Besonderes Interesse beanspruchen accessorische Elemente, die sich dem tibialen Tarsusrand anfügen und einem, auch äußerlich am Fuß hervortretenden Fersenhöcker eingelagert sind (Fig. 255, 6. Z.). Diese Elemente reiben sich in Drei- bis Fünfzahl phalangenartig aneinander, so daß sie ziemliche $̈$ llnlichkeit mit einer sechsten tibialen Zehe erlangen und auch bäufig in diesem Sinne gedeutet werden.

Sie erinnern an die zuweilen in ähnlicher Weise gedeuteten Elemente am radialen Carpusrand der Vorderextremität. Trotz dieser Zehenähnlichkeit läßt sich vorerst kanm entscheiden, ob es sich hier wirklich um einen sechsten Zehenstrahl handelt. Selbst wenn wir dies im Prinzip zugeben, so ist doch nicht wahrscheinlich, daß diese sechste Zehe als Erbstück eines älteren sechszehigen $\mathrm{Zu}$ stands des FuBes angeseben werden darf, sondern eher als eine sekundäre Vermehrung der Strahlen, wie sie als Abnormităt auch sonst auftritt, die aber hier zu einem regelmäßigen $\mathrm{Be}$ standteil wurde.

Reptilia. Am Femur der ursprunglicheren Reptilien (Rhynchocephala, Chelonia, Figar 256) sind die beiden Trocbanteren, besonders der Tr. fibularis (major), stärker entwickelt und rücken dichter an den Condylus empor, was eine große Ähnlichkeit mit dem proximalen Humerus-

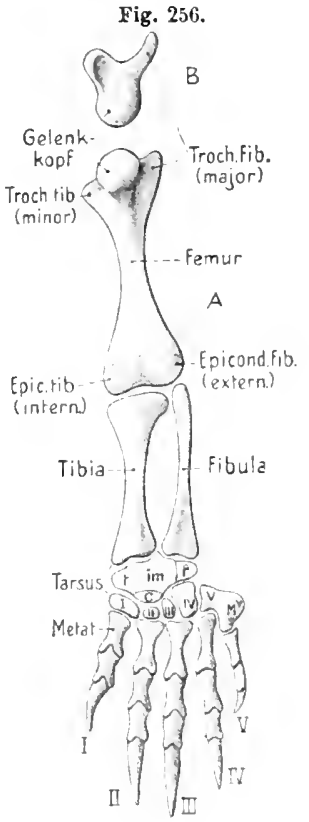

Chelydraserpentina (Schilkrōte). A linke Hinterextremitát von außen. $B$ Der Gelenkkopf des Femur von oben in axialer Ansicht. $\mathrm{C}$. $\mathrm{H}$.

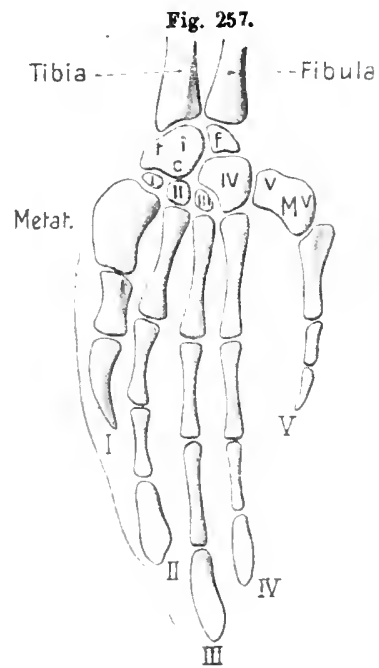

Thalassochelys caretta feorticata), Seeschildkröte. Skelet des zur Flosse umgebildeten Fubes von außen. C. H.

ende hewirkt. Bei Sauriern und Krokodiliern (Fig. 258) ist der 'Trochanter fibnlaris dagegen stark rïckgebildet, und bei lerzteren auch der 'Tr. tibialis (minor) recht schwach.

Da die Tibia sämtlicher Amnioten bedeutend stärker wird als die Fibula, so greift ihr proximales verbreitertes Ende auch auf den distalen Epicondylus fibularis (externns) des Oberschenkels ubber, und das Proximalende der Fibula gelenkt bei den Reptilien nur mit dem änßeren (oder hinteren) Teil dieses Epicondylus. -Beide Unterschenkelknochen sind bei den rezenten Reptilien stets vollstandig entwickelt und nnvereinigt; nur bei den fossilen Pterosauria war die Distallälfte der Fibula vogelartig verkümmert. 
An der Streckseite des Kniegelenks mancher Saurier tritt zum erstenmal in der Sehne des großen Streckmuskels des Unterschenkels ein accessorisches knorpeliges bis knöchernes Skeletgebilde auf. Es ist dies die Kniescheibe oder Patella, welche bei Vögeln und Säugern regelmäßiger anftritt nnd ansebnlicher wird.

Der Tarsus hat sich, ausgehend von einer wohl amphibienartigen Urform, spezialisiert, was mit dem Überwiegen der Tibia in Zuaammenhang steht. Schon bei

Fig. 258.

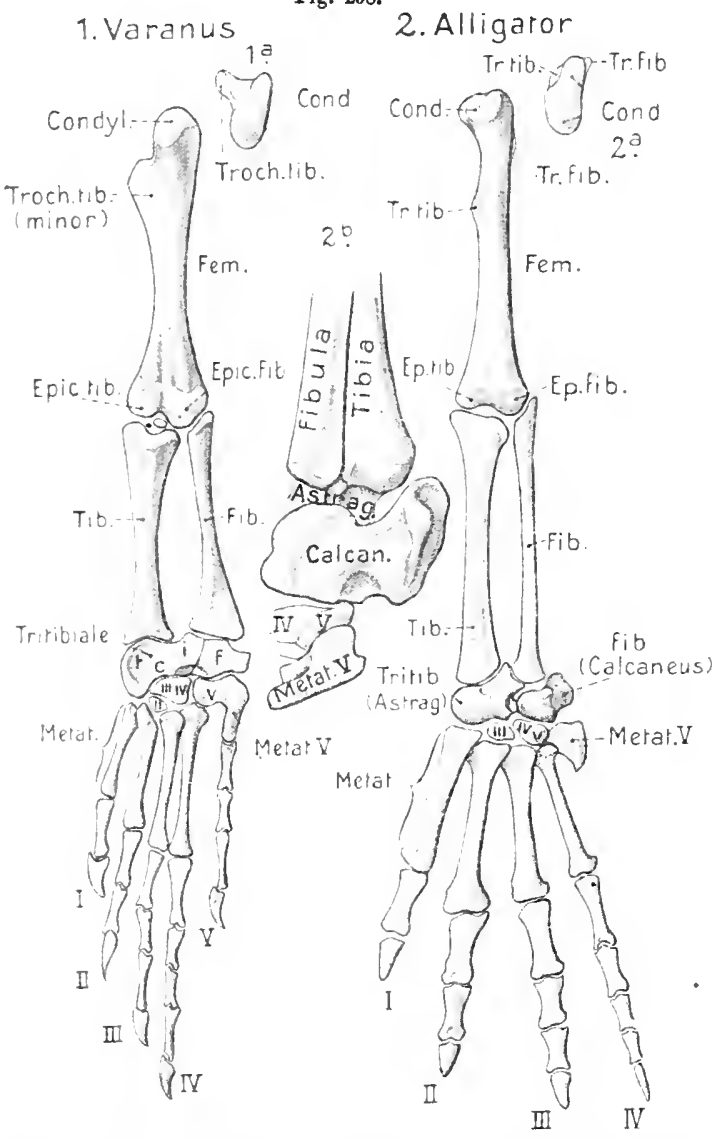

1. Varanus nilotic as. Skelet der linken Hinterextremităt ron außen. $1 a$ Der Gelenkkopf des Femur in derselben Stellung wie 1 von oben in der Achsenricbtung der Femur gesehen. 2. Alligator mississippiensis. Linke Hinterextremitát von außen. $2 a$ Gelenkkopf des Femur wie $1 a$ $2 b$ Tarsus von der Fibularseite gesehen. den Cheloniern (Fig. 256, 257), welche noch ziemlich ursprüngliche Verhältnisse zeigen, tritt an Stelle des Tibiale, Intermedium und Centrale ein einheitlicher Knochen (Tritibiale, sog. Astragalus), dessenHervorgehen aus einerVereinigung der drei genannten Elemente sicher erscheint; ein Zustand, wie or schon für die ältesten Reptilien charakteristisch gowesen ist. Daneben erhält sich in Verbindung mit der Fibula das Fibulare, vereinigt sich aber schon recht fest mit dem Tritibiale, oder verwächst anch damit. Eiu, selten zwei Centralia, wurden ontogenetisch noch bei Sphenodon, gewissenCheloniern und Sauricrn nachgewiesen. - Die Distalreihe enthält bei den Cheloniern in AnsuhluB an die Finger I bis IV vier Tarsalia, von welchen das größte, 4 , gewöhnlich als eine Vereinigung von T. $4+5$ gedentet wird; nach der On-

togenie aber wohl richtiger nur das 4 . ist, während sich das 5. Tarsale vielleicht mit dem Metatarsus V vereinigt hat. - Nur sehr alte Reptilien (gewisse Proganosauria) scheinen noch fünf Tarsalia und vereinzelt ein Centrale besessen zu haben.

Die Vereinfachung, welche so schon im Tarsus der Sehildkröten eingetreten ist, geht bei den Rhymchocephalen und Sauricrn (Fig. 258 1) noch weiter, wo das 
Fibulare stets mit dem Tritibiale verwächst, die Proximalreihe also nur noch einen ansehnlichen Knochen enthält, der sich den Unterschenkelknochen relativ wenig beweglich anschließt. Die Tarsalreihe hat sich reduziert, indem sio bei den Rhynchocephalen noch aus drei, boi den Sauriern nur ans zwei kleinen knöchernen Elementen besteht, welche wohl am richtigsten als Ta. 3 und Ta. 4 gedeutet werden (bei den Rhynchocephalen dazu noch Ta. 2), während ein Rest des Ta. 5 wohl mit dem Metacarpus $\mathrm{V}$ vereinigt ist. Die auf Fig. $258^{1}$ eingezeichnete Deutung ist weniger wahrseheinlich. Das noch stärker rückgebildete Tarsale 1, und bei den Sauriern auch 2 sind mit den betreffenden Metatarsalia vereinigt. - Eine bei vielen Sauriern und Sphenodon zwischen dem Metatarsale I und dem proximalen großen Tarsalknochen sich einschiebende Knorpelscheibe, der sog. Meniseus, konnte bis jetzt nicht sicher gedentet werden.

Der innige Ansehluß des proximalen Fußwurzelknochens an die Unterschenkelknochen einerseits, der der rudimentären Tarsalia an die Metatarsalia andrerseits, bewirkt bei den Sauriern, daß die Bewegung im Fußgelenk zwischen die beiden Reihen der Tarsusknochen verlegt ist, wie es in goringerem Grad schon bei den Cheloniern, ja sogar den Anuren angedentet war. Dies Intertarsalgelenk vervollkommnet sieh, wie wir sehen werden, in der Sauropsidenreihe noch weiter nnd führt schließlich bei den Vögeln zum Verschwinden des ganzen Tarsus.

In einer etwas anderen Richtung hat sich der Tarsus der Krokodile (Fig. 2582) entwickelt. Das Tritibiale (sog. Astragalus) ist erbalten und schließt sich als das ansehnlichste Element der Tibia innig an. Auch das Fibulare (Caleaneus) ist kriftig. und bildet einen nach hinten gerichteten Fortsatz, zur Anheftung der Sehne des Hauptstreckmaskels des Fußes (Fig. $258^{2 b}$ ).

Da sich das Fibulare, sowie die sehr reduzierten Farsalia (gewöhnlich als 3 mit damit vereinigten knorpeligen Rudimenten von 1 und 2 , und $[4+5]$ anfgefaßt) an den Metatarsus anschließen, so fällt das Intertarsalgelenk der Krokodile zwischen das Tritibiale und die übrige Wurzel. Der fünfte Finger ist auf das Metatarsale $\mathrm{V}$ reduziert.

Unter den fossilen Reptilien besitzen die Dinosaurier wegen ibrer wabrscheinlichen Beziehungen zu den Vögeln besonderes Interesse. Die Wurzel scheint der der Krokodile recht ähnlich gewesen zu sein, da in der Proximalreihe Tritibiale und Fibuláre krokodilähnlich ausgebildet waren. Beide schließen sich innig an die Enden der Unterschenkelknochen an, ja bei gewissen (Stegosauria) verwächst das Tritibiale (Astragalus) mit der Tibia. Interessanterweise wird die Verbindung des Tritibiale mit der Tibia bei einzelnen Gattungen noch dadurch inniger, da $\beta$ es einen vor dem distalen Tibiaende aufsteigenden Fortsatz bildet, der sich einer Vertiefung der Tibia einfïgt; was sehr an die entsprechende Einrichtung der Vügel erinnert.

Die distale Reihe der Tarsalia blieb bei den Dinosauria häufig knorpelig; wo sich verkn̈̈cherte Elemente erhielten, sind sie klein und in geringer Zahl (zwei bis drei), ähnlich den Krokodilen; sie gehören wie bei diesen der ulnaren Region an. Wie die Vorderextremität, so wurde auch die hintere der Dinosanrier zum Teil digitigrad, womit häufig Verkümmerung der fünften, zuweilen auch der ersten Zehe verbunden war, von denen sich zum Teil noch die Metatarsalia crhielten. Die Metatarsalia II-IV waren dann relativ stark und lang, ja konnten selten (Ceratosaurus) miteinander verwachsen. Auch bierin, wie in der 
Erscheinung, daß die Hinterextremität der Theropoda und Ornithopoda meist viel länger wird als die vordere, zeigt sich eine gewisse Annäherung an die viingel.

Bei den Sauriern mit rudimentären Extremitäten läßt sich die vom Distalende beginnende Verkümmernng gut verfolgen, ähnlich wie an der Vorderextremität. SchileBlich (z. B. Psendopus) finden sich nur noch geringe Kadimente von Femur und Tibia, oder nur des Femur (einzelne Anphisbaenoiden), ja auch gar nichts mehr (Angnis und Verwandte). - Bei den Schlangen (Fig. 224c, S. 359) erhalten sich zuweilen Reste der IIinterextremität; so besouders bei den Riesenschlangen leste ron Femur und Tibia; letztere ist bei diesen krallenartig und trägt äußerlich ein Nagelrudiment.

Die Vögel (Fig. 259) erweisen sich auch hinsichtlich ihrer Hinterextremität als ein einseitiger Zweig der Sauropsiden, in welchem die Eigentümlichkeiten des FuB-

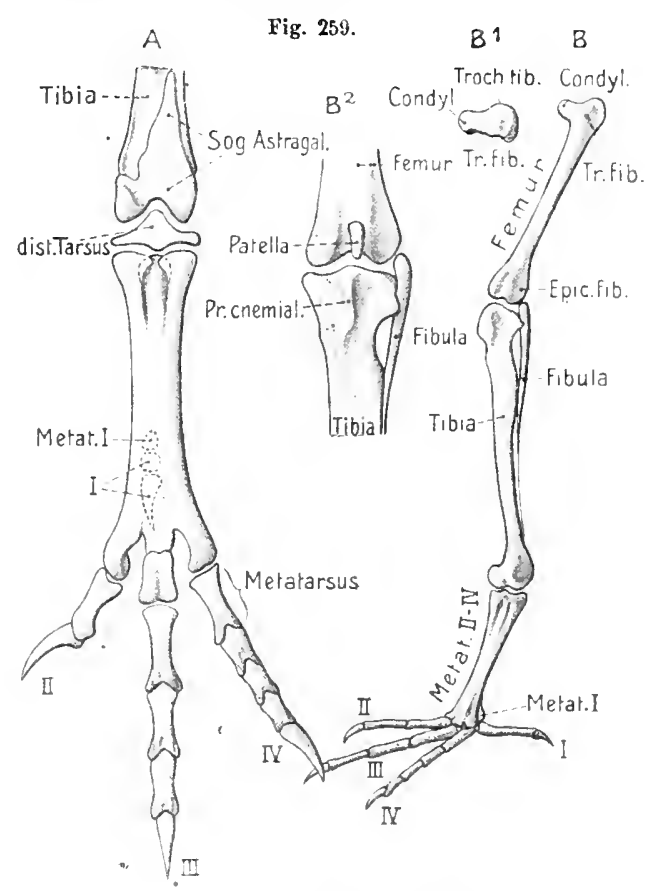

Vōgel. Skelet der linken Hinterextremitat. A Apteryx. Distales Endo der libia und Fuls von vorn (Ǩopfseite) gesehen. Die 1. Zehe ist pnnktiert hinter dem Laufknochen angegeben. $B$ Columba. Linke llinterextremität von auben und etwas vorn. Die Jatella ist weggenommen, damit das Kniegelenk bescer sithtbar. $h^{3}$ Gelenklopf des femur ron oben nnd axial. $B:$ hiniegelenk von vorn. skelets bis zum Extrem gesteigert wurden. Die Hinterextremität, die das ausschließliche Organ für die Bewegnng auf dem Boden und dem Wasser bildet, ist dementsprechend im allgemeinen ansehnlich entwickelt. In gewissen Gruppen (Lauf- und Stelzvŏgel) wird sie sogar sebr lang. -- Das Femur (Fig. $259 B$ ) bleibt jedoch stets relativ kurz, kürzer als der Unterschenkel, und liegt unter der Haut und Muskulatur verstcekt, so $\mathrm{da} B$ die Extremitat erst am Kniegelenk frei wird ; was wegen der Autrichtung des Vogelkörpers notwendig erscheint, $d a$ die freie Extremität so etwa unter den Schwerpunkt des Rumpfs verlegt ist (s. Fig. 115, S. 213). Bei den Schwimmvögeln wird sogar noç der Unterschenkel teilweis bis ginzlich in den Rumpf einbezogen, so daß wesentlich nur der Faß als Ruder frei beweglich bleibt (am extremsten bei den Pinguinen). - Das Femur ist gavz nach vorn gerichtet und steigt schief abwärts, ïhnlich dem der meisteu Sänger, womit eime Veränderung seines Proximalendes verknüpft ist. Der Vergleich mit dem Gelenkende des Femur einer Schildkröte (Fig. 256 B) oder Eidechse (Fig. $258 \mathrm{~B}$ ergibt, daß dies Ende bei den Vŏgeln eine Verdrehung (Torsion) errahren haben muß, infolge deren seine nrsprlinglich dorsale und etwas nach vorn schauende Fläche bei den Vögeln nach innen (median) gewendet wurde; der Gelenkkopf 
wurde hierdurch ebenfails nach innen gerichtet und springt stark vor, so daß er senkrecht zur inneren Femurfläche steht (ähnlich schon bei den Dinosauriern zum T'eil). Der Trochanter fibularis (major) schaut nun nach vorn, der wenig entwickelte Troch. tibialis (minor) nach hinten.

Die Tibia hat sich so stark entwickelt, daß die Fibula ganz zurücktritt und in ihrer Distalhälfte verkümmert. Die Proximalhälfte, namentlich ihr Gelenkteil, bleibt erhalten, verwächst jedoch hänfig fest mit der Tibia. Stets nimmt die Fibula noch an der Bildung des Kniegelenks teil, indem sie sich dem Epicondylus fibularis (externus) des Femur außen anfiagt (Fig. $259 \mathrm{~B}, \mathrm{~B}^{2}$ ), der auch gewöhnlich eine Art Gelenkleiste bildet, die zwischen Fibula nnd Tibia eingreift (äbnlich den Sauriern nnd Dinosauriern). - Das Proximalende der Tibia erhebt sich auf der Streckseito zn zwei sehr ansehnlichen Leisten (Cnemialfortsatz, Pr. cnem.), die Muskeln des Fußes zum Ansatz dienen. Vor und zwischen den beiden Epicondyli des Femur liegt die nur selten fehlende, meist recht ansehnliche Patella (Fig. 259 $\mathrm{B}^{2}$ ). - - Das Distalende der Tibia verwächst mit dem Proximalknochen der Fußwurzel fast stets sehr friihzeitig, so daß dieser ihr Gelenkende bildet.

In der Fußwurzel treten embryonal zwei proximale Knorpelelemente auf, die sich jedoch frühzeitig vereinigen. Es liegt nahe, in ihnen das Tritibiale und Fibulare der Reptilien zu suchen, die ja bei den Sauriern gleichfalls verschmelzen und sich der Tibia innig anschließen. Bei den Vögeln tritt, wie gesagt, fast stets und frühzeitig völlige Verwachsung dieses Tritibiale-Fibulare (sog. Astragalus der Vögel) mit der 'Tibia ein. Nur bei Apteryx (Fig. 259 A) erhält sich der Knochen bis ins Alter gesondert, jedoch fest an die Tibia angeschlossen. Charakteristisch erscheint, daß dieser sog. Astragalus einen aufsteigenden Fortsatz längs der Vorderseite der Tibia entsendet, wie er schon gewissen Dinosauriern zukam.

In der Distalreihe des Tarsus tritt auch ontogenetisch meist nur ein eizziges Element auf (bei Pinguinen drei bis vier), welches sich über die Metatarsalia II-IV ausbreitet und schließlich mit ihnen verwächst; länger gesondert bleibt es nur bei Apteryx (Fig. 259). Es entspricht daher wohl den Tarsalia II-IV. Der Tarsus der Vögel ist demnach als selbständige Bildang völlig geschwunden, indem er, unter schärfster Ausprägung des Intertarsalgelenks, teils mit der Tibia, teils mit dem Metatarsus verwuchs.

Da die V. Zehe bei allen bekannten Vögeln völlig geschwunden ist, so fehlt auch das Metatarsale V. Die Metatarsalia II-IV sind fast stets ansehnlich verlängert, zum Teil sehr stark, und verwachsen frühzeitig innig miteinander (am dentlichsten gesondert und recht kurz bleiben sie bei den Pinguinen). Der so entstandene einheitliche Lauflinochen endigt distal mit drei Condyli für die II.-IV.Zehe. Hinten nnd etwas nach innen ist ihm bei den Vögeln mit erhaltener I. Zehe der kleine Metatarsus I frei angefigt. Den meisten Ratiten und einzelnen Carinaten (z. B. Otis) fehlt jedoch die I. Zehe im erwachsenen Zustand völlig, und beim afrikanischen Strauß anch die II., so daß nur die III. und IV. verbleiben. Wie I. Zehe ist gewöhnlich nach hinten gerichtet und berührt den Boden käufig nicht mehr, indem sie mehr oder weniger verkümmert. Bei den sog. Klanmer- und Ruderfüßen 
dagegen schant sie nach vorn; bei den Wendefüßen kann die II. Zehe nach hinten gewendet werden, welche Stellung sie bei den Kletterfüßen dauernd angenommen hat. - Der Vogelfuß ist, wie schon aus dem Bemerkten hervorgeht, digitigrad; am wenigsten bei den Pinguinen mit ihrem stark verkürzten Metatarsus.

Die Phalangenzahl der Sauropsiden mit unverkümmerten Zehen beträgt in der Regel 2, 3, 4, 5, 4. Abweichend verhalten sich die Chelonier, die gewöhnlich $2,3,3,3(4), 3$ Phalangen haben. Entsprechend verhielten sich wohl die fossilen Theromorpha, was wegen ihrer Beziehung zu den Sängern von Interesse. Bei den Landschildkröten sind sämtliche Zehen auf 2, 2, 2, 2, 1 verkürzt.

Mammalia. Die Hinterextremität der Säuger zeigt gegenüber den Amphibien u Reptilien die schon früher erwähnte Stellungsänderung durch scharfe Richtung

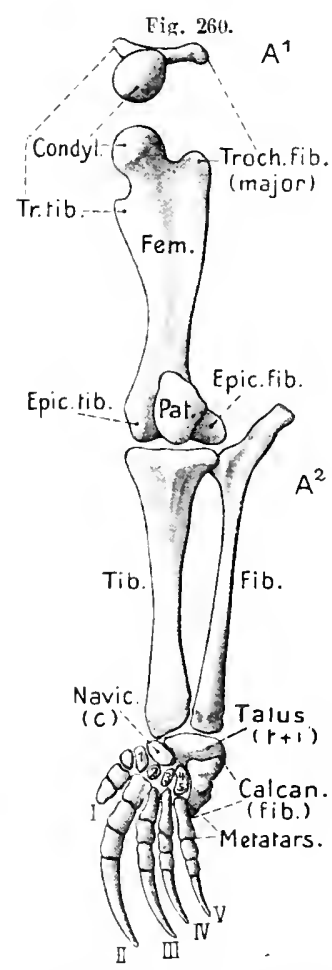

Echidna hystrix. 1: linke Hinterextremitä von außen und etwas von vorn. Al Gelenktopt des Femur von oben und axial in der Stellung wie Fig. $A$ ?. des Kniegelenks nach vorn (s. Fig. 112, S. 211), wie wir es schon bei den Vorgeln fanden. Genauere Betrachtung ergibt jedoch, daß diese Stellung der Extrenität bei den Säugern selbständig erlangt wurde. Das Femur primitiver Säuger (Monotremen, Fig. 260, und einige andere) schließt sich nämlich recht innig an das ursprünglicher Reptilien (speziell Chelonier, sowie der fossilen Theromorpha) an. Der Oberschenkel ist noch weniger stark nach vorn gewendet und sein Condylus (Caput femoris) fast ebenso schief naeh oben und etwas nach innen geriehtet, wie bei den Cheloniern (vgl. Fig. 256). Beiderseits des Condylus springen die Trochanter fibularis (major) und tibialis (minor), die selbständig verknöchern, vor, ähnlich wie bei Schildkröten. - Mit der schärferen Vorwärtsrichtung des Femur der neogenen Säuger wendet sich seine ehemalige Dorsalfläche uach vorn, so daß nun der Trochanter fibularis nach außen, der Tr. tibialis medianwärts schsut. Der Condylus riehtet sich mehr naeh innen und steigt weniger schief auf, bis er schließlieb, besonders bei den Primaten, fast senkrecht zur Längsachse des Femur steht. Im Gegensatz zu den Vögeln erfährt daher das proximale Femurende keine Torsion, viclmehr wendet sich nur der Condylus nach der Medianfläche des 'Tierkörpers. - Die Troehanteren sind gewöhnlich sehr gut entwickelt, doch tritt der Tr. tihialis zuweilen stark zurüek. Der kräftigere äußere Troebanter (Tr. major) bildet häufig eine am Femur weit herabziehende Leiste Crista glntaei, deren Distalende sieh bei vielen Sängern als ein Trochanter tertins melu oder weniger erheht (besonders bei Perissodactylia Fig. 2631, und einzeluen Formen der Edentata, Insectivora, Rodentia nsw.). - - Die Epicondylen des distalen Feunrendes sind ziemlieh gleich groß. 
Von den beiden, ursprtinglich freien, aber auch dann nur wenig gegeneinander beweglichen Unterschenkelknochen ist die Tibia stets viel stärker. Schon bei den Monotremen (Fig. 260) verbreitert sich ihr Proximalende so beträchtlich, daß es die Fibula fast vőllig von der Gelenkung mit dem Condylus fibularis des Femur verdrängt. Bei den neogenen Säugern ist dies meist völlig eingetreten, so daß sich das Proximalende der Fibula an einen äußeren Vorsprung der Tibia anlegt, am Kniegelenk sich jedoch nicht mehr beteiligt. - Die Vorderfläcbe der proximalen Tibiaregion kann eine starke Crista bilden. - Interessant erscheint die nur den Monotremen eigentümliche ansebnliche Verlängerung des proximalen Fibulaendes zu einem, auch funktionell dem Olecranon der Ulna entsprechenden Fortsatz, der auch bei gewissen anomodonten Reptilien vorkommt (Peronecranon, Fig. 260).

Nicht wenige Marsupialia und Edentata besitzen an Stelle dieses Fortsatzes ein selbständiges accessorisches Knöchelchen (Fabella, Paraflbulare). Ein ähnliches Knöchelchen oder Knorpelchen soll sich nach neueren Erfahrungen auch bei vielen Reptilien finden, das jenem Peronecranon auch wohl entspricht.

Selbst bei denjenigen Sängern, deren Fibula keine Verkümmerung zeigt, ist sie doch nicht selten der Tibia fest angelagert, ja sogar mehr oder weniger mit ihr verwachsen (besonders häufig bei Edentaten, Nagern und Insectivoren). Wenn die Ulna der Vorderextremität rudimentär wird, verkümmert auch die Fibula; vor allem bei den Huftieren. So ist sie bei Tapir und Rbinozeros unter den Perissodactylen (Fig. $263^{1-2}$ ) noch gut, aber zart vorhanden, bei den Pferden (Fig. 263 3 ) dagegen bis auf das proximale, jedoch freie Ende verkiimmert. Die Fibula der Ruminantia (Fig. $264^{2-3}$ ) ist tast vollig riickgebildet bis auf ihr Distalende, das der Tibia außen fest angefugt bis verwachsen ist (Os malleolare). Zuweilen persistiert auch noch ein kleines Stück ibres Proximalendes als ein mit der Tibia verwachsener Fortsatz. - Stark reduziert erscheint ferner die Fibula der meisten Chiropteren, wo sich nur der distale Teil mehr oder weniger verkümmert erhält, der übrige jedoch gewőhnlich noch dureh ein Ligament repräsentiert wird.

Eine Patella kommt den Sängern als ansehnliche Verknöcherung (selten nur knorpelig) fast ausnahmslos zu. Auch an der Hinterseite des Kniegelenks treten zuweílen 1-2 kleine Accessoria (sog. Fabellae) in den Ursprnngssehnen des Musculus gastrocnemius anf.

Der Tarsus erbält sich relativ ursprünglich, zeigt jedoch eine eigenartige Ausbildung in ganz anderer Richtnng als bei den Sauropsiden, indem sich kein Intertarsalgelenk entwickelt and ein Centrale stets erhalten bleibt. Die Proximalreihe (s. Fig. 261) wird von zwei ansehnlichen Knochen gebildet, dem tibialen sog. Talus (Astragalus, Sprungbein) und dem fibularen Calcaneus (Fer'senbein). Die Distalreihe enthält stets nur vier Elemente, indem die Metatarsalia IV und V an einem Tarsale gelenken. Dies sog. Cuboid.wird daher als die Tarsalia 4+5 umfassend angesehen, um so mehr, als diese beiden bei gewissen Marsupialiern noch ontogenetisch gesondert auftreten. Zwischen die beiden Reihen schiebt sich am tibialen Wurzelrand stets ein weiterer Knochen ein, das Naviculare, welches allgemein als ein Centrale gedeutet wird. Hiernach ergibt sich der primitive Säugertarsus nebst der 
Dentung (Gegenbaur) und der Bezeichnung seiner Elemente, die sie beim Menschen erhielten, folgendermaßen:

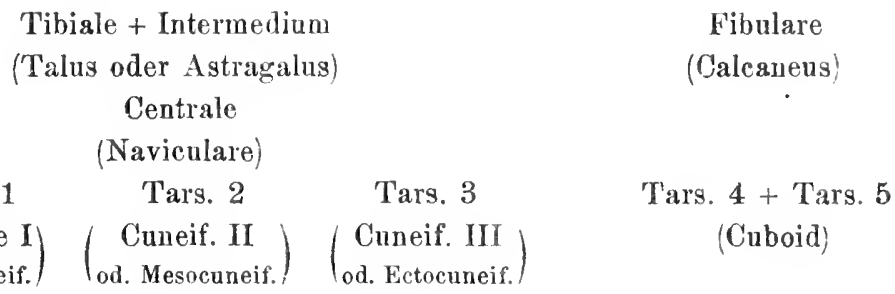

Die vergleichende Anatomie scheint die Deutung des Talus als Tibiale + Intermedium zu unterstützen, obgleich hierfür wohl die leider noch unsichere Auffassung des sog. Astragalns

Fig. 261.

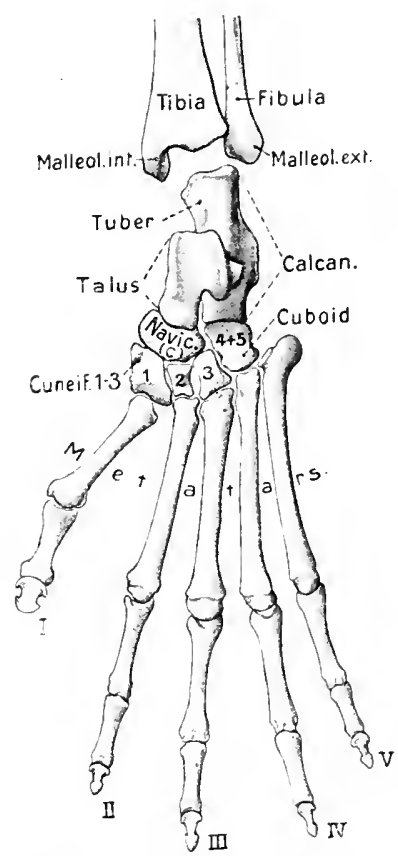

In us :caudat us (altweltlicher Affe). Skelet des linken Fußes on der Vorderoder Doralseite. Hier, wie auf den Figuren 264 und 265 wurde der Tarsus vom Unterscbenkel abgerūckt gezeichnet, um Talus und Calcaneus besser hervortreten za lassen. $\quad$ P. He. der Anuren wichtig wäre. - Eine andere Ansicht will aber im Talus nur das Intermedium, oder das Intermedium + dem proximalen der ursprünglich mehrfachen Centralia erkennen, und sucht das Tibiale in einem bei nicht wenigen Säugern (nicht selten bei Marsupialia, Edentata, Rodentia nnd einigen anderen) am tibialen Wurzelrand vorkommenden knöchelchen (Tibiale tarsi, Fig. 262 access. 1), das gewöhnlich als Accessorium gedentet wird, und dem sich zuweilen noch ein folgendes Knöchelchen anschließt, das dann als 6. Zehe (Prähallux) aufgefaßt wurde. - Die Verhältnisse bei den Cheloniern, welche in manchen Punkten sängeräbnliche sind, machen die erstere Auffassung

Fig 262.

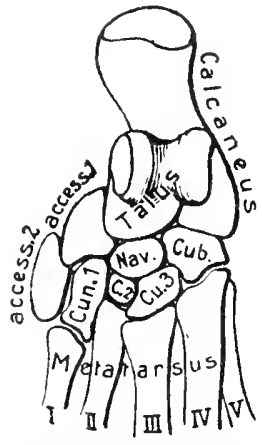

Castor fiber (Biber). Fußwurzel von vorn. (Aus LECHEBronn nach Ajbrecilt.) v. Bu. wallrscheinlicher: Gewisse Theriodontia(Theromorpha) unter den fossilen Reptilien sollen außer Astragalus und Calcaneus ein Naviculare besessen haben und kämen daher auch im Bau ihres Tarsus den Säugern nahe.

Der ansehnliche $T a$ lus articuliert mit dem Distalende der Tibia, das zuweilen von seinem Medialrand einen Fortsatz distalwärts sendet, der zur Führung des Talus dient (Fig. 261).

Das Fußgelenk liegt also auf der Grenze zwisehen Tibia und Tarsus. Die Fibula beteiligt sich bei den paläogenen Säugern (Monotremen Fig. 260, manchen Marsupialiern und Placentaliern noch an der Bildung des Fußgelenks, indem sie mit dem Calcaneus articuliert. Bei den neogenen Säugern wird sie durch einen Fortsatz des Talus, sowie durch Verkïrzung mehr aus dem Fußgelenk herausgedrängt (Fig. 261). 
Durch diese Verbreiterung des Talus kann die Fibula anch \%ur Articulation mit diesem gelangen, wie es namentlich bei den Edentaten geschieht. Besonders bei den Faultieren bildet sie einen Fortsatz, der mit der ih: zugewendeten Seitenfläche des Talus gelenkt; um diesen Fortsatz kaun der unit der Tibia wenig articulierende Talus rotieren, so daß die Ventralfächs des FuBes nach innen gerichtet $\mathrm{zu}$ werden vermag, was beim Klettern vorteilbaft ist.

\section{Der Caleaneus bildet auf seiner} Hinterseite einen vorspringenden Fersenhöcker (Tuber) zur Befestigung der sog. Achillessehne, der, je nach der Funktion der Extremität. schwächer oder stärker ist.

Tine besondere Eigentümlichkeit. gewisser Halbaffen ist die Verlängerung von Talus und Naviculare, die bei der Gattung Tarsius ganz extrem erscheint, so $\mathrm{daB}$ beide Knochen lang eylindrisch werden.

Die bei vielen Säugern erhaltenen ursprünglichen fünf Zehen zeigen dieselben Phalangenzahlen wie die Finger, also fast stets 2, 3, 3, 3, 3. - Obgleich der FuB im allgemeinen einförmigere Bowegungen ausführt als die Hand, und daher auch weniger mannigfaltig wird, so kann doch bei kletternden Formen eine ähniche Opponierbarkeit der großen Zehe (II:llux) auftreten, wie sio vom Daumeu beschrieben wurde (unter den Marsnpialieru dio Didelphiden und Phalangista, eiuzelne Nager und uamentlich die Primaten).

An Fuß des Menschen tritt, infolge des aufrechten Ganers, die Opponierbarkeit der I. Zehe, welche ontogenetisch noch durch ihre ursprürglicb mehr mediale Richtung angedentet ist, zurick. Sie wird gleichzeitig die größte Zehe, während sie bei den Affen fast immer kleiner bleibt, ja sogar zuweilen (z. B.

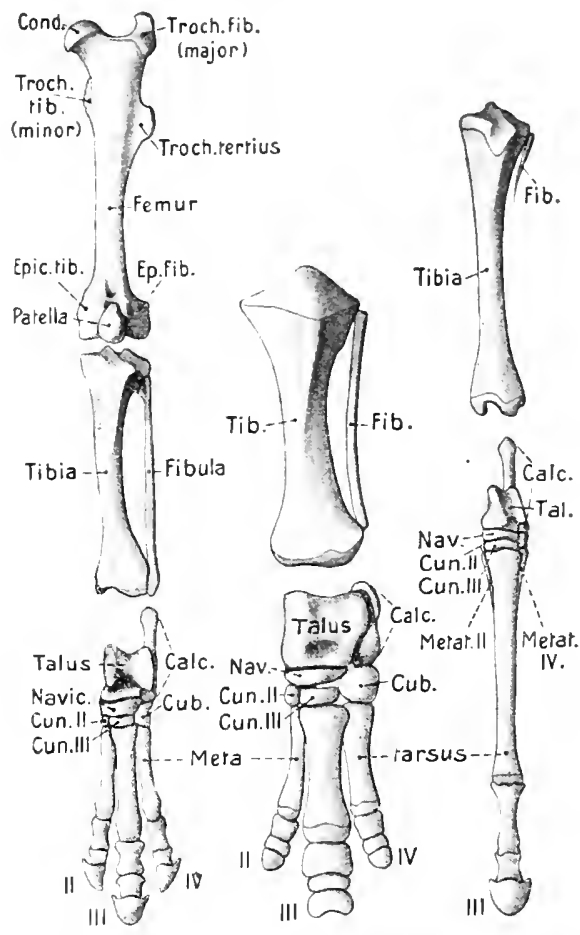

1. Tapirus

2.Rhinoceros 3. Equus,

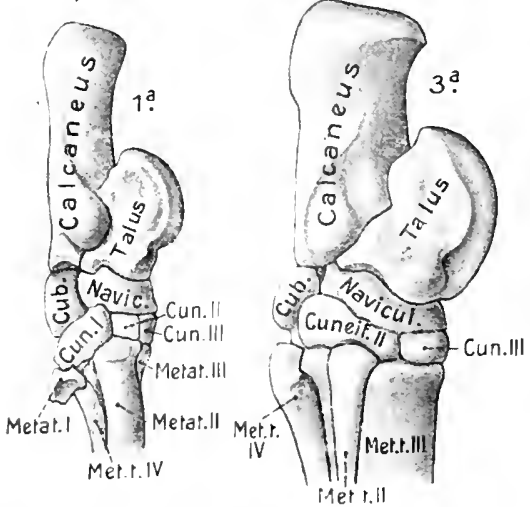

Skelet der linken Hinterextremität von peris sodactylen Ungulaten. $l$. Tapiras. Hxtremitât von iorn. $1 a$ Tsrsus von der Innenseite (Medianseite). 2. R hinoceros (jung). Untersebenkel und Fub rou vorn. $\because$. Equab. Unterschenkel und Fulj von vorn. 3 a Tarsus von der Innenseite.

Orang) stark reduziert ist. Die Fußwurzel des Menschen wird relativ sehr groß und kräftig, länger vie der Mittelfuß, während sie bei den Affen hinter diesem zuräckbleibt. Auch 
dies muß als Folge der veränderten Funktion beurteilt werden, da der menschliche Fuß hauptsächlich auf der Wurzel und den Distalenden der Metatarsalia ruht. Der zum Klettern

Fig. 264.

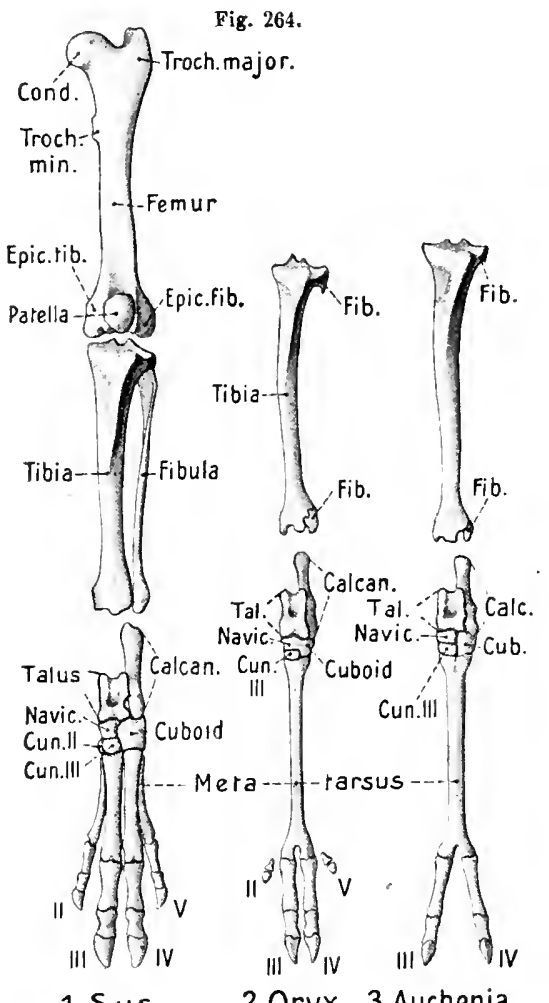

1.Sus

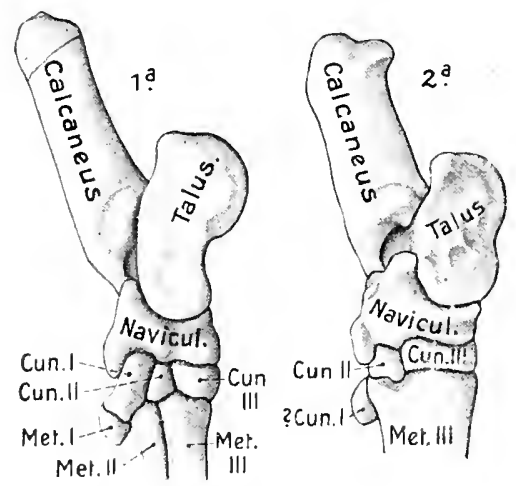

Skelet d. linken Hinterextremitit ron artio dactyIon Ungulaten 1 Sus scrophadom. Extremităt von vorn. 1 a Tarsus ron der Innenseite (Medianseite). 2. Oryx (Aniloper. Unterscbenkel nnd Fuß von vorn. 2 a Tarsus von der Innenseite. 3. An chen i (Lama). Unterschenkel und Fuß von vorn. eingerichtete $\mathrm{Fu} B$ der $A f f e n$, insbesondere der Anthropoiden, wird beim Gehen auf dem Boden mehr oder weniger mit dem flbularen Rand aufgesetzt, da seine Soblenfläche in verschiedenem Grad medianwằrts gerichtet ist. Dies wird auch durch eine Modiflkation im Bau der Wurzel begïnstigt, welche eine freiere $\mathrm{Be}$ wegung des Talus auf dem Calcaneus und damit auch des Naviculare und Cuboid gestattet.

Rückbildung von Zehen findet sich recht häufig und erfolgt in der Reihe der Huftiere ganz ebenso, wie es für die Vorderextremität dargelegt wurde, weshalb eine Wiederholung unnőtig scheint. Hervorgehoben sei nur, $d a ß$ dabei im allgemeinen der $\mathrm{Fu} B$ in der Reduktion vorangeht. Auch die allgemeinen Verhältnisse der Plantigradie, Digitigradie und Unguligradie sind für den $\mathrm{FuB}$ dieselben wie für die Vorderextremität. I. und V. Zehe werden auch bei den Edentata, Marsupialia, Insectivora, Rodentia, Carnivora bäufig rudimentär. Bei den Känguruhs (Poëphaga) und Beuteldachsen (Peramelidae) ist die 4. Zehe sehr groß, alle iibrigen sind meist stark riickgebildet. - Die Verlängernng des Metatarsus III bei den Pferden (Fig. 2633), sowie die Bildung eines Laufknochens durch Verwachsnng der Metatarsalia III und IV bei den Ruminantien (Fig. 264,2,3) volizieht sich wie an der Vorderextremität. Ähnliches kann jedoch anch bei einzelnen Nagern mit verlängerter, zum Springen dienender Hinterextremität eintreten (Dipus, Alactaga), wo sich durch Verwachsung der Metatarsalia II-IV ein Laufknochen entwickelt, ähnlich wie bei Vögeln; wogegen sich bei den mit analog funktionierenden Hinterextremitäten versehenen Insectivoren (Macrosceliden) die Metatarsalia sehr verlängern. 


\section{VORLESUNGEN ÜBER \\ VERGLEICHENDE ANATOMIE}

VON

\section{OTTO B ÜTSCHLI \\ PROFESSOR DER ZOOLOGIE IN HEIDELBERG}

2. LIEFERUNG:

ALLGEMEINE KÖRPER- UND BEWEGUNGSMUSKULATUR;

ELEKTRISCHE ORGANE UND NERVENSYSTEM

MIT DEN TEXTFIGUREN $265-451$

HA NULDRUCK 1921

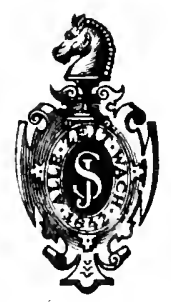

BERLIN

VERLAG VON JULIUS SPRINGER 
Alle Rechte, besonders das der Übersetzung, sind vorbehalten. 
Wie der Carpus, zeigt anch der Tarsus der Ihftiere, trotz der weitgehenden Zelıenreduktion, relativ geringe Veräudernug. Bei den Perissodactylia (Fig. 263) sind fast stets sïmtliche Elemente vorhanden. Die Ruminantia (Fig. 264 2 , 3 ) hingegen zeigen häufig Vereinfachung durch Verwachsungen in der Reihe der Tarsalia; so sind znweilen Ta. $2+3$ (Cervus, hos) vereingt, selten damit ancl noch das Cuboid (Tragulus u. a.). Cnboid und Naviculare sind meist verschmoizen (Ausnalıme Kamelartige).

Eine Besonderheit des FuBes gewisser Faultiere (Bradypus) bildet die weitgehende Verwachsung der Elemente, welche sich anf Naviculare, simtliche Cuneiformia und Cuboid, die Metatirsalia sowie die ersten Phalangen der erlaltenen Finger II-IV erstrecken kamm.

Von der änßerlich völlig verschwundenen Hinterextremität der Cetacea bleiben bei gewissen Bartenwalen noch Reste des Femm und zuweilen anch der 'Tibia erhalten (s. Fig. 234, S. 368). Den rezenten Zahuwalen und den Sirenen soll dagegen jede Spur freier Extremitätenknochen fehlen; dagegen besa $B$ die fossile Sirene Halitherium noch ein verkümmertes Femur, was jedoch anch für einzelne Manatusformen gelegentlich angegeben wird.

\section{Kapitel: Allgemeine Körper- mnd Bewegungsmuskulatır.}

Unter allen Organsystemen zeigt die Körpermuskulatur eine besondere Anpassungsfähigkeit an die Bewegungsbedürfnisse der einzelnen Formen und daher auch eine große Wandlungsfähigkeit, sowie Spezialisierung zu besonderen Leistungen. Es ist natiurlich hier nicht möglich, diese Anpassung's erscheinungen ins Einzelne zu verfolgen, vielmehr kam es nur unsere Aufgabe sein, die Grundzïge zn verfolgen, welche den Ban in den Hauptgruppen beherrschen. -In diesem Kapitel wird nur die allgemeine, zur Körperbewegnng dienende Muskulatur betrachtet werden, während die Muskeln der besonderen Organsysteme (Darm, Geschlechtsapparat usw.) bei diesen zu erörteru sind.

In gewissen Protozoenzellen salien wir contractile Fäden auftreten (Myoneme, vgl. S. 75), welche in bis jetzt noch nicht himeichend ermittelter Weise rom Plasma hervorgebracht, nach verbreiteter Meinung abgeschieden werden. Dasselbe tritt in gewissen Zellen der Metazoen anf und verleiht ihmen Contractionsvermögen, d. h. die Eigenschaft, sich in der Richtung der contractilen Fäden (hier gewöhnlich Fibrillen oder contractile Elemente genannt) zu rerkiirzen, nnter entsprechender Verdickung in der Quere. Anf diese Weise werden solche \%ellen zu Muskelzellen. Fs ist leicht begreiflich, daß sie fast stets zu langen Fasern answaclisen, was ilıre Verkiirzungsfähigkeit relativ erhöht.

\section{A. Wirbellose Tiere.}

1. Schon den Spongien kommeu solch contractile Faserzellen (Myocyten) zu, obgleich sie den Kalk- und Glasschwämmen zu fehlen scheinen. Es sind faserartige, langgestreckte Zellen der :inßeren Körperlage (Epiblast, Sceletoblast), ohne deutliche fibrilläre Elemente. Sie finden sich häufig in ringfürmiger Anordnung 
(Sphincter) um die Oscula, wozu sich zuweilen auch strahlenförmige Ziige gesellen; ferner längs der oberflächlichen Kanäle, an denen sie stellenweise gleichfalls sphincterartig angeordnet sein können.

2. Die Coelenteraten zeigen recht ursprüngliche Verhältnisse, indem sich sowohl ibre Ecto- als Entodermzellen zu contractilen Zellen entwickeln können. Hieraus folgt, daß die beiden Gewebsschichten (Keimbliitter) der lyypothetischen Gastraea-Urformen der Eumetazoen diese Befähigung besaßen. Gleichzeitig erweisen sich die Verbältnisse in vielen Fällen noch deshalb recht ursprïnglich, weil eine größere oder geringere Zahl der Ecto- und Entodermzellen zu Muskelzellen werden, ohne dabei aus den betreffenden Epithellagen auszutreten. So fiuden wir denn bei Hydroiden (sowohl im Polypen- als Medusenzustand), aber auch noch bei den Acalephen und Authozoen, häufig Ecto- und Entodermzellen, die an ihrem Basalende, welches der sog. Stützlamelle, oder dem gallertigen

Fig. 265 .

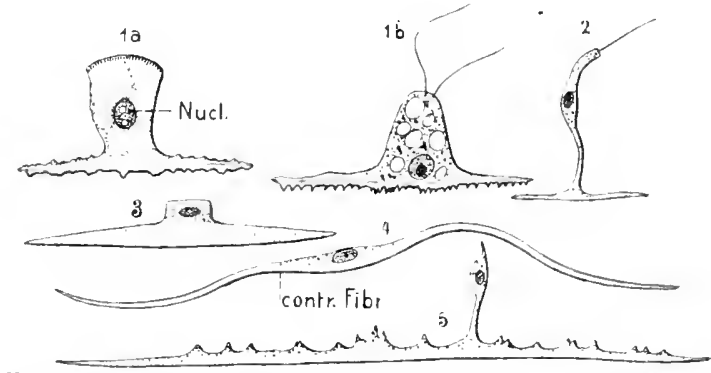

Verschiedene Epithelmuskelzellen von Cölentersten. Muskelfibrillen rot. I Von Hydra. $1 a$ aus Eetoderm, Ib aus Entoderm (n. C. Schneider 1890). \& Sagartia (Actinie) aus Entoderm. 3. Lizzia (Hydromeduse) aus Tentakelectoderm, quergestreift. 4 Anthea (Aetinie) aus Ectoderm der Mundscheibe. 5 Edwardsia (Actinie) aus Tentakelectoderm ( $2-5$ nach 0 . und R. HEITWIG 1978 u. 79 ).
Mesenchym (Mesogloea) aufsitzt, in einen (gelegentlich anch mehrere) auf der Oberfläche des Mesenchyms hinziehende contractile Fortsätze ausgewachsen sind, während der übrige Zellkörper, samt dem Kern, zwischen dengewöhnlichenEcto. oder Entodermzellen eingeschaltet blieb und die freie Oberfläche des Epithels häufig noch erreicht (Fig. 265). Man bezeichnet solche Zellen als Epithelmuskelzellen (frii-

her auch Neuromuskelzellen). Im Plasma ihres Muskelfortsatzes können sich eine oder mehrere contractile Fibrillen entwickeln, die bei den Hydromedusen, Siphonophoren und Acalephen nicht selten quergestreift sind. - Bei manchen Formen verkiirzt sich jedoch der zwischen den gewöhnlichen Epithelzellen liegende, nicht contractile Teil der Zelle, so daß er der muskulösen Faser schließlich nur noch als schwacher Anhang oder Verdickung anhängt, ja auch ganz eingezogen wird. Auf diese Weise entsteht eine Lage besonderer, faserartiger Muskelzellen unter dem Ecto- oder Entoderm, dereu Herkunft von diesen Epithellagen leicht erkennbar ist. Bei Ausbildnng eines dickeren Mesenchyms können sich die frei gewordenen Muskelzellen auch in dieses einsenken, was namentlich bei der Anthozoen auftritt.

An den Tentakeln und dem Körper der Hydropolypen. (dagegen nicht an den Stielen der Kolonien) entwickelt sich so ein ectodermales System vou Läugsmuskelfasern (meist Epithelmuskelzellen), die zur Verkürzung des Körpers dienen. Auf der Innenseite der Stützlamelle bilden die Entodermzellen quer ringförmig 
verlaufende Muskelfortsätze, welche demnach, als Antagonisten (Gegenwirker) der Längsfasern, den Körper zu strecken vermögen. - Der häufig sehr lange Stamm der Siphonophoren-Kolonien ist recht contractil nnd besitzt eine starke Längsmusknlatur, deren Komplikation weiter unten erwähnt wird.

Die Musknlatur der frei beweglichen Hydromedusen und der in vieler Hinsicht ähnliclien Acalephen ist komplizierter (s. Fig. 266). Die aborale Oberfläche des glocken- bis schirmförmigen Körpers (Exumbrella) besitzt überhaupt keine muskulösen Elemente; diese konzentrieren sich auf die orale Schirmfläche, die sog. Subumbrella. Ferner entwickelt fast ausschließlich das Ectoderm Muskelfasern. Bei beiden Abteilungen tritt vor allem ein am Schirmrand, unter dem Subumbrellarepithel verlaufendes Ringband quergestreifter Fasern, der sog. Kran:musliel hervor, der bei seiner Contraction die Schirmhöhle verengert und durch das ausgestoßene Wasser die Meduse vorwärts bewegt. Der Kranzmuskel der primitiveren Acalephen ist ein zusammenhängendes Band, wie der der Hydromedusen. Bei den höheren erscheint er meist entsprechend dem Strahlenbau in 4-32 und mehr Partien zerlegt. Bei den Hydromedusen ist auch der Saum des Schirmrands (Velum, s. Fig. 314, S. 466) häufig mit Ringmuskulatur versehen. Außerdem finden sich an der Subumbrella radial und interradial radiäre Zuige glatter Fasern in verscbiedenartiger Ausbildung, die sich zuweilen auf das Manubrium fortsetzen. - Die Randlappen der Acalephen sind ebenfalls mit radiären Faserzïgen ausgestattet. Auch die Tentakeln des Schirmrands, sowie die Mundarme der Acalephen und ibre etwaigen Auhänge sind meist muskulös. - Wenn es vorteilhaft erscheint, daß solche Muskelzüge besonders kräftig werdeu, wird dies dadurch erreicht, daß sich die

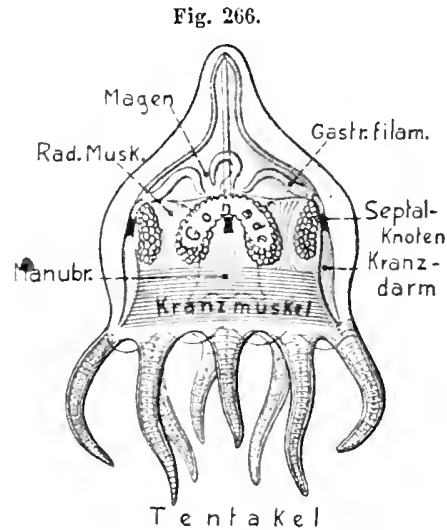

Tessera prineeps (Acalephe). Zur Demonstration der Muskulatur. Ansicht auf einen lnterradius. Muskeln rot $(n$. IlAE, $K \mathrm{~K}$ 1579). v. Bu.

Stïtzlamelle, oder die Oberfläche der Gallerte, in Falten erhebt, an welche sich die Muskelfasern anheften, und so in mehrfacher Schicht iibereinander liegen (vgl. Fig. 268,3), was auch fiur die starke ectodermale Längsmnskulatur des Siphonophorenstamms gilt

Die Muskulatur der Forallenpolypen (Anthozoen) differenziert sich reicher als die der Hydropolypen, in Kusammenhang mit der komplizierteren Gastralhöhle. Schon bei den Jngendformen der Acalephen (Scyphopolypen) tritt in jedem der vier interradialen Gastralsepten ('Taeniolen) ein Längsmuskel auf, der aus dem sich einsenkenden Ectodermepithel der Mundscheibe hervorgeht. - Bei den entwickelten Acalephen schwindet er wieder; nur bei den festsitzenden Lncernariden (Calycozoen) blieb er erhalten. - Öhnliche septale Längsmuskeln sind an den größereu Gastralsepten der Korallenpolypen fast stets ausgebildet uud bewirken vor alleın die Einziebung der Mundscheibe samt ihrer Tentakel (s. Fig. 267). 
Diese Muskeln der Anthozoen sind jedoch entodermaler Herkunit. Überhanpt ist die entodermale Musknlatur der Korallenpolypen reicher entfaltet als die ecto-

Fig. 267.

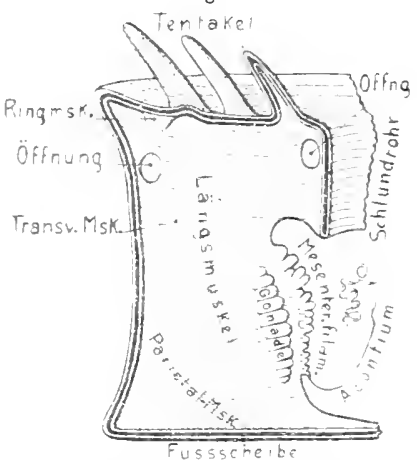

Achinie. Schemalische Darstellung eine tiantralseptums mit dem angrenzenden Tejl der Mnalscheilie und der Wand des Schlundrolirs. Muskulalur rot. Der Lăngsmuskel liegt anf der anderen Seite des Sertums als der Trinsversal. nnd 1'arie. tobasilarmuskel (l'arielalmuskel) und ist Atber durchseheinend gezeichnet nit benutzung ron likn rug 1>79). B. Bu.

dermale und bildet, wie bei den Hydropolypen, unter dem Enıderm eine allgemein verbreitete Ringmuskellage, welche an den Tentakeln, der Munds and Fußseheihe, dem Manerblatt und Sehlundrohr gut entwickelt ist. Bei den Aetinien (Seerosen), sowie manchen Madreporarien, verdickt sie sich am Rand der Mundscheibe, auferhalb des Tentakelkranzes, zuweilen sogar zn einem starken Sphincter (Fig. 267). Auf die Gastralsepten breitet sie sieh in Form radiairziehender, sog. Transrersalmuskeln ans, die jedoeh nur anf der einen Fliche der Septen schwich entwickelt sind, während die andere eine Lüngsmuskellage besitzt, die sieh zu den starken Längsmuskelziigen verdiekt, welche sehon oben erwähnt wurden. 1)iese L:ïngsmnskeln sind jedoch bei den Cerianthiden, welche auf beiden Septenflächen Transversalmuskeln besitzen, sehr riickgebildet. - Bei den Octokoralley und Hexactinarien erheben sich diese Längsmuskeln st:ukk iiber die Septalttichen, weshalb die Querselunitte größerer Septen fahnen-

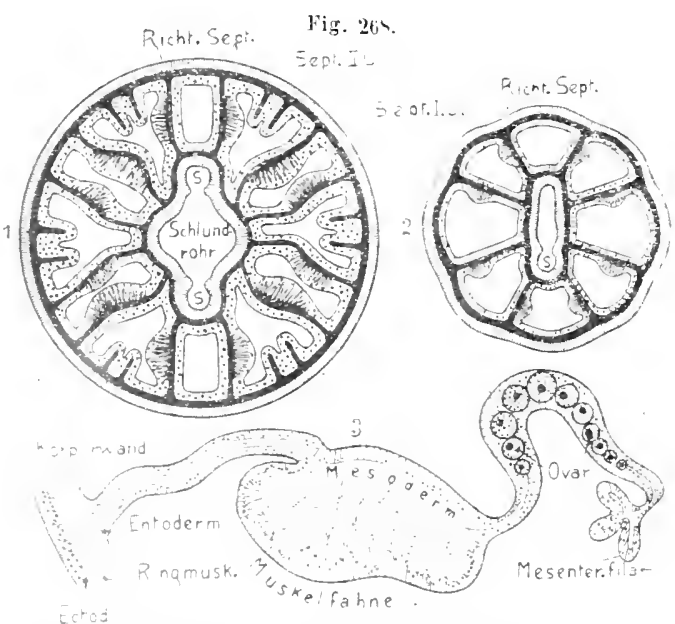

Schematische Querschnitte durch eine 11 exakoral le ( $l$, Actinie und eine fetokoralle $(2)$; beide in der Höhe des Schlundrohrs. : Schematischer Quersebnit durch tin grolkeres Septum einer Actinie. Mesencbym weir. Muskulibor rot (n. Hertwia 1879). v. $\mathbf{B u}$. artig erscheinen; daher auch der Name Muskelfahnen für die Querschnitte der Längsmuskeln. Ihre charakteristisehe Anordunng an den Septen, wie sie Fig. 268, 2 u. 1 für die Octokorallen und typisehen Hexakorallen (Hexactinaria) zeigt, bewirkt namẻntlich den sekumdar bilateralen Bau der ersteren und den sekundär zweistrahligen der letzteren, wie ans der Figur hervorgeht. DiegrößerenGastralsepten der Actinieu mit gut entwickelter F'ußscheibe besitzen auf der. init Transversalmuskelu versehenen Fliiche noch einen sog. Parietobasilarmuskel, der häulig von den Transversalmuskeln abgegleitet wird, was eher unwahrscheinlieh ist. Diese Mnskelı können zuweilen bis zur Mundseheibe emporsteigen und scheinen 
bei einzelnen Formen anch auf der auderen Fläche des Septums vertreten zu sein (s. Fig. 267, Pariet. Msk.). - Zu ihnen gesellen sieh meist noch sog. Basilarmuskcln anf beiden Seiten des Septums längs dessen Auheftung an die Fußscheibe.

Die eetodermale Längsmuskulatur der Anthozoen ist fast stets schwïher entwickelt, und beschrïnkt sich gewöhulieh anf die Tentakeln und die Mundseheibe, auf der sie radiär zieht. Die Cerianthiden, sowie die ganze Unterabteilung der Protantheae (Carlgren) dagegen besitzen ansuahmsweise noch eine recht starke Längsmuskelsehicht der seitliehen Ǩ̈̈rperwand (Mauerblatt), die bei den übrigen rückgebildet wurde, in dem Maße als siclr die septalen Läingsmuskeln entwickelten. Die Muskulatur der skeletbildenden Madreporarien bleibt im allgemeinen schwächer. - Wo die Muskelschichten dicker werden, so an dem erwähnten Sphincter der Mundscheibe, den MInskelfahnen und auch zuweilen anderwärts, geschieht dies stets auf die schon oben erwähnte Art, indem sich das Mesenchym faltet, wobei sich die Falten anch hïufig verzweigen, und die Muskelfasern, den Falten anliegend, übereinander gesehichtet ersebeinen (Fig. 268, 3). - Wührend die entodermale Muskulatur der Anthozoa fast stets ans typisehen Epithelmuskelzellen besteht (ausgenommen zuweilen im Sphincter), sondert sich die ectodermale manchmal vom Epithel ab und kann sogar stellenweise ins Mesenchym verlagert werden.

Im Stamm (Coenosark) der Anthozoenkolonien findet sich gewöhnlich keine besonlere Nuskulatur. Nur in dem der Seefedern (Pennatularia) wurde \%. T. kräftige Läıgs- und Ringmuskulatur beobachtet, deren Funktion mit der Aufıahme und Abgabe vor Wasser in das gastrale Kanalsystem des Stamms zusammenhängt.

Die Verlagerung der Muskeln in das Mesenehym ist bei den in vieler Hinsicht von den ïbrigen Coelenteraten abweichenden Ctonophoren vorherrschend, einer Gruppe, die sich jedoch in der Ontogenese ihrer Muskulatur von den typisehen Coelenteraten wesentlich unterseheidet und den Bilaterien nähert. Charakteristisch ist, daß bei ihnen typisehe Epithelmuskelzellen fehlen, obgleich bei nicht wenigen unter dem Ectoderm der Oberfläche und des sog. Schlundrohrs (Magen) eine bis zwei Schichten von Muskelzellen vorkommen, die bald mehr ringförmig, bald mehr longitudinal ziehen, sich zuweilen auch recht unregelmäßig kreuzen; ihr inniger Anschluß an die Epideruris befürwortet ihre ectodermale Abstammung. Fig. 269.

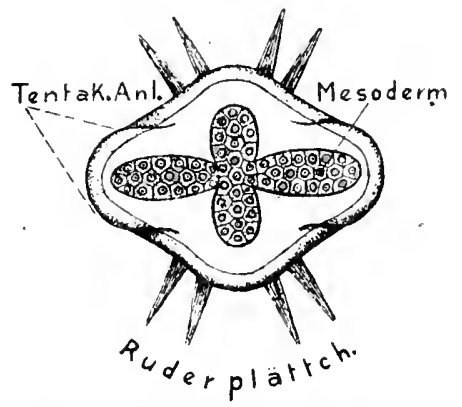

Entwicklungsstadium ron Callianira lialat a (Ctenophore) von der Apicalseite, zur llemonstration des sog. Mesoderms (n. MrczNinof
18 , etwas schenatisitit). E. W. Die größte Menge der Muskelzellen ist aber gewöhulich der Mesenøhymgallerte eingelagert und verläuft bald mehr längs, in derRichtung der Hanptachse, bald zirknlär, namentlich aber radiär, indem sie von der Epidermis der Körperoberfläche durch die Gallerte zum Sehlundrohr, bzw. dem Centralteil der Gastralhöhle (sog. Triehter zieht.

Die Ontogenese macht es recht wahrscheinlich, daß sowohl die Hauptmenge der Mesenchymzellen, als auch die in Mesenchym befindlichen Muskelzellen von einem Paar be- 
sondrer mesodermaler Anlagen ausgehen, die entodermalen Ursprungs sind (s. Fig. 269); während aus einem zweiten Paar, senkrecht hierzu gestellter ähnlicher Anlagen die sehr starke Muskulatur und das Stützgewebe der beiden Tentakel hervorgelıt. Demgemäß sind auch die Muskelzellen der Ctenophoren gewöhnlich recht verschieden von denen der übrigen Coelenteraten, vielkernig und häufig mit reich verästelten Enden; die der Gallerte in der Regel mit innerem Sarcoplasma und äußerer contractiler fibrillärer linde, wie es bei den Muskelzellen der Bilaterien häufig vorkommt. Nur an den Tentakeln finden sich gelegentlich quergestreifte Muskelfasern.

3. Wirbellose Bilateria. Wie schon in der allgemeinen Einleitung geschildert wurde, geht die Körpermusktalatur dieser Formen, wenigsteus in ihrer Hauptmasse, aus einem besonderen, zwischen Ento- nnd Ectoderm auftretenden Mesodern hervor. Wenn die Riickführung dieses Mesoderms anf ursprïngliche Ausstülpnngen des Urdarms zutrifft, wie wir es für wahrscheinlich erachten, so folgt hierans, daß die Muskulatur der Bilaterien wesentlich entodermaler Herkunft ist, und etwa vergleichbar der entodermalen Mnskulatur der Gastraltaschen der Anthozoen. In der Hauptsache ist es jedoch nur die änßere, dem Entoderm sich anlegende Wand einer solch hohlen Mesodermanlage, aus welcher die Muskulatur der Körperwand hervorgeht, während die innere Wand, welche sich mit dem Entoderm des Darms vereinigt, die Darmmuskulatur erzeugt. Für die große Mehrzahl der Bilaterien, wenn nicht für alle, ist diese Bildung einer zusammenhängenden Muskulatur der Körperwand (HautmuskeIschlanch) wohl das ursprüngliche.

Termes. Bei den Wïrmern hat sich dieser Zustand allgemein erhalten. Abgesehen von solchen Formen, welche besondere Bewegungsorgane erlangten, beschränkt sich daher die von der Muskulatur hervorgerufene Körperlokomotion auf Biegungen, Schlängelungen oder wellenförmige Kriechbewegungen der Bauchseite.

Im allgemeinen ist dieser Hautmuskelschlauch, welcher die Epidermis meist direkt unterlagert, von recht einförmiger Bildung; er besteht in der Regel zum unindesten aus zwei, sich antagonistisch entgegenwirkenden Schichten, einer Ringfaserschicht, welche gewöhnlich die äußere ist, und einer Längsfaserschicht. Dieser einfache Bau kann sich in zweierlei Form darstellen. Bei den Wïrmern, welche eine Leibeshöhle besitzen (gleichgiiltig ob dies eine primäre oder sekundäre ist), unșchließt der Hautmuskelschlanch diese Höhle (Nemathelminthen, Chaetopoden, Gephyreen). Bei denjenigen hingegen, welche eine mesenchymatöse Erfüllung zwischen Körperwand und Darm zeigeu (PIathelminthen, Hirudineen), umschließt er dies Hesenchym oder Parenchym. Im letzteren Falle treten außer dem eigentlichen Hantmuskelschlauch stets auch im Parenchym Muskelfasern anf, unter welchen namentlich die vom Rücken zum Bauch herabsteigenden sog. Dorsoventralfasern eine wichtige Rolle spielen, indem sie mit der Abplattung des Körpers in Beziehung stehen.

Der einfache Hautmuskelschlanch kann sich einerseits durch Vermehrung der ihn zusammensetzenden Schichten kompliziereu, andrerseits auch vereinfachen. Bei den Anneliden bleibt natürlich die Metamerie nicht ohne Einfluß auf seinen Bau.

So wird der Hautmuskelschlauch der aprocten Plathelminthen gewöbnlich durch das Auftreten einer gekreuzten sog. Diagonalfaserschicht kompliziert, d. h. 
einer Schicht, deren Fasern schief zur Körperachse ziehen, und sich dabei unter etwa rechtem Winkel kreuzen (s. Fig. 270). Ihre Lage kann etwas verschieden sein, teils zwischen der äußern Ring- und der Längsfaserschicht, teils auch innerhalb letzterer. Auch bẹi den Nemertinen tritt diese Diagonalfaserschicht zuweilen auf und kehrt ebenso bei den Hirudineen wieder; wogegen sie den Cestoden fehlt. Die Komplikation kann jedoch anch durch Vermehrung der Ring- und Längsmuskelschichten, besonders der letzteren, erhöht werden. Bei dendrocoelen Turbellarien und zahlreichen Nemertinen (Heteronemertinen) tritt noch.eine äußere, zwischen die Epidermis und die

Fig. 270 .

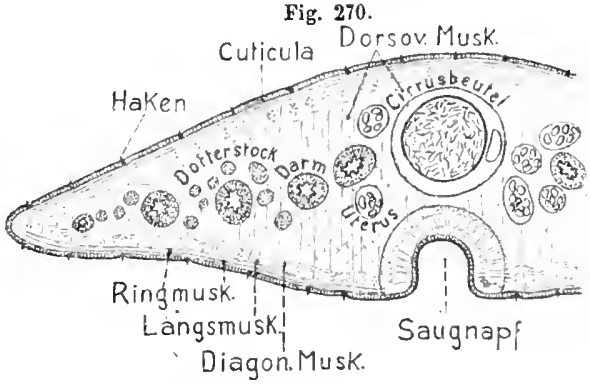

Distomum (Fasciola) hepaticum. Schematiseh. Querschnitt in der Gegend des Bauchsangnapfs, zur Demonstration der Mfuskulatur (rot). Epidermiszellen nicht eingezeicbnet.

Ringmuskelschicht eingeschobene Längsmuskellage hinzu (Fig. 271), während bei ersteren die innere Längsmuskelschicht am Rücken gewöhnlich fehlt. Übrigens herrscht in dieser Hinsicht viel Variabilität, was im Einzelnen nicht näher ausgeführt werden kann. Meist ist die ventrale Hantmuskulatur der aprocten Plathelminthen stärker entwickelt. - In dickeren Lagen gruppieren sich die Muskelzellen häufig zu Bïndeln inniger zusammen (s. Fig. 270), welche von Bindegewebe gesondert werden. Bei den Nemertinen ist eine fiederartige Gruppierung der Muskelzellen za beiden Seiten dünner Bindegewebslamellen (Fig. 271) recht verbreitet. - Wie gesagt, sind die im bindegewebigen $\mathrm{Pa}-$ renchym eingelagerten Fasern hauptsächlich dorsoventrale, deren verästelte Enden đie Schichten desHantmuskels durchsetzen und bis zur Epidermis treten (Fig. 325, S. 477). Bei dendroeoelen Turbellarien $u$. Nemertinen schieben sie sich namentlich zwischen die seitlichen Darmverästelungen ein, wodurch Bildungen entstehen, welche an die

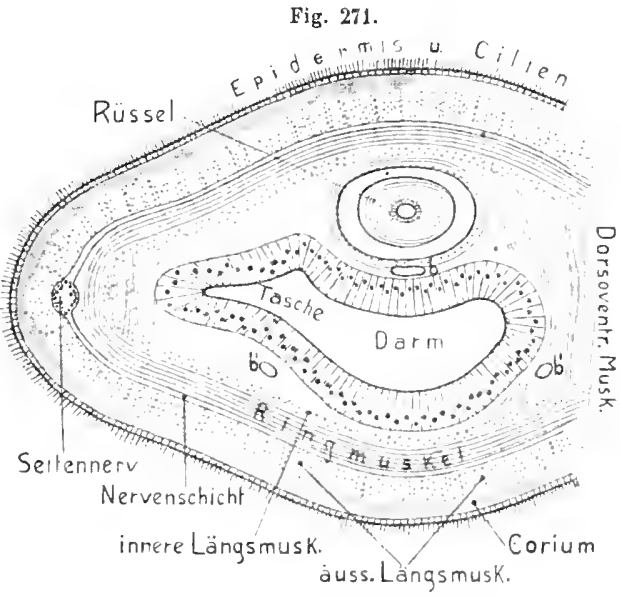

Ceretratulus (Nemertine). Schenatischer Querschnitt in der" Rússelgegend. Links durch eine Darmtusebe, lechts zwischen zwei aufeinanderfolgendon Darmaschen. $b$ dorsales Blutgefäß. $b$ die beiden seitlichen Blutgefäße (mit Benutzung v. Búkskik 1 1) 15$)$.

Dissepimente der Anneliden erinnern; dies ist bei den Hirudineen noch ausgesprochener, wo jedoch die Ansammlungen dorsoventraler Fasern zwischen den Darmtaschen auch ontogenetisch den wirklichen Dissepimenten entsprechen. - 
Ferner treten bei den aprocten Plathelminthen auch Muskelfasern auf, welche das Parenchym längs und quer, sogar schief durchiziehen; bei den Cestoden erreichen die transversalen eine besondere Stärke (sog. innere Ringmuskulatur, Fig. 272).

Als besondere lokale Differenzierungen des Hantmuskels, und unter Teilnahme der Parenchymfasern, entwickeln sich bei vielen aprocten Plathelıninthen (gewissen

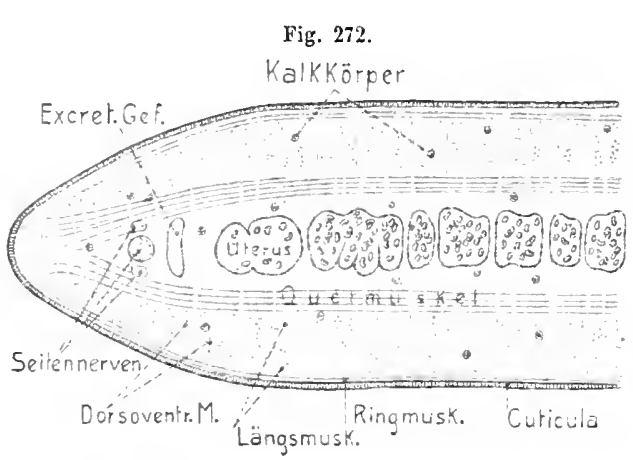

Taenia saginat a (Cestode). Schematischer Querschnitteiner Proglottis. zur Demonstration der Muskulalut. Epidermiszellen nicht eingezeichnet.
Dendrocoelen, den Trematoden [Fig. 270], Cestoden) und Hirudineen Haftapparate in Form von Saugnäpfen oder-gruben. Ohne hier auf die Mannigfaltigkeit dieser Saugnïpfe in Zahl, Anordnung und Bau näher einzugehen, werde nur bemerkt, daß sie grnbige Vertịefungen der Köiperoberfläche sind, deren Außenrand gewöhulich etwas verdickt vorspringt. Sie können sich jedoch auch auf sticlförmigen Fortsätzen

iiber die Körperoberfläche erheben. Die Hautmuskulatur wird in ihrem Bereich sehr stark und ist im allgemeinen in äquatoriale, meridionale und radiäre Züge angeordnet. Durch Contraction der äquatorialen und meridionalen Mnskelfasern wird das Lumen des Saugnapfs verengert und sein Rand der Unterlage angepreßt, worauf die Contraction der Radiärnuskeln das Lumen zu erweiteru strebt

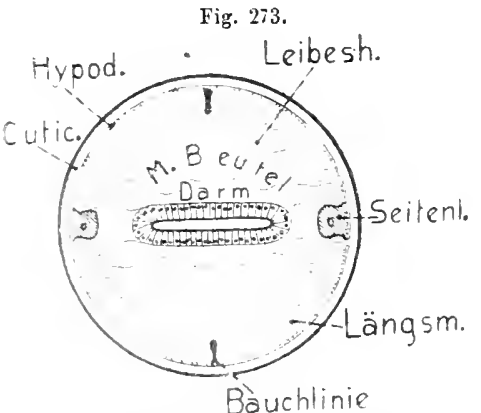

Schematischer Querschnitt eines polymyaren Nematoden zur Demonstration der Muskulatur. (Bildnng eines luft-, bzw. dampfverdünnten Raums), so daß der äußere auf dem Tier lastende Druck den Körper an die Unterlage anpreßt. Nicht sclten bestehen auch besondere Abzweigungen des Hantmuskels zur Bewegung solcher Saugnäpfe im Ganzen.

Auf die eigenartige Muskulatur des rüsselartig aus- und einstuilpbaren sog. Trostellums am Scheitel des Taeniadenscolex untẹr den Bandwürmern und der analogen rüsselartigen Bildungen einzelner Turbellarien, gewisser Trematoden, Cestoden, sowie des mächtigen. teils bewaffneten, teils unbewaffneten ein- und ausstülpbaren Rüssels der Nemertinen kaun hier nicht näher eingegangen werden. Auf letzteren werden wir bei dem Darm zu sprechen kommen, da er, obgleich eine selbständige Bildung, mit der Mundöifnung in nähere Beziehung treten kann.

Eine Vereinfachung des Hautmuskels kann bei kleinen Wurmformen dadurch eintreten, daß die Muskelzellen so spärlich werden, daß sie keinen geschlossenen Schlauch mehr bilden, wie es namentlich bei den kleinen Rotatorien hervortritt, die gewöhnlich noch Ring- und Längsmuskelzellen besitzen, auch besondere Züge 
zur Einziehung des Vorderendes (Rïderorgans) und des Fußes (Fig. 329 S.484). Im Hautmuskelschlauch der Nematoden (Fig. 273) jst nur eine Laingstaserschicht ansgebildet und die Beweggungsweise daher entsprechend vereinfacht. Der IIantmuskel dieser Wiurmer ist ferner in der Regel kein geschlossener, sonderu durch vier schmïlere oder breitere Unterbrecliungen (zwei Seitenfelder, ein Bauch- und ein Rückenfeld, oder - Linien) in vier Längsmuskelfelder zerlegt; manchmal sogar in acht. Die Zahl der Muskelzellreihen in jedem Feld kann grob seiu (Polymyarier), andrerseits bis auf zwei herabsinken (Meromyarier). Eine ähnliche Beschränkung des liantmuskels auf eine Laingsmuskelschicht besteht anch bei den Chaetognatha, wogegen der der Bryozocn mehr an die Einrichtungen der Rotatorien erinnert.

Auch die Muskulatur der gewöhnlich den Nemathelminthen zugerechıten Acanthoecphalen bewahıt den ursprünglicheren Charakler, indem sie aus einer äußeren Ring- und einer imneren Längstaserschicht besteht. Zur Rückziehung. des später zu besprechenden Rüssels und seiner Scheide haben sich besondere Retractoren vom Hautmuskel abgelöst.

Die Körpermuskulatur der metameren Anneliden wird auch ontogenetisch segmental augelegt, da sie, wie wir früher sahen (vgl. S. 17 ff.) im wesentlichen aus der sog. Somatupleura (Außenwand) der Somiten hervorgeht, während deren Vorder- und Hinterwände sich zu den Dissepimenten, d. b. den queren Scheidewänden der Cölomhöhle entwickeln. Die segmentale Bildung spricht sich auch im erwachsenen Zustand häufig noch dadurch aus, daß die äußere Ringmuskellage auf den Segmentgrenzen sehr dünn wird, oder fast schwindet, was eben die oberflächliche Abgrenzung der Segmente durch ringförmige Eiuschnïrungen bewirkt. In der Längsmuskellage schwindet die segmentale Bildung dagegen meist völlig, indem die Muskelzellen sehr lang werdeu und viele Segmente dnrchwachsen; selten erhält sich die segmentale Abgrenzung auch hier, indem die später zu erwähuenden bindegewebig-muskulösen Dissepimente den Hautmuskelschlauch durchsetzen (z. B. Eunice).

Wie bemerkt, wird der Hautmuskelschlauch der Auneliden fast ausnahmslos von einer äußeren Ring- und einer gewöhnlich viel dickeren Längsmuskellage gebildet; uur den wolll rückgebildeten, borstenlosen sog. Archianneliden mnd Dinophilus fehlt die Ringmuskellage, oder ist doch sehr reduziert. Während letztere fast immer ganz kontiunierlich zusammenhängend ist, erscheint die Längsmuskellage der Chätopoden mehr oder weniger deutlich in eine Anzahl Längsmuskelfelder gesondert (s.Fig. 274), was von verschiedenen Umständen bedingt wird. Eine Sonderung in der Dorsallinie wird häufig durch die Anheftung des dorsalen Mesenteriums des Darms hervorgerufen; eine solche in der Ventrallinie durch das Bauchmark. Weitere Sonderungen bewirken die beiden Borstentaschenreihen jeder Seite samt ihren Borsten, resp. die acht oder mehr Borstentaschenreihen der Regenwürmer. So differenziert sich denn die Längsmuskellage häufig in zwei dorsale und zwei ventrale ansehnliche Felder (Stränge), zu denen sich noch ein oder mehrere laterale gesellen können. Der Zerfall in Längsfelder kann jedoch viel weiter gehen. Alles dies variiert abcr bei deu verschiedenen Formen und in den verschiedenen Körper- 
regionen sehr. - Die gleiche Sonderung des Hautmuskelschlauchs in zahlreiche Stränge spricht sich bei den Gephyreen sowohl in der Längs-als Ringmusknlatur aus; wobei ähnlich den Hirudineen auch eine Diagonalmuskellage auftritt. Die Anordnung der Fasern innerhalb der dickeren Isängsmuskelfelder der Chätopoden kann recht kompliziert fiederartig werden, wie wir Entsprechendes schon bei den Nemertinen fanden.

Dorsoventrale Fasern sind nur bei den Hirudineen in ähnlichem Reichtum entwickelt wie bei den Plathẹlminthen. Bei den Chätopoden beschränken sie sich auf die Dissepimente, die meist recht muskulös sind; ihre Muskelzüge verlaufen in verschiedener Richtung und dringen durch die Hautmuskellagen bis zur Epidermis vor. Vielleicht lassen sich zum System der Dorsoventralmuskeln anch

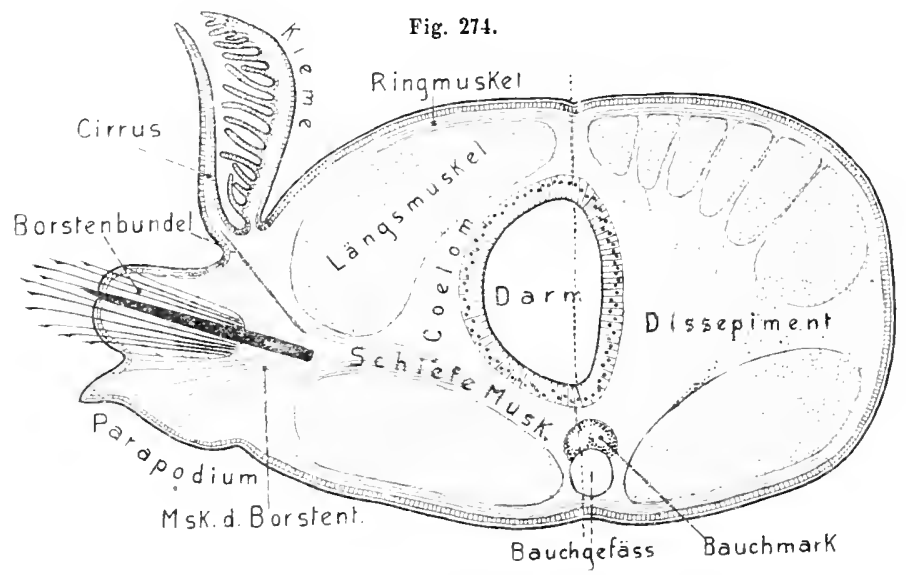

Eunice gigantea (Polychäte). Schematischer Querschnitt zar Demonstration der Muskulatur. Auf der linken Hälfte der Figor geht der Sehnitt etwa durch die mittlere Region eines Segments und das Para podiuın, auf der rechten Hālfte dagegen durch die Grenze zweier Segmente, sodaß das Dissepiment zu

die bei den Polychäten häufigen schiefen (transversalen) Muskeln rechnen, welche von der ventralen Medianlinie nach den beiden Körperseiten emporsteigen. Sie stehen wohl hanptsächlich mit der Bewegung der Parapodien in Beziehung und sind daher bei den Errantia stärker entwickelt (Fig. 274). Ganz ähnliche Muskeln finden sich bei den männlichen Nematoden eine Strecke weit vor dem After (Bursalmuskeln). - Besondere Abzweigungen des Hautmuskels des Chätopoden sind die zur Bewegung der Borstenbiindel dienenden Retractoren und Protractoren (s. Fig. 274).

Bei den Larven der Anneliden (insbesondere der der Polychäten) findet sich schon eine mehr oder weniger reich entwickelte Muskulatur, welche etwas an jene einfacher Nemathelminthen (z. B. Rotatorien) erinnert und aus längs- und ringförmig gerichteten Muskelfasern besteht, die keinen zusammenhängenden Hautmuskelschlauch bilden. Im allgemeinen besitzt diese Larvenmuskulatur den Charakter eines Mesenchyms (s. vorn S. 15). In dem segmentierten Wurmkörper bleibt von ihr jedenfalls nur sehr wenig erbalten, vielmehr entwickelt sich dessen gesamte Muskulatur nach der verbreitetsien Ansicht aus den Somiten 
der beiden Mesodermstreifen, die sich in derRumpf hälfte (Hyposphäre) der Larve hervorbildeten. Dieser Meinung steht jedoch eine' andere entgegen, nach der nur die Längsmuskulatur des Annelidenkörpers aus der Außenwand der Somiten hervorgehe, alle übrige Muskulatur (Ring-, Diagonal-, Transversal-, Dissepiment-, Mesenterial-, Borstell- und Darmmuskeln) aus dem Mesenchym des Larrenkörpers, welches zwischen die Somiten eindringe. Da nun das Mesenchym nach dieser Ansicht in letzter Iustanz rom Ectoderm abstamme, so wäre auch die aus $\mathrm{hm}$ hervorgehende, vorhin erwähnte Iuskulatur eine ectodermale; die Längsmuskulatur allein entodermal.

Die Muskelzellen der Würmer sind fast durchweg nicht quergestreift; nur die Rotatorien und Echinoderen, auch einzehne Bryozoen zeigen zum Teil schön quergestreifte Fasern. Die Form der Muskelzellen der besprochenen Würmer erinnert zuweilen noch sehr an Epithelmuskelzellen, indem die Faser einen ansehnlichen beutelförmigen Anhang gewöhnlichen Plasmas (Sarcoplasma) besitzt, welcher den Kern enthält (besonders Nematoden, Fig. 273 S. 408 und Acanthocephalen). Da dieser Anhang stets gegen das Körperiunere gerichtet ist, so spricht dies gegen eine etwaige Herkunft der Fasern aus dem Ectoderm, harmoniert dagegen mit ibrer Ableitung aus der äußeren epitheliaien Wand einer Cölomhöhle. Ein solcher Aubang kann immer kleiner werden und schließlich ganz schwinden, so daß die Muskelzelle ringsum von contractiler Substanz völlig umschiossen wird und sich nur ein inneres protoplasmatisches sog. Mark mit dem Kern erbält. Auch völlig marklose Fasern sollen vorkommen, und namentlich bei den Plathelminthen häufig auch kernlose Letzteres ist jedoch insofern etwas zweifelhaft, als namentlich bei den Cestoden und Trematoden in der ăußeren Hautmuskulatur ansehnliche kernhaltige Muskelbeutel (Myoblasten) in Verbinduıg mit den Fasern nachgewiesen wurden und zwar stehen bei den Trematoden gewöhnlich mehrere Fasern im Zusammeuhang mit einem sog. Myoblast (s. Fig. 275).

Arthropoden. Die Muskulatur der primitivsten Arthropodengruppe, der Protracheaten, besitzt nahe Beziehungen zu jener der Anneliden. Bei den Übrigen erscheint sie dagegen bedeutend verändert, im Zusammenhang mit der Entwicklung des meist dicken Cuticularpanzers, welcher insofern die Rolle eines Skelets spielt, als er den Mruskeln Fig. 275 .

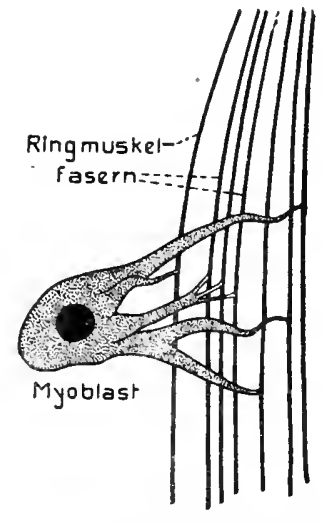

Dis tom um a u a tum, Larre (Cereariaeum helicis). - Eine Iuskelzelle (Myoblast) der Ring. innskelschieht mit einer Anzahl Mnskelfasern; die letzteren sind nicht in ganzer Ausdehnung ge. zeichnet (n. Bettendorf 18:77). zum Ansatz dient. Die Verschiedenheit der Muskulatur bei v. Bu.

den einzelnen Gruppen wird noch dadurch vermehrt, daß die der Protracheaten fast völlig aus glatten, -nicht quergestreiften Fasern besteht (ansgenommen die Kiefermuskeln), während die gesamte Musknlatur der übrigen Arthropoden (mit einziger Ausnahme der Tardigraden) von quergestreiften und die Bewegungsmuskulatur von meist vielkernigen Muskelzellen gebildet wird. - Die Ähnlichkeit der Protrucheaten mit den Anneliden spricht sich auch im Besitz eines kontinnierlichen Hautmuskelschlauchs aus, der dem der Hirudineen ziemlich gleicht (s. Fig. 276). Er besteht aus einer äußeren dünnen Ringmuskellage, auf welche eiue gekreuzte Diagonalfaserlage folgt, wälırend die darunter liegende Längsmuskulatur in eine Anzahl diskreter Stränge differenziert ist. Dazu gesellen sich schief aufsteigende, das System der Dorsoventralmuskeln repräsentierende Züge, deren Verlauf aus der Figur ersichtlich ist. 
Wie gesagt, wird die Muskulatur der übrigen Arthropoden von dem metamer gegliederten Cuticularpanzer beherrscht, welcher im allgemeinen aus dickeren, die

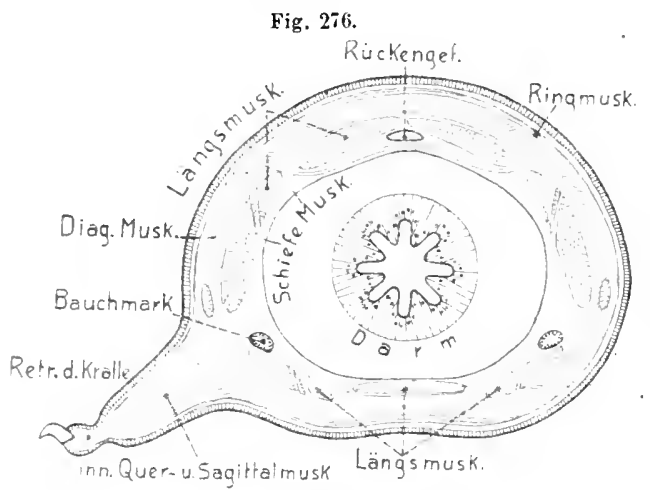

Peripatus edwardsii (Prutracheate). Suhematischer Quersehnitt zur Demonstration der Muskulatur (rot). Auf der linken Seite ein Fū Bchen mit den Hanptmnskeln im Lāngsschnitt wiedergegeben (n. GafFron 18ৎ3). einzelnen Segmente umkleidenden Ringen besteht, deren Beweglichkeit gegeneinander dadurch ermöglicht wird, daß die Chitinhaut auf ihren Grenzen diinn bleibt (Gelenkhäute) und gewöhnlich auch mehr oder weniger eingestïlpt ist(s. Fig. 278). Auch die gegliederten Extremitäteuanhänge sind, wenn nicht verkümmert, nach demselben Prizzip gebaut, setzen sich also ans nohlen Cuticularröhren zusammen, die hebelartig gegeneinander beweglich sind. Die

Cuticularringe der Segmente sind hänfig noch dadnrch kompliziert, daß sie in eine dickere Rücken- und Baachplatte (Tergit und Sternit) differenziert erscheinen,

Fig. 277.

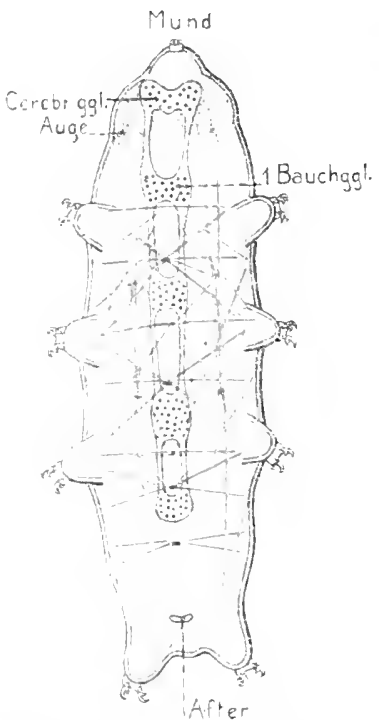

Macrobiotus hufelandii (Tardigrade) von der Ventralseite. Zur Domonostratiog der Mrassulatior und des Nervensystems (n. Plate 1485). v. Bu. welche seitlich durch dünnere Cuticula verbunden sind; seitliche Platten (Pleurae) können sich (speziell am Thorax) noch dazu gesellen. Die Bewegung dieser Chitinringe, -röhren oder -platten gegeneinander kann dadurch gesichert werden, daß sich beiderseits, auf der Grenze der aufeinander folgenden Riuge, gelenkartig ineinander greifende .Vorspriinge und Gruben bilden, so daß die Bewegnng der äußeren Skeletstücke gegeneinander in solchen Gelenken und in bestimmter Ebene un eine durch die beiderseitigen Gelenke gehende Achse geschieht. Diese Einrichtnng bedingt denu auch die Anordnung der Muskulatur.

Im allgemeinen gilt für die typischen Arthropoden, daß eine Ringmuskulatur kanm irgend wo ausgeprïgt ist, und daß statt eines zusammenhïngenden Ilantmuskels zahlreiche, biinfig sogal nugemein viele gesonderte (diskrete) Muskeln vorhanden sind. Da solche schon bei den Anneliden nicht selten differenziert waren, so erseheint es möglich, daß anch die Einrichtungen der Arthropoden dureh Differenzierung eines ursprïnglich kontinnierlichen Hautmnskels entstanden; wofür ja auch die Protracheaten spreehen, deren Verwandtschaft mit den typischen Arthropoden sich nicht leugneu liißt. Die Nuskulatur 
wurde nicht nur in zahlıciche diskrete Längsmuskelziige zerlegt, sonderu namentlich auch in metamerer Weise, so daß bei den primitiveren Formen (anch Larven), sowie in den sich mrsprünglicher erhaltenden Körperregionen, besouders dem Abdomen, die Längsmuskeh je von einem zum naichstfolgenden Segment ziehen (Fig. 278), indem sie an den cutienlarringen, bzw. deren Cnterteilen, inserieren, und sie bei ihrer contraction in den Gelenken gegeneinander drehen. 1)a die Gelenke der Segmentringe, wenn vorbanden, seitlich liegen, so werden sich die Muskeh, welche die Bauchseite ventralwirts einbiegen (Flexoren oder Benger), ventral finden, vom Vorderrand des vorhergehenden Segmentrings zn dem des nïchstfolgenden ziehend. Die entgegengesetzt wirkenden Streckmuskeln (Extensoren) dagegen liegen dorsal (Fig. 278). Im allgemeinen handelt es sich hier $u \mathrm{~m}$ dorsale nud ventrale Längsmuskeln, zu denen sich aber mehr oder weniger reichlieh sehiefe gesellen können (Fig. 277). Weiterhin treten jedoch in den einzelıen Segmenten auch Muskeln auf, die nicht iiber den Segmentring linausgehen, sondern, schief lis quer verlanfend,

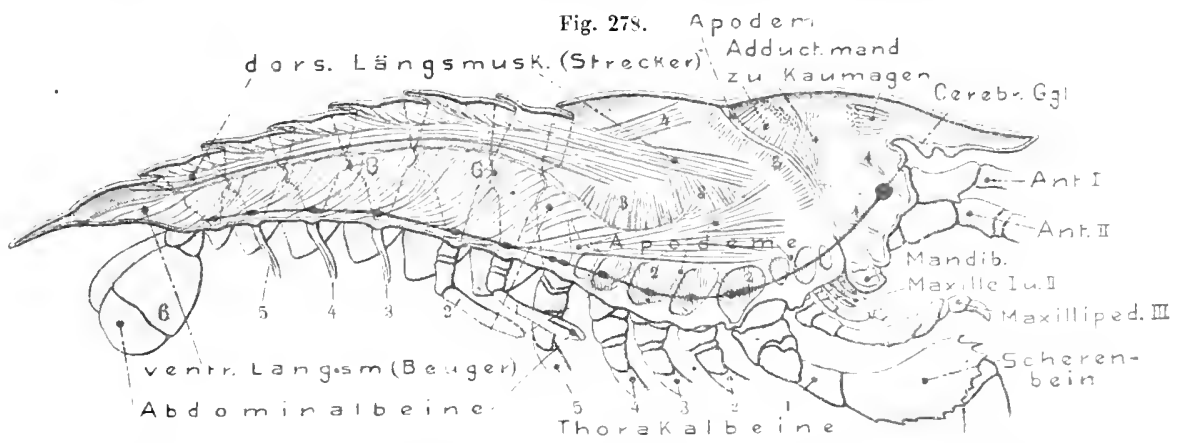

Astacus fluviatilis, in dur sugitalebene halbiert, zur lhonstration der wichtigsten MInskeln (rot) Centraluerveusystem schwarz eingezichnot. Im Thotax verläuf das Bauchmark in einem, durch die ven. tralen (hitineinwüchse (Apodeme) gebildeten Ventralkanal. Im Abdomen sind die stark chitinisierten Tergitplatten, welche ventral, zugeschärt auslaufen, durch Strichlinien ungrenzt, sowie bei $f_{8}$ die Gelenkvorsprüge angegeben, um welche die Bewegung dieser Platten aufeinander erfolgt. - 1 Musheln zur 2 Antente; 2 und 3 Museln zn den Thorakalbeinen und Guathiten; 1 Mnskeln zn 1 . Thorakalsegrent. v. Bn.

sich in beiderseits symmetrischer Anordnung innerhalb des Segments ausspannen. Namentlich gesellen sich auch dorsoventrale Muskeln zn, die schief oder grade vom Rïeken zum Bauch herabsteigen, wie wir sie schon bei den Protracheaten fanden. Bei ihrer Contraction nähern sie die liücken- und Banchtläche. Die Zahl der Muskeln eines Segments kann gering sein, sich jedoch auch hoehgradig steigern. - Im allgemeinen muß die geschilderte segmentweise Erstreckung der Flexoren und Extensoren als das urspringliche gelten. Iräufig begegnen wir aber auch einem Zusammenhang solcher Muskeln durch eine Anzahl der Segmente, miter Abgabe einzelner Zweige an die jeweiligen Segmentringe (Fig. 278); oder, wenn diese unbeweglich vereinigt sind, sie iiberspringend.

Analoge, wenn auch einfachere Muskelanordnungen und Differenzierungen haben sich unter übereinstimmendeu Bedingungen schon bei manchen Rotatoricn und den sich ähnlich verhaltenden Echinoderen entwickelt, deren Cuticularpanzer gleichfalls in gegeneinander bewegliche Ringe gegliedert ist. Da es sich hier jedoch um unegmentierte Wïrmer handelt, so liegt nur eine funktionelle Ähnlichkeit vor. 
Die Muskeln, welche die Extremitäten in toto an ihren Basalgelenken bewegen, gehören im allgemeinen den Systemen der dorsoventralen und der schiefen Muskeln an, und sind im einfachsten Fall (z. B. Kiefer) ein Heber und Senker, oder Benger und Strecker, meist jedoch viel zahlreicher entwickelt, zur Bewegung der Extremität in den verschiedenen Richtungen, so namentlich häufig auch zu Drehungen um die Achse. Bei starker Entwicklung der Extremitäten gewisser Körperabschnitte können diese Muskeln das Innere der Segmente fast völlig ausfüllen, so besonders im Thorax der Insekten und dem Cephalon der Araneinen, wozu bei erste-

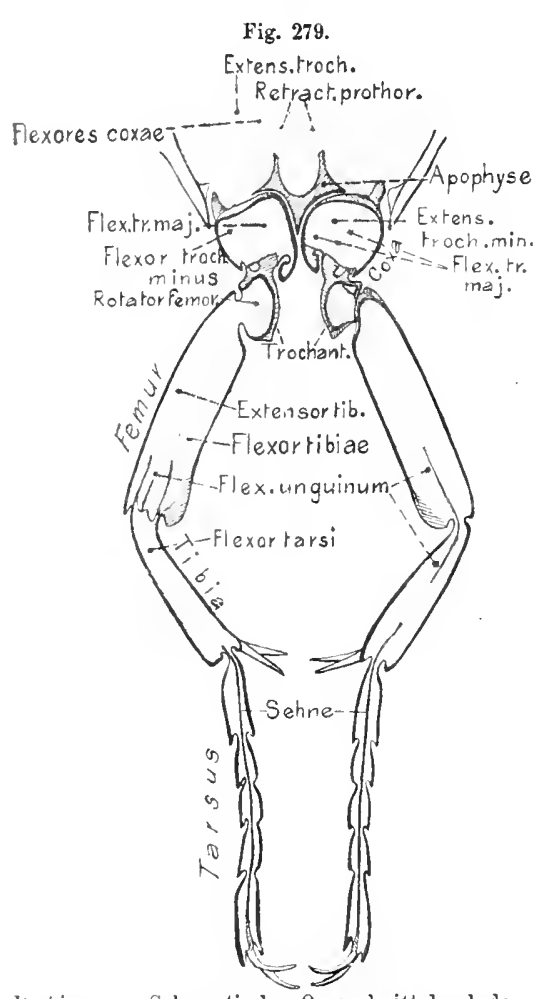

Lytiscus. Schematischer Querschnitt durch den Ventralteil des Mesothorax mit den Mittelbeinen, zur Demonstration der Beinmuskulatur. Ansicht von vorn. Im rechten Bein sind die Plexores tíbiae und tarsi weggenommen, um den Flexor unguinum zu zeigen (n. BAuEr 1910). ren namentlich auch die Flügelmuskeln beitragen. Letztere sind gleichfalls dorsoventrale Muskeln, dio in sehr verschiedner Zahl und Größe auftreten; nach der Art ihrer Befestigung an der Flügelbasis, d. h. ob distal oder proximal vom basalen Flügelgelenk, funktionieren sie als Herabzieher oderHeber. - Die Muskelanordnung innerhalb derExtremitäten ist prinzipiell dieselbe wie die der Beuger und Strecker im Rumpf. Im allgemeinen entspringt in jedem Glied ein Flexor und Extensor für das nächst distale, die sich an dessen Proximalende befestigen (Fig. 279). Es kommt jedoch auch vor, daß sich .ein solcher Muskel in eine längere Sehne fortsetzt und daher mehrere Glieder iiberspringt (so bei den Insekten z. B. der Flexor unguinum, der Beuger der Krallen des Tarsus, s. Fig. 279).

Derartige Sehnenbildungen finden sich öfters, so namentlich anch an den Flügelmuskeln der Insekten. Andrerseits entwickelt jedoch auch der Cuticularpanzer häufig Einwïchse ins Innere (Apodemen, Apophysen), die als eine Art Chitinsehne zur Befestigung distaler Muskelenden dienen, oder auch gewissermaßen als innere feste Skeletteile zum Ausatz proximaler Muskelenden; was im Thorax von Krebsen (s. Fig. 278) und Iusekten (Fig. 279) häufig in ansehnlicher Ausbildung vorkommt.

Daß sich die Muskulatur bei parasitischen oder sehr klein werdenden Arthropoden stark vereinfachen kann, ist leicht begreiflich. Charakteristisch tritt dies namentlich bei den kleinen Tardigraden auf (Fig. 277), deren Muskelstränge nur aus einer einzigen Zelle bestehen. Natïrlica konnte es sich für uns nur darum bandeln, das Prinzip ler Muskelanordnung bei den Arthropoden darzulegen. Im Einzelnen findet sich eine ungemeine Mannigfaltigkeit, und bei größeren Formen eine so weitgehende Komplikation, daß wir uns in der. Schilderung auf die allgemeinen Grundzüge beschränken mußten. 
Mollusken. Auch die Muskeleinrichtungen der Weichtiere lassen sich von dem Hautmuskelschlanch der nrsprünglicheren Wuirmer ableiten. Im Zusammenhang mit der weitgehenden Reduktion des Cöloms durch bindegewebige Erfüllung und mit der Ausbildung des muskulösen Fußes, wurde jedoch bei den meisten Mollusken der regelmäßige Ban des Hantmuskelschlauchs mehr oder weniger verwischt. . Die Mnskelschichten senkten sich tiefer in das Bindegewebe hinein, lockerten sich anf und verloren so ihren Charakter als besondere Lagen, so daß ein mehr unregelmäßiges Flechtwerk von Fasern entstand, die sich in verschiednen Richtungen kreuzen, wobei der Schichtenbau meist stark zurïcktrat. Dennoch zeigen gerade diejenigen Formen, welche zahlreiche primitive Charaktere bewahren (Solenogastres), noch einen recht typischen Hautmuskelschlanch ibres auch äußerlich wurmähnlichen Körpers. Er setzt sich aus einer äußeren Ringmuskellage, einer Lage diagonal gekreuzter schiefer Fasern(diejedoch gewissen Formen fehlen soll) und einer inneren Längsfaserlage zusammen. Letztere ist die mïchtigste und auf der Venralseite besonders stark. Sie ist entweder kontinuierlich oder in vier, stellenweise sogar mehr Muskelstränge gesondert, ähnlich wie bei Anneliden. Am Vorder- nnd Hinterende differenzieren sich namentlich die Längsmuskeln erheblich, indem sie mit dem Schlund und anderen Organen in Beziehung treten. - Das die Leibeshöhle stark erfüllende Bindegewebe (Parenchym) enthält gleichfalls Muskelfasern, die teils mehr radiär, teils dorsoventral ziehen, und im allgemeinen den Parenchymmuskeln der Würmer entsprechen dürften.

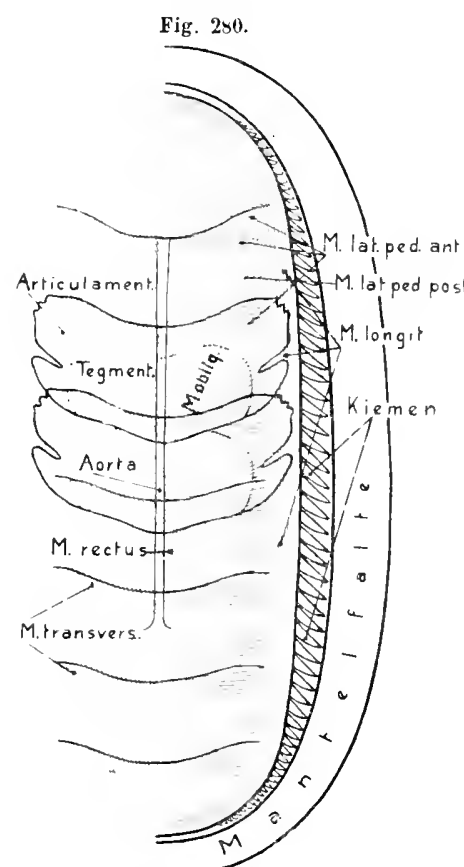

Chiton (Placoptrorel. Muskulator (rot) der Dorsalseite, nach Wegnahme des Fußes und der Eingeweide von der Ventralseite gesehen (n. Plate 1897; etwas verändert\% v. Bu.

Eine auffallende Differenzierung in zahlreiche, mehr oder weniger diskreto Einzelmuskeln hat das System der verwandten Placophoren erfahren. Bedingt wird dies durch die merkwiirdige Entwicklung der acht, hintereinander gereihten und sich mehr oder weniger iiberdeckenden, dorsalen Schalenplatten. Im Znsammenhang damit wurde der Hautmaskel des Rückens, ahnlich wie bei den gegliederten Arthropoden, in ein System längs und schief verlaufender Muskeln differenziert (s. Fig. 280 u. 281), welche teils die Schalenplatten untereinander, teils mit der Haut verbinden. Auch die mächtig entwickelten, von den Schalenplatten schief in den großen Fuß hinabsteigenden Parenchymmuskeln baben sich als besondere Muskeln differenziert, so daß sich im Bereich jeder Schalenplatte beiderseits ein vorderer und ein hinterer solcher $»$ Lateropedalmuskel « (Columellarmuskel) findet, der selbst wieder aus mehreren Zügen besteht. Diese absteigenden Muskeln bilden 
die IIanptmasse der Fußmuskulatur, neben Längsfasern (die jedoch wahrscheinlich aus ihnen hervorgehen), und wirken als Retraktoren des kräftigen Saugfußes. Auch bei den Placophoren erfährt die Mnskulatur des Vorder- und Hinterendes erhebliche Modifikationen.

Indem wir die Muskulatur der Körperwand und ihre Spezialisierung bei den iibrigen Mollusken übergehen, berichten wir nur über die besonderen Muskeln, welche sich, im Anschluß an die schon bei den Placophoren vorgezeichneten Verhältnisse, ausgebildet haben. Vor allem hat sich das System der dorsoventralen Parenchymmuskeln bei allen beschalten Mollusken kräftig entwickelt als ein, bei den symmetrischen Formen symmetrisch paariger Muskelapparat, der einerseits zum Einziehen und zur Bewegnng des Fußes dient, andererseits anch zur Befestigung und zum Tragen der Schale. Es ist dies der kräftige Columellarmuskel der Gastropoden, so bezeichnet, weil er bei den Formen mit schraubiger Schale vou der Spindel (Columella) der Ietzten Schalenwindung schief nach vorn in den Fuß

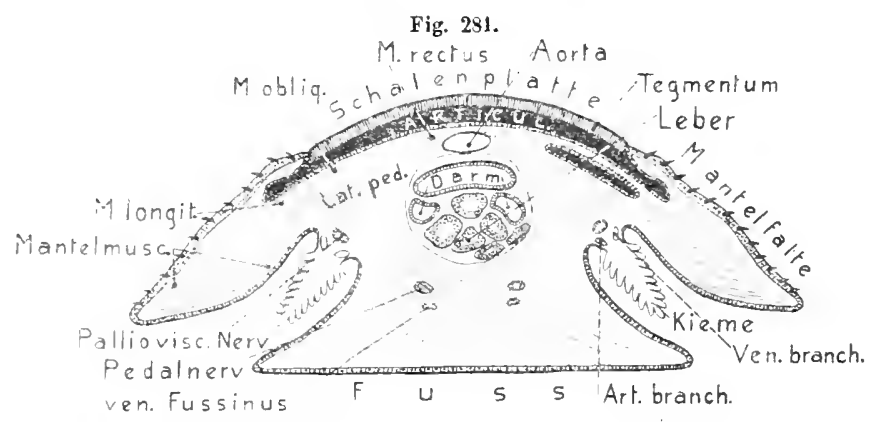

thiton (Placophore). Schematischer Quersehnitt der mittleren Körperregion. Muskeln rot (n. Prate 1s97). v. $\mathrm{Bn}$.

hinabsteigt (s. Fig. 29, S.102), wobei seine hintere Partie bei den gedeckelten Prosabranchiaten am Deckel inseriert. Wälurend der Columellarmuskel der Pulmonaten stets parig ist, wird er bei den Prosobranchiaten in der Regel unpaar und ist daun etwas asymmetrisch gelagert. Bei Prosobranchiaten mit konisch symmetrischer Schale wird er symmetrisch und jedenfalls wieder recht ursprïnglich, da er sich anf der Innentläche der Schale längs beider Seitenränder und am Hinterrand befestigt, im Querschritt also hufeisenförmig, auch paarig (Fissurella) oder in zahlreiche Biindel zerlegt (Patella), erscheint. Bei den schalenlos gewordenen Gastropoden ist der Muskel gewölnlich völlig rïickgebildet. - Wie bcmerkt, nimmt er am Anf'hau des Fußes erheblichen Anteil, doch gesellen sich hier namentlich noch liings verlanfende und vertikale, jedoch auch in den verschiedensten Richtungen ziehende schiefe Fasern zu -.. Der Columellarmuskel dient auch zum Einziehen des Körpers in die Schlale, wobei in der liegel der Fuß in der Mitte quer eingeknickt wird; hei den gedeckelten Gastropoden wird dabei die hintere FuBhïlfte mit dem Deckel nach rorn ungebogen, so daß der Deckel die Schalenmiindnng verschließt.

Vollknmuen symmetrisch parig verhält sich der entsprechende Muskelapparat bei den symmetrischen Sraphopoden, Cephatoporlen und Lamellitranchiaten. Bei 
letzteren ist es das System der Fußbeweger, welches als Homologon des Columellarmuskels erscheint. Gewöhrilich sind vier Paar solcher Muskeln ausgebildet (s. Fig. 50, S. 136): ein Protractor, ein vorderer und hinterer Retractor und ein Elevator. Bei primitiven Muscheln sind sie zuweilen noch wenig scharf gesondert. Der Apparat vermag sich jedoch auch zu vereinfachen, ja bei gewissen asymmetrischen Lamellibranchiaten kann er asymmetrisch werden, d. h. nur die Muskulatur einer Seite entwickelt sein. Die Proximalenden der Fußbeweger inserieren ziemlich hoch dorsal, unter dem Nabel oder längs dem Dorsalrand der Schale; die Ansatzstellen sind auf der Schaleninnenfläche häufig als Eindrücke erkennbar.

Zum System der Parenchymmuskeln gehören jedenfalls auch die Schlie $\beta$ muskeln (Adductores) der Muschelu, die sich bei den ursprünglicheren in Zweizahl finden, ein vorderer etwa dorsal vom Mund, ein hinterer nahe dem Hinterende und ventral vom Darm. Es sind in der Regel starke, den Körper quer durchsetzende Muskeln, deren Insertionen tiefe Eindrücke an der Schaleninnenfläche hervorrufen (s. Fig. 36, S. 108). Der vordere Adductor kann bei manchen Lamellibranchiern klein werden und bei den asymmetrischen und aufgewachsenen Muscheln (sog. Monomyarier, keine natürliche Gruppe) vollständig schwinden, obgleich er ontogenetisch noch angelegt wird. Der hintere Adductor riickt dann gewöhnlich etwa in die Körpermitte, ventral vom Nabel. Selten kann auch Rückbildung beider Adductoren eintreten (so Aspergillum und Chlamydoconcha). - Die Contraction der Adductoren schließt die Schalen häufig mit großer Kraft; die Öffnung dagegen wird durch die Elastizität des bei der Schale erwähnten Ligaments (s. S. 107) bewirkt. - Längs der freien Ränder der beiden muskulösen Mantellappen bildet sich ein schmales Muskelband aus (M. orbicularis), welches diese Ränder in ihrer ganzen Ausdehnung an die Innenfläehe der Schalenklappen befestigt, indem es hier meist einen deutlichen Eindruck erzeugt (Fig. 36, S. 108). Bei den Muscheln, deren hintere Mantelräuder unter Verwachsung zwei Siphonen hervorbringeu (Siphoniata), entwickeln sich aus dem hinteren Teil des Orbicularmnskels Siphonalretractoren, deren Anheftung an die Schaleninnenfläche gewöhnlich ebenfalls einen Eindruck, verbunden mit einer Einbuchtung des Manteleindrucks nach vorn (Mantelbucht) bewirkt. - Wenn sich die Verwachsung der beiden Mantelränder von den Siphonen aus noch weiter oralwärts erstreckt, entwickeln sich in diesem verwachsenen Mantelabschnitt, der sich zwischen den beiden Schalenrändern ausspannt, häufig quere bis schief gekreuzte Muskelzüge, die als accessorischer Schalenschließer funktionieren.

Is verdient erwähnt zu werden, daß sich bei Tierformen die mit einer äbnlich gebauten Schaleneinrichtung versehen sind, auch eine analoge Muskulatur der Schale entwichelt hat. Auffallend tritt dies bei den Brachiopoden hervor (vgl. Fig. 28, S. 101). Die prinzipielle Verschiedenheit der Einrichtung ergiht sich jedorh leicht daraus, daß hier außer Schließnuskeln auch besondere Öffner vorhanden sind, und daß die Schalenmusheln symmetrisch parig vorkonmen, entsprechend dem symmetrischen schalenban. - Noch eigentümlicher erscheint die Ansbildung eines den Adductoren der Muscheln analogen Sthalenschließers bei den mit einer zweiklappigen Schalenduplikatur verselıenen Ostracoden (Muschelkrebsen).

Die Muskulatur der symmetrischen Ceplealopoden ist sehr kräftig und dureh die gewöbuliche Rückbildung der Schale, sowie die Entwicklung des Kopfknorpels 


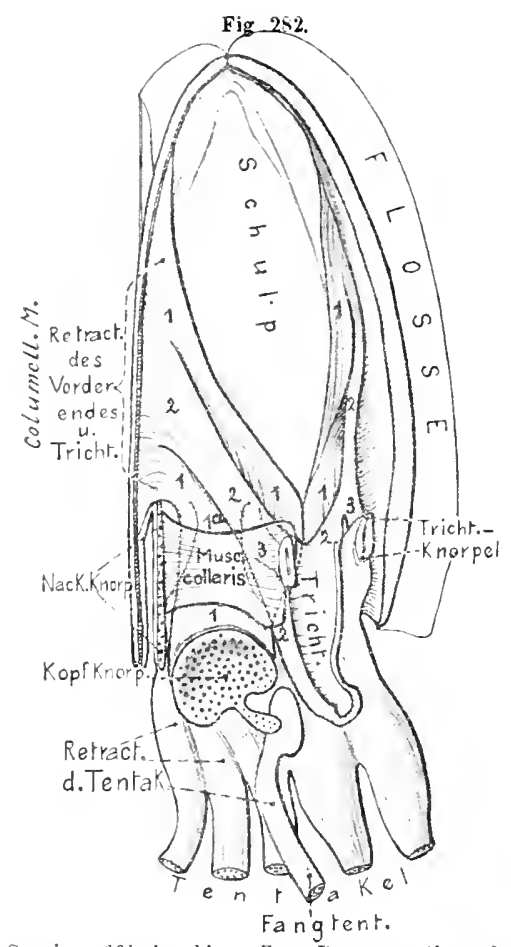

Stpia officinalis. Zur Demonstration der Muskulatur. Mantel grüftenteils wegreschnitten. besouders anf der linken Sejte bis zum Rande des schulps. Elenso ist dip llinterwand des Trichters grēbtenteils abgatragen. Der anseluliche Columellarmuskel spaltet sich kupfwats in mehrere Portionen, von welchen sicl der Haupttoil (1) zum loptknorpel hegilit, und eine Alzweigung $(/(k)$ zar Inuenfache des Yuse. collaris entaendet. Die Por. tion 2 zieht in allgemeinen zur Trichterwand und sendet eine Ahrweigung (o) zum Trichter-

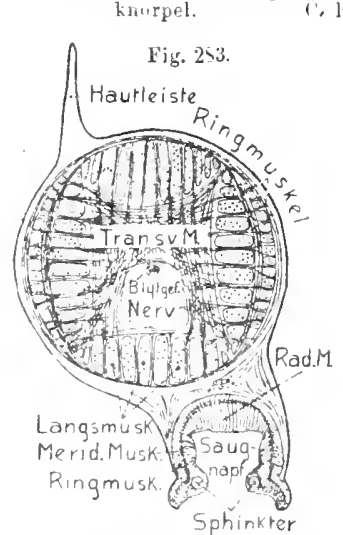

Octopus. Sibematiscler Quer selnitt eines Arms samt einem saugnall l'der winen Reihe. Kur I benonstration dar Miskulalur din Aruns und des simagnapfs. C. H. mehr oder weniger modifiziert. Abgesehen von der oberflächliehen Muskulatur, welehe in der Flossenbildung der Decapoden und den Tentakeln besondere Umbildungen erfahrt, ist es wieder das System der Colameliarmuskeln, das den Hauptanteil bildet. Bei Nautilus (Tetrabranehiata) wird es von zwei kräftigen Muskeln gebildet, dit sich seitlich im Grunde der Wohnkammer an die Schale lose anheften, und zum Kopfknorpel hinabziehen. You letzterem entspringen ferner die Muskeln der' beiden 'Triehterlappen, sowie die. Retractormuskelu der zahlreichen Tentakel; sehließlich ein eigentïmlieher Mnskel jederseits, der quer-oder ringförmig nach vorn zieht und sich in der Gegend des vorderen Mantelrands mit dem der Gegenseite vereinigt (M collaris); er kehrt auch bei den Dibranchiaten wieder. - Bei letzteren is. Fig. 282) ist der Columellarmuskel jeder Seite teils mehr einheitlich, teils in drei bis vier starke Portionen gesondert, von dewen mehrere (s. Fig. 282, 2-3) zum Triehter zieheu (1)epressores oder Retractores infundibuli), während die Hauptmasse (1) zumkopfknorpel geht (Retractor capitis). Bei den Decapoden entspringen die erwähnten Muskelu entweder von den Seitenrïudern des Sehulps, den Seiten der Schale (Spirula), oder vou der Hant des Eingeweidesacks (Octopoda). Vou Kopfknorpel gehen ferner bei gewissen ein Adductor oder Protractor infundibuli aus, sowie von seiner Mundseite die zu den 'Tentakelu ziehendeu starken Muskelzüge. - Der M. collaris ist entweder einheitlich, wie bei Nautilus, und breitet sich mit seinen Enden in der Waad des Trichters aus, oder wird bei den Deeapoden, die einen Nackenknorpel besitzen (so Sepia, Fig. 282), dureh dessen Einschaltung in zwei seitliche Hïilften zerlegt.

Die Muskulatu der Saugnäpfe der Dibrauchiatenarme verhält sich im Prinzip ähulich wie die der friber erwähnten Samguäpfe der Plathelminthed, was del 
Querschnitt eines Arms mit dem Axialschnitt eines Sangnapfs auf Fig. 283 (Octopus) zeigt.

Die Muskelzellen der Mollusken sind in der Regel glatte Fasern; ausnahmsweise finden sich jedoch auch spiral- und quergestreifte, so gelegentlich in den Schließmuskeln der Laniellibranchiaten wnd den Buccalmuskeln der Gastroporlen.

Echinodermata. Eine kurze Erörtering verdient die Muskulatur der radiär umgebildeten Echinodermen. Auch ihnen kormet zum Teil noch ein typischer Hautmuskelschlauch zu, so den Holothurien, deneu ein zusammenhängendes Hautskelet fehlt. Da diese Grupue jedoch kaum sehr primitiv seiu dülfte, so könute anch eine uachträgliehe Wiederherstellung ursprünglicher Verhältnisse vorliegen. - Wir finden bei ihnen eine äıßere Ringmuskulatur (Fig. 284), die jedoch nur bei der Rỉckbilduug der radiäreu Ambulacralgefäße (Synaptiden) eine kontinuierliche Lage darstellt, sonst von diesen Gefäßen unterbrochen wird (s. Fig. B.). Auf sie folgen innen fünf starke radiäre Längsmuskeln, die sich voru am Kalkring des Schluuds inserieren, und bis zum Aftel nach hinten ziebeu. Sie sind bei einem 'Teil (besonders Aspiduchirota) laarig geworden. - Von diesen Längsmuskelu $z$ weigen bei den dendiochiroten Pedata und gewissen Apoda in der vorderen Körrperhälfte besoudero Muskelstränge ab, die gleichfalls zum Kalkring ziehen, also besondere Retractoren desselben und des vorderen Körperendes darstellen (Fig.389).,-Natülich sind auch die Ambulacralfuißehen (s. Fig. 387) mit kräftiger Längsmuskulatur versehen, wie bei den Echinodermen überhaupt; ihre Ausdehnung und Schwellung dagegen wird von der AmbulaeralHüssigkeit bewirkt.

Die mit festen Kalkplatten des Hautskelets ausgeriisteten ïbrigen Kilassen be-
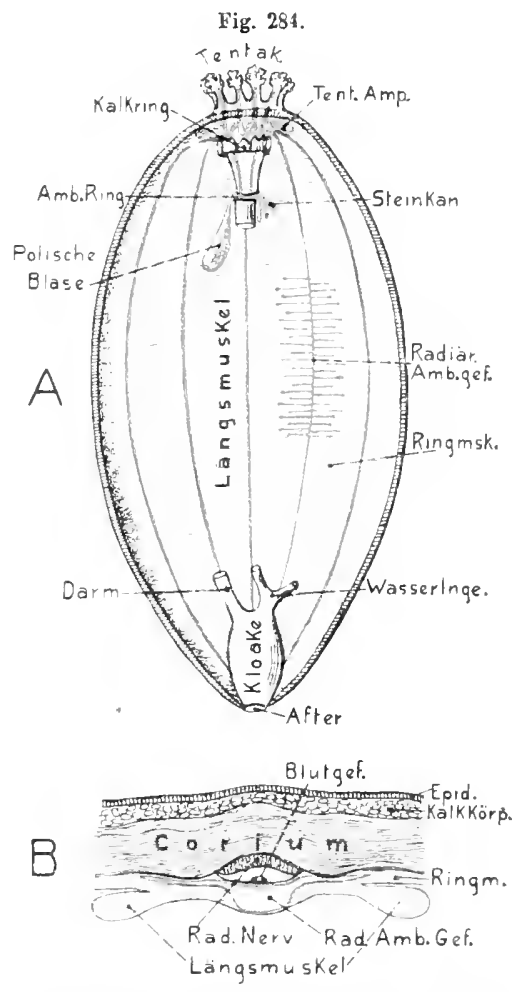

Holothurie. A Ein im dursalen Interradius aufgeschnittenes u. ausgebreiteles 'lier; Iarm und Wasserlungen eutfernt; zur Denionstration der $\mathbf{l}$ uskulatur (rot), des Kalkrings und des Ambulaeral. gefußsysterns (blau). In einem Radius ist ein sturk des Lāngsmuskels entfernt, um das radiare $A u-$ hulucralgefăk u. die von ibm abgebenden Füluchevgefäßo z" zeigen. 13 Querschnitt durch die Körperwand eines liadius. C. II

sitzen höchstens geringe Reste eines allgemcinen Ilautmuskels. So finden sieh an der Dorsalwand (Autiambulacralfiche) der Asterienarme (6. Fig. 285, A uoch schwache Quermuskelfasern, als Reste einer Ringmuskulatur, und darunter auch eiuige stärkere Züge radiärer Fasern (Längsfasern), die bis zmm Apiealpol ziehen könuen, wo sie sich vereinigeu. - Gewisse Seeigel der 'liefsee (Echinothuridae) mit beweglichea Hautplattenskelet besitzen woeh in jedem Radius (Ambulacrum) 
zwei Hantmuskeln, welche an die partigen Längsmmskehn lr Holothurien erinnern. Bei guter Entwicklung reichen sie rom Peristom befestigt an den sog. Auricular-

Fig. 25.5.
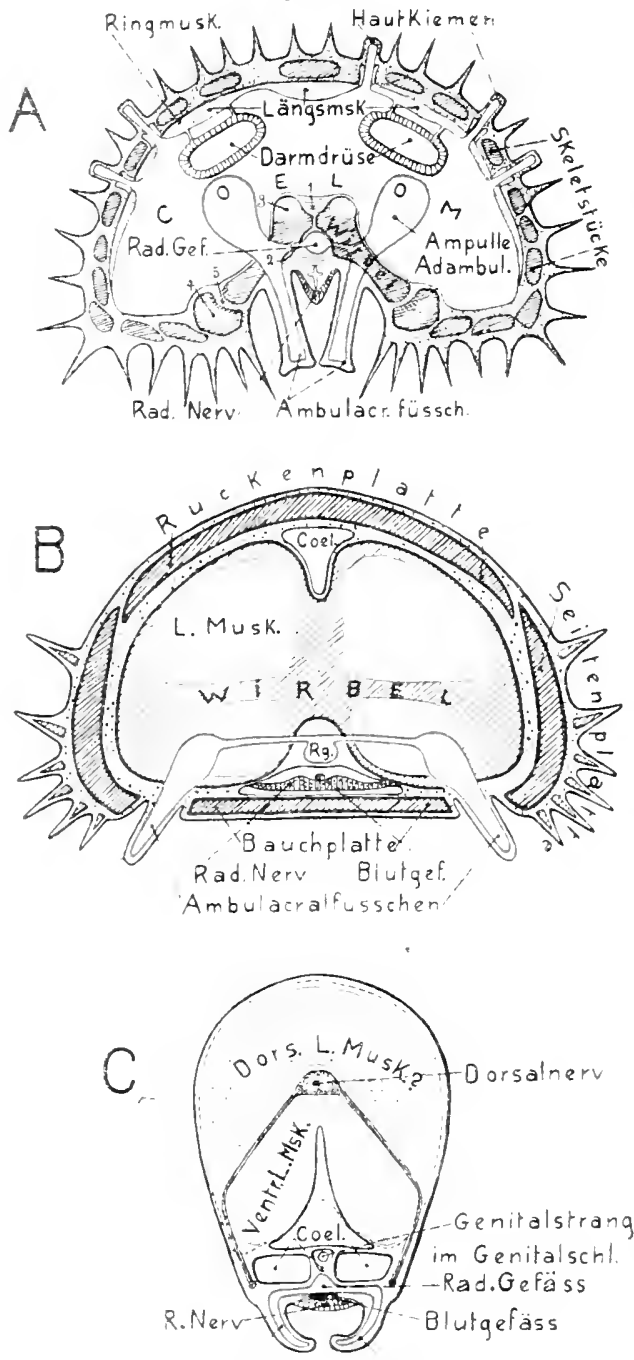

Ambulacralfüsschen

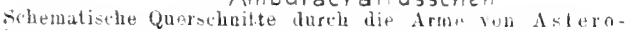
iden mud l'rinoiden zor lemonstration ler lluskulator

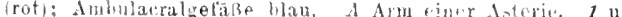

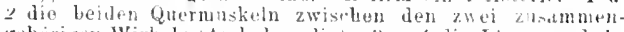
gehorigen Wirbeln (Ambularralia); "̈ u. the Limganuskeln \%wisthen den aufeinanderlugenden Mirheln und Nambnla-

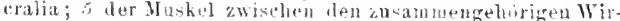

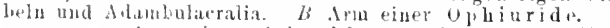
Alm mer trinoide (Auteduni). fortsätzen desskeletsibis zum Periprokt. Wer Verlanf ihrer Fasern ist jedoch nicht eigentlich liings: sie entspringen nämlich am äuern Rimd der Ambulacralplatten and konvergieren nach Inmen gegen die Mitte jedes Muskels, wo sie sich an einer sehnigen Platte betestigen. Gewiss: Spatangoiden zeigen etwas Beweglichkeit der l'atten ihres hintern Interambulacrums, indem sich zwischen den bejden l'lattenreilsen imnen quere Wuskelatige ansspannen. Dieskeletplatten der iibrigen rezenten Seeigel simul stets fest vereinigt und dalier muskellos. - Dalgegen sind die häulig su \%ahlueich und ansehnlich entwickelten Hautstachelu stets beweglich und dienen auch als llilfsorg:ne hei der Lokomotion; dementsprechend gehen von der AnBentiache der Skeletplatten Mnskelı zu ilurer Basis (s. Fig. $285,(i)$. Wbenso sind die eigentiimlichen Greiforgane (Pedicellarien der Asterien und Echinoiden mit einer zirmlich komplizierten Muskulatur ansgeriistet.

Die mehr immerlichen skeletgebilde der Crinoiden und Asteroiden sind lessonders in den Armen durch Muskeln verbunden nud daher mels oder wenger bowegrlich gegeneinander. So findet sich zwischen den Armeliedtern (Brachialia) der Crinoider" näber der Ambulat(ralliache, jederseits ein krititiger Längsmnskel s. Fig. 285, ( ) durel: dessen Contriction dic Arme gregen

die Mundscheibe gekrïmmt, ofler hei einseitiger contration scitlich grebogen werden.

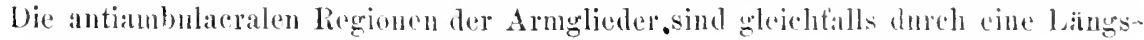


fasermasse verbunten, die sich jedoch histologisch erheblich von den crst erwähnten Muskeln unterscheidet, und daher hald als muskulös, bahl als sehnig-lindegewebig betrachtet wird. Anch die stiel- mud Cirrenglieder sind hurch Fasermassen letzterer Art verbunclen. Da dir (irlen liewegungen austïhren können, so spricht dies für die musknlïse Natnr jener Fascru. - Ahnliche Verlualtnisse zeigen dic Ophiuroidea (Fig. 285, B), deren musatre Aruwirbel (Ambulacralstiicke) durh zw ei sehr starke autiambulaerale Längsmuskln verbunden sind, während zwei sehwächere unter ihnen, nälier der Amlulateralläehe liegen. Wa die Baneh- und Riickenplatten Kribmmungen nach der Oral- mul Aboralfläche verhindern, so wirken diese Muskeln bei den ophinren wesentlish als Krïmmer der Armo in der IIorizontalebene.

Mannigfaltiger beweglieh sind die parigen Wirbel und damit die Arme der Asterien (s. Fig. 285, 4). Zul paarigen Lingsmmskeln (3), welehe sich zwischen den aufeinander folgenden Wirbeln an ihrer Antiambulacraltiahe ansspinnen, gesellen sich zwischen je zwei zusammengehirigen Wirheh noch ein oberer antianbulacraler (1) und ein unterer, unter dem Anbulacralgefif ziehender (luermuskel(2). Die Contraction letzterer Muskeln erweitert und rerengert die Ambularalrinne. Fou jedem Wirbel (Ambulacralstiek) steigt ein Mnskel (5) sehief abwiirts zum zugehörigen Adambulacralstiick: simtliche Ad:mhulaeralial sind durch zwisehen sie gesehobene Längsmuskeln (4) untereinander rerbunden. - l)aß die Wirbelmuskulatur des Asteroideen in der Mundregion wesentlich moditiziert und kompliziert werden muB, ist begreiflich; es würde jedoch zu weit führen, hierauf näher cinzugehen.

Die ein- bis uehrkernigen Muskelfasen der Echinotermen sind gewohlich recht fein, jedoch nicht selten von ziemlicher länge; ihre Enden z. T. zerfasert. Längs- bis Schrägstreifung tritt häufig dentlich herror. Typisch quergestreifte Fasern wurden nur in den Pedirellarien der Seeiget autgetunten.

Tunveata. Die Muskelverhältnisse dieser primitiven Chordaten machen es wahrscheinlich, daß auch ihnen der allgemeine, ans Ring- und Längsfasern auf'gebaute Hautmuskelschlauch zugrunde lag. Am besten erhalten zeigen ihn die. Ascidien (Fig. 286, A), wo sich unter der Mantelepidermis eine äuBere Liings- und innere Ringmuskelschicht findet, welche den ganzen Körper sackartig umgeben. Beide Lagen hestehen aus mehr oder weniger voneinander gesonderten Muskelbïndeln. An der Mund- und Kloakenöffnung drängen sich die Ringmuskeln in der Regel zn krättigen Sehließmuskeln (Sphincteren) zusammen.

Bei den Thuliarcue (Salpen, Fig. $286, B$ ) tritt die Längsmuskulatur meist stalk bis völlig zuriick. Auch die Ringmuskelbïndel rücken weiter anseinander, so daß sie den Körper als relativ wenige (bis ca. zehn) Muskelhöineler reifenartig ungirten. Bei Woliolum sind dirse Bänder kontinuerliche Ringe; die der Salpen sind dagegen auf der Tentralseite dureh sehmale his hreite Zwisehemräume nuterbrorhen; dorsal und seitlich sind sie zuweiten mehr orler weniger versehanolzen. An dor filoakalöfinung der Salpen werden die Ringmuskch zärter nud rüeken zu eincm geschlossenen Sphincter dichter zusammen. An der Hundöthung modifizieron sieh die beiden vordersten Bäuder ebenfalls zu ventral und dorsal gesehlossenen splhineteren, die seitlich zusanmenhingen, und daher hier eine Art fixen Pmkt besitzen. bie 
- Oberlippe kann auch mit einem Paar längs gerichteter Rückzieher (Heber) versehen sein; wie denn iiberhaupt die Muskulatur dieser Gegend ziemlich mannigfaltig ist.

Im Gegensatz zu den Salpen ist die- Ringmuskulatur der Copelaten ganz geschwunden, die Längsmuskulatur an Schwanz dagegen kräftig entwickelt; der Rumpf erscheint fast stets völlig muskellos. Der Schwanz bildet ein in der Querebene des Körpers stark abgeplattetes Band, welches, wie schon früher geschildert, in seiner Achse von der Chorda durchzogen wird (s. Fig. 77, S. 174). Die Horizontalstellung des bandförmigen Schwanzes dürfte wahrscheinlich aus einer ursprünglich vertikalen durch Drehung um $90^{\circ}$ hervorgegangen sein, womit auch die Lage des Centralnervenstrangs neben der Chorda harmoniert. - Auf jeder Breitseite
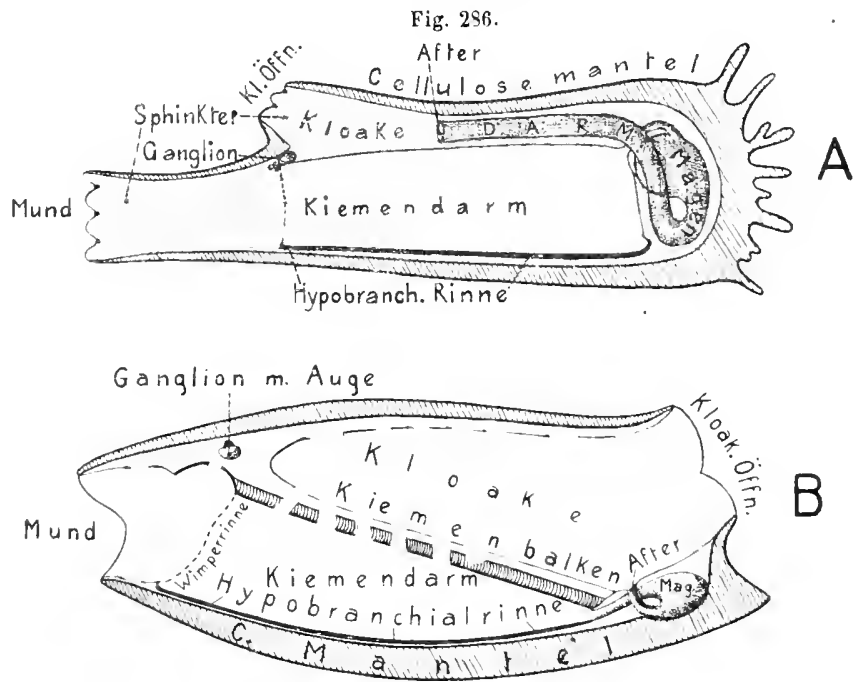

Zur Demonstration ler Muskulatur (rot) der Tunicaten. A linksseitige Ansicht einer Ascidie (Ciona intestinalis). $\quad b \mathrm{~S}$ alp a runcinata-fusiformis (ungeschlechtliche Generation) vou links. E. W.

des Schwanzes zieht fast in der ganzen Chordalänge ein flaches Längsmuskelband von größerer bis geringerer Breite hin (s. Fig. 287, A). Die bei manchen Formen noch regelmäßige Hintereinanderreihung von zehn Zellkernen, die jedem der Bänder zukommen, sowie qnere Grenzen zwischen je zwei dieser Kerne, erweisen die Zusammensetzung jedes Bands aus zehn Zellen. Bei vielen Formen verschwinden jedoch die Grenzen der Muskelzellen, ja es können sogar die sich netzförmig ver:isteltenden Kerne jedes Bands zn einem Streifen verschmelzen. - Die Musknlatur des Schwanzes der Ascidienlarven verhält sich ähnlich wie die der Copelaten (vgl. Fig. 287, Fig. $B^{1-2}$ ).

Dit lamellenartigen comtractilen Elemente der Muskelzellen der Copelaten sind sehr ausgesprochen quergestreift. Die Muskelfasern der Salpen sind ziemlich breite vielkernige Bänder, die gleichralls quergestreift erscheinen, wogegen die Ascidien recht feine, glatte Fasern besitzen. - Von einer eigentlichen Segmentation der Muskelbänder des Copelatenschwanzes kann wohl nicht mit mehr Recht die Rede sein, als etwa von der des Längsmuskelschlauchs mucher Nematoden, der gleichfalls aus hintereinander gereihten Zellen besteht. 


\section{B. Wirbeltiere.}

\section{Einleitung. Muskulatur der Acranier und Ontogenie der Stamm- muskulatur.}

Die Körpermuskulatur der Vertebraten geht von einem relativ einfachen $\mathrm{Zu}-$ stand aus, wie er bei den Acraniern dauernd besteht; bei den böheren Gruppen kompliziert sie sich allmählich in erstaunlicher Weise. Dies bedingt, daß wir allein die einfacheren Ausgangszustände etwas genauer studieren können, dagegen die ungemein verwickelten Verhältnisse der höheren Abteilungen nur in allgemeinne Zügen anzudeuten vermögen. - In der Körpermuskulatur tritt vor allem der segnentierte Bau der Vertebraten hervor, was gegenüber den Tunicaten wichtig erschcint, die, wie erwähnt, nichts deutliches von Metamerie erkennen lassen. Doch dürfte dies vielleichtvon einergewissen Rückbildung herrühren; möglicherweise könnte jedoch die Metamerie der Vertebratenmuskulatur auch ganz selbständig entstanden sein. - Die Körpermuskulatur der Wirbeltiere wird bekanntlich von quergestreiften Muskelzellen gebildet, die der Eingeweide dagegen größtenteils von glatten.

Bevor wir die ontogenetische Herkunft der Muskulatur erörtern, wollen wir ihren Aufbau bei der pi imitivsten Gruppe, den Acraniern, betrachten, 1 m einen Überblick uber den Grundbau zu gewinnen. Entsprechend deu einfachen Körperbewegungen, welche wesentlich in seitlichen Biegungen bestehen, ist auch die KörperFig. 287.

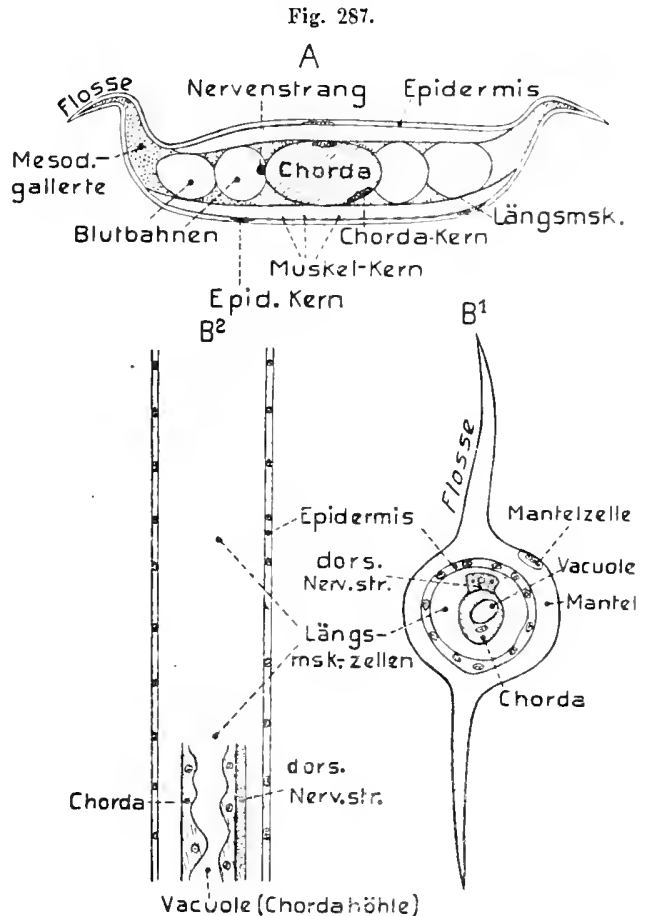

A Oicopleura cophocerca (Copelate). Etwas schenatischer Quersehnitt des Schwanzes. Lāngsmuskeln ret (n. SEELIGER 1900). - Bl a. $B^{2}$ Larre ron Ciona intestinalis (Ascidie) $B^{1}$ Querschnitt durch den Scliwanz. $B^{2}$ ein Stück des Schwanzes in Lāngsausicht, um die Muskelzellen zn zeigen; unten auch ein Stück der Chorda und des Nervenstrangs im Sagittalschnitt ein. gezeichnet (n. HEINEMAN 1905). muskulatur verhältnismäßig einfach gcbaut. Längs jeder Körperseite (s. Fig. 80, S. 176; Fig. 81, S. 177 und Fig. 183, S. 311), von der Kopf- bis nahe zur Schwanzspitze, erstreckt sich ein sehr ansehnlicher dicker Längsmuskel, die beiden sog. Seitenrumpfmuskeln. Zwischen ihnen liegt die Chorda, die sie fast in ihrer ganzen Ausdehuung begleiten, sowie das Rückenmark. Das Bindegewebe, welches letztere Organe umhüllt, setzt sich dorsal als eine mediane Scheidewand 
zwisehen die beiden Seitenmuskeln fort; in der Schwanzregion gesehieht dies :ihnlich ventral vou der Chorda (Fig. 183), wiihrend sich in der Rumpfregion (Fig. 81) der Darm, sowie die Peribranchialhöhle (Atrium) zwischen die ventrialen IIälften der Seitenmuskeln einschalten und sie auseinander drängen. Jerler Seitenrumpfmuskel ist jedoch uicht einheitlich, sondern durch Zwischenschaltung zarter querer

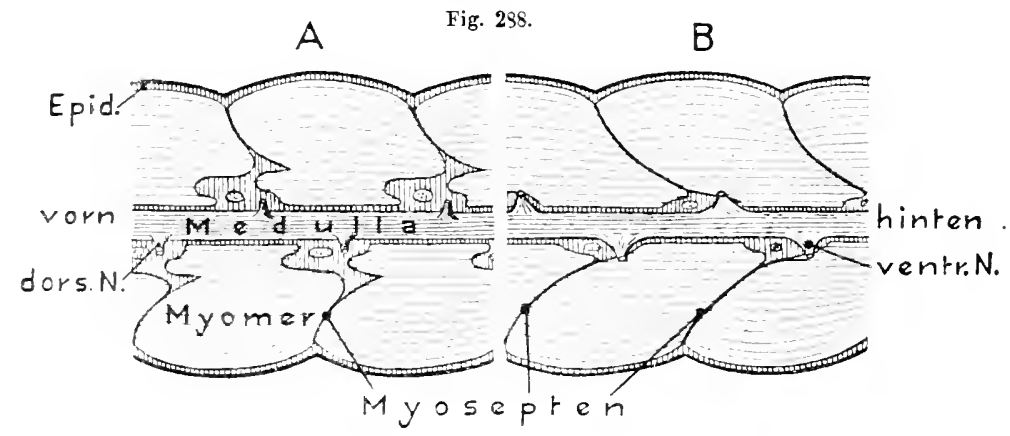

liranchiostoma (Amphioxus) lanceolatum. Schematische IIorizonlalscbnitte in der Hobe des Ruckenrashs (Medulla). 1 ln der llohe des Ursprungs der dorsalen Spinaluerven. - $B$ In der Höle der ventralen (motorischen) Spinalnerveu. Muskulatur rot. E. IV.

Bindegewebssepten in eine große Zahl lintereinander gereihter Abschnitte gesondert, die Muskelsegmente oder Myjomeren (Myocommata). Die sie trennenden Myosepten (Ligamenta intermuseularia) gehen innen in das die Chorda numbïllende Bindegewebe und seine Fortsetzungen über, äußerlich in das Hantbindegewebe (Corium). Anfänglich, in der Ontogenese, stehen diese Myosepten senkrecht zur

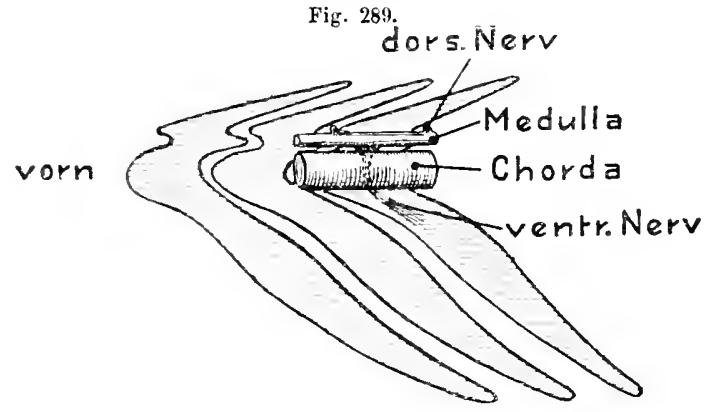

liranchiostoma (Anphioxus) lanceolatum. Drei rechtoeitige Myomere samt der Medulla und thorda von der Medianseite gesehes (schemalisch). Zur Erläuterung des Alternierens der spinalen Nerven.
Chorda, haben daher einen rein queren Verlauf und liegen sich beiderseits genan gegenüber. Bei den Erwachsenen ist beides nicht mehr der Fall, da die Septen (und dementsprechend auch die Myomeren) in der Höhe der Chorda eine starke, kopfwärtsgerichtete Knickkung erfahren (s. Fig. 181 11. 289), und aueh in illrem Verlauf gegen die Chorda

ziemlich stark kopfwiirts gerichtet sind. Ferner haben sich die linken Septen und Myomeren etwas nich vom verschohen, so daß die beiderseitigen Myomeren alternieren (s. Fig. 288). 1) ie winklige Kniekung der Myomeren hat zur Folge, daß wegen ihrer verhältnismißßig geringen Dieke in der Längsriehtung des Körpers auf jedem Körperquersehnitt gleichzeitig eine größere Zahl von Septen getroffen wird, und zwar im allgemeinen jedes Septum zweimal, einmal sein dorsaler und ein zweites 
Mal sein ventraler Schenkel. Daher riihrt das eigentïmliche Bild, welches ein solcher Querschnitt bietet (Fig. 81, S. 177 und Fig. 183). - - Zu jedem Myomer tritt vom Rückenmark in kurzem Verlauf die ventrale Wurzel eines Spinalnervs (s. Fig. 81 u. 288).

Die Bedeutung der llyomerenknickung wurde häufig darin gesucht, laß dadurch eine größere Anzahlı lätgsgerichteter Muskelzellen in einem Myomer Platz fänden. Nun ist ja richtig, daß die geknickten Septen länger sind als nicht geknickte und deshalb eine größere Ansatzfläche für Mnskelfasern hieten; der rerfïgbare Rauminlalt eines Myomers wird jedoch dadurch nicht vergrößert, weshalb auch die Zahl der Muskelfaseru sich nicht vermehren kann. Die Bedentung der Knickung muß also eine andere sein. Die längsgeriehteten Muskelelemente jedes Myomers wirken bei ihrer Contraction auf die zugehörigen Septen, speziell das vor ihnen gelegene, und durch dieses auf die Chorda; die Septen verhalten sich daher etwa wie Sehnen, welche sich an der Chorda befestigen. Da sich nun die Wirkung erhöht, wenn der Muskelzug möglichst direkt auf die Chorda übertragen wird, so muß eine solche Knickung der Septen in der (hordahöhe vorteilhaft sein, indem nun jedes Myomer gewissermaßen wie ein nach vorn zugespitzter Muskel wirkt, dessen Sehne direkt zur Chorda zieht.

Der muskulöse Teil des ersten Hyomers reicht bis zum Vorderende des Centralnervensystems nach rom; der des hintersten etwa bis zum Beginn der Schwanzflosse; ron beilen aber zieht eine feine Sehne bis zu den entsprechenden äußersten Chordaenden, ebenso eiu besonderer Fortsatz der ursprünglichen Hohlräume (Myocöl) dieser beiden Myomeren bis in die Enden dieser Sehnen.

Die Muskelelemente der Myomeren sind dünne, längs gerichtete plattenfürmige Gebilde, die im allgemeinen den ganzen Raum eines Myomers durchziehen, sich also von der Chorda bis zur äußeren Haut und von Septum zu Septum erstreckell. Jede längstibrilläre Platte scheint aus einer einzigen Embryonalzelle hervorzugehen; doch ist die Beziehnng der Muskelelemente zu denen der höheren Wirbeltiere noch etwas unsicher.

In den ventralen Hälften der zwischen Mund und After sich erstreckenden Iyomeren erfährt dieser Verlauf der Muskelelemente eine Differenzierung, indem sie in der innersten Zone der Myomeren nicht mehr radiär von innen nach außen gerichtet silld, sondern absteigend, etwa parallel der inneren Grenzfläche des Seitenrumpfmuskels (s. Fig. 81, S. 177). Auch ist diese Zone der Myomeren ron der etwas dickeren äußeren, in welcher sich der ursprüngliche Verlauf der Muskelplatten erhält, durch eine zarte Bindegewebseinlagerung abgesondert, in welcher der ventrale Nerv herabsteigt. Hiernit ist schon die Abgliederung eines besonderen Muskels von den Seitenrumpfinuskeln angedeutet, der, wie es scheint, ähnlich dem gleich zu erwähnende $M$. transversus auf die P'eribranclialhöhle wirkt.

Außer der ansehnlichen Seitenrumpfmuskulatur findet sich nur noch ein größerer Muskel, der sich an der Ventralseite vom Mund bis zum Porus branchialis erstreckt, der M. trunsversus oder Ptcrygialmuslel (s. Fig. 81 Seite 177). Wie die Benennung andeutet, ist es ein Quermuskel, oder genauer ein paariger, da er in der Ventrallinie geteilt ist. Auch er scheint durch bindegewebige quere Septen wie segmentiert; doch sind diese Abteilungen viel zahlreicher als die Myomeren.

Der M. transversus, welcher von den sng. Visceralisten der dorsalen Spinalnerven innerviert wird, stelt jedenfalls in leziehung zu den beiden Metapleuralfalten, durch deren ventrales Verwachsen das sog. Atrium oder die T'eribranchialhöle entstant. Er wirkt auch wohl hauptsächlich als Yerengerer der Peribranchialböhle.

Anßer ilın tindeu sich nur noch einig" zarte Muskclchen, nämlich in der den M!nn] umziehenden lippe ein äußerer und ein innerer ringformiger Lippenmustirl (sphincter), ron welchen der erstere aus den linken Transiersalmuskel hervorgehen soll. Anf der Girenze zwischen Mundhöhle unl Darm. die durch das sog. Velun ansgezeichnet ist, findet sich ein querer bis ringfömiger Sylhineter veli; ferner auch ein sylhincter des liters. 
Die Ontogenese der Acraniermuskulatur erweist sich jedenfalls als sehr ursprünglich und daher in mancher Hinsicht typisch für die Wirbeltiere. Wie bei den früher besprochenen gegliederten Bilaterien wird die Metamerenbildung durch die Entwicklung von Mesodermsomiten eingeleitet. Bei den Acraniern geschieht dies in einer, nach unserer Meinung sehr ursprünglichen Weise, indem die Dorsalwand des Urdarms, jederseits von der Chordaanlage, Ausstülpungen bildet (Fig. 290, 1), welche sich hierauf als die Somiten abschnïren. Letztere stellen gleichzeitig das gesamte Mesoderm dar. Ihre Bildung verläuft successive von vorn nach hinten. Jedes Somit ist demnach ein hohles, von einer einschichtigen Epithelwand gebildetes Bläschen, das anfänglich seitlich von Chorda und Rückenmark
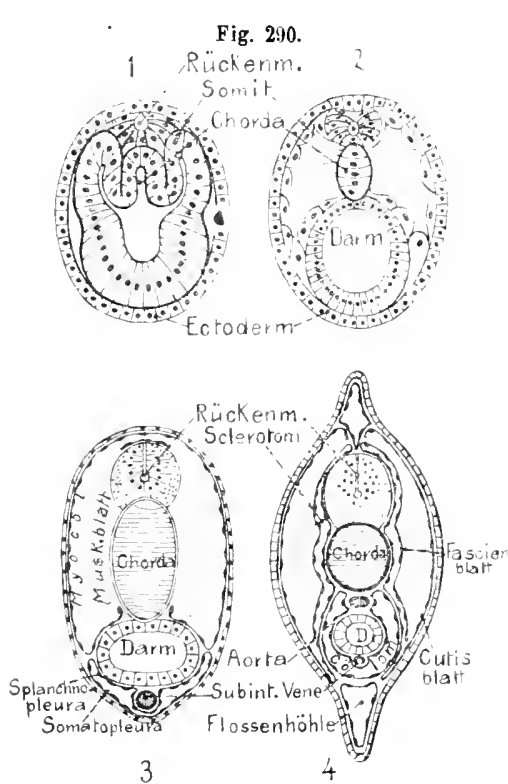

Branchiostoma (Amphioxus) lanceolatum. Querschnitte durch Embryonen, zur Entwicklung der Seitenrumpfmnskulatur (n. HATSCHEK 185: v. 1888).

1. Embryo mit 9 Somiten, Quersehnitt durch das 9. Somit. 2. Embryo mit 10 Somiten; Querschnit aus der Körpermitte. 3. Larve mit 5 Kiemenspalten. Querschnitt durch die Körpermitte. 4. Junges Tier direkt nach der Hetamorphose, Querschnitt zwischen Porus und After. 3 und $z$ Schemata. 0 . B. liegt, also nur die Dorsalregion des Embryo erfällt. Später beginnen die Somiten ventralwärts um den Darm hinabzuwachsen, bis sie schließlich in der Bauchlinie zusammenstoßen (Fig. 290,2). In dieser, seitlich vomDarm gelegenen, ventralen $\mathrm{Re}-$ gion derSomiten sch winden allmäblichibre Vorder- und Hinterwände, und ebenso auch die in der Bauchlinfe zusammenstoßenden Wände der beiderseitigen Somiten (sog. ventrales Mesenterium des Darms), so daß also die ursprünglich voneinander gesonderten ventralen Somitenabschnitte jeder Seite (die jedoch nie stärker ausgebildet zu sein scheinen) sich zu einer einheitlichen sog. Seitenplatte $\langle\mathrm{Pa}-$ rietalplatte) vereinigen, deren gemeinsame Höhle, welche durch Zusammenfluß der einzelnen Somitenhöhlen entstand, den Darm umgibt und das Cölom darstellt (Fig. 290, 3-4). Die dorsalen Anteile der Somiten soudern sich hierauf von der so entstandenen Seitenplatte ab und sind die sog. Urwirbel oder Myotome, aus welchen die Seitenrumpfmuskulatur hervorgeht.

Diese Myotome liegen demnach seitlich von Chorda und Rückenmark. Schon vor ihrer Absonderung von den Seitenplatten sind die Zelleu der Medialwand der hohlen Myotome stark in die Myotomhöhle (Myocöl) hineingewachsen, so daß diese Wand (Muskelplatte), welche der Chorda und dem Rückenmark anliegt, sich sehr verdickt and das Myocöl einengt (Fig. 290, 2-4). Dlese Zellen sind es, welche sich zu den Muskelelementen entwickeln, indem fibrilläre Bildungen in ihnen auftreten. Sie wachsen schließlich so stark gegen die Außenwand des Myotoms heran, daß das ursprüngliche Myocöl fast völlig verdrängt wird. - Die Außenwand 
dagegen, das sog. Cutisblatt, bleibt stets dïnn und gelst in die Bildung des bindegewebigen Teils des Integuments (Corium oder Cutis) ein.

Wie hervorgehoben wurde, liegen die Myotome urspriinglich nur in der dorsalen Region, seitlich von Chorda und Riickenmark. Später wachsen ihre Ventralenden jederseits zwischen dem änßeren Ectoderm und der äußeren Wand des Cöloms (Somatopleura) hinab bis gegen die Bauchlinie. In der Region des Atriums treten die Myotome auch in die Metapleuralfalten ein, wie es schon der Bau der fertigen Muskulatur ergab. Bei dem.ventralen Auswachsen bildet sich gleichzeitig aus dem Ventralrand jedes Myotoms, da, wo das Muskelblatt in das Cutisblatt nmbiegt, eine gegen die Chorda gerichtete Ausstïlpung der dünnen Epithelwand des Myotoms (s. Fig. 290,4). Diese Ausstullpnug wächst zwischen dem Muskelblatt einerseits und der Chorda sowie dem Rückenmark andererseits dorsal empor, bis sie über letzterem mit der der anderen Seite zusammenstößt. Man bezeichnet diese hoble Ausstülpung jedes Myotoms als Sclerotom, weil aus ihrer Innenwand das perichordale und perineurale Bindegewebe hervorgeht, in welchem bei den höheren Vertebraten die Wirbelbogen und -körper entstehen. Das äußere Blatt des Sclerotoms dagegen schließt sich dem Myotom innerlich an und wird deshalb Fascienblatt genannt, weil es gewissermaßen die Rolle spielt, welche den bindegewebigen Fascien der Muskeln höherer Wirbeltiere zukommt. Ein Rest der Sclerotomhöhle erhält sich bei Branchiostoma dauernd.

Der M. transversus der Ventralregion hat einen anderen Ursprung. Er gelit aus der inneren oder medialen Wand der Höblen hervor, welche sich in den Metapleuralfalten und den sog. Bauchfalten finden (s. Fig. 81, S. 17\%). Die Deutung dieser Höhlen ist etwas unsicher, da sie teils als abgetrennte Partien der Myocöle aufgefaßt werden, und ihre Wand daher von der der Myotome abgeleitet wird, teils dagegen als abgelöste Partien des eigentlichen Cöloms. Im ersten Falle wäre daher der M. transversus von den Myotomen abzuleiten, im zweiten dagegen ein Produkt der Seitenplatten.

Die Ontogenese der Körpermusknlatur der übrigen Wirbeltiere stimmt in den Grundzügen mit der bei den Acraniern beobachteten iiberein, doch finden sich einige tiefgehende Modifikationen, welche aber mit Recht als Vereinfachungen oder Abänderungen des ursprünglichen Entwicklungsgangs gedeutet werden. Statt der gesonderten Anlage einzelner Somiten entsteht jederseits der Chorda eine einheitliche solide Mesodermplatte, welche bei ihrer Entstelıung zuweilen noch Andeutungen eines Ausstülpungsvorgangs aus dem Entoderm, oder der Grenze von Ecto- und Entoderm anfweist, was ihre Ableitung vou den Verhältnissen bei den Acranieru ermöglicht. Erst secundär tritt in der soliden Mesodermplatte jeder Seite durch Spaltung oder Aushöhlıng ein Ilohlraum auf, welcher dem in den Seitenplatten der Acranier durch Verschmelzung entstehenden entspricht. Hierauf entsteht in der dorsalen Region der Mesodermplatten, welche jederseits an die Chorda stößt, eine Gliederung, die wie bei den Acraniern successive von vorn nach hinten fortschreitet. Friiher oder später lösen sich die so gebildeten Urwirbel oder Myotome mit ihrem Myocöl von den ungegliederten Ventralteilen der Mesodermplatten völlig ab. Letztere bilden demnach die Seitenplatten, welche hier nie segmentiert erscheinen, im Gegensatz zu dem jedenfalls primitiveren Verhalten bei 
Branchiostoma. Anch in der weiteren Entwieklmug der Myotome kehren die sehon bei den Acraniern geschilderten wesentlichen Vorgiinge wieder, wenn anch zum Teil etwas abgeaindert; so gilt allgemein, daß die Hyomerenmuskulatur ans dem medianen Muskelblatt der Myotome entsteht, wiilnend das äußere Blatt das Corium bildet. Doch wird vielfach behauptet, daß auch das Cutisblatt an der Entwieklung der Muskulatur teiluehme.

libenso intsteht ans dem ventralen Riand jedes Myotoms, bald mehr dureh eine Ansstiilpnng ähnlich den Acraniern, bald abweiehender dureh Wueherung, ein Sclerotom, welches das skeletogene Gewebe liefert, ans dem die axialen Skeletgebilde hervorgehen. - An der Bildung der liumpfumskulatur nimmt die Seitenplatte nach der verbreiteteren Ansielit keinen Anteil; dagegen entsteht aus illr in der Kopfregion ein ansehnlieher Teil der Muskulatur, welcher sich in naher Beziehnng zum Vorderabselonitt des Darms, insbesondere den Visceralspalten, entwickelt, die sog. Visceralmuskulatur. Indem dic Myotome wie hei Branchiostoma bis zur ventralen Mittellinie heralıwaehsen, nngreifen die völlig ansgebildeten Myomeren den ganzen Rumpf von der Dorsal- bis zur Ventralseite.

\section{Rumpf- und Kopfmuskulatur der Cyclostomen und Fische.}

\section{St aminuskulatur.}

Die Stammuskulatur der Cyelostomen und Fisehe bewabrt in ihren Grundziigen noeh den bei den Acraniern gefundenen Bau, wemn aueh gewisse Weiter-

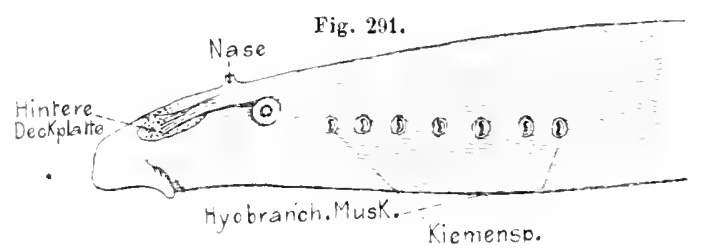

Petromyzon ftuviatilis. Kopfregion von links. Muskulatur nach Weguahme der Haut.

U. B. bildungen und Ver:̈indernngen eingetreten sind. Die beiden mächtigen segmentierten Seitenrumpfmuskeln erstrecken sieh jederseits von der Dorsalbis zur liauchlinie herab und vom Hinterrand des Sehädels bis zum Beginn der Sehwanzflosse. A uf den Schädel selbst dehnen sie sieh bei den Fiselien kaum mehr ans. Dagegen erstreekt sieh bei den Cyelostomen das vorderste Myomer mit seiner Dorsalpartie bis zum Auge, ja der Nase (Fig. 291), mit seinem Ventralteil bis zum 1linterrand des Munds. Jedenfalls entspricht jedoch dies vorderste Myomer nieht dem der Acr:mier. Vielmehr ergibt die Ontogenie der Cranioten recht allgemein, daß vor diesem vordersten Myomer, diss seiner Lage nach direkt hinter der Ohranlage folgt, noch mindestens 3 Hyomere angelegt werden, von welehen dats vorderste als sog. priiluandihulares vor den Mund anftritt. Von diesen 3 Nyomeren werden nach reeht iibereinstimmenden Angaben die Angemnuskeln gebildet, wie bei diesen später noch genauer darzulegen sein wird. Aneh die vordersten Myomere der ('yclostomen diirften hei den Ginathostomen wahrscheinlich rïekgebildet sein, wie aus ihrer Innervierung folgt, so daß also der Seitenrumpf fun weiter hinten gelegenen Myomer beginnen dürtte. 
Bei den Petromyzunten ist der Rumpfmnskel in del Kemenregion jederseits in einer Horizontallinie unterbrochen, da sich hier die Öfnnngen der Kiemensäcke einschieben Fig. 291). Bei den Myxinoiden dehnt sich diese Unterbrechung, wegen der in gleicher Höhe mit den Kiemenöfhnugen liegenden und sich über den gesamten limupf erstreckenden Schleimsïcke (s. S. 127), iiber den ganzen Kürper aus, ist jedoch verdeckt durch den spïter zu erwähnenden schiefen Bauchmuskel. Auch folgt hieraus, daß bei ihnen in der ganzen schwanzregion weseutlich nur der dorsale Teil des Rumpfmuskels entwickelt ist und bis zur Banchseite herab reicht. -.-. Die postbranchialen Myomeren der Petromyzonten (Fig. 291) sind dagegen wie die der Acrauier noch ganz einheitlich, ohne Scheidung in einen dorsalen und ventralen Teil.

Die Myomeren der Cyclostomen werden im allgemeinen ron längsgerichteten Muskelzellen gebildet, welche die Eigentümlichkeit zeigen, daß sie innerhalb der Myomeren zu zahlreichen platten- oder bandförmigen (Myxinoiden) Aggregaten vereinigt sind, welche Platten anf dem Querschnitt des Tiers etwa radiär zur Körperachse stehen (Fig. 292). Bei den Petromyzonten ist nur die periphere Zone dieser Platten scharf in Muskelzellen gesondert, während die Fasern der inneren Region nicht durch Bindegewebe voneinander geschieden sinı. - Auch in der Entwicklung der Fische und mancher höheren Wirbeltiere läßt sich die Bildung solcher Muskelbänder noch mehr oder weniger deutlich verfolgen: später zerlegen sie sich in Fasern.

Bei den Fischen ist die Souderung des jederseitigen Seitenrumpfmuskels in eine dorsale und ventrale Hälfte fast immer gut ausgeprïgt (Fig. 294 u. 295), indem in der Seitenlinie, welche durch die Einlagerung des Ramus lateralis des Nerrus vagus charakterisiert wird, eine quere horizontale Bindegewebsscheidewand vom Corium bis zur Wirbelsäule einwächst,

Fig. 292.

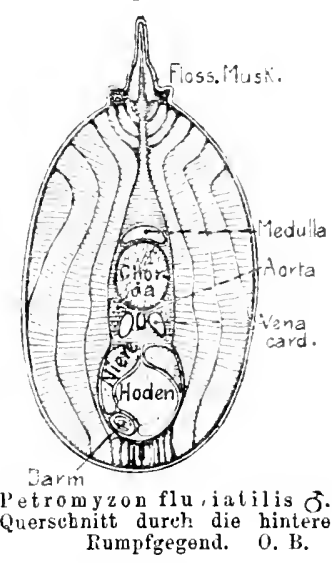
indem sie die Myosepten gewissermaßen durchschneidet. Dies Horinontalseptum sondert demnach jeden Seitenrumpfmuskel in eine dorsale und ventrale Hiilfte.

Die beschriebene Sonderung wird manchnal mit der Einlagerung des erwähnten Seitennervs in Beziehung gebracht: wahrscheinlicher dürfte es jedoch sein, daß sie eine funktionelle Vifterenzielung ist, und sich mit der gesonderten Wirkung der dorsalen und rentralen Muskulatur auf die Caudallosse herrorgebildet hat.

Jedes Myomer wird ron einem zugehörigen Spinalnerv des Rtickenmarks innerviert und zwar seine dorsale Iläfte ron dem dorsalen Spinalnervenast, die ventrale von dem Ventralast.

Der Verlauf der Myosepten anf der Obertäche des Muskels bleibt bei den Cyclostomen relativ einfach, ziemlich quer mit schwachen Knickungen oder sogar einer nittleren Ausbiegnng nach hinten (Fig. 291), wobei sich die Dorsalund Ventralenden der Septen scharf nach vorn richten (Petromyzon). Die Septen ziehen jedoch in ihrem Gesamtverlauf gegen die Chorda stark kopfwärts. 
Hierauf beruht es, daß auf einem Querschnitt (s. Fig. 292) stets zahlreiche Septen gleichzeitig getroffen werden. - Die beiderseitigen Myomeren der Myxinoiden alternieren ein wenig, ähnlich wie die der Acranier.

Bei den Fischen bleibt die scharf kopfwärts gerichtete Knickung der Septen, die wir schon bei Branchiostoma fanden, in der Höhe des Horizontalseptums erhalten. Während der Verlanf der Septen bei den Chondropterygiern, Ganoiden und Dipnoern gewöhnlich relativ einfach erscheint, ähnlich dem der Acranier, wird er bei den Teleosteern sowohl in der Dorsal- als Ventralhälfte meist viel komplizierter. In der Schwanzregion, wo sich die dorsale und ventrale Hälfte der Seitenmuskeln ganz symmetrisch ausbilden, da hier die Leibeshöhle fehlt, tritt dies sehr klar hervor. Im allgemeinen beruht die Komplikation darauf, daß jede dorsale und ventrale Septenhälfte in ihrem etwas kopfwärts gerichteten Verlauf eine oder auch zwei nach hinten gerichtete, kegelförmige Ausbuchtungen bildet, die zum

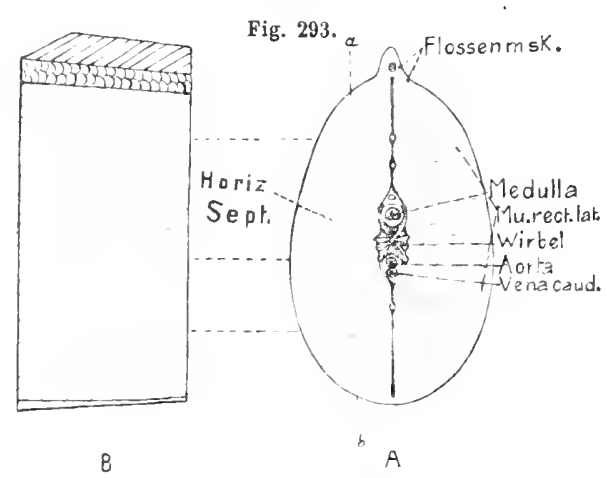

Perca fluviatilis (Barseh). A Querschnitt in der Gegend des Hinterendes der 2. Rückenflosse (vgl. Fig. 184). $B$ Lings. schnitt in der Ebene $\mathrm{a}-\mathrm{b}$ der Fig. $A$, un die kegelförmige Ineinandersehachtelung der Myomeren zu zeigen. $0 . \mathrm{B}$.
Teil auch im Septenverlauf auf der Muskeloberfläche hervortreten (Fig. $293 B$ u. 295). Innen heften sich die Septen an die Mitte der Wirbelkörper, bzw. in ihrem dorsalen und ventralen Verlauf an die Aeuralund Hämalbogen und ihre Dornfortsätze; in der Rumpfregion anch an die Rippen, die ihnen ebenso wie die Fleischgräten der Knochenfische eingelagert sind. So kommt es zustande daß die beiden Myomerenhiilften in jedem Seitenmuskel die Gestalt von liegeln annehmen, die sich mit ihren nach hinten gerichteten Spitzen ineinander schachteln. Die Bedeutung dieser Bildung ist wohl die, wie wir ähnlich schon für die Knickung der Myomeren der Acranier hervorhoben, daß die Zugwirkung jeder dorsalen und ventralen Seitenmuskelhälfte anf eine mittlere, bzw. axiale Linie übertragen und so schließlieh auf die dorsale und ventrale Hälfte der Caudalflosse geleitet wird.

Ein Querschnitt durch die Schwanzmuskulatur eines Teleosteers (s. Fig. 293 A) muß deshalb ein recht kompliziertes Bild geben, da in jeder Hälfte des Seitennuskels die nach hinten gerichteten kegeligen Myomeren zweimal, oder bei doppelkegeliger Bildung sogar 3-4mal getroffen werlen können. Da, wo der Schnitt durch die Spitzen der Kegel geht, sind die Myomeren wie konzentrische Ringe ineinander geschachtelt; dit, wo er die Kegelbasis getroffen hat, also namentlich dorsal und ventral, erscheint der Schnitt durch ein Myomer bogenförmig. - In der Rumpfregion, wo die Leibeshöhle die ventrale Rumpfmuskulatur auseinander drängt, wird letztere natiirlich dünner und einfacher; kegelförmige Bildung der Myomeren fehlt hier in ventralen Rumpfiunskel. 
Wie bemerkt, heftet sich der dorsale Rumpfmuskel vorn teils an die Occipitalregion des Schädels, teils an den Dorsalteil des Schultergürtels; der ventrale inseriert einerseits am Becken, oder bei Ganoiden und Teleosteern am Basalstück der Bauchflossen, andrerseits am Ventralteil des schultergürtels; er setzt sich jedoch noch ïber letzteren zu den Ventralenden der Visceralbogen, bis zum Hyoidund Kieferbogen fort. Bevor wir anf diesen sog. hypolranchialen Teil der Ventralmuskulatur eingehen, wollen wir die Differenzierungen, welche schon bei den Cyelostomen am Seitenrumpfmuskel anftreten, kurz betrachten.

Eine interessante Weiterbildung zeigt die ventrale Seitenrumpfwnskulatur der Myxinoiden, indem sich von ihr eine änßerliche Lage abgesondert hat, deren Fasern schief von dorsal und vorn nach ventral und hinten herabziehen (sog. Descendenz), also denselben Verlauf haben, welchen der Musculus obliquus externus in der Pauchmuskulatur der höheren Wirbeltiere besitzt. Septen finden sich in diesem Obliquus externus nicht. - In der vorderen Körperhälfte verhalten sich die beiden, an die Ventrallinie stoßenden Regionen des Obliquus seln eigen-

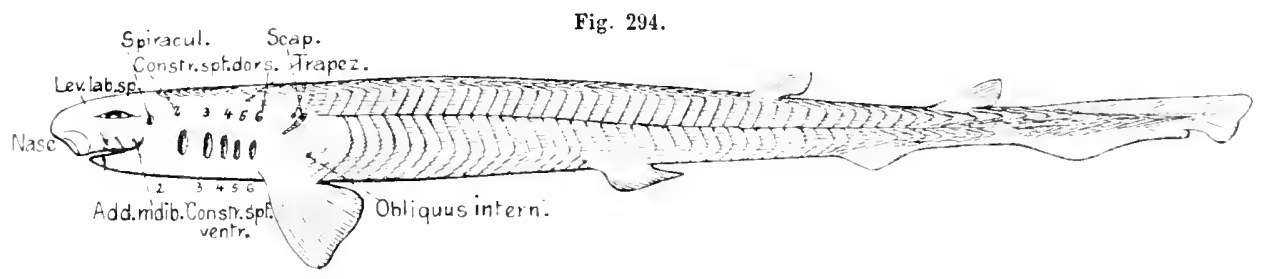

Seylliam canicula (jung. Haifisch) von links. Muskulatar (rot) nach Wegnahme der Haut. O. B.

tümlich, indem sie, sich in der Ventrallinie überkreuzend, noch ein Stück wcit auf die entgegengesetzte Körperseite übergreifen. Auf diese Weise bildet jeder wieder aufsteigende Teil, seinem Faserverlanf nach, gewissermaßen einen Obliquns internus, der jedoch anßerhalb des Externus liegt.

Bei den Fïschen erhält sieh in der dorsalen Rumpfmuskulatnr der längsgelichtete Faserverlauf im allgemeinen ziemlich unverändert. Die an die Wirbelsäule grenzenden tiefsten Partien befestigen sich direkt an dieser. - An der ventralen Rumpfunskulatur dagegen macht sich eine gewisse Differenziernng im Faserverlauf geltend. Bei den Haien (s. Fig. 294) ist der Verlauf in der dorsalen Partie des Ventralmuskels längs, wird jedoch hierauf schief absteigend vón hinten nach vorn und in der Tentralgegend endlich wieder längs. Durch diese Verianderung des Faserverlaufs welche in der Schwanzregion noeh nieht ansgesprochen ist, scheinen der bei den Tetrapoden gesonderte M. obliquus interuus, sowie der grade Bauchmuskel (M. rectus abdominis) angedeutet, obgleich noch keinerlei eigentliche Sonderung in diskrete Muskeln bestelıt. - Bei den Telrosteern geht die Differenziernng noch etwas weiter (Fig. 295), indem die dorsale, ansehnliehere Partie des ventralen Rumpfmuskels, schief absteigend, von vorn oben nach linten unten (descendent) gefasert ist, und erst in der Gegend der Bauchlinie wieder in geraden Verlauf übergeht. Der Faserverlauf dieser ansehulichsten und dicksten Partie des ventralen Rumpfwuskels entsprieht daher der des sogenanuten 
Obliquus e.cternus der tetrapoden Wirbeltiere; er erhält sich in solcher Weise in der Tiefe bis zu den Rippen. Zwischen letzteren aber geht eine tiefste diinne Lage, die sich an die Rippen und den Sehultergiirtel anheftet, in einen gerade entgegengesetzten Verlauf tiber (ascendent; s. Fig. 295), entspricht also dem Obliquns internus, wie wir ihn bei den Haien in ansehnlicher Entfaltung trafen.

Bei den Dipnoi sind die beiden schief gefaserten Lagen der ventralen Rumpfunskulatur noch besser entwickelt und von gleicher Dicke, so daß sich 1 m die tiefste Schicht des Obliquus internus an den Rippen befestigt. Protopterus zeigt sogar schon eine Sonderung des Obliquus externus durch etwas rerschiedene Faserrichtung in eine obertlächliche und tiefe Laqe, ähnlich wie die urodelen Amphibien. Interessant ist ferner die mögliche Andeutung eines Transversus abdominis bei den Dipnoi, wie ihn die tetrapoden Wirbeltiere regelmäßig besitzen. - Die Ontogenie scheint übrigens dafür zu sprechen, daß die descendente äußere Schicht des ventralen Rumpfunuskels der Teleosteer ans einer besonderen, sich erst später bildenden äußeren Lage der ursprünglichen Muskelplatte der Myotome hervorgeht.

Fig. 295.

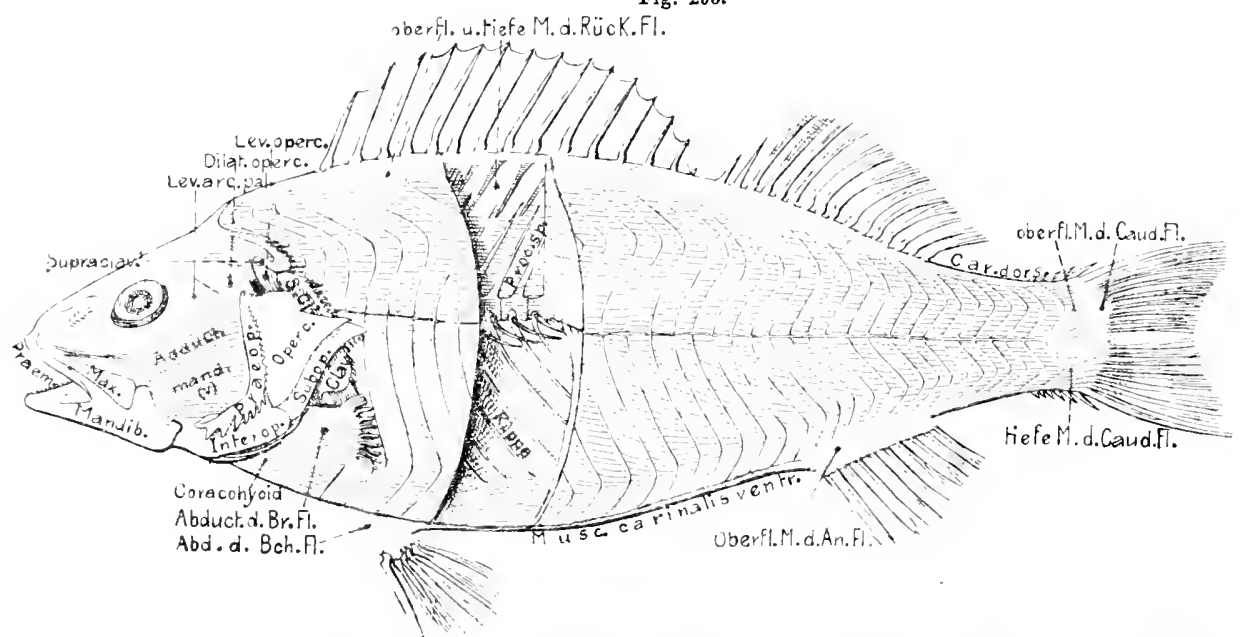

Perea fluviatilis (Barsch) von links. Oberflăchliche Muskulatur nawh Wegnahme der Hant. ln der Mlitte des Rumpfs ist ein Stuck des Seitenrump fouskels herausgeschnitten, so daß die tieferen Muskeln der Rúckenflosse, sowie die tiefo Lage des Seitenrumpfmuskels zwischen den Rippen, einige Wirbel nebst Gräten siehtbar sind. An der borsalhälfte der Caudalfosse sind dje oberfläblicben, an der veutralen die tiefen Flossenmuskejn gezeichnet (n. C'vier und Valesciesses Hist. nat. d. poise. u. Originalpräparat). O. B.

Eine besondere Ditterenzierung erfährt der Rumpfmuskel vieler Knoehenfische in der Gegend des horizontalen Septums, indem sich hier eine oberflächliehe dünne Lage als diskreter Muskel abgesondert hat (sog. Rectus lateralis, Fig. 293 A); sein Faserverlauf ist längs, wie schon die Bezeichnung andeutet.

Dieser, gewöhnlich durch rote Fārbung und sonstige Besonderheiten seiner Muskelfasern von der farblosen liumpfmuskulatur abweichende lectus lateralis kann sich sehr verschieden weit dorsal und rentral vom llorizontalseptum aus über die Rumpfrmuskulatur erstrerken. Sein Herrorgehen aus dieser folgt daraus, daß die Myosepten ihn noch durchsetzen.

Eine weitere Differenzierung zeigt die Rumpfmuskulatur an der Riicken- und Bauehkante, indem sich hier zwischen den Rüeken- wie den Analflossen ferner nach hinten bis zur Candaltlosse, nach vorn bis zum Schiidel oder dem 
Schultergürtel, ein längs verlaüfender paariger schwacher Mruskel abgegliedert hat (sog. M. carinalis dorsalis und ventralis, s. Fig. 295). - Abgliedernngen der dorsalen und ventralen Rumpfmuskulatur sind ferner die besonderen Muskeln, welche die Form- und Stellnngsänderung der unpaaren Flossen, insbesondere ihrer Flossenstrahlen, bewirken. Schon bei den Petromyzonten (s. Fig. 292) hat sich jederseits an der Basis der nnpaaren Flossen ein solcher Muskel mit zu der Flosse schief aufsteigenden Fasern entwickelt. - Bei den Fischen wurde im allgemeinen das Hervorgehen dieser Flossenmuskeln aus den dorsalen oder ventralen Enden der Myomeren durch eine Art Knospung erwiesen (sicher wenigstens für die sog. Erectores der Flossenstrablen). Gewöhnlich (besonders Teleostei) findet sich eine oberflüchliche Muskulatur an jeder Flossenseite, die von der äußeren Fascie des Seitenrumpfmuskels entspringt, und deren einzelne Bäuche sich an die Basis der Flossenstrahlen heften (Inclinatores, Fig. 295); unter ihnen entspringen jederseits von den Flossenträgern tiefere Muskeln: für jeden Flossenstrahl ein Aufrichter (Erector) nnd ein Niederzieher (Depressor, s. Fig. 295). Anch die Caudaltlosse besitzt jederseits ähnliche Muskeln ihrer Flossenstrahlen, oberflachliche und tiefe (Fig. 295); zu denen sich auch sog. interradiale, zwischen den Basen der benachbarten Flossenstrahlen, gesellen können.

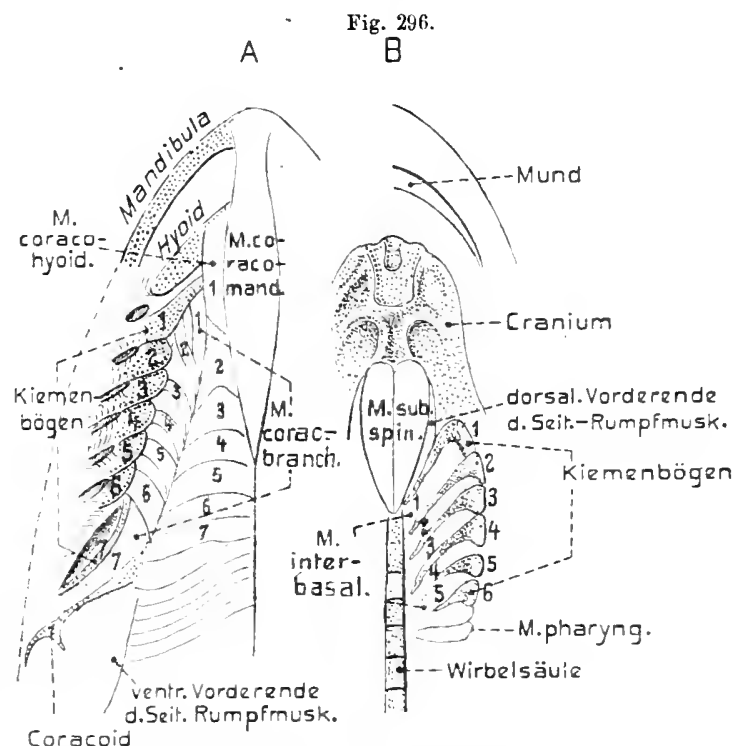

Heptanchas (Baifisch). A hypobranchiale MIusknlator der Kopfregion von der Ventralseite. $B$ Ventralseite des Schādels und der Wirbelsānle zar Demonstration des Vorderendes des dorsalen Seitenrumpfmuskels und eines Teils der Muskulatur der Kiemenbogen (nach

Auf die im allgemeinen ähnliche Musknlatur der paarigen Flossen, welche gleichfalls eine Abgliederung der Myomeren ist, soll erst später bei der Muskulatur der parigen Extremitäten der Tetrapoden eingegangen werden.

Besondere Beachtung verdient die in die Kiemen- und Kieferregion sich ausdehnende vorderste Partie der Seitenrumpfmuskulatur, und besonders deren ventraler oder hypobranchialer Teil. Ein epibranchialer oder dorsaler, der sich in der Gegend der dorsalen Enden der Kiemenbogen findet, besteht nämlich nur noch bei den Haien und wird gebildet von einem meist parigen M. subspinalis und sog. Interbasales (auch Interarcuales I genannt), die sich zwischen den dorsalen Gliedern der Kiemenbogen (Pharyngobranchialia) ausspannen (s. Fig. 296). - Schon bei Petromyzon fanden wir eine anschnliche Fortsetzung der ventralen Rumpfmuskulatur 
durch die gesamte Kiemenregion. Die Ontogenese ergibt jedoch das Eigentümliche, daß sich die vordereu branchialen Myotome an der Bildung dieser Muskulatur nicht beteiligen, sie vielmehr erst vom Ventralende des zehnten Myotoms ausgeht, das nach vorn unter die Kiemen auswächst. Später beteiligen sich noch die folgenden Myotome bis etwa zum 17. an ihrer Entstehung.

Ähnlich dürfte sich die homologe Muskulatur auch bei den Haien entwickeln; das achte oder neunte Myotom bildet bei ihnen die erste Knospe für die hypobranchiale Nuskulatur. Die spätere Gliederung dieser Aulage scheint jedoch selbständig zu geschehen und sich mehr nach den Kiemen als nach den dariiberliegenden dorsalen Myomeren zu richten, mit denen sie anch nicht genan iihereinstimmt.

Die Besonderheit dieser Hypobranchialmuskulatur folgt auch aus ihrer Innervierung, welche bei Petromyzon von einer Anzahl Ventralisten der ventralen Spinalnerrenwurzeln geschieht, die sich zu einem Plexus rerbinden, der hinter der letzten Kiementasche ventralwärts umbiegt, und hierauf, kopfwärts ziehend, die hypobranchiale Muskulatur bis vorn hin innerviert. Ganz ähnlich geschieht die Innervierung bei den Haien (s. Fig. 449), nur daß es hier die sog. spinooccipitalen Nerren (auch als Ilypoglossus aufgefaßt) sind, die sich mit vorderen Spinalnerven zu einem Plexus cervicalis verbinden, der gleichfalls hinter den Kiemen ventral herumzieht. Die Spinooccipitalnerven, resp. die Äste des Plexus cervicalis der Haie, versorgen jedoch auch die oben erwähnte epibranchiale Muskulatur.

Bei den Chondropterygiern erstreckt sich die hypobranchiale, meln oder weniger durch Quersepten gegliederte Muskulatur (Mm. coraco-arcuales) voin Schnltergürtel nach vorn bis zum Unterkiefer; durch besondere Zipfel an den Kiemenbogen (coraco-branchiales), dem Hyale (cor--hyoidalis) und schließlich der Mandibel (coraco-mandibularis) sich befestigend (Fig. 296,A). - Die Ganoiden verhalten sich im allgemeinen noch ähnlich; die einzelnen Muskelpartien sind jedoch bäufig schärfer gesondert. - Die Coracobranchiales der Knochenfische sind bis auf zwei jederseits rückgebildet, die vom Claviculare zum fünften Kiemenbogen gehen; außerdem hat sich ein Coracohyoidmuskel erhalten.

Viscerale Muskulatur der Kopf-und Kiementegion der Cyclostomen und Fische.

In der genannten Region der Cyclostomen und Fische tritt eine besondere quergestreifte Muskulatnr anf, die sich sowohl morphologisch als ontogenetisch eigenartig verhält. Ihre Bezeichnung als Visceralmuskulatur verrät, daß sie zu den Visceralbogen in naher Beziehung steht. Im Gegensatz zu den Stammuskeln geht sie nicht aus den eigentlichen Myotomen hervor, da sich die Somiten in der KopfKiemenregion, soweit bekannt, nicht in Myotome und Seitenplatten sondern; vielmehr spricht alles dafür, daß die Visceralmuskeln aus dem Teil des Mesoderms der genannten Region entstehen, welcher den Seitenplatten des Rumpfs entspricht. Dieser Anteil des Mesoderms wird durch die Kiemenspalten in schlauchförmige oder solide Stränge gesondert, ans welchen sowohl die erwähnte Muskulatur, als auch die Visceralbogen selbst entstehen. - Es ist jedoch auch die Ansicht vertreten worden, daß die Myotomantcile der ursprünglichen Somiten dieser Region ventral 
herabgerïckt, gewissermaßen mit der Seitenplatte verschmolzen seien (Gegenbaur).

Wenn wir zmächst auf die ziemlich cigenartigen Verhältnisse der Cyclostomen einen Blick werfen, so finden wir besonders bei den Myxinoiden, weniger entwiekelt bei den Petromyzonten, in den Scheidewinden zwischen den anfernanderfolgenden Kiemensäcken ein quer oder ringfürmig zur Kürperacliso ziehendes System von Muskeln (sog. Constrictorcn), die sich bei den Myxinoiden über dem Kiemendarm eigentümlich verstricken, rentral dagegen voneinander gesondert bleiben. llinten hängen sie mit der Muskulatur des nutritorisehen Darmanfangs und des l'ericardiums, vorn mit der '/ungenmuskulatur zusammen. - Bei den Petromyzonten liegen die entsprechenden Constrictoren den Kiemenbogen medial an. Irsprïnglieh sollen sie aus Muskeln hervorgehen, welehe die einzelnen Kiementasehen ringtörmig umziehen. Das ganze Constrictorensystem der Cyclostomen aller liegt nach innen von den Seitemrumpfmuskeln, was besonders bei den Myxinoiden, mit ihren zum Teil weit naeh hinten versehobenen Kiementasehen, hervortritt. Trotzdem wird diese Muskulatur von den Nn. glossopharyngeus und ragus innerviert, befand sich daher jedenfalls ursprünglich in der hinteren Kopfregion.

Zur Visceralmuskulatur gehört ferner die boch komplizierte Zungenmuskulatur der Cyclostomen, deren Ausbildung eine ganz einseitige und eigenartige Spezialisierung dieser Gruppe darstellt, für welehe sich bei den übrigen Vertebraten niehıs Entspreehendes findet. Sie wird von dem fïnften Hirnnerv, dem Trigeminus, innerviert.

Gewissermaßen ursprünglicher erhielt sieh die Visceraluuskulatur bei den primitiven IIaien als eine die Kopf- und Kiemenregion tiberziehende lage ringrörmig angeordneter Muskelfasern, welehe von den Visceralspalten durehsetzt wird (Fig. 294, S. 431). Horsal steigt sie jederseits bis zur. Region des Schädeldachs, etwas höher als die Visceralspalten, empor; ventral gehen dié beiderseitigen Anteile urspriinglich ineinander iber. - Eine Bildung, wie die beschriebene, dürfte als walnscheinlieher Ansgangszustand auzusehen sein, hat jedoch bei allen lebenden Fisehen durch Spezialisierung und Sonderung in einzelne Partien oder diskrete Muskelı (oder aueh zum Teil durch Reduktion) eine erhebliche Veränderung erfahren. Las ganze System wird im allgemeinen als das der Constrictoren (Constrictor communis) bezeichnet. Innerviert wird es von den lirnnerven $\mathrm{V}$ bis $\mathrm{X}$, Trigeminns bis Vagus (abgesehen vom Acustieus, VIII), nnd die Vergleichung seiner einzelnen Anteile bei den verschiedenen Formen gründet sich daher vor allem auf deren Innerviermng durch die einzelnen Hirnnerven.

Es kann wobl keinem Zweifel unterliegen, daß das Constrictorensystem der Cyclostomen unt Fische in allgemeinen homolog ist. $O b$ es sich lagegen etwa con dem M. transversus der Acranier ableiten läßt, ist ein zurzeit schwer lösbares Problem. Da dieser Muskel in den beiden Metapleuralfalten entsteht, welche die Peribranchialhöhle bilden, von der sich bei den Cranioten nichts lindet (abgesehen von der Möglichkeit den sog. Vornierengang auf sie zurïckzuführen), so verhält er sich vou dem Constrictor communis recht verschieden. Sollte daher eine solche Ableitung nöglich sein, so müßte sie von einem Zustand ausgehen, wo sich der M. transversus noch bis in die eigentliche Körperwand erstreckte. - Die eigen- 
tümliche Lage der Cyclostomen-Constrictoren nach innen von der Rumpfmuskulatur ließe sich teils auf eine nachträgliche Versehiebung der Kiemensäcke nach hinten, teils auf ein Vorrücken der seitlichen Rumpfmuskulatur zurückführen, wie ès sich ja in dem hypobranchialen Anteil der ventralen Rumpfmuskulatur sehr bestimmt ausspricht. Bemerkenswert ist aber jedenfalls die recht innige Verbindung der Constrictoren mit der Darmmuskulatur.

Eine eingehende Schilderung der bedeutenden Komplikation, welche das allgemeine Constrictorensystem bei den Fischen erfährt, würde hier zll weit führen, es müssen daher einige Hinweise gentigen, - Bei den Knorpelfischen (vgl. Fig. 297) wird der Constrictor jeder Seite durch die Einlagerung der Kiementaschen in eine dorsale und ventrale Partie geschieden, die sich mehr oder weniger scharf in einzelne Portionen für jeden Visceralbogen sondern (Constrictores superficiales dorsales und ventrales). Ein zum Mandibularbogen zu rechnender vorderster dorsaler Constrictor 1, der vom Trigeminus innerviert wird, findet sich bei primitiven Haien (Notidaniden) noch als einheitlicher, vor der ersten Visceralspalte (Spiraculum) liegender Muskel (s. Fig. 297, A); bei den höheren Haien treten an seine Stelle zum Teil mehrere.gesonderte Muskeln, die, neben Beziehungen zum Spritzloch, zuweilen auch solche zu den Augenlidern erlangt haben (M. nictitans und M. palpebrae superioris).

Aus dem Trigeminusabschnitt des allgemeinen Contrictors sind weiter auch die den Kieferbogen bewegenden Muskeln hervorgegangen, welche daher sămtlich vom Trigeminus (Ram. mandibularis) versorgt werden. Es sind dies ein Levator labii superioris (auch Praeorbitalis gen.), der von vorn zum Hinterende des Unterkiefers zieht, während der eigentliche Adductor mandibulae, vom Palatoquadrat entspringend, sich mehr von hinten und oben an dieselbe Stelle der Mandibel begibt (bei den Rochen sind beide Muskeln meist in mehrere Portionen gesondert). Das Palatoquadrat wird seinerseits durch einen gewöhnlich abgesonderten Levator maxillae (L. palatoquadrati), der von der Labyrinthregion des Schädels entspringt, festgehalten und gehoben. - Im Bereich des Hyoidbogens wird der Constrictor vom N. facialis versorgt: Aus seiner dorsalen Partie geht ein Constrictor superficialis dorsalis 2 hervor, der eine sich häufig als besonderer Muskel absondernde Partie zum Hyomandibulare sendet (Levator hyomandibularis); während sich bei Rochen aus dem Facialisconstrictor noch ein sog. Levator und Depressor rostri hervorgebildet haben. - An den C. superficialis dorsalis 2 schließen sich hinten die entsprechenden dorsalen Constrictoren für die Kiemenbogen an, die vom $\mathbf{N}$. glossopharyngeus (3) und vom Vagus (die folgenden) innerviert werden. Diese Constrictoren heften sich auch an die dorsale Region der Kiemenbogen, und ihre Fortsetzung erstreckt sich in die tiefen Scheidewände (Septen) zwischen die Kiementaschen hinein bis zu den Bogen selbst. Letzterer Teil hat sich (mit Ausnahme der Notidaniden) zu den sog. M. interbranchiales differenziert, welche die Kiemenbogenstrahlen verbinden und sich innen an die Bogen, außen an die sog. äußeren Kiemenbogen (Extrabranchialia) insericren. An den Kiemenbogen selbst sind ans tiefer gelegenen Partien der Constrictoren besondere Muskeln hervorgegangen; so zwischen den Pharyngo- und Epibranchiclia die Arcuales dorsales $I$, und, vom Epibranchiale zu dem Pharyngobranchiale des folgenden Bogens schief aufsteigend, die Arc.dorsales II, während sich zwischen dem Epibranchiale und Hypobranchiale 
jedes Bogens die Adductores arcum branchiarum ausspannen, zu denen auch wohl der schon frïher erwähnte Adductor mandibulae als homolog gerechnet werden darf.

Aus dem tiefen Bereich der ursprünglichen Constrictores dorsales hat sich noch ein Muskel abgesondert, der etwa vom dritten C. superficialis dors. ab laings der Constrictoren hinzieht (mit schief nach hinten absteigenden Fasern) und sich am Scapulare des Schultergürtels befestigt. Dieser $M$. traperius wird rom Vagus versorgt (er fehlt den Rochen).

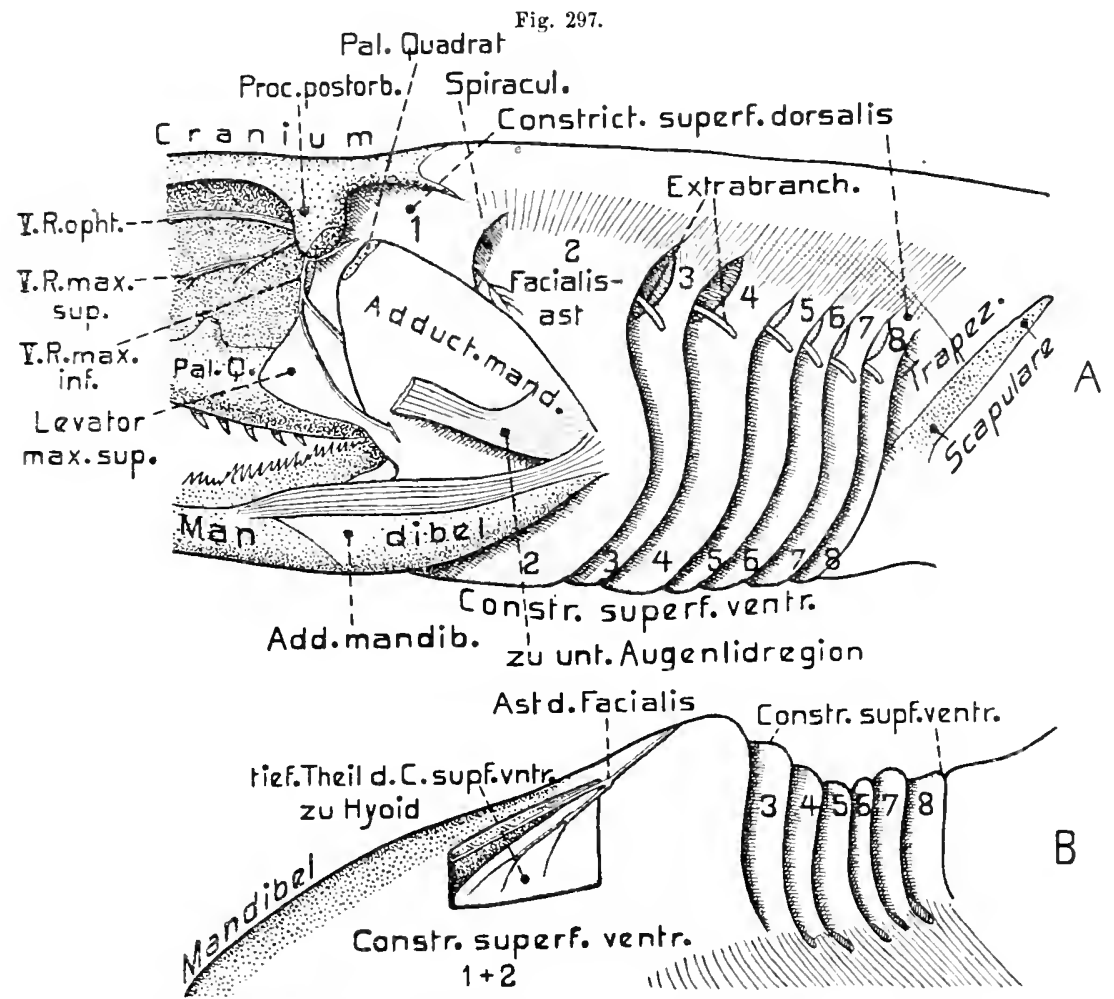

Heptanchus. Viscerale Muskulatur der Kiefer-Kiemenregion, nach Wegnahme der Haut. $\rightarrow A$ Linkseitige Ansicht; das Palatoquadrat ist an der Gelenkung mit dem Postorbitalfortsatz des Sebadels gelöst, so daß der Levator max. sup. sichtbar wird. - B Ventralansicht der linken Hälfte. Aus dem Constrictor super ficial is rentralis ist ein Teil der oberfächlichen Schicht herausgeschnitten, so daß die tiefere Sehicht. welche sich am Hyoid befestigt, za sehen ist (n. VETTEk 1574) E. W.

Ein ventraler Constrictor 1 ist möglicherweise mit dem folgenden 2 vereinigt, oder z. T. auch riickgebildet (s. Fig. 297, B). Dieser Muskel erstreckt sich zwischen den Hyalia und den Unterkieferästen bis nach vorn; hinten kann er das Coracoid erreichen (bei Rochen ist er komplizierter). Er differenziert sich hänfig in eine oberflächliche und eine tiefe Lage. - Für die non folgenden Kiemenbogen finden sich entsprechende Constrictores superficiales ventrales, die sich auch an den Ventralteilen der Kiemenbogen befestigen. Ibre Innervierung geschieht von den zugehörigen Nerven der Kiemenbogen, wie es für die dorsalen Constrictoren schon geschildert wurde. 
Bei den Garroiden und Trlostecen sind erhebliche Reduktionen im hinteren Bereich der dorsalen und ventralen Constrictores superficiales eingetreten, was jedenfalls mit der Umbildung und Zusammendrängung der Kiemenspalten und Bogen zusamuenhiingt, worait auch der Trapezius stets geschwnden sein soll. Im Trigeninusbereich besitzen die Störe einen ansehnlichen Protractor lyomandibularis, der wohl dem sog. Inentor areus palatini der Teleosteer in allgemeinen entspricht. Der Adductor mandibulae ist bei den Stören sehr reduziert und entspringt hier noeh vom Palatoquadrat. Bei den Teleostei (Fig. 295, S. 432) ist er meist recht ansehnlich und hat seine Ursprïnge stark ansgedehnt (Quadrat, Metapterygoid, Hyomandibulare, Praeoperculam, sogar auf Sphen- und Pteroticum); er ist stets in mehrere Portionen gesondert (ähnlich schon bei Polypterus), die sich teilweise überlagern, und von denen sich die obe !läehliche an der Maxille, die beiden tieferen an der Mandibel inserieren, so daß der Adductor der Knochenfisehe fast stets auch den Oberkiefer etwas nach hinten ..nd abwärts zieht.

Einen Repräsentanten des sog. Levator maxillac superioris der Knorpelfische stellt bei den Teleostei wohl der Levator arus palatini dar (Fig. 295), an den sich hinten noch ein sog. Dilatator operculi anschließt, der, obgleich vom 'Trigeminus innerviert, seine Insertion an der Dorsalregion des Opereulums besitzt. - Im Bereich des Facialis besitzen die Chondrostei einen Rctiactor lymmandibularis und einen Levator operculi, die Knochenfische einen Adductor hyomandibularis, Levator operculi und Addurtor operculi. Dem Facialisgebiet gehört bei den Teleosteern endlich ein Adductor areus palatini an, der vom Parasphenoid entspringt und zum Ganmenbogen, oder auch dem Hyomandibulare zieht. - Von den an die Kiemenbogen tretenden tieferen Constrictorenteilen begegnen wir in beiden Gruppen sog. Leratores areum branchialium in verschiedener Zabl, welche die dorsalen Glieder der Kiemenbogen an der Lnterseite des Schïdels betestigen (bei den Knochenfischen gibt es äußere und innere). - An den Kiennenbogen wiederholen sich die schon bei den Chondropterygiern gefundenen Irterliranchirts; bei den Stören, ferner bei den Teleostei die Arcules dorsales (Interarcuales dorsales), während bei beiden Gruppen sog. Interereuates ventrales vou dell Ceratobranchialia zu den Hypobranchialia ziehen. - Anch Riickziehmuskelu für den gesamten Kiemenapparat kommen bei 'Teleosteern vor, die von vorderen Wirbeln zu hiuteren Kiemenbogen gehen (Tietrotor arcum bumclicalium dorsalis).

Aus den ventralen Constrictores superticiales lïßt sich bei den Chondrostei tin ausehnlicher Muskel ableiten, der con der ventralen Mittellinie, schiet nach vorn alufsteigend, zur muteren Angengegend zieht mod zwei Portionen zum Hyale und Operculum sendet. In der IIauptsache entspricht er jedenfials dem Constrietor ventralis 2; sein vorderster Teil nach der Innervierung jedoch möglicherweise 1. Noch einige weitere kleine Mnskelı in der Ventralregion des Kopfs gehören wohl ehenfalls hierher.

Bei den Teleostei finden wirvorn zwischen den Unterkieferhälften den sog. Intermamlibularis, der anf Grund der Inuervienug ebenlalls zum C'oustr. ventr. superf. 2 zal gehören sheint. Dies gilt ebenso ron den sog. Geniohyoideus, der sich vom 
liyale zum vorderen Unterkieferwinkel erstreckt. Eigentümlich ist der gleichfalls dem Facialisgebiet angehörige M. hyoideus; sein dorsaler Teil gleicht den Interbranchiales, da er sich zwischen den Kiemenhautstrahlen ausspannt (bis zum Suboperculum und Operculum), seine ventrale Fortsetzung endigt teils am Hyale, teils am Mundhöhlenboden; dabei kann sich dieser Ventralteil mit dem der Gegenseite kreuzen oder vereinigen. - Auf einige Muskelchen, die sich iei den Knochenfischen zum fünften Kiemenbogen (Os. pharyngeum inf.) begeben, resp. von ihm entspringen, gehen wir hier nicht näher ein.

\section{Rumpf- und Kopfmuskulatur der tetrapoden Wirbeltiere.}

Stamunskulatur.

Im Zusammenhang mit den komplizierten Bewegungsverbältnissen, welche sich bei den Tetrapoden durch die besondere Ausbildung und Wirkung der Extremitäten in steigender Entfaltung entwickelten, erlangt die Stammuskulatur, ebenso wie die der Extremitäten, allmählich einen sehr verwickelten Bau. Im Rahmen des vorliegenden Werks erscheint es daher ganz aúsgeschlossen, eine susfiilnlichere Schilderung derselben zu geben. Es kann sich nur darum handeln, einige Grundzüge ihrer Ausgestaltnng hervorzuheben, und etwa die allmähliche Differenzierung an einigen Beispielen etwas genauer zu erörtern. - Die beginnende Differenzierung des Seitenrumpfmuskels, welche wir bei delf Fischen wesentlich durch die Sonderung in einen dorsalen und ventralen Rumpfmuskel, sowie die Abgliederung der Flossenmuskulatur angebahnt sahen, schreitet bei den Tetrapoden immer weiter"fort, was zunächst dadurch bedingt wird, daß die Insertionen an den Elementen des Achsenskelets, dem Schädel, den Wirbeln nebst ihren Fortsätzen und den Rippen, andrerseits aber auch den Extremitätengürteln und dem proximalen Abschnitt des Extremitätenskelets selbst, ausgiebiger werden, obgleich nicht wenige Muskeln auch Insertionen an den änßeren Fascien bewahren, oder erlangen. Mit dieser Tendenz geht eine Sonderung der ursprünglich einheitlichen Seitenrampfmuskeln in diskrete Muskeln Hand in Hand, die sich teils nur über ein oder wenige Segmente erstrecken, teils dagegen uiber zahlreiche. - Ebenso tritt jedoch auch eine Sonderung in der Tiefenrichtung ein, wodurch mehrere iibereinander gelagerte diskrete Muskeln aus der urspringlichen Rumpfmuskulatur hervorgehen können. Bei längeren Muskeln, die sich aus mehreren bis zahlreichen ursprïnglichen Myomeren hervorgebildet haben, können sich bei den Amphibien und zum Teil auch den Reptilien die Myosepten als sog. Ligamenta intermuscularia oder Inscriptiones tendineue, noch recht ausgiebig erhalten. Bei den Amnioten schwinden die Reste der Myosepten immer mebr und kommen nur noch in der Schwanzregion oder in einzelnen Muskeln vor

Das allmähliche Verkitmmern der ursprïnglichen Dissepimente kann in etwas verschiedener Weise geschehen. Einmal so, daß sich die Zugrichtung der Muskelfasern der Verlanfsrichtung der Ligamente mehr und mehr annäherte, wobei letztere funktionslos wurden und daher allmählich verkümmerten; andrerseits dadurch, daß die Muskelfasern allmählich durch die Ligamente hindurchwuchsen und sie zerstörten. 
Recht konservativ verhält sich im allgemeinen noch die Schwanzregion bei Amphibien, Sauriern und Crocodilen. Die Längsmuskulatur bietet hier fast noch völlig das Bild wie bei den Fischen; bei den genannten Reptilien mit je zwei nach hinten gerichteten Knickungen der Myosepten im dorsalen und ventralen Seitenrumpfmuskel, die zum Teil sogar noch kegelartige Bildungen der Myomeren hervorrufen (s. Fig. 298).

Schon bei gewissen Wirbellosen mit besonders abgegrenzten diskreten Muskeln bilden sich an deren Ansatzstellen eigenartige, zuweilen chitinöse Verlängerungen, die die Anheftung an die Cuticula bewirken (speziell Arthropoden). In analoger Weise laufen die durch Differenzierung entstehenden Muskeln der Wirbeltiere an beiden Enden, oder dem sog. Insertionsende, d. h. demjenigen, welches sich an den zu bewegenden Teil befestigt, in eine bindegewebige Fortsetzung aus, welche die Anheftung bewirkt: sog. Sehnen (Tendines). Diese Sehnen der Vertebraten bestehen aus festerem, sog. straffem Bindegewebe. An mehr fläwhenhaft ausgebreiteten Muskelı, jedoch auch solchen gewöhnlicher Form, können die Sehnen sich gleichfalls membranartig in die Fläche entwickeln; sie werden dann gewöhnlich als

Fig. 298.

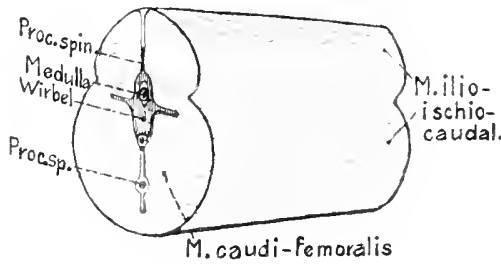

Alligator mississipiensis. Ein Stück des Schwanzes nach Wegnahme der Hant. Von links and etwas vorn, so daß auch der vordre Querschnitt sichtbar. Aponeurosen bezeichnet. Die einzelnen Muskeln, oder auch eine Gruppe solcher, werden von den benachbarten Muskeln, orler auch dem äußeren Integument, durch gleichfalls aus straffem Bindegewebe bestehenden Membranen geschieden, welche den Muskeln eine gewisse Freiheit ihrer Bewegungen gestatten. Dies sind die sog. Muskelbinden oder Fascien. Schon bei den Fischen schiebt sich zwischen den Seitenrumpfmuskel und das Integument eine solche Fascie. Die Fascien können zuweilen stellenweis eine sehnig-aponeurotischè Beschaffenheit annehmen, umsomehr als. sie nicht selten auch Teilen der Muskulatur Ansatz bieten.

Bei den seither betrachteten Wirbeltieren fanden wir eine sehr regelmäßige und einfache Innervierung der Stammuskulatur, indem jede Myomerhälfte von dem Spinalıerv der bezüglichen Seite versorgt wurde, d. h. dem dem betreffenden Segment zugehörigen Spinalnerv. Die tiefgehende Umbildung und Differenzierung der einfachen Seitenrumpfmuskulatųr bei den Tetrapoden muß natürlich auch diese Innervierungsverhältnisse beeinflussen nnd verwickelter gestalten. Im allgemeinen wird zwar die aus einem Myomer hervorgegangene Muskulatur die Versorgung durch den ursprünglich zugehörenden Spinalnerv bewahren; deshalb wirl eben die Feststellung des Muskelbezirks, welcher von einem bestimmten Spinalnerv versorgt wirl, Licht verbreiten über die Muskeln, welche sich aus dem betreffenden Myomer allmählich hervorbildetel. Die genaue Verfolgung der Muskel-Innervierung ist daher vergleichendanatomisch ron größter Wichtigkeit. Wie wir später sehen werden, treten jedoch nicht selten Verbindungen und Faseraustausch zwischen benachbarten Spinalnervenästen ein, wodurch das Problem erschwert wird, indem Muskeln von Ästchen gewisser Spinalneıven versorgt werden können, die ursprünglich vielleicht gar nicht an ihrer Innervierung beteiligt waren. In solchen Fällen werden dann die Deutungen zweifelhâfter.

Da gewisse Muskeln von ihrem ursprünglichen Entstehungsort weit verlagert werden, oder mit ihren Ursprüngen in weit abliegende Gebiete übergreifen, so kann ihre Innervierung in solchen Fällen Aufschluß über diese Vorgänge geben, indem sie auf den ursprünglichen Ort des Muskels hinweist. Da ferner zahlreichr Muskeln der Tetrapoden aus einer größeren bis großen Zahl ursprünglicher Myomeren hervorgingen, deren Grenzen verschwanden, so deutet doch die Versorgung durch zahlreiche Spinalnerven noch auf diese Entstehungsweise hin. - 
Schon bei der Besprechung der Wirbelsäule wurde berrorgeboben (vgl. S. 215), daß Schulter- und Beckengürtel, und damit die gesamten Extremitäten häufig beträchtliche Verschiebungen an der Wirbelsăule erfahren haben müssen. Dies muß sich auch in der Innervierung ilırer Muskulatur aussprechen, welche, obgleich im allgemeinen homolog, doch nicht durch die gleichzähligen Spinalnerven geschieht. Wie schon früher hervorgehoben, liegt jedoch kein Grund zur Annahme von crentueller Fin-oder Ausschaltung von Segmenten vor. Es läßt sich diese verscniedene Innervierung der Extremitäten daher nur so verstehen, daß bei ihrer Verschiebung nächst angrenzende Spinalnerven einbezogen, entgegengesetzte dagegen ausgeschaltet würden; was, wie wir später flnden werden, dadurch begünstigt wird, daß die Ventraläste der Spinalherven, welche die Extremität versorgen, zunächst ein Nerven-

Fig. 299.

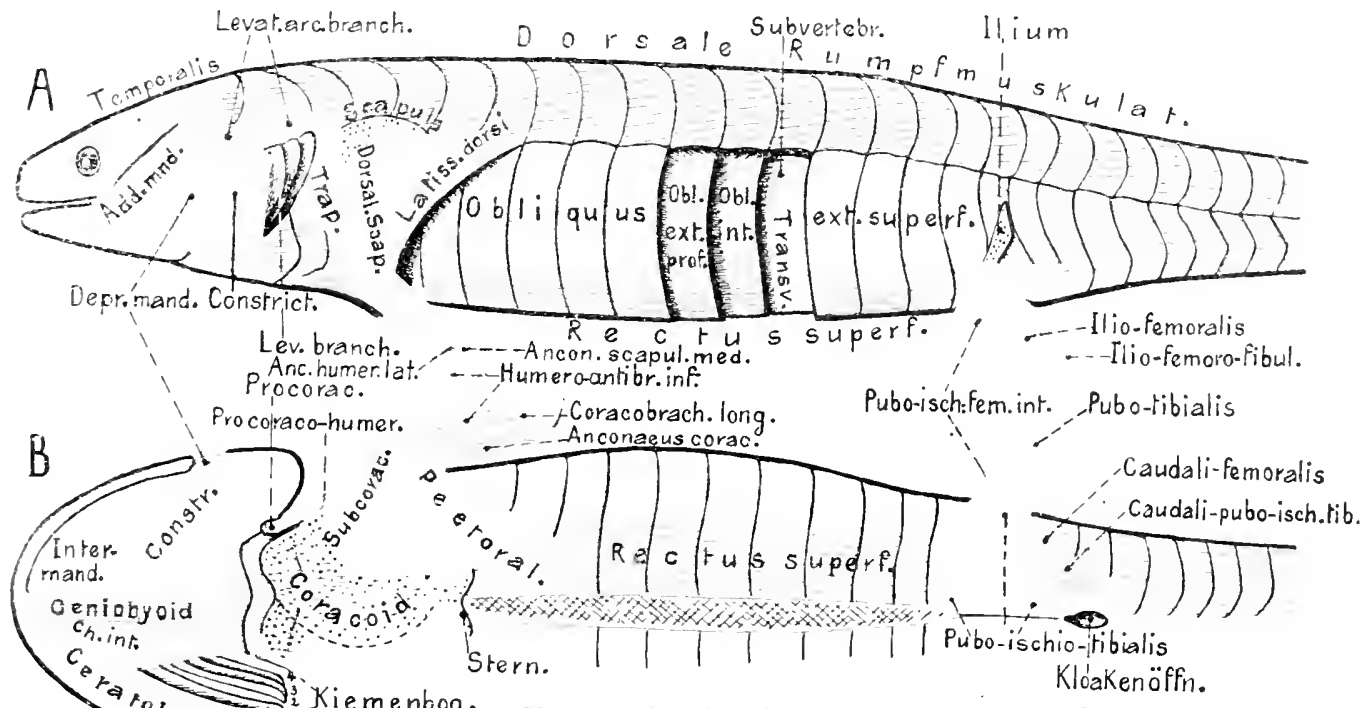

Siredon pis c iform is (Larve. Axolotl). Oberfächliche Muskulatur nach Wegnahme der Haut. - A Von der linken Seite. Am Rumpf sind an drei Myomeren die äußeren Muskellagen abgetragen, um den Obliquns externus profundus, den 0 bl. internus und den Transversus zu zeigen. $-B$ Von der Banchseite. Am Kopf ist in der oberen Hălfte die oberfächliche ventrale Musknlatur (Constrictoren) gezeichnet; unten (rechts) die hypobranchiale Stammuskulatnr. Knorpel punktiert.

geflecht (Plexus) bilden, von dem erst die Extremitätennerven entspringen. Schwieriger zu beurteilen ist dagegen das Verhalten der Extremitätenmuskulatur in diesem Falle; doch läßt sich nicht wohl daran zweifeln, daß sie in ähnlicher Weise aus benachbarten Myomeren ergänzt werden mußte, während Anteile andrer Myomeren ausschieden. Es würde sich in solchen Fällen also für die Extremitätenuerven und -muskeln um eine Art substitutioneller Homologie (imitatorische, Fürbringer) handeln.

Rumpfmuskulatur. Der dorsale Seitenmuskel zeigt bei den Amphibien (Fig. 299) noch recht wenig Differenzierung und ausgiebige Erhaltung der Myosepten, die auch bei den Reptilien in ihr im allgemeinen noch gut ausgebildet sind. Bei den Amnioten sondert sich der dorsale Rumpfmuskel allmählich in immer zahlreichere Muskeln, welche ihre Abstammung durch die Innervierung aus den dorsalen Spinalnervenästen verraten. Oberflächlich bilden sich so längere, über viele Segmente ausgedehnte Muskeln, die hinten sowohl vom Os ilium, als auch von der hinteren oberfächlichen Fascie entspringen (so der sog. Longissimus 
dorsi, der Iliorostulis), und sich ihrem Verlauf nach vorn an die Querfortsätze der Wirbel heften, von denen sie jedoch auch wiederum Zuwachs erhalten, schließlich auch zu Rippen gehen (Iliocostalis), oder sogar bis zum Craninm reichen können (Long. dorsi). Ein anderer hierher gehöriger Teil bildet den von vorderen Wirbeln zum Schädel tretenden M. splenius.

Aus tieferen Lagen des dorsalen Rumpfmuskels geht ein System von Muskeln hervor, die sich allmählich immer mehr komplizieren. Oberflächlich sind sie in der liegel länger und heften sich an zahlreiche Wirbel an, oder ïberspringen eine größere Zahl derselben: so Muskeln, die sich zwischen den Dornfortsiitzen oder Querfortsätzen ausspannen (Spinales, Interspinales und Intertranstersarii). Ferner

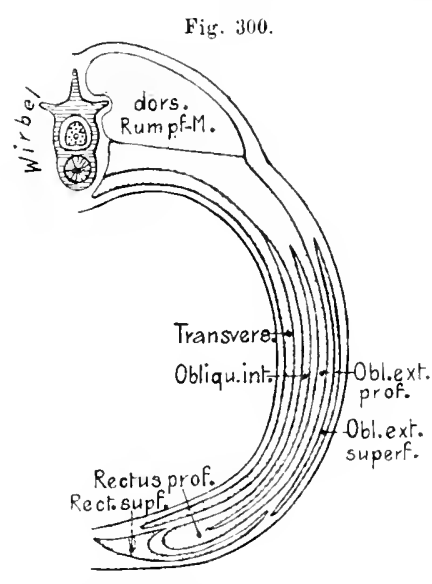

DolgelTrito titeniatus. Schematischer Querschnitt der Stammuskulatur in der Runpfgegemi (n. Mliurer isg'). O. B. solche, die von Dornfortsätzen zu Querfortsätzen ziehen (Transversospinales), von denen dic oberflächlichen zahlreiche Wirbel überspringen, die mittleren weniger, die tieferen einige, die tiefsten nur einen oder gar keinen. A uch bis zum Schiidel können sie sich erstrecken. - Zur Bewegung des letzteren besteht bei den Säugern ein recht kompliziertes Systeur von Muskeln, das bei den Reptilien zum Teil noch durch eine einzige Muskelmasse oder durch zwei Muskelpaare vertreten ist, die von den Halswirbeln entspringen.-- Auch in die dorsale Schwanzregion ziehen vom Ilium oder Sacrum Fortsetzungen des ursprünglichen dorsalen Seitemrumpfmuskels. - Daß die dorsale Rumpfmuskulatur der Chelonier mit der Bildung des knöchernen Rückenschilds stark bis völlig rückgebildet wurde, ist begreiflich.

Die ventrale Stammushulatur geht aus dem ventralen Seitenrumpfmuskel der Fische hervor, was schon ans ihrer Innervierung durch die Ventraläste der Spinalnerven folgt, andrerseits auch ans ihrem Hervorwachsen aus der Ventralkante der ursprünglichen Myomeren. Sie bildet die Muskulatur der Banchwand, die hinten an die ventrale Beckenhïlfte, davor an die Rippen und auch den Schultergürtel sich befestigt, endlich weiter vorn in den spitter zn erwähnenden hypohranchialen Lnteil der ventralen Mnsskulatur übergeht. - Da die Entwicklung der Bauchmuskulatnr bei den primitiveren Tetrapoden ziemlich gnt bekannt ist, gehen wir etwas nüher auf sie ein. Die schon bei den Teleosteern aufgetretene Differenzierung des ventralen Rumpfmnskels in eine äıßere Lage mit descendenten Fasern, eine tiefere unit ascendenten und eine ventrale mit längs gerichteten, kehrt bei allen Tetrapoden wieder, indem sich diese drei Lagen gleichzeitig zu diskreten Mnskeln sondern, tem M. obliquus abdominis extermus mit descendenten Faseru, dem obliques internus mit ascendenten und dem Rectus ubdominis mit längsgerichteten (s. Fig. 299). Während der Obliquus internus bei dên Amphibien aus dem medialeu Muskelhlatt des ventralen Myomerenfortsitz hervorgeht, entsteht der 
Obliquus externus sekundär aus einer äußeren Lamelle, welche sich durch Umbiegen des Ventralrauds des medialen Muskelblatts nach außen nnd sein dorsales A uswachsen entwiekelt (s. Fig. 300). Der Rectus geht ans dem ventralen Cnbiegungsrand der beiden Lamellen hervor, welche die Obliqui externi und interni bilden (vgl. Fig. 300).---Bei sämtlichen Tetrapoden sondert sich ferner von der Medialtäche der Inlage des Obliquus internus ein tiefster Bauchmuskel ab, der Transievsus abinminis, dessen Fasern quergerichtet sind (s. Figg. 299, 300-302).

Bei den urodelen Amphibicu (s. Fig.'299) erstrecken sich diese Bauchmuskelu, welche noch von zahlreichen Myosepten durchsetzt sind, über die ganze ventrale Rumpfwand zwisehen Becken und Schultergïrtel. Sie komplizieren sich dadureh, daß sowohl vom Rectus, als dem Obliquas externus eine äußere Lage abgesondert ist, als Rectus superficialis und Obliqun cxternus superficintis. Diese änßere, bei den Ichthyoden noch diinne Lage der beiden Muskeln wird bej den Salaman-

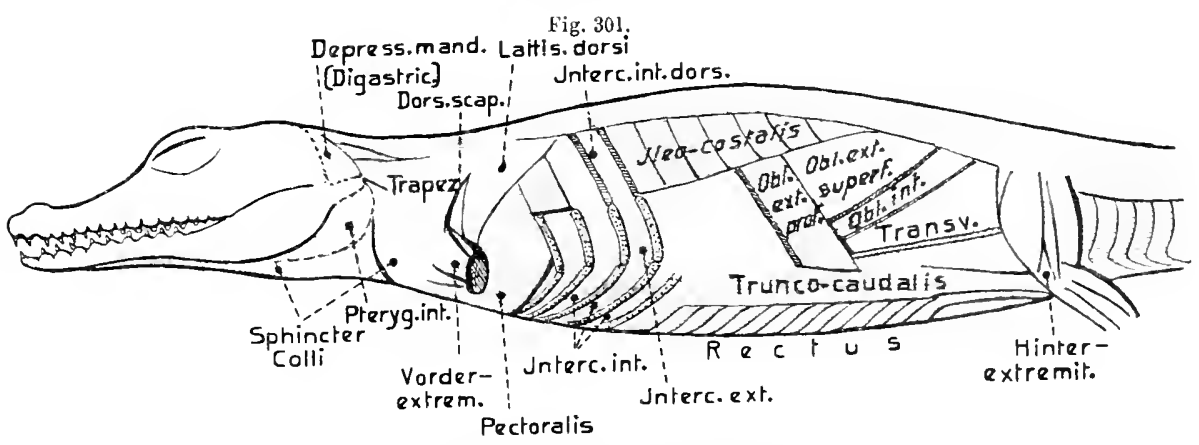

Crocodilus palustris, Lesson. Von der linken Seite. Die Haut entfernt, un die anßßere Muskulatur 20 zeigen. Vordre Extremitat abgeschnitten. Aus den M. iliocustalis, obliquus externus, superficialis und profundus, sowie dem M. oblinuus internus sind Stücke herausgeschnitten, um die tiefer liegenden Muskeln zu zeigen. (Mit Benatzling von MACHER lsoti.) 0. B.

drinen stärker als die tiefe (profundes); wogegen bei den Anura die profunden Rectus und Obliquus externus wahrscheinlich völlig eingegangen sind, so daß deren einfacher Rectus und Obliquus externus nur die superficialen der Urodelen reprïsentieren. Der Obliquus internus, der schon bei manchen Urodelen (z. B. Salamandra) mit dem Transversus verschmolzen ist, scheint bei den Anuren geschwunden zu sein. -.- Während die beiden primären seitlichen Bàchmuskeln, Obliquus externus profundus und Obliquns internus, stets segmentiert bleiben, treten die Myosepten im Obliquus externns superficialis und ${ }^{\circ}$ Transversus allmählich stark zurïck und schwinden manchmal völlig.

Die ventrale Rumpfmuskulatur der Reptilicn ist viel komplizierter gewordeir, was vor allem mit der ansehnlichen Entwicklung der Rippen zusammenhängt, die sich über die ganze Rumpfwirbelsäule ausbreiten können. Zwischen den Ohliquus internus, der sich urspriinglich (Sphenodon und die meisten Saurier) uiber den ganzen Rimpf erstreckt, und den Obliquus externus profundus, der selten fehlt (z. B. Chamaeleo), schalten sich nämlich die sog. M. intereostrles externi und interni ein, die sich zwischen je zwei aufeinander folgenden Rippen ansspannen, 
selten weiter greifend; wobei die Verlaufsrichtıng ihrer Fasern denen der Obliquii externus und internus entspricht (Fig. 301). Während die Intercostales externi meist die Vertebralstiicke der Rippen verbinden, erstrecken sich die Intercostales interni weiter ventral hinab; doch gilt dies zum Teil auch für die äußeren. - Es ist nun recht wahrscheinlich, daß sich die Intercostales externi aus der tiefen Lage des Obliquus externus profundus hervorgebildet haben, während die Intercostales interni aus der änßeren Schicht des Obliquus internus entstanden. Zuweilen (Crocodilus, Chamaeleo) ist jedoch der eigentliche Obliquus internus stark rückgebildet, so daß nur ein hinterer Teil in der Lendenregion erhalten blieb, der wie eine direkte Fortsetzung der Intercostales interni erscheint.

Der Transversus der Reptilien ist in der Regel ansehnlich entwickelt und erstreckt sich über den ganzen Rumpf. - Der Rectus, welcher selten undeutlich ist (Chamaeleo), differenziert sich bei den Sauriern in zwei lateralc und einen medianen Anteil. Bei Sphenodon und den Crocodilen sind seiner oberflächlichen Lage die Bauchrippen (vgl. S. 211) eingelagert, die jedoch auch in inniger Verbindnng mit dem Integument stehen. -- In der Beckenregion sondert sich vom Rectus gewöhnlich ein Teil ab (sog. M. triangularis), der vom Praepubis zur Linea alba ${ }^{1}$ ) zieht; er gleicht dem später zu erwähnenden M. pyramidalis der Süuger. --Vom dorsalen Rand des Obliquus internus wurde eine Gruppe besonderer Muskeln abgegliedert, die von den proximalen Rippenenden, seltener von der Ventralseite der Wirbelsäule schief nach vorn absteigend zu den Vertebralstücken der Rippen ziehen, sog. Retractores costaruin (=Obliquns interuus dorsalis longus Maurer); schon bei den Urodelen findet sich eine entsprechende Muskulatur als sog. Subvertebralis (s. Fig. 299). - Vom Intercostalis externus der Crocodile hat sich in der Lumbarregion ein Muskel gesondert, der, von der Ventralseite der Lendenwirbelsäule nach hinten ziehend, bis zum Proximalende des Femur geht, der sog. Quadratus lumborum; er findet sich auch bei Vögeln und Säugern allgemein.

Die Bauchmuskulatur der Schildliröten ist wegen der Panzerbildung stark rednziert, jedoch teilweise erhalten. - Eine hochgradige Komplikation erfährt sie bei den Schlangen, wo die Rückbildung der Extremitäten eine völlige Veränderung der Bewegungsweise hervorrief, indem der Körper gewissermaßen anf den Ventralenden der bis zur Bauchhaut herabreichenden Rippen kriecht. Damit differenziert sich die aus den schiefen Bauchmuskeln hervorgegangene Rippenmuskulatur sehr. Aus den oberflächlichen schiefen Bauchmuskeln und dem Rectus entstandeu jederseits zwei Reihen sich schief kreuzender Mnskelchen, welche von den Rippen zur Bauchhaut ziehen. Ein recht kompliziertes System von Hautmuskeln ist ferner zwischen den Hornschildern der Banchfläche entstanden und bildet gleichfalls ein wirksames Hilfsmittel bei den Bewegungen. - Inscriptionen finden sich nur bei gewissen Reptilien noch im Rectus.

Die Bauchmuskulatur der Vögel schließt sich im allgemeineu der der Reptilien an, wird jedoch durch die mächtige Entfaltung, welche das Brustbcin in die Breite

1) Als Linea alba wird die bindegewebige längsliuie hezeichnet, welche die beiden paarigen Anteile des graden Bauchmuskels scheidet. 
und Läıge erfährt, in ihrer Ausdehnung anf die nach binten und seitlich vom Sternum liegenden Regionen beschränkt.

Auch die Bauchmuskulatur der Säuger (s. Fig. 302) bewahrt die schon bei den Amphibien und Reptilien festgelegten Grundzüge. Der Rectus und Obliquus externus

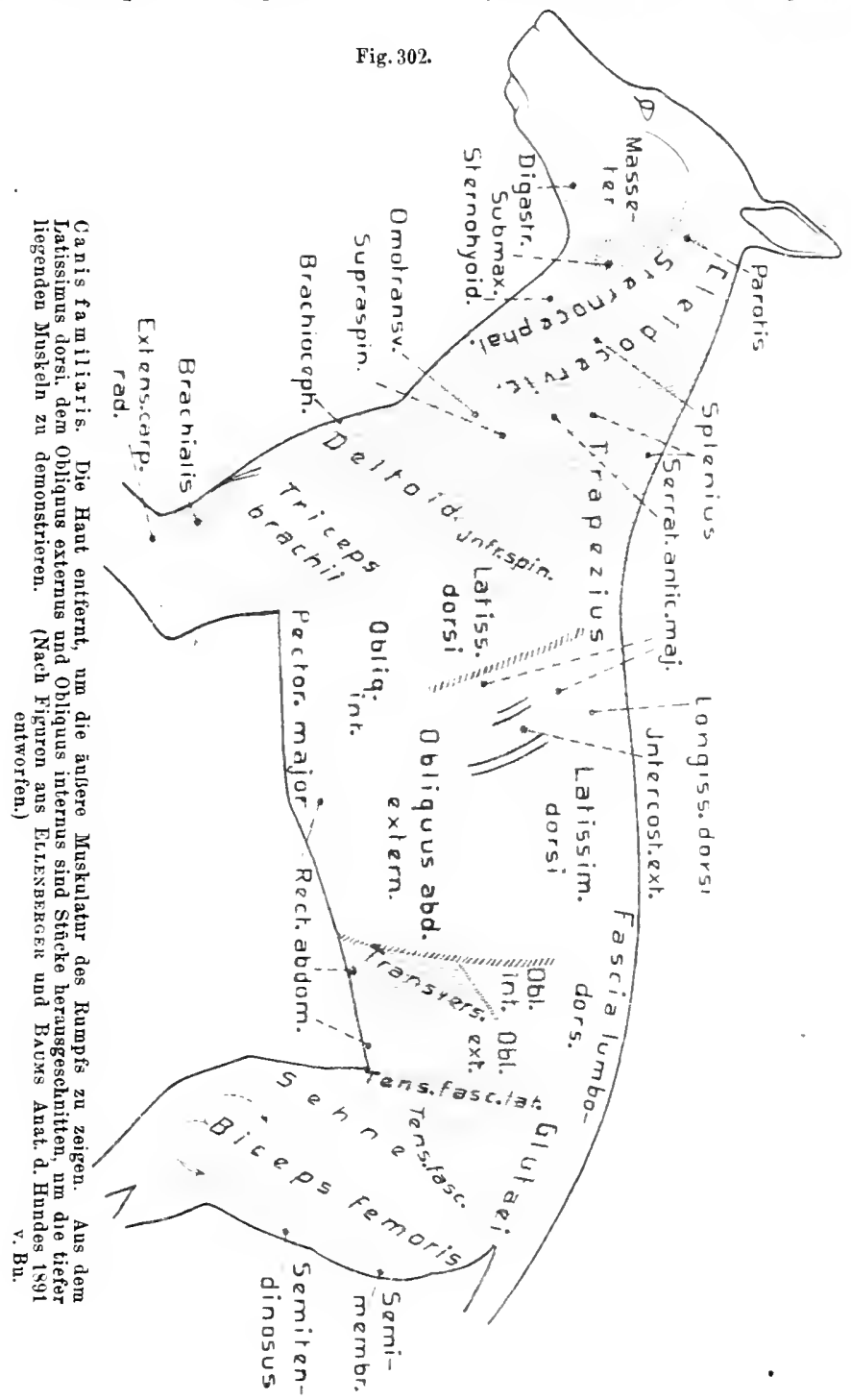

erstrecken sich bei den paläogenen Formen noch bis in die vorderste Brustregion und zeigen meist Inscriptionen, der Rectns sogar fast stets. Obliquus internus, Transversus, sowie der fruther erwähnte Quadratus lumborum, der vom Ilium entspringt und ventral an der Wirbelsäule bis zu den hinteren Rippen zieht, sind regel- 
mäßig vorhanden. - Dorsal, längs den Seiten der Wirbelsäule, von den Wirbeln zu den Vertebralstiicken der Rippen ziehend, finden sich noch die Serrati postici superior und inferior, nach ihrer Innervierung Ventralmuskeln.

Die Vergleichung ergibt, daß die beiden Serrati postici kein nrsprünglich einheitlicher Muskel sind, wie aus ihrem. mittleren Zusammenstoßen hänfig geschlossen wurde, sondern daß sie sich aus dorsalen zur Wirbelsäule emporgerückten Partien der Intercostales externi (Serr. p. sup.) und interni (Serr. p. inf.) ableiten. Wahrscheiulich rollzog sich diese Differenzierung im Zusammenhang mit der Entwickluug des Zwerchfells und der Zwerchfellatmung der Mammalia. Auch die sog. M. levatores costumen der Mammalia gingen aus Teilen der Intercostales externi herror.

Als eine Abgliederung des hintersten, an die Schambeine inserierenden Rectusabschnitts tritt bei den Säugern der paarige M. pyramidalis auf, der bei Monotremen und Marsupialiern ron den Beutelknochen schief nach vorn zur Linea alba, $\mathrm{j}:$ bei gewissen Beutlern bis zum Sternum zieht. Bei den Placentaliern inseriert er hinten am Pubis und ist zuweilen noch recht ansehnlich, zum Teil aber auch ganz rïckgebildet.

Daß der M. pyramidalis dem schon bei den Reptilien gefundenen M. triangularis, eventuell sogar einem ähnlich gelagerten Muskel der Urodelen entspreche, wird teils befürwortet, teils geleugnet.

Auf eine vom Transversus ausgehende Abzweignng, welche als sog. M. cremaster bei den männlichen Sängern in Beziehung zum Hoden, bei den weiblicheu Aplacentaliern als Compressor mammae zur Milehdrüse tritt, wird bei den männlichen Geschlechtsorganen näher: einzugehen sein. - Auch das Zwerchfell (Diaphragma) soll erst später bei der Leibeshöhle besprochen werden.

Wie wir schon früher sahen, bewabrt die 8 tammuskulatur der Schwanzregion bei den urodelen Amplibien und Reptilien hiufig einen sehr ursprünglichen Bau, ähnlich dem der Rumpfinuskulatu der Fische; dies gilt für ibren dorsalen Teil noch mehr als für den ventralen. Aus letzterem differenzieren sich ir der vorderen Schwanzgegend schon bei deu Urodelen (Fig. 299), äbnlich auch den Reptilien, einige ansehnlichere Längsmuskeln, die von vorderen Caudalwirbeln zum Becken ziehen, und daher im allgemeinen als Beuger der Schwanzwurzel funktionieren; so der parige Ischiocaudalis der Urodelen, der anch bei Reptilien wiederkehrt und, die Kloake beiderseits umziehend, anch als ihr Schließmuskel (Sphincter) funktioniert. Schon bei einem Teil der Reptilien (so Saurier) hat sich jedoch ein selbständiger Sphincter cloacae abgegliedert, was auch bei den Vögeln und aplacentalen Sängern der Fall ist, wïhrend er bei den placentalen, wegen der Trennung von $\Lambda$ fter und Urogenitalöffnung, umgestaltet wird, wovon später bei diesen öffnungen Genaueres. - Auch ein zum llinm ziehender Muskel (Ilio-caudalis) findet sich bei den Reptilien. Gleichzeitig haben sich jedoch bei Urodelen und Reptilien einige Muskeln abgesondert, die vou der ventralen vorderen Scluwanzwirbelsäule zur Extremität gehen (Caudali-femoralis, s. Fig. 298, Candali-ischio-pubo-tibialis, Fig. 299). - Mit der Verkümmerung des Scliwanzes bei den Anuren trat die Schwanzmuskulatur zurück, doch sind die vom Sacrum und Ilium zum Os coccygis ziehenden Muskeln (M. coccygeo-sacralis und coccrgeo- 
iliacus) bierher zu stellen. - Auch bei den Vögch hat die Riïckbildung des Schwanzes die Muskulatur beeinflußt. Sie besteht in paarigen Leratores (s. Fig. 5i, S. 144) und Depressores coccygis und zwei ebensolehen Muskeln (Pubo-coceygeus und llio-coccygeus), die auch zu den Steuerfedern Ziige senden und dieselben daher spreizen.

Die Sehwanzmuskulatur der Säıger erweist sieh (abgesehen von Verkiimmerungsfällen, wie bei Anthropoiden und dem Mensehen) recht kompliziert. In den vom Beeken zur Sehwanzwurzel ziehenden Muskeln, wie den Ischio-, Pulo- und Ilio-coccygeus, doeh aueh dem paarigen vom Saerum, sowie vorderen Candalwirbeln zu den meisten folgenden Schwanzwirbeln gehenden ventralen Sacro-coccygeus finden wir Repräsentanten der sehon erwähnten Muskeln. Die dorsalen Sehwanzmuskeln (Strecker) sind reeht verwiekelt und zeigen im allgemeinen ähinliche Differenzierungen wie die der Rumpfwirbelsäule. Wie an dieser ziehen die oberflächlieheren Muskeln meist iiber mehrere Wirbel und haben daher hänfig recht lange Sehnen. Bei den Cetaceen (ähnlieh auch den Sirenen) sind mit der Umbildung des Sehwanzes zu einem wieder fisehartig funktionierenden Bewegungsorgan aueh besondere Mnskelverhältnisse verbunden. Dies tritt besonders an den vorhin erwähnten paarigen Sacro-coccyyei hervor, den Hauptbeugern, welche sehr mäehtig werden; sich auf der Ventralseite der Wirbelsäule, unter Reduktion des Beckens, bis in die Prustregion ausdebnen können, in Stelle der M. psoas und quadratus-lumborum, und sich mit sehr langen Sehnen nach hinten bis zum Sehwanzende erstrecken,

Die hypobranehiale Stammuskulatur der Tetrapoda. Bei den Fischen fanden wir, daß sieh eine Forisetzung der ventralen Rumpfmuskulatur von den Coracoiden bis zum Unterkiefer ausspant (M. M. coraeo-arcuales) und mannigfache Differenziernugen erfahren kann. Diese Muskulatur erhält sieh in ähnlichen Beziehungen durch die ganze Wirbeltierreibe als Muskelzüge, die sich vom Sehultergiirtel zum Zungenbeinbogen und Unterkiefer erstrecken. Die vom Sternum znm Hyoid gehende mittlere Partie wird daher als M. sternohyoideus bezeichnet; bei den Urodelen bildet sie noch eine direkte Fortsetzung des Reetus abdominis. Vorn ist sie von der zur Unterkiefersymphyse treteuden Fortsetzung, dem M. geniolyyoideus noeh wenig gesondert (s. Fig. 299, B). - Bei den Anuren ist eine Partie abgegliedert, die als M. omolyyoideus vom Sebulterblatt zuın Zungenbeinkörper tritt. - Differenzierungen des Geniohyoidens sind die bei den Urodelen noch wenig gesonderten, bei den Anuren selbständig gewordenen Muskeln der Zunge, der Genio- nnd Hyoglossus; der erstere vom Zungenbein, der letztere vom Unterkiefer in die Zunge tretend. - Diese, schon bei den Amphibien ausgebildete Muskulatur erhält sich im allgemeinen bei den Ammioten ahnlich. Mit Verlängerung des Halses wird sie länger. - Auch ein Omohyoideus ist (mit Ausnahme der Schlangen und Vögel/gewölnnlich vorhanden. Es treten jedoch mancherlei Differenzierungen, auch Vermehrungen der Muskeln auf. - Der Ursprung des Sternohyoideus, oder der von ihm sieh herleitenden Abgliedernngen, wird häufig verlegt auf die Coracoide (Croeodile, Monotremen), die Clavieulae (Vögel, Säugetiere), das Episternum (Crocodile), ja auf die Traehea oder die Haut des Halses 
(Vögel). Auch die bei den Vögeln zum Herauf- nnd Herabziehen der Trachea dienenden Muskeln (Sterno- und Cleidotrachealis) gehören hierher. - Bei den Säugern kompliziert sich der Sternohyoideus häufig, da er in seinem Verlauf Fortsätze zum Thyreoidknorpel abgibt, wodurch sich schließlich von ihm vorn ein Thyreohyoideus und ein Sternothyreoideus absondern kann (s. Fig. 303).

\section{Visceralmuskulatur der Tetrapoden.}

Wie schon bei den Fischen betrachten wir die hierher gehörigen Muskeln an der Hand der sie versorgenden Hirnnerven und beginnen daher mit den vordersten, in der Kieferregion befindlichen, die vom Trigeminus inněrviert werden. Der bei den Fischen schon starke und häufig recht komplizierte Adductor mandibulae, der Anzieher des Unterkiefer's, wiederholt sich in der ganzen Reihe der Tetrapoden. Eine Sonderung in mehrere Portionen, die sich schon bei Fischen nicht selten fand, tritt auch bei Amphibien regelmäßig auf, nnd setzt sich in ziemlich iibereinstimmender Weise bis zu den Säugern fort. So finden wir bei den Amphibien (Fig. 299) allgemein eine oberflächlichere Portion, den M. masseter, der bei Urodelen von der seitlichen Schädelregion (besonders dem Paraquadrat), bei den Anuren rom Quadratomaxillare zum Hinterende des Unterkiefers hinabsteigt; wogegen eine tiefere Portion, der M. temporalis, die höher am Schädel entspringt (bei den Urodelen sogar bis auf den Anfang der Wirbelsïule ausgedehnt sein kann), sich am Kronfortsatz der Mandibel befestigt. - Häufig findet sich noch ein dritter Muskel (Pterygoideus), wohl eine Sonderung der tieferen Portion des ùrsprünglichen Adductors, der vom Pterygoid (Ichthyoden zum Teil), oder von der Augenhöhlengegend (Anüren) zur Medialfäche der hinteren Unterkieferregion tritt.

Der Hauptnuskel der Sauropsiden ist weniger deutlich in Masseter und Temporalis gesondert nnd wird daher häufig allein als Temporalis bezeichnet, obgleich er namentlich bei den Schlangen und Vögeln in eine größere Anzahl von Portionen (bis fünf) differenziert ist. Sein Ursprungsgebiet bildet im allgemeinen die Schläfenregion des Schädels, doch dehnt er sich zuweilen auch anf das Quadrat aus. Ein häufig in zwei Anteile gesonderter Pterygoideus ist allgemein verbreitet und wird bei dem Crocodilen sowie manchen Vögeln (besonders Papageien) zum stärksten Muskel des Unterkiefers, dessen Hinterende er dann umgreift und anf seiner Außenseite inseriert. - Die Beweglichkeit des Kiefergaumcnapparats bei den Schlangen bedingt komplizierte Finrichtungen, indem die Pterygopalatinreibe von einer Anzahl Muskeln bewegt wird, die hanptsächlich vom Basisphenoid entspringen. Ähnliches findet sich jedoch auch schon bei Sauriern.

Die entsprechende Muskulatur der Säuger (Fig. 303 u. 302) schließt sich, wie es scheint, direkter der der Amphibien an. Masseter, Temporalis und in der Regel zwei Pterygoidei (externus und internus) bilden das normale Vorkommen. Der Masseter entspringt teilweise vom Jochbogen, teilweise vom Oberkiefer nnd zieht außen auf dem Unterkiefer zu dessen hinterem Winkel. Der Temporalis, der zuweilen nicht ganz scharf vom Masseter abgesondert ist, nimmt seinen Ursprung böher am Schädel in der Schläfengrube und am Jochbogen, kann jedoch (besonders 
Carnivoren) bis zum Scheitel emporsteigen; er inseriert am Kronfortsatz und tiefer am Unterkiefer. Beide Muskeln zeigen gewöhnlich eine oberflächliche und eine tiefe Lage von etwas verschiedenem Charakter. Die Stärke ihrer Entwicklung hängt von der Art der Nahrung, der Ausbildung des Gebisses usw. ab; sie treten daher namentlich bei den Edentaten und Monotremen stark zurück. - Die beiden Pterygoidei sind meist, jedoch nicht immer deutlich gesondert und entspringen gewöhnlich von der Keilbeinregion bis zu den Pterygoid- und Palatinknochen; der innere zieht zum hinteren Winkel, der äußere zum Gelenkfortsatz der Mandibel.

Der vom Facialis versorgte Constrictoranteil der Fische erhält sich bei den Tetrapoden recht ausgiebig; aus ihm gehen einige wichtige Muskeln hervor. In der Kiemenregion der urodelen A mphibien (Fig.299) tritt er noch als eine Lage äußerer ringförmig verlaufender Muskelfasern recht nrsprïnglich auf, der sich hinten ähnliche Fortsetzungen anschließen, die von den folgenden Hirnnerven versorgt werden. Dieser Ringmuskel erstreckt sich dorsal mehr oder weniger hoch empor nnd entspricht im allgemeinen dem bei den Amnioten als Sphincter colli bezeichneten Halsmuskel. Den Anuren fehlt dieser Anteil des FacialisConstrictors gewöhnlich. - Vorn setzt sich der. ventrale Teil des Constrictors zwischen die beiden Unterkieferäste fort (Fig. $299 \mathrm{~B}$ ), ähnlich wie bei den Chondropterygii und Dipnoi, und inseriert auch mit einèr abgezweigten Partie am Hyoid, weiter davor als sog. Intermandibularis an den Unterkieferästen. Letzterer Anteil wird vom Facialis, vorn aber z. T. von einem Trigeminusast innerviert, was, wie bei den Fischen, wahrscheinlich daher rïhrt, dals sich der betreffende Facialisast dem Trigeminus angeschlossen hat. Bei Urodelen wie Anuren kann

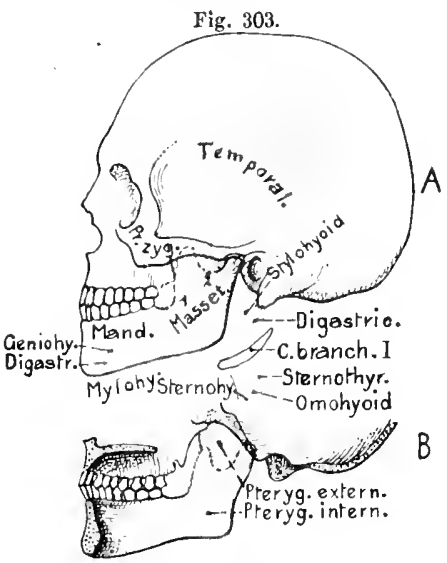

Ka umusulaturdes Menschen (etwas schematisch). A Schädel mit den Muskeln von links, Das Zungenbein etwas nach hinten verschoben, so daß es siehtbar ist. Der vordere Verlauf des M. digastricus and der M. geniohyoideus, die auf der Innenseile des Unterkiefers liegen, so gezeichnet. als wenn sie durch den Unterkjefer sjehtbar wären. 7 u. 2 die oberflächliche und die tiefe Lage des M. masseter. $-B$ Unterkiefer und Schädel in der Medianebene halbiert. Rechte Unterkieferbälfte von innen, um die $\mathrm{Mm}$. pterygoidei zu zeigen. Schnittflüchen der Knochen punktiert. $\quad 0.8$. der Intermandibnlaris in zwei hintereinander folgende Muskeln (anterior und posterior) gesondert sein; sie entsprechen im allgemeinen dem sog. $\boldsymbol{M}$. mylohyoideus der Sänger und des Menschen. -- Ein mehr dorsal gelegener Anteil des Facialiscontrictors hat ebenfalls am hinteren Unterkieferwinkel Befestigung erlangt, dorsal dagegen an der hinteren seitlichen Schädelregion (besonders dem Paraquadrat), ja z. T. auch weiter hinten an der Dorsalfascie, dem Hyoid und der vorderen Wirbelsäule. Dieser Muskel, der schon bei Protopterus unter den Dipnoern auftritt, wirkt als Herabzieher (Depressor) des Unterkiefers, welche Funktion ja der ventralen Constrictorpartie urspriinglicherer Fische überhaupt zukommt. Er kann auch in zwei Portionen gesondert sein. - Dieser Depressor mandibulae oder Digastricus setzt sich in ähnlicher Weise durch die ganze Tetrapodenrejhe fort. Teils einfach (placoide 
Reptilien, Säuger s. Fig. 301-303), teils in mehrere Portionen gesondert (bis vier bei Srquamata und Aves), dehnt "er seinen Ursprung bei den Squamaten zuweilen noch über die hintere Schädelregion auf die Dorsalfascie oder die Wirbelsäule ans, während er sich bei den iibrigen Amnioten auf die hintere Sch:̈delregion beschränkt. Bei vielen Säugern (auch fast stets bei Affen nnd Menseh) erscheint er dadurclı eigentümlich, daß er seine Insertion am hinteren ventralen Unterkieferrand aufgibt und sich durch eine $Z$ wischensehne mit einer oberflichlichen Partie des Intermandibularis verbindet. Der so aus einem vorderen (vom Trigeminus innervierten) und einem hinteren Banch zusammengesetzte Muskel (Biventer, Digastricus) inseriert also am vorderen Unterkieferwinkel (s. Fig. 303), kaun aber auch mit dem Zungenbeinkörper in Verbindung treten; die eben vorgetragene gewöhuliche Dentung des Digastricus wird jedoch anch bestritten.

Anch der Intcrmandibularis erhält sich bei den Amnioten fast ausnahmslos als ein Quermuskel zwischen den beiden Unterkieferästen, der (wie bei den prinitiven 'Tetrapoden) gewöhnlich paarig erscheint, wegen eines selnigen Streifs in seiner Mittellinie. Bei Crocodilen und gewissen Süngern (als M. mylohycidcus bezeichnet, Fig. 303) geht diese Scheidung verIoren. - In mehrere Portionen sondert er sich bei den Sauriern, manchen Vögein und Singern. Bei letzteren verbindet sich der Mylohyoidens häufig mit dem Basibyale oder auch dem Thyreohyale (Branchiale I des Zungenbeins). -- Bei Schlangen und schlangenartigeu Sauriern ist er stark reduziert.

Der hintere dorsale Absehnitt des Facialisconstrictors, der schon bei den Amphibien als Sphincter colli bezeichnet wurde, ist bei den Amnioten gleichfalls eine sehr konstante Bildung und dehnt sich als oberflächlicher, ring- oder querfaseriger Muskel mit der Verlängerung des Halses bei den Sauriern und Schildkröten weit nach hinten, bis in die Schulterregion aus. Bei den Vögeln beschränkt er sich gewöhnlich auf die vordere Halsregion. Nur selten befestigt er sich anch am Skelet, so bei den Crocodilen am hinteren Unterkieferwinkel (Fig. 300).

Die Morotremen besitzen noch einen recht ansebnlichen Sphincter colli, der vom hinteren Mundwinkel bis zum Schultergürtel reicht und hier mit dem allgemeinen Hautbauchmuskel in Beriihrung tritt (s. Fig. 306, S. 456). Bei den höheren Säugern tritt er stark zurïck, auch fehlt sein ursprï̈nglicher Halsteil bäufig völlig. Außer dieser ventralen Facialismuskulatur findet sich bei den Monotremen noch eine dorsale, welche sich von der hinteren dorsalen Kopfregion aus nach vorn bis in die Ohr-- und Augengegend erstreckt (namentlich Echidna), aber auch seitlich schief absteigend zur Unterkieferregion zieht, wo sie vom dorsalen seitlichen Rand des Sphincter colli überlagert wird. Aus dem hinteren Abschnitt dieses Dorsalteils geht bei den höheren Säugern ein ansehnlicher Hautmuskel hervor, welcher von der Dorsilseite der Halsgegend schief nach vorn und ventral gegen den Ünterkiefer herabsteigt, aber den Sphincter colli ïberlagert. Esist dies das sog. Platysma myoilles (Fig. 304). Sowohl von der dorsalen Facialismuskulatur, welche sich auf die dorsale und seitliche Schädelregion erstreckt (also dem sig. Platysma im weiteren Sinne) als vom Vorderende des Sphincter colli sondern sich bei den Säugern allmählich 
immer reichlicher Muskeln ab, die sich auch am Schiidel inserieren künnen. Sie treten als sog. Gesichtsmuskeln in Beziehung zur Obrmuschel als deren Hewrger, zum Auge als dessen Sphincter, zur Nase, zu den Lippen und den seitlichen Mundhöhlenwänden. Genauer auf diese, bei den Primaten sich besonders komplizierende mimische Gesichtsmuskulatur einzıgehen, wïrde zu weit führen. Fig. $30+$ gibt eine Vorstellung ihrer Ausbildung in mäßiger Komplikation bei einem Halbaffen. Wie aus ihrer Entstehung folgt, wird die gesamte Gesichtsmuskulatur von Zweigen des Facialis innerviert.

Die bej den Fischen aus der tieferen Constrictorenregion hervorgegangene Muskulatnr der Kienenbogen ist bei den kiementragenden Amphibien (Peremuibranchiaten, jedoch anch den Derotremen nnd Salamandrinen) z. T. noch vertreten; den Larven der Kiemenlosen kommt sie gleichfalls noch $\mathrm{zu}$ (vgl. Fig.299 A) Es sind einerseits Heber der Kiemenbogen (Levatores arcuum branchiarum), die sich teils an sämtlichen, teils nur an einigenKiemenbogen finden (auchbeiGymnophionen), von deren Proximalendell sie zum Schädel oder

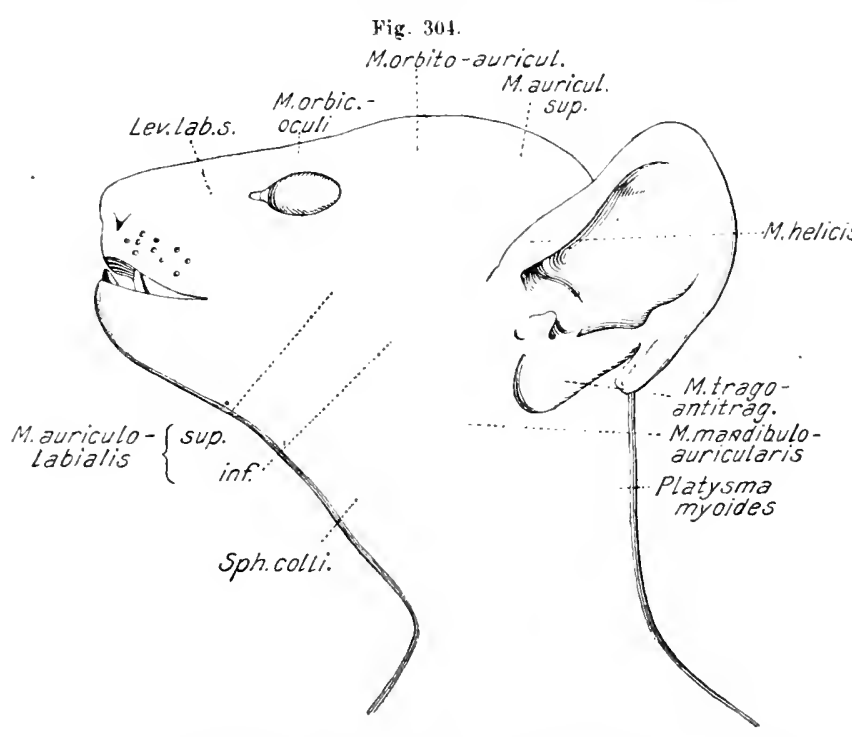

Lepilemur wustelinns (Prosimier). Gesichtsmuskulatur ron der linken Seite. (Nach Roge 18xti, aus Gegenbaur 1598). einer Fascie aufsteigen.' Andrerseits gehören hierher Muskeln, die sich zwischen den Visceralbogen ausspannen; so bei den Ichthyoden ein ansehnlicher sog. Ccratohyoidcus cxtermus und ein schwächerer intorus zwischen dem Zungenbein- und dem ersten Kiemenbogen, innerviert vom Glossopharyngeus (s. Fig. 299 B): feluer die sog. Constrictores arcum hranchiarm zwischen den Kiemenbogen. Bei den Perennibranchiaten und Laven finden sich noch Heber, Senker und Adductoren der äußeren Kiemenbüschel, die von den Kiemenbogen entspringen. Bei den Anuren ist diese gesamte Musulatur hochgradig riickgebildet, wohl mur durch zarte Muskelchen (sog. Petrohyoidei) repräsentiert, die vom Prooticum zum Zungenbeinkörper ziehen.

Wie begreiflich, hat sich auch die Hyobranchialmuskulatur der Amnioten stark reduziert, oder zum 'Teil in ihrer Funktion geändert, da sio in Verbindung mit dem Kehlkopf und dem Pharynx trat. Dennoch finden sich am großen Zungenheinhorn der Saurier Vögel ind gelegentlich auch der Säuger noch Mnskıln, die 
hierher gehören diirften. Ehenso läßt sich der sog. Stylohyoideus der Säuger $(303)$, wenn auch zur Facialisgruppe gehörig. hierher rechnen.

Schon bei den Knorpelfischen differenzierte sich aus der hinteren dorsalen Constrictorenregion, die vom Vagus innerviertwird, ein ansehn!icher, zum Scapulare des Schultergïrtels ziehender Muskel, der Trapezius (oder Cncullaris), der bei den operculaten Fischen einging. Bei sämtlichen Tetrapoden bleibt er dagegen erhalten, als ein im allgemeinen von der hinteren Schädelgegend zum Schulterblatt ziehender Muskel, der die Innervierung durch den Vagus, oder den als Accessorius abgelösten Teil desselben, bewahrt. Bei den Urodelen (s. Fig. 299) entspringt er teils vom Schädel, teils von der vorderen Fascie, bai den Anuren nur vom Schädel, und heftet sich an den Gelenkteil der Scapula. - Der Trapezins dei Amnioten kann sein Ursprungsgebiet weit nach hinten anf die Hals- und Brustwirbel, ja sogar bis anf die Lendenwirbel (gewisse Sänger) ansdehnen, wobei der Schädelursprung znweilen eingeht. Dies führt bei nicht wenigen Sängern zur Differenzierung des Mnskels in eine vordere und hintere, gelegentlich sogar in drei Portionen; mit dieser caudalen Ausdehnung steht wohl in Zusammenhang, daß sich danu außer dem Accessorius auch Äste cervicaler Spinalnerven an seiner Innervierung beteiligan können. - Als eine Abgliederung vom ventralen seitlichen Trapeziusrand wird gewöhnlich der bei Säugern verbreitete M. sterno-cleido-mastoideus gedentet, wegen der gleichen Innervation mit dem Trapezius. Er ist häufig in einen Cleidomastoidens nnd einen Sternomastoideus gesondert.

\section{Muskulatur der paarigen Extremitäten der Wirbeltiere.}

Fiscbe. Tährend die ersten Anfänge der Extremitätenmuskulatur bei den Fischen noch recht einfach erscheinen, erlangt sie bei den Tetrapoden rasch eine hochgradige Komplikation, wie es die mannigfaltigen Bewegungen der Extremitäten erfordern. Die Komplikation wird schon bei den Amphibien so groß, daß eine genauere Schilderung, um einigermaßen verständlich zu werden, viel Raum beanspruchen wiirde. Wir sind daher gezwungen, uns auf einige allgemeinere Bemerkungen zu beschränken.

Der Seitenrumpfmuskel der Fische heftet sich vorn an den Schnltergürtel, ebenso wie auch der Beckengïrtel in die ventrale Rumpfmuskulatur eingeschaltet ist. Schon bei den Haifischen (s. Fig. 234, S. 431) erfährt die vorderste Partie des ventralen Seitenrumpfmuskels, die sich an das Scapulare inseriert, eine gewisse Differenzierung zu einem besonderen Sehultermuskel, der bei den Holocephalen noch dentlicher hervortritt und sich in zwei Portionen sondert, von denen die vordere bis zur freien Flosse herabsteigt und sich am Propterygium inseriert. Bei Ganoiden und Teleosteern, deren Schultergürtel am Schädel aufgehängt ist, findet sich kaum etwas ähnliches, obgeich znm Teil ein vou der hinteren Schädelregion zum Claviculare, oder den Supraclavicularia ziehender Muskel beschrieben wurde. Zur Bewegung der freien Flossen dienen platte Muskeln, welche im allgemeinen so angeordnet sind, daß eine solche Muskelplatte der urspriinglich dorsalen, uud eine der ventralen Flossenflaiche zukomint. Die erstere wirkt als Heber 
oder sog. Adductor der. Flosse, die letztere als Senker oder Abductor. Jede dieser Platten besteht in der Regel aus einer oberflächlichen und einer tiefen Lage, deren Faserverlauf sich häufig kreuzt. Die Zusammensetzung jeder Lage aus einer größeren Zahl schmaler Muskelchen, welche etwa den cinzelnen primären Flossenstrahlen entsprechen, ist bei Haien und Ganaiden meist deutlich zu erkennen, oder ergibt sich anch darans, daß das distale Ende in sehnige Fortsätze ausläuft, die sich an die Basen der einzelnen sekundären Flossenstrahlen heften. - Während die oberffächliche Lage des Hebers und Senkers häufig von der äußeren Fascie entspringt, befestigt sich die tiefe am Ventralteil des Schulter- oder Beckengürtels:

Einen interessanten Bau besitzt die Flossenmuskulatur von Ceratodus, im Zusammenhang mit der bosonderen Flossenform. Hier ist in der Tat eine Abzweigung des ventralen Seitenrnmpfmuskels anf die beiden Flächen der Flosse hinabgerückt und iiberzieht deren Achse als ein Längsmuskel, mit einer Anzahl Inscriptionen, his etwa zur Flossenmitte. Nach den beiden Flossenrändern strahlen von diesem Axialmuskel zahlreiche zärtere Muskelchen zu den knorpligen

Fig. 305.

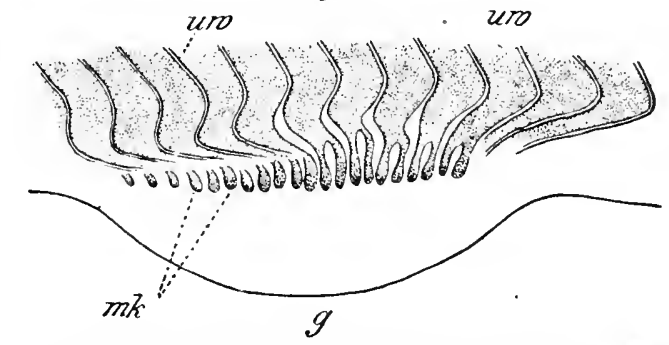

Pristiurus (Hai). Anlage der rechten Bauchflosse. $t w$ Myotome; $m k$ Mnskelknospen der Flosse (n. RABL 1993 aus Gegen BAUR, Vergl. Anatomie d. Wirbeltiere 1898). Flossenradien aus. Auch die vom Schulter- oder Beckengïrtel zur Flossenbasis gehenden tieferen Maskeln sind hier komplizierter.

Schon der Bau der ausgebildeten Flossenmuskulatur der Fische, sowie ihre Innervierung durch Nervenzweige, welche von ventralen Spinalnervenästen herkommen, spricht für ihre Abstammung vom ventralen Seitenrumpfmuskel. Das Gleiche erweist die Ontogenie. - Bei den Chondropterygiern und Ganoiden sprossen aus der ventralen Kante derjenigen Myomeren, welche im Bereich der urspriunglichen Flossenleiste (vgl. S. 318) liegen, je zwei hintereinander folgende (Chondropterygier) oder auch nur eine (Ganoiden) solide, oder anfänglich hohle Muskelknospen hervor (s. Fig. 305). Diese Knospen wachsen in die Flossenanlage hinein und lösen sich früher oder später von den Nyomeren ab. Sie sondern sich hierauf in einfacherer oder komplizierterer Weise in je eine dorsale und ventrale Partie, in welcher wir die Anlagen der dorsalen und ventralen Flossenmuskeln erkennen, zwischen denen die primären kzorpligen Radien auftreten. Je nach der Ausdehnung dẹ paarigen Flossen ist die Zahl der Myomeren, welche sich an der Bildung der Muskulatur beteiligt, recht verschieden; von fünf an den Bauchflossen des Störs bis 26 bei gewissen Rochen. Auch bilden zuweilen Myomeren, die nicht in den Bereich der Flossen fallen, Muskelknospen, welche später wieder eingehen. - Leider ist die Weiterentwicklung der gescbilderten Anlage zur fertigen 
Muskulatur bis jetzt wenig erforscht, doch ergab sich, daß die Muskelknospen nicht einfach in die Muskelchen der Flossenstrahlen ïbergehen, sondern zuvor Verbindungen eingehen und Zellenmaterial austanschen. - Weder bei den Teleosteern, noch bei den tetrapoden Vertebraten (ausgenommen Saurier) wurden bis jetzt ähnliche Muskelknospen sicher erwiesen, vielmehr scheint die Extremitätenmuskulatur hier so zu entstehen, daß von der ventralen Myomerenkante Zellen in unregelmäBiger und zerstreuter Weise in die Extremität einwandern. Doch wird auch vielfach noch angegeben, daß die Seitenplatte (Somatopleura) an der Bildung dieser Muskulatur teilnehme.

Die eben kurz dargeleote und jedenfalls primitive Entwicklung der Extremitätenmuskulatur bei den ursprünglichen Fischen wird in recht verschiedener Weise aufgefaßt, je nach der theoretischen Anschauung über die phylogenetische Ableitung der Extremitäten (vgl. S. 325). Die Hypothese, welche die Extremităten von lateralen Flossensäumen ableitet, erblickt in dem Hervorgehen der Muskulatur aus einer größeren Anzahl Myomeren, sowie in dem ganzen Verlauf des Vorgangs, eine wichtige Bestätigung ibrer Meinung. Es ist auch nicht zu leugnen, daß sich dieser Entwicklungsvorgang mit jener Hypothese am besten vereinbaren läßt. - Die Lehre, welche die Extremităten von ursprünglichen Visceralbogen ableitet, muß dagegen die geschilderte Entwicklung für eine abgeänderte, nicht ursprüngliche ansehen, und das Hervorgehen der Muskulatur aus einer größeren Zahl von Myomeren als etwas sekundäres, indem sich mit der stärkeren Entwicklung der Extremitäten successive eine größere Zahl von Myomeren an ihrer Muskularisierung beteiligte.

Tetrapoda. Die Extremitătenmuskeln der Tetrapoden bestehen zunächst aus solchen, welche, vom Achsenskelet entspringend, zu den Gürteln, zuweilen auch dem Humerus und Femur, oder noch distaler ziehen. Manche dieser Muskeln dïrften sich direkt aus den ventralen Seitenrumpfmuskeln hervordifferenziert haben. - Die Nichtbefestigung des Schultergtirtels an derWirbelsäule bedingt, daß zu seiner Fixierung und Bewegung in verschiedenen Richtungen ein besonderer Muskelapparat entwickelt ist, von welchem der Trapezius schon früher besprochen wurde. Die dorsalen Muskeln des Schultergürtels (vgl. Fig. 299, 301 u. 302) ziehen in verschiedener Richtung zur Scapula; einzelne, wie der sog. Latissimus dorsi, auch noch ther sie hinaus zum Proximalende des Humerus. Auch die ventralen Muskeln, die vom Sternum oder den Rippen entspringen, gehen teils zur Scapula (wie der Serratus anticus, Pectoralis minor), teils znr Clavieula oder dem Coracoid, oder auch distaler. Der oberflächlichste dieser Ventralmuskeln, der Pectoralis major, ist meist besonders kräftig und zieht im allgemeinen von Sternum zum Proximalende des Humerns. Er ist der Hauptherabzieher des Oberarms, der daher bei den Vögeln sehr stark und dick wird, auch seinen Ursprung weit ausdehnt, sogar auf die Bauchhaut und bis zum Schambein caudalwärts. Die schwache Entwicklung des Sternums bei den Amphibien bedingt, daß er hauptsächlich von der ventralen Fascie entspringt.

Wegen der sacralen Befestigung des Beckengürtels an der Wirbelsänle sind besoudere Bewegungsmuskeln des Beckens kaum erforderlich; als solche könnten höchstens die vom Schwanz zum Becken tretenden Muskeln und der früher erwälınte Quadratus lumborum wirksam sein, ebenso bei Sängern eine besondere Partie des 
sog. Psoas (der von der Ventralseite der Wirbelsäule zum Proximalende des F'emur zieht), die sich als Psoas minor am Processus ilio-pectineus befestigt.

Von den Gürteln entspringen zahlreiche Muskeln zur Bewegung der Extremität, die sich, wie die Muskeln der freien Extremität iberbaupt, im allgemeinen als Beuger und Strecker unterscheiden Jassen. Im allgemeinen rerbinden dieselben je zwei in der Längsrichtung anfeinander folgende Hebelabschnitte der Extremität; doch erstrecken sie sich nicht selten auch weiter, wobei als notwendige Regel gilt, đaß es die oberflächlicheren Muskeln sind, welche die längere Ausdehnung besitzen. So können die oberflächlichen Fingerbeuger vom unteren Ende des Humerns ansgehen, die tieferen von den Unterarmknochen.

Wie schon früher (vgl. S. 370) erörtert wurde, haben sich die Vorder- und Hinterextremitit in einem funktionellen Gegensatz entwickelt, wobei ja ihre Muskulatur ansschlaggebend war. Sie zeigen daher auch betrachtliche Verschiedenheiten der Muskulatur, da in der vorderen im allgemeinen die Beuger etwas überwiegen, in der hinteren die Strecker. Auf eine genanere Ausfïhrung der seln komplizierten Verhältnisse näher einzugehen, ist hier unmöglich.

\section{Hautmuskulatur der Wirbeltiere.}

Da sowohl die Stamm- als die Extremitätenmuskeln vielfach an den oberflächlichen, unter der Haut liegenden Fascien inserieren, so können auch Teile dieser Muskulatur innigere Beziehnngen mit der Haut eingehen, sich sogar ablösen und za besonderen Hautmuskeln werden, indem sie die Befestigung am Skelet zum Teil völlig aufgeben. Schon bei den Schlangen fanden wir eine reiche derartige Muskulatur der ventralen Hornschilder. Auch bei den Vögeln spielen Abzweigungen oberflächlicher Muskeln, wie des Trapezius, Latissimus dorsi, Pectoralis n. a., die sich zur Haut der Federfuren begeben, eine wesentliche Rolle beim Sträuben der Conturfedern. Ebenso begeben sich Abzweigungen proximaler Muskeln der Vorderextremität (Pectoralis major; Deltoides, Biceps) zur vorderen und hinteren Flughaut der Flügel (Pro- und Metapataginm) als deren Spanner; ihre Sehnen ziehen zum Teil bis zum Metacarpus.

Bei der großen Mehrzahl der Süuger ist eine solche Hautmuskulatur gleichfalls stark entfaltet (abgesehen von der zum Facialisgebiet gehörigen, schon oben erwähnten Hautmuskulatur). Nur bei den Primaten und dem Menschen tritt sie stark zurück, ja fehlt letzterem meist völlig. - Dieser häufig recht komplizierte Hautmuskel wird in der Regel als Panniculus carnosus bezeichnet, welchem auch das oben (S. 450) erwähute Platysma myoides meist zugerechnet wird. Schon bei den Monotremen (vgl. Fig. 306) überkleidet dicse sehr entwickelte Muskulatur mit mehr orler weniger längs gerichteten Fasern die ganze Bauchfläche, von der Schultergegend bis zum Schwanzbeginn, und dehnt sich auch anf die Extremitäten mehr oder weniger aus. Da sich ihre tieferen Anteile am Humerus, dicht bei der Ansatzstelle des Pectoralis major, befestigen, so kann sie von letzterem abgeleitet werden, womit auch ihre Innervierung iibereinstimmt. - Bei Echidna und den Marsupialiern bildet ein mittlerer Anteil des ventralen Hautmuskels den Sjhineter marsupii (Sph. mars.), 
der den Beutel der Weibehen umzieht: bei Eehidna auch einen oberfläehlicheu Sphineter cloacae (Sph. el. supf.). Die Hautmuskulatur greift anch auf den Rücken über, den sie bei Ornithorhynehus bis zur Schwanzwurzel überzieht, und erlangt sogar Befestigung an Dornfortsätzen. Bei Eehidna, deren Rüekenmuskulatur weniger

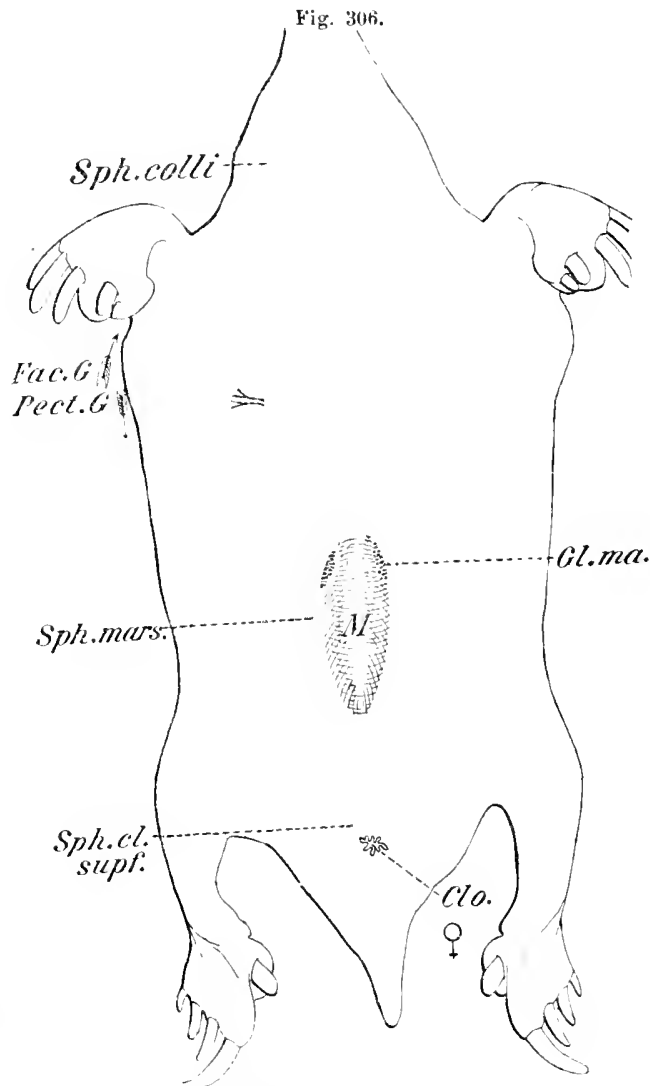

Fibidna hystrix (Mvibherl. Ilautmuskulatur der Bauchseit. Far. G. Gebiet lus N. Favialis. Fect. $G$. Gebiet des $\mathbf{M}$ jectoralis. M. Marsupium. Gl. ma. Irüsenfeld der Mammar-

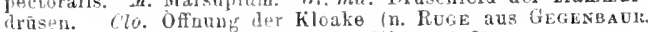
Vargl. Anat. d. Wirbeltiere 15:18). weit naeh hinten reieht, gibt sie. wie auch die seitliehen Ränder des Ventralmuskels, Bündel zu den Staeheln ab.

Eine ähnliche Ùmbïllung des gesamten Rumpfs dureh den Hautmuskel erhält sich noeh bei nrsprünglieheren Säugern reeht allgemein, ebenso aneh seine Insertion an dem vorderen Extremititenskelet; seltener befestigt er sich aneh an dem der hinteren Extremität. Häufig sondert sich die Hantmuskulatur jedoch in einen dorsalen und ventraleu Muskel. Wie schon die Monotremen, zeigen anch manehe anderen Säuger eine reichere Differenzierung des Muskels, so manche Ihsectivoren und Edentaten, wo er (z. B. Igel, Gürteltiere) die Einrollung des Körpers und die Bewegung der Staebeln(Igel bewirkt $_{\text {b }}$ und damit eine beträchtliche Komplikation erfährt (s. Fig. 307). Die mit llughäıten versebenen Säuger (Galeopitheeus, Chiroptera) besitzen aueb $\mathrm{Abz}$ weigungen des Hantmuskels zu diesen, ana$\log$ den Verhältuissen der Vögel.

Inwiefern sich noch weitere oberflächliehe Stammuskeln, außer dem Pectorolis, an der Bildung der Hantmuskeln beteiligen, bedurfte genauerer Feststellung.

\section{Kapitel. Die elektrischen Organe der Fische.}

()rgaue, welche bei nervïser Reizung elektrische Energie liervorbringen unà \{eshalb als elektrische bezeichnet werden, finden sieh nur bei gewissen Fischen. Anch in dièser Klasse sind sie keineswegs allgemeiner verbreitet, ja kommen nieht einmal einer größeren Untergruppe regelmäßig zu, soudern treten bei recht verschiodenen Formen, gewissermaßen vereinzelt und zusammenhangslos auf. Aneh 
ihre Besonderheiten bei den verschiedenen Formen weisen darauf hin, daß sie mehrfach selbständig entstanden sein werden; wozu ja bei den Fischen eine gewisse Tendenz bestehen muß, wie die Verbreitung der Organe bei systematisch weit entfernten Arten beweist.

$\mathrm{Zu}$ den bekanntesten elektrischen Organen gehören die der marinen Zitterrochen (Familie der Torpedinida, mit der Hauptgattung Torpedo und mehrereu andern), wogegen sie bei den zahlreichen Arten der Rochengattung Raja viel schwächer und andersartig ansgebildet sind. - Unter den Teleosteern treten sie bei gewissen Physostomen in guter Entwicklung auf, so bei dem sog. Zitteraal, Gymnotus electricus (Süßwasser Sïdamesikas, der jedoch nach neueren Ansichten den karpfenartigen Fischen näher verwandt sein soll); ferner bei der Gattung Malapterurus (Zitterwels, Siißwasser Afrikas, mit mehreren Arten). Geringer entwickelt

Fig. 307 .

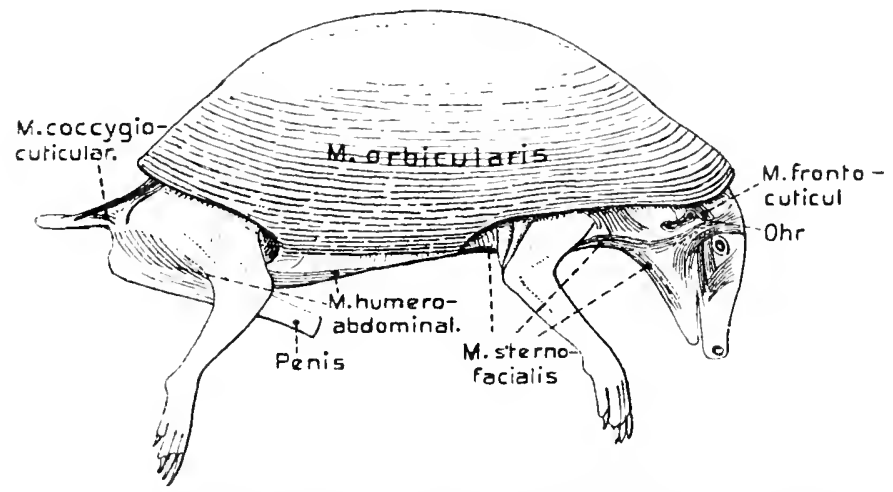

Erinaceus europaeus (Igel). Von rechts, nach Entfernung der Haut; zur Demonstration der wichtigsten Hautmuskeln, besonders des großen M. orbicularis.

O. B.

sind die Organe in der Familie der Mormyriden (Gatt. Mormyrus mit zahlreichen Arten); wogegen die bei dem verwandten Gymnarchus niloticus (Süßwasser, Afrika) beschriebenen kaum elektrischer Natur sein dürften. Erst in neuester Zeit wurde auch bei einer marinen Gattung der Acanthopterygier: Astroscopus (Uranoscopus) ein elektrisches Organ entdeckt.

Das weit zerstreute und isolierte Vorkommen der Organe fällt demnach sehr auf. - Hiermit stimmt ferner ihre recht differente topographische Lage, sowie die ebenso verschiedenartige Innervierung überein. Entsprcchend ihrer Größe, aber auch im Zusammenhang mit ibrem Ban, vermögen die verschiedenen Organe größere (Torpedo, Gymnotus, Malapterurus) oder geringere Elektrizitïtsmengen (Raja, Mormyriden) zu entwickeln. Letztere ()rgane wurden deshalb früher häufig psendoelektrische genannt, da vielfach bezweifelt wurde, daß sie Elektrizität erzengen; richtiger ist ihre Unterscheidung als schwach elektrische Organe. Daß die ersteren durch ihre Befähigung zur Erteilung kräftiger elektrischer Schliige zum Sehutz, aber auch zum Beuteerwerb dienen können, unterliegt keiner Frage. - Die Ontogenie und vergleichende Anatomie haben (abgesehen von Malapterurus), ergeben, daß die 
Organe durch eine eigentïmlicke Unwandlung der Muskelzellen aus der quergestreiften Muskulatur hevorgehen.

Eine Betrachtung ihrer allgemeinen Lageverhältnisse und Innervation ergibt etwa Folgendes. Bei den Torpediniden liegen sie als ein Parr große kuchenförmige weißliche Organe in der Kopfkiemenregion, die gesante Körperdicke durch-

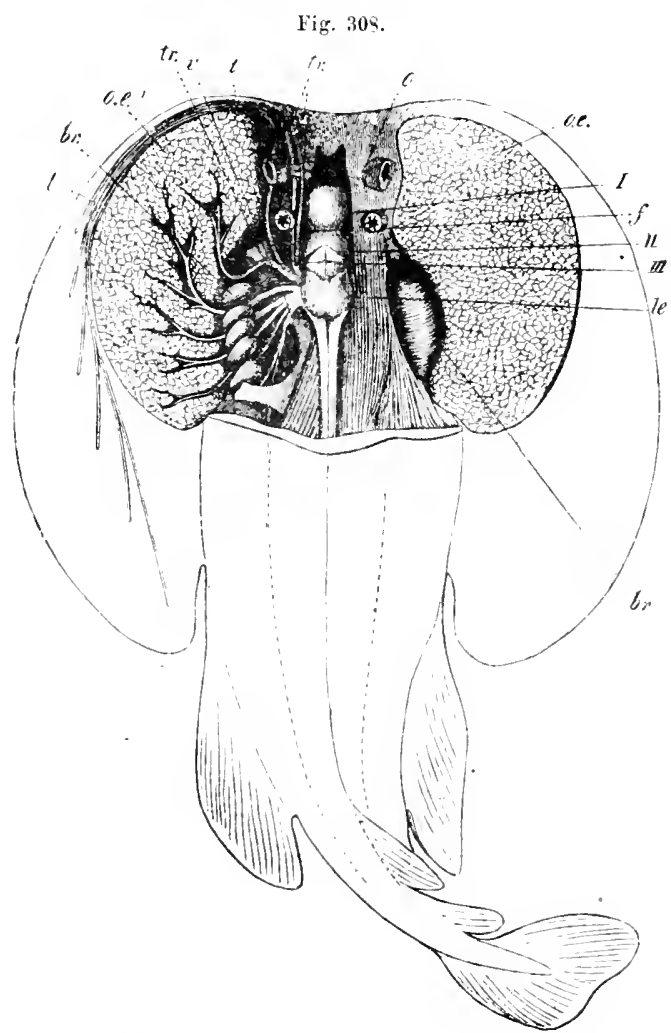

Torpedo (Zitterrochen) von der Dorsalseite. Das rechte elektrische Organ (o.e) freigelegt; das linke Organ $\left(0, e^{2}\right)$ sow eit $a b-$ getragen, daß die zntretenden Nerren zu sehen sind. br. Kiemensãcke. Am Gehirn IVorder-, II Mittel-, III Hinterhirn; le. Lobi electrici. o Auge. Der hier mit $(r)$ bezeichnete elektrische Nerv ist ein Ast des Facialis; die drei hinteren gehen vom Glossopharyngeus und Vagns aus (Vgl. Fig. 430). (aus Gegenbaur, Vergl. Anat. d. Wirbeltiere 1898). setzend (s. Fig. 308 u. 309). Die Innervierung geschieht durch je eineu Zweig des Facialis, Glossopharyngeus und der beiden ersten Kiemenäste des Vagns (3. anch Fig. 412). Die Organe sind wohl sicher ans dem Musculus constrictor superficialis (vgl. S. 436) hervorgegangen und zwar, wie lnnervierung und $\mathrm{On}$ togenie erweisen, ans mindestens vier Segmenten.

Eine aibnlich kopfständige Lage haben die Organe ron Astroscopus, welche als zwei dicke, nahezu würfelförmige Platten, welche direkt hinter den Augen liegen, die erweiterten Augenhöhlen ausznfüllen scheinen. Dies zeigt sich auch dariu, daß ein Teil der Augenmuskeln, sowie der Nervus opticus, die Organe geradezu durchsetzen, und daß sie ron einem starken Ast des Nervus oculomotorius innerviert werden. Es kann daher kaum zweifelhaft sein, daß die Organe aus den Angenmuskeln entstanden.

Eine geradezu entgegengesetzte Lage besitzen die elektrischen Organe von Raja, Gymnotus und den Mormyriden. Sie gehören der Schwanzregion an und gingen ans der Seitenrumpfmuskulatur hervor. Bei Raja (Fig. 310) durchziehen sie jederseits als ein sehr langgestrecktes Organ etwa die zwei hinteren Drittel des Schwanzes und sind aus der Mittelpartie des jederseitigen Seitenrumpfmuskels entstanden. Eine ähnliche Beschränkung auf die Schwanzregion zeigen sie auch bei Mormyrus, bestehen aber jederseits aus zwei länglichen Anteilen, von welchen der eine ïber, der andere unter der Seitenlinie liegt; sie leiten sich daher jedenfalls ans einem Teil des dorsalen und ventralen Seitenmuskels ab. 
Besonders ansehnlich werden die Organe von Ciymnotus, wo sie sich fast über den gesamten, hier sehr langen Schwanz erstrecken; der After dieses Fischs liegt nämlich sehr weit vorn an der Kehle. Auf dem Querschnitt (Fig. 311 A) bemerkt man, daß jederseits zwei sehv lange säulenförmige Organe vorhanden sind, die übereinander liegen, und ron welchen das dorsale sehr groß ist, das ventralc dagegen, welches an der langen Analtlosse hinzieht, klein. lyer Querschnitt ergibt ferner, daß das große Organ aus dem ventralen Teil des rentralen Seitenrumpfmuskels hervorging, das kleine dagegen wahrscheinlich aus der basalen Partie der inneren Muskeln der Analflosse. Fine kleine Partie des ventralsten Teils des Seitenrumpfmuskels hat sich als sog. Zwischenmuskel (s. Fig. 311) erhalten und steht noch in recht innigem Verband mit den großen elektrischen Organel. Die Innervierung der elektrischen Schwanzorgane geschieht durch Äste der Spinalnerven nnd zwar, je nach der Länge der Organe, von einer verschieden großen Zahl (bei Gymnotus bis über 200.

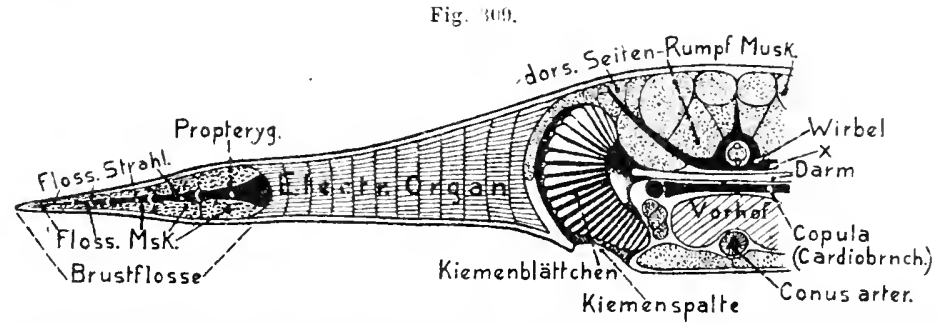

Torpedo marmorata. Quersehnitt in der Region der 3. Kiementasche, zur Đemonstration der Lage des elektrischen Organs. Muskeldurchschnitte punktiert. Skeletgebilde schwarz. $x$ Kinorpelleiste. die sich jeder. seits ih der vorderen Kegion der Wirbelsäule von den Querfortsătzen der verschmolzenen Wirliclkorper er. hebt.

E. W.

Ganz abweichend von dem seither Beschriebenen verhält sich das Organ des Zitterwels (Malapterurus, s. Querschnitt Fig. 311 B). Es bildet eine etwa mittlere, dicke Lage des Integuments, und umkleidet daher den Gesamtkörper von der dorsalen Kopfregion und dem Schultergürtel ab bis nahe an die Schwanzflosse. Die ganz besondere Bildung des Organs wird durch die Eigenart seiner Innervierung noch erhöht. Jede Seitenhälfte wird nämlich von einem einzigen Nerv versorgt, der weit vorn, zwischen dem zweiten und dritten Spinalnerv, aus dem Rückenmark entspringt und etwa längs der Seitenlinie an der Innenfläche des Organs weit nach hinten zieht, viele dorsale und ventrale Äste abgebend. Die genauere Untersuchung ergab, daß dieser Nerv nur aus einer einzigen, gar nicht sehr starken Nervenfaser besteht, welche von einer sehr dicken Bindegewebshïlle umschlossen wird. Jeder Nerv entspringt im Ruickenmark vou einer einzigen großen Ganglienzelle, die senkrecht über seiner Austrittstelle liegt.

Während die Entstehung der übrigen Organe aus quergestreiften Muskeln zweifellos erscheint, konnte sie für Malapterurus bis jetzt nicht erwiesen werden; im Gegenteil wurde zu zeigen rersucht (Fritsch), daß die Organe hier wahrscheinlich aus einzelligen IJautdrüsen hervorgegangen seien. Für eine eventuelle Ableitung von Muskeln wäre wohl nur an den früher (S. 432) erwähnten M. rectus lateralis zu denken, ler sich jedoch bei Malapterurus unter dem Integument vorfindet. 
In ihrem feineren Bau stimmen die elektrischen Organe im allgemeinen gut überein. Änßerlich werden sie in der Regel von einer Hülle strafferen Bindegewebs umschlossen. Das Innere baut sich ans zahlreichen dünn plattenförmigen Elementen anf, den sog. elektrischen Platten (Elektroplax), die einem gallertigen Bindegewebe, mit verästelten Zellen und Fasern, eingelagert sind, und in dem auch die Nerven und Blutgefäße verlanfen. Die besondere Anordnung der elektrischen Platten innerhalb der Organe bedingt ihre eigenartige Ausbildung bei den verschiedenen Fischen.

In den kopfständig n ') rganen der Torpediniden und des Astroscopus sind die Platten dorsoventral übereinander geschichtet (s. Fig. 309). Bei letzterer Gattung kommt im allgemeinen nur eine Platte auf die ganze Breite (Horizontalschnitt) eines Organs; bei Torpedo hingegen sehr viele, die sämtlich in vertikalen Reihen übereinandergelagert sind, wobei jede Reibe oder Säule von den benachbarten

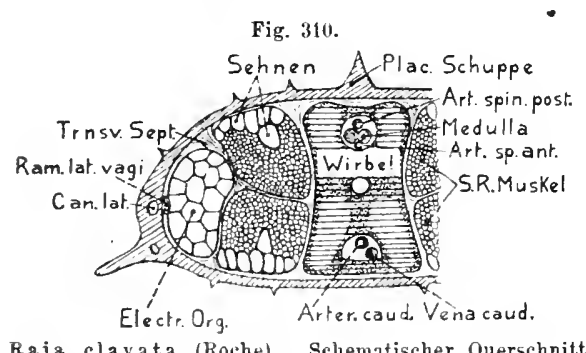

Raja clavata (Roche). Schematischer Querschnitt
durch das aweite Drittel des Schwanzes zur Demonstration des elektrisehen Organs. O. B. u. E. W. durch eine dickere Bindegewebseinschaltung gesondert erscheint. Diese Anordnung der Platten bedingt daher die Zusammensetzung der elektrischen Organe der Torpediniden aus vertikalen, sog. elektrischen Sänlchen, die im Querschnitt polygonal erscheinen, und der Oberfläche der Organe ein facettiertes Aussehen verleihen (Fig. 308).

In den Schwanzorganen (Raja, Mormyrus, Gymnotus) ist die Anordnung der elektrischen Platten anders, indem sie mit ihrer Fläche senkrecht zur Längsachse des Tierkörpèrs stehen, also in der Längsrichtung hintereinander gereiht sind. Bei Raja sind sie weniger regelmäßig angeordnet, weshalb säulenartige Bildungen nicht entstehen; auf jedem Querschnitt des Organs liegen zahlreiche Platten. - Bei Mormyrus dagegen besteht jedes der vier Organe aus einer einzigen Längsreihe ansehnlicher Platten, welche daher in ihrer Gesantheit eine längsgerichtete elektrische Säule bilden. - Die Organe von Gymnotus sind komplizierter, indem sie von zahlreichen, etwa horizontalen stärkeren Bindegewebssepten in längs gerichtete Säulen zerlegt werden (Fig. 311.1 u. 312), in denen die elektrischen Platten hintereinander gereibt liegen. Jede Platte der beiden Ilauptorgane wird also hier sehr groß, indem sie nahezu die halbe Körperbreite erreichen kann. Bei Mormyrus und Gymnotus ist die Gallerte zwischen je zwei aufeinander folgenden Platten noch von einer Bindegewebsscheidewand (Septum) durchzogen, so daß sich jeder elektrischen Platte eine vordere und hintere Gallertlage nïher ansehließen, die etwas verschieden sind.

Die umfangreichen Organe von Malapterurus reihen sich im allgemeinen dem ecen geschilderten an; sie bestehen aus einer ungeheuren Zabl etwa kreisförmiger Piatten, die wie jene der Schwanzorgane quer zur Körperachse stehen und von dünnen Bindegewebsscheidewänden gesondert werden (Fig. 312). In der Dicken- 
richtung des Organs liegen mehrere Platten ïbereinander. Eine säulige Anordnung der Platten fehlt, da die an und für sich wenig regelmäßigen Platten nicht hintereinandergereiht sind, sondern unregelıäßig alternieren, im hinteren Abschnitt des Organs sogar recht unregelmäßig verteilt sind.

Der feinere Bau der elektrischen Platten (Fig. 312) ist im ganzen uiberall sehr ähnlich. Jede Platte wird äußerlich von einer zarten Membran umschlossen (sog. Elektrolemma). Das Innere besteht aus fein alveolärem Plasma; dem längs der beiden Plattenflächen je eine Zone von Zellkernen eingelagert ist, weshalb man gewöhnlich drei Lagen in der Platte zu unterscheiden vermag, nämlich die beiden oberflächlichen Kernzonen und die.mittlere kernlose. In den sehr dünnen Platten

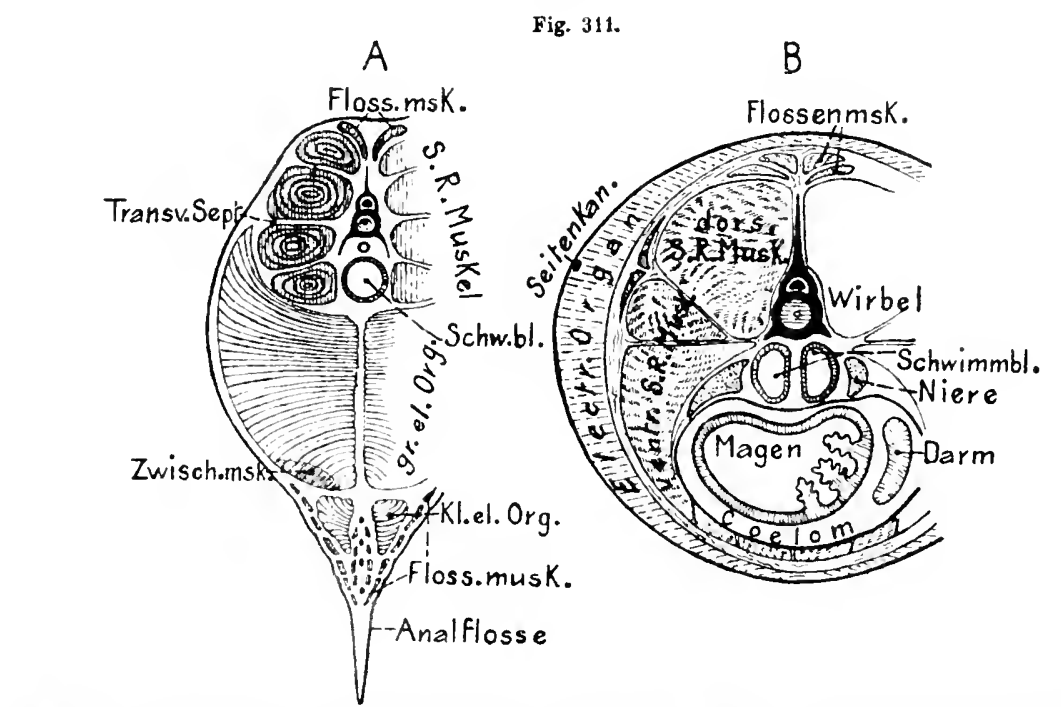

Schematische Querschnitte von: I Gymnotns electricus, etwas vor der Mitte der Schwanzregion. $b$ Malapterurus electrieus, etwa durch das hintere Eude des ersten Körperdrittels inach G. Frirscu. 1 bei SACHS 1881, B 1ssi).

von 'Torpedo läßt sich diese Unterscheidung nicht durchführen, die Kerne liegen hier etwa einschichtig. Mit Ausnahme von Torpedo und annähernd auch Malapterurns, zeigen die elektrischen Platten noch die besondere Eigentïmlichkeit, đaß von ibrer caudalen Fläche (Raja, Mormyrus, Gymnotus) meist zahlreiche zottenförmige Fortsätze entspringen, die bei Raja gewöhnlich vielfach schwammartig anastomosieren. Diese Fortsätze werden vom Plasma der hinteren Kernzone gebildet und enthalten deshalb viele Kerne.

Bei manchen Rajaarten entsendet die Caudalfläche der Platten nur einen ansebnlichen stielförmigen Fortsatz, neben dem sich bei anderen noch kürzere auf der ganzen Fläche vorfuden, und schließlich bei gewissen nur noch die letzteren bestehen, indem der Stielfortsatz ganz eingegangen ist. Die Iorderfläche der Platte vieler Rajaarten erscheint becherförmig vertieft. - Die eben erwähnten Kerne der elektrischen Platten werden auch jetzt noch von manchen Forschern als besonderen Zellen zugchörend aufgefaßt, welche der Plattensubstanz eingelagert seien. Sowobl die Entwicklungsgeschichte als der Umstand, daß die eigentliche Plattensubstanz dann ganz kernlos wäre, widersprechen dieser Meinung. 
Nur bei Gymnotus 's. Fig. 312) bildet auch die craniale Plattenfäche ähnliche Fortsätze (sog. Papillen). - Die elektrischen Platten von Astroscopus tragen an ihrer Ventralfläche gleichfalls die charakteristischen Zottenfortsätze, wogegen sie, wie bemerkt, Torpedo völlig fehlen, bei Malapterurus dagegen anf beiden Plattentlächen nur schwach angedeutet sind (Fig. 312).

Die mittlere Zone der Raja-Platten ist besonders interessant, da sie von einer Lage feiner, flächenhaft ausgebreiteter Lamellen durchzogen wird, die sich vielfach

Fig. 312.
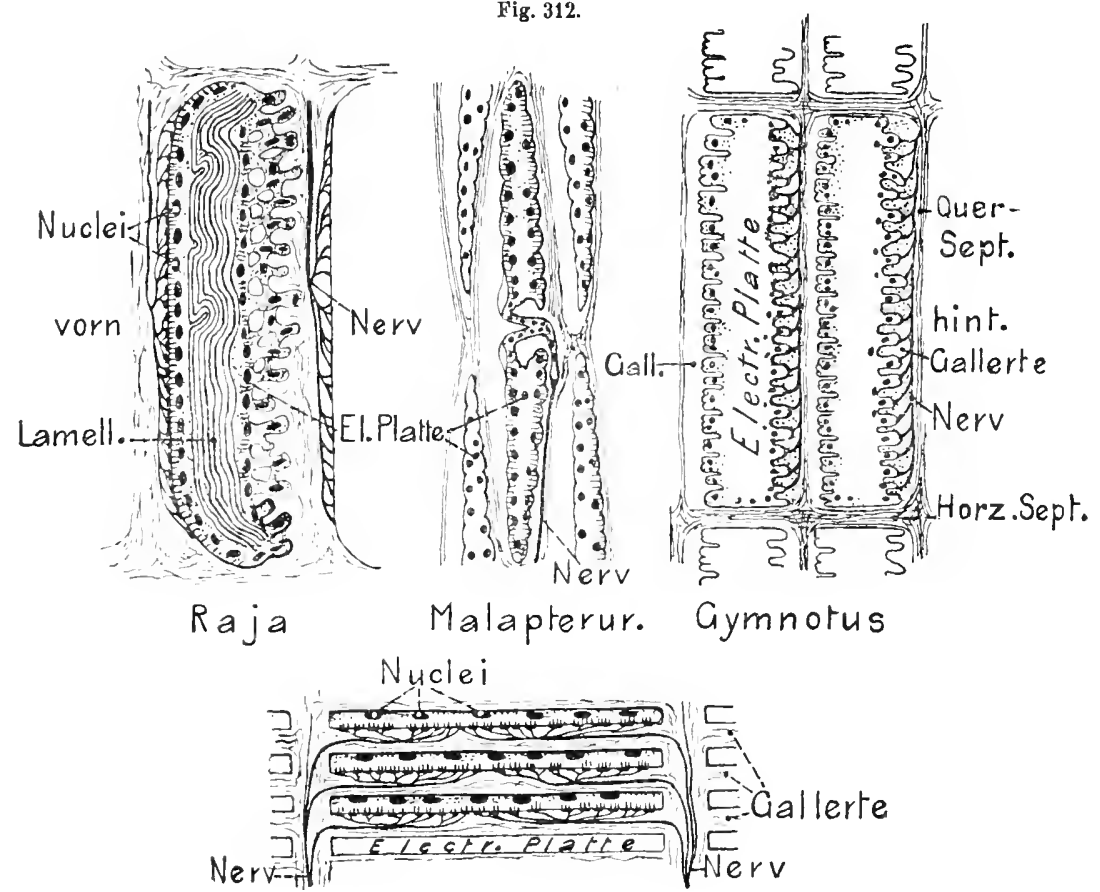

\section{Torpedo}

Schematische Durchschuite der elektrischen Platten von Raja, Malapterurus, Gymnotus nnd Torpedo. Die Durchschnitte der drei ersteren parallel zur Sagittalebene der Tiere gefúhrt; bei Tor. pedo dagegen geht der Durchschnitt quer durch die Achse einer elektrisehen Sănle. Die Platten ron Torpedo sind in Wirklichkeit viel breiter und düner als hier dargestellt. (Nach verschiedenen Autoren kombiniert). o. B.

mäandrisch hin- und herbiegen (Fig. 312). Die Ontogenie ergab, daß dies Lamellensystem ein Rest der contractilen Substanz der quergestreiften Muskelfasern ist, ans welchen die Platten hervorgingen.

Bei einzelneı Rajaarten (z. B. R. radiata) scheint die mäandrische Lage sogar aus noch wenig reränderter fibrillärer, contractiler Substanz zu bestehen. - Auch in den elektrischen Platten von Astroscopus und Mormyrus finden sich ähnliche Bildungen, die hier nicht eingehender erörteıt werden hönnen; bei Mormyrus sind diese fibrillenartigen Einlagerungen quergestreift.

Zu jeder elektrischen Platte tritt i. d. R. ein Nervenästchen, bei Torpedo jedoch mehrere, welches (mit Ausnahme von Malapterurus) aus einer größeren Zahl 
von Nervenfasern besteht. Das zutretende Nervenästchen teilt sich allmählich sehr reich, worauf die viclen marklos gewordenen Endfasern sich iber die ganze Plattenfläche ausbreiten, auf der sie dem Elektrolemm angelagert, ein zusammenhängendes Endnetz bilden (Torpedo, Raja, Gymnotus). -- Die Plattenfläche, mit der sich die Nervenfaser verbindet, liegt etwas verschieden; bei 'Torpedo ist es die ventrale, bei Astroscopus dagegen die dorsale; bei Gymnotus und-Mormyrus die caudale zottige, bei Raja dagegen gerade umgekehrt die vordere zottenlose (s. Fig. 312). Wie schon hervorgehoben, tritt zu den Platten von Malapterurus nur je ein Ästchen der einzigen Nervenfaser des elektrischen Nervs, und zwar zur caudalen Plattenfläche, wo es sich mit dem etwas angeschwollenen Ende eines stielförmigen, keruhaltigen Fortsatzes der Platte verbindet (s. Fig. 312), der vom Boden einer centralen Grube der hinteren Plattenfläche entspringt, während sich auf der vorderen Plattenfläche eine centrale trichterförmige Vertiefung in den Stiel einsenkt. An dieser Stelle ist demnach die Platte sehr dünn und die drei Lagen sind nicht deutlich zu unterscheiden.

Dies Verhalten wurde als eine Durchbohrung der Platte durch den von ininten zutretellden Nerv gedeutet, der sich daher nit der vorderen Plattenfläche verbindet (MI. Schultze). Dies sollte erklären, warum bei Malapterurus die craniale Plattenfläche die elektronegative ist. Bei gewissen Mormyrusarten treten die Nerren, abweichend von den iibrigen Arten, zur Cranialfläche der Platten und verbinden sich hier mit den Plattenfortsätzen der Hinterfläche, welche nach vorn umbiegend die Platte durchbohren und so auf deren Cranialseite gelangen. Bei gewissen Arten werden sogar die Platten von den Fortsätzen zweimal durchbohrt.

Das Gesetz, daß die nervöse Fläche der Platte bei der Elektrizitätsbildung negativ wird, die entgegengesetzte positiv, wodurch die Stromrichtung (von - zu +) bestimmt erscheint; dürfte mit Ausnahme volı Malapterurus (s. oben), allgemein gelten. - Daß die feinen zarten Strichelungen (sog. Fädchen- und Stäbchenbildungen), welche rom Elektrolemm ausgehend, sich in das periphere Plasma ber elektrischen Platten erlieben (s. Fig. 312), mit den Endigungen der Nervenfasern etwas zu tum haben, ist unwahrscheinlich, umsomehr als solche Bildungen zum Teil auch da rorkommen, wo sie keine Beziehung zum Nerren haberı könıen, so an der nervenfreien Plattenfläche.

Wie schon betont wurde, ergab die ontogenetische Untersuchung der Organe von Raja und Torpedo, daß sie durch Umbildung quergestreifter Muskelzellen entstehen. Am klarsten zeigt dies Raja, deren Organe sich auch beim el'wachsenen Tier noch deutlich als eine Modifikation der caudalen Seitenrumpfmuskulatur darstellen, in welche sie eingeschaltet sind, indem die Anordnung ihrer elektrischen Platten die der Muskelfasern der anstoßenden Myomeren geradezu fortsetzt; und auch noch Reste der kontraktilen Substanz als die sog. mäandrische Lamellenlage in den Platten sich vorfinden.

Die elektrische Platte von Raja entsteht aus der embryonalen quergestreiften .Iuskelzelle etwa so, daß das Vorderende der spindelförmigen Muskelzelle stark anschwillt, wohtureh die Zelle keulenförmig wird. Gleichzeitig vermehren sich ihre Kerne reichlich. Indem sich das Vorderende der Zelle scheibenförmig rerbreitert, bildet sich die Anlage der Platte, welcher der hintere, nicht verbreiterte Zellbezirk ais der oben erwähnte stielförnige Fortsatz zeitlebens anhängt, in dessen Umgebung dann die melır oder weniger zahlreichen Plattenfortsätze an der caudalen Plattenfläche hervorsprossen können. Die Doppelbrechung der kontraktilen quergestreiften Elemente schwindet frühzeitig und ibre einfach brechenden 
Glieder scheinen sich zu den Lamellen der Mittellage zu entwickeln, indem sie in der Querrichtung zusammenschmelzen. Interessant ist, daß die Umbildung der quergestreiften Muskelzellerl der Rajaarten auf recht verschiedener Stufe stehen bleibt, was die verschiedene Beschaffenheit der elektrischen Platten bei den einzelnen Arten bedingt. - Auch bei Torpedo wurde das Hervorgehen der Organe aus lang spindelförmigen, dorsoventralen, einkernigen Muskelzellen verfolgt, die frühzeitig zu Säulchen zusammengruppiert sind. Die quergestreifte kontraktile Substanz dieser Zellen ist jedoch relativ wenig entwickelt und schwindet bald völlig. - Für Mormyrus (gelegentlich auch für Torpedo) wird angegeben, daß die elektrischen Platten aus der Verschmelzung mehrerer embryonaler Muskelzellen herrorgingen, doch kaun dies corerst kaum als sicher erwiesen gelten. Für Malapterurus fehlen embryologische Untersuchungen.

\section{Kapitel. Das Nervensystem.}

Die Funktion des Nervensystems, welches sich bei den Metazoen allmähich hervorbildete, besteht in der Aufnahme von Reizen (energetischen Einwirkungen) der ungebenden Anßenwelt, jedoch anch energetischer Veränderungen im Inneren des Organismus, und der Überleitung dieser Reize (oder der von ihnen hervorgerufenen Veränderungen im Nervenapparat selbst) auf andere Organe des Tierkörpers, vor allem üie Muskeln (doch auch Driisen und anderes), welche hierdurch in Tätigkeit versetzt, z. T. aber auch in ihrer Tätigkeit gehemmt werden können. Auf solche Weise entwickelue sich eine der Erhaltung des tierischen Organismus förderliche reaktive Tätigkeit auf äußere und innere Reizwirkungen. Dabei können die Veränderungen, welche die Reize im Nervenapparat hervorrufen, dem betreffenden Individunm entweder bewußt werden (wahrgenommen werden, Empfindungen, Gefühle, Willensakte), oder es kann sich der ganze Vorgang unbewußt (reflektorisch) abspielen. - Aus diesen Leistungen des Nervenapparats folgt schon, daß sich derselbe aus verschiedenen, ungleich funktionierenden Abschnitten aufbanen muß. Einmal ans Teilen, die zumeist an der Körperoberfläche liegen, und daher zunächst von äußeren Reizen getroffen, verändert und so in Tätigkeit versetzt werden. Dies sind die Sinneszellen und die komplizierteren Siunesorgane im allgemeinsten Umfang. - Von ihnen miissen leitende Teile (Nervenfasern im allgemeinen) ausgehen, welche die nervösen Änderungen auf diejenigen Organe überleiten, welche in Tätigkeit treten, oder sonstwie verändert werden sollen. Stets sind jedoch in den Verlanf solcher Nervenfasern gewissermaßen noch Zwischenstationen eingeschaltet, nervöse Zellen (Ganglienzellen), an welche eine besondere Ausbreitung undVerteilung der nervösen Strömung, oder auch eine Verstärkung, sowie das etwaige Bewußtwerden der Vorgänge gebunden scheint. Diese Zwischenstationen zwischen uführenden (centripetalen), von den Sinnesorganen kommenden Nervenfasern und den ausstrahlenden (centrifugalen), zu den reizbaren Organen fiihrenden, bilden dann meist einen Centralteil des ganzen Apparats, ein sog. Centralnerensystem. Letzteres wird daher auch, soweit sich nach der Analogie mit unserem eigenen Nervensystem urteilen läßt, der Sitz der höheren psychischen Leistungen (bewußte Empfindung, Gedächtnis, Vorstellung, Association, Begriffsbildung, Urteil) sein, welche im Zusammenhang mit der Komplikation des centralen Nervensystems in der Tierreihe allmählich zur Entwicklung gelangen. 
Da der Nervenapparat vor allem dazu dient, äußere Einwirkungen aufzunehmen und auf diese erhaltungsgemäße Reaktionen des Organismus folgen zu lassen, so ist selbstverständlich, daß el, und besonders sein Centralteil, in der Regel aus dem Ectoderm bervorgeht. Gerade die urspriinglichsten Metazoen zeigen jedoch unzweifelhaft, daß auch das Entoderm nervöse Elemente hervorbringen kann. In wiefern dies auch für die höheren gilt, ist bis jetzt wenig sicher.

Über die mögliche erste Entstehung eines Nervensystems bei den Urformen aer Metazoen wollen wir erst dann einiges bemerken, nachdem wir die Bauverhältnisse les Systems der Cölenteraten geschildert haben

Obgleich bei manchen Spongien kontraktile muskulöse Zellen rorkommen, ließen sich Lis jetzt nervöse Elemente nicht auffinden. Was gelegentlich als solche beschrieben wurde, hat wenigstens der Kritik nicht widerstanden.

\section{A. Coelenterata.}

Wie zu erwarten, begegnen wir der primitivsten, überhaupt bekannten Bildung des Nervensystems Bei den Hydropolypen. In der Tiefe des Ectoderms und Entoderms, also beiderseits der sog. Stiitzlamelle aufliegend, finden sich Zellen deren Bau und sonstiges Verhalten sie als Nervenzellen (Ganglienzellen, Neuronen), erkennen läßt. Diese, meist ziemlich zerstreut liegenden Zellen (Fig. 313) senden zwei bis etwa fünf sehr feine fibrillenartige Fortsätze aus, durch welche sie in der Regel untereinander zusammenhängen und ein weitmaschiges Netzwerk (Plexus) bilden. Reich entwickelt findet sich ein solcher Plexus besonder's im Ectoderm der Tentakel, am sog. Riissel (Proboscis) und dem Fußende der einzellebenden Polypen (speziell Hydra).

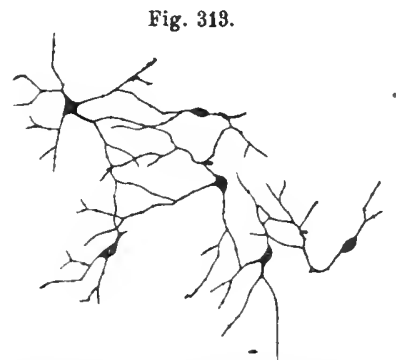

H ydra fusca. Kleiner Tejl des Gangliemellenplexus (n. C. SCHNEIDÉ 1890) etwas verāndert, in demAnastomosen zwischen den Zellen eingezerchnet sind v. Bu. Ebenso sind die Ganglienzellen auch in den verbindenden Stammteilen der Kolonien (Cönosark) nachgewiesen worden und finden sich auch nach innen von der Stiitzlamelle im Entoderm. Obgleich also lokal stärkere Anhäufungen der Zellen vorkommen können, so ist doch keine Einrichtung nachweisbar, welche als ein besonderer Centralteil, ein Centrum der Reflexbahnen, angesehen werden diirfte; womit anch die Ergebnisse der an Hydropolypen ausgefiibrten Reizversuche iubereinstimmen. - Die äußerst feinen Ausläufer der Nervenzellen, die Nervenfasern, konnten einerseits zu den Nesselkapselzellen verfolgt werden, mit denen je ein Fäserchen sich verband (was jedoch neuerdings geleugnet wird); andrerseits wurde auch ihr Zusammenhang mit den Epithelmuskelzellen und bei gewissen Formen mit besonderen Ecto- und Entodermzellen (Hydra) erwiesen, welche als reizaufnehmende Sinneszellen gedeutet werden. Letztere Rolle wird aber gewöhulich auch den mit einem Cnidocil ausgerijsteten Nesselkapselzellen (vgl. S. 12S) zugeschrieben.

Zu viel höherer Stufe hat sich der Nervenapparat der Nedusengeneration dor Iydroiden (einschließlich der' sog. Trachymedusen) erhoben. Im Zusammenhang 
mit der Ausbildung komplizierterer Sinnesorgane am Rande des schirm- bis glockenförmigen Körpers (sog. Randkörper, d. h. Ocellen, Statocysten) wurde am Schirmrand ein besonderer Centralteil des Nervenapparats entwickelt. Derselbe

Fig. 314,

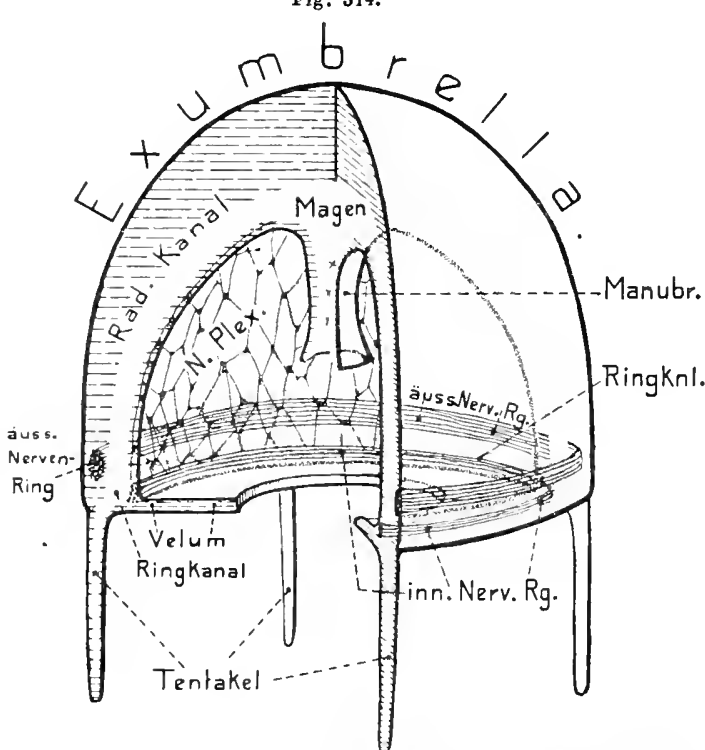

Schema einer einfachen Hy dromeduse. Der linke vordere Quadrant durch zwei Radialschnitte, die his zur Achse gehen, herausgeschnition. Schniltflächen schraffiert. Gastrovaseularsystem rot. Die beiden Nervenringe, samt dem subumbrellaren Nervenplexus angegeben. Der äuBere Ring ist der lleutlichkeit wegen in etwas höherer Lage gezeichnet.

C. H. findet sich dicht am Schirmrand, wo das für die Hydromedusen charakteristische Vehm, ein dünnhäutiger muskulöser Randsaum, entspringt (s. Fig. 314).

Am Ursprung dieses Velums wird der ganze Schirmrand von zwei dicht benachbarten nervösenRingen umzogeu, die aus circulär verlaufenden Nervenfasern init eingelagerten Nervenzellen bestehen. Jndem die zarte Stiitzlamelle, welche die beiden Eetodermblätter des Velums tremnt, sich am Übergang in die Gallerte des Medusenschirms verdickt, scheidet sie die beiden Nervenringe voneinander. Der umbrel-

lare (anch obere oder äußere) Ring liegt in der Tiefe des umbrellaren Ketoderms, der subumbrellare oder innere in der des subumbrellaren. Während die Nerven-

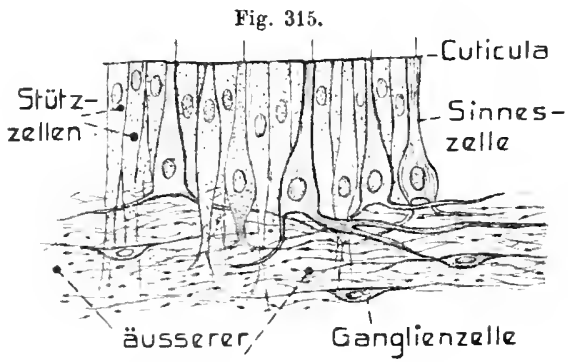

Nervenring

Carmarina (Hydromeduse). Kleiner l'eil des äußeren (oberen) Nervenrings, mit dem darüberliegenden äußeren Epithel, das zablreiche Sinneszellen enthălt, die ihre Fortsatze in den Nervenring senden; dazwischen Stŭtzzellen (n. O. п. R. Hentwig 1578). C. H. fasern des nmbrellaren Ringes meist äußerst fein sind, sind die des subumbrellaren stärker, mit zahlreichen Ganglienzellen. Ein meist spärlicher Faseraustausch zwischen beiden Ringen durch das Mesenchym wurde vereinzelt beobachtet. - Der umbrellare Nerveuring steht in sehr innigem Zusammenhang mit dem ihn bedeckenden Epithel, das aus miteiner Cilie versehenen Zellen besteht, deren Basalenden in feine Nervenfasern auslaufen, die sich dem Nervenring beimischen, der also großenteils von solchen Fasern gebildet wird (s. Fig. 315). Diese Geißelzellen werden daher gewöhnlich als Sinneszellen anfgefaßt, obgleich dies etwas zweifelhaft erscheinen kaun. -Der subumbrellare Ring ist schärfer von der darüberliegenden Epidermis gesondert; 
doeh verraten seine Ganglienzellen, die sich zwischen den Basen der Epidermiszellen erheben, noch nahe Beziehungen zu ihr. Sinneszellen finden sich in diesem Epithel spärlicher

Unter der Epidermis der Subumbrella, des Mamubriums nnd der Tentakel breitet sich ein ähnlicher. Plexus multipolarer Nervenzellen ans (s. Fig. 314), wie

Fig. 316.

A
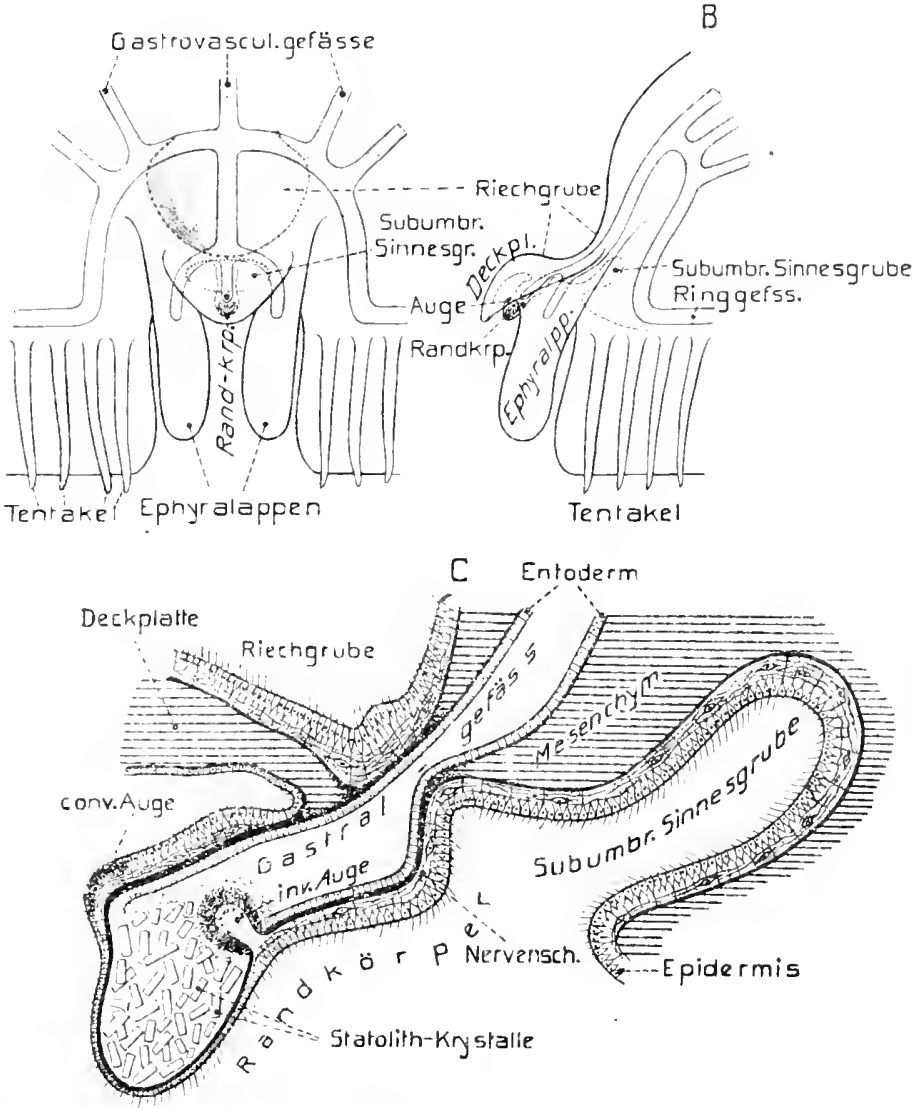

Randkürper von $\mathrm{Medusa}$ a u ita. A Randhorper mit dem Schirmrand von anßen; $B$ von der Seite. Gastro-

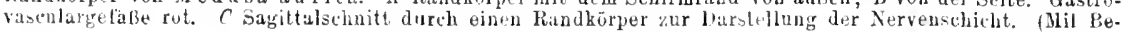
nutљung ron SCIEWIAKOFF 185\%.

o. B. u. 1. lik.

er für die Hydropolypen besehrieben wnde; er innerviert jedenfalls die subumbrellare Muskulatur. Ansammlungen von Fasern zn radiüren Ziigen (Nervenstämmehen an der Subumbrella wurden nur bei manehen 'Trachymedusen nachgewiesen. - Die Umbrella ist stets ohne Nervenelemente.

Unter den Scyphozoa zeigen die Seyphomedusen. (Aealephen) ebenfalls dio höhere Entwieklung des Apparats, was anf denselben Bedingungen berult wie bei den Hydromedusen. Die Centralteile des Systems stehen sogar hier noeh in inni- 
gerer Beziehnng zu den Sinnesorganen, welche bei den Acalephen (speziell Discomedusae) von rudimentären Tentakeln (sog. Randkörpern) des Schirmrandes getragen werden. Jeder dieser gestielten Randkörper (siehe Fig. $316 A-B$ ), die zu 4, 8, selten 12 oder 16, vorhanden sind, besitzt an seiner Basis, in der Tiefe der Epidermis, eine starke Anhäufung von Nervenfasern (Nerventilz), die auch noch auf den umgebenden Schirmrand übergreifen kann (Fig. $316 C_{\text {\% }}$. Gewöhnlich umgreift diese Nervenmasse die ganze Randkörperbasis und dehnt sich peripher anch auf den Randkörper aus. Nervenzellen finden sich gleichfalls darin, während mit einer Geißel versehene sog. Sinneszellen der Epidermis ihre Ausläufer in die Nervenmasse senden. Doch finden sich gewöhnlich anch Epidermiszellen, deren faserartig ausgezogenes Basalende durch die Nervenmasse bis zur Stittzlamelle oder Mesenchymgallerte tritt, und welche deshalb als Stützzellen bezeichnet werden. Auch die Hydromedusen zeigen zum Teil ähnliches (Fig. 315), wahrscheinlich sogar verbreiteter, als gewöhnlich angenommen wird. Dies Verbalten verrät dentlich, daß eigentlich die gesamte Nervenmasse noch in der Tiefe der Epidermis liegt. - Bei den Cubomediesen (Charybdaea) sind die vier Centralteile durch einen subumbrellaren Nervenring verbunden; bei den Discomedusen hingegen ist ein solcher wenig ausgeprägt. Dennoch wurde bei gewissen (Rhizostomeae) ein subumbrellarer Ring in einiger Entfernung vom Schirmrand nachgewiesen, der durch radiäre Faserzüge mit den Randkörpercentren in Zusammenhang steht (s. Fig. 317). Er verbindet ein Centrum mit den beiden benachbarten, doch anch mit weiter entfernten. - Auf der muskulösen Subumbrella der Acalephen breitet sich ebenfalls ein Nervenzellen-Plexus aus, der sowohl mit der Muskulatur als der ihn uberziehenden Epidermis in Verbindung stehen soll; auch an den Tentakeln ist ein solcher Plexns erwiesen.

Ziemlicb abweichend verhält sich das System bei den festsitzenden Scyphomedusen (Lucernariden); es sei nur hervorgehoben, daB sich die Centralteile (stärkste Ansammlung von Nervengewebe) an den Enden der acht Arme finden, die adradialen Randlappen der übrigen Acalephen entsprechen. Von hier erstreckt sich ein Plexus über die ganze umbrellare Körperfläche, hier und da mit stärkeren Ansammlungen. Auch entodermale Nervenelemente wurden beobachtet, sowie Nervenfasern, welche die Gallerte durchsetzen.

Im Gegensatz zu den Scyphomedusen bleibt der Nervenspparat der Scyphopolypen (insbesondere der Anthozoen) auf einer viel niederen Ausbildungsstufe stehen, ähnlich dem der Hydropolypen. Am genauesten bekannt ist er bei den Actinien, am wenigsten bei den Madreporarien. Im allgeneinen findet sich in der Tiefe der Epidermis eine über den ganzen Körper verbreitete ectodermale Nervenschicht, ebenso jedoch eine entodermale, die aber bedeutend schwäeher bleibt. Das ectodermale System ist lokal recht verschieden stark entwickelt, in gewisser Parallelität mit der stärkeren oder schwächeren Ausbildung der ectodermalen Körpermuskulatur. Meist ist die Nervenschicht (s. Fig. 214, S. 95) auf der Mundscheibe besonders stark, wo sie anch reichlich mit Ganglienzellen versehen ist, und breitet sich von da, wenn auch dïnner, auf die Tentakeln und das ectodermale Schlundrohr (mit mehr oder weniger Ganglienzellen) aus, während das Manerblat (seitliche Körperwand) und die Fußscheibe nur spärlichere, plexusartige Nervenzüge besizen. 
Bei Formen mit stark muskulösem Mauerblatt (z. B. Cerianthus) besitzt auch dieses eine dicke Nervenschicht; ebenso manchmal auch die Fußscheibe. Bei gewissen Gattungen soll das Nervensystem sogar an der Mundscheibe und den 'Tentakeln sehr wenig ausgebildet sein (Ptychodactis, Andracia). - Das entodermale System ist im allgemeinen schwächer und mehr plexusartig; stärker entwickelte Züge erstrecken sich längs der Mesenterialfilamente und setzen sich anch auf die Acontien fort. Beide Systeme hängen wohl durch das Schlundrohrsystem zusammen; dagegen sind im Mesenchym weder Nervenzelien noch -fassern, die etwa beide Systeme verbänden, sicher erwiesen. Ebensowenig wurde auch im Cönosark der Kolonien Octocorallia) ein dieEinzeltiere verbindendes Nervensystem sicher erwiesen, dürfte jedoch wohl nicht ganz fehlen. In Ectoderm wie im Entoderm finden sich Sinneszellen, deren basale nervöse Auslänfer in die Nervensehichten eintreten. Verbindungen zwischen Nerven- und Muskelfasern wurden beobachtet.

Fig. 317.

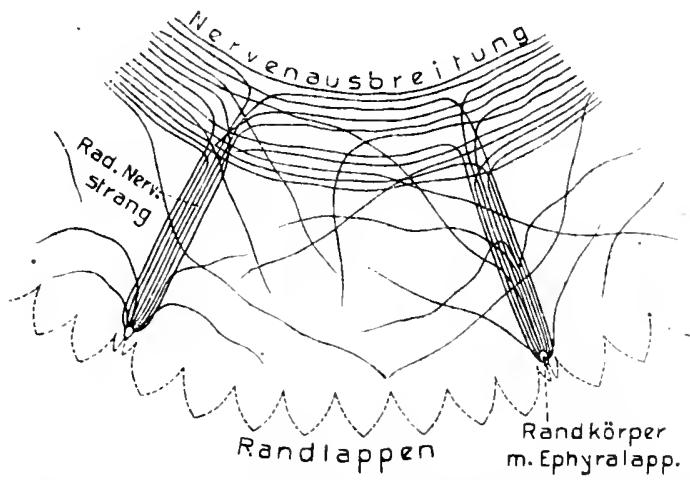

Rhizostoma cuvieri (Acalophe). Ein kloiner Teil des Schirnrands mit $z$ wei Randkōrpern und den von ihnen ansgehenden Nervellausbreitungen. Schema (n. K. Hesse 1595). v. Bu.

Die Frage nach dem Nervensystem der Ctenophoren ist leider noch kontrovers, was um so eigentümlicher eršcheint, als diese Formen ein sehr ansehnliches apikales Sinnes-. organ (Statocyste) besitzen, weßhalb ein damit zusammenhängendes Nervensystem wohl nicht fehlen kann. Zwar wurde unter der Epidermis der Körperoberfläche und dem Epithel des sog. Schlund- oder Mundrohrs ein aus Ganglienzellen zusammengesetzter nervöser Plexus beschrieben, sowie auch Sinneszellen in der Epidermis. Die Zweifel über die nervöse Natur dieses Plexus, oder seine etwaige Deutung als ein zwischen den zahlreichen Drüsenzellen der Epidermis sich ausbreitendes Gewebe von epithelialen Stützzellen, sind aber noch nicht gehoben. Eigentümlich ist auch, daß dieser Plexus in keiner Beziehung zum apikalen Sinnesorgan stehen soll. Auch die dem Mesenchym zugeschriebenen Nervenfasern sind zweifelhaft. Die Möglichkeit scheint nicht ausgeschlossen, daß die erwähnten epithelialen Stützzellen nervöse Leistungen primitiver Natur besitzen, obgleich sie ihrer Lagerung nach noch als echte Epidermiszellen erscheinen. Ilierfür spricltt auch die Beobachtung, daß die Basen der hohen und schmalen Epithelzellen der Polster, von welchen die Ruderplättchen entspringen (siehe Fig. 222, S. 96), sich durch meridional ziehende Fasern mit denen der benachbarten Ruderplättchen verbinden. Wahrscheinlich muß dies als ein nervöser Zusammenhang einfachster Art gedeutet werden, wie ihn auch das physiologische Experiment für die Ruderplättchenreihen zu fordern scheint, welche unter dem Einfluß des apikalen Sinnesorgans stehen.

Die Erfahrungen über die einfachsten Baurerhältnisse des Nervenapparats, wie er sich bei den Cölenteraten findet, lassen die mögliche erste Entstehung eines solchen Organsystems erwägen. Wie dargelegt wurde. handelt es sich um die Ausbildung geordneter Einwirkungen von Zellen aufeinander, insbesondere oberflächlicher Ectoderm- und Entodermzellen auf Epithelmuskelzellen oder tiefer gelegene typische Muskelzellen. Fine solche Einuirkung ist eigentlich nur dann verständlich, wenu die sich beeinflussenden Zellen direkt unl hontinuier- 
lich verbunden sind, $d$. h. wenigstens durch protoplasmatisehe zarte Brücken iueiuander iibergehen. Dies ist auch deshalb um so wahrscheinlicher, als solch feine plasmatischen Verbindungen (Plasmodesmen) der benachbarten Zellen in den einzelnen Geweben, ja auch zwischen den Zellen verschiedener Gewebe nngemein verbreitet sind, sogar schon bei Protozoenkolonien bestehen (Volrocineen usw.) und ebenso den pllatzlichen Geweben zukommen. Bei den wirbellosen Tieren sind soleh direkte Zusammenhänge zwischen Sinneszellen und Nervenfaserm, sowie von Ganglienzellen untereinander und von Nervenfasern mit Mluskelzellen, iberal] nachweisbar. Es ist daher sowohl aus allgenteinen Erwägungen, als audererceits auf Grund tatsächlicher Erfahrungen recht wahrscheinlich, daB die Elemente. durch welche die Zellen aufeinamderwirken, aus solchen direkten Verbindungsfasern zwisehen ihuen hervoroingen. Man kann sich auch leicht vorstellen, daß ans Plasmodesmen zwischen Nesselzellen und henachbarten Epitholmuskelzellen, oder auch zwischen sich entwickelnden reizaufnebmenden Epithelzellen (Sinneszellen) und Epithelmuskelzellen, Nervenfasern hervorginger, indem sich gewisse Verbindungsfasern hiertür besonders ausbildeten (differenzierten). Die Beobaclitungen erweiren jedoch im allgemeinen keinen soleb direkten nervösen 7usamenhang; vielmehr int derselbe komplizierter, indem sich zwischen Sinneszelle (bzw. Nessclzello) und Muskelzelle zum mindesten eine Ganglienzelle einsehaltet. Die tatsächlichen Erfahrungen, wie die thenretischen Erwägmngen iiber die Entstehung solcher Ganglieuzellen, weisen un hei den IIydrozoen ant die früher (S.128) erwähnten tieferen, sogenannten interstitiellen Ectollemzellen hin aus wellien anch die Nesselkapselzellen sich entwickeln. Es i=t daher sehr wahrscheinlich, daß solch tiefe, zwischen dic Basen der E:todermzellen eingeschaltete interstitielle Zellen, die ja auch einer direkten Verbindung der Epithelmuskelzellen un sinneszellen in allgemeinen im Wege stehen, die Reizübertragung vermittelteis.

Indem sich bei gewissen dieser interstitiellen 7ellen die Befähigung zur Reizleitung besser hervorbildete, kounten sie zu spezitischen einfachsten Nervenzellen werden, welche die Reize ïberleiteten, eventuell auch noch verstärkten und auf eine größere Zahl von Muskelzellen übertiugen. Wenn dies in einem jugendlichen Zustand eintrat, und soleb ursprüngliche Nervenzellen sich wenig weiter rermehrten; jedoch bei ihrer Teilung dureh Verbindungsasern in Zusammenhang blieben, so mußten sie im erwachsenen Zustand allmählieh weiter auseinander rïken, wobei ihre lang ausgezogenen Verhindungsfasern zu einfachsten Nervenfasem wurden, die sie plexusartig rerbanden, und andererseits auch die Zusammenhänge mit den Epithelnuskelzellen, Sinneszellen und Nesselkapselzellen herstellten. Fortgesetzte Vermehrung der letzterwähnten Zellformen, an welcher auch ihre nervösen Ausläufer teilnahmen, konnte eine Verästelung der zu ihnen ziehenden Nervenfasern hewirken, und so auch die gleichzeitige Innervierung größerer Bezirke durch eine Ganglienzelle. Obgleich eine solche Hypothese über die erste Entstehung des Nervenapparats, rorerst die Grenzen einer erlaubten fast ïberschreitet, so bietet sie foch die Möglichkeit eines Verständnisses. $Z u$ betonen wäre noch, daß auch eine Verbindung zwisehen Ecto- unı Entodermzellen durch Plasmodesmen keineswegs unmöglich ist, da auch die in das Mesenchym der Cölenteraten eintretenden Zellen (vorwiegend Ehtodermzellen) in der Regel durch Auslänfer reichlich zusammenhängen, so daß die Möglichkeit eines Zusammenhang: zwischen lem ectodermalen und entodermalem Anteil des Nervensystems durch das Mesenchym nicht ausgeschlossen scheint. - Wenn wir die frïher verbreitete Vorstellung ablehnen, daß die Epithelmuskelzellen der Cölenteraten gleichzeitig ein nervöses und kontraktile: Element repräsentieren, d. h. sich bei weiterer Entwicklung in eine Sinneszelle, eine Nervenfaser und eine Muskelzelle differenzieren könnten (daher ibre trühere Bezeichnung als Neuromuskelzellen), so soll damit nicht ausgesprochen werden, daß die Epithelmuskelzellen nicht vielleicht mittels ihrer epithelialen Fortsätze direkt reizbar sein dürten; doch spricht alles lagegen, daß hei tortsclireitender phylogenetischer Entwicklung aus ihrem epithelialen Fortsatz Nervenelemente hervorgegangen seien. 


\section{B. Bilateria.}

\section{Vermes.}

Die urspriinglichste Bildung des Nervensystems in der großen Reihe der Bilaterien war wahrscheinlich der der primitivsten Cölenteraten sehr ähnlich. Auch ihr Nervensystem ging vermutlich von einem, die gesamte Epidermis unterlagernden dichten Nervenplexus ans. Die Hervorbildung des bilateralen Baus, unter Bedingungen, wie sie schon in der Einleitung (s. S. 13) erörtert wurden, führte zur Entstehung von Sinnesorganen am vorderen Körperende, welche ibrerseits wieder die Differenzierung von Centralteilen des ganzen Nervensystems aus dem allgemeinen Plexus bewirkten, in welchen die ebenfalls aus dem Plexus hervorgehenden Nervenstränge unter Entwicklung geordneter Reflexbahnen zusammenliefen. Die Entstehung solcher Centralteile durch eine Art Verdichtnng, oder gewissermassen Konzentration des allgemeinen ventralen Plexus, sowie durch reichere Anhäufung von Ganglienzellen in diesen Regionen, läßt sich bei einzelnen Gruppen z. T. noch vergleichend anatomisch verfolgen. Ein sich auf diese Weise in der Vorderregion des Körpers entwickelnder Centralteil des Nervenapparats wird im allgemeinen als IIirn-oder-Cerebralganglion bezeichnet, oder, da er entsprechend dem Bilateralban gewöhnlich mehr oder weniger deutlich bilateral gebildet ist, als cerebrales Ganglienpaar. Ebenso entwickelten sich durch Differenzierung innerhalb des allgemeinen epidermalen Plexus stärkere Nervenfaserzüge, -stämme oder -stränge, besonders in der Längsrichtung.

Es ist eine schwer zu lösende Frage, wie man den Centralteil des sich so entwickelnden Nervensystems begrenzen soll, d. h. ob man ihı auf die Cerebralganglien beschränken, oder auch die größeren Nerrenstämme darunter begreifen soll. Schon die Vergleichung mit den Gliederwürmern, bei denen auch die Hauptlängsstämme dem centralen Nervensystem mit Recht zugeteilt werden, ergibt, $d a \beta$ es wenigstens theoretisch gerechtfertigt erscheint, auch bei den einfacheren Würmern die Hauptstämme zum centralen System zu ziehen.

Über das Schicksal des entodermalen Anteils des Cölenteraten-Nervensystems bei den Bilaterien ist kaum Sicheres bekannt, wenn es auch wahrscheinlich ist, $\mathrm{da} B$ dieser 'Teil nicht verloren ging, sondern sich am Anfban der peripherischen Nerven des Urdarms, vielleicht aber auch von dessen mesodermalem Anteile beteiligt.

Plathelminthen. Wie zu erwarten, begegnen wir bei dieser Gruppe der einfachsten Bildung des Nervensystems der Bilaterien, an welchem sich sogar die ehen dargelegten Entwicklungsvorgänge noch vergleichend-anatomisch nachweisen lassen. Obgleich der allgemeine Ban des Systems noch recht urspriinglich crscheint, so finden sich doch schon Verhältnisse, die sich von der primitiven Bildung der Cölenteraten erheblich entfernen. Namentlich haben sich die Centralteile des Systems von der Epidermis abgelöst und tiefer ins Körperinnere, in das sog. Parenchymgewebe (Bindegewebe), verlagert, welches das ganze Innere dieser Wiirmer erfüllt. Dies gilt besonders für die Cerebralganglien, welche häufig mitten in Parenchymgewebe der Kopfregion liegen, obgleich ihre ectodermale IIerkunft ontogenetiseh und vergleichend anatomisch nachznweisen ist. - Der allgemeine primäre Hautplexus scheint überall eine Sonderung in einen tieferen, nach innen 
von der Muskulatur gelegenen, und einen oberflächlichen erfahren zu habeu; aus ersterem entwickelten sich dann die Centralteile des Systems: die Cerebralganglien und die Iranptnerver tämme.

Die primitivsten Bildungsverhältnisse liegen zweifellos bei den dendrocölenTurbellarien (Dendrocöla) vor, und unter diesen wieder bei den landhewohnenden 'Tricladen (Landplanarien). Bei einem T'eil derselben (gewissen Geoplanaarten) findet sich an der ganzen Ventralfäche ein relativ dichter und dicker tiefer Nervenplexus, der keinerlei Differenzier'ung besonderer Nervenzüge oder -stränge zeigt, sich jedoch in der Kopfregion, heiderseits der Mittellinie, verdickt und verdichtet, als erste An-

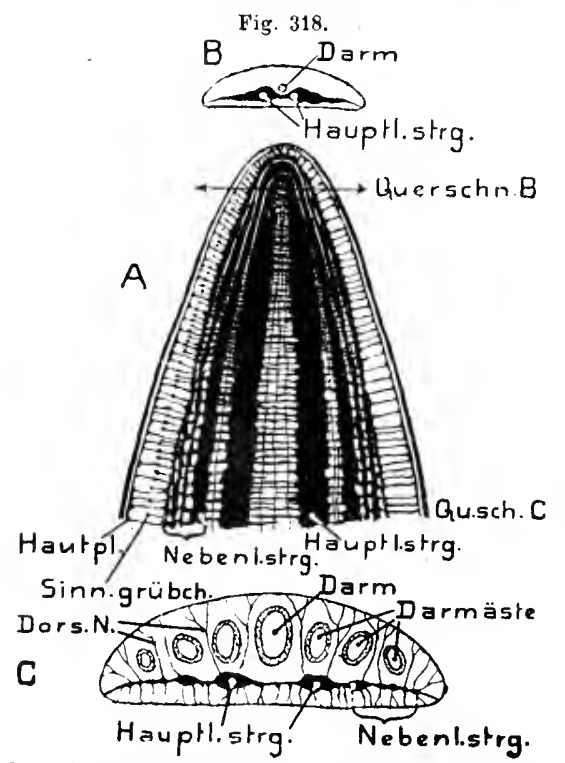

Gooplana pullav. Graff (Landplanarie). Schemata. $A$ Vorderende in Flâchenansicht mit dem ventralen Nervensystem. $B$ Quersehnitt des vordersten Kórperendes. $C$ Querschnitt etwa am Hinterende der Fig. A (n. v. GrafF 1899). dentung der sich entwickelnden Cerebralganglien. Bei anderên Arten setzt sich diese vordere Verdickung des Ple. xus beiderseits der Ventrallinic durch die ganze Nervenplatte nach hinten fort (s. Fig. 318), wodurch zwei ventrale Längsnervenstrïnge angedeutet werden, wie sie für die meisten Süßwassertricladén charakteristisch sind, indem sich der urspriinglich diehte Plexus der Nervenplatte $z u$ einem meist ziemlich unregelmäßigen System zahlreicher Quercommissuren zwischen den beiden Bauchnerven, sowie zu seitlich von diesen abgehenden Querästen (bzw. Netzen) umgestaltet (Fig. 320). - Bei gewissen Geoplanaarten können sich jedoch aus der ventralen Nervenplatte neben den beiden starken Hauptsträngen noch zahlreiche sekundäre ventrale Stämme entwickeln (s. Fig. 318).

Bei einzehnen Tricladen (so z. B. Gunda s. Fig. 319) folgen die Quercommissuren zwischen den beiden liauchnervensträıgen, ebenso auch die seitlich von letzteren entspringenden Nerven, sehr regelmäßig aufeinander und fallen ziemlich genau mit den Darmästen zusammen, so daß eine Art Strickleitersystem entsteht.

Ganglienzellen sind nicht nur den Cerebralganglien, sondern dem ganzen Plexus und den sieh daraus entwickelnden Hạptnervensträngen eingelagert. Außer dem eben erwähıten tiefen Ventralplexus findet sich bei den Dendrocölen stets noch ein oberfächlicher, direkt unter dem Ilautmuskelsehlauch gelegener, feiner Hantplexus, der Ästchen in die Muskulatur und zu: Epidermis sendet. Dieser oberflächliche Plexus dehnt sich bei den Landplanarien ïber die ganze Korperoberfläche, also auch die Dorsalseite aus und entwickelt sich zuweilen an den seitlichen Körperrändern zu einem Seiteurandnerv. - Der tiefe Ventralplexus seudet absteigende und anfsteigende Ästchen zuı Hautplexus 
(Fig. $318 c$ ). Ob letzterer bei den Süßwassertricladen in ähnlich vollständiger Entwicklung vorhanden ist, erscheint fraglich. - Von den Cerebralganglien gehen mehr oder weniger zahlreiche Nervenfaserzüge zum vorderen Körperrand, darunter typiscle nervenzellenreichere Sinnesnerven zu den Augen und Teutakeln. - Wie sich aus vorstehender Schilderung ergibt, ist bei deu Tricliden eine scharfe Grenze zwischen den Cerebralganglien und den beiden Banchsträngen häufig kaum zu ziehen.

Anch das Nervensystem einzelner polyclader Dendrocölen bietet ähnlich ursprüngliche Verhältnisse wie die Landplanarien (Fig. 321), indem ein tiefer weitmaschiger Ventralplexus ausgebildet ist, in welchem zwei stiirkere Bauchstränge,

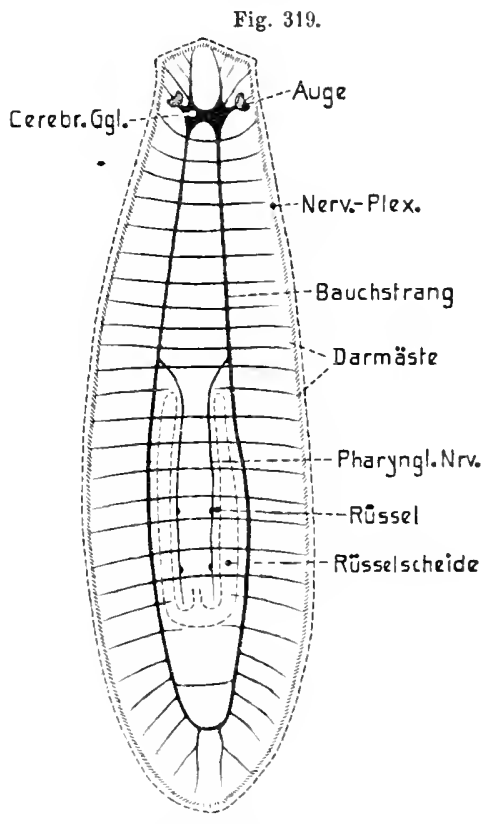

Gunda segmentata (Torbellarie). Nervensystem und Jarm (orange) von der Bauchseite. Sihematisch (n. A. LANG 1881). v. Bu.
Fig. 320 .

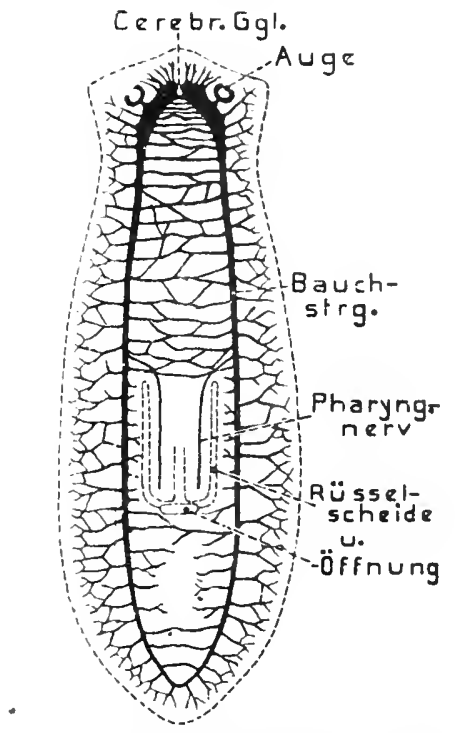

I'lan ariagonocephala. Nervensystem der Bauchsoite. srhematisch. v. Bu.

sowie von diesem abgehende Stränge hervortreten. Mit den Maschen dieses Ventralplexus steht wieder ein feinmaschiger oberflächlicher Ventralpiexus in Zusanmenhang, der in der Hautmuskulatur liegt, während der liefe Plexus sich unter ihr findet. Der dorsale Plexus ist in der Regel feiner als der tiefe ventrale und dürfte daher in allgemeinen dem oberflächlichen Hautplexus entsprechen: er erhält wie bei den Landplanarien ans dem tiefen Ventralplexus anfsteigende Faserzüge, die das Parenchym durchsetzen. Die stets gut ausgebildeten Cerebralganglien liegen weit vor der stark nach hinten gerückten Mundöffnung, sind wenig oder dentlicher paarig und entsenden nach vorn und seitlich Nerven, die ebenfalls nur stärkere Züge des allgemeinen Plexus sind, wie die zahlreichen Commissuren zwischen ihnen crweisen (Fig. 321 B). - Die Ganglienzellen in den Cerebralganglien liegen vorwiegend oberfächlich, wie ès für die Wirbellosen die Regel ist. Ihre parige 
Anordnung tritt stets deutlich hervor, was überhaupt für alle Plathelminthen gilt. Das Innere der Hirnganglien wird von einer feinen Nervenfasermasse (Punktsubstanz, Neuropil) gebildet, in der quere Faserzüge, zur Verbindung der beiden Hirnhälften besonders hervortreten. - Dieses Neuropil wird von feinen sich verästelnden Faseranslänfern der Ganglienzellen gebildet, die unter sich netzförmig

Fig. 321 .

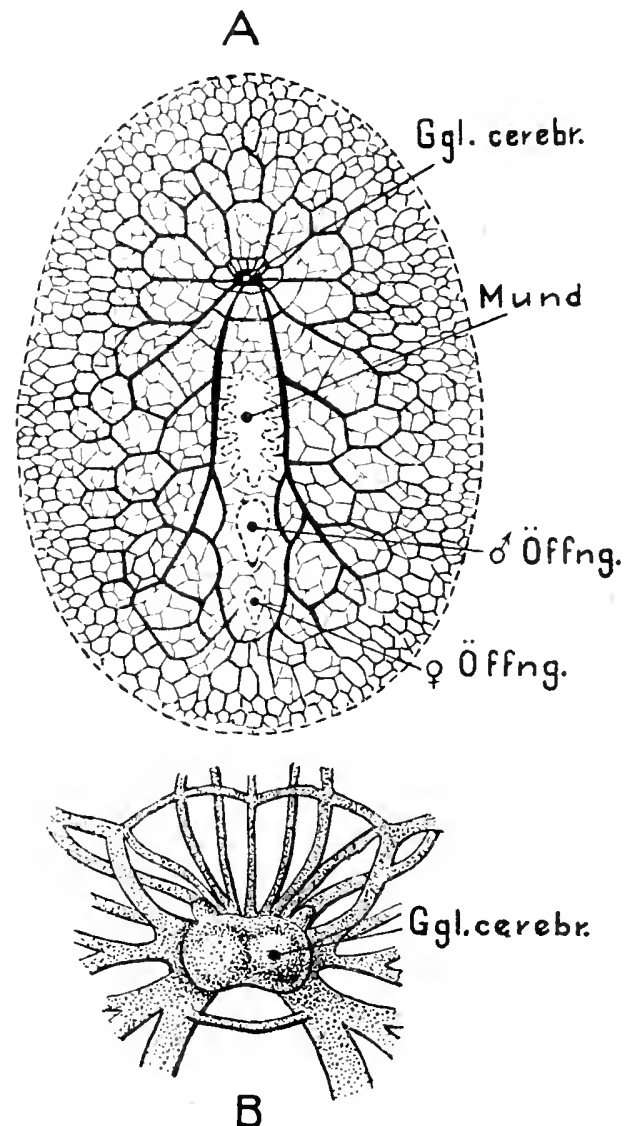

Planocera graffi i polyclade Dendrocolel. A Nervensystem der Bauchseite. $B$ Cerebralganglien mit den von ihnen abgehenden Nerven; starker vergroßert von der Dorsalseite (n. A. LaNg 1884). zusammenhängen, oder nach gewisser Auffassung sich auch nur berühren (Kontaktlehre); vom Neuropil können Nervenfasern ihren Ursprung nehmen.

Die rhabdocölen Turbellarien zeigen keine prinzipiellen $\mathrm{Ab}$ weichungen von dem seither Gefundenen; teils kommen noch zahlreichere Längsstränge vor (so bei Acöla), teils weniger; meist finden sich zwei starke Bauchstränge und zwei schwächere Dorsalstränge (s. Fig. 322). Die ventralen sind stets durch mehr oder weniger Quercommissuren verbunden. Die ziemlich ansehulichen Cerebralganglien erscheinen manchmal etwas gelappt $(\mathrm{zw}$ ei bis drei Lappen jederseits). Vom oberflächlichen Hantplexus ist wenig bekannt. Zum Rüssel tritt jederseits aus dem Bauchstrang oder dem Cerebralganglion ein Pharyngealnerv (ähnlich auch bei Tricladen).

Aus der kurzen schilderung der Verhältnisse bei den Turbellarien geht hervor, daß die Cerebralganglien, sowie die stärkeren rentralen Nervenstränge aus der Konzentrierung und Verdichtung des tieferen Ventralplexus hervorgingen. Dies macht es erklärlich, daß beide
häulig mehr oder weniger reichlich von dorsoventralen Muskelfasern und Parenchymgewebe durchsetzt werlen, die bei der Konzentration der betreffenden Plexuspartien aufgenommen wurden. Überhaupt sind die Ganglien und Nercensträıge von einem Stïtzgewebe (Neuroglia) durchsetzt, in dessen Lücken die Nervenfasern verlaufen und die Ganglienzellen liegen. Ot dies Stïtzgewebe ectodermaler oder mesodermaler Herkunft ist, erscheint unsicher.

Auch die beiden parasitischen Gruppen der Plathelminthen, die Trematoden und Cestollen, bewahren im Prinzip den typischen Bau des Turbellariensystems. 
Dies gilt in höherem Grad von den Trematoden, deren Gesamtbau ja auch ursprünglicher blieb. Mit der Verlegung des Trematodenmunds an das Vorderende mußten die Cerebralganglien ihre Lage vor dem Mund natiirlich anfgeben und dorsal iiber den Anfang des Darms, den sog. Pharynx, gelangen. Sie finden sich hier (Fig. 323) als paarige Anschwellungen, die namentlich hei den Digenea (Distomea) meist seitlich ziemlieh weit auseinandergerï̈kt sind, weshalb die sie verbindende Quercommissur lang wird. Ursprünglieh finden sich anch bei den Trematoden zahlreiche Lïngsstränge, die sich noch bei gewissen Mono- nnd Digenea erlielten. Überall treten zwei stärkere, mittlere Bauchstränge auf, zu denen sich bei gewissen Formen noeh zwei :iußere gesellen können, die znweileu an den Seitenrand riieken als sog. Seitennerven (s. Fig. 323). Überall scheint ferner ein Paar Horsalstränge vorhanden zu sein. AlleLängsstr:iug*e sind durch regelmäßiger oder unregelmïßiger sich wiederholende Quercommissuren verbunden, die stellenweise (so z. B. 'Tristomum) am seitliehen Körperrand noch die Form des ursprïnglichen Plexus besitzen können. Bei den meisten Digenea

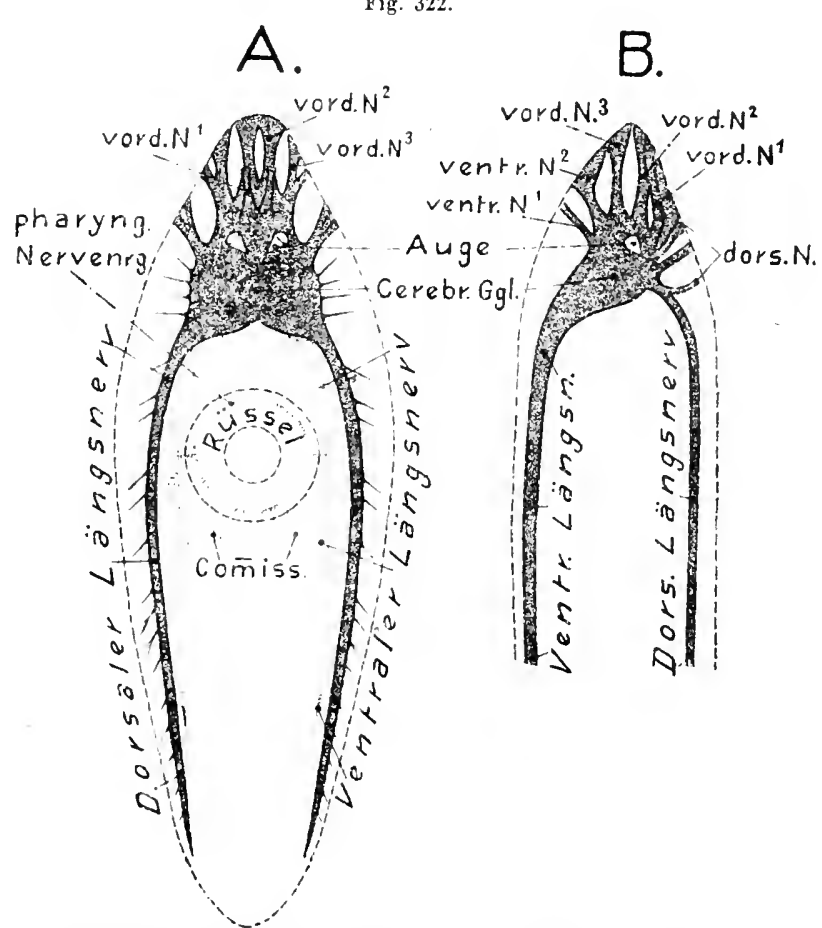

A I esostomutn lingua (Rhablocöle). Nervensystem von der Dorsalsoite. $\quad b$ II esoslomum joductum. Nervensyslem rou der linken Seite (11. LüTHR 1904). v. Bil.

sind nur die beiden IIauptbauehstränge ansgebildet und auch die dorsalen Längsstränge relativ kurz. Am Ilinterende gehen die Jängsnerven zuweilen ineinander über. - Wie bei den Turbellarien entspringen von den Cerebralganglien oder den beiden Bauchnervensträngen zwei PharyngeaInerven zur Versorgung des l'haryux, die sich zuweilen commissurenartig unter dem I'harynx verbinden und sogar Ganglien bilden (sog. Schlundring und unteres Schlundganglion von Distomum hepaticum), oder auch im Pharynx eine Ringcommissur bilden, wie ähnlich schon bei Turbellarien (s. Fig. 322). Die von don Cerebralganglien vorn und seitlieh entspringenden Nerven verhalten sich :̈lınlieh wie hei den'T'ubellarien. - Ein oberflächlicher, direkt unter der Muskulatur liegender IIantplesns dirfte sich aueh bei den 
Trematoden allgemein finden, ist jedoch nur bei einzelnen Formen erwiesen. Häufig wurden periphere, der Muskulatur (speziell der Saugnäpfe) eingelagerte Ganglienzellen beschrieben, deren nervöse Natur jedoch recht unsicher ist.

Eine eigenartige Aasbildung hat das Nervensystem der Cestoden erlangt und ist daher wabrscheinlich aus recht primitiven Verhältnissen hervorgegangen. Im Zusammenhang mit der gleichartigen Ausbildung der Rücken- und Bauchfläche

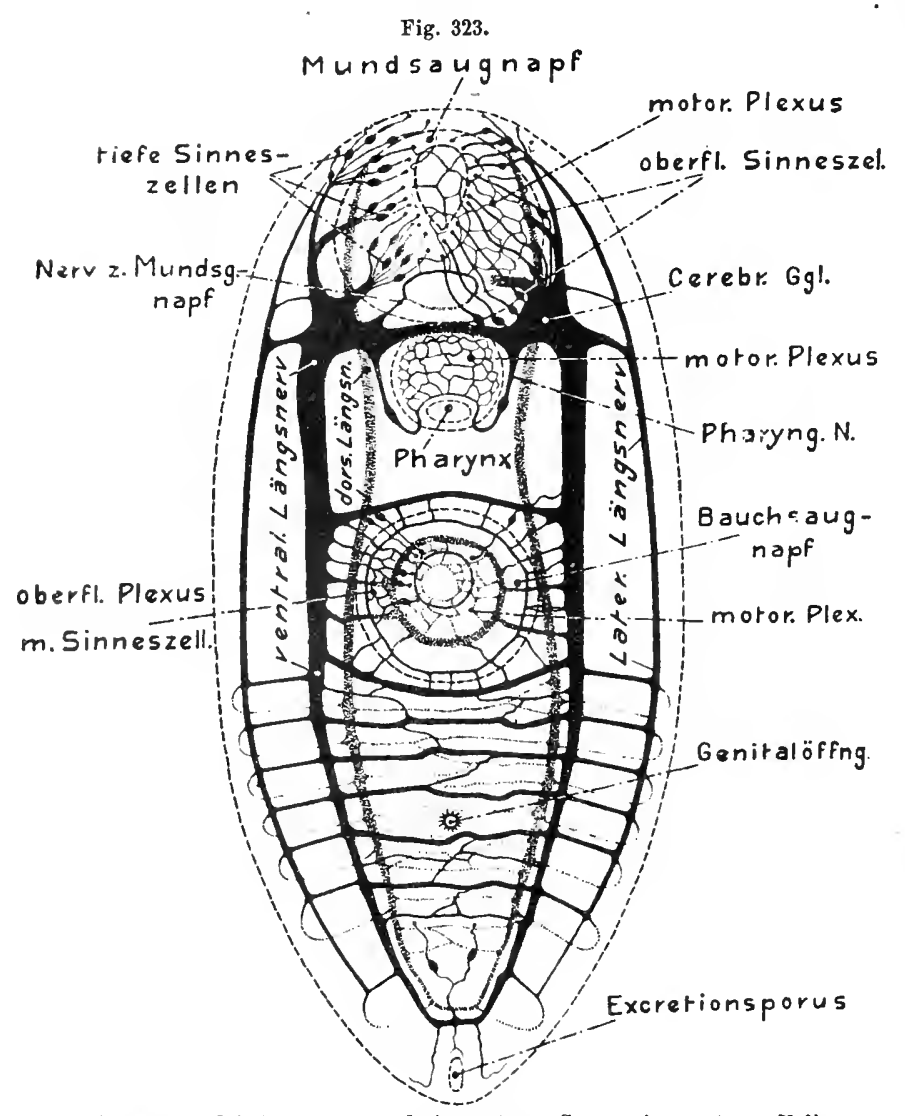

Larve von Distomum caudatum (sog. Cercariaenm) aus Helix, von der Ventralseite mit eingezeichnetem Nervensystem der Bauch-(schwarz) und Ruckenseite (punktiert). Die Körper- und Organumrisse gestrichelt. v. Bu. des Cestodenkörpers, die ihm eine Art Zweistrahligkeit verleiht, hat auch das Nervensystem eine gleichförmige Bildung an der Rücken- und Bauchseite erlangt, welche sich ja iiberhaupt nur durch denCeschlechts:uparat z. T. einigermaßen unterscheiden lassen. Auch die Cerebralganglien zeigen keinen Unterschied zwischen Bauch- und Rückenseite. Mit dieser Eigentümlichkeit hängt es wohl zusammen, daß von den stets zahlreichen Längsnervensträngen, die sich aus dem ursprünglichen tiefen Plexus entwickelten, die beiden des Seitenrands die stärksten sind und daher lange Zeit allein bekannt waren. Sie

werden deshalb als Hauptstränge bezeichnet, dürften aber wohl den bei deu übrigen Plathelminthen zuweilen vorkommenden Seitenrandnerven entsprechen. Sie liegen nach innen von der Hantmuskalatur in der sog. Markschicht (s. Fig. 272, S. 408); die übrigen Längsnerven teils ebenfalls oder in der tieferen Muskulatur. Im Vorderende des Scolex schwellen die beiden Hauptstrïnge in der Regel zu Cerebralganglien an nnd verbinden sich durch eine Quercommissur (Fig. 326). Bei den primitiven Cestoden (Ligula usw.) ist die Zahl der Längsnerven, die sich neben den seitlichen Hanptsträngen noch finden (Nebennerven), und sich vorn gleichfalls init den Cerebra]- 
ganglien verbinden, im Scolex 12; sie künnen sich jedoch in dem darauffolgenden Körper durch dichotomische Spaltung noch reichlich vermehren. Sonst (Bothriocephalus, Taenia) beträgt ihre Zahl, wie es scheint, durchweg acht (Fig. 324). Zwei randliche dieser acht Nebennervenbegleiten dann dorsal und ventral die beiden Hauptstränge (sog. Begleitnerven) und entspringen rorn meist ans den Iauptsträngen (Taenia, Fig. 326 B). Die beiden anderen Paare finden sich als dorsale und ventrale sog. Mediannerven an den beiden Flächen des Bandwurmkörpers.-Alle Längsstränge hängen wieder durch ein plexusartiges, oder regelmäßigeres Quercommissurenwerk zusammen, das sich bei manchen Formen (speziell Tänien) am Hinterrand der Proglottiden (zuweien auch am Vorderrand) zu einer Ringcommissur verdichtet, die den ganzen Körper umzieht. - Ein oberflächlicher Nervenplexus scheint allgemein verbreitet und liegt gewöhnlich zwischen der äußeren und inneren Längsmusku-

Fig. 324 . Begleir-Nerv.

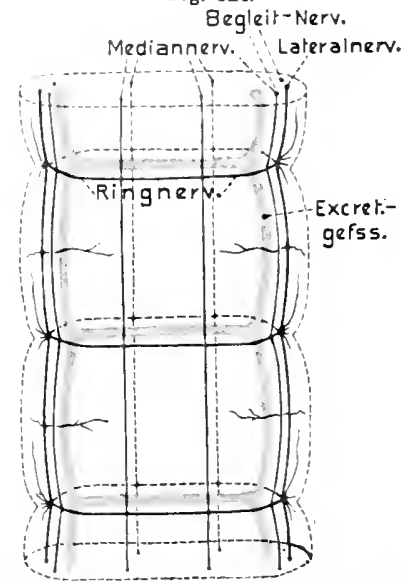

Ta enja expinsa. Schemad. Nervensystems in einigen Proglottiden; etwas perspektivisch dargestellt. Excretionsgefäße blau (n. TOWER 19(00). v. Bu. latur; von ihm gehen wie bei den übrigen Plathelminthen die Sinneszellen der Haut aus (Fig. 325).

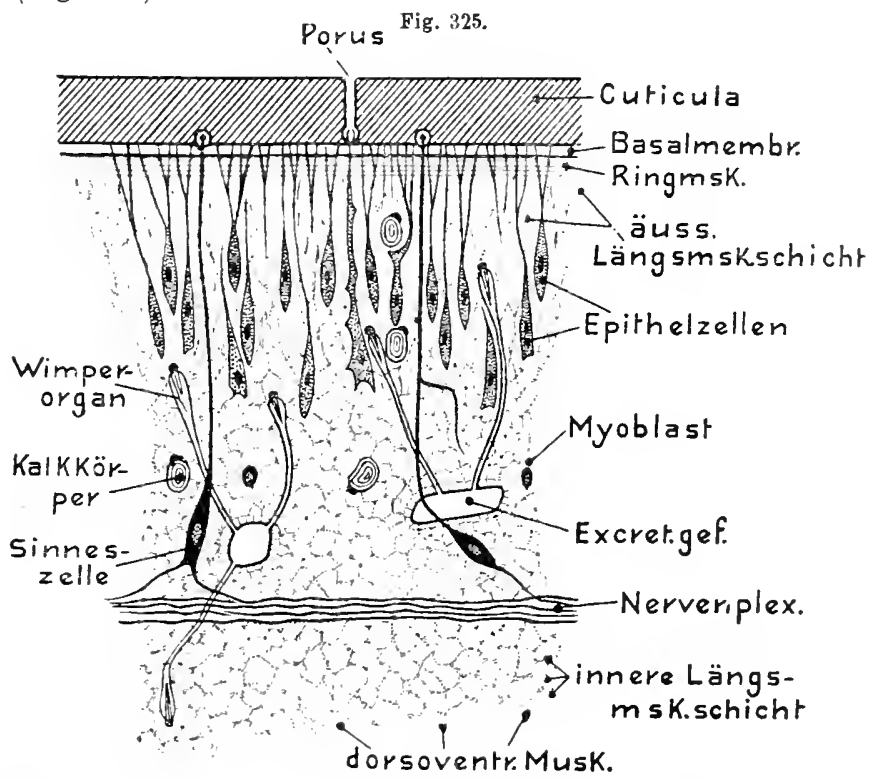

Ligula (Cestode). Schematischer Querschnitt durch eimen Teil der oberfāchlichen Körperregion (nach Blochmana 1596). v. Bu.

Die Cerebralganglien bleiben teils recht einfach, indem sie sich nur als quere stärkere Commissur der Hauptnervenstrïnge darstellen, oder werden komplizierter, 
namentlich bei den Tänien. Hier (ähnlich auch schon bei Schistocephalus) findet sieh im Umkreis der queren Commissur der Cerebralganglien meist noch eine sog. polygonale Commissur, die von den seitlichen Anschwellungen der Hirnganglien ausgeht: und mit welcher sich die vier Mediannerven verbinden, deren Fasern unter der Quercommissur noch eine eigentümlich gekreuzte Commissurenverbindung eingehen (s. Fig. 326). Die vier Mediannerven setzen sich in das Vorderende des Scolex als vier apikale Nerven fort, zu denen sich jedeiseits gewöhnlich noch zwei seitliche gesellen, die von den Cerebralganglien entspringen. Bei den hakentragenden Tänien vereinigen sich diese acht Apicalnerven an der Basis des

Fig. 326.

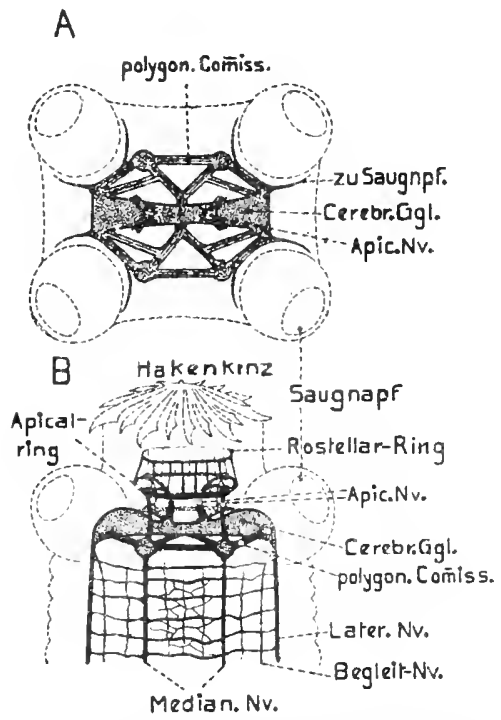

Taenia crassicollis. Schema des Nervensystems in Srolex. A von der Apicalseite, $B$ von der Breitseite des hopfes gesehen (n. Conris 189y). $\checkmark$ Bu.
Rostellums zu einem sog. Apicalring, ans dem feine Nerven in das Rostellum treten.

Es sei hier nochmals betont, daß bei den Trematoden und Cestoden in die Nervenstränge häufig Ganglienzellen eingestrent sind, die zuweilen auch kleine lokale Anschwellungen hervorrufen, so hauptsächlich an den Abgangsstellen von Nervenïstchen.

Nemertina. Die nahen Beziehungen der Nemertinen zu den aprocten Plathelminthen treten im Nervenapparat deutlich hervor. Obgleich er eine ansehnlichere Entwicklung erlangt, bleibt er doch bei gewissen Formen sogar urspringlicher als bei den Aproeta, indem bei einzelnen sog. Protonemertinen (Gruppe der Anopla) das gesamte System noch dicht unter der Epidermis liegt, bei den übrigen Protonemertinen dagegen dem dünnen Corinm zwischen Epidermis und Hautmuskel-

schlauch eingelagert ist. - Bei den übrigen Anopla (Meso- und Heteronemertinen) liegt es in der Muskulatur, bei den Bewaffneten (Enopla = Metanemertina) ist es sogar nach innen von der Muskulatur, in das Körperparenchym verlagert. Die deutlich paarigen Cerebralganglien sind stets recht ansehnlich und liegen im vordersten Körperende (s. Fig. 327). Ihre Beziehung zur Mundöffnung variiert etwas, je nach deren Lage. Ist der Mund etwas vom Vorderende entfernt (Proto- und Heteronemertina), so liegen die Cerebralganglien vor ihm; wegen der Verschiebung der Mundiffnung bei den Enopla bis fast an die vordere Körperspitze finden sich die Hirnganglien hiuter ihr, also dorsal vom Vorderdarm. Jedes Ganglion besitzt eine dorsale und eine meist voluminösere ventrale Anschwellung (Lappen, Lobi). Die entsprechenden Lappen beider Sciten sind je durch eine quere Commissur verbunden, also die beiden Cerebralganglien dureh eine schwachere dorsale und eine stärkere rentrale Commissur. Die ('inglien liegen an den Seiten des vorderen Riissel- 
endes; die dorsale Commissur iiber, die ventrale unter dem Rïssel, so 'daß letzterer ringförmig von den Ganglien und Commissuren umzogen wird. Bei einem Teil der Unbewaffineten (Heteronemertina) besitzen die Dorsalganglien gewissermaßen einen besonderen hinteren Lappen, der jedoeh von einem eigentüm-

Fig. 327 .

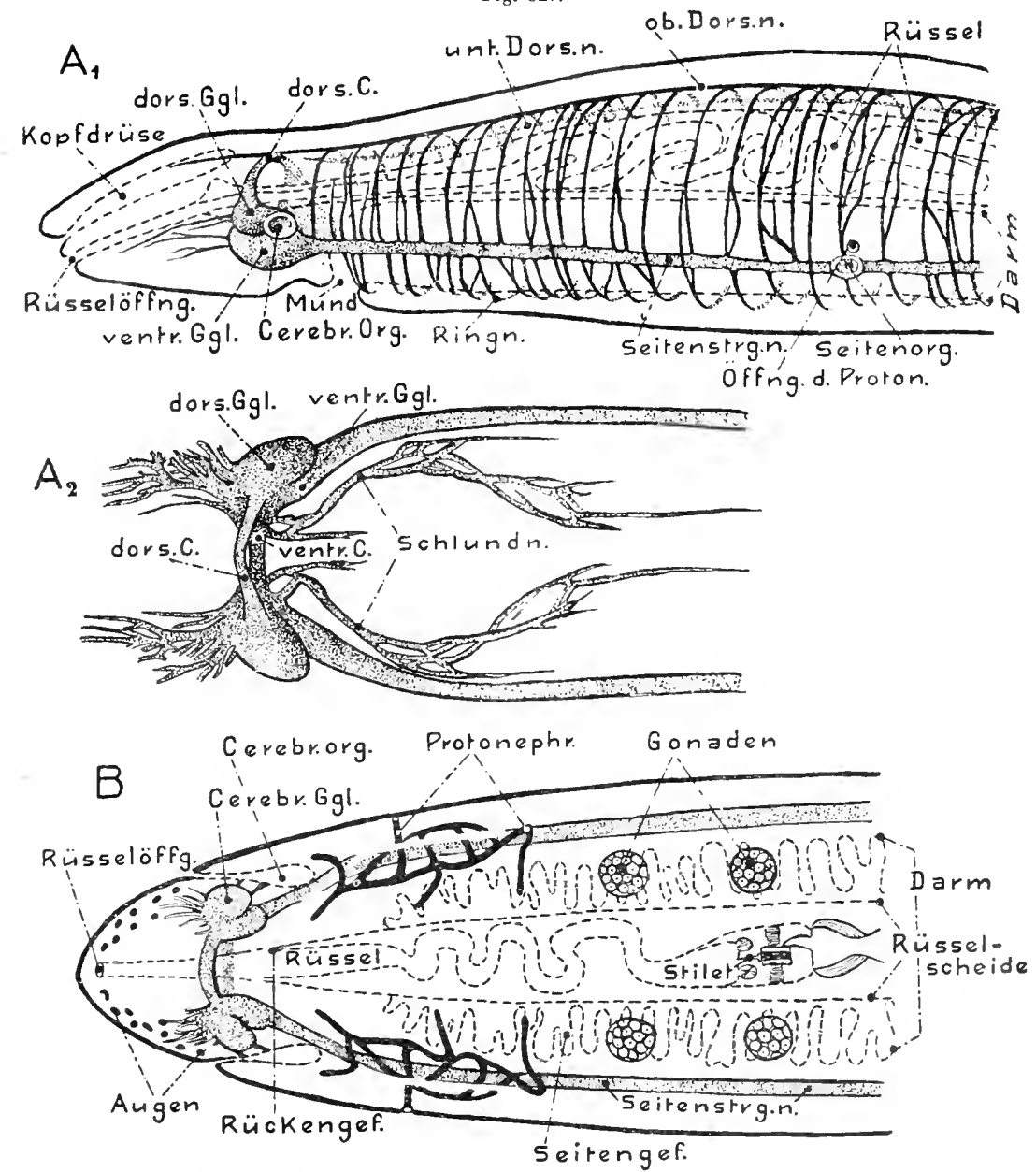

Nemertinen; Nersensystem usw. Al-A. Carinellia. A schematisele Ansicht des vorderen hörper. endes von links. 12 Carinella annulata. Vorderer Teil des ceutralnervensystems von der Lorsalseite-

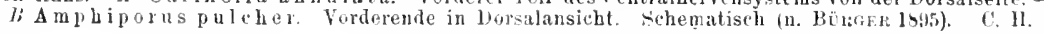

lichen Sinnesorgan (Cerebralorgan) gebildet wird, das bei deu ibrigen durch Nerven mit den Dorsalganglien zusammenhängt (s. Fig. 327 B).

Die Ventralganglion entsenden analwärts je einen starken Längsuervenstrang, der wegen seiner Lage am Seitenrand des Körpers gewöhnlich als Seitennerv bezeichnet wird, aber wohl den beiden Ifauptbatchsträngen der Aprocta entsprechen dürfte; selten liegen diese beiden Nervenstränge der ventralen Mittellinie 
näher (Drepanophorus). Sie ziehen bis ans Hinterende und gehen bei gewissen Formen dorsal vom After ineinander ïber. Wre die Cerebralganglien so liegen die Seitenstränge bei den Protonemertinen außerhalb der Muskulatur, sind dagegen bei dem größten Teil der Unbewaffineten (Heteronemertina) zwischen die äußere Lüngsmuskulatur und die sie unterlagernde Ringmuskulatur geriiekt (Fig. 271, S. 407); bei wenigen (Mesonemertina) in die innere Lingsmuskulatur; sehließlich bei den Enopla ins Körperparenehym, also naeh innen vom Hautmuskelschlaueh. - Cerebralganglien und Seitenstränge sind oberfächlich dieht mit Ganglienzellen bedeckt, die, wie es seheint, sämtlich unipolar sind nnd ihre Nervenfasern in das Innere der Ganglien oder Seitenstränge senden. Es lassen sich nach Größe und sonstigen Eigentümliehkeiten verschiedene (vier) Arten von Ganglienzellen unterscheiden. Unter diesen fallt eine (sog. Neurochordzellen) durch ihre exceptionelle Größe und die dieken von ihnen ausgehenden Nervenfasern (Neuroehorde) sehr auf; doch finden sieh diese Neurochordzellen nicht bei allen Nemertinen. Im Gehirn gibt es gewöhnlich nur je eine in den beiden Ventrallappen; an den Seitensträngen dagegen treten sie zuweilen reiehlich in gewissen Abständen auf.

Ein erheblicher Inteil der Cerebralganglien und Seitenstränge wird von einem nicht nervösen feinfaserigen kernhaltigen Gewebe gebildet (Neuroglia), das als bindegewebig aufgefaßt wird. Um die oberflïhlichen Ganglienzellmassen bildet es fast stets eine äußere Hülle und auf der Grenze zwischen Ganglienschicht und innerer Nervenfasermasse eine innere (sog. äußeres und inneres Neurilemm); selbst feine Läıgsmuskelfasern finden sich in dem äußeren Bindegewebe der Seitenstränge.

Die von den Seiteusträngen ausgehenden Nerven verhalten sich bei den Unbewaffneten noch sehr ursprünglieh, da sie einen dichten Plexus bihlen, der den Körper allseitig umzieht (Nervensehicht, s. Fig. 271). Bei den Protonemertinen liegt dieser Plexus, wie die Seitenstränge, subepithelial oder außerhalb der Muskulatur; bei dem Heteronemertinen zwischen der äußeren Längs- und der Ringmuskulatur; doch findet sich hier häufig noch ein ähnlicher Plexus zwisehen der Ring- nud der inneren Lïngsmuskulatur, der durch radiäre Nervenästehen mit dem äußeren zusammenhängt. In dem Plexus wiederholen sich zahlreiche ringförmige (quere) Stränge, die durch viele Anastomosen verbunden sind (Fig. $327 A_{1}$ ). Ganglienzellen sind darin nur spärlich verbreitet. Jedenfalls ziehen von dem äußeren Plexus auch Ästchen zur Epidermis. -- Bei den Enopla (Metanemertina) findet sich ein soleher Plexus nicht mehr; vielmehr entspringen von den Seitensträngen dorsal und ventral in regelmäßigen Abständen (den sog. Septen zwischen den Darmtaschen eingelagert) Nerven. Die dorswen verzweigen sieh raseh und lassen sich bis in die Diagonalmuskelschicht verfolgen, in der sie sich ausbreiten, doch auch Zweige zum Epithel abgeben.

Von der dorsalen Cerebralcommissur ontspringt ein bis zum After ziehender Riickennerv (s. Fig. $327 A_{1}$ ) mit Ganglienzellenbelag, der bei den Inopla im äußeren Plexus verlänft, mit dem er sich verbindet. Von ihm zweigt such bald ein tiefer gelegener zweiter Rückennerv ab (fehlt den Enopla), der gewöl llich in der. Ringmuskelsehieht liegt und uit dem ersteren durch ¿ venfüdchen zu . vinmenhïngt. 
Die Cerebralganglien entsenden Nerven zum Vorderende, den Augen, dem sog. Froutalorgan und den Kopffurchen. - Von deu Ventrallappen der Cerehralganglien entspringt je ein Șchlunduerv mit Ganglienzellenbelag (Fig. $327 A_{2}$ ). Diese Pharyngealnerven verästeln sich in der Regel plexusartig und verbreiten sich am Mund und Schlund, zuweilen anch an Mitteldarm. - Ferner gehen von den Ventrallippen zwei (Anopla) bis zahlreiche Risselnerven ans (Lnopla), die im Rïssel einen weitmaschigen bis dichten Plexus mit Ganglienzellen bilden; in ter Stiletregion (Enopla) auch ringförmige Commissuren. DaB von den dorsalen Lappen Nerven zu den sog. Cerebralorganen gehen, insofern letzteru nicht mit den Lappun verschmolzen sind, wurde schon oben erwïhnt.

Der Nervenapparat der übrigen Würmer läßt sich mehr oder weniger bestimunt rou dem der Plathelminthen ableiten, indem der Centralteil in Prinzip aus dem Cerebralganglienpaar und zwei Hauptlïngssträngen besteht, welche in allgemeinen wohl den beiden Bauchsträngen der Plattwïrmer entsprechen.

Bei den Rundwïrmom (Nemathelminthes) tritt dies z. 'T. Rotatoria, Nematurhyncha, Acanthoeephala) noch ziemlich dentlich hervor, doch erscheint das System der beiden ersten Gruppen wegen ihrer Körperkleinheit bedentend vereinfacht. das Aer letzteren durch den Parasitismus stark modifiziert. Ua feruer das Nervensystem der Rotatorien und Nematorhynchen eben wegen ihrer Kleimheit weniger genau bekanit ist, so beginnen wir mit der Besprechung der Nematoden, deren Apparat wenigstens bej einzelnen größeren Formen (besonders _tsearis) sehr griindlich untersucht wurde und jedentalls bei allen Eunematoden in den Girundziigen nahe ibereinstimmt. Er zeigt jedoch in mancher Hinsicht starke Modifikationon und kann daher nicht als ein sehr ursprünglicher gelten. Diese Nodifikationen scheinen großenteils mit der besonderen Körperform der Fadenwürmer zusammenzuhängen, die im Querschnitt fast stets genau kreisrund ist, also gewissermaßen monaxon in Bezug auf die Längsachse. Dies führte auch zu einer gewissen liegelmäBigkeit in der Verteilung des Nervensystems und der Sinuesorgane im. Umkreis der Körperachse, d. h. zu einer Art sekundären Strahlenbaus nm die Längsachse. $\mathrm{Da}$ darin jedoch niehts Urspriingliches liegt, wie es manchmal aufgefint wurde, lassen der typisch bilaterale Gesamtbau, sowie die Beziehungen ‘u den iibrigen Würmern.erkennen. Das Nervensystem der Nematoden (besonders Ascaris, den wir der Schilderung zu Grunde legen) verrait, trotz seiner Modifikationen, eine gewisse Ursprünglichkeit, indem sich eine größere Zahl von Längsnervensträngen findet, wie es fuir die primitiven Plathelminthen gilt (s. Fig. 328). Diese Längsstränge scheinen jedoch gegenüber letzteren erheblich verändert, indem zwei mediane, ein starker Ventral- und ein schwächerer Dorsalstrang vorbanden sind. Etwas vor der mittleren Region des Ösophagus geht der Bauchnerv, unter paariger Verteilung seiner Fasern, in einen den Schlund quer dorsalwärts umgreifenden Nervenfaserring über (Commissura cephalica), der sich in der Dorsallinie mit dem Dorsalnerv vereinigt. Beide Medianstränge entspringen daher nach hinten aus dem Nervenring. Sie sind den sog. Medianlinien (od. -wiilsten) eingelagert, welche die 
Hantmuskulatur in eine reehte und linke Hälfte sondern. Wie bei der Besprechung der letzteren bemerkt wurde (s. S. 409), ist in der Regel auch eine sog. Seitenlinie vorhanden, welehe jede Muskelhälfte in ein dorsales und ventrales Feld teilt. Diese Linien werden gewöhnlieh als Einwueherungen der Hypodermis gedentet(obgleich die

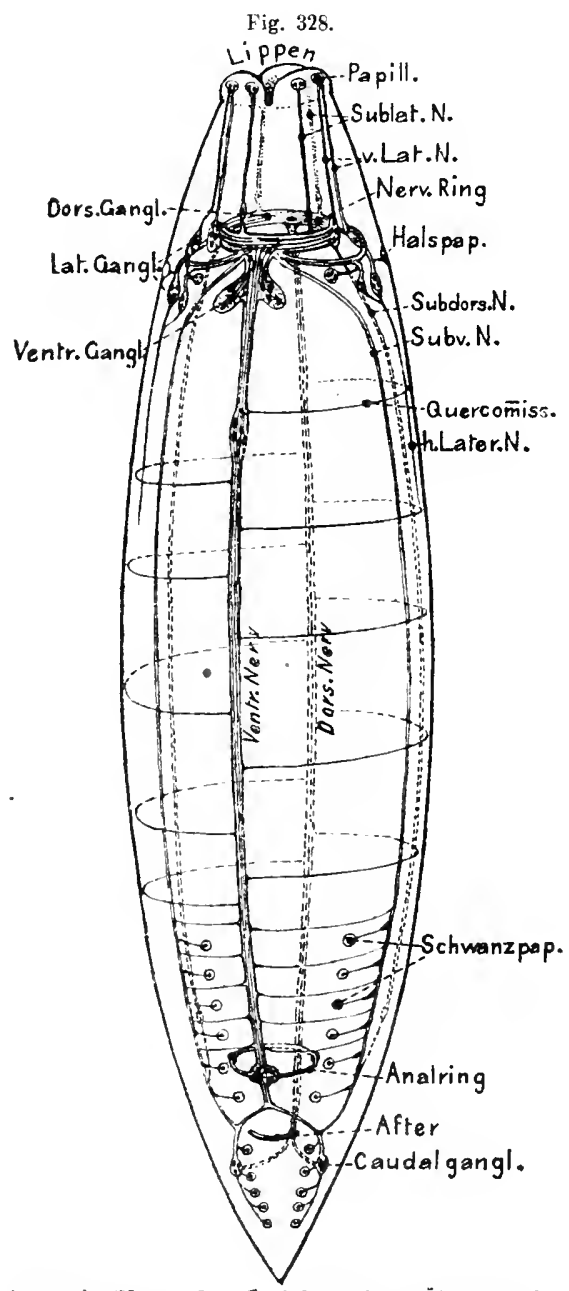

A searis (Nematode). O3. Schematische Übersieht des Nervensystems von der Bauchseite. Auf Grundlage der Untersuchungen v. R. GoLDschmint 1908 and 1909 u. Volzeviogel 1902 konstruiert. 0 . B.
Teilnahme des Mesoderms an ihrem Aufbau nicht ganz ausgesehlossen seheint). Wenn das erstere zutrifft, so liegen die beiden Mediannerven noch in der Epidermis, was für andere Nerven sicher gilt. Am Ursprung des Bauchnervs aus dem Nervenring findet sich eine größere Anzahl Ganglienzellen; diese Stelle ist daher zu einem mehr oder weniger ansehnlichen Ventralganglion (G. eephalicum ventrale) verdickt. Ein ebensolches, jedoch viel zellenärmeres Ganglion findet sich am Ursprung des Dorsalstrangs. Die Median- und Seitenlinien dringen vorn bis zum Nervenring ins Innere ein, so daß dieser, der den Sehlund dicht umzieht. seinen Znsammenliang mit der Epidermis in gewissem Grade bewahrt. Diesem Teil der Seitenlinien sind ebenfalls zahlreiche Ganglienzellen eingelagert, die sich auch noch eine Strecke weit nach hinten in ihnen ausdehnen, und meist eine Sonderung in Gruppen, oder eine Art sekundärer - Ganglienbildung zeigen (s. die schemat. Fig. 328). Von den Seitenganglien zieht ein schwacher Seitennerv nach hinten, der bald endigt. Zu den erwähnten vier hinteren Längsnerven gesellen sich gewöhnlich noch vier sehwache weilere, die beiden Subventrales (oder Sublaterales ventrales) und die beiden Subdorsales, welche etwas ventral und dorsal von den Seitenlinien hypodermal verlaufen und etwa am Abgang des Bauchnervs (Subventrales), bzw. des Seitennervs (Subdorsales), vom Nervenring entspringen.

In den Bauchnerv sind Ganglienzellen eingestreut, die in kurzer Entfernung von seinem Ursprung auch eine gangliöse Anschwellung bewirken können. Die medianen und die sublateralen Nervenstränge sind wesentlich motoriseh; von den 
Mnskelzellen tritt je ein Fortsatz zu ihnen und verbindet sich mit einer Nervenfaser (s. Fig. 273, S. 408); dagegen treten die Muskelfortsätze in der Region des Nervenrings direkt zu diesem.

Zum Kopfende entsendet der Nervenring seehs Nerven: vier sublaterale und zwei laterale, welche die seehs Doppelpapillen des Kopfendes versorgen, ,also rein sensibel sind.

Das Verhalten der Längsnervensträuge am Hinterende des Körpers ist beim Männchen und Weibehen etwas versehieden, was mit der Ausbildung der Begattungsorgane (Spieula) und der gewöhnlieh zahlreichen Tastpapillen am männlichen Hinterende zusammenhängt. In beiden Geschleehtern bildet der Bauchnerv am Beginn des Enddarms ein Ganglion (s. Fig. 328), das beim Männeben viel stärker ist. Von diesem Analganglion gehen einige Nervenfasern aus, die den Enddarm ringförmig umfassen (Analring). Kurz vor dem After gabelt sich der Bauchnerv, worauf sich seine beiden, rechts und links vom After nach hinten ziehenden $\ddot{A s t e}$ mit dem Hinterende der beiden Sublateralnerven jeder Seite vereinigen. Die beiden Sublateralnerven jeder Seite sind hinten in die Seitenlinien gerückt und schließlich zu einem Strang zusammengetreten. Etwas hinter dem After bildet jeder Ast des Fauehstrangs ein schwaehes Ganglion (Caudalganglion) und gibt $\mathrm{Zweige} \mathrm{zu}$ den hinter dem After stehenden Tastpapillen ab, die sieh beim Männchen meist reiehlieh, beim Weibehen zuweilen zu einem Paar finden (Ascaris). Anch der Dorsalnerv spaltet sich etwas hinter dem After und verbindet sich mit den Gabelästen des Bauchnervs. Wenn sich vor dem .After des Männchens zahlreiche Papillen finden, so werden sie von den subventralen Nerven versorgt; letztere sind dann sehr stark (Bursalnerven); die Sinneszellen der Papillen liegen in dem Nerv selbst.

Abgesehen von der Verbindung im Nervenring, stehen der Dorsal- und Rüekenstrang mittels Nervenfasern in Zusammenhang, die in der Hypodermis verlaufen und gewöhnlich asymmetrisch reehts und links in gewissen Abständen verteilt sind (s. Fig. 328). Auch in der Region des Nervenrings finden sieh sehon solehe Commissuren. Zwisehen dem Banehnerv und dem hinteren Teil der Subventralnerven bestehen ähnliche Verbindungen, die bei den Männehen sehr zahlreieh vorkommen, was diesen hinteren Teil der Subventralnerven zum sog. Bursalnerven verstärkt.

Auf die Besonderheiten des Systems bei den Gordiiden näher einzugehen, würde zu weit fübren; es sei bemerkt, daß sich nur ein sehr ganglienzellenreicher Bauchnerv findet, der. in seiner Gesamtheit jedenfalls die Baucblinie der Eunematoden repräsentiert. Am Vorderende geht er in eine, den rudimentären Schlund umfassende Ganglienzellenmasse (Cerebralganglion) über. Eine Afteranschwellung (Afterganglion) flndet sich in der Gegend des Enddarms (Kloake). Der Bauchstrang gabelt sich hinten wie bei den Eunematoden, indem er sich in die beiden Schwanzfortsätze erstreckt.

Wie bei den Rundwürmern überhaupt, ist die $Z_{a h l}$ der Ganglienzellen, selbst bei großen Fadenwürmern nur eine mäßige; so bei Ascaris in den mit dem Nervenring direkt zusammenhängenden Ganglien nicht höher als zirka 160. Auch die Zahl der Fasern in den Nervelı ist vielfach eine mäßige, ja zuweilen eine sehr geringe. Mit aller Sicherheit läßt sich gerade für die Fadenwürmer nachweisen, daß die Ganglienzellen vielfach direkt durch kürzere oder längere, zu Nervenfasern ausgezogene Brückell initeinander zusammenhängen, und zwar sowohl motorische mit sensibeln, als auch jede dieser Arten gelegentlich 
unter sich. Ebenso finden sich häufig Verbindungen der Nervenfasern durch Anastomosen. Nur an wenigen Stellen des Nervenrings tritt eine sehr feine Zerteilung der Nervenfasern zu einem Netz- oder Flechtwerk ein, wie es sich als sog. Punktsubstanz oder Neuropil im Innern des Cerebralganglions der seither betrachteten und später noch zu besprechenden Formen gewöhnlich findet. Jedenfalls scheint sicher, daß die Zusammenhänge im Nervensystem der Nematoden überail durcu direkten Übergang (Kontinuität), nie dagegen durch bloße Berïhrung (Kontiguität) gescheben.

Die Herleitung des Nervensystems der Fadenwürmer von Einrichtungen, wie sie den Plathelminthen und wahrscheinlich auch den Urformen der Rundwürmer eigen waren, scheint nicht allzı schwierig. Alles dürfte darauf hinweisen, Aaß sowohl der Ventral-als der Dorsal-

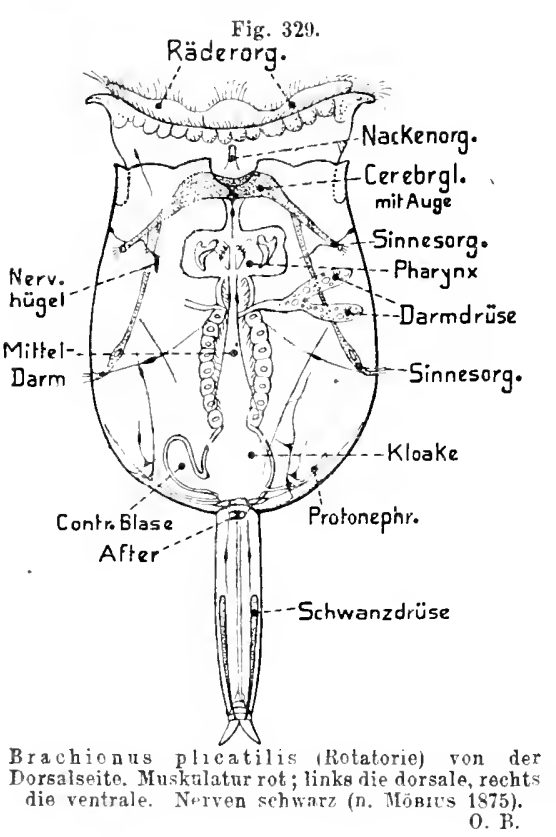
strang aus einer medianen Vereinigung ursprünglich paariger Längsstränge herrorgingen, und daß insbesondere der ansehnliche Bauchstrang aul die beiden Hauptbauchstränge der Plathelminthen rückführbar ist. Damit erklärt sich die Umbildung der Cerebralganglien 7.11 einem Nervenring mit angefügten Ganglien. Die Verteilung der ursprünglich parigen Cerebra]ganglien auf verschiedene Stellen dieses Rings darf als eine Folge dieser L'mgestaltung und der besonderen Körperform der Fadenwürmer aufgefaßt werden, ließe sich jedoch auch möglicherweise aus einer sehr primitivell allgemeinen Umbüllung des Schlunds mit Ganglienzellen ableiten, wie sie sich bei den Gordiiden findet. Sowohl die sublateralen Nerven als die hypodermalen Quercommissuren denten gleichfalls noch auf die zahìreichen Längsstämme der Plathelminthen, sowie deren primitiven allgemeinen Plexus hin.

Das Nervensystem der meist mikroskopisch kleinen Rotatorien und Nematorhynchen ist wenig bekannt und wohl sicher, wie der Gesalutkörper, gegenüber dem der Ausgangs-

formeu betrïchtlich vereinfacht. Ein meist recht großes, zuweilen etwas lappiges Cerebralzanglion läßt sich ïherall in Forderende, dorsal vom Schlund oder Pharynx (Rotatorien s. Fig. 329), leicht nachweison und greift häufig (namentlich Nematorhyncha) beiderseits weit un den Schlund rentralwärts herm, ja soll bei den Echincderen nach einer Angabe zu einem Nerrenring um len Schlund revellossen sein, wie bei den Nematoden. Äußerlich ist seine Parrigkeit in der Regel wenig angedeutet, innerlich dagegen ausgeprägt. Vom Cerebralganglion zichen bei den Rotatorien mehr oder weniger zahlreiche Nerven nach vorn zum Räderorgan und lessen Tastapparaten, ebens, dem sog. Rïssel (wenu er sorhanden), zum unpaaren oder paarigen vorderen dorsalen Taster, doch auch zu den Muskeln des Vorderendes. - Bei den Nematorhynchen scheint das Cevebralganglion ïberall mit der Hypodermis direkt zusammenzuhäıgen und die Sinneszellen des Vorderendes (Gastrotricha) solleu im Ganglion selbst liegen. Caudalwärts entsendet das terebralganglion der Gastrotrichen zwei Nerven, hie his ans Hinterende verlaufen, während bei den Erhinoderen ein unpaarer Bauchners vom Nervenring nach hinten zieht, der jedoch wohl aus einer Vereinigung der beiderı Stränge der Gastrotrichen hervorging. In diese Nervenstränge (auch die vorderen) sind Ganglienzellen eingeligert, welche bei den Echinoderen leṇ Cuticularringen entsprechende ganglï̈se Anschwellungen des Bauchners herrorrufen (was jedoch auch bestritten wird). Zwei seitliche und ein dorsaler epidefmaler Strang wurden ferner bei den Fchinoderen beschrieben. die 
mit entsprechenden Längsreilien von Sinnesorganen zusammenhängen und wohl von Cerebralganglion entspringen.

Bei gewissen Rotatorienweibchen (Callidina, Discopus) gehen ebenfalls vom Cerebralganglion noch mehrere nach hinten zichende Nerren aus, die jedoch sehr fein sind, gewöhnlich sogar nur aus einer oder weuigen Fasern bestehen, in die' Ganglienzellen eingeschaltet sind; jederseits ein Lateralnerv, weiter ein Paar Bauchnerven, die sich bald in zwei spalten; ferner ein zarterer Rückennerv, der zum Darm und den Geschlechtsorganen verfolgt wurde, - Bei den meisten Rotatorien wurde jedoch jederseits nur ein Lateralnerv beobachtet (s. Fig. 329), von dem aus auch der fast überall vorhandene sog. Lateraltaster innerviert wird.

Im Allgemeinen läßt sich daher das Nerrensystem der Nematorbynchen und Rotatorien, ebenso wie das der übrigen Nemathelminthen, von den primitiven Einrichtungen der Plathelminthen leicht ableiten. Es blieb jedoch primitiver als das der Nematoden, indem ein unpaarer Bauchstrang nur bei den Echinoderen gebildet wurde, die in ihrem Nervenapparat überhaupt nahe Beziehungen zu den Nematoden darzubieten scheinen (insbesondere nach der Darstellung Zelinka's).

Acanthocephala. Jaß sich auch bei den Acanthocephalen die allgemeine Anordnung des Nervensystems der primitiven Rundwürmer wiederholt, wird eine kurze Schilderung ergeben. Das mit einer mäßigen Menge, meist unipolarer Ganglienzellen versehene einheitliche Cerebralganglion liegt in Innern der hinteren Region der Riisselscheide (s. Fig. 330), zwisehen den Retractoren des Rüssels. Hieraus dürfte hervorgehen, daß die Rüsselscheide der Urformen noch vom Vorderdarm durchzogen wurde, welchem das Cerebralganglion dorsal auflag. Die beiden ansehnlichsten Nerven entspringen jederseits von der hinteren Region des Ganglions und verlassen die Riisselscheide, indem sie schräg nach hinten und seitlich zu den Seitenlinien der Körperwand ziehen. Durch die Leibeshöhle verlaufen sie frei und sind von feinen Muskelfasern ungeben (sog. Retinacula). Die Lateralnerven ziehen dann in der Seitenlinie zwisehen den Hantmuskeln bis zum hinteren Körperpol, indem sio beiderseits Fasern an die Ring- und Längsmuskulatur, wie auch einige /weige an die Retractoren des Rüssels

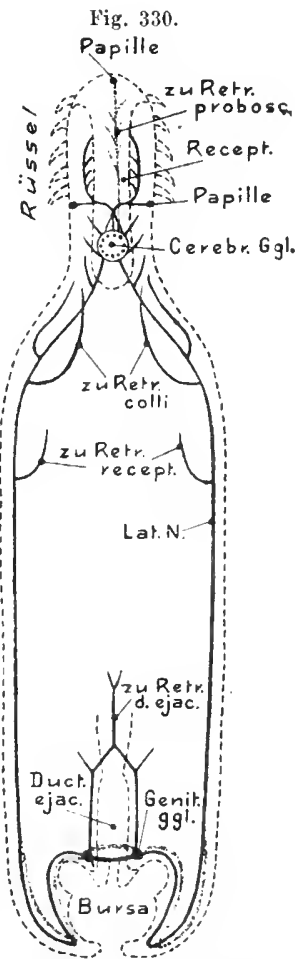

Echinorhynchus gigas 0 (Acanthocephale). Sehema des Nervensystems von der Dorsal. seite (auf Grandlage der Unter. suchungen von KaIsEr 1\$93 u. mit Benutzung einer Figur von BRANDES 1899). C. H. und Halses (Eeh. gigas) abgeben. In einiger Entfernung vor dem Hinterende kann (Eehinorhynchus gigas) sich der Lateralnerv in zwei Äste teilen. Bei den Mänuchen (Fig. 330) biegen diese zwei oder vier Nerven an der Genitalöffnung nach vorn um und steigen am sog. Bursalsack empor. An dessen Guunde, da wo sich der Duetus ejaculatorius mit ihm vereinigt, bilden sie zwei ansehnliche Genitalganglien, die durch eine dorsale und ventrale Commissur ringförmig um den Dnetus ejaeulatorius zusammenhängen. Zarte paarige Nerven gehen von den Genitalganglien teils nach vorı zur Muskulatur des männliehen Ausführapparats, teils naeh hinten 
zu den Muskeln des Bursalsacks, zum Penis und den Tastpapillen der Bursa. Bei den Weibchen verhalten sich die Lateralnerven am Hinterende einfacher, namentlich fehlen die Genitalganglien.

Nach vorn und seitlich entsendet das Cerebralganglion teils paarige, teils unpaare Nerven in verschiedener Zahl (s. Fig. 330), die sowohl die Rüsselmuskulatur und Riisselhaken als die Tastpapillen innervieren, welche sich wenigstens bei gewissen Arten am Kiissel in geringer Zahl finden.

Wie gesagt, 1̈ßt sich der Nerrenapparat der $A$ canthocephalen mit dem der ursprünglichen Rundwürmer, die paarige Bauchseitenstränge besitzen, wohl vergleichen; denn daß die Lateralstränge der Acanthncephalen den seitlichen Strängen der Rotatorien und Nematorhynchen, sowie den Hauptlängssträngen der Plathelminthen entsprecheı, kann wohl kaum zweifelhaft erscheinen.

Anneliden. Es scheint sicher, daß sich das Nervensystem der typischen (xliederwürmer (Chaetopoda und Hirudinea) aus einem primitiven Zustand eñt-

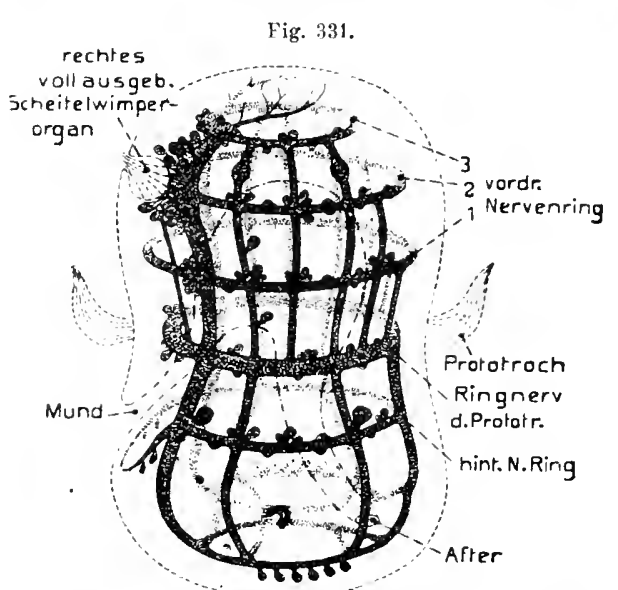

L o yad or ly nutus (Polychate). Nervensystem der Larve (n. E. Mlexer lyol konslrujert). v. Piu. wickelte, welcher dem der Plattwürmer ïhnlich war. Hierfü sprechen sowohl die anatomische Vergleichung als die Ontogenie, indem die Trochophoralarven der Polychäten ein Nervensystem besitzen (Fig. 331), das aus einer Anzabl Längsnerven besteht, die von einer am vorderen Körperpoł gelegenen, mit Sinnesorganen verbundenen Anlage des Cerebralganglions (Scheitelplatte) ausgehen, sowie einigen Ringnérven, von welchen die zum äquatorialen Cilienkranz (Prototroch) gehörigen, die ansehnlichsten sind. Auch ein allgemeiner Nervenfaserplexus, welcher das Ectoderm unterlagert, wurde bei gewissen Larven nachgewiesen (Polygordius). - Das Nervensystem der erwathsenen Gliederwürmer ist hei typischer Entwicklung dadurch ausgezeichnet, $\mathrm{da} B$ vom Cerebralganglion zwei ansehnliche Längsnervenstränge nach hinten ziehen, welche den Nund und Schlund umgreifen und sich hinter dem Mund an der Bauchseite gewöhnlich sebr nähern, so daß sie sich ventral vom Darm als ein gemeinsamer Strang (Banchstrang, Bauchmark) bis zum hinteren Körperende erstrecken. Daß dies Strangpaar den bei den Plathelminthen gowöhnlichen beiden stärkeren Bauchnervensträngen (Lateralnerven) entspricht, scheint kaum zweifelhaft, obgleich es auch bestritten wirl. Dies Banchmark der Gliederwtirmer ist ferner dadnrch ausgezeichnet, daß die Ganglienzellen, welche wir in den Banchnerven der Plattwürmer reichlich, ja bei den Nemertinen in ihrer ganzen Ausdelnung fanden, sich im Zusanmenhang mit der ausgeprägten Netamerie in der. Regel in jedem Metamer konzentrieren, nnd so an deu beidיn Strängen jedes Segments eine Gauglienamschwellung 
(Bauchganglien) bilden (s. Fig. 335 u. 336). Die die aufeinanderfolgenden Bauchganglienpaare verbindenden Teile der Stränge wer̨den als Längscommissuren oder -connective bezeichnet. Das vorderste Connectiv, welches die ersten Bauchganglien mit den Cerebralganglien verbindet, also den Schlund umgreift, ist das Schlundconnectiv (-commissur).

Im allgemeinen kommt daher jedem Segment ein Paar Bauchganglien zu, während die Cerebralganglien, die, wie oben bemerkt, am Vorderpol der Larve ('Trochophora), in deren sog. Episphäre entstehen, welche später zum Prostomium oder Kopfzapfen des Wurus wird, eben in diesem Prostom ilure ursprïngliche Lage haben. Die queren Commissuren zwischen den Längssträngen derPlathelminthen, die zuweilen schon eine, an Segmentation erinnernde regelmäßige Aufoinanderfolge zeigten, vérbinden bei den Anneliden die beiden zusammengehörigen Pauchganglien jedes Segments und gehen weiterhin seitlich als periphere Nerven vom Bauchmark ab.

Im allgemeinen scheint es gerechtfertigt, daß man das System der Cerebral- und Bauchganglien zusammen als das centrale Nervensystem auffaßt und ihm die, von den Gauglien entspringenden Nerren als peripheres System entgegenstellt. - Gehirn wie Bauchmark gehen aus dem Ectoderm hervor, jedoch in der Regel derart, daß ihre Anlagen anfänglich ohne sichtbaren Zusammenhang sind. Erst später verbinden sich die aus den beiden stärksten Längsnerven der Larve entstehenden Schlundconnective mit dern Vorderende der beiden ectodermalen Längswülste, welche das Banchmark bilden. Es ist jedoch mehr wie wabrscheinlich, daß diese Eigentümlichkeit der Ontogenese eine Abänderung des ursprünglichen Entwicklungsgangs darstellt, welche mit der beschleunigten ontogenetischen Ausbildung der Metamerie in der sog. Hyposphäre (Metastom) der Larve zusammenhängt; denn ein phylogenetischer Zustand, in welchem rlie Cerebralganglien tatsächlich vom Bauchmark getrenut gewesen wären, erscheint als eine unmögliche Annahme.

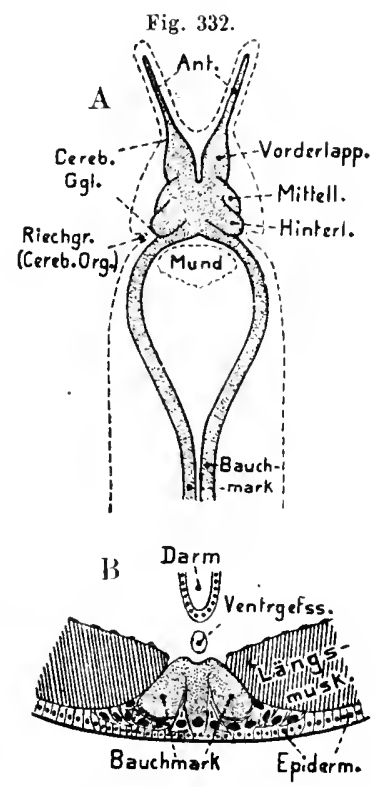

Poly gordi us (Archiannelide). Schematisch. $A$ Vorderer'Teil d. Centralnervensystems v. d. Bauchseite. Körperumrisse in Strichlinien (nach FratPoNT 1589) BQuersebnitt durch das Bauch mark und die angrenzende Kôrperregion (nach SALENSKY 1907). C. H.

Interessanterweise erbält sich die ontogenetische Verbindung des Centralnervensystems mit dem Ectoderm bei den Chätopoden und Gephyreen nicht selten im erwachsenen Zustand, indem es znweilen in seiner Gesamtheit direkt unter der Epidermis, außerhalb der Körpermuskulatur liegt (Archiannęliden [Fig. 332 B] und manche echte Polychäten, einfachere Oligochäten, Priapuliden unter den Gephyreen). Dieser Zustand scheint sich daher bei manchen Formen selbständig erhalten, oder wieder hergestellt zu haben. Bei anderen ist das Centralnervensystem in die Körpermuskulatur gerückt; bei den meisten aber durch diese hindurch in das Cölom. Nicht selten blieb jedoch die Verbindung mit der Epidermis teilweise erhalten, so gilt dies für die Cerebralganglien zahlreicher Polychäten und ebenso recht allgemein für das Analende des Chätopoden-Bauchmarks iiberhaupt. 
In dieser Hinsiclt bestehen große Vèrschiedenheiten, sogar bei nahe verwandten $\Lambda$ rten, ja bei einer und derselben, sodaß das Bauchmark in einer Körperregion epidermal in einer anderen cölomal liegen kann. Dłe peripheren Nerven, welche von den Ganglien entspringen, durchsetzen häufig, nach kurzem Verlauf in der Leibeshöhle, die Muskulatur, um unter der Epidermis weiter zu ziehen.

Wie bemerkt, liegen die Cerebralganglien ursprünglich im Prostom und sind meist deutlich parrig gebildet. Es kommt jedoch nicht selten vor (nameutlich Terricola und Hirudinea), daß sie mehr oder weniger weit über den Darmanfang nach hinten verschoben sind, bis ins dritte und vierte Körpersegment (s. Fig. 337). Sie erscheinen teils als ein Paar einfache gangliöss Anschwellungen, die in verschiedenem Grad verwachsen sind (namentlich Terricolen, gewisse Polychäten); doch sind sie manchmal auch nur schwach ausgeprägt, so daß die vorderen Enden der Schlndconnective fast ohne Anschwellung ineinander ubergehen.

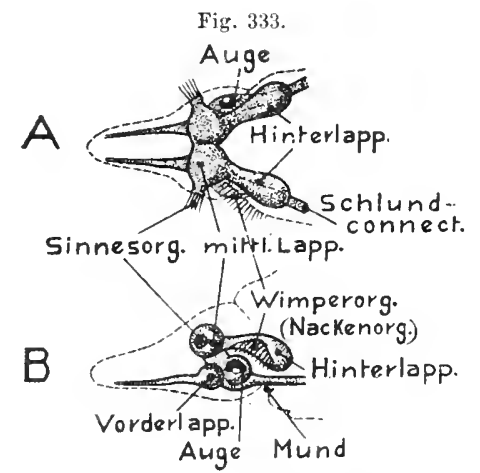

Cha etozone setosa (Polychăte), Cerebralganglien mit den Kopfamrissen (gestrichelt). $A$ von der Dorsalseite. $-B$ von der linken Seite (n. E. MeYer 1886). v. Bu.

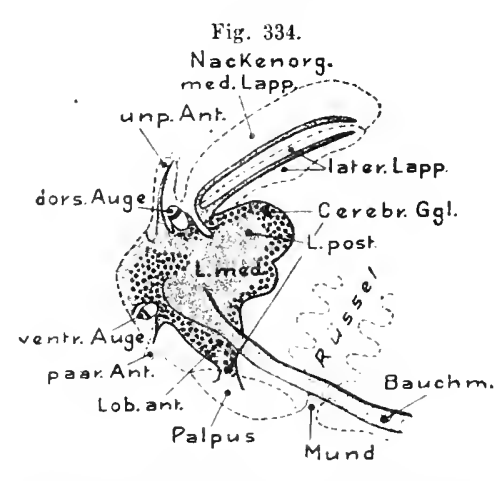

Eujhrosyne audouini (l'olychāte). C'ere bralganglion von links. Sehematisch. Kōrperumrisse in Strichlinien (n. Racoresza 18:46).

Dies gilt namentlich auch für die chätiferen Gephyrcen, bei denen jede Hirnanschwellung der langen Schlundconnective fehlt, während die Sipunculiden (unter den Achaeta) wohl entwickelte Cerebralganglien besitzen, die Priapuliden jedoch nur eine sehr schwache Anschwellung des Schlundrings. - Wie bei den seither besprochenen Würmern liegen die Ganglienzellen oberfächlich, die Nervenfasermasse im Innern (s. Fig. 340, S. 494).

Die Cerebralganglien zahlreicher Polychäten, Archianneliden und mancher limicolen Oligochäten, werden jedoch komplizierter, indem sie eine Anzahl lappiger Anschwellungen bilden. Im allgemeinen tritt namentlich eine Art Dreiteilung der Cerebralganglien dieser Formen auf (s. Fig. 332-333), nämlich in ein vorderes Lappenparr (Vorderlappen), von welchem die beiden Nerven zu den Palpen. (bzw. den Kiemenbüscheln der Serpuliden) entspringen, ein mittleres Lappenpaar (mittlere Lappen), welches die Antennen und Augen versorgt, und ein hinteres, das von der dorsalen Region des mittleren nach hinten ausgeht, und sich zu besonderen Sinnesorganen (Wimpergruben oder Nackenorgane) begibt, welche wohl den Cerebralorganen der Nemertinen homolog sind; weshalb auch 
die hinteren Hirnlappen denen der Nemertinen entsprechen dürften. Von dem Ausbildungsgrad der Simnesorgane, die durch die Hirnlappen versorgt werden, hängt natırgemäß deren Größe ab; zuweilen sind sie stark bis völlig rückgebildet.

Eine eigentümliche Bildung zeigen die Hirnganglien der Hirudineen (Fig. 338), deren Ganglienzellen zu Gruppen (Paketen) vereinigt sind, die meist lappig über die Oberfläche vorspringen (6-10 jederseits). Eine direkte Beziehung zu dell für die Polychäten geschilderten Verhältnissen scheint jedoch nicht zu bestehen.

Wie bemerkt, sprechen sowohl die vergleichend anatomischen als die ontogenetischen Verhältnisse dafür, daß das Bauchmark der Anneliden ursprünglich aus zwei gesondert nebeneinander hinziehenden Nervensträngen bestand, und daß jedes Segment ein Paar Banchganglien oder -knoten enthielt (Bauchganglienkette). Es gibt jedoch nur relativ wenige Formen, welche diesen Bau in ausgebildetem Zustand zeigen, und auch für diese ist es fast wahrscheinlicher, daß sich die beiden Stränge erst seknndär mehr gesondert haben (s. Fig. 336). Bei der großen Mehrzahl sind die Bauchstränge in ihrer ganzen Ausdehnung in der ventralen Mittellinie so innig zusammengetreten, $d a ß$ sie zu einem einzigen verwuchsen (Fig. 335). Dies gilt in gleicher Weise für die Ganglienpare jedes Segments, welche in der Regel so völlig vereinigt sind, daß die Paarigkeit äußerlich nur selten angedeutet ist. Innerlich läßt sie sich jedoch sowohl an der Sonderung der beiden Längsnervenfaserzüge in den Connectiven, als an dem, oder den queren Faserzügen in den Ganglien noch erkennen, welche den ursprünglichen Quercommissuren entsprechen.

Hüchst auffallend erscheint daher, $\mathrm{da} \beta$ bei gewissen tubicolen Polychäten (Serpulacea und Hermellacea, sowie vereinzelten Errantia nnd den Archianneliden Polygordius, Fig. 332, und Saccocirrus) eine völlige Sonderung der Bauchstränge, und bei den Tubicolen z. T. ein weites Auseinanderrücken derselben vorkommt; womit natürlich verbunden ist, daß sich zwischen den weit voneinander gerückten Ganglien jedes Segments lange Quercommissuren ausspannen. Das Bauchmark erlangt so den strickleiterfömigen Habitus (s. Fig. 336). Der Grad des Auseinanderweichens beider Stränge ist recht variabel, meist sogar bei demselben Wurm in den verschiedenen Körperregionen. Obgleich die weite Trennung der Stränge neuerdings gewöhnlich als eine sekundäre Erscheinnng beurteilt wird, so dürfte doch der Zustand geringerer Sonderung, in welchem sie noch dicht nebeneinander hinziehen, dem primitiven entsprechen. - Sehr variabel erscheint die Anschwellung und damit die Deutlichkeit der Bauchganglienknoten. Bei den Chätopoden treten sie häufig nur recht schwach hervor, so daß sich der gegliederte Charakter des Bauchmarks wenig ausspricht, namentlich dann, wenn sich, wie es gleichzeitig nicht selten vorkommt, die Längsconnective sehr verkürzen und undentlich werden. - Dazu kann sich (Terricolae, manche Polychäten mit ähnlichem Bauchmark) eine Ausbreitnng der Ganglienzellen anf die Connective gesellen, was die Gliedernng natürlich ebenfalls zurïcktreten läßt. Aus solchen Zuständen leiteten sich wohl diejenigen ab, wie sie bei den Archianneliden (Polygordius, Protodrilus, doch auch einzelnen echten Polychäten) vorkommen, 
die keinerlei Ganglienanschwellungen des Bauchmarks mehr zeigen, sondern eine gleichmäßige Verteilung der Ganglienzellen über das ganze Mark. Dasselbe gilt für die Gephyreen, deren Bauchmark ein gleichmäßiger Strang ist.

$\mathrm{Da} B$ es sich auch bei den letzteren um eine Rückbildung handelt, welche mit der der gesamten Metamerie Hand in Hand geht, läßt sich für die chätiferen Gephyreen (insbesondere Echiuren) ontogenetisch erweisen, da der Bauchstrang bei der Entwicklung paarig auftritt und Ganglienanschwellungen besitzt, die sogar bei dem jungen Wurın noch zu beobachten sind.

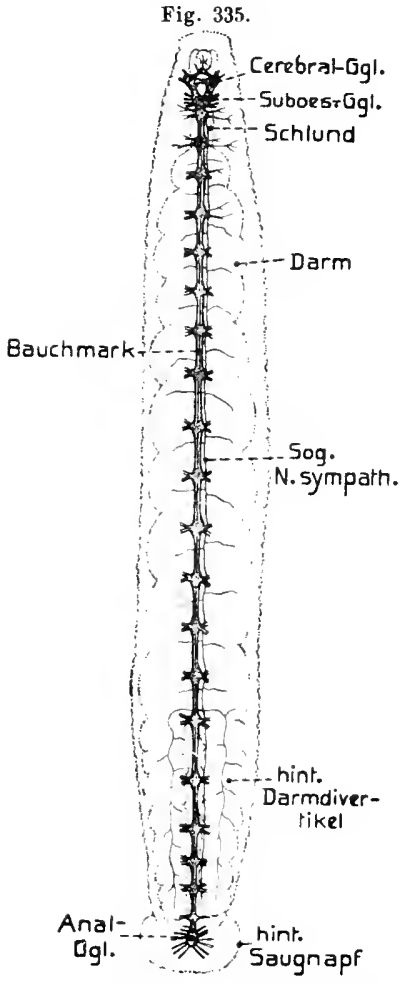

Hirudo medicinalis (Blutegel). Centralnervensystem von der Dorsalseite. Körperumrisse und Darm in Strich]inien; letzterer nicht sehr korrekt wiedergegeben (n. LeYdig 1864). P. He.

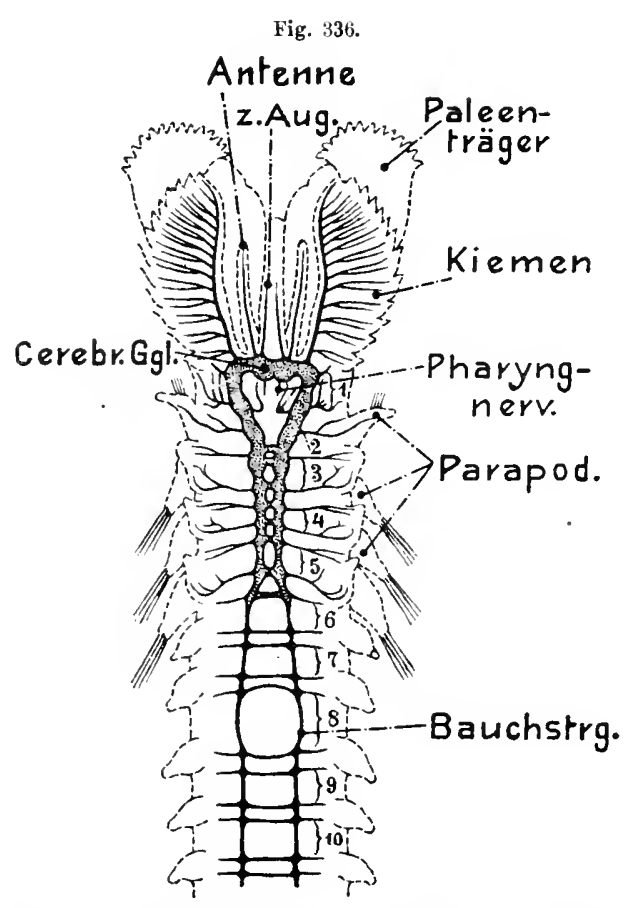

Sabella alveolata (sedent. Polychāte). Vorderer Teil des Centralnervensystems von der Ventralseite. Die eingeschriebenen $Z$ ahlen geben die betreffenden Segmente, nebst den zugehörigen Nerven an (n. E. Merer 1886). v. Bu.

Die Ganglienzellen nehmen in den Ganglienknoten die ventralen und lateralen Partien ein (s. Fig. 340, s. 494). Bei den Hirudineen gruppieren sie sich in ähnlicher Weise zu Pąketen wie in den Cerebralganglien, so daß sich in jedem Ganglion gewöhnlich zwei hintereinander liegende medioventrale und jederseits zwei hintereinder liegende laterale Pakete unterscheiden lassen, wobei die vorderen und hinteren Lateralpakete je durch einen queren Faserzug verbunden sind.

Mit einer ähnlichen Differenzierung der Ganglien muß es zusammenhängen, daß sie bei gewissen Polychäten (besonders den Serpulacecn und Hermellaceen) sogar in zwei Knoten gesondert sind, von denen ein Paar ganz vorn, das andere 
hinten im Segment liegt (Fig. 336). Selbst Auflösung der Ganglien in drei Knoten soll vorkommen (Pectinaria).

Häufig sind die vordersten Ganglienknoten des Bauchmarks sehr dicht zusammengerïckt, ja innig miteinander verwachsen. Fiur die Hirudineen (Fig. 338, S. 492) gilt dies allgemein; es scheint sugar, daß regelmäßig die ersten vier Knotenpaare zu einem sog. Unterschlundganglion (Subösophagealganglion) vereinigt sind. Auch bei den Chätopoden kommt ähnliches wohl häufiger vor; so zeigt z. B. Myxicola ein ans den drei vordersten Knoten bestehendes Unterschlundganglion und anch bei Lumbricus erweist die lnnervierung der drei vordersten Körpersegmente, daß die drei ersten Ganglien im Unterschinndganglion vereinigt sind (Fig. 337). - In ähnlicher Weise sind die hintersten Ganglien der Hirudineen (gewöhnlich sieben) zu einem Analganglion verschmolzen (Fig. 335), was mit der Bildung des linteren Saugnapfs in Beziehung steht.

Periphere Nerven. Bei den Oligochäten und Hirndineen entsendet das Gehirn häufig ein Nervenpaar (oder wenige Pare) in den Kopfzapfen, welches auch die Angen versorgt, wenn solche vorhanden sind. Viel zahlreicher sind meist die Cerebralnerven der Polychäten, indem solche für die, im Höchstfall fünf Antennen, die beiden Palpen, die Angen (event. auch die Statocysten), sowie die Muskeln der Kopf-

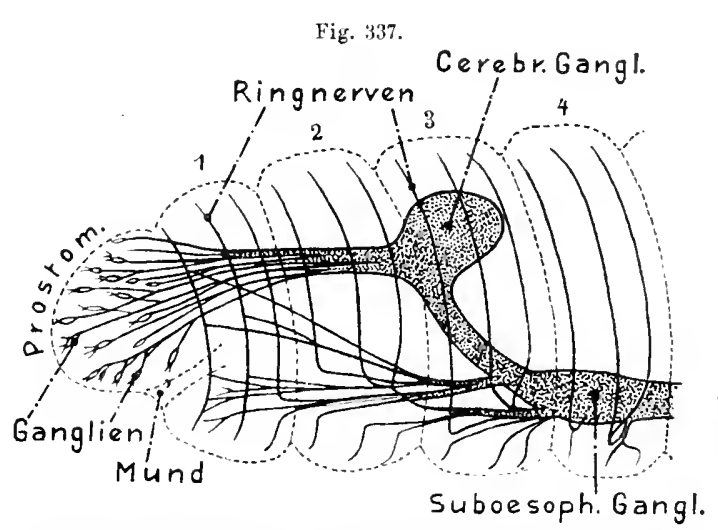

Lumbricus terrestris. Vorderende des Centralnervensystems von links. Etwas schematisiert. Körpernmrisse in Strichlinien. Die Zahlen geben die Segmente an (n. Hessf. 1894). v. Bu. region vorbanden sind; doch zeigen diese Verhältnisse im Einzeluen natürlich große Mannigfaltigkeit. Auch die Schlnndconnective entsenden z. T. Nerven, die aber wohl meist solche sind, deren Ursprung aus dem Untersehlundganglion auf die Connective verlagert wurde.

Die '/ahl der peripheren Nerven, welche von den Banchganglien entspringeu, variiert; häufig finden sich nur ein bis zwei Paare, znweilen jedoch auch mehr (s. Fig. 337-339); doch könmen auch von den Längsconnectiven zwischen den Ganglien Nerven ansgehen, die dann in den Dissepimenten verlanfen. Die Hauj, nerven der Segmente steigen inner- oder außerhalb der Muskulatur ringförmig gegen den Rïcken empor und vereinigen sich nicht selten dorsal zu einem Ring. So tinden sich sowohl bei Terricolen (Fig. 337) als Hirudineen (Fig. 338) in jedem Segment gewöhnlich drei solche Ringnerven, die teils die Muskulatur, teils die IIantsinnesorgane innervieren. Auch bei den meisten Gephyreen ist die Ringbildung der Nerven gut entwickelt. Bei den Polychäten besitzen die Hauptnerven, die zu den Parapodien ziehen, Läufig sekundäre Ganglienanschwellungen (Fig. 339, S. 493) 
Ein Schlund- oder Pharyngealnervensystem (sog. Vagus, Visceralnervensystem) scheint allgemein verbreitet und entspricht wohl den Schlundnerven, die wir schon bei den Plathelminthen trafen. Im einfachsten Fall sind es zwei Nerven, die von den Cerebralganglien oder den Schlundconnectiven entspringen und zum Pharynx ziehen, in dessen Wand sie einen Plexus bilden, dem Ganglienzellen eingelagert sind. Hänfig verbinden sich anch die beiden Schlundnerven zu einer

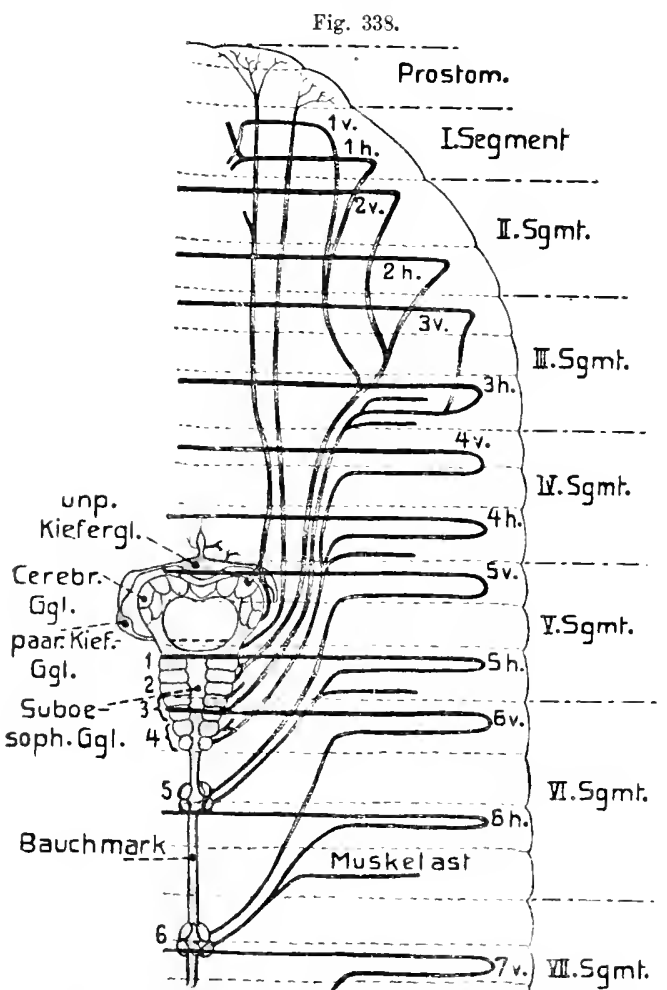

Hirndo medicinalis. Vorderer Teil des Centralnervensystems von der Dorsalseite. Körperumrisse in Strichlinien. In jedes Segment gehen ein vorderer $(1-7 v)$ and ein hinterer $(1-7 h$ sensibler ringförmiger Hautnerv, welche die Hautsinnesorgane versorgen. Ein Teil des Schiuudnervensystems ist angegeben (i. Liwasuw Igot, etwas verandert). queren Schlinge, oder zu einem, den Pharynx umziehenden Ring, in den Ganglien eingeschaltẹt sind. Letzteres ist z. B. bei den gnathostomen Hirudineen der Fall (Fig. 338), wo sich für jeden der drei Kiefer ein Ganglion in dem Ring findet.

Ist ein ausstülpbarer Rüssel vorhanden, wie bei den rhynchobdellidenHirudineen undinsbesondere den erranten Polychäten, so wird auch dieser vom Schlundnervensystem versorgt, welches bei den Errantia eine hohe Komplikation erlangen kann (s. Fig. $339 \mathrm{~A}$ ). Dies geschieht einmal dnrch Vermehrung seiner Wurzelursprünge, andrerseits durch Bildung zahlreicher Längsnerven, die in der Rüsselwand verlaufen nnd durch mehr oder weniger zahlreiche Ringnerven verbunden sind, wobei dem System gleichzeitig zahlreiche Ganglien eingeschaltet sind.

Ein eigentïmlicher, sog. sympathischer Nerv findet sich bei Hirudo (Fig. 335, S. 490), der über oder neben dem Baucbmark an der Ventralseite des Darms hinzieht und zu den Darmtaschen Äste abgibt, in deren Wänden sie eiven reichen Plexus mit Ganglienzellen bilden. Yorn steht Aer Plexus wahrscheinlich mit dem des Pharynx und Schlunds in Verbindung, was nmso wahrscheinlicher ist, als ein Zusammenhang des sympathischen Nerrs mit dem Bauchmark nicht gefunden wurde. - Eventuell hierher gehörige, jedoch paarige Stränge längs des Bauchmarks wurden bei gewisssen Polychäten beobachtet (Euniciden).

Im Centraluervensystem der Chätopoden treten die schon bei den Nemertinen, ja den \#ydromedusen, gefundenen dicken Nervenfasern (sog. Neurochorde, riesige Nerrenfasern, Nervenröhren) häufig, und zum'Teil in sehr regelmäßiger Weise auf, obgleich sie auch einzelnen Gruppen ganz fehlen. In der Regel durchziehen ein, zwei, drei, oder ziemlich riele solche Neurochorde das ganze Bauchmark in der Längsrichtung (bei Terricolen, Fig. 340, meist drei), die gewöhnlich dorsal 
liegen, seltener ventral. Sie hören entweder vor dem Beginn des Schlundrings auf, oder können auch in die Schlundconnective eindringen, ja sich in die Cerebralganglien fortsetzen. Diese Neurochorde erreichen zuweilen eine ganz auffallende Dicke, namentlich bei gewissen Serpulaceen: so wird z. B. das einzige Neurochord ron Myxicola so voluminös wie das ganze übrige Bauchmark. Die Neurochorde besitzen in der Regel eine recht dicke, geschichtete Neurogliahülle, auch scheint ihnen zuweilen eine dem sog. Nerrenmark der markhaltigen Nervenfasern der Vertebraten entsprechende Scheide zuzukommen. Die eigentliche, von diesen Scheiden umschlossene Nervenfaser ist ziemlich strukturlos. Stellenweise finden sich auch Verzweigungen, sogar reichere Verästelungen der Neurochorde, sowie Anastomosen zwischen denen des Bauchmarks. Ebenso kommt Vereinigung mehrerer Neurochorde $z$ n einem einzigen vor. Dagegen wurde der Eintritt von Zweigen in die peripheren Nerren fast nie beobachtet.

Daß die Neurochorde ihren Ursprung voll ansehnlichen, bis sehr großen Ganglienzellen des Bauchmarks nehmen, wurde sowohl bei Oligochäten als Polychäten mehrfach erwiesen. Solch große (riesige) Granglienzellen können sich sogar ziemlich regelmäßig in einer größeren $Z$ ahl der Bauchganglien wiederholen. - Über die physiologische Bedeutung der Neurochorde ist kaum Sicheres bekanut; nur soriel scheint, gegenüber älteren Meinungen, festzustehen, daß es sich in der Tat nm nerröse, nicht etwa um stützende Elemente handelt.

Oligomera. Im Anschlusse an die Gliederwürmer möge kurz üher das Nervensystem der ron uns als Oligomera (siehe S. 40) zusammengefaßten Metazoen berichtet werden. Es sind dies Formen, welche eine'geringe Anzahl (2-3) wenig deutlicher Segmente erkennen lassen. Die Zählung dieser Segmente hängt $a b$ von der Auffassung des vor dem Mund liegenden Körperabschnitts (Kopfschild der

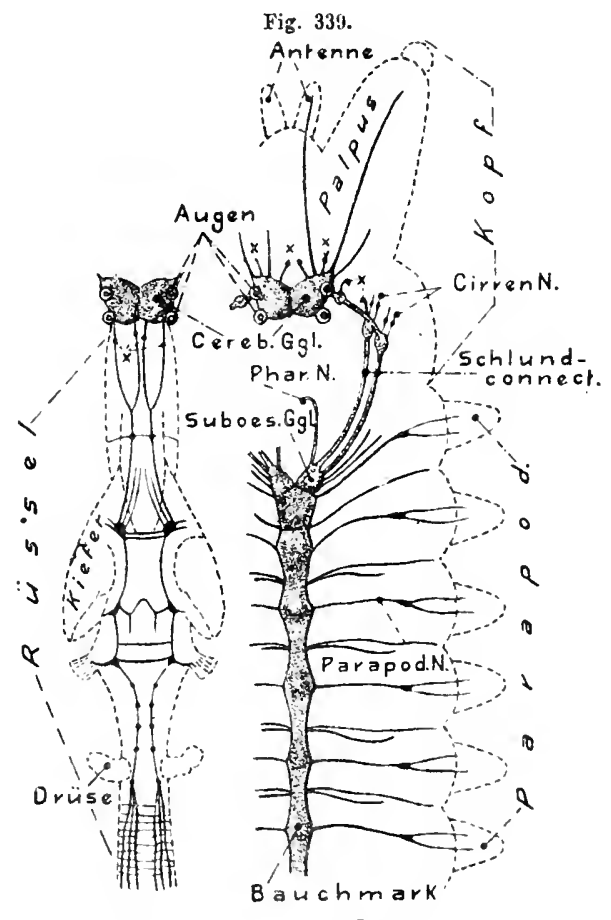

A

Nereis (Polychäte). $B$ Vorderregion des Centralnerven. systems mit den Körperumrissen (gestrichelt), von der Dorsalseite (n. QUatrefages 1550 nnd Verānderungen $n$. HAMACKer 1898). - A Der Rässel, in seiner natürlichen Lage zum Cerebralganglion von der Dorsalseite daneben gezeichnet, mit dem Schlundnervensystem (n. QuathafaGes $1850)$.

Pterotranchia, sog. Eichel des Entero-

pneusta) als Prostomium, oder als ein vorderstes Segment; die erstere Auffassung ist wohl die wahrscheinlichere. Die Möglichkeit wäherer Beziehungen der Oligomeren zu den Gephyreen mit ihrer weitgehenden Iä̈ckbildung der Segmentation und Vereinfachung des Nervensystems läßt die Vermutuıg zu, daß die Oligomeren eine Vereinfachung ihrer ursprünglich komplizierteren Organisation und vielleicht anch reicheren Gliederung erfahren haben könnten; dies ist umso wahrscheinlicher, als die meisten festgeheftete und daher wohl in gewissem Grad rückgebildete Tiere sind.

Der AnschluB an dle Anneliden spricht sich im Nervensystem derjenigen Oligomeren, welche keine weitgehende lieduktion dleses Systems erfahren baben, darin aus, daß sich ein vorderes, dorsal über dem Darm gelegenes Cerebralganglion findet, welches durch ein Paar 
Schlundconnective mit einer ventral rom Darm und weiter hinten liegenden Ganglienmasse zusammenhängt, die im allgemeinen ein Bauchmark, oder richtiger den vordersten Teil desselben, ein Subösophagealganglion darstellt. Rei reicherer Entfaltung des Systems, wie es die Brachiopoden und Chätognathen zeigen, ist dies Unterschlundganglion bedeutend ansebnlicher als das Cerebralganglion und sendet auch zahlreichere Nerven aus (s. Fig. 341 u. 343). Bei starker Vereinfachung des Systems (Bryozoen und Phoroniden) fehlt dagegen ein Unterschlundganglion ganz, oder es blieb nur ein den Schlund rentral umgreifender Nervenring bei den Phoronlden erhalten, der auch für manche Bryozoen (Lophopoda Fig. 342) angegeben, jedoch auch geleugnet wirl; bei der Mehrzahl der Bryozoen kominte er nicht aufgefunden werden. Wenn also diese Auffassung der Verwandtschaftsverhältnisse zutrifft, so erfuhr das Centralnervensystem eine wcitgehende Vereinfachung innerhalb dcr Gruppe. Einen nahezu allgemeinen Charakter der ganzen Gruppe bildet die epidernale Lage fast des gesamten Systems, speziell seiner Centralteile. Dieselben liegen dicht unter der Epidermis, ja meist in ihrer Basalregion, sodaß die histologische Beziebung des Nervensystem zur Epidermis

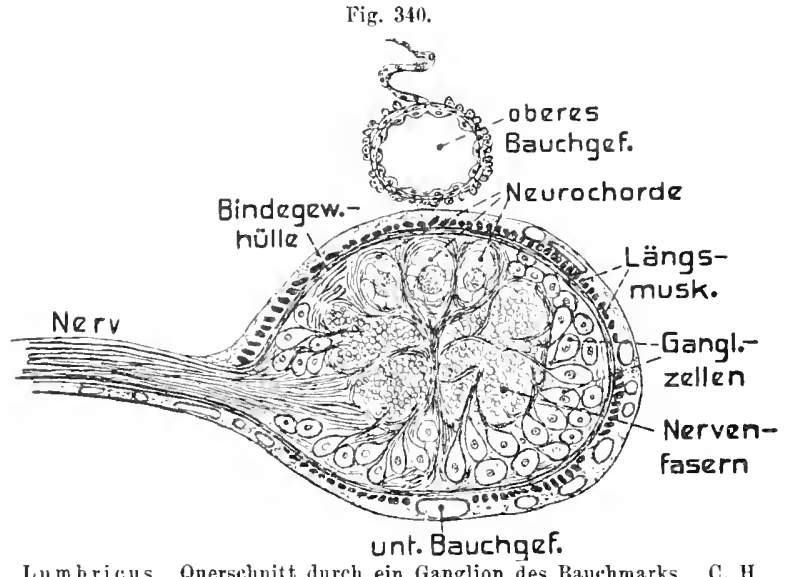

vielfach noch direkt an jene der Cölenteraten erinnert. In diesem Punkt erhält sich daher das Nervensystem sehr primitiv; doch galt dies woll anch für die ursprünglichsten Anneliden, wie schon oben dargelegt wurde.

Am interessantesten verhalten sich in dieser Hinsicht die sonst im allgemeinen hochorganisierten Enteropncusten, deren gesamites Nerrensystem, soweit es bekannt ist, in der Tiefe der Epidermis liegt, von Stützzellen derselben durchsetzt. Das Nerven-

systen der Enteropneusten erscheint sogar primitiver als alles, was wir seither unter den Würmern fanden, da die gesante Oberfläche des Körpers in der Tiefe der Epidermis von einer ziemlich gleichmäßigen Nervenschicht mit eingestreuten Ganglienzellen unterlagert wird, und die besonderen Nervenstränge nur als Verdickungen dieser Schicht erscheinen. - Bei den Brachıopoden und Chätognathen ist solch eine subepilermale Nervenschicht gleichfalls in ausgedehnter Weise erbalten, erscheint aber als ein Nervennetz (Plexus). Nur bei den Bryozoen hat sich das Cerebralganglion, das, wie bemerkt, hier das ganze System repräsentiert, von der Epidermis abgetrennt, und liegt zwischen Mund und After dem Schlnnd dorsal auf. Das Cerebralganglion der Chätognathen (s. Fig. 341) und Pterobranchier (s. lïg. 79, S. 175) ist gut entwickelt, weniger hingegen das der Brachiopoden (Fig. 343), wo es nur als eine Verdickung der dorsalen Partie des Schlundrings erscheint (Testicardines), oder anscheinend gar nicht hervortritt (Ecardines), indem seine Ganglienzellen auf die Hauptarmnersen, die sonst ron dem Ganglion entspringen, verlagert sind, das Cerebralganglion also gewissermaßen in seine beiden Hälften zerlegt ist, die seitlich weit von einander abgerïckt sind. Die Bryozoen zeigen es, wie bemerkt, in guter Entwicklung, jedoch wie bei den Oligomeren überhaupt, nur wenig leutlich'parig. Es liegt dem Schlund dorsal meist dicht anf, zwischen Mund und After. Bei den meisten Bryozoen wird es als ein solides Gehilde geschildert; nur für die Lophopoden (Fig. 342) wird angegeben, daß es einc ziemlich kompliziert gebaute innere Höhle besitze. Die Vergleichung init dem Nervensystem der verwandten Oligomeren läßt kaum bezweifeln, daß es sich um das gewöhnliche Cerebralgang- 
lion handelt; es möge jedoch erwäbnt werden, daß zuweilen nocb die Meiıung verfochten wird, es sei dem Subösophagealganglion zu homologisieren.

Im Nervensystem der Enteropneusten kann man elgentlich kaum von einem wirklichen Cerebralganglion sprechen. Die allgemeine Nervenschicht verdichtet sich in der dorsalen und ventralen Mittellinie zu einem dorsalen und ventralen Nervenstrang, von welchen letzterer vorn bis zum Hinterrande des Kragens zieht, hieranf jedelseits in der hinteren Kragenfurche zur Rückseite emporsteigt, um sich mit dem Rückennerv zu vereinigen (vgl. Fig. 78, S. 174). Daß der so gebildete Nervenring den Schlundring vertritt, ist daber recht wahrscheinlich, ebenso da $\beta$ der innerhalb des Kiragens liegende Teil des Dorsalnerss im Allgemeinen dem Cerebralganglion entspricht. Dies sog. Kragenmark ist dadurch eigentümlich, daß es sich von der Epidermis ablöst und in das Kragencölom einsenkt, aber, wenigstens bei gewissen Formen (Ptychodera), noch durch Zellstränge (Wurzeln) mit der dorsalen Epidermis und ihrer Nervensehicht zusammenbängt. Iras Kragenmark ist ziemlich reich an Ganglienzellen, darunter auch sog. "riesige", von denen röhrige Nervenfasern oder Neurochorde entspringen. Neurochorde wurden ferner auch bei den Chätognathen und Phoroniden beobachtet. Bei letzteren in sehr eigentümlicher Weise, indem vom Cerebralganglion aus eine solche Faser asymmetrisch linksseitig (selten paarig) weit nach hinten 20 verfolgen ist (sog. Seitennerv). - Das Eigentümlichste des Kragenmarks der Enteropneusten ist jedoch, daß es bei gewissen Formen von einem etwas unregelmäßigen Achsenkanal, oder ron Reihen von HohIräumchen durchzogen ist. liei einer jungen Ptychodera fand sich sogar eine vordere und hintere Öffnung des Achsenkanals nach außen. Diese Erfahrungen machen es wahrscheinlich, daß das Kragenmark einer Einstülpung der dorsalen Nerrenschicht seinen Ursprung verdankt, wodurch sich der Achsenkanal oder die Hohlräumchen erklärten. Dies ist umso interessanter, als sich die Enteropneusteh bekanntlich auch in anderen Organsystemen den Chordaten nähern. - Auch bei der Knospung der Bryozoen entsteht das Cerebralganglion durch Einstülpung; die Einstülpungshöble soll sich, wie bemerkt, bei gewissen Lophopoden sogar dauernd erhalten.

Fig. 341 .

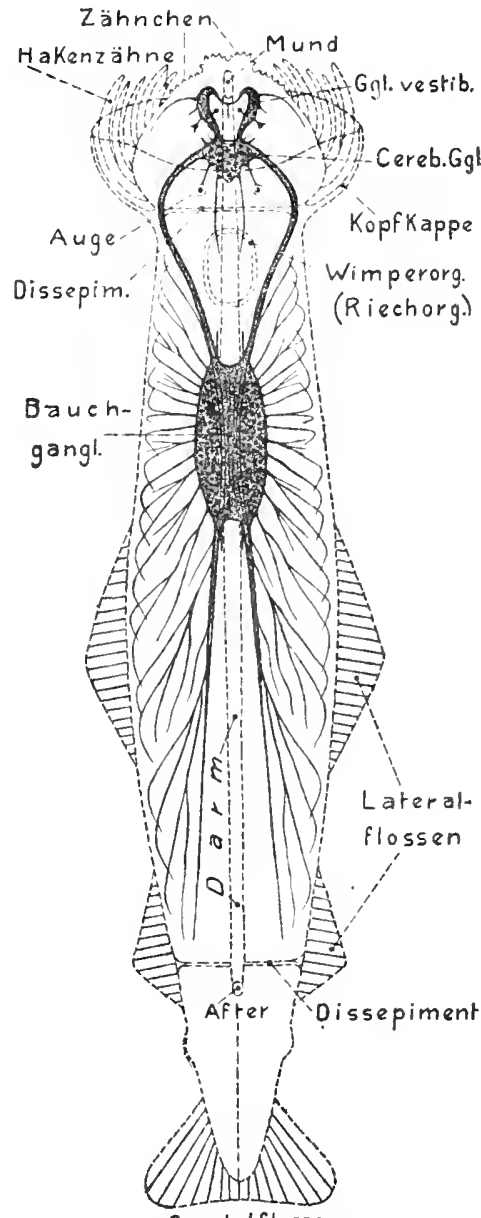

Caudalflosse

Sagitta (Chătognathe). Von der Bauchseite mit eingezeichnetem Nervensystem. Körper umrisse und Darm gestrichelt. Schematisch (n. O. Hertwig 1880 u. Grassi 18s3). v. Bu.

Das Cerebralganglion der Chätognathen (Fig. 341) liegt im vordersten Abschnitt, dem sog. Kopf (ob dieser jedoch dem Prostomium gleich zu setzen ist, ist etwas schwierig zu beurteilen, da die Mundïfnung weit rorn in diesem Abschnitt liegt). Bei den Pterobranchiern liegt'es im zweiten Abschnitt, dem sog. Halssegment, in welchem sich ja auch das Kragenmark der Enteropneusten findet. Da bei den übrigen Ordnungen der vorderste Abschnitt (Prostomium?) sehr verkümmert ist. so hat ibr Ganglion vermutlich eine ähnliche Lage.

Vom Cerebralganglion gehen Nerven zum vorderen Körperabschnitt und seinen Anhängell, so bei den Bryozoen und Phoroniden zu den Tentakeln (Cirren); und zwar bei den lopho- 
poden Bryozoen derart, daß in jeden Lophophorarm ein ganglienzellenreicher Nerv tritt, von dem feine Zweige zu den Tentakeın abgehen (Fig. 342). Man könnte diese beiden Nerven geradezu als ausgewachsene Teile des Cerebralganglions auffassen. In ähnlicher Weise tritt auch in jeden der beiden Brachiopodenarme (s. Fig. 343) ein starker Nerv (Hauptarmnerv), der längs der Basis der Armfalte hinzjeht, und zu den Cirren Äste abgibt, die sich an deren Basis gewöhnlich zu einem sog. Nebenarmnerv rerbinden. Zu dem Hauptarmnerv gesellen sich noch zwei weitere: ein sog. äußerer und ein unterer Armlängsners, die von den Schlundconnectiven entspringen. Auch bei Rhabdopleura (Pterobranchia) treten zu jedem Arm drei Nerven, ein dorsaler und zwei ventrale (Fig. 79, S. 175).

Vom Cerebralganglion der Chätognathen (Fig. 341) entspringen die Nerven für die beiden Augen und das Wimperorgan (Riechorgan, Hertwig); ferner nach vorn zwei an-

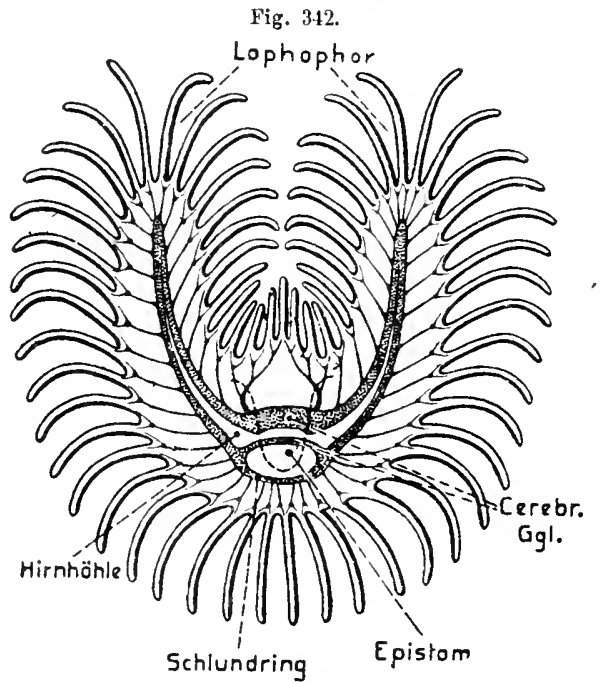

Scbema des Lophophors einer lophopoden Bryozoe mit dem Centralnervensystem. Ansicht auf die Mundscheibe. r. Bu. sehnliche Nerven, die einige sekundäre Ganglien bilden, und sich vor dem Mund zu einem Ring vereinigen. Die Zweige dieser Nerven gèen hauptsächlich zun Schlund, sie scheinen daher im wesentlichen eil Schlundnervensystem darzustellen, das auch bei gewissen Brachiopoden nachgewiesen wurde. Auch bei den lophopoden Bryozoen sendet das Cerebralganglion ein Paar Nerven zur ösophaguswand. - Vom Cerebralganglion der Pterobranchier entspringen ferner ein vorderer und ein hinterer medianer Dorsalnerv, die der vorderen und hinteren Fortsetzung des Kragenmarks der Enteropneusten in den dorsalen Nervenstrang vergleichbar erscheinen. Der vordere Dorsalstrang der Enteropneusten bildet um die Basis der Eichel einen Nervennug.

Das Unterschlundganglion ist uur bei den Brachiopoden und Chätognathen ansehnlich entwickelt, dew übrigen $\mathrm{Ab}$ teilungen fehlt ein solches Ganglion, doch Andet sich bei den Phoroniden, den Pterobranchiern (s. Fig. 79. S. 175) und Enteropneusten ein den Darm umziehender Schlundring der auch für die lophopoden Bryozoen von einzeinen Beobachtern beschrieben wird. Der Schlundring der Pterobranchier und Enteropneusten setzt sich nach seiner ventralen Vereinigung als ein ventraler Mediannerv bis ins hintere Körperende fort, sodaß sein Vorderteil wohl als ein Rudiment des Unterschlundganglions angesehen werden darf. - Von dem ansehnlichen länglichen Subösophagealganglion der Chätognathen (Fig. 341) entspringen, wie schon vom hinteren Teil der Schlundconnective, zahlreiche seitliche Nerren, die sich reich verästeln; hinten setzt es sich in zwei stanke Nervenstränge fort, die sich in ähnlicher Weise reich verzweigen. Alle diese Nerven gehen schließlich in den epithelialen Plexus über; irgend welche Beziehungen von ihnen zur Muskulatur wurden seither nicht aufgefunden.

Das breitere und kürzere Unterschlundganglion der Brachiopoden (Fig. 343) läuft nach hinten ebenfalls in zwei ansehnliche Nerven aus, welche die Stielmuskulatur versorgen. Bei gewissen Ecardinen (Crania) können die beiden Hälften des Ganglions seltlich weit auseinander gerückt und vorn durch eine breite Quercommissur verbundeu sein (analoge Verhältnisse wie bei gewissen Polychäten). Seitlich entsendet das Ganglion die Nerven für die Schlundmuskulatur, die des dorsalen und ventralen Mantellappens, deren Ursprung jedoch auch auf die Schlundconnective nach rorn, oder zuweilen auf die Stielnerren nach hinten verlegt 
sein kann, sowie jederseits einen dorsalen und ventralen Seitennerv, die an der Körperseite nach hinten ziehen und bei den Ecardinen hinten ringförmig ineinander äbergehen können. In die Nerven sind, wie bei den Chätognathen und Pterobranchiern, vielfach auch Ganglienzellen eingestreut.

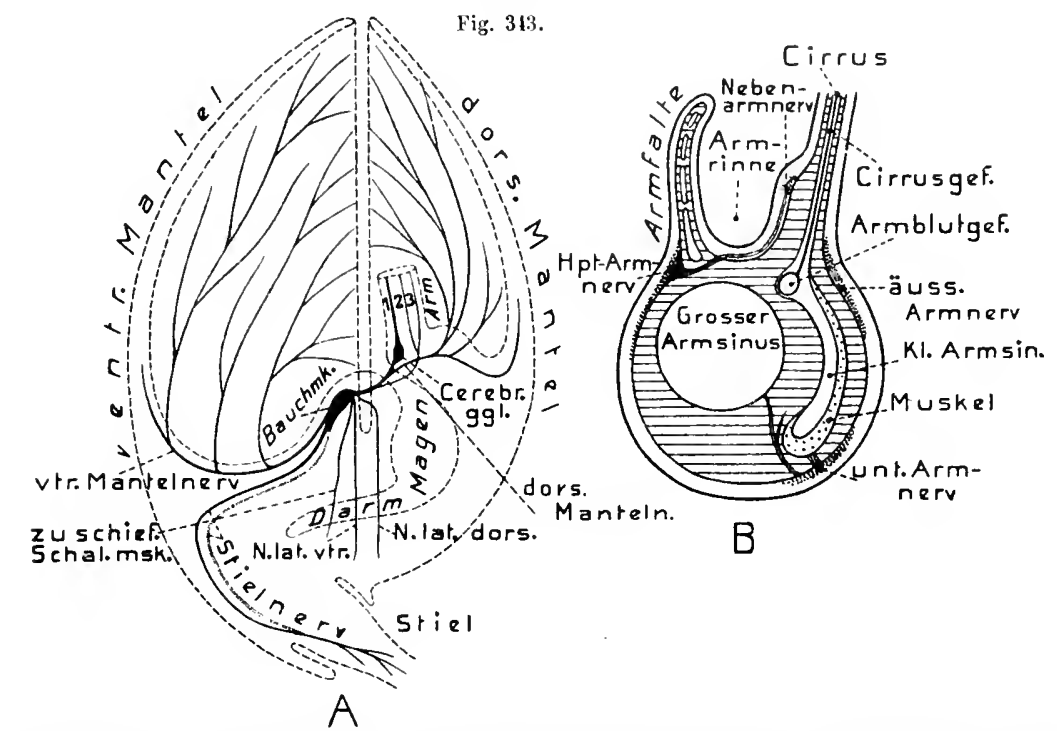

Nervensystem der Brachiopoden. A Schematische Darstellung des Nervensystems eines Erachiopoden von der linken Seite. 1. Halptarmnerv; 2. äußerer und 3. unterer Armnerv. - $B$ Querschnitt des Arms eines ecardinen Brachiopoden (Lingula). (N. v. Bemuelen 1892 und BlochmanN 1900). 0. B. n. v. Bu.

\section{Arthropoda.}

Das Centralnervensystem dieses größten Phylums der Bilaterien wiederholt in seinem allgemeinen Bau das der gegliederten Würmer so genau, daß alles, was dort ïber die Zusammensetzung des Apparats aus dem Cerebralganglion und dem gegliederten Bauchmark dargelegt wurde, wörtlich auch für die Arthropoden gilt. Es läßt sich daher kaum bestreiten, daß diese große Ähnlichkeit für den phyletischen Zusammenhang der beiden Gruppen in ibren Ausgangspunkten spricht. Wir hätten daher die Besprechùng des Systems der Arthropoden den Anneliden direkt anreihen können, wenn sich nicht die Schilderung der von den typischen Anueliden aberranten, jedoch wurmartigeren Gruppen zunichst empfohlen bätte.

Die Eigentiumlichkeiten, die sich am Centralnervensystem der Arthropoden hervorbildeten, hängen innigst mit den besonderen morphologischen Diflerenzierungen zusammen, welche die ursprïnglich bomonome Metamerie der Artbropoden in den

- sich entwickelnden verschiedenen Körperregionen erfulur. In dem Maß, als sich diese Differenzierung in dem Phylum allmählich komplizierte, nahm auch das Centralnervensystem daran 'l'eil, wobei sich aber als Endziel vielfach nicht eine höhere Komplizierung, sondern eine Vercinfachung des ursprïnglichen Baus ergab, wie wir ähnliches schon bei den von den Anneliden abgeleiteten Gruppen fanden.

Das Nervensystem besteht also überall aus dem vorn über dem Schlund liegenden ursprïnglichen Cerebralganglieupaar, das auch hier die Augen, d. h. so- 
wohl die seitlich paarigen Komplexaugen als die einfachen Augen (Ocellen), versorgt. Es entsteht in einem dem Prostomium der Gliederwürmer entsprechenden präoralen Körperabschnitt. Hierzu tritt postoral die ventrale Bauchganglienkette,

Fig. 341 .

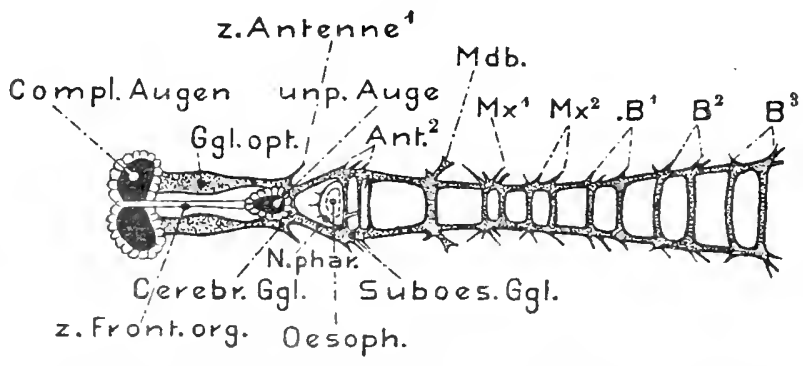

Limnadia lenticularis (Branchiopode). Vorderteil des Centralnervensystems von der Ventralseite. Der stark ventral herabgebogene Vorderteil ist in einer Ebene ausgebreitet dargestellt. $B^{1}-B^{3}$ die Nerven $z u$ den drei ersten Thorakalbeinen; $M x^{2}-M x^{2}$ zu den beiden Maxillen, $M d b$ zu Mandibel ( $\mathrm{xach}$

$$
\begin{array}{ll}
\text { NovikofF 1905). } & \text { C. H. }
\end{array}
$$

die sich jedenfalls wie bei den Anneliden ursprünglich aus ebensoviel Ganglienpaaren aufbaute, als Rumpfsegmente vorhanden waren (ansgenommen den hintersten Körperabschnitt, dassog. Telson). Da nun die Zahl der Rumpfsegmente bei den ver-

schiedenen Arthropodengruppen, ja zuweilen in einer und derselben, sehr schwankt (z. B. Crustaceen, Myriopoden), so ist natïrlich auch die Anzahl der Rumpfganglien sehr verschiedell.

Das primitive, im Kopf liegende Cerebralganglienpaar (Archencephalon), von welchem wie bei den Anneliden die Schlundconnective entspringen, erhielt sich jedoch bei den Arthropoden kaum irgendwo in seiner ursprünglichen Einfachheit,

Fig. 345 .

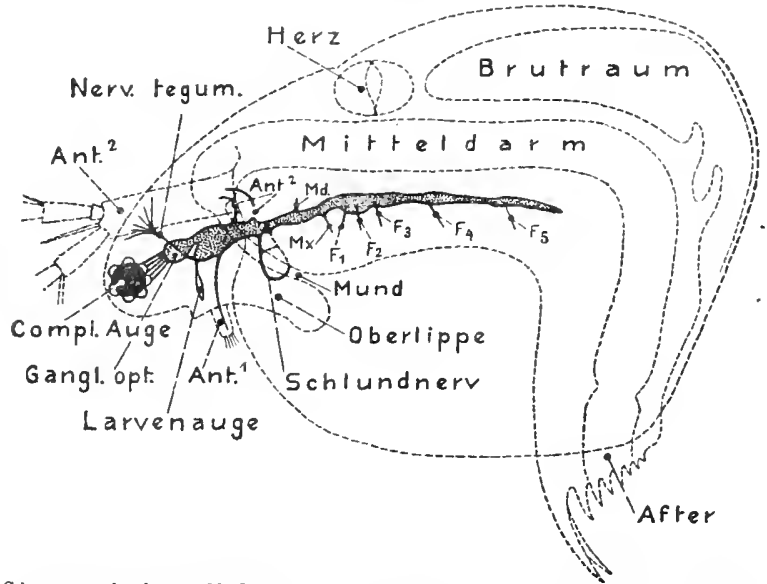

Simocephalus (Cladocere). Von links, mit eingezeichnetem Centralnervensystem. Körperumrisse gestrichelt. $F_{1}-F_{5}$ die Nerven der fünf Thorakalbeine (n. Connington 1!02). sondern komplizierte sich dadurch, daß unter. Verktirzung der primitiven Schlundconnective ein bis mehrere der vordersten Bauchganglien mit ihm als ein sekundäres Gehirn (Neoencephalon) innig zusammentraten. Nur die sebr primitiven Tardigraden (vielleicht anch die Pöcilopoden) ergaben bis jetzt keine Anbaltspunkte, daß ihre Cerebralganglien in dieser Weise kompliziert wurden.

Bei der Schwierigkeit, welche insbesondere die ontogenetische Untersuchung der kleinen Tardigraden bietet, läßt sich jedoch vorerst nur die Möglichkeit zugeben, daß die Cerebralganglien dieser Gruppe ausschließlich das ursprüngliche Archencephalon repräsentieren. 
Der Zutritt des Neoencephalon zum primären Archencephalon, wofür sich vielleicht auch schon bei gewissen Chätopoden Analogien finden, wurde bedingt durch die Hervorbildung eines besonderen Kopfabschnitts (Cephalon) bei sämtlichen Arthropoden (mit Ausnahme der Tardigraden; Rückbildungen dieses Abschnitts bleiben hier natürlich außer Betracht). Die vordersten Extremitäten (erstes oder erstes und zweites Paar) wurden dabei modifiziert, indem sie besondere Funktionen erlangten; sie wirken teils noch bei der Bewegung oder Ergreifung der Beute mit, teils sind sie reine Sinnesorgane für Geruchs- und Tastwahrnehmungen (Fühler) geworden. Dabei wurden sie in verschiedenem Grad vor den Mund verschoben, was auch die Vorwärtsverlagerung der ihnen zugehörigen ersten Ganglienpaare der Bauchkette und ihre endliche Verschmelzung mit dem Archencephalon bedingt. Wir können den Bildungsvorgang eines Neoencophalon bei den primitiven Crustaceen sogar noch vergleichendanatomisch verfolgen. Überall zwar ist bei diesen das Ganglienpaar des ersten Rumpfsegments, welches die ersten Antennen versorgt, mit dem Archencephalon vereinigt, doch entspringen die Nerven für die ersten Antennen bei den Phyllopoden häufig noch von den Schlundconnectiven (Apus, Cladoceren, s. Fig. 344),

Fig. 346.

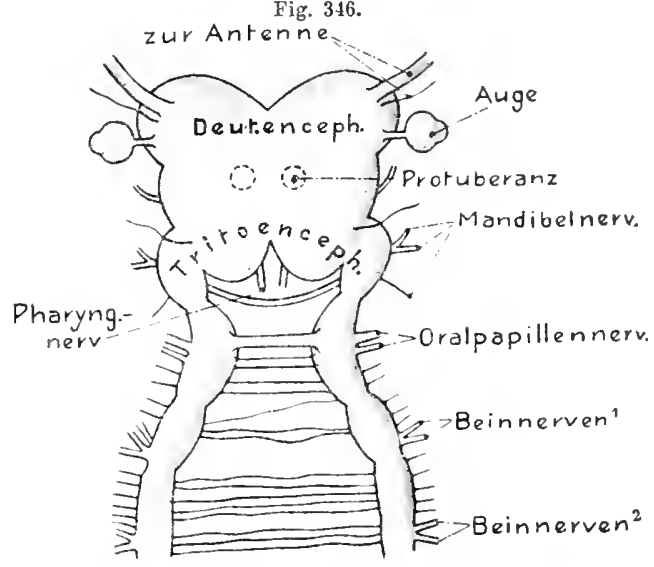

Peripatus jamaicensis Gv, et Cock. Gehirn von der Dorsalseite (n. Bouvier etwas verändert). v. Bu.

was eine gewisse Ursprïnglichkeit verrät; die Ganglien der zweiten Antennen dagegen sind bei den Phyllopoden noch ganz selbständig geblieben (s. Fig. 344) und bilden die voldersten Rumpfganglien. Bei den übrigen Crustaceen ist auch das Ganglienpaar der zweiten Antennen durch Verkürzung der Connective mit dem Hirn vereinigt (s. Fig. 350). Man bezeichnet diese beiden Ganglienpaare des Neoencephalon häufig als Deuterencephaion (1. Antenne) und Tritencephalon (2. Antenne) im Gegensatz zum Archencephalon (das auch Protencephalon genannt wurde 1). Sie treten häufig als lappige Vorsprünge (Lobi) auch änßerlich am Gehirn noch deutlich hervor (Fig. 350-351), und sind innerlich kenntlich durch Anhäufungen feinfaseriger Nervensubstanz (Punktsubstanz, Neuropil, Marksubstanz), sowie durch quere Fasercommissuren, wie sie ja jedem Bauchganglienpaar eigentümlich sind.

Selbst für die Protracheata (Peripatus, s. Fig. 346) ist der Zutritt der beiden vordersten Rumpfganglienpaare zum Archencephalon wohl sicher erwiesen; diese

1) Die Bezeichnungen Deutero- und Tritoencephalon, die häufig gebraucht und auch auf den Figuren verwendet wurden, sind unrichtig gebildet, daher die im Text gebrauchten vorzuziehen. 
Ganglien versorgen hier das einfache Antennenpaar und die zweiten Extremităten oder Kiefer, doch ist das Tritencephalon noch ziemlich deutlich abgesetzt. - Die Vereinigung von Deuter- und Tritencephalon mit dem Archencephalon gilt in gleicher Weise für die Myriopoden (Fig. 349) und Insekten (Fig. 347), bei denen jedoch die dem Tritencephalon zngehörigen zweiten Antennen fehlen. - Bei den Arachnoideen ließ sich, soweit ermittelt, nur die Vereinigung des Archencephalon mit dem ersten Rumpfganglion (Denterencephalon) erweisen, das zu den Cheliceren gehört, die den ersten Antennen der Krebse und den Antennen der Myriopoden und Insekten entsprechen.

Bei den mit den Arachnoideen nahe verwandten Pöcilopoden (s. Fig. 356, S. 506) entspringen die Nerven für die Cheliceren aus der vorderen Partie der Schlundconnective, so daß hier eigentlich noch keine völlige Vereinigung des Deuterencephalon mit dern Archencephalon besteht. Da jedoch die Transversalcommissur, welche diese kaum ganglionär angeschwollenen Partien der Schlundconnective verbindet, vor dem Ösophagiis verläuft, so spricht sich die Zugehörigkeit des Cheliceren-Ganglions zum Gehirn recht deutlich aus. - Die Ontogenie der chilopoden Myriopoden ergab jedoch, daß vor dem Deuterencephalon (Antennenganglien) noch ein Kopfsegment (sog. praeantennales) auftritt, dessen Ganglien sich ebenfalls mit dem Archencephalon vereinigten, daß also das Neoencephalon hier aus drei Ganglienpaaren hervorgehe. Dies Praeantennalsegment wird auch für die Arachnoideen und Pöcilopoden entwicklungsgeschichtlich vermutet, ist jedoch bei diesen nicht ganz sicher erwiesen. Bei den diplopoden Myriopoden, Insekten und Crustaceen ließ es sich nicht feststellen, soda $B$ es hier als rückgebildet, oder sein Ganglion frühzeitig und völlig in das Archencephalon eingegangen, gelten muß.

Die Quercommissur des Denterencephalon (1. Antenne) verläuft stets im Hirn selbst (anggenommen Limulus), also präoral, während sie wegen der eigentlich postoralen Lage der ersten Antennen ursprünglich postoral liagen müßte.

Wegen dieser Schwierigkeit wurden die ersten Antennen der Arthrาpoden früher als Homologa der Chätopoden-Antennen, nicht als eigentliche Extremitäten gedeutet, wogegen jedoch die Ontogenese spricht. Es scheint daher möglich, daß die Quercommissur des Deuterencephalon nicht die ursprüngliche, sondern eine sekundäre ist, welche sich aus Faserverbindungen im Archencephalon hervorbildete.

Die ursprüngliche Quercommissur der Tritencephalonganglien (2. Antenue) dagegen hat sich meist (Crustaceen und Insekten, Teil.der Myriopoden: Scutigera, Diplopoda) isoliert erhalten, und verbindet die beiden Schlundconnective direkt binter dem Ösophagus. Bei den meisten chilopoden Myriopoden soll sie im Gehirn liegen, wäre daher wohl ebenfalls als eine sekundäre zu deuten. - Vom Gehirn der mit Deuter- und Tritencephalon versehenen Arthropoden entspringen daher (abgesehen von den Augen- und sonstigen Sinnesnerven) stets die Nerven des einen oder der beiden Antennenpaare, ferner Nerven zur Haut und gewissen Kopfmuskeln und das später zu erwähnende Schlundnervensystem.

Bevor wir das Bauchmark der Arthropoden in seiner Ausgestaltung karz betrachten, mögen einige allgemeine Bemerkungen über dasselbe vorausgeben. Deutlicher als bei den Anneliden läßt sich seine nrsprüngliche Ableitung von zwei lateralen Banchsträngen bei den Arthropoden verfolgen, und zwar nicht nur ontogenetisch durch die ursprünglich weit getrennten seitlichen, ectodermalen 
Anlagen der Stränge, sondern auch vergleichend-anatomisch. Die beiden Stränge der sehr primitiven Protracheaten «ämlich (Fig, 348) bleiben dauernd in dieser Lage, indem sie die seitlichen, oder sog. Neuralkammern der Leibeshöhle durchziehen. Ihre sehr ursprüngliche Beschaffenheit verrät sich wohl auch darin, daß sie nur ganz schwache Gauglienanschwellungen besitzen und an ihrem Hinter-

Fig. 347.
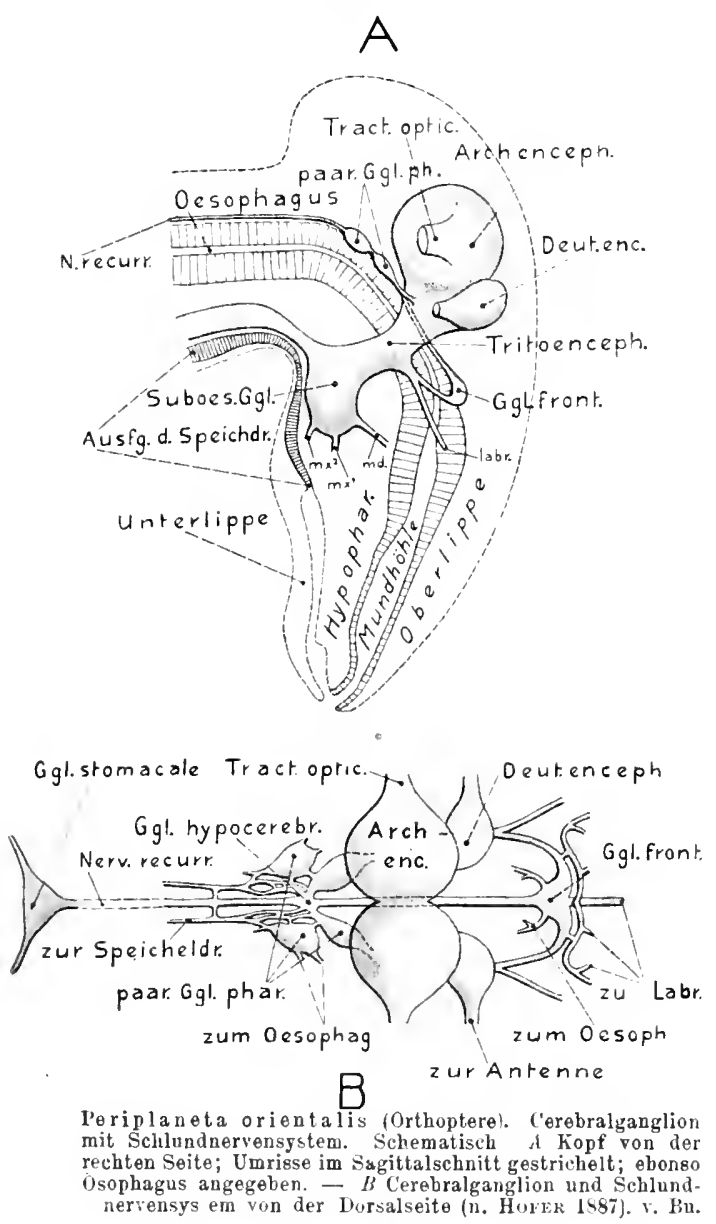

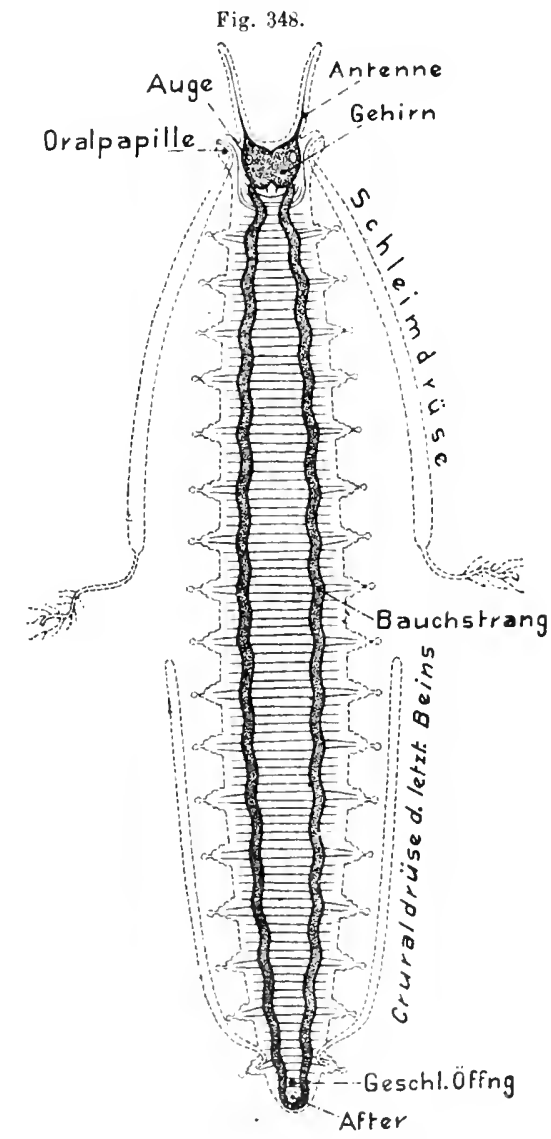

Peripatus capensis $\vec{\delta}$. Centralnervensystem von der vorsalseite; schematische höperumrisse $u$, sonstige Organe gestrichelt. l'er hintere $\Delta$ bschnitt der Schleindrüsen abgeschnitten (n. Balfour 1885). v. Bu.

ende dorsal über dem Darm in einander tibergehen. In jedem Segment sind sie durch zahlreiche Quercommissuren verbunden und entsenden pro Segment seitlich gleichfalls zahlreiche Nerven, von denen je zwei zu den Extremitäten geben (dazwischen je noch 8-9). - Eine : ihnliche Beschaffenheit des Bauchmarks findet sich sonst nirgends mehr, wenn sich auch viel häufiger, als es bei den Anneliden vorkommt, die Paarigkeit der dicht nebeneinandergerïckten Stränge dauernd erhält. Diese Paarigkeit des Bauchmarks ist bei den Phyllopoden (insbesondere Branchiopoden, s. Fig. 344) noch sehr ausgeprägt, wo auch die Gang- 
lien noch darchweg paarig sind und durch je zwei aufeinanderfolgende Transversalcommissuren zusammenhängen, so daß ein typisches Strickleitersystem vorliegt. Bei den übrigen Arthropoden, sogar schon den Tardigraden (s. Fig. 277, S.412), sind die paarigen Ganglien jedes Segments durch Verkürzung der Transversalcommissuren verwachsen. Doch erhält sich der paarige Charakter äußerlich häufig gut, obgleich er bei innigerer Vereinigung nicht selten schwindet; innerlich bleibt jedoch die ursprüngliche Paarigkeit meist angedentet, ebenso gilt dies für die beiden Transversalcommissuren, welche für die typischen Arthropoden charakteristisch zu sein scheinen. - Häufig erhalten sich aber die Connective

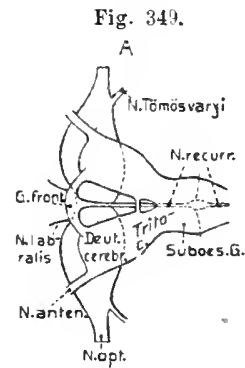

B

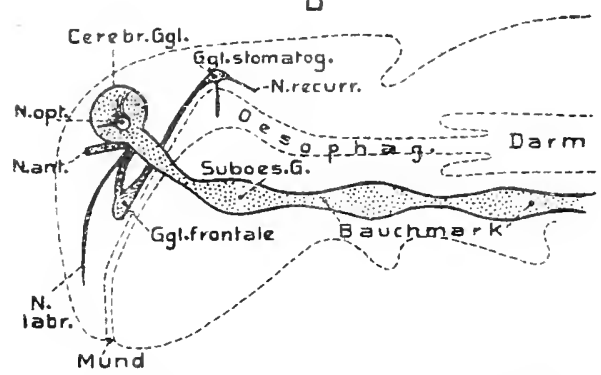

Scutigera coleoptrata (Chilopode). Cerebralganglien nnd Anfang des Bauchmarks. A von der Ventralseite ( $n$. ST. Remr 1897, etwas verändert). $-B$ Sehematisch $\theta$ Ansicht von der linken Seiie mit den gestrichelten Körperund Darmumrisseu (n. HERBst 1891). C. H. zwischen den Ganglienknoten des Bauchmarks paarig. Dies gilt ebenso für die primitiveren Crustaceen (Arthrostraken wie Thoracostraken), die chilopoden Myriopoden, sowie für zahlreiche primitivere Insekten. Wenn sich die Längsconnective verkürzen und die Ganglien dichter zusammenrïcken, tritt jedoch gewöhnlich eine Vereinigung der Connective beider Seiten auf, was auch in dem ganzen Bauchmark, oder Regionen desselben bei Krebsen, Myriopoden und Insekten ausgesprochen sein kaun. - 'Die peripheren Nerven entspringen teils nur von den Ganglien des Bauchmarks, teils auch von den Connectiven; in beiden Fällen in recht variierender Zabl.

In den Kopfabschnitt sind bekanntlich auch die Segmente der Kiefergebilde (Gnathiten) oder der ihnen entsprechenden Anhänge nebst ihren Ganglien aufgenommen worden. Da nun diese Segmente meist sehr innig mit den ïbrigen vorderen Cephalonsegmenten und dem Prostomium verschmelzen, so sind auch in der Regel die sämtlichen Ganglien der Kiefersegmente zu einem einzigen verwachsen, dem sog. Unterschlundganglion (Sub- oder Infraösophagealganglion), wofür sich Analoges schon bei den Anneliden fand. Bei den Protracheaten und Tardigraden (Fig. 277, S.412) findet sich jedoch kein Unterschlundganglion in diesem Sinne, vielmehr kann hier nur das erste Ganglion der Bauchkette, welches bei den Protracheaten (Fig. 346) die sog. Oralpapillen innerviert, bei den Tardigraden dagegen keine Extremitäten oder Gnathiten versorgt, als Unterschlundganglion bezeichnet werden. - Daß das Subösophagealganglion der übrigen Arthropoden tatsächlich ein komplexes ist, erweisen sowohl die Untogenie als die vergleichende 
Anatomie. Bei primitiveren Krebsen, so den Phyllopoden (Fig. $344-345$ ), jedoch auch manchen Arthrostraken (Fig. 350) und Schizopoden sind die Ganglien der drei Kiefersegmente noch gesondert, während sie bei den ubrigen Crustaceen stets zu einem Subösophagealganglion verschmolzen sind, mit dem sich jedoch meist auch die Ganglien der Segmente der Kieferfüße vereinigen. Die Verschmelzung der Ganglien der Kiefersegmente gilt ebenso allgemein für: die Myriopoden und Insekten.

Eine gleichfalls schon bei den Gliederwürmern vorgebildete Erscheinung ist die Verwachsung einiger der hintersten Bauchmarkganglien zu einem komplexen Analganglion, eine Erscheinung, welche schon bei recht primitiven Formen vorzu-

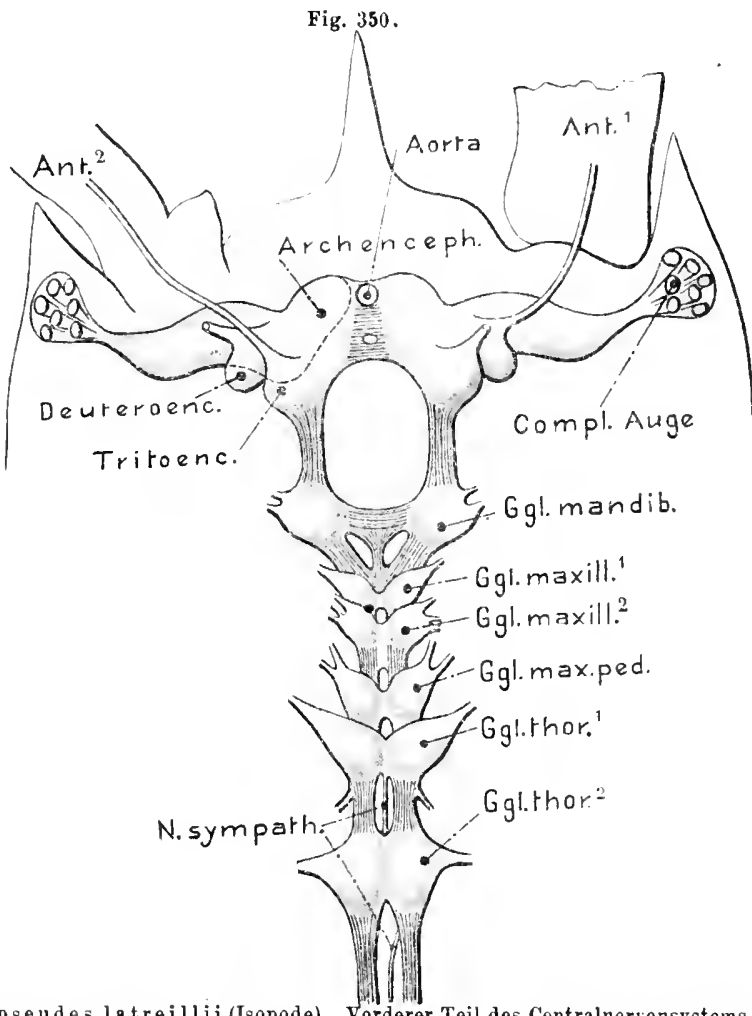

A pseudes latreillii (Isopode). Vorderer Teil des Centralnervensystems von der Ventralseite. Vorderes Kopfende im Umrissen (n. Claus 1957). kommen scheint, jedenfalls aber sehr hänfig ist. Aus allem dem ergiebt sich, $\mathrm{da} B$ bei den Arthropoden, vielleicht mit Ausnahme der Tardigraden, die primitive Zahl der Bauchmarkganglien mehr oder weniger reduziert erscheint.

Die gleichmäßig homonome Ansbildung des Bauchmarks der Protracheata, welche sich auch bei den Tardigraden mit ihren nur fünf Bauchganglienpaaren findet, erhielt sich, abgesehen von den Subösophagealganglion, im allgemeinen auch bei den Myriopoden, im Zusammenhang mit der gleichmäßigen Ausbildung ihrer Rumpfsegmente. Im Bauchmark der Chilopoden

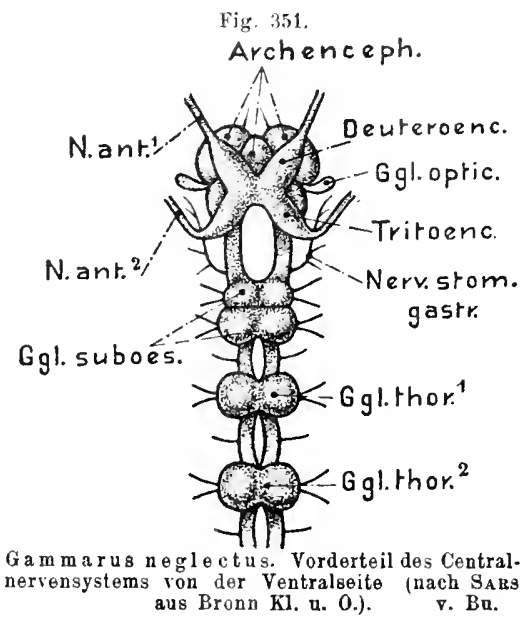


sind die Ganglien durch meist parige Connective verbunden, wogegen die der Diplopoden (die sich in den sog. Doppelsegmenten zu zwei finden) durch die starke Verkürzung der Längsconnective meist ganz dicht zusammengerïckt sind; nur diejenigen, welche zu den vordersten einfachon Segmenten gehören, blieben gesonderter (Fig. 365, S. 512).

Bei den Arachnoideen enthält das eigentliche Subösophagealganglion die Ganglien der zweiten Extremitäten (Pedipalpen) und der vier, hier als Bein-

Fig. 352.

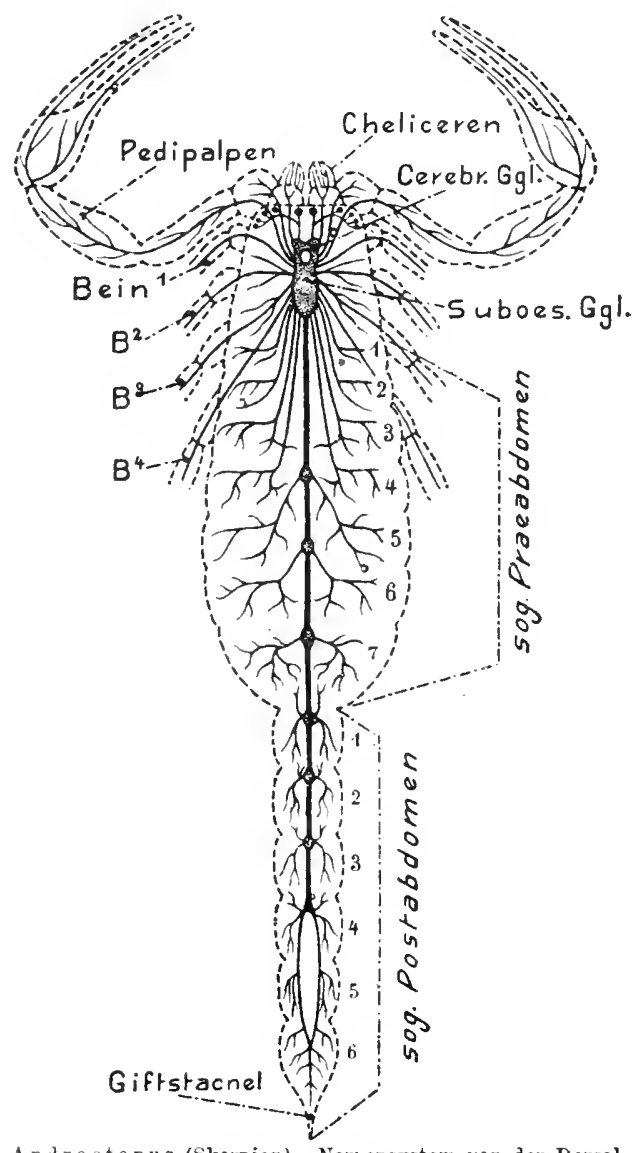

Androctonus (Skorpion). Neriensystem von der Dorsalseite. Köperomrisse gestrichelt (n. Newront 1513). v. Bu.

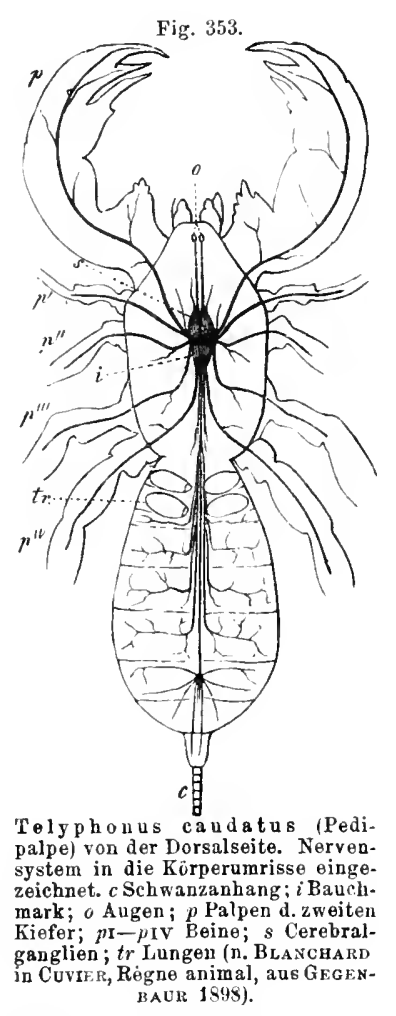

paare entwickelten folgenden Extremitäten des Cephalons, im ganzen also fünf Ganglienpaare. Da die Schlundeonnective :iußerst verkürzt sind, so ist die Vereinigang des Hirns mit dem großen Subösophagealganglion sehr innig. Doch verwachsen mit diesem ursprünglichen Subösophagealganglion bei allen rezenten Arachnoideen noch eine größere Anzahl vorderer, bis sämtliche sog. Abdominalganglien. Bei den Scorpionen (s. Fig. 352) gilt dies für die vier vorderen des 
Praeabdomens, worauf noch sieben freie hintere Ganglien folgen; bei den Pedipalpen (Fig. 353) für die sieben vorderen bis sämtliche Abdominalganglien, wobei sich im ersteren Falle im Abdomen ein komplexes isoliertes Analganglion erhält, wie ähnlich bei den Solpugiden und ansnahmsweise bei gewissen Araneinen (Mygale). Bei den übrigen Araneinen (s. Fig. 354) und den Acarinen (Fig. 355) sind sämtliche Ganglien der Bauchkette zu einem einzigen großen, im Cephalon liegenden Knoten verschmolzen, der bei den Acarinen ohne jede Connectivbildung mit dem Cerebralganglion vorwachsen ist; die Vereinfachung des Centralnervensystems ist daher hier die denkbar weitestgehende.

Etwas anders liegen dagegen die Verhältnisse bei den Pöcilopoden, welche den Arachnoiden nahe stehen (Fig. 356). Ein eigentliches Subösophagealganglion
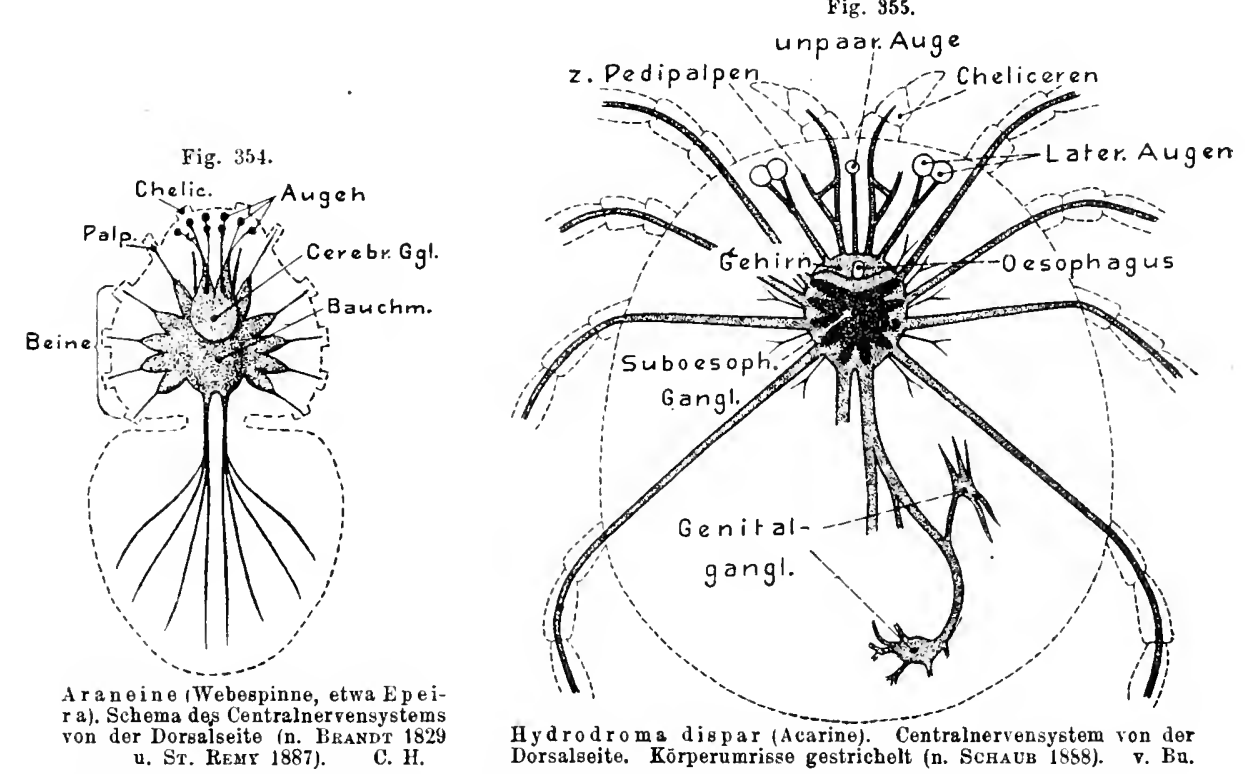

findet sich hier nicht, da sich die beiden ursprünglichen lateralen Stränge des Bauchmarks im ganzen Cephalon ähnlich wie lange Schlundconnective verhalten, so daß die Nerven für sämtliche sechs Extremitätenpaare des Cephalons von diesen Connectiven entspringen, ohne Bildung deutlicher Ganglienknoten. Außer der schon oben (S. 500) erwähnten prïoralen Transversalcommissur findet sich zwischen den beiden Strängen noch eine varierende Zahl postoraler. - Im Rumpf (sog. Abdomen) ist das Bauchmark dagegen wenig verkürzt und läßt etwa noch sieben Ganglien unterscheiden, von denen die drei hintersten stark zusammengedrängt sind. Das Ganglion des ersten Rumpfsegments scheint, nach dem Ursprung des Nervs zu urteilen, der zu seinen Anhängen (Opercula) tritt, mit dem Cephalonteil des Bauchmarks vereinigt.

Eine ähnliche Vereinfachung des Bauchmarks, wie bei den Arachnoideen, tritt auch bei den ubbrigen Arthropodengruppen ibberall da auf, wo sich die 
Segmente gewisser Regionen innig zusammendrängen oder verschmelzen; doch können noch andere Momente bei dieser Umbildung im Spiel sein. - So finden wir vielfach bei den Crustaceen (besonders den Malacostraca), daß die Ganglien der sog. Kieferfïße, welche sich den Gnathiten innig anschließen, mit dem Unterschlundganglion verwachsen; bei manchen Arthrostraken (s. Fig. 351) gilt dies fiir das Ganglion des einzigen Kieferfußpaars; bei den decapoden Thoracostraca (Fig. 357) hingegen für die der drei Kieferfußpaare, so daß deren sog. Subösophagealganglion aus sechs Ganglien zusammengesetzt ist, auf die bei den ursprüng-

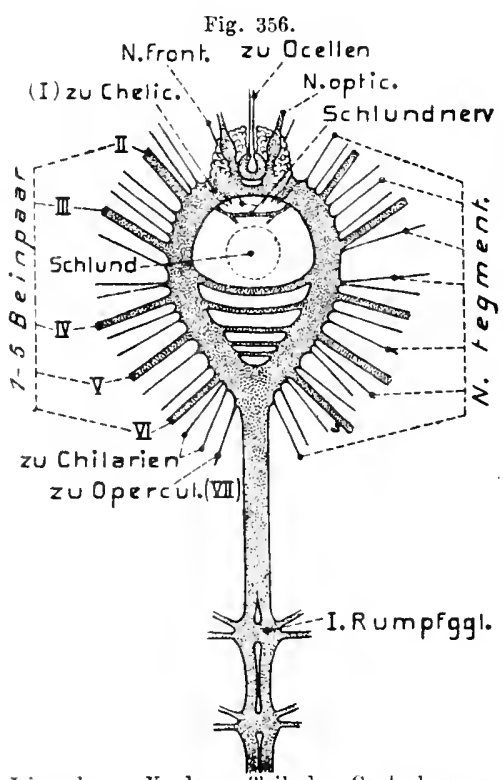

Limulus. Vorderer 'T'eil des Centralnerven systems mit dem Anfang des Rumpfteils von der Worsalseite tnach A. MILnE-EDwarns 1873 und Viallanes $18: 2$ kombiniert). O:B. n. v. Bu. lichen macruren Formen (z. B. Astacus, Fig. 357) noch die fünf freien Ganglien der fïnf thorakalen Bewegungsextremitäten folgen; doch künnen diese bei anderen Macruren sowohl mehr oder weniger untereinander, als mit dem Unterschlundganglion verwachsen, so daß gewisse Formen $(z$. B. Palinurus) nur noch ein einziges ansehnliches Komplexganglion im Cephalothor'ax besitzen. Im Abdomen folgen bei den $M a-$ cruren meist sechs freie Ganglien des Bauchmarks. - Die brachyuren Decapoden besitzen stets ein einfaches Ganglion des Cephalothorax, dagegen gar keine Ganglien mebr im Abdomen, das von einem einfachen Nervenstrang oder -bündel durchzogen wird (Fig. 358). Es ist aber weniger wahrscheinlich, daß hier eine Verwachsung der Abdominalganglien mit dem Cephalothoraxganglion eingetreten ist, eher eine Reduktion der Abdominalganglien in Zusammenhang mit der Verkiimmerung des Abdomens.

Auch bei den übrigen Crustaceen kann eine teilweise bis völlige Verschmelzung der Ganglien der Bauchkette stattfinden, im Zusammenbang mit der Verkürzung gewisser Körperregionen oder des Gesamtkörpers. So vereinigen sich bei den Asseln (Isopoda) mit stark verkürztem Abdomen die Abdominalganglien zu einem Knoten, der schließlich mit dem hintersten Thorakalknoten verschmelzen kann. Viel weiter geht die Zusammendrängung und Verkürzung des gesamten Bauchmarks bei den parasitischen Asseln (Bopyriden), unter völliger Rückbildung der Connective.

Auch bei den entonostraken Crustaceen tindet sich unter entsprechenden Bedingungen z. T. eine ähnliche Verkürzung und Konzentration des Bauchmarks. So tritt dies bei den stark rückgebildeten parasitischen Copepoden (Suctoria) häufig auf, kommt jedoch auch schon bei manchen freilebenden vor (z. B. Sapphirina). Die Konzentration kann bei den parasitischen Copepoden so weit gehen wie bei Milben, indem das gesamte Centralnervensystem zu einem Knoten zusammenschmilzt, der vom Ösophagus durchbohrt wird.

Währenıl die sog. Entenmuscheln (Lepadidae) unter den Cirripedien noch ursprünglichere Verhältnisse aufweisen, indem auf ein ansehnliches Subösophagealganglion fünf oder 
vier freie Ganglien des Bauchmarks folgen, trat bei den Balaniden völlige Verschmelzung des Bauchmarks zu einem Knoten ein. - Sehr weit geht die Reduktion auch bei den parasitischen rhizocephalen Cirripedien, bei denen sich nur ein Ganglion mit ausstrahlenden Nerren findet. Da hier der Darm völlig rückgebildet ist, so hat dies Ganglion natürlich auch keine Beziehungen mehr zum Schlund.

Auch in der umfangreichen Klasse der Insekten lassen sich entsprechende Vereinfachungen des Centralnervensystems in alleu möglichen Übergangsstufen Fig. 357.

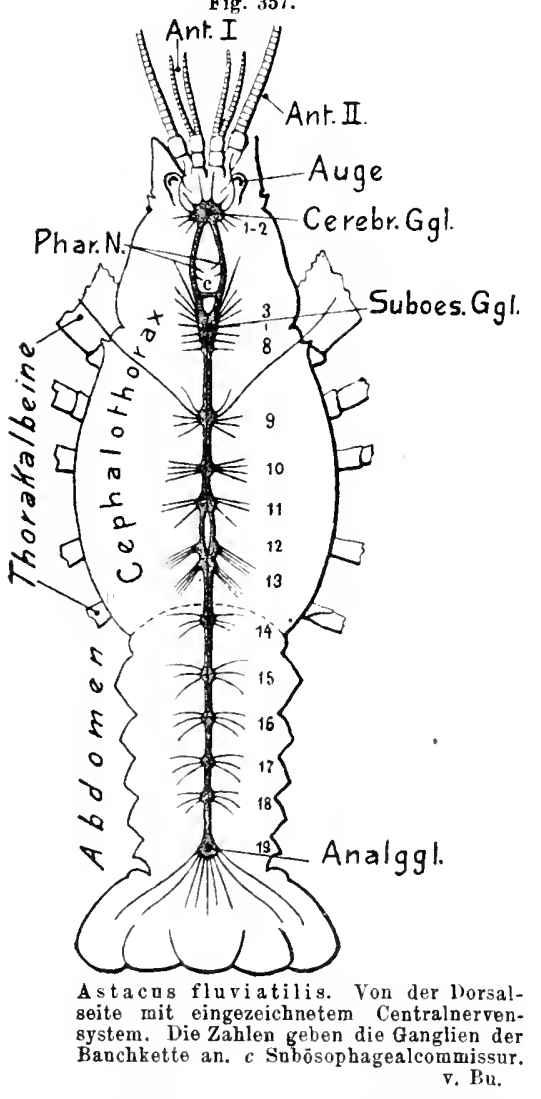

Fig. 358 ,

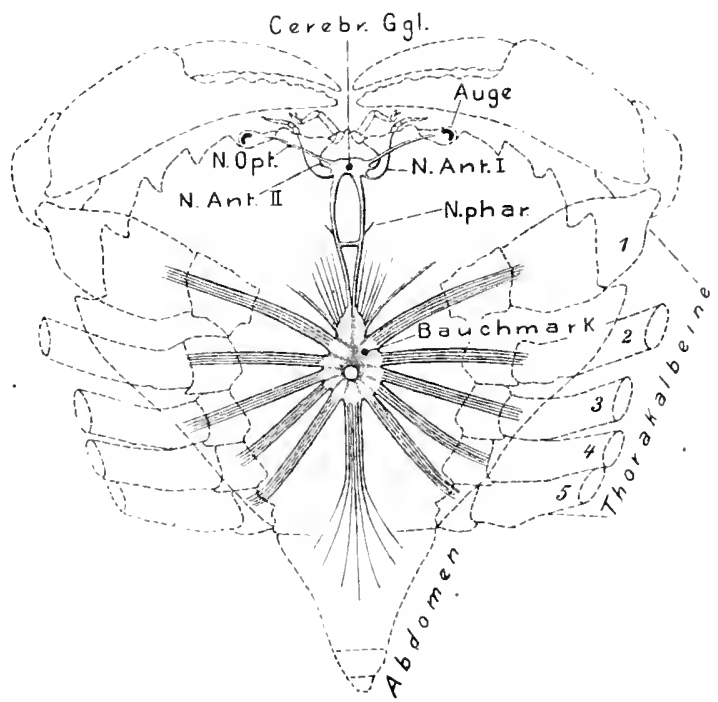

Carcinus maenas (brachyurer Decapode) von der Dorsalseite. Körperumrisse gestrichelt. Centralnervensystem $\theta$ in gezeichnet. v. Bu.

verfolgen. Die ursprünglichste Bildung des Bauchmarks, wie sie sich ontogenetisch, sowie bei den primitiveren Apterygota (Thysannra) und manchen Larven pterygoter Insekten findet, dürfte ein Unterschlundganglion, drei Thorakalganglien und acht Abdominalganglien gewesen sein, wobei das letzte Abdominalganglion (Analganglion) einen Komplex der vier hintersten ursprünglichen Ganglien bildet (gewisse Coleopterenlarven besitzen sogar noeh neun Abdominalganglien). Bei den erwachsenen Pterygoten erhält sich diese Zahl von Abdominalganglien nur noch vereinzelt (namentlich gewisse Orthoptera, Neuroptera); gewöhnlich kommen wegen weitergehender Verschmelzung weniger vor (so sind vier bis sieben Abdominalganglien bei vielen Ordnungen recht verbreitet, s. Fig. 359, Carabus). 
Die gesamte Ganglienkette des Abdomens kann sich, unter Rückbildung der Connective, bei manchen Formen sehr verkürzen, wobei sie gleichzeitig weit nach vorn rückt und sich dem hintersten Brustganglion dicht anschließt. Bei gewissen Käferfamilien (z. B. Lamellicornier, Melolontha Fig. 359 u. a.) ist dies sehr ausgeprägt. Ähnliches findet sich auch bei manchen Dipteren (Fig. $360 B$ ) und allgemein bei den Rhynchoten (Fig. 361), deren gesamte Abdominalkette stets in einem Knoten konzentriert ist. - Die drei ursprünglichen Thorakalganglien erhalten sich bei den meisten Insekten gesondert; bei Hymenopteren, Lepidopteren und einigen Käfern (Fig. 359) sind sie auf zwei rerringert, da die beiden hinteren rerschmelzen; wogegen dies bei manchen Dipteren für die beiden ersten Thorakal-

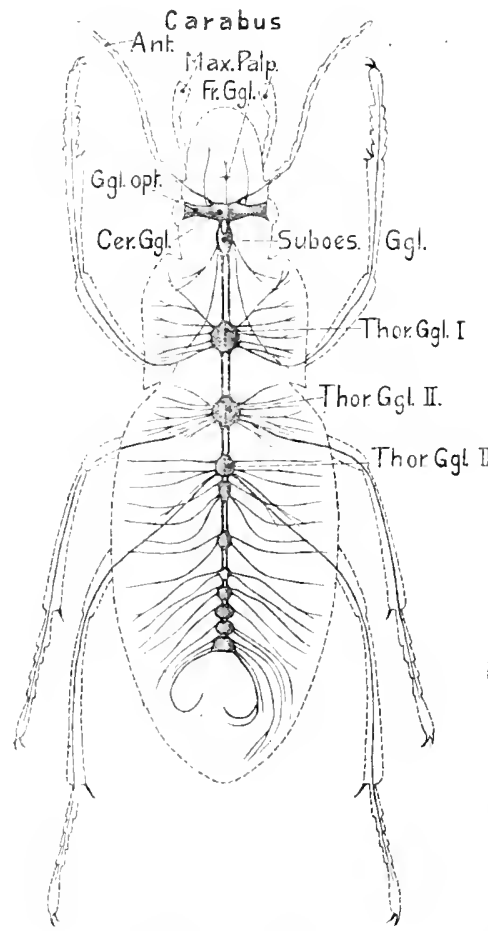

Fig. 359

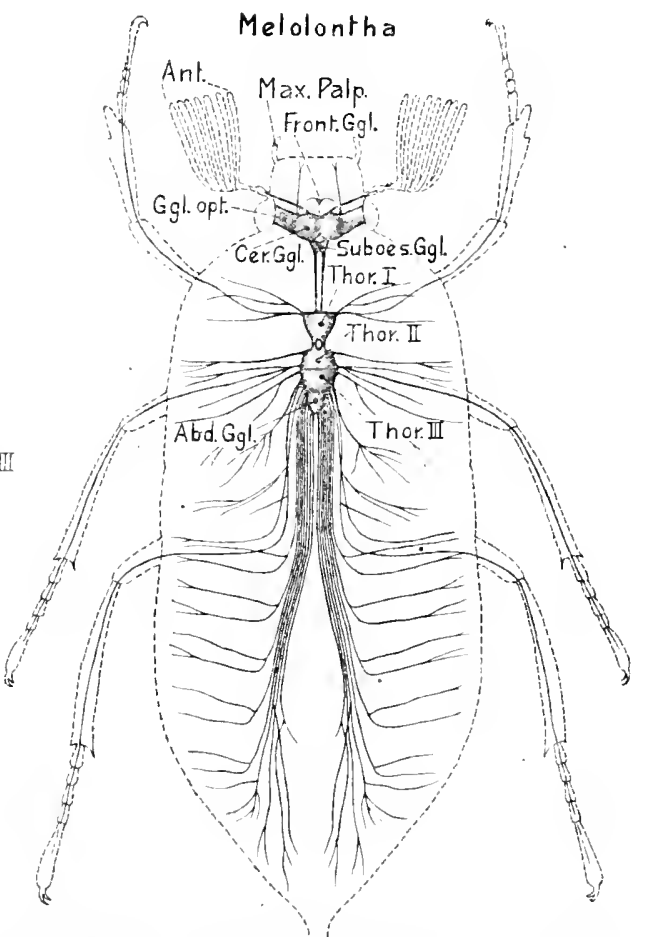

Carabus und Melolontha (Käfer)

Von dør Dorsalseite mit einge
in Cuviers Règne animal). v. Bi.

ganglien gilt, und sich bei anderen sogar auf die sämtlichen drei Thorakalganglien ausdebnt, denen sich (wie bei den Dipteren gewöhnlich) das erste Abdominalganglion anschließt. Endlich kann sich diesem ansehnlichen Brustknoten gewisser Dipteren die zu einem Knoten rerschmolzene Abdominalganglienkette nahe anfügen, ja damit rerwachsen (Musciden Fig. $360 B$, Oestriden, Pupiparen), so daß ein einziger ansehnlicher, in der Brust gelegener Bauchknoten entsteht. Ob jedoch in diesen Fällen nicht zum Teil auch die Ganglien der Abdominalkette unr stark verkümmert sein können, scheint etwas fraglich.

Eine älnliche Konzentration des Bauchmarks gilt allgemein auch für die Rhynchota, derem, wie oben erwähnt, einfachen 'Thorakalknoten sich der ebenfalls einfache Abdominalknoten in der Regel direkt anfügt (Fig. 361). Auch das Unterschlundganglion ist hier meist mit dem Thorakalknoten inniger vereinigt, so daß bei stark verkürzten Rhynchoten (Aphiden und Cocciaen, ähnich auch bei den Pediculiden, Psylliden und Mallophagen) die 
sämtlichen Knoten der Bạuchkette, einschließlich des Unterschlundganglions, dicht rereinigt oder zu einem ansehnlichen Kinoten verschmolzen sind (Fig. 362).

Von Interesse erscheint, daß nicht nur die Imagines gewisser Insekten ein so stark konzentriertes Bauchmark besitzen, sondern zuweilen schork manche Larven (wie es bei einzelnen Dipteren, Coleopteren und Neuropteren vorkommt). Manchmal (z. B. Myrmeleo) kann sogar das System der Larve stark konzentriert sein, das der Imago dagegen nicht.

Besondere Verhältnisse des Hirns. Wie wir fanden, ist zn dem ursprünglichen Archencephalon der meisten Arthropoden ein aus Denter- und 'Tritencephalon bestehender sekundärer Teil hinzugetreten. Dies spricht sich am Hirn der Krebse und Tracheaten (speziell Myriopoden und Insekten) auch äußerlich zuweilen noch aus, indem die drei Ganglienpaare als Anschwellungen

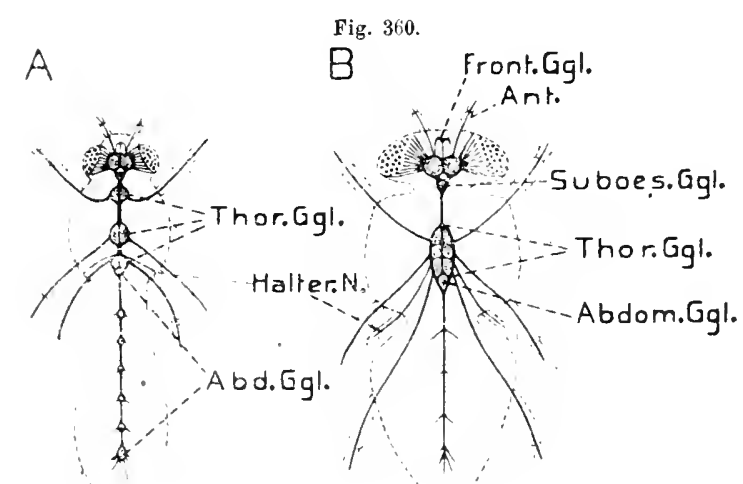

Dipteren (Fliegen). Centralnervensystem ron der Dorsalseite. $A$ ron ('hironomus. $-B$ von Sarcophaga (n. E. Brasur 1573 , etwas veründert).

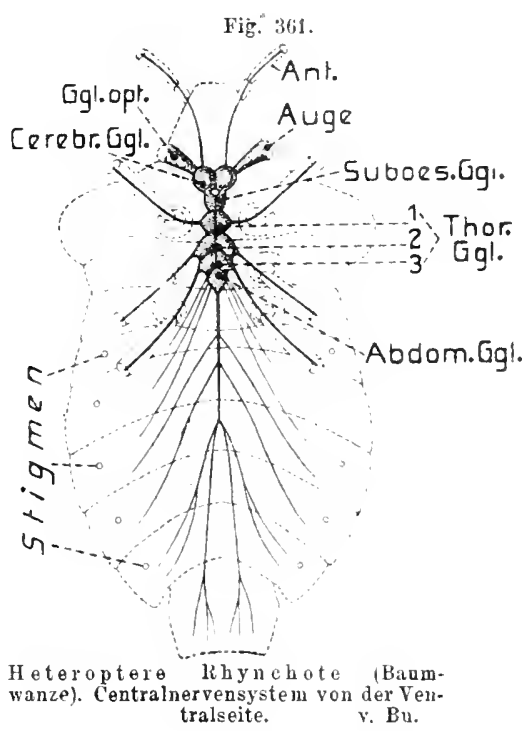

(Lappen, Lobi) des Gehirns mehr oder weniger vorspringen. Das Archencephalon, der vorderste und dorsalste Hirnteil, verrät in seiner Entwicklung häufig eine gewisse Zusammensetzung aus mehreren Abschnitten, einem unpaaren und zwei bis drei Paar seitlichen. Der unpare, im entwickelten Gehirn meist șehr geringfügige Abschnitt dürfte wohl die ursprüngliche Scheitelplatte der Anneliden repräsentieren; die parigen entsprechen ursprünglich Ganglienbildungen, welche Kopfsinnesorganen angehörten, und sich dann dem Hirn zugesellten. Dies gilt besonders für den seitlichsten, oder die beiden seitlichsten der paarigen Abschnitte (Lappen), die sich in Verbindung mit den parigen Komplexangen (Insecta, Crustacea), oder den an ihrer Stelle vorhandenen Ocellen (Myriopoden, Arachnoideen) entwickeln, und zu den in der Regel sehr umfangreichen Augenganglien (Ganglia optica, Lobi optici)werden. Diese Augenganglieu können mit dem ïbrigen Archencephalon sehr innig verschmolzen sein, so daß sie nur als seitliche, oder auch mehr nach vorn gerichtete Lobi (Arachnoideen, Fig. 354) an ihm vorspringen; sie können jedoch auch schärfer abgesctzt 
sein, indem sie durch eine Art Tractus opticus mit dem übrigen Arehencephalon znsammenhängen (Fig. 359). Seltener (z. B. Phyllopoda, Fig. 344, S.498) ist dieser Verhindungsstrang lang nervenartig ausgezogen und wird dann gewöhnlich als Nervas opticus bezeichnet. - Der Bau der meist recht voluminösen Augenganglien ist gewöhnlich sehr kompliziert, indem in ibnen, von ihrer distalen Verbindung mit den Sehzellen der Augen aus, bis zum eigentlichen Hirn mehrere (gewöhnlich drei) quere Ganglienzellenlager mit Neuropil eingeschaltet sind (s. Fig. 363), die untereinander durch Nervenfasern, welche häufig schief gekrenzt verlaufen, verbnnden sind.

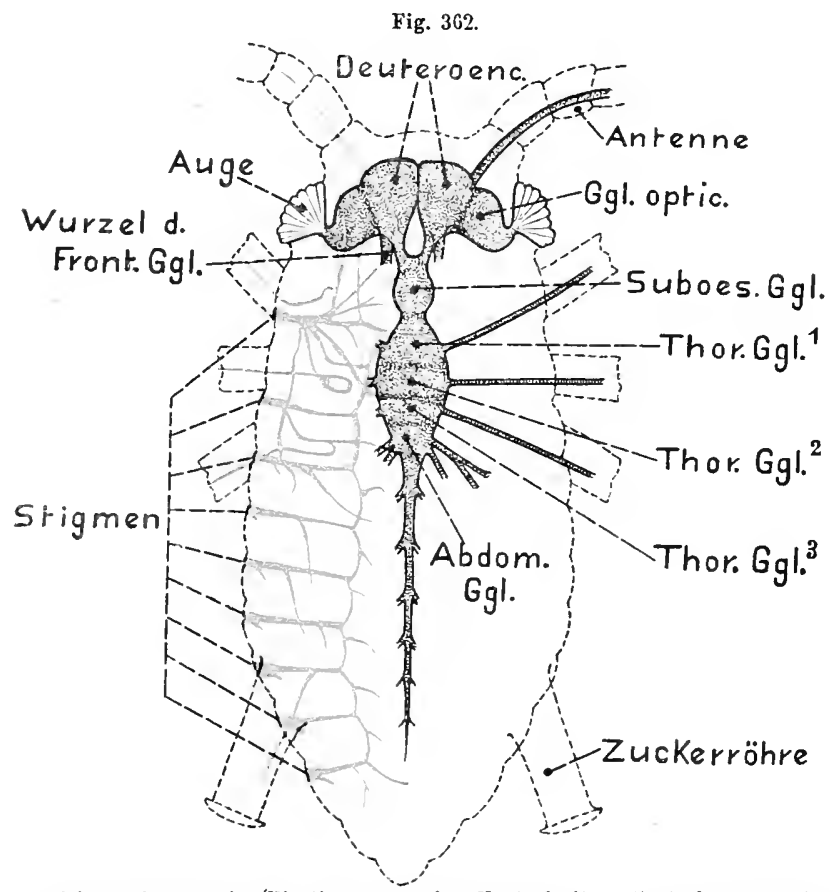

Aphis polargoni (Blattlaus) von der Ventralseite. Centralnervensystem und links die Haupttracheen (blau) eingezeichnet. Die sog. sZuckerröhren. verdienen diese Bezeichnnng eigentlich nicht, da sie nicht Honig, sondern ein schmieriges, zur Abwehr dienendes Secret ausscheiden (n. Witcaczil 1s52).

Auch die mittleren Teile des Archencephalon, von denen seitlich die optischen Ganglien ausgehen, sind mehr oder weniger kompliziert, nicht nur durch den sehr verwickelten inneren $\mathrm{Fa}$ serverlanf, von dem Figur 363 eine gewisse Vorstellung zu geben versucht; und die Einlagerung innerer Nenropilbezirke (sog. Centralkörper u. Brticke), sondern auch durch das Auftreten eigentiimlicher Bezirke kleinerGanglienzellen(sog. chromatischer Kerne), die in Verbindung mit Nenropilmasse und Nervenfasern ein Paar eigentümlicher Einlagerungen bilden, die gewöhnlich als pilzförmige oder Stielkŏrper bezeichnet werden (s. Fig. 363). - Bei den Insekten sind die Stielkörper sehr entwickelt und ihre zuuehmende Komplikation in dieser Klasse scheint darauf hinzudeuten, daß sie mit der Steigerung der psychischen Leistungen in Beziehnng steht. - So erhebt sich ihre Zahl bei gewissen Hymenopteren (Vespa usw.) auf zwei Paar von komplizierterem Bau. Auch bei den Crustaceen und selbst Limulus sind Stielkörper nachgewiesen worden. Da sich nun ähnlich gelagerte Bezirke kleiner Ganglienzellen schon bei den Protracheaten finden, so scheinen diese Organe, wenn auch in ellfacherer Form, sehr weit, wenn nicht allgemein verbreitet. Selbst in den Cerebralganglien der Anneliden hat man sie nachzuweisen versucht. 
Auch die Ganglien des Denterencephalons (Ganglia olfactoria) zeigen eine wobl weit verbreitete Struktureigentiimlichkeit, indem ibnen eine grëßere Zahl kleiner Neuropilhanfen (sog. Glomeruli) eingelagert ist (s. Fig. 363).

Äbnlich den Anneliden finden sich auch im Bauchmark der Arthropoden und sẹiner Nerven jene großen Nervenfasern (Neurochorde) neben den gewöhnlichen feinen. Besonders ansehnlich werden sie häufig bei Krebsen (so Astacus) und sollen hier in der 'Tat markhaltig sein.

Schlund-oder. Eingeweidenervensystem (anch Visceral-oder sympathisches Nervensystem und Vagus genamnt). - Ähnlich den Ameliden kommt den

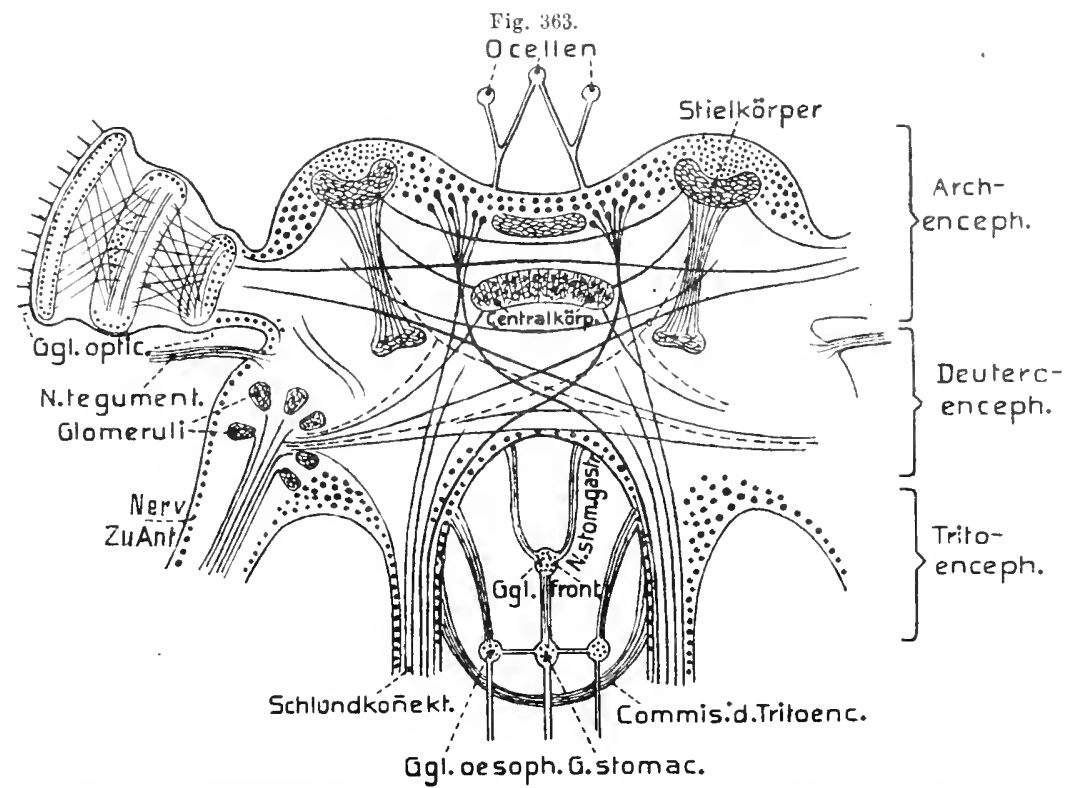

Schematische Darstellung einiger Hauptzŭge der Nervenfasern im Gehirn der Insekten. Die Zngrichtung der Faserbündel ist meist nur dureh eine einfache Linie angegeben. Ganglienzellen als sehwarze Punkte angedeutet; die retikuläre Substanz netzig, das sog. Neuropil weiß (n. VIaLlanes 1s!2). 0. B.

Arthropoden ein, vom Hirn oder den Schlundconnectiven entspringender Nervenapparat zu, der den Anfang des Darms, insbesondere den Vorderdarm (Stomodäum) versorgt. Dies System ist in so weiter Verbreitung nachgewiesen, daß es zweifellos iiberall vorkommt, auch da, wo es noch nicht sicher erkaunt wurde.

Schon bei den Protracheata (Fig. 346, S.499) treten zwei Nerven auf, die rom Archencephalon zu entspringen scheinen, und sich, nach hinten ziehend, zu einem vereinigen, der der Pharynx versorgt. Auch die Pöcilopoden (Fig. 356, S.506) besitzen zwei Schlundnerven (Nerri stomatogastrici), die jedoch rom Ganglion der Cheliceren (Denterencephalon) zu entspringen scheinen; sie begeben sich zum Schlund und Darm, wo sie sich unter Ganglienbildung verbreiten. - ̈̈hnhch liegen die Verhältnisse bei den Arachnoideen, deren beide Schlundnerven gleichfalls rom Chelicerenganglion (Ganglion rostro-mandibulare) ausgehen, obgleich sie sich erst in der Gegend des Archencephalon (Ganglion opticum) vom Gehirn ablösen. Bei den Skorpionen aber sollen sich die beiden Visceralnerven, ähnlich wie die Nervi stomatogastrici der Myriopoden und Insekten, zu einem Ganglion (frontale) rereinigen, von dem ein sog. Nerrus recurrens nach hinten entspringe (Newport). 
Die Einrichtungen bei den Crustaceen verraten eine ziemlich weit gehende Übereinstimmung. Bei den sehr ursprünglichen Phyllopoden (Fig. 344-345, S. 498) findet sich an den Schlundconnectiven, im Bereich der Ganglien der zweiten Antennen (Tritencephalon), je eine besondere gangliöse Anschwellung, von denen ein Schlundnerv entspringt, der sich, den Schlund dorsal (resp. nach vorn) umgreifend, mit dem der Gegenseite zu einem Ring vereinigt

Fig. 364.

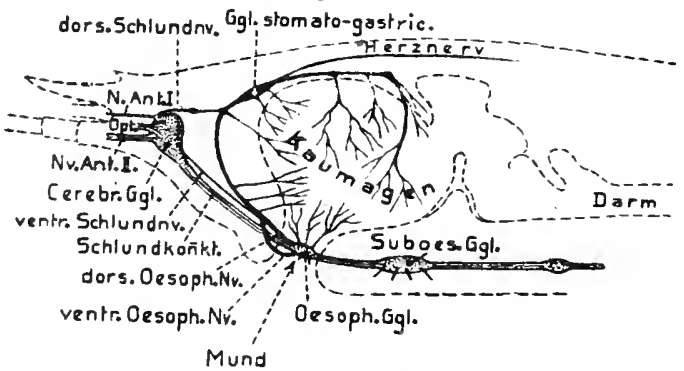

Astacus fluviatilis. Vorderende von links mit dem Schema des Eingeweidenervensystems (schwarz). (Nach BRANDT 1835 und LEMOINE 1868).

(Lippenring). Von diesem gehen Nerren zur Oberlippe und dem Schlund, zuweilen unter Plexusbildung. - Auch die übrigen Entomostraken lassen $z$. T. ein stark entwickeltes Eingeweidenervensystem erkennen, so z. B. die Cirripedien (Thoracica). - Bei den Malacostraca, deren Ganglien der zweiten Antennen, oder doch ihr vorderer Hauptteil, als sog. Tritencephalon mit dem Hirn rereinigt ist, entspringen die beiden Schlundnerven (Pharyngealnerven) dennoch mit besonderen Ganglien anschwellungen (Ösophagealganglien) weit hinten an den Schlundconnectiven, etwas vor der Stelle wo letztere durch die Tritencephaloncommissur verbunden sind (s. Fig. 357). Die beiden Schlundnerven der Arthrostraken (N. stomatogastrici) scheinen sich meist direkt zum Schlund zu begeben, doch wurde zuweilen auch eine ähnliche Ringbildung beobachtet, wie sie bei den Phyllopoden vorkommt (Apseudes). - Eine solche Ringbildung kommt bei den Thoracostraca (speziell den Decapoden) häufig vor. Indem hier von den Ösophagealganglien der Schlundconnective jederseits zwei Nervenwurzeln ausgehen können, die sich beide über dem Schlund

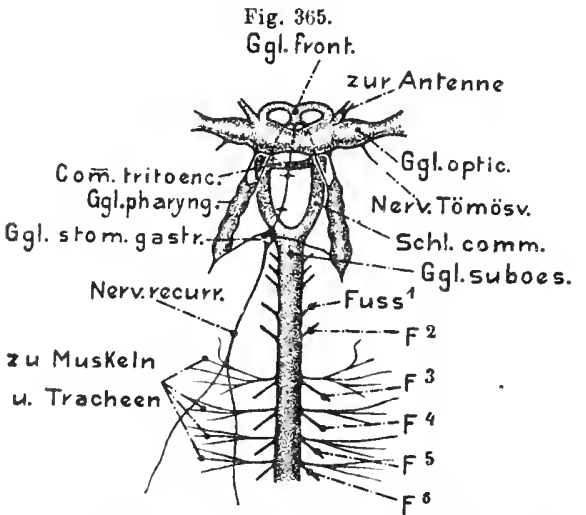

Julus terrestris (Myriopode). Forderended. Central nervensystems v. d. Dorsalseite (n. NawPORT 1813). v. Buvereinigen, wird der Ring sogar häufig doppelt (z. B. Astacus usw. Fig. 357 u. 364). Eine weitere Komplikation tritt hinzu, indem vom Hirn ein pis zwei unpaare Nerven (jeder mit doppelter Wurzel) nach hinten entspringen, die sich mit jenen beiden Ringen vereinigen und sich dann als gemeinsamer Nerv (Nervus recurrens) über den Kaumagen fortsetzen, ein ansehnliches Ganglion stomatogastricum bilden und sich schließlich in zahlreiche Ästchen ausbreiten, die den Kaumagen, den Anfang des Mitteldarms, die Leberdrüsen, vermittels eines Zweigs auch das Herz versorgen. Die beiden vom Hirn ausgehenden Nerven scheinen aus dem sog. Deuterencephalon (1. Antenne) zu entspringen.

Im allgemeinen läßt sich auch das Schlundnervensystem der Myriopoden (Fig. 349, S.502 u. 365) und Insekten (s. Fig. 347, S.501) mit dem der seither besprochenen Arthropoden in nähere Beziehung bringen. Die beiden Nervi stomatogastrici fluden wir allgemein wieder; sie entspringen aus der Region des Tritencephalon, also rom Hirn selbst, weil hier die Schlundconnective stark verkürzt sind, und daher die Region der Ösophagealganglien in das Hirn einbezogen wurde. Wie schon bei den Krebsen vereinigen sich diese beiden, den Schlund vorn umgreifenden Nerven bald zu einem Ring (Lippenring) und bilden an der Vereinigungstelle, wie es auch scbon bei Krebsen rorkommt, ein Ganglion frontale, von dem ein Nerrus recurrens 
ausgeht, der unter dem Ilirn auf dem Schlund nach hintell zieht. Nach rorn sendet das Ganglion frontale auch Nerven in die Oberlippe (Labrum). Der Nerrus recurrens, welcher in seinem Verlauf Ganglien (G. oesophageale und stomacale) bildet, kanı weit nach hinten über den Schlund hinablaufen und sich schließlich in zwei laterale Äste teilen. Er breitet sich am Ösophagus bis auf den Anfang des Mitteldarms aus. - Bei gewissen chilopoden Myriopoden (z. B. Scolopendra usw.) werden die paarigen Wurzeln des Nervus recurrens, sowie das Ganglion frontale in das Gehirn aufgenommen, so daß der Nerv direkt vom Hirn entspringt.

Ncben dem N. recurrens findet sich bei den Insekten und vielen Myriopoden noch ein Paar Nerven, die vom Deuterencephalon ausgehen, und direkt auf dem Schlund nach hinten verlaufen. Sie dürften daher wohl den beiden ursprünglichen Schlundnerven der Protracheaten, Pöcilopoden und Arachnoideen entsprechen. Auch diese paarigen Nerven (N. pharyngeales) bilden bei den Insekten und Diplopoden Garıglien (G. pharyngealia, bei Insekten gewöhnlich zwei jederseits), die sich mieist mit dem N. recurrens plexusartig verbinden, und Äste zum Schlund, den Speicheldrüsen und Tracheen, auch dem Herz senden. Ontogenetisch entstehen die Ganglien des Schlundnervensystems aus der Dorsalwand des ectodermalen Vorderdarms (Stomodäum).

Sog. sympathisches System. Abgesehen von Nerven, die, vom Analganglion entspringend, den hinteren Abschnitt des Darms und der Geschlechtsorgane rersorgen, wobei sie in ihrem Verlauf zuweilen Ganglien bildeı, findet sich bei manchen Krebsen (hauptsächlich bei gewissen Isopoda nachgewiesen, Fig. 350, S. 503), recht verbreitet aber bei den Insekten (nicht aufgefunden bei Rhynchoten und Dipteren), noch ein eigentümliches System von Nerren, das vielfach dem sympathischen der Vertebraten rerglichen wurde. Wie die Schlundnerven wird es ron charakteristischen, sehr durchsichtigen (hellen) Nerrenfasern gebildet. Die morphologischen Verhältnisse dieses Systems liegen etwas verschiedenartig, doch im allgemeinen so, daß von den einzelnen Ganglien des Bauchmarks ein medianer, nach hinten ziehender Nerv ausgeht (s. Fig. 361), der sich bald, oder erst im Bereich des folgenden Ganglions (mit dem er sich auch verbinden kann), in zwei seitliche Äste spaltet, die mit den gewöhnlichen peri-

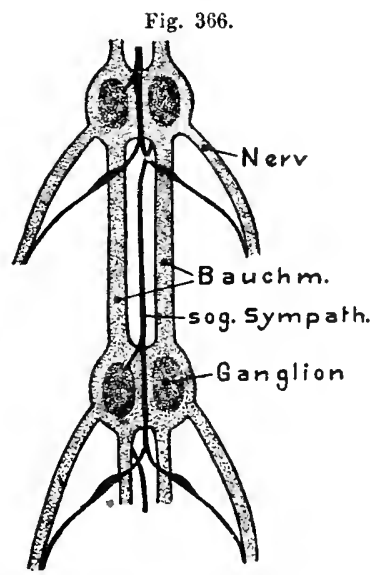

Locusta virjdissima (Heuschrecke). Zwei Ganglien d. Bauchmarks mit dem sog. sympathischen Nervenstrang, seinen Verbindungen mit den Banchganglien, sowie den Ästen zu den Seitennerven d. Bauch. ganglien (n. LFrdig 1864). C. H. pheren Nerven des Banchmarks weiter ziehen, und sich an Tracheen und Stigmen, sowie ihren Muskeln, aber auch noch anderwärts rerbreiten. Mit den gewöhnlichen seitlichen Nerven der Bauchmarkganglien vereinigen sie sich häufg vorübergehend oder bleibend, und bildeı auch plexusartige Umhüllungen derselben mit Ganglieneinschaltung. - Die Mannigfaltigkeit der besonderen Ausbildung dieses Systems dürfte darauf beruhen, daß es in recht verschiedenem Grad mit dem Bauchmark und den von ibm abgehenden Nerven rerschmolzen sein kann, so daß nur geringe Anteile von ihm, oder auch gar keine mehr, gesondert hervortreten. Hierauf scheint es zu beruben, daß es bei gewissen Insekten und den übrigen Tracheaten, ebenso auch den meisten Crustaceen, zu fehlen scheint. Wabrscheinlich ist das System aber allgemein verbreitet, jedoch vom Bauchmark nicht gesondert. Für diese Annahme spricht: $\mathrm{da} B$ es ontogenetisch aus einer besonderen unpaasen ectodermalen Verdickung in der ventralen Mittellinie hervorgeht, die sich dann als sog. Mittelstrang vom Ectoderm ablöst, und meist völlig in das Bauchmark aufgenommen wird. Da dieser Mittelstrang schon in der Ontogenie der Protracheaten anftritt, und auch sonst vielfach nachgewiesen wurde, so dürfte seine allgemeine Verbreitung, und daher auch die des sog. sympathischen Nerrenapparats, recht wahrscheinlich sein. $\mathrm{DaB}$ er meist völlig in das Bauchmark aufgenommen wird, ist sehr wahrscheinlich, da er gerade bei den Dipteren ontogenetisch klar hervortritt, später aber ganz mit dem Bauchmark verschmilzt.

Bût $6 \mathrm{chli}$, Vergl. Anstomie. 
Die Beziehungen dieses sog. Sympathicus zu den einzehnen Ganglien. der Bauchkette lassen die Möglichkeit erwägen, ob nicht eine gewisse Homologie zwischen dem oben geschilderten Schlundnervensystem und den einzelnen Anteilen des Sympathicus besteht, da ja auch das Schlundnervensystem zu den beiden ersten Ganglien der ursprünglichen Bauchkette in ähnlicher Beziehung steht.

\section{Mollusca.}

Das Nervensystem der Weichtiere erinnert in seiner primitivsten Ausbildung auffallend an jenes der ursprünglichen Bilaterien, der Plathelminthen, weshalb es wohl zweifellos von dem wurmartiger Urformen abzuleiten ist. Dieser ursprüngliche Charakter tritt bei der primitivsten Molluskengruppe, den Amplineura, dentlich hervor (s. Fig. 367 u. 368), indem von einem ganz vorn im Körper, ïber dem Schlund gelegenen Cerebralganglion, wie es sämtlichen Weichtieren zt1kommt, zwei Paar Längsnervenstränge entspringen, die bis zum hinteren Körperende ziehen, und durch zahlreiche Quercommissuren plexusartig zusammenhängen. Beide Strangpaare besitzen in ihrer ganzen Ausdehnung eine Rinde von Ganglienzellen, welche die innere Fasermasse nmschließt, ähnlich wie es etwa die beiden Nervenstränge der Nemertinen zeigen.

Eine weitere Annäherung an die Verhältnisse der Plattwürmer scheint auch darin zu bestehen, daß sich bei den Mollusken noch oberflächliche Nerrennetze finden, $d$. $h$, wenigstens bei einer Reihe von Formen nachgewiesen sind. Es wurde z. T. ein oberflächlicher IIantund ein tieferer Muskelplexus unterschieden. - Auch physiologisch ergab sich eine diesem anatomischen Verhalten entsprechende Öbereinstimnung, indem sich, wie bei den Plattwürmern, die Erregbarkeit der IIaut (Drüsensecretion) und der Muskulatur auch nach Entfernung der Centralteile des Nervensystems erhält.

Das der Bauchlinie genäherte Strangpaar liegt ventral vom Darm und ist bei den Placophoren in die Fußmuskulatur eingebettet (s. Fig. 281, S. 416); diese Stränge werden daher in der Regel als Pedalstränge bezeichnet, um so mehr als sie die Fußmuskulatur innervieren. Bei den Aplacophoren, deren Fuß stark bis völlig rückgebildet ist, liegen die Pedalstränge ventral und sind der Längsmuskulatur an- oder eingelagert. - Die beiden üußeren Stränge verlaufen lateral, bei den Placophoren etwas dorsal vom Grund der Mantelrinne (s. Fig. 281), an der sie entlang ziehen. Bei den Aplacophoren, deren Mantelfalte meist völlig rückgebildet ist, ziehen sie etwa längs der Seitenlinien des Körpers hinab. Letztere Stränge wurden daher häufig laterale genannt; wir wollen sie wegen ihrer Beziehung zum Mantel und den Eingeweiden, die bei den Placophoren deütich hervortritt, als Palliovisceralstränge bezeichnen. - Wie bemerkt, erinnert die Ausbildnng des Apparats an d e n mancher Turbellarien mit seinen Ventral- und Lateralsträngen, welche durch einen reichen Plexus verbunden sind; weshalb auch die oben erwähnten verwandtschaftlichen Beziehungen begriundet erscheinen dürften.

Das Cerebralganglion, von welchem die beiden Strangpaare entspringen, ist bei den Aplacophoren stets gut entwickelt, zeigt sogar manchmal einige schwach hervortretende Lappen (Chätoderma, s. Fig. 367 A), jedoch fast nie eine deutlich paarige Bildung. - Die beiden Strangpaare der Aplacophoren gehen vom Cerebralganglion gewöhnlich gesondert ab, selten jederseits mit gemeinsamer 
Wurzel, die sich erst später teilt (Neomenia). - Den Plicophoren (Fig. 368) fehlen eigentliche Cerebralganglienanschwellungen fast stets, sic werden durch eine ganglienzellenreiche Cerebralcommissur vertreten, die vor dem Mnnd hinzieht und sich hinten jederseits in die beiden Stränge teilt.

Wahrscheinlich dürfte nur der mittelste oder rorderste Teil dieser Quercommissur dem Cerebralganglion der Aplacophoren entsprechen, die seitlichen Hauptteile dagegen den beiden verwachsenen Wurzeln der Sträıge; anch bewahrten die Aplacophoren wohl die ursprünglicheren Verhältnisse. Bei den Placophoren sind die Derebralganglien vermutlich stark rïckgebildet (nur Callochiton zeigt gangliöse Anschwellungen der Cerebralcommissur); dies ist wegen der soust allgemeineu Verbreitung der Cerebralganglien bei den Mollusken wahrscheinlich; auch spricht die in manchen Pulukten primitivere Organisation der Aplacophoren in diesem Sinne.

Vom Cerebralganglion oder derCerebralcommissur derAmphineuren gehen Nerven zur Mundregion des Körpers; bei den Placophoren in großer Anzahl.

\section{Die Pálliovisceralstrünge} der letzteren senden seitlich zahlreiche Nerven in die Kiemen (für jede zwei) und den Mantel, sowie dorsale Nerven zur Rückenregion. Am hinteren Körperende gehen die beiden Stränge dorsal vom Darm ineinander über. Dies erinnert an den gleichen Zusammenhæng der Längsstränge der

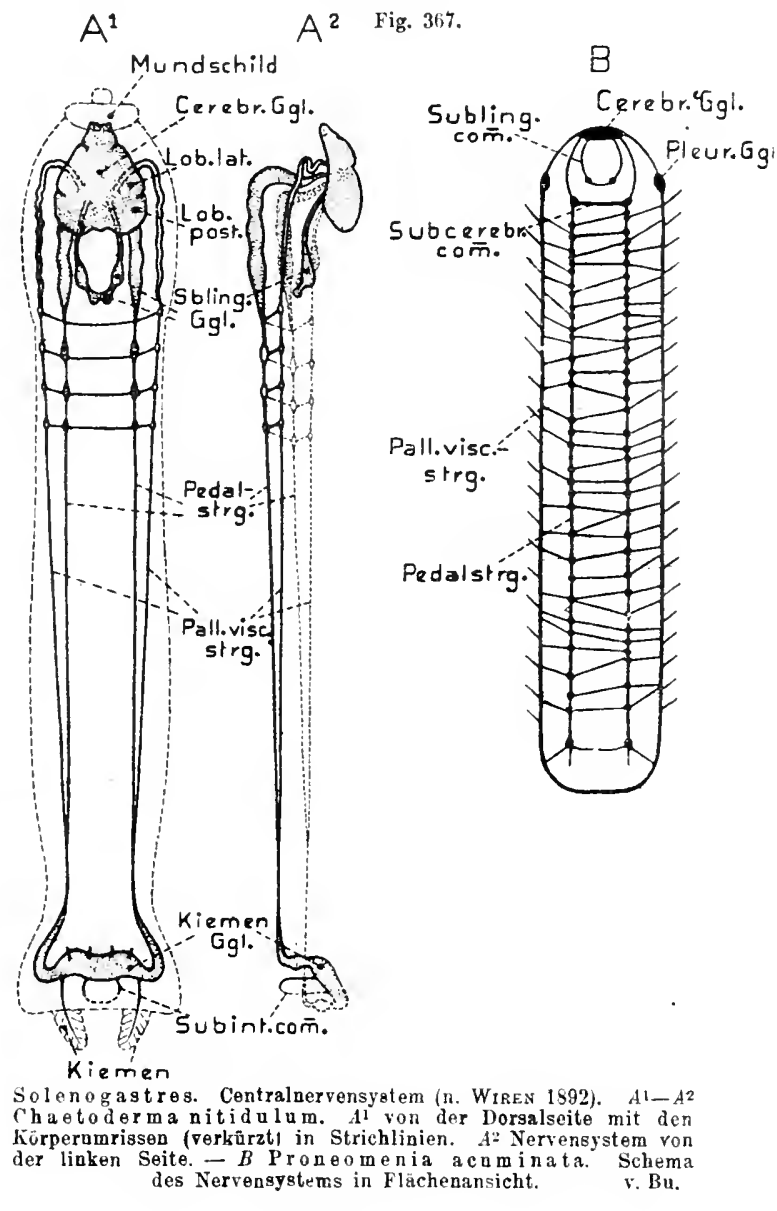
Nemertinen und Protracheaten. - - Ähnlich verhalten sich auch die Palliovisceralstränge der meisten Aplacophoren (s. Fig. 367), doch ist ihre hintere Commissur gewöhnlich ganglienartig verdickt. Bei gewissen Formen (Chätoderma, weniger ausgesprochen Neomenia) verschmilzt jedoch der Palliovisceralstrang vor dem Hinterende jederseits mit dem Pedalstrang zu einem gemeinsamen Strang, welcher sich mit dem der Gegenseite über dem Darm vereinigt, und dabei ein starkes Ganglion (Kiemenganglion, Visceralganglion) bildet. Von diesem geht jedoch eine, den Enddarm ventral umfassende zarte Commissur alıs (Subint. comm.), 
die man als einen gesondert bleibenden Rest der Pedalstränge deuten könnte. Sowohl die Pedal- als die Palliovisceralstränge der Aplacophoren, besonders aber die ersteren, zeigen an den Abgangsstellen der Transversalcommissuren meist schwache Anschwellungen, weshalb die Stränge etwas knotig erscheinen. Die vorderste und hinterste dieser Anschwellungen der Pedalstränge sind stärker entwickelt, und die Quercommissur, welche die vordersten Anschwellnngen (auch Unterschlundganglien genannt) verbindet, ist zuweilen stärker als die folgenden. Letzteres tritt auch bei den Placophoren hervor (die jedoch keine Anschwellnngen

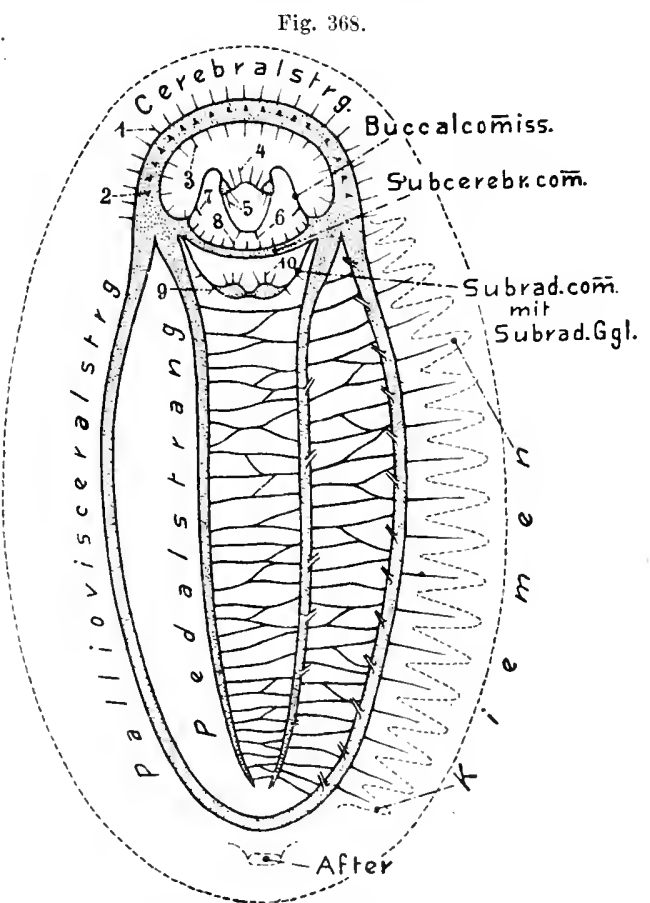

A canthople ura (Placophore). Nervensystem vond. Dorsalseite; etwas schematisch (nach PLate 1897 u. Hallar 1882). 1 Nerven zu Mantel: 2 sog. mediane Nerven zu Rücken; 3 znr Mundscheibe; 4 zu Dach der Mundhôhle; 5 zn Speicheldrụ̂sen und wahrscheinlich Osophagus und Darm; 6 zu Radulatasche und Pharynx; 7 zu Retractoren der Buccalmasse; 8 zar Mandscheibe; 9 zur Baccalmuskulatur; $10 \mathrm{zu}$ Subradularorgan. der Stränge zeigen), wo diese vorderste Quercommissur, die sog. Subcerebralcommissur, zusammen mit der Cerebralcommissur einen den Schlund umziehenden Ring bildet. - Das System der Quercommissuren zwischen den Pedalund Palliovisceralsträngen ist gewöhnlich überall reich entwickelt. Unter den Aplacophoren scheint es sich nur bei Chätoderma auf das Vorderende zu beschränken, was vielleicht eine Annäherung an die Verhältnisse der höheren Mollusken darstellt.

Vom Cerebralganglion der Aplacophoren (Fig. 367) entspringen hinten zwei Nerven, die, den Anfang des Darms ventral umgreifend, sich zu einer Ringcommissur vereinigen (Sublingualcommissur) and in der Gegend der Radulatasche zwei bis vier kleine Ganglien bilden (Sublingualganglien). Bei den Placophoren (Fig. 368) wird diese Sublingualcommissur wohl durch die sog. Subradulareommissur und die Subradularganglien vertreten. - Das sog. Buccal- oder Eingeweidenervensystem der Placophoren soll erst später, gemeinsam mit dem der übrigen Mollusken, besprochen werden.

Sämtliche übrigen Mollusken, die wir als Ganglioneura (s. S. 48) zusammenfassen, haben eine wesentliche Veränderung des Systems erfahren. Alle besitzen gut ausgebildete Cerebralganglien, von welchen die im $F u ß$ nach hinten ziehenden Pedalstrünge entspringen. Gewöhnlich ist eine Zusammenhäufung der Ganglienzellen an den Fußsträngen zu einem Paar besonderer Fu $\beta$ - oder Pedalganglien 
eingetreten, die mit dem Cerebralganglion durch zwei Connective zusammenhängen. - Die wichtigste Umgestaltung erfuhren die Palliovisceralstränge. In ihnen tritt nicht weit hinter ihrem Ursprung einę Ganglienanschwellung auf, wie sie auch schon bei gewissen Aplacophoren ausgeprägt ist, die sog. Pleuralganglien. Die darauf folgende Fortsetzung der Palliovisceralstränge hat ihre Beziehung zum Mantel bewahrt und sich zu den Hauptpallialnerven entwickelt, welche sich auch hinten, dorsal vom Enddarm, noch vereinigen können. Zwischen den beiden Pleuralganglien ist eine, häufig weit nach hinten ziehende und den Darm ventral umgreifende Commissur entstanden, die Visceralcommissur, welche in ihrem Verlauf Ganglien bildet (Intestinal- und Abdominalganglien). Diese Visceralcommissur enthält die Nervenfasern für die Kiemen und Eingeweide, welche bei den Amphineuren noch den Palliovisceralsträngen angehörten.

Wir müssen daher annehmen, da $B$ bei den Vorfahren der Ganglioneuren eine Art Spaltung der Palliovisceralcommissur in zwei Stränge eintrat; in einen, der die ursprünglichen Beziehungen zur Mantelfaite bewahrte, und einen zweiten, der sich, vielleicht unter Teilnahme von ventralen Quercommissuren der Pedaistränge, zur Visceralcommissur entwickelte. - Vielleicht geben gewisse Aplacophoren mit ihrer ventralen Commissur des sog. Kiemenganglions am Enddarm einen Fingerzeig, wie sich eine solche ventrale Visceralcommissur bei der Spaltung des primitiven Palliovisceralstrangs entwickeln konnte.

Zwischen den ursprünglichen Palliovisceralsträngen nnd den Pedalsträngen erhält sich bei den Ganglioneuren nur noch eine einzige Quercommissur, die von den Pleuralganglien zu den Pedalganglien zieht, die Pleuropedalcommissur. Dagegen können sich bei den primitiveren Formen zwischen den Fußsträngen (oder -nerven) noch zahlreiche Quercommissuren erhalten (s. Fig. 370, S. 519).

Gastropode. Während die seither besprochenen Molluskengruppen den ursprünglicheu bilateralen Körperbau und damit die bilaterale Symmetrie des Nervensystems (von geringfügigen Abweichungen abgesehen) bewahrten, bildet hingegen eine weitgehende Asymmetrie des Systems den grundlegenden Charakter der Gastropoden, hervorgerufen durch asymmetrische Verschiebung und Verlagerung innerer und äußerer Organe. Doch kann diese Asymmetrie bei gewissen Gruppen wieder stark bis nahezu völlig rückgebildet werden und damit auch die des Nervensystems. Bestimmend bei diesen Vorgängen ist die Verschiebnng des Afters aus der symmetrischen Hinterlage anf die rechte Seite und schließlich in die rechte vordere Region der Mantelrinne. Dabei wird der Organkomplex, welcher sich um den Enddarm und den After gruppiert, vor allem die seitlich vom After stehenden beiden Kiemen, die beiden Nieren, sowie das Herz, welches durch seine Vorhöfe mit deu Kiemen verbunden ist, gleichfalls mit dem After verlagert(vgl. Fig. 369). Dieser Verlagerungsprozeß aus der embryonal hinterständigen symmetrischen Lage muß sich notwendigerweise dadurch vollziehen, daß die Mantelrinne linkseitig stärker wächst als rechtseitig, wodurch die Verschiebung der in ihr liegenden, oder mit ihr zusammenhängenden Organe hervorgerufen wird. Der übrige Körper, Eingeweidesack, Fuß, Mantelfalte usw., bleibt dabei völlig symmetrisch, und die meist vorhandene Asymmetrie des Eingeweidesacks und der Schale ist eine selbständige Erscheinnng, welche mit der des Organkomplexes um den After (Pallialkomplex) 
nicht zusammenhängt. Es kann daher auch Gastropoden geben, deren Eingeweidesack die der gewöhnlichen entgegengesetzte Aufrollung zeigt, während die Verlagerung des Komplexes der Pallialorgane davon gar nicht berührt wird.

Die Nerven, welche die beiden ursprünglichen Kiemen und die sie tragende Region der Mantelrinne (Mantelhöhle) innervieren, entspringen an der Visceralcommissur meist von zwei Ganglienanschwellungen, den sog. Intestinalganglien.

Fig. 369 .

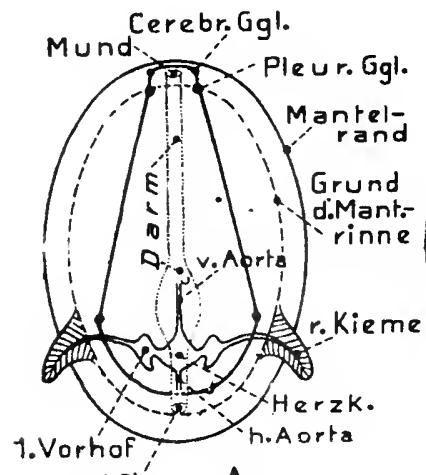

After $A$

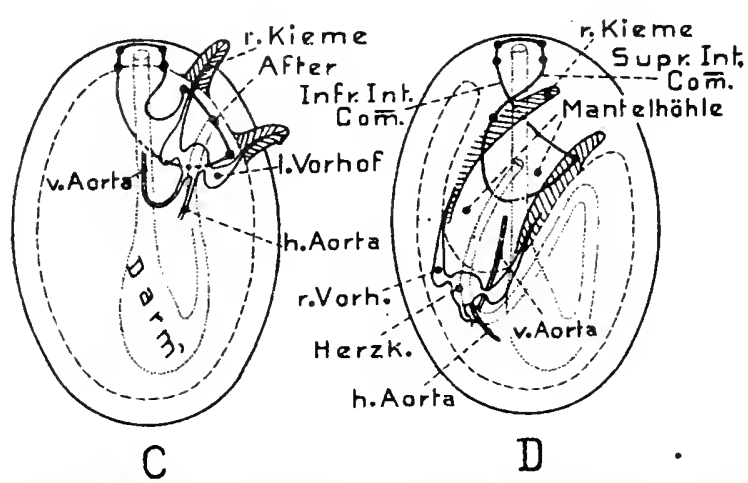

Vier Schemata zar Erläuterung der Kreuznng der Visceral. commissaren der Prosobranchiaten. Von der Dorsalseite. $A$ der Ausgangszustand. $B-D$ die allmāhliche Verlagerang des Afters und des um ihn befindlichen Organkomplexes (Kiemen, Herz und Kiemenganglien (Intestinalg.|) nach rechts and vorn zeigend. Die Verschiebnng erfolgt durch Wachstumsprozesse, unter Zunahme der Körpergrōße, wovon hier abgesehen ist. D Einsenkang der Mantel (Kiemen) -höhle, wodurch die eigentliche Kreuzungr der beiden Visceralcommissaren hervorgerufen wird. 0 . B. u. v. Bu.
Wenn nun die beiden Kiemen mit dem After dic erwähnte Verlagerung nach vorn erleiden, so daß die ursprünglich rechte Kieme jetzt links vom vorderständigen After liegt und die ehemalige linke rechts (s. Fig. $369 C$ ), so muß auch die mit den Kiemen zusammenhängende Visceralcommissur eine entsprechende Verschiebung erfahren haben. Die Kiemen werden bei den primitiven Gastropoden recht ansehnliche Organe, in deren Umgebung sich die Mantelrinne nach hinten und etwas nach links zu einer tiefen Kiemenhöhle (Mantelhöhle) einsenkt, an deren Decke die beiden Kiemen und żwischen ihnen der After geschützt liegen (s. Fig.

$369 D$ ). Diese Einsenkung der Kiemen in die Kiemenhöhle muß einen eigentümlichen Verlanf der Visceralcommissur hervorrufen, wie er aus Fig. $369 \mathrm{D}$ ersichtlich ist. Die rechte Hälfte der Visceralcommissur, die vom rechten Pleuralganglion entspringt, verläuft nun schräg nach links und hinten iiber den Darm, die linke dagegen zieht ventral vom Darm schräg nach rechts und hinten; beide vereinigen sich dann nnter dem Enddarm. Auf solche Weise bildet die gesamte Visceralcommissur eine achterförmige Schlinge, und die beiden Intestinalganglien, am Abgang 
der Kiemen- und gewisser Mantelnerven, liegen dann so, daß sich das der rechten Hälfte der Visceralcommissur über dem Darm (Supraintestinalyanglion) findet, das der linken unter dem Darm (Infraintestinalganglion). Die gekreuzte (chiastoneure) Innervierung der Kiemen und der ihnen benachbarten Regionen der Mantelhöhle ist daher sehr deutlich ausgesprochen. Alle übrigen Teile des Nervensystems: die Cerebralganglien, Fußstränge oder Fußganglien, sowie die aus der Fortsetzung der Pleurovisceralcommissur der Amphineuren hervorgegangenen Pallialnerven erhalten sich typisch symmetrisch.

Die charakteristische Kreuzıng der Visceralcommissur der primitiven Gastropoden wurde als Chiastoneurie oder Streptoneurie bezeichnet und ist bei den ursprïnglichsten Prosobranchiaten, den z. T. noch mit den beiden ursprünglichen Kiemen verseheiten Aspidobranchia (Diotocardia), sehr klar ausgesprochen (s. Fig. L.Branch. Ggl. 370); bei den Monotocardiern wird sie nicht selten durch Verbindung derVisceralcommissur mit andern Nerven etwas verwischt; bei den übrigen Gastropoden schließlich durch gewisse Vorgänge auch wieder ganz rïckgebildet.

Die Cerebralganglien sind stets gut entwickelt, ja zuweilen mit einigen hervorspringenden Lobi versehen (z.B. Basommatophoren, Fig. 376, 377, S. 524). Sie senden Ner-

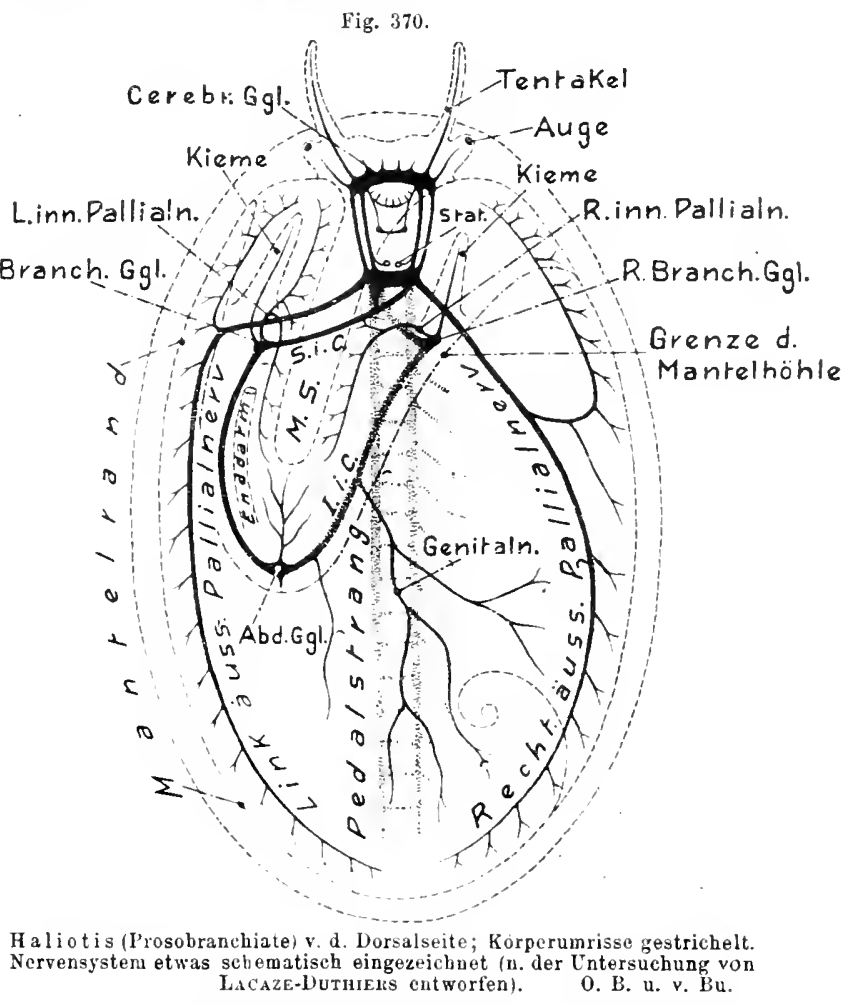
ven zur Kopfwand, deu Kopfsinnesorganen (Tentakel, Augen, Rhinophoreu. doch auch zu den Statocysten). Meist sind sie deutlich paarig, mit einer gewöhnlich kurzen queren Cerebralcommissur. Bei den primitiven Aspidobranchiern ist die ganglienzellenreiche Cerebralcommissur selır lang (Fig. 370), so daß die Cerebralganglien weit voneinander geriickt sind, was an die Placophoren erinnert. Dasselbe findet sich auch bei den thecosomen Pteropoden (Fig. 375 B), deren Cerebralganglien daher fast an die Ventralseite des Schlunds rücken. - In ihrer Lage variieren die Hirnganglien etwas, da sie teils ganz vorn auf der Buccalmasse (Aspidobranchia), teils hinter ihr liegen können. - Bei vielen Gastropoden (Dioto- 
cardier, sowie nicht wenigen Ctenobranchiern und Opisthobranchiern, Fig. 378, S. 525) sind die beiden Cerebralganglien durch eine zarte Quercommissur unter dem Schlund verbunden, von der gewöhnlich die Buccalnerven entspringen (sog. Labialoder Subcerebralcommissur). Sie entspricht wohl der Sublingualcommissur der Amphineureu.

Vom Hinterrand der beiden Cerebralganglien entspringen das Cerebropedalund das Cerebropleuralconnectiv, die ursprünglich (Aspidobranchia, sowie primitive Formen der Ctenobranchia, Opisthobranchiata und Pulmonata) lang sind, sich aber bei den beiden letzteren Gruppen häufig sebr verkürzen. Die Pleuralganglien der Aspidobranchier sind vom Vorderende der Fußstränge wenig oder nicht ge-

Fig. 371.

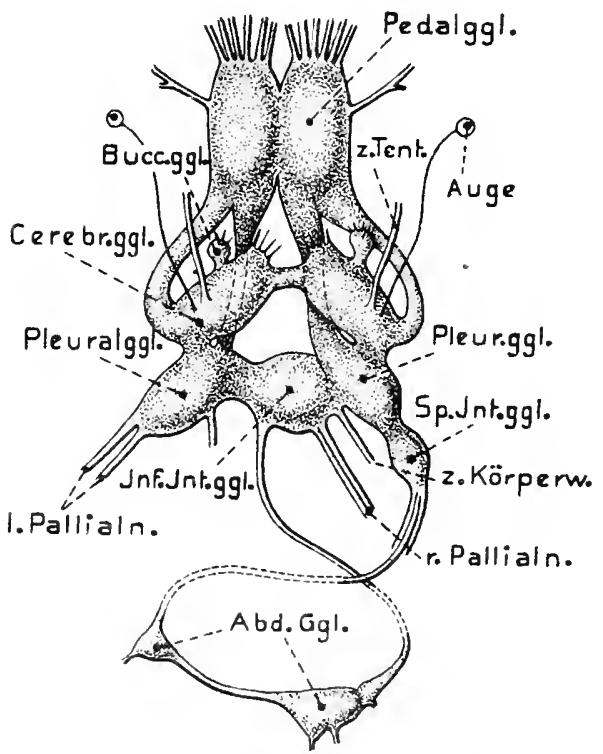

B uccinum undatum (Prosobranchiate). C'entralnervensystem von der Dorsalseite. Die Visceralcommissuren sind sehr stark verkürzt gezeichnet (gestrichelter Teil). (Nach Bouvikl 1557 kombiniert and etwas verándert). y. Bu. sondert, so daf hier eigentliche Pleuropedalcommissuren kanm vorhanden sind. Bei den iibrigen Gastropoden, ohne starke Konzentration des Systems, sind die Plcuropedalcommissuren dagegen gewöhnlich gut, z. T. sogar recht ansehnlich entwickelt (vgl. Fig. 371). 一 Die Pedalstränge bewahren bei den Aspidobranchiern (Fig. 370) und den ursprünglichen Ctenobranchiern noch den Bau wie bei den Amphineuren, sind daher lange ganglienzellenreiche Strïnge, welche durch mehr oder weniger zahlreiche Quercommissuren zusammenhängen. Bei den übrigen Ctenobranchiern konzentrieren sie sich in zwei am Vorderende der Stränge liegende Pedalganglien, denen zuweilen noch ein kleines accessorisches Ganglion angefiigt ist. - Von diesen Pedalganglien entspringen die meist zahlreichen Fußnerven. Solche Fußganglien sind für sämtliche übrigen Abteilungen der Gastropoden charakteristisch.

Sie sind fast stets deutlich paarig und durch eine transversale Pedalcommissur verbunden, die bei den primiticeren Formen wenig bis gar nicht ausgebildet ist; bei abweichenderen Formen (namentlich Opisthobranchiern, auch gewissen Pulmonaten) kann sie sich jedoch durch Auseinanderrïcken der Ganglien stark verlängern. In diesem Fall (namentlich Opisthobranchia (Fig. 372), gymnosome Pteropoda (Fig. 375 A) flndet sich häufig noch eine zweite zarte Qnercommissur zwischen den Fußganglien (Parapedalcommissur).

Von den Pleuralganglien entspringen die meist ansehnlichen Nerven für die Mantelfalte (Pallialnerven), die sich bei den Aspidobranchiern recht ursprünglich erhalten und hinten dorsal vom Darm ineinander übergehen, oder doch anastomo- 
sieren können (s. Fig. 370). Von den Pleuralganglien geht ferner die Visceralcommissur aus, deren charakteristischer Verlauf bei den typischen Prosobranchiaten schon oben (S. 518) geschildert wurde. In dieser Commissur treten stets Ganglienanschwellnngen anf; so, wie erwähnt, am Abgang der Nerven fur die Kiemen und die zugehörige Mantelregion das Infra- und Supraintestinalganglion. Wenn die rechte vorderständige Kieme rïckgebildet ist, kann auch das sie innervierende Infraintestinalganglion ausfallen (Aspidobranchia z. T. und nicht wenige Ctenobranchia), doch kann es bei letzteren, sowie den Opisthobranchiern und Pulmonaten, wieder auftreten (s.Fig.373) und innerviert dann die rechte Mantelhöhlenregion, zu der sich auch von der rechten Hälfte der Visceralcommissur (Supraintestinalcommissur) zahlreiche weitere Nerven begeben können, ebenso wie zu der linken Mantelhŏhle von der linken Hälfte (Infraintestinalcommissur). - Bei den Pulmonaten findet sich meist vor dem Infraintestinalganglion, in der linken Hälfte der Visceralcommissur, noch ein besonderes Ganglion (Parietalganglion, s. Fig. 373), von dem

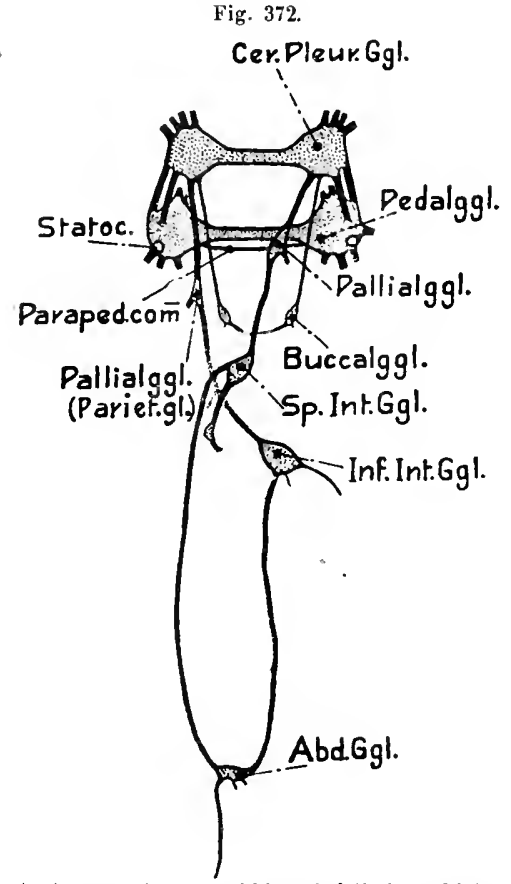

Actaeon tornatilis (Opistbobranchiate). Nervensystem von der Dorsalseite (n. Pelseneer 1893). r. Bn.

Nerven zur linken vorderen Körperregion gehen. Ähnliche Ganglien finden sich bei manchen primitiven Pulmonaten und Opisthobranchiern in beiden Hälften der Visceralcommissur; sie werden gewöbnlich als Pallialganglien bezeichnet (s. Fig. 372 ).

An der Übergangsstelle der beiden Hälften der Visceralcommissur findet sich mindestens ein sog. Abdominalganglion (Visceralganglion), welches die Organe des Eingeweidesacks (Darm, Leber, Herz, Genitalorgane) innerviert. Bei den Prosobranchiaten (Fig. 374) kann die Zahil der Abdominalganglien jedoch auf $2-3$ steigen.

Zwischen den peripheren Ansbreitungen der Pallialnerven und den Kiemennerven jeder Seite scheinen ursprunglich überall Anastomosen zu bestehen. Aus diesen geht bei einem Teil der Aspidobranchier (Rhipidoglossa) und Ctenobranchier eine

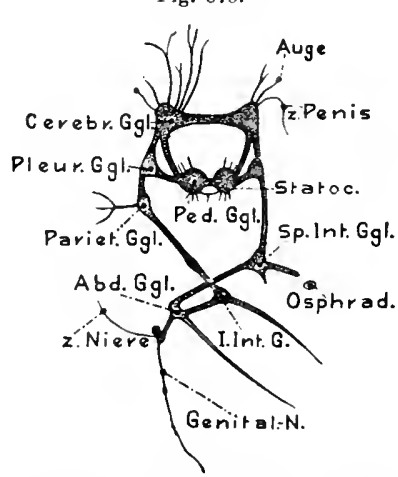

Chilin a dombeian a (Pulmonate) Nervensystem von Dorsalseite (nach Plate 1895). v. Bu. stärkere Anastomose zwischen den Pallialnerven und den Kiemennerven hervor, teils nur einseitig, teils beiderseitig; ein Zustand, welcher als Dialyneurie be- 
zeichnet wird. Auf der rechten Seite der Ctenobranchier wird diese Verbindung häufig. in der Weise abgeändert, da $B$ der vom rechten Pleuralganglion entspringende rechte Pallialnerv (z.r.) direkt zum Infraintestiualganglion zieht und mit ihm verwächst, um sich erst dann weiter zu verbreiten; dieser Znstand wird als Zygoneurie bezeichnet nnd tritt zuweilen auch allein linkseitig auf. Wenn er auf beiden Seiten entwickelt ist, indem auch der linke Pallialnerv ( $x . l$. ) sich in ähnlicher Weise mit dem Supraintestinalganglion verbindet(s.Fig. 374), so spricht man von Orthonewrie. Hierdurch wird die ur-

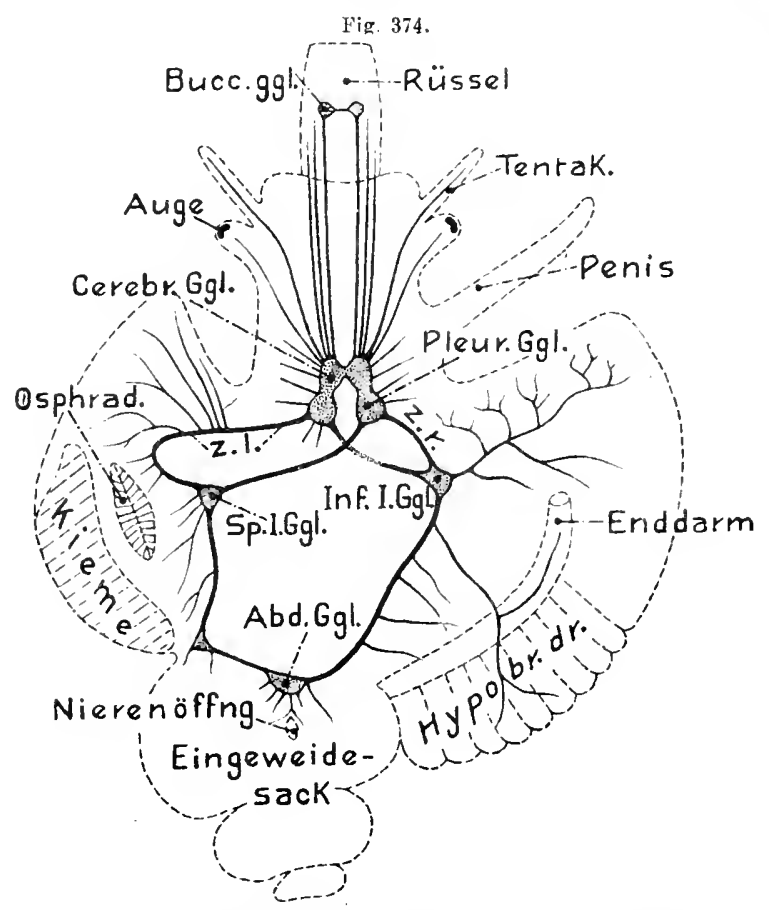

Triton $\delta$ (ctenobranchiate Prosobranchiate). Centralnervensystem mit den hauptsáchlichsten übrigen Organen an der dorsal geöffneten Schnecke dargestellt. Inf. I. Ggl. = Infraintestinalga日glion. - Sp. I. Ggl. = Supraintestinalganglion. $-z \cdot l .=$ linke, $z . r=$ rechte Verbindung der Pallialnerven mit Supra- und Infraintektinalganglion (sog. Orthoneurie). Die Pedalganglien nicht eingezeichnet (n. Bouvifr issz). v. Bu. sprïngliche Chiastoneurie der Visceralcommissur stark verwischt, ist aber bei genauerem Zusehen stets noch nachzuweisen. - Bei gewissen Ctenobranchia kann die ursprünglich sehr lange Visceralcommissur in ihrem vorderen Abschnitt stark verkürzt werden (s. Fig. 371 ), wobei die beiden Intestinalganglien dicht an die Pleuralganglien heranriicken und mit ihnen mehr oder weniger verwachsen. Auch bei gewissen Aspidobranchia (Neritidae n. Helicinidae) tritt eine so starke Verkiurzung des vorderen $\mathrm{Ab}$ schnitts der Visceralcommissur auf, ja, wie es scheint, sogar eine Rückbildung der ganzen linken

Hälfte der Commissur (dosh sind die Verhältnisse noch etwas unsicher); die Chiastoneurie ist daher hier, wenigstens anscheinend, geschwunden.

Eine solche Rückbildung der bei den Urformen der Gastropoden jedenfalls allgemein verbreiteten Chiastoneurie der Visceralcommissur konnte nun sehr leicht eintreten, wenn die gesante Commissur, die bei den Prosobranchiaten stets'recht lang ist, sich bedeutend verkürzt, was im allgemeinen für die Pteropoden, Opisthobranchiaten und Pulmonaten gilt. Bei starker Verkürznng muß die achterförmige Commissur der Prosobranchiaten wieder in eine symmetrisch ungekreuzte Lage gezogen werden, unter Verlängerung der Nerven, die zu den Kiemen und ihrer Mantelhöhlenregion gehen. In der nun wieder symmetrisch gewordenen Commissur wird daher nur noch die Kreuzung der Mantelnerven (Pulmonaten) 
die ursprtungliche Chiastoneurie andenten. - Bei den Opisthobranchiern und den Pteropoden dagegen, wo sich gleichzeitig die Verschiebung des Komplexes der Afterorgane, die embryonal noch ansgesprochen ist, wieder bis etwa zur Hälfte (rechtseitig Tectibranchiata), oder völlig (Nudibranchiata) riickbildet, muß dadurch natürlich die Rückbildung der Chiastonenrie noch mehr befördert werden. Daß sich diese sog. Euthyneurie der Opisthobranchier und Pulmonaten aus ursprünglicher Chiastoneurie herleitet, folgt sicher daraus, daß die ursprünglichen Formen

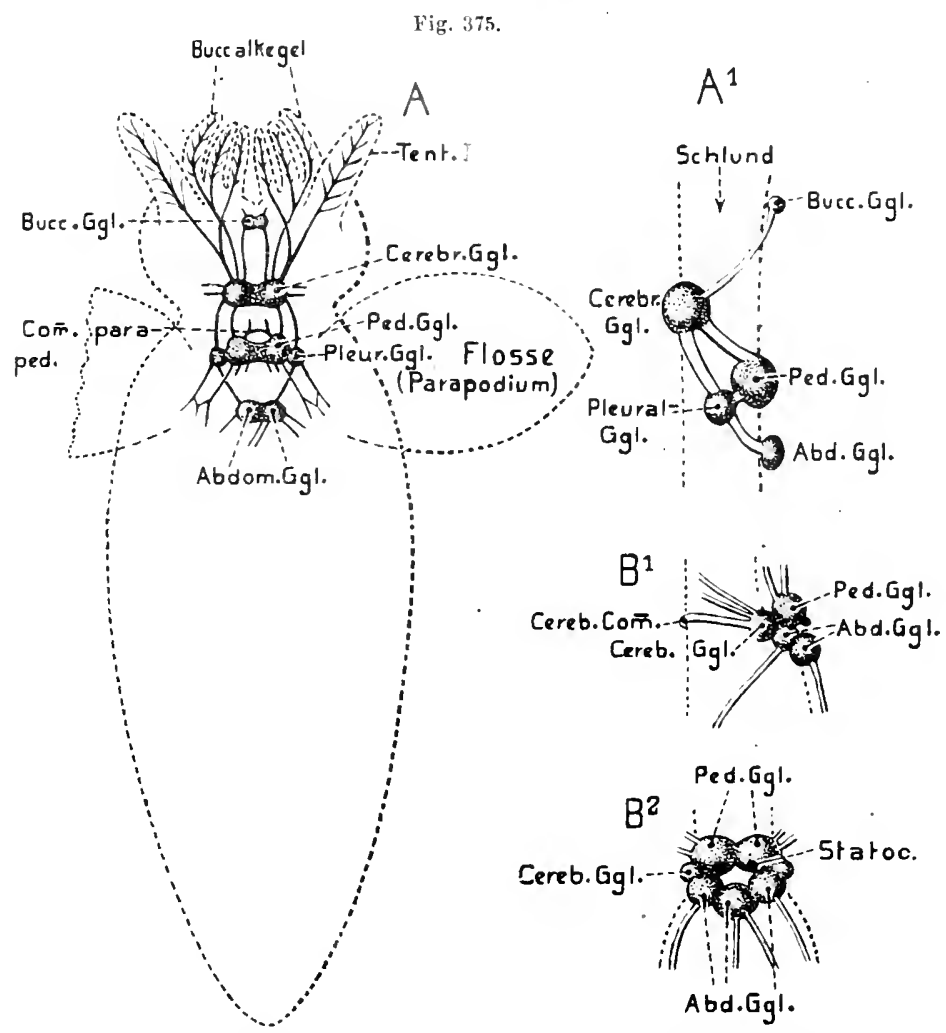

Pteropoden. Nervensystem. A und Al Clione limacina. A von der Dorsalseite; Körperumrisse punktiert. 1 die Ganglien um den Schlnnd (punktiert) von rechts, - $B 1-B^{2} \mathrm{Cymbulja} p$ ronij. Schlund (pnnktiert) mit den Certralganglien. $b^{1}$ ron rechts; $B^{2}$ von der Bauchseite (n. PeLseseer 1s86). E. W.

der ersteren (Bulla, Aplysia usw, noch eine lange Visceralcommissur besitzen, die bei Actaeon (Fig. 372) sogar noch chiastoneur ist. Auch einzelne Pulmonaten zeigen noch die chiastoneure Visceralcommissur (Chilina s. Fig. 373, S. 521), andere noch eine längere und unverdrehte (Auricula, Latia).

Was jedoch die meisten Opisthobranchiaten, die Pteropoden und Pulmouaten besonders charakterisiert, ist die starke Verkiirzung der Visceral- und Pedalcommissuren, sowie die Zusammendrängung oder Konzentration sämtlicher Ganglien des Centralnervensystems um den Schlund, in nächster Nähe der Hirnganglien. Dies geschieht bei den Pteropoden (s.Fig. 375), den ursprünglicheren Opisthobranchiaten 
(Fig. 378) und den Pulmonaten (Fig. 376 u. 377) so, daß die einzelnen Ganglien noch gut unterscheidbar bleiben, obgleìch die Connective und Commissuren zwischen ihnen stark verkürzt sind. Die Cerebralganglien sind dann gewissermaßen durch zwei ventrale, den Schlund umziehende Commissuren verbunden, die Cerebropedalcommissur, der die Pedalganglien eingelagert sind und die Cerebropleurovis-

Fig. 376.

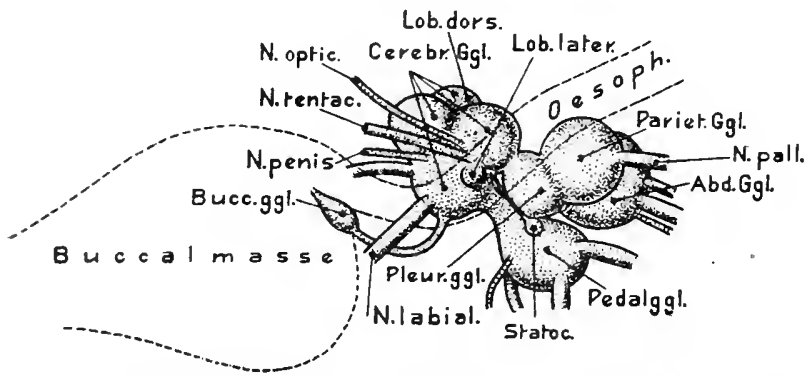

Limnaea stagnalis (Pnlmonate). Centralnervensystem von links. Die Buccal. masse und der Ósophagus gestrichelt angegeben. (n. Pelseneer 1906). ceralcommissur mit den Pleural- und Abdominalganglien.

Bei den Opisthobranchiern (insbesondere den Nudibranchiern) geht die Konzentration noch viel weiter, indem die ursprünglich ventral vom Schlund liegenden Pedal- und Pleu-

ralganglien, unter starker Verkiirzung der sie mit den Cerebralganglien verbindendeu Connective, dorsal nnd seitlich an die Cerebralganglien dicht heranrücken, bis sie schließlich mit ihnen verwachsen können (Fig. 378). Die Pleuralganglien verschmelzen auf diese Weise häufig mit den Cerebralganglien, während die Pedalganglien gewöhnlich noch erkennbar bleiben. - Eine ähnliche Konzentration gilt auch fïr die meisten thecosomen Pteropoden (Fig. $375 \mathrm{~B}$ ), doch geschieht sie hier unter Herabrïcken der Cerebralganglien an die Ventralseite des Schlunds. - Bei

Fig. 377 .

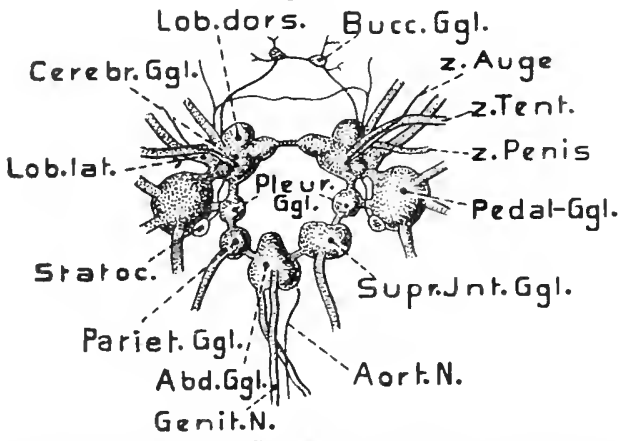

Limnaea stagnalis. Centralnervensystem von der Dorsalseite. Das Infraintestinalganglion soll mit dem Abdom.Ganglion vereinigt sein. (n. LACAZE-DUTHERS 1872). gewissen Nudibranchiern (Tethys, Fig. 379) kann schließlich völlige Verschmelzung der Cerebral-, Pleural- und Pedalganglien zu einem einzigen dorsalen Schlundganglion eintreten, also der höchst denkbare Zustand der Konzentration. - Die erwähnten Verhältnisse der Nudibranchiaten bedingen eine relativ ansehnliche Entwicklung der Pedal- und Visceralcommissuren, obgleich diese denSchlund direkt ventral umgreifen; zu ihnen können sich als dritte und vierte

Commissur noch die Subcerebral- und Parapedalcommissur (s. oben S. 520) gesellen. - In der Visceralcommissur finden sich fast nie melır gesonderte Intestinalganglien, die daher wohl mit der Commissurenverkürzung in die Pleuralganglien eingingen; ebenso ist auch ein Abdominalganglion häufig nicht mehr erhalten. Die Konzentration des gesamten Centralnervensystem erreicht demnach in 
diesen Fällen ihren höchsten Grald, was früher gelegentlich, aber irrig, als primitiver Ausgangszustand anfoefaßt wurde.

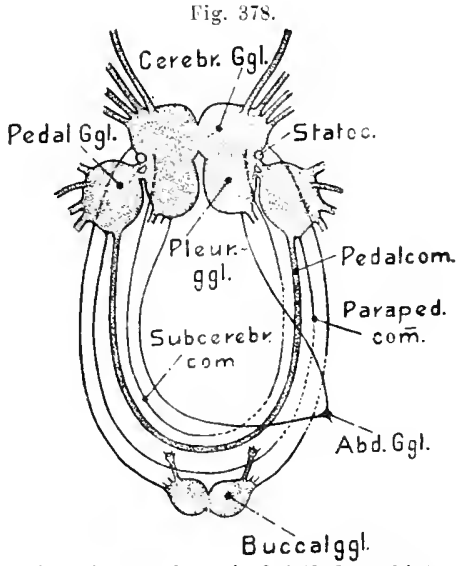

Tritonia homber i (Opisthohranchiate). Nerrensystem ron der Dorsalseite (nach Plecseverer 18!3). v. Bn.

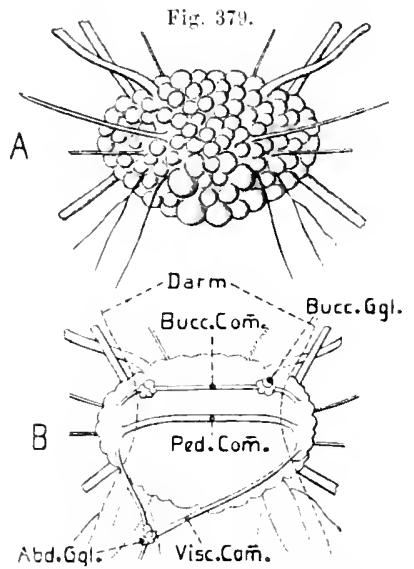

Tethys leporina copisthobras. chiate). Centralnervensystem. $A$ Central. ganglion you der Dorsalseite. I)ie tratubigen Erhebungen anf der Oberfläche des Ganglions sind die hier riesig grobin Ganglienzellen. $-B$ Dasselbe von der Ventralseite mit Angabe des Darms in Strichlinien. (Mit Benutzung von Pr. SENEER 1893 n. Originalpräparat). v. Bu

Die ïbrigen Klassen der Ganglioneura (Lamellibranchiata, Solenoconcha und Cephalopoda) bewahren die primitive symmetrische Bildung des Nervensystems Wir beginnen unsere Bespreehung mit den Lamcllibranchiatcn, obgleich sie in vieler Hinsicht Reductions- und besondere Anpassungserscheinungen anfweisen, jedoch im Nervensystem recht urspriinglich bleiben.

Lamellibranchiaten. Sämtliche Muscheln besitzen die drei typischen Ganglienpare: Cercbralganglien, welche, in meist geringer Entfernung hinter dem Mund, dem Schlund auf-oder seitlich anliegen; Pedalganglien, die in der Muskulatur der Basal-

Fig. :3so.

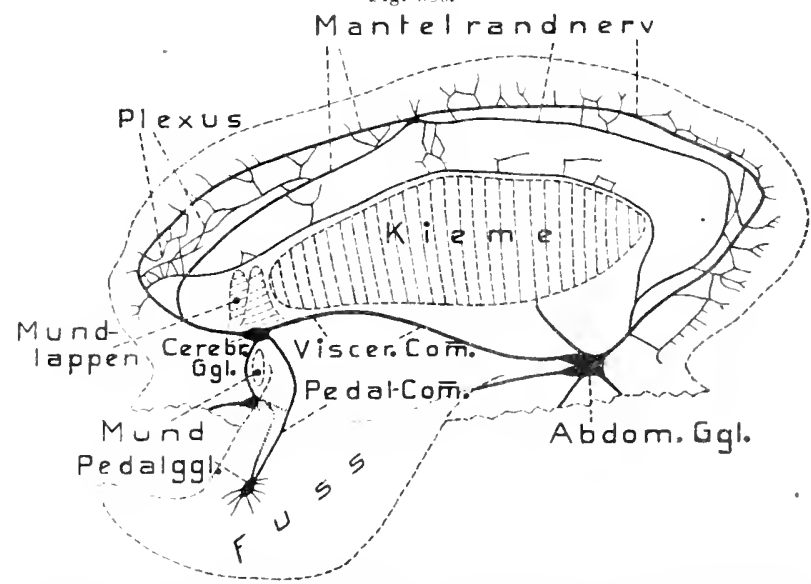

('ar d i um $\Leftrightarrow$ du le, r. d. Fanchseite; Körperumrisse gestrichelt. Rechter llantel. lappen nebst kiemen entfernt. Nerrensystem schwarz (n. Dinost 1556). v. Bu. l'egion des Fußes eingebettet sind, und Abdominal-oder Visceralganglien, die sich in der Gegend des hinteren Schließmuskels finden. Die drei Ganglienpare sind 
daher in der Regel weit voneinander entfernt und die beiden zwischen ihnen ausgespannten Connective: die Cerebropedal- und die Cerebrovisceralconnective, daher recht lang (Fig. 380).

Die beiden mäßig großen, zaweilen auch recht kleinen Cerebralganglien sind gewöhnlich ziemlich weit voneinander gerückt, also durch eine längere Cerebralcommissur verbnnden; selten dicht zusammen gelagert bis verschmolzen (Teredo, Fig. 381).

Bei den primiticsten Muscheln, den Protobranchiern, Nucula (Fig. 381) und Solenomya, ist das Cerebralende des Visceralconnectivs zu einem länglichen Ganglion angeschwollen, das einen Nerv zur vorderen Mantelregion schickt. Diese Ganglien entsprechen daher Pleuralganglien, welche stark cerebralwärts gerückt und mit den Cerebralganglien verwachsen sind.

A.

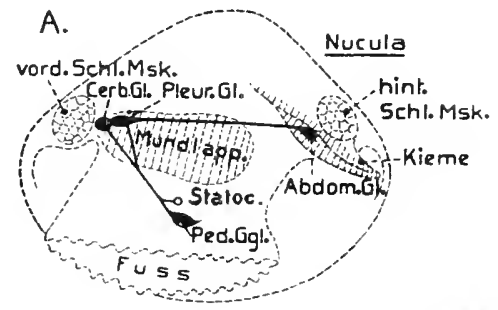

Fig. 381 .

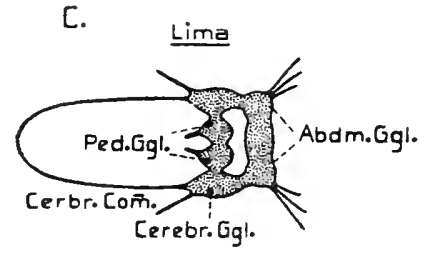

Teredo

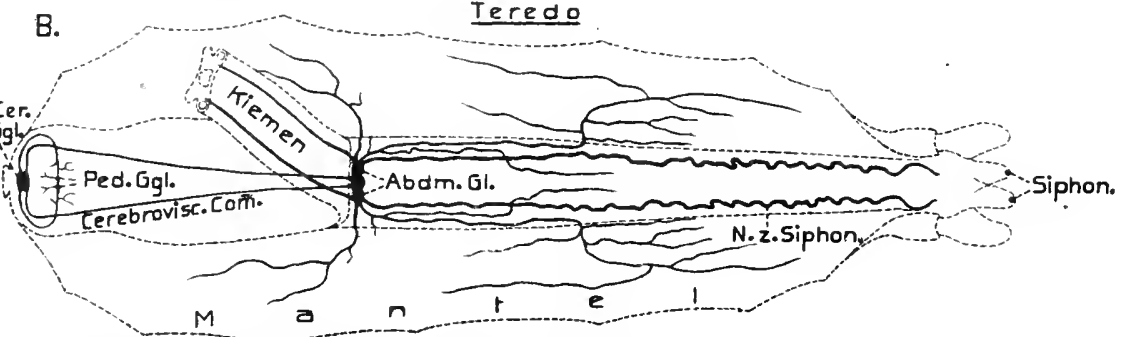

Lamellibranchiata, Nervensystem. A Nucula nucleus von links. Umrisse und einige sonstige Organe gestrichelt. Nervensystem schwarz eingezeichnet. (n. PEseneel 1891). $B$ Teredo fatalis. Von der Ventralseite. Der Mantel ist in der Ventrallinie anfgesehnitten und seitlich ausgebreitet Die Kiemen sind abgelöst, $z$. 'T. abgeschnitten und nach vorn umgelegt. Körperumrisse gestrichelt (nach QUATREFAGEs 1S49). C L i ma squamosa. Schema des Nervensystems in Flächenansicht (n. PELsexeEk 1910). v. Bu.

1)a 3 diese Deutung zutrifft, ist sicher, da von jedem Pleuralganglion eine Pleuropedalcommissur entspringt, die aber nach kurzem Verlauf mit lem Cerebropedalconmectiv verschmilzt. Bei Solenomya rereinigt sich diese Commissur sofort nach ihrem Beginn mit dem Cerebropelalconnectiv, ein freies Stück der Pleuropedalcommissur fehit daher. Es darf demnach als erwiesen erachtet werden, daß die Pleuralganglien in die Cerebralganglien der übrigen Muscheln einbezogen sind, was um so sicherer erscheint, als die Cerebralganglien in diesem Falle die vorderen Mantelnerven abgeben, und weil bei einzelnen Formen (z. B. Dreissensia) ontogenetisch Anlagen der Pleuralganglien beobachtet wurden, die später mit den Cerebralganglien verschmelzen.

Von den Cerebralganglien entspringen die beiden vorderen Mantelnerven, sowie die Nerven für den vorderen Adductor, die Mundregion und die beiden Paare der sog. Mnndlappen (-segel oder Palpen), welche rechts und links vom Mund stehen.

Die beiden Pedalganglien sind stets dicht aneinandergeriickt, ohne Pedalcommissur, doch nur selten inniger verschmolzen. Die meist langen Cerebro- 
pedalconnective verkiirzen sich bei Muscheln mit stark verkïmmertem und nahe an den Mund verlagertem Fuß sehr (Teredo, Pecten, Ostrea etc.), wobei sich die Ganglien gleicizeitig stark reduzieren. Bei Lima sind die Connective sogar völlig geschwunden, so daß die Cerebral- und Pedalganglien direkt zusammenhängen (Fig.381). Zahlreiche Nervenstrahlen gewöhnlich von letzteren in die Fußmuskulatur; ebenso versorgt jederseits ein Nerv die Statocysten, welche den Pedalganglien meist dicht anliegen; seine Fasern kommen jedoch direkt aus den Cerebralganglien.

Die Abdominal- und Visceralganglien sind bei den primitiven Muscheln in der Regel durch eine ganglienzellenreiche Commissur verbanden, bei den tibrigen dicht zusammengeriickt. Sie liegen fast ausnahmslos sebr oberflächlich unter dem Integument, an der Ventralseite des hinteren (oder des einzigen) Adductors, selten (Protobranchia, Teredo) hinter diesem; noch seltener etwas davor. Von ihnen entspringen zwei ansehnliche Kiemennerven (s. Fig. 380 u. 381), ferner zwei oder mehr starke Nerven für die hintere Mantelregion (hintere Pallialnerven), die sich

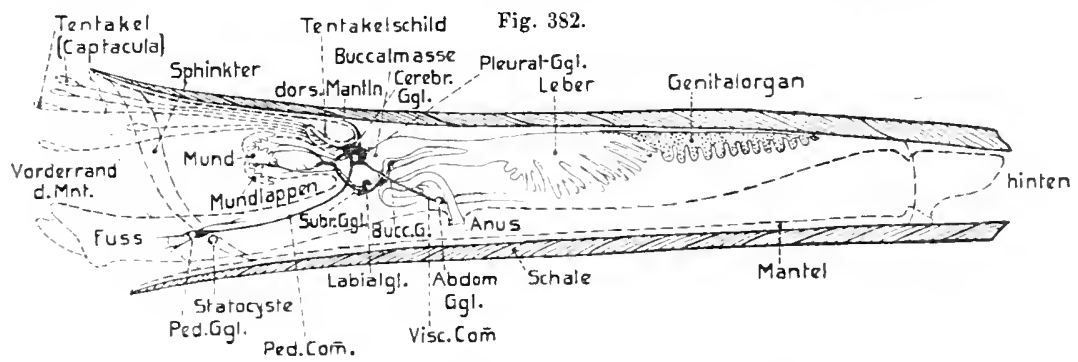

íeutalinm vulgare (Scanhopode), linkseitige Ansicht. Körperumrisse gestrichelt. Schale im Durchschnitt dargestellt. Darm gelbliann. Nervensystem schwarz (n. Lacaze-Dothiers 1656j57, mit Korrektur n. Plate J892).

unter Verästelung und Plexusbildung in der Mantelrandregion verbreiten und hier in den von vorn kommenden Plexus der vorderen Mantelnerven übergehen. - Bei gewissen Formen (Pecten usw.) entwickelt sich am Mantelrand ein zusammenhängender Randnerv, so daß hier gewissermaßen die beiden Spaltungsprodukte des ursprünglichen Palliovisceralconnectivs der Ganglioneura: das Cerebrovisceralconnectiv und der Pallialnerv noch ziemlich primitiv vorliegen. - Bei den Muscheln, aus deren analer Mantelregion sich Siphonen entwickeln, werden letztere gleichfalls von Nerven der Abdominalganglien reichlich versorgt, in denen, wie im Mantelplexus, auch kleine sekuıdäre Ganglien auftrefen können. - Der Ursprung der Branchialnerven ist zuweilen gangliös angeschwollen; es sind dies die Ganglien der beiden Geruchsorgane (Osphradien), deren Nerven stets von den.Abdominalganglien ausgehen, obgleich ihre Fasern vom Cerebralganglion kommen. Außerdem senden die Abdominalganglien noch Nerven zum Herz.

Bei einigen Formen (besonders Dreissensia, doch auch Unionidae und andere) wurde in jedem 0.-Visceralconnectiv ein kleines Ganglion beschrieben, das Nerven zu den Kiemen und der mittleren Nantelregion sendet, und deshalb dem Intestinalganglion der Gastropoden verglichen wurde. - Eine besondere Differenzierung der Abdominalganglien zeigen Pholas und Teredo, indem sich eine kleine vordere Partie abgelöst hat, welche durch seitliche Verbindungen mit den Ursprüngen der $\mathrm{C},-\mathrm{V}$ isceralconnective zusammenhängt. 
Eine eigentümliche Umformung erfuhr das Nerrensysten gew isser Limaarten (Fig. $381 C$ ), inden sich die Cerebralcommissur sehr verlängerte, die G.-Visceralconnective dagegen starh verkürzten, wodurch die Cerebralganglien so weit nach hinten rückten, daß sie mit den $\mathrm{Ab}$ dominalganglien direkt zusammenhängen. Da bei Lima auch die Cerebropedalconnective gan? verkürzt sind, so liegen die drei dicht zusammengerückten Ganglienpaare sämtlich der Ventra]fläche des einzigen Adductors an und werden vom Integument durch den sich zwischen schiebenden Darm getrennt.

Das Nervensystem der Scrphopoden (Fig. 382) gleicht dem der Lamellibrauchiaten sehr, abgesehen von der Erhaltung der Pleuralganglien und des sog. Buccalnervensystems, das den Muscheln fehlt, wie wir später sehen werden. Es dürfte daher genügen, auf die Figur zu verweisen, welche das System von Dentalium etwas schematisiert darstellt.

Cephalopoda. Wie zu erwarten, erhielt sich die primitive symmetrische Bildung des Nervenapparats durchaus; die starke Konzentration sämtlicher Ganglien um den Schlundanfang, ähnlich wie bei den Opisthobranchiern und Pulmonaten, spricht dagegen für eine erhebliche Umbildung. - Das Nervensystem der Tetrabranchiaten (Nautilns) bietet in mancher Hinsicht mrsprünglichere Verhältnisse, doch ist schwer zu beurteilen, wieweit es vielleicht von Um-oder Rückbildungen beeinfusst wurde. Es liegt dem bei Nautilus unvollständigen Kopfknorpel (s. S. 164) dorsal auf, so daß nur wenige ventrale Nerven durch den Knorpel treten; wogegen das um deu Schluudbeginn Konzentrierte System der Dibranchiaten den becherförmigen Kopfknorpel eingelagert ist, also zahlreiche Nerven den Knorpel durchbrechen. Das centrale System von Nautilus (Fig. 383) wird nicht von Ganglienanschwellungen, sondern von ganglienzellenreichen Bänderı (Commissuren) gebildet, die dorsal und ventral vom Schlund liegen. Dorsal findet sich das ansehnliche Querband des Cerchralganglions, von dem nach rorn zahlreiche feine Nerven zu den Mundrändern (Lippen) entspringen; seitlich dagegen die sehr starken Augennerven mit ihren großen Ganglien, mnd wohl auch die Nerven der beiden Rhinophore(Geruchsorgane). Jederseits gehen endlich die beiden Wurzeln des Buccalnervensystems ab, sowie ganz seitlich, anf der Grenze zwischen Cerebral- und Pedalband, die beiden Statocystennerven. - Lateral spaltet sich das Cerebralband in zwei den Schlund ventral umgreifende Bänder, ein vorderes schwächeres und ein hinteres stärkeres. Ersteres, das Pedalband, entsendet in seiner laterodorsalen Region die Nerven für die beiden Augententakel; seitlich die zahlreichen Kopftentakelncrven, von welchen beim Weibchen die beiden ventralsten sehr stark sind nnd ein ansehnliches Ganglion bilden, das die zahlreichen Nerzenzweige für die sog. inneren Labialtentakel abgibt. Letzterem Tentakelnerv reiht sich schließlich der Trichternerv an.

bas hintere ventrale Band (Visceratband) schickt seitlich zahlreiche kleinere Nerven in den Mantel, die darin keine Ganglien bilden; mehr ventral zwei ansehnliche sog. Visceralnerven, welche die Kiemen und die Organe des Eingeweidesacks versorgen, vielleicht sogar hinter dem After (richtiger dorsal von ihm), anastomosieren. ver Bau des cerebralen und der beiden ventralen Bänder, die gewöhnlich als Reprä sentanten der l'edal- und Visceralcommissur der Gastropoden samt ihren Ganglien 
gedeutet werden, erinnert an die Verhältnisse der Placophoren und der primitiven Prosobranchiaten und darf daher wohl als ursprïnglicher als die Ganglienbildung der dibranchiaten Cephalopoden beurteilt werden.

Die Dibranchiaten besitzen statt der strangförmigen Bänder des Nantilus starke Ganglien, welche im allgemeinen als Cerebral-, Pedal- und Visceralganglien bezeichnet werden. Ihre Lage zum Kopf knorpel wurde schon oben hervorgehoben. Das Cerebralganglion (Fig. 384) ist ein einheitlicher Knoten, der seitlich in zwei sehr dicke kurze Augennerven übergeht (N. optici, Tractus optici), die sofort zu den kolossalen Augenganglien anschwellen, deren Volumen das des gesamten Nervensystems übertrifft. Von einer kleinen dorsalen Ganglienanschwellung der Augennerven entspringt derzarteRiechnerv ( $\mathrm{N}$. olfactorius). Vorn gehen bei den Decapoden zwei Nerven $a b$, die lıäufig teilweise vereinigt sind, zu einemGanglion buccale superius, das bei dieser Abteilung (Fig. 384 A) mehr oder weniger weit vor dem ('erebralganglion liegt.

Fig. 39.

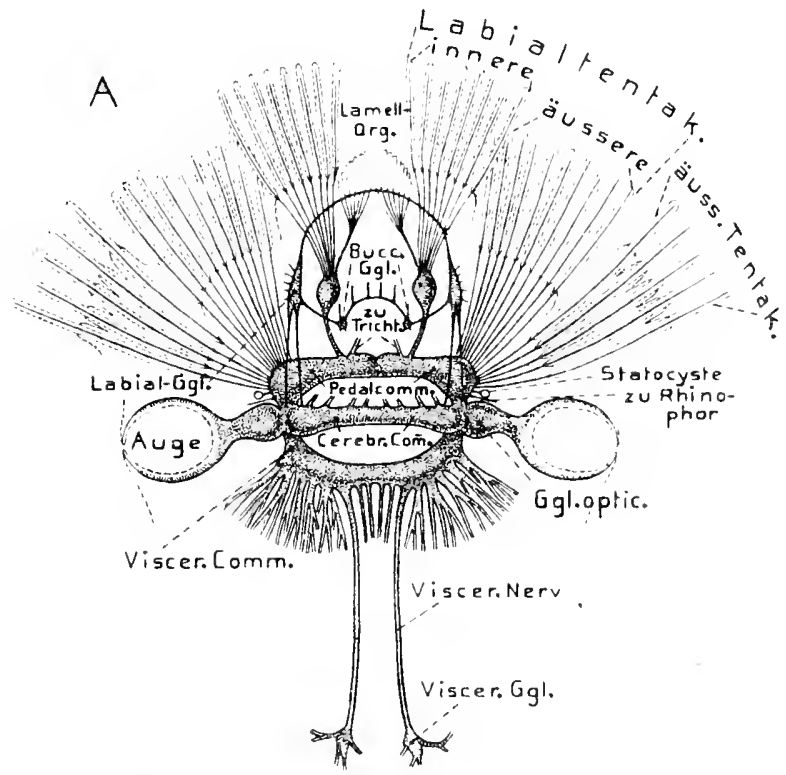

I)

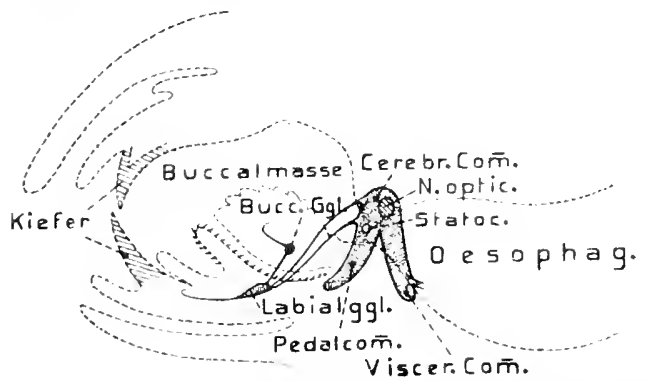

Nautilus o Centralnervensystem. A Centralnervensystem (schematisch) ron der Dorsalseite. mit Andeutung der Iabialtentakel und eines Teils der äniseren Tentakel (gestrichelt) (n. 0wlex $\backslash>32$ u. KERR 1895). - B Sagittal schuitt der Bucualmasse mit dem ('entralneriensystem; stark athematisiert (nach P'ELSLNELE 1905 , etwas verändert). O. I. U. v. Bn.

Bei den Octopoden (Fig. $384 \mathrm{~B}$ ) ist es mit dem Vorderende des Cerebralganglions verschmolzen und wird daher zuweilen als sein vorderster 'Teil aufgefaßt, der sich bei den Decapoden abgesondert babe (Pelseneer). - Ventral vou Schlund liegen hintereinander drei starke Knoten, die gleichfalls wenig Andentung von Paarigkeit zeigen, und, untereinander verwachsen, mit den Seiten des Cerebralganglions direkt znsammenhängen. Von dem sehr ansehulichen vorderen Knoten 
(Brachialganglion) entspringen die 8 oder 10 starken Nerven für dic Kopfarme (Fig. 384 u. 85). Das Brachialganglion ist, ähnlich dem oberen Bnccalganglion, entweder weiter nach vorn gerïckt (Decapoden) und durch eine Art Tractus mit dem zweiten Ganglion (G. infundibulare oder pedale) verbunden, oder letzterem vorn direkt angeschlossen (Octopoda). Jederseits steht es mit dem Cerebralganglion durch eine schwache bis stärkere aufsteigende Commissur in Verbindung, worauf bei dem Buccalnervensystem noch einmal zurückzukommen ist. - Das zweite Ventralganglion (G. infundibulare) entsendet hauptsächlich die beiden Trichternerven. In der Nähe
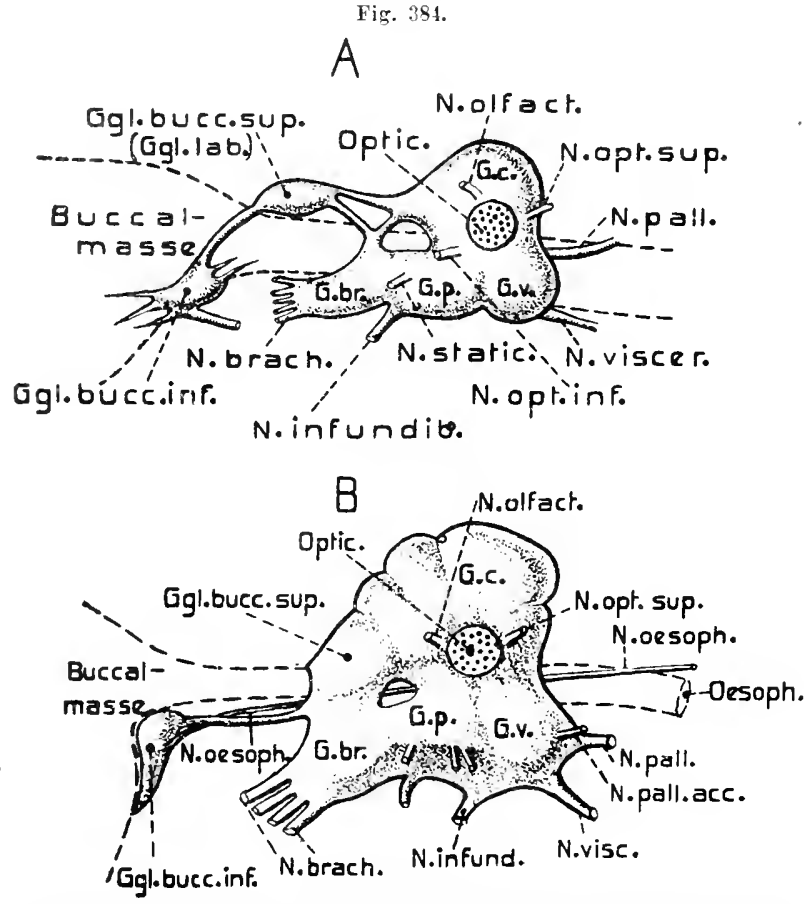

Centralnervensystem von dibranchiaten cephalopoden. $A$ Von Se pia officinali s, linkseitige Ansicht (n. Garxkr, etwas verăndert). $-B$ Von Octopus vulgaris linkseitig. G. c. = Gangl. cerebrale. - G. p. = Gangl. infundibulare. - G. v. = Gangl. viscerale. C. H. des Trichternervs entspringt der N. staticus (acusticus). Dem Ganglion infundibulare reiht sich hinten das ansehnliche sog. Visceralganglion an, das deutlicher paarig ist. Von ihm entspringen, zum Eingeweidesack anfsteigend, zwei ansehnliche $\mathrm{Pa}$. lialnerven und dazwischen zwei Visceralnerven (Fig. 385), deren Ursprünge auch verwachsen sein können; doch schicken die Visceralganglien auch zwei hintere Nerven in den Trichter. Infundibular- und Visceralganglion sind mit dem Cerebralganglion

seitlich in ganzer Ausdelnung verwachsen. Zwischen dem Cerebrobrachialconnectiv und dieser Verwachsung bleibt jederseits ein enges Loch.

Brachial- und Infundibularganglien werden gewöhnlich als Differenzierungen des gemeinsamen Pedalbands der Tetrabranchiaten, d. h. der Pedalganglien der übrigen Mollusken, beurteilt. Diese Auffassung bildet (abgesehen von ontogenetischen Momenten) den Hauptgrund: die Kopfarme der Cephalopoden als Bestandteile des Fußes, hervorgegangen aus dem Epipodium, zu deuten. Das Infundibularganglion wird dementsprechend als der dem Fußrest (Trichter = Parapodium) zugehörende Teil der Pedalganglien angesprochen. -.- In Visceralganglion wären die Pleural- und Abdominalganglien vereinigt; erstere sollen sich bei den Octopoden zuweilen noch als schwache seitliche Lappen markieren. 
Die starken Brachialnerven formieren an den Armbasen sekundäre Ganglien (Fig. 385), die untereinander durch Querverbindnngen zusammenhängen; aber anch in ihrem weiteren Verlanf innerhalb der Arme sind sie häufig mit zahlreichen kleinen Ganglien versehen. - Die beiden Pallialnerven bilden. dicht unter der Haut der vorderen Mantelhöhlenflüche zwei ansehnliche Ganglien (G. stellata), welche zahlreiche Nerven in den Mantel senden, und sich bei länger gestreckten Formen in einen hinteren Nerv fortsetzen, der die Flossen versorgt (Fig. 385). Bei zahlreichen oigopsiden Decapoden hängen die G. stellata durch eine Quercommissur zusammen, welche dorsal vom Schlund verläuft, und daher wohl mit Recht der hinteren dorsalen Vereinigung der Pallialnervenstränge homologisiert wird, die sich bei den primitiven Gastropoden noch findet. - Die beiden Visceralnerven entsenden vor allem Zweige zu den Kiemen, die auch Ganglien bilden können; ferner zu Herz, Gefäßen, Kiemenherzen; Genitalorgan, u. vereinigen sich ebenfalls zoweilen (Sepia, Eledone usw.) in der Kiemenregion durch eine ventral vom Darm (auf der Vorderseite des Enddarms) gelegene Quercommissur, die auch als ein ansehnliches Ganglion entwickelt sein kann (Ommastrephes).

Die gewöhnliche Ansicht ist, $\mathrm{da} B$ das primäre Visceralconnectiv samt seinen Ganglien bei den $\mathrm{Ce}$ phalopoden zu dem Visceralband der Tetrabranchiaten oder den Pleurovisceralganglien der Dibranchiaten

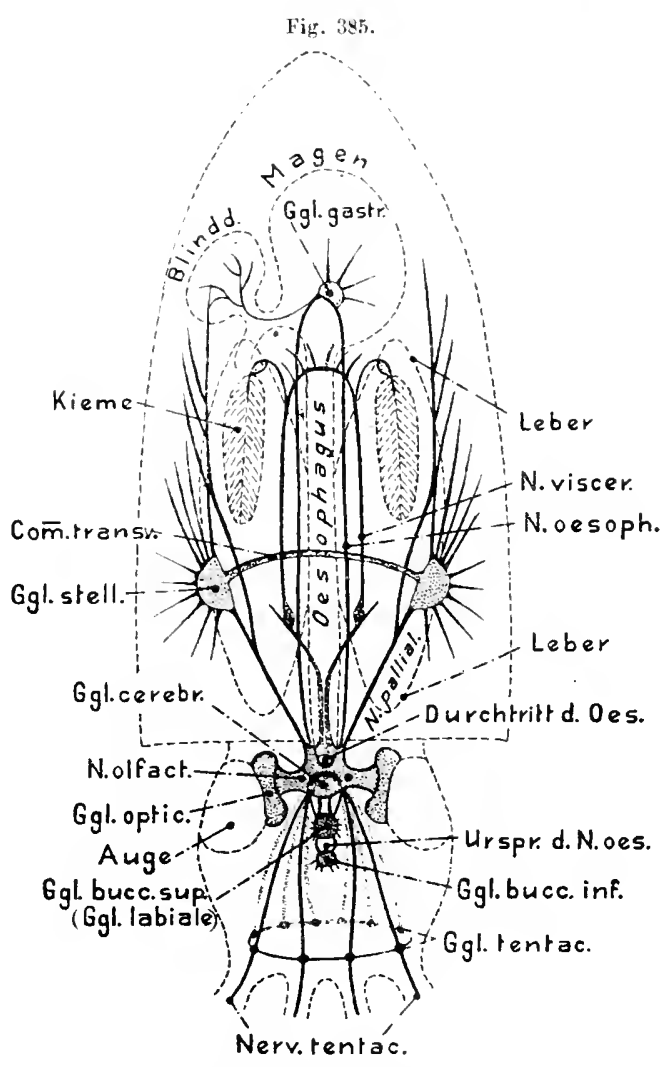

Nervensystem eines dibranchiaten Cephalopoden schematisiert, von der Dorsalseite (n. Brandt 1829, lHERING 1877 nud Haveock 1852 konstruiert). O. B. u. C. H.

verkürzt sei. Die tatsächlichen Verhältnisse, besonders der Dibranchiaten, dürften jedoch gewisse Zweifel an der Richtigkeit dieser Deutung zulassen. Es scheint nicht ausgeschlossen, daß die Visceralnerven mit ihren zuweilen gut ausgeprägten Kiemenganglien und ihrer Quercommissur, manchmal sogar mit einem Ganglion, das dem abdominalen der Gastropoden ähnlich ist, der Visceralcommissur der letzteren entsprechen könnten. In diesem Falle müßten die sog. Visceralganglien derDiblanchiaten wohl den Pleuralganglien gleichgesetzt werden.

Sogenanntes Schlund-oder Buccalnervensystem der Mollusken. Übereinstimmend mit den Einrichtungen der seither besprochenen Bilaterien, besitzen auch die Mollusken ein wohlausgebildetes Schlundnervensystem mit entsprechendem Ver- 
breitungsgebiet. Es zeigt in dem ganzen Phylum ziemlich große Übereinstimnung. Wie schon früher erwïhnt wurde, entspringen vom Cerebralganglion der Solenogastres (s. Fig. 367, S. 515) zwei nach hinten und ventral ziehende Nerven, die sich unter dem Pharyux (Buccalmasse) ringförmig vereinigen, wobei sie zwei Ganglienauschwellungen bilden. Die so entstandene Commissur wird gewöhnlich als sublinguale bezeichnet, ihre Ganglien als Sublingualganglien. Da die Commissur jedoch der sog. Labialcommissur der Prosobranchiaten entspricht, so dürfte letzterer Namen vorzuziehen sein. Für einige Formen wurde erwiesen, daß die beiden Hälften dieser Labialcommissur durch eine zarte, den Pharynx dorsal umgreifende Commissur verbunden sind, und $\mathrm{da}$ bon den Labialganglien noch eine ventrale Commissur ansgeht, welcher zwei kleine Ganglien eingelagert sind, die das sog. Subradularorgan innervieren (ein Simnesorgan, das etwas vor der Radnla auf dem Pharynxbolen liegt), weshaib diese Commissur und ihre Ganglien als subradulare bezeichnet werden.

Mit dieser Bildung des Buccalsystems der Solenogastren stimmt das der Placophoren prinzipiell iiberein (s. Fig. 368, S. 516). Der Ursprung der Labialcommissur (die bier gewöbnlich Subccrebralcommissur genannt wird), ist jedoch mit der breit strangförmigen Entfaltung der C'erebralganglien stark seitlich und nach hinten geriickt. Die Labialcommissur gibt zahlreiche feine Nerven zur Mundscheibe. Kurz nach ihrem Ursprung entsendet sie etwas nach hinten die Subradularcommissur mit ibren beiden Ganglien, und von der gleichen Stelle nach vorn (selten direkt vom Cerebralganglion) die sog. Bucculconmissur, die sich vorn in einen die Buccalmasse dorsal und ventral umgreifendeu Nervenring spaltet, an dessen Ursprung jederseits ein sog. Buccalganglion liegt. Diese Buccalcommissur entspricht daher im wesentlichen der erwähnten dorsalen Commissur der Solenogastren. Die zahlreicheu Nerven, welche von der Buccalcommissur und ihren Ganglien ansgehen, versorgen die Buccalmasse, Radulatasche, Speichel- und Zuckerdriisen; wahrscheinlich verbreiten sich jedoch die Nerven, welche von den Buccalganglien nach hinten ziehen, am größten Teil des Darms und seiner Anhänge.

Gastropoden. Wie schon früher erwähnt, ist bei zahlreichen primitiven Prosobranchiaten (Fig. 370, s. 519), doch auch gewissen Opithobranchiaten (Fig. 378, S. 525), die sog. Labialcoumissur (Subcerebralcommissur) erhalten und verbindet die Cerebralganglien ventral von der Buccalmasse; auch Labialganglien kïnnen sich bei den Aspidobranchiern noch finden. In diesen Fällen entspringt die stets rorhandene Buccalcommissur mit ihren beiden Buccalganglien von dieser Labialcommissur und ungreift die Buccalmasse nur ventral, da die dorsale Verbindung den Gastropoden fehlt. Bei den Gastropoden ohne Labialcommissur entspringt die Buccalcommissur von den Cerebralganglien. Die Lage der Bucealganglien varriiert ziemlich; bei gewissen Prosobranchiaten können sie dicht an die Cerebralganglien rücken (Fig. 371, S. 520). Die Buccalcommissur dringt meist frühzeitig in die Wand der Buccalmasse ein und ist daher schwierig zn verfolgen. Die Ausbreitung der Buccalnerven ist ähnlich wie bei den Placophoren; am Darm wurde sie nicht iiher den $\ddot{O}$ sophagus hinaus verfolot. 
Während die Scaphopoden sehr ursprüngliche Verhältnisse zeigen (s. Fig. 382): eine Labialcommissur mit zwei Labialganglien, von welchen zwei Subradularnerven mit Subradularganglien, sowie die Buccalnerven mit zwei bis vier Bucealganglien abgehen, ist das ganze System bei den Lamellitranchiaten mit der Rückbildung der Buccalorgane eingegangen.

Cephalopoden. Die Verhältnisse bei Nautilus (Fig. 383, S. 529) erweisen sich noch als recht ursprtinglich, jedoch darin eigentümlich, daß die vom Cerebralband ausgehende und nach vorn gerichtete Labialcommissur jederseits mit zwei Wurzeln entspringt, welche sich erst in den Labialganglien (Pharyngealganglien, Kerr) vereinigen. Von letzteren geht die Buccalcommissur mit ihren beiden Ganglien aus. Von Subradularganglien oder -nerven wurde nichts beobachtet. - Die Einrichtungen der Dibranchiaten wurden schon oben (S. 529) insofern berührt, als deren sog. oberes Buccalganglion manchmal als ein vorderer Abschnitt des Cerebralganglions aufgefaßt wird. Bei den decapoden Dibranchiaten (Fig 384, S. 530) liegt das unpaare obere Buccalganglion mehr oder weniger weit vor dem Vorderende des Cerebralganglions und ist mit ihm durch zwei Paar Connective oder Wurzeln verbunden, von welchen die inneren häufig strecken weise unpaar werden. Diese beiden Connective erinnern sehr an die beiden Wurzeln der Labialcommissur von Nautilus, und demnach auch das obere Baccalganglion der Dibranchiaten an dessen Labialganglien, denen es wohl entsnricht. Die äußere Wurzel dieses Labialganglion entspringt aber nicht vom eigentlichen Cerebralganglion sondern von der Verbindungsstelle des Cerebrobrachialconnectivs mit dem Brachialganglion, sodaß man dies Connectiv vielleicht größtenteils dem Cerebralganglion zurechnen dürfte. Wenn die obige Auffassung richtig ist, so wäre das obere Buccal- oder Labialganglion bei Octopus (Fig. 384 B) mit dem Vorderende des Cerebralganglions, nnter Einziehung der beiden Wurzeln, vereinigt (doch wird dieser Vorgang von Pelseneer gerade umgekehrt aufgefaßt.) Vom Labialganglion entspringen zwei, die Buccalmasse hinten umgreifende Connective, welche sich mit dem ventral liegenden unteren oder eigentlichen Buccalganglion vereinigen. Labial- und Buccalganglien senden Nerven zur Buccalmasse; letzteres ferner nach hinten zwei lange Nerven (N. oesophageales Fig. $384 B$ und 385, S. 531) am Ösophagus hinab, welche sich am Magen zu einem ansehnlichen $G$. gastrale vereinigen (bei Nautilns doppelt vorhanden), von dem zanlreiche Äste zum Ösophagns, Magen und Blinddarm ausstrahlen.

\section{Echinodermata.}

Die strablig gebauten Echinodermen, deren Nervensystem den Radiärbau sebr ausgeprägt zeigt, gehen bekanntlich aus bilateralen Larvenformen hervor. Es kann daher nicht $\mathrm{z}$ weifelbaft sein, daß auch das Nervensystem anfänglich bilateral angelegt war, und sich erst später strahlig umformte. Nun wurde in der Tat bei gewissen Larven (Holothurien, Ophiaren, annähernd auch Crinoiden) ein bilaterales Nervensystem einfacher Art gefunden, während andere (Asteroiden, Echinoiden) eine Art nervöser Scheitelplatte am vordcren Pol besitzen sollen, 
die auch den Crinoidenlarven (Antedon) zukommt, wo sie in zwei ventrale L:ïngsfaserzüge ausläuft. Wie nun bis jetzt noch ein tieferer Einblick in das Hervorgehen des Radiärbaus aus dem bilateralen der Larven feblt, so gilt dies auch fiir das Entstehen des definitiven Nervensystems aus dem der Larve. Nur bei den Holothurien wurde darüber einiges ermittelt; wogegen für die Crinoiden sogar angegeben wird, daß sich das System der erwacnsenen Form ganz unabhängig von jenem der Larve bilde, indem letzteres völlig eingehe. - Auch der Nerrenapparat der ausgebildeten Echinodermen bietet noch viele offene Fragen, ja unser derzeitiges Wissen zeigt gewisse Befunde, welche eigentlich apriori wenig wahrscheinlich sind. Vor allem gilt dies für die ziemlich allgemein adoptierte Ansicht, daß bei den Echinodermen zwei, ja sogar drei von einander ganz unabhängige Nervensysteme existierten, von welchen das eine, uiberall verbreitete, sog. ecto neurale, aus dem Ectoderm hervorgehe, was auch morphologisch und ontogenetisch erwiesen ist. Diesem System schließt sich (mit Ausnahme der Crinoiden) ein zweites innig an, gewissermaßen als ein ihm gegen das Körperinnere aufliegender Teil; weshalb es als das hyponeurale bezeichnet und damit gewöhnlich die Vorstellung verbunden wird, daß es aus dem Epithel der Cölomböhle, also entodermal entstehe. Es werden ihm vorwiegend motorische Funktionen zugeschrieben, während das ectoneurale hauptsïchlich sensibel sei. Von den ectoneuralen Nervensträngen sollen die hyponeuralen durch eine zarte Membran völlig geschieden sein; doch liegen einzelne Angaben vor, nach denen gewisse der abgehenden Nerven aus beiden Systemen Fasern bezögen.

Es ist nun jedenfalls wenig wahrscheinlich, daß ein sensibles und ein motorisches Nervensystem unabhängig voneinander existieren, es wäre dies ein physiologisch kaum annehmbares Verhalten. Wenn also die beiden Systeme, die sehr innig aneinander liegen, als nervös zu betrachten sind, was sich kaum bezweifeln läßt, so müssen sie wohl inniger zusammenhängen, als gewöhnlich angenommen wird.

Zu diesen beiden Systemen gesellt sich bei den Crinoiden, Asteroiden und Echinoiden noch ein sog. apicales am Apex, gegenüber der Mundöffinung, welches bei den Crinoiden eine gewaltige Entwicklung erreicht. Es soll gleichfalls entodermaler oder mesodermaler Herkunft, sowie unabhängig von den übrigen Teilen des Nervenapparats sein. - Es muß jedoch betont werden, daß über das sog. hyponeurale gar keine, über das apicale kaum sichere ontogenetische Erfahrungen vorliegen.

Sogenunntes ectoneurales oder ectodermales (auch oberflächliches) System. Wie bemerkt, kommt es sämtlichen Klassen zu. Es zeigt die Eigentümlichkeit, daß wenigstens seine Centralteile sich nur über die ambulacrale Kŏrperfläche erstrecken. Diese Centralteile bestehen überall, abgesehen von den Crinoiden, aus einem den Anfang des Schlunds umziehenden Nervenring, der zuweilen auch etwas polygonale Form besitzt. Von ibm entspringen so viel radiäre, bandförmige Nervenstränge, als sich Radien oder Ambulacren finden, also in der Regel füuf. Diese Radiärnerven durchziehen die Radien längs der Oral- (oder Ventral-)fläche bis zu ihren äußersten Enden, indem sie sich allmählich verschmälern. Wenn die Radien 
(Arme) sich verzweigen (Crinoiden, Euryaliden), so machen auch die Radiärnerven alle Teilungen mit; sie schicken daher bei den Crinoiden auch in jede Pinnula einen Ast. - Bei den primitiveren Echinodermen (Semiambulacrata, mit Ausnahme der Ophiuren) besitzt das estodermale System noch eine sehr ursprüngliche Beschaffenheit, indèm es intraepithelial liegt (bei den Crinoiden, Fig. 285 C, S. 420, zwar nach manchen Angaben direkt subepithelial). Bei den Asterien verhält es sich daher fast ebenso, wie etwa die Nervenstränge der Hydromedusen. Die Radiärnerven der Crinoiden und Asterien (Fig. 285.A, 386) ziehen Iängs der Basis eines hohen Wimperepithels hin, welches die Tiefe der Ambulacralrinnen auskleidet und sich bei den Asterien an dieser Stelle zu einer Längsfirste erhebt. Die hohen Epithelzellen dieser Firste laufen in der Tiefe in feine Fasern (Stützfasern, aufrechte Fasern) ans, zwischen welche die (wie bei allen Echinodermen) sehr feinen und in ihrer Hauptmasse längs verlanfenden Nervenfasern eingelagert sind. Ganglienzellen, mit ihren feinen Ausläufern, sind nur spärlich und unregelmäßig in das radiäre Nervenband eingelagert. Außerdem sollen in diesem Epithel der Asterien und Crinoiden auch Sinneszellen vorkommen; bei den ersteren anch Drüsenzellen.

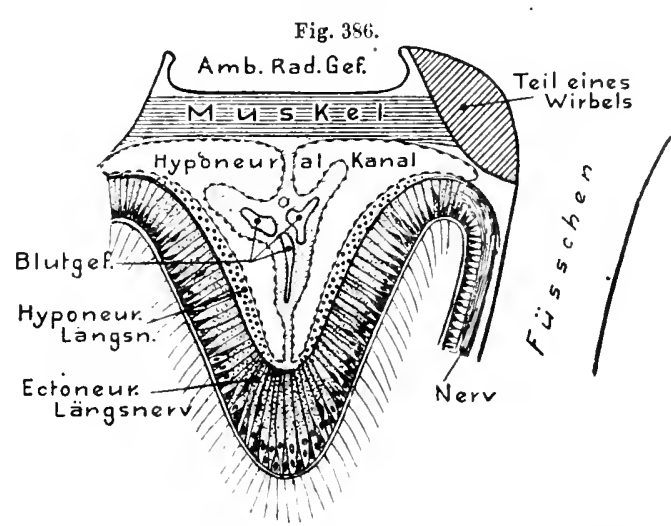

Asterie. Schematischer Querschnitt durch die Ambulacralrinne zur Demonstration des radiāren Nervenbands ( $n$. Lodwig in Brann K1. u. Ordn., etwas verändert). C. H.

Die Auffassung der sog. Stützzellen des Neuroepithels ist noch etwas controvers, da ihnen manche Forsche: auch eine Art nervöser Nebenfunktion zuschreiben. - Ob sich die Radiärnerven der Crinoiden um den Schlund zu einem Ring vereinigen, ist nicht sicher, aber sehr wahrscheinlich, da sich auch die Ambulacralrinnen zu einer Ringfurche um den Mrnd verbinden; es dürfte daher wohl der Ringnerv nur weniger deutlich entwickelt sein als bei den übrigen Echinodermen.

Über, d. h. apical vom Radiärnerv und dem Ring der Asterien nnd Crinoiden (Fig. 386) findet sich ein ziemlich weiter Kanal (Hyponeuralkanal, Peri- oder Pseudohaemalkanal), der bei den Crinoiden eine Fortsetzung der Cölomhöhle des Kelchs darstellt, während er bei den Asterien von der Cölomhöhle abgeschlossen erscheint, aber ontogenetisch aus ihr hervorgeht.

Das ectoneurale System der Ophiuren (Fig. $285 \mathrm{~B}$ ) und der Totiambulacrata (Echinoiden und Holothurien, s. Fig. 387-389, 284B) liegt tiefer im Körperinnern, hängt also mit der Epidermis nicht mehr direkt zusammen. Bei den Ophiuren nnd Echinoiden erklärt sich dies daraus, daß sich die Ambulacralrinnen der Semiambulacrata durch Verwachsnng ibrer Ränder nach außen abgeschlossen haben, also zu geschlossenen Kanälen wurden (Epineuralkanäle). Die Ontogenie hat 
dies für beide Klassen sicher erwiesen. Auch die paläogenen Crinoiden zeigten hänfig einen solchen Abschluß der Ambulacralrinnen, so daß dieser Zustand gewissermaßen schon in dieser Klasse vorbereitet wurde. - Die Radiärnerven und der Ringnerv, samt dem ihnen zugehörigen, ursprünglich äußeren Epithel wurden so zum Boden der Epineuralkanäle, während sich nach innen vom Nervenband der Hyponeuralkanal findet. Die distalsten Enden der Radiärnerven bewahren jedoch ihre intraepitheliale Lage. Die bandförmigen Radiärnerven nnd der Ringnerv spannen sich demnach bei den erwähnten Formen wie eine quere Scheidewand zwischen den beiden Neuralkanälen aus (siehe Fig. 387). - Am Ringnerv ist die Lage der beiden Kanäle zueinander insofern etwas verschoben, als der Hyponeuralkanal peripher vom Ringnerv liegt, während der, bei den Ophi-

Fig. 387 .

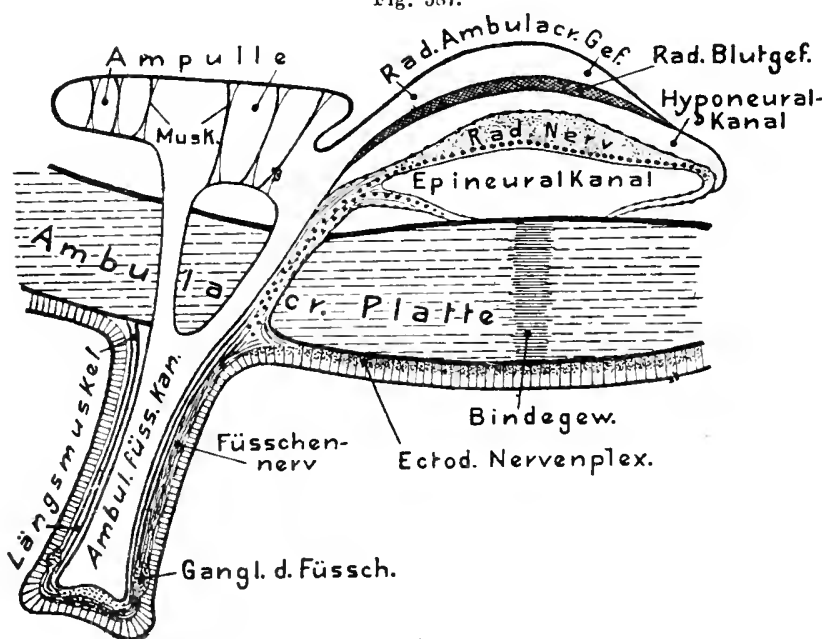

RegulärerEchinoide. Schematischer Querschnitt durch das Ambulacrum eines Seeigels zur Demonstration des Radiärnervs nsw. (z. T. n. Cú́xot 1891) uren recht schwach entwickelte Epineuralkanal axial liegt. Der Epineuralkanal des Ringnervs ist bei den regulären Echinoiden sogar fast völlig obliteriert. Diese Umlagerung $d$. Kanäle beruht daranf, da $B$ die Radiärnerven am Schlund etwas emporsteigen, um den Nervenring zu bilden. - Etwas anders liegen dio Verhältnissebei den

Holothurien (Fig. 284 B); ihre Radiärnervenbänder darchziehen die tiefste Lage des dicken Coriums und werden auf ihrer Innenseite von einem ansehnlichen Hyponeuralkanal begleitet, dem das radiäre Ambulacralgefäß innerlich dicht anliegt (den Synaptiden soll jedoch nach vielen Angaben der Hyponeuralkanal fehlen). Wahrscheinlich verbinden sich die Hyponeuralkanäle innen vom Nervenring zu einem Ringkanal. Der Ringnerv (Fig. 389) umzieht den Mund im Corium der Mundscheibe, etwa an den Tentakelbasen. Epineuralkanäle sind bei den Holothurien nicht sicher erwiesen, da die als solche bezeichneten Spalten vielleicht nur ktinstliche waren; jedenfalls fehlen sie aber dem Ringnerv.

Es liegt nabe, die Verhältnisse der Holothurien entsprechend denen der Ophinren und Echinoiden zu beurteilen; also die tiefe Lage des Ectoneuralsystems gleichfalls auf den AbschlnB ehemaliger Ambulacralrinnen zurückzuführen. Der wahrscheinliche Mangel echter Epineuralkanăle macht dies jedoch etwas unsicher und die Ontogenese ließ bis jetzt von einem solchen Vorgang nichts erkennen. Es könnte sich daher möglicherweise um eine Ablösung der Nervenbänder vom Ectoderm und ihre Verdrängung in die Tiefe durcb das zwi- 
schen wachsende Corium handeln, analog wie etwa die Bauchstränge der Würmer in die Tiefe verlagert werden.

Die Radiärnerven sind im allgemeinen iiberall ziemlich breite Bänder, die zuweilen eine annähernd paarige Bildung zeigen, indem sie in ihrer Mittellinie ein wenig diinner sind. Nur die Ophinren zeigen eine Art Gliederung der Radiäruerven, da sie in der Mitte jedes Armskeletwirbels (Ambulacralstück) knotig anschwellen

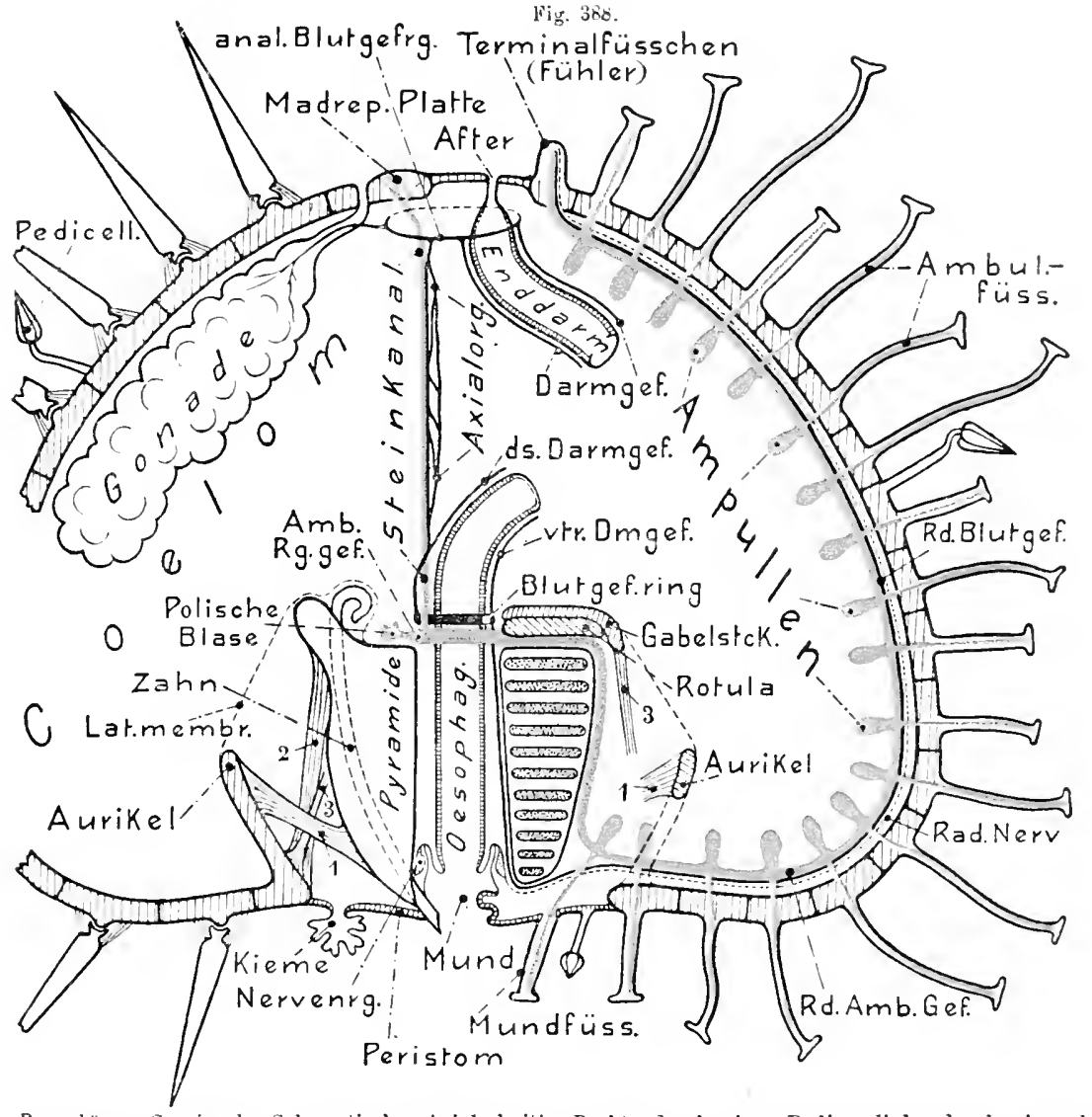

Regulärer Seoigel. Schematischer Axialschnitt. Rechts aurch einen Radius, links durch einen lnterradius. Zur Demonstration der Anordnung der Hauptorgane. Ambulacralgefảßsystem blan. 1-3 Muskeln des Eanapparats (mit Benutzung von Figuren von A. Lang Vergl. Anat., Cuevot 18y1 usw.).

(Fig. 390). Diese Knoten erinnern anch insofern an Ganglien, als die gleich zu erwähnenden oberflächlichen Zellen der Radiärnerven in ihnen zahlreicher, d. h. mehrschichtig sind, dagegen in den dünneren Verbindungsstrecken nur einschichtig. - Der feinere Bau der tiefliegenden Radiäl- und Ringnerven ist im wesentlichen derselbe wie bei den Asterien und Crinoiden. Auf ihrer Außenseite findet sich oine ein- bis mehrschichtige Zelllage, die jedenfalls zum Teil aus Stiitzzellen besteht, welche aufrechte Stützfasern durch das Nervenband senden. Bei den Holothurien und Ophiuren (hier speziell in den Anschwellungen) treten seitliche, 
mehrschichtige Verdickungen dieser Zelllagen auf (Zellsäulen), was eine paarige Bildung des Radiärmervs andeutet. "Die tieferen Zellen dieser Verdickungen erweisen sich durch ihre besondere Beschaffenheit sicher als Ganglienzellen (namentlich bei manchen Ophiuren); doch sind solche auch vereinzelter im gesamten Nervenband zerstrent.

Periphere Nercen des ectoneuralen Systems. Die Radiärnerven senden stets seitliche Nerven zu den Ambulacralfüßchen (auch zu den sie vertretenden sog. Hautpapillen gewisser Holothurien), welche in deren Haut ziehen und im allgemeinen denselben Bau wie die Radiärnerreu besitzen, daher auch intraepithelial liegen,

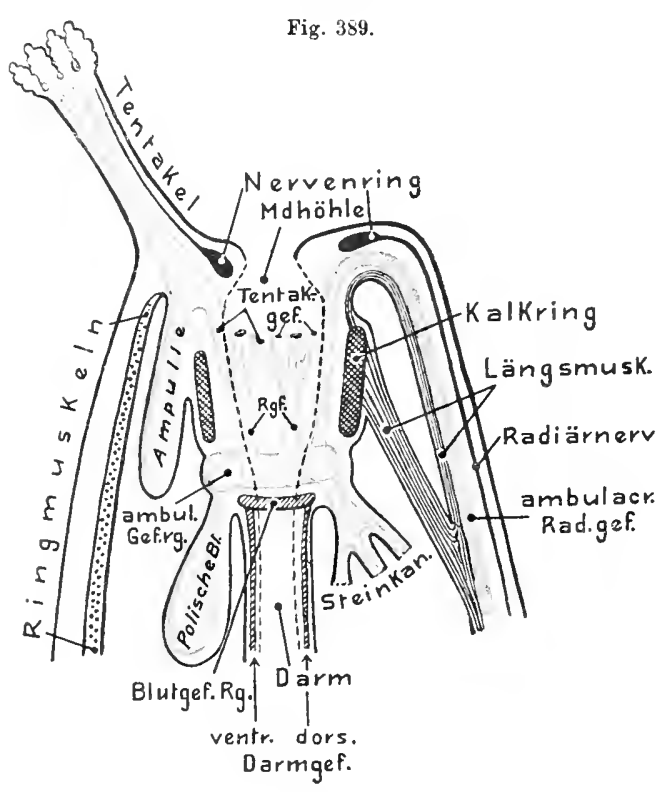

Dendrochirote Holothurie. Schema des Vorderendes. Köperwand im Längsschnitt; rechts durch oinen Radius, links durch einen Iuterıadius. Zur Demoustration der Lage des Nerrenrings und der Centralteile des Ambulacralsystems (blau) radiär eingezeichuet ist; er liegt in Wirklichkeit interradiur. us $\pi$. Die Figur ist insofern nicht korrekt, als der Steinkanal wo dies für die Radiärnerven gilt (doch auch bei den Echinoiden, s. Fig. 388). In diesem Fall (besonders bei den Asterien) sind auch die Nerven nur wenig scharf nmschrieben. Die Nerven versorgen die versehiedenen Sinnesorgane der Füßchen. Die Füßchennerveu der Ophimren entspringen zwischen zwei Wirbeln, also etwa in der Mitte der diinnen Verbindungsstrecke zweier aufeinander folgender Anschwellungen des Radiärnervs (s. Fig. 390). An der Basis jedes Ambulacralfüßchens bilden sie eine Anschwellnng, welche das F'üßchen halb ringförmig umzieht (Ganglion pedale). Das distalste, unpare Endfüßchen (Terminalfüßchen, Fühler der Asteroiden und Echinoiden, bei letzteren jedoch sehr zurückgebildet) wird direkt vom Distalende des Radiärnerven versorgt, ebenso anch die Augen der Asterien. - Die centralsten, den Mund direkt umstehenden Füßehen der Ophiuren, ebenso anch die zu den Tentakeln umgebildeten der Holothurien, erhalten ihre Nerven vom Kingnerv. Yom Anfang der Radiärnerven entspringen ferner die kurzen Nerven für die Statocysten (Otocysten) gewisser Holotburien (Dynapta usw.). - Von den Radiirnerven gehen endlich Äste zur Haut, die ihren Ursprung entweder direkt von ihnen, oder auch gemeinsan mit den Pedalnerven nehmen und sich später abzweigen. Auch der Ringnerv sendet gewöhnlich Nervenzüge zum Integument der Mundregion.

Bei den Ophiuren (s. Fig. 390, N. lat. 1 u. II, N. apic.) entspringen melırere solcher llautnerven entweder direkt vom Ganglion pedale, in dessen Nähe, oder etwas davon entiernt, 
doch wird auch angegeben, daß sie selbständig, aber dicht beim Pedalnerven vom Radiärnerven abgehen. - Der rentrale dieser Hautnerven vereinigt sich (wenigstens bei gewissen Arten) mit dem der Gegenseite äußerlich vom Epinerralkanal unter Ganglienbildung (G. ventr.).

Die Hautnerven der Echinodermen, welche unter vielfacher Verzweigung und zuweilen auch Ganglienbildung zum Integument treten, bilden in der Hant einen reich entwickelten Plexus, der entweder intraepithelial liegt (Asterien, irreguläre Seeigel) oder subepithelial; bei den Holotlurien sogar im äußeren Corium. Er versorgt die integumentalen Anhänge, wie Stacheln, Pedicellarien (Asterien und Echinoiden) und Hautkiemen (Asterien), wobei an der Stachelbasis ein besonderer Nervenring (Echinoiden) oder ein Ganglion (Ophiuren) anftreten kann.

Bei den Ophiuren anastomosieren die Haupthautnerven derjenigen proximalen Skeletwirbel, welche sieh in verschiedener Zahl an Autbau der Körperscheibe beteiligen, längs jeder

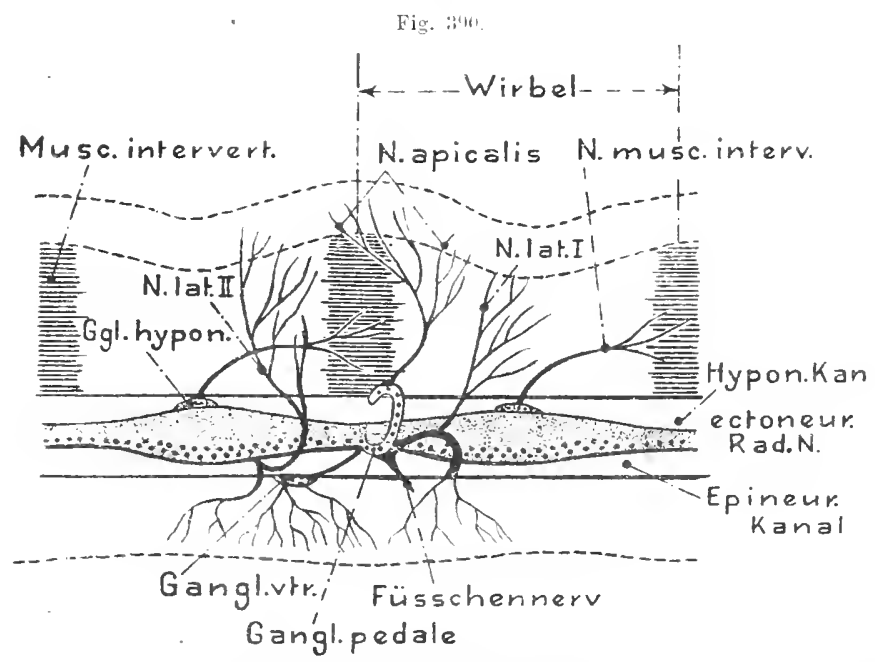

Ophiuride. Schema des Nervensystems im Arm, in der Ausdehnung zweier Wirbel. Seitliche Ansicht (n. HAMANN 15sit, etwas verändert).

Armseite und Bursalspalte, indem sie einen sog. Lateralnerv bilden. Ton diesem geht auch ein interradialer Muskelnerv aus. Die Lateralnerven steigen distalwärts gegen die Apicaltläche hinauf und bilden den llautplexus der peripheren Scheibenwand.

Vom Centralnervenring sämtlicher Echinodermen geben ferner Zweige oder Ausbreitungen in etwas verschiedener Anordnung zum Schlund und Darm, um letzteren und seine Anhänge, wie es scheint, in ganzer Ausdehnung zu versorgen. Da dieser Nervenplexus der Darmwand entweder intrapithelial oder subepithelial liegt, so läßt sich kaum bezweifeln, daß er entodermaler Herkunft sein muß, wie die Nerven der Gastralhöhle der Cölenteraten; woraus also hervorgehen würde, daß zwischen dem ectonearalen System und dem entodermalen Darmsystem ein inniger Zusammenhang besteht.

Sogenantes hyponewales Nerensystem. Bei den Asteroiden liegen aut der Aboralfäche der Radiärnerven in zwei seitlichen Läingslinien Zellenbänder, die im allgemeinen wie Verdicknngen des Peritonealepithels erscheiuen, das den 
Hyponeuralkanal auskleidet (Fig. 386, S. 535). Vom ectoneuralen Nervenband werden sie durch eine zarte, strukturlose Membran getrennt, die gewöhnlich als bindegewebig angesehen wird. Diese Zellbänder wurden daher häufig als nicht nervös beurteilt, während jetzt die Meinung vorherrscht, daß sie nervös seien und aus Ganglienzellen und Nervenfasern bestehen, welche jedoch mit den Fasern des ectoneuralen Radiärnervs nicht zusammenhingen. Die Verhältnisse bei den Ophiuren, wo diese hyponeuralen Nervenbänder an den Anschwellungen der ectoneuralen Radiärnerven gleichfalls gangliös verdickt und mehrschichtig sind, sowie an diesen Stellen einen Nerven abgeben (Fig. 390, S. 539), sichern wobl die nervöse Natur des hyponenralen Systems. Längsnervenfasern scheinen in den byponeuralen Strängen vorhanden zu sein; dagegen konnten quere Faserverbindnngen der beiden Stränge eines Radius nicht festgestellt werden. - Der eben erwähnte Nerv, welcher von jeder hyponeuralen Ganglienanschwellung der Ophiuren ausgeht (sog. Nerv. mnsculorum intervertebralium), wendet sich gegen das Armende und versorgt die Muskeln zwischen je zwei Skeletwirbeln auf der betreffenden Armseite. - Auch für die Asterien wurde die Innervierung der Muskulatur der Wirbel durch Nerven, die von den Hyponeuralsträngen ausgehen, wahrscheinlich gemacht, jedoch nicht sicher erwiesen. - Die Hyponeuralstränge setzen sich bei den Asteroiden auf den Ringnerv fort. Zugehörige Nervenzellenanhäufungen aber finden sich am Ringnerv hauptsächlich interradial und sollen Nerven zur oralen Muskulatur aussenden. Bei den Ophiuren entspringen in jedem Interradius je zwei solcher Nerven, in welche jedoch auch Fasern des ectoneuralen Ringnervs treten sollen.

Die Echinoiden zeigen nur wenig von einem hyponeuralen System; bei den Spatangoiden wird es sogar ganz vermißt. Dies hängt vielleicht mit der meist völligen Reduktion der Hautmuskeln zusammen. Die mit Kauapparat versebenen Seeigel dagegen (Regularia und Clypeastroidea) besitzen an den Ursprungsstellen der fünf Radiärnerven am Nervenring plattenförmige Anbäufungen von Ganglienzellen, die dem hyponeuralen System angehören. Von jeder Platte gehen zwei Nerven aus, die an den Seitenflächen der Pyramidenstücke des Kauapparats aufsteigen und wahrscheinlich dessen Muskeln versorgen.

An den Radiärnerven der Holothurien, nicht jedoch am Ringnerv, läßt sich gleichfalls eine innerste dünne Lage unterscheiden, welche von dem viel dickeren Hauptteil durch eine zarte Membran getrennt wird, die man gewöhnlich als bindegewebig beurteilt. Abweichend von den Asteroiden, handelt es sich jedoch um eine uiber die ganze Breite des Radiärnervs ausgedehnte Nervenschicht. Nach gewissen Angaben sollen die Nerven für die Hautmuskulatur von dieser tiefen Schicht entspringen, doch ihre Äste sich gleichzeitig in der Haut verbreiten; in anderen Fällen (Synapta) seien die vom Radiärnerv abgehenden Hautnerven gemischter Natur, $d$. b. bezögen Fasern aus beiden Lagen des Radiärnervs. - Wie schon oben betont wurde, scheint eine solch scharfe Trennung des sensiblen und motorischen Nervenapparats nicht sehr wahrscheinlich; es zeigt sich ja auch, daß vom hyponeuralen System sensible Nerven ansgehen können; 
möglicherweise dürften also doch nähere Beziehungen zwischen beiden Systemen existieren, als bis jetzt zn ermitteln war.

Sogenaintes apicales (oder dorsales) Nerensystem. Wie schon hervorgehoben wurde, ist dies Sy stem bei den Crinoiden am stärksten entwickelt. Bei den gestielten Formen liegt sein Centralteil im Apex des centralen Körpers oder Kelchs, innerhalb der als Basalia bezeichneten, interradialen Skeletstücke; bei den ungestielten (Antedon) im sog. Centrodorsale. Es bildet eine ansehnliche Nervenfasermasse, der vorwiegend oberflächlich zahlreiche Ganglienzellen eingelagert sind, und nmlü̈lt ein aus fünf schlauchartigen vertikalen Hohlräumen bestehendes Organ (das gelammerte Organ), in dessen Achse das sog. Axialorgan verläuft. Von diesem Centralteil strahlen im allgemeinen 5 oder $5 \times 2$ interradiäre starke Nerven aus (s. Fig. 391), die in der apicalen Kelchwand verlaufen. Im ersteren Fall spalten sie sich bald, wobei sich zwei benachbarte Zweige in jeden. Radins begeben, ihn dicht nebeneinander durchziehend. In jeden Arm tritt schließlich einer dieser Zweige ein, oder bei größerer Armzahl ein durch weitere Teilung dieser Zweige entstandener Ast. Cirkuläre Anastomosen der zehn Nervenzweige treten in der Kelchwand häufig auf, und an jeder Verzweigungsstelle des Radius findet eine eigentümliche Kreuzang oder Chiasmabildung der sich trennenden oder teilenden Nervenzweige statt (s. Fig. 391). In den Armen verlaufen die starken Längsnerven (Dorsalnerven) in den Armskeletgliedern (Brachialia) bis an die

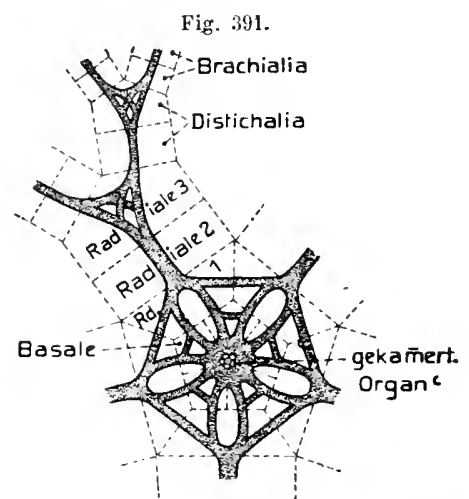

Pentacrinus decorus. Sog, apicales Nervensystem (pnnktiert) von der Aboralseite in die Skeletplatten des Kelchs uingezeichnet in. Reichensperger 1905). v. Bu. Enden der Pinnulae (s. Fig. 285 C, S. 420), wobei sie in jedem Armskeletglied (Brachiale) häufig etwas anschwellen. Sie enthalten in ihres ganzen Ausdehnung Nervenzellen. Von den erwähnteu Anschwellungen entspringen jederseits zwei Nerven, die sich sofort reich verästeln; die apicalen gehen zu den Interbrachialmuskeln (doch anch zur Epidermis), die oralen zur Epidermis. - Der Centralteil setzt sich bei den gestielten Crinoiden, ebenso wie die Kanäle des gekammerten Organs, durch die ganze Stielachse als ein Faserstrang fort, von welchem Nervenfaserzüge für die Cirren abgehen. Bei den ungestielten entspringen die Nerven der apicalen Cirren direkt vom Centralteil.

Außer den erwähnten Nerven sendet der apicale Armnerv auf beiden Seiten eine Reihe alternierender $\ddot{\text { ste }}$ aus, die gegen die Ambulacralrinne emporsteigen und in einen rechts und links von letzterer hinziehenden Armlängsnerv (sog. mesodermaler Nerv) ïbergehen (Fig. 285 C, S. 420). Von diesen beiden Längsnerven gehen Ästchen zur Muskulatur des Ambulacralgefäßes, doch auch in die Fïßchen, besonders zu deren Sinnespapillen. Die sämtlichen ambulacralen Armlängsnerven vereinigen sich in der Kelchdecke schließlich zu einem pentago- 
nalen Nervenring, welcher den ambulacralen Gefäßring äußerlich umziebt und ebenfalls im Bindegewebe liegt. Dieser Nervenring sendet Zweige in die Mundfüßchen und zehn stärkere ausstrahlende Äste, die sich in der Haut der Kelchdecke und in den Mesenterien der Leibeshöhle verbreiten, aber auch mit dem Schlundnervensystem im Zusammenhang stehen sollen.

In der apicalen Leibeshöhlenwand der Arme zahlreicher Asterien wurden zarte, dem Peritonea]epithel eingelagerte Längsnervenbänder geiunden, welche nach innen von den apicalen Längsmuskelı hinzieben (vgl. Fig. 285, s̀. 420). Diese Nervenbänder rereinigen sich im Centrum der Apicaltläche und solleu sich zım Peritonealepithel gerade so rerbalten wie die ectoneuralen radiăren Nerrenbänder zur Epidermis, also entodermaler Herkunft sein. Bei den Ophiuren und gewissen Echinoiden wurde ein feiner Nersenring mit Nerrenzellen am Apicalfeld aufgefunden, ler also bei den regulären Echinoiden den Aftcr umzieht. Dieser Genitalnervenving rerläuft bei den Ophiuren an der Axjalseite der Wand des apicalen Blutgefäßrings und marht daher dessen eigentümlichen ab- und aufsteigenden Verlauf mit. $O b \cdot e r$ lie Genitalorgane innerviert ist nicht sicher. - Vom Genitalring der Echinoiden, der etwa in der Gegend der Geschlechtsöffnungen verläuft, entspringen Nerven für die Ausführgănge der Geschlechtsorgane. - Der liing der Ophiuren hängt mit dew ectoneuralen System zusammen, da zwischen den interradialen, zur Oralfäche sich herabsenkenden Partien des Genitalnervenrings und einem Interradialnerren des ectodermalen Systems Verbindungen beobachtet wurden. - Fïr die Serigel bestehen in dieser Hinsicht Zweifel da die Verbindung des Genitalrings mit den Enden der ambulacralen Radiärmersen, die angegeben wurde, unsicher ist. - Es scheint wohl t'entgestellt, daß das mächtig entwickelte apicale System der Crinoiden in dem stark reduzierten der Asterien wiederkehrt; ob dagegen auch der Genitalnervenring ler Ophiuren und Echinoiden ans dem Apicalsystem der Crinoiden abgeleitet werden darf, ist kaum bestinmt zu entscheiden. - Das sog. mesolermale System der Crinoiden, d. \. die beiden ambulacralen lü̈ngsnerven samt ibrem centralen Ring, erinnert etwas an die hyponeuralen Stränge der Asteroiden, weshalb sich die Nöglichkeit erwägen läßt, ob das hyponeurale System nicht durch innigere Verbindung des Mesodermalsystems der Crinoiden mit dem eetoneuralen eutstanden sei. Mesodermales Aystem kann jener Nervenapparat der Crinoideu nur insofern genannt werden, als er im Bindegewebe liegt, was ja auch für das gesamte Apicalsystem gilt; die Ontogenese der sog. mesodermalen Nerren ist unbekannt, wăhrend das Ilervorgehen des Centralteils des Apicalsystems und der apicalen Armmerven aus dem Peritonealepithel der Cölomhöhle wahrscheinlich. wenn auch nicht gan\% sicher erwiesen ist.

\section{Chordata.}

Das Nervensystem dieser Gruppe erscheint sowohl nach seiner Entwicklung als seinem Bau besonders charakteristisch. Bei den primitiven Formen der Tunicaten (Copelatae, Fig. 77, S. 174) erstreckt es sich als ein ursprünglich hohler Strang (Nerven- oder Neurahrohr), dorsal vom Darm und der Chorda, durch die größte Länge des Kï̈rpers. Diesen Charakter bewahrt es bei sümtlichen Wirbeltieren danernd. Sowohl durch seine dorsale I,age, als namentlich den hohlen, röhrenförmigen Bau, nnterscheidet sich das Centralnervensystem der Chordaten daher von dem sämtlicher bisher besprochenen Gruppen. - Die Röhrenform erklärt sich leicht aus seiner Entwicklung. Dieselbe verläuft bei den Tunicaten (Ascidien) und Vertebraten wesentlich iibereinstimmend, indem sich das Ectoderm der embryonalen Dorsalseite längs der Mittellinie etwas verdickt zu einer sog. Medullarplatic, deren Seitenränder sich hierauf zu zwei I,ängsfalten erbeben (Medullar- 
falten), die eine Rinne (Medullurinne) begrenzen (Fig. 392). Die beiden Medullarfalten umgreifen den auf der hinteren Dorsalfläche gelegenen Blastoporus (insofern er deutlich ist), indem sie hier ineinander ïbergehen. Bei den 'Tuuicaten und Acraniern verengt sich die Medullarrinue hieranf, von hinten nach vorn fortschreitend, indem sich die beiden Medullarfalten einander nähern und schließlich verwachsen. Der Verschluß setzt sich bis zum vordersten Ende der Medullarrinne fort, wo er unterbleibt, so daß die abgeschlossne Rinne hier durch einen feinen Porus (Neuroporus) geöffnet bleibt. - Aus der Medullarrinne wurde so ein, von einschichtigem Epithel gebildetes Medullarolv das sich endlich vom äuBeren Ectoderm ablöst. Vorn mïndet es durch den Neuroporus aus; binten steht es durch den ursprünglichen Blastoporus mit dem Hinterende des Darms in Verbindung (sog. Cunclis neurentericus). - Bei den cranioten Vertebraten beginnt der Verschluß der Medullarrinne in der späteren hinteren Hirngegend und schreitet von da nach vorn und hinten fort.

Das Medullarrohr kann sich bei manchell T'unicaten und Vertebraten etwas abweichend entwickeln. Bei den Acraniern stülpt sich die Medullarplatte nicht eigéntlich ein, vichmehr wird sie rom benachbarten Ectoderm überwachsen und billet sich erst danu durch dorsale Aufkrümmung zum Nervenrohr um. Bei Petromyzon, Lepilosteus und den Teleostei entsteht das Medullarrohr durch eine solide Einwucherumg des Eetoderms, in welcber sekundär eine Aushöhlung auftritt. Daß diese beiden Vorgänge durch cäno-

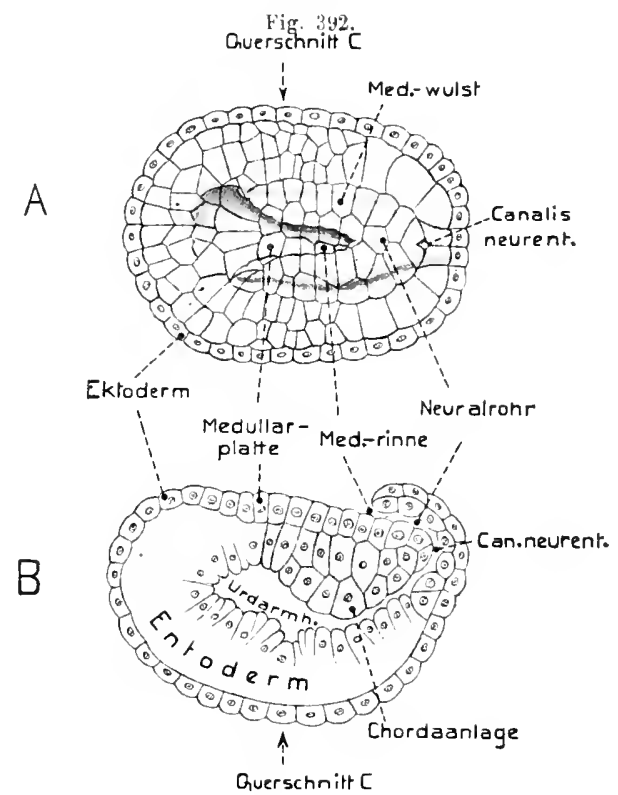

Med.-platte Med:wulst

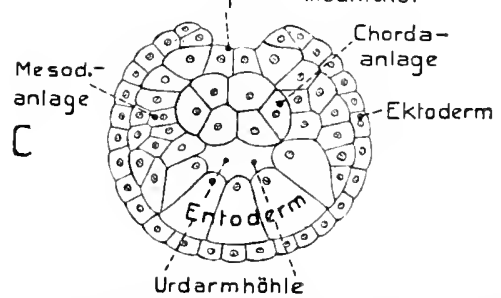

Clavellina rissoana (Ascidie). Embrye in Stadin der Bildnng des Neuralrohrs. Etwas schematisiert. $A$ von der Dorsalseite. IJ im Sagittalschnitt. C Querschnitt in der Gegend des Pfrils der Fig. A (nach v, Bexfinen und JULIN 1567). E. W.

genetische Modifikation der ursprünglichen Einstülpung entstanden, scheint sicher, um so mehr als sich bei Petromyzon noch Andeutmgen der Einstälpung finden. Auch die solide Anlage des Ganglions bei den Thaliaceae muter Aen Tunicaten muB in ählicher Weise als sekundăre Modifikation beurteilt werden.

Die bohle Beschaffenheit des Centralnercensystems ler Chorlaten erklärt sich also aus der Ontogenese; cbenso folgt aus dieser auch, daß sich die Nervenzellen bei den Vertebraten axiai um den Gentralkanal entwickehn, während sie boi den bisher betrachteten Wirbellosen oberflächlich in den Nervensträngen liegen. - Wie jedoch die Bildung des Nervensystems der Chordaten durch Einstülpung phylogenetisch abzuleiten ist, larïber läßt sich vorerst. nichts Sicheres angeben; ebensowenig auch über die phylogenetische Bedeutung des Neuro- 
porus und des Canalis neurentericus. - Die dorsale lage des Centralnervensystems der Chordaten, speziell der Vertebraten, welche häufig von Anneliden abzuleiten versucht wurden, rief die Vermutung hervor, daß das Nerrenrohr dem Bauchmark der Anneliden und Arthropoden entspräche, und daher auch die Bauchseite der letzteren Formen der Rückenseite der Chordaten. Obgleich nun auch ontogenetische Momente dafür sprechen, daß ein ansehnlicher Teil der späteren Rückenseite der Chordaten aus der ursprünglichen Bauchseite hervorgegangen sei, so läßt sich doch die behauptete Homologie zwischen dem Bauchmark der Gliedertiere und dem Rückenmark der Ghordaten in keiner Weise wahrscheinlich machen. Die allgemeine Homologie des Cerebralganglions der wirbellosen Bilaterien mit dem Hirn der Chordaten scheint viel besser begründet, was die erstere Vergleichung natürlich aus-. schließt. Eher dürfte zu vermuten sein, daß der Ursprung der Chordaten bis auf Formen zurückgeht, die noch eine über den Körper gleichmäßig verbreitete Nervenschicht besaßen, wofür ja auch die Verbältnisse der Enteropneusten sprechen dürften.

\section{5 a. Tunicaten.}

Wir betrachten zunächst den Bau des Nervensystems bei einer geschwänzten Ascidienlarve (siehe Fig. 393), da hier jedenfalls sehr ursprüngliche Verhältnisse

Fig. 393.

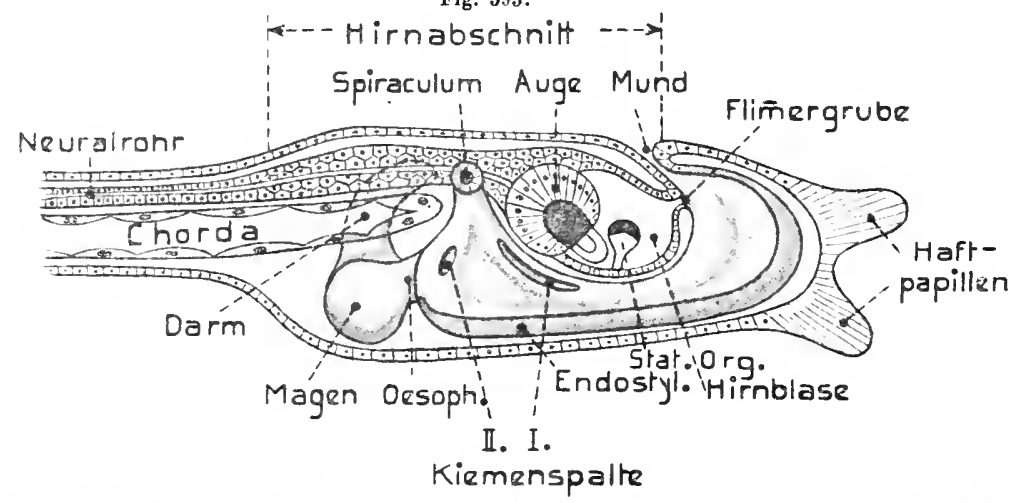

Phallusia mainmillata (Ascidienlarve). Vorderende mit Anfang des Schwanzes von rechts. Zwei sog. Spiracula (Kloake!, jedes mit zwei Kiemenspalten, vorhandeo. Darm (gelbbraun) noch blind geschlossen (n. Kowalewskr 1871 , etwas veräudert). E. W.

bestehen. Es geht ảus dem dorsalen Neuralrohr hervor, das oben geschildert wurde, und erstreckt sich fast durch den ganzen Körper, vom Mund bis nahe zur Schwanzspitze. Der vorhin erwähnte Neuroporus verschließt sich bald. Der vordere, im sog. Rumpf der Larve gelegene Abschnitt des Rohrs wird dicker, worauf seine orale Region blasenförmig anschwillt, indem sich der Centralkanal hier sehr erweitert und die Wand verdünnt. Die so gebildete vordere Blase wird als Sinnesblase bezeichnet, weil sich an ibrer Decke gewöhnlich ein augenartiges, an ibrem Boden ein statisches larvales Sinnesorgan entwickelt, welch beide bei den Sinnesorganen genauer zu betrachten sind. Die linke Region der Sinnesblase, deren Wand dicker ist, sondert sich durch eine vordere mediane Einschnürung vom rechten Teil auf eine größere Strecke ab und wächst hieranf nach vorn kanalartig aus. Das vordere Ende dieses sog. Flimmerkanals (Flimmergrubenkanals) verwächst schließlich mit dem ectodermalen Anfang des Darms 
an der Stelle des früheren Neuroporus, und öffuet sich hier wieder in den Darm (sog. Flimmer- oder Wimpergrube). - Der auf den Sinnesblasenteil folgende Abschnitt des Nervenrohrs (sog. Rumpfganglion) verdickt seine Ventralwand sehr, indem in ihr zahlreiche große und eigentümliche Ganglienzellen auftreten. Die Sinnesblase samt dem Rumpiganglion dürfen zusammen wohl als Hirnteil bezeichnet werden. - Der caudale Abschnitt des Nervenrohres bleibt stets sebr schmächtig, als ein einschichtiges zartes Nervenrohr (s. Fig. 287 B, S. 422).

Copelatae. Diese, bei den Ascidienlarven vorübergehenden Bauverhältnisse bleiben in der Gruppe der Copelaten allgemein erhalten. Sinnesblase nebst Rumpfganglion finden sich als sog. Hirn-oder Cerebralganglion nicht weit hinter dem Mund (Einströmungsöffnung). Auf der Dorsalseite des respiratorischen Darms (s. Fig. 77, S. 174) bildet das Cerebralganglion ein länglich spindelförmiges bis kürzeres Gebilde (Fig. 394). Mit ihm aufs innigste verbunden ist die sog. Otocyste, oder richtiger Statocyste, eine etwa kugelige Blase, welche eine Konkretion enthält. Genauere Untersuchung zeigt, daß diese dünnwandige Blase, wie die Sinnesblase der Ascidienlarve, ein Hirnteil selbst ist, inr Lumen daher ein Teil des urspriuglichen Kanals des Nervenrohrs. Sie liegt gewöhnlich asymmetrisch linkseitig in der Mittelregion des Ganglions, seltener vorn oder hinten, selbst ventral. Die Siunesblase bewirkt hauptsächlich, daß sich

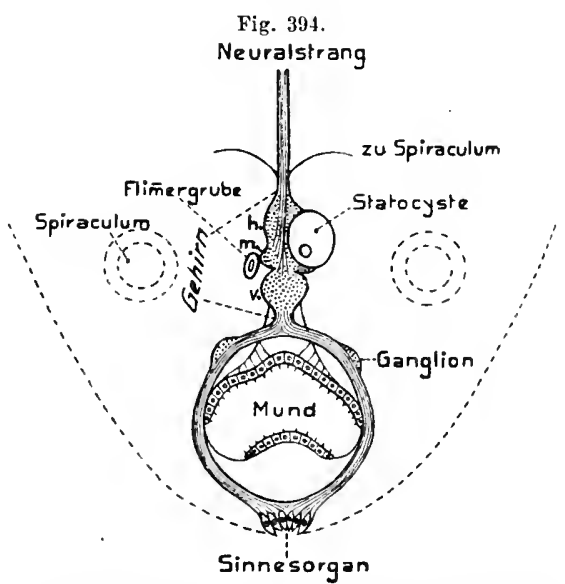

Oicopleura longicauda (Copelate). Vorderende mit Centralnervensystem von vorn und dorsal. Schematisch (n. MARTiNi 1909.) E. W. zuweilen drei Hirnabschnitte unterscheiden lassen (Fig. 394), ein mittlerer, dem die Blase angehört, ein vorderer (zuweilen mit kleiner Höhle) und ein hinterer, der sehr große Ganglienzellen enthält. Der hintere Abschnitt setzt sich in einen dorsalen Nervenstrang fort, der caudalwärts zieht, hierauf in der Region des Ösophagus, rechtseitig, scharf ventralwärts zum Ursprung des Schwanzes herabbiegt, sich dann links wendet und links von der Chorda den ganzen Schwanz durchzieht, indem er der Chorda dicht anliegt (Fig. 287 A, S. 422). Dieser gewöhnliche Verlauf des Nervenstrangs erklärt sich daraus, daß der Copelatenschwanz ursprünglich vertikal gestellt war, wie der der Ascidienlarven, im erwachsenen Zustand aber eine Drehung um $90^{\circ}$ erfahren hat, weshalb seine ursprüngliche Dorsalkante nun nach links schant. Der von früheren Beobachtern angegebene Kanal des dorsalen Nervenstrangs, scheint sich nicht, oder doch nur selten zu finden. - In seinem Rumpfteil enthält er nur vereinzelte Ganglienzellen, besteht daher wesentlich aus Fasern. Der Caudalteil dagegen zeigt mehr oder weniger zahlreiche (etwa 7--40) Anschwellungen mit Ganglienzellen. Das erste dieser Ganglien ist das ansennlichste und enthält viele Zellen; die übrigen nur sehr wenige. - Daß 
das Cerebralganglion und der dorsale Nervenstrang dem Nervenrohr der Ascidienlarve entsprechen, kann nicht bezweifelt werden. Auch dürfte wahrscheinlich sein, daß das Cerebralganglion der Copelaten der Sinnesblase, samt dem sog. Rumpfganglion, der Ascidienlarve homolog ist.

Vom vorderen Abschnitt des Cerebralganglions entspringen (abgesehen von einigen zärteren) in der Regel ein Paar vordere sensible Nerven, welche die Sinnesorgane der Mundregion versorgen, und sich bei Oicopleura unter dieser ringförmig vereinigen sollen (Fig. 394). Zwei vom hinteren Abschnitt ausgehende Nerven versorgen die Spiracula (Kiemenspalten). - Vom Rumpfteil des Dorsalstrangs entspringen gewöhnlich keine Nerven, zahlreiche dagegen vom Schwanzteil; die-

Fig. 395 .

A

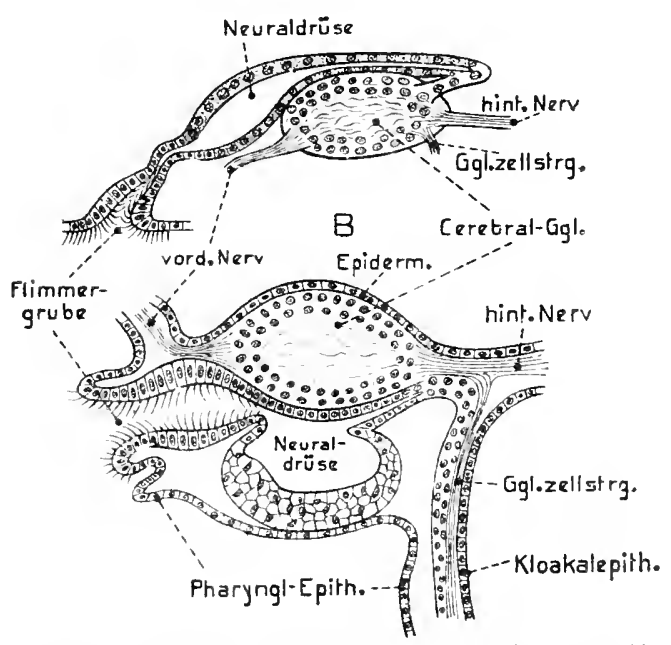

A seidien. Centralnervensystem. A liotry 11 us crouldi. Linkseitige Ansicht des Hirnganglions mit der Flimmergrube nnd Nenraldrüse. $-B$ Amauroeeium constellatum. Sagittalsehnitt durch das Hirnganglion, die Flimmergrabe, Neuraldruse nnd den Ganglienzellenstrang (n. Mercal. 1900) E. W. selben gehen teils von den Ganglien, teils vom Strang selbst aus, und sind zweierlei Art. Stärkere, die paarig und in regelmäßigen Abständen abgehen, lassen sich zu den Schwanzmuskeln verfolgen und sind daher wohl sicher motorisch; zahlreichere feine, reich verästelte Nerven, die unregelmäßiger verteilt sind, wurden als sensible gedentet.

Ascidiae. Das larvale Nervensystem der Ascidien wird bei der Metamorphose reduziert. Der Caudalteil des Nervenrohrs zerfällt völlig, ebenso wie der gesamte Schwanz. Auch die Sinnesblase mit ihren Sinnesorganen löst sich auf, ebenso der ventrale verdickte Teil des Rumpfganglions. Der Flimmerkanal, welcher, wie oben

erwähnt, linkseitig in die Sinnesblase miindet, schließt sich in seiner Fortsetzung nach hinten zu einem Kohr ab, ebenso auch die dorsale Wand des Rumpfganglions zu einem bald solid werdenden Strang, der die hintere Fortsetzung des Flimmerkanals bildet. Im allgemeinen erscheint daher dieser Rïckbildungsprozess wie die Rückkehr zu einem primitiven Ausgangszustand (abgesehen von dem gänzlich zugrunde gehenden Schwanzteil). - Etwa auf der Grenze der frïheren Sinnesblase und des Rumpfoanglions beginnt hierauf die Wand des wieder vereinfachten Neuralrohrs sich zu verdicken und zu einem ansehnlichen soliden Ganglion, dem späteren Hirnganglion der fertigen Ascidie anszuwaehsen. Geht diese Verdickung, wie gewöhnlich, ans der dorsalen Wand des Rohrs hervor, so bleibt der Flimmerkanal ventral rom Ganglion erhalten; entwickelt sich das Ganglion umgekehrt aus der Ventralwand, so findet sich der Flimmerkanal spïter dorsal von ihm (Fig. 395). 
Durch Answachsen der vom Ganglion abgewendeten Wand des Flimmerkanals entsteht ferner eine, von wenigen bis zahlreichen Schlänchen gebildete Drüse, deren Secret in den Flimmerkanal entleert wird, die sog. Neuraldrüse (Hypophysen(rïise). Der Flimmerkanal schließt sich endlich von dem unter oder uiber ihm liegenden Ganglion ab und trennt sich von ihm als besonderes Gebilde; doch bleibt häufig in der hinteren Region des Ganglions ein direkter Zusammenhang beider erhalten (s. Fig. $395 \mathrm{~A}$ ).

Aus dem Bemerkten geht hervor, daß die Yeuraldrüse ventral oder dorsal vom Gehirn liegen kann; das erstere ist der gewöhnlichere Fall; ferner, daß sie mit dem Ganglion in sehr inniger Beziehnng steht, da ja ihr Ausführgang (Flimmerkanal) aus dem ursprünglichen Neuralkanal hervorgeht.

Die hintere Fortsetzung des Nervenrohrs bildet sich entweder einfach zu einem ganglienzellenreichen Strang um, der sich als sog. Gunglienvellenstrang (Visceralstrang) nach hinten erstreckt z. B. bei Molgula), ventral herabsteigt und zwischen den beiden Darmleberdrüsen endigt (vgl. Fig. $395 \mathrm{~A}$ ). Aus ihm sollen Nerven bervorgehen, die Ösophagus, Magen und Leber versorgen. Bei vielen Ascidien setzt sich aber die Abtrennung des Flimmerkanals noch auf diesen hinteren Teil des Nenralrohrs fort, so daß derselbe sich in einen Ganglienzellstrang und eine hintere Fortsetzung des Flimmerkanals spaltet; beide verschmelzen dann gewöhnlich in geringer bis gröBerer Entfernung hinter dem Ganglion zu einem gemeinsamen Strang (Fig. $395 B$ ).

A Fig. 396.

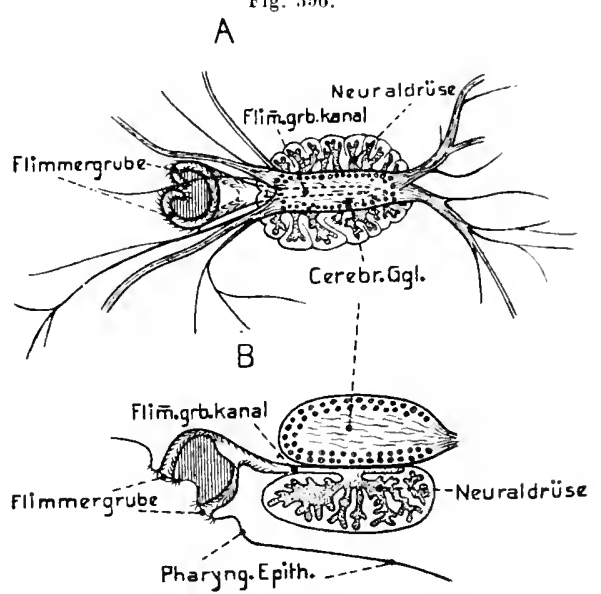

Ciona intestinalis (Ascidiel. A Hirnganglion mit der Neuraldrüse und Flimmergrube von der Dorsalseite gesehen. $B$ Sagittalschnitt durch dieselben Organe (nach SEeliger in Bronn Kl. u. 0., etwas verāndert). E. W.

Das Cerebralganglion der erwachsenen Ascidien liegt demnach dorsal vom respiratorischen Darm zwischen der sog. Ein- und Ausströmungsöffnung (Fig. 286, S. 421 ) als ein solides Gebilde von rundlicher bis länglicher, zuweilen etwas X förmiger Gestalt. Es wird von einem aus der primären Leibeshöhle hervorgegangenen Blutraum umgeben. Ähnlich wie in den Ganglien der seither besprochenen wirbellosen Tiere bilden seine Ganglienzellen eine oberflächliche, ein-bis mehrschichtige Jage, während das Innere aus sog. Neuropil mit weniøen eingestreuten Ganglienzellen besteht (Fig. 396).

Diese eigentümliche Abweichung von den Verhältnissen bei den Vertebraten, welche sich auch am Cerebralganglion der Salpen wiederholt, bönnte vielleicht daher rühren, daß das Ganglion nur aus einer der Wände des ursprünglichen Neuralrohrs hervorgeht; doch widerspricht dem seine Entwicklung bei den Salpen.

Ähnlich wie bei den Copelaten, scheinen die peripheren Nerren ursprünglich als ein vorderes und ein hinteres Paar vom Ganglion auszugehen, und sich dann 
rasch nnd reichlich zu verzweigen (Fig. $396 . A$ ); die vorderen an der Mundregion und dem respiratorischen Darm, die hinteren hauptsächlich an der Kloake und der Ausströmungsöđ̛́nung. Beide Paare können jedoch an ihrem Ursprung vereinigt sein und sich erst später trennen, oder es entspringen auch gleich vorn und hinten mehr Nerven. Seitliche Nerven fehlen häufig ganz, finden sich jedoch namentlich bei den Synascidien reichlicher, Auch unpaare Nervon gehen manchmal vom Ganglion ab. Die Nerven erhalten zuweilen zellige Einlagerungen. - Über den sog. Ganglienzellenstrang wurde oben das Nötige berichtet; er scheint sehr allgemein verbreitet zu sein. - Ähnlich dem Ganglion der Ascidien erscheint anch das von Pyrosoma und Doliolum. Die Neuraldrüse ist bei beiden nur wenig entwickelt.

Thaliaccue. Das Cerebralganglion der Salpen gleicht nach Lage und Bau dem der Ascidien (s. Fig. 397). Ein Flimmerkanal findet sich gleichfalls und geht aus

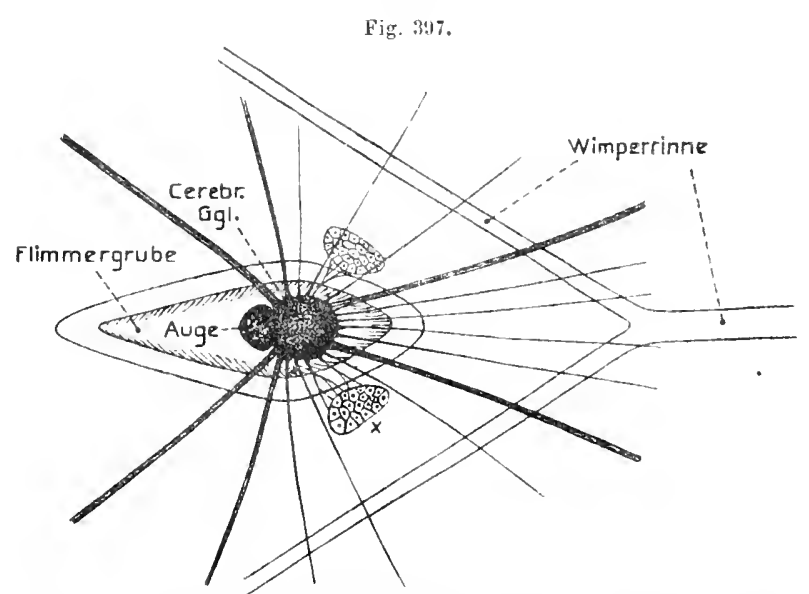

Salpa cordiformis-zonata (gesehleehtl. Form). Gehirn mit Flimuergrabe und Wimperrinne ron der Dorsalseite (Original). E. W. dem vorderen Ende des Neuralrohr's hervor, das, wie schon erwähnt, als eine solide Anlage anftritt, die sich erst später blasenförmig anshöhlt. Die Neuralblase ist stets sehr kurz, so daß ein Rumpf-u. Schwanzteil wohl iiberhaupt nicht mehr angelegt werden. Jedenfalls wurde seither, weder bei Salpen, noch bei

Doliolum und Pyrosoma, etwas gefunden, was dem Ganglienzellstrang der Ascidien entsprechen könnte. - Interessant erscheint die bei vielen Salpen an der schlauchförmigen Neuralblase beobachtete, mehr oder weniger dentliche Dreiteilung, welche. gewöhnlich durch nach innen vorspringende Verdickungen der Wand bewirkt wird. Aus dem vordersten der drei Abschnitte geht der Flimmerkanal hervor; die beiden hinteren werden durch Verdickung ihrer Wände solid und bilden das Ganglion, dessen feinerer Ban dem der Ascidien entspricht. Der Flimmerkanal erstreckt sich bei einem Teil der erwachsenen Salpen noch bis zum Ganglion nach hinten, bei andern endigt er mehr oder weniger weit vor demselben, scheint aber stets durch zwei an ihm sich verbreitende feine Nerven mit dem Ganglion zusammenzubängen. Eine Neuraldriise, die schon bei Pyrosoma und Doliolum sehr wenig entwickelt ist, findet sich bei den Salpen nicht mehr.

Daraus zu schließen daß die Neuraldrüse hier den ventralen Teil des Cerebralganglions bildet, wie dies geschehen (Metcalf), scheint mir wenig begründet. Dagegen flndet sich zuweilen ein Paar dorsal aufsteigender schlauchartiger Ausstilpungen der Dorsalwand des 
respiratorischen Darms (Pharynx, oder auch der Kloake), die sich mit einer scheibenförmigen Abplattung dem hinteren Teil des Cerebralganglions latereventral anlegen (Fig. 397 ). Sie wurden gelegentlich als Ilörorgane, oder auch als Teile der Neuraldrüse gedeutet, da diese, wie wir später sehen werden, bei gewissen Ascilien hintere Verbindungen mit der Kloake besitzen kann.

Das Cerebralganglion der Salpen ist dadurch ausgezeichnet, daß sich auf seiner Dorsalfläche ein bis drei Augengebilde finden, die ans ibm selbst hervorgehen. Das Nähere wird bei den Sinnesorganen mitgeteilt werden. - Zahlreiche periphere Nerven strahlen in paarig symmetrischer Anordnung ziemlich allseitig vom Ganglion aus (s. Fig. 397).

\section{5 b. Vertebrata.}

Acrania. Das Centralnervensystem der Acranier beharrt auf einer so niedrigen Entwicklungsstufe, daß es sich empfiehlt, es zunächst in einem besonderen Abschnitt zu betrachten. Seine Einfachheit zeigt sich vor allem darin, daß eine Hirnanschwellung des Vorderendes völlig fehlt, also, im Gegensatz zu sämtlichen Cranioten, änßerlich kein Unterschied zwischen einem Hirn- und Rückenmark besteht. Es ist ein einheitlicher, im Querschnitt nugefähr dreieckiger Strang, der vorn vor dem Mund verschmälert endet, so daß die Chorda ein ansebnliches Stiick über ihn vorspringt (s. Fig. 80, S. 176 u. Fig. 398). Hinten verjüngt sich das Rückenmark allmählich und endigt fast am Chordaende mit einer schwachen knopfförmigen Anschwellung (Vesicula terminalis). - Etwas ventral von der Mittelachse des Rückenmarks findet sich der Centralkanal (Fig. 399), dessen Herknnft schon bei der allgemeinen Betrachtung des Nervensystems der Chordaten erörtert warle. Dieser Kanal erweitert sich im vordersten zugespitzten Teil des Nervenstrangs zu einem ansehnlichen Hohlraum (Ventrikel), weshalb dieser Abscbnitt dem Hirn der Cranioten im allgemeinen vergleichbar erscheint (Fig. 398).

In ler Ontogenese ist der Centralkanal ursprünglich sehr weit und die Wand des Neuralrohrs nur von einer einfachen Zellschicht gebildet. Durch das Auftreten von Nerrenfasermassen und die Vermehrung der Zellen verdickt sich die Wand allmählich, wobei der Kanal eingeengt wird. Dies geschieht so, daß sich nur der Ventralteil des Kanals offen erhălt, während die daruberliegende Region durch den Zusammentritt der seitlichelı Wände geschlossen wird. Aber auch im ausgebildeten Rückenmark bleibt letzterer Teil als eine aufsteigende spaltartige Naht (Raphe) noch kenntlich (Fig. 399).

Der Centralkanal ist von einer Schicht von Epithelzellen (Ependym) ausgekleidet, deren häufig $\vee$ rästelte Fortsätze durch die nervöse Masse des Rückenmarks ziehen und eine Nenroglia bilden (Stützgewebe). - Hinten biegt das. Rǘckenmarksrohr ursprünglich in das Hinterende des Las nrobrs um (Canalis neurentericus), welcher Zusammenhang sich später völlig löst. Vorn mündet es anfänglich durrh den Neuroporus auf den Scheitel der Kopfregion auf. Später wird diese Stelle linkseitig verschoben und zur sog. Riechgrube, indem die Öfinung sich schließt; doch bleibt ein zur Grube gehender Fortsatz als Lobus olfactorius (s. L. impar, Recessus neuroporiens, Fig. 398) erlalten, ja soll nach gewissen Angaben dauernd offen bleiben.

Der mit dem Craniotenhirn vergleichbare vorderste Abschnitt des Neuralrohrs läßt zwei Regionen nnterscheiden; eine vordere, deren Decke dachartig abfällt, wodurch die Zuschärfung des Vorderendes entsteht, und einc hintere längere. Die erstere nmschließt den erweiterten Ventrikel. 
Ihre Wand, besonders der dorsale Anteil, bleibt dünn und ist wesentlich ron flimmernden Ependymzellen gebildet, mit wenig oberflächlichen Nervenfasern. - Am Hinterende dieses Abschnitts tritt die oben erwähnte Verschmälerung des Ventrikels zu einem medianen Spalt und dem rentralen Centralkanal ein; doch bleibt in der darauffolgendelı hinteren Hirnregion bis zum Ursprung des 5. bis 6. Nerrenpaars der Dorsalrand dieses Spalts als ein horizontaler Querspalt weit geöffnet (Fig. 389) und kann dorsal noch einige blasenartige. hintereinanderfolgende Erweiterungen bilden. Die Eigentümlichkeiten dieser Region rechtfertigen es wohl, sie als hinteren Abschnitt dem Gehirn zuzurechnen. - Auf dem Boden des Hirnventrikels, da wo er in den hinteren Hirnabschnitt übergeht, findet sich (wenigstens bei jungen Individuen) eine Gruppe besonderer flimmernder Epithelzellen, die auch etwas papillenartig vorspringen kann (sog. Tuberculum posterius, auch als Sinnesorgan gedeutet). Dicht dasor wurde zuweilen eine vom Ventrikelraum in die Bodenwand herabsteigende röhrenförmige Einsenkung gefunden und mit dem Infundibulum der Cranioten verglichen (Fig. 398).

Auf fruber Entwicklungsstufe ist die gesamte spätere Hirnregion etwas stärker angeschwollen als das daranffolgende Rückenmarksrohr, was sich später verliert. Ferner zeigt

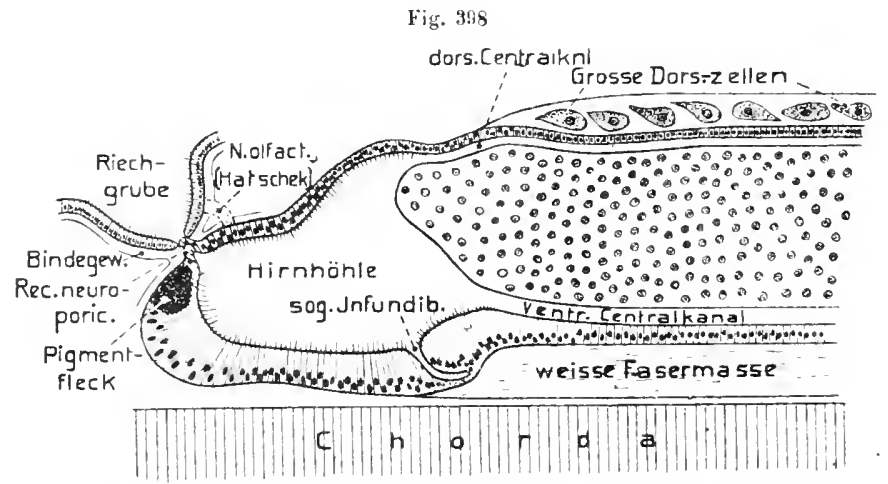

B la nehiostotua (Amphioxns) lance olatu m, $4 \mathrm{~cm}$ lang. Vorderende des Centralnervensystems itu sagrit talschnitt (n. KUPFFEr ly(t). Etwas abgeändert darch Eintragung der etwas linkseitig gelegenen Riechgrnbe (eigenes Präparat) und des sog. Nerv. olfactorius (n. Hatscher 1s92).

E. W.

die Derke der Hirnregion drei schwache Emporwölbungen, von denen die beiden vorderen dem vorderen Hirnabschnitt entsprechen, die hintere dem binteren. Auch findet sich auf frühen Stadien eine deutliche Herabknichung des rentralen Bodens der Hirnregion, indem sich der spätere Hirnventrikel in der Gegend des erwähnten T. posterius plötzlich ventralwärts stark erweitert. Die geschilderten Verhältnisse erinnern an die primitive Bildung des Craniotenhirns, weshalb die vordere Hirnregion der Acranier dem sog. Archencephalon der Cranioten, die hintere dem Deuterencephalon, speziell dem Rhombencephalon verglichen wurde. - Aus dem Erörterten dürfte hervorgehen, daß der Mirnteil des Centralnervensysteus der Acranier wahrscheinlich ziemlich rückgebildet ist, worauf anch die mangelnden Augen und Hörorgane hinweisen; daß also die Ahnen der Acranier vermutlich einen craniotenähulicheren Hirnabschnitt besaßen.

Die nicht sebr zahlreichen Ganglienzellen des Rïckenmarks gruppieren sich um den Centralkanal (graue Substanz), namentlich dessen dorsale spaltartige Fortsetzung, und ziehen nicht selten quer durch sie hindurch. Die Hauptmasse des Rückenmarks wird von den meist längs verlaufenden marklosen Nervenfasern gebildet (weiße Substanz). Die Ganglienzellen sind recht versehieden groß. Vor allem findet sieh eine Lage ansehnlicherer Nerrenzellen in der Decke der hinteren Ilirnregion (Fig. 398). Ferner tritt im Verlauf des Rückenmarks eine 
Reihe hintereinander gelagerter riesiger Ganglienzellen auf, die seltsamerweise in der Raphe des Centralkanals liegen und in beide Hälften der Medulla feine Fortsätze senden; außerdem aber je eine kolossale Nervenfaser ventralwärts.

Eine Reihe solcher Riesenzellen liegt vorn, dicht hinter dem Gehirn (bis zum 11. Spinalnerv), eiue hintere Reihe reicht etwa vom 39. his 5.. Spinalnerv. Die vordere Reihe sendet ihre Riesenfasern abwecbselnd nach rechts und links als zwej candalwärts ziehende Faserstränge $(h v)$; die hintere Reihe ibre Fasern in ähnlicher Weise oralwärts $(v h)$. Die dem Centralnervensystem eingelagerten Sehzellen mit ihrem schwarzen Pigment sollen später bei den Sinnesorgatuen besprochen werlen.

I)je peripheren Nerven, welche vom Centraluervensystem ansqehen, werden zusanmen mit denen der Cranioten besprochen werden.

Craniota. In der Kopfregion sämtlicher Cranioten ist das Vorderende des ursprünglichen Nervenrobrs zu einer besonderen Hirnanschwellung entwickelt, welcher ein, durch die Reibe sich allmählich sehr komplizierender gemeinsamer Bauplan zugrunde liegt. Der sich primitiver erhaltende, anschließende Teil des Neuralrohrs wird als Rëckenmarl: (Medulla spinalis) bezeichnet. Beide $\mathrm{Ab}$ schnitte gehen ganz allmäblich ineinander riber, da der hinterste Hiruabschnitt (Medulla oblongata) dem Rückenmark sehr ähnlich bleibt. Wir beginnen mit dem Riickenmark als dem primitiveren Abschnitt.

Rëchermark (Medulla spinalis). Das Rückenmark erstreckt sich als ein langer Strang ursprünglich durch die gesamte Rumpf- und Schwanzregion. Es liegt anfänglich der Chorda unmittelbar anf und wird von den neuralen Skeletbogen um-

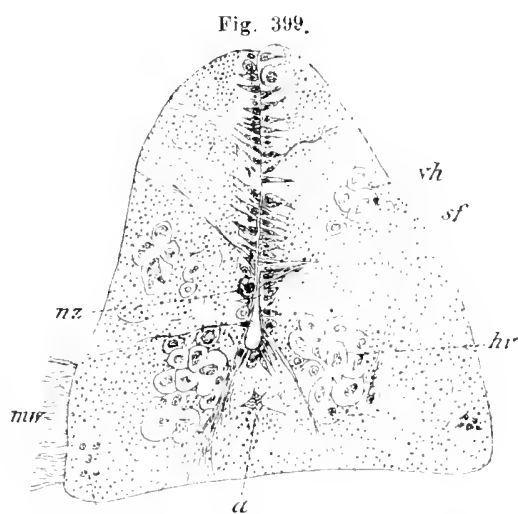
iif

Bralichiostoma (Amphioxus) lanceulat um. Querschnitt durch die mittlere Region des lícben narks, a Ausliufer einer grobth Ganglienzelle mv motorischer oder ventraler spinalnerv. Nervenfasern. nE Nervenzelle. si Stút $/$ aserm die von den um den Centralkanal liegendan Ependymzellen augehen. wh cranial wärts 14 . he radalwäts ziehende kolossale Nervenfaseru (n. RHor.

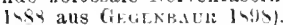
schlossen, so daß es bei allen, mit ansgebildeten Wirbeln versehenen Cranioten den Rïckgratskanal (Canalis spinalis) durchzieht. In regelmäßig segmentïren Abständen entspringen von ihm nach beiden Seiten die sog. Spinalnerven mit je zwei Wurzeln, einer dorsalen (oder beim Mfenschen hinteren) und ventralen (oder vorderen). Überall wird das urspriinglich weite Lumen des primitiven Neuralrohrs durch die starke Verdickung seiner Wünde, besonders der seitlichen, so eingeengt, daß sich nur sein ventraler Teil als bleibender feiner Centralkanal erhält, während der dorsal aufsteigende Teil, ähnlich wie bei Branchiostoma, jedoch viel vollständiger, geschlossen wird, und sich nur durch Gliazellen hïufig als eine Art mediane Scheidewand (Septum dorsale) iiber dem Centralkanal noch bemerklich macht (Fig. 400). - - Wie bei den Acraniern, entwickeln sich im Umkreis des Centralkanals die Ganglienzellen als sog. graue Substan\%, während sich äußerlich die Nervenfasermassen ausbilden, welche schließlich, als sog. weiße Substanz, die graue 
völlig umbüllen. Bei den Cyclostomen bleiben die Fasern sämtlich marklos, wie die der Acranier, wogegen die der Gnathostomen größtenteils markhaltig werden.

So stellt das Riïckenmark also im allgemeinen einen etwa zylindrischen Strang dar, dessen Dicke in der Schwanzregion allmählich abnimmt und der am hintersten Fnde häufig in einen feinen Endfaden (Filum terminale) ausläuft, von dem in der Regel keine Spinalnerven mehr entspringen.

Eine sog. Vesicula terminalis (s. Acranier, S. 549) findet sich embryonal vorübergehend noch bei Haien, im ausgebildeten Zustand bei manchen Teleosteern (besonders Physostomen), entspricht aber hier nicht der eigentlichen Vesicula terminalis, da con ihr erst der Endfaden ausgeht, der in dem verkümmerten Caudalteil der Wirbelsäule (s. S.317) emporsteigt.

Von der annühernd zylindrischen Form weicht das Rückenmark der Cyclostomen (Fig. 400, Petromyzon) erheblich ab, da es bei erwachsenen Tieren dorsoventral stark abgeplattet, also bandförmig erscheint (s. auch Fig. 84, S. 179), und nur einen beschränkten Teil des Riickgratkanals erfïllt. Das Band ist in der Querriclitung gebogen, ventral konkav, dorsal konvex. Auch das Riickenmark von Chimaera ist in seinem hinteren Teil bandförmig abgeplattet; das der perennibranchiaten Amphibien (Fig. 400, Siren) gleichfalls noch breiter als hoch Einen wesentlichen Einfluß auf die ävßere Gestalt des Rückenmarks besitzt die Entfaltung der centralen grauen Substanz. Im bandförmigen Rückenmark der Cyclostomen breitet sie sich vom Centralkanal ebenfalls bandförmig beiderseits aus. - Die um den Centralkanal angehäufte graue Substanz der iibrigen Wirbeltiere scndet gegen die Ursprünge der ventralen und dorsalen Spinalnervenwurzeln gerichtete, leistenartige Längserhebungen aus, welche auf dem Querschnitt natürlich als zwei dorsale und zwei rentrale hornartige Fortsätze erscheinen, und deshalb gewöhnlich als ventrale (oder vordere) und dorsale (oder hintere) Hörner bezeichnet werden. Diese Erhebungen (oder Columnae) der grauen Substanz sind jedoch nicht ganz scharf von der umgebenden weißen abgegrenzt; feinere Ziige der ersteren strahlen in der Regel durch die letztere gegen die Oberfläche aus (s. Fig. 400, Testudo, Homo). Die beiden Rückenmarkshälften werden innerlich dureh das schon oben erwähnte gliöse Septum dorsale geschieden; nicht selten findet sich auch ein ähnliches Septnm ventrale, das vom Centralkanal zur Ventralfläcbe hinabsteigt.

Die Fische und Urodelen zeigen im allgemeinen nur schwach entwickelte Dorsalhörner, die nahezu senkrecht emporsteigen; die Ventralhörner sind gut entwickelt, divergieren jedoch ziemlich stark nach außen, und bedingen daher keine stïrkeren seitlichen Erhebungen der Ventraltläche des Riickenmarks. Diese Fläche ist daher in der Mittellinie meist nur schwach oder nicht konkav eingesenkt; ebenso lindet sich nur eine schwache Furche in der dorsalen Mittellinie, oberbalb des Septum dorsale (Sulcus dorsalis). - Von den Amphibien ab wird die Einbuchtung in der ventralen Mittellinie starker, was jedenfalls durch die ansehnlichere Entwicklung der Ventralhörner bedingt wird, die das beiderseitige Auswachsen des Marks veranlassen (Fig. 400). Schon bei den Anoren findet sich, wie bei den Annioten allgemein, eine tiefe sog. Fissura centralis, die bis nahe an 
den Centralkanal aufsteigt, und von einer Fortsetzung der Gefäßhaut (Pia mater) ausgefüllt wird. Im Gegensatz hierzu, dringt der Sulcus dorsalis auch bei den höheren Wirbeltieren nur wenig tief ein und ist nicht zu verwechseln mit dem Septum dorsale.

Die Erhebung der granen Hörner bedingt auch eine Scheidung der Fasermasse der weißen Substanz in Längsstränge (Funienli, Fascicnli), welche vor'wiegend

Petromyzon

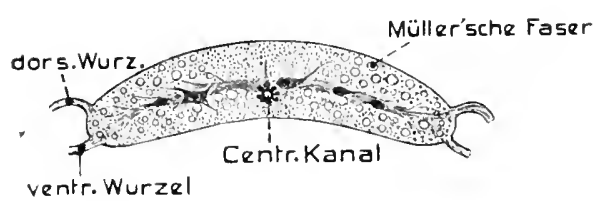

Siren

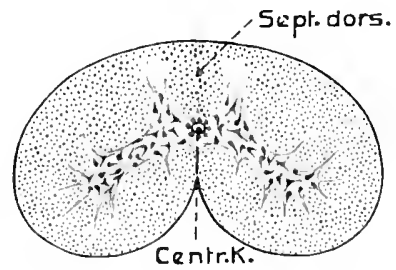

Columba

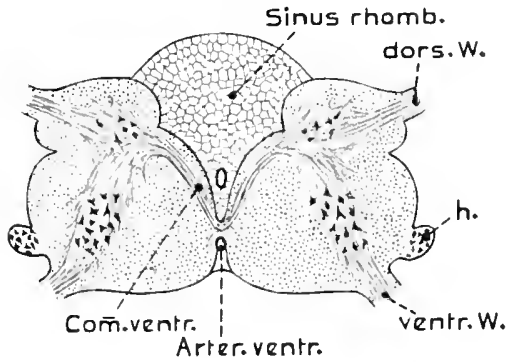

Arter.ventr.
Fig. 400 .

\section{Salmo fario}
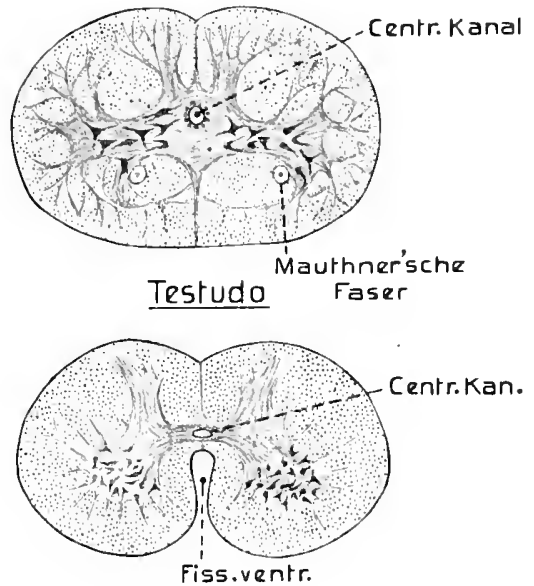

Homo

Com.dors. Sept.d. dors.w.

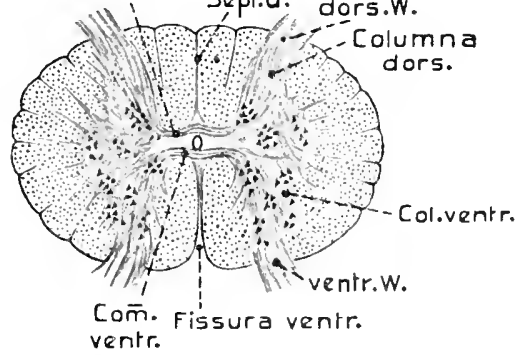

Querschnitte durch das Rückenmark verschiedener Wirbeltiere. Der Querschnitt von Columba geht durch das Lendenmark und zeigt den sog. Sinns rhomboidalis; $h$ sog. HoFFanN-KöLlikfrscher Kern (wiederbolt sich regelmäBig an den Ursprüngen der Ventralwarzeln). (Petromyzon, Salmo, Siren und Testudo n. Kültiker, Gewebelehre 1896; Columba nach Gadow in Bronn Kl. n. O.; Homo nach Rauper-Kopsci, Anat. d. Mensch.). E. W.

aus längsgerichteteu Fasern bestehen; so die beiden Dorsal- (oder Hinter-) Stränge zu den Seiten des Septum dorsale, die von cranial- und kaudalwärts ziehendeu $\mathrm{Fa}$ sern đer dorsalen Nervenwurzeln gebildet werden; die Seitenstränge, die jederseits zwischen Dorsal- und Ventralhorn liegen, und die Ventralstränge zwischen den Ventralhörneru.

Seiten- und Ventralstränge werden von sog. Associationsfasern gebildet, die sowohl zwischen den, in verschiedenen Höhen des Marks gelegenen Zellen der Dorsalhörner, als auch 
Fig. 401.

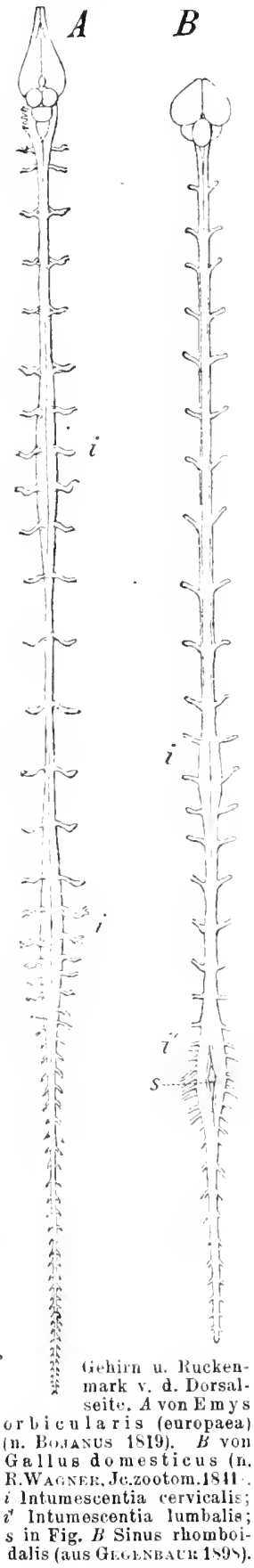

mit dèn Zellen des Hirns Beziehungen herstellen; ferner ron Fasern, die $\mathrm{zwischen}$ den verschiedenen Hirnteilen und den motorischen Ganglienzellen der Vorderhörner Verbindungen vermitteln. Associations- oder Reflexfasern gehen jedoch auch von den Dorsalhörnern zu den Ventralhörnern und kreuzeu sich dabei ventral vom Centralkanal als sog. Commissura ventralis, in der jedocb anch ein Teil der Fasern der Ventralwurzeln sich kreuzt; wãhrend dies ein Teil der Dorsalstrangfasen in einer Commissura dorsalis über dem Centralkanal tut. Die erwähnten Commissuren fehlen den Cyclostomen noch; bei den Fischen findet sich unter der Ventralcommissur noch eine ähnliche commissura accessoria,

Die Masse der grauen und weißen Substanz und damit auch die Dicke des gesamten Riickenmarks steht im allgemeinen im Verhältnis zur Aushildung der Spinalnerven. Wo letztere daher stärker werden, tritt eine Neigung zur Verdickung des Rückenmarks auf. Dies ist namentlich an den Stellen der Fall, wo die Nerven für die Extremitäten entspringen, and um so mehr, je stärker letztere entwickelt sind. - Die Fische und Urodelen mit ihren im ganzen schwachen Extremitäten, ebenso diejenigen Wirheltiere, dẻren Extremitäten rückgebildet sind, zeigen keine oder nur sehr schwache solche Anschwellungen. Bei den iibrigen Klassen treten sie gewöhnlich fiir beide Extremitäten anf und werden als Hals- und Lendenanschecllung (Intumescentia cerciealis und lumbalis) bezeichnet (Fig. 401).

Ihre Stärke steht in direktem Verhältnis zu der der Extremititen. Besonders gut entwickelt sind die Anschwellưngen daher bei den Anzren, Cheloniern, Vögeln und im allgemeinen auch den Mammaliern. Bei den Vögeln (auch Fledermäusen) ist die Halsanschwellung meist die ansehnlichere, bei den Straußen dagegen die lumbale. Letztere ist auch bei starker Vergrößerung der Hinterextremitäten (z. B. Känguruh.) sehr ausehnlich, war aber besonders bei den ornithopoden Dinosauriorn viel stärker als lie vordere; zuweilen sogar abnorm groß, wie sich aus der Erweiterung des Rïckgratkanals schließen läßt.

Die Lendenanscbwellung der Vügel zeigt eine besondere Eigentümlichkeit, da die Dorsalstränge in ihr seitlich auseinanderweichen, indem sich ein gallertiges, ans dem Ependym hervorgehendes Gewebe zwischen sie einschaltet (liig. 400, Columba). Die hierdurch auf der Dorsalseite der Lendenanschwellung hervorgerufene, langestrecht rhombische, etwas eingesenkte Grube wird als Foss rhomboidalis bezeichnet (s. Fig. $401 \mathrm{~B}$ ).

Abgesehen von jenen beiden Anschwellungen erscheint das kiickenmark gleichmäßig, wamentlich fehlen segmentale, etwa den Jrsprüngen der Spinalnerven entsprechende Verdickungen fast stets. Innerlich läßt sich zwar in den Dorsal- und Ventralbörmern eine den Wurzeln entsprechende Kernbildung z. T. wahrnehmen. - Eine Ausnahme findet sich bei gewissen Teleosteern, besonders der Gattung 
Trigla und Verwandten, wo an der Basis der dorsalen Wurzelı der drei vordersten Spinalnerven starke ganglienartige Anschwellungen auftreten, die in Beziehung zur Innervierung der fingerförmigen freien Strahlen der Brustflosse stehen sollen. Sie werden von den angeschwollenen Dorsalhörnern gebildet.

Bei zahlreichen Wirbeltieren erstreckt sich das Rückenmark durch den gesamten Spinalkanal bis in das hinterste Ende der Schwanzwirbelsäule; wobei jedoch sein Caudalende hänfig zu dem erwähnten Filum terminale verkümmert. Bei gewissen Formen, oder in ganzen Gruppen, kann jedoch im erwachsenen Zustand eine mehr oder weniger starke Verkïrznng des Rïckenmarks eintreten, indem sein hiuterer Teil ganz verkiimmert, oder das Wachstum des ganzen Rückenmarks hinter dem der Wirbelsäule zurïckbleibt. - Schon gewisse Fische, namentlich sine Anzahl gymmodonter Plectognathen, zeigen dies anffallend, indem das Rïckenmark sebr kurz bleibt (mit nur zehn bis elf Spinalnerven, Orthagoriscus). Die hinteren Spinalnerven ziehen dann im Spinalkanal als eine sog. Cauda equina nach hinten zu ihren ursprïnglichen Austrittsstellen. - Sehr stark verkürzt ist das Rückenmark auch bei Loplizus (Seeteufel), jedoch mit langem Endfaden. - Elheblich verkülzt erscheint es ferner bei den Anuren. Die Lumbalanschwellung (Rana) hört schon zwischen dem sechsten und siebenten Wirbel anf, aber das Filum terminale reicht bis tief in das Os coccygis. Die hinteren Spinalnerven bilden daher eine Cauda equina. - Das eigentliche Rïckenmark der Mammalia erstreckt sich in der Regel bis in die Lumbal- oder Sacralregion, wäbrend der Endfaden bis in die vordere Candalregion reicht. Die starke Zusammendrängung der Medulla ergibt sich jedoch überall durch die Bildung einer Cauda equina der hinteren Spinalnerven, die natiulich um so ansehnlicher ist, je stärker die Verkïrzung. Bei gewissen Säugern (Echidna, Erinaceus, Chiropteren) bleibì das eigentliche Rückenmark sehr kurz; bei Echidna liegt sein Hinterende etwa in der Mitte der Rumpfwirbelsäule und die Canda equina ist demnach sehr lang.

Von Interesse erscheint es, daB im Rückenmark der Anamnia ïber dem Centralkanal besonders große Ganglienzellen auftreten können, die jenen gleichen, welche bei den Acraniern in der hinteren Hirnregion vorkommen. Gewöhlich treten diese Zellen uи noch embryonal zuf, um später zu schwinden (Chondropterygii, Dipnoi, Amphibien; auch fiir Reptilienembryonen werden sie angegeben). Nur bei den Petromyzonten und manchen Knochenflschen erhatten sie sich im erwachsenen Zustand. Besonders große Ganglienzellen filden sich bei den Cyclostomen jedoch auch in der Ventralregion ler grauen Substanz, wie denn die ventralen Hörner sich i. d. R. durch große motorische Ganglienzellen auszeichnen, die im Bereich der elektrischen Organe von Gymnotus und Malcpterurus besonders zahlreich und groß werden. - Im Rüickenmark der Cyclostomen und Fische fiuden sich gewölınlich besonders starke Längsfasern mit sehr dicker Markscheide. Bei den Cyclostomen sind sie (sog. MUrmensche Fasern) reichlich in der weißen Substanz verbreitet, mit Ausnahme der Dorsalregion (Fig. 400). Bei Chondropterygiem sollen ähnliche Fasem im Ventralstrang verlaufen. Die Dipnoer, Ganoiden und meisten Teleosteèr (Fig. 400) besitzen nur zwei solch' große Fasern (Mautunensche Fasern), welche auch bei Amphibienlarven und Saurierembryonen vorkommen sollen. Die erwähnten Riesenfasen wurden z. T. bis zu großen Ganglienzellen in der Medulla oblongata verfolgt, welche in Beziehung zum labyrinth, speziell dessen statischem Teil (Vestibulum) treten. Die Vermutung liegt daher nahe, daß sie mit der Innervierung ron II skeln 7.11 tun haben, die der Gleichgewichtserhaltung dienen. 
Gehirn (Cerebrum). Einleitung. Dieselben Bedingungen, welche bei den Cranioten znr Entwicklung einer sich successive entfaltenden und bestimmter abgrenzenden Kopfregion führten, nämlich die ansehnliche Entwicklung der Kopfsinnesorgare (Riech-, Seh- und Hörorgane), bewirken auch die mächtige Entfaltung des Centralnervensystems zn dem sich eigenartig ausgestaltenden Gehiru. Diø Anfänge seiner Bildung fanden wir schon bei den Acraniern, bei deren Vorfahren sie wahrscheinlich craniotenartiger entwickelt waren. - Das Hirn der Cranioten ist also der in besonderer Weise fortentwickelte Kopfteil des Neuralrohrs, das caudalwärts ganz allmählich in das Rückenmark übergeht. Wie wir sahen, springt die Chorda dorsalis der Acranier weit über das Vorderende des Nervenrohrs bis an die vordere Körperspitze vor. Bei den Cranioten dagegen endet sie stets in der Mittelregion der Hirnanlage, so daß ein hinterer chordaler und ein vorderer prächordaler Hirnabschnitt zu unterscheiden sind.

Sowohl in der Ontogenese als im fertigen Bau des Craniotenhirus ergeben sich eine Reihe gemeinsamer Züge, die kurz zu erörtern sind. Schon vor ihrem AbschluB erweitert sich der Vorderteil der dorsalen Neuralrinne, der zum Gehirn wird, bedeutend; auch beginnt der Abschluß der Rinne gewöhnlich in der mittleren Hirm egion und schreitet von da nach vorn und hinten fort. Die durch den Verschluß gebildete blasenförmige Himanlage mündet längere Zeit an der vorderen Körperspitze durch den Neuroporus aus, der sich später stets verschließt und vom Ectoderm ablöst; obgleich an dieser Stelle am erwachsenen Hirn niederer Formen noch ein kleiner Vorsprung des inneren Hohlraums angedentet bleiben kann (Recessus netroporicus). - Der prächordale Teil der Hirnblase erweitert sich nun vor dem Vorderende der Chorda hauptsächlich ventralwärts, wobei sich der Boden der Blase an der Chordaspitze gleichzeitig zn einer stark emporsteigenden Querfalte erhebt (Plica ventralis encephali, s. Fig. 402). Der prächordale Hirnabschnitt erscheint dann gegen den chordalen ventral herabgebogen oder abgeknickt, eine Erscheinung, welche sich allmählich fast überall noch verstärkt, indem sich eine wirkliche Herabbiegung dieses vorderen Ilirnabschnitts und der ganzen ihn umschließenden Kopfregion ausbildet (Hirnscheitelbeuge, Kopfbeuge). - Der prächordale Hirnabschnitt entspricht wohl sicher der Hirnblase der Acranier und kann daher wie dort als Archencephalon bezeichnet werden, dem sich die chordale IIirnanlage als Deuterencephalon anschließt.

Der so angedeutete zweiteilige Zustand der Hirnanlage kompliziert sich bald, indem sich etwa in der Grenzgegend beider Abschnitte, also der der sog. Plica ventralis, ein mittlerer Abschnitt (Mescncephalon) abgliedert, dessen Decke sich emporwölbt, so daß er dorsal durch eine vordere und hintere Querfurche abgegrenzt wird, während seitlich nnd ventral die Grenzen weniger scharf erscheinen 1). Die so gegebenen drei Abschnitte (oder Hirublasen) bezeichnet man als Pros-, Mes- und Rhombencephalon (Vorder-, Mittel- und Hinterhirnblase). In der Hirndecke werden die Grenzen der drei Blasen noch dadurch verschärft, daß sich

1) Vgl. bei der folgenden allgemeinen Schilderung der Himbildung die Fig. 402. 
allgemein am Vordereude des Mesencephalon ein Zug querer Nervenfasern ausbildet (sog. Commissura posterior), und ein ähnlicher auch am Beginn des Rhombencephalon (spätere Commissur des Kleinhirns, C. cerebelli). - Während das Mesencephalon keine weitere Differenzierung in Abschnitte erfährt, gliedern sich das Pros- und Rhombencephalon in je zwei Unterregionen, die jedoch weniger scharf gesondert sind als die Arei anfänglichen Hirnblasen. Am Rhombencephalon, das sich vorn bald stark verbreitert, und daher durch die erwähnte Querfalte (Fissura rhombencephalica, Isthmus) scharf vom Mesencephalon abgegrenzt wird, hängt diese Differenzierung hauptsächlich damit zusammen, daß sich der größte Teil

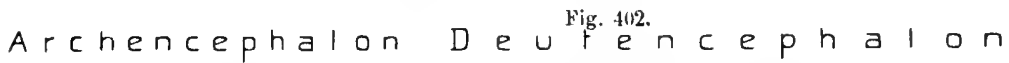

Prosencephal. Mesenceph. Rhombencephal.

Telenceph. Dienceph. Mesenceph.Metenceph. Myelencephal.
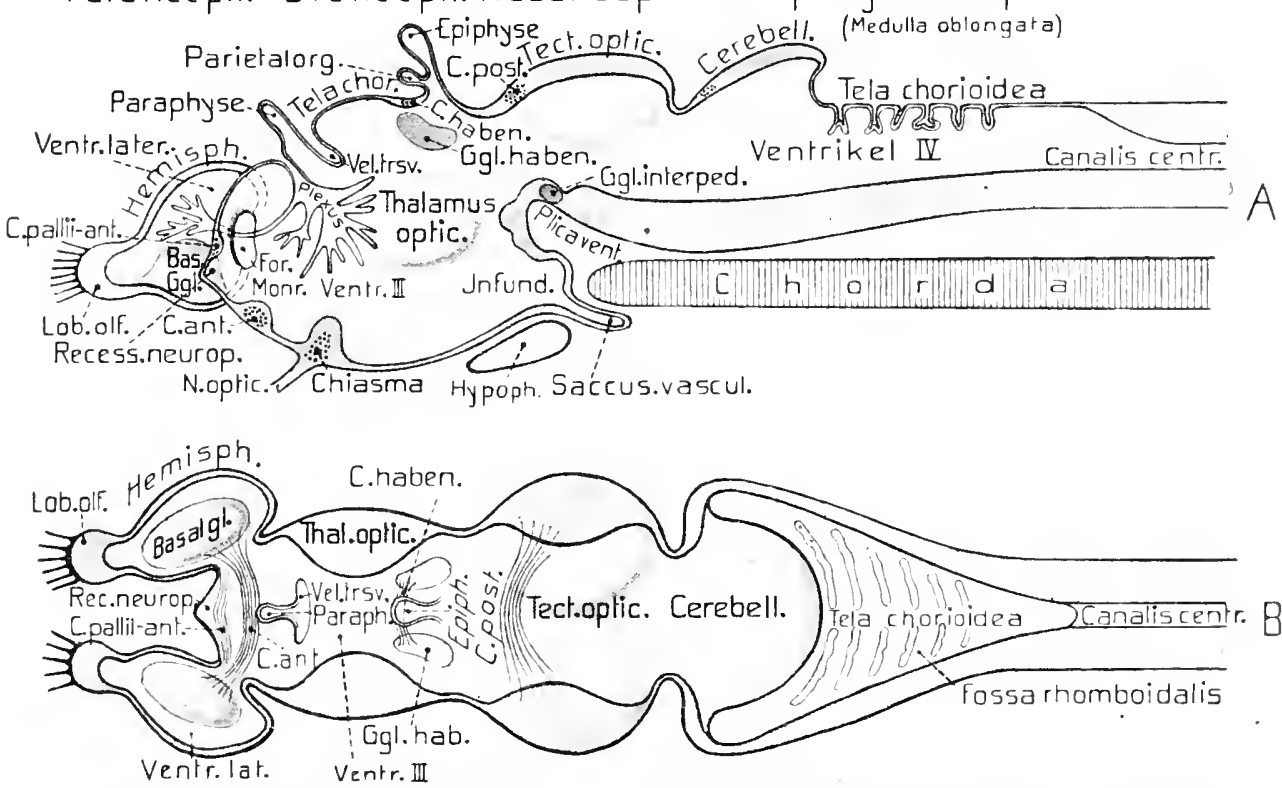

Schema des allgemejnen Aufbaus (Abschnittsbildung) des Hirns der Vertebraten. A Sagittalschnitt von der linken Seite; die rechte Hemisphăre des Telencephalon ist eingezeichnet. $B$ Aneicht von der Dorsalseite. Statt "Deutencephalona lies"Denterencephalon

o. B.

seiner Decke (Dach) nicht zu nervöser Substanz entwickelt, sondern ein einschichtiges dünnes Epithel bleibt (Ependym), das mit der umgebenden, blutgefäßreichen inneren Hirnhaut (Pia) in innige Verbindung tritt, und so zu einer sog. Tela chorioidea wird. Von seiner Übergangsstelle ins Rückenmark an, verbreitert sich das Rhombencephalon immer mehr und erreicht vorn die größte Breite. Dies erscheint bei genauerer Untersuchung so, daß der Centralkanal des Rückenmarks sich, von der Übergangstelle in das Rhombencephalon ab, fortgesetzt erweitert, wobei sein dorsaler Teil (Raphe) sich wieder öffnet. Die seitlichen Hälften des Rückenmarks (Lateral- und Dorsalstränge) werden dabei auseinandergedrängt und bleiben nur durch die dünne, in die Breite auswachsende Tela chorioidea verbunden. - 
Der erweiterte Centralkanal im Rhombencephalon wird nach dem Vorgang der menschlichen Anatomie als der vierte Ventriliel (Ventric. quartus) bezeichnet, und seine Bedeckung durch die Tela chorioidea als Rautengrube (Fossa rhomboidea), da die Tela am heransgenommenen Hirn gewöhnlich in den vierten Ventrikel einsinkt oder abgerissen wird, und diese Region daher grubenartig erscheint. - Nur der vorderste Teil der Rhombencephalondecke, der an das Mesencephalon grenzt, entwickelt sich fast überall nervös, zu einem verdickten queren Streif oder einer Platte, die als ein besonderer Abschnitt, das sog. Hinterhirn oder Metencephalon, von dem ubrigen Rhombencephalon (dem Myelencephalon oder der Medulla oblongata) unterschieden wird. Ein scharf umschriebener ventraler Teil kommt jedoch dem Metencephalon am Boden des Rhombencephalon, wenigstens bei niederen Vertebraten, nicht zu.

Aus der ventrolateralen Region des ursprïnglichen Archencephalon haben sich schon frühzeitig die beiden Angenblasen hervorgestülpt, welche die nervösen Teile der paarigen Augen samt den Augennerveu bilden. Später entwickelt sich jederseits ans der vorderen Region des Archencephalon eine Ausstïlpung, von deren Vorderenden die beiden Riechnerven (N. olfactorii) ausgehen, und welche daher ursprïnglich wohl allein zu den Riechorganen in Beziehung standen. Bei den höheren Wirbeltieren wäehst der seitliche und hintere Teil dieser Ausstülpungen stark aus zu den sog. Hemisphären des Grosshirns, welchen der, den Nervus olfactorius entsendende Vorderteil als $\mathrm{s} 0 \mathrm{~g}$. Riccllappen (Lobi olfactorii) voru angefïgt ist. Die beiden Hemisphärenansstillpungen, zusammen mit dem zwischen ihnen liegenden Teil des ursprünglichen Prosencephalon, werden daher gewöhnlich als Telencephalon (Vorderhirn) unterschieden, wogegen der hintere Abschnitt des ursprünglichen Prosencephalon als sog. Diencephalon (Zwischenhirn) bezeichnet wird. Aus dem Bemerkten folgt jedoch, daß die Scheidung von Tel- und Diencephafon wenig scharf ist nnd daher auch mit Recht mehr als konventionell wie rationell betrachtet wird.

Die centrale graue Substanz des Rückenmarks setzt sich auch in das Gehiru fort und bildet hier das den Ventrikelräumen anliegende, sog. centrale Höhlengrau, in dem sich zablreiche Anhäufungen von Ganglienzellen, sog. Kerne entwickeln können. Dazu gesellen sich jedoch, in allmählich fortschreitender Entwicklung, in verschiedenen Hirnabschnitten, besonders den Hemisphïren des Telencephalon und dem Kleinhirn, oberflichliche Lagen ron Ganglienzellen, sog. grane Rinde (Cortex).

Wir wollen nun die fünf so unterschiedenen Hirnabschnitte, das Myelencephalon, Met-, Mes-, Di- und Telencephalon, von hinten nach vorn fortschreitend, in ihren gemeinsamen Ziigen noch etwas eingehender betrachten.

Das Myelencephalon oder die Medulla oblongatu (verlängertes Mark) des erwachsenen Hirns wurde in seinem Verhältnis zum Rïckenmark, in Hinsicht auf seine den vierten Ventrikel darstellende Höhle und die von der Tela chorioidea gebildete dünne Decke (Rautengrube), schon oben besprochen. Die Länge der Medulla oblongata ist stets sehr ansehnlich, indem die große Mehrzahl der Hirnnerven 
(der fïnfte bís zwölfte) von ihr entspringen, was ein starkes Anwachsen ihrer nervösen Masse bedingt. Es wurde erwähnt, daß die seitlichen Hälften des Rückenmarks bei der Bildung des vierten Ventrikels auseinanderweichen, so daß die sensiblen Dorsalstränge an den lateralen Rand der Fossa rhomboidea verlagert werden, wälrend die motorisehen Ventralstränge die Medianregion der Fossa bilden, und die Seitenstränge sich zwischen sie und die Dorsalstränge einschieben. Für die Nerve der M. oblongata sondern sich mehr oder weniger zahlreiche Kerne von Ganglienzellen (Nuclei), in welchen die motorischen Anteile der Nerven ihren Ursprung nehmen, oder die sensiblen enden (Fig. 434, S. 605).Die Tela chorioidea des vierten Ventrikels wächst fast stets sehr in die Fläche, so d:1 $B$ sie sich melhr oder weniger stark faltet, teils quer, teils unregelmäßiger. Diese blutreichen Falten und Fortsatzbildungen, Plexus chorioidei (Adergeflechte), hängen in den Ventrikelhoblraum hinein, können sich jedoch auch über die Tela erhebeı und an der Medulla oblongata seitlich herabhängen.

Dem Metencephalon oder Kleinhim (Cerebellum) begegneten wir oben als einer schmalen ^nervösen Querbrücke, welche die vorderste Region der ursprünglichen Rhombencephalondecke bildet. Dieser anfänglich schmächtige, ja vielleicht bei einzelnen Formen (Myxine, Proteus) ganz fehlende Hirnteil, kann schon bei niederen Vertebraten eine bedeutende Vergrößerung und Komplikation erfahren, mehr noch bei den höchststehenden (Vögel, Säuger). Das Cerebellum besitzt jedenfalls Beziehungen zur Regulation der Bewegungen und der Spannung (Tonus) der Bewegungsmuskeln. So fällt auf, daß es bei den gut schwimmenden Formen verschiedener Abteilungen bedeutend voluminöser ist als bei den weniger beweglichen Verwandten. - Abgesehen von verschiedenartigen Kernen grauer Substanz, die aus dem Grau um die Centralhöhle hervorgehen, kommt dem Cerebellum nnter seiner äußeren Oberfläche stets eine sogenannte Rinde (Cortex), eine Lage eigentümlich gestalteter Ganglienzellen (sog. PurkinJesche Zellen) zu. Es erscheint daher auf dem Querschnitt mehrfach geschichtet. - Erst bei hőchster Entwicklung (besonders Mammalia) erhält das Kleinhirn eine starke quere commissurenartige Bildung an der Ventralseite der vordersten Region der Medulla oblongata, die sog. Brücke (Pons Varolii); letztere bildet also dann gewissermaßen einen ventralen Abschnitt des Cerebellums.

In dieser Gegend erscheint der ventrale Boden der Medulla embryonal mehr oder weniger stark bauchwärts vorgewölbt, weshalb diese Stelle gewöhnlich als Brückenberıge bezeichnet wird. Bei Vögeln (Kig. 416) und Säugern (Fig. 403) tritt ferner auf der Grenze zwischen der Medulla oblongata und dem Rückenmark eine Abwärtsknickung des Nervenrohrs auf, die sog. Nackenbeuge, welche mit der mehr oder weniger ausgesprochenen Herabknickung des $\mathrm{K}$ op fs in diesen Klassen zusammenhängt.

Das Mittelliirn (Mesencephalon) ist bei den Anamniern und den Sauropsiden ein relativ ansehnlicher Hirnteil, der das Telencepbalon ursprünglich an Grơße übertrifft. Erst bei den Mammaliern tritt es sehr zuriink (Corpora quadrigemina). Es bildet fast stets in seiner ganzen Wand nervöse Substanz, wodurch sich dieselbe mehr oder weniger verdickt. Dadurch wird der in ihm enthaltene Ventrikelraum eingeengt, bleibt jedoch bis zu den Vögeln hinauf noch ziemlich ausgedehnt. Bei den 
Säugern verengt er sich dagegen zu einem feinen Kanal, dem sog. Aquaeductus Sylvii, aus welchem Grund dieser Abschnitt der Hirnhöhle nicht als besonderer Ventrikel gezählt wird. - Vom Mittelhirn entspringen die motorischen Hirnnerven III und IV (Augenmuskelnerven: Oculomotorius und Trochlearis), deren Kerne in der Bodenmasse (Haube) liegen. Die Fasern des Trochlearis nehmen einen eigentïmlichen Verlauf, indem sie caudalwärts bis zur Grenze zwischen Mittel- und Kleinhirn ziehen, sich hier völlig kreuzen und dann wieder etwas nach vorn und seitlich zur dorsal gelegenen Austrittstelle des Trochlearis sich begeben. Diese Trochleariskreuzung (Decussatio N. trochlearis) bildet daher auch eine scharfe Grenzmarke zwischen Klein- und Mittelhirn. - Ganglienzellenanhäufungen (Kerne) finden sich in der ventralen und den lateralen Regionen des Mesencephalon, wälırend

Fig. 403.

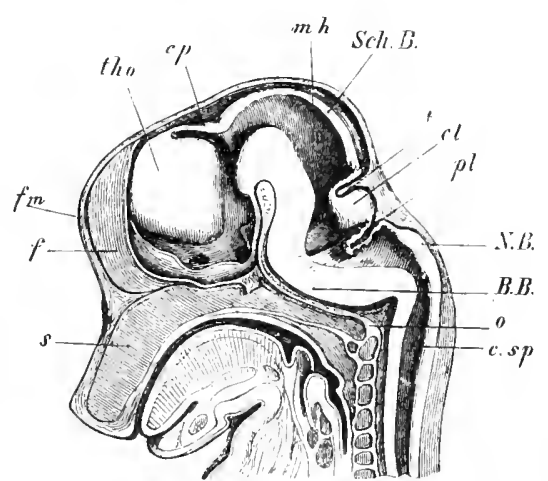

Kopf eines Embryo von sus domestica son $2,4 \mathrm{~cm}$ Länge im Sagittalschnitt (Vergr. 3). B.H. Bräckenheuge; N.B. Nackenbeuge; Sch.B. Scheitel. beuge. c $p$ Commissnra posterior; $c l$ Cerebellum $f$ Hirnsichel; Linie $m$ verlängert führt zu Foramen IIonroi; mh Mittelhirn; o Basioceipitale; $p l$ Plexus chorioideus ventric. IV; $s$ Nasenscheidewand; $t$ Tentorium cerebelli; tho Thalamus opticus (n. KöLuksk, Entwicklungsgesch. 1979). die Dachregion (Tectum opticum) in ihrer ganzen Ausdehnung mit Ganglienzellen versehen ist. Von den ventralen Kernen oder Ganglien seien hier nur erwähnt die sich iiberall findenden beiden kleinen Ganglia oder Corpora interpeduncularia, welche sich auf der Grenze zwischen Mittelhirn und der Medulla oblongata finden, und auch äußerlich an der Ventralfläche vorspringen können; ferner die paarigen ansehnlichen gangliösen Erhebungen (Ganglia mesencephalica lateralia), die bei den meisten Vertebraten vom Boden und etwas seitlich in den Ventrikel hineinragen und ihn stark einengen. - Zum Dach des Mittelhirns (Tectum opticum) zieht der größte Teil der Opticusfasern und findet hier seine End-

station. Das Tectum erhebt sich in der Regel als ein Paar Lappen (Lobi optici). An seinem Vorderende findet sich die frïher schon erwähnte Quercommissur, C. posterior, deren Fasern sich jederseits bis in die Haubenregion des Mittelhirns erstrecken.

Da die scharfe Sonderung des Di- und Telencephalon, wie schon oben bemerkt, recht schwierig ist, so wollen wir beide Abschnitte gemeinsam besprechen. Die dorsale Decke des ursprïnglichen Prosencephalon, aus welchem bcide hervorgehen, bleibt fast in ihrer ganzen Ausdehnung diunn nnd epithelial, wie die Tela chorioidea des Myelencephalon. Diese Decke erstreckt sich nach vorn zwischen die Anlagen der beiden IIemisphären des Telencephalon bis zum ehemaligen Neuroporus, jedoch auch noch etwas ventral unter den Neuroporus hinab, so daß sie in eine Lamina supra- und infrancuroporica geschieden werden kann. Sowtit diese dünne Lamina vorn zwischen die beiden Hemisphären des Telencephalon reicht, sie miteinander verbindend, wird sie gewöhnlich als Lamina terminalis bezeichnet. 
Ihre dorsale Fortsetzung hinıer dem Ursprung der Hemisphären bildet das Dach des Diencephalon; doch wird zuweilen (Kupfter) die dorsale Grenze des Telencephalon etwas mehr caudalwärts verlegt bis zu einer sich häufig bildenden queren Einfaltung der epithelialen Decke in den Ventrikel, dem V'elum transversum (s. Fig. 402). Dicht vor diesem Velum bildet die Decke eine mehr oder weniger lange schlauchartige Ausstillpung, die Paraphyse. Dies, in der Ertwicklang meist angelegte Organ, dessen Funktion nicht festgestellt ist, erhält sich bei vielen primitiveu Vertebraten, geht jedoch nicht selten aueh ganz ein.

Von der caudalen Region der Zwischenhirndecke entspringt stets eine ähnliche, sich dauernd erbaltende schlanchartige Ausstülpung, die sog. Epiphyse, welche am er'wachsenen Gehirn eine sehr verschiedene Länge erreicht. Wie die ganze Tela des Zwischenhirns, tritt sie in innige Beziehung zu den Blutgefäßen der inneren Hirnhaut und erlangt durch Aufknäuelung, sowie wahrscheinlich anch Verzweigung von den Amphibien ab einen drüisenartigen Charakter (daher auch Zirbeldrüse oder Glandula pinealis genannt).

Dicht vor der Epiphyse, ursprünglich vielleicht sogar im Zusammenhang mit ihr, bildet sich bei gewissen Formen durch eine ähnliche Ausstülpung das Parietalorgan, das sich bei manchen Vertebraten in Form eines rudinentären Sehorgans (Parietalauge) erhalten kann.

Wie schon erwähnt, stiilpen sich die Hemisphärcn aus der seitlichen Vorderregion des Prosencephalon aus, so daß in jede eine Fortsetzung von dessen Ventrikelraum eintritt (Tentriculi laterales, s. hemisphaerici). Im erwachsenen Gehirn sind die Ausstïlpungsöffnungen, welche in die seitlichen Ventrikel führen, meist sehr verengt und werden als Foramina Monroi oder F: interventricularia bezeichnet. Der vordere Enḋteil des gemeinsamen Ventrikelraums des Prosencephalon, in welchen die beiden Foramina führen, wird namentlich dann, wenn die Grenze des Telencephalons etwas weiter caudal verlegt wird (s. oben), als Ventriculus communis oder impar bezeichnet. Da dieser Raum im erwachsenen Gehirn sehr klein ist und gewissermaßen mit den beiden Foramina Monroi zusammenfließt, so spricht man häufig auch nur von einem Foramen Monroi. Die gesamte Hemisphärenwayd wird gewöhnlich stark nervös verdickt.

Wie wir oben salıen, treten vorn die Fäden der beiden Riechnerven zu den Hemisphären. Diese vordere Hemisphärenpartie grenzt sich mehr oder weniger scharf von der folgenden ab und steht in direktester Beziehung zum Nervus olfactorius, weshalb dieser Abschnitt Lobus olfactorius genannt wird. Als ein Teil der ursprünglichen Hemisphären ist er, wie diese, hohI, indem sich der Seitenventrikel ursprïnglich stets in ihn erstreckt. Die Riechnervenfasern endigen großenteils im Vorderteil des Lobus, wo sie mit den Ausläufern der Ganglienzellen des Lobus zu eigentümlichen, verworrenfasrigen Körpern, den Glomeruli, zusammentreten (vgl. S. 511). Dieser Vorderteil des Lobus ist meist etwas angeschwollen und erhielt daher die Bezeichnung Bulbus olfactorius. Bei starker Längsstreckung des Gesamtlobus kann der Bulbus mit dem hinteren Lobusteil durch einen längeren stielartigen Strang zusammenhängen, weshalb dann gewöhnlich eiu vorderer Bulbus, ein Tractus und ein hinterer eigentlicher Lobus olfactorius (in engerem 
Sinn) unterschieden werden. - Wie schon betont, werden die primitivsten Hemisphären zum größten, oder doch einem sehr ansehnlichen T'eil von den Lobi olfactorii gebildet, was anch dadurch erwiesen wird, daß die aus dem Bulbus hervorgehenden, sogenannten sekundären Riechfasern sich auf ihnen ansbreiten. Der auf den Lobus folgende, ursprünglich sehr kleine Teil bildet die eigentlichen Hemispharen des Telencephalon (Großhirn) im engeren Sinne. Diese wachsen bei den höheren Wirbeltieren immer ansehnlicher aus, sowohl nach vorn nnd hinten als dorsal. So erlangen die eigentlichen Hemisphären ein immer stärkeres Übergewicht ïber die Lobi olfactorii, welche schließlich sogar zu kleinen Ańhängseln an ihnen werden können. -- Die Höhlen der Hemisphären werden nach dem Vorgang der menschlichen Anatomie auch als die Ventrikel $I$ und $I I$ bezeichnet, der Ventrike] des Diencephalon als der III. - Wie bemerkt, verdickt sich die nervöse Wand der Hemisphären, wodurch die Seitenventrikel verengt werden. Überall aber verdickt sich ihre ventrolaterale Bodenregion stärker, manchmal sogar ganz kolossal, und steigt als das Stamm-oder Basalganglion (Corpus striatnm) in den Ventrikel empor. Im Gegensatz zu der Boden- und Seitenregion wird die Dachregion der Ventrikel gewöhnlich als deren Pallium bezeichnet. - Die beiden Ilemisphären, samt den Lobi olfactorii, sind stets durch eine quere Fasercommissur, welche sich in der Lamina terminalis entwickelt, verbunden (Commissura anterior). Ursprünglich bildet diese vorwiegend eine Verbindung der beiden Lobi olfactorii. Bei den meisten Wirbeltieren tritt noch ein zweites, dorsat von der Commissura anterior liegendes, queres Commissurensystem hinzu, welches im allgemeinen, hesonders aber in der Ontogenie, als C. pallii anterior bezeichnet wird. - Mit steigender Entwicklung der Hemisphären entwickelt sich in ihrem Pallium eine zuerst sehr kleine Region, welche durch eigentümlich gestaltete, oberflächlich gelegene Nervenzellen (Pyramidenzellen) ausgezeichnet ist. Dies ist die sog. Rindenlage oder Cortex pallii; jedoch ist zu bemerken, daß auch die Lobi olfactorii eine Cortex von Nervenzellen besitzen. - Das IIeranwachsen der Hemisphären bei den höheren Wirbeltieren geschieht vor allem durch eine VergröBerung des Palliums nnd die allmähliche Ausbreitung seiner Cortexregion, welche schließlich bei den Mammalia die gesamte Ilemisphärenoberfäche überzieht.

Wie Ontogenie und vergleichende Anatomie zeigen, bildet das Dicncephalon oder Zwischenhirn ursprünglich einen sehr ansehnlichen Itirnabschnitt, der jedoch in der Vertebratenreihe in dem Maße zurücktritt, als sich die Ilemisphären des Telencephalon vergrößern. Wie wir schon sahen, bleibt seine Decke in großer Ausdehnung diinn epithelial (Ependym) und bildet, unter Anteilnahme der inneren Hirnhaut und ihrer Blutgefäße, eine ähnliche Tela chorioidea, wie die der Medulla oblongata. Epiphyse und Parietalorgan, welche von der Decke gebildet werden, wurden schon oben erwähnt; ebenso daß die Paraphyse gewöhnlich zum Zwischenhirn gerechnet wird. Dicht vor deren Ursprung stiblpt sich die Tela fast überall als ein verästelter, blutreicher Plexus chorioideus, ähnlich der Plexusbildung der Medulla oblongata, in den Ventrikel des Zwischenhirus ein (Plexus inferior oder anterior). Dieser Plexus ventriculi III. sendet ferner durch die beiden Foramina 
Monroi in jeden Hemisphärenventrikel meist einen ansehnlichen Zweig (Plexus hemisphaerici). Bei gewissen Formen bildet jedoch die Tela chorioidea auch dorsal gerichtete sackartige Ausstülpungen, die das Hirn mehr oder weniger überlagern können. - In der Gegend des Epiphysenursprungs (sog. Epitbalamusregion) treten überall zwei relativ kleine Ganglien anf (Ganglia habenulae), die sich vor der Epiphysenbasis durch eine Qnercommissur verbinden (Commissura habenulae s. superior).

Die Seitenwände des Diencephalon verdicken sich stark nervös, wodurch der Ventrikel III eingeengt wird; sie bilden die Thalami optici (Sehhügel), in denen sich sekundär gewöhnlich eine größere Anzahl Kerne (Ganglien) differenzieren. Hier ziehen auch die zahlreichen Nervenfaserzüge, welche das Zwischenhirn mit den Hemisphären, dem Mittelhirn und weiter caudal gelegenen Teilen des Centraluervensystems verbinden, d. h. Züge, welche ans den Hemisphären zu den letztgenannten Regionen gehen, oder von ihnen herkommen. - Die ventrale Region des Zwischenhirns (häufig Hypothalamus genannt) entwickelt sich schon frühzeitig in der Ontogenie sehr eigentümlich, indem ihr, durch die Plica ventralis gewissermaßen abgeknickter Caudalteil sich nach hinten noch stärker trichterartig aussackt (sog. Infundibulum, Hirntrichter). Das blinde Ende dieses Infundibulums stülpt sich bei den Anamnia zu einem gefalteten, dünnwandigen Sack aus, der wegen reicher Umspinnung mit Blntgefäßen als Saccus vasculosus (Infundibulardrüse) bezeichnet wird, den Manche anch als eine Art Sinnesorgan denten wollen. Er führt nämlich wie das Infundibulum auch Nervenfasern. - Mit der Ventralseite des Infundibulums vorwächst ein drüsiges Gebilde, die Hypophysis (Hirnanhang, Glans pituitaria), welche bei den Gnathostomen durch eine Ausstïlpung der ectodermalen Decke der embryonalen Mundhöhle entsteht, sich von dieser abschnürt und zahlreiche epitheliale Drüsenschläuche entwickelt. Hierauf verwächst sie mit dem Infundibulum, ohne daß aber eine Kommnnikation mit dessen Hohlranm sicher erwiesen wäre. Im ausgebildeten Zustand sondert sich die Hypophyse häufig in mehrere hintereinander gelegene Abschnitte. Auf ibre in vieler Hinsicht interessante morphologische Auffassung soll später näher eingegangen werden. Auch in der Hypothalamusregion treten fruhzeitig zahlreiche Ganglien auf, von denen hier nur die sog. Ganglia mammillaria hervorgehoben werden sollen, die wabrscheinlich schon bei den Anamnia vorkommen. - Etwas vor dem Infundibulum entspringen von dem hier verdickten Zwischenhirnboden die beiden Nervi optici, wobei sie sich kreuzen, gewöhnlich unter Verflechtung ihrer Fasern zu einem sog. Chiasma.

Neuromerie. Schon an der noch nicht geschlossenen Medullarplatte der Wirbeltiere beobachtet man sehr allgemein eine Art querer Gliederung, welche durch schwache Verdickungen der Platte und dazwischenliegende zarte Querfurchen hervorgerufen wird. Diese Gliederung (sog. primäre Neuromerie) wurde nicht selten (z. B. bei Haien 'und Urodelen) noch weiter nach hinten in den Bereich des späteren Rückenmarks verfolgt. Auch am geschlossenen Hirnrobr tritt eine ähnliche Gliederung in hintereinanderfolgende Abschnitte (Neuromeren) durch äußere seitliche Furchen in der Regel hervor, denen innerlich vorspringende Leisten entsprechen (sekundäre Neuromerie). - Es ergab sich sogar bei den verschiedenen Klassen eine 
ziemlich weitgehende Übereinstimnung linsichtlieh der Beziehungen der sog. Neuromeren zu den späteren Hirnabschnitten. Die drei vordersten entspreehen den späteren Prosencephalon, die zwei folgenden dem Mesencephalon. Auf das Rhombencephalon kommen mindestens fünf; hăufig finden sich jedoch noch Andeutungen folgender, die in diese Hirnregion eingehen. Die Neuromeren des Rhombencephalon lassen sieh sogar mit dessen späteren Einzelgebieten in Beziehung bringen: so scheint das erste stets zum Cerebellum gehörig, das zweite, oder die zwei folgenden fallen in das Ursprungsgebiet des fünften Hirnnerrs (Trigeminus), das vierte in das des siebenten und achten (Facialis und Acusticus), das fünfte in das des neunten (Glossopharyngeus). Die Beziehungen des Nervus vagus (X) und accessorius (XI) zu etwaigen weiteren Neuromeren sind noch unklar. - $O b$ die sog. primäre und sekundäre Neuromerie völlig zusammenfallen, blieb noch etwas unsicher. - Hinsichtlich der morphologischen Bedeutuıg der Neuromerie wurde vorerst keine Übereinstimmung erzielt. Hnerseits erblikkt man in ihr eine wirkliche primäre Metamerie des Nervenrobrs; andererseits wird die Ansicht vertreten, daß die Erscheinung nur durch Wachstumsverhältnisse der Umgebung, besonders der Mesodermsomiten (Urwirbel), also sekundär herrorgerufen werde. Da die primäre Neuromerie, wie es scheint, sowohl vorn als hinten, auth in Regionen auftritt; wo Vesodermsouiten nicht, oder noch nicht entwickelt sınd, so dürfte die erstere Ansicht wahrscheinlicher sein. - Wie wir jedoch schon hervorlıben, läßt sich am ausgebildeten Centralnervensystem der Wirbeltiere ron einer solchen Neuromerie nichts mehr erkennen.

Schilderung der Mirnbildung in den einzelnen Gruppen. Im Hirn der erwachsenen Anamnia liegen sämtliche Einzelabschnitte in etwa horizontaler Ebene hintereinander, da sich die Hirnscheitelbeuge und die Kopfbeuge in den späteren Entwicklungsstadien zurückbilden, d. h. Tel- und Diencephalon sich wieder aufwärts drehen. Dagegen bleibt die Plica ventralis stets dentlich markiert, wenn auch meist stark verflacht.

Cyclostomata. Wir werfen zuüchst einen Blick anf das Petromyzongehirn, da es wobl sicher arsprünglichere Verhälnisse hewahrt hat als das der Myxinoiden und deshalb die primitivsten Einrichtungen unter den Cranioten darbieten ditrfte. Es zeigt (Fig. 404) noch eine ansehnliche Entfaltung des Diencephalon, an das sich seitlich und yorn die beiden Ausstülpungen des Telencephalon anschließen, welche namentlich in dorsoventraler Ansdehnung hinter dem Diencephalon stark zurïckbleibcn. Diese beiden Telencephalonhälften sind mebr oder weniger deutlich in einen vorderen und hinteren Lappen differenziert. Vom vorderen entspringt der N. olfactorius, er wird daher gewöhnlich als Lobus olfactorius bezeichnet. Sein innerer Ban entspricht jedoch dem eines Bulbus olfactorius, von welchem die sekundären Riechnervenfasern ausstrahlen, die den größten Teil des hinteren Lappen überziehen. Hieraus folgt, daß letzterer in der Hauptsache noch einem sekundären Lobus olfactorius gleich zn setzen ist; gewöhnlich wird er als Hemisphäre bezeichnet, was ja auch insofern berechtigt erscheint, als er die Anlage der Hemisphärè der höheren Wirbeltiere enthalten muß. Die gesamten Telencephalonausstülpungen repräsentieren also in der Hauptsache den primären Lobus olfactorius der höheren Cranioten. -- Ihre Wände sind stark verdickt, so daß ihr Ventrikelraum, der sich mit einem vorderen Ast (Horn) in den Bulbus olfactorius, mit einem binteren in die Hemisphärenanlage (oder den sekundären Lobus olfactorius) erstreckt, sehr eingeengt wird. Eine kleine Stelle an der Hemisphäre (auf 
der Figur $A$ durch Punktierung angegeben) enthält l'yramidenzellen und kaun daher als die erste Andeutung einer Hemisphäronrinde betrachtet werden (sie wird gelegentlich anch als Epistriatum bezeichnet). Vom Boden des hinteren Ventrikelastes erhebt sich ein schwaches Basalganglion. - Die ansehnliche Commissura anterior (C. ant.), welche aus Fasern des Bulbus und Lobus olfactorius (Hemisphären) hervorgeht, verläuft in der Lamina terminalis; es scheint sich ein dorsaler

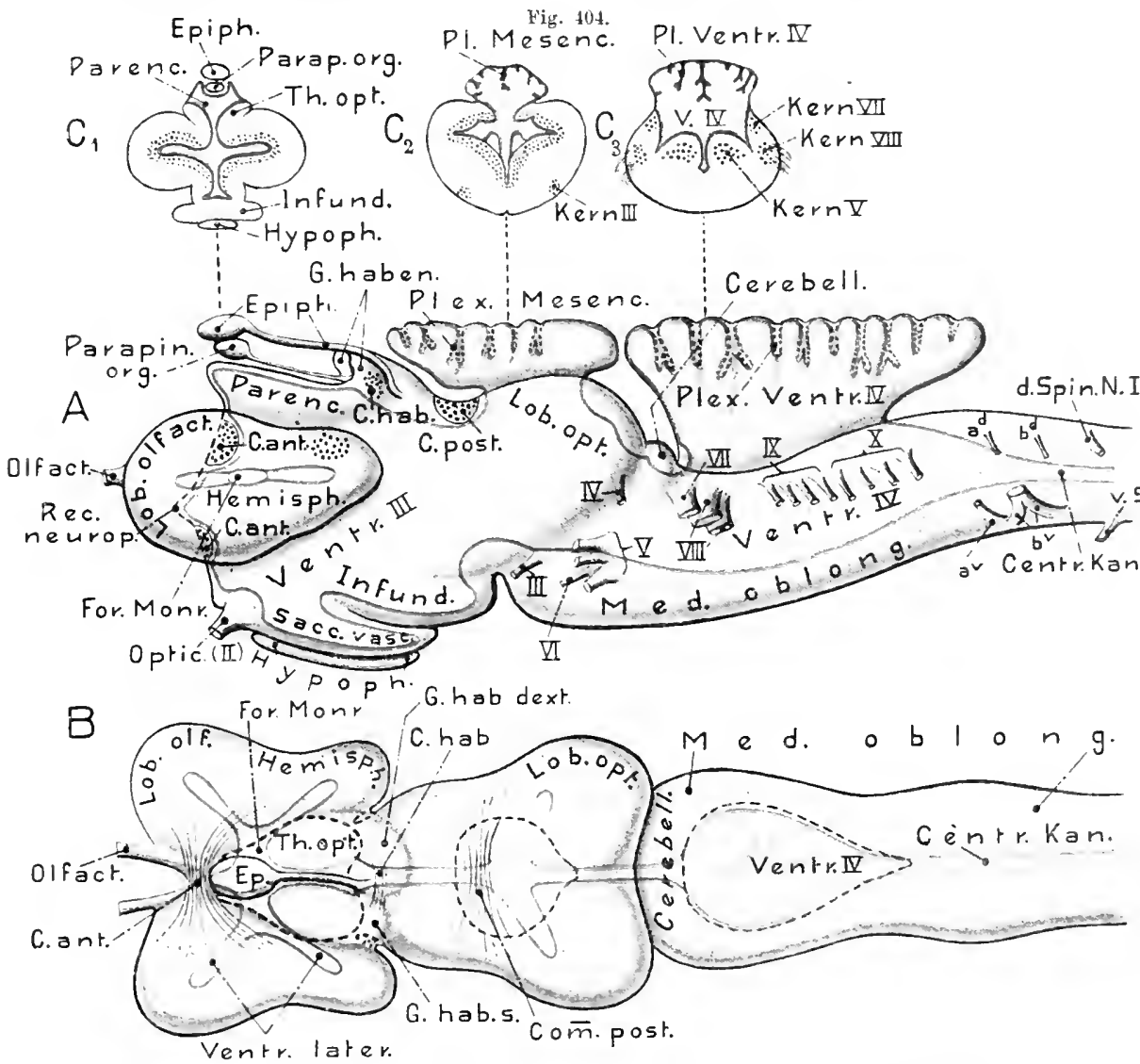

I'etrom yzon planexi, Aehiro etwas schematisch. Ventrikelräume lloendym rot einge\%tchnet. A Hirn von links. $B$ yon der Dorsalseite. Die Lmgıenzung der Telae des Di-, Meso-und Myelencephalon in Strichlinien angegeben. $-C_{1}-C_{3}$ Querschuitte des lIirns an den tellen, welche durch die von den Figuren $C_{1}-C_{3}$ alsgehenden strichlinien angedeutet sind. Die limnerven sind, wio in den tolgenden Figuren dureh die

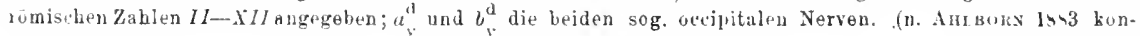
struiert und etwas rerāndert). o. 1). 1. E. W.

und ventraler Teil an ihr unterscheiden zu lassen, so daß möglicherweise schon bei den Cyclostomen eine Commissura paliii anterior angedentet ist. - Die Decke des Diencephalon bleibt bis zur Lamina terminalis nach vorn eine dïnne Tela, welche sich daher zwischen die beiden Telencephalonhälften hineinerstreckt. Sie bildet vorn eine paraphysenartige Erhebung (Parencephalon); caudal entspringen von der Decke dicht hintereinander zwei ansehnliehe, schlanchartige A usstulpungen, 
vou welchen die hintere sicher die Epiphyse ist, die vordere, deren Ende zu einem augenartigen Gebilde anschwillt, als P'arietal- oder Parapinealoryan bezeichnet wird (wovon später bei den Sinnesorganen mehr). In der Gegend dieser beiden Organe liegen die Ganglia habenulae, von welchen das rechte viel größer ist als das liuke, das Nervenfisern in das Parapinealorgan sendet. Diese Asymmetrie der Ganglia habennlae wiederholt sich gewöhnlich bei den Fischen. - Die Thalamusregion des Diencephalon ist stark gangliös verdickt, weshalb der dritte Ventrikel sehr eingeengt erscheint. - Am Hypothalamus finden wir ein Infundibulum (anch Lobus. posterior genannt), dessen Seitenwände sich zu schwachen gangliösen Lobi inferiores (laterales) ausbuchten; darunter liegt eine dünnwandige Aussackung (Saccus infundibuli), die wobl dem Saccus vasculosus entspricht, jedoch der reichen Blutgefäßentwicklung entbehrt. Der Ventralwand dieses Sacens liegt die längliche, im allgemeinen einfach sackförmige Hypoplyyse an.

Wie wir später noch genauer sehen werden, bietet die Ilypophyse der Cyclostomen großes Interesse, da sie sich nicht von der Decke der Mundhöble abschnürt, wie die der Gnathostomen, sondern von dem blinden Hinterende eines sich in der Gegend des Neuroporus aus dem äußeren Ectoderm einstülpenden Schlauchs (Ductus neuropharyngeus, IIypophysenschlauch), welcher nach hinten bis unter das Zwischenhirn reicht und hier bei den Myxinoiden in die Mundhöhle mïndet. Wahrscheinlich dürfte diese Herkunft der Ilypophyse die ursprüngliche gewesen sein, und der Zustand bei den Gnathostomen ließe sich derart deuten, $d a ß$ bei ihnen nur das Hinterende des ursprünglichen Ductus neuropharyngeus, $\mathbb{d}$. h. die eigentliche llypophyse, und zwar von der Mundhöhle aus, angelegt, der übrige Teil dagegen nicht mehr gebildet wird.

Das Mittelhirn bildet einen sehr ansehnlichen Hirnabschnitt mit änßerer Andeutung paariger Lobi optici und starken paarigen Bodenanschwellungen (s. anch Fig. 404, $C_{2}$ ). Sein Tectum ist, im Gegensatz zu allen übrigen Cranioten, dadurch ausgezeichnet, daß es eine große mittlere häutige Stelle zeigt, die sich stark dorsal erhebt, itls ein ansebnlicher Telasack mit Plexusbildung. Ebenso erhebt sich auch die Tela des IV. Ventrikels iuber der Rantengrube zu einem noch ansehnlicheren Sack, an dessen vorderer Ursprungsgrenze sich das minimale Cerebellum als eine schwach verdickte quere Lamelle findet. Die Medulla oblongata ist ansehnlich lang.

Das Hirn der Myxinoiden ist offenbar bedeutend verändert. Seine Abschnitte sind voll vorn nach hinten sehr stark zusammengedrängt und verkürzt, das Gesamthirn ist relatir kurz. Die Iemisphären des Telencephalon treten selbst ontogenetisch wenig herror und repräsentieren jedenfalls fast ausschließlich die Lobi olfactorii, welche im erwachsenen Gehirn so .innig mit dem Diencephalon verwachsen, daß eine scharfe Grenze zwischen Tel- und Dieucephalon nicht besteht. Dagegeu gliedert sich von den primären Lobi olfactorii die Bulbusregion als ein kurzplattenartiges Gebilde ab. - Das Mittelhirn ist relativ stark entwickelt und wird durch eine dorsale Querfalte in eine größere Vorder- und kleinere Ilinterregion gesondert, sodaß, zusammen mit der mittleren dorsalen Längsfurche, eine Art Vierhügel angedeutet sind. Paraphyse und Epiphyse sind nicht sicher nachweisbar, doch dürfte letztere als sehr kurzes Gebilde vorhanden sein. Ein Kleinhirn scheint ganz zu fehlen. - Eigentümlich ist die starke Reduktion der Ventrikelräıme durch Verdickung und schließliche Verwachsung der Wände, weshalb im Telencephalon nur ventral ein kleiner Ventrikelraum offen bleibt, im Diencephalon allein der Hohlraum des Infundibulum. Auch der Mittel- 
hirnventrikel ist stark einge sngt und ohne Verbindung mit dem des Diencephalon. Diese Verhältnisse bedingen ferner, daß das Myxinoidenhirn nur eine Tela chorioidea der Medulla oblongata besitzt, während sie dem Tel-, Di- und Mesencephalon vïllig fehlt.

Pisces. Das Hirn der Fische schließt sich ziemlich innig dem Zustand an, wie er etwa bei den Petromyzonten besteht. Das embryonale Telencephalon, dessen dorsale hintere Abgrenzung gegen das Dieneephalon wir dureh das Velum transversum gegeben annehmen, bildet zwei Hemisphärenausstülpungen, die sich jedoch fast überall rein nach vorn entwickeln, ohne hintere Ausbuchtung:

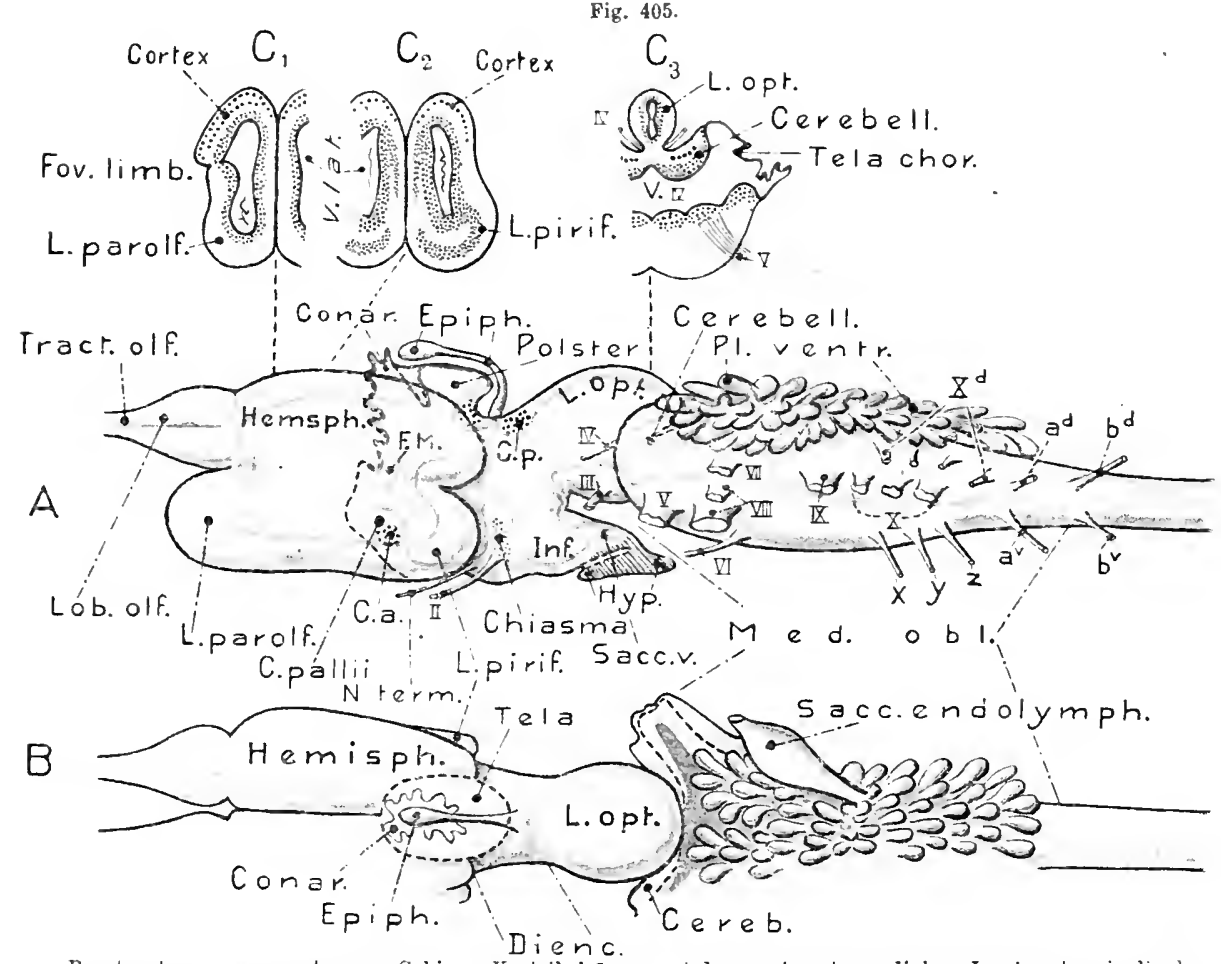

Protopterus annecteus. Gehirn. Ventrikelrăume rot begrenzt. A von links. Isamina terminalis des Telencephalon als Strichlinie angegeben. $x, y, z$ die occipitalen Nerven. B Dorsalansicht. Vie Tela des 4. Ventrikels ist in viele zottige Fortsätze erhobea, die sich mit den Saccus endolymphatici des Labyrinth verbinden. Grenzen der Telae in Strichlinien. $C_{1}-C_{3}$ Querschnitte in der Richtung der Strichlinien (nach B овкHARDT $1 \$ 92$ konstruiert).

wie sie bei Petromyzon angedeutet ist. Sie gehen daher nach hinten meist allmählich in den unpaaren Telencephalonrest über. .Die Ausstillpungen repräsentieren daher wesentlich den primüren Lobus olfactorius, ein pariger eigentlicher Hemisphirrenteil ist an ihnen nicht scharf abgegrenzt, er findet sich vielmehr in dem meist ansehnlich auswachsenden Telencephalonrest. Man kann daber anch sagen, daß die eigentlichen Telencephalon-Hemisphären bei den Fischen (mit Ausnahme gewisser Dipnoi) am ursprünglichen Telencephalon nicht seitlich hervorgestiilpt worden seien, oder sich doch nur dorsal und ventral etwas vorgewölht haben, stets jedoch so, daß sich eine weit offene Kommunikation (Ventriculıs impar) 
zwischen den beiden seitlichen Hälften des hinteren Telencephalonabschnitts findet, eigentliche Foramina Monroi also fehlen.

Nur die dipneumonen Dipnoer (Fig. 405) verhalten sich abweichend, da sie wohl ausgebildete Hemisphären besitzen, wie die sich zunächst anschließenden Amphibien. Die Hemisphärenausstïlpungen des Telencephalon der Dipneumonen sind stark nach vorn ausgewachsen und grenzen sich auch hinten gegen das Diencephalon durch eine candale Ansbuchtung ab. Vorn hat sich von ihnen der primäre Lobus olfactorius abgesondert. Auf diese Weise entstanden bei Protopterus und Lepidosiren zwei in ibrer größten Ausdehnung durch einen mittleren Zwischenraum (Sulcus medianus, Fissura sagittalis) gesonderte Hemisphären, die nur hinten, im Bereich der Lamina terminalis, und der hier deutlich ausgeprägten Foramina Monroi zusammenhängen. Bei allen übrigen Fischen (auch Ceratodus) findet sich dagegen die Lamina terminalis ganz vorn im Telencephalon, d. h. etwa da, wo die Lobi olfactorii ihren medianen Ursprung nehmen. - Wie Petromyzon besitzen die Fische, denen deutlich gesonderte Hemisphären fehlen, eine ansehnliche epitheliale Decke des nnpaaren Telencephalon (Fig. 406), die vorn von der Lamina terminalis ausgeht, und sich hinten in die epitheliale Decke des Zwischenhirns fortsetzt. Ein mehr oder weniger entwickeltes Velum transversum kann, wie bemerkt, als Grenze zwischen Tel- und Diencephalon dienen. -- Bei den Ganoiden (besonders Amia) und Ceratodus spricht sich dennoch eine gewisse Paarigkeit des Telencephalon darin aus, daß die epitheliale Teladecke in der dorsalen Mittellinie in den Ventrikelraum etwas eingestülpt ist. Am stärksten ist dies bei Ceratodus ausgeprigt, wo die Falte (sog. Lingula) so tief in den Ventriculus impar hinabdringt, daß sie dessen Boden fast erreicht und plexusartig kompliziert erscheint. Bei Ceratodus springen auch die beiden seitlichen Telencephalonbälften ventral stark vor, oder sind hier ventralwärts ausgestülpt, weshalb man von zwøi Hemisphären reden könnte, die jedoch in ihrer ganzen Länge zusammenhängen und ineinander übergehen.

Den Chondropterygiern fehlt eine solche Medianfalte meist (Fig. 406), oder ist doch nur wenig ausgeprägt; völlig vermißt wird sie bei den Knochenfischen (Fig. 409 u. 410), deren Telencephalondecke daher vollkommen unpaar erscheint.

Die primüren Lobi olfactorii entspringen in der Regel als direkte Verlängernng der vorderen Telencephalonhälften, von denen sie sich mehr oder weniger scharf absetzen kŏnnen. In einzelnen Fällen kann ihr Ursprung auch etwas nach hinten und seitlich am Telencephalon verschoben sein; dies tritt bei gewissen Haien und Rochen (z. B. Lamna, Carcharias, s. Fig. $407 \mathrm{~A}$ ), jedoch auch bei Ceratodus auf, während die Lobi olfactorii der dipneumonen Dipnoer sich den Hemisphären ganz vorn auschließen, jedoch an deren Dorsalhälfte (Fig. 406), was sich auch bei manchen Chrondropterygiern zeigt. - Eine Differenzierung des primären Lobus in Bulbus und sekundären Lobus spricht sich in der Regel nur in einer vorderen bulbösen Anschwellung des Lobus aus. Nur wenn der primäre Lobus sebr lang wird, wie dies bei den Chondropterygiern meist der Fall ist (Fig. 406) und sich unter den Teleostei bei den Cyprinoiden (Fig. 410), Siluroiden und Gadiden (Fig. 409) 
findet, tritt die Differenzierung in einen endständigen Bulbus, einen langen Tractus und einen, dem Telencephalon angefügten sekundären Lobus hervor. - Die mächtigen Bulbi der Chrondropterygier liegen der Riechschleimhaut der Nasen-

Fig. 406.
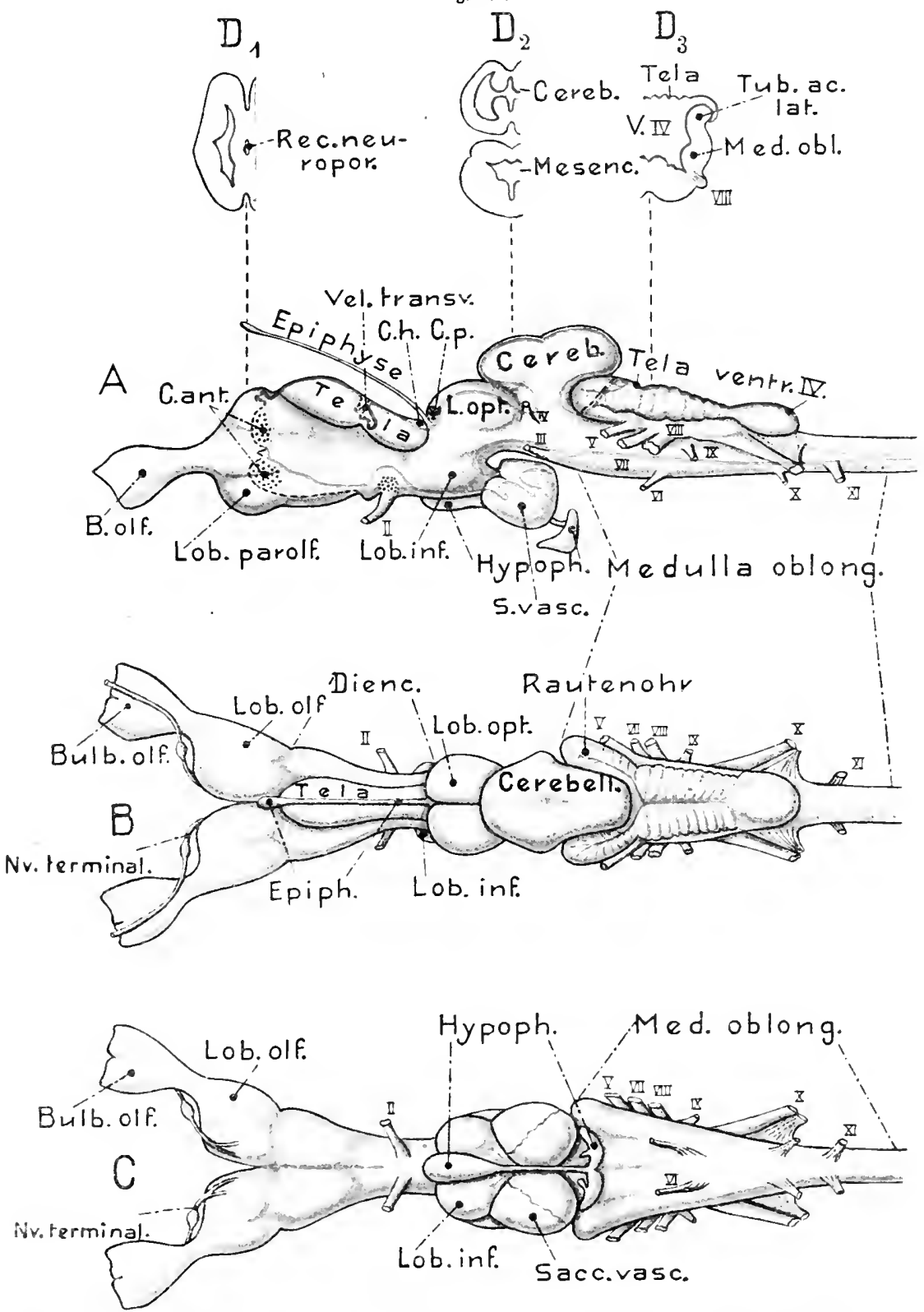

Scymnus lichia (Hai). Gehirn. A von links. $B$ ron der Dorsalseite. $C$ von der Ventralseite. $D_{1}-l$. Querschnitte in der Richtung der Strichlinien. In Fig. $A$ u. $D$ die Ventrikelräume rot begrenzt. E. W. 
gruben dicht an (wie bei Myxine); bei den übrigen Fischen gehen zu ihnen die Nervi olfactorii von den Nasengruben. Recht verschieden verhalten sich die primären Lobi olfactorii hinsichtlich der in sie eindringenden Fortsetzung des Ventrikelraums des Telencephalon.

Ihre ursprüngliche Höhlung kann sich im erwachsenen Zustand bis in die Bulbi hinein erhalten; die Bulbi können sogar noch hohl bleiben, während die Tractus solid geworden sind, oder letzteres gilt für beide Abschnitte. Die Wand der primären Lobi ist ursprünglich allseitig nervös verdickt, was bei den Chrondropterygiern und den Dipneumonen allgemein der Fall ist. Wenn sich jedoch die Tela des Telencephalon sehr ansehnlich entwickelt, wie bei Ganoiden und Teleosteern, so kann sie sich auch auf einen Teil der sekundären Lobi, ja bis auf die Bulbi fortsetzen, sodaß diese dorsomedial häutig erscheinen.

Die nervose Wandverdickung der Lobi olfactorii setzt sich auch auf die ventrolaterale Wand des unpaaren Telencephalons fort und bildet hier paarige, mehr oder weniger in den Ventriculus impar aufsteigende, sich gegen die dorsale

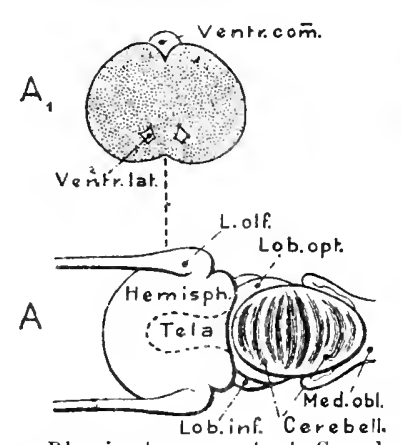

Fig. 407.

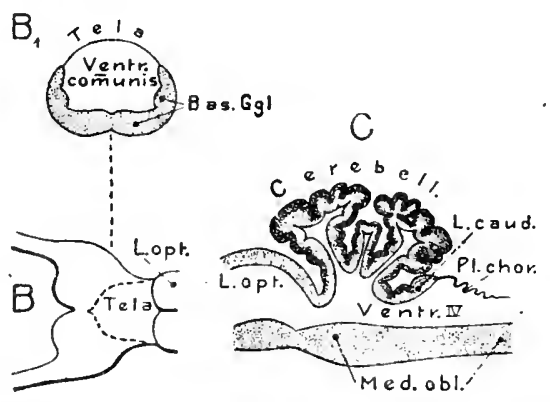

Gehirne von PJagiostomen. A-d Carcharias lamia. A Gehirn von der Dorsalseite (u. Rolios lsis). Al schematischer Querschnitt dureh dis Telencephalon in der Richtung der Strichlinie. $B-B_{1} H$ exanchns griseus. $B$ Vorderer Teil des Hirns von der Dorsalseite; $B_{1}$ Querschnitt dureh das Teleucephalon in der'

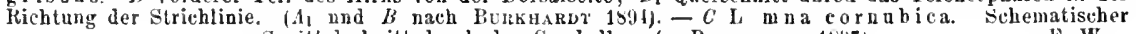
Sagittalschnitt durch das Cerebellum (n. Bunknamot 18!)7).

epitheliale Decke allmählich verdünnende Anschwellungen, die Basalganglien oder Corpora striata. - Bei den primitiveren Haien (Notidaniden u. a., s. Fig. $407 B_{1}$ ) bilden diese Ganglien nur schwache Verdickungen, so daß der Ventrike! weit offen bleibt und dorsal von der dünnen Teladecke abgeschlossen wird. - Im allgemeinen ist jedoch bei den Haien das transversale Commissurensystem in der Lamina terminalis (Commissura anterior im allgemeinen) sehr stark und dick und läßt einen tiber dem Recessus neuroporicus und einen unter diesem liegenden Abschnitt unterscheiden (Fig. $406 \mathrm{~A}$ ). Von hier ausgehend, kann auch die Tela des Telencephalon mancher Haie candalwärts mehr oder weniger nervös verdickt werden, ja bei einzelnen Formen (Isistius) sogar in ganzer Ausdehnung. Die Stammganglien schwellen bei gewissen Haien ungemein an, sodaß sie median untereinander verschmelzen, ebenso auch mit der Commissura anterior, wobei der Ventrikelraum bis auf einen geringen dorsalen und zwei parrige ventrale Reste, die sich in die Lobi olfactorii fortsetzen, ganz schwindet (Fig. $407 A-A_{1}$ ). Bei den Rochen kann schließlich völlige Verdrüngung des Ventrikels eintreten (z. B. Myliobatis, Trygon), also das Telencephalon eine ganz solide Nervenmasse werden. 
Die Entwicklnng des Telencephalon schlägt bei den Ganoiden und Teleosteem gewissermaßen den umgekehrtcu ( Chondropterygiern. Die 'Tela verbreitert sich schon bei den Ganoiden stark, so daß die Verhältnisse etwa an jene primitiver Haie erinnern (Fig. 408). Bei den Teleosteern endlich hat sich die enitheliale Decke ungemein verbreitert, sodaß sie die gesamte Dorsalseite der ansehnlichen Basalganglien ïbcrzielt, ja sie anch lateral umgreift, und erst in der seitlichen Ventralregion in sie tibergeht (s. Fig. $410 \mathrm{C}$ ).
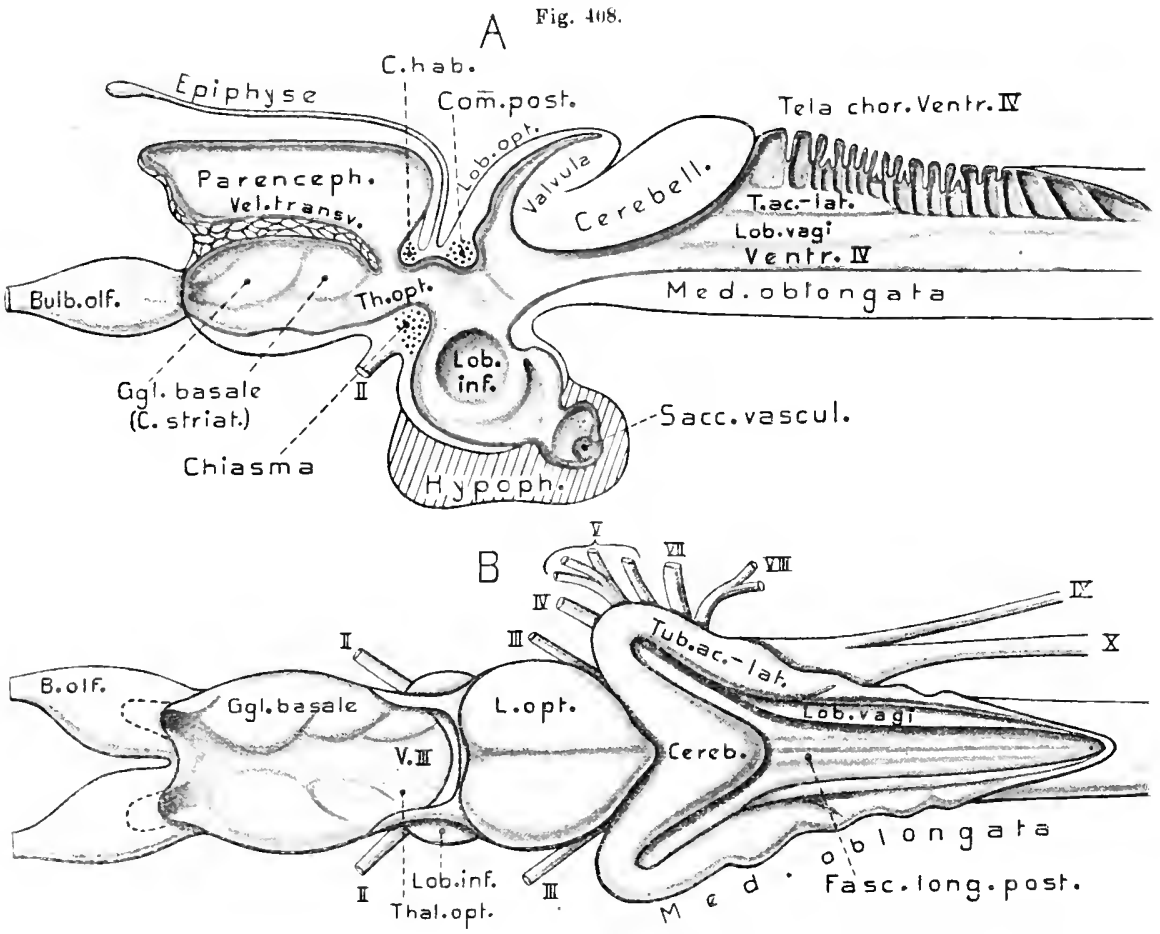

Acipenser sturio. Gelirn; etwas schematisch. A In der Sagittalebene halbiert; rechte llälfte von der Mediunfiache. B Ilirn von der Dorsalseite. Das Parencephalon, Velum transversum, die Epiphyse, sowie die 'Tela des $I$ Y Ventribels entfernt (n. Johsstos 1902, Gowosowitsch 18ss u. Originalprāparat). 0. B. u. E. W.

Da die epitheliale Decke bei den Ganoiden und Knochenfischen früher ganz übersehen wurde, deutete man lange Zeit die Basalganglien als dieigentlichen parigen Iemisphïren.

Das Verhalten der Teleosteer läßt sich vielleicht darauf zurüchfülıren, daß sich die seitlichen Teile der Basalganglien flach horizontal ausbreiteten, also gewissermaßen nach außen umgeklappt werden (Exversion), unter starkem scitlichem Auswachsen der Decke; womit auch übereinstimmt, daß die Decke hier von einer dorsalen Längsfalte gar nichts zeigt. - An den Basalganglien der Ganoiden und Teleosteer, vermutlich auch der Dipnoi, läßt sich ein dorsaler bis dorsomedialer Teil unterscheiden, der häufig durch eirse Furche mehr oder weniger abgegrenzt ist, das sog. Epistriatum, das durch die ganze Wirbeltierreihe wiederkehrt. Der übrige Teil des Stammganglions wird als Corpus striatum bezeichnet. Das Epistriatum nimmt einen Teil der sekundären Riechnervenfasern auf. 
Bei den Chondropterygiern tritt in der Decke der hinteren paarigen Hemisphärenteile eine kleine Partie auf, die als einfache Rinde (Cortex) gekennzeichnet ist, ähnlich wie bei den Petromyzonten; dieselbe erhebt sich häufig als ein Höckerpaar etwas über die Oberfläche der Decke (wie bei Petromyzon wurde sie anch als Epistriatum gedentet). - Die Wände der wohl ausgeprägten paarigen Hemisphären von Protopterus und Lepidosiren sind überall nervös verdickt (siehe

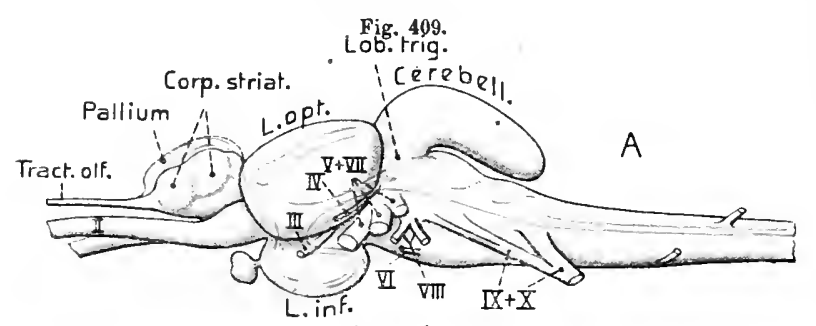

Fig. $405 C_{1}-C_{2}$ ). Anch findet sich, ähnlich wie bei den Amphibien, in ihrer Decke ein Anfang der Rindenbildung, der sich über einen ansehnlichen Teil derselben auszadehnen scheint.

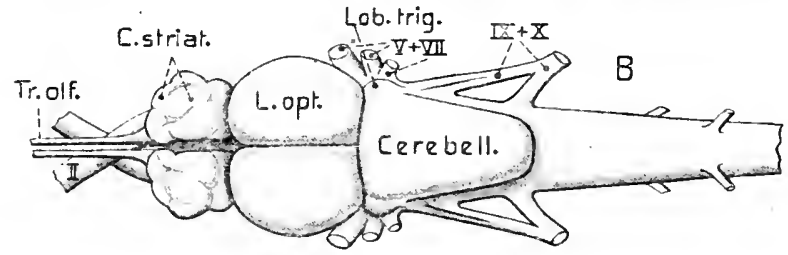
DieBasalganglien springen dagegen hier sehr wenig in die Seitenvęntrikel vor. - Charakteristisch erscheint für Protopterus die Sonde-

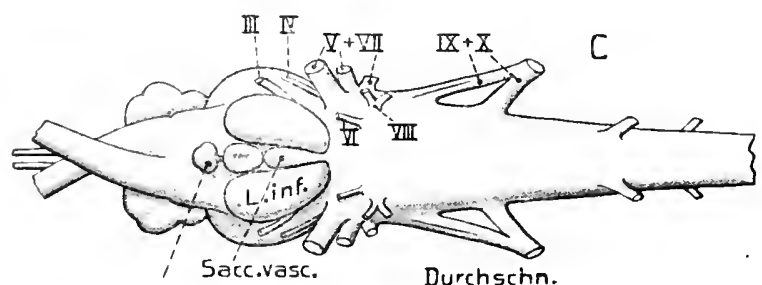
rung der Hemisphären in einen dorsalen, mit dem Lobus olfactorius verbundenen und eineu ventralen Teil, der vorn undhinten etwaslappenartig vorspringt (Figur Hypoph. opric. Ao d.Cereb. $405 A$ ). Die horizontale Furche, welche diese Sonderung wenigstens vorn und hinten andentet, wird Fovea limbica oder auch Fissura endorhinalis externa genannt Gadus morrhua Gehirn. A von der linken Seite, $B$ yon der Dorselseite. $C$ ron der Ventralseite. $D$ Mittel- und Nachhirn von der Dorsalseite. Die Decke des Mittelhirns (Tectum upticum) und das Cerebellnm sind weggenommen, sodaß die Valvnla cerebelli, der sog. Torus semicireuIaris, and die Lobi vagi zu sehen sind. O. B. u. v. Bu.

und ist auch bei Ceratodus und Amia an-

gedeutet. Der vordere Lappen des ventralen Hemisphärenteils (sog. Lobus postolfactorius Burkhardt), der wohl auch bei den Knorpelfischen z. T. angedeutet ist (s. Fig. 406), dürfte dem sog. Lobus parolfactorius der höheren Wirbeltiere entsprechen; der hintere Lappen dagegen dem Lobus piriformis der Sängetiere (er wurde auch als Lobus hippocampi oder temporalis bezeichnet). An diesem hinteren Lappen findet sich ebenfalls eine Art Rindenbildung, die später weiter zu verfolgen sein wird. 
Es ist möglich, jedoch nícht sicher erwiesen, daß in die Basalganglien der Teleosteer und Ganoiden ein der Cortexdecke der Chondropterygier entsprechenden Teil eingegangen ist, der bei der sog. Exversion ventral verlagert wurde.

Die Commissura anterior, welche wesentlich aus queren Faserverbindungen des Bulbus und Lobus olfactorius, sowie der Basalganglien besteht, also dem Riechgebiet angehört, gestaltet sich, wie schon hervorgehoben wurde, bei den Chondropterygiern sehr eigentïmlich; aber auch bei den iibrigen Fischen, besonders den Teleosteern, lassen sich verschiedene sekundärc Anteile in ihr unterscheiden. Bei letzterer Gruppe ist sie stark candalwärts verschoben, in die hintere Region der Basalganglien. - Bei den dipneumonen Dipnoern gesellt sich zu ihr noch eine Commissura pallii unterior (Fig. 405), die vielleicht schon bei den Cyclostomen augedentet war, und welche, wie bei den höheren Wirbeltieren, wohl Veıbindungen zwischen den Anfängen der Rindenbildungen des Pallinm herstellt'.

Das Zucischenhim erstreckt sich bei den primitiveren Fischen, (hondropterygier (Fig. 406), Chondrostei (Fig. 408) und Dipnoi (Fig. 405), als ein velschmälertes Verbindungsstück zwischen dem breiteren 'Tel- und Mesencephalon; seine Decke ist dann auch in der Dorsalansicht dentlich sichtbar. Bei den Holocephalen scheint es abnorm lang; doch dürfte diese Verlängerung, bei Berücksichtigung der Lage der Paraphyse, sowohl auf einer Streckung des unparen Teils des Telencephalon, als der des Zwischenhirns beruhen. Das Zwischenhirn der Holostei und Teleostei (Fig. 409 u. 410) ist dagegen stark verkiirzt, weshalb es in der Dorsalansicht wenig hervortritt und das Mittelhirn dem Telencephalon sehr nahe riickt. Wie schon bemerkt, scheint die vordere Grenze der Zwischenhirndecke durch das gewöhnlich vorhaudene Velum transversum bezeichnet, vor dem sich eine, meist nur schwach entwickelte Paraphyse erheben kann. Die Epiphyse, welche caudal von der Decke entspringt, wird bei den Chondropterygiern gewöhnlich sehr lang; sie reicht weit nach vorn und kann mit ihrem Ende in die knorpelige Schädeldecke eindringen. Auch bei den Knorpelganoiden besitzt sie noch eine ähnliche Länge, wogegen sie bei den Holostei und Dipnoi mäßiger, bei den Teleostei meist nur schwach ausgebilḋet ist. — Die epitheliale Decke zwischen Velum transversum und Epiphyse erhebt sich bei den Ganoiden und Dipnoern (weniger dagegen bei den Teleostei) zu einem zuweilen (Acipenser Fig. 408, Polypterus, Ceratodus) recht ansehnlichen Sack (sog. Zirbelposter, Parencephalon), der sich nach vorn dem Telencephalon auflegen kann, und in dessen Dach die Zirbel eingebettet ist.

Bei den Knochenganoiden (Lepirosteus, Amia) bildet dieser Sack seitliche Ausstïlpungen in Lin- bis Zweizahl, die bei Lepidosteus ventralwärts um das gesante Gehirn herabwachsen können, ja sich nach hinten bis über das Rückennark zu erstrecken vermögen.

Von der Gegend des Zirbelpolsters, bei den Chondropterygiern vom Velum. transversum, gehen die Plexus chorioidei aus, die den Teleostei fehlen, und bei den Ganoiden (Acipeuser, Polypterus, doch anch Ceratodus) durch zablreiche Falten der epithelialen Decke des Telencephalon vertreten zu sein scheinen.

Bei den Haien entspringen rom Velum zwei nach rorn, in den Ventriculus impar ziehende Plexus laterales oder hemisphärici; wogegen sich bei den Dipneumona von der 
Zwischenhirndecke ein Paar Plexus inferiores in den dritten Ventrikel hinabsenken, von denen die Hemisphärenplexus nach vorn abgehen. Auch das Velum transversum, sowie die gesamte $\mathrm{Zwischenhirndecke} \mathrm{ist} \mathrm{zuweilen} \mathrm{plexusartig} \mathrm{gebildet.}$

Auf die bei den Fischen gerade in der Thalamusregion recht zahlreichen Nervenkerne kann hier nicht näher eingegangen werden.

Am Hypothalamus springen die bei den Cyclostomen schon angedeuteten paarigen Lobi inferiores (L. laterales) fast stets ansehnlich vor (Fig. 406-409), zuweilen unter Bildung eines ihnen zugehörigen Recessus des dritten Ventrikels. Von ihnen kann sich bei den Teleostei ein hinterer Teil (Lobus mammillaris) etwas

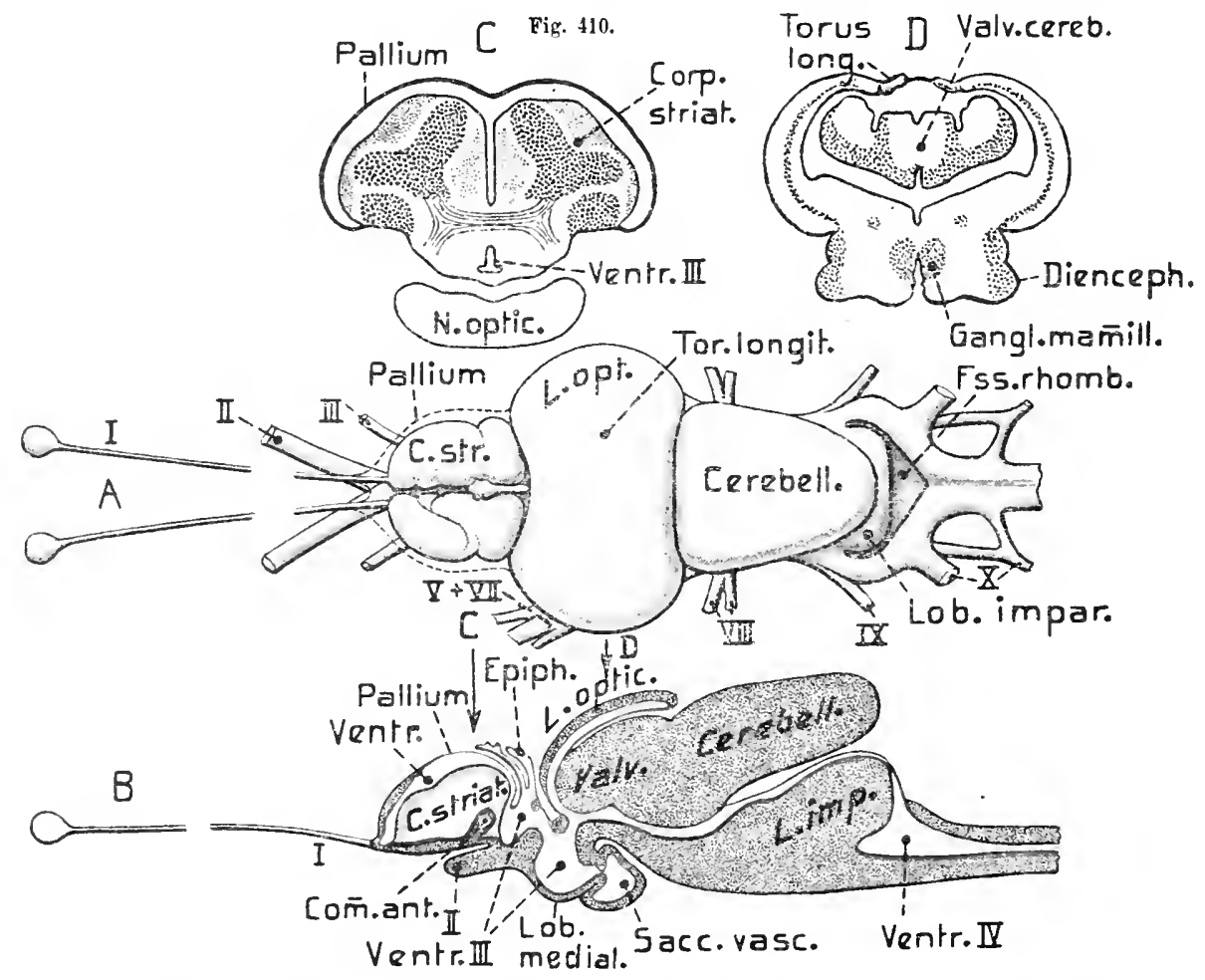

Barbus fluviatilis. Gehirn. A von der Dorsalseite. $B$ Sagittaler Längsschnitt. $C$ u. $D$ Querschnitte an der Stelle der Pfoile in Fig. $B$. - Ependym rot. (A n. $B$ Originale mit Benutzung von Guevs'reix 1905 $C$ u. $D$ nach Goldstetn.) O. B. a. v. Bu.

absondern, in welchem ein Ganglion auftritt, das den Corpora mammillaria (candicantia) der Säuger entspricht. - Zwischen den Lobi inferiores erhebt sich ein Lobus medialis. Ein von diesem entspringender Saccus vasculosus ist fast stets vorhanden und kann bei den Chondropterygiern (Fig. 406 C) auch paarig entwickelt sein. Sein Epithel soll Sinneszellen enthalten.

Das Mittelhirn bildet fast stets einen sehr nmfangreichen Abschnitt, zuweilen (Teleostei) sogar den größten. Äußerlich erhebt sich seine Decke (Tectum opticum) meist in zwei seitliche, durch eine mittlere Längsfurche gesonderte Lappen (Lobi optici, Corpora bigemina). Wenn es klein bleibt, so kann diese 
Sondernng wenig deutlich sein, z. B. Acipenser, oder ganz fehlen (Protopterus, Lepidosiren). Sein Ventrikelraum ist mäßig eingeengt, hauptsächlich durch die ansehnliche Verdickung des Bodens, während die Decke im allgemeinen dünner bleibt.

Die schwächste Entwicklung des Crebellum findet sich bei den Dipnenmona (Fig. 405), indem es hier, ähnlich wie bei den Cyclostomen, aber anch im Anschluß an die Verhältnisse der Amphibien, nur eine wenig verdickte quere Lamelle der vorderen Rautengrubendecke bildet; es kann von dem sich dariiber lagernden Mittelhirn fast völlig verdeckt werden. Schon bei Ceratodus wird es bedeutend länger und beträchtlich dicker; es wölbt sich dorsal empor, indem sein Ventrikelraum an der Emporfaltung teilnimmt. Letzteres Verhalten läßt sich mit dem der Chondroptcrygier vergleichen, deren Kleinhirn im allgemeinen eine bedeutende Größe erreicht (s. Fig. 406, 407 C). Dementsprechend bildet es einen ziemlich langgestreckten, eiförmigen bis rhombischen Körper, der durch eine starke Emporfaltung der Kleinhirnplatte entsteht, und sich oralwärts iiber den hinteren Teil des Mittelhirns, candalwäts iiber die Vorderregion der Rautengrube ausdehnen kann. An seiner Decke findet sich stets eine mehr oder weniger deutliche Längsfurche, welche daher riihrt, daß die Kleinhirndecke zwei Lüngsverdickungen bildet, die in den Ventrikel vorspringen, und zwischen denen die Decke diunn bleibt (Fig. $406 \mathrm{D}_{2}$ ). Andeutungen einer solch parigen Entwicklung des Cerebellum kŏnnen auch die zuerst besprochenen Formen schon zeigen. - Bei den primitivsten Chondropterygiern gesellt sich zu dieser Längsfurche noch eiue Querfalte auf dem Kleinhirngipfel, indem sich die Decke hier mehr oder weniger tief in den Ventrikel einfaltet. Vor und hinter dieser Querfalte entwickeln sich bei den übrigen Chondropterygiern noch mehr oder weniger zahlreiche sekundäre (im Höchstfall 10-20), die jedoch meist weniger tief eindringen (s. Fig. $407 A$ und $C$, S. 570). Das Kleinhirn solcher Formen besitzt daher einen Bau, welcher an den bei Vögeln und Säıgeticren erinnert. Eigentümlich ist, daB in diesen Fällen nicht selten eine asymmetrische Bildung der beiden Hälften auftritt (z. B. Zygäna u. a.). An der Übergangsstelle in die Tela der Rautengrube steigt die Kleinhirnplatte nochmals etwas empor und bildet einen vorderen queren Saum der Rautengrube (Caudallippe des Cerebellum, Lobus caudalis, Rautenlippe, Fig. 406 C).

Wesentlich anders entfaltet sich das Kleinhirn der Ganoiden und Teleosteer. Die ursprïnglichsten Formen (Acipenser, Polypterus) besitzen ein Cerebellnm, das ans einer schräg caudalwärts aufsteigenden Platte besteht, wie wir sie bei den Dipneumouen trafen. Schon bei Lepidostens und Amia vergrößert sich die Platte nach hinten und wölbt sich empor, so daß deren Cerebellum etwa an die Verhältnisse von Ceratodus erinnert. Gleichzeitig ist es bei Polypterus, Lepidosteus und Amia noch ähnlich paarig verdickt wie bei den Jhondropterygiern. - Die Kleinhirnplatte von Acipenser dagegen ist ganz unpaar (Fig. 408), ja besitzt sogar einen inneren medianen Kiel, der in den vierten Ventrikel vorspringt (ähnlich auch bei Ceratodus). Gleichzeitig entwickelt sich die vordere, an das Mittelhirn grenzende Übergangspartie des Kleiuhirns stark, so daß sie nach vorn etwas in den Mittelhirn- 
ventrikel vorspringt, eineErscheinung, die bei Polypterus und den übrigen Knochenganoiden sehr wenig entwickelt ist. Der in den Mittelhirnventrikel vorspringende Teil wird als Valvula cerebelli bezeichnet. - Die Teleosteer (Fig. 409 u.410), deren Cerebellum meist sebr voluminös wird, zeigen in der Ontogenie gleichfalls ein emporgefaltetes Kleinhirn und eine sich stark entwickelnde Valvula. Die paarigen lateralen inneren Verdicknngen ihres Cerebellum wachsen jedoch so stark heran, $\mathrm{da} B$ sie schließlich in der Mittellinie zusammenstoßen und sich vereinigen. So wird das ursprïnglich emporgewölbte Cerebellum ein solider Körper, in dem sich meist nur noch ventral ein Rest des emporsteigenden Fortsatzes des vièrten Ventrikels erhält. Indem das Mittellirn gleichzeitig stark nach hinten auswächst, legt sich der eingefaltete dünne, zиm Teil epitheliale Teil seiner Decke der Valvula des Kleinhirns dicht anf und verwächst mit ihr. Anf solche Weise kommt es, daß die Valvula der Teleosteer als ein ansehnliches Gebilde in den Mittelhirnventrikel vorspringt. Durch eine Längs- nnd Querfalte, die auf ihrer Oberfläche auftreten, zeigt sie gewöhnlich zwei- bis vier paarige, tuberkelartige Erhebungen (daher früher zuweilen als Corpora quadrigemina bezeichnet; s. Fig. $409 \mathrm{D}$ ), doch kann ibre Bildung noch komplizierter werden (z. B. Thynnus).

Die ansebnliche Entwicklung der Valvula bei den Knorpelganoiden und Knochenfischen scheint mit der sehr bedeutenden Ausbildung von Centren (Kernen) in den Seitenteilen des Cerebellum zusammenzuhängen, die.mit den knospenförmigen Sinne organen der Haut in Beziehung stehen. Bei den erwähnten Fischen sind gerade diese Sinnesorgane sehr reich entwickelt.

Äußerlich erscheint das Kleinhirn der.Ganoiden und Teleostei meist glatt und ungefurcht. Das der Knochenfische wird, wie erwähut, häufig sehr groß, so daß es sich weit über die Rautengrube nach hinten erstreckt; ja seine dorsale Erbebung kann sich auch nach vorn itber das Mittelhirn ansdehnen (z. B. Silurus, Thynnus, Malapterurus, Gymnotns).

Die Medulla oblongate der primitiven Fische (Chondropterygii, Ganoidei, Dipnoi) zeichnet sich durch bedeutende Länge aus, wogegen sie bei den Teleostei gewöhnlich stark verkürzt ist. Dementsprechend ist auch die Rautengrube der ersteren länger gestreckt; ihre Tela wird in der Regel von einer mittleren Längsfalte und zo dieser symmetrisch angeordneten seitlichen Plexusfalten überzogen (Fig. 406 und 408). Der Boden der Rantengrube erhebt sich bei den erst erwähnten Formen in eine Anzabl Längswülste (Lobi, s. Fig. 408 u. 411). In der Medianlinie verlaufen die sog. Tractus (Fasciculi) dorsales longi (Eminentiae teres); seitlich daneben je ein Längswulst, welcher durch die Kerne des Nervus vagus und der davor entspringenden Nerven IX, VII und V hervorgerufen wird (sog. Lobi vagi oder L. viscerales Johnston); äußerlich, die Seitenränder der Rautengrube bildend, findet sich ein Längswulst, der sich nach vorn zu meist stark verdickt und am Vorderende der Medulla mehr oder weniger ausbucbtet (sog. Rautenrohr; früher auch als Corpus restiforme, Lobus posterior oder Lobus trigemini bezeichnet). Diese Randwülste enthalten die Ursprungskerne des Hörnervs (Acusticus) und des Seitenasts (Ramus lateralis) des Vagus; sie werden daher jetzt 
gewöhnlich als Lobi (oder Tubercula) acustico-laterales bezeichnet. -- Bei den Chondropterygiern (Fig. 411) legen sich die erwähnten Rautenohren meist in zahlreiche Falten oder Windungen und erscheinen so recht kompliziert. Ihre Vorderenden biegen in die früher geschilderte Caudallippe des Kleinhirns tiber. Die Rauteriohren sind bei den erwähnten Fischen noch von der Kleinhirnrinde überzogen (sog. Crista cerebellaris), weshalb sie gelegentlich auch dem Cerebellum zugerechnet werden.

Die Lobi ragi der Chondropterygier (Fig. 411) besteben aus einer Reihe hintereinander gereihter, knötchenartiger Anschwellungen. - Bei den elektrischen Rochen (Torpedo) schwellen sie zu einem Paar mächtiger Lappen (Lobi electrici) an (Fig. 412), die sich vom Boden der Rautengrube hoch erheben; von ihnen entspriugen die Nervenfasern zu den Hirnnervenästeı, welche die elektrischen Organe versorgen (s. vorn S. 458).

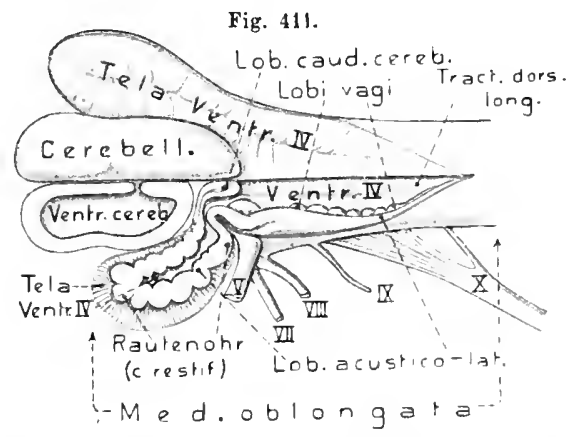

Acanthias vulgaris (Hail. Cerebellum und Me d n $11 \mathrm{a}$ oblongat a von der Dorsalseite. Die linke Hälfte des Cerebellum ist abgetragen, so da 13 der Ventrikelraum sichtbar ist. Auf der rechten Ilälfte der Med. oblongata ist die Tela chorioidea erhalten, auf der linken grositenteils entfernt. Die Ansatzlinie der Tela, sowie ihre Reste anf der linken Hälfte sind rot angegeben. O. B. u. E. W.

An der Medulla oblongata der Teleosteer (Fig. 409 u. 410) treten die Längswülsto des Rautengrubenbodens weniger hervor. Eigentliche Rautenohren sind nicht ausgebildet und die Lobi acustico-laterales mehr ventral herabgedrängt, so daß sie nicht deutlich hervortreten. Dies beruht darauf, daß die Lobi vagi häufig sehr stark anschwellen, sich auf die Tela des vierten Ventrikels ausdehnen und bis zu gegenseitiger Berührung, ja Verwachsung in der Mittellinie gelangen können (s. Fig. 409 D). Die Fossa rhomboidea und ihre Decke erscheint dann auch stark rückgebildet oder verkiurzt.

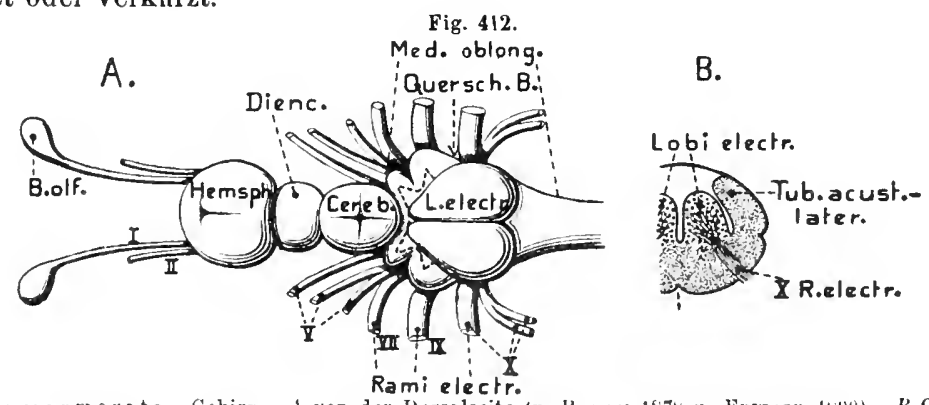

Torpedo in armorata. Gehirn. A von der Dorsalseite (n. Kouos 1875 u. Fursen 1s90). B Querschnitt dnrch die Medulla oblongata und die Lobi electriei (n. EDINGEr 1908).

E. W.

Bei den Cyprinoiden und Siluroiden erhebt sich vom vorderen Boden der Rautengrube, unter dem Kleinhirn, ein starker unpaarer Lappen (Lobus impar), der von den sehr vergrößerten sensiblen Facialiskernen der vorderen Partie der erwähnten Lobi vagi gebildet und daher zuweilen auch als Lobus facialis bezeichnet wird (Fig. $410 \mathrm{~A}, \mathrm{~B}$ ). Dies hängt wohl mit der reichen Entwicklung der vom Facialis versorgten Hautsinnesorgane (knospenförmigen Organe) der Kopfregion zusammell. Am Ursprung des Nervus trigeminus mancher 
T'eleosteer tindet sich gleichfalls eine Anschwellung (Fig. 409). - Das Gehirn der Fische füllt im erwachsenen Zustand die Schädelhöhle meist nicht röllig aus. Bei den Knorpelfischen und Ganoiden tritt dies in geringerem $\mathrm{MaB}$ bervor, bei den Teleosteern dagegen sehr hăufig. Der Raum zwischen Hirn und Schädelwand wird dann ron einem Schleim- oder Fettgewebe erfüllt, das bei den Uirnbäuten genauer zu betrachten ist.

Amphibia. Das Amphibienhirn, welches wie das der höheren Vertebraten die Schädelhŏhle meist völlig erfüllt, schließt sich dem der dipneumonen Dipnoi nahe an, indem sich an ihm fast alle typischen Verhältnisse des letzteren wiederholen. Wir finden daher stark vorgewachsene, langgestreckte Hemisphären mit allseitig nervöser Wand, die besonders bei den Urodelen und Gymnophionen

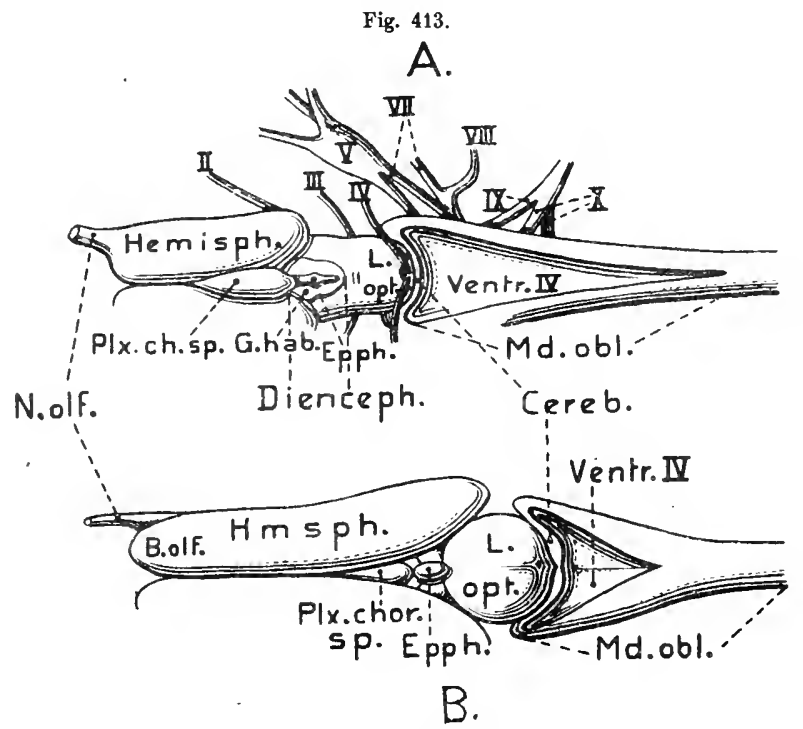

Hirne urodeler Amphibien, von Dorsalseite. A ron Necturnsmaculosus (n. OsborN 1885). B $B$ von Molge (Triton) cristatus (nach
Burkhard 189i). recht lang und schmal sind. Bei ersteren (Fig. 413) wird dies anscheinend noch dadurch verstärkt, daB die Lobi olfactorii, welche sich bei den Amphibien im allgemeinen von den $\mathrm{He}-$ misphären wenig absetzen, ohne dentliche Grenze in letztere übergehen. Die Lobi bilden hier direkte Fortsetzangen des vorderen Hemisphärenendes, und die Ventriculi laterales erstrecken sich, wie gewöhnlich, noch etwas in sie. Die Lobi der Anuren (Fig. 414) und Gymnophionen (Fig. 415) sind durch eine Querfurche etwas schärfer abgegrenzt. Eine deutliche Bulbusbildung und ein Tractus olfactorius fehlen den Amphibien. - Der einfache Riechnerv entspringt bei den Urodelen etwas lateral vom Vorderende des Lobus, wogegen die Gymnophionen und Anuren die Eigentümlichkeit zeigen, daß der Riechnerv zwei Wurzeln besitzt, von welchen die eine etwa wie die der Urodelen entspringt, während die zweite bei den Gymnophionen ventraler hervortritt, bei den Anuren dagegen auf der hinteren Lateralfläche des Lobus olfactorius. Charakteristisch für die Anuren ist ferner die mediane Verwachsung der Lobi (anf den Figuren als Bulbi bez.).

An den Hemisphären der Urodelen ist äußerlich keine deutliche Unterteilang wahrzunehmen; die der Anuren (Fig. $414 \mathrm{~A}$ ) zeigen dagegen in ihrem lateralen Teil, der sich caudalwärts über das Zwischenhirn ein wenig ausdehnt, eine etwas schief nach vorn herabsteigende Furche, welche einen ventralen Teil (Pars subpallialis) von dem dorsalen Pallialteil abgrenzt. Diese Furche entspricht wohl derjenigen, 
welche wir schon bei Protopterus fanden (Fovea limbica, Fissura rhinalis externa). Bei den Gymnophionen (Fig. 415) ist sie wenig deutlich und anf die Ventralseite der Hemisphäre verschoben, da hier der hintere lateropalliale Teil der Hemisphären als ein kleiner Lappen ventral etwas vorspringt. Dieser Lappen, sowie die erwähnte Pars subpallialis der Annren, entsprechen wohl dem schon bei Protopterus angedeuteten Lobus piriformis. Die Hemisphären der Anuren sind in ihrer hinteren Region auf eine gewisse Strecke median verwacbsen. Über die Ausdehnung

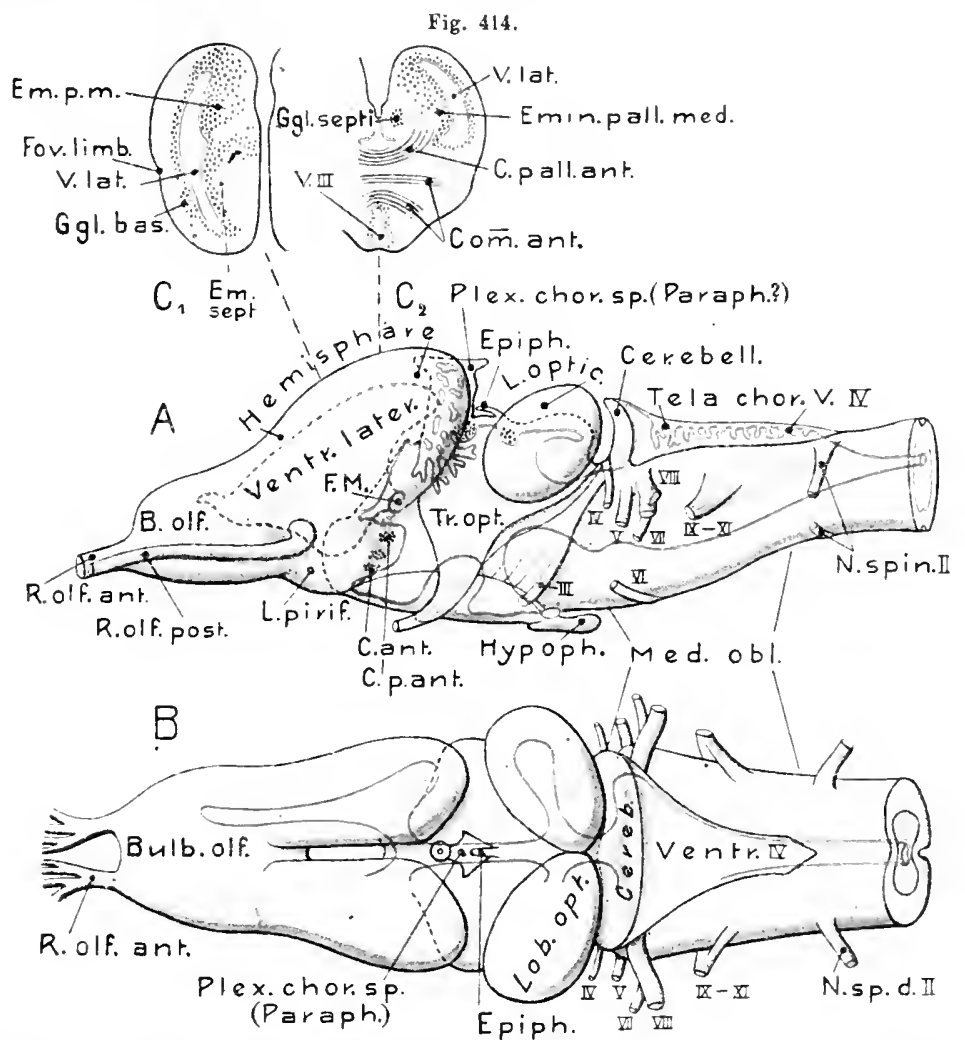

Rana. Gehirn. A von links. Ventrikelnmgrenzung rot; Lamina terminalis, Plexns chorioideus sup. z. T., sowie Sagittalschnitt durch Mesencephalon in Strichlinien angegeben. $F$. M. Foramen Monroi. $B$ von der Dorsalseite. $C_{1}-C_{2}$ Querschnitte an den durch die beiden Strichlinien angegeben Stellen (nach $\mathrm{G}_{\mathrm{A}} \mathrm{UP1}$. 1896 ).

und die allgemeine Form der Seitenventrikel geben die Figuren Aufschluß.

Wie schon hervorgehoben, ist die gesamte Hemisphärenwand nervös verdickt, doch bleibt die seitliche äußere Wand relativ dünn (Fig. $414 C_{1}-C_{2}$ ). Um die Ventrikelhöhlen findet sich überall das sog. Höhlengrau. - Eine typische Rindenbildung (Cortex) wie bei den höheren Vertebraten besteht in dem Deckenteil (Pallium) der Hemisphären noch nicht, d. h. es sind zwar dem lateralen, dorsalen und medialen Pallium nach außen vom Centralgrau Zellen eingelagert, die den Pyramidenzellen der Höheren entsprechen dürften; sie bilden jedoch noch keine geschlossene Lage wie bei den Reptilien. - Busalganglien 
(Corpora striata) springen bei den Amphibien am Boden der Seitenventrikel nur wenig empor (Fig. $414 C_{1}$ ). Dagegen ist die mediane oder septale Hemisphärenwand relativ dick; besonders bei den Anuren (Fig. $414 C_{1}$ ), wo sie in Form zweier, von einer schiefhorizontalen Furche getrennter Anschwellungen in die Ventrikelhöble hineinragt (Eminentia pallii u. Em. septalis). Wahrscheinlich repräsentieren diese Anschwellungen mit ihren gangliősen Einlagerungen die erste $\Lambda$ ndentung der bei den Amnioten sich ansehnlicher entwickelnden Ammonshornbildung. Sie werden manchmal auch mit dem Epistriatum der Fische in Znsammenhang gebracht. Wie bei den Dipnoi finden sich die beiden Commissurensysteme der Hemisphären, die Commissura anterior und die Commissura pallii anterior (Fig. $414 C_{22}$ ). Diese Commissuren liegen bei den Urodelen in ziemlicher Entfernung hinter der Lamina terminalis, bei den Anuren und Gymnophionen dagegen in deren Basis. In letzteren Fall ist daher der sog. Ventriculus impar der Hemisphäre recht klein, im ersteren dagegen ansehnlicher. Die Commissura pallii anterior (früher häufig als Corpus callosum bezeichnet) sendet ihre Fasern in die septale Hemisphïrenwand; die Commissura anterior hingegen in die ventrale und laterale.

Das Zwischenhirn der Urodelen, besonders der Ichthyoden (Fig. 414.4), ist vom paarig entwickelten Mittelhirn sehr wenig gesondert, so daß beide wie ein gemeinsames Verbindungsstück zwischen Vorderhirn und Nedulla oblongata erscheinen. Schon bei einem Teil der Salamandrinen (Fig. $413 B$ ) und den Gymnophionen (Fig. 415) schwillt das Mittelhirn jedoch stärker an; am größten wird es bei den Anuren (Fig. 414). Überall jedech bleibt seine Decke in der Dorsalansicht erkennbar (am wenigsten bei den Gymnophionen) und läßt dic Ganglia habemulae fast immer dentlich wahrnehmen. - Eine mäßig große Epiphyse findet sich stets. Ihre Entwicklung verläuft bei den Anuren eigentumlich, indem ibr Endstïck sich ablöst und anßerhalb der Schädelhöhle als sog. Stirnorgan (Stirndrüse) erhält.

Die vordere Tela des $Z$ wischenbirns erhebt sich stets zu einem, namentlich bei Ichthyoden und Gymnophionen (Fig. 415) ansehnlichen, gefäßreichen Gebilde (Adergeflechtknoten, Supraplexus, Plexus chorioidens superior), der sehr an das sog. Parencephalon (Polster) von Protopterus erinnert. Die Ontogenie der Amphibien scheint zu lehren, daß dies Gebilde aus der Paraphyse hervorgeht. An seiner Basis senken sich die Plexus chorioidei ein ; in den dritten Ventrikel ein unparer bis pariger Plexus inferior, von dem bei Urodelen und Gymnophionen die beiden Hemisphärenplexus ausgehen, welche den Anuren fehlen. Nach hinten erstreckt sich ein unpaarer Plexus medius, der bei den Urodelen, namentlich den Ichthyoden, so lang werden kamn, daß er den vierten Ventrikel fast erreicht. Wahrscheinlich entspricht dieser Plexus medins dem Velum transversum. - Die seitliche Thalamusregion des Zwisehenhirns ist stark nervös verdickt. Der Hypothalamus sackt sich in einen schwach paarigen Lobus infundibuli ans, der im allgemeinen den Lobi inferiores der Fische entspricht; ihn schließt sich hinten die ansehnliche Hypophyse an. Ein Sacens vaseulosus scheint den Urodelcu zu fehlen oder sehr rudimentär zu sein; dagegen wurde bei den Anuren cin ansehnlicher und 
kompliziert gebauter beschrieben (HALLER). Nach anderen Angaben soll er jedoch den Amphibien selbst embryonal fehlen.

Die geringfiigige Entwicklung des Nittelhirns der Ichthyoden wurde schon obcn erwïhnt; es bleibt hier zum Teil schmäler als das Zwischenhirn (Proteus) und ist von letzterem kaum abgesetzt. Bedeutend größer wird es schon bei vielen Salamandrinen (Fig. 413B) und Gymnophionen (Fig. 415); seine Decke erhebt sich dann zu den beiden Lobi optici. - Am größten werden letztere bei den Anuren (Fig. 414), als zwei nach vorn divergierende starke Anschwellnngen, zu denen die ansehnlichen Tractus optici von den Sehnerven aufsteigen. In die Lobi optici dringt jederseits ein Fortsatz der Ventrikelhöhle ein. Der hintere, gegen das Cerebellum absteigende Teil des Tectum opticum bildet bei den Anuren eine starke, schwach paarige Verdickung, die von hinten in den Ventrikel des Mittelhirns vorspringt (Fig.414 $A$ ). Diese, an die Valvula cerebelli der Teleosteer erinnernde Bildung wird in der Regel, und wohl richtig, mit den sog. Corpora quadrigemina posteriora der Mammalia verglichen.

Die schwache Ausbildung des Cerebellum der meisten Amphibien verleiht ihrem Gehirn einen recht piimitiven Charakter, um so mehr, als es nicht wahrscheinlich ist, daß dies von Riickbildung herrïhrt.

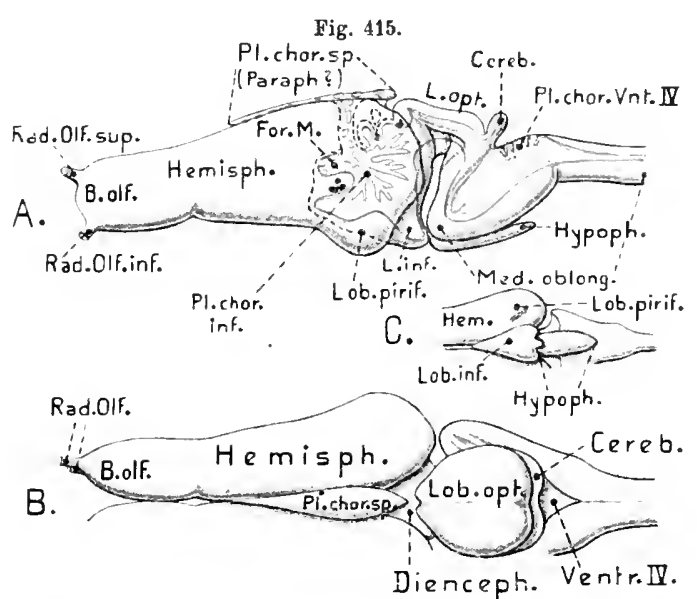

lehthyophis glutinosus. Gehirn. A ron links. Lamina terminalis und Tela Ventr. $H I$ in Strichlinien. $B$ von der Doraalseite. C Diencephalon mit auschließenden T'oilen, ron der Ventralseite (n. Burkhakd 189t).

In einzelnen Fallen zwar, z. B. bei Proteus und Siren, wo ein Cerebellum kaum existiert, mag Reduktion im Spiel sein. Das Kleinhirn erhebt sich daher nicht über die schon bei den Dipnoern gefundene Ausbildung. - Bei den Urodelen (Fig. 413) bildet es eine ganz schwache nervöse Verdickung des vorderen Rands der Rautengrube, bei den Ichthyoden handelt es sich sogar nicht um eine eigentliche Erhebung dieser Verdickung, vielmehr senkt sie sich in den Ventrikel hinab. Die Kleinhirnplatte der Gymnophionen (Fig. 415), Salamandrinen (Fig. $413 B$ ) und Anuren (Fig. 414) dagegen steigt schief nach hinten empor und wird bei letzteren am größten und stärksten. Stets ist jedoch nur ein aufsteigender Teil entwickelt, ein hinterer absteigender fehlt, $d . h$. er wird durch die Tela des vierten Ventrikels gebildet. Äußerlich erscheint das Cerebellum der Anuren unpaar; bei Urodelen und Gymnophionen kann es schwach paarig sein.

Die geringe Größe des Kleinhirns bedingt, daß die liuutengrube mit ihrem stark entwickelten Plexus kaum verdeckt ist. Rautenohren sind meist noch gut angedeutet. Längswülste am Boden der Rauteugrube treten nicht mehr so 
dentlich hervor wie hei den Fischeu. Dagegen sind die Seitenränder der vorderen Region der Rautengrube bei Gymnophionen und Anuren stark wulstig verdickt, eine Bildung, die im allgemeinen den Lobi acustico-laterales der Fische entsprielit. Charakteristisch für die Gymnophionen erscheint, daß die Plica ventralis noch im erwachsenen Gehirn zwischen Mittelhirn und Medulla oblongata hoch emporsteigt, weshalb eine sog. Brïckenbeuge recht ausgesprochen erscheint.

Sauropsidu. Am erwachsenen Hirn der Sauropsiden erhält sich die Brückenbeuge an der Ventralseite der Oblongata meist gnt; weniger die Nackenbenge. Die embryonale Scheitelbeuge geht dagegen bei dẹn Reptilien stark zurück, weshalb die Hirnteile, ähnlich denen der Anamnier, ziemlich horizontal hintereinander liegen. Das Vogelhirn dagegen ist in der Normalstellung des Kopfs gegen das Rückenmark herabgebogen, was durch die stark ausgeprägte Nacken-

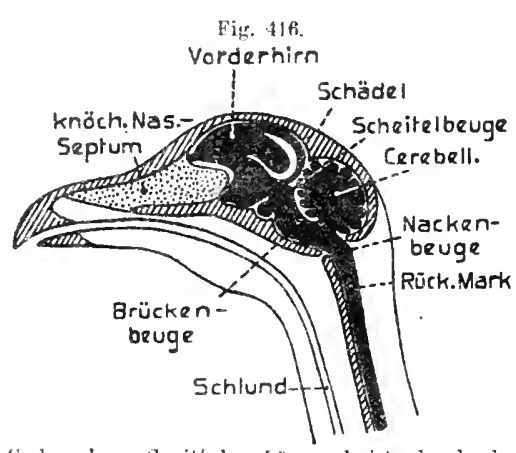

Columba. Sagittaler Längsschnit durch den Kopf, zur lemonstration der Hirnbeugen. E. W. beuge ermöglicht wird (Fig. 416).

Das Hirnvolumen der Reptilien bleibt noch mäßig, obgleich es bei den Crocodilen ziemlich zunimmt; das mancher fossiler Reptilien, so namentlich der größeren Dinosaurier, blieb sehr klein, wie das geringe Volum ihrer Schädelhöhle beweist; kleiner sogar als die hier sehr ansehnliche Lendenanschwellung des Riickenmarks. Das Vogelhirn aber gewinnt erheblich an Umfang, so daß sein Gewicht das des Rijckenmarks ïbertreffen kann.

Die allmähliche Vergrößerung des Sauropsidenhirns beruht wesentlich auf der Volumzunabme der Hemisphären, in geringerem MaB auch auf der des Cerebellum. - Ije Ilemisphären der Reptilien erscheinen in der Dorsalansicht oval bis ungefähr dreieckig, indem sich ihr Vorderende etwas znspitzt. Gegen das hintere Drittel erheben sie sich im allgemeinen ziemlich stark und ihr Caudalteil (Polus occipitalis) ragt (besonders bei den Placoiden) über das Zwischenhirn, ja auch die vorderste Mittelhirnregion hinuiber, weshalb das eigen tlicheZwischenhirn, abgesehen von dem Zirbelende, dorsal wenig sichtbar ist. Ein sog. Lobus temporulis erscheint in der Regel ziemlich gut ontwickelt. - Die ansehnlichen primären Lobi olfactorii bilden die Fortsetzung der vorderen Hemisphärenenden; die Lateralventrikel erstrecken sich gewöhnlich bis in die Lobi. Der Riechnerv entspringt meist sofort wit zahlreichen Fädehen (Fila). Eine Differenzierung des Lobus in Bulbus, Tractus und sekundären Lobns olfactorius zeigen zahlreiche Saurier, Sphenodon, sowie die Crocodile (Fig. 417 u. 418). - Die Hemisphüren des Vogelhirns (Fig. 419) haben im allgemeinen dieselbe Grundform, verbreitern sich jedoch nach hinten sehr ausehnlich und werden auch höher. Ihr Occipitalteil reicht soweit nach binten, daß er das gleichfalls stark vergrößerte Cerebellum beruhrt und die beiden Lobi optici des Mittelhirns seitlich ganz auseinander drängt, wobei sie von den beiden Temporallappen häutig so bedeckt werden, daß sie von der Dorsalseite unsichtbar 
siud. Die Temporallappen der Vögel sind in der Regel gut entwickelt und auch seitlich durch eine etwas aufsteigende Furche einigermaßen abgegrenzt. Auf der Dorsalfäche der Hemisphären findet sich meist eine, dem äußeren Rand parallel ziehende schwache Furche, die Tallecula. - Im Gegensatz zu den Hemisphären bleiben die Lobi olfactorii der Vögel sehr klein und entspringen etwas hinter dem Vorderende auf der Ventralseite der Hemisphären. Wenn sie stark reduziert sind (z. B. Aquila, Picus, Papageien), kann man sie in der Dorsalansicht nicht mehr sehen; sie können đann auch miteinander rerwachsen. - Hinter den Lobi olfactorii spriugen auf der Ventralseite ein paar schwache Anschwellungen vor, die sog. Lobi parolfactorii, welche auch den Reptilien schon zukommen, aber

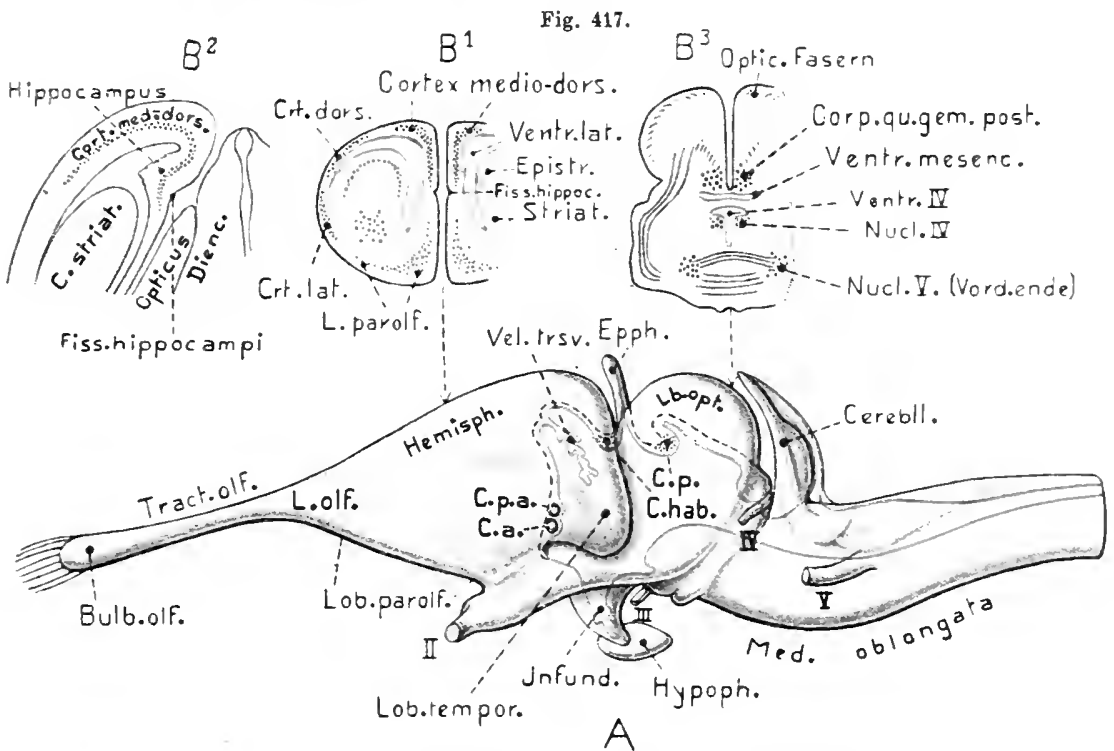

Varanus griseus (Snnrier). Gehırn. A von links. Ventrikelumgrenzung rot. Jamina terminalis und Sagittalschnitt durch Il esencephalon gestrichelt. Ca. Commissura anterior; $C . p^{\prime} \cdot a$. Cormiss. pallii anterior. (Orig. mit Benutzung von Ebriver 1905). $B_{1}$ a $B_{3}$ Querschnitte in der Richtang der Strichlinien. $B_{2}$ Querschnitt du:ch den Caudalteil einer Hemisphäre des Telencephalon, urn die Hlppociampusbildung zu zeigen. (n. Enxger i90s nnd früher).

äußerlich wenig hervortreten. Es ist möglich, daß diese Gebilde, welche bei den Säugern genauer erwähnt werden sollen, mit den bei den Chondropterygiern und Dipnoern ebenso bezeichneten Lobi (od. L. postolfactorii) homolog sind.

Die Hemisphärenventrikel der Reptilien sind stets spaltartig eingeengt, wegen der starken Vergrößerung der Basalganglien (Corpora striata), die sich vom Boden und mehr oder weniger auch von der seitlichen Hemisphärenwand erheben und die Ventrikelhöhle fast erfüllen (s. Fig. $417 B^{1}-2,418 C^{1}$ ).

Die genauere Untersuchung der Faserverteilung und der Nervenzellenanhäufungen läßt in den Basalganglien besondere Abschnitte unterscheiden, die wir schon bei den Fischen trafen. Eine dorsale und mehr caudale Partie, welche bei den Scbilukrüten (und Crocodilen?) auch durch eine horizontale mediane Furche abgesondert ist (Fig. 420 ), wird als Epistriatum von dem darunter und davor liesenden Striatum unterschieden. 
Die mächtigste Entwicklung erlangen die Basalganglien der Vögcl (Fig. 419D); in ihrem vorderen Teil dehnt sich ihr Ursprung auf die ganze laterale und dorsale Hemisphärendecke aus, so daß nư längs der medialen Hemisphärenwand noch ein Ventrikelrest offen bleibt. Im occipitalen Hemisphärenabschnitt breitet sich jedoch der Ventrikelraum rings um das gesamte Hinterende des Basalganglions aus, weshalb es nach hinten frei in den Ventrikel hineinragt, was auch für die Reptilien allgemein gilt.

Entsprecbend seiner Größe ist das Basalganglion der Vögel auch innerlich recht kompliziert gebaut, indem sich ein dorsaler Teil (Hyperstriatum), ein ventraler (Mesostriatum), sowie ein laterałer (Ectostriatum) unterscheiden lassen. Das sog. Epistriatum hat seine Lage verändert, es findet sich laterobasal im Lobus temporalis.

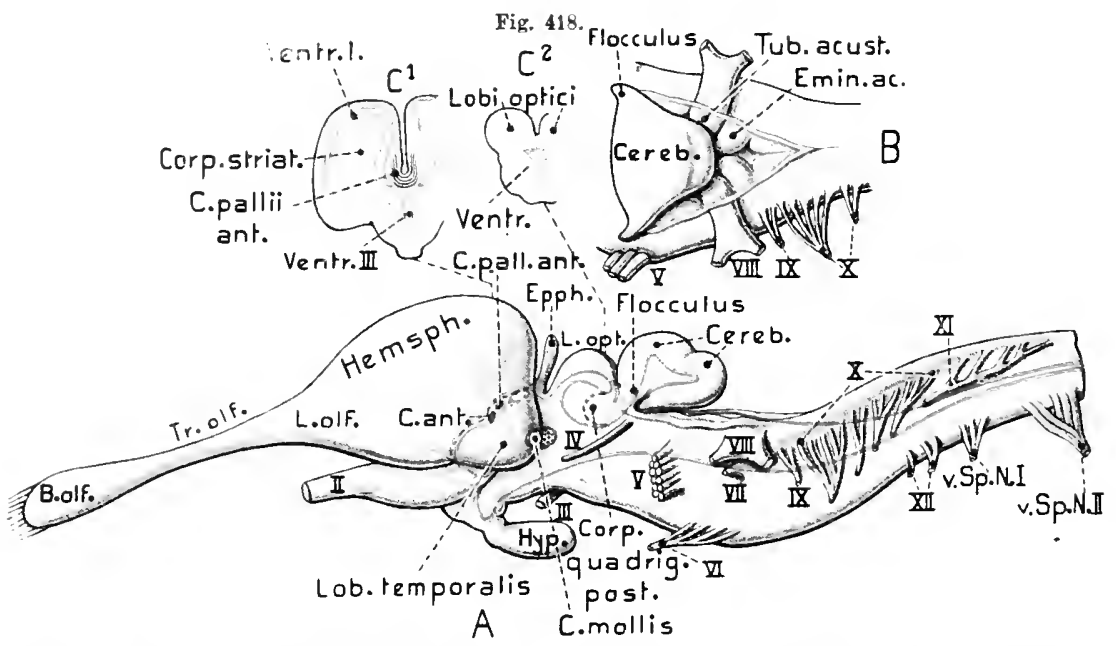

Alligator mississipionsis. Gehirn. A von links. Lamina terminalis gestrichelt. Ventrikelnmgrenzungen rot. $B$ Cerebellum und Medulla oblongata von der Dorsalseite. $C_{1}-C_{2}$ Querschnitte an den von den Strich linien angegebenen Stellen. $C_{\mathrm{t}}$ durch den binteren Abschnitt der linken Hemisphäre. $C_{2}$ durch den hinteren Teil des Mlesencephalon (n. $R_{A B L}$-Rücknardt $1878, z$. T. nach Originalpräparat etwas verändert). P. He.

Eine deutlicher geschichtete Rindenbildung mit Pyramidenzellen. findet sich im Pallium der Reptilien allgemein; sie erstreckt sich fast durch das gesamte Pallium und läßt gewöhnlich je eine Partie in der medialen, der dorsalen und der lateralen Palliumwand unterscheiden (s. Fig.420B). Wegen der innigen Vereinigung des größten 'Teils des Pallium mit dem Basalganglion, ist bei den Vögeln nur die mediale Cortexpartie schärfer ansgebildet. - In der candalen Region der medialen Cortexpartie findet sich bei den Reptilien eine etwas geschwungene Längsfurche der medialen Palliumwand, die sog. Fissura arcuata (F. hippocampi, anch Fovea limbica interna gen.), welche an dieser Stelle eine schwache Einfaltung der Wand in den Ventrikel hervorruft; auch ist hier dio Medialwand meist etwas verdickt (s. Fig. 421). Es ist dieselbe Verdickung, welche wir schon bei den Amphibien trafen, und bei den Anuren als Eminentia septalis und pallii bezeichneten: die erste Anlage einer Bildung, welche dem Ammonshorn (Hippocampus), samt der Fascia dentata, der Mammalia entspricht. - Bei den Squamaten scheint 
sie im allgemeinen besser ausgebildet zu sein als bei den Placoiden. Embryonal tritt sie wohl schärfer hervor als bei den Erwachsenen. Diese Ammonshornbildung sendet Fasern in die allen Reptilien zukommende Commissura pallii anterior, zu der sich anch zwei vom Hypothalamus anfsteigende Faserbündel begeben, welche wir bei den Mammalia als die Süulen (Columnae) des Fornix wiederfinden werden. Etwas ventral von dieser Commissur findet sich die Commissura anterior. Beide Commissuren sind bei den Sauropsiden etwas vor das Foramen Monroi verschoben, was mit der starken Reduktion des Ventriculus impar zusammenhängt. Die Commissura pallii der Vögel ist stark reduziert, was damit in Beziehung stehell dürfte, daß ihnen die oben erwähnte Ammonshornbildung fehlt.

Die Saurier zeigen in der vordersten Decke des Zwischenhirns, direkt hinter der Basis der embryonal gut entwickelten Paraphyse, noch eime quere Commissur (Commissura pallii posterior), die ihre Fasern in die Medialwand des Schläfenlappens sendet. Sie scheint auf diese Ordnung beschränkt zu seill.

Wie schon hervorgehoben wurde, ist das Zwischenhirn der Sauropsiden kurz und von der Dorsalseite kaum sichtbar; nur die mäßige bis ziemlich ansehnliche Epiphyse tritt zwischen den Hemispären und dem Mittelhirn hervor. Eine Paraphyse, die embryonal (speziell Saurier) gut ausgebildet ist, läßt sich am erwachsenen

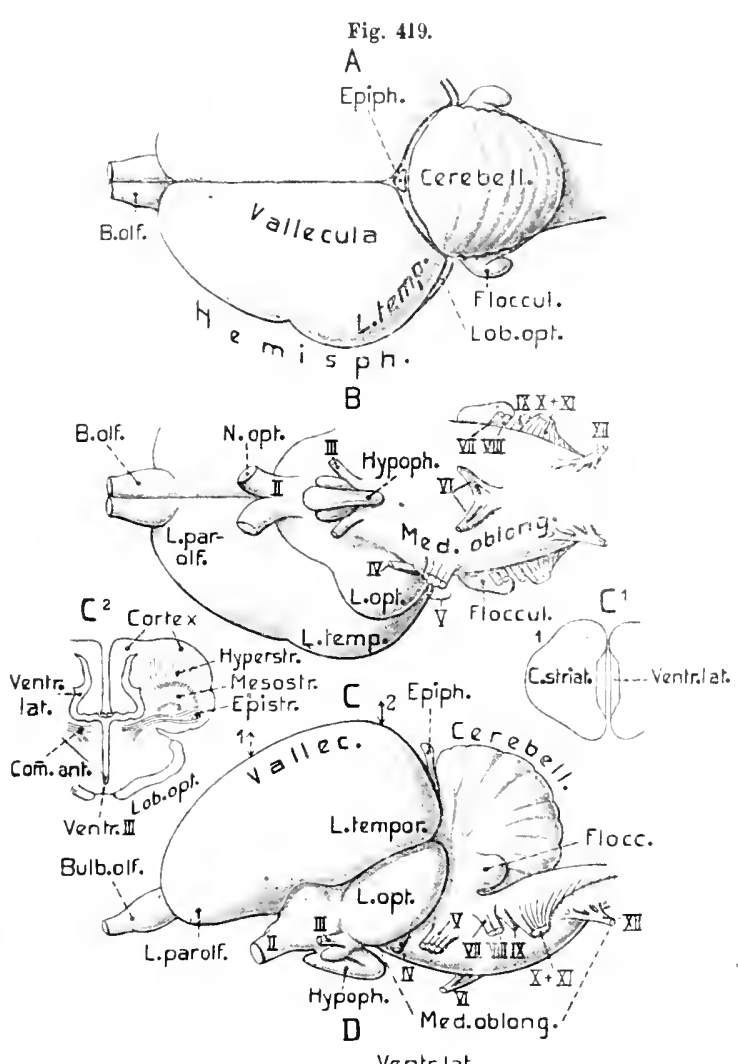

Fig. 419.

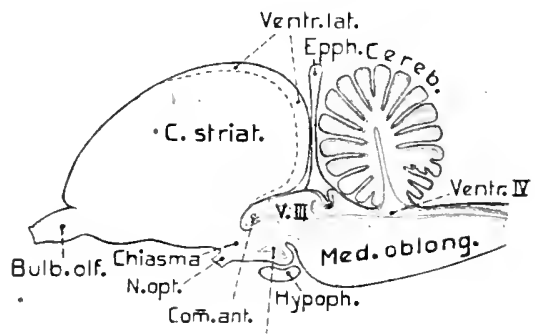

Jnfund.

Anser domestica (Gans). Gehirn. I ron der Dorsalseite. $B$ von der Ventralseite. C von links. $D$ in der Sagittalebene halbiert; rechte Hālfte von der Medianebene gesehen. $C_{1}-C_{2}$ Querschnitte durch die Hemisphären in der Gegend 1 u 2 von Fig. $C$. ( $A, B$ u. $C$ Originale; $C_{1}$ and $C_{2}$ nach Edivger 1908$)$. P. He.

Gehirn wenig bemerken. - Die Plexuseinstülpung der Tela des Zwischenhirndachs erscheint in der Dorsalansicht kurz schlitzförmig (sog. Hirnschlitz), und die Einsenkung der seitlichen Plexus in die Lateralventrikel im Bereich des Foramen Monroi setzt sich bei den Squamaten nach vorn auf die Medialwand der 
Hemisphären als eine Furche etwas fort (Fissura chorioidea, Fig. 421). - Die starken Thalamusanschwellungen engen den dritten Ventrikel sehr ein. Etwa in ihrer mittleren Höhe verdicken sie sich bei den Reptilien so stark, daß sie median zusammenstoßen und bei Schlangen, Crocodilen und Schildkröten verwachsen (Commissura mollis, Massa intermedia, s. Fig. 418; bei den Sauriern ist diese Verwachsung nicht sicher erwiesen). Der dritte Ventrikel der Reptilien wird dadurch in einen dorsalen und ventralen Abschnitt zerlegt. - Das Ende des Infundibulums läuft, wie bei den Amnioten gewöhnlich, in einen kurzen säekchenartigen

Fig. 420.
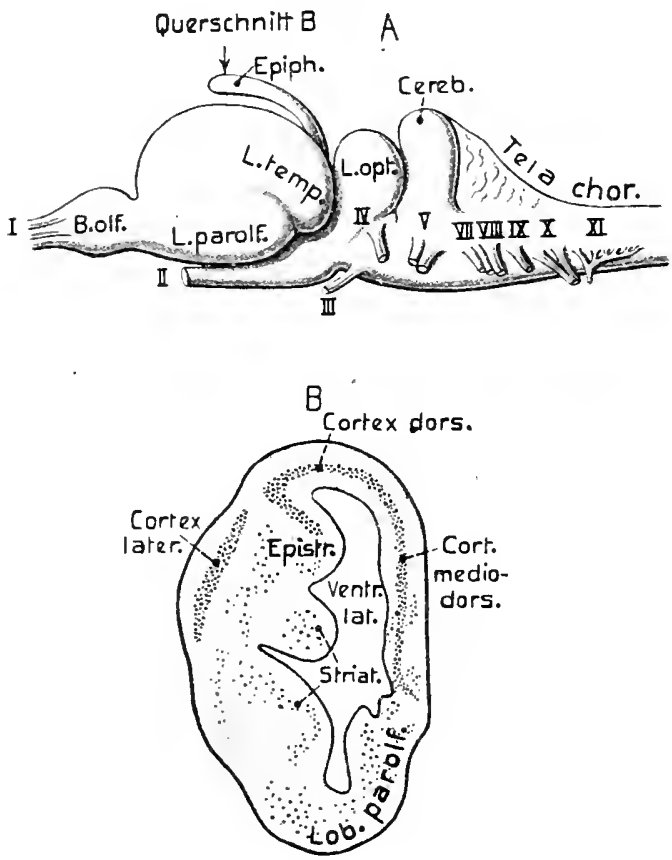

Tha lassochelys earetta (Carettschildkrōte). Gehirn. A von links (Original). $B$ Querschnitt der. linken Hemisphäre, etwa in der Gegend deg Pfeils auf Fig. $A$ (n. Eninger 1896). P. He.
Fortsatz aus (Saccus infundibuli), dem die Hypophyse angefitgt ist. Ein eigentlicher Saccus vasculosus fehlt.

Das Mittelhirn ist stets recht ansehnlich und seine Decke meist zn paarigen Lobi optici stark erhoben. Wie schon erwähnt, werden diese Lobi bei den Vögeln seitlich weit auseinander gedrängt und ventral herabgeschoben, so da $\beta$ sie großenteils bis völlig vom Occipitalabschnitt der Hemisphären verdeckt werden. Der sie verbindende mittlere Teil des Tectum bleibt relativ dünn. - Die Ventrikel höhle erstreckt sich allgemein in die beiden Lobi. - Nur die Crocodile zeigen, ähnlich den Anuren, an der Übergangsstelle der caudalen absteigenden Partie des Tectum in das Cerebellum ein

Paar starker Verdickungen, die nach voru in den Ventrikel vorspringen. Es sind die sog. Corpora quadrigemina posteriora, welche bei fast allen übrigen Sauropsiden nicht als Anschwellungen hervortreten. - Die Lobi optici der Schlangen (speziell der Riesenschlangen, Fig. $421 \mathrm{~A}$ ) erheben sich nur wenig; dagegen greuzt sich ihr kleinerer hinterer Teil durch eine schwache Querfurche etwas ab und zeigt zuweilen auch eine paarige Bildung. Dieser hintere Abschnitt entspricht wobl ebenfalls den Corpora quadrigemina posteriora, so $\mathrm{da} \beta$ hier die Bildung des Tectum an das der Säuger erinnert; in den Ventrikel springen jedoch diese hinteren Vierhügel nicht vor.

Unter allen Hirnabschnitteu zeigt das Cerebellum in der Reihe der Sauropsiden die fortschreitende Entwicklung am deutlichsten. Bei den Squamaten iiberschreitet es im allgemeinen die bei den Amphibien (speziell Anuren) schou erlangte 
Bildung nicht viel. Nur der vordere aufsteigende Abschnitt der Cerebellarfalte ist bei den Sauriern als eine gewöbnlich etwas konkav nach vorn gekriimmte, ziemlich dicke Platte entwickelt; der caudale, absteigende Teil bleibt noch ganz dinn als Fortsetzung der Tela des vierten Ventrikels; jedoch steigt die Cerebellumplatte ziemlich hoch empor (Fig. 417). Fast horizontal dagegen, bis wenig ansteigend, erstreckt sich die Cerebellarplatte der Schlangen nach hinten, so daB sie einen ansehnlichen Teil der Rantengrube iiberlagert (Fig. 421). - Das Kleinhirn der Placoiden und Vögel dagegen ist emporgefaltet und beide Teile der Falte sind stark nervös verdickt. Das der Chelonier (Fig. 420) ist im ganzen mäßiger entwickelt. Bei den Crocodilen dagegen wird es bedeutend ansehnlicher (Fig. 418); auf seiner Oberfläche zeigt es eine seichte quere Einfaltung, sowie an seinem lateralen Basalrand jederseits einen Vorsprung, der sich in die Răder ('Taeniae)derRautengrube fortsetzt; diese Bildung erinnert daher etwas an das Rautenrohr der Chondropterygier. Man betrachtet diese seitlichen Vorsprünge gewöhnlich als erste Audeutung seitlicher Teile(Hemisphären) des Kleinhirns und vergleicht sie meist mit den Flocculi der Säuger. - Eine weitere Steigerung in der eingeschlagenen Richtung zeigt das Cerbellum der Vögel (Fig. 419). Wie schon früher bemerkt, wird es sehr voluminös, wobei sich seine Wände so verdicken, daß der aúfsteigende Ventrikelspalt sehr eingeengt ist. Durch die Entwick-
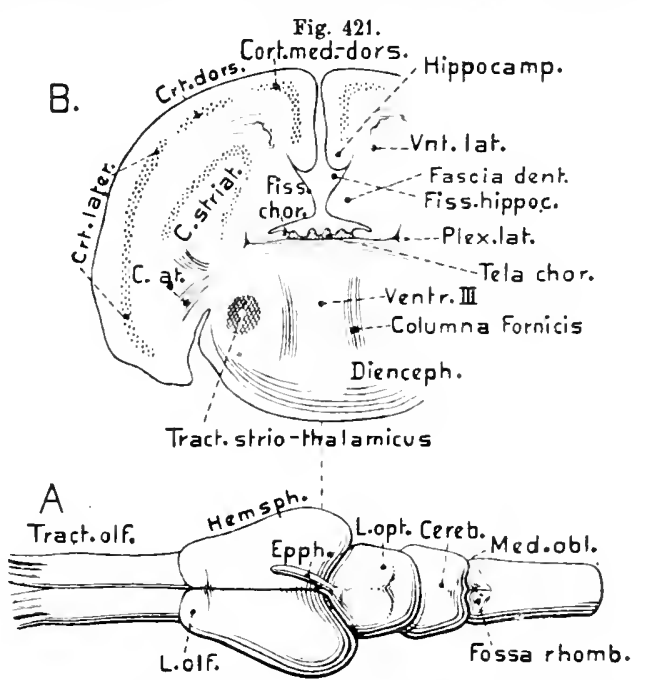

Pythoi (Riesenschlange). Gehirn. A Gehirn von Python molnrus von der Dorsalseite. (Original). $B$ Querschnitt in der Richtung der Strichlinie (Caudalregion der Hemisphăre) von Python birittatus (n. EDINGer 1596, etwas iträndert)

lung mebr oder weniger zahlreicher Querfurchen, dio bis nahe zum Ventrikelspalt eindringen können, vergrößert sich seine Oberfläche sehr. Die seitlichen Anhänge (Flocculi), die schon den Crocodilen zukommen, sind am Vogelcerebellum noch besser entwickelt.

Über die Medulla oblongata ist ohne Eingehen auf Einzelheiten wenig zu berichten. Die Bedeckung der Fossa rhomboidea hängt natürlich vom Entwicklungsgrad des Cerebellum, doch anch von seiner Stellung zur Medulla ab.

Mammalza. Die hohe Entwicklung, welehe das Säugerhirn allmählich erlangt, beruht hauptsächlich auf der immer mehr zunehmenden Vergrößerung der Hemisphären des Telencephalon (Großhirn) und des Cerebellum. Gegen diese Abschnitte treten Mittel- und Nachhirn stark zurück, während das Zwischenhirn, im innigen Anschlaß an die Hemisphären, sich ziemlich ansehnlich erhält. - Die Volumvergrößerung der Hemisphären ruhrt von einer starken und 
immer mehr steigenden Ausdelnung, namentlich aber auch Verdickung ibrer dorsalen Decke oder des Pallium (Episphärium, Neoencephalon) her, wäbrend der ventrale Boden oder Basalteil (auch Stammteil oder Archencephalon genannt) sich relativ wenig vergrößert. Die allmähliche Entwicklung der Großhirnhemisphären erweckt daher zunächst das Hauptinteresse. Wie bemerkt, nimmt ihr Volum, von den ursprünglichsten Formen ausgehend, immer mehr zu, indem sich das Pallium einerseits stark dorsal hervorwölbt und lateral in die Breite ausdehnt, anderseits jedoch auch nach vorn (frontalwärts) und nach hinten (caudalwärts) auswächst. Auf solche Weise kommt es, daß die Lobi olfactorii, welche bei den meisten Säugern über den Vorderrand der Hemisphären vorspringen, schließlich bei den Affen und Menschen von den stark entwickelten Frontallappen der Hemisphären ganz überdeckt werden (vgl. Fig.423), was jedoch auch bei starker Reduktion der Lobi eintritt (Pinnipedia und Cetacea). - Das Zwischenhirn wird stets vom Caudalteil der Hemisphären überlagert, wogegen der bintere Teil des Mittelhirns bei den Aplacentaliern und vielen primitiveren Placentaliern noch unbedeckt bleibt (Fig. 423); bei Ungulaten, Carnivoren, Cetaceen und Primaten wird er aber durch die starke caudale Ausdehnnng der Hemisphären ebenfalls verdeckt (Fig. 423, $7,424,430$ ). Die Hemisphären der Simiae erstrecken sich durch allmählich steigende Entwicklung ibres Occipitallappens immer weiter iiber das Kleinhirn, welches sie schließlich bei den Anthropoiden und Menschen völlig überlagern können (Fig. $423^{8}$ ). - Die Breite der Hemisphären wird bei den Pinnipediern und Cetaceen besonders groß, so daß sie die Länge iibertrifft.

Der dorsale oder palliale Teil der Hemisphïren grenzt sich bei den palaeogenen Säugern von dem Basalteil, der wegen seiner innigen Beziehungen za den Riechorganen auch als Rhinencephalon bezeichnet wird, lateral durch eine nahezu horizontale Furche ab (Fig. $422 \mathrm{~A}, \mathrm{C}$ ), welche vorn die seitliche Grenze des Lobus olfactorius gegen das Pallium bezeicbnet, und sich von da bis zum Hinterende der Hemisphären verfolgen läßt. Der durch diese Fissura rhinalis externa (Fovea limbica) abgegrenzte Basalteil beginnt vorn mit den Lobi olfactorii, die sich caudalwärts in die Tractus olfactorii fortsetzen, und in der hinteren Region endlich in stärkere Anschwellungen übergehen, welche auch seitlich vom Zwischenhirn und ventral etwas hinabsteigen. Es sind dies die Lobi piriformes (od. L. hippocampi) (Fig. $422 B, 424 B$ ).

Schon bei den Diphoern (S. 572) und den Anuren (S. 579) fanden wir eine der Fissura rhinalis externa wohl entsprechende Furche. Bei den Sauropsiden Jäßt sich schwer entscheiden, ob und wo sich eine ihr homologe Furche findet. Es hängt dies ab von der Beurteilung des oben als Lobus temporalis bezeichneten Vorsprungs der Uemisphären. Derselbe kömnte entweder dem Lobus piriformis oder dem später zu erwähnenden Lobus temporalis der Säuger gleichgesetzt werden. Letzteres ist jedenfalls die gewöhnliche Auffassung. - Die Vogelhemisphären zeigen jedoch bäufig eine Bildung, welche der der ursprünglichen Säuger ziemlich gleicht, indem die oben als Vallecula beschriebene Furche einen dorsalen Teil der Hemisphären abgrenzt (Fig. 419), ganz ähnlich wie die Fissura rhinalis am primitiven Säugerlirn. Ließe sich daher diese Vallecula der Vögel der Fissura rbinalis der Säuger vergleichen, so müßte der Lobus temporalis des Sauropsidengehirns dem Lobus pririformis gleichgestellt werden. 
Wie bemerkt, sind die Lobi olfactorii bei denjenigen Säugern, deren Riechorgane gut entwickelt sind, groß und entspringen, ähnlich wie bei den Vögeln, auf der Ventralfäche des vorderen Hemisphärenendes. Ihr Distalende verdickt sich zu dem Bulbus, der hänfig recht mächtig werden kann (Fig. 422-424). Nach hinten setzt sich jeder Lobus auf der Ventralseite der Hemisphären in Faserbündel fort, die Tractus olfactorii. Bei ansehnlicher Entwicklung (macrosmatische Säuger) ist der Lobus stets hohl, indem sich vom Hemisphärenventrikel ein enger Kanal in ihn fortsetzt, der sich im Bulbus ansehnlich erweitert (s. Fig. 425, 426). Bei Affen und Menschen wird der gesamte Lobus stark reduziert (microsmatische Säuger); das Gleiche ist im allgemeinen bei den dauernd im Wasser lebenden Säugern (Pinnipedia, Sirenia und Cetacea) eingetreten; bei letzteren lassen sich nur noch mikroskopisch Spuren der Lobi nachweisen und die Riechnerven sind meist völlig. eingegangen. - Mit einziger Ausnahme von Ornithorbynchns entspringen vom Bulbus stets sofort zahlreiche Olfactoriusfädchen (Fila), welche die Löcher des Ethmoids durchsetzen; Ornithorhynchus besitzt dagegen ein geschlossenes Bündel solcher Fila.

Dicht hinter jedem Tractus olfactorius und etwas mehr median tritt bei allen Sängern mit stark entwickelten Lobi olfactorii eine verschieden ansehnliche Anschwellung auf, nämlich der schon bei den Sauropsiden angedeudete Lobus parolfaétorius (Tubercul. olf., Area olfactoria, Fig. 422 bis 424), der nach neueren Erfahrungen Beziehungen zum Trigeminuskern be-
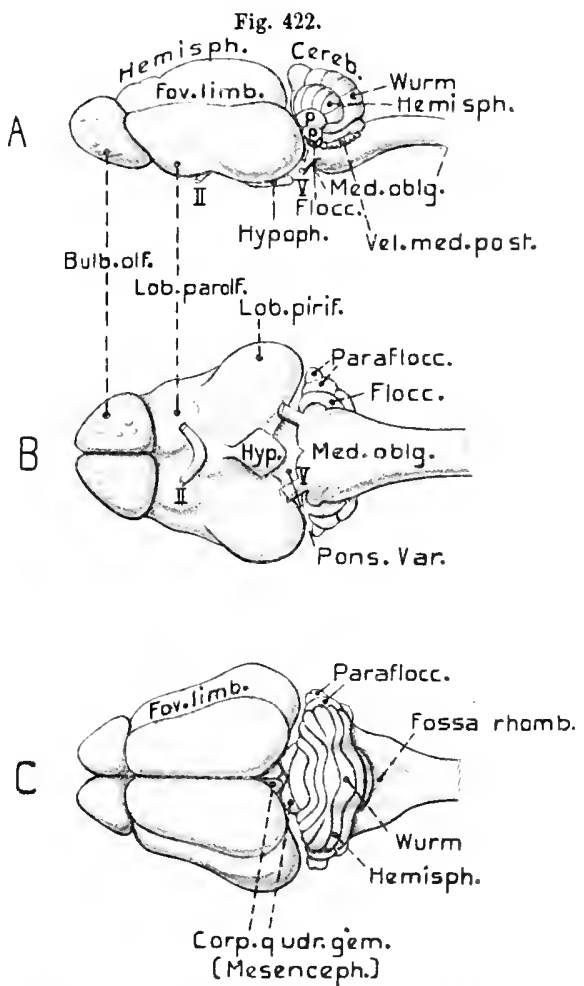

Erinaceus ouropaeus (Igel). Gehirn. A von links. $b$ von der Ventralseite. $C$ von der Dorsalseile. sitzen soll, weshalb in ihm manchmal ein Centrum für die Gefühlsorgane der Schnauze gesucht wird (sog. Oralsinn Edrscer). Bei den Formen mit stark rückgebildetem Lobus olfactorius verkümmert anch der L. parolfactorius und läßt sich bei den Primaten kaum noch in Spuren nachweisen.

Eine ganz eigenartige Bildung hat die Verbindung der IIemisphären mit dem Zwischenhirn erlangt, was vor allem mit der caudalen Ausdehnung der Hemisphären in Beziehung stehen dïrfte. - Die starke Vergrößerung der Hemisphären bedingt im allgemeinen auch eine ansehnliche Entwicklung des Zwischenhirns, wamentlich ein Anschwellen der Fasermassen, die ans den beiden Thalami optici und den 

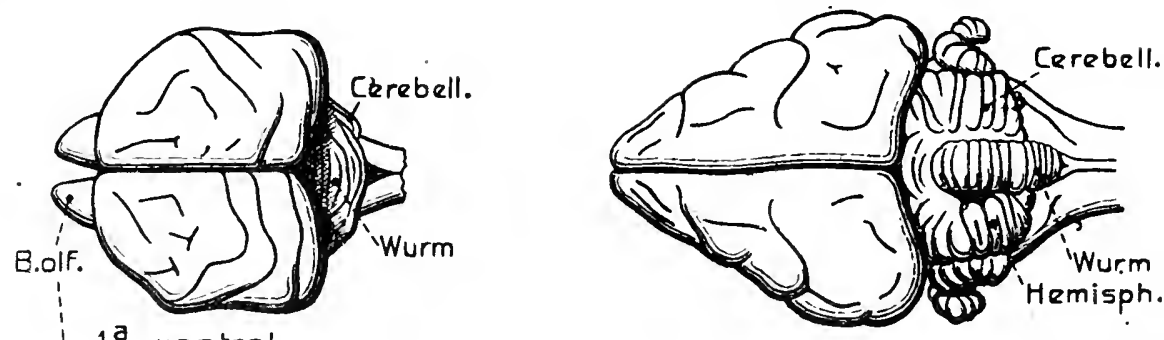

3. Vesperugo pipistrellus (dors.)

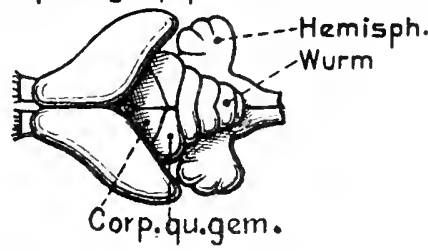

L.parolf. C.mam.

Tub.ciner.

4. Ovycteropus (dorsal)

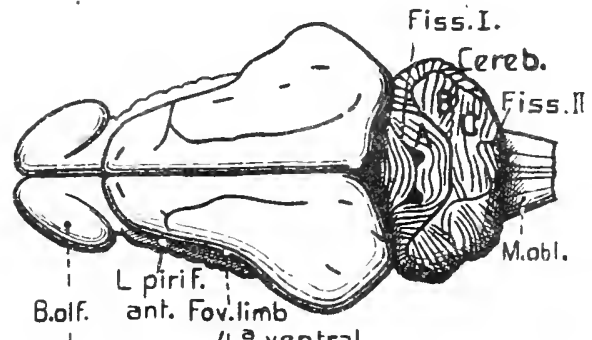

is5.I.

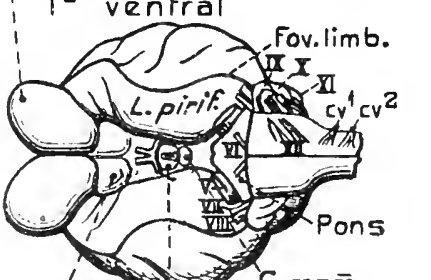

\section{Canis familiaris (dorsal)}
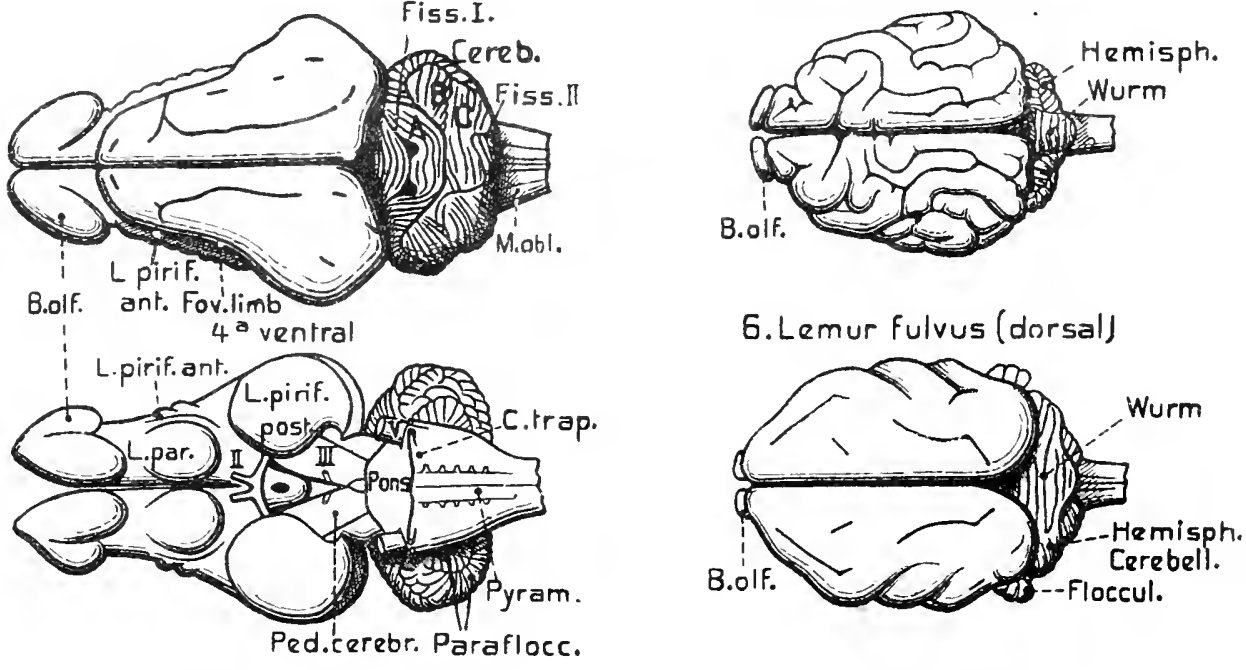

7. Phocaena communis
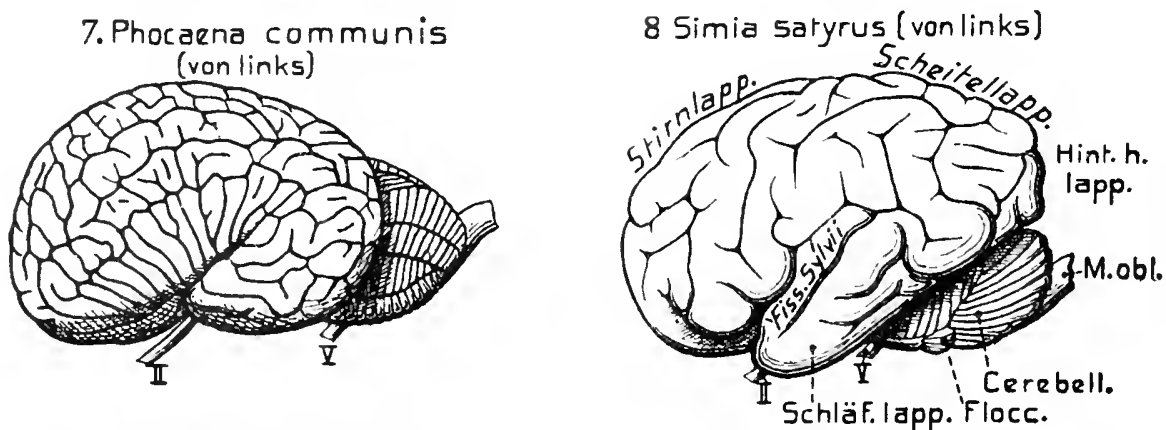

Hirne yersebiedener Sängtiere, teils dorsal, teils ventral, teils seitlich; zur Demonstration der Entwicklung der einzelnen Abschnitte, sowie der Windnngsentwicklung der Hemisphăren des Großhirns. (1. u. 2.

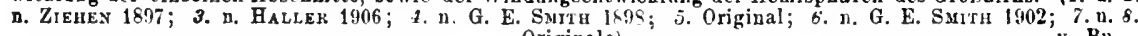


hinteren Hirnabschnitten durch die beiden sog. Hirnstiele (Pedunculi cerebri) in die Hemisphären eintreten. Bei den bisher besprochenen Vertebraten, deren Hemisphären sich caudalwärts nur wenig ïber das Zwischenhirn ansdehnen, bildet die Region des Foramen Monroi die Verbindungsstelle des Zwischenhirnventrikels mit den Seitenventrikeln. Indem num der oben erwähnte Lobus piriformis, in dessen Bereich die Verbindung zwischen Thalamus und Hemisphäre fallt, lateral vom Thalamus stark ventral und eaudalwärts answächst, und, wie wir sehen werden, damit auch der hintere Teil des eigentlichen Pallium in ähnlicher Weise auswächst, dehnt sich die seitliche vordere Partie der Tela des Diencephalons, auf der Grenze zwischen Thalamus und Lobus piriformis, caudalwärts spaltartig aus (sog. Hirnspalt, Fissura chorioidea), so daß sie als ein candalwärts konvexer bogenförmiger Spalt, vom Foramen Monroi aus, an der Medialseite des Lobus piriformis bis zu dessen Ventralende herabzieht (Fig. 427, 428). Durch diese Fissura chorioidea und das Foramen Monroi dringt der Plexus chorioideus lateralis in den Seitenventrikel ein.

Das Entstehen der Fissura chorioidea dürfte sich nur so begreifen lassen, daß gleichzeitig mit dem ventralen Auswachsen des Lobus piriformis auch die ursprüngliche Verbindungsregion zwischen Thalamus und Hemisphäre stark nach unten und hinten auswächst, sodaß die Tela des Zwischenhirns, an diesen Wachstumsprozeß teilnehmend, sich beiderseits nach hinten zur Fissura chorioidea entwickelt. Dieser Entste-

Fig. 424.
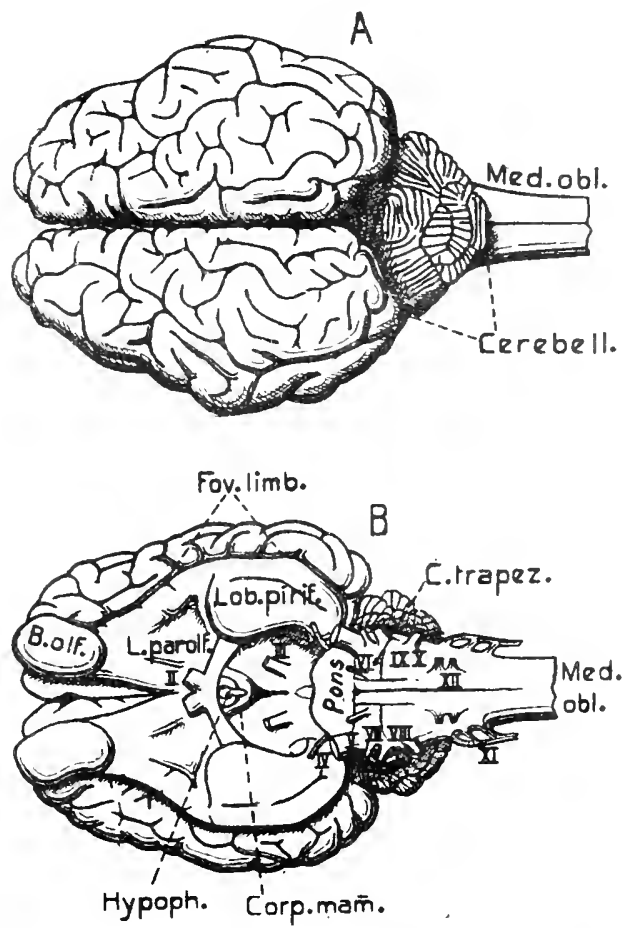

Bos taurus, jux. (Kalb). Hirn. A Dorsalansichl. B. Ventralansichl.

hungsvorgang scheint mir natürlicher als die häufig gemachte Annahme, daß bei den Säugern eine Verwachsung zwischen den Lateralfächen der Thalami und den Medialflächen der Lobi piriformes eingetreten sei. bie Ontogenie zwar soll einen solchen Vorgang erweisen, doch ist die anscheinende Verwachsung wohl eher ein Auswachsen der ursprünglichen Übergangsregion des Thalamus in den Lobus.

Wie schon oben dargelegt wurde, ergibt die Betrachtung der Hemisphären eine zunehmende dorsale Erhebung nnd ein Auswachsen in frontaler und caudaler Richtnng. Man unterscheidet daher an ihnen einen Frontal- und Parietallappen; bei ansehnlicher Entwicklung der Occipitalregion (speciell Simiae und Mensch, Fig. $423_{8}$ ) auch einen Occipitallappen. Dicse Lappen siud jedoch in keiner Weise 
scharfgesondert, sondern gehen ineinander iiber, weshalb ihre Grenzbestimmung auch am Menschenhirn eine Sache der Konvention bleibt. Zu den genannten drei Lappen gesellt sich jedoch bei den Hemisphären, deren Caudalteil sich mehr entwickelt, noch ein Schläfen-oder Temporallappen, der von der hinteren lateralen Region des Pallium ausgeht. Den Hirnen mancher primitiverer Sänger (z. B. gewisse Insectivora Fig. 422, Rodentia, Edentata Fig. $423_{4}$ ) fehlt der Temporallappen noch ganz, odcr ist doch nur sehr schwach angedeutet, als ein ventrolateraler Vorsprung des Pallium über den Lobus piriformis. Meist wächst aber der Temporallappen seitlich vom Lobus piriformis mehr oder weniger stark herab, ihn in verschiedenem Grad überdeckend; wobei sich sein Ventralpol gleichzeitig etwa schief nach vorn richtet. Schon die Monotremen (Fig. 427 $7_{1}$ ) zeigen solche Verhältnisse. - Diese Vorwölbung und das Vorwachsen des Temporallappens bedingen ferner das Entstehen einer bei primitiven Gehirnen nur schwach

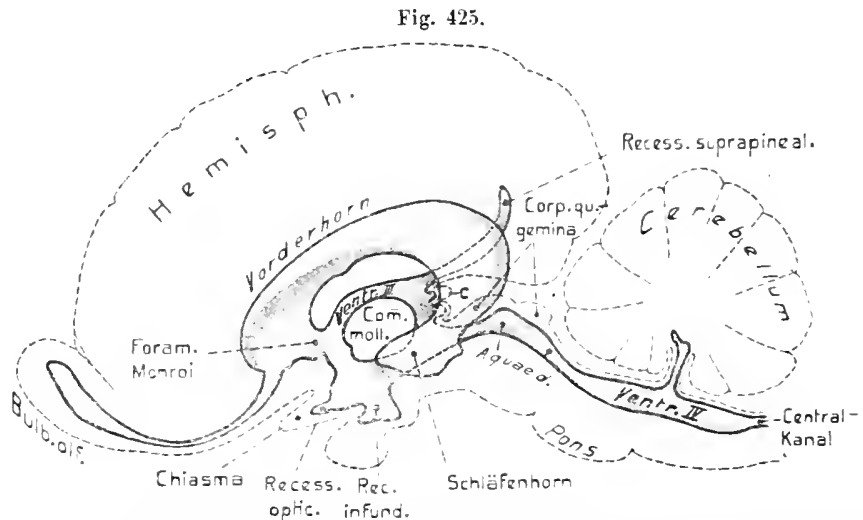

Equus caballus. Ausguß der Hirnböhlen in die Umrisse des Hirns (Stricblinien) eingezeichnet. Ansicht von links. Es ist daher nur der linke Seitenventrikel za sehen. Die Umrisse des verdeckten Teils des I11. Ventrikels sind gestrichelt (n. Ellenberger n. BAum, Handb. d. Vgl. Anat. d. Haussäugetiere; etwas verändert).

angedenteten Furche, die von der Fissura rhinalis externa etwas schief nach hinten aufsteigt und die Vordergrenze des Temporallappens markiert (Fossa Sylvii). Bei den höheren Sängetieren (Ungulata, Carnivora, Cetacea, Primates) entwickelt sich der Temporaliappen immer mächtiger, wobei er den Lobus piriformis so bedeckt, $\mathrm{da} B$ letzterer in der Seitenansicht nur noch wenig, oder gar nicht mehr zu sehen ist. - Endlich wird auch auf der Ventralseite des Hirns die scharfe Grenze zwischen dem Lobus piriformis und dem Temporallappen verwischt, so daß der erstere von den Windungen des Temporallappens nicht mehr bestimmt zn unterscheiden ist, obgleich er selbst bei Affen noch dentlich erkennbar bleiben kann. Im Menschenhirn wird der Lobus piriformis im allgemeinen von dem sog. Gyras hippocampi repräsentiert. - In dem Maße, als sich der Temporallappen stärker entwickelt, wird anch die oben erwähnte Fossa Sylvii länger und tiefer. Bei höchster Entwicklung (Primaten) ist sie zu einer tiefen Grube geworden, die vom vorderen Teil des Schläfenlappens und einem herabhăngenden Teil des Parietallappens 
(Operculım) überdeckt wird, weshalb ihr Boden (Insula Reilii) von anBen nicht mehr sichtbar ist, sondern nur die in die Grube fübrende Fissura Sylvii (s. Fig. 423 8 ).

Mit dem Auswachsen der Hemisphären entfaltet sich auch ihr Seitenventrikel entsprechend (Fig. 425 u. 426). Er erstreckt sich vorn bis in den Frontallappen und schickt gewöhnlich eine Fortsetzung in den Bulbus olfactorius. Dieser vordere Ventrikelabschnitt wird gewöhnlich als Vorderhorn bezeichnet. In dem Maße als ein Occipitallappen auswächst, setzt sicb der Ventrikel als Hinterhorn in diesen fort und schickt ebenso eine Abzweigung in den Schläfenlappen hinab, welche diesen in seiner ganzen Lünge durchzieht, das Unter-oder Schläfenhorn.

Wie bei den seither besprochenen Vertebraten wird der Ventrikelranm durch ein ansehnliches Corpus striatum (Basalganglion), das sich vom Boden und der lateralen Wand erhebt, stark eingeengt. Entsprechend der Längsausdehnung der Hemisphïren sind die Corpora striata ebenfalls langgestreckt; ibr verschmälertes Hinterende reicht bis in das Unterhorn hinab (Fig. $426 \mathrm{~B}$ ).

Innerlich sind die $\mathrm{Cor}$. pora striata ziemlich kompliziert gebaut; es lassen sich zwei ausehnliche Ganglienzellmassen unterscheiden, der sog. Nucleus caudatus, der, dorsaler gelegen, das gesamte Corpus durchzieht, und der ventralere Nucleus lentiformis, der selbst wieder aus mehreren Partien besteht. Beide Kerne

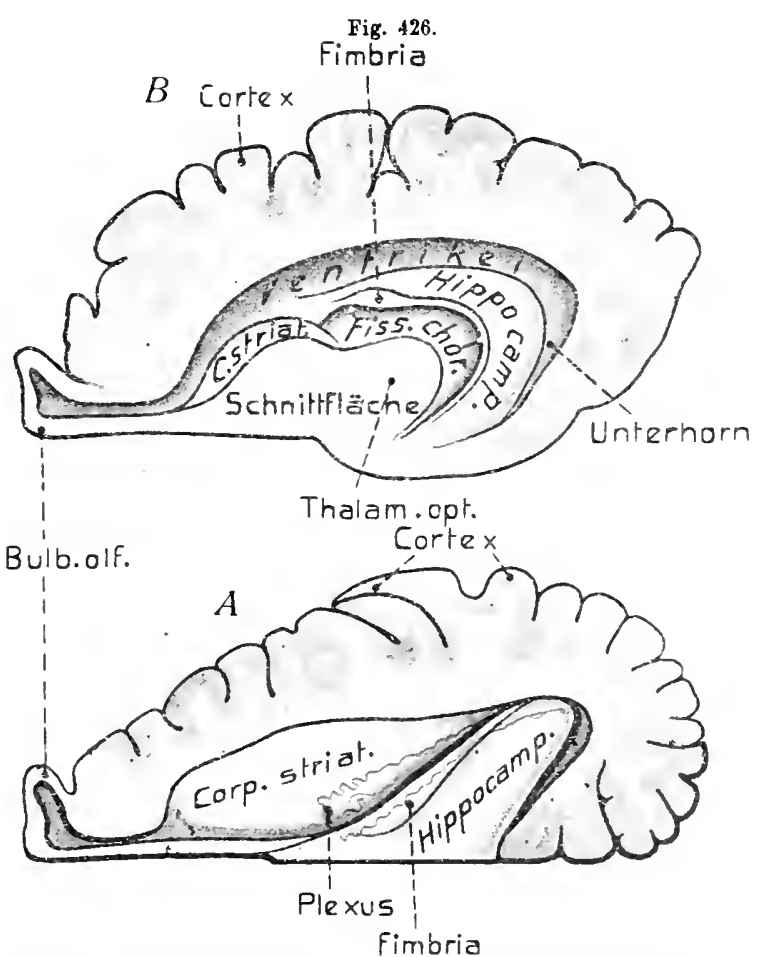

Bos taurus juv. (Kalb). A Rechte Hemisphāre von der Dorsalseite geoffnet; die Decke abgetragen, sodaß der Seitenventrikel, das Corpus striatum. sowie der dorsale Teil des Hippocampus za sehen sind. Der Plexus chorioidalis des Seitenventrikels rot eingezeichnet. $B$ Linke Hemisphăre ron der Außenseite geôffnet, sodaß ein Teil des Corpus striatum, sowio das Unterhorn des Ventrikels mit dem Hippocampus, der Fimbria und der Fissura chorioidea zu sehen sind. $\quad 0$. B. n. v. Bu.

werden durch die Fasermasse der Capsula interna geschieden, die, vom Thalamus kommend, als sog. Corona radiata in das Pallium ausstrahlt. - Auch ein Repräsentant des Epistriatum soll sich flnden, ist jedoch ganz an das Ende des Corpus striatum, ins Iuterhorn verlagert, wo er den Nucleus amygdalae bildet.

Ein schwieriges Kapitel in der Morphologie der Süugerhemisphären bilden die Commissuren, welche mit dem Auswachsen der Hemisphären natürlich eine besondere Entfaltung erlangen. Zwar erhält sich die Commissura anterior (oder ventralis), welche wie bei den Sauropsiden in der Lamina terminalis liegt, wenig 
verändert durch die gesamte Reihe. Bei den niederen Formen ist sie relativ ansehnlicher (Fig. 427). Sie läßt stets zwei Portionen unterscheiden: eine vordere, die ihre Fasern aus den Bulbi olfactorii bezieht, und eine hintere, die in Verbindung mit den Lobi (Tractus) olfactorii, den Lobi piriformes und wohl auch den Temporallappen steht.

Die Commissura pallii anterior, die wir von den Dipnoern an verfolgten, erfährt bei den Säugern eine eigentümliche Weiterentwicklung, welche durch ihre Verbindung mit der schon bei den Amphibien und Sanropsiden angedeuteten Ammonshornbildung (Hippocampusformation) bedingt wird, die sich bei den Säugern viel ansehnlicher und komplizierter entwickelt. Bei den Amphibien und Reptilien fanden wir den sog. Hippocampus als eine gangliöse Verdickung der medialen Hemisphärenwand, welche zuweilen durch eine seichte Furche der Medialwand (Fissura hippocampi oder arcuata) etwas in den Lateralventrikel eingestûlpt war (vgl. Fig. 421, S. 587). Die Commissura pallii anterior bildete eine Faserverbindung $\mathrm{z}$ wischen den Hippocampusformationen beider Hemisphären.

Die Weiterentwicklung der Hippocampusbildung der Mammalia zeigt sich vor allem darin, daß sie, im Gegensatz zu den Sauropsiden, nicht auf die Region der medialen Hemisphärenfläche vor der Lamina terminalis beschränkt bleibt, sondern sich auf die Medialfäche des Lobus piriformis fortsetzt, im Zusammenhang mit dessen caudalen Auswachsen um den Thalamus, so daß sie etwa parallel der oben erwähnten Fissura chorioidea und etwas tiber (dorsal) ihr, fast bis ans Ende des L. pirif. zieht (Fig. 427 2 ). Die Fissura hippocampi wird daher bei den Säugern sehr lang, ja läßt sich bei den Aplacentaliern bis ans Vorderende der medialen Hemisphärenwand verfolgen (Fig. 4271). Gleichzeitig ist ihre Einfaltung in die mediale Hemisphärenwand viel stärker geworden; sie springt daher tief in den Seitenventrikel vor, als das sog. Ammonshorn (Cornu ammonis) oder der Hippocampus (Fig. 426). Auf einem Querschnitt durch die Hippocampusformation eines primitiven Sängers (Aplacentalier), etwa in der Gegend der Lamina terminalis (Fig. 429), finden wir die Verhältnisse noch ganz ähnlich wie bei den squamaten Reptilien. Die Fissura hippocampi ist jedoch tiefer eingedrnngen, die Einfaltung also viel stärker und gleichzeitig etwas bogenförmig nach der Ventralseite eingerollt. - Die dorsale Lippe der Einfaltung, welche nach ihrer spiralen Einkrtimmung gegen die Ventrikelhöhle schaut, entwickelt innerlich eine besondere Rindenstruktur, mit einer mittleren Lage von Pyramidenzellen und einer Nervenfaserlage (Alveus) auf der inneren Oberfläche. Auf der medialen Hemisphärenfläche tritt jedoch diese Beschaffenheit der Dorsallippe in der Regel nicht hervor, da sie hier von der gewöhnlichen Rindensubstanz des Palliuns gebildet wird. Die so beschaffene Partio der Falte, welche die freie Oberfläche gegen den Ventrikel bildet, stellt den eigentlichen Hippocampus oder das Ammonshorn dar. - Die Ventrallippe der Fissura hippocampi und der aus ibrer Einfaltung hervorgehende Teil erlangt eine etwas andere Beschaffenheit nnd wird daher als Fascia dentata (auch Gyrus dentatus) bezeichnet. Im Gegensatz zum Hippocampus ist die Fascia dentata anf der medialen Hemisphärenfläche, am Ventralrand 
der Fissura hippocampi stets frei zu sehen, wäbrend der Hippocanpus nur stellenweise sichtbar sein kann (sog. Alveus externus s. Fig. 4272). Die vom Hippocampus uach der Medialseite und vorn ziehenden Nervenfasern treten zum Teil auf der Medialfläche der Hemisphäre, am Ventralrand der Fascia dentata her-

Fig. 427.1
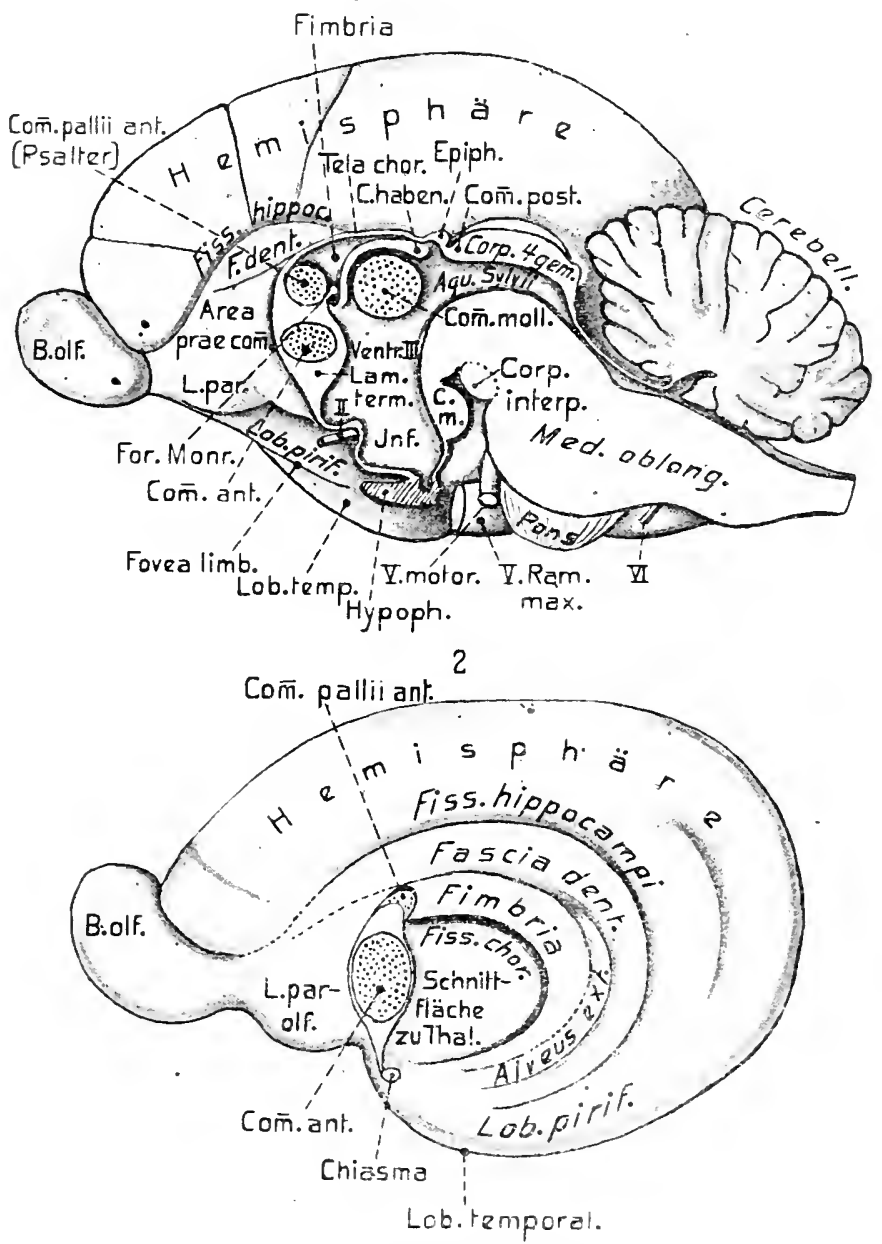

1. Nrnjthorhy nehus paradoxus. Hiru in der Sagittalebene halbiert; recbte Hälfte lou der Sagictalebene gesehen (n. G. F. Surtu 1899). 2. Phascolaritus. Rechte Hemisphäe sagittal von der linken gotrent und rom Diencephalon algelust, sodali die Sagittalfiache des s.hialenlajpens sichtbar ist (nach G. F. Sinti 1>94). 0. P.

vor und bilden die Fimbria (s. Fig. 426-429). Diese Fasern ziehen nach vorn bis zar Commissura pallii anterior, wo sie, sich teilweise kreuzend, in die andere Hemisphäre übertreten. Die Commissura pallii bildet daher bei den ursprünglichsten Säugern (Aplacentalier), wie bei den Sauropsiden, eine Commissur zwischen den beiden Hippocampi der Hemisphären. 
Die Verhältnisse wurden im Vorstehenden so gesehildert, wie sie bei den Aplacentaliern in der vorderen Region der Hippocampusbildung erseheinen. Nun erstreckt sich aber der Hippocampus der Säuger weit nach hinten auf den Lobus piriformis, bis an dessen herabgekrümmtes Ende. Indem die Fissura hippoeampi an dem Lobus bogenförmig herabsteigt, wendet sieh ihr hinteres Ende schließlich wieder naeh vorn, weshalb in diesem Endteil die Lagebeziehungen des Hippocampus zur Fascia dentata und Fimbria geradezu umgekehrt werden, indem hier der Hippocampus ventral, die Faseia dentata dorsal von ihm, und iiber letztrer die Fimbria liegt (Fig. 428).

Die Hippocampusformation bildet ein wichtiges Centrum des Rhinencephalon; zu ihr treten Faserzuige aus dem Lobus olfactorius und parolfaetorius. - - Sehon

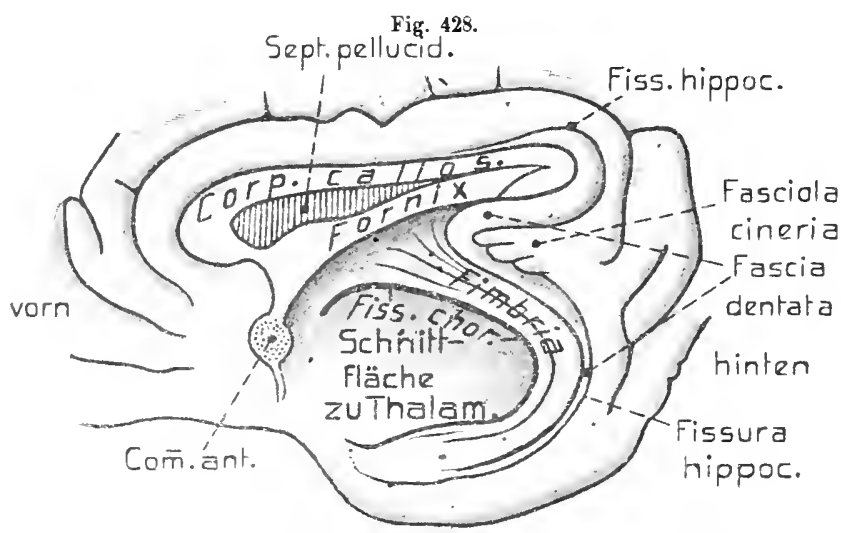

Bos taurus jur. (Kalb). Der Schlatenteil der rechten Hemisphăre durch einell Sagittalschnitt von der linken getrent und vom Diencephalon abgelost sudal die Sagittalflüche les Schläfenlappens mit Fascia dentata, Fissura hippo. campi, Finbria und ihren Beziehungen zum Corpus eallosum und dem Fornix hervortreten. bei denMonotremen ziehen jedoch zur Commissura pallii anterior noch weitere Nervenfasern; einmal solche, die aus der vor der Commissura anterior gelegenen Area waecommissuralis der medialen Jlemisphärenfläche herkommen, ferner solche aus der Region des Hypothalamus (Corpora mammillaria). Der Sagittalschnitt der Commissura pallii, der bei den Monotremen (Fig. 427, rundlich erseheint, erfährt bei den meisten Marsupialiern eine dorsalwärts und nach hinten geriehtete Knickung (Fig. 4272), so daß sich zwei Regionen unterseheiden lassen, eine dorsale und eine etwas ventralere; wobei der ventrale Abschnitt seine Fasern vom hinteren 'Teil der Hippocampusformation bezieht. - Die primitiven Placentalier (so namentlich Chiropteren) besitzen noch eine ähnlieh gestaltete Commissura p. a., deren dorsaler, aufsteigender Teil jedoch eine sehr wesentliche Veräinderung erfährt, indem in ihn Fasern aus der Palliumrinde eindringen und sich hier kreuzen. Auf solche Weise wird dieser dorsale Teil zur ersten Anlage des bei deu höheren Placentaliern sich immer ansehnlicher entwickelnden Balkens uder Corpus callosum. Bei letzteren nehmen die Palliumfaseru allmählich so zu, daß die Hippocampnsfasern schließlich aus dem Balken völlig versehwinden und er zll einer ausschließlichen Commissur der Palliumrinde wird. In dem Maße als đie Hemisphären bei den Placentaliern nach hinten auswachsen, verlängert und verdickt sich auch das Corpus callosum, wobei es etwas schief dorsocaudal aufsteigt; die Commissura anterior dagegen verkleinert sicb. In demselben Maße 
wie der Balken, verlängert sich aber auch der ventrale Teil der ursprünglichen Commissura pallii, in welchen die Hippocampusfasern einströmen, nind wird zn dem als Gewölbe oder Fornix bezeichneten Gebilde (Fig. 428, 430). - Bei den primitiveren Placentaliern bleiben Balken und Fornix noch recht kurz und sind steil dorsocaudal aufgerichtet. Je mehr sich die Hemisphären caudal ausdehnen, desto mehr verlängern sich Balken und Gewölbe und erlangen einen immer horizontaleren Verlauf, speziell der Balken. Mit dem Auswachsen des Frontallappens der Hemisphären verlängert sich der Balken auch etwas nach vorn. Die größte Länge erreichen beide Gebilde natïrlich bei den Primaten und dem Menschen. - Der Fornix bildet, wie schon bemerkt, eigentlich die Fortsctzung der beiden Fimbrien nach vorne; ein wirklicher querer Faseraustausch in ihm fiudet sich jedoch nur an einer beschräukten, etwa mittleren Stelle, die als Psalterium fornicis bezeichnet wird. - In dem Maße als das Corpus callosum der Placentalier nach binten auswächst, verkümmert der ihm dorsal aufliegende Teil der ursprünglichen Ilippocampusbildung zu einer ganz dünnen Lamelle (Stria longitudinalis Lancisii) und nur del hintere, im Lobus piriformis gelegene, absteigende Teil der Hippocampusbildung erbält sich dauernd in guter Entwicklung. Esläßt sich

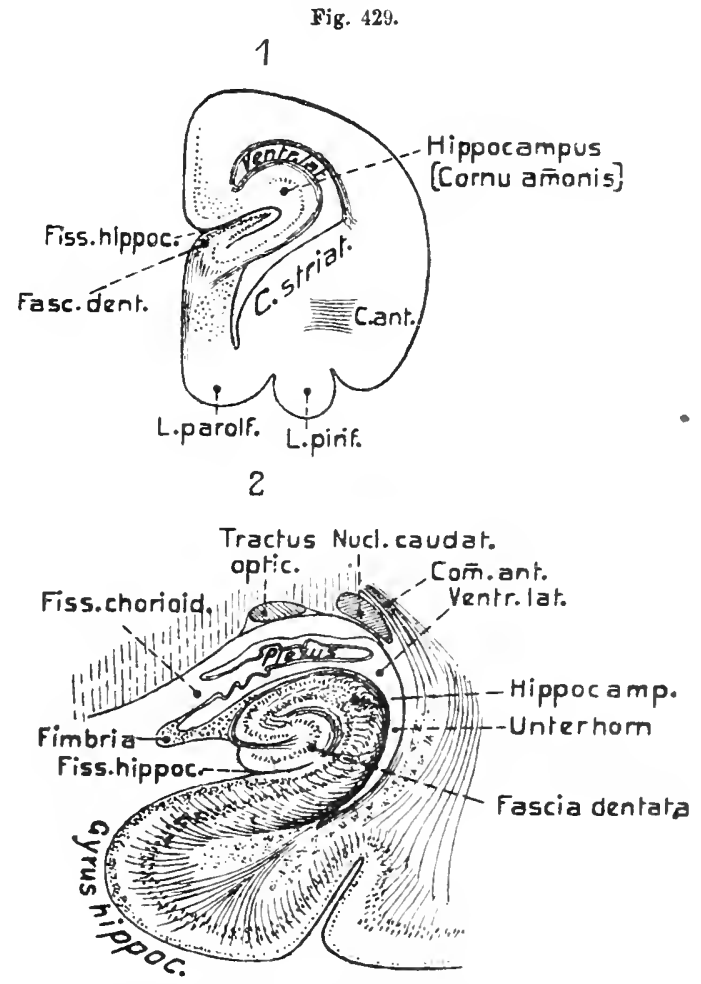

1. Ornithorhynehus paradoxus. Quersehnitt durch den vorderen Teil einer Hemisphäre, etwas vor der Lamina terroinalis. (n. G. E. Smitil 18!18). - 2. Menseh. Querschnitt durch den ventralen Teil des Schläfenlappens (n. Edinger 1911). 0. B.

jedoch nachweisen, $d a ß$ der letztere Teil in den verkiummerten vorderen direkt ühergeht. - Wie eiwäbrt, findet also bei der Bildung des Corpus callosum und Fornix eine schief dorsocaudal gerichtete Einknickung oder Einstälpung der ursprünglichen Commissura palliistatt. Die eingestülpte Membran z wischen Corpus callosum und Fornix, welche $\mathrm{ja}$ beide der Lamina terminalis angehören, wird durch die gleichfalls nach hinten auswachsenden Areae praecommissurales der medianen Hemisphärenflächen gebildet. Die beiden Verbindungsmembranen zwischen den Seitenrändern des Balkens und des Gewölbes bleiben stets dünn (enthalten jedoch auch grane Substanz) und bildeu zusammen das Septum pellucidum (Fig. 427-429!. Da 
sich nun das Vorderende des höher entwickelten Balkens veutral und nach hinten umknickt (Knie, Genu) und zugespitzt, als sog. Rostrum, bis zum Fornix zieht, so kann bei den höheren Säugern und dem Menschen der Raum zwischen den beiden Membranen des Septum pellncidum ganz abgeschlossen werden und stellt dann den sog. fünften Ventrikel (Ventr. septi pellucidi) dar, der jedoch, wie sein Entstehen beweist, nit den eigentlichen Ventrikeln nichts zu tun Lat. - Das Hinterende des Balkens dehnt sich bei den höheren Placentaljern so stark candalwärts ans, da $B$ es den dorsalen Teil der unverkïmmerten Hippocampusformation nach hinten ausbuchtet, weshalb eine Partie der letateren das hintere Balkenende, das sich als Splenium (Wulst) gegen den Fornix nach vorn umbiegt, unterlagert (Fig. 428).

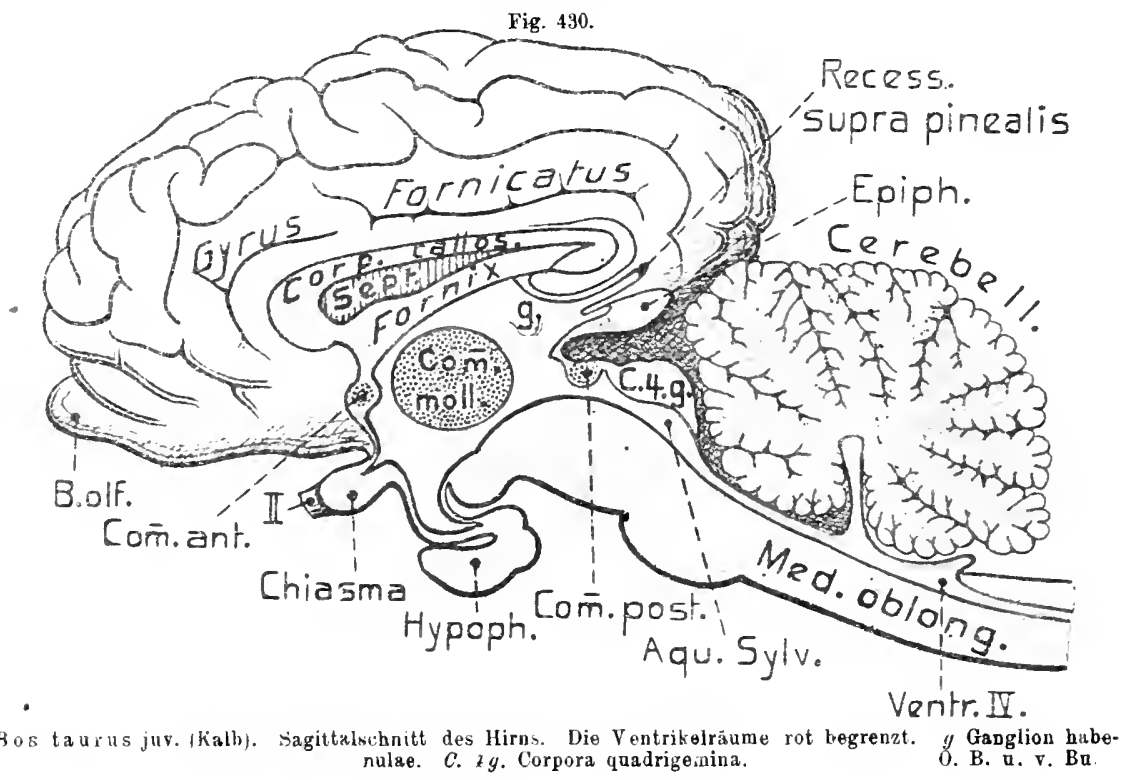

Wie erwähnt, setzt sich der Fornix nach hinten in die beiden Fimbrien fort; vorn treten die schon frïher erwähnten beiden Faserztige, welche hinter der Commissura anterior zu den (orpora mammillaria des Zwischenhirns hinabziehen, in ihn ein und bilden die Fornixsï̈lten (Columnae fornicis); doch treten anch Fasern aus dem verkïmmerten Teil der Hippocampusbildung (Striae Lancisii) zum Fornix und ziehen als Fornix longus vor der Commissura anterıor zum Hypothalamus hinab. 1) ie komplizierten Gestaltverhältnisse des Großhirns erschweren das Verständnis der beschriebenen Commissurenbildungen sehr; doch hoffen wir, daß unsere Beschreiłung, ergänzt durch die begleitenden Figuren, die Grundziige verständlich machen kanu.

1) Hemisphären der Mammalia verdanken ihre miichtige Entwicklung der immer stairkeren Vergrößerung des Pallium (auch Neopalliun genannt, im Gegensatz zı demjenigen 'T'eil der Rinde, welcher in die Hippocampusbildung eingeht, dem sug. Arehipallium). Es ist also weseutlich der dorsale und laterale Teil des Pallinm 
der Sauropsiden, welcher bei den Sängeru so ansehnlich auswächst. Hand in Hand damit geht eine allmählich immer mächtiger werdende Verdickung des Pallium, so dab die Volumzunahme der Gesamthemisphären zum erheblichen Teil hierauf beruht (s. Fig. 426, S. 593). Die Verdickung hängt wieder zusammen mit der starken Zunabme der grauen Rinde, des Cortex, die aus zahlreichen (gewöhnlich sechs) Schichten von Pyramideuzellen besteht und das gesamte Neopallinm durchzieht. Nach innen von dieser Rinde folgt die weiße aus Fasern sehr verschiedenen Verlaufs bestehende Marksubstanz (vgl. Fig. 426).

Der ungemein komplizierte Bau der Rinde ist auf den verschiedenen 'Teilen der Hemisphären keineswegs ganz gleich, sodaß sich zahlreiche Rindenfelder unterscheiden lassen, die wegen ihrer Beziehung zu besonderen Funktionen sehr wichtig sind, jedoch hier nicht genauer erörtert werden können. Ebensowenig kann auf die zahlleichen Associationsbahnen zwischen den verschiedenen Rindengebieten und die Zusammenhänge der Rinde mit den übrigen Hirnabschniften näher eingegangen werden.

Die wichtige Bedeutung der Rinde für die psychische Tätigkeit folgt aus ihrer, der letzteren parallel gehenden Größenzunahme. Da derselben durch die Schädelkapsel eine gewisse Grenze gesetzt wird, oder da ein zu starkes Anschwellen der Schädelkapsel mit erheblichen sonstigen Nachteilen verknüpft wäre, so finden wir, daß die Flächenvergrößerung der Rinde bei den psychisch höher stehenden und größeren Sängern dadurch erreicht wird, daß sich die Hemisphärenoberfläche mehr oder weniger reich faltet. Auf diese Weise bilden sich auf der Oberfläche gewunden verlaufende Erhebungen (Windungen, Gyri), welche durch zwischen sie eindringende Falten (Sulci) geschieden werden (Fig. 423). Die Zahl dieser Sulci nnd Gyri steigert sich mit der Entwicklung der psychischen Tätigkeit immer mehr, so daß bei zahireichen Säugern, namentlich den Anthropoiden und dem Menschen, die gesamte Hemisphärenoberfäche dicht gewunden ist (s. Fig. 423). Der Windungsreichtum hängt aber keineswegs nur mit der Steigerung der psychischen Leistung zusammen, sondern steht auch offenbar in Beziehung zur Größe der betreffenden Sănger. Wir finden wenigstens in zahlreichen Gruppen, am auffallendsten bei den Affen, $\mathrm{da} a$ die kleinen Formen, unbeschadet ihrer intelektuellen Fähigkeiten, sehr furchenarme Hemisphären haben, die großen dagegen furchenreiche. Andererseits wird diese Regel auch dadurch bestätigt, daß die Hemisphären großer Sänger, wie die der meisten Ungulaten, Cetaceen nñd anderer, fast stets reich gefurcht sind, obgleich ihre Psyche häufig recht minderwertig erscheint.

Dies Verhalten dürfte sich auch einigermaßen verstehen lassen, wenn man bedenkt, daß bei gleichen Leistungen wohl ein gewisses Verhä]tnis zwischen Volum und Obertläche der Hemisphären (richtiger Cortex) bestehen muß. Da sich nun das Verhältnis zwischen Volum und Oberfläche bei Zunahme des Hirnvolums immer ungünstiger für die nur im Quadrat sich vergrößernde Oberfläche gestaltet, so läßt sich einigermaßen einsehen, daß bei großen Hemisphären dieser Ausfall durch Windungsbildungen der Oberfläche ersetzt werden muß. Stets vorhanden ist ja die schon früher erwähnte Fissura Sylvii, wenn auch bei den niederen Săugeun recht schwach; doch gehört sie nicht zu den eigentlichen Sulci. Letzrere fehlen Ornithorhynchus noch vollständig, sind dagegen bei Echidna (Fig. 423) ziemlich reich entwickelt. Nahezu furchenlos sind auch die Gehirne kleiner Marsupialier, Edentaten, Nager, 
Insectivoren, Chiroptera und Propitheci, wogegen die Ungulaten, Carnivoren, Cetaceell und Primaten (abgesehen von sebr kleinen, z. B. Arctopitheci) reich gefurchte Hemisphären haben. Auffallend groß ist die Windungszabl namentlich bei den wasserlebenden Pinnipediern, den Cetaceen (bei den Sirenen dagegen sehr gering) und den größeren Affen, speziell den Anthropoiden.

Die Hauptfurchen dringen bei reichgefurchten Hemisphären häufig sehr tief ein; neben ihnen finden sich jedoch meist noch zahlreiche weniger tiefe Nebenfurchen, die auch im allgemeinen weniger konstant sind. Überhaupt unterliegt die Furchen- und Windungsbildung mancherlei Variationen, selbst bei der gleichen Art, was sich nicht selten auch darin äußert, daß beide Hemisphären nicht genau übereinstimmen. - Da eine typisch fortschreitende Entwicklung der Sulci und Gyri durch die Reibe der Mammalia nicht zu bestehen scheint (oder sich doch bis jetzt nicht feststellen ließ), so gehen wir hier nicht auf eine genauere Schilderung ein, sondern beschränken uns auf die Wiedergabe einiger Abbildungen (vgl. Fig. 423). - Wie die Figuren ergebell, erstreckt sich die Windungsbildung auch auf die Medialfläche der Hemisphären, selbst auf den ursprïnglichen Lobus piriformis; was wohl hauptsächlich bedingt, daß dieser bei höheren Placentaliern ron den Lobus temporalis wenig scharf abzugrenzen ist. - Erwähnt werde hier nur eine auf der Medianfläche des Occipitallappens, namentlich bei den Affen und Menschen, sich findende Furche (Fissura calcarina), die bei diesen Formen so tief eindringt, daß sie einen in das Hinterhorn einragenden Vorsprung, den Calcar aris. erzengt.

Die innigen Beziehungen des Zwischenhirns zu den großen IIemisphären, sowie die relativ ansehnliche Entwicklung dieses Abschnittes, worden schon früher erwähnt; ebenso wurde der eigentümlichen Entwicklung der epitbelialen Tela chorioidea am Dach des Zwischenhirns gedacht. Diese Tela (Lamina epithelialis) erstreckt sich über einen relativ schmalen, nach hinten sich etwas verbreiternden medianen Teil des Zwischenhirnđachs, vom Foramen Monroi vorn bis zur Basis der Epiphysis hinten (Hirnsehlitz) und sendet in den sie unterlagernden dritten Ventrikel in ihrer ganzen Ausdehnung die beiden Plexus chorioidei ventriculi III (Plexus medii, Fig. 431). Vom Vorderende der epithelialen Tela gehen die beiden Fissurae chorioideae aus, die sich, wie wir schon oben sahen, auf der Grenze zwischen den Thalami optici und den Lobi piriformes, auf der ganzen Medialfläche dieser Loben, bis an ihr Ende erstrecken, wobei sie sich, wie die Lobi, in der oben beschriebenen Weise um die Thalami ventralwärts herumkriummen (s. Fig. $427_{2}$, S. 595). Die epitheliale 'Tela schließt diese Fissuren bis an ihr Ende ab und stïlpt sich in deren ganzer Ausdehnung, samt der inneren Hirnhaut (Pia), als die Plexus chorioidei laterales in die Seitenventrikel hinein (s. Fig. 431, 426 A). - Die Pia nimmt am Aufban der Tela innigen Anteil, so daß sie die epitheliale Tela des Hirnschlitzes mit der der Fissurae chorioideae verbindet (Fig. 431). Es ist die Gesamtheit dieser Masse, welche das Zwischenhirndach als dreieckige Platte in fast seiner ganzen Ausdehnung überlagert, die gewŏbnlich als Tela chorioidea bezeichnet wird.

Am Hinterende der Tela erhebt sich die Epiphyss, deren Größe bei den verschiedenen Formen sehr schwankt (Fig. 430). In ihren Basalteil erstreckt sich ein Fortsatz des dritten Ventrikels (Recessus pinealis).

Die beiden Ganglia habcmulac, welche an den Seiten der Epiphysenbasis liegen, bleiben klein (Fig. 430g). - Dicht vor der Epiphyse erhebt sich bei manchen Säugern die 
epitheliale Tela zu einer Ausstülpung (Saccus dorsalis, Recessus suprapinealis, Fig. 430), der mit der dorsalen Epiphysenwand verwachsen ist. Er ist vielleicht mit dem Parencephalon oder Epiphysenpolster niederer Formen zu vergleichen. - Eine Paraphyse tritt in der Ontogenese einzelner Säuger schwach auf, scheint sich jedoch im erwachsenen Zustand nicht zu erhalten.

Die Thalami optici bilden gewöhnlich ansehnliche, mit zahlreichen Kernen ausgestattete Anschwellungen, die in der Reihe der Säuger ständig an Größe zunehmen (s. Fig. 432). Wie bei den Reptilien verwachsen sie in der Sagittalebene zu einer Massa intermedia (oder Commissura mollis), die bei den primitiveren Säugern relativ größer ist $\left(427^{1}, 430\right)$. In dieser Commissur findet ein wirklicher Faseraustansch statt; auch liegt in ihr, wie schon bei den Sauropsiden, ein unpaarer Kern (Nucleus reuniens). Dicht hinter dem Chiasma der Sehnerven springt am Hypothalamus das Infundibulum vor (Fig. 425,430 ), dessen gangliöse Vorderwand auch als Tuber cinereum bezeichnet wird. An der Basis der Caudalwand des Infundibulums findet sich eine bei den meisten Säugern unpaare gangliöse Anschwellung, das Corpus mammilbare (C. candicans), das bei den Primaten auch äußerlich

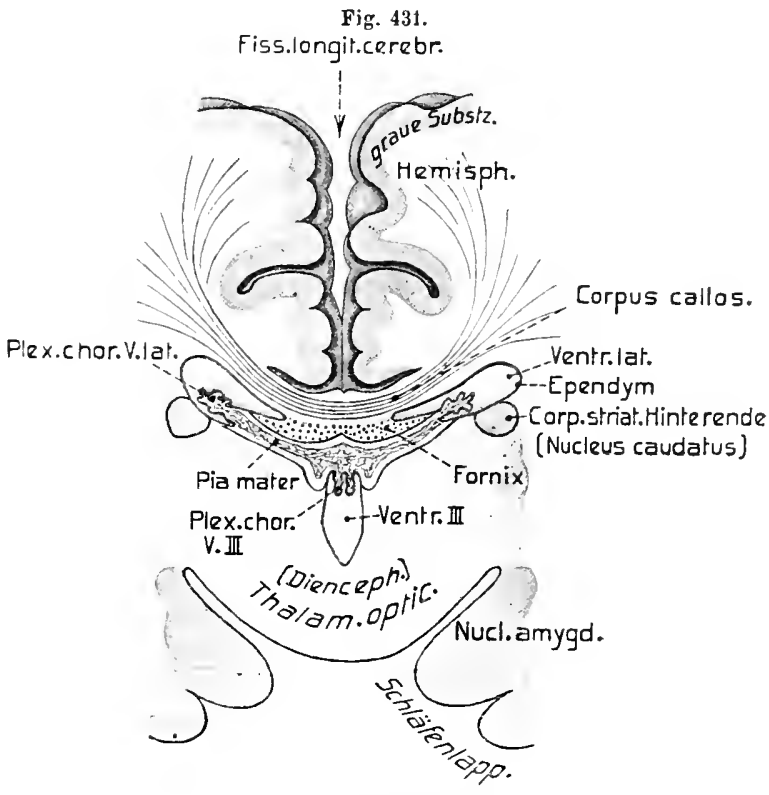

Mensch. Querschnitt durch den mittleren Teil der Hemisphāren (nur zum Teil gezeichnet) und das Diencephalon. Znr Demonstration der Tela chorioidea des Diencephalon, ihrer Beziehung zur Pia mater und zu den Plexus chorioideae. Ependym rot. (11. RACBEL-KOPSCH 1912). E. W. paarig wird. Den Corpora mammillaria entsprechende Ganglien sind schon von den Fischen ab angedeutet, treten jedoch erst bei den Sängern äußerlich hervor. - Die eigentliche Hypophyse heftet sich der Vorderwand des Infundibulum an, dessen hinter ihr herabsteigender Teil auch als Pars posterior der Hypophyse bezeichnet wird. - Hinter dem 'Thalamus, auf der Grenze gegen das Mittelhirn, treten jederseits noch zwei gangliöse Anschwellungen auf, die hiviehöcker (Corpora geniculata, s. Fig. 432 ${ }^{3-4}$ ). Die mehr lateralen Corpora geniculata lateralia (oder anteriora) sind stets dentlich und auch bei den Sarropsiden innerlich schon vertreten. Sie nehmen einen Teil der Opticusfasern auf, was bei den neogenen Sängern zunimmt, so daß bei den Primaten der größere Teil der Opticusfasern zu ihnen geht; die ibrigen begeben sich zum hinteren Teil des Thalamus und den vorderen Vierhïgeln. Die Corpora yeniculata medialia 
(oder posteriora), welche bei den Vögeln schon innerlich angedentet sein sollen, treten bei den Monotremen äußerlich nicht hervor. Sie empfangen Fasern aus dem Kern des Hörnerven und sollen bei Säugern mit gut entwickelten Hörorganen größer sein; bei den Primaten treten sie relativ zurück.

Die geringe Größe des Mittelhirns, sowie die Reduktion seines Ventrikels zum Aquacductus Sylvii (oder cerebri) wurde schon oben betont. Das Dach des Mittelhirns, oder die Corpora quadrigemina (Vierhügel), wird charakterisiert dnrch zwei Paar hintereinander geordneter Erhebungen, die vorderen und hinteren Vierhügel (auch Colliculi). Dieselben variieren in der Schärfe ihrer Ausprägnng und ihrer relativen Größe bei den verschiedenen Säugern ziemlich (s. Fig. 432).

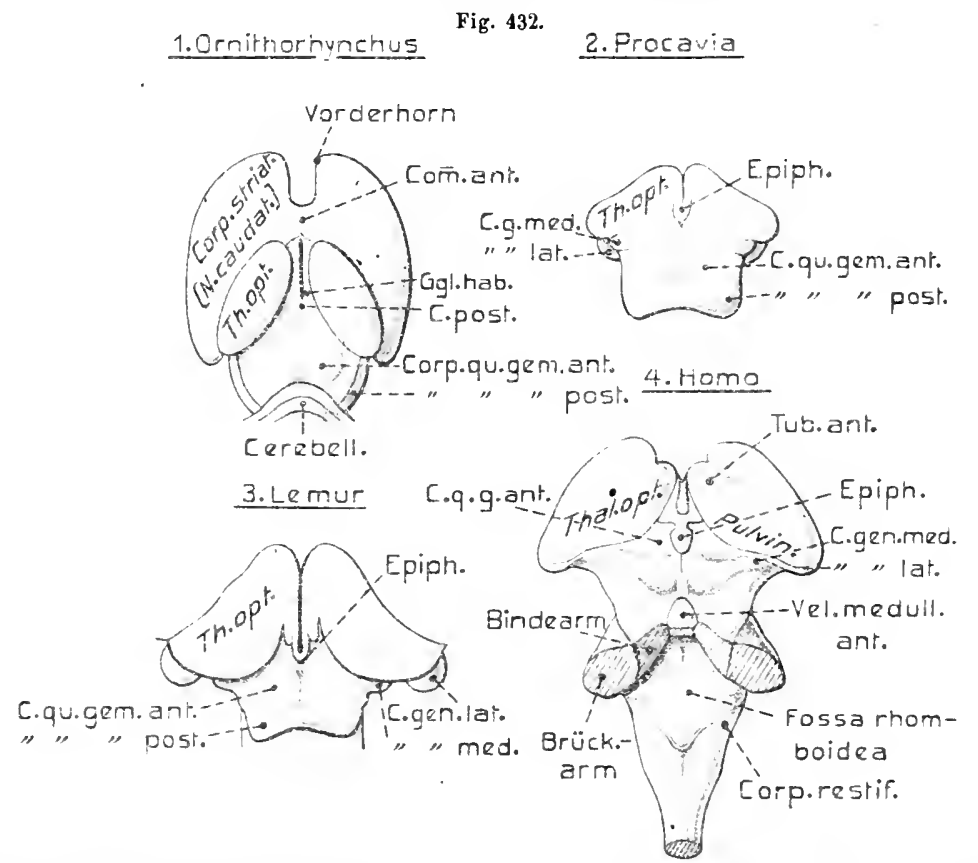

Mesencephalon verschiedener Säuger von der Dorsalseite, z. T. mit den angrenzenden Regionen. Speziell zur Demonstration der Corpora quadrigemina nnd geniculata. (1. n. ZIвHEN IS97; 2.-3. n. G. E. SMITH 1896; 2. 11. VILLIGER 1910).

P. He.

Die Beziehung der Corpora quadrisemina anteriora zum Opticus wurde schon vorhin erwähnt; die hinteren Hügel dagegen steheu in Verbindung mit den Acusticuskernen. Wie wir sahen, waren die hinteren Vierhügel schon bei den niederen Tetrapoden angedeutet, ohne jedoch äußerlich hervorzutreten. - Anf der Ventralseite des Mittelhirns springen die starken Faserzüge, welche vom Kleiuhirn und der Medulla oblongata zum $\mathrm{Z}$ wischenhirn und Telencephalon ziehen, als die Hirnschenkel (Crura, s. Pednnculi cerebri) hervor.

Die ansehnliche, und sich in der Reihe immer mehr steigernde Entfaltung des Cerebellum charakterisiert die Säuger. Wie die Hemisphären des Telencephalon erlangt auch dieser Abscluitt bei den Mammalia die bedeutendste 
Größe und Komplikation. - Der allgemeine Ban des erwachsenen Cerebellum schließt sich dem der höheren Sauropsiden nahe an, indem es einen emporgewölbten, diek gangliösen Teil der Hirndecke bildet, in den sich ein Fortsatz des Ventriculus $I V$ etwas erhebt (Fig. 430). Es lassen sich also ein vorderer aufsteigonder und ein hinterer absteigender Teil unterscheiden.

Die Ontogenese des Cerebellum serläuft jedoch bei den Säugeru etwas anders, weshalb auch die Meinung geäußert wurde: seine Übereinstimmung mit dem der löheren Sauropsiden sei nur eine konvergente, keine phyletische; die Ontogenese spreche mehr für eine Beziehung zu dem der Amphibien. - Diese Meinung stïtzt sich larauf, daß die Anlage des Säugercerebellum als eine sich schief dorsocaudal erhebende Platte auftritt, ohne hinteren absteigenden Teil, ähnlich dem erwachsenen Cerebellum der Amphibien. Es scheint jedoch, daß die Platte sich später weiter caudalwärts ausdehnt und emporwölbt. Bei der großen Übereinstimuung der fertigen Zustände, ist eine solche Differenz des Cerebellum der Säuger und Sauropsiden nicht wahrscheinlich.

Vorn geht die anfsteigende Kleinhirnwand durch eine sehr duinne Lamelle der Decke in das Mittelhirn über (Velum medullare anterius oder Valvula); hinteu durch ein ähnliches Velum medull. posterius in die Tela der Medulla. Die Verbindung mit dem Mittelhirn bilden ferner zwei laterale Faserziige (Bindearme, Braehia s. Crura conjunctiva); die Verbindung mit den Seitenteilen der Vorderregion der Medulla oblongata wird dureh die Brückenarme (Brachia cerebelli ad pontem) und die Corpora restiformia hergestellt (vgl. Fig. $432_{4}$ u. 434).

Der eigentliche Kleinhirnkörper ist stets recht voluminös, meist nahezu kugelig, und wird bei den höheren Säugern immer größer. Als charakteristisehe Erscheinung tritt dabei die Sonderung in einen mittleten Teil (Wurm, Vermis) und zwei seitliche (Hemisphären) hervor, weleh letztere an ibrer lateralen Basis, da wo sie sich mit den Corpora restiformia verbinden, noch eine Ansehwellung besitzen, die Flocculi. Letztere entsprechen wohl sieher den sehon bei den Crocodilen und Vögeln gefundenen Seitenteilen des Cerebellum und lasseu sich vielleicht auf die sog. Rautenohren der Chondropterygier zurückführen. - Die Kleinhirnhemisphären scheinen sich dagegen erst bei den Sängern entwickelt zu haben, was damit harmoniert, daß sie bei den primitiveren Gruppen noch relativ klein bleiben gegenüber dem Mittelteil oder Wurm.

Ähnlich wie das Cerebellum der Chondropterygier und der Vögel zeigt das der Säuger stets eine meist starke Oberflächenvergrößerung durch quere Faltenbildungen. Bei den niederen Gruppen sind diese Querfalten oder-furehen (Sulci oder Fissurae) weniger zahlreich; bei den höheren werden sie mit der Volumvergrößerung immer zahlreieher. Die Erscheinung ist ganz analog der Faltenbildung der Großhirnhemisphären, indem sie gleichfalls eine ansehnliche Oberfïichenivergrößerung der granen Kleinhirnrinde bewirkt. Die Querfalten dringen sehr versehieden tief ein und die tieferen sind sekundär gefaltet. - Der Sagittalschnitt des Cerebellnm erhält dadurch ein eigentümliches Aussehen, indem die tiefliegende weiße Markmasse (Fasermasse) aller. Falten von grauer Rinde überzogen wird und reich baumförmig verzweigt erscheint (sog. Arbor vitae, s. Fig. 430, 433 3 ). Ontogenetisch treten $\mathrm{z}$ wei dieser Querfalten sehr friih auf und dringen auch 
am erwachsenen Cerebellum am tiefsten ein. Die vordere (auch Fissura prima genannt) sondert einen vorderen Lobus anterior ab, der bei der hohen Emporwölbnng des Cerebellums großenteils tief liegt; die hintere Furche (Fissura secunda) einen Lobus posterior (vgl. Fig. 433, anch 4234). Der Teil zwischen diesen beiden Lappen ist größer und bildet den Lobus medius (s. centralis). Letzterer wird in der Regel durch zwei in ihm auftretende Sulci in drei hintereinander folgende Regionen $(A, B, C)$ gesondert (s. Fig. 433, 423). Der Lobus medins ist es, welcher
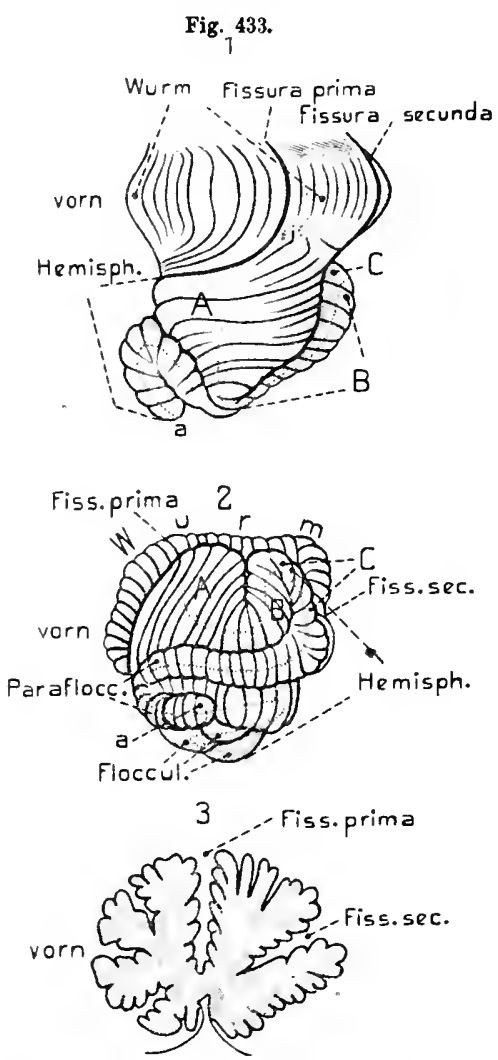

Canis familiaris. Cerebellum. 1. von der Dorsalseite. 2. von links. 3. Sagittalschnitt. $A-C$ die drei Regionen, welche SMrth an den Hemisphären unterscheidet. Der Buchstabe a dient nur zur Kennzeichnung der sich entsprechenden Punkte in den Figuren 1 u. 2. Die punktierte rote Linie in Fig. 1 u. 2 soll den Verlauf der bier besonders deutlichen Windungen der Hemisphären angeben. O. B. u. v. Bu. bei zunehmender Entwicklung des Cerebellum beiderseits immer stärker auswächst und die sog. Hemisphären hervorbringt. Bei den primitivsten Formen (Monotremen, primitive Insectivoren u. Rodentia) ist dieser seitlich ausgewachsene Teil des Mittellappens einfach quergefurcht, wie seine dem sog. Wurm angehörige mediane Region. - Seitlich und basal, da wo er sich mit dem Corpus restiforme der Medulla oblongata verbindet, findet sich stets eine Anschwellung, welche gewöhnlich gefurcht ist, der schon erwähnte Flocculus (Fig. 433, auch 423). - Mit der höheren Entfaltung der Hemisphären bilden sich an ihnen mehrfache schlingenförmige Windungen aus, ähnlich den Gyri der Hemisphären, von welchen die dorsalste, die sich dem Wurm seitlich anlegt, den eigentlichen Hemisphären zugerechnet wird, während die seitlich gegen den Flocculus hinabsteigenden als Paraflocculus bezeichnet werden (Fig. 4331-3). - Dieser Paraflocculus wird schon bei denMarsupialiern,namentlich aber den meisten Placentaliern, recht ansehnlich. Bei den Anthropoiden und Menschen dagegen ist er fast völlig rückgebildet, wie denn überbaupt dasKleinhirn dieser Formen, trotz seiner Größe, wenigstens anscheinend, eine ziemlich primitive Bildung darbietet.

Wie Fig. 433 zeigt, beruht auch die Bildung der drei Regionen im mittleren Lappen des Cerebellum, ebenso wie die des Paraflocculus und Flocculus, wahrscheinlich nur auf den Windungsbildangen der Seitenregionen dieses Lappens. Doch bedarf' der Sachverhalt weiterer Untersuchung.

Recht häufig treten asymmetrische Zustände am Cerebellum auf; namentlich zeigt der Wurm nicht selten asymmetrische Verkrümmungen. 
Charakteristisch für die Sälger ist ferner die Ausbildang eines starken queren Faserzugs zwischen den beiden Kleinhirnhälften an der Ventralseite der vordersten Region der Medulla oblongata. Dies ist die Pons Varolii (Fig. 423 a. 424). Sie besteht wesentlich aus Fasern, die von der Rinde der großen Hemisphären durch die Hirnschenkel zu ansehnlichen Ganglien in der Britckengegend herabziehen, wäh-

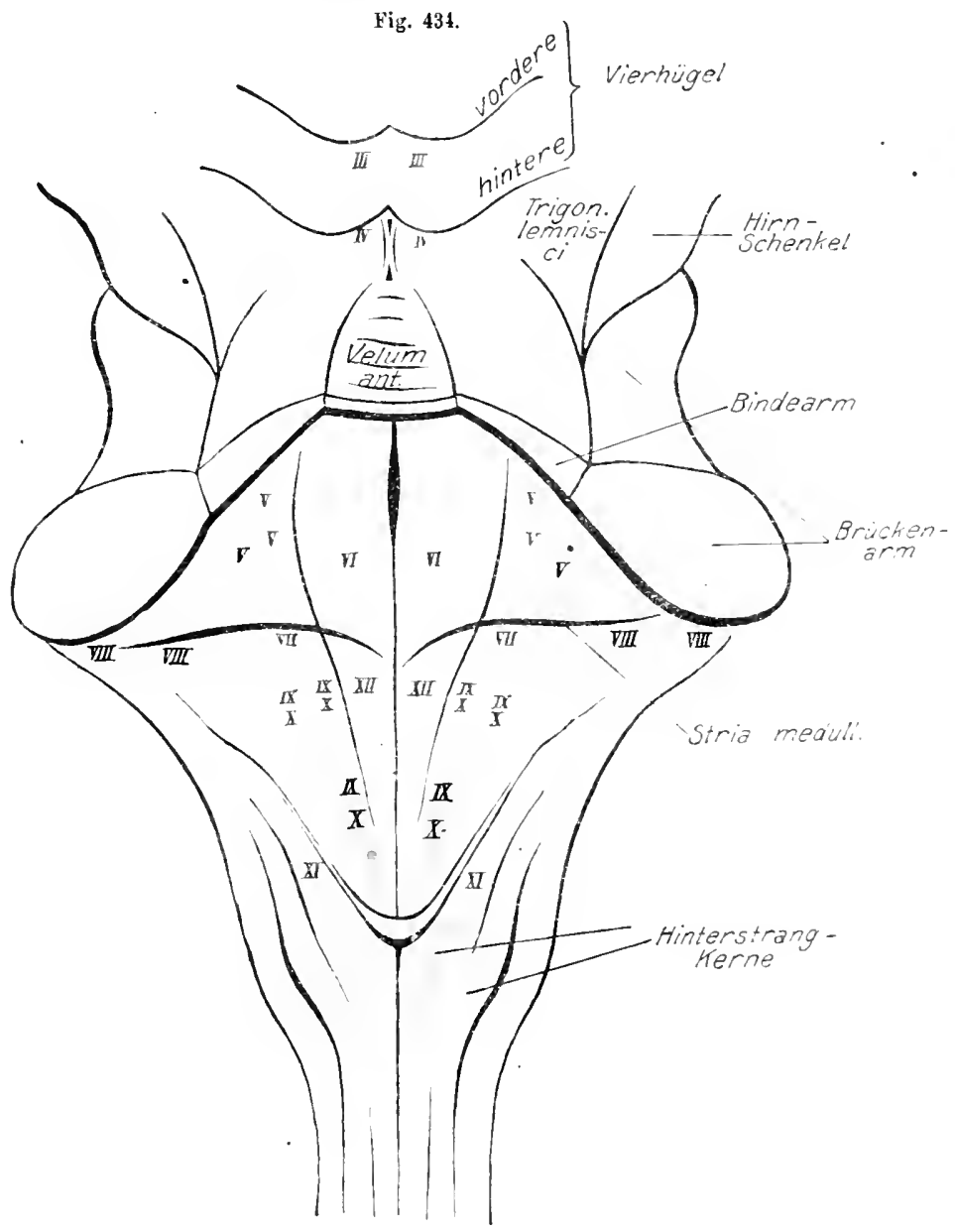

Menech. Medulla oblongata und Mittelhirn von der Dorsalseile; Kleinhirn abgelōst. Die Kerne der Hirnnerren $I I I-X I I$ schematisch eingetragen, und zwar die Kerne der motorischen Anteile rot, der sensiblen blan (aus VILLIGER, Gehirn und Rñckenmark 1910).

rend von hier Fasern ausgehen, die, sich kreuzend, zu den Kleinhirnhemisphären treten. Der Ausbildungsgrad der Brïcke hängt daher sowohl von der Größe der Kleinhirnhemisphären, als von der der großen Hemisphären ab.

Die soeben besprochene Brückenbildung gehört schon als vorderster ventraler Teil zur Medulla oblongata. Direkt hinter der Brücke findet sich ein ihr ähnliches, jedoch etwas kürzeres Feld, das Corpus trapezoideum (Fig. 424), welches 
von Fasern gebildet wird, die von einem Gehörkern kommen. Beim Menschen wird es von der Briicke überlagert. Jederseits der Ventralluie der Medulla findet sich eine strangförmige Anschwellung, die sog. Pyramiden (Fig. 423, 4a), in welchen die Fasern aus den Ventral- und Seitensträngen des Rückenmarks zu den verschiedenen Regionen des Hirns ziehen, wobei sie sich im Verlauf der Pyramiden großenteils kreuzen (Decussatio pyramidum). Die Pyramiden sondern das Corpus trapezoideum in zwei Hälften. - Bei den meisten Primaten erhebt sich jederseits der Pyramiden eine kleine Auschwellung, die Oliven(Olivae), die einen ansebnlichen Kern (Nucleus olivaris inferior) enthalten. Bei den übrigen Sängern sind die Oliven samt ihrem Kern weniger ausgebildet und äußerlich hänfig kaum sichtbar. - Wegen der relativen Kürze der Medulla obl. wird die Fossa rhomboidea durch das Kleinhirn fast völlig ïberdeckt. - Die etwas angeschwollenen strangartigen Partien der Medulla, welche die Ränder der Fossa bilden, setzen sich als die Corporarestiformic (Strickkörper) in die Brachia ad cerebellum fort. - Etwas medial von den Corpora restiformia findet sich am Boden der Rautengrube jederseits eine Anochwellung, die Tubercula acustica, welche die Kerne des Acusticus einschließen, und daher im allgemeinen den schon bei den Fischen stark ausgebildeten Lobi acusticolaterales entsprechen. - Auf die weiteren Einzelheiten, welche der Boden der Rautengrube noch darbietet, kann hier nicht eingegangen werden; ebensowenig auf die Anordnung der sehr zahlreichen und wichtigen Kerne in der Oblongata. Es sei anf die Fig. 434 verwiesen, welche ihre Verteilung beim Menschen schematisch darstellt.

\section{Periphere Nerven der Wirbeltiere.}

Acrania. Es empfiehlt sich, die primitiven Verhïltuisse der Acrainer zuerst zu besprechen. - Für sämtliche Wirbeltiere gilt im allgemeinen, daß jede Segmenthälfte des Körpers aus dem Centralnervensystem einen sensiblen und einen motorischen Nerven erhält, wodurch sich die Segmentierung im Centralpervensystem deutlich ausspricht. Die sensiblen Nervenfasern treten stets an der Dorsolateralseite des Rückenmarks als ein Dorsalnerv (Wurzel) jederseits aus, dem jedoch auch einige motorische Fasern beigemischt sein können. - Die motorischen Fasern für die Körpermuskeln bilden in jedem Segment ein ventrales Nervenpaar (Wurzelpaar), das ventrolateral entspringt.

Die Acranier verhalten sich darin primitiv., daß sich die dorsalen und ventralen Nerven jeder Segmenthälfte nicht zu einem einheitlichen Spinalnerven verbinden, wie es bei den Cranioten fast ohne Ausnahme geschieht. Da die ersten Nervenpaare der Acranier, welche in der vorderen Region des Hirnabschnitts entspringen, Besonderheiten zeigen, so besprechen wir zunächst die darauf folgenden dorsalon und ventralen Spinalnerven. - Die vom Rückenmark einheitlich entspringenden Dorsalnerven treten in die Myosepten ein und steigen in ihneu schief dorsal bis zur Cutis empor. Hier teilt sich jeder Nerv in einen dorsal aufsteigenden kürzeren und einen ventral herabsteigenden Ast (Rami dorsales und ventrales). Jeder dieser Rami verzweigt sich in seinem Verlauf in der Cutis vielfach, aus welchen Verzweigungen endlich in der Dorsal- und Schwanz- 
flosse, sowie den Metapleuralfalten und Mundlippen, reiche Nervenplexus hervorgehen (Rami cutanei dorsales und ventrales, vgl. Fig. 435). Etwas stärkere Zweige der Rami dorsales und ventrales warden auch als Rami laterales dorsales und ventrales bezeichnet; sie scheinen sich aber von den übrigen Ästen nur wenig scharf zu unterscheiden. - Am Ventralrand des Seitenrumpfmuskels zweigt sich vom Ramus ventralis jedes Dorsalnervs ein Ramus visceralis ab, der zwischen dem Seitenrumpfmuskel und dem Lateralrand des Mnsculus transversus medialwärts nach iunen tritt. Er zieht hierauf mit einem aufsteigenden Ast (Ramus ascendens) auf der Innenfläche des Seitenrumpfmuskels dorsal empor; diese Äste treten auf die respiratorische Körperwand (Kiemensack) uber und innervieren die Kiemenbogen, wobei sie durch einen Liingsnerv verbunden sein sollen, der'sich, wie es scheint, bis in die Region der vorderstenVisceraläste verfolgen läßt (Nervus recurrens, $N$ Fig. 435). In der Darmregion sollen die aufsteigenden Äste der Rami viscerales den Darm innervieren. - Die absteigenden Visceraläste bilden einen reichen Plexus auf der Innenfläche

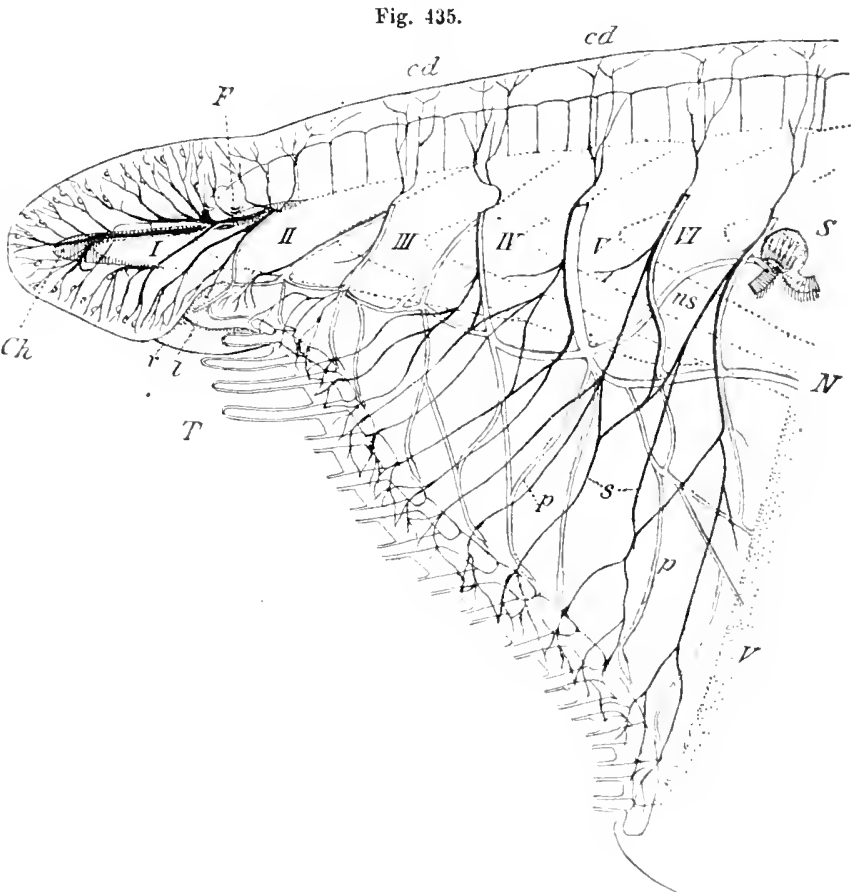

Branchiostoma (Amphioxas) lanceolat um. Vorderes Körperende von links. Die Nerveu sind schwarz wiedergegeben, mit Ausuabme der Visceraläste, die braun eingezeichnet sind. $C h$ vorderes Ende der Chorda. $k$ Flimmer- oder Riechgrube. $S$. Sinnesorgan, znm sog. Ráderorgan gebörig. $T$. Mundeirren, größtenteils ab. geschnitten. $\because$. n. $l$. Die Vorderenden der rechten und linken Lippen des etwas asymmetrischen Mundes. I-VI Myomeren. V Velum. Über $I$ der erste llirnnerı; über $I I$ der zweite. cd. Rami cutanei dorsales der Spinalnerven. s. Rami cutanei ventrales, die unter Plexnsbildung zu den Mundeirren gehen. $p$. tiefgelegener Plexus der Rami viscerales zum Sphinkter des Mundes. I sog. Nerras recurrells zur. Plexus des Kiemendarms gehend. ns. Nerv zum Sinnesorgau $S$. (n. HATsilk 1992 aus GegenBaOr, Vergl. Anat. d. Wirbeltiere I-95).

der beiden Transversalmuskeln, von dem wohl die Innervierung dieser Muskeln ausgeht. Demnach fübren allein die Visceraläste der Dorsalnerven motorische Fasern, was auch daraus folgt, daß sie wohl die übrigen Visceralmuskeln (s. S. 425) versorgen.

Über den Ursprung der Dorsalnerven im Rückenmark ist wenig bekannt. Namentlich konnte er nicht sicher auf Zellen zurückgeführt werden. Dagegen finden sich im Verlauf der Dorsalnerven zerstreute zellige Gebilde, reichlicher, namentlich an ibrer peripheren Teilungsstelle in die Rami ventrales und dorsales. Hieraus wurde geschlossen, daß letztere 
Ganglienzellenanhäufungeu den Spinalganglien entsprechen, welche in die dorsalen Wurzeln der Cranioten eingeschaltet sind. Dagegen wurde jedoch auch angenommen, daß die Spinalganglienzellen der Acranier noch im Rückenmark selbst liegen.

Dieventralen motorischen Nerven erscheinen sehr eigentämlich, da sie fächerartige Faserbüschel sind (also keine eigentlich geschlossenen Nerven), die etwas vor der Mittelregion jedes Myomers auî eine ziemlich lange Strecke aus dem Rückenmark austreten. Sie dringen sofort in die Muskelmasse des Myomers ein, wobei sie einen Dorsalast für dessen Dorsalpartie abgeben. Der Hauptast verbreitet sich zwischen dem früher (S. 425) erwähnten medianen Teil und dem äußeren Hauptteil des ventralen Myomerabschnitts (s. auch Fig. 81, S. 177, Fig. 288 u. 289).

Wegen dieser Besonderheiten der ventralen Wurzeln, sowie der gelegentlich beobachteten Querstreifung ihrer Fasern, wurde zuweilen angenommen, daß sie eigentlich den Muskelzellen angehörten, die wirklichen Nervenfasern dagegen ganz kurz seien; es sollte hier ein ähnliches Verhalten der Muskelfasern zu den Nerven vorliegen, wie es S. 482 für die Nematoden geschildert wurde. - Die Nervenfasern befestigen sich mit besonderen dreieckigen Terminalorganen an den einzelnen Muskelzellen.

Wie oben erwähnt, sind die beiden vordersten Nerven, welche in der Region des erweiterten Hirnventrikels entspringen, eigentümlich modifiziert und werden daher als besondere Hirnnerven angesprochen.

In jüngster Zeit wurde jedoch noch ein vorderstes, ventral von der vorderen Hirnspitze ausgehendes feines Nervenpaar beschrieben (N. terminalis, Edinger, Wolff), das ein im Kopfende liegendes schlauchförmiges Sinnesorgan (Frontalorgail) versorgen soll. In diesem Fall wäre also das seither als erstes beschriebene Nervenpaar das zweite. Nach älteren Angaben sollte ferner ein sehr kurzer Nerv linkseitig von der vorderen Decke des Ventrikels entspringen und sich zur etwas links liegenden Wimper- oder Riechgrube begeben (s. Fig. 398, S. 550), doch ist seine kixistenz in neuerer Zeit wohl mit Recht bezweifelt worden.

Das früher als erstes, jetzt wohl richtiger als zweites bezeichuete Hirunervenpaar geht aus dem ventralen Vorderende des Nervenrohrs hervor und ist rein sensibel. Es verläuft unter Abgabe zablreicher dorsaler nnd ventraler Äste bis zum Ende der Kopfspitze (Rostrum, s. Fig. 435).

Seine Vergleichung mit einem Ramus lateralis der dorsalen Rückenmarksnerven scheint ohne tiefere Bedeutung, wohl noch weniger aber seine Deutung als eines Komplexes mehrerer vor der Mundöffnung gelegener rudimentärer dorsaler Nerven (R. Goldschmidr). Sein ventraler Ursprung, sowie eine kurze Fortsetzung des Hirnventrikels in seinen Anfang, ließen ihn auch mit dem Nervus olfactorius der Cranioten vergleichen, was mehr wie zweifelhaft erscheint.

Der sog. zweite Hirnnerv entspringt dorsal am Nervenrohr, also in der Flucht der dorsalen Rückenmarksnerven, und verläuft direkt am Vorderrand des ersten Myomers (Fig.435). Er zeigt eine Sonderung in eine vordere und hintere Portion, die zuwilen auch gesondert entspringen sollen, weshalb der Nerv manchmal als aus zweien zusammengesetzt betrachtet wurde. Die vordere Portion ist rein sensibel und versorgt mit ihren Ästen die hintere Rostralregion. Die hintere Portion wird wesentlich von einem motorischen Ramus visceralis und zwei sensiblen Dorsalasten (Cutanei dorsales) gebildet. Ersterer Ast versorgt die vordere Partie der Muudsphincteren. 
Die folgenden drei dorsalen Rückenmarksuerven besitzen den oben beschriebenen typischen Bau, zeigen jedoch leichte Modifkationen, auf die hier nicht näher eingegaugen werden kann. Ebenso kann eine eventuelle Vergleichung der erwähnten Nerren mit den Hirnnerven der Cranioten nicht ausgeführt werden, da sie vorerst recht unsicher erscheint. Auf die interessante Asymmetrie in der Innervierung der Mundregion und ibrer Organe sei nur kurz hingewiesen; hier greifen linkseitige Nerven auf die rechte Körperhälfte ïber, was jedenfalls damit zusammenhängt, daß der Mund embryonal linkseitig angelegt wird.

Das früher erwähnte Alternieren der beiderseitigen Myomerenhälften der Acranier, d. h. die Verschiebung der linkseitigen etwa um die Hälfte eines Myomers nach vorn, muß natiirlich auch eine entsprechende Verschiebung der beiderseitigen dorsalen und ventralen Nervenurspriinge bewirken (s. Fig. 288). Ein Querschnitt durch das Ruickenmark trifft daher nie zwei dorsale oder zwei ventrale Wurzeln gleichzeitig, sondern einer ventralen der einen Seite steht eine dorsale der andern gegenüber. Wie schon erwähnt, alternieren ja die dorsalen und ventralen Wurzeln jeder Seite ebenfalls miteinander. Da letzteres anch bei den primitiven Cranioten wiederkehrt, so läßt sich schließen, da $B$ je ein ventraler Nerv und der hinter ihm folgende dorsale zusammen einem Spinalnerv der Cranioten entsprechen.

\section{Die Rïckenmarksnerven (Spinalnerven) der Cranioten.}

Wie zu erwarten, trat mit der besonderen Entwicklung der Hirnegion der Cranioten auch eine eigenartige, und im allgemeinen typische Ausbildung zablreicher besonderer Hirnnerven ein. Ibre größte Zahl entspringt von der Medulla oblongata, welche sich als ein modifizierter Rückenmarksteil erwies. Schon deshalb ist es wahrscheinlich, daß auch ihre Nerven modifizierte Rïckenmarksnerven sein werden. Wir wollen daher zunächst die Riickenmarksnerven besprechen.

Bei sämtlichen Cranioten, mit einziger Ausnahme von Petromyzon, vereinigen sich der zu ciner Segmenthälfte gehörige dorsale und ventrale Spinalnerv bald nach ihrem Anstritt aus dem Rückenmark zu einem gemeinsamen Spinalnerv,

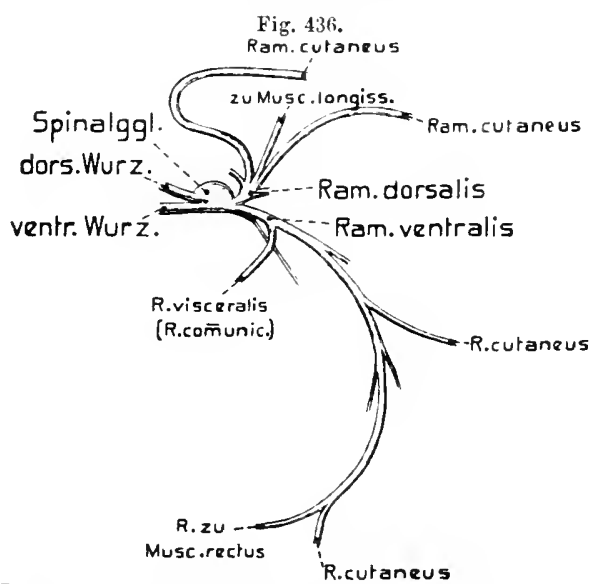

Rana. Schematische Darstellung eines Spinalnerien der Rumpfregion und seiner Verăstelungen (nach GAUPp 1896). E. W.

welcher also eine dorsale (oder hintere) und eine ventrale (oder vordere) Wurzel besitzt (s. Fig. 436). Die dorsale Wurzel bildet in ibrem Verlauf stets eine Ganglienanschwellung (Spinalganglion).

Die ontogenetische Entwicklung der Spinalganglien nud der dorsalen Wurzeln beginnt frühzeitig am primitiven Neuralrohr, indem sich aus dessen Dorsalwand eine unpare bis parige Leiste erhebt (Neuralleiste), welche dann in regelmäßig metameren Abständen zu den Spinalganglien seitlich auswächst; oder indem die Anlagen der Spinalganglien als Büt s chli, Vergl. Anatomie. 
paarige Leisten aus dem Strang, welcher das noch nicht abgelöste Neuralrohr mit dem Ectoderm verbindet, hervorwachsen. Aus den Zellen der Spinalganglienanlagen sollen die Nervenfasern, welche die eigentlichen Dorsalwurzeln bilden, sowobl central in das Rückenmark als peripher hervorwachsen. - Die Fasern der Ventralwurzeln dagegen wachsen aus den Ganglienzelien der Ventralbörner herror. Andeutungen ventraler Neuralleisten für die Bildung der Ventralwurzeln wurden nur bei den Cyclostomen beobachtet.

Die Spinalnervenwurzeln entspringen häufig nicht als einfache Stämmchen, sondern namentlich die dorsalen als ein fächerartiges Bündel feıner Fädchen, die sich erst allmählich zu einem geschlossenen Nerv vereinigen. Der erste oder die beiden ersten Spinalnerven sind häufig etwas rudimentär, indem ihnen die Dorsalwurzel fehlen kann.

Wie bei den Acraniern fuhren die Dorsalwurzeln hanptsächlich sensible Fasern. Erst in der Neuzeit wurde erwiesen, daß sich ihnen acch motorische in geringer Zahl beimischen. Letztere werden als sympathische Fasern gedeutet, die wahrscheinlich von motorischen Ganglienzellen entspringen, die im Rückenmark, beiderseits des Centralkanals, einen kleinen Strang bilden (Nucleus paracentralis, s. Fig. 441, Fisch). Diese Fasern begeben sich demnach durch den Sympathicus zur Eingeweidemuskulatur. Die Ventralwurzeln dagegen führen vorwiegend motorische Fasern, welche zur Stammuskulatur treten, doch auch sympathische Fasern, die wie jene der Dorsalwurzel in den gleich zu erwähnenden Visceralast ziehen.

Die dorsalen und ventralen Wurzeln jedes Segments bleiben, wie erwähnt, nur bei Petromyzon unvereint; es hat sich also der Acranierzustand hier erhalten - Jeder dorsale und ventrale Spinalnerv teilt sich sehr bald in einen dorsalen und ventralen Ast, von welchem sich dio Zweige des dorsalen an der Haut, dio des ventralen an der Seitenrumpfmuskulatur verbreiten. Peripher können wohl auch Verbindungen dorsaler und ventraler Nervenverzweigungen eintreten.

Bei den übrigen Cranioten (auch den Myxinoiden) verschmelzen die beiden Wurzeln sehr bald. Viele Fische (besonders primitivere) zeigen die Vereinigang erst außerhalb des Wirbelkanals; bei den höheren Wirbeltieren geschieht sie dagegen schon im Rückgratskanal oder doch vor dem Austritt aus ihm.

Bei den Cyclostomen, den Chondropterygiern, Ganoiden (auch bei sonstigen Fischen nicht selten) entspringen die zusammengehörigen Wurzeln eines Segments nicht in derselben Querebene. Bei Petromyzon nach der gewöhnlichen Annahme die dorsalen etwas kopfwärts voul den ventralen, wobei die Wurzeln in der legel zwischen zwei neuralen Skeletbogen hindurchtreten, die ventralen z. T. jedoch auch durch die hinteren Neuralbogen des Segments. - Bei den Fischen dagegen liegen die Ventralwurzeln rostral, die dorsalen caudal; erstere treten bei den Haien in der Regel durch die Neuralbogen, die letzteren durch die Intercalaria (s. Fig. 88-90, S. 184). - Bei Ganoiden und Teleosteern herrschen in dieser Beziehung recht wechselnde Verhältnisse, indem beide Wurzeln teils zwischen den Neuralbogen austreten, durch eine gemeinsame oder gesonderte öffnungen (viele Teleostei), teils durch die Bogen (z. B. Perca), teils die dorsalen zwischen, die ventralen durch die Bogen (z. B. Cyprinus). - Die Spinalnerven der Tetrapoden verlassen den Spinalkanal gewöhnlich durch eine zwisehen de. Neuralbogen gelegene Öffnung (Foramen intervertebrale); bei einzelnen Säugern kann jedoch das Foramen gewisser Spinalnerven den Neuralbogen durchsetzen.

Im allgemeinen teilt sich jeder Spinalnerv der Cranioten nach sehr kurzem Verlauf in einen dorsalen und einen ventralen Ast (Ramus dorsalis und ventralis; s. Fig. 436). 
Die Verhältnisse, die sich bei den Myxinoiden und den primitiveren Fischen (Haie, Störe, gewisse Knochenfische, z. B. Cyprinus) finden (s. Fig. 437), machen es wahrscheinlich, $d a ß$ diese beiden $\ddot{A}$ ste ursprünglich so entstanden, daß sich jeweils die Rami dorsales und Rami ventrales der beicen primitiven dorsalen und ventralen Wurzeln zu einem gemeinsamen Ramus dorsalis und ventralis vereinigten. - Bei gewissen Knochenfischen (Gadiden) finden sich sogar pro Segment je zwei dorsale Wurzeln, jede mit einem Ganglion, und ebenso zwei ventrale Wurzeln, was vielleicht so aufzufassen ist, daß hier die Spaltung ,jeder Wurzel in Dorsal- und Ventralast schon vor dem Austritt aus dem Rückenmark erfolgte.

Die Rami dorsales und ventrales der Spinalnerven, welche gemischte Nerven sind, begeben sich in den Myosepten zur Seitenrumpfmuskulatur und der Hant. Bei den Teleosteern treten die aufeinander folgenden Dorsaläste häufig durch längsverlaufende Rami communicantes in' Verbindung.

Von jedem Ramus ventralis zweigt sich kurz nach seinem Ursprung stets ein Ästchen ab, seltner zwei bis mehr (Rami viscerales s. communicantes), welche dicht um die Wirbelsäule anf deren Ventralseite herumbiegen. Wie wir später sehen werden, geht ans ihnen das sympathische Nervonsystem hervor.

Der Ramus ventralis der Fische (speziell der Teleosteer) gibt kurz nach scinem Ursprung noch einen sog. Ramus medius $a b$, der im Horizontalseptum zwischen dem dorsalen und ventralen Seitenrumpfmuskel verläuft, weiter außen jedoch den Fleischgräten folgt. Er versorgt besonders den dorsalen Seitenrumpfmuskel, jedoch auch die Haut. - Gewöhmlich geht vom Ursprung des Spinalwerven der Cranioten auch ein Nervenăstchen aus, welches in den Spinalkanal eindringt und die Rückenmarkshäute versorgt (Ramus meningeus).

Die Ventraläste innervieren die ventrale Seitenrumpfmuskulatur, $d$. h. bei den Tetrapoden den aus ihr hervorgehenden Teil der Stammuskulatur, also alch die Muskulatur der Extremitäten; sie sind deshalb in der

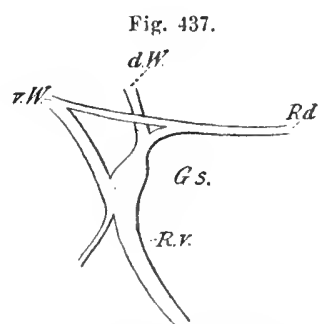

seylli u in (Hai). Dorsaler Te eines Spinalnerven. $d \mathrm{JV}$ dorsale, $v v$ ventrale Wurzel. Gis Spinal. ganglion. Rd Ramus dorsalis. liv Ramns ventralis (n. v. Ihpreing 1,78 aus GegENBaur j\$98). Regel stärker als die Dorsaläste. Diejenigen Ventraläste, welche die Extremitäten versorgen, zeigen stets das eigentümliche, daß sie (bzw. ibre zur Flosse gehenden Rami pterygiales) sich in ihrem Verlauf durch zwischen ihnen auftretende Anastomosen zu einem Geflecht (Plexus) verbinden, aus welchem erst die zur Gliedmaße tretenden peripheren Nerven hervorgehen.

Plexus cervicobrachialis (Geflecht der Vorderextremitä). Bei den Chondropterygiern verbinden sich auf diese Weise meist eine recht erhebliche Zahl der vordersten Spinalnerven (2-10 bei Haien, bis 26 bei Rochen) zu einem Plexus der Vorderextremität (s. Fig. 438). Wie wir später sehen werden, gesellen sich demselben jedoch noch davorgelegene rudimentäre Spinalnerven bei, welche innerhalb des Schädels von der Medulla oblongata entspringen (sog. Spinooccipitalnerven). Von diesem Plexus cervicobrachialis, über dessen Verlauf bei den Fischen gleichfalls noch später zu berichten sein wird, entspringt ein mehr vorn gelegener Nervenstrang, der die sog. hypobranchiale Muskulatur versorgt und im allgemeinen von weiter vorn gelegenen Spinalnerven gebildet wird, dem jedoch auch häufig 
Zweige von hinteren zugeführt werden. Der Anteil des Plexus, welcher diesen Strang hervorgehen läßt (bis 25 Spinalnerven bei Rochen), wird als Plexus cervi-

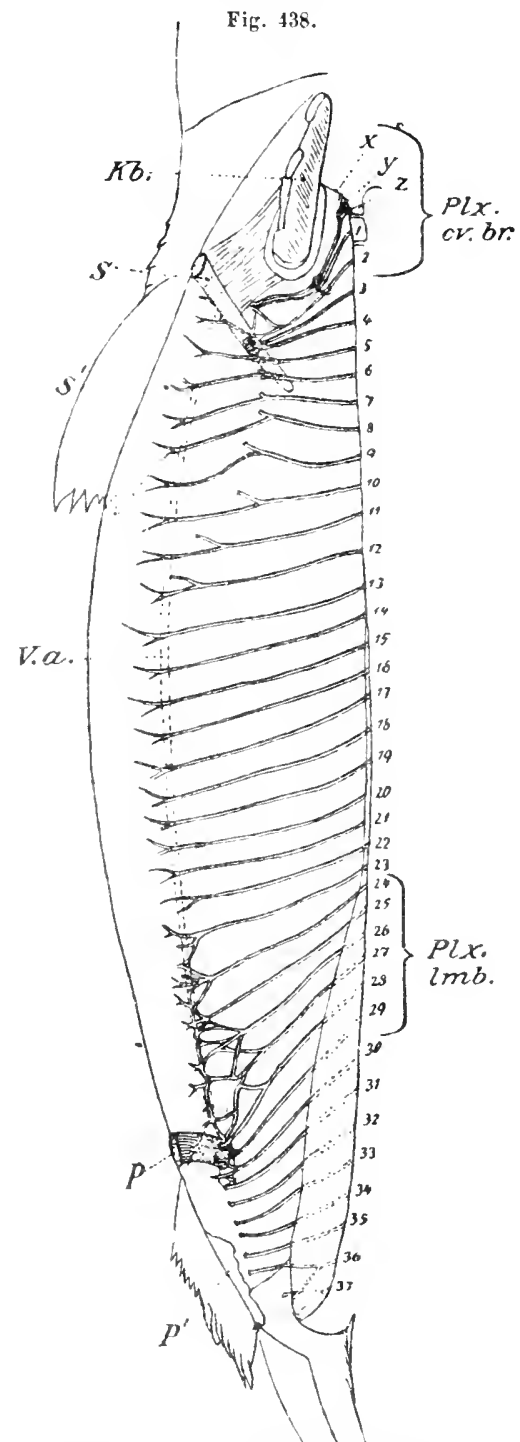

spinax niger. Ventralabte der Spinalnerven der rechten Seite von der Innenfläche der Bauchhöhle gesehen. $x, y, z$, Occipitalnerven. $p$ Beckengürtel. 1 Bauchflossa. $S$ Schultergūrtel. S1 Brustflosse. Die Urniere in Umrissen angedentet. Die Nerven $1-4$ geher in den Plexus brachialis, die $27-29$ in den Plexus lumbosacralis ein (n. Brads la9s ans Gegenbatr, Vergl. Anat. d. Wirheltiere 1895). calis bezeichnet; der weiter hinten gelegene Teil, an dessen Bildung sich jedoch auch eine verschiedene Zahl der Spinalnerven des Plexus cervicalis beteiligen kann, bildet den Plexus brachialis, welcher die Nerven zum Schultergürtel und der Brustflosse entsendet, die sich als dorsale und veutrale Äste anf deren Dorsal- und Ventralfläche verbreiten. Zu den sich nach hinten ungemein weit ausdehnenden Brustflossen der Rochen (in gcringerem Grad auch der Haie) treten jedoch noch mebr oder weniger zablreiche Zweige candalwärts folgender Ventraläste, die an der Bildung des Plexus brachialis nicht teilnehmen.

Durch die erhebliche Zabl der zum Plexus cervicobrachialis zusammentretenden vorderen Ventraläste schließen sich die Ganoiden und Ceratodus an die Chondropterygier an (bis sechs bei Acipenser, neun bei Amia, Fig. $439_{1}$ ). Bei den Dipnoi scheinen die Plexus cervicalis und brachialis nicht mehr verbunden zu sein. Der Plexus der Teleosteer (s. Fig. $439_{2}$ ) ist meist erheblich reduziert, indem er gewöhnlich nur von den drei vordersten Spinalnerven gebildet wird, die jedoch manchmal noch mit den beiden folgenden Verbindungen eingehen. - Das Verbreitungsgebiet der Plexus cervicalis und brachialis bleibt bei allen Fischen das gleiche und erhält sich auch im wesentlichen so bei den Tetrapoden.

Die Amphibien besitzen noch dengemeinsamen Plexus cervicobrachialis, der bei den Urodelen gewöhnlich (s. Fig. $493_{3}$ ) aus den fünf bis sechs vordersten Spinalnerven hervorgeht, bei den Anuren da-

gegen nur aus drei (selten vier). Beide Plexus sind gewőhnlich etwas selbständiger, d. h. weriger innig vereinigt als bei den Fischen. 
Die beiden Plexus der Amnioten haben sich rollständig von einander gesondert. Der vordere Anteil des ebemaligen Plexus cervicalis geht, wie es scheint, ursprünglich ans drei ventralen Spinalnervenwurzeln hervor und wurde in den Schädel aufgenommen, ans dessen Occipitalteil er als sog. XII. Hirunerv (Nervus hypoglossus) austritt; er soll daher später bei den Hirnuerven besprochen werden. $\mathrm{Da}$ er sich mit den folgenden, ersten bis dritten eigentlichen Spinalnerven (Cervicalnerven) verbindet, so ist ein Plexus cervicalis auch hier entwickelt ${ }^{1}$ ).

Der Plexus brachialis der Sauropsiden umfaBt eine recht verschiedene Spinalnervenzahl, von zwei bei den Schlangen bis drei, vier und fiunf bei den übrigen Reptilien; bei den Vögeln vier bis sechs. Daß sich bei den Reptilieu mit verkümmerter Vorderextremität (Schlangen, schlangenartige Saurier) ein rudimentärer Plexns brachialis erhielt, ist interessant. Vie Ordnungszahl der
1. Amia.
2. Mullus.
3. Necturus.
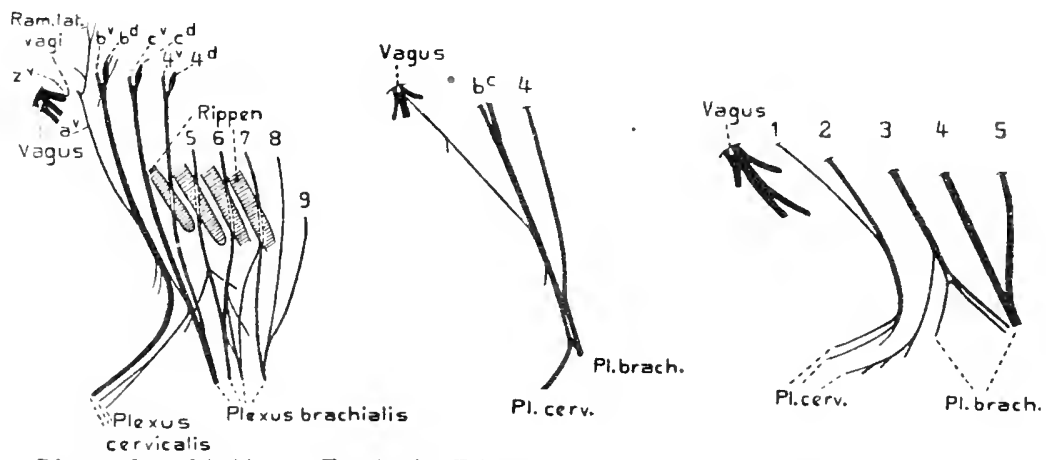

Linker Plexus brachialis, 1. Fon Amia (Holosteer). 2. Von Mollus (Teleosteer). 3. Von Necturus (perennibranchiate Urodele). $a v, b v, c v$, Occipitalnerven (Ventrale Wurzeln), ad, $b^{d}, c^{d}$, dorsale Wurzeln. * u. ff. die folgenden Spinalnerven (n. M. Fórbrisger 1s97).

in den Plexus brachialis eingehenden Nerven erfährt von den squamaten Reptilien an durch die Reihe dex Placoiden und weiterhin bei den Vögeln eine fortschreitende candale Verschiebung.

Bei den Sauriern beginnen die Brachialnerven mit Nr. 2, 3, 4, 5 und 6 (selten 7) der Spinalnerven; bei den Placoiden mit 6 und 7 ; bei den Vögeln mit 7 (Cypselus) und schließlich immer weiter caudal bis mit 22 (Cygnus). Daß diese Verschiebung durch die allmähliche Ausbillung und Verlängerung der Halsregion und die damit verbundene Rückwärtsverlagerung der Vorderextremität hervorgerufen wird, ist leicht ersichtlich.

Der Plexus brachialis der Säuger umfaßt gewöhnlich fünf Nerven, die vier hintersten Hals- (Cervical-) und den vordersten Thoracalnerven; er kanu sich jedoch selten bis auf sieben Nerven erhöhen, oder auf vier erniedrigen. - Allge-

1) Die Unterscheidung der Spinalnerven auf Grund der Regionen der Wirbelsäule in IIals (Cervical-), Brust (Thoracal-), Lumbal , Sacral- und Caudal (Coccygeal) -Nerren geschieht so, daß jeder binter einem Wirbel austretende dem bezïgliwhen Wirbel zugerechnet wird. Da nun der erste Spinalnerv zwischen dem Schädel und dern ersten Wirbel (Atlas) austritt, so kommt auf die Halsregion ein Ners uehr als sich Wirbel tindell, bei den Mammalia also z. B. acht. 
mein gilt jedoch für alle diese und sonstige Plexusbildungen, daß eine erhebliche Variabilität, sogar bei derselben Spezies, bestehen, ja sich nicht selten auf beiden Seiten des gleichen Individuums aussprechen kann.

Aus dem Plexus brachialis der Tetrapoden entspringen eine Anzahl teils rein sensibler, teils gemischter Nerven, welch letztere die Muskulatur des Schulter-

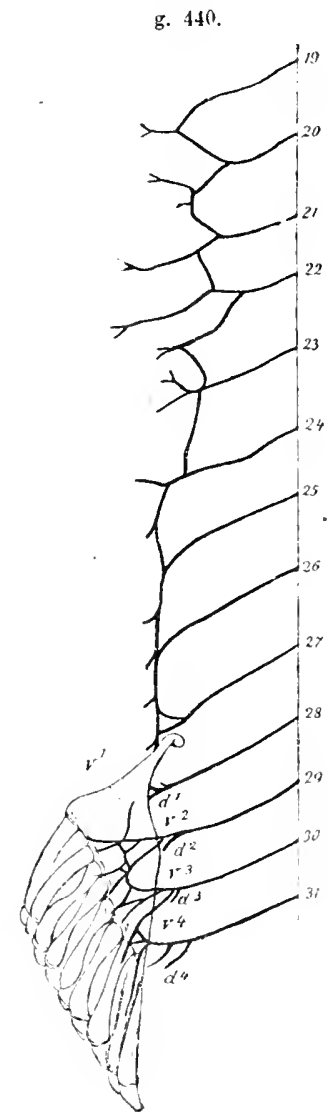

Acipenser sturio. Dieventralen Äste der zuin 15.-31. Wirbel gehörigen Spinalnerven, mit dem sie rereinigenden Collector. Das knorplige Skelet der hinteren Extremitât eingezeichnet, sowie die zur Bauchflosse gehen den dorsalen $\left(d^{1}-d^{3}\right)$ und ventralen $\imath^{1}-\imath^{*}$ Nervenzweige des Plexas (n. v. DavinuF alls GLGeNBaUr, Vergl. Anat. d. Wirbeltiere 1898). gürtels und der freien Extremität versorgen. Unter den letzteren treten auf der Ventralseite der Extremität der Nervus medianus und ulnaris zur Versorgung der Beugemuskeln besonders hervor, während die Dorsalseite (Streckmuskeln) nur durch den ansehnlichen N. radialis versorgt wird.

Plexus lumbosacralis. Die Rami pterygiales der Ventraläste, welche zur hinteren Extremität gehen, bilden in gleicher Weise einen Plexus lumbosacralis, so genannt, weil er in der Regel aus Nerven der Lumbal- und Sacralregion hervorgeht. Bei den primitiven Fischen (Chondropterygii, Ganoidel und Ceratodus) gehen recht zablreiche Nerven in ihn ein (bei Haien 3-14, letzteres bei Chlamydoselachus, bei Acipenser bis 13, s. Fig. 440, Holostei etwa 9-10, Ceratodus 12). Die hinteren derselben treten direkt zur Flosse; eine verschiedene Zahl der vorderen dagegen (Haie zwei bis neun), welche noch Zweige zur Seitenmuskulatur schicken, verbinden sich peripher durch einen regelmäßiger bis unregelmäßiger gebildeten Längsnerv (Collector), der sich hinten in den Plexus der direkt zur Flosse tretenden Nerven fortsetzt. Bei den Knochenganoiden ist dieser Collector stark verkürzt, wodurch der gesamte Plexus einheitlicher wird. Eine kleinere oder größere Zahl auf den Plexus folgender freier Ventraläste der Chondropterygier (bis 14 ( hlatmydoselachus) senden noch $\mathrm{Zweige}$ zur Bauchflosse. Die zur Flosse tretenden Nerven teilen sich wieder in Ventral- und Dorsaläste, welche die entsprechenden Flossenflächen versorgen.

Die Bildung des zuweilen recht langen Collectors wird meist als ein Beweis für die allmähliche Wanderung der Hinterextremität in caudaler Richtung angesehen. - Auch auf der dorsalen und ventralen Flossenhälfte selbst können sich längsverbindungen der zutretenden Nerven bilten (Haie); in einen derselben setzt sich der Collector fort.

Bei den Teleostcem verringert sieh die Zahl der Nerven des Plexus sehı (z. 13 bis zwei bei Cyprinus). - Von Interesse ist das Verhalten derjenigen Knochenfische, deren Banchflossen in die Region der Brustflossen vorgerïekt sind; ihre Innervierung geschieht durch weit vorn gelegene, jedoch hinter dem Plexus bra- 
chialis entspringende Spinalnerven, so den vierten und fünften, dritten und vierten, oder fünften und sechsten. Ein Collector, welcher etwa auf die rostrale Wanderung dieser Bauchflossen hinwiese, findet sich nicht.

Bei den Tetrapoden tritt eine Collectorbildung meist nicht mehr auf, dagegen sondert sich der Plexus häufig in einen vorderen (lumbalen oder cruralen) und einen hinteren sacralen (oder ischiadischen) Anteil. Im allgemeinen bilden die Nerven der Sacralregion den Plexus, dem sich jedoch noch eine Anzahl der hinteren Lumbal- und der vorderen Caudalnerven (prä- nnd postsacrale Nerven) beigesellen können. Die Zahl der Nerven bleibt bei den Amphibien gewöhnlich mäßig, meist drei bis vier (bei den Urodelen zuweilen auch fünf, s. Fig. 444, S. 620) Der Plexus ist recht einheitlich, so daß sich ein lumbaler und sacraler Abschnitt nur durch den Abgang der beiden Hauptnerven der Extremität, des vorderen $N$. sacralis (s. femoralis anterior) nnd des hinteren $N$. ischiadicus, des stärksten Nerven der Extremität, unterscheiden lassen.

Die Zahl der am Plexus teilnehmenden Nerven erhöht sich bei den Sauropsiden, womit gewöhnlich auch eine schärfere Scheidung des lumbalen und sacralen Anteils verbunden ist. Beide hängen zwar meist durch einen Verbindungsnerv zusammen, können sich aber zuweilen völlig isolieren. Die Reptilien besitzen fünf bis sieben Nerven des Ploxus, während sich ihre Zahl bei den Vögeln bis auf zehn erhöhen kann, von welchen auf den Plexus lumbalis drei (zwei) bis vier (fünf), den Plexus sacralis vier bis sechs (sieben) kommen.

Auch bei den Säugern gehen zahlreiche, nicht selten sämtliche Lumbal- und Sacralnerven in den Plexus ein, der bis elf Nerven aufnehmen, sich andrerseits aber bis auf fünf beschränken kann. Die beiden Abschnitte sind meist gut differenziert und der Plexus lumbalis, wie stets, besonders dadnuch charakterisiert, daß von ihm als ansehnlichste Nerven der N. femoralis (s. cruralis) und der N.opturatorius ausgehen (abgesehen von untergeordneten, die zur Bauchmuskulatur ziehen), während vom Sacralplexus der stärkste Körpernerv (N. ischiadicus) entspringt. Der Femoralis versorgt Streckmuskeln, der Obturatorius und auch großenteils der Ischiadicns gehen zn Beugemuskeln der hinteren Extremität.

Von den Amphibien ab tritt caudal vom Plexus lumbosacralis noch ein kleines Geflecht auf', welches gewöhnlich durch Verbindungsschlingen mit dem Sacralplexus zusarmenhängt. Dieser Plexus pudendus geht aus hinteren Sacral- und vorderen Caudalnerven hervor. Von ihm sondert sich zuweilen noch ein hinterster Plexus coccygeus ab. Die rom Plexus pudendus entspringenden Nerven versorgen namentlich die Muskeln der Kloake, de: Afters, des Penis und der Vagina, die Harnblase, sowie die Haut der Analgegend.

Natürlich variiert auch der Plexus lumbosacralis sehr, wie es schon für den Brachialplexus herrorgehoben wurde. Daß die in ihn eingehenden Nerven hinsichtlich ihrer Ordnungszahl sehr verschieden sind, geht schon aus der sehr verschiedenen Ordnungszabl der Sacralwirbel hervor. Gerade die Variationen in Bereich des Plexus lumbosacralis beweisen, daß seine rerschiedene Lage, wie die des Beckens und der Extremitäten, durch Wanderung des Beckens und der Extremität herrorgerufen wurde, nicht etwa durch Einschaltung neuer Wirbel (vgl. S. 215). 
Sympathisches (viscerales) oder Eingeweidenervengystem.

Schon bei gewissen Wirbellosen fanden wir Teile des Centralnervensystems, die vorwiegend zur Innervierung gewisser Darmabschnitte und sonstiger Eingeweide bestimmt waren, und daher als Eingeweide- oder Darmnervensystem (häufig auch als sympathisches) bezeichnet wurden. Analoge, jedoch viel kompliziertere Einrichtungen haben sich bei Wirbeltieren entwickelt. Was bei diesen als sympathisches System bezeichnet wird, beschränkt sich keineswegs auf die Versorgung des Darms, sondern dehnt seine Beziehungen auch auf die ïbrigen Eingeweide, namentlich die Driisen, den Gefäßapparat, Atmungsorgane, Geschlechtsorgane usw. aus,

Fig. 441 .
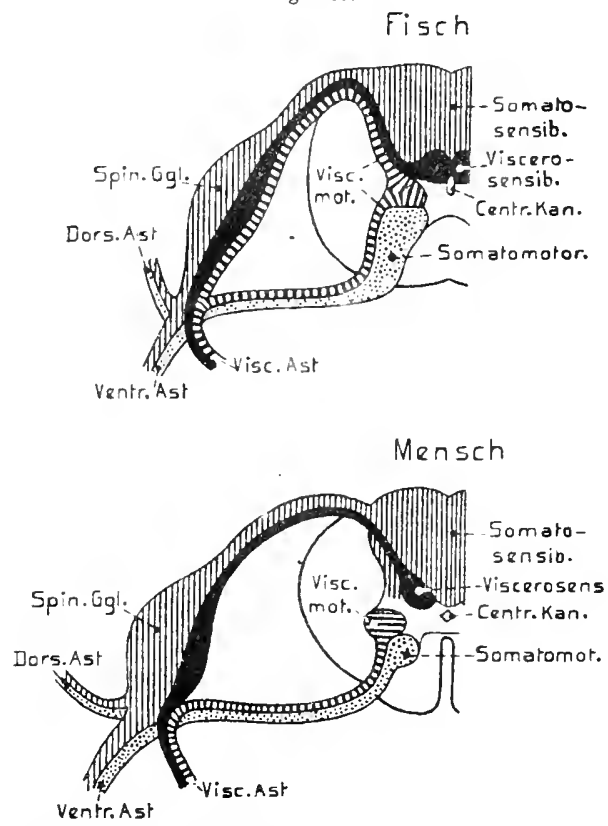

Schematisehe Querschnitte durch das Rückenmark eines Fisches und des Menschen, mit den Wurzeln eines Spinalnerven, um den Anteil, welchen die somatischen und die sympathischen (visceralen) Fasern an dem Aufbau der Wurzeln und den Ästen des Spinalnerven nehinen, zu zeigen (n. Johistoy 1910). steht jedoch auch dureh Vermittlung sympathischer Fasern, die sich den Spinalnervenzweigen beimischen, mit der Haut und ihren Organen in Verbindnng. Die sympathischen Fasern innervieren als motorische oder excitatorische die meist glatte Muskulatur der genannten Organe oder die Driisenzellen, nehmen andrerseits aber anch als sensible Fasern Reize aus diesen Organen auf, welche sie oder andere Organe reflektorisch erregen, d. h. gewöhnlich obne Bewußtwerden dicses Vorgangs. Andrerseits treten jedoch aus dem Hirn und dem Rüickenmark auch markhaltige motorische und sensible Fasern in die sympathischen Nerven ein. - Die im besonderen als sympathische bezeichneten $\mathrm{Fa}$ sern, d. h. solche, welche im sympathischen System von sympathischen Ganglienzellen entspringeu, sind bei siimtlichen Cranioten meist durch Mangel oder ganz geringe Entwicklung des Marks ausgezeichnet; nur bei den Cyclostomen tritt dieser Unterschied nicht hervor, da ihre Nervenfasern iiberhaupt marklos sind. Allo diese eigentlichen sympathischen Fasern sollen wahrscheinlich motorischer Natur sein, während die sensiblen des sympathischen Systems (viscero-sensible) cerebro spinaler Herkunft, also markhaltig sind. Letztere Fasern entspringen aus einer ventralen Partie der Dorsalhörner des Rückenmarks, den sog. Clarkschen Säulen (s. Fig. 441). Außerdem treten zum sympathischen System jedoch auch noch cerebrospinale motorische Fasern, welche aus Kernen der Ventralbürner des Rückenmarks hervorgehen, die ventral von den eben erwihnten Cłarksschen Säulen liegen. Bei niederen Verte- 
braten ziehen derartige viscero-motorische Fasern durch beide Wurzeln der Spinalnerven, bei den Mammalia nach manchen Angaben nur in den Ventralwurzeln (s. Fig. 441). - Eine allgemeine Eigentümlichkeit der symiathischen Nerven ist, daß sich ihre Ausbreitungen gewöhnlich den arteriellen Blutgefäßen anschließen; weiterhin ibre große Neigung zur Bildung von Geflechten mit eingelagerten Ganglien. Es erscheint daher als ein besonderer Charakter dieses Systems, daß seine Nervenfasern die zu innervierenden Zellen meist nicht direkt versorgen, sondern in ihrem Verlauf durch Einschaltung von einer, vielleicht manchmal auch zwei sympathischen Ganglienzeilen unterbrochen sind. Die peripheren Ausbreitungen der sympathisehenNerven verbinden sich sehr häufig mit den Verzweigungen des Nervlis vagus.

Von den Ventralästen der dorsalen Spinalnerven des Branchiostoma gehen, wie früher dargelegt wurde (s. S. 607), Visceraläste aus, die, soweit bekanut, wesentlich motorischer Natur sind. Es.wurde auch früher hervorgehoben, daß diese Äste längs des Dorsalrands der Peribranchialhöhle einen Längsnerv bilden, der zuweilen dem gleich zu besprechenden Hauptteil des sympathischen Systems der Cranioten, dem sog. Grenzstrang, rerglichen wurde, was jedenfalls sehr problematisch erscheint.

Wir wollen nun den Aufbau des sympathischen Systems in seinen Grundzügen verfolgen.

Bei Petromyzon (die Myxinoiden sind in dieser Beziehung wenig erforscht) ist ein

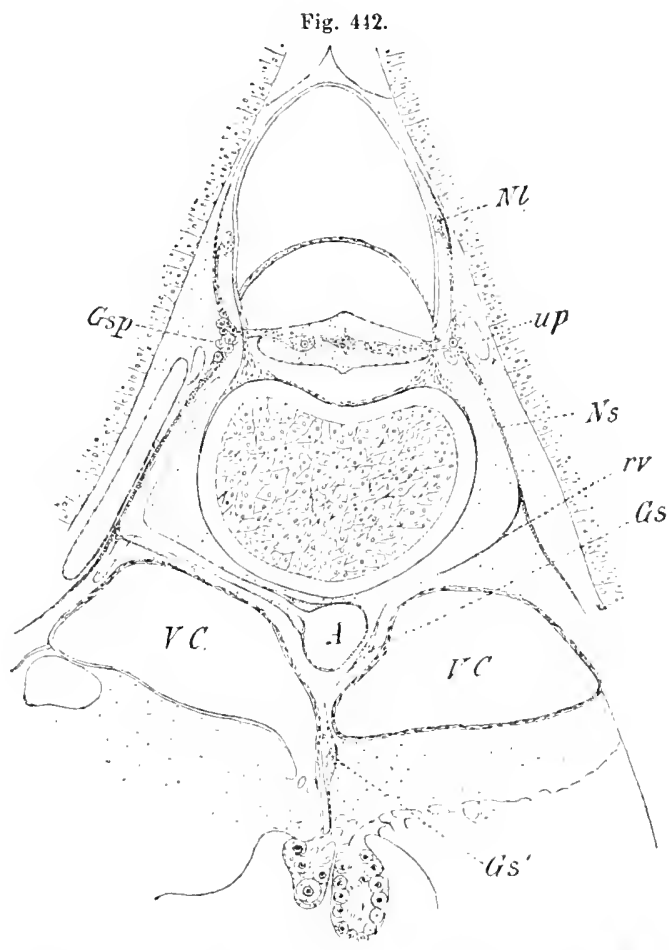

Petromyzon planeri (I arve, Ammocoetes). Quersclinit durch Chorda, Rückenmark und die angrenzenden Partien. $A$. Aorta. Gs. sympathisehes Ganglion. Gsp. Spioalganglion. $\mathrm{Nl}$. Ram. lateralis vagi. Ns. Spinalnerv. IC. Vena cava. rv. Visceralast. $u p$. Parietalnerv (nach JutiN 1887 ans GEGENBAUR, Vergl. Anat. d. Wirbeltiere 1898).

sympathisches System einfachster Form wohl entwickelt. Von der Herzgegend ab bis nahe an den After findet man an der Dorsalwand der Leibeshöhle, ventral von der Chorda, segmental sich wiederholende kleine Ganglienpare, die jederseits zwischen der Aorta und den Cardinalvenen liegen (Fig. 442, Gs). Die Ganglicnpaare liegen je in der Region der Spinalnerven und jedes empfängt von den Ventralïsten des zugehörigen dorsalen und ventralen Spinalnerven einen zarten Ast $(r v)$, so daB also die sympatbischen Ganglien einen gemischten Charakter besitzen. In der Längsrichtung sind die jederseitigen Ganglien nicht verbunden. Von ihnen entspringen Nervenfädchen, in denen auch weitere kleine Ganglien $\left(G s^{1}\right)$ 
auftreten. Diese sympathischen Nerven treten zu den verschiedensten Eingeweiden, wo sie netzartige feflechte mit kleinen Ganglien formieren (Herzgeflecht, Geflecht des Vorderdarms, jedoch sind solche auch in der Leber, den Urnieren und den Genitalorganen nachgewiesen).

Das sympathische System der Gnathostomen erreicht eine höhere Fntwicklungsstufe, indem die im Prinzip sich metamer wiederholenden, der Ventralseite

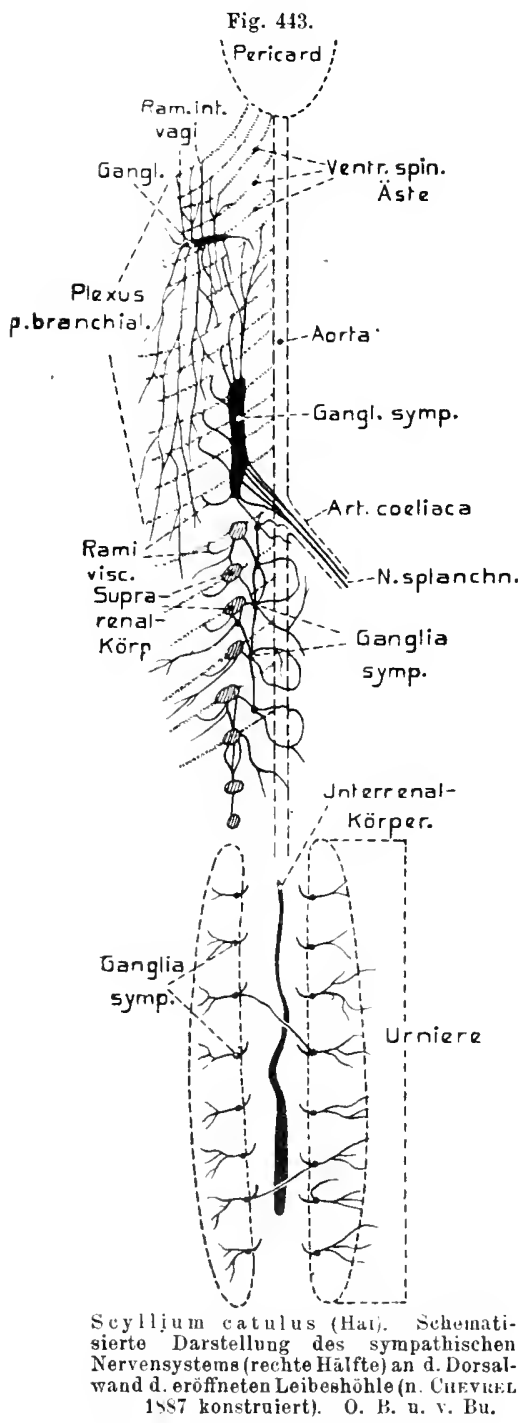
des Achsenskelets angelagerten Ganglienparre durch $\mathrm{Z}$ wischenstränge jederseits za einem Längsnervenstrang verbunden sind, den sympathischen Grenzsträngen (Trunci sympathici). Die beiden Grenzstränge ziehen im allgemeinen der ganzen Wirbelsänle entlang, erstrecken sich jedoch auch in die Schädelregion und können hier mit den Hirnnerven in Verbindung treten, so daß sich ein Kopf- nnd ein Rumpfteil des Sympathicns unterscheiden läßt. Wie schon früher bemerkt, entspringt von jedem Ventralast der Spinalnerven ein Ramus visceralis (oder R. communicans, zuweilen jedoch auch mehrere), der auf die Ventralseite der Wirbelsäule umbiegt und hier in das sympathische Ganglion des betreffenden Segments iibergeht. - Die Bedeutung der Grenzstränge ist jedenfalls darin zu suchen; daß die Fasern, welche den sympathischen Ganglien durch die Rami viscerales zugefïhrt werden, andrerseits aber auch die in den Ganglien selbst entspringenden sympathischen Fasern, in benachbarte und entfermere Segmente des Nervensystems überzutreten vermögen. - Von den sympathischen Ganglien, zuweilen auch den sie verbindenden Abschnitten der Grenzstränge, entspringen dann die peripheren sympathischen Nerven.

Bei den Chondropterygiern finden sich insofern noch primitive Verbältnisse, als eigentliche geschlossene Grenzstränge nicht entwickelt sind, sondern an ihrer Stelle beiderseits ein Geflecht feiner sympathischer Nerven mit eingeschalteten meist sehrkleinen Ganglien. Ein eigentlicherKopfteil fehlt noch völlig. - Bei den Haien (Fig. 443) beginnt das sympathischeSystem vorn, dicht hinter den Kiemen, jederseits mit einem eigentümlichen Plexus postbranchialis, dessen Centrum gewissermaßen von einem ansehnlichen Ganglion gebildet wird (den Rochen fehlt dieser Plexus). Der Plexus entspringt hauptsächlich aus zahlreichen Ästchen 
des Ramus intestinalis des Vagus, erhält jedoch anch Zweige vom Plexus cervicobrachialis und den ersten Spinalnerven. Er steht in Verbindung mit den Wurzelu des vordersten ansehnlichen länglichen Sympathicusganglions, welche aus vorderen Spinalnerven entspringen. An letzteres Ganglion schließt sich jederseits, längs der Cardinalvenen, ein feiner Längsplexus an, welcher die Visceraläste der Spinalnerven aufnimmt, die mit eigentümlichen Körpern in Verbindung stehen, den sog. Suprarenalkőrpern, welche erst bei den Nebennieren genauer zu betrachten sind. Diesem Längsplexus sind jederseits kleine sympathische Ganglien ziemlich unregelmäßig eingestreat. In der hinteren Rumpfregion wiederholen sich die kleinen Ganglien ziemlich regelmäßig metamer am Innenrand der Urnieren, sind jedoch hier nicht mehr durch einen Plexus verbunden. Ein Candalteil des sympathischen Systems soll völlig fehlen. - Von dem vordersten sympathischen Ganglion entspringen zahlreiche Nervenbündel, welche zusammen den Norius splanchnicus bilden, der die Arteria coeliaca begleitet und mit dem Intestinalast des Vagus anastomosiert.

Da das sympathische Nervensystem der Teleosteer verhältnismäßig genan bekannt ist, schließen wir gleich einige Bemerkungen übor dasselbe an. Gegenüber dem der Chondropterygier verrät es eine höhere Ausbildung dadurch, daß sich längs der ganzen Wirbelsäule zwei kontinuierliche Grenzstränge hervorgebildet haben, mit regelmäßig den Spinalnerven entsprechenden Ganglien, und daß sich ferner ein gut entwickelter Kopfteil findet. Die Grenzstränge sind in der Rumpfregion gewöhnlich dentlich parig gesondert, obgleich sie bänfig dureh Anastomosen zusammenhängen. Im hinteren Rumpfabschnitt vereinigen sie sich jedoch zuweileu za einem gemeinsamen Strang, was bei den Aalen (Apodes) fứr den ganzen Rumpf gilt. Der gut entwickelte Caudalabschnitt, der im Kanal der Hämalbogen verläuft und bis zur Caudalflosse reicht, erhält sich stets paarig und ənastomosiert an seinem Hinterende mit einem von den Ventralästen der letzten Spinalnerven gebildeten Candalplexus. - Der Kopfteil besteht in einer Fortsetzang der Grenzstränge an der ventralen Schädelseite und besitzt gleichfalls eine Anzahl Ganglien, die sich im allgemeinen den Ganglien des Nervus trigeminus, facialis, glossopharyngeus, vagus und dem Plexis cervicobrachialis dicht anlegen und aus ihnen Wurzeläste erhalten. Außerdem entsenden sie jedoch auch sympathische Ästchen in diese Nerven oder ihre Äste, so z. B. zu den Branchialästen des Vagus. Das vorderste Kopfoanglion gibt auch ein Ästchen zum Ganglion ciliare. In ähnlicher Weise senden auch die sympathischen Rumpfganglien z. 'T. Ästchen in die zugehörigen Spinalnerven. Bei den Apodes ist die Zahl der sympathischen Kopfganglien anf zwei reduziert. - Vom hintersten Kopfganglion oder dem ersten bis zweiten Rumpfganglion entspringen die Nervi splanchnici, die an der Arteria coeliaco-mesenterica einen reichen Plexus coeliacus mit Ganglieneinlagerung bilden, von welchem Nerven zu den verschiedensten Eingeweiden gehen, dabei auch sekundäre Plexus bildend. An der Bildung des Plexus coeliacus sowie der sekundären beteiligen sich die Verzweigungen des Intestinalasts des Vagus reichlich. - Von der Fortsetzung der Grenzstränge entspringen namentlich Nerven zu den Körpermuskeln, den Nieren, Geschlechtsorganen und der Harnblase. 
Die an der Aorta hinziehenden Grenzstränge der Amphibien erinnern bei den ichthyoden Urodelen durch plexusartige Bildung (zwei Stränge jederseits) zuweilen noch an die oben geschilderten Verhältnisse der Chondropterygier. Bei den Salamandrinen und Anuren ( $\mathrm{Fig} .444$ ) werden sie dagegen zu gesehlossenen Strängen. Die Fischähnlichkeit verrät sich a ach darin, daß die Grenzstränge der Urodelen noch einen großen Teil des caudalen Hämalkanals durchziehen, welcher Abschnitt den Anuren naturlich fehlt. Ein Kopfteil ist in verschiedenem Grad ausgebildet,

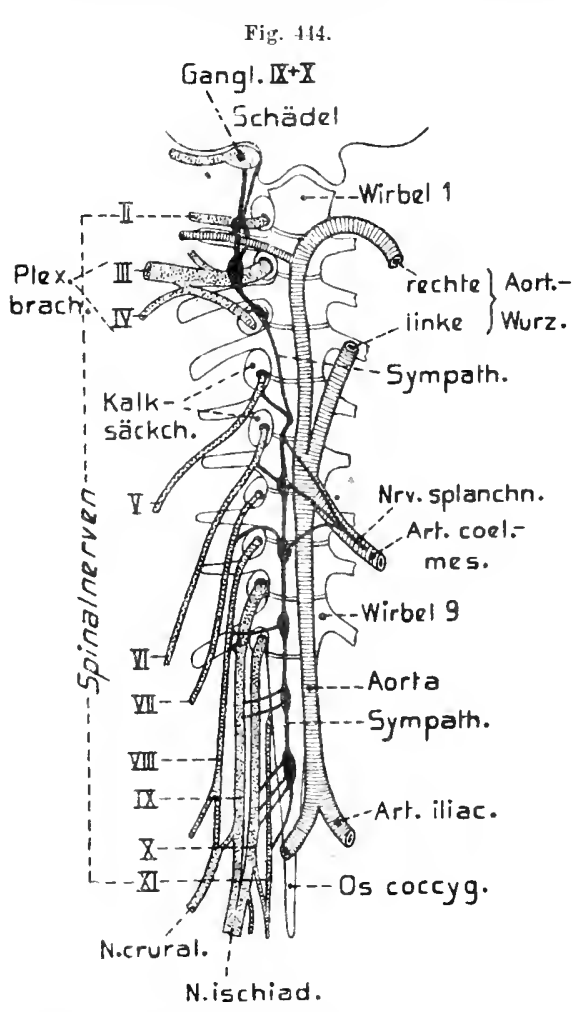

$\mathrm{R}$ a $\mathrm{n}$. Der rechte Grenzstrang des Sympathicus in seinem Verlauf an der Ventralseito der Wirbelsäule; etwas schematisch. Daneben noch die Ventraläste der Spinalnerven, sowie deren Plexus brachialis und lnmbosacralis eingezeichnet. Von den aus dem Grenzstrang entspringenden Nerven sind nur die $N$. splanehnici angegeben (n. GAUPP 1896; etwas vereinfacht). v. Bn. indem die Grenzstränge der Salamandrinen vorn vom GlossopharyngeusVagusganglion entspringen, bei den Ichthyoden jedoch bis zum Facialisganglion ziehen können. Auch bei den Anuren stehen sie mit dem Vagusganglion und dem gemeinsamen Ganglion für die Nerven V-VII in Verbindung. - EigentümlicheVerhältnisse haben sich bei gewissen Ichthyoden (besonders Menobranchus, s. Fig. 445) gebildet, indem hier neben den beiden eigentlichen Grenzsträngen $(g)$ jederseits noch ein tiefer gelegener collateraler entstanden ist $(s c)$, welcher mit der Arteria vertebralis in dem Vertebralkanal verläuft, der von den beiden Wurzeln der Querfortsätze gebildet wird. Diese collateralen Strïnge gehen aus accessorischen Rami communicantes collaterales ( $\mathrm{rcc}$ ) der spinalen Ventraläste $(n s p)$ hervor und hängen mit deu Hauptgrenzsträngen durch Rami intermedii $(r i)$ zusammen; sie zeigen auch Ganglien und Geflechtbildung.

Die Ammioten sind im allgemeinen mit einem gut entwickelten Kopfteil des

Sympathicus versehen, der meist von einem Paar sympathischer Ganglien in der vordersten Hals- oder der hinteren Schädelregion entspringt, die in der Regel wie bei den Sängern als Ganglia cervicalic superiora bezeichnet, jedoch z. T. auch anders als bei letzteren beurteilt werden. Bei Vögeln und Säugern sind sie keine primären sympathischen Ganglien, sondern Verschmelzungen vorderer sympathischer Hals- und sympathischer Hirnnervenganglien. Von diesen Ganglien erstreckt sich der Kopfteil nicht als ein einfacher Strang rostralwärts, sondern in Form von Verbindungen mit den Hirnnerven (Trigeminus, Facialis, Glossopharyngeus, Vagus, 
Hypoglossus). - Auch sympathische Ganglien finden sich im Kopfteil.`So gehört hierher bei den Sängern als vorderstes das $G$. sphenopalutinum, das dem Ramus maxillaris des Trigeminus zugerechnet wird, während die übrigen sog. sympathischen Ganglien, die sich bei Säugern und z. T. auch bei Niederen im Kopfteil noch finden (G. oticum, ciliare, submaxillare und sublinguale, vgl. Fig. 446, S. 628), als eigentliche sympathische Grenzstrangganglien zweifelhaft sind. Bei den Sängern wird die vordere Fortsetzung des Ganglion cervicale supremum namentlich von einem Plexus gebildet, welcher die Carotis interna umflicht.

Die eigentlichen Grenzstränge der Halsregion sind zuweilen ganz ohne Ganglien, wie meist bei den Reptilien. Bei Säugern finden sich außer dem schon erwähnten Ganglion cervicale supremum meist 110ch zwei Halsganglien, zuweilen auch a lur eins (doch werden embryonal acht angelegt). Das hintere derselben (Ganglion cervicale inferius) kann mit einem bis mehreren der vorderen Brustganglien verschmelzen und wird dann sehr anselnnlich. - Brustganglien finden sich stets; bei den Säugern ist das vorderste besonders groß und zuweilen durch Vereinigung mehrerer gebildet. - Bauchganglien sind bei den Reptilien nicht immer deutlich entwickelt. - Daß bei den geschwänzten Formen ein Caudalteil, entsprechend dem der Urodelen, vorkommt, ist wahrscheinlich, jedoch wenig untersucht. - Eigentïmlich verhalten sich die Schlangen (wenigstens Python), da hier im Rumpf ein Grenzstrang fehlt; die Rami viscerales verlaufen einzeln zu deu Eingeweiden.

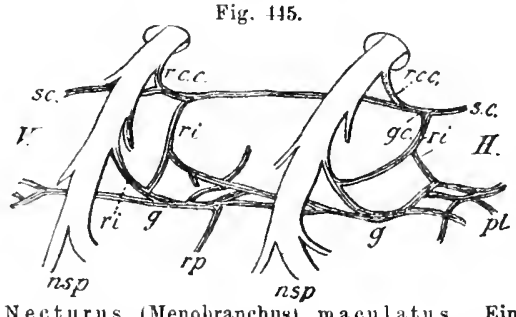

Necturus (Menobranchus) maculatus. Ein Stück des linken sympathischen Grenzstranges. $V$ vorn; $H$ hinten. If sympathische Gauglien des Hauptgrenzstrangs. $g c$ Ganglion. nsp. ventraler Ast der Spinalnerven. $r c$ Ramus communicans $=$ visceralis. rec Ramus communicans zum kollateralen Grenzstrang. $r i$ Rami intermedii. $r p$ Peripherer sympathischer Nerv. sc Kollateraler Grenzstrang (n. A NDERsos 1592 aus Gegenbaur, Vergl. Anat. d. Wirbeltiere 1898).

Der Halsteil des Sympathicus besitzt stets nahe Beziehungen zum Vagus, ja kann sich bei Säugern mit demselben zu einem gemeinsamen Strang vereinigen. Er verhält sich bei den Sauropsiden eigentümlich, indem häıfig jederseits oberflächliche und tiefer gelegene Stränge vorkommen. Bei den Sauriern sind die tiefen Stränge der tiefen ventralen Halsmuskulatur eingelagerte Schlingenbildungen zwischen den Rami viscerales; bei Chamaeleo bilden sie jederseits einen deutlichen Strang. - Die tiefen Stränge der Crocodile und Vögel verlaufen im Vertebralkanal mit der Arteria vertebralis und gehen in die Bruststränge über; die oberflächlichen ziehen dagegen als paarige Stränge mit den gemeinsamen Carotiden und werden, wenn sich letztere zu einer Carotis primaria vereinigen, gleichfalls unpaar. Bei den Vögeln setzt sich die Verdopplung des Grenzstrangs auf den Brustteil fort, indem dessen Ganglien dnrch doppelte Längsverbindungen zusammenhängen, von welchen die dorsalen durch die Rippengabelnngen gehen. - Die Bildung solch tiefer Stränge der Halsregion erinnert sehr an die oben erwähnten collateralen Stränge der ichthyoden Amphibien und leitet sich vielleicht von solchen Vorlänfern ab. 
Die Nervi splanchnici, welche wir schon bei den Fischen trafen, entspringen = auch bei den Tetrapodeu etwa in der Region des Schultergïrtels oder der Brust und begleiten die großen Darmarterien. - Wie erwähnt, ist charakteristisch für die sympathischen Nerven ihre große Neigung zar Bildung von Geflechten (Plexus) mit Ganglieneinlagerung an den verschiedeneu von ihnen innervierten Organen, welche Plexus daher in den verschiedensten Körperregionen anftreten. Unter ihuen sind die des Darms auch" bei den Amnioten besonders ansehnlich (Plexus coeliacns oder solaris).

\section{Hirnnerven der Craniota.}

Wir erkannten das Hirn als einen durch besondere Bedingungen modifizierten vorderen Teil des Centralnervensystems, das sich als Rückenmark nach hinten fortsetzt. Es läßt sich daher von vornherein vermuten, daß die vom Hirn entspringenden Nerven den Spinalnerven des Rüekenmarks entsprechen werden. Bei den Acraniern erscheinen, abgesehen von dem zweifelhaften Nervus olfactorins und dem $\mathrm{N}$. terminalis, nur die beiden vordersten Nervenpaare besonders modifiziert; bei den Cranioten hingegen viel mehr solcher Paare, woraus hervorgeht, daß das Craniotenhirn eine viel längere Strecke des vorderen Centralnervensystems umfaßt. Srhon fruher wurde hervorgehoben, daß die größte Zahl der Hirnnerven vom Myelencephalon (Medulla oblongata) entspringt, ja man darf vielleicht mit gewissem Recht sagen, daß ursprünglich sämtliche Hirnnerven, mit Ausnahme der zwei ersten, aus diesem Abschnitt hervorgingen, und daß die Beziehungen, welche der dritte (Nervus oculomotorius) und der vierte (N. trochlearis) zum Mesencephalon haben, sekundär erworben sein könnten.

In Gegensatz zu dieser Auffassung wird jedoch auch nachzuweisen versucht, daß die Hirnnerveu vom V. (Trigeminus) ab, bei der Ontogenese etwas caudalwärts verschoben werden, so daß die Anlage des sog. Ophthalmicus profundus des Trigeminus ursprünglich im Geviet des Mesencephalon liege, die des folgenden Trigeminusanteils im Metencephalon usf.

Nicht selten wurde versucht, sämtliche Hirnnerven ånf Spinalnerven oder modifizierte Antelle solcher zurückzuführen. Für die beiden.vordersten, welche reine Sinnesorgannerven sind, den Riech- und Sehnerv, N. olfactorins u. N. opticus, ist eine solche Deutung wohl sicher irrig. Wie wir bei der Besprechung dieser Organe sehen werden, bildeten sie sich in innigster Beziehung mit dem vorderen Hirnabschnitt selbst, dem Archencephalon, so daß ihre nervösen Anteile eigentlich als ursprüngliche Hirnteile aufgefaßt werden müssen, was für die Augen besonders klar hervortritt. Der eigenartige Charakter der beiden ersten Nervenpaare läßt sich daher kaum bezweifeln.

Fïr die iabrigen Hirnnerven dagegen scheint die Ableitung von Spinalnerven gerechtfertigt, wenn auch die Deutungen im Einzelnen sehr weit auseinandergehen, und von einer anch nur annähernden Übereinstimmung der Ansichten keine Rede sein kann. Die Schwierigkeiten, welche sich der Lösnng dieses Problems entgegenstellen, sind auch besonders groß. Abgesehen von denjenigen, welche die technische Untersuchung selbst bietet, ergeben sich weitere aus den Modifikationen 
und Umgestaltungen, welche die nrsprünglichen Spinalnerven im Hirngebiet erfuhren. Es konnten einerseits Verwachsungen ursprünglich getrennter, andrerseits auch Auflösungen anfänglich einheitlicher Nerven in gesonderte Anteile eintreten.

Es fragt sich daher zunächst, welche Kriterien besonders maßgebend sein werden für die Erkenntnis der spinalen Natur eines Hirnnervs. - Bei den primitivsten Vertebraten (Acranier und Petromyzon) bleiben, wie früher erwähnt, die dorsalen und ventralen Spinalnerven noch unvereinigt. Sowohl die Ontogenie als die Vergleichnng scheint nun sicher zu erweisen, da $B$ die meisten, und gerade die ansehnlichsten Hirnnerven rein dorsalen Spinalnerven entsprechen. Sie entspringen ontogenetisch vom Hirn ungefähr in der Fortsetzung der Ursprünge der dorsalen Spinalnerven, von del vorderen Verlängerung der sog. Neuralleiste, aus welcher letztere hervorgehen. Es läft sich daraus wohl schließen, daß in der Hirnregion die ursprüngliche Nichtvereinigung der dorsalen und ventralen Spinalnerven erhalten blieb und die anfänglich vorhandenen ventralen Spinalnerven (oder Wurzeln) in dieser Region großenteils riickgebildet wurden. Abgesehen von rudimentären ventralen Spinalnerven, die wir später als sog. occipitale Nerven in der hinteren Region der Medulla oblongata gewisser Fische finden werden, sind es nur die Augenmuskelnerven (III, IV und VI), welche sowohl nach ihrer Entstehung, als wegen ihres ventralen Austritts (abgesehen von IV) und der ventralen Lage ihrer Kerne, sowie wegen ihrer Beziehung zu den Angenmuskeln, mit großer Wahrscheinlichkeit als ventrale Spinalnerven gedeutet werden dürfen. Diese Reduktion der ventralen Spinalnerven in der Hirnregion hängt jedenfalls damit zusammen, daß die Myomeren der Hirn- (bzw. Kopf-) region gleichfalls großenteils rủckgebildet wurden, indem, wie früher erwähnt, die Muskulatur des Kieferkiemenapparats, welcher von den Hirnnerven versorgt wird, nicht aus den Myomeren, sondern aus den beiden Seitenplatten hervorgeht, deren Innervierung durch die dorsalen Spinalnerven geschieht. - Die Augenmuskeln entwickeln sich hingegen nach den recht übereinstimmenden Angaben vieler Beobachter aus den drei vordersten, vor dem Gehörbläschen gelegenen Myomeren (prootischen), womit ihre Innervierung durch ventrale Spinalnerven gut harmoniert.

Ein primitiver Dorsaluerv des Rückenmarks, wie ihn etwa die Acranier zeigen, verläuft, wie wir fruher sahen, im Septum zwischen zwei Myomeren zur Hant, teilt sich hier in einen dorsalen und ventralen Ast, wobei an der Teilnngsstelle ein wenn auch schwaches Ganglion auftritt. Beide Äste lassen mehr oder weniger deutlich einen nach vorn gerichteten sog. Lateralast unterschèiden, während sich vom Ventralast noch ein $R$. visceralis abzweigt, der die viscerale Muskulatur versorgt (vgl. \$. 607). Ähnlich verhalten sich im allgemeinen die primitiven dorsalen Hirnnerven, wie sie bei Cyclostomen und Fischen angetroffen werden. Auch sie teilen sich bald nach ihrem Ursprung in einen schwächeren dorsalen und einen viel ạsehnlicheren ventralen Ast. Ersterer entsendet nach vorn einen sensiblen Ram. lateralis dorsalis und setzt sich dann als sensibler $R$. cutaneus dorsalis fort. Der ventrale Ast zieht im allgemeinen zum Dorsalende einer Visceralspalte, wobei 
sich auch die Mundspalte wie eine solche verhält. Hier teilt er sich in einen schwächeren sensiblen vorderen Lateralast, der am vorderen (rostralen) Rand der Visceralspalte hinabzieht (daher anch R. praetrematicus genannt) und einen stärkeren Ast der den hinteren (caudalen) Rand der betreffenden Spalte begleitet (R. posttrematicus). Von der Teilungsstelle geht auch cin Ramus visceralis (R. pharyngens od. palatinus) aus, welcher zum Darm tritt. Jedem typischen spinalen Hirnnerv kommt ferner an der Teilungsstelle in den Dorsal- und Ventralast ein Ganglion zu, das im allgemeinen den Spinalganglien der dorsalen Ruckenmarksnerven entspricht.

Aus dem Bemerkten folgt, daß die typischen spiนalen Hirunerven einerseits durch einen besonderen Verlauf charakterisiert sind, andrerseits aber durch ihre Beziehungen zu der Mund- oder den Visceralspalten. In letzterem Verhalten spricht sich auch eine metamere Anordnung der Nerven aus, insofern die Kiemenspalten ebenfalls den Segmenten entsprechen, $d . h$. in den Zwischenräumen zwischen den Somiten angeordnet sind, was wenigstens für die ursprünglichen Kiemenspalten der Acranier und die der Cranioten gültig scheint. Aber die spinalen Hirnnerven selbst zeigen sich, wenigstens in der Ontogenie der Cyclostomen (Petromyzon), metamer angeordnet, so daß der erste (Trigeminus I) auf die Grenze des ersten und zweiten prootischen Somits fällt, die folgenden zwischen die daranf folgenden Som ten. Wir finden demnach, als Kriterien zur Entscheidung über die spinale Natur der Hirnnerven: 1) ihre metamere Beziehung zu den Somiten, 2) ihre entsprechende Beziehung zu den ursprünglich metamer geordneten Visceralspalten und 3) ihren den ursprünglichen dorsalen Spinalnerven des Rückenmarks gleichenden Bau und Verlauf.

Oben wurde hervorgehoben, daß auch die Bildung eines, den Spinalganglien in allgemeinen entsprechenden Ganglions für die spinalen Hirnnerven charakteristisch erscheint. Die Entwicklung dieser Ganglien verläuft in vieler Hinsicht abweichend von jener der eigentlichen Spinalganglien. Die Anlage der typischen spinalen Hirnnerven zieht direkt zum Ectoderm und läuft unter diesem, also vach außen vom Mesoderm herab. Deshalb wurde auch gelegentlich angenommen, daß diese unter dem Ectoderm und zwischen den Kiemenspalten herabziehenden Anlagen (die späteren Rami posttrematici) gar nicht die eigentlichen Spinalnerven seien, sondern besondere Kiemenäste derselben; gleichzeitig wurden Nervenanlagen nachzuweisen gesucht, die innerhalb des Mesolerms herabzögen und auch Ganglien bilden, welche also die eigentlichen Spinalnerven der Hirnregion darstellten. Eine solche Annahme scheint umso weniger wahrscheinlich, als ja die Spinalnerven der Acranier gleichfalls außerhalb der Muskulatur verlaufen und es wohl möglich ist, daß die spinalen Hirnnerven die ursprünglichen Verhältnisse bewahrten. - Die Ganglienbildung der Hirnnerven erfolgt unter direkter Teilnahme des Ectoderms, indem die unter letzterem herabziehenden Nervenanlagen sich im allgemeinen an zwei Stellen mit besonderen Ectodermverdickungen (sog. Placoden) innig verbinden. Die eine dieser Verbindungsstellen liegt dorsaler (sog. Lateralplacoden), die andere ventraler, und zwar dicht an den Dorsalenden der Kiemenspalten (daher epibranchiale Placoden oder Kiemenspaltenorgane genannt). In der Region der Lateralplacoden entwickelt übrigens auch die Nerrenanlage selbst eine Ganglienanlage, welche sich. mit der Placode innig verbindet. Lateral- und Epibranchialplacoden bilden demnach jederseits zwei Läıgsreihen. Die ersteren eine dorsale, etwa in der vorderen und hinteren Fortsetzung der Hörblase, die selbst gewöhnlich als eine eingesenkte Lateralplacode betrachtet 
wird; die Epibranchialplacoden eine melır ventrale Reihe in der IIöhe der dorsalen Kiemenspaltenenden. Später lösen sicb die Anlagen der Nerven vom Ectoderm ab und nehmen einen Teil der Zellen der Placoden als Nervenzellen mit sich. Lateralplacoden scheinen sich wenigstens hei den Cyclostomen für sämtliche dorsale spinale Firnnerren zu bilden; epibranchiale dagegen erst rom VII. Nerv (Facialis) ab; doch differieren die Beobachtungen hierüber etwas.

Nach dem Vorgang der menschlichen Anatomie werden die Hirnnerven von vorn nach hinten gezählt, und so bei den Anamnia in der Regel zehn, bei den Amnioten zwölf Paare gerechnet, indem bei letzteren noch zwei Nerven, die bei den Anamnia weniger deutlich differenziert sind, in die Schädelhöhle aufgenommen wurden, und daher den übrigen Hirnnerven beigesellt erscheinen. Diese zwölf Nervenpaare sind von vorn nach hinten: I. N. olfactorius" (der Riechnerv, II. N. opticus (der Sehnerv), III. N. oculomotorius (Augenmuskelnerv), IV. N. trochlearis (Augenmuskelnerv), V. N. trigeminus, VI. N. abducens (A ugenmuskelnerv), VII. N. facialis, VIII. N. acusticus (Hörnerv), IX. N. glossopharyngeus, X. N. vagus, XI. N. accessorįus Willisii, XII. N. hypoglossus.

Der Riechnorv, Nervus olfactorius (I) wurde schon oben als ein spezifischer Sinnesorgannerv charakterisiert, dem die Bedeutung eines spinalen Hirnnervs nicht zuerkannt werden kann, obgleich dies manchmal versucht wurde. Er tritt, wie ebenfalls schon erörtert wurde, zum Lobus olfactorius, oder, wenn dieser in Bulbus, Tractus und sekủndären Lobus differenziert ist, zum Bulbus. Wenn letzterer dem Geruchsorgan sehr dicht anliegt, wie bei Cyclostomen, Chondropterygiern und gewissen Teleosteern, so ist der Olfactorius sehr kurz und ein geschlossener Riechnerv gar nicht vorhanden, indem von der Riechschleimhaut zablreiche Bündel von Nervenfasern (Fila) ausgehen, welche zum Bulbus treten.

Diese Zusammensetzung des Riechnervs aus zahlreichen, nicht fest zusammengeschlossnen Fila wiederholt sich auch bei den Reptilien häufig und gilt fast allgemein für die Sänger, wo die Fila durch die feinen Löcher der Siebbeinplatten treten. Nur Ornithorhynchus besitzt, wie früher erwähnt, eine einfache öffnung für den Durchtritt jedes Olfactorius. Schon beim Gehirn wurde hervorgehoben, daB der Olfactorius der Anuren nnd Gymnophionen mit zwei Wurzeln entspringt. - Wie es scheint, besteht der Riechnerv stets aus marklosen Nervenfasern, bewahrt also eine ursprünglichere Beschaffenheit.

Bei gewissen Fischen (zablreichen Haien und Rochen, Protopterus, Ceratodus [Embryo] und Amia) findet sich neben jedem Olfactorius ein eigentümlicher sog. Nervus terminalis (oder apicalis), der sich, dicht neben ihm hinziebend, ebenfalls zur Schleimliaut der Nasengrube begibt. In seinem Verlauf bildet er bei den Chondropterygiern ein Ganglion (siebe Fig. 406, S. 569); sein Ursprung liegt hier weit vorn am Telencephalon, dicht neben dem Recessus neuroporicus, bald mehr ventral, bald mehr dorsal. Bèi Protopterus entspringt er dagegen ans dem Zwischenbirn. Er soll entweder nur marklose Fasern (Protopterus), oder daneben auch markhaltige führen (Chondropterygii). Daß der N. terminalis nur ein abgelöster Teil des Olfactorius sei, ist wenig wahrscheinlich; auch wurde die Vermutung aufgestellt, daß er das Rudiment eines bei den Vorfahren ansehnlicher entwickelt gewesenen Nerrs bilde. Neverdings wurde auch bei Rana ein entsprechender Nerv beobachtet.

Der Sehnerv, Nervus opticus (II), geht, wie wir später sehen werden, ontogenetisch direkt aus dem Stiel der Augenblase hervor, die sich jederseits aus dem 
Diencephalon hervorstillpt, und hauptsächlich den nervösen Teil des Auges, die Netzhant, bildet. Die Optici entspringen daher vom Boden des Zwischenhirns vor dem Infundibulum; doch sind ihre Fasern als Tractus opticus in die zum Mesencephalon gehörigen Lobi optici und bei den Säugern auch zu den Corpora genicnlata lateralia des Diencephalon zu verfolgen. - Die Stärke der Optici steht natürlich in direktem Verhältnis zur Größe der Augen; wenn diese verkümmern, reduzieren sich auch die im allgemeinen sonst recht starken Sehnerven. - Der meist dreh-

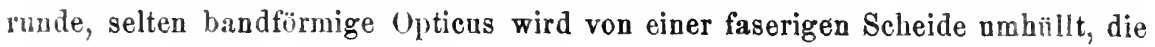
aus den Hirnhäuten hervorgeht. Er tritt gewöhnlich direkt in die Urbita zum Grunde des Augapfels, in welchen er eindringt. Sein feinerer Ban ist meist eigenartig, indem von der bindegewebig-faserigen Scheide radiale, verzweigte Scheidewände in ihn eindringen und ihn in Faserbündel zerlegen. Bei vielen Knochenfischen greifen diese Bindegewebsscheidewunde von beiden Seiten alternierend zwischen einander, weshalb sich der Nerv, nach Entfernung ler Hülle, zu einem Band ausbreiten läßt. Anch bei den Vögeln erlangt er wegen der Beschaffenheit dieser Septer meist eine blätrige Znsammensetznng. Besonderes Interesse besitzt die Kreuzung der Kehnervenfasern (C'biasmabildung), welche bei den verschiedezen Klassen in verschiedener Weise geschieht. Die Cyclostomen und Dipnoer zeigen änßerlich keine Andeutung de: Kreuzung; jeder Opticus begibt sich zum Auge seiner Seite; es ist jedoch erwiesen, daß sich die Opticnsfasern in diesen Fällen im Hirninnern großenteils kreuzen. - Bei den meisten Wirbeltieren erfolgt die Kreuzning dagegen erst, nachdem die Opticusfasern als freier Nerv ans dem Zwischenhirnboden hervorgetreten sind, in einem dicht vor dem Infundibulum gelegenen, deutlich sichtbaren Chiasma. Ein solches findet sich unter den Fischen schon bei den Chondropterygiern und Ganoiden, ebenso bei allen höheren Klassen. Der feinere Ban des Chiasmas variiert je nach den Abteilungen nnd dem Bau der Sehnerven etwas, indem sich teils gröbere Faserbündel kreuzend durchflechten, bald nur feinste (Säuger). Die Frage nach dem Grade der Faserkreuzung erscheint noch immer etwas unsicher. Für die Säuger ist ziemlich sicher festgestellt, daß die Kreuzung der Fasern in den meisten Fällen keine totale ist (ausgenommen gewisse Rodentia). Bei den übrigen Klassen dagegen wird die Kreuzung jetzt i.d. R. als eine vollständige betrachtet, was besonders für die Teleostei klar erscheint, da sich die beiden freien Optici hier überkreuzen, ohne sich zn durchHechten (s. Fig. 409 C, S. 572), weshalb die Krenzung sicher eine totale ist, wenn nicht etwa schon im Innern des Hirns ein Faseraustausch sich zugesellt.

Im allgemeinen scheint die Kreuzung bei dem niederen Wirbeltieren vollständiger zu sein als bei den Säugern, und auch hei diesen umso ausgiebiger, je seitlicher die Augen gerichtet sinul, also je weniger sich ihre Sehfelder überdecken.

An dieser Stelle möge kurz erwähnt werden, daß auf der Grenze von Di- und Mesencephalon der Embryonen gewisser Haie die Anlage eines sensiblen Nerven (N. thalamicus) beobachtet wurde, die jedoch bald wieder schwindet, nachdem sie in Beziehungen zum Ramus ophthalmicus des Trigeminus und dem Oculomotorius trat.

Die spinalen Hirnnerven. Oben wurden die Kriterien erörtert, welche für die Beurteilung der spinalen Natur eines Hirnnerven maßgebend zn erachten sind, und 
die wir daher unsrer Betrachtung zugrunde legen mlissen. Wie zu erwarten, sind es die Verhältnisse der primitiveren Wirbeltiere (insbesondere der Cyclostomen und Fische), welche den klarsten Aufschluß bieten, wogegen bei den höheren Formen zahlreicheVeränderangen eingetreten, ja ganze Partien des ursprthnglichen Nervenapparats geschwunden sind. - Abgesehen von den Augenmuskelnerven (III, IV und VI), die wir ihrer besonderen Natur wegen zuletzt betrachten wollen, sondert man die auf den Opticus folgenden Itirnnerven, welche im allgemeinen den Charakter dorsaler Spinalnerven darbieten, häufig in zwei Gruppen: eine vordere, die den V., VII. und VIII. Nerv umfaßt, und nach dem ansehnlichen V. als Trigeminusgruppe bezeichnet wird, und eine hintere, die Vagusgruppe (IX.XI. Nerv), nach dem X. genannt; ibr scbließt sich auch der XII. Nerv an, der jedoch, wie wir sehen werden, einen eigenartigen Charakter besitzt. Die Znsammenfassung der betreffenden Nerven zu den beiden Gruppen basiert hauptsằchlich daranf, daß ihre Angebörigen häufig nähere Beziehungen, Verbindungen, ja zuweilen gemeinsame Ursprïnge besitzen, also eine gewisse Zusammengebðrigkeit verraten.

Trigeminusgruppe. Der bezeichnende Nerv dieser Gruppe ist der V., der Trigeminus. Er ist meist der stärkste Hirnnerv und entspringt vom Vorderende der Mednlla oblongata. Er führt seinen Namen deshalb, weil er sich in drei Hauptäste verzweigt, also gewissermaßen dreiteilig erscheint. Ob der Trigeminus einem einfachen Spinalnerv entspricht, oder aus der Vereinigung zweier hervorging, ist ein noch nicht völlig gelöstes Problem, obgleich es sehr wahrscheinlich ist, daß er aus zwei ursprünglichen Spinalnerven entstand, die zwischen dem ersten und zweiten und zweiten und dritten Kopfsomit liegen. Manche Morphologen sind sogar geneigt, ihn aus einer größeren Zabl ursprunglicher Spinalnerven abzuleiten, doch ist dies wenig wahrscheinlich. - Wir betrachten zuerst seinen Bau und seineVerbreitung bei den primitivenWirbeltieren, besonders deu Fischen (s. Fig. 445). Der Trigeminus entspringt au dem angegebenen Ort mit zwei bis mehr Wurzeln (Portionen), die bei den Anamnia in sehr naher Beziehung zu den Wurzeln des VII. Nervs (Facialis) stehen. Kurz nach seinem Ursprung bildet er ein einfaches oder aus mehreren Portionen zusammengesetztes Ganglion, oder auch ein gangliöses Geflechtwerk (sog. Ganglion Gasseri oder semilunare), das einem Spinalganglion gleichgesetzt werden darf. Von dem Ganglion entspringt in rostraler Richtung ein rein sensibler Ast, der Ramus ophthalmicus (entsprechend einem Ramus lateralis dorsalis), so genannt, weil er in die Augenhöble eintritt, diese dorsal durchzieht und aus ihr vorn hervortritt, um die Haut der Schnauze, sowie die Schleimhaut der Nasengrube oder Naseuhöhle zu versorgen. - Bei den Chondropterygiern und Ganoiden treten zwei Rami ophthalmici (eiu superficialis und ein profundus) durch die Angenhöhle, welche sich jedoch gewöhnlich vor dem Austritt aus letzterer vereinigen.

Bei gewissen Chondropterygiern und Polypterus besitzt der R. profundus einen vom übrigen Trigeminus gesonderten Ursprung in der Region des Mittelbirns, wie es embryonal auch bei Amia vorkommt. Bei letzterer Form und einzelnen Chondropterygiern kommt ihm ein besonderes kleines Ganglion zu, das sonst mit dem gemeinsamen Trigeminusganglion vereinigt zu sein scheint. Auch der Ramus ophthalmicus zablreicher Reptilien besitzt ein besonderes Ganglion. 
Bei den Tetrapoden (vgl. Fig. 446) findet sich nur ein Ramus ophthalmicus, welcher dem profundus der Fische entspricht, und ein ähnliches Verbreitungsgebiet besitzt; auch an die Augendrüsen (Tränen- und Hardersche Drüse), die Conjunctiva und das obere Augenlid Zweige abgibt und sich bis zur Schnauzenspitze (bei Vögeln z. B. in den Schnabel) fortsetzt. Die Beziehungen des Ramus ophthalmicus zu dem sog. Ganglion ciliare und dem N. oculomotorius sollen erst bei letzteren erörtet werden.

Von der Fortsetzung des Trigeminus, oder auch direkt aus seinem Ganglion, zweigt sich ferner der Ramus maxillaris (superior) ab, der als sensibler Nerv die Ober- und $Z$ wischenkieferregion versorgt und gleichfalls meist die ventrale Region der Orbita durchsetzt. Auch er erhält sich bei den Tetrapoden ähnlich nnd ver-

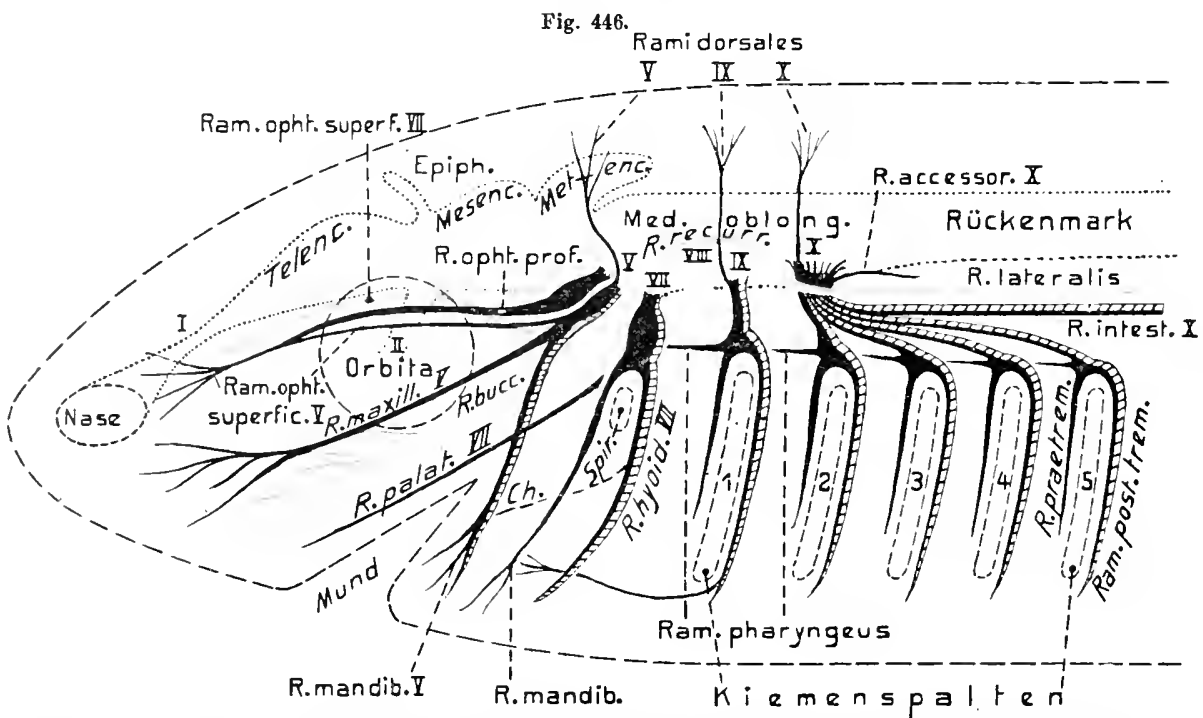

SchemaderHirnnerven undihrerAusbreitnngbei einemursprünglichonkiemenatmenden Wirbeltier (die Grundlage bilden etwa die Verhälnisse eines Chondropterygiers. Das sog. Lateralis. system, welches die Seitenorgane innerviert, ist rot angegeben; diejenigen Nerven nnd $Z$ weige, welche anch motorische Fasern führen, sind mit gestrichelten Begleitlinien versehen; die rein sensiblen Nerven nnd Zweige schwarz. Die Augenmuskelnerven sind weggelassen. o. B.

sorgt hier Teile der Gesichtshaut, den Schnabel der Vögel, die Rüsselbildungen und Barthaare der Säuger, jedoch auch die Zähne des Oberkiefers und steht mit dem Kopfteil des Sympathicus durch das hänfig ausgebildete Ganglion sphenopalatinnm in Verbinùug. Bei den Säugern bildet seine Hauptfortsetzung der $N$. infraorbitalis (s. Fig. 447).

Der ansehnlichste Trigeminusast ist fast stets der $R$. mandibularis (s. maxillaris inferior), der, wie sein Name sagt, zum Unterkiefer geht und gemischter Natur ist ${ }^{1}$ ). Bei den Knorpelfischen noch längs der Außenseite des knorpligen

1) Auf Fig. 446 sind die motorischen Anteile der Hirnnerven durch horizontale Strichelung angedeutet; die sensiblen Haut- oder Darmnerven schwarz; die Seitenorgane versorgenden Anteile rot. 
Unterkieferbogens hinziehend, tritt er mit der Verknöeherung der Mandibel in deren inneren Kanal. Seine Muskelzweige innervieren die Muskulatur des Unterkiefers, wie wir schon frïher (s.S. 436) erwähnten. Die sensiblen $\ddot{A}$ ste versorgen die Unterkieferhaut, die Unterkieferzähne, Barteln usw.; bei den höheren Wirboltieren auch $z$. T. die Schlïfenregion, Obrgegend, die Wangenschleimhaut und die Speicheldrïsen; bei den Sängern (und schon manchen Reptilien) ebenso die Zunge (N. lingualis, vgl. Fig. 447). Dieser Ast kann gleiehfalls mit dem Kopfteil des Sympathicus verbunden soin (Säuger), unter Bildung eines besonderen Ganglion oticum (s. Fig. 447).

Fig. 41 .

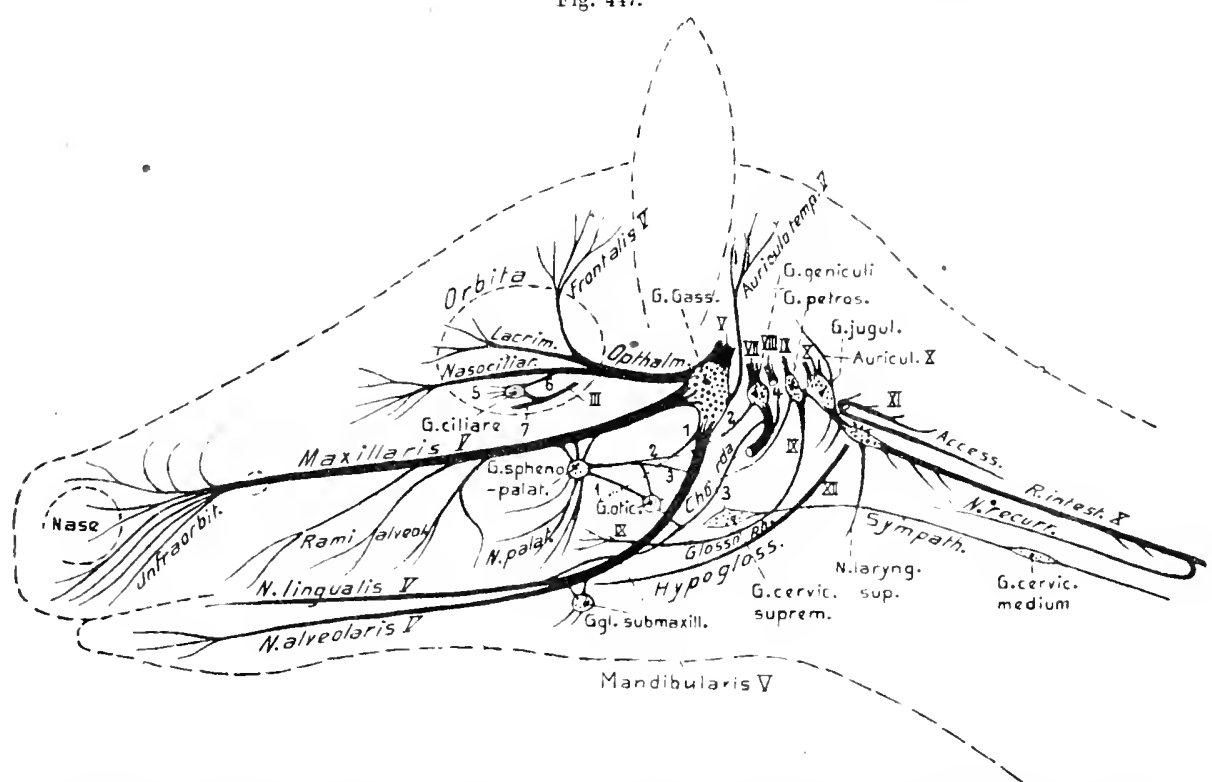

Sāugetier. Schema der Hirnnerven und ihrer wichtigsten Ausbreitungen. Anch der Kopfteil des sympathischen Grenzstrangs ist teilweise dargestellt. Die Nerven $I, I I, I Y$ und $I I$ sind weggelassen. 1 . Nerv. bueciuatorius $I:-2 . \mathrm{N}$. petrosus superf. major. $-3 . \mathrm{N}$ jetros. profund. - 4. N. auricularis post. VII. 5. Nn. ciliares. - 6 . Radix longa gangl. cil. $-i$. Ram. inf. N. oculom.

Eigenartige Verhältntsse zeigt der Trigeminus zahlreicher Knochentische, indem von seineın Gangliengeflecht dorsale sensible Ästchen als Rami cutanei dorsales in die Schädelböhle aufsteigen. Sie verbreiten sich entweder nur in dem das Hirn umhüllenden Fettgewebe, wobei sie zuweilen Verbindungen mit ähnlichen Dorsalästen des Vagus ( $X$ ) eingehen, oder treten bei gewissen Formen auch auf die Schädeloberfläche hinaus, um sich an der Versorgung der Sinnesknospen (Geschmacksknospen) zu beteiligen. Bei einer Anzahl Teleosteer (namentlich den Gadidae) tritt ein solch sensibler Dorsalast des Trigeminus aus der hinteren dorsalen Schädelregion aus und zieht als sog. R. lateralis trigemini jederseits an der Basis der Dorsalflossen längs der ganzen lïickenkante hin (s. Fig. 448). Dabei steht er mit den Dorsalästen der Rückenmarksnerven durch Rami communicantes in regelmäßiger Verbindung. Von diesem Lateralis trigemini (auch R. lateralis accessorius genannt), welcher dnrch den Zutritt der Rami communicantes gemischter Natur wurde, gehen Nepvenästchen zur Hant (Sinnesknospen) der Rückenkante und der Rückenflossen; bei gewissen Formen jedoch auch solche zu den kehlstänligen Bauchflossen, zuweilen (Gadidae) auch den Brustflossen und sogar der Analflosse (s. Fig. 448). Andrerseits erhalten auch die Muskeln der Rückenflossen Ästchen der Rami laterales V. - Diese eigentümliclie Ausbreitung eines IIirmuerven über 
den ganzen Körper ist besonders wegen der Analogie mit dem Ramus lateralis des Vagus von Interesse. Die regelmäßigen Verbindungen der Rami laterales $Y$ mit den Spinalnerven machen ihre Eıtstehung als sog. Collectornerven durch Schlingenbildung zwischen den Dorsalästen des Trigeminus und der Spinalnerven sehr wahrscheinlich, woran sich zuwsilen auch ein dorsaler Vagusast beteiligt. Wir werden auf diese Analogie bei der Besprechuug des $R$. lateralis ragi nochmals zurückkommen. In neuerer Zeit wird jedoch der sog. R. lateralis $\mathrm{V}$ auch als zum Facialis gehörig aufgefaßt.

Oben wurde schon hervorgehoben, daß der Trigeminus jetzt gewöhnlich als ein doppelter dorsaler Hirnspinalnerv gedeutet wird, und zwar meist so, daß der Ramus ophthalmicus profundns als ein stark reduzierter vorderer (1.) Nerv, der ubrige Trigeminus als ein zweiter (2.) betrachtet wird. Der K. ophthalmicus profundus wäre dann wobl einem allein erhaltenen dorsalen Lateralast des Trigeminus 1 gleichzusetzen, während der Maxillarast dem praetrematischen Ast des Trigeminus 2, der Mandibularast dessen posttrematischen und der R. "ophthalmicus superficialis dessen Dorsolateralast entspräche. Gelegentlich wurde jedoch auch der Maxillarast dem Trigeminus 1 zugerechnet.

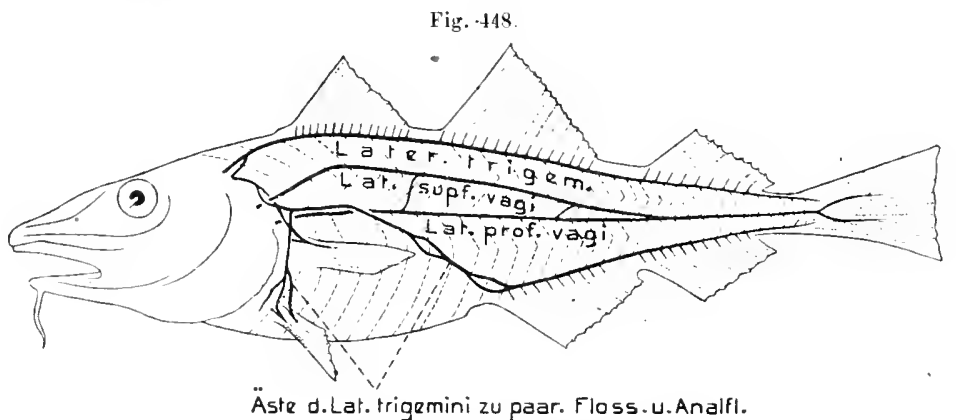

Gadus morrhua; von liuks. Der Verlanf des Ramus lateralis des Trigeminus und seiner $\ddot{A}$ ste zu den paarigen Flossen, den Rücken- und Analflossen eingezeichnet; ebenso die beidev $\tilde{A}$ ste des $R$ a $m$ us lateralis vagi (superficialis und protundus) (n. Stan nius 1849). v. Bu.

Facialis (VII). Schon oben wurde hervorgehoben, daß die Ursprünge des Trigeminus und Facialis bei den Anamnia sehr eng verbunden, die Ganglien beider sogar meist innig verwachsen sind. Ferner wird als ursprünglicher Anteil des Facialis der VIII. oder Hörnerv (N. acnsticus) gedeutet, der den sensorischen Nervenzweigen (dorsolaterale $\ddot{A}$ ste) zazurechnen ist, welche die sog. Seitenorgane innervieren. Der Acusticus hat sich vom Facialis abgesondert, doch stehen seine Wurzeln mit denen des letzteren häufig noch in naher Beziehung. Bei schärferer Sondernng des Facialis vom Trigeminus, so bei den Amnioten, bildet er ein eigenes Ganglion (G. geniculi). Sein weiterer Verlauf erweist ilun als den zur ersten Visecralspalte (Spritzloch oder Spiraculum der Fisehe) gehörigen spinalen Hirnnerv (Fig. 446). Dementsprechend verteilt er sich bei den Fischen und den sich ähnlich verbaltenden ichthyoden Amphibien (sowie den Larven der übrigen) an den beiden ersten Visceralbogen, indem sein kurzer Ursprungsstamm (bei den Fischen Ramus lyoideo-mandibularis) einen posttrematischen gemischten Ramus hyoideus abgibt, der längs des Hyomandibulare und Zungenbeinbogens herabzieht, wäh- 
reud ein praetrematischer sensibler, auch Seitenorganc imnervierender $R$. mandibularis zum Unterkiefer zieht und sich in einen h. internus und externus teilen kann. Als vorderen dorsolateralen, die Seitenorgane iiber der crhita versorgenden und lein sensorischen $A$ st finden wir bei den Fischen und den ichthyoden Amphibien einen $R$. ophthalmicus supcrficialis facialis, der etwa im Bereich des Ophthalmicus superficialis $\mathrm{V}$ hinziebt, nud sich mit letzterem Nerv biufig innig vereinigt. Bei den erwähnten Amphibien scheint der entsprechende Nerv wesentlich nur vom Facialis gebildet zu werden, obgleich er zuweilen auch als Ophthalmicus superficialis trigemini aufgefaßt wurde. - Ein sensorischer Zweig, der die Seitenorgane unter dem Auge versorgen soll, erstreckt sich als 1 . bucenlis längs des Oberkiefers, häufig in inniger Verbindung bis Versclmmelzung mit dem R. maxillaris $V$, wïhrend sich ein sensibler R. palatinus zur Schleimhaut der Mundhöble begibt.

Bei den Amnioten bilden sich die sensiblen Facialisäste meist stark oder völlig zuruck (hamus ophthalmicus superficialis facialis, R. buccalis). Dagegen bleibt der posttrematische, zum Hyoid ziehende und vorwiegend motorische Ast erhalten und versorgt Muskeln dieser Region, wie schon früher angegeben wnrde (so namentlich den Depressor mandibulae, den Mylohyoidens, Stylobyoideus, Sphineter colli, Platysma myoides bei Säugern). Bei letzteren sendet ex, unter verwickelter Geflechtbildung (Plexus parotideus oder Pes anserinus), an der sich auch Trigeminuszweige beteiligen, zahlreiche Äste zur Gesichtsmuskulatur, die sich, wie frïher (S. 450) hervorgehoben, aus dem Sphincter colli und dem Platysma myoides entwickelte.

Als R. palatinus VII wird bei den Säugern zuweilen der sog. $N$. petrosus superficialis major aufgefaßt, der sich zum sympathischen Ganglion sphenopalatinum begibt (s. Fig. 447), zu dem auch ein Trigeminusasi geht. - Ein Facialisast zieht bei den Säugern als sog. Chorda tympani durch die Paukenhöhle zum Boden der Mundhöhle und verbindet sich hier mit dem früher erwähnten R. lingualis trigemini. Bei niederen Wirbeltieren wurde der Vertreter der Chorda tympani zuweilen in einem R. mandibularis internus $V$, oder in einem Ast des $R$. palatinus VII gesncht, vielfach jedoch auch im R. mandibularis VII, was jedoch insofern nicht zutrifft, als die Chorda tympani von dem posttrematischen Facialisast ausgeht.

Acusticus (VIII). Daß der Hörnerv ein zum Facialis gehöriger Teil ist, folgt auch daraus, daß sein Ursprung häufig noch innig mit der Facialiswarzel verbunden ist; stets aber tritt er sehr dicht beim Facialis aus. Er entspringt bald mit einem, bald mit mehreren Wurzelbïndeln, die sich vereinigen, oder gesondert zum Labyrinth treten, inden sie meist gemeinsam mit dem Facialis in das Prooticum (Petrosum) eintreten. Auch Ganglienanschwellnngen treten an ihnen auf. Aus dem Nerv entwickeln sich zwei $\ddot{A}$ ste, ein vorderel Ramus vestibularis und ein hinterer $R$. exchlearis, deren Verteilung an ciehörorgan spüter zu besprechen sein wird.

Tagusgruppe. Die folgenden drei Himerven, der Glossopharyngeus (IX), Iagus (X) und leccssoriws (XI) werden hänfig zn ciner Gruppe vereinigt, da ihre Ursprünge oft innig verbunden sind (so namentlicl bei Amphibien, Crocodilen, Vögeln), indem IX und X ein gemeinsames Ganglion bilden, ans dem auch aler $\mathrm{N}$. accessorius (Amphibien) entspringen kann. Der letztere Nerv elgibt sich, wie wir sehen werden, als ein abgesonderter Teil des Vagus. 
Der N.glossopharyngeus (IX) zeigt bei Petromyzon und den Fischen (s. Fig. 446) alle Eigenschaften eines typischen spinalen Hirnnervs (bei den Myxinoiden wurde ein gesonderter Glossopharyngeus vermißt). Er entspringt bei ersteren selbständig, jedoch häufig sehr dicht beim. Vagns und bildet ein Ganglion (bei Mammalia als Ganglion petrosum bezeichnet). Sein weiterer Verlauf erweist ihn als Nerv der ersten Kiemenspalte. Er teilt sich in einen stärkeren posttrematischen Ast, der am 1. Kiemenbogen herabzieht und mit seinen Endverzweigungen zur Schleimhant des Mundhöhleubodens und der Zunge geht, und einen praetrematischen sensiblen Ast oder R. hyoideus, der zum Zungenbeinbogen (auch Mundhöhle, Pseudobranchie der Teleostei) tritt. Beide Äste schließen demnach die 1. Kiemen spalte ein. Ein sensibler Dorsalast des IX. wurde bei Petromyzon, den Haien nni gewissen Ganoiden (Larven von Amia und Polypterus) beobachtet. Ferner findet sich wenigstens bei manchen Fischen ein R. pharyngeus (palatinns).

Wie schon hervorgehoben wurde, sind bei den Amphibien die Ganglien des IX. und $X$. Nervs meist völlig verschmolzen. Der dem Glossopharyngeus entspre('hende Nerv dieses Ganglions innerviert bei den Perennibranchiaten anch das auf dem ersten Kiemenbogen stehende erste Kiemenbüschel nnd wie bei den ïbrigen Amphibien gewisse Muskeln dieser Region; er endigt in der Schleimhant des Mundhöhlenbodens und der Zange als N. lingualis. Ein bis mehrere Rami pharyngei (palatini) köunen aus dem Cilossopharyngeus hervorgehen. - Der Glossopharyngeus del Ammioton verhält sich ähnlich, indem er im allgemeinen entsprechende Äste entsendet. Seine innigen Beziehungen zum Vagus dokumentieren sich zuweilen durch Verbindungen mit denselben, woraut es auch wohl zurickzufiihren ist, daß bei den Sauropsiden vom Glossopharyngeus Nervenäste ausgehen können, welche bei den Säugern dem Vagns angehören, so ein Ast zum Keblkopf (Laryngeus superior) nnd zuweilen auch I'haryngealäste. Seine Endzweige begeben sich auch bei den Amnioteı zur Zungenwurzel und bilden deren Geschmacksnerv (besonders Säuger). Ferner versorgt er auch Muskeln des Zungenbeins und des Pharynx.

Trayus (X). Dieser ansehnliche Nerv besitzt besonderes Interesse, da er sich als ein Komplex ebenso vieler ursprünglicher Hirnspinalnerven erweist, als Kiemensualten hinter der ersten folgen. Bei Cyclostomen und Fischen (s. Fig. 446) läßt sich meist eine Sonderung der Vagusursprïnge mit ihrem Ganglion in zwei Portionen mehr oder weniger deutlich erkennen, eine vordere und mehr dorsale Portion, welche dem Ursprung des Glossopharyngeus genähert ist, und eine hintere, zuweilen mehr ventrale. Die vordere Portion verbindet sich, wie es scheint, gewölnlich nur ziemlich locker mit der hinteren und setzt sich in den rein sensorischen Rumus laterilis des Tayus fort, der ähnlich wie der R. lateralis dorsalis des VII (1) phthatmicus superficialis VII) zur Innervierung von Seitenorgaven bestimmt ist. bie linterc Wurzelportion entspringt bei den Chondropterygiern mit zahlreichen Wurzelfiddchen, bei den übrigen Fischen mit einer beschränkten Zahl und geht in den sog. Truncus branchio-intestinalis uber, der gemischter Natur ist und, wie sein Name sagt, die Kiemen, sowie einen 'Teil der Eingeweide versorgt. - Dieser Truneus teilt sich in so viele sekundäre $\ddot{A}$ ste als Kiemenspalten hinter der ersten 
folgen. Jeder dieser Äste verhält sich so wie die zu den beiden ersten Visceralspalten tretenden Äste des VII oder IX, a. h. er teilt sich am Dorsalende der Spalte in einen R. praetrematicus, der am Vorderrand der Spalte herabzieht, und eineu $R$. posttrematicus der am hinteren Rand hinzieht. Die Zahl dieser Kiemenäste hängt also von der der Kiemenspalten ab; sie beträgt bei Petromyzon 6 , ähulich auch $5-6$ bei den Notidaniden unter den Haien, dagegen 4 bei den übrigen Fischen. IVenn die Kiemenspalten wie bei Petromyzon und den meisten Chondropterygii in weiteren Zwischenräumen aufeinander folgen, so ist der gemeinsame Truncus branchio-intestinalis, von welchem die Kiemenäste entspringen, langgestreckt ıpnd bildet bei Petromyzon, sowie gewissen Chondropterygiern am Ursprnng jedes Kiemenasts ein besonderes Ganglion (entsprechend den sog. epibranchialen Placoden), während sich bei andern Knorpelfischen eine gemeinsame lïngere Ganglienmasse findet. Mit der Zusammendrängung der Kiemenspalten bei deu übrigen Fischen verkürzt sich der Truncus branchio-intestinalis stark und die Ganglien (mit Ausnahme des ersten) vereinigen sich zu einer gemeinsamen Nasse, ołer bilden ein gangliöses Geflechtwerk, wie es sich bei Knochenfischen gewöhulich findet.

Ein dorsaler, in die Schädelhöhle aufsteigender Vagusast kommt den ryclostomen und Fischen häufig zu; er kann sich bei gr vissen Fischen anch an der Kopfhaut verbreiten, sowie Verbindungen mit dem $R$. dorsalis trigemini oder dem R. lateralis vagi eingehen. - Bei den Chondropterygiern entspringt ferner von jedem Ramus branchialis ein Ramus pharyngens zur Muskulatur und Selleimhant des Schlundes; bei dè Knochenfischen sind diese Rami anf wenige (3-1) heschränkt, welche direkt vom Ganyliengeflecht ausgehen.

Der 'Truncus branchio-intestinalis setzt sich caudalwärts, über die Kiemenregion hinans, längs des Üsophagus als Ramus intestinalis fort, der Zweige zum Ösophagus uud Magen, zuweilen sogar zum Anfang des Mitteldarms sendet, andrerseits auch den Herzvorhof und die Schwimmblase versorgt, wenn sich eine solche indet. Daß diese Eingeweidenerven häufig Verbindungen mit dem Sympathicus eingehen, wurde schon bei diesem erwähnt.

Besomlers eigentümlich erscheint das Verhalten der beilen Rami intestinales bei Myxine, indem sie sich in ihrem Verlauf bald vereinigen und dann als unpaarer Nerv auf der Dorsalseite des Darms bis zum After ziehen.

Aus dem Verhalten der Kiemenäste des Vagus folgt, daß jeder derselben dem Branchialast eines arsprüunglichen spinalen Hirnnerven entsprechen muß. Dies bewoist, daß der Vagus kein einfacher Hirnnerv sein kann, sondern ein Komplex ebenso vieler, als er Kiemenäste entsendet. Fraglich muß aber erscheinen, ob wir den Vagus (abgesehen von seinem R. lateralis) als ein Verschmelzungsprodukt ebenso vieler vollständiger Spinalnerven zu betrachten haben, oder ob nicht die auf den ersten folgenden Kiemenäste nur rudimentäre Spinalnerven repräsentieren, welche sich dem vordersten vollständigen angeschlossen haben, unter Reduktion ihrer Wurzel. Die ontogenetischen Beobachtungen, besonders an Petromyzon, scheinen mehr für letztere Deutung zu sprechen. - Die weit caudalwärts fiber die Kopfregion hinaus reichende Verbreitung des $R$. intestinalis am Darm, Ilerz 
und Schwimmblase (oder Lunge), wie sie bei den höheren Wirbeltieren noch mehr hervortritt, wird meist und wohl mit Recht auf eine candale Verlagerung dieser Organe zurückgeführt, womit auch der $R$. intestinalis nnd seine Ausbreitungen allmählich weiter caudalwärts geführt wurden. Immerhin könnten bierbei auch noch andere Momente im Spiel sein.

Der sensorische $R$. oder $N$. latcralis des Yagus findet sich bei sämtlichen Anamnia, welche Seitcnorgane am Rumpf besitzen, also nicht nur den Cyclostomen (ausgenommen die Myxinoiden) und Fisclen, sondern auch den ichthyoden Amphibien, Urodelen und einzelnen Salamandrinen, z. B. Molge, sowie den wasserlebenden Larven der uibrigen. Nur selten ist er bei gewissen Fischen (Plectognathen) sehr riickgebildet. - Er erstreckt sich gewöhnlich bis zum Schwanzende und gibt Ästchen zu. den Seitenorganen orler dem Seitenkanal ab. An seinem Ursprung entsendet er bei den Fischen gewöhnlich einen R. opercularis, hanptsächlich zur inneren Fliche des Kiemendeckels; häufig auch einen Ast zur hinteren Kopfund der Schultergegend. Wenn eine Sonderung des dorsalen und ventralen Seitenrumpfmuskels besteht, wie bei den Fischen, so vellänft der häufig allein ausgebildete Ifautstamm des Lateralis stets auf der Grenze beider Muskelpartien in dem borizontalen Septum, bald tiefer zwischen der Muskulatur lïngs der Wirbelsäule oder den Rippen (Petromyzon, Haie, einzelne Knochenfische, besonders Anguilla), bald dagegen oberflächlich unter der Hant. Am Schwanzende tritt er jedoch gewöhnlich unter die Haut.

Wenn der Seitenkalıal der Fische (speziell Teleostei). Welcher Seitenorgane enthält, von dem IIorizontalseptum gegen die Dorsil- oder Ventraltläche zu verlagert wird, was nicht selten vorkommt, so entwickelt sich ein sog. R. superficialis des Lateralis, der früher oler später ron ihm abzweigt und, unter dem Seitenkanal hinziehend, diesen mit Nervenästchen versorgt (s. Fig. 448, S.630). Er enthält zuweilen noch weitere Verstärkungen rurch Zutritt von Zweigen des Ifauptasts (des sog. Ramus lateralis profundus). In der Schwanzgegend vereinigen sich beide Äste wieder. - Bei gewissen Knochenfischen (z, B. Clupeiden, Cyprinoiden, auch Polypterus) kann an Stelle des früher erwähnten R. lateralis trigemini (sielee S. 629) ein besonderer Rückenkantenast des R. lateralis X (R. lateralis superficialis superi: treten, der die Rü̈ckenflossen versorgt.

Bei den Dipnoern und Amphibien (Ichthyoden, sowie Larven) finden sich außer dem in der Muskulatur der Seitenlinie verlaufenden Hauptstamm (profundus) in der Regel noch ein dorsaler und ein ventraler Ast des R. lat. X, die der Riickenund Bauchlinie sehr genähert sind. - Bei den Anuren und Amnioten wurde der sog. R. auricnlaris des Vagus (s. Fig. 447), welcher bei den ersteren mit der Arteria cutanea zur Haut zieht, häufig als Rest des Ramus lateralis gedentet; bei den Amnioten aber auch als ein R. cutaneus dorsalis X.

Der R. lateralis X läßt sich in ähnlicher Weise wie der des 'Trigeminus als durch Schlingenbildung zwischen ursprünglichen Zweigen dorsaler Spinalnerven entstanden deuten. Dies ist sehr wahrscheinlich, weil sich bei Pctromyzon vom Dorsalast jedes dorsalen und ventralen Spinalnervs ein Verbindungszweig zum R. lateralis begibt; auch bei Haifisch-Embryonen wurden solche Verbindnngen mit den dorsalen Wurzeln noch gefunden. Dies macht es sebr plausibel, daß der $\mathbf{R}$. 
lateralis urspriinglich ans einer solchen Schlingenbildung hervorging, sich erst nachträglich von den Spinalnerven isolierte und durch bleibenden Zusammenhang mit dem Vagus zu einem Hirnuerv von anscheinend ganz abnormer Ausbreitung wurde. Der rein sensorische R. lateralis $\mathrm{X}$ gehört zn den dorsolateralen sensorischen Ästen der spinalen Hirnnerven, die wir auch schon am 'Trigeminus und Facialis trafen. Die übereinstimmende funktionelle Bedentung gibt diesen Ästen einen gewissen gemeinsamen Charakter, der sich auch in ihren Urspriingen in Gehirn ausspricht. In dieser Ilinsicht scheint es ferner von Bedentung, daß sich bei den Anamnia, welche Seitenorgane besitzen, gewöhnlich eine noch weiter rostraloärts ziehende Ausbreitung des R. Iateralis $\mathrm{X}$ darin ausspricht, daß zwischen dem Facialis- und dem Vagusganglion eine Anastomose durch einen sog. $R$. recurrens des Facialis hergestellt erscheint (s. Fig. 446), welche gewissermaßen durch den R. ophthalmicus superfacialis facialis auch auf den R. ophthalmicus superficialis des Trigeminus fortgesetzt wird, so daß in diesem Fall das System des Lateralis iiber die gesamten spinalen Hirnnerven sich rostralwärts auszudehnen scheint. - Bei dieser Gelegenheit sei erwähnt, daßsich zwischen Ästen von Hirnnerven noch vielfach lokale Anastomosen finden, die hier nicht besonders erwähnt werden können.

Bei den himmenlosen Wirbeltioren geheu die Kiemenäiste des Vagns natiurlich sehr zuriick, sollen sich jedoch wenigstens teilweis als Schlundäste (Rami pharyngci) erhalten, wenn dies nicht etwa die schon bei den Fischen vertretenen Schlundäste sind. In der Hauptsache erhält sich also bei diesen Vertebraten der R. intestinalis, während der R. lateralis fust oder völlig rïckgebildet ist, wie wir schon oben sahen. Am Vagusursprung findet sich auch hier ein Ganglion, das bei den Mammalia als G. jugulare bezeichnet wird. Im Verlauf des $R$. intestinalis tritt jedoch meist

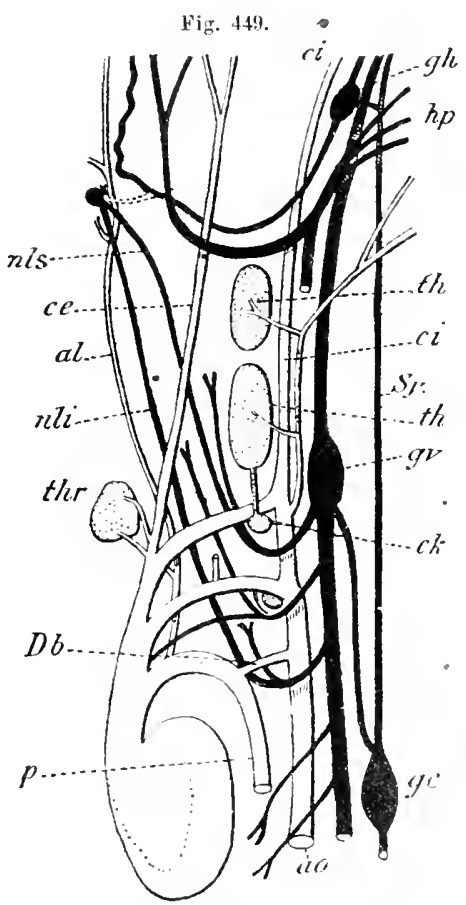

Schematische Darstellung der $\mathrm{H}$ als $\mathrm{nerpen}$ (schwarz), Arterien (weiß) nnd Kiemenspaltenderivate (punktiert) einer Eidechse (speziell Sphenodon). - Db Ductus hotalli. sy Sympathicus. - ao Aorta. - ce Caroti externa. - ci C'arotis interna. - al Art. laryngea inf. - $c k$ Carotiskürperchen. - $g h$ Ganglion petrosum $(I \mathrm{X})$. - gc Ganglion cel. vicale des Sympathicus. - $h p$ Hippoglossns. gi Ganglion nodosum vagi. - vli N. laryngens inferior (recurrens). - nls N. laryngeus superior. - $t h$ Thymus. - th. Thyreoidea. Die punktierte Anastomose zwischen N. IX und d. N. laryngeus superior findet sich bei Sphenodon nicht (n. VAN Bemmeles 1869 aus Gritinbaur, Vergl. Anat. d. Wirbeltiere 1s9s).

ein weiteres Ganglion (G. nodosum s. trunci) auf, das gewöhnlich auf dies Kiemenganglien der Rami branchiales der Fische zurückgefïhrt wird (vgl. Fig. 447 u. 449). In der Halsregion entspringen vom $R$. intestinalis einige Nerven, welche bei den Reptilien (besonders den Samriern) noch eine deutlich metamere Anordnung zeigen, indem sie in regelmäßiger Lagebeziehung zu den hier gewöhnlich noch in 
der Dreizahl vorhandenen Aortenbögen stehen (s. Fig. 449). Der vorderste dieser Äste (nls, motorisch-sensibel) wendet sich zum Kehlkopf und seiner Muskulatur (häufig auch dem Schlund) und wird deshalb als R. laryngeus superior bezeichnet. Bei den Sauriern ist sein Ursprung und ebenso das Ganglion nodosum $(g v)$, von dem er ausgeht, weit in die Halsregion zarückverlegt, da hier gewöhnlich noch ein vorderer Aortenbogen (Carotisbogen) besteht, hinter dem er herumgreift, um sich zum Kehlkopf nach vorn zu wenden. Mit dem Ausfall dieses Carotisbogens bei den übrigen Amnioten entspringt der R. laryngeus superior weiter vorn und bildet daher die nach vorn gewendete Schlinge nicht melhr. - Der zweite Ast versorgt Schlund und Herz und ist bei den Säugern dorch mehrere Herzästchen repräsentiert. - Der dritte Ast (nli, motorisch-sensibel) entspringt stets in der hinteren Halsregion und wendet sich als $R$. laryngeus inferior (R. recurrens) nach vorn zum Larynx. Diese, segmentale Anordnung verratenden drei Nervenäste sind mit der Rückwärtsverlagerung des Herzens und der Lungen jedenfalls stark caudalwärts verschoben worden, woraus sich ihr teilweis recur'renter Verlauf erklärt. Von der Fortsetzung des R. intestinalis entspringen Zweige zur Trachea, den Bronchien und Lungen, dẹm Ösophagus, Magen und der Leber. Dabei bilden diese Äste vielfach Geflechte, welche mit denen des Sympathicus innige Verbindungen eingehen können. Wie schon früher erwähnt, vereinigen sich der Sympathicus und der R. intestinalis vagi in der Halsregion gewisser Säuger zu einem gemeinsamen Stamm.

Nervus accessorius Willisii (XI). Bei der Beschreibung der Muskeln, welche aus dem allgemeinen Konstriktormuskel der Knorpelfsche hervorgeben, wurde schon des Musc. trapezius und seiner Innervierung durch einen Vagusast gedacht (s. S. 437). Bei den Cyclostomen ließ sich ein entsprechender Ast nicht finden. Wie der Musculus trapezius erhält sich der fragliche Nervenast bei den tetrapoden Vertebraten allgemein und isoliert sich in gewissem Grad vom Vagus, weshalb er bei den Amnioten, vor allem den Sängern, als besonderer XI. Hirnnerv gezählt wird. Bei den Amphibien verhält er sich im Allgemeinen noch wie bei den Chondropterygiern, d.h. er entspringt als Zweig vom Vagns, dessen hintere Wurzel zuweilen dem Accessorius zngerechnet wird. - Während der Ursprungskern der Accessoriusfasern bei den Amphibien noch ganz in der Medulla oblongata liegt, erstreckt er sich bei den Amnioten bis in den Anfang des Rückenmarks hinein, was zur Folge hat, $\mathrm{da} B$ auch aus diesem vordersten Teil des Rückenmarks Wurzelfädchen des Accessorius entspringen, welche, nach vorn ziehend und in die Schädelhöhle eintretend, sich den von der Medulla ausgehenden Wurzelfäden beigesellen, um mit ihnen vereint als Accessorius, samt dem Vagus, durch das Foramen jugulare den Schädel zu verlassen. - Bei den Sauropsiden (s. Fig. 418, 419) reichen diese "vom Ruickenmark entspringenden Wurzelfädehen bis zum 2. oder 3. Cervicalnerv herah, während sie bei den Säugern zahlreicher sind, so daß sie sich vom 2. bis zum 5-7. Cervicalnerv erstrecken (s. Fig. 424); mit den vordersten Cervicalnerven können sie sich auch verbinden. Dementsprechend ist der Ursprungskern des Accessorius der Mammalia sehr lang (s. Fig. 434). Die vom Riickenmark aus- 
gehenden Wurzelfadchen liegen bei den Sauropsiden im allgemeinen in der Flucht der dorsalen "Wurzeln, welche den vordersten Cervicalnerven häufig feblen; bei den Säugern dagegen zwischen Dorsal- und Ventralwurzeln.

Wie bemerkt, innerviert der Accessorius stets den Musculus trapezius und den von ihm abgeleiteten Musculus sterno-cleido-mastoideus der Säuger.

Die Wurzelfädchen der Sauropsiden zeigen häutig eine Art segmentaler Anordnung, indem sie dem 1.-3. Cervicalnerv coordiniert sind; bei den Sängern dagegen sind sie vielfach sehr zahlreich und nur die hinteren den Cervicalnerven zuweilen coordiniert. Die Accessoriusfasern vereinigen sich bei den Sauropsiden innig mit dem Vagus; bei den Schlangen verschmelzen sie sogar völlig mit demselben, so daß kein gesonderter Accessorius besteht. Die Săuger zeigen nur eine Anastomose mit denı Vagus, weshalb ihr Accessorius am selbständigsten geworden ist.

Wie ans dem Mitgeteilten folgt, muß der Accessurius als ein aus dem ursprünglichen Vagus hervorgegangener und zu einer gewissen Selbständigkeit gelangter Nerv gedeutet werden. Die Eigentïmlichkeit, daß er seine Ursprünge bei den Amnioten fortschreitend weiter nach binten auf den Anfang des Rückenmarks ausdehnt, womit sich auch sein Ursprungskern candalwärts verlängert, wurde verschieden beurteilt; entweder als eine allmähliche Ausbreitung seiner Ursprungsfasern nach hinten, oder gerade entgegengesetzt als ein allmäbliches Vorrücken der vordersten Spinalnerven in das ursprüngliche Accessoriusgebiet, oder auch als ein sekundärer Zutritt von Nervenzweigen aus den Wurzeln der cervicalen Spinalnerven. Es sind visceralmotorische Fasern, welche der Accessorius führt, was $j_{a}$ auch mit seinem Verbreitungsgebiet ïbereinstimmt..

Der Hypoglossus (XII) und die Spinooceipitalnerven. Wie schon beim Schädel erwähnt wurde (vgl. S. 228), finden sich bei den Chondropterygiern noch einige auf den Vagus folgende zarte Hirnnerven, die den Schädel durch besondere feine Öffnuugen verlassen. Diese sog. Occipitalnerven, deren vorderste bis unter den Vagus nach vorn rücken können, wurden daher früher als ventrale Wurzeln des letzteren gedeutet. Da der hinterste Occipitalnerv zuweilen noch eine dorsale Wurzel besitzt (Notidaniden), was auch embryonal bei anderen Chondropterygiern erwiesen wurde, so scheint sicher, daß die Occipitalnerven ursprünglich vollständige Spinalnerven waren, welche sich der Medulla oblongata innig zugesellten und in den Schädel aufgenommen wurden. Auch die Skeletelemente ihrer Segmente, soweit sie etwa ursprünglich vorhanden waren, müssen daher ị die occipitale Schädelregion eingegangen sein. Die Zahl der Occipitalnervenpare kann bis 5 betragen (hauptsächlich Notidaniden), siukt jedoch bei den meisten Haien und den Holocephalen auf $2-3$, bei den Rochen sogar auf 1 herab; ja sie fehlen letzteren häufig ganz. Die Verminderung geschah jedenfalls durch von vol'n nach hinten fortschreitende Reduktion, weshalb es möglich scheint, daß die Occipitalnervenzahl bei den Urformen der Chondropterygier noch größer war. Die Holocephalen zeigen hinter den beiden eigentlichen Occipitalnerven noch drei weitere (ebenso auch gewisse Rochen noch $1-2$ ), die sich von den ersteren etwas unterscheiden und daher als Occipitospinale bezeichnet werden, während all accessorischen Nerven zusammen auch spinooccipitale genannt wurden. - Nach ihrem Austritt ans dem Schädel vereinigen sich die Occipitaluerven (ebenso damit auch die occipitospinalen, weun solche vorhanden) zu einem nach hinten ziehenden 
Nervenstamm, der sich mit einer mehr oder weniger großen Zahl der folgenden freien Spinalnerven zu einem Geflecht, dem schon früher (S. 611) erwähnten Plexus cervicobrachialis vereinigt (s. Fig. 450). Bei den Chondropterygiern können sich jedoch einer bis mehrere, ja sämtliche Occipitalnerven isoliert erhalten. - Der cervicobrachiale Plexus nimmt den schon früher erwähnten eigenttimlichen Verlauf, indem er am Dorsalrand der Kiemenbogen, die bei den Chondropterygiern weit nach hinten über den Schädel hinausgesehoben sind, hinzieht, hierauf hinter dem letzton Kiemenbogen zur Ventralseite herabbiegt und die hypobranchiale spinale Mnskulatur (Plexus cervicalis), ferner die der Brustllosse (Plexus brachialis) innerviert, zuvor jedoch anch schon die epibranchiale spinale Muskulatnr; doch gibt er im Bereich der Coracoide anch Hautzweige ab.

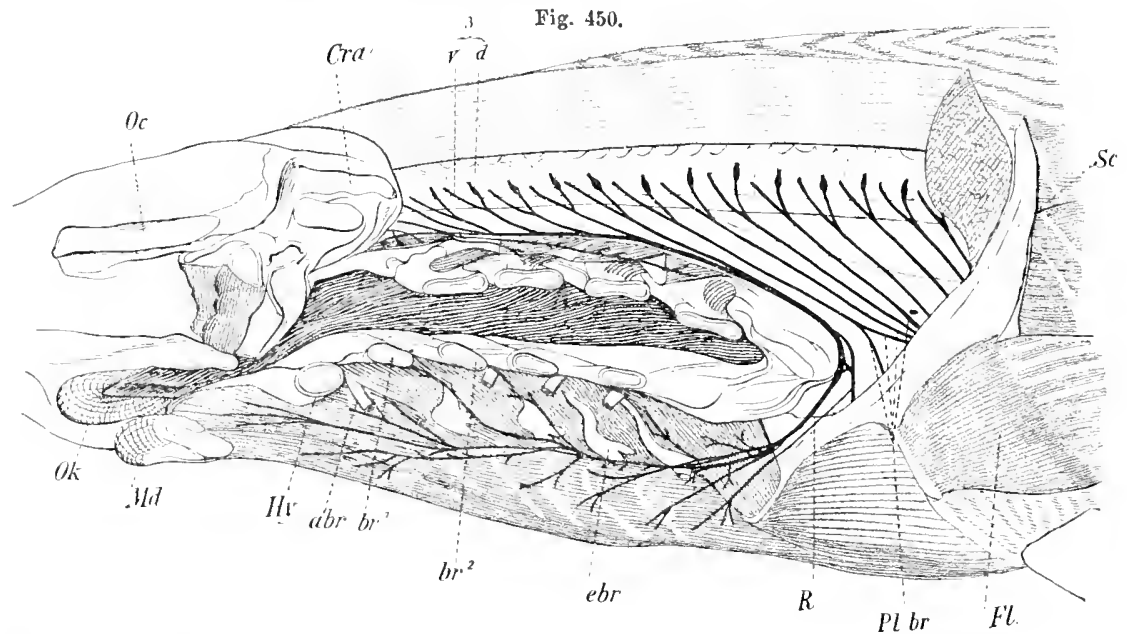

Mnstelus vulgaris. Kopf und Kiemenregion von links. Die seitliche Körperwaud ist abgetragen, sedal die Pharynz-oder Kiemenhöhle erótinet ist, und die beiden occipitalen und die spinalen Nerven trei liegen. Glossoptaryngeus und Vagus sind entfernt. Iuskeln und Kiemenarterien rot. Cra Schädel. - Fl Brustflosse. Hy Der durchsehnittene Hyoidbogen. - M $l$ Mandibel. - Oc Auge. - Ok Palatoquarlrat. - Plbr Plexus brachialis. - $R$ Fortsetzung des ventral nni nach vorn umbiegenden Plexus cervicalis. - Sc Scapulare. $a b r$ erste Kiemenarterie, die folgenden sind ebenfalls angegeben. $b r \cdot 1$ und $w^{2}$ die durchselunittenen beiden ersten Kiemenbogen. Die Dorsalenden der vier ersten Kiemenbogen mit den Mm. arcuales dors. und den M. interbranchiales sind ebenfalls zu sohen. Ventral sind die Mu coracobranehiales and die Fortsetzung des ventralen Rumpfmuskels bis zum Coracomandibularis sichtbar. - cbr Letobranchiale. $v 3 d$ dritter Spinalner mit dorsaler und ventraler Wurzel (n. M. Fúrbinger 1897 aus Gegknsaur, Vergl. Anat. d. Wirbeltiere 1:98).

Bei den Cyclostomen (s. Fig. 404, S. 565, $a_{r}^{\prime}-b_{r}^{l}$ ) finden sich zwei, etwas rudimentäre vorderste Spinalnerven, welche die Verbindnngsmembran zwischen Schädel und dem ersten Neuralbogen (Petromyzon) durchsetzen, und dorsale wie ventrale Wurzeln besitzen. Bei Petromyzon versorgen sie die beiden praebranchialen Myomeren. - Die Vergleichung macht es wahrscheinlich, daß diese beiden Nerven noch vor den Occipitalnerven der Chondropterygier einzureihen sind, daß sich also bei den Cyclostomen spinale Nerven erhielten, welche bei ersteren nicht mehr vorkommen. - Die Ventraläste der Spinalnerven der Kiemenregion bilden bei Petromyzon einen ganz ähnlich verlaufenden Plexus cervicalis; welcher die hypobranchiale Muskulatur innerviert, wogegen sich bei den Myxinoiden kein solcher Plexus fndet. Der eigentümliche Verlauf des Plexus cervicalis ron Petromyzon und des entsprechenden Plexus cervicobrachialis der Chondropterygier spricht, wie schon früber angedeutet wurde, dafür, daß die rückwärtige Lage der Kiemenbogen dieser Formen durch caudale Verschiebung entstand, was bei ersterem auch ontogenetisch erwiesen ist. 
Während die Dipnoi noch 3 Occipitalnerven besitzen (Fig. 405, S. 567, $x-$ i), kommen den Ganoiden nur 2-1 zu; die Teleostei zeigen überhaupt keine mehr (fast ausnahmslos werden diese Occipitalnerven nur durch ventrale Wurzeln repräsentiert). - Dagegen treten bei den Chondrostei wegen der Verschmelzung zahlreicher vorderer Wirbelelemente mit dem Schädel eine große Zahl (Acipenser bis 8) occipitospinaler Nerven hinzu, welche sämtlich beide Wurzeln besitzen. Bei Dipnoi (Fig. 405, $a-b$ ) und Holostei dagegen kommen, ähnlich wie bei den Knochenfischen, nur $1-3$ Occipitospinalnerven vor. Auch boi den letzterwähnten Fischen bildet sich unter Zutritt einer verschiedenen Zahl von Cervicalnerven ein Plexus cervicobrachialis, wobei jedoch der Cervicalteil, an dessen Bildung sich die Occipital- und Occipitospinalnerven beteiligen, schärfer vom Brachialteil geschieden ist (besonders Dipnoer). Der Cervicalplexus versorgt wieder die hypobranchiale Muskulatur.

Occipitalnerven fehlen den Amphibien völlig; auch die erwachsenen Ammioten zeigen davon jedenfalls nichts mehr (wahrscheinlich jedoch embryonal). Bei den Amphibien geht ans den Ventralästen der 2 oder 3 ersten Spinalnerven (die meisten Urodelen, Gymnophionen, einige Anuren), oder allein des 2. (meiste Anuren) ein Plexus cervicalis hervor, der bei den kiemenatmenden noch an die Verhältnisse der Fische erinnert, und sich hauptsächlich zu Zungenmuskeln (M. hyoglossus und genioglossus) begibt. Der Cervicalplexus ist von dem darauf folgenden Brachialplexus in der Regel schärfer gesondert (Ansnahme Pipa).

Die den Cervicalplexus der Amphibien repräsentierende Bildung wird bei den Amnioten in den Schädel einbezogen und so zu einem Hirnnerv, welcher als der XII. oder Hypoglossus bezeichnet wird. Seine Ursprünge reichen nie so weit zurück wie die des Accessorius. Bei den erwachsenen Sauropsiden finden sich meist drei (seltener zwei) ventrale Hypoglossuswurzelı, die sich wohl den drei ersten occipitospinalen Nerven der Fische und den vordersten Spinalnerven der Amphibien vergleichen lassen. Wenn dies richtig ist, so wäre hieraus auch wohl zu entnehmen, daß die zu ihnen gehörigen Wirbelelemente der Amphibien in den Schädel der Amuioten aufgenommen wurden (s. S. 271). Der aus diesen Wurzeln hervorgehende Nerv (Hypoglossus) bildet anch bei den Amnioten mit dem ersten oder den beiden ersten freien Spinalnerven eimen Plexus cervicalis, welcher jedoch den Crocodilen lehlt; vom Plexus brachialis ist er meist völlig isoliert. Der Hypoglossus der Sauropsiden verbreitet sich mit seinen Hauptästen in der Zungenmuskulatur, sowie den Längsmuskelu zwischen Brustgürtel und Unterkiefer; untergeordnete Zweige gehen jedoch auch zu den Nackenmuskeln. Bemerkenswert erscheint, daß bei den Vögeln auch die Muskulatur des unteren Kehlkopfs (Syrinx) von ihm versorgt wird.

Auch die erwachsenen Süuyer besitzen häufig noch drei Hypoglossuswuzeln, welci e teils ventral vom Vagus, teils etwas hinter ihm, zwischen den Pyramiden und ren Oliven, aus der Medulla oblongata entspringen. Die nicht selten anscheinend größere Wurzelzahl ist auf die Bildung einzelner Wurzelfädchen zurückzuführen, welche sich daun zu den eigentlichen Wurzeln vereinigen. Doch sinkt die Wurzelzahl bei nicht wenigen Sängern auf zwei, ja sogar eine herab. 
Im allgemeinen diurften auch hier die drei Wurzeln den drei vordersten occipitospinalen Nerven der Fische entsprechen. Embryonal wurden jedoch zablreichere Nerven (bis sechs) bei verschiedenen Mammaliern beobachtet, weshalb es möglich scheint, daß ontogenetisch selbst noch einige hintere Occipitalnerven der Fische voritibergehend auftreten. Von Interesse ist,daß bei erwachsenen Säugern nicht selten eine der Hypoglossnswurzeln noch eine dorsale Wurzel besitzt (häufig bei Huftieren, einzelnen Carnivoren); auch embryoual wurden solch dorsale Wurzeln mit Ganglion als vorübergehende Bildnngen erwiesen. Eine Plexusbildung des Hypoglossus mit dem ersten bis dritten Cervicalnerv kommt den Sängetieren gleichfalls zu. - Der Hypoglossus der Mammalia innerviert nur aus der hypobranchialen Muskulatur hervorgegangene Muskeln (M. omo- und sternobyoideus, sternothyreoideus, thyreobyoideus, sowie die anf den gleichen Ursprung zurïckführbaren Zungenmuskeln).

Das Mitgeteilte erweist, daß der bei den Amnioten zum XII. Hirnnerv gewordene Hypoglossus im allgemeinen dem Cervicalplexus der niederen Wirbeltiere entspricht, welcher daher auch rielfach als Hypoglossus bezeichnet wurde. $\mathrm{Zu}$ betonen ist jedoch, daß die beiden Occipitalnerven der Cyclostomen nicht dem Hypoglossus gleichgesetzt werden dürfen, wic dies häufig geschah; letzterem -ließen sich nur Nerven des Cervicalplexus von Petromyzön vergleichen.

Augenmuskgelnerven (III, IV und VI). Diese fast rein motorischen Nerven steben im Gegensatz zu den typisch spinalen Hirnnerven; ihre Beurteilung sehwankt nngemein. Selten, wie z. B. bei den Myxinoiden, sind sie ganz verkïmmert. Sie wurden vielfach als Anteile schon früher besprochener spinaler Hirnnerven (besonders des V. u. VII.), namentlich aber als diesen zugehörige ventrale Wurzeln gedentet; andrerseits zuweilen auch als vollständige Hirnnerven, ja sogar als Komplexe (Verschmelzungsprodukte) mebrerer solcher. Da sie im wesentlichen die Augenmuskeln innervieren, so ist deren Herkunft für ihre Beurteilung besonders wichtig. Wie schon früher angedeutet, ergaben die ontogenetischen Untersuchungen (besonders bei Petromyzon und den Knorpelfischen), daß die Angenmuskeln aus drei vor dem Hoorrorgan auftretenden Somiten hervorgeben und zwar so, daß die meisten der Augenmuskeln (Rectus anterior, superior und inferior, sowie der Obliquus inferior) ans dem ersten Somit, der Obliquas superior aus dem zweiten, der Rectns posterior aus dem dritten entstehen. Hiermit harmoniert auch die Innervierung dieser Muskeln durch die drei Nerven bei den Gnathostomen, inden der Oculomotorius (III) die aus dem ersten Somit entstehenden Muskeln, der Trochlearis (IV) die des zweiten (Obliquus superior) und der Abducens (VI) die des dritten Somits (Rectus posterior) ver'sorgt.

Bei Petromyzon sind die Verhältuisse etwas unsicher, obgleich gewöhnlich angegeben wird, daß hier auch ter Rectus inferior vom Abducens innerviert werde; doch könnte dor fragliche Muskel nur ein abgetrennter Teil, des Rectus posterior sein (Koltzoff).

Für die Deutung der Angenmuskelnerven als ventrale Wurzeln, welche sich am Hirn erhielten, spricht ibr Ursprung von ventralen im Hirnboden liegenden Kernen. Der Oculomotorius und Trocnlearis entspringen bei den Gnathostomen rom Mittelhirn, der Abducens dagegen von der Medulla oblongata; da ihre Ursprïnge auch ontogenetisch an diesen Stellen auftreten, so ist es zweifelhaft, ob 
sie, wie bäufig angencmmen wird, aus der Nachhirnregion nach vorn verschoben wurden. Der Ursprung des Oculomotorius bei Petromyzon rom Vorderende der Medulla oblongata (Fig. 404) würde jedoch dafür sprechen (vgl. oben S. 622). -

- Während Oculomotorius und Abducens ibre ventrale Austrittsstelle bewahren, steigen dagegen die Trochlearisfasern im Mittelhirn dorsal anfwärts, kreuzen sich an dessen Decke mit denen der Gegenseite und treten dann ziemlich hoch dorsal, etwa anf der Grenze von Mittel- und Kleinhirn aus (s. z. 13. Fig. 414).

Ontogenetisch treten aus der Hirnanlage Nervenzellen in den Oculomotorins ein, die auch zu einer Ganglienbildung in seinem Verlanf fiibren können. Dies Ganglion tritt mit einem $\mathrm{Zweig}$ des Ram. ophthalmicus profundus des Trigeminus in Verbindung und erhalt so wohl direkt sensible Nervenfasern und Zelleu aus dem Trigeminus. Andrerseits steht es mit dem Sympathicus in Zusammenhang. Bei den meisten Sängern (anch Mensch) isoliert es sich als sog. Ginglion ciliare mehr vom Oculomotorius, mit dem es nur durch einen seiner Äste (Radix brevis) in Verbinduug bleibt (s. Fig. 447). Das Ganglion ciliare entsendet einen bis zahlreiche Ciliarnerven (gemischter Natur) für den Ciliarmuskel des Anges, den Sphincter pupillae und die Augenwände. Gewöhnlich wird es dem sympathischen System zngerechnet; seine Beziehungen zum Ocnlomotorins und Trigeminus sprechen sich anch darin alus, daß bei Fischen Cilianerven von diesen beiden Nerven ansgehen können.

Der eigentiimliche dorsale Anstritt des Trochlearis ließ sich bis jetzt nicht genïgend erklären, obgleich mancherlei Versuche hierzı gemacht wurden. Bemerkenswert erscheint, daß der Trochlearis der Anamnia sensible Fasern enthält, 'zur Versorgung der Conjunctiva des Auges.

Der Abducens entspringt von der Ventralseite der Medulla, etwas vor oder hinter dem Trigeminus, mit dessen Ramus ophthalmicus er sich bei manchen Fischen und den Amphibien innig verbinden kann, weshalb er bei den meisten Anuren als cin Ast des Ramus ophthalmicus erscheint. Außer dem Musculus rectus posterior imnerviert er noch den sog. Retractor bulbi und die Nickhautmuskeln des Anges, wenn solche Muskeln vorhanden sind.

Wie schon hervorgehoben wurde, gilt hente als die verbreitetste Ansicht, daß die Augenmuskelnerven ventrale Wurzeln gewisser Hirnnerven darstellez; doch gehen die Meinungen im einzelnen weit anseinander. Der Oculomotorius wird meist dem spinalen Trigeminus 1. (R. ophthalnicus profundus) als ventrale Wurzel zugerechnet, doch auch gelegentlich (ebenso wie der Trochlearis) von dessen Visceralast abgeleitet. Wegen des Ganglions, das gewöhnlich an ihm auftritt, wurde er zuweilen auch als selbständiger spinaler Hirnnerv gedeutet. - Auf eine Ventralwurzel des Trigeminns 2. wird in der Regel der Trochlearis zurückgeführt; der. Alducens dagegen meist in dieselbe Beziehung zum Facialis gebracht.

\section{Hirn - und Rïckenmarkshäute (Meninges).}

Bei den Cranioten findet sich zwischen dem Centralnervensystem und dem Rückgratskanal oder Schiidel ein häutiges, mesodermales Zwischengewebe, welches 
Hirn und Rückenmark umhüllt und den Raum zwischen ihnen und dem Skelet ausfüllt. - Dies Zwischengewebe erfährt in der Wirbeltierreihe eine fortschreitende Entwicklung. Seine äußerste Lage schließt sich der Innenfläche des Knorpels oder Knochens des Axenskelets innig an und verhält sich wie ein inneres Perichondrium oder Periost desselben. Diese Lage wird daher auch häufig den Skeletteilen selbst zugerechnet und zuweilen als Endorhachis bezeichnet. Meist

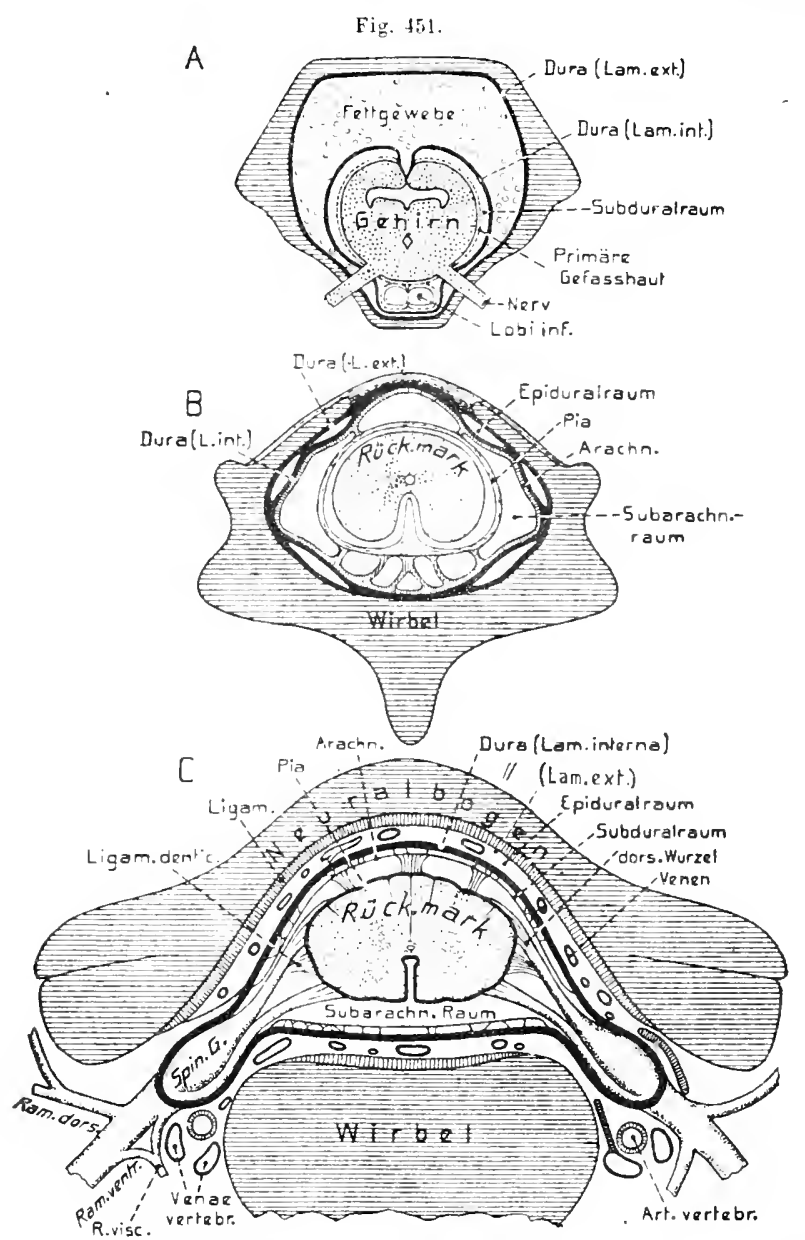

Schemata zur Darstellung der Hirn-und Rückenmarkshäute. A Querschnitt durch den Schädel mit Hirn eines Cy prinoiden (Barbus etwa) in der Region des Mittelhirns (nach SAGEarenL 1s81). - $B$ Testudo graeca. Querschnitt durch einen Halswirbel (n. ZANDER 1899). - $C$ Quer- Bchnitt durch den vierten Halswirbel des Menschen (nach RaUBer-Kopsch, Anat. d. Menschen 1912). betrachtet man sie aber als eine oberflächlicie Lamelle der äuBeren Riickenmarkshaut, odv: der sog. Dura mater des Menschen, und bezeichnet sie deßhalb als $A$ Benlage derDura oder als deren Lamina externa. Schon bei den Cyclostomen und Fisehen (s. Fig. $450 A$ ) findet sich in demZwischengewebe, dicht an der Oberfläche des Hirns oder Rückenmarks, ein feiner, von Lymphe erfiiliter Spaltraum, welcher eine innerste diinne membranartige u. blutgefüßreiche Lage des Zwischengewebes von der äußeren, viel dickeren Lage trennt. Letztere Lage, deren oberffächliche Grenzmembran die vorhin erwähnt , als Perios̀t fungierende Lamelle (Lamina externa) bildet, wird in der Regel als äußere Meninx (Ectomeninx) bezeichnet und der Dura mater der Sänger

homologisiert, der erwähnte Lymphraum daher auch Subduralraum genannt; doch wird die Existenz dieses Raums bei den Fischen auch geleugnet. Die blutgefäßreiche und Nerven enthaltende dïnne Haut, welche das Hirn und liiiekenmark direkt überzieht, kann dann als primäre Gefäßhaut oder Meninx minitim bezeichnet 


\section{VORLESUNGEN ÜBER \\ VERGLEICHENDE ANATOVIE}

VUN

\section{OTTO B Ü'TSCHLI}

PLOFESSOR DER ZOOLOGIE IN HEIDELBERG

\section{LIEFERUNG:}

SINNESORGANE UNI) LEUCHTORGANE

MIT IEN 'I'EX'TFIGUREN 452-72\%

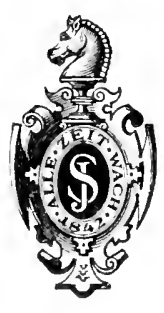

BERI,IN

VERLAG VUN JUIAUS SPRINGER 
Alle Rechte, insbesondere das der Übersetzung in fremde Sprachen, vorbehalten. Copyright 1921 by .Julius Springer in Berlin. 
Mitten aus der angestrengtesten Mrheit an don Werke, dem seit daluren der größte 'T'eil seiner. 'Tätigkeit gewidmet war', wurde Utto Bülsclıli :bbgreruten. Er durte nicht einmal melu die Vollendung der Drucklegung des 1. bandes seiner vergleichenden Anatomie erleben, der mit der jetzt vorliegenden dritten Lieferung abgeschlossen ist. Unermiddich hat er bis zum 'Tage seiner Erkrankung an der fortfïlurung dieses ihm ganz besonders am llerzen liegenden Werkes gearbeitet.

Bütschli hat das im großen und yanzen drucklertige Manuskript fiir die noch fehlenden Kapitel bis einschließlich des Abschnittes iiber das Blulgetäßsystem hinterlassen, so daß nnr noch die 1)arstellung der Exkretionsund Geschlechtsorgane fehlt.

Daß von diesem umfangreichen Manuskript bisher nichts weiter erschicn, hängt mit allerlei Schwierigkeiten zusammen, die zum 'I'eil in den Kriegsverhältnissen lagen, zum 'Teil auch dadurch bedingt wurden, daß das Werk aus Gründen, die hier nicht zu orörtern sind, in den Verlag von Julins Springer iiberging.

Unter der durch diese Verhältnisse beelingten Verzögerung des Druckes litt Biitschli schwer, und es war für ihn die letate Frende, als am 'l'age vor seiner Erkrankung von Julius Springer die Nachricht eintraf, daß sichere Aussicht fiir die baldige Wiederaulnahme des 1917 unterbrochenen Druckes der aritten Lieferung bestehe, von welcher Bit tschli die ersten 11 (bei Eugelmann gedruckten) Bogen noch selbst durchkorrigiert hatte.

Nacl dem Tode des unvergeßlichen Lehrers und Freundes leiten dic Unterzeichneten die weitere Herauggabe des Werkes. Während Blochmann, wie anch frïher die sachliche Durcharbeitung des Maunskriptes übernahu, wobei ihm Clara Hamburger nur helfend zur Seite steht, hat diese die Vorbereitung und Überwachung des Druckes unter sich. - Iferr Ur. Loeser ist bei der Durchsicht der Korrekturen behilflich und hat, z. 'I' in Gemeinschaft mit 0 . Bütschli, Berichtigungen zu den zwei ersten lieferungen zusammengestelit. Er bearbeitet feruer ein ausführliches Sachregister des ganzen Werkes, welches den zweiten Band abschließen wird.

Das Manuskript soll soweit als möglich so, wie es vou dem Verfasser hinterlassen wurde, znm Abdruck kommen. Ganz auszuschließen sind $\ddot{A u d e}_{\text {- }}$ rungen in 'Text und Abbildungen nicht, wie ja auch Butschli selbst bei der Korrektur noch allerlei geändert hätte. Genaneres in dieser Hinsicht zu berichten mag einer späteren Gelegenheit vorbehalten bleiben.

Abbildungen, die von Blochmann herrühen, sind wit Blo bezeichnet.

Die noch fehlenden Abschnitte ïber Fxkretions- und Geschlechtsorgane wird Blochmann bearbeiten.

Tiibingen und Heidelberg.

F. Blochmann, C. Hamburger. 


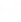


werden (anch Endomeninx). Von ihr gehen die Blutgefäße aus, welche in die Nervensubstanz selbst eindringen. Wo tiefere Einfaltnngen des Hirns bestehen, so namentlich zwischen Mittel- und Kleinhirn, da senkt sich die tiefere Lage dieser Gefäßhaut in jene Falten hincin.

1)ie Hauptmasse der dicken äußeren Hant (Dura mater wird bei einem Teil der Fische und den Cyclostomen von einem Gallertgewebe gebildet (Chondropterygii, Chondrostei, Dipnoi und gewisse Teleostei, so Siluriden, Esox, Gadiden usw.), dem sich außen die periostale Lamina externa anschließt, während es innen durch eine festere Bindegewebslamelle Lamina interna gegen den Subduralraum abgegrenzt wird. Bei den meisten Holostei und Teleostei sind diesem Gallertgewebe viele Fettzellen eingelagert, weshalb es, namentlich im Schïdel, zu einem iiber dem Gehirn mächtig entwickelten Fettgewebe wird, das die vom Gehirn meist nur zum kleineren Teil eingenommene Schädelhöhle erfüllt und auch reich an Nerven und Gefäßen ist. - Während dies Gewebe nach der eben vorgetragenen Auffassung einen Bestandteil der Dura mater bildet, etwa vergleichbar dem sog. Epiduralgewebe in der Dura des Sänger-Riiekenmarks, betrachtet es eine andere Ansicht (Ster:i) als ein anßerhalb der eigentlichen Dura befindliches sog. l'erimeningealgewebe. Die eigentliche Dura wäre nach dieser Meinnng bei den Fischen noch in der primären Gefäßhaut undifferenziert enthalten, und der oben als Subduralraum bezeichnete Lymphraum soll dem sog. Epiduralraum der Sänger gleichznsctzen sein. Ich halte die erstere Ansicht für wabrscheinlicher.

Bei den modelen Amphibirn erimnern die Verbältnisse der Rüickenmarkshänte jedenfalls noch sehr an die der Fische, besonders durch die Ansbildung eines ähnlichen Gallert- oder Fettgewebes in der Dura, welches sich anch in die Schädelhöhle erstreckt. Bei den Anuren findet sich an seiner Stelle ein ansehnlicher Lymphranm (sog. Epi-, Peri- oder Interduralraum und nur im vorderen Teil der Schädelhöhle noch Reste von Fettgewebe. Die der prinüren Gefäßhaut der Fische entsprechende Haut differenziert sich bei den Amphibien schon in zwei Lagen, indem zahlreiche kleine Lymphräume in ilır anftreten; die Anuren zeigen dies viel dentlicher als die Urodelen.

Anch die Amnioten zeichnen sich dadureh aus, daß in der sog. primären Gefäßhaut spaltenartige Lymphränme anftreten, wodurch sie sich in zwei Hänte sondert, eine äußere dïnne gefäßlose trachmoidea und eine innere gefäß- und nervenreiche Piu mater (Fig. $451 B, C$ ). Namentlich bei den Sängern $(C)$ wird diese Sonderung sehr dentlich, indem der die Arachnoidea und die Pia trennende sog. Subarachnoidalraum weit wird. Er ist vou radiären Bindegewebssträngen durchsetzt, welche iln in mehrere Abteilungen scheiden können. Unter diesen Strängen treten bei den Säugern die lateralen sog. Ligamenta denticulata besonders hervor und setzen sich bis zur Dura nach anßen fort, so daß an diesen Stellen die urspriingliche Einheitlichkeit der drei Hïnte erhalten blieb.

Schon bei den Fischen finden sich in der primitiven Gefäßhaut drei verdickte längsbänter, die elastische Fasern enthatten, ein ventrales in der Mittellinie, zwei laterale zwischen 
den Ursprüngen der dorsalen und rentralen Wurzeln. Letztere geben in jedem Wirbel seitliche Fortsätze zu der Lamina externa der Dura (Endorhachis) ab und erinnern dadurch an die Ligamenta denticulata der süuger. Entsprechende Ligamente wiederholen sich im allgemeinen auch bei den höheren Formen.

Die gefäßreiche Pia senkt sich mit ihrer inneren Lage in die Vertiefungen der Hirn- nnd Rïckenmarksoberfläche ein, so in die Furchen der HemisphärenoberHäche der Sänger und in die Fissura ventralis des Rückenmarks. - Wie wir schon frïher sahen, beteiligt sich die Pia der Amnioten, oder die primitive Gefüßhaut der Anamnia, auch am Anfbau der Telae chorioideae des Gehiris und besonders der Plexus der Hirnventrikel, indem sie mit deren Ependym innig verwächst. - Die ebenfalls nerven- und gefäßhaltige Dura der Sänger besitzt zahlreiche Lymphräume

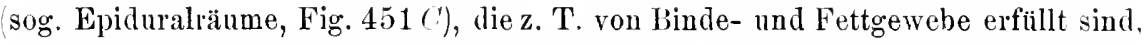
und ihre Sonderung in eine äußere (L. externa) und eine innere (L. interna) bewirken. Im Hirnteil der Dura treten solche Lymphränme nur spärlich anf; sie bleibt hier gewöhnlich einheitlich und daher von ursprïnglicher Bildung. Der Subarachnoidalraum dagegen erweitert sich an der Hirnbasis häufig sehr ansehnlich zu sog. Cisternen. Er steht, wie dies wenigstens für die Sänger erwiesen ist, mit dem vierten llirnventrikel durch drei Öffnungen in der Tela, von jedenfalls sekundärer Entstehung, in offener Verbindung. - Sowohl die epidnralen Lymphräume des Rückenmarks, als namentlich der ansehnliche subarachnoidale Raum werden auch mit dem Schutze des Centralnervensystems bei den Bewegungen der Wirbelsäule in Beziehung gesetzt, was anch teilweise zutreffen diirfte. - Oben wurde schon hervorgehoben, daß eine etwas abweichende Auffassung die innere Lage der Säugerdura ebenfalls ans der Differenzierung der primären Gefäßhaut der Fische abzuleiten versucht.

Die Dura der Sänger senkt sich von der Dorsalseite und vorn zwischen die Hemisphären des Großhirns als Hirnsichel Fal.r cerebri) hinein, welche hinten in eine ähnliche quere Einfaltung der Dura zwischen dem großen und kleinen Hirn ïbergeht, das Kileinhirnelt (Tentorium cerebelli). Sowohl in der Sichel als dem Hirnzelt kömnen Verknöcherungen anftreten, die bei starker Entwicklıng des Tentoriums (Carnivoren und gewisse Ungulaten) oder der Falx (besonders bei Delphinen auch mit den Schädelknochen verwachsen kömnen, und dann innere scheidewandartige Vorsprïnge der Schädelkapsel bilden.

Die Spinalnervenwurzeln werden, soweit sie im Riickgratskanal verlanten, gleichfalls ron Fortsetzungen der Dura scheidenartig nmhïllt.

\section{Kapitel: Sinnesorgane.}

\section{Einleitung.}

Uie Anfinahme äußerer Reize geschieht durch die Körperoberfläche, im einfachsten Falle also durch das Ectoderm. Ebenso wird aber auch das Entoderm, wenigstens in vielen Fällen, reizanfnehmend sein können. In der Regel haben sich für diese Funktion besondere Ectodermzellen in geeigneter Weise differenziert, 1. h. zu sinncs:ellen entwickelt. Bei den Wirbellosen sind diese Zellen dadurch 
charakterisiert, daß sie proximal in eine feine Faser anslaufen, welche alle Eigenschaften einer Nervenfaser besitzt, die sich mit dem Nervensystem verbindet; nnd zwar geschieht dies gewöhnlich so, daß sich zahlreiche solche Fasern zu einem Nerv vereinigen, welcher schließlich in das Centralnervensystem cintritt. In letztercm scheinen sich die ursprïnglichen Sinneszellenfasern in der Regel zu verästeln und so mit einer größeren Zahl von Ganglienzellen in Zusammenhang, oder wenigstens nahe Bertihrung zu treten, woriiber die Meinungen noch recht anseinander gehen. Anch das Distalende der ectodermalen Sinneszellen wasserlebender Wirbelloser ist meist in besonderer Weise ausgebildet, indem es ein bis zahlreiche zarte, unbewegliche, plasmatische Ilärchen trägt, die sich über die Epidermisoberfläche mehr oder weniger erheben. Diese Sinneshärchen dentet man als die eigentlich reizanfnehmenden Organellen der Sinneszellen. - Bei luftlebenden Tieren, gelegentlich aber auch anderen, können jedoch anch stark modifizierte Endigungsweisen der Sinneszellen anftreten. - Durch Vereinigung von Sinneszellen zu Gruppen, wobei aber fast stets indifferente Epidermiszellen zwischen ibnen erhalten bleiben, entstehen die komplizierteren, bis sehr hoch entwickelten Sinnesorgane, die sich ontogenetisch und vergleichend anatomisch stets von solch einfachen Zuständen lokaler, sinneszellenreicher Epidermispartien ableiten lassen.

Die einfachen Sinneszellen der Wirbellosen sind urspriinglich stets in die Epidermis ganz eingelagert, indem sich nur ihr basaler Nervenfortsatz ins Körperinnere erstreckt. Hänfig wachsen sie jedoch nnter die Epidermis in die Tiefe, so daß nur ihr distaler, mehr oder weniger fadenförmig ansgezogener Teil zwischen die Epidermiszellen bis zur Oberfläche tritt. So kann der eigentliche Sinneszellenkörper mehr oder weniger in die Tiefe verlagert werden, in manchen Fällen sogar sehr tief, so daß von ihm eine lange distale Faser, die den Charakter einer Nervenfaser besitzt, his zur Epidermisoberflïche zieht. Ja, die proximale Verlagernng der Sinneszelle kann zuweilen bis zu ihrem Eintritt in das Centralnervensystem führen. Dann entsteht der Inschein, daß vou letzterem Nervenfasern entspringen, welche zur Epidermis gehen und zwischen deren Zellen, ohne Verbindung mit besonderen Sinneszellen, endigen (freie Nervenendigungen). Solche Fialle sind bei Wirbellosen sicher erwiesen, obgleich bei ihnen solch freie Nervenendigungen im allgemeinen seltener vorkommen. Um so verbreiteter finden sie sich in der Wirbeltierepidermis und lassen sich wohl gleichfalls in der geschilderten Weise als Endigungen ursprïnglich oberflächlicher Sinneszellen auffissen, die sekundär in das r 'entralnervensystem riickten, weshalb die zu ihnen gehörenden Sinneszellen nun meist als Ganglienzellen bezeichnet werden. - So läßt sich wohl annehmen, daß die Nervenzellen der Spinalganglien der Wirbeltiere solche in die Tiefe gerïckte ursprïngliche Sinneszellen darstellen. - Die Sinneszellen der Wirbeltiere (mit einziger Ausnahme jener der Geruchsorgane) unterscheiden sich nämlich von denen der Wirbellosen anffallend, indem sie nicht in eine proximale Nervenfaser anslaufen, sondern von feinen Nervenfaserendigungen mehr oder weniger umsponnen werden, die sie nach der gewöhnlichen Annahme nur berïhren, d. h, nur durch Contignitït zu ihnen in Beziehnng treten. Dies abweichende Verlalten wird deshalb 
gewöhnlich so gedeutet, daß (abgesehen von den Geruchsorganen) in der Epidermis der Vorfahren der Vertebraten nur freie Nervenendigungen vorhanden gewesen seien, und sich erst später besondere Sinneszellen entwickelten, welche mit diesen Endigungen in Beziehung traten. - Wenn diese Auffassung richtig ist, so müßten die erwähnten Sinneszellen derVertebraten, im Gegensatz zu den primitiven (oder primären) der Wirbellosen, als selundäre bezeichnet werden, da ja aller Wahrscheinlichkeit nach die freien Nervenendigungen aus ursprünglich vorhanden gewesenen Sinneszellen hervorgegangen sind, also die mit ihnen später in Beziehung tretenden Epidermiszellen sekundärer Entstehung sein müßten.

Immerhin ließe sich dies Verhalten auch noch in anderer Weise deuten, nämlich so, daß die Sinneszellen der Vertebraten, wie die der Riechorgane, zwar primäre seien, aber keine längere proximale Nervenfaser eutwickelten, vielmehr die Verbindung mit dem distalen Ausläufer einer Ganglienzelle, welche ja nach der verbreiteten Ansicht stets durch Contiguität stattfinden soll, hier obertlächlich in der Epidermis geschehe, während sie bei den Wirbellosen erst im Centralnervensystem stattfinde. Die Annahme einer Entstehung sekundärer Sinneszellen bei den Wirbeltieren hat nämlich wegen der in manchen Fällen großen Übereinstimmung ihrer Sinnesorgane mit jenen Wirbelloser etwas Hißliches. In der Tat wurdeu denn auch die Sehzellen der Wirbeltiere wohl aus den oben entwickelten Gründen neuerdings wieder als prinäre gedeutet.

Die primitiven Sinneszellen und freien Nervenendignngen der änßeren Körperoberfläche, sowie die Gruppen ersterer, sind, soweit bekannt, häufig durch verschiedene Reize erregbar, so daß sie in gewissem Sinn einen indifferenten physiologischen Charakter besitzen. Ob von ihnen bewußte Empfindungen ausgehen, und welcher Art diese sind, liißt sich natïrlich meist nicht entscheiden. Von den Wirbeltieren und speziell dem Mensehen wissen wir, daß solch primitive Organe durch mechanische Einwirkungen (Druck, Berührung), Wärme, Kälte und chemische Stoffie erregt werden können, wozu sich bei Wirbellosen wohl vielfach auch das Licht gesellen kann. Uaß sich.die Endorgane des Menschen für diese verschiedenen Reize in besonderer Weise differenzierten, ist sicher und folgt anch schon daraus, daß ihnen besondere eigenartige Emptindungen entsprechen. Da wir für die primitivsten Endorgane ähnliches nicht voraussetzen dürfen, und wohl auch annehmen miissen, daß eine von ihnen auf verschiedenartige Reize ausgehende etwaige Empfindung gleichmäßiger Natur sein wird (anelektive Organe), so ist es wahrscheinlich, diß sich eine allmähliche Sonderung nnd Differenzierung der einfachen Endorgane für verschiedene Reize erst allmählich hervorbildete, womit auch die Qualität der von ihuen hervorgerufenen Empfindungen verschieden werden konnte, so daß derart differenzierte Endorgane (elektive) auf beliebige Reize dann stets nur diese besondere Empfindung vermitteln (spezifische Qualität der Empfindnngen). Von solch besonders abgestimmten Endorganen der Hant ausgehend, die auf chemische Stoffe (Geruch und Geschmack; Lichtreize Auge), Schallschwingungen (Gehör) reagierten, leiteten sich die spezifischen Sinnesorgane $\mathbf{a b}$, welche allmählich zu komplizierten bildungen wurden. Letzteres gilt besonders fî̀r die Gehör- nnd Seborgane, welche deshalb zuweilen als höhere Sinnesorgane, im Gegensatz zu den übrigen, bezeichnet werden, weil sie dıreh Zutritt einer Reihe von Hilfsapparaten 
einen recht verwickelten Ban erlangen können. Eine solche Unterscheidung erscheint aber von geringer Bedentung, da anch diese lı̈̈heren Organe ursprünglich ron ebenso einfachen Eiurichtungen ausgehen wie die niederen.

Fiir einfache Endorgane der ünßeren Haut bereitet die Feststellung ihrer besonderen Funktion, d. h. der ihnen vadaiquaten Reize«, Läntig große Schwierigkeiten, weshalb dies Problem selbst für die Wirbeltiere noch nicht völlig lösbar erscheint. Viel mehr noch gilt dies fiir die Wirbellosen, wozu sich gesellt, daß solche Organe, wie erwähnt, nicht selten anf yerschiedene Reize reagieren. Diese Schwierigkeit läßt es daher rätlich erscheinen, jene einfachen Endorgane der Haut, für welche eine spezifische Reizbarkeit vorerst vielfach nicht sicher nachweisbar ist, als Hautsinncsorgane gemeinsam zu betrachten, wogegen diejenigen, für welche dieselbe feststellbar oder doch wahrscheinlich ist, bei den betreffenden Sinnesorganen zu besprechen sind. Im allgemeinen werden diese Hautsinnesorgane ja besonders durch mechanische, thermische und chemische Reize beeinflußt, wenn es auch in manchen Fällen sicher scheint, daß anch optische nicht ohne Wirkung anf sie sind.

\section{A. Hautsinnesorgane (einschließlich Geschmacksorgane mit Ausnahme derer der Arthropoden).}

Die einfächsten derartigen Organe, wie sie bei Wirbellosen weit verbreitet vorkommen, sind besonders modifizierte Epithelzellen, welche sich zwischen die gewöhnlichen Epidermiszcllen, in gewissen Fällen (so bei eimzelnen Cölenteraten erwiesen) aber auch die des Entoderms der Gastralhöhle einschalten. Abgesehen von ihrer Fortsetzung in eine proximale Nervenfaser, sind sie meist dadurch ansgezeichnet, daß ihr freies Distalende, welches die Epitheloberflizche erreicht, ein bis mehrere starre, leicht vergängliche plasmatische Sinneshärchen trägt; in manchen Fillen wurden jedoch auch Sinneszelleu ohne solche beschrieben. Auch wurden häufig, namentlich bei Cölenteratert (Hydromedusen und Acalephen), mit einem Wimperhaar versehene Epidermiszellen, welche die Centralteile des Nervensystems iiberlagern (s. S. $466 \mathrm{fi}$ ), als Sinneszellen gedeutet, ebenso auch bei manchen Mollusken.

()b aber Zellen mit beweglichen Cilien. auch wenn sie mit einer Yerventaser verbunden sind, tatsïchlich als Sinneszellen gedeutet werden dürfen, scheint nicht ganz zweifellos. um so mehr, als schon bei gewissen Hylroilpolypen, Hyilromedusen, Acalephen und Actinien besonders geartete Zellen, die teils mit einem starren Sinneshaar versehen, teils haarlos sinı, als sinneszellen beschrieben wurden; loch wurden neuerdings auch Zellen beobachtet. welche außer einer Geißel noch kurze Sinneshare tragen. - Ebenso werden auch die an die Epithelobertläche gerückten Nesseliellen der Cölenteraten, die ja einen freien, sinneshaarähnlichen Fortsatz tragen (Cuidocil. s. S. 129), häutig als Sinneszellen betrachtet, was nicht unwahrscheinlich ist, da sie sicher reizbar sind, und ibr Zusammenhang mit Nervenfasern rielfach angegeben wirl.

Die einfachen Sinneszellen liegen meist völlig im Epithel, obgleich es auch vorkommt, daß sie sich mit ihrem Proximalteil nnter es erstrecken. Wenn die 
Körperoberfläche von dieker Cntieula itberkleidet wird wie bei manchen Wïmern, uamentlieh aber den Arthropoden, so treten besondere Modifikationen der Hantsinneszellen anf, die wir später besprechen werden. - Ton den einfaehen sinneszellen kaum scharf zu unterseheiden sind die lokalen Anhäufungen soleher zn höher entwickelten, immerhin aber noch recht primitiven Sinnesorganen, welehe aus wenigen bis zahlreichen Simneszellen bestehen, die sich etwa knospenfürmig der Epidermis einlagern. Im allgemeinen können solehe Organe als Scrsillen bezeichnet werden. Sie bestehen, soweit bekannt, entweder nur ans Sinneszellen, oder es nehmen auch indifferente Epithelzellen, gelegentlieh sogar Driisenzellen, an ihrem Aufbau teil.

Die im Epithel zerstreuten einfachen Sinneszellen können sieh bei manehen Wirbellosen über die ganze Körperoberfläche verbreiten. Gewöhnlieh finden sie sich aber besonders reichlich an solehen K̈̈̈rperteilen, die mit der Umgebung in nähere Beziebung treten, so Tentakeln, Körperfortsätzen und ähnlichem.

\section{Coelenterata.}

Bei gewissen Hydroidpolypen (z. B. Syneoryme, IIydra) wurden sinneszellen (Fig. 452), ja sogar Gruppen solcher (2-3 Zellen, Palpoeil) namentlich an

Fig. 452
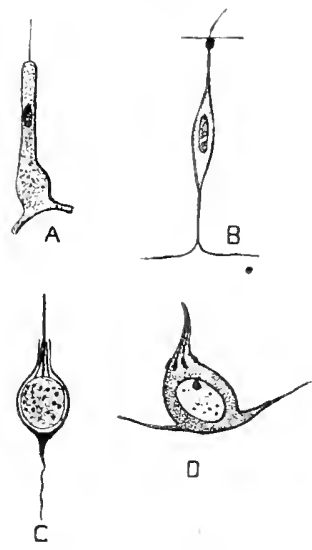

D den 'Tentakeln beobaehtet, doeh aueh weiter' rerbreitet. Gewisse solcher Zellen (Sinnesnervenzellen, Hydru, Actinicu) sollen den eigentliehen Ganglienzellen ähnlieher bleiben. Auch die Tentakel maneher IIydromeduscn (besonders Trachyncmiden) besitzen Lïngsreihen sog. Tastzellen'mit langem starrem Sinneshaar, wozu sich am Umbrellarrand, an der 'Tentakelbasis, noch Querreihen ähnlieber Zellen als sog. Tastlï̈mme gesellen können (z. B. Rhopalonema). - Besondere Sinneszellen mit starrem Haar wurden auch an der Subumbrella und den Tentakeln gewisser Acalephen (Pelagia und eimzelner Hydromednsen) beschrieben (s. Fig. $452 \mathrm{C}-\mathrm{l}$ )). Reieher verbreitet sind hartragende Simneszellen in der Epidermis der Anthonoa besonders der Actinaria), vor allem wieder' an den 'Tentakeln und der

Hautsinneszellen ron (i) en teraten. A Aus Ectoderm yon Hydra (nach HADZY 1909). Li Actinie (Bunodes): aus Schlundrolir nach GROSELY 1909). (-J) Sinneszellen von Camourina: (' von 'Tentakel. I ron Manubrium (nach KRASIxSKA 1911). ('. H. Mundselieibe, sowie im Sehlnndrohr (namentieh an den Siphonoglyphen); doch wurden sie anch bei einzelnen Formen im Mauerblatt und der Fußseheibe angegeben. - Besonders interessant erseheint die Verbreitung soleher Simneszellen im Entodrm mancher Cölenteraten Hydra, Actinien, gewisse IIydromedusen), was mit dem friiher (S. 465, 469 erwähnten entodermalen Nervensystem dieser Formen iibereinstimmt. Die Sinneszellen der Mesenterialfilamente der Actinien branehten zwar nicht notwendig entodermal zu sein, dà das Eetoderm am Aufban dieser Organe teilnimmt. 
Über die Verbreitung freier Nerrenendigungen in les Epidermis ist wenig bekannt, toch sollen rom subumbrellaren Nerrenplexus gewisser $\Lambda$ calephen (Rhizostoma) viele solehe lindigungen in die Epidermis aussteigen.

\section{Vermes.}

Anch in der Epidermis der Turbellarim finden sich häntig einfache Sinneszellen mit ein oder mehreren Haaren, doch anch schou Gruppen solcher, die den Charakter von Sensillen besitzen. Die namentlich bei den I'ulycladen und manchen Tricladen (selten bei Rhabdocöliden, Torticevos) verbreiteten Tentakel des Vorderendes werden meist als Tastorgane gedentet; das gleiche gilt von dem zuweilen einstülpbaren Rüssel des Vorderendes einzelner Rhabdocöliden (z. B. Alamina), sowie einer manchmal vorkommenden plattenartigen Verbreiterung des Vorderendes, deren Tastfunktion jedoch nusicher ist.

Die bei gewissen Rhabdocöliden auf der Dorsal- oder Ventralseite vorkommenden grübchcnartigen Einscnliungen (sog. Grübchenflecke) scheinen als Hantsinnesorgane etwas zweifelhaft. - Bei einzelnen deöla findet sich eine latorale Simneskante, die jederseits vom Vorderende ziemlich weit nach hinten zieht, anch rinnenförmig eingesenkt sein kann, und Sinneszellen enthält. Diese Bildung ist deshalb interessant, weil sie in höherer Entwicklung bei den Landtricladen (Landplanarien) wiederkehrt. Bei vielen der letzteren umzieht die Sinneskante das Vorderende ventral als ein Band, in dem ein oder zwei Reihen wimperloser Papillen stehen, welche wohl als Tastorgane dienen. Gewöhnlich findet sich aber in dieser Sinneskante neben den Papillen noch eine Reihe eingesenkter Griibchen (Simesgrïbchon), die eine größere Zahl von Sinnesharen enthalten. Die Grübchen werden vom Centralnervensystem, die Papillen dagegen vom äußeren Nervenplexus innerviert. - Auch freie Nervenendigungen, welche vom subepithelialen Plexus (s. S. 472) durch die Epidermis anfsteigen, wurden bei Planarien beschrieben und sollen z. 'T. von besonderen Nervenzellen ausgehen.

Am Kopf- und schwanzende der Nemertinen wurden in der Epidermis haartragende becondere Zellen beobachtet, die jedocb hinsichtlich ihrer ventung als Sinneszellen nicht ganz sicher erscheinen. - Fernerhin tindet sich an der Kopfspitze, dicht ïber der Rüsselöfinung zalılreicher formen (speziell bei Metanemertinen [Enopla], einzelnen Heteromemertimen [Eupolia]) ein meist ein- und ausstülpbares Organ (Frontatorgan). das im eingestülpten 7ustand gruben- his etwas schlauchartig erscheint, rorgestiilpt dagegen hügelartig. Es wird ron zahlreichen fadenförmigen, borstentragenden Epithelzellen gebildet, die fom Cerebralganglion innerviert werden. Bei gewissen Leteronemertimen (\%. li. Micrura und Cerebratulus) finden sich an Stelle des einfachen Organs drei kleinere von ähnlichem Bau. - Das Epithel der Frontalorgane ist frei von Drüsenzellen; doch hiehen meist Ausführgänge der Kinffitrise $(s .8 .13: 3)$ durch dasselbe.

Eine eigentiumliche Modifikation erfuhren die Hantsinnesorgane hei den parasitischen Trematoden und Cestoden, im Zusammenhang mit der starken cuticularen bedeckung. I lie Sinneszellen (s. Fig. 325, S. 477) sind tief in das Körperparenchym verlagert und stehen mit dem ïuBeren Nervenplexus in Zusammenhang. Eine feine distale Faser steigt von der Zelle bis in die Cuticula empor und durchsetzt in dieser ein kugeliges Bläschen, um an dessen l ristalwand mit einem etwa. 
nagelförmigen, dunkleren und dichteren Stift zu endigen, welcher in der Cuticula eingeschlossen ist; letztere kann sich iiber ihm papillenartig etwas erheben. Obgleich solche Endorgane iiber die ganze Körperoberfläche verbreitet sind, finden sie sich bei den Trematoden doch besonders reichlich in den Sangnäpfen, namentlich dem vorderen der Distomeen (s. Fig. 323, S. 476).

Eine ähnliche Modifikation der Hautsinnesorgane scheint unter gleichen Bedingungen auch bei den Nemutoden, besonders den parasitischen eingetreten zu sein. Inie dicke Cuticula dieser. Würmer bedingt jedenfalls, daß ihnen freie plas-

Fig. 453.
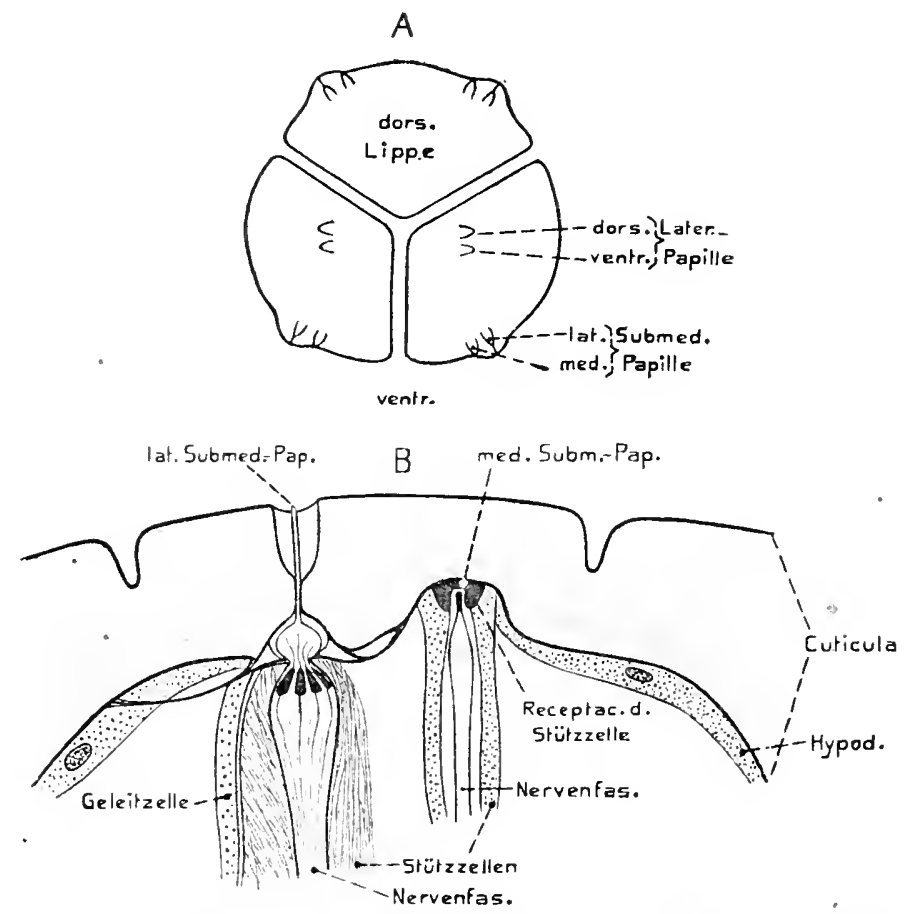

Ascar is megalocephala. Mundpapillen. A Die 3 Lippen von vorn gesehen mit den 6 Paar Papillen. $B$ Längsdurchsehnitt durch the beiden submedianpapillen (nach R. Goldschant 1943). v. Bu.

matische Sinneshaare fehlen, die Endorgane der Sinneszellen vielmehr entweder in cuticulare hohle Borsten oder in nicht oder wenig erhobene Cuticularpapillen eingeschlossen sind; doch sollen sie in gewissen Organen auch bis zur " Cuticulaobertliiche treten können. - Bei den freilebenden Nematoden sind solche Cnticularborsten, die wohl sicher mit Sinneszellen in Verbindung stehen, häufig weit über den Körper verbreitet. - Am regelmäßigsten finden sie sich in einem Kranz un die Mundöff̉nung, aber in sehr verschiedener Zahl (4, 6,8 und 10). Letztere Borsten werden nicht selten sehr klein und stehen dann häufig anf papillenartigen Vorspringen (Borstenpapillen), wie sie sich anch bei den Parasiten meist um die Mundöffinung fiuden, aber der borstenartigen Fortsätze gewöhnlich entbehren. Bei 
den Par:asiten kann die Zahl dieser Mundpapillen bis 12 betragen (z. B. Ascaris, Fig. 453), wobei je $z w e i$ dicht genähert sind, so daß man von 6 Paaren sprechen kann, die sich zu je zweien anf die 3 Lippen verteilen. Bemerkenswerterweise ist der Ban dieser Mundpapillen bei Ascuris (wo sie am genanesten erforscht sind) keineswegs gleich. Im allgemeinen sind sie so gebant, daß die dicke Cuticula von innen nach außen stark trichter- oder röhrenartig verdïnnt ist und der nervïse Endapparat sich in diesen Trichter einlagert. Letzterer wird vou den feinen distalen Endfasern gebiidet, in welche die Sinneszellen, die sich in den verschiedenen Papillen in wechselnder Zahl finden, auslaufen.

So treten in die dorsalen Lateralpapillen nicht weniger als 12 Endfasern von Sinneszellen, die sich jedoch distal zu einem Endzapfen rereinigen, in die ventralen dagegen nur 2. Die 8 Submedianpapillen enthalten nur je eine Faser, wobei aber die medianen und lateralen wieder verschieden gebaut sind (s. Fig. $453 \mathrm{~B}$ ). In gewissen der Papillen soll die Endfaser die Cuticula vollständig durchsetzen und frei an der Oberfläche endigen. - Der Körper der Sinneszellen der l'apillen ist tief, bis in die hintere Ösophagusregion hinabgerückt. Das periphere linde der distalen Sinnesfasern bildet fast stets einen eigentümlichen stiftartigèn Endapparat. - Zu jeder Papille gehören in der Regel noch gewisse accessorische Zellen, welche die Endfasern begleiten: 1. sog. Stïtizellcn, welche die distalen Enden der Fasern völlig umlüllen. und 2. meist sog. Geleitrellen, welche erst distal, in der eigentlichen $\mathrm{Pa}-$ pille, mit dem Endapparat in nähere Beziehung treten. Diese beiden accessorischen Zellarten reichen ebenfalls weit nach hinten; die Stützzellen bis in die Region des Nervenrings, an dessen Umhüllung sich sogar die der medianen Submedianpapillen beteiligen.

Einen ähnlichen Ban zeigen die sonst bei den Nematoden vorkommenden Papillen, also die schon früher (S. 482) erwähnten Halspapillen, auf die wir bei den Geruchsorganen nochmals zurïckkommen werden, und die Schwanz(oder Anal-)papillen der Männchen, welche in meist charakteristischer Anordnung, gewöhnlich in zwei Lateralreihen, vor und hinter, oder auch nur hinter dem After stehen (s. Fig. 328, S. 482).

$1 D_{\mathrm{a}} \mathrm{B}$ auch bei den Acanthocephalen papillenartige Endorgane rorkommen, wurde schon früber erwähnt (s. Fig. 330, S. 485).

Gewisse Anklänge an die Nematoden verraten die Rotıtoricr, namentlich die an ihrem Rumpfe gewöhnlich auftretenden Sinnesorgane, die meist als Taster bezeichnet werden, obgleich sie nur selten tasterartig über die Körperoberfläche vorspringen. In der Regel findet sich ein vorderes oder dorsales und ein hinteres oder laterales Paar solcher Organe. Das dorsale (nur Conochilus fehlende) liegt gewöhnlich in der Region des Cerebralganglions und ist meist unpar, steht also in der dorsalen Mittellinie (Nackentaster oder -organ, s. die Fig. 23, S. 97 ก. 329 , S. 484 ).

Fig. 454 .

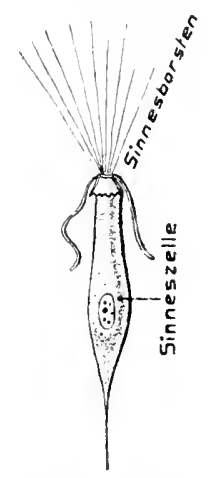

Apsilus vorax. Lateraltaster nach GAST 1900). C. H

Da es hei einigen Genera (z. B. Asplanchna) paarig auftritt und, wenn unpaar, meist von cinem Nersenpar versorgt wird, so war wohl die Parigkeit der primitive Zustand, aus lem erst der unpaare Dorsaltaster hervorging.

Die stets parrigen Lateralorgane (Taster, s. Fig. 454) stehen in der Seitenlinie oder -kante (znweilen auch mehr ventral) in sehr verschiedener, meist aber 
erhebblicher Entfernmng hinter den Nackenorganen, und springen selten tasterartig vor. Jedes der beiderlei Organe scheint meist nur mit einer, selten zwei oder mehr Sinneszellen versehen, die eine Anzahl freier, gewöhulich ziemlich langer Haare tragen.

Die beiden Organpare erinnern etwas an die Hals- und Analpapillen der Nematoden, wodurch vielleicht eine ursprüngliche Übereinstimmung angedentet wird. - Auch das Räłerorgan ist häufig mit Sinneszellen verselien, wie schon daraus hervorgeht, daß zwischen

Fig. 155

\section{A}

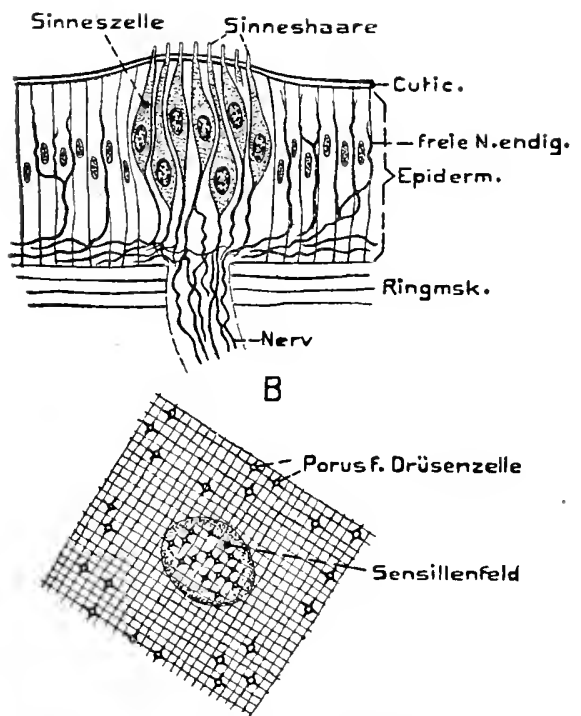

Lumbricus ter restris. A Qnerschnitt durcheinen Teil des Integmments mit einer sensille und freien Nervenendigungen. $L$ Ein kleines stiuck der abgełösten Cuticula mit eintm sensillenfeld und den Poren für den lyurchtrit der sinneslatare, sowie den Poren für die eim\%elligen Hatutriisen nach LAxtbos $1<45$ seinen Cilien zuweilen starre Tastborsten stehen. Ferner finden sich auf dem rom Räderorgan umsclılossenen Stirnfeld manchmal Büschel von Tasthaaren, die auch beweghich sein kömmen; oder bei einzelnen Formen ein Paar sog. "Strutaster, kegelfïrmige Fortsätze mit distalem Sinneshaarbüschel, welche den Dorsal- und Lateraltastern gleichen. - Ob sich die besprochenen Stirnorgane den Mundorganen der Nematoden vergleichen lassen, ist vorerst daum zu entscheiden. - Als Tastorgan wird meist anch der sog. Rïssel der Philodinen gedeutet, d. h. die etwas eigentümlich umgebildete vordere Körperspitze, welche Cilien oder Borsten trägt und Sinneszellen, ja zuweilen ein besonderes kleines Ganglion (Callidina) enthält. Das Organ ist mit dem Vorderende einziehbar und tritt bei der Ausstïlpung früher als das Räderorgan lıervor, wobei es tastende Bewegungen ausführt. In gewissen Fällen soll es durch eine grubenförmige Bildung ersetzt sein.

Anmcliden. Besondere taster-und fühlerartige Anhänge sind am Kopf der Polychacten sehr verbreitet,in Form der Antemen und Palpen des Prostominms sowie der Fühlercirren des Metastomiums (s. Fig. 332, 334, 336 n. 339, S. 487-493). Älnliche Organe entspringen meist (besonders Errautia) von den Parapodien als deren Dorsal- und Fontralcirns. Endorgane von Hantuerven, die z. T. anf Papillen dieser Organe stehen, sind mehrfach nachgewiesen worden; doch breiten sie sich auch auf der iibrigen Körperoberfläche mehr oder weniger reich aus. Im allgemeinen seheinen aber einfache Simneszellen in der Annelidenepidermis nicht allzu hänfig zu sein, obgleich sie bei gewissen Formen (Lumbriens, Nereis u, a.) beschrieben, doch anch wieder bestritten wurden. Bei den Oligochacten, Polychactcn, Ihimdincen und Gephyreen finden sich lingegen sensillenartige Organe, welehe ans bruppen mehr oder weniger zahlreicher, meist hartragender Sinneszellen bestehen (Simmeshospen, becherfärmige Organe, Sensillen; s. Fig. 455). Bei Oligochacten (Limicolen wie'Terricolen, besonders Lumbrims sind sie in der Epidermis ïber den ganzen Körper 
verbreitet und schließen sich bei Lumbricus, wo sie ungemein zahlreich sind, den drei frïher (Fig. 337, S. 491) erwähnten língnerven jedes Segments ungeführ an, so daß hänfig von drei Ringen solcher Organe in jedem Segment die Rede ist; jedenfalls sind sie in einer vorderen und mittleren Zone der Segmente reichlicher, ebenso auch um die Mïndungen der Nephridien. Bei Lmmbricus terestris wurden bis durchschnittlich 1000 Urgane in einem Segment gezählt. Am Kopf- und Hinterende des Körpers finden sie sich reichlicher. I Tnter der Epidermis breitet sich ein reicher Nervenplexus aus (basiepithelialer Plexus, von dem bei Lumbricus (s. Fig. 455) auch freie Nervenendigungen zwischen den Epidermiszellen hoch emporsteigen, die ebenso bei einzelnen Polyrharten (z. B. Plyyllodore) und Himdincen erwiesen sind. Solch freie Nervenendigungen sollen sich ferner reichlich um die Borstentaschen der Chaetopoden verbreiten, so daß anch die Borsten als Tastorgane funktionieren können.

Die Sensillen der Hirudincen sind ebenfalls ïber den ganzen Körper verbreitet, in besondererGrößeundzah! auf dem Prostomium, wo sich Organe finden

Fig. 456.

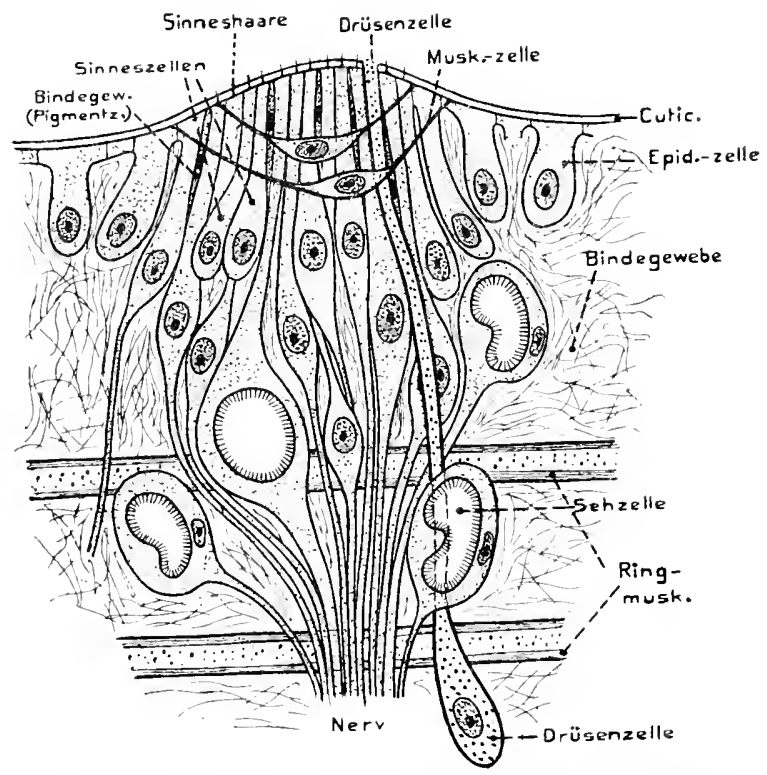

Hirudo medicinalis. Sensille ans einem Querschuitt durch den Körper. Schematisch (nach Hacmlov 19l(1, etwas veränctert). v. Bu. sollen, die bis viele Inuderte von Zellen enthalten. Ihre Körpersensillen sind sehr verschieden grof und insofern von jenen der Chaetopoden verschieden, als sich ilne Zellen meist reeht tief unter die Epidermis in das Bindegewebe erstrecken (s. Fig. 456). Die größeren Organe sind meist dadureh ansgezeichnet, daß in ilırer l maebnng einige der später zu besprechenden Sehzellen liegen.

Diese größcren Sensillen der Gnathobdelliden stehen auf dem dritten Ringel der Segmente un sind in 14 Längsreihen (8 dorsalen und 6 ventralen) angeordnet. - Etwas lraglich erscheint es, ob die Blutegelsensillen nur ans sinneszellen mit knzen Härehen bestehen. oner oh sich dazwischen auch indifterente Zellen (Stïtzzellen) finden; jedenfalls ist sicher. daß Hauthrïsenzellen durch sic treten k̈̈nen. Nicht unwichtig erscheint, dab die Sensillen etwa vor- ml rückziehbar sind, indem sirh unter ihnen eine ansehniche, sternförmige ruristelte Muskelzelle findet, deren Kontraktion die 1)rgane papillenartig vortreibt.

Die Sensillen oder becherförmigen Organe (wie auch die freien Nervenendigungen von Lumbricus erstrecken sich bei den drei Ordunngen der Anneliden 
auch in die Mundlöhle, wo sie jedenfalls als Geschmacksorgane dienen. Hieraus läßt sich wohl schließen, daß die Organe der Körperoberfläche chemisch reizbar sind, wofür auch die physiologischen Versuche sprechen. - Daß sie daher anch auf dem Rüssel der crranten Polyelaten und aekaten Gephyreen reichlich vorkommen, ist begreiflich; sie stehen auf dessen Papillen, Wïlsten und Rippen.

Verwandt mit den beschriebenen Sensillen, aber in mehrerer Hinsicht eigenartig, erscheinen die Seitenorgane gewisser Chaetopoden, welche besonders bei den Capitelliden genauer studiert wurden; sie kommen jedoch anch bei Polyophthatmus, Glyeeriden, Amphicteniden (Pectinaria) Spioniden, einzelnen Aricüden und einigen anderen, sowie bei gewissen Oligochaeten (Lumbriculiden) vor. Den Haupt-

A

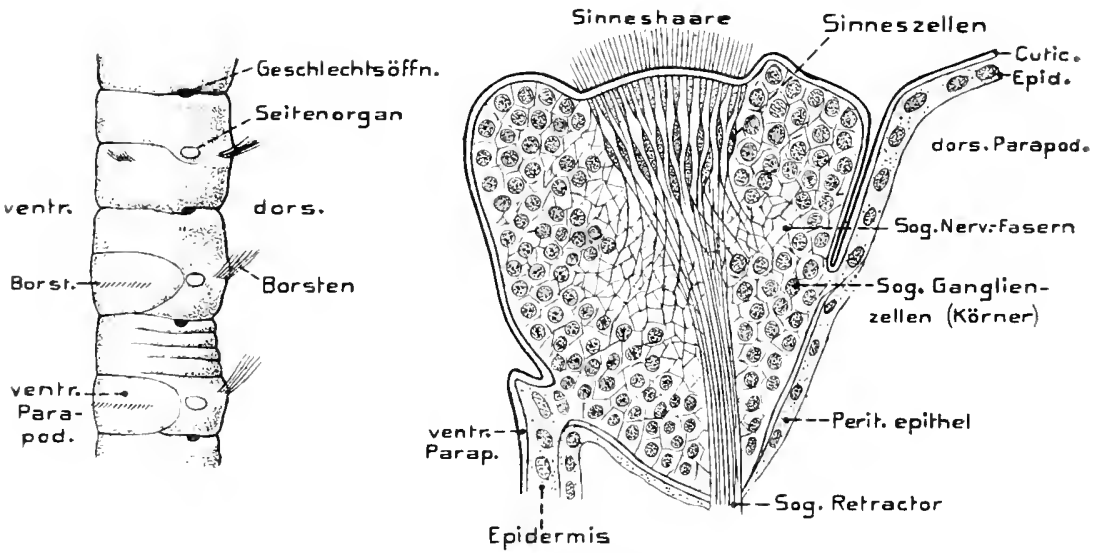

Capitellide. Seitenorgane. A Einige Segmente von Mastobranchus trinchesei ron links, mit (leu seitenorganen. - B Ein Seitenorgan von Notomastus fertilis im Längschnitt (nach Eisıa 1887). v. Bir.

charakter dieser Organe (Fig. 457) bildet ihre Lage in den Seitenlinien des Körpers, d. h. anf der Grenze zwischen der dorsalen und ventralen Hälfte der Längsmuskeln (s. S. 410), also auch gewöhnlich zwischen den dorsalen und ventralen Parapodienlappen. Da nun die so bestimmte Seitenlinie in den verschiedenen Körperabschnitten keineswegs genau lateral liegt, so gilt dies auch für die Seitenorgane. Weiterhin erscheint charakteristisch, daß in jedem Segment nur ein Paar der Organe anftritt, nnd zwar bei den Capitclliden (wo sie nur selten fehlen), bei Polyophthalmus, Scalipregma und den Lumbriculiden fast in sämtlichen Segmenten. Es sind papillen- oder hiügelartig vorspringende Gebilde, die auf ihrem Gipfel eine ansehnliche Zahl von meist ziemlich langen und feinen Sinnesharen tragen Fig. 457 B). Diese haartragende Platte ist bei den Capitelliden n. a. stets einziehbar, doch können anch die vorderen (thorakalen) Organe hier wie bei anderen Formen im Ganzen in eine sich dabei bildende Grube zurïckgezogen werden. Hierzu dienen besondere Mruskeln. - Über den feineren Baı der Organe läßt sich vor- 
erst nur sagen, daß sie in der Regel von zahhreichen haartragenden Simneszelleu gebildet werden; ob sich, wie beschrieben, unter letzteren wirklich ein zellenreiches Ganglion findet, in dessen Achse bei gewissen Formen noch eine Anzahl besonders großer Ganglienzellen (oder etwa sinneszellen?) beschrieben wurde, sowie die Art der Innervierung der Organe bedarf jedenfalls ernenter Untersuchung.

Während die Organe früher als umgebildete Dorsalcirren der ventralen Parapodien (Neuropodien) gedentet wurden, werden sie jetzt als aus einem zwischen Neuro- und Notopodium bei manchen Polychaeten auftretenden Intercirrus entstanden betrachtet. Auf die Vergleichbarkeit der Seitenorgane mit den ebenso genannten Organen der Wirbeltiere, worauf phylogenetisch großer Wert gelegt wurde, wird später, bei der lesprecbung der letzteren einzugehen sein. - Auf diese Vergleichung stützt sich namentlich die mehrfach geäußerte, jedoch rorerst nicht erwiesene Ansicht, daß die seitenorgane ler Chaetopoden als eine Art statischer Organe funktionierten.

Unsicher in ihrer lleutung sind die Bayerschen Organe der Rïsselegef (lihynchobdellida), welche höchstens aus zwei Zellen, einer Sinnes- und einer unter ihr liegenden Muskelzelle bestehen. - Eine sehr eigentümliche Art vermutlicher sinnesorgane sind ferner die Spiralorgane der Nereisparapodien. Es handelt sich um tiefe röhrenförmige Einsenkungen der Cuticula, um welche sich eine große Zahl langgestreckter sinneszellen in mehreren Schraubenwindungen lagert. Da die Distalenden dieser Zellen einen lichtbrechenden Körper enthalten, so wurde vermutet, laß sie lichtempfindlich seien: was jedoch weuig sicher erscheint.

Oligomera. Die Bryoroen führen in ilurer Epidermis (besonters ałf den Tentakeln) zahlreiche hartragende Sinneszellen. - Bei den Chartognathen hingegen sind sensillenartige Tasthuigel (Sinneshügel) von sehr verschiedener lirïße iiber den Gesamtkörper unregelmäßig zerstreut. Sie besitzen zahlreiche lange Sinneshaare, die zuweilen aus einer Einsenkung aul lem Cripfel des Hügels hervortreten. Die in großer Zahl rorhandenen Sinneszellen scheinen unter die eigentliche Epidermis hinabgesenkt zu sein; doch ist der leinere Bau nicht genügend anfgeklärt. Auch bei dieser liruppe verbreiten sich ähnliche urgane von melır knospen- oder becherförmigem Pau in der Mundbiihle. - Sowohl bei den Brachiopoden als den Enteropmeusten ist von Hautsinnesorganen kaum etwas Sicheres bekannt.

\section{Mollusca.}

Bei den Weichtieren (besonders den Lamellibranchiern mid Gastropoden) sind einfache hartragende Sinneszellen in der Epidermis der freien Körperoberfläche sehr verbreitet, reichlicher wieder an vorspringenden Stellen, wie den Kopf-, Epipodial- und Mantelrandtentakelu der Gastroporden, doch anch an den Fußseiten 
und in der Mundgegend. an den Kiemen und dem Mantelrand der Lamellibranchier, wo sich häutig papillen- bis tentakelartige Fortsätze finden, ebenso jedoch anch an den Enden von deren Siphonen, welche ja ans dem Mantelrand hervorgehen (Fig. 458). - Recht häufig finden sich jedoch an solchen Orten auch sensillenartige (becherfürmige) Organe, ähnlich denen der Anneliden. - Daß auch freie Nervenendigungen vorkommen, wie sie bei den Aplacophoren sogar ans der Cnticula erwähnt werden, scheint für gewisse Formen (speziell Pulmonaten) erwiesen.

Bei den Aplarophoren werden als besondere lokalisierte Hantsinnesorgane, außer Sinnesborsten. die wohl mit einfachen sinneszellen zusammenhängen, gedeutet: was Mundschild

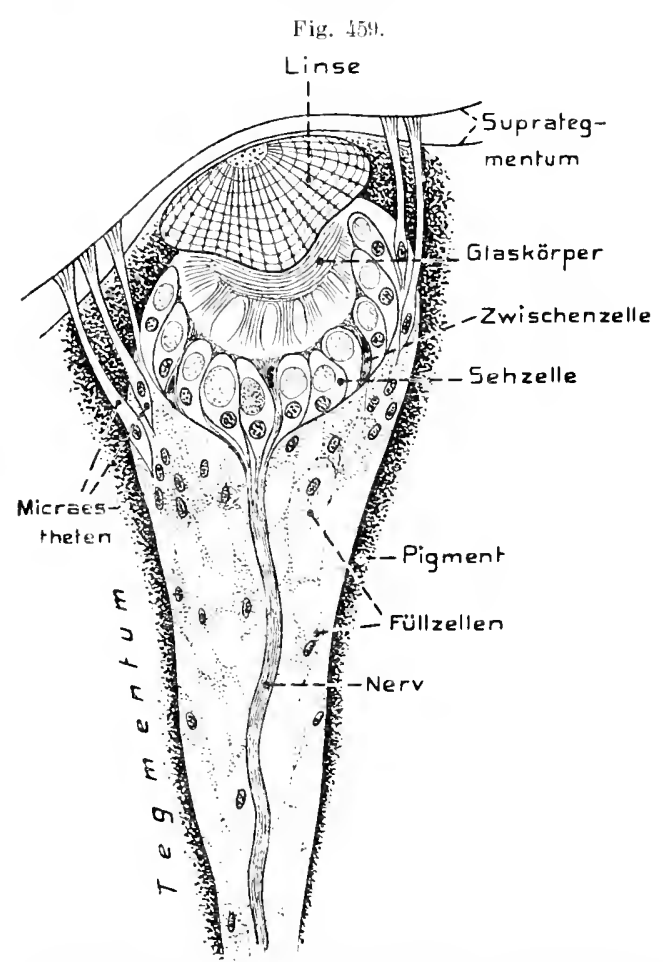

Acanthoplenra ja ponica llacophore), längsschnitt durch ein helatenauge mit meheren Mieraestheten (nach NOV1KOFF 1,07? con Chactoderma (s. Fig.367, S. 515). sowie ein zuweilen flimmerndes, einund ausstiilpbares Frontalorgan (Siuneshügel), endlich ein caudales dors:les ()roan gewisser Formen, das gleirhfalls vor-und riickziehbar sein kanu. Bei Rhopalomenia wurden sensillen (Sinneskuospen) am Hinterende nachgewiesen, die sich bis in die (uticula erheben, Auch die früher erwähnten Kalkspicula der Hant sollen bei gewissen Formen mit Nerven versehen sein. Recht fraglich erscheinen die Sinñeskolben in der Cuticula.

An die Sinnesknospen der lihopalomenia erinnern die in den Schalenplatten der Placophoren reichlich vorhandenen Megalaestheten (Macraesth.), welche dieselben bis zu Cuticnla (Periostracum) durchsetzen (s. S. 109 . Es sind dies Organe, welche aus einer langgestreckten Knospe ron Sinneszellen bestelien, die sich, in den Schalenplatten antsteigend, bis zu einer äußeren kappenartigen Verdickung der Cuticula erstrecken. Teben ihnen finden sich in dem Kanälchen der Schalenplatte auch noch indifferente sog. Fïllipllen, zuweilen anch Drïsen:ellen. Im Umkreis dieser Megalaestheten gehen rom Ilauptkanal ähnliche feinere Kanälchen bis zur Cuticulabbertläche (Micraesthetes), welche nur eine einzige Zelle enthalten (Fig. 459), und gewöhnlich als Simnesorgane beurteilt wurden; neuerdings hat man sie jedoch anch als eine Art Schutzorgane gedeutet, die das Periostracum ernenerten. Später werden wir sehen, daß sich die Macraestheten gewisser Placophoren auch zu lichtempfindlichen Organen entwickeln können.

Megalo- und Micraestheten gehen aus der Epidermis hervor, wie sich an den Seitenrändern der Schalemplatten leicht nachweisen lïßt, wo bei fortschreitendem Wachstum der 
Platten andanernd nene Organe aus der Epidermis entsteben. - Bei einzelnen Placophoren (Lepidopleuriden) wurden höckerartig vorspringende sensillen (sog. Seitenorgane) an der Ventralläche der Mantelfalte in einer Längsreihe gefunden (Zahl $i$-30); sie wuden auch als Geruchsorgane gedeutet.

Sensillenartige Organe tinden sich bei manchen .Tusthchn (z. B. Curdium nsw., s. S. 837, k'ig. 633) an den 'Tentakeln oder der Außentliche des Atemsipho als Gruppen hatrtragender Sinneszellen, zn denen sich jedvch gewöhnlich indifferente Zellen gesellen und gelegentlich auch Einziehmuskeln. -- Ebensolche Organe finden sich bei gewissen Prosolnanchiatm insbesondere rhipidoglossen Diotoeardia, sog. Seitenorgane) an der hasis der Epiporlialtentakel, doch anch gelegentlich am Kopf und FuB. Sie enthalten neben Sinneszellen gleichfalls indifferente Zellen und sind ein- nnd ausstiilphar.

Unsicher in ilner Bedentung als Hautsinnesorgane blieben rorérst lie in großer Zahl iiber die Kärperoberflïche gewisser Heteropoden (Pterotrachea) verbreiteten kleineren und grïßeren scheibenartigen tiebilı.

Die knospenartigen Sensillen der Mollusken breiten sich gleichfalls anf die Umgebung des Mundes, die Riisselspitze (Heteropoda) und die Mundhöhle ans, was auch schon bei den Placophoren vorkommt. - Ein eigentümliches Sinnesorgan (Subradnlarorgan) findet sich ferner am Mnndhöhlenbolen der Placophoren als eine scheibenartige, etwas parrig geteilte Erhebung, in welche vorn eine lniise miindet. I)ie Sinnesscheibe besteht ans Sinnes-, Flimmer- und unbewimperten indifferenten Zellen. Die zutretenden Nerven kommen voll den Subratularganglien (s. Fig. 368, S.516). In l'ulimentäres Form wurde ein solches Organ anch bei gewissen Diotocardiern und den solmoconrhen beoluachtet.

\section{Echinodermata.}

Eintache Sinneszellen sind nach den meisten Angaben bei den Asterim und Crinoiden, deren liadiärnerven intraepithelial liegen (s. S. 535 ), im Epithel der Ambulacralrin-

Fig. ftio.
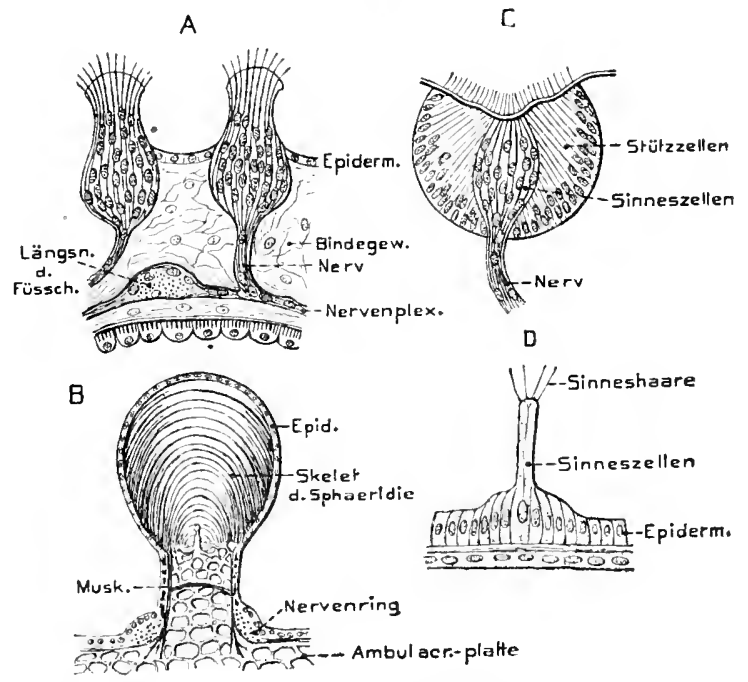

Il it isimesorgane von behinodermene A () phiothrix flagilis (Mphiurode). Querschnitt durch die Wand eines Ambu-

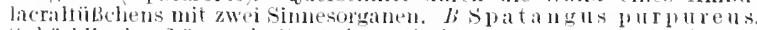

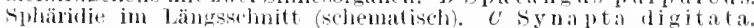

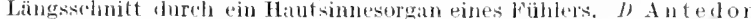

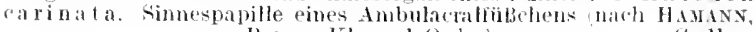
Brom. Kl. minl Ordn.). C. 11.

nen verbreitet und setzen sich anf das unpaare tïhlerartige Endfiißchen der Arme (Tentakel) fort, das sich in gleicher Weise auch bei Oplimroiden findet, wogegen 
es den Crinoiden (Antedon) nur im Larvenzustand zukommt. Es wird gewöhnlich als Tastorgan gedentet. - In ähnlicher Weise funktionieren jedoch auch die Endscheiben der Ambulacralfüßchen (Asterien, gewisse Ophiuroiden, Echinoiden und Holothurien), deren Epidermis verdickt und mit zahlreichen Sinneszellen, sowie einer terminalen Nerrenplatte versehen ist, ja sogar ein besonderes Ganglion besitzen kann (s. Fig. 387, S. 536). - - Daß anch die Ambulueralpapillen der Holothurien, welche modifizierte Füßchen sind, solche Sinnesscheiben tragen, da-

Fig. $\mathrm{flil}$.

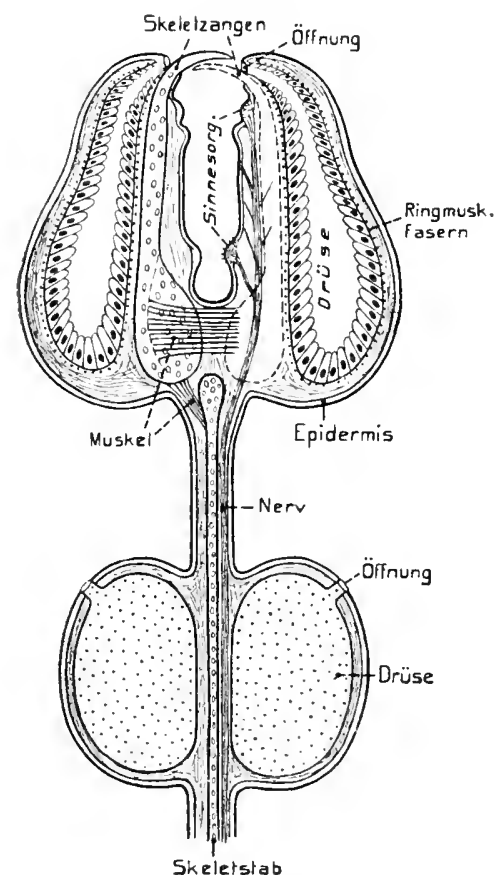

Genuniforme Pedicellarie eines régulären Seeigels. Schematische Darstellung de distalen Teils, großenteils Längsclurchschnitt. Skeletteile kreisförmig punktiert nach HAMANN. Bronn. Ki. und Ordn.). gegen die zu den Mundtentakeln (-fühlern) vergrößerten und verzweigten Fïßchen solche an ihren Endästchen besitzen, erklärt sich aus ilner Ableitung. Die Sinnespapillen der F'ïhler und der Hant der Synaptiden (Tastpapillen) besitzen eine ähnliche Sinnesplatte.

Etwas anders verhalten sich die Ambulacralfüßchen gewisser Ophiuroiden (Ophiotrichida), indem ihr Epithel Längsreihen von hiigelartig vorspringenden Sinnesknospeu enthält (s. Fig 460 A). Solche Knospen finden sich etwas grubenförmig eingesenkt auch an den Fïhlern der Synapten (Fig. $460 \mathrm{C}$ ). Die achsiale Knospe von Sinneszellen mit kurzen Härchen (angeblich wimpernd) wird von einem dicken Mantel cilientragender Stiitzzellen umhiillt. - Sinniesknospenartige Gebilde stehen ferner in Längsreihen auf den Ambulacralfüßchen der Crinoiden ( $A n-$ tedon Fig. $460 \mathrm{I}$, Pentacrines) als cylinArische, sich über die Oberfläche erhebende kontraktile Gebilde, die aus wenigen haartragenden simneszellen bestehen, jedoch auch eine Geißel besitzen sollen; ähnliche Organe tragen auch die Füßchen gewisser Ophiuroiden (Ophiactis). - Knospenartige, hügelig vorspringende Endgebilde sind ferner anf der Aboralfäche, den Armseiten und Pinnulae von Antedon verbreitet; sie empfangen ihre Nervenfasern von dem apicalen Nervensystem (s. S. 541). - lieich an Nerven sind schließlich die eigentiimlichen, als Perlicetlarien bekannten Greiforgane der Echinoiden, welche sich in vier rerschiedenen Formen finden, von denen nicht selten mehrere bei einer und derselben Art vorkommen. Sie funktionieren teils als Verteidigungs-, teils als Schutz- und Reinigungsorgane. Die Epidermis anf der Innenfläche ihrer drei distalen Zangen ist gewöhnlich reich :n Simneszellen (s. Fig. 461), die zwischen den indifferenten wimpernden Epithelzellen zerstreut sein können, oder sich an gewissen Stellen 
mit verdicktem Epithel zu besonteren Sinnesorgamon lasthïgeln, Neurodermorganen) reichlich anhäufen.

Letzteres tinlet sich besonders bei den gemmiformen I'edicellarien (fiiltzangen, s. s. 141 und Fig. 461), wo an der Innenfläche jeder Zangenbasis ein solches Sinnesorgan rorkommt, zn dem sich bei gewissen Arten noch ein distales, sogar noch ein drittes mittleres gesellen kann. Diese Organe sind entwedes platten- oder hügelartige Ephdermiscerdiknngen mit zahlreichen Simneszellen, oder können auch ron einer Gruppe von Sinnesknospen gebildet werken. Starre Hlare wurden an ihren Sinneszellen zum Teil nachgewiesen. - Ob die zweiklappigen Pedicellarien der Asterion ähnliche Einrichtnngen hesitzen, ist norh festznstellen.

Zn den Simnesorganen sind wohl anch die bei den Echinuden ansgenommen (Cidaris) fast allgemein verbreiteten sphöridien zu rechuen (s. Fig. $460 \mathrm{~B}$, welche sich nur in den Ambulaeren, und meist nu ihrer oralen Region finden.

Es sind kleine, den Kalkstacheln ähnliche (iebilde mit kuglig angeschwollenem Distalende, das ans besonders dichter Kalksubstanz hesteht, die wie lie Stacheln anf Papillen der skeletplatten beweglich oler unbeweglich sitzen. Zuweilen sind sie in Ein- his Mehrzahl in eine Crube der Ambulacralplatten eingesenkt, welche sogar (Clypeastriłen) gegen außen nahezu abgeschlossen sein kann. An der Basis ihres Stiels findet sich, wie bei den Stacheln, gewöhnlich Muskulatur, sowie ein Nervenring mit Ganglienzellen, der aus dem Ifautnerrenplexus hervorgeht. Die Hrgane sind ron Wimperepithel überzogen, besontere Sinneszellen jedoch nicht nachgewiesen, Obgleich ihre Deutnng als Sinnesorgane, wie bemerkt, kaum zweifelhalt ist, laßt sich doch ihre besondere Funktion vorerst nicht sicher benrteilen; sie wurden als ()rgane des chemischen Simns oder als statische gedentet.

\section{Chordata.}

\section{a) T'micata.}

lie Hantsinnesorgane dieser Abteilung sind im allgemeinen wenig bekannt. In der Epidermis finden sich teils einfache Sinneszellen, teils Gruppen solcher. Die Zellen tragen entweder starre Härchen, oder sollen auch mit Wimperharen versehen sein (besonders Copelata); doch erscheint die Dentung letzterer Zellen als Sinneszellen etwas zweifelhaft. - Bei stïkerer Entwicklnng des Cellulusemantels ragen die peripheren Fortsätze der Sinneszellen nicht frei hervor, sondern sind im Mantel eingeschlossen. Daß die Sinneszellen namentlich an der Einströmungsöifnung (Mund) und der Kloakenöthnug aultreten, erseheint natiulich; doch sollen gerade die nm die Einströmungsüftuung der L watlien läntig vorkommenden, tentakelartigen Anhänge nicht reizlya sein, vielmehr Ael Mundrand; obgleich bei manchen (so Ciona) im Epithel der Anhïinge Zellen beohachtet wurden, welche Sinneszellen gleichen; bei anderen (Botryllus) wurden solche \%ellen an der Kloakenöffunng gefunden. -- Bei gewissen Sulp'l treten an der Oberlippe des Mundes Simneszellen mit staren Haaren anf, die mit einem Nervenplexus unter der Epidermis zusammenbängen. - - Anch bei Doliolum finden sich in den Einschnitten zwischen den Mundliipjeheu und denen der Kloakenöffunng einfache Sinneszellen oder Gruppen weniger, und :ihnliche Gruppen treten noch an einzelnen stellen der Körperoherfläche, sowie am Dach der Kloake und der Basis des dorsalen Stolo prolifer der ersten ungesehlechtlichen Generation auf. - Mit diesen Organen liibt sich vielleicht das interessante Simnesorgan vergleichen, welches bei dur 
Geschlechtsgeneration von Salpa democratica-murromtn beiderseits dicht hinter der Mundöftinung vorkommt (Fig. 462).

Es bestelıt aus einer Gruppe ron etwa 14 Sinneszellen, die sich in der Basis eines ziemlich langen, schlauchförmigen Fortsatzes der Manteloberfläche flnden und ihre langeu hæarförmigen Distalfortsätze durh den Schlaurh emporsenden. Die Figur erläutert den Ban

Hig. 462 .

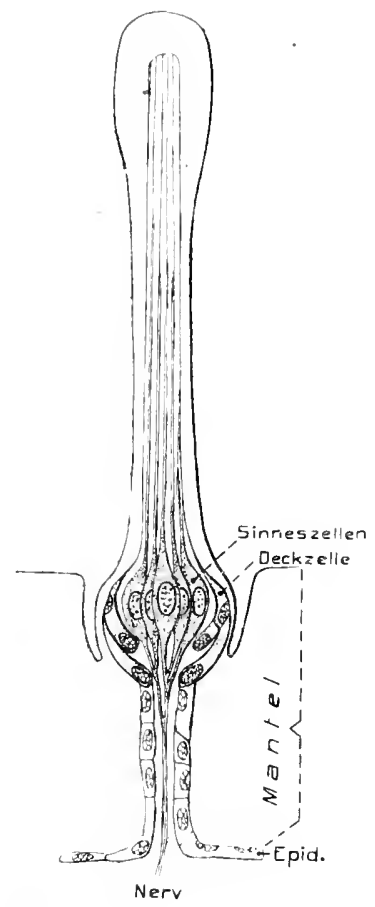

Sitlpa lemoclatica-muclonat: (Geschlechtsgeneration). Hautsimesorgan (nach LEE 1891). U. H. der Organe näher. Ein, wie es scheint, ähnliches unpares dorsales Organ soll sich bei ler Geschlechtsgeneration gewisser Salpen rechts rom Himganglion finden.

Sowohl an der Ober-als Unterlippe der Copelaten sind Zellen, die einen verklebten bewegliehen Wimperschopf tragen, reeht verbreitet (s. Fig. 394, S. 545); doch finden sieh solche Urgane anch in der Atemhöhle, in der Nähe des Vorderendes der Hypobranchialrime. - Ein unpares mehrzelliges Organ an der Ventralseite der Unterlippe Oikopleura, s. Fig. 394, Sinnesorgan) wurde als eine Art Gernehsorgan gedentet.

Die letzterwähnten Grgane mit beweglichem C'ilienbusch sint, wje früher erwähnt, als Sinnesorgane zweifelhaft. - Nur selten wurden bei gewissen Copelaten Zellen mit starren Borsten an Nund wnd Schwanz gefunden. lie eher als echte Sinneszellen gelten könuten.

\section{b) Vertebrata.}

Fiir die Wirbeltiere erseheint die allgemeine Verbreitung freier Nervenendigungen in der Epidermis und in Sehleimhäuten, soweit sie geschichtetes Epithel haben, charakteristisch. Neben ihnen treten aber in der Epidermis der wasserlebenden primitiveren Vertebraten besondere Sinneszellen anf, welehe jenen der Wirbellosen recht :ihnlich sind, da sie die freie Oberfläehe erreiehen und hier ein bis mehrere freie plasmatisehe Simeshare tragen. Im Geruchsorgan aller.Vertebraten finden sich derartige Sinneszellen als primäre, von derselben Besehaffenheit wie jene ler Wirbellosen; wogegen die der änßeren Hant stets den Charakter sekundärer besitzen sollen, d. l. von freien Nervenendigungen umsponnen werden. - Die Hantsinnesorgane der luftlebenden Wirbeltiere erreichen dagegen die freie Epidermisobertliche nie mehr und sincl teils durch besondere Modifikation einfacher freier Nervenendigungen eutstanden, teils aus solchen, welche mit besonderen Zellen in Verbindung traten, die jedoch jetzt meist nieht als Sinneszellen angesehen werden.

Acruniu. In die einschichtige Epidermis eingelagerte Sinneszellen mit einem feinen starren Simneshar wurden, neben freien Nervenendigungen, bei Branchiostoma vielfaeh beschrieben, ihr Vorkommen jedoeh auch manchmal bezweifelt; nenere Angaben bestaitigen sie jedoch (s. Fig. 463 A-B). Sie sollen besonders 
reichlich am Vorder- und Hinterende stehen, hänfig auch par'weise. - An den Hundeiren finden sich ziemlich ansehnliche papillenartige Erhebnngen, zwischen deren Zellen zahlreiche älnliche Simneszellen vorkommen (Fig. 463 D). — Dem Epithel des l'clums und seiner Fortsätze, das die Mundhöhle vom respiratorischen Darm scheidet, sind viele knospenartige Gruppen ähulicher Sinneszellen eingelagert (Fig. $463 \mathrm{C}$ ), welche den bei Wirbellosen beschriebenen Sensillen der Mundhöhle gleichen and wie letztere wohl als Geschmacksorgane zu denten sind; daß dies auch für die Cirrenorgane gilt, ist weniger wahrscheinlich. Ob die Hantsinneszellen der Acranier primäre oder sekundäre sind, scheint vorerst nicht sicher.

Craniota. Sensillenartige Simnesorgane der ïuperen Haut sind bei den wasserlebenden niederen Wirbeltieren Cyclostomen, Fischen und wasserlebenden erwachsenen Urodclen, sowie den Larven der Anuren) weit verbreitet. sie treten in zweierlei Form und Funktion auf. Die der einen Art sind

Fig. 4 ti3.

A
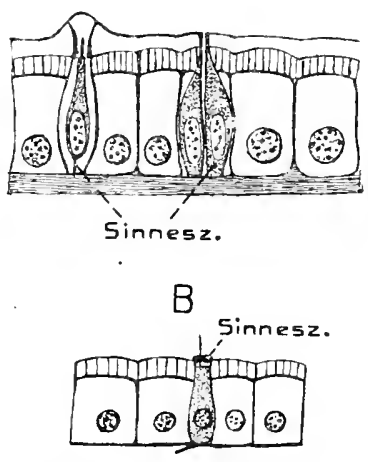

Hianchiostoma lanceolatum. simmeszellen und Hautsinnesorgane. A- $H$ Vertikalscimitt durch lipidermis mit simneszellen (1 nagh JosEPH 1908, b nach LAxGERHAxs 1876). - " Knospenförmiges Organ vom Velum. - $D$ Papillenlörniges Organ von einem Cirms $(c-\nu$ nach MERKEL 1880).

im allgeneinen Sinn mechanisch reizbar und zeigen Beziehungen zn den Hörorganen der Vertebraten, speziell deren statisch wirksamen Abschnitten. Es ist sehr wahrscheinlich, daß sie auf relativ schwache Strömungen des umgebenden Wassers reagieren und den betreffenden Tieren daher hinsichtlich ihrer Haltung gegenüber solehen Strömungen nuitzlich sind. Dies sind die Seitenorgane in ihren verschiedenen Modifikationen (auch Nerven- oder Endhigel, Endplatten, Nemromasten, Organe des sechsten Sinnes genannt). - Die Organe zweiter Art sind ehemisch reizbar und stehen in phylogenetischer Beziehung zu den Geschmacksorganen der luftlebenden Wirbeltiere, was sich darin ausspricht, daß sie auch bei den wasserlebenden schon in der Mundhöhle auftreten. Letztere Organe werden wir daher zngleich mit den Geschmacksorganen der Wirbeltiere genaner betrachten. Die hierher gehörigen Organe der äußeren Haut werden meist als becherförmige Oryane, Terminal-oder Endknospen (auch als Simnesknospen oder Geschmarksknospen) bezeichnet. - Der feinere Bau del beiderlei Organe ist recht ähnlich; dagegen soll ihre Innervierung nach den neneren Erfahrungen wesentlich versehieden sein, wemn es anch häufig dieselben Nerven sind, von denen sie ansgeht. Die Seitenorgane empfangen ihre Nervenfasern nämlich, soweit festgestellt, ans dem Centrum in der Medulla oblongata, welehes wir früher 
bei den Fischen als die Lobi (Tubercula) acustico-laterales (s. S. 577) schilderten, in welchem anch die Acnsticusfasern der Hörorgane entspringen. - Die Nervenfasern der becherförmigen Organe dagegen sollen ihr Centrum in den Lobi vagi der Fische (s. S. 577), bzw. auch dem Lobus impar (Lobus facialis) gewisser Physostomen besitzen, dem Ort, wo anch die Fasern für die Geschmacksorgane der Mundhöhle entspringen. - Im allgemeinen erinnern beiderlei Organe an die bei den Wirbellosen beschriebenen Sensillen und liegen in der geschichteten Epidermis. Sie selbst aber sind im Gegensatz zu ihrer Umgebung einschichtig und, soweit bekannt, ans zweierlei Zellen zusammengesetzt: 1. Simueszellen, deren Distalenden bei den Seitenorganen in der Regel lïngere protoplaswatische Sinneshaare tragen, wïhrend die becherförmigen Organe nur kurze Stiftchen oder Spitzchen besitzen; 2. indifferenten oder Stiitz:ollen (auch Fadenzellen genannt), welche zwischen die Simneszellen eingestrent sind und sich zuweilen in der Peripherie der meist knospenförmigen Organe reichlicher finden. Die Stützzellen ziehen stets gleichförmig durch die ganze Vicke der Organe hindurch, während die Sinneszellen sich nur bei den becherförmigen in dieser Form bis zur Basis hiuab erstrecken, jene der Seitenorgane dagegen meist birnförmig erscheinen, indem sie sich etwa in $1 / 3$ bis $1 / 2$ der Organdicke nnter der distalen Fläche zu einem feinen Faden verdünuen, der bis zum Corium reichen kamn (s. Fig. 467, S. 664 u. 475-478). Dieser Faden wurde früher als die zutretende Nervenfaser gedentet; die neneren Erfahrungen zeigten jedoch, daß sich die Sinneszellen beider Organe stets wie sekundäre verhalten, daß also die zu ihnen tretenden, marklos gewordenen Nervenfasern, sich reich verästelnd, die Sinmeszellen umspinuen, ja neben ihnen auch im simnesepithel noch freie Endigungen bilden können, wie arch zuweilen reichlich in der die Endorgane umgebenden Epidermis. Das Sinnesepithel der Seitenorgane gleicht demnach in manchen Punkten dem des Gebörlabyrinths. - Dic die Organe umhüllenden Zellen der geschichteten Epidermis sind häufig, im Übergang zur gewöhnlichen Epidermis, etwas verlïngert und bilden dann nm das Organ einen Mantel, Deckzellen (s. Fig. 475, S. 671). - Charakteristisch erscheint, daß diese Hantorgane sich durch Teilung $\%$ vermehren vermögen, womit zusammenhängt, daß sie hänfig gruppenweise vorkommen, indem eine solche Gruppe aus einem oder wenigen ursprünglichen Organen hervorgeht.

Seitenorgane. Wie erwibnt, sind sie bei den dauernd wasserlebenden Anamnial, also den Cyclostomen, Pisces, ichthyodon Amphibien, sowie den Luren aller iibrigen, jedoch anch im erwachsenen Zustand bei manchen Salumantinen, ja sellist yewisen - Inmen (Xenopus) iiber den ganzen Körper (Kopf und Rumpf) verbreitet. Die nrsprïnglichen Seitenorgane sind, wie dies bei der vorhergehenden Erörterung roranggesetzt wurde, frei in der Epidermis liegende Gehilde, die deren Oberflache erreichen, was auch bei den Cyclostomen Fig. 465 nnt Amphihien (Fig. 475, S. 671) stets der Fall ist, wogegen viele Fische in dieser Hinsicht Veränderungen erfabren haben.

Bei den Petromyzonten sind solche Organe über den gamzen Körper verbreitet, wenn sie auch gegen das Jinterende spirlicher und kleiner zu werden 
scheinen, was mit der Erfahrung übereinstimmt, daf die Organe ontogenetisch zuerst in der Kopfregion auftreten und sich allmählich eaudalwärts fortsehreitend entwickeln. Es seleint, daf ihre Entstehnng mit den friiher S. 624 erwilhnten Lateralplacoden in

Beziehnng steht, Fis. flit.

und daß speziell die Rnmpforgane ans dem ectodermalen 'Teil der' Vagusplicode, der nach hinten answïchst, hervorgehen, wobei

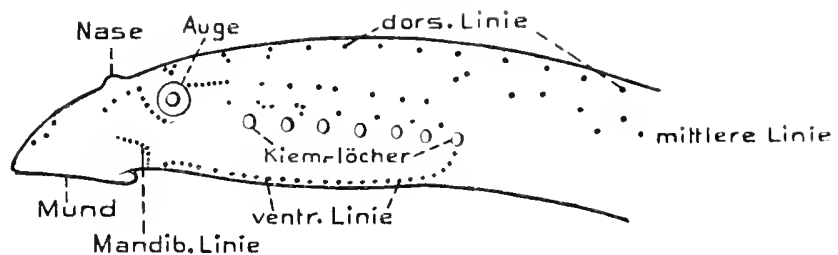

Petromyzon lluviatilis. Foplende von links: lie Seitenorgane sind als Punkte eingezeichnet nach MERkel 18s0. v. Bu. gleichzeitig der Ramus lateralis vagi ans dem Vagusganglion candalwiirts hervorwächst. Wrenn dies zutriflt, dann dürften die Kopforgane sich wohl in ihnlicher Weise von den Lateralplaeoden des 7. und 9. Nervs herleiten.

Daß die Seitenorgane der Wirbeltiere, ebenso wie lie becherfirmigen, an ähnliche IIantsinnesorgane der Wirbellosen lebhaft erimern, ist sicher. Ob sie sich jedoch phylo-

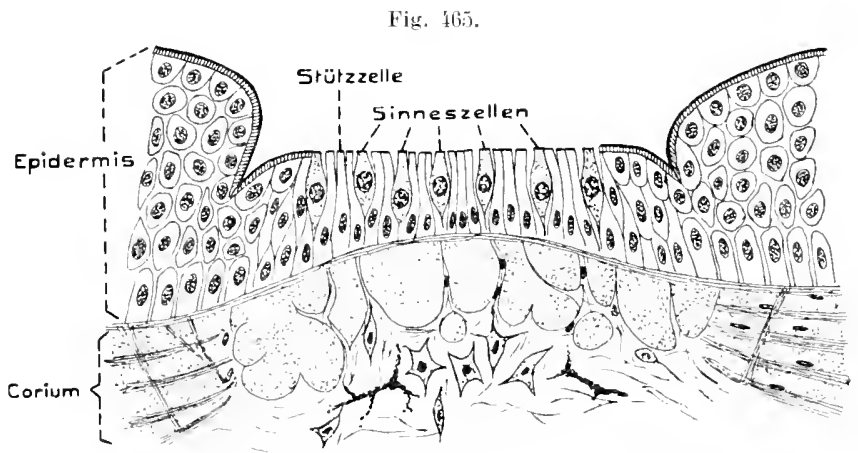

Petromyzon planeri. Längsschnitt durch ein seitenorgan in der Nackenregion (nach Mucher 1s:50). v. 1311.

genetisch ron denen gewisser Wirbellosen direkt ableiten lassen, besonders den segmentweise rerteilten sog. Seitenorganen gewisser (hatopolen (s. S. 654), erscheint vorerst recht 7.Weifelhaft, um so mehr als der Bau ler letzteren noch veiterer Aufklärmng belarf. Es wnrde früher, im Bestreben, die Vertebraten ron Anueliden abzuleiten, gerale auf die IIomologie dieser Organe in beiden Gruppen besonderer Wert gelegt.

Bei den Myxinoiden wurden die Organe bis jetzt nur in der Kopfregion gefunden. - Am Rimmpfe, hinter der Kiemenregion der Pctromyionten, stehen die O)gane in zwei Längsreihen, teils einzeln, teils in Gruppen von einigen (s. Fig. 464). Die dorsale Längsreihe folgt dem Ramus lateralis vagi, wie es ïherhaupt die Regel für die Seitenorgane des Rumpfes ist, und wird auch von diesem Nerv versorgt. Die mittlere Reihe beginnt in der Kiemenregion mit Gruppen ron Urganen, die 
etwas ïher den Kiemenöffnungen stehen. Beide Längsreihen setzen sich bis in die Schwanzregion fort. Die Organe der Kopfregion siud etwas unregelmäßig angeordnet und bilden (abgesehen ron einigen zerstreuten oberhalb des Mundes) wohl Fortsetzungen der lateralen Reile, die sich etwa anf die bei den Fischen zu schildernde Supra- und Infraorbitalreibe zuriickfïhren lassen. - In der Kiemenregion gesellt sich zu den beiden erwähnten Längsreihen noch eine ventro-

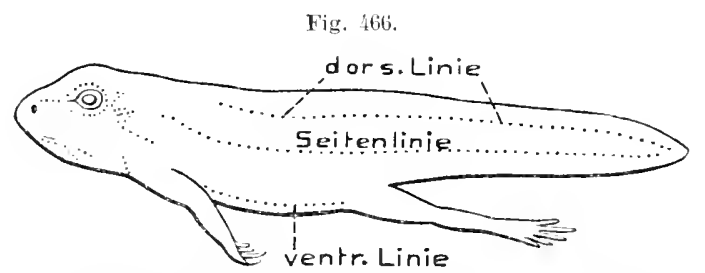

Rana Lave v, $2.5 \mathrm{~cm}$ von links. Seitenorgane als Punkte angegeben nach MALBRAxC 1sifi). ․ Bu. laterale, welche dem Verlauf des Plexus cervicalis (s. S. 638 , Recurrens vagi) folgt und großenteils ron diesem, vorn jedoch anch vom 9. und 10. Nerv innerviert wird; von ihr geht auch eine die Unterlippe umgreifende Reihe aus. Diese ventrolaterale Reihe der Kiemenregion diufte wohl der Opercularreihe der Fische entsprechen. - Die recht rerschieden großen Organe (s. Fig. 465) erheben sich meist flach hügel- oder papillenartig; die Hïgel sind aber in grul,enförmige Vertiefungen etwas eingesenkt. Der feinere Bin ist der schon erwïhnte mit Sinneszellen und

Fig. 467.

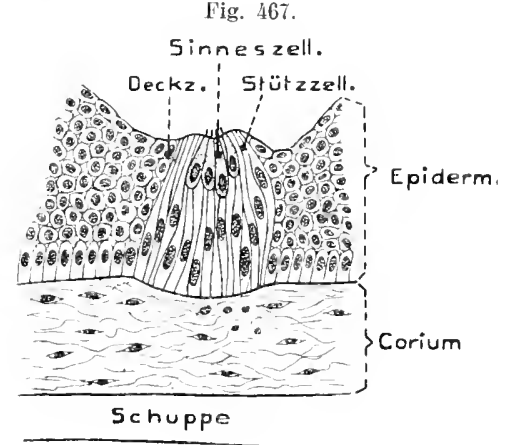

Barbus fluviatilis. Längsselnitt dnrcll das Seitenorgan eurer bejupje (uach MACRER 1845). v. Iiu. zahlreichen Stiitzzellen; unter jedem Organ findet sich gallertiges Bindegewebe. Die Kopforgane der Myxinoiden (Bdellostoma) dagegen, die in zwei Gruppen stelen, sind in tiefe Rinnen eingesenkt und erreichen die Epidermisol,erfliche nieht.

Gewisse Knochenfische (z. B. Cobitis und andere, die Lophobranchii) und, wie wir später scheu werdeu, auch die Amphibien schließeu sieh den Petromyzonten darin an, daß ihre Seitenorgane freistehen. Vollstïndig vermißt wurden die Organe bei den Fisehen sehr selteu (z. B. bei Ballistes).

Die Rumpforgane folgen ursprïnglich jerlenfalls dem Ramus lateralis vagi, so daß sie längs der Seitenlinie hinziehen, welche jedoch, wie schon friilier (S. 634) bemerkt wnrde, keineswegs stets der Grenzlinie zwischen dem dorsalen und ventralen Seitenrumpfmuskel entspricht. Doeh findet sich die Beschräıkung der Organe anf die Seitenlinien nur selten (z. B. Syngnatlens, wo auf jeder Schuppentafel seehs lis acht Organe stehen). Bei anderen Fischen (so Nerophis, Cobitis, Amiu) tritt anßer der lateralen Linie der Organe jederseits noch eine Riickenlinie hervor, ähnlich wie bei Petromyzon, was wohl Beziehungen zur Teilung des Ramns lateralis in die beiden Äste profnndus und superficialis, s. S. 634) hat. - Polyptems besitzt zwischen der Lateral- und Dorsallinie noch eine dritte. Bei den dipnermonen Dimoi finden sich anf dem Rumpf 
freie Organe, die läugs einer Seitenlinie geordnet, jeloch noch weiter ïber die Hant verbreitet sind, wahrscheinlich besonders im Bereich des dorsalen und ventralen Ramus lateralis vagi (vgl. S. 634), so daß ein gewisser AnschluB an die Amphibien besteht, bei welchen sich mit Ausuahme der Gymnophionen) drei Seitenlinien finden, indem sich der lateralen noch eine dorsale und ventrale zugesellen (Fig. 466), entsprechend den hier vorhandenen drei Ïsten des Ramus lateralis. - Doch besehränken sich die Organe der Kunochenfische nur selten aut die Seitenlinie, sondern breiten sieh häufig ïber die gesante Rnmpftläche ans, indem sie auf den meisten oler doch vielen Schuppen vorkommen; zuweilen auch in längslinion geordnet (so bei Fierasfer neben der Seitenlinie noch vier Reihen). Aneh auf deu Schuppen finden sieh häufig Gruppen von mehr oderweniger Organen, welche bald in einer Qner-, bald in einer Längsreihe stehen. - Die freien Organe kïnnen sich flach hiigelig erhehen (s. Fig. 467) oder in Griibchen, selhst Rimnen einsenken. Sie sind hänfig, besonders bei jungen Fischen, dadmch ansgezeichnet, daß sich um den Busch ilırer Sinneshärchen eine zarte gallertige Schutzröhre erhebt (vgl. Fig. 475, S. 671, naeh Analogie mit den Verhältnissen der Cristae der Hörorgane auch Cupula genannt).

Es scheint zweifellos, daß die freien Organe der Seitenlinie gewisser Knochenfische ursprünglich segmental angeorlnet sind, d. h., daß jedem Segment eine Organgruppe zukommt; meist ist dieser Charakter aber verwiseht, soll jedoeh ontogenetisch hervortreten können. Mehrfach warde zwar der ursprünglich metamere Charakter der Seitenorgane völlig geleugnet.

Ehen wurde claranf' hingewiesen, daß die Organe der 'Teleosteer häutig in Längsrimnen stehıen, namentlich auf den Schuppen der Seitenlinie. Hierau schließen sich bei Knochentisehen Zustände, wo sich diese Rinnen dureh Verwachsung ihrer Ränder geschlossen haben, so daß sich nur am Candalende der Schuppe noch eine äußere Öffnung des so entstanclenen Kanälchens erhält. Dabei wird gleichzeitig auf der Außenfläche jeder Sehmppe h:intig eine knöcherne, rinnenartige Umhïllung des Kanälchens gebildet, die endlich beim Weiterwachsen der Schuppe zu einem Kanal in deren Knoehenmasse wird. Endlich tritt bei den meisten Fischen eine Verbindnng der so entstandeneu Einzelkanälchen der Seitenlinie zn einem zusammenhängenden Kanal Seitentunal ein, ker die Schuppen ïherlagert oder durehsetzt und sich in der Regel in jedem Segment durch ein distales Ǩanälchen nach anßen öfnet. Dieser Kanal scheint sich so zu bilden, daß urspriinglieh vorn und hinten geöffinete Einzelkanälchen sich in ihrem mittleren Verlauf schließen, während gleichzeitig die heiden benaehbarten Öftuungen zweier anfeinanclerfolgender Einzelkanälehen zu einer verschmelzen Fig. 468). - Die Endorgane der Seitenlinie sind nun anf die proximale Wand dieses Seitenkanals geriiekt, sowie vou der Außenwelt völlig abgesondert; und zwar findet sich ursprünglich wohl je ein Organ zwischen zwei Kanalöffunngen, doch können sich dieselben nachträglich vermëhren. - Die Endorgane (Endhïgel, -platten oder -leisten) des Kanals werden häutig sehr groß; anch finden sich im Kinulepithel Sehleimzellen: wie denn die Seitenkanile friiher als schleimabsondelude 
gedentet wurden. Auch bei Cerutodus, den Ganoiden mit Ausnahme von Polypterus) und den Chondropterygiern finden sich die Seitenkanäle am Rump̃e. Bei primitiven Formen der Knorpelfiselie jedoch (wie Chimaera, Iteptanchus, Chlamydoseluche und in der Candalregion von Echinorkinus n. a.) ist der Kanal noch eine offene linne, welche nur durch die Schuppen ihrer Ränder einen gewissen Abscbluß erhält. Bei Chimaera (Fig. 505, ${ }^{1}$ S. 709) hleiben anch die Kanäle, welche sich als Fortsetzung des Seitenkanals am Kopf ausbreiten, offene Rinnen mit erweiterten Öffinungsstellen, während bei den übrigen genannten Formen, wie auch den Dipnoi und Teleostei mit freien Organen des Rumpfs, am Kopf stets geschlossene Kanäle vorkommen. - Die Seitenkanäle der Holostei zeigen ähnliche Beziehungen zu den Schuppen der Seitenlinie, wie dies bei den Teleostei

Fig. 468.

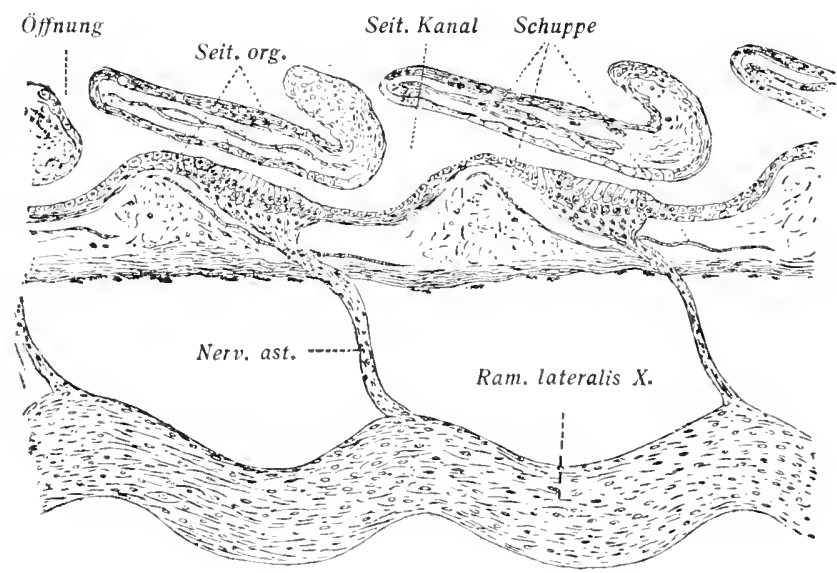

Amia calva. Horizontaler Längschnitt durch den Seitenkinal mit den Endorganen und den äußeren ¿̈finmingen (aus GEGENBtr. Vergl. Anatomie, nach Allis 1888).

meist der Fall ist. Bei den Chomdrostei und Chondropteryyii sind sie unabhängig ron den Knochenplatten oder Placoidschuppeu, zeigen jedoch zuweilen selbständige knorpelige (z, B. Chimaera) oder knöcherne ring- oder röhrenförmige Umliïllungen, wie letzteres anch bei Teleosteern (z. B. Salmo) vorkommen kann. Im Gegensatz zu den bei den meisten Teleosteern gefundenen Verhältnissen besitzen die Öffnungsröhren der Ginoiden und Chondropterygier einen komplizierteren Ban, indem sie sich in der Regel gegen die Hantoberfläche sekundär verästeln Fig. 470, 8. 668), dabei sogar nicht selten netzförmig anastomosieren und so durch mehrere bis sehr zahlreiche Poren münden.

Diese Verästelungen gehen besonders bei den Rochon sehr weit. - Mit der ansehnlichen Entwicliung her Brustflossen hat sich das Seitenkanalsystem hier ungemein entfaltet (Fig. 469), indem von jedem kianal ein ansehnlicher Seitenzweig (Pleuralkanal) in die Brustflosse eintritt und sich, deren Seitenrand meist völig umziehend, vorn mit den Kopikanälen rerbindet. Fon diesen Kanal tritt rorn auch eine Fortsetzung auf die Ventralläche der Flosse hinab, die am Floscenrand nach hinten zieht und, sich dann nach rorn 
wendend, gleichfalls mit den Kopfkanälen in Verhindung trilt. In den Einzelheiten herrscht große Mannigfaltigkeit. - Es ist schwer zn entscheiden, wie groß der Anteil der Koptkanäle an der Bildung dieses Brustflossenkanalsystems der Rochen ist.

Bei allen Fischen sind die Seitenorgane auch am Kopf reich verbreitet. Einmal setzt sich der Seitenkanal stets anf den Kopf fort nud erlangt hier eine verwickelte Ausbreitung, welche sich zwar in allgemeinen in ähnlicher Weise überall wiederholt, im einzelnen aber viele Modifikationen aufweist (Fig. 470). Diese Kopfkanäle treten bei den Gilnoiden und Teleosteern meist in dieselbe Beziehung zu den Hantknochen des Schädels wie der Seitenkanal zu den Schuppen, indem sie wenigstens großenteils in Kanäle der Hantknochen eingeschlossen werden. Sie öfrnen sich durch eine verschieden große Zahl vou Distalröhrehen und Poren nach anßen, die bei Ganoiden (Ausnahme Polypterns), Chondropterygiem und gewissen Physostomen. dieselben Veristelungen zeigen, wie die Röhrchen des Seitenkanals. - Der Seitenkanal (vgl. Fig. 470 1. 471) zieht vorn meist etwas dorsal empor und tritt in die supratemporale Kopfregion (Gegend der Supraclavicularia) ein (Postorbitralla$(a)$, wo er sich dorsocaudal vom Ange in zwei Kanäle spaltet, von denen der eine als Suproorbitallamal uiber dem Ange gegen die Schnanze verläuft, der andere als Infiaorlitallirmal unter dem Allge hinzieht. In der Schnauzenregion

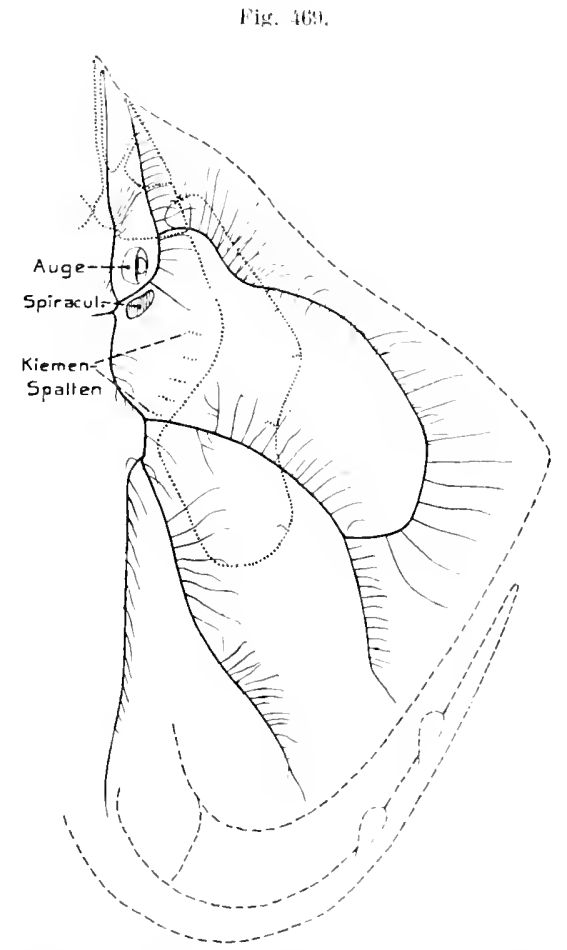

Iraptera ayasizii (Rochen). Rechte Halite von der Lorsalkeite, mit eingetragenem seilenkanalsystem: die Fanale der Ventralseite sind punkliert angegeben (nach G.MHAN 1888). v. Bu. gehen beide Kanäle meist ineinander über. In der Supratemporalregion stehen die beiden Lateralkanäle (Postorbitalkanäle) fast stets durch eine, das Schideldach quer iberziehende Commissur (Suprotemporal-oder Oceipitallaral) in Verbindung; eine ihnliche Commissur kamn bei Ganoiden und Chondropterygiern in der Ethmoidalregion zwischen den beiden Supraorbitalkanälen auttreten. - Mit der starken Entwicklung des Rostrums nnd der Riickwärtsverlagerung des Mauls bei den meisten Knorpelfischen dehnen sich die rostralen Enden der Kanäle anch anf die Ventralseite der Schnauze aus, wo sie eine charakteristische Entfaltung ellangen (Fig. 471), deren Riickfïhrung auf die Verbältnisse der übrigen Fische bis jetzt noch nicht geniigend aufgeklärt ist. Schon bei den Chondropterygiern tritt ferner ein Kanal aut, welcher vom Infraorbitalkanal wach hinten zieht und, nach 
vorn umbiegend, einen Zweig zum Unterkiefer sendet (Fig. 471); es ist dies wohl das Homologon des Hyomandihularkanils (Opercularkanal), der iher dem

F'ig. 470.

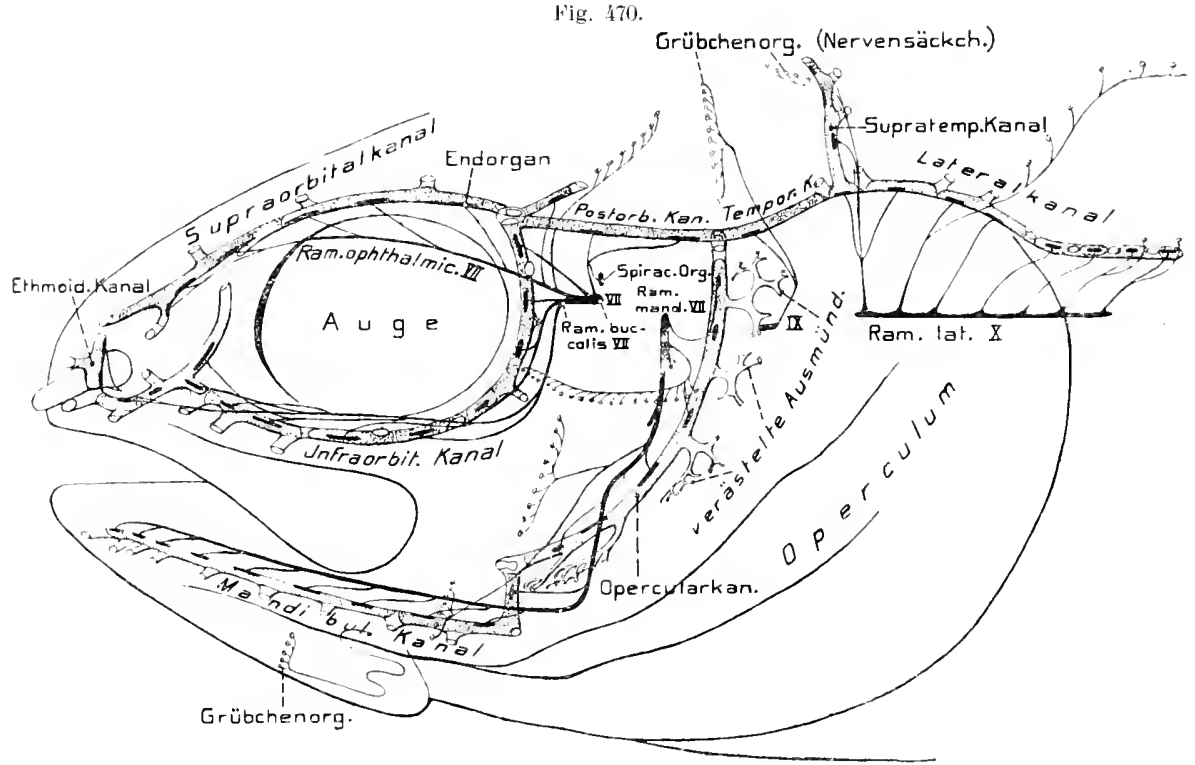

Amia calva, Kopt ron links mit dem seitenkanalsystem muden zu ihm tretenden Nerven. Die Kanäle sind punktiert dargestellt, ihre Ausfïhgänge abgeschnitten gedacht, nur die des Opercularkanals sind in ihrer verästelten Beschalfenheit wiedergegeben. Die Endorgane in den Kanälen sehwar?

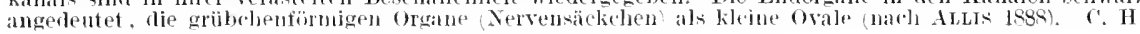

Hig. 471

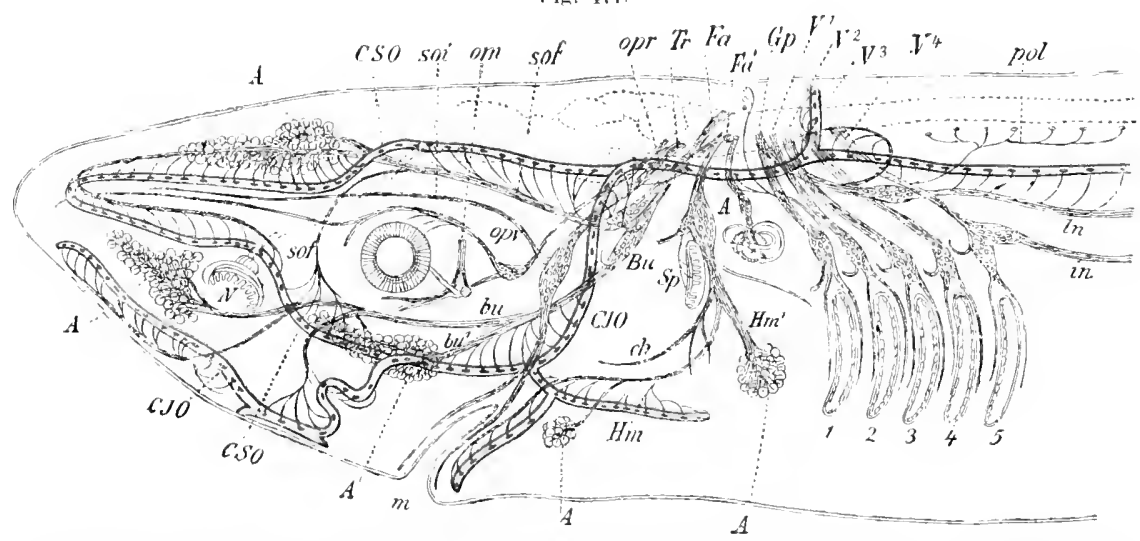

Laemargus borealis von der linken seite. Seitenkinalsystem (blant) sowie die Konfuerven sint eingezeichuet. (Ais Gedexbacr, Vergl. Anatomie n. Ewart 1842). A Ampullen, d' Acusticus, bin

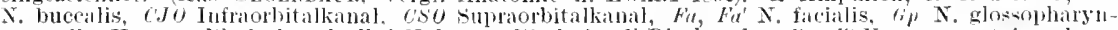

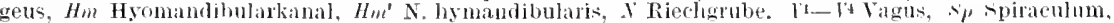

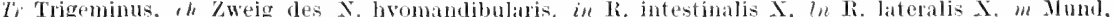
om $\mathrm{N}$. oculomotorius, on" num opm Ophthahnicus profundus $\mathrm{V}$, pol Zweig des R. lateralis, sof Ophtlalmieus superficialis Vul, sot ophthahnicus superficalis $V, 1-5$ Kiemenspalten.

Kiemendeckel der Ganoiden mil Knochenfisehe z.nm Unterkiefer zieht nnd meist mit dem Postorbitalkanal verbunden ist (Fig. 470). 
schon bei zahlreichen patäozoischen lischen (Fanoiłlu, Dipnoern und Verwandten der (hondropterygii) timlen sich am Schädel Reste sou Kanälen und Puren, woraus herrorgeht. daß die Seitenorgane und -kanäle schon ten älesten Fischen zukmen; wie es z. B. die lig. 138, s. ¿41 ron Coceostors zeigt. Wo der Verlaul der Kopfhanäle durch punktierte Linien angerlentet ist. - Dies frühzeitige Auftreten ler Kande hat zu ler Insicht gefüht. laß die freien Urgane, wie sie sich anl dem kumpt rezenter Knochenfische nnd Dipnoer anch in ter Seitenlinie vielfach linden, durch kïekbildung von Kanälen entstanden seien, dem-

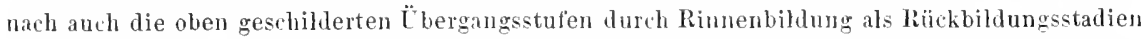
zu deuten wären. Bis jetzt kann aber diese Insicht nicht für himreichend begründet gelten.

Freie Organe sind auch am Kopf zuweilen zerstrent, so bei einzelnen Chondropterggiern (Squatina, Mustelus) und ebenso bei Knochenfischen; bei Mustelus breiten sie sich anch am Rumpf dorsal aus. Bei den Ganoiden finden sie sich neben den Kopfkanälen in Form der sog. Nerensäclichen der Chondrostei und der sog. Gribchenorgane der Holostei Pit-Organs, vgl. Fig. 470). Es sind dies Gruppen oder Reihen mehr oder weniger tief siickchenfürmig eingesenkter Einzelorgane, die sich in verschiedener Verteilung an Kopf, anch seiner Ventralseite, tinden.

Wa ker Grumd ter äckchen (stör) sich häufig in eine Anzahl scheidewände erheben soll, so erlangen tiese Hrgane z. T. eine genisse Ahnlichkeit mit den gleich zu schildernden Ampullen der Chomtropterygirs.

Eine besondere Form eigentiimlich modifizierter Urgane sind die bei den

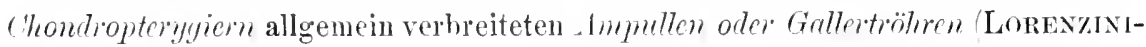
sche Ampullen). Dieselben lassen sichetwa alufassen als dicht zusammengerückte Gruppen säckchenaltig eingesenkter Seitenorgane (event. aber auch unvollständig geteilter), welehe sieh, unter Einstïlpung einer mit gallertigen Sekreterfillten Rïhre, tief in das Interhant-

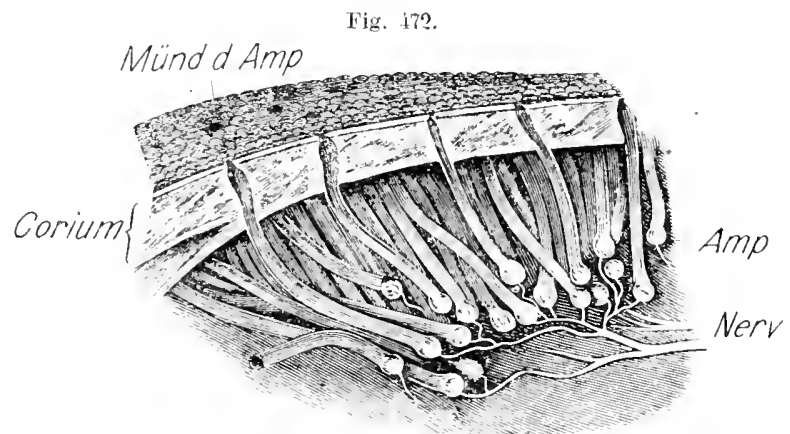

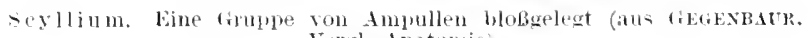
Tergl. Inatonite.

bindegew ebe hinabgesenkt laben und dureh einen feinen bis gröberen Porus auf der Hantoberfläche miinden. Die Gallertröhren werden hänig sebr lang und ziehen dann mehr oder weniger horizontal im Bindegewebe hin (s. Fig. 472). Das Proximalende der Röhre elweitert sich zu einer verschiedenen Zahl (etwa 8-30) ampullenartiger Aussackungen, die meist etwa strahlig um eine mittlere, sich schwach erhebende Achse (Centralplatte) angeordnet sind; doeh tinden sich aueh Ampullen, bei denen diese Divertikel dureh eine mehrfache Teilung der Riöhre entstehen und die Centralplatte fehlt (Acanthias). Nur in diesen Anssackungen (Fig. 47311. 474) finden sich birnförmige Sinneszellen, welche zwischen Stiitzzellen verteilt sind, während die Röhre von einschichtigem indifterentem Epithel ausgekleidet wird. Der Nerv tritt in der Aclse zu und verteilt sich dann in den Septen zwischen 
den Anssackungen. - Eine vielleicht primitivere Form solcher Organe, die sich bei einzelnen Haien (Hexanclus) findet, besitzt keine gemeinsame Gallertröhre,

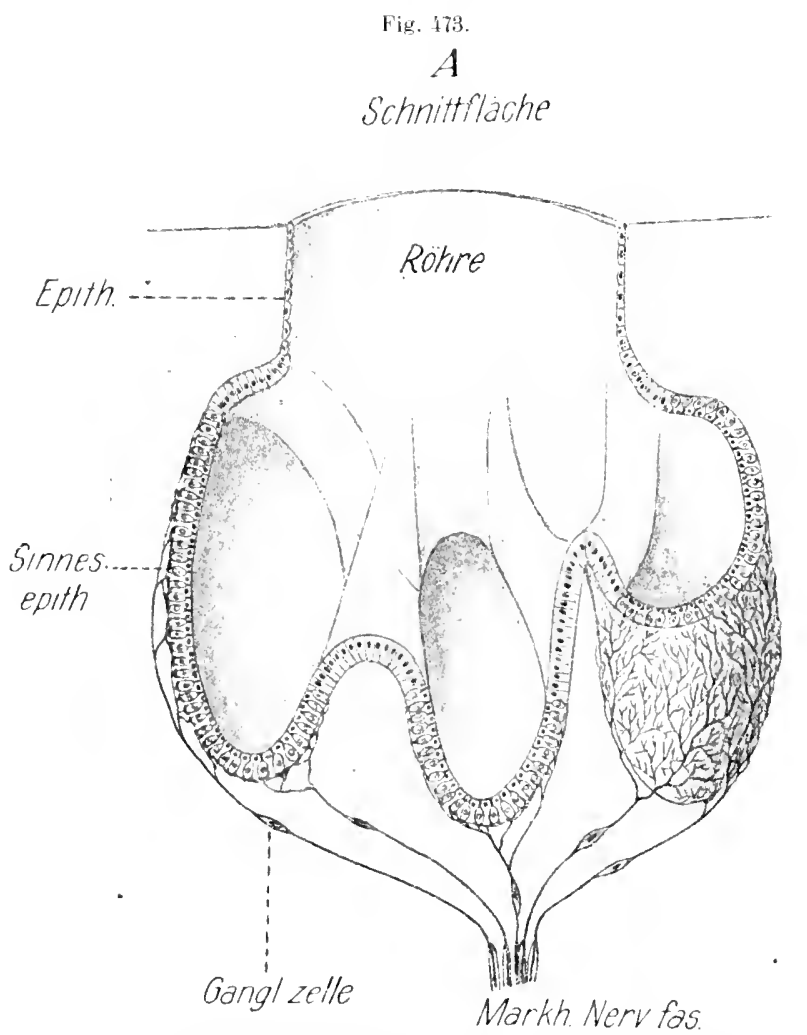

A eanthias. Längsschuit des proximalen Endes einer Ampulle mit drei ampullären Anschwellungen (aus HEsse, Holwb. d. Natw, kombinierl nach

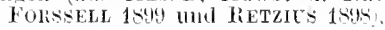

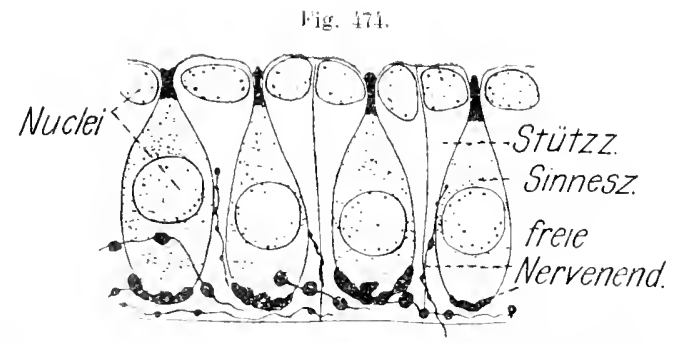

Acantlias. Sinnesepithel einer Ampulle (aus Hesse, Holwh. d. Xatw. niach liETZIC' 1sis). sondern für jede der proximalen Aussackungen eine Verbindungsröhre mit der Oberflïche. - Die Ampullen kömmen spärlicher und ziemlich unregelmäßig iiber die Kopfläche zerstreut sein. Wenn sie, wie meist, sehn' zahlreich vorkommen, so häufen sich ibre Mündungen an gewissen Stellen der dorsalen und ventralen Kopffläche zu dichten Gruppen zusammen, die in regelmiißiger Verteilung anftreten (Fig. 471, S. 668); von diesen Centralpunkten strahlen daun die Gallertröhren aus, wobei jede Röhrengruppe gewöhnlich von einer festeren Bindegewebshiille umschlossen wird. - Die Ampullen der Rochen können sich bis in die Afterregion ansbreiten.

Als moditizierte Seitenorgaue werden gewöhnlich anch die sog. Sarischen Blïshlen der Tarpedoarten gedentet.

Es sind dies nach außeu röllig abgeschlossene, mit gallertiger Flüssigkeit erfïllte Bläschen, die sich in der Region der Nasengruben ausbreiten mu auch anf die Dorsalseite 
der schnauze etwas übergreifen. Vun der Nasalregion ziehen ventral jederseits eine kürzere und eine längere Reihe am Rande der elektrischen Organe nah hinten, letztere lieihe längs des Propteryginms (rgl. Fig. 194, S. 324). Die Reilıen ler (1rgane sinl auf einem platten, sehnigen Strange befestigt. Jedes Bläschen wird von einfachem I'lattenepithel ausgekleidet. das sich auf dem Bläschengruml, der an dem erwïhnten vtrang befestigt ist, zu Cylinderepithel verdickt. In letzterem finden sich drei runde Stellen, eine mittlere größere und zwei kleinere, wit höherem Epithel, das eingestreute haartragende Sinneszellerr entbält; die Organe werden von Trigeminusästchen innerviert. Die (1ntogenie scheint dafür zn sprechen, daß die Bläschen ron Seitenorganen abzuleiten sind: welche sich röllig geschlosen hahen. thre Funktion ist unbekannt.

Die Innervierung der Endorgane der Kopfkanäle und Ampullen geschieht durch Zweige des Facialis (Ramus ophthalmicus, buccalis, mandibnlaris), doch können sich auch Ästchen des Glossopharyngeus und Vagus daran beteiligen (s. Fig. 470 , S. 668).

Wie schon erwibnt, finden sich bei denusserlebenden Amphibien, insbesondere den Ichthyoden, sowie den Larven der übrigen, stets Seitenorgane am Kopf und Rumpf, die entweder frei in der

Fig. 475.
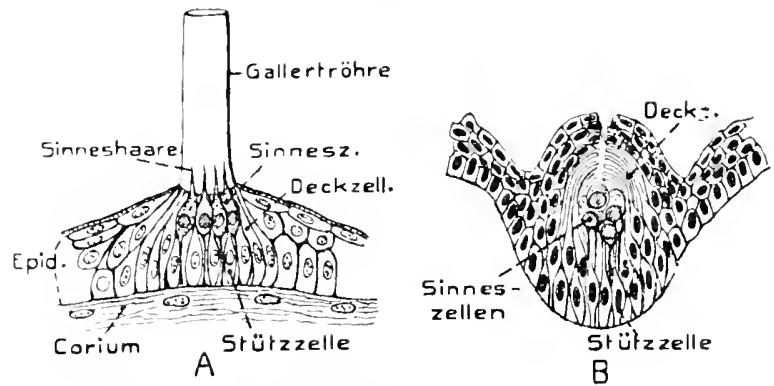

Tritom. Seitenorgan schematindì. 1 Organ der Larve mil dialtert röhre, rtwa im optischen Vertikalschitt gesehen nach F. L. ScHuLze 1870 ind MATRER 1595). - If Organ von der erwachsenen Landforn im

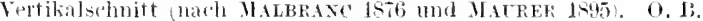

Hautoberfläche liegen oder sich etwas hïgelig erheben, wie es bei den Larven meist der Fall ist, jedoch auch mehroder weniger tief follikelartig eingesenkt sein kömmen z. B. Ichthyoden und erwachsene Salamandrinen), so daß sie dann an die Nervensäckehen der Ganoiden erinnern. Kanäle fehlen den jetzt lehenden Imphibien stets. Der allgemeine Ban der Organe gleicht dem der freien der Fische selı, anch besitzen die der Larven häufig das freie Gallertröhrchen Cupula) zum Sehntze der Sinneshare (Fig. 475 A). Die Verteilnng der Organe am Kopf erinnert an jene bei den Fischen, indem sich meist eine Supra- und Infraorbitallinie, sowie anch eine zum Unterkiefer ziehende Hyouandibularlinie erkennen lassen (Fig. 466, S. 664); doch ist die Verteilung im ganzen unregelmäBiger als bei den Fischen. Die erwachsenen Individnen zeigen am Kopt" und Rumpf meist Gruppen- oder Reihenbildnng der Organe; da die Termehrung der Organe dureh Teilung sicher erwiesen ist, so sind jene Gruppen oder Reiben jedenfalls anf diesen Vorgang zurïckzufïhren. - Am Rumpf stehen die Organe im allgemeinen jederseits in drei Laterallinien, welche besonders bei den Larven (Fig. 466), doch auch vielen Ichthyoden, dentlich hervortreten, dagegen bei den Erwachsenen (hesonders Salamandrinen) weniger gut erhalten sind. Eine mittlere Reihe folgt dem Verlauf des Ritmus lateralis profundus des Vagus; eine dorsale, jedersojts liings der lijekenkanto 
hinziehende, dem Ramus lateralis superficialis (oler superior) und eine ventrolaterale dem Verlauf des Ramns lateralis inferior; letztere Reihe endigt am After, während die beiden ersteren his zum Schwanzende ziehen. Auch in den Seitenlinien der erwachsenen Formen stehen die Organe zuweilen in dentlichen reihenförmigen Gruppen (so Proteus, Menobranchus, Plcurodeles u. a.), nnd zwar sind diese Gruppen in der Dorsallinie vertikal, in den beiden anderen längs gerichtet, Verhälltnisse, welche an Petromyzon eriuner'n. Auch die Einzelorgane sind häufig länglich oval und dann entsprechend gerichtet. Ursprïnglich soll sich im Rumpf der Urodelen auf jedes Segment nur ein Organ in jeder der drei Linien finden.

Bei den encachscnen Salamandrinem erhalten sich die Organe nicht selten (z. B. Amblystoma, Pleurodeles, Triton, Salamandrina, nicht dagegen Salamandra). Sie senken sich jedoch während des Luftlebens meist tiefer ein (Fig. $475 B$ ); indem die umgebenden Hüll- und Deckzellen die Sinneszellengruppen ïberwölben und gleichzeitig verhornen, so daß unr cin enger kanalförmiger Zngang bleibt, tragen sie zum Scbutz der Organe während des Luftlebens bei. Während des Wasserlebens, zmr Fortpflanzungszeit, bildet sich der ursprïngliche bau wieder hervoi, wobei anch Regenerationsprozesse mitspielen sollen. - Unter den erwachsenen Antren ist nur eine Gattung bekannt (Dactylctlora), die zahlreiche follikelartig eingesenkte Organe an Kopf und Rumpf, dorsal und ventral, besitzt. Anch hier steben die Organe in reihenförmigen Gruppen ron 3-7; am Rumpfe lassen sich drei, ziemlich dicht benachbarte Längslinien erkennen, in welchen dje Reihen quer oder längs stehen.

Bei Amphibien und Fischen (besonders Cyprinoiden) scheint es sicher, daß die freien Urgane der Hautoberfläche degenerieren können und dabei ausgestoßen werden, was ja bei der Metamorphose vieler Amphibien für alle Organe eintritt. An dem Ort der degeneriertell Organe sollen sich bei den Cyprinoiden die kegelartigen Epidermiscerhornungen auf den Schuppen bilden, welche als Perloryane bekannt sind. - Degeneration von Seitenorganen wurde ferner namentich bei Cryptobranchus bekanut; hier rerbleibt an der Stelle, wo ein Organ verschwunten ist, eine sich in die Epidermis erhebende Corinmpapille. - Andererseits wird angegeben, daß an den Stellen der larvalen Seitenorgane der Anuren die später zu besprechenden Tastflecken ( $s$. . . (682) auftreten, was eine gewisse Beziebung zwischen beiderlei organen anzeigen würle.

Die larvalen Seitenorgane der Gymmophionen (Ichthyophis) stehen am Kopf in :ihnlicher Verteilung wie hei den iibrigen Amphibien, wogegen sich am Rumpf nur eine ziemlich dorsal stehende Linie von ihuen findet.

Die Organe sind zweierlei Art: 1. sog. Hïycloryane, welche jenen der ibrigen Amphibien gleichen und nicht bis mehr oder weniger follikelartig eingesenkt sind. Auf der Spitze des IIügels tindet sich um die Sinneshaare ein Gahleıtröhrchen. Die Seitenlinie enthält nur solche Organe; '?. sog. /leschenförmige Oryane (Fig. 476) kommen nur am Kopf vor und erscheinen als kugelige, drüsenartig eingesenkte Follikel, in deren Grund Sinneszellen mit Haaren stehen. Ihre Ilauptauszeichnung bildet ein etwa kolbenförmiges, stark lichtbrechendes Stäbchen, das den Ausführungsgang fast erfüllt. Etwas $̈$ hnhliches soll gelegentlich bei Fischen (Fieraster) beobachtet sein. Daß den flaschenförmigen Organen Hörfunktion zukomme, ist jedoch kaum anzunehmen, vielmebr dürfte das keulenförmige Gebilde wobl nur die mechanischen Reize, welche nach der verbreiteten Ansicht von den Seitenorganen per- 
«ipicrt werden, unterstützen. - Die wahrscheinlichste Ansicht ïber die Funktion der Seitenorgane überhaupt schreibt ibnen nämlich, wie oben benerkt, lieizbarkeit tureh schwache Wasserströmungen $z u$, so lah sie auch bei den hïufigen Wandermgen der Fische entgegen 11.asserströmungen in Betracht kommen.

Bei gewissen fossilen Strgocephalen (speziell Labyrinthodontia) lindet sich auf der Dorsalseite des Schïdels ein System von Furchen oder Rinnen, das in seinem Verlauf und seiner Beziehung zu den Schädelknochen an die supra- und hnfraorbitalkanäle der Fische erinnert. Daß diesen Furchen Seitenorgane eingelagert waren, scheint zweifellos; ob es sich aber um abgeschlossene Kanäle oder Rinnen handelte, ist zweifelhaft.

Schon $\therefore$. 119 wnde herrorgehoben, daß versucht wurle, die Ilaare ter Säuger ron sich rück- und umbillenden Seitenorganen der Anamnia abzuleiten. Diese Hypothese stïtzt sich einmal auf das urspröngliclie Auftreten der Hare in Längsreihen, sowohl am Kopf wie Rumpf, wobei die Verteilnng der ansehnlichen Tasthaare (Sinushaare) am kopf etwas an die ler Seitenorgane erimnert. Eine weitere Ähnlichkeit wird in der häutigen Gruppenbillung ler IIare (s. S. 116). sowie der Beziehnng dieser Gruppen zu ten schnpengebilden gefunden. indem je eine Gruppe hinter jecler schuppe oder auch auf ihrem freien Caulalrand steht. Dabei wird als sicher betrachtet, $l a ß$ jelle Haargrupe: wie lie Seitenorgangmpen durch Termehrung eines ursprïnglichen Einzelorgans entstehe. - Anch die etwas knospenförmige Anlage der $\mathrm{H}$ aare aus der tiefen Epidermisschicht (s. Fig. $38 c$, S. 115) gleicht der ontogenetischen Bildung der Seitenorgane der Amphibien. - Im einzelnen wird die Entstehung eines Haares ans

Fig. $\$ 76$.

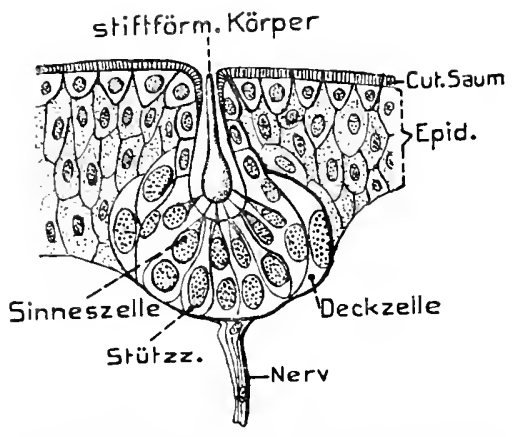

lehthyophis elutinosus (Larve), Flastinenfömiges seitenorgan im Achsialschnitt (nach SARRASIS IST). C. H. einem eingesenkten Śeitenorgan, wie sje sich etwa bei len zum Luftleben ïbergegangenen Salamanirinen oder auch alten Ichtbyoden bilden. etwa folgentermaßen gedacht. Inlem ein solches Organ in die Tiefe einer epidermoidalen Röhre hinabsinkt, bilflet sich die Anlage des Harfollikels (s. Fig. $38 a$, S. 115) mit der äußeren Wurzelscheide. In dem verhornenden und auswachsenden eigentlichen Organ würden die simneszellen zu Markzellen, die sog. Stützzellen (Jüllzellen) zu den Rindenzellen, die Dechzellen zum Oberhäuthen, während die innere Wurzelscheide aus den Lyithelzellen hervorgehe, welche das eingesenkte Seitenorgan außerlich bedecken. Waß sich in solch eingesenhten Seitenorganen der Amphibien (Cryptobranchus) eine schwache Corinmpapille erheben kann, billet gleichalls eine Annäherung, ebenso auch lie Blutgefäße, namentlich ler ringformige Blutsinus, ler sich mm die eingesenkten Organe der Amphibien in der hegel finclet. Wie schon frïher hervorgehoben, erscheint daher diese hypothetische Ableitung der Haare recht beachtenswert, wens sie aud weiterer sicherung bedart.

Becherfïrmige Orgune und Geschmuchsoryune der Wrirbeltien. Schon oben (S. 662) wurde hervorgehoben, daß der bau dieser chemisch reizbaren Organe jenem der Seitenorgane selı gleicht (s. Fig. 477), die Innervierung jedoch aus wesentlich anderer Qnelle erfolgt. Ihrer Funktion entsprechend, finden wir sie, wie die ähnlich gebanten und funktionierenden Geschmackssensillen Wirbelloser, hauptsächlich in der Mundhöhle. Bei vielen Fischen verbreiten sie sich jedoch anch auf der äußeren Hant. Es sind knospenförmige, in die Epidermis eingelagerte Gebilde, die sich nu' selten etwas in das Corium einsenken, häufig sogal 
(besonders lei Fischen) nur die periphere Lage der Epidermis durchsetzen, in welchem Fall dann eine Coriumpapille zn ilınen anfsteigt. Sie bestehen aus Stützund Sinneszellen; letztere, welche häufig in der Achse der Knospe zusammengedrängt sind, unterscheiden sich von jenen der Seitenorgane dadurch, daß sie

Fig. 477.

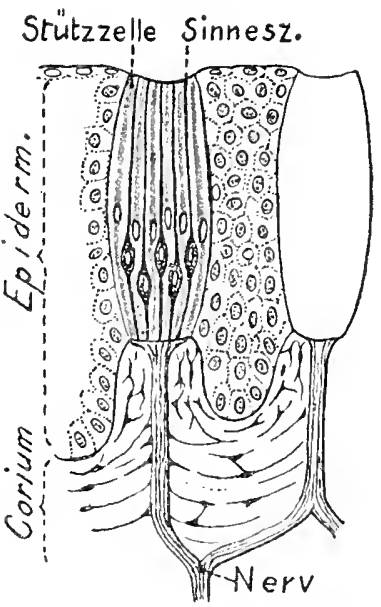

Tinca (schleie). Schnitt clurch die Gammenscileimlant mit zwei bechertöruigtn Organen (uach F. E. ScruLzF 1863, mit Bemtzung von MLATRER 1895). O. $\mathrm{B}$. distal ein stiftchen- bis stäbchenfürmiges (selten haarförmiges) Endgebilde tragen und sich als cylindrische, wenig angeschwollne Kellen bis zur Knospenbasis erstrecken, also nicht die birnförmige distale Anschwellung der Sinneszellen der Seitenorgane zeigen. Die Innervierung geschieht nach den meisten Erfahrungen durch freie Nervenendignungen, welche die Sinneszellen, oder nach gewissen Angaben anch dio Knospen umspinnen, sich jedoch anch in der Epidermis um die Organe reichlich verbreiten.

Es wurde gelegentlich behauptet, daß die becherförnigen Urgane stets aus tem Entoderm hervorgingen, wie es ja fïr die des Vorderdarms mäglich erscheint; daß dies aber für die Organe der äußeren Haut der Fische gelte, ist kamm annehmbar.

Bei den Petromyanten kennt man solehe ()rgane (besonders bei Larven und jungen Tieren) im respiratorischen Darm, wo sie sich in einer Vertikalreile von 5-10 am Innenrand der meisten Diaphragmen, welche die Kiementaschen voneinander trennen, ausbreiten. Es sind flach schüisselförmige, etwas hügelartig vorspringende Knospen.

llantorgane, die als Geschmacksorgane gedeutet wurlen, fanden sich nur bei der $\mathbf{C y}$ clostomengattung Lampreta in hex dorsalen und rentralen Mittellinie der Kopf- und Kiemenregion; ihr Bau ist jedoch so ahweichend, daß sie mit den ejgentlichen Geschmacksknospen kaun vergleichbar erscheinen.

Unter den Fischen kommen becherförmige Organe stets in der Mundhöhle ror, gewöhnlich auch auf den Lippen. Bei Chondropterygiem scheinen sie sich rorwiegend auf die Mundhühle zu beschränken. Bei vielen Knochenfischen (besonders reichlich bei Cyprinoiden und Siluroiden) aber verbreiten sie sich auch üher die äufere Körperhaut und stehen besonders hänfig am Kopf, vielfach auch am limmpf bis zum Schwanze, obgleich sie nach hinten spärlicher werden. Sie finden sich meist in Ein- und Mehrzahl frei auf den Schuppen und können sich auch auf die Flossen ausdehnen. Besonders reich treten sie häufig im Umkreis der Cornea, namentlich aber an den Barteh der damit versehenen Knochentische nnd Ganoiden (Chondrostei) auf. - Die freien Hautorgane springen meist etwas hïgelartig vor, kömnen jedoch auch schwach vertieft sein, was ebenso an den Mundhöhlenorganen vielfach beobichtet wird. -- In đer Mundhöhle stehen sie häntig anf papillewartigen, nicht selten ansehnlichen Frhebungen in Win- bis Vielzahl. 
Sie finden sich hier anf Falten oder Wiilsten längs der Zahnreiben, doch anch auf der Zunge, sowie am Gaumen und erstrecken sich ferner in die respiratorische Darmregion bis zum Ösophagnseingang. Namentlich bei den Teleosteern finden sie sich sehr zahlreich anf hänfig großeu papillenartigen Fortsätzen der InnenHäche der Kiemenbogen. Wie schon oben bemerkt, stehen die becherförmigen ()rgane der Fische in der Regel auf einer Coriumpapille.

Hinsichtlich ihrer Innervierung ist hervorzuheben, daß sie von Ästehen des 7., 9. nnd 10. Hirnnervs versorgt werden. Die Organe der Mundhöhle erbalten ihre Fasern von Pharyngealisten dieser Nerven. Wie schon friiher bemerkt, scheint sich das Centrum für ibre Innervierung in den sog. Lobi vagi (s. S. 577), bzw. dem ihnen im allgemeinen zugehörigen Lobus impar (Cyprinoiden) oder den sog. Lobi trigemini der Silnroiden zu finden. Auch die Geschmacksfasern sollen einem entsprechenden Centrum entstammen. Das betreffende Fasersystem wird häufig als Communissystem bezeichnet, im Gegensatz zu dem Acnstico-Iateralis-System. Die freien Rumpforgane, im besonderen die der Flossen, erhalten Nervenfasern aus dem Ramus lateralis trigemini (s. S. 629 u. Fig. 448), der jedoch, wie dort bemerkt, jetzt hänfig dem Facialis zugerechnet wird. - Daß anch die freien becherförmigen Organe der Fische als Geschmacksorgane funktionieren, ist experimentell ziemlich sichergestellt.

Bei den Amphibien, wie den Tetrapoden ïberhaupt, beschränken sich die Geschmacksknospen auf die Mnndhöhle; was frïher anf der äußeren Hant gelegentlich von solchen Organen erwähnt wurde, bezog sich jedenfalls auf Seitenorgane. Die Geschmaeksknospen der Urodelen erinnern nach Ban und Verbreitung sehr an jene in der Mundbühle der Fische; sie stehen auf Papillen oder Falten der Zunge und des Gaumens bis zum Ösophaguseingang. - Die Organe der Inuren hingegen sind eigentümlich gestaltet, da sie zu flachen, scheibenförmigen Gebilden (Geschmacksscheiben, Endscheiben) geworden sind, die am Distalende der pilzförmigen Papillen (Papillae fungiformes) des Zungenrïckens stehen, sich ferner am Gaumen bis zu den Mundwinkeln erstrecken, namentlich auch um die Vomerzähne reichlich anftreten, elenso aber der Unterkimnlade und dem Mundhïhlenboden nicht fehlen.

Diese Geschmacksscheiben enthalten neben sinneszellen (Stäbchenzellen) noch zweierlei Zellformen, nämlich cilienlose Cylinder- und sog. Flügelzellen, fon welchen die ersteren ebenfalls mit freieu Nervenendigungen in Beziehung stehen sollen. Freie Nervenendigungen treten jedoch anch zwischen die Zellen bis an die Obertliche der Organe. - Aus verschiedenen Gründen ist aber die Bedeutung her Endscheiben als (ieschmacksorgane bezweifelt und ihnen Tastfunktion zugeschrieben worden.

In der Mundhöhle der Sanropsiden haben sich đie Geschmacksknospen meist mehr lokalisiert. Bei den Sauricm und Chelonicm schließen sie sich gleichfalls den Ober- mud Unterkieferzähnen oder len Kieferleisten an, als eine ihnen median folgende Reihe. Bei Sauriem tritt jederseits noch eine mehr mediane Dorsalreihe anf, deren Verlauf wohl den ciaumenzilhnen entspricht, sowie eine mittlere Dorsalreihe an dem, weit voru gelegenen Tuberculum pharyugenm. Auch des 
Zungenriicken kann Knospen tragen, entweder an seiner Spitze (Angnis) oder anf hinteren Querfalten (Lacerta). - Ebenso führt die Chelonicrzunge Knospen, die auf zottigen Fortsätzen (Papillen), oder um solche, oder anf unregelmäßig verlanfenden Wülsten stehen kïnnen; dazn gesellen sich weitere am Gaumen. -- Daß

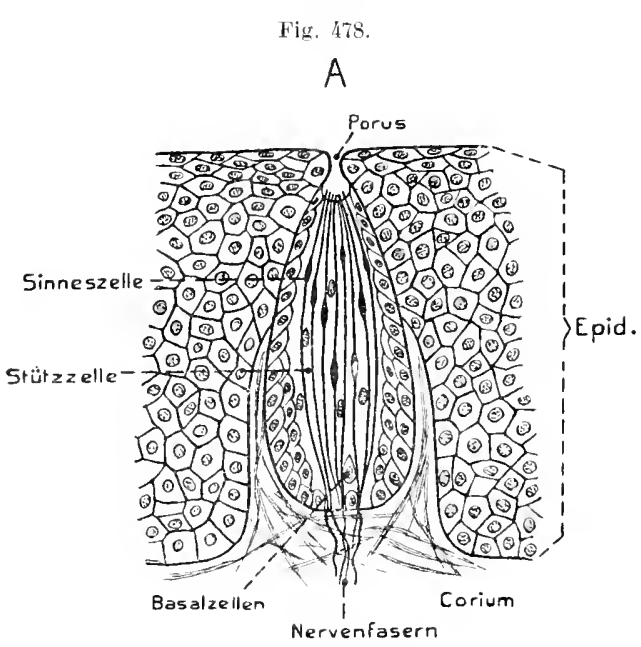

B

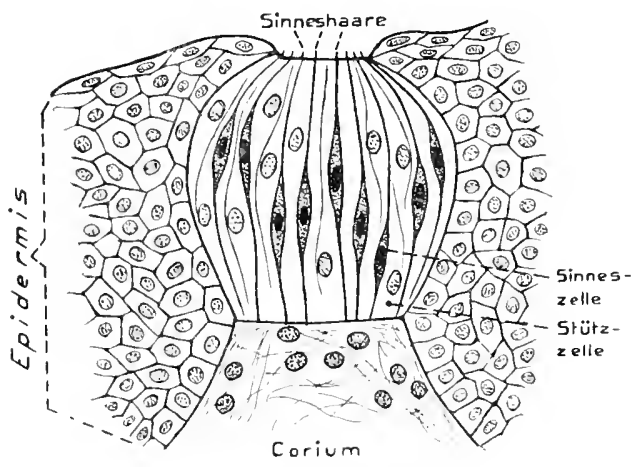

freschmacksknospen von logel u. hokodit. - Schenat fische längsschnitte lurch die Epidermis mit einer Ge schmacksknospe. A Ton einem Togel. / Tou Alligator (nach BATH 1906 ). v. Bur. sie den Sichlangen nicht völlig fehlen, ist wohl sicher, Genaneres dariiber aber wenig bekannt. Dagegen sind bei den Krolio, dilen (Crocodilus und AlligatorFig. $478 \mathrm{~B}$ ) nur am ciaumen anf zweilW ülsten unterhalb der P'terygoidea, sowie im Ösophagus Geschmacksknospen gefunden worden, die obertlächlich eine weitere bis engere Einsenkung zeigen, eine Art Geschmaclisporus wie bei Vögeln und Säugern.

Die Knospen der Trägel (478 A) wurden erst in neuerer Zeit festgestellt. Sie finden sich hauptsächlich am weichen, drüsenreichen Ganmen zu beiden Seiten der Choane bis zum Ösophaguseingang, vereinzelter auch am davorliegenden harten Ganmen. Bei Vögeln mit schmaler Zunge (z. B. Raptatores; viele Passeres, Rasores, Gyrinae usw.) sind sie dagegen besonders am Mundhöhlenboden, zu beiden Seiten der Zunge, verbreitet, oder in der Gegend des Larynxeingangs (sog. Epiglottispapille). Bei Papageien treten sie sowohl am Ober- als Unterschnabel an entsprechenden Orten auf. - Im grinzen bleibt die Zahl der Knospen gering; am größten wird sie bei Papageien (auf etwa 300 geschäitzt). Sie können anch zu deu Ausführgängen der Schleimdrüsen der Mundhöhle in nahe Beziehung treten, indem zwei bis drei Knospen die Driisenmindung direkt umstehen.

Die ellipsoidisch bis cylindrisch gestalteten Knospen (Fig. 478 A) erreichen entweder die Schleimhautoberfläche direkt oder sind grubenartig eingesenkt, so daß nur eine feine $\ddot{i f f-}$ nung (Geschmacksporus) in das Grübchen führt, auf dessen Grund die Geschmacksstiftchen der Sinneszellen stehell. Anßer Sinnes- und Stiitzzellen beteiligen sich am Aufbau der 
linospen vieler Vögel noch änßere sog. Ilüllzellen, welche ähnlich den Deck\%ellen vieler Seitenorgané die Knospe nmschließen. Auch sog. Basalzellen sind, wie bei Krokodilen und Säugem, vorhanden und wurden mit der Knospenregeneration in Beziehung gebracht, wogegen sie nach anderer Meinung nur die Knospenbasis umhülende Epithelzellen seien, die sich beim. Teilungsprozesse der Knospen betitigten.

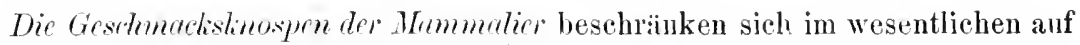
den Zungenriicken, greifen aber vorn manchmal auf die Ventralfläche der Zungenspitze iiber. Auch am weichen tianmen kommen sie vor (selten und vereinzelt am harten) und dehnen sich anf die Hinterfläche der Epiglottis his.in den Kehlkopf hinein aus. Je nach der Epidermisdicke sind die Knospen mehr kugelig oder cylindrisch. Sie sind sehr verschieden groß, meist etwas eingesenkt, so daß nur ein feimer Porus in das Knospengribchen führt, wie es fiur die Vägel erwähnt wurde.

Es tinden sich (speziell an den Papillae foliatae des Kaninchens) auch mittlere bis große Knospen, die 2-6 Joren besitzen und sich wohl als nnvollständig geteilte deuten lassen. Bemerkenswert erscheint ferner, daß auch den Stützzellen der Säugerknospen neuerdings Sinneshare zugeschrieben werden und der scharfe Tuterschied der beiderlei Zellformen iiberhaupt bezweifelt wird.

Die Zungenknospen stehen immer anf besonderen papillösen Erhebungen, wie sie die Zunge der meisten Säuger in sehr großer Anzahl dicht iiberkleiden (ansgenommen Sirenia und Cetacea).

Sie fehlen völlig auf' den mehr oder weniger verhornten fadenförmigen $I^{\prime}(t-$ rillae fïliformes (auch zum Teil als coronatae und fasciculatae bezeichnet), welche am reichlichsten vorkommen und sich an ihrem Ende häufig in feine Fäden zerschlitzen.

Doch sollen diese Papillen bei menswhlichen Embryonen zu gewisser Zeit Anlagen von kinospen besitzen.

In weiter Verbreitung iiber den 'Zungenriicken, bald in der Nittelgegend, bald an dessen Rändern dichter gehäuft, finden sich die pil:förmigen I'upillen (Papillae fungiformes) mit in der Regel pilzhntförmig etwas verbreitertem Distalende; doch erscheint ihre Gestalt recht variabel. Alle oder viele tragen anf ihrer distalen Endfäche, zuweilen auf kleineren Sekundärpapillen, eine bis mehrere Geschmacksknospen. - Za den Papillae fungiformes gesellen sich auf dem hinteren T'eil des Zungenriickens meist noch zwei Arten komplizierterer, die I'rpillue vallatae (oder circumiallatae, umwallte Papillen) nnd die Papillas foliatac (Fig. 479 u. 80), welch beide durch Übergangsformen mit den Papillae fungiformes verknüpt sind. Die Papillae vallatae sind dadurch gekennzeichnet, daß die gewöhnlich cylindrische Papille in eine sie eng umgebende cylindrische Vertiefung der Oberfläche eingesenkt ist, so daß das Papillenende meist gerade mit der Zungenoberfläche abschneidet, sich zuweilen anch etwas darüber erhebt oder selten die Oberfïiche nicht erreicht. Der erwähnte Wall wird gelegentlich von verschmolzenen Papillae filiformes abgeleitet. Die Knospen stehen gewöhnlich nur an der Seitenfläche der Papille in senkrechten Reihen iibereinander (häufig sehr dicht gedrängt), seltener auch anf der Innenfläche des Walls und anf dem freien Papillenende. Sie sind 
demnach meist gegen di€ direkte Berührung mit Nahrungsteilchen geschützt und nur Flïssigkeiten zngänglich. Die Zahl der Papillae vallatae schwankt sehr; die darüber vorliegenden Angaben differieren aber ziemlich.

Bei den primitiveren Säugern findet sich häufig nur ein Paar (so bei Monotremata, einem Teil der Insectirora, der Chiroptera, Rodentia, den meisten Edentata und einzelnen Carnivora, selten bei Ungulata, Pferd, Sehwein). Selten sinkt die Zahl sogar auf eine einzige herab, so bei gewissen Rodentia (Muridae, Arvieolidae), Zu dem erwähnten Paar gesellt sich recht häufig noch eine hintere unpaare Papille, so daß die drei Papillen in Form eines Dreiecks zusammengestellt sind, welcher Zustand vielleicht als die phyletische Ausgangsbildung angeseben "werden darf (bäufig bei Marsupialia Fig. 479 A, Insectirora, Chiro-

Fig. 479.

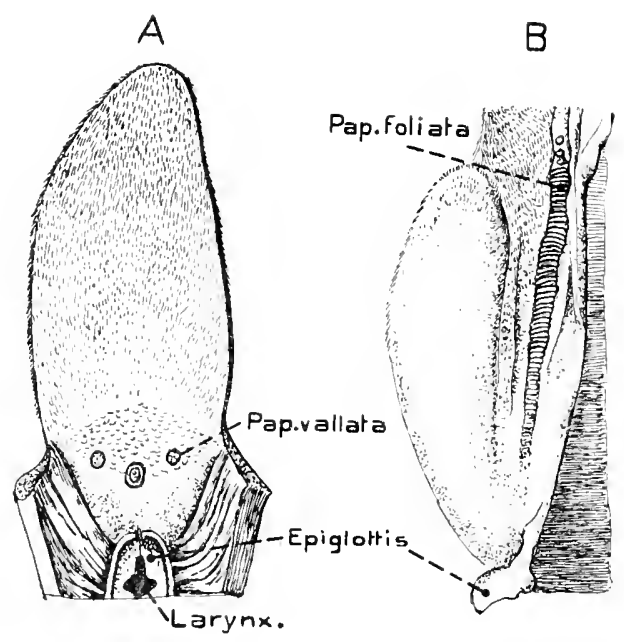

A $\mathrm{Zunge}$ von Phascolomys wombat. von der Dolsalseite.

$B$ Zunge von Hydrochoerus capybara (Wasserschwein) von der rechten Seite (nach 1 Ứ
Fig. 480 .
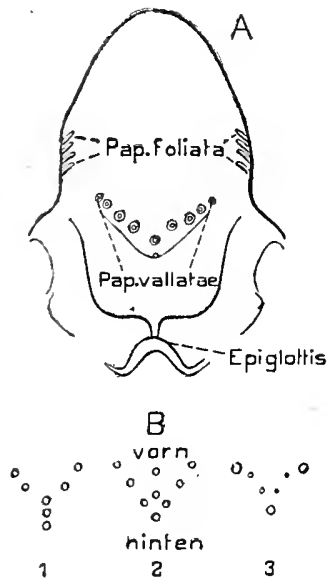

Homo. A Umrisse der Zunge von der Dorsalseite (nach RAUBER-KOPSCH, Anatomie), - $B$ Allordnung der Papillae vallatae: 1 Lemur varius, 2 Macacus nemestrinus 3 Cynocephalus porcarius

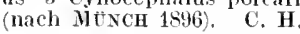

ptera, gexissen Edentata, Rodentia, Carnirora [Viverridae], einzelnen Prosimiae und Simiae). Eine Vermehrung der Papillen tritt bei den meisten Carnivora (etwa 4-20), bei zahlreichen Ungulata, namentlich den Ruminantia (bis zu 40 u. 60, besonders Cervidae, Cavicornia und Camelopardalis) auf; ferner bei Elephas (6), den Sirenia, vielen Prosimiae, den meisten Simiae (Fig. 480 B 2-3), sowie dem Mensehen, meist 9, variierend von 6-16); wobei die unpaare hintere Papille teils erhalten ja vermehrt wird (Prosimiae, Fig. 480 BI) oder auch ausfallen kann. Solch zablreiche Papillae vallatae stehen gewöhnlich in zwei Längsreihen. Selten fehlen die Papillae vallatae ganz, so bei Pedetes, Cricetus(?) unter den Rodentia, den Hyracoidea und Cetacca (meistens sehr reduziert) und vielleicht noch einigen anderen.

Bei vielen Säugern gesellt sich zu den beschriebenen Papillen jederseits am hinteren Seitenrand der Zunge noch eine Papilla foliata (Fig. 479 B), d. h. ein mehr oder weniger scharf umschriebenes, meist mäßig großes Feld, auf dem sich eine verschiedene Zahl quer oder etwas schief gerichteter Falten erhebt, welche in der Regel nur auf ihren beiden Flächen Reihen von Geschmacksknospen tragen 
(Fig. 481), selten nur auf einer Fläche oder am distalen Riand der Falten. Die Zahl der Falten, wie überhaupt die Größe der Papillae foliatae, schwankt sehr. Am größten und faltenreichsten werden sie bei den Rodentia; beim Menschen und vielen anderen treten sie stark zurïck und fehlen den meisten Wiederkäuern und manchen anderen Formen aus verschiedenen Orduungen ganz.

Die Zahl der Gescbmacksknospen an den Papillae vallatae und foliatae ist häufig sehr, ja manchmal ungemein groß; so trägt jede der beiden lapillae vallatae des Schweins 4760 Knospen und beim Rind soll die Gesamtzahl auf den beiden Papillae vallatae etwa 3500 erreichen. Im allgemeinen ergibt sich daher, daß gerade diese Papillen besonders wirksame Geschmacksorgane sein müssen. Im Grunde des Walls der Papillae vallatae und der Falten der Papillae toliatae münden Eiweißdrïsen aus, die der ïbrigen Zunge fehlen.

Hinsichtlich der Innervierung der Geschmacksknospen der Tetrapoden ist hervorzuheben, daß die des Zungengrunds wohl allgemein vom Glossopharyngeus ihre Fasern empfangen, während jene der vorderen Zungenregion, sowie weitere, vom Facialis, zum Teil durch Vermittlung der Chorda tympani, innerviert werden.

Freie Nerrenemdigungen und ats ihnen herrorgehende Hautsinnesorgane der Wirbeltiere. Wie schon betont wurde, sind freie Nervenendigungen in der Epidermis, sowie im geschich-

Fig. 181 .

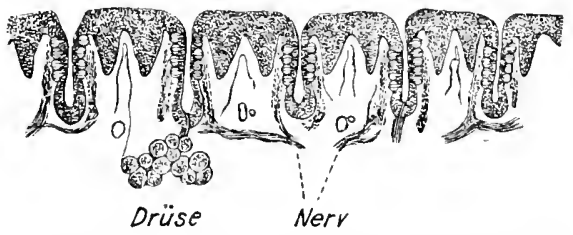

Lepus cuniculus. Längsschnitt durch eine Papillit foliata (aus (GEGENBACR, Vergl. Anitomic: nach EXGEL-
MANN). teten Epithel von Schleimhäuten allgemein verbreitet und treten anch im Bindegewebe reichlich auf. Gerade im letzteren führen sie zur Entstehung komplizierterer Endorgane. - Die marklos gewordenen Nervenfäserchen, welche zwischen den Zellen in der geschichteten Epidermis anfsteigen und in der Regel bis zur Oberfläche der Malpighischen Schleimschicht ziehen, wo sie mit kleinen knopfartigen Anschwellungen endigen, entspringen von einem Netz (Plexus) markhaltiger Nervenfasern im Corium. Doch wurde anch mehrfach beobachtet, daß Nervenfasern aus den weiter unten zu beschreibenden nervösen Endorganen des Coriums (so Tastkörperchen, Herbstschen Körperchen, Nervenknäueln u. a.) sich in die Epidermis fortsetzen und in ihr freie Endigungen bilden. Die in die Epidermis aufsteigenden Fäserchen verästeln sich häufig reichlich.

Ob sie bei gewissen Formen (z. B. Rana), von dicht unter der Epidermis liegenden verzweigten Sinneszelleı ausgehen können, ist unsicher, da die Natur dieser Zellel zweifelhaft erscheint. Jedenfalls liegen die zugehörigen Sinneszellen meist in den Ceutralorganen (speziell den Spinalganglien).

Selbstverständlich erscheint ferner, daß die Menge der freien Nervenendigungen, sowohl an der Oberfläche als im Innern des Körpers an den verschiedenen Körperstellen schwankt, je nach deren Eignung für Gefühlswahrnehmungen. Auch im Bindegewebe sind freie Endigungen dieser Art als dendritisch verzweigte oder anch netzig anastomosierende kuäuelartige Bilduugen weit verbreitet, sowoh! 
im Corium (Fig. 482) als im Bindegewebe der verschiedensten Organe, in mannigfach modifizierter Ausbildung. Das Charakteristische dieser Endigungen, gegenüber den sonst im Bindegewebe verbreiteten, ist besonders, daß sie nicht weiter umhüllte, sondern gewissermaßen diffuse Endigungen darstellen. Hierher werden namentlich anch die sog. Murkkelspindeln der Muskeln, die Endigungen in den Sehnen (Sehnenspindeln, Fig. 483) und noch zahlreiche weitere, die im Bindegewebe der Hant und innerer Organe vorkommen, gerechnet (so z. B. bei den Säugern

Fig. 482.

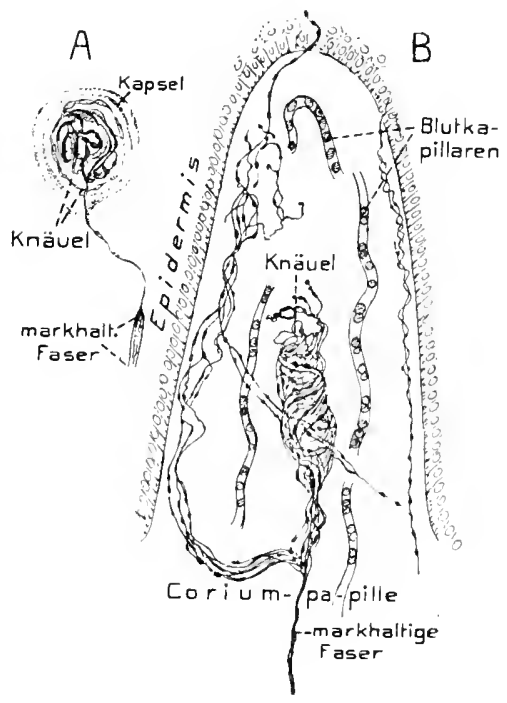

Homo. I Eingeknpselter einfacher Nervenknäuel aus einer Coriumpapille sog Golgi-Mazzonisches körperchen). $-B$ ('oriumpapille mit einem nueingekapseiten Nervenknäuel und Nervenfäserchenbün 'el, die teils frei in Binde. gewebe entigen, teils bis in die Evidermis aufsteigen (uach Dobiet 1903). 0. 1?.
Hig. 483.

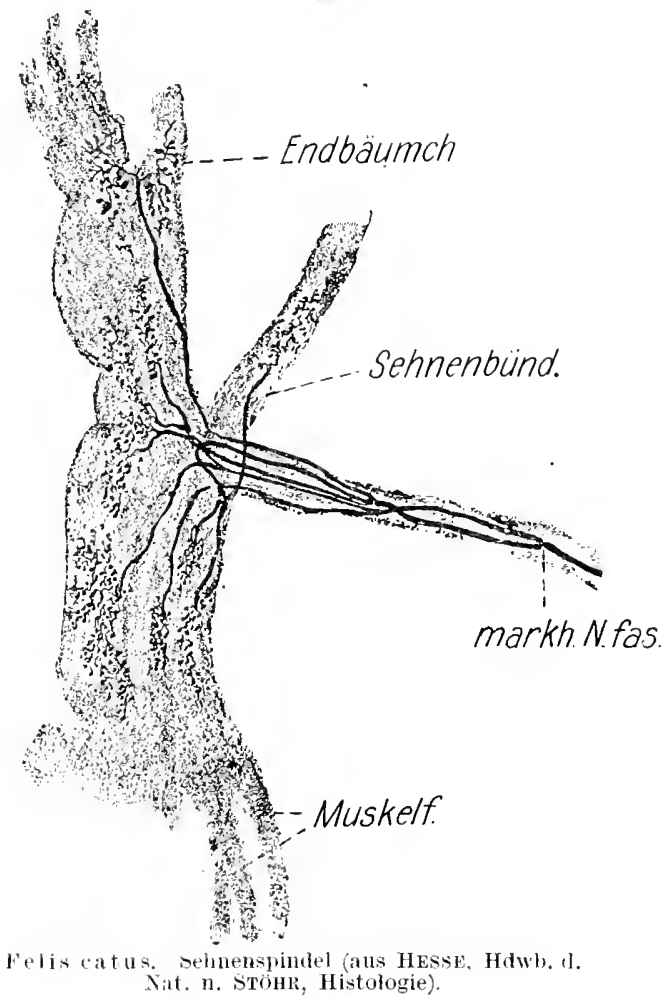

die sog. Ruffinischen Körperchen, die baumförmigen Endverzweigungen, die nicht eingekapselten Nervenknänel, die papillären Nervenbüschel in den Corinmpapillen und weitere). lei den Fischen wurden solche Endorgane im Bindegewebe der Flosseñ bei Rajiden beobachtet, "anch aus der Schwimmblasenwand von Knochenfischen beschrieben, ebenso von Amphibien gelegentlich angegeben. Im allgemeinen können auch die sensiblen Nerven der sïngethatre zu den freien Endigungen im Bindegewebe gerechnet werden; durch diese Versorgung mit Nerven werden die Haare zu einem wichtigen Teil des allgemeinen Gefühlsapparates. $\mathrm{Zu}$ den gewöhnlichen Hilaren (vgl. auch Fig. 484) treten von den Nervenzweigen des Coriums ein, seltener mehrere $\ddot{A}$ stchen, die am Haarbalg herab- oder hinaufziehen, und etwas proximal von der Einmändung der 'Talgdriisen den Balg unter 
Gabelung ringförmig umgreifen. Von diesem ungeschlossenen, die sog. Glashaut (Basalmembran der äußeren Wurzelscheide) nmziehenden Ring gehen distal- und proximalwärts, der Glashant außen anliegende und freiendigende Fiserchen ab. Nerven in der Pulpa warden nur selten beobachtet, namentlich bei den Sinushaaren, wo sie aber wahrscheinlich zu den Pulpagefäßen treten. Ebenso scheinen nur selten einzelne Endfäserchen in das Epithel der äußeren Wurzelscheide einzudringen. - Die Schnauze vieler Säuger ist bekanntlich mit größeren Haaren ausgestattet, die häufig als Spïr-oder Tastharre bezeichnet werden und an anderen Körperstellen nur selten auftreten. Dadie Blutgefäße des Follikels dieser Haare zu einem ansehnlichen einfachen odercavernösenSinus erweitert sind (Fig. 484), so werden diese Haare jetzt meist Sinushatre genannt. Sie sind reicher mit Nerven versehen. Außer den anf der' Glashaut sich ansbreitenden, am ganzen Follikel entwickcIten Nervenendigungen verschiedener Art, die sicls anf die Wand und die Bïlkchen des Blutsinus ausdehnen, finden sich proximal von den 'Talgdrüsen aluch Nervenendigungen nach innen von der Glashaut, und im Epithel der äußeren Wurzelscheide Tastzellen, wie sie gleich genauer er-

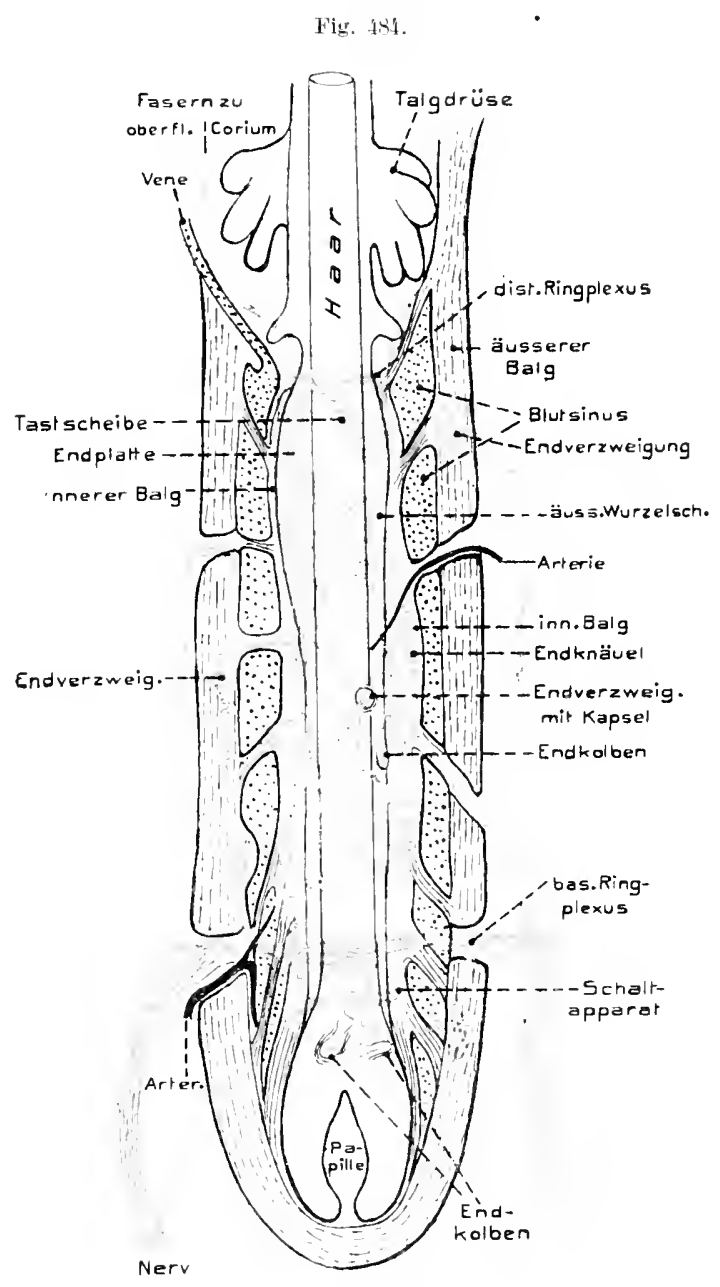

sinushar rom lind mit der Nervenversorgung (schematisch nach TRETJKOFF $\mathbf{l} 11$, stark veremacht). Äußerer bindegewebiger Haarbalg gestrichelt. Blutsinus, sowic die ablührende Yene punktiert. Arterien schwar\%. Nerven, sowie deren verschiedenartige Endigungen im änBeren und inneren Harbag, cowie ant der Glashaut blau. wähnt werden sollen.

Trastzellen und Tustflcclie. Indem etwas eigenartig moditizierte freie Endigungen der geschichteten Epidermis mit einzelnen Epithelzellen in innige liseziehungen treten, entstehen die Endzellen, welche als Tasticllon (Merkelsche Zellen, bezeiehnet werden. Schon im Epithel der Gaumenhaut des Frosches wurden ein- 
zelne Zellen der tiefen Epidermislage gefunden, zn welchen ein markloses Nervenfäserchen tritt, das sich zu einer der Zelle anliegenden kreis-oder kleeblattförmigen Tastscheibe (Meniscus) verbreitert, die wahrscheinlich durch Aufknänelung

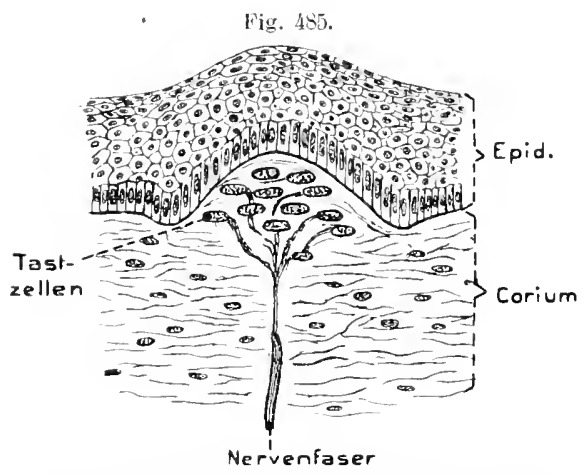

Ralla. Vertikalschnitt clureh das Integument mit pinem Tastfleck hach Merket lisol. ('. H. der Faser entsteht, oder auch als plattenförmige Ausbreitung der Faser mit nemrofibrillärem innerem Knäuel aufgefaßt wird (vgl. Fig. 488). Ob sich, wie manchmal beschrieben wurde, Fibrillen ans der Tastscheibe in die Tastzellen begeben, ist unsicher. Einzelne solche Tastzellen haben sich auch an gewissen Stellen der Säugerepidermis erhalten, so besonders an wenig oder nicht behariten Orten (Schnanze, Lippen, Nasenöffunngen, Untertläche der Fïße, harter Gaumen). Es sind rundliche Zellen, die in der Tiefe der Epidermis häufig gruppenweise vereint liegen. Selten sind sie unter die Epidermis in das Corinm geriekt, gehen jedoch sicher ans ihr hervor. Ein in die Lidermis tretendes Nervenfäserchen versorgt gewöhulich nnter Verzweigung eine Gruppe solcher Tastzellen, indem es an jeder einen der erwähnten Menisken

Fig. Liti.

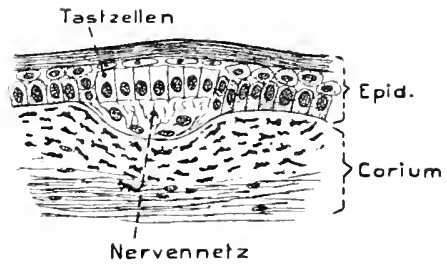

Sphenodon punctat um. Längschnitt Iurch den Tastfleck auf einer schuppe (nach MACRER 1895). v. Bu.
Fig. 487

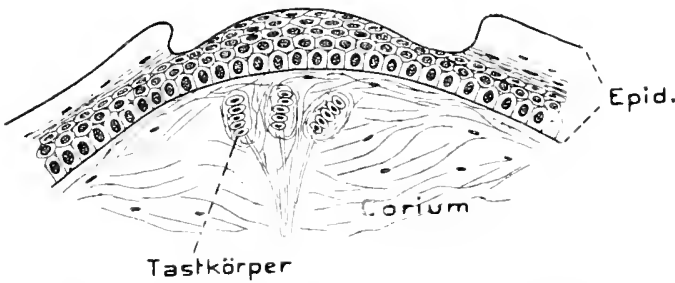

Crocodilus (jung). Längsschuitt durch Integument mit einel Gruppe sog. Tastkörper (nach MLtrer 18y5). v. Bu.

bildet. Hänfig sind aber auch die einzelnen Tastzellen noch durch feine Nervenfüserchen untereinander verbunden, oder es zieht von einer 'Tastzelle ein Nervenfaserchen zu benachbarten, so daß gewissermaßen mehrere Tastzellen traubig einer Nervenfaser aufgereiht erscheinen. - Außer den eben geschilderten Tastzellen wurden aus der Epidermis gelegentlich auch solche beschrieben, die von einem Netzwerk der zutretenden Nervenfaser umsponnen sind. - Die 'Tastzellen selbst werden jetzt gew ̈hulich nicht mehr als wirkliche Sinneszellen bemteilt, vielmehr wird ihnen meist eine mechanische (eventuell anch chemische) Wirkung bei der Übertrayung von Druck oder anderen Reizen zugeschrieben. - Schon bei den Amiren (Rana, Fig. 485, Bufo) sind Gruppen solcher 'Tastzellen, zu verschieden großen sog. Tristfleclifn vereint, iiber die Rijckentiäche verbreitet (doch auch an den 
Fußsohlen). Sie liegen im Corium, und die sie bedeckende, nicht selten pigmentierte Haut springt hänfig etwas halbkugelig vor.

Anch die bei gewissen weiblichen Anuren zur Fortptlanzungszeit auftretenden Brmensraraen scheinen solchen Tastlecken ähnliche Gehilde zu sein, obgleich dies anch bezweifelt wird und die sog. Tastzellen als Binlegewebszellen gedentet werlen. Wie früher angegeben (s. S. 672), sollen die Tastflecken bei der Metamorphose an Stelle larvaler Seitenorgane auftreten, wobei jedoch ihre Tastzellen nicht etwa ans deren simneszellen hervorgehen.

Den Tastflecken der Anuren ähnliche Bildungen sind bei Reptilien verbreitet: sie treten bei Samier" (z. B. Trumuns, Lacertu, Anyus, Asculdbotap), sehr häufig anch bei den Sctrlangen auf, entweder anf die Kopfschilder beschränkt oder ïber' die Schuppen des ganzen Körpers verbreitet, wo sie, auch äußerlich meistals helle runde Flecke erkennbar, in Ein- his Zweizahl, seltener in größerer Zahl am Hinterrand oder den Seitenrändern der Schuppen oder Schilder stehen. Bei den Wrokodilen finatet sich auf jeder Horuplatte ein solcher Fleck. Die Tastzellen der Reptilien liegen unter diesen Flecken in einer Coriumpapille, so daß die Epidermis iiber dieser Papille meist verdiunnt erscheint. Bei Sphemodom (Fig.486 sollen die Tastzellen noch in der tiefsten Epidermislage liegen. Die Krokodile dagegen besitzen unter jedem der ètwas grubenartig eingesenkten Flecke eine Anzahl soleher Tastgebilde im Corium (Fig. 487). Da die Tastzellen in den Papillen der Reptilien häufig säulenartig übereinander gereilit

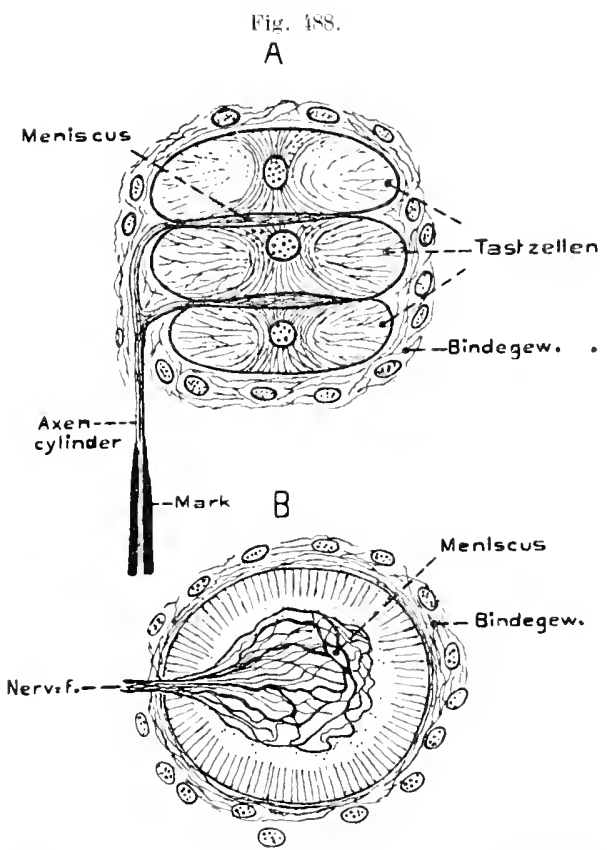

Anas Grandrysches hörperehen). I Lin dreizelliges Körperchen im Längssinnit. - L Eine Tastzelle mit lleniscus im Flächenschnitt. Schematisch (nach SzYwoxowicz 1si7 und Dogiel 1909 ' konstruiert.). 0 . B. sind, so erinnern diese Endorgane etwas an die spätel zu schildernden Tastkörperchen, doch diirften sie wohl den gleich zu besprechenden Grandrysehen Körperehen der Tögd näher stehen. - Eigentumlich erscheinen diese Tastorgane bei gewissen Sauriern, den Ascalaboten, wo sie grubenartig eingesenkt sein können, und der Grubenboden zahlreiehe kleinere oder eine sehr ansehnliche Borste ans Hornsubstanz trägt. Unter dem Organ findet sich im Corim ein Tastfleck. Von besonderem Interesse aber ist, daß die Epidermiszellen, welche das Organ uiberlagern, in ihrer Anordnung lebhaft an ein eingesenktes Seitenorgan der Amphibien erinnern (s. S. 671), so daß eine Beziehung der Organe zu jenen Seitenorganen nicht ausgeschlossen, wenn auch nicht hinreichend erwiesen scheint. 
Bei den Vögeln finden sich im Corium der Schnabelspitze (Ober- und Unterschnabel), sowohl anßen, namentlich aber innen, ferner in der Wachshant der Schnabelbasis nnd in der Zunge bald einzelne, etwa scheibenförmige Tastzellen, bald Gruppen von zwei bis sechs solcher, die zu einer Art Säule ïbereinander geschichtet (Grandrysche. Körperchen) und von einer zarten Bindegewebshülle umschlossen sind (Fig. 488). Die zu den einfachen Tastzellen tretende Nervenfaser bildet an ihr den frïher beschriebenen Meniscus, während an den aus zwei oder mehr Zellen bestehenden Körperchen zwischen je zwei benachbarte Zellen ein solcher Meniscus eingeschoben ist(Fig. 488). Jeder Meniscns soll eine Artstrahlig-netziges

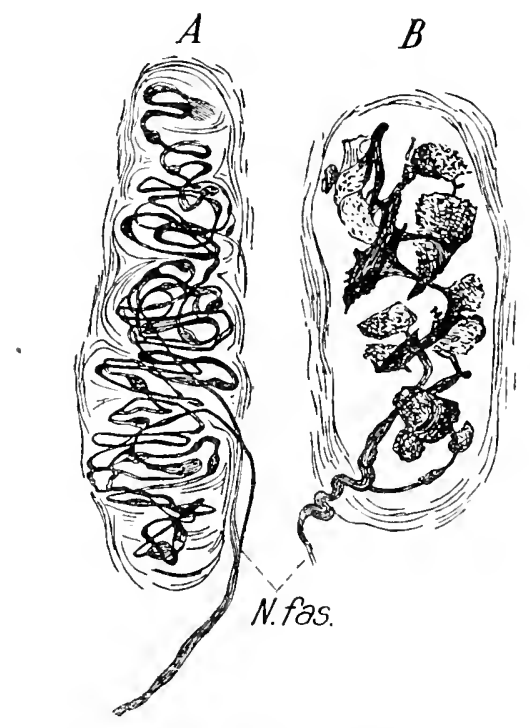

Fig. 489 .

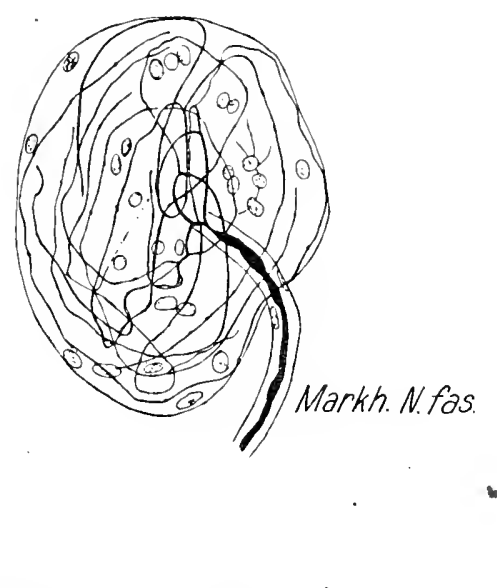

1) Typisches Meißnersches Tastkörperchen. - b Tasthörperchen mit blattörmigeu Endretikolaren aus der Haut des Menschen (nach Dogiel 1903). - " Kugliger Endkolben aus der Brust flosse eines Haies (Segllium) (nach Wexderer 1908; sämtlich aus Hesse Hdwb. d.. Naturw.).

Fibrillenwerk sein, mit am Rande schleifenförmig ineinander umbiegenden Fibrillen. Außerdem wird nenerdings auch ein die ganzen Körperchen umspinnendes feines Nervennetz angegeben.

Als nahe verwandt mit den mehrzelligen Tastflecken und den Grandryschen Körperchen wurden frïher die Tastlörperchen (Meißuersche) vieler Säuger und des Menschen erachtet, indem sie gleichfalls ans einer Gruppe von 'Tastzellen mit Nervenansbreitungen bestehen sollten, die aber von einer gut entwickelten Bindegewebshïlle umschlossen sind (Fig. 489). In Gegensatz zu den seither erwihnten Endapparaten wurden daher diese, sowie die weiterhin zu schildernden als cingeliapselte bezeichnet. Die 'Tastkörperchen sind hauptsächlich an den Volarflächen von Hand und Fuß, jedoch anch an andern Orten verbreitet und liegen meist in Einzahl (jedoclı auch bis zu fünf bei Mensch) in den Coriumpapillen als ovale bis längliche Körperchen. Die jetzt verbreitete Ansicht spricht ihnen jedoch 'Tastzellen 
völlig ab, und erklärt ihren Innenkolben fiir einen netzigen Knäuel feiner markIoser Nervenfäserchen ohne eigentliche freie Enden.

Auch zu diesen Körperchen treten noch feine markhaltige Nertenfasern; die sich anf der Ibertläche des Innenkolbens als ein feines Netzwerk ausbreiten oler anch die Nervenfasern des Innenkolbens umflechten sollen. Die Körperchen können sich dadurch komplizieren, daß quere bis schiefe Bindegewebsepten den Innenkolben hurchsetzen, was schließlich zu Endorganen führt, die aus einer Anzahl einzelner Auschwellungen zusammengesetzit erscheinen und deshalb auch als zusammengesetzte Tastkörperchen bezeichnet werden.

Nahe verwandt mit diesen 'Tastkörperchen und durch Übergangsformen verknüpft sind die sog. Genitalliörperchen der Sünger, die sich in tieferen Coriumschichten der Clitoris nnd der Peniseichel finden. Als eine vereinfachte Art letzterer werden meist die sog. "hicuseschen Endkiolben betrachtet, die in Schleimbäuten der Nase, der Mundhöhle, der Conjunctiva, wie auch der äußeren Genitalien anftreten (vgl. Fig. 482 A, S. 680). Sie unterscheiden sich von den spezifischen Tast- und Genitalkörperchen wesentlich nur durch den einfacheren Ban des Nervenknäuels, derin den primitivsten Endkolben sogar nur

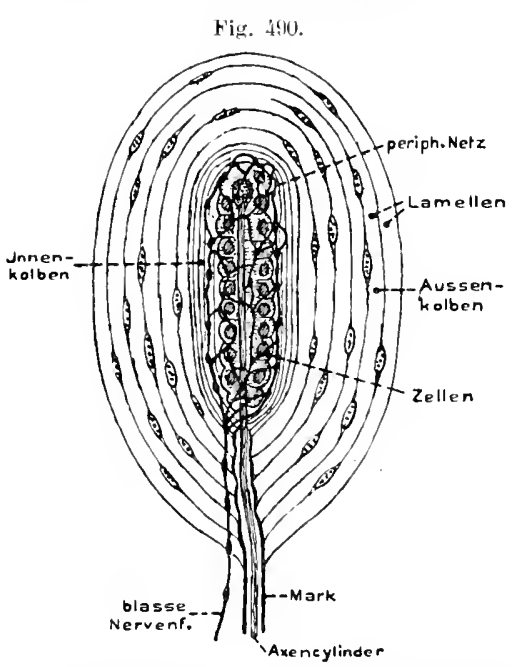

Herbstsches $\mathbf{h} \ddot{r} \mathbf{r}$ erchen von einem Vogel. schematischer Iängsschnitt (nach SzYMoxowic' 1897 und DoGIEL 1S99). Der Hinweisstrich zu Innenkolben * collte bis zu den "Zellen seichen. O. B. von einer einfachen geraden Endfaser gebildet werden kann. Daß äluliche Bildungen anch schon bei primitiven Wirbeltieren auftreten können, scheinen die Funde bei Itcien zu erweisen, wo im Bindegewebe der Flossen kngelige bis längliche Endkörperchen vorkommen mit innerem Nervenknäuel, jedoch sehr zarter äußerer Hïlle (s. Fig. $489 \mathrm{C}$ ).

Der Knäuel soll sich in einem inneren Gerüst netzförmig anastomosierender Zellen ausbreiten. welches Gerüst walıscheinlich aus der Schwannschen Scheide der zntretenden Nerrenfaser hervorgehe. Abgesehen ron der nur sehr zarten llülle erinnern diese Gebilde, wie gesagt, an manche der Säuger.

Solchen Endkolben reiht sich nun eine Kategorie von Nervenendigungen nahe an, die von den Reptilien an weit verbreitet anftreten und sich allmählich ziemlich komplizieren. Soweit die Erfahrungen reichen, könnte man auch die einfachsten Endkolben diesen Tater-Pacinischen Körperchen als primitive Ausgangsbildungen zurechnen, wie es manchmal geschah. Das Bildungsprinzip letzterer Endorgane läßt sich kurz etwa so darstellen: es handelt sich um eine gerade marklos gewordene, frei endigende Nervenfaser (Fig. 490), welche im Bindegewebe liegt und von einer mehr oder weniger dicken und eigentümlich gebanten Hülle geschichteter feiner Bindegewebslamellen, mit zwischengeschalteten Bindegewebszellen umgeben wird, so daß das Gesamtkörperchen etwa eiförmig bis zuweilen 
schanchartig erscheint. Die Komplikation im Ban dieser Endorgane heruht hauptsächlich anf der mehr oder weniger starken Entwicklung jener Hülle. - Bei strumaten Reptilien kommen solche Körperchen teils in der Kopfhaut (Lacerta), teils an den Lippen und in der Nähe der Zähne vor; ihre Hülle ist relativ dünn, läßt abel schon zwei Regionen unterscheiden, eine änßere (Außenkolben) und eine innere Innenkolben), welch letztere die Nervenfaser direkt umgibt. - Jenen Körperchen scheinen sich die bei den Vögeln weit rerbreiteten Herbstschen (Fig. 490) näher anzuschließen. In recht verschiedener Grüße sind sie in der ganzen Körperhant zerstrent, besonders um die Follikel der Konturfedern, jedoch auch in größerel Tiefe, so zwischen den Muskeln und an den Gliedmaßengelenken; in größerer Zahl finden sie sich auch an der Vorderseite der Jibia. Ebenso treten sie im Schnabel und der Zunge, sowie der Mundhöhle überhanpt, reichlich anf. Die Lamellen ihres Anßen- und Innenkolbens sind meist dentlich erkennbar und daneben noch zahlreiche Bindegewebsfibrillen. Im Innenkolben liegt jederseits der Achsialfaser eine charakteristische Längsreihe von Zellkernen Zellen) in der Abplattungsebene der Nervenfaser, was auch schon bei Reptilienkörperchen vorkommt. Es sind dies jedenfalls dem Innenkolben angehörende Bindegewebskerne. - In zuweilen recht erheblicher Größe und reicher Verbreitung kommen die Vater-Pacinischen Kïrperchen bei säuger" vor. Wie bei den Vögeln erstrecken sie sich bis in das Bindegewebe tiefer Körperregionen hinab. Besonders charakteristisch erscheint, daß sie in ibrer Ausbreitung die Nerven begleiten. Oberflächlich treten sie im Unterhantbindegewebe der Hände und Füße, besonders deren Unterflächen, auf, breiten sich jedoch noch weiter ant die Extremitäten und sonstige Hautstellen aus. Auch bei den Säugern finden sie sich reichlich um die Gelenknerven, erstrecken sich aber anch anf die Periost- und Knochennerven, sowie die der Pleura, des Bauchfells, des Mesenteriums und nicht weniger Eingeweide. - Ihre Hïlle ist dadurch ausgezeichnet, daß der Außenkolben im allgemeinen recht dick und Iamellenreich wird. Die Lamellen besitzen einen verwickelten feineren Ban, der hier nicht genauer geschildert werden kann; zwischen ihnen finden sich mit Flüssigkeit erfüllte spaltartige Räume. Auch der Innenkolben ist deutlich lamellös, doch ohne die beiden charakteristischen Kernreihen der Sauropsiden.

Blutgefäße dringen in die Kapsel ein und breiten sich zwischen den Lamellen des Außen- und Imnewkolbens als ein Capillarwerk aus. An Stelle einer einfachen Nerrenfaser, wie site früher in der Achse des Innenkolbens beschrieben wurde, findet sich nach den neueren Erfahrungen anch hier ein längsmaschiges Nervenfasergeflecht, in welches sich die zutretende Nervenfaser aufliist.

In ihne und den Herbstschen Körperchen wurde noch ein zweiter nervöser Apparat erwiesen, der von einer feinen Fasel gebildet wird, die in das Körperchen eindringt und sich auf der Grenze von Innen- und Außenkolben als markloses Nervennetz ausbreitet. - Eine Anzahl Modifikationen der Vater-Pacinischen Körperchen wurden bei den Säugern beschrieben und z. T. anch mit besonderen Namen bezeichnet. 
Arthropoda. Wir besprechen diese große Abteilung zuletzt, da ilure Hautsinnesorgane wegen der dieken Cuticula (Chitinpanzer) eigenartig ansgebildet sind. Sie stehen nämlich fast stełs in Verbindung mit den beim Integument erwïhnten (s. S. 98), die Körperflïche häufig in Menge bedeckenden Cuticularhar'en, welche daher neben ihren sonstigen Funktionen in der Regel noch die von Sinnesborsten erfülleu. Freie plasmatische Sinneshare, wie wir sie als Endigungen der seither besprochenen Sinneszellen meist fanden, fehlen den Arthropoden durchius oder sind doch in die cuticularen Sinnesborsten eingesehlossen, - ̈̈hnlich wie die Hantsinnesorgane vieler anderer Wirbellosen haben sich die cuticularen Sinnesborsten der Arthropoden zu spezihschen Sinnesorganen für verschiedene Reize differenziert, indem sie wohl von einer Urform ausgingen, welehe anf verschiedene Reize reagierto.

Große Verbreitung besitzen bei den meisten Gruppen die einfaehen Tastborsten, die, wio sehon ihre Anordnung meist erweist, vor allem anf Druckreize reagieren; doch läßt sich schwer feststellen, inwiefern sie auch noch anderen Reizen zugänglich sind. Ihrer Funktion entspreehend, erheben sie sich gewöhnlich mehr oder weniger hoch ïber die Körperfläehe und stehen besonders reichlich an solchen Stellen, die mit der Umgebung in Berïhrung treten, also den Fïhlern, Beinen und sonstigen Anhüngen des Körpers (z. B. aueh auf den Flïgelu und den Abdominalanhängen (Cerci und Styli) der Insekten. - Mehrfach wurde angegeben, daß überhaupt zu sïmtliehen Haaren und Borsten der Körperoberfläehe - und viele Arthropoden, so zahlreiche Alachnoideen und Insekten, sind ja dieht behart - Sinneszellen treten; doch läßt sich dies vorerst wohl nieht ganz allgemein behaupten. - Solehe Tastborsten sind teils einfache, mit relativ dicker Cutienla versehene Gebilde, deren Länge und Form sehr variieren kann, d. h. vom langen Haar bis zur mäßigen Borste und schließlich kurz zapfenartigen Form; oder nicht selten, namentlich bei Crustaceen, kann die Borste wieder mit feineren Härchen besetzt, d. h. einfaeh bis doppelt gefiedert sein. - Die Befestigung der Borsten in der Cuticula ist häulig mehr oder weniger gelenkig, indem sich ihre Basis in ein Cnticulargribehen einsenkt, unter welehem sich der die Cutienla durehsetzende Porenkanal findet; die Borsteneuticula ist nur durch eine diinne Menbran mit dem Rand des Porenkanals verbunden. - Wie wir triiher sahen, wird die Borstencutieula von einer bis melreren, ja zahlreichen verlängerten Hypodermiszellen abgeschieden, zn denen bei den Sinnesborsten noeh eine bis mehrere Sinneszellen kommen, welche jhre zarten distalen Ausliufer in die Borste, und zwar manchmal bis zu deren Ende senden; doch ist gerade dieser Punkt vielfach noch zweifelhaft. - Im allgemeinen seheinen jedoch Borsten miteiner einzigen Sinneszelle seltener zu sein (z. B. die an den Beinen der Lepadiden, manche Borsten der Insekten und Arachnoideen); vielmehr findet sich häufiger eine etwa spindelförmige Gruppe weniger z. B. Phyllopoden bis zablreicher Sinneszellen (z. B. Thoracostraca), a. h. eine Art von Sensillen, deren distale Fasern als ein Strang (Terminalstrang) die Borste durehziehen. Gewöhnlich liegt diese Sensille in geringer bis mäßiger Entfernumg nnter der Epidermis, doch 
wurden bei Krebsen (gewisseu Arthrostraken) Fälle beobachtet, welche darauf hinweisen, daß die Sinneszellen bis in die Nähe des Bauchmarks, ja in dieses selbst verlagert sind, in welchem Falle anscheinend freie Nervenfasern in die Borste eintreten. - Für die Tastborsten gewisser Insekten und Myriopoden mit einer einzigen Sinneszelle wird jedoch auch angegeben, daß ihre Terminalfaser an der Haarbasis endige. - Unter der Epidermis mancher Insekten und Crustaceen (Astacus) wurden mehrfach reich verästelte Zellen oder ein Plexus solcher beobachtet und gelegentlich als Sinneszellen gedeutet. Dies wurde für gewisse In-

Fig. 491.

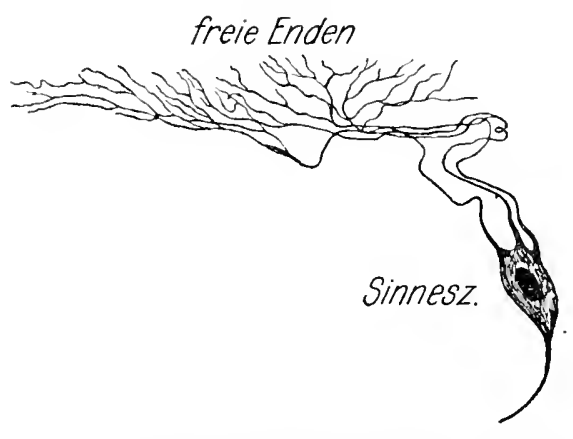

Libellenlarve. Simeszelle, deren Endverzweigrmgen in der Epidermis frei endigen (aus Hesse, Hdwb. d. Natw., nach Zawarzis 1912 ). sektenlarven (Aeschna, Fig. 491) nenerdings bestätigt. Die Zellen sollen sich namentlich unter den diunnen Gelenkbäuten finden und ihre reich verzweigten distalen Auslïnfer an letztere senden, während der einfache proximale Fortsatz zum Centralnervensystem gehe. Obgleich das Verhalten dieser Sinneszellen, wenu es wirklich solche sind, an die freien Nervenendigungen erinnert, kann man sie doch nur im allgemeineu mit solchen vergleichen.

Aus modifizierten cuticularen Sinnesborsten lassen sich bei den Arthropoden die Geruchs-, Geschmacks-, statisehen und eventaell anch die Hörorgane ableiteu. Morphologisch könnten letztere daher wegen ihrer nahen Verwandtschaft mit den Tasthaaren unter den Hautsinnesorganen besprochen werden; doch erscheint es geeigneter, sie den Kapiteln über die betreffenden Sinnesorgane einzureihen, obgleich im Einzelnen üher ihre Funktion noch mancherlei Unsicherheit besteht.

An der vorderen Körperspitze der branchiopoden Phyllopoden, in naher Beziehung zum unpaaren Entomostrakenauge, und anch den Complexaugen benachbart, findell sich eigentïmliche kleine Sinnesorgane, welche entweder dem Integument dicht anliegen, oder etwas nuter es verlagert sind, die Frontalorgane. In der Regel fundet sich ein dorsales Paar solcher Organe, die aus einer AnzahI, dem Integument eingefügter Sinneszellen ohne Sinneshaare oder sonstige Anhänge bestehen, sowie ein unpaares ventrales, ron einigen Zellen gebildetes (1rgan, das bei Limnadia (s. Fig. 671, bei Ange) in einen vorderen und hinteren Anteil gesondert ist. Die Nerven dieser Organe gehen von jenen des Entomostrakenauges aus. Beziehungen zu letzterem zeigen sich namentlich am Ventralorgan von Branchipus und Limnadirt, zwischen dessen Sinneszellen stäbchenfürmige Gebilde auftreten, ähnlich jenen, die im Entomostrakenauge vorkommeu. Abgesehen von einer eventuellen Lichtemptindlichkeit jener Ventralorgane, werden die Frontalorgane meist den Tastapparaten zugerechnet.

\section{B. Geruchsorgane (einschließlich der Geschmacksorgane der Arthropoden).}

Chemisch reizbare einfache Sinneszellen oder Gruppen solcher sind unter den Hantsinnesorganen weit verbreitet. Wenn sie an besonderen Stellen lokalisiert 
oder als kompliziertere Gebilde anftreten, so werden sie als Geschmacks- und Geruchsorgane unterschieden. Physiologisch stehen sich diese beiden Arten von Organen sehr nahe, ja lassen sich häufig nicht scharf auseinander halten. Beide reagieren ja auf chemische Stoffe, die entweder in wäBriger Auflösung (Geschmacksorgane) oder als der Luft beigemischte (Geruchsorgane der Lufttiere) anf sie wirken. Man hat den wasserlebenden Tieren deshalb die Gernchsorgane iiberhaupt abgestritten und ihre chemisch reizbaren äußeren Sinnesorgane als Geschmacksorgane oder Organe des chemischen Sinnes bezeichnet. - Nun besteht ein Charakter der typischen Geschmacksorgane darin, daß sie sich gewöhnlich in nïchster Nähe der Mundöfỉung, in der Mundhöhle oder an den die Nahrung ergreifenden Organen finden, also nur wirksam sind, wenn sie die Nahrung beriihren oder doch in deren nächste Nähe gelangen, so daß gelöste Stoffe, welche der Nahrung anhaften oder von ihr ausgehen, zu ihnen gelangen. - Die typischen Geruchsorgane zeichnen sich hingègen dadurch ans; daß sie anf größere, häufig anf weite Entfernungen wirken, indem die in der Luft verbreiteten Riechstoffe, sei es durch Diffusion, sei es gleichzeitig durch Luftströmumgen zu ihmen dringen. Das Gleiche gilt jedoch meist von den als Geruchsorganen bezeichneten Sinnesorganen der wasserlebenden 'Tiere, die sich sowohl durch die Orte ihres Anftretens als ihr sonstiges Verhalten, zum Teil auch durch das physiologische Experiment, als Organe ergeben, welche zwar wie die Geschmacksorgane von in Wasser gelösten Stoffen gereizt werden, aber von den Nahrungskörpern oder dergleichen nicht direkt berïhrt zu werden brauchen, sondern die von der Nahrung ansgehenden chemischen Stoffe auf gewisse Entfernungen zn wittern vermögen. Dies wird aber nur die eine Seite ihrer Tätigkeit bilden; häufig wird ihre Anforabe wesentlich darin bestehen, daß sie auf schädliche Stoffe des umgebenden Wassers, das ja, wie die Luft den lnftlehenden Tieren, als Atmungsmedium dient, reagieren und so die Vermeidung schädlicher Wasserregionen und das Anfsuchen gïnstiger berbeiführen. So ergibt sich gerade in dieser Hinsicht eine weitgebende Analogie $z$ wischen den eigentlichen Luftriechorganen und jenen der Wassertiere, weshalb ihre Znsammenfassung wohl gerechtfertigt erscheint; wozu sich weiterhin gesellt, daß wir sowohl bei den Arthropoden als den Vertebraten den direkten Übergang solcher Organe von wasserlebenden zu luftlebenden Formen veriolgen können, worans sich schließen läßt, daß ihre Funktion dabei keine prinzipielle Änderung erfährt.

Die Geruchsorgane der Wassertiere (abgesehen von jenen der Arthropoden) sind im allgemeinen relativ einfach gebante, sinneszellemreiche Stellen der änßeren Epidermis, die sich häufig gruben- bis schlauchförmig einsenken, oder auch papillen- bis wulstartig erheben. Neben Sinneszellen enthält ihr Epithel meist wimpernde Zwischen- oder Stiitzzellen. Letztere haben für das Funktionieren der Organe eine wesentliche Bedeutung, da sie eine Wasserströmung längs des Organs oder durch dasselbe hervorrufen, was für seine fortdanernde Tätigkeit nützlich, ja notwendig erscheint. 


\section{Coelenterata.}

Unter diesen besitzt nur die Mehrzahl der Discomedusen Organe, welche sich Geruchsorganen vergleichen lassen, obgleich der physiologische Versuch bis jetzt keine Bcweise hierfür ergab. Sie finden sich an der Basis der Randkörper oder Pleopalien, also dicht bei den frïher geschilderten Centralteilen des Nervensystems, die ja die Basis der Randkörper umgeben (s. S. 467). Auf der Umbrellarseite des Medusemandes findet sich am Ursprung jeder sog. Deckplatte (s. Fig. 316, S. 467), welche das Rhopalium überlagert, eine kleinere bis größere grubenförmige, häufig strablig bis konzentrisch gefurchte Einsenkung, die Trichtr $r$ - oder Riechgrube (anch äußere Sinnesgrube genanut). Die dreieckige Grube ist von Nervenfilz dicht unterlagert; ihr Epithel setzt sich aus geißeltragenden Simmeszellen und wimpernden Stïtzzellen zusammen, doch finden sich anch spärlich Drüisenzellen.

Bei vielen Formen findet sich noch eine zweite Art ähnlicher Organe, die sich dicht am subumbrellaren Rand des Medusenschirms, an der achsialen oder inneren Seite der Rhopalien grubenförmig einsenken und daher auch innere Sinnesgruben genannt werden (s. Fig. 316, S. 467). Um sie nnd um den Basalteil der Randkïrper breitet sich die Hauptmasse der Nervencentren aus.

Bei gewissen Formen (Rhizostoma) zeigt letztere Grube eine Neigung zur Verdoppelung, indem sich ron ihrer Umbrellarfläche ein mittlerer Kiel in sie etwas hinabgesenkt; bei Aurelia soll die Grube in der Tat parig geworden sein. Das Epithel der inneren Grube gleicht jenem der äußeren. Ob die innere Grube, wie es fïr eine Art von Cyanea angegeben wurde, durch einen vorspringenden, rerdickten Epithelwulst vertreten sein kann, erscheint etwas unsicher.

\section{Vermes.}

Simnesorgane, deren Bau ehenfalls anf Riechfunktion hinweist, treten bei gewissen Plathelmintlen und Chaetopoden in der Kopfregion, dem Cerebralganglion sehr

Fig. $4+12$

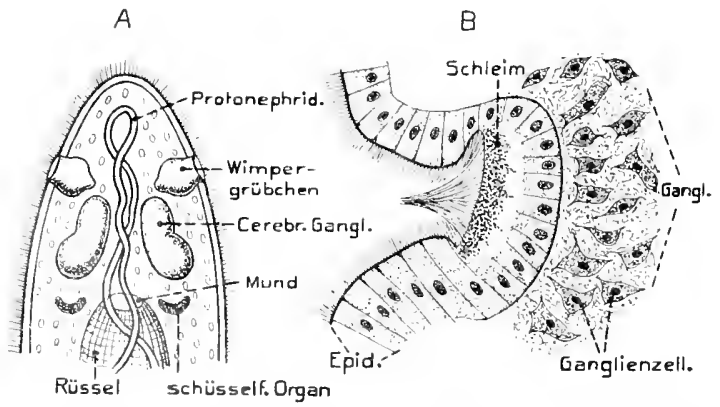

stenostomum leucops. A Vorderende von der Dorsalseite mit Wimpergrübcheu, schiisselförmigen Orgaten usw, (nach v. GRAFF 1875). - $B$ simitt durch die Wimpergrube (nach OTt 1892). У. Bu. genähert, häufig anf. Im allgemeinen erscheinen sie als ein Paar von Grübchen bis tiefer eingesenkten Schläuchen, die von den Cerebralganglien innervier't werden und ausstiulpbar sein können. Es ist wohl nicht ansgeschlossen, daß diese Organe morphologisch den einfachen Hantsimmesorganen Seitenorganen, Seitempapillen), wie sie in ähnlicher Stellung bei manchen Nemathelminthen auftreten, verwandt sind. - Unter den Platleclminthen begegnen wir ihnen nur bei den freilebenden Turbellarien und Nemertinen. Bei den Rhabdoriblen sind sie schr verbreitet als ein 
P'ar (selten zwei Paar bei Euporobothria v. Gratf) seitlieher, etwas vor den Cerebralganglien liegender Hacher Gribehen (Fig. 492, seltener schlanchartiger, zuweilen ein- und ausstiilpbarer Epitheleinsenkungen. Das sie anskleidende Epithel besitzt lïngere Cilien als die umgebende Epidermis. Im (trunde der Grïbehen findet sich meist eine Schleimsehicht, welehe wohl von 1)riusenzellen, die in Verbindung mit ihnen beschrieben wurden, abgeschieden wird. Jedes liribchen wird ron einem Ganglion unterlagert, das mit den cerebralganglien in Verbindung stehen diirfte. Der feinere Ban der Organe ist wegen ihrer Kleinheit nur wenig erkannt, doch kann es wohl nicht zweifelhaft sein, daß sie Sinnesorgane darstellen. - Mit diesen Wimpergrübchen läßt sich wohl die Wimperrinne homologisieren, die sich bei gewissen Familien der Allöorölen findet. Sie erstreckt sich in ähnlicher Lage wie die Griibehen quer über die Ventralflüche, kann jecloch lateral auf die Dorsalseite iilrergreifen, ja zu einer dorsal geschlossenen, den Körper ganz umziehenden Ringfurche werden. - Ob die Grïbrhentlectien, die nur bei wenigen Formen vorkommen, gleichfalls hierher zu ziehen sind, ist unsicher. Dagegen dürften die bei vielen Süßurtsserticlulen (z. B. P'lanaria gonocephala) anftretenden Amicularorgane, die wie die Wimpergribchen der Rhabdocölen am Kopf liegen, homologe Gebilde sein. Es sind ein Paar länglicher bis rundlieher Grübchen, auf deren Boden siel von einem nierenförmigen fasrigen Körper zahlreiche dieke Börstchen erheben, welehe kürzer bleiben als die umgebenden Cilien. Die Innervierung erfolgt dureh den iußeren Nervenplexus.

Hohe Ausbildung und fast allgemeine Verbreitung erlangen hierhergehörige Simnesorgane der Nemertinen (Fig. 493). Es sind die Cerebralorgane (früher meist Seitenorgane genannt), welehe fast stets (ansgenommen Mesonemertini und einzelne andere Gattungen zu einem Par in der seitlichen Kopfregion liegen. Daß sie im allgemeinen den Wimpergriibchen der Turbellarien entsprechen, scheint sicher. Es sind flimmernde gruben- bis schlanchförmige Einsenkungen des Körperepithels, welche direkt vom Cerebralganglion innerviert werden und hänfig eine bedentende Größe erreichen. Charakteristisch erscheint ferner, daß sie in naher Beziehung zu besonderen Einrichtnngen der benachbarten Körperoberfläche stehen, nämlich den Kopffurchen oder den Kopfspalten, die daher bei Mangel der Cerebralorgane ebenfalls fehlen. Die hopffuchen sind bei den Irotonemertinen. nur angedentet, dagegen bei den meisten Mesonemertinen (Enopla, doch auch gewissen Heteronemertinen (lnopla, Gattung Eupolia) als quere, etwas vor dem Cerebralganglion liegente drïsenfreie Rinuen entwickelt, die anf der Ventral- und Dorsalseite unterbroehen sind, aher dorsal nahe aneinanderstoßen. Das mit längeren Cilien versehene Epithel der Furchen senkt sich meist zu zahlreichen gribehenartig en Vertiefungen ein, welehe, in einer Reihe liegend, die Kopffurehe gewissermaßen zusammensetzen. In diesen Furchen findet sich danu seitlich oder etwas ventral die Einsenkung (Miundung) der beiden Cerebralorgane. Da die Furchen den oben erwähnten Wimperrimnen gewisser 'Turbellarien sehr gleichen, so sind sie letzteren wohl homolog. - Die Kopfspalten dagegen sind laterale, lïngs gerichtete Furchen oder schlitzartige Einsenkungen in der Kopfregrion, an 
deren Candalende, oder etwas davor, die Cerebralorgane sich einsenken (Fig. 493 A). Sie sind charakteristisch für zahlreiche Ileteronemertincn (Anopla, früher daher auch als Schizonemertinen bezeichnet). Sie beginnen meist an der vorderen Körperspitze und erstrecken sich verschieden weit nach hinten, bis zum Gehirn oder anch noch hinter dasselbe. Ebenso verschieden ist die Tiefe ihrer Einsenkung, welche von vorm nach hinten zunimint, und so betrïchtlich werden kann, daß sie die Cerebralganglien nahezu erreichen. Ähnlich dem Kopffurchenepithel ist das der Spalten drüsen- und pigmentfrei, sowie länger bewimpert. Ob die Kopffurchen und -spalten als besondere Sinnesorgane zu denten sind, scheint fraglich, obgleich sich nnter ßem Epithel der letzteren viele kleine Ganglienzellen

Fig. 499

A

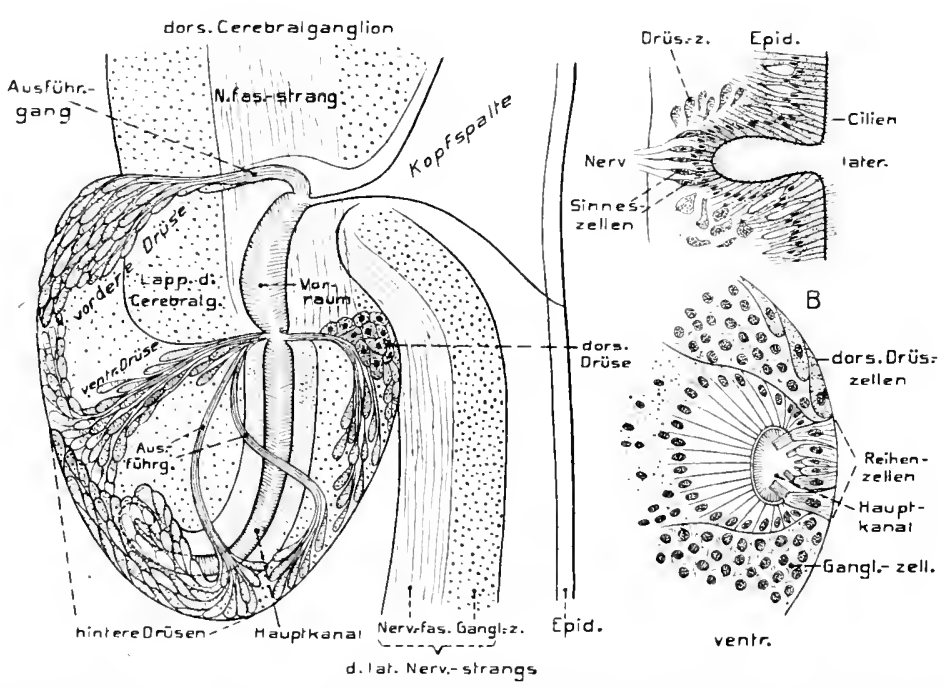

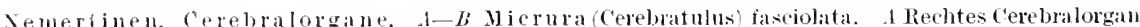
von der Dossilseite. Totalpräparat. If Querschnit durch den Hanptkanal, nebst den benachbarten Teilen des Gewebes des Cerebrabrons. - C: Tubulanus Carinella) amulatus, Querschnitt durch das

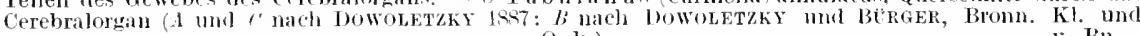
Orili).

finden, ebenso wie um die Cerebralorgane. Möglicherweise könute man beiderlei (iebilde iberhanpt den Cerebralorganen als besondere Abschnitte zurechnen.

Die Cerebralorgane liegen im allgemeinen seitlich von den Hirnganglien, können sich jedoch anch erheblich äber sie hinaus, nach hinten ausdehnen. Selten gewisse Metan'mertinen finden sie sich vor den Ganglien, sind dann aber meist klein. - Sie zeigen in der Nemertinenreihe eine anfsteigende Entwicklung. Bei den paläogenen Protonemertinen (z. B. manchén 'Tubulanus[Carinella]-Arten, Fig. 327, S. 479) sind es einfach hecherartige Einsenkungen der Epidermis (Fig. $493 \mathrm{C}$ ), welche sich nicht in das unterliegende Gewebe erstrecken, sondern durch Höherwerden der umgebenden tlimmernden Epithelzellen entstehen. Im Grunde des so gebildeten Kanals miinden eine Anzahl rosettenartig gruppierter Driisenzellen. Bei 
anderen P'rotonemertinen (gewissen Tubulamusarten, Curinima) kompliziert sieh das in Epithel liegende Organ, indem sein Kanal länger wird und sich caudalwärts krïmmt, sowie seine Epithelzellen von zahlreichen kleinen Ganglienzellen umlagert werden. - Bei der Protonemertine ILubrertia, sowie den Metı- und Heteronemertinen senkt sich das Organ schlanchartig nach innen und candal unter die Epidermis hinal,; seine Hauptmasse liegt also in der Cutis (Fig. $493 \mathrm{~A}$ ). In der Regel ist es mehr oder weniger kuglig angeschwollen, was daher rührt, daß ler eingestiilpte epitheliale Schlanch von einer großen Menge kleiner Ganglienmnd Driisenzellen umlagert wird. Bei den Proto- und Metanemertinen liegen die (1rgane in gewisser Entfernung vor oder hinter den Cerebralganglien, so daß aus letzteren Nerven zu ihnen treten. Bei den Heteronemertinen hingegen verwachsen sie mehr oder weniger mit dem Caudalteil der dorsalen Cerehralgangliempartie, so daß sie wie ein hinterer Anhang dieser Hirnlappen erscheinen (Fig. 493 A nnd ron der bindegewebigen Ilülle der Cerebralganglien umschlossen werden. Der von tlimmernden Epithelzellen gebildete Kanal des Organs liißt meist zwei (selten his vier) Abschnitte unterscheiden (Fig. 493 A), einen distalen, vorderen und weiteren (sog. Vorraum) und einen proximalen engeren, der in der Regel länger ist und daher im hinteren Abschnitt des kugligen ()rgans gekrümmt verläntt. Selten, bei gewissen Drepuntphumarten (Metanemertinen), kam der proximale Kanal als langer Schlauch dem kugligen Organ hinten anhängen.

lie flimmermden Epithelzellen heider Kanabschnitte sind ziemlich serschieden. Bei den Heteronemertinen haben sich sogar in proximalen hanal besondere eigentümliche Epithelzellen differenziert, die sich als ein bandförmiger Streif lïngs dessen lateralwand himziehen, während die Medialwanl ans gewönlichen Ilimmerzellen bestelit. Dieser Jateralstreif (s. Fig. $493 \mathrm{~B}$ ) wird meist ron sechs \%ellreihen gebildet, von welchen die Zellen der beiden Grenzreihen größer sind, lie der zwei bis drei Paar inneren lieihen kleiner. Die Zellen des Streifs zeichuen sirh hamptsichlich dadurch ans, daß ron ihuen eigentiimliche hegelformige Fortsitze, welche möglicherweise nur rerklebte Cilienbüschel sind, frei in das Kanallumen vorspringen. (1) man sie als spezifische Sinneszellen deuten darf, scheint traglich, da ihre Verbindung mit Verven unsicher ist, ja neben ilnen sogar freje Nervenendigungen beschrieben wurlen. - Außer der llasse kleiner Ganglienzellen, welche den Kanal fast völlig umhüllen um bei len lleteronemertinen mit den Zellen der dorsalen Cerebralganglien lirekt zusammenhängen, sind es Jrïsenzellen, die in anselulither Menge am Aulbau der Organe teilnehmen. Ilänig läßt sich eine rordere und hintere ciruppe solcher anterscheiden (lig. 49:3 A), von welhen letztere den proximalen lianal mehr oder weniger umbiilt. Bei len lleteronemertinen mündet die vorlere Gruppe in den Anlang res Vorraums, die hintere auf der Grenze zwischen den beiden Abshnitten in den Kanal: doch kïnnen die linmündungen der brïsenzellen (Metanemertinen) anch weniger lohalisiert sein. - Eine besondere Auszeichnung besit»t der Vorraum mancher Metanemertinen, indem silh an seinem Beginn eine sackartige dorsale Ansbuchtnmg bildet, die namentlich bei Dremonophorks zu einem ansehnlichen faltigen Sack wid, der das Grgan bis hinten durchzieht.

Interessanterweise findet sich bei ler Protonemertinengattung Tubulamus (= Carinella) ein kleines zweites Paar ähnlicher Organe in nächster Nihe der in den laterallinien liegenden beiden Poren der Protonephrialien (s. Fig. 327.4 1, S. 479). Es sind flawe Grübchen oder Erhebungen, die aus Wimper- und Drïsenzellen oder nur aus ersteren bestehen und mit besonderen Mnskeln versehen simd, welche wohl zu ihrer Ein- mud Austülpung dienen. Sir liegen dicht nach außen von den lateralen Verrensträngen: ihre Innervierung jot unbekant. 
Phylogenetisch bemerkenswert ist, daß auch bei zahlreichen Chactopoden, besonders Polyeliacten, Organe vorkommen, welche mit den Cerebralorganeı der Nemertinen in jeder Hinsicht vergleichbar sind, weshalb ihre Homologie nicht zweifelhaft erscheint. Dies folgt vor allem aus ihrer ganz ïbereinstimmenden Beziehung zu den Hinterlappen der Cerebralganglien (vgl. S. 488). Diese Vaclienoder Nuchalorgane, wic sie gewïhnlich genannt werden, finden sich paarig oder auch unpaar atuf der Dorsal- oder Lateralfäche des Prostomiums zuweilen lateroventral, Capitelliden); seltener weit vorn, meist hinter den Augen, häufig auf der Grenze zwischen Prostomium und dem ersten Segment. Wie gesagt, kommen sie vielen Familien der erranten und sedentïren Polychaeten zu, ebenso den Archianneliden, nur selten dagegen den Oligochaeten (gewissen Ctenodrilus und Aeolosoma). Die Banverhältnisse der Nuchalorgane sind viel mannigfaltiger als jene der Cerebralorgane der Nemertinen. Im morphologisch einfacbsten Fall (z. B. Nereis, 1)iopatra) handelt es sich um ein Paar bewimperte rundliche Stellen der Epidermis auf der hinteren Dorsalfläche des Prostomiums, wo das Epithel ansehnlich verdickt und bentelartig eingesenkt ist. In anderen Fällen sind die Organe wohl durch Vereinigung unpaar geworden und finden sich dann in der dorsalen hinteren Kopfzapfenregion in Form einer Erhebung, die entweder lang kammartig erscheint und von einer Anzahl Iängsgerichteter Wimperrinnen durchzogen wird (s. Fig. 334, S. 488), oder als ein kugelförmiges, gestieltes Gebilde mit einer queren Wimperzone; ja in gewissen Fällen kann ein solcher Basalteil mehrere lange tentakelartige Fortsätze anssenden, die von je zwei Wimperrinnen überzogen werden. Auch als parige tentakelartige, flimmernde Anbänge sind die Nackenorgane mehrfach beschrieben worden; da aber die gleich zu schildernden eingesenkten Organe nicht selten ansstiilpbar sind, so könnte es sich in manchen Fällen auch um vorgestïlpte Organe handeln. Sehr häufig haben sich nämlich, ähnlich wie bei Plathelminthen, gruben- bis schlanchartig eingestiilpte, paarige Organe entwickelt, die entweder mit einer rundlichen Öftunng oder mit länglich schlitzartiger alsmiinden. Einfache gruben- his becherartige bewimperte Organe dieser Art finden sich bei den Arrhiameliden (Fig. 332, S. 487) und einzelnen Oligocharten, ebenso bei gewissen Sedentariern (s. Fig. 333, S. 488) und auch Dimoplitus, wie hier erwähnt sei. Hänfig werden die Gruben schlauchartig lnd erstrecken sich dann tiefer ins Innere. In letzterem Falle ist meist anch eine Differenziernng der Schlauchwand eingetreten, indem sie nur in ihrem Grunde hohes l,cwimpertes Epithel besitzt, während das übrige niedrig und cilienlos bleilst. Solch eingesenkte Organe kïnnen ein- nnd ansstülpbar sein (Capitelliden, P'olyophthalmus usw.), wozu ein besonderer Muskelapparat dient.

Die nahe Beziehung der Organe zu den Hinterlappen der Cerebralganglien tritt hänfig in ähnlicher Weise wie bei den Nemertinen hervor, indem entweder Nerven von diesen Lappen zu einer Lage kleiner Zellen unter den Organen treten, die meist als Ganglienzellen gedeutet wurden, aber wahrscheinlicher die Sinneszellen sind, deren periphere Fortsätze sich zwischen die Wimperzellen erstrecken; oder die Organe verwachsen direkt mit den Hinterlappen 
des Ilirns, so daß die erwihnten kleinen Zellen in letzteres aufgenommen wurden.

Obgleich die feineren Untersuchungen noch viel zu wïnschen ïbrig lassen, wnden doch im Epithel der (Irgane gefunden: 1) Stïtzzellen, 2) Wimperzellen, 3) die eben erwähnten Ganglien- oder Sinneszellen, wozu sich häutig noch Drïsenzellen mu an gewissen Stellen zuweilen Pigmentzellen gesellen.

Eine sehr eigentïmliche Beziehung sollen die Nuchalorgane bei ten Serpuliden und Tevelelliden zn dem hier, in der sog. Thoracalregion jederseits ansgebildeten Verbindungsyang der Yephridien erlangt haben, indem letzterer rorn in die Nackenorgane einmünde, so laß diese zum Ausmündungsteil der Nephriłialgänge geworden seien.

Ub das unpaare grubenförmige Organ, das sich bei gewissen Tubificilen (Bothrioneuron) anf dem Prostomium findet, hieher gehört, ist zweifelhaft.

Den Nuchalorganen der ('haetopoden scheinen die sog. Cerebralorgane (anch llirn-. Hypophysen- oder Gcularöhren gen.) der Sipunenliden zu entsprechen. Bei gewissen (einzelnen Phascolosoma) sind es zwei kopfstïndige Röhren, die in der llundhöhle beginnen und sich bis in die (erebralganglien einsenken. Bei den übrigen münden sie anf' der borsalseite der Kopfregion, dicht hinter dem Tentakelkranz (Plymosoma) und ihr Epithel, las flimmern kaun, ist z. T. schwarz pigmentiert, weshalb die Organe zuweilen als Augen gedeutet wurden. Bei Sipunculus haben sich die Organe in der dorsalen littellinie vereinigt, indem sich wohl eine sekundäre röhrentörmige tiefe Einstiilpung gebiłdet hat, die sich bis an die l'erebralganglien erstreckt, während sich die beiden ursprïnglichen Röhren sehr reduzierten. Im Grund der röhrenförmigen Organe, der in orler am firn liegt, tindet sich Simnesepithel, lessen bau jedoch nur wenig bekannt ist. Wie gesagt, ist die Homologie lieser Organe mit den Nuchalorganen der Chaetopoden recht wahrscheinlich, obgleich nelen ihnen bei gewissen sipunculiden noch hesontere wimpernde Tuberkel heschrieben und als Nuchalorgane gedeutet wurden.

line Art Witterungssermögen (Rierhsermögen, chemische keizbarkeit für lutterstoffe) wurde bis jetzt bei Lumblricus, den Hirndinefn und gewissen Sïßwasserplanarien nachgewiesen. Bei ersteren sind es jetenfalls die Sensillen ler lipidermis, welche in dieser Weise funktionieren.

Unter den Oligomern besitzen allein the Chactognathen ein den seither besprochenen einigermaßen vergleichbares un aares Urgan, indem sich ein auf der Dorsalseite der Vorlerregion, etwa auf der Grenze zwischen Kopf und Rumpl. liegendes sog. Geruchsorgan (Coronulorgan) tindet (s. Fig. $341,5.495)$. Es ist eine etwas erlöhte, runlliche bis längliche l'latte. die sich nach vorn bis zwischen die Augen erstrecken kann und nach hinten manchmal weit auf den Rumpt hinabreicht. Es wird von einem Streifen lileiner Zellen gebildet, welche den gewöhntichen, viel größeren Epidermiszellen aufsitzen, und deren mittlere 2 his :Zellreihen bewegliche (ilien tragen. Diese bewimperten Zellen werden meist als die eigentlichen sinneszellen gedentet. Lin rom Cerebralganglion nach hinten ziehendes Nervenpaar versorgt das Wrgan nuter reichlicher Verzweignug. Der feinere Bau bedarf noch oenauerer I'ntersuchung.

\section{Mollusca.}

In diesem Stamm treten Grgane, welchen Rierhvermögen zugeschrieben wird, an verschiedenen Körperstellen anf. Bei den luftlebenden Pulmomaten funktionieren die Kopffühler lintere Fühler der Stylommatophoren) nacliweislich in solcher Weise, indem gewisse Gerïche in ziemlicher Entfernung anf sie wirken. Die linden dieser Fühler sind reichlich mit dichten Anhäufungen von Simneszellen ausgerïstet, deren eigentlicher Körper unter der Epidermis liegt, während ihr peripherer Fort- 
satz zwischen die Epidermiszellen eindringt, und hier etwas kolbig angeschwollen endigt (Fig. 494). Der ansehnliche Fühlernerv schwillt an seinem Ende zu einem

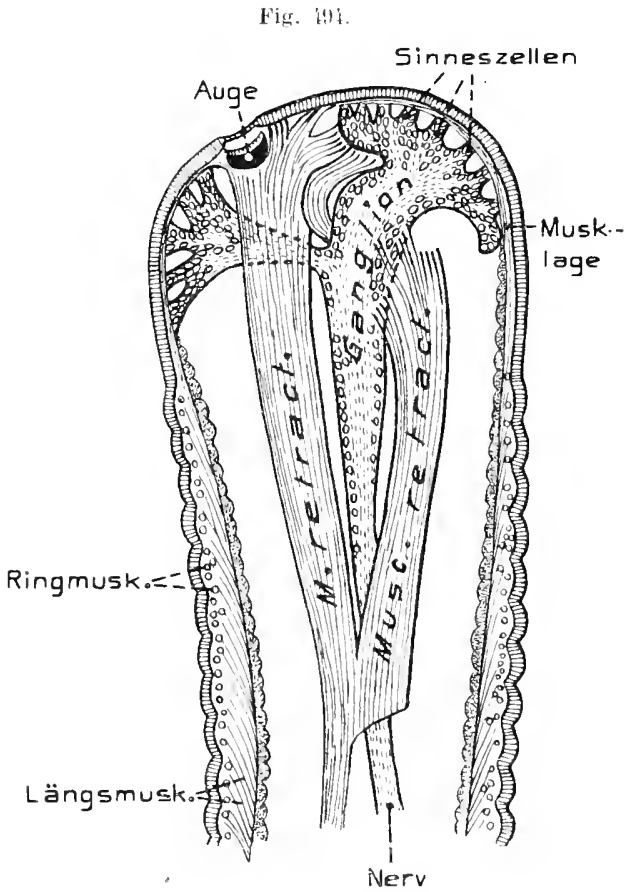

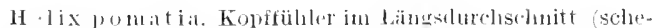
matisch), zur Demonstration der reiclien Anläitung von

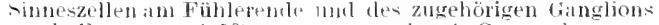

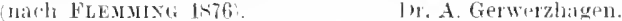

\section{Pig. $\{4$,}

Cer-Visc. Connetiv.

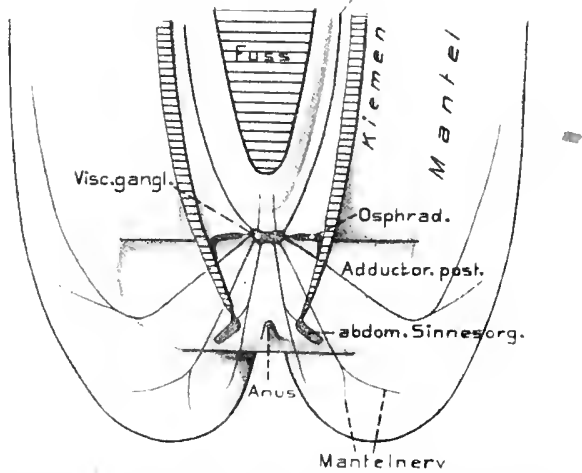

Arca barbata lameltimanchiater. Hintere Hälite fon

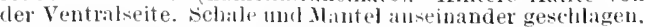
so dab ter lintere Arlductor, ler After, die Ospliradien und die aldominalen sinnesorgane zu sehen siud. FuB und Kiemen abgesclnitten. Die Visceralganglien, sowie die von ihnen atugehemden Verven eingezeichnet. Gerw.
Ganglion an, von dem nicht nur die Nerven dieser Sinmeszellen. sondern auch der Augennerr ausgeht. - Den Sïßwasserpulmonaten fehlt das Ganglion des Fühlers und dessen Sinneszellen bleibeu jenen der übrigen Hant ahmlich. - A uch die Kopffiihler der mudibranchen Opistlohranchim sind nicht selten eigentïmlich entwickelt, so z. B. gefiedert, und werden meist als Rlinoplrove bezeichnet, da ihnen gleichfalls Riechfunktion zugeschrieben wird.

Bei vielen I'larophoren, den Lamellibranchiern, Prosobranchier"r und Cephlolopoden finden sich in der Nähe der Kiemen eigentümliche ()rgane (Osplra(lien), die so gelagert sind, dab der Strom des Atemwassers iiber sie hinstreicht, weshalb sie wohl mit Recht als Organe zu dessen Prïfung betrachtet werden. Die Osphradien der Lamellibrunchier liegen dicht vor dem After nud hinter den Kiemen selten auf deren Innenseite, Nuculidae) anf der Ventraltliache des Kïrpers als ein Paar sehmaler Querstreifen erhöhten, flimmernden Epithels, das häufig pigmentiert ist (Fig. 495. Die Organe siud also hier in den, von der Einströmungsöfinung ioder dem ventralen Sipho kommenden Wasserstrom eingeschaltet. Hinter ihnen, dieht neben dem After, findet sich häufig noch ein Paal papillen- bis tentakelfür- 
miger ähnlicher Organe sog. abdominale Sinnesorgane «) welche bei den mit Siphonen versehenen Muscheln am Proximalende des Einstrïmungssipho liegen sollen. Letztere Organe werden von einem Ast der hinteren, von den Visceralganglien kommenden Pallialnerven versorgt, während der Osphradiennerv direkt zum Visceralganglion geht; doeh sollen seine Fasern nach gewissen Angaben bis in das Cerebralganglion $\mathrm{zu}$ verfolgen sein. Unter jedem Osphradium schwillt der Nerv zu einem Ganglion an, voll dem die peripheren Fasern zum Simnesepithel treten.

An die 11 phratien erinnern in mancher llinsirht auch die bei gewissen Nuruliden vorkommen den Pallialor:"rne: strecken ron arisigem, Sinneszellers fiihrentem

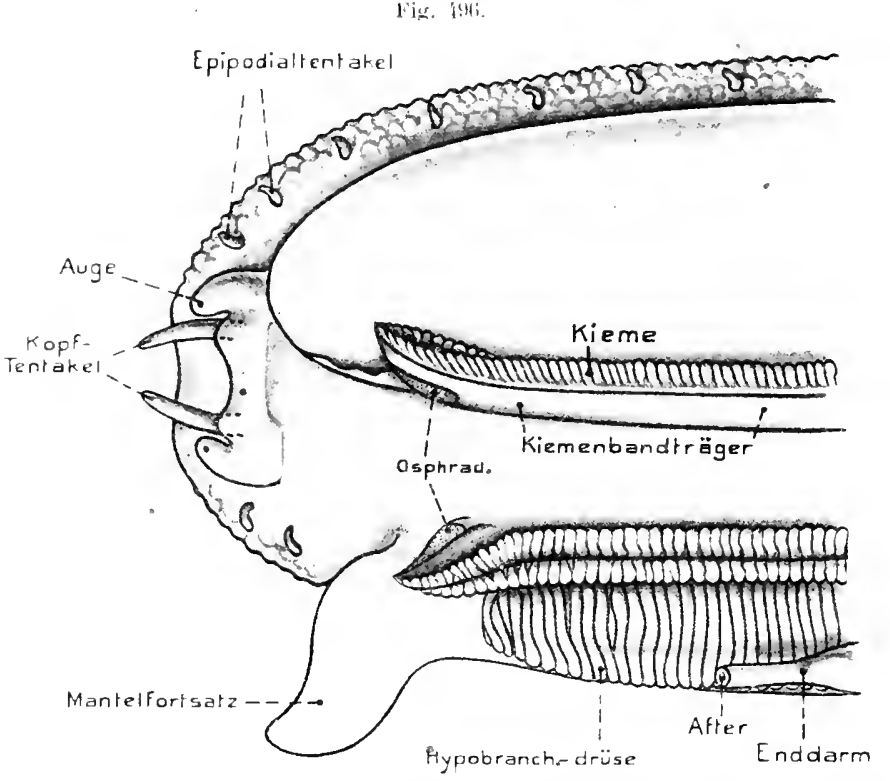

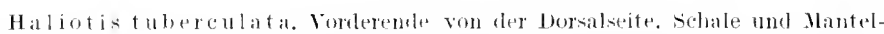
derke twas rents som diter längs anteseshnitten nnd nath links und rechts um-

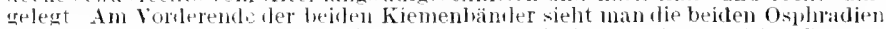

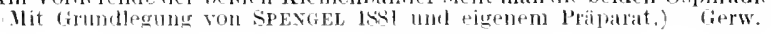

Epithel hie parrig

an der dorsalen liegion des sipho vorkommen; selten tindet sich noch ein ähnliches Grganpar ventral wm vorderen Schließnuskel. Die Deutung als Simnesorgane ist unsicher.

Grgane, welche den 1)sphatien der Lamellibranchiaten sehr ähnlich sind. finden sich auch bei vielen Plonphom jederseits vom After in Einzahl. Sie sind entweder häckerartig ader linger streifenartig un reichen dann nach orn lis neben die hintersten kiemen. liei len Lepidoplewidon, denen sie fehlen. lindet sich angegen anf der Außenkante jeder kieme eine trecke von sinnesepithel, die als Geruchsorgan gententet wirl um mit den cigentlichen "Isphrabien wohl phylogenetisih nicht zusammenhängt.

Die parrige bildung soleher Osphradien, sowie ihre nahe Beziehming zu den Kiemen erhält sich noch hei den zuciliemigen Prosobranchialen (Diotocarlin, Aspidobranthin). Bei den Formen mit gut entwiekelten, gefiederten Kiemen z. 13. Maliolis, Fig. 496 bilden die (sphradien einen Streifen erhöhten, br:unn pigmentierten Epithels an der Dorsalseite des doppelt gefiederten, freien Distalteils der Kiemen, dịe an der Dorsalwand der Mantelhöhle stehen; die (rrgane setzen sich noch parig auf den befestigten proximalen Kiementeil fort. - Bei Fiswurlla tritt das Organ kaum deutlich herror, und hei den Docoglossen (Patclla), deren Kiemen stark rïckgelildet sind, erscheint es als kleiner Anhang an ihrer 
Lateralseite. - Mit der Riickbildung der rechten Kieme bei den meisten Prosobranchiaten ist auch das rechte Osphradiun eingegangen. Das erhaltene linke hat sich gewöhnlich von der Kieme emanzipiert und liegt an der Decke der Mantelhöhle, links vou der Kieme, als selbständiges, ebenfalls häufig braun pigmentiertes Organ. Es bleibt meist kürzer als die Kieme und bildet entweder einen einfachen schmalen erhöhten Epithelstreif oder erscheint wellig, hänfig aber doppelt gefiedert Fig. 374, S. 522 u. Fig. $497 \mathrm{~B}$, indem von einer mittleren Achsialleiste

Fig. 497.

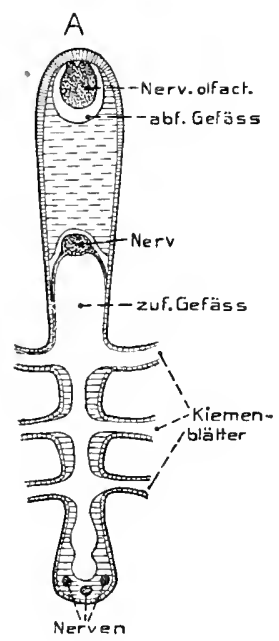

B

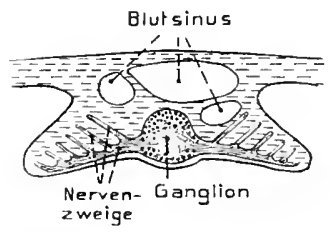

A H aliotis. Querschnitt durels das freie Ende der Kieme mit dem Nervus olfactorius. - B R a nella. Querschnitt durch dits dopyelt ute fiederte Osphradium. Bejies schematisch. (Nach liEsxart is90.) (1, 18 in. beiderseits kammartig je eine Lamellenreihe ansgeht. Wegen dieser Bildnng wurde das (Isphradium frïher meist als die verkiimmerte linke Kieme jener Prosobranchiaten betrachtet. - Der zum Osphradium gehende Nerv zweigt sich in der Regel vom Kiemennerv ab und bildet fast stets ein sich in der Länge des Osphradinm erstreckendes Ganglion s. Fig. 497 13), von dem die Nervenfasern zu den Sinneszellen im Flimmerepithel des Organs ziehen.

Bei ten zum Luftlehen iibergegangenen P'rosobranchiaten ist das Osphradium meist geschwunden (Cerithidar, Hclicimidae, (yrlophoridac), doch erhielt es sich bei Cyclostoma. Den kiemenbesitzenden Hrteroporen kommt es als nimmernde dirnbe an der Kiemenbasis zu. - Unter den Opistholwanchiern tindet es sich hei den Tectibranchiata hïutig als einfaches Urgan. welches lem der llonotocardier entspricht; es breitet sich jelloch zuweilen auf die Kieme aus," wogegen es den Nudilranchiern gewibnlich fehlt. Lin unpares Osphradium konmt ferner den Pteropoden wohl allgemein zu. Das der Theeosomata liegt als quer oder längsverlanfende flimmernde Leiste in der Regel rechtsseitig in ler Mantelhijlle: hei den mit gewundener Schale versehenen (Limacina) hingegen linkseitig. Das (1rgan der Gymnosomata, deren Hantellbölle riickgebildet ist, liegt rechtsseitig, nahe dem Vorderenle als eine mehr oder weniger hufeisenartig gekrümmte Flimnerleiste. Ien erwachsenen stylommatophoren Pilmonaten lehlt es fast stets (eine Ansnahme soll Testacella bilden), wirt jedoch emliryonal angelegt; dagegen besitzen viele basommatophore Pulmonaten ein kleines mit Ganglion rersehenes Osphradium (Laca:eDuthiersshes Organ), das selten in der Lungenböble. nahe an deren Cofnung. liegt. meist etwas außerhalb der öffnung. Es ist häutig sthlauch törmig eingestïlpt, so daß das eigentliche O-phradium in Grunde des znweilen auch gegabelten Schlauches liegt. Yur am einfach leistenförmigen Osphradium der l'rosobranchiate Paludina wurde etwas Ahnliches beobarhtet, indem die Leiste eine Reihe schlauchartiger Einstülpungen hesitzt, in welchen ehenfalls Sinneszellen vorummen. - Auch die früher (s. 135) erwähnte Hypolranchialdriase der Prosobranchiaten entlält Sinneszellen, weshalb ihr zuweilen ebenfalls Geruchshuktion aneschrieben wird.

Den Osphradicn der geschilderten Mollusken entsprechen jedenfalls die bei den tetrabranchinten Cephatrpordon. Nautilus in ähnlicher Weise an der Kiemen- 
basis vorkommenden Urgane (Fig. 498). '\%wischen den Basen der beiden Kiemenpare liegtjederseits eine Papille (interbranchiales Organ), während sich etwas abanal von dem dorsalen oder abanalen Kiemenpar ein Organ erhebt, das jedenfalls durch mittlere Verwachsung zweier ähnlicher Papillen entstand; dies erscheint um so wahrscheinlieher, als es in verschiedenem Grad in seine beiden Komponenten gesondert sein kann. Diese sog. postanalen Papillen entsprechen daher wohl einem zweiten Osphradienpaar, das mehr oder weniger verwachsen ist. Beiderlei Organe besitzen hohes flimmerndes Epithel und empfangen $Z$ weige rom Visceralnerv, was mit der Innervierung der Osphradien der iibrigen Mollusken übereinstimmt. - Außer den besehriebenen Organen finden sich in der Augenregion von Nantilus noch andere, welchen ebenfalls meist Riechfunktion zugeschrieben wird. Oral und aboral vom Auge erhebt sich je ein muskulöses, retractiles, tentakelartiges Gebilde (Angententakel, das einseitig mit einer Reibe vorspringender Lamellen besetzt ist, deren Epithel aus bewimperten und unbewimperten Zellen besteht. Die zu den beiden Augententakeln s. Fig. 499 tretenden Nerven entspringen von der

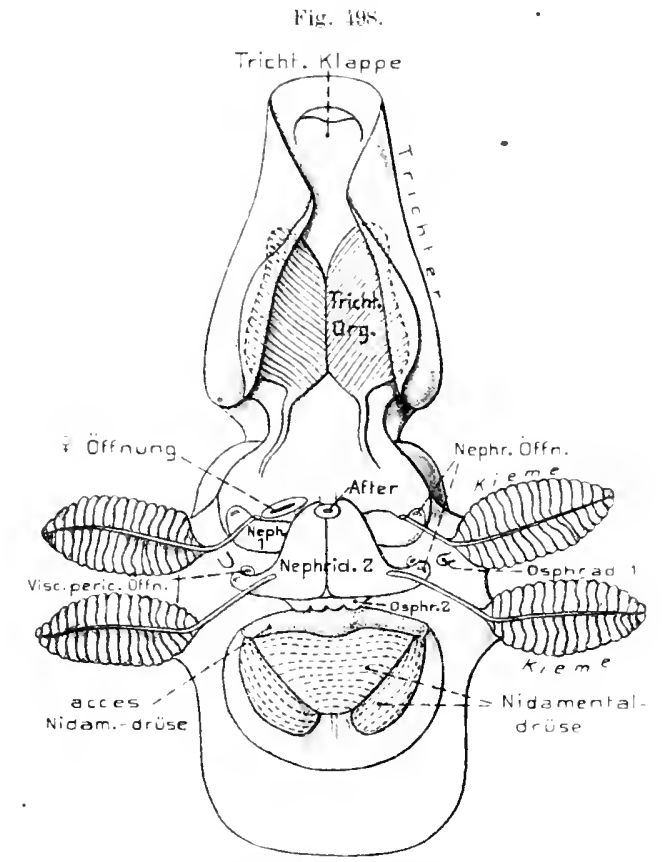

Nautilus pompilius. Mantelhöhle geöfnet, so dab ihre Forderwand mit dem Triehter, den beiden Kiemenparen, den Ocphradien usw, zu sehen ist. (Nach Willer 1900.) (ierw.

Fie. itsi.

vorn

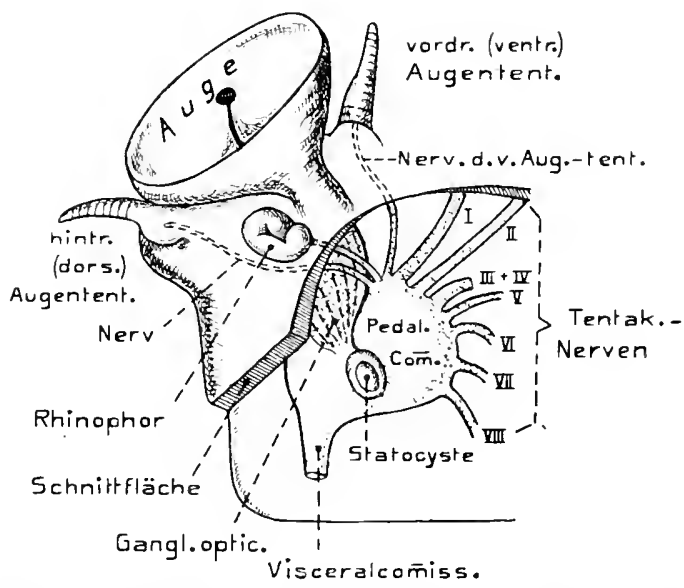

Natilus pompilius. Augenregion von rechts nit den beislen Angententakeln und dem Rhinophor. Das Ange ist etwas naeh oben herumgeklappt und ein Teil des Zentralnervensystem frei präpariert. Dasselbe zeigt die Statocyste, das Ganglion opticum, sowie die Nerven zu den Angententakeln, dem Rhinophor und die Tentakelnerven J-VIII. (Nach WILLEY 1!00, etwas schematisiert.) Gerw. 
Pedalcomimissur, als die dorsalsten in der Reihe der Kopftentakelnerven, weshalb es wahrseheinlich ist, daß diese Augententakel den Kopftentakeln homolog sind. Caudal (oder anal) vom Auge entspringt ein papillenartiges Gebilde, an dessen Basis sich ein ziemlich tiefer Himmernder Schlanch einsenkt. Diesem sog. Mhinophor wird ebenfalls Riechfunktion zngeschrieben. Der es versorgende Nerv entspringt dicht beim Nervus opticus und geht wahrscheinlich vom Cerebralganglion ans (s. Fig. 383, S. 529 n. Fig. 499). Wie nachgewiesen, vermag Nautilus seine Bente auf verhältnismäßig große Entfermungen zu wittern.

I ie Dibrancliuten besitzen stets ein l'aar ()rgane, welche den erwähnten Rhinophoren der Tetrabranchiaten entsprechen dürten. Sie stehen im allge-
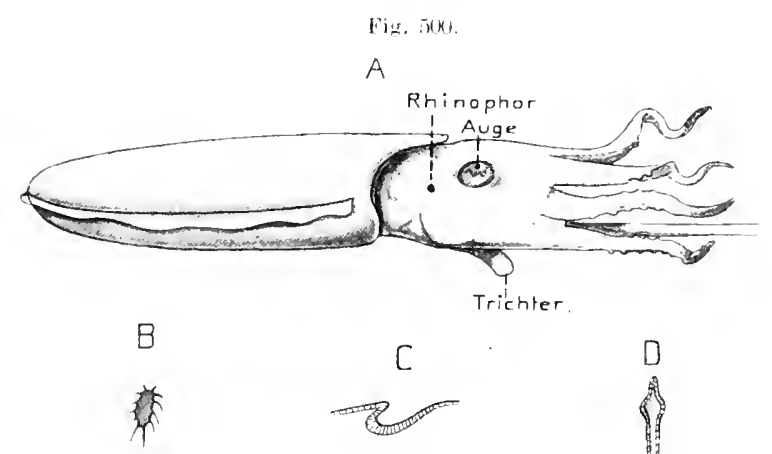

bibranchiate cephatopoden: 0xphratien, 1 - te sepia phegans: A Ganzes lier von rechts: $b$ das Osphradium rom auben, stablel vergrobert, o langsschnitt dusch das 0sphradinm. - I) G hi loteut hi

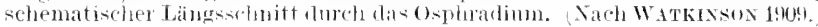

meinen lateral und etwas dorsal iiberden Angen Fig. 500 , an Eingang in die Mantelhöhle ocier sogar ein wenig in letztere hineingerïckt. I'ei den Octopoden sind sie ein wenig nach vorn verschoben oder nach der iiblichenbezeichnungsweise dorsal $\rangle$, so daß sie nahe der Stelle liegen, wo der Mantelrand in die Vor-

derfläche des Eingeweidesacks iibergeht. Hhrer Lage nach wären die Dibranchiatenorgane also sehr geeignet zur Prüfung des in die llantelhöhle einströmenden Wassers, was ja anch für die Tetrabranchiaten-Osphradien gilt. Die Organe sind teils tlimmerude eingesenkte Griibchen Fig. 500 1-C), deren Öffinung sich wegen der muskulösen Beschaffenbeit der Hant erweitern und verengern kann, wie anch die Grube sich zu vertiefen und alozuflachen vermag, ja hei gewissen Formen (besonders Octopoden sogar mehr oder weniger ausstïlphar ist. Durch thache (Aruben mit vorspringendem Rand (Loligo gehen sie schließlich in frei ibber die Hautfäche sich erhebende papillenartige (gewisse Oetopoden: Argonanta, Tremoetopns und Ögopsiden bis tentakelartige Bolitaena, Chiroteuthis Fig. $500 \mathrm{~L} /$ ) üher. Bie Organe erimnern demnarh in vieler Hinsicht an die Rhinophore von Nantilus. - Das hohe Epithel der Grulue oder der freien Organe lesteht ans Flimmerzellen, zwischen denen sich zihlreiche nicht flimmernde finden, die einen eigentümlichen knänelartig gelanteu Körper enthalten.

Daß letztese Zellen Sinneszellen seien, ist nnwabscheinlich; sie dürten rielmehr woh] eigentümliche Irüsenzellen sein. Wie sie sish auch in der Rhinophorgrube von Tautilus reichlich finden. 
'Zn den Rhinophoren der Dibranchiaten tritt ein Nerv, iler meist direkt vom Nervus opticus abzweigt (jedoch nicht, wie S. 529 fülschlich erwïhnt, von der ganglienïhnlichen Anschwellung, dem Ganglion pedunculatum, sondern neben diesem. Zuweilen kann der Ursprung dieses Nervus olfactorius anch vom Nervus opticns abgerückt sein. Ob seine Fasern in letzter Instanz vom Cerebral-oder Visceralganglion entspringen, ist unsicher.

l)ie lihinophore der Cephalopmlen wurden wegen inrer lage und Innervienng znweilen den Kopffühlem der Gastropolen homologisiert; ob hies richtig, bedürfte genauerer Feststellung. Die Muskellosigkeit der lihinophorpapille con Nantilus spricht eher gegen eine solehe Deutung.

Aus vorstehender barlegung folgt, daß sich bei Hen Mollushen zweierlei Typen von Gerudisorganen tinden: eimmal die lïhlerartigen lihinophore, welche rom rerebralganglion innerviert werden und dam die mit den Kiemen in Beziehung stehenden Osphradien, welche ihre Jerven von her Visceralcommissur emplangen. Wenn sich gewisse dieser Grqane mit jenen der Würmer homologisieren ließen, so könnten wohl nur die lihinophore in Betracht kommen, whihrend die Usphradien Organe sind, die sich jedenfalls erst im Molluskenstamm hervorbildeten. - Gernchsvgrmïgen wnrde hei gewissen Gastropolen (Helix) unl Cephalopoden physiologisulı erwiesen.

\section{Chordata.}

\section{a) Tunicata.}

liei der Schildernng des Nervensystems $\langle$ S. 544 wnrde schon der Flimmeroder Wimpergrube auch Flimmertrichter) gedacht, die bei allen Formen, deren Entwicklung genaner bekannt ist, an der Stelle des urspringlichen Nemroporus aus dem vordersten Teil des Neuralkanals hervorgeht; doeh scheint die Möglichkeit nicht ausgesehlossen, daß sich auch das äm an ihrem Anfbau beteiligt. Da die Entwicklungsverhälnisse der Flimmergrube und des sie caudalwirts fortsetzenden Flimmergrubenkanals, sowie ihre Beziehnng zum Cerebralganglion, schon friiher geschildert wurden, so sei daraut verwiesen. bie Flimmergrube, welche meist als eine riechorganartige Bildung gedentet wird uhgleich physiologische lieweise dafür fehlen, findet sich daher bei allen 'Tunicaten als ein unparues ()rgan, und zwar in der liegel etwas vor dem Gianglion: gewöhnlich in der dorsalen Mittellinie des respiratorischen Darms Kiemendarms), in dessen vorderster, wahrscheinlich iiberall ectodermaler Region. Sie steht in nalıer Lageheziehmng zu den parrigen Wimperbogen oder Wimperrimnen, die, wie später genatuer zu schililern ist, an der Innenflïche des Kiemendarms von der ventralen Dittellinie dorsal his in die Gegend der Grube emporsteigen, jedoch nur selten mit ilı in Verbindung zu stehen scheinen gewisse Ascidien, Doliolum). Im einfachsten Fall (Copelaten; s. Fig. 394, S. 545 n. Fig. 501 A) ist die (xrube ein etwa trichter- bis schlauchförmiges, dorsal anfsteigendes Gebilde, das mit rnndlicher bis länglicher Öffnung in den Kiemendarm mündet. Sie liegt bei den Copelaten ausuahmsweise asymmetrisul, rechtsseitig neben oder vor dem Ganglion. Ihr blindes Ende kamn dorsal iiber dem Ganglion lang kanalartig und fein zugespitzt auslanfen, wobei es sich dem dorsalen Körperepithel meist dicht anlegt. 
Wie überall bestehen die Grube und (łer Kanal aus einem einschichtigen Epithel, dessen Zellen im distalen, die eigentliche Grube darstellenden nnd erweiterten Abschnitt ansehnliche Cilien oder Cilienbiischel tragen, während der kanalartige Fortsatz umbewimpert ist und manchmal nur aus wenigen Zellen hesteht. Überhaupt wird das Organ der Copelaten nur von relativ wenigen Zellen gebildet. Der Zutritt eines Nervs vom Cerebralganglion zur Wimpergrube wnde mehrfach angegebell.

Einfache, ja vielleicht noch primitivere Verhälnisse finden wir bei Lotiolım, dem sich auch die Thuliace anschließen. Die Wimpergrube ron Doliolum liegt
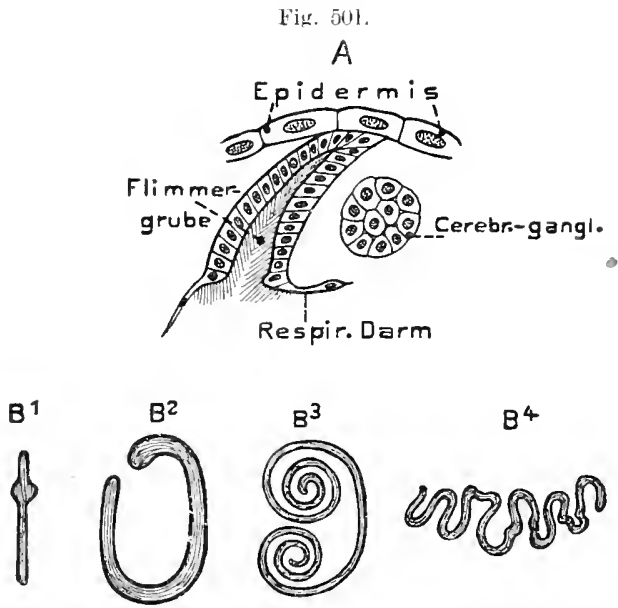

A Copelat e (Oicoplenra cophocerea). Längsichnitt durch die Flimmergrube und das Cerebralganglion (nach seeliger. Bronn, Kl. u. O.). - $H^{1-t}$ Einmündmugstellen der Flimmergrube in den respirator. Darm bei verschiedenen Ascidien in Flächenan-icht: $b$ \& Polycarpa pilella, $b 2$ Ascillia falcigeri. $b^{3}$ C'snthia cerebriformis. $B^{3}+A s c i l i a$ translucida. (Nach HeRuMAs ativ Bromn. Kl, u. $O$. v. Bu. als ein trichterartiges Gebilde ziemlich weit vor dem Ganglion und öffnet sich an Dorsalende des linken Wimperbogens. Vom llinterende der eigentlichen Grube entspringt der lange und feine unbewimperte Kanal, der ziemlich weit nach hinten zieht und iu einell warzenartigen Fortsatz der vorderen Ventralfläche des (ranglions iibergeht. Figentlich nervöse Struktur wurde jedoch in der Kanalwand nicht heobachtet.

In der Untogenese der Salpen scheint voribergehend ein ähnlicher Zustand wie der von loliolnm anfzutreten, welcher sich später dadurch vereinfacht, daß der dem Kanal entsprechende, hintere Teil des Organs verschwindet, während sich der distale, bewimperte und trichterförmige 'T'eil, die eigentliche Wimpergrabe, erhält. Letztere mïndet mehr oder weniger weit vor dem (xanglion ans und reicht als trichter- oder schlauchfirmige Bildung entweder bis zum Ganglion nach hinten oder endet in verschiedener Entferung vor ihm. Es wurden jedoch zarte Nerven beschrieben, die vom Ganglion zur Wimpergrube ziehen, ja sogar anf ihrer Wand einen Plexus von Nervenzellen und Fasern bilden sollen.

Das Wimperorgan der. Ascidien und Pyrosomew erscheint dadurch kompliziert, daß der wohl stets vorhandene Kanal einen drisigen Anhang, die Neuratdriise besitzt, welche den seither besprochenen Formen fehlt. Die Wimpergrube öffnet sich meist in einiger Entfernung vor dem Ganglion und ist in einfachen Fällen, wie auch bei Pyrosoma, ein schief aufsteigender flimmernder Schlanch, der nach hinten gegen die Ventralfläche des Ganglion zieht. Bei Pyrosoma, wo der Kanal nur wenig diffenziert ist (doch ist der hintere Abschnitt wimperlos), legt sich das Organ der ventralen Hirnfläche dicht an. - Bei den Ascirlim kompliziert 
sich die Wimpergrube häufig sehr, vor allem bei den größeren Monaseidien. In der Regel bleibt sie nieht einfach triehter- oder schlauchförmig, sondern erscheint entweder seitlieh komprimiert oder von vorn nach hinten zusammengepreßt, so daß ihre ớfinung sowie ihr Querschnitt mehr oder weniger schlitzartig werden. Diese Komplikation kann dadurch sehr geșteigert werden, daß sich der Querschnitt der Grube hogen- bis sehleifenartig krimmt oder selbst einrollt Fig. $\left.501 B^{1}-B^{1}\right)$. Anf solehe Weise nimmt besonders die Grubenötinung eine recht komplizierte, häufig asymmetrische bis unregelmäßige Form an, die sieh natürlich gegen die Übergangssteile in den Kanal vereinfaehen muß. In seltenen Fällen kann sich hieraus sogar eine Auflösung der Mündung in eine Anzahl gesonderter Öftinungen hervorbilden (Cynthia imegularis). Wer Ban der Grube zeigt jedoeh weitgehende Variationen, selbst bei derselben Art. Ausgekleidet wird sie stets von Flimmerepithel. - Ner ihr Hinterende fortsetzende Kanal scheint nie zu fehlen und zieht sich in verschiedener Länge, meist dicht an der Ventralflaiche des Ganglions hin, kamn jedoch auch seitlich rïcken, ja bei einigen Arten sogar dorsal iiber das Ganglion (Fig. 395, s. 546); hinten geht er zwweilen direkt in die Gehirnmasse über (s. Fig. 395.1, oder vereinigt sich mit dem f'üher geschilderten Ganglienzellenstrang. Er wird von unbewimperten Epithelzellen gebildet.

Besonlers eigentïmlich verhäl siih ter Kanal von Pliallusia mammilata nnd einigen Ascidiaarten, wo er auch sehr lang werden kann. IIer sendet er seitliche Ästchen aus, die sich sekmulär verzweigen können und wenigstens zum Teil durch flimmernde Erweiterungen in die P'eribranchialhöhle münden. Diese öffnungen mit der ler Wimpergrube zu vergleichen, scheint aber nicht gerechtfertigt. Bei Plallusia soll sich die Cifluung der -Wimpergrube im Alter rïckbilden. so daß das sekret des Kanals zur l'eribranchialhöhle abgeleitet wird.

Eine Nenraldrïse vgl. Figg. 395, 396, S. 546/47) tritt schon bei Pyrosoma auf als eine kleine, von drïsigen Zellen gebildete, im Alter solide Aussackung der ventralen Kanalwand. In :ihnlicher Besehaffenheit wiederholt sie sich bei zahlreichen kleinen Ascidien, scheint aber zuweilen nur eine drüsige Stelle oder Erweiterung des Kanals zu sein, die sich an seinem Hinterende oder in seinem Verlanf bildet. Wenn die Driise größer und komplizierter wird, wie bei den Monaseidien, so entwickelt die aus der ventralen Kanalwand hervorgehende Ausstiilpung sekundäre, zuweilen verzweigte, acinöse bis tubulöse Aussackungen, deren Epithel gleichmäßig oder nur im Grunde der Aussackmngen drüsig modifiziert erscheint. An der Bildıng soleh komplizierter Driisen beteiligen sich auch das Bindegewebe und die Blutlacnnen. - Wegen der Einschaltung der Driise in den Kanal, läßt dieser dann gewöhnlich drei Absehnitte unterseheiden: 1) den vor der Drïse gelegeneu, 2 den mit der Drïse verbundenen und 3 ) den candal gelegenen, der häufig in den Ganglienzellenstrang ïbergeht.

In einzelnen Fällen scheint die 1)rïse rürkgebildet zn werden, woranf sich selten an ihrer Stelle accessorische Nebendrüsen entwickeln (Phallusia mammillata). Im Irüsensehret finden sich bei den Ascidien zablreiche abgestoßene Epithelzellen, die offenbar allmählich zerfallen. Ïber die Funktion der Irïse ist Sicheres nicht ermittelt; sie wurde als Schlcindrïce oder sogar als Exkrelionsorgan gedentet. Gerade bei den Ascidien fehlen bis jetzt 
Beobachtungen ïber die Junervation der Wimpergrnbe, obgleich ihre Auffassung als Riechorgan für wahrscheinlich erachtet wird, wofïr, abgesehen won ihrem allgemeinen Bau, uamentlich die Lage im Zustrom des Atemwassers spricht.

Auf die hänfig erörterten Heziehnngen der geschillerten Organe zu denen der Wirbeltiere kann erst bei letateren eingegangen werden.

\section{b) Vertebrata.}

Acrania. Wie schon hei der Beschreibung des Nervensystems hervorgehoben wurde (S. 549), bildet sich bei Branchiostoma anf dem Kopfscheitel eine flimmernde grubenförmige Einsenkung der Epidermis, in deren Grunde der Neuroporus mündet. Durch das Vorderende der Dorsalflosse wird diese Koelliliersche Flimmergrube Riechgrube) später linksseitig verschoben. Beim Erwachsenen (s. Fig. 398, S. 550) öffuet sich der Hirnventrikel nicht mehr in der Grube nach außen, dagegen erheht sich die dünne dorsale Decke der Hirnblase vorn zu einem kurzen Fortsatz (Recessus neuroporicus, Lobus olfactorins), der sich zwischen die Epithelzellen des Riechgrubengrundes einzuschieben scheint. Ein besonderer Nerv $(\mathrm{Ol}-$ factorius), der von der Hirndecke zur Grube geht, scheint nach den neueren Beobachtungen nicht zu existieren, wurde jedoch früher öfter beschrieben (s. S. 608), .ja sollte sogar zuweilen paarig vorhanden sein. Gewissen Acranierformen (Epigonichthys und Asymmetron) fehlt die Grube.

Unsicher erscheint auch, ob zwischen den Wimperzellen der Grube oder in deren Grund besondere Simneszellen vorkommen, wie sie manche lieobachter erwähnen. Daß die Riechgrube nach ihrer Entstehung und sonstigen Bildung jener der Tunicaten recht ähnlich ist, läßt sich kaum leugnen; daß sie bei letzteren in den ectodermalen Vorraum des Kiemendarms gerückt ist, dürfte als sekundäre Bildung unschwer zu versteben sein. Die Ilomologie der Wimpergrube der Acranier mit dem Nasenorgan der Granioten wurde jedoch auch geleugnet, vielmehr die bei der Mundhöhle zu besprechende Hatsehelselie Grube nit letzterem homologisiert. Näheres hierüber später. Bemerkenswert erscheint, daß manche Individuen ron Branchiostoma auch rechtsseitig eine ähnliche kleinere Grube besitzen sollen.

Craniota. Das Geruchsorgan der (yclostomen besitzt wegen seiner in gewissem Sinne vermittelnden Stellung zwischen jenem der Acranier und dem der Gnathostomen hohes Interesse, doch bleibt in seinen Beziehungen eintweilen noch vicles dunkel. Es wird zuerst als eine unpaare verdickte Ectodermstelle (Riechplatte oder -placode) an der vorderen Körperspitze des Embryos angelegt, und zwar an der Stelle des geschlossenen Neuroporus oder ein wenig ventral von derselben (Myxinoiden). Diese unpaare Anlage (s. Fig. $502 A$ ) sowie ihre Entstehungsweise erinnern an die Riechgrube der Acranier. Die Riechplatte verschiebt sich dann auf die ventrale Kopffläche vor die Mundanlage und stiilpt sich dorsalwärts zn einer gruben- bis schlauchartigen Bildung ein, während sich dicht hinter ihr eine zweite ähnliche Einstïlpung entwickelt (Hypophysenanlage), welche mit der Riechgrube durch eine Längsrinne zusammenhängt. Bei den Myxinoiden (Bdellostoma) ist diese Rinne viel länger als bei Petromy:on, so daß die beiden Einstïlpungen weit voneinander entfernt sind. Diese Rinne der Myxinoiden schließt sich durch Entwicklung und Verwachsung zweier seitlicher horizontaler Falten zu einem horizontal verlaufenden Rohr ab, das nur vorll eine öffnung, die künftige äußere 
Nasenöflnung bewahrt. Später erhält anch das Ilinterende dieser Röhre, das ans der Hypophyseneinstïlpung hervorging, eine öffunng in den Vorderdarm. bei Petromyion (s. Fig. 502 B) dagegen ricken die, sich tiefer einsenkenden Anlagen der Nase und des Hypophysenschlauchs allmählich anf die 1)orsalseite des Kopfes hoch hinauf, wobei der Schlanch zu einer langen Röhre answächst, die das lliru vorn rentralwiirts umgreifend, durch die Hypophysenöffnung der ventralen Schädeltlïche hindurchtritt und zwischen Chorda und Schlund etwa bis zur zweiten Kiementaschezieht (s. Fig. 128, S. 228 u. 503 4), aber lifine Öfnung in den schlund erhält. Schon friiher (S.566) wurde hervorgehoben, daß sich die eigentliche IIypophyse der Cyclostomen aus dem Hinterende des $\mathrm{Hy}_{y}-$ pophysenschlanchs entwickelt, woher dessen Bezeichnung stamint.

Beiden Cyclostomen bildet sich demnach auf die geschilderte Weise

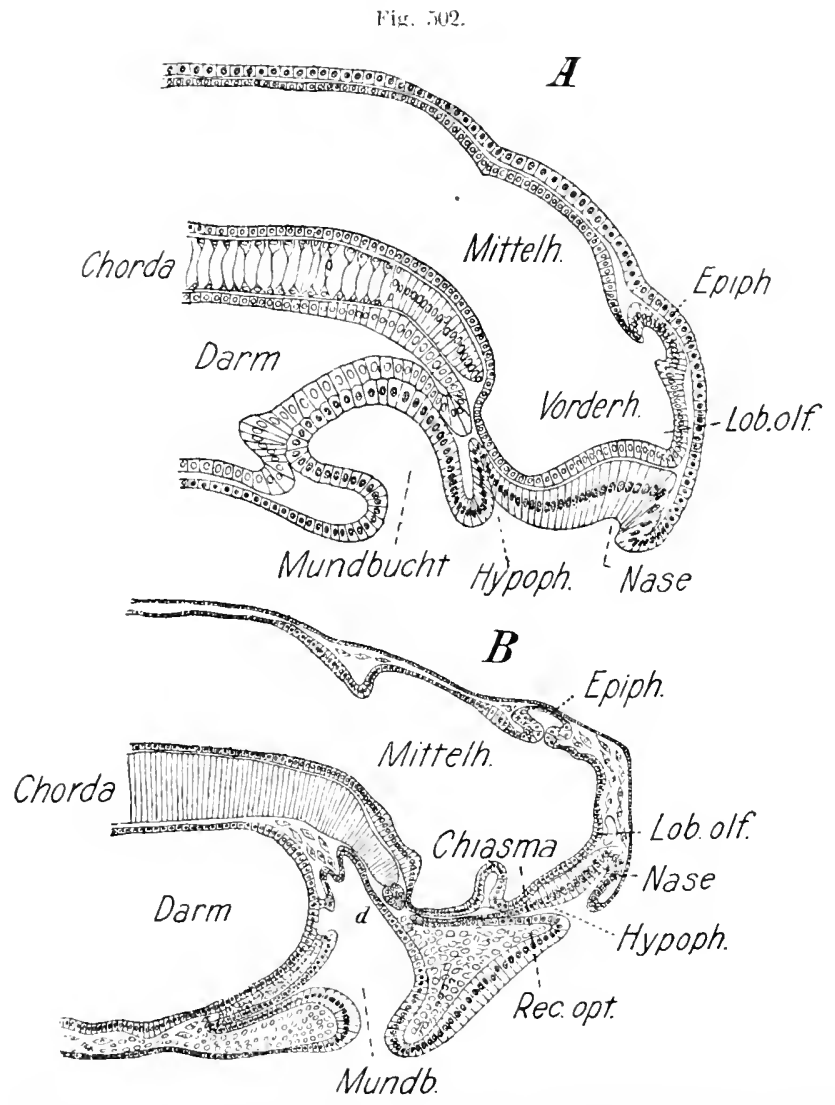

Petromyzon planeri (Larve. Ammocoetes. Medianschnitte durch deu

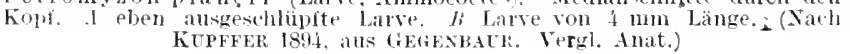

als Geruchsorgan ein langes Rohr, das in seinem vorderen Teil ans der eigentlichen Naseneinstiilpung, in seiner Fortsetzung aus dem Hypophysenschlauch (Ductus nasopharyugeus, Nasengaumengang) besteht.

Bei I'ctromy:on führt die hoch auf dem Scheitel gelegene enge Nasenöffinung (s. Fig. 503, 1 u. Fig. 504) in einen, jedenfalls durch sekundäre Einstïlpung entstandenen, mäßig langen unbewimperten Vorraum (Nasenrohr), von dessen Ende sich dorsocandal der eigentliche, schwarzpigmentierte Nasensack ansstülpt, wiihrend sich der Vorraum in den Hypophysenschlauch fortsetzt, desseu blindes Hinterende etwas sackartig erweitert ist. Anf der Grenze von Vorraum unil eigentlichem 
Nasensack erhebt sich in das Lumen eine schief aufsteigende Klappe, welche das Eindringen von Fremdkörpern abwehrt. - Der Nasensack wird ron einer Knorpel-

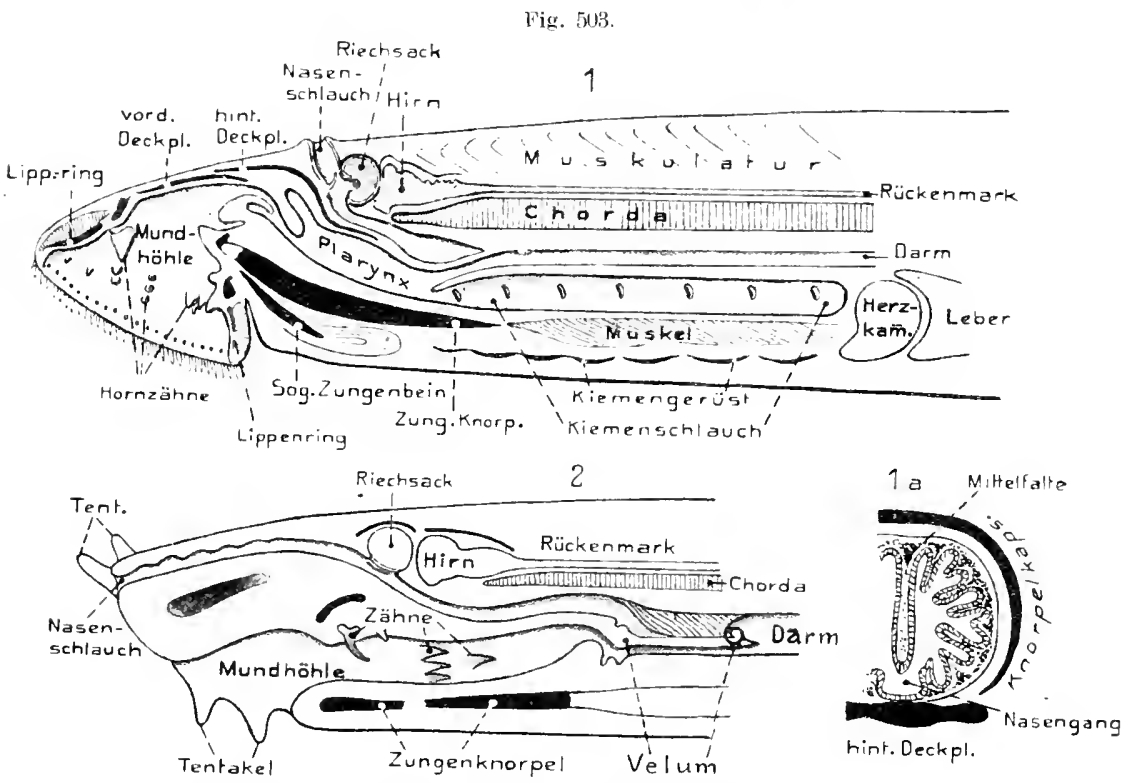

1. Petromyzontluviatilis; 2. Myxineglutinosa. Kopfregion in der Medianebene halliert, rechte Hälfte in tnsicht auf die Schuittfläche, la. Petromyzon fluviatilis. Querschnitt des Rieehsarks "twa in seiner mittleren hegion.

Orig. O. B

Fig. 5int.

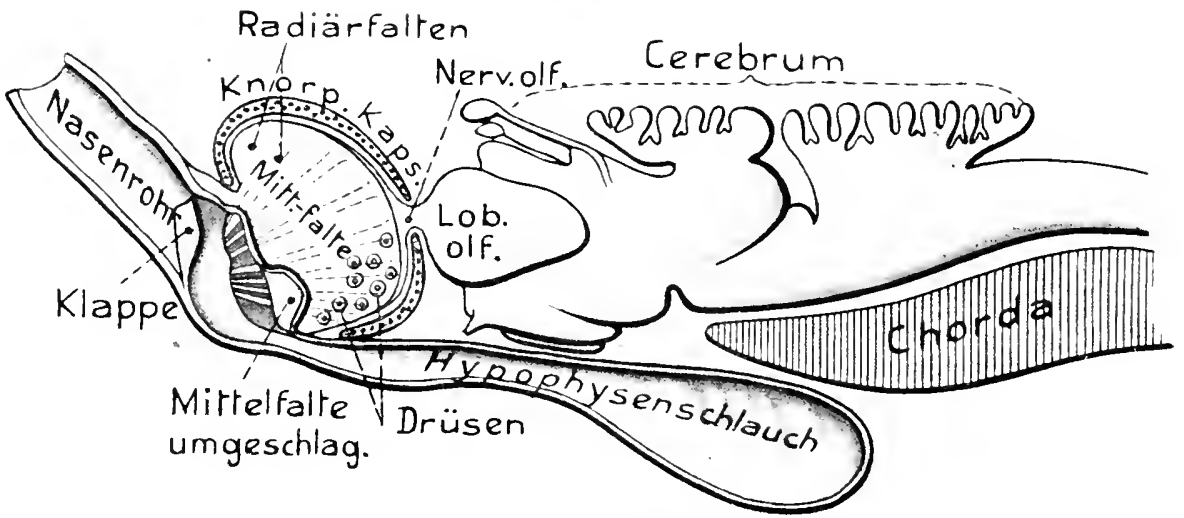

Tefromyzon fluviatilis. Tiseuorgan in nahezu medianem Sagitalschnitt von links geseluen. De! Riechsack et was linksieit io vou der mittleren Haupt falte get roffen, so daB diese in Flächenansieht zu selıen: ihr freier Rand ist unten efwas nmgeschagen. um Einsicht in die rechte Hälfte des Sacks mit seinen Rieehfalten zu gewähren die soweit sie dureh die ultelfalte verdeckt werden, in Strielulinien angedentet sind. Hiru und Chorda pingezelchmet. (Niclı Käsch 1877. PAkKk und Haswell, sowie eigenem Präparat.)

kapsel umschlossen, deren schon beim Schädelskelet gedacht wurde (s. Fig. 127 и. 28, S. 227 8). Sowohl die Ontogenie als der definitive Bau ergeben bei beiden Abteilungen, daß das fertige Nasenorgan eine parige Bildung ist, indem sich ans dem 
urspriinglich unpaaren Nasensäckchen zunïchst zwei laterodursale sekundäre Säcke hervorstïlpen, deren Wand hierauf durch sekundäre Ausstïlpungen eine erhebliche Zahl Längsfalten bildet, wodurch der parige Bau wieder etwas verwischt wird (Fig. 503, 14. 11. 504).

Die viel ansehnlichere Entwicklung der ursprünglichen Mittelfalte, welche die beiden primitiven Nasensäcke voneinander scheidet, namentlich aber der $\mathbf{J}$ mstand, daß diese beiden Sïke sich bei Petromyzon sowohl distal als proximal ïber die Linmündungsstelle in das Nasenrohr vorstiilpen, so daß hier die sekundïren Säcke zu abgeschlossenen Ausstiilpungen werden, macht die parige Bilimg deutlich. - Sinnes- und Wimperepithel findet sich nur in Innern der sekundären Sïcke. Drüsige, follikelartige Gebilde treten bei Petromyzon am (irunde der Nasensïcle anf.

Im Gegensatz zu den Petromyzonten liegt die Nasenöftnung der Myrinoiden am vorderen Körperende dicht über der Mundöftnnng (Fig. 503, 2), womit wohl zusammenhängt, daß hier die Nasenröhre lang röhrenförmig ausgezogen ist und der eigentliche Nasensack etwa in der Mitte des ganzen Organs liegt. Er bildet hier nur eine relativ mäßige Anschwellung der Röhre. Die Ontogenie (Bdcllostoma) verrät ebentills, daß urspriüglich zwei Nasensäcke aus der unpaaren Anlage hervorgestülpt werden; im erwachsenen Zustand ist dies wenig deutlich. Die Dorsalwand des Nasensacks bildet eine mäßige Zahl von Längsfalten und enthält ein Knorpelgeriist, während die Wand des Vorraums von zahlreichen Knorpelringen gestiitzt wird; anch bei Petromyzon enthält seine Wand Knorpel. Die mit einer Klappe versehene Mündung des Nasengaumengangs in den Schlund liegt dicht am Vorderende des sog. Velums.

Daß der Nasensack der Cyclostomen aus einer unpaaren Anlage in eine paarige übergeht, wird anch durch die paarigen Nervi olfactorii (\$. 565) bestätigt. Das ontogenetisch roribergehende Vorkommen eines unparen Nervs hat sich nicht bestïtigt.

Die nitgeteilten Ergebnisse machen es wahrscheinlich, daß die nnpare Geruchsgrnbe der Acranier, die Nasensücke der Cyclostomen und die paarigen Nasenorgane der Griathostomen homologe Gebilde sind. Sehr schwierig erscheint dagegen die Beurteilung des Hypophysenschlauchs. Die Verbindung des Nasenorgans mit letzterem trug jedenfalts wesentlich dazu bei. ৯aß seine parige Bildung zurücktritt. Iläntig wurde der Hypophysenschlaneh mit

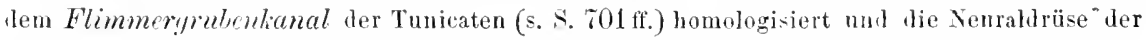
letzteren der ejgentlirhen Iypophyse vergliclsen. Da jedorh die beiderlei orgaue der Tunicaten wenigsteus in ihrem Ilauptteil aus dem Neuralrohr selbst herrorgeheu, so können sie schwerlich mit dem Hypophysenschlanch der Cyclostomen identifiziert werden. Ob sich bei den Leranjerı etwas mit ihnen Vergleirhbares findet, soll später bei der Iundhöhle erörtert werden. Wahrscheinlich dürfte es sein, daß die Entwicklung und das spätere Verhalten les burtus narpharyngens der llyxinoiden die primitivere Bildung darstellt.

Gnathostomen. Die höheren Wirbeltiere unterscheiden sich durch die stets sclarf ausgeprägte Paarigkeit ihrer Nasenorgane (Amphirhinie) von den Acraniern und Cyclostomen (Monorhinie). Dic Organe treten schon embryonal fast stets als parige Riechplatten am vorderen Kopfende anf, rechts und links vom ehemaligen Neuroporus. 
Immerhin wurde bei gewissen Fischen (Spinax, Polypterus) eine umpare Riechplatte gefunden, aus der durch seitliclie Verdickungen erst lie parigen Anlagen entstehen, weshalb deren Iterleitung aus ursprünglicher Nonorhinie durch Vermittlung cyclostomenartiger Zustände nicht unmöglich scheint. Vielleicht läßt sich damit anch die Verbindung łer Nasengrubenanlagen ron Ceratodus durch eine Querfurche in Zusammenhang bringen. Iab die parige Sonderung der Organe bei den Erwachsenen auch eine ontogenetisch doppelte Anlage hervorrufen konnte, und daß die Nervi olfactorii paarig wurden, ist unschwer begreiflich; schon bei den Cyclostomen ist die Paarigkeit der Riechnerven verständlich, ja notwendig, da ihre Fasern ron den Riechzellen entspringen und diese auf die beiden Riechsïrke verteilt sind, was die Paarigkeit der Nerren herrorrufen mußte. - Die gelegentlich versnchte IJomologisierung der parigen Geruchsorgane mit einer vordersten Kiemenspalte wurde bald rerlassen; dagegen wird ihre Vergleichung nit einer der früher bei den IIirnnerven bescbriebenen Placoden (s. S. 624), ja sogar der Augenlinse, die häufig gleichfalls als eine epibranchiale Placode angesprochen wim, noch vielfach festgehalten. Daß aber eine Bezielnung der Nasen- unl Ohrgrube zur linsengrube bestehe, ist doch recht unwalırscheinlich, la die Linse zweifellos ein Organ ist, las sich selbstindig im Dienste der paarigen Angen entwickelte.

Ein weiterer Charakter aller Gnathostomen ist ferner, daß die Geruchsorgane keine Beziehung mehr zu einem Hypophysenschlauch oder der Hypophyse besitzen.

Nur in der Ontogenie von Acipenser un der Amplibien finden sich eigentïmliche Verhätnisse, indem hier die Ilypophyseneinstülpung auf her Horsalseite des Kopfes dicht an Neuroporus entsteht und, ähnlich dem Ilypophysenschlauch ron Petromyzon, um das Vorderhim ventralwärts herumgreift. um durch eine Öffnum in den Vorderdarm zn münden. Nur dieser hintere Teil des Schlauchs bleibt erhalten und wird unter Alschnürung vom Darm zur Iypophyse. Diese ihnhichkeit mit den Cychostomen liefje sich, wie schon s. 566 bemerkt, so reuten, haß sich bei den Gnathostomen mur der hintere, zur Hypophyse werdende Teil des Iypophysenschlituchs der Cyclostomen erhält und daher die Ausstiilpungsöfrnung der llypophyse bei ihnen der Einmändungstelle in den Darm bei Myxinoiden entspräche; doch stelıt dem entgegen, daß die Hypophyse der Gnathostomen sich stets aus dem Etoderm des späteren Mundhöhlendaches cntwickelt. - Jedenfalls mus ahes der Ilypophysenschlauch bei den Gnathostomen seine Verbindung mit den parig auseinamlergetretenen Nasenorganen aufgegetren haben, was sich aus dem erwähnten Vorgang in gewissem Grade erklären ließe.

Die Geruchsorgane der Fische behar'en auf einer primitiven Entwicklungsstufe, indem sich die liechplatten einfach zu einer Riechgrube vertiefen, welche nur in gewissen Fällen und auf besondere Weise eine Verbindung mit der Mundhöhle erlangen kamm. Die anfünglich etwas lateral, zwischen den Angen und der vorderen Kopfspitze, anftretenden Organe verlagem sich bei fast allen Chondropterygiern und den Dipnoi danernd anf die Ventralseite der Schnauze vor den Mund, was wohl in Rïicksieht auf die Cyclostomenentwicklung einen ursprünglichen Zustand darstellt. - Bei Ganoiden und Teleostrem rïcken sie dagegen aus der ursprïnglichen Lage auf die dorsale Schnanzentiiche (nur bei den fossilen Ganoiden Ostcolepidue seheinen sie ventral verblieben zn sein). - Wie schon früler (S. 225) erörtert wurde, bildet sieh um jede Riechgrube eine Knorpelkapsel, die sich mit der ethmoidalen Sehïdelregion vereinigt, so daB die Riechorgane in Gruben oder Kapseln des Primordialeraniums eingelagert und bei den 'Teleosteern von Knochen mehr oder' weniger geschïtzt werden; sie liegen hier in der Regel etwa zwischen den Nasalia und den Pleuroethmoidea. 
Die Gernehsorgane der (Hondropterygier nud Dipmos\% bieten besonderes Interesse, weil sie die nïchsten Beziehnngen zu denen der Tetrapoden zeigen. Wie homerkt, liegen sie bei den Chondropterygiern fast stets anf der Ventraltliche der Schnanze, in geringer oder ansehnTieherer Entfermung vor dem queren Mnnd (Fig. 505, 2a, 3). Wenn letzterer, wie bei den Holocephalen (Fig. 505, I) und Chlmmydosflache, an das Forderende der Sehnauze riickt (oder letztere nur wenig iiluer den Mund vorspringt), so liegen die Organe ebenfalls rom, dicht iiber dem Mund und sind bei den Irolo-

Fir. 505.

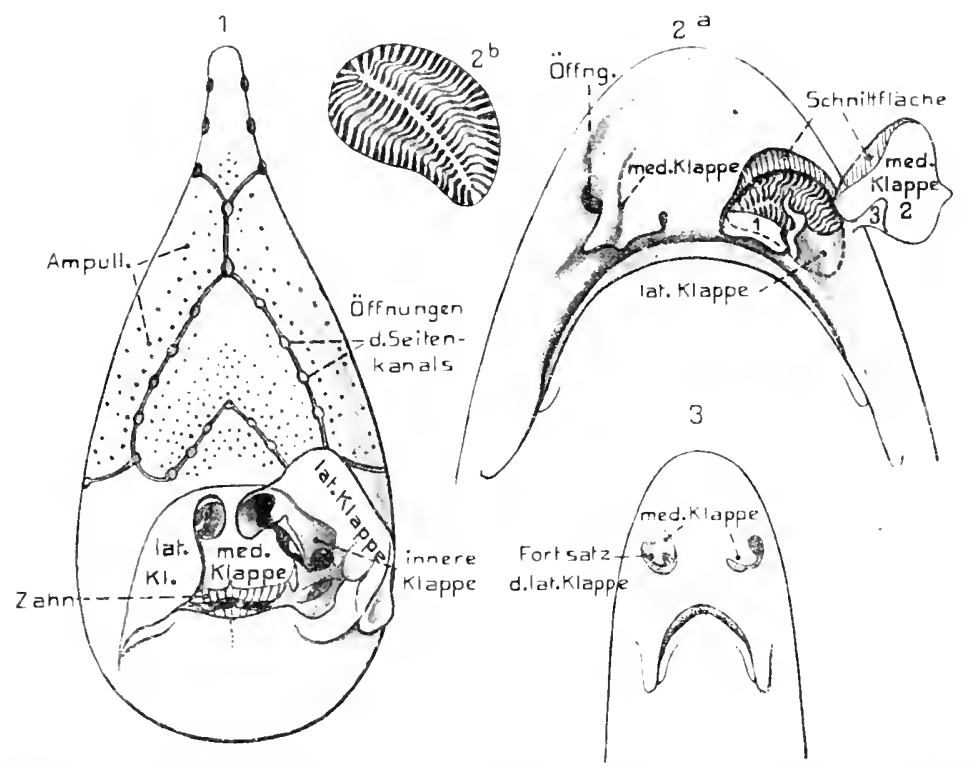

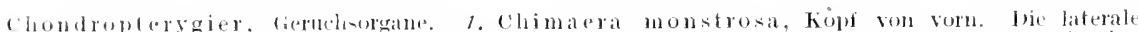

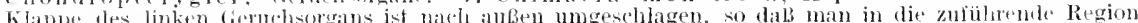

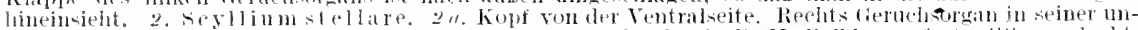
veranderten lieschaffenheit, der Eingang in die Nasengrube dureh die Hedialklappe fast roblig vertleckt. - Links die Medialklapoe innen und vorn abgeschnitten (schnilfliche schraflert) nnd nach an Ben um-

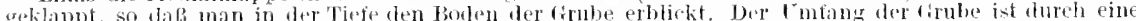
pmuktierte hinie angegeben. - 1) Klapuenartiger fortsitz am Oralrand der Nasengrube; 3! ähnlicher

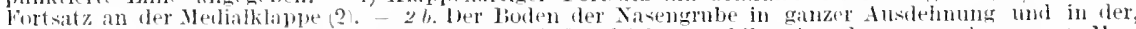

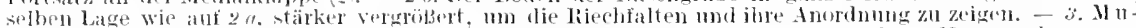

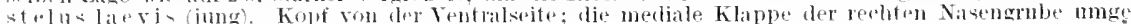
siblitgen.

1). 13 .

cephalrn nahe zusammengeriekt, wis an die Verhältuisse der Tetrapoden erinnert. Bei CHamydoselache sind sie, ähnlieh wie bei Ganoiden, dorsolateral versehoben. - Wenn die Nasengruben weit vor dem vorderen Mundrand liegen (zahlreiche Haie, z. B. Mustelus, Fig. 505, 3), so zeigen sie keinerlei Beziehungen zum Mund; wenn sie dagegen Ietzterem nahe riicken (viele Ilaie, Roehen, Holoeephala), so zieht von ihrer Mündung eine liinne gegen die Seiten des vorderen Mundrands und mehr oder weniger dentlich in die Mundhöhle hinein (Fig. 505, 2a). Die Nasengrube ist etwa quer bis sehief oval und ihre änBere Mündung stets mehr oder weniger vou einer ringfürmigen Hantfalte überdeckt, die sieh im Unkreis ihres Eingangs entwickelt. - Bei den Chondropterygiern vergrößert sich der mediane'Teil dieser Falte (Klappe) 
meist stark und legt sich lateralwärts klappenartig uiber den Naseneingang mehr oder weniger hinïber. Wenn eine Nasenmundrinne vorhanden ist, so wachsen die beiden Medianlappen zusammenhängend gegen den vorderen Mundrand ans (Fig. 505,1,2a), so daß ihre Seitenteile die Rinnen überdecken. Diese Lappen erinnern dann lebhaft an den später zu beschreibenden Stirnnasenfortsatz der Amnioten (vgl. Fig. 514, S. 717).

Auch eine laterale Nasenklappe entwickelt sich bei den Chondropterygiern mehr oder weniger und wird zuweilen ziemlich kompliziert. Bei Chimaera (Fig. 505,1), mit ihren dicht zusammengerïckten Nasengruben ist diese laterale Klappe groß und kompliziert; sie legt sich medianwärts ïber die mittlere, so daß diė Nasenrinne durch

Fig. 506 .

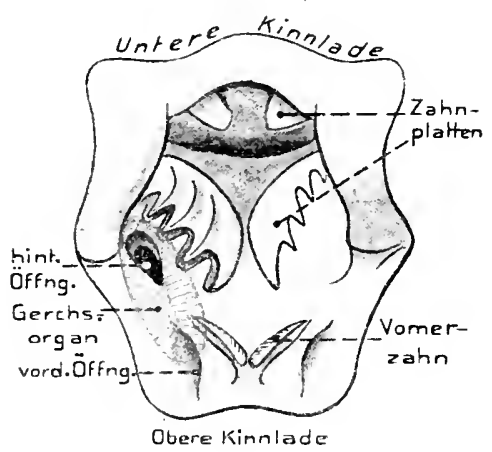

Ceratodus Forsteri. Tie Unterkinnlade aufgehohen, so daß man von vorn unc etwas veniral in das geöffnete Mranl sieht, auf dessen vorderer Dachregion sich die beiden ötînungen der Geruchsorgante finden. Das linke Geruchsorgan ist rot eingezeichnet. Orig. 0.13 sie noch mehr abgeschlossen wird und gleichzeitig viel tiefer in die Mundhöhle hineinführt. Die erwiihnten Klappenbildungen kömuen besondere Knorpel entlialten, sowie eine eigene Muskulatur besitzen.

An jene Verhältnisse der Chondropterygier schließen sich die der Iripnocr an. Die ursprïnglich diclit vor der Mundanlage anf der ventralen Schmanzenfliiche liegenden Anlagen der Nasengruben rücken spïter nach hinten an das Dach der Mnndhöhle selbst, wobei sich längs der Mittelregion der rimnenförmigen Grube jederseits eine Hantfalte entwickelt, durch deren Verwachsung der Grubeneingang in

eine vordere Öffinung, die an der Ventralfläche der Oberlippe liegt, und eine hintere am Dach der Nundhöhle, etwas vor dem Palatopterygoid gelegene, geschieden wird (Fig. 506). Daß diese verwachsenden Falten den Klappen der Chondropterygier entsprechen, ist wohl sicher; andererseits zeigen jedoch die Dipnoer anch Anschlïsse an die Ganoiden und Telcostcer.

Wie bemerkt, sind bei beiden letzteren Gruppen die Nasengruben auf die Dorsalseite der Schnauze in die Ethmoidalregion geriickt und ihre Mündung ist, wie die der Dipnoer, fast immer durch eine mittlere IIantbriicke in zwei Öftnnngen gesondert, eine vordere und eine hintere, von welchen die erstere zum Ein-, die letztere zum Austritt des Wassers dient. Nur einigen Pharyngognathen, Scomberesocilen, sowie Gasterosteus, fehlt diese Einrichtnng: sie haben nur eine einzige Nasenöfinung. Da die Nasengruben häufig lïngsoval bis sogar röhrenförmig werden, so liegen die beiden öff̈nungen hintereinander, und zwar bei verschiedenen Formen in recht verschiedener Entfernung, teils dicht beieinander (z. B. Acipenser, Salmo Fig. 508, Gadus Fig. 507 und viele andere), bis anch sehr weit entfernt, d. h. die vordere dann dicht an dor'salen Mundrand, die hintere vor bis oberhalb des Anges (z. B. bei Polypterus, den Apoden Fig. 507 nsw.; bei gewissen Aporlen kann die 
lintere Öffinung in die Oberlippe gerüekt sein, ja sogar in die Mundhöhle münden). — Wenn die Öffnungen weit auseinander gerïckt sind, so liegen sie an den beiden Enden der röhrenförmig verlängerten Grube oder riehtiger Höhle; wenn sie dicht stehen etwa ïber der mittleren Region der Grube (Fig. 507). - Die (iffmungen kömmen mit Hautfortsätzen versehen sein, ja sieh sogar röhrenförmig erheben, entweder nur die vordere (z. B. Anableps) oder beide (Apoden, Fig. 507). Vordere und hintere Öfnnung sind manehmal reeht verschieden gebaut.

bie frühere Innahme, laß bei der dorsalen Verlagerung der Nasengrube eine Imkehr jhres Vorder- und Ilinterendes eintrete, so daß die vordere örnung dann der ursprünglich hinteren entspreche, hat sich nicht bestätigt; die Ansicht. daß die hintere Öffıung der iußeren Nasenölinung der Tetrapolen entspräche, die rordere der Choant ist daher auch unrichtig.

Der feinere Bau der Nasengruben erinnert an die Verhältnisse der Cyclostomen, indem sich der Grubenboden

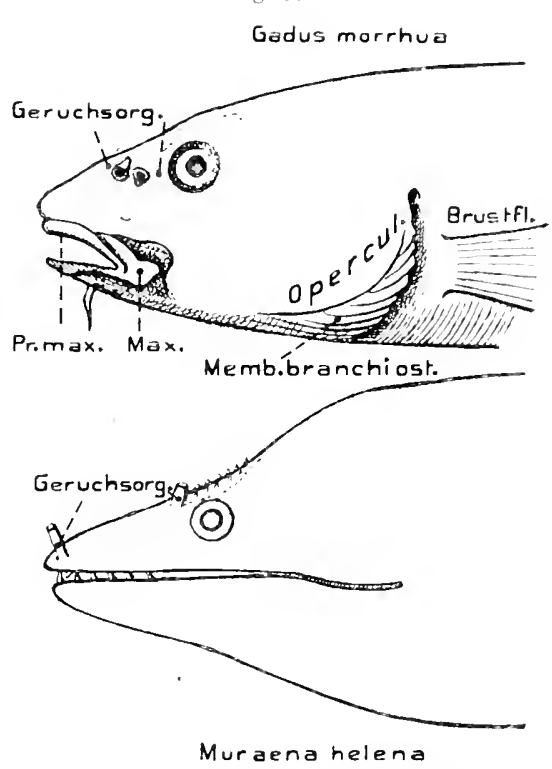

vorderende von Gadus morthua und Muraena helena von links mit rot eingezeichnetem Geruchsorgan. Orig. O. B. stets in eine Anzahl Sehleimhantfalten (Schneidersehe Falten) erhebt, die sich in sehr verschiedener Zahl, bei lang röhrenförmigen Gruben gewisser Teleosteer namentlich in sehr großer, finden können (besonders Apoden, weniger Solea, Situroiden). Diese, nur in seltenen Ausnahmefällen verkïmmerten Falten (Fig. 505, 2b, $506-508$ ) stehen in jeder Grube meist quer zu einem vom Boden anfsteigenden mittleren Lïngsseptum (das selten mehr quer gerichtet ist), so daß das Septum gefiedert erscheint. Bei den Teleosteern reicht das Septum vorn in der Regel

Fig. 508 .

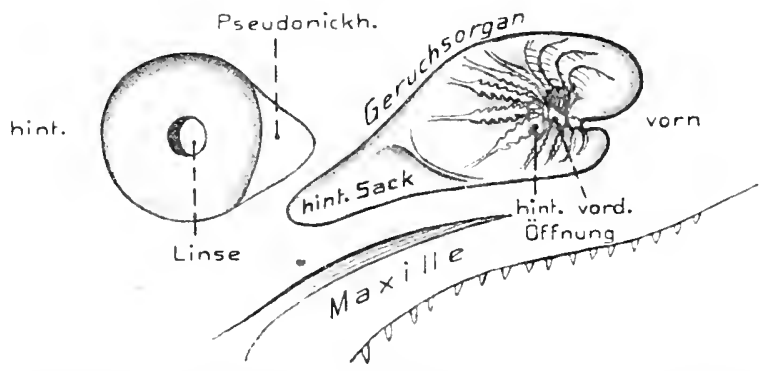

Salmo salar (lachs). Rechtes Geruchsorgan und Auge in seithcher Ansieht. Von dem Geruehsorgan jst die äuBere Decke in ganzer Ausdehnung entfernt, um den Bau des Bodens zu zeigen; die beiden ofinungen sind rot eingezeichnet. Orig. 0 . 13.

bis zu der oralen Lippe der vorderen öffnung und steigt hier häutig senkreeht empor. Wenn die Grube rundlich wird, so verkürzt sich das Längsseptum stark, so daß die Falten eine mehr radiaire Anordnung erlangen z. B. Esox, Cottus u. a.). 
Die Falten können sieh dureh Entwieklung sekundärer fiederartiger Fältchen komplizieren und sind häufig noch dadureh ansgezeiehnet, daß sich ihr mittlerer 'Teil stärker erhebt, wodurch jederseits vom Septum eine Art Längswnlst entstelit (Fig. 505, 2b). Das Wimper- und Riechepithel findet sich wie bei den Cyclostomen anf den Seitenflichen der Falten.

Bei nicht wenigen Kinochentischen kann sich die Nasengrube kouplizieren, indem ihr hinterer 'Teil nach vorn oder gegen das Auge nach hinten (Salmo, Clupea u. a.) in einen faltenlosen, häufig recht ansehnlichen, accessorischen Blindsack auswächst (Fig. 508), oder gleichzeitig in einen dorsalen und ventralen (die meisten Acanthopterygii, Clupca u. a.). Diese Säcke sollen bei gewissen Formen Schleim absondern (z. B. Pleuronectiden), in vielen Fällen aber durch Erweiterung und Verengerung bei den Mundbewegungen zum Ein- und Ausströmen des Wassers der Nasenorgane beitragen. - Daß die Nasen der Fische die Witterung der Nahrung vermitteh, wurle für gewisse Haie und Teleosteer erwiesen; doch wirl es anch für zahlreiche gelengnet. Wahrscheislich dïrfte es sich hesonders um eine Prüfung des Atemwassers hanleln.

Trtraporla. Die Beziehungen der (ieruchsorgane znr Mundhöhle, die wir sehon bei den Dipnoi, aler auch in eigentïmlicher Ausbildung bei vielen Chondropterygiern finden, setzte sich auf die Tetrapoden fort und bewirkte hier, daß die Riechorgane allmälllich eine wiehtige Bedentung fïr die Respiration erlangten, indem sie bei gesehlossenem Maul die Zufulir von Wasser in die Mundhöhle zu den Kiemen oder von Luft zu den Lungen ermöglichen. Überall finden wir daher eine äußere Öffuung jedes Organs (Apertura externa, Narina) und eine innere (Apertura interna oder Choane), welche in die Mundhöhle führt. Ontogenetisch bildet sieh dieser Zustand in ähnlicher Weise wie bei den erwähnten Fischen, indem sich am hinteren Rand der ursprüngliehen Nasengruben eine linne bildet, die bis zum Mundhöhlendach führt. Indem sieh die Ränder dieser linne in ihrer mittleren Region schließen, entstehen die beiden öffnungen, welche also denen der Fische homolog sind. Bei den Amnioten werden wir auf diese Verhältnisse noch näher eingehen.

Nur bei den Amphibien (und z. T, auch den Säugern) scheint der Lntwicklungsgang sekundär modifiziert, indem dje Rinne bei den Gymnophionen als eine solide Einfaltung des Ectoderms angelegt wird, welche sich erst später öffnet; bei den übrigen Amplibieı lagegen wächst die Nasengrubenanlage caudal aus und die Choanen brechen sekundär durch. Die Besonderheit, daß die Choanen der Urodelen und Anuren im Bereich des Entoderms 'ntstehen, nicht wie sonst in Jem des Ectoderms des Ilundhöhlendaches, ist wohl gleichfalls als sekundär zu beurteilen.

Eine gemeinsame Eigentümlichkeit der 'Tetrapoden ist ferner, daß die Trönennasenyänge in die Nasenhöhlen münden. - Die ursprünglieh selı einfaehen Organe komplizieren sich in der Tetrapodemreile bedentend, wie die folgende Besprechung ergeben wird.

Dic Organe der primiticen Amphibien (Ichthyoden, besonders Perennibran(thiaten) bleiben sehr einfach; ihre Narinen liegen seitlieh am Kopf in der Oberlippe (z. 'T'. sogar noch ventral gerichtet), während sich die Choanen ebenfalls noeh ziemlich weit vorn finden (speziell Proteus), so daß die etwa schlauch- 
artigen lïngsgerichteten Nasenhöhlen verhältnismäßig kurz bleiben (Fig. 509). Bei den übrigen Amphibien rïcken die Narinen auf der Dorsalseite der Schnanze nüher zusammen und die Choanen etwas weiter nach hinten; innen und hinten numrahmt von den Vomeres und den Palatina, anßen von den Maxillen. Die Ableitung von den VerhäItnissen der Dipnoer ergibt, daß das l)ach der etwa schlauchförmigen Nasenhröhlen urspriinglich mit Riechepithel, der Boden mit indifferentem Cylinderepithel bekleidet sein mußte. An die Narinen schließt sich bei den Aunphibien allgemein ein, je nach ihrer Lage, etwas schief nach innen anf- oder absteigendes Eingangsrohr (Atrium, $V_{\ell}$ stibulum) an, das jedeufalls dureh sekundïre Einsenkung entstand, dil es von geschichtetem Plattenepithel ansgekleidet wird. - Der Nasenschlanch erfährt im Laufe seiner Entwicklung eine Drehung um seine Längsachse, wodurch das ur-

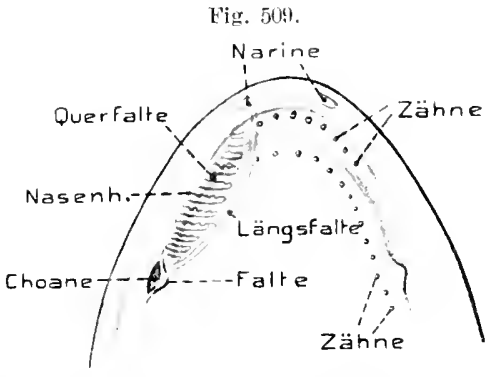

Necturus (Menobranchus kateralis). Gaumen dach von der Ventralseite gesehen; die rechte Nasenhöhle, sowie ilre Falten schematiseh rot eingezeichnet. (Original mit Benutzung v. Axtos 1912.) O. B.

spriingliche Dach mit dem Riechepithel die mediale, das indifferente Epithel die dorsolaterale Seite einnimmt. Auf dieser Stnfe verharrt etwa das Gernchsorgan von Proteus und Vecturus (Ienobranchns, Fig. 509) unter den Perennibranchiaten; doch breitet sich die Riechschleimhant hier zum Teil weiter ans, so daß sie bei Protens die mittlere Region des Nasensacks völlig auskleidet. Von der Riechschleimhaut erhebt sich eine lateroventrale Längsfalte, von der jederseits Querfalten ausgehen, die sich ringförmig verbinden und selbst wieder gefaltet sein können; in den so entstehenden vertieften Feldern finden sich die Riechzellen in Form von Riechlinospen (siehe später S. 733). In den Falten kann sich mehr oder weniger Knorpel entwickeln, so daß eine eigentïmliche, durchbrochene Knorpel-

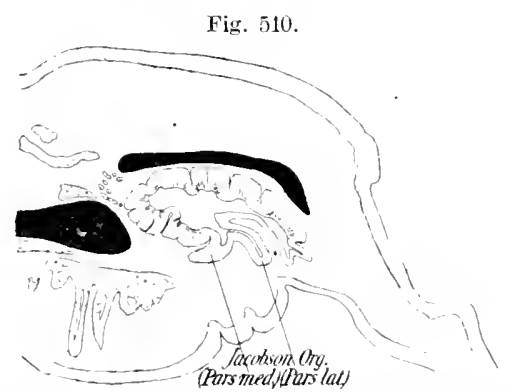

siren lacertina. Querschnitt hurch Nasenhöhle und Jacolisonsches Orgatn nach SEYDEL ISt5 aus GE(iENBAClt vergl. Anat.). kapsel entsteht. Die Gesamtbildung des Gernchsorgans der Proteiden erinnert daher noch an die der Dipnoer. - Bei der Perennibranchiate Siren erfihrt das Organ eine wesentliche Weiterentwicklung, indem sich etwa vom Boden der hinteren Hälfte des Nasensacks eine längsgerichtete sackförmige Ansstïlpung (unterer Blindsack, Jacobsonsthes Orgun) bildet, welche durch eine offene Rinne, die bis zur Choane nach hinten zieht, mit dem eigentlichen Nasensack (Haupthöhle) kommuniziert (Fig. 510). Das Vorderende dieser Ansstïlpung wächst etwas nach vorn ans, so daß es einen mit der Haupthöhle nicht mehr direkt zusammenhängenden vordersten Teil des Blindsacks darstellt. Da sich dieser nntere Blindsack etwa anf der 
medioventrilen Grenze des Riechepithels ausstiilpt, so erstreckt sich letzteres auch auf die Medialseite des Sacks. - Ein ähulicher unterer Blindsack tritt bei allen ïbrigen Amphibien anf und entwickelt sich ursprïnglich stets an ähnlicher Stelle, d. h. medioventral; wegen der oben erwähnten Drehung des Organs um seine Längsachse verschiebt sich jedoch die rinnenartige Ansstülpung des Blindsacks an den ventrolateralen Rand des Nasensacks, d. h. es ist eigentlich die ganze Zone des hier gelegenen indifferenten Epithels, die sich gegen den Oberkieferrand ausstiilpt.

Auf diese Weise entsteht bei den Sulamandiznen (ähnlich jedoch auch schon bei den Derotiemen unter den lchthyoden, speziell Cryptobianchus) eine ventro-

Fig. 511 .

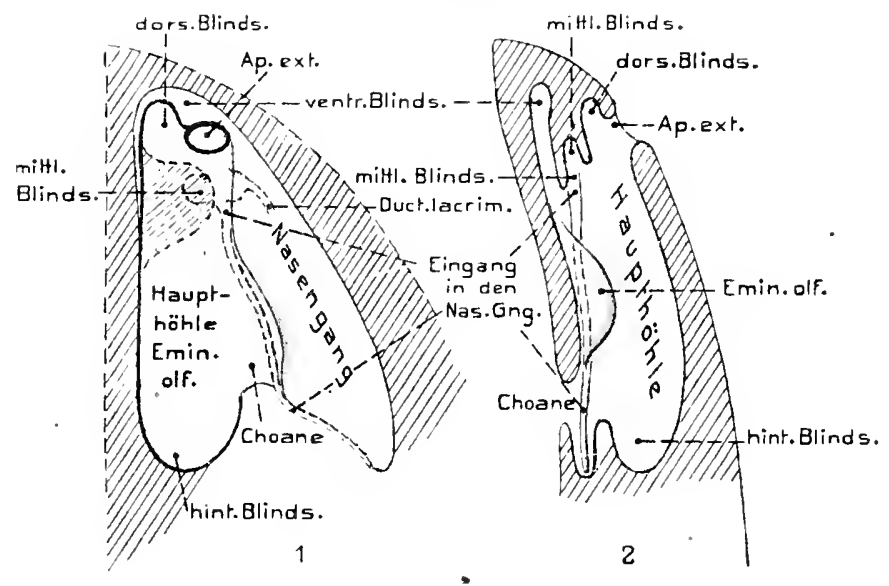

Rana. Schema der Nasenhöhle (nach den Querschnitten von SEYDEL und GAUPP konstruiert). - l. Ansicht von ler Dorsajseite. Der mittlere Blindsack, sowie der in ilın mündende Ductus lacrimalis durch Strichlinien angegeben, ebenso der enge spaltartige lingang in den seitlichen Nasengang. Die Verengelung der Nasenhöhle in ter legion des mitteren Bjindsacks ist fein schraffiert angedeutet. (Vgl. Fig. 512.) - 2. Mediane Ansicht. Die Verengerung in der vorhin erwähnten Gegend ist hier nicht angedentet.

laterale Rimne, die sich von der Narine bis zur Choane erstreckt, und nur selten (z. B. Siredon) in ihrer mittleren Region, wo sie anch Riechepithel führt. (das jedoch hier von dem der Haupthöhle völligo abgetrennt ist) eine blinde, nach vorn gerichtete Anssacknng bildet, ähnlich Siren. Die erwähnte Naseminne (seitlicher Naseng:ng) setzt sich jedoch bei den Salamandrinen anch auf der Lateralseite der Choane am Dach der Nundhöhle candalwärts noch eine gewisse Strecke fort, wo sie, ebenso wie die Choane, von einer an ihrem lateralen Rand vorspringenden II autfalte (Giamenfortsatz oder -falte) mehr oder weniger überdeckt wird. Letztere Bildung ist, wie wir spaiter finden werden, die erste Andentung des bei den Amnioten sich viel höher entwickelnden sekundïren Ganmendaches und der sekundären Choane. Die Schleimhautfalten der Perennibranchiaten haben sich bei den Derotremen noch im vorderen Teil der Nasenhöhle schwach erhalten, doch finden sich außer der Längsfalte nur mediale Nebenfalten; den übrigen Amphibien fehlen sie. Gelegentlich wird angenommen, daß die Region der lateralen Neben- 
falten von Proteus bei den übrigen Amphibien in die seitliche Nasenrinne oder das sog. Jacobsonsche Org:in iibergehe.

Viel komplizierter wird der Nasensack der tumen nnd sehließt sich näher an die Verhïltnisse von Siren an als an jene del Salamandrinen. Die, im Zusammenhang mit der Kopftorm, in ihrer Mittelregion sich stark verbreiternde und abtlachende Nasenhöhle (s. Schema Fig. 511) bildet zunächst an ihrer lateralen Ventralflïche einen sehr ansehnlichen unteren Blindsack, der sich seitlich gegen den Oberkiefer hinabsenkt (seitlicher Nasengang, s. Fig. 512). Er steht durch eine enge Nasenrinne, die sich nahezn von der Choane bis etwa an die Narine erstreckt, mit der Haupthöhle in Verbindung, indem der Zusammenhang mit letzterer durch eine anf der Grenze zwischen beiden von der Dorsalwand heribsteigende Längsfalte eingeengt wird. Das Vorderende dieser Nasenrimue setzt sich jedoeh noch betrïichtlich iiber die vordere Grenze ihres Znsammenhangs mit der Hanpthöhle fort als eine voru blind geschlossene Aussackung (ventraler Blindsack im engeren Sinne oder Jacobsonsches Organ, s. Fig. 511-12. Diese Aussackung trïgt anf ihrel vorderen mediodorsalen Wand Riechlig. 512.

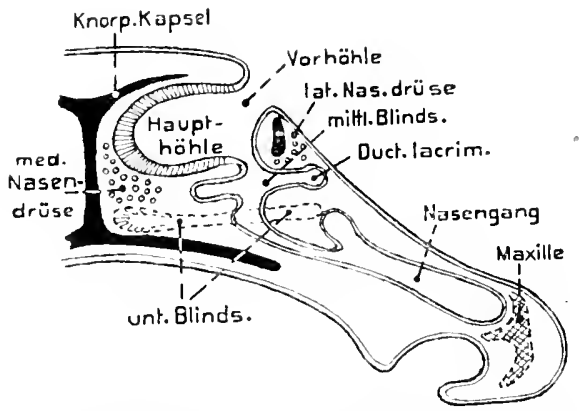

Ra na. Querschnilt durch die rechte $\mathrm{N}$ ase n höhle in (ler Region des mittleren Blindsacks und der Narine; der davor getegene ventrale Blindsack ist in Strichlinien angerleutet; der seitliche Nasengang, der sich erst weiter hinter so ansehnlich entwickelt, mit eingezeichnet. Knorpel seliwarz; Knochen gekreuzt schraffiert. epithel. Die vorderste Region des Verbindungsschlitzes zwisehen dem ventralen Blindsack und der Haupthöhle erweitert sich medial und etwas lateral und springt gleichfalls nach vorn blindsackartig vor (mittlerer Blindsack). Im letzteren miindet lateral der Tränennasengang, • der bei den Salamandrinen etwa in die mittlere Region der lateralen Nasenrinne, bei Siren etwas vor dem unteren Blindsack lateral einmündet (den Ichthyoden fehlt er zum 'Teil, so Proteus, Necturus und Cryptobranchus). Das vorderste Ende der Haupthöhle der Anuren springt blindsackartig in die Schnanzenregion vor die Narine vor (dorsaler Blindsack), so daß in dieser Gegend drei Blindsäcke ïbereinander liegen. Anf mancherlei sekundïre Aussackungen dieser vorderen Region der Nasenböhle, sowie auf die sehr komplizierte knorplige Nasenkapsel, kanı nicht eingegangen werden.

Die Gymnophionen (Fig. 513) zeigen eigenartige Verhältnisse, iudem der untere Blindsack (Jacobsonsches Organ), der als rinnenartige Aussackung angelegit wird, sich von vorn nach hinten fortschreitend, vom Boden der Haupthöhle ablöst und nur noch etwas vor der Choane oder an deren Nedialrand in die Nasenhöhle mïndet, also von letzterer fast völlig isoliert wurde. Der Ductus lacrimalis mündet vorn in die Lateralseite des unteren Blindsacks, was ja ans seiner Einmündung bei den,übrigen Anphibien verständlich wird. Tom Boden der 
Hanpthöhle erhebt sich ẻin Läugswulst, der sie in einen medialen und lateralen Teil sondert. Diese Bildung entspricht wohl der bei den Anuren schwach entwickelten Eminentia olfactoria (s. Fig. 511).

Eine ans zahlreichen Schläuchen bestehende Drïse mündet bei den Amphibien in den unteren Plindsack, den sie medial und ventral nmlagert; sie wird als antere Nasendriise oder Jacobsonsshe Drïse (auch Glandula nasalis medialis, Fig. 512 u. 513) bezeichnet. -

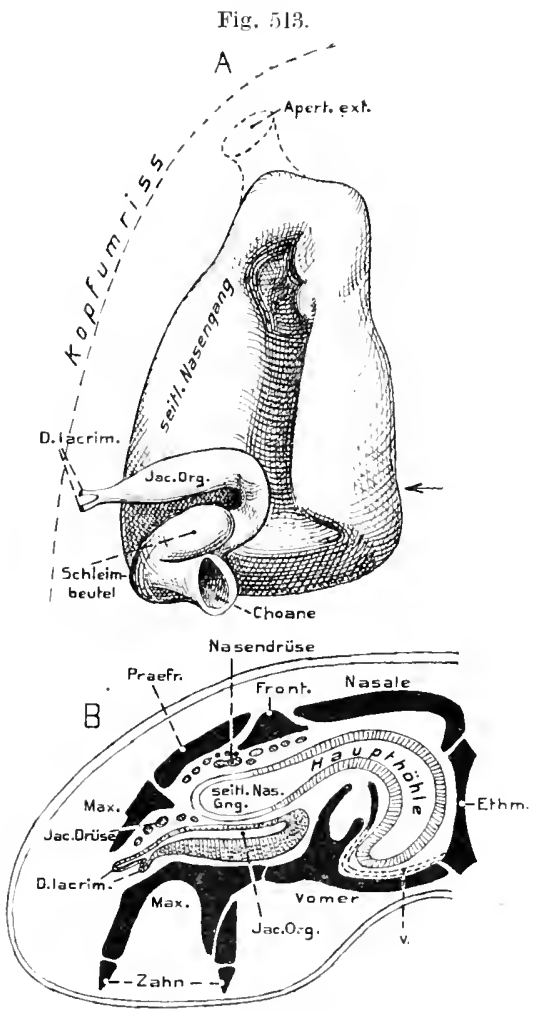

I chthyophis glutinosus. Nasenhöhle nit Jatobsonschem Organ. - 1 Rekonstruktion der rechten Nasenhöhle nach Schnitten: Ansicht von der Ventralseite in den Kopfumriß eingezeichnet. - I Querschnit durch die linke Kopftälfte in der Gegenil tes Pfeils in Fig. 1. Die Verbindung $(r$.) des Entlreils les Lateralflügels des lithmoids mit dem mittleren Teil ist in strichlinien angerleutet. Riechepithel schraffiert; Knochen schwarz (nach SARAsix 1 șt? 90 etwals verändtert). O.B.
Bei den Ammen und manchen Urodelen finctet sich ferner eine tubulöse Glandula nasalis externa (auch vordere oder laterale Nasendrüse), die auf der Grenze zwischen Vestibulum und Haupthöhle mündet (s. Fig. 512$)$.

Amniota. Das Geruchsorgan der Amnioten entwickelt sich im allgemeinen ursprïnglicher als das der Amphibien, wobei recht auffallende Anklainge an den fertigen Zustand gewisser Fische anftreten. Die primitiven Nasengruben, welche ursprünglich lateral liegen, riicken bald mehr an das Vorderende (Fig. 514), indem sich zwischen ihnen ein gegen die Mundanlage herabsteigender Lappen (Stirmasenfortsatz) bildet, dessen laterale Ränder direkte Fortsetzungen des die Nasengruben nmziehenden Wulstes sind. Gleichzeitig wachsen die beiden Oberkieferfortsätze rechts und links hervor, welche später die Seitenwände der Mundhöhle bilden. Zwischen dem Stirn- und jedem der Oberkieferfortsätze bildet sich so eine von der Nasengrube absteigende Rinne, die Nasenrinne, die an das Mundhöhlendach umbiegt. Indem schließlich der Stirmnasen- und dic (berkieferfortsätze jederseits und

untereinander verwachsen, bihlen sich die Nasenhöhlen mit iuferer und innerer Öffinung, welche durch den sogenannten primären Gaumen von der Mundhöhle gesondert werden. Demnach vollzieht sich die Entwicklung ganz so, wie es die vergleichende Anatomie der Nasenorgane der Fische erwarten lieB; ja, wem wir z. B. die fertigen (1ranane von Chimaera (s. Fig. 505, 1, S. 709) mit Fig. 514 vergleichen, so eriunern sic geradezu auffallend an dies Entwicklungsstadium der Amnioten. Die schon bei gewissen Amphibien aufgetretene,Verlängerung der pri- 
mirren Cloamen in candaler Richtnng vermittels einer linne und einer hingsfalte des seitliehen Mundhöllendaches (Ganmenfalte oder-fortsatz) tritt bei den Imnioten gewöhulich viel stärker hervor nnd führt endlich, indem diese Falten in der Mittellinie miteinander verwachsen können, zn einer röhrenfömigen, nehr oder wenign ansehnlichen eaudalen Verlängerung (Dnetus nasopharyngeus) der primären Nasenhöhlen, sowie zur Bildung sekundärer Choanen nnd eines sekundïren Ganmens.

Reptilia. Die Nasenhöhlen der lieptilien sind im allgemeinen geräumiger als jene der Amphibien, was mit der Gesamtform der Schnanze harmoniert, welche bedentend höher wird (Squamata, Cheloniae), wobei sich anch die Nasenhöhle dorsal sturker erhebt. Bei den Crocodilen (Fig. 517, S. 718) mit ihrer stark verlängerten Schnauze wird die Nasenhöhle

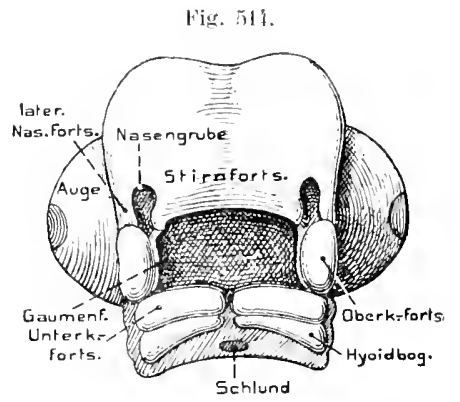

Hown. Embryokout von vorn man a len Lehrlitchern von KïLIKER UmI 0 . HERTWit:. zwar sehr lang, bleibt aber wegen Abplattung der Sehnanze niedrig. - Die primären Choanen fiuden sich an ähnlicher Stelle wie jene der Amphibien, d.h. zwisehen Vomer, l'alatinum und Maxillare. Die der Synamaten sind lang schlitzförmige Spalten, welche weit voru begimnen, da der primäre Nasenboden (primärer Ganmen sich stark verkürzt und sich gleichzeitig in die lig. 51 is.

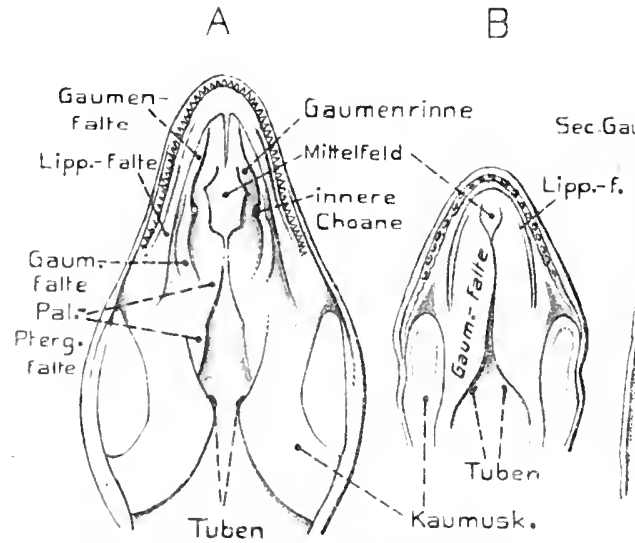

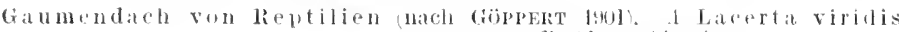
sper. - e lython tiuris.

\section{C}

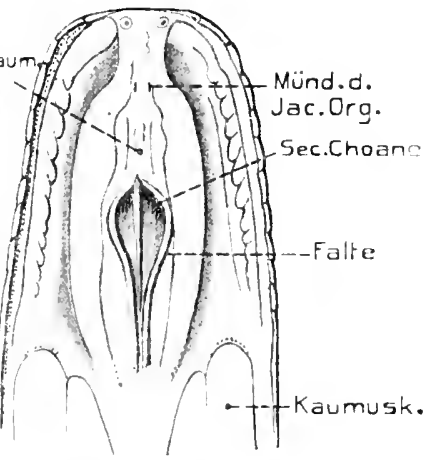

li Chathatelis U. I.

Mundhöhle herabsenkt. Dureh die an der Lateralseite der primären Choanen auftretenden Gaumenfalten, die meist weit naeh hinten ziehen (Fig. 515), wird eine seitliche Nasenrinne, gewissermaßen eine Fortsetzung der primären (inneren j Choancu gebildet, wobei letztere von diesen Falten stark überlagert werden. Die Nasenrinnen erinnern an die Fortsetzung der seitlichen Nasengänge der Amphibien, denen sie wohl anch entsprechen. Die Ausbildnng des Jacobsonsehen Organs bei den š́qu- 
maten, das als eine imediale Ausstiilpung der Nasenhöhle, etwa am Vorderende der primären Choane entsteht (s. Fig. 520, S. 720), bewirkt eine Verändernng der letzteren, indem durch eine quere Hantfalte, welche etwa am Dorsalrand der Ein-

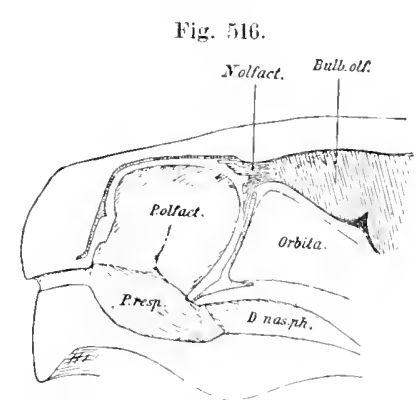

Testudo. bagittalseduitt durch den Vorlerkopi; lias Nasalseptum fortgenommen (aus GEGExBAtr, Tergl. Allatomie, nach SEYDEL IS!6). mündung des Jacohsonschen Organs in das Vorderende der Nasenrinne auftritt, dies Organ völlig von der Nasenhöhle abgetrennt wird, wobei sich gleichzeitig ein sekundärer Boden der Nasenhöhle bildet, welcher anf eine Strecke weit die primïre Choane gegen die Nasenrinne abschließt und so die primäre Choane verkiirzt. Die beiden Gaumenfalten der Saurier bilden, wem sie besonders lang werden und stark gegen die Mittellinie des Mundhöhlendachs vorspringen, zwischen sich eine Art Lüngsrinne, welche demnach die Andeutung eines Nasenrachengangs darstellt. Bei manchen Sauriern (Scincoiden, gewisse Chamaleoarten, Fig. $515 \mathrm{~B}$ sind die Gammenfalten in ihrem vorderen 'T'eil sogar so stark entwickelt, daß sie sich in der Mittellinie aneinanderlegen nnd, wemn auch ohne Verwachsung, einen Nasenrachengang formieren, Die Ophidier endlich

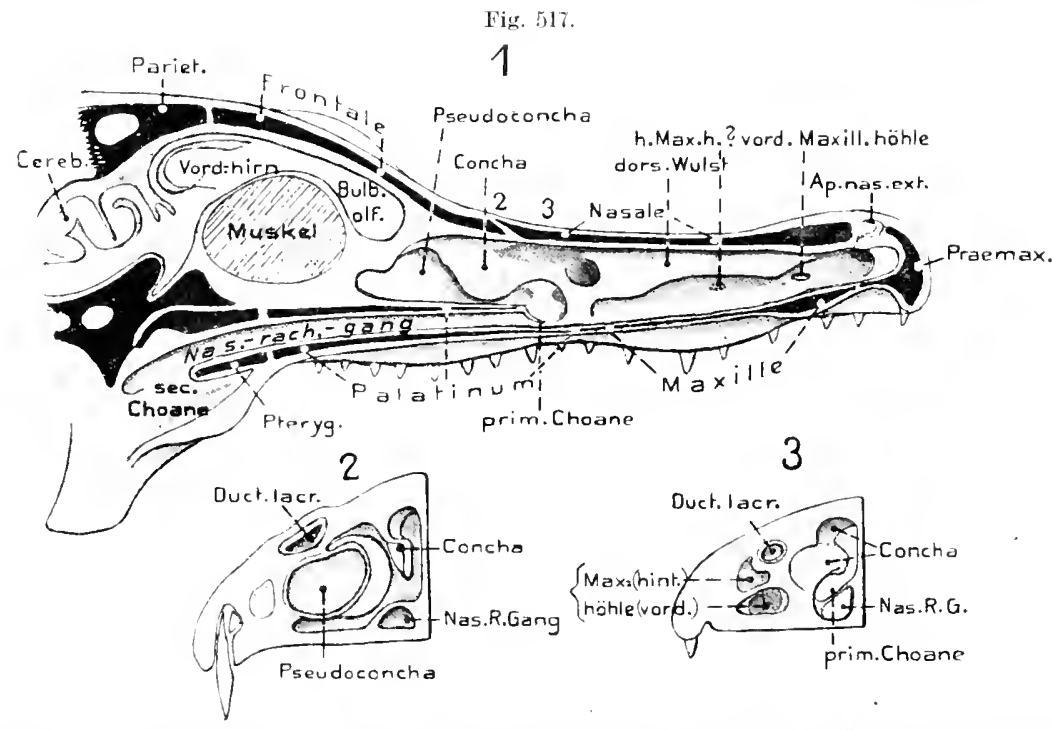

Alligator mississij)iensis. 1. Konf mexian halbiert, linke Hälite mit der Ansicht auf die Sclnnitt fläche. Knochen selıwar. - 2. und 3 . Zwei Querschnite durch die rechte Kopfluälfte in der Region? unil 3 inuf Fig. 1 ; Ansicht von vorn. Orig. O. 1;.

(Fig. 515 C) zeigen anf eine kurze Strecke eine Verwachsung der Vorderregion der Gaumenfalten, so daß ein kurzer Nasenrachengang und wirkliche sekundäre Choanen gebildet werden. Das Nasenseptum setzt sich durch diesen Ductus nasopharyngeus bis nahe an sein Hinterende fort. I er vor dem Dnetus gelegene Teil 
der Gaumenfilten verkümmert bei den (pphidiern und gewissen Sauriern stark, so daß die Nasenrinne vorn fehlt und die Jacohsonsehen (rgane weit vorn in der Gegend des Vorderendes der primären Choane, sowie des 1nctus lacrimalis direkt in die Mundhöhle führen (Fig. 515 (!).

Einen durch die Verwachsung der Gaumenfalten gebildeten Nasemachengang besitzen die Placoiden stets, doch bleibt er bei den Chetonicm Fig. 516) knrz, wird aber (wals anch bei Sauriern angedentet sein kanu) von ventral ahsteigendeu Lamellen der Palatina vorn knöchern nmhiillt (siehe Fig. 165, S. 287). Bei dieser Billung muß anch eine Stellungsänderung der primären ('hoanen eine liolle spielen, inlem die ventrale Region der Nasenhöhlen sich ventral vertiefte und die primairen Choanen daher eine mehr senkrechte Stellung zum Dach der Mundhöhle erlangten, wogegen sie bei den sqummaten durch einen ähnlichen Vorgang schief von vorn nach hinten anfsteigen.

Eine ganz auferordentliche Länge erreichen, wie frihler schon geschildert (S. 287), die luctus nasopharyngei der Cocolite, so daß die sekundïre Choane nahezu unter das Hinterhauptsloch, dicht an den

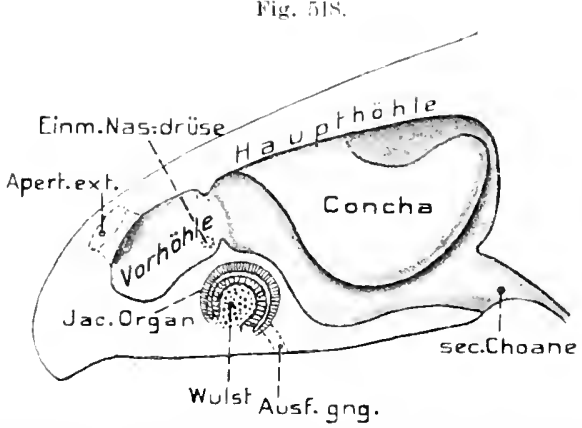

L, atcerta. Längsschnitt durch den Kopf; rechte Nasenhühle geiifnet und ron der Medianseite gesehen. Etwas schematisch. Narine nnil Ausfiilhrgang des Jacobsonschen Organs in Strichlinien angedentet nach LEYDIs 157 , etwas verändert). 1). 1 .

Fig. 51!

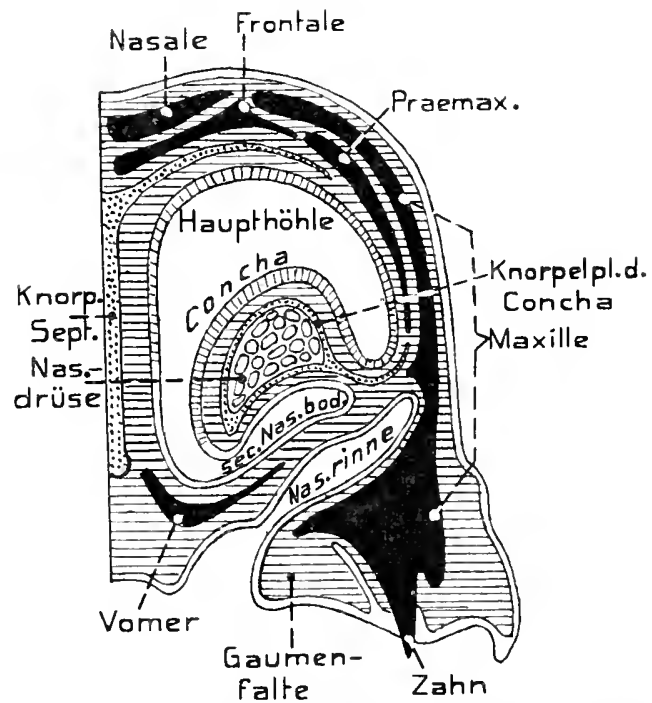

tacerta. Querschnitt durch die rechte sasenhöhte nach Bulix 1.47\%

(1. 1 .

Kehlkopf, verschoben wird (Fig. 517). Daß dieser Ductus der Crocodile eine paarige Bildung ist, nicht einfach, wie eigentlich zu erwarten, rührt daher, daß sich die Gaumenfalten bei ihrer Verwachsnng auch mit dem primären Gaumendach vereinigen und so ein den Ductus durchziehendes Septum bilden. Physiologisch hängt die Entwicklung des Ductus nasopharyngeus jedenfalls mit der Sicherung der Respiration bei geschlossenem Mumd zusammen.

Ein Nasenvorhof (Atrium), wie è schon dell Amphibien zukommt, ist bei - 
den Reptilien meist ansgel,ildet und tritt besonders hei den Samiorn (s. Fig. 518 und Schildliröten (Fig. 516) als engerer Anfangsteil der Nasenhöhle deutlich hervor, inden sich die anschließende Haupthöhle plötzlich stark erweitert. Den Srhlangen fehlt der Torhof und auch bei den Crocoliten nuterseheidet er sich nicht dentlich vou der Haupthöhle. Während sein vorderer Teil stets von Pflasterepithel ansgekleidet ist, kann der hintere anch Cylinderepithel besitzen. - Die Haupthöhle erweitert sich, wie bemerkt, meist stark dorsalwärts, doeh anch in seitlicher Richtnng und wird nach hinten allmählich höher. Ihr blind geschlossenes Hinterende erstreckt sich gew öhnlieh mehr oder weniger ïber die primäre Choane hinans. Besonders lang wird es bei den Crocodilen (Fig. 517), wo der hintere Teil

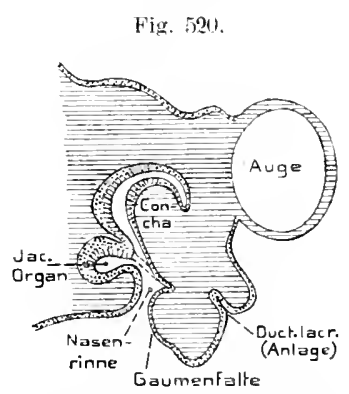

Lacertit. Embrys, Querschnitt clurch Nisenhöhle mit der Anlage des . Facobsonschen Organs, des Ductus lacrimalis usw. (nach BORX 187!!. O. B. der Hanpthöhle ïber den Nasenrachengang bis zur Vorderwand der eigentlichen Hirnkapsel reicht. Relativ klein bleibt dagegen meist die Hanpthöhle der Schildkröten.

Yon der Lateralwand der Hanpthöhle senkt sich ein ungefähr lamellenartiger, längsverlaufender Auswuehs in die Hanpthöhle hinab, die Muschel (Concha). Ls ist dies eine meln oder weniger gegen die Medialseite gekrïmmte Lamelle (Fig.518 u. 519), in welehe ein Fortsatz der Knorpelkapsel der Nasenhöhle eintritt. Gut ausgebildet ist die Muschel besonders bei den Srquamaten (Fig. 518), wo sie fast dureh die ganze Haupthöhle zieht. Bei den versehiedenen Formen weehselt ihre Gestalt ziemlich. Dureh ihr Vorspringen in die Nasenhöhle markieren sieh verschiedene Abteilnngen derselben mehr orler weniger selırf.

Die embryonale Anlage der Muschel tritt nicht als ein Einwuclss in die Nasenhöhle, sondem als eine lateralwärts gerichtete Krimmung der dorsalen Partie der IIaupthöhle auf (Fig. 520). Bei den Auphibien scheint die Andentung einer solchen Bildung, freilich olne knorpelige Einlagerung, schon durch the l.ängsfalte gegeben zu sein, welche namentlich bei den Anuren den seitlichen Nasengang von der Haupthühle abgrenzt.

Die Crocodile (Fig. 517) besitzen eine entsprechende Mnsehelbildnng (Hauptmuschel) in der mittleren Region der Nasenhöhle, etwa da, wo sich der Eingang in den Duetns nasopharyngens (prim. ('hoane) findet. Nach rorn setzt sie sich am bach der Nasenhöhle als ein flacher Vorsprung fort, der fast bis an die Narinen reicht. Etwas hinter und lateral von dieser Hanptmusehel wïlbt sich die Lateralwand der Nasenkapsel als ein musehelähnlieher Vorsprung in die Nasenhöhle hinein. Dieser Wulst (Preudoeoncha, Fig. 517,1-2) wurde häufig ebenfalls als Musehel beselrieben, namentlich deshalb, weil sich der Nervus olfactorius vorä̈glieh an ihm nud dem benachbarten Septum ausbreitet. Die Psendoconcha unterseheidet sich jedloeh wesentlich von der eigentlichen Muschel, indem sie dadureh gebildet wird, daß sieh in ihr ein anselnnlieher, vom Knorpel der Nasenkapsel nmschlossener luftführender Hohlranm (Sinus) findet, der in der Gegend der Hanptmuschel mit der Nasenhöhle kommuniziereu soll. 
Die Chelonier zeigen an Stelle der Muschel nur einen flachen wulstartigen Vorsprung in die Hanpthöhle, der nach voln in eine Falte ansläuft (Fig. 516). Ihre Haupthöhle bleibt relativ klein, besonders bei den Seescliildkröten, wo sie an ilurer Dorsalwand noch eine bis zwei blinde Aussackungen mit Riechepithel bebesitzt. Am Beginn der Hampthïhle findet sich bei den Seeschildkrïten eine ventrale Aussackung, auf die wir später zuriickkommen werden, da sie als Jacobsonsches Organ gedentet wurde.

Das Riechepithel breitet sich bei den Reptilien im allgemeinen an der dorsalen und medialen Wand der IIaupthöhle, sowie an der Muschel ans; auf die Verhïltnisse der Crocodile wurde soeben hingewiesen.

Größere Vasendräsen mit einheitlichen Auslührgängen stehen mit dem Vorhof in Verbindung oder münden, wo dieser fehlt (Ophidia), an ten Narinen aus. Eine Glandula nasalis cxterna (lateralis, auch obere genannt) ist bei Squamaten und Cheloniern ansehnlich entwickelt und lagert sich bei den ersteren meist in die Nuschel ein (Fig. 519). l)ie Chelonier besitzen gewöhnlich noch eine Glandula medialis (auch untere genannt), die rorn in der Gegend des sog. Jacobsonsclien Organs mündet. - Bei den Crocorlilen, wo die VerhäItnisse, besonders im erwachsenen Zustand, noch etwas unsicher sind, scheint nur eine Drüse vorhanden zu sein, die nach der Ausmündung am Septum, dicht bei den Narinen, sowie ihrer Lage dorsal von der knorpligen Nasenkapsel, wobl der Gl. externa entsprechen dürfte. - Der Tränennasengang mündet bei den Crocodilen (Fig. 517, 2-3) etwa in der Vittelregion des vorderen muschelähnlichen Wulstes am Boden der Nasenböhle aus. l)agegen zeigen die Squamaten die Eigentümlichkeit, daß der Tränenkanal ursprünglich dicht neben dem Jacolsonschen Organ in die oben beschriebene Nasenrinne münlet, die hinten bis zur Choane fïhrt. liei dell Schlangen und gewissen Sauriern (Ascalaboten) erhält sich dieser Zustand, wogegen bei den übrigen die Einmündnug nach hinten auf die Choane verschoben ist. Die Tränendrüse hat daher im ersteren Fall ihre Beziehnng zur Nasenhöhle ganz aufgegeben.

Nebrnhöhlen der Nase, die wie bei den Vögehn und Süngern durch Ausstïlpung aus den Nasenhöhlen entstehen usd kein Riechepithel führen, simd bei den Crocodilen ansehnlich entwickelt, als zwei hintereinander in das Maxillare eingelagerte, langgestreckte Sinus (Fig. 51 5,3 ), von denen der vordere nahe dem Eingang der Nasenhöhle, der hintere etwas weiter candalwärts in die Yasenhöhle mündet. Die Saurier besitzen selten eine laterale Xebenliölle.

Trïgcl. Die Nasenhöhlen der Vögel schließen sich in mancher Ilinsicht denen der primitiveren Reptilien, speziell jenen der Saurier an, haben sich jedoch eigentïmlich kompliziert.

Fig. 5?

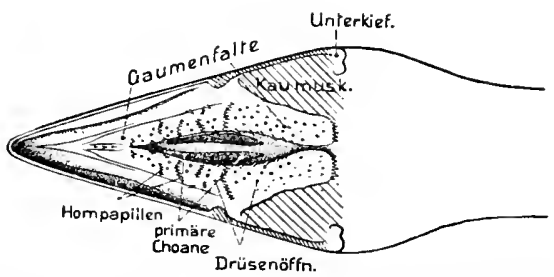

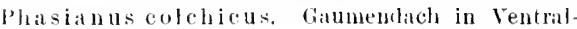
ansicht, die ciamenfilten etwas auseinaudergezogen, corlal b hie ('homen sichtbar sind.

()rig. v. Bil.

Primitiv erscheint namentlich, גaß kein gegen die Mundhöhle abgeschlossener Ductus nasopharyngeus besteht, sondern die Gaumenfalten die primäre Choane sowie die Nasenachenrinne nur überlagern, ohne in der Mittellinie zu verwachsen (s. Fig. 521). Der Mangel eines Jacobsonschen Organs dürfte eher als eine Vereinfachung zu deuten sein, da eine voribergehende, schwache Anlage desselben embryonal rolzukommen scheint. Die primären (hoanen liegen zwischen dem 
Vomer, den Palatina und den Gaumenfortsätzen der Maxillen \{s. Fig. 159, S. 278 u. Fig. 521) sehr dicht nebeneinander und sind häutig gegen das Mundhöhlendach wenig scharf abgegrenzt. - Die rundlichen bis schlitzförmigen Narinen (Fig. 522), welche mit einer Klappe (Operculum.) versehen sein können, finden sich meist in der mittleren Region des Schnabels, können aber bis an seine Spitze (Apteryx) oder auch nahe an seine Basis riicken. Hiervon, wie von der Schnabellänge ïberhaupt, hängt die Länge der Nasenhöhlen ab. Die Narinen gewisser Vögel (z. B. mancher Eulen) werden selı eng, ja es kommt vor (Sulaarten), daß sie sich verwachsend schließen; die Nasenhöhlen also nur von den Choanen aus zugänglich sind. Das meist knorpelige, doch hinten vom knöchernen Mesethmoid fortgesetzte Septum mancher Vögel ist an seinem Vorderende von einem Loch durchbrochen (Nares perviae); zuweilen verknöchert auch das Septum in ganzer Ausdehnung.

Fig. 522 .

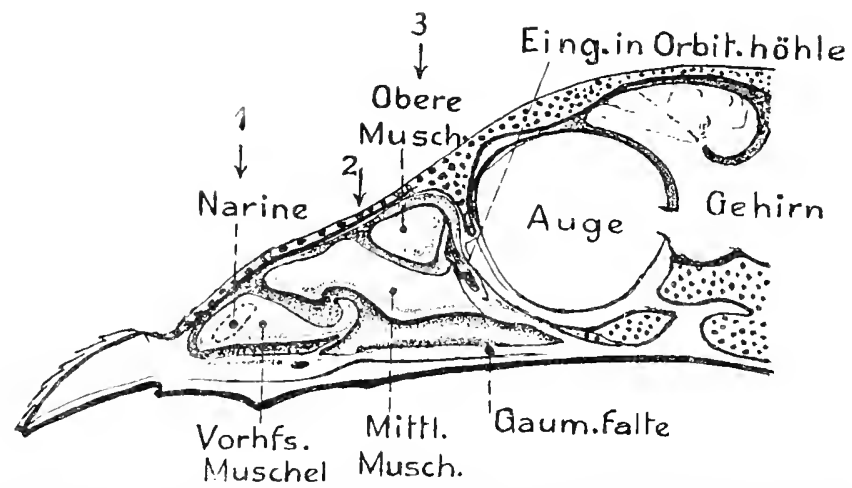

Phasianns colchicus. Sagittalschnitt durch den Kopf, etwas rechtsseitier vom Xasenseptum. Ansicht der rechten Saseuhïhle von innen mit den 3 Muscheln. Knochen punktiert. Narine in Strichlinien angegeben.

Orig. C. H.

Der vorderste Teil der Nasenhöhle (s. Fig. 522) erweist sich als Torkof, der dadurch kompliziert ist, daß von seiner Seitenwand in ihn ein einfacher bis komplizierter, lamellenformiger und muschelartiger Vorsprung hineinragt (gewöhnlich als Tonkofsmuschel bezeichnet; s. Fig. 522 11. 523, 1; er fehlt nur wenigen Formen (z. B. Gyporgermus). Wie der iibrige Torhof ist diese Muschel mit Ptlasterepithel bekleidet. - Etwas dorsal und caudal von ihr springt in die Ilaupthöhle von deren Lateralwand stets eine ansehnliche Lamelle vor, welche sich ventralwärts kriummt und einrollt (s. Fig. 522 u. 523, 2), wobei die Windungen bis auf $2^{1}{ }_{2}$ steigen können. Diese ansehnlichste, mittlere oder mimüre Thw hel ist ontogenetisch mit Riechepithel bekleidet, das aber später von indifferentem Wimperepithel ersetzt wird. - Endlich tritt im dorso-caudalen Winkel der Haupthöhle meist noch eine dritte muschelartige Bildung anf (obere oder sekundäre Muschel, wclche sich von den beiden ersten dadurch unterscheidet, dafi sie nicht von einer Lamelle mit eingelagertem Knorpel, sondern durch eine Einbuchtung der lateralen Knorpelwand der Nasenhöhle gebildet wird, hervorgerufen von einem luftfïhrenden 
simus. Dieser Sinns der oberen Muschel hängt mit dem (J)italsimles -höhle), der sich in der vorderen Region der (rrbitalhöhle tindet und weiterhin auch mit einem Kirfersinus (-höhle) s. Fig. 523, 3) zusammen. Der Orbitalsinus kommuniziert durch eine spaltförmige Öffinung mit der Nasenhöhle am Ilinterende der mittleren Muschel (s. Fig. 522. - Nur die obere Muschel, oder wenn sie fehit (z. B. ('olumba), die ihr entsprechende Stelle der Nasenhöhle besitzt Riechepithel, daher auch ihre Bezeichnung als » Riechwulst«. Ihre Bildung erinnert an die Pseudoconcha der Crocodile, obgleich eine Homologie nicht sicher erscheint.

Eine ansehuliche, doch recht verschieden grobe Drïse mïndet nittels eines Austïhrgangs medial in den Vorhof. Nach ihrer Entwicklung dürfte sie der medialen oder septalen Driise der Amphibien und Reptilien entsprechen; manchen Vögeln stheint aber anch eine tilandula externa zuzukommen.

Mammulia. Wie schon bei der Besprechung des Schädels erwähnt (S. 293 u. 301), werden die Nasenhöhlen der Säuger, die keine scharf abgegrenzte Vorhöhle zeigen, sehr geräumig, erstrecken sich weit nach hinten bis unter die vordere Region der Hirnschädelbasis, ähnlich wie bei den Crocodilen, und erheben sich gleichzeitig nach hinten ansehnlich vgl. Fig. 174 C; S. 298). Ihr blinder hinterer Abschnitt wird von den Ethmoidea abgeschlossen, die ja. wie früher erwähnt, durch ihre besondere Entwicklung an der komplizierten Bildung der Höhlen teilnehmen.

Im Gegensatz zu den Sauropsiden steht das Geruchsvermögen der Säuger meist auf hoher bis sehr hoher Stufe. weßhalb es die übrigen Sinne häutig an Feinheit ïbertrifft. Wie schon beim Gehirn(s. S. 589) hervorgehoben, unterscheidet man macro- und microsmatische Säuger, je nach dem Entwicklungsgrade des fieruchsvermïgens und der entsprechenden Komplikation der Riechorgane. - Die Geruchsorgane entstehen ontogenetisch wie bei den übrigen $\mathrm{Am-}$
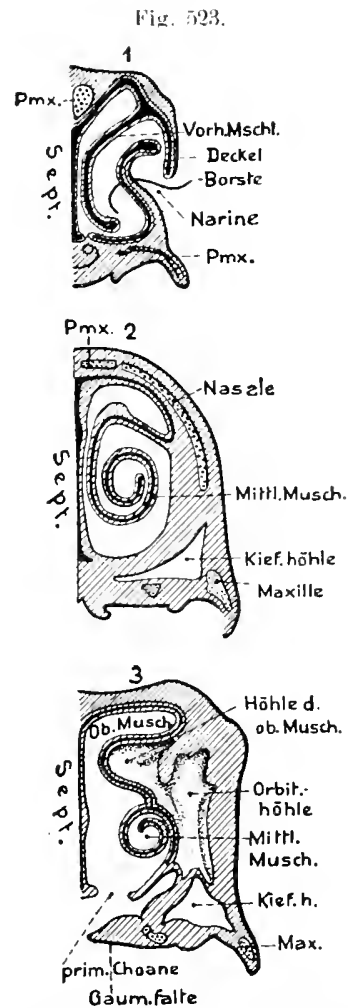

Gallus domesticus. 3 Querschnitte durch die rechte Nasenhö̈lle in der Gegend der Pfeile 1- 3 aut Fig. 522. Knorpel sehwarz; Knochen punktiert. Orig. C. H.

nioten. Die Eigentiimlichkeit, daß die primären Choanen (mit Iusuahme von Echidna) anfänglich geschlossen simb und erst spüter dnrchbrenen. erscheint. wie hei den Amphibien. als sekundäre Modifikation.

Ähnlich wie bei den placoiden Reptilien, wird bei sämtlichen Säugern durch Verwachsung der Gaumenfalten ein Nasenrachengang gebildet, was schon beim Schädel hervorgehoben wurde S. 304. Das Nasenseptum setzt sich caudalwärts bis nahe an die sekundären Choanen fort und der unpaare Vomer stïtzt das Septum durch seine absteigende Lamelle. Im allgemeinen bleibt der Nasenrachengang kürzer als bei den Crocodilen, die Choanen liegen daher meist in der Mittelregion de. 
Gaumendachs: doch könneu sie auch weiter nach hinten verlagert werden, so bei Honotremen, Cetaceen und namentlich Myrmecophergu, wo sie, unter Beteiligung der Palatina und Pterygoidea an der Cmschließung des Ductus nasopharyngeus, nilhe ans Hinterhauptsloch gerïckt sind. Der blinde Candalteil der Nasenhöhlen erstreckt sieh aber bei den Siugern gewöhnlich noch weit hinter die Choanen.

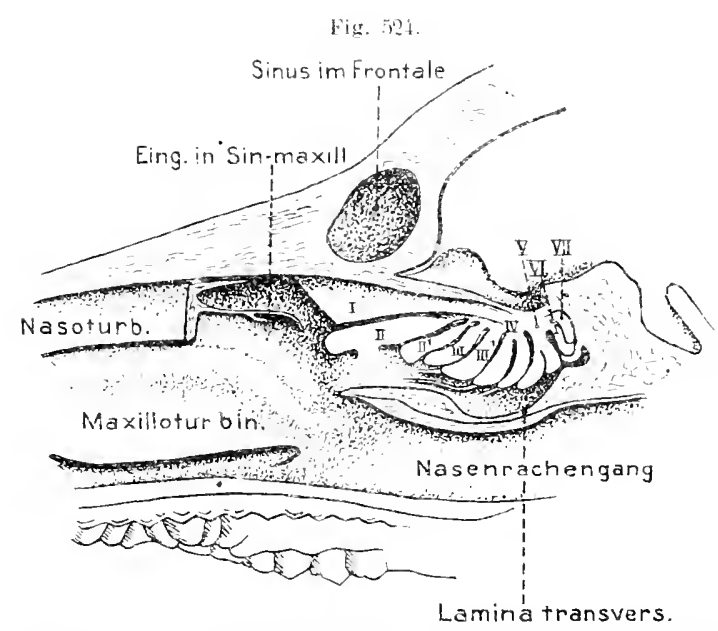

Sus scruta lomestira. Juhl alt. Caulaler Teil ler rechten

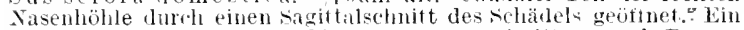
mittleres stuck des Nasoturbinale int weggesehnitten nach PiULu 1400 .

\section{lie. 525.}

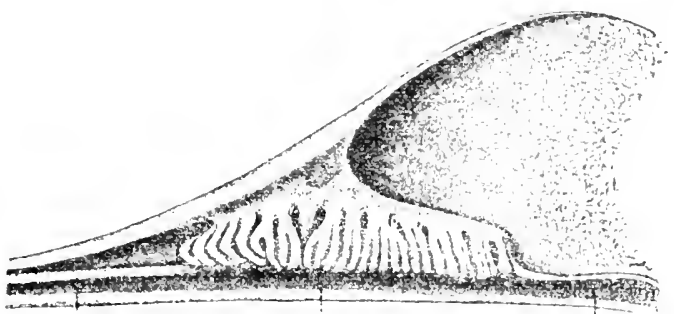

Maxturb.

Ethim.turb.

Nas.r.gang.

Erhitha. Medianchnit dureh die Nasenhohle, Geptum enternt alls GEGEXBACR, Vergl. Anatomie”.

Wie schon beim Sch:idel bemerkt, beruht die Komplikation der Nasenhöhlen :iuf der ansehnlichen Entricklung der Muscheln, womit eine bedentende Vergrößerung der Schleimhantoberfläche der Uöh!en verbunden ist. Die Inschelnsind urspriuglich längsgerichtete oder schiei absteigeude Schleimhantfalten, welche von der lateralen und dorsalen Höhlenwand gegen das Septum rorspringen. Doch entstehen sie auch hier weniger durch Erhebung der Sehleimlinut als dureh Ausbuehtungeu der Nasenhöhlen wand, zwischen welchen die IInschelfalten stehen bleiben. Alle Miuscheln besitzen ontogenetisch anfänglich Sinnesepithel: im erwaehsenen Zustand dagegen beschräukt sieh dieses anf das candale blinde Ende der Nasenhöhle hinterer

Blindsack, sodal die Muschehn nur noch in dieser Region, gewisse alber anch gar kein lieehepithel mehr tragen. - Von der knorpligen Nasenkapsel ans entwickeln sich zur Stiitze der Schleimhantmuseheln Knorpellamellen (Thrbinalia). die sie durchziehen und schließlich verknöehern, sowie mit benachbarten Knochen verschmelzen, worauf die knöchernen Muscheln als Auswüehse dieser Ḱnochen erscheinen. - In der Vorderregion deriNasenhöhle finden sich regelmäßig zwei solcher Muscheln (s. Fig. 174 C u. D, S. 298 n. Fig. 524): eine meist sebr ansehuliche ventrale, deren Knochenlamelle mit dem Maxillare verwächst, und welche 
daher gewöhnlich als Kicfermuschel oder Maxilloturbinale bezeichnet wird. Diese Muschel ist anf den vor der Choane gelegenen Teil der Höhle beschränkt und besitzt kein Riechepithel. - Dorsal von ihr fiudet sich eine sehr langgestreckte Muschel, die caudal bis in die ethmoidale Regio olfactoria reicht und sich knöchern, sowohl mit dem Nasale als dem lateralen Ethmoid verbindet, das Tasoturbinale, las aber bei gewissen Formen stark rïkgebildet ist. Im hinteren, blindgeschlossenen Teil der Nasenhöhlen endlich tritt eine verschiedenc Zahl kleinerer Muscheln auf, deren knöcherne Lamellen sich wie das Nasoturbinale sämtlich mit dem seitlichen Ethmoid vereinigen, so daß sie als Auswïchse desselben erscheinen; sie sind alle, wenigstens in ihrem hinteren Teil, mit Riechepithel versehen. Letztere Muscheln werden daher als Ethmoturtinatia bezeichnet. Das Nasoturbinale, welches sich als dorsalste oder oberste Muschel iiber sie hinzieht, wird ihnen in der Regel als besonders modifiziertes Ethmoturbinale I zugerechnet.

Hinsichtlich ihrer Entwicklung sollen sich das Maxillo- und Nasoturbinale dadurch von den eigentlichen Ethmoturbinalia unterscheiden, daß sie sofort an der Lateralwand der Nasenhöhlen entstehen, die letzteren dagegen ursprünglich und successive an der dorsalen Region des Septums und erst später durch Verschiebung an die Lateralwand gelangen. Daher werden die beiden erstgenannten Mnscheln zuweilen anch als laterale von den letzteren orler den septalen, die auch etwas früher angelegt werden, unterschieden.

Je nach ihrer Verlaufsrichtung liegen die Ethmoturbinalia entweder mehr iibereinander, wie bei den meisten Säugern, oder mehr hintereinander (z. B. Monotremen [Fig. 525] und Primaten). Im allgemeinen hängt dies mit der Stellung des Ethmoids zusammen, zu dessen Siebplatte die Muscheln etwa senkrecht ziehen; steht daher die Siebplatte annähernd vertikal, so ziehen die Muscheln längs und stehen iibereinander (Fig. 524), steht dagegen die Platte stark schief oder nahezu horizontal, so steigen die Muscheln abwärts und folgen hintereinander Fig. 525, 529'. .

Wenn sich nur eine kleinere Zahl von Ethmoturbinalia tindet, so sind sie meist von ähnlichem lian nnd erstrecken sich auch in tingeführ gleicher Ausdehnung von der Worsolateralwand der Nasenhöhle gegen das Septum, so daß sie die hintere Nasenhöhle stark erfüllen. In diesem Fall sind daher die Ethmoturbinalia bei betrachtung der sagittal anfgeschnittenen IIöhle säntlich zu sehen. Deshalh hat man die sich so verhaltenden Ethmoturbinalia Harptmuscheln oder, da sie das Septum fast erreichen, Endoturbinalic genannt. Sie werden von der Dorsal- gegen die Ventralseite gezählt, also das Nasoturbinale als I., das darauf folgende Endoturbinale als II. und so fort bezeichnet (Fig. 524 u. 526). - Es scheint, daß für die placentalen Säuger im allgemeinen fünf Endoturbinalia typisch sind, welche jedoch in gleich zu schildernder Weise vermindert oder vermehrt werden können. Bei den meisten Sängern tritt nämlich eine bedentende Vermehrung der Ethmoturbinalia auf, indem sich in den Zwischenrïumen der Endoturbinalia sekundäre Turbinalia bilden, die meist kleiner bleiben, namentlich weniger weit gegen das Septnm vorspringen. Letztere werden deshalb Ectotubinalia ge- 
nannt (Fig. 526 B 1-6): sie sind an der aufgeschnittenen Nasenhöhle fast nie direkt sichtbar, da sie von den Endoturbinalia verdeckt werden (daher anch als Conchae obtertae bezeichnet). Die Zahl dieser Ectoturbinalia ist sehr verschieden.

Einzelnen Formen (Ornithorhynehus, vielen Primaten) fehlen die Ectoturbinalia ganz (wohl durch Redubtion). Bei anderen finden sie sich in geringer Zabl (so 2-3, Insectirora usw.), können sich aber, namentlich bei Ingulaten und Elcphas, ungemein vermehren, bei ersteren bis auf 31. Pei hoher Zahl der Eetoturbinalia sind sie häutig selbst wieder verschieden groß. so daß sich zwei Arten: größere (sog. mediale) nnd kleinere (sog. laterale) unterschejden lassen.

Die Ethmoturbinalia sind im einfachsten Falle etwas gekrïmmte Lamellen. In der Regel werden sie jedoch komplizierter, indem sich der freie Rand der La-

Fig. .726.

A

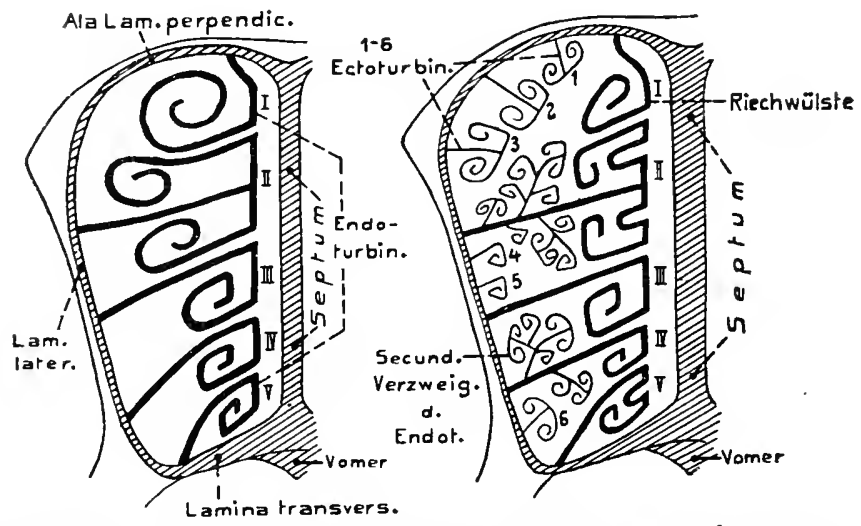

Schematische Querschuitte durch deu hinteren Teil ler Nasenhöhle vón sängetieren mit den Ethmoturbinalia, dicht vol der siebplatte und parallel mit ihr. - A Eintacher Bau, nur Endoturbinalia $\left(I-I^{\prime}\right)$ ausgebiliet, teils mit einfacher, teils mit doppeller Aufrollung (Riechwỉste). - B Komplizierterer Bau. Zu den 5 lindoturbinalia haben sich 6 lictoturbinalia (1- $b$ ) geselit: die landoturbinalia $(I I$ und $I /)$ mit sekundären und tertiären Verzweigungen: II. und $I$. Riechwulst mit Längsfurchen (nach PAULLI 1900 .

v. Bu.

melle ventral umbiegt und in verschiedenem Grad einrollt (Fig. 527). Am Distalende des Ethmoturbinale ist diese Einrollung stets blind geschlossen. Noch komplizierter wird der freie Rand der Muschellamellen hïufig dadurch, daß er sich in zwei Blätter spaltet, von denen sich das eine ventral, das andere dorsal aufrollt Fig. 526). Durch diese Bildungen erscheinen die gegen das Septum schauenden freien Ränder der Ethmoturbinalia als Riechwïlste verdickt. Es kommt auch häutig vor, daß sich ein Endoturbinale in seinem Verlauf gegen das Septum in zwei Blätter spaltet und jedes derselben einen frei sichtbaren Riechwulst bildet; daher rührt es, daß die Zahl der Riechwiilste größer sein kann als die der Endoturbinalia (z. B. bei Carnirora: 4 Endot. und 5 R.W., und ähnliches mehr). - Diese Spaltung von Endoturbinalien in zwei Blätter (Riechwülste) kann sich selbst bis auf die laterale Höhlenwand vertiefen, was eine Vermehrung der Endoturbinalia hervorruft, die namentlich bei den Ungulaten (s. Fig. 527, auch 
Erhilna Fig. 525, Eilentuta) vorkommt, bei welchen sich bis zu acht finden können. Andererseits dürfte die lieduktion der lindoturbinalia auf 4, wie sie vielen Placentaliern (so Insectivor, Chiroptera, Carnivore, Rodentia) eigen ist, auf der Verwachsung zweier benachbarter der ursprïnglichen 5 (nämlich von II und III) beruhen.

Einzelne Endoturbinalia gewisser Sïuger können sich ferner sehr komplizieren, indem ihre Basallamelle auf einer oder beiden Flächen seitliche Lamellen aussendet, dic sich ebenfalls aufzurollen vermügen, jedoch das Medianende der Endoturbinalia nicht erreichen, also hier nicht sichtbar sind (Fig. $526 \mathrm{~B}$ ). Selbst tertiäre Lamellen können sich zuweilen von solch sekundären erheben nnd die Komplikation steigern.

Eine analoge Komplikation, sogar in noch viel höherem Grade, erlangt häufig das Maxilloturbinale. Diese, des Riechepithels entbehrende Muschel, welche der ventralen, respiratorischen Nasenhöhlenregion angehört, funktioniert hauptsächlich als Staubfänger und Erwärmer der Atemlnft. Dementsprechend kompliziert sie sich häufig sehr, indem sich ihre Lamelle unter Aufrollung vielfach banmförmig teilt, so daßschließ-

Fing. 527.

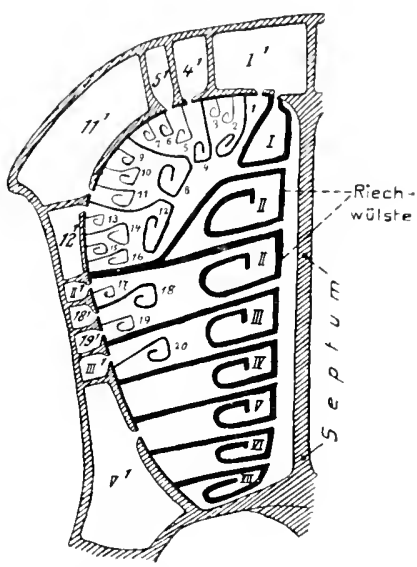

Sus serofa lomestica. Schematischer Querschuitt lurch die Ethmoturbinalia und die Nasenhöhle dicht vol und parallel zur Sielsplatte: 7 Endoturbinalia und 20 Ectoturbinalia. $I^{\prime}-I^{\prime}$ und $t^{\prime}, 5^{\prime}, 11^{\prime}, 12^{\prime}, 15^{\prime}, 1 y^{\prime}$, sogen. Cellulae ethmoidales, luftführejde Ausstülpungen der Nasenhöhle zwischen den Muscheln. Nasoturbinale $(I)$ ist von $I^{\prime}$ aus lufthaltig aufgetrieben (nach PAULLI J100). V. Bu.

lich (besonders bei Camiroren, namentlich Piminedicrn) ein äußerst verwickeltes Labyrinthwerk entsteht, in dessen engen Gängen die einströmende Luft filtriert und erwärmt wird.

Eine eigentïnliclıe Veränderung erfahren gewisse Endoturbinalia nancher Säuger, indem ihre Basallamelle durch von der Nasenhöhle eindringende Lufträume wulstartig aufgebläht wird (Fig. 527), wie wir ähnlirhes schon bei Crocodilen und Vögeln tralen. Diese Pneumaticität der Endoturbinalia berulit, wie wir später sehen werden, teils auf dem Eindringen von Fortsätzen der sog. Nebenhöhlen der Nase, teils aber aut dem lindringen besonderer Aussackungen der Haupthöhle in die Basallamellen.

Wie schon bemerkt, ist das Nasoturbinale das längste und dorsalste Endoturbinale, welches weit nach vorn, ja zuweilen bis nahe zur äußeren Nasenöffnung zieht. Nur sein hinterster, in der olfactorischen Region liegender Abschnitt besitzt Riechepithel. Bei Reduktion des Geruchsorgans (microsmatische Säuger), besonders bei den Primaten, wird anch das Nasoturbinale allmählich reduziert, ist jedoch bei den Prosimiern (Fig. 528) und Simiern (Fig. 529) in der Regel noch ziemlich entwickelt, bei Anthropoiden und dem Menschen dagegen völlig oder fast völlig eingegangen (der beim Menschen zuweilen angedeutete Agger nasi, sowie der Processus uncinatus des Siebbeins werden auf Reste des Nasoturbinale zuliickgeführt). 
Die Reduktion der Nase spricht sich bei ten Primaten sowohl in der liückbildung ler Ectoturbinalia, die schon bei Prosimiern uur noch als zwei stark rednzierte aut'treten, bei den Primaten aber meist völlig fehlen, als der der Endoturbinalia ans. Letztere sinken ron 5 bis auf 2 herab. Anch dem Menschen kommen gewïhnlich nur zwei besser ausgebildete zu (mittlere und obere Muschel der menschlichen Anatomie), obgleich noch bis zu 5 angelegt werden künnen. Die Endoturbinalia der Primaten sind gleichzeitig einfache. nicht oder nur sehr wenig aufgerollte Lamellen. Die schon trïher beim Schädel (s. S. 294) erörterte steile Aufrichtung der Gesichtsknochen der Primaten, insbesondere der Anthropoiden und des Menschen, bewirkt, daß das Ethmoid (speziell dessen Lamina cribrosa) sich immer horizontaler umlagert. Damit ist auch eine Verinderung in lichtungslanf der Ethmoturbinalia rerbunden, indem riese nun einen absteigenden, ja einen schiel caudalwärts absteigenden Verlauf annehmen. Damit muß die Lagerung der Endoturbinalia zueinander insofern geändert werden, als nun das sonst oberste oder zweite Endoturbinale (ahgesehen

lig. $52 !$

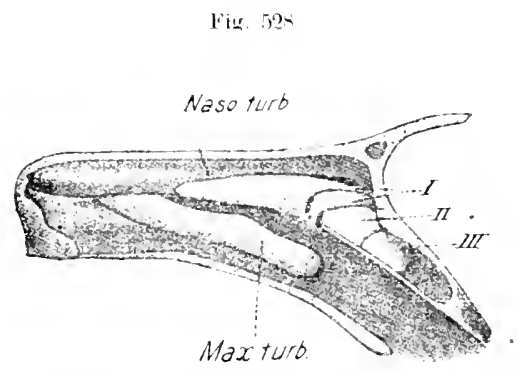

Lemur catta. Rechte Nasenböhle yon innen

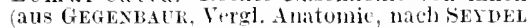
18i) 1 .

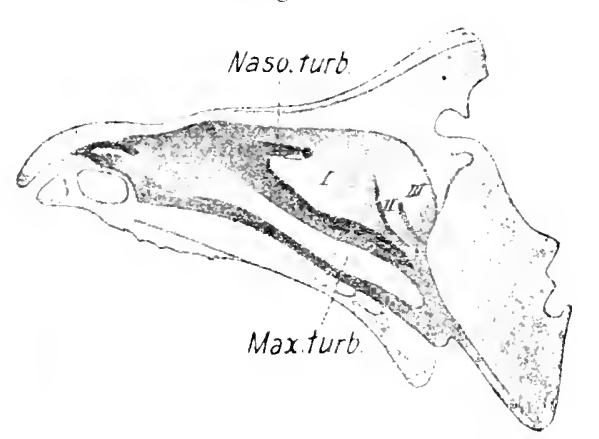

(crooceltialus mormun. Rechte Vasenhöhle von

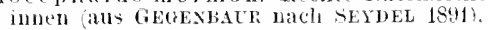

rom Nasoturbinale) -ich unter das dritte schiebt und so fort: die mittlere Muschel des Menschen entspricht also einem der Zahl nach nielderen Ethmoturbinale ter neisten Sunger und die obere. cowie tie gelegentivh rorhandene oberste (santorinsche). solchen hiblerer Zahl.

Die weites gehende lieduhtion der Dasenorgane erfmen die Cotaccen: im Zusammenhang mit dem ansshließlichen Wasserleben. Wie schon beim schädel hervorgehoben (S. 302 11. 304) rücken ihre Narinen weit anf den scheilel hinanf (besonders Denticeti), wo sic sich als eine nupare (Denticeti) orler zwei dicht zusammengerückte parige öfnumgen (Mysticeti) finden. bej den Zilhuwalen wird der Verlauf der Nasenhöhlen so ein senhiechuer, bei den Bartenwalen ein schräg nach hinten absteigender. Die Turbinalia der ersteren sim in erwachsenen Zustand ganz eingegangen, lei letzteren wenigstens in ther Jugend in geringer Zahl beobachtet worden. Bei erwachsenen Cetaceen ist der Yervus olfactorius fast stets vollig reduziert und die Lamina cribrosa undurchbohts; die libebfunktion aler organe ist. also gesthwmben mul allein die respiratorische ibrig goblieben.

Nicht sicher gelöst ist die Frage nach der Homologie der Säugermuscheln mit denen der Samropsiden. In der Regel wird das Maxilloturbinale mit der Sauropsidenmuschel (IIauptmuschel) verolichen; doch wird dies anch bezweifelt. Die Ethmoturbinalia der Sïuger scheinen demnach im allgemeinen Bildungen eigener Art zu sein, welche eventuell an den sog. Riechwulst der Crocodile und die obere Muschel der Vögel erinnern. 
Nobemhïhlen der Süugemase. Für die allermeisten placentalen Säuger (sowie vereinzelte Marsupialia, so Phascolaretos) ist charakteristisch, daß nachembryonal rou den Nasenhöhlen in die sie begrenzenden Knochen Ausstiilpungen eindringen, đie von der Schleimhaut der Nasenhöhlen ausgekleidet werden. Diese Nebenhöhleu erlangen zuweilen eine erstaunliche Ausdehunng. Ihre allmähliche Entwicklung geschieht unter Resorption der Knochen. Alle Nebenhöhlen sind lufterfüllt, und die Schädelknochen werden so häufig in großer Ausdehnung pneumatisch. Ton diesen Nebenhöhlen (oder Sims) sind jedoch zwei zu unterscheiden, welche direkte Fortsetzungen des blinden Caudalendes der Nasenhöhle (Regio olfactoria) bilden, nämlich der ventral gelegene, in das Praesphenoid sich erstreckende Sphenoidaloder Krilbein-) Simus und der höher gelegene eigentliche Frontalsinus, der in das Stimbein tritt (s. Fig. 524, S. 724). Diese beiden Höhlen enthalten zuweilen Fortsetzungen ventraler oder dorsaler Ethmoturbinalia und charakterisieren sich so als direkte Ausbreitungen des Nasenhöhlengrundes. Da auch von verschiedenen der weiterhin zu erwähnenden Nebenhöhlen Fortsätze in die Stirmbeine eindringen können, so ist das, was gemeinhin als Frontalsinus beschrieben wurde, recht verschiedener Natur und nicht mit dem eben erwälnten Frontalsinus zu verwechseln. - Von den eigentlichen Nebenhühlen ist am konstantesten die Kieferhölıle (Maxillarsinus, Highmorè's Höhle), so genannt, weil sie sich in del Regel besonders im Maxillare verbreitet, aber bei ansehnlicher Pneumatisation (so. besonders Ungulata und Proboscidea) auch in die angrenzenden Knochen Lacrimale, Patatinum, Jugale, doch auch Prae- und Basisphenoid, Frontale und Nasoturbinale) eintreten kann.

Sie fehlt den Pinnipediern nul Cetaceen, welche äherhaupt keine Nebenhöhlen besitzen: sonst ist sie nur rereinzelt reduziert. Eigentümlich erscheinen solche Fälle ( $z$. I). Dicotyles, Hippopotamus), wo ler Kiefersinus, sich überhaupt nicht im Maxillare, sondern nur in angrenzenden linochen verbreitet.

Der spaltartige Eingang in die Kieferhöhle liegt dicht am Forderrand des seitlichen Ethmoids, zwischen diesem und dem Nasoturbinale, im sog. mittleren Nasengang, d.h. dem Gang zwischen Maxilloturbinale und den Ethmoturbinalia; wïhrend sich die Miindnng des Ductus lacrimalis im unteren Gang findet (s. Fig. 52t, 5. 724).

Rei den perissoductylen Ungulaten tritt for dem Maxillarsinus noch ein besonderes Wherkiefersinus auf (rinus malaris), dessen Lingang etwas ror dem des kiefersinu- liegt.

Während sich bei zahlreichen, namentlich kleineren Säugern (so Insecticora, meisten Liontentia, Chiroptera, einem Teil der Eilentutu usw. die Nebenhöhlen anf den Kiefersinus beschräken, tritt besonders bei den Cugulutrn, den fissipeden Carniform, auch dem Menschen, ein von der Regio olfactoria ausgehendes System weniger bis zablreicher. Nebenhöhlen (im allgemeinen als Cellulae ethmoirlales bezeichnet) auf, deren Eingänge in den Zwischenriumen der Ethmoturbinalia liegen (Fig. 527, S. 727,. Sie umlinllen die Regio olfactoria dorsal mud lateral, künnen sich aber bei Ungulaten und Proboscidiern von hier aus mehr oder weniger in den Sehädelknochen ausbreiten, so daß sie (vor allem bei Rhinoceros und Elcphas) in zahlreiche Knochen, selbst bis in die Occipitalia und das Basisphenoid ein- 
dringen (Fig. 530); sogar die Kuochenzapfen der Wiederkäner (Ossa cornna) werden von ihnen aus pneumatisiert. Die einzelnen Höhlen sind gegeneinander abgeschlossen; bei Elephas zeigen sie das Besondere, daß von ihren Wänden viele Lamellen vorspringen, welche ihnen einen zelligen Charakter verleihen.

Auf einzelne besondere Tebenhöhlen kann hier nicht eingegangen werden; erwähnt sei nur, daß auch das Septum pneumatisch werden kann (Dicotyles) und bei gewissen Formen (z. B. Hystrix, Choloepus) sogar rom Pharynx aus luftfülrende Höhlen in die Schädelknochen eindringen. - Ebenso sei auf die parigen (Spritzsitcke), oder unpaarigen Nebenböhlen kurz hingewiesen, welche sich bei den Zahnwalen aus dem distalen Teil der Nasenliöhle entwickelt haben.

- Die Pneumatisation nimmt in allgemeinen mit der Größe der Formen zu; bei kleinen beschränkt sie sich sehr, kann sogar vereinzelt ganz schwinden, ebenso auch bei dauernthem Wasserleben (Pinnipedia, Cetacea). Sie ermöglicht eine Vergrößerung der Knochen ohne erhebliche Gewichtsznnahme; zur Gernchsfunktion lat sie keine Beziehungen.

Außer den kleinen Bowmansehen Driiscn (s. Fig. 532, S. 733) finden sich auch bei Säugern größere Nasendrüsen. Am verbreitetsten ist eine laterale, recht

Fig. 534

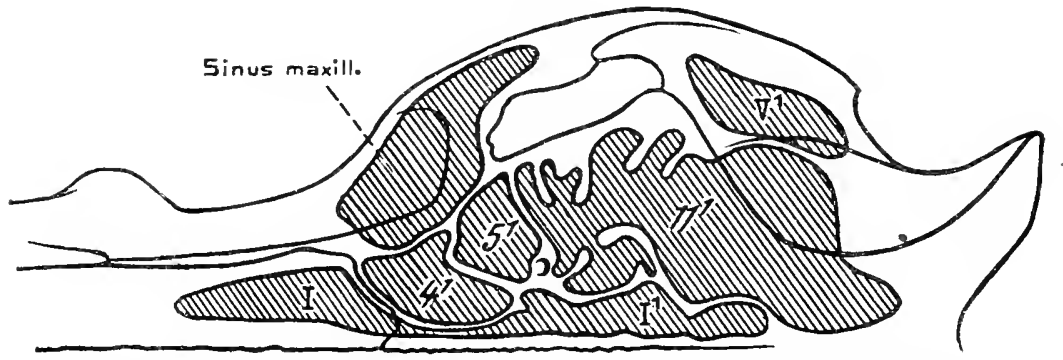

sus scroía domestica. Rechte Hältte des Schärlels von der Dorsalseite mit den pneunatiscluet Höhlen (schraifiert, die in derselben Weise bezeichnet sind wie auf Fig. 527. Nach PAvLLI 1900.

verschieden große, deren Ausführgang weit vorn, in der Endregion des Nasoturbinale im unteren Nasengang mündet (Stenosche Irïse). Sie dehnt ihre tubulösen Verzweigungen häufig in das Maxilloturbinale und die Kieferhöhle aus. Daß sie der lateralen Drïse niederer Wirbeltiere entspricht, ist recht wahrscheinlich, denn der Umstand, daß ihre erste Anlage in der liegion des vordersten Sinnesepithels auftritt, läßt sich unschwer durch Verschiebung erklären. Dem Menschen fehlt sie. Seltener findet sich noch eine septalc Drïse (z. B. gewisse liodentia, Chriroptera).

Jacobsonsches Organ. Schon bei den Nasenhöhlen der Amphibien und Sanropsiden (speziell der Squamata, hier selten fehlend, z. B. Chamaeleo) wurde ein besonderer Abschnitt derselben erwähnt, der sich bei den Gymmophionen und Squumaten von den eigentlichen Höhlen ganz abtrennt und eine eigene Einmündung in die Mundhöhle erlangt. Er wird überall von einem besonderen'zweig des Nervas olfactorins versorgt. Es sind dies die Jacobsonschen Organe. - Was bei den Chelomiern und Amphibicn als Homologon desselben gedentet und schon früher kurz geschildert warde (s. S. 713 u. 721), speziell der seitliche Nasengang der Amphibien, wird jedoch in seiner Ilomologie mit den Jacobsonschen Organen der Squamaten und 
Mammalia vielfach bestritten. - Die Organe der Squanuten sind, wie frïher angedentet, ein Paar etwa kugliger, seltener schlauchförmiger Gebilde, die ventral von den eigentlichen Nasenhöhlen, in der Region zwischen Vor- und eigentlicher Nasenhöhle, überdeckt ron den Ossa septomaxillariu (sog. Conchae, vgl. S. 276) liegen. Das Lumen jedes ursprünglich bläschenförmigen ()rgans (s. Fig. 518, S. 719) wird von einem halbkugligen ventralen Vorsprung Jacobsonschen Wulst) spaltartig stark eingeengt. Ein von der knorpligen Nasenkapsel ausgehender Fortsatz bildet den Hauptteil dieses Vorsprungs. Die dorsale Wand des Organs besteht aus Riechepithel, der Wulst hingegen ist von indifferentem Epithel überzogen. - Den Mammaliu kommt das Organ ursprünglich allgemein zn, wenn es auch bei gewissen Formen im erwachsenen Zustand verkiummert so bei Pimipedia, Cetacea, gewissen Chiroptera, ratarhinen Affen und dem MFnschen). Ansehnlich entwickelt findet es sich besonders bei den Monotremen (speziell Echidna), Ifarsupialia, Rodentia und Ungulate. Ontogenetisch tritt es frühzeitig an demselben (Irt auf, wie bei den Reptilien (mediale Wand der Nasenrinne), als eine rinnenartige mediale Ausstïlpung (vgl. Fig. 520, die sich hierauf von vorn und hinten oder auch nur von hinten aus abschnïrt, so daß sich in der mittleren Region oder vorn eine Mündung in die Nasenrinne erhält. Beim Abschluß der Nasenrinne von der Mundhöhle und der Bildung des Ductus nasopharyngeus erhält sich am Boden der Nasenböhlen, da wo die Jacobsonschen Organe münden, eine feine kanalartige Verbindung der Nasenhöhlen mit der Mundhöhle, die beiden Stensonschen Gänge (am knöchernen Schädel durch die Camales incisivi repräsentiert, die zwischen Praemaxillen und Maxillen liegen . Demnach münden die Jacobsonschen Organe fast aller Säuger in diese Gänge, welche wohl als Reste der primären Choanen angesehen werden dürfen.

bie ursprünglich am nasalen Ende lieser Gänge liegende Einmündung der Jacobsonschen ()rgane rückt bei vielen Sängern tiefer gegen die Mundhöhle hiıab. Rei Rückbildung der Jacobsonschen 1rgane rerkümmern in der Regel aurh die Stensonschen Gänge, können sich jedoch anch erhalten (Catarrhina, gewisse Chiroptera, ebenso in lindimenten beim Menschen). Zuweilen vereingen sich lie oralen 'Teile der Stensonschen Gänge zu einem Kanal; gelegentlich (gewisse Ungulati, Equidae) schwindet dieser orale Teil, so daß sich nur die nasalen Abschnitte der Gänge als trichterförmige Einsenkungen am Nasenhöhlenborlen erhalten, in welkhe die Jacotsonschen Organe münden. Die Organe können sich jedoch auch ron den Sten-onschen Gïngen emanzipieren und vor ihnen in die Naseuhöhle münden Shodentiu, gewisse Edentota).

Im Gegensatz zu denen der Saurier sind die Jacobsonschen Organe der Sänger schlanchförmig und liegen jederseits dicht an der Basis des Nasenseptums, wobei ihre Mündung sich entweder etwas hinter ihrem Vorderende findet (Ornithorhynchus und gewisse Marsupialia), so daß ein vorderer Recessus des Organs besteht, oder an ihrem Vorderende (I'lacentalia).

Das Organ der Monotrcmen wird von einer knorpligen Hülle völlig umschlossen (Cartilago paraseptalis, Jacobsonscher Knorpel, Fig. 531), die eine Fortsetzung der basalen und lateralen knorpligen Nasenkapsel ist; bei den übrigen Säugern ist dieser Knorpel meist weniger vollständig. An jedes der Organe von Orrithorlynchus legt sich mediodorsal das S. 302 erwähnte Os partulormu. In das 
Organ der Monotremen springt von seiner lateralen Wand ein etwas muschelartig gekrümmter, gefäß- und drüsenreicher Wulst vor; in welchen sich auch der Knorpel erheben kann (Fig. 531 A) ; er trägt indifferentes Wimperepithel, die Medialseite des Organs dagegen Riechepithel. Die Homologie dieses Wulstes mit jenem der Squamaten wurde bestritten, aber wohl mit Unrecht. Den iibrigen Sạ̈ugern fehlt der Wulst oder ist doch nur schwach angedentet.

Außer dem Olfactoriusast geht auch ein Trigeminusästrhen znu Jacobsonschen Organ. - Eire Jacobsonsche Driise wude hei einer Anzahl Sänger beobachtet, doch bedarf ihre Homologie mit jener der Amphibien und Reptilien mäheren Beweises. Charakteristisch fü die Mammalia ercheint ferner, daß noch zahbreiche kleine Irüschen in das Organ mündan

Fig. $-i 31$

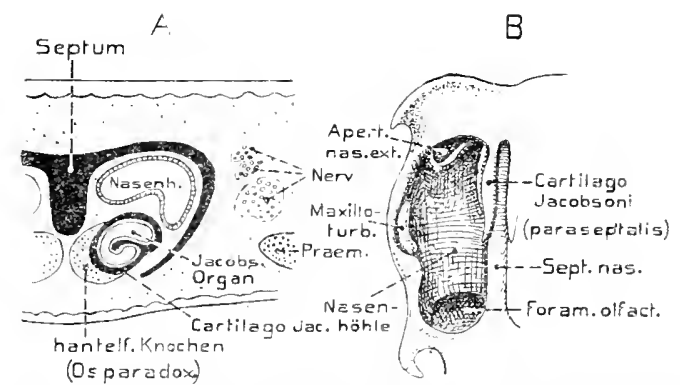

A Ornithorhynchus. Quersehnitt durch die Nasenhöhle mit dem Jacobsonschen Organ. Schematisch. (Nach. SYkMINGTus 1891.) - J Echillna. Nasenknorpet eines Embryos in Ventratausicht nach SEYDEL 1899. (auch anf dem Wulst der Monotremen), ähnlich wie bei Gymnophionen. - Funktionell hat da: Jacobsunsche Organ wohl eine ahnliche liedeutung wie das eigrentliche Geruchsorgan, obgleich sich iber seine Besonderheit rorerst kaum Sicheres sagen lubt. Iußre Nase tor Mamma-. lia. In verschiedenen Abteilungen der Sänger hat sich selbständiı ein mehr oder weniger rïsselartiger Fortsatz der Schnauze gebildet, welcher die dicht zusammenstehenden äußeren Nasenölnungen trägt nut seiner inneren Beschaflembeit mach an die Vorhöhte der niederen Formen erinnert. Derartiges nudet sich namentlich bei Tapiren, Swweinen, gewissen Insectivoren, einem catarrhinen Affen (Nasalis) mnl am höchsten entwickelt im Rüissel ron Elephas. - Im allgemeinen darf auch die äuBere Nase des Menschen hierhes grechnet werben, ebenso wie die aufbähbaren, etwas rüsselartigen 入asenhöhlenenten, die bei gewissen Antilopen (speziell Saiga) nnd männhichen Pinmipediern (besonders Cystophora) vorkommen. - Das Knorpelpar, wekhes gewöhulich die äuBeren Nasenöfnumgen seitlirh stützt (Cartilagines alares) trägt aub zur stiitze dieser hïsselbillungen bei, nozu sich jedoth noch weitere Knorpelbihlungen, ja auch Verkü̈cherumgen gesellen bönen (s. . 302 ). Gerade dem ansehulithsten liissel, dem des Elephanten, lehlen aber besondere Slieletgebille, er ist rein musklös, mit sebr hompliziertem Bau. - Ihe Moskulatus. Welche sich zur Bewegung solcher Riisselgebilke, oder zum Verschlub der Naseniflnumgen bei wasserlebenden Sïngern entwichelt hat, jedoch schon hei gewönlicher Nasenbildung angedentet ist, geht ans der Gesichtsmuskulatur hervor mnd wird daher vom Facialis versorgt. Anf die liesunderheiten der äuBeren Nase genisore Chiropteren (Blattuasen) lasm hiser nisht uither cingegangen werden.

Riechrpitlet. Das eigentliche Riechepithel unterscheidet sich häufig schon äußerlich rom iudifferenten Epithel der Nasenhöhlen durch Pigmentiernng, so schwarze bei Cyclostomen und Amphibion Chromatophoren im Bindegewebe, gelbe bis bräunliche bei Ammioton (Pigment in den Stïtzzellen). Es ist ferner dadurch ausgezeichnet, daß es zwischen indifferenten Zellen (Stützzellen, Zwisehenzellen), die meist Cilien tragen, Rich:ellen'mit einem Besatz feiner, kurzer bis längerer, und wohl meist unbeweglicher Sinneshärchen fühı't $(\mathrm{Fig}, 532 \mathrm{~B}$. Mor- 
phologisch sind die Riechzellen alle gleieh: nach physiologischen Versuchen am Menschen scheint es jedoch möglich, daß Verschiedenheiten zwischen ibnen bestehen. Die proximalen Enden der Riechzellen setzen sich in feine marklose Nervenfasern fort, die in ibrer Gesamtheit den Nervis olfactorius formieren und sich im Bulbus olfactorius zu den frïher (s. S. 561) erwälnten Glomeruli begeben. Im Riechepithel finden sich jedoch anch fireie Endigungen von Trigeminusfasern, ebenso wird das indifferente Epithel der Nasenhöhlen von solchen innerviert.

Zahlreiche Telrosteer und iclethyole Amplribicm, sowie gewisse Salamandrinen (Triton) zeigen eine Komplizierung, indem ihre Riechzellen $z u$ sehr verschiesten großen unit häuî auch eingesenkten Knospen vereinigt sind (Kig.532 A), welche an die früher beschriebenen becherfömigen Organe (Endlinospen) erinnern. Die linospen sind in der Regel Lurch geschichtetes Epithel roneinander geschieten. - Wi. die ontogenetischen Erfahrungen ergaben, ist aher diese Bikdung der Riechschleimhaut wohl sicher eine sekuntäre und dentet nicht aul eine Ableitung ler Riechorgane ron becherförmigen Ilautsinnesorganen hin. Die Angahe. dab Huliche knospenförmige Bildungen auch in der liechrhleimhant der Säuger vorkommen, hat sich nicht bestätiæt.

\section{Geruchs- und Geschmacksorgane der Arthropoda.}

Sie sind bei fast allen Klassen mehr oder weniger sicher erwiesen und, wie schon friiher hervorgehoben, in verschiedenem Grade modifizierte Sinnesborsten. In der Regel stehen sie auf den Fühlern, welche ja anch als besonders geeigneter Ort für sie erscheinen. Daß die Funktion der Riechborsten von jener der gewöhnliehen Sinnes- oder 'Tastborsten abweicht, spricht sich meist dentlich darin ans, daß

A.

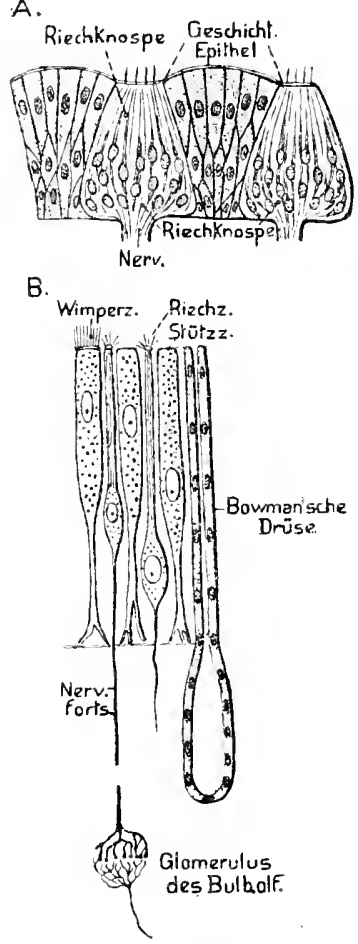

A Trigla (Teleosteer. I) urchschnitt durch tie Riechschleimhat mit zwei Ritedinospen nach BLAUE 1857). - $b$ sollenla des ge wöhnlichen liechepithels (z. B Siuger) mit einer bowmanschen Drüsce, Der Eortsatz der liechzelle ist unterbrochen gezeichut, un seinen Gbergang in eintn Glomerulus des Lohns olfitctorius anzudeuter. $\quad$ (, $\mathrm{H}$. -ie ron letzteren iiberragt werden, also durch feste Körper nicht mechanisch reizbar orscheinen, oder sogar in Gruben eingesenkt, đie Körperoberfläche nicht erreichen, sowie daß gewisse Organe ihren Borstencharakter völlig verloren haben. Daß in der Tat die Fühler, häutig wohl auch die Palpen, mit Geruchsvermögen ansgestattet sind, ist sowohl für Krebse als Insekten physiologisch erwiesen. Inmerhin ist die Funktion mancher der hier zu erwähnenden Organe wohl eine abweichende.

Wie die Tastborsten stehen auch die Riechborsten (Aesthetica) mit Sinneszellen und zwar, soweit genauer bekannt, gewöhnlich mit einer Gruppe solcher Sensille) in Verbindung, deren Terminalstrang die Borsten bis an iln Ende lureh- 
zieht. Bei Decapoden können die Sensillen sämtlicher Riechhaare einer Antenne zu einem gemeinsamen Körper vereint sein, von dem die Terminalstränge ausgehen. - IIäufig, besonders bei Crustaceen und zahlreichen Insekten, tragen die Fiihler der Männchen viel mehr Riechhare als jene der Weibchen, was mit ihrer Funktion grit harmoniert; auch bei manchen im Danklen lebenden Crustaceen

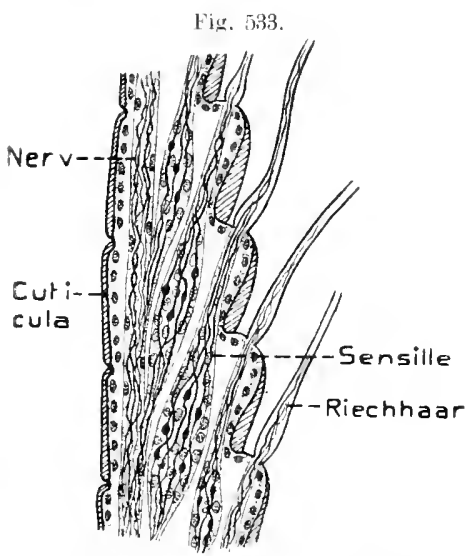

Riechhatevon Crustaceen. Squilla (Heuschreckenkrebs). Längsischnitt iurch einen Teil der 1. Antenne mit \& Riechhaaren (nach v. RiTH 189(i). v. Bu.
Höhlen- und Tiefseeformen) wurde ihr reicheres Vorkommen erwiesen.

Bei den Krebstieren finden sich die liechhaare in mäßiger bis größerer Zahl fast ausschließlich ouf den ersten Anteunen (bei Decapoden an deren Außengeißel), selten auch einige auf den zweiten; häutig sind sie gruppenweise lokalisiert. Es sind zapfenartige bis cylindrische oder haarartige, an ihrem Ende znweilen knöpfchenartig verdickte Gebilde ohne gelenkige Einpflanzung in die Cuticula (s. Fig. 533). Ihr Basalteil besitzt in der Regel eine stärkere Cuticula, der Endteil eine zarte; daß aber das Distalende ungeschlossen sei, der 'Terminalstrang also hier ganz offen liege, ist nnwahrscheinlich; vielmehr scheint das Riechborstenende aller Arthropoden von einer sehr feinen, leicht durchgängigen Cuticularmembran abgeschlossen zn sein.

Wie luftatmenden Mfyriopoden und Irseliten tragen anf ihren beiden Fühleru meist eine große Menge solcher Organe, welche besonders bei den Insekten häutig in erstaunlicher Zahl auftreten und eine auffallend rerschiedenartige Differenzierung erlangen können. - Die Riechborsten der Myriopoden bleiben im allgemeinen spärlicher und sind von zweierlei Form. Erstens ansehnlichere zapfenbis kegelartige Gebilde, Geruchskegel, die sich am Distalende des letzten Fühlerglieds, meist in geringer Zahl erheben (bei Diplopoden in der Regel 4), und kleinere ähnliche, gewöhnlich mehr cylindrische Gebilde, welche sowohl am Endglied, als auch vorhergehenden Gliedern zerstreut oder gruppenweise vorkommen (Zapfeu oder blasse Cylinder). Daß das Distalende der Kegel geöffnet sei, ist, wit gesagt, unwahrscheinlich. Zu jedem Kegel gehört ein typisches nervöses Endorgan, das ans einer spindelförmigen Gruppe zahlreicher Sinneszellen besteht, deren Distalfasern bis in die Kegelspitze ziehen und hier zusammen ein etwas eigentiimliches, ıngefähr stiftartiges Terminalorgan bilden. Proximal von der Sinneszellengruppe fiudet sich eine Anhänfung größerer Zellen, die entweder al Ganglien- oder als Simneszellen, oder als nicht nervöse, sog. Begleitzellen, welche den zutretenden Nervenast nu umhiillen, gedentet wurden. Auch die Zapfen oder blassen Cylinder stehen mit Sinneszellen in Verbindung, doch ist ihr histologischer Bau weniger bekannt. 
Schon die Protracheata (Peripatus) tragen aul' ihrer Körperoberlläche, besonders reichlich an den Beinen, kegelartige Sinnesorgane, deren histologischer Bau dem der Geruchskegel der Myriopoden ähnlich zu sein scheint. Daß sie spezilische bieruchsorgane seien, ist jedoch wegen ihrer Verbreitung wenig wahrscheinlich: eher diirften sie Tastkegel darstellen. Immerhin spricht ihre İnlichkeit mit len Riechkegeln der Myriopoden für einen phylogenetischen Zusammenhang.

Inseliten. Wie schon bemerkt, erlangen die Geruchsorgane der Inselitrufüller eine hohe und gleichzeitig sehr verschiedenartige Entwicklung. Ihre Zahll wird hiutig außerordentlich groß (so besonder's bei IIymenopteren, Coleopteren und

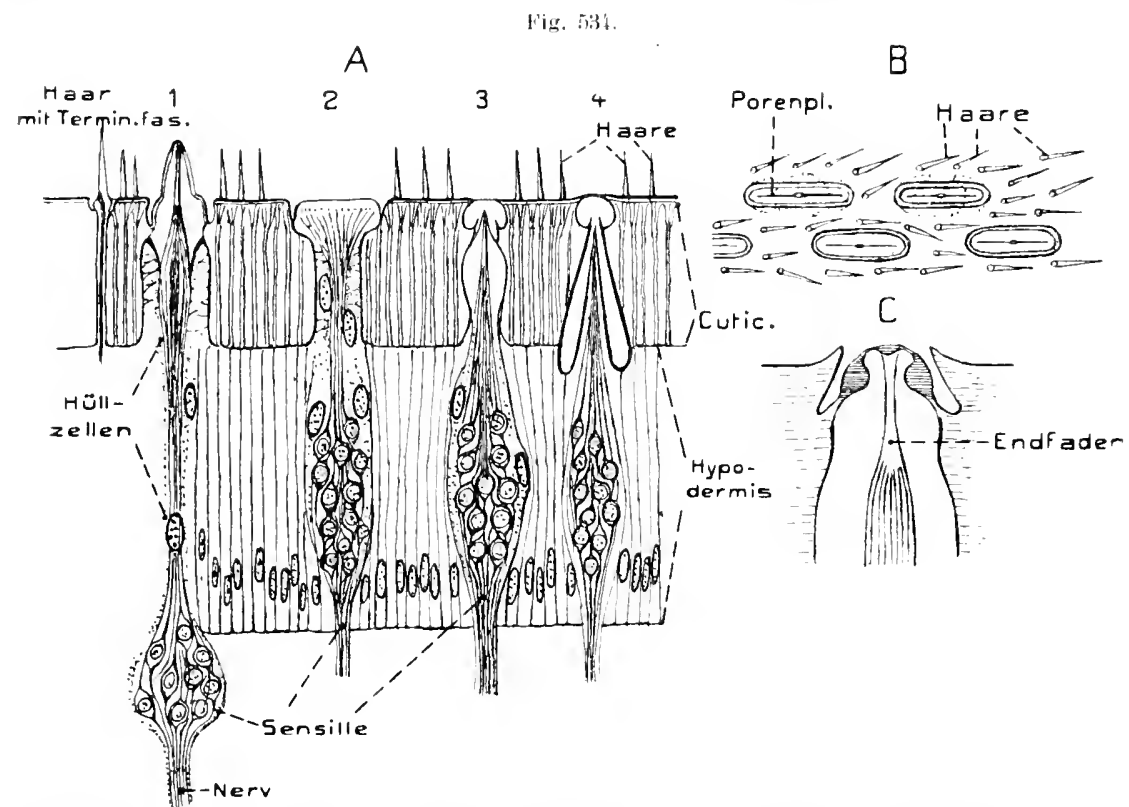

Verschiedene sinneshatre von len Antennen der Hymenopteren etwa Vespal. A Achsial. schnitte (schematisch). 1 Zaj)fenorgan. 2 Porenplatte inı Längssclinitt. 3 chanpagnerpfropfartiges r)gan. t Flaschenförmiges Organ. B Kleines Stück der Antennenoberfläche nit dichtstehender Porenplatten. C'Eine Porenplatte im Querschnitt; stärker vergrößert. O. B. II, v, Bu

Lrpidopteren); wobei, wie erwïhut, die männlichen Fühler, die sich anch nicht selten durch bedentendere Größe, reichere Entfaltung .ler Oberfläche durch Fiederung 1 , dgl, auszeichnen, bevorzugt sind.

So wurden die Urgane (speziell die sog. Porenplatten) bei Apis an einem männlichen Lühler auf etwa 15000, am weiblichen nur anf 2000 geschätzt; beim Maikäfer (Nelolontha) soli ihre Zahl aui einem mänulichen Fühler sogar etwa 50000, auf dem des Weibchens nur etwa 3000 hetragen. Damit harmoniert die Erfahrung, daß das Witterungsvermögen der läunchen für die Weibchen. besonders bei schmetterlingen, eiu ganz erstaunliches sein kann.

Die einfachsten Organe erimnern lebhaft an die Riechborsten oder Zapfen der Crustaceen und Myriopoden, indem sie stab- bis kegelartige, sich auf der Antennenflïche frei erhebende Anhänge darstellen (Sensillar styloronicar), wie sie natmentlich hei den primitiveren Ordnungen vorkommen, doch anch den höheren 
nicht fehlen Fig.535 A solch freie Kegel /Zapten schließen sich jene eng an, welche in verschiedenem Grade in griibchenförmige Vertiefungen der Antennenoberfläche eingesenkt sind, sog. Gmbr micgol (Fig. 534 A, 535C) mit dickerer (solide oder diinner Wand (hohle Grubenkegel). Bei diesen kann der Geruchskegel entweder noch melur oder weniger frei ans dem Gribehen herrorragen S.basicomim oder sich nur bis zu dessen Üffunngstand erheben, sich schließlich anch nur anf den Grund der Grube beschrinken ( Niundung nicht erreicht. Es kommt anch vor, daß ein sich frei erhebender Kegel von einem cuticularen Borstenkranz nmgeben ist Fig. 535 A) oder daß sich (namentlich Lepidopteri) in der Grube ein bis mehrere Krïnze solch solider Chitinbörstchen nm den basalen Kegel erheben Fig. $535 \mathrm{~B}$. _ Ähnlich erscheinew

Fig. 58 .

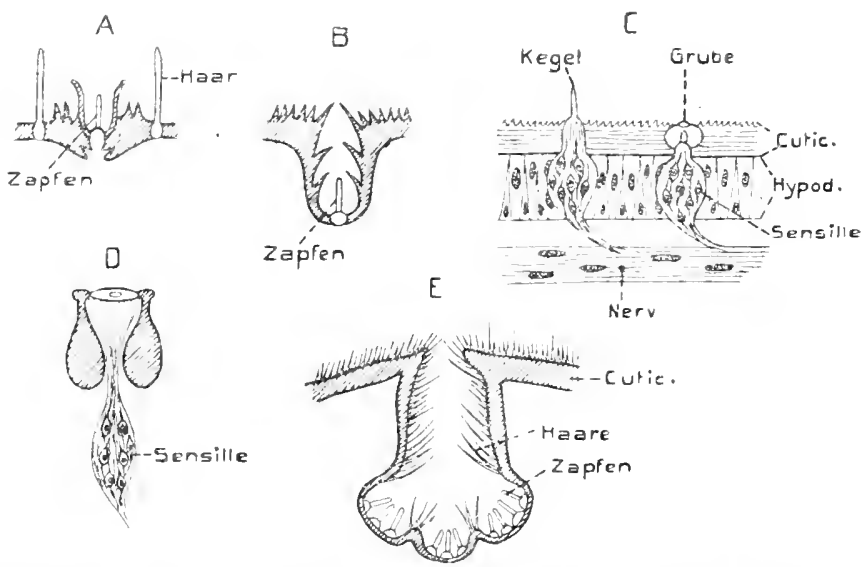

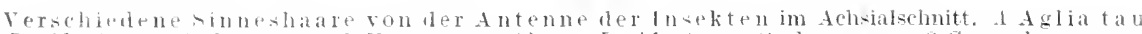

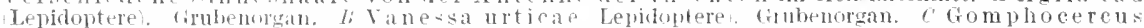

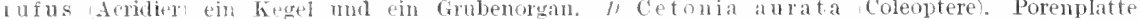

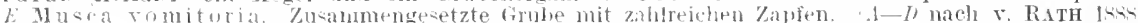
b nach liohler: 1:40s. o. B.

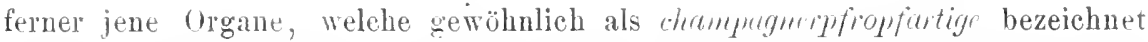
wurten (s. Fig. 534 A, B) nud sich speziell bei Hymemoptrren finden; hei ibnen erhebt sich etwa in der mittleren Höhe des Griibchens ein ringförmiger Chitinwall, so daß die Gestalt des Grïbchens nngefulhr an die eines C'hampagnerpfropfs erinnert. - Aus den Grubenkegeln gingen jedenfalls die sog. flaschenförmign" organe ( Gribchen in einen die Cnticula dnrehsetzenden Porenkanal fortsetzt, der sich proximal in ein langes, tief unter die Hypodermis reichendes, feines Chitinröhrchen verlängern kann, anf dessen etwas erweitertem Proximalende sich erst der sehr diinnwandige Kegel erhebt. - Eine weitere sehr eigentïmliche Modifikation der Organe bilden die sog. Porcmplatten oder Mrmbranliamile (s. placoideaf, anch kelchförmige Organe gen. , welche sich etwa von jenen Grubenkegeln ableiten lassen, deren Kegel sich bis zur Distaloffunng der Grube erhebt. Wird ein solcher Kegel lang und in der Fühlerachse meist schmal verlängert, dabei gleichzeitig 
so niedrig, daß er als eine dickere Chitinplatte mit feinem Längsschlitz die Grube nahezn ansfïllt und nur dureh eine sehr feine eingesenkte Chitinhant mit dem Grubenrand zusammenhïngt, so entsteht eine solche Porenplatte lig. $534 \mathrm{~A}, 2$, $B$ n. $C$. Ver Umriß der Poreuplatten schwankt jedoch in der Flichenansicht zwischen kreisrund und oval bis lang spaltartig, wie letzteres namentlich bei Hymenopteren vorkonmt, bei denen und den Colcoptern" Fig. 535 I) solche Organe häufig massenhaft :uftreten. Nimentlich tinden sich gelegentlich auch feine Poren- und Membrankaniile, die äußerlich nur von einer'sehr zalrten Chitinnembran :logeschlossen sind.

Bei einem und demselben Insekt kömen gleichzeitig verschiedenartige Organe anf den Antennen vorhanden sein, so z. B. bei Hignemopteren und Kïfern freie Geruchskegel, Grubenkegel und l'orenplatten und bei erstereu auch champaguerpfropfartige und flaschenförmige Organe. - Interessant erscheint ferner, daß sich bei gewissen Insekten, so vor allem anf dem großen dritten Fühlerglied (Ler brachyeren Diptricn, anch kompliziertere Organe entwickeln können, indem sich mehrere bis zahlreiche benachbarte Gernchskegel in eine gemeinsame säckchenartige Einstülpung einsenken und ein zusammengesetztes Organ bilden (Fig. $535 \mathrm{E}$ ), wie sie in Ein- bis Vielzahl, meist neben einfachen Geruchskegeln, auf einem Fühler vorkommen können; ja es tinden sich auch Organe, welche aus der gemeinsamen Winstiilpung mehrerer solcher Gruppen mit vielen Kegeln hervorgingen. Ähnlich vergesellsehaftete Gruben finden sich auch bei manchen Käfern (z. B. Melolontha) und Lepidopteren.

Hinsichtlich ihres feineren Bans stimmen die Organe der Insekten im allgemeinen mit jenen der Myriopoden wahe ïberein. Zu jedem trit cine spindelförmige Sinneszellengruppe, die von einem Ast des Antennennervs innerviert wird (s. Fig. $534 A$ ); ferner ziehen in jeden Porenkanal oder dessen Fortsetzung in den Kegel ein bis mehrere verlängerte Hypodermiszellen (Hüllzellen, anch Neurolemmzellen $;$, welche eine Art Seheide um die Sensille bilden. (ob sich eventuell Organe mit nur einer Sinneszelle finden, wie es besonders für die Porenplatten z.T. angegeben wird, scheint zweifelhaft, wäre aber jedenfalls ungewöhnlich.

Der so rerschiedenartige Bau der beschriebenen Fühlerorgane der Insekten macht e: wabrscheinlich, daß sie nicht sämtlich derselben Sinnesfunktion dienen. Daß die freien, sowie die Crubenkegel als Geruchsorgane zu denten sind, erscheint wohl sicher. Zweifelhaft ist dies jeduch für die häufig so zahlreichen l'orenplatten wegen ihrer ziemlich dicken, terminalen Chilinplatte, die aber einen mittleren nur sehr dïn geschlossenen Schlitz besitzt; sie wurden gelegentlich für mechaniscb, besonders. durch Luitbewegungen (auch Lultwiderstand) reizbare Gebilute erklirt. - Auch die Funktion der tief eingesenkten flaschenfömigen Organe ist wentag sicher, aber ihre gelegentliche Aufiassung als Ilörorgane doch unwahrscheinlich. da sie vou den charakteristischen IJïrorganen der Insekten vällig abweichen.

Ähnliche Organe, speziell freie Kegel und Gruben mit kleinen oder zum Teil auch fehlenden Kegelchen, tinden sich gewöhnlich auch auf der ersten um zaceiten Maxille (Unterlippe) der Insekten, und zwar sowohl auf deren Laden (resp. Glossen und Paraglossen der Unterlippe) als den Palpen. Sie breiten sich 
anch anf der Ventralseite der Oberlippe (und dem Epipharynx), sowie auf dem von der Unterlippenfläche sich in die Mundhöble erhebenden Hypopharynx aus. Häufig sind sie am Ende der Palpen oder Laden in einem besonderen Feld reichlicher vereinigt, so namentlich auch am Distalende der Glossen und Paraglossen der Hymenopteren (wo letztere besser ausgebildet) und anf der Dorsalseite der Zungenbasis dieser Formen. - Auch die Rüsselspitze der Rhynchoten und Dipteren trägt häufig solche Organe. Selbst zusammengesetzte Organe können sich anf dem Ende der Maxillar- und Unterlippenpalpen bei Dipteren und Lepidopteren finden. Daß diese Organe, besonders jene der Mundhöhle, zum Teil als Geschmacksorgane funktionieren, scheint um so sicherer, als das physiologische Experiment das Geschmacksvermögen mancher Insekten außer Zweifel stellt. Wegen ihrer großen Übereinstimmung mit den Geruchsorganen mußten sie hier besprochen werden. Von den Crustaceen ist kaum etwas Sicheres uiber Geschmacksorgane bekannt.

Nur wenige lälle scheinen bis jetzt bei Insekten beobachtet (Ameisen, einzelnen Käfern, Aeschnalarve), wo sich Geruchskegel und Porenplatten auch an gewissen Stellen des Thorax, des Abdomens und der Beine finden.

Arachuoilem. Nur hei relativ wenigen Formen dieser Klasse wurden Organe beobachtet, welche jenen der Insektenfühler gleichen. Um so auffallender erscheint es daher, daß die eigentümlichen Solifugon (Wüstenspinnen) am Endglied ihrer Maxillarpalpen (Pedipalpen) und dem des ersten Beinpaares zahlreiche Organe besitzen, deren Bau, insofern die chitinösen Teile in Betracht kommen, teils den rhampagnerpfropfartigen, teils den Flaschenorganen der Insekten sehr gleicht. Die ersteren stehen anf den Tastern, zum Teil sogar in gemeinsamer Grube. Ob sich diese $\ddot{A}$ hnlichkeit auch auf den nervösen Endapparat erstreckt, ist bis jetzt unsicher.

Den Riechorganen werden gewölınlich auch die zahlreichen Endorgane an den sog. Kümmen ter Sliorpione zugerechnet; doch könnten sie auch als Tastorgane funktionieren, die mit dem Geschlechtsleben in Beziehung stehen.

Wie die (Intogenese lehrt, sind die Kämme umgebildete Extremitäten des zweiten $\mathbf{A b -}$ dominal(liumpf)-Segments, d. h. ein Paar lanzettförmiger platter Anhänge, deren Caudalrand eine dichte lieihe bltförmiger Anhänge trägt, welche an die Zälıne eines Kamms erinnern. Auf letzteren findet sich endständig je ein ovales Feld nit zahlreichen cylindrischen Zapfen, $z u$ denen je ein Sensillenorgan gehört. ähnlich dem der Riechkegel der Insekten. Außerdem finden sich an den Kämmen noch lange Sinnesborsten mit Sensille, sowie einzellige Sinnesorgane ohne Cuticularborste.

Eigentümliche Sinnesorgane, welche sich vielleicht ebenfalls hierher stellen lassen, sind die sog. fücherförmigen Organe (Mulleoli, Raquettes) der Solifugen, die sich in Fünfzahl auf der Ventralseite der Basalglieder (Coxa und 1. Trochanter) des vierten Beinpaares finden.

Jedes Urgan hat etwa die (iestalt eines gestielten lächers. Jm Proximalteil des rächer: finden sich in seiner ganzen Ausdehnung zahlreiche, dicht nebeneinanderliegende Sensillen, deren Terminalstränge in ihrer distalen Fortsetzung ein zusammenhängendes Band bilden und deren Einzelfasern endich am freien Distalrand des Füchers in zwei alternierende Reihen von dunkleren Jindspitzen auslanfen. die in einer schmalen, schwach eingesenhten Rinne des Fächer- 
rands, an der hier sehr zarten Cuticula endigen. Bemerkenswert erscheint, daß in den Einzelfisern, etwas proximal von ihren distalen buden kirperchen rorkommen, welche an die

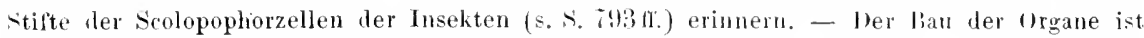
namentlich wegen des eigentümlichen Verhaltens der Hyportermis in lärher recht komplizient und lonnte daher nur angedentet werden.

Endlich wïre noch zu erwähnen, dab sich im distalen dilied der Maxillarpalpen der Solifugen eine langkegulförnige, tiel eingesenkte Tasche timdet, dio ansgestülpt und durch besondere lluskeln wieder eingezogen werden lann. An ibrer lentralthiche enthält diese Tasche ein Feld mit zahlreichen, die Cuticula hurhsetzemlen Vervenendigungen ohne besondere liorsten, wie es scheint, Daß es sich mm ein Sinnesorgan luandelt, ist wohl sicher, wahrscheinlich um ein chemisch reizbares.

Die beiden (oder sogar drei) di،ht nebeneinander liegenden. qrübchen-bis bläschenartigen Einsenknngen mit zarton Sinnesborsten am distalen Glied des ersten Beinpares gewisser Milben (Ixodidae oder Zecken) erinnern gleichfalls an liechorwane; es scheint, daß zu jeder Borste eine Sensille gehört. Insicherer sind die bei then Heibchen dieser Milben an ler lorsalen Basis der Maxillarpalpen vorkommenden lorenfelder mit sinneszellen.

Auch die sog. leierfïmigen Organe, welche auf der Körperobertläche der Aruchoidecn recht verbreitet sind, werden nenerdings als Geruchsorgane gedeutet (vermißt wurden sie vollständig bei den meisten tearinen, gewissen Opilioniden und den den letzteren ähnlichen Ricinuleen.

Im einfachsten Fall erscheinen diese fiebilde als schmale schlitzönnige Einsenkungen in der Cnticula, welche in charakteristischer Weise etwas neben ihrer Mitte eine kreislümige Erweiterung besitzen. Jeder Schlitz vertieft sich zu einer sclimalen, komprimierten, in der Breitenansicht etwa becherformigen Jöhle. Welche sich bis zur Innenfläche der Cuticula hinabsenkt and hier mit dem Terminalfortsatz einer ansehnlichen Sinneszelle verbunden ist. Bei den Stiorpionen, Solifugen, Opilioniden und Acrrinen linden sich nur soleh eintache Grgane, zum Teil am lörper, zum Teil an den Extremitäten. liei den Pseuloslorpionen, I'edipalpen und Araneinen treten noch kompliziertere Organe aul, indem mehrere bis zahlreiche solche Schlitze, etwa parallel und dicht nebeneinander, auf einem besonderen Cuticularfeld stehen; außer ihnen finden sich daun gewönlich noch einfache Schlitze. Die zusammengesetzten Organe stehen in geringer Zahl an den Lxtremitäten gewisser Pedipalpen, in viel größerer an denen der Araneinen, wogegen sich aut' deren eigentlichem körper, speziell ler Ventralseite des Cephalon (auch der Spinnwarzen). nur einfache Schlitze finden.

l)e hohe Zahl und Entwicklung der leierförnigen Organe. besonders bei den jagenden Araneinen, spricht für ihre physiologische Bedentung, die jedoch noch weiterer Aufklärmg hedart. - ob sie morphologisch den an den foxen des zweiten bis fünlten Extremitätenpaars des Cephalon ron Limulus und den Scheeren des ersten bis sechsten des Weibchens sich tindenden Grganen vergleichbar sind, ersheint zweifelhat. liese haben etwa den ban der von den Insektenfühlern bekanten Porenplatten, sollen jedoch nur je eine einzige Sinne-zelle besitzen, was etwas zweifelhatt erscheint. Sie wurden als Geschmacksorgane gedeutet. - Dagegen dürtten die ïher die Körperoberfläche weit verbreiteten vielzelligen angeblichen Simnesorgane des Limulus wohl sicher Drüsen sein. Anch las vor dem Mum gelegene sog. Rierhorgan les Limulus erstheint recht unsicher.

\section{Statische Organe (Gleichgewichtssinnesorgane) und Hörorgane.}

Die Zusammenfassung dieser Organe in einem Kapitel scheint gerechtfertigt, weil ihre Funktionen bei den Vertebraten in verschiedenen Abschnitten eines und desselben Organs vereinigt sind, und es auch vorerst nicht ganz ausgeschlossen er- 
scheint, daß die jetzt als statische Organe erwiesenen, wenigstens in manchen Fällen, auch von Tonschwingungen gereizt werden können. Bis vor kurzem wurden die statischen Organe der Wirbellosen als Hörorgane gedentet. Erst die neuere Zeit wies nach, daß sie wohl fast allgemein, oder doch in erster Linie, von der Ilaltung des tierischen Körpers im Raum, sowie von den Körperbewegungen affiziert werden, und infolgedessen auf reflektorischem Wege die Haltung wie die Bewegungen zu regulieren vermögen, ganz abgesehen von etwaigen Empfindungen, welche mit ihrer Reizung verbunden sein könnten. Schädigung oder Zerstörung der statischen (Irgane ruft daher Störungen der normalen Haltung und der Bewegungen hervor, womit jedoch nicht selten auch Herabsetzung der Spannnng (Tonus der Bewegungsmuskulatur verbunden ist, sowie Störung oder Anfhören der bei der Lageveränderung zahlreicher Tiere auftretenden sog. kompensatorischen Augen- oder Kopfbewegungen, welche die Erhaltung der Augen in der Normallage anstreben.

Nit Ausnahme der Insekten, erscheint heute die statische Funktion der früher als Hörorgane der Wirbellosen gedeuteten Gebilde gesichert. Bei den Vertebraten sind es, wie erwähnt, gewisse Abschnitte des Hörorgans, welche als statische funktionieren. Aber die allmähliche Entwicklung des eigentlichen Hörteils des Urgans in der Vertebratenreihe macht es wahrscheinlich, daß es ursprünglich rein oder vorwiegend statisch funktionierte, und der zum Hören eingerichtete Teil sich erst sekundär entfaltete. Wir beginnen mit der Betrachtung der rein statischen Organe.

Das allgemeine Banprinzip derselben grïndet sich zunächst auf die Schwerewirkung; es bestehtnämlich darin, daß Sinneszellen durch den I)ruck frei sch webender, oder doch der Schwere folgender Körperchen, gereizt werden. Da nun bei verschiedener Körperhaltung zur Sch wererichtung verschiedene Sinneszellen gedriickt oder gereizt werden können, so mul der Erfolg ein entsprechend verschiedener sein, und eine Regulation der Körperhaltung eintreten können, wenn die nervösen Beziehungen zur Körpermuskulatur so eingerichtet sind, daß diese bei der Reizung verschiedener statischer Sinneszellen in geeigneter Weise reflektorisch funktioniert. - Andererseits können jedoch die schweren Körperchen auch bei den Bewegungen des Tieres Reize auf die Sinneszellen ausüben, indem sie entweder den beginnenden Körperbew egungen nicht sofort folgen und dadurch gegen die sich bewegenden Sinneszellen drücken, oder umgekehrt bei plötzlichem Stillstehen des Körpers noch einige Zeit in Bewegung bleiben und dabei ähnlich wirken.

Das Vorkommen statischer Organe in der Tierreibe ist auffallend unregelmäßig, weshalb sich vorerst ein bestimmtes Verbreitungsprinzip nicht erkennen läßt. Von vornherein erscheint zwar begreiflich, daß sie sich bei frei beweglichen Formen finden und daher auch unter dem Einfluß der Festheftung hänfig verkümmern.

Unter den Cïlenteraten begegnen wir ihnen bei zahlreichen frei schwimmenden Hydromedusen und Acalephen, sowie regelnäßig bei den Ctenophoren. In der Reihe ler Würmer finden sie sich häufiger bei Turbellarien, vereinzelt bei Nemertinen und gewissen Polychacten (besonders grabenden Sedentariern). Fast stets vorhanden sind sie im großen Stamm der Mollusken, wo sie nur den Amphineuren völlig fehlen. - Den höheren Krebsen (Thoracostraca) kommen sie hänfig zu. Dagegen treten sie unter den Echinodermen allein bei gewissen Ilolothurien auf. - Regelmäßig finden sich statische Organe eigentiimlicher Art 
bei den copelaten Tumicuten und den ihnen ähnlichen Ascidimhurrn, hei den übrigen eswachsenen Tunicaten dagegen mu ganz vereinzelt. - Unter den Tortcbraten fehlen sie den Acrania nud sind bei den Craniota, wie bemerht, Teile der llörorgane. Das vereinzelte Auftreten in manchen Gruppen marht es recht wahrscheinlich, daß die Grgane vielfach selkständig entstanden sein dïrften, wofür anch ihr verschiedenartiger Bau spricht.

Abgesehen von den Wirbeltieren, lassen sich im allgemeinen etwa folgende Hauptformen der Organe unterscheiden : 1) Kleine, sich auf der Oberfläche frei beweglich erhebende klöppelartige Gebilde (tentakelartig), deren freies Ende innerlich durch eine Konkretion (Stntolith) besehwert ist, wodurch sie auf Sinneshaare ihrer Umgebung drücken, oder die selbst Sinneshare tragen, welche an ihrer Umgebung Widerstand erfahren können. Sie vermögen sich auch unter die Körperoberfläche einzusenken nnd liegelı dann in geschlossenen Bläschen statorystrm. Organe dieser Kategorie linden sich bei Trarhymertusen und Acalphen. 2) Das Ectoderm der Körperoberfläche bildet grübehenförmige linsenkungen mit Sinneszellen nnd frei beweglichen oder an der Wand befestigten Statolithen, welche jedoch auch durch Fremdkörperchen, die von außen aufgenommen werden, ersetzt werden können. Solch offene Statocysten senken sich häufig tiefer ins Körperinnere ein, wobei sich ein nach anßen geöffneter Einstïlpungskanal erhalten kann, oder sie lösen sich als geschlossene Bläschen vom Ectoderm ab und enthalten dann einen Statolithen oder zahlreiche kleine Strtocomirn, welche von den Zellen der Blasenwand abgesonderte, meist ans kohlensaurem Kalk bestehende, sphärokristallinische oder kristallinische Gebilde sind. Diese Statolithengebilde sind gewöhnlich frei in der wäßrigen Flüssigkeit (Statolympler) der Cyste suspendiert und dann häufig in zitternder Bewegung. Derartige Organe finden sich bei den resiculatr" ilydromerhesen Leptomertusen), den Wiirmern, Molluskis", Holothurien und gewissen Tuniraten (Doliolum). Auch die sich hoch komplizierenden statisch-akustischen Organe der Wirbeltiere gehören prinzipiell hierher. 3) Ähnlich erscheinen im allgemeinen die statischen Organe der malacostialen Kirbse, nämlich als teils geifffnete, teils geschlossene Statocysten, aber von den seither erwähnten dadurch verschieden, $d a ß$ sie innerlich von Cuticnla ansgekleidet und ihre Sinneshaare keine gewöhnlichen, sondern cuticulare Haare sind, wie sie fïr die Arthropoden charakteristisch erscheinen. 4) Das eigentümliche statische Organ, welches sich in der Hirnblase der Copelaten und Ascidiemlarven unter den Tunicaten findet.

\section{Coelenterata.}

Ein Teil der Trarlymmodus"n (Aeginiden) zeigt einfache Verhältnisse, indem sich (Fig. 536) auf der randlichen Umbrella, etwas über dem Ursprung des Velums nnd außen vom umbrellaren Nervenring radiär angeordnete, kleine, freie Kölbchen in zum Teil sehr großer (mit dem Wachstum sich vermehrender) Zahl erheben. Jedes Kölbchen entspricht einem schwach entwickelten Tentakel und entspringt von einer polsterartigen Verdickung oder stärker vorspringenden Papille, welche durch Erhöhung des Epithels und Anschwellıng des äußeren Nervenrings gebildet wird. Wie ein Tentakel besteht es ans änßerem Ectoderm und einer 
soliden Achse von Entodermzellen, die sich bis auf zwei reduzieren können. Ein oder zwei distale Entodermzellen scheiden innerlich je eine Statolithenkonkretion aus, die nur in seltenen Fällen (so der Süßwassermeduse Limmocodium) fehlen soll. Sowohl im Ectoderm des Basalpolsters als dem des Kölbchens finden sich Sinnes-

Fig. 536.

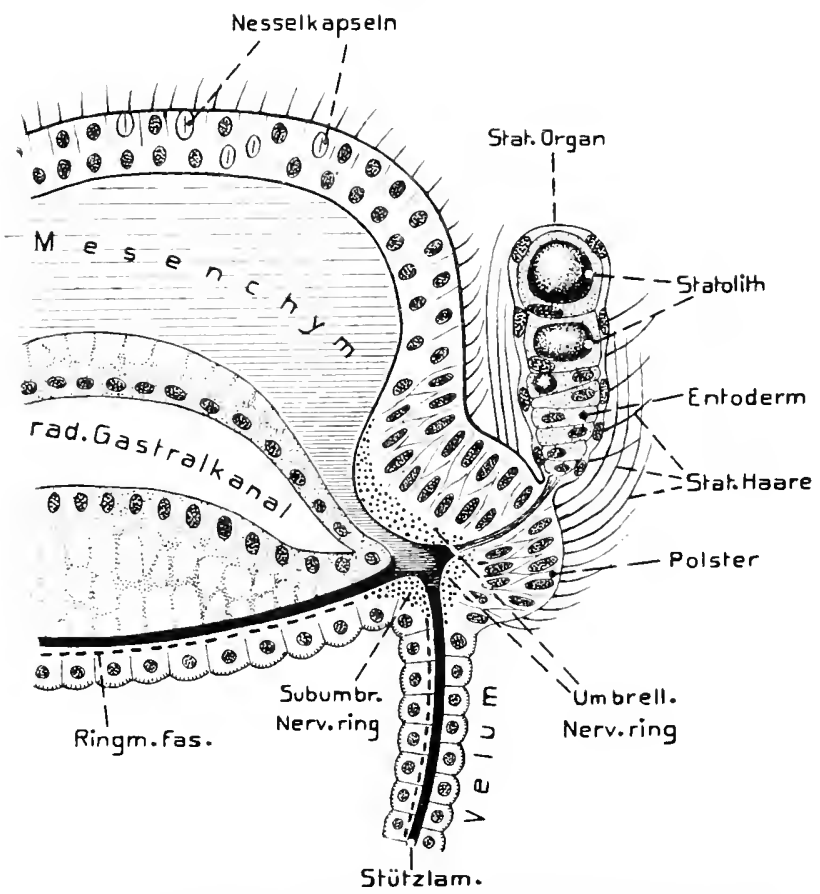

(unina lativentris Trachrmerlnse). Raclialschuitt durch den schirmrand mit einem statischen Kölbchen (nach $O$. und li. HerTwIG 1878). zellen, die mit dem äußeren Nervenring verbunden sind und lange starre Sinneshaare tragen. - Auch gewisse Trarleymentden (z. B. Iglaura) besitzen noch solch freie Kölbchen; bei anderen z. B. Rhopalonemu, Gryyoridr" u. a. werden sie, vom angrenzenden Integument ringförmig umwachsen, zu fast oder ganz geschlossenen Bläschen, die sich bei den Geryomiden ziemlich tief in die Schirmgallerte einsenken, nach innen von dem.randlichen

Nesselwulst (Fig. 537), selten sich schlauchartig tief in das Velum erstrecken (z. B. Limnocodium). In die von einer flachen Epithelwand gebildete Statocyste (Lithocyste springt das Kölbchen mit seinen langen Sinneshaaren vor.

Die freien statischen Kölbchen der Aralephen, welche nur cinem Teil der primitiven Formen (Stauromedusen) fehlen, wurden schon früher (S. 467 ), bei der Besprechung des Nervensystems, erwähnt. Es sind die dort nach Vorkommen, Zahl und allgemeiner Bildung besprochenen Rumliörper oder Rhopatien, ebenfalls gewöhnlich als verkürzte Randtentakel gedeutet (was jedoch auch geleugnet wird, welche je in eine Art Höhle hinabhängen, die von der Deckplatte (Trichterplatte) überdacht und bei den Discomedusen seitlich von den beiden Ephyralappen begrenzt wird. In das Rhopalinm setzt sich das Entoderm fort, samt einem von ihm umschlossenen Gastralgefäß. Das distale Entoderm des Rhopaliums ist eigentümlich syncytial netzförmig umgebildet und scheidet in seinen Zellen zahlreiche Kriställchen aus (Calcinmsulfat), die den sog. Kristallsack bilden. Wie wir schon 
oben fanden, breitet sich unter dem Epithel der Rhopalien eine Nervenfaserschicht ans, die eine direkte Fortsetzung des Zentralteils des Nervenapparats an der Basis jedes Rhopaliums bildet. Das basale Epithel des Rhopalinms ist reich an flimmernden Sinneszellen, die bei gewissen Formen auch längere Sinneshaare tragen sollen (Nausithö̈).

Die statischen Organe der Leptomedusf zu den Campanulariden gehörig, häutig Tesiculutar genannt), neben denen sich selten auch (Teellen finden (z. B. Tiaropsis, Sturrostoma), sind nach Lage und Entstehung von jenen der Trachymedusen so verschieden, dal' sie jedenfalls selbständig entstanden sein müssen. Sie gelı̈̈ren der Subumbrella an und tinden sich, dicht einwärts vom Ursprung des Velums, als im primitiven Zustand (z. B. Mitrocoma flach grubenförmige Epitheleinsenkungen (Fig. 538). Ihr Hauptcharakter besteht darin, daß sie nur aus dem Ectoderm hervorgehen, indem sowohl ihre Sinnes- als Statolithenzellen ectodermaler Herkuntt sind. An der umbrellaren Grubenwand fnden sich eine, bis eine ganze Querreihe (bei Vitrocoma sogar zwei benachbarte Querreihen) frei in die Grube vorspringender Zellen, die in sich je einen Statolithen abscheiden. Die

Fig. 537

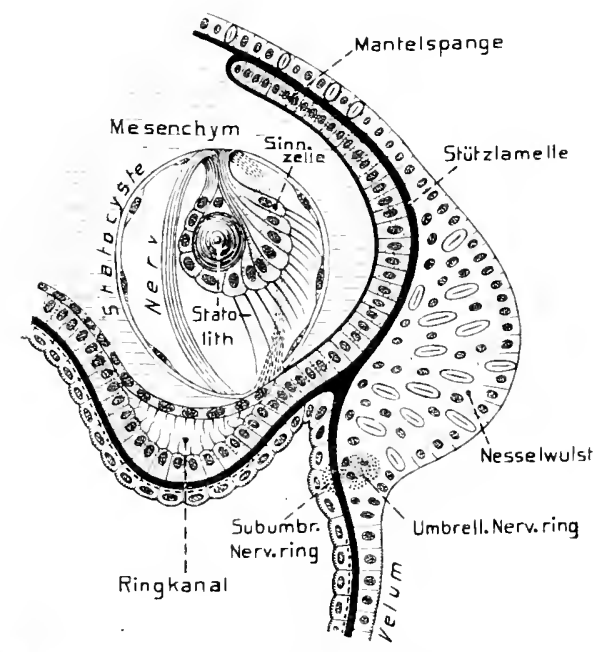

Carmarina hastata (Trachymeduse). Radialschnitt durch den Schirmrand mit einer statocyste und Hantelspange nach $O$. und R. HERTwig 1878). E. W. an diese Statolithzellen proximal

angrenzenden Zellen sind zu eigentümlichen Sinneszellen entwickelt, von welchen sich stets mehrere his 8) dicht an eine der Konkrementzellen anschmiegren und sie mit ihren Sinneshaaren umgreifen. Die Inuervierung der Sinneszellen geschieht jedenfalls vom subumbrellaren Nervenring aus, obgleich dies nicht direkt erwiesen ist. Bei zahlreichen Leptomedusen (z. B. Obelia, Afquorer, usw.) senken sich diese statischen (Gruben tief nach außen in die Schirmgallerte ein und schließen sich endlich zu Statocysten ab, welche sogar am Ursprung des Velums häufig umbrellar stark bläschenartig vorspringen (s. Fig. 539). Die Zahl der Statolithzellen kaun recht verschieden sein eine bis sehr zahlreiche), und da zu jeder dieser Zellen eine Sinneszellengruppe gehört, so schwankt auch deren Anzahl erheblich. - Auch diese Organe sind, dem Radiärban entsprechend, am Rand des Medusenschirms verteilt, teils an der Basis der 'Tentakel, teils zwischen denselben, an Zahl sehr variierend und mit dem Wachstum gewöhnlich zunehmend (bis 600 bei Aequorea z. B. . 
Die Deutung der geschilderten Organe der Hydromedusen und Acalephen als statische wurde durch das physiologische Experiment bis jetzt nicht sicher bestätigt; im Gegenteil

lig. 53:

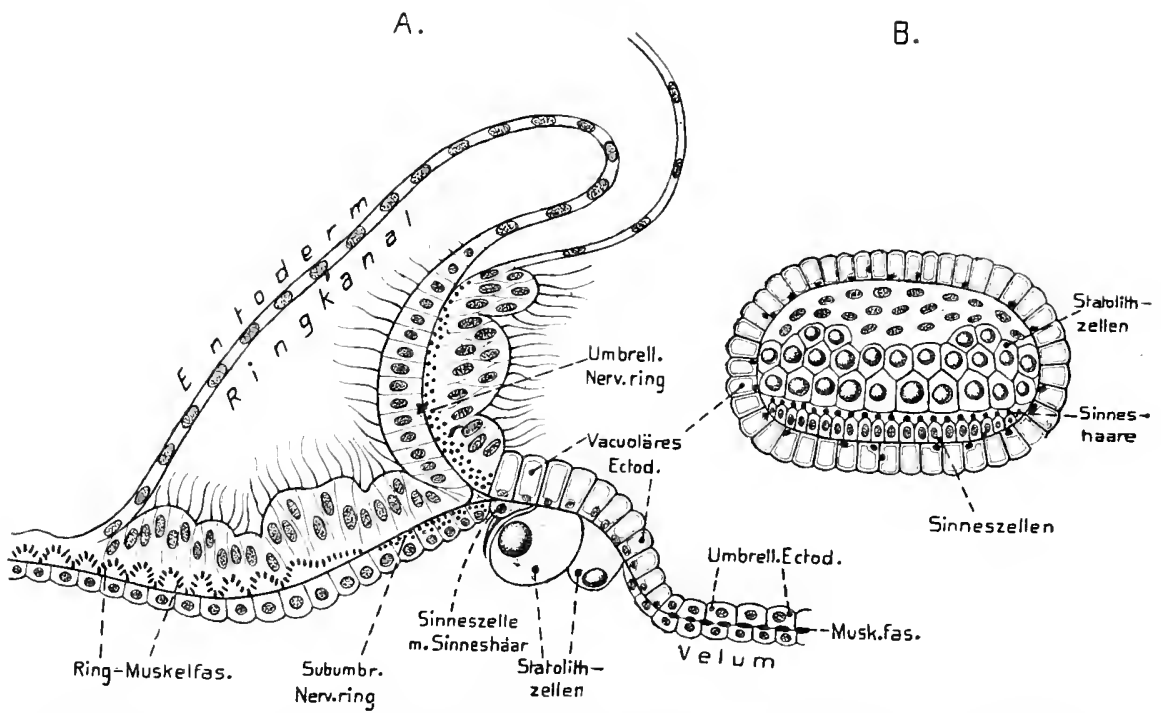

Mitrocoma an na e (Leptomeduse). A Rodialsednitt durch den Schimirant mit rinem statischen Organ im Jurchschnitt. - $b$ Ansicht des statischen (organs von (ler Umbrellarseite: das umbrellare Epithel (vacuoläres Ectoderm im optischen Jurchschnitt nitch O. und R. HERTwig 1878). E. W.

scheinen die vorliegenden Versuche gegen ihre statische Funktion zu sprechen. Jedenfalls kann das l'roblem einstweilen noch nicht als sicher gelöst gelten. Für lie Acalephen wurk"

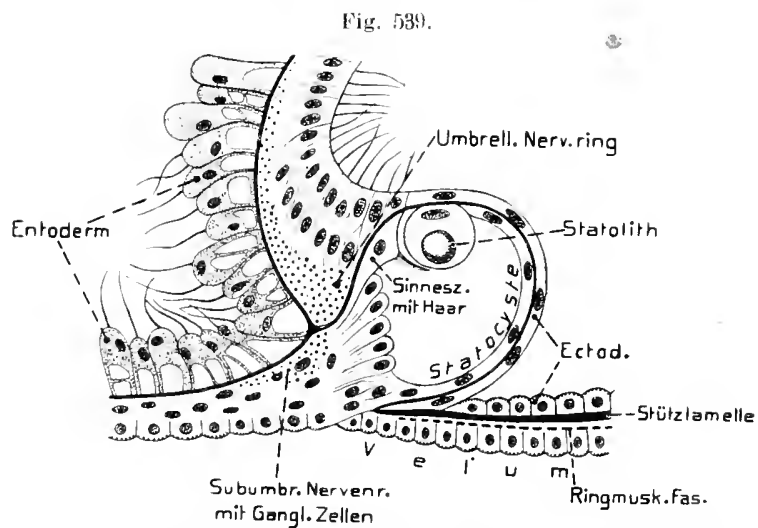

A equorea torskali Leptomeduse). Radialschuitt durch len Sehlinrand und eine statoryte nach (1. und R. HerTwli 1k78), L. W. nachzuweisen gesucht, daß durch die Reizung der lhopalien die Bewegungen der Meduse ausgelöst werden.

Ctenophore. Statische Organe eigener Art und Entstehung sind die der Ctenophoren, welche sich nur in Einzahl auf dem Apex aboralen Pol dieser eigentümlichen Metazoen finden. Schon dieser Umstand läßt sie sowohl von jenen der seither besprochenen Cölenteraten, als auch denen der meisten ïbrigen Meta-
zoen sehr verschieden erscheinen. Das statische Organ erhebt sich am Apicalpol als eine durchsichtige halbkugelige Blase (s. Fig. 22, 1, S. 96 u. Fig. 540), die hei den Beroiden und Saccaten frei vorspringt, bei den iibrigen Ctenophoren von 
lappigen Körperfortsätzen der Umgebung stark überwachsen nnd daher mehr oder weniger tief eingesenkt ist. Die gewöhnlich länglich ovale Blase erliebt sich über einer stark verdickten Epithelplatte, die früher meist als das centrale Nervensystem gedeutet wurde, deren fein-fadenförmige, bewimperte Epithelzellen jedoch keine Verbindung mit Nervenfasern erkennen lassen. Die Blase selbst sitzt dem etwas abgesonderten, wulstartigen Rand der Epithelplatte auf. Ihre Wand besteht wabrscheinlich nnr aus sehr langen verklebten Cilien. Ursprïnglich entsteht nïmFig. 5iv. lich die Blase aus der Verwachsung von vier Platten, welche an die Ruder-oder Kammplättchen erinneru. Die von der Blase umschlossene Flüssigkeit enthält einen ansehnlichen Statolith, der von vier aufsteigenden, S-förmigen Federn getragen wird, deren Enden sich etwas in ihn einsenken. lie vier Federn stehen in den vier Radien der Ctenophore und sind gleichfalls je ein Biischel verlängerter und verklebter Cilien. - Der Statolith setzt sich aus vielen einzelnen Konkrementen (angeblich Calciumphosphat) zusammen, von denen jedesin einer Zelle liegt; es sind dies losgelöste \%ellen der Epithelplatte, die schon vor ihrer Ablösung die Konkremente
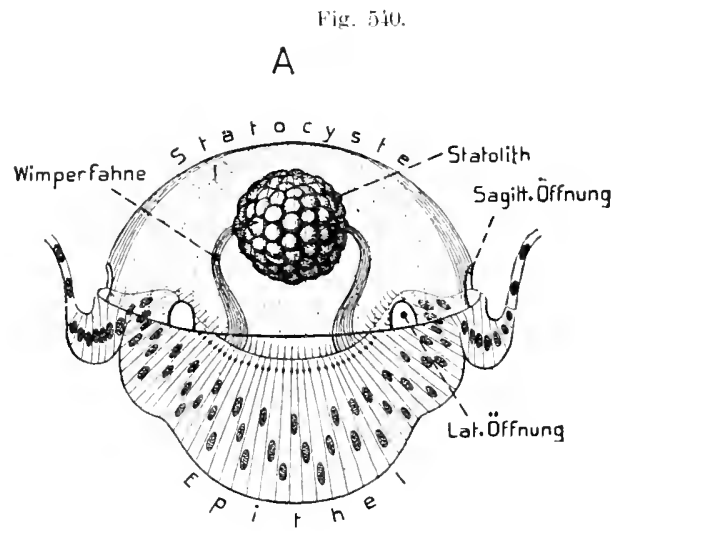

B

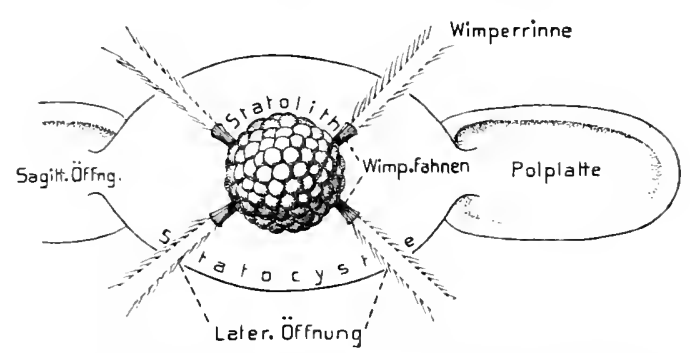

('tenophor" letwa ('allianira). Schema der statuegste. I lat terale tnsicht: Epithel im optichen lowchschnitt; die statocyte körperlich, doch der optische burchschnitt ihrer wand eingezeichnet. $\rightarrow b$ Die statocyte in Apicalansicht mit den Polplatten umb dem Anfang der Wimperrinmen nath R. HERTwi: liso mul ('HCX ISGO lion-truiert' 1. W.

abzuscheiden beginnen. - Die Statocyste ist nicht ganz geschlossen, sondern zeigt an ihrer Basis sechs Öffumugen (Fig. $540 \mathrm{~B}$ ), von welchen zwei sagittal, die vier anderen radial liegen. l)urch die ersteren setzt sich die Wimperung auf die sog. Polplatten fort, die lüutig als Geruchsorgane gedeutet wurden. Durch die vier radialen ̈̈ffinungen verlaufen je zwei schmale Cilienstreifen (Wimperrinnen), die an der Basis der vier Federn, beginnent, nach ihrem Durchtritt durch die Blasenöffinungen auseinander weichen und zu den ersten Ruderplättchen der beiden Reihen eines liadius ziehen. Bei den Lobaten setzen sie sich aber auch zwischen die aufeinanderfolgenden Ruderpliittchen jeder lieile fort, sie untereinander verbindend. 
Trotz des bis jetzt noch unsicheren Nervensystems wurde gerade fïr die Ctenophoren die Beziehung des statischen Apparats zur Körperhaltung und den Bewegungen als leicht ersichtlich dargestellt und durch Versuche als erwiesen betrachtet. Von der Haltung des Körpers soll der Druck oder Zug, welchen der Statolith auf die vier Federn ausübt, abhängen; beim Schwimmen ist nämlich der Mundpol der ('tenophoren in der Regel gegen die Wasseroberfläche gerichtet. In einer von der senkrechten abweichenden Körperhaltung würden daher die verschiedenen Federn in verschiedener Weise und rerschiedenem Grade gereizt, was durch die Wimperrinnen auf' łie Ruderplättchenreihen wirke und deren Tätigkeitsgrad reguliere, wodurch endlich die Körperhaltung geregelt werde. Neuere Versuche haben jedoch diese Deutungen nar teilweise bestätigt, so daß auch die statische Funktion des Ctenophorenorgans nieht als einwandsfrei erwiesen erachtet werden liann.

Ziemlich abweichend erscheint die Cyste der stark ungebildeten Ctenophoren Ctenoplana und Cocloplana, inden sie eine offene, flimmernde, eingesenkte Grube ron Beutelgestalt bildet, in der sich der von vier Federn gestiitzte Statolith findet. Eine eigentliche Blase scheint zu fehlen, wenn sie nicht (Coeloplana) duch eine Ait querer Scheidewami in der Grube vertreten wird. - Bei Coeloplana wurden in Verbindung mit den vier Federn vier Ganglien beschrieben, die aber bei Vergleich mit denen der Ctenophoren ziemlich zweifelhalt erscheinen. Bei der hierhergehörigen Tjalficlla ist das (1rgan rudimentär.

\section{Vermes.}

Wie schon früher erwähnt, besitzen relativ nur wenige Würmer Statocysten, die stets dem Typus der eingesenkten offenen oder geschlossenen bläschenförmigen Organe angehören. Unter den Plathrlmintlern finden sie sich ziemlich häufig bei den Turbrllarien, so stets den Acoelon und nicht wenigen Rhabdocoelidcu, fehlen dagegen den Mmdroroelen stets (abgesehen von einer unsicheren Angabe); nur vereinzelt treten sie bei den Nrmertiren auf (Gattung Ototyphlonemertes).

Die Organe liegen dem Cerebralganglion stets dicht an, manchmal sogar in ihm, und zwar interessanterweise bei den Turbellarien fast immer als ein unpaares Gebilde, meist dicht an der Ventralseite des Ganglions, selten (Haplodiseus) aut dessen Dorsalseite. Ob sie bei gewissen lhabdocoeliden auch zu einen Paar vorkommen wie bei den Nemertinen. scheint nicht ganz sicher. Pei letzteren sind sie in die Dorsalseite des rentralen Knotens des Cerebralganglions eingebettet (vgl. S. 479). Die gelegentliche Angabe, daß bei gewissen Nemertinen auch mehrere Pare vorkommen können. scheint zweifelhaft. - Die Statocysten sind stets völlig abgeschlossene, relatis lileine bläschen, deren Entstehung aus dem Ectoderm kaum zweifelhaft ist. Wegen ihrer Kleinheit läßt sich der feinere Bau schwierig feststellen. Die von einem sehr llachen Epithel gebildete Cystenwand entlält nur wenige Kerne (zwei bei Acoelen, zahlreichere bej Nemertinen). um die noch eine bis zwei feine cuticulare llüllen vorkommen kïnmen (Basalmembran). Cilien oder Sinmeshare wurden am lipithel nicht beobachtet. - Die Statolymphe. welche in gewissen Fällen (Acoelcn) etwas rötlich bis violett gefärlot ist. enthält einen, wohl aus Calciumkarbonat bestehenden Statolith von recht verschiedenartiger form, der jedoch, wie es scheint, wohl stets ein Sphärit ist, seltener (gewisse Nemertinen) aus kleineren Sphäriten besteht; doch wurden auch mehrere Statolithen bei Temertinen angegeben. Zitternde Bewegungen les Statoliths, wie sie sonst bei Gegenwart vos Gilicn meist vorkommen. wurden vermißt. - Von der Innervierung ist wenig bekannt: bei den Acoelen treten zwei kurze Nerven von rechts und links zur Cyste, ja sollen sie bei gewissen Formen brückenförmig umgreifen und gewissermaßen tragen. Diese Nerven treten zu einer eigentïnlichen Zelle (Statolithzelle), welche der Cystenwand äußerlich anliegt, und von der in einzelnen Fällen feine Fädchen zur Wand verfolgt wurden. Genateres über diese Zelle und ihre Funktion ist jeloch nicht hekant. - Was von einem 
Cestoden (Octobothrium) als Hörorgan beachrieben wurde. ist sellst als Sinnesorgan zweilelhaft. - Ebenso scheint anch die von einer zweilelhatten Gastrotriche (Plilosyrtis) erwähnte inpaare Statocyste vorerst unsicher.

Unter den Ammliden kommen uur einem Teil der swlmlïrm I'oly-hacten Statocysten zu, was vermutlich mit deren Bohrvermögell im Meeresboden in Beziehung steht, speziell mit dem vertikal abwärts gehenden Einbohren; doch finden sie sich in dieser Gruppe ziemlich unregelmäßig und nicht allzu hänfig.

Den Arenieoliden fehlen sie zwar selten und liegen zu einem Paar im ersten Segment (sog. Peristomium); häutig sind sie ferner bei den Sabelliden im ersten borstentragenden Segment (zweites Segment), und zwar vewïhnlich zu einem l'aar; doch können sich bei gewisen llyxicolaarten auch mehrere Paare in diesem Segment finden. Vereinzelt treten sie bei gewissen Arimialae und Trebellidae aul: bei letzteren im zweiten Segment. während sie sich bei den ersteren in mehreren rorderen Segmenten (5-6 ja bis 23 und meln) paarig wiederholen. Auch tï̈r einzelne andere formen liegen noch Angaben ror, die wir iibergehen, da ihre Sicherheit gering ist.

Die Organe sind im ursprünglichsten Fall offene. durch Einsenkung der Epidermis entstandene schlauch- bis flaschen- oder retortenförmige Gebilde, deren Epithel wenigstens in ihrem kanalartigen äußeren Abschnitt flimmern kam (Ariciidue, Arenicola marina Fig. 541, gewisse Terebrllitar und Sabellitru. Weiterhin finden sich auch ganz abgeschlossene Cysten ohne Kanal gewisse Atemicolidae, häutig rabellidar. Statolithen finden sich wohl stets und sind bei Formen mit geöffinetem

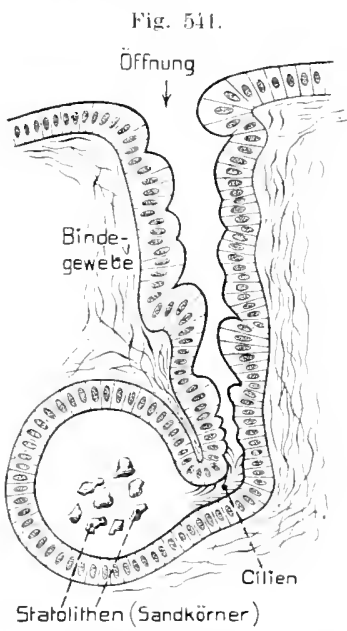

Arenicola marina. at in touste im Längsschnit schematisch) (nach

Kanal kieselige Fremdkörper, in den geschlossenen Cysten dagegen secernierte kuglige Gebilde, die aus organischer Substanz bestehen sollen $(? /$, in Ein- oder Vielzahl auftreten und sich in zitternder Bewegung befinden. Die einschichtige. Epithelwand der Statocysten läßt mcist Sinnes- und Zwischenzellen unterscheiden, vou denen letztere häufig, jedoch nicht stets, Cilien tragen. Sinneshare wurden bis jetzt nicht sicher nachgewiesen. - Die zu den Statocysten tretenden Nerven entspringen fast stets vom Bauchmark, nicht vom Cerebralganglion: bei Arenicoln vom Schlundconnectiv. - Die genanere Erforschung der Organe läßt noch viel zu wiinschen iibrig.

Das Paar statorystenähulicher Grgane. die sich gewihulich im Prostomimu der Archiannelide Protolrilus unden. sind sehr einfach gebaut, da sie mr aus einer einzigen Zelle bestehen, in deren anselnnlicher Vacuole ein statolith. an einem faserigen Stiel (ob simeshare?) befestigt, liegt. Ine (rgane sind entweder ler llypodemis oder dem Cerebralganglion eingelagert; ein Vers tritt ron letzterem zu dem erwähnten faserigen stiel.

In der Gruppe der Oliyomeren besitzt nur die Brachiopodengattung Limyula ein Har Statocysten (im Larvenzustancl auch die verwante Discina. der erwachsenen fehlen sie jedoch). Diese linsentörmigen geshlosenen liäschen liegen hateral an der Dorsalthähe. dicht 
oral rom Ursprung des vorderen Ijssepiments (sog. Gastroparietalband). Ihr hohes Epithel ließ weder Cilien noch besondere Sinneszellen sicher erkenmen. Die Cyste enthält zahlreiche kleine Statoconien, die sich zitterud heweren: sie sollen aus organischer Substanz bestehen.

\section{Mollusca.}

Wie schon erwähnt, sind die Statocysten in diesem Phylum fast allgemein verbreitet, da sie nur den Amphimeren fehlen. Ein plausibler Grund für ihr regelmäßiges Vorkommen dürfte vorerst kaum anzugeben sein. Stets findet sich nur ein Paar der Organe, deren ontogenetische Entstehung durch Einstiilpung des Ectoderms ibberall festgestellt wurde. Interessint ist ihre Lage, indem sie ursprünglich wohl stets in der Nähe der Pedalganglien in die Fußmuskulatur eingebettet sind, diesen Ganglien häufig ganz dicht anliegend, ja bei Gastropoden und Lamellibranchiaten manchmal in ihre Olyerfäche etwas eingesenkt. Bei der häufigen Verlagerung der Pedalganglien nach vorn in die Nähe der Cerebralganglien, wandern auch die Statocysten mit und finden sich dann in der Kopfregion. Obgleich der Nervus staticus in vielen Fällen von den Pedalganglien ansgeht, so läßt sich doch häufig nachweisen, daß er weiter vorn vom Cerebropedalconnectiv abzweigt und, mit letzterem nur lose verbonden, zu den Cerebralganglien zieht; in allen genauer erforschten Fällen wurde sicher festgestellt, daß er seinen eigentlichen Ursprung im Cerebralganglion hat. Bei den Hrtronporlen und gewissen (opisthobrumehirm (den meisten Nudibranchia) entspringen die beiden Statocystennerven direkt vom Cerebralganglion nnd treten, ohne Beziehungen mit den Cerebropedalconnectiven einzugehen, zn den Statocysten, die hier in die Kopfregion vorgerückt sind.

Der ursprïnglichste Ban der Statocysten erhielt sich bei einer Anzahl primitiver Muscheln Protobramchiu: Nueula, Lrila, Solrmomya, Arca, manchen Mytilidar und gewissen P'retrnarten, deren Organe noch einen langen flimmernden Einstïlpungskanal besitzen, der sich in der dorsalen Fußregion seitlich nach anßen öffnet (s. Fig. 542 A . Bei Follia wird dieser Kanal im Alter geschlossen. - Die Statocysten der iibrigen Lamellibranchier sind zu geschlossenen kngligen Bläschen geworden, die den Pedalganglien dicht anliegen oder sogar in sie eingesenkt sein (z. B. Galcomma), aber anch etwas seitlich von ihnen liegen können.

Bei den Gustropoden wurde bis jetzt kein Rest des Einstülpungskanals gefunden, während die dibranchiaten Cephalopoden einen solchen besitzen (Koellikerscher Kanal), der jedoch nicht mehr nach außen geöfnet ist. Die relativ großen Cysten der Cephaloporlen sind mit den Pedalganglien kopfständig geworden und liegen bei Nautilus dem Ursprung der Pedalcommissur jederseits an (s. Fig. 383, S. 529) und dem Kopfknorpel auf. Bei den Dibranchiat'n dagegen sind sie ganz dicht nebeneinander und ventral unter die Visceralganglien geriickt, sowie in den Kopfknorpel eingeschlossen, ähnlich wie die Ḧ̈rbläschen der Vertebraten in die Schädelwand. - Der feinere 13an der neist kugligen Statocysten bei Lamellibranchiaten, Solenoronchen und Gastroporlen ist, soweit bekannt, recht einfach (s. Fig. 542 u. 543). Die häutig ziemlich dünne, manchmal jedoch auch dickere 
Lpithelwand soll zuweilen nur von einer einzigen Art bewimperter Epithelzellen gebildet werden und ist äußerlich von einer etwas dichteren Bindegewebshülle umschlossen. Gewöhnlich, wahrscheinlich aber immer, lassen sich in ihr zwei bis mehr Zellformen nuterscheiden. Erstens solche, die auf ihrem inneren Ende ein Cilienbüschel tragen, oder doch bewimpert sind, und zweitens zwischen ihnen cilienlose Stïtzzellen; doch wird für gewisse Formen angegeben, daß auch die Zwischenzellen bewimpert seien. Da die ersterwähnten Zellen mit Nervenfasern in Verbindung stehen und besondere Sinneszellen neben ihnen nicht nachweisbar sind, so werden sie als Sinueszellen aufzufassen sein, gleichgïltig, ob ihre Cilien

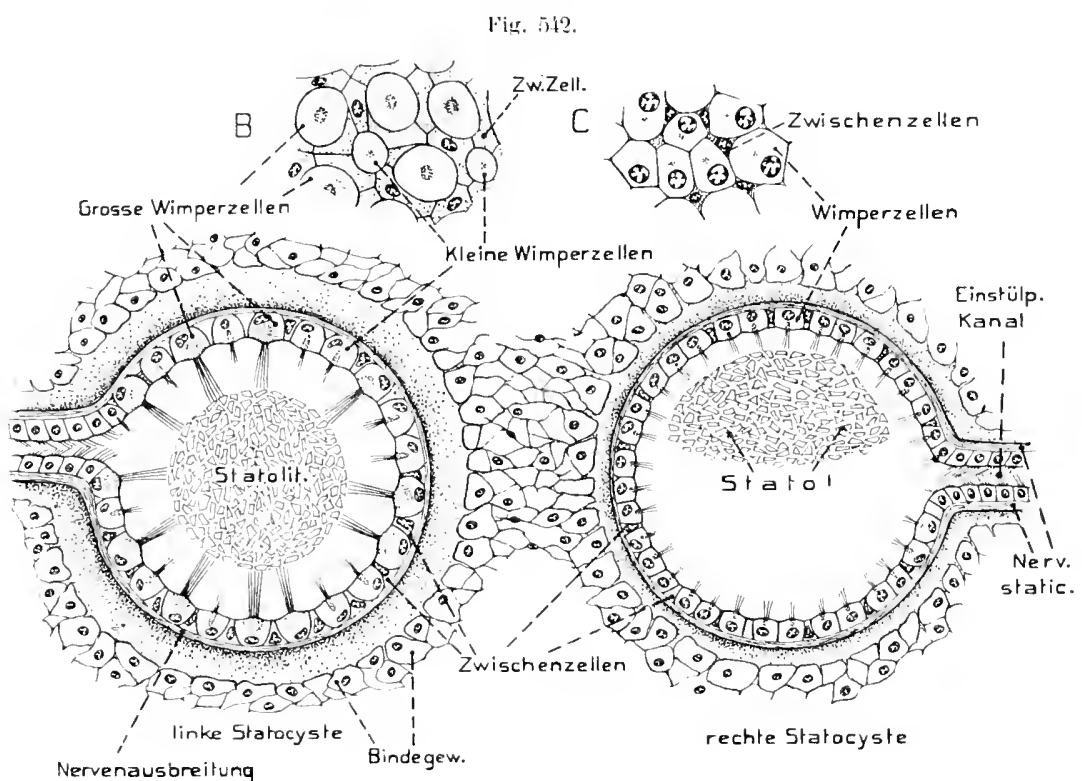

A

lecten inflexus. Statocysten. A Horizontalschnitt durch die beiren verschieden arebinten itatocsiten eines Tieres. - I und $/$ Elächeninsicht der Evithelwand der beiden Cysten.

Orig. v. Fiu.

beweglich oder stary erscheinen. Meist sind diese wimpertragenden Zellen viel yrößer als die Stiitzzellen und senden bei manchen Gastropoden, vielleicht auch gewissen Muscheln (Cyclas), seitlich strahlige Ausläufer aus, die zwischen den Stützzellen hinziehen und die Sinneszellen netzförmig untereinander verbinden (Fig. 543). Die Stützzellen sind häufig stark vacuolisiert und wenig scharf voncinander gesondert. - Bei den IIeteropoden, deren relativ große und leicht zu untersuchende Statocysten am besten bekannt sind, verdickt sich das dorsale Epithel der Cystenwand, gegenüber der Zutrittsstelle des Nerv. staticus zu einem ansehnlichen rundlichen Feld, der sog. Macula statica (s. Fig. 543). Auch für andere Gastropoden wurde eine solche Macula angegeben, jedoch neuerdings wieder geleugnet. Auf diese Macula der Heteropoden konzentrieren sich die eigentlichen Sinneszellen, die zweierlei Art sind. Im Zentrum der Marula steht nämlirh 
eine sehr große Sinneszelle und um diese in 3-5 Kreisen kleinere, welche gegen die Peripherie der Macula an Größe abnehmen. Diese Sinneszellen tragen je ein Büschel kurzer Sinneshaare, die nur schwach, wenn überhaupt beweglich sind.

Es sei hier eingeschaltet. $\mathrm{da}$ große und kleine Winpersinueszellen auch in der linken Statocyste ler Pectenarten mit geöffinetem Kanal (s. Fig. 5f?) ïber die ganze Cystenwand

Fig. 543.

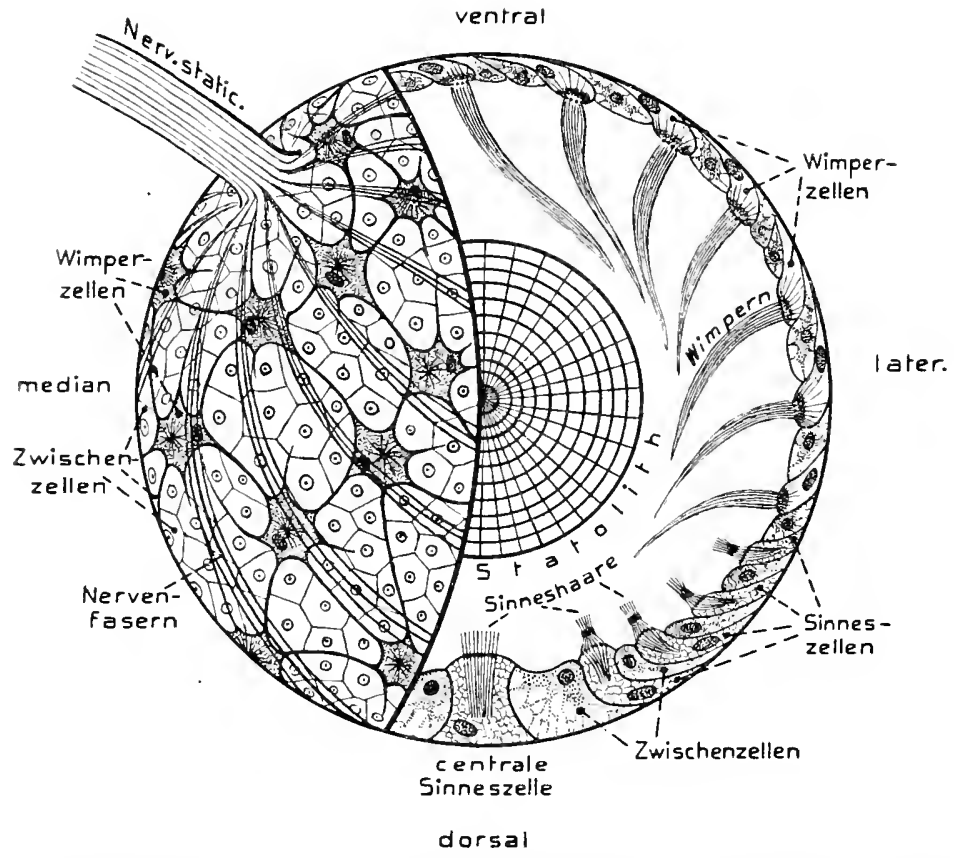

Pterotrachea (Heteropocle). Seliema der statocyste (nach T'schachotrs 1908 konstruiert). Linke Hälfte mit crhaltener Wand: zeigt den Zutritt des Nervus staticur und dessen Ausbreitung über die Cystenwand, sowie deren Zellen in Flächenansicht. - Rechte Hälfte zeigt den Durchschnit der Cystenwand durch die Nitte der Macula statica. Die Wimperbüschel der Wimperzellen in Ruhestellung, in welcher der statolith frei in der cyste selwebt.

verteilt sind. Bei len Arten mit geschlossenen Kanal sind die kleinen Zellen cilienlos geworden.

In dem viel dünneren Epithel der übrigen Cystenwand der Heteroporlen finden sich gleichfalls bewimperte Zellen (sog. Wimperborstenzellen (s. Fig. 543, deren Cilienbiischel viel länger sind und gegen die Nervenzutrittsstelle an Größe zunehmen. Letztere Cilienbüschel können sich heftig schlagend bewegen nnd tixieren dabei den Statolithen in exzentrischer, der Macula genäherter Lage. Auch zu diesen Zellen treten Nervenfäserchen. Der Nerv, der, wie erwähnt, an dem der Macula entgegengesetzten Pol (etwa Ventralpol) der Cyste tritt, verteilt sich anf deren Wand in 12-16 meridian ziehende Bündel, die sich zu den Sinneszellen der Macula begeben Fig. 543). 
Die Statocysten ler Heteropoden (Fig. 544) sind in her Leibeshihle an mehreren bindegewebigen Strängen ziemlich frei aulgehängt, bo denen der medianwärts zur Cyste tretende auch etwas kontraktil sein soll und wabrecheinlich den Spanumgszustand der Cystenwand $\%$ ändern vermag. Auch bei gewissen Gastropoden (Paludina) wurlen an der Cystenwand zarte Muskellaserı heschrieben. - Für die ïbrigen liastropoden und Lambellibranchier ist über die Nervenverbreitung an der Wand nur wenig bekannt. Bei zahlreichen Gastropoden aber findet sich ein sehr eigentïmlicher Ban des Nervs, indem sich die statocystenhöhle in ihn fortsetzt, er also hohl ist; dies läBt sich namentlich daran erkenmen, daB die Statoconien bei leiclitem 1)ruck oft tiet in ihn eindringen. Da der Nervos staticus auch bei Pecten den Viustülpungskanal umhüllt (Fig. 642), so ist eswahrscheinlich, daß der in len Nerf einAringende Kanal der Gastropolen dem lin-tülpungskanal entepricht.

Die Statolithenverhältnisse zeigen bedentende Verschiedenheiten, indem sich teils zahlreiche Statoconien, teils ein einziger ansehulicher Statolith findet. Die durch einen Kanal geöffneten Statocysten der Muschelı verhalten sich wie die ähnlichen $\mathrm{Or}$ -

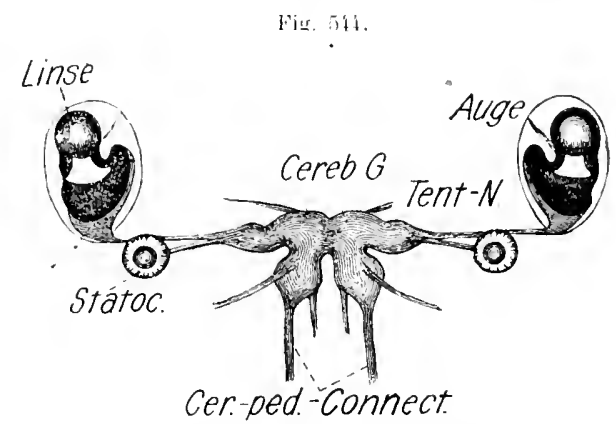

Pt erotrachea. Cerebralganglien mit den $\mathrm{x}$. ontici und statici, den tugen und statocysten in natiorlicher lage. Cerebropedal-Comnectiv, Pigment der Augenblase, Linse, franglion opticum (aus GEGENBAtr, Grundrib der vergleichenten Anatomie 1 (N7)

gane der Anneliden, indem sie kleine unregelmäßige Fremdkörper (Kieselgebilde) enthalten, die durch organische Substanz verklebt sind.

Im allgemeinen tritt besonders bei den Lamellibranchiern hervor. daß the palaeogenen Formen (Filibranchia) zahlreiche kleine Statoconien führen, die neogenen (Fulamellibranchice und Septibranchia) dagegen einen Statolithen. Auch die Gastroporlen verraten Ännliches; so besitzen die primitiveren Prosobranchier (Aspidobranchia) und viele Ctenobranchia Statoconien, doch von letyteren auch nicht wenige einen Statolithen (Heteropoda u. a.). Die meisten Opisthobranchier, Pteropoden, Pulmonaten und Solenoconchen haben fast stets Statoconien. - Selten finden sich bei gewissen Muscheln und Gastropoden neben einem großen Statolithen noch zahlreiche Statoconien (z. P. Saxicava, Anatinaceae, Cerithiden). Die Larven besitzen, wie es scheint, regelmäßig nur einen einzigen statolithen, so laß die Vermehrung zu Statoconien erst allmählich eintritt.

Statolith mul Statoconien bestehen aus Calciumkarbonat mul etwas organischer Substanz (fonchiolin). Der erstere ist ein charakteristischer, meist rein kugliger, doppeltbrechender Sphärokristall (Sjphärit); er zeigt gewölnlich deutlich konzentrische Schichtung und Radiärstreifmug. Auch die Statocnnien sind meist spluäritische Gebilde von verschiedener Form (kuglig, ellipsoidisch, wetzsteinlörmig); häufig treten auch Verwachsungen einfacher Statoconien zu Doppel- und Melırfachbildungen aul. Ligentliche Kristäl hen scheinen sich nur selten zu timlen.

Einige Besonderheiten seien noch kurz erwähnt. So besteht bei sämtlichen untersuchten Pertenarten eine Ungleichheit der beiden Statocysten, inden die linke einen großen Statolithen entlält (Fig. 542), die rechte dagegen zahlreiche Statoconien. Der Statolith wi» die Statoconien sinl bei geöfnetem Kanal von Kieselsplittern gebildet, bei geschlossenem rom Sphïrokristallen. Auch enthält die rechte Statocyste bei den Formen mit geïfnetem lianal nur eine Art von Wimprzellen. die linke dagegen große und kleine. Wahrschein- 
lich dürte diese Verschiedenheit der Statocysten bei den asymmetrischen Huscheln verbreiteter sein. Ostrea sollen Statolithen ganz letılen und die Statocysten von Solenomya im Alter schwinden.

Cephalopoden. Die Lage der kugligen Statocyste von Nautilus wurde schon oben (S. 748) erwähnt. Über ihren feineren Bau ist nur bekannt, daß sie zahlreiche kleine wetzsteinförmige Statoconien enthält. - Wie hervorgehoben wurde, liegen die verhältnismäßig großen Statocysten der Dibramrhiaten im Ventralteil des Kopfknorpels unterhalb der Visceralganglien dicht nebeneinander, so daß sie nur durch eiı dünnes-längsgerichtetes Knorpelseptum geschieden sind Fig. 545 . Ihre Form ist nicht kuglig, sondern mehr oder weniger nnregelmäßig ellipsoidisch

Fig. 54i.

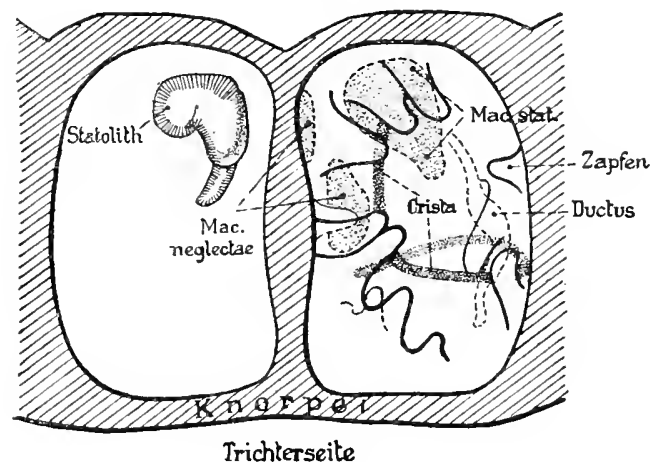

sepia officinalis. Die beiden Statocysten in aboraler Ansicht schematisch). In der rechten die Zapfen, die Macular und die Crista eingezeichnet. Die Zapten der aboralen Wand dicker konturiert. In der linken statocyste nur der Statolith eingezeichmet (nach HAMLYYHARRIs 1903). C. H. bis parallelopipedisch, mit abgeplatteten Medianwänden, wenn die beiden Cysten sehr genähert sind. Die Cystenwand der Decapoden liegt dem umgebenden Ḱnorpel dicht an ; bei den Octopoden ist dies nur dorsal der Fall, da wo der Nerv zutritt, sonst ist sie vom Knorpel durch einen ziemlich weiten, mitFlïssigkeit (Perilymphe) erfüllten Raum getrennt. Zahlreiche blutgefäßhaltige Bindegewebszüge durchziehen den Perilymphraum und befestigen die Cysten am Knorpel. -

Wäbrend die Wand der Octopodeneyste innerlich ziemlich glatt und ohne Vorsprïnge ist (abgesehen von einem, etwa an ihrer oralen Dorsalseite befindlichen Bindegewebswulst) springen bei den Decapoden (Fig. 545) zahlreiche 6-12) zapfenartige Knorpelfortsätze, welche die Wand einstïlpen, in die Cyste vor und verleihen ihr ein unregelmäßiges Anssehen. Gewisse dieser "Zapfen s stehen in Beziehung zur Crista statica, andere scheinen auch den Statolith in seiner Lage zu erhalten. - Von der lateralen Statocystenwand entspringt der schon früher erwähnte Rest des Einstülpungskanals, der mit flimmerndem Epithel ausgekleidet ist (Koellikerscher Kanal. Bei den Octopoden liegt er im Perilymphraum; bei den Decapoden verläuft er dagegen im Knorpel. Schon oben wurde erwähnt, daß er nach den neueren Erfahrungen blind endigt, nicht nach außen geöffnet ist.

Im Gegensatz zu den einfachen Statocysten der seither besprochenen Mollusken erscheinen die der Dibranchiaten komplizierter, indem sich die Sinneszellen anf einzelne verdickte Wandzellen konzentrieren, während die übrige Wand aus niedrigem cilienlosem Epithel besteht; nur in der Umgebung der Einmündungsstelle des Koellikerschen Kanals breitet sich die Bewimperung anch an der Wand 
aus. Von solchen Endigungsstellen des statischen Nervs sind zwei allgemein verbreitet, einmal die an der Oralwand liegende Maculustuticu, von etwa ovaler bis tränenförmiger Gestalt, und dann die Cristu statica Fig. 545. Letztere ist eine lange schmale verdickte Epithelleiste von eigentiumlich schraubigem Verlauf. Sie beginnt in der Gegend der Macula an der Dorsalwand der Cyste, zieht von da aboralwärts und gegen die Lateralwand, steigt an letzterer auf die Ventralwand hinab und wendet sich an dieser median- und etwas aboralwirts. Anf solche Weise beschreibt die Crista einen Schraubenumgang. Bei den Octopoden ist ihr Verlauf zusammenhängend, bei den Decapoden dagegen weist sie zwei Unterbrechungen auf, die durch gewisse der oben erwähnten Zapfen bedingt sein können; auch die beiden Cristaenden werden von je einem Zapfen bezeichnet. Die Decapoden besitzen an der Medianwand der Statocyste noch zwei kleinere maculaartige Stellen (mit Sinneszellen), welche hintereinander liegen und im Gegensatz zur Hauptmacula (Macula princeps) als Marular meglertar anterior und posterior) bezeichnet werden. - Die Maculae Fig. 546 i) bestehen aus größeren Sinneszellen mit starren Härchen und cilienlosen schmalen Stützzellen, die erstere voneinander sondern und an der freien Epithelfäche eine Art cnticularer Membrana terminalis bilden; im Centrum der Macula princeps befindet sich eine Stelle, welcher die Sinneszellen fehlen. - Die Crista Fig. $546 \mathrm{~B}$ ) ist eine Epithelverdickung, die zwischen den Stützzellen zweierlei Arten von Sinneszellen enthält, Fig. jiti.
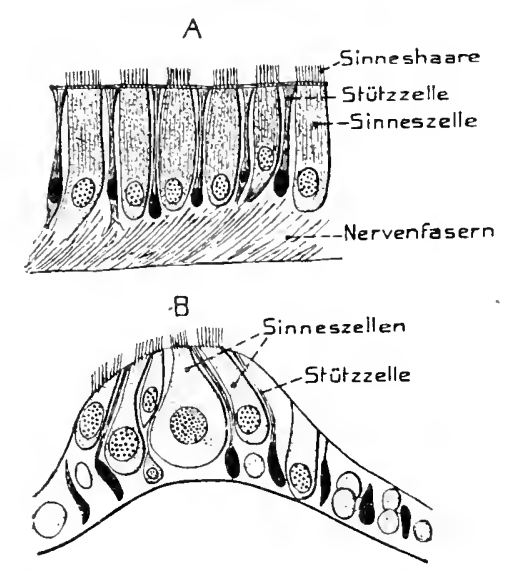

sepia officillalis. statisclues organ 1 Querschnitt eines kleinen Teils der Marula tatica. - $B$ Querschnitt durell die Crista statiea (lach HAMLYN-HARRIS). ('. H.

nämlich eine einfache Decapoden) oder doppelte (Octopoden) mittlere Reihe großer, und beiderseits von dieser noch einige Reihen kleiner. - Der Nervus staticus teilt sich gewöhnlich sofort in drei Äste, von welchen einer die Maculae, die beiden andern die Crista versorgen.

Auf der Macula princeps liegt stets ein ansehnlicher Stutolith, dessen Gestalt im allgemeinen kegelförmig, meist aber ziemlich unregelmäßig und asymmetrisch ist (Fig. 545. Mit der Kegelbasis inht er der Macula auf, wobei sich die Sinneshärchen in kleine IIöhlen seiner Basalı̈iche einsenken. Eigentümlicherweise ist der Statolith nur teilweise verkalkt; sein basaler Teil besteht aus organischer Substanz, der apicale dagegen jedoch häufig etwas einseitig aus radiärstrahligem kohlensaurem Kalk. Bei den Octopoden soll dieser Kalkteil aus relativ losen prismatischen Elementen bestehen. - Wie schon oben bemerkt, tragen bei gewissen Decapoden besonders Loligo) einzelne Zapfen dazu bei, den Statolith in seiner Lage zu erhalten. - Den Maculae neglectae der Decapoden liegen spindel- bis 
nadelförmige Statoronien auf, die durch eine gallertige Masse zusammengehalten werden. Anf der Crista finden sich keine festen Gebilde.

Leider ist über die physiologische Bedeutung der an die Wirbeltiere erimernden verschiedenen Endorgane in der Statocyste der Dibranchiaten Niheres nirllt bekannt.

\section{Echinodermata.}

Unter den Echinortorme" begegnen wir Statocysten nur bei gewissen grabenden Holothurien. Wie es scheint, finden sie sich allgemein bei mehreren Gattungen der apoden Symaptiden (Familie) und der verwandten Gattung Rhabdomolgus, ferner bei den pedaten Tiefseeholothurien der Familie der Elpilliilar. Die symaptidon zeigen je ein Paar Cysten an den Austrittsstellen jedes Radiärnerven aus dem Kalkring des Schlunds. Bei den Elpitiiden dagegen ist die Anordnung der Cysten fast stets bilateral geworden, indem diese sich nur längs der oralen Region der beiden dorsalen (Bivium) und der beiden seitlichen ventralen liadiärnerven (Trivium) finden, und zwar an den ersteren meist nur je eine, an den letzteren dagegen häufig eine größere Zahl (bis 40 hintereinander gereihter Cysten.

llinsichtlich der ectodemalen oder mesodermalen Entstehung der organe bestehen lifferenzen; jedenfalls wäre das Letztere sehr auflallend und ist daher vorerst unwahrscheinlich. - Die Organe sind im Bindegewebe eingelagerte, kleine kuglige Bläschen mit einfacher dïnner lpithelwand, an der weder Cilien noch sinneshare sicher erwiesen sind. Sie liegen entweder den Radiärnerven dicht an oder sind durch einen kurzen, den statischen Verr einschliebenden Stiel an ihnen befestigt. Die Endolymphe enthält fast stets mehrere, manchmal sehr viele Statoconien (bis über 100 hei gewissen Elpidiiden) von länglicher (Elpidiiden) oder kughiger (Synaptiden) liestalt. Bei den ersteren sind es sicher geschichtete Konkretionen; bei den letzteren, wo um jede Statoconie eine plasmatische, mit einem liern versehene Itïlle vorkomnt, wurden sie auch fïr flüssig (Vacuole) gehalten, was aber woh\} irrig sein dürfte. Es scheint demnach, daß jede Statoconie noch in ihrer Bildungszelle liegt. Zitternde Bewegungen der Statoconien finden sich, werden aber wohl nur Molekularbewegungen sein. Die statische Bedentung ter Organe ist durch Versuche wahrscheinlich gemacht worken.

\section{Chordata.}

\section{a) Tunicata.}

Eigentümlich liegen die Verhältnisse in dieser Gruppe, da hier zweierlei statische Organe anftreten können. Die erste Art, welche sich den seither bes]rochenen anreiht, und ebenso den statisch-akustischen der Wirbeltiere, findet sich allein bei dem mit den Thaliaceae verwandten Doliolum und seltsamerweise auch nur bei der ersten ungeschlechtlichen Generation Amme`. Ebenso merkwürdig erscheint das unpaare, linksseitige Vorkommen dieser Statocyste zwischen dem 3. und 4. Ringmuskel, etwa in halber Körperhöhe.

- Die geschlossene, aber durch Einstiilpung des Epithels entstehende Cyste hat eine äßBerst dünne Epithelwand, welche sich an der Nervenzutrittsstelle zu einer Art runder Macula verdicht. in her zwei größere Zentralzellen zu unterscheiden sind. Weder Cilien noch Sinneshärchen wurden bekannt. Der einfache Statolith rulıt mit etwas ausgehöhlter Fläche der Macula anf' und soll sich in rerdïnnten säuren nicht lösen. 
Die zweite Art statischer Organe findet sich dauernd bei den Copelaten und voriibergehend bei den ihnen ähnlichen Ascidienlarven. Wie das Auge ist es der sog. Sinnesblase des Cerebralganglions eingelagert. - Bei den Copelatrn bildet die Sinnesblase selbst das statische Organ und wnrde daher schon friiher (S. 545) geschildert. - Das Organ der Ascidienlarven verhält sich etwas anders. Hier (s. Fig. 393, S. 544) ruht anf dem ventralen Boden der Sinneshirnblase ein kugliges Gebilde, unter welchem die Epithelwand etwas verdickt ist. Es geht aus einer Zelle der Hirnwand hervor, die an ihrem freien Ende eine starke Pigmentanhäufung zeigt und mit ihrem stielförmigen Basalteil zwischen die Epithelzellen der Verdickung (Maenlir statica) eingefïgt ist. Von den Zellen der Macula sollen Sinneshärchen entspringen. Eine Concretion wurde in der Statolithenzelle nicht gefunden.

()bgleich es wahrscheinlich ist, daß hier wirklich ein statisches Organ vorliegt, so fehlt doch noch viel zn seiner genaueren Kenntnis. Interessant erscheint, daß das früher erwhite Ange unI das statische Organ aus einer gemeinsamen pignentierten Anlage an der Dorsalwand des vorderen Neuralrohres hervorgehen sollen und sich erst später durch Wachstumscorgänge von einander sondern und verlagern.

\section{b) Statisch-akustische Organe der Vertebrata.}

Wie schon frïher erwähnt, vereinigen sich im Hörorgan der Wirbeltiere die statische und akustische Funktion. Es ist deutlich zn verfolgen, wie sich der der Hörfunktion dienende Teil (Cochlea, Schnecke) erst allmählich entwickelt und zu hoher Komplikation vervollkommnet. Ob jedoch die niederen Formen (besonders die Fische), welchen dieser Abschnitt fehlt, ganz taub sind, ist eine noch umstrittene Frage, obgleich das Hören gewisser Fische sicher erwiesen scheint; jedenfalls steht es aber in dieser Abteilung auf sehr niederer Stufe.

$O b$ das vollständige lehlen des statisch-akustisehen Organs bei den Aeranicrn ursprünglicher Natur ist older auf Rückbillung beruht, läßt sich vorerst nicht entscheiden. Das Vorkommen statischer Organe bei den Tunicaten spricht eher in letzterem Sinne.

Die Organe der Wirbeltiere gehören im allgemeinen zu den im Vorhergehenden besprochenen eingestiilpten Cystenorganen und bieten daher mit jenen mancher Wirbellosen (besonders Mollusken) gewisse Analogien, welche aber sicher nur Konvergenzen sind. Das Hörorgan, wie wir es der Einfachheit wegen künftighin nennen wollen, ist immer paarig und entsteht beiderseits in der hinteren Kopfregion, zu den Seiten des Metencephalon (Medulla oblongata), da wo del 8. Hirnnerv (Acusticus) von letzterem entspringt. Hier verdickt sich das Ectoderm zn einer Iörplatte, die sich bald nach innen und etwas ventral als eiu IJörbläschen einstülpt, das durch einen, kiilzeren oder längeren Einstïlpungskanal nach außen mïndet (Fig. 547 A). Es scheint, daß dieser Kanal (der spätere Ductus endolymphaticus) überall angelegt wird; aber nur bei den Plagiostomen bleibt er vollständig, samt der äußeren Ausmündıug, dauernd erhalten; sonst schließt el sich stets vom Ectoderm ab und endigt daher blind.

Daß das spätere Hörbläschen gelegentlich (I)ipnoi) solid angelegt und spïter hohl wird. ist eine Modifikation, der wir auch bei der Bildung des liückennarks begegneten. — Schon bei 
den Hirnnerven (S. 624) wurde erwähnt, daß die plattenförmige erste Anlage des Hörbläschens gewöhnlich als eine der sog. Lateralplacoden gedentet wird, d. h. jener ursprünglichen Hautsimnesorgane, von welchen sich das zum Nervus acustico-facialis gehörige als Hörorgán weiter entwickle.

Der geschilderte, einfach bläschenförmige Zustand mit Ductus endolymphaticus erbält sich bei keinem lebenden Cranioten dauernd; stets tritt höhere Komplika-

- Fig. 547.

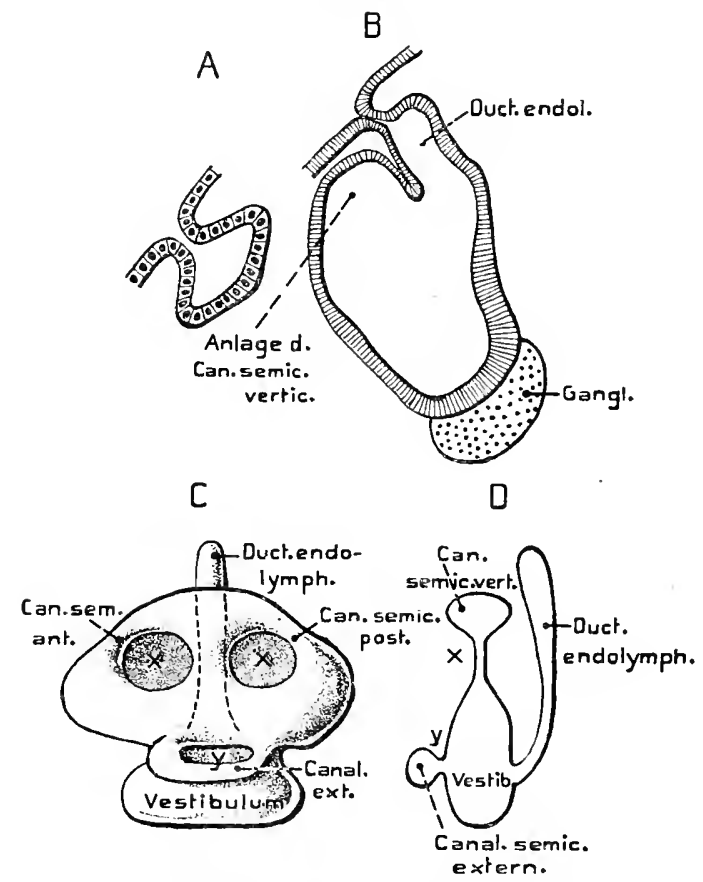

Schemata zur Entwicklung des Labyrinths der Gnathostomen. A Querschnitt durch eil eben eingestülptes Hörbläschen. - is Weiter entwjckeltes Stadium mit Anlage des Ductus endolymphaticus und des Vestibulun: Ganglion acusticum angedentet. - $C$ und $/$, Schemata zur Bildung der 3 halbzirkelförmigen Kanäle. - $f$ 'In lateraler Ansicht, , die Stellen, wo sicll die Wände genäliert haben, später verwachsen und durchbrechen, was zur Ablösung der beiden vertikalel Kanäle führt. y die Ablösuugsstclle des horizontalen Kanals. - Der Querschnitt / ist so gedacht, laB er durch eine der Stellen $x$ (Fig. (.) geht, die Stelle $y$, sowie den Ductus endolymphaticus zeigt, was ja nicht ganz möglich, da letzterer zwischen den beiden stellen $x$ tiegt (mit Benutzung voll R. KRAUSE 1901 in O. Hertwig, Entw. d. Wirbt.). O. B. U. C. H. tion eiu, deren allmählicher Verlauf sich in der Craniotenreihe noch verfolgen läßt. - Zunächst sei hervorgehoben, $\mathrm{da} ß$ die dorsolaterale Region des Bläschens allmählich dorsalwärts mehr oder weniger emporwïchst (Fig. $547 \mathrm{~B})$, was zur Folge hat, daß die Einmündungsstelle des Ductus endolymphaticus auf die mediale Bläschenwand verschoben wird, wo sie sich am ansgebildeten Organ stets findet. - Wie wir schon bei der Schilderung der Schädelentwicklung fanden(S. 225), tritt im Umfang des Hörbläschens frübzeitig Knorpel auf; später verschmilzt die so gebildete knorplige Hörkapsel mit den Parachordalia und wird in die Lateralwand der Labyrinthregion des Primorialcraniums aufgenommen. Weun deren Verknöcherung eintritt, wird auch der Knorpel des Hörblïschens ganz oder teilweise durch Knochen ersetzt; so bildet sich ein linorpliges oder linöchemes Labyrinth um das Hörbläschen oder das härtige Labyrinth ans. Vor allem beteiligt sich das Prooticum am Einschlaß des Hörbläschens, doch können anch benachbarte Sclıädelknochen daran teilnehmen. - Wäbrend das primitive Hörbläschen von mesodermalem Gewebe dicht umschlossen wird, tritt in letzterem im Umfang des Bläschens allmählich eine Einschmelzung in geringerem oder größerem Maße auf. Dadurch entstehen lympherfüllte Räume (Perilymphräume, 
im Gegensatz zu dem Endolymphraum im Bläschenj, durch welche sich zwischen dem häutigen und dem knorpligen oder knöchernen Labyrinth Bindegewebszüge ausspannen, die von der Knorpel-oder Knochenwand zum häutigen Labyrinth ziehen. - Indem sich die Medialwand des Bläschens verdickt, tritt sic mit dem. Distalende des Nervus acusticus in Verbindung, wobei letzterer, dieser Wand dicht anliegend, eine Ansammlung von Ganglienzellen (Gunglion acusticum) bildet (Fig. $547 \mathrm{~B}$ ). So entsteht an der Medialwand eine besondere, sinneszellenfiihrende Nervenendigungsstelle (Macula acustira communis), wodurch das Organ zu einem Sinnesorgan wird, in welchem, ähnlich wie bei Wirbellosen, Statolithen oder Statoconien auftueten.

Wie bemerkt, bleibt das Hörorgan nie anf so einfacher Stufe stehen, sondern zeigt stets eine Differenzierung der Nervenendstelle in mehrere, unter gleichzeitiger Entwicklung eigentiumlicher, aus der Dorsalwand des Bläscliens hervorgeliender bogenförmiger Anhänge, der sog. halblirpisförmigen Kanäle (Canales semicirculares). - Den einfachsten Verhältnissen begegnen wir bei den Myxinoiden unter den Cyclcstomen (Fig. 548). Bei hnen Fig. 548.

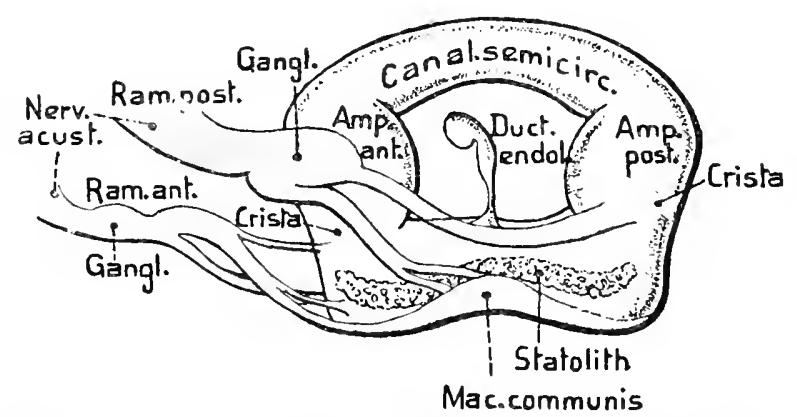

Myxine glutinosa. Linkes häutiges Labyrinth in dorso-medialer Ansicht; Nerven und Macula braun (nach ReTziUs 1881). C. H. hat sich an der Dorsalwand des etwas schief nach außen geneigten Labyrinthbläschens ein in rostrocaudaler Richtung verlaufender, dorsal aufsteigender halbkreisfömiger Kanal gebildet, der vorn und hinten in das Bläschen (das nun gewöhnlich als Vestibulum bezeichnet wird) einmiindet. Jede der beiden Einmiindungsstellen ist etwas angeschwollen zu einer Ampulle, und in jeder Ampulle findet sich eine leisten- oder bandförmige Partie höheren Epithels mit Sinneszellen (Cristae acusticae, besser staticae), die quer zur Kanalachse ziehen und die Ampulle nicht völlig umgreifen. Ontogenetisch entstehen diese Cristae als eine Ablösung von der ursprïnglichen Macula acustica communis. Anf der Ventralwand des Vestibulums ziebt eine langgestreckte Macula acustica hin, gewöhnlich Hucula communis genannt, der eine Statolithenscheibe aufliegt: wogegen die Cristae keine solche besitzen.

Das Hörorgan der Petromyzonten hat schon eine böbere Ausbildungsstufe erreicht, indem sich an Stelle des einen halbkreisförmigen Kanals der Myxinoiden zwei finden, ein vorderer (oraler) und ein hinterer (caudaler); das Verständuis des Hörorgans ist jedoch ziemlich schwierig. Das bei Myxine schlauchartige ursprüngliche Vestibulum erscheint recht kompliziert (Fig. 549 u 550); ans seiner Dorsalregion hat sich eine etwa kugelförmige Partie hervorgewölbt (sog. Com- 
missur), von welcher zwei Bogengänge ausgeben, die etwas lateral- und ventralwärts hinabsteigen, wobei sie dem Vestibulum dicht anfliegen. Der gemeinsame Ursprungsteil der beiden Bogengänge steht durch eine weite Öffnung mit dem, im besonderen als Vestibnlum bezeichneten Teil in Verbindung, der durch eine quer-

Fig. 549 .

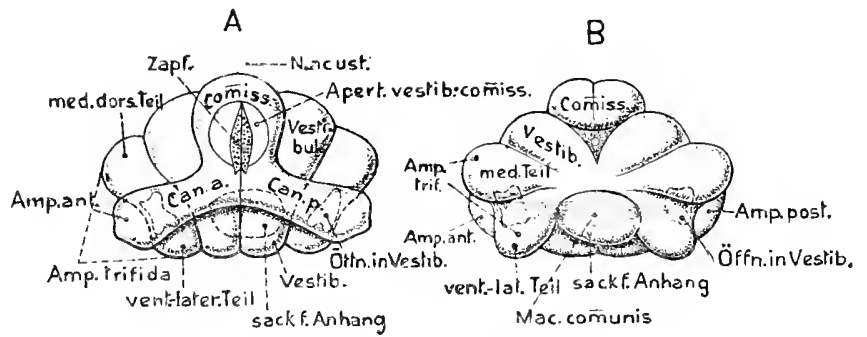

Petromyzon fluviatilis. Häntiges Labyrinth mit x. areustiens. - A Ansicht des linken Labyrinths

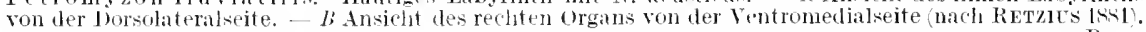
ง. Bu.

verlanfende oberflächliche Furche, welcher inmerlich eine Leiste (Crista frontalis) entspricht, in eine orale und eine candale Kammer nnvollständig geschieden wird

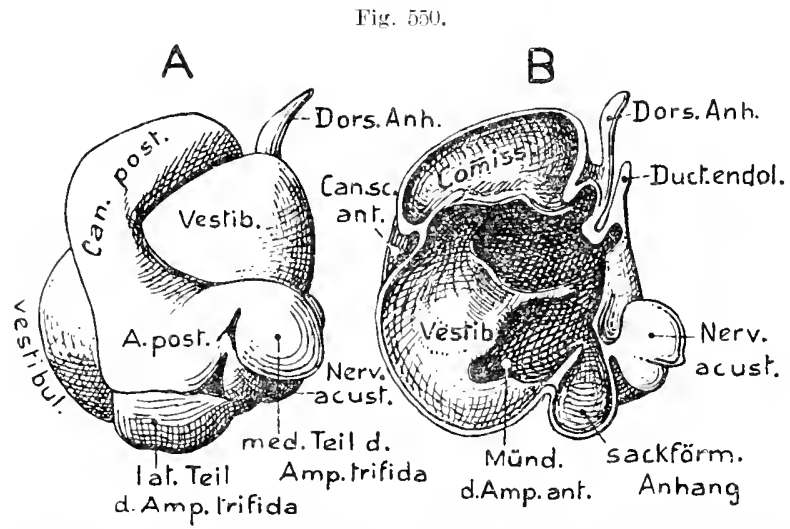

l'utrongzon flusiatilis. linkes labyrinth. A Ansicht von candalseite. - $B$ basselle durch einen Quprschnitt habbiert, Ansicht der oralen Hälfte von hinten in lie Höhlung liekonstruktionen ans schniten, nache li. KRACSE 1906i). (vgl. Fig. $550 \mathrm{~B}$ ). -

Die ventralen Enden der beiden Bogengänge sind etwas ampullär angeschwollen und enthalten je eine Crista acustica. Sie münden in die beiden Vestibularkammern, wobei sie aber gleichzeitig medial- und ventrolateral wärts noch je eine ansehnliche Aussackung bilden (anch Sacculi genannt), welche ge-

meinsam mit der zwischen ihnen liegenden eigentlichen Ampulle häufig als Ampulla trifida bezeichnet werden. An der Ventralseite des Vestibulums findet sich ferner eine etwas asymmetrisch liegende sackförmige Ansstïlpung (sackfirmiger Auhang), an deren Medialwand eine Macula acustica liegt, die jedoch noch je einen Auslaufer in die medialen Ausehwellungen der beiden Anpullae trifidae sendet, von denen der vordere ansehulieher ist, sowie eine grubenförmige Vertiefung anfweist (s. Fig. $549 \mathrm{~B}$ ).

Es dürte vorerst kaum mörlich sein, in diesen l)ifferenzienngen des Vestibulums der Petromyzonten diejenigen wielerzuerkennen, welchen wir bei den Gnathostomen begegnen 
werden; jedenfalls ist dies zurzeit nicht sicher ausführbar. Ls sei nur kurz erwähnt, taß der sackförmige Anhang der Lagena der Fische, der mediale Anbang der vordern Ampulla trifida dem lecessus utricularis und die grubenformige Vertiefung dem Saculus verglichen wurle.

Sicher ist, daß die beiden halbkreisförmigen Bogeng:inge der l'etromyzonten dem einzigen der Myxinoiden entsprechen, indem ein mittleres Teil des letzteren in Zusammenhang mit der dorsalen Vestibulumwand blieb; ein Verhalten, welehes sich bei allen Gnathostomen wiederholt. Im Hinbliek hieranf erseheint daher das Hörorgan der Neunangen als eine Zwischenstıfe zwvischen jenem der Myxinoilen und dem der Gnathostomen, welehes sieh jedoch in einseitiger Weise modifiziert hat.

Am häntigen Labyrinth sämtlicher Gruthostomen tinden wir also die beiden aufsteigenden oder vertikalen Bogengïnge wieder, den vorderen und hinteren. Da sie stets in mehr oder weniger winklig zueinanderstehenden Ebenen verlaufen, nnd zwar der hintere der Querebene (beim Menschen etwa der Frontalebene) annähernd parallel, der vordere dagegen der Median- oder Sagittalebene; so werden sie anch als frontaler (hinterer) und sagittaler (vorderer oder oberer) miterschieden. Fast stets miinden beide Gïnge dureh einen gemeinsamen Absehnitt (Simus superior utriculi) in den mittleren Dorsalteil des Vestibulums (z. B. Fig. 553 B, S. 761); ilure anderen Enden dagegen sind zu Ampullen (Ampulla anterior oder posterior) mit den Cristae entwiekelt. Die Erhebung der vertikalen Bogengänge ist sehr verschieden; ursprü̈nglich gering, wird sie hänfig selır ansehnlich. Zn diesen beiden Gängen tritt nun bei allen Gnathostomen noch ein dritter, horizontaler (lateraler oder änßerer), der mit seiner Ampulle (A. Latrialis oder rxterioi) dieht hinter oder ventral von der Ampulla anterior entspringt und in einer annäherud horizontalen Ebene, lateral vom Vestibulnm, nach hinten zieht, nm in der Regel in den erwïhnten Sinns superior ntriculi einzumiinden. Die Ampulle dieses Bogengangs besitzt gleiehfalls eine Crista. Die Lagebeziehnngen der drei Bogengänge zueinander stehen physiologiseh zweifellos mit den Raumempfindungen in direktem Zusammenhang.

Die Ontogenese der Gänge verläult etwas verschieden; bei den meisten Guathostomen durrh bogenartige Ansbuchtung der Wand des Vestibulums an den Stellen, wo die Bogenginge entstehen, nnd darauf folgende Verwachsung der beiden Wïnle lieser Ausbuchtungen an den Stellen wo die Bogengänge sich später rom Vestibulum ablösen (lig. 547 C - D, S. 756), woraul schließlich hier liesorption md Murhbruch der Wänle erfolgt. Daß sich für die beiden vertikalen Gänge eine gemeinsame Ausbuchtung bildet, die später an zwei Stellen durchbricht, bestätigt ilne llomologie mit dem einzigen Gang der Myxinoiden. - Als eine Modifikation der Entwicklung (Teleostei und Amphibia) erscheint es, daß die Bogenginge nicht durch Ausbuchtung entstehen, sondern derart, laß sich die Vestibulumwinde an zwei gegenibberliegenden Stellen einstülpen (oder hjer cine sheidewand hereinwärlst) und sich, nachlem diese Einstïlpungen miteinander verwuhsen. der Durchbruch fïir jeden liang bildet. Der horizontale Bogengang tritt häufig etwas später aul als die vertikalen, was seinem pliylogenetisch späteren Entstehen entspriclit.

Die Macnla acustica erfilurt hei allen Gnathostomen eine Sondermug in mehrere getrennte Endignngsstellen, womit sich frihzeitig eine bifferenzierung des 
Vestibulums in eine Anzahl Unterabschnitte verbindet. Die drei Bogengänge mïnden in den dorsalen Teil des Vestibulums (Pars superior), und zwar fast stets so, daß sich, wie erwähnt, die mittleren Enden der beiden vertikalen Gänge zu

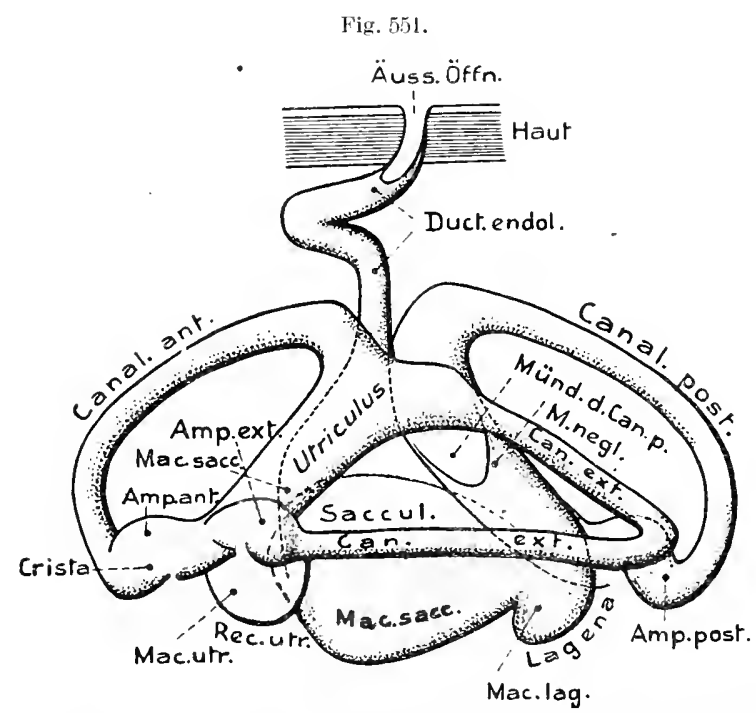

A canthias vulgaris. Linkes häntiges Labyrinth von der Lateralseite (nach ReTzIUs 1851).

Fig. 552 .

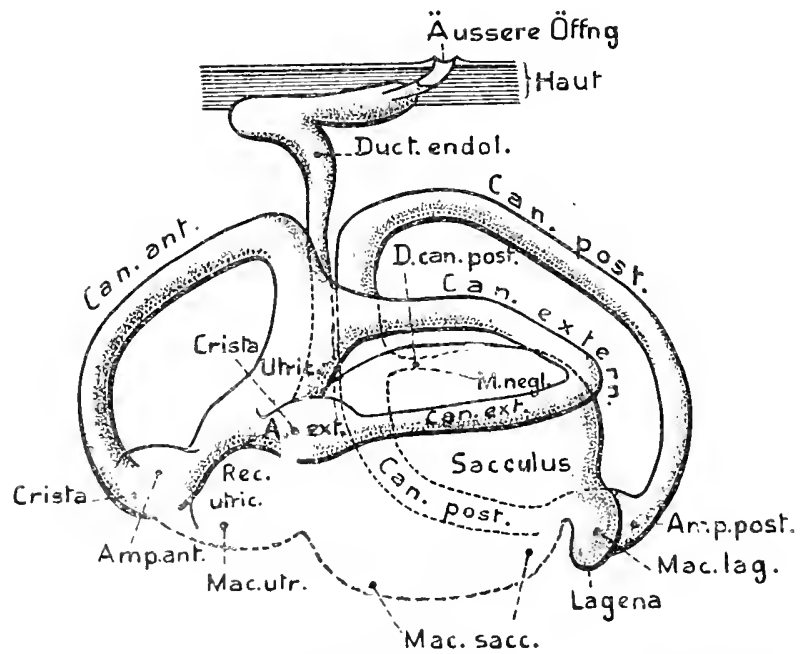

Raja clavata. Linkes häutiges Labyrinth von der Jaiteralseite (nach RETZIUS (XSI). einem gemeinsamen anfsteigenden röhrenförmigen $\mathrm{Ab}$ schnitt des dorsalen Vestibulıms vẻreinigen. Diese Pars superior sondert sich durch eine etwa horizontale Einschuïrung in sehr verschiedenem Grade vom Ventralteil des Vestibulums (Pars inferior) $a b$, mitwelchem der Ductus endolymphaticus verbunden bleibt. Der dorsale Teil, von welchem die Bogengänge entspringen, wird nun als Ltriculus bezeichnet. An seiner vorderen Medialwand, dicht hinter oder etwas ventral von der Ampulla lateralis, findet sich eine Hacula utriculi (Fig. 555), die meist in einer schwachen, nach vorn und medial gerichteten Ausstiilpung des Utriculus, dem Recessus utriculi, liegt. In der Gegend der urspriinglich weiten

Einmündung des Utricnlns in die Pars inferior des Vestibulums bildet sich eine besondere kleine Endigungsstelle, die Alucula neglecta (Fig. 553), welche auch doppelt anftreten kann (Fig. 555, S. 762). Sie liegt in der liegel im Utriculus selbst, 
riickt aber bei den Amphibien in die Pars inferior (Saceulus) hinab. Diese Pars inferior besitzt an ihrer Medialwand stets zwei besondere Macnlac, eine oralwärts gelegene, die Macula saculi, und eine mehr candale, die Macula lagenae. Erstere ist gewöhulich gröBer und in eine ansehnliche, häufig recht große ventrale Aussackung der Pars inferior eingelagert, den Saceulus Fig. 553). Auch für die Macula lagenae ist fast stets eine solche Ausbuchtung vorhanden, welche als ein Anhang des Sacculus erscheint, die Lagena (oder Lagena cochleae, s. Fig. 551 11. 555). - Erst beiden $S a$ lamandrinen, nnter den Amphibien tritt eine wichtige Komplikation dieser Lagena anf, indem sich an ihrer Medialwand, etwas ïber der Macula lagenae, eine kleine besondere Nervenendigungsstelle $a b$ sondert, die Pupilla basilaris, welche sich bei den anuren

Fig. 553

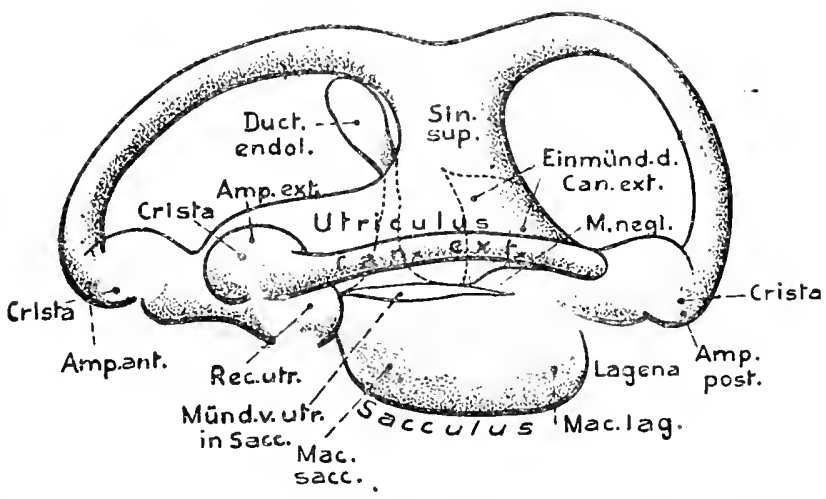

Acipenser sturio. Linkes häutiges Labyrinth von der Lateralseite (nach RETZIUS 1881).

Fig. 554 .

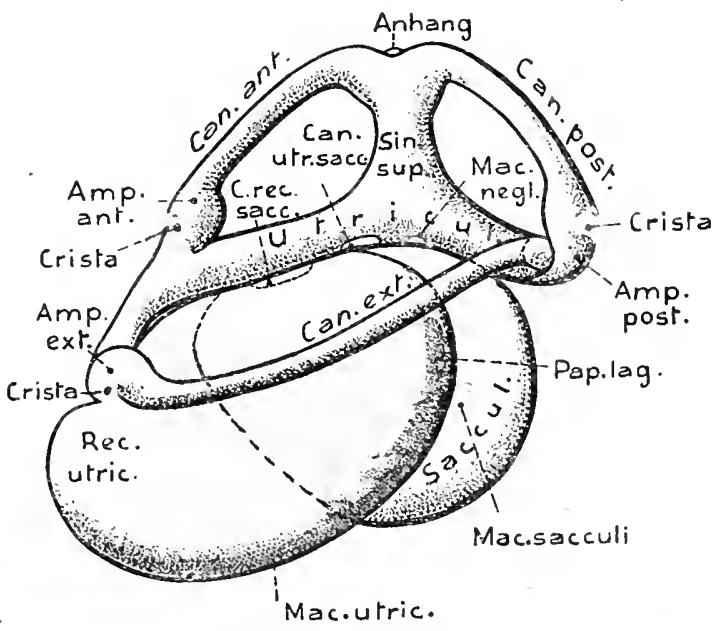

Protopterus annectens. Linkes Lalisinth von der lateralseite (nach livTZIL'S 18S1). Sch.

Amphibien und Amnioten einer besonderen Aussackung der Lagena eiulagert (s. Fig. 571, S. 773), der Purs basilaris lugemae. Die Pars basilaris ist die erste Anlage des eigentlichen Hörteils des Labyrinths und wächst bei den höheren Sauropsiden und Sängern immer stärker röhrenförmig ans, wobei sie die Lagena an ihrem blinden Ende trigt. Das sich so bildende Organ ist die Cochlea oder schneclie, deren lang bandförmige Papilla basilaris zum Cortischen Orgon wird, dem speziellen Endapparat für die Hörwahrnehmungen. 
Da die Cochlea sich etwa auf der Grenze von Sacculus und Lagena berrorbildet, so harmoniert dies im allgemeinen mit den Ergebnissen physiologisch-biologischer Beobach-

Fig. 555.

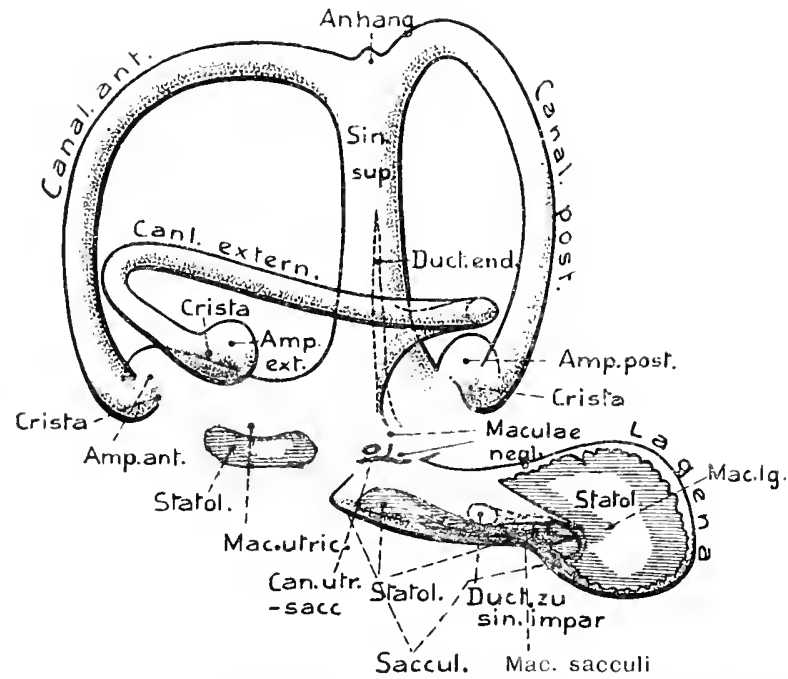

Idus idus. Linkes Labyrinth von der Lateralseite (nach Retzus 1881).

Fig. 556.

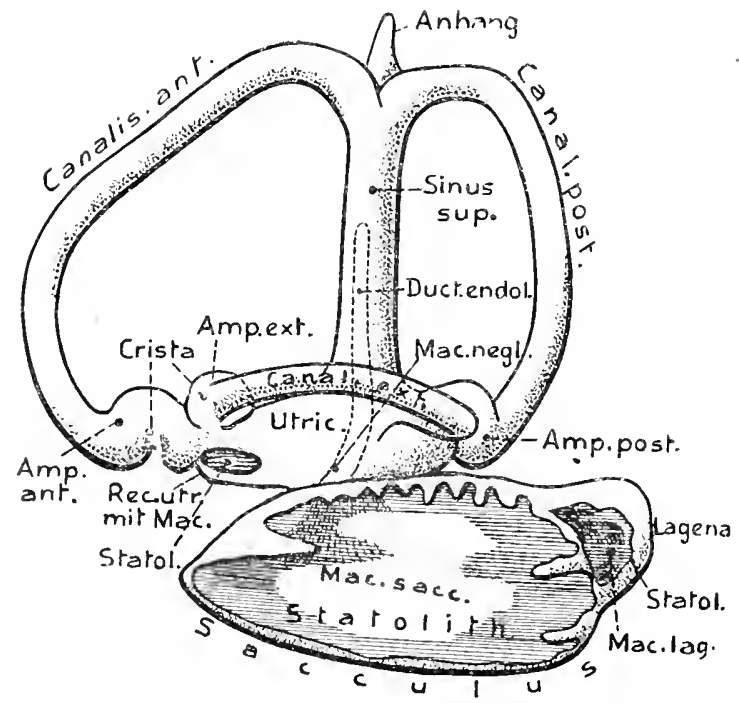

Perea fluviatilis. Linkes labyrinth von der Lateralseite (nach
lietzies losl). tungen an gewissen Kuno'henfischen, die es walıscheinlich machten, daß sich der sitz ihres Jiirvermiigens im Sacculns tindet.

Im folgenden sollen die einzeluen Bestandteile des liäntigen Labyrinths durch die Gnathostomenreihe etwas genanes verfolgt werden.

Die drei Bogrugänge erheben sich bei vielen primitiven Formen, wie Ganoiden (Fig. 553), Dipnoem (Fig. 554), manclien Teleosteen, Uiodelen (Fig. 557), Gymmophionen, Cheloniern nur wenig. IBei den

Choudropterygier"

(Fig. 551 52) und den meisten Teleostecm. (Fig. 555) ragen sie stäker empor, was in noch größerem Maße den höheren Sarrojrsiden,namentlichaber den Vügeln (Fig. 560) und den meisten sï̈ugril (Fig. 562) zulkommt. - Bei Clitnuera, den huochengenoiden und hrochenfischen ist das häutige Labyrinth medial gegen die Schädelhöhle nicht knorplig oder knöchern, sondern unr hïntig abgegrenzt, so daß die vertikalen Bogengiinge hier (besonders Knochenfische) anscheinend frei in die Schädelhöhle hineinragen. - Wenn die Bugengänge besonders groß werden, 
wie bei höheren Reptilien, Aves und Mammalieru, dann ist der vordere vertikale meist viel größer und steigt höher empor als der hiutere; dies tritt anffallend bei den Vügeln (Fig. 560) hervor, wo aneh der horizontale Gang stark sehief naeh hinten aufsteigt. Wenn letzterer Gang großwird, wie bei vielen Chomlioptrigyiorn und bägrln, so tritt er mit seiner hinteren Umbiegungsstelle meist dureh die Ansbuchtung des hinteren vertikalen Kanals caudalwärts hindureh. — Die mittleren Enden der beiden Vertikalgänge mïnden, wie bemerkt, gewöhnlich in den vou Utrieulus aufsteigenden Sinus superior, in dessen Basis sich anch das Hinterende des horizontalen Kianals öffnet. Dieser Sinus steigt meist $\mathrm{nm}$ so höher empor, je mehr sieh die vertikalen Bogengänge erheben. Bei den Vögeln ist auch die Einmündungsstelle des Horizontalkanals am Sinus superior stark emporgeriuekt, in die Nähe des Zusammenflusses beider Vertikalgainge.
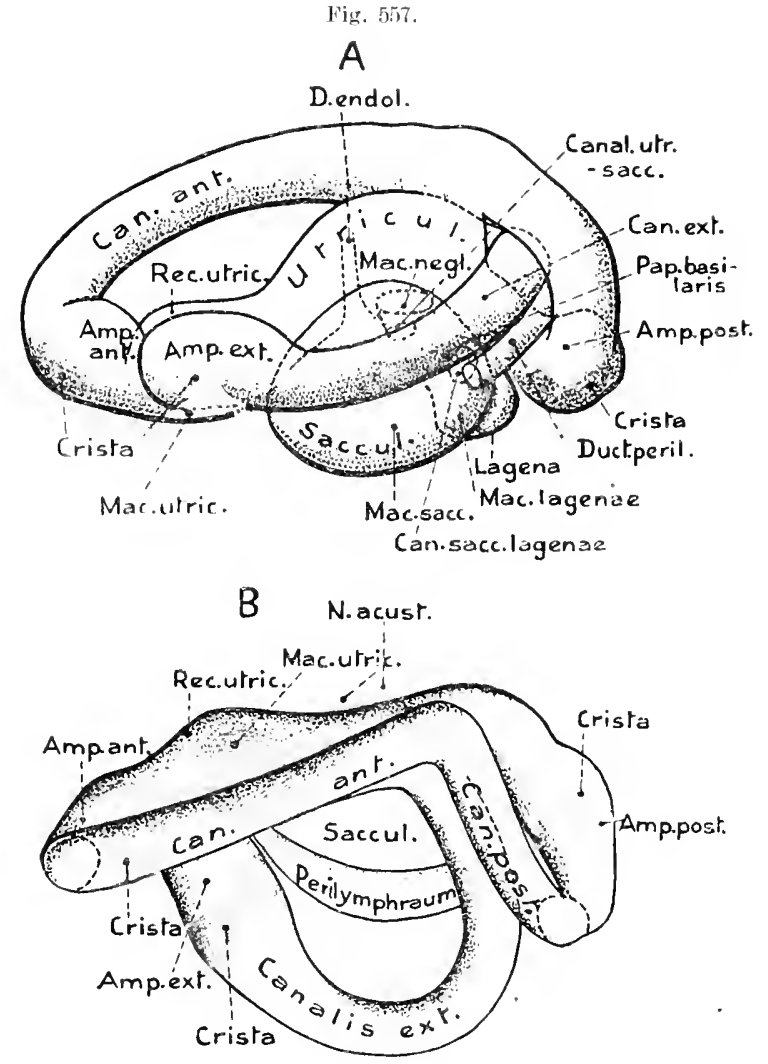

Salanander maculosa. Linkes Labyrinth. A Laterilansicht. li Dorsalansicht (mach ReTziUs 1881). Sch.

Fig. 5is.

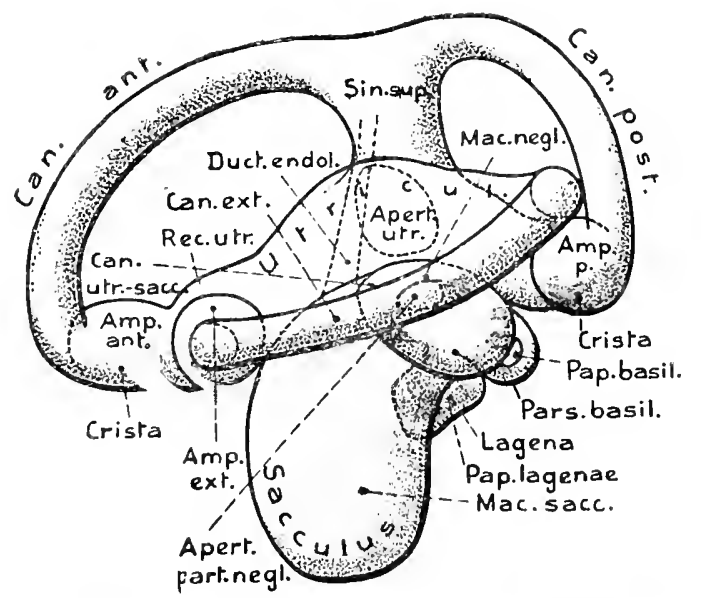

Rana esculenta. Linkes Labyrinth in Lateralansichi $\begin{gathered}\text { (nach } \\ \text { Retzios 1881). }\end{gathered}$ 
Eigentïmlich abgeändert erscheinen die Verhältnisse bei Haien und Rochen; wogegen Chimaera sich den übrigen Fischen ansehließt. Bei-ersteren (Fig. 551 u. 552, S. 760) hat sich nämlich der hintere Bogengang ganz rom Simus superior abgelöst und ist zu einem in sich geschlossenen Kanal geworden, der einerseits durch seine Ampnlla posterior, andererseits durch eine Öfnung oder einen liurzen Kanal (Ductus posterior, Fig. 552) in den hinteren Teil des Sacculus mündet. Das Hinterende les horizontalen Kanals dagegen vereinigt sich mit dem

Fig. 559 .

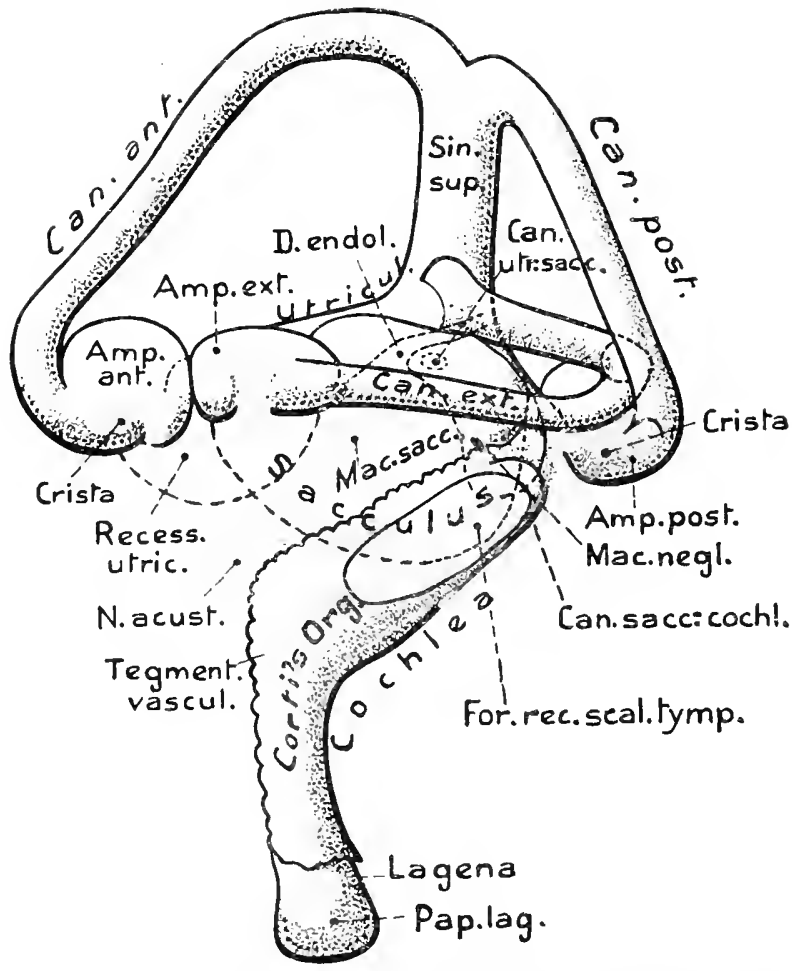

Alligat or mississipiensis. Linkes Labyrinth vonder Lateralseite (nach RETZILS 1881 ). sorderen vertikalen zu einer Art Sinus superior utriculi. Dies Yerhalten dürfte vielleicht so entstanden sein, daß eine Spaltung des ursprünglichen Sinus superior in eine vordere und hintere Partie eintrat. - Pei den Fischen findet sich an der Eingündungsstelle der beiden vertikalen Gänge in den Sinus superior häufíg ein zipfelförmiger Anhang (s. Fig. 556), der namentlich bei $C h i$ macra ansehnlich wird.

\section{Der Utriculus} ist eine meist längsgestreckte röhrenförmige Bildung, die in ihrer dorsalen Mitte als Sinus superior emporsteigt, und auf ihrer medialen Vorderseite die oben als Recessus utriculi erwähnte, meist mäßige Aussackung bildet, welche die Maculc utriculi enthält, und dicht neben oder etwas ventral von der Ampulla anterior liegt.

Wie bemerkt, ist der liecessus meist nur schwach entwickelt, zuweilen sogar sehr wenig; besonders groß wird er bei den Dipnocm (Fig. 554, S. 761). Er kann auch mit der vorderen und lateralen Ampulle in direkter Verbindung stehen; selten (Chondropterygii) besitzt er auch eine Mïnlung in den Sacculus.

Die Pars inferior des Vestibulums setzt sich als Succulus durch eine horizontale Einschniirung vom Utriculus ab und bildet urspriinglich einen einheitliehen saekartigen ventralen Auhang, der durch eine spaltartige weite Öfïung Canalis utriculo-saccularis) mit dem Utrieulus kommuniziert (Ganoiden, Dipnoer, Chimaera). 
Fig. 560.

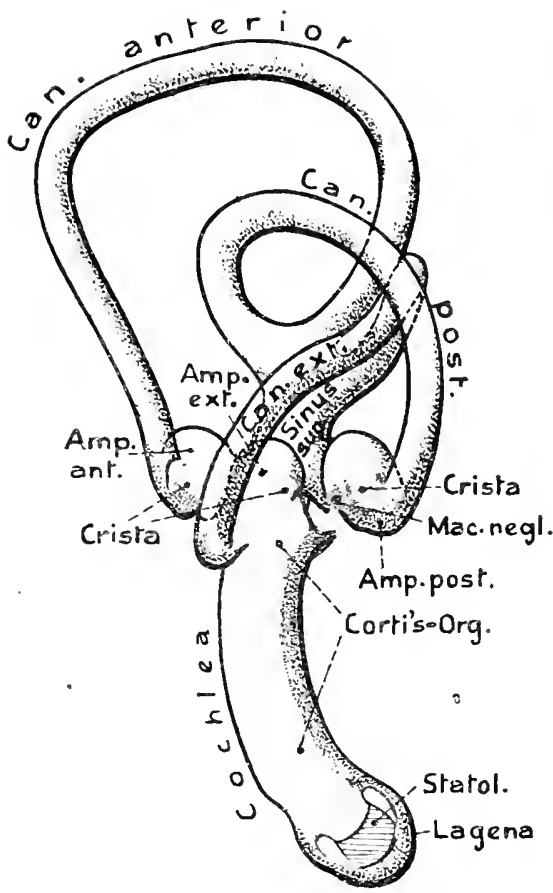

Columba domestica. Linkes Labyrinth von der Lateralseite (nach Retzius 1884). sich.

Fig. 561.

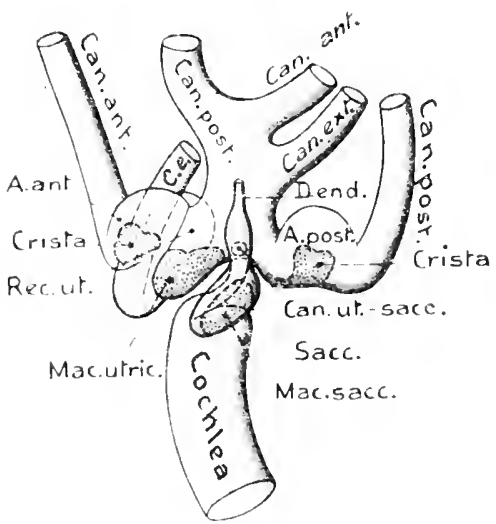

Columba domestica. Centraler Teil des rechten Labyrinths von der Medialscite; zur Demonstration der Verbindung von saceulus und Cochlea Canalis sacculo-cochlearis) (nach Retzius 1834, etwas verändert). v. Bu. liig. 562 .

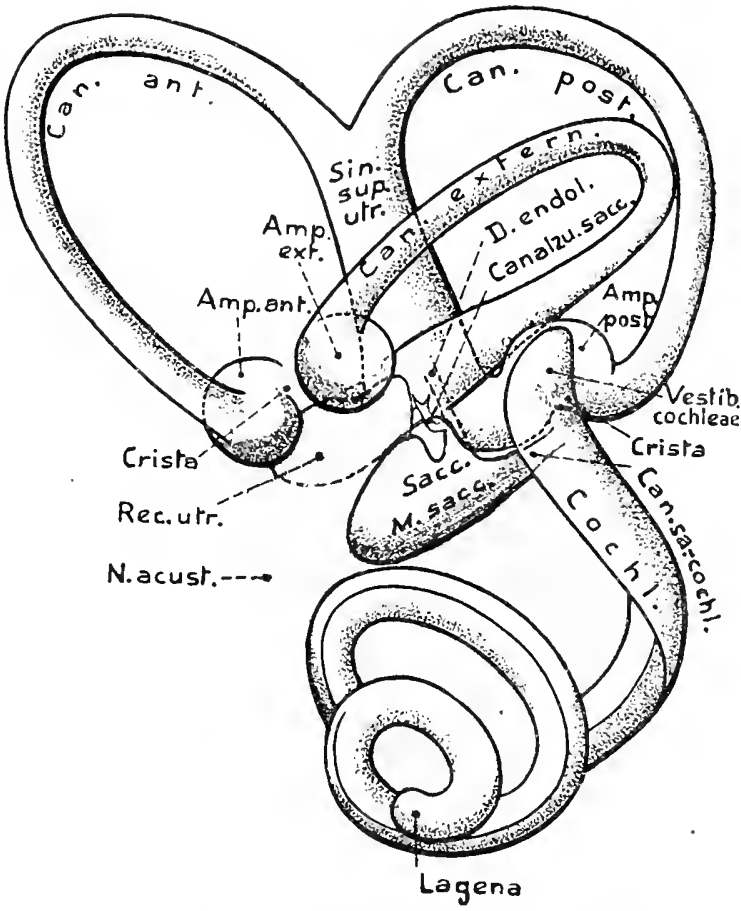

Lepus cuniculus. Linkes Labyrintly ron der Lateralseite (nach Retzius 1854). Sel.

Fig. 563.

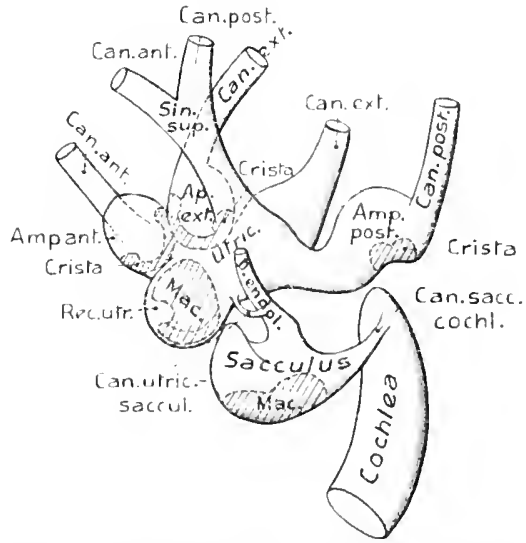

Ii o mo, Centraler Teil des rechten Labyrinths von der Medialseite; zur Demonstration der Terbinclung von Utriculus umil Saceulus, sowie des letateren mit der Cochlea (etwas schematisiert, nach RETzICs 1884). 
Bei primitiven Formen (Chimaera) enthält der Saculns noch eine einheitliche Macula; bei allen übrigen hat sich diese in eine vordere, gewöhnlich größere $M H a-$ cula sacruli und die in der Caudalregion gelegene Ilacula lagenar gesondert. Trotz dieser Differenziernng ihrer Maculae kann die Par's inferior änßerlich noch einheitlich sein (Knorpelganoiden, Fig. 553, Dipnoi, Fig. 554), ist aber in diesen Fällen (besonders Dipnoi) recht groß. Sonst sackt sich ihre candale Wand mit der Macula lagenae zu einer besonderen, hinten angefïgten Ansbuchtung ans, so daß die Pars inferior nun zwei Teile: den vorderen Sacenlus und die hintere Laypua unterscheiden läßt (Fig. 555/56). - Bei den Fischen bleibt die Lagena fast stets viel kleiner als der Sacculns nnd ist in recht verschiedenem Grad von ibm gesondert; manchmal ist sie nur eine kleine (Holostei und manche Tẹleostei) bis ansehnlichere Ansbuchtung seines Hinterendes, häufig aber auch vom Sacrulus stark abgeschnürt, so daß bei den Teleostei die Verbindungsöfthnng zwischen beiden Abschnitten (Canalis sacenlo-lagenalis) meist ziemlich eng wird. - Anch die, wie erwähnt, urspriïnglich weite Verbindungsöthinnng zwischen Utriculus und Sacculus kann sich bei den Teleostei sehr verengern, ja bei vielen völlig schlie ßen Bei gewissen (besonders Physostomi) verlängert sie sich zu einem engen Kanal, so daß der Sacculus samt der Lagena vom Utricnlus ventral stark abrïckt.

Etwas. ̈hnnliches wiederholt sich nur bei den Nammalia allgemein (Fig. 562 u. 563), und der so gebildete Canalis utriculo-surcularis wird bei ihnen besonders dadurch charakterisiert, daß sich der Ursprung des Ductus endolymphaticus, welcher sich sonst am dorsalen Teil des Sacculus findet, anf ihn verschoben hat.

Bemerkenswert erscheint, daß bei gewissen Physostomon (speziell Cyprinoiden und Siluroiden), die, wie spïter auszufïhren ist, eine eigentümliche Beziehung der Schwimmblase zu den Labyrinthen besitzen, diese durłh einen querverlaufenden röhrenförmigen Gang, der die beiden Sacculi miteinander verbindet, kommunizieren. Das Genauere über diese Einrichtung soll später bei der Schwimmblase geschildert werden.

Schon bei annren Amphibien sendet der Sacculus einen dorsalen Fortsatz lateral vom Utriculns empor, wïhrend medial ein ähnlicher schwächerer vom Ursprung des Ductus endolymphaticus gebildet wird. Die Reptilien zeigen diese laterale Unfassung des Utriculns durch den Sacculns noch ansehnlicher, wogegen der Vogelsacculus (Fig. 561) sehr klein bleibt, der der Säuger (Fig. 563) ebenfalls nur mäßig entwickelt ist und den Utricnlns nicht umfaßt.

Anf der Grenze von Utricnlus und Sacculus, der Utriculo-Saccularöfinung angelagert, findet sich, wie schon bemerkt, mit Ansuahme der allermeisten Sünger (nur bei Echirlna wurde sie noch gefunden), fast stets eine kleine Maculu meglecta, die bei gewissen Ganoiden und Knochenfischen in zwei gesondert sein kam, bei einigen Teleostei und IIolostei jedoch vermißt wurde. Gewöhnlich liegt sie im Utriculus; nur bei Plagiostomen und Amphibien ist sie in den Canalis ntrienlosaccularis oder den Sacculus gerïckt, was ja anch erklärlich scheint, da sie, wie bemerkt, der Grenzregion beider angehört.

Auch bei den Gymmophionn wurlen zwei Endignngsstellen in der Nähe des Canalis utriculo-saccularis beschrieben, cine im Utriculus und eine im Sacculus, welche demnach wohl beide den Maculae neglectat entsprechen. 
Wie schon hervorgehoben, tritt in der kleinen Lagena der Sulumumbinen, etwas oberhalb der Macula lagenae, erstmals eine besondere Endigungsstelle auf, die Papilla basilaris, welche jedenfalls durch Differenzierming der Macula lagenae entstand. Bei den Anuren. (Fig. 558 wird sie ansehmlicher und ligert sich einer besouderen kleinen Anssackung der basalen Lagenaregion ein, der Purs basilaris layenac. Die Wand der Anssackung ist dick, mit Ansmahme einer kreisrunden Stelle ihrer Medianseite, welche sehr diunn bleibt und daher als Mrmbrana basilaris bezeichnet wird. - Bei den Ammioten wächst diese l'ars basilaris samt der Membrana basilaris immer mehr aus nnd entwickelt sich so zur Seluncke oder Cochlea. Die Pars basilaris der sich urspriinglicher verhaltenden Reptilien (Cheloniar nnd Squrmata) bleibt im allgemeinen mäßig groß nnd schnürt sich vom Sacculus stark ab, so daß nnr eine enge Öffinng oder ein kurzer Kanal (Cumalis saculo-cochloris oder mminus) die Kommunikation herstellt. Die eigentliche Lagena bildet dam den meist wenig abgesetzten Endteil der Pars basilaris oder Cochlea; die Papilla basilaris vergrößert sich in dem Maße, wie die Cochlea auswächst, und mit ilı anch die Membrana basilaris, auf welche die Papille gerückt ist. Beide werden bei dem etwa dorsoventralen Answachsen der Cochlea länglich elliptisch bis bandförmig. Bei einigen Sauriern sondern sich Papille nnd Basalmembran in zwei Partien, eine dorsale und ventrale.

Die Cochlea der Crocorlile (Fig. 559) und Tögol (Fig. 560) verlängert sich so stark, daB sie etwa dieselbe Höhe wie das iibrige Labyrinth erreicht. Sie wird so zu einem schlanchförmigen Gebilde, das sich in seinem ventral gerichteten Verlanf etwas nach hinten krimmt und auch ein wenig schraubig gedreht ist. Der lagenare Endteil schwillt meist etwas an. Der gleichfalls schwach anfgeblähte Basalteil steht durch einen engen Canalis sacculo-cochlearis mit dem Sacculns in Verbindnng (Fig. 561). Der häutige Schneckenkanal (Ductus cochlearis) ist mediolateral ziemlich stark abgeplattet und seine Medialwand zur streifenförmigen Membrana basiliris verdiunnt, längs der sich die Macula cochlear (Papilla basilaris, C'ortisches Oryan) erstreckt. In das Basalende der Schnecke setzen sich die Macula und die Membrana basilaris nicht fort, wogegen sich im Distalende (Lagena) die Macula lagenae findet. - Bei den Samropsiden tritt eine eigentümliche Befestigung der häutigen Schnecke an dem sie nmschließenden knöchernen Kanal auf, indem sich an dem Vorder- und Hinterrande des letzteren eine knorplige Längsleiste bildet (Fig. 566 n. 567, S. 770), an welcher der Dnctus cochlearis so befestigt ist, daß die Membrana basilaris zwischen beiden Leisten ausgespannt erscheint. Diese Leisten, sowie der Ductns cochlearis, scheiden also den Perilymphranm nm die Schnecke in zwei, einen medialen (Sculu tympami) und einen lateralen (scala irstibuli), die am Distalende der Schnecke ineinander übergehen, und von welchen der laterale mit den Perilymphrïnmen nm das ïbrige Labyrinth zusammenhängt. Wir kommen auf diese Verbältuisse später zurïck.

Die Schnecke der Monotremen bleibt auf einer ähnlichen Entwicklungsstufo stehen wie jene der Crocodile und Vögel. Bei den iibrigen Süngern wächst sie dagegen sehr lang aus, indem sio sich nach voln und etwas nach außen ein- 
krümmt (Fig. 562); sie rollt sich also schneckenhausartig auf, wobei der Apex der Schnecke lateral und etwas nach vorn schaut. Die Zahl der Windungen kann von $1 \frac{1}{2}$ (Cetaceen) bis auf etwas über 4 (Mensch etwa 3) steigen. Natürlich macht auch der knöcherne Schneckenkanal diese Windungen mit, ebenso wie die Achsialleiste (in bezug auf die Schneckenachse) oder Lamina spiralis ossea, an welcher sich der Ductns cochlearis heftet, da er abachsial der Wand des knöchernen Schneckenkanals direkt anliegt (Fig. 568, S. 771). Die Macula lagenae, welche sich bei den Monotremen noch findet, ist bei den ditremen Mammaliern geschwunden; nnr das sehr schwach angeschwollene Distalende des Ductus cochlearis, in welches das lange Cortische Organ nicht mehr eintritt, wird als Lagena bezeichnet. Wir kommen auf diese Verbältnisse bei dem Cortischen Organ nochmals zuriick.

Ductus conlolymphaticus. Das Hervorgehen dieses Kanals ans dem Einstiilpungskanal des ursprünglichen Hörbläschens wurde früher geschildert (S. 755). Am fertigen Labyrinth entspringt er stets von der medialen dorsalen Region des Sacculus und steigt dorsal empor.

Er scheint, nit Ausnalıme gewisser Teleosteer, allgemein verbreitet zu sein. Für letztere Abteilung wirl jedoch die Homologie des an der gleichen Ursprungsstelle sich findenden Kanals mit dem Ductus endolymphaticus der übrigen Cranioten häufig bezweifelt. Er soll nämlich hier nicht aus dem Einstülpungskanal hervorgehen, sonderu sich relativ spät und selbständig bilden; dennoch dürfte es seine sonstige Übereinstimmung sehır wahrscheinlich machen, daß er dem Ductus endolymphaticus entspricht.

Bei den Chondropterygiern (Fig. 551 u. 552, S. 760) steigt der Ductus im Knorpelschädel vertikal hoch empor, bildet eine Ausbiegung nach vorn, die häufig sackartig erweitert ist (Sacens endolymphaticus) und mündet schließlich auf der Kopfoberfläche ans. Hier erhielt sich also sein urspriünglicher Charakter. Bei allen übrigen Wirbeltieren endigt er blind, fast stets (ausgenommen Teleostei und Holostei) jedoch mit einer schwachen, zuweilen aber sehr mächtigen Anschwellung, einem Saccus cndolymphaticus. - Der Ductus tritt durch eine Öffnung oder einen Kanal in der medialen Scbädelwand (Aquacductus restibuli) in die Schädelhöhle ein, so daß der Saccus endolymphaticns seitlich vom Hirn liegt und gewöhnlich mit den Hirnhänten (besonders der Dura mater) in innige Verbindung tritt. Häufig (so Mammalier und manche andere) bleibt der Saccus sehr klein. In gewissen Fällen kann er dagegen auffallend groß werden. So liegt bei Protopterus (Dipnoi) jederseits von der Medulla oblongata ein ansehnlicher Saccus, von dem ein System netzartig verzweigter Kanäle ansgeht, welche die Tela chorioidea iiberspinnen und sich in zahlreiche Divertikel erheben. Die Systeme der beiden Sacci bleiben jedoch voneinander getrennt (Fig. $405 a$ n. $b$, S. 567, die jedoch in bezug hicrauf nicht ganz richtig ist, ebenso nicht ihre Erklärung). Ähnlich große endolymphatische Säcke wiederholen sich bei den Amplibien, und ihre Endolymphe enthält hier gewöhnlich bedentende Mengen ron Kalkkarbonatkriställchen. Bei den Urodelen liegen die beiden Säcke seitlich vom Hir'n, schieben sich aber manchmal anch etwas dorsal über dasselbe. Besonders groß werden sie bei den Aunren (s. Fig. 572, S. 774). 
Die beiden gelappten Säcke senden hier (Rana) dorsale und ventrale Fortsätze aus, welche, in die Dura eingelagert, das llirn umgreifen und dorsal zusammenstoßen; doch bleibt der für gewisse Urodelen und Rana gelegentlich angegebene ZusammenfluB beider zweifellaft. Von jedem Sack zieht bei Rana ein hinterer dorsaler Fortsatz über die Tela chorioidea der Medulla oblongata; beide Fortsätze legen sich dicht aneinander und setzen sich ïber dem Rückenmark durch den Spinalkanal bis zum 7 . Wirbel fort. Dabei senden sie nach rechts und links durch die Foramina interfertebralia Queräste zum 1.—10. Spinalganglion, welche diese Ganglien als drüsige, säckchenartige Bildungen umhüllen (Kalksäckchen) und wie die Kanäle Kalkkristalle enthalten.

Ähnliche große Säcke kommen unter den Satriern bei gewissen Asealaboten vor; sonst bleiben sie bei den Sauropsiden meist mäßig groß.

Bei den erwähnten Ascalaboten tritt jeder Ductus aus ler linteren seitlichen Schädelregion aus und rerlängert sich, vielfach gewunden, bis in die Nacken- oder Schultergegend,

Fig. 56."

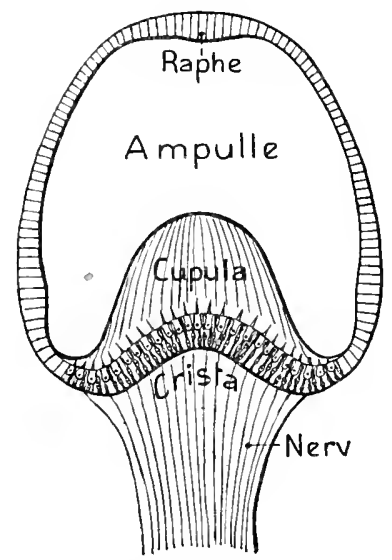

Schematischer Schnitt durch eine A mpulle mit ihrer Crista (nach RetzIUS 1884). C. H.
Fig. 565 .

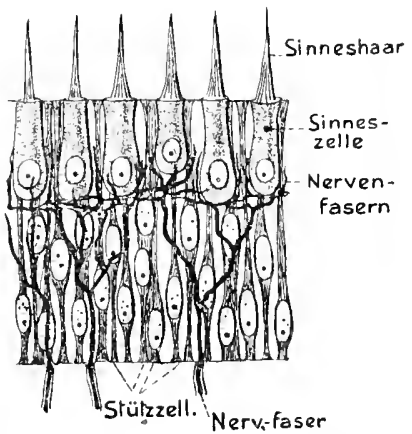

Schematischer Schnitt durch die Macula (oder Critsa) eines Wirbeltiers (nach RETzius 1481).

wo er zu einem ansehnlichen gelappten Saccus anschwillt; auch in die Orbita kann sich ein Fortsatz wach vorn erstrecken und den Augenbulbus melır oder weniger umhüllen. Die Säcke und ihre Verzweigungen sind von Kristallbrei erfïllt. - Über die plysiologische Bedentung der erwälnten abnormen Vergrößerungen und Ausbreitungen der Saccus endolymphatici ist kaum Sicheres bekannt.

Der feinere Bau der Nerecuendigungsstellen der Cristue und Maculae ist ein sehr iibereinstimmender. Sie bestehen ans Sinneszellen und viel zahlreicheren Zwischenzellen (Stiitzzellen, Fadenzellen). Während das einschichtige Epithel des häutigen Labyrinths im allgemeinen niedrig, plattenförmig bis eylindrisch bleibt, verdickt es sich an den Endstellen beträchtlich und erlangt hier einen anscheinend mehrschichtigen Chirakter, was aber nur daher riihrt, daß die Kerne der fadenartigen Stätzzellen in sehr verschiedener Höhe liegen und die Sinneszellen sich etwa nur durch das obere Viertel bis die obere Hälfte der Epithelhöhe einsenken (Fig. 564 u. 565). Der Bau der Siuneszellen erinnert au den 
von Flimmerzellen; sie sind etwa birnförmig und tragen an ihrem freien Ende ein Büschel feiner bis etwas gröberer starrer Sinneshare, die meist zu einem langkegelförmigen Fortsatz verklebt sind. Die im Epithel netzartig ansgebreiteten,

Fig. 566.

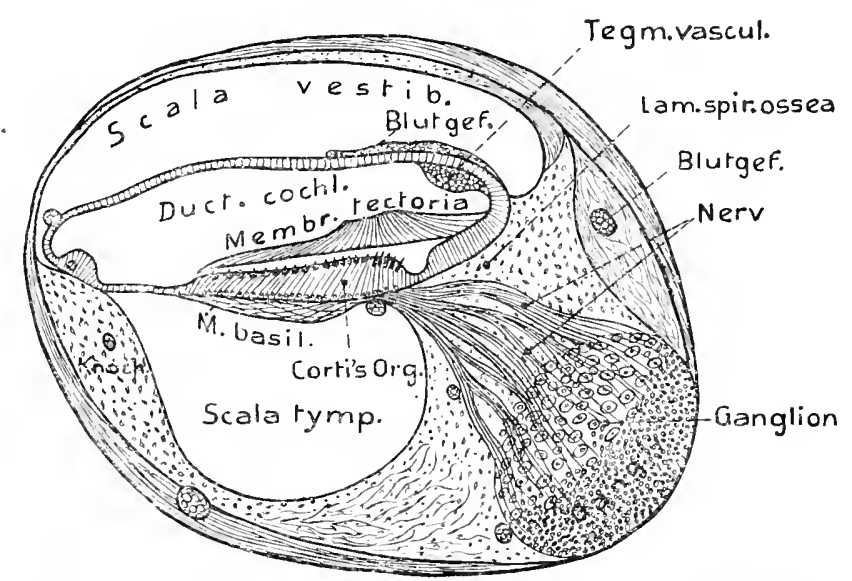

Alligator mississipiensis. Querchnitt der. Cochlea etwas distal von ihrer Hitte (nach RETzus 1884). Hörzellen schwarz.

marklos gewordenen Nervenfasern umspinnen schließlich die Basalenden der Sinneszellen; doch sollen sich gelegentlich auch freie Nervenendigungen im Epithel finden. - Anf den Maculae utriculi, sacculi und lagenae tindet sich stets

Fig. 567 .

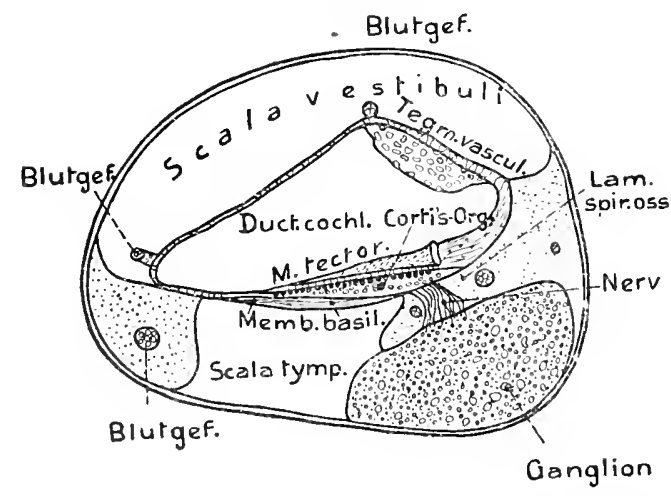

Columba domestira. Querschnitt der Cochlea etwas distal von ilırer Mitte. Hörzellen schwarz (nach keTzius 1sit). Sch. eine Statolitlecubillung, über die später näher berichtet werden soll. Auf den Cristae fehlt sie (nur für Myxine wurde sie gelegentlich angegeben); diesensitzt eine eigentümliche, im Querschnitt kuppelförmige und fein längs gestreifte Masse (Cupula, s. Fig. 564) anf, in welche sich die Sinneshare einsenken; häufig wurde diese Cupula aber als Kinnstprodukt gedeutet.

Eine besondere l)arstellung erfordert der kompliziertere Bau des Endorgans der Amniotencochlea, des Cortischen (rgans. Sein Vorläuter, die Papilla basilaris der Amphibien, besitzt im allgemeinen noch den Ban gewöhnlicher Haculae.

In dem zu einem langen Band ausgewachsenen Cortischen Mrgan der Crocodile (Fig. 566) und Vögel (Fig. 567) finden sich zwischen den stützzellen zahlreiche Längs- 
reihen von sinneszellen, die bei den Vägeln sämthich gleich sinch bei den Crocoditen haben sie sich zu zwei Arten differenziert, nämlich größere, die in eingen Längsreihen lem Caudalrand des Cortischen Organs angehören und zahlreichere kleinere, die sich durch das ïhrge Mrgan erstrechen. Damit scheinen Verhälnisse angebahnt, wie sie sich. bej

Fig. 568 .

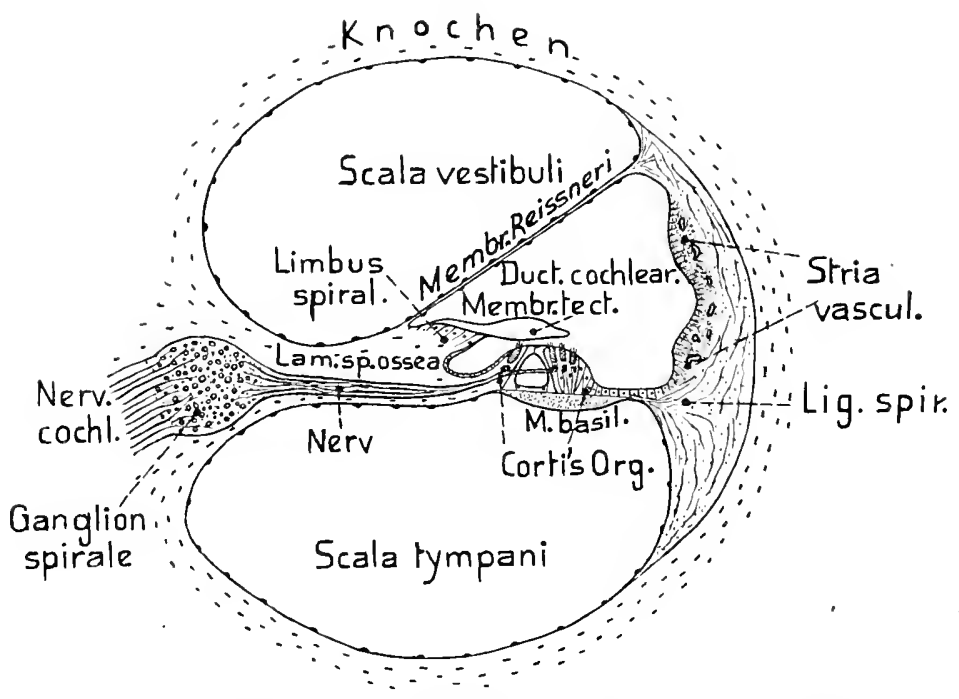

Homo, schematischer Querschnit durch die Cochlea und ilıre Emgehung (mit lemutzung von ströHr, Histologie mach RETzIC's 189t).

v. Bir.

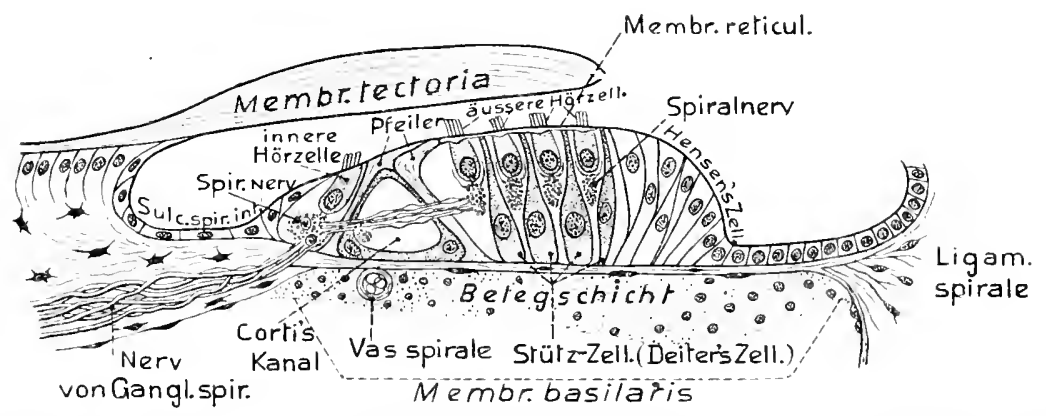

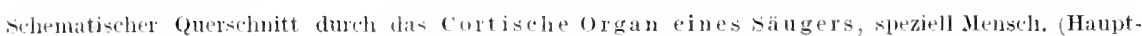
sathlich nach letzres 1stit.)

v. 1311 .

den süugern tinden. Letztere (Fig. 568 u. 569) zeigen das Eigentümliche, daß die Epithelverdickung, welche, auf' der oben erwähnten bindegewebigen Membrana basilaris anfruhend, das Cortische Organ bildet, näher dem gegen die Schneckenachse schauenden Rand (Vorderrand) eine kanalartige Unterbrechung zeigt, die schon bei den Crotodilen (Fig. 566) angedeutet ist (Cortischer kinal oder Tunnel). Hierdurch wird das (Jrgan in einen schmäleren achsiaten und einen breiteren abachsialen Streif gesondert. Dies spricht sich aurh lariu 
aus, dlab der erstere meist nur eine Läugsreihe fon sinneszellen enthäl (selten stellenweise zwei), der abachsiale dagegen meist drei, seltener vier (doch können sich in dieser Jeziehung bei lemselben Tier an rerschiedenen Stellen der Schnecke einige Abweichungen finden). Der fortische Kanal wird achsial und abachsial ron einer Reihe eigentümlich modijizierter stützzellen hegrenzt (lig. 569), deren Körper zum größten Teil zu cuticularen pfeilerartigen Gebilden umgeformt sind, so daß nur an ihrer Pasis noch ein Plasmarest mit lem zugelörigen Zellkern verbleibt. Die achsialen oder inneren Pfeiler sind zalılreicher al die äßßeren. Da die beilen Pfeilerreihen konsergieren und ihre distalen, abachsial umgekrümmten Eulen (Ruder) sich übereinanderschieben, so schließen sie den Cortischen Kanal völlig al.

Die drei Stritzzellenreihen (Deitersche Zollcn), welche sich zwischen die drei abachsialen Iörzellenreiben einschiehen, besitzen gleichtalls eigentümlich modifizierte cuticulare, plattenförnige Distalenden (Phalangcn), die, zusammenstoßend, eine Art Rahmenwerk (Membrana reticularis) biden, in welchem die Distalenden der Hörzellen befestigt sind. Die rom Ganylion cochleae (G. spirale), das in der Schneckenachse verläuft, ausgehenden Nervenäste treten zwischen die Zellen des achsiaten und abachsialen Streifs des Cortischen (rgans ein und ziehen hier als sog. Spiralstränge noch eine Strecke längs, um alhmählich die Nervenfasern tür die Ilözellen abzugeben. - Die früher erwälmte Membrama busilaris enthït eine mittlere Lage mit zableichen eingetagerten quer (achsial-abachsial) ziebenden Faseun, die sieh gegen das Schneckenende allmählich verlängern, da die Breite des Ductus chochlearis apicalwärts allmählich zumimmt. Die Helmholt.zsche Annalıme, daß diese Fasern llurch ibre rerschjedene Länge die Wahrnehmung der Tonhöhen rermitteln, ist immer noch nicht rölig gesichert; ihre Richtigkeit winl sogar fon manchen direkt geleugnet; dorh sprechen gewisse Versuchsergebnisse dafür.

Die Papilla basilaris cochleae und das sich aus ihr entwickelnde cortische Organ besitzt nie Statolithengebilde, wird dagegen von einer pigentümlichen cuticularen Membrana lectoria üherlagest, welche ron deu, an die achsiale Seite des Cortischen Organs anstoßenden Epithelzellen des Limbus spiralis algesontert wird. Diese Membran wind bei den Amptribien und Samopsiden von zahlreichen Löchern (oder Kanälchen) durchsetzt, bei den Säugern ron einer feinlaserigen Masse pebillet.

Wie schon bemerkt, teilt sich der Nerms ansticus frïher oder später in zwei Äste, die sich moter reicher Weiterverweigung zu den vershiedenen wmstellen begeben, was bei den Anamniern in der Weise geschieht, daß der vordere oder obere Ast (liamus vcstibmli) die romtere und laterale Ampulle mod die Macula recessus utriculi rersorgt, der hintere (läutig Ramus cochleac genannt) die hintere Ampulle, die Maculae sacculi, neglecta unt lagenae. Die Japilla basilaris, welche sich bei den Amphibien entwickelt, erhält einen Ast les Ramus cochleae. Mit der hohen Entwicklung der Pars basilaris bei den Amnioten verstïrkt sich dieser Ramus cochleae sehr und nimmt zahlreiche Ganglienzellen in sich auf. ein besonteres Ganglion cochleae (G. spirale der Siugerschneche) bildend. Eine scharfe scheirung der zu den statischen Organen und zu dem eigentlixhen Ilörorgan (Cochlex, Macnlia nowlecta) ziehenden Nervenfasern besteht nicht.

Stato- oder Otolithonbildungen finden sich, wie erwïhnt, anf den Maculae utrieuli (Lapillus der Teleostei, sacculi. (Sagitta der Tel.) nnd lagenae (Asteriscus der Tel.), nud zwar gewöhnlich in Form scheihenartiger Gebilde, die in der Regel ans Massen kleiner Kalkgebilde (Aragonit), seltener Kriställchen, bestehen, und von einer gallertigen Misse zusammengehalten werden. Bei einem Chondropterygier (Rhina) mit offenem Ductus endolymphaticns sollen diese Otoconien jedoch, ahnlich manchen Wirbellosen, durch Sandkörnchen ersetzt sein. - Bei den IIolnstei und Telpostei bilden sieh dagegen kristallinisch-sphärische, harte und 
feste Statolithen von bäufig sehr bedentender Größe und geschichtetem Bau Fig. 555 и. 556, S. 762); die Zahl ihrer Schichten wächst mit dem Alter.

Die allgemeine Beschaffenheit sowie die Entstehung der prilymphatischon liimme nm das häntige Labyrinth wurde schon friiher S. 756) erörtert. Diese Räume umgreifen nicht das gesamte Iabyrinth, rielmelu heftet sich namentlich dessen mediale Wand an das skelettöse Labyrinth mehr oder weniger direkt an; auch sind die Bogengänge an letzterem befestigt. Die den Perilymphraum durchsetzenden bindegewebigen Züge zerleyen ihn in verschiedene Abteilungen, von welchen einer an der Lateralseite der centralen Labyrinthregion besonders ansehulich ist Spatium sacculi, Cisterna vestibuli. Von den Amphibien an entspringt ron diesem Ranm, etwa in der mittleren Region des Labyrinths ein Kanal (Dnetrs perilymphaticns, s. Fig. $557 \mathrm{~B}$, S. 763 ), der etwa horizontal candalwärts zieht, auf die mediale Seite des Labyrinths umbiegt, und schließlich durch eine öftumng in die Scbidelwand tritt, $11 \mathrm{~m}$ sich mit den subarachnoidalen Lymphräumen um das Ilirn zu rerbiuden. In seinem Verlanf tritt dieser Ductus perilymphaticus entweder direkt oder durch einen von ihm ansgebenden Fortsatz in nabe Bezielnngen znr Pars basilaris der Lagena, indem er sich der Membrana basilaris dicht anlegt (Fig. 570 n. 571 ). Wenn nun bei den Crocodilen, Vö-

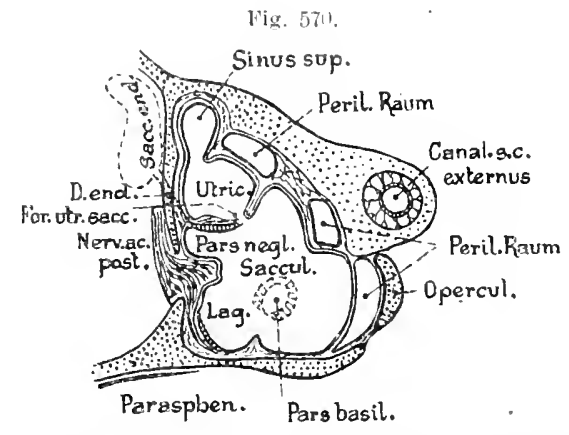

Rana. Querschnitt durch daa Gehörorgan, etwa in der mittleren Region des Labyrinths. Der Dnctus endolymplaticus mit seinem saceus, der etwas weiter vorn liegt, sowie die l'ars bisilaris, die etwas weiter hinten liegt, sind mit strichlinien eingezeichnet mach fatPP, Frosch 19u4)

o. $\mathrm{B}$

\section{Fig. 571 .}

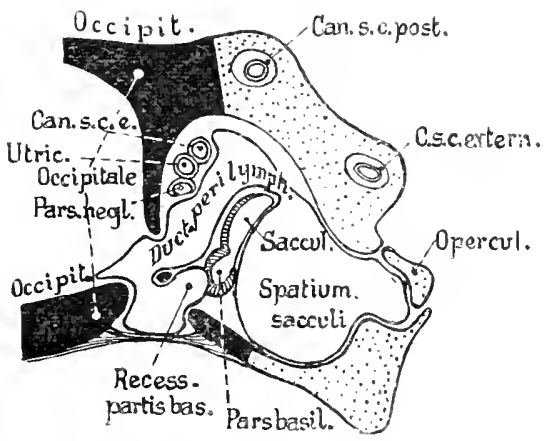

Rana. Quersehnitt durch das fiebiororan, etwas weiter nach hinten als Fin. 570, durch die Pars basilaris, um den Verlauf dpi Duetus perilymphaticus und seine Peziehtung zur Pars basilaris zu zeigen (nach GACPP. FROSCl1 19uí). geln und Sängern die Pars basilaris zum Schneckenkanal auswächst, so stïlpt sie den sie iiberlagernden Ductus perilymphaticns gleichzeitig gewissermaßen ror sich her, oder die Cochlea wächst in den sich ventral ausstiilpenden Ductus perilymphaticus hinein, wobei sie ihn, in Gemeinschaft mit dem entsprechenden Knorpelrahmen, in welchem die Membrana basilaris ausgespannt ist, in einen lateralen absteigenden Kanal (Scala vestibuli) und einen medialen anfsteigenden (Scala tympani scheidet (s. Fig. 566-68, die nur am Distalende der Schnecke ineinander ïbergehen (Helicotrema). - Die Scala vestibuli steht daher an der Schneckenbasis (an ihrem Proximalende mit dem Perilymphiranm des ibrigen labyrinths in 
Verbindung, wogegen die Scala tympani an diesem Ort durch einen Lymphgang (Canaliculus s. aquaeductus cochleae) mit den subarachnoidealen Lymphräumen zusammenhï̈nt.

Accessorische, schallleitemde Teile des Höroryons. Den Fischen fehlen șolche Eimrichtungen völlig. Bei allen übrigen Wirbeltieren sind sie in allgemeinen vorhanden, aber bei gewissen stark rï̈ckgebildet. Sämtliche Tetrapoden besitzen an der Lateralwand der knorpligen oder knöchernen Olrkapsel eine nur hïutig geschlossene kleine Stelle, die sich gegen den ansehnlichen lateralen Perilymphraum wendet. Diese Stelle wird als Foramen oder Fenestra vestibuli (ovalis) be-

Fig. 572 .

Sacc.endol.

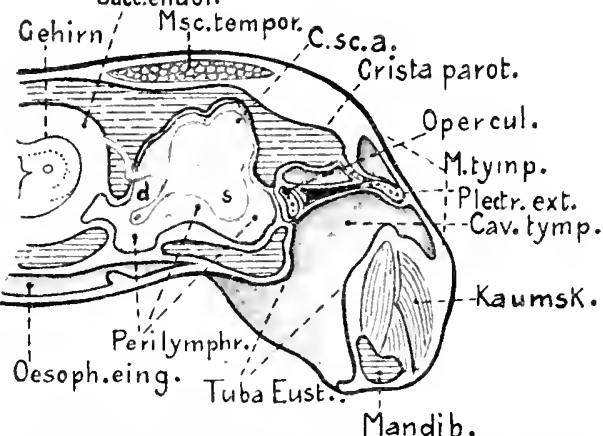

Rana. Schema eines Querschnitts turch den Kopi in der Region ler Paukenhöhle. Schädel schralfiert; Fuorpel des rehörkinals punktiert. Das häutige Labyrinth ist in Wirklirhkeit viel gröBer, namentlich splingen die halbzirtielförmigen Kanäle viel stärker vor und ragen in das schärlelslielett hinein, was hier der Einfachheit wegen nicht dargestellt werten konnte. Die Perilymphräume, die dunkel getönt sind, als gleichmäBiger lioum um das Labyrinth angegeben, was gleichfalls nicht der Wirklichkeit entsurielit da sie sehr liompliziert gestaltet sincl. ¿der sog. Duetus perifymphaticus: s seceulus. Mit Benutzung vou (iAUPP, Frosch 1904, komstruiert.) 0. B. zeichnet, und ihre Verschlnßmembran vermag durch die Schwingungen, in welche sle versetzt wird, die I'erilymphe zum Schwingen zu bringen und so schlieBlich die Hörzellen zu reizen. - Die Amnioten besitzen etwas candal und ventral vou der Fenestra vestibuli, an der Basis der Cochlea stets noch eine zweite :̈hnliche Stelle, welche gegen den Lymphraum der Scala tympani gewendet ist und mit dem Endorgan des Ductus cochlearis, dem Cortischen Organ, in Beziehung steht, die Fenestia cocklecae (s. rotunda, s. triquetra). Es ist wahrscheinlich, daß die Entstehung der beiden Fenster anfünglich mit der eines luftführen-

den, schalleitenden Apparats Hand in Hand ging, weshalb die bei Amphibien und Reptilien vorkommenden Fialle, wo zwar das eine oder die beiden Fenster vorhanden sind, der schallleitende Luftraum dagegen fehlt, wahrseheinlich anf dessen nachtr:iglicher Rückbildnng beruhen. - Der luftführende Raum, das Mittelohe, tritt zuerst bei deu meisten Anuren auf, als eine ansehnliche Höhle (Paukeuhöhle, Caum tympuni, die hinter dem Schidelsuspensorium und dem Paraquadrat, nach außen vou der knorplig-knöchernen Ohrkapsel liegt, und durch einen meist weiten, ventral absteigenden Gang (Tubu Eustactiii) in die Mundhöhle führt (Fig. 572). Nach anßen wird die Pankenhöhle durch eine von der übrigen Kopfhaut mehr oder weniger abweichende Membran abgeschlossen, das Panlienfell (Trommelfell, Membranc tympani). Gegen diese Höhle schant demnach die bei deu Anuren allein vorhandene Fenestra vestibuli und bei den Amnioten auch die Fenestra cochleae. Mit Ansu:hme gewisser Reptilien (Ophidier, Amphisbaeniden unter den Sauriern) findet sich die Pankenhöhle bei allen Amnioten in prinzipiell gleicher Bildung; d. h. sie mündet innen in die Mundhöhle und wird nach außen durch 
das Paukenfell abgeschlossen. - Von letzterem zieht zur Fenestra vestibuli stets ein knorpliges bis knöehernes Skeletgebilde, das im allgemeinen als Colmmrlla. unris bezeichnet wird und die Funktion hat, die Schwingungen des Trommelfells auf die Schlußmembran, der Fenestra vestibuli zu ïbertragen. Dies Hörskelet ist eine Bildung, welche urspriüglich der Pankenhöhlenwand nur :iußerlich anlag, sich dann aber, nnter faltenartiger Einstiilpung der die IIöhle anskleidenden Sehleimhant mehr oder weniger in sie einsenkte, - Obgleieh nun die Paukenhöhle den Cyelostomen und Fisehen fehlt, so ist doch sieher, daß sie aus einer sehon bei den ursprünglichen Fischen bestehenden Bildung hervorging, nämlich der ersten Viseeralspalte, deren dorsaler Teil, zwischen Mandibular- nud Iyoidbogen liegend, sich bei den Chondropterygiern und Ganoiden meist als Spritzlochkanal (Spiraeulum) erlielt.

Die Ontogenie beweist dies wohl sicher, da die Pankenhïhle in direkter oder etwas modifizierter. Weise aus dem dorsalen Teil der bei simtlichen Tetrapoden embryonal auftretenden ersten Visceralspalte entsteht. Diese Spalte (Schlundtasche) ist meist, wenn auch nur vorübergehend, nach außen geöfnet, rerschließt sich aber dann äußerlich, und ans dieser Verschlußstelle billet sich das Paukenfell hervor. Natürlicherweise mub sich die änßere Spaltregion stets zur Paukenhöhle erweitern, was manchmal (Amplibien) durch eine modifizierte soljde, sich erst spüter aushöhlende Anlage ron der ersten Visceralspalte aus geschieht. Auch die rorühergehende Rückbildung der Spalte, wie sie bei den Säugem eintreten soll, kann nicht dahin ausgelegt werden, daß ilure Paukenhöhle eine selbständige Neubilıng der Mundhöhle sei. Für die Ableitung der Paukenhöhle von der Spritzlochspalte wird auch angeführt, daß der spritzlothkanal mancher Rochen eine besondere Ausbuchtung zur Labyrinthregion der Schïdelwand sendet.

Wenn wir zunäehst die Paulienliöhle, welche mit Flimmerepithel ausgekleidet sein kann, etwas genauer verfolgell, so ist noehmals hervorzuheben, daB sie den Trodelen und Gymnophionen, sowie gewissen Amurm. (Pelobatidae, Bombinator, Rhinoderma, Phryniscus, Brachycephalas) fehlt; dasselbe wiederholt sich bei den shlangen und Amphisbaenen.

Die Paukenhöhle der Amphitricn und Sauropsiden wird meist nur medial und dorsal kuöchern umschlossen, sonst von Mluskeln umgrenzt. Die der Chelonier besitzt eine ausgedehntere Knochenwand, da das bei den übrigen Sauropsiden die l'aukenhihle vorn begrenzende Qnadrat die Höhle hier dorsal, ventral und caudal unwächst, wobei gleichzeitig ein äußerer, com Paukenfell lateral abgeschlossener Teil der llöhle von einem inneren mehr oler weniger gesondert sein kann, bis auf einen feinen Kanal, durch den die Columella tritt (vgl. S. 282 u. Fig. 161. S. 281 u. Fig. 166. S. 288). Bei "len Crocodilen, Vögeh und Säugern wird lie knöcherne Umgrenzung der Paukenhöhle viel vollständiger, was bei den Süugern teilweise auf der ansehnlidhen Lntwicklung des Paraquadrats zum Tympanicum berulıt (vgl. hierïber s. 299).

Das Paukenfell sehließt die Höhle nach außen ab, als eine bei den Anuren, Samriern und Cheloniern in der Kopfoberfläche liegende dünnere, meist halbdurchsichtige, kreisrunde bis ovale Haut. Bei den Anuren befestigt es sich durch einen vom Quadrat abstammenden Knorpelsanm am Hinterrand des Paraquadrats (Fig. 573); dieser nur selten (Bnfo) fehlende Saum setzt sich als geschlossene' Ring um die ganze Membran fort. 
Das Paukenfell besteht äuBerlich aus einer Fortsetzung der Körperhaut, innerlich aus Jer die Paukenhöhle auskleidenden Fortsetzung der Mundhöhlenschleimhant. Zwischen beiden Lagen liegt noch eine dïnne, strahlig-faserige Bindegewebshaut, welche auch glatte Muskelfasern enthalten hann; letztere Membran wird häulig als das eigentliche Paukenfell angesehen.

Indem bei zahlreichen Anuren, gewissen Satricm (so vielen Agumiden, Chamateonten, besonders grabenden Formen) die änßere Lage des Paukenfells sich verdickt und die Beschaffenheit der äußeren Körperhant annimmt, läßt sich das Pankenfell äußerlich nieht mehr von der Kopfhant unterscheiden (verstecktes Paukenfell); natürlich fehlt es anch allen Formen, die keine Pankenhöhle mehr besitzen.

Die sich znnächst darbietende Anffassung wäre, daß̧ das Paukenfell nur eine äußere Verschlußmembran der ersten Visceralspalte darstellt. Dengegenüber wurde jedoch die An-

Fig. 573.

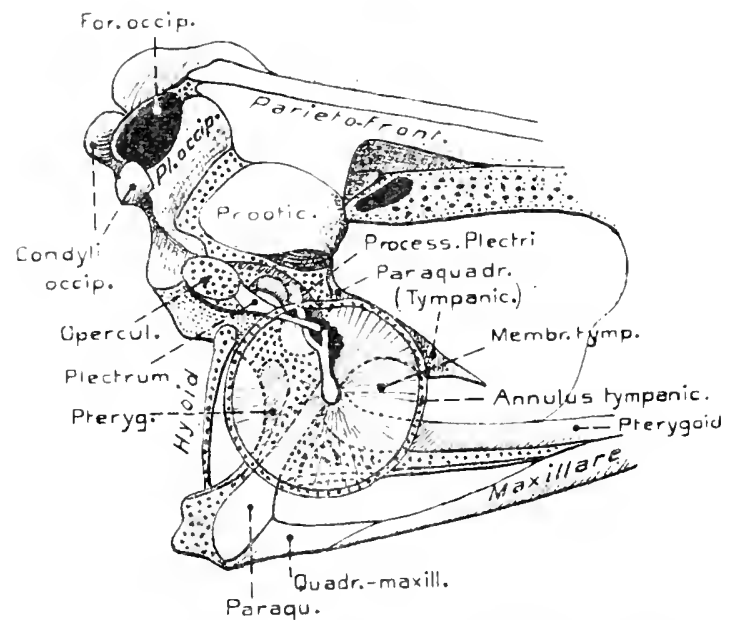

liana. Hinterer Teil des Schädule rectitsneitig mol etwas von linten und dorsolateral mit der columella aturis (Operculum und Plectrum). Der knorplige Anmulus tympanicus mit dem in ihm ancgespanten Tronmelfell, an dem sich das Plectrum befestigt, eingezeirhnet (nacli (ridUPP 1:10\%, "twas veräntert). O. B. sicht ausgesprochen, daß es anf rudimentäre knorplige Kiemenstrablen zurïckzuführen sei, the sich am Palatoquadrat mancher Chondropterygier (spritzlochknorpel, rgl. S. 248) erhalten haben, und welche bei den Rochen eine Art Klappe im Spritzlochtanal stützen können. Mir scheint diese Beziehung vorerst wenig gesichert.

Wie bemerkt, üfinen sich die Paukenhöhlen dureh die Tuben in den hinteren Absehnitt der Mundhöhle. Bei den Amin bleiben diese Gänge kurz und weit; bei den Samiern läßt sich sogar von eigentliehen Tuben kaum

reden. Die Tubengänge der aglussen Amuren, der Chelonier, Crocorlite und Säuger (mit Ausnahme von Ornithorhynchus) werden länger nnd enger. Gewöhnlich münden sie durch getrennte Öfinungen in die Mundhöhle; bei den Aglossen, den Crocodilen und Tögelı sind jedoch die beiden Öffinungen zn einer unpairen vereinigt.

Eigentümlich kompliziert erscheinen die Tuben der Crocodile (Fig. 574), indem von der gemeinsamen Rachenöffung außer den beiden eigentlichen Tuben $(p)$ noch zwei mediale Kanäle $(q, r)$ emporsteigen, die sich unter Gabelung mit den beiden Paukenhöhlen verbinden. Bei gewissen Süngern (I'ferd) hann sich das innere Tubenende zu einen ansehnlichen Luftsack erweitern. - Die hïutig etwas unregelmäßige Gestalt der Paukenhöhle kann zur Entwicklung ron Aussarhungen (Nebenhöhlen) Veranlassung geben (schon Sanria), die sich

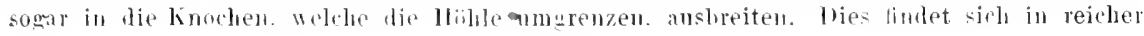


Entwicklung bei den Crocodilen, wo solch luftrïhrende Fortsetzungen in das Qnadrat, das Supraoceipitale, Parietale, sogar das Articulare des Unterkielers eindringen, wobei in dem supraoccipitale eine Kommunikation bejder Höhlen hergestellt wird. - Die Tögcl zeigen Fortsetzungen ins Quadrat und den Unterkiefer, währent sich bei len Sïngern solche in das Squamosum, Perioticum (namentlich in dessen Pars mastoddea) erstrecken kömnen, wo sie die Cellulae mastoideae bilden. Auch dureh selieilenartige linöcherne Einwïchse wird die Paukenhöhle mancher Säuger in Zellen oder Kammern geteilt (z. B. Pferd).

Wie wir fanden, liegt das Paukenfell der niederen Tetrapoden (Amphibien, Saurier) oberflächlich. Bei vielen Samiern senkt es sich jedoch mehr oder weniger stark in die Tiefe, wobei es gleichzeitig durch eine vordere und hintere Hantfalte, in verschiedenem Maße iiberlagert wird. So bildet sich die Anlage eines äußeren Gehörgangs. Bei gewissen Sauriern (Seincoiden, Gecloniden) wird die iußere Üffunng der Einsenkung sehr klein, schlitzartig und kann sich bei manchen Scincoiden (Anguis gewöhnlich) sogar völlig schließen. So entsteht eine zweite Art von ver-

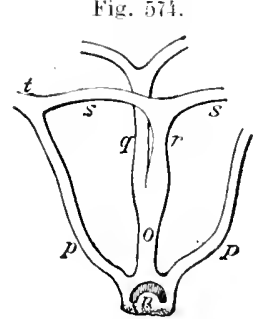

Crocodilus. Tubate Eu stachii in ihpem komplizierten Verlauf. Ausicht vou hinten aur den Schädel aus Geomibick, Vergl. Anatomie nach OWEN?

O. $\mathrm{B}$. stecktem Paukenfell. -- Anch bei Splennorlon erklärt sich das Fehlen des Paukenfells wohl in solcher Weise, doch ist die äußere Pankenhöhle lier stark reduziert. - Ein mißßig tiefer äußerer Cehörgang mit weiter distaler Miundung entwickelt sich bei Crocotilen und Tögch, weshalb ihr Pankenfell äußerlich weniger sichtbar ist. - Viel länger wird jedoch der :iußere Gehörgang der Sänuger.

Er entstelit aus dem rentralen Teil der ersten Kiemenfurche; phylogenetisch jedenfall mehr durch laterales Herrorwachsen der Ungebung des ursprïnglichen Pankenfells als dureh Einsenkung. Eigentïmlich erscheint, daß sich das mediale Eude des Gelürgangs ursprünglich ventral unter die Anlage der Paukenhöhle schiebt, weshalb das zwischen beiden entstehende Paukenfell anfïglich nahezu horizontal liegt (was hei Monotremen dauerud besteht) nml sich erst später anfrichtet. Mas Paukenfell der Mammalier ist last stets gregen die Paukenlü̈lle zu schwach konkav eingesenkt (Fig. 582, s. 783). So findet es sich auch noch bei den Zahmalcu, während es bei den Bartenualen eine eigentümliche Umbildung erfährt, indem es sich nach anßen in den äußeren Gehürgang schlanchartig rorstülpt.

Wie schon friiher bemerkt vgl, \&. 249), befestigt sich der Paukenfellrand der Sïnger an dem ursprünglich unvollstindig ringförmigen Tymplńicum (Fig. 583, S. 783 , In dem Maße wie sich der inß Gere Gehörtung verlängert, kann dieser Ring um deu letzteren nach auBen zu eincr Röhre anwachsen (Fig. 582, an deren Bildung sich gewöhnlich noch das Sqnamosum beteiligt. Das äußere Ende des Gelı̈rgangs ist jedoch von Knorpel umhiüllt.

Im Zusammenlang mit dem dauemden Wasserleben hat sich der äuBere Gehörgang der Cetaceen (ähnlicb auch der der Sivenia) sehr rerengt und ist mehr oder weniger ron sekret oder Epithelablösungen verstopit; nur sein imerer Teil erweitert sich in verschiedenem Grat. Jedenfalls dient der äußere Gang hier nicht mebr als Leitapparat der Schallwellen. sonderu diese gelangen vermutlich durch die Tuben zur Paukenhöhle und dem Paukenfell.

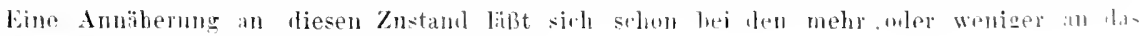
II anerleben angeraßten säugern verlolues. 
Ein Gchörskelet findet sich bei sämtlichen Tetrapoden, auch denen, welchen die Pankeuhöhle fehlt; wenn anch in diesen Falle häufig etwas rückgebildet. Bei den Amphibien und Samopsilen wird der Gesamtapparat meist als Colnmella amiis bezeichnet, obwohl er keineswegs immer ein einheitliches Gebilde ist. Wie schon hervorgehoben, liegt er ursprünglich der Paukenhöhlenwand nur dicht an und senkt sich erst durch Einfaltung in sie ein.

Es werde hier gleich betont, daß der Columellarapparat der Ammhibion und Sauropsiden vergleichend anatomisch meist von dem dorsalsten Teil des ursprïnglichen Hyoidbogens abgeleitet wird. Da nun bei allen Tetrapoden das Hyomandibulare der Fische nicht melur als solches vorhanden ist, und das Schïdelsuspensorium, an welchem der Unterkiefer gelenkt, in der Regel nur vom Palatoquadrat abgeleitet wird, so wird das Hyomandibulare meist als derjenige Teil des Hyoidbogens gedentet, ans welchem der Columellarapparat hervorgegangen sei. Daß dieser Ansicht gewisse Bedenken gegenüberstehen, wurde schon früher (S. 270 betont, und wird für die Amphibirn gleich etwas näher auszuführen sein.

Die Columella auris der Trodolon besteht im einfachsten Fall aus einem knol'pligen bis kniichernen rundlichen Plïttchen (Operculmm), welches der Fenestra vestibuli anfliegt. Gewöhnlich setzt sich dies Operculum anf seiner Außenseite in ein knorpliges his knöchernes Stielchen fort, das sich nach vorn oder außen bis zur Caudalseite des knorpligen Suspensoriums (Palatoquadrat) oder bis zum Paraquadrat erstrecken kann (s. Fig. 147, S. 261), bei gewissen Formen sogar mit dem ersteren knorplig verschmilzt. In anderen Fällen ist der distale Teil dieses Fortsatzes nur durch ein Band vertreten oder fehlt ganz.

Komplizierter wird der Apparat meist bei den mit einer Pankenhöhle versehenen Amuren. (z. B. Rana, Fig. 573, S. 776). Er besteht aus zwei in proximodistaler Richtung aufeinander folgenden 'Teilen, von denen der proximale, der sich der. Fenestra vestibuli anfsetzt, als Stapes oder Operculum bezeichnet wird, der distale als Plectrum oder Extracolumellare.

Das Operculum liegt als eine orale knorplige Platte auf dem caudalen Teil der Fenestra restibuli und ist mit dem Plectrum durch Bindegewebe verbunden. Letzteres ist mejst langgestreckt stielfömig und schiebt sich mit seinem knorpligen Proximalende unter das Operculum. Hieranf folgt ein rerknöcherter proximaler Teil des Plectrums (seltener zwei Verknöcherungen Bufo, Dactylethra) und schließlich ein knorpliger distaler Abschnitt, der am Paukenfell bis zu lessen Nitte hinabsteigt. Nahe seinem proximalen Beginne steigt som knorpligen äußeren Teil des Plectrums meist ein Fortsatz nach vorm und innen aut, der zur knorpligen Ohrkapel (an die sog. Crista parotica) tritt nnd in sie ibbergeht. las Distalende des äußeren l'lectrumabschnitts kann sich manchmal zu einer großen knorpligen Scheibe rerbreitern (manche Frösche, Pipa), welche fast das ganze Paukenfell erfüllt. Fehlt die Paukenhöhle, so bildet sich der Apparat zuweilen etwas zurück; doch findet sich das Operculum stets.

Eigentïmlich verhalten sich die Gymnophionen (Ichthyophis), inden das kurze, großenteil verknöcherte Colnmellargebilde, das von einem Loch zum Durchtritt einer Arterie durchbohrt wird, mittels eines Gelenks mit einem hinteren Fortsatz des Quadrats artikuliert (Fig. 575). 
Die ontogenie hat die morphologische Bedentung des folmmellarapparats der Amphibien bis jetzt wenig anigeklärt. Bei Urodelen, Anuren unl Gymnophionen ließen sich keine bezichungen zum Dorsalende des Ilyoilbogens feststellen. vielmelı entsteht das Operculum sntweder als selbstindige Verknorplum in ler Membran der Venestra vestibuli oder als Alösung rom vorderen knorpligen Rand derselben (Trodelen). Der stiel der Urohlelen und das Plectrum bilden sich erst später, doch tritt das letrtere bei den Anuren, wo es als selbstindiger linorpel entsteht, ebenfalls rorïbergehend in Perïhrung mit dem Ialatoquadrat. ron dem es sich später ablist und die Verbindung mit der l'aukenmembran eingeht. (1bgleich also die Ontogenie keine direkten Bezichungen zum Hyoid erweist, wird dennoch gewöhnlich an der Ableitung des Columellarapparats von letzterem lestgehalten. Bedeutsam erscheint jedenlalls die uiberall bleibem oder rorïbergehend lestehende Verbindung mit dem Palatoquadrat, was ja lïr die mögliche Dentung des Columellarapparats als Iyomandibulare wichtig ist. Tha jedoch aie Frage, ob das I Iyomandibulare

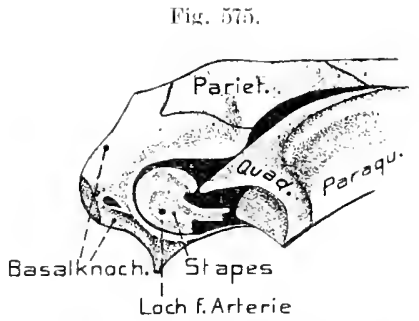

lathyophis. Hinterente des shoinlels rom rechts, um llite Artikulation des stapes nit dem Processis oticus des suspensoriums zu zelgen mith siks 185793$.$) \quad C. 11$. der Fische hei der Aushildung der Autostylie erhalten hlieb oder sich mit dem Palatoquadrat vereinigte, unsicher erscheint. so kann auch die Herkund des Columellarapparats nicht bestimmt entschieden werlen. Wire letzteres der Fall. so ließen sich etwa dem Hyomandibulare angefïgte knorplige Kiemenstrahlen oder das anf solche rückführhare sog. Operculum der Dipnoer fïr die Ableitung heranziehen (rol. s. 270). deren Iagebeziehungen den Anforderungen gleichfalls entsprechen wïrden.

Der Columellarapparat dor Sauropsinlon erinnert insofern an jenen der Anureu, als er auch aus zwei Stiicken besteht, einem preximalen, das der Fenestra

Fig. 576.

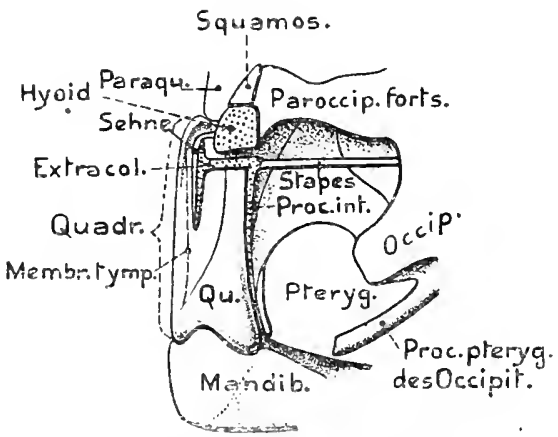

Cromatix spinipes samier Paukenhöle mit den ansrenzenden knochen von hinten erölinet: C'audalemle des Pterygoirls alogebrorhen. Yom Zungenheinbogen ist nur dis forsalende ethalten, dis sild an den Paroccibitalfortaty lefestigt. Pankentell als strichlinie schematisch eingezeichnet narh VERstris lsy?, etwas verïndert).
Fig. 577 .

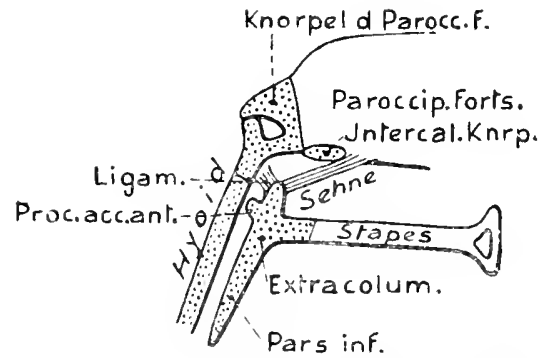

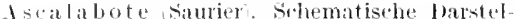
lung der linken colmmella auris in ihrer Begiehuner zum sichäilel umet Hyoil. Ansicht vou hinten mach Velsutes 190it). v. But.

ovalis anfsitzt ctures) und einem distalen (Extracolumella), dessen Distalende zam Paukenfell zieht und sich ihm einlagert oder anheftet. 'Wwischen beiden Teilen besteht bei vielen Sauriern, Sphenodon und jugendlichen. Crocodilem ein Gelenk, das jedoch nur wenig oder nicht beweglich ist. Bei den iibrigen fehlt es; 
doch wäire nicht unmöglich, daß die gelenkige Sonderung m'sprünglich weiter verbreitet war, also den primitiven Zustand darstellt.

Der Stapes (s. Fig. 576 u. 57\%) ist im allgememen lang stielrörmig, also gewöhnlich ler längere Teil, unt sein der Fenestra restibuli aufsitzendes Proximalende fast stets zu einer ovalen bis kreisfümigen Platte erweitert. $\mathrm{Er}$ ist stets rerknöchert, nur sein das (ielenk bildendes Distalende besitzt häufig (Sauria) eine knorplige Epiphyse. Nahe der FuB platte ist er bei manchen saniern (gewisse Asculabotac, Fig. (z. B. Dromaeus, Onocrotalus) durchbohrt zum Durchtritt einer Arterie (ähnlich wie bei (iymnophionen).

Die Extracolmmella bleibt stets knorplig (manchmal verkalkt) und zieht gewöhnlich als horizontale Fortsetzung des Stapes bis zur Mitte les Paukenfells, wo sie sich bei den

Fig. 578.

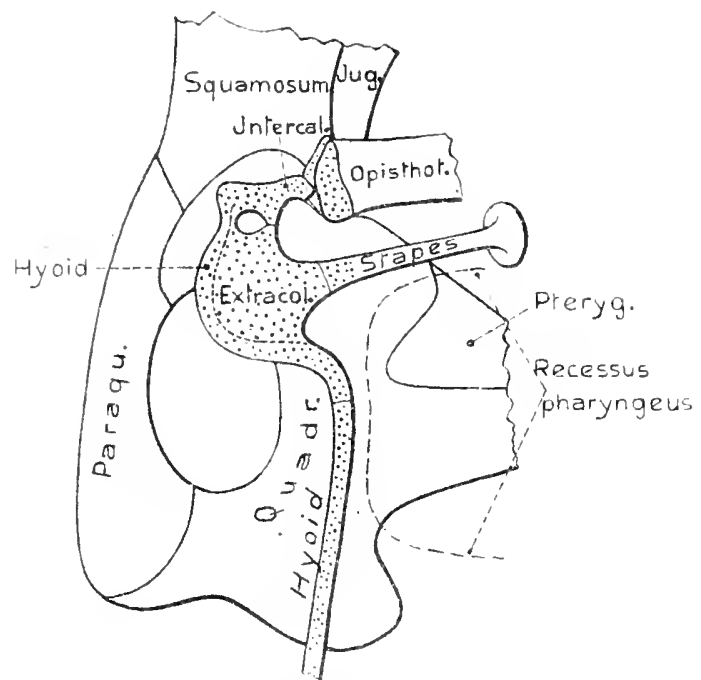

sphenudon. Linke Columellil, linkes Hyoid nud dis mmgebenden Teile des Siluälels von linten gesehen, um die Buziehungen zwischen der Colmmella und den Hyoid zu zeigen sauriern in einen dorsalen (Pars superior) und ventraleu (Pars inferior) Fortsatz am Trommelfell verlängert (Fig. 576/7 u. 584 . S. 786)y denen șich häutig anch noch einige schwächere accessorische Processus zugeselleu. Diese Fortsätze liegen meist in den Paukenfell selbst. Außerilem entspringt bei den Sauriem rom Proximalende der Extracolumella

Fig. 579.

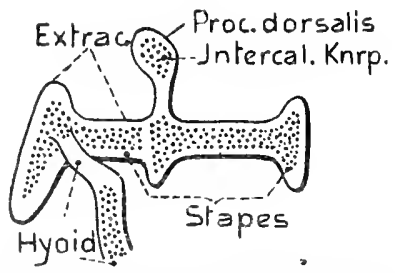

sa urierembryo. Embryonale linke Columella und der Dorsalteil des Hyoids, von hinten geselien. Yerknorpelte Partien punktiert, vorknorplige weis. schematisch, nach Vers. 1,ETS 194.) V. B 31.

lıäufg ein ventral absteigender Processus intrmus (Fig. 576 u. 584, s. 786), der sich zur Vedialtliche des Quadrats crstreckt und mit dessen Periost verbindet; er kann bis zum Pterygoidende des guadrats hinabreichen. An derselben stelle geht ontogenetisch ron der Anlage der saurier-Extracolumella ein Dorsalfortsatz ab (Fig. 5i9), der sich an das Distalende des Parocipitallortsatzes des schädel heftet und hier einen linorpel (Intercalare) bildet, der sich dem sidinlel anfügt (Fig. 5\%氵). Der iibrige Teil dieses Processus dorsahis wird zu einem Band oder geht ein. Dieser Worsalfortsatz hat eine gewisse Älnnlichkeit mit dem Processu. ascendens des Anurenplectrums und wäre laher vielleicht anl ihn zurïckzuführen. Charakteristisch für die saurier ist femer. duß das Dorsalende des Hyojdbogens im vorknorpligen Stadium mit ler späteren Lxtracolumella zusammenhängt (Fig. 579), obgleich sich eine knorplige Verbinhung nie heretellt. Später löst sich aber diese Verbindung, und das Dorsalende des knorplioen Ilyoidbogens schiebt sich bei gewissen Formen höher hinauf und heftet sich an das Lateralcume des Parocripitalfortsatyes, mit dessen kinorpel es rerwarhen kam (Fir. 577 ). 
Eigentümliche Verhä]tnisse bilden sich bei Sphenodon (Fig.578), indem hier eiu dauernder knorpliger Zusammenhang zwischen der Extracolumella und lem Hyoillogen besteht. DerseJbe ist wahrscheinlich so entstanden, laß das Dorsalente les Hyoids, unter Lösung seiner - ursprünglichen Verbindung mit der Extracolumelli, an deren Lateralseite emporrückte und Jann mit ihr, sowie dem sich knorplig erhaltenden Processus dorsalis (Interealare, s. oben) rerwuchs. wodurch sich das hier in der Extracolumella befindliche Loch erklärte. Wenn diese Ansicht zutrifft, so wäre also der Zusammenhang ter Extracolumella mit lem Hyoidbogen bei sphenodon kein nrsprünglicher.

Die Extracolumella der Fögel (Fig. 580) erinnert ziemlich an jene von Sphenorton. da sie ebenfalls das erwähnte, charakteristische Lin besitzt. Sie sendet einen mehr oder weniger ausehnlichen Tentralfortsatz (fnfrastapediale) Aurch die Paukenhöhle, der sich bei embryonalen Ratiten bis oder nahe bis zum Unterkiefer rerfolgen ließ. Dieser Fortsatz wird daher jetzt gewöhlich als vom Hyoidbogen abstamment gedeutet, obgleich er alem

Fig. 580 .
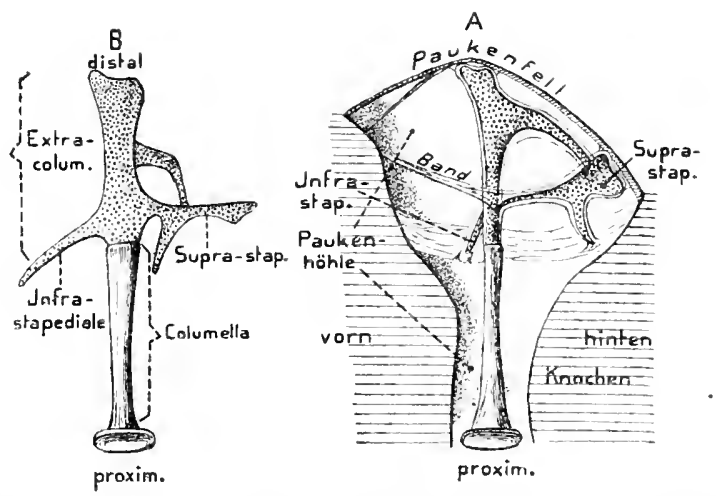

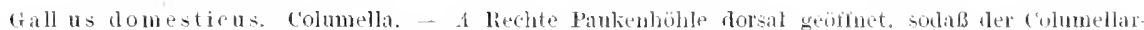
apparat in seiner natülichen Lage, suwie seine Befestigung am Paukenfell sichtbar jst. Das lufritstapediale angedeutet, obgleich es in genan dorsaler Ansicht nicht sichtbar ist. Die Figur zeigt "lie Belestigung der Extracolumella am Paukenfell, sowie die des proximal gerichteten Fortsatzes les suprastapediale am Ventrahrand des paukeniells. - I Der rechte columellaranparat in der Ansicht von der.

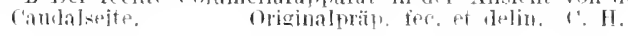

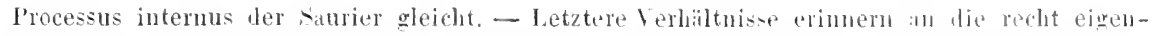
tümlichen der Crocodile. Deren Extracolumella (Fig. 501) besitzt im jugendlichen Zustand einen Dorsalfortsatz, der sich dem Quadrat und Paraoccipitalfortsatz anlegt (sog. Suprastapediale, Parker) ụnd einen nach außen gerichteten Fortsatz (Extrastapediale = Extracolumella), der zum Paukenfell zieht. Fom Distalteil lieses Extrastapeniale geht ein Fortsatz (Infrastapediale) rentro-caudal ab. ler sich mit einem knopelbogen rerbindet, welcher embryonal bis zum Articulare des Interkiefers hinabricht nm in dieses übergeht. Nach Vergleich mit den berhälnissen der samier hinn die-ar bogen wohl nur das Hyoid sein. nnd der fortsatz der Extracolunella, an welluen ar entspingt entspricht daher nicht den Processus internus der Saurier. In Mter ahwinden ibrimes der Processus dorsalis umd her lufrastapedialtortsatz und simd mur nocl durch schleimhatlalten vertreten.

DaB eine Verbindung les llyoidbogens mit der Anlage des Columellarapparats bei den sauropsiden bestehen kann, ist demnach sicher. Dennoch dürte sich lieraus nicht bestimmt ergeben, daß die Columella einen dorsalen Teil dieses Bogens dirstellt. Hurallgemeinen scheint nämlich der Columellarapparat der Sauropsiden jenem der Imphibien zu chtsprechen, worauf auch die wohl wrpringlich stets vorhandent beziehume zmm (handrat

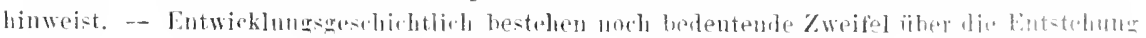


Les Stapes der Samopsiden, welcher teils vom Dorsalende tes Hyoidbogens, teils dagegen von ler Labyrinthkapsel abgeleitet wird, ähnlich wie bei den Amphibien; selbst für den gesamten Columellaraparat wirl letztere Nöglichkeit ron manchen behauptet, ja sogar die Ansiclit rertreteu, daB iler Columellarapparat der Amnioten dem đler Amplibien nicht homolog sei.

Das listalende der Schildliöten-Extracolumella verbreitert sich ähnlich wie bei gewissen Anuren zu einer im Paukenfell gelegenen ansehnlichen kreisrunden Platte, wellie last das ganze Paukenfell erfïllt.

l)ie Reptilien nit reduzierter F'ankenhöhle zeigen eine gewisse Iiüchbildung der Co-

Fig. 581 .

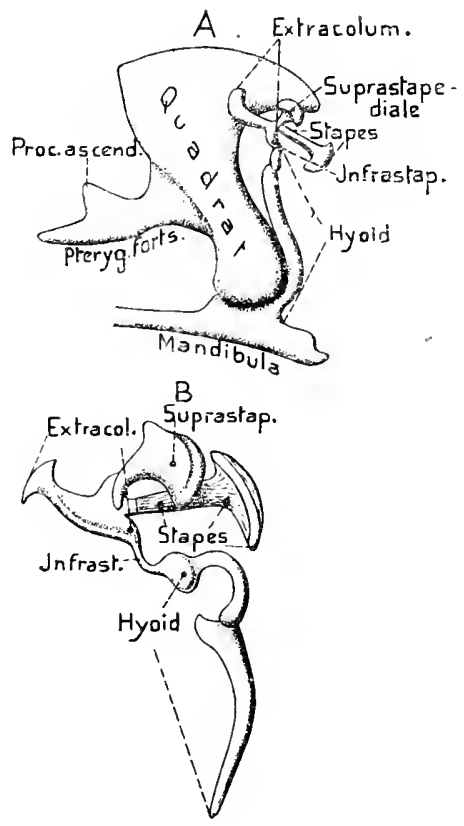

Crocodilus palustris. A Embryo von $3,7 \mathrm{~cm}$ Länge. Linkes Quadrat, Mandibel und Hyoid nebst Columellarapparat, von auBen. - $b$ Embryo von $11.2 \mathrm{~cm}$ Länge. Columellarapparat uud Hyoidbogen is yleicher Ansicht. Der Stapes schon zum Teil verknöchert (nach PARKER 188't) v. Bu. lumella. An den sehr kurzen Stapes der Amphisbacniden schließt sich eine lange fadenfürnige knorplige sog. Extracolumella (rielleicht Hyoidbogen?) an, die lateral rom Quadrat und Unterkiefer weit sach rorn zicht. - Der Apparat der Ophillier ist klein und heftet sich mit seinem Distalende der llinterseite des Yuadrats an. Er soll zuweilen auf ein knöchernes Operculum beschränkt sein; bei gewissen Formen (Stemostomata) wurde er sogar gan\% vermißt.

Besondere Schwierigkeiten bietet die Deutung den Einrichtungen der Mammaliu, wo sich eine Kette von drei gelenkig verbundenen Kü̈chelchen zwischen Fenestra vestibuli und Paukenfell ausspannt (Fig. 582 11. 583). Jlicselben werden von innen nach anßen als stapos (Steigbiigel), lucus (Ambofi) und Mallrus (Hammer) bezeichnet. Der Stapes bleibt meist ziemlich klein und setzt sich mit seinem verbreiterten Fußblatt dem ovalen Fenster auf. Sein Name bezieht sich daranf, daß er fast stets, ähnlich wie die Columella der Gymmoplionen, Gertionen und einiger Vögel, von einem Loch durchbrochen wird, durch welches die Arteria stapmlialis tritt. Doch kann diese Durchbrechung zuweilen verkümmern, ja sogar fehien (Nonotimmen

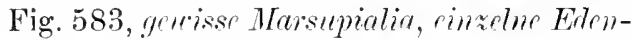
tata und ('rtarea). - Der Bau des Incus ist recht gleichförmig, indem von seinem gedrungenen Körper, der dnreh eine ansehnliche Gelenkgrube mit dem Mallens artikuliert, zwei Fortsätze entspringen, von welchen sich einer (Processus longus des Menschen) zum Stapes begibt und mit ihm gelenkt, wihrend der andere (Fror. hrevis) nach hinten in die Paukenhöhle zieht und sich durch ein Band an deren Wand befestigt. In der Jngend bildet sich am Ende des Processus longus eine besondere kleine Verknöcherung (Os lenticulare), welche später mit ihm verwächst und daher nicht als selbständiges Element angesehen wird. - Der Malleus zeigt größere Formverschiedenheiten. Von seinem Körper-oder Kopfteil, welcher mit 
dem lneus gelenkt, entspringt ventralwirts stets ein mehr oder weniger ansehnlicher Fortsatz, der in das Paukenfell eintritt und bis zu seiner Mitte hinabsteigt (Handyriff oder Mambrimm mallei : allein bei den c'etaceen ist er sehr rüekge-

Fis. 582.

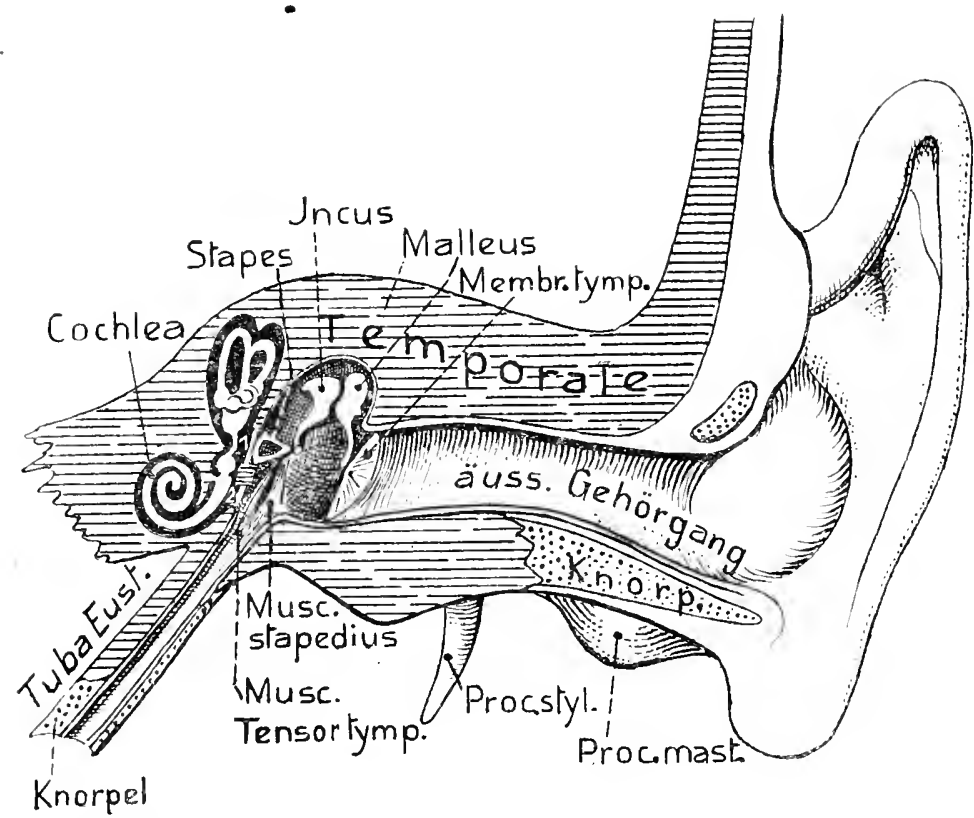

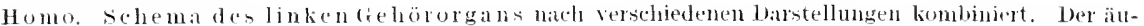
Rere Gioürgams, die Pankenhöhle und die Tuba durch einen Querschnitt durch das Temporale ge¿ifnet: Ansicht von vorn. Die Perilymphräume und das knörherne Labsrintls schwarz, das lä̈utige

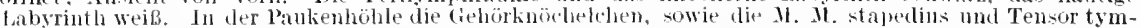
pani angegeben: die feine Selone des letgteren zieht zur Basis des Hammergritis. I Fenestra vestibuli (ovalis); 2 Fenestra cochleate rotunda). Kuchen schraffiert: Knorpet punktiert. 0.13.

bildet. Weniger konstant ist ein etwa vom Ursprung des Manubrium ausgehender, rostral gerichteter, meist schlanker Fortsatz, der Processus folii s. graeilis, s. anterior), der zur Paukenhöhlenwand, an die Grenze zwischen Tympanicum und Perioticum, geht (Fig. 583).

Bei primitiven Säugern (Aplacentalia, doch auch Inseetivora, Chiroptera) ist der Proe. folii sehr groß und häutig stark kreisförmig gekrümmt. Bei den Aplacentaliem tritt er zum un-
Fig. 583.

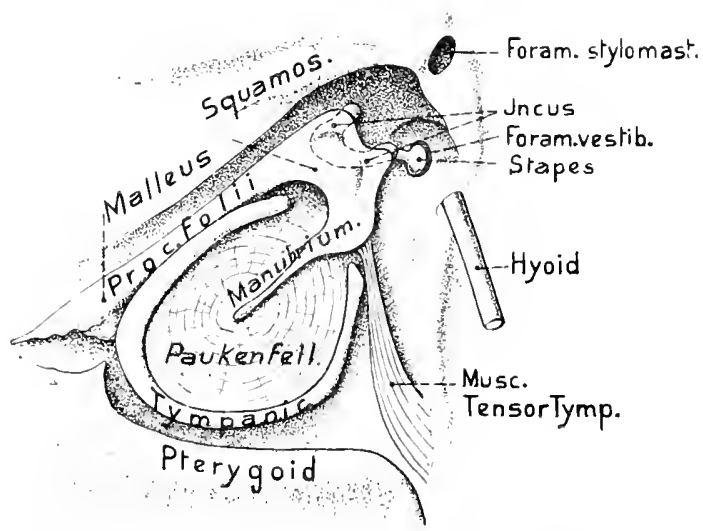

Eehidnat. Rechtes Paukenfell mit der umgebenten schähelrexion von der Ventralseite, samt den Gehöknöchelrhen usw.

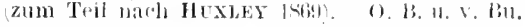


geschlossenen Tympanicum und trägt zu dessen Vervollständigung bei (Fig. 583). Sehr verkïmmert ist er bei vielen Affen, Halbaffen, den Phociden, Elentaten, auch Cetuceen z. T. Fine feste Verbindung zwischen Malleus und Incus tritt hei Monotremen (Fig. 583 ) auf und tïbrt im Alter zur Terwachsung, ebenso hei den hystricomorpleon Rodentia (z. B. Hystrix, Cavia n. a.); wogegen der Halleus der Cetaceen mit dem Tympanicum durch den Proc. folii rerwächst; die Gehörknüchelchen letzterer Gruppe (ähnligh auch die der Sirenia) sind im allgemeinen groß, plump und aus dichter Kuochenmasse gebildet. Eigentümlicherweise luängt der Ilammer der Cetaccen mit dem I'aukenfell nicht direkt zusanmen, sondern bei len Denticeten mit einem spornartigen Fortsatz der Mitte des Paukenfells; bei den Mysticeten dagegen, deren Paukenfell die oben (S. ii) erwähnte schlauchförmige Vorstiilpung zeigt, zieht rom Hammer ein langes Band zum Distalende dieser Vorstülpung: es soll au einer Einfaltung des PaukenfelIs herrorgehen.

Die morphologische Deutung der Säuger-Hörknöchelchen ist bis jetzt nicht zu übereinstimmenden Ergebuissen gelangt. Vier Deutungscersuche namentlich stehen sich gegenüber:

1) Jhre Ableitung rom Columellarapparat der Sauropsiden; d. h. die Rüclführung tes Stapes auf den der Sauropsiden (woriber ja allgemeine Übereinstimmung besteht) und die des Incus und Malleus anf die Extracolumella. Das Quadrat der Sauropsiden sucht diese Ansicht entwerler im Tympanicum der Säuger oder läßt es mit dem Gelenkteil des Squamosum verschmelzen.

2) Die Ableitung des Incus fon der Extracolumella ter Sauropsiden, des Mallens: rom Quadrat.

3) Die Ableitung des Incus rom Quadrat, des Nalleus rom Articulare des Unterhiefers der Sauropsiden. Diese Ansicht ist wohl die verbreitetste.

4) Eine Art Kombination der Ansichten 1 und 2. An Aufbau des Hammers und Amboß sollen sich Teile des dorsalen Quadratendes beteiligen, mit denen aber solche der Extracolumella der Sauropsiden rerwachsen seien. Es gehe nämlich der Proc. longus des $\triangle \mathrm{mboB}$ aus dem sog. Proc. internus der Sauropsiden-Extracolumella, das Manubrium des IIammers aus einem der accessorischen Fortsätze der Extracolume'la (Proc. accessorius anterior, s. Fig. 577, S. 769) herror, da sich nach dieser Heinung die ontogenetische Entstehung des Manubriums aus dem Dorsalende des Hyoidbogens erweisen lasse. Der mittlere Teil des Quadrats rerkümmere, sein distaler Unterkiefergelenkteil scheine sich dagegen mit dem Squamosum als dem Knorpelïberzug seiner Gelenktläche zu rereinigen.

Die miter 2-4 angeführten Deutungen stïtzen sich auf die sehr wichtige ontogenetische Tatsache, daß die rorknorplige Anlage des Incus und Mal'eus mit jener des Kieferhogens direkt zusammenhängen und sich erst später ron ihm durch Resorption des rerbindenden Teils isolieren. Aus dem dorsalsten Teil der gemeinsamen Anlage bildet sich Aurch selbständige Verknorplung der Amboß, distal daran anschließend der IIammer, der auch noch knorplig mit dem Mandibularbogen zusammenhängt. Ans diesem Grund wurden her Incus, oder der Incus samt Mallens, von der unter 2 und 3 angetührten Ansicht rom Handibularbogen abgeleitet. Der dorsale Teil des Hyoidbogens stelıt oder tritt in der vorknorpligen Anlage mit jener des Stapes in Terbindung, letztere aber mit jener des Amboß, woranf der Stapesknor elel selbständig rerknöcbert. Das Forsalende des Zungenbeinbogens rerbindet sich spiiter mit der knorpligen Ohrkapsel und gebt die früher (S. 309) geschiherte Weiterentwicklung ein. - Das Problem erscheint nun noch dadurch kompliziert. daß, wie oben betont, bei den Crocodilen eine Verbindung der Extracolumella mit dem knorpligen Unterkiefer besteht, welche doch unmöglich aul' ilen Kieferbogen bezogen werden kann, da der Palatoquadratknorpel neben ihr rorhanden ist. Andererseits scheint es ausgeschlossen, daß die Verbindung des Mandibularbogens mit der Stapesanlage der Sïuger einem Teil des Ilyoidbogens entspreche, da dieser sich anscheinend rolständig daneben rorfindet. Die Deutung dieser Knorpelserbindung bei den Mammaliern als Palatoquadratanteil des Kieferhogens erscheint daher wohl als die annehmbarste. - Wam erhebt sich aher 
die weitere Frage, ob in diesem Fall Incus a nd Malleu ans lem lieferbogen litrorgingen. Die Deutung, welche dies annimmt, also, wie hervorgehoben, den llammer ron Articulare des Unterkiefers ableitet, muß die schwierige Hypothese machen, daß sich bei den Vorfahren der sïuger eiu ganz neues Unterkiefergelenk gebilıt hahe, unter Lösung des Articulare aus dem Verband des ursprïnglichen Unterkicfers. Diese Annahue hat nun so vixl Unwahrscheinliches und wird lureh vergleichend anatomische Tatsachen so wenig gestützt, laß nur absolnt zwingende Gründe ihre Berechtigung erweisen könnten. Da aber schon hei den Samropsiden eine Zweiteilung des Columellarapparats rorkonmt, so scheint die Ableitung des lncus von der Extracolumellí nicht ansgeschlossen. - I)ie nahen Beziehungen, welche das Quadrat der Sauropsiden zur Paukenhöhle mul den Paukenfell besitzt, machen es unschwer begreiflich, daß dieser knochen seine urspringliche Funktion anfgab und unter Verkleinerung in die Paukenhöhle rückte. Auch die Form des Jammers bei den prinitiren Sïugern (namentlich llonotremen, s. Fig. 589, S. 783) erinnert in mancher Hinsicht an das Reptilienquadrat; doch erhebt sich hier cine neue Schwierigkeit, indem der erwähnte Proc. folii des Malleus, der bei den primitiven Sängern besonders groß ist un hei Vergleichnng des IIammers mit dem Quadrat den eigentlichen Köruer des Jetzteren bei den Sauropsiden entsprechen mäßte, mach den ontogenetischen Erfahrungen als ein sellsständiger Deckknochen entstehen und sich erst priter mit dem eigentlichen llammer vereinigen soll. - Der Proc. folii wird daher bei her Dentung des Jammers als Irticulare anf eineu Derkknochen des Unterkiefers (Postoperulum der Saurier, s. S. 291) znrückzuführen gesucht, was aber rorerst noch recht zweilelhaft erscheint. Eine Entstehung les Hammers und Incus ans zwei guellen nimmt auch die 4. Ansicht an.

Die Columella nud das Pankenfell können mit kleinen Muskiel" verbunden sein, die teils Spannung, teils Erschlaffung des Paukenfells bewirken, oder auch noch in anderer Weise funktionieren.

Eigentümlich erseheint, daß vou der äußeren Fläche des Operculums der LnurenColumclla Muskelfasern ausgehen, die sich dem Musculus lecator scapulac superior beigesellen, der am Schïdel in der Gegend der Fenestra vestibuli eutspringt und zur lentralseite der Scapula zieht.

Bei den mit einer Paukenhöhle versehenen Sauropsidcn treten solche Iuskeln häuị auf. So besitzen die Ascalaboten (Sauria) einen solthen der rom Paroccipitalfortsatz de: schädels ausgeht und sich an einen Fortsatz der Extraculumella (Proc. accessorius posterior) heftet. Er gehört zur Facialismuskulatur und soll als Erschlaffer (Laxator) des Paulieufells wirken. Bei andem Sauriern wurde er in der Anlage beobachtet, geht jedoch später ein. Zum Muskelapparat ist weiterhin eine bei Sanriorn nud Sphenodon allgemein verbreitete Selıne zu reclnen, die rom Ventralende der Parsinferior der Extracolumella entspringt und längs des Trommelfells aufsteigt, sich hierauf dorsal und medial wendet und zum Paroccipitalfortsatz oder dem oben erwähnten sog. Intercalarknorpel zielit (s. Fig. 576, s. 779). )iese Sehne bildet vielleicht den liest eines besonderen, früher vorhanden gewesenen Muskels.

Die Crocodile besitzen einen rom Squamosum, Paroccipitalfortsatz und f'leuroccipitale zum hinteren dorsalen Quadranten les Paukenfells ziehenden AIsculus tonsor tympani, der vom Facialis innerviert wird und sich enbryonal am Dorsalfortsatz der Extracolnmella (Suprastapediale) befestigt. Er dürfte dem bei Geckonen rorkommenden Iuskel homolog sein. Auch bei Chelonien wurden Mlıskelı, die sich zur Columella begeben, nachgewiesen. - Den Tögeln kommt ebenfalls ein $\boldsymbol{M}$. tensor tympani zu, der, rom Schüdel entspringend, sich ursprünglich am sog. Infrastapediale befestigen soll, später aber seinc Insertion auf das Paukenfell verlegt.

Den Süugen kommen allgemein zwei Muskeln zu (s. Fig. 582, s. 783): einual ein son Trigeminus versorgter Tcnsor tympani, der, hauptsächlich am Perioticum entspringent, wn

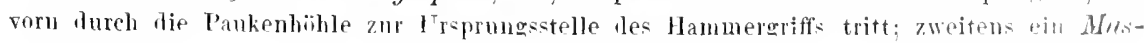


culus stapedius (den Honotremen fehlend), der in der Gegend der Fenestra ovalis beginnt und sich zum Distalende des stapes begibt; er wird rom Facialis imnerviert.

Schon bei den anuren Amphibien zieht der Ram. hyomandibularis des Facialis unter der medialen Schleimhaut der Paukenhöhle, dorsal von der Columella, von vorn nach hinten. Lr gilb dann den Ramus mandibularis internus ab, weleher meist mit der Chorda tympani der Ammioten homologisiert wird (s. s. 631). Letztere (s. Fig. 447, s. 629) tritt in ähnlicher Abzweigung rom llauptstamm des lacialis frei durch die l'aukenhöhle ventralwïrts, von deren Schleimhant ïberzogen, um sich nach Eintritt in den Unterkiefer mit einem

Fig. 584 .

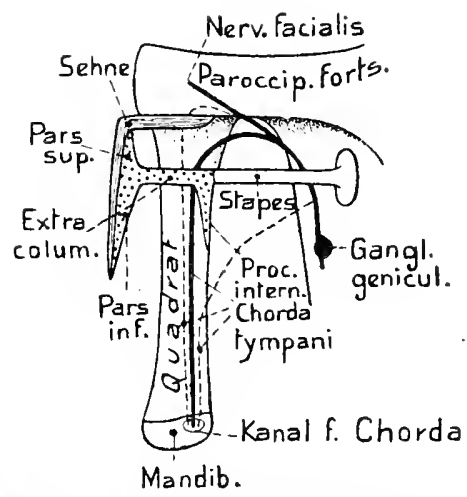

sauria, Schema des Verlaufs der Chorda tympani. Linkes Quadrat und Columella von linten; die eine Modifikation des Verlaufs der Chorda ist ausgezogen dargestelit, die beiden anderen dagegen in strichlinien nach VERsLUY' 1899 kombiniert?. v. Bu.

Ast des Ramus mandibularis des Trigeminus (k. lingualis) zu vereinigen. Ihr verlauf in der Paukenhöhle ist etwas versclieden; wie es für die Sanrior auf Fig. 584 angedeutet ist.

Ïußeres Oher(Ohrmuscherl). Ein solehes Organ findet sich als ein die Schallwellen auffangender und konzentrierender Apparat nur bei den Sängern. Zwar begegnen wir schon bei den Crocolliten einer vom Dorsalrand der äußeren Öffinung des Gehörgangs entspringenden, deckelartigen Hautfalte, welche eine Verkuöcherung enthält und mit einem Mnskel versehen ist; doch fungiert sie wesentlich als Schutzklappe. - Auch die ansehuliche klappenartige vertikale Hautfalte, welche sich bei gewissen Tögeln (besonders Eulen) am Vorderrand der äuBeren Ohröffnung findet, hat wohl eine ähnliche Bedentung. Zu ihr gesellt sich hinter der Öfnumg znweilen noch eine balbkreisförmige Falte, die mit ansehnlicheren Federn besetzt sein kann z. B. Bubo).

Bei den Süuye'” wächst der Rand der Öffunng des Gehörgangs ringförmig und vor allem dorsal mehr oder weniger empor, wodurch eine äußere Ohrmuschel (Auricula auris) entsteht, die im allgemeinen eine schief abgestutzt trichterförmige Gestalt besitzt.

Bei den Monotrmen ist sie noch kaun entwickelt; bei den ïbrigen Säugern kann sie zuweilen rudimentär werden oder ganz eingehen (so bei wasserlebenden Carnivoren, l'innipediern, Sirenen, ('etaceen), bei unterirdisch lebenden oder grabenden, so Talpa und Verwandten, sowie gewissen Yagern und einzelnen Edentaten, wie Manis. Besonders groß wird die Ohrmuschel namentlich bei gewissen nächtlichen Sïlgern, so Chiroptercn und anderen. Bei ersteren erreicht anch die am vorderen Rand der llïröftnung sich erhebende llautfalte, der Trayus, znweilen eine außerordentliche Größe. lirst bei den Iffen nimmt die Ohrmuschel allmählich die flache Gestalt und Ausbreitung an, welche sie beim Menschen besitzt, und zejgt zuweilen auch die Einrollung (Helix) des freien Muschelrands, die dem menschlichen Ohr eigentümlich ist, bei welch letzterem die sonst gewöhnliche dorsale $Z_{11-}$ spitzung der lluschel meist ganz schwindet.

Die Ohrmuschel wirl von einer inneren huorpelplatte gestützt, welche ihre äußere Form im allgemeinen wiederholt und auf deren Einzelabschnitte nicht näher eingegangen werden kann, Fig. 587 gibt eine ungefïhre Vorstellung davon. Am Eingang in den äußeren Gehörgang hïngt der Muschelknorpel mit dem schon früher erwilunten Knorpel des distalen 
Teils dieses Gangs zusammen. Die Vergleichung innerbalb der Säugerreihe lebrt, daß der Muschelknorpel sich aus dem les Gangs allmählich entwickelte. -- Die Verhältnisse bei den Monotremen (speziell Echidna, Fig. 585), welchen eine lreie Ohrmuschel fehlt,

Fig. 585 .

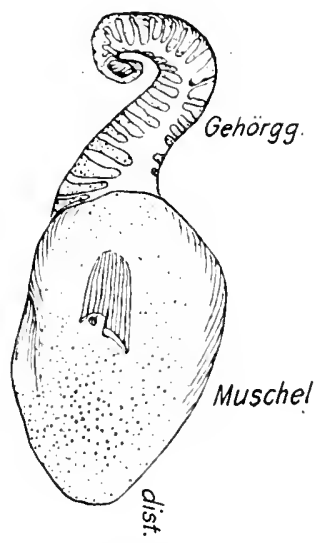

Echidna. Linker äuBerer Gehörgang mit den Knorpelskelet und der Auricula punktiert) in Medialansieht (aus GegenbaUR, Vergl. Anatomie, nach G. RUGE 1097).
Fig. 5siti.

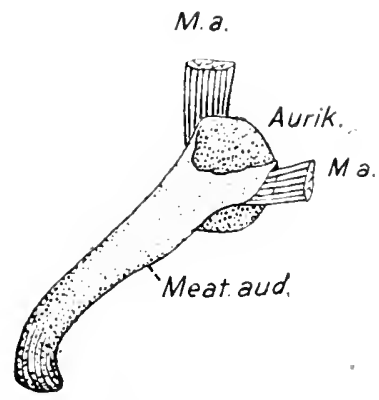

Ornithorlyyulus. Rechter äuBerer Gehorgang mit dem Kuorpelskelet der Auricula und

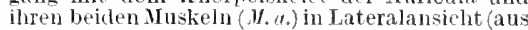
Gegenbaur, Vergl. Anatomie, naeh Ruge 1897).

Iassen erkennen, daB der Uhrknorpel ursprünglich mit dem Worsalente des Hyoidbogens zusammenhing, jedenfalls aus ihm hervorging und sich um den äußeren Gehörgang ausbreitete, ja sich sogar an dessen Distalende schon muschelartig rerbreiterte, bevor eine eigentliche Ohrmuschel herrorwuchs. Hei Echidna gabelt sich das Dorsalende des Hyoidbogens auf eine kurze Strecke, indem sich das mediale Gabelende an das sog. Mastoid, etwas hinter dem Tympanicum. ausetzt (vgl. Fig. 173, S. 296), während der nach vorn gehende Ast ein wenig rentral rom Trommelfell eine kreisförmige Knorpelplatte in der Ventralwand des proximalen Gehörgangendes bildet. Diese Platte verbindet sich num durch einen zarten kurzen Knorpelstrang mit dem etwa bandförmigen Knorpel des äußeren Gehörgangs (Fig. 585), von dessen beiden Rändern zahlreiche Kuorpelfäden ausgehen, die den rang yuer umgreifen, sich aber nicht zu geschlossenen Ringen vereinigen. Auch die nicht unansehnliche knorplige thrmuscliel am Distalende des

Fig. 587.

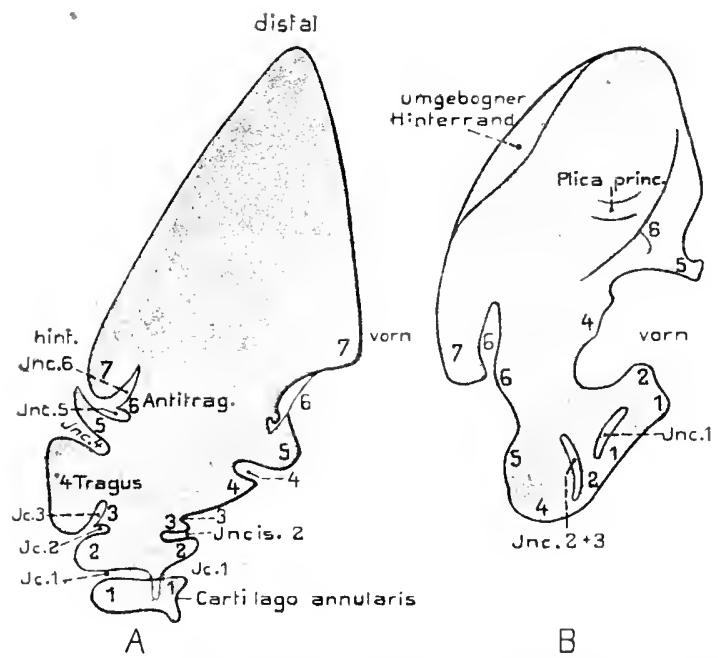

Ohrmuschelknorpel von Säugetieren. Wer Knorpel autge rollt und in einer Fläche ausgebreitet. - A Allgemeines Sclient:

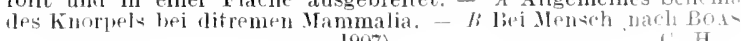
$1907 \%$. 
frangs ist wohl aus einigen solchen Knorpelfortsätzen hervorgegangen. - Schon bei Ornithorhynchus (Fig. 586) ist der Zusammenhang zwischen dem Ilyoidbogen und hem Ohrknorpel nur noch durch Bänder angelentet. Der Gangknorpel erscheint hier nahezu röhrenförmiv ohne Fortsätze, jedoch mit schlitzartigem Spalt in ganzer Länge, also rinnenförmig. Die übrigen säuger zeigen keinen Zusammenhang zwischen dem Gangknorpel und dem Ilyoilbogen mehr; der erstere ist relativ sehr kurz, so daß er wie ein Anhang des Iluschelknorpels erscheint (Fig. $587 \mathrm{~A}$ ). Letzterer hat die rinnenförmige Gestalt bewahrt und läßt häntig noch mehrere (bis 7) ähnliche halbringförmige Knorpelfortsätze erkennen, wie sie Erlidna so zahlreich hesitzt. Die distalen dieser Fortsätze gehören schon dem Basalteil der eigentlichen knorpligen Ohrmuschel an. und der vierte, rom Proximalrande gezählt, bildet den Tragzis. Einige proximale vorkere und hintere Fortsätze liönnen an ihren Enden zuweilen verwachsen, so daß die zwischen ihnen befindlichen Einschnitte dann als gesthlossene Spalten (Incisurae Santorini des Menschen, Fig. 587 B) erscheinen. - Bei vielen Säugern haben sich ein (selten zwei) proximale halbringfömige Stiicke des Gangknorpels (Cartilago anuularis) röllig abgetrennt.

Die Entwicklung der Ohrmuschel der Sïnger erscheint eigentümlich, indem sie (spec. Mlensch) ron je drei höckerartigen äußeren Erhebungen ansgeht, die sich auf dem Kieferund Zungenbeinbogen finden; dazu gesellt sich nocl eine hinter ihnen und eine dorsal ron ihnen auftretende Iautfalte. Auch bei den Sauropsiden wurlen Andentungen solcher Iöcker beobachtet. Anf das Nälere der Entwicklung einzugehen, ist lier niclut der 1/rt, un so mehs als es nicht 70 allgemeinen Sichliissen führte.

Die häutig reiche Muskulatur zur Bewegung und Stellungsïnderung der Ohrmuschel, wodurch ihre Wirksamkeit wesentlich gesteigert wird, ist schon bei den Monotremen angedeutet und geht aus der rom Facialis innerriertei Gesichtsmuskulatur hervor (s. Fig. 304, S. 451). Sie kann hier nicht näher besprochen werden.

\section{Statische und Hörorgane der Arthropoda.}

Wir betrachten diese Abteilung gesondert, weil ihre Organe eigenartiger Natur sind, auch wenn ihr Bau bei den Crustaçeen dem der früiher besprochenen Statocysten prinzipiell gleicht.

Statocysten findeu sich bei den hïheren Crustacesw, vor allem den Decaporden und den Mysideen unter den Schizopoden.

Einzelne Amphipoden (Familien der Oxyceplatidue und Lycacidae) und Isopoden, (Tanais, Anthwa) besitzen ähnliche Organe; ganz vereinzelt und etwas zweifelhaft tritt ein statocystenähnliches Organ bei einem Copepoden (Contropages) auf.

Das Charakteristische dieser Statocysten besteht darin, daß sie innerlich von der Chitinenticnla ausgekleidete Einstïlpungen der Epidermis sind und die in ihnèn befindlichen Gefïhlshare eigenartige Chitinhaare, welche die Stelle der seither gefundenen Sinneshärehen vertreten. Ähnliche Haare sollen sich bei Decaporlen, Schivoporten und gewissen Ampliporlen auch frei auf der Körperoberfliche finden, namentlich an den Fühlerpaaren, doch zuweilen anch an der Schwanzflosse. Wegen der Übereinstimmung im Bau solch freier llaare mit jenen der Statocysten ist es wahrscheinlich, daß anch sie ähnlich den letzteren funktionieren. Das Vorkommen freier statischer Haare an verschiedenen Körperstellen macht es verständlicher, daß Statocysten an recht verschiedenen Orten auftreten können. 
Bei den Decoporlen findet sich ein solches Organ stets im Basalglied der ersten Antennen (Fig. 588); ähnlich bei gewissen Amplipoden ein Paar dorsal rom Cerebralganglion. - Das Statocystenpaar der Mysiden lingegen liegt im Innenast der hintersten Abdominalbeine

(Schwanztlosse, Fig. 590 A); bei dem Isopoden Awthure dagegen im hintersten Segment ('Telson). Die Männehen des Isopoden Tunais sollen eime Cyste im Scherenfuß besitzen; früher wurde jedoch eine in der Antenne beschrieben. - Die verschiedene Lage bedingt natiülieh auch eine verschiedene Innervierung; der Nerv der antenualen $\mathrm{Or}^{\circ}$ gane sowie der freien Antennenhare entspringt von dem der ersten Antenne oder selbständig vom Hirn; die Schwanzorgane werden vom letzten Abdominalganglion innerviert.

Genauer bekannt sind nur die Statoeysten der Decaporlen. und Schinopoden. Die ersteren entstehen durch eine IIauteinstiilpung auf der Dorsalseite des Basalglieds der ersten Antenne (selten etwas lateral) und bewahren bei den Macmuen (Fig. 588) fast stets eine dorsale, kleinere bis größere, rundliche bis sehlitzartige, weitere bis sehr enge Öffnnng. Diese Öfrnung kann von Haaren oder durch eine sie deckelartig' überragende Hantfalte geschuitzt werden. Die Organe der meisten Brachinwen sind datgegen anscheinend geschlossen, indem sich die Räinder der Einstïlpungsöffunug ganz dicht zusammenlegen; jedenfalls ist jedoch del Verschlnß keine wirkliche Verwachsung, da anch die Chitinanskleidung solch geschlossener Cysten, wie jene der offinen, bei der Häntung $a b-$ gelöst und ernent wird. Kurz nach der Häutung sind daher auch die BrachyzorenCysten geöffnet, ebenso im Larvenzustand. - Die Cysten der Anommren sind teils offen, teils geschlossen. - Die lig. 588.
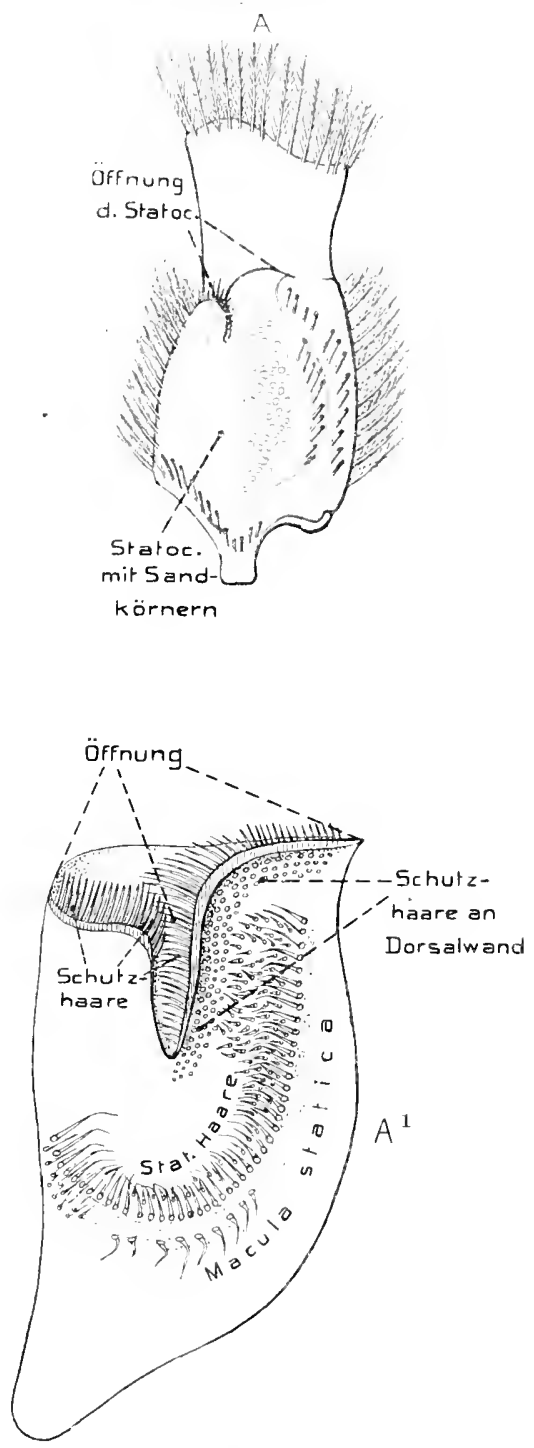

Homarus, statocyste. - 1 l)as basalglied der rechten 1. Antenne von der Dorsalseite; die Statocyste mit ihren Fremulkörpern rot. - 1' Statocyste herauspräpariert iu Dorsalansicht; von den sichutzhaaren an der dorsalen Eingangawand der Statocyste ist nur die Basis gezeichnet. Dir Nacula statica aul der Ventralwand in dir lourchsicht eingetrizen. Oris. (). 1;. 
Schwanzcysten von Mysis und Anthura (ebenso die von Tanais) baben gleichfalls noch eine feine Öffnung, und die Häutung der Cyste warde bei Mysis sicher beobachtet.

Die Organe der Decapoden sind z. T. recht groß, so daß sie das Basalglied der Antenne ganz erfüllen, z. T. kleiner bis verhältnismäßig sehr klein, und ihre Ge-

Fig. 589 .

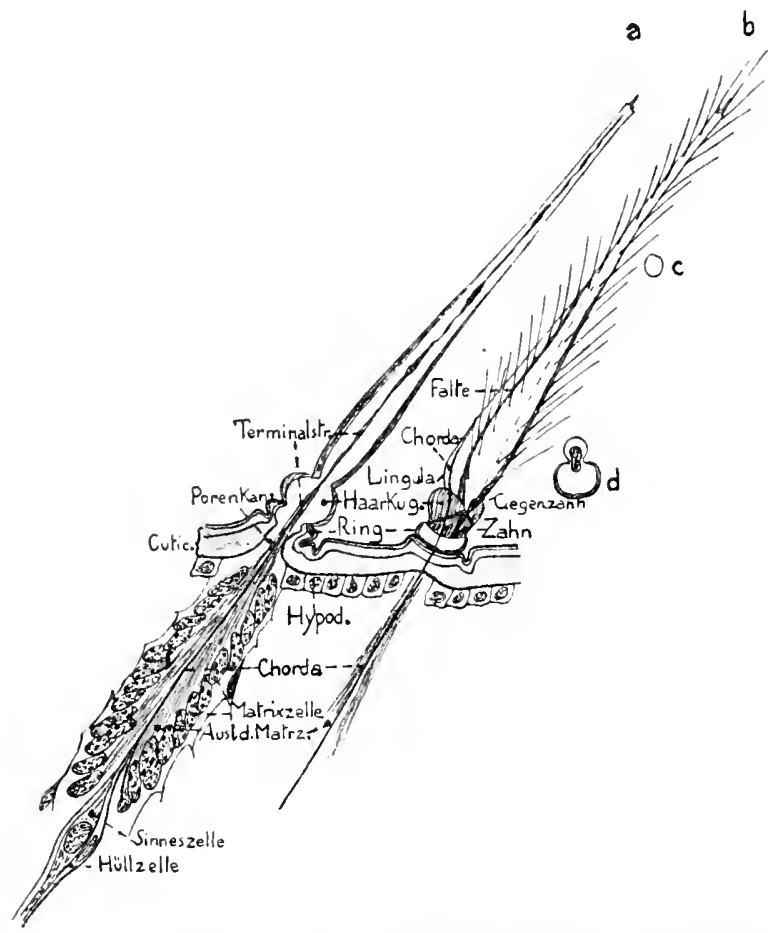

Decapode Crustacee. Schema der statischen Haare aus der Statocyste. " Ein solehes Haar im Läugsschnitt nit der Sinneszelle nnd den Bildungszellen (Matrixzellen). - $b$ Ein ebensolches Haar in Oberflächenansicht mit ler zutretenden Chorka, die sich an der Lingula befestigt, und den Auslänfern der Bildungszellen. - $c$ und $d$ Querschnitte des Hars an den betreffenden stellen; $d$ zeigt die beiden charateristischen Längsfalten, sowit den Terninalstrang stalt ist entweder regelmäßig sackartig oder durch innere Vorbuchtungen unregelmäßiger (namentlich Brachyuren). Die besonderen statischen Haare, welche zu den gleich zu erwähnenden Statolithen in Beziehung treten, sind bei den Macmeren und Schicopoden meist in einer bogigen bis nahezu kreisförmigen Reihe auf einem verdickten Epithelpolster (Macula) der Ventralwand angeordnet, welche Reihe aus einer bis mehreren Unterreihen nicht immer gleicher Haare besteht (Fig. $588 A^{1}$ ). Neben solch statischen Haaren können auch

noch weitere, die keine direkten Beziehungen zu den Statolithen haben, vorkommen. Dies gilt namentlich für die Brachyuren, denen Statolithen fehlen. Bei letzteren finden sich drei Gruppen verschiedenartiger Borsten: geknickte, fadenförmige und sehr zahlreiche kleine gestreckte (Gruppenhare).

Der Bau der typischen statischen Haare ist charakteristisch (Fig. 589). Ihr etwas kuglig angeschwollener und sehr gelenkig befestigter Basalteil (Haarkugel) zeigt meist innerlich eine einseitige, zahnartige eingefaltete Chitinverdickung (Zahn), während an der Gegenseite, etwas distal von der Haarkugel, eine verdickte Längsleiste (Lingula) hinzieht. Die Lingula steht in Zusammenhang mit zwei Längsfalten des Haarschafts, die ziemlich *weit gegen das IIaarende 
reichen und hier allmählich verstreichen, wodurch der Querschnitt des basalen Haarabschnitts eine eigentiumliche Gestalt erbält (Fig. 589 ). Die Haare sind mit feinen Härchen ziemlich dicht besetzt (gefiedert) und entweder gerade gestreckt, gebogen oder in ihrem Verlauf scharf geknickt. Unter jedem Haar senkt sich die Hypotermis schlanchartig ein; es sind dies die Bildungs- oder Matrixzellen des Haars, die distal sämtlich je einen zarten Terminalfortsatz entsenden, welche Fortsätze sich zu einem Terminalstrang vereinigen, der bis zar Haarspitze zu verfolgen ist. Am proximalen Ende des Matrixzellenschlauchs liegt die Sinneszelle des Haars, die einen distalen feinen Fortsatz entsendet, der in der Achse des Terminalstrangs hinzieht und sich wahrscheinlich an der er'wähnten Lingula der Haarbasis anheftet. In diesem Fortsatz der Sinneszelle verlänft ein feiner chitinöser Faden (sog. Chorda), der sich ebenfalls an der Lingula anheftet. Von diesem typischen Bau finden sich bei den verschiedenen IIaarformen einzelne Abweichungen, doch scheint die Haarkugel stets charakteristisch ausgeprägt zu sein.

Mit Ausnahme der meisten Biachyuren enthält die Cyste Statolithengebilde, die bei den offenen meist Fremdkörper (Sandkörner u. a.) sind, welche natürlich bei jeder Häutıng entfernt und wieder neu aufgenommen werden.

Auf solche Weise lassen sich daher auch besonders geartete feine Teikhen (z. B. Eisenteilchen) als Statolithen ein-
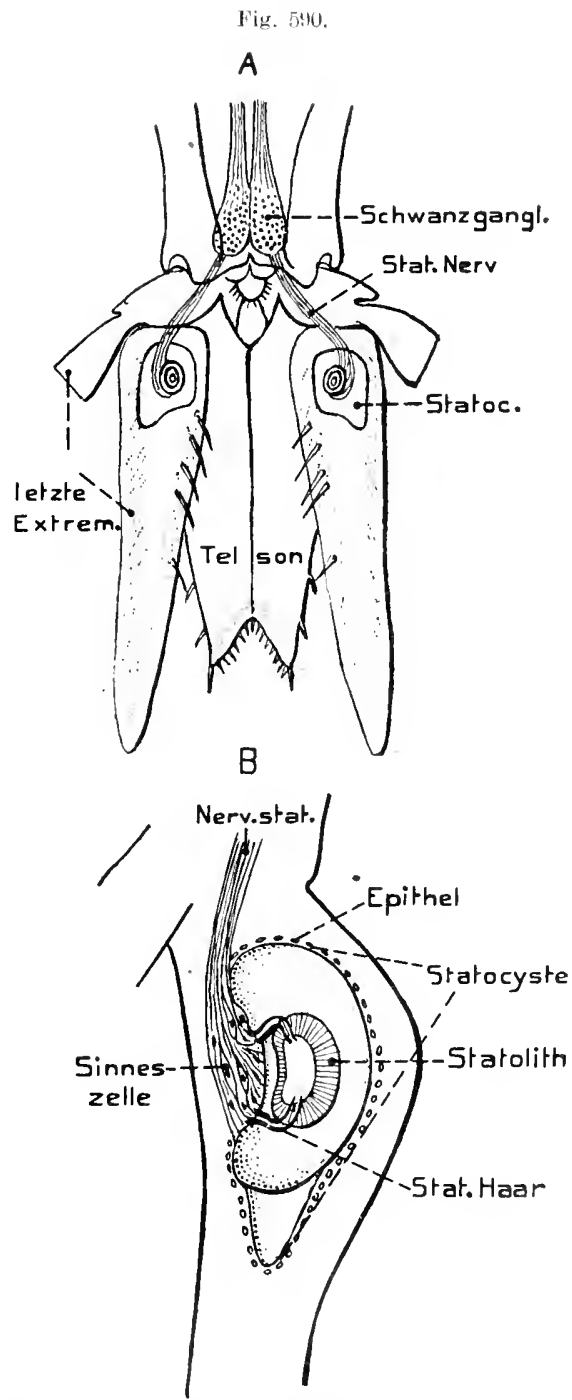

Hysis relicta. A schwanzflosse von der Dorsalseite mit den Statocysten (nach Sars Crust. norweg.). $B$ Statocyste im Endopodit des letzten Beinpaars (Schematisch; nach HENSEN 1863 und BETHE 1895). führen, was bei den Macruren GelegenC. $\cdot \mathbf{H}$. heit zu interessanten physiologischen Versuchen über die Funktion der Statocysten bot, th Eisenteilchen der Wirkung magnetischer liräfte unterworfeu werden können.

Gewisse Cysten (Mysideen Fig. 590 B, eine Hippolyte, Sergestiden, Amphion. enthalten einen einzigen (selten zahlreiche, Lithoderma) kugligen bis linsen- 
förmigen Statolith, der wohl überall ein Abscheidungsprodukt ist nnd bei Mysis aus einem Kern organischer Substanz und einem Mantel besteht, der wesentlich Fluorcalcium enthält; doch wird auch dieser Statolith bei der Häntung entfernt und nen gebildet. Die statischen Haare von Mysis dringen in den Statolith bis zum Kern ein. Auch bei Macruren reichen sie manchmal zwischen die Statolithenkïrperchen, die hier durch das Sekret von Hautdrïsen, welche auf der Cystenwand münden, zu eimer Masse vereinigt sein können.

Anzuführen wäre noch, daß bei einigen (iattungen ron Lamdisopoden (Onisciden), bei welchen die Augen verkümmert oder ganz rückgebildet sind (z. B. Titancthes, Platyarthrus u. a.), in den sich etwas kegelfümig erhebenden Kopfecken, hinter der Fühlerbasis, je ein Organ vorkommt, das wegen seines Baues, sowie auf Grund physiologischer Experimente, als Statocyste gedeutet wurde. Ls ist ein kugliges bis eiförmiges, aus wenigen ansehnlichen Zellen bestehendes Gebilde, zu dem rom Cerebralgnglion ein Nerv tritt. Die Zellen umschließen eine bis mehrere IIöhlen, in denen sich kleine Kalkkonkremente tinden sollen. Der Mangel irgendwelcher spezitischer Sinneszellen und der typischen Sinneshaare der Crustaceen sowie einer cuticularen Juskleidung der Höhlen läßt jedoch die Pentung der Organe als Statocysten zweifellaft erscheinen.

Arachnoidea. Verschieden lange, in becherförmige Grübchen eingepflanzte, zuweilen keulenförmige IJaare, die sich an den Extremitäten der Avachnoidcen (ausgen. Solifugen, Opilioniden und viele Aearinen) finden und mit Nerren verbunden sind, wnrden als llörhaare gedentet; doch erscheint dies unsicher, ja wird sogar direkt geleugnet und z. Is. den Araneinen von manchen jedes Hörvermögen abgesprochen. - Thre Verbreitung über den Körper ist recht verschieden; so finden sie sich bei den S\%orpionen und Pseudostorpionon nur auf den Endgliedern der Palpen, den Araneinen auf Palpen und Beinen, den Pedipalpen nur auf letzteren und den Aearinen auf der vorderen linmpfregion.

Unsicher in seiner physiologischen Bedeutung erscheint ferner ein Sinnesorgan, das bei vielen Myriopoden jederseits zwischen den Antennen und ten Augen liegt, das sog. Tömösvarysche oder Schläfenongan. Im einfachen Fall ist es eine runde bis hufeisenförmige Grube, zu deren von der Cuticula ausgekleidetem Boden der früher erwähnte Nerv (s. Fig. 349, S. 502) tritt und sich an dem hier befindlichen sinnesepithel rerbreitet. Bei den Diplopoden wird das Organ häufig komplizierter, indem sich die Grube zu einer Röhre vertieft, vou deren Boden sich ein zapfenartig aufsteigender Fortsatz erheben kann, der das Sinnesepithel enthält. Genaueres über das letztere ist nicht bekannt. Jedenfalls ist die Deutung als IÏ̈rorgan wenig wahrscheinlich. - Nur bei einigen Chilopoden (z. B. Lithobius) soll sich in der llitte des Grubenbodens eine öffnung in der Cuticula tinden, so daß die Sinneszellen hier direlit mit der Außenwelt in Berührung treten würden.

Ein bei apterygoten Inselten vorkommendes, ähnlich gelagertes und gebautes Urgan (postantennales Oryan) wird dem eben beschriebenen der Myriopoden meist homologisiert.

Was bei gewissen Inscliten als statische Organe beschrieben wurde, bedarf noch weiterer Aufklärung nnd soll daher nur kurz erwähnt werden. Das bei einer Generation von Plyglloxerc und bei einer Chermes (Rindenlans) an der Basis der Vordertlügel beschriebene Paar sog. Statocysten, welche einen glänzenden runden Statolith enthalten, erscheint vorerst sehr zweifelhaft. Der Statulith soll durch spangenartige Vorsprünge an der Bläschenwand befestint sein, und letztere trägt eigentümliche Nervenendigungen, aber keine statischen Haare.

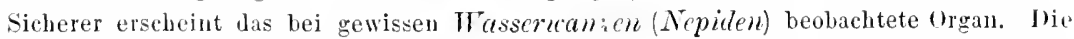
Larven dieser Wanzen besitzen an jedem Seitenrand der ventralen Abdominalthäche eine Längsinne, durch welche die luft von der Atemröbre des Ilinterendes zu den in ihr liegenden Stigmen geleitet wirl. Diese Rinne wird von einer ventralwärts umgesehlagenen Falte des abduminalen Seitenrands bedeckt, sowie durch zahlreiche Borsten, die von ibren beiden 
Rändern entspringen, noch weiter abgeschlossen. Im dritten bis sechsten Abdominalsegment zeigt die erwïhnte Deckfalte kleine Ausschnitte, die gruhenartig vertieft sind (Sinnesgruben) und an deren Rand kleinere Borsten (Sinnesborsten) stehen. - Bei der Imago gehen. unter Verlust der Rinne und der Deckfalte, aus den drei hinteren dieser Organe eigentümliche Gebilde hervor, welehe dicht medial von den Stignen der betreffenden Segmente liegen. Es sind dies etwa ovale plattenförmige Stellen des rentralen Integuments, die randlich von einem verdickten Chitinring umschlossen werden. An ihrem medialen liand und auf der ganzen Fläche der Platte entspringen zahlreiche, an ihrem Encle quer schildartig verbreiterte Borsten (Schildborsten und Siiulenborsten), die sich mit diesen Enden zı einer Art Deckmeml,ran zusammenfügen, welche die ganze Platte überlagert, und zwischen welcher und der Plattendïche ein Luftraum bleibt. AuBerdem trïgt die Platte zwischen den eigentïmlichen Sïnlenborsten zahlreiche feine hegelförmige Börstchen, die mit je einer Sinneszelle verbnnden sind und daher als sinnesborsten anfgefaßt Werden. - Die Wirkungsweise der Organe wird darin gesucht, daß die Luft in den Atentinnen der Larven oder den Organen der Imago bei verschielener Körperhaltung durch ihren Auftrieb im Wasser in verschiedener Weise auf die Endorgane wirke und so zur Regulation der Kïrrperhaltung, namentlich aber der Regulation des Aufsteigens an die Wasseroberfläthe bei der Atmnng, beitrage, indem sich die Nepiden ausgesprochen negativ geotropisch verhalten.

\section{Die chordotonalen und tympanalen Organe der Inseliten.}

Organe ganz besonderer Art sind bei den Insekten weit verbreitet und wohl in gewissen Fällen sicher von Schallwellen erregbar, was namentlich dann zweifellos scheint, wenn die Organe komplizierter gebaut sind und die betreffenden Insekten Töne hervorbringen können; immerhin bieten die physiologischen Versuche über diese Organe, selbst bei den Töne produzierenden Insekten, noch so zahlreicho Widersprüche, daß kein abschließendes Urteil möglich ist und ihre Deutung als Hörapparat der festen physiologischen Grundlage noch entbehrt. Im allgemeinen sind die Versuche über das Hörvermögen der Insekten so widerspruchsvoll, daß sich kaum in einem einzigen Fall sicher sagen läßt, ob die beobachteten Reaktionen wirklich von Tonschwingungen hervorgerufen wurden, im Sinne der Wirbeltierhörorgane oder durch einfache mechanische lieizung. Es scheint jedoch, daß die Kritik der modernen Physiologie etwas über das Ziel hinausschießt, wenn sie, seit dem Aufkommen der Statocystenlehre, die frïheren Erfahrungen über Tonreaktionen bei Wirbellosen fast völlig verwirft.

Es ist wahrscheinlich, daß solche Organe einfachster Art ursprüunglich über den ganzen Insektenkörper verbreitet waren, oder sich doch die Möglichkeit ihrer Bildung auf den ganzen Körper erstreckte. Charakteristisch ist, daß ihre Endorgane nicht mit Chitinharen in Verbindung stehen, sondern von Sinneszellen gebildet werden, deren Distalenden in eigentümlicher Weise differenziert sind, und die entweder noch bis an die Innenfläche der Cuticula reichen oder sich auch von iln' vollständig abgelöst und in die Tiefe verlagert haben. Die typische Bildung eines solchen Endorgans (Endschlanch, Scolopophor) ist folgende (Fig. 591): Die etwa eibis spindelförmige, meist ansehnliche Sinneszelle läuft distal in einen Faden aus, dessen Ende zu einem stiftartigen, etwa doppelkegelförmigen, manchmal auch endwärts abgestutzten Gebilde anschwillt (sog. Stift oder Stiftkörper, Scolopsi. 
Wer stift besitzt eine ziemlich derbe (angeblich chitinöse) Wand und distalwärts eine eigentümliche Endverdickung (Endknopf), häufig auch rippenartige Längsverdickungen seiner Wand. Achsial verläuft in dem Endfaden der Sinneszelle eine Fibrille, die durch die helle Innensubstanz des Stifts bis zum Endknopf zieht und sich bei gewissen Scolopophoren auch noch bis in die zuretende Nerrenfaser verfolgen läßt. An manchen Stiften wurde beobachtet. daß ihre Endspitze als ein feiner Faden oder ein Fadenbündel bis zur Körpercuticula reicht, wogegen in anderen Fällen eine solche Fortsetzung sicher zu fehlen scheint.

Ein allgemeiner Charakter der Scolopophoren besteht ferner darin, daß ihr peripheres Ende von einer besonderen Hïllzelle umschlossen wird (Fig. 591,

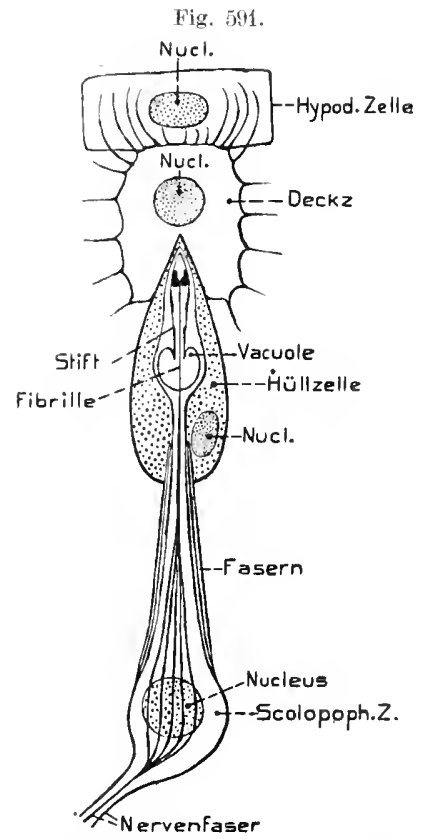

Sicolopophores Endorgan ischematisch) rom Tympanum eines Acritiers (nach $\begin{array}{ll}\text { SCHWABE 1906). C. H. } & \end{array}$
Fig. 592.

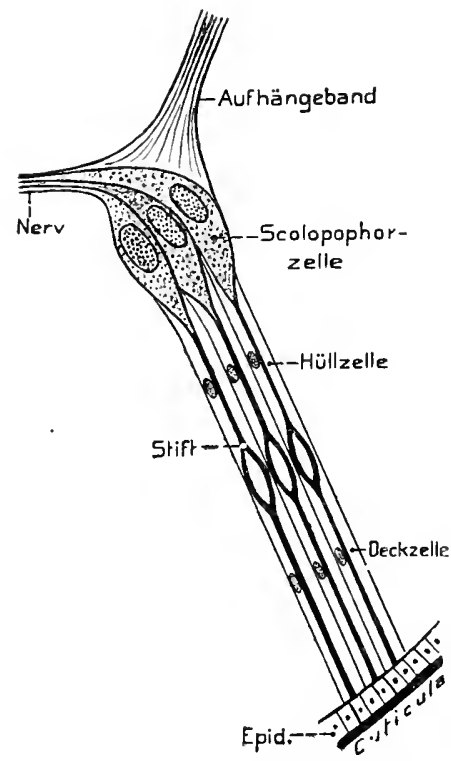

Corethra plumicornis (Larve). Ein Chordotonalorgan aus dem s. Rumpfsegment; schematisiert (nach GRABER 185\%).

die es entweder samt dem Stift einschließt, oder letzterer tritt ïiber die Hüllzelle distal hinaus, liegt aber anch dann nicht frei, weil der Hiillzelle distal stets noch eine dritte Zelle aufsitzt, die Deck-oder Kappenzelle, welche das Distalende des Scolopophor's bildet, und bei den Organen, welche die Cuticula erreichen, zwischen die Hypodermiszellen eindringt, sei es direkt, sei es mit feinen von ihr ausgehenden Fortsätzeu. - Viele Scolopophor-Organe zeigen noch eine weitere Komplikation, indem vou den Sinneszellen besondere faserig-strangförmige Zellen entspringen, die zum Integument ziehen und so eine Art zweites Aufhängeband herstellen (Fig. 592); sie können gleichzeitig eine zarte faserige Umhüllung der Sinneszellen bilden. Vielleicht gehören hierher auch die besonderen keulenförmigen und accessorischen Zellen, die bei den Hymenopteren die Verbindung zwischen den I)eckzellen und der Hypodermis herstellen. 
Selbst das einfachste Chordotonalorgan, das nur cine einzige Sinneszelle enthält, ist also recht kompliziert gehaut, da es mindestens ans drei Zellen besteht: Sinnes-, Hïll- und Deckvelle, welche jedenfalls sämtlich aus der Hypodermis hervorgegangen sind; wogegen die Anfhängezellen möglicherweise mesodermaler Natur sind.

Meist sind jedoch die Chordotonalorgane komplizierter, indem sich Gruppen oder Bündel solcher Scolopophoren in sehr verschiedener Zahl zu einem kegel- bis fächerförmigen Organ vereinigen, ans welchem schließlich durch Zutritt accessorischer Einrichtungen die höher entwickelten tympanalen. Organe hervorgehen.

Die weite Verbreitung der Scohophororgane über den körper zeigt sich namentlich an den sog. Rumpforgancu, die besonders bei Larsen (Diptern, gewisse Blattuespen, Lepi(doptcren, einzelne Kïfer [Dytiscus]) in regelmäßiger segmentaler Anordnung an zahlreichen Segmenten (besonders des Abdomens) vorkommen, meist als ein Paar in jedem Segment, seltener in mehreren und sogar verschieden gebanten Paaren. - Sehr verbreitet sind die Organe in den Beinen. Selten treten sie im Femnr (Pediculus, Plthirius) und den Tarsen (Larve von Dytiscus, Melolontha und Mystacides) auf. Sehr hïntig tinten sie sich als sog. subgenuale Oryane in der Tibia, etwas distal vom Femorotibialgelenk, und zwar wohl stets in allen drei Beinpaaren. Allgemein verbreitet scheinen sie hier bei den typischen Orthopteren (Blattiden, Bacillus, Acridiiden, Locustiden und Grylliden). Ebenso wurden sie bei einer Perlide (Isoptcryx) und der Neuroptere Mystacides erwiesen. Bei den Forficuliden, den Larven der Ephemeriden, Libelluliden, sowie den Termitcn wurden ähnlich gelagerte Organe beobachtet, die jedoch meist keine typischen Stifte enthalten sollen. Relativ ansehnliche Subgenualorgane der drei Beinpare sind ferner wohl für die Hymenopteren allgemein charakteristisch.

In der Basis der beiden Flügelpaare zahbreicher Insekten (besonders nachgewiesen bei den Lepidopteren, den Hinterflügeln gewisser Coleopteren, sowie den zu Halteren FSchwingkölbchen] reduzierten Hinterflügeln der Dipterch) finden sich meist in mehrfacher Zahl Chordotonalorgane (Lepidopteven 3-4, Dipteren '). Daneben treten auf den Flïgeln der meisten Insekten, wie auch den Halteren, eine große Menge ähnlicher, aber doch erheblich abweichender Organe (Poren- oder Kuppelorgane) auf, welche wohl nicht zu den 'hordotonalen in engerem Sinne gerechnet werden dïrfen.

Fast stets enthält die Basis der Insektenfühler ein ansehnliches Sinnesorgan (Johnstonsches Organ), dessen Sinneszellen sich zwar durch etwas weniger kräftig ausgebildete Stilte von den typischen Chordotonalorganen unterscheiden, das aber jedenfalls mit ihnen nächstverwandt ist. Mit Ausnahme der Apterygoten wurde es bei allen Ordnungen gefunden, bei den Orthopteren zwar in etwas abweichender Aushildung. Das Organ liegt als eine ringförmige Masse ron meist selır zahlreichen Scolopophoren in zweiten Glied der Fiihler und heftet sich distal an die Gelenkhaut zwischen diesem und dem dritten. Es empfängt seine Nerren rom Fühleners, der gewissermaßen durch das Organ tritt. Das Gesamtorgan wird ron zahlreichen. dicht stehenden einzelnen Scolopophorenbüscheln gebildet, die distal entweder in Porenkanile der erwähnten Gelenkhant eintreten (\%. B. Colenpteren, Hymenopteren, Lepidopteren) orler sich, wenn die Organe sehr umfangreich sind (Dipteren), an fadenartige Chitinfortsiitze befestigen, die ron der Gelenkhaut ins Innere rorspringen. Bei den Dipteren ist das Organ häufig besonders groß3 und zeigt bei Culiciden und Chironomiden anch Geschlechtsunterschiede, da das der Männchen größer ist. Sein Hervorgehen aus der Hypodermis wurde ontogenetisch erwiesen.

Über die Ontogencse der Chordotonalorgane ist im allgemeinen wenig bekannt; da aller tie Sutgenualorgane der Hymenopteren in allen ihren Bestandteilen aus einer Einsenkung der Hypodermis herrorgehen, so ist die Ableitung rom Eetoderm wohl allgemein sehr wahrecheinlich. 
Die Tympanuloryune gewisser Insekten entstehen aus den Rumpforganen; so bei den Acridiiden. (Schnarheuschrecken), bei einzelnen Wasserwamm (Corixu und Sigara) und nicht wenigen Lepidopteren. Aus den Subgenualorganen dagegen haben sie sich bei den Grylliden (Grillen) und namentlich den Lornstiden (Lanbheuschrecken) entwickelt. — Es erscheint wichtig, daß gerade die Männchen der genannten Orthopteren (selten anch die Weibchen) gewöhnlich Täne hervorbringen.

Bei dieser Gelegenheit werde erwähnt, daß das Zirpen der Acridier so geschieht, daß eine stärkere Längsrippe der Chitinhant an der Innenseite des Oberschenkels des dritten Beinpaares eine lieihe zähnchenartiger Fortsätze trïgt. Indem diese Stridulationsleisten. rasch über die Flügehlecken oder die beiden Seitenränder der lï̈ckenplatte des Prothorax (Tettigidae), hin- und herbewegt werden, wobei sie sich an einer stärker vorspringenden Längsader der Decken reiben, entstehen die Tüne. - Bei den Grillen und Locnstiden findet sich an der Basis der Flügeldecken eine stärker entwickelte Querader, die auf ihrer Ventralseite eine Reihe zalmartiger Vorsprünge besitzt (Schrillader). Indem diese über eine Ader (Schrillkante, Saite) an Innenrand der andern Flügeldecke hin- und herbewegt wird, bilden sich die Geränsche. Die Grillen können so abwechselnd beide Flügeldecken übereinander - bewegen, da diese gleich gebant sind; dagegen sind die beiden Decken der Locustiden ungleich, nur die linke (doch bei manchen lormen anch umgekehrt) besitzt auf ihrer Ventralseite eine Schrillarler, welche auf der Schrillkante der rechten Decke geigt und dabei eine an letztere angrenzende, größere, dünnhäutige Flïgelzelle (Spiegel, Speculum, Tympanum) in Schwingurgen rersetzt. Dem Weibchen fehlt der Tonapparat nicht röllig, ist aber schwächer oder in anderer Art ausgebildet.

Bekanntlich bringen vereinzelte Insekten der verschiedensten Abteilungen Geränsche oder 'Töne hervor, und zwar auf' recht verschiedene Weise. Finerseits als Reibungsgerïusche, wie bei den erwähnten Grthopteren, wobei sich recht verschiedene körperteile gegeneinander zu reiben vermögen. Häufig, besonders bei den Dipteren, werden jedoch die brummenden Töne durch die raschen Bewegungen der Flügel oder angeblich auch durch Ausströmen der Lu1t aus den Stigmenöfinungen erzengt. - Am merkwürdigsten erscheint das Stimmorgan der männlichen Cieadem, die bekanntlich z. T. laut ssingen«, bei welchen jedoch Gehörorgane nicht bekannt sind. Die Stimmorgane der Cicaden liegen seitlich am ersten Abdominalring als ein Par ungefähr ovaler dümner Hembranen (Trommelfelle), welche nach Lage und lieschaffenheit dem Trommelfell der Acrididen gleichen. Diese Trommelfelle sind mit zahlreichen Querfalten versehen und werden häufig von einer deckelartigen Hautfalte, welche von hinten und dorsal iber sie vorspringt, mehr oder weniger bedeckt; so kommen sie in eine Art llöhle zu liegen. Auf der Veutralseite des Abdomens finden sich zwischen den beiden Trommelfellen noch zwei ansehnliche dünnhäutige, rundliche Stellen (Spiegel), die gleichfalls ron zwei Deckplatten (Schuppen), welche vom hinteren liand des letzten Brustsegments ausgehen, überlagert werden. Zwischen den Spiegehn entspringen innerlich die schräg dorsolateral aufsteigenten beiden Muskeln, welche sich mit einer eigentümlichen Sehne am Dorsalrand der entsprechenden Trommelfelle anheften, und deren kontraktionen letztere in Schwingungen versetzen. Die gelegentlich geïnßerte Ansicht, daß die Töne durch die hintersten hruststigmen herorgebracht würden, ist jedenfalls unrichtig. - Das Abdomen der Männchen enthält zwei große Tracheenblasen, die sich wohl irgendwie als liesunanzapparate an der Tonbildung heteiligen.

Die Eigentümlichkeit der erwïhnten Tympanalorgane besteht darin, daß ihr Chordotonalorgan, oder ein 'Teil desselben, mit einer aus dem Integument hervorgegangenen diinnen Membran (Trommelfell, Tympamm) in Beziehung tritt. Das 
parige Organ der Acridier liegt jederseits in ersten Abdominalsegment iiber der Coxa des dritten Beinparres in Form einer etwa ovalen, dünnen Chitinmembran, deren Lüingsachse nahezu dorsoventral steht (Fig. 593). Jedes 'l'rommelfell wird

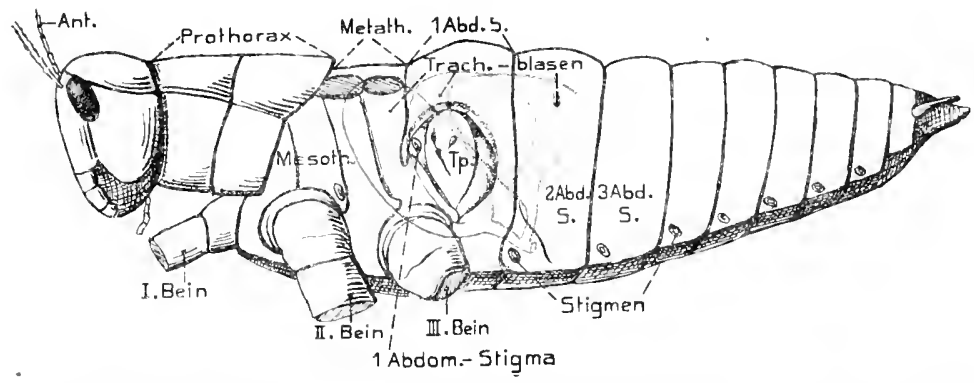

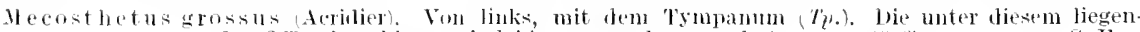

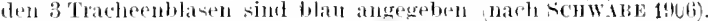
(.) H.

von einem leistenförmig verdickten Chitinring fast vollständig umschlossen. Dicht vor ihm findet sich das Stigma des ersten Abdominalsegments. Vennoch diirfte das Organ vielleicht dem Metathorax angehören, da es rom dritten Thoracalganglion imuerviert wird, und das Trommelfell ist wohl ans einer Einsenkung der Gelenkhant zwischen drittem Brust- und erstem Abdominalsegment in das erste Abdominalsegment entstanden. Nahe seinem Centrum zeigt das Trommelfell einige Chitinverdickungen (Fig. 594). Am dorsalsten einen soliden Chitinzapfen (sticlformiges hörperchen), der ziemlich tief ins Körperinnere vorspringt; etwas ventral davon eine hohle zapfenartige, nach anßen geöffnete Chitineinstiilpung (Zapfen). Von letzterem zieht schief nach hinten und ventralwärts eine eingesenkte Falte, die an illrem Vorderrand ron einer leistenartigen Ausstülpung (rinnenförmiges Körpercleen) begleitet wird. Etwas can-

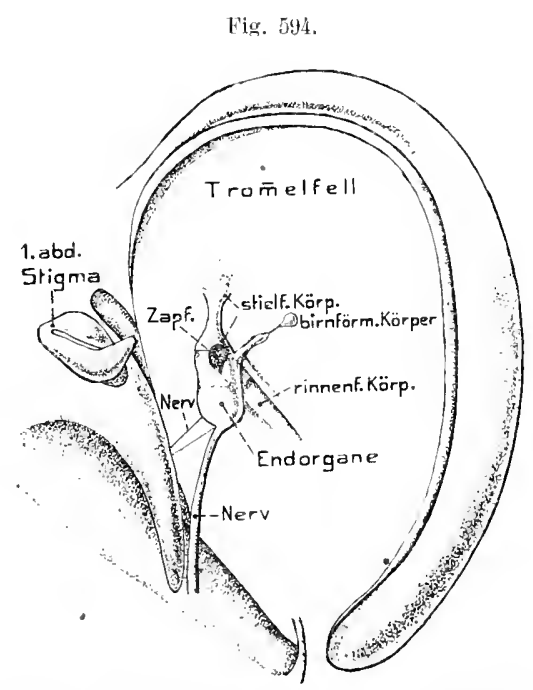

Hecosthetus grossus Acriclier). Das rechleTym binum von der [nnenseite gesehen (nach schwinz $190(i)$. C. H. dal vou den eben beschriebenen Gebilden findet sich eine kleine Verdickung des Trommelfells (birufürmiges hürpercleeu). Bei manchen Arten steigen von der Gegend des Hiiftgelenks des dritten Beinpaares zwei Muskeln auf, die sich vorn und hinten am Trommelfellrand befestigen; besonderen Einfluß auf die Bewegungen des Tympanums scheinen sie jedoch nicht zu besitzen. - Das nervöse Endorgan, welches nach dem Typus der 
Chordotonalorgane gebant ist, heftet sich innen an das stielfïmige, zapfenförmige und birnförmige Kürperchen an als ein im allgemeinen birn- bis becherförmiges Gebilde (Fig. 595), welches sich jedoch distal in zwei Abschnitte sondert, ron denen der eine zum Zapfen, der andere zum stielförmigen Körper geht; von letzterem zweigt ein kleiner Abschnitt zum birnförmigen Körperchen ab. Am rinnenförmigen Körper finden sich keine Scolopophoren, dagegen zahlreiche Endorgane, die den frïher beschriebenen Geruchsorganen der Insekten gleichen.

Der Nerv, welcher, wie hervorgehoben, rom letzten Tloracalganglion ausgeht, gibt, becor er zum Tympanalorgan tritt, einen Zweig zum ersten Abdominalstigma und einen zum Herz ab. Zu dem rimenförmigen lörperchen tritt ein besonderer feiner Nerr. - Das

Fig. $54 \%$

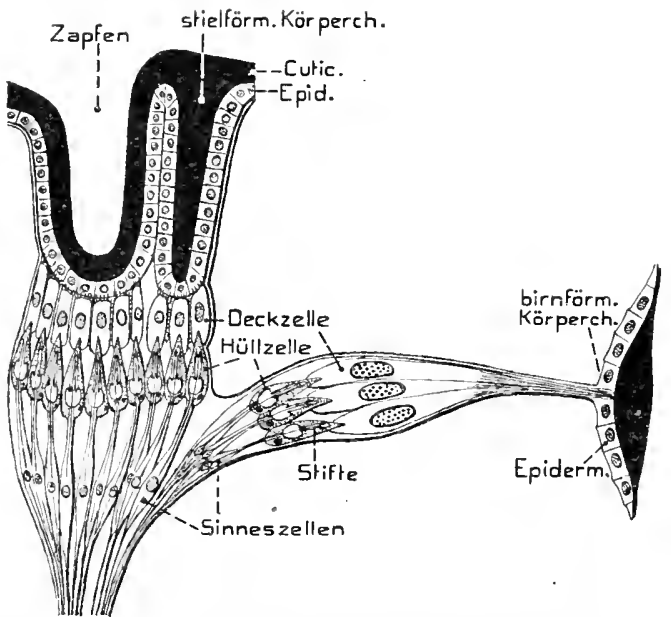

Acridier. Fehema der Nervenendigungen am Trmpanmm: im Querschnitt dureh dieses dargestellt nach scHWABE 1!n6 kon$\begin{array}{ll}\text { struiert } & \text { (1. B. II. C. H }\end{array}$
Tympanalorgan tritt in innige $\mathrm{Be}$ ziehungen zu ansehnlichen Tracheeublasen (Fig. 593), wie sie sich im Abdomen der Acridier regelmäßig in den stigmenführenden Segmenten paarweise wiederholen. Dicht am ersten Ahdominalstigma entspringt die erste Blase, welche das Trommelfell direkt unterlagert. Tach innen lagern sich dieser Tracheenblase zwei noch größere an, die beide zum zweiten Abdominalsegment gehören. So erscheint das Trommelfell mit seinem Endorgan gewissermaßen zwischen zwei Lufträumen, d. b. der umgebenden Luft „und der äußeren Tracheenblase, ausgespannt, was für einen hohen Grad von Schwingfähigkeit jedeufalls rorteilhaft ist.

Ein ähnlich gelagertes Tympanalorgan findet sich bei den

Hasserwanzen Corixa und Sigara dicht ror jedem metathoracalen Stigma. Es wird (speziell Corixa) ron einer etwas schief quer gelagerten kleinen trommelfellartigen, annäbemd ovalen Nembran gebildet, die in ihrer mittleren Region eine hügelartige Erhebung besitzt, ron der noch ein freier kolbenartiger, nach binten und etwas nach innen gerichteter Fortsatz entspringt. Auf,der Spitze des Hügels finden sich zwei schwache luppelartige Erhebungen, zu lenen je ein einzelner Scolopophor tritt. Es liegt also ein sehr einfaches oder rereinfachtes Organ ror. Corixa kann Töne erzeugen.

Hier schließen sich ferner urgane an, welche bei gewissen Lepidopteren (Noetuinen [Enlen], Aretimen [Bären], Geometriden [Spanner] und Pyraliden [Zünsler]) weit rerbreitet sind, dagegen uur ron einem Tagfalter (Coenonympha) angegeben werden. Ihre Beschreihung und Abbildmg ist bis jetzt noch mugenügend und schwer rerständlich, weshalb nur Weniges ̈̈her sie berichtet werden soll. Es findet sich stets ein Paar solcher Organe, entweder an der Ventralseite der beiden ersten Abdominalsegmente (Pyraliden, Geometriden) oder lateral am Metathorax, und zwar etwas hinter der Basis der Hinterflügel, auf der Grenze von Metathorax nud Abdomen (Noctainen). I)ie Organe werden entweder ron einem freiliegenden Trommelfell gebildet (gewisse Pyraliden) oder einem durch Einstïlpung der Conticula eingesenhten (Geometiden, gewisse Pyraliden), wogegen sie bej den 
Noctuinen von einer von hinten nach vorn ziehenden deckelartigen lildung überlagert werden. Dem Trommelfell schließt sich auch hier stets die äußere Wand einer es unterlagernden Tracheenblase imnig an. Der Scolopophorenapparat besteht aus einem Strang weniger Sinneszellen, der sich etwa an die Nitte des Trommelfells heftet, durch die Tracheenblase hindurchieht und ein rom Banchmark zutretendes Nerrenästchen erhält. Ans dem Pemerkten geht hercor, daß die Organe dieser Lepidopteren jenen der Acridier recht ähnlich, jedoch viel einfacher sind.

Wahrscheinlich stehen sie in naher beziehung zu den shon oben ( $\$$. 795) vou der Basis der Flügel zahlreicher Schmetterlinge erwähnten. Wie dort bemerkt, finden sich letztere in der Regel in mehrfacher Zahl (3-4) und ziehen von der dorsalen dicken Cuticula der Flügel an die ventrale dünne als strangartige Gebilde hinab. Bei gewissen Tagschmetterlingen (Satyridae) heften sich ihre Distalenden an eine verdünnte trommelfellartige Bildung der ventralen Flügetliache. In diesem Fall werden die Organe ferner von einer ansehnlich angeschwollenen Tracheenblase umschlossen, die sich mit dem Trommelfell innig rerbindet. Derartige Organe haben demnach ebenfalls eine rewisse Ähnlichkeit mit den Tympanalorganen erlangt.

Das Tympanalorgan der Locustiden und Grylliden ist jedenfalls aus dem so verbreiteten Subgenualorgan der Tibien hervorgegangen, das schon bei gewissen Orthopteren (so Bacillus) eine Differenziernng in zwei Abschnitte zeigt, nämlich einen proximalen, nahe am Kniegelenk gelegenen, und einen etwas distal davon befindlichen. Beide Abschnitte, die aus einer mäßigen Zahl von Scolopophoren bestehen, sind etwa fächerförmig gestaltet und befestigen sich distal an einer Chitinvorwölbung der caudalen Tibiafläche.

Bei den Grylliden und Locustiden sind die Organe des ersten Beinpaares viel größer, wobei sich gleichzeitig meist ein besonderer Trommelfellapparat an der ersten Tibia entwickelt hat. Derselbe kommt jedoch

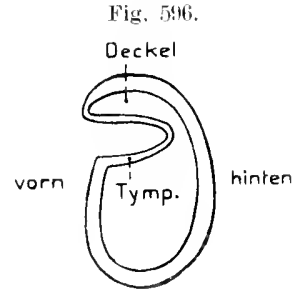

Gryllotalpa. Quersolnitt durch die Tibia, wn die besondere Bildung des Tympatnums und des Derkels zuzeigril nach GRABER 1S76).

(1. Hl. nicht sämtlichen Arten beider Abteilungen zn, wobei wichtig erscheint, daß er namentlich den Formen fehlt, wclche keine Tonapparate besitzen. - Die Trommelfellbildnng der Grylliden ist sehr verschieden.

Teils findet sich nur ein längliches Trommelfell an der Vorler- odler Hintertliche der Tibia, teils je eines an den beiden Flächen, die entweder gleich groß sind, oder es bleibt das vorlere viel kleiner als das hintere (z. B. Gryllus). Zuweilen senkt sich das rordere Trommelfell in die Tibia stark ein (z. B. Gryllotalpa, Fig. 596), so laß es nabezu quer zur Beinachse steht und dann ron einer leckelartigen Falte schützend überlagert wird.

Die Locustiden besitzen stets zwei gleiche 'Trommelfelle, ein vorderes und ein hinteres, die entweder frei und unbedeckt in der Oberfläche der Tibia.liegen oder je von einer, sich ans dem ventralen Trommelfellrand hervorstülpenden integumentalen Deckelfalte teilweise bis völlig ïberlagert werilen (Fig. 597 u. 598).

Die Deckel beider Trommelfelle sind entweder gleich (Locusta, Decticus) oder ungleich, inlem bald der hintere, bald der fordere gröber ist; auch kann der hintere gewissen Formen fehlen.

Das distale Endorgan, welches wir schon boi Bacillus fanden, ist an den Tympanalorganen der Grylliden und Locustiden sehr ansehulich entwickelt und tritt 
in nahe Beziehung zu einer der tibialen Tracheen. Der Haupttracheenstamm des Beines spaltet sich nämlich beim Eintritt in die Tibia in einen vorderen und hinteren (s. Fig. 596 u. 597 ), wie es anch bei anderen Orthopteren, sowie vielen sonstigen Fig. 597.

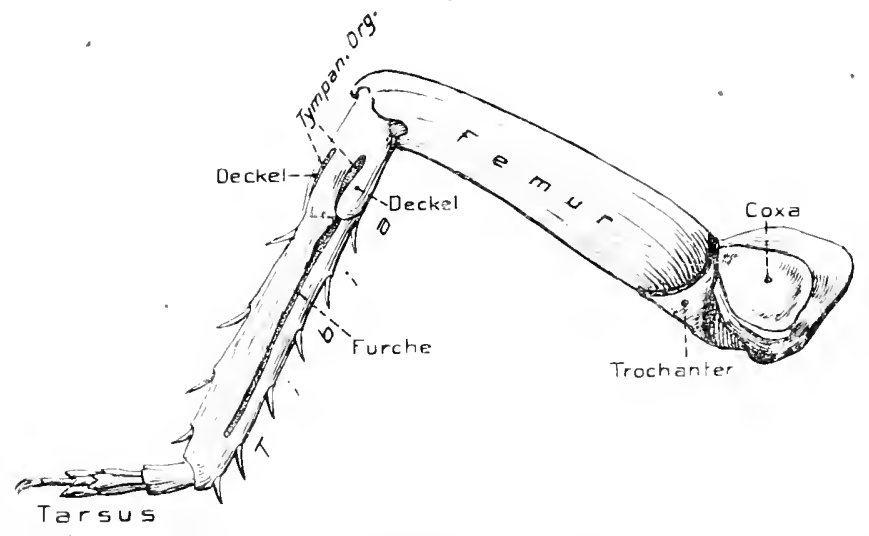

Decticus verrucivorus Locmstide). Linkes Vorderbein, etwas von hinten und dorsal gesehen: zur Demonstration der Tympanalorwathe. Orig. C. H.

Fig. 598.

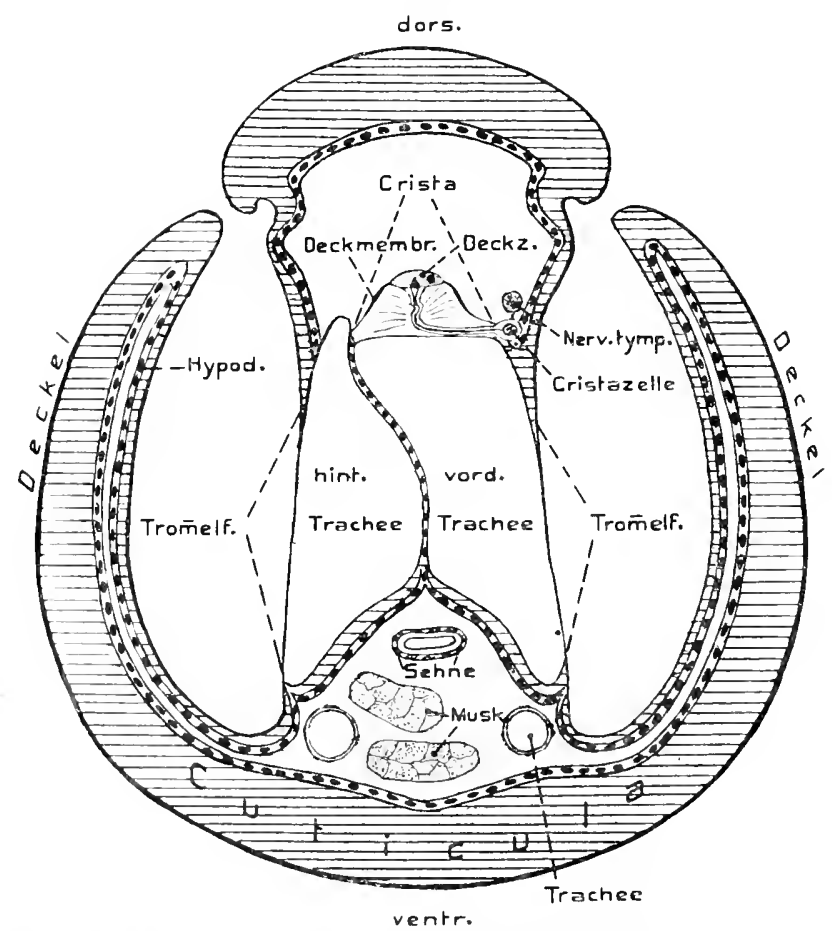

Decticus (Locustide). Querschnitt durch die 'Tibia des Vorderbeins mit der Crista usw. (nach

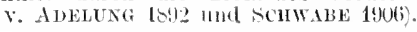


Insekten vorkommt. Diese beiden'Tracheenstämme vereinigen sich bei den Grylliden und Locustiden am Distalende der 'Tibia wieder zu einem gemeinsamen. Sie legen sich so dicht aneinander, sowie an die Hypodermis des einen oder der beiden Trommelfelle, daß sie das Lumen der Tibia in zwei Kanäle teilen, einen dorsalen oder äßßeren, in welchem sich die Endorgane tinden, und einen ventralen oder inneren, der besonders Muskeln enthïlt (s. Fig. 598). Das distale Endorgan lagert sich nun der Dorsaltläche der vorderen Trachee anf. Bei den Grillen bleiben die Endorgane anf einer primitiveren Stufe stehen. Das proximale, welches gewöhnlich als Snbgenualorgan im engeren Sinne (anch Supratympanalorgan) bezeichnet wird, zieht als ein fächerförmiges Bündelvon Scolopophoren quer durch den Dorsalkanal der'Tibia und heftet sich distal etwas dorsal vom hinteren Trommelfell an die Tibiawand. In seiner Ilistalregion finden sich noch einige unregelmäßig gelagerte Scolopophoren. - Das viel größere distale Organ (Trachealorgan) liegt, wie bemerkt, anf der Dorsalwand der vorderen Trachee und enthält viel mehr Scolopophoren. Diese ruhen mit ihrer

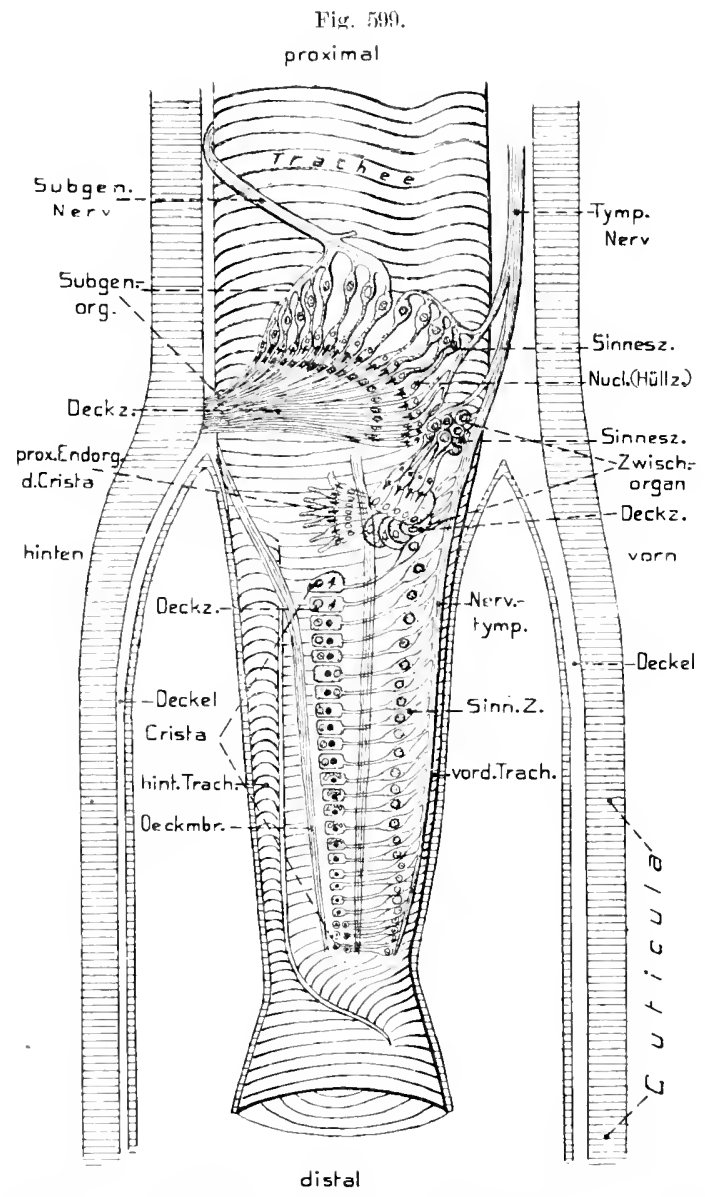

1)eticus (Locustide). Tchema des lympanalormans von der Dorsalseite gesehen (nach ScHWABE 1906, etwas vereinfacht. i. H.

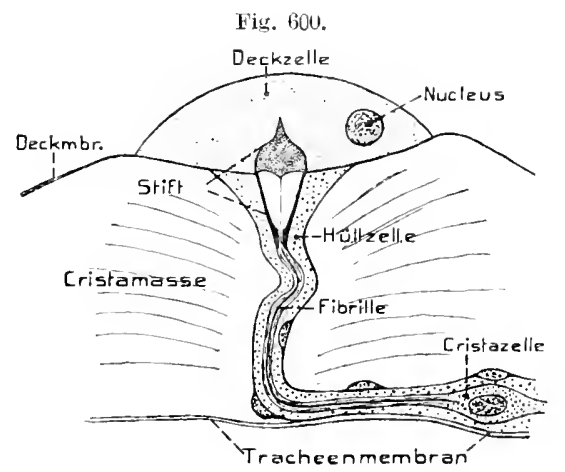

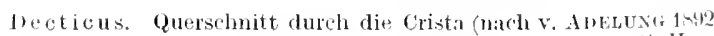
und SCHWABE 1906). 
proximaleu Partie der Trachea auf und heften sich mit ihrem Distalende der dorsalen Tibiawand an, indem sie zusammen ein etwa kegelförmiges Bündel bilden. Dabei nehmen jedoch diese Scolopophoren einen etwas verschiedenen Verlauf. Die proximalen oder basalen liegen bis anf ihren Distalteil der Tracheenwand anf und sind etwa tarsalwärts gerichtet; die distalen dagegen bilden eine längsgestreckte Gruppe, in der sich die einzelnen Scolopophoren quer zur Längsachse des Beins anordnen, während ihr Distalteil sich senkrecht anf der dorsalen Tracheenwand erhebt. Die Scolopophoren des Trachealorgans werden von einer zarten sog. lleckmembran nmschlossen.

Von den Verhältnissen der Grillen Iassen sich jene der Locustiden als eine Weiterbildung ableiten (Fig. 598 u. 599). Das subgenuale Organ (Supratympanalorgan) besitzt etwa dieselbe Lage und ähnlichen Bau. Das Trachealorgan dagegen hat sich stark verändert, hauptsächlich dadurch, daß sein, bei den Grillen schon wesentlich verschiedener Distalteil zu einem schmalen, band- oder leistenförmigen Gebilde (Crista) ansgewachsen ist, welches nur aus einer einzigen längsgerichteten Reihe von Scolopophoren besteht, die distalwärts immer kleiner werden (Fig. 599). Diese Crista bildet ein langes schmales Dreieck. Ihre Scolopophoren haben die urspriingliche Verbindung mit der Hypodermis ganz verloren, und die zu ihnen gehörigen Simneszellen liegen in einer Reibe längs der" vorderen Tibialwand und senden ihre Ausläufer (umgeben von der Hällzelle) quer zur dorsalen Mittellinie der vorderen Trachee; hier richten sich dieselben senkrecht empor und bilden die Endstifte, welche je von einer Deckzelle ïberlagert werden (Fig. 600). Diese Deckzellen sind es eigentlich, welche in der Flächenansicht die eigentümliche Crista formieren. Wie bemerkt, liegen die Deckzellen tief unter der Epidermis, ohne Verbindang mit ihr. Beiderseits von den sich erhebenden Scolopophorenenden findet sich noch eine protoplasmatische feinstreifige Masse (Cristamasse) mit spärlich eingestreuten Zellkernen und einer äußeren Membran (Deckmembran), wodurch wohl eine Art Stïtze der Crista gebildet wird. - Das proximale Ende des Trachealorgans, das schon bei den Grillen eine abweichende Anordnung seiner Scolopophoren zeigte, hat sich bei den Locustiden zu einem etwaś unregelmäßigen Scolopophorenhaufen am proximalen Cristaende entwickelt, dessen feinerer Bau schwer zu beschreiben ist (s. Fig. 599). Charakteristisch fïr dies sog. Zwischenorgan erscheint aber, daß die Deckzellen seiner Scolopophoren, obgleich sie ziemlich tief unter dem Integument liegen, doch mit der dorsalen Tibiafläche durch einen faserigen Strang verbunden sind, der wohl aus faserig ansgewachsenen Hypodermiszellen hervorgegangen ist.

Zum Subgenualorgan der besprochenen Orthopteren tritt ein Nerv (Subgenualnerv), der sich in der Kniegegend rom Reinnerv abzweigt; ein zweiter Nerv (Tympanalnerv) versorgt das Trachealorgan der Grillen, das Zwischenorgan sowie die Crista der Locustiden, gibt jedoch proximal auch einige Fasern zum Subgenualorgan ab. Dieser Tympanalnerv ist wohl gleichfalls ein Zweig des Beinners. Der Beinnerv spaltet sich, nach Abgang des Subgenualnervs, in einen Tibial- und einen Tarsalnerr.

Daß die Tympanalorgane dem Hören dienen, dürfte kaum fraglich sein; weshalb es wahrscheinlich ist, daß auch tie einfacheren Chordotonalorgane von Schallschwingungè er- 
regt werden. Nerhwürdig; und his jetzt ganz manfgeklärt, bleibt jeduch vorerst die l)ifferenzierung der tympanalen Organe in rerschiedene Abschnitte, lie, wie wir bei den Subgenualorganen der Orthopteren sahen, allmählich so ansehuliche Fortschritte marht, aber schon an den Tympanalorganen der Acridier angedentet ist. - Auch die Ialteren ler Inipteren enthalten zwei etwas verschiedene Chordotonalorgane. - Es wäre daher immerhin möglich, daß diese differenten Organe auch verschieden funtionierten, wohei natürlich neben der eigentlichen Hörfunhtion zunächst die statische in Betracht läme. - Für letzteres spüche wohl. daß die Chordotonalorgane vielleicht mit den Endorganen in den statischen llaren der Crustaceen Ähnlichkeit haben. und $d a B$ ferner bei den Insekten noch lindorgane rorkommen. welche eine rewisse Vermandtschaft mit den chordotonalen besitzen. und deren Funktionsich wohl der statischen nähert.

Es sind dies die papillen- oder linpprtfömiycm Oryane, welche sich. wie oben bemerkt. an der Flïgelbasis vieler Insekten finden und namentlich auf den zu schwingkölbchen (Halteren) reInzierten Hinterflüneln der Dipteren reich entwickelt sind.

Diese Simuesolgane der Flügel (Sirnesliuppeln oder -papillen) sind bei den Lepidopteren am genauesten bekannt. wo

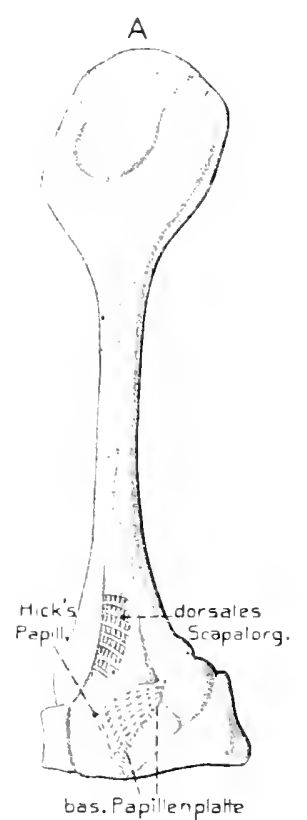

Fir. B.11

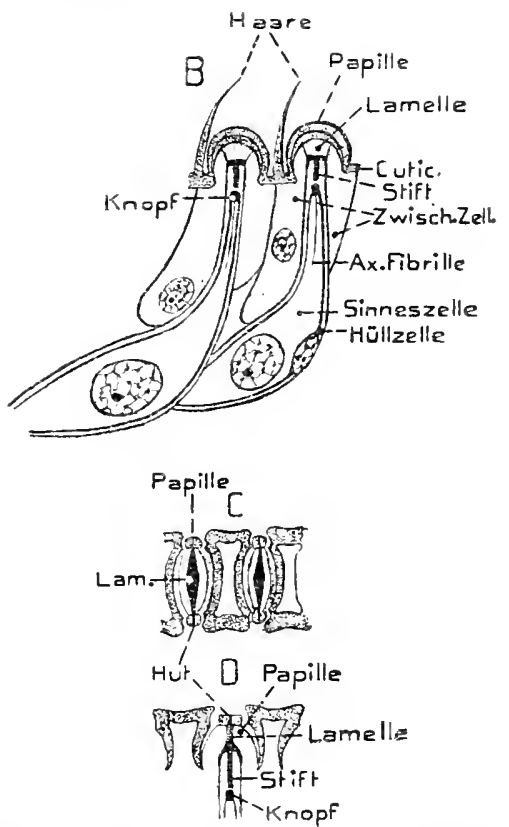

A Rechte Haltere von sarcophaga in Dorsalansicht. - $B$ Ventral scapale Papillen von Eristalis im Länsschnitt. - $-D$ Calliphora. dorsale scapale Papillen: $C^{\prime}$ Im Tangentialschnitt durch den inneren Teil der Papille. - I Soren. Querschnitt durch eine Papille, senkrecht zu

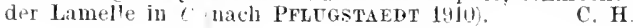
sie allgemein vorhom-

men, ebenso ron den Halteren der Dipteren, doch wurlen sie auch hei Coleopteren gefunden. In beiden Fällen stehen sie besonders zahlreich an der fiugelbasis. um zwar in Gruplen oder Fellern dicht zusammengehäutt, verbreiten sich aber hei den Lopidopteron noch an Rand del ventralen Flügelnäche meist in kleinen limppen von 2-6. sowie aul des Dorsalläche an den Flügeladern. Wie bemerkt, findet sich jedoch bei den Lepidopteren die llanptanhäulun an der Fliiłrelbasis. und zwar auf der Dorsaltläche als Subcostalgruppe, an der Ventralfäche als Costalgmppe. Jede Gruple besteht selbst wieder aus ?-3. ja sogar + Intergruppen.

An den Haltorn liegen ähuliche Vemälnisse vor. doch fmben sich hier mur lie Basal„ruppen der Dorsal- und Ventrahliche, und zwar auf ersterer ein proximales Basalorgan und etwas distal dason ein dorsales scapalorgun (Fig. G01.A), dem auf del Ventralseite ein rentrales gegenübersteht. -- Ilierzu gesellt sich auf beiden flächen noch eine klejne fruple sog. Ilicks'scher l'apillen. - Inie Sinneskupeln nnterscheiden sich ron den Chordotonalongnen. mit denen sie in vieler Ilinsicht übereinstinmen, dadurch. daß sie den allıemeinen lharakter der llantsinnesorgane der lnsekten mehr bewahrt haben. indem sie hupet- oler 
papillenformige cuticulare Erhehnngen sind, in welche, wit bei łen Borsten, durch die Cuticula ein Poren- oder Memlinankanal fïhrt; sie erinnem also an niedrig gewordene haarartige Gebilde. Dieser Bau ist noch gut ausgesprochen an den Scapalorganen der llalteren (Fig. 601 B) und den Randkuppeln der Lepidopteren; lod sind letztere in Grübohen eingesenkt, weslalb sie sirh iiber die oberfläche nicht obre wenig erheben. Die Pafillen dagegen sind in beiden Füllen sehr flache niellere Erhebungen ohne Grübcheneinsenkung. In den Gruppen oder Feldern stehen die Einzelorgane. benonders jene der Ilalteren. sehr dicht gebänft, wobei die Papillen länglich oral erscheimen und in regelmäßigen lieihen dicht nebeneinanker geordnet sind (Fig. 601 A). Zwischen diesen Reihen sind zahlrejehe ansehnliche Tasthaare mit je einer sinmeszelle eingeschaltet. Die Kupleln der Lrpidoptern dagegen sind kreisrund. - Zn jerler kuppel oder Papille gehört eine ansehnliche

Fig. 602.

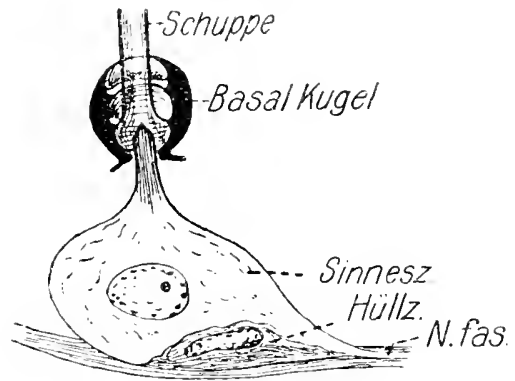

Lepidupterc chimabiachet. simmestle piner sinnesschuplue rom Flïgelrand nath VotieL 1911 ans Hesse Hdwb. 1. Naturw? Simneszelle, deren Distalende sich in eine Endlaser verlïngert, die in den Kanal ther kinpel eintritt und sich direkt an deren Cuticula befestigt (Fig. 601 $B-I)$ ) letztere zeigt namentlich an den länglichen $\mathrm{Pa}$ pillen ter llalteren eigentïmliche Differenzitrungen, welche hier nicht näher besprochen werben kinnen. - bas Distalende der sinneszelle hesitzt stets eine stiftartige. einfachere bis kompliziertere Bildung äłnlich ben Chordotonalstiften; doch wurden newerlings auch kleine stiltartige (iebilde an Ente Aer Terminalfaser in gewöhnlichen sinnesborsten gelegentlich beobachtet. - Zwischen die simneszellen schieben sich llypodermiszellen in verschiedner Zahl ein; bei den dicht stehenden Organeu der Ilalteren meist nur wenige, die den Charakter wirklicher IIiillzellen anehmen kïnnen, da die Endfaser del Sinneszelle sie geradezu lurchset\%t.

(Hhgleich die Funktion der liuppelorgane nicht sicher ermittelt ist, so läßst sich doch nach Versuchen an den Halteren wohl sagen, daß sie in irgendeiner wichtigen lieziehum zur lilugbewegung stehen, da ein geordneter Flux nach Weguahme der Ilalteren nicht mehr möglich ist. - Kuppelförnige organe wurden anch am liopf nud Thorax gewisser käfer beschrieben (Dytiscus) unt sind hier tief in Cuticulargrïbchen eingesenkt. - Inc schmetterlingsflïgel besitzen noch eine weitere Form von Juntsinnesorganen, nämlich Sinnesschuppen (Fig. 6(1), die gleichfalls zur allgemeinen Giruple der Stilorgane zu gehören sheinen. Es sind molifizierte, lange und schmale, also etwas haarartige Schuppen, die namentlich auf den Flügelatern, besonders der Randader, doch an grewissen Fłügelstellen anch außerhalb der Adern stehen. Ihre Einpflanzung ist eigentümlich, da ihre Basis ein Anschwellung (Alveole) besitzt, wie sie änlich an gewissen IJaren vorkommt. Zu jeder scluppe tritt eine Sinneszelle (mit lläll- orler Matrixzelle), theren kurzer Dorsaliortsatz mit stiftbildum bis in die Basalanschwellung der Schnple reicht. - Daß diese Orant möglicherweise durch Luttströmungen reizbar und daher fär die flugbewegun wichtig sind, arscheint als eine heaclitensuerte Vermutung.

Ein unjaares, an der Morsalseite des hinteren Koptabshnits der Ephomeriden (Lintagstliegen, tarven nud Erwachsene) liegendes eigentümliches Grgan (Palmónsches Oryan) wurde vermutungsweise als statisches qedeutet. Ïber seinen Bau lïßt sich in Kürze sagen, daß es aus dem Vereinignngspunt son vier Tracheenzweigen hervorgeht, also selbst eine kleine Tracheenblase ist, die sich aber dadurch eigentümlich kompliziert, daß sich bei den successicen Häutungen die nacheinander gebildeten Chitinintimae in diesem Bläschen. das gelegentlich jeluch auh als solid geschildert wurle, erhalten, wolurch es einen 
konzentrisch geschichteten ban erhält. Doch werden die konzentrischen Clitinlamellen łurch die Einü̈ndunssstellen der vier Tracheen unterbrowhen. Vom lerehralıanglion zieht ein unpaarer Ver zuni llinterrand les Kopt's, der bei dom Imago dicht unter lem Organ verlänft. - Wie bemerkt, ist we bentung dieses (Mgan als statisches redht unsicher, doch nicht unmöglich.

Ein l'aar :̈hnlich gebauter Grane. doch ohne deutliche Beziehung zn Tracheen, findet sirh bei genissen Thasmidrn (Racillus) in Zusammenhang mit den beiden seitlichen Nerven des röher (S. 512) besprochenen Eingeweidenervensystems (s. Fig. 347, S. 501). bei den meisten Insektenorinungen wurden an dem gleichen ort, d. h. an diesen Nerven, zwei hintere Ganglien beschrieben (Canglia pharyngealia posteriora oder G. allata), die wegen der gleichen ontowenetischen Entstehung. nämlich a]s Einstïlpungen an ler Basis der l. Maxillen, den erwihnten Phasmidenorganen jedentalls entsprechen und auch nach ihrem Ban - es sind gewöhnlich einfache Zellanhäıfungen - sicher keine Ganglien sind. Die Versuche sprachen jedoch nicht fïr die statische Funktion der Phasmidenorgane.

Ebenso unsicher erscheint dis bei einer Tabanidenlare (Diptere) gefundene Organ. das ganz hinten (Grenze rom 8. und 9. Segment) liegt. Es hat eine entfernte $̈$ hnlichkeit mit dem Palménschen (Iron, da es sich aus einigen (bis 7 ) hintereinander gereihten Blasen aufbaut, hie sich bei hen successiven lläutungen remehren un auch ineinander geschachtelt zu sein scheinen. Die vorderste, jüngste Blase mïmlet durch einen Ausführgang weit hinten aus. In jede Blase hängt ein Paar birnförmiger dunkler Körper hinein, die je von einer Zelle gebildet werden und daher ('uticularhaaren vergleichbar sein sollen. Terren und Mnskeln treten an das Orıan heran. - Es wurde zuerst als ein llörorọan (oder statisches) gedeutet, in neuerer Zeit aber als ein tonerzeuondes. - Zweifelhafter Natur sind auch die zwei Paare bläschenförmiger Organe, die am Hinterende der Larve und der Imago von Plychoptera contaminata $\mathrm{L}$. (biptere) gefunden wurten.

\section{Sehorgane.}

\section{Einleitung und allgemeine Morphologie der Augen.}

Bei der Besprechung der Stigmen gewisser Protozoen S. 80) wurde schon erwähnt, daß nicht wenige Einzellige lichtreizbar sind.

Wenn dies auch vorzüglich für chromatophorenhaltige und mit einem stigma versehene gilt. so wurde doch ähnliches auch bei einzelnen farb- und stigmenlosen Arten (so bei gewissen Bacterien, Pelomyxa nnl manchen Amäben, einer Bodoart, Chilomonas zuweilen. Meuronema chrysalis und Stentor comuleus) beobachtet. Soweit feststellbar, äuBert sich liese Reizharkeit lurch Beeinflussung der Bewegungsorganellen, wodurch sich die Organismen entweder der Lichtquelle nähern oder ron ihr entfernen. Daß die Stigmen. welche in früherer Zeit häufig als eine Art einfachster Augen geleutet wurlen, nicht als wirklich lichtreizbare (percipieremle) Organellen funktionieren, obgleich dies auch jetzt noch häntig lehauptet wird, wurde ebenfalls schon betont (s. S. 80).

Es erscheint daher leicht begreiflich, daß auch primitive, in der Epidermis der Metazoen anftretende Sinneszellen lichtreizbar sein können, was auch daraus hervorgeht, daß zahlreiche niedere, doch auch höhere angenlose Metazoen oder solche, welchen die Angen weggenommen wurden, auf plötzliche Belichtung oder Verdunkelung (Beschattung) oder anch auf beiderlei Reize durch Bewegungen reagieren.

(1) sich in diesen Fülen stets besondere Sinneszellen finden, die vorwiegend von Licht reizbar sind. oder ob sinneszellen vorliegen können. Welche von rerchiedenartigen Reizen 
(darunter auch Licht) in ähnlicher Weise erregt werden, lïbt sich einstweilen wolıl nicht bestimmt sagen, da sich ja morphologisch nicht unterscheidbare Sinneszellen hinsichtlich ihrer Reizbarkeit verschieden verhalten könnten.

Jedenfalls steht aber fest, daß bei gewissen Metazoen, welche :ihnliche Reaktionen auf Belichtung zeigen, besonders gebante lichtempfindliche Zellen vorkommen. Ein grtes Beispiel hierfür bieten die Lumbriciden (Regenwiirmer, s. Fig. 603), in deren Epidermis, zwischen den gewöhnlichen Zellen, eigenartig geformte eingelagert sind, welche die Oberfläche nicht erreichen; die gleichen Zellen treten bei gewissen Arten auch unter der Epidermis auf, namentlich im Prostomium und im hintersten Segment, welch beide auch viel reicher an ihnen sind. Sie schließen sich hier, zu Grappen vereint, dem Verlauf der Nervenver-

Fig. 603.

A

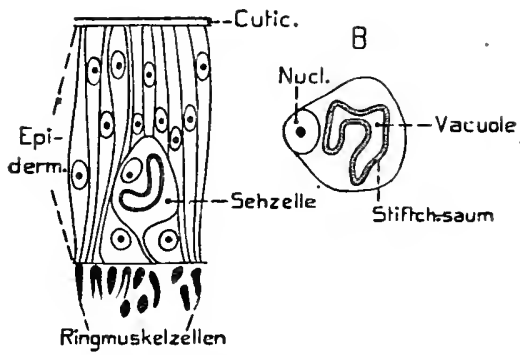

Lumbricus castaueus. A Sehnit durch die Epidermis mit einer behzelle. - $b$ line Sehzelle stärker vergrößert (nach HEssE 1896).
Fig. 60

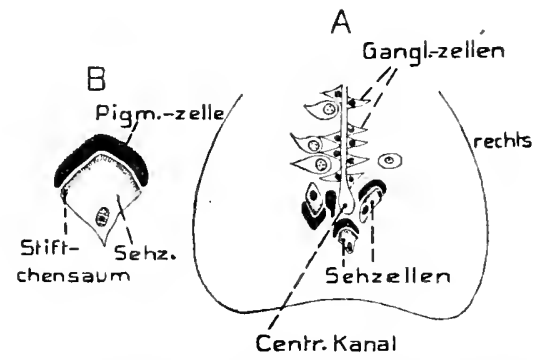

Branchiostoma Amphioxus lanceolatum. A Querschnitt les Ruickenmarks in der Gegend des 5. segments. - $b$ Eine selizelle mit zugehöriger Pigmentzelle nacli Hesse 1898\% v. Bu.

zweigungen an, ja kommen auch im Cerebralganglion selbst vor. Jedenfalls stammen alle diese Zellen vom Ectoderm ab. Ihre Lichtempfindlichkeit läßt sich sowohl aus ihrem Ban, der später zu betrachten ist, als ihrer Verteilung recht sicher erschließen; wir dürfen sie deshalb als Schzcllen bezeichnen, womit nicht mehr als ihre Lichtreizbarkeit ansgesprochen werden soll. - ̈̈hnliches findet sich bei den Hirulinecu, wo Sehzellen unter der Epidermis im Parenchym zerstrent auftreten, besonders in nächster Umgebung der schon früher geschilderten Sensillen (Fig. 456, S. 653 ; sie sind ebenso gebaut wie die Sehzellen der Blntegelangen. -- Anch die. ans einzelnen Sehzellen bestehenden, jedoch teilweise von Pigment umhiillten einfachen Angen mancher Turbellarien, Trematorlen und Polychacten ließen sich hierher ziehen, sollen aber erst später, im Zusammenhang mit den komplizierteren Augengebilden dieser Würmer, besprochen werden.

Ein weiteres interessantes Beispiel zerstrenter lichtempfindlicher Zellen bietet Branchiostoma. Die Sohzellen, welche denen gewisser Plathelminthen gleichen, liegen hier im Innern des Rückenmarks, rechts nnd links, sowie ventral von dessen Centralkanal (Fig. 604). Sie beginnen erst im dritten bis vierten Segment und sind in annähernd segmentalen Gruppen angeordnet. Jede Zelle wird teilweise von 
einer becherförmigen Pigmentzelle umhïllt, : ahnlich wie es die vorhin erwähnten einfachen Plathelminthenaugen zeigen; loch kann diese Umhüllung einzelnen Zellen feblen. - Auch die beim Nervensystem der Acranicr friiher erwähnten großen dorsalen Zellen der hinteren Hirnregion (s. S. 550) zeigen den charakteristischen Bau der Sehzellen, jedoch ohue Pigment, wogegen der Pigmentfleck der Hirnspitze ans gewöhnlichen cylindrischen Pigmentzellen besteht.

Wenn sich in der Epidermis gewisser Körperstellen eine größere Anzahl Sehzellen entwickelt, so entstehen Sehorgane einfachster Art. In solchen Fällen bilden sich jedoch meist nicht alle Epidermiszellen der betreffenden Stelle zu Sehzellen aus, vielmehr werden letztere durch zwischengeschaltete gewöbnliche Epithelzellen (Zwischenzellen, Stiitzzellen, indifferente Zellen) voneinander gesondert. Hänfig bilden die Zwischenzellen, welche die einzelnen Sehzellen zunächst umgeben, reichlich I'igment, so daß das Licht nur in annähernd achsialer Richtung in die Sehzellen dringen kann. Es sei aber gleich bemerkt, daß auch in den Sehzellen Pigment auftreten kann, was für nicht wenige einfachere und kompliziertere Augen gilt.

Über dem Distalende einer solchen Sehzellengruppe kann sich ein lichtbrechender, linsenartiger Körper bilden, sei es durch Verdickung der äußeren Cuticula, sei es unter der c'nticula durch Abscheidnng der Sehzellen selbst. Derartige Sehorgane, die einfache Umbildungen der Epidermis darstellen und wegen ilhrer Pigmentierung frïher häufig Aregrufleck genannt wurden, können am besten als epiltrmale Plutten- oder Flï̈limangen bezeichnet werden (Platyommen, Fig. 605 A). Sie bilden jedenfalls den phylogenetischen Ansgangspunkt der meisten höher entwickelten Sehorgane. - Sicher sind solch einfachste Augengebilde selbstïndig in verschiedenen Gruppen aufgetreten; so bei manchen Cölenterven (1Frhusen), Asterisu, bei manchen Ammliden und sogar primitivsten Inscliten. Ein solch epidermoidales Plattenauge kann zuweilen in verschiednem Grad iiber die Epidermisfläche emporgewölbt sein; viel häufiger aber senkt es sich bei seiner Weiterentwicklung napf- his grubenförmig nach innen ein. Auf diese Weise bildeten sich die nach außen geöffineten Becker-oder Grubenuugen (Bothriommen, Fig. $605 \mathrm{~B}$ ), wie sie weiterverbreitet bei Cölenteraton, einzelnen Chactoprolen und primiticen Gastropords" vorkommen und in diesen Gruppen wohl phylogenetisch selbständig entstanden. In solehen Fällen fehlt die Cuticula iiber der sich einsenkenden lichtempfindlichen Epithelschicht oder stilpt sich mit dem Epithel als eine sehr dünne Membrana limitans ein. Bei andern in ähnlicher Weise entstehenden Augen beteiligt sich dagegen die Cuticnla nicht an der Einstülpung, sondern zieht geschlossen über die Augenöffinung hinweg (Asterien, Ocellen oder Ommatidion der Myrioporden, Arachnoiden und Inseliten). Durch linsenförmige bis kuglige Verdickung der das Auge abschließenden Cuticnla bildet sich in diesen Fällen gewölnnich eine das Licht konzentrierende Linse aus. Das Grubenauge kann einen kleinen inneren Hohlranm besitzen oder anch nicht, indem sich dann die distalen Enden der Sehzellen fast beriihren. Im ersteren Falle kommt es häufig zur Abscheidung einer durchsichtigen, stiirker licht- 
brechenden Masse, welche die Höhlung erfiillt und als Glaslörpor (Emplem) bezeichnet wird (Fig. $605 \mathrm{~B}$ ).

Die physiologische Beleutng des eingesenliten (irubenauges unl älnlicher. etwas anders entstehender Bildungen dürte darin zu suchen sein, daß es im Zusammenwirken mit den sonstigen Sinnesorganen und der Beweglichkeit, die Möglichkeit der Orientierung über den ort der Lichtquelle bietet; indem wegen der Pigmentierung nur die anmähernd in der Grubenachse einfallenden Lichtstrahleı zu voller Wirkung gelangen. scheint diese Befähigung qegeben.

In den verschiedensten Abteilnngen entwickehn sich derartige, durch Einstiilpung gebildete einfache Augen mehr blasenartig, d. h. annähernd kugelförmig,

Fig. 605 .
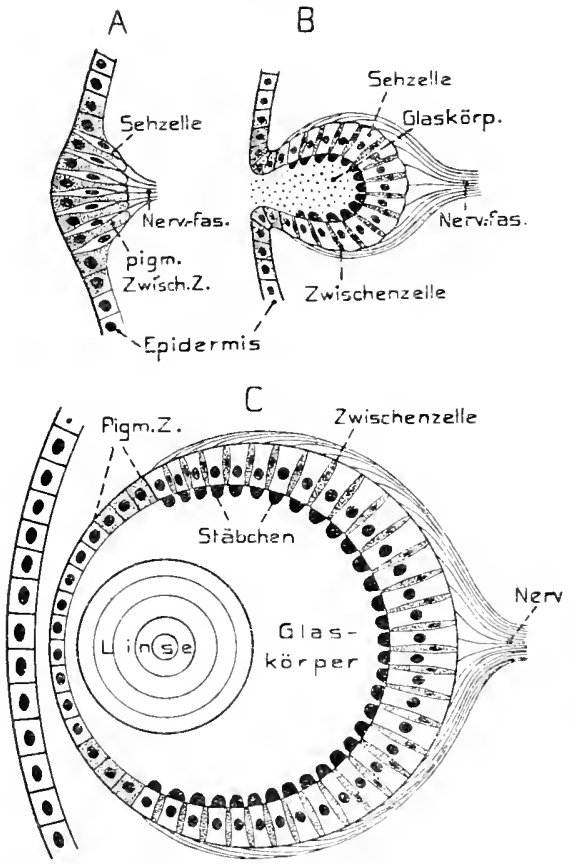

Scluemata einfacher dugembilaungen. - 1 Lintaches epidermales Plattenauge (veellusi. - B Liugesenktes rrubenauge. - $c^{\circ}$ Ahreschlobnes Blasenabse, unter lor Epidermis, mit Linse. r. Bin. mit weitem inneren Hohlraum (Blasenarge, (ystidomma), wobei sich natïrlich die Einstïlpungsöffnung stark verengt, ja gewöhnlich sogar völlig schließt Fig. $605 \mathrm{C}$ ). Dem ersteren begegnen wir z. B. bei der ansehnlichen Augenblase von Noutilus. Bei gewissen solcher Augenbildungen sehließt sich zwar die Einstïlpungsöffnung, hängt aber mit der Epidermis noch direkt zusammen und ist daher dauernd kenntlich (zahlreiche errante Polychaeten). Meist löst sich jedocb die eingestiilpte Angenblase von der sich iiber ihr schließenden Epidermis ab und wird durch zwischenwachsendes Mesoderm hüufig von ihr gesondert Mittelaugen von Charybdro unter den Acalephen, viele Gustropoden, dibranchiate Cephalopoden, gewisse Muschelu, so Pecten usw., Protracleatu). Das Innere der Augenblase wird dann von einem durch Abscheidung gebildeten, durchsichtigen Glaskörper ansgefiillt, zu dem sich bïutig ein lichtbrechender Körper als Linse gesellt, welche jedoch recht verschiedener Herkunft scin kann. Diese Linse bildet einen wichtigen Teil des Sehapparats, indem sie einerseits das anffallende licht anf eine kleinere Fliiche konzentriert und seine Wirkung damit verstirkt, andererseits aber bei genïgenden Bedingungen auf der lichtempfindlichen Schicht ein Bild der Umgeh,ung zu entwerfen vermag, dessen mehr oder weniger gentue Wahrnehmung von der Beschafienheit dieser Schicht, namentlich der Zahl und Feinheit der in ihr vorhandenen Sehzellen abbängt. Anch die Wahrnehmung bewegter Gegenstände wird durch die Linse erleiclitert werden. 
Es ist leieht verständlich, daß in einem derartigen Blasentuge nicht die gesamte Wand liehtempfindlich sein wird, sondern mur ein gewisser Teil, eben der, auf welchen die von der Linse gesammelten Strahlen fallen. Dieser Anteil enthält daher allein Sehzellen und bildet eine verdickte lichtempfindliche IIant (Netzhaut oder Retira). Im ïbrigen Teil der' Wand bleiben die Zellen niedriger nud sind meist stark pigmentiert, zur Abhaltung seitlich auffillenden Lichts. Anch die Retina kann häufig pigmentierte Zwischenzellen enthalten zur optischen Isolierung der einzelnen Sehzellen. - Die weitere Ausbildung solcher Blasenaugen luängt von der Lage der Linse ab. Letztere kann entweder im Innerı der Blase entstehen (Gastroporla, Polycharte, Protracheata) und ist daun stets ein nichtzelliges Abscheidungsprodnkt, ähnlich dem Glaskörper, zuweilen sogar direkt dureh dessen Verdichtung entstanden. In solchen Angen muß natürlich die distale Blasenwand (sog. innere Cornea), ebenso wie die dariberliegende äußere Haut, durchsichtig bleiben, um dem Licht Zutritt zu gewähren. Die Pigmentierung der Blasenwand hört deshalb in gewisser Entfernung vom distalen Pol anf, wodurch eine Art Pupille gebildet wird. - In seltenen Fällen kann sich jedoch die distale Blasenwand selbst als Linse verdicken, indem ihre Zellen stark answachsen und so eine zellige linsenartige Ansehwellung bilden. Eine solehe Linse findet sich in den eigentümlichen Mittelangen der Acalephe Charyldea (Fig. 608 B, S. 814) nnd ist im Parietalauge der Wirbeltiere (Fig. 666, S. 869) angedeutet. In gewisser Hinsieht wäre anch die Linse der dibranchiaten C'ophaloporlen hierher zu reehnen.

Schließlieh kann die Linse auch außerbalb der Augenblase, distal von ihr, entstehen und zwar entweder zellig oder enticulär. Der erstere Fall liegt sehr klar bei denjenigen Blasenaugen vor, welehe sich am Mantelrand gewisser Muscheln (Pecten Fig. 632, S. 835, Spondylus usw.) finden. Die Lage dieser Linse, distal von der Angenblase, macht es verständlich, daß das von ihr konzentrierte Licht auf die distale Blasenwand fällt, dagegen in jenen Augen, deren Linse aus der distalen Augenblasenwand hervorgeht oder in der Augenblase liegt, anf die Innenseite der proximalen Blasenwand, die Retina. In letzterem Falle trifit das Lieht also anf die distalen Enden der Sehzellen, gerade so wie im Platten-oder Grubenauge, während sieh die proximalen Sehzellenenden in Nervenfasern fortsetzen, die sich im Nervus optieus sammeln. Letzterer geht also in diesem Falle ron der proximalen Retina aus oder breitet sich, von innen kommend, an ihr aus, wie man gewöhnlich sagt. Wenn aber, wie bei den erwähnten Muschelaugen, die distale Blasenwand zur lietina wird, so liegen die Verhältnisse grade umgekehrt, indem die Sehzellen dieser Wand ihre ursprünglichen Distalenden gegen das Centrum der Angenblase richten, ihre proximalen dagegen dem eintretenden Licht zu: die Sehnervenfasern, welche von den ursprïnglichen Proximalenden der Sehzellen ansgehen, miissen sich hiel zwischen Linse und Retina einschieben. Das Licht tritt also zunächst durch diese Ausbreitung des Sehnervs und trifft dann erst aut die pereipierenden Sehzellenenden. Derartige Augen, in welchen sich die Selızellen rom Licht abwenden, werden simprtionte genannt, im Gegensatz zu den 
seither besprochenen, bei welchen die Sebzellen ihre freien Distalenden dem Licht zukehren; letztere Angen wären daher als scomrertierte \& zu bezeichnen (häufig anch vertierte genannt). - Entsprechenden invertierten Augen, hervorgegangen aus einer Angenblase, deren Distalwand zur Retina wurde, da sich eine äußere, jedoch enticulare Linse entwickelte, begegnen wir ferner in den Hauptangen der Arachnoidcen; doch kann ihr invertierter Charakter sehr zuriicktreten.

Besonders ansgeprägt ist die Inversion in den paarigen Angen der crarioten Wirbelticre, welche sich gleichfalls als Blasenaugen entwickeln, aber nicht direkt ans dem Ectoderm, sondern aus demjenigen Teil desselben, welcher sich als Hirnanlage eingestïlpt hat. Auf der Grenze des Tel- und Diencephalon buchtet sich jederseits gegen die Lateralwand des Kopf's eine Augenblase hervor, welche durch einen stielartig verengten Teil mit dem Hirn in Znsammenhang bleibt (Fig. 638, S. 842). Eine zellige Linse entsteht distal von der Angenblase durch Verdickung und spätere blïschenförmige Eimstiilpnng des äußeren Ectoderms (Fig. 639, S. 842). Die Verhältnisse liegen also äbnlich wio bei dem besprochenen Muschelange. Anch in diesem Fall wird daher die distale Augenblasenwand zu der invertierten Retina, während sich die dünnbleibende Proximalwand zu einem pigmentierten Epithel entwickelt, wie später genaner darzulegen ist. - Auch das Parietalange der Wirbeltiere geht ans einer dorsalen Ansstïlpung der Hirublase (Diencephalon) hervor.

Die Verlältnisse bei den Tunicaten, besonders den Ascidienlarcen, welche an der dorsalen Decke ihrer Hirmblase ein später schwindendes Sehorgan besitzen, dessen Sehzellen gegen das Blaseninnere gerichtet sind (s. Fig. 398, s. 54t), ebenso auch jene der Thaliaccar, welche auf her Dorsalseite ihres soliden Cerebralganglions (s. Fig. 39\%, S. 548) eigentümliche einfache Angenbildungen tragen, düriten es wahrscheinlich machen, daß auch lie Augen der Cranioten von ähulichen Anlagen ausgingen, welche in der Wand der Hirnblase lagen und erst in Laufe der phylogenetischen Weiterentwicklung gegen die Koptoberfläche vorwnchsen. indem sie sich zu Angenblasen ausstïlpten.

Wir kehren nochmals zum Becher-oder Grubenauge zurïck, zu welchem Typus, wie wir fanden, anch die Ocelli oder Ommatidien (anch Stemmata gen.) der Arthropoden gehören, bei welchen die änßere Cuticula über die Gruben-

Fig. 606

A

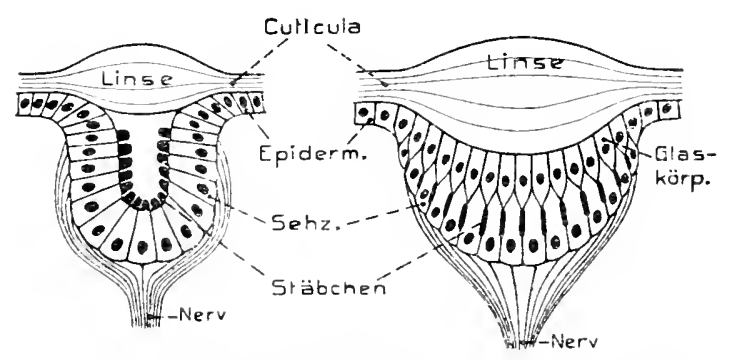

Sehemata einfacher Augenbilunngen ocelli mit cuticularer Linsel. - A Einfaches Becheringe ohne Glaskörperzollen. -

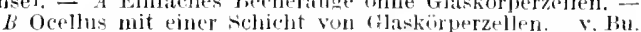

oder Becheröffinung hinwegzieht und hier fast stets zu einer cuticularen Linse verdickt ist (Fig. 606 . Bei den becherartig gestalteten Augen dieser Art füllt die Linse die Becherhöhle meist völlig aus. Derartige Augenbildungen können sich jedoch komplizieren, indem sich zwischen die Retina und die Linse eine besondere, durchsichtige Zellage 
einschiebt, welche meist als Glaskörper bezeichnet wird und wohl ähnlich wie der Glaskörper des Vertebratenauges funktioniert, sich aber auch an der Sekretion der Cuticula (Cornea, Linse) beteiligt. Diese Glaskörperzellen gehen stets aus der ectodermalen Angenanlage hervor und zwar meist so, daß die Sehzellen aus der ursprïnglich einschichtigen Anlage heranstreten und sich allmählich ticfer ins Innere senken, während die Glaskörperzellen unterhalb der Cuticula oder Linse als besondere Schicht zurïckbleiben. Anf solche Weise differenziert sich die ursprünglich einfache Anlage in zwei verschieden funktionierende Zellschichten. In gewissen dieser Ocellen bildet sich der Glaskörper jedoch etwas abweichend, nämlich durch allseitiges oder einseitiges Answachsen der distalen Zellen des Gruben- oder Becherauges, die sich so als Glaskörper zwischen die Linse und den tieferen Retinaanteil des eingesenkten Epithels schieben.

Die nach dem geschilderten Typns gebanten einfachen Arthropodenangen können sich erheblich vereinfachen, so daß sie nur aus verhältnismäßig wenigen Zellen bestehen; dann treten sie aber meist in größerer Zahl an den Kopfseiten auf. Bei dieser Vereinfachnng wird die Bildnng der Angen durch Einstülpung undentlich, da eine Einstïlpung weniger Zellen von einer Verschiebung derselben in die Tiefe nur schwer zu miterscheiden ist. Es ist recht wahrscheinlich, daß durch dichtes Zusammenrücken einer großen Zahl solch stark vereinfachter Augen die ansehnlichen parigen Facetten- orler Complrxangen der Krebse nnd Insekten entstanden. Dies sind Angen, welche ans einer meist großen Menge einzelner, wenigzelliger und dicht nebeneinander gestellter, divergierender Einzelaugen zusammengesetzt sind. Im allogemeinen hesteht jedes Einzelelement (Omma, Ommatidium) eines solchen Anges aus einer Gruppe weniger Sehzellen (Retimula), uiber welche die durchsichtige äußere Cuticula (Cornca, Hornhant) hinwegzieht, und welche gegen die benachbarten Gruppen durch zwischengelagerte faserartige Pigmentzellen optisch isoliert ist. Die cuticulare Cornea kann über jeder Retinula linsenartig verdickt sein (Corvealfacettr). Indem die Retinulae von der Cornea weg und tiefer ins Innere hinabrücken, bildet sich zwischen Cornea und Retinnla jedes Einzelauges ein besonderer lichtbrechender Körper aus, der Kristallliegel, welcher ein Abscheidungsprodukt von meist vier obertlächlichen Hypodermiszellen des Einzelanges ist. Die besondere Ausgestaltung solcher Complexangen wird sehr mannigfaltig. - Im Gegensatz zu ibneı köınen die früher beschriebenen Augengebilde der Arthropoden mit einfacher Linse und obne Znsammensetzung ans Retinulae, als simplexaugen zusammengefaßt werden.

Schon unter den epidermoidalen Plattenaugen finden sich ficbilde, welche eine gewisse Analogie mit den Complexangen der Arthropoden darbietes und sich ilnen daher auch funktionell nähern müssen. Dies sind die Kiemenaugen der Scrpulaceen (Polychaeten) und ähnliche am Mantelrand gewisser Muscheln, welche sich aus zablreichen, dicht gestellten einzelnen Sehzellen, die eine l'irmentumhüllung und einen lichtbrechenden Körper besitzen, anfbaven. Phylogenetisch haben sie jedoch mit den Complexangen der Arthropoden nichts zu tun.

Oben wurde hervorgehoben, daß bei Lumbriciden und IIirndineen pigmentfreie Sehzellen unter der Epidermis vorkommen, die sicher vom Ectoderm her- 
stammen. Es ist nun wahrscheinlich, daß die einfachen bis komplizierteren Augen der Plathelminthen, Hirulimeen und gewisser sedentärer Polycharten aus derartigen Sehzellen hervorgingen, wobei meist für alle diese Bildungen der invertierte Charakter gilt. - Auch gewisse Angenbildungen anderer Formen schließen sich diesem Typus an. - Schon bei einzelnen Hydromedusen und Acalephen treten solch primitive Augengebilde auf, welche sich von den gewöhnlichen dadurch unterscheiden, daß sich die aus der Epidermis hervorgegangenen Sehzellen einwärts gegen das Entoderm wenden, dessen Zellen eine Pigmenthïlle um die nach innen gerichteten freien Enden der Sehzellen bilden. Ähnlich müssen wir wohl die erste Entstehung der Plathelminthenaugru beurteilen, welche meist tief unter der Epidermis im Bindegewebe (Parenchym) liegen und fast immer ausgesprochen invers sind. Größere Augen dieser Art sind mehr- bis vielzellig, kleinere wenig- bis einzellig, dann aber auch meist zahlreicher vorhanden. Gehen wir von den einzelligen Augen dieser Art aus, ohne damit belaupten zu wollen, daß sie anch phylogenetisch die ältesten seien, so finden wir sie von einer Sehzelle gebildet, welche teilweis von einer mesodermalen Pigmentzelle umhüllt wird. Die Nervenfaser tritt an der nicht umhüllten Stelle zur Sehzelle, und da das Licht nur hier zutreten kann, so muß es die Nervenfaser durchsetzen, in zum freien Sehzellenende zu gelangen; die Augen sind also invers. Die komplizierteren derartigen Augen bestehen aus mehreren bis vielen Sehzellen von derselben Anordnung und mit vielzelliger Pigmenthülle. - Prinzipiell ähnlich erscheinen die Hirudiurp-Augen, indem mehr oder weniger Sehzellen von eigentümlichem Bau durch eine mesodermale Pigmentzellenhülle umfaßt werden. Auch bei ihnen tritt der Sehnerv ursprünglich an der pigmentfreien Stelle zu den Sehzellen, also invers, doch kommen bei den gnathostomen Hirudineen höher entwickelte Augen vor, welche durch eine Umwendung (Reversion) der Sehzellen den inversen Charakter verloren haben; ähnliches scheint auch bei gewissen Landplanarien eingetreten zu sein (Rhynchodesmiden).

Augen vom Bau der einzelligen der Plathelminthen knmmen auch bei den sedentären Polychaeten zahlreich vor und sind meist der Oberfläche der Hirnganglien eingelagert. Ehenso dürften die wenig entwickelten Angengebilde der Amelidenlaren, Rotatorien und Tematoden den gleichen Charakter besitzen. -Auch die eigentümlichen Rückenaugen gewisser mulmonaten Gastropoden Oncidiidae) scheinen dem Typus der inversen Becheraugen anzugehören, was nur die Ontogenie endgiiltig zu entscheiden vermag. - Interessanterweise treten inverse mehrzellige Augen ïhnlicher Bildung anch bei gewissen Oligomeren (Chaethognatha) auf und als das sog. Entomostralicn-oder Tauplinsange bei den entomostraken Crustaceen, sowie den Larven und Erwachsenen mancher Malacostraken; sie sind ebenfalls ganz unter die Epidermis gerïckt und liegen in der Nïhe der Cerebralganglien. I)ie Ilaupteigentümlichkeit letzterer Augen ist, daß sie durch eine Verwachsung mehrerer inverser Einzelangen entstanden zu sein scheinen.

Aus vorstehender Ühersicht geht jedenfalls hervor, daß sich Augengebilde ähnlicher Art in verschiedenen Stämmen unabhängig voneinander entwickelten, 
weshalh ein phỵlogenetischer Zusammenhang kaum über die größeren Abteilungen hinaus festzustellen sein dürfte. Ein Vergleich der Linsenangen von Charybdea, der Gastropoden, Polychaeten, des Pecten, Peripatus und der Wirbeltiere zeigt klar, daß alle diese Angen selbständig, ohne direkten phylogenetischen Zusammenhang entstanden sein müssen. Diese Schlußfolgerung wird noch dadurch nnterstuitzt, גaß bei denselben Tierarten häufig verschiedenartig gebaute Augen gleichzeitig vorkommen. Die Entwicklung der Augen konnte demuach sogar bei derselben Form verschiedene Wrege einschlagen.

Übersicht des Baus der Sehorgane bei den einzelnen Metazoengruppen.

Im folgenden wollen wir die Morphologie der Sehorgane in den einzelnen Gruppen etwas genauer betrachten, ohne Rücksicht anf die schon in der allgemeinen Übersicht dargelegten Kategorien der Organe.

\section{Coelenterata.}

Sehorgane kommen nur einem Teil der Hyulromedusen und gewissen Aealephen zu. Unter den ersteren finden sie sich bei den meisten Anthomedusen (oder Ocellatae am Schirmrand oder an den Tentakelbasen (Fig. 607) als meist

Fig. 607.

A
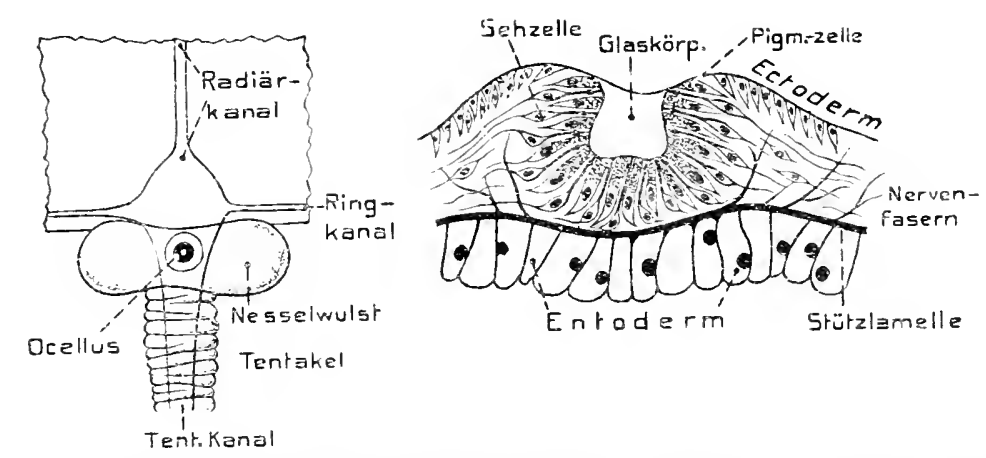

-arsia mirabilis Anthomeduse). I kleines stück des schirmrands mit einem Tentakel nnd Ocellus

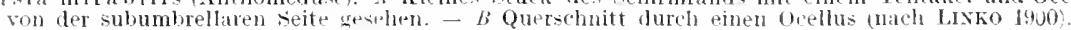

sehr einfach gebaute Angenflecke Ocellen, wogegen sie bei den Acalephen an den Randiörpern (Rhopalien stehen, die verkümmerte Tentakel sind s. Fig. 316. S. 467). Die Augen finden sich an den Rhopalien teils in Ein-, teils in Zweizahl, teils in größerer Zahl (6 bei Charybdea, Fig. 608), und dann an demselben Rhopalium von verschiedenem Bau. Bei beiden Gruppen liegen sie also in unmittelbarer Nähe des centralen Nervensystems. Sie können sich entweder auf der äußeren oder der inneren (achsialen) Seite der Tentakel oder 
Randkïrper finden; in letzterem Fall werden die Tentakel der Hydromedusen gewöhnlich apicalwärts anfgekrïmmt getragen, so daß die Angenorgane dennoch nach außen gerichtet sind. - Die Organe gewisser Hydromednsen und Acalephen sind einfachster Art, nämlich ein lichtempfindlicher Epidermisfleck, also ein epitheliales Plattenauge, das ans Seh- und pigmentierten Zwischenzellen besteht; Pigment rot, braun bis schwarz (z. B. Cuitablema, Actrelia, s. Fig. 316, S.467, converses Auge). Derartige Organe springen manchmal etwas konvex nach außen vor: hänfiger sind sie jedoch wenig bis tiefer grubenförmig eingesenkt (Fig. 607), wobei die Einstuilpungshöhle gewöhnlich von einem durchsichtigen Glaskörpersekret erfilllt wird, das teils als Schntz, teils als lichtbrechendes Medinm dienen
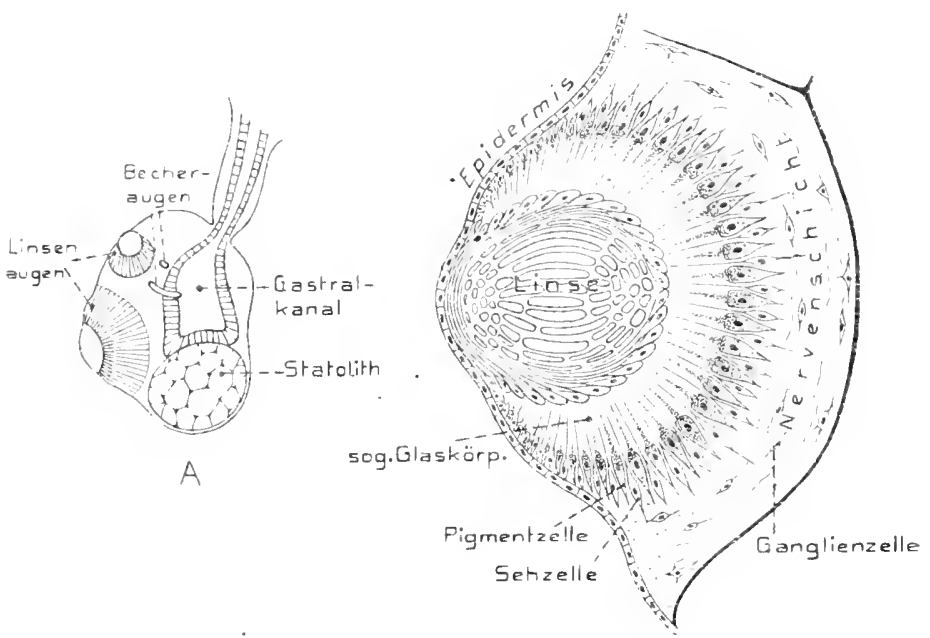

A

B

Charybdea marsupialis bebtelquallel. I lihopalium in seitlicher Ansicht. - B Längsschnitt durch das distale Linsenauge (nach senewlakoff 1849 ). ร. ${ }^{\circ} \mathrm{Bu}$.

mag. Sowohl bei einzelnen Hydromedusen Li:ia als bei gewissen Acalephen wurde iiber dem wenig vertieften Sehepithel eine halbknglige cuticnlare Linse beschrieben, jedoch bei den ersteren Formen anch als Glaskörpersekret gedeutet.

Im Gegensatz zu diesen einfachen Angen der meisten Medusen kommen anffallenderweise bei den Beutelquallen unter den Acalephen (Charybdea) sehr komplizierte vor. An den vier Rhopalien der Charybdea (Fig. 608) finden sich in der Regel je sechs Angen, nämlich zwei mediale ansehnliche nnd zwei Paar kleinere seitliche. Letztere sind einfache Grubenaugen; das distale fällt jedoch dadurch auf, daß es eine ziemlich ansehnliche, quer spaltartigo Grube darstellt. Die beiden Medianaugen besitzen dagegen den Bau hochentwickelter Blasenangen von interessanter Modifikation, was sich namentlich an dom größeren distalen erkennen läßt (Fig. 608 B). Vie ansehnliche, jedenfalls durch Einstälpung entstandene Angenblase tiegt dicht unter der äußeren Epidermis und enthält eine 
große kuglige Linse. Diese besteht aus langgestreckten, z. T. faserartigen Zellen, die sich im allgemeinen in bogigem Verlanf um die Linsenachse gruppieren: sie erinnert daher an die Linse des parigen Vertebratenauges. Die Linsenzellen sind durch Auswachsen der Zellen der distalen Augenblasenwand entstanden; die Linse ist also ein Produkt der Angenblase, und ihre äquatorialen Zellen gehen direkt in die angrenzenden der Augenblase iiber. Letztere sind zunächst nur Pigmentzellen, welche eine Art Iris bilden. Gegen die proximale Wand werden sie allmählich höher und bilden die Retina, indem zwischen ihnen schwach pigmentierte Sehzellen anftreten. Zwischen die Retiua und die proximale Linsenfläche schiebt sich eine homogene Substanz ein, welche gewöhnlich als Glaskörper bezeichnet wird.

Sie kann jedoch mit größerem Recht noch zur Retina gezogen werden. weil die sehzellen mit distalen faserlis stäbchenartigen Fortsätzen durch sie bindurch bis zur Linse reichen, und auch die Pigmentzellen ähnliche Fortsätze bis dorthin semben. Diese Fortsătze der Retinazellen scheinen jedoch in eine homogene Substanz eingebettet zu sein. die wohl ein glaskörperartiges Sekret ist (sogar dreierlei verschiedene Zellen wurden in der Retina beschrieben). In die zur Retina tretenden

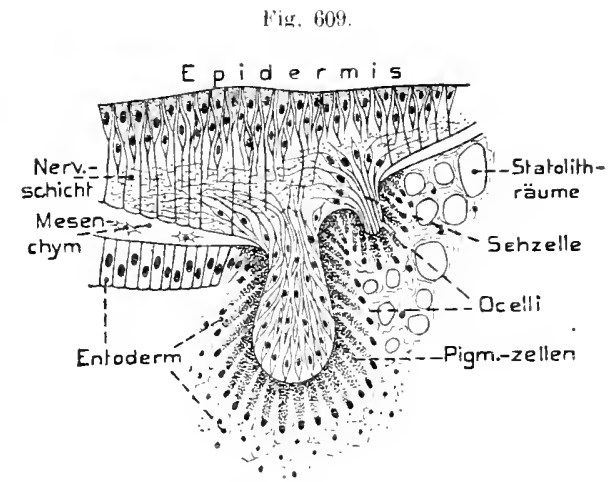

Aurelia a urita (Acalephe). Längsschnitt durch die beiden invertierten Ocellen auf der subumbrellarseite del Rhopalien nach SCHEWTAKOFF 1SS9). v. Bu.

Nerrenfasern sind Ganglienzellen ein-

gelagert: was auch für die einfacheren (ölenteratenangen meist angegeben wird. - Ver Ban der Blasenaugen ron Charybdea erweist klar, daß sie sich in ganz selbständiger Weise innerhalb der Gruppe entwickẻlt haben mïssen.

Interessanterweise kommen bei gewissen Uydromedusen (Tiaropsis) und Acalephen (hesonders Aurelia) auch inverse Augen vor. Bej Aurelia (Fig. 609) finden sich zwei solcher Augen auf ler Achsialseite der Rhopalien (s. Fig. 316, S. 46\%), während das der Abachsialseite ein converses Plattenauge ist. - Die Augen ron Tiaropsis zelgen sämtlich den inversen Bau. I)ie Sebzellen solcher Augen gehen ron der tiefen Grenzfläche der Epidermis aus und wenden sich wh innen, dem Entoderm zu. Die zutretenden Verrenfasern, welche in der Tiefe der Epidermis verlaufen, verbinden sich daher mit den äußeren Enden der sehzellen. Jie Sehzellengruppe wird nach innen ron einer Lage pigmentierter Entodermzellen umhüllt. Es ist wahrscheinlich, daß diese invertierten Sebzellen aus interstitiellen Zellen hervoryegangen sind, die in der Tiefe der Epidermis lagen, von welchen wir ja auch die Nervenzellen abzuleiten versuchten (s. s. 469).

\section{Echinodermata.}

Wir reihen die Besprechung der Augen dieser Gruppe hier an, da sie ebenso einfach sind wie jene der meisten Cölenteraten und ähnlich gebaut. Bei Asterien und Echinoideen ließ sich eine allgemeine Lichtempfindlichkeit der Epidermis nachweisen, was bei deren Reichtum an Sinneszellen rerständlich erscheint. Eigentliche Angengebilde finden sich jedoch nur bei den meisten Asterien anf der Ural- 
seite der äußersten Armenden. Hier ist die Epidermis polsterartig verdickt. Direkt iiber (apical von diesem Angenpolster entspringt das unpaare Endfüßchen, der Fühler. Bei gewissen Asterien z. B. Astropecten, Fig. 610 A erscheint das ganze Epithel des Angenpolsters rot, da es ziemlich dicht von rot pigmentierten Simeszellen durchsetzt wird, von demselben Ban wie die Sehzellen der gleich zu erwähnenden Angengruben anderer Formen; es handelt sich also um ein epitheliales Plattenange. Stellenweise kann sich jedoch das Epithel anch bei Astropecten

Fig. 610.

A
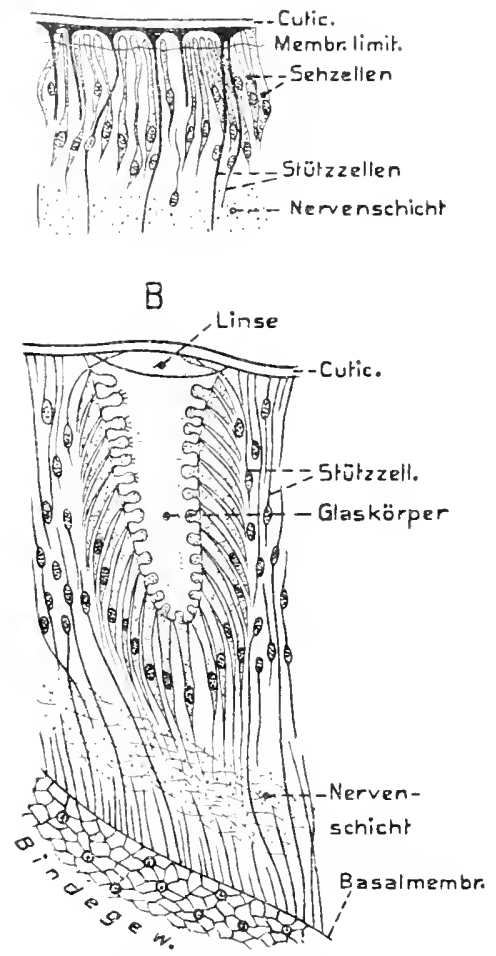

Asteriae. Augen. A Astropecten. Querschnitt durch eine kleine Partie des Augenpolsters. - H Asterias glacialis. Achsialsclmitt durch ein Auge nach PEefrer 1901). unter der Cuticula schon etwas grubenförmig einsenken, was bei anderen Gattungen regelmäßiger und tiefer geschieht (z. B. Luidia) und zur Bildung ron Augenbechern überleitet, die für die iibrigen Asterien charakteristisch sind. Bei letzteren (Fig.610 B hat sich das Epithel zu tief becherförmigen Allgengruben eingesenkt, welche in großer \%ahl $(50-180)$ ïber das Polster zerstrent sind. Die pigmentierten Sehzellen finden sich nur in diesen Augenbechern, welche sogar ansschließlich ans ihnen bestehen sollen, ohne Einschaltung indifferenter Stützzellen. Die äußere Cnticula zieht über die Öffnungen der Augenbecher glatt hinweg. Eine etwas höhere Ausbildung können solche Augen endlich dadurch erreichen, daß sich der Unterseite der Cuticula, die den Augenbecher verschließt, eine linsenförmig verdickte, stark lichtbrechende Masse anlegt (Fig. 610 B). Ob diese als eine tiefe Lage der Cuticula aufzufassen ist, erscheint etwas zweifelhaft, weil die an die Augenbecher angrenzenden faserartigen Epithelzellen (Stiitzzellen) mit ihren Distalenden in die Randregion der Linse eindringen, also an ihrem Aufbau teilnehmen sollen. -- Die Höhle des Angenbechers wird von einer gallertartigen durchsichtigen Glaskörpermasse erfüllt. - Die Sehzellen sind langgestreckt und von verschieden rotem Pigment $z u$ den Lipochromen gehörend) erfuillt. Ihr gegen die Angenbecherhöhle gerichtetes Distalende wird von einem pigmentfreien, stark lichtbrechenden, stäbchenförmigen Fortsatz gebildet. In der Basalregion dieser Stäbchen zieht durch die gesamte Retina (auch im epithelialen Plattenange) eine zarte Membran, die Membrana limitans. - Lie Nervenfasern, welche zum Angenpolster, den Angengruben so- 
wie dem terminalen Ambnlacralfüßchen ziehen, sind die des ambulacralen Radiärnervs, welchem ja die Augengruben gewissermaßen eingelagert sind.

ber rot pigmentierte liteck, ler sich hei manchen Echinochlon anl den nach ihm benannten fünf Ocellarplatten lindet, wurde vielfach als einfaches Sehorgan wedentet; die neueren Untersu'hungen konnten dies nicht bestätiqen. - Ebenso sind die zahlreichen sog. dugenorgane. welche bei den regulären Diadcmatidon (besomlers Diadcmu sctosum) iiber den ganzen hürper verbreitet rorkommen. sicherlich keine solchen, sondern leuchtorgane, und sollen daher bei liesen näher betrachtet werden.

\section{Vermes.}

\section{a) Courerse Angen der Wiirmer.}

Anch bei den Wiirmern können wir die Angen ron einfachsten Anfängen bis zu hoher Ausbildung verfolgen.

Pluttenaugen. Sehr einfache, ganz in der Epidermis liegende parrige Sehorgane finden sich am Kopf einzelner limicolen Oligochaeten, von welchen die der Stylaria lacustris am besten bekannt sind. Das Auge (s. Fig. 611) besteht aus wenigen $5-6)$ annähernd birnförmigen Sebzellen, die in einer Querreilue übereinander liegen und nach innen sowie candal von einer Pigmentzellenlage umgeben sind. Die sehr einfachen Sehzellen enthalten ein sog. Plaasom und mehrere Vacuolen; ihre Innervierung ist kaum bekannt. - Besonderes Interesse verdienen die Plattenangen gewisser sedentärer Polychaeten, der Sorpulacea. Es handelt sich hier ebenfalls $11 \mathrm{~m}$ epitheliale Gebilde, die jedoch das Eigentümliche zeigen, daß sie aus mehr oder weniger isolierten einzelnen Sehzellen bestehen, welche in verschie-

Fig. 611 .

A

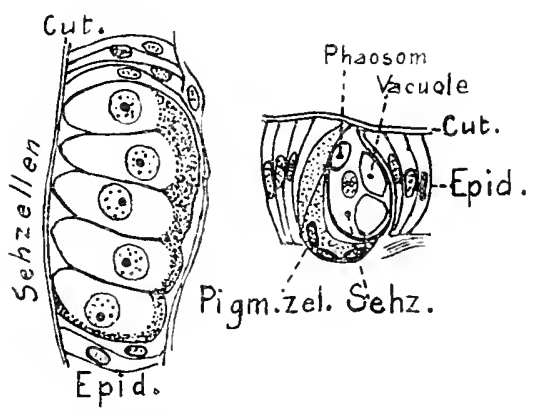

stylaria lacustris (Nais probuseidea). I Auge anif einem Quersehnitt durh das Vorlerende des Wums. - $b$ anf tinem Horizontalichaitt (nach HESSE 1902). denem Grad zu Gruppen (Augentlecken) vereinigt sind. Solche Angenflecke kommen bei gewissen Gattungen in der Seitenregion der Korpersegmente vor; gewöhnlicher finden sie sich jedoch an den für die Serpulaceen charakteristischen kopfständigen Kiemenfäden. Hier sind sie gruppen- bis reihenweis über die Fäden verteilt, oder finden sich auch als ein einziges Augengebilde am Ende jedes Fadens (Branchiomma, Fig. 612 A). — Jede einzelne, etwa langkegelförmige Sehzelle erstreckt sich in der Regel durch die gesamte Iöhe der Epidermis. Sie wird von einigen pigmentierten Epithelzellen in ihrer ganzen Lünge umhüllt (Fig.612 $B-C$ ). Meist sind auch noch weitere Epithelzellen zwischen die einzelligen Augen eingeschaltet, doch können sich letztere auch so zusammendrängen (Sabella, Brunchiomma), daß nur Pigmentzellen zwischen den Sehzellen vorkommen.

Bei gewissen Formen wölbt sich die Cuticula über jeder Sehzelle linsenartig 
empor (Fig. 612), wodurch, in Verbindung mit der darunterliegenden Substanz, eine Konzentration des lichts bewirkt wird. In jeder Sehzelle bildet sich nämlich distal ein stark lichtbrechender Körper (sog. Linse), der sich entweder der Cuticnla dicht anlegt oder etwas unter ihr liegt. Auf die feineren Einzelheiten der Sehzellen kann nicht eingegangen werden.

Wenn die Sehzellen solcher Augen dicht zusammengedränt sind wie bei Sabella nul Pranchiomma. so wailbt sirh dits so gedildete Gesamtange stark konvex empor, was
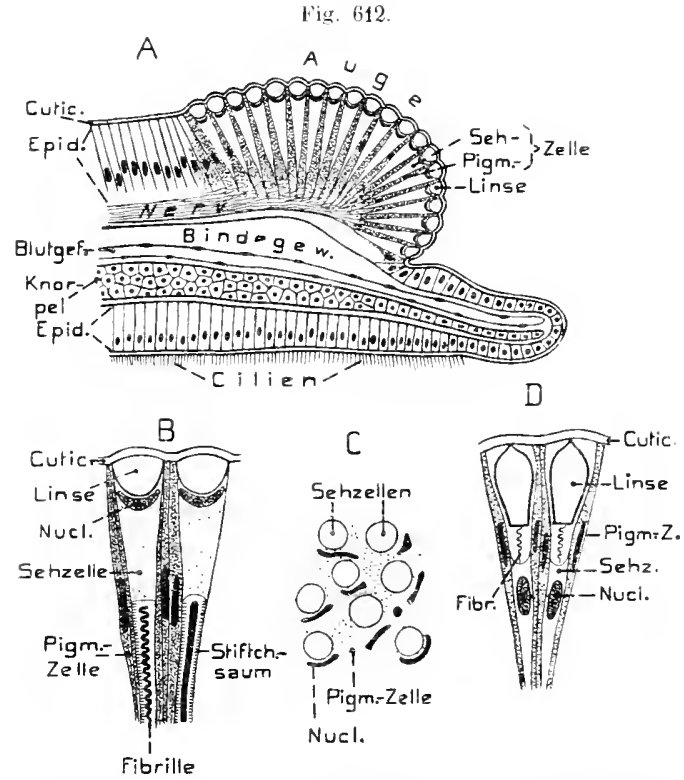

complexaugen vou Polvobateu. - t-r branclid onma vesiculosum. A Lingsschnit. dureh das Ende eines Kiemenfadens mit einem Auge. - b Zwei Einzelaugen stärker vergröBert im Achsialschnitt. - Q Querschnjt durch einen Teil des Auges. - I Zwei Einzelaugen von stabella reniformis im Achsialschnitt nach Hesse 1899. bei Branchiomma (Fig. 612 A) besonders auffillt, deren Angen dir Enden der Kiementäden kuglig umfassen. Inulem jeller Einzelsehzelle solcher Augen ein besonderer lichtbrechender Apparat zukommt, nähern sie sich in-ihrem Bau, jedenfalls aber auch ihrer runbtion, den complexangen der Artbropoden, olgleich ihre bildung kar erweist. daß sie eine selbst茫dige Entwicklung genommen haben missen.

Rein epithelial ist anch das augenartige Gehilde, welches sich bei der epitoken Form des eigentiimlichen Palolowurms (Eunice rividis) in jedem segmente der hinteren Körperhälte, ventral som Bauchmark findet. Ine verdickte, an dieser Stelle mit dem Bauchmark direkt zusammenhängende kpidermis dieser Pauchangen besteht ans Sinnes- und Zwischenzellen; die angrenzende Evidermis ist pigmentiert. Die Cuticula erseheint über jedem organ schwach hinsenartig verdickt. Die Funktion der organe bleiht vorerst noch umsicher. wenngleich ihr Ban an meisten fiir lichtemptimdirhkeit sprint.

Gruben-, riblen-, becherfömige uml Blasmaump. Bei manchen Serpulaceen finden sich außer den Kiemenaugen noch ein bis zwei Paar kopfständiger Augen; ähnliche kommen bei anderen Sedentariern (Chortopterilen und Verwandten) vor.

liese Giebilds sind zuweiten (Ranamin nit zwei Augen) einfache Gruben- oder Becheraugen. wie wir ihnen bei Güenteraten wu brhinolermen begegneten; nur setzt sich die Cuticula in lie Becherhöhle fort und fïllt sie völlig ans. Auch die vier Augen wn Siphonostoma sind schief zur Herfläche eingesenkte, noh offene Berheraugen ohne innert IIihle, mit der Eigentümlichkeit. Aaß mr tie eine Seitenwam des Berhers als Sehepithel entwickelt ist, die andere dagegen aus durchichtigen, faserartigen Epithelzellen besteht. welche, der ersteren sich dicht andlagernd, last an einen Glaskörper ouler eine linsenförmige Bildung erinnern. - Thei anderen cattungen (2. H. Branchiomma. Spirographis) sind solche Augen zu langrahrenformigen. tief' ins Inuere eindringenden liebilden geworden, an welchen gleichfals nu die eine $\|$ anl ans Sehzellem, wie andere ans ligmentyellen lresteht. 
Schließlich können sidh solch eingestülpte Angen von her Epidermis ablïsen und als blasenartige ins Innere rücken (so die zahlreichen Kiopfangen von Chactopterus).

Die fast stets zu ein bis zwei l'aaren vorhandenen Kopfangen der erranten l'olycharten. (s. Fig. 613 bis 616) sind ebenfalls eingestiilpte Bluscnaugen, welche nahezu bis völlig abgeschlossen erscheinen und daher dicht unter der Epidermis liegen, ja zuweilen gewissermaßen noch in ihr. Meist erhält sich noch ein enger Einstïlpungskanal (Fig. 613), der von einer Fortsetzung der Cuticula erfuillt wird, welche allmählich in die stark lichtbrechende, faserige Glaskörpermasse übergeht, die die Augenblase erfiillt. Fast ganz abgeschlossen sind die Augen von Nereis. (Fig. 614); vollständig von der Epidermis abgelöst die großen Augenblasen von Alciopa (Fig. 615). Die Retina, welche ans dem größeren Teil der proxi-

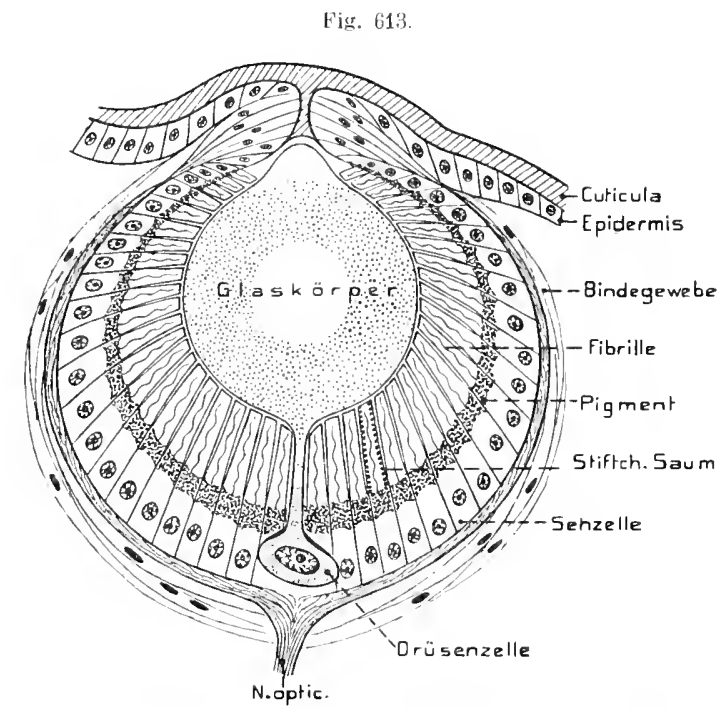

Phrlloduce laninosa. Kopfauge im Aclsialschnit (nach Hesse $1899)$.

v. Bu.

malen Blasenwand hervorgeht, besteht ans stark pigmentierten Zwischenzellen und schw:icher bis nicht pigmentierten Selızellen (Fig. 614). Letztere setzen

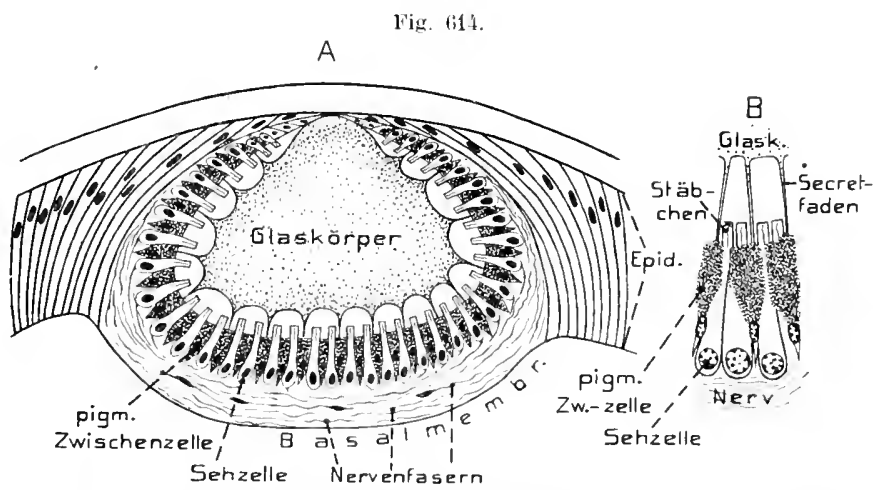
Nereis cultrifera. A Hinteres Kopfatuge im Achsialschnitt. - If Lin 'Tril der lietina stärker ver-

sich an ihrem Distalende in ein stäbchenartiges Gebilde fort, wie es auch bei den eingesenkten Augen der sedentären Polychaeten vorkommt. In diesem Stäbchen verläuft ein feiner achsialer Faden (Neurofibrille). Die /wischen- oder 
Sekretzellen, welche zuweilen nur spärlich vorkommen sollen, sondern einen feinen Faden ab, der in den faserigen Glaskörper übergeht, weshalb dieser als

Fig. 615

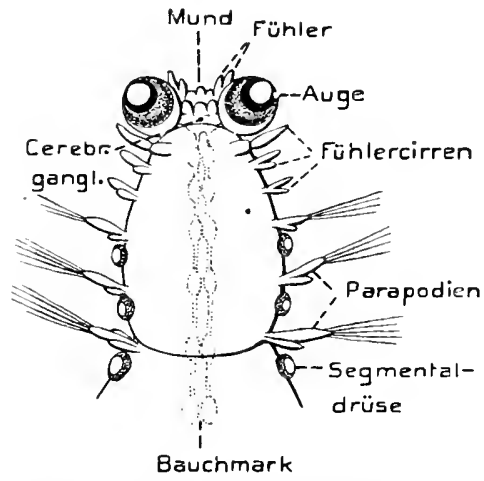

Alciopa cantrainei. Vurlerende von des Ventralseite mit den großen Augen (nach (iREEFF 1S76). v. Bu.

Sekretionsprodukt jener Zellen angesehen wird. - Bei Phyllodoce (Fig. 613) findet sich im Centrum der Retina eine einzige große Drïsenzelle, die den Glaskörper abscheidet.

Abnorme Größe und hohe Entwicklung erreichen die parigen Blasenaugen der pelagischen Alciopiden (Fig. 615 n. 616). Die beiden Augen springen als ansehnliche kuglige Gebilde an den Kopfseiten stark vor. Wie erwähnt, hat sich die große Augenblase von der Epidermis völlig abgelöst, doch liegt ihre duinne distale, aus etwa faserartigen Zellen bestehende Wand innere Cornea) der dünnen durchsichtigen Epidermis (äußere Cornea) dicht an. Der an-

Fig. 616

A

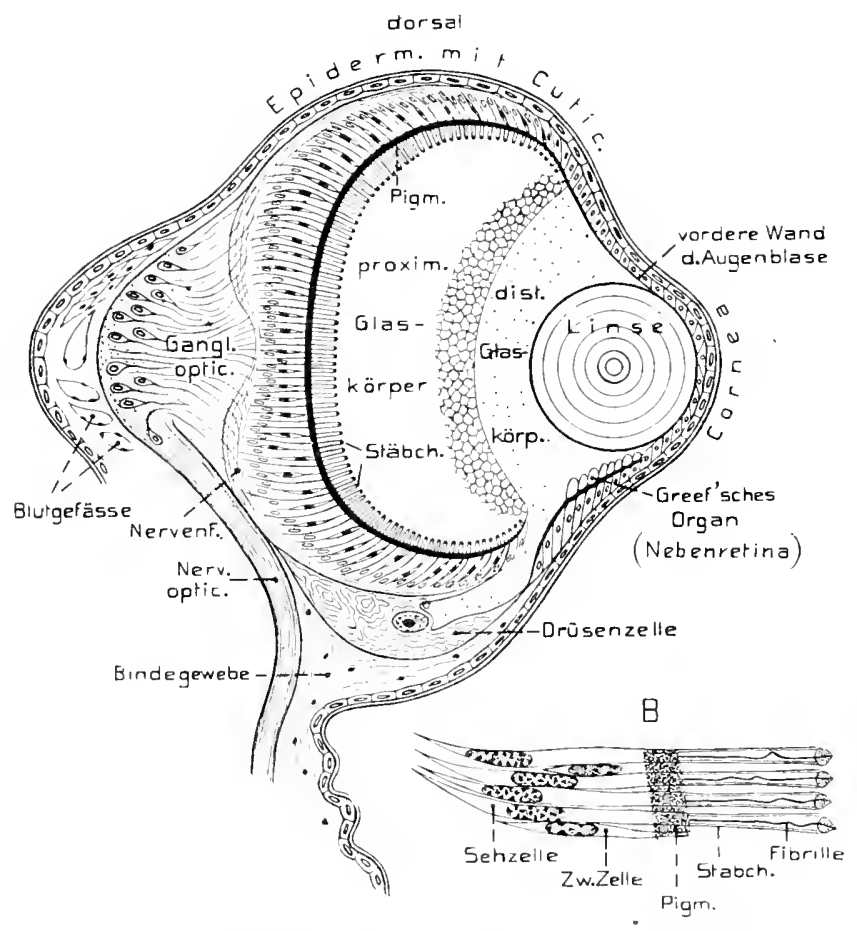

Vaudis formosil 1 ture im dorsoventralen Achsialsehnitt. - $b$ Einige Seh- und Zwischenzellen stärker vergrößert (nach Hesse 1899).

v. Bu. 
schließende dünnwandige Teil der Blase besteht ans Hachen pigmentierten Kellen (Iris), welche in die stark verdickte proximale Retina übergehen. Das Innere der Blase erscheint komplizierter, indem sich ein distaler und proximaler 'Teil unterscheiden lassen, die von einer dünnen Quermembran getrennt werden. Im distalen Teil liegt eine stark brechende, konzentrisch geschichtete Linse und einesubstanzreichere Glaskörpermasse; der proximale Teil dagegen ist von einer wasser- . reicheren ähnlichen Masse erfüllt. Der distale Glaskörper, und daher wohl auch die Linse, werden, ähnlich wie bei Phyllodoce, von einer ein- bis mehrkernigen großen Drüsenzelle abgeschieden, die'ventromedial in den vorderen Blasenabschnitt mündet. Der proximale Glaskörper dagegen ist ein Produkt der \%wischenzellen der lietina, von denen jedoch auch angegeben wird, daß sie bei Erwachsenen schwinden. Die distalen Sehzellenenden (und wohl auch die der Zwischenzellen) sind pigmentiert; die ersteren setzen sich iiber die pigmentierte Zone als ansehnliche röhrenartige Stäbchen mit Neurofibrille und distalem Endknäpfichen fort (Fig. $616 \mathrm{~B}$.

Mit der hohen Entwieklung des Alciopidenauges harmoniert, daß der vom Cerebralganglion zutretende Nerv am Hintergrund der Augenblase ein ansehnliches Ganglion optieum bildet; in geringerer Ausbildung kann ein solches auch an den einfacheren Augen mancher Errantia auftreten (z. B. den Vorderangen von Nereisarten).

Eine rehr eigentïmliche bihlung tindet sich etwas distal bon der Einmïndungsstelle ler Glaskörperdrïse des Alciopidenauges, ungefïlı in der Gegend des Linsenäquators. Hier ist eine Anzahl Zellen der Blasenwand stark fadenartig verlängert, und ragt, kolbig rorspringem, in die Blase hinein (Fig. 6l6 A). Die Bedeutung dieser Einrichtung scheint etwas zweifelhalt; doch ist man geneigt, liese Zellen gleichfalls als sehzellen zu leuten. und die von ihnen gebildete Cruppe als eine sog. s Nebenretina (lentikuläre Retina), al. h. eine besondere Netzhant, welche fïr das Fernsehen adaptiert ist, wie sie anch in anderen Augen gelegentlich auftritt. - Physiologische Versuche haben ergeben, da $B$ das $\Lambda$ uge in der linhe auf die Ferne eingestellt is uml aktiv auf die Nähe accomodiert. Das geschieht in -ehr merkwïdiger Wei-e dadurch, daß durch Mnskelkontraktion die an der ventralen Fläche kes Anges liegende Drüse zusammengedrückt und so eine gewisse Meng» ihres Sekrets in den vorderen Glaskörperraum eingepreßt wird. Dadurch wird die Linse son der lietina entfernt und der Cornea genähert. - Die Sehnerven erfahen am Cerebralganglion eine teilweise kireuzung (Chiasma).

\section{b) Inverse Angen der Wiirmer.}

Die hier zu schildernden, sehr einfachen bis, höher entwickelten Augen sind bei den Plathelminthen ungemein verbreitet, kommen anch bei sedertüren Polychaeten vor und sind ebenso für die Ilimulinen charakteristisch. Aueh die bei manchen Nemathelminthen (Rotatorien und freilebenden Nematoden) anftretenden, sehr kleinen und einfachen Aug'en dïrften diesem Typus angehören. - Derartige Augen finden sich bei den Plathelminthen gewöhnlich am Kopfende, in der Gegend der Cerebralganglien, und zwar in recht verschiedener Zahl.

Bei den kleinen rhabdocoelen Turbellarien meist in geringer Zahl (zwei, vier, sths. loch auch ein unpares); anch die Triclaten besitzen manchmal nur ein Angenpar. doch 
kinnen sich auch sehr zahlreiche kleine finden, was bei den I'olycladen Regel ist. Bej letzteren sind sie meist in Gruppen angeordnet; rïken bei gewissen Formen auch auf die Tentakel, ja können sich lïngs des Körperrands weit nach hinten erstrecken, ihn sogar völlig umsäumen, was auch bei den meist selı vieläugigen Landtricladen vorkommen kann, deren Augen sich zuweilen sogar über den ganzen Rücken und selbst lie Seitenränder der Bauchfläche verbreiten. - Bei den Nemertinen schwankt die Zahl der kopfständigen Augen sehr (etwa von 2 bis 50). - Während die monogenen Trematodrn (Polystomeen) noch ein bi zwej Paar Augen besitzen können. sind sie bei den erwachsenen Digenea (Distomeen)

lig. 617 .

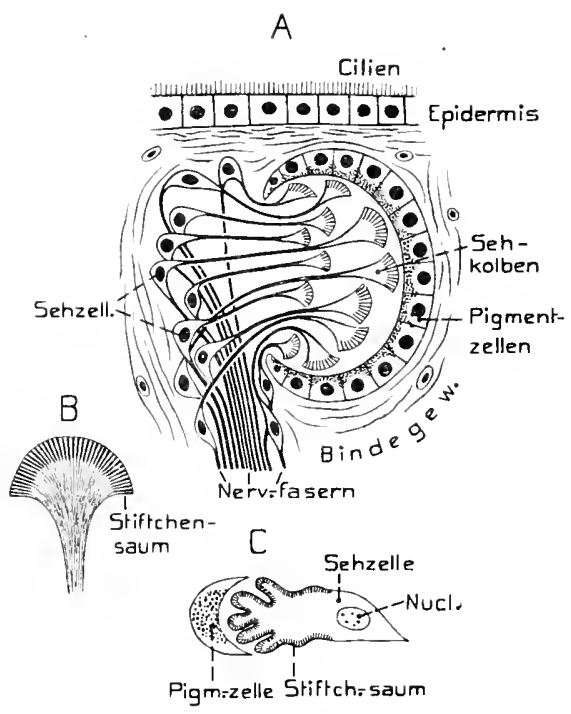

Auge von Plathelmintlen. A Euplanariagonocepluala. Ein Ange im Achsialschnitt. - $b$ bin Endkolben stärker vergröBert. - $C$ Tristo in un pa 1)illosum (Trematode), einzelliges Auge (nach Hesse 1897). v. Bu. fast stets geschwunden, wogegen sie bei Larren und Cercarien nicht selten erhalten blieben. Unter den Cestoden sind nur bei Phyllobothrienlarren zwei Augenflecke beobachtet worten.

Die Augen liegen fast stets nuter der Epidermis im Körperparenchym, selten noch in der Tiefe der Epidermis, was für ihr Hervorgehen ans dieser wichtig scheint. Manchmal sind sie so tief eingesenkt, daß sie den Cerebralganglien direkt aufsitzen.

Der Ban der Plathelminthenangen (Fig. 617) ist recht einförmig, da sie, wie schon früher bemerkt. nur aus einer einzigen oder ans wenigen bis zahlreichen Sehzellen bestehen, die voll einer becherförmigen P'igmentlage umgeben sind, und deren ursprïnglich distales Ende vom zutretenden Licht abgewendet

ist. Diese Hülle wird von einer bis zahlreichen mesodermalen Pigmentzellen gebildet. Natürlich richtet sich die Zahl der Seh- und Pigmentzellen im allgemeinen nach der Augengröße. Kleine, aber meist in größerer Zahl vorhandene Angen sind daher ein- bis wenigzellig, größere, in geringerer Zahl vertretene, komplizierter gebaut; doch finden sich auch zahlreiche Abweichungen von dieser Regel. Bemerkenswert erscheinen die beiden Doppelaugen von Tomnocephala, die aus zwei einander opponierten Sehzellen bestehen, zwischen welche eine doppelbecherförmige l'igmentzelle eingeschaltet ist.

Das X-fömige Auge der Larve des Leberegels (Distomm hepatieum) wird von vier Pigmentzellen gebildet. lederseits \%wischen zweien derselben liegen zwei Sehzellen, die je einen dichteren Binnenkörper enthalten. Die Fortsätze dieser Sehzellen sollen narl kurzem Verlanf durch den Spalt zwischen den beiden Pigmentzellen ibrer Seite in das Cerebralganglion treten. Wenn diese Darstellung zutrifft, so verhielte sich also dies Auge. obgleich es jenem der ïbrigen Plathelminthen sehr ähnlich erscheint. nicht invers. sondern convers. 
Die Sehzellen, deren proximaler, den Kern enthaltender Teil aus dem Pigmentbecher mehr oder weniger hervorragt, um hier die Nervenfaser abzugeben, sind ziemlich verschiedenartig. Im einfachsten Fall erscheinen sie kuglig bis kolbig; häulig werden sie cylindrisch, wobei ihr percipierendes freies Ende sich kolbig bis facherartig verbreitert (Fig. $617 A, B$ ); nicht selten ist anch das, auf die Kernregion folgende freie Zellende lang faserartig ausgezogen und schwillt schließlich zu einem becher-, kolben-oder cylinderartigen Sehkolben an. Die besondere Differenzierung dieses freien Endteils, der sich anch als Stäbchenteil bezeichnen ließe, wird später genaner zu betrachten sein. - Zwischenzellen tinden sich nicht, was für die inversen Aıgen der Wïrmer und ähnliche Sehorgane allgemein gilt.

Merkwürdig erstheint daher, laß in Auge gewisser Nemertinen (Drepanophorus) außer den erwähnten Tehzellen nocb tein faserartige vorkommen, die in der Achse des becherfïrmigen Auges ein l:üudel bilden; auch diese Zellen werden als lichtempfindiche gedeutet.

Pei rerschiedenen Plathelninthen wurden häutig noch einige helle Zellen beschrieben, die außerhalb des Angenbechers in ler Gegend les Nerrenabgangs liegen und als lichtbrechende Linsenzellen funktionieren sollen. Die wirkliche Existenz solcher Zellen scheint jedoch unsicher, obgleich ihr Ilervorgehen aus mesodermalen Parenchym- orler Ectolermzellen leicht zu verstehen wäre. Dagegen ist wohl möglich, daß die frei aus dem becher herrorragenden proximalen sehzellenenden. welche in ihrer fiesamtheit häutig eine halbkuglig abgerundete Masse bilden und ron einer zarten

Fig. 618.
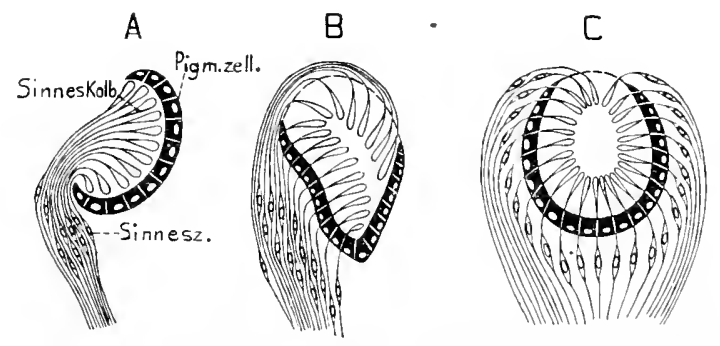

Grematischer Versuch der Ableitung des conversen Trichadenaumes ( 4 aus den inversen der übrigen Turbellarien (.1) nach Hesse 1902 )

tlembran (die auch gelegentlich ab zellig angegeben wurde) gegen das umgebende Parenchym abgeschlossen sein können, linsenartig zu wirken vermögen. - Die Nerven der koptständigen Angen begeben sich zu den Cerebralganglien, die der ïbrigen zum ILautnervenplexus.

Einen von den Augen der äbrigen Plathelminthen auffallend abweichenden lau zeigen die in Zweizahl vorhandenen gewisser Landplanarien (d. h. die Yehrzahl der zur Familie dè Khymchodesmidrn gehörigen). Nach den vorliegenden L'ntersuchungen sollen ،liese sog. lietinaaugen ( Fir. $1518 \mathrm{C}$ ) etwa ellipsoidisch gestaltete, ron einer einschichtigen blasenartigen Pigmentzellenschicht bis auf den distalen l'ol umschlossene trgane sein, die ziemlich ticht unter der Epidernis liegen. Die etwas spindelfömigen Sehzellen liegen im Imkreis der Pigmentschicht und tretell, faserartig verdünnt, zwischen den P'igmentzellen hinlurch, um im Innern des Auges zu stäbchenatigen langen Gebilden (Schretprismen) anzuschwellen, die in radiürer Zusammengruppierung das ganze Innere der Pigmentblase erfüllen. Das Auge soll in einer ganglionartigen Anschwellung des zum Cerebralganglion gehenden Sehners eingebettet sein. Demnach wären dieze Augen, in liegensatz zn denen der übrigen Plathelminthen, convers; es scheint aber wohl sicher, laß ihr Bau noch nicht hinreichend aufgeklärt ist, und daß sie sich wahrscheinlich aus einer ursprünglich inversen Anlag hertorgebihlet haben, so etwa. wie es die Fig. $618 A-C$ erlüutert.

Die Hirudineen-Augen reihen sich denen der Plathelminthen nahe an, weichen jedoch im Ban ihrer eigentümlichen Sehzellen erheblich ab, wie später (S. 896) gst- 
naner zu erörtern sein wird. Phylogenetisch könnten sie daher mit jenen der Plathelminthen nur in den ersten Anfängen verkniipft sein. Sie finden sich meist kopfständig zu einem bis mehreren (etwa bis vier) Paaren; nur Piscicola besitzt anch am hinteren Saugnapf fünf Augenpaare. - Schon früher wurde hervorgehoben, daß im Parenchym der Blutegel vielfach isolierte, pigmentfreie Sehzellen zerstreut vorkommen, und daß sich namentlich um die Sensillen meist einige solche Zellen finden s. Fig. 456, S. 653). Bei Pontobdella repräsentieren sie allein den lichtempfindlichen Apparat. - Die einfachen Augen der Rhynchobdelliden (Fig. 619, $A-B$ ) bestehen ans einer Gruppe solcher Sehzellen, welche ähnlich wie die der Plathelminthen von einer mesodermalen Pigmentzellenschale umhiillt werden, die jedoch bei Branchellion sehr unvollständig bleibt. Von den dem Licht zugewendeten Enden der rundlichen, bis etwa cylindrischen Sehzellen gehen die Nervenfasern ab, sodaß der inverse Charakter klar ausgesprochen erscheint.

Fig. 6119.

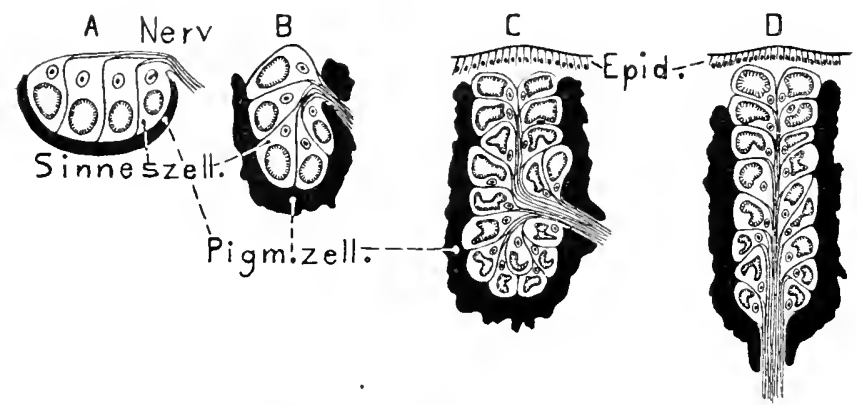

- chematische Ableitung des conversen Hirudineenauges (etwa Hirudo It nus dem inversen (etwa Clespine A. Nephelis $b$ ) (nach Hesse 1902).

Bei den Gnathobdelliden (Fig. 619, $C$ n. $D$ ) indert sich der Bau insofern, als die Sehzellen nicht mehr eine einschichtige Lage bilden, sondern einen etwas unregelmäßigen Haufen, der schließlich bei Hirudo und Verwandten zu einem langzapfenförmigen Gebilde wird, in welchem viele Sehzellen iibereinander gehäuft sind. Die Pigmentzellenschicht umhïllt diesen Zapfen becherartig; der Sehnerv tritt im Bechergrunde ein und steigt in der Augenachse empor, um sich an die Sehzellen zu verteilen. Letztere Angen sind also convers. Daß sie jedoch aus der iuversen Bildung der Rhynchobdelliden, welche bei der Gnathobdellide Nephelis noch bestelit, hervorgegangen sind, läßt sich dentlich verfolgen. Es geschah dies durch starke Vermehrung der Seh- und Pigmentzellen, die allmählich den Selnnerv umfaßten, etwa so, wie es die Fig. 619 erläntert.

Die Rezielnugen der Selızellen zu den Sensilleu spricht sich auch an den Augen häutig 1adurch aus, daß eine Sensille dicht meben dem Auge liegt und ihre Nerrenfasern in den Sehnerv schickt. - Daß die Augen der llirudineen ans der Zusammengruppierung zerstreuter Sehzellen herrorgingen, hamn kaum zweifelhaft sein, dagegen bleibt es unsicher, ob die Sehzellen aus den Sinneszellen der Sensillen abgeleitet werden dürfen.

Auf eine wirkliche Verwandtschaft mit den PlatheJminthen dïrten die bei zahlreichen 
sedentären Polychacten vorkommenden, meist sehr einfachen unl kleincn Inversangen hinweisen, die am Kopf häutig in großer Zahl auftreten (\%. B. bei Capitellidm, vielen Serpulaceen, Terebelliden), oder größer und dann in geringerer Zahl (2-4 bei Spiomilae und Ariciedac). Bei Polyophthalmus und Armandia kommen solche Augen nicht nur am Kopf, sondern auch parweise an zablreichen SegFig. 620 menten vor.

Alle solche Augen bestehen last immer aus einer Sehzelle, welche meist von einer Pigmentzelle umscheidet wirul. Nur vereinzelt (Chone, Dialychome) wurde ein mehrzelliges Auge dieser Art gefunden, das bei ersterer Gattung dem der Gnathohdelliden gleicht, bei letzterer eine Gruple ron Sehzellen ohne Pigment darstellt. - Kopfständige Augen dieser Art lï̈nnen noch im Epithel liegen (Capitelliden), meist sind sie jedoch in die Oberflähe der Cerebralganglien aufigenommen worden. 1)ie Sehzellen sind gewöhnlich einfach rumllich, selten (Segmentaugen von Polyophthalmus und Armandia) mit lingerartigen percipierenden Fortsätzen versehen (Fig. 620).

Sowohl die parigen Koptaugen ron Gphryotrocha als auch die Augengebilde der Chactopolenlarven (Trochophora)

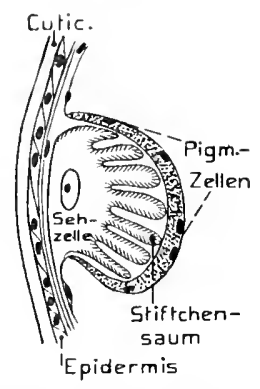

Polyophthalmus pict is (Polychate). Einzelliges firitenatige(nachHesse18.19), v. Bu. und die der Nemathelminthen (Rotatoria. freilebende Nematoden), sowie Dinoplitus dürten sol'h einfache inverse Augen sein, ähulich den im Vorstehenden beschriehenen.

Kompliziertere Kopfaugen des vorliegenden Typus treten unter den oligomeren Wïrmen bei den Chaetognathen auf (vgl. Fig. 941, S.495). Jedes der beiden Augen besteht je1orlı (Spadella. Fig. 621) aus nicht weniger als fïnf eng vereinigten linzelaugen, von wel-

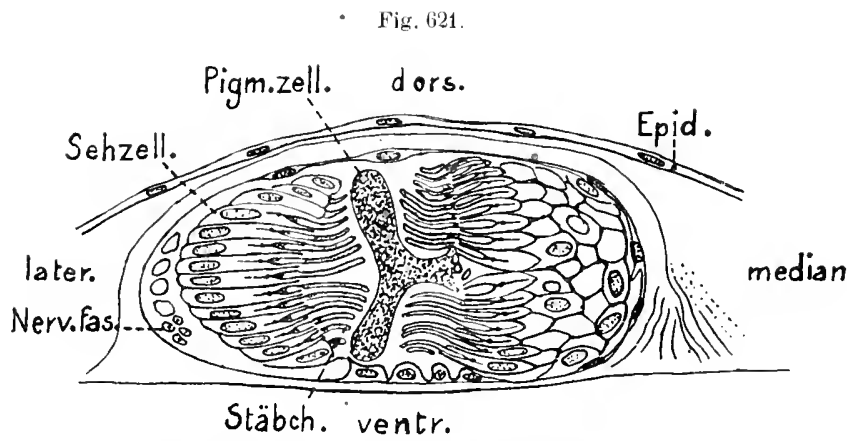

Spadella hexaptera (Chatogmathe). Auge auf einem Quersehnitt durch das Tier (uach HEsse lyo2). o. $\mathrm{B}$.

dhen das größte die laterale Augenlı̈lfte allein bildet, während die mediale Hälfte aus zwei ïbereinanderliegenden Paaren besteht. Im Centrum des Auges liegen die l'igmentzellen, welche жи einem gemeinsamen Pigmentkörper vereinigt sind, der dic distalen Regionen der Einzelangen nur unvolständig voneinander somdert. $\%$ jedem Einzelauge gehören riemiich zahlreiche, etwa cylindrische Sehzellen, die eine einschichtige Retina biluen. Ihre freien percipierenden Endén sind dem Pigment zugewendet und tragen je eiı stark lichtbrechendes Stäbchen, das sich noch eine Strecke weit in die Zelle fortsetzt (Kuanf) und in eint" Neurotibrille ausläuft. Jedes der beiden Augen wird von einer dïnen zelligen Membran umhüllt. Wie wir später (S. 873) sehen werden, erinnern die (haetognathenaugen an dis" larven- oler lintomostrakenaugen der Crustaceen. 


\section{Mollusca.}

\section{a) Converse Angen der Mollusken.}

Epitheliale Plattenangen der Lamellibranchiata. Gewisse Muscheln (Area und Pectunculus) besitzen am vorderen und hinteren Mantelrand (an der Mittelfalte, Fig. $622 \mathrm{~A}$ ) zahlreiche Angengebilde, die halbkuglig vorspringen. Ihr feinerer Bau gleicht ungemein dem der früher beschriebenen Kiemenangen der Serpulaceen (besonders denen von Sabella und Branchiomma, s. Fig. 612, S. 818).

Fig. 622.

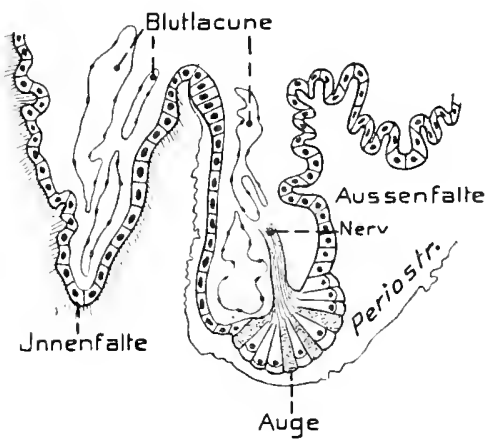

A

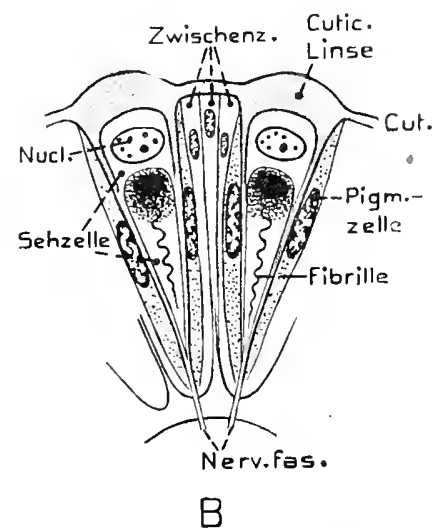

Arca noae (Lamellibranchiate.) I Querschnitt des Mantelrands mit einem Auge nach Hesse 1900). - B Längsschnitt durch 2 sehzellen, nebst Zwischen- und Pigmentzellen nach Carriers 1859 und Hesse 1900 kombiniert). v. Bu.
Wir verzichten daher anf eine genauere Schilderung und verweisen anf dic Fig. 622 .

Graben-und Blasenaugen. Offene, recht primitive Grubenaugen finden sich ebenfalls am Mantelrand gewisser Muscheln (Limaarten, bei Area am Byssusausschnitt des Mantels); sie stehen(Lima) im Gronde der Einsenkung zwischen der Außen- und Mittelfalte des Mantelrands als mehr oder weniger tiefe, becherförmige Gruben mit weiter, von Glaskörpermasse erfüllter Höble. Ihre Retina besteht aus Sebzellen, deren stäbchenartige Enden sich ein wenig in den GIaskörper erheben, und pigmentierten Zẉischenzellen, welche an der Stäbchenbasis endigen. - Nicht wenige primitivere Muscheln besitzen am Ursprung des vordersten Fadens der inneren Kiemen ein ähnliches Grubenauge (Kïmenauge). In diesen Fällen zeigt häufig jede Schalenklappe eine durchsichtige Stelle iiber dem Ange.

Den Gastropoden kommt in der Regel ein Paar Kopfaugen zu, die seltener Gruben-, meist Blasenaugen sind. Sie stehen fast immer an den Kopffühlern (bei Opisthobranchiaten und Stylommatophoren am hinteren Parr) und zwar entweder an deren Basis oder höher, bis an der Spitze (Stylommatophora). Bei den Prosobranchiaten finden sie sich meist anf einem besonderen :äußeren Fortsatz der Tentakelbasis (Augenstiel), der selten lïnger als derTentakel werden kann.

Den einfachsten Bau zeigen die Augen der docoglossen Prosobranchiaten (Patella, Fig. 623), wo sie offene Grubenaugen sind, deren Höhle von einer Mem- 
bran ausgekleidet wird, die entweder als von den Stäbchen der Sehzellen gebildet, oder als Fortsetzung der äıßeren Cuticula gedentet wurde. - Zahlreiche primitivere Prosobranchiaten besitzen noch Blasenaugen mit äußerer Öffinung Haliotidac, Pleurotomaria, Trochielar, Stomatellidae und Delphimulidae). Ihre Blasenhöhle wird von einer durchsichtigen Glaskörpermasse erfüllt. - Die Blasenaugen der iibrigen Gastropoden endlich sind völlig geschlossen und ihr Bau erinnert sehr an die geschlossenen der P'olychaeten. Wir können sie daher kurz behandeln. - Die durchsichtige dünne Epidermis vor dem Ange bildet die änßere Cornea (Fig. 624); zwischen diese und die dünne, durchsichtige Distalregion der Angenblase (innere Cornea) schiebt sich eine schwache Bindegewebslage ein. An die innere Cornea schließt sich ein uur ans pigmentierten Zellen bestehender Teil der Augenblase an (Iris), während die dickere Retina den Hintergrund der Blase bildet. Im Augeninnern findet sich eine Glaskörpermasse, welche bei zahlreichen Formen eine stärker lichtbrechende kuglige, zuweilen konzentrisch geschichtete Linse entlält, die jedenfalls aus einer Verdichtung des Glaskörpers hervorgeht.

Derartige Augen können auch mehr oder weniger rückgebildet sein, was bei Opisthobranchiaten nud Pteropolen, aber auch sonst zuweilen vorkommt, indem sie klein werden und die Sehzellenzahl beträchtlich abnimmt. Sic liegren häutig tiefer unter der (t)erllache. Verbünmerung der Augen tritt anch bei grabenden. subterranen und Tief'seegastropoden, sowie natürlich auch bei den Parasiten anf.

Die Retina besteht immer aus Seh- und Zwischenzellen,

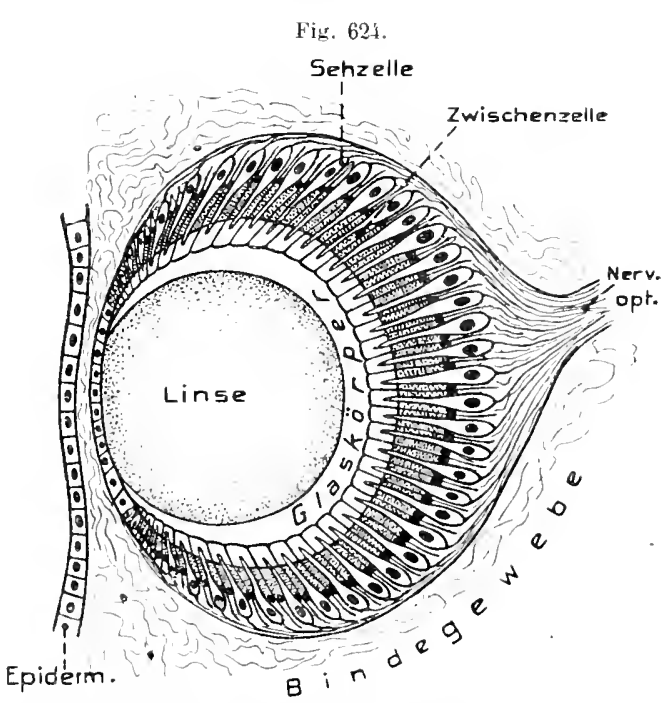

Schema eines geschlobuen blasenauges einer prosobranchiate (etwa Murex). (Jgl. Hilger 1845.) y Bu. 
die beide pigmentiert sein können; häufig beschränkt sich das Pigment jedoch anf die Zwischenzellen, seltener sollen nur die Sehzellen pigmentiert sein. Der zu-

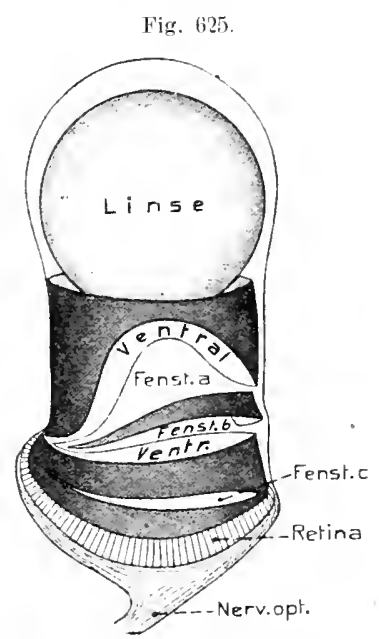

Jerotrachea coromata (Hete ropode). Reclites Auge von der Dor silseile (nach HFsse 1900). V. liv.

Fig. 626

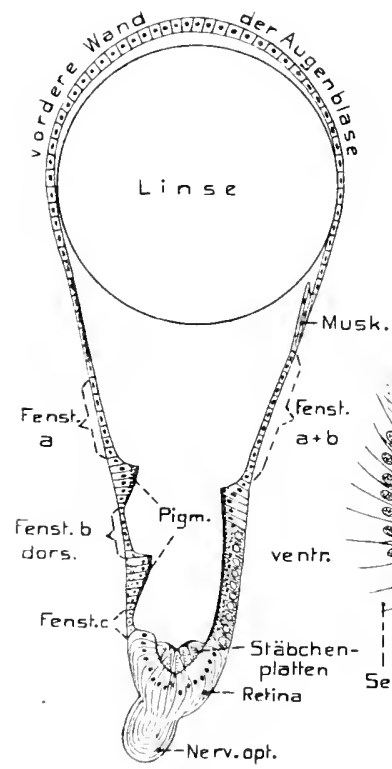

A

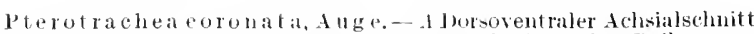
lureh ein Auge. - $b$ loie lietina mit den horizontalen Reihen von stäbchenplatten in Flächenansichıt. - f Der burchschnitt cler Retina in derselben Ansicht wie Figur A, slärker vergrößert (A nach HESsw

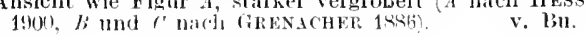

weilen faserige Glaskörper ist ein Produkt der Zwischenzellen.

Besondere Größe und einen sehr eigentümlichen Bau erlangen die Augen der pelagischen Heteroporten (Fig. 544, S. 751). Sie liegen ziemlich tief nuter der Haut und zwar jedes in einem besonderen Blutraum, der von einer bindegewebigen

- Hülle umschlossen wird. Von der Wand dieses Raums treten einige Muskeln zn verschiedenen Stellen der Alugenblase, welche daher recht beweglich ist. Die Form der Blase erscheint wegen ihrer kegelartigen Verlängerung in der Augenachse sehr eigentiimlich (s. Fig. 626) nnd erinnert an die der Trlestiopangen der Tiefseecephalopoden und -fische, sowie an das Vogelange. Die distale Blasenregion umschließt die ansehnliche kuglige Linse eng und springt daber selbst kuglig gewölbt vor; der darauf folgende Teil der Blase dagegen ist dorsoventral stark abgeplattet. Die Retina, welche den proximalen Grund der Augenblase einnimmt, erscheint daher quer bandförmig (Fig. $626 \mathrm{~B}$ ). Die mittlere, stark pigmentierte Blasenregion (Pigmenthant, märetinulüre Memlrane) zeigt meist die Eigentümlichkeit, daß das Pigment streckenweise fehlt, wodurch in ihr ein bis zwei fensterartige seitliche Zutrittsstellen fïr das Licht entstchen.

Die schmal bandförmige Retina ist sehr eigentümlich gebaut, indem sich ihre Zellen in 
eine Anzahl etwa parallel ziehender Liingsleisten erheben (Fig. $626 \mathrm{Bu}$ u. $C$ ); dieselben werden dadurch gebildet, daß einige Reihen von Seluzellen verlïngert sind und ihre Distalenden gleichzeitig gegen die Medianebene des Anges umgebogen erscheinen, sodaß die Enden dieser Zellen annähernd parallel der Augenachse iibereinanderliegen (Fig. 626 C). Das Distalende dieser Sehzellen trïgt eine Anzahl feiner Blättchen, die wohl zusammen einem stäbchenartigen Gebilde entsprechen. Ua nun die Sehzellenenden in jeder Leiste eine senkrecht ïbereinanderstehende Reihe bilden, liegen diese Plättchen anch in entsprechenden Reihen übereinander und sind mehr oder weniger verwachsen, weshalb die Plättchen einer Reihe in ihrer Gesamtheit anch als zusammengesetzte Stäbchen (Rhablome) gedentet wurden. Die funktionelle Bedentung der Retinaleisten hat man deshalb auch so aufgefaßt, daß sie ein gleichzeitiges Sehen von Punkten ermöglichten, die sich in verschiedener Entfernmng vom Auge befinden. - Sowohl in der eigentlichen Retina als der Pigmentregion des Auges kommen zahlreiche Ganglienzellen vor, deren Bedentung vorerst wenig sicher erscheint. — Ije Sehzellen führen in ihrem Distalende reichlich Pigment, wogegen die faserartigen Zwischenzellen (Limitansacllen, Fig. $626 \mathrm{C}$ ), welche zwischen den Retinazellen vorkommen, unpigmentiert sind; sie scheiden eine stellenweise ziemlich dicke Membran ab, welche die Retinaleisten ïberdeckt (Membr. limitans); doch soll auch Bindegewebe zwischen die Retinazellen eindringen. Der Glaskörper ist feinfaserig.

Eine sehr eigenartige Bildung indet sich bei den mit Fensterbildung versehenen Augen, nämlich nicht pigmentierte Nebensehiellen. Diese sind zwischen den Pigmentzellen der Pigmenthaut verteilt, namentlich an den stellen. welche, den erwähnten Fenstern gegenüberstehen, wo sie Nrbenretinac bilden. Da die linse und die Angenachse oral gerichtet sind, so köunten diese Nebenretinae namentlich dorsal und rentral zutretendes Licht percipieren. - Eine analoge Nebenretina wurde

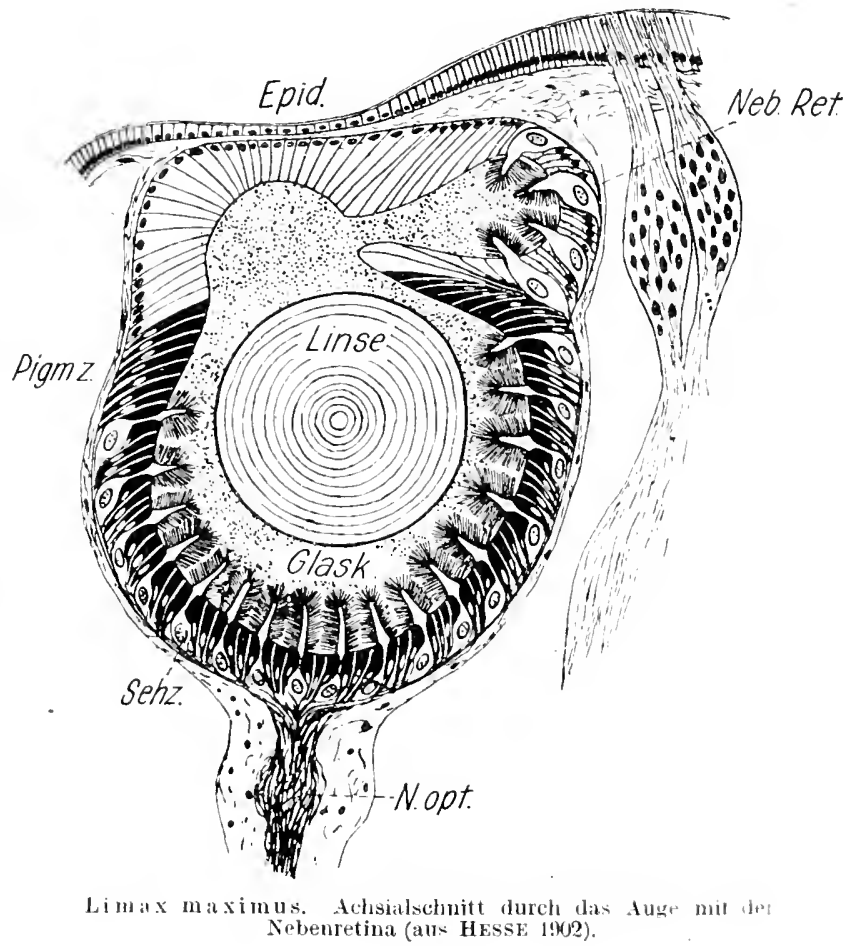


bis jetat unter den Mollusken nur bei einer Pulmonate (Limax maximus, Fig. 627) angetroffen, wo sie sich in einer besonderen nach vorn und rentral gerichteten, pigmentfreien, grubenförmigen Ausbuchtung der Augeriblase findet, etwa auf ler Grenze zwischen Iris und innerer Comea (vgl. auch das Alciopidenauge, S. 820).

Cephaloporten. Die ebenfalls zum Blasentypus gehörigen Cephalopodenangen sind anffallend groß, weshalb sie (besonders bei den Dibranchiaten) einen sehr ansehnlichen Teil des Kopfes bilden; sehr selten werden sie rndimentär (so Cirrothauma).

Die Nautilusangen (Fig. 628, vgl. auch Fig. 31, S. 105 n. Fig. 499, S. 699) bleiben viel primitiver als jene der Dibranchiaten, da sie, wie erwähnt, offene Blasenaugen darstellen, welche sich an den Kopfseiten auf einem kurzen Stiel

Fig. 628.

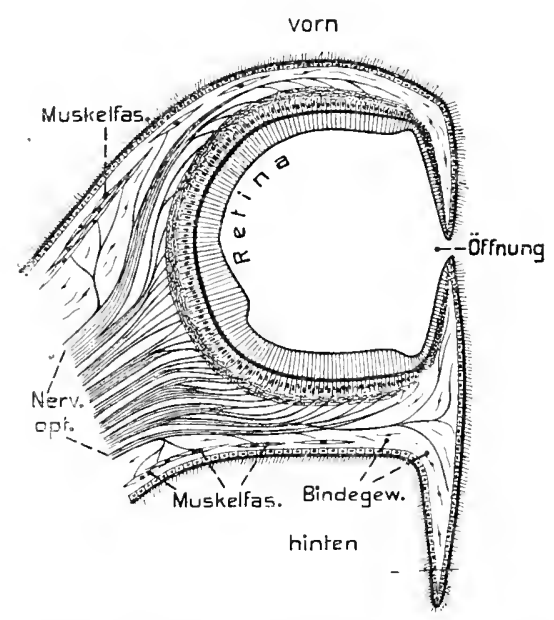

Nautilus, Auge. Schematischer Achsialschnitt (nach HExsex aus brom, hl. und Ordn.). v. Bu. frei erheben. Die distale, etwa dreieckige Angenfläche ist eben und zeigt in ihrem Centrum das kleine Einstïlpnngsloch; von ihm geht eine Himmernde Rinne nach dem Analrand dieser Fläche. Die etwa halbkuglige innere Angenhöhle enthält keinen Glaskörper, ist vielmehr von Meerwasser erfüllt. Ihre Distalregion wird von pigmentiertem Flimmerepithel mit einzelligen Driisen ansgekleidet, die proximale Wand dagegen verdickt sich ansehnlich zur Retina. - Die Erzengung eines sehr lichtschwachen Bildes könnte in diesem Auge daher nur mittels der etwa $1-2 \mathrm{~mm}$ weiten öfinung geschehen.

Im Gegensatz zu diesen einfachen Verhältnissen bei Nautilus erlangt das Dibranchiatenatge (Fig. 629) einen sehr komplizierten Bau, welcher dem des Vertebratenanges gleichkommt. - Die durch Einstïlpung des Ectoderms gebildete große Angenblase schließt sich von der Epidermis vollständig ab, doch bleibt ihre dünne Distalwand in naher Berührung mit ihr. Die Blase wird von einer mesodermalen Hülle umschlossen, die jedoch zwischen ihrer Distalwand und der Epidermis sehr dünn bleibt. Um den übrigen Teil der Blase erlangt sie eine ansehnliche Stärke (hier znweilen Chorioidea genannt) und entwickelt sogar eine mittlere Knorpelschicht, die besonders in der äquatorialen Blasenregion stärker wird (Äquatorialknorpel). Die proximale Blasenwand bildet die sehr dicke Retina, deren Mitte sich das früher (Fig. 385, S. 531) erwähnte mächtige Ganglion optienm dicht anlegt und seine Nervenfaserzïge durch die bindegewebige Hülle zur Retina sendet. Die Augenblase samt dem Ganglion opticum lagern sich in die früher geschilderten seitlichen Aushöhlungen (Orbiten) des Kopfknorpels ein (Fig. 70, S.164). 
und werden bei gewissen Formen auch durch den Augendeckknorpel geschïtzt. Das Innere der Angenblașe ist von wäßriger Fliissigkeit erfüllt.

Die Distalwand der Blase verdickt sich zu einer ansehnlichen Linse von eigentümlicher Beschaffenheit. Wie erwähnt, liegt die distale, sehr dünne Blasenwand der ebenfalls dünnen Epidermis dicht an, indem sich ursprïnglich nur eine zarte Mesodermlage zwischen beiden befindet. Im Umkreis dieser Region verdicken sich die beiden Epithellagen, nämlich die der Blasenwand, sowie das Ectoderm durch Bildung von Radiärfalten ansehnlich zn einem ringförmigen Wulst (Corpus epitheliale, ('orpus ciliare), welcher sich am Linsenäquator befestigt, so daß dieser am Corpus epitheliale gewissermaßen aufgehängt er-

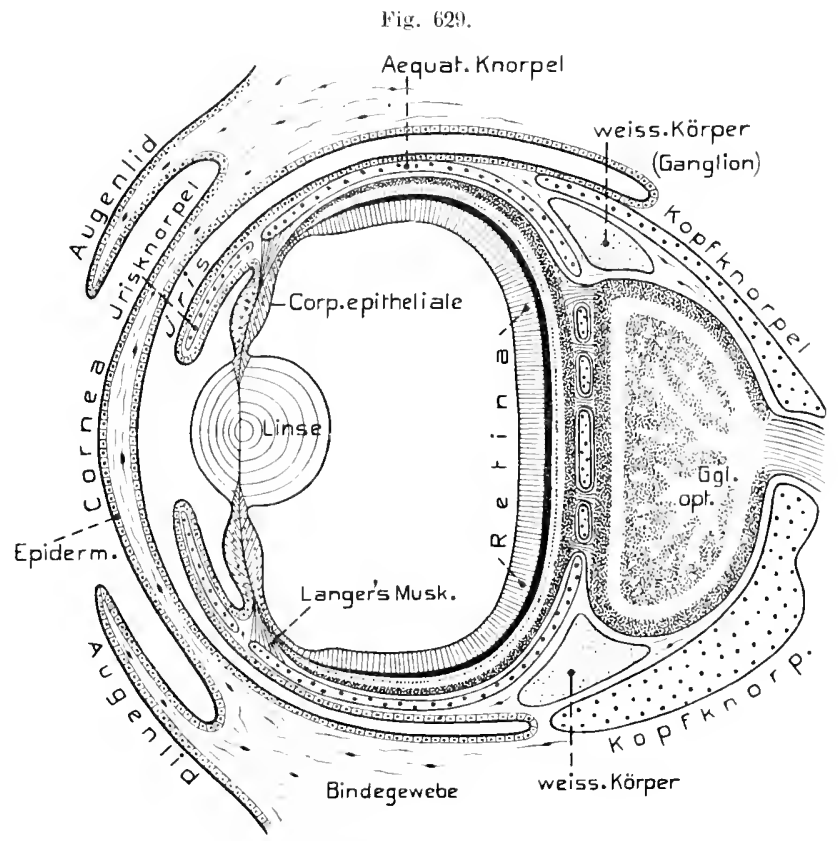

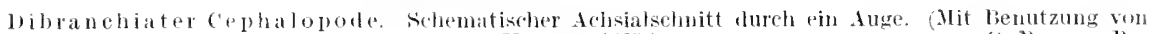
HEXYEX 1N65.)

scheint. Es läßt sich also am Epithelkörper ein :̈ußerer (epidermaler) und ein innerer (ans der Angenblase hervorgehender) Teil unterscheiden, welche beide durch eine dïnne Bindegewebsscheidewand getrennt werden. Diese Scheidewand setzt sich als faseriges, dünnes Septum durch die ganze Linse fort und sondert sie in eine klcinere distale und eine größere proximale Hälfte, welche sich gegenseitig zur Kugel ergänzen. - Die Linsensubstanz selbst besteht aus feinen Fasern von cuticularer Beschaffenheit, die sich in konzentrischen Lotmellen anordnen. - Die Ontogenie lehrt num, daß diese Faseln durch Auswachsen der Epithelzellen des Corpus epitheliale entstehen, und zwar die des :iußeren Linsensegments ans dem epidermalen, die des inneren aus dem inneren oder Blasenteil 
des Corpus. Bei der Linsenbildung ziehen sich die Epithelzellen aus der Linsenregion auf das Corpus epitheliale zuriick, weshalb das Linsenseptum, wie bemerkt, nur von dem zarten Bindegewebe zwischen Epidermis und Augenblase gebildet wird. Am Corpus epitheliale vermehren sich die Linsenfasern bildenden Epithelzellen der beiden Lagen sehr bedeutend, weshalb sie sich zu den radiären Falten einstülpen, welche auf der Proximalfäche des Corpus auch oberflächlich hervortreten.

Im Umkreise des Distalrands des erwähnten Corpus epitheliale erhebt sich die äußere Körperhaut zu einer ringförmigen pigmentierten Falte, der Tris, welche sich ïber die Linse legt und in ihrem Centrum eine bei verschiedenen Formen etwas verschieden gestaltete öftnung, die Pupille, of̉en läßt. Im Unkreis der Irisfalte bildet sich dann eine zweite Ringfalte der Haut, welche sich iiber die Iris lagert und entweder weit geöffinet bleibt (Oigopsidae) oder nur eine enge Öffnung besitzt, ja auch zuweilen völlig geschlossen ist (Myopsidae). Letztere Hautfalte, welche, soweit sie die Iris und Pupille überdeckt, durchsichtig bleibt, wird nach Analogie mit dem Wirbeltierauge als Cornca bezeichnet. Die Einfaltung der Haut zwischen Iris und Comea stïlpt sich sehr tief, ja tiefer als die eigentliche Angenblase ins Körperinnere ein, weshalb sich an dem Auge eine durch diese Faltenhöhle gesonderte innere und äußere Kapsel unterscheiden lassen.

Weitere Bildungen bewirken noch besondere Komplikationen. - So kann durch eine dritte im Umbreis der Cornealfalte sich erhebende Falte eine Art Augenlid gebildet werden, welches das Auge teilweise oder vollständig kreisförmig (besonders Octopoden) umzieht. - Nach außen von der Knorpelschicht der inneren Augenkapsel findet sich eine Iuskellage; ancl die äußere Augenkapsel ist muskulös. Ferner entspringen vom I)istalrand des Äquatorialknorpels radiär Muskelfaserı (langerscher Muskel), die zum Corpus epitheliale ziehen. Sie dienen zur Accommodation, indem sie bei ihrer Kontraktion den binter der Linse gelegnen Bulbusraum verkleinern, wobei die intraoculare Druckerhähung die Linse etwas nach vorn schiebt, also für die Näle einstellt. In der Ruhe ist nämlich entgegen friblerer Meinung. das Auge fern- oder schwach weitsichtig. Außer diesen Muskelfasern sind noch ringförmige und schiel verlautende vorhanden. - Die Ir is ist ebenfall mit ringfömigen, zur Verengerung der Pupille dienenden Muskelfasern (Sphincter) versehen. Endich enthält sie auch Knorpel, sowie zwei silherglänzende Häute (Argentea crterna und interna), die sich bis tief in dis Bulbuswand hinab erstrecken. - In des Ungebung des Ganglion opticum findet sich eine weiße, drüsenartig erscheinende Masse (weißer Körper), die einen nicht nnbeträchtlichen Teil des Bulbus bildet und neuerdings als ein accessorisches Ganglion, zur Versorgung der Bulbuswand, gedeutet wird (zu diesem Ganglion begeben sich die Nervi optici inferior und superior, s. Fig. 384, S. 530). - Bhntgefäße beteiligen sich reichlich am Aut'bau der Bulbuswand. ja bei den Dibranchiaten ist sogar die Basalreoion der lietina gefäßreich.

Der Ban der Cephalopodenretina erscheint ziemlich kompliziert, weshalb er nur in Jen Grundzügen angedentet werden kann (Fig. 630). Die Netzhant ist sehr dick, aber doch nur eine einschichtige Lage holıer Zellen. Diese sind zweierlei Art: Sehzellen und Zwischenzellen (Limitanszellen). Letztere erzengen an ihren Distalenden eine die Augenhöhle begrenzende, ziemlich dicke Membrana limitans, wogegen die proximale Grenzfläche der Retina won einer zartesi Basalmembran umschlossen wird. Bei Nautilus (Fig. 6330 A) stützen sich die Bas'n beider Zellarten auf liese Basalmembran; bei den Dihranchiaten 
hingegen wachsen die Proximalenden ler sehzellen durch die Basalmembran proximal himdurch in das angrenzende Bindegewebe, wher es kommt, daß Bindegewebe mit Blutgefäßen in die Basalregion der Retina gelangt (Fig. 630.B). Die Sehzellen und Limitanszellen ron Nautilus sind in ihrem Proximalteil pigmentiert; da, wo das Pigment aulhört. lindet sich eine feine Grenzmembran, welche die basale Renion der Retina von der listalen oder stähhenregion abgrenzt. Hie allein pigmentierten Sehzellen der Jibranchiaten (rig. $B$ )

Fig. 630.

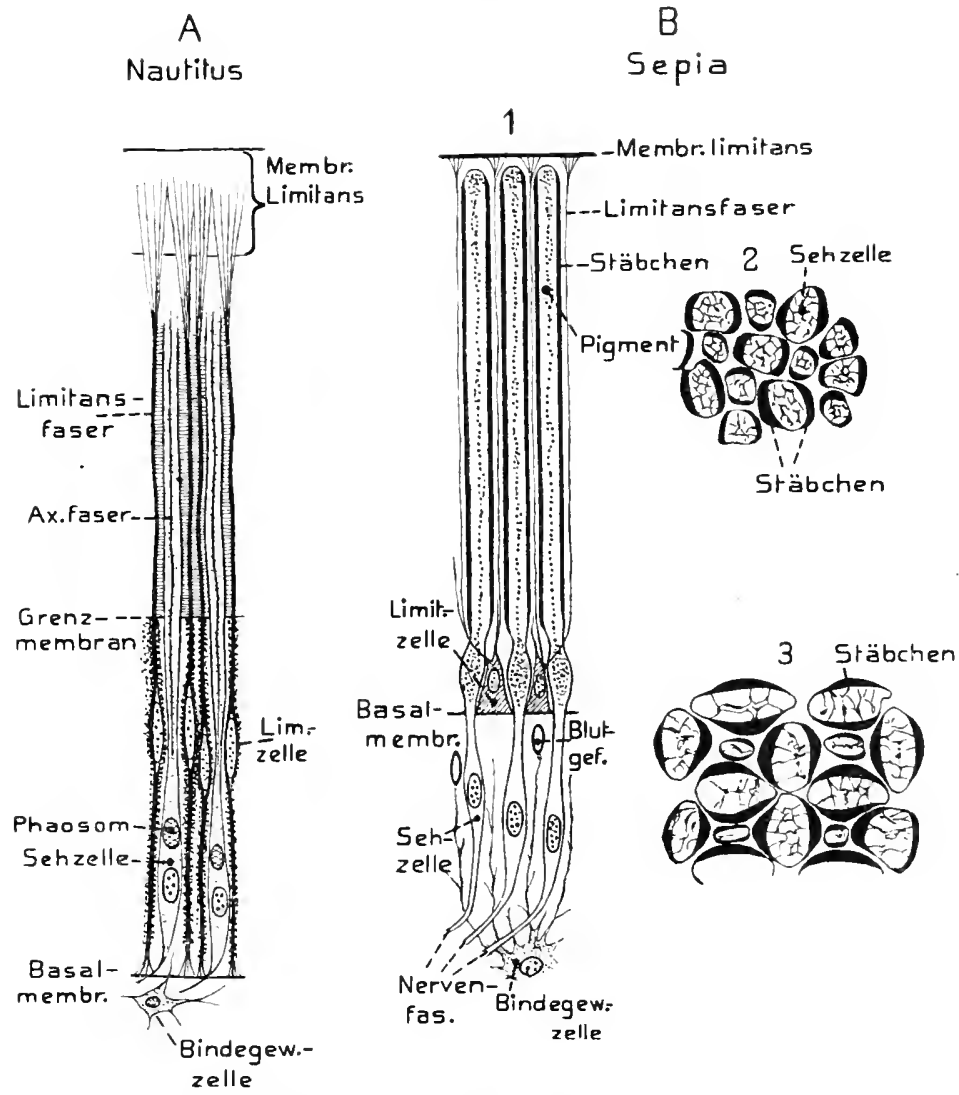

Retina von c'ephalopoden. I Tautilus, Länesschnitt lurch einge seh- mel limitanszellen. - $B$ Dibranchiata: $b^{1}$ Längsschnitt durch einige gels- und Limitinszellen von Sepia officinalis : $b^{* 2}$ u. $B$ : Querschnitte durch die Stäbchenregion von Eledone moschata: $B^{2}$ durch tie proximale, $B^{3}$ durch die mittlere Region (nach MerTon 1904).

․ Bi1.

zeigen das Eigentiimliche. laß sie sich distal von ler Basalmembran spindelförmig verdicken (sog. Stribchensochel). liei Nautilus dagegen setzen sich die Sehzellen als fadenartige plasmatische Gebille his nahe an die Limitans fort. - Die Limitanszellen von Nautilus enthajten eine bis einige Fasern von jedenfalls stützender Funktion; in der Stäbchenregion der lietina scheint das Plasma der Limitanszellen zu einer Art Zwischensubstanz zu verschmelzen, während die Limitansfasem diese substanz durchsetzen und sich distal, an ter Limitans, in ein Faserbüschel zerspalten. - Den Dibranchiaten fehlt eine soluhe Zwischensubstanz in der Stäbchenregion; die Sehzellen liegen vielmehr hier sehr dicht zusammen. Jie Limitanszellen bilden aber atuch hier einige Fasem, welche. sich distal rerzeigeml. 
zwischen den Selzellen autsteigen und wahrscheinlich gleichlalls bis zur Limitans ziehen. - Besonders charakteristisch für die Dibranchiaten ist, daß jeder langgestreckte Stäbchenteil einer Sehzelle zwei etwa rinnenfümige, sog. cuticulare Stïbchengebilde hervorbringt (Fig. B, 2 u. 3), wobei sich gewöhnlich vier solcher Stäbchenrinnen der vier aneinandergrenzenden Sehzellen so zusammengruppieren. daß sie auf dem (gnerschnitt eine etwa viereckige Figur bilden (Fig. B. 3). - In der Retina gewisser Dibranchiaten (z. B. Sepia) wurde ein querer Streif beobachtet. inmerhalb lessen die Stäbchengebilde feiner und länger sind; bei gewissen Tiefseeformen dagegen eine äuliche grubenartige Stelle. Wie bei Wirbeltieraugen werden diese Stellen als solche schär'sten Sehens beurteilt. - Vorwanderung des Pigments in die distale Region der Retina im belichteten Auge wurde bei Dibranchiaten erwiesen.

Jie Augen gewiser Tiefseedibranchiaten sind ähnlich wie jene des Nautilus gestielt (Fig. 631) und einige (xattumgen von Tiefseeuctopoden besitzen kegelfürmig verlängerte Trleskopangen, wie wir sie schon bei den lleteropoden kennen lernten (S. 828).

Plarophora. Kurz erwälnen müssen wir die eigentümlichen Rückenangen, die in großer Anzahl auf Jen Schalenplatten gewisser Placophoren (Sublamilien Tonicionae, Liliophorinae und Chitominar) vorkommen. Diese Organe sind interessant. weil sie sich deutlich als teilweise oder vollständige Umbildungen der Ilautsimesorgane (Megalaestheten) dar-

Fig. 631 .

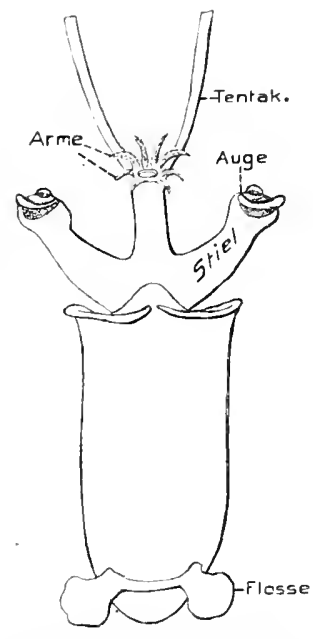

fiat hot ha uma lyom ma. (Tietseecephalopode.) Iorsalansicht (nach CHUN 19tU).

(). 13 stellen. Welche wir in den Schalenplatten der Placophoren verbreitet fanden (S. 656). - Ein solches Auge (Fig. 459, S.656), welches aus der Umbildung einer Megalaesthete entsteht (auch extrapigmentäres Auge genannt) besitzt etwa den Charakter eines mehr oder weniger eingesenkten Gruben- bis Becheranges. das in der äußeren lage der Schalenplatte (sog. Teymentum): dicht unter der äulseren Oberfläche liegt. Iie Höhlung des Bechers wird von einer Linse teilweise erliillt, die wie die Schalemplatte verkalkt ist und von einer oder werigen Epidermiszellen. ahnlich wie die Kalkstacheln der Placophoren, abgesondert wird. $\ddot{A}$ ußerhich ist die Linse vom Periostracum iiberzogen. Die Becher- oder Grubenwanl (Retina) besteht aus liurz cyhudrischen Sehzellen, die sich proximal in Vervenlasem fortsetzen. Letztere verlaufen als cin Faserbindel durch die Röhre, welche das Tegmentum oder auch das Articulamentum durchsetzt und bis zur damnter liegenden kpidermi- reicht. Außerdem finden sich in der lietina moch sehr schmale Zwischenzellen, die sich in das riillgewebe fortsetzen (net»firmig verästelte Zellen ectodermaler Herkunft. welche die eben erwähnte Röhre erfüllen). Die wandstimkigen Fiilzellen bilden Pigment, welches das Tegmentum im Umfang des Auges lärbt und seitlichen Liclutzutritt verhindert. lije l)istalenden der vorhin erwähnten Zwischenzellen erweitern sich an der distalen Retinalnäche heträchtlich und sondern hier einen fein radiärfaserigen lilaskörper ab, der sich zwischen hinse und lietina einschiebt.

Die kleinen Augen. auch intrapigmentäre Augen genannt, welche nur aus einem 'Teil einer Megalaesthete hervorgehen (einzelne Callochiton und Chiton), bilden sich seitlıch an den llegalaestheten herror, höher oder tiefer, indem einige von deren Sinneszellen zn Sehzellen werden. Letztere lagern sich als pigmentierte Zellen unter ein linsenartiges Gebilde, das aus dem Tegmentum hervorgeht (Callochiton), oder als mupigmentierte Sehzellen unter eine linse, welche das Absondernngsprodukt einer besonderen Zelle ist. Die let\%terwähnten Augen werden von cinigen pigmentierten Füllzellen umlagert. Win Glaskörper fehlt den kleinen Augen vïllig. Alle Teile der lïichenaugen der Placophoren gehen dem- 
nach aus der Epidermis herror. und beim Wachstum treten fortgesetzt neue Augen an den Seitenr̈̈ndern der Schalenplatten aut.

\section{b) Inverse Angen der Molluskell.}

a Lamellibranchiata. Invertierte Augen von ziemlich hoher Ausbildung kommen am Mantelrand gewisser Lamellibranchiaten ror und zwar an den Enden eines Teils der tentakelartigen Gobilde, welche sich an diesem Ort meist finden. Bei Pectiniden und Spondyliden sind sie am besten ausgebildet und am ganzen Mantelrand entwickelt, jedoch gewöhnlich von recht verschiedener Größe. Ihre Zahl ist an beiden Mantelrïndern manchmal recht verschieden, indem sich bei Pectiniden, welche mit der rechten Seite festgeheftet sind, am rechten Mantel viel weniger oder keine finden. - liei gewissen Cardiumarten. (Carlium muticum und edule) tragen die Tentakel in der Umgebnng der Siphonenöflnungen Augen von ähnlichem Typus.

Diegenauest bekannten und hoch entwickelten Pertenaugen seien hier zunächst erwähnt (Fig. 632). Das an der 'Tentakelspitze liegende Ange geht aus einer

Fir. 632

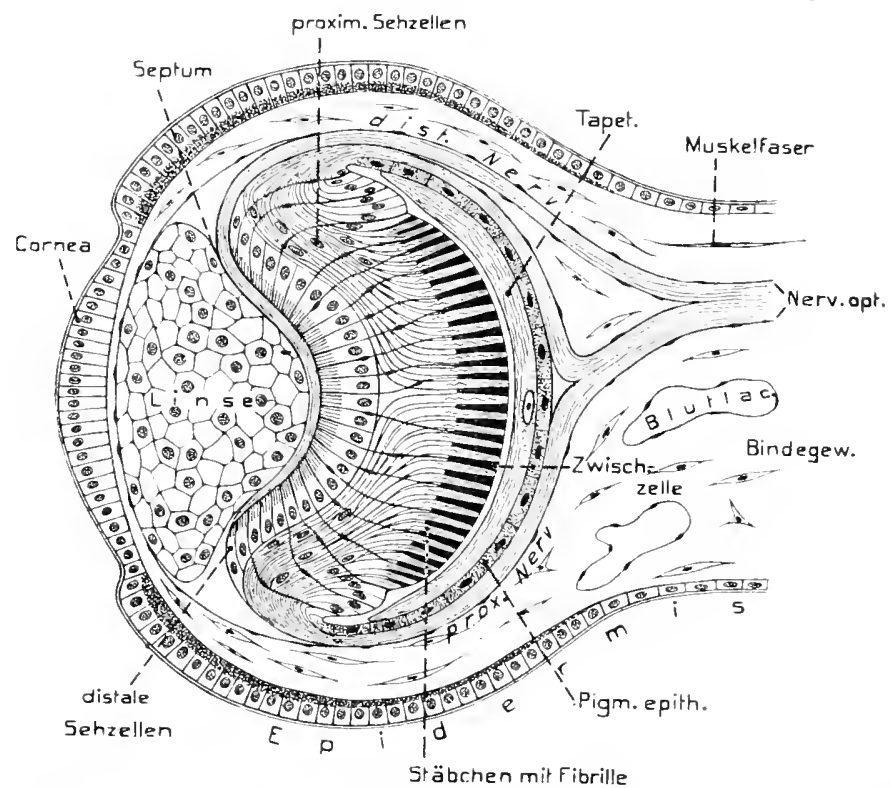

pecten. Ein In anfelrandauge im Achsialschnitt. Schematisch. Zum Teil nach Hesse 190 und B(tKCHLI 1646 kombiniert.)

O. B. u. v. Bu.

Angenblase hervor, welche durch Einstiilpung des Ectoderms entsteht und sich völlig abschniirt. Indem distal von der Blase, durch Vermehrung der Epidermiszellen eine zellige Linse entsteht, wird die distale Blisenwand zu einer dicken und urspriinglich jedenfalls rein imersen Rrtina, während die sehr dümn bleibende proximale Wand ein flaches I'igmentepithel bildet. Im Bereich der Linse bleiht 
die Epidermis durchsichtig (sog. Cornea), während sich die angrenzende Epidermis, im Umfang der Augenblase, pigmentiert und seitliches Licht abhält. Die Linse des erwachsenen Anges besteht aus zahlreichen rundlichen bis polygonalen Zellen und liegt der nngefähr schïsselförmigen Retina dicht an; doch schiebt sich zwischen beide ein bei Pecten nichtzelliges, bei Spondylus zelliges, diinnes Septum. - Die Netzhaut erscheint sehr eigentïmlich, da ihre distale Region von einer Lage cylindrischer Zellen gebildet wird, die einen distalen, längsgestreiften, stäbchenartigen Saum tragen, welcher sich also gegen die Linse richtet. Diese Zellen werden deshalb als distale Sehzellen gedeutet, obgleich ihre Verbindung mit Nervenfasern noch etwas unsicher ist. Zu dieser Zellenlage gesellt sich proximal eine viel höhere, die aus langgestreckten fadenförmigen Sehzellen besteht, welche von der randlichen Peripherie der Retina ausgehen und, gegen deren Centrum ziehend, invers umbiegen. Ihregegen den Angenhintergrund schauenden freien Enden sind zu plasmatischen stïbchenartigen Gehilden entwickelt, die eine achsiale Fibrille entbalten.Die Ontogenie erweist, daß diese proximale Sehzellenlage vom Rand der urspriunglichen lietina über die distale Zellenlage allmählich herüberwächst, was mit dem fertigen Bau gut ïbereinstimmt. Zwischen den proximalen Sehzellen liegen Zwischenzellen, welche sich auch zwischen die distalen Sehzellen erstrecken.

Diese Zwischenzellen sollen nach einer der Auffassungen ebenfalls Sehzellen sein, die sich in die Zwischensubsian zwischen den Stäbchen erstrecken und sich mit dem distalen Nerv verbinden. Es ist aber doch recht nnwahrscheinlich, daß das Pectenauge dreierlei Sehzellen besäße.

Dic Nerven, welche zu den Augen treten, sollen direkt vom Visceralganglion ausgehen, nicht vom Mantelrandnerv, wie früher angenommen wurde. I as zntretende Nervenästchen teilt sich dicht am Ange in zwei Zweige; der eine zieht um das Auge herum und breitet sich auf der distalen Retinatläche unter dem Septum aus; seine Faseln sollen sich mit den distalen Sehzellen und Zwischenzellen verbinden; der andere Zweig verbreitet sich am Rand der lietina und steht mit den proximalen Sehzellen in Verbindung.

Zwischen Pietina und Pigmentepithel findet sich eine dïnne, metallisch (rötlich bis blau) reflektierende Lage (Taprtum), die von einer einzigen Zelle gebildet werden soll.

Demnach besiißen die Angen der Pectiniden und Spondyliden insofern einen sehr eigentümlichen Charakter, als sie zwei Sehzellenlagen enthielten, eine converse und eine inverse. Daß aber die converse Bildung der distalen Lage anf nachträglicher Umlagerung (Reversion) der Zellen beruht, dürfte wohl sicher sein.

Die Cardiumaugen sind ron ähnlichem Typus, jedoch einfacher gebant, besonders bei Cardium edule; wo aher wohl Verkümmerung vorliegt. Cardium muticum (Fig. 633) zeigt eine Augenblase, deren Instalwand eine viel einlachere Retina bildet, da ihr die distale conrerse Sehzellenlage fehlt, wenn man nicht ihren Vertreter in einer Masse radiärer durchsichtiger Zelten suclien will, lie sich ats sog. Glaskörper zwischen Linse und Retina einschaltet; doch ist dies wenig wahrscheinlich. Die lietina läßt Seh- und Zwischenzellen deutlich erkennen. Ein Hauptuntershied von den erstbesprochenen Augen besteht darin, daB bei Cardium muticum las l'jgment, welches die Augenblase umhïllt. nicht in der Epidermis 
liegt, sondern in einer unter ihr betindlichen Zellenlage. welche also wohl den Mesolerm angehoirt; wogegen es sich bei C'arlium ellule so verhält wie bei Pecten, aber weniger ausgerlehnt ist. Ein wahscheinlich bindegewebiges 'lapetum unterlagert die Proximalwand der Augenblase (die sog. Chorioidea).

Oncidiidae. Die eigentïmlichen inversen lückenaugen der pulmonaten Oneidiiden (Fig. 634) gehören einem ganz anderen Typus an: sie sind jedenfalls nicht ans Augenblasen herrorgegangen. Sie verbreiten sich über den Rücken dieser Pulmonaten, wo sie in Gruppen ron etwa 1-6 auf Ilautpapillen stehel, und können mehr oder weniger aus- und eingestülpt werden, wozu besondere Muskeln dienen. Jedes Auge besteht aus eiver Cornea, d, h. der durch-
Fig. 633 .

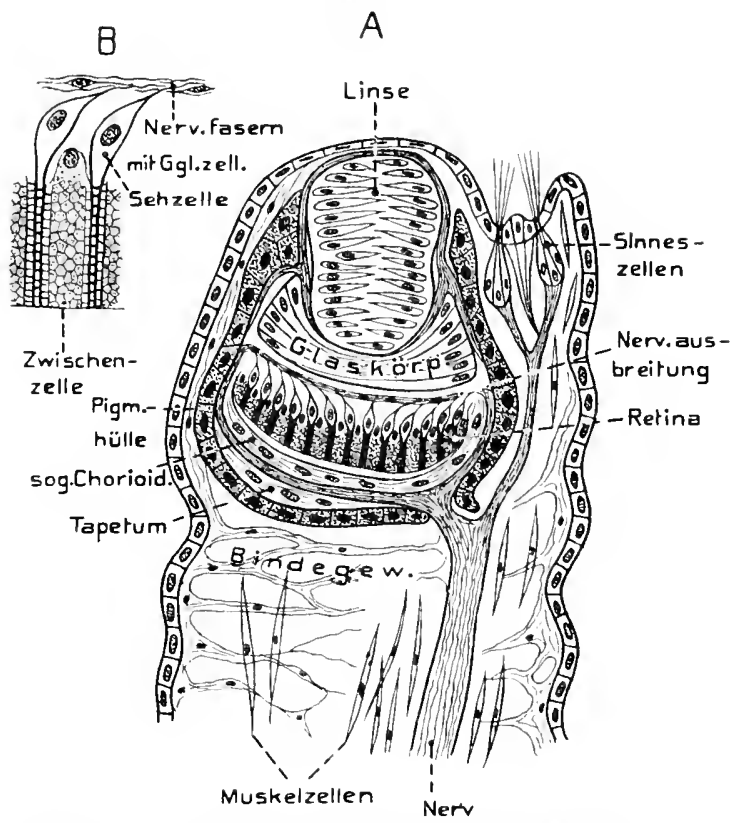

Cardium muticum (Lamellibranchiate). A Medianer Längsschuitt durch einen angentrageuden Siphonaltentakel. $-B$ Ein kleiner Teil der Retina stärker vergrößert (nach ZUGMAYER 1904). v. Bu. Fig. 634.

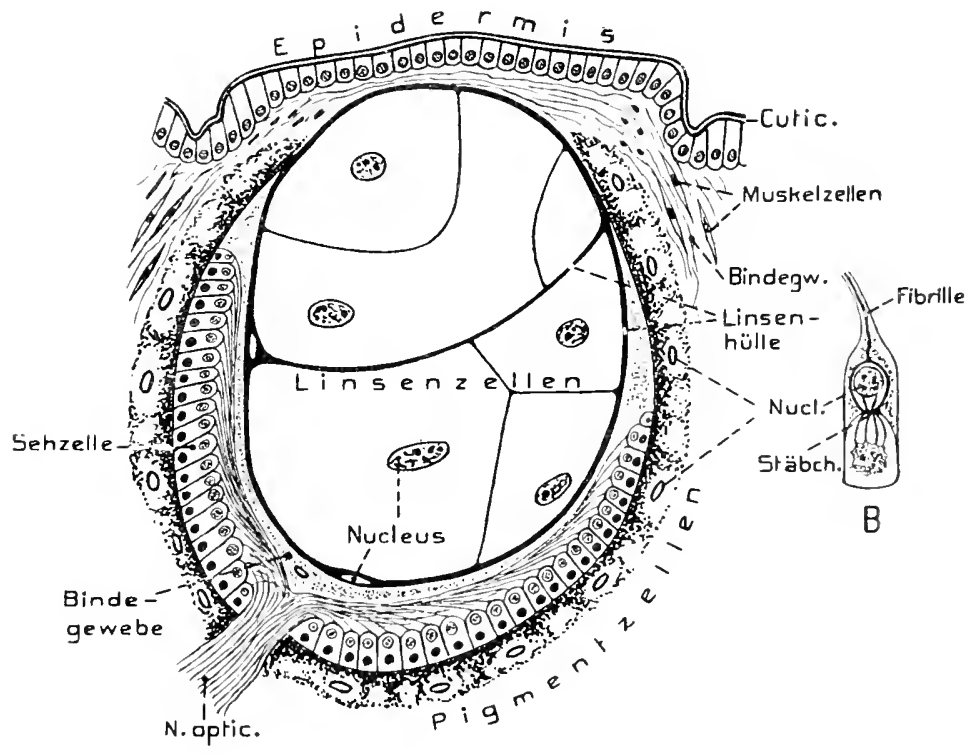

A

Oncidium verruculatum. I Achsialschnitt durch ein Rückenauge. $-b$ Eine Selızelle stärker vergröBert (nach STANSCHINSKY 1908). 
sichtigen Lipidermis über ihn; ferner einer linse, welche von einer bis zahlreichen großen durchsichtigen Zellen gebildet wird, deren Zahl selbst bei derselben Spezies variieren kaun. I) Linse wird proximal von einer Retina umfaßt. die bei den gut entwickelten Augen ans einer einschichtigen Lage inverser cylindrischer Selzellen besteht, und diese Retina wird ihrerseits wieder von einer Pigmentzellenlage umbüllt. Der Sehnerv tritt durch den proximalen $\mathrm{P}_{0}$ der Pigmenthülle zur Retina, um sich zwischen letzterer und der Linse auszubreiten, so daB der inverse Charakter klar herrortritt. - Bei yewissen Arten ist jedoch die Retina sehr unregelmäßig gebaut, indem sie aus polygonalen, mehr- bis vielschichtig übereinandergelagerten Sehzellen besteht, was solche Augen denen der gnathobdelliden Hirudineen ähnlich erscheinen läßt. Wahrscheinlich dürften die Oncidienaugen auch ähnlich jenen der Błutegel entstanden seiı, nämlich durch Zusammengruppierung einzelner, aus dem Ectoderm eingewanderter Sehzellen, während die Linsenzellen vermutlich aus mesodermalen Schleinzellen hervorgehen, und sich die Pigmenthülle von l'igmentzellen ableitet, welch beide Zellformen im llautbindegewebe zahtreich vorkommen.

\section{Chordata.}

Für die typischen Augengebilde der Chordaten gilt als gemeinsamer Claarakter, daß sie ans dem Hirnteil des eingestïlpten Nervenrohrs hervorgehen. In Einzelnen läßt sich jedoch zurzeit ein Vergleich zwischen den Augen der Tunicaten und Vertebraten kaum durchführen, obgleich dies mehrfach rersucht wurde.

\section{5a. Tunicata .}

Nur bei verhältnismäßig wenigen Formen sind Sehorgane mit Sicherheit erwiesen. Sie finden sich regelmäßig bei erwachsenen Thaliaceae nnd Pyrosomer, sowie den Larven der Ascilien. Das Organ letzterer läßt etwaige Beziehungen zu den Vertebratenaugen am dentlichsten erkennen uud soll deshalb zunächst geschildert werden. Das Auge der Ascidienlare liegt am hinteren Abschuitt der dorsalen Decke der Hirnblase, in die es ventralwärts etwas vorspringt (Fig. 393, \$. 544). Es wird von einer größeren Zahl cylindrischer Zellen zusammengesetzt, die zusammen einen habkugeligen Körper bilden, dessen Centrum in der GrenzHäche der Hirnhöhle liegt. Die freien Zellenenden sind schwarz pigmentiert; doch wird auch vermutet, daß die Zellen zweierlei Natur seien, d. h. Seh- und Zwischenzellen. Der nach der Hirnhöhle gerichteten freien Endfläche dieser Retina sitzt eine durchsichtige Linse auf, welche aus mehreren Zellen oder Abschnitten (eigentliche kuglige Liuse und 1-2 Menisken) bestehen soll, von denen aber nur eine die eigentliche Linse bilde. Natürlich geht das Ange mit der Hirnblase später völlig zugrunde.

Die gewöhnliche Ansicht ist, daß das Licht durch den Körper der Larren zu diesem Auge trete; nenere Erfahrungen zeigten jedoch, laß die Liıse so gerichtet ist. đaß äußere. Licht direkt von vor'n und etwas dosral auf die Linse fällt, das Auge der erwachsenen Larven łemnach etwas verdreht ist. I) Frage, ob die parigen Wirbeltieraugen von diesem Ascidienauge ableitbar seien, wurte teils bejaht, teils geleugnet. Die Schwierigkeit, die in der Parigkeit der Graniotenangen berul,t, suchte man durch den Nachweis zu umgehen, daß die Simnesblase der Ascidienlarve ein einseitig und zwar rechtsseitiges Gebilde sei, die entsprechende linke Blase dagegen verkïmmert. Gelegentlich wurde das Auge auch dem Parietalorgan der Cranioten verglichen, oder beiderlei Aneen der Cranioten von den Augengebilden ter Thaliaceae abznleiten versucht. 
Die Anyengrbilde der Thatiuceue und der Pyrosomm liegen in der Oberfläche des Cerebralganglions, das, wie früher erwähnt (s. Fig. 397 S. 548), solide ist. Seltsamerweise liegt das wenig bekannte, jedenfalls relativ einfach gebante Auge von Pyrosoma anf der Ventralseite der hinteren Gangliouregion, wo es sich etwas hiigelig erhebt, wogegen die Salpenaugen der Dorsalseite des Ganglions angehören und zwar in allgemeinen deren Vorderregion. Sie sind bei den beiden Generationen: der ungeschlechtlichen solitären (Ammen) und der geschlechtlichen Kettengeneration stets verschiedenartig gebaut. - Das Auge der Solitirsalpen (Fig. 635) ist stets unpaar und von hufeisenförmig gekrïmmter Form, wobei die Öffnung des Hufeisens oralwärts schant. Es springt über die dorsale Ganglionfläche etwas wulstartig vor, was namentlich fiir die Enden des Hufeisens gilt, welche sich zuweilen auch als freie Fortsätze verlängern könuen. Bei zahlreichen Formen wird es von annähernd cylindrischen Selzellen gebildet, die in der mittleren (hinteren) Region des hufcisenförmigen Gebildes nahezu senklecht oder etwas radiär anf der Hirnoberfläche stehen, wobei die Nervenfasern aus dem llirninnern zu den proximalen Sehzellenden ziehen. Caudalwärts und etwas dorsal wird dieser Teil des Angenwulsts von Pigmentzellen bedeckt, welche, wie die Pigmentzellen rer Salpen- und Pyrosomenaugen ïberhaupt, wohl aus ectodermalen Zellen der Hirnanlage hervorgehen. Zwischen den

Fis. 635 .

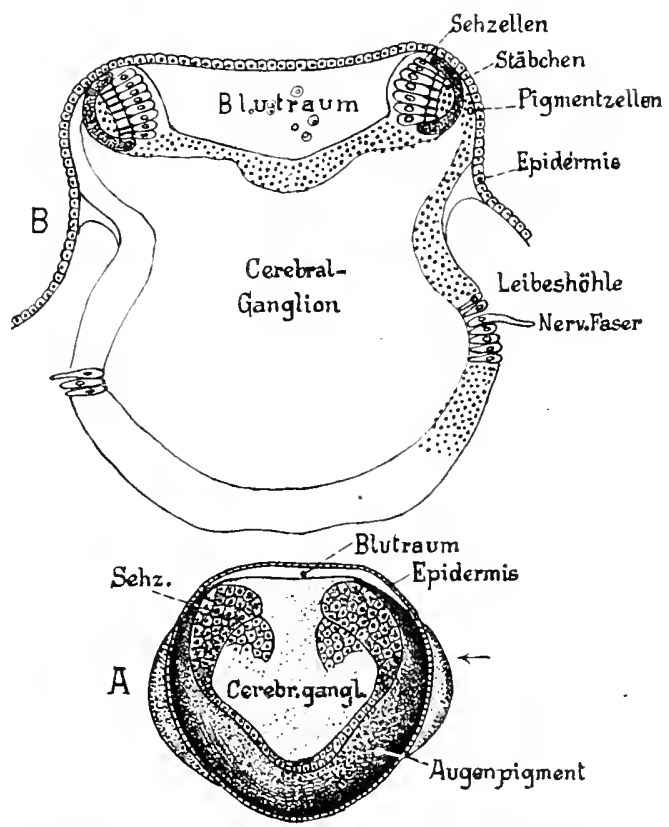

Salpa, Auge der ungeschlechtichen treneration. - I salpa africana-maxima, Cerebralgangtion von der Dorsalseite mit dem hufeisenförmigen Ange (nach GöPPET 1893). - IS Cyelosalpa pinnata. Quersehnitt durch das Cerebralganglion und das lufeisenförmige Auge, etwa in der Gegend des Pfeils auf Fig. I (nach Mercalf 1893). O. B. peripheren Sehzellenden finden sich Bildungen, die verdickten Zellwinden gleichen und als recipierende Elemente (Stäbchen, Rhabdome) gedentet werden. - Wenn diese Auffassung zutrifit, so hïtte dieser mittlere Teil des hufeiscnförmigen Anges eine etwas eigentümliche Beschaftenheit, da sein caudaler von Pigmentzellen bedeckter Teil eine inverse, der orale, von Pigment unbedeckte dagegen eine converse Bildung besäße. - In den Seitenarmen des Hufeisens wird dies anders, indem sich die Sehzellęn hier so drehen, daß sie etwas horizontal und lateralwïrts gerichtet sind, wobei die Pigmentzellenschicht gleichfalls lateral nach anßen riickt (Fig. $635, B$ ). Die zutretenden Nervenfasern steigen daher auf der medialen Seite 
der Hufeisenarme empor, um sich mit den Sehzellen zu verbinden; diese Teile des Anges sind daher ansgesprochen invers.

Die Augenbildungen der Kettensalpen (Fig. 636) sind viel komplizierter und bei den einzelnen Arten recht verschieden. Im allgemeinen gilt, daß sich das Auge als freier zapfenartiger Fortsatz von der Ganglionobertläche érhebt, selten rein dorsalwärts, meist rom Vorderende des Ganglions oralwärts oder zuweilen

Fig. 636.
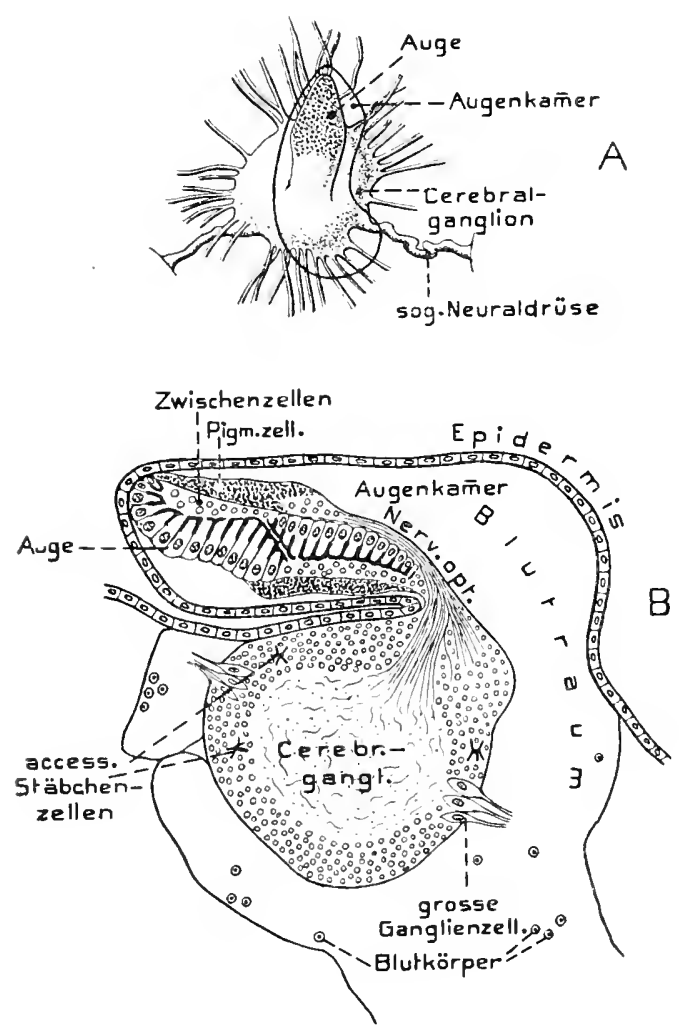

Cyclosalpa dolichosoma-rirgulat Geschlechlsgeneration. A Cerebralganglion mit Auten ron der Dorsalseile. - $b$ Medianschnitt durch das ('erebralganglion mit dem Auge (nach METCaLF 1905). sogar etwas ventral herahbiegend: wobei der Angenzapfen häufig etwas schief nach vorn gerichtet und mehr oder weniger asymmetrisch ist. Er erscheint dadureh merkwürdig, daß er meist zwei differente Regionen unterscheiden läßt, eine basale und eine apicale, deren Unterschied sich zunächst in der verschiedenen Lage der Pigmentzellenschicht ansspricht; diese liegt in der Basalregion ventral lis oralwärts (Fig. $636, B$, in der apicalen dagegen dorsal. Diese beiden Pigmentzonen hängen jedoch gewöhnlich beiderseits durch schief aufsteigende Ver . bindungen zusammen. In beiden Regionen sind die Sehzellen so gestellt, daß ihre st:ibchentragenden Enden gegen die Pigmentschicht gerichtet sind. In der Basalregion ist der Nervenzutritt sicher invers; wahrseheinlich gilt dies aber anch fiur die Apicalregion, obgleich das schwerer feststellbar erscheint. Die Sehzellen erfahren also in ihrem Verlauf von der Basis gegen den Apex eine vollständige Umkehr. Bei einer Reihe ron Salpen sondern sich die beiden Augenregionen schärfer von einander und erscheinen wie zwei getrennte Augen auf gemeinsamem Stiel, ja es kann das basale paarig werden, und sich vom apicalen noch ein Teil alısondern (Nittelauge), so daß sich vier Angengebilde unterscheiden lassen (Cyclosalpu pinnata). - Wie bemerkt, sind wahrscheinlich alle Angen der Kettensalpen invers. In den Retinazellen gewisser Formen finden sich eigentiumliche Einschlinsse (Phao- 
some) und zwischen der Retina und der Pigmentzellenhiille meist noch Zellen, welche wahrscheinlich Fortsätze zwischen die Sehzellen senden und daher als zwischenzellen anfzufassen sind.

Xicht bei allen Salpen wird aber die letina von einer einfachen Sthirht cylindrischer Sehzellen gebildet; vielmehr gibt es nicht wenige, deren Sehzellen rundlich bis unegelmäßig sincl und in usehrfachen Schichten übereinamlerliegen. - lis Ange wirl an den Stellen, wo es nirbt der Hypodermis oder lem Hirn lirekt anliegt, von einem Bhtraum nmschlossen, ler gegen den das Mirn nmgebenden Blutsinus nahezu abgeschlossen ist. Gewöhnlich wird łas hufeisenförmige Ange der Solitärtormen als die phylogenetisch ursprünglichere Bildung angesehen, ron welcher die komplizierten Augen der liettensalpen abzuleiten seien; was aber vorerst noch etwas problematisch erscheint. - Zurzeit scheint es kaum nöglich, einen begründeten Vergleich zwischen den Salpenaugen und jenen der Wirbeltiere auszulïhren.

Bei manchen kettensalpen liegt etwas hinter dem Auge aul der Doralseite des Ganglions eine Retinazellengruppe ohne Pigment um von eigenartigem ronversem Charakter. - Ferner kommen bei manchen 2-4 oder noch mehr kleise pigmentlose Gruppen solcher Zellen im Innern des Ganglions, aber nahe an seiner Oberfläche vor. 1 b sie wirklich als lichtemptludliche Grgane funktionieren, ist fraglich; doch erscheint ihr Vorkommen in Rïcksicht anf lie Verhïltuisse von Branchiostoma nicht ohne Interesse.

Die meist „elb-rötlichen l'igmentflecke, welche sirh bei den Ascidien bäutig am lande des Munds (Einströmmngö̈fnung) und her kloakalöfnung finden (s. Fig. 286 A, s. 422, wo sie als Punkte zwischen ten Lappen hieser "̈ffnungen angedeutet sind), besitzen annäherm! den Bau schwach vertiefter Becheraugen und werden von mesodermalen l'igmentzellen unterlagert. Die Gruben sind som C'ellulosemantel ansofiillt.

\section{5 b. Craniota, Lateralaugen.}

\section{Eivleitung und Ontogenese.}

Wie friiher erörtert wurde, geht die erste Anlage des Craniotenauges nicht vom äußeren Ectoderm, sondern ron der Hirnanschwellung des Nenralrohrs ans. Schon vor deren Einstïlpung tritt häufig auf dem 'Teil der Neuralplatte, welcher

Fig. 637

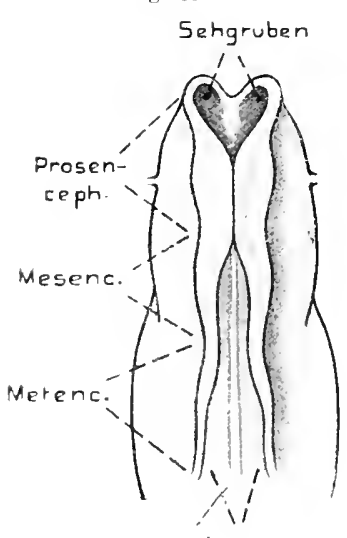

Medultarrinne

Gillus itomesticns. Kopiregion eines Embryo (Aufang des '2. Tiages) son der Dorsalseite (nach l,ersy, ans Fronlep 190.). v. Bu. zum Prosencephalon wird, ein Par grubenartiger Verticfungen anf (s. Fig. 637), die sogar roriibergehend pigmentiert sein kömen. Indem sich die Hirmanlage abschnürt, werden ans diesen Angfnyruben ein Paar Augenblasen, die auf der Grenze zwischen Tel- und Diencephalon entspringen (Fig. 638, 640), ,jedoch mit ihrem größeren Anteil von letaterem. Sie wachsen distal hald soweit hervor, daB sich ihre Distalwand dem Eetoderm anlegt. Die limnenhöhle del Augenblase kommuniziert natürlich mit dem Ventrikelranm des Prosencephalon.

f repringlich entspringt die Augenblase aus der lateralwand des Prosencephalon, ja nach Manchen sogar anlänglich von dessen Horsalregion. Jurlem sich atrer tie Decke des Prosencephalon zwischen len Angenblasen bald stark dorsal emporwölbt. vershiebt sich die Verbindung 
mit den Angenblasen in seine Ventralregion, indem sie sich gleichzeitig rerengt und so zum Stiel der Augenblase wird.

Das einschichtige änßere Ectoderm, an welches sich die Distalwand der Blase anlegt (nur hei den Mammalia schiebt sich zwischen beide vorübergehend eine

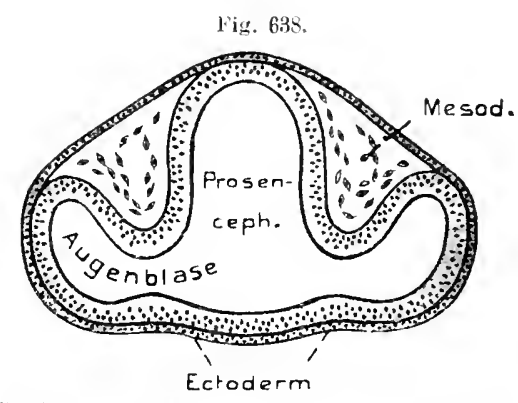

Gallus domesticus. Embryo vom 2. Tag. Querschnitt durch den Vorderkopf mit den Augenblasen (nach FroRiep 1905). v. Bu.

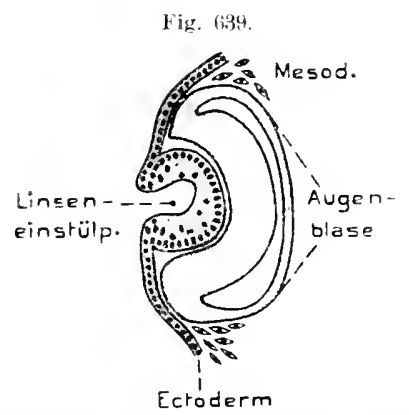

Lacerta ayilis. Enbryo mit 27 Crwirbeln. Horizontalsclmitt durch die Liıseneinstülpung und die eingestülpte Augenblase (nach RABL 18991. v. Bu.

Fig. (40.

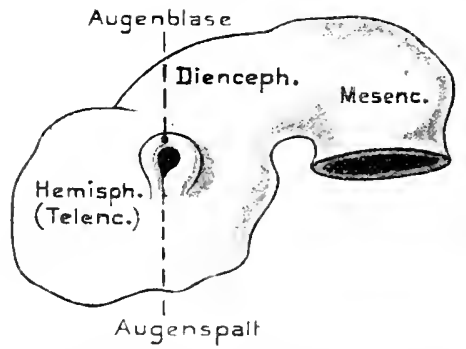

Ho no. Embryo vom Ende der 4. Woche. Modell des Vorder-bis Nittelhirus mit der Augenblase, ron links (nacli Fromite 1!45). v. Bu. dünne Mesodermschicht), verdickt sich hierauf mäßig zur ersten Anlage der späteren Linse. Diese Anlage (Limsrnplatte) stülpt sich dann gegen die distale Augenblasenwand grubenartig ein $\mathbf{F i g}$. 639) und scbnürt sich endlich als ein nun unter dem Ectoderm. liegendes hohles Linsenbläschen ab. Im weiteren Verlanf der Entwicklnng wachsen die einschichtigen Zellen der Proximalwand dieses Bläschens zu hohen Cylinderzellen aus, wodurch sich diese Wand so ansehnlich verdickt, daß sie das Lumen des Bläschens verdrängt; schließlich werden ihre Zellen lang faserartig (Linsenfasern) und bilden später die eigentliche Linsensubstanz, während die Distalwand des Linsenbläschens stets ein diinnes einschichtiges Epithel bleibt fvorderes Linsenepithel).

Die Linsenanlage wurde mehrtach als die vorderste sog. Epibranchialplacode (s. S. 624) gedeutet, da sje etwa in die Nähe derselben lällt: doch erscheint diese Deutung sehr musivber.

In dem Maße wie sich das Linsenbläschen einsenkt, t'acht sich die distale Augenblaseuwand, welche sich allmïhlich stark verdickte, ab und legt sich endlich der Proximalwand dicht an, womit das urspriinglich meist weite Lumen der Blase anf' einen engen spaltförmigen Raum reduziert wird. Indem gleichzeitig der Umschlagsrand der so entstandenen beiden Blätter der Blase distalwärts auszuwachsen beginnt, wird sie zu einem nach außen geöfineten Becher, in dessen Höhle die linse eingesenkt ist (vgl. Fig. 639 Die verdickte Distahwand dieses Augenbechers wird spiter zur lichtempfindlichen Netzhaut (Retina), während aus 
der sich stets als dïnnes Epithel erhaltenden Proximalwand das Pigmentepithel der Retina hervorgeht. Aus dieser Entstehung der Retina folgt notwendig ihr inverser Charakter.

Auch die Ventralwand des Angenstiels, welclie direkt in die distale Becherwand übergeht, verdickt sich wie letztere und wird spiiter zum Schere, welcher sich also direkt in die Retina fortsetzt. An dieser C̈bergangsstelle findet sich demnach kein freier Umschlagsrand der beiden Blätter des Augeubechers; die Folge hiervon wird sein, daß bei der Becherbildnng an dieser Stelle kein distales Answachsen des Umschlagrands stattfindet, weshalb hier in der entstehenden Augenbecherwand eine spaltartige Unterbrechung bleibt (Fig. 641). Dieser " Argonspalt erstreckt sich also von der Übergangsstelle des Stiels in den Augenbecher lïngs der ganzen Ventralseite des letzteren bis zu seinem Distalrand. Del Spalt ist wichtig, weil durch ibn eine Blutgefïßschlinge, und damit auch Mesoderm, in die Becherhöhle eintreten und zu verschiedenartigen Bildungen führen können. Auf späteren Stadien schließt sich jedoch der Spalt durch Verwachsung seiner Ränder fast stets völlig: In der Linsenregion bleibt der distale 'l'eil des Retinablatts ein diunnes einschichtiges Epithel (Pars caeca retinae), das mit dem Pigmentepithelblatt am Aufban des gleich zu besprechenden Ciliarliörpers und der Iris teilnimmt (s. Fig. 642). - In dem Raum zwischen Linse und Retiria entwickelt sich allmählich eine gallertige, wasserreiche und durch-

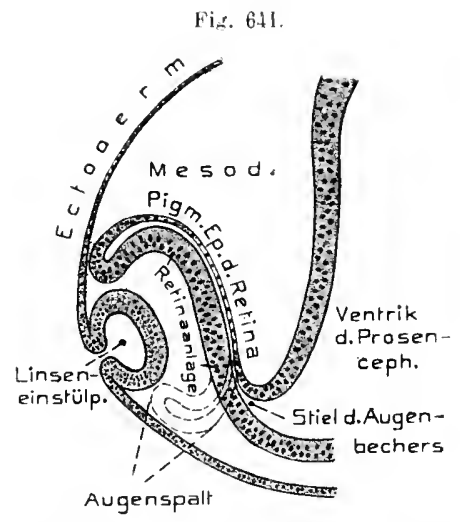

(i) a Il us domesticus. Limbryo (vom Ende des 3. Tages). Querschnit durch die Anlage des Augenbechers. Das spätere Auswachsen zum vollständigen A ugenbecher unter Bildung des Augenspalts ist durch die gestrichelten Linipn angedeutet nach Froriev 1905, etwis verändert). v. Bu. sichtige Masse, der Glashörper (Corpus vitreum,. Er geht teils aus feinfaserigen Fortsätzen der späteren Stiitzzellen der Retina hervor, namentlich aber aus denen der eben erwähuten Pars caeca (ectodermaler Teil des Glaskörpers. - Dazu gesellen sich jedoch noch mesodermate Elemente (Bindegewebs- und $W$ anderzellen), welche sich von dem mit der GefüBschlinge in den Glaskürperaum eintretenden Mesoderm abläsen.

Die so gegebene Augenanlage nukleidet sich zum Schutz und zu anderen Funktionen mit einer hindegewebigen mesodermalen/Hülle, wodurch ein abgeschlossener Augapfel (Bulbus oculi) entsteht; diese Hïlle difterenziert sich weiterhin in zwei Lagen. Die äußere umgibt als geschlossene Bildung den gesamten Angapfel. Distal schließt sie sich als durchsichtige Hornhaut (Cornea) dem geschichteten Epithel der änßeren IIaut so dicht an, đaß ein Corium als selbständige Bildung hier meist nicht unterscheidbar ist. Diese Cornea (Fig. 642) geht im iibrigen Teil des Bulbus in die fibrillär bindegewebige, undurchsichtige und blutarme Sclerc (Sclerotica, harte Hant) ïber, die wesentlich Schntz- und Stiitzgebilde 
ist. - Die innere bindegewebige Hülle, die Chorioiden (Gefäß- oder Aderhaut), besitzt stets blutgefäßreiche und stark schwarz pigmentierte Schichten. Sie umhüllt das Auge nicht vällig, sondern erstreekt sich nur soweit nach vorn wie der ur'sprüngliche Augenbecher, mit dessen ïußerer Wand (Pigmentepithel der Retina) sie eng verwäehst. - Der Umschlagsrand des Augenbeehers, samt dieser Chorioidea, wachsen nun distal von der Linse gegen die Augenachse aus und bilden ein ringförmiges, vorhangartiges Diaphragma, die Regenbogenhaut (Iris) mit einer achsialen Öffuung (Pupille). An der Bildung der proximalen Iriswand beteiligen sich demnach die beiden Blätter (Pars caeca) des vorderen Angenbecherrands. -

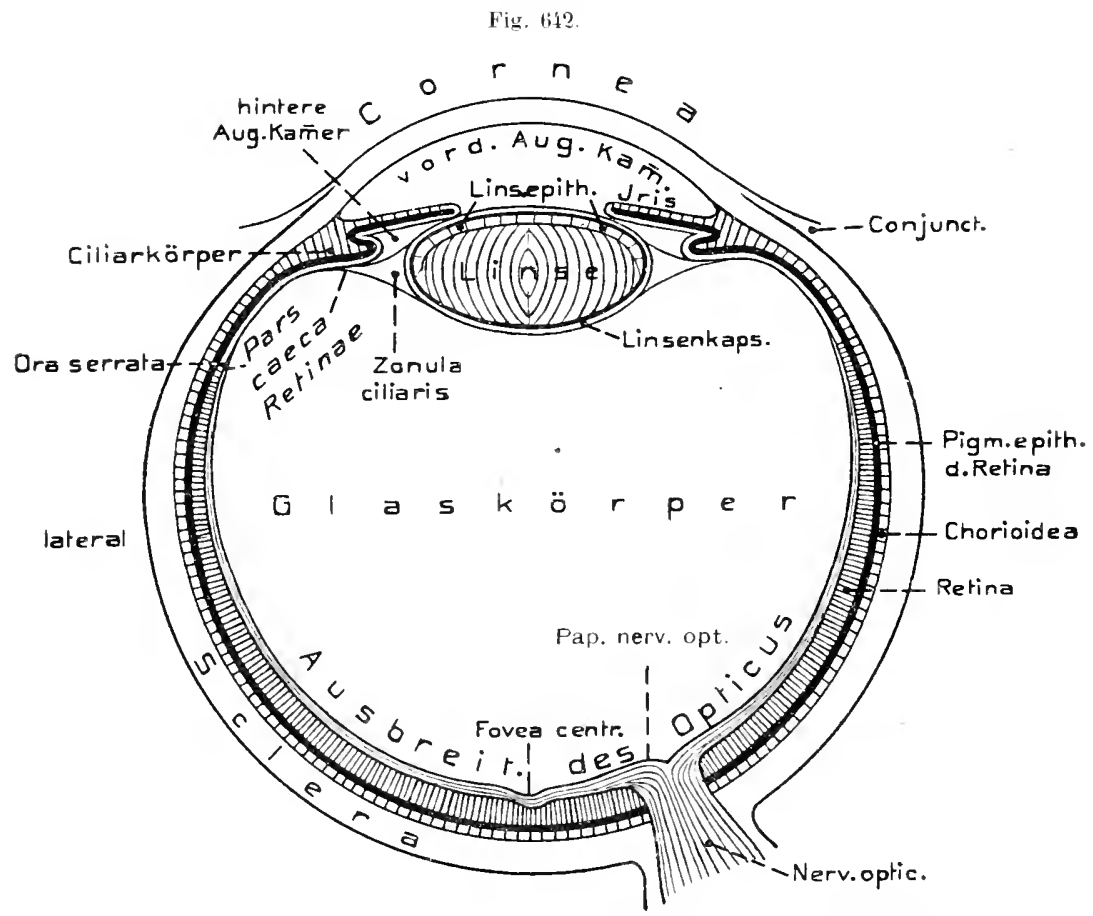

schema lus Wirbellierauges speziell sängetier). Im Horizontalsehnitt. v. Bu

Weiterhin wachsen jedoch in der Region des späteren Linsenäquators faltenartige, radiür gerichtete Fortsitze (Processus ciliares) der Chorioidea, samt der Pars cieca, gegen die linse vor, an die sie sich anlegen können; sie bilden in ihrer Gesamtheit den Giliulinger (Corpus ciliare, Fig. 642). - Zwischen Iris und IJornhaut bleibt ein von wiisseriger Flüssigkeit (Itumor anueus, Lymphe) erfïllter Ranm (rordere Angenliammer). Ein viel engerer ihnlicher Raum zwischen der Iris und Liuse wird als linter sugentammer bezeichnet.

Wir wollen in folgendem die Augen der Cranioten sowohl in ihrer Gesamtbildnng als im Bau ihrer Einzelteile etwas genauer betrachten.

- Allgeneines übre don Bulbus. Ihie Bulbusyrößre schwamkt sehr, doch läßt sich unter sonst gleichen Bedingungen erkennen, daß sie nicht in gleichem Maße wie 
die Körpergröße zunimmt, also die größeren Vertebraten im allgemeinen relativ kleinere Augen besitzen. In allen Klassen, ausgenommen bei Vögeln, finden wir jedoch Formen mit sehr kleinen, ja verkïmmerten Augen. Letzteres tritt, wie anch unter den Wirbellosen, bei im Dunkeln lebenden Arten auf(Höhlentiere, Tiefseetiere, unterirdisch lebende).

Die Augen fast aller Cyelostomen sind klein. ja bei den halbparasitischen Myxinoiden sehr stark verkümmert (nur bei den Männchen von Geotria chilensis wurden ansehnliche. teleosteerähnliche Augen gefunden). - Die Fisclıe besitzen im allgemeinen mittelgroße Augen. dwh kommen unter den Teleosteern auch solche mit sehr kleinen und sogar blinde vor, deren Augen rndimentär sind (blinde Höhlenfische, Amblyopsilae nnd andere). Die im allgemeinen kleinen Amplibienangen sind bei den Peremibranchiaten am schwächsten entwickelt, bei dem höhlenbewohnenden Proteus unl den subterranen Gymnophionen rudimentär. - Auch die Angen der Reptilien bleiben mäßig, bei einigen Sauriem und Ophidicm (Typhlopilae) selbst klein lis rulimentär; wogegen die Vögcl durchweg rerlıältıismäßi. uroße besitzen. IIinter ihnen bleiben die der Mammalia relativ zurück und sind bei subterranen Formen (so Talpidae und Spalaeidae. der Cetacee Platanista) stark verkümmert.

Die bei fast sämtlichen Wirbeltieren (jedoch mit gewissen Ausnahmen) seitlich gerichteten Augenachsen wenden sich bei den Primaten nach vorn. Bei manchen Knochenfischen (z. B. Uranoscopus, gewisse Tiefseefische, Fig. 643) können die Augen ranz auf die Iorsalseite des Kopfes rücken und

Fig. 643 .

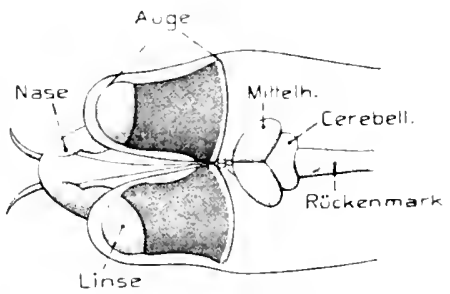

Gigantura ind i ca (Tieiseeknochenfiseh). Kopfende von der Dorsalseile (uach BRACER 1908). v. Bu.

sehr genälert sein. Besonders seltsam ist die Verlegung beider Angen auf eine Seite, wie sie bei den Pleuroneetiden durch Überwanderunc des einen Anges (bald rechtes, balı linkes) ant tie andere Seite auftritt.

Die Bulbusgestalt darf im allgemeinen als annähernd kugelig bezeichnet werden, doch weicht der distale, von der Cornea gebildete Abschnitt häufig ab, da er stärker orler schwächer gekriimmt sein kann als der iibrige Bulbus (auffallend z. B. bei den Chondropterygiern, Fig. 645). Der Bulbus weicht von der Kugelgestalt häufig auch dadurch ab, daß die Angenachse kleiner bleibt als der १uerdurchmesser, seine Gesamtform daher ellipsoidisch wird (Kur:augen, brachyskope Augen), wobei jedoch anch der vertikale und horizontale Durchmesser etwas verschieden sein können. - Bei gewissen Formen, so namentlich bei vielen Vögeln, kann sich die Bulbusgestalt erheblich modifizieren, indem die hier stark gewölbte Cornea Fig. 651 C', S. 857) durch einen mehr oder weniger steil kegelförnigen Mittelteil mit dem proximalen Bulbusabschnitt zusammenhängt, was bei den Nachtraubvögeln (Eulen) am meisten ausgeprägt ist. Solche Augen erinnern daher an ähnlich gestaltete, die wir schon bei den Heteropoden (S. 828) und Tiefseecephalopoden (S. 834) trafen (Teleshopaugen. Anscheinend ähnlich gestaltete Teleskopangen finden sich anch hei nicht wenigen Tirfserfischen (Fig. 644).

Doch sind letztere keineswegs durch eine einfache Verlängerung der Augenarhse entstanlen. Dies folgt schon daraus. daß die Achse dieser röhrenartig verlängerten Augen nicht lateral geriohtet ist, wie die ter gewöhndichen Fischaugen, sondern entweder dnrsal oder 
rostral (Fig. 643), oder diesen Richtungen doch genähert erscheint. Gleichzeitig liegen die beiden parallel gerichteten Augen sehr dicht nebeneinander, indem sie nur son einer dünnen Acheidewand getrennt werden. Diese Fische besitzen daher, im Gegensatz zu den gewöhnlichen, das Vermögen des binocularen Sehens, ähnlich dem Menschen. - Daß jedoch derartiqre Augen nicht etwa durch einfache Drehung und Verlängerung der Augenachsen entstanden. ergibt ihre Ontogenese. Auf frühen Stadien besitzen sie etwa den Bau normaler Augen; aus dieser Form gehen dann die dorsal gerichteten dadurch herror, daß sie in ihrer dorsalen Queracbse stark emporwachsen, wogegen die rostral gerichteten durch ähnliches Auswachsen in der rostralen Querachse entstehen. Daß dabei auch gewisse Verschiebungen un Verdrehungen der einzelnen Angenteile stattinden (Fig. 644), ist begreiflich; kann jedoch hier nicht ge-

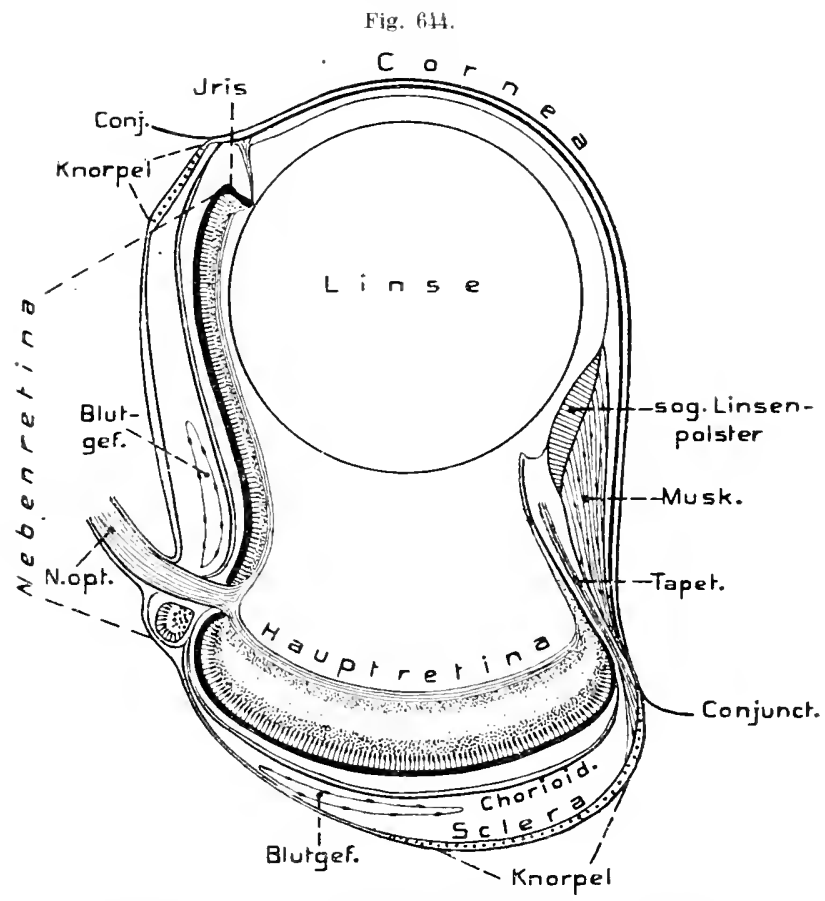

Disomma anale (Tiefsefoknohenfisch). Achsialschnitt durch das Auge (Querschnitt durch den Kopi) (nach BRACER 1908).

v. Bu.

naner erörtert werden. Auf die übrigen Besonterheiten dieser Teleskopangen wird an geeigneten Ort einzugehen sein. - Kurz erwähnt sei, daß bei den Larcen eines Tiefseetisches (Stylophthalmus) nngemein langgestielte, gewöhnliche Angen vorkommen, die sich seitlich erheleu, und in deren Stiel sogar ein Knorpelfortsatz des Scluälels tief hineineicht. Anf spiteren Stalien werten die stiele kürzer und scheinen endlich ganz zu verschwinden.

Der Bulbus der rudimentären Augen, wie sie in den verschiedenen Klassen (s. S. 845) anftreten, ist in ler Regel mehr ouler weniger stark verkleinert und meist anch tiefer in das Kïrperinnere versenkt, indem das Corinm und manchmal anch subcutanes Bindegewebe zwischen ihn ma die Epidermis eindringen.

Cornec (Hornhant). Wir fauden frither (S. 8t3), daß die Hornhaut den distalen durchsichtigen Abschnitt des Bulbus bildet und ans einer Fortsetzung der :ußßeren Epidermis, sowie dem eigentlichen mesodermalen Cornealgewebe (Sub- 
stantia propria corneae) besteht. Da sie fist stets melur oder weniger nach außen gewölbt ist und stïrker lichtbrechend (Brechungsindex ca. 1,36-1,38), nimmt sie bei den luftlebenden Formen an der ${ }_{t}$ Bilderzengnng teil und zwar bei Vögeln und Sängern in sehr erheblichem Grad. - Bei den wasserlebenden Vertebraten kommt diese Wirkung kaum zur Geltung, weil der Brechnngsindex des Wassers den der Cornea nahezu erreicht, ja der des Seewassers ihn etwas iibertrifft. Für solche Tiere ist daher die äußere Corneaform ziemlich gleichgiiltig, woher es riihrt, daß ihre Hornhaut bänfig sehr wenig gekriimmt bis eben, ja sogar unregelmïßig ist (Fische, Fig. 645, Wassersiluger, Fig. 652); doch kommen bei den Fischen anch stark vorgewölbte Corne:te vor (z. B. Tiefseefische, Fig. (i44). Auch der relative Durchmesser der Cornea schwankt im Vergleich mit dem Bulbusdurchmesser betriachtlich, etwa zwischen nahezu gleichem Durchmesser mit dem Bulbus bis zu einem Drittel des letzteren. Ina der Humor aquens, welcher die vordere Angenkammer erfïllt, nahezu denselben Brechungsindex wie die Cornea besitzt, so kommt weder die Form der proximalen Corneafläche, noch ibre Dicke für die Bildgebung wesentlich in Betracht, vielmebr scheinen diese Verhïltnisse hauptsäichlich

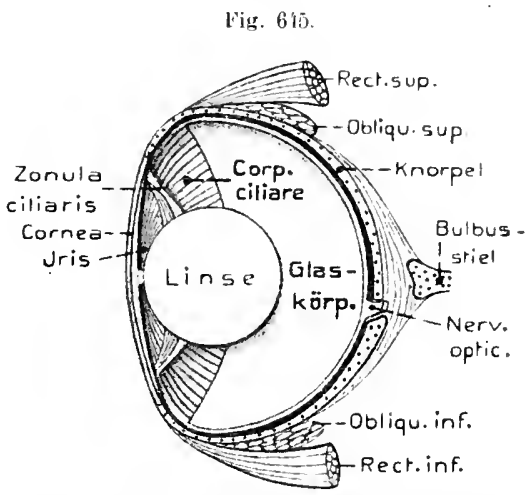

Lam in cornubica Hailisch). Auge durch verlikalen Meridionalschnit habiert (nach Frasz 1905, etwas veränderi.). durch ihre Funktion als Schutzorgan, auch gegen inßeren Druck, bedingt.

bas Corneaepithel gleicht im allgemeinen der Epidermis, ist also mehrschichtig und bei den luftlebenden Formen äußerhich verhornt: die Verhornung kamn sogar auf die Schleinschicht ïbergehen, deren Zellen ïußerlich verhornen (gewisse Pimnipedier und Cetaceen). Der bindegewebige Teil ler Cornea (Substantia propria) geht proximal in die sclera iiber und besteht aus fibrillärem, in zarten lamellen übereinander geschichtetem Bindegewebe. Nur bei primitiven Vertebraten (Cyclostomen, zahlreiche Fische), wie erwähnt aber auch hinlig bei mdimentären Augen, beteiligt sich das Corinm der angrenzenden Ilant (Conjunctiva, Bindehant) am Aufban der llomhant, indem es sich zwischen das Epithel und lie Substantia propria einschiebt, wobei hie G renze zwischen letzterer und dem corinm unleuthel werlen kann.

Die Linse ist der für die Bilderzengung wichtigste Augenteil und daher nur bei ludimentären Angen in verschiedenem Grad rückgebildet, ja sogar geschwunden (Mysinoiden; jedoch embryonal noch angelegt. Wir fanden frïher (S. 844), daß sie der proximalen lristläche dicht anliegt, weshalb ihr mittlerer distaler' 'Teil durch die Pupille mehr oder weniger in die vordere Angenkammer vorspringt. Bei wasserlebenden Formen liegt die Linse im allgemeinen der Cornea nüher als bej luftlebenden. Die Linsengestalt ist natürlich fiir ihre Funktion in allgemeinen maßgebend und schwankt etwa zwischen der einer Kngel und der eines Rotationsellipsoids, dessen Achse mit der Augenachse zusammenfällt; diese Achse ist dịe kiirzere, weshalb solche Linsen in verschiedenem Grad abgeflacht erscheinen. 
Kingeltörmige Linsen finten wir bei Petromyion und nicht wenigen Fischen, besonders Teleosteern; annähernd kngelige bei den Amphibien (besonders Urodelen), einzelnen Reptilien (z. B. Platydactylus nud nicht wenigen Schlangen), sowie größeren Pimipediem und Cetaceen (Fig. 652, S. 858) unter den Mammalia. Die Flachlinsen (lig. 651) sind entweder proximal und distal gleich gekrümmt, recht häufig aber beide Flächen verschieden stark gewölbt; die distale ist dann meist llacher als die proximale, doch kommt auch das Gegenteil ror. Da bei solchen Flachlinsen wesentlich nur die achsiale liegion optisch wirksam ist. so können ohne tiefere Störung anch sonstige Unregelmäßigkeiten der Gestalt auftreten, so Abweichungen des Äquators ron der Kreisform (Schwalben, Cypselus) unl Sonstiges.

Daß sich lingelige Linsen besonders bei wasserlebenden Formen tinden, ist im Hlinblick auf die Unwirksamkeit ihrer Cornea begreiflich; ebenso steht aher die kugelform auch in Beziehung zum Dunkelleben, da derartige Linsen relativ größere Lichtmengen zu konzentrieren vermögen. Dazu kaun sich gleiclızeitig eine relativ ansehnliche Vergrößerung der Linse. sonie ihr auffallend starkes Hervorragen in die vordere Angenkammer gesellen, unter starke! his völliger Rückbildung der Iris, sodaß lie gesamte distale Linsenbälite dem licht exponiert wird. Dieser extreme Fall tritt bei den typischen Teleskopangen der T'iefseefische ein (s. Fig. 644, \$. 846). Es kann aber nicht als allgemeine Regel gelten, laß lie Kugellinsen stets relatir groß sind. Außer con ler Gestalt längt das Brechungsvermögen rom Brechungsindex der Linsensubstanz ab, ler in der Wirbeltierlinse von ler Obertiäche bis zum Centrum allmählich oder zuweilen auch sprungweise zunimmt (etwa ron 1,38 bis 1,4 und 1,5 ), was bewirkt, daß ler Brechungsindex der Gesamtlinse bedentend verorïßert wird, weshalb sogar sollkommen plane linsen wirksam sein kïmen.

Wir fanden frïher (S. 842), daß die Linse ans dem Ectoderm durch Einstiilpung hervorgeht, wobei sich ans der Distalwand des Linsenbläschens das stets

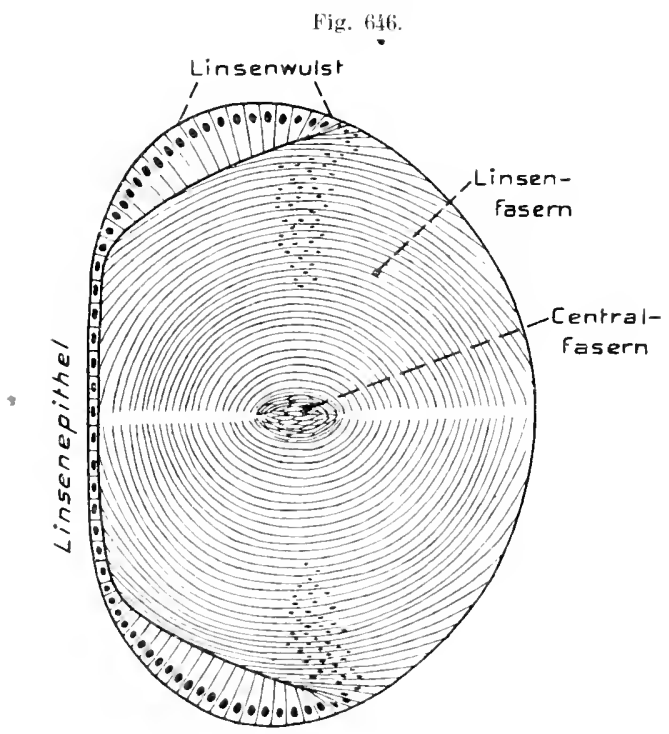

Linse von Lacerta im achsialen Durchschnitt. (Schematisch nath RABL 1899.) dïnn bleibende Linsenepithel bildet, während die sich verdickende Proximalwand die eigentliche Linsensubstanz liefert, indem ihre Zelleu zu langen Fasern auswachsen. Auf der Linsenoberfläche bildet sich eine feine strukturlose oder zuweilen geschichtete Umhiillungsmembran, die Lirsenlapsel. Das Linsenepithel erlialt sich anch im erwachsenen Zustand als einfache, meist flache Zellenschicht, die bis zum Linsenäquator und noch verschieden weit anf die Proximalfliche reicht, indem ihre Zellen an dieser Grenze, unter zunehmender Verlängerung, in die Linsenfasern iibergehen (Fig. 646). Gewisse Besonderheiteu dieses Epithels sollen später erwähnt werden. - Die Zellen der proximalen Linsenwand wachsen in allgemeinen in achsialer Richtung zn langen Fasern ans, wobei 
die oberflächlicheren Fasern, je mehr sich die Linse vergrößert, um so länger werden und sich gleichzeitig in der Richtung der Linsenmeridiane krïmmen. Auf solch einfachem Bau bleibt jedoch die Substantia propria der Linse selten stehen (so bei Ptromy:on). Bei den ibrigen Wirbeltieren wird sie komplizierter, indem nn die erst gebildeten und daher kürzesten, und central gelegenen Fasern (kernlose Centralfasern) diese Anordnnng bewahren, die oberflächlicheren dagegen, also die Hauptmenge der Fasern (Hanptfasern), sich so anordnen, daß sie radiär zur Linsenachse gestellte Lamellen znsammensetzen, was auf einem (Yuerschnitt der Linse (Fig. 647) dentlich hervortritt. Diese Lamellenbildung ist schon in der äqultorialen Grenzregion des Linsenepithels, aus welchem ja del Zuwachs an Linsenfasern hervorgeht, angedentet, indem sich dessen Zellen in meridionalen Reihen anordnen. Zwischen den Centraltasern und den Radiärlamellen findet sich eine Übergangszone (Übergangsfasern), in welcher sich die Anordnung zu Radiärlamellen allmählich ausbildet.

Fig. 4.47 .

\section{Linsenfas}

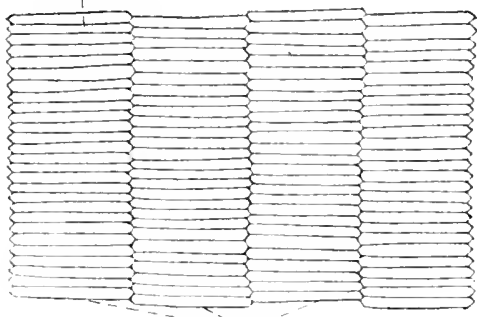

\section{Radiarlamell.}

schlange. K'leinet Teil eines Äquatorialschnitts durcl die Linse, um die Rarliärlamellen den Linsenfisern zu zeigen. (Aus P'̈TTER, Ory. d. Aug. nitch liABL 1s:!9.)

lie Zahl solcher Radiärlamellen ist ungemein verschieden (won 100, gewisse Amphibien, bis über 4000, gewisse Fische und Säuger) und stelıt in keiner direkten Beziehung zur Linsengröße; auch kann die Lamellenzahl gegen die Oberfläche zunelımen (Mammalia) odes nicht (Samropsida).

Die Linsenfaserm, welche rom iquator gegen die Linsenpole ausstrablen, kïnmen mit ihren Enden in eigentümlicher Weise zusammenstoßen. so daß ant der vorderen und hinteren Linsenläche eigentümliche Zusamufenstoßungslinien (Xähte) entstehen; bei den Chondropterygiern und Amplibien bilden sich so eine rordere vertikale und eine hintere horizontale Naht, bei den Mammalia dageten meist zahlreichere, stemfrimig ansstrahleude.

Das oben erwähnte Linsenepithel verdickt sich in der legel gegen den Äquator ein wenig; diese Verdickung wird bei den Samopsiden mit Ausnahme der Ophidier) sehr stark und bildet den sog. Linsen-oder Ringrulst, der häutig ant die proximale Linsentläche ïbergreift (Fig. 646). Die Epithelzellen können hier sogar faserartig werden. Die Verhältnisse der Vöygl vor allem erweisen, daß die Bildung des Ringwulsts mit der Accomodation in Beziehnng steht, indem er die Druckïbertragnng des Ciliarkörpers ant die Linse vermitteln dïrfte (vgl. S. 858).

Die rudimentären Augen zeigen eine mehr orler weniger starke kürkbilung der linke, welche einerseits daraul berult. laß sie auf einer frïleren kutwicklungstufe stelien bleibt, audrerseits auf weitergehender legeneration, die bei Myxine, gewissen Blimb/ischon um! zuweilen Proteus zu välligem Verlust fïhren kann. Die degenerierte Linse kann norh ein Epithel und einfach georduete Linsenfasern (Centralfasern) unterscheiden lassen (Typhlopiden. zuweilen auch $T(a / p a$ ) oder es sind die Zellen der substantia propria nicht mehr laserartig. -onlern rundich bis polygonal (Talpa gewhinlich, Gymmophionen [Siphonops]); schließlich 
findet sich als linse nur noch ein unregelmäßiges Häufchen von Zellen (so gewisse Amblyopsiden [Blindlische] und jugendlicher Proteus); beim erwachsenen Protens geht die Linse durch Eindringen vou Bindegewebe aflmählich zugrunde.

Über den Glashörper (Corpns vitreum) und seine Entstehnng wurde schon oben (S. 843) berichtet, weshalb hier einige kurze Bemerkungen genügen dürften. Wie hervorgehoben, besitzt er einen verworen feinfaserigen Bau mit Einlagerung von Bindegewebs- und Wanderzellen. Das Ganze ist durchtränkt von Flïssigkeit (Humor vitreus). Seine Oberfläche gegen die Retina entwickelt sich durch Verdichtung des Faserwerks zu einer Membrana hyaloidea posterior, welche sich anch auf den Ciliarkörper und die IIinterfläche der Iris fortsetzt. Wie Vorderfläche des Glaskörpers wird von einer ähnlichen Membran (Membrana hyaloidea anterior, s. terminalis begrenzt. - Am Linsenäquator befestigen sich bei fast allen Wirbel-

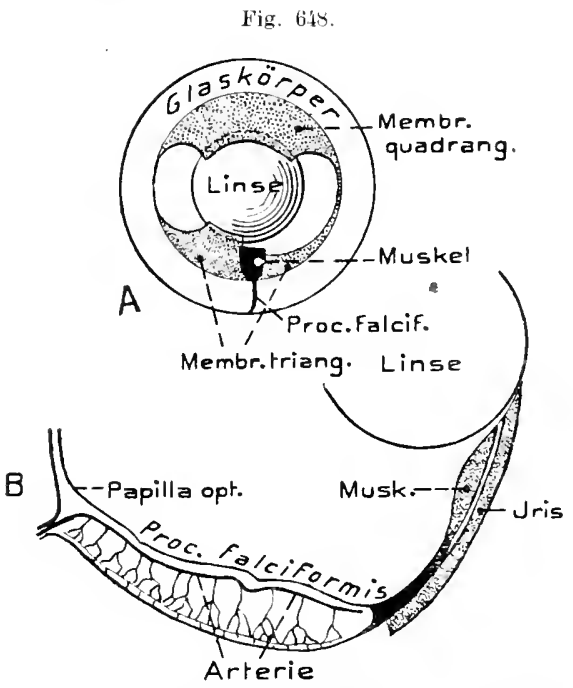

Thynum vulgaris (Thunfischi). - A Augenlinse von innen bloßgelegt. mit der Zonula (Membrana quadrangularis und triangularis), sowie dem Proc. falciformis und dem Retractormuskel der Linse (Campanula Halleri) - B Iner Processins falciformis mit dem Muskel, der Iris und Iinse (Fragment), in seitlicher Ansicht. lie Blutgefäße des Processus sind angedentet (nach H. VIRCHOW Iss2, etwas verändert). tieren Fasern, die vom Ciliarkörper ansgehen und mit diesem sehr innig vereinigt sein können (Vögel). Sie sind ähnlịcher Natur wie die Glaskörperfasern und bilden zusammen einen Aufhängeapparat der Linse (Zomula eiliaris oder Zomula Zimii, s. Fig. (j42, S. 844).

Die Fische haben nur selten (Chondropterygii) eine zusammenhängente Zonula; gewöhnlich (besonders Teleoster) ist die Zounla beiderseits unterbrorhen (rig. 648), so daß sich nur ein dorsaler 'Teil (Membrana quadrangularis, Ligamentum suspensorium) als ein häufig viereckiges Band und ein ventraker Teil ( $\mathrm{Mem}$ bravia trianguluris) erbält. Auch bei den Chondropterygiem ist der dem Ligamentum suspensorinm entsprechende Dorsalteil st.ärker eutwickelt. - Der Glaskörper rudimentärer Augen ist häufig sehr reduziert, indem ihm geformte Bestandteile zuweilen fast fehlen; auch kann der Raum zwischen Linse und Retina sehr eingeengt werlen (z. B. Proteus, gewisse Blindfische). Andererseits wandert jedoch in manche dieser Angen Bindegewebe reichlich ein und tritt an Stelle les Glaskïrpers (Myxine, Proteus).

Retina. Die Entwicklung der Retina aus der Innenwand des Augenbechers lernten wir schon oben kemen, wobei sich ergab, daß der Selmerv die Netzhant durchbohrt und sich anf ihrer Innenseite ansbreitet. Hieraus, wie ans der Gesamtentstehung der Retina, folgte der inverse Charakter des parigen Anges. - Die ausgebildete Wirheltierretina erreicht eine bedeutende Dicke, was namentlich daher rïhrt, daß sie nicht allein von den eigentlichen Sehzellen gebildet wird, welche nur eine äußere (proximale) Lage bilden, sondern daß sich zwischen die Sehnerven- 
und die Sehzellenschicht noch Nervenzellen einschieben, weshalb alles das, was sich auf diese Weise zur Sehzellenschicht hinzugesellt, auch als Hirnteil der Retina bezeichnet wird. Dieser Teil ist dem bei Wirbellosen mehr oder weniger entwickelten Ganglion opticum gleichzusetzen. Die eigentliche Retina (I'urs optica retimac) breitet sich an der Angenwand so weit ans wie der Schnerv; peripher verdünnt sie sich allmählich und endigt etwas hinter (proximal) der Äqnatorialgegend der Linse (Ora serrata oder teminalis, Fig. 642, S. 844). Wie erwähnt, setzt sich jedoch die ursprïngliche immere Angenbecherwand von hier ans als einfache Zellschicht anf den Ciliarkörper (Pars riliuris retinae) und die Hinterfliche der Iris fort (Pars iritliea retinae).

An der Fintrittsstelle des Opticus, die gewöhnlich nicht gen:u central im Augengrund liegt (Fig. 642), fehlen natiirlich die Selizellen (Blinder Flocli); anch k:mn der Sehnerv hier etwas papillenartig in die Angenhöhle vorspringen (Papilla nerri optici). Etwa im Retinacentrum findet sich ein meist kleines Feld (Area centralis), in welchem die Schzellen sehr verfeinert und besonders zahlreich sind; bei den Primuten ist es gelblich pigmentiert (Macula luten) und in der Nitte vertieft (Forea centralis, Fig. 642). Die Area kann rund bis streifenförmig sein, ja es können sogar zwei Areae auftreten (Vögel und gewisse Sänger), selbst drei (einzelne Vögel). Die Area bildet den Ort genanesten Formen- und Farbensehens.

Der feinere Ban der Retina ist sehr kompliziert, weshalb er hier nnr in seinen Grundzügen angedeutet werden kann. -- Zunäehst sei hervorgehoben, daß fast die gesamte Dicke der Netzhant von Zwischenzellen (Stützzellen, Mïller'sche Stütrfasern) durehsetzt wird (s. Fig. 649), deren innere (centrale) Enden eine die Netzhaut gegen den Glaskörper abgrenzende Membrana limitans interma bilden, wïhrend ihre äußeren (proximalen) Enden eine Membrana limitans extern erzengen, iiber welche jedoch die percipierenden Endteile der Sehzellen (Stäbchen, Zapfen) hinausragen. Die Stritzzellen senden seitlich zahlreiche feine horizontale Fortsätze in die Retina. - Die Schicht der eigentlichen Sehzellenkörper liegt direkt nach innen von der Membrana limitans externą. Eine spindelförmig angeschwollene Partie des Sehzellenkörpers (Korn) enthält den Kern, weshalb die gesamte Region dieser Anschwellnngen auch hänfig als äußere Kömerschicht bezeichnet wird. Sind die in einfacher Schicht übereinander stehenden Endteile der Sehzellen dick, so können die zugehörigen Kömer ebenfalls in einfacher Schicht Ranm finden, werden die ersteren dagegen dïnner und liegen sie dicht zusammen, so miissen sich die Körner in verschiedener IIöhe anordnen, um Raum zu finden, weshalb fast ansuahmslos zwei bis zahlreiche Kömerlagen vorkommen. Ganz besonders steigert sich die Zahl der Körnerlagen bei gewissen Sïngern (Pinnipediern und Cetaceen), wo bis 30 gezählt wurden. Bei diesen, wie manchen andern Sängern ergab sich, daß die Zahl der Körner häufig jene der Stäbchen nnd Zapfen beträchtlich übertrifft.

Wie bemerkt, werden die percipierenden Endelemente der Sehzellen als Stäbchen und Zapfen unterschieden, doch ist eine scharfe Sonderung beider 
kaum überall durebzuführen. Die typischen Zapfen bleiben meist erheblich kürzer als die Stäbchen und sind daher zwischen deren Basalregion eingeschaltet.

Die Sehelemente der Cyclostomen sind sämtlich zapfenartig oder doch wenig vershieden. Anch bei den Chondropterygiem treten die Unteıschiede der mehr stäbchenartigen Elemente noch wenig hervor, wogegen sie bei den ïbrigen Wirbeltieren in der Regel bestimmter ausgeprägt sind. Die Reptilien besitzen meist überwiegend zapfenartige Elemente, ja

Fig. 649.

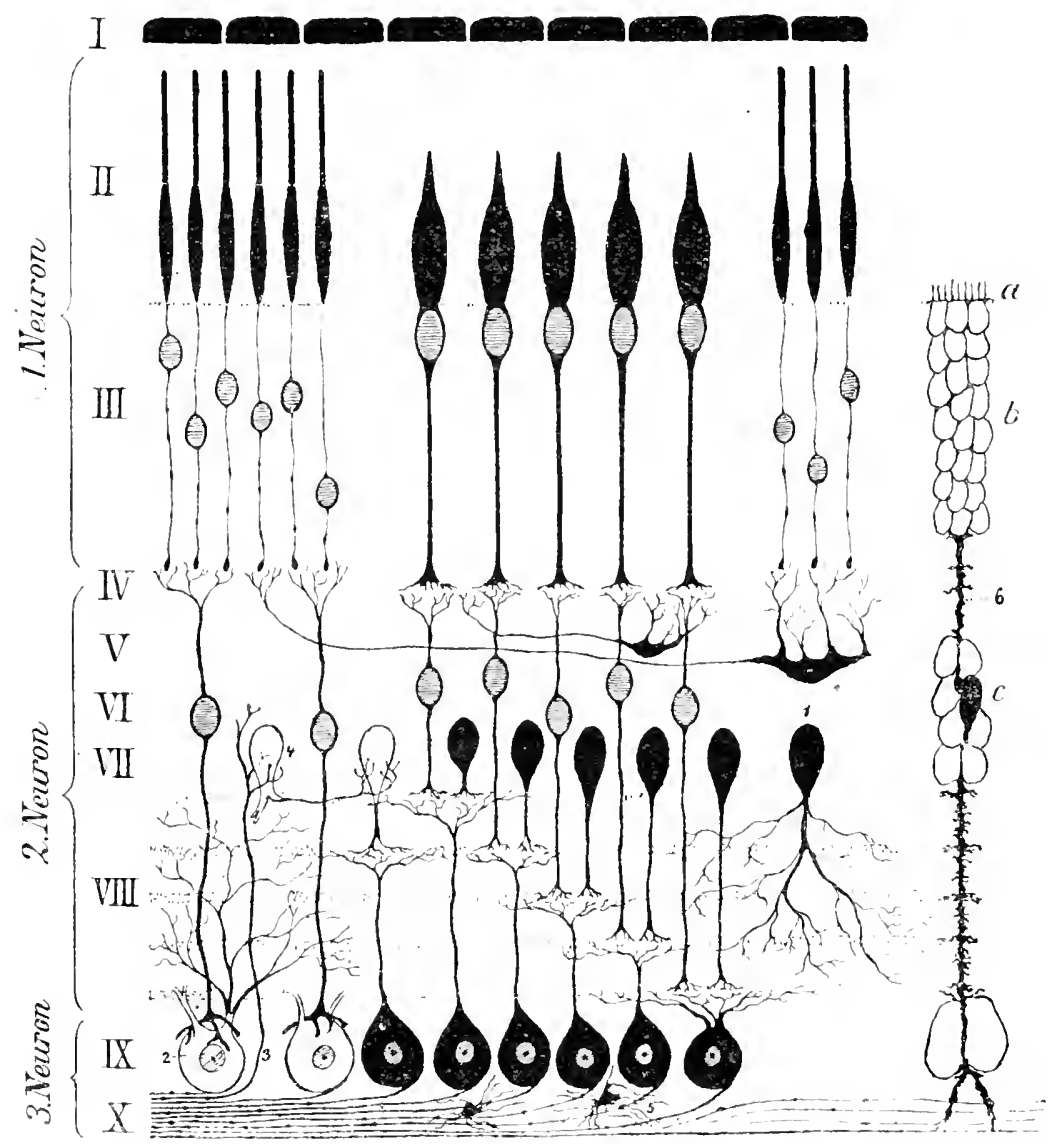

sohematischer lourchschnitt durch die menschliche Retina. I Pignentepithel, $I J$ stäbchen- unt Zaj,fenschicht, III Körper der Sehzellen (äuBere Kömer), II ätubere plexiforme Schicht, $\mathrm{V}$ schicht der horizontalen Zelen, II Schicht der bipolaren Zellen (innere Körner), III Schicht der Amakrinen (1 u. 4), l'I/ Innere plexiforme Schicht, $X$ Ganglienzellenschicht, $X$ Opticusfaserschicht.

Rechts eine stiutzzelle ( $"$ Faserkorb, $b$ seitliche Buchten, "Kern). (Nach GreefF aus Pïtrer 1908.)

solche tinden sich bei manchen ausschlieBlich (namentlich für die Chelonia und Sauria angegeben); ebenso ist auch die Vogelretina gewöhnlich reicher an Zapfen. Wichtig erscheint die Verteilung der beiderlei Elemente, wo sie sich deutlich unterscheiden lassen, besonders bei den Säugern. Hlier finden sich in der Area viel weniger Stäbchen als in der peripheren Retinaregion, in der Fovea centralis sogar nur Zapfen in sehr großer Zahl. Hierans und aus anderem schloß man, daß ten Zaplen, neben ihrer allgemeinen Bedentung für den 
Sehakt, insbesondere, die Farbenwahrnehmung zukomne, währent die Stäbchen farbenblind jedoch für schwache Lichtintensitäten empfindlicher als die Zaplen seien. Die periphere Netzhatregion diene daher hauptsächlich fïr die Bewegungswahruehmungen und das Sehen im lämmerlicht. Damit stimmt im allgemeinen überein, daß die Stäbchen bei nächtlich lebenden Vertebraten Forherrschen, wïhrend deren Zapfen spärlich oder ziemlich verkïmmert sind. Jedenfalls bestehen aber in djesen Dingen noch mancherlei I Insicherheiten. - Im allgemeinen nimmt die Zahl der Sehelemente und damit die Sehschärfe bei den höheren Wirbeltieren ungemein zu; Berechnungen nach der Dicke der Elemente ergeben etwa 2500 (Spelerpes) bis 1400000 (Mus decumanus) anf den (Onädratmillimeter der Retina, Die fiesamtzahl der Stäbchen wurde in der Retina des Menschen anf 130 Mlllionen, die der Zapfen anf 7 Millionen geschätzt. Direkte Zählungen ließen auf den Guadratmillimeter 76000 (Testudo graeca) bis 680000 (Symium aluco) Stäbchen und Zapfen feststellen. Für die Benteilnng der Sehschïrfe haben dorartige vergleichende Zuhhngen immerhin nur beschränkten Wert.

Die zapfenartigen klemente zahlreicher Vertebraten enthalten in ihrem lnnenglied eine

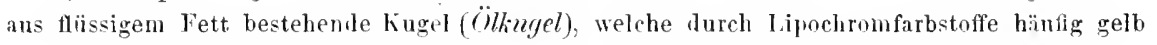
bis rot gefärbt ist.

Physiologisch scheint die Bedentung dieser Ölkugel wesentlich in einer Absorption gewiseer Lichtsorten (vorwiegend also der blauen) zn bestehen, was sich bei Vögehn und Schildköten in einer Terkïrzung des wahrgenommenen Spektrums am kurzwelligen Ende zeigt. Zapfenkugeln finden sich bei Protopterus, vielen amuren Amphibien, zahlreichen Sauriern und Cheloniern, den Vïgelu und Marsupialiern. Die Kingeln sind entweder farblos, bei vielen Sauropsiden dagegen (Samria, Chelonia, Aves, ebenso den Marsupialia) meist gelb unil rot, seltener grün bis blau grefïbt; doch finden sich außer den gefärbten meist gleichzeitig auch ungefärbte Kugeln.

Die feinfaserig ausgezogenen knden der Sehzellen treten mit den peripheren Auslänfern einer Lage von Ganglienzellen (Bipolaren, innere Körnerschicht, Fig. 649) in Verbindung. Dies geschieht etwas verschieden, indem die Sehzellenfaser entweder knöpfchenartig endet (besonders die der Stäbchenzellen) und dann gleichzeitig in Mehrzahl mit den Ausläufern einer Ganglienzelle zusammenhängt, oder indem sie sich wurzelartig auflöst und mit den verzweigten Ausläufern einer einzigen Bipolaren verbindet. Auf die Frage, ob diese Verbindungen durch Übergang oder Berührung geschehen, gehen wir nicht näher ein. - In der Grenzregion zwischen Sehzellen und Bipolaren finden sich anch horizontal verlanfende Nervenzellen mit. wurzelartig verzweigten Ausläufern, die wahrscheinlich dazu bestimmt sind, nervöse Verbindungen von Sehzellen untereinander herzustellen. - Die massenhafte Entwicklung fein verzweigter nervöser Ausläufer in dieser Retinaregion gab Veranlassung, sie als äußere reticuläre oder plexiforme Schicht zu bezeichnen. - Die bipolaren Ganglienzellen.verbinden sich durch ihre wurzelartig verzweigten centralen Ansläufer mit den ebenso beschaffenen, proximal aufsteigenden Fortsätzen einer zweiten Lage von Ganglienzellen (Gangliensollenschicht), die direkt unter (proximal oder außen von) der Opticusfaserschicht liegt. Außerdem finden sich in der centralen (inneren) Region der inneren Körnerschicht noch mehr oder weniger zahlreiche Nervenzellen, welche den oben erwähnten horizontalen Zellen funktionell entsprechen, die Amakrinen, welche durch ibre reich verzweigten Ausläufer Verbindungen zwischen den nervösen Elementen dieser 
Region herstellen. Anf die verschiedenen Formen, welche sich unter diesen Amakrinen unterscheiden lassen, gehen wir hier nicht näher ein. - Auf solche Weise kommt es zwischen der Schicht der Bipolaren (inneren Körnerschicht) und der Ganglienzellenschicht zur Bildung einer inneren reticulären oder plexiformen Schicht, in welche jedoch anch direkt, ohne Vermittelung von Ganglienzellen, einzelne Nervenfasern der Opticusfaserlage aufsteigen können. - - Ein Blick anf Fig. 649 ergibt die Aufeiuanderfolge der Retinaschichten, die bei allen Wirbeltieren große Übereinstimmung zeigen, deutlicher als ihre nochmalige Anfzählung.

Auf die Rethnabeschaffenheit der rudimentären Augen einzugelien, würde zu weit führen. - Besonders eigentümliche Verbältnisse zeigt die Netzlant der Teteskopaugen der Tiefscefische (s. Fig. 644, S. 846). Bei diesen, wie früher erwähnt, in einer der Querachsen stark verlängerten Augen hat sich die Yetzhaut in zwei verschiedene Partieen differenziert nïnlich eine Hauptretina, welche viel dicker und stäbchenreicher, sowie weiter von der Linse entfernt ist, und eine dümnere Nebenretina, die sirh medial von der Linse findet und ihr viel n̈̈her liegt. Beide Retinne sind durch eine Falte oder einen Einschnitt mehr orler weniger roneinander gesondert. Die Gesamtverhiltnisse weisen darauf hin, daß die Hauptretina das eigentliche Objektsehen vermittelt, wïhend die Velenretina, weIche wahrscheinlich keine scharfen Bilder; wenigstens nicht solche naher Olojekte emplängt, liauptsächlich dem Bewegungswahrnehmen dieut. Einer ähnlichen Bildung begegneten wir schon bei den Heteropoden (s. S. 829). Bei einigen Teleskopangen (z. B. bei Winteria, Opisthoproctus u. a.) ist eine eigentïmliche Differenzierung an der Nebenretina eingetreten, indem sich eine streifenförmige Partie derselben rinnenartig ausgestülpt hat. An diesem Teil fehlt ferner das die Retina umbüllende Pigment; weshalb hjer die seltsame Erscheinung auftritt, daß das Licht durch das so gebildete Fenster direkt von außen auf die Sehelemente fallen kann, diese Stelle des Auges also wieder convers geworden ist.

Wie wir erfuhren, entsteht aus der Außenwand des rusprïnglichen Augenbechers, die stets ein dünnes Epithel bleibt, das Pigmentepithel der Retina (Tapetum nigrum), indem ihre Zellen braunschwarzes, meist kristallinisches Pigment (Fuscin) hervorbringen, das nur in gewissen Fillen fehlt. Die Pigmentepithelzellen bilden fast stets Fortsätze, welche sich zwischen die Sehelemente erstrecken (Fig. 649); bei stärkerer Belichtung wandert das Pigment, namentlich bei niederen Vertebraten (besonders, Fischen) in diese Fortsaitze hinein, um die Lichtreizung der percipierenden Elemente abzuschwächen. - In pigmentfreien Retinaepithelzellen werden bei gewissen Teleosteern, Frokodilen (unsicher bleibt das frïher beschriebene Vorkommen bei Struthio), körnig-kristallinische Einschlüsse (bei Fischen Guaninkalk) abgeschieden, die stark reflektieren und einen leuchtenden Angengrund (retinales Tapctum) hervorrufen, ähnlich der gewöhnlicheren derartigen Bildung in der Chorioidea, von welcher gleich die Rede sein wird.

Thlïhlungshäute des Bulbus und ihe Errengnisse. Wie wir friiher fanden, dienen zum Schutz des eigentlichen optischen Apparats die imere oder Gefäßhant (Aderhaut, Chorioidea) und die äußere Sclera, deren als Cornea entwickelter Teil schon besprochen wurde (s. Fig. 642, S. 844). Die Chorioidea bleibt im allgemeinen dünn, selten (große IIaie) wird sie dicker. Sie ist in gewissen Lagen durch Reichtum an Pigment und Blutgefüßen ausgezeichnet. Ihre Fortsetzung in die Linsenregion bildet, unter Beteiligung der beiden Epithellagen des Angenbechers, den 
Ciliarkörper und die Iris. - Der Ciliarkörper (Corpus ciliure) wird von einer kleineren oder größeren Zahl sehr gefïßreicher Falten gebildet, die da beginnen, wo der optische Teil der Retina anfhört, und, allmählich höher werdend (Processus ciliares), bis zum Äquator oder sogar der Distalfläche der Linse (Sauropsiden) ziehen, sich zuweilen auch anf die Proximalwand der Iris fortsetzen. Bei stärkerer Entwicklung (namentlich Vögel und Sänger) reichen die Falten nach

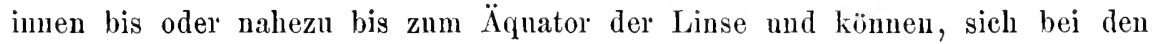
Sauropsiden an deren Kapsel heftend, zu ihrer Befestigung beitragen.

Unter den Fischen besitzen die Chondropterygii und Chondrostei einen schwach entwickelten Ciliarlörper; den Teleostei fehlt er fast stets. Anch bel Amphibien und Reptilien ist er im allgemeinen schwach ausgebildet, stärker nur bej den Placoiden; bei Vögch und Sïugcm erlangt er seine höchste Entwicklung, sowohl in hezug anf the Zahl (bis iiler 100) wie die llöhe seiner Falten und Fortsät\%e.

Wie wir schon fanden, besteht die Iris aus einer Fortsetzung der bindegewebigen Chorioidea, der sich proximal die doppelte Epithellanelle des Augenbecherrands als stark pigmentierte Schicht anflagert. - Die wegen ihrer Pigmentierung als Blende (Diaphragma) wirkende Iris nmschließt die Pupillaröffinung, die meist centrisch liegt und hänfig regelmäßig kreisrnnd ist.

Doch ist sie nicht selten abweichend gestaltet, so elliptisch bis spaltartig (meist nächtliche Tiere) mit horizontalem, seltuer vertikatem längerem Durchmesser, gelegentlich aber auch himförmig (z. B. Pinnipedier). Die Pupille des Teleosteers Anableps ist sogar durch zwei vorn und hinten rorspringende Lappen in eine dorsale und ventrale öffunng geteilt. -Auch die Cornea dieses Fisches wird durch einen pigmentierten Guerstreif der Conjunctica in eine dorsale und ventrale IIälfte geteilt. Diese Zweiteilung soll damit zusammenhängen, daß jener Cyprinodont den Dorsalteil des Kopfes gewöhnlich über Wasser hält, so daß las Auge gleichzeitig für das Sehen in Luft und Wasser adaptiert ist. Bel verschiedenen Gruppen können vorhangartig vom dorsalen Pupillenrand herablängeude Fortsätze, zur Abblendung des aus der Höhe einfallenlen Lichts, auftreten, wie sie analog anch den Sepien yukommen. So bei den Rochen das Opercuhum pupillare; Pleuronectiden, Hyrax: Umbraculum; bei den Artio- und Perissorlactylia die Floceuli oder Gramela iridis (auch Corpus nigrum) am dorsalen, zuweilen auch ventralen Rand. Bei Zahnwalen bildet die lris ein stark muskulöses von oben her in die Pupille eiuragendes Operculum. - Stark bis nahezu völlig rïckgebildet ist die Iris im Teleskopange der Ticfsecfische (s. Fig. 644, S. 846).

Die sehr verschiedene Irisfarbe rührt von Pigmentzellen ihres chorioidealen Anteils und der Pars iridica retinae her. - In der Iris der Fische und Amphibien kommt häufig eine silberglänzende Schicht (Argentea) vor, die sich bei ersteren anch in die eigentliche Chorioidea fortsetzen kann. - Überall ist die Pupille erweiterungs- und verengerungsfïhig, indem die Iris Radiär- und Ringmuskelfasern enthält (Dilutalor und Sphincter). Dieser Muskelapparat ist bei den Fisehen nur schwach entwickelt, sonst fast immer gut. Die ans dem Ectoderm (ainßere Wand des Augenbechers) hervorgehenden Muskelfasern sind nur bei den Sauropsiden quergestreift. Der Sphincter beschränkt sich meist anf den Pupilleurand, der Dilatator erstreckt sich durch die gesamte Iris.

Die Chorioidea enthïlt bei nicht wenigen Vertebraten als besondere Lage cin Tapetum, wie wir es in analoger Weise schon oben ans dem Pigmentepithel 
der Retina gewisser Formen hervorgehen sahen. Dies chorioideale Tapetnm, welches sich nicht immer über den gesamten Augengrund ausdehnt, kommt bei Chondropterygii, Chondrostei, gewissen Teleostei und sahlreichen Mammalia (Ungnlata, Carnivora, Cetacea und Prosimiae) vor. Es liegt nach anßen vom Pigmentepithel ler Retina, welches in diesen Fällen wenig oder kein Pigment enthält.

1)as Tapetum besteht bei den erwähnten Figchen, den Corniroren und Prosimiern, aus polygonalen oder viereckigen Zellen, die entweder in einer Schicht, bei den gesamten Säugern aber mehr- bis vielschichtig angeordnet sind, und reflektierende Plittchen oder kiristälchen enthalten (Tapetum cellulare oder cellulosum). - Bei den übrigen Süngem sind die Zellen in den Schichtflïchen faserig ansgewachsen (Tapetum forosum), sullen jedoch gleichfalls kristallhaltig sein (ob stets?). - Die physiologische Bedeutung des Tapetıms, welches das einfallende Licht in rersehielenem Farbenton zurïckwirft und daher ein Lenchten des Augengrundes bewirkt, wirl in einer Verstïring der Retinareizung durch las rom Tapetun reflektierte Licht gesueht.

Von der Gefüßschlinge, welche durch den frïher erwähnten Angenspalt in den Glaskörperraum tritt, können eigentiimliche Bildungen ansgehen. Bei zahlreichen Teleosteern (auch Stör und gewisse lígiden) erhebt sich durch den sich nicht völlig schließenden Angenspalt eine meist unpigmentierte gefäßreiche Leiste (Processus falciformis) in den Glaskörper, mit dem sie fest verbunden ist (Fig. 648, S. 850 ; beiderseits wird sie von einer anfsteigenden Epithelfalte der beiden Spaltränder begleitet. Vorn reicht dieser Processus bis zur Membrana triangnlaris; ihre Länge und Höhe variiert sehr, und von ihrem Proximalende kann sich ein fingerförmiger, gefäßreicher Fortsatz in den Glaskörper erstrecken. Vom Distalende des Processus falciformis entspringt ein meist plattenförmiger muskulöser Fortsatz (Campamula Halleri, Retractor lentis, s. Fig. 648, Muskel), der in der Membrana triangularis liegt und schief nasalwärts gegen den Liusenäquator anfsteigt, an dem er sich etwas nasal durch eine Selne befestigt. Hiufig ist der Processus falciformis so rednziert, daß sich nur sein distalster Teil als Stiel jenes Muskels erhïlt (Haie, Cyprinoiden, Plemonectiden, Symgnathiden). Znweilen soll der Muskel auch fehlen (z. B. Conger). Seine glatten Muskelfasem sind gleichfalls ectodermaler Herkmnft. Bei den Teleosteern nähert die Kontraktion des Linsenmuskels die Linse der Retina, verschiebt sie jedoch anch etwas nasal; da nun das Teleosteerauge im Ruhezustand für die Nähe eingestellt ist (myop), so dient der Mnskel hier zur Accommodation anf die Ferne.

Line Ausnahme macht der eigentimliche Periophthalmus lioelieuteri, der auch aut dem Strande, außerhalb des Wassers, nach Beute jagt. Seine Augen sind in der Ruhe weitsichtig his anf die Ferne eingestellt (hyper-oder emmetrop) und werden auf die Nühe accommodiert; doch ist nicht bekannt, wie dies geschieht. - Bei den Chondropterygiern und Gamoidcn wurden his jetzt keine Accommodationscorgänge beobachtet.

Eine an den Processus falciformis erinnernde Bildung findet sich bei gewissen Reptilien (sog. Zapten und Polster), sowie den Vögeln (Pecten, Kumm, Fü̈her). Beiderloi Gebilde gehen wenigstens in ihrer Anlage ebenfalls vom Augenspalt und der Burch ihn eintretenden Gefäßschlinge aus. Bei den Reptilien (Fig. 650) handelt es sich $11 \mathrm{~m}$ ein zapfen- bis kegel- oder fingertörmiges, meist pigmentiertes Gebilde (zahlreiche Samrier), welches sich von der Papille des Sehnervs aus in den Glas- 
körper mehr oder weniger erhebt und selnr getüßreich ist. Bei manchen Schlenyen (z. B. Boa, Coluber ete.) sowie den pluroiden Reptilien findet sich an der gleichen Stelle nur eine polsterartige Erlhebnng. - Den l'ögch kommt fast allgemein (Ausuahme Apteryx?) ein viel stärker entwickeltes solehes Gebilde zll, das sich in der Erstreckung des nrspriinglichen Angenspalts, meist aber nur in seiner mittleren Region, als eine ziemlich hoeh aufsteigende, stark pigmentierte Luingsfalte in den Glaskörper erhebt. Wer Hauptcharakter dieses Pecten oder Fiiehers (s. Fig. 651), dem er aneh seinen Namen verdankt, ist seine wellige Faltung (vergleichbar etwa einer Krause oder einem Wellblech), wobei die Faltenzahl recht verschieden ist (ca. 3-30). Am freien Rand des Pecten sind die Falten meist zu einer sog. Brïclie verwachsen.

Fig. 650 .

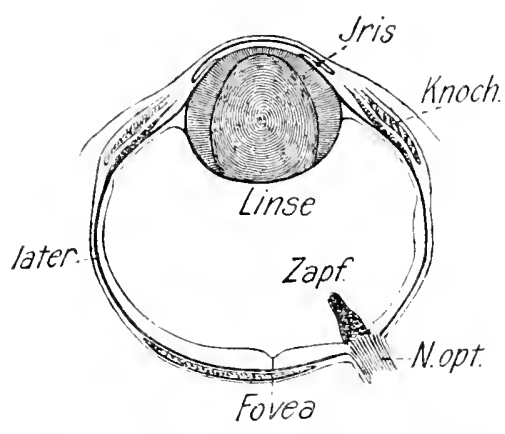

Cham a l eo. Horizontalschnit durch das Auge (aus Gegenbitr, Vergl. Anat. p̧ach H. MULLEH $1872)$.

Eine Befestigung des distalen Pecten-

rindes an der Linse, die mehrfach angegeben wurde, scheint nicht zu bestebeu. Der Pecten ist sehr gefäßreich; die zufiibrende Arterie verläuft an seinem Basalrand und geht aus der embryonalen Gefäßschlinge hervor; von ihr steigen zahlreiche Capillargefüße anf; im Processus falciformis der Fische verlänft dagegen die zuführende Arterie am freien Rand.

Fig. 651 .
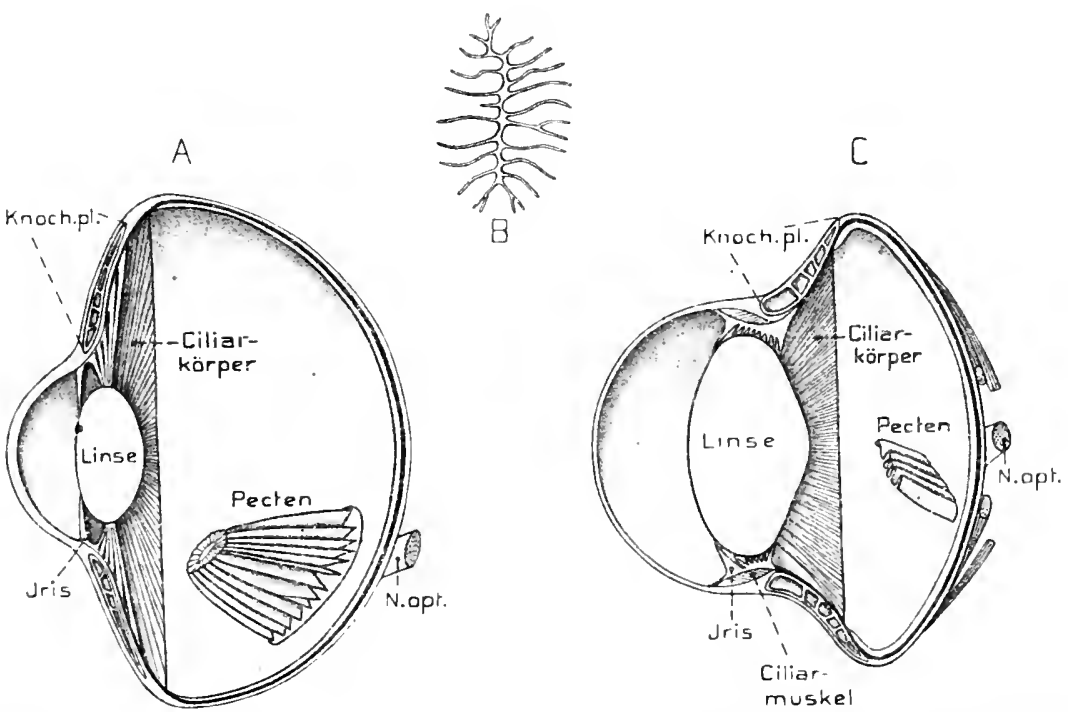

Vogelaugen. A und $b$ struthio camelus, A Rechtes Auge, Verticalschnitt. Temporale llälíte.

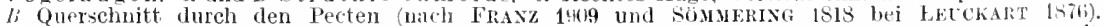

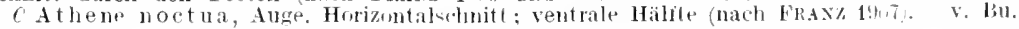


(intogenetisch geht die Pectenanlage ebenfalls von der Gefäßschlinge aus, welche samt etwas Mesodermgewebe durch den Augenspalt eintritt. Das eigentliche spätere Pectengewebe hingegen ist wesentlich ectodermaler IIerkunft, indem die beiden Blätter des Augenbechers, welche den Augenspalt begrenzen, um die mesodermale Anlage emporwachsen und sie ganz ïberziehen; letztere tritt daher im ausgebildeten Fächer sehr zurïck. Daß aber der Pecten ein Sinnesorgan sei, dazu bestimmt, rom intraocularen Druck gereizt zu werden, ist wenig wahrscheinlich, da das Pectengewebe aus dem Stïtzgewebe der Retina (Glia) liervorgeht. Wegen seines Gefäßreichtums wurde ihm, wie auch dem Ciliarkörper, teils die Funktion eines Ausgleichorgans für die intraocularen Druckschwankungen, wesentlich aber die eines Lruährungsorgans für den Glaskörper zugeschrieben. - Daß der Zapfen oder las Polster der Reptilien dem Pecten homolog sind, ist sehr walıscheinlich; unsicherer, wenn auch nicht ausgeschlossen, bleibt dies für den Proc. falciformis der Fische.

Sclera. Bevor wir dem Ciliarmuskelapparat einige Worte widmen, soll die ¿iußere Hüllhaut des Auges, die Sclera, kurz besprochen werden. Wie bemerkt, besitzt sie wesentlich Stiitz- und Schutzfunktion, was sich in ihrem Ban deutlich ansspricht, an dem Bindegewebe, hänfig sogar Knorpel und Knochen teilnehmen,

Fig. 652.

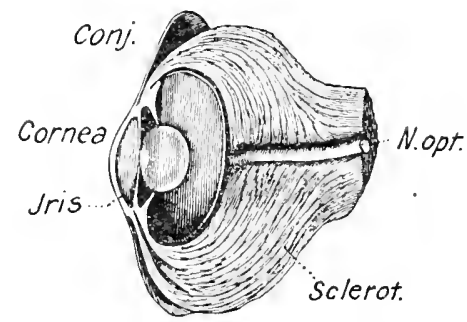

Balaena mysticetus (Auge). Horizontalschnitt. (Aus GeGexbate, Fergl. Anat, nach Sömating isis.) dagegen nur wenig Blntgefüße. Distal geht sie, wie hervorgehoben, in die Cornea über, proximal in die bindegewebige Scheide des Sehuerven (s. diese, S. 626). Ihre Dicke bleibt im allgemeinen mäßig, doch kann sie bei gewissen Vertebraten (größere Säuger: so Cetaeea [Fig. 652], Elephas etc.) am Angengrumd selu bedentend werden. Sehr verbreitet tritt in der Sclera eine verstïrkende Knorpelschicht auf, weshalb man deren völliges Fehlen, wie es sich bei Cyclostomen, cinigen Teleostecm und wodelen Amphibien. (z. B. Salamandri), den Schlungen, sowie den allermeisten Särgorn findet, in der liegel als Riickbildnng beurteilt. Deshalb aber die Selera als eine urepriinglich rein knorplige Bildung zu betrachten und sie gar vom Schädelknorpel ableiten zu wollen, scheint doch sehr gewagt.

Bei ansehnlicher Entwicklung des Knorpels, wie z. B. bei den Chondropterygiern (s. Fig. 645, S. 847) dehnt er sich (häufig verkalkt) durch die gesamte Sclera bis zum Beginn der Cornea aus. Ähnlich verhalten sich im al/gemeinen auch die Chondrostei und Dipnoi, meist anch die Ammen und Sauropsiden, obgleich sich der Knorpel nicht selten auf den Augengrund oder noch in anderer Weise beschränken kamn. - Bei den Tinochenfischen ist die Knorpelkapsel häutig in mehrere Partien zerlegt. Nur bei den monotremen Säugern bleibt der Knorpel noch erhalten und zwar bei Echidna als Kapsel, bei Ornithorhynchus nur als cin Plättchen.

Schou bei Acipenser findet man dorsal und ventral in der Conjunctiva einen zarten Knocheubogen, aber ohne direkte Beziehung zur Sclera; wogegen bei den Teleostcern nasal und temporal in der Sclera ein Knochenplättchen recht verbreitet auftritt (am größten bei gewissen Scombriden); diese Plättehen liegen urspriunglich dem Knorpel anf, treten jedoch später an seine Stelle. 
Die Knochenplättchen von Acipenser erinnern an den Kranz von llautknöchelchen, der bei fossilen Ganoiden die Orbita eng umzieht (s. Fig. 138, 3, S. 241). Dies ist um so mehr der Fall, als sich bei den strgocephalen Amphibien, den Sauriw (s. Fig. 653), Cheloniae, gewissen ausgestorbenen Reptilienordnungen (Ichthyopterygia, Pterosauria) und den Tögeln (Fig. 651) ein vollständiger Ring von meist ansehnlichen Knochenplättchen im distalen Teil dej Sclera findet, der bei den Vögeln den Verbindungsteil des Bulbus stützt (Scleroticaling). Daß die schuppenförmigen Knochenplättchen, welche diesen Ring zusammensetzen, Ilantknochen sind, scheint sicher. Physiologisch steht der Scleroticalring wohl hauptsächlich in Beziehnng zu dem von den Ciliarmuskeln gebildeten Accomodationsapparat. Eine geringfügige Verknöcherung der Sclera umkreist bei vielen Vögelu die Eintrittsstelle des Sehnervs mehr oder weniger.

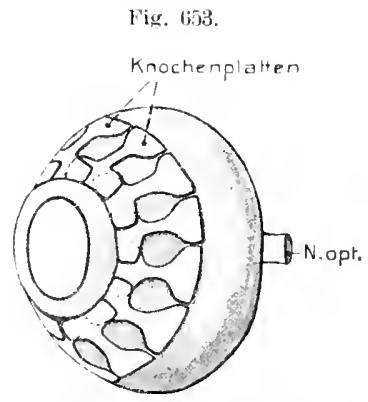

Lacerta viridis. Auge mit des scleroticalplatten in halbseitlicher Ansicht, Orié. C. H.

Ciliarmeslel (Accommodationsmuskel). Der bei den Fischen die Accommodation bewirkende Linsenmuskel wurde schon oben (S. 856) erwïhnt. Doch findet sich schon bei den Teleostei auch ein M. tensor chorioideae, der vom Cornealrand zur Chorioidea zieht, sich jedoch an der Accommodation nicht beteiligen soll. Den iibrigen Wirbeltieren dient hierzu ein besonderer Mnskelipparat, welcher sich in der Region des Ciliarkörpers zwischen die Chorioidea und Sclera einschielt und in sehr verschiedenem Grad entwickelt ist, am stärksten bei Vögeln und Sängern. Nicht stets ließ sich jedoch wirkliche Accommodation nachweisen trotz des Vorhandenseins eines schwachen Ciliarmuskels.

So wurde sie vermißt bei Selachiern, einzelnen Urodelen und bei gewissen Sauriern und Schlangen; meist sind es Dunkeltiere, welche dies Yerhalten zeigen. - Der Ciliarmuskel besteht zu-

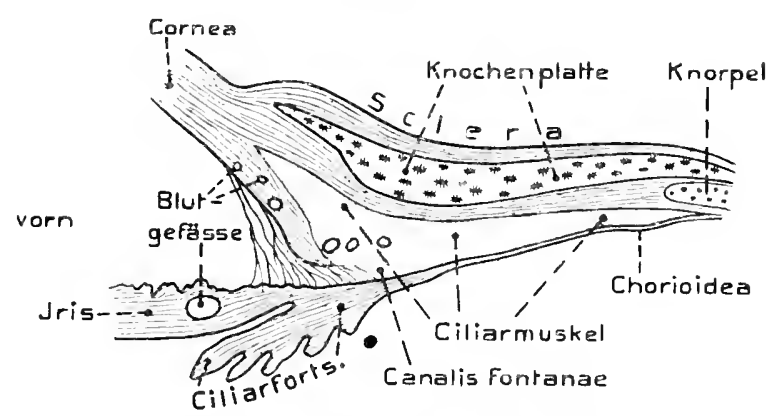

Gallopavo meleagris (Truthahu). Meridionalschnitt durch die Angenwant in ter Gegend der Grenze von solcra und Comea. Die Ciliarmuskeln rot, Crampton'scher, Ifüller'scher, Brücke'scher lluskel (nirli LUVCKART 1876). v. Bu. nächst aus meridional bis radiär gerichteten, bei Sauropsida quergestreiften Fasern, die in der Gegend der Cornea-Scleragrenze, etwa an der Irisbasis entspringen und mehr oder weniger weit gegen den Augengruni ziehen, wo sie sich an der Chorioidea befestigen; bei gewissen Säugern konnten sie sogar bis zun Augengrund verfolgt werden. Bei starker Entwicklung kann der Muskel in wehrere I'ortionen gesondert seiu, so bei Tögeln (Fig. 654), wo eine vordere, sich an die Cornea heftente 
(Crumpton'scher Mhskcl) von einer hinteren (Brïcke'scher Muskel) differenziert ist, ja häutig . sugar noch der linterste Teil der letzteren als besonderer Iuskel angesehen wurte. Zu diesen Jasern gesellen sich bei rewissen formen auch äquatorial bis schief verlaufende, so an der Irishasis mancher Amphibien und Schlangen, während bei gewissen Süngern (hesonders auch dem lleuschen) solche Fasern noch weiter serbreitet sind. Bei den Amphibien gesellen sich zu dem eigentlichen Ciliarmuskel ( $M$. tensor chorioidcae), ter jedoch nasal und temporal unterbrochen ist, noch Muskeln, welche vom. Ciliarkörper nach vorn zur Cornea-Scleragrenze ziehen; ein ventraler solcher 1 . protractor lentis tindet sich bei den Urodelen und Ameren, zu dem sich bei den letzteren noch ein dorsaler gesellt. Fraglich erscheint es, ob sich der sentrale mit dem ketractor lentis der Iische vergleichen läßt. - Lin eigentümlicher, rom Ciliarkïrper quer nasalwärts ziehender Muskel wmde bei Sauriern und Schildkrïten gefunclen.

Der bei den Primaten besonders ansgiebige Accommodationsvorgang der Mammalia verlïnlt so, daß die Kontraktion des Ciliarmuskels das Befestigungsband der Linse (Zonula) vorschiebt, oder zngleich durch tie Kontraktion der Ringlasern eine Verkleinerung des Durthmessers der Zomulabasis eintritt, wolurch die Linse entspannt wirl, da sie im Ruhezustand samt ihrer Kapsel lurch den rałlären Zug der Zonula unter einer gewissen Spannung steht. Inrch Aufhebung desselben muß daher die linsenkrümmung (besonders distal) zunehmen und eine Accommodation für die Nähe eintreten. - Kis in die neneste Zeit wurde auch den allemeisten Sauropsiden ein entsprechender Accommolationsvorgang zugeschiehen. Eingehende Untersuchungen ergaben aber, daß die hier z. T. recht ausgiebige Accommodation wolıl iiberall durch eine stärkere Herrorwölbung der distalen Linseuregion geschieht, welche dadurch bewirkt wird, daß die Ciliarfortsätze einen I)ruck auf die distal rom Z̈quator gelegene Linsenpartie ansïben, was seinerseits wieder durh the Ciliamuskulatur und die lingmuskulatur der peripheren Irisregion hervorgerufen wird. Je ausgiebiger die Accommodation, um so weicher ist bei den Sauropsiden im allgemeinen auch die Linse. - Ausnahmsweise soll ein ähnlicher Accommodationsrorgang anch bei gewissen Säugem (Lutra) vorkommen, in Znsammenhang mit lem Sehen in Luft und Wascer, was ïberhaupt ausgiebige Accommodation erfordert. Die Accomodation der Amphibien und gewisser Schlangen dagegen soll so geschehen, daß die Linse durch den M. protractor lentis (Amphibien) nach roln rerschoben, also ihre Entfernung con ler Retina vergrößert wird, was ebenso wirkt wie die stärkere Krümmung der Linse bei den Mammalien. Immerhin bestehen ïber die Wirkungsweise der Ciliarmuskeln bei der Acrommodation noch mancherlei $Z$ weifel.

Fig. 655 .

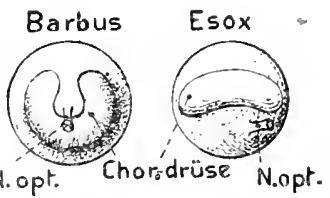

A 11 \& yon biathus und lisox vol hinten gesehen, um die ('ho rioidealirüst zn zeigrn. ‥ Pill.

Die Blutgefïße des Auges lassen sich unterscheiden in solche, welche die Bulbuswand und solche, welche die inneren Teile: Glaskörper, P'rocessus falciformis, Pecten und zuweilen auch die Retina versorgen. Die Gefäße der Tetrapoden kommen sämtlich oder doch zum größten Teil aus einer Arteria ophthalmica, die gewöhnlich ein Ast der Carotis interna ist, oder es gasellt sich dazu noch eine zweite Ophthalmica aus der Carotis externa (riele Säuger). Bei den Fischen ist ter Ursprung der Augengefäße eigentumlich und soll daher erst später besprochen werden. Die Vorderregion des Bulbus, besonders die Iris und Irisregion, kann jedoch auch son anderen Gefußen versorgt werlen. Daf sich die Bulbusgetibe rorwiegend in der Chorioidea verbreiten, wurde sthon herrorgehoben. - Zahlreiche Kuochentische (auch Amia unter den Holostei) besitzen eine besondere Eigentümlichkeit der in den Augengrund tretenden Arteria ophthalmica magua, indem diese sich zwischen Sclera und Chorioilea plötzlich zu einem sog. Wundernetz kapillar auflöst, aus welchem dann die Chorioidealgefäße hervorgehen. Auch die rückkehrenden Venen erleitlen an dieser Stelle eine entsprecheude Auflïung. Diese Bildung wirl als Chorioidealwriise bezeichnet (lig. 655) und kann so stark entwickelt sein, daß sie um die lintrittsstelle 
des Sehnervs eine wulstige Anschwellung bilket. Die Hypothese, laß das Gefäßwerk der Chorioidealdrïse in Beziehung zu einer ehemaligen Kieme stehe, ist nuwahrscheinlich.

Die imeren Blutgefäße gehen wahrscheinlich sämtlich ans der embryonalen (refïßschlinge hervor, welehe durch den Augenspalt in den Glaskörper eindrang. Sie scheint bei den meisten Vertebraten ebenfalls ein Ast der ursprünglichen Arteria ophthalmica zn sein. hei den Fischen aber eigenen Ursprungs. Bei vielen nieteren Vertebraten: Holostei, zahlreiche Telcostei (jedoch nicht den Acanthopterygii), Anura und Oplidia gehen an: ihr bleibende Gefiiße des Glaskörpers hervor, die sich auf lessen (1bertläche in der M mbrana hyaloidea rerbreiten. - Aus der Schlinge leiten sich auch die Gefäße des Processus falıiformis, des Zaptens und Kamms ab, bei Vögeln nnter vorheriger doppelter Wumdernetzbilumg. - Der zufïhrende Teil (Arterie) der embryonalen Gefißschlinge der Sänger wirl bei da Eutwicklung des Augenspalts vom Sehnerv uuschlossen und tritt daher als Artcria centralis retinae in ihn ein. Embryonal entwickelt sie gleichfalls Gilaskörpergefïße und setzt sich, mach Durchbohrung der Retina, durch den Glaskörper bis zur linse fort, um sich als eiu Gefïßwerk auf deıen Proximallläche zu verbreiten, und, ihren Iquator mmgreifend, auch die vordere Linsenfläche zu ülerziehen. Dieser ganze GefïBapparat des Glasliörpers und les linse der entryonalen Säuger bihlet sich aber später völlig zurïck. Dagegen gehen von der Arteria centralis retinae der meisten Säuger (nicht bei Monotremen und einigen /)itr $\rho$ men, z. 1:. Cacia) Gefißse aus, welche sich in der Opticusfaserschicht der Retina verbreiten. Den übrigen Vertebraten fehlen solche Netzhautgefäße mit selteren Ausuahmen (z. B. Amynilla, Muraena unter den Fischen, wo sie von den Glaskörpergefäßen ansgehen).

Der Angenbulbus liegt in der Orbitu (Angenhöhle), die, wie wir schon beim Schärlel sahen, in sehr versehiedenem Grad von Knorpel oder Knochen umsehlossen wird. Erst bei den höchst stehenden Sängern (Affrn uud Monscli) wird die kn̈̈cherne Orbita vollständig. Wo ein soleh knorpliger oder knöeherner Abseh̆luß fehlt, findet sich eine bindegewebige, häufig auch muskulöse Membran (Orbitalmemlnan), welche die Umschließung vervollständigt. - Der Bulbus erfüllt meist nur den äußeren Teil der Orbita, indem sich noch die Bnlbus- nud Lidmusknlatur, die Angendrïsen, sowie Binde- nud Fettgewebe in sie einlagern. - Bemerkenswert ersebeint, daß bei den meisten Chondropterygiem vom Grunde der Orbitil ein knorpliger Fortsatz (Bulbusstiel) entspringt, dessen 1)istalende sieh häufig schïsselförmig ausbreitet (Fig. 645, S. 847); auf ihm bewegt sich der Bulbus. Bei den übrigen Fischen findet sich statt dessen häufig eine bandartige Bildnng (Tenaculum), welehe den Bulbus am Orbitalseptum befestigt.

Augentider. Die an die Corneaperipherie ansehließende änßere Haut ist meist deutlieh als Bindehaut (Conjunctica) entwiekelt, welche in der Regel weicher und durchsichtiger bleibt als die gewöhnliche Haut. Neist kommt es im Unfang der Conjunetiva zur Bildung einer ringförmigen Hautfalte, der Augenlidfalte, welehe mehr oder weniger über die Cornea, bis zu vollständigem VersehlnB, heriibergezogen werden kann. Meist sind der dorsale und ventrale 'Teil dieser Falte stäker entwickelt, so daß sich ein dorsales und ventrales Lid unterscheiden lassen, die ïußerlich von der gewöhnlichen Hatut, innerlieh von der Conjunctiva palpebrarum überkleidet sind, welch letztere zuweilen besondere histologische Eigentiimlichkeiten zeigt.

Unter den Fischen besitzen nur die Chondropterygier (Fig. 656) zwei derartige Lider in guter Entfaltmig. - Bei den ̈̈brigen Fischen lindet sich gewöhnlich eine circuläre Angen- 
lidfalte, die jedoch häufig dorsal und ventral, oder nasal und temporal (vorn und hinten) stïrker entwickelt ist. Sie kann auch stellenweise bis gäuzlich rudimentïr werden. Bei gewissen Kuochentischen (z. P. Clupea und Salmo [Fig. 508, S. 711]) entspringt von der Innentläche des vorderen Augenlirls eine ansehnliche Hautfalte, die einen Teil der vorderen Corsea ïberzieht und nach Bau und Lage an die später zu erwähnende Nickhaut der Chondropterygier erinnert (sie wurle daher auch als Pseudonichlaut oder Extrapalpebralfalte

Fis. 650.

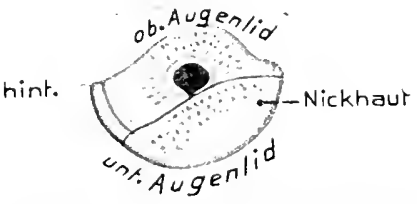

(ralens canis (Haifisch) rechtes Altige mit den Augenticlern. 0.1 . bezeichnet). - Die Lirlislten der wrodelen Amphibien. besonders der Ichthyoden, sind, wenn überhaupt, sehr schwach entwickelt, wogegen die Amuren ein schwaches oberes und ein sehr ansehnliches nuteres Lid besitzen. Letzteres ist dadureh bemerkenswert (Fig. 657). daß das eigentliche untere Lid eine mäßig erlobene Falte darstellt, ron deren innerem, freiem Rand eine halbdurchsichtige, etwas dünnere ansehnliche Nembran ausgeht, die im zurückgezogenen Zustand größtenteil zwischen dem ventralen Lid und der Cornea einge-

faltet liegt, aber dorsalwärts iiber die ganze Cornea herübergezogen werden kann. Diese meist als Nielihant bezeichnete Nembran ist also eine Fortsetzung des unteren Lids unl unterscheidet sich dadurch ron der gleich zu besprechenden eigentlichen Nickhaut. - 1)ie beiden Lider der ïbrigen Wirbeltiere sind häufig etwas ungleich entwickelt; so ist bei den Samropsiden (besonters Samiern und Tögch) das untere in der liegel größer und be-

Fig. 657 .

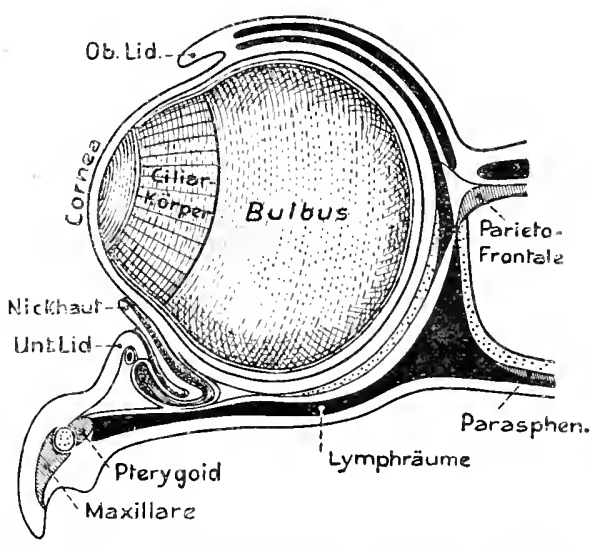

Rana esculenta. Auge nit Tmgebung vertical halbiert, zur Demonst nation der lider. besonders ter sog. Nickhant: Knorpel punktiert: Knoclen schraffiert; lymphranme schwarz (nich iatup, Frosch 1904). weglicher (Ausnahme Krokodile), während dasselbe für das obere der Süuger gilt. Eigentümlich erscheint die circuläre Bildung der ansehnlichen Lidfalte mit enger ïffnung bei den Chamacleontiden. Den Ascalaboten und Amphisbaenilen (Sauria), sowie den Sehlangen fehlen die Lider scheinbar; dagegen findet sich bei ihnen eine durchsichtige geschlossene Membran (sog. Brille), welche die gesamte Cornea in einjem Abstand ïberlagert, ähnlich etwa wie die sog. Cormea der Cephalopoden (s. S. 832) die Linse. Diese Membran wird gewöhulich rom unteren Augenlid abgeleitet, welches mit dem Rest des oberen über der Cornea vijlig verwachsen ist, was um so wallrscheinlicher ist, als bei gewissen Sauriern las untere Lid ganz oder teilweis durebsichtig erscheint und über die gesamte Cornea emporgezogen werden kann. Die Ansieht, da B die Schlangenbrille die Nickhaut repräsentiere, scheint weniger begründet. Nenerdings wurde beobachtet, daß bei nicht wenigen grumbewohnenden Fischen (so Golviden, Cothus u. a.) eine an die Sednangenbrille erinnernde äußere durchsichtige Haut den Bulbus iberzieht, welche Haut durch einen mit FIüssigkeit erfülten Hohhaum ron der distalen Versehlußmembran des Bulbus (Fortsetzumg der Sclera) geschieden ist. - Es scheint aber sicher, daß diese Einrichtung nichts mit der Schlangenbrille zu tun hat, sondern durch Differenzierung und Sonderung der Cornea samt Conjunctiva coneae in zwei Lagen entstanl.

Die Lider können von einer Knorpeleinlagerung gestützt werden, so das untere vieler Sauropsiden (besonders Sauria, hier zuweilen auch knöchern, und Vögel), wälırend bei den 
Säugern eine verdichtete Bindegewebsbildung (Tarsus) um die Talgdrüsen ('Tarsaldrüsen), die läutig auch als Knorpel beschrieben wurde, den Rand beider Lider stiitzt. - Bei Sauriern und Krokoditen dienen auch die in verschiedener Zahl am Dorsalrand der Orbita vorkommenden Hautknöchelchen (Ossa supraorbitalia, s. Fig. 157 P, s. 274) zur Stïtze des oberen Lils.

Schon bei einigen Maim (z. B. Mnstelns, Galens, Carcharias) findet sich anßer den zwei geschilderten Lidern noch ein drittes, die Nichlaut (Membrana nictitans, Palpebra tertia, s. Fig. 656) als eine diunere bis dickere, wenig durchsichtige Hantfalte, die sich im inneren (vorderen) Augenwinkel, im Grunde der Einfaltung der Augenlider (Fmmix), ans der Conjunctiva erhebt und sich längs des Grundes der unteren Lidfalte, schief abfallend, noch mehr oder weniger weit gegen den änßeren Augenwinkel erstreckt. Ob diese Nickhant der Haie jener der 'Tetrapoden streng homolog ist, erscheint etwas unsicher. - Sie kann mehr oder weniger nach oben nud gegen den äußeren Angenwinkel riber die Comea heriibergezogen werden. - Den Amphibien feblt diese IIant, da ihr, wie schon bemerkt (s. S. 862), die sog. Nickhaut der Anuren wahrseheinlich nicht entspricht. - Den Sauropsiden kommt sie allgemein zu (ansgenommen den mit der Brille versehenen Schlangen mnd Sauriern) und ist bei den Tögctn besouders stark entwickelt. - Anch die Nickhaut maneher Süuger (besonders der IInftiere) ist noch recht ansehnlich, bei den I'rimaten kommt sie jedoch nur rudimentär, als Plica semilunaris, im vorderen inneren Angenwinkel vor. Die Nickhant der Sänger (und gewisser Saurier) wird durch eine nicht unansehnliche Knorpeleinlagerung gestïtzt, die selbst den Affen und manchen Menschen nicht fehlt.

\section{Zur Bewegung der Lider dient eine besondere Mruskulatur.}

schon bei den Haien existiert ein lietractor der beiden Augenlider, gewöhnlich als Retractor palpebrae superioris bezeichnet, der von hinten zu ihnen tritt. Zu ihm gesellt sich bei den mit einer Nickhant rersehenen noch ein Lexator membranae nictitantis, ler ron ler hinteren Schälelsegion mit.einer Srhne zur Nielshaut zieht. Beille Muskeln baben jedenfalls mit den Lilmuskeln der Tetrapoden nichts zu tun, da sie sich nicht ron den Bulbusmuskeln, sondern rom Constrictor superficialis dorsalis (s. S. 436) ableiten und vom Trigeminus innerviert werden. - Von den Sauropsiden ab besteht die Lidmuskulatur meist in einem Verengeser oder Schließer (Muscutus orbicularis), der die Lidspalte ringföruig umzieht, jedoch auch noch im Umkreis der Orbita ansgebreitet sein kann und sich, wenigstens bei den Säugern, von der Gesichtsmuskulatur ableitet. - Iljerzu gesellen sich bei den Sauropsiden gewöhnlich noch Rückzieher (Depressor und Levator) der leiden Lider, die in der Orbita entspringen, während den Säugern meist nur einer des oberen Lids zukommt (bei Elephas auch des unteren; bei den Sauria meist nur einer des unteren). Wahrscheinlich leiten sich die Lidmuskeln von den gleich zu besprechenden geraden Inskeln des Bulbus ab, was sich bei den Cetaceen und gewissen Carnicoren (besouders Pinnipediem) deutlich ausspricht, inden hier säntliche Recti Fortsetzungen in die beiden Augenlider senden. Der Muskelapparat der Nickhaut wird bei den Bulbusmuskehn besprochen werden.

Bulbusmuskeln. Zur Bewegung des Bulbus in der Orbita dient ein besonderer Mnskelapparat, der bei sämtlichen Cranioten recht übereinstimmend gebant, und nur bei den rudimentären Angen mehr oder weniger rïckgebildet ist, ja ganz feblen kann (Myxinoiden). Auch die Teleskopangen der Tiefseefische sind unbeweglich und ibre Muskulatur manchmal defekt. - Schon frïher (S.640) wrde 
die Entwieklung đieser Muskeln aus den drei vordersten Kopfsomiten erwähnt, sodaß wir daranf verweisen dürfen. - Bei sämtliehen Cranioten finden sieh 6 Bulbusmuskeln (s. Fig. 658), die von der Orbitalwand entspringen, und sich etwas innen vom Äquator an den Bulbus anheften. Es sind dies die 4 geraden Mhuskeln (Recti), die im allgemeinen rom IIintergrund der Orbita ausgehen mul in der Riehtung der Augenachse verlaufen: ein dorsaler oder oberer (Rectus superior), ein ventraler oder unterer (Rectus inferior), ein vorderer oder innerer (Liectus anterior oder internus) und ein hinterer oder :iußerer (Rectus postcrior oder externus). Diese Muskeln können den BnIbris um seine dorsoventrale und transversale Aehse rotieren oder ihn auch bei gleiehzeitiger Kontraktion retrahieren. Wie wir frïher sahen (S. 640), werden die drei erstgenannten Muskeln vom Nervus ocnlomotorins, der Reetus posterior dagegen rom Nervus abdneens versorgt; anch wurde schon dilrauf hingewiesen, daß ïber die Bedeutung des Rectus inferior bei den Crelostomen gewisse Zweifel bestehen, da er vom Nervus abducens versorgt wird.

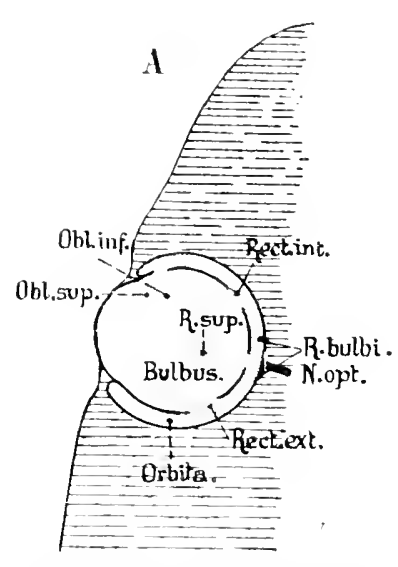

Fig. 65.

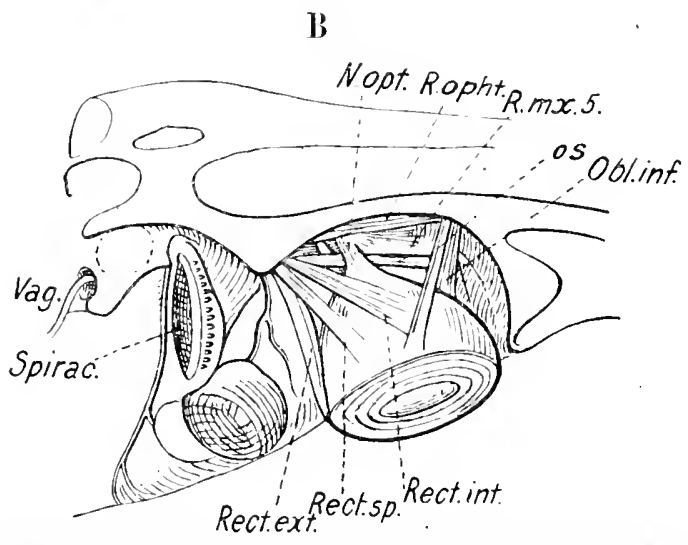

A schema der Augenmuskeln eines Wirbeltiers; linker Bullus von dev borsalseite. D Muskeln des rechten Auges von Centroplorus crepiallous. A Orig. B (aus likgexbarli, Vergl. Anat.)

O. B.

Bei den meisten Wirbeltieren entspringen die geraden Muskrin in Her Umgebung der Durchtrittsstelle des Nervus optious im Orbitalurund; bei den Fischen lagegen ist ihr Ursprung meist ziemlich weit von dieser Stelle auf die caudale Region der Orbita gerülht (Fig. 658B); bei gewissen Knochenfischen (besonders Physostomen) sind ilıre Ursprünge sogar mehr oder weniger tief in den beim Schädel erwähnten Augenhöhlenkanal (lyodom) verlegt (s. S. 240). Auch bei den Sauriern ist dic Insertion der meisten Recti stark ventral rerlingert,

'/u den geraden Muskeln gesellen sich stets noch zwei schiefe, der Obliquus inferior (Nervus oculomotorius) und superior (Nervus trochlearis). Beide entspringen an der nasalen (vorderen oder inneren) Orbitalwand, ihrem Außenrand mehr genähert oder weiter innen, und ziehen schief zur Augenachse, der erstere zur ventralen Bulbuswand, der letztere zur dorsalen. Die beiden schiefen Mnskeln können den Bulbus um die Augenachse rotieren. 
Der Ubliquas superior der Säuger erfïlnt eine Verändermng, welche bei den Womotremen (Echidna) noch in der IIervorbilung begriffen ist, indem hier ein ansehnlicher Teil des Mnskels seinen Ursprng tiefer in den Orbitalgrumb verlegt hat un sich erst distal nit dem äneren Anteil. der seine ursprüngliche lefestigung bewahrte, vereinigt, inden er an dieser Stelle durch eine Sehnenschlinge tritt. Schon hei Onithorhynchus ist aber der äußere Teil ganz geschwumden, wie bei allen ährigen Sïugern; der obliquus superior entspringt daher bei letzteren ganz in Orbitalgrund neben den geralen Muskeln und tritt außen an ker Nasalseite der Orbita durch eine rerkmospelte Sehnenschlinge (Trochlea), wounrch er erst den schiefen Verbanf zur Dorsalwand des Bulbus erhält.

Von den Amphibien an gesellt sich zu den geschilderten Bulbusmuskeln noch ein Lï̈krieher des Bulbus (Retractor bulbi, Huseulus choanoides), der in Grunde der Orbita, innerhalb der Recti entspringt und, den Nervus opticus ambiillend, zum Bulbus zieht. Er retrahiert den Augapfel in die Orbita; bei den Ophirlin und den P'rimaten ist er rïckgebildet.

Bei manchen Formen (Amuen, Cletonicrn, Sizugern) ist her Retractor in drei bis vier Portionen gesondert, was, ebenso wie seine lmeriermg lurch den Oculomotorius uml Abducens (Sïnger), dafüir spricht, daß er durch Abghederung ans den gerarlen Muskeln hervorging, oder, wenn er un vom Abducens innerviert wirl. allein aus den lectus externus, mit dem er zuweilen auch noch zusammenlïngt (z. B. Krokodile). Eigentümlich erscheint die enorme Entwicklung des Retractor butbi bei den Cetacen um einzelnen Pinnipcdiem (z. B. Trichechus), obgleich deren Augen wenig heweglich sein sollen. ls wurde dalıer sogar vermntet, daß dieser mäthtige Muskelapparat hier als Wärmequelle diene.

Der Retractor der Anuren besitzt anch die Funktion, die sog. Nickhaut (unteres Augenlid) iiber die Cornea heraufzuzieben.

Dies wird dadurch erreicht, daß an der Ventraltliche des bulbus eine Sehue (Nirkhautsehne) etwa quer hinzieht. (s. Fig. 659) und mit ihren Enlen, die seitlich aufsteigen, zu dem inneren und äußeren Ende der Nickhaut tritt. I) Sese Sehne ist in eigentïmlicher Weise (z. T. anch direkt) mit dem letractor verbunden. der so bei jeder Rückziehung des Bulbus die Nickhaut über das Auge emporzieht. Mas Herabziehen der Nickhaut bewirkt ein kleiner hesonderer Muskel (Depressor membranae nictitantis):

Komplizierter erscheint der Muskelapparat der Sauropsidenniclihaut. $\mathrm{Zu}$ ilırer Bewegung dient ein besonderer Muskel (Musculus pyramidalis), der bei den Kroliodilen (Fig. 660), Schildlirïten (Fig. 661) und rö̈geln (Fig. 662) von der nasalen (medialen) Hinterwand des Bulbus entspringt und dorsal vom Nervus opticus znr Temporalseite zieht, um die er mit seiner langen Sehne anf die Vorderfläche des

Fig. 659.

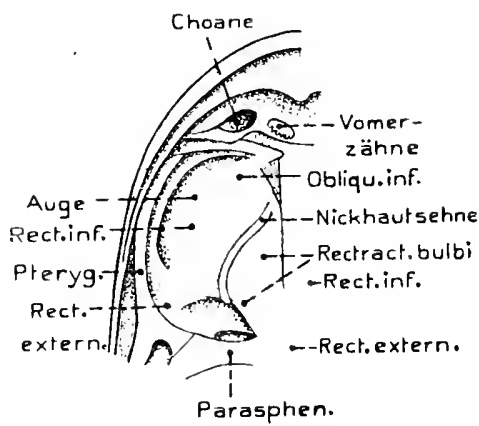

liana esculenta. Reelites Auge ron der Gaumenseite freigelegt, mit den Augenmuskeln und der Nickhautsehne. Rectus externus lateralis) und inferior durcigesehnitten und zuziickgesehlagen (nach GAUPP, Frosch 1904). v. Hiu.

Bulbus herumgreift; hier verbindet er sich mit dem temporalen Nickhantende. Bei seiner Kontraktion wird demnach die Nickhaut temporalwärts über das A uge gezogen. Da dieser Muskel bei gewissen Reptilien noch mit dem Retractor bulbi 
zusammenhängt, so läßt er sich ans diesem ableiten (Innervation durch den Nervus abdncens). Der Pyramidalis der Schildliröten (Fig. 661) sendet noch einen \%weig zum unteren Augenlid. - Bei den Tögeln (Fig. 662) kompliziert sich die Einrichtung dadurch, daß die lange Sehne des Pyramidalis durch die röhrenförmige Sehnenschlinge eines besonderen platten Muskels tritt (Musculus quadratus oder bursalis, N. abduc.), welcher an der Hinterwand der dorsalen Bulbushälfte entspringt. Daß dieser Muskel bei seiner Kontraktion die Wirkung der Nickbantsehne unterstiitzen muß, ist klar. - Ein offenbar diesem $M$, quadratus entsprechender

Fig. 660.

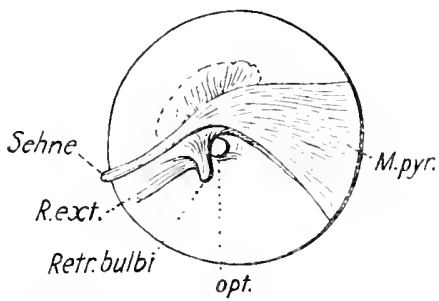

Alli gator. Bulbus von innen mit den Augenmuskeln(aus GEGENBAOR Ygl.Anat.).

Fig. 661

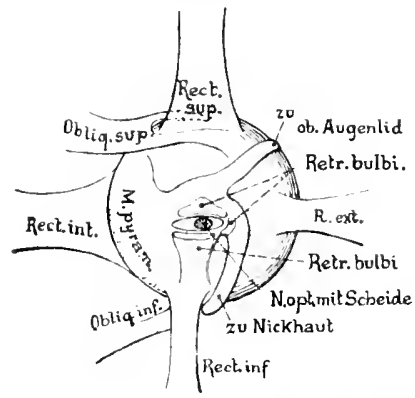

Cheloue viridis (seeschildkiöte). Rechter Bulbus von innen; die Augenmuskeln von ihren Ansätzen an der Or hita abgelöst und ausgebreitet.

Orig. O. B.

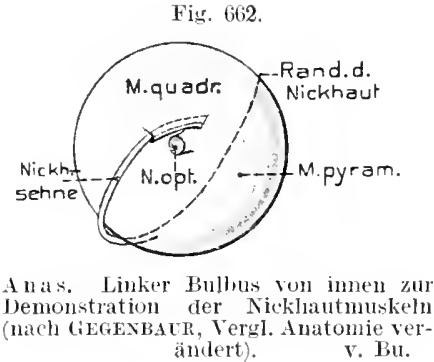

Fig. 663

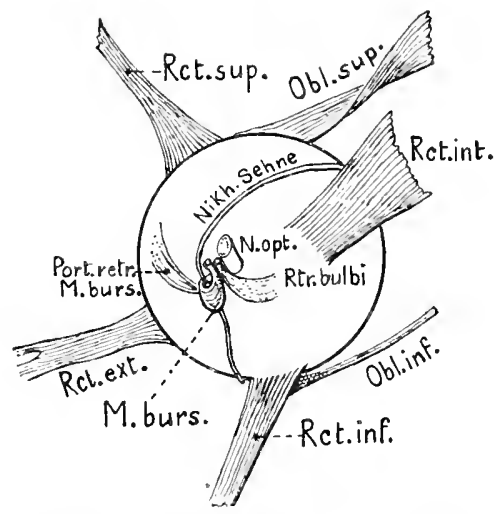

Likcertaviridis. Linkes Auge von innen mit len Muskeln. II, rect, int. zurückgeschlagen um den Opticus, sowie den M. Jursalis und den Retr. bulbi, die beide in dieser Ansicht stark verkiurzt erscheinen, zu zeigen (nach 11 . WEBEn 1877). $0 . \mathrm{B}$.

Muskel (Portio retrahens M. bursalis) entspringt bei den Sauriern (Fig. 663) von der temporalen Hinterwand des Bulbus, vereinigt sich aber in der Gegend der Nickhautsehne (Lacerta) mit einem vom Orbitalgrund, neben dem Retractor bulbi entspringenden Muskel (M. bursalis), dessen Distalende die Nickhautsehne schlingenartig umfaßt und sie nebst der Nickhaut bei seiner Kontraktion vorzieht.

Offenbar sind diese beiden Muskelu, die vom $\mathrm{N}$. abducens versorgt werden, Teile eines einheitlichen; doch fragt es sich, ob sie ursprïnglich aus einem wie bei den Vögeln beschaffenen II. quadratus hervorgingen, indem dieser sich verlängerte und sekundär im $O_{r}$ - 
bitalgrund inserierte, oder, was wahscheinliher, ob der Zustand bei den Sauriern der prinitivere ist, welher noch auf die Ableitung des Quallatus rom Retrartor bulbi linweist.

Bei den Säıgern, denen besondere Nickhautmuskeln fehlen, soll ler Retractor bulbi dies Lid bewegen, indem er bei seiner Kontraktion hen Nickhautknorpel in eigentiimlicher Weise vershiehe nnd damit auch die Nickhant.

Augendrüsen fehlen den Fischen völlig. Bei den iibrigen Wirbeltieren entwickeln sich dagegen aus der Conjunctiva des Lidfaltengrundes (Fornix) Hautdrïsengebilde, welche bei den urodelen Amphibien im Grunde der unteren Lidfalte zahlreieh vorkommen. - Aus ihnen geht bei den Anuren und Gymmopliomen meist eine ansehnlichere, an der Nasalseite des Bulbus liegende Drïse (Har(lersche Drïse) hervor, welehe durch einen Hanpt- und mehrere Nebenausführgänge (Anuren) im vorderen Angenwinkel, an der Innenfläche des nnteren Lids mündet. - Die Sauropirden und Mammalier besitzen meist am gleichen Ort diese, in der Regel tnbulöse 1)riise, die gewöhnlich mit einem einzigen Auṣührgang (bei Mammalia auch mehreren) versehen ist, welcher an der inneren Nickbautfläche mündet. Dadurch steht die Hardersche Wrïse in naher Beziehung zur Nickhant und ist auch bei den Sauropsiden mit gut entwickelter Nickhaut meist sehr ansehnlich (Fig. 664 A), größèr als die gleich zn erwähnende Tränendrüse.

Die meist recht große Angenuriise der Schlangen (s. Vig. 664 B), welche sich häufig noch außerhalb der Orbita caulalwärts ausbreitet, wird wegen ihrer Mindung an vorleren Angenwiukel jetzt gewïhnlich als Hardersclse Drüse gedeutet. während sie friiber als Trü̈nendrüse galt. sie breitet sich ventral vom Bulbus aus.

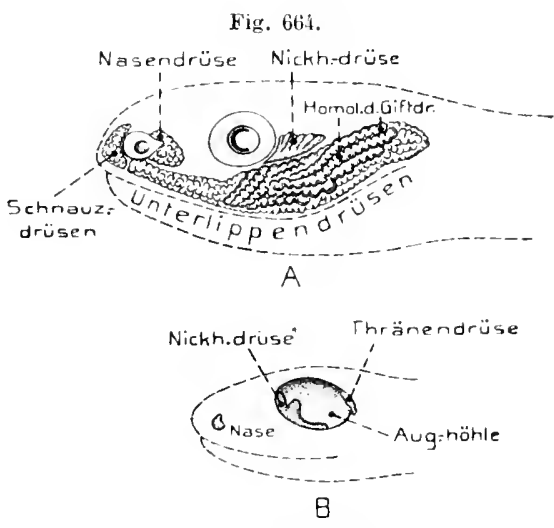

1 Tropidonotus natrix (Ringelnitter). Kopf von links. Unterlipyendrüsen (einschl. sogen. Schmauzendrïsen), Nasendrüse und Nickhautdrüse. $-b$ La certa agilis. Kopf von links. Auge herausgenommen, um die Tränen- und Nickhautdrüse zu zeigen (nach leydo 1873). ähnlich wie bei manchen Saurieru.

Der Entwicklungsgrad der Harderschen Drïse der Mammalia entspricht in der Regel jenem der Nickhant; sie ist daher bei Affen und Menschen riickgebildet, doch ihre Anlage ontogenetisch noch nachweisbar. Das Sekret der IIarderschen Driise ist meist mehr fettiger Natm.

Von den Sauropsiden an findet sich (ausgenommen bei Schlangen) auch im hinteren (änßeren) Augenwinkel eine Drüse, die Träncndrüse, mit gewöhnlich wässerigem Sekret. Ihre meist zalılreichen feinen Ausfiihrgänge münden in der Regel auf der Innenseite des oberen oder auch beider Lider. Bei gewissen Schildkröten (Sceschildkröten) wird sie sehr großs. Bei manchen Sïugern bleibt sie dagegen sehr klein (z. B. Elephas).

Daß sie den Cetaceen lehle, wie lı̈̈ntig angegeben wird, scheint nurichtig: viehmeh sollen bei ihnen sowohl die Hawlersche als die Tränendrïse ansehnlich entwickelt sein, 
jedoch gleichartig ausgebildet und längs des gesamten oberen lides ausgebreitet. so daß hier gewissermaßen ein vereinfachter Zustand vorliege.

Die Sekrete der beiden Drüsen werden durch einen feinen Kanal, den Tränennasengang (Ductus nasolacrimalis) in die Nasenhöhle abgeleitet. Ontogenetisch geht er aus der Epidermis zwischen Auge und Nasengrube hervor, ursprünglich also wohl ans einer offenen Rimne zwischen Ange und Nase.

Er heginnt meist im inneren Angenuinkel (hei den Amuren in der Mitte des unteren Lids) und zwar in der Regel mit zwei feinen, rumlen bis spattö̈migen frfmungen (Träncnpunlte), die sich in zwei Kanälchen fortselzen, aus deren Zusammentluß (manchmal muter Anschwelhng zn einem sackartigen Teil) der Tränenkanal eutsteht. Lir durchsetzt in seinem

Fin. $60 \%$.

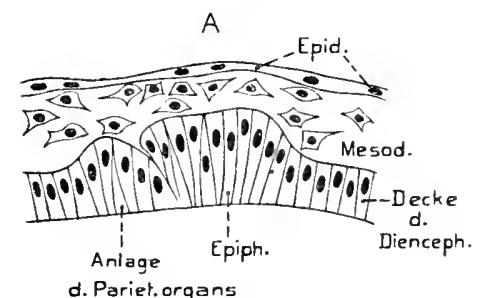

d. Pariet.organs
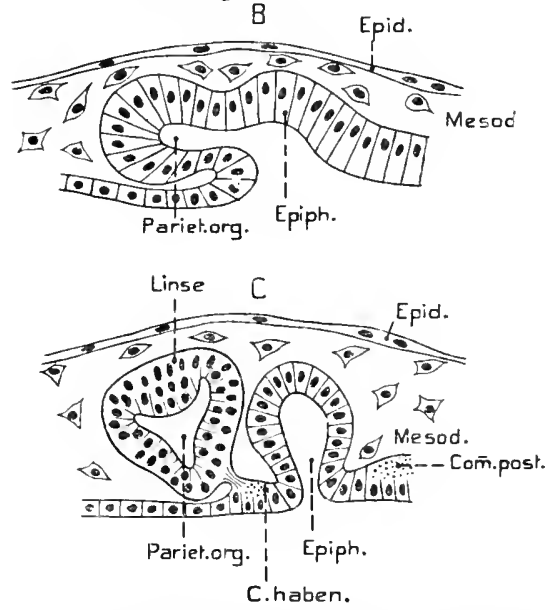

La certa (Jmbryo). Zur Entwicklung rer Epiphyse und des Parietalorgins. - A Embryo ron $3 \mathrm{~mm}$. Merlianschnitt durch die l)ecke les biencephalon: rechte Anlage dos l'arielalorgans nud der Epiphyse - B libenso efwas ialter. - " Parietalorgan umi Epiphyse haben sich sesondert und der Nerv. parietalis ist andelegt limbryo v. $7 \mathrm{~mm}$ ) (nach NovK(1) 1910). r. Bu. weiteren Verlanf gewisse Schädelknochen (bosonders das Laerimale, welches nach ihm benamnt wurle) und mündet schließlich in die Nasenhöhle, was an ziemlich rersuhiedenen itellen geschehen kanu (s. bei Geruch:(rganen).

bie anselmbiche Nicklanturise der Schlangon mimlet direht in den Antang les Tränenkanals, weshalb ihr Sekret wahrscheinlich gar keine Rezielıungen melır zum Auge besitzt, somdern an der Einnü̈nlumgsstellı der Jacobsonsthen Grgane in die Mundhöhlt ablließt (s. S. T19; Anmäherungen an dieser Zustand zeigen schon manche Sazrier); die 1)riise ler Schlangen hat also ihre Funhtion geändert um scheint wesentlich die lolle einer speicheldrüse übernommen zu halien. - Die Augenlider der Mammalia sind ziemlich reich mit llauthrüsen versehen. In dit Bälue der Cilien (Augenuimpern), die ledoch nicht allen Siugern zukommen, müulem Talg- mml słlıeiß-( Knäuel-)drüsen, und an dem immeren lreien Rand der Lider tindet sich eine lieihe ansehnlicher moditizister Talıdrïsen, die Meibom'schen oder Tassaldriisen. Anf der Conjunctiva der Augenliner können ferner kleinere Drüschen son ähnlichn. Funktion wie die Tränendrüse autreten.

\section{5c. Unpaare Augen der Craniota.}

Pineal-und Perapinealorgane oder-augrn

bei der Schildermug des schädets her Stegoecplialen, Rhynchoeephalen (sphenolon) und Samire w urle hervorgehuhen (s. s. 26i um 276), daß zwischen den beiden Parietalia in ler kegel eine kleine Ciftumg bleibt (Foramen parietale, scheitelloch), welche auch den meisten ausgestoblenen lieptilienulnumgen zukommt, un sogar bei Ornithorhynehus gelegentlich angetroflen wurle. Die Samier mul Khymchoecphalen zeigen, daß sich in dem das Scheitelloch erriblemlen Bindegewebe, seltwer etwis ibber oder unter dem Foramen ein

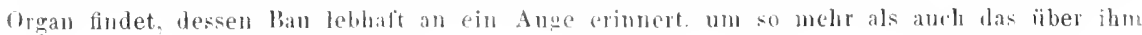


liegende Gewebe: Bindegewebe, Corium, Epirlermis, sowie die Ilornschuppe (Cornealschuppe pigmentirei und durchsichtig bleiben (Scheitelfleck), das Organ also dem Licht zugänglich ist. Unter den Sauriern fehlt das Organ den Geckoniden und vereinzelten anderen Formen. Nur selten hat sich das Scheitelloch ïber ihm knöchern geschlossen. - D Da auch den ausgestorbenen Reptilien, sowie den Stegocephalen, welche ein solches Scheitelloch besaßen. ein entsprecheudes Organ zukam, kamn nicht zweifelhaft sein.

Bei den Sauriem und Rhynchocephalen wird das Organ gewöhnlich als Parietalauge (anch Parietalorgan) bezeichnet, zuweilen auch als Parapinealorgan. aus Gründen, die sich im Folgenden ergeben.werden. Wir wollen dies Parietalauge zuerst etwas genaner betrachten. neil es bei den genannten keptilien am besten ausgehildet ist, um besprechen anschließend eine ähnliche lildung bei niederen Wirbeltieren. - Wie die Seitenaugen der Vertebraten entsteht es durch Ausstiilpung der Ilimblase und zwar ans der Decke des Diencephalon, licht vor der Epiphyse (lig. 665 A-B). Es ist aber bis jetzt noch strittig, ob es sich wirklich ganz unabhängig rou der Epiplyyse bildet, oder ob beide Organe aus einer gemeiusamen Anlage herrorgehen; iu welchem Fall das Parietalange also eine aus der rostralen Wand der ursprünglichen Epiphysenausstülpung entstchembe Bildung wäre. Inmerhin sprewhen die neueren Erfahrungen mehr lür seine selbstinlige Entstehung, dicht vor der Epiphyse. Die ausgestiilpte Aulage schnürt sich lierauf als ein geschlossenes Bläshen rom Zwischenhirndarh al nud liegt ihm linht aut (Fig. $665 C$ ); seine l'roximalwand schiskt dann bali Nersenfasem in die Ilirndecke zu der sich hier bildendeu Commissura habenularis. Indem der so angelegte Nerv des Urgans (Parietalnerv) auswächst, entfernt sich las l'arietalange allmählich on der Hirndecke mul gelangt schließlich an seinen oben erwähnten, definitiven (1rt Fig. B66).

bas duge erscheint als eine Blase. deren fiestalt jerloch recht variabel ist, sogar bei einer und derselben Art. Bald erscheint sie anühernd kugelig, balıl etwas schlauchantig lïngsgestreckt, bald mehr oder weniger, bis recht stark aboeplattet. bie distale. gegen die InBenwelt schauemle Wand hesteht aus einer

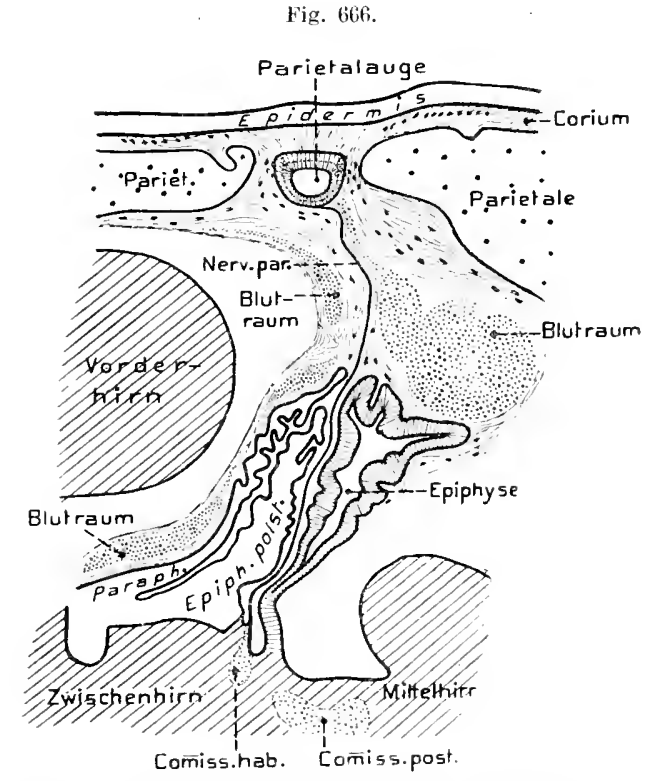

Lacerta a gilis (erwachsen). Schematischer Medianschnit durch die Schieitefregion des Kopfes mit dem Parietalauge (nach NovikofF 1!10). v. Bu.

shicht durchsichtiger, selten etwas

liguentierter, langgestrerkter Zellen (Fig. 667). In der Regel ist diese Wand mehr oder weniger liusentirmig rerdikt, plankonşex bis bikonvex. seltener beiderseits tlach; nur vereinzelt (z. H. Chamaeleo) ist ilı lian ron dem der Proximalwand nicht wesentlich verschieden. Die letztere oder die Retma, von wel her der l'arjetalnerv ausgelit, ist ebenfalls meist stark verdickt min setzt sirh aus unpigmentierten Simmeszellen zusammen, welche durch eingeschaltete braun pigmentierte Zwischen- oder Stiitzzellen vonemander gesondert werden (lig. 667: für Sphenodon wirl jedorh angegeben, daß das Pigment nicht in, sondern zwischen den Zellen liege und won außen in die Retins eingewandert sei). Die Zwischenzellen durhsetzen die gesamte Handicke, m sich proximal an eine zarte Membrana limitans oxterna zu befestigen. Die Sehzellen reichen etwa ur bis zum basalen Drittel der Retius 
hinab, wo sie in Nervenlasern umbiegen, die zusammen eine horizontale l'aserschicht bilden, lier auch bipolare Ganglienzellen in mäßiger llenge eingelagert sind. - Die ins Blasenlumen schauenden freien Selnzellenenden sind in feine Fortsätze verlängert, die Cilienbüschelı gleichen; doch tragen auch die Linsenzellen ähnliche, kürzere Fortsïtze. Beiderlei Fortsätze gehen in ein die Blasenhöhle durchziehendes feines Netzwerk ïber (Glaskörper), welches las Lumen ganz erfüllt, oder einen centralen laum freilïßt. Im Glaskörper finden sirh auch einige verästelte Zellen, welche als eingewanderte Bindegewebszellen gedentet werden. - Der Parietalnerv, welcher embryonal meist vorhanden ist. wurde im erwarhsenem Zustand nur bei einigen Aiten (Anguis, Lacerta, Sphenodon) beobachtet. Lr zielit caudalwärt; bis zụr Epiphyse und an dieser hinab; seine Jasern treten zwischen die der Commissura habenularis ein (s. Fig. 402, S. 557 u. Fig. 666), wo sie sid entweller zum rechten (Anguis. Lacerta) oder zum linken (Sphenodon) Ganglion habenulae verfolgen ließen.

Im allgemeinen marht das Parietalauge einen mehr oder weniger rudimentären lindruch. was sich auch in der verhältnismäßig großen Variabialität seiner Banverhältnisse. selbst bei einer und derselben Art, ausspricht. Dennoch läßt sich nicht leugnen, daß es bei gewissen erwachsenen Sauriem wohl norh zu funktionieren vermag, wenn auch nur zur Wahrnehmung verschiedener Lichtintensitäten. Die Beobachtung, daß das Pigment der Stützzellen auf hell und dunkel lurch Wanderung reagiest. spricht wenigstens einigermaßen hierfür.

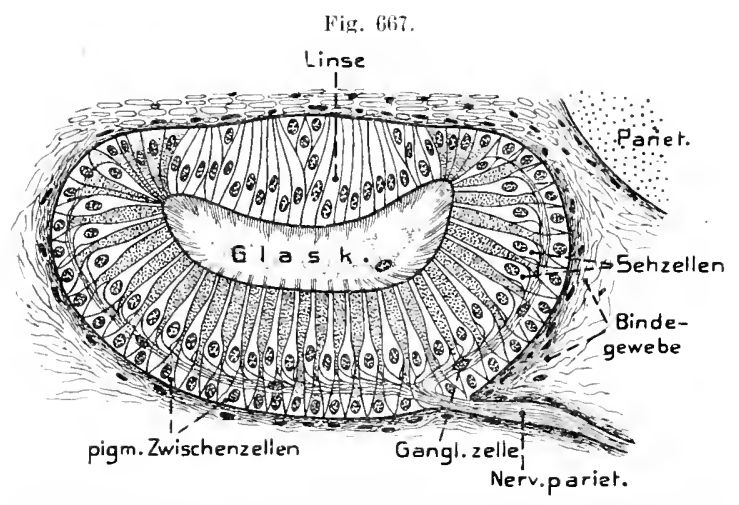

Anguis fragilis. Schema eines Sagittalschnitts durch das Parietalauge (nach NovikofF 1910). v. Bu.

Bei gewissen Sauriern (vielleicht auch Sphenodon.) tindet ruan außer dem Parietalorgan ein oder zuweilen auch mehrere Nebenparietalorgane; lı̈ufiger bei Limbryonen als bei Erwachsenen. Diese, meist etwas unregelmäßigeu, bläschenförmigen, gelegentlich auch soliden Organe sind teils der $\mathrm{E}_{\mathrm{p}}^{\mathrm{i}-}$ physe, teils dem Parietalorgan genühert oder liegen auch zwischen beiden. Sie gehen aus Ausstülpungen eines dieser beiden Organe hervor und können nit ihnen manchmal dauernd zusammenhängen. Wie zu erwarten, sind sie in Größe, Form und Ban recht variabel. Ihre Ähnlinkeit mit dem Parietalorgan spricht sich meist nur darin aus, daß die distale Wand dïnner und unpigmentiert erscheint, die proximale diclier und pigmentiert; weiter geht die Übereinstimmung nicht. - Vergleichend anatomisch läßt sich aus dem Vorkommen der Nebenorgane, die wegen ihrer Variabilität und ilıres unregelmäßiqeu Auftretens lebhaft an Mißbildungen erinnern, kaum etwas entnehmen, es sei denn, daß ihr Ilervorgehen, auch aus der Lpiphyse, darauf hinweise, daß auch letztere bei den Vorfahren ler Saurier ein entsprechendes Sehorgan bidete, wie wir es bei llen Petromyzonten als Pinealorgan noch antreffen werden.

Unter den iibrigen Wirbeltieren besitzen nur die Petromyzontiden ïlnliche Organe; im Gegensatz zu den besprochenen Reptilien jedorh zwei, die, dicht bei einander liegend, gleichfalls aus der Zwishenhirndecke hervorgehen. Wir haben dieser beiden Organe schon bei ter schilderung des Petromyzonhirus kurz gedatht (s. S. 565, lig. 404); das hintere ist die Epiphyse, das ditht davorliegende das sog. Parapincalorgan (s. Hig. 668). Die Epiphyse der Petromyzonten zeichnet sich dadurch aus, daB ihr freies Ende, welhes zu einer abgeflachten I3lase erweitert ist (Pincalorgan). einen Bau zeigt, der lebhatt an den des Parietalauges erinnert. Der ursprüngliwh hohle Epiphysenstiel wird später solid und ent- 
wickelt sich zu einen Nerv (Nerus pinealis), welıer das P'inealoryn mit der Hirndecke verbindet; seine Fasern treten in die Commissura posterior ein und gehen möglicherweise zum rechten Ganglion habenulae. Am Pinealorgan, das einen mehr oder weniger abgegrenzten caudalen, in den Pinealnerv übergehenden Teil (Atrimm) erkennen läßt, ist ebenfalls eine durchsiclstige distale Wand (Pellucida) ron einer froximales, retinaartigen zu anterscheiden. Erstere ist selten (Petromy:on marimus) ein wenig linsenartig verdickt, häntig auch nach innen unregelmäßig gefaltet. l)ie lietina erinnert sèhr an jene des Parietalanges der Sanrier, da sich gleichlalls Simneszellen, Zwischenzellen (Stützzellen), Ganglienzellen (letztere besonders reichlich im Atrium) und eine Nerventasershicht finden. Die freien Enden der Sinneszellen springen ziemlich tief' in das flache Lumen des Organs vor. - Statt des dunklen Pigments findet sich in den Zwisthenzellen eine undurchsi‘htig weiße, körnige Substanz (möglicherweise Calciumphosphat), die auch in den lianglienzellen vorkommt, ja sich bis in die Retina ausbreiten kann. Der llohlraum des Pinealorgans wird von einem ähnlichen Netzwerk (Glaskörper) erfiillt wie im Parietalauge (auch als Syncytium aufgefaßt), das aus Fortsätzen ter Pellucid- mul Sinneszellen herrorgeht, und sirh im Centrum des Lumens zu einer protoplasmatischen Masse gewissermaßen verdichten kann (Petromyzon fluriatilis). Ans allem ergibt sich eine weitgehenłe Übereinstimmung zwischen dem Pinealorgan der Petromyzonten und dem Parietalauge. Das Organ liegt der häutigen Schädelderke dirht an; die es überlagernde Ilaut (Corium und Epidermis) ist ziemlich durchsichtig, so daß ein Scheitelfleck srhon äuBerlich erkenubar ist.

Tnterhalb der vorderen Ilälfte des Pinealorgans findet sich das Parapinealorgan (Fig. (i68), das gleichlalls aus einer sich abschürrenden Ansstiilpung der DienceFig. 665 .

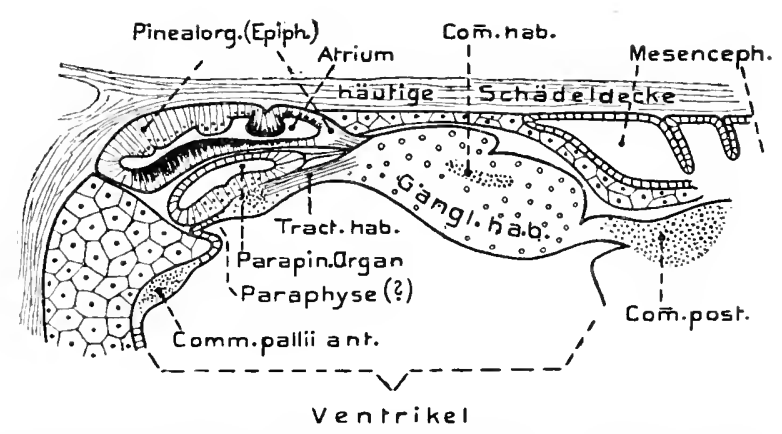

Petromyzon planeri, Larve (Ammocotes). Läıgsschuitt durch die Decke des Vorder- bis Mittelhirns, mit Pineal- und Parapineatorgan (nach STIDNITZKa 1892).

phalondecke, dicht vor der Epiphyse, hervorgeht. aber mit seiner Proximalwand stets in direkter Verbindung mit der Hirndecke bleibt. Es varijert in Form und Größe erheblich. Im allgemeinen besitzt es gleichfalls die Form einer stark abgeflachten Blase mit verlickter proximaler und dïnner distaler Wand. Die erstere zeigt ähnliche Bauverhälnisse wie die Retina les l'inealorgans. entbehrt aber des weißen J'igments vällir. Die von dem Gran ansgohenden NervenIasern ließen sich bis zum linken Ganglion habenulae rerfolgen. - Narl seiner Lage zur Epiphyse. sowie seiner Entstehung, mnß das Parapinealorgan der Petromyzonten dem Parietalange der heptilien entsprechen. loch kommen wir aut diese Be\%iehnngen nochnals zurïch.

Die Myxinoiden besitzen nithts lem l'ineal-oder Parapinealorgan Vergleichbares; lagegen ließ sich in der Untogenese ron Amia und einiger Tcleosteer (z. B. Salmo) die Anlage eines Parapinealorgans als eine Ausstülpung der Derke des Diencephalon (ganz ähnlich jener des Parietalauges der Saurier) beohachten; es schwindet aber bald wieder. - Nur bei Hen ammen Amphibion (ausgenommen Ilyla) tindet sich ein Organ, Welches dem Pinealorgan der l'etromyzonten vergleichlor scheint, nämlich das Stimorgan (Stimulrïse, Corpus (pitheliale); es geht ans den blischenförmigr erweiterten Epiphysenende hervor, löst. sich jerloch rom Epiphysenstiel ab und wankert dicht unter das Corium der Stirnhut außerhalb res Schädels, wo es mitten zwischen den Augen liegt. Das ursprünglich vorhandene Lumen geht im erwachsenen Zustand meist verloren, so daB das Organ ein solides. zelliges. von einer 
bindegewebigen Kapsel umgebenes (iebilde darstellt, dessen meist pigmentlose Zellen keine weitere Differenzierung zeigen. Ein zarter Nerv (Nervus pinealis) geht ron ihm aus und tritt zum Epiphysenende, so daß er als der umgebildete ursprüngliche Verbindungsstrang zwischen beiden Organen anzuseben ist. Da die Ilaut über dem Stirnorgan wenig oder kein Pigment enthält, so zeigen auch tie Anuren einen Scheitelfleck mehr oder weniger deutlich. Es scheint demuach wohl sicher, daß das Stirnorgan als ein stark rïckgebildetes Pinealauge aufzufassen ist. - An Jer Epiphyse der übrigen Wirleltiere wurde bis jetzt nichts von eiuem solchen Organ gefunden.

Die lieziehmugen zwischen l'arapineal- mml l'mealorgan wurlen rerschieden gedentel teils als die zweier homonomer, hintereinamler folgender Organe, teils dagegen als die eines Paars zusammengehöriger, also eines rechten und linken, welche allüihtich hinterejuand rerschoben wurden. Letztere Meimung, die in neuerer Zeit an Boden gewomnen hat, grïndet sich hauptsächlich anf lie beziehung beider (1)gane zu den beiden (ianglia habenulae, ihren ähnlichen Bau, sowie das oben erwähnte Iervorgehen von Nebenparietalorganen aus der Epiphyse von Sauriern. Da das Pinealorgan nur einen Enlabschnitt der Epiphyse repräsentiert, so wäre letztere selbst als der dem Parapinealorgan (Parietalauge) zugehörige Partner zu betrachten. Man hat dies um so mehr hetont, als die Epiphyse der Saurier in ihrer Wand eine ähnliche Differenziemmg ler Epemlymzellen in Simnes- nm stützollen anfweisen kann, wie sie fiir die lietina les l'arietalauges charaleristisch ist.

Von einer Ilomologie der Scheitelsehorgane der Wirbeltiere mit den paarigen Augen zu reden, hat vorerst jedenfalls geringe Bedeutun: schon der sehr eigentümliche Ban der Scheitelorgane, die unter sämthchen Sehorganen mu mit jenen der Charybdea Analogien bieten (s. S. 814), läßt eine solche Vergleichung zweifelhaft erscheinen. - Ebenso kann anch der Versuch, diese Organe mit den Angengebilden ther Tunicaten (Larvenauge der Ascidien, Salpenaugen) in phylogenetische Beziehungen zu setzen. vorerst nur zn sehr problematischen Vermutungen führes.

\section{Arthropoda.}

Wir besprechen die Angen dieser Gruppe an letzter Stelle, weil sie viel Eigentümliches bieten und sich in ihrer höchsten Entwicklung zu dem seltsamen Typns der Complexangen erheben, der bei den seither betrachteten Tieren nur andeutungsweise auftrat. Wie gewisse schon behaudeIte Gruppen besitzen auch die Arthropoden Augen von verschiedenem 'Typus, welche bei manchen Formen sogar gleichzeitig vorhanden sein können. - Sehorgane sind bei den Arthropoden allgemein verbreitet, doch kommt, wie auch sonst, unter dem Einfluß besonderer Lebensverhältnisse (Aufenthalt im Dunkelı, in Höllen, der 'Tiefsee oder unterirdisch, durch Parasitismus [z. B. bei Cirripedien, Copepoden, Amphipoden; Milben]) Riickbildung ler Augen nicht allzuselten vor, wobei alle Grade der Reduktion bis zu völligem Schwund verfolgt werden können.

a. Blasenange der Protracheata. Vollkommen isoliert stehen die einfachen parigen kopfangen der Protracheaten (Peripatus; Fig. 669), indem sie den Typus der Blasenangen hei erragten Polychaeten mul Jollusken in naher Öbereinstimung wiederholen nnd wie letztere durch Einstïlpung unł Ablösung einer ertodermalen Augenblase entstehen, mit einer secernierten Linse in ilrem Inneren. Die Übereinstimnung ist so groß, daß wir anf eine genauere lieschreibung verzichten; es werde nur hervorgehoben, daß die Sehzellen mit langen stäbchenartigen Fontsätzen von cigentümlichem ban versehen sind, die his zur linse reichen, und daß Zwischenzellen in der lintina nicht sirher erwiesen sinul.

b. Das unpare Mrdianumge (Larven- oder Entomostrakenange, Naupliusauge) ist bei den erwachsenen entomostraken Crustaceen sehr allgemein verbreitet, 
so bei deu Phyllopoden und Ostracoden meist neben den paarigen oder unpaaren Complexaugen, bei den Copepoden (auch den Parasiten zum Teil) in der Regel ohne letztere und ebenso bei den Thoracica unter den Cirripedien, wo die im Larvenzustand vorhandenen Complexangen sich rïckbilden, das Medianauge sich dagegeu mehr oder weniger degeneriert erhält. Daß dies Organ bei den primitiven Krebsen wohl allgemein verbreitet war, erweist das gewöhnliche Vorkommen eines kleinen Medianauges bei den Larven der 'Thoracostraken, denen es jedoch im erwachsenen Zustande hänfig fehlt; doch soll es sich bei nicht wenigen mehr oder weniger verkiummert erhalten. Das Medianange liegt meist ziemlich tief unter der Hypodermis, rostral oder veutral vom Cerebralganglion, dem es zuweilen auch direkt aufruht. Wie wir schon frïher sahen (S. 825), besteht es ähnlieh dem Chaetognathenauge aus einer Gruppe von meist drei, seltener vier (meiste Branchiopoden), ja sogar fünf (gewisse CopeFig. 669.

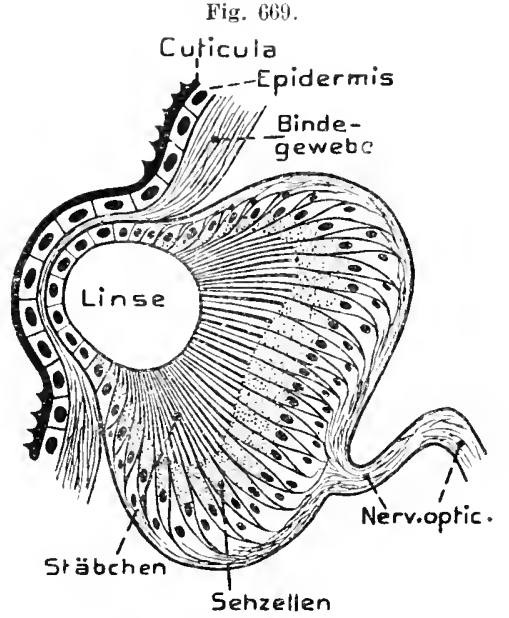

Perjpatus edwardsii. Auge im achsialen Durchschnitt (nach CARRIÈre 1855). v. Bu. porden der Fatmilie der Asterocherinae, deren Lateralangen in je eiu vorderes und hinteres geteilt sind, dicht zusammenstoßenden, inversen, becherförmigen Einzelaugen, welche jenen der Plathelninthen in mancher Hinsicht gleichen. - Drei Einzelaugen sind nämlich so zusammengeordnet (Fig. 670), daß dorsal nebeneinander zwei seitlich geriehtete liegen (Seitenaugen), das dritte unpaare dagegen ventral unter den ersteren, nach der Bauchseite schanend. Letzteres Auge wird bei den meisten Branchiopoden durch das sich einsenkende Pigment in zwei hintcreinanderliegende Becher gesondert (Fig. 670 C). Die drei Augenbecher sind fast stets so dicht zusammengeriickt, daß ihre roten bis schwarzen Pigmenthïllen zu einer gemeinsamen Nasse ver-

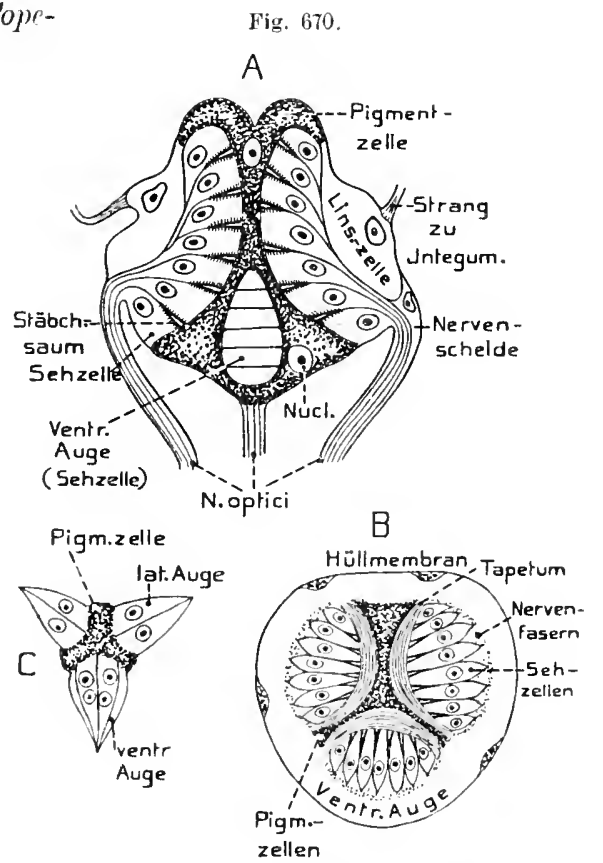

Entomostrakenauge. I Querschnitt des Auges von Cypris crassa (Ostracole) (nach Novikori 1908). - L' Querschnitt des Auges von ('y pridina meditercanea. $\rightarrow C$ Querschnit des Auges vou

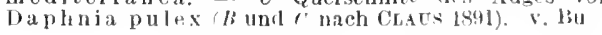


schmelzen; in der Dorsalansicht erscheinen sie daher wie ein x förmiger Pigmentfleck; selten (z. B. bei der Ostracode Notodermas) sind die Einzelangen etwas auseinandergeriickt, wobei jedoch die Pigmenthiillen im Zusammenhang bleiben (ähnlich pararig anseinandergerïickt ist auch das Medianange von Balanus). - Jedes Einzelauge besteht aus einer Anzahl ungefähr eylindrischer, pigmentfreier Sehzellen, die ihre freien Enden der Pigmenthülle zukehren, wogegen ihre Anßenenden in die Nervenfasern übergehen.

Doch wurde für Copepodenangen (besonders Eucalanus) neuerdings mehrfach angegeben, daß sie convers innerviert würden, was jedoch im Hinblick anf die ïbrigen Entomostraken recht fraglich erscheint.

Die Nervenfasern ziehen meist als drei (oder zwei, Branchiopoden) gesonderte Nerven zum Vorderende des Cerebralganglions (Archencephalon). Die Sehzellellzahl schwankt mit der Größe des Mediananges beträchtlich und kann sich (Cladoceren und Copepoden ) anf wenige reduzieren. - Auf den sich berührenden Seitenflächen der inneren (proximalen) Endregion der Sehzellen bilden sich in der Regel cuticulare Säume aus, welche meist als Stäbchen bezeichnet werden (Fig. 670 A). Bei Apus wurde auch eine rhabdomartige Bildung zwischen den Sehzellen beschrieben. Im Plasma finden sich häufig stärker brechende Einschlüsse. - Die Pigmentmasse zwischen den Einzelangen besteht aus zahlreichen bis wenigen Zellen (so nur zwei bei Artemia und den Ostracoden), die selten auch pigmentfrei sein können.

Die Seh- und Pigmentzellen scheinen sicher aus der Hypodermis hervorzugehen, und die Frage, ob die Einzelaugen phylogenetisch ursprünglich gesondert waren, oder ob sie wachträglich durch Sonderung einer gemeinsamen Anlage durch die Pigmentzellen entstandeı. ist nicht scharf entschieder.

Zwischen Pigmenthülle und Sehzelle schiebt sich bei den Ostracoden (Fig. $670 B$ ) Argulis, gewissen Branchiopoden und Cludoceren (angeblich auch der Copepode Encalanns) eine besondere Lage ein, die als reflektierendes Tapetum dient und bei den Ostracoden aus schïppchenartigen Gebilden, bei den Branchiopoden (besonders Limnadia) aus eigentümlich gewundenen Fortsïtzen der Pigúentzellen besteht; auch im ersteren Fall scheint sie ein Produkt der Pigmentzellen zu sein. Jedes Einzelauge der Ostracoden ist meist mit einem lichtbrechenden Körper (Linse, Fig. $670 \mathrm{~A}$ ) versehen, der aus wenigen durchsichtigen Zellen besteht, welche den Sehzellen anßen direkt anfliegen; bei der Branchiopode Artemia besitzen nur die Seitenaugen zuweilen eine Linsenzelle, die noch in der Hypodermis liegt, weshalb die Herleitung der Linsenzellen aus der Hypodermis wahrscheinlich ist. - Bei gewissen Copepoden wurde anch eine cuticulare oder corneale Linse (anch Sckretlinsen genannt) beschrieben. Üherhaupt bieten die Medianaugen dieser Gruppe zahlreiche Eigentümlichkeiten, welche genauere Untersuchung verdienen.

Bei Gigantocypris scheint die über den seitlichen Angen vorgewölbte Cuticula und dit unter ihr befimlliche Flüssigkeit als dioptrischer Apparat zu dienen. Das Merlianauge dieser Form ist überhaupt recht abweichenl gebaut und jedenfalls norh nicht hin reichend aufgeklïrt.

Das Medianange wird häufig durch bindegewebige Strünge am Integnnent befestigt. Da es bei manchen Formen beweglich ist (z. B. den Calaniden unter den Copepoden), so dürten diese Stränge zuweilen muskulös sein. - Ebenso meıkwürdig, wie interessant er- 
scheint es, daß bei gewissen wasserlebenden Dipterenlarven (Chironomidae) an den kopiseiten ein bis zwei Paar kleiner, wenig zelliger Augen von insersem Bau vorkommen. Dies unvermittelte Anftreten in einer işolierten Gruppe läßt kaum eine andere Auffassung zu, als daß es sich hier um selbständig entstandene Organe handelt; eine Erscheinung, die wir gerade für die Seh- nud andere Simnesorgane vielfach anzunehmen gezwungen sind. Auch bei rerwandten Dipteren (Culiciden, Corethra usw.) finden sich eiı bis zwei Paar Larvenaugen, möglicherweise von ähnlichem Bau, doch reicher an Sehzellen. Diese Larrenaugen erhalten sich häufig anch bei ler Imago ventral von den Complexangen und wurden bei zahlreichen Formen gefunden, wo sie im Larrenzustand nicht genauer bekannt sind.

c. Die Ocellen (Stemmata, Punktangen, (Hmmatidien, Larvenaugen, Simplexaugen) der Arthropoden haben, wie wir friiher fanden (s. S. 810), den gemeinsamen Charakter, daß sie fast ausnahmslos eine einfache cuticnlare Linse und eine einheitliche Retina besitzen, welche nicht oder doch nur andentungsweise durch

Fig. 671 .

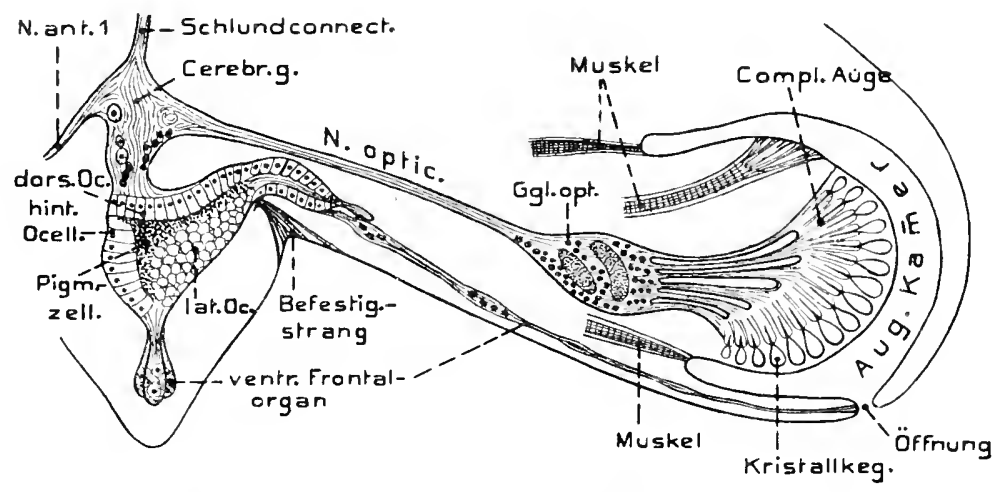

L im na dia (Branchiopode). Kopfende von rechts mit Entomostrakell- und Complexauge, sowie Frontalorgan, schematisch (uach NovikofF 1905, etwas verändert). v. Bu.

zwischengeschaltete pigmentierte Zellen in eine Anzahl Sehzellengruppen (Einzelaugen) gesondert wird Da jedoch die Complexaugen aus der Vereinigung einer größeren Anzahl einfaeherer Ocellen hervorgingen, so ist natürlich die Grenze zwisehen den beiden Organen nieht ganz scharf zu ziehen.

Den Crustaccen fehlen solche Ocellen; bei den Trachcaton dagegen sind sie allogemein verbreitet, ebenso aueh bei den Palacostralicn (Poecilopoden und Merostomeen). Entweder bilden sie bei den betreftenden Formen die einzigen Sehorgane, oder neben ihnen tritt noeh ein Paar lateraler Complexaugen auf (Palaeostraca, Insecta). Das erstere findet sich bei den Arachnoidcen und Myriopoden, sowie gewissen anf niederer Stnfe verbarrenden Insekten: manchen Poduriden (Apterygota), Aphaniptera (ein Par', C'occidar, Mullophaga, den Männchen von sitrepsipteren (Xenos, etwa 50 Ocellen, die, dicht zusammenstehend, jederseits am Kopf eine Art Complexange bilden). - Viele Insekten besitzen anßer den parrigen Complexaugen noch Ocellen auf dem Kopfscheitel als Stim- oder Scheitflangen; doch fehlen sie bald hier bald dort, namentlieh bei nicht fliegenden Formen. 
Häufig finden sich die Stimaugen der Insekten in Dreizahl, ein unpares und zwei paarige, in einem Dreieck angeordnet (manche Apterygota, die meisten Orthoptera und viele Neuroptera, fast stets bei Iymenoptera, einzelne Rhynchota [Cicada, I'hytophthires] und Dipter $a$; selten auch vier bei gewissen Cocciden). Doch treten sie auch in $Z$ weizall $\mathrm{auf}$ lurch Verkümmerung des umpaaren (gewisse Orthoptera, [so Blatta, Gryllotalpa,] Diptera, Lepido. ptera, einzeIne Käfer, die meisten Rhynchota); ein einziger Stirnocellus kommt gewissen Käfern (Dermestidae), Lepidopteren mul Poduriden zu.

Daß die Ocellen phylogenetisch ältere Gebilde sind als die Complexaugen folgt darans, daß sie, wie bemerkt, bei den Arachnoideen und Myriopoden die einzigen Sehorgane biłden und bei letzteren an den Kopfseiten in größerer Zahl $(4,6,8$ bis sehr zahlreich) stehen, da, wo sich sonst die Complexangen finden. Das letztere wiederholt sich bei zahlreichen Insektenlarven, was ebenfalls die phylogenetische Urspriinglichkeit der Ocellen erweist.

Auch bei diesen barven treten sie in recht verschienlener Zahl auf, so als ein Paar (Larsen von Phryganiden und Tenthediniden. viele Dipteren, einzelne Käfer); in vierbis áchitfacher Zahl bei den Larven gewisser Neuroptercn (Myrmeleo u. a.). der Lopidopteren, gewisser Kïfor und der Strepsizteren.

Nur zwei scheitelständige kleine Acellen besitzen die Palacostraea, was anch bei Milben, Pseudoseorpioniden und vielen Opilioniden vorhommt; doch erhöht sich ihre Zahl manchmal auf vier (Obisium, Hydrachnidae [auch zum Teil fünt], wobei letztere Familie hänig eine parmeise Vereinignng ter Angen zu Doppelangen zeigt). - Vier auf einem scheitelstïndigen Ilügel nahe zusammengerückte Ocellen sind den Puntopoden eigen, ebenso gewissen Opilioniden, leren heide Angenpare verschieden groß sind, eine Lrscheinung, die bei den Arachnoideen mit zahlreichen Ocellen verbreitet ist. Bei den Solifugen steigt die Ocellenzahl auf vier und sechs, bei den meisten Pclipalpen und Araneincn anf acht (selten sechs) und kam sich schließlich bei Scorpionen und einzehnen I'cdipalpen bis zwöl erheben. - Im allgemeinen siml hei Anwesenheit zahlreicher Ocellen die beiden vorderen mittleren wesentlih anders gebant als lie übrigen und werden deshalb als Haupt-

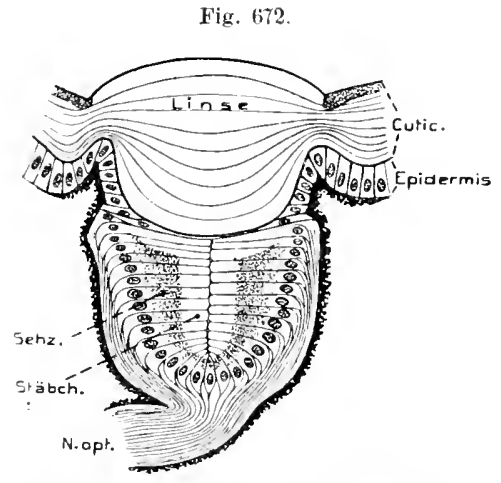

Heterostoma australic um (Myriolode). Achsialschnil durch rinen Ocellus (nach Gresacner 1880). v. Bu. augen (Frontaugen, invertierte Augen) den übrigen (Seiten-oder Ncbenaugcn, convertierte) entgegengestellt, wie wir noch genauer erfahren werden. Letztere sind bei len Solifugen stark rudinentär.

Die Ocellen gehen ans der Umbildung einer beschrïnkten Hypodermisstelle hervor, indem sich deren Zellen zu Sehzellen entwickeln, sich aber gleichzeitig mehr oder weniger becherförmig einsenken und durch stärkere Chitinsecretion eine linsenförmig, nach innen oder auch zugleich nach anßen vorspringende cutienlare Verdickung hervorbringen, welche als Linse funktioniert. Gewissen Ocellen, die jedoch wahrscheinlich nur vereinfachte Bildungen sind, kanı eine solche Linse fehlen, indem die Cuticula (Cornea) das Auge unrerdickt iiberzieht (Oeellen gewisser Poduriden [Machilis,] zahlreicher Orlhopteren). Ganz vereinzelt (bei der Nenroptere Osmylus) zeigt die Cornea einc Facettiermng ähnlich jener des 
Complexauges. - Daß die Sehzellen selbst die Linse abseheiden können, ist wenig wahrseheinlich; vielmehr geschieht dies wohl ïberall von besonderen, wenig veränderten Hypodermiszellen (corneagenen Zellen, Glaskïrper:ellen), welche versehieden angeordnet sind. Sehr deutlich tritt dies an den Ocellen der Myriopoden und den lateralen gewisser Kïferlarven (Dytiscus, Acilius) ineh den Nebenaugen gewisser Spinnen (s. Fig. 672, 673) hervor. Die Hypodermis hat sich hier meist tief beeher- bis schlauchförmig eingesenkt und die Beeherzellen sind gewöhnlich sämtlich zu Sehzellen entwiekelt. Die Zellen aber, welehe den peripheren Rand

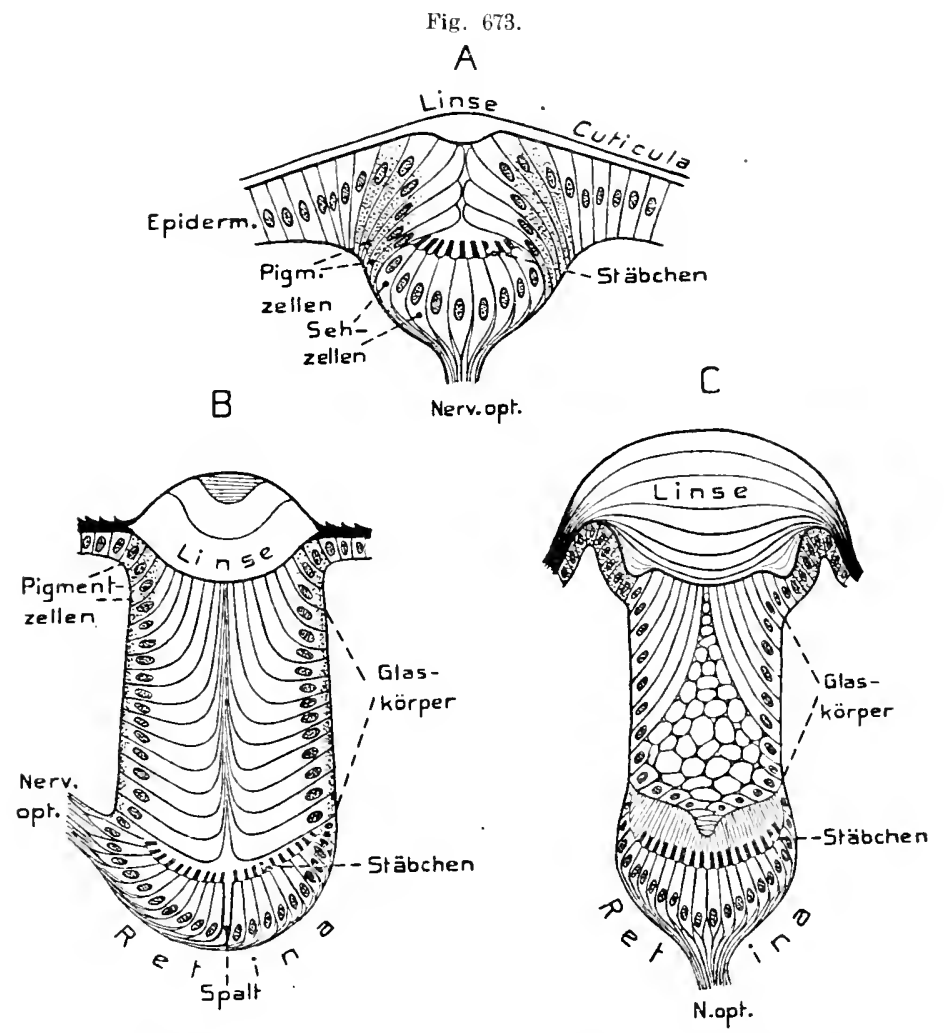

cohematische Achsialschnitte von Ocellen. A Larve von lotiscus. - $B$ Larve von Acilius (Wasserkäfer). - $G$ von Salticus (spinne), (nach (irexacher I‘-9). v. Bu

(ver die periphere Region des Bechers bilden und an die Cuticula grenzen, sind mehr oder weniger verlängert, bis faserförmig, sowie derart gegen die Angenachse geriehtet, daß sie unterhalb der Linse zusammenstoßen, wodureh der Beeher eigentlich zu einer schlanchförmigen Angenblase wird. Letztere Zellen sind es, welche die Linse abscheiden und gleichzeitig als eine Art Glaskörper deren lichtbrechende Wirkung verstärken können. - In gewissen Fällen (z. B. Lithobizus $)$ können jedoch diese eorneagenen Zellen nur in sehr geringer Zahl vorhauden sein, zuweilen sogar ganz fehlen. 
Thnlich verhalten sich auch die Nebenangen convertierte Augen) der Araneinen, bei denen lang faserartige Hypodermiszellen allseitig oder einseitig zwischen die etwa napfförmige Retina und die Linse als eine Glaskörperlage hineinwachsen (Fig. 677, S. 880). Auch die Augenbecher der Pantopoden sind durch das Znsammenwachsen der faserartig verlängerten Glaskörperzellen fast ganz geschlossen (Fig. 678 B, S. 881).

In gewissen Fällen (so bei der erwachsenen Larve von Dytiscus) nindet sich unter der Linse ein von den Glaskörperzełlen abgeschiedener, etwa uhrglastörmiger, gallertiger Glas-

Fig. 674.

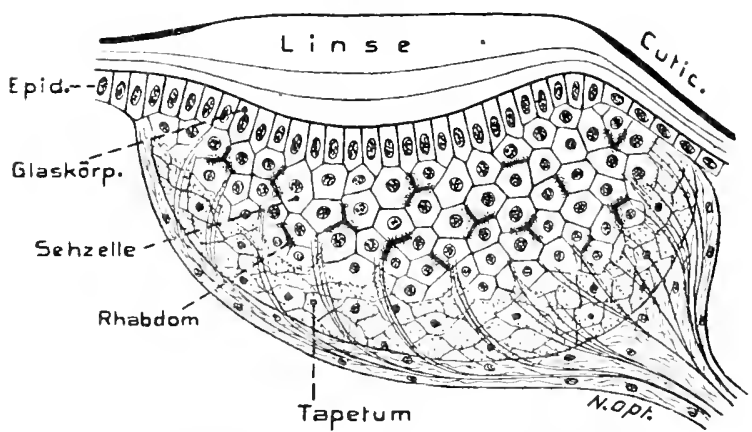

Periplaueta orientalis (Küchenschabe). Querschnitt durch einen seitlichen Stirnocellus (nach LINk 1:08). v. Bu.

Fig. 675 ,

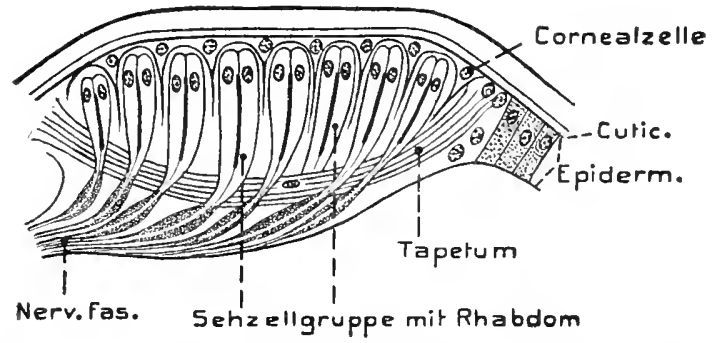

Machilis (Apterygote). Querschnitt durch einen Stimocellus (nach HESSE 1901). körper. Auch sind die Retinazellen des Augengrundes hier in zwei leihen besonders großer differenziert.

Anders verhalten sich die Nebenocellen der Scorpione (Fig. $679 A$, S. 882), sowie die Ocellen der Hydrachniden, welche beide, soweit bekannt, keine Glaskörperlage besitzen. Da jedoch zwischen ihren Sehzellen pigmentierte indifferente Zellen (intornrurale Zellen; bei Scorpio, doch anch gelengnet) eingeschaltet siud, so diurften diese wohl die Linse ahscheiden.-Die Stirnorellen der Insekten (Fig. 674, $676)$ und gewisse Latrralocellen inrer Larven

('Tenthrediniden) besitzen zwischen Linse und Retina stets eine Lage vou Glaskïppercllen, als ein einschichtiges und meist ziemlich flaches durehsichtiges Epithel, das peripher direkt in die Hypodermis ïbergeht. Die Ontogenese erwies, daß diese Zellenlage durch Sonderung der urspringlich einfachen Hypodermislage entsteht, indem sieh die Sehzellen, welche anfïnglich zwischen den Glaskörperzellen liegen, in die Tiefe zmrïekziehen.

Die gelegentlich ansgesprochene Ansicht, daß Glaskörper- und Retinalage der in vorhergehenden erwähnten Insehtenocellen aus Ien Wänden einer Augenblase entständen, was in her Tat für die invertierten Ilauptocellen des Scorpione und Araneinen zutrifft, hat sich niwh hestätigt. - Auh vergleichend anatomisch lïßt sich die Entstehung ler Glaskörper- 
schicht verfolgen, indem sie bei manchen Insektenocellen ron der Retina noch wenig scharf gesondert ist, ja in gewissen eintachen Fällen (Machilis, Fig. 6i5) die Corneal- oder Cilaskörperzellen noch zwischen die Retinazellen eingelagert sinl. Immerhin ist zu beachten, daß es sich mäglicherweise z. T. auch nm eine veränderte Entwicklung hambln könnte und die Glaskörperzellen ursprünglich durch Einwachsen, also ähnlich einer Einstïhnug entstanden seien. wie bei den Nebenocellen von Spinnen, denen der k̈̈ferlarven und den accessorischen 1)ellen Jer Coccidenmännchen, wo dieser Vorgang beobachtet wurle.

Die Glaskörperschicht gewisser Insekten (Acrilier, Ephemeriden) wind ansuahmsweise recht dich und beteiligt sich dann an der Lirhthrechung, intem sie dip flathe Gornea zu winer Art linse ergänzt. Bei gewissen Ephemeriden (Clö̈on, Fir. 676 , Baitis) hat sich die Glaskörpermasse muter der Cornea sogar zu einer zelligen linse ungestaltet, unter welcher jedoch ron einigen Beobachtern noch eine Glaskörpersehicht angegeben wird. Völligen Nangel des Glaskïrpers zeigen die seitlichen (1)e]len her männhichen Cocriden. loch hamlelt es sich jedenfalls un Vereinfachung. da das dorsale und rentrale par acces-

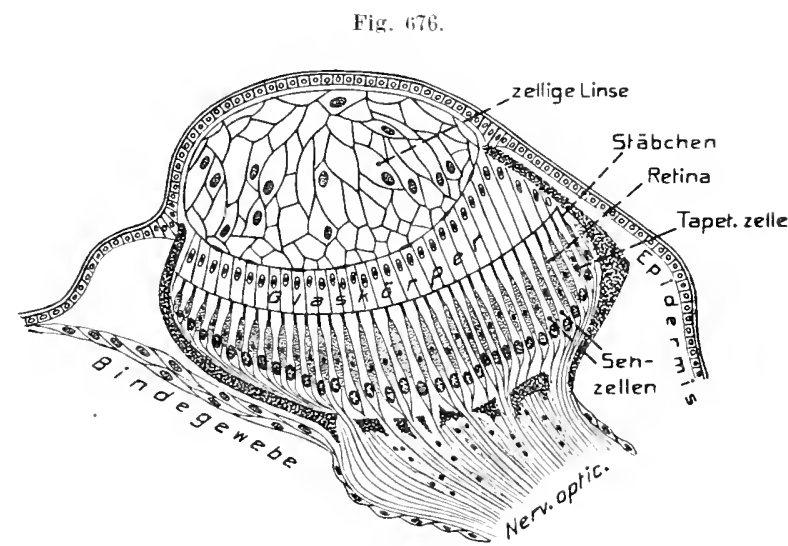

('loèon (Eintagsfliege). Achsialschnitt lurch einen stimocellus mit. zelliger Linse (nach Hesse 1901). v. Bu.

\section{sorischer twellen dell}

(ilaskörper besitzt. Gine niedrige Lage corneagener Zellen kommt anch den Medianocellen von Limulus (fig. 68:. S. 885) zu und ist wohl gleichen U'sprungs wie jene der Insekten.

Die Hypotermiszellen, welche den Linsenrand umgeben, sind in der Regel stark pigmentiert, wodurch eine Art Iris gebildet wird; sie wird häutig noch dadurch vervollständigt, daß auch die Cntienla im Umkreis der Limse dunkel pigmentiert ist (s. Fig. 672, 673, S. 876, 877), ja die pigmentierte Cuticula kann sich sogar mehr oder weniger tief um das Ange einsenken. -

Die Retina besteht ans mehr oder weniger Sehzellen, deren freie Enden bei den zunächst zu betrachtenden conversen Ocellen dem Licht zugewandt sind, während ihre proximalen Enden in die Nervenfaser ïbergehen. In den Ocellen der meisten Insekten, der Arachnoideen und Pantopolen liegen die meist cylindrisehen Sehzellen in einfacher Schicht nebeneinander, so daß sie etwa gegert den Mittelpunkt der Linse konvergieren. - In den mehr schlauchförmig becherartigen Ocellen der Myriopoden (Fig. 672) und gevisiser Käferlaren (z. B. Dytiscus, Fig. $673 \mathrm{~A}$ ) bewahren nur die im Bechergrund stehenden Zellen diese Richtung, wogegen die seitlichen qner zur Augenachse gestellt siud und ilre stäbchenartigen Enden also quer zum einfallenden Licht verlanfen. Auf die Natur der stäbchenartigen Endelemente gehen wir nicht näher ein, da hierüber später berichtet werden wird; hervorzuheben ist aher, daß die Sehzellen des Bechergrundes 
der. Myriopoden häufig von denen der Seitenwand etwas abweichen, indem sie entweder eigenartige Stäbchenelemente besitzen oder ihnen eigentliche Stäbchen fehlen.

Die Retinu bietet noch mancherlei Eigentümliches, wovon hier besonders hervorgehoben werde, daß sie in den Stirnocellen der meisten Orthopteren nicht an. einer einfachen Sehzellenschicht, sondern ans mehreren Lagen polygonaler bis rundlicher Zellen besteht (Fig. 674, S. 878). - Die Retinazellen der Stirnangen zahl-

Fig. $67 \%$.

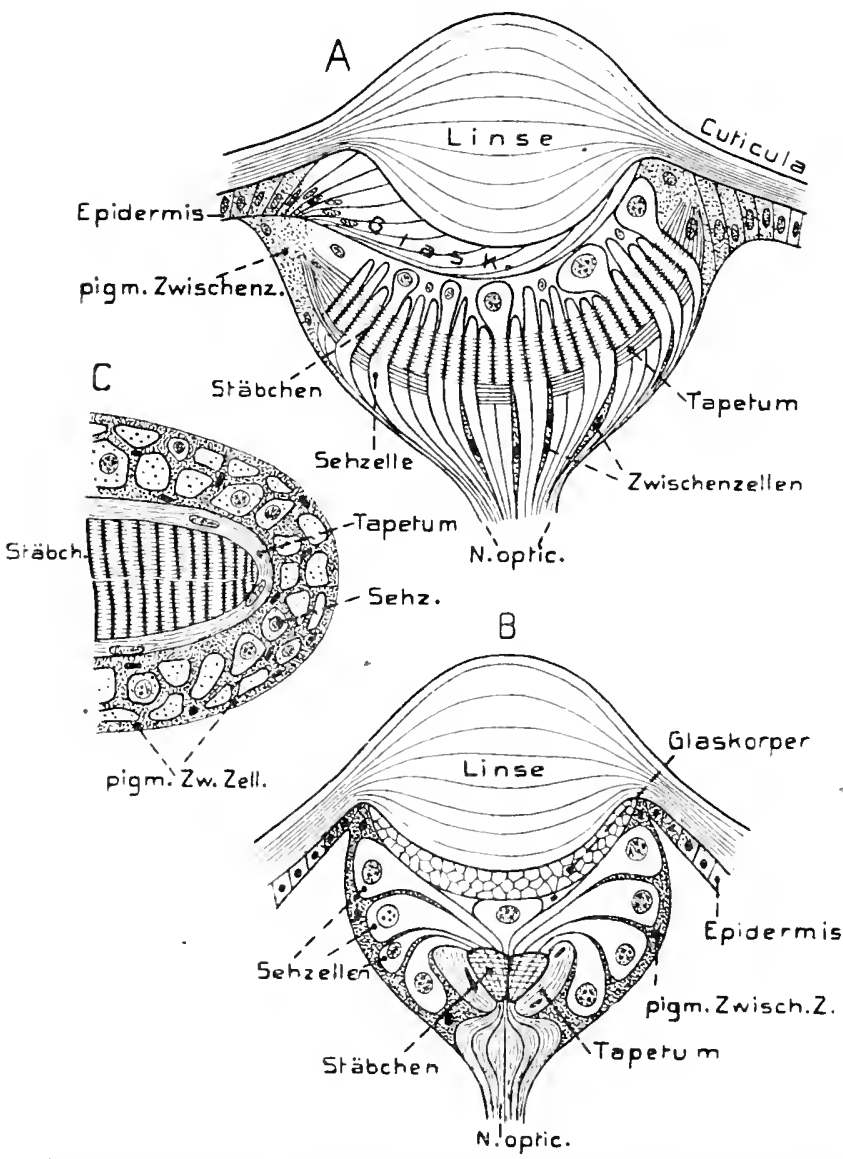

Tegeuaria dumestica Cl. (Hausspinne). Converses Mittelauge. A sagit taler Achsialsuhitt. - b Querer Achsialschuitt. - $t$ Schnitt ruer zur Augenachse (mach WIDMANN 1008). v. Bu. reicher Libellen dagegen sind ungleich. indem regelmäßig verteilte Gruppen längerer, mit distal gelegenen Kernen, mit Gruppen kürzerer abwechseln, deren Kerne proximal liegen; auf solche Weise kommen scheinbar zwei Sehzellenschichten zilstande, die für gleichzeitiges Sehen in verschiedener Entfernung eingerichtet $\mathrm{z} \|$ sein scheinen. -

II den stitnoceller der Wespen (besonders I'espa crabro) ist der an den Linserä̀uator stoßende Retinarand, wie es scheint, zu einer Art Nebenretina dillerenziert, welche auf Fernsehen eingerichtet sein diillte.

Die Sehzellen in den Nebenangen der Spinnen (Fig. 677) sind so gruppiert, da sie die beiden Hälften

des im Querschnitt meist etwas ovalen Oeellus einnehmen, und zwar besteht jede Hälfte im Ange der Sedentariae (anch Hydrachniden unter den Milben) ans einer einzigen Sehzellenreihe, bei den Vagabundac dagegen aus zahlreiehen Zellen Eigentümlicherweise können diese beiden Typen auch in einem Auge vereinigt sein (Mittelauge der zweiten Reihe von Epeira). indem die laterale Hälfte der Retina 
nach dem ersten Typus, die mediale nach dem zweiten gebaut ist. Eine ähnliche Sonderung der lietinazellen in zwei einreihige Hälften zeigt auch das Pantopodenange (Fig. 678).

Zwischen die Retinazellen der Araneinen sind häutig Zwischenzellen (Stiitzzellen) eingeschaltet, deren Körper und Kerne meist proximal liegen; sie können pigmentiert oder unpigmentiert sein. - In den Nebenaugen der Spimen und nicht wenigen Stirnaugen von Insekten (Mrathis, zablreiche Orthopteren) enthalten diese Zellen sämtlich oder teilweise körnige bis kristallinische Einschlïsse und bilden daher ein reflektierendes Tipetum. Daß sie gleichfalls besonders differenzierte Ectoderm- und nicht Mesodermzellen sind, diurfte sicher sein. - In den beiden Typen

Fig. 17 .

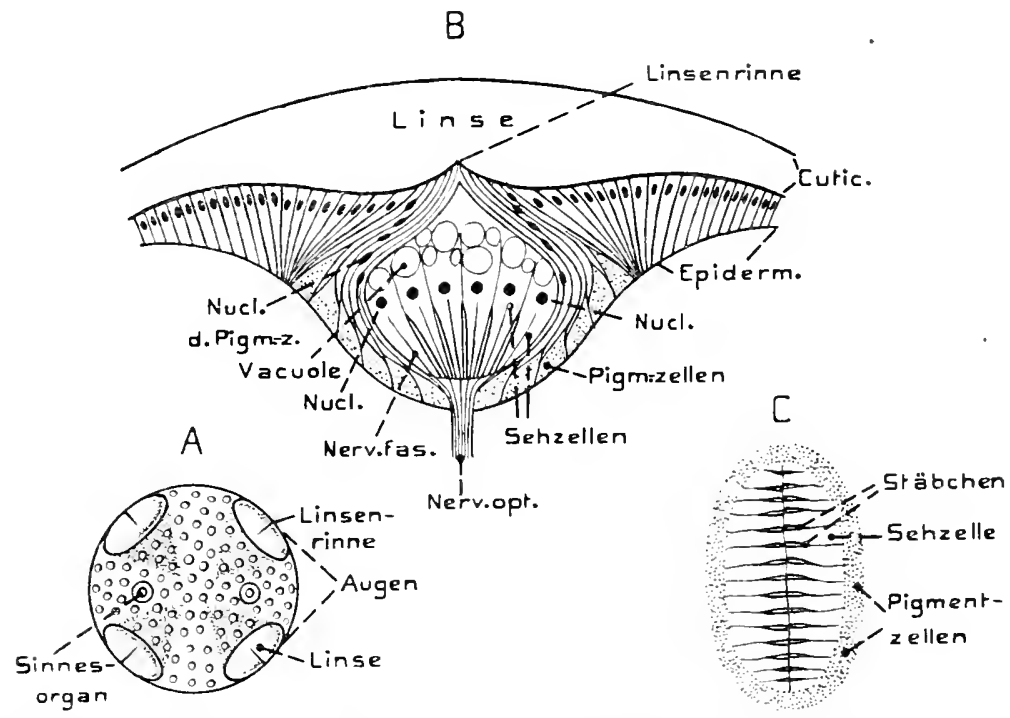

l'antopodenauge (Nymphon. - I Augenhügel mit $\&$ Ocellen, von der Dorsalseite. $-B$ schemaijscher horizontaler Achisialschnitt durch ein Auge. - $C$ Querschnit durch die Retina umd die Stäbehen (nach SOROLOFF 1911).

ler convertierten Nebenocellen der spinnen besitzen die Tapetumzellen entsprecbend dem Netzhautban eine recht verschiedenartige Anordnung, wovon die Figuren 677 A-C das Wichtigste erkennen lassen.

Besonderes Interesse bietet die Retina in den Ocellru der Xiphosuren, Scorpione, den Hauptaugen der I'elipalpen und den Stimungen der Inseliten wegen der gewöhulich ansgesprochenen Gruppenbildung ihrer Sebzellen und der dadurch bedingten Entwicklung zusammengesetzter stäbchenartiger Gebilde (Rhabdome) (Fig. 679). Da die invertierten Hauptocellen der Scorpione und Pedipalpen Öbnliches zeigen, so beriicksichtigen wir sic hier ebentalls. - Ein allgemeiner Charakter der Arachooidecu- und tast aller Insektenocellon ist nämlich, dalf die Sehzellen an ihren seitlichen Flächen meist distal, zuweilen jedoch anch tiefer, alveoläre cuticuläre säume bilden, welche als percipierende Elemente gedentet 
werden. Wenn die Sehzellen nicht durch Zwischenzellen voneinander gesondert sind, so können diese Säume im ganzen Umfang der Seitenfläche der Sehzellen

Fig. 6iz9.

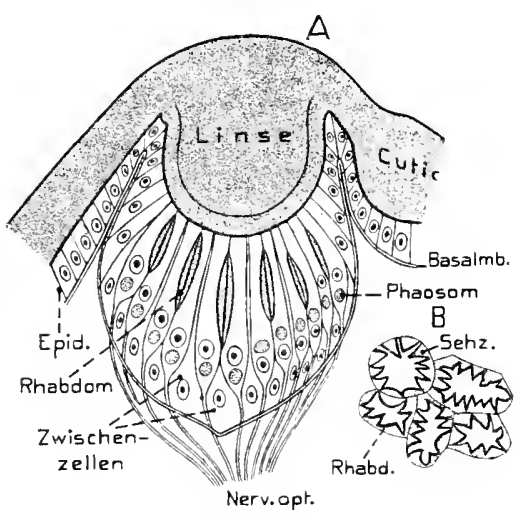

Euscorpio. Converses Lateralauge A Schematischer Achsialschnitt (nach LANKESTER und BovRne 1883). - $k$ Querschnit durch die Retina, um die Rhabdome zu zeigen (nach Hesse 1:101). v. Bin. auftreten und die benachbarten sich dann zu einer Art Netzwerk (im Querschnitt) vereinigen (invertierte Hauptocellen der Sedentariae, Fig. 698a, S. 897).

Bei völiger Sonderung der Sehzellen durch Zwischengewebe, wie in den Hauptund Tebenocellen der ragabunden Spinnen, bildet jedemsehzelle an ihren Seitenflächen zwei sich gregeniiberstelıende Sänme oder Stäbchen (lig. 69Se); wogegen die Sehzellen jeder der beiden Reihen in den Nebenocellen der Sedentariae sich seitlich berïhren und hier einen gemeinsamen Saum oder Stäbchen bilden (Fig. 698 b, s. 897). Ähnliches zeigen aurh die Augen der Pantopoden (Fig.6ise). - Sind Zwischenzellen eingelagert, so rufen sie I'nterbrechungen in den Säumen hervor.

Wenn sich dagegen Schiellengruppen bilden, was mit und ohne Zwischenzellen geschehen kann, so bildet jede solche Gruppe an den sich berihrenden Seitenflächen ihrer Zellen ein zusammen-

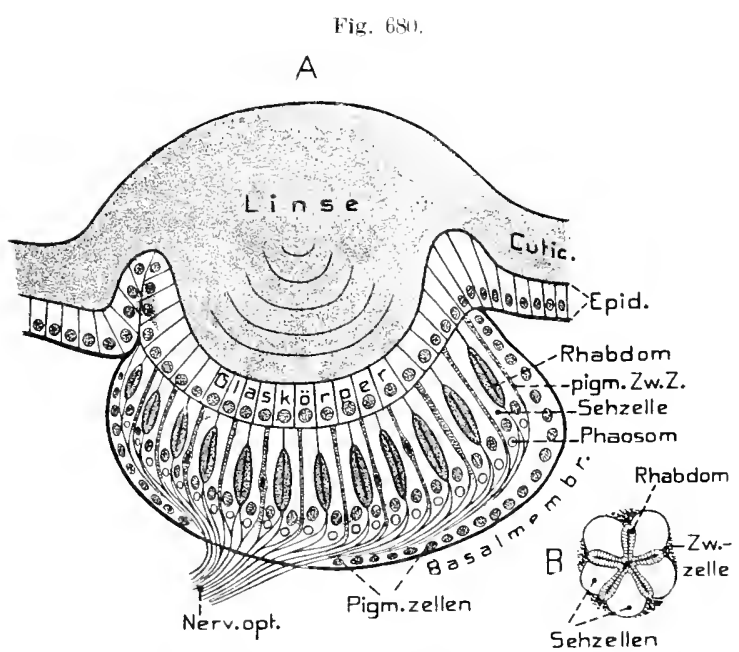

Euscorpio. Inverses Medianange. I Achsialschuitt eines Auges. - $B$ Querschnitt durch eine sehzellengruppe mit Rhabdom (Hach IANKESTER 1.83). bängendes derartiges Saumgebilde (rig. 698 d-h.) Die Zahl der zu einer Gruppe vereinigten Sehzellen ist ziemlich verschieden, worüber später Genaueres.

Auf der Greme von Glaskörper und Retina findet sich in gewissen Inselitenocellen(Diptera, Phryganiden) eine zarte, aus ganz thachen Zellen bestehende Membran (priirctinale Membran), die vielfach als bindegewebig angesehen wird. - Gegen die Leibeshähle wird der gesamte Rulbus häufig von einer pigmentierten Zellenlage (Pigmenthïlle, postretinale Membran) umkleidet (besonders ansgeprägt bei manchen Myriopoden und Insckten). welche wenigstens bei letzteren hypodermaler Natur zu sein scheint.

Invertierte Ocellen, Hauptocellen der Arachmoideen. Die vorderen mittleren Oeellen der Seorpione und Araneinen, ebenso die beiden Augen der Opitioniden, 
und wohl auch die Hauptocellen der Pedipalpen und Solifugn entwickeln sich nicht in der früher angegebenen Weise, sondern durch etwas schief nach innen gerichtete Einstiilpung einer Augenblase, welche sich später von der Epidermis ahlöst.

Wie ohen ( $\$ .876 \mathrm{u} .77$ ) bemerkt, wurde diese Ent-tehnug auch für lie Stimangen einzehner Insekten mehrfach angegeben, ist jerlorh nach den sonstigen Erhahrungen unwahrscheinlich. Imgekehrt wurde jedoch die Bildung der llauptangen der Scorpione durch Einstülpung nenerdings geleugnet und andrerseits behanptet, daß die Nebenangen der Araneinen invers und daher den Ilanptaugen der Scorpione homolog seien. Da sich diese Ansicht jedoch un auf' die lage der Stibchen und nicht anl die Ontogenese stiitzt, so kann sie vorerst night als hegrïndet erachtet werden.

In den erwähnten Fällen entwickelt sich die distale Wand der abgeflachten Angenblase zur Retina, da sie von dem durch die Linse konzentrierten Licht zunächst getroffen wird; die Proximalwand bleibt dïnn und wird zu einer postretinalen Membran, teilweise auch zu pigmentierten Zwischenzellen der Retina. In den Scorpionangen (Fig. 680) scheint sie wesentlich das sog. intrusive pigmentierte Gevebe zu bilden, das wohl fälschlich auch als Bindegewebe gedentet wurde. Die distal von der Angenblase liegende Hypodermis bildet sich zum Glaskörper um (corneagenc Lage). Besonderes Interesse erweckt die Retina, welche, ihrer Entstehung nach, eine inverse sein miißte, diesen Charakter aber meist nicht mehr zeigt, vielmehr in der Regel rein conver's gebildet ist, indem dèr Sehnerv von inuen zutritt und, die postretinale Membran durchsetzend, sich mit den proximalen Sehzellenenden verbindet (Fig. $680 \mathrm{~A})$. - Die Verhältuisse in den Hauptocellen der Sodentariae lassen aber erkemnen, daß diese converse Bildung jedenfalls dureh eine Umformung (Reversion) der Sehzellen entstand. In letzteren Augen (Fig. 681) tritt nämlich der Sehnerv dorsal ein, ja breitet sich in der Ontogenese ursprïnglich zwischen der distalen Augenblasenwand und der GlaskörperBütschli, Vergl. Anatomie.

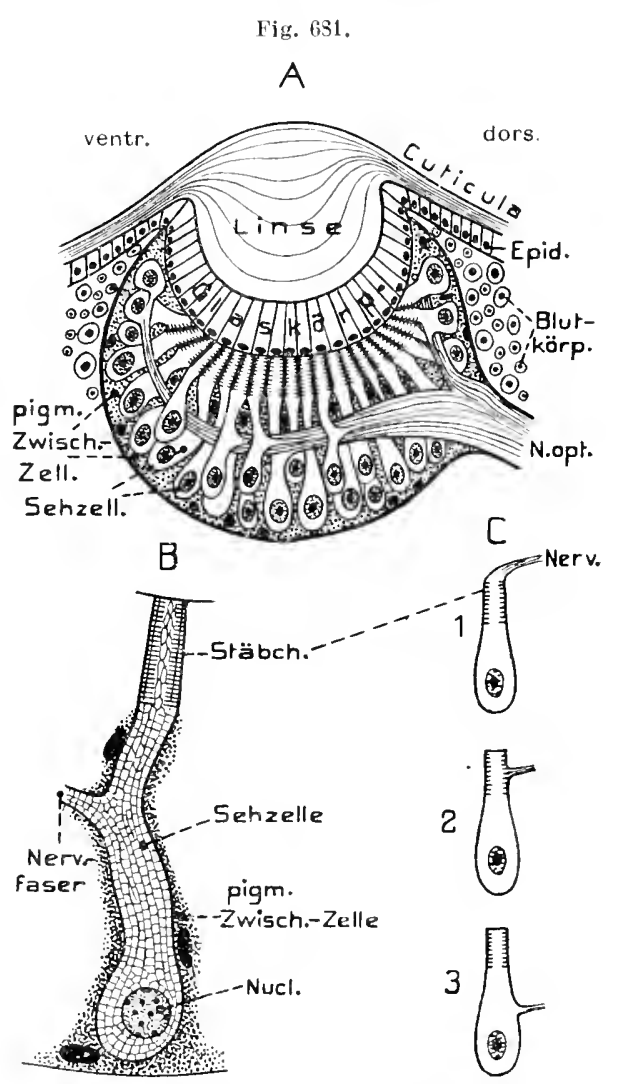

'Tegenaria domestica Cl. (Hanspinne). Inverses" Auge (Hauptauge). - I Sagitialer Achsialschnitt des Auges. $-B$ Eine Sehzelle in gleicher Ansicht, stärker vergröBert. - $C$ 1-3. 3 Schemati zur Ableitung der sehzellen aus dem inversen Ausgangszustand durch allmähliches Anwachsen des Distalendes, der Zelle (2-3), (nach WIDIAST 1:08). 
schicht ans. Im erwachsenen Auge durchsetzen seine Fasern die Retina etwa in ihrer mittleren Höhe und verbinden sich mit den Sehzellen ziemlich in der Mitte ihrer Seitenwand $(681 \mathrm{~B})$. Dies ist so zu deuten, daß sich die Nerventasern ursprïnglich mit den Distalenden der Sehzellen verbanden, woranf letztere distal answuchsen, und an diesen Distalenden die Stäbchen bildeten (Fig. 681C1-3). Die vollständige Reversion der Sehzellen bei den ragabunden Spinnen und Scorpionen entstand wahrscheinlich so, daß der proximal vom Nervenfaserzutritt befindliche 'Teil der ursprünglichen 'Zellen ganz verkümmerte, während der distale sich stärker' entwickelte, wodurch die Sehzellen den rein conversen Charakter erlangten. Charakteristisch für die Hauptocellen der Spinnen (Fig. 681) ist, daß die Sehzellkerne proximal von den Stäbchengebilden liegen (postbacilliir), in den Nebenocellen dagegen (Fig. 677, S. 880) distal von ilhen (präbacilliir). Im übrigen gleicht der Ban der Retina jener der convertierten Augen sehr; das Tapetum fehlt jedoch den Hauptocellen stets.

Die Hauptocellen der Araneinen sind mreh den Besitz von'Muskeln ausgezeidnet, die sich entweder in Zweizahl, rom Integument entspringend (dorsal und rentral), an den Bulbus ansetzen ( agabundae), oder nur in Einzahl (dorsal). Ungemein kompliziert wird dieser Apparat bei Sattirus, wo sich nicht weniger als sechs Muskeln zu jedem Hauptauge begeben, zw dorsale unl vier ventrale. J)ie Muskeln bewirken teils eine lichtungsveränderung der Augenachse, teils dienen sie auch zur Accommodation. - Auch das rordere Paar der Hydraehnidenaugen besitzt einen Muskel. der sich an die Linse heftet und bei seiner hontraktion die Augenache ventral richtet. .

Nach Fertigstellung des Manuskriptes ershienene Intersuchungen zeigen, daß die Anorhnung der lihabdome im Jlauptange ler scorpione eine inserse ist. Die Sehzelle zeigt einen der Linse zugewandten scharfen linick, ron dem aus, sowohl der rhabdomtragende, als auch der den Kern enthaltende und die Nervenfaser entsendemle Teil der Zelle nebeneinander von der Linse fortzielien, sodali also beide Enden gegen die Oberfläche des Auges (proximal) schaueı. Fermer scheint sich für die Nebenaugen der Araneidae durch ein ähnliches Verlatten der beilen Abschnitte der Sehzelle und durch eine entsprechende Art des Nervenursprungs ain inverser Bau zn ergeben. Auch dte Augen der Psendoscorpione sollen invers sein. Die liaupt- und rulimentären Nebænaugen der Solifngen, die Aǘn der Phalangiden und Hauptangen der Arachniden solten ronvers sein.

Die lateruten. Ocellen mancher Inselitenlarren (Newroptern, Lepidoptera) der strepsipterenmënnchen und der Myriopoden treten in größerer Zahl auf (s. S. 875) und nähern sich in ihrem Bau den Eimzelelementen der Complexangen z. 'T. sehr, was bei der Myriopode rcutigera besonders hervortritt.

Bevor wir diese Augen näher besprechen, mögen jedoch die Lateralaugen der Tiphosuren und Strepsipteren erwähnt werden. die gewöhnlich als ('omplexaugen angeführt werden. Das Seitenange von Limulus (Fig. 682) wird von einer großen Zabl nahe zusammenstebender Einzelocellen gebildet, welche insofern ursprünglicher erscheinen als die frülıer (S. 875) erwähıten . Medianocellen. als ihnen ein Glaskörper fehlt, doch wirhen die Distalenden der Epidermiszellen als ein solcher (Fig. 682A). Jedes kinzelauge liegt im Grund einer trichterförmigen Einsenkung đer Iypodermis und eine etwa kegelförmige Verdickung der Cuticula fïllt die Trichterhöhle aus; äußerlich bleibt die Cuticula (Cornea) glatt, ohne Facettenbildung. Jede Sehzellengruppe besteht aus 10-15 radiär angeordneten Zellen, die an ihrer achsialen Fläche einen cuticularen Saum (Rhabdomer, Stäbchen) bilden. 
Achsial treten die Zellen nicht dicht zusammen, -ondern lassen einen sich distal verjüngenten, pfriementömigen kaum zwischen sich, welcher von einem centralen Rbabdomer nusgefüllt wird, das von einer excentrisch zwischen den sebzellon liegenden pigmentfreien Zelle ausgeht ( Fig. $682 \mathrm{~B}$ ). Zwischen den Sehzellen tinden sich Zwischenzellen. deren ectodermale Natur wahrscheinlich ist. Ob die Seitenaugen der Xiphosuren phylogenetisch mit den Complexangen der C'rustaceen znsammenhängen, dürfte nach ihren lian zweifelhat: erscheinen. - Die fossilen Trilobiten besiben jedentals gauz älnliche Augen, 、ieltach mit deutlich facettierter Cornea.

Eine analoge Augenbilumg lintet sich, wie schon oben erwähnt, bei ten Minnchen der Strepsipteren, wo lateral am Kopt nicht wentger als etwa 50 solcher Ocellen dicht zu-ammenstehen. leder Acellus hesitzt. ihnlich wie bei limulus, eine sich tief' einsenkende Corneallinse, lie auch nach außen convex vorgewölbt ist. und unter welcher sich, abgesehen rou der eingesoukten Iypodermis, einige lileine Zellen finden (corneagene Zellen) und sthließlich eint bechertörmige liruppe ron iiber 50 Sehzellen, die zwischen ihren distalen Partien einen netzförmig zusammenhängenLen Stäbchensanu abscheiden. DaB diese

Fig. 682 .

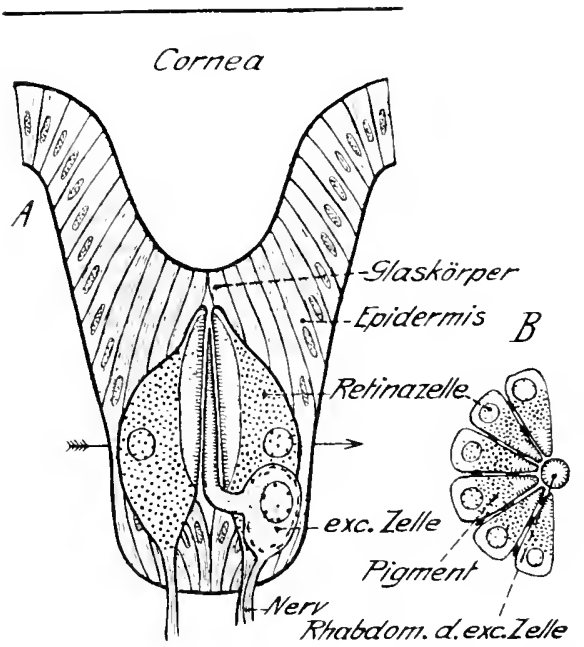

Limulus polyphemus. Complexauge (schenutisch). - A Achsialschnitt durch ein Ommatidium. Corne: viel dicker als gezeichnet. - $k$ Querschnitt turch ein (Onmatidium nit Rhabdom (nach ()+moll l!nt). (. H.

Angen eime Häufung von treellen. uicht aber ein wirkliches Complexauge larstellen, erscheint hlas!.

Die Lateralocellen der Inseltenlarven und der s'cutigera (Fig. 684-686) zeigen im allgemeinen den Bau der oben geschilderten conversen, relativ einfachen Ocellen mit verhältnismäßig wenig Sehzellen (zahlreicher noch bei Newropteren, ca. $30-40$ bei Myrmelco und sialis, bei Scutigera etwa 12-16; dagegen bei Lepidopteren und Pleryganiden

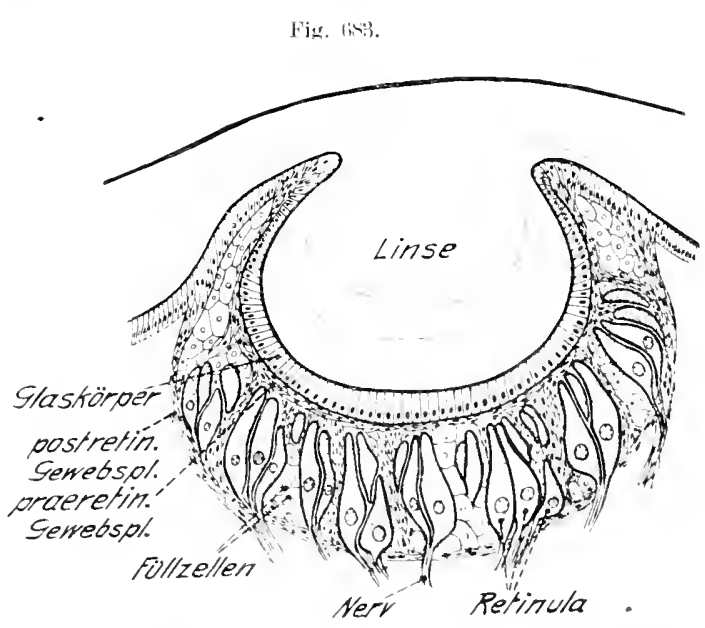

Limulus wolyphemus ocellus, - Etwas schematisiertet

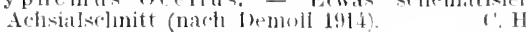

meist nur 7, ähnlich wie in den Einzelelementen der Complexaugenj. Eiuige an die Cuticularlinse angrenzende Hypodermiszellen schieben sich als corneagene Zellen unter diese, wälrend im Umkreis der Linse einige pigmentierte Zellen als 
Hiillzellen (Manteliflen um die Retina in die Tiefe wachsen. Die corneagenen Zellen oder auch besondere, unter jhnen befindliche Zellen scheiden proximalwärts einen eigenartigen lichtbrechenden Körper ans Kristallkïrper oder-liegel), welcher distal von der Retina liegt und aus einigen radiär zusammengestellten Segmenten besteht, die wahrscheinlich von je einer Zelle abgeschieden sind. Auch

Fig. (68'.

A

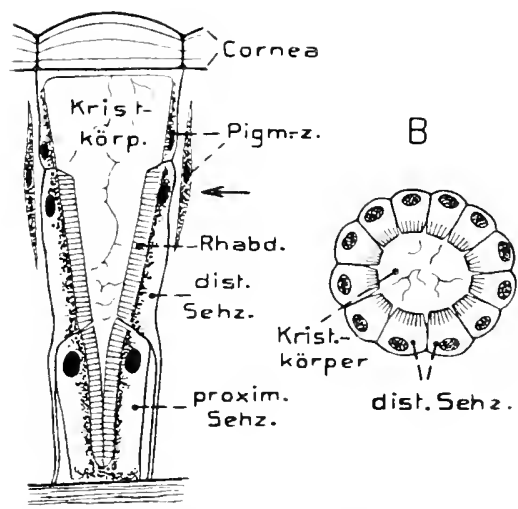

scutigera coleoptrata (Myriopode). Com plexauge. - A lin Ommatidium im Achsial schnitt. - $b$ Querschnitt rluch eine Retinula in (fer Richtung des Pfeils auf Fig. $A$ ( $A$ nacl fiExACHEH 1880, B nach HESSE 1901). Y. Bn.

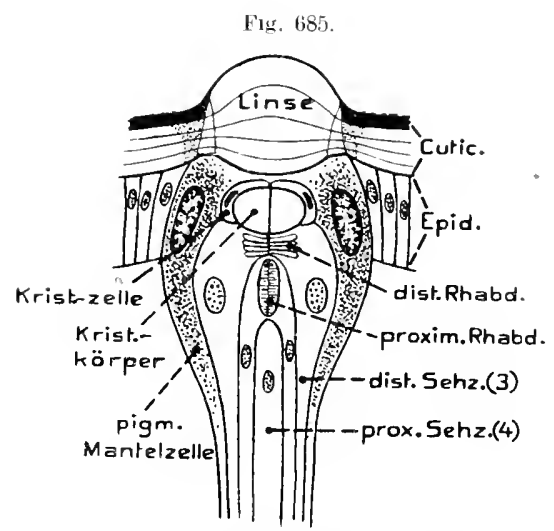

Gastropartha. Larve (Iepidoptere). Achsialschnitt durch einen Ocellus, schematisch (nach Pankratu 1890, und IIEsse 1901). v. Bu. bei Scutigera (Fig. 684) findet sich unterhalb der Cuticnlarlinse ein ähnlicher Körper, dessen Ursprung aber nicht genan bekannt ist. Charakteristisch für die hierher gehörigen Augen erscheint schließlich, daß die Sehzellen (ausgenommen Nenropteren, Hig. 686) in zwei Kränzen, einem distalen und einem proximalen angeordnet sind (bei Lepidopteren [Fig. 685] und Phryganiden drei distale und vier proximale Zelleu, bei Soutigera [684 B etwa neun und drei), wobei jede dieser Zellgruppen ein besonderes Stäbchen (Rhabdomer) bildet. - Die sehr zilhlreichen Ocellen von Scutigera sind so dicht zusammengeruickt, daß ihre Cnticularlinsen zusammenstoßen und die Retinae der Einzelaugen nur von wenigen faserartigen Pigmentzellen gesondert werden. Der Gesamtban einer solchen Ocellengruppe stimmt daher mit dem der Complexangen nahe iiberein. weshalb das Entstehen letzterer aus nahe zusammengerrickten, zahlreicheu einfachen Ocellen sehr wahrscheinlich ist.

d. Complexangen (facettierte oder Fiicheraugen) der Thselitem und Crustacren.

Wie wir sahen, finden sich die Complexangen schon in einfacher Ausbildung bei den Palaeostraken: gut ausgebildet sind sie namentlich hei den meisten Trilobiten, wo sie nur selten (Harpes) durch zwei Ocellen jederseits vertreten werden. Auch die Augen des Myriopoden Scutigera erheben sich, wie bemerkt, auf eine ähnliche Entwicklungsstufe.

Nlgemein verbreitet Waren sie jedenfalls urspriinglich bei den Crustaceen und Inseliten: die relativ wenigen Fialle, in denen sie in beiden Gruppen fehlen, betreffen Formen, welche teils durch Kleinheit, teils durch Parasitismus rückgehildet sind, orler in Innkeln leben (siehe auch $\$ .872$. 
Wie wir fanden, bestehen nahe Beziehnngen zwischen den Ocellen und Complexaugen, weshalb auch manche Augengebilde, die zu den Complexaugen gezogen werden, mit demselben liecht als aggregierte Ocellen aufgefaßt werden kömnten. Hierher gehören die Complexaugen der aptcrygoten Inscliten und der Isopoden, hei welchen die Einzelangen (Ommen, Ommatidien, Ficettenglieder) noch so weit voneinander entfernt sind, daß eine gemeinsame facettierte Cornea fehlt. Die typischen Facettenaugen sind dadurch charakterisiert, daß ihre Einzelelemente so dicht zısammenrücken, daß sie nur von wenigen Zwischenzellen geschieden werden. - Die Differenzierung ihrer Cuticula (Cornea) in den Einzelommen zugehörige Facetten (Linsen) ist kein notwendiger Chitrakter, da er den Complexangen vieler Krebse Plyllopoden, Ostracoden, Amphipoden, manchen Thorceostraken ganz fehlt. - Gewöhnlich wird die Zahl der Ommen, und dalher aneh die Größe der Complexaugen sehr bedentend, so daß sie bei vielen Insekten (hier bis zu 30000 bei Neerophorts gezählt), doch auch Crustaceen die ganzen Kopfseiten einnehmen. Andererseits kann jedoch ihre Zahl auch sehr abnehmen, was wohl ant Reduction beruht, so bei gewissen Apterygoten anf fünf bis zwölf, bei Asellhs auf vier, ja bei Copepoden und Perliruliden bis anf ein Omma, welehes daher auch als Simplexauge

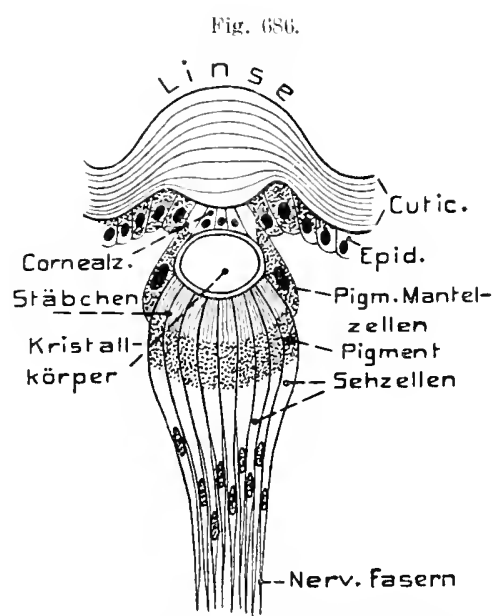

Iyrmeleo (Lirve), schematischer achsialel Durchsenuit eines Ocellus (nach Hesse 1901) ง. Bu. betrachtet werden könnte, wenn sein Ban es nicht als Abkömmling eines Complexanges erwiese. - Die große Übereinstimmung der Complexangen bei Crustaceen und Insekten weist darauf hin, daß sie recht frühzeitig aufgetreten sein müssen, und scheint fermer dafür zu sprechen. daß ihre Modifikationen, welche namentlich bei gewissen Insekten vorkommen, auf Um-oder Rückbildung beruhen. Dies ist um so wahrscheinlicher, weil solehe Modifikationen keineswegs bei primitiven, sondern bei spezialisierten oder riickgebildeten Insektengruppen auftreten.

Der Bau eines typischen Ommas oder Facettenglieds ist ungetähr derselbe, den wir schon bei den aggregierten Seitenocellen der Scutigern, sowie Aer Lepidopteren- und Phryganidenlaven finden. Jedes Omma besitzt in der Regel äußerlich eine cuticulare Linse (Frcette), die meist nach anfen und innen gewölbt ist: doch kann die äuBere oder innere Wölbung auch fehlen (Fig. 691, S. 890), ja sogar beide (s. Fig. 689, S. 889), wie wir schon für zahlreiche Krebse liervorhoben. Wenn die Einzellinsen (Facetten) direkt zusammenstoßen, wie das meist der Fall ist, so bilden sie hexagonale, seltener mehr viereckige Feldchen (gewisse Deeapoden; Fig. $689 B^{1}$ ). In der Masse der Corneasubstanz treten häufig Grenzlinien zwischen den benachbarten Facetten hervor; auch kann die Cornea auf den Facettengrenzen 
pigmentiert sein, wodurch schon eine optische Isolierung der Facetten bewirkt wircl. Die Cuticularsubstanz der Facetten ist nicht selten geschichtet.

In der Ontogenese wird die Cornea ursprünglich von der Hypodermis gleichmäßig unterlagert, aus der sich dann später die einzelnen Ommen samt ihren Zwischenzellen hervorbilden. Bei den Crustaceen erhält sich auch direkt unter

Fig. 687.

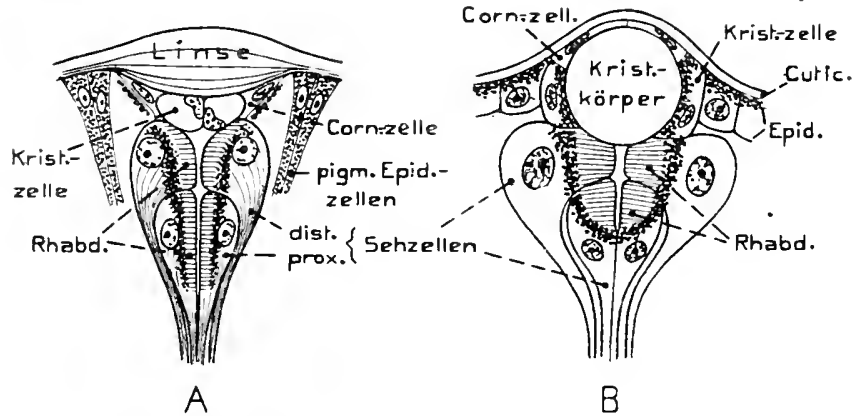

Complexillgen apterygoter lnsekten. - A lepisma. - borche sella, je ein Ommatiom in Achsialschnit (nach Hesse 1901). v. Bu. der Cornea im allgemeinen eine Lage Hacher durchsichtiger Hypodermiszellen, welche in der Regel unter jeder Facette in Zweizahl vorhanden sind corneayene Zellen, Fig. $688 \mathrm{~A}$, bei Branchipus jedoch zu sechs[Fig. $689 \mathrm{~A} 11$. $\mathrm{A}^{1}, \mathrm{Cz}$, ebenso bei

den Amphipoden gewöhnlich in größerer Zahl). Den meisten Insekten fehlen die corneagenen Zellen anscheinend; doch linden sie sich noch bei primitiven Formen (gewissen Thysumuren, z. B. Machilis, Embia; den Ephemeriden) in Zweizahl und in ganz ähnlicher Lage unter jeder Facette (Fig. 687). Bei den iibrigen

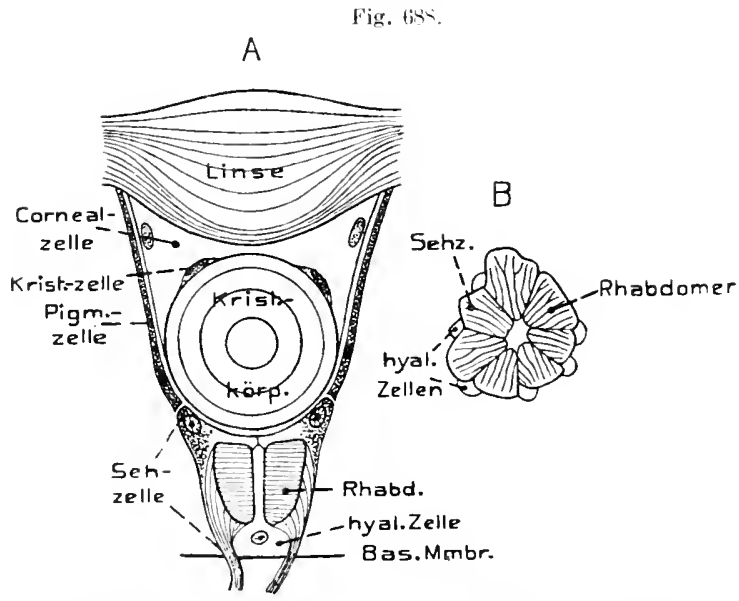

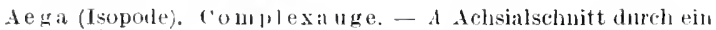
Ommatidium. - $B$ Querselmit dureh eine Retinula (nach Hesse 1901) v. Bu. Insekten haben sie sich vom Mittelpunkt der Facette zurï̌ckgezogen und sind gewöhnlich tiefer ins Innere hinabgewachsen, indem sie den gleich zu erwähnenden Kristallkegel mehr oder weniger umhüllen; sie enthalten hier in der Regel Pigment. Uiese beiden charakteristischen Pigmentzellen der Insekten werden als Hauptpigmentiellen bezeichnet/nur in den Frontaugen der Ephemeriden wurden sie vermißt).

Unter jeder Facette eines typischen Ommas findet sich gewöhnlich ein stark lichtbrechendes, meist kegelförmiges Gebilde, der Wristalliegel oder - lïrper (Conus), welcher dem Auge der Crustaceen nie fehlt. Im Zusammenhang mit der sehr verschiedenen Iänge der Ommen ist er bald kürzer 
(sehr kurz bei gewissen Brachyuren), bald länger und gestreckter. Ubgleich er, wie bemerkt, meist die Form eines sich proximal verjüngenden Kegels besitzt, kann er zuweilen auch gedrungener, ja sogar kngelig werden (so bei Isopodcn, z. B. Acga, Fig. 688 A, und gewissen Apterygoten, z. B. Orehesella, Fig. 687 B). - Der Kristallkegel wird fast stets von vier besonderen Zellen (Kristull:cllon) erzengt, die ursprïnglich zwischen die corneagenen Zellen eingeschaltet waren, dann aber unter letztere hinabrïckten oder von ihnen ïberlagert wurden (Crustaceen, Fig. 688, 689), wogegen, wie erwähnt, die Corneagenzellen der meisten Insekten als Hauptpigmentzellen in die Tiefe rückten, weshalb die Kristallzellen hier direkt tunter der Facette liegen (Fig. 690, 691). Aweichungen von der Vierzahl der Kristallzellen sind selten; so finden sich bei den Cladoceren und gewissen Branchiopoden fünf, bei den Arthrostralien meist nur zwei. - Ver Kristallkegel entsteht im Innern der Kristallzellen (Fig. 689), indem diese eine stark lichtbrechende Substanz abscheiden, die allmählich so zunehmen kann, daß sie das gesamte Zellinnere erfüllt. Daher kommt es, daß auch die fertigen Kristallkegel meist noch deutlich aus ebensoviel zusammengefiigten Segmenten bestehen, als Kristallzellen vorhanden sind. Vom Plasma der Zellen erhalten sich häufig nur geringe Peste, die sich mit ihren Kernen (sog. Sempersche Kerne am Distalende des Kegels finden.

lieste rer Zellen bleiben, jerlor auch iu I mfang des liegels häufig als rine Art Scheide orler Ilialle erhalten.

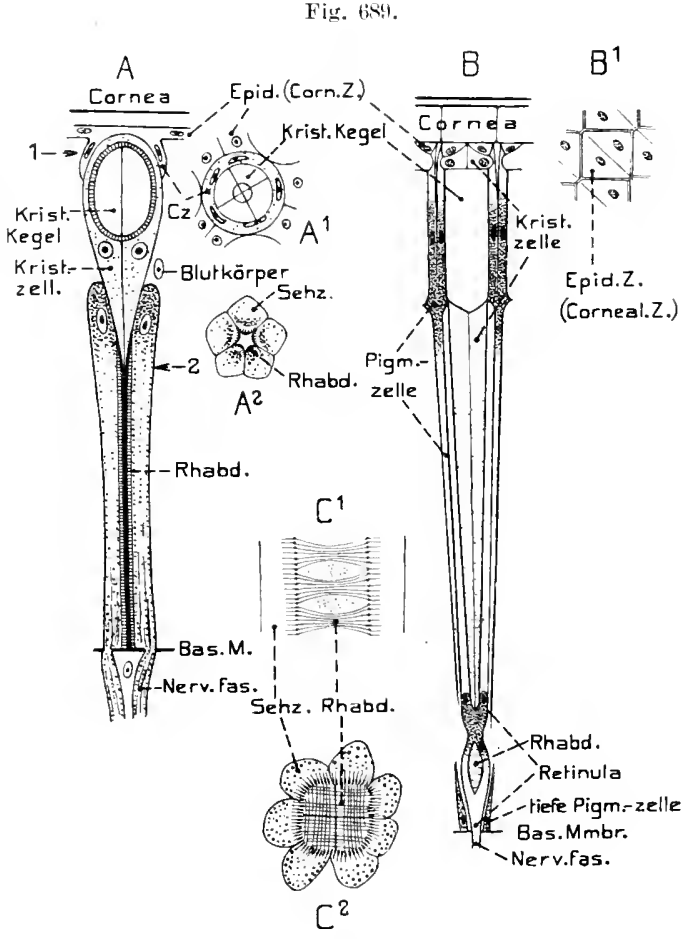

('omplexinge von Crustace en. - 1- lablanchipus. - A Ein Ommatidium im Achsialsehnit. $\hat{l}_{1}$ und l. Quer schnitte durch ein Ommatillium in aler liegion der Pleile und 2 anf Figur .1. $C z$ anf Fig. A Cornealzellen (bach NoviKOFF 1!105). - b Homarus vulgaris. Ein Ommatidium im

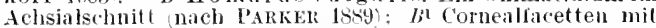
Cornealzellen in Frächenansicht. - $C^{\prime}$ lam t"s Palae mon sruilla: " Achsialschnit durch eine Retinula; $C^{2}$ Querschnitt durch eine solche nit lihablom, um die Struktur des Letzteren zu zeigen (nich Hesse 1!01). $\checkmark$ Bu

\section{boch kommt es auch vor, daß der}

Conus sich nur im Distaiteil der selır lang geworlenen Kristallmellen bildet, so daß deren l'roximalteile sich. muter allmällicher Verschmälerung, noch tief hinab bis \%n den lietinulae fortsetzen (was namentlich in sehr langgestreckten Ommen von Decapolen |rig. 689\} unl Lepidopteren [Fig. 691] aufritt). Andrerseits kann sich bei manchen Decapoden die Kegelbildung auf den Proximalteil der Kristallzellen beschränken. - lı gewissen Fïlen zeigt der Kristalkegel dichtere innere Partien mud nach den Untersuchungen an manchen Imsekten um] ('mitaceen nimmt sein lichthrechumgsermïgen von der Oherfïche gegen die dehse zu. was 
fiir seine Wirkungsweise im dioptrischen Apparat des Auges von besonderer Wichtigkeit ist. Er bildet nämlich auf diese Art eine optische Vorrichtung, welche ähnlich einer Linse wirkt: d. h., er vermag ein umgekehrtes verkleinertes Bild äußerer Gegenstänle zı entwerfen (Linsencylinder. Auch die Cornealfacetten zeigen eine ahnliche Zunahne ihres Brechungsvermögens gegen tie Achse und wirken daher ebenso, wenn auch gleichzeitig als gewöhnliche Linseı.

Typisehe Kristallkegel (eucone Augen) finden sieh, wie bemerkt, bei den ( staccen fast uiberall (ansgenommen Apseudes unter den Isopoden und gewisse Brachyurem, z. B. Pimnothcres und eine Cyclodorippe), nieht immer dagegen bei den Insekten. Von letzteren besitzt sie ein Teil der Apteryyotu (z. B. Hachilis), die Orthoptern, Neuroptern, ein Teil der Coleoptera (z. B. Lamellicomiu,

Fig. 690.

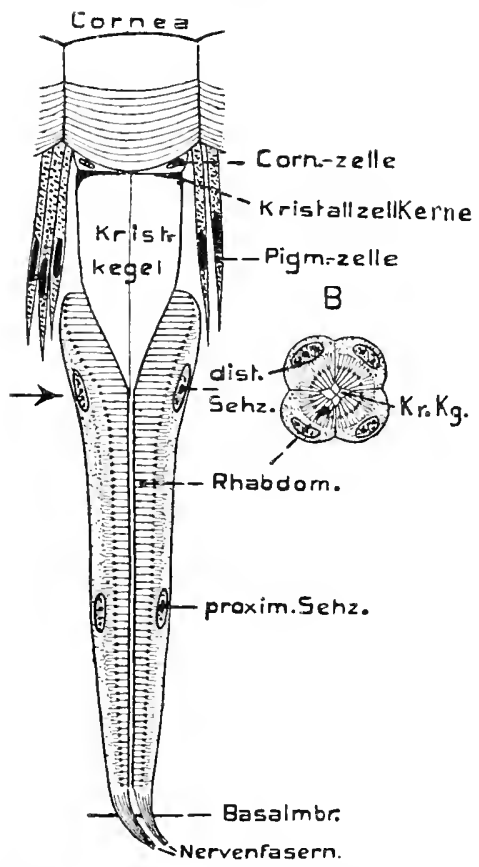

Periplaneta orientalis. Complexauge. I Ein Onnatidium in Achsialschnitt - B Querschnitt durcll die Retinula in der Richtung des Piejls a fut Fig. I nach Hesse 1401). v. Bu.

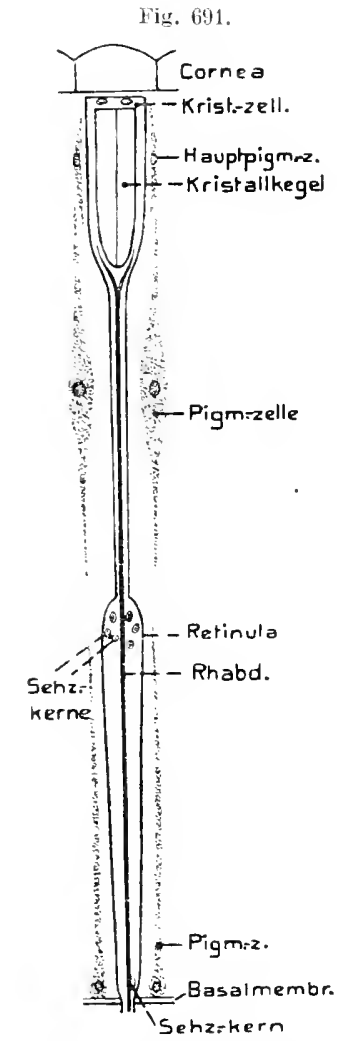

Il acroglossa stellatarum (Lepidoptele). Complexauge. Lin Ommatidium im $A\left(c_{1}\right.$ sialschnitt (nach JoHsis 1911). $\quad$. Bu.

Carabitue u. a.), die Hymenopteri und Lepirloptera (mit Ausnahme der (iattnng Adela), die Homoptera (speziell Cicaden) unter den Rhynehota, von den Diptera nur gewisse Culicilac (so Corethra). - Dagegen findet sieh bei manchen Apteryyoten (z. B. Lepisma), sullieichen Coleopteren (ausgenommen viele Pentameren), den nematoceren Dipteren Longicormia), Forficula Dermaptera) und den hemipteren Rhynchoten ein viel einfacherer Augenbau, indem Kristallkegel ganz fehlen (Fig. 692). Die Ommen bleiben daher hier relativ kurz. 
bie vier gut ausgebildeten Kristallzellen dieser Augen liegen zwar direkt unter der Cornealtacette, und ihnen schließen sich die beiden llamptpigmentzellen seitlieh, oder etwas tiefer geriickt, an; nach innen folgt aber direkt die Retinula. Solche Augen werden daher als acone bezeichnet, zu denen auch die der oben erwähnten Crustaceen zu rechnen wïren.

Bei anderen pentameren Küfer" (Mulacodermata, Elateridae 11. a.) sowie zahlreichen brachyceren. Dipteren bildet die innere Fläiche der Faeetten einen meist ansehnlichen kegelförmigen Fortsatz (Processus cornccue, Pseudocomus), an dessen Grund die Kristallzellen nnd die Hauptpigmentzellen liegen (Fig. 694). Dieser Fortsatz wurde frïher als der mit der Facette verwachsene Kristallkegel gedentet. Nach nemeren Untersuehmugen ist er ein Corneagebilde, und hat jedenfalls die Funktion des eigentlichen Conus iibernommen. An seiner Erzeugung beteiligen sich wohl hauptsïehlich die Kristall- und Hauptpigmentzellen.

Bei manchen brachyeeren Dipteren (so Muscidac, Tabanidue [Fig. 693] u. a.) scheint der Psendoconus rudimentär geworden zu sein, indem seine Stelle von einer weichen Masse oder Flissigkeit eingenommen wird.

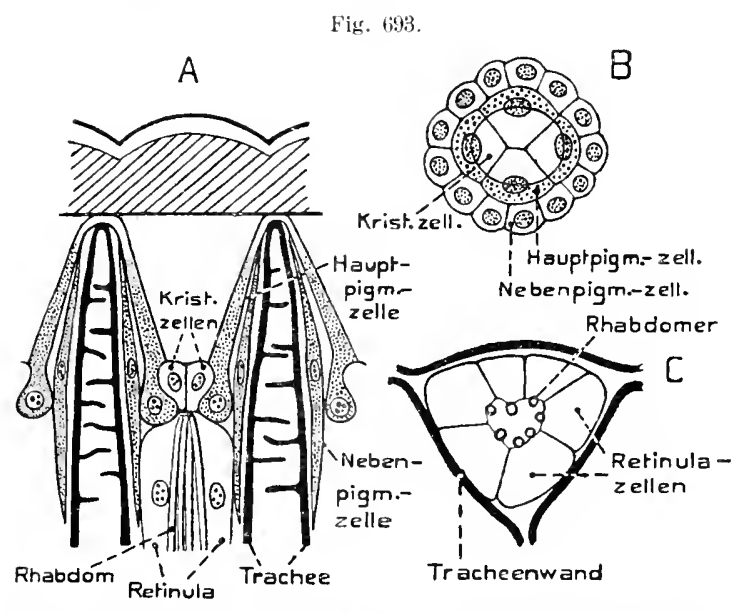

Pseudocones Complexamue von Tabaniden (Hremsen). 1 Ha ematopota. Achsialschuitt dured flie Cornea und das Distalende eines Onmatidiums nach DIETRICI 1909). - $B$ ' Tabanus. Querselnitt eines Ommatidiums in der Hölıe der Kristallzelleı. $C$ Querschnit durch eine lietinulia ( $b$ - nach GRENacher 15i9).
Fig. 692 .
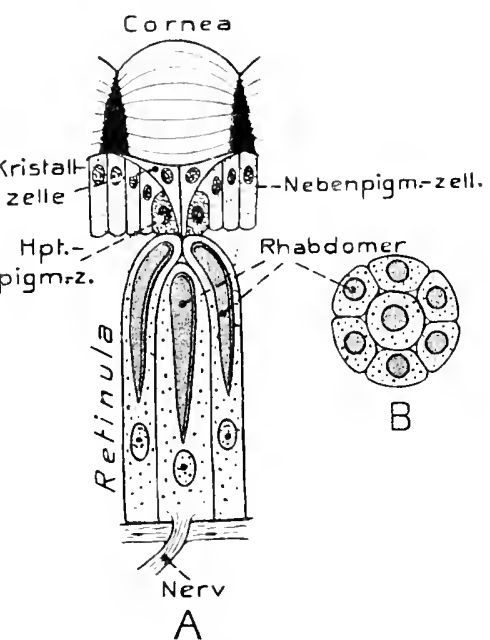

Tipula (Diptere), Acones complex a uge. - A Längsschnitt durch ein Omma idim. - $B$ Quersclinitt durch eine Reti nula (nach GRENACHER 157!?). v. Bu.

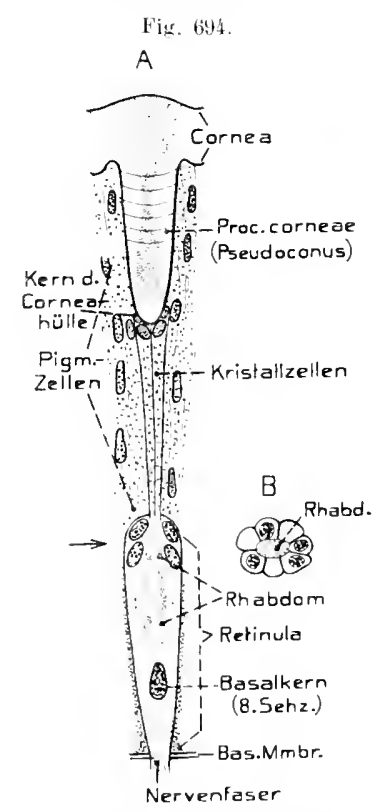

La m y y is (Lenchtliiter, ( 0 o $n$ plexauge). $-A$ Ein Ommatidium in Achsialschnitt. - BQue'schnitt durch den Distaiteil einer Retinula in tler Region des l'feila aui Fig. 1 (natch KIRCHHOFFE? (1908). v. lia. 
Im allgemeinen werden die Augen mit solchem Processus corneae, sowie die letzterwähnten als pseudocone bezeichnet.

Das für einzelne Brachyuren (so Ocypoda eeratophthalma Pall.) erwälnte Vorkommen pseudoconer Auge scheint sich nicht zu bestätigen.

Angesirhts der weiten Verbreitung der euronen Augen bei Crustaceen und Insekten dürte es wahrscheinlich sein, daß tie aconen und pseudoconen ans ersteren durch Rückbildung entstanden sind. worauf auch ibre Verbreitung unter den Insektenabteilungen hinweist; obgleich Jas acone Auge bei dieser lieduktion wieder einen recht ursprünglichen Charakter annahm.

Die lietimula, welche den basalen Abschluß jedes Ommas bildet, besteht aus einer Anzahl meist strahlenförmig um die Ommaachse gruppierter, mehr oder weniger langer Sehzellen, deren Distalende häufig etwas kolbig angeschwollen ist. In nenerer Zeit wird vielfach angenommen, daß ursprünglich ïberall acht vorhanden gewesen seien, eine Zahl, die sich in der Insektenretinula häufig findet (so zahlreiche Käfer, gewisse Neuropteru, die IIymenoptera, die meisten Lepidoptera, Rhynchota). Nicht selten finden sich jedoch auch nur sieben, was wohl auf der Reduktion einer Zelle beruht (so Apterygota, Orthoptera soweit bekannt, gewisse Lepidoptera); doch wurde in einzelnen Fïllen (Lepidoptera) auch Vermehrung anf zehn gefunden. Viel variabler ist die Sehzellenzahl der Crustacea.

So tinden sich hei einzelnen Isopoden (Onisens) 14. bei den Thoracostralien nul Leptostralien gewöhntich sieben manchen Isopoden arth sechs), dorh soll bei den Thoracostraken nach gewissen Angatien noch eine radimentire achte vorhanden sein. - Ine Amphipoden und Phytlopoden sowie Argutus besitzen meist fünt (doch liegt eime Angabe vor. daß bei Apus urspringlich acht vorhanden seim, von denen eine bis einige rudimentär werden; meist sieben). Yur vier Retimnlazehlen zeigen gewisse Isopoden (Serolis). - Es muß daher einstweilen dahingestellt bleiben. ob sirh die Zahl der Sehzellen anch bei den Crustacen von acht ursprünglichen ahleiten laßt. Da auch bei den Insekten gelegentlich einige Sehzellen mimentïr werden. so wire die Vereinfachng. wie sie nirht wenige Crustaceen zeigen, wohl möglith.

Die Anordnung der Sehzellen in distale und proximale, der wir schon im lateralen Larvenange gewisser Insekten und bei Scutigera begegneten, wiederholt sich noch bei den Apterygoten (vier distale und drei proximale, Fig. 687, S. 888) und gewissen Orthopteren (z. B. Embia, Periplanetu, Fig. 690, S. 890).

" ahrscheinlich ist jedoch anch lie bei nicht wenigen Insekten Coleopteren, Neuropteren Khynchoten, Dipteren, Lepidopteren sich tindente Eigentïmhchlieit, daß siehen oder sech: der lietimlakeme distal, einer oder zwei tagegen in der Hasalregion hiegen (wobei die achte Zelle häutig rudimentär wird eine entsprechende Erscheinung. Bei den Crustaceen finder sich kaum etwas Ahnliches. - Gelegentlich tindet sich bei einzelnen Insekten (so gewisse Hymenopteren) auch eine g.m\% nnregelmißßige Verteilung ter ant kerne.

Die Retinulazellen sind meist pigmentiert und bilden gewöhnlich alle an ihrer Achsialfläche ein Rhabdomer (Stibchen). Diese Rhabdomere kömuenganz gesondert bleiben (Fig. 692 A u. B, S. 891), was namentlich in den aconen und pseudoconen Dipterenaugen häufig vorkommt. Dabei kann zwischen den lietinulazellen ein achsialer Hohlraum bleiben oder dieser dadurch ausgefüllt werden, daß sich eine der Sehzellen bis in die Achse erstreckt und sie auf eine längere Strecke durchzieht. - Meist aber stoßen die Rhabdomere achsial zusammen und verwachsen mehr 
oder weniger zu ëinem gemeinsamen L'habdom (Fig. 689 B, C, S. 889, Fig. 690, 691). Doch kommt es anch vor, daß nicht sämtliche Retinulazellen Rhabdomere bilden (so manche hïfer), wo das Rhabdom also nur von einer geringeren Zellenzahl (sechs bis sieben) erzeugt wird. Die rudimentäre achte Sehzelle gewisser Inseliten kann manchmal ein besonderes Rhabdomer bilden, das sich mit dem Rhabdom nicht verbindet. - Charakteristisch für die thoraeostiaken Krebse ist die Zusammensetzung ihres Rhabdoms aus nur vier Segmenten, obgleich sich an seiuer Bildung sieben Retinulazellen beteiligen (Fig. 689 C2), ebenso sein Aufbau aus zahlreichen übereinandergeschichteten horizontalen Plättchen (Fig. $689 \mathrm{C}^{1}$ ).

Die einzelnen Ommen werden fast stets durch pigmentierte, faserartige Zwischenzellen (Neberpigmenticllon) von einander isoliert, die in recht verschiedener Zahl auftreten: ibre Ableitung von Hypodermiszellen läßt sich ontogenetisch und vergleichend anatomisch erweisen. Die distalen dieser Nebenpigmentzellen (das Irispigment) reichen nämlich in der Regel noch bis zur Cornea und umhüllen den Kristallkegel; tiefere in der Region der Retinulae oder der lihabdome liegende Pigmentzellen bilden das Retinapigment, das selten ganz fehlt.

Bei nächtlichen Tieren wandert das Irispigment bei starker Belichtung in die Tiefe. während das Retinapigment der Krebse unter diesen Verhältuissen meist in die Distalregion der lihabdome tritt: auf diese Weise wird der Lichtzutritt abgeschwärht. - 1)as Irispigment (oder auch eine besondere Substanz) kann bei gewissen Decapoden glei'hzeitig als Tapetum funktionieren, inden die Zellen sowohl lichtreflectierende als auch fluorescierende Einschlïsse enthalten. - AuBer diesem Tapetum besitzen viele Decapoden all der Basis der ommen noch ein tief gelegenes, von je zwei Zellen gebilletes; selbst in Ganglion opticum kann eine reflektierende Schicht aultreten. - Vielen Nacht- und Tagschmetterlingen kommt ebentalls ein tief gelegenes. stark leuchtendes Tapetum zu, weldhes jedoch von einem Geflecht zablreicher. zwisthen die Ommen eindringender Tracheen gebildet wird, die das licht total reflektieren. - Tracheen treten auch zwischen die (Immen der Dipteren und libellen ein. dienen jedoch hier durh ilıe Totalreflektion zu deren optlscher Isolierung (s. Fig. 69:3 A, S. 891.

Den Abschlnß der Retinulaelage gegen das Körperinnere bildet eine Fortsetzung der Basalmembran der Hypodermis, die von den zahlreichen Nervenfasern. welche aus dem großen Ganglion opticum (s. S. 509) zu den Sehzellen treten, durchsetzt wird (daher auch gefensterte Membran, Membrana fonestrata genannt.

Die Ausgestaltung der Complexaugen hietet im Einzelnen viele lesonlerheiten. welche hier nur angedentet werden könmen. Sie werden namentlich bei den Insektcn und manchen Crustaceen häufig sehr groß, so daß sie lie gesamten kopfseiten einnehmen, ja aul dem scheitel zusammenstoßen können. Die einzelnen ommen divergieren dam natürlich sehr bedeutend, und der Divergenzwinkel ist recht verschieden. sogar in den verschielenen liegionen des Auges: ebenso auch die Größe der Facetten. - Bei den Cladoccren verschmelzen sogar die beiden Augen auf dem sheitel zu einem einzigen. was auch bei gewissen Amphipoden unl Cumaccen vorkommt. Schon bei einem Teil der Branchiopoden (z. B. Limnadia. Fig. 671, S. 875) sind sie dicht zusammengeriickt. Gleichzeitig wird das Scheitelauge ler Branchiopoden und Cladoceren von einer durchsichtigen Hautfalte überwachsen. so daß es in einem bei letzteren ganz abgeschlossenen laum liegt (was sich auch bei Argulus lindet), in dem es durch besondere Nuskeln neist recht beweglich erscheint. - Erhebung des Complexauges auf einen besonderen stiellömigen fortsatz der Kopfseiten findet sich schon bei gewissen Entomostraca (Branchipus; selten auch gewissen Trilobiten) und ist namentlich fïr die Leptostraca und zahlreiche Thoracostraca (Schiropoda. Stomatopola und Decapodu) 
Harakteristioch, wo dieser Auvenstiel beweglich ist. - liei len Insekten ist die Bildung (unbeweglicher) Augenstiele sehr selten (so bei der Diptere Diopsis).

Von Interesse erscheint die seltene Sonderung der Complexaugen in einen dorsalen und ventralen Abschnitt, was sich bei rerschiedenen Inseliten (so Cerambyciden, Vespiden) darin anssprechen kann. daß las Auge lnıch eine vordere Einbuchtung nierentörmig wird. Bei gewissen Lamellicomiern (Coleoptera) wächst ron vorn eine Leiste der ('uticula in die Cornea hinein und kann das Auge vïllig in ein dorsales und ventrales teilen (Geotrupes, ähnlich auch Gyrimus und Tetrops). Eine wesentliche Banverschientenheit der beiden Augenabschnitte scheint aber zu fehlen. - Viele andere Inseliten zeigen dagegen einen recht rerschiedenen Ban der dorsalen und ventralen Augenregion, die sich danı häutig durch rercolietene Firbung und Wïlbung charakterisieren, so daß das Auge von einer horizontalen Furche in ein dorsales, meist größeres Front-(oder Scheitel-) und ein Lateralauge geschieden wirl. In rewissen Fälen (E)hemeriden. Clö̈, zahleiche Diptera, Ascalaphus [Neurop-

Fing. 695.

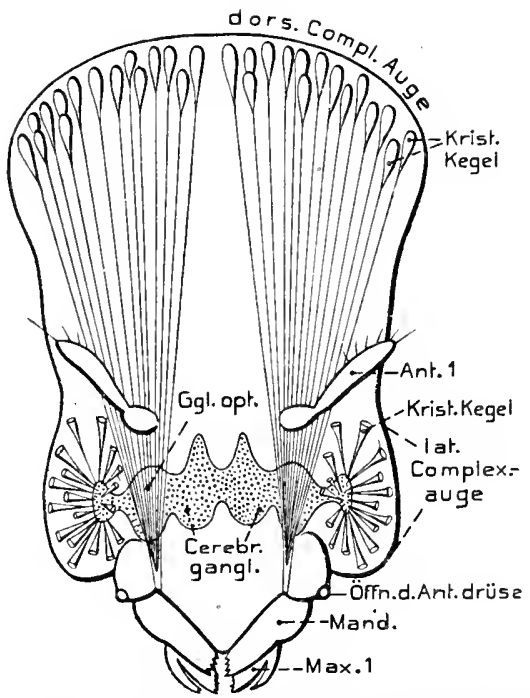

Phronima sellentaria (Amphipole). Kopt von vorn, um die Differenzierung der Complexangen in einen dorsilen und lateralen Teil zu zejgen nach CLAcs 1479 vereinfacht). v. Bu. tera]) beschränkt sich diese Differenzierung aut lie Minnchen. bei anderen (viele Diptera, Hydroeores) tritt sie in beilen Geschlechtern anf.

I)ieselbe Erscheinung houmt auch bei Crustacen vor: in geringen Grad im unparen Auge gewisser Cladoreren (Polyphemiden), ferner hei ler Amplipode Phromima (nebst Verwanlten) unt einer Anzahl schwimmender Tiefscedichelopodcn (frïher zu Schizopuden gestellt) und Amphipoden. In diesen lälen zeichnet sich das Frontange «luwh mehr oler weniger starke Verlängerung seiner Onmen ans. dic manchmal (besonders Phronima [rig. 695] und gewisse Dichelopoden) eine ganz abnorme Entwicklnng erreichen nud dann relativ wenig divergieren. Weiterhin wird das Frontange durch mehr oler weniger starke Rïckhildung bis villigen Mangel les P'igments charakterisiert, was sowohl für die letinula- als auch für die Jigmentzellen in verschielenem Grade gilt; zuwcilen auch (Dichelopoden) durch sehr starke Wöbung der Cornealaretten. - Auch das Ganylion opticnm kann. dieser Differenzierung des Auges entsprechend. eine Zweiteilung zeigen. Eine besondere Eigentümlichlieit besitzen die stark verlingerten ommen ler Frontangen gewisser

Cladoceren (z. 1). Bythotrephes). indem die Noreufasem zn den bistalenden der lietinulazellen treten, was jedenfalls llaher rülıt. daß die Proximalenlen der Sehzellen stark ausgewarhsen sind. Erwähnenswert ist schließlich die eigentümliche Differenzierung des Facettenanges der Ampelisciden unter den Ampliporlen. Hier ist lasselbe in Arei l'atien gesondert, eine dorsale, eine ventrale und eine mittlere. Besonders benerkensuert ersucint aber. dab die so entrtantenen dorsalen und ventralen Angen pine einfache cuticular linse besitzen, welche den mittleren t'ehlt.

Kur\% \%u "rwähen sind noch die parigen Angen. die nebun dem Medianage bei gewissen marinen Copepoden vorkommen (Corycaciden und Pontclliden). Ls liirtite wahrstheinlich sein, daß sie stark rückgehildete Complexaugen darstellen, wie es fïr die ler Pontelliden meist zugegeben wird, während die der Coryeaeiden, wes sogar die sämtlicher Copepolen, aum als Vertreter ler lateralen Teile des Mediananges gedentet werten. Die

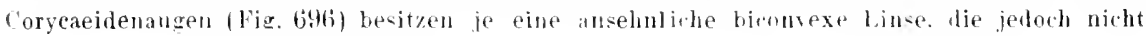


rein cuticularer Satur zn sein scheint, sonden deren ltaptteil von einer besonderen, unter der Cuticula gelegenen Masse gebildet wird. In mäßiger bis sehr bedeutenler Entfernung hinter dieser, in Vorderende liegenden Linse findet sich ein hegelfömiger bis ellipsoidischer, Kistallconus (Seliretlinsf), an den sich pine schmale, wohl iberall aus drei Zellen bestebende, stark pigmentierte Retinula mit drei Rhabdomeren anschlieBt. die hei Copilia (Fig. 696) sehr lang und gleichzeitiw fast rechtwinklig gegen die lledianehene des Tieres abgehnickt ist. Der Sehnerr tritt nicht proximal in die Retinula. sondern nahezu in oder ror der Nitte ihrer Länge ein. ïnnlich wie es im lrontauge ther Polyphemiden rorkommt. Von der lietinula ziehen zahlueiche Fïlen, die wahrsheinlich großenteils nervis sind. zum Iquator der linse: doch lieftet sich anch ein Muskel an die Retinula, wellhe sant dem hristallkegel sehr beweglich ist.

Das parige Auge ler Pontelliden hann mit einer (Pontellina) vder zwei cuticularen linsen (Anomalocera) versehen sein. Die letimulae lieqen dicht unter ler linse: hristallhegel fimlen sich wohl ehenfalls. Teltsam ersheint. da $B$ unter der einfachen Linse wn Pontellina vier. muter der doppelten on Anomalocera drei Retinulae (1;echer) sicb tinden sollen, ron denen jede nur ans zwei Thzellen besteht: doch bedürten diese Angen genauerer Intersuchung. Eine eigentümliche lä̈ckbillung haben anch die Complexangen der großen (1)tracode Gigantocypris erfahren: es wïrde jedoch zı weit führen, daraut näher einzugehen, um so mehr, als ihre Cutersuchung nicht ausreichend ist.

Goglein wir oben fanden. dab die Complexaugen der Tracheaten durch eine Iggregation einfach gebauter lateraler ocellen entstanden sein dürten, so läßt sich doch die rage erheben. ub dies überall. namentlich anch bei den Crustaceen, der liall war. In dieser Hinsicht scheint von liedentung. daß auch. in ler lietina der mit einfacher linse versehenen simplexangen retinulaatige (iruppen und Rhablombildung hïutig antritt und andererseits die Facettenbillung der correa den Krebsen rielfach tehlt. E ließe sich thater erwägen, ob nicht der Lrzustand ter Gcellen und Complexamen der Arthropoden ein ähnlicher war. indem eine Hypodermisstrecke mit unfacettierter Conea und (iruplenbildung von Sehzellen den Ansgangspunkt bildete, ilie dann durch Entwicklung einer einzigen ansehulicheren Linse zn einem simplexauge, oder durch tiefergehende Isolierung der Gruppen (letinnlae) und die meist auttretende Bildung ron Linzellinsen um kristall-

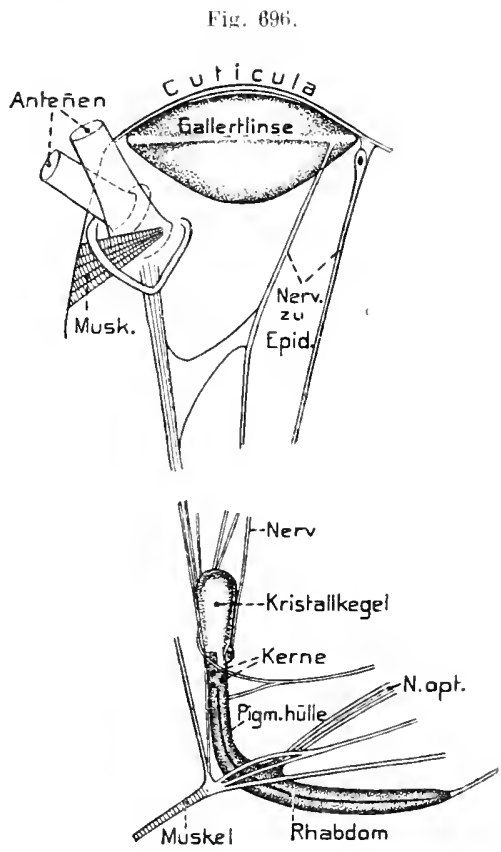

Copitia copepole). Rechtesseitenauge von der Ventratsejte. Dje Entfernung zwi schen der Linse mud dem ommatidium ist durch Weutassing des mitteren Teils der verbindenden stränge verkiurzt dargesteft

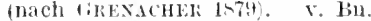
kegeln zu einem complexauge werden konnte.

Es ist hier natiirlich nicht der Ort, auf die optischen Verhälnisse der Irthopodenanqen, insbesondere aut das Zustandekommen eines von ler Retina walımelnnbaren Bildes. näher einzugehen. DaB im Simplexauge von der Cuticularlinse ein umgekehrtes Bild aut der Retina entworten und von djeser, entspredhend der Zahl ihrer lichtemptindichen Jiemente. mehr oder weniger dentlich wahrgenommen werden kann, analog allen Linsenangen, ist begreiflich. - In Facettenauge dagegen konmt es zur Walunehmung eines anfechten liha. nnl zwar in etwas verschedener Weise. Entweler so, daß die Lichtstrahlen. Welche von einem in der Verlängerung der ommenachsen gelegenen kleinen objehtberirk auf die betretfende 
Facette fallen, auf der Retinula (bzw. dem Rhabdom) zu einem Lichtpunkt vereinigt werden, $\therefore$ laß also jedes Omma einen sehr kleinen Bezirk des Objekts wahrnimmt (Appositionsbild) - oder so, daß auch die von einem Punkt des Objekts auf die benachbarten Facetten fallenden strahlen des objektsbezirks sämtlich zu einem Bildpunkt vereinigt werden, weshalb derartige Corneae samt Kegel in ler Tat ein aufrechtes Bild des änßeren Gegenstands in der Region ler Retinulae entwerfen (Superpositionsbild). Bedingung fiir das Zustandekommen eines solchen Pilds ist, daß kein Pigment, welches sich zwischen die spitzen der Kristallkegel und die Rhabdome einschaltet, die Vereinigung der von benachbarten Kegeln kommenden Strahlen verhindert. Da wir shon fanden, laß das Pigment sich verschieben kann, so erscheint es möglich. ¿aß wanche Complexaugen, je nach der Pigmentrerteilung bald Appositions-, balı superpositionsbilder geben können. Letztere kommen ihrer größeren llelligkeit wegen namentlich für Duıkeltiere oder Dänmerlicht in betracht. - Die Complexaugen scheinen aber im allgemeinen besonders geeignet lür Wahrnehmungen von liewesungen unl. im weiteren simne. von Veründerungsvorgängen an den Objekten.

\section{Allgemeiner Bau der Sehzellen.}

Ls fällt auf. „aß die Sehzellen eigentlich nie den Pan der sonst so verbreiteten haartragenden simneszellen besitzen. Dagegen zeigen ibre freien Enlen oder auch Teile ihrer wbertäche, welche jedoch keineswegs immer lem einfallenten licht zugewendet zu sein hrauchen, meist eigenartige Differenzierungen, von welthen daher gewöhnlich angenommen wird, laß sie die lichtreizbaren (percipierenten) Partien seien. Diese erscheinen bei den Wirbellosen häutig in Form eines ïußeren Saums. der senkrecht zur Zelloberfläche gestreift ist (Stiftchensanm). und in seinen Verhalten zum Zellkörper erhebliche Verschiedenheiten bietet. So tindet sich ein solcher Saum bei zahlreichen Plathelminthen (Fig. 617, \$. 822) nud in den :̈hulichen inversen Augen sedentïrer Ameliden (Fig. 620, S. 825), und sitzt dem freien Ende der cylindrischen oder fächer- bis kolbenförmig gestalteten, gelegentlich auch in fingerartige lortsitze verlängerten Selizellenden als niedere bis ansehnlich bohe Bildung aut:

Fig. 697.

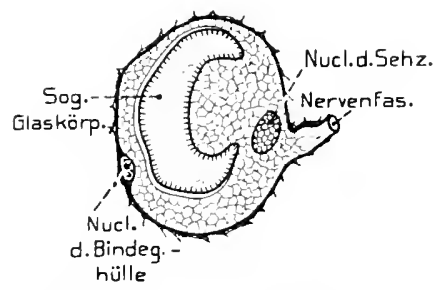

Hirudu. Sieflzelle aus der Umgebung einer Tonsille (nach HACHov 1910), v. Bu. Wenn der Fortsatz eine cylindrische Verlängermug der Zelle darstellt, wurde er häutig auch als Ktäbchen bezeichnet. Ganz änlich verhalten sich anch die selızellen ron Branchiostoma (Fig. 604, S. 806). Ebenso wird den Sehzellen ler Asterien (Fig. 610, S. 816) und ler Gastropoden (Fig. 626; s. 828) ein solcher. bei letzteren manchmal fïcherartig ansgebreiteter Endsaum zugeschrieben. - Nach der gewöhnlichen Aulfassung besteht ein solcher Saum aus dicht gestellten feinen Stäbchen oder llärchen, in welchen man die percipierenten Elemente der Sehzellen erblickt, d. h. eigentlich die knden der in der Zelle in Ein- oder Mehrzahl verlaufenden Nemrofibrillen. welche nach

lieser Ansicht natïrlich als die nervös leitenden Teile gelten. Der Stiftchensaum besitzt jedoch große Ähnlichkeit mit dem Endsaum der Wimperzellen, andererseits jedoch auch mit len Cnticularsänmen ron Darmepithelzellen. Er dürfte laher wohl wie die letzteren Säume als plasmatiches Differenzierungsprotukt des freien Sehzellenendes zu deuten sein. - Da nun ähnliche Säume von Arthropoden-Sehzellen, welche gleichfalls als Stäbchensaum aufgefaßt wurden, sicher nicht den erwähnten Bau besitzen, sondern wie das Plasma einen alreolïren. so scheint es, daß es sich in allen Stäbchensäumen im Grunde nur um eine besondere, saumartige Dillerenzienung des alveolären l'lasmas der Zellobertlïche handelt; an dessen Anfbau hei einzelnen Formen vielleicht auch eine Art feiner Sinneshirchen teilnebmen könnte.

Recht eigentümlich erscheinen die Selıellen der Himdincen (Fig. 69i), in deren Innerem sich ein bis mehrere ansebnliche Vacuolen finden, lie balł regelmäßiger, bald unregelmäßiger 
gestaltet sind, indem ihre Wand einen bis mehrere fortsätze ins Vacuoleninnere sendet. Die Vacuolenwand wird ron einem zarten ähnlichen Sam gebilulet, wic er soeben beschrieben wurde. Es ist deshalb wahrscheinlich, daß ler Sam hier ins Zellinnere verlagert wurde, was sich möglicherweise durch eine Einstülpmg ler Zelloberfäche verstehen ließe, obgleich die Entwicklung dason nichts zeigte. - Eine gewisse Öhnlichkeit mit dieser Bildung besitzen auch die Sehzellen der Oligochaeten (Lumbriciden und Naideen), welche gleichlalls ein vacuolenartiges Gebilile enthalten, das bei den Lumbriciden sehr verschielenartig restaltet sein kann (lig. 603), S. 806 ): doch werden diese Einschlüsse anch den später zu erwähenden Phaosomen gleichgestellt.

lläutig hat sich ein Stiltchensam nicht an freien linde der Sehzellen, somlern an ihren Seitenrändern liflerenziert. Jergleichen lindet sich schon in den eigentümlichen complexen Kiemenaugen der selentïren Anneliden (besonders Branchiomma, Fig. 612 $B$, S. 818), deren Sehzellen im Basalteil einen obernächlichen Stäbchensaum zeigen. - hesonders verbreitet aber tritt die Bildung seitlicher, siume an den Sehzellen der Arthropoden auf', wo wir sie shon in ler obigen Schildermg als viäbhengebilde erwähnten. Zwar tinden sich

Fig. 1698.

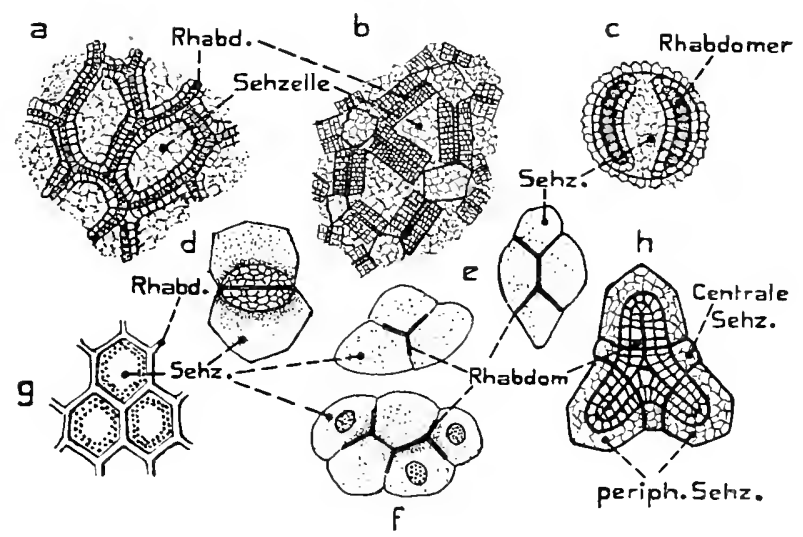

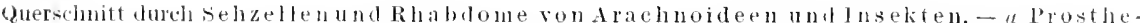
sima terrestris (Araneine), Querschnitt durch einen Teil der Retinn eines inversen Anges. 1) Tegenaria domestica (Araneine), Querschnitt eines Teils ler Retina eines inversen Anges.

Lycosa agricolin Araneine) Querschnitt einer Sehzelle des inversen duges. - / Perla (Afterfrühlingsfliege), Querschnitt einer ,eluzellengruppe alls lem Larvenocellus. - r Calopteryx (Libelle), 2 Sehzellengruppen vom Scheitelocellus. - t Prophus (Schmarrheurchrecke), Sejzellengruppe aus Scheitelocellus. - "sy r pus (Schwebtliege), Querschnitt eines T'ils der Retina enes Scheitelanges. -

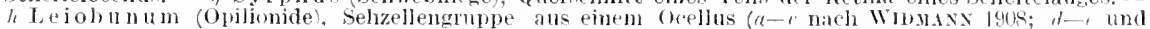

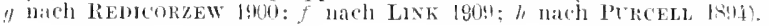
H.

auch hier Sänme, welche den lreien Sehzellenenden als stibchenartine Verlingerungen anlsitzen, so besonders in den Ocellen ler Myriopoden und den lateralocellen mancher Inseltenlaren (Coleoptera. Neuroptera [s. Fig. 673, S. 877, 686, S. 886|). Die Regel ist jedoch, daB sich die Sänme sowohl in den Ocellen der Arachnoidecn als in den Stirnocellen, in den Lateralseellen der Lepidopteren- und Tenthredinidenlarren, wie in len romplexangen, an den Seitenrändern der langgestreckten Sehzellen linden. Verbältuismäßig selten bildet sich aul diese Weise ein Saum im ganzen Tmang der Oberfliche des dem Licht zugewendeten Endteils der sehzelle, wobei gleichzeitig die süume ler aneinanderstoßenden Sehzellen zu einen gemeinsamen Netz- oder Fächerwerk zwischen den Zellen verwachsen erscheinen (Nebenangen gewisser Sedentariae (Fig. 698h) und der Pedipalpen, Ocellen der Solifugen; Stirnocellen einzelner Dipteren, so Syrphus). Bei andern invertierten Angen von Sedentariae treten solche Sänme un an den drei his vier, oder sogar sechs znsammenstoßenten seitenMächen der Sehzellen and (lig. 698 h), und die sich berihrenden sionme der benachbarten Zellen 
sind zu einem stäbchenartigen fiebilde verwachsen. - Wenn die Sehzellen solcher Ucellen durl, Zwischenzellen ganz voneinander gesondert sind, so tinden sich an ibrer Seitentiäche nur zwei im Querschnitt etwa bogenförmige Stäbchen (lhabdomeren, Fig. 698c), wie sie ähulich auch in den Sehzellen der Nebenaugen der vagabunden Araneinen vorkommen, während sich in den Nebenaugen vieler Sedcntariae zwischen dem mittleren Teil je zweier Sehzellen ein plattenförmiges solches Stäbchen entwickelt (̈̈nnlich anch bei den Pantopoden, Fig. 678C, S. 881). - Wenn die Säume oder Stäbchengebilde sich an oder in jeder Zelle als gesondertes Gebilde tinden, bezeichnet man sie als Rhabdomere, wogegen die gleichzeitig von zwei benachbarten Zellen gebilueten, also verwachsenen, den Namen Rhabdome verdienen. Ïhnliche, von zwei Sehzellen erzeugte lihabdombildungen finden sich auch in den Stirnocellen mancher Insekten (z. B. Syrphus, Fig. $698 \mathrm{~g}$ ); gewöbnlich kommt es in ihmen aber, wie anch in den vellen der Scorpione, Opilioniden, Hauptocellen der Pedipalpen und in den Medianocellen von Limulus zu den schon früher erwähnten Gruppenbildnngen von Sebzellen, indem sich bei Insekten zwei bis vier, seltener sogar fünf und acht Sehzellen zur Bildung eines Rhaldoms vereinigen (Fig. 698e-f'). das auf ihren zusammenstoßenden Seitenflächen entsteht, und in Querschnitt daher meist drei- bis mehrstrahlig erscheint. - Bei den Scorpionen zeigen namentlich tie IJauptaugen die Gruppenbildung (5) sehr deutlich (Fig. 680 B. S. 882), obgleich sie auch den Lateralocellen (Fig. 679 B. . 882 ) nicht fehlt, jedoch weviger ansyesprochen uml unregelmäßiger ist (Gruppen von zwei bis zehn Selszellen). Die Rhabdome der Medianocellen sind daber meist fïntstrahlig. - Die Opiliomiden (Fig. 698h) besitzen (iruppen von vier (selten fünf') Sehzellen. von welchen sich eine achsiale zwischen den drei ïbrigen tindet. Die peripheren Zellen bilden an ihrer Achsialseite oberflächliche Rhabdomere, die centrale dagegen ein in Zellinnen gelegenes, etwas verschiedenes, las mit den drei peripheren zu eitem strahligen Rhabdom verwächst. - Seltsam ist, dah bei gewissen Opilioniden (Acantholophusgrupe) die distalen Enden der benachbarten Rbabdome netzlömig untereinander verwarhsen. was an die oben erwähıten Verhältuisse bei gewissen Insekten und Araneinenocellen erinnert.

Die siinme oter Stibchen der Araneinen un Opilioniden zeigen hesonders deutlirh, daß sie nicht aus Stiftchen besteheu. sundern alveolär gebant sind, init quer verlaufender Alseolenanordnung, woranf die Streifnng und vermeintliche Stiftchenbildung beruht. Auch Hie Khabdome der P'antopoden- und lnsektenocellen zeigen zum Teil Andeutungen dieses Baues. woraus wohl geschlossen werden darf, daß len Rhabdomeren der Arthropoden dieser liau b̈berhaupt eigen ist. und sie baher besser als cutiularsaum aulgefaßt-werden dürften (was jedoch auch gelengnet wird). Oben (s. 881 ) wurde schon darauf hingewiesen, daß die Rhabdomere und lihabdome in den Complexaugen der Arthropoden ahnlich gebaut sind wie jene der Simplexaugen. Ihr Querschuitt ist recht verschiedenartig. häufig sogar an demselben Rhabdom in verschiedener löhe. Zuweilen beiben die lihabdomere noch völig gesondert. meist aber sind sie zn einem im ouerschnitt mehrstrahligen. doch anch kreisformig bis viereckigen lihahdom verwallsen, an dem die Zusammensetzung aus mehreren lihabdomeren häutig noch zu erkennen ist (Fig. 689. 690). - Elgentïmlich erscheint der Bau der Rhahhome vieler Crustaceen (Thoracostraca, Fin. $689 \mathrm{C}^{1}, C^{2} .8 .889$. Cladocera). welche eine Plittchenstrulitur zeigen, indem das Rhabdom aus mehr oder weniger zahlreichen iibereinander geschichteten Plättchen zusammengesetzt ist, die (Astacus u. a.) noch eine Zusammensetzmng aus zwei Häliten zeigen, deren Grenzlinien sich jedoch in den alternierenden Plättchen rerhtwinklig kreuzen. Jedes Plättchen ist senkrecht zu dieser Grenzlinie (anch zur Zelloberfläche) fein gestreift. so daß sich die Streifnng in den alternierenden Pättchen ehenfalls kreuzt.

$\mathrm{Zu}$ den cuticularsanmartigen Gebiklen sind jedenfalls auch die der Sehzellen der dibranchiaten Cephatopoden zu rechnen, welche sich, wie l'rüher bemerkt (S. 833), an der Uberfläche des peripheren Endteils oder des Stäbchenteils der Sehzellenoberfläche als zwei rinnenförmige Bildungen finden, und zuweilen auch eine feine ()uerstreifung (Plättchenstruktur) zeigen (Fig. 630 S. 833). Soweit Genaneres dariber bekannt ist, diilften hierher anch die 
stäbchengebilde im Medianauge dev Crustaccn gehören, die sich zwishen den Enden Jer Sehzellen als eine Art Grenzsaum entwickelı. Die Stäbchengebilde der Salpenaugen seheinen sich ähnlich zu verhalten. Ob auch die cuticularen Săume gewisser Polychaetenaugen (namentlich Alciopiden, Fig 616, S. 820) hierher gelören, welche die gesante Oberträche des stäbchenartigen Endteils der Sehzellen umklejken und ilınen daher einen röhrenartigen Charakter erteilen, scheint fraglich.

Manche Sehzellen lassen jedoch gar keinen solchen saum erkemen, sondern besitzen nur ein etwas cylindrisch oder fädig verlängertes freies Ende, welches als plasmatisches Stäbchen bezeichnet wurde. Derartige Sehzellen finden sich in den Mantelangen der Muscheln (Fig. 632, \$. 335 ). bei manchen Polychacten (Fig. 613, 14. S.819). im allgemeinen auch bei den Cölenteraten. In solchen Fällen, jertoch auch bei m+nchen anderen Sehzellen, wurde eine die Achse lurchzishende Fibrille beobachtet, die als Neurofibrille gedeutet wurde; sic geht bei Alciope (Fig. $616 B$, S. 820) alt ihrem Distalende in ein knöpfchenartiges Gebilde ïber, das dem Stäbchenteil der Zelle aufsitzt. Bei gewissen Schzellen der Insektenocellen und namentich bei denen ler dibramchiaten Cephaloporten wurde anch das Eindringen einer Nenrofibrille ins Innere der Sehzellen beobarhtet.

$\mathrm{Zu}$ den plasmatischen stäbchengebillen ohne Cuticularsaum lassen sich im allgemeinen auch die Sehzellenden ler manioten Trirbeltiere rechnen, tie, wie schon erwähnt, meist als Släbchen und Zapfen unterschieden werden (s. S. 851). Diese häufig längsgestreiften, von einer leinen Membran umhïllten Endgebilde (s. Fig. 699,) ragen proximal über die Membrana limitans externa hinaus unt sind dem den Kern enthaltenden Zellkörper (änßeve Kömer) entweder direkt aulgesetzt, oder durch einen fadenartig. rerscbmälerten Teil der Zelle mit ihm ver bunden. Auf die Schwierirkeit der scharlen morphologischen Unterscheidung vou Stïbchen und Zipfen wurle schon früher hiu-

Fig. 69!.

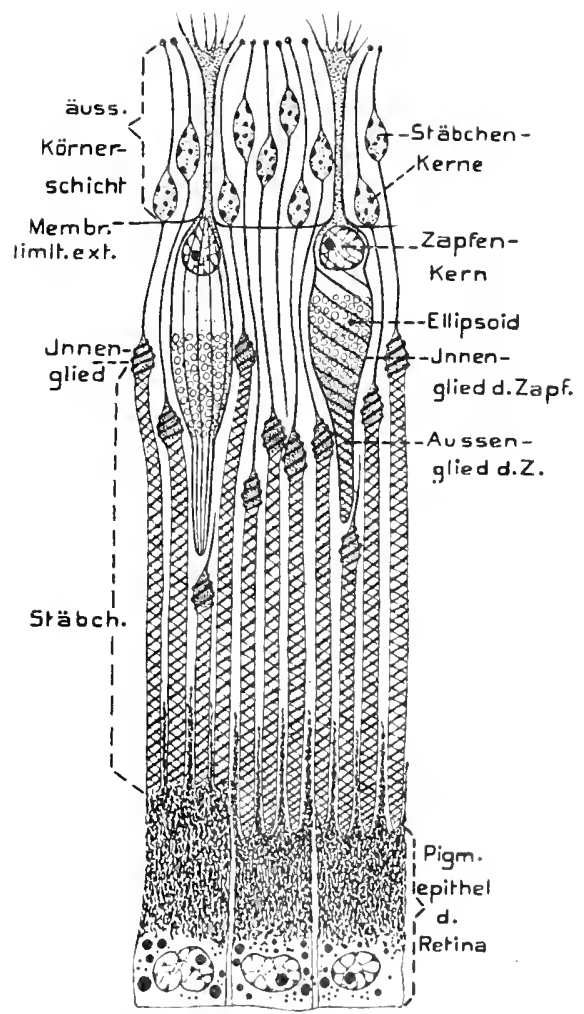

Chondrostoma nasus Knochenfisch), schema. tischer Längsschnitt durch die Sehzellenregion des Retiua. Linker Zilpfen uur längs gestreilt, rechter nur spimal gestreit nach Hesse 1904). v. Bu. gewiesen. In der liegel besteht jedes solche Gebilde aus einem Imnen- unl Ampenglicd. Letzteres ist bei den Stäbchen meist linger und mehr cylindrisch, bei den Zapfen kürzer und langkegelförmig; doch kann die länge der Außenglieder cler Stäbchen unter dem Einfluß der Belichtung variieren, wälurent ähnliches an den Innengliedern der Zapfen beobachtet wurde. An den doppelbrechemun Anßengliedern wurde häufig eine quere Streifung, d. h. eine Plaitchcnstrultur beobachtet oder auch eine schraubig verlaufende obertlächliche Faserung, welche anf Neurotibrillen bezogen wurde, und sich noch auf die tieferen Gebicte der Sehzellen fortsetzen kann (Fig. (i i 19). - l:as Innenglied, welches häufig dicker als das Außenglied und mebr oder weniger cllipsoiBïtarhli, Vergl. Anatomie. 
disch ist, setzt sich nicht scharf gegen den \%ellkürper (Außenkoru) ab und ist eigentlich nur als ein Teil desselben zu betrachten. Eine feine Lingsstreifung, welche am Basalteil der Innenglieler läufig vorkommt, wird im wesentlichen auf zarte Fortsätze der Membrana limitans odel der früher (\$.851) erwïhnten Stützzellen zurückgeführt, welche die Innenghieder teilweise unhüllen (sog. Faserlïrbe). - Die Außenglieder der Stäbchen sind meist rötlich bis rotviolett gefärbt (Selpurpur), doch kommen bei den Fröschen zwischen derart gefärbten auch grüne ror. Bei Wirbellosen wurde nur selten eine rötliche Färbung der percipierenden Teile der Sehzellen beobachtet, so bei gewissen Sïßuasserplanarien, Polystomum, namentlich aber in den Stäbchen gewisser dibranchiater Cephalopoden: Sepia, Loligo. Doch ist nur in letzteren Fall sicher erwiesen, daß der Farbstoff durch Licht rerändert wird, wie der Sehpurpur der Wirbeltiere. Der periphere Teil des Immenglieds der Stähchen und Zapfen ist gewöhnlich von einer stark färbbaren Nasse erfüllt, die häufig wenig scharf abgegrenzt ist (Ellipsoid, linsenförmiger Körper, Fadenapparat der Säugerstäbchen); distal ron ihr liegt hei den leptilien meist ein ellipsoidischer bis paraboloidischer Körper (Paraboloid). Letztere Bildung erinnert an die gleich zu erwähnenden Phaosome mancher Wirbellosen. Die Öllixgeln, welche in den Zapfen häufig auftreten, wurden schon oben (S. 853) erwähnt. -

Im Plasna der Sehzellen gewisser Wirbelloser finden sich zuweilen besonlere Einschliisse, die als Phaosome (Phaosphären) bezeichnet wurdeu. Schon oben (S. $81 \%$ ) wurden sie aus den Sehzellen Aer (Jigochaeten erwähnt (Fig. 611), doch scheint es bei diesen etwas zweifelhaft, ob es sich um derartige Gebilde handelt. - Solche stark lichtbrechende Einschlüsse wurden ferner in len Sehzellen der Scorpione (Fig. 680, S. 832), Opilioniden und Pedipalpen. in der Nähe des lierns, meist in Einzahl, gefunden. - Auch die Nautilussehrellen enthalten luäufig ein ähnliches Gebilde (Fig. 630 A, S. 833), das eine eigentümlich schraubigalreoläre Struktur besitzt. Phaosomartige Eiuschlïsse finden sich endlich in den Sehzellen mancher Salpen und Placophoren. - Was im Nledianauge der Crustaceen als Binnenkörper der Sehzellen beschrieben wurde, dürfte eher mit der Tapetumbildung zu tuu haben. - Daß die Phaosome bei der Lichtperception mitwirken, nnd daher etwa inneren Stäbchenbildungen vergleichbar seien, ist unwalıscheiulich, um so mehr, als bei den Scorpionen auch in anderen Gewebezellen ähnliche Einschlüsse vorkommen. Die Unterscheidung einer besonderen Kategorie phaosomhaltiger Sehzellen scheint daher nicht angezeigt.

Daß die Sebzellen in vielen Fällen teilweis bis ganz pigmentiert sind, wurde schon frïher erwähnt, ebenso aber, daß auch völlig pigmentfreie häufig vorkommen. Nicht selten beschränkt sich die I'igmentierung auf die äußere Region der Zelle, wïhrend die achsiale farblos bleibt.

\section{Kapitel. Lenchtorgane.}

\section{Einleitung.}

Wenn wir die iu der Tierwelt weitverbreiteten Organbildungen, die licht hervorbringen, an dieser Stelle, gewissermaßen als Anhang zu den Sinnesorganen, besprechen, so geschieht dies mehr ans einem Verlegenheitsgrund. Schon bei den IIautdriisen wurde gelegentlich (S. 126) auf das Vorkommen solcher Organe von drïsenartigem Bau hingewiesen; dennoch wiire es nicht ganz korrekt gewesen, die Lenchtorgane an jener Stelle zusammenhängend zn behandeln, da sich unter ihnen anch solche finden, welche nicht den Charakter ejgentlicher Hautdrïsen darbieten. Es steht eben anßer Zweifel, daß die Lenchtorgane in ihrer Gesamtheit keine einheitliche morphologische Gruppe bilden, sondern phylogenetisch verschiedencr und selbstïndiger Entstchung sind, wie etwa dio Schalen- und Skeletbildıngen der Wirbellosen. Demnach ist es der physiologische Charakter, welcher sie miteinander verbindet, was bei der weiteren Betrachtung festzuhalten ist. 
Das Vermögen der Lichterzengung ist in der Organismenwelt weit verbreitet und keineswegs anf das Tierreich beschriukt, sondern tritt sowohl bei einzelligen Protisten, als typischen Pflanzen (besonders Mycelien ron hyphom!yceten. Pilrem, doch anch erwachsenen) nicht selten anf. -

Unter den Protisten begegnen wir ihm bei zahlreichen liakterienarten mo nicht wenigen Protozoen, so namentlich relativ schwach bei marinen Dinoflagcllaten (Ceratium, Provocentrum Pyrodinium, Peridinium, Blepharocysta), besonders intensis aber bei der marinen Cystoflagellate, Noctiluea und der rerwandten, bis jetzt jedoch noch ungen̈̈gend hekannten Pyro'ystis. Auch manche Radiolarien lenchten (speziell die koloniebildenden Sphaeroropu, doch anch einzehe andere). -

Schon aus diesen Erfahrungen folgt, daß das Leuchtvermögen der Metazoen an gewisse Zellen geknïpft sein wird, und daß dies Vermögen wohl in verschiedenartigen Zellen selbständig hervortreten konnte, vorausgesetzt, daß dem Organismus dadurch ein Vorteil erwnchs oder zum mindesten kein Nachteil. - Die Erfahrung lehrt denn auch, daß sich Leuchtvermögen bei den verschiedensten Metazoengruppen hervorbilden konnte, ja bei vereinzelten Gattungen einer größereu Abteilung oder selbst bei einzelnen Arten.

Dies erweist schon, daß sich das Vermögen in den einzelnen Abteilungen, ja vielleicht bei einzelnen Formen kleinerer Gruppen selbständig hervorgebildet haben muß, und daß die Leuchtorgane der verschiedenen Gruppen demnach nur analoger Natur sind, daß Homologien hier eine untergeordnete Rolle spielen. - Die Erfalurung lehrt ferner, daß es Zellen verschiedener Herkunft sein können, in denen sich Lichtproduktion entwickelte, wenn auch im allgemeinen die Ectodermzellen (Epidermiszellen) voranstehen. Doch scheint sicher, daß auch Entodermzellen diese Fähigkeit erlangten, selbst die Gonaden und Eizellen können lenchten. Ob sich noch andere Gewebszellen daran zu beteiligen vermögen, ist musicher, obgleich es für Nervenzellen gelegentlich angegeben wurde. Jedenfalls liegen keine Angaben vor, daß sichere Bindegewebs- oder Muskelzellen leuchten. - Die weite Verbreitung leuchtender Bakterien hat gewiß vielfach Irrtiimer iiber das Leuchten mancher Tiere hervorgerufen, indem sich teils anf ihrer Oberfliche, teils parasitisch in ihrem Innern Leuchtbakterien ansiedeln können, oder anch nur zufällige Verunreinignng mit solchen vorliegt. Eiue erhebliche Anzahl älterer Angaben erscheint daher recht unsicher. Auch andere, durch eigentïmliche Lichtreflexion hervorgerufene Phänomene wurden gelegentlich mit,wirklichem Lenchten verwechselt.

Im allgemeinen scheiut sicher, daß das Licht von einer in den leuchtenden Zellen gebildeten organischen Substanz ansgeht, die eben die Eigenschaft besitzt, unter gewissen Bedingnngen zu lenchten. Es ist demnach nicht das eigentliche Protoplasma, welches phosphoresciert, sondern die ron ihm hervorgebrachte Leuchtsulsstanz. Über deren Natur liegen jedoch bestimmte Erfahrungen nicht ror, höchstens unsichere Vermutungen. Daß aber in der Tat eine solch anscheinende Unabhängigkeit des Leuchtens von dem eigentlichen Leben der Zelle besteht, folgt daraus, daß das Lenchten häutig noch einige Zeit andauert, nachdem die Leuchtzellen völlig zerstört (zerdrïckt, zerrieben) wurden; wie auch das Leuchtveruögen 
bei manchen tuten und rasch ansgetrockueten Urganismen bei trockener Aufbewabrung lange erhalten bleiben kann, um wieder für einige Zeit hervorzutreten, wenn man sie befeuchtet. Dazı gesellen sich noeh weitere Griinde.

Für gewisse Lenchttiere (Pholas,) wurde auch nachzuweisen versucht, daß das Leuchten erst durch das Zusammentreten zweier Substanzen, ron welchen die eine als eine Art Enzym wirke, entstehe. Doch läßt sich mit Recht bezweifeln, ob Derartiges allgemeiner gilt. - Daß zu den Bedingnngen des Lenehtens Sanerstoftgegenwart und -mitwirkung gehört, ließ sich in gewissen Fällen (Lenchtkäfer usw.) sicher erweisen, wurde jedoch in anderen nieht bestätigt. Da diese Feststellungen jedoch sehr subtiler Natur sind, so läBt sich vorerst wohl nicht bebaupten, daß die Phosphorescenz in den letzteren Fällen ganz ohne Sanerstoffmitwirkung geschähe.

In den meisten Fällen (Protozoen wie Metazoen) zeigt sich sehr deutlich, daß das Lunchten nur anf verschiedene, den Körper treffende Reize eintritt, und bei Metazoen eine direkte oder indirekte Beziebung zum Nervenapparat existieren muß. Andererseits verläuft aber das Leuchten der Bakterien und Pilze ganz unabhängig von Reizen und daher anch kontinuierlich, was bei Tiereu unter gewissen Einwirkungen gleichfalls eintreten kaun. - Natiorlich ist das hervorgebrachte Licht von sehr verschiedener Intensität, was ja schon von der Größe der Organismen oder ihrer Leuchtorgane abhängt; seine Farbe ist ziemlich verschieden, meist weiß bis bläulich oder grïnlich, doch auch rötlich; soweit genaner untersucht, ist das Speetrum stets kontinuierlich. - Nur in seltenen Fällen (Beroë) ließ sich eine Hemmung des Leuehtvermögens durch vorhergehende Beliehtung beobachten.

Bei den einfacheren leuchtenden Metazoen sind kaum besondere Lenchtorgane aufzufinden. Bei andern sehen wir die Liehtentwicklung an einzellige bis melnzellige drisenartige Organe des Integnments geknüpft, welche an reeht verschiedenen Körperstellen auftreten kömnen und deren Leuehtsekret zuweilen auch entleert wird. Bei böheren Formen (Arthopoden, Cephalopodon, Fischen) können sich schärfer umschriebene Organe ausbitden, an welchen sich zu den lichtprodnzierenden driisigen Zellen noch ein das Licht nach anßen reflektierender Teil (Refletor) und sogar ein es konzentrierender linsenartiger Apparat gesellen kann, wodurch die Organe eine gewisse Ähnlichkeit mit einfachen Augen erbalten und deshalb trither mehrfach als solche gedentet wurden. Im Folgenden sollen die einzehuen Metazoengruppen hinsichtlich ihres Lenchtvermögens und ihrer Lenchtorgane kurz besprochen werden; da eine weitergreifende Homologie der Organe nicht besteht, so ist diese Art der Bespreehung die gegebene.

Betrachtung der einzelnen Gruppen.

spongiac. Was gelegentlich über leuchtende schwämme und schwammlarren berichtet wurde, ist zu un-inher, um berïcksichtigt zn werden.

\section{Coelenterata.}

Bei den marinen Cülenteraten tritt das Lenchtvermögen in sämtlichen Gruppen aut, doch bieten der derzeitige Stand nuserer Kenntnisse und die systematischen, 
wie sonstigen Unsicherheiten der älteren Mitteilnngen keine Möglichkeit, die Verbreitung genaner festzustellen.

Sicher ist, daß eine Anzahl Iydroulpolypen (besonders Campamelarilen: so Arten von Campanularia, Obelia, Clytia, doch anch Sertularia und Plumularia usw.) diffus leuchten; ebenso auch deren Modusen (cpeziell erwicsen für Olelia, Clytia, Thanmantias, ?Tiara, Phialidium [Dianaea Lam.], Mesonema (Aequoride), Turris: sowie die Trachymedusen Liriope, Cunina und Grryonia).

Ebenso wurden auch leuchtende Siphonophoren beobachtet, so nach P.1NeER Abyla und Praya. - Unter den Acalephen sind als leuchtend namentich Pelagianten (phosphorea Esch. und noctiluca P'ér. Ls.) bekannt; (toch werden noch weitere Gattungen angegeben. Am genanesten studiert wurte das Lenchten gewisser Octokorallen, nämlich der Pemaiuliden, unter denen es weit verbreitet scheint; die eingehenderen Untersuchungen beschränken sich jedoch auf die Gattung Pematula (besonders Pennatula phosphoren Ellis und rubru Boh. [granulosa Lam.]). Über die etwaige weitere Verbreitung unter den Octo- und Hexakorallen ist wenig Sicheres bekannt. - Ïber die Ctenophoren wird später Näheres berichtet werden.

Bei den Hydroidpolypen soll der gesamte Körper lenchten und der Sitz des Vermögens im Ectoderm sein; bei Reizung eines Polypen schreitet das Lenchten anf die benachbarten Individuen der Kolonie tort. Anch bei den Hydromedusen und den Acalephen leuchtet zuweilen die gesamte Körperobertï̈che besonders Pelagia), bei andern lenchten nur Teile derselben, so die 'Tentakel, bzw. deren hasale Anschwellungen, oder das Velum (z. B. Cumina moncta). In diesen Fällen geht das Leuchten jedenfalls vom Ectoderm aus; doch ist dic Frage nicht sicher entschieden, ob der Inhalt der Eetodermzellen leuchtet oder eine anf ihrer OberAäche abgeschiedene Substauz (Schleim). - Bei größeren Hydromedusen dagegen lenchten die radiaren Gastralkauäle, ja sogar die Gonaden; in ersterem Fall muß die Lichtentwicklung also rom Entoderm ansgehen. - Ebenso sollen bei Pelagia die inneren Teile anf starke Reizung lenchten.

Wie bemerkt. besitzen zahlreiche Pennatuliden (Seefedern) ein intensives Lenchtvermögen. Es sind die Eimzelpolypen der Kolonien, welche lenchten und zwar sowohl die tentakeltragenden als die tentakellosen Zooide. Das Licht tritt in acht Längsstreifen anf, die sich dem Schlundrohr entlang bis zo den sog. Mundpapillen erstrecken; es liegt also nahe, den Sitz des Leuchtens in den acht Gastralsepten zu suchen, doch scheint dies etwas zweifelhaft, da sich uach den einzigen, aber recht unvollständigen Untersuchungen, die Leuchtstreifen als Verdickmngen an der Außenwand des Schlundrohrs zwischen den septen finden sollen. Demnach scheint wohl das Entoderm zu lenchten.

Bei den Pennatuliden wurden interessante Untersuchungen aber las Fortschreiten des Leuchteus längs der Kolonie bei lokaler Reizung angestellt; doch ist hiel nicht der Ort, auf thiese physiologischen Fragen näher einzugehen.

Zahlreiche Rippenquallen (Ctenophoren) strahlen bei Reizung intensives Licht ans, so namentlich die Arten der Genera Beroë, Plewrobrachia, einzelne Lobaten (Mnemia, Mnemiopsis, Enchuris, Cullinnira, Bolina) und Taeniater (Cestus). Das Leuchten tritt längs der acht gastralen kippengefäße aut, wclche unter den gewöhnlich voll ausgebildeten acht Reihen von linderplattehen hinriehen is. Fig. 22. 
S. 96). Daß aber das Licht mit den Ruderplättchen selbst nicht zusammenhängt, wie neuere Darstellungen vermuten ließen, scheint sicher, da auch das Leuchten längs solcher Gefüße anftritt, welche nicht von Ruderplättchen begleitet werden; so bei Cestus an den vier lateralen Rippengefäßen, deren Ruderplättchen fast völlig verkümmert sind, sowie an den sog. Magengefäßen; in ähnlicher Weise bei Berö̈ forskali auch an den Gefünetzen, welche die acht Rippengefäße untereinander verbinden. - Das Licht geht von den Entodermzellen der Gastralgefäße (speziell Rippengefäße) ans. An diesen finden sich ein oder zwei Streifen hoher vakuoliger Entodermzellen (Gefäßwïlste), welche jedenfalls die Leuchtorgane sind, weshalb auch an jedem Rippengefäß meist-zwei Lenchtstreifen auftreten (z. B. Beroë). Ebenso scheinen jedoch die Gonaden, welche den Gefäßen beiderseits anliegen, Lenchtvermögen zu besitzen, was um so wahrscheinlicher ist, als sie vielfach vom Entoderm hergeleitet werden. - Schon die Eirr mancher Ctenophoren lenchten; bei andern tritt das Lenchten erst während der Entwicklung des Embryo auf.

Bemerkenswert erscheint die mehrlache Erfahrung, dah das Lenditvermögen der (tenophoren (speziell Beroë und Mnemiopsis) bei Pelichtung aufhört und sich in der Dunkelheit. erst nach einiger Zeit wieder einstellt; eine Erscheinung, die bej den sonstigen Leuchttieren uicht rorkommt, da diese im Dunkeln, ja selbst im mäßigen Tageslicht, sofort leuchten.

\section{Vermes.}

Sichere Erfilnungen ïber Leuchtvermögen von Würmern liegen nur für die Chatopodon vor, denn die vereinzelten Angaben über Turbellarien, Rotatorien und Oligomeren sind zweifelluft.

Unter den marinen Polychacten sind leuchtende Formen recht verbreitet, wenn anch meist wenig genau studiert.

Hierher gehüren namentlich gewisse Syllideen (Odontosyllis (ir., Pionosyllis), einzehe Amyditeen (Photoeharis Ehrb.), nicht wenige Polynoina (Familie Apleroditidae, speziell Polynö̈arten unl Acholoë), gewisse Tomopteris, Nereis, Heteronereis (:), zahlreiche Chactopteriden (speziell Chactopterus), einzelne Terebellidae (Polyeimus Gr.) und Cirratuliden (Hetevocirrus Gr.); auch leuchtende Larven wurlen gelegentlich beobachtet.

Soweit bekannt, scheint das Leuchten fast stets auf Reizung einzutreten, welche auch durch die Eigenbewegangen der' 'Tiere bewirkt werden kann. Ferner' scheint sicher, daß das Licht stets von dem schleimigen Sekret gewisser epidermaler Leuchtdrisen ansgeht. Das Leuchten wurle entweder nur an gewissen Körperstellen beobachtet, so z. B. den Cirren, Parapodien, Kopftentakeln oder den Elytren von Polynö̈, sowie der nahe verwandten Acholö; auch bei dem genaner untersuchten röhrenbewohnenden Chactopterus leuchten gewisse Körperstellen besonders oder doch stairker, wie dies Fig. 700 zeigt, auf der die leuchtenden Partien braun angegeben sind. Bei starker heizung breitet sich jedoch hier wie auch bei andern Formen das licht weiter iiber den Körper aus (schon die Larve leuchtet). Das Licht geht hier von dem lenchtenden Schleim aus, der von drüsig modifizierten Epidermiszellen abgeschieden wird. Es sind mehr oder weniger umfangreiche Streckeu der Epidermis, der'en Zellen sich, abgesehen von sehr zarten fadenförmigen 
\%wischen-oder Stützzellen, zuLenchtzellen differenziert lıabeu, so daß die Gesamtheit dieser Lenehtzellen an den betreffenden Körperstellen als Lenchtorgane erseheinen, ım so melur, als abgesehen von den T'entakelu und den Endspitzen der dorsalen Parapodien des hinteren Körperabschnitts die Leuchtzellen sich durch sehr ansehnliche Höhe von den gewöhnlichen, Epidermiszellen unterscheiden, weslalb sich die Lenehtorgane als vorspringende, ant ihrer Ober-Aäche meist stark gewnlstete weißliche Anschwellungen kennzeichnen. Besonders eigentümlich verhalten sich jedoch die der dorsalen Parapodien des Hinterleibs, indem sich zwar ein Teil der Epidermis auf der Medialseite des Parapodiums zu solchem Leuehtepithel entwickelt hat, der Hauptteil der Lenehtorgane aber durel das ectodermale Epithel der Endbahnen der Nephridien gebildet wird, das sich direkt in jenes änßere Leuchtepithel der Oberfäche fortsetzt. - Die Leuchtdrüsenzellen Aer Epidermis sind, wie gresagt, sehr hohe prismatische Zellen, deren Plasma dicht von Kiigelehen erfüllt wird, und die in ihrer Basis haiutig unregelmäßige, stark färbbare Körper enthalten. Jede Zelle besitzt an ihrem freien Ende einen Entleerungsporus. Mit Schleimfarben tingieren sich die Lenchtzellen sehr stirk. Der abgeschiedene Sehleim bewahrt nach der Vermischung mit Seewasser sein Lenehtvermögen bei mechanischer Erregung noch lange.

Bei den Polynoinen, wo die sehuppenartigen Elytren der Dorsalseite allein leuchten, pflanzt sich bei starker Reizung das Lenehten einer Elytra anf die ibrigen fort; die Elytren sind die nugebildeten Dorsalcirren zahlreicher Parapodien. -

Besondere Lenchtorgane wurden.nenerdings auf der Dorsalseite der Elytren von Acholoë besehrieben, wïhrend im Gegensatz dazu eine friihere Untersuchung das Lenchtvermögen in zahlreiche einzellige Driisen der ventralen Elytrenfläehe von Polynö̈ verlegte. Hie dorsalen Leuchtorgane der Acholoëelytren (s. Fig. 701 A) sollen sich als zahlreiche papillenförmig vorspringende Gebilde anf

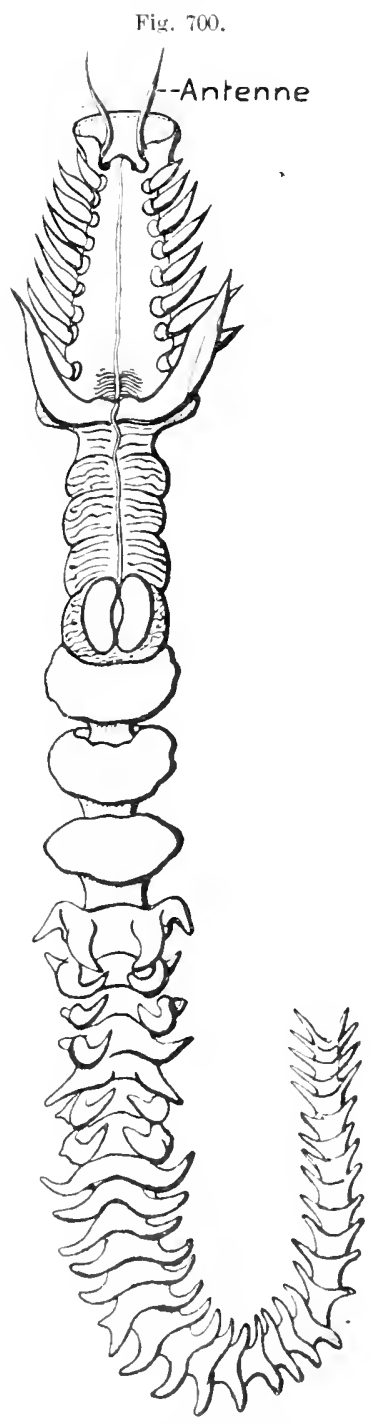

(ilatopterus variopedatus Clap. (Polychaete.) Ansicht von der Dorsalseite; die lenchtenden Partien sind braun angegeben; nach Alkoholpräparat. U. B. der eaudalen Hälfte der Elytren finden (s. Fig. $701 \mathrm{~B}$ ). In den achsialen Kanaljeder Papille mündet eine Gruppe von Drüsenzellen, deren Sekret beim Austritt ins Wasser leuchte. Obgleich die Elytren reich an Nerven sind, ließ sich die Inner- 
viernng der Papillen nicht sicher erweisen. - Die frỉhere Ansicht, welche das Lenchten auf die Ventralseite der Elytren verlegt, erklärte die Lenchtpapillen tïr nervöse Endorgane; wogegen die neuere die angeblichen Leuchtdriisen der ventralen Elytrenfläche als Querschnitte von Muskeln deutet. Vorerst ist kaum bestimmt zn entscheiden, welche Ansicht richtiger erscheint.

Bestimmte Leuchtorgane wurden feruer bei den pelagischen Tomopteris als rosettenförmige Organe beschrieben, die sich in Einzahl entweder an den beiden Flossenlappen der Parapodien oder nur an dem ventralen finden, aber auch auf die

Fig. 701.
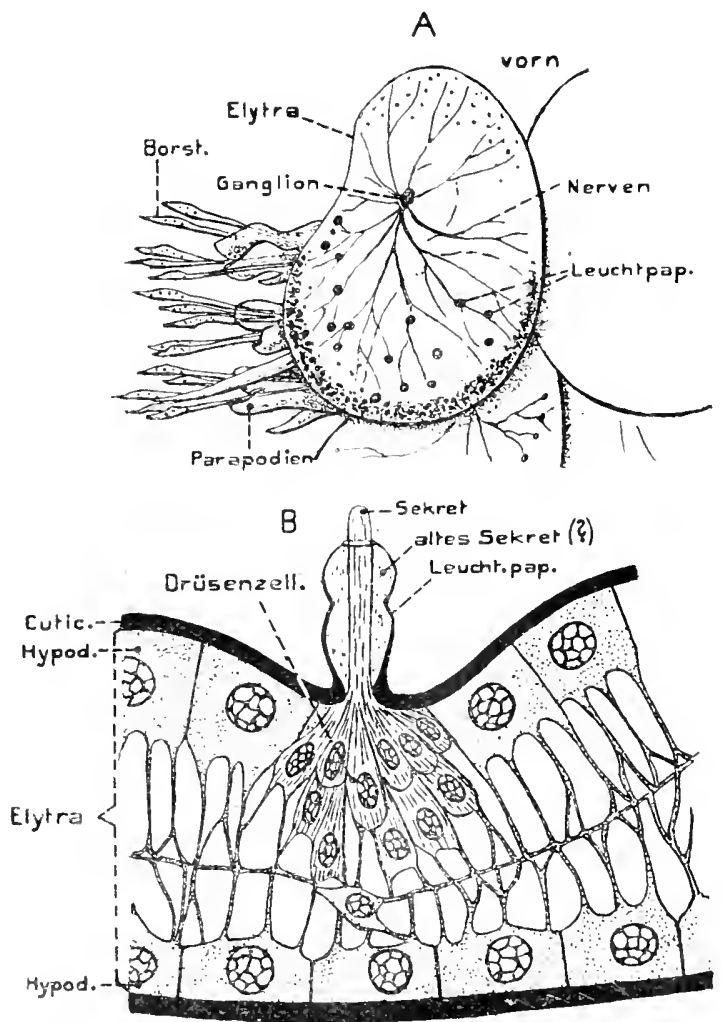

Acholoë astericola (Polychaete). - i eine Elytra von der Dorsalseite mit den Leuchtpapillen. - $\vec{B}$ ein Teil ein r Elytra mit einer Leuchtpapille im Achsialschnitt (etwas schematisch), (nach

$$
\text { KUTSCHERA 1909). }
$$

Parapodien selbst gerïckt sein können, ja an der Bauchseite des Wurms aufzutreten vermögen.

Der Bau der Organe ist wenig anfgeklärt; es sind kugelige kleine Gebilde, die aus einer Anzahl rosettenförmig zusammengepreßter schlauchartiger hörper bestehen, dereı Distalenden gelbliches bis bräunliches, wohl fettartiges Sekret enthalten. Nerrenzutritt wird angegeben. Eine äußere Mündung wurde nicht beobachtet. Obgleich Tomopteris sicher leuchtet, so fehlt doch der Nachweis, daß das Leuchten ron den beschriebenen Organen ausgeht. - Es wurde auch versucht, die fraglichen Organe als Augen zu deuten und ihnen ein linsenartiges distales Gebilde zugeschrieben. was jedoch mit ihrer Auffassung als Leuchtorgane nicht unvereinbar wäre.

Bei Odontosyllis enopla scheint das Leuchten zur Alllockung der Geschlechter, die beide phosphorescieren, bei der Fortpflanzung zu dienen; das Licht der Weibchen soll

kontinuierlich, das der llännchen intermittierend sein; auch die Eier sollen einige Zeit nach ihrer Ablage leuchten.

Im allgemeinen sehen wh laher, daß die Erfahrungen ïber die Leuchtorgane und das Leuchtvermögen der Polychaeten noch recht spärlich sind.

Oligochaeta. Obgleich aus älterer wie neverer Zeit zahlreiche Beobachtnngen über intensives Leuchten von Regenwiirmern (Lumbriciden) vorliegen, so wurde bis jetzt doch nicht hinreichend aufgeklärt, ob deren Lenchten wirklich ein eigenes. ofler Aurh hakterielle ofler 
Pilzinfektion erzengtes ist. Bis jetzt wurden vier Arten festgestellt (Henlea rentriculosa d'Ud. Photodrilus phosphoreus Giard. Microscolex modestus Rosa und dubius Rosa, die aber wahrscheinlich als in Europa eingeschleppte zu betrachten sind), bei denen in der wirmeren Jahreszeit Leuchten des ganzen Körpers regelmäßig rorzukommen scheint. Bei Heulea soll das Hinterende stärker leuehten. Gelegentlich, aber nicht konstant, wurden auch lenchtende Allobophora foctida (Sarigny) beobachtet. Nach den meisten Beobachtungen scheint es sich um lenchtenden Schleim zu hankeln, welcher von der Oberfläche der Tiere abgeschieden wird, weshalb anch Gegenstände, die mit ihnen in Berührung kommen, einige Zeit leuchten. Daß das Leuchten bei mechaniseher Reizung anftritt oder dadureh rermehrt wivl, dürite daher auf Verstärkung der Schleimabsonderung bernhen. - Besondere Lenchtorgane fehlen; mr bei Photodrilus sollen es eigenartige Drüsen (wohl einzellige) um den Ösophagus sein, welche das Lenchten bewirken: und für Henlea wird direkt angegeben; daß es der con den vorn und hinten besonders reichlich vorhandenen Hautdrüsen abgesonderte Schleim sei, der leuchte. Frühere Beobachter berichteten mehrfach, daß besonders die Clitellarregion leuchte, was bei deren Reichtum an einzelligen Hautlrüsen verstïndlich wäre. - Auch iür gewisse Enchytraeusarten wurde Leuchten angegeben.

Gewissen Oligomeren scheint Phosphorescenz sicher zuzukummen; so einzelnen Bryozoen (gewissen Membranipora- und Flustraarten; wahrsebeinlich ist sie jedoeh weiter rerbreitet). Von leuchtenden Sagittaarten (Chaetognathen) wurde mehrfach berichtet, ebenso von gewissen Enteropneusten (speziell Ptychodera minuta Kowal. sp.). In keinem dieser Fälte liegen aber genanere Untersnchungen ïbre die tirmulagen der Erscheinme vor.

\section{Arthropoda.}

Grustacetu. Leuchtende marine Crustaceen w mden in zahheichen Abteilnngen angetroften: aus dem Sïßwasser dagegen ist bis jetzt kejne Form bekannt. Es sind hänfig Tiefseebewohmer und in der Regel einzelne Gattungen, welchen Lenchtvermögen zukommt; ja selbst nur eimzelne Arten einer Gattung.

Einer Anzahl mariner Copepoden aus den Familien der Centropayiden und Oncueiden kommen neben gewöhnlichen einzelligen IIantdrüsen an verschiedenen Körperstellen auch solebo za, die ein gello-grimliches, nach dem Anstritt in das Wasser leuchtendes Sekret absondern, das znweilen mit zienlicher Kraft ansgestoßen werden kann. Neben einfachen solehen Drisen finden sich anch geparte Heterochaeta), welche durch einen gemeinsamen Porus mïnden. Zahl und Vel'teilung der Leuchtdrüsen weehselt sehr. Sie finden sich rom Kopt bis zur Furta des Hinterendes, ibre Zahl erreicht etwa 17 und 15, bei Oneaca conifera sogar etwa 70. - Leuchtende Nauplinslarven wurden gleichfalls beoharhtet: die Orgatue treteu also jedenfalls fribzeitig auf.

Unter den marinen Ostracoden Schalenkrebsen, wurden in den wämeren Meeren einige Leuchtformen gefnnden. Am bekanntesten ist die pelagische Untergattung Pyrocypris G. W. Müll.; doch lenchten wohl auch gewisse Cypridinen und einzelne Halocypridinen (Conchoecia, sowit eine große Form aus dem japanischen Meer\%. - Als Lenchtdrüsen funktionieren Gruppen einzelliger Drüsen, die in der Oberlippe liegen (bei Pyrocypris 3, bei der großen Halocypridine nur eine ; sie ergießen ihr Sekret in ein distales Reservoir, ans dem mehrere ant zapfenförmigen Fortsätzen der Oberlippe gelegene Öffunngen nach auben fuhren. Anch hies kann das Lenchtsekret hervorgespritzt werden, wozı eine besondere Muskulatur dient. 
Die beiden sog. Reflektororrane, die sich bei der riesigen Ostracode Gigantoeypris (i. W. Müll. an Kopt' fiuden, sind als Leuchtorgane vorerst unsicher. - Was über lenchtende Amphipoden (Orchestia, Talitrus) und Isopoden (Porcellio) berichtet wurde, ergab sich bei genauerer Lntersuchung (speziell Talitrus) als Infektion mit Leuchtbakterien, die sich auch auf andere Individuen und Arten ïbertragen ließen.

Den Leuchtdrüsen der Ostracoden schließen sich die gewisser Schiropoden (Gnathophansia) an; hier liegen die parrigen Driisen jedoch in den zweiten Maxillen nnd münden an deren Lateralseite anf einer knopfartigen Hervorragnng durch eine
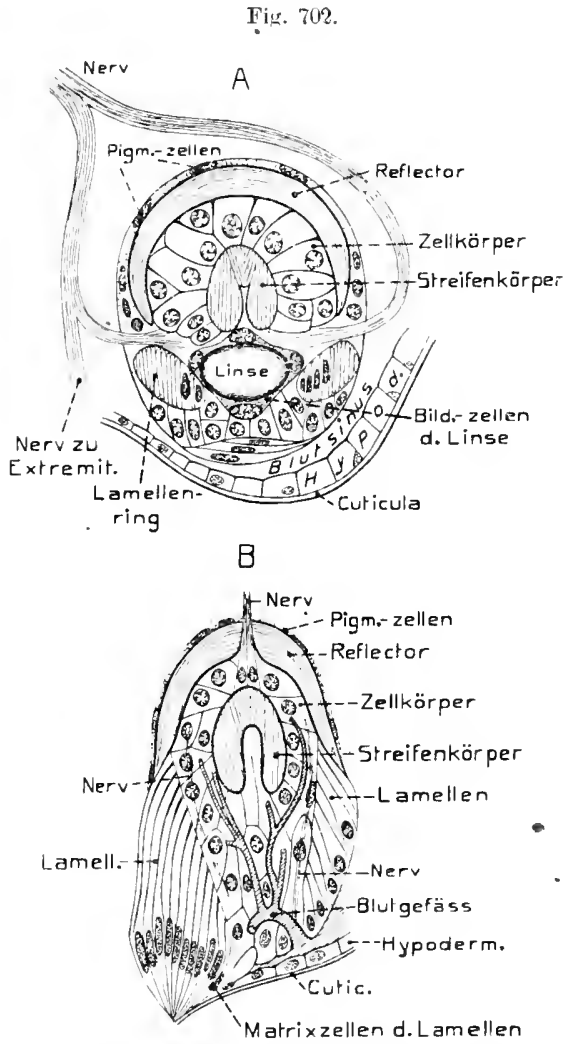

Nem at os celis (dichelopode Crustacee), - I N.mall tis, thoracalcs Lcuchtorgan, Achsialschnitt. I) K. rostrat a, ebenso (nach CHUN 1896). v. lin. einfache Öfinung ans. Die Drïse besitzt ein Reservoir, in welches zwei Driisenschlänche mïnden, die einer Gruppe einzelliger Driisen gleichen. Anch diese Drïsen stoßen fädiges Sekret ans, dessen Lenchten direkt beobachtet warde.

Die höchst entwickelten Lenchtorgune (Photospheirrn, Photophoren) treten in der mit den Schizopoden nahe verwandten, ihnen früher zugerechneten Unterordnung der Dichelopoda auf, besonders bei einigen Tiefseegattungen. Bei dem bekanntesten Genns Euphausia wurden die Organe zuerst beobachtet, jedoch lange für Augen gehalten. Bei dieser Gattung und einigen anderen findet sich in jedem Angenstiel ein Organ, ferner je eines an den Basen des zweiten und siebenten Thoracal-Fußpars und schließlich je ein nupartes in der Ventrallinie der vier ersten Abdominalsegmente. Die Gattung Stylochciron dagegen besitzt nur ein thoracales Paar und ein mupares am ersten Abdominalsegment. Die Orgame (s. Fig. 702), über welche die Cuticula etwas vorgewölbt ist, sind entweder mehr ellipsoidisch (Augenorgan, B) oder annähernd kugelig $(A)$. Die ersteren hängen mit der Hypodermis noch zusammen, die letzteren hingegen liegen etwas nach innen von ihr in einem Blntsinus. - Jedes Organ enthält etwa in seinem Centrum einen ziemlich verschieden gestalteten, halbkugeligen bis kugeligen oder ellipsoidischen sog. Streifenkörper, der aus annähernd parallel und achsial gestellten oder radiär angeordneten stark lichtbrechenden Lamellen besteht, die vielleicht selbst wieder aus stäbchen- 
artigen Gebilden zusammengesetzt sind. Dieser Körper wird gewöhulieh als das eigentlich Lenchtende gedentet, doch scheint dies etwas unsicher, da sich die ihn umhïllenden Zellen wahrscheinlich an dem Vorgang beteiligen. Der'Streifenkörper wird nïmlieh von eiuer im allgemeinen einschiehtigen Lage blasser großkeruiger Zellen bis anf seinen Distalpol umhüllt, und diese Zellen sind ihrerseits wieder von einem kontinuierliehen oder zweihälftigen (Angenorgane) Mantel nugeben, der aus feinen konzentrischen Isamellen besteht. Dieser Reflektor fungiert jedenfalls als Spiegel, der das Lieht nach außen wirft. - In den Rumpforganen (A) liegt distal rom Streifenkörper ein homogenes linsenförmiges bis kngeliges Gebilde, das den Augenorganen fehlt. Es wird von einigen sehr flachen Zellen umhïllt, die es jedenfalls abscheiden. Daß letzterer 'Teil als Linse zur Konzentration des ansgestrahiten Lichts dient, seheint zweifellos. - Vor der Linse wird die Photosphäre durch eine Zellmasse abgeschlossen, die sich anch proximalwärts über den Reflektor alş cine dort mit rotem Pigment erfüllte Lage fortsetzt und den Austritt des Liehts gegen das Körperinnere verhindert. Von der distalen Zelimasse aus können sich anch einige Zellen in die Achse des Streifenkörper's erheben. Um die Linse entwickelt sich ferner ein Ring ähnlicler Lamellen wie jene des Streifenkürpers; er wird gelegentlich als ein zweiter lieflektor oder Refraktor gedeutet, und scheint von Zellen erzengt zu werden, diẹ seinem achsialen Rand anliegen. Ob den distal von der Linse liegenden Zellen, welche jenen um den Streifenkörper recht ähnlieh sind, ebenfalls Leuehtvermögen zukommt, wie auch behauptet wurle, scheint fraglieh. Zu jedem Organe tritt ein Nerv, der entweder am proximalen Pol (Angenorgane) oder seitlich, zwischen Streifenkörper und Linse eindringt; wie er sich weiter verteilt, ist zweifelhaft. - Aneh Blutgefäße treten in die Photosphären ein (s. Fig. 702 B). - Die Rumpforgane stehen ferner mit Muskeln in Verbindung, welche sie zu drehen vermögen, und zwar ist sowohl die Achsenriehtung der einzelnen Organe etwas versehieden als ihre Drehungsriehtung.

Daß die Photosphären der Dichelopoden aus dem Ectoderm hervorgehen, ist wegen des Zusammenhangs der äußeren Zellen der Augenorgane mit der Hypodermis wahrscheinlich. Ligentïmlich erscheint, daß bei den Larven (Euphausia) die Augenorgane zuerst auftreten und zunächst nur aus dem Streifenkörper sowie einigen ihn umhüllenden Zellen bestehen, während sich die übrigen Teiłe erst später bilden.

Die Bedeutung der Organe dürtte hauptsächlich in der Anlockung von Beutetieren bestehen, weniger in der Lrleuchtung des Ciesichtsfelds, wozu vor allem die Angenorgane etwas beizutragen vermögen.

Bei einzelnen Arten von Tirfseedecapoden, so Sergestes (Familie Penaeiden, zwei Arten), Acanthephrya und Hoplophorus (Fam. Caridae, je zwei Arten) wurden Lenchtorgane gefunden, bei einer der Sergestesarten das I Leuchten auch direkt beobachtet. Bei Sergestrs treten die Organe in großer Zahl an der Bauehseite nnd den Extremitätenanhängen auf, so daß bis 150, ja mehr gezählt wurden. Am eigentümlichsten erscheint, daß auch im Innern der Kiemenhöhle, an der Innenseite des Kiemendeekels, eine Längsteihe von Organen steht. Bei Acanthephryaund Hoploploorus finden sieh 12 größere Organe, je eines an der Basis der Abdominalbeine. Jie Organe sind überall so geriehtet, daß ihr Licht ventralwärts füllt. - Sie sind 
erkenubar an ibrem blauen Pigment, und daher ist es wahrscheinlich, daß bei Acanthephrya noch zahlreiche blan pigmentierte, jedoch sonst nicht besonders ausgezeichnete Flecke der Körperoberfläche (etwa 133) ebenfalls zulenchten vermögen. Die höher entwickelten Organe besitzen eine cuticulare biconvexe bis concav-convexe Linse, nuter welcher sich eine Schicht niederer (Sergestes. Fig. 703) bis

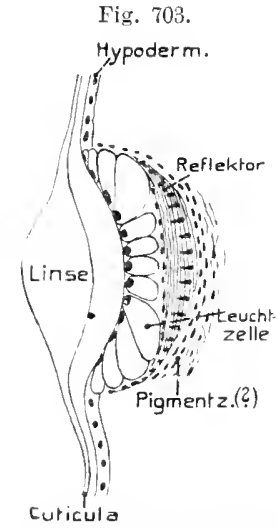

sergestes decalude (rustacee). Achsialschnit furch ein Leuchtorgan (nach KEMP $19 \downarrow U$ ). O. B. hocheylindrischer Hypodermiszellen findet. Bei Sergestes enthalten diese Zellen das blane Pigment, bei A canthephrya dagegen findet es sich in der Linse. - Wäbread sich bei ersterer Gattung unter den Hypodermiszellen, die aller Wahrscheinlichkeit nach lenchten, ein fastiger Reflektor mit eingelagerten Zellkernen findet, fehlt ein solcher bei Acanthephrya. Bei letzterer soll ein starker Nerv direkt zam Proximalpol der Iypodermisverdicknng treten, doch ist diese Dentung etwas zweifelhaft. Auch die Organe von Sergestes scheinen von Nerven versorgt zu werden. Eine etwas unregelmäßige Zellanhäufnng am Proximalteil der Organe ist vielleicht eine Pigmenthïlle.

Für gewisse Decapoden (Aristheus cornscans und Hetcrocurpus alphonsi) wirl angegeben, daß das Seliret der Antennendrüse phosphoresciere, wogegen Polycheles phosphoreus möglicherweise lenłlonde Hantdrüsen, ähulich denen der Copepoden, besitzt. Das lı̈utig erwibnte Leuchten der Decapodenaugen war in den meisten Fälen wohl nur eine Wirkung des hei den Augen erwähnten Tapetums (s. S. 893).

Myriopoden. Seit alter Zeit wurden Jeuchtende Myriopoden erwähnt. Die genauere Vertolgung ergab, daß es sich um einige Geophiliden (unter den Chilopoden) bandelt. Für Chälognathen liegen nur unsilhere Angaben iiber Julus ror. - Die beiden bekanntesten leuchtenden Geophiliden sind die enropäische Scolioplanes cranipes C. Koch sp. und die nordafrikanische Orya barbarica lierv, doch werden noch einige andere Arten erwähnt. ob diese Formen andanemd leuchten. ist zweifelhaft; es scheint rielmehr, daß dies nur zeitweise der Fall ist. Nach den nicht allzu genauen Untersuchmgen dürfte sicher sein, daß es einzellige, auf der ganzen Ventralseite verbreitete Hautlrüsen sind, dio anf den Sterniten (Banchplatten) und den sich anschließenten sog. Epimeriten (Coxen) ausmünden, welche leuchtenden Schleim abscheiden, ter heim hriechen als leuchtende Spur zurückbleibt. Bei Orya wurden gelegentlich auch die Analdrïsen für die Lenchtorgane erklärt. Bei dieser Form soll der srhleim eiweißartige Kügelchen enthalten, die bald in Kristalle übergehen. - Trotz aller dieser Erfahrungen ist doch noch zweifelhaft, ob das Levchten der erwähnten Myriopoilen nicht nur von Bakterieninfektion oder auch rom Fressen Jeuchtender Pilze herrülnt wnfiì namentlich sprechen würde, daß es keine regelmäßige Erscheinung ist.

Insceta. Über leuchrende Insekten verschiedenster Ordnungen liegen eine große 'Lahl unsicherer Angaben vor, da die betreffenden Fälle nicht näher untersucht und der Sitz des Lenchtens nicht genaner ermittelt wurde, weshalb die Möglichkeit intektiösen Lenchtens vielfach besteht. Genauer nntersucht wurden nur die bekannten Leuchtkäfer. Üher die sonstigen Angahen soll daher hier nur kurz Einiges berichtet werien.

Von Apterygotcn werden trewise Thysunuen mo Poduriden als lenchtend erwähut. Die lälle können jedoch nicht alle als sicher betrachtet werlew. Inter den Orthopteren 
in weiteren sinn wurden Gryllotalpa, sowie gewiso Ephemeriden (Eintagniegen): Cacmis, Telaganodes, leuchtend beobachtet. Auch leuchtende Termitenhügel wurden erwähnt. Seltsam erscheint die mehrfache und alte Behauptung, daß der große Stirnaufsatz des südamerikanischen sog. Latementrägers (Fulgora, eine Cicade) lenchte, was jedoch wohl sicher irrig ist; sonstige Augaben äber leuchtende Rhynchoten liegen nicht vor.

In der Ordung der Dipteren wurden mehrfach total lenchtende Larren, ja anch hurgintes von Chironomiden (speziell Chironomus) und einzelner Pilvmirelen beobachtet. Das näher Bekannte macht es sehr wahrscheinlich, daß es sich un eine Infektion mit Leuchtbakterien handelte. - Ebensowenig können die vorliegenden Perichte über lenchtende Raupen (Lepidoptera) für deren autonomes Leuchtvermögen sprechen, da gerade diese Larven häufig Pilziufektionen ausgesetzt sind. Wie gesagt, bleiben daher nur gewisse Käfer (Coleoptera) als zweifellose und sehr interessante Fälle von Lenchtvermögen bestehen.

Coloptera. Leuchtende Kïfer treten besonders in drei Familien anf: LamIyridac, Elateriduc nud Telephoridar. Das Lenchten des Carabiden Physodera ist nicht hinrejchend festgestellt. In der ersterwähnten Familie gibt es eine grobe Zahl von Gattungen und Arten mit lenchtorganartigen Bildungen, doch warde das Lenchten nur bei einer beschrinkten Anzahl direkt erwiesen, so besonders bei europäischen und amerikamischen Vertretern der Gattungen Lammyris Geoffr., Plosphacmus Lap., Luciola Lap., den anerikanischen F'ormen Photimus und Lrcontia, sowie den ceylonischen Harmatelia und Dioptoma, von welchen Lammyis und Phosphaenus auch bei nus vorkommen, Lnciola in Siidemropa.

Unter den uahverwandten Telephoriden wuden die Gattungen Phengodes Illig. (N.-Amerika) und Zarhipis. (Siidamerika) lenchtend heobachtet. Has intensivste Lenchtvermögen besitzen gewisse Elateriden Südamerikas, speziell Arten der Gattung Pyroptorus Illig, besonders Pyropleorus noctilucus (L.). - Bei den Lenchtkifern, die sich, so weit bekinnt, durch nächtliche Lebensweise auszeichnen, lenchten in der Regel nicht nur die Imagen, soudern anch die Larven und Puppen, selbst die Eier, was für Lampyris-, Lamprophorus-, gewisse Luciola-, Photiunsnnd Pyrophorusformen festgestelit wurde.

Während bei Pyrophorus Männchen und Weibchen geflügelt sind (s. Fig. 704 B), sind bei den Weibchen von Lampyris (s. Fig. 705), Luciola italica nud Plıosphacnus, sowie den erwïhnten Telephoriden die Flïgel sehr bis nahezu völlig verkiimmert, so daß sie nicht zn fliegen vermögen; bei Phospluaenus hominterus gilt Fier. 704 .

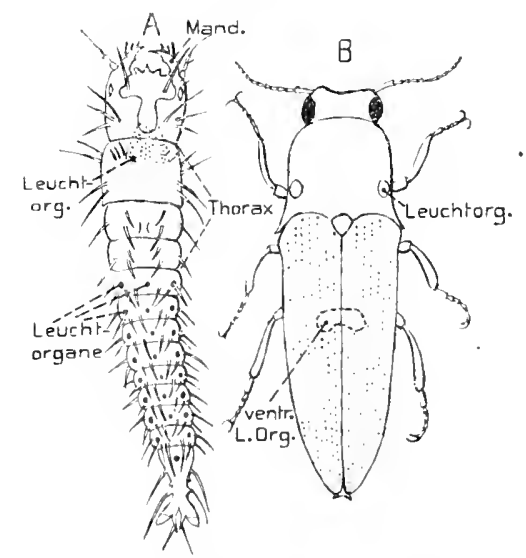

Pyrophorus noctilucus (Coleoptere). l Larve von der Dorsalseite; die abdominalen Lenchtorgane sind als schwarze Punkte angegeben. - L' Imago von Dorsalseite; die Lane des ventralen Leuchtorgans ist puiktiert angerlentet (it nach Dubors 1858; H Oris.). O. P.

dies fur beide Geschlechter. In diesen Fällen tritt ziemlich klar hervor, dab das Lenchten im Dienst der Geschleclitsfunktion steht, d. h. das gegenseitige Antsuchen 
đer Geschlechter erleiehtert. - Wie bemerkt, besitzen auch die Larven Leuchtorgane, wobei mehrfach hervortritt, daß sich die Organe der Larven weiter iiber den Körper verbreiten als bei den zugehörigen Imagen. So zeigt die Larve von Lammyris (Lamprorhiza) splendidula an den Abdominalsegmenten 2--8 jederseits ein kleines Organ, die von Phengodes außer einem Dor'salorgan auf der Grenze von Kopt' und Prothorax, 10 Parr leuchtende laterale Punkte auf den folgenden Segmentgrenzen. - Ähnlich verhält sich auch die Pyrophoruslarve (Fig. 704 A.), welche gleichfalls ein zweilappiges dorsales Kopforgan besitzt und auf jedem der acht ersten Abdominalsegmente ein Paar seitlicher kolbig hervorragender Leuchtpunkte, zu denen sich noch je ein medianer gesellt, von dem es aber zweifelhaft ist, ob er ein

Fis. 705.

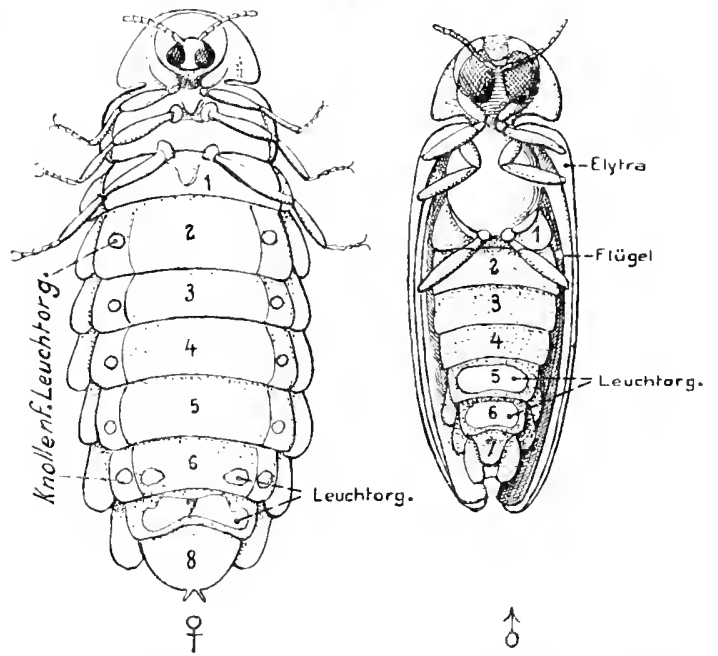

Lampyris splendiclula, s mal of von der ventritseite (mit Benutzung von BoxGardT 1903). (). B.

liei o sind die Nummern der Abd. segm. je um eine Zalil zu erhöhen. selbständiges Organ darstellt. - Andererseits kann sich die Zahl der Organe gewisser Larven stark reduzieren, so besitzen die von Lampyris noctiluca und Plosphaenus nur ein Pas. lateroventraler Organe am 8. Abdominalsegment. Die Imagen der einheimischen Lampyrisformen zeigen beträchtliche Verschiedenheiten der Organe in den beiden auch sonst so differenten Geschlechtern. Die Grgane beschränken sich jedoeh in der Riegel auf die hintere Ventialregion des Abdomens. Bei den Weibchen von Lampyris splendidula (Fig. 705) gleicht die Verteilung der Organe jener der Larven, da sich die lateralen parigen, sog. linollenfömigen Organe am 2. bis 6. Banchsegment erhalten, zu denen sieh abor am 7. Segment noch ein ansehnliches unparres Organ gesellt und am 6. noch ein Paar kleiner, am 3. ein kleines unpares in der Mittellinie. - Bei den Weibchen der Lammyis nortiluc hingegen finden sich am 6. und 7. Segment des Abdomens zwei ansehnlich breite unpaare Organe, am 8. ein Par kleinere und gelegentlich am 5. noch einige kleine Lenchtflecke. - Bei den Lampyrismännchen sind die Organe im allgemeinen spärlicher; bei $L$. spendidula zwei ansehnliehe mpare am 6. und 7. Segment (Fig. 705), bei L. noctiluca nur ein Paar am 8. - Bei den Männchen von Luciola italica und africanu lenchtet die Ventralseite des 6. und 7. Segments, die Weibehen dagegen besitzen ein Par Lenehtflecke am 5. Die Männchen von Photimus margincllus haben im 6. und 7. Segment je ein Paar Jeuchtflecke, die Weibehen nur eine unpare Leuchtplatte im 6. Segment, Phot. 
marginellatus im 6. und 7. Segment; die somstigen Arten dieser Gattung zeigen ähnliches Verhalten. Bei den Männchen der oben erwähnten ceylonischen'Formen sollen sich auch anf dem Thorax Lenchtorgane finden. - Wesentlich verschieden erweisen sich die Pyrophorusarten, da beide Geschlechter die gleichen Isenchtorgane. besitzen $($ Fig. $704 B)$. Fin Paar steht dorsal auf den hinteren Seitenecken des Prothorax; dazu gesellt sich ein abdominales ansehnliches unpares Ventralorgan, das auf der Gelenkhant zwischen Metathorax und erstem Abdominalsegment liegt. In Ruhezustand ist dies Bauchorgan unsichtbar, da die Gelenkluat eingefaltet ist; leim Flug tritt es dagegen hervor, da die Käfer dabei ihren Hinterleib emporheben und die Gelenklıant ausstïlpen. Dies Bauchorgan ist ungefähr dreieckig und beim Männchen mit einer mittleren Quer- und Längsfurche.

$\mathrm{lm}$ allgemeinen ist der feinere Bau der Leuchtorgane der Coleopteren ziemlich iibereinstimmend und einfach. Sie bestehen aus einer mehr oder weniger dicken Zellplatte oder -masse, die sich entweder der Hypodermis direkt anschließt oder etwas unter ihr liegt. Die Organe werden gewöhnlich vom Fettkörper mehr oder weniger eingehiullt und scheinen nur ausnahmsweise eine besondere Hïlle zu besitzen. Fast stets bestehen sie aus zwei Lagen: einer durchsichtigeren äußeren, die von deu eigentlichen Lenchtzellen gebildet wird (Lenchtlage), und einer unAurchsichtigen weißen, welche gegen die Leibeshöhlf schant (Tratlage, Fig. 706). Jede Lage wird von einigen Zellschichten gebildet; die Lenchtzellenlage ist in der Regel die dickere. Hünfig bleibt die Cuticula ibber den Organen durchsichtig, so daß letztere anch an nichtleuchtenden oder' toten Tieren erkenubar sind. - Die undurchsichtige Lage, welche nur den knollenförmigen $\mathrm{Or}$ ganen der Lampyris splendidula-Weibchen fehlt, verdankt ihre Beschaflenheit der massenhaften Einlagerung rundlicher Konkretionen (Sphälolithen) oder

Fig. 706 .

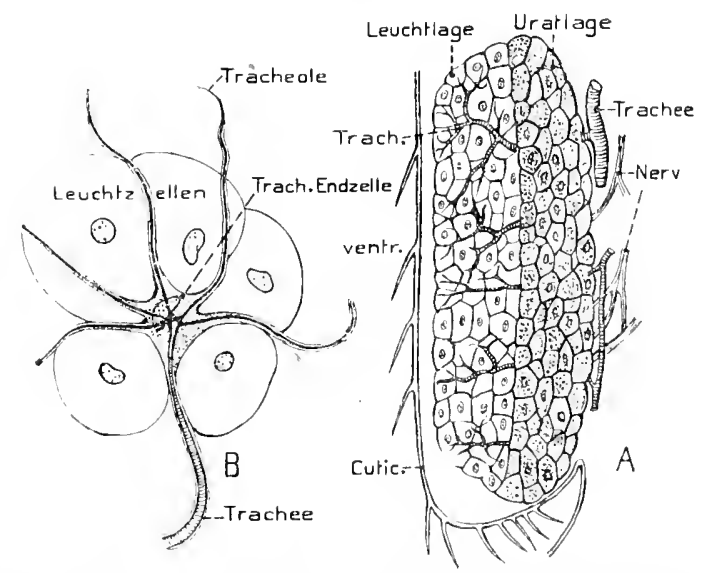

Tamprris splendidula o, - A Längschnitt durch eins de beuchtorgane. Schematicen (nuf cirund einer Figur von M. S'chuLTze 1865). - I'Tracheen und Zelle alls der Urallage (nach BUNGARDT 1903). Kriställehen im Zellplasma, die aus harnsaurem Ammoniak (Lampyris) oder anderen harnsauren Salzen (Pyrophor'ss) bestehen, wie sie sich ja auch in den Fettkörperzellen der Insekten häntig finden. Diese Lage wirkt jedenfalls als Reflektor, der das Licht zuriickwirft, und so seine Intensität verstärkt. In den Lateralorganen von Lampyris- und Phosphaenuslarven, sowie den Thoracalorganen von Pyrophorns liegt die Lratlagf ventral oder ventrolateral von der Leuchtlage, sodaß das Licht dorsalwairts 
geworten wird. Gewöhulich folgen beide Lagen dicht aufeinander ohne ganz scharfe Grenze, so daß häufig Ưbergänge zwischen ihren Zellen vermutet wurden, ologleich dies unwahrscheinlich ist; in den Thoracalorganen von Pyrophorus soll sich jedoch nach gewissen Angaben ein Blutraum zwisehen sie schieben. -. In die Uratlage dringen Tracheen ein, die sich nnter feiner Verzweigung, die Tellen umspinnend, darin verbreiten. Je nach der Lage der einzelnen Organe entspringen sie ron verschiedenen Stigmen. - Die Leuchtlage besteht aus durchsichtigeren Zellen von teils unregelmäßig rundlicher bis polygonaler oder auch vereinzelt mehr schlauchförmiger Gestalt und ziemlieh verschiedener Größe. Doch wird anch angegeben (Plotims), daß Zellgrenzen kanm erkenubar seien. Ihr Plasma enthält keine gröberen Granulationen, dagegen große Mengen feiner, die gewöhnlich als der eigentliche Lenchtstoft angesehen werden, deren Natur verschieden benrteilt wurde; auch Pigment soll sich bei Pyrophorus darin finden. Die Zellen dieser

Fig. 7017

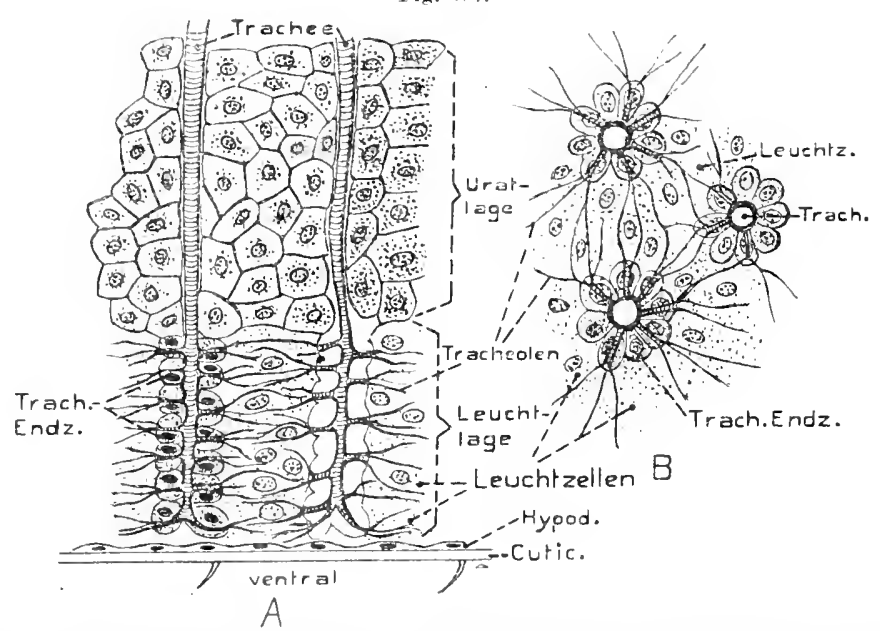

Photinus sp, (Coleoptere) Leuchtorgan. - A Sehema eines Querschitts durch einen Teil eines leuchtorgans, - Schema cines Flächenschnitts durch die Lenchthage mit is Trącheenstämmehen, nebst

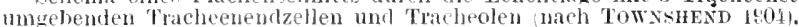

O. B.

Lage sind entweder unregelmïBig angeordnet (Lammyris, Pyrophorus) (Fig. 706), ader mit einer gewissen Regelmäßigkeit, welche durch die ans der Uratlage in sie eindringenden Tracheen bedingt wird (Photinus, Fig. $707 A$ u. $B$ ). Im allgemeinen sind es dickere Tracheenstämmchen, die aus der Uratlage in ziemlich regelmäßigen Abständen senkrecht zur Oberfäche in die Lenchtlage treten und sich unter Abgabe zahlreicher seitlicher Äste oder unter mehr biischelig diehotomischer Verzweignug verteilen; doch ist der Reichtum an Tracheenverzweigungen in der Lenchtschicht meist größer als in del Uratschicht. In der letzteren kommt es dabei zu keiner Ditterenziernng der Zellmasse in besondere Abschnitte, und diese fehlt anch, soweit bekannt, im allgemeinen in der Leuchtlage der Lampyrisarten und bei Pyrophorus. Die feinsten noch mit Spiralfaden versehenen Traeheenastchen zerteilen sich schlieBlich in beiden Lagen ler Jampyrisorgane plötzlieh 
in eine Anzahl (3-7) feinster, nicht mehr mit spiralfiden versehener und mit Flïssigkeit erfüllter Röhrchen (Tracheolen, Capillarn, s. Fig. 706 B) die, auf den Zellgrenzen verlaufend, die Zellen unter Anastomosenbildnng reichlich umspimien, jedoch nach den meisten Angaben nicht in sie eindringen, was aber neuerdings fiur Photinus bestimmt behauntet wird, aber woht sicher nurichtig ist. Dabei zeigt sich namentlich in den Organen der Männchen und den ventralen der Lampyris splendidula das Eigentïmliche, daß an dieser Auflösungsstelle der Tracheenästchen in die Tracheolen eine der umhitlenden Epithelzelfen (Matrixzellen) der Tracheen zu einer großen Zelle anschwillt, die eben so viele Fortsitze anssendet, als sich Tracheolen finden, welche in diesen Fortsätzen verlanfen (Fig. 706 B). Ess sind dies die sog. Trueheenendiellen, welche sich mit Osmiumsäure stark schwärzen. Anch die Uratschicht der Lampyris soll, wie gesigt, solche Zellen enthalten, die ja im Insektenkörper weit verbreitet sind. In der Lenehtlage von l'yrophorns fehlen diese 'Tracheenendzellen dagegen völlig.

Bei Luciola und I'hotimus findet sich eine cigentiumliche Itiftrenzierung der Lenchtlige (Fig. 707). Ihre Zellen sind im allgemeinen in vertikalen Reihen angeorduet, die in regelmäßigen Abständen von den ans der Uratschicht eindringenden vertikalen Tracheenstämmehen durehsetzt werden. Isetztere guben allseits kleinere horizontal riehende Ästchen ab, welche schließlich in wenige 2-4 Tracheolen zerfallen. Um diese Tracheenstämmchen findet sich eiue Lage besonderer Zellen, von Tracheenendzellen nïmlich, in denen die Auflösung der Trachcenïstchen zu Tracheolen geschieht Fig. 707 F). Anf solche Weise kommt es. daß die Lenchtlage dieser Formen aus zahlreichen nicht leuchtenden cylindrischen tiebilden zusammengesetzt erscheint, die aus den Tracheenstämmchen mit ihren Veristelungen und den Endzellen bestehen. zwischen welehe sich dann die Lenchtrellen einschiehen.

Jie zn deu Grganen tretenden 'Tracheen werden von Nerrenïstchen begleitet, welche sich. ebenso wie die ersteren, reichlich in ihnen veristeln, und, wie fur Lampyris angegeben wird, sowohl die 'Tracheenendzellen als die Leuchtzellen innervieren sollen. - Auch Muskeln treten mit den Organen häntig in Verbindung. So werden die Ventralorgane von Lampyris und Photinus von den dorsoventralen Muskeln des Abdomens durehsetzt. Aneh die von Pyrophorus stehen mit Muskeln im Zusammenhang.

Dies Verhalten ist un so wichtiger, als lie liage, ob das lenchten direht unter der Herrschaft des Nervensystems steht, oder ob dessen sicher erwiesener Winfluß ein indirekter ist, d. h. eventuell durch Vermittlung der Atemorgane oder durh Muskrtitigkeit gesehieht. vorerst noch zweifelhaft erscheint.

Die Ontogenie der Lenchtorgane ist nirlıt genïgend aufgeklïrt; jedoch wurde fïr hannpyris gelegentlich angereben, daß ihr Zellmaterial aus der Hypoderuis hervorgehe; doch kann dies uicht als gesichert gelten, - Die hitutig ausgesprochene Vermutmig, daß dic Organe moditizierte Teile des lettlörpers, also mesolermale Gebilde seien, scheint möglich: la ihru Zellen ja in mancher Hinsicht an jene des Fettkörpers erinnern, und das leuchtrermägen in den versbielensten Zellen anftreten kann; auch wumle diese Ansiclit nenerdings für lampyris netiluca ontogenetisch zu erweison verucht. 


\section{Mollusca.}

Leuchtende Weichtiere sind nur in der Abteilnng der Cephalopoden in größerer Zahl bekannt. Unter den Opisthobranchiaten ist die eigentïmliche pelagische Phyllirhö̈ bucophahum Pér. dnrch Leuchtvermögen ausgezeichnet. Das Lieht geht von zahlreichen kleinen bis etwas größeren Punkten ans, die über die Oberfläche des ganzen Körpers und die Tentakel ztrstrent, besonder's reichlich aber an der Dorsal- und Ventralkante des stark komprimierten Körpers angehäuft sind. Die neneren Erfahrnngen érgaben, daß es jedenfalls in einzelligen Hantdriisen entsteht, die sich ähnlich Schleimzellen verhalten, und daß jeder der kleinen lenchtenden l'unkte einer solchen einzelligen Driise entspricht; während die gröBeren

Fig. 708

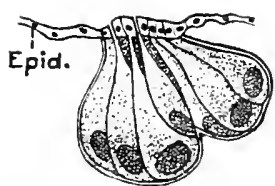

Phyllirhoë bucepha lum (Opisthobrinchiale) Zwei mehrzellige Jeucht lrïsen ter Haul (nach TROJAN 1910). ('. H. Lemehtpunkte von Gruppen solcher (bis zu 20) gehildet werden Fig. 708). Dicse Schleimzellen entsprechen in ihrer Verbreitung den Leuchtpunkten, worauf sich ihre Jentung als Lenchtzellen hauptsïchlich stïtzt. Es scheint, daß sie sich mit Ausliufern feiner IImtnervenfasern verbinden, worans sich erklïren wiirde, daß sie frïher dem Nervensystem selbst zugerechnet wurden. - In geringerer Zahl findet sich eine zweite Art einzelliger IIautdrïsen, die nach ihren Reaktionen als Eiweißdriisen angesprochen wurden. Ob sich auch letztere vielleicht am Lenchtvorgang beteiligen, konnte vorerst nicht sicher entschieden werden. Da das Sekret der beiden Drüsenarten auf der Körperoberfï̈che hervortritt, so handelt es sich bei Phyllirhoë wahrscheinlich nm extracelluliires Lenchten, obgleich bis jetzt lenehtender Schleim anf der Körperoberffiche nicht beobaehtet wurde.

Die sonstigen Erfahrungen über leuchtende Gastropoden sind recht unsicher; sie beziehen sich auf einzelne Opisthobranchiatenformon (so Glancus, Tethys, Placmophorus), gewisse Pteropoden und einzelne Heteropoden (Pterotracleca). Für letztere scheint die Beobachtung ziemlich sicher, und zwar soll der Eingeweideknänel (Nucleus) schwach leuchten.

Unter den Lamellibramchiaten finden sich lenchtende Formen in der Gattung Pholas (besonders Pholas dactylus), den bekanntesten Bohrmuseheln. Sie zeigen das Eigentiumliche, daß ihre Leuchtorgane, sehon wegen der versteckten Lebensweise der Tiere, dann aber auch wegen ihrer Lage, änßerlich gar nieht siehtbar sind, so daß jedenfalls nur der ausgestoßene Schleim lenchtet und entweder als Abschreckungsmittel gegen Feinde oder anch zur Anlocknng kleiner, als Nahrung verwerteter Organismen dient. - Die lenchtenden Organe tinden sich an verschiedenen Stellen der Mantellappen (s. Fig. 709). So leuchtet der freie Mantelrand des Fnßschlitzes, indem sich hier eine etwa hufeisenförmige, oralwärts geöffnete schwach wulstartige Verdiekung findet (Lippenorgan, s. Fig., Leuchtorg. 1). Etwas hinter dem FuB, ungefïhr in der Mittelregion des Körpers, liegt auf der Innenflïche jedes Mantellappens ein annähernd drei- bis viereckiges, sehwach vorspringendes nnd querfaltiges Leuchtorgan (Mantelorgan, s. Fig., Leuchtorg. 2); sehließlich ein weiteres Par jederseits auf der dorsalen Innenfläche des ventralen oder Einströmungssipho (Branchialsipho), dem Septum 
anfgelagert, welches diesen Sipho von dem über ilın hinziehenden Analsipho scheidet (Siphonalorgan, Lenchtorg. 3). Letztere Organe bilden jederseits einen schmalen, schwach vorspringenden Längswulst, der den ganzen Sipho durchzieht, sich jedoch längs der Basis der beiden Kiemenpaare bis in die Gegend der Mantelorgane fortsetzt. Auch diese beiden Wiilste sind oberflächlich fein quergefaltet. Ob sich das Lenchtvermögen vielleicht noch weiter auf die Innentliiche des Mantels verbreitet, ist etwas unsicher, jedoch nicht sehr wahrscheinlich.

$\ddot{A} u ß e r l i c h$ sind die Organe mit Flimmerepithel bekleidet, in dem eine große Menge einzelliger Drüsen ausmiünden. Mehr oberflächlich liegen zahlreiche Schleimdriisen, wie sie auf der Innenfläche des Mantels weit verbreitet sind; tiefer hinab reichen viele langgestreckte Leuchtdrïsen, welche sich durch ihr spezifisches Sekret, das zahlreiche eigentïmliche eiweißartige Grannlationen einschließt, auszeichnen. Daß letztere Drïsen die eigentlichen Lenchtdriisen sind, folgt daraus, daß sie nur in den Leuchtorganen vorkommen. Die 1)rïsenanhäufungen werden von Längsund Quermuskeln unterlagert, wozn sich auch zarte Muskelfasern gesellen, die senkrecht durch die Drïsenmasse bis zur Epidermis aufsteigen; die Kontraktion dieser Muskulatur trägt jedenfalls zur Entleerung des Sekrets bei. - Die Lenchtorgane werden ferner reichlich mit Blut versorgt, das sich in Lakunen unter ihnen ausbreitet. Auch Verren treten zn ihnen, doch ließ sich ilıre Endigungsweise vorerst nicht sicher ermitteln. Die beiden vorderen Organe erhalten ihre Nerven von den Mantelrandnerven, die Siphonalorgane dagegen durch die beiden Septalnerven aus dem Visceralganglion.

Physiologische Versuche ergaben, daß die

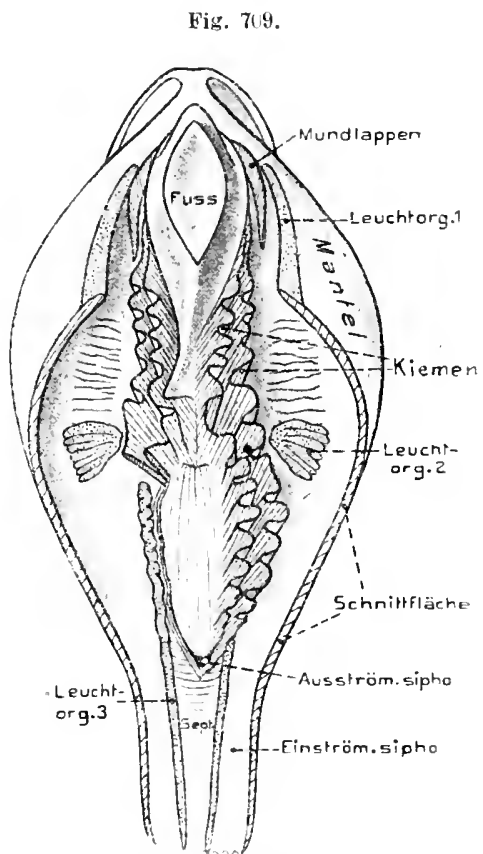

Pholas dactylus (Muschel). Leuchtorgan e. Tier von der Ventralseite. Schale entiernt. Der Mlantel und seine Verlängerung in den Einströmungssipho in der Ventrallinie aufgeschnitten; Schnittfiächen schraffiert. Die hintere Hälfte des rechten Kiemenpars an der Basis abgeschnitten, so daB das Leuchtorgan 3 deutliclier zu sehen.

Orig. O. B. und v. Bu.

siphonalorgane unter dem Einfluß der Visceralganglien stehen, und zwar funktionieren letztere als Ilemmungscentren, so daß nach dem Durchschneiden des Nerven einer Seite das entsprechende Siphonalorgan konstant schwach leuchtet. Sonst tritt unter normalen Verhältnissen das Leuchten nur bei Reizung auf.

Daß es der abgesonderte Sxhleim mit seinen Granulationen ist, der leuchtet, unterliegt keinem Zweifel; er bewaht seine Leuchtkraft nach Vermischung mit Wasser und sogar nach Filtration. - Der lenchtende Schleim von Pholas diente zu eingehenderen Untersuchungen über die in ihm enthaltenen Leuchtsubstanzen. Obgleich diese Versuche bisher zu keinen recht klaren Ergebnissen führten, so scheint aus ihuen doch hervorzugehen, daß 
die Lichtentwicklung erst beim Zusammenwirken zweier Substanzen entsteht (ursprünglich Luciferin und Luciferase genannt), oder daß die leuchtfähige Substanz erst hei diesem Vorgang gebildet wird, und daß inr Leuchten auf "xydation heruht.

Cephaloprodu. Unter den Decapoden, besonders Tiefseeformen, sind Lenchtorgane weit verbreitet und erlangen meist eine hohe Entwicklung, wogegen sie bei Octoproden noch nie gefunden wurden. Eine erhebliche Zahl (etwa 25) Gattungen der oigopsiden Decapoden sind mit solchen Organen ausgerüstet. während sie unter deu Myopsiden bis jetzt nur bei Sepiola, Moteroteuthis und Rossia gefunden wurden. Das Lenchten der Organe wurde aber vorerst nur bei zwei Arten von Histioteuthis und einer von Thanmatolumpas, sowie den Myopsiden Sepiola und Heteroteuthis beobachtet, für sämtliche übrigen Arten nur aus der Ähnlichkeit der

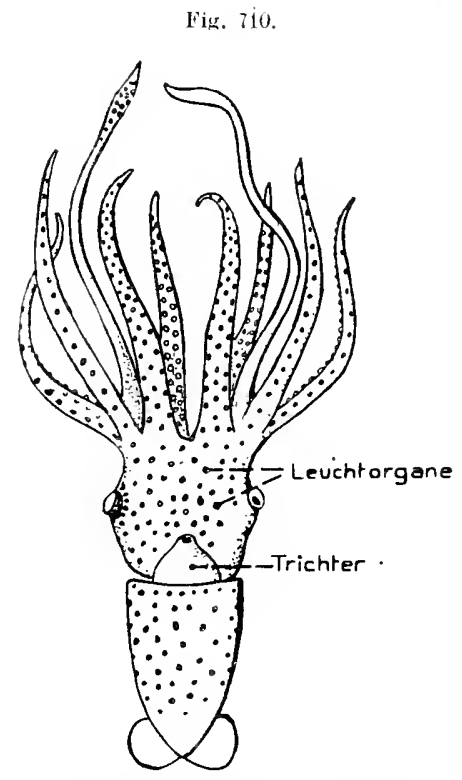

Colliteuthis hoylei (Tierseecephalopode). Von der Ventralseite; die $L$ e ucht organe als sehwarze Punkte angegeben (nach CHON 191(1). (O. B.
Organe erschlossen. - Im einfachsten Fall (Srpiola) findet sich ein Paar Leuchtorgane in der Mantelhöhle, die dem Tintenbentel jederseits dicht an-oder anfliegen. Bei Heterotcuthis. sind diese beiden Organe zu einem unparen versehmolzen. - Unter den Oigopsiden dagegen treten sie gewöhnlich in größerer bis sehr ansehnlicher Zahl auf. Sie sind häılig verschieden grof nud nicht selten anch recht verschieden gebant, so daB sich bei derselben Art 2 bis mehr, ja bis 10 (Thaumatolampas) Kategorien von Organen unterscheiden lassen. Sie stehen teils frei auf der äußeren Haut, indem sie gewöhnlich etwas papillenartig hervorragen und zwar teils als äußere Hautorgane auf dem ganzen Eingeweidesack (oder Mantel, Fig. 710) in regelmäßigeren bis unregelmäßigen Längsreihen, doch auch auf dem Trichter, dem Kopf und den Armen und zuweilen auch auf der Dorsalseite der Flossen 1). Die Ventralregion ist meist reicher an Organen als die dorsale, was anch an den Armen hervortritt, indem die

beiden Ventralarme im allgemeinen bevorzugt erscheinen. - An den 'TentakeIn stehen die Organe in einer bis mehreren Längsreihen in geringer bis hoher Zahl. Eine besondere Kategorie bilden die Angenorgane Fig. 711-712), welche auf dem vorspringenden 'Teil des Auges stehen und zwar fast ansschließlich auf dessen Ventralseite in sehr verschiedener Zahl, so hei den Cionchiidac 5-13 (Fig. 711); bei Ptcrygotenthis (Fig. 712) kann ihre Zahl an jedem Angenbulbus sogar bis aut 20, in drei Reihen angeordnet, steigen. Den Cortholivden kommen fast ausnahms-

1) Wir orientieren den Cephahpodenkörper hier in ter alten Weise, d. h. bezeichnen die Trichterseite als ventrale, den Kopf als rom. die Spitge des Eingeweidesacks als hinten. 
Ios nur solche Augenorgane zu; sonst finden sie sich häntig anch neben anderen Lenehtorganen. - Eigentiimlich ist, daB sich bei nieht wenigen Formen aueh an dej Dorsalwand der Mantelhöhle Lenehtorgane Tentralorgane) finden, bis zu 8 und 10 (Fig. 711). Zwei stehen gewöhulich rechts und links, etwas hinter dem After (Analorganc), zwei weitere je an der Kiemenbasis, zn denen sich damn noch sonstige parrige bis unpare zwischen Anal- und Kiemenorganen oder weiter hiuten gesellen köunen. Anch dem 'Tintenbentel können solche Organe aufliegen:

Fig. 711 .

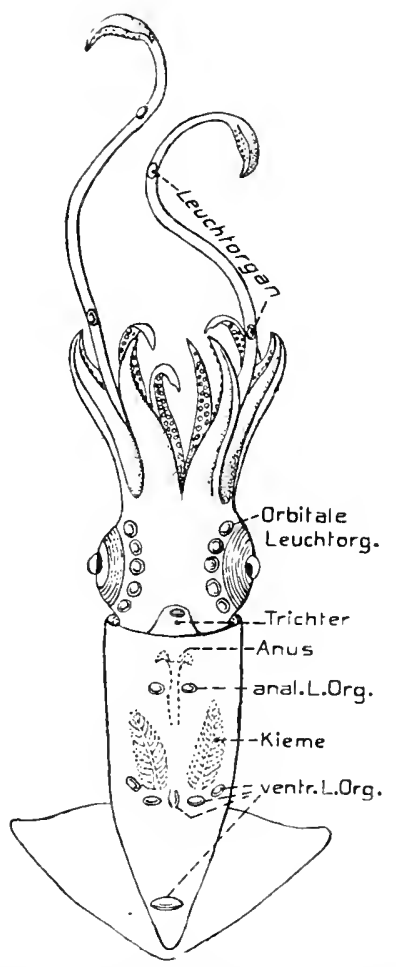

Thaunatolampas diadema. Von der Ventralseite, Lage der Kiemen und des Afters punktiert angegeben nach CHON 1!10). O. B. letztere erinnern daher in ihrer Lage an jene ler Myopsiden.

Wie schon hervorgehoben, ist der Ban der Organe reeht versehieden, einfach bis ziemlich kompliziert. Im ersteren Fall (Myopsiden) bilden

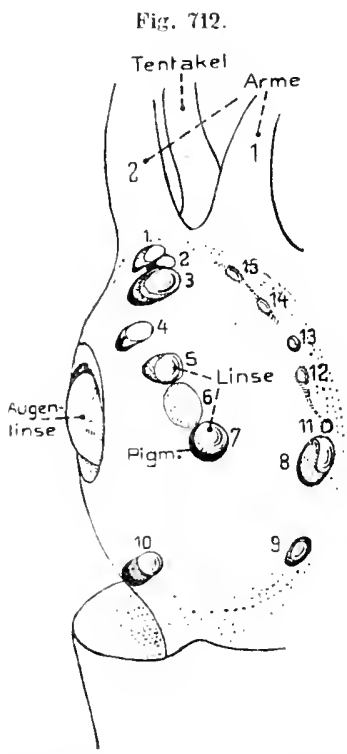

P'terygoteuthis giardi. liechtes Auge von der Ventralseite mit den Augenleuchtorganen (nach (Hus l:10). O. B.

sie mehrzellige IIantdrisen, die mit einer Öff̈nng jeilerseits des Afters münden. Jede Drïse besteht (Sepiola) aus einigen (3-5) Schlänelıen. Bei Heteroteuthis dispar (Rïpp.) sind, wie bemerkt, die beiden Drïsen zu einem unpaaren mittleren Organ zusammengetreten, ihre beiden Mündungen jedoch erhalten. Bei dieser Art wurde das Ausstoßen lenchtenden Schleims auf Reizung beobachtet; bei Sepiola romdelofti jedoch nicht. Die Drïse der letzteren Form wird von eines irisierenden Schicht mantelartig umhïllt, die wohl als Reflektor dient; da beide Organe gewissermaßen in den Tintenbentel eingesenkt sind, so wirkt dieser gleichzeitig wie eine schwarze Pigmentumhüllung. 
Sehr einfach erscheinen auch die Augenorgane der Cranchiiden (Fig. 713), die ebenfalls einen dickwandigen einfachen Drïsenschlanch darstellen, dessen Lenchtzellen in die angrenzende Epidermis übergehen, und der znweilen noch ein spaltartig eingesenktes Lumen besitzt; wemn letzteres schwindet, so bildet das Organ einen eingesenkten soliden Zellhaufen. Die Leuchtzellen haben hier, wie bei den noch zu schildernden Organen, den drïsigen Charakter verloren. Ein feinfaserig zelliger Reflektor umhïlt auch die Leuchtzellenmasse der Cranchiiden.

Der verschieulen gestaltete Lenchtzellenkörper der übrigen Cephalopoden ist stets von der Epidermis abgelöst und mehr oder weniger tief ins Innere ver-

Fig. 713.

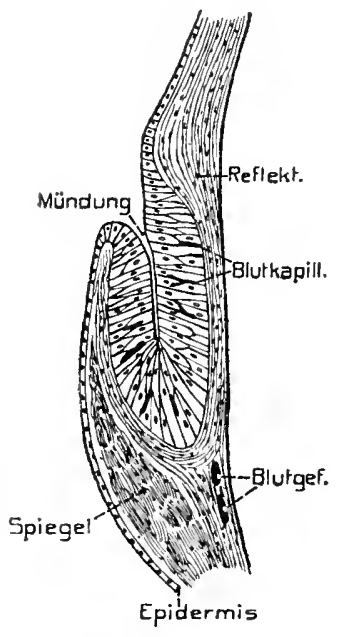

Cranchio rubra. Achsial schnitt durch ein Leuchtorgan, etwas schematisch (nach CHUX 1910). O. B senkt. Wenn die Lenchtzellen scharf begrenzt sind, erscheinen sie polyedrisch bis schlanchförmig, $j:$ faserartig, hänfig vacuolig, in der Regel aber ohne besondere Einschlïsse (abgesehen von selten vorkommenden stäbchenartigen Gebilden). Vielfach sind sie aber nicht mehr scharf gesondert, sondern teilweise bis völlig zu einem Syncytium verschmolzen, so daf der Leuchtkörper von einer plasmatischen kernhaltigen Masse gebildet wird. Anch faserige Differenzierung und faserige Auflösung der Zellen kommt vor. Bei gewissen Formen (Abralia, Abraliopsis) finden sich in der Mitte des Lenchtkörpers ein oder zwei stark lichtbrechende Gebilde, die ans der Verschmelzung und Umwandlung von Zellen, unter Kernverlust, entstehen sollen.

Selır häutig wird der Lenchtkörper auf seiner Proximalfläche von einer l'igmentlage umbiillt, die von Zellen hervorgebracht wird, aber anch aus Chromatophoren bestehen kann. An den Organen des Tintenbeutels wird sie durch diesen ersetzt (wie schon von den Myopsideu erwähnt); an den Augenorganen kann sie auch durch das Retinapigment vertreten werden. Das Licht solcher Organe kann daher nur an der pigmentfreien Außenstelle austreten und strahlt daher in gewisser Richtung zum Tierkörper. - Zwischen die Pigmenthülle und den Leuchtkörper schiebt sich häufig eine glïnzende, irisierende Lage ein, das Tapetum oder der Reflektor, welcher das Licht nach außen wirft (Fig. 714). Dieser Reflektor kamn ans mehreren Lagen körniger Zellen bestehen oder anch ans Schuppen:sllen, die ein schuppenartiges, den Nuclens umfassendes, stark lichtbrechendes Gebilde enthalten. Andererseits kann der lieflektor jedoch anch von zahlreichen feinen Lamellen gebildet werden oder von feinfaserigem Gewebe, olme orler mit Schuppenzellen. Solche Schuppenzellen können sich jedoch auch zwischen den Leuchtkörper und die äußere Haut einschieben, so daß sie den ersteren mahezn umhïllen (Fig. 714). Diese äußere Partie der Schuppenzellen hat dann wohl eine linsen- 
artige Wirkung zur Konzentration des anstretenden lichts. Ein linsenartiges (rebilde wird jedoch bei gewissen Organen an demselben Urt auch von Fasern gebildet, die in großer Zahl, etwa senkrecht gegen die Körperoberfläche gerichtet sind und wohl aus Zellen hervorgegangen sein dïrften; ja es finden sich sog. linsenutige Körper, die ans einem Maschenwerk von Bindegewebe bestehen oder aus verschiedenen Gewebspartien (Schupenzellen, Lamellen ma Bindegewebe) zusammengesetrt sind; selbst Muskulatur soll sich daran heteiligen kïnnen. Bei Calliteuthis und Ilistiotenthis findet sich ferner eine Kinrichtung vor dem Organ, welche als reflektierender spiegel für dis anstrotende Licht dienen soll.

Blutgefäpe dringen reichlich in die Organe, besonders den Lenchtkïrper, ein, dessen Zellen von wnndernetzartigen Ausbreimugen der Gefäße mmsponnen werden. Ehenso wurde eine reiche Inneviomng des Lenchtkinpers testgestellt. Die zutretenden Nervenaiste verzweigen sich innerhalb des Leuchtkörpers reich. - Jurch

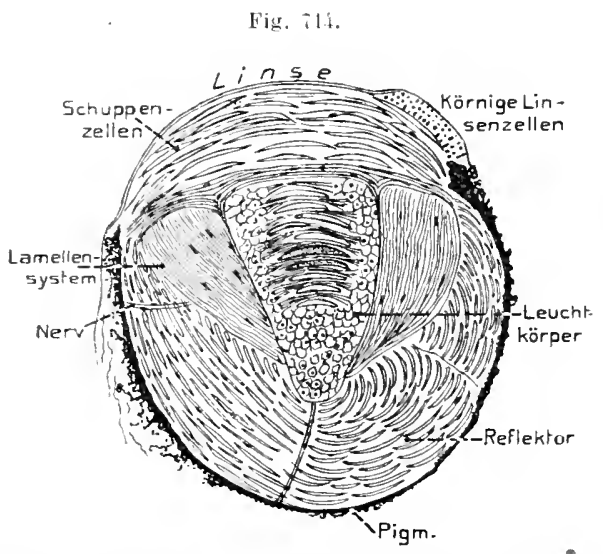

l'terggotenthis. Achsialsehnit dureh ein Lenchtorgan (nach CHUN 19t0).

O. B.

Organe kommt es vereinzelt zur Bildung von lopprlorgmun; selbst melurere Organe können sich inniger vereinigen.

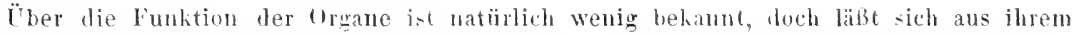
Bau un ihrem Verhalten Einiges ersphließen. So ist es wahrshlinhich, daß die versuhieden gebauten Organe auch verschiedenartiges Licht ausstrahleu, wie sie denn auch am toten Tiere schon eine rerschierleue Farbe (rot bis blan) zeigen, Wahrscheinlich dïrte die Farbe des ansgesendeten Lichts auch durh die besonteren Strukturverbiltnise der Linse und des Retlektors moditiziert werden. In gewissen Fälen scheint dahei ath eine lem Organ vorgelayerte Chromatophorenschicht mitzuwirken. - Die biologische liesleutung ler Mrgane wirl teils in ter Anlockung von Nahrungstieren, teils in der Anlockung und Erkennung bein Geschlechtsakt gesucht, wozu ja die viufach tharakteristische Anorinumg ler organe. sowie ihr verschiedenfarhiges Licht beitragen mag.

\section{Echinodermata.}

Die zuverlässigsten Angahen iiber Lenchtvermögen beziehen sich auf gewisse (H)himen und Exhinoiden, wogegen die Behauptung, daß anch die interessante Tiefseeasterie Brisinga und ane verwande Form (Mdirin) lenchten. vorerst nicht geniigend sicher erscheint.

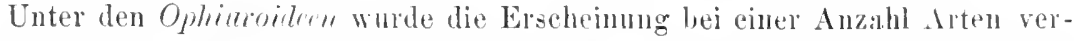
sebiedener Genera festgestellt, so namentlich Amphima. Ophimsita, Ophimmenth und Ophiosolex; genanere Untersuchungen liegen jedoch nur ül,er die beiden 
ersten Gattungen vor. Der Sitz des Leuchtens findet sich bei gewissen Formen nur an den Stacheln der Seiten- oder Ambulacralplatten (.Imphinera filiformis Müll sp.), während bei Ophiopsiln ammlosa Sars sp. außer den Stacheln anch die Seiten- nnd Banchplatten lenehten, bei den ibrigen Ophiopsila-Arten dagegen nur die proximale Region der Seitenplatten. - Den Sitz des Lenchtens bilden, wie dies besonders für Ophiopsila ziemlich sicher erwiesen scheint, lang sehlanchfrimige einzellige Drïsen, die sich recht tief unter die körperobertläche, bis in das tiefere Bindegewebe, ja das Skeletgewebe erstrecken. - Die mehrfach wiederkehrende Angabe, daß auch die Ambulaeralfüßchen zu lenchten vermögen, ließ sich nicht sicher erweisen. - Das anf Reiz eintretende Leuchten pflanzt sich von den gereizten Stellen auf dem Al'm fort und hängt insofern mit dessen hadiärnerv zusammen, als bei seiner Durchschneidung das Fortschreiten des Reizes ïber die Schnittstelle hinaus anfhört. - Obgleich Angaben vorliegen, daß beim Lenchten ein Schleim anf die Körperoberfläche alogeschieden werde, von welchem die Erscheinung ausgehe, so sprechen doch manche Erfahrungen gegen diese Ansicht; die Lichtentwicklung scheint vielmehr in den Hrisenzellen selbst zu geschehen und nur selten etwas Sekret auszutreten. - Ob die Lenchtzellen ectodermaler oder vielleicht mesodermaler Herkunft siud, wurde bis jetzt nicht festgestellt; das erstere ist wohl wahrseheinlicher.

Unter den regulären Echinoideen tinden sich interessanterweise Formen mit lïher entwickelteu, eigentümlichen Lenchtorganen, die, wie es anch sonst geschah, urspriinglich für Augen gehalten wuden. Es sind dies gewisse Diademutirlue, speziell Diudrma setosum Gray und Asteropyga, bei welchen gutes Leuchtvermögen festgestellt warde, das sieh in fünf meridionalen Bändern ïber die Körperoberflache hinzieht. Inf dieser finden sich bei Diadema sctosum zahlreiche blaue größere und kleinere Punkte, die, von den Genitalplatten ansgehend, in zahlreichen Reihen über die Interambulacren verlaufen, sich jedoch anch etwas auf die Ambulacren ansdehnen. Diese Punkte sind höchst wahrscheinlich die Lenchtorgane und wurden, wie oben bemerkt, zuerst als Augen gedeutet. - Jedes Organ besteht ans einer Schicht senkrecht gegen die Obertläche gerichteter durchsichtiger prismenartiger Gebilde, dic unter der hier verdünnten Epidermis liegen und deren proximales Ende vou schwarzem Pigment nmhüllt ist. Die blaue Farbe soll eine Strukturfarbe sein. Jedes Prisma wird von einer Anzahl blasig-vacuoliger Zellen gebildet. Unterlagert wird das Organ von einem Nervenplexus, der dem allgemeinen Hautplexus angehört. Wenn die Dentung als Lenchtorgane, wie sehr wahrscheinlich, richtig ist, so diuften die Prismenzellen wohl die drüsigen Lenchtzellen darstellen, obgleich keinerlei Ausfïhrgänge an ihnen beobachtet wurden, wie sie den einzelligen lIantdrïsen der biadema znkommen. - Haß sich die Organe aus der Epidermis entwickeln, ist Z̈iemlich sicher.

\section{Chordata.}

6a. Tunicatı. Intensives Lenchtvermögen besitzen die Pyrosomen (Fenerwalzen), jene freibeweglichen interessanten Kolonien, welche entweder den Asci- 
dien oder den Thaliaceen genähert werden; sie gehören zu den prächtigsten Leuehttieren des Meeres. Das Licht wird bei den meisten Arten von einem Paar verhältnismäßig kleiner Organe der Einzelindividuen hervorgebracht, die als annähernd linsenförmige Gebilde nicht weit hinter dem Mund (Einströmungsöfỉnung) jederseits liegen, etwas wach anßen oder iiber jedem sog. Flimmerbogen, die voun Vorderende der Hypobranchialrime jederseits zur Dorsallinie des respiratorischen Darms emporziehen. Nur bei Pyrosomu agrssizi haben die Organe eine abweichende, verïstelte Gestalt, auch besitzt diese Art noch ein zweites ventrales Paar solcher Gebilde an der Kloakenöffunng (Ansströmungsöff̈nnng). Die Organe (besonders die gewöhnlichen vorderen) besitzen keine Hülle nud liegen in einem Blutsinus, der den vorderen Teil des respiratorischen Darms umzieht (Peripharyngeal- oder Pericoronalsinus). Sie bestehen ans wenigen Schichten kugliger bis birnförmiger oder unregelmäßiger Zellen von eigentïmlichem Ban. Jede Zelle (Fig. 715) enthält nämlich einen rundlichen, oberflächlich gelagerten Nueleus, daneben aber noch einen maiandrisch gewndenen Strang (fraglich jedoch, ob ganz kontinuierlich), der f:ist das gesamte Plasma durchzieht und recht kernähnlich ist, namentlich viel feine Körnchen von nucleinähnlicher Bescbatfeoheit enthält. Nach neneren Erfahrumgen soll dieser Strang das eigentlich Lenchtende sein, wïhrend es frihher meist in fettigen Einschlüssen des Plasmas gesucht wurde.

Dit un die bei den Tnnicaten um die Eizelle vorkommenlen unl bei der Entwickhng in den Embryo eindringenden Zellen, die Tostarellen, bei den Pyrosomen

Fig. 715 .

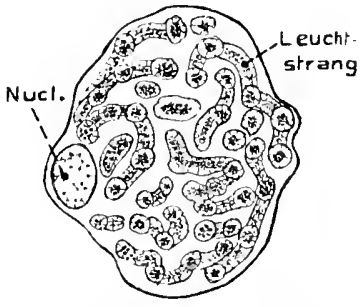

Py rosomagigantenm. Lencht. zelle (nacli JULIN 1912). C. H. gauz denselben Bau besitzen und außerdem leuchten, so wurde die Ansicht aufgestellt, dab3 die Leuchtorgane der Pyrosonen aus jenen Testazellen hervorgehen, also aus Zellen, welche garnicht aus der Eizelle selbst entstehen, la die Testazellen vou den Follikelzellen des Ovariums abgeleitet werden. Im Gegensatz. dazu steht die Meinung, welche die Testazellen bei den Salpen in Embryo allmählich resorbiert werlen läßt; doch wurle gerade die Frage nach der Natur und dem Verbleib dieser Zellen recht verschieden beantwortet und kann auch njcht als sicher entschieden betrachtet werden. - Ein Zusammenhang der ()rgane mit Nerven ließ sich nicht erweisen, obgleich Nerven dicht an ihnen vorbeiziehen. - Die frühere Angabe. daß die Lenchtzellen häutig degenerierten und sich ans Blutzellen ergänzten, konnte in neuerer Zeit nicht bestätigt werden.

I)as Lenchten tritt auch bei den P’yrosonen gewöhnlich erst anf Reizung ein, obgleich auch schwaches spontanes Jenchten angegeben wird. Dic Lichtlarbe soll selbst bei dem pleichen Individuum zuweilen recht variabel sein, von gelblirh durcli grönli,h und blan bi: rot. Wie bei den kolonialen Pennatuliden pflanzt sich das Lenchten bei lieizung eines Indi、ilums durch die ganze kolonie lort, wobei jedoch mancherlei kigentïmlinkeiten auf†reten, so z. B. daß auch entiernte Stellen aulzuleuchten vermögen, ohne die dazwischen betindlichen. Da keine Nerven zu den Organen zu treten stheimen, so muß die Leitung des Leizes auf andere Weise geschehen. Es wnte daranf hingewiesen, daß die Kloakalmukeln ler Einzeltiere dureh faserartige Zellstringe (Nantelfasern) mit denen ihrer Narhbarn rerbunden sind, und daß durch diese stränge (welche vielleicht selbst koutrahtil sind) der Reiz ïbertragen oder Kontraktionen der Tiere ausgelöst werlen, die zu ihrom Ionchten 
führen. - Bemerkenswert ist die Erfahrung, daß auch starke Belichtung gewöhnlich als Rei\% wirkt, der Leuchten hervorruft.

Neuerdings wurde festgestellt, daß das Paar Lateraloryane der beiden Generationen von Cyclosalpa pimualu, welche als länglich bandförmige oder in mehrere hintereinander gereihte Abschnitte geteilt, in der hinteren dorsalen Körperhälfte liegen, gleichfalls, neben Blutzellen, die charakteristischen Lenchtzellen der Pyrosomen enthalten und Lenchtvermögen besitzen. Diese Lateralorgane, welche in den Blntstrom eingeschaltet sind, d. b. eigentlich dem Blntsinussystem angehören, sind von einem Netzwerk feiner Bindegewebszellen durchsetzt, in dessen Maschen die Blut- und Lenchtzellen liegen. Frïlıer wurden sie deshalb, fiir blutbildende Organe gehalten.

Die Angaben iiber leuchtende Copelaten, bei denen eigentümlicherweise die Chorda Licht aussenden soll, ïber Salpen, deren Eingeweideknänel (Nucleus) schwach leuchte, und iber einzelne Ascidien (so Ciona intestinalis unl eine Botryllus-Art) sind zu unsicher, um genauer erörtert zu werden. Besondere Leuchtorgane wurden bei diesen Formen nie beobachtet, und es kann vorerst nicht als ausgeschlossen gelten, daß in diesen källen andere. mikroskopische Leuchtorganismen mitwirkten

6 b. Tertelrata. In der Wirbeltierreihe sind es allein die Fische, welche, Leuchtorgane besitzen.

Alles, was sonst gelegentlich ïber Leuchten bei Amphibien, Reptilien nnd gewissen Vögeln berichtet wurke, bezog sich jedenfalls teils auf bakterielle Verunreinigung oder Infektion, teils (Vügel) anf' den eigentümlichen und lebhaften Glanz gewisser Federn oder auf Reflexerscheinungen, wie das Lenchten der an den Schnabelwïlsten befindlichen Papillen bei den Nestjungen vou Pö̈phila Gouldiar.

Unter den Fischen wurden Lenchtorganc bei einer ansehnlichen Zahl von Gattungen (70 mit 241 Spezies) der Chondropterygier und Telcosteer erwiesen. Wie bei den Cephalopoden und thoracostraken Crustaceen (Dichelopoda) sind es fast nur Tiefseeformen, welche lenchten. Dies Vermögen hat sich in recht verschiedenen Abteilungen sicherlich ganz selbständig entwickelt, ebenso, wie wir die elektrischen Organe bei weit entfernten Abteilungen anftreten sahen. Unter den Knorpelfischen wurden bis jetzt nur bei Haien der Spinaciden-Familie ( 7 Gattungen, darunter allein genaner bekannt Spimax niger und Etmopterus-Arten Lenchtorgane gefunden. - Unter den Physostomon finden-sich zahlreiche Lenchtfische in den Familien der Stomiatidae (18 Genera), der Stcrmoptychidue (17 Genera) und der Scopclidar (4 Genera). Hinsichtlich einer Form der Aporlen (Aale) bestehen Zweifel. Relativ spärlicher finden sich Lenchtorgane bei den Physorlysten. Sie sind bekannt bei den Gattungen Aluomalops und Photobleplaron (Familie Carangirlae oder besondere Fam. Anomalopsidar), Porichthys (Fan. Batrachidu') und scỉließlich von zahlreichen Formen der Familic (auch Unterordnung) der Pediculati. - Ilervorgehohen muß aber werden, daß das Lenchten nur bei einer geringen Zahl der erwïhten Fische direkt beubachtet wude, daß vielmehr, wie bei den Cephalopoden, nur ans dem Besitz älnlicher Organe mit Recht anf dies Vermögen geschlossen wurde. So fehlt z. B. für alle Pedicnlaten, dener Leuchtorgane zugeschrieben werden, his jetzt der dirckte Nachweis, so daß fiir 
diese immerhin gewisse Zweifel nicht gan ansgeschlossen erseheinen. Das wäre ım so eher möglich, als iuch einer Anzilhl vou 'Tiefseefischen Leuchtorgane zugeschrieben wurden, die sich bei genanerer Vergleichung als Gebilde ergaben, die dem Seitenliniensystem (s. S. 664) amgehören und dalıer hinsichtlich ibrer Lenchttähigkeit zweifelhaft erseheinen.

Die Leuchtorgane der Fische sind tist stets scharf umschriebene, verschieden gestaltete, fleckenartige Gebilde, die, in oder dicht unter der IIant liegend, gewöhnlich in ausehnlicher Zalhl ïber den Körper, hänfig vom Kopf bis zum Schwanz-

Fig. 7lii.

A

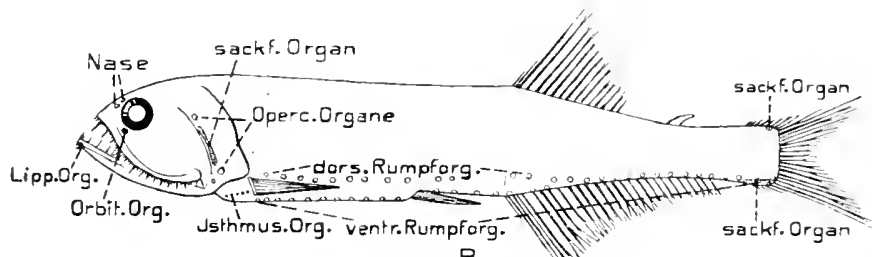

B
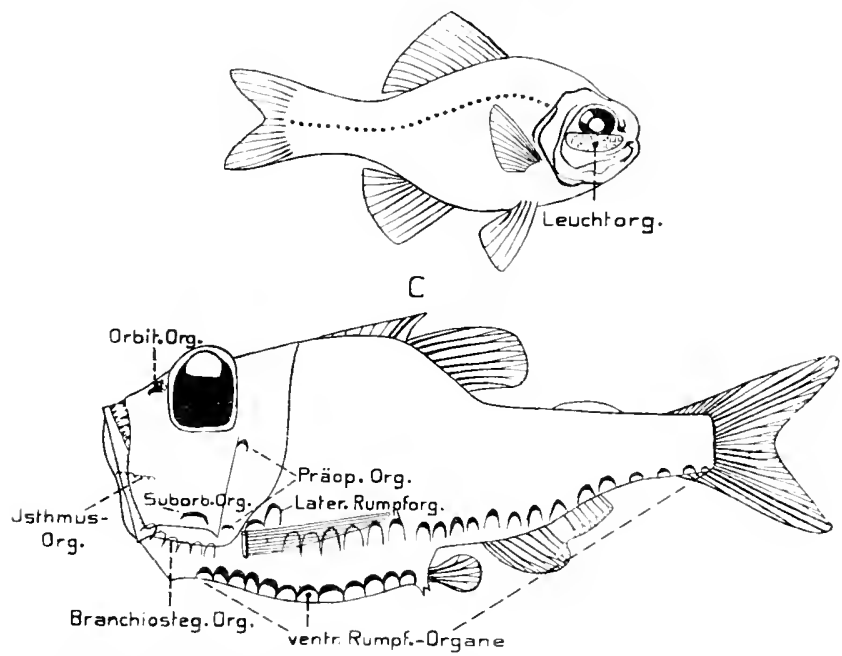

Leuchtiosche Teleostei). - at lionostoma denuditum liar. - B Photohlephiron palpe-

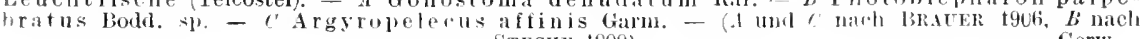
STECHE 1909).

tnde, verbreitet sind $(\mathrm{s}$. Fig. 716 A u. C). Äuberlich sind sie teils als weißliche bis gelbliche Flecke oder vielfach anch wegen ihres schwarzen l'igments melu oder weniger leicht zn erkenuen, besonders die größeren Organe. Seltner treten sie in beschränkter Zahl anf, so bei den beiden erwälnten Anomalopsilen nur dicht nuter jedem Auge ein lingliches, ansehnliches Organ (Fig. $716 \mathrm{~B}$. - Bei den Kairn (Spimaciden) verbreiten sie sich als punkt- bis strichartige kleine Gebilde über den Gesantkörper, vom Kopt bis zur Schwanzllosse; in griißrer Menoe anf der Ventralseite. wo nur beschänktr bezirke von ilmen trei hleibru. An h 
bei den Teleostern (abgeseben von den Pediculaten ist die Zialu der Organe meist ansehnlich bis sehr groß und ihre Verbreitung ïber den Körper recht verschieden; doch herrscht im allgemeinen die Tendenz zur Anordnung in Längsreihen vor (Fig. 716), wobei sich die Reihen der größereu Organe gewöhnlich auf die Banchhälfte beschränken. - Ähnlich wie bei den Cephalopoden finden sich häufig bei einer und derselben Art recht verschiedene Organe, die in Größe, Gestalt, Richtnng und Ban stark differieren. Die kleinen und einfachst gebauten Organe (Stomiatidue) sind nicht selten iiber den ganzen Körper zerstrent und können sich anch anf die Flossen erstrecken. Größere finden sich in verschiedener Anordunng auf dem Kopf, namentlich in der Nähe der Angen, als Orbital-, Sub-, Supra- und Antorbitalorgane; auch kleinere Organe könneu sich, das Ange umziehend, dazu gesellen. Leuchtorgane finden sich ferner nicht selten am Oberund Unterkiefer, am Mundwinkel, dem Bartfaden (Bartel), anf dem Präoperculum (Opercularorgane), der Kiemenhant (Branchiostegalorgane); hieran schließen sich dann die Reihen der Rumpforgane. Zuweilen neigen die Organe zur Bildung von Gruppen (speziell Sternoptychidue), indem sie sich in verschiedener Zahl dicht zusammenlegen, ja sugar mehr oder weniger miteinander verschmelzen. - Bei Neoscopelus Familie der Scopelidae) findet sich sogar in der Mundhöhle, an den Seitenr:̈̈ndern der Znnge, je eine Reihe. - Eigenartig verhalten sich schließlich die Podiculat'n, bei denen ein Leuchtorgan am Ende des sog. Tentakels, d. h. des langen freien vordersten Strahls der vorderen Rückenflosse liegt, welche Flosse hier zu einem oder einigen solch freier fadenartiger Strahlen aufgelöst oder reduziert ist. Dazn gesellen sich bei Ceratias vor dem Beginn der hinteren Rïickenflosse noch einige warzen- oder karmnkelartige Organe. - Bei den Formen mit zahlreichen Organen läßt sich verfolgen, daß sie sich allmählich vermehren, indem anfänglich nur ein bis wenige Organe vorhanden sind, die übrigen mit dem Wachstum snccessive anftreten.

Wie bemerkt, sind die Organe recht verschieden gebaut, von äußerst einfacher bis zu sehr komplizierter Bildnng. Stets scheint jedoch sicher erwiesen. daß ihr wichtigster Bestandteil (d. h. die cigentlichen Leuchtzellen) aus der Epidermis hervorgeht, wozn sich aber bei den komplizierten Organen noch zahlreiche, dem Mesoderm entstammende Teile gesellen. Die Organe erlangen so häufig einen verwickelten Ban, der im Prinzip jenem gleicht, den wir schon bei den Cephalopoden und Dichelopoden fanden, so diß hier ein Beispiel weitgehender Konvergenz vorliegt, hervorgerufen durch übereinstimmende Anforderungen und dadurch bedingte Vorteile.

Den einfachsten leuchtorganen begegnen wir wohl bei den spinacider (näher erforseht nur bei Spinax niger Fig. 717 und Etmopterusj, wo sie etwa halbkuglige, in das Corium vorspringende Lpidermisverdickungen darstellen, deren tiefste Zellen $(2-5$ Lagen blasig vacnolär angeschwollen, radiär zusammen gruppiert und sekrethaltig sind. Es sind dies jedenfalls die eigentlichen Leuchtzellen, während die distal gelegenen Zellen, zwischen welchen auch größere, drüsige Schleimzellen (sog. Linsenzellen) eingeschaltet sind, möglicherweise eine 
linsenartige Wirkung ansüben. Unterlagert werden die Organe von schwarzen Pigmentzellen des Coriums und einem sie nmfissenden Blntsinus. - Eine sehr einfache Form ler Organe ist ferwer bei den Stomiatiden (speziell Chauliortus) meist in großer Zahl iiber den Kärper verbreitet bis anf die unparrn Flossen, wo sie sieh längs der Flossenstrahlen ausdehmen, und ebenso anf del Bartel. Es sind kuglige bis ellipsoidisehe Zellgruppen ohme irgendwelche accessorischen Teile. die nach anßen von den Schuppen im Corium liegen und mit der Epidermis, ans der sie jedlenfalls hervorgingen, nicht mehr zusammenhängen. Zuweilen enthält die Zellgruppe in ilurem Centrum einen Sekretballen.

Eine Anzahl Leuehtorgane hat den charakteristisehen Ban einer mehrzelligen Hautdrïse, was sehr antfäll, weil wir friiher fanden (s. S. 127), daß sonstige mehrzellige Ilautdrïsen gerade den Fisehen völlig fehlen. Ein Brispiel hierfü bieten die becherförmigen Organe gewisser Sternoptychidae, speziell jene von Gomostoma flongatum (Fig. 718). Es handelt sich $1 \mathrm{~m}$ eine kuglige Driise mit mäßigem Lnmen und ziemlich langem Ansführgang. Die genanere Betrachtung zeigt, daß die dicke Driisenwand nicht einfach ist, sondern von zahlreichen, radiär angeordneten, etwa schlanchförmigen lumenlosen Acini gebildet wird, die vom Centrallnmen oder -sinus ansstrablen. Umhiillt wird der kuglige Driisen- oder Lencht-

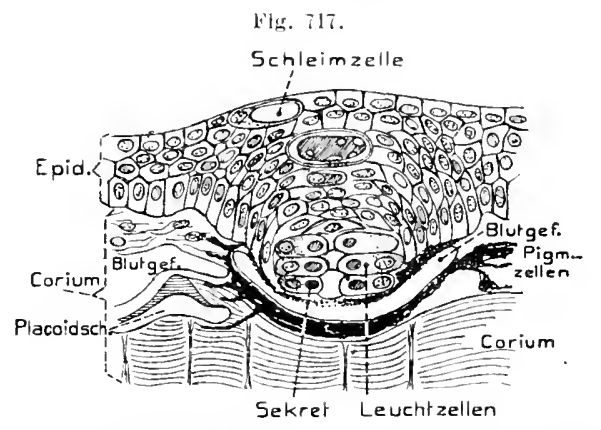

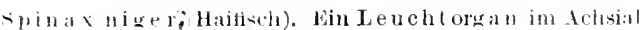
achnitt (nach JoHAxs lisys

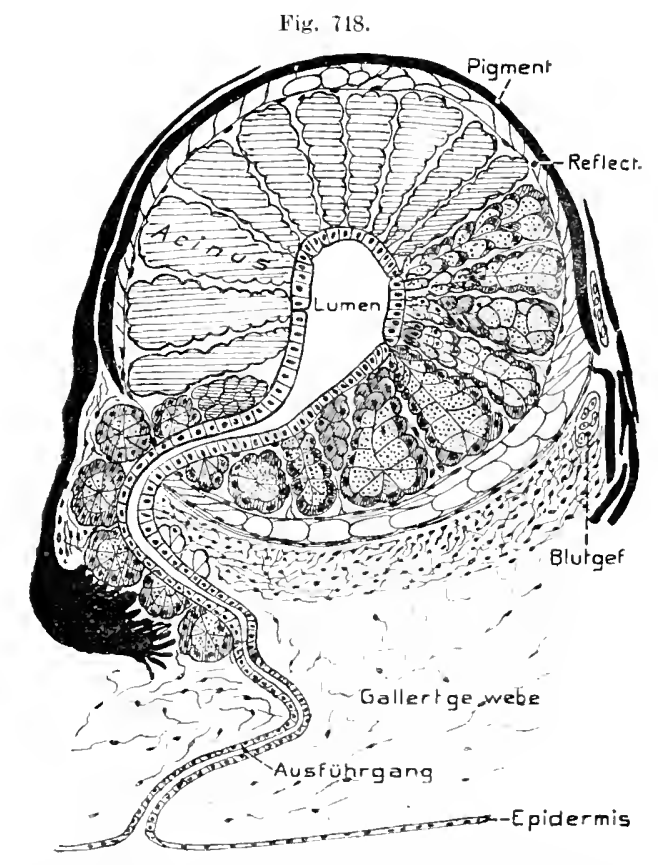

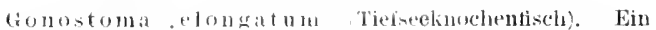
Leuchlorgin der ventralen limulfeihe trol. Fig. 716 im Achsial-chnitt. Jue Acini sind links nur in Umrissen :urgegeren, rechts dagogen die Zellen eingezeichnet nach lindFer latisi,

körper von einer lage finserartiger Bindegewebszellen, welche als Retlektor dienen, und dieser lieflektor ist wiederum von einer Schale schwarzer P'igmentzollen nmgeben, so dafs nur die distale Region des lousenkärpers den liehtaus- 
tritt gestattet. - Schon bei anderen Gonostomaarten, ebenso den übrigen Sternoptychiden besitzt der Ausfïhrgang, insofern er nicht, wie hänfig, ganz geschwunден ist, keine Öffummg mehr, sondern endet nach kürzerem oder längerem Verlauf blind Fig. 719 und ist anch hänfig ohne Lumen. Ehenso verengt sich das Lumen der Lenchtdriisen sehr und schwindet häufig völlig, so daß die kuglige Driise ein solides Gebilde wird, das entweler noch ähnlich wie bei Gonostoma gebaut ist oder nur ans einer einfachen Schicht radiär gestellter, langer Leuchtzellen besteht, endlich aber auch (Triplophos, Stemoptyx) in zahlreiche kleine, unregelmïßig geformte Gruppen von Leuchtzellen zerfallen kamn, die, in zwischengeschaltetes Bindegewebe eingebettet, den Lenchtkörper zusammensetzen. Wahrscheinlich

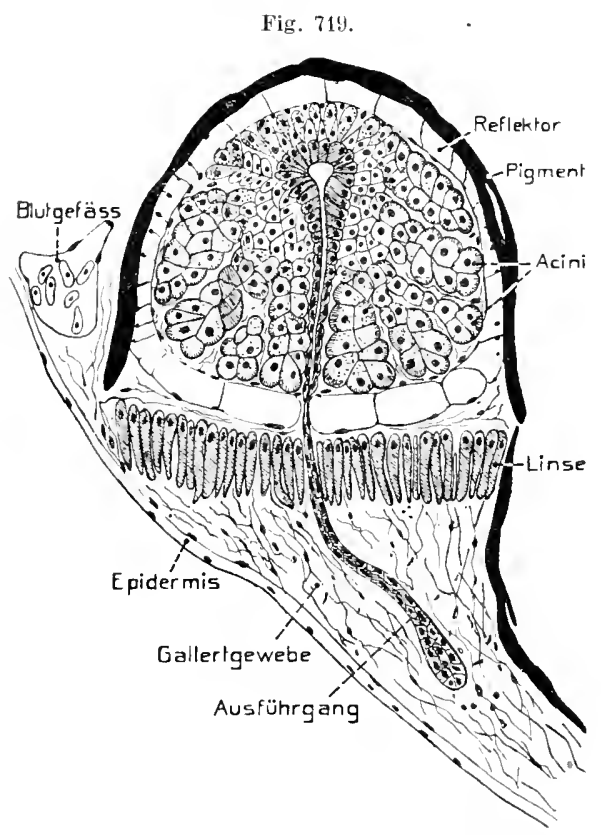

Cyclothone microdon (Tiefseeknochenfiscli). A ein Leuclitorgan der Branchiostegalliut im Achsialschnitt (nach BrdUER 19us). O. F. leiten sich diese Gruppen von Leuchtzellen von der Acinibildung ab, die wir bei Gonostoma fanden, indem die Driise sich allmählich, in die Acini zerfallend, auflöste. Zwischen die Acini oder anch die radiären Lenchtzellen dringt Bindegewebe ein, woher es wohl auch kommt, daß unter Riückbildung des Ausfiihlhrgangs bindegewebe mit Blutgefäßen in das Rudiment des Drisenlumens eindringen und es erfïllen kann. - Ein Reflektor und die Pigmenthiille finden sich bei den geschilderten geschlossenen $\mathrm{Or}-$ gamen ähnlich wie bei den erst beschriebenen mit Ausführgang; aber es gesellt sich hierzu, distal vom Lenchtkörper, noch ein mäßig großer bis sehr ansehnlicher Zellkörper, welcher der Öffunng der Pigmentschale eingelagert ist und entweder ans einer Lage zylindrischer Zellen

(Fig. 719) oder aus zahlrcichen polyedrischen Zellen besteht. Auf die mannigfachen Verschiedenheiten und Differenzierungen, welche dieser Körper darbieten kann, gehen wir nicht uäher ein; erwähnt sei nur, daß seine Zellen sprödes Sekret, in einem Fall sogar stäbchenartige Bildungen, enthalten können. Der Körper dient offenbar als lielitbreehende Linse für die anstretenden Strahlen. Die Zellen dieser Linse gehen zweifellos ans der gleichen Qnelle hervor, wie jene des Lenchtkörpers, und in manchen Fïllen dürften vermutlich die stark verïnderten Zellen des urspringlichen Ausführgangs zur Bildung der Linse wesentlich beitragen. - Zwischen den Linsenkörper und die :iußere II:ul schiltet sich meist eine Anhäufung von gallertigem Bindegewebe (Gallertliomper) ein, das sich anch noch weiter um das 
Organ ausbreiten kann. Auch der Gallertkörper wurde gelegentlich als lichtbrechendes Gebilde gedentet.

Ähnliche geschlossene Organe sind anch bei den titomiatilae als sog. flaschenförmige sehr verbreitet (Fig. 720), eine Bezeichnung, die sich auf ihre Gestalt bezieht, da sie zwisehen dem Lenchtkörper und der Linse mehr oder weniger stark ringförmig eingeschinirt $\operatorname{sind}(A, B)$, was anch bei den Sternoptychiden schon angedentet ist. Eine Abweichung zeigen diese (1rgane darin, daß ihr Linsellkörper meist alls zwei Abschnitten besteht, welche sich ans etwas versehiedenen Zellen. anfbanel, einem centralen oder proximalen und einem peripheren oder distilen Teil. Der Reflektor, welcher wie gewöhnlich aus faserartigen Zellen besteht $(C, D)$ breitet sich hier nur nm den Linsenkörper; nicht jedoch den Lenchtkörper aus, setzt
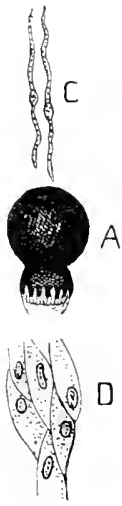

lice. $72(1$.

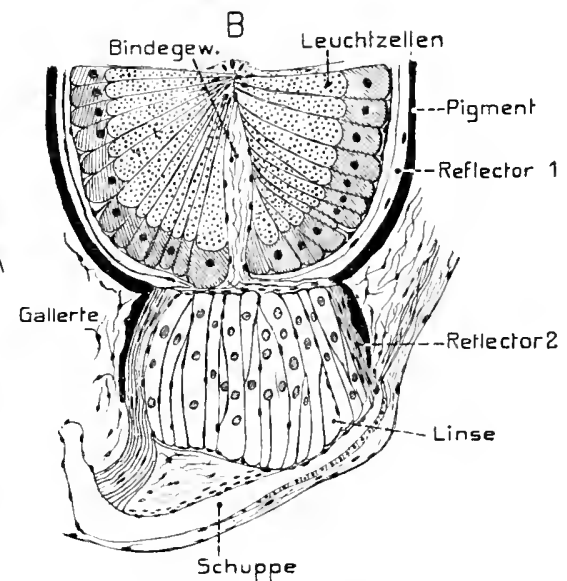

L-B lchthyococens ornatus ('liefseknochenfisch). I ein Leuclitorgan von ler Branchiostegalmenbran in toto. - b R u mp forgan im Aclısialschnitt, die proximale Hälfte nicht gezeichnet. - C-I, Pliotichthys. Reflektorzellen. ('im Durchischnitt; I' von der Fläche (nach BRaUER 1908).

O. B.

Sternoptychiden, hïnfig einseitig noch eine erhebliche Strecke über das eigentliche Urgan distal fort, so daß dieser Abschnitt des Reflektors etwat wie ein schräg vor das Organ gestellter Spiegel wirken muß. - Außer diesen flaschenfơrmigen (1) rganen finden sich bei den Stomiatiden in großer Zahl noch einfachere, schalen-oder bccherförmige, von sehr verschiedener Größe. Wie ihre Benennung andeutet, sind sie etwas verschieden gestaltet, im allgemeinen kleiner als die flaschenförmigen und darin einfacher, daß ein Reflektor fehlt und keine Einschniirnug zwischen Leuchtund Linsenkörper besteht, sondern die Linsen-
Fis. 721

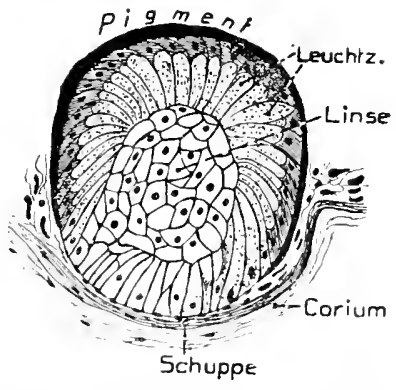

Chan biolus sloanei ('liefseeknoclienfisch). Jin lenclutorgan des Rumules im Achsialschnitt nach BRALER leOS). O. B. zellen die Höhlung des schalen- bis becherförmig vertieften, aus radiär gestellten Zellen zusammengesetzten Lenchtkörpers ausfüllen (Fig. 721). Öhnlich erscheinen im allgemeinen anch die Organe des Batrachiden Poridhthys.

Einiger sehr abweichender Organbildnugen sei hier noch kur\% gedarht. So treten bei Gonostoma elongatum (Sternoptychiden) am Ausführgang gewisser der Drïschorgalle eigentümliche, vielfach gelappte Erweiterungen oler Anhïnge auf, Sie sind innerlich von ein- 
shichtigem, sebr llachem Epithel ansgekleidet. An gewissen hörperstellen (präcaudal s. Fig. 716 A) finden sich nun derartige vielbuchtige, lang saclstörmige Gebilde ohne Ausführgang und ejgentlichen Wrisenkörpèr, doch mit Reflehtor mol einer l'igmenthappe an einen Enłe. Es stheint wohl sicher, daß es sich hier num ein rudimentär gewordenes Organ handelt. Sehr eigentiumlich ist anch der Bau der sub- und postorbitalen Organe gewisser Stomiatiden. Sie erscheinen etwa wie eine kuglige Drüse ohne Ausfübrgang, deren einschichtige Zellwand viele schlauchartige Einfaltungen ins Innere erfalren hat, welche sich zum Teil anch ablisten mu nun als ein vershlungenes Siblanchwerk das Innere erfüllen.

Relativ einfach, jedoch sehr mannigfaltig in ihrer äußeren Gestaltung sind die Organe der Scopelidue. Im allgeneinen lassen sich unterscheiden: drïsen-, becher- und flaschenförmige Organe, welchen eine zellige Linse stets fehlt, die also umr aus Lenchtkörper, Reflektor', l’igmenthülle nnd Gallertmasse bestehen. Sie liegen meist selır oberflächlich in Corimm. Die Organe von Nooscoprlus sind gut entwickelte Drïsen mit geöffnetem Ausfuhrgang und acinös verzweigtem Driisenkörper. Die des Rumpfs liegen dicht unter deu Schuppen, was fiir die Organe der Scopeliden iiberhaupt giiltig erscheint, - Die Organe von Myctoplbum hingegen (Fig. 722) haben den Driisencharakter völlig verloren, da ein Ausfïlırgang fehlt und der recht verschieden gestaltete Lenchtkörper kein lımen mehr

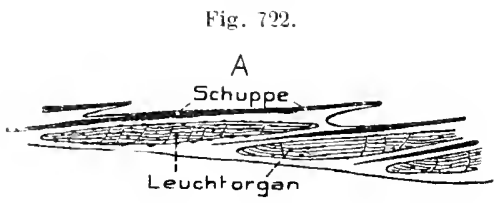

B

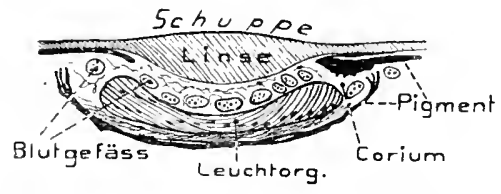

A Myctophum warmingi (Tietiseknochen fisch, Längsschnitt durch einige Leucht schuppeu. - $B$ Myetophum macro pter $1 \mathrm{~m}$. Längsschmitt durch ein A u alorgan (bach Brater 1908). O. P. hesitzt. Die Gestalt dieser Organe ist teils plattenförmig (Lcuchtplatten), bald schließen sie sich den einzelnen Schuppen, sie dicht unterlagernd, an (Leuchtsclenppen, Fig. A), bald sind sie flach schïsselförmig und unterlagern dahei eluenfalls je eine Schuppe (Fig. $B$ ), bald tiefer becherförmig eingesenkt. Die Einsenkung wird duch Entwicklung eines gallertigen Bindegewebes hervorgerufen, welches den Lenchtkörper in sich anf- ninumt und ihn gewöhnlich allseitig umschlicBt, während er proximal vom fasrigen Reflektor und dem Pigment umhïllt wird. Die Leuchtkörperzellen sind flich lamellenartig und entweder senkrecht zur Ober-

1lïche gerichtet oder ihr parallel in viclen Lagen angeordnet, wobei die den Leuchtkörper meist zahlreich durchsetzenden Blutkapillaren ihn häinfig in sänlenartig zusammengestellte Partien soudern. Als Ersatz für die fehlende zellige Linse findet sich an manchen, die Schuppen unterlagernden Organen von Myetophum (Fig. 722 B), wahrscheinlich aber auch bei Neoscopelus und ähnlich schon bei der Sternoptychide Liplophos eine linsenartige Verdickung der Schuppe iiber dem Lenchtorgin.

Den Charakter einfacher Hautdrisen zeigen anch die beiden Angenorgane der Anomalopsiden (Fig. 716 B). Wie anselnlichen, länglich bandartigen Organe bestehen aus einer großrn \%ahl senkrecht zur Oberflache gestellter 1)risenschlänche, 
von denen je eine Gruppe von etwa 8-10 durch einen gemeinsamen Gang ausmïnden soll. Bei der Sekretion sollen die Zellen eingehen und der Ersatz am Grunde der Schlïuche stattinden. Der gemeinsame Reflektor jedes Organs besteht aus platten Zellen, die ihren Glanz Guanineinschlissen verdanken. Ein Pigmentmantel sowie Knorpelgewebe umhïllt die Organe.

Eine einfache Hautdriise von meist kugliger, zuweilen jedoch auch verzweigter Form, mit kurzem Ausfïhrgang ist anch das vermutliche Leuchtorgan, welches sich am Ende des Tentakels gewisser Pediculaten findet. Ein Reflektor nebst Pigmenthülle ist vorhanden und spricht für seine Dentung als Lenchtorgan. - Auch die sog. Karunkelu vor der hinteren Riuckenflosse von Caertia enthaiten je eine kuglige Draise.

Blutgefüße treten häutig reichlich zu den höher entwickelten Organen und dringen bis in den Lenchtkörper ein. - Ilinsichtlich der Innevvierung verhalten sich die Organe recht rerschieden; meist scheinen sie lieine eigentliche Yerrenversorgung zu besitzen; bei gewissen Formen aber sind Nerren bis in den Leuchtkörper verfolgt worden, dorh ist ihre feinere Endigung nicht näher bekannt. - Auch Muskelfasem können zu manchen Organen treten und ihre Stellungsveränderung bewirken. - Amomalops vermag das Augenorgan rentralwärts gegen die Augenhöhle herabzudrehen, su đaß der Lichtanstritt nach außen rerhindert wird; bei Photoblepharon hingegen kami eine schwarze IIautfalte, welche einem unteren Augenlid gleicht, über das Organ heraufgezogen werden. Diese beiden Leuchtfische weichen darin $a b$, daß ihre Organe kontinuierlich leuchten, die der übrigen Fische, soweit bekanıt, erst bei leizung.

Oben wurde hervorgehoben, daß bei den Sternoptychidae häufig zwei bis mehr Organe zu Gruppen dicht zusammentreten, wobei der l'igmentmantel und der Rieflektor der Organe zu einer gemeinsamen Umbüllung rerschmelzen können. In manchen Fällen erstreckt sich die Verschmelzung auch auf die Leuchtkörper selbst, während lie Linsen und etwaige rudimentäre Ausführgänge gesondert bleiben.

Wie schon bemerkt, entstehen Leuchtkörper, Linse und Ausführgang aus dem Ectoderm, was wohl für sämtliche Organe gilt. Da nun manche Leuchtorgane der Stemoptychiden, Scopeliden, Anomalopsiden und Pediculaten als offene Hautdriisen erscheinen, von denen sich wenigstens bei der ersterwähnten Familie die geschlossenen Organe gut ableiten lassen, so liegt es nahe, die Gesamtheit der Organe auf Hautdrïsen zurïckzuführen. Gegen diese Ansicht ließe sich eventuell geltend machen, daß mehrzellige Hautdrïsen sonst bei den Fischen ganz fehlen, die phyletische Ableitung der Lenchtorgane von solchen also ausgeschlossen erscheint. Die Organe mancher Formen ließen sich ebenso leicht als einfache Ablösungen von der tiefen Epidermisschicht, ohne eigentlichen ehemaligen Driisencharakter, auffassen. Daher wäre es wohl möglich, daß die Organc nur in gewissen Fällen und Gruppen den Drisencharakter erlangten, in anderen ihn dagegen nie besaßen. Entleerung eines Leuchtsekrets wurde bis jetzt anch hei den offenen Leuchtdrïsen nie sicher festgestellt.

Die biologische Bedeutung der Lenchtorgane der Fische dürfte ähnlich zu beurteilen sein wie bei den Cephalopoden, so daß von einer besonderen Erörterung abgesehen werden kan. 
Druck von Breitkopi \& Härtel. Leipzigr. 



$\therefore=$

(*)

$m$

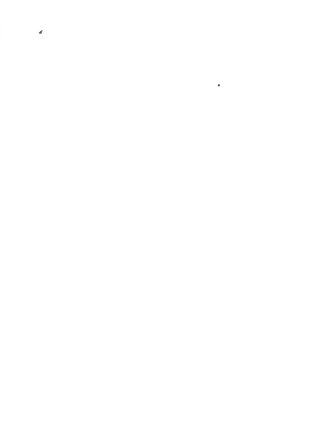

"3is
$40+1$
$\vdots$

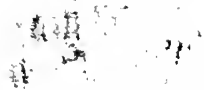

$r_{1}+\cdots$

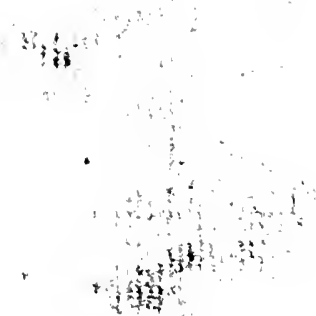

